\title{
Stadtarchiv Emden
}

Internes Findbuch

zum Bestand

IV

Vierte Registratur 
Vorwort

\author{
Der Bestand der IV. Registratur im Stadtarchiv Emden
}

Stadtgeschichte Emdens, 1866 - 1918

1. Langersehnte Rückkehr der preußischen Herrschaft, Erwartungen und Enttäuschungen

Die Ära der Hannoverschen Landesherrschaft zwischen 1815 und 1866 war für Emden eine Phase der wirtschaftlichen Stagnation. Ein Indikator war die Bevölkerungszahl. Sie stieg zwischen 1815 und 1866 nur relativ leicht an (1815: 11.000; 1866: 13.000). Eine durchgreifende Industrialisierung blieb unter der Hannoverschen Herrschaft weitgehend aus. Die Strukturprobleme des Emder Hafens (Verschlammung) blieben ungelöst. Unter der Emder Bürger-schaft herrschte eine latente Unzufriedenheit mit der Hannoverschen Regierung, die sich durch eine absolutistisch zentralistische Verwaltung noch unbeliebter machte. Die Emder begannen, besonders die letzte Phase der preußischen Herrschaft zwischen 1790 und 1805 als "goldenes Zeitalter" zu glorifizieren. Tatsächlich bildeten Emden und Ostfriesland für das regierende Haus der Welfen ein Nebenland. Der Schwerpunkt der Strukturförderung lag im welfischen Kernland, dem ehemaligen Kurfürstentum Hannover. Dennoch entstanden für Emden und Ostfriesland zwei Projekte unter Hannoverscher Herrschaft, die zukunftsweisend waren. Das war der Bau der Westbahn und der Nesserlander Schleuse. Die Westbahn stellte eine Verbindung mit dem Ruhrgebiet her und die Nesserlander Schleuse ermöglichte eine Entwicklung des Emder Hafens. Auf-grund der hohen Tarife für den Gütertransport bei Nutzung der Westbahn blieb ihr Effekt auf den Hafenumschlag in Emden gering. Als im Juni 1866 der preußisch - österreichische Krieg um die Vorherrschaft im Deutschen Bund ausbrach, stellte sich der überwiegende Teil der Emder Bürgerschaft auf Seiten Preußens. Der Hannoversche König Georg V. verhielt sich loyal zum bisherigen Deutschen Bund. Eine Aufforderung Preußens zur Neutralität und Duldung des Durchmarsches preußischer Truppen lehnte Georg V. rundweg ab. Als Reaktion darauf marschierte die preußische Armee bei Ausbruch des offenen Krieges sofort in das Kgr. Hannover ein. Die Hannoversche Armee, - es war keine Mobilisierung erfolgt -, leistete keinen Widerstand. Vielmehr wich König Georg V. mit seinen bewaffneten Kräften über Göttingen nach Thüringen aus. Er wollte seine Armee mit den Armeen der süddeutschen Bündnispartner vereinigen, um im Verein mit Österreich sein Stammland zurück zu erobern. Da sich die bayerische Armee nicht schnell genug nach Norden bewegte, misslang die geplante Vereinigung. Die Hannoveraner wurden eingekesselt. Auch der taktische Sieg ihrer Armee bei Langensalza am 26./27. Juni $1866 \mathrm{im}$ Gefecht gegen preußische Truppen unter General Flies änderte nichts an der aussichtslosen strategischen Lage. Ohne Munition und Verpflegung musste König Georg V. mit seiner Armee am 30. Juni 1866 kapitulieren.

Georg V. ging ins Exil nach Wien. Nach der entscheidenden Niederlage der österreichischen Armee bei Königgrätz am 03. Juli 1866 schied Österreich im Vorfrieden von Nikolsburg (26. Juli 1866) und nach den Bedingungen des Friedensvertrages von Prag (23. August 1866) aus dem Deutschen Bund aus. Preußen annektierte das Kgr. Hannover, Kurhessen und die Freie Stadt Frankfurt. Damit verlor der Hannoversche König seinen Thron. Georg V. sah sein ehemaliges Reich nicht wieder. Die preußische Besetzung vollzog sich in Emden und Ostfriesland widerstandslos. Am 17. Juni 1866 kapitulierte die Hannoversche Garnison vor preußischen Marinesoldaten vom Aviso "Loreley" und dem Kanonenboot "Tiger" im Zollhaus an der Nesserlander Schleuse.

Der Wechsel der staatlichen Zugehörigkeit vollzog sich in Emden reibungslos. Die bisherige Stadtverwaltung mit Oberbürgermeister Ernst Heinrich Hantelmann, einem gebürtigen Hannoveraner, blieb im Amt. Auch an der Struktur der bisherigen kommunalen Aufsichtsbehörde, der Landdrostei in Aurich, änderte sich wenig. Sie wandelte sich zu einer kgl. preußischen Behörde.

Schon wenige Tage nach dem Einmarsch der preußischen Truppen in Emden verfasste die Emder Bürgerschaft eine Ergebenheitsadresse an den König Wilhelm I. Sie brachte ihre Freude über die sich einbahnende Rückkehr Emdens und Ostfrieslands unter der Staatshoheit der Hohenzollernmonarchie zum Ausdruck.

Während des Winters 1866 / 67 verfassten verschiedene Bürger unter Führung der Handels-kammer eine Eingabe an die preußische Staatsregierung, in der sie das Ausscheiden Ostfrieslands aus dem Verband der nunmehrigen Provinz Hannover unter Eingliederung in die Pro-vinz Westfalen forderten. Emden sollte dadurch zum Exporthafen der Ruhrindustrie werden. Die Initiatoren versprachen sich von einer Neugliederung Nordwestdeutschlands eine Be-schleunigung des Infrastrukturausbaus (Kanalbau, Eisenbahn), der die Vernetzung mit dem Ruhrgebiet herstellte. Doch aller hochgespannten Erwartungen an die neue preußische Landesherrschaft blieben unerfüllt. Sie veränderte die vorgefundenen Verwaltungsstrukturen des annektierten Kgr. Hannover zunächst nur in der Spitze. Erst 1885 erfolgte eine Kreisreform für die Provinz. Emden war nun Stadtkreis im Regierungsbezirk Aurich. Die für die Kommunalverfassung maßgebliche Hannoversche Städteordnung von 1851 blieb in Kraft. Nach deren Bestimmungen wurden die Geschicke der Stadt vom Magistrat, einem kollegial 


\section{Vorwort}

organisiertem Gremium, das die Verwaltung regelte und dem auf Basis des Klassenwahlrechts gewählten Bürgervorsteherkollegium als Vertretung der Bürgerschaft gelenkt. An der Spitze der städti-schen Gremien stand der Bürgermeister, der nach einer gewissen Amtszeit zum Oberbürgermeister befördert werden konnte. Das Stadtoberhaupt fungierte zugleich als Leiter der Poli-zeiverwaltung. In dieser Funktion unterstand der Bürgermeister direkt dem preußischen Landdrosten bzw. ab 1885 Regierungspräsidenten in Aurich. Diese Doppelfunktion des Bürgermeisters, einerseits Leiter der Polizeiverwaltung, andererseits Chef der Kommunalverwal-tung, bedingte, dass er von den städtischen Gremien und dem Landdrosten / Regierungspräsi-denten gemeinsam bestimmt wurde. In der Praxis schlug die Stadt der kommunalen Auf-sichtsbehörde in Aurich einen Bewerber als neuen Bürgermeister vor. Der Landdrost / Regie-rungspräsident bestätigte diesen Vorschlag.

Die erste Phase der neuen preußischen Herrschaft brachte der Emder Stadtentwicklung wenige neue Impulse. Zur Enttäuschung vieler Anhänger der neuen Herrschaft blieben die Strukturen der ehemaligen kgl. Hannoverschen Verwaltung erhalten. Diese Form der Herrschaftsor-ganisation in einer neu erworbenen Provinz war kennzeichnend für Preußen. Die preußische Monarchie war kein monolithischer Zentralstaat. Sie zeichnete sich durch ein Nebeneinander verschiedener Strukturen der einzelnen Provinzen aus.

Ab 1875 begann eine Strukturentwicklung, die in Emden tiefgreifende Veränderungen bewirkte. Den Antrieb dazu lieferte die Politik des 1871 entstandenen deutschen Kaiserreichs vor dem Hintergrund rascher Industrialisierung und des Aufbaus einer schlagkräftigen Marine unter Kaiser Wilhelm II. Dazu kam das Engagement des Oberbürgermeisters Leo Fürbringer und des Geheimen Oberregierungsrats Carl Schweckendiek als Referent im preußischen Ministerium der öffentlichen Arbeiten, einem gebürtigen Emder.

\section{2. Ära Fürbringer, 1875 - 1913}

Als der aus Thüringen stammende Jurist Leo Fürbringer ( ${ }^{\star 21.03 .1843) ~ i m ~ J u l i ~} 1875$ als neuer Bürgermeister Emdens vereidigt wurde, begann eine 38 jährige Ära, die die Emder Stadtgeschichte prägte. Leo Fürbringer erwies sich als fähiger Verwaltungsorganisator und unermüdlicher Lobbyist. Dabei kam inm seine Funktion als nationalliberaler Abgeordneter des Hannoverschen Provinziallandtags (1904 - 1914) und des preußischen Landtags (1907 - 1918) entgegen. Darüber hinaus wurde Fürbringer Mitglied in zahlreichen regionalen und überregionalen Verbänden, die sich mit kulturellen, maritimen, wirtschaftlichen und gesellschaftlichen Fragen beschäftigten. So schuf er sich ein Netzwerk, das seine Karriere, u.a. die Verleihung des Titels eines Oberbürgermeisters (1877) und die Verleihung des Charakters eines Geheimen Regierungsrats (1901), förderte.

Der erste konkrete Erfolg seiner Lobbypolitik war die Errichtung eines Telegraphenamtes. Emden wurde zum Schnittpunkt des Fernkommunikationsverkehrs zwischen dem Deutschen Reich, Großbritannien und den USA. Bei der Umsetzung dieses Projektes arbeitete der Ober-bürgermeister eng mit dem kaiserlichen Poststaatssekretär Heinrich v. Stephan zusammen. 1883 wurde der Platz vor dem neuen Telegrafenamt nach dem Staatssekretär benannt und dort eine Büste von ihm aufgestellt. Inzwischen wurde mit der Emdener Papierfabrik die erste Industriefabrik gegründet. Sie ver-arbeitete Stroh als Rohstoff. Schon mit der Gründung dieser Fabrik wurden die Probleme der Industrialisierung sichtbar. Bei überlangen Arbeitszeiten, unzureichendem Schutzeinrichtungen und einer rigiden Arbeitsordnung erhielten die Fabrikarbeiter nur einen geringen Lohn. Eine soziale Fürsorge fehlte völlig. Dazu kamen ökologische Probleme durch Verunreinigung von Luft und Wasser.

Die weitere Industrialisierung vollzog sich parallel zum Ausbau des Emder Hafens. Hierbei spielen strategische und wirtschaftliche Aspekte der Reichspolitik eine wichtige Rolle. Der 1888 fertig gestellte Ems-Jade-Kanal sollte die Versorgung des Kriegshafens Wilhelmshaven sichern. Den entscheidenden Anstoß für die weitere Entwicklung des Emder Hafens gab der Bau des Dortmund-Ems-Kanals, der 1899 durch den Kaiser Wilhelm II feierlich eröffnet wurde. Hierbei engagierte sich auch der Oberbürgermeister Fürbringer. Unter dem Schlagwort "Neue Rheinmündung" sollte die Ems zu einer Ausgangspforte zum Export von Ruhrkohle und einer Eingangspforte zum Import von Eisenerzen aus Skandinavien werden. Um diese Funktion erfüllen zu können, musste der zwischen 1879 und $1882 \mathrm{im}$ preußischen Staatsbesitz übergegangene Emder Hafen ausgebaut werden. Die Vergrößerung des Emder Hafens erfolgte bis 1901 in mehreren Phasen. Mit dem Bau des Außenhafens, der durch die Nesserländer Schleuse mit der Ems verbunden wurde, entstand ein Areal, das den Aufbau moderner Kaianlagen und Verladeeinrichtungen ermöglichte. Zugleich wurden Dortmund-Ems-Kanal und Ems-Jade-Kanal durch die Kesselschleuse miteinander vernetzt (1887 / 1913). Als im Sommer 1902 die Emder Hafenanlagen durch den Kaiser feierlich eingeweiht wurden, war das der Höhepunkt in der Amtszeit des Oberbürgermeisters Fürbringer.

Er begann, Investoren für die Ansiedlung von Industrie im Emder Hafen anzuwerben. Inves-toren aus 


\section{Vorwort}

dem Rheinland und Westfalen errichteten die Hohenzollernhütte als Stahlwerk und die Emder Brikettfabrik. Die Stadt Emden engagierte sich bei der Errichtung der Nordsee-werke als Großwerft (1903) Allerdings unterschätzten der Magistrat und private Anleger den Kapitalbedarf bei dem Aufbau einer Werft. Verschärft wurde die Lage durch den Bau der Werft während einer Wirtschaftskrise. Die Werftindustrie besaß nun Überkapazitäten, für die es kaum Aufträge gab. Schon 1907, zwei Jahre nach ihrer Eröffnung, gerieten die Nordsee-werke in Zahlungsschwierigkeiten. Immer wieder folgten Kapitalerhöhungen und Sanie-rungskonzepte, die das Engagement der Stadt Emden vergrößerten. 1909 verweigerte die Stadt Emden eine weitere Kapitalspritze. Die Nordseewerke gerieten in die Insolvenz. 1911 wurden sie durch die Deutsch-Luxemburgische Hütten- und Bergwerks AG aufgekauft. Für die Stadt Emden und ihren Oberbürgermeister endete ein verlustreiches Projekt. Überhaupt investierte sie große Kapitalsummen bei dem notwendigen Ausbau der Infrastruktur. Dazu kamen der Bau von Arbeitersiedlungen und die Modernisierung des Kanalnetzes. Sie vergrößerten die städtische Schuldenlast.

Emden verfügte 1903 über einen modernen und leistungsfähigen Hafen. Allerdings wurde er nicht zur "deutschen Rheinmündung", d.h. zum ernsten Konkurrenten der niederländischen Häfen. Die Transportkosten für Industrieprodukte vom Ruhrgebiet nach Emden waren trotz des Dortmund-Ems-Kanals höher als für die Route über den Rhein nach den niederländischen Umschlagshäfen. Oberbürgermeister Fürbringer versuchte durch eifrige Werbung den Emder Hafen für die Wirtschaft interessant zu machen. Traditionell war Emden Heimat der Heringsfischerei. Sie expandierte nach dem Hafenausbau.

Fürbringer versuchte auch die kaiserliche Marine für den Emder Hafen zu interessieren. Eine Bekanntschaft mit maßgeblichen Persönlichkeiten der Marineführung vermittelte inn die Patenschaft der Stadt Emden für den kleinen Kreuzer SMS "Emden", der zu Beginn des Ersten Weltkriegs durch seine Gefechte im Indischen Ozean und seine Versenkung vor der australi-schen Küste berühmt wurde. 1912 schien mit der Stationierung des Minenschiffes SMS "Arcona" im Emder Hafen eine militärische Nutzung bevorzustehen.

Das letzte vom Oberbürgermeister Fürbringer angeschobene Projekt zur Belebung des Emder Hafens war die Einrichtung einer Auswandererlinie. Nach langen Verhandlungen mit dem Direktor des HAPAG-Lloyd, Albert Ballin, wurde in Emden eine Auswandererlinie einge-richtet. Die dafür gebaute Auswandererhalle eröffnete im April 1914 ihren Betrieb. Drei Mo-nate später brach der Erste Weltkrieg aus und machte die Hoffnungen auf einen florierenden Auswandererverkehr zunichte.

Im Sommer 1912 stellte der Oberbürgermeister Fürbringer nach 37jähriger Amtszeit den An-trag auf Versetzung in den Ruhestand. Die städtischen Gremien verabschiedeten inn unter Verleihung der Ehrenbürgerschaft am 26.2.1913 feierlich aus dem Amt. Unter seiner Ägide war Emden zur modernen Seehafen- und Industriestadt geworden. Der Wandel drückt sich bereits in der Bevölkerungszahl aus. Sie betrug 187512.866 und erreicht 1913 die Zahl von 25.000 Einwohnern. Emden verfügte über eine ausgebaute städtische Struktur.

Der Wandel hin zur Industriestadt verursachte einen tiefgehenden Wandel der Bevölkerungsstruktur. Die bisher dominierende reformierte Konfession geriet in die Minderheit. Mit dem Ausbau von Industrie und Hafen nahm die Zahl der Arbeiter zu. Sie organisierten sich in der SPD und den Gewerkschaften, die aber durch das Klassenwahlrecht keinen Eingang in die kommunalen Vertretungsgremien (Bürgervorsteherkollegium) fanden. Die Politik des Oberbürgermeisters zielte auf die Aufrechterhaltung eines Gleichgewichts zwischen den einzelnen gesellschaftlichen und konfessionellen Gruppen ab. Im Stadtbild wird dieses Bestreben durch die Festlegung verschiedener Wohnviertel für Arbeiter (Arbeitersiedlungen Transvaal und Friesland) sichtbar. Energisch ging der Oberbürgermeister gegen offenen Antisemitismus vor, der den konfessionellen Frieden gefährdete. Dass er die religiösen Minderheiten als integralen Bestandteil der Emder Bürgerschaft sah, demonstrierte er durch seine Rede bei der Einwei-hung der erweiterten Synagoge (1910). Die Organisation des Gemeinwesens nach getrennten Klassen drückte sich augenfällig im Bildungssystem aus. In der Fürbringer-Ära erfuhr der Schulbereich eine große Differenzierung. Die gravierendste Veränderung im Schulwesen ge-genüber der Situation vor 1875 ist die Kommunalisierung des Volksschulwesens. Die Kirchengemeinden verloren ihre Schulzuständigkeit, behielten aber einen großen Einfluss auf die Volksschule als Schule für die Kinder der Arbeiter und des Kleinbürgertums. In die städtische Zuständigkeit fiel die Verwaltung und Organisation der Höheren Töchterschule, ab Januar 1905 Kaiserin-Auguste-Viktoria-Schule. Aus der höheren Bürgerschule entwickelte sich die Kaiser-Friedrich-Schule, ein Realgymnasium. Die beiden genannten Schulen wurden von Kindern des höheren Bürgertums besucht. Das Wilhelms-Gymnasium als klassisches Gymna-sium blieb die Domäne des Großbürgertums. Zwischen 1880 und 1914 entstand neben den allgemeinbildenden Schulen ein differenziertes Berufsschulsystem, das von der Navigationsschule bis zur Gewerbeschule reichte.

Die Differenzierung des Bildungssystems ist Teil der Anpassung der Emder Stadtgesellschaft an die 


\title{
Vorwort
}

Bedingungen der Industrialisierung. Allerdings führte sie vor dem Hintergrund des wilhelminischen Staates nicht zu einer Demokratisierung. In Emden behaupteten sich die tra-ditionellen oligarchischen Strukturen.

Am Ende der Fürbringer-Ära präsentierte sich Emden einerseits als dynamische, moderne Seehafenund Industriestadt, andererseits als oligarchisch regierte Stadt mit vorindustriellen Strukturen.

3. Erste Phase der Amtszeit des Bürgermeisters Dr. Wilhelm Mützelburg unter dem Vorzeichen des Ersten Weltkriegs, 1913 - 1918

Am 26. November 1912 wählten die städtischen Gremien den Bürgermeister von Uelzen, Dr. Wilhelm Mützelburg ( ${ }^{\star} 01.10 .1877$ ) zum Nachfolger von Oberbürgermeister Leo Fürbringer. Per Allerhöchstem Erlass bestätigte Kaiser Wilhelm II. die Wahl, so dass Mützelburg das Amt des Bürgermeisters von Emden (Beförderung zum Oberbürgermeister 1921) am 01. März 1913 antreten konnte. Bis zum Ausbruch des Ersten Weltkriegs konnte Mützelburg das von Fürbringer begonnene Projekt der Einrichtung einer Auswandererlinie beenden. 1913 erfolgte die zweite große Erweiterung des Emder Hafens mit dem Bau einer neuen Schleuse, der Großen Seeschleuse.

Im August 1914 wurde Dr. Mützelburg als Reserveoffizier in das Heer eingezogen. Er nahm bis zu seiner Verwundung 1916 an den Kämpfen in Ostpreußen und Russisch-Polen teil. Bis zu seiner Rückkehr nach Emden wegen der durch seine Verwundung verursachten dauernden Kriegsdienstunfähigkeit wurde er durch seinen Vorgänger, Oberbürgermeister Fürbringer, kommissarisch vertreten. Er leitete den Übergang zur Kriegswirtschaft ein. Bis 1916 entstand ein komplexes System der Rationierung von Lebensmitteln und Gütern des täglichen Bedarfs, das eine Verwaltung des immer größer werdenden Mangels war. Im Emder Hafen hörte der Handelsverkehr auf. Er wurde zum militärischen Sperrgebiet. Die Nordseewerke bauten U-Boote für die Kriegsmarine. Im Sommer 1916 übernahm Dr. Mützelburg wieder sein Amt. Bis zum Beginn der Novemberrevolution 1918 führten die immer höher werdenden Kriegsopferzahlen und die desolate Versorgungslage (Kohlrübenwinter 1916/17) zu einer großen Kriegsmüdigkeit.

Die Novemberrevolution von 1918 leitete am Ende des verlorenen Ersten Weltkriegs eine neue Epoche ein.

\section{Bestandstektonik}

Der Bestand der IV. Registratur umfasst 45 Ifde. Meter. Er besteht aus Schriftgut der zweiten Hälfte des 19. Jahrhundert und des frühen 20. Jahrhunderts. Voneinander unterscheiden lassen sich Amtsbücher, allgemeine Sachakten und Einzelfallakten.

Der Bestand der IV. Registratur spiegelt die Organisation der Emder Stadtverwaltung zwi-schen 1866 und 1918 wider. Seine Struktur basiert auf einem Aktenplan, der aus der Hanno-verschen Zeit fortgeschrieben wurde (Hannoversches Dezimalschema). Dieser Aktenplan basierte auf eine numerische und sachgruppenbezogene Ordnung, die sich als sehr ausbaufähig erwies.

Die dem Plan zugrunde liegenden Hauptsachgruppen wurden mit römischen Zahlen gekennzeichnet. Ihre Titel sind:folgende:

\author{
I. Stadtverfassung \\ II. Geschäftsführung Ratsgremien und Verwaltungsorganisation \\ III. Hoheitssachen Beziehung zur Landesherrschaft \\ IV. Verwaltungspolizei Aufgabenbereiche der Stadtverwaltung \\ V. Domanialsachen Städt. Grundbesitz in den ehemaligen Herrlichkeiten \\ VI. Steuersachen Finanzverwaltung: Steuern und Abgaben \\ VII. Militärsachen \\ VIII. Kämmereisachen Finanzverwaltung: Abgaben, städtisches Vermögen \\ IX. Konsistorialia Aufsicht über Kirchen und Schulen \\ X. Nesserland Gemeinde Nesserland, 1910 aufgelöst \\ XI. Stadtausschuss des Stadtkreises Emden
}

Der Registrator, später Kämmerer Ernst August Gebest organisierte das Verwaltungsschrift-gut nach den Gesichtspunkten des beschriebenen Aktenplans.

Die Emder Stadtverwaltung war bis 1914 noch nicht nach städtischen Ämtern gegliedert. Kämmerei und Bauamt waren die ersten Abteilungen, die bereits vor dem I. Weltkrieg Züge eigenständiger Ämter annahmen. Sie bildeten jedoch keine eigenständigen Registraturen. Vielmehr gliederten sie ihr Schriftgut nach dem zentralen Aktenplan und gaben es nach der Bearbeitung an die zentrale Registratur. Dasselbe Verfahren kam bei den Aktenbeständen der Kriegsämter, Lebensmittelamt und Wirtschaftsamt, zur Anwendung. In der Folge entstand ein sehr heterogener Bestand, der die zunehmende Komplexität der Em-der 


\section{Vorwort}

Stadtverwaltung im wilhelminischen Kaiserreich abbildet. Er zeigt aber auch die Grenzen eines zentralen Aktenplans auf. Einige Sachbereiche waren nur mit Mühe in den Plan ein-zugliedern. Es entstanden strukturelle Verwerfungen, die eine Recherche oder eine Suche nach bestimmten Akten erschwerten.

Die Akten der IV. Registratur bestehen aus Papier als Beschreibstoff. Zum Teil wurden sie durch preußische Fadenheftung gebunden. Etwa $30 \%$ der Akten blieben ungebunden. Die Stadt Emden unterhielt keine eigene Buchbinderei. Aktenbindungen wurden von Zeit zu Zeit nach Maßgabe der Haushaltslage vergeben. Die Organisation von Schriftgut im losen Akten-deckel ist nicht unproblematisch. Es drohen Verluste von Einzelblättern und damit von wich-tigen Informationen. Die Provenienzstelle der Akten der IV. Registratur ist der Magistrat der Stadt Emden. Um eine Abgrenzung zum Schriftgut früherer Epochen vorzunehmen, wurde das Jahr 1866 gewählt. Als zweites Grenzjahr definierte die Registratur das Jahr 1918.

Bis Mitte der 1930er Jahre blieben die Akten der Fürbringerära in der städtischen Hauptregistratur. Der Archivar Dr. Louis Hahn übernahm den gesamten Aktenbestand ohne eine Bewer-tung und begann mit ersten Ordnungsarbeiten. Eine archivische Erschließung konnte vor dem Ausbruch des Zweiten Weltkriegs nicht mehr erfolgen. Während des Krieges wurden die Ak-ten des Bestandes wegen der akuten Gefährdung durch Luftangriffe in ein Salzbergwerk in Südostniedersachsen verlagert. Von hier kehrten sie im Sommer 1945 im guten Zustand nach Emden zurück. 1958 fertigte Stadtarchivar Dr. Schöningh ein Findbuch des Bestandes an, das bisher maßgebend war. Schöningh verzeichnete die Akten auf der Basis des Hannoverschen Aktenplans. Er legte die Akten nach ihrem Aktenzeichen und nicht nach einem Numerus Currens an. Da nicht alle Thematiken des Aktenplans mit Akten zu belegen bzw. diese verloren gegangen waren, entstanden im Findbuch leere Themenbereiche. So entstand ein Findbuch, das für gezielte Recherchen nur bedingt einsetzbar ist.

Für die Aufnahme der IV. Registratur in die Datenbank iznAIDA musste eine Neuerschließung des Bestandes erfolgen. Ein Numerus Currens war zu erstellen. Die sachthematische Gliederung lehnt sich zwar an den Hannoverschen Aktenplan an, aber durch moderne Be-zeichnungen der Themenbereiche entstand das vorliegende Findbuch nach einem modifizie-ren Ordnungssystem.

Verzeichnis der Akten der Vierten Registratur in iznAIDA

iznAIDA ist eine Datenbank, die die Verzeichnung eines Bestandes nach sachthematischer Ordnung unter Erstellung eines Indexes ermöglicht. Die eingegebenen Daten können als Findbuch editiert werden. Das vorliegende Findbuch besteht aus folgenden Elementen

1. Sachthematische Ordnung

Der Bestand wird nach in den Akten benannten thematischen Zusammenhängen geordnet. Jede dieser Themen bekommt eine inhaltliche Kennzahl, nach der die Datenbank die Einzel-akten zuordnet.

\section{Verzeichnete Einzelakte}

Die Einzelakte erhält zunächst eine laufende Signatur (Bestellnummer). Dann erfolgt die An-gabe des Aktentitels mit inhaltlichen Enthältvermerken. Diese Vermerke werden indiziert. Sie informieren kurz über den Akteninhalt und orientieren sich nach den Betreff-Einheiten.

\section{Indexe}

Die Indizierung soll einen gezielten Zugang zu den Bestandsakten der IV. Registratur nach thematischen Fragestellungen ermöglichen. Vier Indexarten sollen die Recherche erleichtern:

1. Geografischer Index

2. Institutionsindex

3. Personenindex

4. Sachindex

Die Indexbegriffe verweisen auf eine vom Datenbanksystem vergebene laufende Nummer unter der die betreffende Akte verzeichnet ist. Sie kann unter der fett hervorgehobenen Bestellnummer zur Benutzung geordert werden.

Literatur

Zeitgenössische Abhandlungen zur Fürbringer-Ära 


\section{Vorwort}

Fürbringer, Leo:

Die Stadt Emden in Gegenwart und Vergangenheit, .Emden 1892.

Fürbringer, Leo:

Zweck, Bedeutung und Erweiterung des Emder Hafens. Ein Vortrag, gehalten von Oberbür-germeister Fürbringer - Emden auf der Wanderversammlung des Zentralvereins für Fluss- und Kanalschiffahrt im großen Saale des Rathauses zu Emden am 11. Juni 1904, in: Beilage zur Rhein-Ems-Zeitung, Emden 1904

Leber, E.:

Die Emdener Hafenanlage: Sonder-Abdruck aus der Zeitschrift "Stahl und Eisen", Nr. 9, Düs-seldorf, 1906

Reinke, W.:

Plan der Stadt Emden mit der projektierten Hafenerweiterung; Emden. 1888

Schultz, H. L.:

"Nordseewerke" Emder Werft und Dock Aktien-Gesellschaft (Gründungsbericht), Emden, 1906.

Schweckendieck, Carl

Der Hafen von Emden: Festschrift zur Eröffnung des neuen Emder Seehafens durch seine Majestät den Kaiser und König Wilhelm II. im August 1901(verschoben auf den 30. Juli 1902), Berlin 1901.

Stadt Emden:

Der Emsstrom und der Seehafen von Emden, kartographische Darstellung der Unter-Ems, der geplanten Correction der Ems im Baukreise Emden und des für die Emsmündungen projectir-ten Leitfeuer-Systems, ferner der Hafenanlagen der Stadt Emden mit der neuen Seeschleuse und der daselbst projectirten neuen Verkehrs-Anlagen und Hafen-Einrichtungen in 6 li-thographirten Tafeln mit vorgedrucktem Inhaltsverzeichnisse auf Grund amtlicher Quellen und beglaubigter Originalkarten, Berlin 1883/4

\section{Allgemeine Abhandlungen}

Claudi, Marianne, Claudi, Reinhard:

Goldene und andere Zeiten, Emden - Stadt in Ostfriesland, Emden 1982,

Deeters, Walter; Schroer, Bernard, Siebert, Ernst:

Geschichte der Stadt Emden 1750 bis zur Gegenwart, in: Niederemsische Deichacht - Deich-acht Krummhörn [Hrsg.]:. Ostfriesland im Schutze des Deiches: Beiträge zur Kultur- und

Wirtschaftsgeschichte des Ostfriesischen Küstenlandes; Band 7, Leer 1980

Eichhorn, Helmut

Emden - Zur Geschichte der Ostfriesischen Seehafenstadt, Emden, 1972

Uphoff, Rolf

Emden. Historische Stationen in der ostfriesischen Metropole; darin:

Thorsten Harms, Topographie der Stadt Emden.

Fokke Müller: Von Berlin über Paris nach Emden: ein Beitrag zur Geschichte der Denkmäler des Großen Kurfürsten und Friedrich des Großen.

Axel von Schack: Die Heringsfischerei in der Fürbringer Ära.

Aiko Schmidt: Die Emder Papier- oder Strohpapierfabrik: ein Beispiel der frühen Industrali-sierungsphase in Emden.

Rolf Uphoff, Emden-Transvaal: ein Stadtteil als Arbeiterdomizil in der Wilhelminischen Zeit, Rolf Uphoff [Hrsg.].: (Schriftenreihe des Stadtarchivs Emden; Band 5), Horb am Neckar, 2009,

Specialia

Sozial- und Wirtschaftsgeschichte 


\section{Vorwort}

Buß, Jan Eve:

Wandlungen der Emder Wirtschaftsstrukturen während der "Ära Fürbringer" 1875 - 1914, Emden 1978

Hapag-Lloyd AG Hamburg:

1847-1997 Unser Feld ist die Welt. 150 Jahre Hapag-Lloyd; darin: Emder

Verkehrsgesellschaft AG (EVAG), Hamburg 1997,

Harms, Knut:

Geschichte der Emder Verkehrsgesellschaft AG (EVAG) Internetausdruck., Emden, 2004

Henkel, Henry:

Industrialisierung und Umweltverschmutzung aus historischer Sicht. Der Fall "Emdener Pa-pierfabrik und die Verschmutzung des "Hinter Tiefs" 1873 - 1887 ; 1979

Janßen, Dietrich; :

Emder Straßenbahn, 2. Auflage, Emden 2010

Müller, Annemarie:

Emdens Seeschiffahrt und Seehandel von der Besitzergreifung Ostfrieslands durch Preußen bis zur Eröffnung des Dortmund-Ems-Kanals 1744 - 1899, Lübeck 1930

Peters, Dirk J.:

Die Nordseewerke 1903 - 2003. Von den Nordseewerken Emder Werft und Dock Aktienge-sellschaft zu den Nordseewerken. Hundert Jahre industrieller Schiffbau in Emden, Nordsee-werke GmbH

[Hrsg.]., Emden 2003

Schack, Axel von:

Arbeit alleine, da wirst nicht satt! Zur Sozialgeschichte der Stadt Emden 1848 - 1914, Bre-men 1994.

Sonntag, Johannes-Hendrik:

Heimathafen Emden. Die Geschichte der Emder Heringsfischereigesellschaften in vier Jahrhunderten, Emden, 1998 


\section{Gliederung}

Verfassung der Stadt Emden

01.01

Ortstatut

02

Ratsgremien und Verwaltungsorgane der Stadt Emden

02.01

Magistrat

02.01 .01

Magistratsmitglieder und Untergebene

02.01 .02

Bürgermeister

02.01 .03

Senatoren

02.01 .04

Stadtsyndicus

02.01 .05

Magistratsprotokolle

02.02

Bürgervorsteherkollegium

02.03

Bezirksvorsteher

02.04

Gemeinsame Tagungen der städtischen Gremien

03

Funktion der Stadt im Bereich der Rechtsprechung

03.01

Gerichtsverfassung und Rechtspflege

04

Beziehungen der Stadt Emden zur Landesherrschaft und zu übergeordneten Landes- und Reichsorganen

04.01

Regierendes Königshaus

04.01 .01

Huldigung und Landestrauer

04.01 .02

Reisen des Königs und seiner Familie

04.01 .03

Nationale Gedenktage und Symbole

04.02

Landesparlamente und - Institutionen

04.02.01

Provinziallandtag in Hannover

04.02.02

Ostfriesische Landschaft

04.02 .03

Kreis Emden

04.02.04

Preußischer Landtag

04.03

Reichstag 


\section{Gliederung}

04.03.01

04.03.02

04.04

04.04.01

04.04.02

04.04.02.01

04.04.02.02

04.04.02.03

04.04.03

04.04.04

04.04.05

05

05.01

05.01 .01

05.01.02

05.01 .03

05.01.04

05.02

05.02.01

05.02.01.01

05.02.01.02

05.02.01.03

05.02.01.04

05.02.01.05

05.02.01.06
Reichstag des Norddeutschen Bundes, 1867

Reichstagswahlen

Hoheitssachen

Beziehungen der Stadt Emden zum Umland

Eingemeindungen

Erweiterung des Stadtgebietes

Eingemeindung der Gemeinde Borssum nach Emden

Eingemeindung von Harsweg, Uphusen und Wolthusen nach Emden

Münzsachen

Orden, Titel, Gratifikationen

Sonstige Hoheitssachen

Stadtverwaltung

Verwaltungsführung

Registratur

Geschäftsberichte

Bekanntmachungen des Landdrosten und Regieruingspräsidenten in Aurich

Geschäftsbereiche

Personal der Stadtverwaltung

Untergebene des Magistrats

Mittlere Beamte des Kanzleidienstes

Polizei-Bedienstete

Beamte für Gewerbe- und Verkehrssachen

Beamte für direkte und indirekte städtische Abgaben und Steuern

Sonstige städtische Angestellte

Angestellte der Stadt Emden auf Nesserland 
IV

\section{Gliederung}

05.02 .02

05.02 .03

05.03

05.03 .01

05.03.01.01

05.03.01.02

05.03.01.03

05.03.01.04

05.03.02

05.03.02.01

05.03.02.02

05.03.02.03

05.03.02.04

05.03.03

05.03.03.01

05.03.03.01.01

05.03.03.01.02

05.03.03.01.03

05.03.03.02

05.03.03.02.01

05.03.03.02.02

05.03.03.02.03

05.03.03.02.04

05.03.03.02.05

05.03.03.02.06
Technische Beamte

Gehalts- und Besoldungsfragen

Aufgabenbereiche der Stadtverwaltung

Meldewesen und Statistik

Erlaubnis und Verweigerung der Niederlassung

Auswanderung

Familiennamen

Statistische Berichte und Erhebungen

Judensachen

Landesrabbinat

Verfassung der jüdischen Gemeinde

Angelegenheiten der jüdischen Synagoge

Jüdisches Armenwesen

Öffentliche Ordnung und Sicherheit

Fremdenpolizei

Auslieferungen und Ausweisungen

Passwesen

Polizeiaufsicht

Schutz der öffentlichen Ordnung

Organisation der Gewährleistung der öffetlichen Ordnung

Geisteskranke

Gefängnisse und Gefangene

Gast- und Schankwirtschaften

Öffentliche Veranstaltungen und Unterhaltung

Lotterien und Glücksspiele

Säufer und Ruhestörer 


\section{Gliederung}

\begin{tabular}{|c|c|}
\hline 05.03.03.02.08 & Feiertagsregelungen \\
\hline 05.03.03.02.09 & Vereine \\
\hline 05.03.03.02.10 & Überwachung der Presse \\
\hline 05.03.03.02.11 & Bettelei und Bettler \\
\hline 05.03.03.02.12 & Erlaubte Sammlungen und Sammlungen für wohltätige Zwecke \\
\hline 05.03.03.02.13 & Prostitution \\
\hline 05.03.03.02.14 & Tierschutz \\
\hline 05.03.03.02.15 & Gemeingefährliche Handlungen \\
\hline 05.03 .04 & Öffentliches Gesundheitswesen \\
\hline 05.03.04.01 & Aufgabenbereiche des öffentlichen Gesundheitswesens \\
\hline 05.03.04.01.01 & Einrichtungen der Gesundheitsförderung \\
\hline 05.03.04.01.02 & Lebensmittelüberwachung \\
\hline 05.03.04.01.03 & Gesundheitsvorsorge \\
\hline 05.03.04.02 & Stadtphysikat und Stadtchirurgen \\
\hline 05.03.04.03 & Medizinische Berufe und Betriebe \\
\hline 05.03.04.03.01 & Hebammen \\
\hline 05.03.04.03.02 & Bader \\
\hline 05.03.04.03.03 & Apotheken und Arzneiwesen \\
\hline 05.03.04.04 & Bekämpfung von Epidemien \\
\hline 05.03.04.05 & Öffentliche Schlachthäuser \\
\hline 05.03 .05 & Aufsicht über die Landwirtschaft \\
\hline 05.03.05.01 & Organisierung der Landwirtschaft \\
\hline 05.03.05.02 & Gemeinheitsteilungen \\
\hline 05.03.05.03 & Schädlingsbekämpfung \\
\hline 05.03.05.04 & Statistische Berichte aus der Landwirtschaft \\
\hline
\end{tabular}




\section{Gliederung}

05.03.05.05

05.03.05.06

05.03.05.07

05.03.06

05.03.06.01

05.03.06.02

05.03.06.02.01

05.03.06.02.02

05.03.06.02.03

05.03.06.02.04

05.03.06.02.05

05.03.06.03

05.03.06.04

05.03.06.05

05.03.06.05.01

05.03.06.05.02

05.03.06.05.03

05.03.07

05.03.07.01

05.03.07.01.01

05.03.07.01.02

05.03.07.02

05.03.07.03

05.03.07.04

05.03.08
Be- und Entwässerung

Pflanzenkrankheiten und Missernten

Jagd und Fischerei

Öffentliche Anlagen, Straßenpolizei und Organisation der Ver- und Entsorgung

Straßenpolizei

Straßenreinigung und öffentliche Hygiene

Straßenreinigung und -Unterhaltung durch die Anlieger

Straßenreinigung durch die Stadt Emden

Stadtentwässerung und Abfallentsorgung

Öffentliche Bedürfniseinrichtungen

Parkanlagen

Wasserleitungen

Straßenbau

Versorgung der Stadt Emden mit Energie

Organisation der Straßenbeleuchtung

Emder Gaswerk

Aufbau eines elektrischen Kraftwerks und eines Leitungsnetzes

Baupolizei

Organisation der Baupolizei

Baugesetzgebung und Bauvorschriften

Baupolizeiliche Zuständigkeiten

Baukommission

Bauliche Missstände

Bekämpfung der Wohnungsnot

Brandschutz 


\section{Gliederung}

05.03.08.01

05.03.08.01.01

05.03.08.01.02

05.03.08.02

05.03.08.03

05.03.08.04

05.03.08.05

05.03.08.06

05.03.08.07

05.03.09

05.03.09.01

05.03.09.01.01

05.03.09.01.02

05.03.09.01.03

05.03.09.02

05.03.09.03

05.03.09.04

05.03.09.05

05.03.09.06

05.03.09.07

05.03.09.08

05.03.09.09

05.03.09.10

05.03.09.11

05.03.09.12

05.03.09.13
Organisation des Brandschutzes

Feuerpolizeiliche Vorschriften

Feuerpolizeiliche Zuständigkeiten

Feuerversicherungen

Brände

Städtische Brandordnungen

Feuerwehr-Personal

Ausrüstung der Feuerwehr

Besonders feuergefährliche Einrichtungen

Wasser- und Schifffahrtssachen

Schifffahrts- und Schifffahrtsverkehrseinrichtungen

Schifffahrt und Schiffsverkehrseinrichtungen

Wasserbauten und Hafenanlagen

Werftanlagen

Pegelkommission

Siele, Verlaate und Kajungen

Wasserläufe

Rats- und Falderndelft

Hafenpolizei und Hafenordnung

Fahrwasser und Nesserländer Schleuse

Deichwesen

Überströmungen

Schifffahrts- und Handelsverträge

Schifffahrtsabgaben

Qualifizierung der Schiffsführer und -Offiziere

Seepasssachen und Schiffsstatistik 


\section{Gliederung}

\begin{tabular}{|c|c|}
\hline 05.03.09.14 & Flaggennummern \\
\hline 05.03.09.15 & Schiffsmusterungen \\
\hline 05.03.09.16 & Navigationsschule \\
\hline 05.03.09.17 & Strandungen \\
\hline 05.03 .10 & Bestattungswesen \\
\hline 05.03.10.01 & Leichenhalle \\
\hline 05.03.10.02 & Friedhöfe \\
\hline 05.03.10.03 & Leichenpässe \\
\hline 05.03 .11 & Sozialfürsorge \\
\hline 05.03.11.01 & Institutionen zur Verbesserung der Wohlfahrt \\
\hline 05.03.11.01.01 & Arbeits- und Unterstützungsvereine \\
\hline 05.03.11.01.02 & Kranken- und Versicherungskassen \\
\hline 05.03.11.01.03 & Krankenhospitale \\
\hline 05.03.11.01.04 & Waisenfürsorge \\
\hline 05.03.11.02 & Armenpflege und Milde Stiftungen \\
\hline 05.03.11.02.01 & Diakonie der Haussitzenden Armen \\
\hline 05.03.11.02.02 & Gasthaus \\
\hline 05.03.11.02.03 & Armensteuer \\
\hline 05.03.11.02.04 & Klementiner- Brüderschaft \\
\hline 05.03.11.02.05 & Fremdelingen-Diakonie \\
\hline 05.03.11.02.06 & Schifferwitwen- und -Waisenkasse \\
\hline 05.03.11.03 & Ortsarmenverband \\
\hline 05.03.11.03.01 & Organisation des Armenwesens \\
\hline 05.03.11.03.02 & Zentral-Armendeputation \\
\hline 05.03.11.03.03 & Armenkollegium \\
\hline
\end{tabular}




\section{Gliederung}

05.03.11.04

05.03.12

05.03.12.01

05.03.12.01.01

05.03.12.01.02

05.03.12.01.03

05.03.12.02

05.03.12.02.01

05.03.12.02.02

05.03.12.02.02.01

05.03.12.02.02.02

05.03.12.03

05.03.12.03.01

05.03.12.03.01.01

05.03.12.03.01.02

05.03.12.03.01.03

05.03.12.03.01.04

05.03.12.03.01.05

05.03.12.03.01.06

05.03.12.03.02

05.03.12.03.02.01

05.03.12.03.02.02

05.03.13

06

06.01

06.01 .01
Landarmenverband

Handels- und Gewerbeförderung

Wirtschaftsförderung

Wirtschaftsstatistik

Gesetzliche Regelung von Handel und Gewerbe

Bankwesen

Förderung des Handwerks

Organisiertes Handwerk

Gewerbliche Konzessionen

Freies Gewerbe

Straßenbahnbetrieb

Förderung von Handel und Industrie

Förderung von Handel und Verkehr

Maßnahmen zur Handels- und Verkehrsförderung

Institutionen des Handels, Gewerbes und Verkehrs

Märkte

Maße und Gewichte

Zulassung technischer Anlagen

Bildungseinrichtungen für Handel und Gewerbe

Förderung der Industrie

Fabriken

Überwachung des produzierenden Gewerbes

Kunst- und Kulturpflege

Finanzverwaltung der Stadt Emden

Städtisches Vermögen

Städtische Gebäude und Grundstücke 


\section{Gliederung}

06.01.01.01

06.01.01.02

06.01.01.03

06.01.02

06.01 .03

06.01 .04

06.01 .05

06.01 .06

06.01 .07

06.02

06.02.01

06.02.01.01

06.02.01.02

06.02.01.03

06.02.02

06.02.02.01

06.02.02.02

06.02.03

06.02.03.01

06.02.03.02

06.02.03.03

06.02.03.04

06.02.03.05

06.02.03.06

06.02.03.07
Unterhaltung städtischen Eigentums

Städtische Gebäude

Städtische Grundstücke

Sonstiges städtisches Eigentum

Renten und Gerechtigkeiten

Einnahmen aus den Emder Herrlichkeiten

Städtische Forderungen

Vererbpachtung, Verkauf und Veräußerung städtischer Grundstücke

Ablösungen

Steuern und Abgaben

Direkte und indirekte Steuern

Direkte Steuern

Grundsteuer und Wertzuwachssteuer

Indirekte Steuern (Zölle)

Gewerbesteuer

Besteuerung des Wandergewerbes

Besteuerung von Gewerbebetrieben

Städtische Abgaben

Stüber- und Straßengeld

Ratelergeld

Städtische Akzise auf Waren und Dienstleistungen

Sonstige städtische Abgaben

Erhebung der Kommunalsteuer

Direkte Gemeindesteuern

Schankerlaubnissteuer 


\section{Gliederung}

06.03

Städtische Schuldenverwaltung

06.04

Rechnungswesen

06.04.01

Haushaltspläne

06.04.02

Rechnungsabnahme

07

Militärangelegenheiten (1866 - 1914)

07.01

Preußische Garnison in Emden

07.02

Aushebung und Rekrutierung

07.03

Freiwillige

07.04

Entlassung aus dem Wehrdienst

07.05

Militärlasten

07.06

Kaserne in Emden

08

Der Erste Weltkrieg (1914 - 1918)

08.01

Mobilmachung

08.02

Kriegsfürsorge

08.03

Kriegswirtschaft

08.04

Propaganda im Ersten Weltkrieg

09

Kirchen

09.01

Aufsicht über die Kirchen

09.01 .01

Organisation des Kirchenwesens

09.01 .02

Kirchensteuer

09.02

Evangelische Kirchen

09.02.01

Kirchenkommissionen der evangelischen Gemeinden

09.02.01.01

Kirchenkommission der Reformierten Gemeinde

09.02.01.02

Kirchenkommission der evangelisch lutherischen Kirche

09.03

Evangelische Kirchengemeinden

09.03.01

Evangelisch Reformierte Kirchengemeinden 


\section{Gliederung}

09.03.01.01

09.03.01.02

09.03.01.03

09.03.01.04

09.03.02

09.03.03

09.03.04

09.04

09.04.01

09.04.02

09.05

10

10.01

10.01 .01

10.01 .02

10.02

10.02.01

10.02 .02

10.02 .03

10.02.04

10.02.05

10.02.06

10.02.07

10.03

10.03.01
Deutsch reformierte Gemeinde

Rechnung der Großen Kirche

Französisch Reformierte Gemeinde

Gasthauskirche

Evangelisch Lutherische Kirchengemeinde

Gemeinden in den Emder Herrlichkeiten

Mennonitengemeinde

Katholische Kirche

Überwachung der katholischen Kirche

Katholische Kirchengemeinde

Sonstige Kirchen und Sekten

Schulaufsicht

Schulsachen

Organisation des Schulwesens

Kommunalisierung des Schulwesens

Volksschulen

Volksschule der deutsch reformierten Gemeinde

Volksschule der französisch reformierten Gemeinde

Volksschule der evangelisch lutherischen Gemeinde

Volksschulen in den Emder Herrlichkeiten

Städtische Volksschule

Katholische Volksschule

Hilfsschule in Emden

Höhere Schulen

Organisation des Höheren Schulwesens 


\section{Gliederung}

10.03.02

10.03 .03

10.04

10.05
Gymnasium in Emden

Kaiser-Friedrich-Realschule

Höhere Töchterschule / Kaiserin-Auguste-Viktoria-Schule

Privatschulen 
01

- Übersicht über gezahlte Gehälter an die Mitglieder des Emder Stadtgerichts, 1848

- Übersicht über Einnahmen und Ausgaben des Stadtgerichts, 1848

- Verfügung des hannoverschen Landdrosten in Aurich an den Magistrat der Stadt Emden über Erfassung von Grund besitzenden Bürgern zur Absicherung ihres Einflusses bei den Wahlen, August 1849

- Verfügung des hannoverschen Landdrosten in Aurich an den Magistrat der Stadt Emden über Erfassung von Bürgern ohne Hausbesitz zur Absicherung ihres Einflusses bei den Wahlen, September - Oktober 1850

- Verfügung des hannoverschen Landdrosten in Aurich an den Magistrat der Stadt Emden über Erfassung von Bürgern mit einem Mindeststeuersatz von 2 Rthlr. zur Absicherung ihres Einflusses bei den Wahlen,

- Regelung der Wahl der Bürgervorsteher nach der hannoverschen Städteordnung, August 1859

- Initiative der Stadt Hannover zur Änderung der Städteordnung der preußischen Provinz Hannover, Januar 1889 - April 1890

- Regelung der Akteneinsicht durch Bürgervorsteher, Februar 1891 März 1904

- Regelung des Mitspracherechts der Bürgervorsteher in Sachen, die städtischen Grundstücke betreffend, Juli 1892

- Regelung der Verwendung des Magistratssiegels, September -

Oktober 1897

- Initiative des Provinzialverbands der hannoverschen Bürgervereine zur Revision der Stadtordnung hinsichtlich Bürgerrecht, Wahl der Magistratsmitglieder, Zahl der Bürgervorsteher und Wahlrecht, Januar 1906 - Februar 1909

- Regelung der Verwaltungsgeschäfte bei kriegsbedingter

Abwesenheit von Bürgermeister unde Syndicus, April 1915

$1848-1915$

Klassifikation Teil B: 00055

Trägermaterial: Papier

Alte Reg.-Sig.: I Cb 1

Bestell-Nr.: IV 00055 
01.01

\section{Ortstatut}

Lfd. Nr. Titel

Laufzeit

2 Entwurf einer Stadtverfassung

- Möglichkeiten des Erwerbs des Bürgerrechts durch Arbeiter, 1917

- Initiative des Oberbürgermeisters Dr. Wilhelm Mützelburg zur kostenlosen Verleihung des Bürgerrechts an Kriegsteilnehmer, August 1917

- Diskussion unter den Städten der preußischen Provinz Hannover über die Zweckmäßigkeit einer Bürger- und Wahlrechtsreform, August 1917 - November 1918

- Verzeichnis der Mitglieder des Bürgervorsteher-Kollegiums, 1906 1917, 1917

- Verfügung des Magistrats der Stadt Emden über Neuwahl des

Bürgervorsteher-Kollegiums im Januar 1919, November 1918

$1917-1918$

Klassifikation Teil B: 00056

Trägermaterial: Papier

Alte Reg.-Sig.: I Cc 4

Bestell-Nr.: IV 00056

3 Ortsstatut

1903

- Neueinteilung der Bezirke der Stadt Emden, 1903

1903

Klassifikation Teil B: 00057

Trägermaterial: Papier

Alte Reg.-Sig.: I Cc 4

Bestell-Nr.: IV 00057

4 Entwurf einer neuen Städteordnung

- Vorlage für den preußischen Landtag über Entwurf einer neuen Städteordnung für verschiedene Provinzen des Kgr. Preußen, März 1876

- Protokolle der Verhandlungen der Vorlage vor dem preußischen Landtag, März 1876

- Diskussion einer Reform der Städteordnung in den städtischen Kollegien Emdens, März - Mai 1876

- Petition des Hannoverschen Städtetages an den preußischen Landtag über Bitte um Berücksichtigung seiner Bedenken gegen die Reformvorlage, Mai 1876

- Diskussion einer Bürgerrechtsreform durch Ausdehnung der Bürgerberechtigten, August 1907

$1876-1907$

Klassifikation Teil B: 00268

Trägermaterial: Papier

Alte Reg.-Sig.: II A 03

Bestell-Nr.: IV 00268 
IV

01 Verfassung der Stadt Emden

01.01 Ortstatut

Lfd. Nr. Titel

Laufzeit

5 Revision des Ortsstatuts $1858-1893$

- Anpassung des Emder Ortsstatuts an die revidierte Hannoversche Städteordnung, hinsichtlich Wahl der Magistratsmitglieder, Juli 1858 Januar 1859

- Revision des Ortsstatuts der Stadt Emden, hinsichtlich Funktion des Oberbürgermeisters, Gehälter der Senatoren, Festlegung des Stadtgebiets und Gewerberichtlinien), Februar 1860 - März 1861

- Revision des Ortstatuts der Stadt Emden hinsichtlich der

Eingemeindung Nesserlands, August 1866

- Neufestlegung des Bürgergewinngeldes, Mai 1867

- Reform des Ortsstatuts der Stadt Emden, Januar 1867 - August 1868

- Neufestsetzung des Bürgergewinngeldes, Mai 1867

- Revision des Ortsstatuts hinsichtlich der Finanzorganisation, Mai 1867

- Einstellung eines Cämmereischreibers, April 1892

$1858-1893$

Klassifikation Teil B: 00269

Trägermaterial: Papier

Alte Reg.-Sig.: II A 06

Bestell-Nr.: IV 00269 
IV

02 Ratsgremien und Verwaltungsorgane der Stadt Emden

02.01 Magistrat

02.01.01 Magistratsmitglieder und Untergebene

Lfd. Nr. Titel

Laufzeit

6 Bürgermeister, Beamte, Bürgervorsteher und Senatoren der Stadt $1870-1887$ Emden

- Verzeichnis der Bürgermeister, Beamte, Bürgervorsteher und Senatoren der Stadt Emden, 1870 - 1887

$1870-1887$

Klassifikation Teil B: 00052

Trägermaterial: Papier

Alte Reg.-Sig.: I Ca 2

Bestell-Nr.: IV 00052

7 Aufhebung der Verbindung der Amtsanwaltschaft mit der Magistratsassassorenstelle

- Konzept eines Schreibens des Oberbürgermeisters Dr. Wilhelm Mützelburg an den Oberstaatsanwalt in Celle über Bitte um Trennung der Aufgabenbereiche des Magistratsassessors von denen des Amtsanwalts am Amtsgericht Emden und Stellung eines eigenen Staatsanwalts beim Gericht, Juli 1913

- Ausschreibung der Stelle eines Amtsanwalts beim Amtsgericht Emden, August 1913 / August 1914

- Verschiedene Bewerbungen um die Stelle des Amtsanwalts am Emder Amtsgericht, September 1913 / August 1914

- Verfügung des Oberstaatsanwalts in Celle über Bitte um Vorschlag einer Person zur Besetzung der Amtsanwaltsstelle nach der Entlassung des Amtsanwalts Ehlert wegen schlechter Amtsführung, August 1914

- Festlegung des Gehalts für den Amtsanwalt beim Emder Amtsgericht, August - Oktober 1914

$1913-1914$

Klassifikation Teil B: 00297

Trägermaterial: Papier

Alte Reg.-Sig.: II Be 3

Bestell-Nr.: IV 00297

8 Vereidigung des Magistrats und der Verwaltungsangestellten auf die preußische Verfassung

- Verfügung des preußischen Landdrosten in Aurich über Durchführung der Vereidigung der Kommunalbeamten auf die preußische Verfassung, Januar 1868

- Liste der zu vereidigenden Emder Verwaltungsbeamten und

Angestellten, Februar 1868

- Eidesformel, 1868

1868

Klassifikation Teil B: 00337

Trägermaterial: Papier

Alte Reg.-Sig.: III Ac 11

Bestell-Nr.: IV 00337 
02 Ratsgremien und Verwaltungsorgane der Stadt Emden

02.01 Magistrat

02.01 .01

Magistratsmitglieder und Untergebene

Lfd. Nr. Titel

Laufzeit

9 Emder Magistratsmitglieder im Ersten Weltkrieg 1914-1915

- Feldpostbriefe und Karten von im Kriegsdienst befindliche Magistratsmitglieder über Fronterlebnisse:

Oberbürgermeister Dr. Wilhelm Mützelburg

Syndicus Trommershausen

Magistratsassistent Paul Völker

$1914-1915$

Klassifikation Teil B: 00862

Trägermaterial: Papier

Alte Reg.-Sig.: IV N 16

Bestell-Nr.: IV 00862 
02 Ratsgremien und Verwaltungsorgane der Stadt Emden

02.01

Magistrat

02.01 .02

Bürgermeister

Lfd. Nr. Titel

Laufzeit

10 Funktion des Oberbürgermeisters Leo Fürbringer als 1904-1912 Landtagsabgeordneter

- Schriftverkehr des Oberbürgermeisters Leo Fürbringer in seiner Funktion als Abgeordneter des preußischen Landtags, 1909 - 1912

Presseberichte über eine Rede des Leo Fürbringer als

Landtagsabgeordneter, 1912

$1909-1912$

Klassifikation Teil B: 00135

Trägermaterial: Papier

Alte Reg.-Sig.: I Db 3

Bestell-Nr.: IV 00135

11 Bewerbungen um die Emder Oberbürgermeisterstelle

- Verzeichnis über die Bewerber um die Stelle des

Oberbürgermeisters der Stadt Emden, 1912

1912

Klassifikation Teil B: 00136

Trägermaterial: Papier

Alte Reg.-Sig.: I Db 2

Bestell-Nr.: IV 00136 
IV

02

Ratsgremien und Verwaltungsorgane der Stadt Emden

02.01

Magistrat

02.01 .02

Bürgermeister

Lfd. Nr. Titel

Laufzeit

12 Bürgermeister und Oberbürgerneister Ernst Heinrich Hantelmann

1853-1891

- Stellung eines Vertreters für den erkrankten Bürgermeister D.W.

Suur, Dezember 1853

- Nachricht über Tod des Bürgermeisters Suur, Dezember 1853

- Protest des Bürgervorsteher-Kollegiums gegen die Verweigerung

einer beantragten Verlegung der Bürgermeisterwahl durch die

Hannoversche Landdrostei in Aurich, Januar 1854

- Bewerbung und Erklärung des Ernst Heinrich Hantelmann,

Bürgermeister von Gifhorn, über Bereitschaft zur Annahme seiner

etwaigen Wahl zum Bürgermeister, Februar 1854

- Wahl des E.H. Hantelmann zum Bürgermeister der Stadt Emden,

Februar 1854

- Vereidigung und Amtseinführung des Bürgermeisters E.H.

Hantelmann, April 1854

- Wahl eines Stellvertreters des Bürgermeisters Hantelmann,

September 1855 / März 1862

- Vereidigung des Bürgermeisters E.H. Hantelmann auf die

preußische Verfassung, Februar 1868

- Versetzung des Oberbürgermeisters Hantelmann in den Ruhestand, November - Dezember 1874

- Diskussion einer nochmaligen Vereidigung des ehemaligen

Oberbürgermeisters Hantelmann wegen seines von inm angestrebten

Notariats in Hannover, April 1875

- Ehrenbürgerbrief der Stadt Emden für E.H. Hantelmann, Mai 1876

- Nachricht von der tödlichen Erkrankung des ehemaligen

Oberbürgermeisters und des Ehrenbürgers E.H. Hantelmann,

Dezember 1890

- Nachruf auf Ernst Heinrich Hantelmann im "Hannoverschen Courier",

18. Dezember 1890

- Protokoll der Versammlung der Bürgervorsteher über Genehmigung der Tragung der Reisekosten des Oberbürgermeisters Leo Fürbringer zur Teilnahme an den Bestattungsfeiern für E.H. Hantelmann, Februar 1891

- Einsendung des Ehrenbürgerbriefs des E.H.Hantelmann als testamentarisch verfügte Gabe an die Gesellschaft für bildende Kunst und vaterländische Altertümer, März 1891

$1853-1891$

Klassifikation Teil B: 00292

Trägermaterial: Papier

Alte Reg.-Sig.: II B 7 b

Bestell-Nr.: IV 00292 
IV

02

Ratsgremien und Verwaltungsorgane der Stadt Emden

02.01

Magistrat

02.01 .02

Bürgermeister

Lfd. Nr. Titel

Laufzeit

13 Bürgermeister und Oberbürgermeister Leo Fürbringer

$1875-1913$

(1923)

- Bewerbung des Oberbürgermeisters Leo Fürbringer aus Weimar um die Stelle als Bürgermeister in Emden, Februar 1875

- Wahl des Leo Fürbringer zum Bürgermeister in Emden, April 1875

- Bestätigung der Wahl durch den preußischen Landdrosten in Aurich, Juni 1875

- Vereidigung des Bürgermeisters Leo Fürbringer, Juli 1875

- Festlegung des pensionsfähigen Dienstalters des Bürgermeisters

Leo Fürbringer, September 1875

- Allerhöchster Erlass des preußischen Königs und deutschen Kaisers

Wilhelm I. über Verleihung des Titels Oberbürgermeister an Leo

Fürbringer, März 1877

- Ernennung des Oberbürgermeisters Leo Fürbringer zum

Reichskommissar für das kgl. Seeamt in Emden, Juli 1878

- Rücktritt des L. Fürbringer vom Amt des Reichskommissars, Juni -

Juli 1880

- Verleihung des Roten Adler Ordens IV. Klasse an

Oberbürgermeister Leo Fürbringer, September 1881

- Gewährung einer persönlichen Zulage für Oberbürgermeister

Fürbringer, Juni 1886

- Feier des 25-Jährigen Dienstjubiläums des Oberbürgermeisters Leo

Fürbringer, April - Juli 1900

- Personalbogen des Oberbürgermeisters Leo Fürbringer, 1900

- Beileidskundgebung der städtischen Kollegien zum Kriegstod des

Leutnants Edzard Fürbringer, Sohn des Oberbürgermeisters Leo

Fürbringer, März 1905

- Allerhöchster Erlass des deutschen Kaisers und preußischen Königs Wilhelm II. über Verleihung des Titels "Geheimer Regierungsrat" an

Oberbürgerneister Leo Fürbringer, August 1907

- Neufestlegung des Gehalts des Oberbürgermeisters Leo Fürbringer, November 1907

- Gesuch des Oberbürgermeisters Leo Fürbringer über Bitte um Versetzung in den Ruhestand, September - Oktober 1912

- Verleihung der Ehrenbürgerwürde an Leo Fürbringer, Januar -

Februar 1913

- Ruhestandsgehalt, 1912 - 1923

- Herstellung eines Porträts des Oberbürgermeisters Leo Fürbringer, Juni 1915

- Nachruf und Bestattungsfeier für Leo Fürbringer, September -

Oktober 1923

$1875-1923$

Klassifikation Teil B: 00293

Trägermaterial: Papier

Alte Reg.-Sig.: II BC

Bestell-Nr.: IV 00293 
IV

02

Ratsgremien und Verwaltungsorgane der Stadt Emden

02.01

Magistrat

02.01 .03

Senatoren

Lfd. Nr. Titel

Laufzeit

14 Senatorenwahl

1904-1905

- Klage des Bürgervorstehers und Kaufmanns Friedrich Brons gegen seine Wahl zum Senator durch das Bürgervorsteher-Kollegium beim Bezirksausschuss in Aurich und dem Oberverwaltungsgericht Berlin, April 1904 - März 1905

$1904-1905$

Klassifikation Teil B: 00062

Trägermaterial: Papier

Alte Reg.-Sig.: I Cd 1

Bestell-Nr.: IV 00062

15 Senator Johannes Brons

$1866-1872$

- Wahl des Kaufmanns Johannes Brons zum Senator, August 1866

- Bestätigung der Wahl des Johannes Brons zum Senator durch den preußischen Landdrosten in Aurich, September 1866

- Vereidigung des Senators Johannes Brons, Oktober 1866

- Vereidigung des Senators Johannes Brons auf den preußischen König und die preußische Verfassung, Februar 1868

- Amtsniederlegung des Senators Johannes Brons aus Altersgründen, November 1872

$1866-1872$

Klassifikation Teil B: 00137

Trägermaterial: Papier

Alte Reg.-Sig.: I Dc

Bestell-Nr.: IV 00137

16 Senator G.N. Ronda

$1866-1872$

- Wahl des Kaufmanns G.N. Ronda zum Senator, Oktober 1870

- Bestätigung der Wahl des G.N.Ronda zum Senator durch den preußischen Landdrosten in Aurich, September 1866

- Vereidigung des Senators G.N. Ronda, November 1870

- Amtsniederlegung des Senators G.N. Ronda, November 1877

$1870-1877$

Klassifikation Teil B: 00138

Trägermaterial: Papier

Alte Reg.-Sig.: I Dc

Bestell-Nr.: IV 00138 
IV

02

Ratsgremien und Verwaltungsorgane der Stadt Emden

02.01

Magistrat

02.01 .03

Senatoren

Lfd. Nr. Titel

Laufzeit

17 Senator Johannes Mustert

- Wahl des Kaufmanns Johannes Mustert zum Senator, März 1872

- Vereidigung des Senators Johannes Mustert, April 1872

- Amtsniederlegung des Senators Johannes Mustert aus Alters- und

Gesundheitsgründen, Juli 1889

- Nachricht über den Tod des ehemaligen Senators Johannes Mustert, Juni 1890

$1872-1890$

Klassifikation Teil B: 00139

Trägermaterial: Papier

Alte Reg.-Sig.: I Dc

Bestell-Nr.: IV 00139

18 Senator Helmer H. Foget

- Wahl des Kaufmanns Helmer H. Foget zum Senator, August 1875

- Bestätigung der Wahl des Helmer H. Foget zum Senator durch den preußischen Landdrosten in Aurich, September 1875

- Vereidigung des Senators Helmer H. Foget, September 1875

- Ernennung des Senators Helmer H. Foget zum Geschworenen des

Schwurgerichts in Aurich durchj die Staatsanwaltschaft, Februar -

Oktober 1885

- Nachruf auf den verstorbenen Senator Helmer H. Foget, Juli 1889

$1875-1890$

Klassifikation Teil B: 00140

Trägermaterial: Papier

Alte Reg.-Sig.: I Dc

Bestell-Nr.: IV 00140

19 Senator Johann Cornelius Loesing

- Wahl des Particuliers Johann Cornelius Loesing zum Senator, April 1894

- Bestätigung der Wahl des Johann Cornelius Loesing zum Senator durch den preußischen Regierungspräsidenten in Aurich, Mai 1894

1894

Klassifikation Teil B: 00141

Trägermaterial: Papier

Alte Reg.-Sig.: I Dc

Bestell-Nr.: IV 00141 
02.01

Lfd. Nr. Titel

Laufzeit

20 Senator C.H. Gittermann

- Wahl des Kaufmanns C.H. Gittermann zum Senator, Januar 1883

- Bestätigung der Wahl des C.H. Gittermann zum Senator durch den preußischen Landdrosten in Aurich, März 1883

- Vereidigung des Senators C.H. Gittermann, März 1883

- Antrag des Magistrats der Stadt Emden bei der Staatsanwaltschaft in Aurich auf Dispensation des Senators C.H. Gittermann vom Amt eines Geschworenen beim Schwurgericht in Aurich, Juni 1884

- Amtsniederlegung des Senators C.H. Gittermann, November 1887

$1883-1887$

Klassifikation Teil B: 00142

Trägermaterial: Papier

Alte Reg.-Sig.: I Dc

Bestell-Nr.: IV 00142

21 Senator T. Dreesmann-Penning

- Wahl des Kaufmanns T. Dreesmann-Penning zum Senator, Juli -

August 1889

- Bestätigung der Wahl des T. Dreesmann-Penning zum Senator durch den preußischen Regierungspräsidenten in Aurich, August 1889

- Vereidigung des Senators T. Dreesmann-Penning, September 1889

- Amtsniederlegung des Senators T. Dreesmann-Penning, April 1908

- Nachruf auf den verstorbenen ehemaligen Senator T.

Dreesmann-Penning, Februar 1912

$1889-1912$

Klassifikation Teil B: 00144

Trägermaterial: Papier

Alte Reg.-Sig.: I Dc

Bestell-Nr.: IV 00144

22 Senator Carl Dantziger

- Wahl des Kaufmanns Carl Dantziger zum Senator, Dezember 1872

- Bestätigung der Wahl des Carl Dantziger zum Senator durch den

preußischen Landdrosten in Aurich, Januar 1873

- Vereidigung des Senators Carl Dantziger, Januar 1873

- Amtsniederlegung des Senators Carl Dantziger, Februar 1879

$1866-1872$

Klassifikation Teil B: 00145

Trägermaterial: Papier

Alte Reg.-Sig.: I Dc

Bestell-Nr.: IV 00145 
02.01

Lfd. Nr. Titel

Laufzeit

23 Senator T.D.H.S. Wiarda

- Wahl des Kaufmanns T.D.H.S. Wiarda zum Senator, April 1869

- Bestätigung der Wahl des T.D.H.S. Wiarda zum Senator durch den preußischen Landdrosten in Aurich, Mai 1869

- Vereidigung des Senators T.D.H.S. Wiarda, Juni 1869

- Übergabe städtischer Dokumente aus dem Nachlass des verstorbenen Senators T.D.H.S. Wiarda, Mai 1875

$1869-1875$

Klassifikation Teil B: 00146

Trägermaterial: Papier

Alte Reg.-Sig.: I Dc

Bestell-Nr.: IV 00146

24 Senator Theodor Juzi

- Wahl des Kaufmanns Theodor Juzi zum Senator, Oktober 1869

- Bestätigung der Wahl des Theodor Juzi zum Senator durch den preußischen Landdrosten in Aurich, November 1869

- Vereidigung des Senators Theodor Juzi, November 1869

- Amtsniederlegung des Senators Theodor Juzi wegen Weggangs nach Geestemünde als Direktor der Geestemünder Bank, 1879

- Todesanzeige des Bankdirektors Theodor Juzi, Juli 1905

$1869-1905$

Klassifikation Teil B: 00147

Trägermaterial: Papier

Alte Reg.-Sig.: I Dc

Bestell-Nr.: IV 00147

25 Senator Bernhard Brons, jun.

- Wahl des Kaufmanns und Konsuls Bernhard Brons, jun. zum Senator, Juni 1877

- Ablehnung der Wahl zum Senator durch den Konsul Bernhard Brons jun. wegen geschäftlicher Anforderungen, Juni 1877

- Bescheid des preußischen Landdrosten über Vorschlag zur

Nominierung eines anderen Kandidaten zum Senator, Juli 1877

- Vereidigung des Senators Bernhard Brons jun., Oktober 1886

- Amtsniederlegung des Senators Bernhard Brons jun., August 1890

- Nachruf auf den ehemaligen Senator Bernhard Brons jun., Juli 1911

$1877-1911$

Klassifikation Teil B: 00148

Trägermaterial: Papier

Alte Reg.-Sig.: I Dc

Bestell-Nr.: IV 00148 
IV

02

Ratsgremien und Verwaltungsorgane der Stadt Emden

02.01

Magistrat

02.01 .03

Senatoren

Lfd. Nr. Titel

Laufzeit

26 Senator A.F. Brons

1890-1901

- Wahl des Kaufmanns und Konsuls A.F. Brons zum Senator, Oktober

- November 1890

- Amtsniederlegung des Senators A.F. Brons wegen

Nlchtberücksichtigung einer von inm verfassten Denkschrift bei einer

Magistratsentscheidung, Mai 1901

$1890-1901$

Klassifikation Teil B: 00149

Trägermaterial: Papier

Alte Reg.-Sig.: I Dc

Bestell-Nr.: IV 00149

27 Senator H. Klug

$1879-1885$

- Wahl des Landschaftsrats H. Klug zum Senator, Januar 1879

- Bestätigung der Wahl des H. Klug zum Senator durch den

preußischen Landdrosten in Aurich, März 1879

- Vereidigung des Senators H. Klug, März 1879

- Amtsniederlegung des Senators H. Klug aus Alters- und

Gesundheitsgründen, März 1885

$1879-1885$

Klassifikation Teil B: 00150

Trägermaterial: Papier

Alte Reg.-Sig.: I Dc

Bestell-Nr.: IV 00150

28 Senator M. F. Wallrath

$1859-1870$

- Wahl des M.F. Wallrath zum Senator der Stadt Emden, Januar 1859

- Bestätigung der Wahl durch den Hannoverschen Landdrosten in

Aurich, März 1859

- Vereidigung und Amtseinführung des Senators Martin Friedrich

Willrath, März 1859

- Vereidigung des Senators Willrath auf die preußische Verfassung,

Februar 1868

- Entlassungsgesuch des Senators Martin Friedrich Willrath wegen

gesundheitlicher Probleme, September 1870

$1859-1870$

Klassifikation Teil B: 00295

Trägermaterial: Papier

Alte Reg.-Sig.: II B 7b, 41

Bestell-Nr.: IV 00295 
02 Ratsgremien und Verwaltungsorgane der Stadt Emden

02.01

Magistrat

02.01 .03

Senatoren

Lfd. Nr. Titel

29 Senator H.C. Barth

1885-1894

- Protokoll über Wahl eines Wahlmännergremiums wegen

Senatorenwahl, Dezember 1885

- Wahl des H.C. Barth zum Senator der Stadt Emden, Dezember 1885

- Bestätigung der Wahl durch den Regierungspräsidenten in Aurich,

Januar 1886

- Vereidigung und Amtseinführung des Senators H.C. Barth, Januar

1886

- Entlassungsgesuch des Senators H.C. Barth wegen gesundheitlicher

Probleme, Februar 1892 / März 1894

$1885-1894$

Klassifikation Teil B: 00296

Trägermaterial: Papier

Alte Reg.-Sig.: II B 7b, 7

Bestell-Nr.: IV 00296 
IV

02

Ratsgremien und Verwaltungsorgane der Stadt Emden

02.01

Magistrat

02.01 .04

Stadtsyndicus

Lfd. Nr. Titel

Laufzeit

30 Stadtsyndicus Gottfried R. Metger

- Besetzung der neu geschaffenen Stelle eines Stadtsyndicus durch den rechtskundigen Magistrats-Assessor Gottfried R. Metger, Mai

1868

- Wahl des Magistrats-Assessors Gottfried R. Metger zum

Stadtsyndicus, Februar - April 1869

- Vereidigung des Stadtsyndicus Gottfried R. Metger, Juni 1869

- Antrag des Stadtsyndicus Gottfried R. Metger beim Magistrat der

Stadt Emden auf Gehaltserhöhung, September 1873

- Antrag des Stadtsyndicus Gottfried R. Metger beim Magistrat der

Stadt Emden auf Pensionierung, Januar - Juni 1898

- Nachruf auf den verstorbenen Stadtsyndicus a.D. Gottfried R.

Metger, Jaqnuar 1912

$1868-1912$

Klassifikation Teil B: 00130

Trägermaterial: Papier

Alte Reg.-Sig.: I Dd 1

Bestell-Nr.: IV 00130

31 Stadtsyndicus Dr. Hans Riese

$1901-1908$

- Ausschreibung der Stelle eines Stadtsyndicus, September - Oktober 1901

- Bewerbung des Rechtsanwalts Dr.jur. Hans Riese aus Berlin um die Stelle des Stadtsyndicus der Stadt Emden, Oktober 1901

- Wahl des Stadtsyndicus, Oktober - November 1901

- Bestätigung der Wahl des Dr. Hans Reise zum Stadtsyndicus durch eine Allerhöchste Kabinettsordre des preußischen Königs (deutschen Kaisers) Wilhelm II., Dezember 1901

- Vereidigung des Stadtsyndicus Dr. Hans Riese, Januar 1902

- Antrag des Stadtsyndicus Dr. Hans Riese beim Magistrat der Stadt

Emden auf teilweise Erstattung seiner Umzugskosten, Mai - Juni 1902

- Vertretung des Oberbürgermeisters durch den Stadtsyndicus, März

1904

- Wahl des Stadtsyndicus in den Aufsichtsrat der Fischerei AG

"Neptun", September 1907

- Verabschiedung des Stadtsyndicus Dr. Riese, April 1908

$1901-1908$

Klassifikation Teil B: 00131

Trägermaterial: Papier

Alte Reg.-Sig.: I Dd 4

Bestell-Nr.: IV 00131 
IV

02

Ratsgremien und Verwaltungsorgane der Stadt Emden

02.01

Magistrat

02.01 .04

Stadtsyndicus

Lfd. Nr. Titel

Laufzeit

32 Stadtsyndicus Walter Leinberger

1907-1911

- Ausschreibung der Stelle eines Stadtsyndicus, November 1907

- Bewerberlisten, 1908

- Wahl des Walter Leinberger aus Barmen zum Stadtsyndicus,

Februar 1908

- Vereidigung des Stadtsyndicus Walter Leinberger, April 1908

- Bestätigung der Wahl des Walter Leinberger zum Stadtsyndicus durch eine Allerhöchste Kabinettsordre des preußischen Königs und deutschen Kaisers Wilhelm II., April 1908

- Antrag des Syndicus Walter Leinberger beim Magistrat der Stadt Emden auf Honorierung seiner Funktion als Vorsitzender des Kaufmanns- und Gewerbegerichts, Oktober - November 1909

- Bewerbungen des Stadtsyndicus Walter Leinberger um Stellen im Kommunaldienst anderer Städte, November 1910

- Weggang des Stadtsyndicus Walter Leinberger als Bürgermeister nach Gevelsberg, Januar 1911

$1907-1911$

Klassifikation Teil B: 00132

Trägermaterial: Papier

Alte Reg.-Sig.: I Dd 5

Bestell-Nr.: IV 00132

33 Stadtsyndicus Werner Mensching

1911-1917

- Ausschreibung der Stelle eines Stadtsyndicus, November 1907

- Wahl des Magistrats-Assessors Werner Mensching aus Stargard zum Stadtsyndicus, Februar 1911

- Antrag des Stadtsyndicus Werner Mensching auf Erstattung der

Reisekosten von Stargard nach Emden, März 1911

- Vereidigung des Stadtsyndicus Werner Mensching, April 1911

- Gewährung eines Gehaltszulage für den Stadtsyndicus Werner

Mensching, März 1912

- Weggang des Stadtsyndicus Werner Mensching als Bürgermeister nach Demnin, 1917

1907 - 1917 (1927)

Klassifikation Teil B: 00133

Trägermaterial: Papier

Alte Reg.-Sig.: I Dd 6

Bestell-Nr.: IV 00133 
IV

02 Ratsgremien und Verwaltungsorgane der Stadt Emden

02.01

Magistrat

02.01.05

Magistratsprotokolle

Lfd. Nr. Titel

Laufzeit

34 Sitzungen des Magistrats

- Protokolle der Beratungen des Magistrats über verwaltungstechnische und kommunalpolitische Angelegenheiten

$1872-1875$

Klassifikation Teil B: 00486

Trägermaterial: Papier

Bestell-Nr.: IV 00486

35 Sitzungen des Magistrats

- Protokolle der Beratungen des Magistrats über

verwaltungstechnische und kommunalpolitische Angelegenheiten

1878

Klassifikation Teil B: 00487

Trägermaterial: Papier

Bestell-Nr.: IV 00487

36 Sitzungen des Magistrats

- Protokolle der Beratungen des Magistrats über verwaltungstechnische und kommunalpolitische Angelegenheiten

1879

Klassifikation Teil B: 00488

Trägermaterial: Papier

Bestell-Nr.: IV 00488

37 Sitzungen des Magistrats

- Protokolle der Beratungen des Magistrats über

verwaltungstechnische und kommunalpolitische Angelegenheiten

1880

Klassifikation Teil B: 00489

Trägermaterial: Papier

Bestell-Nr.: IV 00489

38 Sitzungen des Magistrats

- Protokolle der Beratungen des Magistrats über

verwaltungstechnische und kommunalpolitische Angelegenheiten

1881

Klassifikation Teil B: 00490

Trägermaterial: Papier

Bestell-Nr.: IV 00490 
IV

02 Ratsgremien und Verwaltungsorgane der Stadt Emden

02.01

Magistrat

02.01.05

Magistratsprotokolle

Lfd. Nr. Titel

Laufzeit

39 Sitzungen des Magistrats

1882

- Protokolle der Beratungen des Magistrats über

verwaltungstechnische und kommunalpolitische Angelegenheiten

1882

Klassifikation Teil B: 00491

Trägermaterial: Papier

Bestell-Nr.: IV 00491

40 Sitzungen des Magistrats

1885

- Protokolle der Beratungen des Magistrats über

verwaltungstechnische und kommunalpolitische Angelegenheiten

1885

Klassifikation Teil B: 00491

Trägermaterial: Papier

Bestell-Nr.: IV 00494

41 Sitzungen des Magistrats

- Protokolle der Beratungen des Magistrats über

verwaltungstechnische und kommunalpolitische Angelegenheiten

1883

Klassifikation Teil B: 00492

Trägermaterial: Papier

Bestell-Nr.: IV 00492

42 Sitzungen des Magistrats

1884

- Protokolle der Beratungen des Magistrats über

verwaltungstechnische und kommunalpolitische Angelegenheiten 43

Klassifikation Teil B: 00493

Trägermaterial: Papier

Bestell-Nr.: IV 00493

43 Sitzungen des Magistrats

- Protokolle der Beratungen des Magistrats über

verwaltungstechnische und kommunalpolitische Angelegenheiten

1886

Klassifikation Teil B: 00495

Trägermaterial: Papier

Bestell-Nr.: IV 00495 
IV

02 Ratsgremien und Verwaltungsorgane der Stadt Emden

02.01

Magistrat

02.01.05

Magistratsprotokolle

Lfd. Nr. Titel

Laufzeit

44 Sitzungen des Magistrats

1887

- Protokolle der Beratungen des Magistrats über

verwaltungstechnische und kommunalpolitische Angelegenheiten

1887

Klassifikation Teil B: 00496

Trägermaterial: Papier

Bestell-Nr.: IV 00496

45 Sitzungen des Magistrats

1888

- Protokolle der Beratungen des Magistrats über

verwaltungstechnische und kommunalpolitische Angelegenheiten

1888

Klassifikation Teil B: 00497

Trägermaterial: Papier

Bestell-Nr.: IV 00497

46 Sitzungen des Magistrats

- Protokolle der Beratungen des Magistrats über

verwaltungstechnische und kommunalpolitische Angelegenheiten

1889

Klassifikation Teil B: 00498

Trägermaterial: Papier

Bestell-Nr.: IV 00498

47 Sitzungen des Magistrats

1890

- Protokolle der Beratungen des Magistrats über

verwaltungstechnische und kommunalpolitische Angelegenheiten

1890

Klassifikation Teil B: 00499

Trägermaterial: Papier

Bestell-Nr.: IV 00499

48 Sitzungen des Magistrats

- Protokolle der Beratungen des Magistrats über

verwaltungstechnische und kommunalpolitische Angelegenheiten

1891

Klassifikation Teil B: 00500

Trägermaterial: Papier

Bestell-Nr.: IV 00500 
IV

02 Ratsgremien und Verwaltungsorgane der Stadt Emden

02.01

Magistrat

02.01.05

Magistratsprotokolle

Lfd. Nr. Titel

Laufzeit

49 Sitzungen des Magistrats

1893

- Protokolle der Beratungen des Magistrats über

verwaltungstechnische und kommunalpolitische Angelegenheiten

1893

Klassifikation Teil B: 00500

Trägermaterial: Papier

Bestell-Nr.: IV 00502

50 Sitzungen des Magistrats

1892

- Protokolle der Beratungen des Magistrats über

verwaltungstechnische und kommunalpolitische Angelegenheiten

1892

Klassifikation Teil B: 00501

Trägermaterial: Papier

Bestell-Nr.: IV 00501

51 Sitzungen des Magistrats

- Protokolle der Beratungen des Magistrats über verwaltungstechnische und kommunalpolitische Angelegenheiten

1894

Klassifikation Teil B: 00503

Trägermaterial: Papier

Bestell-Nr.: IV 00503

52 Sitzungen des Magistrats

- Protokolle der Beratungen des Magistrats über

verwaltungstechnische und kommunalpolitische Angelegenheiten

1895

Klassifikation Teil B: 00504

Trägermaterial: Papier

Bestell-Nr.: IV 00504

53 Sitzungen des Magistrats

- Protokolle der Beratungen des Magistrats über

verwaltungstechnische und kommunalpolitische Angelegenheiten 61

Klassifikation Teil B: 00505

Trägermaterial: Papier

Bestell-Nr.: IV 00505 
IV

02 Ratsgremien und Verwaltungsorgane der Stadt Emden

02.01

Magistrat

02.01.05

Magistratsprotokolle

Lfd. Nr. Titel

Laufzeit

54 Sitzungen des Magistrats

1897

- Protokolle der Beratungen des Magistrats über

verwaltungstechnische und kommunalpolitische Angelegenheiten

1897

Klassifikation Teil B: 00506

Trägermaterial: Papier

Bestell-Nr.: IV 00506

55 Sitzungen des Magistrats

1898

- Protokolle der Beratungen des Magistrats über

verwaltungstechnische und kommunalpolitische Angelegenheiten

1898

Klassifikation Teil B: 00507

Trägermaterial: Papier

Bestell-Nr.: IV 00507

56 Sitzungen des Magistrats

- Protokolle der Beratungen des Magistrats über verwaltungstechnische und kommunalpolitische Angelegenheiten 98
Klassifikation Teil B: 00508
Trägermaterial: Papier
Bestell-Nr.: IV 00508

57 Sitzungen des Magistrats

- Protokolle der Beratungen des Magistrats über verwaltungstechnische und kommunalpolitische Angelegenheiten

1900

\author{
Klassifikation Teil B: 00509 \\ Trägermaterial: Papier \\ Bestell-Nr.: IV 00509
}

58 Sitzungen des Magistrats

- Protokolle der Beratungen des Magistrats über verwaltungstechnische und kommunalpolitische Angelegenheiten

1901

Klassifikation Teil B: 00510

Trägermaterial: Papier

Bestell-Nr.: IV 00510 
IV

02 Ratsgremien und Verwaltungsorgane der Stadt Emden

02.01

Magistrat

02.01.05

Magistratsprotokolle

Lfd. Nr. Titel

Laufzeit

59 Sitzungen des Magistrats

1902

- Protokolle der Beratungen des Magistrats über

verwaltungstechnische und kommunalpolitische Angelegenheiten

1902

Klassifikation Teil B: 00511

Trägermaterial: Papier

Bestell-Nr.: IV 00511

60 Sitzungen des Magistrats

1906

- Protokolle der Beratungen des Magistrats über

verwaltungstechnische und kommunalpolitische Angelegenheiten

1906

Klassifikation Teil B: 00511

Trägermaterial: Papier

Bestell-Nr.: IV 00516

61 Sitzungen des Magistrats, Bd. 1

- Protokolle der Beratungen des Magistrats über

verwaltungstechnische und kommunalpolitische Angelegenheiten

1903

Klassifikation Teil B: 00512

Band: 1

Trägermaterial: Papier

Bestell-Nr.: IV 00512

62 Sitzungen des Magistrats, Bd. 2

1903

- Protokolle der Beratungen des Magistrats über

verwaltungstechnische und kommunalpolitische Angelegenheiten

1903

Klassifikation Teil B: 00513

Band: 1

Trägermaterial: Papier

Bestell-Nr.: IV 00513

63 Sitzungen des Magistrats

- Protokolle der Beratungen des Magistrats über

verwaltungstechnische und kommunalpolitische Angelegenheiten

1904

Klassifikation Teil B: 00514

Trägermaterial: Papier

Bestell-Nr.: IV 00514 
IV

02 Ratsgremien und Verwaltungsorgane der Stadt Emden

02.01

Magistrat

02.01.05

Magistratsprotokolle

Lfd. Nr. Titel

Laufzeit

64 Sitzungen des Magistrats

1905

- Protokolle der Beratungen des Magistrats über

verwaltungstechnische und kommunalpolitische Angelegenheiten

1905

Klassifikation Teil B: 00515

Trägermaterial: Papier

Bestell-Nr.: IV 00515

65 Sitzungen des Magistrats

1907

- Protokolle der Beratungen des Magistrats über

verwaltungstechnische und kommunalpolitische Angelegenheiten

1907

Klassifikation Teil B: 00517

Trägermaterial: Papier

Bestell-Nr.: IV 00517

66 Sitzungen des Magistrats

- Protokolle der Beratungen des Magistrats über verwaltungstechnische und kommunalpolitische Angelegenheiten

1911

Klassifikation Teil B: 00518

Trägermaterial: Papier

Bestell-Nr.: IV 00518

67 Sitzungen des Magistrats

- Protokolle der Beratungen des Magistrats über

verwaltungstechnische und kommunalpolitische Angelegenheiten

1912

Klassifikation Teil B: 00519

Trägermaterial: Papier

Bestell-Nr.: IV 00519

68 Sitzungen des Magistrats

- Protokolle der Beratungen des Magistrats über

verwaltungstechnische und kommunalpolitische Angelegenheiten

1914

Klassifikation Teil B: 00520

Trägermaterial: Papier

Bestell-Nr.: IV 00520 
IV

02 Ratsgremien und Verwaltungsorgane der Stadt Emden

02.01

Magistrat

02.01.05

Magistratsprotokolle

Lfd. Nr. Titel

Laufzeit

69 Sitzungen des Magistrats

1916

- Protokolle der Beratungen des Magistrats über

verwaltungstechnische und kommunalpolitische Angelegenheiten

1916

Klassifikation Teil B: 00520

Trägermaterial: Papier

Bestell-Nr.: IV 00522

70 Sitzungen des Magistrats

- Protokolle der Beratungen des Magistrats über

verwaltungstechnische und kommunalpolitische Angelegenheiten

1915

Klassifikation Teil B: 00521

Trägermaterial: Papier

Bestell-Nr.: IV 00521

71 Sitzungen des Magistrats

- Protokolle der Beratungen des Magistrats über

verwaltungstechnische und kommunalpolitische Angelegenheiten

1919

Klassifikation Teil B: 00523

Trägermaterial: Papier

Bestell-Nr.: IV 00523

72 Sitzungen des Magistrats

- Protokolle der Beratungen des Magistrats über

verwaltungstechnische und kommunalpolitische Angelegenheiten

1920

Klassifikation Teil B: 00524

Trägermaterial: Papier

Bestell-Nr.: IV 00524

73 Sitzungen des Magistrats

- Protokolle der Beratungen des Magistrats über

verwaltungstechnische und kommunalpolitische Angelegenheiten

1910

Klassifikation Teil B: 02519

Trägermaterial: Papier

Bestell-Nr.: IV 02519 
Lfd. Nr. Titel

- Einberufung der Versammlungen der Bürgervorsteher, 1854

- Regelung der Kommunikation zwischen dem

Bürgervorsteher-Kollegium und dem Magistrat, 1854 - 1913

- Beteiligung der Bürgervorsteher an vom Rat eingesetzte

Kommissionen, 1855

- Beschlussfassungen auf gemeinsamen Sitzungen des

Bürgervorsteher-Kollegiums und des Magistrats, März 1874 - Juni

1904

- Verfügung des preußischen Landdrosten in Aurich über

Unzulässigkeit einer Abfassung von Resolutionen durch das

Bürgervorsteher-Kollegium ohne Genehmigung und Vorwissen des

Magistrats, Februar 1885

- Streit um Einspruch des Bürgervorsteher-Kollegiums gegen einen

Beschluss des Magistrats, 1887 - 1888

- Geschäftsordnung des Kollegiums der Bürgervorsteher, Januar 1902

$1854-1914$

Klassifikation Teil B: 00031

Trägermaterial: Papier

Alte Reg.-Sig.: IV Cd 02, 2

Bestell-Nr.: IV 00031

75 Wahl der Bürgervorsteher

- Streit um die Gültigkeit der Wahl des T. Houtrouw zum

Bürgervorsteher, Januar 1898

- Streit um die Gültigkeit der Wahl des Apothekers C. Hermann zum

Bürgervorsteher, März 1898

- Verzeichnisse der Mitglieder des Bürgervorsteher-Kollegiums, 1872 -

1920

- Wahl der Führung des Bürgervorsteher-Kollegiums und Verteilung

von Zuständigkeitsbereichen unter den Bürgervorstehern, Januar

1896

- Verzeichnis der Wahlberechtigten zur Bürgervorsteherwahl aus Wyk

II, Januar - Februar 1903

- Vereidigung der Bürgervorsteher, März 1903

$1832-1903$

Klassifikation Teil B: 00051

Trägermaterial: Papier

Alte Reg.-Sig.: I Cd 2

Bestell-Nr.: IV 00051

76 Anfechtung einer Bürgervorsteherwahl

$1901-1903$

- Klage des Gastwirts Dirk Mennenga und Cons. gegen das

Bürgervorsteher-Kollegium der Stadt Emden auf Annulierung des

Ergebnisses der Bürgervorsteherwahl vor dem Bezirksausschuss in

Aurich und vor dem Oberverwaltungsgericht in Berlin, Dezember 1901

- September 1903

$1901-1903$

Klassifikation Teil B: 00053

Trägermaterial: Papier

Alte Reg.-Sig.: I Cd 8

Bestell-Nr.: IV 00053 
IV

02

Ratsgremien und Verwaltungsorgane der Stadt Emden

02.02

\section{Bürgervorsteherkollegium}

Lfd. Nr. Titel

Laufzeit

77 Anfechtung einer Bürgervorsteherwahl

1901-1902

- Klage des Gastwirts Dirk Mennenga und Cons. gegen das

Bürgervorsteher-Kollegium der Stadt Emden auf Annulierung des

Ergebnisses der Bürgervorsteherwahl vor dem Bezirksausschuss in

Aurich und vor dem Oberverwaltungsgericht in Berlin, Dezember 1901

- November 1902

- Eintragung neuer Bürger in das Wählerregister, 1901

- Neuwahl von Bürgervorstehern, Oktober 1901 - November 1902

$1901-1903$

Klassifikation Teil B: 00058

Trägermaterial: Papier

Alte Reg.-Sig.: I Cd 2

Bestell-Nr.: IV 00058

78 Wahl der Bürgervorsteher

- Bekanntmachung über Wahl neuer Bürgervorsteher, Dezember

1867 - Januar 1868

- Vereidigung der neu gewählten Bürgervorsteher, Januar 1868

- Wahl eines neuen Bürgervorstehers für die Wyk II, September 1869

$1867-1869$

Klassifikation Teil B: 00059

Trägermaterial: Papier

Alte Reg.-Sig.: I Cd 1

Bestell-Nr.: IV 00059

79 Wahl der Bürgervorsteher

- Bekanntmachung über Wahl neuer Bürgervorsteher, Oktober 1879 -

Oktober 1871

- Vereidigung neu gewählter Bürgervorsteher, Dezember 1879 - April

1886

- Antrag des Klempners W.J. Schmidt auf Aufnahme in das

Wählerregister der Wyk V, November 1882

- Bekanntmachung von Ersatzwahlen für ausscheidende

Bürgervorsteher, Dezember 1883 - Januar 1890

- Mandatsniederlegung des Bürgervorstehers Dr. jur. Plagge wegen

Wechsels als Bürgermeister nach Meuselwitz (Sachsen), Oktober

1886

$1879-1890$

Klassifikation Teil B: 00060

Trägermaterial: Papier

Alte Reg.-Sig.: I Cd 1

Bestell-Nr.: IV 00060 
Lfd. Nr. Titel

- Klage des Apothekers C. Hermann in Emden gegen das

Bürgervorsteher-Kollegium auf Gültigkeitserklärung seiner Wahl zum

Bürgervorsteher beim Bezirksausschuss in Aurich, 1898

1898

\author{
Klassifikation Teil B: 00061 \\ Trägermaterial: Papier \\ Alte Reg.-Sig.: I Cd 1 \\ Bestell-Nr.: IV 00061
}

81 Medaillen für Bürgervorsteher

- Finanzierung der an die Bürgervorsteher beim Ausscheiden aus dem Amt nach Ende der Wahlperiode überreichten Ehrenmedaille, Februar 1854 - Februar 1919

- Überreichung von Ehrenmedaillen an Bürgervorsteher, Dezember 1912

- Antrag es Bürgervorstehers H. Eckhoff beim Magistrat der Stadt Emden auf Verleihung eines Ehrengeschenks für ausscheidende Bürgervorsteher mit bereits erhaltender Medaille, November 1919

$1854-1920$

Klassifikation Teil B: 00063

Trägermaterial: Papier

Alte Reg.-Sig.: I Cd 1

Bestell-Nr.: IV 00063

82 Wahl der Bürgervorsteher

1901

- Liste der Wahlberechtigten zur Bürgervorsteherwahl, 1901

1901

Klassifikation Teil B: 00067

Trägermaterial: Papier

Alte Reg.-Sig.: I Cd 1

Bestell-Nr.: IV 00067

83 Wahl der Bürgervorsteher

- Wahlen und Ersatzwahlen von Bürgervorstehern, November 1911 Januar 1917

- Listen der Wahlberechtigten zur Bürgervorsteherwahl, 1914 - 1916

- Anträge des G. V. Fresemann, des Remmer Folkerts und des Wilhelm Rewolle auf Registrierung in die Wählerlisten, November 1915

- Instruktion für die Bezirksvorsteher der Stadt Emden über ihre polizeilichen Pflichten, Juli 1908

$1908-1916$

Klassifikation Teil B: 00068

Trägermaterial: Papier

Alte Reg.-Sig.: I Cd 1

Bestell-Nr.: IV 00068 
IV

02 Ratsgremien und Verwaltungsorgane der Stadt Emden

02.02 Bürgervorsteherkollegium

Lfd. Nr. Titel

Laufzeit

84 Bürgervorsteher-Kollegium

- Einladungen zu den Sitzungen des Bürgervorsteher-Kollegiums mit Tagesordnung, 1868 - 1869

$1868-1869$

Klassifikation Teil B: 00100

Trägermaterial: Papier Alte Reg.-Sig.: I Cd 7

Bestell-Nr.: IV 00100

85 Bürgervorsteher-Kollegium

- Einladungen zu den Sitzungen des Bürgervorsteher-Kollegiums mit Tagesordnung, 1870 - 1871

$1870-1871$

Klassifikation Teil B: 00101

Trägermaterial: Papier

Alte Reg.-Sig.: I Cd 7

Bestell-Nr.: IV 00101

86 Bürgervorsteher-Kollegium

- Einladungen zu den Sitzungen des Bürgervorsteher-Kollegiums mit Tagesordnung, 1872 - 1873

$1872-1873$

Klassifikation Teil B: 00102

Trägermaterial: Papier

Alte Reg.-Sig.: I Cd 7

Bestell-Nr.: IV 00102

87 Bürgervorsteher-Kollegium

- Einladungen zu den Sitzungen des Bürgervorsteher-Kollegiums mit Tagesordnung, 1874 - 1875

$1874-1875$

Klassifikation Teil B: 00103

Trägermaterial: Papier

Alte Reg.-Sig.: I Cd 7

Bestell-Nr.: IV 00103

88 Bürgervorsteher-Kollegium

- Einladungen zu den Sitzungen des Bürgervorsteher-Kollegiums mit Tagesordnung, $1876-1877$

$1876-1877$

Akte fehlt !

Klassifikation Teil B: 00104

Trägermaterial: Papier

Alte Reg.-Sig.: I Cd 7

Bestell-Nr.: IV 00104 
IV

02 Ratsgremien und Verwaltungsorgane der Stadt Emden

02.02 Bürgervorsteherkollegium

Lfd. Nr. Titel

Laufzeit

89 Bürgervorsteher-Kollegium

- Einladungen zu den Sitzungen des Bürgervorsteher-Kollegiums mit Tagesordnung, 1878 - 1879

$1878-1879$

Klassifikation Teil B: 00105

Trägermaterial: Papier

Alte Reg.-Sig.: I Cd 7

Bestell-Nr.: IV 00105

90 Bürgervorsteher-Kollegium

$1880-1881$

- Einladungen zu den Sitzungen des Bürgervorsteher-Kollegiums mit Tagesordnung, 1880 - 1881

$1880-1881$

Klassifikation Teil B: 00106

Trägermaterial: Papier

Alte Reg.-Sig.: I Cd 7

Bestell-Nr.: IV 00106

91 Bürgervorsteher-Kollegium

- Einladungen zu den Sitzungen des Bürgervorsteher-Kollegiums mit Tagesordnung, 1882 - 1883

$1882-1883$

Klassifikation Teil B: 00107

Trägermaterial: Papier

Alte Reg.-Sig.: I Cd 7

Bestell-Nr.: IV 00107

92 Bürgervorsteher-Kollegium

1884

- Einladungen zu den Sitzungen des Bürgervorsteher-Kollegiums mit Tagesordnung, 1884

1884

Klassifikation Teil B: 00107

Trägermaterial: Papier

Alte Reg.-Sig.: I Cd 7

Bestell-Nr.: IV 00108

93 Bürgervorsteher-Kollegium

- Einladungen zu den Sitzungen des Bürgervorsteher-Kollegiums mit Tagesordnung, 1885 - 1886

$1885-1886$

Akte fehlt !

Klassifikation Teil B: 00109

Trägermaterial: Papier

Alte Reg.-Sig.: I Cd 7

Bestell-Nr.: IV 00109 
IV

02 Ratsgremien und Verwaltungsorgane der Stadt Emden

02.02 Bürgervorsteherkollegium

Lfd. Nr. Titel

94 Bürgervorsteher-Kollegium

- Einladungen zu den Sitzungen des Bürgervorsteher-Kollegiums mit Tagesordnung, 1887

1887

Akte fehlt !

Klassifikation Teil B: 00110

Trägermaterial: Papier

Alte Reg.-Sig.: I Cd 7

Bestell-Nr.: IV 00110

95 Bürgervorsteher-Kollegium

- Einladungen zu den Sitzungen des Bürgervorsteher-Kollegiums mit Tagesordnung, 1888 - 1889

$1888-1889$

Klassifikation Teil B: 00111

Trägermaterial: Papier

Alte Reg.-Sig.: I Cd 7

Bestell-Nr.: IV 00111

96 Bürgervorsteher-Kollegium

- Einladungen zu den Sitzungen des Bürgervorsteher-Kollegiums mit Tagesordnung, $1890-1891$

$1890-1891$

Klassifikation Teil B: 00112

Trägermaterial: Papier

Alte Reg.-Sig.: I Cd 7

Bestell-Nr.: IV 00112

97 Bürgervorsteher-Kollegium

- Einladungen zu den Sitzungen des Bürgervorsteher-Kollegiums mit Tagesordnung, $1892-1893$

$1892-1893$

Klassifikation Teil B: 00113

Trägermaterial: Papier

Alte Reg.-Sig.: I Cd 7

Bestell-Nr.: IV 00113

98 Bürgervorsteher-Kollegium

- Einladungen zu den Sitzungen des Bürgervorsteher-Kollegiums mit Tagesordnung, 1894 - 1895

$1894-1895$

Klassifikation Teil B: 00114

Trägermaterial: Papier

Alte Reg.-Sig.: I Cd 7

Bestell-Nr.: IV 00114 
IV

02 Ratsgremien und Verwaltungsorgane der Stadt Emden

02.02 Bürgervorsteherkollegium

Lfd. Nr. Titel

Laufzeit

99 Bürgervorsteher-Kollegium

- Einladungen zu den Sitzungen des Bürgervorsteher-Kollegiums mit Tagesordnung, 1896 - 1897

$1896-1897$

Klassifikation Teil B: 00115

Trägermaterial: Papier

Alte Reg.-Sig.: I Cd 7

Bestell-Nr.: IV 00115

100 Bürgervorsteher-Kollegium

- Einladungen zu den Sitzungen des Bürgervorsteher-Kollegiums mit Tagesordnung, 1898 - 1899

$1898-1899$

Klassifikation Teil B: 00116

Trägermaterial: Papier

Alte Reg.-Sig.: I Cd 7

Bestell-Nr.: IV 00116

101 Bürgervorsteher-Kollegium

$1900-1901$

- Einladungen zu den Sitzungen des Bürgervorsteher-Kollegiums mit Tagesordnung, 1900 - 1901

$1900-1901$

Klassifikation Teil B: 00117

Trägermaterial: Papier

Alte Reg.-Sig.: I Cd 7

Bestell-Nr.: IV 00117

102 Bürgervorsteher-Kollegium

- Einladungen zu den Sitzungen des Bürgervorsteher-Kollegiums mit Tagesordnung, 1902 - 1903

$1902-1903$

Klassifikation Teil B: 00118

Trägermaterial: Papier

Alte Reg.-Sig.: I Cd 7

Bestell-Nr.: IV 00118

103 Bürgervorsteher-Kollegium

- Einladungen zu den Sitzungen des Bürgervorsteher-Kollegiums mit Tagesordnung, 1904

1904

Klassifikation Teil B: 00119

Trägermaterial: Papier

Alte Reg.-Sig.: I Cd 7

Bestell-Nr.: IV 00119 
IV

02 Ratsgremien und Verwaltungsorgane der Stadt Emden

02.02 Bürgervorsteherkollegium

Lfd. Nr. Titel

104 Bürgervorsteher-Kollegium 1905

- Einladungen zu den Sitzungen des Bürgervorsteher-Kollegiums mit Tagesordnung, 1905

1905

Klassifikation Teil B: 00120

Trägermaterial: Papier

Alte Reg.-Sig.: I Cd 7

Bestell-Nr.: IV 00120

105 Wahl der Bürgervorsteher

- Wahlen und Ersatzwahlen der Bürgervorsteher bzw. der ausscheidenden Bürgervorsteher, April 1903 - Mai 1911

- Wählerverzeichnisse, April 1903 - März 1911

- Vereidigung der gewählten Bürgervorsteher, Mai 1905 - November 1909

$1903-1911$

Klassifikation Teil B: 00123

Trägermaterial: Papier

Alte Reg.-Sig.: I Cd 1

Bestell-Nr.: IV 00123

106 Bürgervorsteher-Kollegium

1906

- Einladungen zu den Sitzungen des Bürgervorsteher-Kollegiums mit Tagesordnung, 1906

1906

Klassifikation Teil B: 00124

Trägermaterial: Papier

Alte Reg.-Sig.: I Cd 7

Bestell-Nr.: IV 00124

107 Bürgervorsteher-Kollegium

- Einladungen zu den Sitzungen des Bürgervorsteher-Kollegiums mit Tagesordnung, 1907

1907

Klassifikation Teil B: 00125

Trägermaterial: Papier

Alte Reg.-Sig.: I Cd 7

Bestell-Nr.: IV 00125

108 Bürgervorsteher-Kollegium

- Einladungen zu den Sitzungen des Bürgervorsteher-Kollegiums mit Tagesordnung, 1908

1908

Klassifikation Teil B: 00126

Trägermaterial: Papier

Alte Reg.-Sig.: I Cd 7

Bestell-Nr.: IV 00126 
IV

02

Ratsgremien und Verwaltungsorgane der Stadt Emden

02.02

\section{Bürgervorsteherkollegium}

Lfd. Nr. Titel

Laufzeit

109 Bürgervorsteher-Kollegium

1909

- Einladungen zu den Sitzungen des Bürgervorsteher-Kollegiums mit Tagesordnung, 1909

1909

Klassifikation Teil B: 00127

Trägermaterial: Papier

Alte Reg.-Sig.: I Cd 7

Bestell-Nr.: IV 00127

110 Bürgervorsteher-Kollegium

- Einladungen zu den Sitzungen des Bürgervorsteher-Kollegiums mit Tagesordnung, 1910

1910

Klassifikation Teil B: 00128

Trägermaterial: Papier

Alte Reg.-Sig.: I Cd 7

Bestell-Nr.: IV 00128

111 Bürgervorsteher-Kollegium

1871-1903

- Anwesenheitslisten zu den Sitzungen des

Bürgervorsteher-Kollegiums mit Tagesordnung, 1871 - 1903

$1871-1903$

Klassifikation Teil B: 00129

Trägermaterial: Papier

Alte Reg.-Sig.: I Cd 7

Bestell-Nr.: IV 00129

112 Bürgervorsteher-Kollegium

$1854-1890$

- Wahl des Vorsitzenden und der Funktionsträger im

Bürgervorsteher-Kollegium, 1854 - 1884

- Antrag des Stadtverordneten J. Hemkes auf Gewährung eines

Wartegeldes nach der Auflösung des Bürgervorsteher-Kollegiums,

Januar - Februar 1854

- Antrag des Bürgervorsteherkollegiumsvorsitzenden Brons auf Mittel für die Einrichtung eines Bürodienstes zur Erledigung der Geschäfte des Bürgervorsteher-Kollegiums, Januar 1854

- Bestellung von Mitgliedern in städtischen Kommissionen von Seiten des Bürgervorsteher-Kollegiums, 1880 - 1890

$1854-1890$

Klassifikation Teil B: 00134

Trägermaterial: Papier

Alte Reg.-Sig.: I Cd

Bestell-Nr.: IV 00134 
IV

02 Ratsgremien und Verwaltungsorgane der Stadt Emden

02.02 Bürgervorsteherkollegium

Lfd. Nr. Titel

Laufzeit

113 Einladungen zu den Sitzungen des Bürgervorsteherkollegiums 1886-1904

- Einladungsschreiben an die Mitglieder des

Bürgervorsteherkollegiums zu den Sitzungen ihres Gremiums

$1886-1887 / 1901-1904$

Klassifikation Teil B: 00525

Trägermaterial: Papier

Bestell-Nr.: IV 00525

114 Protokolle der Sitzungen des Bürgervorsteherkollegiums

- Sitzungen des Bürgervorsteher-Kollegiums mit Verhandlungen zu kommunalpolitischen, haushaltsrechtlichen und verwaltungstechnischen Fragen

1867

Klassifikation Teil B: 00526

Trägermaterial: Papier

Bestell-Nr.: IV 00526

115 Protokolle der Sitzungen des Bürgervorsteherkollegiums

- Sitzungen des Bürgervorsteher-Kollegiums mit Verhandlungen zu kommunalpolitischen, haushaltsrechtlichen und verwaltungstechnischen Fragen

1868

\author{
Klassifikation Teil B: 00527 \\ Trägermaterial: Papier \\ Bestell-Nr.: IV 00527
}

116 Protokolle der Sitzungen des Bürgervorsteherkollegiums

- Sitzungen des Bürgervorsteher-Kollegiums mit Verhandlungen zu kommunalpolitischen, haushaltsrechtlichen und verwaltungstechnischen Fragen

1869
Klassifikation Teil B: 00528
Trägermaterial: Papier
Bestell-Nr.: IV 00528

117 Protokolle der Sitzungen des Bürgervorsteherkollegiums

- Sitzungen des Bürgervorsteher-Kollegiums mit Verhandlungen zu kommunalpolitischen, haushaltsrechtlichen und verwaltungstechnischen Fragen

1870

Klassifikation Teil B: 00529

Trägermaterial: Papier

Bestell-Nr.: IV 00529 
IV

02

Ratsgremien und Verwaltungsorgane der Stadt Emden

02.02

Bürgervorsteherkollegium

Lfd. Nr. Titel

Laufzeit

118 Protokolle der Sitzungen des Bürgervorsteherkollegiums

- Sitzungen des Bürgervorsteher-Kollegiums mit Verhandlungen zu kommunalpolitischen, haushaltsrechtlichen und

verwaltungstechnischen Fragen

1871

Klassifikation Teil B: 00530

Trägermaterial: Papier

Bestell-Nr.: IV 00530

119 Protokolle der Sitzungen des Bürgervorsteherkollegiums

- Sitzungen des Bürgervorsteher-Kollegiums mit Verhandlungen zu kommunalpolitischen, haushaltsrechtlichen und verwaltungstechnischen Fragen

1872

Klassifikation Teil B: 00531

Trägermaterial: Papier

Bestell-Nr.: IV 00531

120 Protokolle der Sitzungen des Bürgervorsteherkollegiums

- Sitzungen des Bürgervorsteher-Kollegiums mit Verhandlungen zu kommunalpolitischen, haushaltsrechtlichen und verwaltungstechnischen Fragen

1873

Klassifikation Teil B: 00532

Trägermaterial: Papier

Bestell-Nr.: IV 00532

121 Protokolle der Sitzungen des Bürgervorsteherkollegiums

- Sitzungen des Bürgervorsteher-Kollegiums mit Verhandlungen zu kommunalpolitischen, haushaltsrechtlichen und verwaltungstechnischen Fragen

1871

Klassifikation Teil B: 00533

Trägermaterial: Papier

Bestell-Nr.: IV 00533

122 Protokolle der Sitzungen des Bürgervorsteherkollegiums

- Sitzungen des Bürgervorsteher-Kollegiums mit Verhandlungen zu kommunalpolitischen, haushaltsrechtlichen und verwaltungstechnischen Fragen

1875

Klassifikation Teil B: 00534

Trägermaterial: Papier

Bestell-Nr.: IV 00534 
IV

02

Ratsgremien und Verwaltungsorgane der Stadt Emden

02.02

Bürgervorsteherkollegium

Lfd. Nr. Titel

Laufzeit

123 Protokolle der Sitzungen des Bürgervorsteherkollegiums

- Sitzungen des Bürgervorsteher-Kollegiums mit Verhandlungen zu kommunalpolitischen, haushaltsrechtlichen und verwaltungstechnischen Fragen

1876

Klassifikation Teil B: 00535

Trägermaterial: Papier

Bestell-Nr.: IV 00535

124 Protokolle der Sitzungen des Bürgervorsteherkollegiums

- Sitzungen des Bürgervorsteher-Kollegiums mit Verhandlungen zu kommunalpolitischen, haushaltsrechtlichen und verwaltungstechnischen Fragen

1877

Klassifikation Teil B: 00536

Trägermaterial: Papier

Bestell-Nr.: IV 00536

125 Protokolle der Sitzungen des Bürgervorsteherkollegiums

- Sitzungen des Bürgervorsteher-Kollegiums mit Verhandlungen zu kommunalpolitischen, haushaltsrechtlichen und verwaltungstechnischen Fragen

1878

Klassifikation Teil B: 00537

Trägermaterial: Papier

Bestell-Nr.: IV 00537

126 Protokolle der Sitzungen des Bürgervorsteherkollegiums

- Sitzungen des Bürgervorsteher-Kollegiums mit Verhandlungen zu kommunalpolitischen, haushaltsrechtlichen und verwaltungstechnischen Fragen

1880

Klassifikation Teil B: 00538

Trägermaterial: Papier

Bestell-Nr.: IV 00538

127 Protokolle der Sitzungen des Bürgervorsteherkollegiums

- Sitzungen des Bürgervorsteher-Kollegiums mit Verhandlungen zu kommunalpolitischen, haushaltsrechtlichen und verwaltungstechnischen Fragen

1881

Klassifikation Teil B: 00539

Trägermaterial: Papier

Bestell-Nr.: IV 00539 
IV

02

Ratsgremien und Verwaltungsorgane der Stadt Emden

02.02

Bürgervorsteherkollegium

Lfd. Nr. Titel

Laufzeit

128 Protokolle der Sitzungen des Bürgervorsteherkollegiums

- Sitzungen des Bürgervorsteher-Kollegiums mit Verhandlungen zu kommunalpolitischen, haushaltsrechtlichen und verwaltungstechnischen Fragen

$1882-1883$

Klassifikation Teil B: 00539

Trägermaterial: Papier

Bestell-Nr.: IV 00540

129 Protokolle der Sitzungen des Bürgervorsteherkollegiums

- Sitzungen des Bürgervorsteher-Kollegiums mit Verhandlungen zu kommunalpolitischen, haushaltsrechtlichen und verwaltungstechnischen Fragen

$1884-1885$

Klassifikation Teil B: 00541

Trägermaterial: Papier

Bestell-Nr.: IV 00541

130 Protokolle der Sitzungen des Bürgervorsteherkollegiums

1886

- Sitzungen des Bürgervorsteher-Kollegiums mit Verhandlungen zu kommunalpolitischen, haushaltsrechtlichen und verwaltungstechnischen Fragen

1886

Klassifikation Teil B: 00542

Trägermaterial: Papier

Bestell-Nr.: IV 00542

131 Protokolle der Sitzungen des Bürgervorsteherkollegiums

- Sitzungen des Bürgervorsteher-Kollegiums mit Verhandlungen zu kommunalpolitischen, haushaltsrechtlichen und verwaltungstechnischen Fragen

1887

Klassifikation Teil B: 00543

Trägermaterial: Papier

Bestell-Nr.: IV 00543

132 Protokolle der Sitzungen des Bürgervorsteherkollegiums

- Sitzungen des Bürgervorsteher-Kollegiums mit Verhandlungen zu kommunalpolitischen, haushaltsrechtlichen und verwaltungstechnischen Fragen

1888

Klassifikation Teil B: 00544

Trägermaterial: Papier

Bestell-Nr.: IV 00544 
IV

02

Ratsgremien und Verwaltungsorgane der Stadt Emden

02.02

Bürgervorsteherkollegium

Lfd. Nr. Titel

Laufzeit

133 Protokolle der Sitzungen des Bürgervorsteherkollegiums

1889

- Sitzungen des Bürgervorsteher-Kollegiums mit Verhandlungen zu kommunalpolitischen, haushaltsrechtlichen und

verwaltungstechnischen Fragen

1889

Klassifikation Teil B: 00545

Trägermaterial: Papier

Bestell-Nr.: IV 00545

134 Protokolle der Sitzungen des Bürgervorsteherkollegiums

- Sitzungen des Bürgervorsteher-Kollegiums mit Verhandlungen zu kommunalpolitischen, haushaltsrechtlichen und verwaltungstechnischen Fragen

1890

Klassifikation Teil B: 00546

Trägermaterial: Papier

Bestell-Nr.: IV 00546

135 Protokolle der Sitzungen des Bürgervorsteherkollegiums

1891

- Sitzungen des Bürgervorsteher-Kollegiums mit Verhandlungen zu kommunalpolitischen, haushaltsrechtlichen und verwaltungstechnischen Fragen

1891

Klassifikation Teil B: 00547

Trägermaterial: Papier

Bestell-Nr.: IV 00547

136 Protokolle der Sitzungen des Bürgervorsteherkollegiums

- Sitzungen des Bürgervorsteher-Kollegiums mit Verhandlungen zu kommunalpolitischen, haushaltsrechtlichen und verwaltungstechnischen Fragen

1892

Klassifikation Teil B: 00548

Trägermaterial: Papier

Bestell-Nr.: IV 00548

137 Protokolle der Sitzungen des Bürgervorsteherkollegiums

- Sitzungen des Bürgervorsteher-Kollegiums mit Verhandlungen zu kommunalpolitischen, haushaltsrechtlichen und verwaltungstechnischen Fragen

$1893-1894$

Klassifikation Teil B: 00549

Trägermaterial: Papier

Bestell-Nr.: IV 00549 
IV

02

Ratsgremien und Verwaltungsorgane der Stadt Emden

02.02

Bürgervorsteherkollegium

Lfd. Nr. Titel

Laufzeit

138 Protokolle der Sitzungen des Bürgervorsteherkollegiums

1895

- Sitzungen des Bürgervorsteher-Kollegiums mit Verhandlungen zu kommunalpolitischen, haushaltsrechtlichen und

verwaltungstechnischen Fragen

1895

Klassifikation Teil B: 00550

Trägermaterial: Papier

Bestell-Nr.: IV 00550

139 Protokolle der Sitzungen des Bürgervorsteherkollegiums

- Sitzungen des Bürgervorsteher-Kollegiums mit Verhandlungen zu kommunalpolitischen, haushaltsrechtlichen und verwaltungstechnischen Fragen

$1896-1897$

Klassifikation Teil B: 00551

Trägermaterial: Papier

Bestell-Nr.: IV 00551

140 Protokolle der Sitzungen des Bürgervorsteherkollegiums

1897-1898

- Sitzungen des Bürgervorsteher-Kollegiums mit Verhandlungen zu kommunalpolitischen, haushaltsrechtlichen und

verwaltungstechnischen Fragen

$1896-1897$

Klassifikation Teil B: 00552

Trägermaterial: Papier

Bestell-Nr.: IV 00552

141 Protokolle der Sitzungen des Bürgervorsteherkollegiums

$1899-1900$

- Sitzungen des Bürgervorsteher-Kollegiums mit Verhandlungen zu kommunalpolitischen, haushaltsrechtlichen und

verwaltungstechnischen Fragen

$1899-1900$

Klassifikation Teil B: 00553

Trägermaterial: Papier

Bestell-Nr.: IV 00553

142 Protokolle der Sitzungen des Bürgervorsteherkollegiums

1900-1902

- Sitzungen des Bürgervorsteher-Kollegiums mit Verhandlungen zu kommunalpolitischen, haushaltsrechtlichen und verwaltungstechnischen Fragen

$1900-1902$

Klassifikation Teil B: 00554

Trägermaterial: Papier

Bestell-Nr.: IV 00554 
IV

02

Ratsgremien und Verwaltungsorgane der Stadt Emden

02.02

Bürgervorsteherkollegium

Lfd. Nr. Titel

Laufzeit

143 Protokolle der Sitzungen des Bürgervorsteherkollegiums

1902-1904

- Sitzungen des Bürgervorsteher-Kollegiums mit Verhandlungen zu kommunalpolitischen, haushaltsrechtlichen und

verwaltungstechnischen Fragen

$1902-1904$

Klassifikation Teil B: 00555

Trägermaterial: Papier

Bestell-Nr.: IV 00555

144 Protokolle der Sitzungen des Bürgervorsteherkollegiums

1904-1908

- Sitzungen des Bürgervorsteher-Kollegiums mit Verhandlungen zu kommunalpolitischen, haushaltsrechtlichen und verwaltungstechnischen Fragen

$1904-1908$

Klassifikation Teil B: 00556

Trägermaterial: Papier

Bestell-Nr.: IV 00556

145 Protokolle der Sitzungen des Bürgervorsteherkollegiums

$1908-1910$

- Sitzungen des Bürgervorsteher-Kollegiums mit Verhandlungen zu kommunalpolitischen, haushaltsrechtlichen und

verwaltungstechnischen Fragen

$1908-1910$

Klassifikation Teil B: 00557

Trägermaterial: Papier

Bestell-Nr.: IV 00557

146 Protokolle der Sitzungen des Bürgervorsteherkollegiums

- Sitzungen des Bürgervorsteher-Kollegiums mit Verhandlungen zu kommunalpolitischen, haushaltsrechtlichen und verwaltungstechnischen Fragen

$1910-1912$

Klassifikation Teil B: 00558

Trägermaterial: Papier

Bestell-Nr.: IV 00558

147 Protokolle der Sitzungen des Bürgervorsteherkollegiums

$1912-1913$

- Sitzungen des Bürgervorsteher-Kollegiums mit Verhandlungen zu kommunalpolitischen, haushaltsrechtlichen und verwaltungstechnischen Fragen

$1912-1913$

Klassifikation Teil B: 00559

Trägermaterial: Papier

Bestell-Nr.: IV 00559 
IV

02

Ratsgremien und Verwaltungsorgane der Stadt Emden

02.02

\section{Bürgervorsteherkollegium}

Lfd. Nr. Titel

Laufzeit

148 Protokolle der Sitzungen des Bürgervorsteherkollegiums

- Sitzungen des Bürgervorsteher-Kollegiums mit Verhandlungen zu kommunalpolitischen, haushaltsrechtlichen und

verwaltungstechnischen Fragen

$1913-1914$

Klassifikation Teil B: 00560

Trägermaterial: Papier

Bestell-Nr.: IV 00560

149 Protokolle der Sitzungen des Bürgervorsteherkollegiums

- Sitzungen des Bürgervorsteher-Kollegiums mit Verhandlungen zu kommunalpolitischen, haushaltsrechtlichen und verwaltungstechnischen Fragen

$1914-1917$

Klassifikation Teil B: 00561

Trägermaterial: Papier

Bestell-Nr.: IV 00561

150 Protokolle der Sitzungen des Bürgervorsteherkollegiums

- Sitzungen des Bürgervorsteher-Kollegiums mit Verhandlungen zu kommunalpolitischen, haushaltsrechtlichen und

verwaltungstechnischen Fragen

$1917-1919$

Klassifikation Teil B: 00562

Trägermaterial: Papier

Bestell-Nr.: IV 00562 
Lfd. Nr. Titel

Laufzeit

151 Bezirksvorsteher 1892-1912

- Liste der Bezirksvorsteher

$1892-1912$

Klassifikation Teil B: 00006

Trägermaterial: Papier

Bestell-Nr.: IV 00006

152 Bezirksvorsteher

1878-1892

(1916)

- Wahl von Bezirksvorstehern, 1878 - 1888

- Verzeichnis der Wahlberechtigten für die Bezirksvorsteherwahl, 1878

- Vereidigung neu gewählter Bezirksvorsteher, Dezember 1882 - April 1892

- Bekanntmachung der Ergebnisse von Bezirksvorsteherwahlen,

Dezember 1885 - Februar 1892

- Verhängung einer Geldstrafe gegen nicht zur Bezirksvorsteherwahl erschienenden wahlberechtigten Bürgern, April 1892

$1878-1892(1916)$

Klassifikation Teil B: 00054

Trägermaterial: Papier

Alte Reg.-Sig.: I Ce 1

Bestell-Nr.: IV 00054

153 Bezirksvorsteher

- Aufstellung der Bezirksvorsteher von 1865 mit eingetragenen Veränderungen, 1865 - 1871

- Wahl von Ersatzmänner für den wegen Wegzugs zurückgetretenen

Bezirksvorsteher V. R. Janssen und den verstorbenen

Bezirksvorsteher W.H. Klaassen, Mai - Juli 1865

- Vereidigung der neu gewählten Bezirksvorsteher , Juli 1865

- Verzeichnis der zur Wahl der Bezirksvorsteher berechtigten Bürger,

Dezember 1870

- Bezirksvorsteher-Wahlen, Dezember 1870 - Januar 1877

$1865-1877$

Klassifikation Teil B: 00064

Trägermaterial: Papier

Alte Reg.-Sig.: I Ce 1

Bestell-Nr.: IV 00064 
Lfd. Nr. Titel

- Ersatzwahl für den verstorbenen Bezirksvorsteher, Sattlermeister J.G. Schmidt, Februar 1893

- Verzeichnis der Wahlberechtigten für die Bezirksvorsteherwahlen in den Wyken I - IV, November 1894

- Verhängung von Geldstrafe gegen von den Bezirksvorsteherwahl fern bleibende Bürger, Januar 1895 - Oktober 1896

- Bekanntmachung über gewählte Bezirksvorsteher, Januar 1900

Ersatzwahl für den verzogenen Bezirksvorsteher P.I. Lorenz, November 1902 - März 1903

$1893-1903$

Klassifikation Teil B: 00066

Trägermaterial: Papier

Alte Reg.-Sig.: I Ce 1

Bestell-Nr.: IV 00066 
IV

02

Ratsgremien und Verwaltungsorgane der Stadt Emden

02.04

\section{Gemeinsame Tagungen der städtischen Gremien}

Lfd. Nr. Titel

Laufzeit

155 Plenarsitzungen des Magistrats und des Bürgervorsteher-Kollegiums

1867-1869

- Gemeinsame Beratungen des Magistrats und des

Bürgervorsteher-Kollegiums über verwaltungstechnische und

kommunalpolitische Angelegenheiten

$1867-1869$

Klassifikation Teil B: 00474

Trägermaterial: Papier

Bestell-Nr.: IV 00474

156 Plenarsitzungen des Magistrats und des Bürgervorsteher-Kollegiums

- Gemeinsame Beratungen des Magistrats und des

Bürgervorsteher-Kollegiums über verwaltungstechnische und

kommunalpolitische Angelegenheiten

$1870-1872$

Klassifikation Teil B: 00475

Trägermaterial: Papier

Bestell-Nr.: IV 00475

157 Plenarsitzungen des Magistrats und des Bürgervorsteher-Kollegiums

- Gemeinsame Beratungen des Magistrats und des

Bürgervorsteher-Kollegiums über verwaltungstechnische und kommunalpolitische Angelegenheiten

$1873-1874$

Klassifikation Teil B: 00476

Trägermaterial: Papier

Bestell-Nr.: IV 00476

158 Plenarsitzungen des Magistrats und des Bürgervorsteher-Kollegiums

- Gemeinsame Beratungen des Magistrats und des

Bürgervorsteher-Kollegiums über verwaltungstechnische und kommunalpolitische Angelegenheiten

1873

Klassifikation Teil B: 00477

Trägermaterial: Papier

Bestell-Nr.: IV 00477

159 Plenarsitzungen des Magistrats und des Bürgervorsteher-Kollegiums

- Gemeinsame Beratungen des Magistrats und des

Bürgervorsteher-Kollegiums über verwaltungstechnische und kommunalpolitische Angelegenheiten

$1875-1878$

Klassifikation Teil B: 00478

Trägermaterial: Papier

Bestell-Nr.: IV 00478 
IV

02

Ratsgremien und Verwaltungsorgane der Stadt Emden

02.04

\section{Gemeinsame Tagungen der städtischen Gremien}

Lfd. Nr. Titel

Laufzeit

160 Plenarsitzungen des Magistrats und des Bürgervorsteher-Kollegiums

1879-1881

- Gemeinsame Beratungen des Magistrats und des

Bürgervorsteher-Kollegiums über verwaltungstechnische und kommunalpolitische Angelegenheiten

$1879-1881$

Klassifikation Teil B: 00479

Trägermaterial: Papier

Bestell-Nr.: IV 00479

161 Plenarsitzungen des Magistrats und des Bürgervorsteher-Kollegiums

- Gemeinsame Beratungen des Magistrats und des

Bürgervorsteher-Kollegiums über verwaltungstechnische und

kommunalpolitische Angelegenheiten

$1882-1884$

Klassifikation Teil B: 00480

Trägermaterial: Papier

Bestell-Nr.: IV 00480

162 Plenarsitzungen des Magistrats und des Bürgervorsteher-Kollegiums

$1885-1888$

- Gemeinsame Beratungen des Magistrats und des

Bürgervorsteher-Kollegiums über verwaltungstechnische und

kommunalpolitische Angelegenheiten

$1885-1888$

Klassifikation Teil B: 00481

Trägermaterial: Papier

Bestell-Nr.: IV 00481

163 Plenarsitzungen des Magistrats und des Bürgervorsteher-Kollegiums

- Gemeinsame Beratungen des Magistrats und des

Bürgervorsteher-Kollegiums über verwaltungstechnische und

kommunalpolitische Angelegenheiten

$1889-1893$

Klassifikation Teil B: 00482

Trägermaterial: Papier

Bestell-Nr.: IV 00482

164 Plenarsitzungen des Magistrats und des Bürgervorsteher-Kollegiums

$1894-1910$

- Gemeinsame Beratungen des Magistrats und des

Bürgervorsteher-Kollegiums über verwaltungstechnische und kommunalpolitische Angelegenheiten

$1894-1910$

Klassifikation Teil B: 00483

Trägermaterial: Papier

Bestell-Nr.: IV 00483 
Lfd. Nr. Titel

Laufzeit

165 Plenarsitzungen des Magistrats und des Bürgervorsteher-Kollegiums 1910-1914

- Gemeinsame Beratungen des Magistrats und des Bürgervorsteher-Kollegiums über verwaltungstechnische und kommunalpolitische Angelegenheiten

$1910-1914$

Klassifikation Teil B: 00484

Trägermaterial: Papier

Bestell-Nr.: IV 00484

166 Plenarsitzungen des Magistrats und des Bürgervorsteher-Kollegiums

- Gemeinsame Beratungen des Magistrats und des

Bürgervorsteher-Kollegiums über verwaltungstechnische und kommunalpolitische Angelegenheiten

$1915-1919$

Klassifikation Teil B: 00485

Trägermaterial: Papier

Bestell-Nr.: IV 00485 
Lfd. Nr. Titel

\section{Gerichtsverfassung und Rechtspflege}

167 Aufstellung von Geschworenenlisten

Laufzeit

$1867-1875$

- Auslegung der vom Magistrat der Stadt Emden erstellten Liste der nominierten Geschworenen für das Schwurgericht, Oktober 1867 Oktober 1875

$1867-1875$

Klassifikation Teil B: 00320

Trägermaterial: Papier

Bestell-Nr.: IV 00320

168 Errichtung eines Amtsgerichtsgebäudes mit Gefängnis

- Planung eines neuen Amtsgerichtsgebäudes mit Gefängnis, November 1902

- Verhandlungen über die Finanzierung, Mai 1904

- Verhandlungen zwischen dem preußischen Finanzminister, dem preußischen Justizminister und der Stadt Emden wegen eines

Grundstückes für das projektierte Amtsgerichtsgebäude, Juni 1904 -

Oktober 1906

- Verhandlungen zwischen der Stadt Emden und den Auktionatoren Georg Schmidt und Anton Meyer wegen Erwerbung eines Grundstückes für das geplante Amtsgerichtsgebäude, 1904 - 1905

$1902-1906$

Klassifikation Teil B: 00382

Band: 1

Trägermaterial: Papier

Alte Reg.-Sig.: III Bc 34

Bestell-Nr.: IV 00382 
Lfd. Nr. Titel

- Verhandlungen zwischen dem preußischen Justizminister, dem preußischen Minister für öffentliche Arbeiten und der Stadt Emden wegen des Neubaus des Amtsgerichtsgebäudes in Emden, März Juni 1907

- Beschluss des Bürgervorsteher-Kollegiums über

Zurverfügungsstellung des Bauplatzes gegenüber der Höheren Töchterschule an der Ringstraße für den Gerichtsneubau unter der Bedingung der Aufnahme des Katasteramts in das Gebäude, April 1907

- Anbindung des neuen Amtsgerichtsgebäudes an das Straßennnetz, April 1907 - April 1913

- Planskizze des Amtsgerichtsgebäudes mit Gefängnis, Mai 1907

- Vertrag zwischen dem preußischen Justizminister und der Stadt Emden über Austausch eines Grundstücks gegen ein anderes, in der Ringstraße gelegenes zum Bau des Amtsgerichts, Juni 1907

- Anschluss des neuen Gebäudes an das städtische

Wasserleitungsnetz, Juli - Oktober 1909

- Übernahme der Gaseinrichtungen des alten Amtsgerichtsgebäudes durch die Stadt Emden nach dem Erwerb des alten Gerichtsgebäudes durch die Stadt Emden, Oktober - November 1911

- Einweihungsfeier für das neue Amtsgerichtsgebäude, Juli 1912

- Umbauarbeiten am Amtsgerichtsgebäude zur Unterbringung des Eichamtes, Januar 1912

$1907-1913$

Klassifikation Teil B: 00383

Band: 2

Trägermaterial: Papier

Alte Reg.-Sig.: III Bb 04

Bestell-Nr.: IV 00383

170 Anstellung von Rechtsanwälten

- Initiative des Kaufmanns Friedrich Graepel für die Zulassung von mehr Anwälten wegen Mangel an Rechtsanwälten in Emden und dadurch verursachte Beeinträchtigung von Prozessen, August 1876 März 1877

- Absicht des Amtsgerichtsrats A. Schmidt zur Niederlassung als Rechtsanwalt und Notar, September 1901

- Absicht des Rechtsanwalts Mahlmann zur Niederlassung in Emden, Februar - März 1903

- Antrag des Rechtsanwalts Mahlmann auf Zulassung als Notar, Juni 1904

$1876-1904$

Klassifikation Teil B: 00384

Trägermaterial: Papier

Alte Reg.-Sig.: III Bb 22

Bestell-Nr.: IV 00384 
IV

03

03.01 Gerichtsverfassung und Rechtspflege

Lfd. Nr. Titel

Laufzeit

171 Gebühren und Reisekosten für Zeugen und Sachverständige in Strafsachen

1868-1904

- Verfügung des preußischen Landdrosten in Aurich über Festsetzung der Reisekosten-Entschädigung für den Emder Polizeikommissar Lubich, Juli 1868

- Regelung der Entschädigungsgebühren für Zeugen, 1869 - 1904

$1868-1904$

Klassifikation Teil B: 00385

Trägermaterial: Papier

Alte Reg.-Sig.: III Bb 13

Bestell-Nr.: IV 00385

172 Strafgesetzbuch

- Einführung und Umsetzung des Strafgesetzbuches für das Deutsche Reich, 1874 - 1913

- Verweigerung der Annahme einer festgenommenen Obdachlosen durch den Wärter des Amtsgerichtsgefängnisses wegen fehlenden Haftbefehl infolge der Abwesenheit des Untersuchungsrichters, Januar 1893

- Stellungnahme der Polizeibehörde der Stadt Emden für eine Amnestierung des wegen Diebstahls zu drei Tagen Haft verurteilten Zimmerlehrlings Theodor Veltjes, September 1899

$1874-1913$

Klassifikation Teil B: 00386

Trägermaterial: Papier

Alte Reg.-Sig.: III Bb 23

Bestell-Nr.: IV 00386

173 Ausstellung von Zeugnissen zur Erlangung des Armenrechts

$1868-1913$

(1859)

- Gesetzliche Regelungen und Ministerialerlasse zur Ausstellung von Zeugnissen zur Erlangung des Armenrechts, (1859) 1868 - 1913 - Verfügungen des Regierungspräsidenten in Aurich über Anordnung einer strengen Prüfung der Kriterien vor Ausstellung von Zeugnissen zur Erlangung des Armenrechts, 1887 - 1889

- Verfügung des Magistrats an die Bezirksvorsteher über Anordnung der Prüfung der Zahlungsfähigkeit der Armenrechtsantragsteller bei Beleidigungsprozessen hinsichtlich der Gerichtsgebühren, Januar 1900

(1859) 1868 - 1913

Klassifikation Teil B: 01672

Trägermaterial: Papier

Alte Reg.-Sig.: IV Qu 12

Bestell-Nr.: IV 01672 
04

IV

Beziehungen der Stadt Emden zur Landesherrschaft und zu übergeordneten Landes- und Reichsorganen

04.01 Regierendes Königshaus

04.01.01

Huldigung und Landestrauer

Lfd. Nr. Titel

Laufzeit

174 Annektion des Königreichs Hannover durch Preußen 1866

- Initiative des Bürgervorsteher-Kollegiums zur öffentlichen Kundgebung zugunsten des preußischen Königs als Zeichen der Dankbarkeit für die Rückkehr Emdens uind Ostfrieslands nach Preußen, August 1866

- Beschluss der städtischen Kollegien über Beflaggung Emdens anlässlich des Übergangs nach Preußen und zur Entsendung einer Delegation nach Berlin zum Ausdruck des Dankes für das Ende der Hannoverschen Herrschaft, August 1866

- Emder Delegation zur Audienz beim preußischen König Wilhelm I., September 1866

1866

Klassifikation Teil B: 00353

Trägermaterial: Papier

Alte Reg.-Sig.: III Aa 09

Bestell-Nr.: IV 00353 
IV

04

Beziehungen der Stadt Emden zur Landesherrschaft und zu übergeordneten Landes- und Reichsorganen

04.01 Regierendes Königshaus

04.01 .02

Reisen des Königs und seiner Familie

Lfd. Nr. Titel

Laufzeit

175 Besuch des preußischen Königs Wilhelm I. in Emden

- Reiseplan des Königs durch die von Preußen annektierten

Provenzen Hannover, Westfalen und Hessen-Nassau, Mai - Juni 1869

- Organisation des Empfangs des Königs in Emden, Unterbringung

des Trosses und Verpflegung, Mai 1869

- Verfügung des Oberpräsidenten der Provinz Hannover über

Aufgaben der Landdrostei und anderer Obrigkeiten im Rahmen der

Reise des Königs Wilhelm I. durch die Provinz Hannover, Mai 1869

- Abstimmung zwischen dem Magistrat der Stadt Emden und der preußischen Garnison in Emden über die Aufgaben beim Empfang des Königs Wilhelm I., Mai 1869

- Verschiebung des Besuches des Königs wegen Unpässlichkeit, Mai 1869

- Abschrift der Berichte der "Ostfriesischen Zeitung" zum Besuch des Königs Wilhelm I. in Emden und Ostfriesland, Juni 1869

- Ausgaben für den Königsbesuch, Juni 1869

1869

Klassifikation Teil B: 00341

Trägermaterial: Papier

Alte Reg.-Sig.: III Ab 06

Bestell-Nr.: IV 00341

176 Geplanter Besuch des Kaisers Wilhelm II. in Emden

1900-1901

- Schutz des Kaisers während seines geplanten Besuches in Emden, 1900 - 1901 (Juni 1902)

- Einladungen der Stadt Emden zur Einweihung des Außenhafens und zur Enthüllungsfeier der Denkmäler des Großen Kurfürsten und

Friedrichs d. Großen, Juli 1901

- Rundschreiben der Emder Polizeiverwaltung wegen Anarchisten, Juni 1901

- Verteilung de Polizeikräfte während des geplanten Kaiserbesuchs, Juli 1901

- Programm der Einweihungsfeier des Emder Außenhafens, August 1901

- Material zu Denkmalsenthüllungen und Kaiserempfängen in anderen Städten, 1900

$1900-1901(1902)$

Klassifikation Teil B: 00342

Band: 1

Trägermaterial: Papier

Alte Reg.-Sig.: III Ab 09

Bestell-Nr.: IV 00342 
IV

04

Beziehungen der Stadt Emden zur Landesherrschaft und zu übergeordneten Landes- und Reichsorganen

04.01 Regierendes Königshaus

04.01.02

Reisen des Königs und seiner Familie

Lfd. Nr. Titel

Laufzeit

177 Besuch Kaiser Wilhelm II. in Emden

1902-1903

- Korrespondenz der Stadt Emden mit dem Baurat Grunert und dem

Architekten Milde in Berlin über die Anfertigung eines Monuments der Rede des Kaisers Wilhelm II. während seines Besuchs in Emden, 1902 - 1903

$1902-1903$

Klassifikation Teil B: 00343

Trägermaterial: Papier Alte Reg.-Sig.: III Ab 10

Bestell-Nr.: IV 00343

178 Besuch Kaiser Wilhelm II. in Emden

- Anschaffung eines von Grete Waldau in Berlin geschaffenen

Wandgemäldes vom Besuch des Kaisers Wilhelm II. in Emden, 1915

$-1919$

$1915-1919$

Klassifikation Teil B: 00344

Trägermaterial: Papier

Alte Reg.-Sig.: III Ab 10

Bestell-Nr.: IV 00344

179 Besuch Kaiser Wilhelm II. in Emden

1902

- Einladungskarten, Eintrittskarten, Speiseplan

1902

Klassifikation Teil B: 00345

Trägermaterial: Papier

Alte Reg.-Sig.: III Ab 11

Bestell-Nr.: IV 00345

180 Geplanter Besuch des Kaisers Wilhelm II. in Emden

1900-1901

- Festschrift des Geheimrats Carl Schweckendieck zur Geschichte des Emder Hafens anlässlich des geplanten Besuches des Kaisers

Wilhelm II. in Emden, 1900 - 1901

- Materialien für die Festschrift

- Subscription der Festschrift, 1901

$1900-1901$ (1906 - 1909)

Klassifikation Teil B: 00358

Band: 2

Trägermaterial: Papier

Alte Reg.-Sig.: III Ab 09

Bestell-Nr.: IV 00358 
04.01

Lfd. Nr. Titel

181 Geplanter Besuch des Kaisers Wilhelm II. in Emden

- Einräumung des Festsaals im Tivoli für das Festessen anlässlich des Kaiserbesuches durch den Innungsausschuss der Stadt Emden, Juli 1901

- Programm der Einweihungsfeier für den Emder Außenhafen und der Enthüllung der Standbilder im Stadtgarten unter Anwesenheit des Kaisers Wilhelm II., August 1901

- Entwürfe verschiedener Tafeln für historische Gebäude der Stadt Emden, Juli 1901

- Dekorationsarbeiten: Angebote, Durchführung und Kosten, Juli 1901

- Entwurf der neuen Deckendekoration im Rathaus-Vorraum, Juli 1901

- Verschiedene Schreiben über Bedauern wegen der Absage des Kaiserbesuchs, Reaktionen auf Einladungen und Glückwünsche zur Hafeneinweihung, August - September 1901

- Kostenaufstellungen zum agesagten Kaiserbesuch; u.a. 986,80 Mk. für das Goldene Buch der Stadt Emden, August - September 1902 - Revision der Rechnungen durch die Finanzkommission für den Kaiserbesuch, Oktober 1901

- Bewilligung einer Abschlagszahlung über 9000 Mk für die Firmen Heio von Norden und Otto Fischer Sohn in Berlin für Dekorationen anlässlich des geplatzten Kaiserbesuches, September 1901

Klassifikation Teil B: 00359

Band: 3

Trägermaterial: Papier

Alte Reg.-Sig.: III Ab 09

Bestell-Nr.: IV 00359 
04.01

Lfd. Nr. Titel

- Erörterungen der Planung für einen in Aussicht gestellten Besuch des Kaisers Wilhelm II. in Emden anlässlich der Eröffnung des Dortmund-Ems-Kanals, November 1897

- Planungen zur Ausschmückung des Rathauses anlässlich des in Aussicht stehenden Kaiserbesuches, November 1897

- Erörterungen der Planung für einen in Aussicht gestellten Besuch des Kaisers Wilhelm II. in Emden anlässlich der Einweihung des Emder Außenhafens, Mai 1900 - Juli 1901

- Einladung des Kaisers zum Besuch der Stadt Emden anlässlich der Einweihung des Außenhafens, Juni - Dezember 1900

- Festlegung des Kaiserbesuches auf den 9. August 1901, Juni 1901

- Angebot der Buchdruckerei Schwalbe wegen Herausgabe einer Festschrift zum Kaiserbesuch, Juli 1901

- Vorverlegung des Kaiserbesuches auf den 7. August 1901, Juli 1901

- Telegraphische Absage des Kaiserbesuches wegen Krankheit der Kaisermutter Viktoria, 3. August 1901

- Absage aller Feiern in Emden wegen Staatstrauer wegen Tod der Kaisermutter, 5. August 1901

- Verschiedene Artikel über die neuen Hafenanlagen, Juli 1901

$1897-1901$

Klassifikation Teil B: 00360

Band: 4

Trägermaterial: Papier

Alte Reg.-Sig.: III Ab 09

Bestell-Nr.: IV 00360

183 Besuch des Kaisers Wilhelm II. in Emden am 30. Juli 1902

- Einladungen der Stadt Emden zu den Veranstaltungen anlässlich des Kaiserbesuches, Juni - Juli 1902

- Bildung einer Einladungs-Commission zur Koordinierung der Platzreservierungen und der Unterbringung der Gäste, Juni 1902 - Schreiben über Zusagen oder Absagen der Einladungen zum Kaiserbesuch, Juli 1902

1902

Klassifikation Teil B: 00361

Band: 5

Trägermaterial: Papier

Alte Reg.-Sig.: III Ab 10

Bestell-Nr.: IV 00361 
04

IV

Beziehungen der Stadt Emden zur Landesherrschaft und zu übergeordneten Landes- und Reichsorganen

04.01 Regierendes Königshaus

04.01.02

Reisen des Königs und seiner Familie

Lfd. Nr. Titel

Laufzeit

184 Besuch des Kaisers Wilhelm II. in Emden am 30. Juli 1902

- Bildung einer Bau-Commission und einer Aufstellungs-Commission zur Koordinierung der Bau- und Dekorationsmaßnahmen anlässlich des Kaiserbesuches, Juni 1902

- Ausschreibung des Baus und Bau der Ehrentribüne, Juni 1902

- Durchführung und Kosten der Straßenausschmückung anlässlich des Kaiserbesuches, Juli 1902

- Antrag der Ausschmückungskommission für den 1. und 2. Bezirk der 3. Wyk auf Beihilfe durch die Stadt Emden zur Ausschmückung der Straßen, Juli 1902

1902

Klassifikation Teil B: 00362

Band: 6

Trägermaterial: Papier

Alte Reg.-Sig.: III Ab 10

Bestell-Nr.: IV 00362

185 Besuch des Kaisers Wilhelm II. in Emden am 30. Juli 1902

- Drucksachen zum Kaiserbesuch, Juni 1902

- Verteilung der Durchlasskarten zu den Besuchsstationen, Juli 1902

- Eintrittskarten zu den Besuchsstationen, Juli 1902

- Presseberichte zum Kaiserbesuch, August 1902

1902

Klassifikation Teil B: 00363

Band: 7

Trägermaterial: Papier

Alte Reg.-Sig.: III Ab 10

Bestell-Nr.: IV 00363 
04.01

Lfd. Nr. Titel

186 Besuch des Kaisers Wilhelm II. in Emden am 30. Juli 1902

- Schreiben des Oberhofmarschalls des Kaisers Wilhelm II. an den Magistrat der Stadt Emden über eventuellen Besuch des Kaisers Ende Juli / Anfang August in Emden, Mai 1902

- Bildfung von Kommissionen zur Organisation der Festlichkeiten anlässlich des Kaiserbesuches, Juni 1902

- Programm des Kaiserbesuches, Juli 1902

- Bekanntmachung über Sperrung von Wasserstraßen und

Verkehrswegen anlässlich des Kaiserbesuches, Juli 1902

- Presseberichte über Vorbereitungen des Kaiserbesuches und zum

Kaisserbesuch, Juli - August 1902

- Antrag der Hamburg-Amerika- Linie (HAPAG), auf Erlass der Hafengebühren für einen zur Repräsentation der Reederei nach Emden anlässlich des Kaiserbesuchs entsandten Dampfers, Juli 1902 - Bildung einer Ehrenkompanie für den Kaiser aus der geretteten Mannschaft des Torpedobootes "S 42", Juli 1902

- Antrag des Fotographen Rudolf Rothe und der Familie Souade auf Erlaubnis zum Verkauf von Bildern des Kaisers Wilhelm II. und seiner Familie während des Kaiserbesuches, Juli 1902

- Verzeichnis der im Rathaus anlässlich des Kaiserbesuches auszustellenden Urkunden zur Stadtgeschichte, Juli 1902

- Rede des Oberbürgermeisters Leo Fürbringer bei der Enthüllung der Standbilder des Großen Kürfürsten, des Königs Friedrich II. und des Kaisers Wilhelm I. in Anwesenheit des Kaisers Wilhelm II. und bei der Begrüßung des Kaisers im Rathaus, Juli 1902

- Danktelegramm des Magistrats der Stadt Emden an den Kaiser wegen seines Besuchs, Juli 1902

- Kritik des ostfriesischen Sängerbundes wegen der Unmöglichkeit seiner Mitwirkung beim Kaiserbesuch, August 1902

- Bericht über Einfahrt des Kaisers Wilhelm II. mit der Yacht "SMS Hohenzollern" in die Ems, August 1902

1902

Klassifikation Teil B: 00364

Band: 8

Trägermaterial: Papier

Alte Reg.-Sig.: III Ab 10

Bestell-Nr.: IV 00364 
04.01

Lfd. Nr. Titel

- Prägung einer Erinnerungsmedaille anlässlich des Kaiserbesuches, September 1901 - Dezember 1902

- Vorlage des Oberbürgermeisters Leo Fürbringer an das Bürgervorsteher-Kollegium über Bitte um Zustimmung zur Verwendung einer Erinnerungsmedaille zum Kaiserbesuch als Geschenk zur Einweihung des Schulneubaus der Lutherischen Gemeinde, August 1902

- Überreichung von Erinnerungsmedaillen an die Mitglieder des Bürgervorsteher-Kollegiums, August 1902

- Überreichung von Erinnerungsmedaillen an verschiedene

Persönlichkeiten, August 1902 - Oktober 1913

$1901-1913$

Klassifikation Teil B: 00365

Band: 9

Trägermaterial: Papier

Alte Reg.-Sig.: III Ab 10

Bestell-Nr.: IV 00365

188 Teilnahme des Oberrbürgermeisters Leo Fürbringer an den

Feierlichkeiten anlässlich des Besuches des Kaisers Wilhelm II. in Hannover

- Einladung an den Oberbürgermeister Leo Fürbringer zum vom Provinziallandtag zu Ehren des Kaisers veranstalteten Festmahl, Juni 1898

- Einladung an den Oberbürgermeister Leo Fürbringer zur kgl. Tafel anlässlich des Kaiserbesuches in Hannover, August 1898

- Einladung an den Oberbürgermeister Leo Fürbringer zur

Galavorstellung im kgl. Theater in Hannover, August 1898

- Speiseplan und Musik bei der kgl. Mittagstafel, September 1898

- Feierliche Kaiserparade in Hannover, September 1898

- Speisen- und Musikfolge beim Festmahl des Provinziallandtags zu Ehren des Kaisers und seiner Gemahlin Auguste Viktoria, September 1898

- Sitzordnung mit Platzierung des Oberbürgermeisters Leo Fürbringer, September 1898

- Presseberichte zum Kaiserbesuch in Hannover, September 1898

1898

Klassifikation Teil B: 00366

Trägermaterial: Papier

Alte Reg.-Sig.: III Ab 08

Bestell-Nr.: IV 00366 
04.01

Lfd. Nr. Titel

Laufzeit

189 Besuche von Mitglieder der königlichen und kaiserlichen Familie in Emden

- Organisation der Feierlichkeiten anlässlich des Besuches des Prinzen Adalbert von Preußen in Emden, September 1866 - Januar 1867

- Verhandlungen im Magistrat der Stadt Emden über eine Einladung des Kronprinzen Friedrich Wilhelm von Preußen zum Besuch Emdens, Juni - Juli 1867

- Verhandlungen im Magistrat der Stadt Emden über eine Einladung des Königs Wilhelm von Preußen zum Besuch Emdens, Juni 1868

- Einladung des Königs Wilhelm I. durch die Stadt Emden, Juni 1868

$1866-1868$

Klassifikation Teil B: 00367

Band: 1

Trägermaterial: Papier

Alte Reg.-Sig.: III Ab 05

Bestell-Nr.: IV 00367

190 Besuche von Mitglieder der königlichen und kaiserlichen Familie in

$1874-1911$

- Anzeige des Kommandanten der Garnison in Emden über Aufenthalt des Prinzen Albrecht von Preußen zur Besichtigung des Bataillons in

Emden, Mai 1874 - Mai 1887

- Reglement wegen der Bestimmungen zum Verhalten der

Zivilbehörden bei Reisen des Kaisers und seiner Familienmitglieder,

August 1879

- Empfang der Kronprinzesin Auguste Viktoria bei ihrer Station in

Emden, August 1882

- Erlass des preußischen Innenministers über vorgeschriebene Garderobe beim Empfang des Kaisers vor Führungen durch Museen etc., April 1890

- Anzeigen über Durchreise von Mitgliedern der königlichen und kaiserlichen Familie durch Emden, 1885 - 1911

- Erlass des Ministers für öffentliche Arbeiten über Verkehrsbeschränkungen bei Reisen der kaiserlichen Familie, August 1890

- Novellierung der Bestimmungen zum Verhalten der Zivilbehörden bei Reisen des Kaisers und seiner Familienmitglieder, August 1896 - Gratulation der Stadt Emden an den Admiral Prinz Heinrich von Preußen anlässlich seines 25-jährigen Dienstjubiläums bei der kaiserlichen Marine, April 1902

- Ankündigung des Besuches des Admirals Prinz Heinrich von Preußen in Emden zur Besichtigung der neuen Hafenanlagen, Juli 1902

$1874-1911$

Klassifikation Teil B: 00368

Band: 2

Trägermaterial: Papier

Alte Reg.-Sig.: III Ab 07

Bestell-Nr.: IV 00368 
IV

04

Beziehungen der Stadt Emden zur Landesherrschaft und zu übergeordneten Landes- und Reichsorganen

04.01 Regierendes Königshaus

04.01 .03 Nationale Gedenktage und Symbole

Lfd. Nr. Titel

Laufzeit

1913

(1926)

brandenburgischen Festung Großfriedrichsburg (Guinea) an die Stadt

Emden durch Kaiser Wilhelm II.

- Bescheid des Staatssekretärs im Reichsmarineamt über Ankündigung des Transports der zwei der Stadt Emden vom Kaiser geschenkten Kanonen der ehemaligen brandenburgischen Festung Großfriedrichsburg, Juni 1913

- Berichte über Geschenk des Kaisers Wilhelm II. an die Stadt Emden, Juli 1913

1913
Klassifikation Teil B: 00029
Trägermaterial: Papier
Bestell-Nr.: IV 00029

192 Hof- und Staatshandbuch

- Mitteilungen der Daten zur Verwaltung und Gremien der Stadt

Emden für das Hof- und Staatshandbuch des Kgr. Hannover und des Kgr. Preußen, 1823 - 1914

$1823-1914$

Klassifikation Teil B: 00036

Trägermaterial: Papier

Alte Reg.-Sig.: IV C 25

Bestell-Nr.: IV 00036 
IV

04

Beziehungen der Stadt Emden zur Landesherrschaft und zu übergeordneten Landes- und Reichsorganen

04.01 Regierendes Königshaus

04.01 .03 Nationale Gedenktage und Symbole

Lfd. Nr. Titel

Laufzeit

193 Errichtung eines Kaiserstandbildes

- Verhandlungen im Magistrat über Errichtung eines Kriegerdenkmals in Emden, März 1876

- Verhandlungen des Komitees für das Kaiserstandbild über Finanzierung und Ausführung des Projektes eines Standbildes des preußischen Königs und deutschen Kaisers Wilhelm I. in Emden, 1879

- Vertrag der Gesellschaft für bildende Kunst und vaterländische Altertümer und dem Bildhauer Heinz Hoffmeister in Berlin über Anfertigung eines Standbildes des Kaisers Wilhelm I., März 1879 - Eingabe des Komitees für das Kaiserstandbild an den Magistrat der Stadt Emden über Bitte um eine Beihilfe zu dem Projekt, April 1879

- Spendenaufruf für das Standbild, 1879

- Verhandlungen der städtischen Kollegien über teilweise Realisierung des Standbildprojekts durch die Stadt Emden, Mai 1879

- Supplication des Magistrats und des Bürgevorsteherkollegiums der Stadt Emden an den preußischen König und deutschen Kaiser Wilhelm I über Bitte um Genehmigung des geplanten Standbildes als Huldigung an die Person Wilhelm I. anlässlich seiner silbernen Hochzeit, Mai 1879

- Bescheid des Ministers für Geistliche, Unterrichts- und Medizinalangelegenheiten über Ablehnung des Standbildes durch Wilhelm I. während seiner Lebenszeit, Mai 1879

- Entschädigung des Bildhauers H. Hoffmeister, Juli 1879 - Februasr 1880

$1879-1880$

Klassifikation Teil B: 00348

Trägermaterial: Papier

Alte Reg.-Sig.: III Ad 3

Bestell-Nr.: IV 00348 
04.01

Lfd. Nr. Titel

Laufzeit

194 Errichtung eines Kaiserstandbildes 1888-1902

- Angebote verschiedener Firmen und Künstler für die Erstellung eines Standbildes des Kaisers Wilhelm I., März 1888 - Dezember 1896 - Supplication der Städtischen Kollegien an den Kaiser Wilhelm II. über Bitte um Genehmigung eines Standbildes seines verstorbenen Großvaters Wilhelm I., Mai 1888

- Konstituierung einer Denkmalskommission in Emden, November 1894

- Vertrag zwischen der Stadt Emden und dem Bildhauer Georg Küsthardt über Herstellung des Standbildes des Kaisers Wilhelm I., November - Dezember 1894

- Korrespondenz mit Georg Küsthardt wegen Fertigung des

Standbildes, Dezember - November 1896

- Umgestaltung des Gebiets an der Rathausbrücke für das Standbild (Stadtgarten), 1894 - 1895

- Kostenaufstellung: Fundament des Reiterstandbildes des Kaisers

Wilhelm I., März 1896

- Erlass des preußischen Innenministers über grundsätzliche

Genehmigung von Kaiserstandbildern durch den Kaiser, Juni 1897

- Erlass des Ministers für geistliche Unterrichts- und

Medizinalangewlegenheiten über Auflagen für Material und Gestaltung von Kaiserstandbildern, Januar 1902

$1896-1902$

Klassifikation Teil B: 00349

Trägermaterial: Papier

Alte Reg.-Sig.: III Ad 3

Bestell-Nr.: IV 00349

195 Kaisertage in Hannover

- Teilnahme des Oberbürgermeisters Leo Fürbringer an den Kaisertagen in Hannover

1907

Klassifikation Teil B: 00350

Trägermaterial: Papier Alte Reg.-Sig.: III Ab 11

Bestell-Nr.: IV 00350 
04.01

Lfd. Nr. Titel

Laufzeit

196 Silberne Hochzeit des Kaiserpaars Wilhelm II. und Auguste Viktoria

1903-1906

- Erlass des Oberpräsidenten der Provinz Hannover über geplante Sammlungen für wohltätige und kulturelle Zwecke anlässlich der silbernen Hochzeit des Kaiserpaars, März 1903 - März 1904

- Spendenliste der Stadt Emden, Mai 1904

- Erlass des preußischen Innenministers über Geschenke für das

Kaiserpaars anlässlich seiner silbernen Hochzeit, August 1905

- Erlass des preußischen Innernministers über

Glückwunschdeputationen zur Silberhochzeit des Kaiserpaars, Januar 1906

- Schulfrei anlässlich der Silberhochzeit des Kaiserpaars, Januar 1906

- Feier des Tages in Emden, Februar 1906

$1903-1906$

Klassifikation Teil B: 00351

Trägermaterial: Papier

Alte Reg.-Sig.: III Aa 17

Bestell-Nr.: IV 00351

197 Hochzeitsgabe für Friedrich Wilhelm, Kronprinz des deutschen Reiches und Cäcilie, Herzogin von Mecklenburg

- Planungen des Landesdirektoriums für ein Geschenk der hannoverschen Städte an das kgl. Brautpaar, Oktober - November 1904

- Initiative der Städte Naumburg / Saale und Lüneburg für ein gemeinsames Geschenk der preußischen Städte an das kgl. Brautpaar, November - Dezember 1904

1904

Klassifikation Teil B: 00352

Trägermaterial: Papier

Alte Reg.-Sig.: III Aa 19

Bestell-Nr.: IV 00352

198 25-jähriges Regierungsjubiläum des Kaisers Wilhelm II.

- Spendenaufrufe von Stiftungen für wohltätige Zwecke anlässlich des Regierungsjubiläums des Königs und Kaisers Wilhelm II., April 1913 - Angebote über Festschriften und Utensilien für Fackelumzüge, Festcommerse etc., 1913

- Erlass des preußischen Mini sters für geistliche, Unterrichts- und Medizinalangelegenheiten über Abhaltung von Schulfeiern zum Regierungsjubiläum des Kaisers, April 1913

- Programm des Bürgerschaftskommerses der Stadt Emden zum Regierungsjubiläum des Kaisers, Juni 1913

- Organisation des Festumzuges zum kaiserlichen

Regierungsjubiläum in Emden, Juni 1913

1913

Klassifikation Teil B: 00354

Trägermaterial: Papier

Alte Reg.-Sig.: III Aa 20

Bestell-Nr.: IV 00354 
04.01

Lfd. Nr. Titel

199 Geburtstag des Kaisers Wilhelm II.

- Erlass des kommandierenden Generals des X. Armeekorps über Weisung zur festlichen Begehung des Kaisergeburtstags, Januar 1917 / Januar 1918

- Organisation der Feier in Emden, Januar 1917 / Jamuar 1918

$1917-1918$

Klassifikation Teil B: 00355

Trägermaterial: Papier Alte Reg.-Sig.: III Aa 16

Bestell-Nr.: IV 00355

- Erlasse des preußischen Ministers für Handel und Gewerbe sowie des preußischen Innenministers über Empfehlung an alle Behörden zur Anschaffung des Werkes von Otto Hintze "Die Hohenzollern und inr Werk", September - Oktober 1915

- Beflaggung des Emder Rathauses anlässlich des

Regierungsjubiläums, Oktober 1915

- Glückwunschtelegramm der Stadt Emden an den Kaiser Wilhelm II. anlässlich des Regierungsjubiläums der Hohenzollern-Dynastie, Oktober 1915

1915

\author{
Klassifikation Teil B: 00369 \\ Trägermaterial: Papier \\ Alte Reg.-Sig.: III Aa 22 \\ Bestell-Nr.: IV 00369
}

201 Gedenktag der 25 jährigen Wiederkehr der Wiederzugehörigkeit Ostfrieslands zu Preußen

- Initiative des Kaufmanns C. Dantziger zur Abhaltung einer offiziellen Feier zum Gedenken der Rückkehr Ostfrieslands nach Preußen 1866, August 1891

- Ergebenheitstelegramm der Stadt Emden an den Kaiser Wilhelm II. anlässlich der 25 jährigen Wiederkehr der Wiederzugehörigkeit Ostfrieslands zu Preußen, Oktober 1891

1891

Klassifikation Teil B: 00370

Trägermaterial: Papier

Alte Reg.-Sig.: III Aa 15

Bestell-Nr.: IV 00370 
IV

04

Beziehungen der Stadt Emden zur Landesherrschaft und zu übergeordneten Landes- und Reichsorganen

04.01 Regierendes Königshaus

04.01 .03

Nationale Gedenktage und Symbole

Lfd. Nr. Titel

Laufzeit

202 Denkmal für Kaiser Wilhelm I.

- Protokolle der Verhandlungen der Kommission zur Errichtung einer Kaiser-Denkmals wegen Planung und Errichtung eines Denkmals für Kaiser Wilhelm I., 1895 - 1899

- Einladung zur Enthüllungsfeier für das Kaiser-Denkmal, Mai - Juni 1896

- Zu- und Absagen der Eingeladenen, Juni 1896

- Programm der Enthüllungsfeier und der Veranstaltung des

Kriegertages des ostfriesischen Kriegervereins, Juni 1896

- Schreiben des Geheimen Oberregierungsrates Carl

Schweckendieck über Dank für den zugesandten Prospekt über die

Enthüllungsfeier, September 1896

1895 - 1899 (1905 - 1906)

Klassifikation Teil B: 00565

Trägermaterial: Papier

Bestell-Nr.: IV 00565 
04.01

Lfd. Nr. Titel

203 Standbilder von Friedrich Wilhelm, des Großen Kurfürsten von

Brandenburg und des preußischen Königs Friedrichs II.

- Gewinnung eines Künstlers für die Standbilder von Friedrich Wilhelm, des Großen Kurfürsten von Brandenburg und des preußischen Königs Friedrichs II., Mai 1900

- Verhandlungen des Oberbürgermeisters Leo Fürbringer mit dem Geheimen Civil-Kabinett des Kaisers Wilhelm II über Vewendung des auf der Weltausstellung in Paris ausgestellten Modells des preußischen Königs Friedrich II. für ein Standbild in Emden, Juni.- Juli 1900

- Finanzierung der Standbilder, Juli 1900

- Angebote verschiedener Firmen zur Herstellung der Standbilder von Friedrich Wilhelm, des Großen Kurfürsten von Brandenburg und des preußischen Königs Friedrichs II., Juli 1900

- Zeichnung des Standbildes des Großen Kurfürsten, September 1900 - Positionierung der Standbilder im Stadtgarten, September November 1900

- Entwurf eines Vertrages zwischen dem Magistrat und den Künstlern Prof. Uphues und Prof. Schaper wegen Konzeptionierung der Standbilder, Oktober 1900

- Anfertigung der Postamente der Standbilder durch die Kunstgewerbliche Werkstätte Gebr. Küsthardt $\mathrm{GmbH}$, Hildesheim, Dezember 1900 - Juli 1901

- Guss des Standbildes des Großen Kurfürsten nach dem Modell von Prof. Schaper durch die AG Bildgießerei Friedrichshagen, Februar April 1901

- Verfügung des Regierungspräsidenten über Genehmigung der Standbilder durch den Kaiser, Februar 1901

- Ausschreibung des Baues der Fundamente der Standbilder, Februar 1901

- Planung der Enthüllungsfeier der Denkmäler, Juli - August 1901

- Kritik des Geschichtsschreibers Onno Klopp an der Verherrlichung des preußischen Königs Friedrich II. durch das Standbild in Emden, August 1901

- Abrechnung der Kosten für die Errichtung der Standbilder, August November 1901

$1900-1901$ (1905 - 1912)

Klassifikation Teil B: 02520

Trägermaterial: Papier Alte Reg.-Sig.: III Ad 7

Bestell-Nr.: IV 02520 
04.02

Lfd. Nr. Titel

Laufzeit

204 Wahl der Emder Abgeordneten für den Provinziallandtag $1867-1915$

- Verfügung des preußischen Landdrosten in Aurich über Stellung und Wahl der Kandidaten für den Provinziallandtag aus den Magistraten und Bürgervorstehern der Städte, September 1867

- Protokolle über die Wahl der Provinziallandtagsabgeordneten der Stadt Emden, September 1867 - Oktober 1915

- Reglement für die Provinziallandtagswahlen, 1870 - 1884

- Verfügung des preußischen Landdrosten in Aurich über kurzfristige

Einberufung der städtischen Kollegien in Emden zur Wahl eines

Provinziallandtagsabgeordneten, März 1885

- Verfügung des Oberpräsidenten der Provinz Hannover über Verfahren zur Wahl der Provinziallandtagsabgeordneten, Juli 1885 Mai 1903

- Eröffnung eines Provinzialmuseums in Hannover, Februar 1902

- Dank des Magistrats der Stadt Emden an den pensionierten Oberbürgermeister Leo Fürbringer nach dessen Niederlegung des Mandats als Provinziallandtagsabgeordneter, Januar 1914

$1867-1915$

Klassifikation Teil B: 00371

Trägermaterial: Papier Alte Reg.-Sig.: III Be 1

Bestell-Nr.: IV 00371

205 Ersatzwahl eines Landtagsabgeordneten

- Verfügung des Regierungspräsidenten in Aurich über Ersatzwahl nach der Mandatsrückgabe des bisherigen Landtagsabgeordneten, Amtsgerichtsrat Meyer, Dezember 1902

- Aufstellung von Wählerlisten für die Stadt Emden, Dezember 1902

- Aufstellung der Wahlvorsteher in Emden, Dezember 1902

- Verfügung des Regierungspräsidenten in Aurich zur Wahl des Landtagsabgeordneten in einer Wahlmännerversammlung, Januar 1903

$1902-1903$

Klassifikation Teil B: 00380

Trägermaterial: Papier

Alte Reg.-Sig.: II Bc 35

Bestell-Nr.: IV 00380 
04

04.02

04.02 .02
IV

Beziehungen der Stadt Emden zur Landesherrschaft und zu übergeordneten Landes- und Reichsorganen

Landesparlamente und - Institutionen

Ostfriesische Landschaft

Lfd. Nr. Titel

Laufzeit

206 Bericht des ostfriesischen Landschaftskollegiums 1902

- Gedruckter Bericht des Landschaftskollegiums über Finanzlage und Aktivitäten der ostfriesischen Landschaft, Mai 1902

1902

\author{
Klassifikation Teil B: 00372 \\ Trägermaterial: Papier \\ Alte Reg.-Sig.: III Bd 18 \\ Bestell-Nr.: IV 00372
}

207 Ostfriesische Landschaft

1867-1877

- Berichte über Revision der landschaftlichen Kassen, April 1867 - Mai

1870

- Protokoll der Verhandlungen der ostfriesischen Landschaft, Mai 1869

- Ladungen zur und Tagesordnung der Landschaftsversammlung, Mai 1867 - Mai 1870

- Bestellung der Deputierten der Stadt Emden für die ostfriesische Landschaftsversammlung, April 1870

- Vollmacht für die Emder Deputierte bei der

Landschaftsversammlung, Mai 1876 - Mai 1877

- Finanzielle Unterstützung für die Ostfriesische Sparkasse und die ostfriesische Landschaft, März 1907

1867 - 1877 (1909)

Klassifikation Teil B: 00374

Trägermaterial: Papier

Alte Reg.-Sig.: III Bd 18

Bestell-Nr.: IV 00374

208 Ostfriesische Landschaft

- Gedruckter Bericht des Landschaftskollegiums über Finanzlage und Aktivitäten der Landschaft, Mai 1909

- Jahresbericht der Ostfriesischen Landschaftlichen Brandkasse, 1910

Klassifikation Teil B: 00375

Trägermaterial: Papier

Alte Reg.-Sig.: III Bd 18

Bestell-Nr.: IV 00375 
04

\section{IV}

Beziehungen der Stadt Emden zur Landesherrschaft und zu übergeordneten Landes- und Reichsorganen

04.02

04.02 .02

Landesparlamente und - Institutionen

Ostfriesische Landschaft

Lfd. Nr. Titel

Laufzeit

209 Gesetze und Verordnungen für Ostfriesland

- Verfügung des Regierungspräsidenten in Aurich über

Zusammenstellung einer Sammlung von nur in Ostfriesland gültigen

Gesetzen und Verordnungen, August 1912

- Zusammenstellung spezieller Gesetze für Ostfriesland durch die Stadt Emden, Oktober 1912

1912

Klassifikation Teil B: 00391

Trägermaterial: Papier

Alte Reg.-Sig.: III Bd 19

Bestell-Nr.: IV 00391 
04.02 Landesparlamente und - Institutionen

04.02.03

\section{Kreis Emden}

Lfd. Nr. Titel

Laufzeit

210 Bestellung des Kreishauptmanns für den Kreis Emden

1868-1887

- Verfügung des preußischen Landdrosten in Aurich über

Amtseinführung des Amtmanns von Weyhe als Kreishauptmann des Landkreises Emden, April 1868

- Schreiben des Kreishauptmanns von Weyhe an den Magistrat der Stadt Emden über Bekanntmachung seines Urlaubs und seiner Urlaubsvertretung, Juli 1869

- Verfügung des Oberpräsidenten der Provinz Hannover über Befreiung des Kreishauptmanns vom Wegegeld bei Dienstreisen, März 1870

- Teilnahme des Magistrats und der städtischen Kollegien an der Trauerfeier für den verstorbenen Landrat von Weyhe, August 1887

$1868-1887$

Klassifikation Teil B: 00376

Trägermaterial: Papier

Alte Reg.-Sig.: III Bg 1

Bestell-Nr.: IV 00376

211 Kreisordnung für die Provinz Hannover

$1880-1881$

- Gedruckte Statistiken zu den Landkreisen der Provinz Hannover, 1880

- Verhandlungen zu Petitionen über Verwaltungsreform in Preußen, Januar - Mai 1880

- Gedruckte Eingabe des Ständischen Verwaltungsausschusses und des Landesdirektoriums der Provinz Hannover an den preußischen Innenminister über Bedenken der Hannoverschen Provinzialgremien zur geplanten Kreisordnung, November 1880

$1880-1881$

Klassifikation Teil B: 00377

Trägermaterial: Papier

Alte Reg.-Sig.: III Bf 5

Bestell-Nr.: IV 00377

212 Kreistagswahlen

$1868-1879$

- Erlass des Oberpräsidenten der Provinz Hannover über Zusammentritt der Kreisvertretungen und Vornahme der Kreistagswahlen, August 1868

- Verfügung des preußischen Landdrosten in Aurich über Ungültigkeit von Kreistagswahlen bei Verstoß gegen die Formvorschriften, Oktober 1874

- Verfügung des preußischen Landdrosten in Aurich über Verpflichtung zur Neuwahl des gesamten Kreistages beim Ausscheiden eines Ktreistagsabgeordneten vor dem Ende der Wahlperiode, November 1879

$1868-1879$

Klassifikation Teil B: 00387

Trägermaterial: Papier

Alte Reg.-Sig.: III Bd 01

Bestell-Nr.: IV 00387 
04

IV

Beziehungen der Stadt Emden zur Landesherrschaft und zu übergeordneten Landes- und Reichsorganen

04.02 Landesparlamente und - Institutionen

04.02.04

Preußischer Landtag

Lfd. Nr. Titel

Laufzeit

213 Wahlen zum Abgeordnetenhause (Landtag)

- Erlass des preußischen Innenministers über Vornahme von

Ersatzwahlen zum Landtag bei vorzeitigem Ausscheiden eines Mitgliedes, Februar 1875

- Erlass des preußischen Innenministers über Stellung und Ernennung von Wahlkommissaren, Mai 1875

- Verschiedene Gesetze und Erlasse zur Wahl und Wahlmodus des

Landtags, 1882 - 1912

$1875-1912$

Klassifikation Teil B: 00388

Trägermaterial: Papier

Alte Reg.-Sig.: III Bc 29

Bestell-Nr.: IV 00388

214 Landtagswahlen

$1880-1913$

- Richtlinien zur Durchführung und Organisation der Landtagswahlen, $1890-1913$

$1880-1913$

Klassifikation Teil B: 00389

Trägermaterial: Papier

Alte Reg.-Sig.: III Bc 02

Bestell-Nr.: IV 00389

215 Landtagswahlen

- Erlasse und Bestimmungen zur Landtagswahl, Januar - April 1913

- Abgrenzung der Urwahlbezirke in Emden, März - April 1913

- Wahl der Urwahlmänner, März 1913

- Wahl des pensionierten Oberbürgermeisters und geheimen

Regierungsrats Leo Fürbringer zum Landtagsabgeordneten, Juni 1913

1913

Klassifikation Teil B: 00390

Trägermaterial: Papier

Alte Reg.-Sig.: II Bc 29

Bestell-Nr.: IV 00390 
04.03

Lfd. Nr. Titel

Laufzeit

216 Wahl zur ersten Legislaturperiode des Norddeutschen Reichstages 1866-1867

- Verfügung des preußischen Generalgouverneurs in Hannover über Vorbereitungen und Erstellung der Wählerlisten zur Wahl zum Reichstag des Norddeutschen Bundes, Dezember 1866 - Juli 1867 - Verfügung des Hannoverschen Landdrosten in Aurich über Bildung von Wahlbezirken für die Wahl zum Norddeutschen Reichstag, Auigust - September 1866

- Gesetz über die Wahl zum Reichstag des Norddeutschen Bundes, Oktober 1866

- Bekanntmachung der Auslage der Wählerlisten für die Wahl zum

Reichstag des Norddeutschen Bundes in Emden, Januar 1867

- Liste der wahlberechtigten Soldaten des in Emden stationierten Infanterie-Regiment Nr. 78, Januar 1867

- Widersprüche gegen die Wählerliste, Januar 1867

- Aufstellung über Wahlbezirke der Stadt Emden und deren

Wahlvorstände, Januar 1867

- Gedruckte Wählerliste der Stadt Emden, Januar 1867

- Bekanntmachung der Reichstagswahl, Februar 1867

- Bekanntmachung einer Stichwahl zwischen dem Konsul Ysaac

Brons und Prof. Jhering, Februar 1867

$1866-1867$

Klassifikation Teil B: 00429

Band: 1

Trägermaterial: Papier

Alte Reg.-Sig.: III Eb 1-2

Bestell-Nr.: IV 00429

217 Wahl zum Norddeutschen Reichstag

- Ernennung des Bürgervorstehers $\mathrm{H}$. Tito zum stellvertretenden Wahlleiter des 6. Wahbezirks in Emden, August 1867

- Niederlegung seines Mandat als Abgeordneter des Reichstages des Norddeutschen Bundes durch den Emder Oberbürgermeister Hantelmann, November 1868 - Januar 1869

- Ersatzwahl eines Reichstagsabgeordneten für Emden nach der Mandatsniederlegung durch Oberbürgermeister Hantelmann, Januar 1869

$1867-1869$ Klassifikation Teil B: 00430

Band: 2

Trägermaterial: Papier Alte Reg.-Sig.: îll Ea 3

Bestell-Nr.: IV 00430 
04.03

Lfd. Nr. Titel

- Verfügungen des preußischen Landdrosten in Aurich über Vorbereitungen der und Erstellung der Wählerlisten zur Wahl des 2.

Reichstages des Norddeutschen Bundes, August 1870

- Verfügungen des Regierungspräsidenten in Aurich über

Organisation des Reichstagswahlen, November 1873 - April 1903

- Bekanntmachung der Stadt Emden über Ergebnis der

Reichstagswahlen und Fälligkeit einer Stichwahl wegen fehlender

absoluten Mehrheit eines der drei Kandidaten, März 1871

- Ansetzung von Neuwahlen wegen Auflösung des Reichstages,

November 1876 - Mai 1893

- Wahl des Gutsbesitzers Theodor van Hülst aus Lintel (Norden) zum

Reichstagsabgeordneten des I. Hannoverschen Wahlkreises, Februar 1887

- Wahl des Dr. Theodor von Bart zum Reichstagsabgeordneten des I. Hannoverschen Wahlkreises, Februar 1890

- Wahl des Justizrats Dr. Franzius zum Reichstagsabgeordneten des

I. Hannoverschen Wahlkreises, Juni 1898

- Wahl des Fürsten Edzard von Inn- und Knyphausen zum

Reichstagsabgeordneten des I. Hannoverschen Wahlkreises, Juni 1903

$1870-1903$

Klassifikation Teil B: 00431

Band: 1

Trägermaterial: Papier

Alte Reg.-Sig.: III Ea 3

Bestell-Nr.: IV 00431

219 Wahl der Reichstagsabgeordneten, Bd. 2

- Auflösung des Reichstages und Ausschreibung von Neuwahlen, Dezember 1906

- Verfügung des Regierungspräsidenten in Aurich über Organisation des Reichstagswahlen, Dezember 1906

- Aufstellung über Wahlbezirke und Wahlvorstände in der Stadt

Emden, Januar 1907

- Wahl des Fürsten Edzard von Inn- und Knyphausen zum

Reichstagsabgeordneten des I. Hannoverschen Wahlkreises, Februar 1907

- Ersatzwahl im I. Hannoverschen Wahlkreis, 1908

$1906-1908$

Klassifikation Teil B: 00432

Band: 2

Trägermaterial: Papier

Alte Reg.-Sig.: III Ea 3

Bestell-Nr.: IV 00432 
04.03

\section{Reichstag}

04.03.02

\section{Reichstagswahlen}

Lfd. Nr. Titel

Laufzeit

220 Wahl der Reichstagsabgeordneten, Bd. 3

- Aufstellung über Wahlbezirke, Wahllokale und Wahlvorstände in der Stadt Emden, April 1908

- Wahl des Domänenpächters Jan Fegter zum

Reichstagsabgeordneten des I. Hannoverschen Wahlkreises, April 1908

1908

Klassifikation Teil B: 00433

Band: 3

Trägermaterial: Papier

Alte Reg.-Sig.: III Ea 3

Bestell-Nr.: IV 00433

221 Wahl der Reichstagsabgeordneten, Bd. 4

- Auflösung des Reichstages und Ausschreibung von Neuwahlen, Oktober 1911

- Erlass des preußischen Innenministers über Durchführung der Reichtahswahl, November 1911

- Ernennung des Emder Oberbürgermeisters Leo Fürbringer zum stellvetrenden Wahlleiter des Ersten Hannoverschen Wahlkreises, Dezember 1911

$1911-1912$

Klassifikation Teil B: 00434

Band: 4

Trägermaterial: Papier

Alte Reg.-Sig.: III Ea 3

Bestell-Nr.: IV 00434

222 Wahl der Reichstagsabgeordneten, Bd. 5

- Erlass des preußischen Innenministers über Durchführung der Reichtagswahl, November - Dezember 1911

- Aufstellung über Wahlbezirke und Wahlvorsteher in der Stadt

Emden, Dezember 1911

- Bekanntmachung des Emder Wahlergebnisses, Januar 1912

- Wahl des Domänenpächters Jan Fegter zum

Reichstagsabgeordneten des I. Hannoverschen Wahlkreises, Januar 1912

$1911-1912$

Klassifikation Teil B: 00435

Band: 5

Trägermaterial: Papier

Alte Reg.-Sig.: III Ea 3

Bestell-Nr.: IV 00435 
IV

04

04.04 04.04.01
Beziehungen der Stadt Emden zur Landesherrschaft und zu übergeordneten Landes- und Reichsorganen

Hoheitssachen

Beziehungen der Stadt Emden zum Umland

Lfd. Nr. Titel

Laufzeit

223 Streit zwischen dem Restaurantbesitzer H.B. Aalfs und der Gemeinde Wolthusen wegen Grenzverletzung

- Beschwerde der Gemeinde Wolthusen bei der Stadt Emden gegen den Restaurantbesitzer H.B. Aalfs wegen Grenzverletzung durch die Anlage einer Kegelbahn, Oktober 1904

- Bescheid der Stadt Emden über Nichtzuständigkeit in der Sache, Oktober 1904

- Bescheid der Stadt Emden an den Restaurantbesitzer H.B. Aalfs über Erteilung der Baugenehmigung für die geplante Kegelbahn, November 1904

- Widerspruch der Gemeinde Wolthusen gegen die von Emden erteilte Baugenehmigung bei der Regierung in Aurich, November 1904

1904

Klassifikation Teil B: 00325

Trägermaterial: Papier

Alte Reg.-Sig.: III C 21

Bestell-Nr.: IV 00325

224 Veränderung der Gemeindebezirksgrenze zwischen Emden und Borssum

- Bericht des Katasteramts über Notwendigkeit der Grenzkorrektur wegen Anlegung einer Schleuse und Anlage eines neuen

Entwässerungsgrabens für den Königspolder, Dezember 1892 - Juni 1893

- Regulierung der Grenze zwischen Emden und Borssum wegen Anlage eines Vorflutkanals, August 1898 - Mai 1899

$1892-1899$

Klassifikation Teil B: 00326

Trägermaterial: Papier

Alte Reg.-Sig.: III C 10

Bestell-Nr.: IV 00326

225 Grenzkorrektur: Stadt Emden - Gemeinde Wolthusen

- Umgemeindung einer Parzelle am Stadtgraben von Wolthusen nach Emden, 1885

1885

Klassifikation Teil B: 00328

Trägermaterial: Papier

Alte Reg.-Sig.: III C

Bestell-Nr.: IV 00328 
04

IV

Beziehungen der Stadt Emden zur Landesherrschaft und zu übergeordneten Landes- und Reichsorganen

04.04 Hoheitssachen

04.04.01

Beziehungen der Stadt Emden zum Umland

Lfd. Nr. Titel

Laufzeit

226 Zweckverbandsgesetz

- Verhandlungen im preußischen Landtag und im preußischen

Städtetag über Vorlage eines Zweckverbandsgesetzes zur

Verbesserung der Zusammenarbeit der Kommunen und Städte, 1911

1911

Klassifikation Teil B: 00329

Trägermaterial: Papier

Alte Reg.-Sig.: III C 25

Bestell-Nr.: IV 00329

227 Schulverband Wolthusen

1908-1909

- Erweiterung der Schule in Wolthusen, 1908 - 1909

- Einschulung katholischer Kinder aus Wolthusen in die katholische

Volksschule in Emden und Verhandlungen wegen des

Gastschulgeldes, 1908

- Besetzung einer dritten Lehrerstelle in Wolthusen, 1908

$1908-1909$

Klassifikation Teil B: 00330

Trägermaterial: Papier

Alte Reg.-Sig.: III C 33 IIh

Bestell-Nr.: IV 00330

228 Regulierung der Grenze zwischen der Stadt Emden und der

Gemeinde Wolthusen

$1871-1904$

- Verhandlungen zwischen der Stadt Emden und dem Landrat des Kreises Emden wegen der Regulierung der Grenze zu Wolthusen, 1871 - 1904

$1871-1904$

Klassifikation Teil B: 00378

Trägermaterial: Papier

Bestell-Nr.: IV 00378 
IV

04

04.04

04.04 .02

04.04.02.01
Beziehungen der Stadt Emden zur Landesherrschaft und zu übergeordneten Landes- und Reichsorganen

Hoheitssachen

Eingemeindungen

Erweiterung des Stadtgebietes

Lfd. Nr. Titel

Laufzeit

229 Umgemeindung des Königspolders von Borssum nach Emden

- Klage der Landgemeinde Borssum beim Bezirksausschuss in Aurich gegen die Umgemeindung des Königspolders nach Emden wegen Verlustes des größten Teils des Gemeindegebietes, Februar 1900 - Klage der Landgemeinde Borssum beim Provinzialrat in Hannover gegen den für sie negativen Beschluss des Bezirksausschusses, April 1900 - September 1903

- Entwurf einer Verpflichtungserklärung der Stadt Emden gegenüber der Gemeinde Borssum über Entschädigung für die Umgemeindung des Königspolders zur Erzielung eines Vergleichs mit Borssum, Mai Juni 1900

$1900-1903$

Klassifikation Teil B: 00331

Trägermaterial: Papier

Alte Reg.-Sig.: III C 12

Bestell-Nr.: IV 00331

230 Umgemeindung des Kaiser Wilhelm - Polders von Larrelt nach Emden

- Verhandlung zwischen der Stadt Emden und der Gemeinde Larrelt wegen der Umgemeindung des Kaiser Wilhelm - Polders nach Emden wegen notwendiger Stadterweiterung und der damit verbundenen Infrastrukturanlagen, Dezember 1904 - Oktober 1906

- Votum des Gemeindeversammlung in Larrelt gegen die

Umgemeindung, Januar 1905

- Antrag des Magistrats der Stadt Emden beim Bezirksausschuss in Aurich auf Umgemeindung des Kaiser Wilhelm - Polders nach

Emden, Januar 1905

- Votum der Gemeindeversammlung in Larrelt für den von der Stadt Emden vorgeschlagenen Vertrag wegen der Umgemeindung des Kaiser Wilhelm - Polders, Oktober 1905 / April 1906

- Klage des preußischen Domänenfiskus als Eigentümer des Kaiser Wilhelm - Polders beim Bezirksausschuss in Aurich gegen die Umgemeindung des Kaiser Wilhelm - Polders wegen

Steuermehrbelastung durch den Wechsel nach Emden, April - Juni 1906

- Katasteramtliche Neuvermessung des Gebietes, 1906 - 1908

$1904-1908$

Klassifikation Teil B: 00332

Trägermaterial: Papier

Alte Reg.-Sig.: III C 23

Bestell-Nr.: IV 00332 
Lfd. Nr. Titel

- Anfrage des Magistrats der Stadt Emden an die Umlandgemeinden nach Kartenmaterial wegen der Absicht der Anfertigung einer neuen Umlandkarte der Stadt Emden, September - Oktober 1883

- Antrag des Magistrats der Stadt Emden beim Katasteramt auf Herstellung einer Karte vom Umland der Stadt Emden, November Dezember 1883

- Gutachten des Baurats J. Stubbe aus Köln über Notwendigkeit der Erweiterung des Stadtgebiets, März 1884

- Verhandlungen der Stadt Emden mit der preußischen Regierung über Erwerb des fiskalischen Kaiser-Wilhelm-Polders und des fiskalischen Königspolders durch Emden, Juni 1884 - März 1890 - Kartographische Darstellung: Der Emsstrom und der Hafen von Emden, 1884

- Umgemeindungen von fünf Grundstücken der Gemeinde Wolthusen nach Emden, Juli 1884

- Eingemeindung des Kasernengrundstücks an der Auricher Straße nach Emden, 1911

$1883-1911$

Klassifikation Teil B: 00416

Trägermaterial: Papier

Alte Reg.-Sig.: III C 12

Bestell-Nr.: IV 00416

- Anregung des Regierungspräsidenten in Aurich zur Eingemeindung der Gebiete um die Borssumer Schleuse nach Emden, Februar - Juni 1897

- Verhandlungen der Stadterweiterungskommission wegen

Eingemeindung des Königspolders, Juni - August 1897

- Verhandlungen der Stadt Emden mit dem Reguierungspräsidenten in Aurich und dem Landrat des Kreises Emden wegen der

Eingemeindung des Königspolders nach Emden, August 1897 -

Dezember 1898

- Vorlage für die städtischen Kollegien über die Eingemeindung des Königspolders, August - Dezember 1899

- Denkschrift der Stadt Emden über Notwendigkeit der Eingemeindung des Königspolders nach Emden hinsichtlich der Hafenerweiterung und der Ansiedlung von Industrie sowie der unakzeptablen

Entschädigungsforderungen von Seiten der Gemeinde Borssum, Januar 1900

- Klage der Stadt Emden gegen die Entschädigungsforderungen aus Borssum beim Bezirksausschuss in Arich, Januar - September 1900

$1897-1900$

Klassifikation Teil B: 00417

Trägermaterial: Papier

Alte Reg.-Sig.: II C 11

Bestell-Nr.: IV 00417 
04

04.04

04.04 .02

04.04.02.01
IV

Beziehungen der Stadt Emden zur Landesherrschaft und zu übergeordneten Landes- und Reichsorganen

Hoheitssachen

Eingemeindungen

Erweiterung des Stadtgebietes

Lfd. Nr. Titel

Laufzeit

233 Grundstückstausch mit dem preußischen Domänenfiskus

- Verhandlungen zwischen der Stadt Emden und dem preußischen Domänenfiskus wegen Tausch eines Grundstücks im Vorland des Kaiser-Wilhelm-Polders, Oktober 1899 - März 1900

- Erwerb der betr. Grundstücke durch die Stadt Emden, März - Juli 1900

- Antrag der Stadt Emden beim Bezirksausschuss auf Durchführung der Eingemeindung der betreffenden Grundstücke von Larrelt nach Emden, September 1900 - September 1901

$1899-1901$

Klassifikation Teil B: 00418

Trägermaterial: Papier

Alte Reg.-Sig.: III C 19

Bestell-Nr.: IV 00418

234 Festlegung der zur Stadt Emden gehörigen Teile der Ems

1900

- Antrag der Stadt Emden beim Bezirksausschuss in Aurich auf Feststellung der zur Stadt Emden gehörigen Fläche der Ems, Juli 1900

1900

Klassifikation Teil B: 00419

Trägermaterial: Papier

Alte Reg.-Sig.: III C 16

Bestell-Nr.: IV 00419

235 Anschluss der Emder Feldmark an die Stadt Emden

1861-1865

- Verfügung des Hannverschen Landdrosten in Aurich über

Feststellung der Grenze der Emder Feldmark, Dezember 1863

- Aufstellung über die betroffenen Landstücke und ihrer Besitzer, 1864

- 1865

1861 - 1865 (1875)

Klassifikation Teil B: 00420

Trägermaterial: Papier

Alte Reg.-Sig.: III C 33

Bestell-Nr.: IV 00420 
04.04

Lfd. Nr. Titel

Laufzeit

236 Eingemeindung des Vorlandes des Königspolders nach Emden

- Antrag der Stadt Emden beim Bezirksausschuss in Aurich auf Durchführung der Eingemeindung des Vorlandes vor dem Königspolder nach Emden, Februar - Mai 1906

- Verhandlung zwischen der Stadt Emden und der königlichen Wasserbau-Inspektion wegen Katasteraufnahme des betr. Vorlandes, November 1908 - Februar 1909

- Verfügung des Regierungspräsidenten in Aurich über Unterstützung des Standpunktes der Gemeinde Borssum hinsichtlich des Grenzverlaufs im Vorland vor dem Königspolder, Juli - August 1909 - Festlegung der Grenze durch den Bezirksausschuss, August 1909 November 1912

$1906-1914$

Klassifikation Teil B: 00421

Trägermaterial: Papier Alte Reg.-Sig.: III C 16

Bestell-Nr.: IV 00421

237 Anschluss der Emder Feldmark an die Stadt Emden

- Verhandlungen der Stadt Emden mit der Hannoverschen

Landdrostei in Aurich über Anschluss der Emder Feldmark an die

Stadt Emden im Zuge des Stadtausbaus, 1862 - 1864

- Verhandlungen der städtischen Kollegien über Anschluss der Emder

Feldmark an die Stadt Emden als Notwendigkeit für die weitere

Stadtentwicklung, 1862 - 1863

- Bescheid des kgl. Hannoverschen Innenministeriums über

Verweigerung des Anschlusses der Emder Feldmark an die Stadt

Emden, November 1862

- Bestimmung der Grenzen der Emder Feldmark, 1863

- Anschluss der Emder Feldmark an die Stadt Emden, Dezember

1864

- Regulierung der Grenze zwischen der Stadt Emden und der

Gemeinde Wolthusen, 1867

- Verfügung des preußischen Landdrosten in Aurich über Festlegung der Grenzen zwischen der Stadt Emden und den Gemeinden

Uphusen und Marienwehr, Januar 1868 / April 1868

- Regulierung der Grenze zwischen der Stadt Emden und der

Gemeinde Borssum, 1875 - 1876

- Klärung der Kirchengemeinden-Zugehörigkeit des Gebiets "Außer dem neuen Tor", März 1906

- Gebietsaustausch zwischen der Stadt Emden und der Gemeinde Larrelt (Teil des fiskalischen Besitzes im Kaiser-Wilhelm-Polder gegen Emder Hammrich), 1905 - 1907

(1862 - 1864) 1867 - 1907

Klassifikation Teil B: 03403

Trägermaterial: Papier

Alte Reg.-Sig.: III C 23

Bestell-Nr.: IV 03403 
Lfd. Nr. Titel

238 Entschädigungsforderung des Schlachters Johann Hummerich wegen der Unterstellung seines Betriebes unter dem Schlachthauszwang nach der Eingemeindung Borssums

- Verhandlungen des Eingemeindungsausschusses wegen Ausdehnung der Schlachthauspflicht auf Borssum nach der Eingemeindung und Entschädigungsforderungen des Schlachters Johann Hummerich, Februar 1914

- Abfindung des Schlachters Johann Hummerich für seine Kosten wegen des Schlachthauszwanges, Febuar - April 1914

- Aufkündigung der Abmachung wegen Verlegung der Schlachterei des Johann Hummerich nach Oldersum, Mai- Juni 1914

1914

Klassifikation Teil B: 00324

Trägermaterial: Papier

Alte Reg.-Sig.: III C 22

Bestell-Nr.: IV 00324

239 Eingemeindung von Borssum nach Emden

- Beschluss des Magistrats der Stadt Emden über Vorverhandlungen wegen der Eingemeindung von Borssum und Wolthusen wegen Planungen zur Erweiterung des Hafengebietes, Oktober 1904

- Konzept eines Schreibens des Oberbürgermeisters Leo Fürbringer an den Regierungspräsidenten in Aurich über Notwendigkeit der Eingemeindung Borssums wegen Ansiedlungspläne von Industriebetrieben (Brikettfabrik) und damit verbundenem Raumbedarf, Dezember 1904

- Antrag der Stadt Emden beim Regierungspräsidenten auf Genehmigung der Eingemeindung von Borssum, Dezember 1904 - Schreiben des Magistrats der Stadt Emden an den Gemeindevorstand von Borssum über Dringlichkeit der Eingemeindung und Angebot von Vergünstigungen bei Zustimmung, Januar 1905

- Ablehnung der Eingemeindung durch Borssum, September 1905 Juli 1907

$1904-1907$

Klassifikation Teil B: 00327

Trägermaterial: Papier

Alte Reg.-Sig.: III C 22

Bestell-Nr.: IV 00327

240 Eingemeindung von Borssum nach Emden

- Änderung des Ortsstatuts der Stadt Emden wegen Eingemeindung von Borssum, 1915

1915

Klassifikation Teil B: 00336

Trägermaterial: Papier

Alte Reg.-Sig.: III C 22 I

Bestell-Nr.: IV 00336 
IV

04

04.04

04.04 .02

04.04.02.02
Beziehungen der Stadt Emden zur Landesherrschaft und zu übergeordneten Landes- und Reichsorganen

Hoheitssachen

Eingemeindungen

Eingemeindung der Gemeinde Borssum nach Emden

Lfd. Nr. Titel

Laufzeit

241 Eingemeindung von Borssum nach Emden

1913-1915

- Übersichtskarte: Stadtgemeinde Emden, Gemeinde Borssum, Gemeinde Wolthusen, April 1913

- Verhandlungen der Eingemeindungskommission des Magistrats der

Stadt Emden wegen Eingemeindung von Borssum nach Emden,

April 1913 - Februar 1915

- Verhandlungen des Magistrats der Stadt Emden mit dem Landrat des Kreises Emden über Eingemeindung von Teilen der Gemeinde Wolthusen nach Emden wegen Ausbau der Kanalisation, Juli 1913

Juli 1914

- Übersicht über katholische Schüler aus Wolthusen in der katholischen Volksschule in Emden, Juli 1913

- Verhandlungen des Oberbürgermeisters Dr. Wilhelm Mützelburg mit dem Borssumer Gemeindevorsteher Janssen über die

Eingemeindung Borssums nach Emden, Oktober 1913 - Januar 1914

- Verhandlungen der Stadt Emden mit dem Regierungspräsidenten in Aurich wegen der Eingemeindung von Borssum, Dezember 1913 -

Februar 1915

- Entwurf eines Vertrages zwischen der Stadt Emden und der

Gemeinde Borssum über Bedingungen für die Eingemeindung

Borssums, Januar - Februar 1914

- Verhandlungen des Magistrats der Stadt Emden mit dem Landrat des Kreises Emden wegen der Eingemeindung Borssums, Juli 1913 Januar 1915

- Übersicht über Grundbesitzer in der Gemeinde Borssum, 1915

- Memorandum über Begründung der Notwendigkeit der

Eingemeindung von Borssum nach Emden u.a. wegen des benötigten

Terrains zum Bau von Arbeitersiedlungen, 1914

$1913-1915$

Klassifikation Teil B: 00405

Band: 1

Trägermaterial: Papier

Alte Reg.-Sig.: III C 22

Bestell-Nr.: IV 00405 
- Modifizierung des Eingemeindungsvertrages durch

Entgegenkommen der Stadt Emden gegenüber den Forderungen aus Borssum, Februar 1915

- Korrespondenz zwischen der Stadt Emden und dem als

Landtagsabgeordneter in Berlin weilenden kommissarischen Oberbürgermeister Leo Fürbringer, Februar - März 1915

- Schreiben des Regierungspräsidenten in Aurich an die Stadt Emden über Benachrichtigung zum Erlass des preußischen Innenministers über Erfordernis eines förmlichen Gesetzes zur Eingemeindung von Borssum nach Emden, März 1915

- Verwaltungsstreitverfahren vor dem Bezirksausschuss in Aurich und dem Provinzialausschuss in Hannover wegen Steuerstreit zwischen der Stadt Emden und dem Landrat des Kreises Emden um Verteilung der Steuern nach einer Eingemeindung von Borssum nach Emden, März - Mai 1915

- Antrag der Stadt Emden auf Eingemeindung von Borssum durch Notverordnung des preußischen Innenministers, April 1915

- Erlass des preußischen Innenministers über Einfrierung des Projektes der Eingemeindung Borssums durch Nichteinreichung eines Gesetzentwurfes beim preußischen Landtag, Oktober 1915

- Streit um die Einziehung der Wertzuwachssteuer aus Borssum, 1915 $-1916$

- Denkschrift der Stadt Emden: Die Bedeutung der Eingemeindung Borssums in die Stadt Emden für die Entwicklung des fiskalischen Emder Hafens, Dezember 1915

- Gutachten des Justizrats Müller über rechtliche Verbindlichkeit des Eingemeindungsvertrages zwischen der Stadt Emden und Borssum nach der ministriell verfügten Einfrierung des Projektes, Januar 1916

$1915-1918$

Klassifikation Teil B: 00406

Band: 2

Trägermaterial: Papier

Alte Reg.-Sig.: III C 22

Bestell-Nr.: IV 00406

243 Haushaltsplan der Gemeinde Borssum

- Gedruckter Etat der Gemeinde Borssum für 1915 / 1916, 1915

- Verhandlungen wegen der Eingemeindung Borssums nach Emden, $1915-1916$

$1915-1916$

Klassifikation Teil B: 00407

Trägermaterial: Papier

Alte Reg.-Sig.: III C 22

Vorprovenienz: Landratsamt Emden

Bestell-Nr.: IV 00407 
04

04.04

04.04.02

04.04.02.02
IV

Beziehungen der Stadt Emden zur Landesherrschaft und zu übergeordneten Landes- und Reichsorganen

Hoheitssachen

Eingemeindungen

Eingemeindung der Gemeinde Borssum nach Emden

Lfd. Nr. Titel

Laufzeit

244 Haushaltsplan der Volksschule in Borssum

1915

- Hauhalt der Volksschule Borssum, 1915

1915

Klassifikation Teil B: 00408

Trägermaterial: Papier

Alte Reg.-Sig.: III C 22

Vorprovenienz: Landratsamt Emden

Bestell-Nr.: IV 00408

245 Gehalt der Lehrer und Kirchendiener in Borssum

1898

- Festlegung eines Grundgehalts für die Lehrer und Kirchendiener in Borssum, 1898

1898
Klassifikation Teil B: 00409
Trägermaterial: Papier
Alte Reg.-Sig.: III C 22
Vorprovenienz: Landratsamt Emden
Bestell-Nr.: IV 00409

246 Gemeindevorsteher in Borssum

- Rücktritt des Gemeindevorstehers B.J. Wykhoff und Wahl seines

Nachfolgers Ubbe Engelkes Groeneveld, August - Oktober 1892

- Rücktritt des Gemeindevorstehers Ubbe Engelkes Groeneveld und

Wahl seines Nachfolgers Remmer Schoneboom, September -

Dezember 1895

$1892-1895$

Klassifikation Teil B: 00410

Trägermaterial: Papier

Alte Reg.-Sig.: III C 22

Vorprovenienz: Landratsamt Emden

Bestell-Nr.: IV 00410 
Lfd. Nr. Titel

Laufzeit

247 Gemeindevorsteher in Borssum

- Kampagne gegen den Gemeindevorsteher Peterssen wegen angeblicher Unterschlagung von für die Feuerwehr in Borssum beantragter Mittel und wegen Aufnahme einer nicht von der Gemeinde autorisierten Anleihe, März - April 1911

- Rücktritt des Gemeindevorstehers Peterssen und seine Wiederwahl durch die Gemeindeversammlung, April - Mai 1911

- Einspruch der Landwirte G. Schoneboom, Ahlrich Schoneboom und Engelke Groeneveld gegen die Gemeindevorsteherwahl wegen Nichtberücksichtigung auswärtiger Stimmberechtigter mit Landbesitz in Borssum, April - Mai 1911

- Ermittlungen gegen den Gemeindevorsteher Peterssen wegen Unregelmäßigkeiten in der Rechnungsführung der Gemeindekasse, Mai - Juni 1911

- Rücktritt des Gemeindevorstehers Peterssen, Juni 1911

- Vermerk über Freispruch des ehemaligen Gemeindevorstehers

Peterssen vom Vorwurf der Unterschlagung, April 1912

$1911-1912$

Klassifikation Teil B: 00411

Trägermaterial: Papier

Alte Reg.-Sig.: III C 22

Vorprovenienz: Landratsamt Emden

Bestell-Nr.: IV 00411

- Zwangseintreibung der rückständigen Staatssteuern und der Beiträge zur Alterszulagenkasse für Lehrer bei der Gemeinde Borssum, November 1910 - März 1911

- Aufstellung über Steuer-Restanten, 1910 - 1911

$1910-1911$

Klassifikation Teil B: 00412

Trägermaterial: Papier

Alte Reg.-Sig.: III C 22

Vorprovenienz: Landratsamt Emden

Bestell-Nr.: IV 00412

249 Fernbleiben von der Gemeindeversammlung in Borssum

- Beschwerde der Grenzaufseher Schönburg, H. Franke und D. Unverzagt beim Landrat des Kreises Emden gegen die Verhängung einer Geldstrafe wegen Fernbleibens von der Gemeindeversammlung in Borssum, April - Mai 1893

1893

Klassifikation Teil B: 00413

Trägermaterial: Papier

Alte Reg.-Sig.: III C 22

Vorprovenienz: Landratsamt Emden

Bestell-Nr.: IV 00413 
04

04.04

04.04.02

04.04.02.02
IV

Beziehungen der Stadt Emden zur Landesherrschaft und zu übergeordneten Landes- und Reichsorganen

Hoheitssachen

Eingemeindungen

Eingemeindung der Gemeinde Borssum nach Emden

Laufzeit

250 Baufälligkeit des Hauses der Grietje Brauer in Borssum

1907

- Antrag des Gemeindevorstehers Peterssen beim Landrat des Kreises Emden auf Weisung an Grietje Brauer zur Instandhaltung ihres Wohnhauses und der Nebengebäude wegen Gefährdung der Passanten durch herabfallende Bauteile, März 1907

- Gutachten des Baurats Mentz über Baufälligkeit des Hauses der Grietje Brauer, Juli 1907

- Aufhebung der Strafverfügung des Landrats des Kreises Emden gegen Grietje Brauer wegen nicht erwiesener Baufälligkeit ihres Hauses durch das Schöffengericht in Emden, Oktober 1907

1907

\author{
Klassifikation Teil B: 00414 \\ Trägermaterial: Papier \\ Alte Reg.-Sig.: III C 22 \\ Vorprovenienz: Landratsamt Emden \\ Bestell-Nr.: IV 00414
}

251 Kanalisation in Borssum

$1909-1910$

- Stellungnahme des Gemeindevorstehers von Borssum zum

Kanalisationsprojekt der Firma Ysaac \& Bernhard Brons hinsichtlich der Reinhaltung des als Viehtränke genutztren Ringschloots,

November - Dezember 1909

- Plan des Kanalisationsprojektes, 1910

$1909-1910$

Klassifikation Teil B: 00415

Trägermaterial: Papier

Alte Reg.-Sig.: III C 22

Vorprovenienz: Landratsamt Emden

Bestell-Nr.: IV 00415 
IV

04

04.04

04.04 .02

04.04.02.03
Beziehungen der Stadt Emden zur Landesherrschaft und zu übergeordneten Landes- und Reichsorganen

Hoheitssachen

Eingemeindungen

Eingemeindung von Harsweg, Uphusen und Wolthusen nach Emden

Lfd. Nr. Titel

Laufzeit

252 Eingemeindung von Wolthusen nach Emden

Akte des Landrats des Kreises Emden als kommunale Aufsichtsbehörde zu verschiedenen polizeilichen Angelegenheiten in der Gemeinde Wolthusen

- Unfall eines Kohlefuhrwerkes; Begräbniswesen in Wolthusen; Verstopfung der Kanalisation; Baugesuche; Streitigkeiten um

Entwässerung; Streitigkeiten wegen der Veranlagung zur

Gemeindesteuer

$1890-1910$

Klassifikation Teil B: 00333

Trägermaterial: Papier

Alte Reg.-Sig.: III C 33

Vorprovenienz: Landrat des Kreises Emden

Bestell-Nr.: IV 00333

253 Eingemeindung von Wolthusen nach Emden

1906-1912

Akte des Landrats des Kreises Emden als kommunale Aufsichtsbehörde zu verschiedenen polizeilichen Angelegenheiten in der Gemeinde Wolthusen

- Streit um Wasserentnahme aus der Leitung des Emder Wasserwerkes, Einführung neuer Mitglieder des Wolthusener Gemeindeausschusses, Annnulierung einer Gemeindewahl durch den Kreisausschuss in Emden; Anschluss an die Kanalisation, 1906 1912

- Feststellung des Unterstützungswohnsitzes der Antje Bruns in Wolthusen, April 1837

- Unerlaubter Aufenthalt der ledigen Frauke Heiden Leurog in

Wolthusen, April 1858

- Vereidigung der Gemeindeausschussmitglieder auf die preußische

Verfassung, Februar 1868

(1837 - 1868) 1906 - 1912

Klassifikation Teil B: 00334

Trägermaterial: Papier

Alte Reg.-Sig.: III C 33

Vorprovenienz: Landrat des Kreises Emden

Bestell-Nr.: IV 00334 

zu übergeordneten Landes- und Reichsorganen

Akte des Landrats des Kreises Emden als kommunale Aufsichtsbehörde zu verschiedenen polizeilichen Angelegenheiten in der Gemeinde Wolthusen

- Wohnungsräumung gegen die Familie Hoten; Baugesuche; Streitigkeiten um Entwässerung; Straßenordnung für die Gemeinde Wolthusen; Streit um Nachtwächtergeld; Zahlung der Unterbringung der Taubstummen Geske Dose in einer Hannoverschen Anstalt; Einschränkung der Fischereigerechtigkeit Wolthusens durch den Ems-Jade-Kanal

$1880-1913$

Klassifikation Teil B: 00335

Trägermaterial: Papier Alte Reg.-Sig.: III C 33 Vorprovenienz: Landrat des Kreises Emden Bestell-Nr.: IV 00335

- Protokoll der Sitzung der Akzise-Commission über Mitteilung über Umzug vieler Staatsbediensteter und in Emden Arbeitender nach Wolthusen zur Umgehung städtischer Steuern, November 1900 - Vermerk über Dringlichkeit einer Eingemeindung von Wolthusen nach Emden wegen Verkehrsprojekte, Kanalisationsanschluss und Verhinderung der Steuerflucht, Januar 1902

- Katasterauszüge: Grundstücke der Gemeinde Wolthusen zur Umgemeindung nach Emden, 1902

- Protokoll der Magistratssitzung über Festlegung von Angeboten für die zur Eingemeindung nach Emden vorgesehenen Orte, Oktober 1904

- Vortrag des Geheimen Oberregierungsrat Carl Schweckendieck über Notwendigkeit der Eingemeindung von Borssum und Wolthusen nach Emden wegen Kosten und Unterhaltungsträgerschaft der neuen Schleusen und Rechtseinheitlichkeit des Hafengebiets, Oktober 1904 - Antrag der Stadt Emden beim Regierungspräsidenten in Aurich auf Durchführung der Eingemeindung von Wolthusen nach Emden, Dezember 1904 - Februar 1905

$1900-1905$

Klassifikation Teil B: 00426

Band: 1

Trägermaterial: Papier Alte Reg.-Sig.: III C 18

Bestell-Nr.: IV 00426 
04

IV

Beziehungen der Stadt Emden zur Landesherrschaft und zu übergeordneten Landes- und Reichsorganen

04.04 Hoheitssachen

04.04.02

Eingemeindungen

04.04.02.03

Eingemeindung von Harsweg, Uphusen und Wolthusen nach Emden

Lfd. Nr. Titel

Laufzeit

256 Eingemeindung von Wolthusen nach Emden

- Probleme beim Anschluss Wolthusens an die Emder Kanalisation als Argument für die Eingemeindung, Juli 1913

- Aufstellung über Kinder aus Borssum und Wolthusen in Emder Schulen, Juli 1913

- Verzeichnis in Emden Beschäftigter mit Wohnsitz in Wolthusen, Juli 1913

- Gescheiterte Initiative des Bürgermeisters Dr. Wilhelm Mützelburg zur Eingemeindung Wolthusens, 1918 - 1922

$1913-1922$

Klassifikation Teil B: 00427

Band: 2

Trägermaterial: Papier

Alte Reg.-Sig.: III C 18

Bestell-Nr.: IV 00427 
04

IV

Beziehungen der Stadt Emden zur Landesherrschaft und zu übergeordneten Landes- und Reichsorganen

04.04 Hoheitssachen

04.04.03

Münzsachen

Lfd. Nr. Titel

Laufzeit

257 Münzen und Banknoten

1866-1912

- Erlasse und Verfügungen preußischer Ministerien und

Regierungsstellen zum Münzwesen, Oktober 1866 - April 1912

- Vorschlag des Akzise-Verwalters Gottfried van Buiren über

Anpassung der städtischen Steuertarife an das nach dem Überrgang des Kgr. Hannover nach Preußen veränderte Münzwesen, Oktober 1867

- Bekämpfung gefälschter Banknoten, September 1877

- Aufstellung über bei Emder Banken vorhandener Taler-Bestände, November 1904

$1866-1912$

Klassifikation Teil B: 00401

Trägermaterial: Papier

Alte Reg.-Sig.: III Dc 6

Bestell-Nr.: IV 00401 
IV

04

Beziehungen der Stadt Emden zur Landesherrschaft und zu übergeordneten Landes- und Reichsorganen

04.04 Hoheitssachen

04.04.04

Orden, Titel, Gratifikationen

Lfd. Nr. Titel

Laufzeit

258 Ehrenzeichen, Gratifikationen, Orden, Titel

- Eingabe des Ehepaars Johannes Wilhelm Heyl und Angela, geb.

Brake an den Regierungspräsidenten in Aurich über Bitte um

Übernahme der Patenschaft für ihren siebten Sohn durch den Kaiser,

November 1886

- Mitteilungen der Stadt Emden über Veränderungen in der Liste der

Ordensträger, 1886 - 1898

- Antrag des Magistrats der Stadt der Stadt Emden auf Verleihung des

Titels "Sanitätsrat" an den Arzt Dr. Theodor Wychgram, Juli 1889 -

September 1890

- Aufstellung über Ordensträger in der Stadt Emden, Oktober 1889

- Vorschläge zur Verleihung "Goldener Kreuze" an langjährig bei einem Arbeitgeber beschäftigter Arbeiter, Angestellte und Hauspersonal, Oktober 1889 - Juni 1892

- Eingabe des Böttchermeisters Georg Mathäus Dancker an den Regierungspräsidenten in Aurich über Bitte um Übernahme der Patenschaft für seinen siebten Sohn durch den Kaiser, Juni 1898

$1886-1898$

Klassifikation Teil B: 00393

Band: 1

Trägermaterial: Papier

Alte Reg.-Sig.: III Df 2

Bestell-Nr.: IV 00393 
Lfd. Nr. Titel

- Liste der Ordensträger in Emden, 1900 - 1918

- Rücksendung der Insignien verstorbener Ordensträger an die kgl.

General-Ordens-Kommission, 1900 - 1909

- Erlass des preußischen Innenministers über Formalien der Anträge auf Ordensverleihungen und Bekanntgabe eines Stichtages bei Ordensanträgen zur Verleihung an Krönungstagen oder Ordenstagen, Oktober 1900

- Verleihung des Allgemeinen Ehrenzeichens und des Titels

"Kommerzienrat" an den Fabrikdirektor und Senator Konrad Hermann

Metger, August 1901

- Vorschläge zur Verleihung von Allgemeinen Ehrenzeichen und

"Goldener Kreuze" an langjährig bei einem Arbeitgeber beschäftigter Arbeiter, Angestellte und Hauspersonal, 1902 - 1909

- Antrag auf Verleihung des Kronenordens 4. Klasse an den

Kämmerer Ernst August Gebest, Januar - Februar 1904

- Antrag auf Verleihung der Roten-Kreuz-Medaille an die Ehefrau des Amtsgerichtrats Lohskötter in Emden, März 1904 - Juli 1905

- Verleihung des Roten-Adler-Ordens 4. Klasse an den Senator a.D.

Tamme Dreesmann-Penning, Mai 1904

- Verleihung von Auszeichnungen an Lehrer der höheren

Töchterschule anlässlich der Einweihung des neuerbauten

Schulgebäudes, Oktober 1904

- Antrag auf Verleihung des Kronenordens 4. Klasse an den

Gaswerksdirektor Carl Möller in Emden, Oktober - Dezember 1904

- Anträge auf Verleihung des Roten-Adler-Ordens 4. Klasse an Sprecher des Bürgervorsteherkollegiums, Conrad Zorn, den Direktor der Nordseewerke, Hans L. Schultz und den Versicherungsdirektor Paul G. Roer, Oktober 1904 - November 1907

- Überreichung der Gedenkmedaille zur Einweihung der restaurierten Schlosskirche in Wittenberg an die Naturforschende Gesellschaft, Gesellschaft für bildende Kunst und Altertümer, lutherische Gemeinde Emden, reformiertes Gemeindearchiv Emden und dem Stadtarchiv, Februar 1905

- Statistik der Ordensverleihungen, 1905

- Verleihung des Titels "Schulrat" an den Direktor der höheren

Töchterschule, August Zwitzers, September 1905

- Verleihung des Hohenzollernordens an verschiedene Lehrer der höheren Töchterschule, 1905

- Antrag auf Verleihung des Kronenordens 4. Klasse an den

Zimmermeister und zahlreiche Ehrenämter bekleidenden Wiardus Taddäus Bruns, Juni - September 1906

- Antrag auf Verleihung des Titels "Kommerzienrat" an den Bankier und Senator Anton Kappelhoff, März 1907

- Antrag auf Verleihung des Roten-Adler-Ordens 4. Klasse an den Reeder Franz Habich, März 1907

- Antrag auf Verleihung des Kronenordens an den Bürgervorsteher und Kaufmann Jacob Pels, Februar 1907 - April 1909

- Erlaubnis für den Konsul Friedrich Brons zum Tragen des

Ritterkreuzes 1. Klasse des kgl. schwedischen Wasa-Ordens, Februar 1908

- Antrag auf Verleihung des Roten-Adler-Ordens 4. Klasse an den Landrabbiner Dr. Jonas Hermann Löb, März 1909

- Antrag auf Verleihung des Roten-Adler-Ordens 4. Klasse an den Rentier und Konsul a.D. Bernhard Brons, September 1909

- Antrag auf Verleihung des Roten-Adler-Ordens 4. Klasse an den 
IV

04

Beziehungen der Stadt Emden zur Landesherrschaft und zu übergeordneten Landes- und Reichsorganen

04.04 Hoheitssachen

04.04.04 Orden, Titel, Gratifikationen

Lfd. Nr. Titel

Laufzeit

Rentier Ysaac Brons, März 1911

$1900-1911(1918)$

Klassifikation Teil B: 00394

Band: 2

Trägermaterial: Papier

Alte Reg.-Sig.: III Df 2

Bestell-Nr.: IV 00394

260 Ehrenzeichen, Gratifikationen, Orden, Titel

$1898-1910$

- Erlasse von preußischen Ministern, der Oberpräsidenten in

Hannover und Verfügungen des Regierungspräsidenten in Aurich zum

Ordenswesen, Dezember 1898 - Dezember 1910

$1898-1910$

Klassifikation Teil B: 00395

Band: 3

Trägermaterial: Papier

Alte Reg.-Sig.: III Df 2

Bestell-Nr.: IV 00395 
04.04 Hoheitssachen

04.04.04

Orden, Titel, Gratifikationen

Lfd. Nr. Titel

Laufzeit

261 Ehrenzeichen, Gratifikationen, Orden, Titel

- Antrag auf Verleihung des Frauenverdienstkreuzes in Gold an Marie

Fürbringer, Gattin des Oberbürgermeisters, wegen 30-jähriger

Verbandstätigkeit im Vaterländischen Frauenverein, Juni 1909

- Rücksendung der Insignien verstorbener Ordensträger an die kgl.

General-Ordens-Kommission, 1910 - 1911

- Antrag auf Verleihung des Kronenordens 4. Klasse an den

Kämmerer Ernst August Gebest anlässlich seines 50-jährigen

Dienstjubiläums, Januar - April 1910

- Antrag auf Verleihung des Roten-Adler-Ordens 4. Klasse an den

Vorsitzenden der Handelskammer, Peter van Rensen, Februar 1910

- Antrag auf Verleihung des Kronenordens 3. Klasse an den

Kommerzienrat, Fabrikdirektor und Senator Konrad Hermann Metger,

Oktober - Dezember 1910

- Vorschläge zur Verleihung von Allgemeinen Ehrenzeichen und

"Goldener Kreuze" an langjährig bei einem Arbeitgeber beschäftigter

Arbeiter, Angestellte und Hauspersonal, 1910 - 1913

- Antrag auf Verleihung des Ordens "Adler der Inhaber des kgl.

Hausordens" an den in den Ruhestand tretenden Armen- und

Arbeitshausvater Johann Christian Panzer, Mai 1910

- Antrag auf Verleihung des Ehrenzeichens an Anton Kuiper, Veteran der Ersten deutschen Marine 1848, Juli 1910

- Antrag auf Verleihung des Roten-Adler-Ordens 4. Klasse an den Lotsenkommandeur Hermann Laermann, Oktober - Dezember 1910

- Antrag auf Verleihung des Kronenordens 4. Klasse an den

Kaufmann Johann Wiemkes und den Direktor Johann Röben wegen

ihrer langjährigen Tätigkeit im Ostfriesischen Verein zur Rettung

Schiffsbrüchiger, März 1911

- Vorschlagsliste zur Verleihung der Roten-Kreuzmedaille an

Sanitätspersonal und Ärzten, Juli 1911

- Verleihung der Erinnerungsmedaille für Verdienste im

Feuerlöschwesen, August - November 1911

$1909-1913$

Klassifikation Teil B: 00396

Band: 4

Trägermaterial: Papier

Alte Reg.-Sig.: III Df 2

Bestell-Nr.: IV 00396

262 Ehrenzeichen, Gratifikationen, Orden, Titel

- Erlasse von preußischen Ministern, der Oberpräsidenten in Hannover und Verfügungen des Regierungspräsidenten in Aurich zum Ordenswesen, Dezember 1898 - Dezember 1910

$1911-1919$

Klassifikation Teil B: 00397

Band: 5

Trägermaterial: Papier

Alte Reg.-Sig.: III Df 2

Bestell-Nr.: IV 00397 
04.04 Hoheitssachen

04.04.04

Orden, Titel, Gratifikationen

Lfd. Nr. Titel

Laufzeit

263 Ehrenzeichen, Gratifikationen, Orden, Titel

- Rücksendung der Insignien verstorbener Ordensträger an die kgl. General-Ordens-Kommission, 1912 - 1915

- Vorschläge zur Verleihung von Allgemeinen Ehrenzeichen und "Goldener Kreuze" an langjährig bei einem Arbeitgeber beschäftigter Arbeiter, Angestellte und Hauspersonal, 1912 - 1918

- Antrag auf eine Patenschaft der Kaiserin Auguste Viktoria für die siebte Tochter des Maurers Berend Martens Doolmann, Januar 1912 - Antrag auf Verleihung des Kronenordens 4. Klasse an den Kapitän Hinderk Huizenga anlässlich seines 60 -jährigen Seemannsjubiläums, Mai - August 1912

- Antrag auf Verleihung des Kronenordens 4. Klasse an den Dampfschifffahrtsdirektor Wilhelm Philippstein (Hapag), Oktober 1912 - Antrag auf Verleihung des Kronenordens 4. Klasse an den Apotheker Carl Hermann wegen seines Engagements bei der Naturforschenden Gesellschaft, Februar 1913

- Antrag auf Verleihung des Roten-Adler-Ordens 4. Klasse anlässlich des 25-Jährigen Regierungsjubiläums des Kaisers Wilhelm II. an den Kaufmann und Senator Carl Thiele, Heringsfischereidirektor Gerhard Zimmermann, Kaufmann und Konsul Karl Fisser, Professor Friedrich Ritter, Rentier Ysaac Brons, Heringsfischereidirektor Louis Ruyen, Schiffsmakler und Vizekonsul Johann Hermann Schulte, Februar 1913

- Antrag auf Verleihung des Titels "Geheimer Kommerzienrat" anlässlich des 25-jährigen Regierungsjubiläums des Kaisers Wilhelm II. an den Kommerzienrat Fabrikdirektor und Senator Konrad Hermann Metger, Februar 1913

- Antrag auf Verleihung des Roten-Adler-Ordens 2. Klasse anlässlich des 25-Jährigen Regierungsjubiläums des Kaisers Wilhelm II. an den Großindustriellen Hugo Stinnes, Februar 1913

- Antrag auf Verleihung des Titels "Kommerzienrat" anlässlich des 25-jährigen Regierungsjubiläums des Kaisers Wilhelm II. an den Senator und Kaufmann Friedrich Brons, Februar 1913

- Antrag auf Verleihung des Kronenordens 3. Klasse anlässlich des 25-jährigen Regierungsjubiläums des Kaisers Wilhelm II.an den Senator, Kaufmann und Bankier Anton Kappelhoff, Februar 1913 - Antrag auf Verleihung des Kronenordens 4. Klasse anlässlich des 25-jährigen Regierungsjubiläums des Kaisers Wilhelm II.an den Bürgervorsteher und Kaufmann Jacob Pels, Februar 1913

- Antrag auf Verleihung des Verdienstkreuzes in Gold anlässlich des 25-jährigen Regierungsjubiläums des Kaisers Wilhelm II.an den Stadtsekretär Georg Bornscheuer, der Stadtbauführer Friedrich Schulte, den Stadtkämmerer Bernhard Visser und den

Polizeikommissar Gustav Lauter, Februar 1913

- Verleihung des Titels Sanitätsrat an die Ärzte Dr. Gerhard Bakker, Dr. Salli Goldschmidt, Dr. Wilhelm Tillmann und Dr. David Borma, Januar - Dezember 1914

$1912-1918$

Klassifikation Teil B: 00398

Band: 6

Trägermaterial: Papier

Alte Reg.-Sig.: III Df 2

Bestell-Nr.: IV 00398 
IV

04

Beziehungen der Stadt Emden zur Landesherrschaft und zu übergeordneten Landes- und Reichsorganen

04.04 Hoheitssachen

04.04.04

Orden, Titel, Gratifikationen

Lfd. Nr. Titel

Laufzeit

264 Ehrenzeichen, Titel und Orden sowie Milde Stiftungen

- Sammlung zur Unterstützung für notleidende Invaliden, 1909

- Verleihung des Roten-Adler-Ordens III. Klasse an den

Oberbürgermeister Fürbringer, Mai 1900 - August 1901

- Protokoll der Sitzung der städtischen Kollegien über Verleihung von

Orden und Auszeichnungen an Oberbürgermeister Fürbringer und

Mitglieder des Magistrats und des Bürgervorsteherkollegiums, August 1901

- Einziehung der Ehrenzeichen verstorbener Träger, 1902

- Überweisung eines Kaiserbildnisses mit Autogramm an die Ehefrau des Sanitätsrats Lohmeyer, September 1902

- Verleihung der Roten-Adler-Medaille an den Lotsen Jakob Santjer für die Lotsung des Torpedoboots "Sleipner" mit dem Kaiser an Bord nach Emden, September 1902

$1900-1909$

Klassifikation Teil B: 02717

Trägermaterial: Papier

Alte Reg.-Sig.: III Df 2

Bestell-Nr.: IV 02717

265 Titel, Orden und Ehrenzeichen

- Verfügung des preußischen Landdrosten in Aurich wegen

Patenschaft des preußischen Königs für den siebten Sohn einer

Familie, Februar 1867

- Regelung der Trägerschaft von Wappen und der Verleihung von

Auszeichnungen, 1868 - 1899

- Verleihung des Oberbürgermeistertitels an Bürgermeister Leo

Fürbringer, April 1877

- Regelung der Rückgabe von Ordeninsignien verstorbener

Ordensträger, 1886 - 1897

$1867-1899$

Klassifikation Teil B: 02718

Trägermaterial: Papier

Alte Reg.-Sig.: III Df 2

Bestell-Nr.: IV 02718 
Lfd. Nr. Titel

Laufzeit

266 Neubau eines Post- und Telegraphenamts 1876-1908

- Sicherung der Baustelle des Post- und Telegraphenamts, April 1876

- Mai 1877

- Bau einer Kaimauer zwischen dem Postgrundstück und dem Graupferdstief, April 1876 - November 1877

- Antrag der Oberpostdirektion Oldenburg an die Stadt Emden auf

Erteilung der Baugenehmigung für das Postgebäude, Juni - Juli 1877

- Einweihungsfeiher für das neu erbaute Postgebäude, April - Mai 1879

- Antrag der Postverwaltung auf Genehmigung zum Abriss der Kaimauer zwischen Graupferdstief und dem Postgrundstück wegen Absicht der Erweiterung des Postgebäudes, Mai 1894

- Baupolizeiliche Genehmigung zum Bau eines weiteren Gebäudes auf dem Postgrundstück, April - Mai 1905

$1876-1908$

Klassifikation Teil B: 00043

Trägermaterial: Papier

Alte Reg.-Sig.: III Dc 5

Bestell-Nr.: IV 00043

267 Ehrenbürger: Geheimer Oberregierungsrat Carl Schweckendieck

- Biographie des Geheimen Oberregierungsrat Carl Schweckendieck, 1901

- Organisation der Feier zur Verleihung des Ehrenbürgerrechts an den geh. Oberregierungsrat Carl Schweckendieck, Juli - September 1901 - Protokoll der Plenarsitzung der städtischen Kollegien über Verleihung der Ehrenbürgerwürde an den geheimen Oberregierungsrat Carl Schweckendieck, 26. September 1901 - Trauerkundgebung für den verstorbenen Emder Ehrenbürger, geheimer Oberregierungsrat Carl Schweckendieck, Januar 1906 - Presseberichte über Ableben des geheimen Oberregierungsrat Carl Schweckendieck, Januar 1906

$1901-1906$

Klassifikation Teil B: 00265

Trägermaterial: Papier

Alte Reg.-Sig.: II A 13

Bestell-Nr.: IV 00264

268 Bronzebüsten von verstorbenen Ehrenbürgern

- Anfertigung einer Bronzebüste des Ehrenbürgers Carl Schweckendieck, Geheimer Oberregierungsrat, Oktober 1904 - Mai 1907

- Anfertigung einer Bronzebüste des Ehrenbürgers Fürst Otto v Bismarck, Reichskanzler und preußischer Ministerpräsident, Februar Juni 1907

$1904-1908$

Klassifikation Teil B: 00265

Trägermaterial: Papier

Alte Reg.-Sig.: II A 12

Bestell-Nr.: IV 00265 
04.04 Hoheitssachen

04.04.05

\section{Sonstige Hoheitssachen}

Lfd. Nr. Titel

Laufzeit

269 Ablösung der Emder Postgerechtsame 1877-1909

- Verhandlungen zwischen der kaiserlichen Post und der Stadt Emden wegen Ablösung der Zahlungen der Post an die Stadt Emden nach einem Vertag zwischen der Stadt und dem preußischen König Friedrich II. von 1746 über Entschädigung für die Einstellung des Emder Postwesens zugunsten der preußischen Post, Juli 1877 Dezember 1907

1877 - 1909 (1930)

Klassifikation Teil B: 00402

Trägermaterial: Papier

Alte Reg.-Sig.: III Dc 3

Bestell-Nr.: IV 00402

270 Patenschaft der Stadt Emden über SMS Emden

$1908-1910$

- Einladung des Staatssekretärs im Reichsmarineamt, Admiral Alfred Tirpitz, an den Oberbürgermeister Leo Fürbringer zur Taufe und Stapellauf der SMS Emden in Danzig, Februar - Mai 1908

- Festlegung und Beschaffung des Taufgeschenks für die SMS Emden sowie Auswahl für die Mannschaftsbibliothek, März - April 1908

- Konzepte der Rede des Oberbürgermeisters Fürbringer vor dem Stapellauf der SMS Emden, Mai 1908

- Glückwunschtelegramm des Kaisers Wilhelm II. zum erfolgreichen Stapellauf der SMS Emden, Mai 1908

- Presseberichte zuum Stapellauf der SMS Emden, Mai 1908

- Zusendung eines Bildalbums vom Stapellauf der SMS Emden durch den Staatssekretär im Reichsmarineamt, Admiral Alfred Tirpitz, Juni 1908

- Schreiben des Künstlers Oskar Wichtental an Oberbürgermeister Fürbringer über Angebot eines Reliefs der Stadt Emden für SMS

Emden, Oktober 1908

- Presseberichte über Teilnahme der SMS Emden an der Niederschlagung des Aufstands auf den Karolinen-Inseln im Pazifik, Dezember 1910

$1908-1910$

Klassifikation Teil B: 00403

Band: 1

Trägermaterial: Papier

Alte Reg.-Sig.: III Dg 08

Bestell-Nr.: IV 00403 
04

IV

Beziehungen der Stadt Emden zur Landesherrschaft und zu übergeordneten Landes- und Reichsorganen

04.04 Hoheitssachen

04.04.05 Sonstige Hoheitssachen

Lfd. Nr. Titel

Laufzeit

271 Patenschaft der Stadt Emden über SMS Emden 1908-1914

- Anschaffung und Finanzierung des Patengeschenks der Stadt Emden für SMS Emden, April 1908 - Mai 1909

- Schreiben des Staatssekretärs im Reichsmarineamt, Admiral Alfred Tirpitz, über Dank für das Patengeschenk der Stadt Emden für SMS Emden, Mai 1908

- Anschaffung von Büchern für die Mannschaftsbibliothek der SMS Emden, Dezember 1908

- Liste der Bücher für die Mannschaftsbibliothek, Dezember 1908 Januar 1909

- Telegrafische Nachricht des Kommandeurs der SMS Emden, Fregattenkapitän Engels, über erste Hissung der Emder Stadtflagge und Wimpel auf der SMS Emden, Juli 1909

- Schreiben des Staatssekretärs im Reichsmarineamt, Admiral Alfred Tirpitz, an Oberbürgermeister a.D. Fürbringer über Bitte um handschriftliche Fassung der Taufrede für SMS Emden, Juli 1914 - Presseberichte von der Taufe des Kreuzers "Emden" (III), 1925

$1908-1914$ (1925)

Klassifikation Teil B: 00404

Band: 2

Trägermaterial: Papier

Alte Reg.-Sig.: III Dg 08

Bestell-Nr.: IV 00404

272 Festlegung der Polygon-Punkte (Katastervermessung)

- Festlegung, Finanzierung und Instandhaltung der Polygon-Punkte zur Katastervermessung, November 1889 - Februar 1891

$1889-1891$

Klassifikation Teil B: 00428

Trägermaterial: Papier

Alte Reg.-Sig.: III C 09

Bestell-Nr.: IV 00428 
IV

04

Beziehungen der Stadt Emden zur Landesherrschaft und zu übergeordneten Landes- und Reichsorganen

04.04 Hoheitssachen

04.04.05 Sonstige Hoheitssachen

Lfd. Nr. Titel

Laufzeit

273 Denkmal für den Ehrenbürger Geheimer Oberregierungsrat Carl Schweckendieck

- Anfertigung einer Vergrößerung der Fotoaufnahme von Carl Schweckendieck durch den Berliner Fotografen E. Buber als Vorlage für die Anfertigung einer Büste oder eines Denkmals, Mai - Juli 1906 - Beschluss des Magistrats über Anfertigung einer Büste des verstorbenen Ehrenbürgers Geheimer Oberregierungsrat Schweckendieck, Oktober 1906

- Verhandlungen der Kommission für Errichtung eines Schweckendiekdenkmals über Konzipierung und Anschaffung eines Denkmals für den verstorbenen Ehrenbürger Carl Schweckendieck, August 1912 - März 1913

- Angebote von Künstlern zur Herstellung des Denkmals, September Oktober 1912

- Verhandlungen des Magistrats mit dem Bildhauer Anton Ruller aus Münster wegen Schaffung des Schweckendieckdenkmals, September 1912 - November 1914

- Risszeichnung des Postaments des Schweckendieckdenkmals, 1913 / 1914

- Aufbewahrung des Büste Schweckendiecks beim Bildhauer Anton Rüller, 1914 -1915

- Organisation der Feier zur Enthüllung des

Schweckendieckdenkmals, Juni - Juli 1915

- Rede des pensionierten Oberbürgermeisters Fürbringer als kommissarischer Bürgermeister zur Enthüllung des Schweckendieckdenkmals, Juli 1915

- Reparatur des Schweckendieckdenkmals, 1920

$1906-1915(1920)$

Klassifikation Teil B: 02467

Trägermaterial: Papier

Alte Reg.-Sig.: IV Ba 13

Bestell-Nr.: IV 02467 
IV

05

Stadtverwaltung

05.01

Verwaltungsführung

05.01.01

Registratur

Lfd. Nr. Titel

Laufzeit

274 Anschaffung von Stempeln 1893-1912

- Erlass des preußischen Innenministers über Gebrauch von Stempeln, Dezember 1893 / August 1894

- Anschaffung von Stempeln und Papier, 1907 - 1908 (1923)

- Antrag auf Anschaffung eines Staubsaugers zur Staubentfernung von den Altakten der Registratur und des Archivs, September 1912

$1893-1912(1923)$

Klassifikation Teil B: 00027

Trägermaterial: Papier

Alte Reg.-Sig.: IV C 07

Bestell-Nr.: IV 00027

275 Produktenbuch

- Amtsbuch über (postalische) Ein- und Ausgänge der Stadtverwaltung Emden, 1869

1869

Klassifikation Teil B: 00069

Trägermaterial: Papier

Alte Reg.-Sig.: II A 01

Bestell-Nr.: IV 00069

276 Produktenbuch

1870

- Amtsbuch über (postalische) Ein- und Ausgänge der Stadtverwaltung Emden, 1870

1870

Klassifikation Teil B: 00070

Trägermaterial: Papier

Alte Reg.-Sig.: II A 01

Bestell-Nr.: IV 00070

277 Produktenbuch

- Amtsbuch über (postalische) Ein- und Ausgänge der Stadtverwaltung Emden, 1871

1871

Klassifikation Teil B: 00071

Trägermaterial: Papier

Alte Reg.-Sig.: II A 01

Bestell-Nr.: IV 00071 
IV

05

Stadtverwaltung

05.01

Verwaltungsführung

05.01.01

Registratur

Lfd. Nr. Titel

Laufzeit

278 Produktenbuch

1872

- Amtsbuch über (postalische) Ein- und Ausgänge der Stadtverwaltung Emden, 1872

1872

Klassifikation Teil B: 00072

Trägermaterial: Papier

Alte Reg.-Sig.: II A 01

Bestell-Nr.: IV 00072

279 Produktenbuch

- Amtsbuch über (postalische) Ein- und Ausgänge der Stadtverwaltung Emden, 1873

1873

Klassifikation Teil B: 00073

Trägermaterial: Papier

Alte Reg.-Sig.: II A 01

Bestell-Nr.: IV 00073

280 Produktenbuch

- Amtsbuch über (postalische) Ein- und Ausgänge der Stadtverwaltung Emden, 1874

1874

\author{
Klassifikation Teil B: 00074 \\ Trägermaterial: Papier \\ Alte Reg.-Sig.: II A 01 \\ Bestell-Nr.: IV 00074
}

281 Produktenbuch

- Amtsbuch über (postalische) Ein- und Ausgänge der Stadtverwaltung Emden, 1875

1875
Klassifikation Teil B: 00075
Trägermaterial: Papier
Alte Reg.-Sig.: II A 01
Bestell-Nr.: IV 00075

282 Produktenbuch

- Amtsbuch über (postalische) Ein- und Ausgänge der Stadtverwaltung Emden, 1876

1876

Klassifikation Teil B: 00076

Trägermaterial: Papier

Alte Reg.-Sig.: II A 01

Bestell-Nr.: IV 00076 
IV

05

Stadtverwaltung

05.01

Verwaltungsführung

05.01.01

Registratur

Lfd. Nr. Titel

Laufzeit

283 Produktenbuch

1877

- Amtsbuch über (postalische) Ein- und Ausgänge der Stadtverwaltung

Emden, 1877

1877

Klassifikation Teil B: 00077

Trägermaterial: Papier

Alte Reg.-Sig.: II A 01

Bestell-Nr.: IV 00077

284 Produktenbuch

- Amtsbuch über (postalische) Ein- und Ausgänge der Stadtverwaltung

Emden, 1878

1878

Klassifikation Teil B: 00078

Trägermaterial: Papier

Alte Reg.-Sig.: II A 01

Bestell-Nr.: IV 00078

285 Produktenbuch

- Amtsbuch über (postalische) Ein- und Ausgänge der Stadtverwaltung Emden, 1879

1879

\author{
Klassifikation Teil B: 00079 \\ Trägermaterial: Papier \\ Alte Reg.-Sig.: II A 01 \\ Bestell-Nr.: IV 00079
}

286 Produktenbuch

- Amtsbuch über (postalische) Ein- und Ausgänge der Stadtverwaltung Emden, 1880

- Fehlt -

1880

\author{
Klassifikation Teil B: 00080 \\ Trägermaterial: Papier \\ Alte Reg.-Sig.: II A 01 \\ Bestell-Nr.: IV 00080
}

287 Produktenbuch

- Amtsbuch über (postalische) Ein- und Ausgänge der Stadtverwaltung Emden, 1881

1881

Klassifikation Teil B: 00081

Trägermaterial: Papier

Alte Reg.-Sig.: II A 01

Bestell-Nr.: IV 00081 
IV

05

Stadtverwaltung

05.01

Verwaltungsführung

05.01.01

Registratur

Lfd. Nr. Titel

Laufzeit

288 Produktenbuch

1882

- Amtsbuch über (postalische) Ein- und Ausgänge der Stadtverwaltung Emden, 1882

1882

Klassifikation Teil B: 00082

Trägermaterial: Papier

Alte Reg.-Sig.: II A 01

Bestell-Nr.: IV 00082

289 Produktenbuch

- Amtsbuch über (postalische) Ein- und Ausgänge der Stadtverwaltung Emden, 1883

1883

Klassifikation Teil B: 00083

Trägermaterial: Papier

Alte Reg.-Sig.: II A 01

Bestell-Nr.: IV 00083

290 Produktenbuch

- Amtsbuch über (postalische) Ein- und Ausgänge der Stadtverwaltung Emden, 1884

1884

\author{
Klassifikation Teil B: 00084 \\ Trägermaterial: Papier \\ Alte Reg.-Sig.: II A 01 \\ Bestell-Nr.: IV 00084
}

291 Produktenbuch

- Amtsbuch über (postalische) Ein- und Ausgänge der Stadtverwaltung Emden, 1885

1885
Klassifikation Teil B: 00085
Trägermaterial: Papier
Alte Reg.-Sig.: II A 01
Bestell-Nr.: IV 00085

292 Produktenbuch

- Amtsbuch über (postalische) Ein- und Ausgänge der Stadtverwaltung Emden, 1886

1886

Klassifikation Teil B: 00086

Trägermaterial: Papier

Alte Reg.-Sig.: II A 01

Bestell-Nr.: IV 00086 
IV

05

Stadtverwaltung

05.01

Verwaltungsführung

05.01.01

Registratur

Lfd. Nr. Titel

Laufzeit

293 Produktenbuch

1887

- Amtsbuch über (postalische) Ein- und Ausgänge der Stadtverwaltung Emden, 1887

1887

Klassifikation Teil B: 00087

Trägermaterial: Papier

Alte Reg.-Sig.: II A 01

Bestell-Nr.: IV 00087

294 Produktenbuch

- Amtsbuch über (postalische) Ein- und Ausgänge der Stadtverwaltung Emden, 1888

1888

Klassifikation Teil B: 00088

Trägermaterial: Papier

Alte Reg.-Sig.: II A 01

Bestell-Nr.: IV 00088

295 Produktenbuch

1889

- Amtsbuch über (postalische) Ein- und Ausgänge der Stadtverwaltung Emden, 1889

1889

\author{
Klassifikation Teil B: 00089 \\ Trägermaterial: Papier \\ Alte Reg.-Sig.: II A 01 \\ Bestell-Nr.: IV 00089
}

296 Produktenbuch

- Amtsbuch über (postalische) Ein- und Ausgänge der Stadtverwaltung Emden, 1890

1890
Klassifikation Teil B: 00090
Trägermaterial: Papier
Alte Reg.-Sig.: II A 01
Bestell-Nr.: IV 00090

297 Produktenbuch

- Amtsbuch über (postalische) Ein- und Ausgänge der Stadtverwaltung Emden, 1891

1891

Klassifikation Teil B: 00091

Trägermaterial: Papier

Alte Reg.-Sig.: II A 01

Bestell-Nr.: IV 00091 
IV

05

Stadtverwaltung

05.01

Verwaltungsführung

05.01.01

Registratur

Lfd. Nr. Titel

Laufzeit

298 Produktenbuch

1892

- Amtsbuch über (postalische) Ein- und Ausgänge der Stadtverwaltung

Emden, 1892

1892

Klassifikation Teil B: 00092

Trägermaterial: Papier

Alte Reg.-Sig.: II A 01

Bestell-Nr.: IV 00092

299 Produktenbuch

- Amtsbuch über (postalische) Ein- und Ausgänge der Stadtverwaltung

Emden, 1893

- fehlt -

1893

Klassifikation Teil B: 00093

Trägermaterial: Papier

Alte Reg.-Sig.: II A 01

Bestell-Nr.: IV 00093

300 Produktenbuch

- Amtsbuch über (postalische) Ein- und Ausgänge der Stadtverwaltung Emden, 1894

1894
Klassifikation Teil B: 00094
Trägermaterial: Papier
Alte Reg.-Sig.: II A 01
Bestell-Nr.: IV 00094

301 Produktenbuch

- Amtsbuch über (postalische) Ein- und Ausgänge der Stadtverwaltung Emden, 1895

1895

\author{
Klassifikation Teil B: 00095 \\ Trägermaterial: Papier \\ Alte Reg.-Sig.: II A 01 \\ Bestell-Nr.: IV 00095
}

- Amtsbuch über (postalische) Ein- und Ausgänge der Stadtverwaltung Emden, 1896

1896

Klassifikation Teil B: 00096, 01

Trägermaterial: Papier

Alte Reg.-Sig.: II A 01

Bestell-Nr.: IV 00096 a 
IV

05

Stadtverwaltung

05.01

Verwaltungsführung

05.01.01

Registratur

Lfd. Nr. Titel

Laufzeit

303 Produktenbuch

1896

- Amtsbuch über (postalische) Ein- und Ausgänge der Stadtverwaltung Emden, 1896

1896

Klassifikation Teil B: 00096, 02

Trägermaterial: Papier

Alte Reg.-Sig.: II A 01

Bestell-Nr.: IV 00096 b

304 Produktenbuch

- Amtsbuch über (postalische) Ein- und Ausgänge der Stadtverwaltung Emden, 1897

1897

Klassifikation Teil B: 00097, 01

Trägermaterial: Papier

Alte Reg.-Sig.: II A 01

Bestell-Nr.: IV 00097 a

305 Produktenbuch

1897

- Amtsbuch über (postalische) Ein- und Ausgänge der Stadtverwaltung Emden, 1897

1897

\author{
Klassifikation Teil B: 00097, 02 \\ Trägermaterial: Papier \\ Alte Reg.-Sig.: II A 01 \\ Bestell-Nr.: IV 00097 b
}

306 Produktenbuch

- Amtsbuch über (postalische) Ein- und Ausgänge der Stadtverwaltung Emden, 1898

1898
Klassifikation Teil B: 00098, 01
Trägermaterial: Papier
Alte Reg.-Sig.: II A 01
Bestell-Nr.: IV 00098 a

307 Produktenbuch

- Amtsbuch über (postalische) Ein- und Ausgänge der Stadtverwaltung Emden, 1898

1898

Klassifikation Teil B: 00098, 02

Trägermaterial: Papier

Alte Reg.-Sig.: II A 01

Bestell-Nr.: IV 00098 b 
IV

05

Stadtverwaltung

05.01

Verwaltungsführung

05.01.01

Registratur

Lfd. Nr. Titel

Laufzeit

308 Produktenbuch

1899

- Amtsbuch über (postalische) Ein- und Ausgänge der Stadtverwaltung Emden, 1899

1899

Klassifikation Teil B: 00099, 01

Trägermaterial: Papier

Alte Reg.-Sig.: II A 01

Bestell-Nr.: IV 00099 a

309 Produktenbuch

- Amtsbuch über (postalische) Ein- und Ausgänge der Stadtverwaltung Emden, 1899

1899

Klassifikation Teil B: 00099, 02

Trägermaterial: Papier

Alte Reg.-Sig.: II A 01

Bestell-Nr.: IV 00099 b

310 Bibliothek der Stadtverwaltung Emden

$1867-1901$

- Angebote an die Stadt Emden über Gesetzessammlungen und Publikationen staatlicher und kommunaler Verordnungen, Statistiken etc., 1869 - 1901

- Katalog über Anschaffungen für die Ratsbibliothek, 1867

- Überreichung des von der Gesellschaft für bildende Kunst und vaterländische Altertümer herausgegebenen und von Dr. Tergast verfassten Werkes über das ostfriesische Münzwesen an den Magistrat der Stadt Emden, Dezember 1883

- Überreichung von Jahresberichten verschiedener Vereine von Berufsständen oder mit gemeinnützigen Zwecken, 1875 - 1894

- Verhandlungen der Stadt Emden mit den Buchhändlern W. Haynel und W. Schwalbe über Gewährung eines Rabatts für

Buchbestellungen durch die Stadtverwaltung und die städtischen

Schulen, Dezember 1887

- Anschaffungen für die Ratsbibliothek, 1892

- Überreichung von Druckschriften und anderen Publikationen durch

Privatpersonen, 1892 - 1893

- Erwerb von juristischer Fachliteratur durch die Stadtverwaltung, 1895

$-1900$

- Angebote verschiedener Autoren über Fachpublikationen zur Emder

Stadtgeschichte und Stadtansichten, 1896 - 1901

- Angebot von Fotografien der neuerbauten Emder Hafenanlagen und des Emder Rathauses durch das Eisenwerk AG, April 1900

- Angebot von Fotografien der neuerbauten Emder Hafenanlagen durch den Architekten und Hoffotografen Hermann Rückwardt aus

Berlin-Lichterfelde, September 1900

$1867-1901$

Klassifikation Teil B: 00259

Trägermaterial: Papier

Alte Reg.-Sig.: II A 06

Bestell-Nr.: IV 00259 
IV

05

Stadtverwaltung

05.01

Verwaltungsführung

05.01.01

Registratur

Lfd. Nr. Titel

Laufzeit

311 Bibliothek der Stadtverwaltung Emden

$1901-1913$

- Angebote an die Stadt Emden über Gesetzessammlungen und Publikationen staatlicher und kommunaler Verordnungen, Statistiken etc., $1901-1910$

- Anschaffungen für die Ratsbibliothek, 1903 - 1907

- Angebote verschiedener Autoren über Fachpublikationen zu über kulturelle und heimatbezogene Fachliteratur, 1906 - 1913

$1901-1913$

Klassifikation Teil B: 00261

Trägermaterial: Papier

Alte Reg.-Sig.: II A 06

Bestell-Nr.: IV 00261

312 Entleihungen aus der Ratsbibliothek

1903-1909

- Verzeichnis der durch den geheimen Oberbaurat Fülscher in Berlin entliehenen Bücher aus der Bibliothek des Oberbürgermeisters Leo Fürbringer, April 1903

- Verzeichnis der durch den geheimen Oberbaurat Fülscher in Berlin entliehenen Bücher aus der Ratsbibliothek, April 1903

- Schreiben des Magistrats der Stadt Emden an die geheime

Registratur des Nachrichtenbüros im Reichsmarineamt über Bitte um Rückgabe entliehener Pläne zum Hafenbau und zur Stadtplanung, Januar 1905

$1903-1909$

Klassifikation Teil B: 00262

Trägermaterial: Papier

Alte Reg.-Sig.: II A 14

Bestell-Nr.: IV 00262 
IV

05

Stadtverwaltung

05.01

Verwaltungsführung

05.01.01

Registratur

Lfd. Nr. Titel

Laufzeit

313 Registratur der Emder Stadtverwaltung

- Aktenpläne der Stadtverwaltung, 1857 - 1866

- Registraturordnung der Stadt Emden, 1857 - 1866

- Rechnung über Ordnungsarbeiten des Registrators C.J. Schüte,

1857 - 1859

- Verfügung der Kronanwaltschaft in Aurich an den Magistrat der Stadt

Emden über Aufforderung zur Abgabe der Notariatsakten aus dem

ehemaligen Stadtgericht an das Amtsgericht, Mai - Juli 1876

- Abgaben von Gasthaus-Akten an die Magistrats-Registratur,

Dezember 1876

- Bewerbung des Registrators Stärge aus Leer um eine Stelle bei der

Registratur und dem Archiv der Stadt Emden, Mai 1877

- Anfrage des Magistrats der Stadt Emden an verschiedene

Nachbarstädte wegen Registraturordnung, Juli 1883

- Auslagerung der Alten Registratur (I. Registratur) in das Gebäude der ehemaligen französisch reformierten Gemeinde in Emden

(städtische Waage), April 1894

- Verfügung des Magistrats über Abgaben der Akten der

Schulverbände der evangelischen und katholischen Gemeinden an die städtische Registratur wegen Zuständigkeit der Stadt für die

Schulen, April 1908

$1857-1908$

Klassifikation Teil B: 00263

Trägermaterial: Papier

Alte Reg.-Sig.: II A 10

Bestell-Nr.: IV 00263

314 Abgabe von Akten an das Bauamt

- Anforderung von Akten aus der Verwaltungsregistratur durch das Bauamt, Juni 1912

- Liste der von der Registratur an das Bauamt abgegebenen Akten, Juni 1912 - Dezember 1913

$1912-1913$

Klassifikation Teil B: 00266

Trägermaterial: Papier

Alte Reg.-Sig.: II A 16

Bestell-Nr.: IV 00266 
IV

05

Stadtverwaltung

05.01

Verwaltungsführung

05.01.01

Registratur

Lfd. Nr. Titel

Laufzeit

315 Archiv der Stadt Emden

$1899-1916$

(1922)

- Anfragen wegen Recherchen zu historischen Themen, 1899 - 1915

- Initiative des Leiters des preußischen Staatsarchivs in Aurich, geh.

Archivrat Dr. Wachter, zur Eingliederuing des Emder Archivs nach

Aurich, Juni 1906

- Ausleihe von Akten der I. Registratur des Stadtarchivs Emden, 1906

$-1912$

- Eingabe der Gesellschaft für bildende Kunst und vaterländische Altertümer über Bitte um Erlaubnis für den Historiker Dr. Hagedorn zur Veröffentlichung von aus der Ersten Registratur gewonnenen Informationen, Mai 1908

- Eingabe der Gesellschaft für bildende Kunst und vaterländische Altertümer über Protest gegen eine etwaige Einverleibung des Emder Archivs durch das Staatsarchiv Aurich, Juni 1908

- Gutachten des Oldenburgischen geheimen Archivrats Georg Sello zur Notwendigkeit der Neuorganisation des Emder Stadtarchivs,

August - September 1909

- Verhandlungen der Kommission zur Neuordnung des Stadtarchivs,

Oktober - November 1909

- Verfügung des Regierungspräsidenten in Aurich über Entsendung des geh. Archivrats Dr. Wachter zur Durchsicht der älteren Akten des Emder Stadtarchivs, Dezember 1910

$1899-1916$

Klassifikation Teil B: 00267

Trägermaterial: Papier

Alte Reg.-Sig.: II A 05

Bestell-Nr.: IV 00267

316 Produktenbuch

- Amtsbuch über (postalische) Ein- und Ausgänge der Stadtverwaltung Emden, 1867

1867

Klassifikation Teil B: 00270

Trägermaterial: Papier

Alte Reg.-Sig.: II A 01

Bestell-Nr.: IV 00270 
IV

05

Stadtverwaltung

05.01

Verwaltungsführung

05.01.01

Registratur

Lfd. Nr. Titel

Laufzeit

317 Kassierung und Ausscheidung von Akten aus den Registraturen

- Vorschriften über Kassierung von Dokumenten und Vernichtung von Akten aus der Hannoverschen Zeit, 1856 - 1866

- Vernichtung von Steuerakten mit der Aufbewahrungsfrist bis 1866, November 1866

- Erlass des Oberpräsidenten der Provinz Hannover über Anordnung der Hinzuziehung der Staatsarchive oder Archive vor jeder

Aktenvernichtung, April 1870

- Aktenvernichtung bei der Emder Stadtverwaltung, 1913 - 1914

- Verkauf der zu vernichtenden Akten an die Papierfabrik Heinrich

Geldmacher, Mai 1913 - Februar 1914

- Sammlung von Altpapier aus den Behörden für die Kriegswirtschaft, 1914 - 1918

- Verzeichnis der zu vernichtenden Akten der Stadt Emden, Mai 1917

(1856-1866) 1866 - 1914 (1914 - 1918)

Klassifikation Teil B: 00664

Trägermaterial: Papier

Alte Reg.-Sig.: IV A 1

Bestell-Nr.: IV 00664 
IV

05

Stadtverwaltung

05.01

Verwaltungsführung

05.01 .02

Geschäftsberichte

Lfd. Nr. Titel

Laufzeit

318 Statistische Berichte des Magistrats der Stadt Emden

- Statistische Berichte des Magistrats der Stadt Emden über Tätigkeit verschiedener Verwaltungsbereiche (u.a. Polizeiwesen, Schulwesen, Armenwesen), 1868 - 1869

$1868-1869$

Klassifikation Teil B: 00271

Trägermaterial: Papier

Alte Reg.-Sig.: II B

Bestell-Nr.: IV 00271

319 Statistische Berichte des Magistrats der Stadt Emden

$1869-1870$

- Statistische Berichte des Magistrats der Stadt Emden über Tätigkeit verschiedener Verwaltungsbereiche (u.a. Polizeiwesen, Schulwesen, Armenwesen), 1869 - 1870

Nicht vorhanden

$1869-1870$

Klassifikation Teil B: 00272

Trägermaterial: Papier

Alte Reg.-Sig.: II B

Bestell-Nr.: IV 00272

320 Statistische Berichte des Magistrats der Stadt Emden

$1870-1871$

- Statistische Berichte des Magistrats der Stadt Emden über Tätigkeit verschiedener Verwaltungsbereiche (u.a. Polizeiwesen, Schulwesen, Armenwesen), 1870 - 1871

Nicht vorhanden

$1870-1871$

Klassifikation Teil B: 00273

Trägermaterial: Papier

Alte Reg.-Sig.: II B

Bestell-Nr.: IV 00273

321 Geschäftsberichte (Statistik)

- Geschäftsberichte des Eichamtes, 1899 - 1900

$1899-1900$

Klassifikation Teil B: 00277

Trägermaterial: Papier

Alte Reg.-Sig.: II B 7

Bestell-Nr.: IV 00277 


\section{IV}

05

Stadtverwaltung

05.01

Verwaltungsführung

05.01.03

Bekanntmachungen des Landdrosten und

Regieruingspräsidenten in Aurich

Lfd. Nr. Titel

Laufzeit

322 Bekanntmachungen des preußischen Landdrosten in Aurich

$1867-1870$

- Bekanntmachung von Ministerialerlassen, Verfügungen des

Oberpräsidenten in Hannover und des preußischen Landdrosten in

Aurich, 1867 - 1870

$1867-1870$

Klassifikation Teil B: 00306

Trägermaterial: Papier

Alte Reg.-Sig.: II E 38

Bestell-Nr.: IV 00306

323 Bekanntmachungen des preußischen Regierungspräsidenten in

Aurich

- Bekanntmachung von Ministerialerlassen, Verfügungen des

Oberpräsidenten in Hannover und des preußischen

Regierungspräsidenten in Aurich, 1886 - 1905

$1886-1905$

Klassifikation Teil B: 00309

Trägermaterial: Papier

Alte Reg.-Sig.: II E 38

Bestell-Nr.: IV 00309 
05

05.01

05.01.04
Stadtverwaltung

Verwaltungsführung

Geschäftsbereiche

Lfd. Nr. Titel

Laufzeit

324 Gebühren- und sonstige Ordnungen der Stadt Emden

- Statut über Anlegung und Veränderung von Straßen, 1901

- Baupolizei-Gebühren-Ordnung, August 1909 / Oktober 1912

- Müll- und Fäkalienabfuhr-Gebührenordnung, Februar 1914

- Kanalgebührenordnung, Februar 1914

- Statut der städtischen Marktkommission, 1877

- Wochenmarkts-Ordnung, 1877 / August 1908

- Butter- und Käsemarktsordnung, April 1902

- Reglement der Kornbörse in Emden, August 1899

- Armenhaus-Ordnung, 1902

$1877-1912$

Klassifikation Teil B: 00030

Trägermaterial: Papier

Bestell-Nr.: IV 00030

325 Vervielfältigung des aktuellen Stadtplans

$1902-1907$

- Ausschreibung des Projektes der Vervielfältigung des vom

Bauaufseher Braa hergestellten Stadtplans von Emden mit den

Erweiterungen des Stadtgebiets, Dezember 1902

- Angebot der Lithographischen Anstalt Bogdan Gisovius, Berlin über

Vervielfältigung des Plans und Gestaltung, Dezember 1902

- Angebot der Steindruckerei, Buch-, Kunst und Musikalienhandlung

W. Schwalbe, Emden über Vervielfältigung des Plans und Gestaltung, Januar 1903

- Angebot der Lithographischen Anstalt M. Wilkens. Leer über

Vervielfältigung des Plans und Gestaltung, Dezember 1903

- Angebot des Pharusverlages über Herstellung eines Stadtplanes von

Emden, September 1907

- Bitte der Großherzoglichen Hochschule in Darmstadt um Zusendung eines Stadtplanes von Emden, Dezember 1907

$1902-1907$

Klassifikation Teil B: 00303

Trägermaterial: Papier

Alte Reg.-Sig.: II E 68

Bestell-Nr.: IV 00303

326 Verwaltungsgebühren

$1867-1880$

- Verfügungen des preußischen Landdrosten in Aurich über

Eintreibung von Verwaltungsgebühren, 1867 - 1880

- Übersicht über von der Stadtkasse vereinnahmte

Verwaltungsgebühren, 1868 - 1876

$1867-1880$

Klassifikation Teil B: 00305

Trägermaterial: Papier

Alte Reg.-Sig.: I E 45

Bestell-Nr.: IV 00305 
IV

05

Stadtverwaltung

05.01

Verwaltungsführung

05.01.04

Geschäftsbereiche

Lfd. Nr. Titel

Laufzeit

327 Vergebung von Buchdruckarbeiten

1911-1922

- Angebote verschiedener Firmen über Buchdruckarbeiten für die Stadtverwaltung, 1911 - 1922

$1911-1922$

Klassifikation Teil B: 00307

Trägermaterial: Papier

Alte Reg.-Sig.: II E 67

Bestell-Nr.: IV 00307

328 Handakte des Oberbürgermeisters Leo Fürbringer

1. Consistorium zu Aurich

- Revision des französisch-reformierten Predigerwitwenkasse durch

das kgl. Consistorium in Aurich, Januar 1892 - Juli 1897

- Revision der Kirchenrechnung der französisch-reformierten

Gemeinde zu Emden, September 1894 - Juli 1896

2. Regierung zu Aurich

- Verfügungen des Regierungspräsidenten in Aurich zu verschiedenen politischen, polizeilichen, wirtschaftlichen und sozialen Bereichen (u.a.: Kulturkampf gegen die katholische Kirche; Beobachtung der Kriegervereine; Landtagswahlen; Empfehlungen für die Wahl von Landschaftsdelegierten), August 1876 - Januar 1879

$1876-1896$

Klassifikation Teil B: 00308

Trägermaterial: Papier

Alte Reg.-Sig.: II E 79

Bestell-Nr.: IV 00308

329 Geschäftsführung

$1868-1914$

- Ministerialerlasse, Erlasse des Oberpräsidenten in Hannover und Verfügungen des Regierungspräsidenten in Aurich über Normern für Berichterstattung, Papierformate, Firmierungen und Kurialia, 1868 -

1917

- Anordnung des Bürgermeisters Dr. Wilhelm Mützelburg zur Verwaltungsvereinfachung: Abschaffung der Tagebücher, Kürzel für Dienststellen, Oktober 1913

$1868-1917$

Klassifikation Teil B: 00311

Trägermaterial: Papier

Alte Reg.-Sig.: II E 47

Bestell-Nr.: IV 00311 
IV

05

05.01

05.01.04
Stadtverwaltung

Verwaltungsführung

Geschäftsbereiche

Lfd. Nr. Titel

Laufzeit

330 Verträge der Stadt Emden

- Vertrag zwischen dem Provinzial Schulkollegium und der Stadt

Emden über Verstaatlichung des Emder Gymnasiums, März 1872

- Vertrag über den Übergang des Emder Hafens nach Preußen,

Dezember 1879 / September 1882

- Vertrag zwischen der Stadt Emden und dem Wasserwerk für das

nördliche westfälische Kohlenrevier über Bau und Betrieb eines

Wasserwerkes in Emden, Februar 1894

- Statut der Douwe-Stiftung, Juli 1897

- Vertrag über den Verkauf der Nordseewerke an den Industriellen

Hugo Stinnes u.a., Oktober 1911

- Vertrag zwischen der preußischen Staatsbauverwaltung und der Stadt Emden über Lieferung von elektrischem Strom aus dem Kraftwerk Wiesmoor nach Emden, Juni - Juli 1912

- Vertrag zwischen der preußischen Staatsregierung und der Hamburg-Amerika-Linie, Hamburg und dem Lloyd, Bremen über

Einrichtung einer Auswanderer-Linie ab Emden, Dezember 1912

- Vertrag zwischen der Hamburg-Amerika-Linie und der Stadt Emden über Verkauf eines Geländes an die HAPAG zur Errichtung von Abfertigungshallen für Auswanderer, Mai 1913

- Schenkungsvertrag des Johann Martho Schnedermann und seiner Frau Anna Katharina, geb. Brons über Grundstücke von zusammen 21 Ar zur Errichtung einer Siedlung für Kriegsteilnehmer, Dezember 1916

$1872-1916$

Klassifikation Teil B: 00312

Trägermaterial: Papier

Alte Reg.-Sig.: IV A 2

Bestell-Nr.: IV 00312

331 Herausgabe eines neuen Adressbuches

$1910-1913$

- Verhandlungen zwischen Bürgervorsteherkollegium und Magistrat wegen Herausgabe eines neuen Adressbuches und seine

Finanzierung, Februar - Oktober 1910

- Verhandlungen der Adressbuch-Kommission wegen Organisation der Herausgabe und Redaktion des Adressbuches, Februar 1911 Februar 1912

- Aufnahme von Wolthusen in das Adressbuch der Stadt Emden, Mai 1911

- Angebote verschiedener Firmen zum Druck des Adressbuches, Juli 1911

- Anzeigenakquise, 1911

- Abrechnung und Eintreibung offener Beträge, 1912 - 1913

$1910-1913$

Klassifikation Teil B: 00321

Trägermaterial: Papier

Alte Reg.-Sig.: II E 52

Bestell-Nr.: IV 00321 
IV

05

Stadtverwaltung

05.01

Verwaltungsführung

05.01.04

Geschäftsbereiche

Lfd. Nr. Titel

Laufzeit

332 Herausgabe eines neuen Adressbuches

1913-1914

- Verhandlungen zwischen Bürgervorsteherkollegium und Magistrat wegen Herausgabe eines neuen Adressbuches und seine

Finanzierung, Februar - April 1913

- Verhandlungen der Adressbuch-Kommission wegen Organisation

der Herausgabe und Redaktion des Adressbuches, April 1913

- Aufnahme von Wolthusen in das Adressbuch der Stadt Emden, April

1913

- Angebote verschiedener Firmen zum Druck des Adressbuches, April

- Juni 1913

- Anzeigenakquise, 1913

- Abrechnung und Eintreibung offener Beträge, 1914

$1913-1914$

Klassifikation Teil B: 00322

Trägermaterial: Papier

Alte Reg.-Sig.: II E 52

Bestell-Nr.: IV 00322 
IV

05

Stadtverwaltung

05.02

Personal der Stadtverwaltung

05.02.01

Untergebene des Magistrats

05.02.01.01

Mittlere Beamte des Kanzleidienstes

Lfd. Nr. Titel

Laufzeit

333 Stadtsekretär Ernst H. Böse

$1902-1911$

- Ernennung des Registrators Ernst H. Böse zum Stadtsekretär, Januar 1902

- Dienstanweisung für den Stadtsekretär, August 1902

- Ehrengeschenk für den Stadtsekretär Ernst H. Böse anlässlich

seines 25-jährigen Dienstjubiläums, November 1904

- Nachruf auf den verstorbenen Stadtsekretär Ernst H. Böse, April

1911

$1902-1911$

Klassifikation Teil B: 00151

Trägermaterial: Papier

Alte Reg.-Sig.: I E 15

Bestell-Nr.: IV 00151

334 Registrator und Stadtsekretär Adolph Dauwes

$1879-1907$

- Ernennung des Sekretariatsgehilfen Adolph Dauwes zum Registrator unter Erhöhung seines Gehalts, Oktober - Dezember 1879

- Antrag des Registrators Adolph Dauwes auf Verleihung eines Status als Beamter auf Lebenszeit, September 1885

- Ernennung des Registrators Adolph Dauwes zum Stadtsekretär, Juni 1887

- Dienstanweisung für den Stadtsekretär, Juni 1887

- Antrag des Stadtsekretärs Dauwes auf Pensionierung wegen

Nervenleiden, November 1901

- Nachruf auf den Stadtsekretär Adolph Dauwes, April 1907

$1879-1907$

Klassifikation Teil B: 00152

Trägermaterial: Papier

Alte Reg.-Sig.: I E 14

Bestell-Nr.: IV 00152 
Lfd. Nr. Titel

- Wahl des J. Hemkes zum Stadtsekretär durch eine gemeinsame Versammlung von Magistrat und Bürgervorsteher-Kollegium, Mai 1854

- Vereidigung des Stadtsekretärs J. Hemkes, Juni 1854

- Dienstanweisung für den Stadtsekretär J. Hemkes, Juni 1854

- Bewerbung des Registrators W.J. Heise um die Stelle eines zweiten Stadtsekretärs, Januasr 1855

- Gehaltsfestlegung für den zweiten Stadtsekretär, Januar 1855

- Dienstanweisung für den zweiten Stadtsekretär W.J. Heise, Januar 1854

- Vereidigung des Stadtsekretärs W.J. Heise auf die preußische

Verfassung, Februar 1868

- Bewilligung einer Gehaltszulage für den Stadtsekretär W.J. Heise, Januar 1873

- Pensionierung des Stadtsekretärs W. J. Heise, Juni 1887

$1854-1887$

Klassifikation Teil B: 00156

Trägermaterial: Papier

Alte Reg.-Sig.: I E 10

Bestell-Nr.: IV 00156

336 Kanzlist Wilke Hinrichs Janßen

- Einstellung des Kontoristen Wilke Hinrichs Janßen bei der städtischen Kanzlei, Juli 1854

- Anweisung an die Kämmerei wegen der Gehaltszahlungen an den Kanzlisten W.H. Janßen, November 1854

- Vereidigung des Kanzlisten W.H. Janßen, November 1854

- Zeugnis für den Kanzlisten W.H. Janßen, Oktober 1857

$1854-1857$

Klassifikation Teil B: 00158

Trägermaterial: Papier

Alte Reg.-Sig.: I Ga 01

Bestell-Nr.: IV 00158

337 Bürogehilfe Rudolf Siebolds

- Einstellung des R. Siebolds als Bürogehilfe beim Steuerbüro,

Oktober 1916

- Gehaltsfestsetzung für den Bürogehilfen R. Siebolds, Dezember

1916

- Dienstvertrag zwischen der Stadt Emden und dem R. Siebolds,

Dezember 1916

$1916-1917$

Klassifikation Teil B: 00159

Trägermaterial: Papier

Alte Reg.-Sig.: I Ge 52

Bestell-Nr.: IV 00159 
Lfd. Nr. Titel

- Beschäftigung des Christian Schoneboom als Bürogehilfe im Steuerbüro der Stadt Emden, 1900 - 1917

- Vermerk über Einziehung eines Gehaltsvorschusses wegen zuviel gezahlter Teuerungszulagen an Christian Schoneboom, Mai - Juni 1917

- Eingabe des F. Dinkela an den Magistrat der Stadt Emden über Beschwerde gegen Chr. Schoneboom wegen dessen Nebentätigkeit als Steuerberater, Mai 1914

$1900-1917$

Klassifikation Teil B: 00160

Trägermaterial: Papier

Alte Reg.-Sig.: I Ge 51

Bestell-Nr.: IV 00160

339 Maschinenschreiberin Anni Edelmann

- Bewerbung der Anni Edelmann bei der Stadt Emden um eine Stelle als Maschinenschreiberin, November 1916

- Beschäftigung der Anni Edelmann als Maschinenschreiberin,

Dezember 1916 - September 1918

- Gehaltsfestsetzung für die Maschinenschreiberin Anni Edelmann,

August 1918

$1916-1918$

Klassifikation Teil B: 00161

Trägermaterial: Papier

Alte Reg.-Sig.: I Ge 50

Bestell-Nr.: IV 00161

340 Kanzlisten

- Ausschreibungen von Stellen bei der städtischen Kanzlei, Februar 1872 - März 1878

- Bewerbung des Schreibers Ludwig Friedrich Schmidt aus Aurich um eine Kanzlistenstelle, März 1872

- Zeugnis für den Kanzlisten Ludwig Fr. Schmidt, Juli 1879

- Bewerbung des Notariatsgehilfen E. Backhaus aus Leer um eine Kanzlistenstelle, März 1878

- Bewerbung des Amtssekretariatsgehilfen Johann Rewert Monkhorst um eine Kanzlistenstelle bei der Stadt Emden, Juli 1879

- Einstellung des Kanzlisten Johan R. Monkhorst, Oktober - November 1879

- Eingabe des Kanzlisten Monkhorst über Bitte um Gehaltserhöhung,

März 1881 / März 1885

- Beschluss des Bürgervorsteher-Kollegiums über Gehaltserhöhung für den Sekretariatsgehilfen Monkhorst, April 1883 / April 1885

- Kanzlist Richard Pakebusch, 1901 - 1902

$1872-1902$

Klassifikation Teil B: 00196

Trägermaterial: Papier

Alte Reg.-Sig.: I Ga 01

Bestell-Nr.: IV 00196 
05.02

\author{
Personal der Stadtverwaltung
}

05.02.01

Untergebene des Magistrats

05.02.01.01

Mittlere Beamte des Kanzleidienstes

Lfd. Nr. Titel

Laufzeit

341 Kanzleischreiber M. Zeiß

- Antrag des Kämmerers Gebest auf Schaffung einer weiteren Schreiber-Stelle wegen Zunahme der Geschäfte, Oktober1891

- Antrag des Magistrats der Stadt Emden beim Regierungspräsidenten in Aurich auf Genehmigung einer weiteren Schreiberstelle bei der Kanzlei, Dezember 1891 - März 1892

- Beschluss der Bürgervorsteher-Kollegiums über Einstellung des M.

Zeiß als Kanzleischreiber auf der Basis eines Honorarvertrages, März

- April 1892

- Bewerbung des Gerhard Eckhoff um eine Stelle als

Kämmerei-Schreibers, April 1892

- Einstellung des M. Zeiß als Kämmerei-Schreiber, November 1892

- Schreiben der Kreissparkasse Eschwege an den Magistrat der Stadt

Emden über Bitte um Zeugnis für den Kanzlisten M. Zeiß wegen

seiner Bewerbung als Kassenbeamter, Dezember 1891

- Entlassungsgesuch des Kämmereischreibers M Zeiß wegen

Wechselabsicht als Kassenbeamter zur Kreissparkasse Eschwege, April 1892

$1891-1892$

Klassifikation Teil B: 00197

Trägermaterial: Papier

Alte Reg.-Sig.: I Gaa 1

Bestell-Nr.: IV 00197

342 Steuerkanzlist Ernst Hischer

- Bewerbung des Bürogehilfen Ernst Hischer um eine Kanzlistenstelle im Steuerbüro der Stadt Emden, Februar 1907

- Einstellung des Ernst Hischer als Kanzlist, April 1907

- Dienstanordnung für den Kanzlisten Ernst Hischer, Mai 1907

- Entlassung des Kanzlisten Hischer wegen langer Dienstunfähigkeit, August 1908

$1907-1908$

Klassifikation Teil B: 00219

Trägermaterial: Papier

Alte Reg.-Sig.: I Ga 34

Bestell-Nr.: IV 00219 
IV

05

Stadtverwaltung

05.02

Personal der Stadtverwaltung

05.02.01

Untergebene des Magistrats

05.02.01.01

Mittlere Beamte des Kanzleidienstes

Lfd. Nr. Titel

Laufzeit

343 Verschwiegenheitsgebot für Kanzleibeamte

1869-1902

- Verfügung des Oberpräsidenten der preußischen Provinz Hannover über Verschwiegenheitsgebot für Beamte, März 1869

- Verfügung des preußischen Landdrosten in Aurich über Verbot der Anfertigung von Gesuchen für Privatpersonen durch Beamte der

Stadt- und Gemeindeverwaltungen, September 1874

- Erlass des preußischen Ministers der geistlichen, Unterrichts- und Medizinalangelegenheiten über Verbot der Veröffentlichung vertraulicher Erlasse, März 1894

- Verfügung des Magistrats der Stadt Emden über

Amtsverschwiegenheit der Beamten, Mai 1902

$1869-1902$

Klassifikation Teil B: 00220

Trägermaterial: Papier

Alte Reg.-Sig.: I Ga 21

Bestell-Nr.: IV 00220 
05.02

Lfd. Nr. Titel

Polizei-Bedienstete

344 Polizeikommissar Friedrch Soldatow

Laufzeit

- Lebenslauf des Polizeiwachtmeisters Friedrich Soldatow aus Barmen, 1886

- Bewerbung des Polizeiwachtmeisters Friedrich Soldatow aus Barmen um die Stelle eines Polizeikommissars in Emden, Januar 1890

- Gesuch des Polizeikommissars Soldatow um Beihilfe zu den Umzugskosten nach Emden, November 1890

- Berichte über Alkoholmissbrauch des Polizeikommissars Friedrich

Soldatow, Juli - August 1894

- Entlassungsgesuch des Polizeikommissars Friedrich Soldatow, September 1894

$1886-1895$

Trägermaterial: Papier

Alte Reg.-Sig.: I Gb 25

Bestell-Nr.: IV 00227

345 Polizeisergeant Jakobus Dinkela

- Bewerbung des Militäranwärters Jacobus Dinkela aus Ditzum um eine Stelle als Polizeisergeant, Februar 1902

- Vorladung des J. Dinkela zur Gesundheitsprüfung, März 1902

- Führungszeugnis des Gemeindevorstehers in Ditzum, J. Mansholt für den Militärinvaliden, Fischhändler und Gesindemakler Jacobus Dinkela, April 1902

- Gesundheitszeugnis für J. Dinkela, 1892 / 1902

- Bestätigung der Einstellung des Jacobus Dinkela als

Polizeisergeanten durch den Regierungspräsidenten in Aurich, Mai 1902

- Gesuch des Jacobus Dinkela um Entlassung aus dem Polizeidienst wegen zu geringem Gehalt, September 1902

(1892) 1902

Klassifikation Teil B: 00155

Trägermaterial: Papier

Alte Reg.-Sig.: I Gb 25

Bestell-Nr.: IV 00155

346 Polizeisergeant Kryno Bouman

- Bewerbung des Kaufmanns Kryno Bouman um eine Stelle als Polizeisergeant, Dezember 1893

- Verfügung des Regierungspräsidenten in Aurich über Bestätigung der Ernennung Boumans zum Polizeisergeanten, April 1884

- Entlassungsgesuch des Polizeisergeanten K. Bouman, März 1899 Klassifikation Teil B: 00175

Trägermaterial: Papier

Alte Reg.-Sig.: I Gb 25

Bestell-Nr.: IV 00175 
05.02

Lfd. Nr. Titel

- Personalbogen Polizeisergeant Christian Boysen, 1912

- Bewerbung des Unteroffiziers Christian Boysen um eine Stelle als

Polizeisergeant, Januar 1912

- Wahl des Christian Boysen zum Polizeisergeanten, März 1912

- Vereidigung des Polizeisergeanten Christian Boysen, April 1912

Beschwerde des Kaufmanns Johann Gerhard Uffen gegen den

Polizeisergeanten Boysen wegen ungerechtfertigter Festnahme und

Rufschädigung, September 1912

- Beshwerde des Maschinisten Julius Baumann gegen den

Polizeisergeanten Christian Boysen wegen roher Behandlung bei der Festnahme und in der Polizeihaft, September 1912

Beschwerde der Witwe Catharina Dänekas aus Oldenburg gegen den Polizeisergeanten Chr. Boysen wegen Nichtrückgabe von ihm geliehenem Geldes und Beantragung einer Gehaltspfändung, Mai Juni 1914

- Entlassungsgesuch des Polizeisergeanten Christian Boysen, Juni 1914

- Antrag des ehemaligen Polizeisergeanten Chr. Boysen auf Einsicht in seine Personalakte, Juni 1915

- Einstellung des Christian Boysen als Hilfsschreiber im Rahmen eines Honorarvertrages, Februar 1915

$1912-1915$

Klassifikation Teil B: 00176

Trägermaterial: Papier

Alte Reg.-Sig.: I Gb 25

Bestell-Nr.: IV 00176

348 Polizeisergeant Otto Schuppenies

- Bewerbung des invaliden Angehörigen der Schutztruppe für Deutsch-Südwestafrika, Otto Schuppenies aus dem Regierungsbezirk Gumbinnen um die Stelle eines Polizeisergeanten, März 1907

- Vereidigung des Otto Schuppenies, Mai 1907

- Entlassungsgesuch des Otto Schuppenies, Juni 1907 
IV

05

Stadtverwaltung

05.02

Personal der Stadtverwaltung

05.02.01

05.02.01.02

Untergebene des Magistrats

Polizei-Bedienstete

Lfd. Nr. Titel

Laufzeit

349 Polizeisergeant Willy Fischer

1905

- Bewerbung des Militäranwärters Willy Fischer um eine Stelle als

Polizeisergeant, Februar 1905

- Bestätigung der Einstellung des Willy Fischer aus Braunschweig als

Polizeisergeant durch den Regierungspräsidenten in Aurich, März

1905

- Anordnung an die Kämmereikasse über Gehaltsauszahlung an den

Polizeisergeanten Willy Fischer, April 1905

- Gesuch des Polizeisergeanten Willy Fischer über Bitte um

Rücknahme seiner Kündigung wegen unsittlicher Beziehung zu einer

Frau, Juni 1905

- Bericht über Unfähigkeit des Polizeisergeanten Fischer zum

Polizeidienst wegen Trunkenheit, Juni 1905

1905

Klassifikation Teil B: 00177

Trägermaterial: Papier

Alte Reg.-Sig.: I Gb 25

Bestell-Nr.: IV 00177

350 Polizeisergeant Wilke Dirks Flohr

- Bestätigung der Wahl des Wilke Dirks Flohr zum Polizeisergeanten durch den preußischen Landdrosten in Aurich, April 1880

- Vereidigung des Wilke Dirks Flohr, April 1880

1880

Klassifikation Teil B: 00178

Trägermaterial: Papier

Alte Reg.-Sig.: I Gb 25

Bestell-Nr.: IV 00178

351 Polizeisergeant Robert Franz

- Lebenslauf des Polizeidienst-Bewerbers Robert Franz, August 1892

- Bestätigung der Einstellung des Robert Franz als Polizeisergeant

durch den Regierungspräsidenten in Aurich, November 1892

1892

Klassifikation Teil B: 00179

Trägermaterial: Papier

Alte Reg.-Sig.: I Gb 25

Bestell-Nr.: IV 00179 
Lfd. Nr. Titel

- Bewerbung des Militäranwärters Friedrich Fligge um eine Stelle als Polizeisergeant, Februar 1905

- Bestätigung der Wahl des Friedrich Fligge zum Polizeisergeanten durch den Regierungspräsidenten in Aurich, März 1905

- Bericht über Verfehlungen des Polizeisergeanten Fligge:

Gasthausbesuche und Verstoß gegen die Sperrstunde, Juli 1905 - Zeugnis der Polizeiverwaltung für den Polizeisergeanten Friedrich Fligge wegen seiner Bewerbung zum Polizeidienst der Stadt Zappot, Juli 1905

1905

Klassifikation Teil B: 00180

Trägermaterial: Papier

Alte Reg.-Sig.: I Gb 25

Bestell-Nr.: IV 00180

- Personalbogen des Vollziehungsbeamten Karl Guttmann, 1900

- Bewerbung des Militäranwärters Karl Guttmann um eine Stelle als

Polizeisergeant, Juli 1900

- Einstellung des Militäranwärters Karl Guttmann als Polizeisergeant, September 1900

- Bestätigung der Einstellung des Polizeisergeanten Karl Guttmann durch den Regierungspräsidenten in Aurich, September 1900

- Verlängerung der Probezeit des Polizeisergeanten Karl Guttmann, März 1901

- Beförderung des Polizeisergeanten Karl Guttmann zum

Vollziehungsbeamten, Oktober 1904 - Januar 1905

- Antrag des Vollziehungsbeamten Karl Guttmann auf Gewährung eines Regenmantels, Juli 1905

- Stellung eines Vertreters für den Vollziehungsbeamten K. Guttmann, Juli 1907

- Gesuch des Vollziehungsbeamten Karl Guttman und seiner Kollegen um Gehaltserhöhung, April 1910

- Eingabe des Vollziehungsbeamten K. Guttmann an den

Regierungspräsidenten in Aurich über Bitte um Aufhebung einer Anordnung der Stadt Emden über Botendienste durch

Vollziehungsbeamte wegen berufsfremder und autoritätsgefährdender

Tätigkeit, Juni 1914

- Nachruf auf den verstorbenen Vollziehungsbeamten Karl Guttmann, Januar 1919

$1900-1919$

Klassifikation Teil B: 00184

Trägermaterial: Papier

Alte Reg.-Sig.: I Ga 1

Bestell-Nr.: IV 00184 
Lfd. Nr. Titel

- Bericht des Oberbürgermeisters Leo Fürbringer über dienstliches und außerdienstliches Verhalten des Vollziehungsbeamten Heinrich Ludwig Oppermann, März 1890

- Verzeichnisse über nicht abgelieferte Abgaben des H.L. Oppermann, 1890

- Bericht des Kämmerers Gebest über Ermittlungen gegen

Oppermann, März 1890

- Ermittlungsverfahren der Staatsanwaltschaft gegen H.L.

Oppermann, April 1890

- Verfügung des Untersuchungsrichters beim kgl. Landgericht in

Aurich an die Stadt Emden über Ausfertigung eines

Defektenbeschlusses zum Verfahren gegen H.L. Oppermann, April

1890

- Verfügung des Untersuchungsrichters beim kgl. Landgericht in Aurich über Vorladung des Kämmerers Gebest zur Vernehmung, Mai 1890

- Rechtsgutachten des Bezirksausschusses über Defektenbeschluss der Stadt Emden, Juni 1890

- Beschluss des Bezirksausschuss über von Oppermann zu entrichtende Schadenssumme, Juni 1890

- Pfändungsbefehl gegen Oppermann, Juni - Juli 1890

- Streit zwischen der Stadt Emden und der preußischen Lebensversicherungsgesellschaft AG um die Anteile der von Oppermann angelegten Dienstkaution für ihre jeweiligen Zwecke, Juni - Oktober 1890

1890

\author{
Klassifikation Teil B: 00185 \\ Trägermaterial: Papier \\ Alte Reg.-Sig.: I Ga 19 \\ Bestell-Nr.: IV 00185
}

- Bewerbung des Militäranwärters Julius Falke aus Waltershausen um eine Stelle als Polizeisergeant, August 1907

- Einstellung des Julius Falke als Polizeisergeant, Oktober 1907

- Bestätigung der Einstellung durch den Regierungspräsidenten in Aurich, Oktober 1907

- Verschiedene Anfragen von durch Falke beworbener

Polizeiverwaltungen nach Beurteilung des Julius Falke, 1908

- Antrag des Polizeisergeanten J. Falke auf Amtsentbindung wegen

Möglichkeit zum Erhalt einer heimatnäheren Polizistenstelle in

Weimar, November 1908

$1907-1908$

Klassifikation Teil B: 00188

Trägermaterial: Papier

Alte Reg.-Sig.: I Gb 25

Bestell-Nr.: IV 00188 
05.02

Lfd. Nr. Titel

- Verfügung des hannoverschen Landdrosten in Aurich über

Einstellung des Carl Hermann Kuckuck als Polizeisekretär bei der kgl.

Polizeidirektion in Emden, Januar 1863

- Verfügung des preußischen Landdrosten in Aurich über Festlegung der Pension des Polizeischreibers C. H. Kuckuck, September 1879

- Gesuch des ehemaligen Polizeisekretärs C.H. Kuckuck und seiner

Frau beim Magistrat der Stadt Emden über Bitte um Gewährung einer Nebenbeschäftigung zur Aufbesserung des Lebensunterhalts, Januar 1881

- Beiträge des Pensionärs C. H. Kuckuck in die Witwen-Kasse, 1870 1889

$1863-1889$

Klassifikation Teil B: 00189

Trägermaterial: Papier

Alte Reg.-Sig.: I Gb 24

Bestell-Nr.: IV 00189

357 Polizeisergeant Carl Hemstedt

1902

- Bewerbung des Militäranwärters Carl Hemstedt aus Bismark um eine Stelle als Polizeisergeant, Oktober 1902

- Ernennung des Carl Hemstedt zum Polizeisergeant, November 1902

- Bestätigung der Ernennung durch den Regierungspräsidenten in

Aurich, November 1902

1902

Klassifikation Teil B: 00190

Trägermaterial: Papier

Alte Reg.-Sig.: I Gb 25

Bestell-Nr.: IV 00190

- Verfügung des preußischen Landdrosten in Aurich über Pflicht zur Besetzung zweier Polizeistellen mit Militäranwärtern, Mai 1868

- Vereidigung des Polizeisergeanten Adolph Otto Katzke, Juni 1868

- Entlassungsgesuch des Polizeisergeanten Adolph O. Katzke, Juni 1872

$1868-1872$

Klassifikation Teil B: 00193

Trägermaterial: Papier

Alte Reg.-Sig.: I Gb 25

Bestell-Nr.: IV 00193 
05.02

Lfd. Nr. Titel

- Bewerbung des Militäranwärters Wilhelm Diestel um eine Stelle alsd

Polizeisergeant, April - Mai 1897

- Eingabe des Polizeisergeanten W, Diestel an den Magistrat der

Stadt Emden über Gesuch um Rücknahme der Entlassung wegen

Beleidigung der Vorgesetzten, März 1901

- Zeugnis für den Polizeisergeant Wilhelm Diestel, Mai 1901

$1897-1901$

Klassifikation Teil B: 00194

Trägermaterial: Papier

Alte Reg.-Sig.: I Gb 25

Bestell-Nr.: IV 00194

360 Polizeisergeant Pischkalla

- Bewerbung des Militärmusikers Eugen Pischkalla um eine Stelle als

Polizeisergeant bei de Stadt Emden, Februar 1907

- Bestätigung der Einstellung des E. Pischkalla durch den

Regierungspräsidenten in Aurich, April 1907

- Vereidigung des Polizeisergeanten Eugen Pischkalla, Mai 1907

- Ermittlungen gegen den Polizeisergeanten E. Pischkalla wegen

Trunkenheit im Dienst, Juni 1907

- Verweis gegen E. Pischkalla wegen Trunkenheit im Dienst, Juni 1907

- Anzeige der Heirat des Polizeisergeanten E. Pischkalla, Juni 1907

- Entlassungsgesuch des Polizeisergeanten Eugen Pischkalla wegen Mobbing, Juni 1907

$1868-1872$

Klassifikation Teil B: 00195

Trägermaterial: Papier

Alte Reg.-Sig.: I Gb 25

Bestell-Nr.: IV 00195

361 Polizeisergeant Siebo Abegg

- Vereidigung des Polizeisergeanten Siebo Abegg, April 1912

- Ablehnung eines Gesuches des Polizeisergeanten S. Abegg auf Erhöhung der Besoldung, April 1914

- Kriegsbeorderung des Polizeisergeanten Siebo Abegg, Januar -

März 1916

- Vermerk über Kriegstod des Polizeisergeanten Siebo Abegg bei

Langemarck / Belgien, August 1917

- Nachruf auf Siebo Abegg, Agust 1917

$1912-1917$

Klassifikation Teil B: 00198

Trägermaterial: Papier

Alte Reg.-Sig.: I Gb 25

Bestell-Nr.: IV 00198 
IV

05

Stadtverwaltung

05.02

Personal der Stadtverwaltung

05.02.01

05.02.01.02

Untergebene des Magistrats

Polizei-Bedienstete

Lfd. Nr. Titel

Laufzeit

362 Polizeisergeant Heinrich Meinecke

- Anforderung der Personalakte des Polizeisergeanten Heinrich

Meinecke durch verschiedene Polizeiverwaltungen wegen Bewerbung,

September 1909 - Januar 1911

- Festlegung des Gehalts des Polizeisergeanten H. Meinecke, Juli

1909

- Eingabe des Polizeisergeanten H. Meinecke beim Magistrat der

Stadt Emden über Bitte um Rücknahme seiner Entlassung, April 1910

/ Januar 1911

- Anzeige bei der Staatsanwaltschaft wegen Diebstahl der

Personalakte des Polizeisergeanten H. Meinecke, April 1911

$1909-1911$

Klassifikation Teil B: 00199

Trägermaterial: Papier

Alte Reg.-Sig.: I Gb 25

Bestell-Nr.: IV 00199

363 Polizeisergeant Ernst Vogel

$1907-1911$

- Bewerbung des Bergarbeiters Ernst Vogel um eine Stelle als

Polizeisergeant, Februar 1907

- Bestätigung der Einstellung des E. Vogels als Polizeisergeant durch den Regierungspräsidenten in Aurich, April 1907

- Vereidigung des Polizeisergeanten Ernst Vogel, Mai 1907

- Anzeige der Verheiratung des Polizeisergeanten E. Vogel, Oktober 1907

- Anforderung der Personalakte des Plizeisergeanten Ernst Vogel durch die Polizeiverwaltung in Erfurt wegen Bewerbung, März 1911

- Entlassungsgesuch des Polizeisergeanten E. Vogel wegen

beabsichtigten Wechsels nach Erfurt, März 1911

$1907-1911$

Klassifikation Teil B: 00200

Trägermaterial: Papier

Alte Reg.-Sig.: I Gb 25

Bestell-Nr.: IV 00200 
05.02

Lfd. Nr. Titel

- Bewerbung des Reserveunteroffiziers Karl Lechtern um eine Stelle als Polizeisergeant, November 1905

- Einstellung des Karl Lechtern als Polizeisergeant, Januar 1906

- Bestätigung der Einstellung durch den Regierungspräsidenten in Aurich, Januar 1906 / Juni 1906

- Vereidigung des Polizeisergeanten Karl Lechtern, Januar 1906

- Gesuch des Karl Lechtern um Erstattung der Umzugskosten nach Emden, Juni - Juli 1906

- Strafverfahren gegen den Polizeisergeanten Karl Lechtern wegen versuchter Notzucht, März 1907

- Anforderung der Personalajkte des Karl Lechtern durch die

Polizeiverwaltung Halberstadt wegen Bewerbung, April 1907

- Ermittlung gegen und Verurteilung des Polizeisergeanten Karl Lechtern wegen Urkundenfälschung, Juli 1907 - April 1908

- Entlassung des Karl Lechtern aus dem Polizeidienst, August 1907

- Zeugnis für Karl Lechtern, April 1915

$1905-1915$

Klassifikation Teil B: 00203

Trägermaterial: Papier

Alte Reg.-Sig.: I Gb 25

Bestell-Nr.: IV 00203

- Bewerbung des Militäranwärters Franz Gehrs um die Stelle eines Polizeisergeanten, Mai 1908

- Einstellung des Franz Gehrs als Polizeisergeant, Juni 1908

- Vereidigung des Polizeisergeanten Franz Gehrs, Juni 1908

- Gesuch des Polizeisergeanten Franz Gehrs um Heiratserlaubnis, Oktober 1908

- Anforderung der Personalakte des Franz Gehrs durch den Präsidenten des Oberlandesgerichtes von Celle wegen Bewerbung als Gerichtsdiener, August 1910

- Entlassungsgesuch des Polizeisergeanten Franz Gehrs wegen

Wechsels als Gefängnisaufseher zum Amtsgericht Emden, März 1912

$1908-1912$

Klassifikation Teil B: 00204

Trägermaterial: Papier

Alte Reg.-Sig.: I Gb 25

Bestell-Nr.: IV 00204 
05.02

Lfd. Nr. Titel

- Bewerbung des Polizeisergeanten Gustav Motzkus um eine Stelle in Emden, Januar 1902

- Einstellung des G. Motzkus als Polizeisergeant, Januar - April 1902 - Bestätigung der Einstellung des Polizeisergeanten G. Motzkus durch den Regierungspräsidenten in Aurich, April 1902

- Entlassungsgesuch des Polizeisergeanten G. Motzkus, Mai 1902

- Anforderung der Personalakte des G. Motzkus durch verschiedene Behörden wegen Bewerbungen, 1902 - 1907

$1902-1907$

Klassifikation Teil B: 00205

Trägermaterial: Papier

Alte Reg.-Sig.: I Gb 25

Bestell-Nr.: IV 00205

- Bewerbung des Polizeisergeanten Robert Oppermann um eine Stelle in Emden, Juli 1911

- Einstellung des R. Oppermann als Polizeisergeant, August 1911

- Bestätigung der Einstellung des Polizeisergeanten R. Oppermann durch den Regierungspräsidenten in Aurich, August 1911

- Zeugnis für den Polizeisergeanten R. Oppermann wegen

Stellenwechsel nach Eisleben, März 1912

$1911-1912$

Klassifikation Teil B: 00206

Trägermaterial: Papier

Alte Reg.-Sig.: I Gb 25

Bestell-Nr.: IV 00206

368 Polizeisergeant Friedrich Wendt

- Bewerbung des Feuerwehrmannes Friedrich Wendt aus Bremen um eine Stelle als Polizeisergeant in Emden, Juni 1905

- Einstellung des Friedrich Wendt als Polizeisergeant, August 1905

- Verzicht des Friedrich Wendt auf die Stelle als Polizeisergeant, August 1905

$1902-1907$

Klassifikation Teil B: 00207

Trägermaterial: Papier

Alte Reg.-Sig.: I Gb 25

Bestell-Nr.: IV 00207 
IV

05

Stadtverwaltung

05.02

Personal der Stadtverwaltung

05.02.01

05.02.01.02

Untergebene des Magistrats

Polizei-Bedienstete

Lfd. Nr. Titel

Laufzeit

369 Polizeisergeant Deppe

$1859-1915$

- Einstellung des Feuerwerkers Franz Deppe als Polizeidiener bei der kgl. Hannoverschen Polizeidirektion in Emden, Juni 1859

- Gesuch des Polizeidieners Franz Deppe um die Erstattung

versetzungsbedingter Umzugskosten, Februar 1867

- Gesuch des ehemaligen Polizeidieners F. Deppe um

Altersunterstützung, Juni 1890

- Unterstützung der Witwe des Polizeidieners Franz Deppe, Februar 1891 - April 1915

$1859-1915$

Klassifikation Teil B: 00208

Trägermaterial: Papier

Alte Reg.-Sig.: I Gb 25

Bestell-Nr.: IV 00208

370 Polizeisergeant Carl Wilhelm Gernetzky

1882

- Bewerbung des Fußgendarmen Carl Wilhelm Gernetzky um eine

Stelle in Emden, Februar 1882

- Verfügung des Regierungspräsidenten in Aurich über

Nichtbestätigung der Einstellung C.W. Gernetzky als Polizeisergeant

wegen Vorstrafe, April 1882

1882

Klassifikation Teil B: 00209

Trägermaterial: Papier

Alte Reg.-Sig.: I Gb 25

Bestell-Nr.: IV 00209

371 Polizeisergeant August Preiß

$1880-1882$

- Bewerbung des Vize-Feldwebels August Preiß um eine Stelle als

Polizeisergeant in Emden, Februar 1880

- Einstellung des A. Preiß als Polizeisergeant, April 1880

- Zeugnis für den Polizeisergeanten A. Preiß, September 1882

$1880-1882$

Klassifikation Teil B: 00210

Trägermaterial: Papier

Alte Reg.-Sig.: I Gb 25

Bestell-Nr.: IV 00210 
Lfd. Nr. Titel

Laufzeit

372 Polizeisergeant Richard Ueberschär

- Bewerbung des Hilfspolizeisergeanten Richard Ueberschär um eine Stelle als Polizeisergeant in Emden, September 1905

- Einstellung des Richard Ueberschär als Polizeisergeant, September 1905 / April 1906

- Bestätigung der Einstellung des Polizeisergeanten R. Ueberschär durch den Regierungspräsidenten in Aurich, September 1905

- Ermittlungen gegen den Polizeisergeanten R. Ueberschär wegen Misshandlung von Gefangenen, April 1906

- Wechsel des Polizeisergeanten R. Ueberschär nach Sagan, Oktober 1906

$1905-1906$

Klassifikation Teil B: 00211

Trägermaterial: Papier

Alte Reg.-Sig.: I Gb 25

Bestell-Nr.: IV 00211

373 Polizeisergeant Rudolf Richter

- Bewerbung des Militäranwärters Rudolf Richter um eine Stelle als Polizeisergeant in Emden, Februar 1905

- Einstellung des Rudolf Richter als Polizeisergeant, März 1905

- Bericht über Trunkenheitsrandale des Polizeisergeanten R. Richter, Mai 1905

- Bericht über Streit zwischen dem Polizeisergeanten Rudolf Richter und dem Korbmacher Jakob de Weert, Mai 1905

- Entlassungsgesuch des Polizeisergeanten Rudolf Richter, Mai 1905

- Zeugnis der Stadt Emden für Rudolf Richter anlässlich seiner Bewerbung als Kassenbote bei den Nordseewerken, Juli 1905

- Bericht der Stadt Emden an die Staatsanwaltschaft beim Amtsgericht in Hamburg über Führung des Rudolf Richter während seiner

Dienstzeit als Polizeisergeant, November 1910

$1905-1910$

Klassifikation Teil B: 00212

Trägermaterial: Papier

Alte Reg.-Sig.: I Gb 25

Bestell-Nr.: IV 00212 
05.02

Lfd. Nr. Titel

- Bewerbung des Polizeisergeanten Otto Saul um eine Stelle in Emden, Februar 1907

- Einstellung des Otto Saul als Polizeisergeant, April / Oktober 1907

- Bestätigung der Einstellung des Polizeisergeanten Otto Saul durch den Regierungspräsidenten in Aurich, April 1907

- Anforderung der Personalakte des Otto Saul durch verschiedene

Behörden wegen Bewerbungen, August 1909

- Ermittlungen gegen den Polizeisergeanten Otto Saul wegen

Sittlichkeitsvergehen, August - September 1909

- Eingabe des Polizeisergeanten Otto Saul über Bitte um

Verlängerung seiner Kündigungsfrist, November 1909

- Eingabe des Polizeiserganten Otto Saul über Bitte um Unterstützung wegen Krankheit seiner Frau, Mai 1909

- Entlassungsgesuch des Polizeisergeanten Otto Saul, Dezember

1909

- Zeugnis für den Polizeisergeanten Otto Saul, Dezember 1909

1907 - 1909

Klassifikation Teil B: 00213

Trägermaterial: Papier

Alte Reg.-Sig.: I Gb 25

Bestell-Nr.: IV 00213

- Bewerbung des Polizeisergeanten Ulrich Kannegießer aus

Grevelsberg um eine Stelle in Emden, März 1908

- Einstellung des U. Kannegießer als Polizeisergeant, April - Mai 1908

(Januar 1909)

- Anzeige der Verheiratung des Polizeisergeanten U. Kannegießer,

Februar 1909

- Entlassungsgesuch des Polizeisergeanten U. Kannegießer wegen

Stellenwechsels als Hilfsbote zur Regierung nach Aurich, August 1909

$1908-1909$

Klassifikation Teil B: 00214

Trägermaterial: Papier

Alte Reg.-Sig.: I Gb 25

Bestell-Nr.: IV 00214 
IV

05

Stadtverwaltung

05.02

Personal der Stadtverwaltung

05.02.01

05.02.01.02

Untergebene des Magistrats

Polizei-Bedienstete

Lfd. Nr. Titel

Laufzeit

376 Polizeisergeant Karl Lechtern

1906-1907

- Strafverfahren gegen den Polizeisergeanten Karl Lechtern wegen versuchter Vergewaltigung, November 1906

- Anklageschrift gegen den Polizeisergeanten Karl Lechtern, Februar 1907

- Ermittlungen gegen den Polizeisergeanten Karl Lechtern wegen

Besuch einer Gaststätte nach der Polizeistunde und

Urkundenfälschung, Juli 1907

$1906-1907$

Klassifikation Teil B: 00215

Trägermaterial: Papier

Alte Reg.-Sig.: I Gb 25

Bestell-Nr.: IV 00215

377 Polizeisergeant Heinrich Best

1905-1907

- Bewerbung des Militäranwärters Heinrich Best um eine Stelle als

Polizeisergeant in Emden, Januar 1905

- Einstellung des H. Best als Polizeisergeant, Februar 1905

- Entlassungsgesuch des Polizeisergeanten H. Best wegen Wechsel

nach Stade, September - Dezember 1906

$1906-1907$

Klassifikation Teil B: 00216

Trägermaterial: Papier

Alte Reg.-Sig.: I Gb 25

Bestell-Nr.: IV 00216

378 Polizeisergeant Konrad Leck

$1890-1893$

- Bestätigung der Einstellung des Polizeisergeanten Konrad Leck durch den Regierungspräsidenten in Aurich, Mai 1890

- Entlassungsgesuch des Polizeisergeanten Konrad Leck wegen

Annahme einer Grenzaufseherstelle, Januar 1893

$1890-1893$

Klassifikation Teil B: 00217

Trägermaterial: Papier

Alte Reg.-Sig.: I Gb 25

Bestell-Nr.: IV 00217 
Lfd. Nr. Titel

- Ausschreibung einer Stelle als Vollziehungsbeamter bei der Stadt Emden, August 1885

- Bewerbung des Feldwebels Heinrich Ludwig Oppermann um duie ausgeschriebene Vollziehungsbeamtenstelle, Oktober 1885

- Vereidigung des Vollziehungsbeamten Heinrich Ludwig Oppermann, Februar 1886

- Beschwerde gegen die Dienstführung des Vollziehungsbeamten H.L. Oppermann, Juli 1887

- Entlassungsgesuch des Vollziehungsbeamten H. L. Oppermann wegen Wechsel in den Zolldienst, April 1888

- Vorladung des H.L. Oppermann auf das Rathaus wegen

Nichterledigung von Vollstreckungsaufträge, März 1890

$1885-1890$

Klassifikation Teil B: 00218

Trägermaterial: Papier

Alte Reg.-Sig.: I Ga 08

Bestell-Nr.: IV 00218

- Bewerbung des Feuerwehrmannes Schmidt um eine Stelle als

Polizeisergeant, Januar 1905

- Verwarnung des Polizeisergeanten Schmidt wegen

Dienstversäumnis, Juli 1905

- Meldung über Dienstvergehen des Polizeisergeanten Schmidt,

Oktober 1906 - April 1907

- Entlassung des Polizeisergeanten Schmidt wegen wiederholter

Dienstvergehen, August 1907

$1905-1907$

Klassifikation Teil B: 00223

Trägermaterial: Papier

Alte Reg.-Sig.: I Gb 25

Bestell-Nr.: IV 00223

381 Polizeisergeant Friedrich Krüger

- Bewerbung des Militäranwärters Friedrich Krüger um eine Stelle als Polizeisergeant in Emden, Februar 1905

- Bestätigung der Einstellung durch den Regierungspräsidenten in

Aurich, März 1905

- Entlassungsgesuch des Polizeisergeanten Friedrich Krüger wegen

Gesundheitsproblemen, Oktober 1905

- Anforderungen von Zeugnissen für Friedrich Krüger von

verschiedenen Polizeiverwaltungen wegen Bewerbungen, 1910 - 1912

$1905-1912$

Klassifikation Teil B: 00224

Trägermaterial: Papier

Alte Reg.-Sig.: I Gb 25

Bestell-Nr.: IV 00224 
IV

05

Stadtverwaltung

05.02

Personal der Stadtverwaltung

05.02.01

05.02.01.02

Untergebene des Magistrats

Polizei-Bedienstete

Lfd. Nr. Titel

Laufzeit

382 Polizeisergeant Otto Erdbrink

1889-1893

- Bewerbung des Militäranwärters Otto Erdbrink um eine Stelle als

Polizeisergeant in Emden, Juni 1889

- Einstellung des Otto Erdbrink als Polizeisergeant, August 1889

- Bestätigung der Einstellung durch den Regierungspräsidenten in

Aurich, September 1889

- Entlassungsgesuch des Polizeisergeanten Otto Erdbrink wegen

Wechsel als Schuldiener zum Wilhelms-Gymnasium, Februar 1893

$1889-1893$

Klassifikation Teil B: 00225

Trägermaterial: Papier

Alte Reg.-Sig.: I Gb 25

Bestell-Nr.: IV 00226

383 Polizeisergeant Max Gohlke

1906-1907

- Bewerbung des Nacht-Sergeanten Max Gohlke aus Cottbus um eine Stelle als Polizeisergeant in Emden, November 1906

- Bestätigung der Einstellung durch den Regierungspräsidenten in

Aurich, Dezember 1906

- Vereidigung des Polizeisergeanten Max Gohlke, Januar 1907

$1906-1907$

Klassifikation Teil B: 00225

Trägermaterial: Papier

Alte Reg.-Sig.: I Gb 25

Bestell-Nr.: IV 00225

384 Polizeisergeant Paul Stoermer

- Bewerbung des Polizeisergeanten Paul Stoermer aus Lüneburg um eine Stelle in Emden, Mai 1884

- Einstellung des Polizeisergeanten Paul Stoermer, auf Honorarbasis, Juli 1884

- Zeugnis für Polizeisergeanten Paul Stoermer, August 1884

1884

Klassifikation Teil B: 00228

Trägermaterial: Papier

Alte Reg.-Sig.: I Gb 25

Bestell-Nr.: IV 00228 
05.02

Lfd. Nr. Titel

- Bewerbung des Militäranwärters Louis Ritterbusch aus Hameln um eine Stelle als Polizeisergeant in Emden, Februar 1907

- Einstellung des Louis Ritterbusch als Polizeisergeant, April 1907

- Bestätigung der Einstellung durch den Regierungspräsidenten in Aurich, April 1907

- Bericht über unsittliche Affäre des verheirateten Polizeisergeanten Louis Ritterbusch, Juni 1907

- Entlassungsgesuch des Polizeisergeanten Louis FRitterbusch, Juni 1907

1907

Klassifikation Teil B: 00229

Trägermaterial: Papier

Alte Reg.-Sig.: I Gb 25

Bestell-Nr.: IV 00229

386 Polizeisergeant Robert Passow

- Bewerbung des Militäranwärters Robert Passow aus Berlin um eine Stelle als Polizeisergeant in Emden, Juni 1906

- Einstellung des Robert Passow als Polizeisergeant, Juli 1906

- Entlassungsgesuch des Polizeisergeanten Robert Passow,

Dezember 1906

1906

Klassifikation Teil B: 00230

Trägermaterial: Papier

Alte Reg.-Sig.: I Gb 25

Bestell-Nr.: IV 00230

387 Polizeisergeant Siegfried Koerts

- Bewerbung des Schmiedes Siegfried Koerts um eine Stelle als Polizeisergeant in Emden, Januar - Februar 1909

- Bestätigung der Einstellung durch den Regierungspräsidenten in Aurich, März 1909

- Vereidigung des Polizeisergeanten Siegfried Koerts, April 1909

- Anforderungen eines Zeugnisses für Siegfried Koerts von der

Polizeidirektion Bremen wegen Bewerbung, Juni 1910

- Einberufung des Polizeisergeanten Siegfried Koerts zu einer militärischen Übung bei der Marine, August - September 1911

- Ermittlungen gegen den Polizeisergeanten Siegfried Koerts wegen Dienstvernachlässigung, Mai 1911

- Entlassungsgesuch des Polizeisergeanten Siegfried Koerts wegen Stellenwechsel nach Bremen, Juni 1911

$1909-1911$

Klassifikation Teil B: 00231

Trägermaterial: Papier

Alte Reg.-Sig.: I Gb 25

Bestell-Nr.: IV 00231 
05.02

Lfd. Nr. Titel

- Bewerbung des Polizeisergeanten Gergard Brüning um eine Stelle in

Emden, März 1893

- Einstellung des Polizeisergeanten Gerhard Brüning, Juni 1893

- Bestätigung der Einstellung durch den Regierungspräsidenten in

Aurich, Juni 1893

- Gesuch des Polizeisergeanten Gerhard Brüning um Beihilfe zu den Umzugskosten nach Emden, April 1894

- Gehaltseingruppierung und Festlegung des Dienstalters des

Polizeisergeanten Gerhard Brüning, Juli 1904

- Verletzung des Polizeisergeanten G. Brüning bei der Festnahme einer Person, Januar 1913

- Eingabe der Witwe des Polizeisergeanten G. Brünuing an den Magistrat der Stadt Emden über Bitte um Unterstützung, Dezember 1913 / April 1923

1893 - 1913 (1923)

Klassifikation Teil B: 00232

Trägermaterial: Papier

Alte Reg.-Sig.: I Gb 25

Bestell-Nr.: IV 00232

389 Polizeisergeant Karl Pohlhaus

- Bewerbung des Militäranwärters Karl Pohlhaus um eine Stelle als Polizeisergeant in Emden, Mai 1903

- Bestätigung der Einstellung durch den Regierungspräsidenten in

Aurich, Juni 1903

- Vereidigung des Polizeisergeanten Karl Pohlhaus, Juni 1903

- Bericht über Sittenstraftaten der Mutter der Braut des

Polizeisergeanten Karl Pohlhaus, November 1903

- Entlassungsgesuch des Polizeisergeanten Friedrich Krüger wegen

Stellenwechsel als Fahrkartenausgeber bei der Bahn, Dezember 1904

$1903-1904$

Klassifikation Teil B: 00233

Trägermaterial: Papier

Alte Reg.-Sig.: I Gb 25

Bestell-Nr.: IV 00233

390 Polizeisergeant Georg Schott

- Bewerbung des Feldwebels Georg Schott um eine Stelle als

Polizeisergeant in Emden, November 1888

- Vereidigung des Polizeisergeanten Georg Schott, Dezember 1888

1888

Klassifikation Teil B: 00234

Trägermaterial: Papier

Alte Reg.-Sig.: I Gb 25

Bestell-Nr.: IV 00234 
IV

05

Stadtverwaltung

05.02

Personal der Stadtverwaltung

05.02.01

05.02.01.02

Untergebene des Magistrats

Polizei-Bedienstete

Lfd. Nr. Titel

Laufzeit

391 Polizeisergeant Otto Teichgräber

1907

- Bewerbung des Otto Teichgräber, Wärter in einer Irrenanstalt, um eine Stelle als Polizeisergeant in Emden, Februar 1907

- Bestätigung der Einstellung durch den Regierungspräsidenten in

Aurich, April 1907

- Bericht über Alkoholmissbrauch des Polizeisergeanten Otto

Teichgräber, Juni 1907

1907

Klassifikation Teil B: 00235

Trägermaterial: Papier

Alte Reg.-Sig.: I Gb 25

Bestell-Nr.: IV 00235

392 Polizeisergeant Peter Tebbens

1905

- Bewerbung des Schiffers Peter Tebbens um eine Stelle als

Polizeisergeant in Emden, Februar 1905

- Bestätigung der Einstellung durch den Regierungspräsidenten in

Aurich, August 1905

- Vereidigung des Polizeisergeanten Peter Tebbens, August 1905

- Entlassungsgesuch des Polizeisergeanten Peter Tebbens wegen

Dienstunfähigkeit, August 1905

1905

Klassifikation Teil B: 00236

Trägermaterial: Papier

Alte Reg.-Sig.: I Gb 25

Bestell-Nr.: IV 00236

393 Polizeisergeant W.H. Wildhagen

- Einstellung des W.H. Wildhagen als Polizeisergeant in Emden, Juni 1859

- Gratifikation für den Polizeisergeanten W.H. Wildhagen anlässlich seines 25-jährigen Dienstjubiläums, August 1884

- Eingaben der Witwe des Polizeisergeanten Wildhagen, Sophie

Wildhagen, an den Magistrat der Stadt Emden über Bitte um

Unterstützung, 1888 - 1909

1859 - 1884 (1888-1909)

Klassifikation Teil B: 00237

Trägermaterial: Papier

Alte Reg.-Sig.: I Gb 25

Bestell-Nr.: IV 00237 
05.02

Lfd. Nr. Titel

- Einstellung des Karl Robert Wentzel als Nachtwachtmeister der Stadt Emden, Juni - Juli 1897

- Dienstinstruktionen für die Nachtwachtmeister Karl Robert Wentzel, Juni 1897

- Beschwerden gegen den Nachtwachtmeister Karl Robert Wentzel wegen Körperverletzung und Wechselschulden, Oktober - November 1897

- Krankmeldungen des Nachtwachtmeister Wentzel, 1898 - 1905

- Bewerbungen um die Stelle eines Nachtwachtmeisters, Oktober 1899

- Beschwerde des Regierungsrats Neufuth wegen Übergriffe des Nachtwächters Karl Robert Wentzel, Februar 1900

- Dienstanweisung für den Nachwachtmeister der Stadt Emden, März 1901

$1898-1905$
Klassifikation Teil B: 00240
Trägermaterial: Papier
Bestell-Nr.: IV 00240

395 Einstellung von Polizeisergeanten als Ersatz für Nachtwächter

- Ausschreibung von Polizeisergeanten-Stellen für Personen mit Feuerwehrerfahrung durch die Stadt Emden als Ersatz für abgebaute Nachtwächterstellen, Januar 1905 - April 1907

$1905-1907$

Klassifikation Teil B: 00241

Trägermaterial: Papier

Alte Reg.-Sig.: I Gb 25

Bestell-Nr.: IV 00241

- Einstellung des Nachtwachtmeisters Karl Robert Wentzel als

Polizeisergeant, März 1903

- Bestätigung der Einstellung des Karl Robert Wentzel als

Polizeisergeant durch den Regierungspräsidenten in Aurich, April

1905

- Anzeige über andauernde Dienstunfähigkeit des Polizeisergeanten

Karl Robert Wentzel wegen Krankheit, August 1905

- Entlassung des Polizeisergeanten Karl Robert Wentzel, August 1905

- Schuldforderungen gegen Karl Robert Wentzel, September 1905

$1903-1905$

Klassifikation Teil B: 00242

Trägermaterial: Papier

Alte Reg.-Sig.: I Gb 25

Bestell-Nr.: IV 00242 
IV

05

Stadtverwaltung

05.02

Personal der Stadtverwaltung

05.02.01

05.02.01.02

Untergebene des Magistrats

Polizei-Bedienstete

Lfd. Nr. Titel

Laufzeit

397 Armenunterstützung für die Familie des ehemaligen Polizeisergeanten

1902

Carl Wenzel

- Feststellung des Unterstützungswohnsitzes des ehemaligen

Polizeisergeanten Carl Wenzel, März 1902

- Bescheid des Magistrats der Stadt Emden an Carl Wentzel über

Verpflichtung zur Arbeitsaufnahme zur Ernährung seiner Familie,

April 1902

- Bericht des Magistrats der Stadt Emden an den

Regierungspräsidenten in Aurich über Ablehnung eines

Arbeitsangebotes durch Wenzel, März 1902

1902

Klassifikation Teil B: 00243

Trägermaterial: Papier

Alte Reg.-Sig.: I Gb 25

Bestell-Nr.: IV 00243

398 Polizeisekretär Kuckuck

- Pensionierung des Polizeisekretärs Carl Hermann Kuckuck, März -

April 1879

1879

Klassifikation Teil B: 00244

Trägermaterial: Papier

Alte Reg.-Sig.: I Gb 25

Bestell-Nr.: IV 00244

399 Polizeisergeant Heinrich Hubert Nobis

1893-1894

- Bewerbung des Polizeioffizianten Heinrich Hubert Nobis aus

Hamburg um die Stelle eines Polizeisergeanten in Emden, März 1893

- Einstellung des Heinrich Hubert Nobis als Polizeisergeant in Emden, Juli 1893

- Entlassungsgesuch des Polizeisergeanten Heinrich Hubert Nobis,

April 1894

$1893-1894$

Klassifikation Teil B: 00245

Trägermaterial: Papier

Alte Reg.-Sig.: I Gb 25

Bestell-Nr.: IV 00245 
05.02

Lfd. Nr. Titel

- Bewerbung des Nachtschutzmanns Ernst Friedrichs aus Flensburg um die Stelle eines Polizeisergeanten in Emden, August 1907 - Einstellung des Ernst Friedrichs als Polizeisergeant in Emden, Oktober - November 1907

- Bestätigung der Einstellung durch den Regierungspräsidenten in Aurich, Mai 1908

- Gesuch des Ernst Friedrichs über Bitte um Erstattung der Kosten seines Umzuges nach Emden, Mai 1908

- Ermittlungen gegen den Polizeisergeanten Ernst Friedrichs wegen unerlaubten Kneipenbesuchs, Dezember 1913

- Entlassung des Polizeisergeanten Ernst Friedrichs wegen

Verschuldung und Alkoholmissbrauch, Februar 1914

$1907-1914$

Klassifikation Teil B: 00246

Trägermaterial: Papier

Alte Reg.-Sig.: I Gb 25

Bestell-Nr.: IV 00246

401 Polizeikommissar Emil Rehfuß

- Laufbahn (1899: Polizeisergeant; 1909: Kriminalbeamter; 1919:

Kriminalkommissar), 1899 - 1928

- Anzeige der Hochzeit des Polizeisergeanten Emil Rehfuß, März 1902

- Verleihung der Amtsbezeichnung Kriminalpolizeisergeant an den

Polizeisergeanten Emil Rehfuß, Februar 1914

- Gehaltsfestsetzung für den Polizeikommissar E. Rehfuß, November 1919

- Pensionierungsantrag des Kommissars Rehfuß wegen

Herzkrankheit, Dezember 1927 - Januar 1928

$1899-1928$

Klassifikation Teil B: 00247

Trägermaterial: Papier

Alte Reg.-Sig.: I Gb 25

Bestell-Nr.: IV 00247

402 Polizeisergeant Otto Grigoleit

- Bewerbung des Otto Grigoleit aus Essen um die Stelle eines

Polizeisergeanten in Emden, August 1907

- Einstellung des Otto Grigoleit als Polizeisergeant, September -

Oktober 1907

- Vereidigung des Polizeisergeanten Otto Grigoleit, November 1907

- Entlassungsgesuch des Polizeisergeanten Otto Grigoleit, März 1908

- Anforderung eines Zeugnisses für den ehemaligen Polizeisergeanten Grigoleit durch die Polizeiverwaltung in Erfurt wegen Bewerbung, Juni 1908

$1907-1908$

Klassifikation Teil B: 00248

Trägermaterial: Papier Alte Reg.-Sig.: I Gb 25

Bestell-Nr.: IV 00248 
IV

05

Stadtverwaltung

05.02

Personal der Stadtverwaltung

05.02.01

05.02.01.02

Untergebene des Magistrats

Polizei-Bedienstete

Lfd. Nr. Titel

Laufzeit

403 Polizeisergeant Wilhelm Großkopf

- Bewerbung des Militäranwärters Wilhelm Großkopf um die Stelle eines Polizeisergeanten in Emden, April 1907

- Einstellung des Wilhelm Großkopf als Polizeisergeant, Juni 1907

- Vereidigung des Polizeisergeanten Wilhelm Großkopf, Juni 1907

- Anforderung von Zeugnissen für den Polizeisergeanten Großkopf

durch versciedene Polizeiverwaltungen wegen Bewerbungen, Oktober

1907 - Juni 1911

- Entlassungsgesuch des Polizeisergeanten Wilhelm Großkopf,

August 1908

- Zurückziehung des Entlassungsgesuches durch W. Großkopf,

Oktober 1908

$1907-1911$

Klassifikation Teil B: 00249

Trägermaterial: Papier

Alte Reg.-Sig.: I Gb 25

Bestell-Nr.: IV 00249

404 Besetzung einer vakanten Polizeisergeantenstelle

$1874-1875$

- Einstellung des Nachtwächters Meindert van der Velde als

Vakanzvertreter für den ausgeschiedenen Polizeisergeanten Katzke,

Juli 1874 - Januar 1875

$1874-1875$

Klassifikation Teil B: 00250

Trägermaterial: Papier

Alte Reg.-Sig.: I Gb 25

Bestell-Nr.: IV 00250

405 Polizeisergeant Emil Janssen

- Bewerbung des Emil Janssen um die Stelle eines Polizeisergeanten in Emden, August 1882

- Entlassungsgesuch des Polizeisergeanten Emil Janssen, Juni 1884

- Überlassung des Dienstanzuges gegen eine Entschädigung an den ausgeschiedenen Polizeisergeanten Emil Janssen, Juli - August 1884

$1882-1884$

Klassifikation Teil B: 00251

Trägermaterial: Papier

Alte Reg.-Sig.: I Gb 25

Bestell-Nr.: IV 00251 
05.02

Lfd. Nr. Titel

- Einstellung des Otto Weber als Polizeisergeant, April 1912

- Anforderung eines Zeugnisses für den Polizeisergeanten O. Weber durch die Landrätlichen Hilfsbeamten in Wilhelmshaven wegen

Bewerbung, Juni 1912

- Entlassungsgesuch des Polizeisergeanten Otto Weber wegen

Wechsels nach Wilhelmshaven, Juli 1912

- Antrag des Polizeisergeanten Otto Weber auf Zahlung eines von inm in Auftrag gegebenen Uniformteils für seine Dienstkleidung durch die Stadt Emden, März 1913

$1912-1913$

Klassifikation Teil B: 00252

Trägermaterial: Papier

Alte Reg.-Sig.: I Gb 25

Bestell-Nr.: IV 00252

407 Polizeisergeant Adolf Lutz

- Bewerbung des Adolf Lutz aus Danzig um die Stelle eines

Polizeisergeanten in Emden, April 1896

- Einstellung des Adolf Lutz als Polizeisergeant, Mai 1896

- Unterhaltsforderungen gegen den Polizeisergeanten Lutz von Seiten der Agnes Szelosgowski aus Danzig, wegen unehelichem Kind und gebrochenem Heiratsversprechen, Oktober 1896

- Ermittlung gegen den Polizeisergeanten Adolf Lutz wegen falscher Angaben in einem Bericht, Januar 1897

- Bewertung der Leistungen des Adolf Lutz, April 1897

- Anzeige gegen den Polizeisergeanten Adolf Lutz wegen unbefugten Tragens von Zivilkleidung, April 1897

- Entlassungsgesuch des Polizeisergeanten Otto Grigoleit, April 1897

- Anforderung eines Zeugnisses für den Polizeisergeanten A. Lutz durch verschiedene Polizeiverwaltungen wegen Bewerbungen, April 1897 - April 1901

$1896-1901$

Klassifikation Teil B: 00253

Trägermaterial: Papier

Alte Reg.-Sig.: I Gb 25

Bestell-Nr.: IV 00253 
Lfd. Nr. Titel

- Bewerbung des Polizeisergeanten Carl Wentzel um eine

Nachwachtmeisterstelle in Emden, Februar 1901

- Einstellung des Carl Wentzel als Nachtwachtmeister, Juni 1901

- Antrag des Nachtwachtmeisters Carl Wentzel auf Beihilfe zur

Nachholung seiner Familie nach Emden, Juni 1901

- Berichte über Verschuldung des Polizeisergeanten Carl Wentzel, September 1901

- Anforderung eines Zeugnisses für den Polizeisergeanten Wentzel durch verschiedene Polizeiverwaltungen wegen Bewerbungen, Dezember 1901 - Februar 1902

- Gesuch des Polizeisergeanten Carl Wentzel an den Magistrat der Stadt Emden über Bitte um vorläufigen Verbleib im Dienst, Februar 1902

- Antrag des Polizeisergeanten C. Wentzel auf Erstattung seiner Reisekosten wegen Antritt seines Dienstes in Emden im Juni 1901, März 1903

$1901-1903$

Klassifikation Teil B: 00254

Trägermaterial: Papier

Alte Reg.-Sig.: I Gb 25

Bestell-Nr.: IV 00254

- Beschluss der Kollegien der Stadt Emden über Einstellung eines Polizeikontrolleurs, März 1855

- Instruktionen für den Polizeikontrolleur Carl Gottlieb Lubich, Juni 1857

- Vereidigung des Polizeikommissars Carl Gottlieb Lubich auf die preußische Verfassung, Februar 1868

- Beschwerde des Direktors des Emder Gasthauses beim Magistrat der Stadt Emden gegen unberechtigte Kritik von Seiten des Kommissars Lubich, Juli - September 1869

- Nominierung des Polizeikommissars Lubich als Amtsanwaltsvertreter für das Amts- und Schöffengericht in Emden durch die Staatsanwaltschaft in Aurich, Februar 1881

- Pensionierungsgesuch des Polizeikommissars Lubich, Januar 1888 - Unterstützungsgesuch der Witwe des Polizeikommissars Lubich, Bertha Lubich, geb. Meyer, Juni 1896

$1855-1896$

Klassifikation Teil B: 00255

Trägermaterial: Papier

Alte Reg.-Sig.: I Gb 11

Bestell-Nr.: IV 00255 
05.02

Lfd. Nr. Titel

- Ausschreibung der Stelle eines Polizeiboten bei der Stadt Emden,

August 1890

- Bewerbung des Militärinvaliden Georg Friedrich Schnur um die Stelle eines Polizeiboten in Emden, August 1890

- Einstellung des Georg Schnur als Polizeibote, September 1890

- Bestätigung der Einstellung durch den Regierungspräsidenten in

Aurich, Oktober 1890

- Bericht des Polizeikommissars Soldatow über Anregung der

Beförderung Schnurs zum Polizeisergeanten und Betrauung mit der

Aufsicht über die Wallanlagen, März 1893

- Gesuch des Polizeiboten Schnur über Bitte um Stellung von

Dienstkleidung, März 1896

- Gesuch des Polizeiboten Schnur über Bitte um Stellung eines

Regenmantels, Juli - September 1897

- Neufestsetzung des Gehaltes des Polizeiboten Schnur, Mai 1899

- Ruhestandsgehalt, Juli 1921

$1890-1921$

Klassifikation Teil B: 00256

Trägermaterial: Papier

Alte Reg.-Sig.: I Gb 25

Bestell-Nr.: IV 00256

411 Polizeisergeant Michael Rugullis

- Bewerbung des Militäranwärters Michael Rugullis aus Memel um eine Stelle als Polizeisergeant in Emden, November 1906

- Einstellung des Michael Rugullis als Polizeisergeant in Emden, Dezember 1906

- Vereidigung des Polizeisergeanten Michael Rugullis, Januar 1907

- Beschwerde des Wachtmeisters Strippelmann gegen den

Polizeisergeanten M. Rugullis wegen Dienstpflichtverletzung und frechem Benehmen, Februar - April 1907

- Bericht des Wachtmeisters Lauter über Dienstpflichtverletzungen des Polizeisergeanten M. Rugullis, Mai 1907

- Entlassung des Polizeisergeanten M. Rugullis aus dem Polizeidienst, Mai 1907

- Anforderung eines Zeugnisses für den Polizeisergeanten M. Rugullis von der Polizeiverwaltung Peine wegen Bewerbung, Juni 1907

$1906-1907$

Klassifikation Teil B: 00257

Trägermaterial: Papier

Alte Reg.-Sig.: I Gb 25

Bestell-Nr.: IV 00257 
IV

05

Stadtverwaltung

05.02

Personal der Stadtverwaltung

05.02.01

05.02.01.02

Untergebene des Magistrats

Lfd. Nr. Titel

Polizei-Bedienstete

Laufzeit

412 Anstellung neuer Polizeidiener

$1887-1888$

- Bericht des Polizeikommissars Bracke über Unmotiviertheit der

Rateler und Vorschlag über deren Ersetzung durch reguläre

Polizeisergeanten unter Zusammenlegung der Nachtwächterbezirke

mit den Polizeibezirken, Oktober 1887

- Memorandum des Senators Metger über Reorganisation des Emder

Polizeiwesens, Dezember 1887

- Beratung der städtischen Kollegien über die im Memorandum

Metgers und in den Vorschlägen Brackes angeregte Vermehrung des

Polizeipersonals, Februar 1888

$1887-1888$

Klassifikation Teil B: 00258

Trägermaterial: Papier

Alte Reg.-Sig.: I Gb 25

Bestell-Nr.: IV 00258 
- Bewerbung des Schlossers Hillrich van Diepenbrock um eine Stelle als Nachtwächter bei der Stadt Emden, Mai 1887

- Vereidigung des Nachtwächters Hillrich van Diepenbrück, Juli 1887

- Einstellung des pensionierten Fußgendarmen Carl Hartrampf als

Nachtwachtmeister und Gefangenenwärter, Mai - Oktober 1895

- Instruktionen für die Nachwachtmeister der Stadt Emden, November 1884 - September 1895

- Streit zwischen Nachtwachtmeister Carl Hartrampf und den Nachtwächtern um Nebeneinkünfte und Unterordnung, März - April 1897

- Disziplinarverfahren gegen den Nachtwachtmeister und

Gefangenenwärter Carl Hartrampf wegen Diebstahl, März - Juli 1897

- Gesuch des Nachtwachtmeisters und Gefangenenwärters C.

Hartrampf über Bitte um Aufhebung seiner Entlassung, August 1897

- Bewerbung des Nachtwächters Hillrich van Diepenbrock um die

Stelle eines Nachtwachtmeisters und Gefangenenwärters, August 1897

- Entlassungsgesuch des Nachtwachtmeisters und

Gefangenenwärters Carl Hartrampf, September1897

- Gesuch der Witwe des Nachtwachtmeisters T von Diepenbrock an den Magistrat der Stadt Emden über Bitte um Unterstützung, August 1895 - Juli 1897

- Erhöhung der Besoldung des Nachtwachtmeisters H. van

Diepenbrock, März - Mai 1899

- Tödlicher Unfall infolge Trunkenheit des Nachtwachtmeisters H. van

Diepenbrock, September 1899

- Personalakte des Nachtwachtmeisters Franz Lier, Oktober 1899 -

Januar 1901

- Beschwerde des Hausdieners Evert Saathoff gegen den

Nachtwachtmeister H. v. Diepenbrock wegen unberechtigter

Abführung zur Wache, Oktober 1906

$1884-1906$

Klassifikation Teil B: 00260

Trägermaterial: Papier

Alte Reg.-Sig.: I Gb 18

Bestell-Nr.: IV 00260

- Gesuch des Polizeidieners J. Montag an den Magistrat der Stadt

Emden über Bitte um Ausstattung mit einer Uniform, Juni 1855

- Verstärkung des Polizei-Personals wegen Schleusenbauten und damit verbundenem Zustrom fremder Arbeiter, März 1880 September 1887

(1855) 1880 - 1887

Klassifikation Teil B: 00566

Trägermaterial: Papier

Bestell-Nr.: IV 00566 
IV

05

Stadtverwaltung

05.02

Personal der Stadtverwaltung

05.02.01

05.02.01.02

Untergebene des Magistrats

Polizei-Bedienstete

Lfd. Nr. Titel

Laufzeit

415 Gehaltsverhältnisse der Polizeiwachtmeister

1904-1918

- Gesuch der Emder Polizeibeamten um Gehaltserhöhung und

Neufestsetzung des Besoldungsdienstalters, Juli 1904 - September

1914

- Kriegsteuerungszulagen für Polizeibeamte, 1917 - 1918

$1904-1918$

Klassifikation Teil B: 00587

Trägermaterial: Papier

Bestell-Nr.: IV 00587

416 Polizeikommissar Carl Bracke

$1871-1891$

- Bewerbungsunterlagen des Polizeikommissars Carl Bracke mit

Zeugnissen seiner bisherigen Arbeitgeber, 1871 - 1891

$1871-1891$

Klassifikation Teil B: 0222

Trägermaterial: Papier

Alte Reg.-Sig.: I Gb 25

Bestell-Nr.: IV 00222

417 Polizeisergeant Harm Janssen

- Bewerbung des Militäranwärters Harm Janssen um eine Stelle als Polizeisergeant bei der Stadt Emden, August 1912

- Entlassungsgesuch des Polizeisergeanten H. Janssen, September 1914

$1912-1914$

Klassifikation Teil B: 03754

Trägermaterial: Papier

Alte Reg.-Sig.: I Gb 25

Bestell-Nr.: IV 03754 
05 Stadtverwaltung

05.02

Personal der Stadtverwaltung

05.02.01

Untergebene des Magistrats

05.02.01.03

Beamte für Gewerbe- und Verkehrssachen

Lfd. Nr. Titel

Laufzeit

418 Hafenmeister und Sielmeister

- Instruktion über die Erhebung der Hafengebühren durch den Emder Hafenmeister, November 1857

- Antrag der Witwe des Hafenmeisters H. G. Heerma auf Erlass der von ihrem verstorbenen Mann zu entrichtenden Abgabe aus den Hafenmeister-Einnahmen, Juni 1878 - Mai 1879

- Diskussion der Vereinigung der Hafenmeisterstelle für den

Rathaus-Delft mit der für den Faldern-Delft, Juli 1848 - Januar 1879

- Bewerbung des Kapitäns Jacob Meinders Zeeman um die Stelle eines Hafenmeisters, Dezember 1878 - Januar 1879

- Vereidigung des Hafenmeisters und Sielwärters Jacob Meindert Zeemann, Februar 1879

- Widersätzlichkeiten von Schiffskapitänen gegen Anweisungen des Hafenmeisters Zeemann, Aoril 1879 - Dezember 1885

- Verfügung des Magistrats der Stadt Emden über Verwaltung des eingenommenen Kajegeldes durch den Hafenmeister, November 1879

- Verfügung des preußischen Landdrosten in Aurich über Pflicht der Stadt Emden zur Einstellung eines Zivilversorgungsscheininhabers als Hafenmeister, November 1884

- Eingabe des Hafenmeisters J.K.M. Zeemann an den Magistrat der Stadt Emden über Antrag auf Erlass der fälligen Abgaben auf das Kajegeld wegen zu geringer Einnahmen, Juli 1879

$1857-1885$

Klassifikation Teil B: 00168

Trägermaterial: Papier

Alte Reg.-Sig.: I Gc 055

Bestell-Nr.: IV 00168 
05.02

Lfd. Nr. Titel

- Stempelung des Journalbuchs des Getreidemaklers Johann Hinrich Sikken, Juli 1871

- Bewerbung des Kommissionärs C. Kreling um die Anstellung als Getreidemakler, Juni 1871

- Vereidigung des Getreide- und Warenmaklers Friedrich Wilhelm Baumann, August 1872

- Eingabe des Getreidemaklers F.J. Schultze an den Magistrat der Stadt Emden über Bitte um Vorgehen gegen Geschäftsschmälerung der Getreidemakler durch Kommissionäre, Oktober 1872

- Antrag der Kaufmännischen Deputation auf Einstellung eines Dispacheurs durch die Stadt Emden, September 1873

- Stellungnahme der Kaufmännischen Deputation über Bewerbung des Carl Louis Wildermann als Schiffsmakler, März 1877

- Einstellung von Dispacheuren, 1877

- Einstellung des Kaufmanns H.P.Hegen zum Getreidemakler, März 1878

- Vorschlag der Ernennung des Maklergehilfen Weert Ihnen zum Getreidemakler durch die Kaufmännische Deputation, Oktober 1886 - Runderlass der preußischen Regierung zur Regelung des Immobilienmaklerwesens, Juni 1892

- Bewerbung des Kommissionärs H. Bokelmann um die Einstellung als Gold- und Effektenmakler, März 1910

- Ernennung von Siegbold Edmund Siemons und Hero Pool zu Getreidemaklern, Oktober 1913

$1871-1913$

Klassifikation Teil B: 00183

Trägermaterial: Papier

Alte Reg.-Sig.: I Gc 020

Bestell-Nr.: IV 00183

420 Zulassung von Makler für den Butter- und Käsemarkt

- Zulassung von Makler für den Butter- und Käsemarkt, Mai 1902 April 1910

- Rücktritt von Hindrikus Bokelmann und Hero Pool vom Amt des Maklers für Butter und Käse, Januar 1905

- Anonymes Schreiben über Manipulationen des Maklers Hero Pool zur Erzielung eines geringeren Butterpreises, April 1909

$1902-1910$

Klassifikation Teil B: 00191

Trägermaterial: Papier

Alte Reg.-Sig.: I Gc 060

Bestell-Nr.: IV 00191 
05.02

\section{Personal der Stadtverwaltung}

05.02.01

Untergebene des Magistrats

05.02.01.03

Beamte für Gewerbe- und Verkehrssachen

Lfd. Nr. Titel

Laufzeit

421 Hafenmeister am Falderndelft

1873

- Dienstinstruktion für den Hafenmeister am Falderndelft, Mai 1873

1873

Klassifikation Teil B: 00201

Trägermaterial: Papier

Alte Reg.-Sig.: I Gc 108

Bestell-Nr.: IV 00201

422 Schiffsbesichtiger

- Bewerbung des Kapitäns Menno Visser um das Amt des

Schiffsbesichtigers (Ladungskontrolle), Mai 1900

- Empfehlung von geeigneten Personen für das Amt des

Schiffsbesichtigers durch die Kaufmännische Deputation, Juli 1900

- Gutachten des Kämmerers Gebest über Zweckmäßigkeit der

Einstellung von Schiffsbesichtigern durch die Handelskammer für

Ostfriesland und Papenburg, Juli 1900

- Reglement für beeidigte Schiffsbesichtiger, August 1900

- Einstellung des Versicherungsagenten (Expert) $\mathrm{H}$. Heerma und der Altschiffer Menno Visser und H. de Jonge als Schiffsbesichtiger,

September 1900

- Vorschlag der Handelskammer für Ostfriesland und Papenburg zur

Ernennung der Schiffskapitäne H.A. Luers und H. Pool zu

Schiffsbesichtigern, Mai 1902

- Verfügung des Regierungspräsidenten in Aurich über Nichtzulassung der Schiffsbesichtiger als amtliche Gutachter, September 1902

$1900-1902$

Klassifikation Teil B: 00202

Trägermaterial: Papier

Alte Reg.-Sig.: I Gc 039

Bestell-Nr.: IV 00202 
IV

05

Stadtverwaltung

05.02

Personal der Stadtverwaltung

05.02.01

Untergebene des Magistrats

05.02.01.04

Beamte für direkte und indirekte städtische Abgaben und

Steuern

Lfd. Nr. Titel

Laufzeit

423 Kornmesser

$1883-1890$

- Wahl der Kornmesser, März 1883 - Mai 1890

$1883-1890$

Klassifikation Teil B: 00169

Trägermaterial: Papier

Alte Reg.-Sig.: I Gc 029

Bestell-Nr.: IV 00169

424 Torfmesser und Torfträger

- Vereidigung der Torfmesserinnen, 1867 - 1904

- Wahl der Torfmesserinnen, 1897

- Liste der Torfträger, 1880

$1867-1904$

Klassifikation Teil B: 00170

Trägermaterial: Papier

Alte Reg.-Sig.: I Gc 039

Bestell-Nr.: IV 00170

425 Torfaufsetzer, Torfträger und Torfmesserinnen

- Prüfung der Messungen der Torfmesserinnen, Januar 1858

- Wahl der Torfmesserinnen, 1909

- Von den Torfmaklern vorgeschlagene Torfausetzer, Juli 1858

- Instruktionen für Torfaufsetzer, September 1859

- Vereidigung der Torfaufsetzer, Juli 1860 - Juli 1864

- Festlegung der Gebühren für die Dienste der Torfaufsetzer, 1912

$1858-1912$

Klassifikation Teil B: 00181

Trägermaterial: Papier

Alte Reg.-Sig.: I Gc 039

Bestell-Nr.: IV 00181 
IV

05

Stadtverwaltung

05.02

Personal der Stadtverwaltung

05.02.01

Untergebene des Magistrats

05.02.01.04

Beamte für direkte und indirekte städtische Abgaben und Steuern

Lfd. Nr. Titel

Laufzeit

426 Torfbuchhalter Friedrich Bronger

1894-1913

- Bewerbung des Friedrich Bronger um eine ausgeschriebene

Torfbuchalterstelle, Juni 1894

- Wahl des Gehilfen Friedrich Bronger zum Torfbuchhalter und

Stadtdiener, Juni 1894

- Entrichtung einer Dienstkaution durch den Torfbuchhalter Friedrich

Bronger, August 1894

- Antrag des Friedrich Bronger beim Magistrat der Stadt Emden auf

Zahlung eines monatlichen Zuschusses zur Sicherung des

Lebensunterhalts, Mai 1895 - April 1904

- Verzeichnis der Einnahmen des Torfbuchhalters Friedrich Bronger, 1895 - 1911

- Gesuch der Witwe des Torfbuchhalters Friedrich Bronger um eine Unterstützung, Juni 1928

1894 - 1911 (1928)

Klassifikation Teil B: 00182

Trägermaterial: Papier

Alte Reg.-Sig.: I Gc 057

Bestell-Nr.: IV 00182

427 Akzise-Kontrolleur

- Ausschreibung der Stelle eines Akzise-Kontrolleurs, Januar 1902

- Dienstanweisung für den Akzise-Kontrolleur, Febr. 1902

- Einstellung des Militäranwärters Franz Jacobi aus Kiel als

Akzise-Kontrolleur, April 1902

- Entlassungsgesuch des Akzise-Kontrolleurs Franz Jacobi wegen

Ernennung zum Fischmeister durch die preußische Regierung in

Danzig, Juni 1904

- Gnadengehalt für die Witwe des Akzise-Kontrolleurs Eiben, August 1901 - Juni 1924

1902 - 1904 (1901 - 1924)

Klassifikation Teil B: 00192

Trägermaterial: Papier

Alte Reg.-Sig.: I Gd 6

Bestell-Nr.: IV 00192 
05.02

\section{Personal der Stadtverwaltung}

05.02.01

Untergebene des Magistrats

05.02.01.05

Sonstige städtische Angestellte

Lfd. Nr. Titel

Laufzeit

428 Informatorische Tätigkeit des Gerichtsassessors Heinrich

Hoogklimmer

- Schreiben des Heinrich Hoogklimmer als Studentenkorpsbruder an den Bürgermeister Dr. Wilhelm Mützelburg über Anfrage nach einer informatorischen Beschäftigung wegen Absicht des Wechsels zum Kommunaldienst, November1913

- Vermerk über Gang der informatorischen Beschäftigung des H. Hoogklimmer, Dezember 1913

- Vermerk über erfolgreichen Einsatz des H. Hoogklimmer in der Armenverwaltung und die Umsetzung seiner Reformideen, Juni / Juli 1914

- Schreiben des A. Jasper über Bericht seines Sohnes zum Kriegstod des Assessors Heinrich Hoogklimmer, Dezember 1916

1913 (1916)

Klassifikation Teil B: 00154

Trägermaterial: Papier

Alte Reg.-Sig.: I De 2

Bestell-Nr.: IV 00154

- Bewerbung des Oberbuchsenmachersmaaten Fritz Metzner aus Wilhelmshaven um die Stelle eines Rüstmeisters in Emden,

September 1902

- Empfehlung der Einstellung des Fritz Metzner als Rüstmeister von Seiten der Rüstkammer-Kommission, November 1902

- Gesuch des Rüstmeisters F. Metzner um Gehaltserhöhung, Januar 1903

- Eingabe des Rüstmeisters F. Metzner beim Magistrat der stadt Emden über Antrag auf Genehmigung der Kündigung wegen zu geringem Gehalt bei hohen Lebenshaltungskosten, Februar 1903

$1902-1903$

Klassifikation Teil B: 00162

Trägermaterial: Papier

Alte Reg.-Sig.: I Ge 03

Bestell-Nr.: IV 00162 
05.02

Lfd. Nr. Titel

- Bewerbung des Oberbuchsenmachersmaaten Heinrich Jung aus Wilhelmshaven um die Stelle eines Rüstmeisters in Emden, April

1903

- Wahl des Heinrich Jung als Rüstmeister von Seiten der

Rüstkammer-Kommission, April - Mai 1903

- Antrag des Magistrats der Stadt Emden beim Kommandeur der II. Werftdivision Wilhelmshaven auf Freistellung des Heinrich Jung während der Probezeit, Mai 1903

- Einstellung und Vereidigung des Rüstmeisters H. Jung, Juli 1903

- Eingabe des Rüstmeisters H. Jung an den Magistrat der Stadt Emden über Antrag auf Erstattung seiner Umzugskosten, Dezember 1903

- Beschluss der Rüstkammer-Kommission über Empfehlung der Einstellung eines Vertreters für den Rüstmeister, Juli 1905 / August 1906

Genehmigung der Gewährung einer Zulage für den Rüstmeister wegen Durchführung von Führungen an Sonntagen und in der Freizeit, Oktober 1905

- Eingabe des Rüstmeisters Heinrich Jung beim Magistrat der Stadt Emden über Antrag auf Gewährung einer Dienstwohnung, Juli 1906 Kündigungsgesuch des Rüstmeisters $\mathrm{H}$. Jung wegen Nichtgewährung einer Dienstwohnung und Verweigerung von Reinigungsgeld, August 1906 / März 1907

Feststellung der Pension des Kriegsinvaliden und ehemaligen Rüstmeisters H. Jung, März 1907

$1903-1907$ (1908)

Klassifikation Teil B: 00163

Trägermaterial: Papier

Alte Reg.-Sig.: I Ge 03

Bestell-Nr.: IV 00163

431 Stadtausklingler

- Festsetzung der von den Stadtausklingler für seine Leistungen zu erhebenden Gebühren, 1867 - 1869

- Eingabe des Rechnungsstellers Lolling beim preußischen Landdrosten in Aurich über Beschwerde gegen den Ausklingler Hamphoff wegen überzogener Gebührenforderungen, Juni 1867 - Bewerbungen um die vakante Stadtausklinglerstellen in Emden, $1871-1882$

- Instruktionen für den Stadtausklingler Lucas Schröder, Oktober 1871

$1867-1882$

Klassifikation Teil B: 00171

Trägermaterial: Papier

Alte Reg.-Sig.: I Gc 041

Bestell-Nr.: IV 00171 
05.02

Lfd. Nr. Titel

- Bewerbungen um Arbeiter-Stellen bei der Stadt Emden, 1912

- Reinigung der Kanäle durch Kanalisationswärter, November 1906

Enthält auch:

- Gesuche verschiedener Witwen um Gnadenunterstützung durch die Stadt Emden, 1906 - 1912

$1906-1912$

Klassifikation Teil B: 00172

Trägermaterial: Papier

Alte Reg.-Sig.: I Ge 11

Bestell-Nr.: IV 00172

433 Leichenbitter und Leichenträger

- Ermittlungen gegen den Bäckermeister O. Heiland wegen Treiben von Schweinen auf dem Friedhof der Neuen Kirche, Juli - August 1846 - Beschwerde wegen mangelhafter Begräbnisbedienung auf dem Friedhof der Neuen Kirche, November 1850

- Besetzung der Totengräberstelle bei der Großen Kirche, Februar 1844

- Totengräbergebühren und Instruktionen für die Totengräber und Leichenbitter, 1824 - 1825

- Antrag des Leichenbitters A.S. Schmidt beim Magistrat der Stadt Emden auf Stellung eines Vertreters wegen vorgerücktem Alter, März 1879

- Beschwerde gegen den Leichenbitter Plooger wegen Trunkenheit im Dienst, Juni 1880

- Bewerbungen um Leichenbitterstellen, 1879 - 1911

- Vereidigung neu bestellter Leichenbitter, 1880 - 1904

- Wahl eines Ersatzmannes für den erkrankten Leichenbitter P.

Siebolts, Juni 1881

- Streit um die Höhe der Leichenbittergebühren, Oktober 1887

- Beschwerden gegen den Leichenbitter H. Siebolts, 1881 - 1882

- Revision des Instituts der Leichenbitter, 1897

- Gesuche verschiedener Leichenbitter um Amtsentbindung aus Altersgründen, 1896 - 1900

- Gesuche der Leichenbitter um Anhebung ihrer Gebührensätze, August 1900

- Verzeichnis des im Bestattungswesen tätigen Personals der Stadt emden, 1908

- Initiative des Verbandes der Totengräber Deutschlands zur Abschaffung der Berufsbezeichnung "Totengräber" wegen Diskriminierung der Berufsgruppe, Februar 1910

$1824-1920$

Klassifikation Teil B: 00173

Trägermaterial: Papier

Alte Reg.-Sig.: I Ge 11

Bestell-Nr.: IV 00173 
05.02

\section{Personal der Stadtverwaltung}

05.02.01

Lfd. Nr. Titel

- Gesuch des Exekutors W.J. Schultze um Zahlung eines Honorars aus den Gebühren auf die Beiträge zur Feuerversicherungs-Beiträgen, Januar 1884 - Juli 1885

- Eingabe des W.J. Schultze an den Magistrat der Stadt Emden über Weigerung zur Beitreibung der Restanden der

Gesellen-Krankenkasse, Juni - September 1884

- Amtsniederlegung des Exekutors Müller wegen fortgeschrittenen

Alters, März 1888

- Wiederbesetzung der Exekutorenstelle, September 1885

- Antrag des Exekutors W.J. Schulte auf Gewährung einer Pension, März 1886

- Instruktion für die Nachtwächter der Stadt Emden, Februar 1896

$1884-1896$

Klassifikation Teil B: 00187

Trägermaterial: Papier

Bestell-Nr.: IV 00187

- Personalbogen für den Kassenschreiber Franz Hinderks von der Steuerkasse der Stadt Emden, ca. 1914

- Eingabe des Franz Hinderks an den Magistrat der Stadt Emden über Bitte um Erhöhung seines Gehalts wegen Teuerung, November 1873 - Dienstanweisung für den Kassenassistenten Franz Hinderks, März 1889

- Einstellung des Franz Hinderks als Akzise-Kassenschreiber, April Mai 1893

- Festsetzung der pensionsfähigen Dienstjahre des Franz Hinderks, 1914 - 1916

- Pensionierung des Franz Hinderks, September 1916

$1873-1916$

Klassifikation Teil B: 00221

Trägermaterial: Papier Alte Reg.-Sig.: I Ga 25

Bestell-Nr.: IV 00221 
05

05.02

05.02.01

Lfd. Nr. Titel

Laufzeit

436 Turmwächter

- Anweisung an die Kämmereikasse wegen Gehalt des Turmwächters Heinrich Suchsland, Juni 1868

- Gesuch der Turmwächter Johannes Fecht und Heinrich Suchsland über Bitte um Gehaltserhöhung, Januar 1869

- Beschwerden gegen den Turmwächter Heinrich Suchsland wegen unerlaubten Entfernens vom Dienst, März 1870

- Bewerbungen um die Stelle eines Turmwächters bei der Stadt

Emden, Mai 1873 - Februar 1886

- Dienstunfähigkeit und Entlassung des Turmwächters Johannes

Fecht wegen Alkoholmissbrauch, Mai - Oktober 1874

- Dienstinstruktionen für die Turmwächter in Emden, April 1875 -

Oktober 1886

- Beschwerde gegen den Turmwächter Cornelius van Jindelt wegen

Vernachlässigung des Dienstes, April 1875

- Eidesformel der Turmwächter in Emden, 1875

- Entlassungsgesuch des Turmwächters Cornelius van Jindelt wegen Altersrücksichten, Januar 1886

- Anzeige gegen den Turmwächter Diedrich de Vries wegen Schlafen im Dienst, Januar 1889

- Beschwerden gegen die Turmwächter Gerritzen und Müller wegen Vernachlässigung des Dienstes, August 1892 - Februar 1896

- Vorschläge der Kommission zur Reorganisation des

Nachtwachtwesens über Abschaffung der Turmwächterstellen, Februar 1896

- Installierung einer Kontrolluhr für Nachtwächter, August 1896

$1868-1896$

Klassifikation Teil B: 00239

Trägermaterial: Papier

Alte Reg.-Sig.: I Ge 08

Bestell-Nr.: IV 00239 
05.02

Personal der Stadtverwaltung

05.02.01

Untergebene des Magistrats

05.02.01.05

Sonstige städtische Angestellte

Lfd. Nr. Titel

Laufzeit

437 Bauaufseher- und Schreiber A, Höcke

- Vereinigung der Bauaufseher mit der Bauschreiberstelle, September 1876

- Ausschreibung der Bauaufseher- und Bauschreiberstelle, November 1876 - Januar 1877

- Bewerbung des Bautechnikers Albert Höcke aus Berlin um die

Bauaufseher- und Schreiberstelle in Emden, Januar 1877

- Wahl des Albert Höcke zum Bauaufseher- und Schreiber der Stadt

Emden, März 1877

- Einstellung des Albert Höcke, April 1877

- Eingaben des A. Höcke an den Magistrat der Stadt Emden über Bitte um Gewährung einer Gehaltszulage wegen teurer Lebenshaltung in

Emden, August 1878 - Februar 1887

- Einstellung des Bauaufsehers und -Schreibers Albert Höcke als Aufseher über die Arbeiter des preußischen Fiskus in Emden als Nebentätigkeit, Februar 1890

- Entlassungsgesuch des Bauaufsehers und -Schreibers A. Höcke wegen beabsichtigten Stellenwechsel, August 1892

$1876-1892(1902)$

Klassifikation Teil B: 00338

Trägermaterial: Papier

Alte Reg.-Sig.: I F 13

Bestell-Nr.: IV 00338

- Umwandlung der Stadtzimmermeisterstelle in eine

Stadtbauaufseherstelle, März 1865

- Dienstinstruktion für den Statbauaufseher G.D. Giesberts, April 1865

- Ermittlung der Kronanwaltschaft beim Obergericht in Aurich wegen einer Verantwortlichkeit des Bauaufsehers G.D.Giesberts für den Unfalltod eines Jungens bei der wegen Bauarbeiten gesperrten Kettenbrücke, Oktober 1868

- Ausschreibung der Stadtbauaufseherstelle in Emden, Februar 1871 - Bewerbung des Zimmermeisters Peter Steur um die Stelle eines Stadtbauaufsehers in Emden, Februar 1871

- Wahl des Peter Steur zum Stadtbauaufseher, März 1871

. Vereidigung des Peter Steur als Stadtbauaufseher, März 1871

- Entlassung des Bauaufsehers Steur wegen Abrechnungsfehler und zuviel gezahlter Löhne an eingesetzten Zimmerleuten, September 1872

$1865-1871$

Klassifikation Teil B: 00339

Trägermaterial: Papier

Alte Reg.-Sig.: I F 11

Bestell-Nr.: IV 00339 
05

Stadtverwaltung

05.02

\section{Personal der Stadtverwaltung}

05.02 .01

Untergebene des Magistrats

05.02.01.05

Sonstige städtische Angestellte

Lfd. Nr. Titel

Laufzeit

439 Zeugnisse für Beamte

1901

- Verfügung des Regierungspräsidenten in Aurich über Ausstellung von Zeugnissen für Beamte, September 1901

1901

Klassifikation Teil B: 00340

Trägermaterial: Papier

Alte Reg.-Sig.: I Ca 5

Bestell-Nr.: IV 00340 
IV

05

Stadtverwaltung

05.02

Personal der Stadtverwaltung

05.02.01

Untergebene des Magistrats

05.02.01.06

Angestellte der Stadt Emden auf Nesserland

Lfd. Nr. Titel

Laufzeit

440 Schleusenmeister auf Nesserland

1877-1885

- Ausschreibung der Schleusenmeisterstelle auf Nesserland, März

1877

- Bewerbung des Bauschreibers Meinke Groenewold um die

Schleusenmeisterstelle, März 1877

- Antrag des Magistrats der stadt Emden beim preußischen

Landdrosten In Aurich auf Genehmigung der Schleusenmeisterstelle auf Nesserland mit dem Bauschreiber Meinke Groenewold, Mai 1877

- Streit des Schleusenmeisters Groenewold mit dem Bauern

Suchsland um Weiderechte am Schleusendeich, Juli 1878

- Antrag des Schleusenmeisters M. Groenewold auf Klärung der

Verbindlichkeit telegraphisch mitgeteilter Schleusenöffnungs-Befehle

bei kritischem Wasserstand, November 1882

-Verweis gegen M. Groenewold wegen antisemitischer Agitation als städtischer Beamter, Januar 1883

- Streit um Gebührenpflicht für Briefträger für die Übersetzung nach

Nesserland, April - Mai 1883

- Entlassungsgesuch des Schleusenmeisters M. Groenewold wegern geplanter Auswanderung nach Südamerika, November 1883

- Entlassungsgesuch des Schleusenmeisters M. Groenewold wegen

Hass gegen inn und seine Familie, Februar 1885

$1877-1885$

Klassifikation Teil B: 00164

Trägermaterial: Papier

Alte Reg.-Sig.: I Gf 5

Bestell-Nr.: IV 00164 
05

Stadtverwaltung

05.02

05.02.02

Personal der Stadtverwaltung

Lfd. Nr. Titel

Technische Beamte

441 Stadtbaumeister Carl F.C. Robbelen

Laufzeit

- Bewerbung des Ingenieurs Carl F.C. Robbelen aus Hannover um die Stelle eines Stadtbaumeisters in Emden, Januar 1858

- Wahl des Carl F.C. Robbelen zum Stadtbaumeister in Emden, Mai

1858

1858

Klassifikation Teil B: 00153

Trägermaterial: Papier

Alte Reg.-Sig.: I F 09

Bestell-Nr.: IV 00153 
05

Stadtverwaltung

05.02

Personal der Stadtverwaltung

05.02 .03

Gehalts- und Besoldungsfragen

Lfd. Nr. Titel

Laufzeit

442 Besoldung der städtischen Beamten

1914

(1913)

- Besoldungsordnung für die Beamten des mittleren Dienstes in

Emden, April 1914

- Aufstellung über Beamte der Stadt Emden, 1914

- Neuberechnung der Gehälter nach Erhöhung der Besoldungssätze,

April 1914

- Verzeichnis der städtischen Beamten mit Nebeneinkünften,

Dezember 1913

- Vorlage des Gehaltsordnungsausschusses an die städtischen

Kollegien über Reform der städtischen Besoldungsordnung und der anhebung der Besoldungssätze, Februar 1914

- Gesuch der städtischen Baubeamten um Gehaltserhöhung,

November1913

- Verschiedene Gesuche von Vollziehungsbeamten um

Gehaltserhöhung, März - April 1914

- Verschiedene Gesuche von Polizeibeamten um Gehaltserhöhung,

April 1914

- Ortsstatut über die Anstellung und Versorgung der städtischen

Beamten, April 1914

(1913) 1914

Klassifikation Teil B: 00157

Trägermaterial: Papier

Alte Reg.-Sig.: I Ga 03

Bestell-Nr.: IV 00157

443 Regulierung der Beamtengehälter

- Vorlage des Oberbürgermeisters Fürbringer an den Magistrat über Neufestsetzung der Gehälter für die Beamten der Stadt Emden nach dem Vorbild der Staatsbeamten, Oktober 1898

- Berechnung der Mehrausgaben nach der Regulierung der

Beamtengehälter für 1898 / 99, Dezember 1898

$1898-1899$

Klassifikation Teil B: 00422

Band: 1

Trägermaterial: Papier

Alte Reg.-Sig.: III C 02

Bestell-Nr.: IV 00422 
05

Stadtverwaltung

05.02

Personal der Stadtverwaltung

05.02 .03

Gehalts- und Besoldungsfragen

Lfd. Nr. Titel

Laufzeit

444 Regulierung der Beamtengehälter

1899-1908

- Verhandlungen der Vorlage des Oberbürgermeisters Fürbringer über Neufestsetzung der Gehälter für die Beamten der Stadt Emden nach dem Vorbild der Staatsbeamten, Oktober 1898

- "9. Nachtrag zum revidierten Ortsstatut vom 10./20. März 1893" über

Neufestsetzung der Beamtengehälter, März 1899

- Bescheide an die einzelnen Beamten über Gehaltsfestsetzung, Mai

1899

- Aufstellung über Beamte mit einem Jahresgehalt von unter 2000

Mark, 1900

- Festlegung einer jährlichen Gehaltszulage für Beamte mit einem Jahresgehalt von unter 2000 Mark, Januar 1902

- Festlegung einer jährlichen Gehaltszulage für die Beamten der Stadt

Emden, März 1908

$1899-1908$

Klassifikation Teil B: 00423

Band: 2

Trägermaterial: Papier

Alte Reg.-Sig.: III C 02

Bestell-Nr.: IV 00423

445 Regulierung der Beamtengehälter

$1909-1911$

- Festlegung einer jährlichen Gehaltszulage für die Beamten der Stadt Emden, Juli 1909

- Eingabe der städtischen Beamten an Magistrat und

Bürgervorsteherkollegium der Stadt Emden über Bitte um Erhöhung

der Gehälter, Februar 1909 - Januar 1911

- Eingabe der städtischen Beamten an Magistrat und

Bürgervorsteherkollegium der Stadt Emden über Bitte um Gewährung

einer Teuerungszulage, OKtober 1911

- Erhöhung der Anfangs- und Endgehälter der Beamten der Stadt

Emden, Dezember 1911

$1909-1911$

Klassifikation Teil B: 00424

Band: 3

Trägermaterial: Papier

Alte Reg.-Sig.: III C 02

Bestell-Nr.: IV 00424 
05

Stadtverwaltung

05.02

Personal der Stadtverwaltung

05.02 .03

Gehalts- und Besoldungsfragen

Lfd. Nr. Titel

Laufzeit

446 Gehaltsfestlegung für Angestellte der Stadt Emden

$1865-1866$

(1892)

- Erhöhung der Besoldung der Stadtdiener, Dezember 1865 - Juni

1866

- Verfügung des Hannoverschen Landdrosten in Aurich über Mitteilung

der Genehmigung der Änderung des Ortsstatuts hinsichtlich

Neustrukturierung der Angestellten-Stellen und Neufestlegung der

Gehälter in der Stadt Emden durch den Hannoverschen

Innenminister, August 1866

$1865-1866$

Klassifikation Teil B: 00425

Trägermaterial: Papier

Alte Reg.-Sig.: III C 01

Bestell-Nr.: IV 00425 
IV

05

Stadtverwaltung

05.03

Aufgabenbereiche der Stadtverwaltung

05.03.01

Meldewesen und Statistik

05.03.01.01

Erlaubnis und Verweigerung der Niederlassung

Lfd. Nr. Titel

Laufzeit

447 Erteilung von Trauscheinen

1862-1868

- Anträge auf Erteilung von Trauscheinen, Oktober 1862 - April 1868

$1862-1868$

Klassifikation Teil B: 00003

Trägermaterial: Papier

Bestell-Nr.: IV 00003

448 Erteilung von Heimkehrscheinen

$1861-1871$

- Anträge nach Emden zurückgekehrter Personen auf Erteilung eines Heimkehrscheins zum Erhalt des Niederlassungsrechts in Emden, 1861 - 1871

$1861-1871$

Klassifikation Teil B: 00004

Trägermaterial: Papier

Bestell-Nr.: IV 00004

449 Erteilung von Heimatscheinen

- Berichte der Stadt Emden an den Regierungspräsidenten in Aurich über ausgestellte Heimat- und Staatsangehörigkeitsscheine, Januar 1880 - Januar 1910

- Anforderung von Formularen für die Ausstellung von

Staatsangehörigkeitsausweisen durch die Stadt Emden, 1904 - 1922

- Verzeichnis der ausgestellten Heimatscheine, 1879 - 1889

$1879-1922$

Klassifikation Teil B: 00005

Trägermaterial: Papier

Bestell-Nr.: IV 00005 
IV

05

Stadtverwaltung

05.03

Aufgabenbereiche der Stadtverwaltung

05.03.01

05.03.01.02

Meldewesen und Statistik

Auswanderung

Lfd. Nr. Titel

Laufzeit

450 Auswanderung

1905-1912

- Erlasse des preußischen Ministers für Handel und Gewerbe sowie des preußischen Innenministers zur Bekämpfung von

Auswandereragenten, 1905 - 1912

- Emder Auswandererstatistik, 1901 - 1906

- Berichte über Gründe der Auswanderung, 1907 - 1908

- Erlass des preußischen Innenministers über Art der Warnung vor

unüberlegter Auswanderung, Mai 1909

- Erlass des preußischen Innenministers über bessere

Bekanntmachung der Tätigkeit der Zentralauskunftstelle für

Auswanderer in Berlin, November 1909

$1905-1912$

Klassifikation Teil B: 00291

Trägermaterial: Papier

Alte Reg.-Sig.: IV Bc 8

Bestell-Nr.: IV 00291

451 Auswanderer

$1852-1875$

- Liste der mit dem Schiff "Marie Agnes" unter Kapitän Johann Watkes von Emden nach New Orleans transportierten ostfriesischen

Auswanderer, April 1852

- Eingabe des Schiffsmaklers der "Marie Agnes", G. Broer, an den

Magistrat der Stadt Emden über Bitte um Befreiung vom Kaigeld, April

1852

- Unterstützungen für Auswanderer, April - August 1865

- Votum der Stadt Emden gegen eine einseitige Begünstigung

Geestemündes bei der Förderung des Auswandererverkehrs, Oktober

1865

- Verfügung des preußischen Landdrosten in Aurich über Vorlage

einer Statistik zur Auswanderung, März 1867 - September 1872

- Bekämpfung betrügerischer Auswandereragenten, August 1872

- Erhebung von Gebühren zur Erlangung einer

Auswanderungserlaubnis, Dezember 1875

$1852-1875$

Klassifikation Teil B: 00310

Trägermaterial: Papier

Bestell-Nr.: IV 00310 
IV

05

05.03

Stadtverwaltung

05.03 .01

05.03.01.02

Aufgabenbereiche der Stadtverwaltung

Meldewesen und Statistik

Lfd. Nr. Titel

Auswanderung

452 Auswanderungen

Laufzeit

1866-1913

- Erlasse des preußischen Generalgouverneurs in Hannover über Einführung des preußischen Staatsbürgerrechts im eroberten und annektierten Kgr. Hannover, Dezember 1866 - August 1867

- Warnungen vor Auswandererwerbungen, November 1867 - April

1913

- Verfügung des preußischen Landdrosten in Aurich über Nachricht zu Abkommen zwischen den USA und dem Norddeutschen Bund wegen Straferlass für sich im Bundesgebiet aufhaltende US-Bürger deutscher Abstammung bei Vorliegen einer als Straftat bewerteten

Auswanderung ohne Erlaubnis, Juli 1868

- Nachricht über Einwanderungsbeschränkungen in Kanada,

November 1868

- Warnungen vor Auswanderung nach Russland, 1868 - 1903

- Warnungen vor Auswanderung nach Brasilien, 1869 - 1880

- Warnungen vor Auswanderung nach Venezuela, 1875 - 1879

- Warnungen vor Auswanderung nach Serbien, 1880

- Gesetzliche Regelung des Auswandererwesens, Juni 1897

- Ernennung des Kapitäns Chuden zum Reichskommissar für das

Auswandererwesen im Unterwesergebiet, Januar 1903

- Gesetzliche Regelung der Durchreise von Auswanderer und

Rückwanderer durch Deutschland, 1905 - 1910

- Auswandererwerbungsinserat für Kanada in der "Ostfriesischen

Zeitung", November 1905

$1866-1913$

Klassifikation Teil B: 00438

Trägermaterial: Papier

Alte Reg.-Sig.: IV B 03

Bestell-Nr.: IV 00438

453 Beherbergung von Auswanderern

- Verhandlungen zwischen dem Regierungspräsidenten in Aurich und der Stadt Emden über Erlass einer Polizeiverordnung zur Regulierung der Beherbergung von Auswanderern vor ihrer Weiterreise über den

Emder Hafen, Juni - August 1914

1914

Klassifikation Teil B: 00604

Trägermaterial: Papier

Alte Reg.-Sig.: IV Fb 24

Bestell-Nr.: IV 00604 
IV

05

Stadtverwaltung

05.03

Aufgabenbereiche der Stadtverwaltung

05.03.01

Meldewesen und Statistik

05.03.01.03

Familiennamen

Lfd. Nr. Titel

Laufzeit

454 Änderung von Familiennamen

1869-1916

- Verfügung des Regierungspräsidenten in Aurich über Richtlinien zur

Genehmigung von Gesuchen um Namensänderungen, April 1869 /

September 1898

- Anträge auf Namensänderungen, 1871 - 1912

- Anträge auf Adoption, 1881 - 1916

$1869-1916$

Klassifikation Teil B: 00436

Trägermaterial: Papier

Alte Reg.-Sig.: IV Bd 1

Bestell-Nr.: IV 00436 
05

05.03

05.03.01

05.03.01.04
Stadtverwaltung

Aufgabenbereiche der Stadtverwaltung

Meldewesen und Statistik

Statistische Berichte und Erhebungen

Lfd. Nr. Titel

Laufzeit

455 Topographie der Stadt Emden (Statistik)

- Erlasse des preußischen Innenministers über Erstellung statistischer Berichte zur Stadtentwicklung, Dezember 1871 / November 1886

- Entwürfe der statistischen Berichte der Stadt Emden, 1872 - 1891

- Material für die statistischen Berichte, u.a.: Stadtverschuldung,

Einkommenssteueraufkommen, Krankenhaus, Brandwesen, Insassen

des Gasthauses, Religionsgemeinschaften, Schulwesen,

Kleinkinderbewahranstalt, Kindergärten, verschiedene

Geschäftsberichte, Güter- und Personenverkehr, Im- und Export, Hafenwirtschaft, Werftindustrie, 1888 - 1891

- Verwendung des Material für den vom Oberbürgermeister Leo

Fürbringer herausgegebenen Stadtführer, 1891

$1871-1891$

Klassifikation Teil B: 00021

Trägermaterial: Papier

Alte Reg.-Sig.: IV Cd 12

Bestell-Nr.: IV 00021

456 Topographie der Stadt Emden (Statistik)

$1904-1911$

- Statistischer Bericht und Ortsbeschreibung der Stadt Emden, 1905

- Vortrag des Oberbürgermeisters Leo Fürbringer vor dem

Centralverein zur Hebung der deutschen Fluß- und Kanalschiffahrt

über "Zweck, Bedeutung und Erweiterung des Emder Hafens", 1904

- Verschiedene Publikationen zum Emder Hafen, 1905 - 1911

$1904-1911$

Klassifikation Teil B: 00022

Trägermaterial: Papier

Alte Reg.-Sig.: IV Cd 12

Bestell-Nr.: IV 00022

457 Hausbesitzer in der Stadt Emden

1914

- Verzeichnis der Hausbesitzer in der Stadt Emden nach dem

Adressbuch von 1914, 1914

1914

Klassifikation Teil B: 00024

Trägermaterial: Papier

Alte Reg.-Sig.: IV Cb 02

Bestell-Nr.: IV 00024

458 Einwohner der Stadt Emden

$1850-1860$

- Verzeichnis der Einwohner der Stadt Emden, 1850 - 1860

$1850-1860$

Klassifikation Teil B: 00025

Trägermaterial: Papier

Alte Reg.-Sig.: IV Cb 02

Bestell-Nr.: IV 00025 
IV

05

05.03

05.03.01

05.03.01.04
Stadtverwaltung

Aufgabenbereiche der Stadtverwaltung

Meldewesen und Statistik

Statistische Berichte und Erhebungen

Lfd. Nr. Titel

Laufzeit

459 Volkszählung von 1916

1916

- Erlass des preußischen Ministers für geistliche und

Unterrichtsangelegenheiten über Beteiligung der Lehrerschaft als

Zähler bei der Volkszählung, November 1916

- Durchführung der Volkszählung in Emden, November - Dezember

1916

1916

Klassifikation Teil B: 00032

Trägermaterial: Papier

Alte Reg.-Sig.: IV Cb 16

Bestell-Nr.: IV 00032

460 Volkszählung von 1917

- Durchführung der Volkszählung in Emden, November - Dezember 1917

1917

Klassifikation Teil B: 00033

Trägermaterial: Papier

Alte Reg.-Sig.: IV Cb 16

Bestell-Nr.: IV 00033

461 Volkszählung, 1918

- Verordnung des Bundesrats über Volkszählung, Oktober 1918

- Bekanntmachung der Volkszählung, November 1918 (September

1919)

- Beteiligung der Lehrer an der Volkszählung als Zähler, Oktober 1918

- Runderlass des preußischen statistischen Landeamts zur

Volkszählung, Oktober 1918

1918 (1919)

Klassifikation Teil B: 00034

Trägermaterial: Papier

Alte Reg.-Sig.: IV Cb 16

Bestell-Nr.: IV 00034 
05

05.03

05.03.01

05.03.01.04
Stadtverwaltung

Aufgabenbereiche der Stadtverwaltung

Meldewesen und Statistik

Statistische Berichte und Erhebungen

Lfd. Nr. Titel

Laufzeit

462 Statistische Berichte des Magistrats zur Stadtentwicklung

- Statistische Berichte über Tätigkeit verschiedener

Verwaltungsbereiche (u.a. Polizeiweswen, Standesamt, Armenwesen,

Schulwesen), 1896 - 1914

- Verschiedene Jahresberichte von Firmen in Emden, u.a. Emder

Gewerbebank, Emder Genossenschaftsbank, AG Ems, Emder

Reederei AG, Rheinisch-Westfälisches Kohlensyndikat, Emder

Heringsfischerei AG, 1914

- Gebührentarif des Dortmund-Ems-Kanals, 1898

- Presseberichte über besondere Ereignisse, 1855 - 1914

- Auswanderungsstatistik,1895

- Verfügungen des Regierungspräsidenten in Aurich über Anforderung

von statististischen Berichten, 1895 - 1901

- Beschäftigungsstatistik, 1898 - 1914

- Preistatistik, 1900 / 1914

$1895-1914$

Klassifikation Teil B: 00274

Trägermaterial: Papier

Alte Reg.-Sig.: II B 5

Bestell-Nr.: IV 00274

463 Statistische Berichte des Magistrats zur Stadtentwicklung

1914-1918

(1928)

- Statistische Berichte über Tätigkeit verschiedener

Verwaltungsbereiche (u.a. Polizeiweswen, Standesamt, Armenwesen,

Schulwesen), 1914 - 1918

- Bevölkerungsstatistik, 1914 - 1918

- Statistik über Verkehr im Emder Hafen, 1914 - 1918

- Verfügung des Bürgermeisters Dr. Wilhelm Mützelburg über Form

der statistischen Berichte, April 1914

$1914-1918$

Klassifikation Teil B: 00275

Trägermaterial: Papier

Alte Reg.-Sig.: II B 8

Bestell-Nr.: IV 00275

464 Statistische Berichte des Magistrats zur Stadtentwicklung

- Statistische Berichte über Tätigkeit verschiedener

Verwaltungsbereiche (u.a. Polizeiweswen, Standesamt), 1911

- Bevölkerungsstatistik, 1911

- Preisstatistik, 1911

- Beschäftigungsstatistik, 1911

1911

Klassifikation Teil B: 00276

Trägermaterial: Papier

Alte Reg.-Sig.: II B 9

Bestell-Nr.: IV 00276 
IV

05

05.03

05.03.01

05.03.01.04
Stadtverwaltung

Aufgabenbereiche der Stadtverwaltung

Meldewesen und Statistik

Statistische Berichte und Erhebungen

Lfd. Nr. Titel

Laufzeit

465 Statistische Berichte über die Emder Stadtentwicklung 1900

- Statistische Berichte an den Regierungspräsidenten in Aurich über die Emder Stadtentwicklung (Hafenausbau, Bevölkerungsentwicklung, Kriminalität, Wirtschaft), teilweise als Pressebericht publiziert, 1900

1900

Klassifikation Teil B: 00278, 01

Trägermaterial: Papier

Alte Reg.-Sig.: II B 9

Bestell-Nr.: IV 00278 a

466 Statistische Berichte über die Emder Stadtentwicklung

1901

- Statistische Berichte an den Regierungspräsidenten in Aurich über die Emder Stadtentwicklung (Hafenausbau, Bevölkerungsentwicklung, Kriminalität, Wirtschaft), teilweise als Pressebericht publiziert, 1901

1901

\author{
Klassifikation Teil B: 00278, 02 \\ Trägermaterial: Papier \\ Alte Reg.-Sig.: II B 9 \\ Bestell-Nr.: IV 00278 b
}

467 Statistische Berichte über die Emder Stadtentwicklung

- Statistische Berichte an den Regierungspräsidenten in Aurich über die Emder Stadtentwicklung (Hafenausbau, Bevölkerungsentwicklung, Kriminalität, Wirtschaft), teilweise als Pressebericht publiziert, 1902

1902

Klassifikation Teil B: 00279

Trägermaterial: Papier

Alte Reg.-Sig.: II B 9

Bestell-Nr.: IV 00279

468 Statistische Berichte über die Emder Stadtentwicklung

- Statistische Berichte an den Regierungspräsidenten in Aurich über die Emder Stadtentwicklung (Hafenausbau, Bevölkerungsentwicklung, Kriminalität, Wirtschaft), teilweise als Pressebericht publiziert, 1903

1903

Klassifikation Teil B: 00280

Trägermaterial: Papier

Alte Reg.-Sig.: II B 9

Bestell-Nr.: IV 00280 
IV

05

05.03

05.03.01

05.03.01.04
Stadtverwaltung

Aufgabenbereiche der Stadtverwaltung

Meldewesen und Statistik

Statistische Berichte und Erhebungen

Lfd. Nr. Titel

Laufzeit

469 Statistische Berichte über die Emder Stadtentwicklung 1904

- Statistische Berichte an den Regierungspräsidenten in Aurich über die Emder Stadtentwicklung (Hafenausbau, Bevölkerungsentwicklung, Kriminalität, Wirtschaft), teilweise als Pressebericht publiziert, 1904

1904

Klassifikation Teil B: 00281

Trägermaterial: Papier

Alte Reg.-Sig.: II B 9

Bestell-Nr.: IV 00281

470 Statistische Berichte über die Emder Stadtentwicklung

- Statistische Berichte an den Regierungspräsidenten in Aurich über die Emder Stadtentwicklung (Hafenausbau, Bevölkerungsentwicklung, Kriminalität, Wirtschaft), teilweise als Pressebericht publiziert, 1905

1905
Klassifikation Teil B: 00282
Trägermaterial: Papier
Alte Reg.-Sig.: II B 9
Bestell-Nr.: IV 00282

471 Statistische Berichte über die Emder Stadtentwicklung

- Statistische Berichte an den Regierungspräsidenten in Aurich über die Emder Stadtentwicklung (Hafenausbau, Bevölkerungsentwicklung, Kriminalität, Wirtschaft), teilweise als Pressebericht publiziert, 1906

1906

Klassifikation Teil B: 00283

Trägermaterial: Papier

Alte Reg.-Sig.: II B 9

Bestell-Nr.: IV 00283

472 Statistische Berichte über die Emder Stadtentwicklung

- Statistische Berichte an den Regierungspräsidenten in Aurich über die Emder Stadtentwicklung (Hafenausbau, Bevölkerungsentwicklung, Kriminalität, Wirtschaft), teilweise als Pressebericht publiziert, 1907

1907

Klassifikation Teil B: 00284

Trägermaterial: Papier

Alte Reg.-Sig.: II B 9

Bestell-Nr.: IV 00284 
IV

05

05.03

05.03.01

05.03.01.04
Stadtverwaltung

Aufgabenbereiche der Stadtverwaltung

Meldewesen und Statistik

Statistische Berichte und Erhebungen

Lfd. Nr. Titel

Laufzeit

473 Statistische Berichte über die Emder Stadtentwicklung 1908

- Statistische Berichte an den Regierungspräsidenten in Aurich über die Emder Stadtentwicklung (Hafenausbau, Bevölkerungsentwicklung, Kriminalität, Wirtschaft), teilweise als Pressebericht publiziert, 1908

1908

Klassifikation Teil B: 00285

Trägermaterial: Papier

Alte Reg.-Sig.: II B 9

Bestell-Nr.: IV 00285

474 Statistische Berichte über die Emder Stadtentwicklung

1909

- Statistische Berichte an den Regierungspräsidenten in Aurich über die Emder Stadtentwicklung (Hafenausbau, Bevölkerungsentwicklung, Kriminalität, Wirtschaft), teilweise als Pressebericht publiziert, 1909

1909
Klassifikation Teil B: 00286
Trägermaterial: Papier
Alte Reg.-Sig.: II B 9
Bestell-Nr.: IV 00286

475 Statistische Berichte über die Emder Stadtentwicklung

- Statistische Berichte an den Regierungspräsidenten in Aurich über die Emder Stadtentwicklung (Hafenausbau, Bevölkerungsentwicklung, Kriminalität, Wirtschaft), teilweise als Pressebericht publiziert, 1910

1910

Klassifikation Teil B: 00287

Trägermaterial: Papier

Alte Reg.-Sig.: II B 9

Bestell-Nr.: IV 00287

476 Statistische Berichte über die Emder Stadtentwicklung

- Statistische Berichte an den Regierungspräsidenten in Aurich über die Emder Stadtentwicklung (Hafenausbau, Bevölkerungsentwicklung, Kriminalität, Wirtschaft), teilweise als Pressebericht publiziert, 1911

1911

Klassifikation Teil B: 00288

Trägermaterial: Papier

Alte Reg.-Sig.: II B 9

Bestell-Nr.: IV 00288 
05

\subsection{3}

05.03.01

05.03.01.04

\section{Stadtverwaltung}

Aufgabenbereiche der Stadtverwaltung

Meldewesen und Statistik

Statistische Berichte und Erhebungen

Lfd. Nr. Titel

Laufzeit

1912

477 Statistische Berichte über die Emder Stadtentwicklung

- Statistische Berichte an den Regierungspräsidenten in Aurich über die Emder Stadtentwicklung (Hafenausbau, Bevölkerungsentwicklung, Kriminalität, Wirtschaft), teilweise als Pressebericht publiziert, 1912

1912

Klassifikation Teil B: 00289

Trägermaterial: Papier

Alte Reg.-Sig.: II B 9

Bestell-Nr.: IV 00289

478 Statistische Berichte über die Emder Stadtentwicklung

1913

- Statistische Berichte an den Regierungspräsidenten in Aurich über die Emder Stadtentwicklung (Hafenausbau, Bevölkerungsentwicklung, Kriminalität, Wirtschaft), teilweise als Pressebericht publiziert, 1913

1913

\author{
Klassifikation Teil B: 00290 \\ Trägermaterial: Papier \\ Alte Reg.-Sig.: II B 9 \\ Bestell-Nr.: IV 00290
}

479 Erhebungen über Lebensmittelpreise

$1911-1913$

- Erlass des preußischen Ministers für Landwirtschaft, Domänen und Forsten über Regelungen zur Datenerhebung und Erstellung einer Preisstatistik für Lebensmittel, September 1911

- Denkschriften veschiedener Verbände wegen Steigerung der Lebensmittelpreise, 1911

- Verhandlungen des Magistrats der Stadt Emden mit der Fleischer-Innung wegen Maßnahmen gegen Preissteigerungen bei

Fleisch und Wurst, September 1911

- Steigerung der Milchpreise in Emden wegen Dürre, Oktober 1911

- Erhebung über Fleischpreise in Emden, August 1912

- Angebot der Firma Swift Packing Company über argentinische

Fleischimporte, September 1912

- Nachrichten über Fleischpreise in anderen Städten, September 1912

- Angebote über Fischlieferungen, 1911 - 1912

- Angebot über Lieferung von Gefrierfleisch (Hammel, Kaninchen) aus Australien, 1913

$1911-1913$

Klassifikation Teil B: 00439

Trägermaterial: Papier

Alte Reg.-Sig.: IV Cd 84

Bestell-Nr.: IV 00439 
IV

05

\subsection{3}

05.03.02

05.03.02.01
Stadtverwaltung

Aufgabenbereiche der Stadtverwaltung

Judensachen

Landesrabbinat

Lfd. Nr. Titel

Laufzeit

480 Gebührentaxe des Landesrabbiners

1867-1894

- Bescheid des preußischen Landdrosten in Aurich über Festlegung der vom Landrabbiner festgelegten Traugebühr, Dezember 1867

- Monita des Magistrats der Stadt Emden gegen die vom Landrabbiner vorgeschlagene Gebührenordnung, Dezember 1871

- Gedruckte Gebührentaxe des Landrabbiners, Mai 1874

- Festlegung der Traugebühr des Landrabbiners durch den

Oberpräsidenten der Provinz Hannover, Februar 1894

$1867-1894$

Klassifikation Teil B: 00046

Trägermaterial: Papier

Alte Reg.-Sig.: IV Dc 08

Bestell-Nr.: IV 00046

481 Neuwahl des Landrabbiners

$1870-1886$

- Aufbewahrung der Akten des Landrabbinats nach dem Tode des Landrabbiners Dr. Hamburger, August 1870

- Wahl des Dr. Buchholz zum Landrabbiner der Landdrosteibezirke Aurich und Osnabrück, April - September 1874

- Verzögerung des Amtsantritts des Landrabbiners Dr. Buchholz wegen Krankheit seiner Frau, Oktober 1874 - Januar 1875

- Streit um die Zuwendung kostenlosen Brennmaterials an Rabbiner und Landrabbiner, September - Oktober 1878

- Streit zwischen dem Landrabbiner Dr. Buchholz und der Stadt

Emden wegen Finanzierung von Reparaturarbeiten in der

Dienstwohnung des Landrabbiners, März - April 1881

- Streit um die Honorierung des vom Landrabbiner erteilten

Religionsunterichts für jüdische Kinder in den höheren Schulen

Emdens, November 1883

- Streit zwischen Landrabbiner und der Israelitischen Gemeinde

Emdens um Honorierung der Vornahme kultischer Handlungen durch den Landrabbiner an den Feiertagen, November 1883

- Verfügung des Regierungspräsidenten in Aurich an

Oberbürgermeister Leo Fürbringer über Anforderung eines Berichtes zum Gerücht von staatsfeindlichen Handlungen des Landrabbiners Dr. Buchholz, März 1886

$1870-1886$

Klassifikation Teil B: 00047

Trägermaterial: Papier

Alte Reg.-Sig.: IV Dc 10

Bestell-Nr.: IV 00047 
IV

05

\subsection{3}

05.03.02

05.03.02.01
Stadtverwaltung

Aufgabenbereiche der Stadtverwaltung

Judensachen

Landesrabbinat

Lfd. Nr. Titel

Laufzeit

482 Neuwahl des Landrabbiners

1911-1922

- Abschrift der Bekanntmachung des kgl. hannoverschen Innenministers über Pflichten der Landrabbiner vom 19.01.1844, 1911

- Neuwahl des Landrabbiners für die Regierungsbezirke Aurich und

Osnabrück nach dem Tode des Amtsinhabers Dr. Jonas Löb, Juni

1911 - Juni 1912

- Verfügung des Regierungspräsidenten in Aurich über Einsetzung des Dr. Lewinsky, Landrabbiner in Hildesheim, zum

Interims-Landrabbiner der Bezirke Aurich und Osnabrück, August

1911 / April 1921

- Beschwerde des Joseph Italjener gegen das Verfahren der

Landrabbinerwahl, Januar 1912 / November 1912

- Einführung des Dr. Hoffmann in das Amt des Landrabbiner der

Bezirke Aurich und Osnabrück, Dezember 1912

- Neuwahl des Landrabbiner nach dem Weggang des Dr. Hoffmann,

Oktober 1921 - Februar 1922

- Bestätigung der Wahl des Rabbiners Blum zum Landrabbinerr der

Bezirke Aurich und Osnabrück durch den Regierungspräsidenten in

Aurich, April 1922

$1911-1922$

Klassifikation Teil B: 00048

Trägermaterial: Papier

Alte Reg.-Sig.: IV Dc 14

Bestell-Nr.: IV 00048

483 Juden

- Verfügung des preußischen Landdrosten in Aurich über

Unterstützung für die jüdische Schul- und Synagogengemeinden in

Ostfriesland, März 1867 - Dezember 1868

- Verfügung des preußischen Landdrosten, später

Regierungspräsidenten in Aurich über Anforderung von Daten zur

Struktur und Vermögenslage der Israelitischen Gemeinde zu Emden,

Oktober 1875 / November 1900

- Erlass des preußischen Innenministers zu Änderungen der

Familiennamen von Juden im Falle des Übertritts zum Christentum,

September 1900

$1867-1903$

Klassifikation Teil B: 00050

Trägermaterial: Papier

Alte Reg.-Sig.: IV Dh 07

Bestell-Nr.: IV 00050 
IV

05

Stadtverwaltung

05.03

05.03.02

05.03.02.01

Aufgabenbereiche der Stadtverwaltung

Judensachen

Landesrabbinat

Lfd. Nr. Titel

Laufzeit

484 Auswanderung von Juden

1867-1876

- Beantragung und Ausstellung von Auswanderererlaubnisscheinen

für Juden nach in- und ausländischen Orten, 1867

- Ausstellung von Entlassungsscheinen aus dem preußischen

Untertanenverband für Juden zum Zweck der Auswanderung, 1871 -

1876

$1867-1876$

Klassifikation Teil B: 00319

Trägermaterial: Papier

Bestell-Nr.: IV 00319

485 Zionistischer Verein "Lemaan Zion"

1904

- Satzung der Zionistischen Ortsgruppe "Lemaan Zion" (um Zions

Willen), August 1904

- Eingabe der Zionistischen Ortsgruppe Emden an den Magistrat über

Bitte um Genehmigung der Vereinssatzung, Dezember 1904

- Mitgliederliste des Vereins "Lemaan Zion", 1904

1904

Klassifikation Teil B: 00446

Trägermaterial: Papier

Alte Reg.-Sig.: IV Dh 15

Bestell-Nr.: IV 00446

486 Verein zur Beförderung der Ausübung handwerklicher u.a.

bürgerlicher Berufe durch Juden

- Jährliche Rechenschaftsberichte des Vereins zur Beförderung von Handwerken und sonstiger bürgerlicher Geschäfte unter den Juden, Mai 1867 - Mai 1877

- Gedruckte Statuten des Vereins, 1858

- Rechnungslegung, 1877 - 1909

$1867-1909$

Klassifikation Teil B: 00450

Trägermaterial: Papier

Alte Reg.-Sig.: IV Dh 08

Bestell-Nr.: IV 00450 
IV

05

05.03

05.03.02

05.03.02.02
Stadtverwaltung

Aufgabenbereiche der Stadtverwaltung

Judensachen

Verfassung der jüdischen Gemeinde

Lfd. Nr. Titel

Laufzeit

487 Statutenänderung der Israelitischen Gemeinde Emdens

- Stellungnahme des Magistrats der Stadt Emden zur beantragten

Statutenänderung der Israelitischen Gemeinde Emden, September

1902

- Gedruckte Statuten des Israelitischen Gemeinde Emden, 1903

- Antrag der Israelitischen Gemeinde beim Magistrat der Stadt Emden

auf Einreichung des veränderten Statuts an den

Regierungspräsidenten in Aurich zur Bestätigung, Februar 1903

- Einberufung einer Versammlung der Mitglieder der Israelitischen

Gemeinde zur Billigung der vom Gemeindevorstand geplanten

Revision der Gemeinde-Statuten, Mai 1902 - Januar 1903

- Berichte über Beschlussunfähigkeit der Gemeindeversammlung,

Juni 1902 - Januar 1903

- Bescheid des Magistrats der Stadt Emden über Monita des

Regierungspräsidenten gegen das revidierte Statut des Israelitischen

Gemeinde Emden, Januar 1903

- Genehmigung des Gemeindestatuts durch den

Regierungspräsidenten in Aurich, Februar 1903

$1902-1903$

Klassifikation Teil B: 00044

Trägermaterial: Papier

Alte Reg.-Sig.: IV Db 11

Bestell-Nr.: IV 00044

488 Wahlrecht der jüdischen Lehrer

- Eingabe des jüdischen Hauptlehrers W. Selig und des jüdischen Lehrers B. Apt an den Magistrat der Stadt Emden über Bitte um

Zuerkennung des Wahlrechts in der jüdischen Gemeinde, Dezember 1895

1895

Klassifikation Teil B: 00443

Trägermaterial: Papier

Alte Reg.-Sig.: IV Db 25

Bestell-Nr.: IV 00443 
IV

05

Stadtverwaltung

05.03

Aufgabenbereiche der Stadtverwaltung

05.03.02

05.03.02.02

Judensachen

Lfd. Nr. Titel

Verfassung der jüdischen Gemeinde

489 Statuten der Israelitischen Gemeinde zu Emden

Laufzeit

1858-1911

- Antrag der Israelitischen Gemeinde beim Magistrat auf Novellierung des Gemeindestatuts, Juni 1858

- Bemerkungen des Landrabbiners Dr. Hamburger zum

Statutenentwurf der Israelitischen Gemeinde, Dezember 1859

- Verhandlungen der Israelitischen Gemeinde über Novellierung des

Gemeindestatuts, Dezember 1864 - September 1865

- Genehmigungsverfahren über das novellierte Gemeindestratut vor dem hannoverschen Landdrosten, Februar 1865

- Revision des Gemeindestatuts hinsichtlich der Erhöhung des

Schächtegeldes, Dezember 1867 - Januar 1868

- Streit um Teilnahme von Gemeindemitglieder an der Revision der

Schulkasse, Dezember 1876 - Januar 1877

- Statuten der Israelitischen Gemeinde zu Emden, 1903

- Nachträge zum Gemeindestatut, September - Dezember 1911

$1858-1911$

Klassifikation Teil B: 00444

Trägermaterial: Papier

Alte Reg.-Sig.: IV Db 06

Bestell-Nr.: IV 00444 
IV

05

\subsection{3}

05.03.02

05.03.02.03
Stadtverwaltung

Aufgabenbereiche der Stadtverwaltung Judensachen Angelegenheiten der jüdischen Synagoge

Lfd. Nr. Titel

Laufzeit

490 Wahl des Gemeindevorstands und der Gremien der Israelitischen Gemeinde

- Protest des Louis Meyer gegen die Wahl des Simon de Beer zum Vorstand des Israelitischen Gemeinde, November 1893

- Antrag der Israelitischen Gemeinde auf Bestätigung des neu gewählten Vorstandes, Januar 1897 / Dezember 1898

- Antrag des Wilhelm Stein beim Magistrat der Stadt Emden auf Entbindung vom Amt des Spendengeldbuchführers wegen

Beeinträchtigung der Ausübung seiner religiösen Pflichten, März 1900

- Einberufung einer Versammlung der Israelitischen Gemeinde wegen Neuwahl von Funktionären des Gemeindevorstandes, November 1901

- Ladung neuer Vorstandsmitglieder der Israelitischen Gemeinde zur Vereidigung durch den Magistrat, November 1901

- Vertagung der Vorstandswahl der Israelitischen Gemeinde wegen Beschlussunfähigkeit der Gemeindeversammlung, November 1903 - Vereidigung des neu gewählten Gemeindevorstands durch den Magistrat, 1872 - 1903

- Mitteilung der Israelitischen Gemeinde an den Magistrat der Stadt Emden über Vorstandsneuwahlen und Antrag auf Bestätigung der Wahl, November 1866 - November 1904

- Protest des Abraham Nordheimer gegen die Wahl des Simon de Beer zum Vorsitzenden der Israelitischen Gemeinde, August -

September 1865

- Antrag der Israelitischen Gemeinde beim Magistrat der Stadt Emden auf Suspendierung des Synagogenvorstehers Simon de Beer vom Amt wegen Ruhestörung in der Synagoge, August - November 1869 - Rücktrittsgesuch des Synagogenvorstehers Simon de Beer, Oktober 1869

$1865-1903$

Klassifikation Teil B: 00045

Trägermaterial: Papier

Alte Reg.-Sig.: IV Db 24

Bestell-Nr.: IV 00045 
Lfd. Nr. Titel

- Schreiben des kommissarischen Landrabbiners von Ostfriesland über Einladung von Vertretern der Synagogengemeinde zu Emden in die Kommission zur Wahl eines neuen Landrabbiners zur Herstellung einer Mitbestimmung der Synagogengemeinde, Januar 1874

- Verfügung des Magistrats der Stadt Emden an die israelitische Gemeinde über Vornahme der Wahl eines Landrabbiners als Nachfolger des verstorbenen Dr. Hamburger, Februar 1874

- Bewerbungen um die Position des Landrabbiners, Februar - März 1874

- Verhandlungen von Vorstand und Auschussmitgliedern der Israelitischen Gemeinde über Prüfung der eingegangenen

Bewerbungen, März 1874

- Einladung der Mitglieder der Israelitischen Gemeinde zur Wahl eines der drei vom Gemeindevorstand vorgeschlagenen Bewerberr um das Landesrabbinat, März 1874

- Verzeichnis der wahlberechtigten Mitglieder der Israelitischen

Gemeinde zu Emden, März 1874

- Aufstellung über zur Wahl erschienender Gemeindemitglieder, März 1874

- Wahl der Gemeindevertreter für die Wahlkommission zur

Bestimmung des Landrabbiners, März 1874

- Wahl des Landrabbiners, April 1874

1874

Klassifikation Teil B: 00442

Trägermaterial: Papier

Alte Reg.-Sig.: IV Bc 4

Bestell-Nr.: IV 00442

492 Vorsänger der jüdischen Synagogengemeinde

- Einstellung eines Nachfolgers für den pensionierten Vorsänger de Haas, Mai 1883

- Antrag des Landesrabbiners beim Magistrat der Stadt Emden auf Aufforderung an die jüdische Synagogengemeinde zur Einberufung einer Gemeindeversammlung wegen Festsetzung der Pension für den Vorsänger de Haas und Festsetzung des Gehalts seines Nachfolgers, Mai 1883

- Bericht der jüdischen Synagogengemeinde über haushaltstechnische Probleme bei der Einstellung eines neuen Vorsängers, Juni 1883

- Wahl des Österreichers Fellner zum Vorsänger und Schächter der Israelitischen Gemeinde, August 1897

- Verfügung des Regierungspräsidenten in Aurich über Genehmigung der Einstellung des Aaron Weiß als Vorsänger und Hilfsschächter der Israelitischen Gemeinde in Emden, August 1905

$1883-1905$

Klassifikation Teil B: 00448

Trägermaterial: Papier

Alte Reg.-Sig.: IV Dc 12

Bestell-Nr.: IV 00448 
05

05.03

05.03.02

05.03.02.03

fd. $\mathrm{Nr}$. Titel

\section{IV}

Stadtverwaltung

Aufgabenbereiche der Stadtverwaltung

Judensachen

Angelegenheiten der jüdischen Synagoge

493 Israelitischer Gemeindemitgliederverein

Laufzeit

1910-1913

- Anzeige über Begründung des Israelitischen

Gemeindemitgliedervereins und seine Vorstandsmitglieder, Dezember

1910

- Satzung des Vereins, 1910

- Anzeigen über Veränderungen im Vorstand, Januar 1911 - Februar 1913

$1910-1913$

Klassifikation Teil B: 00449

Trägermaterial: Papier

Alte Reg.-Sig.: IV Dh 16

Bestell-Nr.: IV 00449 
IV

05

\subsection{3}

05.03.02

05.03.02.04
Stadtverwaltung

Aufgabenbereiche der Stadtverwaltung

Judensachen

Jüdisches Armenwesen

Lfd. Nr. Titel

Laufzeit

494 Kranken- und Begräbnisanstalt der Israelitischen Gemeinde

- Antrag der Israelitischen Gemeinde an den Magistrat der Stadt Emden auf Verpflichtung des Simon Moses Valk zur Tragung der Kosten für Medikamente und Beerdigung seiner Schwester, der verwitweten und mittellosen Hinderine Moses Valk, Juni 1847 - Statuten der Israelitischen Kranken- und Beerdigungsbruderschaft, August 1847 / August 185 / Juli 1902

- Streit um Bestrafung von Pflichtverletzungen von

Bruderschaftsmitgliedern, November - Dezember 1847

- Antrag des Vereinsvorstands beim Magistrat der Stadt Emden auf Genehmigung der Erhöhung der Beiträge zum Israelitischen Krankenund Beerdigungsvereins wegen gestiegener Krankenkosten, November 1889

- Verfügung des Magistrats der Stadt Emden über Verbot der Ausdehnung des jüdischen Friedhofs auf ein von der Israelitischen Kranken- und Beerdigungsanstalt erworbenes Grundstück ohne Genehmigung durch die Stadt Emden, Juli 1875

$1847-1902$

Klassifikation Teil B: 00049

Trägermaterial: Papier

Alte Reg.-Sig.: IV Dh 05

Bestell-Nr.: IV 00049

495 Verein zur Erziehung verwaister jüdischer Kinder "Esrath Jersomin"

- Gründung des Vereins "Esrath Jersomin", Dezember 1903

- Eintragung der Veränderung des Vorstands und der Statuten in das Vereinsregister, April 1908

- Einladung zur Einweihungsfeier des jüdischen Waisenhauses, April 1909

- Legat der Auguste Rosenthal aus New Orleans in Höhe von 4.000

USDollar für das jüdische Waisenhaus, Oktober 1916 - Januar 1917

$1903-1917$

Klassifikation Teil B: 00445

Trägermaterial: Papier

Alte Reg.-Sig.: IV Dh 14

Bestell-Nr.: IV 00445

496 Asyl für hilfsbedürftige, alte und würdige Israeliten

- Statuten der Jubiläumsstiftung "Asyl für hilfsbedürftige, arbeitsunfähige, altersschwache würdige Israeliten", 1885

- Genehmigung der Änderung der Statuten, 1895

$1885-1895$

Klassifikation Teil B: 00447

Trägermaterial: Papier

Alte Reg.-Sig.: IV Dh 18

Bestell-Nr.: IV 00447 


\section{IV}

05

05.03

05.03.03

05.03.03.01

05.03.03.01.01

Stadtverwaltung

Aufgabenbereiche der Stadtverwaltung

Öffentliche Ordnung und Sicherheit

Fremdenpolizei

Auslieferungen und Ausweisungen

Lfd. Nr. Titel

Laufzeit

497 Auslieferungsverträge zwischen dem Deutschen Reich und anderen Staaten

1873-1914

- Bekanntmachungen über geschlossene Auslieferungsverträge und Vereinbarungen über Umsetzung der Verträge, 1873 - 1914

- Übersicht der preußischen Grenzorte für Auslieferungen in die Niederlande, 1908

$1873-1914$

Klassifikation Teil B: 00563

Trägermaterial: Papier

Bestell-Nr.: IV 00563

498 Ausgewiesene Ausländer

- Bekanntmachung des Polizeipräsidenten in Berlin über flüchtige, ausgewiesene russische Juden, November 1914

1914

Klassifikation Teil B: 00569

Trägermaterial: Papier

Alte Reg.-Sig.: IV Ea 18

Bestell-Nr.: IV 00569

499 Auslieferungsvertrag mit den Niederlanden,

- Außerkraftsetzung des Auslieferungsvertrags zwischen dem Kgr. Hannover und den Niederlanden durch den preußischen

General-Gouverneur in Hannover, Juli 1867

- Erlass des preußischen Innenministers über Anordnung der Weiterleitung von niederländischen Auslieferungsbegehren an das Auswärtige Amt und von Begehren deutscher Behörden an die kaiserliche Gesandtschaft in Den Haag, Januar 1880

$1867-1880$

Klassifikation Teil B: 00570

Trägermaterial: Papier

Alte Reg.-Sig.: IV Ea 13

Bestell-Nr.: IV 00570 
IV

05

05.03

05.03.03

05.03.03.01

05.03.03.01.01
Stadtverwaltung

Aufgabenbereiche der Stadtverwaltung

Öffentliche Ordnung und Sicherheit

Fremdenpolizei

Auslieferungen und Ausweisungen

Lfd. Nr. Titel

Laufzeit

500 Verträge mit anderen Staaten wegen Ergreifung und Auslieferung von Deserteuren der Handelsmarine

1874-1909

- Verfügung des Reichskanzleramts über Abwicklung von Auslieferungsbegehren wegen desertierter Matrosen in Frankreich über die kaiserliche Botschaft in Paris, November 1874

- Umsetzung des Abkommens zwischen Deutschland und Großbritannien über Auslieferung von Deserteuren der Handelsmarinen beider Staaten, Februar 1886 - Oktober 1909 - Umsetzung des Abkommens zwischen Deutschland und Dänemark über Auslieferung von Deserteuren der Handelsmarinen beider Staaten, Juli 1881

- Umsetzung des Abkommens zwischen Deutschland und Spanien über Auslieferung von Deserteuren der Handelsmarinen beider Staaten, August 1895

$1874-1909$

Klassifikation Teil B: 00571

Trägermaterial: Papier

Alte Reg.-Sig.: IV Ea 19

Bestell-Nr.: IV 00571

501 Ausweisung von Deutschen aus anderen Staaten

$1882-1910$

- Verhandlung über die Aufnahme des aus Österreich abgeschobenem Arbeiters Diedrich Ferdinand Hoffmann von seinem Geburtsort Emden, 1882

- Feststellung einer Aufnahmepflicht der Stadt Emden gegenüber dem aus Belgien abgeschobenen Bäcker Enno de Vries und dem

Seemann Wiard Martin Wiers, 1882

- Ablehnung der Aufnahme der von der Polizeiverwaltung Halle abgeschobenen Johanne Sporree durch die Stadt Emden wegen Verlust des Status der Stadt als Unterstützungswohnort nach über zehnjähriger Abwesenheit, 1882

- Ablehnung der Aufnahme des aus Belgien abgeschobenen Tagelöhners Berend de Vries durch die Stadt Emden wegen Verlust des Status der Stadt als Unterstützungswohnort nach über zehnjähriger Abwesenheit, 1883

- Ablehnung der Aufnahme des aus Bayern abgeschobenen Schuhmachergesellen Andreas Matthiesen Rein durch die Stadt Emden wegen schlechten Leumund, 1889

- Bekanntmachung über aus dem Großherzogtum Oldenburg als unerwünschte Ausländer ausgewiesene Personen, 1910

$1882-1910$

Klassifikation Teil B: 00578

Trägermaterial: Papier

Alte Reg.-Sig.: IV Ea 21

Bestell-Nr.: IV 00578 
IV

05

05.03

05.03.03

05.03.03.01

05.03.03.01.02

Lfd. Nr. Titel
Stadtverwaltung

Aufgabenbereiche der Stadtverwaltung

Öffentliche Ordnung und Sicherheit

Fremdenpolizei

Passwesen

502 Passwesen

Laufzeit

- Erlass des preußischen Generalgouverneurs in Hannover über Ausweisung festgenommener Vagabunden, Januar 1867

- Regelung des Reiseverkehrs nach Russland (Anerkennung der

Pässe, Visa), 1879 - 1895

- Reiseverbot für und Ausweisung von ausländischen Juden aus

Russland und den von von ihn beherrschten polnischen Gebieten,

November 1889 - Februar 1890

$1867-1895$

Klassifikation Teil B: 00572

Trägermaterial: Papier

Alte Reg.-Sig.: IV Ea 06

Bestell-Nr.: IV 00572 


\section{IV}

05

05.03

05.03.03

05.03.03.01

05.03.03.01.03

Lfd. Nr. Titel

\section{Stadtverwaltung}

Aufgabenbereiche der Stadtverwaltung

Öffentliche Ordnung und Sicherheit

Fremdenpolizei

Polizeiaufsicht

503 Verhängung von Polizeiaufsicht

Laufzeit

- Erlasse des preußischen Innenministers über Polizeiaufsicht, 1898 -

1907

- Erlasse des Oberpräsidenten der Provinz Hannover über

Polizeiaufsicht, 1868 - 1873

- Veröffentlichung im Amtsblatt der Regierung in Aurich über Instruktion zu Bestimmungen des Strafgesetzbuches über

Polizeiaufsicht, Juli 1900

$1868-1907$

Klassifikation Teil B: 00573

Trägermaterial: Papier

Alte Reg.-Sig.: IV Ee 1

Bestell-Nr.: IV 00573 
05

05.03

05.03.03

05.03.03.02

05.03.03.02.01

\section{Stadtverwaltung}

Aufgabenbereiche der Stadtverwaltung

Öffentliche Ordnung und Sicherheit

Schutz der öffentlichen Ordnung

Organisation der Gewährleistung der öffetlichen Ordnung

Lfd. Nr. Titel

Laufzeit

504 Erlass von Polizeiverordnungen

1867-1914

- Verordnung des preußischen Landdrosten über Vorgaben zum

Erlass kommunaler Polizeiverordnungen, Oktober 1867

- Einbeziehung der Bürgervorsteher in den Erlass von

Polizeiverordnungen, August 1877 - September 1884

- Polizeiverordnungen der Stadt Emden betr. Preise im

Gaststättenwesen, öffentliches Fuhrwesen und betr. auf Straßen und

öffentlichen Plätzen auf Beschäftigung wartende Personen, Mai 1883

- Veröffentlichung von Polizeiverordnungen, Dezember 1885 -

November 1898

- Verfügung des Regierungspräsidenten in Aurich über Vorlage der von den Landräten und dem Emder Magistrat erlassenen

Polizeiverordnungen zur Prüfung vor deren Inkraftsetzung, November 1887

- Definition von Strafbestimmungen in Polizeiverordnungen, 1890

- Form der Polizeiverordnungen, November 1807 - Januar 1914

- Verzeichnis der Polizeiverordnungen der Stadt Emden, 1900

$1867-1914$

Klassifikation Teil B: 00001

Trägermaterial: Papier

Bestell-Nr.: IV 00001

505 Central-Polizeiblatt

1896-1914

- Veröffentlichungen über Nachforschungen nach Verbrechern

(Fahndungen) im Central-Polizeiblatt des Kgr. Preußen, 1896 - 1914

$1896-1914$

Klassifikation Teil B: 00002

Trägermaterial: Papier

Bestell-Nr.: IV 00002

506 Polizeiverordnungen des Magistrats

1858-1903

- Sammlung und Verzeichnis der vom Magistrat erlassenen

Polizeiverordnungen, 1858 - 1903

$1858-1903$

Klassifikation Teil B: 00065

Trägermaterial: Papier

Alte Reg.-Sig.: I Cc 10

Bestell-Nr.: IV 00065 
05

05.03

05.03.03

05.03.03.02

05.03.03.02.01
Stadtverwaltung

Aufgabenbereiche der Stadtverwaltung

Öffentliche Ordnung und Sicherheit

Schutz der öffentlichen Ordnung

Organisation der Gewährleistung der öffetlichen Ordnung

Lfd. Nr. Titel

Laufzeit

507 Behinderung des Bahnbetriebs durch die Badeanstalt am Eisenbahndock

1891

- Verfügung der kgl. Eisenbahnbau-Inspektion über Schließung der Badeanstalt am Eisenbahndock wegen Gefährdung des Bahnverkehrs durch Überquerung der Schienen durch Besucher der Badeanstalt, Juni 1891

1891

Klassifikation Teil B: 00166

Trägermaterial: Papier

Bestell-Nr.: IV 00166

508 Beflaggungsvorschriften

1866-1914

- Aufhebung des Verbots des Aushangs außerpreußischer Flaggen in der Provinz Hannover, Oktober 1866

- Beflaggung Emder Schulen anlässlich des Geburtstages der

Kaiserwitwe Viktoria, November 1889

- Erlass des preußischen Innenministers über Normen bei der Hissung der deutschen Nationalfahne Schwarz Weiß Rot. Oktober 1903 - Januar 1905

- Erlass des preußischen Innenministers über Festlegung der

Beflaggungsanlässe, September 1905

$1866-1914$

Klassifikation Teil B: 00400

Trägermaterial: Papier

Alte Reg.-Sig.: III Dg 07

Bestell-Nr.: IV 00400 
05

05.03

05.03.03

05.03.03.02

05.03.03.02.01
Stadtverwaltung

Aufgabenbereiche der Stadtverwaltung

Öffentliche Ordnung und Sicherheit

Schutz der öffentlichen Ordnung

Organisation der Gewährleistung der öffetlichen Ordnung

Lfd. Nr. Titel

Laufzeit

509 Aufrechterhaltung von Ruhe und Ordnung während des Krieges von 1866

1866

- Bericht über Unzuverlässigkeit (pro preußische Haltung) des Bahnpersonals und Anregung der Bildung eines Bürger-Corps zur Sicherung von Ruhe und Ordnung, Juni 1866

- Bereitschaft des Schützen-Corps zum Dienst als Hilfspolizei, Juni 1866

- Verfügung des Hannoverschen Landdrosten in Aurich über Billigung des Einsatzes von Schützen-Corps und Turnern als Hilfspolizei ohne Bewaffnung und Bereitschaft der preußischen Armee zur Entsendung von Truppen bei Bedrohung der öffentlichen Ordnung, Juli 1866 - Schreiben des Kommandanten des preußischen Kriegsschiffes "Cyclop". Kapitänleutnant Ulffers, über Billigung der Funktion des Schützen-Corps und der Turnerschaft als Hilfspolizei in Emden, Juli 1866

- Verfügung des Hannoverschen Landdrosten in Aurich über Auflösung der Hilfspolizei in Emden wegen stabiler öffentlicher Ordnung, Juli 1866

- Erlass des preußischen Militärgouverneurs in Hannover über Vorgehen gegen antipreußische Agitation, Juli 1866 - Bekanntmachung des preußischen Militärgouverneurs in Hannover über Haftung der Gemeinden für Schäden durch Aufstände bei Nichtermittlung der Schuldigen, September 1866

1866

Klassifikation Teil B: 00567

Trägermaterial: Papier

Alte Reg.-Sig.: IV Ea 11

Bestell-Nr.: IV 00567

510 Aufsicht über die politische Sicherheitspolizei

- Bekanntmachung des preußischen Landdrosten in Aurich über Umorganisation der Aufsicht über die politische und Sicherheitspolizei in der Provinz Hannover, November 1867

- Verfügung des preußischen Landdrosten in Aurich über

Berichterstattung in Fällen von Landes- und Hochverrat, Dezember 1884

$1867-1884$

Klassifikation Teil B: 00568

Trägermaterial: Papier

Alte Reg.-Sig.: IV Ea 12

Bestell-Nr.: IV 00568

511 Tätigkeitsberichte der Emder Polizei

- Statistischer Jahresbericht über Tätigkeit der Emder Polizei, 1903

Klassifikation Teil B: 00579

Trägermaterial: Papier

Alte Reg.-Sig.: IV Ea 22

Bestell-Nr.: IV 00579 
IV

05

05.03

05.03.03

05.03.03.02

05.03.03.02.01
Stadtverwaltung

Aufgabenbereiche der Stadtverwaltung

Öffentliche Ordnung und Sicherheit

Schutz der öffentlichen Ordnung

Organisation der Gewährleistung der öffetlichen Ordnung

Lfd. Nr. Titel

Laufzeit

512 Anleitung über Behandlung von Ballonen

$1899-1910$

- Erlasse des preußischen Innenministers zum Ballon- und

Zeppelinwesen, 1899 - 1910

- Werbeschrift des Grafen von Zeppelin für seine

Luftschiffskonstruktion, Juni 1903

- Druckschrift: Benachrichtigung und Anleitung über die Behandlung von Ballonen der Wetterstation bei Auffindung im Stadtkreis Emden, Juni 1901

$1899-1910$

Klassifikation Teil B: 00588

Trägermaterial: Papier

Alte Reg.-Sig.: IV Fa 14

Bestell-Nr.: IV 00588

513 Polizeiliche Kontrolle von Handel und Gewerbe

$1870-1910$

- Regelung des Trödlerwesens, 1870 - 1914

- Aufstellung über Trödler in Emden, 1870 - 1872

- Eingabe der Trödlerin Eeske Heiten über Bitte um Befreiung von der Pflicht der Führung eines Geschäftsbuches wegen Analphabetismus und Bitte um Erlass der verhängten Geldstrafe, Juni 1871

- Antrag der Emder Trödler auf Erlass der Pflicht zur Führung eines

Geschäftsbuches, Juli - August 1871

- Vermerke über Beglaubigung der Geschäftsbücher von Trödlern und

Gesindemaklern, Juli 1885 - Juli 1888

- Revision der Geschäftsbücher der Trödler und Gesindemakler, Dezember 1885

- Erlass des preußischen Ministers für Handel und Gewerbe über

Organisation des Versteigerungswesens, Juli 1902

- Erlass des preußischen Innenministers über Pflicht der Trödler und

Kleinhändler zur Führung eines Geschäftsbuches , August 1902

- Druckschrift des Deutschnationalen Handlungsgehilfenverbandes

über Missstände der kommerziellen Stellenvermittlung, 1906

- Regelung des Immobilienmaklerwesens, 1907 - 1909

- Anzeige gegen den Handelsmakler H. Bokelmann wegen vebotener Immobilienmaklerei, September 1910

$1870-1910$

Klassifikation Teil B: 00589

Trägermaterial: Papier

Alte Reg.-Sig.: IV Fa 14

Bestell-Nr.: IV 00589 
05

05.03

05.03.03

05.03.03.02

05.03.03.02.01
Stadtverwaltung

Aufgabenbereiche der Stadtverwaltung

Öffentliche Ordnung und Sicherheit

Schutz der öffentlichen Ordnung

Organisation der Gewährleistung der öffetlichen Ordnung

Lfd. Nr. Titel

Laufzeit

514 Räumung von Mietwohnungen

1857-1907

- Anträge auf polizeiliche Räumung von Mietwohnungen wegen unsittlichem Lebenswandel der Bewohnerinnen, 1857 - 1907

- Gutachten des Medizinalrats Dr. Tergast über Unbewohnbarkeit einer Wohnung wegen Feuchtigkeit und Schimmel, September 1882

- Anträge auf polizeiliche Räumung von Mietwohnungen, 1883 - 1903

- Räumung von vier Wohnungen in der Alten Kaserne wegen ungebührlichem Verhalten der Mieter, Juni - September 1887

- Antrag der Mieterin C. Bindern auf polizeiliches Einschreiten gegen ihren Vermieter, Juwelier Franz Richter, wegen der Unbewohnbarkeit ihrer Wohnung aufgrund von Feuchtigkeit, Oktober 1904

$1857-1907$

Klassifikation Teil B: 00590

Trägermaterial: Papier

Alte Reg.-Sig.: IV Fa 08

Bestell-Nr.: IV 00590

515 Kammerjäger

1870

- Verfügungen des preußischen Landdrosten in Aurich über Regelung des Kammerjägerwesens, 1870

1870

Klassifikation Teil B: 00591

Trägermaterial: Papier

Alte Reg.-Sig.: IV Fa 04

Bestell-Nr.: IV 00591

516 Fürsorge für die schulentlassene, erwerbstätige männliche Jugend

Statuten des christlichen Jünglingsvereins in Emden, 1892

- Förderung christlicher und staatsbejahender Jünglings- und

Lehrlingsvereine sowie von Vereinen der Innungen zur Jugendpflege,

1902 - 1912

- Berichte über Sachbeschädigungen durch Jugendliche, 1902 - 1907

- Verschiedene Denkschriften und Publikationen zur Jugendpflege

und zum Jugendschutz, 1907 - 1913

$1892-1913$

Klassifikation Teil B: 00593

Band: 1

Trägermaterial: Papier

Alte Reg.-Sig.: IV Fa 16

Bestell-Nr.: IV 00593 
05

05.03

05.03.03

05.03.03.02

05.03.03.02.01
Stadtverwaltung

Aufgabenbereiche der Stadtverwaltung

Öffentliche Ordnung und Sicherheit

Schutz der öffentlichen Ordnung

Organisation der Gewährleistung der öffetlichen Ordnung

Lfd. Nr. Titel

Laufzeit

517 Fürsorge für die schulentlassene, erwerbstätige männliche Jugend

1913-1914

- Förderung christlicher und staatsbejahender Jünglings- und

Lehrlingsvereine sowie von Vereinen der Innungen zur Jugendpflege,

1913 - 1914

- Verschiedene Denkschriften und Publikationen zur Jugendpflege

und zum Jugendschutz, 1913

- Statistischer Bericht über Einrichtungen der Jugendpflege in Emden,

1913

- Haftpflicht- und Unfallversicherung der Träger der Jugendpflege,

1913 - 1914

- Antrag des Vereins "Jugendwohl Frisia" auf Unterstützung durch die Stadt Emden, März 1913

- Satzung des Vereins "Patriotische Jugendwehr", August 1913

Militärische Vorausbildung der Jugend im Ersten Weltkrieg, August

1917

$1913-1914(1917)$

Klassifikation Teil B: 00594

Band: 2

Trägermaterial: Papier

Alte Reg.-Sig.: IV Fa 16

Bestell-Nr.: IV 00594

518 Gefährdung der Schulkinder durch Zuckerwaren-Automaten

- Bericht der Stadt Emden als Antwort auf eine Verfügung des Regierungspräsidenten in Aurich anlässlich einer Initiative des Regierungspräsidenten in Arnsberg (Provinz Westfalen) zum Erlass einer Polizeiverordnung zur Begrenzung der Zuckerwaren-Automaten wegen Gefährdung der Jugend hinsichtlich drohender Straffälligkeit, August 1901

1901

Klassifikation Teil B: 00595

Trägermaterial: Papier

Alte Reg.-Sig.: IV Fa 18

Bestell-Nr.: IV 00595 
- Druckschrift: Dr. Albrecht Erlenmeyer, Entmündigung wegen

Trunksucht, Koblenz/Leipzig, ca. 1900

- Erlass des preußischen Innenministers über Möglichkeit eines

Antrages auf Entmündigung wegen Trunkenheit durch den kommunalen Armenverband, November 1899

- Erlass des preußischen Innenministers über Anforderung von Berichten zur Anwendung der Entmündigungsbestimmungen gegen Alkoholiker im BGB, Juni 1912

- Anwendung der neuen Vorschrift zur Entmündigung von

Trunksüchtigen auf Swalina Niehofen, September - Oktober 1906

- Antrag des Armenkollegiums beim Magistrat der Stadt Emden auf Entmündigung des alkoholsüchtigen Arbeiters Johannes Petrus Lange, September - Oktober 1910

$1899-1912$

Klassifikation Teil B: 00392

Trägermaterial: Papier

Alte Reg.-Sig.: III Bb 35

Bestell-Nr.: IV 00392

520 Geplante Errichtung einer Irrenanstalt in der Umgebung der Stadt Emden

- Verhandlungen zwischen der Stadt Emden und dem Gutsbesitzer Siewert Heyen Ringena wegen Erwerb eines Grundstücks in Groß-Albringwehr zur Errichtung einer Irrenanstalt, März - Oktober 1896

- Ermittlung weiterer für das Projekt infragekommender Grundstücke, Juni 1896

- Initiative des Oberbürgermeisters Leo Fürbringer zur Errichtung einer Provinzialirrenanstalt für Ostfriesland in der Nähe Emdens, Juni - Juli 1896

- Artikel des "Hannoverschen Couriers" über Bewerbungen um den Standort einer Provinzialirrenanstalt, Juli 1896

- Anschluss der Landkreise Wittmund und Leer sowie der Stadt Leer an die Initiative des Emder Oberbürgermeisters, August - Oktober 1896

- Übersicht über Geisteskranke und Epileptiker in Ostfriesland, 1896

1896

Klassifikation Teil B: 00599

Trägermaterial: Papier

Alte Reg.-Sig.: IV Ef 9

Bestell-Nr.: IV 00599 
- Erlass des kgl. hannoverschen Innenministers über Zulassung der Privatanstalt in Neusandhorst für die Unterbringung "ungefährlicher Geisteskranker", Oktober 1855

- Anträge auf Einweisung von Personen nach der privaten

Pflegeanstalt für Geisteskranke in Neusandhorst, Juli 1857 - Februar 1912

- Verfügung des hannoverschen Landdrosten in Aurich über Ausstattung der Insassen der Pflegeanstalt Neusandhorst, Mai 1862 - Verfügung des preußischen Landdrosten in Aurich über Verbot der ungenehmigten Entlassung von Insassen der privaten Pflegeanstalt in Neusandhorst, Juli 1878

- Verfügung des preußischen Regierungspräsidenten in Aurich über Bedingung der Vorlage eines medizinischen Gutachtens vor der Einweisung eines Patienten nach der privaten Pflegeanstalt für Geisteskranke in Neusandhorst, März 1887

- Erlasse des preußischen Ministers der geistlichen, Unterrichts- und Medizinalangelegenheiten über Abwicklung der Kosten der Einweisung Geisteskranker in Irrenanstalten, Dezember 1889 / Mai 1896

- Erlass des preußischen Innenministers über Regelung der Unterbringung von Geisteskranken in privaten Anstalten, März 1901

$1855-1912$

Klassifikation Teil B: 00600

Trägermaterial: Papier Alte Reg.-Sig.: IV Ef 1 Bestell-Nr.: IV 00600 
IV

05

05.03

05.03.03

05.03.03.02

05.03.03.02.03
Stadtverwaltung

Aufgabenbereiche der Stadtverwaltung

Öffentliche Ordnung und Sicherheit

Schutz der öffentlichen Ordnung

Gefängnisse und Gefangene

Lfd. Nr. Titel

Laufzeit

522 Polizeigefängnis in Emden

1879-1904

- Ablehnung der Beschwerde des Carl Hesse wegen der

Haftbedingungen im städtischen Gefängnis, Mai 1879

- Einschränkung der Benutzung der Gefängniszellen im

Kellergeschoss des Rathauses, Februar 1883

- Verblendung der Fenster des Polizeigefängnisses, 1893

- Bericht des Polizeikommissars Lauter über Notwendigkeit der

Reinigung und Desinfizierung der Zellen und Möbel des

Polizeigefängnisses, August 1895

- Reparatur eines zerstörten Fensters im Polizeigefängnis, April 1895

- Erlass des preußischen Innenministers über Vorschriften zum

Betrieb der Polizeigefängnisse, Juli 1903

- Betrieb des Emder Polizeigefängnisses, 1903 - 1904

$1879-1904$

Klassifikation Teil B: 00580

Band: 1

Trägermaterial: Papier

Alte Reg.-Sig.: IV Ei 05

Bestell-Nr.: IV 00580

523 Polizeigefängnis in Emden

$1899-1913$

- Aufgaben und Pflichten der Gefangenenwärter im Emder

Polizeigefängnis, Dezember 1899 / März 1908

- Inspektionen des Emder Polizeigefängnisses, 1907 - 1909

- Überführung des Untersuchungsgefangenen Wilhelm Bildt zum

Gerichtsgefängnis Stettin und Liquidierung der Kosten, Januar - April

1907

- Antrag des Gefängniswärters Folkers auf Anschaffung von

Matratzenschonern für Gefängnisbetten, Juni - Juli 1907

- Erlass des preußischen Innenministers über Vorschriften wegen

Überstellung von Untersuchungshäftlingen in die Gerichtsgefängnisse,

Mai 1908

- Erlass des preußischen Innenministers über Einrichtung des

Polizeigefängnisses in Hannover als zentrale Haftanstalt für

Abschiebegefangene und Gefangene im Auslieferungsverfahren,

November 1910

$1899-1913$

Klassifikation Teil B: 00581

Band: 2

Trägermaterial: Papier

Alte Reg.-Sig.: IV Ei 05

Bestell-Nr.: IV 00581 
IV

05

05.03

05.03.03

05.03.03.02

05.03.03.02.03

Lfd. $\mathrm{Nr}$ Titel
Stadtverwaltung

Aufgabenbereiche der Stadtverwaltung

Öffentliche Ordnung und Sicherheit

Schutz der öffentlichen Ordnung

Gefängnisse und Gefangene

524 Nutzung der Gefängnisse

Laufzeit

- Erlass des Oberpräsidenten der Provinz Hannover über Möglichkeit der Unterbringung von Geisteskranken in Gerichtsgefängnissen durch zuständige Behörden, Oktober 1869

- Verfügung des preußischen Landdrosten in Aurich über

Unmöglichkeit der Nutzung von Gerichtsgefängnissen durch

Polizeibehörden, März 1882

- Vorschlag des Leiters des Amtsgerichtsgefängnisses in Emden über

Funktion der Gefängniszellen im Rathaus als Ausweichsort im Fall

des Brandes im Amtsgerichtsgebäude, September 1886

- Verwendung der Polizeigefängnisse als Arrestort für Bahnbeamte bei Dienstvergehen, März 1887

- Anträge des Gefängniswärters Folkerts auf Erhöhung der Verpflegungssätze für Polizeigefangene wegen Preissteigerung der Lebensmittel, Februar - März 1904 / Dezember 1911

- Statistik über Polizeigefangene vom Oktober 1912 - September

1913,1913

- Neufestsetzung der Verpflegungssätze für Polizeigefangene, 1913/

1917

- Verpflegungssätze für im Polizeigefängnis arretierte

Marineangehörige, September - Oktober 1914

$1869-1917$

Klassifikation Teil B: 00582

Trägermaterial: Papier

Alte Reg.-Sig.: IV Ei 26

Bestell-Nr.: IV 00582

525 Gefangenentransporte und Kostenträgerschaft

- Verfügung des Oberpräsidenten der Provinz Hannover über Neufestlegung der Routen für Gefangenensammeltransporte, September 1906

- Organisation der Gefangenensammeltransporte, 1881 - 1911

- Kostenabwicklung der Gefangenensammeltransporte, 1868 - 1911

- Erlass des preußischen Innenministers über Tragung der Kosten für evtl. anzuschaffende Kleidung für Transportgefangene durch die Landesverwaltung, September 1889

- Erlass des preußischen Ministers der geistlichen, Unterrichts- und Medizinalangelegenheiten über Regelung der Beschäftigung von

Gefangenen im Privatgewerbe, November 1897

- Betreuung der Häftlinge nach ihrer Entlassung, 1902 - 1904

$1868-1911$

Klassifikation Teil B: 00583

Trägermaterial: Papier

Alte Reg.-Sig.: IV Ei 27

Bestell-Nr.: IV 00583 
05

05.03

05.03.03

05.03.03.02

05.03.03.02.03
Stadtverwaltung

Aufgabenbereiche der Stadtverwaltung

Öffentliche Ordnung und Sicherheit

Schutz der öffentlichen Ordnung

Gefängnisse und Gefangene

Lfd. Nr. Titel

Laufzeit

526 Flucht von Gefangenen aus dem städtischen Gefängnis

1902-1907

- Festnahme und Flucht des niederländischen

Auslieferungsgefangenen Johannes Frank, Juni - September 1902

- Verhängung einer Geldstrafe gegen den Gefängniswärter Folkerts wegen durch seine Fahrlässigkeit verursachte Flucht des

Niederländers Jurco Bronsema, August 1907

1902 / 1907

Klassifikation Teil B: 00584

Trägermaterial: Papier

Alte Reg.-Sig.: IV Ei 33

Bestell-Nr.: IV 00584

527 Beschäftigung von Gefangenen

1899-1908

- Erlasse des preußischen Innenministers über Einsatz von Häftlingen

in der Landeskultur, November 1899 / Juni 1900 / Mai 1902 / Juni

1904

- Bericht des Oberbürgermeisters Leo Fürbringer an den

Regierungspräsidenten in Aurich über Beschäftigung von Gefangenen bei der Cassens-Werft, August 1905

- Gedruckter Jahresbericht des Provinzialverbandes der hannoverschen Vereine zur Fürsorge für entlassene Häftlinge, 1901 1906

- Initiative des Amtsgerichts zur Gründung eines Vereins für

Häftlingsfürsorge in Emden, März 1911

$1899-1908(1911)$

Klassifikation Teil B: 00585

Trägermaterial: Papier

Alte Reg.-Sig.: IV Ei 32

Bestell-Nr.: IV 00585

528 Unbefugter Verkehr mit Gefangenen

- Polizeiverordnung über Verbot der unbefugten Kontaktaufnahme mit Untersuchungshäftlingen, Januar 1886

1886

Klassifikation Teil B: 00586

Trägermaterial: Papier

Bestell-Nr.: IV 00586 
05

\subsection{3}

05.03.03

05.03.03.02

05.03.03.02.04
Stadtverwaltung

Aufgabenbereiche der Stadtverwaltung

Öffentliche Ordnung und Sicherheit

Schutz der öffentlichen Ordnung

Gast- und Schankwirtschaften

Lfd. Nr. Titel

Laufzeit

529 Polizeiliche Beaufsichtigung der Gast- und Schankwirtschaften

1867-1909

- Regelung der polizeilichen Auficht über die Gast- und

Schankwirtschaften, 1867 - 1878

- Eingabe des Direktors der Gesellschaft "tot nut van't allgemeen" an den Magistrat der Stadt Emden über Notwendigkeit der Beschränkung der Zahl der Gast- und Schankwirtschaften zur Bekämpfung des

Alkoholmissbrauchs, Februar 1872

- Aufstellung über Gast- und Schankwirtschaften in der Stadt Emden,

Februar 1872 - Mai 1891

- Statistische Nachweisung über Gaststätten und

Branntweinverkaufsstellen in Emden, 1872 - 1877

- Revision der Gast- und Schankwirtschaften in Emden, Juni 1875

- Verfügung der Stadt Emden über Verbot des Alkoholausschanks an

Gymnasiasten, Oktober 1877 / Juli - Oktober 1884

- Eingabe des T.S. Heeren etc. an die Stadt Emden über Bitte um

Beschränkung der Zahl der Gaststätten wegen Zunahme des

Alkoholkonsums, Februar 1880

- Festsetzung der Polizeistunde, September 1886 - Mai 1908

- Verfügung des Regierungspräsidenten in Aurich über Haftung der

Gastwirte für Schäden durch den Ausschank von Alkohol an

Alkoholiker, Oktober 1886

- Erlass des preußischen Ministers für Handel und Gewerbe über

Einschränkung des Verkaufs von Waren durch Gaststättenbetreiber, April 1896

- Polizeiverordnung über Beleuchtung der Gaststätten, Oktober 1898

- Publikationen des "Deutschen Vereins für Gasthausreform" zur

Eröffnung alkoholfreier Gaststätten und Restaurants, 1902 - 1903

- Regelung der Arbeitsbedingungen der Bediensteten im

Gaststättengewerbe, 1903 - 1909

- Erlasse des preußischen Innenministers über Überwachung von Bahnhofsgaststätten und von Gaststätten auf Personendampfern, 1906

$1867-1909$

Klassifikation Teil B: 00596

Trägermaterial: Papier

Alte Reg.-Sig.: IV Fb 01

Bestell-Nr.: IV 00596

530 Erteilung der Schankerlaubnis

- Antrag des Steinsetzers Carl Koch an den Stadtausschuss des Stadtkreises Emden auf Erteilung der Schankerlaubnis zur Übernahme der Schankwirtschaft seines verstorbenen

Schwiegervaters in der Neuen Str. 21, Februar - April 1898

- Beschwerde des Carl Koch beim Stadtausschuss des Stadtkreises

Emden gegen Verweigerung der Schankerlaubnis, Mai - Juli 1898

1898

Klassifikation Teil B: 03043

Trägermaterial: Papier

Alte Reg.-Sig.: VIII B8 109

Bestell-Nr.: IV 03043 
IV

05

05.03

05.03.03

05.03.03.02

05.03.03.02.04

Stadtverwaltung

Aufgabenbereiche der Stadtverwaltung

Öffentliche Ordnung und Sicherheit

Schutz der öffentlichen Ordnung

Gast- und Schankwirtschaften

Lfd. Nr. Titel

Laufzeit

531 Erteilung der Schankerlaubnis

1898

- Antrag des Kellners Diedrich Mennenga an den Stadtausschuss des Stadtkreises Emden auf Erteilung der Schankerlaubnis zum Betrieb einer Schankwirtschaft im Haus Neuer Markt 61, April - Juni 1898

1898

Klassifikation Teil B: 03044

Trägermaterial: Papier

Alte Reg.-Sig.: VIII B8 110

Bestell-Nr.: IV 03044

532 Erteilung der Schankerlaubnis

1898

- Antrag des Gastwirts Jannes Frerich Poppinga an den

Stadtausschuss des Stadtkreises Emden auf Erteilung der

Schankerlaubnis zum Betrieb einer Schankwirtschaft im Haus Neuer

Markt 61, April - Juni 1898

1898

Klassifikation Teil B: 03045

Trägermaterial: Papier

Alte Reg.-Sig.: VIII B8 110

Bestell-Nr.: IV 03045

533 Erteilung der Schankerlaubnis

- Antrag des Hotelbesitzers Christian Roschmann an den

Stadtausschuss des Stadtkreises Emden auf Erteilung der

Schankerlaubnis zum Betrieb einer Schankwirtschaft im

Bahnhofshotel "Union", Bahnhofsstr.5, Mai - September 1898

- Beschwerde des Christian Roschmann beim Stadtausschuss des

Stadtkreises Emden gegen Verweigerung der Schankerlaubnis,

September - Oktober 1898

1898

Klassifikation Teil B: 03046

Trägermaterial: Papier

Alte Reg.-Sig.: VIII B8 112

Bestell-Nr.: IV 03046

534 Erteilung der Schankerlaubnis

- Antrag des jüdischen Kaufmanns Albert Italiener an den

Stadtausschuss des Stadtkreises Emden auf Erteilung der

Schankerlaubnis zum Betrieb einer Schankwirtschaft im Haus Kleine

Deichstraße 26, Februar - Mai 1899

1899

Klassifikation Teil B: 03047

Trägermaterial: Papier

Alte Reg.-Sig.: VIII B8 120

Bestell-Nr.: IV 03047 
IV

05

05.03

05.03.03

05.03.03.02

05.03.03.02.04
Stadtverwaltung

Aufgabenbereiche der Stadtverwaltung

Öffentliche Ordnung und Sicherheit

Schutz der öffentlichen Ordnung

Gast- und Schankwirtschaften

Lfd. Nr. Titel

Laufzeit

535 Erteilung der Schankerlaubnis

1899

- Antrag des Gastwirts Annäus Rust an den Stadtausschuss des Stadtkreises Emden auf Erteilung der Schankerlaubnis zum Betrieb einer Schankwirtschaft im "Heerenlogement" am Kattewall , Mai - Juli 1899

1899 (1900)

Klassifikation Teil B: 03048

Trägermaterial: Papier

Alte Reg.-Sig.: VIII B8 124

Bestell-Nr.: IV 03048

536 Erteilung der Schankerlaubnis

$1899-1900$

- Antrag des Oberkellners Hermann Hahlbrock an den

Stadtausschuss des Stadtkreises Emden auf Erteilung der

Schankerlaubnis zum Betrieb einer Schankwirtschaft im Gasthof

"Stadt Mastricht", Neue Straße

1899

Klassifikation Teil B: 03049

Trägermaterial: Papier

Alte Reg.-Sig.: VIII B8 124

Bestell-Nr.: IV 03049

537 Erteilung der Schankerlaubnis

$1900-1901$

- Antrag des Konditors und Restaurateurs Jacobus Gottfried Warring an den Stadtausschuss des Stadtkreises Emden auf Ausdehnung der Schankerlaubnis für sein Haus Neue Str. 66 auf das Haus Große Brückstr. 18 (Cafe "National", Cafe "Japan"), Januar - März 1900 - Beschwerde des J. G. Warsing beim Stadtausschuss des Stadtkreises Emden gegen Verweigerung der Schankerlaubnis, April 1900 - März 1901

$1900-1901$

Klassifikation Teil B: 03050

Trägermaterial: Papier

Alte Reg.-Sig.: VIII B8 131

Bestell-Nr.: IV 03050

538 Erteilung der Schankerlaubnis

- Antrag des Clubs zum Guten Endzweck an den Stadtausschuss des Stadtkreises Emden auf Erteilung der Schankerlaubnis für das Klubgebäude Neuer Markt 16 und das Klubgebäude Am Sandpfad, Januar - August 1900

1900

Klassifikation Teil B: 03051

Trägermaterial: Papier

Alte Reg.-Sig.: VIII B8 135

Bestell-Nr.: IV 03051 
05

05.03

05.03.03

05.03.03.02

05.03.03.02.04
Stadtverwaltung

Aufgabenbereiche der Stadtverwaltung

Öffentliche Ordnung und Sicherheit

Schutz der öffentlichen Ordnung

Gast- und Schankwirtschaften

Lfd. Nr. Titel

Laufzeit

539 Erteilung der Schankerlaubnis

1900

- Antrag des Zimmermanns August Eden aus Bant / Wilhelmshaven an den Stadtausschuss des Stadtkreises Emden auf Erteilung der Schankerlaubnis für die von inm gekaufte Gast- und Schankwirtschaft in der Boltentorstraße, September 1900

1900

Klassifikation Teil B: 03052

Trägermaterial: Papier

Alte Reg.-Sig.: VIII B8 139

Bestell-Nr.: IV 03052

540 Erteilung der Schankerlaubnis

1901

- Antrag des Maurers Albert Jens an den Stadtausschuss des Stadtkreises Emden auf Erteilung der Schankerlaubnis zum Betrieb der Gastwirtschaft im Hotel "Bellevue" in der Bahnhofsstraße 3,

Februar - April 1901

1901

Klassifikation Teil B: 03053

Trägermaterial: Papier

Alte Reg.-Sig.: VIII B8 140

Bestell-Nr.: IV 03053

541 Erteilung der Schankerlaubnis

- Antrag des Restaurateur Jacob Wetsch an den Stadtausschuss des Stadtkreises Emden auf Erteilung der Schankerlaubnis zum Betrieb der Gastwirtschaft im Bahnhofsgebäude Emden-Außenhafen, August 1901

1901

Klassifikation Teil B: 03054

Trägermaterial: Papier

Alte Reg.-Sig.: VIII B8 144

Bestell-Nr.: IV 03054

542 Erteilung der Schankerlaubnis

- Antrag des Restaurateurs Wilhelm Sander in Bielefeld an den Stadtausschuss des Stadtkreises Emden auf Erteilung der Schankerlaubnis zum Betrieb der Schankwirtschaft "Delfthalle", Große Str. 57 / Alter Markt, Dezember 1901 - März 1902

$1901-1902$

Klassifikation Teil B: 03055

Trägermaterial: Papier

Alte Reg.-Sig.: VIII B8 149

Bestell-Nr.: IV 03055 
IV

05

05.03

05.03.03

05.03.03.02

05.03.03.02.04

Stadtverwaltung

Aufgabenbereiche der Stadtverwaltung

Öffentliche Ordnung und Sicherheit

Schutz der öffentlichen Ordnung

Gast- und Schankwirtschaften

Lfd. Nr. Titel

Laufzeit

543 Erteilung der Schankerlaubnis

1901-1902

- Antrag des Vorstands des Clubs zum Guten Endzweck an den

Stadtausschuss des Stadtkreises Emden auf Erteilung der

Schankerlaubnis in den Klubgebäuden Neuer Markt 31 und

Bismarckstr. 4, Dezember 1901 - Februar 1902

$1901-1902$

Klassifikation Teil B: 03056

Trägermaterial: Papier

Alte Reg.-Sig.: VIII B8 149 a

Bestell-Nr.: IV 03056

544 Erteilung der Schankerlaubnis

$1901-1902$

- Antrag des Gastwirt Albert Jens an den Stadtausschuss des Stadtkreises Emden auf Erteilung der Schankerlaubnis für einen geplanten Saalbau am Hotel "Bellevue", Bahnhofsstraße, Oktober 1901 - April 1902

$1901-1902$

Klassifikation Teil B: 03057

Trägermaterial: Papier

Alte Reg.-Sig.: VIII B8 150

Bestell-Nr.: IV 03057

545 Erteilung der Schankerlaubnis

- Antrag des Restaurateur Jacob Wetsch an den Stadtausschuss des Stadtkreises Emden auf Erteilung der Schankerlaubnis für seinen Pächter Hatto G. Janßen zum Betrieb der Gast- und Schankwirtschaft im "Goldenen Adler", Kleine Faldernstraße 22, April - Mai 1902 - Antrag des Restaurateurs Hatto G. Janßen an den Stadtausschuss des Stadtkreises Emden auf Verschiebung der Polizeistunde für seinen Gastronomiebetrieb auf zwei Uhr morgens, Januar - Februar 1904

$1902-1904$

Klassifikation Teil B: 03058

Trägermaterial: Papier

Alte Reg.-Sig.: VIII B8 151

Bestell-Nr.: IV 03058 
05

05.03

05.03.03

05.03.03.02

05.03.03.02.04
Stadtverwaltung

Aufgabenbereiche der Stadtverwaltung

Öffentliche Ordnung und Sicherheit

Schutz der öffentlichen Ordnung

Gast- und Schankwirtschaften

Lfd. Nr. Titel

Laufzeit

546 Erteilung der Schankerlaubnis

1902

- Antrag des Gastwirts Hermann Hahlbrock an den Stadtausschuss des Stadtkreises Emden auf Erteilung der Schankerlaubnis für seinen zum Saal ausgebauten Stall des Gasthofs "Stadt Mastricht", Februar Aprik 1902

1902

\author{
Klassifikation Teil B: 03059 \\ Trägermaterial: Papier \\ Alte Reg.-Sig.: VIII B8 152 \\ Bestell-Nr.: IV 03059
}

547 Erteilung der Schankerlaubnis

- Antrag des Bahnhofswirts Franz Baron an den Stadtausschuss des Stadtkreises Emden auf Erteilung der Schankerlaubnis zum Betrieb der Gastwirtschaft im Bahnhofsgebäude Emden-Außenhafen, März Mai 1902

1902

\author{
Klassifikation Teil B: 03060 \\ Trägermaterial: Papier \\ Alte Reg.-Sig.: VIII B8 153 \\ Bestell-Nr.: IV 03060
}

548 Erteilung der Schankerlaubnis

- Antrag des Restaurateurs J. Fisser an den Stadtausschuss des Stadtkreises Emden auf Erteilung der Schankerlaubnis auf den Dampfern "Emden" und "Borkum", April 1902

1902
Klassifikation Teil B: 03061
Trägermaterial: Papier
Alte Reg.-Sig.: VIII B8 157
Bestell-Nr.: IV 03061

549 Erteilung der Schankerlaubnis

- Antrag des Schankwirts August Eden an den Stadtausschuss des Stadtkreises Emden auf Erteilung der Schankerlaubnis zum ausgedehnten Betrieb der Gastwirtschaft im Gasthof "Nordstern", Boltentorstraße, März - August 1902

1902

Klassifikation Teil B: 03062

Trägermaterial: Papier

Alte Reg.-Sig.: VIII B8 158

Bestell-Nr.: IV 03062 
IV

05

05.03

05.03.03

05.03.03.02

05.03.03.02.04

Stadtverwaltung

Aufgabenbereiche der Stadtverwaltung

Öffentliche Ordnung und Sicherheit

Schutz der öffentlichen Ordnung

Gast- und Schankwirtschaften

Lfd. Nr. Titel

Laufzeit

550 Erteilung der Schankerlaubnis

1902

- Antrag des Gastwirts Wilhelm Forkenbeck aus Schledehausen an den Stadtausschuss des Stadtkreises Emden auf Erteilung der

Schankerlaubnis zum Betrieb des Gasthofs "Frisia" in der

Olivenstraße, März - ASugust 1902

1902

Klassifikation Teil B: 03063

Trägermaterial: Papier

Alte Reg.-Sig.: VIII B8 159

Bestell-Nr.: IV 03063

551 Erteilung der Schankerlaubnis

- Antrag des Kaufmanns Johann G. Peters an den Stadtausschuss des Stadtkreises Emden auf Erteilung der Schankerlaubnis zum

Betrieb einer Gaststätte in der Arbeiter-Kolonie im

Kaiser-Wilhelm-Polder (transvaal), April - Juli 1902

- Klage des Kaufmanns G. Peters gegen den Stadtausschuss beim

Bezirksausschuss in Aurich auf Erteilung der abgelehnten

Schankerlaubnis, August - Oktober 1902

- Protest des Kirchenrats der deutsch-reformierten Gemeinde gegen die Zulassung einer Gaststätte auf Transvaal, OKtober 1902

1902

\author{
Klassifikation Teil B: 03064 \\ Trägermaterial: Papier \\ Alte Reg.-Sig.: VIII B8 160 \\ Bestell-Nr.: IV 03064
}

552 Erteilung der Schankerlaubnis

- Antrag des Oberkellners Friedrich Harenkamp aus Andernach an den Stadtausschuss des Stadtkreises Emden auf Erteilung der Schankerlaubnis zum Betrieb der Schankwirtschaft "Delfthalle", Alter Markt 7 - 8, Oktober 1903 - Juni 1906

$1903-1906$

Klassifikation Teil B: 03065

Trägermaterial: Papier

Alte Reg.-Sig.: VIII B8 176

Bestell-Nr.: IV 03065 
05

05.03

05.03.03

05.03.03.02

05.03.03.02.04

Lfd. $\mathrm{Nr}$. Titel
IV

Stadtverwaltung

Aufgabenbereiche der Stadtverwaltung

Öffentliche Ordnung und Sicherheit

Schutz der öffentlichen Ordnung

Gast- und Schankwirtschaften

553 Erteilung der Schankerlaubnis

Laufzeit

- Antrag des Restaurateurs Hinrikus Barfs an den Stadtausschuss des Stadtkreises Emden auf Erteilung der Schankerlaubnis zum Betrieb der Gastwirtschaft an der Seumestraße /Außer dem Nordertor, JUni November 1902

1902

Klassifikation Teil B: 03066

Trägermaterial: Papier

Alte Reg.-Sig.: VIII B8 161

Bestell-Nr.: IV 03066 
05

\subsection{3}

05.03.03

05.03.03.02

05.03.03.02.05
Stadtverwaltung

Aufgabenbereiche der Stadtverwaltung

Öffentliche Ordnung und Sicherheit

Schutz der öffentlichen Ordnung

Öffentliche Veranstaltungen und Unterhaltung

Lfd. Nr. Titel

Laufzeit

554 Beihilfe für den städtischen Musikdirektor

$1881-1890$

- Bewerbung des Hermann Brandt um das Amt eines städtischen Musikdirektors in Emden, November 1881

- Anträge des Musikdirektors C. Otte auf eine Beihilfe von der Stadt Emden wegen Wirkens seines Orchesters auf Veranstaltungen von Institutionen der Stadt Emden, Juli 1883 - März 1886

- Amtsniederlegung des Musikdirektors C. Otte wegen Umzugs nach Dortmund, Januar 1889

- Antrag des Musikdirektors K. Heyer auf eine Beihilfe von der Stadt Emden wegen Wirkens seines Orchesters auf Veranstaltungen von Institutionen der Stadt Emden, Februar 1889

- Antrag des Musikdirektors Ernst Adami auf eine Beihilfe von der Stadt Emden wegen Wirkens seines Orchesters auf Veranstaltungen von Institutionen der Stadt Emden, Juni 1890

$1881-1890$

Klassifikation Teil B: 00603

Trägermaterial: Papier

Alte Reg.-Sig.: IV Fc 09

Bestell-Nr.: IV 00603

555 Volksvorstellungen des Märkischen Wandertheaters

$1912-1914$

- Spielpläne und Spielorte des Märkischen Wandertheaters mit

Preisen, 1912 - 1914

- Korrespondenz der Stadt Emden mit anderen preußischen Städten über Resonanz auf die aufgeführten Stücke des Märkischen

Wandertheaters und den Ruf des Theaters, 1913

- Verhandlungen der Stadt Emden mit den Nachbarstädten Aurich, Leer, Papenburg und Weener wegen der Absicht der Gewinnung des Märkischen Wandertheaters für eine Tour durch Ostfriesland, Mai 1913

- Beschluss der Plenarversammlung von Magistrat und

Bürgervorsteherkollegium über Übernahme der Garantie für die Kosten der Aufführungen des Märkischen Wandertheaters, Mai 1913

- Garantieerklärungen aus Norden, Papenburg und Weener, Juni

1913

- Bildung eines Ausschusses für das Märkische Wandertheater,

August 1913

- Vertrag zwischen der Stadt Emden und dem Märkischen

Wandertheater über Aufführung zweier Stücke in Emden, September 1913 / April 1914

- Schließung des Märkischen Wandertheaters wegen Kriegsausbruch, August 1914

$1912-1914$

Klassifikation Teil B: 00605

Trägermaterial: Papier

Alte Reg.-Sig.: IV FC 15

Bestell-Nr.: IV 00605 
IV

05

Stadtverwaltung

05.03

Aufgabenbereiche der Stadtverwaltung

05.03.03

05.03.03.02

05.03.03.02.05

Öffentliche Ordnung und Sicherheit

Schutz der öffentlichen Ordnung

Öffentliche Veranstaltungen und Unterhaltung

Lfd. Nr. Titel

Laufzeit

556 Gründung einer Theatergesellschaft

1908-1912

- Einladung zur Beteiligung an der Gründung einer Gesellschaft zum

Bau und Betrieb eines Gesellschaftshauses nebst Stadttheater durch

den Architekten Liegnitz, Dezember 1908 - Januar 1909

- Angebot des Direktors des Schillertheaters in Bremen, Everard, zum

Vortrag über Kriterien zur Etablierung eines Theaters in Emden,

August 1912

$1908-1912$

Klassifikation Teil B: 00610

Trägermaterial: Papier

Alte Reg.-Sig.: IV Fe 13

Bestell-Nr.: IV 00610 
IV

05

05.03

05.03.03

05.03.03.02

05.03.03.02.06
Stadtverwaltung

Aufgabenbereiche der Stadtverwaltung

Öffentliche Ordnung und Sicherheit

Schutz der öffentlichen Ordnung

Lotterien und Glücksspiele

Lfd. Nr. Titel

Laufzeit

557 Lotterien und Kollekten

1868-1914

- Verfügung des preußischen Landdrosten in Aurich über

Genehmigungspflicht von Lotterien und Kollekten, Dezember 1868

- Gesetze zum Lotteriewesen, 1880 - 1911

- Erlasse des preußischen Innenministers zum Lotteriewesen, 1880 -

1914

- Gesuch des Druckers und Zeitungsverlegers Louis Hahn an die

Stadt Emden über Bitte um Zulassung als Lotterie - Einnehmer in der

Stadt Emden, Mai 1886

- Erlass der Oberpräsidenten der Provinz Hannover über Pflicht der

Lotteriebetreiber zur Auszahlung der Preise in der angekündigten

Höhe, Oktober 1893

- Genehmigung der Lotterie des Missionsfrauenvereins in Emden

durch den Oberpräsidenten in Hannover, Oktober 1909

- Genehmigung der Lotterie des Gustav-Adolf-Frauenvereins in

Emden durch den Oberpräsidenten in Hannover, Februar 1911

$1868-1914$

Klassifikation Teil B: 00607

Trägermaterial: Papier

Alte Reg.-Sig.: IV Fd 4

Bestell-Nr.: IV 00607

558 Staats-Classen-Lotterie

1886-1904

- Aufstellung über Lotterie-Einnehmer der staatlichen preußischen

(1916-1921)

Klassenlotterie, 1886

- Bericht des Emder Lotterieeinnehmers B. Davids über Mangel an

Losen angesichts großer Nachfrage nach der Klassenlotterie, Januar 1888

- Verbot des Spiels von nicht zugelassenen, außerpreußischen

Lotterien, August 1904

- Erlass des preußischen Innenministers über Zulassung von Lotterien

für gemeinnützige Zwecke, Dezember 1916 - Juli 1921

1886 - 1904 (1916 - 1921)

Klassifikation Teil B: 00608

Trägermaterial: Papier

Alte Reg.-Sig.: IV Fd 7

Bestell-Nr.: IV 00608

559 Verbot ausländischer Wetten

- Erlass des preußischen Finanzministers über Anordnung der scharfen Durchsetzung des Verbotes ausländischer Wetten, April 1909

1909

Klassifikation Teil B: 00609

Trägermaterial: Papier

Alte Reg.-Sig.: IV Fd 9

Bestell-Nr.: IV 00609 
IV

05

Stadtverwaltung

05.03

05.03.03

Aufgabenbereiche der Stadtverwaltung

05.03.03.02

05.03.03.02.07

Öffentliche Ordnung und Sicherheit

Schutz der öffentlichen Ordnung

Säufer und Ruhestörer

Lfd. Nr. Titel

Laufzeit

560 Errichtung einer Trinkerheilstätte

1900-1909

- Initiative des Vereins für Trinkerrettung zur Gründung einer

Trinkerheilstätte, Dezember 1900

- Jahresberichte des Stiftes Isenwald bei Gifhorn, Heilanstalt des

Vereins für Trinkerrettung, September 1902 - Juli 1903

- Initiative des Industriellen Ernst Wulff zur Gründung einer Schule für

Alkoholgefährdete (Schule für gesunde Lebensweise, Körperpflege

sowie Enthaltsamkeit), November 1902

- Information über Trinkerheilstätte für Frauen in Herford, September

1904

$1900-1909$

Klassifikation Teil B: 00611

Trägermaterial: Papier

Alte Reg.-Sig.: IV Ff 60

Bestell-Nr.: IV 00611 
05

\subsection{3}

05.03.03

05.03.03.02

05.03.03.02.08
Stadtverwaltung

Aufgabenbereiche der Stadtverwaltung

Öffentliche Ordnung und Sicherheit

Schutz der öffentlichen Ordnung

Feiertagsregelungen

Lfd. Nr. Titel

Laufzeit

561 Sonn- und Feiertagsregelungen, Bd. 1

1891-1898

- Erlasse der preußischen Minister für Handel und Gewerbe, für geistliche Unterrichts- und Medizinalangelegenheiten und Innenministers sowie Verfügungen des Oberpräsidenten in Hannover und des Regierungspräsidenten in Aurich über Maßnahme zur Erhaltung der Sonntagsruhe und Ausnahmeregelungen zum Arbeitsverbot an Feiertagen, März 1891 - Mai 1898

- Anträge an die Polizeiverwaltung der Stadt Emden auf Erlaubnis zur Arbeit am Sonntag oder Feiertag, März 1891 - August 1896

- Antrag des Männerturnvereins Emden auf Öffnung der Schaufenster anlässlich des Gauturnfestes am Sonntag, den 17.07.1892, Juli 1892

- Verbot von Theateraufführungen in der Karwoche, Mai 1894

- Anzeigen gegen Gewerbetreibende wegen Verstoßes gegen das Arbeitsverbot am Sonntag, Mai 1895 - Juni 1896

- Erlass einer Polizeiverordnung durch die Stadt Emden zum Schutz der Sonn- und Feiertage, August 1895

$1891-1898$

Klassifikation Teil B: 00622

Band: 1

Trägermaterial: Papier

Alte Reg.-Sig.: IV Fg 02

Bestell-Nr.: IV 00622

562 Sonn- und Feiertagsregelungen, Bd. 2

- Erlasse der preußischen Minister für Handel und Gewerbe, für geistliche Unterrichts- und Medizinalangelegenheiten und Innenministers sowie Verfügungen des Oberpräsidenten in Hannover und des Regierungspräsidenten in Aurich über Maßnahme zur Erhaltung der Sonntagsruhe und Ausnahmeregelungen zum Arbeitsverbot an Feiertagen, April 1898 - Mai 1910

- Anzeigen gegen Gewerbetreibende wegen Verstoßes gegen das Arbeitsverbot am Sonntag, Oktober 1899 - Januar 1908

- Anträge an die Polizeiverwaltung der Stadt Emden auf Erlaubnis zur Arbeit am Sonntag oder Feiertag, Juni 1900 - Mai 1911

- Festlegung der Öffnungszeiten für Bäcker und Konditoren an Sonnund Feiertagen, Juli - August 1907

$1898-1911$

Klassifikation Teil B: 00623

Band: 2

Trägermaterial: Papier

Alte Reg.-Sig.: IV Fg 02

Bestell-Nr.: IV 00623 
IV

05

05.03

05.03.03

05.03.03.02

05.03.03.02.08
Stadtverwaltung

Aufgabenbereiche der Stadtverwaltung

Öffentliche Ordnung und Sicherheit

Schutz der öffentlichen Ordnung

Feiertagsregelungen

Lfd. Nr. Titel

Laufzeit

563 Sonn- und Feiertagsregelungen, Bd. 3

1911-1916

- Erlasse der preußischen Minister für Handel und Gewerbe, für Landwirtschaft, Domänen und Forsten und Innenministers sowie Verfügungen des Oberpräsidenten in Hannover und des Regierungspräsidenten in Aurich über Maßnahme zur Erhaltung der Sonntagsruhe und Ausnahmeregelungen zum Arbeitsverbot an

Feiertagen, Januar 1911 - Juni 1915

- Festlegung der Sonntagsruhe im Emder Handel, April - September 1911

- Anträge an die Polizeiverwaltung der Stadt Emden auf Erlaubnis zur Arbeit am Sonntag oder Feiertag, Juni 1911 - April 1915

- Protest der ev. ref. Kirche gegen die Genehmigung eines

Synphoniekonzertes durch die Stadt Emden am Buß- und Bettag, November 1911

- Vereinbarung von Sonderöffnungszeiten an Sonntagen vor Weihnachten für den Emder Handel, November 1911 - September 1914

- Anzeigen gegen Gewerbetreibende wegen Verstoßes gegen das Arbeitsverbot am Sonntag, Oktober 1911

- Sonntagsöffnungszeiten für Bäcker und Konditoren in Emden, Juli

1912 - November 1914

- Genehmigung eines Konzertes in Emden am Ersten

Weihnachtsfeiertag durch den Regierungspräsidenten in Aurich unter Zensierung der Stücke, Dezember 1913

- Festsetzung der Ladenöffnungszeiten im Emder Handel, September 1914 - September 1916

$1891-1898$

Klassifikation Teil B: 00624

Band: 3

Trägermaterial: Papier

Alte Reg.-Sig.: IV Fg 02

Bestell-Nr.: IV 00624

564 Feier zum 70. Geburtstag des Reichskanzlers Fürst Otto von

Bismarck

- Organisation einer Feier zum 70. Geburtstag des Fürsten von

Bismarck durch die Stadt Emden auf Initiative des

Oberbürgermeisters Fürbringer, Februar - März 1885

- Organisation einer Haussammlung für ein Ehrengeschenk für Otto von Bismarck, Februar 1885

- Suskriptionsaktion für ein Kunstblatt mit dem Porträt des

Reichskanzlers, Februar 1885

- Glückwunschtelegramm der Stadt Emden an des Fürsten Otto von

Bismarck, April 1885

- Dankschreiben des Reichskanzlers, April 1885

1885

Klassifikation Teil B: 00625

Trägermaterial: Papier

Alte Reg.-Sig.: IV Fg 09

Bestell-Nr.: IV 00625 
IV

05

Stadtverwaltung

05.03

05.03.03

Aufgabenbereiche der Stadtverwaltung

05.03.03.02

05.03.03.02.08

Öffentliche Ordnung und Sicherheit

Schutz der öffentlichen Ordnung

Feiertagsregelungen

Lfd. Nr. Titel

Laufzeit

565 Feier zum 90. Geburtstag des Generalfeldmarschalls Hellmuth Graf von Moltke

1890-1891

- Suskription auf eine Festschrift zum 90.Geburtstag des

Generalfeldmarschalls Hellmuth Graf von Moltke , September 1890

- Werbung des "Moltke-Comitees" für Einzahlungen in die

neugegründete Moltke-Stiftung, September 1890

- Grußadresse der Stadt Emden an den Generalfeldmarschall

Hellmuth Graf von Moltke, Oktober 1890

- Schulfeiern zum Geburtstag des Generalfeldmarschalls Graf von

Moltke, Oktober 1890

$1890-1891$

Klassifikation Teil B: 00626

Trägermaterial: Papier

Alte Reg.-Sig.: IV Fg 11

Bestell-Nr.: IV 00626

566 Feiern zum 90.und 100. Geburtstag des Reichskanzlers Fürst Otto von Bismarck

- Organisation einer Feier zum 90. Geburtstag des Fürsten von Bismarck durch die Stadt Emden auf, Februar - März 1885

- Illumination des Rathauses zu Ehren des ehemaligen

Reichskanzlers, März 1895

- Organisation einer Feier zum 100. Geburtstag des Fürsten Otto von

Bismarck, März - April 1915

$1895 / 1915$

Klassifikation Teil B: 00627

Trägermaterial: Papier

Alte Reg.-Sig.: IV Fg 12

Bestell-Nr.: IV 00627 
05

05.03

05.03.03

05.03.03.02

05.03.03.02.08
Stadtverwaltung

Aufgabenbereiche der Stadtverwaltung

Öffentliche Ordnung und Sicherheit

Schutz der öffentlichen Ordnung

Feiertagsregelungen

Lfd. Nr. Titel

Laufzeit

567 Feier der hundertsten Wiederkehr des Beginns der Befreiungskriege und Düppel-Gedächtnisfeier

- Angebote von Literatur und Broschüren zum 100. Jubiläumsjahr des Beginns der Befreiungskriege gegen Napoleon I., 1913

- Mitteilungen über Veranstaltungen zum 100. Jubiläumsjahr des

Beginns der Befreiungskriege gegen Napoleon I. in anderen Städten, 1913

- Rechnung der Emder Stadtkapelle für Musikdarbietungen anlässlich der Jubiläumsfeierlichkeiten, 1913

- Verfügung des Regierungspräsidenten in Aurich über Werbuing für das Tragen eines "Vivat-Bändchens" mit Motiven aus den

Befreiungskriegen während der Jubiläumsfeiern, April 1913

- Programm der Feier in Emden zur 100. Wiederkehr des Datums der Völkerschlacht bei Leipzig, Oktober 1913

- Allerhöchster Erlass des Kaisers Wilhelm II. zur Feier des 100. Jubiläumsjahres des Beginns der Befreiungskriege gegen Napoleon

I., März 1913

- Anträge von Veranstaltern der Feiern zum 100. Jubiläumsjahr des Beginns der Befreiungskriege gegen Napoleon I. auf Befreiung von der Lustbarkeitssteuer, Oktober 1913

- Ankündigung einer Feier zur 50. Wiederkehr des Datums der

Schlacht bei Düppel (Deutsch-Dänischer Krieg 1864), Juni 1914

$1912-1914$

Klassifikation Teil B: 00629

Trägermaterial: Papier

Alte Reg.-Sig.: IV Fg 16

Bestell-Nr.: IV 00629

568 Gedenken zum 100. Todestag von Friedrich v. Schiller

- Einladung zur Schiller-Feier der Gesellschaft to't Nut van't Allgemeen im Saal des Tivoli in Emden, Januar 1905

- Angebote von Jubiläumsliteratur zu Friedrich Schiller, Februar 1905

- Organisation einer Schiller-Feier in Emden, März - April 1905

- Unterstützung der Stadt Emden für die Schillerfeier, März 1905

- Bestellung vion Schiller-Gedenkbüchern durch die Emder

Schulverbände, April 1905

- Anschaffung von Schiller-Gedenkbücher durch die Stadt Emden für schulische Zwecke, Mai 1905

1905

Klassifikation Teil B: 00630

Trägermaterial: Papier

Alte Reg.-Sig.: IV Fg 15

Bestell-Nr.: IV 00630 
05

\subsection{3}

05.03.03

05.03.03.02

05.03.03.02.08
Stadtverwaltung

Aufgabenbereiche der Stadtverwaltung

Öffentliche Ordnung und Sicherheit

Schutz der öffentlichen Ordnung

Feiertagsregelungen

Lfd. Nr. Titel

Laufzeit

569 Feier zum 400. Geburtstag des Reformators Martin Luther

- Angebote über Literatur über Martin Luther, Mai 1883

- Organisation der Feier zum 400. Geburtstag des Reformators Martin Luther in Emden, Mai - Oktober 1883

- Verfügung des kgl. Konsistoriums in Aurich über Richtlinien zur

Organisation von Lutherfeiern, September 1883

- Unterstützung für die Lutherfeier durch die Stadt Emden, November 1883

- Anbietung der von der Stadt Emden erworbenen zehnbändigen

Weimarer Ausgabe "Luther's Werke" an die evangelischen

Gemeinden, Mai 1914

1883 (1914)

Klassifikation Teil B: 00631

Trägermaterial: Papier

Alte Reg.-Sig.: IV Fg 08

Bestell-Nr.: IV 00631

570 Sedanstag (2.September), Bd. 1

1871-1875

- Gedruckter Aufruf zur Begehung des 2. September (Schlacht bei Sedan) als nationalen Feiertag, August 1871 - Mai 1873

- Beschluss während der Plenarsitzung von Bürgervorsteherkollegium und Magistrat der Stadt Emden über Begehung des 2. September (Sedanstag) als "Deutsches Volksfest", August 1871 - August 1875

- Organisation eines gemeinsamen Gottesdienstes aller Konfessionen in Emden zum Sedanstag, August 1872 - August 1873

- Aufstellung über Ausgaben der Stadt Emden für die Sedansfeier, Oktober 1872 - September 1875

- Teilnahme des Musikkorps des Ostfriesischen Infanterie-Regiments Nr. 78 an der Sedansfeier in Emden, August 1875

$1871-1875$

Klassifikation Teil B: 00632

Band: 1

Trägermaterial: Papier

Alte Reg.-Sig.: IV Fg 07

Bestell-Nr.: IV 00632 
IV

05

05.03

05.03.03

05.03.03.02

05.03.03.02.08
Stadtverwaltung

Aufgabenbereiche der Stadtverwaltung

Öffentliche Ordnung und Sicherheit

Schutz der öffentlichen Ordnung

Feiertagsregelungen

Lfd. Nr. Titel

Laufzeit

571 Sedanstag (2.September), Bd. 2

1895-1910

- Angebot von Literatur und Material zum Sedanstag, Februar 1895 -

Juni 1900

- Organisation der Feiern zum Sedanstag in Emden, Juli 1895 -

August 1910

- Ordnung des Fackelzuges zum Sedanstag in Emden, August 1895

- Unterstützung der Stadt Emden für die Sedansfeier, Juli 1895 -

September 1910

- Stiftung eines Kranzes für die Soldatengräber bei Metz durch die

Stadt Emden, September 1910

- Ehrung von Veteranen der Kriege von 1864, 1866 und 1870/71,

August - September 1971

- Eingaben von Witwen verstorbener Kriegsteilnehmer an die Stadt

Emden über Bitte um Einbeziehung in die Ehrenspende für die

Kriegsveteranen, September 1910

$1871-1875$

Klassifikation Teil B: 00633

Band: 2

Trägermaterial: Papier

Alte Reg.-Sig.: IV Fg 07

Bestell-Nr.: IV 00633

572 Beschäftigung gewerblicher Arbeiter an Sonn- und Feiertagen

- Erlass des preußischen Ministers für Handel und Gewerbe über Anordnung zur Erhebung einer Statistik zur Sonn- und Feiertagsarbeit in Preußen, Juli 1885

- Organisation der Erhebung von Daten zur angeforderten Statistik in Emden, August 1885

- Aufstellung über gewerbliche Betriebe in Emden und Sonntagsarbeit, August 1885

- Statistik über Emder Betriebe mit Sonn- und Feiertagsarbeit,

November 1885

1885

Klassifikation Teil B: 00634

Trägermaterial: Papier

Alte Reg.-Sig.: IV Fg 10

Bestell-Nr.: IV 00634 
IV

05

05.03

05.03.03

05.03.03.02

05.03.03.02.08
Stadtverwaltung

Aufgabenbereiche der Stadtverwaltung

Öffentliche Ordnung und Sicherheit

Schutz der öffentlichen Ordnung

Feiertagsregelungen

Lfd. Nr. Titel

Laufzeit

573 Feier zum 25-Jährigen Bestehen des (Zweiten) deutschen Kaiserreichs

1896

- Organisation der Feier zum 25-Jährigen Bestehen des (Zweiten)

deutschen Kaiserreichs durch den Festausschuss unter Leitung des

Gymnasialdirektors Schürzler, Januar 1896

- Unterstützung der Feier durch die Stadt Emden, Januar 1896

- Festprogramm, Januar 1896

1896

Klassifikation Teil B: 1896

Trägermaterial: Papier

Alte Reg.-Sig.: IV Fg 13

Bestell-Nr.: IV 00628 
IV

05

05.03

05.03.03

05.03.03.02

05.03.03.02.09

Stadtverwaltung

Aufgabenbereiche der Stadtverwaltung

Öffentliche Ordnung und Sicherheit

Schutz der öffentlichen Ordnung

Vereine

Lfd. Nr. Titel

Laufzeit

574 Schützenkorps

1886-1914

- Statuten des Schützen-Corps zu Emden, 1886

(1921-1932)

- Antrag des Schützen-Corps auf Genehmigung der Schützenfeste,

Mai 1891 - März 1914

- Anträge verschiedener Schausteller auf Konzessionen für ihre

Geschäfte auf dem Schützenplatz, 1903 - 1911

- Polizeiliche Maßnahmen zur Aufrechterhaltung von Ruhe und

Ordnung auf dem Schützenplatz, Juli 1904

- Eingabe des Ostfriesischen Schützenbundes an die Stadt Emden

über Bitte um Förderung der Veranstaltung eines Bundesschießens in

Emden in Verbindung mit dem Emder Schützenfest, März 1908

- Übersicht über die von den Schaustellern einzuziehende

Lustbarkeitssteuer, 1905 - 1910

- Satzungen des Ostfriesischen Schützenbundes, 1906

1886 - 1914 (1921 - 1932)

Klassifikation Teil B: 00601

Trägermaterial: Papier

Alte Reg.-Sig.: IV Eg 3

Bestell-Nr.: IV 00601

575 Anlegung eines Schießstandes durch das Schützenkorps

$1870-1908$

- Antrag des Schützenkorps auf Genehmigung der Anlage eines Schießstandes auf einem Platz nahe der Straße Zwischen Beiden

Bleichen, Januar - Fenruar 1870 / Februar 1874

- Antrag des Schützenkorps auf Genehmigung der Anlage eines

Schießstandes auf einem Platz am städtischen Grünen Weg am

Hinter Tief, Juli - August 1876

- Anzeige gegen das Schützenkorps wegen Gefährung von Passanten duech seine Schießanlage, Mai 1877

- Antrag des Schützenkorps auf Genehmigung des Neubaus seines

Schießstandes, Januar 1908

$1870-1908$

Klassifikation Teil B: 00602

Trägermaterial: Papier

Alte Reg.-Sig.: IV Eg 2

Bestell-Nr.: IV 00602 
- Verfügungen des preußischen Landdrosten in Aurich zum Vereinswesen, September 1867 - Juli 1869

- Bericht über Vorstandswahl des Emder Turnvereins, September 1868

- Erlass des preußischen Innenministers über Anordnung der behördlichen Überwachung der Gewerkschaften und anderer Arbeiterorganisationen zur Verhinderung von Streiks, September 1872 - Erlass des preußischen Innenministers über Anordnung der behördlichen Überwachung und gegebenenfalls Auflösung katholischer Vereine wegen politischer Agitation, Juli 1874 / Juli 1876 - Bericht der Kronanwaltschaft in Aurich über Anklageerhebung gegen die Maurer Johannes Noortmann, Carl Theodor Benchmann und August Friedrich Wilhelm Hiege wegen Verstoß gegen das Vereinsgesetz durch die Begründung eines Zweigvereins der Deutschen Maurer und Steinhauer, April 1877

- Erlasse des preußischen Innenministers über Vereinsverbote wegen sozialdemokratischer Agitation, Juni 1879 - Dezember 1888

- Erlasse des preußischen Innenministers über Vereinszulassungen, März 1883 - April 1913

- Gerichtliche Verbote gegen welfische und sozialdemokratische Vereine, 1895 - 1899

- Gerichtsurteile zum Vereinswesen, 1897 - 1910

- Eintragung des christlichen Jünglingsvereins Emden in das Vereinsregister, Dezember 1903

- Vereinsgesetz für das Deutsche Reich, April 1908

- Organisation der polizeilichen Überwachung von Vereinen in Emden, Mai 1908

- Statuten des Vereins ostfriesischer Viehhändler, November 1908

- Berichte des Amtsgerichts Emden über Eintragungen in das

Vereinsregister, Februar 1914

$1867-1914$

Klassifikation Teil B: 00636

Trägermaterial: Papier Alte Reg.-Sig.: IV Fi 008

Bestell-Nr.: IV 00636 
05

05.03

05.03.03

05.03.03.02

05.03.03.02.09
Stadtverwaltung

Aufgabenbereiche der Stadtverwaltung

Öffentliche Ordnung und Sicherheit

Schutz der öffentlichen Ordnung

Vereine

Lfd. Nr. Titel

Laufzeit

577 Verein für Diakonissen-Krankenpflege, Bd. 1

1861-1903

- Bildung eines Frauenvereins für christliche Armen- und

Krankenpflege in Emden, März 1861

- Statuten des Frauenvereins für christliche Armen- und

Krankenpflege in Emden / Vereins für Diakonissen-Krankenpflege,

März 1861 / Oktober 1900

- Jahresberichte des Vereins für Diakonissen-Krankenpflege, Februar

1867 - Januar 1903

- Anträge des Vereins für Diakonissen-Krankenpflege auf

Unterstützung durch die Stadt Emden, April 1867 - Januar 1903

- Zuerkennung des Status einer juristischen Person für den Verein für

Diakonissen-Krankenpflege durch den preußischen Landdrosten in

Aurich zur Ermöglichung des Erwerbs eines Gebäudes als

Vereinsheim, August - September 1867

- Antrag des Vereins für Diakonissen-Krankenpflege auf

Genehmigung einer Kollekte, Februar 1876

- Jahresberichte der Henriettenstiftung in Hannover, 1882 / 1885 -

1897

- Fahrpreisermäßigungen der Eisenbahn für Mitglieder des Vereins für

Diakonissen-Krankenpflege, Oktober 1884 - März 1892

- Engagement des Vaterländischen Frauenvereins, Zweigverein

Emden in der Krankenpflege, Oktober 1884

- Erlass des preußischen Ministers der geistlichen-, Unterrichts und Medizinalangelegenheiten über Erlaubnis der Eintragung des Vereins für Diakonissen-Krankenpflege in das Vereinsregister, Dezember 1900

$1861-1903$

Klassifikation Teil B: 00637

Band: 1

Trägermaterial: Papier

Alte Reg.-Sig.: IV Fi 012

Bestell-Nr.: IV 00637

578 Verein für Diakonissen-Krankenpflege, Bd. 2

1904-1915

- Jahresberichte des Vereins für Diakonissen-Krankenpflege, Februar 1904 - Februar 1915

- Anträge des Vereins für Diakonissen-Krankenpflege auf Unterstützung durch die Stadt Emden, November 1904 - Dezember 1911

- Jahresberichte der Henriettenstiftung in Hannover, 1905 - 1909

- Fahrpreisermäßigungen der Eisenbahn für Mitglieder des Vereins für Diakonissen-Krankenpflege, Juli 1905 - Juli 1913

- Einladung an den Magistrat der Stadt Emden zur Eröffnung des

Alten- und Siechenhauses "Bethanien", Mai 1906

- Satzung für das Alten- und Siechenhaus "Bethanien", Oktober 1913

$1904-1915$

Klassifikation Teil B: 00638

Band: 2

Trägermaterial: Papier

Alte Reg.-Sig.: IV Fi 012

Bestell-Nr.: IV 00638 
05

05.03

05.03.03

05.03.03.02

05.03.03.02.09
Stadtverwaltung

Aufgabenbereiche der Stadtverwaltung

Öffentliche Ordnung und Sicherheit

Schutz der öffentlichen Ordnung

Vereine

Lfd. Nr. Titel

Laufzeit

579 Kaiser-Wilhelm-Stiftung für deutsche Invaliden, Zweigverein Emden, Bd. 1

- Quittungen der Empfänger von Unterstützungszahlungen der Kaiser-Wilhelm-Stiftung für deutsche Invaliden, 1885

- Insertionskosten für Anzeigen in der "Emder Zeitung" über

Ankündigung einer Jahreskollekte der Stiftung, 1885

1885

Klassifikation Teil B: 00639

Band: 1

Trägermaterial: Papier

Alte Reg.-Sig.: IV Fi 013

Bestell-Nr.: IV 00639

580 Kaiser-Wilhelm-Stiftung für deutsche Invaliden, Zweigverein Emden,

1887

Bd. 2

- Unterstützungszahlungen der Kaiser-Wilhelm-Stiftung für deutsche Invaliden für bedürftige Kriegsinvaliden, 1887

- Ergebnis der Jahreskollekte der Stiftung, 1887

1887

Klassifikation Teil B: 00640

Band: 2

Trägermaterial: Papier

Alte Reg.-Sig.: IV Fi 013

Bestell-Nr.: IV 00640

581 Kaiser-Wilhelm-Stiftung für deutsche Invaliden, Zweigverein Emden, Bd. 3

- Jahresrechnung der Kaiser-Wilhelm-Stiftung für deutsche Invaliden, Zweigverein Emden, 1894 - 1897

$1894-1897$

Klassifikation Teil B: 00641

Band: 3

Trägermaterial: Papier

Alte Reg.-Sig.: IV Fi 013

Bestell-Nr.: IV 00641

582 Kaiser-Wilhelm-Stiftung für deutsche Invaliden, Zweigverein Emden, Bd. 4

- Kollekte der Kaiser-Wilhelm-Stiftung für deutsche Invaliden, Zweigverein Emden, 1900

1900

Klassifikation Teil B: 00642

Band: 4

Trägermaterial: Papier

Alte Reg.-Sig.: IV Fi 013

Bestell-Nr.: IV 00642 


\section{IV}

05

05.03

05.03.03

05.03.03.02

05.03.03.02.09
Stadtverwaltung

Aufgabenbereiche der Stadtverwaltung

Öffentliche Ordnung und Sicherheit

Schutz der öffentlichen Ordnung

Vereine

Lfd. Nr. Titel

Laufzeit

583 Kaiser-Wilhelm-Stiftung für deutsche Invaliden, Zweigverein Emden, Bd. 5

1899-1908

- Jahresrechnung der Kaiser-Wilhelm-Stiftung für deutsche Invaliden,

Zweigverein Emden, 1899 - 1908

- Jahreskollekte der Kaiser-Wilhelm-Stiftung für deutsche Invaliden,

Zweigverein Emden, 1900 - 1902

$1899-1908$

Klassifikation Teil B: 00643

Band: 5

Trägermaterial: Papier

Alte Reg.-Sig.: IV Fi 013

Bestell-Nr.: IV 00643

584 Kaiser-Wilhelm-Stiftung für deutsche Invaliden, Zweigverein Emden, Bd. 6

- Jahresrechnung der Kaiser-Wilhelm-Stiftung für deutsche Invaliden,

Zweigverein Emden, 1908 - 1909

$1908-1909$

Klassifikation Teil B: 00644

Band: 6

Trägermaterial: Papier

Alte Reg.-Sig.: IV Fi 013

Bestell-Nr.: IV 00644

585 Kaiser-Wilhelm-Stiftung für deutsche Invaliden, Zweigverein Emden, Bd. 7

- Jahreskollekte der Kaiser-Wilhelm-Stiftung für deutsche Invaliden, Zweigverein Emden, 1910

1910

Klassifikation Teil B: 00645

Band: 7

Trägermaterial: Papier

Alte Reg.-Sig.: IV Fi 013

Bestell-Nr.: IV 00645

586 Hannoverscher Städteverein (Hannoverscher Städtetag), Bd. 1

- Einladungen zum Hannoverschen Städtetag mit Tagesordnung,

1888 - 1893

- Beschlussvorlage beim Städtetag zur Novellierung des

Sparkassengesetzes, 1893

$1888-1893$

Klassifikation Teil B: 00646

Band: 1

Trägermaterial: Papier

Alte Reg.-Sig.: IV Fi 013

Bestell-Nr.: IV 00646 
05

05.03

05.03.03

05.03.03.02

05.03.03.02.09
Stadtverwaltung

Aufgabenbereiche der Stadtverwaltung

Öffentliche Ordnung und Sicherheit

Schutz der öffentlichen Ordnung

Vereine

Lfd. Nr. Titel

Laufzeit

587 Hannoverscher Städteverein (Hannoverscher Städtetag), Bd. 2

1894-1901

- Druckschriften über Strukturprobleme städtischer Verfassungen, $1894-1898$

- Entsendung der Vertreter der Stadt Emden zum Hannoverschen

Städtetag, Mai 1899 - Mai 1900

- Einladungen zum Hannoverschen Städtetag in Harburg und

Hannover, 1899 - 1900

- Presseberichte über Städtetag in Celle, Mai 1901

$1894-1901$

Klassifikation Teil B: 00647

Band: 2

Trägermaterial: Papier

Alte Reg.-Sig.: IV Fi 013

Bestell-Nr.: IV 00647

588 Hannoverscher Städteverein (Hannoverscher Städtetag), Bd. 3

1905-1906

- Tagung des Hannoverschen Städtetages in Leer, Mai - Juni 1905

- Tätgkeitsbericht des Hannoverschen Städtetag für den Zeitraum von 1866 bis 1906, 1906

$1905-1906$

Klassifikation Teil B: 00648

Band: 3

Trägermaterial: Papier

Alte Reg.-Sig.: IV Fi 013

Bestell-Nr.: IV 00648

589 Zweigverein vom Roten Kreuz, Emden

1905-1914

- Mitteilungen des Roten Kreuzes über Aktivitäten seiner

Organisationen, 1905 - 1912

- Gedruckte Verwaltungsberichte des Vorstands des Provinzialvereins vom Roten Kreuz, 1908 - 1910

- Sammlungen für das Rote Kreuz, 1914 - 1915

- Jahresberichte des Deutschen Samariter-Bundes, 1903 - 1904

- Kollekte der Kaiser-Wilhelm-Stiftung für deutsche Invaliden,

Zweigverein Emden, 1886

$1905-1914$ (1886)

Klassifikation Teil B: 00653

Band: 1

Trägermaterial: Papier

Alte Reg.-Sig.: IV Fi 015

Bestell-Nr.: IV 00653 
- Regelungen für den Mobilmachungsfall und Umsetzung in Emden, $1901-1912$

- Gründung einer Sanitätskolonne in Emden, Oktober 1908

- Jahresberichte der Kaiser-Wilhelm-Stiftung für deutsche Invaliden, Zweigverein Emden, 1904 - 1908

- Unterstützungen für Invaliden durch die Kaiser-Wilhelm-Stiftung für deutsche Invaliden, Zweigverein Emden, 1901 - 1905

- Antrag der Kaiser-Wilhelm-Stiftung für deutsche Invaliden,

Zweigverein Emden auf Unterstützung durch die Stadt Emden wegen goßer Anzahl bedürftiger Invaliden in Emden, Februar 1909

- Jahresrechnung des Roten Kreuzes, Zweigverein Emden, 1911

$1905-1914$ (1886)

Klassifikation Teil B: 00654

Band: 2

Trägermaterial: Papier

Alte Reg.-Sig.: IV Fi 015

Bestell-Nr.: IV 00654

591 Lokalverein Emden zur Pflege im Felde verwundeter und erkrankter deutscher Krieger

- Unterstützung von Kriegsopfern durch den Lokalverein Emden zur Pflege im Felde verwundeter und erkrankter deutscher Krieger, 1871 1896

- Jahresrechnung des Lokalvereins Emden zur Pflege im Felde verwundeter und erkrankter deutscher Krieger, 1868 - 1872 - Jahresrechnung der Kaiser-Wilhelm-Stiftung für deutsche Invaliden, Zweigverein Emden, 1870 - 1872

- Kollekte des Lokalvereins Emden zur Pflege im Felde verwundeter und erkrankter deutscher Krieger, 1871

$1869-1896$

Klassifikation Teil B: 00655

Band: 1

Trägermaterial: Papier

Alte Reg.-Sig.: IV Fi 015

Bestell-Nr.: IV 00655 
05

\subsection{3}

05.03.03

05.03.03.02

05.03.03.02.09
Stadtverwaltung

Aufgabenbereiche der Stadtverwaltung

Öffentliche Ordnung und Sicherheit

Schutz der öffentlichen Ordnung

Vereine

Lfd. Nr. Titel

Laufzeit

592 Lokalverein Emden zur Pflege im Felde verwundeter und erkrankter deutscher Krieger

1873-1914

- Jahresrechnung des Lokalvereins Emden zur Pflege im Felde verwundeter und erkrankter deutscher Krieger, 1873

- Jahresrechnung der Kaiser-Wilhelm-Stiftung für deutsche Invaliden, Zweigverein Emden, 1873

- Kollekte des Lokalvereins Emden zur Pflege im Felde verwundeter und erkrankter deutscher Krieger, 1873

- Verfügung des Regierungspräsidenten in Aurich über Bestimmung der Gaststätte "Mahlstede's Tivoli" als Reservelazarett im Kriegsfall, September 1909

- Bescheid des Oberbürgermeisters Fürbringer über Ernennung der Mitglieder der Abschätzungs-Kommission mit Tätigkeit im Kriegsfall, September 1909

- Erlass des preußischen Innenministers über Erfassung von

Heilanstalten zur Verwundetenpflege, November 1914

$1873-1914$

Klassifikation Teil B: 00656

Band: 2

Trägermaterial: Papier

Alte Reg.-Sig.: IV Fi 015

Bestell-Nr.: IV 00656

593 Frauenverein für verwundete und kranke deutsche Krieger, Bd. 1

- Verfügung des preußischen Landdrosten in Aurich über Information über einen geplanten Basar des Vaterländischen Frauenvereins Hannover zugunsten der im Krieg gegen Frankreich verwundeten deutschen Soldaten und Bitte um Förderung, Oktober 1870

- Anforderung eines Berichtes über die Aktivitäten des Hilfsvereins durch den Provinzial-Delegierten für die freiwillige Krankenpflege in der Provinz Hannover, Februar 1871

- Bericht des Oberbürgermeisters der Stadt Emden über Tätigkeit des Emder Frauenvereins für verwundete und kranke deutsche Krieger, Januar 1871

- Antrag des Frauenvereins für verwundete und kranke deutsche Krieger auf Genehmigung zur Durchführung einer Lotterie zugunsten verwundeter Soldaten, Januar - März 1871

- Deponierung der Bücher des aufgelösten Frauenvereins für verwundete und kranke deutsche Krieger im Rathaus der Stadt Emden, Dezember 1871 - Januar 1872

- Zahlungen von Unterstützungen an Kriegsopfern aus dem Stiftungsfonds des Frauenvereins für verwundete und kranke deutsche Krieger, 1894 - 1900

1870 - 1872 (1894 - 1900)

Klassifikation Teil B: 00657

Band: 1

Trägermaterial: Papier

Alte Reg.-Sig.: IV Fi 015

Bestell-Nr.: IV 00657 
05

\subsection{3}

05.03.03

05.03.03.02

05.03.03.02.09
Stadtverwaltung

Aufgabenbereiche der Stadtverwaltung

Öffentliche Ordnung und Sicherheit

Schutz der öffentlichen Ordnung

Vereine

Lfd. Nr. Titel

Laufzeit

594 Frauenverein für verwundete und kranke deutsche Krieger, Bd. 2

- Sachspenden, Wohltätigkeitskonzerte und Sammlung der

Schulklassen auf Borkum zugunsten verwundeter Soldaten,

September 1870

- Kollekten des Frauenvereins für verwundete und kranke deutsche

Krieger zugunsten verwundeter Soldaten, Oktober 1870

- Schreiben des Kommandeurs des Ostfriesischen

Infanterie-Regiments Nr. 72, Ersatzbatallon, über Dank für die

Spenden des Frauenvereins für verwundete und kranke deutsche

Krieger, November 1870

- Spenden des Vaterländischen Frauenvereins zu Aurich für das

Lazarett in Emden, Oktober 1870

- Unterstützung für den Frauenverein für verwundete und kranke deutsche Krieger durch das ostfriesische Landschafts-Büro zur Pflege verwundeter und erkrankter Krieger, November 1870

1870

Klassifikation Teil B: 00658

Band: 2

Trägermaterial: Papier

Alte Reg.-Sig.: IV Fi 015

Bestell-Nr.: IV 00658

595 Frauenverein für verwundete und kranke deutsche Krieger, Bd. 3

- Rechnungsbücher über Einnahmen und Ausgaben des

Frauenvereins für verwundete und kranke deutsche Krieger für

Sendungen an Verwundete des X. Armeekorps, 1870

1870

Klassifikation Teil B: 00659

Band: 3

Trägermaterial: Papier

Alte Reg.-Sig.: IV Fi 015

Bestell-Nr.: IV 00659

596 Frauenverein für verwundete und kranke deutsche Krieger, Bd. 4

- Jahresrechnung des Frauenvereins für verwundete und kranke deutsche Krieger, 1870

- Belege zur Jahresrechnung, 1870 - 1871

$1870-1871$

Klassifikation Teil B: 00660

Band: 4

Trägermaterial: Papier

Alte Reg.-Sig.: IV Fi 015

Bestell-Nr.: IV 00660 
IV

05

Stadtverwaltung

05.03

05.03.03

05.03.03.02

05.03.03.02.09

Aufgabenbereiche der Stadtverwaltung

Öffentliche Ordnung und Sicherheit

Schutz der öffentlichen Ordnung

Vereine

Lfd. Nr. Titel

Laufzeit

597 Vereinsfahnen für Krieger- und Marinevereine

1868-1913

- Kabinettsordre des preußischen Königs Wilhelm I. über Verbot der kirchlichen Weihe von Kriegervereinsfahnen, März 1868

- Erlass des Oberpräsidenten der Provinz Hannover über Genehmigungspflicht zur Führung von Vereinsfahnen durch

Kriegervereine, Oktober 1872

- Verfügung des preußischen Landrosten über Missbilligung des eigenmächtigen Führens einer vom Frauenverein für verwundete und kranke deutsche Krieger übernommenen Fahne durch den

Kriegerverein Emden, August 1873

- Erlasse des preußischen Innenministers über Kriterien zur Erteilung der Fahnenerlaubnis für Kriegervereine, Januar 1887 - März 1913

- Fahnenmuster, 1887

- Fahnenmuster für Marinevereine, April 1903

Enthält auch:

- Antrag der Emder Fleischer-Innung auf Genehmigung einer

Fahnenweihe, Mai 1901

$1868-1913$

Klassifikation Teil B: 00661

Trägermaterial: Papier

Alte Reg.-Sig.: IV Fi 016

Bestell-Nr.: IV 00661 
IV

05

Stadtverwaltung

05.03

05.03.03

05.03.03.02

05.03.03.02.09

Aufgabenbereiche der Stadtverwaltung

Öffentliche Ordnung und Sicherheit

Schutz der öffentlichen Ordnung

Vereine

Lfd. Nr. Titel

Laufzeit

598 Krieger- und Marinevereine

$1873-1910$

- Verkauf von Waffen aus Heeresverbänden an Kriegervereine,

Oktober 1873 / Juni 1874

- Allerhöchster Erlass des preußischen Königs Wilhelm I. über

Erlaubnis zum Führen einer Fahne durch den Emder Kriegerverein,

Dezember 1873

- Statuten des Emder Kriegervereins, April 1882

- Erlass des preußischen Innenministers über Verbot einer

überbundesstaatlichen Organisation der Kriegervereine, August 1882

- Erlasse des preußischen Innenministers zur Beaufsichtigung der

Kriegervereine, 1882 - 1910

- Polizeiliche Beaufsichtigung der Kriegervereine, Oktober 1882

- Satzung des deutschen Kriegerbundes, Juni 1886

- Vorschrift über Ausschluss politisch unzuverlässiger Mitglieder aus den Kriegervereinen, 1891

- Erlass des preußischen Innenministers zur Beaufsichtigung der

Marinevereine, April 1898

- Teilnahme des Emder Kriegervereins an der Kaiserparade des X.

Armeekorps in Hannover, Juni 1898

- Satzung des preußischen Landes-Kriegerverbandes, Juli 1898

- Bericht des Emder Oberbürgermeisters L. Fürbringer über das

Kriegervereinswesen in Emden, September 1909

$1873-1910$

Klassifikation Teil B: 00662

Trägermaterial: Papier

Alte Reg.-Sig.: IV Fi 018

Bestell-Nr.: IV 00662 
- Antrag von Interessenten auf Genehmigung der Abhaltung einer Versammlung zur Gründung eines Kriegervereins in Emden, September 1872

- Antrag des Vorstands des Kriegervereins Emden auf Genehmigung der Vereinsstatuten, Oktober 1872

- Antrag des Vorstands des Kriegervereins Emden auf Ausleihung von Gewehren und Trommeln der Emder Bürgerwehr zur Abhaltung militärischer Begräbnisse für verstorbene Vereinsmitglieder, November 1872

- Antrag des Vorstands des Kriegervereins Emden auf Unterstützung durch die Stadt Emden, Januar 1873 - März 1907

- Plan des Kriegervereins zur Errichtung einer Volksbibliothek, Dezember 1874

- Anträge des Kriegervereins auf Genehmigung von

Statutenänderungen, 1875 - 1905

- Statuten und Satzungen des Kriegervereins Emden, 1878 / 1899

- Bericht des Polizeikommissars Bracke über einen unpietätsvollen Volksauflauf bei der vom Kriegeverein mit Musik und Gewehr begleiteten Beerdigung des Postboten Lührs, März 1887 - Verfügung des Regierungspräsidenten in Aurich über Verleihung eines Fahnenschmuckes und eines Wappennagels an den Emder Kriegerverein durch Kaiser Wilhelm II., Februar 1898

- Druckschrift: Kriegervereine gegen Sozialdemokratie, 1899

- Ostfriesischer Kriegertag in Emden in Verbindung mit dem Kaiserbesuch, Juli 1902

- Anträge des Emder Kriegervereins auf Genehmigung der Durchführung eines Marsches mit Musik, Mai 1908 / Juni 1912 - Anträge des Emder Kriegervereins auf Befreiung von der Lustbarkeitssteuer anlässlich von Sedansfeiern und Stiftungsfesten, August 1910 - August 1912

$1872-1913$

\author{
Klassifikation Teil B: 00663 \\ Trägermaterial: Papier \\ Alte Reg.-Sig.: IV Fi 019 \\ Bestell-Nr.: IV 00663
}

600 Verein Naturschutzpark e.V.

- Werbeschrift des Vereins Naturschutzpark e.V., Dezember 1911

- Druckscriften des Vereins mit Werbung für Naturparks, 1911 - 1914

- Unterstützung der Stadt Emden für den Naturpark "Wilseder Berg"

(Lüneburger Heide), Februar 1912

$1911-1914$

Klassifikation Teil B: 00665

Trägermaterial: Papier

Alte Reg.-Sig.: IV Fi 131

Bestell-Nr.: IV 00665 
IV

05

05.03

05.03.03

05.03.03.02

05.03.03.02.09
Stadtverwaltung

Aufgabenbereiche der Stadtverwaltung

Öffentliche Ordnung und Sicherheit

Schutz der öffentlichen Ordnung

Vereine

Lfd. Nr. Titel

Laufzeit

601 Vereinigung zur Erhaltung deutscher Burgen

1912

- Werbeschrift der Vereinigung zur Erhaltung deutscher Burgen, 1912

1912

Klassifikation Teil B: 00666

Trägermaterial: Papier

Alte Reg.-Sig.: IV Fi 132

Bestell-Nr.: IV 00666

602 Haus- und Grundbesitzerverein

- Jahresbericht des preußischen Landesverbands der Haus- und

Grundbesitzervereine, 1911

- Satzungen des Emder Haus und Grundbesitzervereins, 1907

- Initiative des preußischen Landesverbands der Haus- und

Grundbesitzervereine zur Senkung der Grundsteuer, 1911

- Einladung zum II. internationalen Hausbesitzerkongress in Berlin, April 1912

- Verschiedene Druckschriften des preußischen Landesverbands der Haus- und Grundbesitzervereine, 1912 - 1913

$1907-1913$

Klassifikation Teil B: 00667

Trägermaterial: Papier

Alte Reg.-Sig.: IV Fi 123

Bestell-Nr.: IV 00667

603 Lokalverein Emden zur Pflege im Felde verwundeter und erkrankter deutscher Krieger

- Jahresrechnung des Lokalvereins Emden zur Pflege im Felde verwundeter und erkrankter deutscher Krieger, 1874 - 1875

- Jahresrechnung der Kaiser-Wilhelm-Stiftung für deutsche Invaliden,

Zweigverein Emden, 1874

- Kollekte der Kaiser-Wilhelm-Stiftung für deutsche Invaliden,

Zweigverein Emden, 1874

- Kollekte des Lokalvereins Emden zur Pflege im Felde verwundeter und erkrankter deutscher Krieger, 1874 - 1875

$1874-1875$

Klassifikation Teil B: 00668

Band: 3

Trägermaterial: Papier

Alte Reg.-Sig.: IV Fi 015

Bestell-Nr.: IV 00668 
05

05.03

05.03.03

05.03.03.02

05.03.03.02.09
Stadtverwaltung

Aufgabenbereiche der Stadtverwaltung

Öffentliche Ordnung und Sicherheit

Schutz der öffentlichen Ordnung

Vereine

Lfd. Nr. Titel

Laufzeit

604 Lokalverein Emden zur Pflege im Felde verwundeter und erkrankter deutscher Krieger

- Jahresrechnung des Lokalvereins Emden zur Pflege im Felde verwundeter und erkrankter deutscher Krieger, 1876

- Kollekte des Lokalvereins Emden zur Pflege im Felde verwundeter und erkrankter deutscher Krieger, 1876

1876

\author{
Klassifikation Teil B: 00669 \\ Band: 4 \\ Trägermaterial: Papier \\ Alte Reg.-Sig.: IV Fi 015
}

Bestell-Nr.: IV 00669

605 Lokalverein Emden zur Pflege im Felde verwundeter und erkrankter deutscher Krieger

- Jahresrechnung des Lokalvereins Emden zur Pflege im Felde verwundeter und erkrankter deutscher Krieger, 1877 - 1878

$1877-1878$

Klassifikation Teil B: 00670

Band: 5

Trägermaterial: Papier

Alte Reg.-Sig.: IV Fi 015

Bestell-Nr.: IV 00670

606 Lokalverein Emden zur Pflege im Felde verwundeter und erkrankter deutscher Krieger

- Jahresrechnung der Kaiser-Wilhelm-Stiftung für deutsche Invaliden, Zweigverein Emden, 1879

- Kollekte der Kaiser-Wilhelm-Stiftung für deutsche Invaliden,

Zweigverein Emden, 1879

- Kollekte des Lokalvereins Emden zur Pflege im Felde verwundeter und erkrankter deutscher Krieger, 1879

- Kollekte für Hinterbliebene und Überlebende der

Besatzungsmitglieder des Untergangs des Panzerschiffs "Großer

Kurfürst", 1879

$1874-1875$

Klassifikation Teil B: 00671

Band: 6

Trägermaterial: Papier

Alte Reg.-Sig.: IV Fi 015

Bestell-Nr.: IV 00671 
05

05.03

05.03.03

05.03.03.02

05.03.03.02.09
Stadtverwaltung

Aufgabenbereiche der Stadtverwaltung

Öffentliche Ordnung und Sicherheit

Schutz der öffentlichen Ordnung

Vereine

Lfd. Nr. Titel

Laufzeit

607 Lokalverein Emden zur Pflege im Felde verwundeter und erkrankter deutscher Krieger

- Jahresrechnung des Lokalvereins Emden zur Pflege im Felde verwundeter und erkrankter deutscher Krieger, 1880 - 1881

- Jahresrechnung der Kaiser-Wilhelm-Stiftung für deutsche Invaliden, Zweigverein Emden, 1880 - 1881

- Kollekte der Kaiser-Wilhelm-Stiftung für deutsche Invaliden,

Zweigverein Emden, 1880 - 1881

$1880-1881$

Klassifikation Teil B: 00672

Band: 7

Trägermaterial: Papier

Alte Reg.-Sig.: IV Fi 015

Bestell-Nr.: IV 00672

608 Lokalverein Emden zur Pflege im Felde verwundeter und erkrankter deutscher Krieger

- Jahresrechnung des Lokalvereins Emden zur Pflege im Felde verwundeter und erkrankter deutscher Krieger, 1882 - 1883

- Jahresrechnung der Kaiser-Wilhelm-Stiftung für deutsche Invaliden,

Zweigverein Emden, 1882 - 1883

- Kollekte der Kaiser-Wilhelm-Stiftung für deutsche Invaliden,

Zweigverein Emden, 1882 - 1883

- Kollekte des Lokalvereins Emden zur Pflege im Felde verwundeter und erkrankter deutscher Krieger, 1882 - 1883

$1882-1883$

Klassifikation Teil B: 00673

Band: 8

Trägermaterial: Papier

Alte Reg.-Sig.: IV Fi 015

Bestell-Nr.: IV 00673

609 Lokalverein Emden zur Pflege im Felde verwundeter und erkrankter deutscher Krieger

- Jahresrechnung des Lokalvereins Emden zur Pflege im Felde verwundeter und erkrankter deutscher Krieger, 1884 - 1885

- Jahresrechnung der Kaiser-Wilhelm-Stiftung für deutsche Invaliden, Zweigverein Emden, 1884 - 1885

- Kollekte der Kaiser-Wilhelm-Stiftung für deutsche Invaliden,

Zweigverein Emden, 1884 - 1885

- Kollekte des Lokalvereins Emden zur Pflege im Felde verwundeter und erkrankter deutscher Krieger, 1884 - 1885

$1884-1885$

Klassifikation Teil B: 00674

Band: 9

Trägermaterial: Papier

Alte Reg.-Sig.: IV Fi 015

Bestell-Nr.: IV 00674 


\section{IV}

05

Stadtverwaltung

05.03

05.03.03

05.03.03.02

05.03.03.02.09

Aufgabenbereiche der Stadtverwaltung

Öffentliche Ordnung und Sicherheit

Schutz der öffentlichen Ordnung

Vereine

Lfd. Nr. Titel

Laufzeit

610 Lokalverein Emden zur Pflege im Felde verwundeter und erkrankter deutscher Krieger

- Jahresrechnung des Lokalvereins Emden zur Pflege im Felde verwundeter und erkrankter deutscher Krieger, 1886 - 1887

- Jahresrechnung der Kaiser-Wilhelm-Stiftung für deutsche Invaliden, Zweigverein Emden, 1886 - 1887

- Kollekte der Kaiser-Wilhelm-Stiftung für deutsche Invaliden,

Zweigverein Emden, 1886 - 1887

- Kollekte des Lokalvereins Emden zur Pflege im Felde verwundeter und erkrankter deutscher Krieger, 1886 - 1887

$1886-1887$

Klassifikation Teil B: 00675, 01

Band: 10

Trägermaterial: Papier

Alte Reg.-Sig.: IV Fi 015

Bestell-Nr.: IV 00675 a

611 Zweigverein vom Roten Kreuz Emden

1898

- Jahresrechnung des Emder Zweigvereins vom Roten Kreuz. 1898

1898

Klassifikation Teil B: 00675, 02

Band: 5

Trägermaterial: Papier

Alte Reg.-Sig.: IV Fi 015

Bestell-Nr.: IV 00675 b

612 Zweigverein vom Roten Kreuz Emden

$1901-1903$

- Jahresrechnung des Emder Zweigvereins vom Roten Kreuz. 1901 1903

- Jahresrechnung der Kaiser-Wilhelm-Stiftung für deutsche Invaliden,

Zweigverein Emden, 1901 - 1903

$1901-1903$

Klassifikation Teil B: 00676

Band: 6

Trägermaterial: Papier

Alte Reg.-Sig.: IV Fi 015

Bestell-Nr.: IV 00676

613 Zweigverein vom Roten Kreuz Emden

1908

- Kollekte des Emder Zweigvereins vom Roten Kreuz. 1908

1908

Klassifikation Teil B: 00677

Band: 7

Trägermaterial: Papier

Alte Reg.-Sig.: IV Fi 015

Bestell-Nr.: IV 00677 
05

\subsection{3}

05.03.03

05.03.03.02

05.03.03.02.09
Stadtverwaltung

Aufgabenbereiche der Stadtverwaltung

Öffentliche Ordnung und Sicherheit

Schutz der öffentlichen Ordnung

Vereine

Lfd. Nr. Titel

Laufzeit

614 Zweigverein vom Roten Kreuz Emden

$1909-1910$

- Kollekte des Emder Zweigvereins vom Roten Kreuz. 1909 - 1910

$1909-1910$

Klassifikation Teil B: 00678

Band: 8

Trägermaterial: Papier

Alte Reg.-Sig.: IV Fi 015

Bestell-Nr.: IV 00678

615 Vaterländischer Frauenverein, Zweigverein für Emden und Umgebung

- Antrag des Schatzmeisters des Vaterländischen Frauenvereins, Kreishauptmann v. Weyhe, auf Herausgabe von bei der Stadt Emden deponierten, dem Verein gehörigen Schuldverschreibungen der Berlin-Dresdener Eisenbahngesellschaft, Dezember 1880 - April 1897 - Antrag des Vaterländischen Frauenvereins, Zweigverein für Emden und Umgebung auf eine Beihilfe der Stadt Emden zur Unterhaltung der Diakonissen-Station, Januar 1881 - April 1897

- Antrag des Vaterländischen Frauenvereins, Zweigverein für Emden und Umgebung auf Genehmigung einer Verlosung, April 1881 November 1892

- Antrag des Vaterländischen Frauenvereins, Zweigverein für Emden und Umgebung auf Verleihung der Eigenschaft einer juristischen

Person, Mai 1881 - November 1882

- Legitimation des Vorstands des Vorstands der Industrieschule (weibliche Handarbeit) zum Verkauf des Schulgebäudes an den Vaterländischen Frauenverein, Oktober 1882 - April 1885

- Antrag des Vaterländischen Frauenvereins, Zweigverein für Emden und Umgebung auf Befreiung des Gebäudes der Diakonie-Station vom Stübergeld, Januar 1882

- Deponierung von Wertpapieren des Vaterländischen Frauenvereins bei der Stadt Emden, Mai 1883

- Vorstandswahlen beim Vaterländischen Frauenverein, Juni 1887

$1880-1897$

Klassifikation Teil B: 00679

Trägermaterial: Papier

Alte Reg.-Sig.: IV Fi 028

Bestell-Nr.: IV 00679

616 Vaterländischer Frauenverein, Zweigverein für Emden und Umgebung

- Statuten des Vaterländischen Frauenvereins, Zweigverein für Emden und Umgebung, 1882

1882

Klassifikation Teil B: 00680

Trägermaterial: Papier

Alte Reg.-Sig.: IV Fi 028

Bestell-Nr.: IV 00680 
IV

05

05.03

05.03.03

05.03.03.02

05.03.03.02.09
Stadtverwaltung

Aufgabenbereiche der Stadtverwaltung

Öffentliche Ordnung und Sicherheit

Schutz der öffentlichen Ordnung

Vereine

Lfd. Nr. Titel

Laufzeit

617 Verschiedene Vereine

1883-1893

(1857-1858)

- Antrag der Tanzgesellschaft "Concordia" auf Genehmigung ihrer

Statuten, Januar 1857

- Antrag des Emder Schach-Clubs auf Genehmigung seiner Statuten, März 1858

- Antrag des Singvereins "Union" auf Genehmigung seiner Gründung

(Legitimation), September 1858

- Statuten des Deutschen Kolonialvereins, Februar 1883 - Dezember

1886 / Juni 1893

- Jahresbericht des Deutschen Hilfsvereins in Wien, 1885 - 1887

- Antrag des Emder Clubs "Erholung" auf Genehmigung seiner

Statuten, März 1885

- Antrag des Technikervereins Emden auf Genehmigung seiner

Statuten, August 1885

- Antrag des Emder Gesellenvereins (Männergesangverein) auf

Genehmigung seiner Statuten, Februar 1886

- Werbung des "Komitees für ein Pariser Heim für deutsche

Erzieherinnen", April 1886 - Dezember 1887

- Antrag des Technikervereins Emden auf Legitimation seines

neugewählten Vorstandes, August 1886

- Antrag des Clubs "Einigkeit" auf Genehmigung seiner Statuten,

August 1889

- Anzeige über Gründung eines sozialdemokratischen Wahlvereins in

Emden, März 1890

- Druckschriften des Deutschen Kolonialvereins, 1893

(1857 - 1858) 1883 - 1893

Klassifikation Teil B: 00681

Trägermaterial: Papier

Alte Reg.-Sig.: IV Fi 022

Bestell-Nr.: IV 00681

618 Herberge zur Heimat

- Geschäftsberichte der Herberge zur Heimat (Anlaufstelle für Wandergesellen, reisende Arbeiter, Seeleute), 1882 - 1915 (1916 1930)

1882 - 1915 (1916 - 1930)

Klassifikation Teil B: 00682

Trägermaterial: Papier

Alte Reg.-Sig.: IV Fi 027

Bestell-Nr.: IV 00682 
IV

05

05.03

05.03.03

05.03.03.02

05.03.03.02.09

Lfd. Nr. Titel
Stadtverwaltung

Aufgabenbereiche der Stadtverwaltung

Öffentliche Ordnung und Sicherheit

Schutz der öffentlichen Ordnung

Vereine

619 Freimaurerloge in Emden

Laufzeit

- Erwerb eines Hauses in Emden durch die Freimaurer-Loge "Zur

1879-1892

(1854) wahren Treue", 1854

- Antrag der Freimaurer-Loge "Loge zur Ostfriesischen Union, Orient

Emden" auf Erlaubnis zur Deponierung einer Blechbüchse mit

Wertpapieren und Dokumenten bei der Stadt Emden, September -

Dezember 1879

- Aufstellung über Vorstandsmitglieder der Freimaurer-Loge "Loge zur

Ostfriesischen Union, Orient Emden", Januar 1892

(1854) 1879 - 1892

Klassifikation Teil B: 00683

Trägermaterial: Papier

Alte Reg.-Sig.: IV Fi 026

Bestell-Nr.: IV 00683

620 Kaufmännischer Verein

$1880-1913$

- Antrag des Kaufmännischen Vereins auf Genehmigung seiner

Statuten und Vereinszulassung, Mai 1880

- Einladung zu einem Vortrag von Dr. Sternberg vor dem

Kaufmännischen Verein, März 1912

- Einladung zu einem Lichtbildervortrag des Prof. Kindermann als

Werbung für die Deutsche Gesellschaft für

Kaufmanns-Erholungsheime, April 1913

$1880-1913$

Klassifikation Teil B: 00684

Trägermaterial: Papier

Alte Reg.-Sig.: IV Fi 025

Bestell-Nr.: IV 00684

621 Verein gegen das Moorbrennen

$1879-1880$

- Statuten des Vereins gegen das Moorbrennen, Juli 1870

- Mitgliedschaft der Stadt Emden im Verein gegen das Moorbrennen, Januar 1880

$1870-1880$

Klassifikation Teil B: 00685

Trägermaterial: Papier

Alte Reg.-Sig.: IV Fi 024

Bestell-Nr.: IV 00685 
- Verzeichnis der Wertpapiere im Reservefonds der Deutschen Gesellschaft zur Rettung Schiffsbrüchiger, Bezirksverwaltung Emden, 1879 - 1904

- Unterstützung der Stadt Emden für die Generalversammlungen des Vereins zur Rettung Schiffbrüchiger in Emden, April 1880 - April 1905

- Rettungsschuppen der Deutschen Gesellschaft zur Rettung

Schiffsbrüchiger auf Nesserland, April 1882

- Bei der Stadt Emden deponierte Wertpapiere des Bezirksvereins für die Ostfriesische Küste zur Rettung Schiffsbrüchiger, 1891 - 1893

- Verwaltung der bei der Stadt Emden deponierten Wertpapiere des Bezirksvereins für die Ostfriesische Küste zur Rettung

Schiffsbrüchiger, 1895 - 1896

- Jahresbericht des Bezirksvereins für die Ostfriesische Küste zur Rettung Schiffsbrüchiger, 1895

- Leserbrief des Pastors W.H. Janssen in der "Emder Zeitung" gegen Ehrenkränkung ostfriesischer Schiffsbrüchigenretter durch den Vorstand des Bezirksvereins für die Ostfriesische Küste zur Rettung Schiffsbrüchiger und gegen zu opulente Vereinsfeierlichkeiten, Februar 1902

- Jahresrechnung der Deutschen Gesellschaft zur Rettung Schiffsbrüchiger, 1903 - 1905

- Haushalt der Deutschen Gesellschaft zur Rettung Schiffsbrüchiger, 1905

- Verzeichnis der Stiftungsgelder der Gesellschaft zur Rettung Schiffsbrüchiger, 1905

- Protokoll der Versammlung der Gesellschaft zur Rettung Schiffsbrüchiger in Emden, Mai 1905

$1879-1905$

Klassifikation Teil B: 00686

Trägermaterial: Papier

Alte Reg.-Sig.: IV Fi 023

Bestell-Nr.: IV 00686 
05

\subsection{3}

05.03.03

05.03.03.02

05.03.03.02.09
Stadtverwaltung

Aufgabenbereiche der Stadtverwaltung

Öffentliche Ordnung und Sicherheit

Schutz der öffentlichen Ordnung

Vereine

Lfd. Nr. Titel

Laufzeit

623 Nationalliberaler Verein etc.

$1879-1880$

- Satzung des Nationalliberalen Vereins für die Stadt Emden, 1879

- Verzeichnis der Mitglieder des Nationalliberalen Vereins (zahlreiche Juden), 1879 / 1880

- Abschrift eines Erlasses des Oberpräsidenten der Provinz Hannover zur Förderung des Vereins gegen Hausbettelei, November 1879

- Eintritt der Stadt Emden als korporatives Mitglied im Fischereiverein zur Hebung der Fischereibetriebe an den ostfriesischen Gewässern, August 1880

- Gründung eines Vereins für Gabelsbergische Stenographie, Januar 1880

$1879-1880$

Klassifikation Teil B: 00687

Trägermaterial: Papier

Alte Reg.-Sig.: IV Fi 021

Bestell-Nr.: IV 00687

624 Verein für volkstümliche Musik

- Hebelisten (Mitgliedsbeiträge) des Vereins für volkstümliche Musik, 1914 (1923)

1914 (1923)

Klassifikation Teil B: 00688

Trägermaterial: Papier

Alte Reg.-Sig.: IV Fi 020

Bestell-Nr.: IV 00688

625 Filialverein für Vogelzucht, Geflügel- und Singvögelschutz

- Antrag des Filialvereins für Vogelzucht, Geflügel- und Singvögelschutz auf Genehmigung zur Anbringung von Nistkästen in den Wallanlagen und Zerstörung von Elsternestern, April 1873

- Antrag des Filialvereins für Vogelzucht, Geflügel- und

Singvögelschutz auf städtische Unterstützung für eine Ausstellung, März 1875 - Mai 1880

- Antrag des Filialvereins für Vogelzucht, Geflügel- und

Singvögelschutz auf Genehmigung einer Verlosung zur

Erwirtschaftung der Mittel zur Bestreitung von Ausstellungen, Mai

1875 - August 1880

- Druckschriften zum Vogelschutz, 1897 - 1909

- Preußische Ministerialerlasse zum Vogelschutz, 1907 - 1912

$1873-1912$

Klassifikation Teil B: 00689

Trägermaterial: Papier

Alte Reg.-Sig.: IV Fi 019

Bestell-Nr.: IV 00689 
IV

05

05.03

05.03.03

05.03.03.02

05.03.03.02.09

Lfd. Nr. Titel

\section{Stadtverwaltung}

Aufgabenbereiche der Stadtverwaltung

Öffentliche Ordnung und Sicherheit

Schutz der öffentlichen Ordnung

Vereine

626 Club zum Guten Endzweck

Laufzeit

- Verleihung des Status einer juristischen Persönlichkeit an den Club 1881-1912 zum Guten Endzweck, April - Oktober 1887

- Anzeige über Neuwahl des Vorstands des Clubs zum Guten

Endzweck, Dezember 1887 - Mai 1910

- Eingabe des Clubs zum Guten Endzweck an den Oberpräsidenten der Provinz Hannover durch die Hand des Magistrats der Stadt Emden über Bitte um Genehmigung des Ankaufs des Reemtsmaschen Hauses zum Zweck eines Clubhauses und Aufnahme einer Hypothek zur Kauffinanzierung, März - April 1899 - Eingabe des Clubs zum Guten Endzweck an den Oberpräsidenten der Provinz Hannover durch die Hand des Magistrats der Stadt Emden über Bitte um Genehmigung des Verkaufs des Clubhauses am Sandweg, Februar 1907

- Verfügung des Regierungspräsidenten in Aurich über Genehmigung des Erwerbs des Hauses des Architekten Georg Lüpnitz durch den Club zum Guten Endzweck, Mai 1910

- Gedrucktes Mitgliederverzeichnis des Clubs zum Guten Endzweck, Mai 1910

- Genehmigung einer Statutenänderung des Clubs zum Guten Endzweck im HInblick auf die personelle Stärke des Vorstands und das Aufnahmeverfahren, April 1912

$1887-1912$

Klassifikation Teil B: 00690

Trägermaterial: Papier

Alte Reg.-Sig.: IV Fi 035

Bestell-Nr.: IV 00690

627 Beamten-Haushaltungsverein

- Statuten des Beamten-Haushaltungsvereins (Konsum- und

Einkaufsgenossenschaft), 1890

- Antrag des Vorstands des Beamten-Haushaltungsvereins auf Legitimierung des Vereins durch die Stadt Emden, Oktober 1890

- Anzeige über Neuwahl des Vereinsvorstands, September 1891

$1890-1891$

Klassifikation Teil B: 00691

Trägermaterial: Papier

Alte Reg.-Sig.: IV Fi 037

Bestell-Nr.: IV 00691 
IV

05

Stadtverwaltung

05.03

05.03.03

05.03.03.02

05.03.03.02.09

Aufgabenbereiche der Stadtverwaltung

Öffentliche Ordnung und Sicherheit

Schutz der öffentlichen Ordnung

Vereine

Lfd. Nr. Titel

Laufzeit

628 Centralverein für das Wohl der arbeitenden Klassen und Zentralstelle für Volkswohlfahrt

1880-1913

- Werbung des Centralvereins für das Wohl der arbeitenden Klassen mit der Absicht der Bekämpfung der Sozialdemokratie, Februar 1880 März 1907

- Statut des Centralvereins für das Wohl der arbeitenden Klassen, 1872 / 1900

- Druckschriften des Centralvereins für das Wohl der arbeitenden

Klassen, 1894

- Druckschriften der Zentralstelle für Volkswohlfahrt, 1903 - 1913

- Erhebung der Zentralstelle für Volkswohlfahrt über Schulspeisung, Januar 1908

- Einladungen zu Konferenzen der Zentralstelle für Volkswohlfahrt, $1909-1913$

$1880-1913$ (1915)

Klassifikation Teil B: 00692

Trägermaterial: Papier

Alte Reg.-Sig.: IV Fi 034

Bestell-Nr.: IV 00692

629 Deutsch-freisinnige Partei

- Anzeige über Begründung eines Vereins der Deutsch-freisinnigen

Partei in Emden, April 1884

- Statuten der Deutsch-freisinnigen Partei, 1884

- Mitgliederliste der Deutsch-freisinnigen Partei, 1884

1884

Klassifikation Teil B: 00693

Trägermaterial: Papier

Alte Reg.-Sig.: IV Fi 033

Bestell-Nr.: IV 00693 
05

\subsection{3}

05.03.03

05.03.03.02

05.03.03.02.09
Stadtverwaltung

Aufgabenbereiche der Stadtverwaltung

Öffentliche Ordnung und Sicherheit

Schutz der öffentlichen Ordnung

Vereine

Lfd. Nr. Titel

Laufzeit

630 Emder Bürgerverein

1891-1894

- Antrag des Emder Bürgervereins auf Zulassung, März 1891

- Antrag des Emder Bürgervereins auf Genehmigung einer

Volksversammlung zur Werbung für den Verein, März 1891

- Satzungen des Emder Bürgervereins, 1891

- Mitgliederlisten des Emder Bürgervereins, März 1891 - Juni 1893

- Antrag des Emder Bürgervereins auf Genehmigung einer Sammlung

zur Finanzierung einer Eingabe an den Kaiser, März 1891

- Konflikt zwischen Magistrat der Stadt Emden und dem Emder

Bürgerverein wegen Nichtberücksichtigung von Beschwerden des

Bürgervereins unter der Begründung eines nicht vorhandenen

Petitionsrechtes von Vereinen, September 1892 - Januar 1893

- Verfügung des Regierungspräsidenten in Aurich über

Aussichtslosigkeit des Antrages des Emder Bürgervereins auf den

Status einer juristischen Person wegen Mitellosigkeit, April - Mai 1893

- Jahresbericht des Emder Bürgervereins, Mai 1894

- Anmeldungen von Versammlungen des Vereins, 1894

$1891-1894$

Klassifikation Teil B: 00695

Trägermaterial: Papier

Alte Reg.-Sig.: IV Fi 038

Bestell-Nr.: IV 00695

631 Deutscher Tischlerverband, Zahlstelle Emden

$1892-1893$

- Statuten des Deutschen Tischlerverbands, 1888 - 1890

- Mitgliederverzeichnis des Deutschen Tischlerverbands, Zahlstelle

Emden, 1892

- Anmeldung einer Versammlung des Deutschen Tischlerverbands,

Zahlstelle Emden, 1892

- Anzeige über Auflösung des Vereins wegen Austritts aller Mitglieder, Mai 1893

$1888-1893$

Klassifikation Teil B: 00696

Trägermaterial: Papier

Alte Reg.-Sig.: IV Fi 039

Bestell-Nr.: IV 00696 
05

\subsection{3}

05.03.03

05.03.03.02

05.03.03.02.09
Stadtverwaltung

Aufgabenbereiche der Stadtverwaltung

Öffentliche Ordnung und Sicherheit

Schutz der öffentlichen Ordnung

Vereine

Lfd. Nr. Titel

Laufzeit

632 Allgemeiner Arbeiterverein für Emden und Umgebung

1891-1912

- Statuten des sozialdemokratischen Arbeitervereins für Emden und Umgebung, 1891

- Anzeige einer sozialdemokratischen Versammlung durch Carl

Bigitschke, März 1891

- Protokoll des Polizeiwachtmeisters Lauter über

Gründungsversammlung eines sozialdemokratischen Arbeitervereins

in Emden, März 1891

- Statuten des Allgemeinen Arbeitervereins für Emden und

Umgebung, März 1891

- Mitgliederverzeichnis des Allgemeinen Arbeitervereins für Emden und Umgebung, März 1891 - März 1892

- Begründung eines Zweigvereins des Unterstützungsvereins der Bürsten- und Pinselmacher Deutschlands, Oktober - November 1891

- Bannerweihe des Arbeiter-Radfahrer-Vereins "Vorwärts", Emden,

Februar - März 1908

- Vertrauliche Bericht des Gendarmen Strippelmann über Agitation des Transportarbeiterverbandes unter Seeleuten, August 1912

$1891-1912$

Klassifikation Teil B: 00697

Trägermaterial: Papier

Alte Reg.-Sig.: IV Fi 040

Bestell-Nr.: IV 00697

633 Gesellschaft für deutsche Erziehungs- und Schulgeschichte

- Werbeschrift der Gesellschaft für deutsche Erziehungs- und

Schulgeschichte, 1893

- Statuten der Gesellschaft für deutsche Erziehungs- und

Schulgeschichte, 1893

- Mitgliedschaft der Stadt Emden in der Gesellschaft für deutsche

Erziehungs- und Schulgeschichte, 1893 - 1913

- Generalversammlungen der Gesellschaft für deutsche Erziehungsund Schulgeschichte, Juni 1899 - November 1904

- Programm der Hauptversammlung des Vereins für historische

Wappenkunde in Berlin, Juni 1898

$1893-1913$

Klassifikation Teil B: 00698

Trägermaterial: Papier

Alte Reg.-Sig.: IV Fi 043

Bestell-Nr.: IV 00698 
05

\subsection{3}

05.03.03

05.03.03.02

05.03.03.02.09
Stadtverwaltung

Aufgabenbereiche der Stadtverwaltung

Öffentliche Ordnung und Sicherheit

Schutz der öffentlichen Ordnung

Vereine

Lfd. Nr. Titel

Laufzeit

634 Ostfriesischer Kriegerbund

1899-1913

- Antrag des ostfriesischen Kriegerbundes auf eine Beihilfe der Stadt

Emden für ihre Unterstützungskasse für bedürftige Veteranen, deren

Witwen oder Waisen, März 1899

- Geschäftsbericht der Sterbekasse des Deutschen Kriegerbundes,

April 1903 - März 1908

- Erlass des preußischen Innenministers über Aufforderung der

Verwaltungsbehörden zur Durchsetzung der Beitragserhöhung des

Deutschen Kriegerbundes zur besseren Ausstattung der

Unterstützungskasse des Bundes und Verhinderung des Austritts

einzelner Kriegervereine aus dem Verbund, September 1906

- Satzung der Sterbekasse und des Versicherungsverbandes des

Deutschen Kriegerbundes, 1907

Geschäftsberichte des Deutschen Kriegerbundes, 1908 - 1913

- Geschäftsberichts des Preußischen Landeskriegerverbandes, 1902 1912

$1891-1913$

Klassifikation Teil B: 00699

Trägermaterial: Papier

Alte Reg.-Sig.: IV Fi 053

Bestell-Nr.: IV 00699

635 Ortsverband der städtischen Beamten

$1898-1913$

- Statuten des Ortsverbandes der städtischen Beamten, März 1898

- Verzeichnis der Mitglieder des Ortsverbandes der städtischen

Beamten, März 1898

- Beihilfe der Stadt Emden für ein Erholungsheim des

Zentralverbandes der Gemeindebeamten Preußens, Dezember 1904 Januar 1905

- Antrag des Ortsverbandes der städtischen Beamten auf Teilnahme von Vertretern des Magistrats an der 1910 in Emden stattfindenden Jahresversammlung des Verbandes der Gemeindebeamten der

Provinz Hannover, April 1909

- Einladung zur Jahresversammlung des Verbandes der

Gemeindebeamten der Provinz Hannover in Emden, Mai 1910

- Werbung für eine Veruntreuungsversicherung des Bundes

Deutscher Gemeindebeamter, Juni 1912

- Werbung für die Schule für Verwaltungsbeamte in Cottbus, 1913

$1898-1913$

Klassifikation Teil B: 00700

Trägermaterial: Papier

Alte Reg.-Sig.: IV Fi 050

Bestell-Nr.: IV 00700 
05

05.03

05.03.03

05.03.03.02

05.03.03.02.09
Stadtverwaltung

Aufgabenbereiche der Stadtverwaltung

Öffentliche Ordnung und Sicherheit

Schutz der öffentlichen Ordnung

Vereine

Lfd. Nr. Titel

Laufzeit

636 Emder Colonialwaren-Detaillisten-Verein

1898-1908

- Gedrucktes Statut des Emder Colonialwaren-Detaillisten-Vereins,

1898

- Anzeige über Gründung des Emder

Colonialwaren-Detaillisten-Vereins, Mai 1898

- Mitgliederverzeichnis des Emder Colonialwaren-Detaillisten-Vereins,

Mai 1898

- Protest des Emder Colonialwaren-Detaillisten-Vereins gegen den Verkauf von Schokolade und Süßigkeiten zu Fabrikpreisen durch den

Geschäftsführer Stoppel in der Kranstraße, September 1908

$1898-1908$

Klassifikation Teil B: 00701

Trägermaterial: Papier

Alte Reg.-Sig.: IV Fi 051

Bestell-Nr.: IV 00701

637 Technikerverein für Emden und Umgegend

1898-1902

- Statuten des Technikervereins für Emden und Umgegend , 1898

- Protokoll über Konstituierung des Technikervereins für Emden und

Umgegend und Wahl des Vorstands, November 1898

- Antrag des Vorstandes des Technikervereins für Emden und

Umgegend auf Zulassung, Februar 1899

- Verzeichnis der Mitglieder des Technikervereins für Emden und

Umgegend, Februar 1899

- Vorstand des Technikervereins für Emden und Umgegend, 1902

$1898-1902$

Klassifikation Teil B: 00702

Trägermaterial: Papier

Alte Reg.-Sig.: IV Fi 052

Bestell-Nr.: IV 00702

638 Deutscher Flottenverein

1898-1914

(1915)

- Plakat des Deutschen Flottenvereins über deutsche Kriegsschiffe und Flottenstärken der Seemächte, 1898

- Erlass des Oberpräsidenten der Provinz Hannover über Förderung der Bestrebungen des Deutschen Flottenvereins, Januar 1899 /

November 1900

- Finanzierung der Herstellung von fünf Aufnahmen des Emder Hafens für einen Aufsatz in der Zeitschrift des Deutschen

Flottenvereins durch die Stadt Emden, Oktober 1913 - Januar 1914

- Vortragsreihe des Deutschen Flottenvereins, 1915

1898 - 1914 (1915)

Klassifikation Teil B: 00703

Trägermaterial: Papier

Alte Reg.-Sig.: IV Fi 054

Bestell-Nr.: IV 00703 
IV

05

05.03

05.03.03

05.03.03.02

05.03.03.02.09

Stadtverwaltung

Aufgabenbereiche der Stadtverwaltung

Öffentliche Ordnung und Sicherheit

Schutz der öffentlichen Ordnung

Vereine

Lfd. Nr. Titel

Laufzeit

639 Eisenbahnverein Emden

1900-1912

- Satzung des Eisenbahnvereins Emden, 1900

- Antrag des Eisenbahnvereins auf Genehmigung eines Festzuges mit

Musik, Mai 1901

- Statuten der Sterbekasse des Verbandes deutscher

Eisenbahnhandwerker und -Arbeiter, 1905

- Anzeige von Festen des Eisenbahnvereins, 1905 - 1908

- Satzung des Vereins deutscher Lokomotivführer und Heizer, 1906

- Antrag des Vereins "Lokomotive" (Vereinigung von

Lokomotivführern) auf Genehmigung eines Familienabends im Hotel

"Union", Februar 1907

- Antrag des Vereins "Lokomotive" (Vereinigung von

Lokomotivführern) auf Genehmigung eines Festes zum

Dienstjubiläum ihres Vorsitzenden August Zopp, April 1907

- Antrag auf Genehmigung einer Versammlung des Vereins deutscher

Lokomotivführer und Heizer in Emden, Mai 1907

- Antrag des Eisenbahnfahrbeamtenverein auf Erlass der

Vergnügungssteuer wegen seines Stiftungsfestes, Dezember 1911

$1900-1912$

Klassifikation Teil B: 00704

Trägermaterial: Papier

Alte Reg.-Sig.: IV Fi 056

Bestell-Nr.: IV 00704

640 Ortsgruppe des Nationalsozialen Vereins

1900

- Bereitschaft des Tocjterschuldirektors A.E. Zwitzers zur Übernahme der Funktion als Vertrauensmann des Nationalsozialen Vereins, Juni 1900

1900

Klassifikation Teil B: 00705

Trägermaterial: Papier

Alte Reg.-Sig.: IV Fi 055

Bestell-Nr.: IV 00705

641 Zweigverein der Gustav-Adolf-Stiftung

$1900-1910$

- Deponierung der Wertpapiere des Zweigvereins der

Gustav-Adolf-Stiftung bei der Stadt Emden, 1900 - 1910

- Klärung der Erbschaftssteuerpflicht auf ein dem Zweigverein der

Gustav-Adolf-Stiftung vererbtes Legat, 1910

$1900-1910$

Klassifikation Teil B: 00706

Trägermaterial: Papier

Alte Reg.-Sig.: IV Fi 057

Bestell-Nr.: IV 00706 
IV

05

Stadtverwaltung

05.03

05.03.03

05.03.03.02

05.03.03.02.09

Aufgabenbereiche der Stadtverwaltung

Öffentliche Ordnung und Sicherheit

Schutz der öffentlichen Ordnung

Vereine

Lfd. Nr. Titel

Laufzeit

642 Ruderverein Emden

1901-1912

- Eintrag des "Rudervereins Emden" in das Vereinsregister des Emder Amtsgerichts, August - Dezember 1901

- Verfügung des Regierungspräsidenten in Aurich über Mitteilung des ablehnenden Bescheids auf eine Eingabe des Rudervereins Emden über Bitte um Überweisung eines Sportruderbootes, Juli 1901

- Eingabe des Rudervereins Emden an die Stadt Emden über Bitte um Überlassung eines Teils des Tonnenschuppens als Bootslager und um Anlegeerlaubnis an der Kayung des städtischen Bauhofs, Mai 1902

- Eintragung des "Emder Rudervereins v. 1906" in das

Vereinsregister, Februar 1907

- Verzicht des Rudervereins Ostfriesland auf den von der Stadt

Emden angebotenen Platz für das Bootshaus wegen Verschiebung des Bauvorhabens, Juli 1912

- Unterstützung der Stadt Emden für den Schülerruderverein "Wiking" zur Anschaffung eines Bootes, August - September 1912

$1901-1912$

Klassifikation Teil B: 00707

Trägermaterial: Papier

Alte Reg.-Sig.: IV Fi 059

Bestell-Nr.: IV 00707 
05

\subsection{3}

05.03.03

05.03.03.02

05.03.03.02.09
Stadtverwaltung

Aufgabenbereiche der Stadtverwaltung

Öffentliche Ordnung und Sicherheit

Schutz der öffentlichen Ordnung

Vereine

Lfd. Nr. Titel

Laufzeit

643 Militärverein Emden

1901-1912

- Satzung des Emder Militärvereins, September 1901 - Januar 1902

- Antrag des Militärvereins bei der Stadt Emden auf Genehmigung seiner Satzung, Oktober 1901 - Februar 1902

- Mitgliederverzeichnis des Militärvereins, 1901

- Stellungnahme des preußischen Landeskriegerverbands über nichtvorliegende Notwendigkeit der Begründung eines weiteren Kriegevereins in Form eines Militärvereins in Emden, November 1901

- Verfügung des Regierungspräsidenten in Aurich über Zulassung des Militärvereins Emden wegen aus seiner Sicht nicht vorhandener Beeinträchtigung des bestehenden Kriegervereins, Januar 1902 - Programm der Feier des Kaisergeburtstages im "Tivoli" durch den Mllitärverein und Antrag auf Befreiung von der Vergnügungssteuer, Januar 1902 - Januar 1908

- Protest des Ostfriesischen Kriegerbundes gegen die Zulassung des Militärvereins Emden als Konkurrent des Emder Kriegervereins,

Februar 1902

- Beschwerden gegen den Militärverein Emden wegen Lärmbelästigung durch nächtliche Märsche mit Musik, Juni - Juli 1902 - Antrag des Militärvereins Emden beim preußischen Innenminister durch die Hände des Magistrats der Stadt Emden und des Regierungspräsidenten in Aurich auf Gewährung des Rechts zur Führung einer eigenen Fahne, Februar - September 1904 - Antrag des Militärvereins auf Befreiung von der Lustbarkeitssteuer wegen seines Stiftungsfestes, September 1905

- Anzeigen über Ausmärsche des Militärvereins Emden, 1908 - 1912

$1901-1912$

Klassifikation Teil B: 00708

Trägermaterial: Papier

Alte Reg.-Sig.: IV Fi 062

Bestell-Nr.: IV 00708

644 Lesehalle, Volksheime

- Eingabe des Konsuls Bernhard Brons jun. an die Stadt Emden über Bitte um Zuschuss für die Einrichtung und den Betrieb einer öffentlichen Lesehalle, April 1899

- Werbung des Vereins zur Verbreitung guter, volkstümlicher Schriften um Unterstützung, 1899

- Förderung von Lehrlingsheimen zur Weiterbildung der gewerblichen Jugend, 1900

- Initiative zur Errichtung von Volksheimen zur Hebung der Volkskultur und zur Bekämpfung des Alkoholmissbrauchs nach Hamburger Vorbild, 1902 - 1903

- Arbeit der Gesellschaft zur Verbreiterung der Volksbildung, 1900 1905

1899 - 1905

Klassifikation Teil B: 00709

Trägermaterial: Papier

Alte Reg.-Sig.: IV Fi 063 b

Bestell-Nr.: IV 00709 
05

\subsection{3}

05.03.03

05.03.03.02

05.03.03.02.09
Stadtverwaltung

Aufgabenbereiche der Stadtverwaltung

Öffentliche Ordnung und Sicherheit

Schutz der öffentlichen Ordnung

Vereine

Lfd. Nr. Titel

Laufzeit

645 Rotes Kreuz

1870-1902

- Anträge der Kaiser Wilhelm - Stiftung und des Emder Lokalvereins zur Pflege der im Felde verwundeten und erkrankten Krieger auf Genehmigung von Kollekten, 1876 - 1888

- Gemeinsamer Erlass des preußischen Innenministers, des Kriegsministers und des Ministers für geistliche Unterrichts- und Medizinalangelegenheiten über Forderung der Ausbildung von Personal für Erste Hllfe nach Unfällen, Juli 1897

- Werbung des Roten Kreuzes für ihre Erholungsstätten, Januar 1902

$1870-1902$

Klassifikation Teil B: 00710

Trägermaterial: Papier

Alte Reg.-Sig.: IV Fi 064

Bestell-Nr.: IV 00710

646 Deutscher Verein gegen den Missbrauch geistiger Getränke

- Druckschriften des Deutschen Vereins gegen den Missbrauch geistiger Getränke, 1903 - 1905

- Beitritt der Stadt Emden als korporatives Mitglied zum Deutschen

Verein gegen den Missbrauch geistiger Getränke, März 1902

- Gesuch des Deutschen Vereins gegen den Missbrauch geistiger

Getränke um Erhöhung des Beitrags der Stadt Emden, Oktober 1906

$1903-1906$

Klassifikation Teil B: 00711

Trägermaterial: Papier

Alte Reg.-Sig.: IV Fi 065

Bestell-Nr.: IV 00711

647 Historischer Verein für Niedersachsen

- Werbung des Historischen Vereins für Niedersachsen um neue

Mitglieder, 1902

- Veranstaltung des Niedersachsen-Tages durch den Historischen

Verein für Niedersachsen, Juli 1902

- Einladungen zu Tagungen der Historischen Kommission für

Hannover, Bremen und Oldenburg, 1923 - 1928

- Einladungen zu Tagungen des Wirtschaftsbundes Niedersachsen -

Kassel, 1932

$1902(1923-1932)$

Klassifikation Teil B: 00712

Trägermaterial: Papier

Alte Reg.-Sig.: IV Fi 066

Bestell-Nr.: IV 00712 
05

05.03

05.03.03

05.03.03.02

05.03.03.02.09
Stadtverwaltung

Aufgabenbereiche der Stadtverwaltung

Öffentliche Ordnung und Sicherheit

Schutz der öffentlichen Ordnung

Vereine

Lfd. Nr. Titel

Laufzeit

648 Wykverein der VI. Wyk

1902

- Mitgliederverzeichnis, 1902

- Statuten des Wykvereins, 1902

1902

Klassifikation Teil B: 00713

Trägermaterial: Papier

Alte Reg.-Sig.: IV Fi 068

Bestell-Nr.: IV 00713

649 Verein für hansische Geschichte und Verein für niedersächsische

1900-1902 Sprachforschung

- Einladung der Stadt Emden an den Verein für hansische Geschichte und den Verein für niedersächsische Sprachforschung für eine

Tagung in Emden, 1900 - 1901

- Presseberichte über Versammlungen des Vereins für hansische

Geschichte, 1900 - 1901

- Organisation der Tagung des Vereins für hansische Geschichte und des Vereins für niedersächsische Sprachforschung durch die Stadt

Emden, Februar - Mai 1902

- Beitritt der Stadt Emden zum hansischen Geschichtsverein, Mai

1902

- Statuten des hansischen Geschichtsvereins, 1875 / 1902

- Satzungen des Vereins für niedersächsische Sprachforschung, 1902

- Tagesordnung der Versammlung des Vereins für hansische

Geschichte und des Vereins für niedersächsische Sprachforschung,

Mai 1902

- Mitglieder des Lokal - Komitees zur Organisation der Tagung des hansischen Geschichtsvereins in Emden, 1902

- Presseberichte über Tagung des Vereins für hansische Geschichte und des Vereins für niedersächsische Sprachforschung, 1902

$1900-1902$

Klassifikation Teil B: 00714

Trägermaterial: Papier

Alte Reg.-Sig.: IV Fi 060

Bestell-Nr.: IV 00714 
05

\subsection{3}

05.03.03

05.03.03.02

05.03.03.02.09
Stadtverwaltung

Aufgabenbereiche der Stadtverwaltung

Öffentliche Ordnung und Sicherheit

Schutz der öffentlichen Ordnung

Vereine

Lfd. Nr. Titel

Laufzeit

650 Verein zur Unterstützung von elternlosen, nicht mehr pensionsberechtigten, ledigen Töchtern der reformierten Pastoren, später: Ostfriesische reformierte Pfarrtöchterkasse auf Gegenseitigkeit

- Statuten des Vereins zur Unterstützung von elternlosen, nicht mehr pensionsberechtigten, ledigen Töchtern der reformierten Pastoren, 1900

- Eintragung des Vereins in das Vereinsregister beim Amtsgericht Emden, Dezember 1900 - Juni 1904

- Erlass des preußischen Ministers der geistlichen, Unterrichts- und Medizinalangelegenheiten über Verbot der Eintragung des Vereins in das Vereinsregister wegen Versicherungscharakter, Dezember 1901 - Verfügung des Regierungspräsidenten in Aurich über Status des Vereins als Versicherungsunternehmen und notwendige Anpassung der Satzung an das Privatversicherungsgesetz, August 1904

- Revidierte Satzung des Vereins zur Unterstützung von elternlosen, nicht mehr pensionsberechtigten, ledigen Töchtern der reformierten Pastoren, Oktober 1904

- Jahresberichte des Vereins zur Unterstützung von elternlosen, nicht mehr pensionsberechtigten, ledigen Töchtern der reformierten

Pastoren, 1906 - 1910

$1900-1911$

Klassifikation Teil B: 00715

Trägermaterial: Papier

Alte Reg.-Sig.: IV Fi 058

Bestell-Nr.: IV 00715

651 Deutsches Schriftsteller-Heim in Jever

- Werbung um Unterstützung zur Errichtung eines Schriftstellerheims in Jever, 1899 - 1903

$1899-1903$

Klassifikation Teil B: 00716

Trägermaterial: Papier

Alte Reg.-Sig.: IV Fi 061

Bestell-Nr.: IV 00716

652 Singverein "Frohsinn"

- Statuten des Singvereins "Frohsinn", März 1877

1877

Klassifikation Teil B: 00717

Trägermaterial: Papier

Alte Reg.-Sig.: IV Fi 063

Bestell-Nr.: IV 00717 
IV

05

05.03

05.03.03

05.03.03.02

05.03.03.02.09
Stadtverwaltung

Aufgabenbereiche der Stadtverwaltung

Öffentliche Ordnung und Sicherheit

Schutz der öffentlichen Ordnung

Vereine

Lfd. Nr. Titel

Laufzeit

653 Bezirksverein für den 1. und 2. Bezirk der III Wyk

1902

- Anzeige über Gründung des Bezirksvereins für den 1. und 2. Bezirk der III Wyk, September 1902

- Statuten des Bezirksvereins für den 1. und 2. Bezirk der III Wyk,

September 1902

1902

Klassifikation Teil B: 00718

Trägermaterial: Papier

Alte Reg.-Sig.: IV Fi 070

Bestell-Nr.: IV 00718

654 Musikverein Emden

1902-1909

- Gesuch des Musikvereins Emden um Unterstützung durch die Stadt Emden beim Ausbau seines Orchesters, Oktober 1902

- Satzungen des Musikvereins Emden, 1907

- Antrag des Musikvereins Emden auf Befreiung von der

Vergnügungssteuer für seine Veranstaltungen, Juni 1909

$1902-1909$

Klassifikation Teil B: 00719

Trägermaterial: Papier

Alte Reg.-Sig.: IV Fi 071

Bestell-Nr.: IV 00719

655 Zentralverband der Zimmerer Deutschlands, Zahlstelle Emden

$1901-1907$

- Statuten des Zentralverbands der Zimmerer Deutschlands, Zahlstelle Emden, Juli 1901

- Anzeige über Abhaltung des Stiftungsfestes des Zentralverbands der Zimmerer Deutschlands, Zahlstelle Emden, April 1907

$1901-1907$

Klassifikation Teil B: 00720

Trägermaterial: Papier

Alte Reg.-Sig.: IV Fi 072

Bestell-Nr.: IV 00720

656 Deutscher Schulschiffverein

- Werbung um Unterstützung für den Deutschen Schulschiffverein, Januar 1903

1903

Klassifikation Teil B: 00721

Trägermaterial: Papier

Alte Reg.-Sig.: IV Fi 074

Bestell-Nr.: IV 00721 
IV

05

05.03

05.03.03

05.03.03.02

05.03.03.02.09

Stadtverwaltung

Aufgabenbereiche der Stadtverwaltung

Öffentliche Ordnung und Sicherheit

Schutz der öffentlichen Ordnung

Vereine

Lfd. Nr. Titel

Laufzeit

657 Verein der Maschinisten und Heizer "Volldampf"

1903-1908

- Satzung des Vereins der Maschinisten und Heizer "Volldampf"

(Ortsverein Emden), Februar 1903

- Statuten des Seemaschinistenvereins für Emden und Umgegend,

1903

- Gesuch des Vereins der Maschinisten und Heizer "Volldampf" um Unterstützung der Stadt Emden für die Errichtung einer Fachschule zur Ausbildung von Seemaschinisten, Juni 1903

Anzeige über Abhaltung des Stiftungsfestes des Vereins der

Maschinisten und Heizer "Volldampf", März 1907 / Februar 1908

$1903-1908$

Klassifikation Teil B: 00722

Trägermaterial: Papier

Alte Reg.-Sig.: IV Fi 075

Bestell-Nr.: IV 00722

658 Centralverein der Maurer Deutschlands, Zweigverein Emden

1903-1907

- Pressebericht über auf einer Versammlung des Centralvereins der Maurer Deutschlands, Zweigverein Emden erörterte Missstände auf Emder Baustellen, Juli 1903

- Anzeige über Stiftungsfest des Centralvereins der Maurer

Deutschlands, Zweigverein Emden im "Tivoli", Juli 1906 / Juni 1907

- Antrag des Centralvereins der Maurer Deutschlands, Zweigverein Emden auf Genehmigung eines Marsches mit Musik zur Bestattung eines verstorbenen Mitgliedes, September 1907

$1903-1907$

Klassifikation Teil B: 00723

Trägermaterial: Papier

Alte Reg.-Sig.: IV Fi 078

Bestell-Nr.: IV 00723 
05

05.03

05.03.03

05.03.03.02

05.03.03.02.09
Stadtverwaltung

Aufgabenbereiche der Stadtverwaltung

Öffentliche Ordnung und Sicherheit

Schutz der öffentlichen Ordnung

Vereine

Lfd. Nr. Titel

Laufzeit

659 Guttemplerorden, Loge Friesland

$1902-1913$

- Gesuch des Guttemplerordens, Loge Friesland um eine mietweise Überlassung eines Raumes durch die Stadt Emden für

Veranstaltungen des Ordens mit dem Ziel der "sittlichen Hebung und ethischen Vervollkommnung des Menschengeschlechts", September 1902 / Juni 1911

- Mitgliederlisten des Guttemplerordens, Loge Friesland, 1902

- Anträge des Guttemplerordens, Loge Friesland bei der Stadt Emden auf Genehmigung seiner Veranstaltungen, März 1904 - Januar 1913 - Antrag des Guttemplerordens, "Durch die Brandung", bei der Stadt Emden auf Überlassung von Räumlichkeiten für Vereinsveranstaltungen, Februar 1911

- Feier zum zehnjährigen Bestehen des Guttemplerordens mit einer Rede des Oberbürgermeisters Leo Fürbringer, November / Dezember 1911

- Druckschriften des Guttemplerordens, 1905 - 1911

$1902-1913$

Klassifikation Teil B: 00724

Trägermaterial: Papier

Alte Reg.-Sig.: IV Fi 069

Bestell-Nr.: IV 00724

660 Deutscher Zentralverein zur Fürsorge für die schulentlassene Jugend

$1902-1913$

- Druckschriften des Deutschen Zentralvereins zur Fürsorge für die schulentlassene Jugend, 1905 - 1913

- Werbung des Deutschen Zentralvereins zur Fürsorge für die schulentlassene Jugend um Unterstützung, 1903 / 1905

- Jahresberichte des Deutschen Zentralvereins zur Fürsorge für die schulentlassene Jugend, 1902 - 1904

- Von der Stadt Emden ausgefüllter Fragebogen über Einrichtungen der Jugendhilfe für eine Erhebung im Regierungsbezirk Aurich, 1911

$1902-1913$

Klassifikation Teil B: 00725

Trägermaterial: Papier

Alte Reg.-Sig.: IV Fi 073

Bestell-Nr.: IV 00725

661 Ostfriesischer Lehrerverein

1903-1909

- Ostfriesische Schulblätter, Zeitschrift des Ostfriesischen

Lehrervereins, 1905

- Festbuch der Ostfriesischen Lehrerversammlung in Emden, April

1909

- Anzeige über Hauptversammlung des Ostfriesischen Lehrervereins, April 1903

$1903-1909$

Klassifikation Teil B: 00725,01

Trägermaterial: Papier

Alte Reg.-Sig.: IV Fi 076

Bestell-Nr.: IV 00725 a 
IV

05

05.03

05.03.03

05.03.03.02

05.03.03.02.09

Stadtverwaltung

Aufgabenbereiche der Stadtverwaltung

Öffentliche Ordnung und Sicherheit

Schutz der öffentlichen Ordnung

Vereine

Lfd. Nr. Titel

Laufzeit

662 Provinzialverband der Hannoverschen Bürgervereine

1903

- Einladung zum Verbandstag in Hannover, Mai 1903

1903

Klassifikation Teil B: 00725,02

Trägermaterial: Papier

Alte Reg.-Sig.: IV Fi 077

Bestell-Nr.: IV 00725 b

663 Deutsch-Österreich-Ungarischer Verband für Binnenschifffahrt

$1903-1911$

- Einladungen zum Verbandstag des Deutsch-Österreich-Ungarischer

Verbands für Binnenschifffahrt, 1903 - 1911

- Programm der Verbandstage, 1903 - 1909

$1903-1911$

Klassifikation Teil B: 00725,03

Trägermaterial: Papier

Alte Reg.-Sig.: IV Fi 079

Bestell-Nr.: IV 00725 c

664 Turnverein "Freie Turnerschaft"

$1904-1913$

- Antrag auf Genehmigung der Stiftungsfeste des Turnvereins, April 1904 / Februar 1907

- Bericht des Polizeikommissars Lauter über Aktivitäten des

Turnvereins als Arbeiterverein sozialdemokratischer Prägung, April /

September 1906

- Verweis des beobachtenden Beamten aus dem Turnersaal während des Trainings, September 1906

Statuten des Turnvereins, 1906

- Erlasse des preußischen Innenministers über politischen Charakter von Arbeiterturnvereinen, Januar 1911 / Oktober 1913

$1904-1913$

Klassifikation Teil B: 00725,03

Trägermaterial: Papier

Alte Reg.-Sig.: IV Fi 080

Bestell-Nr.: IV 00725 d 
IV

05

05.03

05.03.03

05.03.03.02

05.03.03.02.09

Stadtverwaltung

Aufgabenbereiche der Stadtverwaltung

Öffentliche Ordnung und Sicherheit

Schutz der öffentlichen Ordnung

Vereine

Lfd. Nr. Titel

Laufzeit

665 Internationaler Verband der Schifffahrtskongresse

1903-1908

- Satzungen des Internationalen Verbands der Schifffahrtskongresse, 1903 - 1908

- Beitritt der Stadt Emden zum Internationalen Verbands der

Schifffahrtskongresse, September 1903

- Werbeschrift des Internationalen Verbands der

Schifffahrtskongresse, 1907

- Programm des Schifffahrtskongresses in Mailand, Juli 1905

- Beschreibung des Hafens von Rotterdam, 1906

$1903-1908$

Klassifikation Teil B: 00726

Trägermaterial: Papier

Alte Reg.-Sig.: IV Fi 081

Bestell-Nr.: IV 00726

666 Schiffsbau- und Hafenbautechnische Gesellschaft

1903-1911

- Zahlung des Eintrittsgeldes zum Beitritt der Stadt Emden zur

(1916-1917)

Schiffsbautechnischen Gesellschaft durch die Nordseewerke, Emder

Werft und Dock AG, Dezember 1903

- Übernahme der Beitragszahlungen durch die Stadt Emden, Oktober 1909

- Einladungen zu den Hauptversammlungen der

Schiffsbautechnischen Gesellschaft, 1903 - 1911

- Mitgliederverzeichnis der Hafenbautechnischen Gesellschaft, 1916

- Herausgabe einer Urkunde für die lebenslängliche Mitgliedschaft in der Hafenbautechnischen Gesellschaft, April 1917

$1903-1911(1916-1917)$

Klassifikation Teil B: 00727

Trägermaterial: Papier

Alte Reg.-Sig.: IV Fi 082

Bestell-Nr.: IV 00727 
- Antrag des Wirtevereins auf Wahl eines ihrer Mitglieder in den Stadtausschuss zur Wahrung der Interessen der organisierten Wirte bei der Vergabe neuer Gaststätten-Konzessionen, Januar 1904 - Mitgliederlisten des Wirtevereins, 1904 - 1908

- Gesuch des Wirtevereins um Einschreiten der Stadt gegen die Blockade von Wirten durch organisierte Arbeiter wegen Verkaufs von Produkten der bestreikten Firma Doornkaat in Norden, Dezember 1906

- Eingabe des Wirtevereins an die Stadt Emden über Bitte um Genehmigung des Außerhausverkaufs von Spirituosen durch konzessionierte Wirte, August 1907

- Antrag des Wirtevereins auf Erlaubnis zur Beflaggung der Häuser seiner Mitglieder wegen der Tagung des Deutschen

Gastwirteverbands in Emden, April 1908

- Festbuch zum Wirtetag in Emden, April 1908

- Tagesordnung des Wirtetages, April 1908

- Eintragung des Wirtevereins in das Vereinsregister, Juni 1909

- Protest des Wirtevereins gegen die Konzessionierung der Gaststätte des Anton Vellen an der Bonnesse wegen zahlreicher Lokale seiner Mitglieder in dem Gebiet, Juli 1912

- Antrag des Schankwirts Leigraf auf Bekanntmachung einer Veränderung der Polizeistunde in den Zeitungen wegen Nichtbekanntmachung durch den Vorsitzenden des Wirtevereins, Januar 1915

$1904-1915$

Klassifikation Teil B: 00728

Trägermaterial: Papier

Alte Reg.-Sig.: IV Fi 083

Bestell-Nr.: IV 00728 
05

\subsection{3}

05.03.03

05.03.03.02

05.03.03.02.09
Stadtverwaltung

Aufgabenbereiche der Stadtverwaltung

Öffentliche Ordnung und Sicherheit

Schutz der öffentlichen Ordnung

Vereine

Lfd. Nr. Titel

Laufzeit

668 Evangelischer Arbeiterverein

1888-1915

- Statuten des christlichen (evangelischen) Arbeitervereins, 1888 -

1919

- Anzeige eines Familienabends des evangelischen Arbeitervereins,

Februar 1905 - November 1906

- Verfügung des Regierungspräsidenten in Aurich über Anregung zur

Begründung eines evangelischen Arbeitervereins in Emden mit dem

Zweck der Bekämpfung der Sozialdemokratie, September 1905

- Antrag des evangelischen Arbeitervereins auf Unterstützung der

Stadt Emden für ihre Volksbüros als Mittel zur Agitation in der

Arbeiterschaft, Januar 1907

- Antrag des evangelischen Arbeitervereins auf Befreiung von der Lustbarkeitssteuer für seine Veranstaltungen, Februar 1909 -

November 1912

- Jahresbericht des evangelischen Volksbüros (Sekretariat des

evangelischen Arbeitervereins), 1909 - 1910

- Bericht über Zahl der Mitglieder im evangelischen

Arbeiterinnenverein, Januar 1911

- Tagung des Provinzialverbandes evangelischen Arbeiter- und

Arbeiterinnenvereine der Provinz Hannover und angrenzender

Landesteile in Emden, Juli 1913

- Statistische Berichte über Mitglieder des evangelischen

Arbeitervereins, 1913 - 1915

$1888-1915(1921)$

Klassifikation Teil B: 00729

Trägermaterial: Papier

Alte Reg.-Sig.: IV Fi 087

Bestell-Nr.: IV 00729

669 Verein Emder Baugewerksmeister

$1904-1914$

- Eintrag des Vereins Emder Baugewerksmeister in das

Vereinsregister beim Amtsgericht, September 1904

- Denkschrift des Deutschen Arbeitgeberverbandes für das

Baugewerbe über Massenaussperrung im Tarifstreit mit

sozialdemokratischen und christlichen Gewerkschaften, April 1910

- Denkschrift der Arbeiterverbände über die Tarifbewegung im

deutschen Baugewerbe im Jahr 1910, 1910

- Satzungsänderung des Vereins Emder Baugewerksmeister,

September 1914

$1904-1914$

Klassifikation Teil B: 00730

Trägermaterial: Papier

Alte Reg.-Sig.: IV Fi 086

Bestell-Nr.: IV 00730 
- Satzung des Wykvereins für die III. Wyk, Februar 1904

- Antrag auf Genehmigung einer nichtöffentlichen Versammlung des Wykvereins für die III. Wyk, November 1904

1904

\author{
Klassifikation Teil B: 00731 \\ Trägermaterial: Papier \\ Alte Reg.-Sig.: IV Fi 084
}

Bestell-Nr.: IV 00731

671 Marineverein für Emden und Umgebung

- Satzungen des Marinevereins für Emden und Umgebung, Jui 1905 August 1908

- Eintragung des Marinevereins für Emden und Umgebung in das

Vereinsregister beim Amtsgericht, Februar 1905

- Mitgliederliste des Marinevereins für Emden und Umgebung, 1905

- Beitritt des Marinevereins für Emden und Umgebung zum preußischen Landeskriegerverband zur Erlangung der obrigkeitlichen Bestätigung, April - Mai 1905

- Antrag auf Befreiung von der Vergnügungssteuer für Veranstaltungen des Marinevereins für Emden und Umgebung, Januar 1907

- Antrag des Marinevereins für Emden und Umgebung auf Erlaubnis zur Führung einer Vereinsfahne, Oktober 1911

- Antrag auf Genehmigung eines Festzuges des Marinevereins für

Emden und Umgebung anlässlich einer Fahnenweihe, Januar 1913

$1905-1913$

Klassifikation Teil B: 00732

Trägermaterial: Papier

Alte Reg.-Sig.: IV Fi 089

Bestell-Nr.: IV 00732 
05

\subsection{3}

05.03.03

05.03.03.02

05.03.03.02.09
Stadtverwaltung

Aufgabenbereiche der Stadtverwaltung

Öffentliche Ordnung und Sicherheit

Schutz der öffentlichen Ordnung

Vereine

Lfd. Nr. Titel

Laufzeit

672 Verschiedene Vereine

1888-1906

- Initiative des Kronprinzenpaars zur Gründung eines Vereins zur

Hebung des religiös-sittlichen Notstands in den größeren Städten und

Umsetzung der Initiative in Emden, Mai - Juli 1888

- Statuten und Mitgliederliste des Vereins "Mercur" für gemütliche

Versammlungen junger jüdischer Kaufleute, 1895 - 1898

- Statuten des humoristischen Vereins "Thalia", März 1898

- Statuten und Mitgliederliste des Vereins "Locomotive" (Verbindung

von Eisenbahnern), 1898

- Statuten und Mitgliederliste des Deutschnationalen

Handlungsgehilfen-Verband, Ortsgruppe Emden, 1898

- Johannisfest der Emder Buchdrucker, Juni 1902

- Statuten des Familienvereins "Ressource" (überwiegend jüdische

Mitglieder), Dezember 1902

- Satzungen des Christlichen Gesangvereins, gemischter Chor, Mai 1904

- Antrag auf Genehmigung des Stiftuigsgestes des Radfahrvereins

"Emdena", Juli 1904

- Satzungen des Vereins der Zollbeamten zu Emden, Februar 1905

- Statuten des Fußballvereins "Sparta", Februar 1905 - März 1906

- Satzungen und Mitglieder des Clubs "Typographia" (Buchdrucker), Juni 1905

- Statut des gemischten Chors "Liederkranz", Januar 1906

Klassifikation Teil B: 00733

Trägermaterial: Papier

Alte Reg.-Sig.: IV Fi 022

Bestell-Nr.: IV 00733

673 Verein zur Förderung des Fremdenverkehrs in Emden

$1905-1911$

(1914)

- Gründung des Vereins zur Förderung des Fremdenverkehrs in

Emden, Juli 1905

- Übernahme des Ehrenvorsitzes über den Verein zur Förderung des

Fremdenverkehrs in Emden durch Oberbürgermeister Leo Fürbringer, Juli 1905

- Vom Verein herausgegebener Stadtführer von Emden, 1906

- Initiative des Vereins zur Förderung des Fremdenverkehrs in Emden zur Schaffung eines Stadtparks in Emden, September 1906

- Material zur Internationalen Ausstellung für Reise und

Fremdenverkehr in Berlin, 1911

$1905-1911$ (1914)

Klassifikation Teil B: 00734

Trägermaterial: Papier

Alte Reg.-Sig.: IV Fi 090

Bestell-Nr.: IV 00734 
05

\subsection{3}

05.03.03

05.03.03.02

05.03.03.02.09
Stadtverwaltung

Aufgabenbereiche der Stadtverwaltung

Öffentliche Ordnung und Sicherheit

Schutz der öffentlichen Ordnung

Vereine

Lfd. Nr. Titel

Laufzeit

674 Bund der Industriellen: Tagung in Emden

1905

- Organisation einer vom Direktor der Emder Eisenhütte, Paul.G.

Roer, vorgeschlagenen Tagung des Bundes der Industriellen in

Emden, Juli - September 1905

- Programm der Tagung, September 1905

- Mitglieder des Emder Börsenvereins, 1905

- Vortragsveranstaltung der Deutschen Kolonialgesellschaft, Abt.

Emden, im Rahmen der Tagung des Bundes der Industriellen,

September 1905

- Einladungsliste zur Tagung: Mitglieder von regionalen

Wirtschaftsverbänden, September 1905

- Liste der Gäste und Teilnehmer an de Veranstaltungen und

Feierlichkeiten während der Tagung, September 1905

- Druckschriften der Deutschen Kolonialgesellschaftr über koloniale

Interessen der deutschen Wirtschaft und Wissenschaft, 1905

- Satzungen der Deutschen Kolonialgesellschaft, 1905

- Presseberichte über die Tagung des Bundes der Industriellen in

Emden, September 1905

1905

Klassifikation Teil B: 00735

Trägermaterial: Papier

Alte Reg.-Sig.: IV Fi 091

Bestell-Nr.: IV 00735

675 Schifffahrts- und Handelsbörse

1905-1906

- Eingabe der Schifffahrts- und Handelsbörse an die Stadt Emden über Bitte um Schutz arbeitswilliger Hafenarbeiter gegen Streikende, November 1905

- Gründung des Vereins Schifffahrts- und Handelsbörse als Kartell der Emder Hafenbetriebe gegen die gewerkschaftlich organisierte

Arbeiterschaft, November 1905

- Streit um die Vereinsbezeichnung "Börse" wegen Namensähnlichkeit zur Einrichtung der Kaufmännischen Deputation ("Emder Börse"),

November 1905 - Februar 1906

- Eintragung der Schifffahrts- und Handelsbörse in das Vereinsregister beim Amtsgericht, Februar - Juni 1906

$1905-1906$

Klassifikation Teil B: 00736

Trägermaterial: Papier

Alte Reg.-Sig.: IV Fi 095

Bestell-Nr.: IV 00736 
IV

05

Stadtverwaltung

05.03

05.03.03

05.03.03.02

05.03.03.02.09

Aufgabenbereiche der Stadtverwaltung

Öffentliche Ordnung und Sicherheit

Schutz der öffentlichen Ordnung

Vereine

Lfd. Nr. Titel

Laufzeit

676 Gesellschaft für Milchausschank in Nordwestdeutschland

1906-1908

- Eingabe der Gesellschaft für Milchausschank in

Nordwestdeutschland an die Stadt Emden über Bitte um Zeichnung

von Anteilen, Januar 1906

- Nachricht über Gründung einer deutschen Gesellschaft für

Milchausschank, Mai 1908

$1906-1908$

Klassifikation Teil B: 00737

Trägermaterial: Papier

Alte Reg.-Sig.: IV Fi 096

Bestell-Nr.: IV 00737

677 Emder Hafenverein

1906-1907

- Eingabe des Hafenvereins an die Stadt Emden über Bitte um

Überlassung von Räumen in der Klunderburg für

Vereinsveranstaltungen, August 1906

- Satzung des Emder Hafenvereins mit dem Ziel der Erschwerung von

Hafenarbeiterstreiks, 1906

- Mitgliederliste des Emder Hafenvereins, 1906

$1906-1907$

Klassifikation Teil B: 00738

Trägermaterial: Papier

Alte Reg.-Sig.: IV Fi 097

Bestell-Nr.: IV 00738

678 Nautischer Verein

- Nachricht über Begründung eines Nautischen Vereins in Emden,

Februar 1907

1907

Klassifikation Teil B: 00739

Trägermaterial: Papier

Alte Reg.-Sig.: IV Fi 098

Bestell-Nr.: IV 00739 
05

\subsection{3}

05.03.03

05.03.03.02

05.03.03.02.09
Stadtverwaltung

Aufgabenbereiche der Stadtverwaltung

Öffentliche Ordnung und Sicherheit

Schutz der öffentlichen Ordnung

Vereine

Lfd. Nr. Titel

Laufzeit

679 Gesellschaft Seemannshaus für Unteroffiziere und Mannschaften der Kaiserlichen Marine

1906-1915

- Werbung der Gesellschaft Seemannshaus für Unteroffiziere und Mannschaften der Kaiserlichen Marine um Beitritt, Juni 1906

- Druckschriften und Jahresberichte der Gesellschaft Seemannshaus für Unteroffiziere und Mannschaften der Kaiserlichen Marine, 1906 1907

- Dankschreiben der Gesellschaft Seemannshaus für Unteroffiziere und Mannschaften der Kaiserlichen Marine für Beiträge der Stadt Emden, 1906 - 1915

- Erhöhung des Beitrags der Stadt Emden für die Gesellschaft Seemannshaus für Unteroffiziere und Mannschaften der Kaiserlichen Marine, Mai - September 1913

$1906-1915$

Klassifikation Teil B: 00740

Trägermaterial: Papier

Alte Reg.-Sig.: IV Fi 099

Bestell-Nr.: IV 00740

680 Verein für Feuerbestattung in Emden

- Anzeige der Begründung des Vereins für Feuerbestattung in Emden und Bitte um Unterstützung durch die Stadt Emden, Mai 1907

- Satzungen des Vereins für Feuerbestattung in Emden, 1907

- Angebote von Literatur über Einrichtung von Krematorien, Juli 1911

$1907-1914$

Klassifikation Teil B: 00741

Trägermaterial: Papier

Alte Reg.-Sig.: IV Fi 100

Bestell-Nr.: IV 00741

681 Freier Verein vom Roten Kreuz

- Anzeige über Gründung des Freien Vereins vom Roten Kreuz,

Oktober 1907

- Statuten des Freien Vereins vom Roten Kreuz

(Enthaltsamkeitsverein), 1907

1907

Klassifikation Teil B: 00742

Trägermaterial: Papier

Alte Reg.-Sig.: IV Fi 101

Bestell-Nr.: IV 00742 
05

\subsection{3}

05.03.03

05.03.03.02

05.03.03.02.09
Stadtverwaltung

Aufgabenbereiche der Stadtverwaltung

Öffentliche Ordnung und Sicherheit

Schutz der öffentlichen Ordnung

Vereine

Lfd. Nr. Titel

Laufzeit

682 Hannoversche Gemeinnützige Ansiedelungsgesellschaft

1907-1915

- Initiative des Oberpräsidenten der Provinz Hannover zur Gründung

(1916-1917) und Unterstützung einer Ansiedelungsgesellschaft zur Forcierung der inneren Kolonisation (Urbarmachung von Mooren und Ödland), Juni -

Oktober 1907

- Erklärung der Stadt Emden über Beitritt zur Hannoverschen

Gemeinnützigen Ansiedelungsgesellschaft, September 1907

- Satzungen der Hannoverschen Gemeinnützigen

Ansiedelungsgesellschaft, 1907 - 1908

- Statistischer Bericht über unter Förderung der

Ansiedlungsgesellschaft begründeter bäuerlicher und Arbeiterstellen, 1912

- Zeichnung von Anteilen an der Hannoverschen Gemeinnützigen

Ansiedelungsgesellschaft durch die Stadt Emden, November 1907 -

Juli 1908

- Geschäftsberichte der Hannoverschen Gemeinnützigen

Ansiedelungsgesellschaft, 1908 - 1916

- Erlass des preußischen Ministers für Landwirtschaft, Domänen und

Forsten über Beteiligung des Staates an der Hannoverschen

Gemeinnützigen Ansiedelungsgesellschaft, Juni 1913

- Diskussion der Beteiligung der ostfriesische Gebietskörperschaften, Verbände und Korporationen an der Hannoverschen Gemeinnützigen

Ansiedelungsgesellschaft, März 1914

1907 - 1915 (1916 - 1917)

Klassifikation Teil B: 00742

Trägermaterial: Papier

Alte Reg.-Sig.: IV Fi 102

Bestell-Nr.: IV 00743

683 Telegraphen-Gehülfen-Verein

1907

- Satzungen des Telegraphen-Gehülfen-Vereins, 1907

1907

Klassifikation Teil B: 00744

Trägermaterial: Papier

Alte Reg.-Sig.: IV Fi 104

Bestell-Nr.: IV 00744

684 Windthorst - Bund

- Anzeige der Gründung des Windthorstbundes in Emden als Wahlverein für das Zentrum durch den Telegraphensekretär Blaser, Mai 1907

- Satzung des Windthorstbundes, 1907

- Mitglieder des Windthorstbundes in Emden, 1907

1907

Klassifikation Teil B: 00745

Trägermaterial: Papier

Alte Reg.-Sig.: IV Fi 105

Bestell-Nr.: IV 00745 
05

05.03

05.03.03

05.03.03.02

05.03.03.02.09

Lfd. $\mathrm{Nr}$ Titel

\section{Stadtverwaltung}

Aufgabenbereiche der Stadtverwaltung

Öffentliche Ordnung und Sicherheit

Schutz der öffentlichen Ordnung

Vereine

685 Flottenbund deutscher Frauen

Laufzeit

- Jahresbericht des Flottenbundes deutscher Frauen, 1907

- Aufruf des Flottenbundes deutscher Frauen zur Beteiligung an einer

Sammlung zur Finanzierung eines Kriegsschiffes, ca. 1908

- Schreiben des Flottenbundes deutscher Frauen an die Oberlehrerin

Seyfried über Aufforderung zur Begründung einer Ortsgruppe in

Emden. März 1908

$1907-1908$

Klassifikation Teil B: 00746

Trägermaterial: Papier

Alte Reg.-Sig.: IV Fi 106

Bestell-Nr.: IV 00746

686 Sprachverein

1905

- Anzeige über Begründung eines Sprachvereins zum gemeinsamen Erlernen fremder Sprachen, Mai 1905

- Gesuch des Sprachvereins um Überlassung eines Raumes in der Handelsschule für den abendlichen Sprachuntericht, September 1905

1905

Klassifikation Teil B: 00747

Trägermaterial: Papier

Alte Reg.-Sig.: IV Fi 093

Bestell-Nr.: IV 00747

687 Bauverein Emden

$1890-1911$

(1914)

- Statuten verschiedener Bauvereine anderer Städte als Muster für die Statuten des Emder Bauvereins, 1890 - 1891

- Satzung des Emder Bauvereins mit dem Zweck der Errichtung von

Wohnungen für die Arbeiter der Nordseewerke, 1905

- Revision des Bauvereins durch den Revisor des Verbandes der

Baugenossenschaften Deutschlands, Scheidt, Oktober 1907 / Juli

1909

- Übernahme von Anteilen am Emder Bauverein durch die Stadt

Emden, September - Oktober 1908

- Liquidierung des Emder Bauvereins, 1910 - 1911

1890 - 1911 (1914)

Klassifikation Teil B: 00747

Trägermaterial: Papier

Alte Reg.-Sig.: IV Fi 107

Bestell-Nr.: IV 00749 
05

05.03

05.03.03

05.03.03.02

05.03.03.02.09
Stadtverwaltung

Aufgabenbereiche der Stadtverwaltung

Öffentliche Ordnung und Sicherheit

Schutz der öffentlichen Ordnung

Vereine

Lfd. Nr. Titel

Laufzeit

688 Deutsche Gesellschaft zur Bekämpfung der Geschlechtskrankheiten

$1905-1914$

- Beitritt der Stadt Emden zur Deutschen Gesellschaft zur

Bekämpfung der Geschlechtskrankheiten , Mai 1905

- Mitteilungen der Deutschen Gesellschaft zur Bekämpfung der

Geschlechtskrankheiten, 1905 / 1912

- Beitrittserklärungen prominenter Emder Bürger zur Deutschen

Gesellschaft zur Bekämpfung der Geschlechtskrankheiten, Februar

1905

- Druckschriften der Deutschen Gesellschaft zur Bekämpfung der

Geschlechtskrankheiten, 1911

$1905-1914$

Klassifikation Teil B: 00748

Trägermaterial: Papier

Alte Reg.-Sig.: IV Fi 094

Bestell-Nr.: IV 00748

689 Emder Ruderverein von 1906

$1909-1912$

- Mitteilung über geplante Regatta des Rudervereins, August 1907

- Jahresbericht des Emder Rudervereins, 1909

- Eintragung des Rudervereins Ostfriesland in das Vereinsregister beim Amtsgericht, August 1911

- Programm der Internationalen Ruderregatta im Emder Binnenhafen, Juli 1912

- Stiftung eines Wanderpreises für die Regatta durch die Stadt

Emden, Januar - August 1912

$1909-1912$

Klassifikation Teil B: 00750

Trägermaterial: Papier

Alte Reg.-Sig.: IV Fi 108

Bestell-Nr.: IV 00750

690 Gesellschaft zur Verbreiterung der Volksbildung

- Druckschriften der Gesellschaft zur Verbreiterung der Volksbildung, 1908 - 1912

- Werbung um Unterstützung der Gesellschaft zur Verbreiterung der Volksbildung, 1908

- Jahresbericht der Gesellschaft zur Verbreiterung der Volksbildung, 1911

$1907-1913$

Klassifikation Teil B: 00751

Trägermaterial: Papier

Alte Reg.-Sig.: IV Fi 109

Bestell-Nr.: IV 00751 
IV

05

Stadtverwaltung

05.03

05.03.03

05.03.03.02

05.03.03.02.09

Aufgabenbereiche der Stadtverwaltung

Öffentliche Ordnung und Sicherheit

Schutz der öffentlichen Ordnung

Vereine

Lfd. Nr. Titel

Laufzeit

691 Hauptverein des evangelischen Bundes

1908

- Presseberichte über Jahresversammlung des Hauptvereins des evangelischen Bundes für die Provinz Hannover, Juni 1908

1908
Klassifikation Teil B: 00752
Trägermaterial: Papier
Alte Reg.-Sig.: IV Fi 110
Bestell-Nr.: IV 00752

692 Hafenbautechnische Gesellschaft

- Einladungen zu den Versammlungen der Hafenbautechnischen

Gesellschaft, Mai - Oktober 1908

- Teilnahme der Oberbürgermeisters Fürbringer an der

Herbstversammlung der Hafenbautechnischen Gesellschaft,

November 1908

1908

Klassifikation Teil B: 00753

Trägermaterial: Papier

Alte Reg.-Sig.: IV Fi 111

Bestell-Nr.: IV 00753 
IV

05

05.03

05.03.03

05.03.03.02

05.03.03.02.09
Stadtverwaltung

Aufgabenbereiche der Stadtverwaltung

Öffentliche Ordnung und Sicherheit

Schutz der öffentlichen Ordnung

Vereine

Lfd. Nr. Titel

Laufzeit

693 Gabelsbergerscher Stenographenverein

1901-1913

- Satzungen des Gabelsbergerschen Stenographenvereins, 1901

- Organisation des Verbandstages des Nordwestdeutschen

Gabelsbergerschen Stenographenvereins in Emden, Mai - Juni 1902

/ Juli 1913

- Vergleich des Gabelsbergerschen Stenographie - Systems mit dem

System Stolze - Schrey, 1907

- Einladung der Stadtverwaltung zum 25-jährigen Stiftungsfest des

Gabelsbergerschen Stenographenvereins, Februar 1907

- Druckschrift des Stenographenbundes Stolze - Schrey über

Kurzschrift und Verwaltungsreform, Dezember 1909

- Einladung der städtischen Beamtenschaft zu einem Vortrag des

Gabelsbergerschen Stenographenvereins über Stenografie, Januar 1910

- Gesuch des Gabelsbergerschen Stenographenvereins um Befreiung von der Vergnügungssteuer für eine Veranstaltung zum

Kaisergeburtstag, Januar 1912

- Werbung für den Gabelsbergerschen Stenographenverein,

September 1912

- Gesuch des VIII. Bezirks des Niedersächsischen

Stenographenbundes "Stolze-Schrey" über Bitte um Unterstützung

durch die Stadt Emden bei der Stiftung eines Wanderpreises,

September 1912

- Unterstützung der Stadt Emden für einen Wettbewerb des

Gabelsbergerschen Stenographenvereins, September 1910 - August

1913

- Werbung des Niedersächsischen Stenographenbundes für das

System Stolze - Schrey, September 1913

$1901-1913$

Klassifikation Teil B: 00754

Trägermaterial: Papier

Alte Reg.-Sig.: IV Fi 113

Bestell-Nr.: IV 00754

694 Allgemeiner Konsumverein für Emden

$1907-1915$

- Tagesordnungen der Generalversammlung des Allgemeinen

Konsumvereins, Dezember 1907 / Februar 1915

1907 / 1915

Klassifikation Teil B: 00755

Trägermaterial: Papier

Alte Reg.-Sig.: IV Fi 114

Bestell-Nr.: IV 00755 
IV

05

05.03

05.03.03

05.03.03.02

05.03.03.02.09

Stadtverwaltung

Aufgabenbereiche der Stadtverwaltung

Öffentliche Ordnung und Sicherheit

Schutz der öffentlichen Ordnung

Vereine

Lfd. Nr. Titel

Laufzeit

695 Zentralstelle für Heimatschutz in Niedersachsen

1907-1912

- Information über Begründung eines "Niedersächsischen

Vertretertages" als Zentralstelle für Heimatschutz, August 1908

- Programm des 8., 9. und 11. Niedersachsentages der Zentralstelle

für Heimatschutz, Oktober 1908 - September 1912

- Satzungen des Niedersächsischen Ausschusses für Heimatschutz, 1909

- Initiative der Zentralstelle für Heimatschutz zur Erhaltung von

Bäumen und Alleen, Oktober 1909

- Nominierung des Stadtsyndici Mensching für den Vorstand des

Niedersächsischen Ausschusses für Heimatschutz durch die Stadt

Emden, Januar - Februar 1912

$1907-1912$

Klassifikation Teil B: 00756

Trägermaterial: Papier

Alte Reg.-Sig.: IV Fi 116

Bestell-Nr.: IV 00756

696 Blaues Kreuz

$1903-1914$

- Satzung des Blauen Kreuzes, Ortsverein Emden mit dem Ziel der

Bekämpfung des Alkoholmissbrauchs, 1908

- Genehmigung einer Tellersammlung auf der Hauptversammlung des

Blauen Kreuzes, Juli 1903 / Mai 1909

- Eintragung des Blauen Kreuzes in das Vereinsregister beim

Amtsgericht, September 1908

- Veranstaltungen des Berliner Zentralverbandes vom Blauen Kreuz

zur Bekämpfung des Alkoholmissbrauchs, 1912 - 1913

- Einladung des Oberbürgermeisters Fürbringer zur Grundsteinlegung

des neuen Vereinshauses des Blauen Kreuzes am Kattewall, August

1913

- Einladungen zur Eröffnung des Vereinshauses, März 1914

$1907-1914$

Klassifikation Teil B: 00757

Trägermaterial: Papier

Alte Reg.-Sig.: IV Fi 117

Bestell-Nr.: IV 00757 
IV

05

05.03

05.03.03

05.03.03.02

05.03.03.02.09

Stadtverwaltung

Aufgabenbereiche der Stadtverwaltung

Öffentliche Ordnung und Sicherheit

Schutz der öffentlichen Ordnung

Vereine

Lfd. Nr. Titel

Laufzeit

697 Verein Seemans-Erholungsheim

1909-1913

- Satzungen des Vereins Seemans-Erholungsheim , 1909 / 1910

- Beitritt der Stadt Emden zum Verein Seemans-Erholungsheim,

November 1909

- Einladung zur Einweihungsfeier des ersten

Seemanns-Erholungsheims des Vereins Seemanns-Erholungsheim in

Berlin-Zehlendorf, September 1910

- Bitte der deutschen Seemannsmission um Unterstützung des

notwendigen Ausbaus ihres Heims in Rotterdam, August 1913

$1909-1913$

Klassifikation Teil B: 00758

Trägermaterial: Papier

Alte Reg.-Sig.: IV Fi 120

Bestell-Nr.: IV 00758

698 Katholischer Arbeiterverein

$1911-1913$

- Einladung zum Stiftungsfest mit Fahnenweihe, Juli 1912

- Gesuch des Katholischen Arbeitervereins um Befreiung von der

Vergnügungssteuer für eine Weihnachtsfeier mit Kinderbescherung,

Dezember 1911 / Dezember 1912

$1911-1913$

Klassifikation Teil B: 00759

Trägermaterial: Papier

Alte Reg.-Sig.: IV Fi 121

Bestell-Nr.: IV 00759

699 Deutscher Betonverein

$1909-1912$

- Einladung zur Hauptversammlung des Deutschen Betonvereins,

Januar 1910 - Februar 1912

- Jahresberichte, 1909 - 1912

$1909-1912$

Klassifikation Teil B: 00760

Trägermaterial: Papier

Alte Reg.-Sig.: IV Fi 122

Bestell-Nr.: IV 00760 
05

05.03

05.03.03

05.03.03.02

05.03.03.02.09

Lfd. Nr. Titel
Stadtverwaltung

Aufgabenbereiche der Stadtverwaltung

Öffentliche Ordnung und Sicherheit

Schutz der öffentlichen Ordnung

Vereine

700 Fußballverein "Sparta"

Laufzeit

- Eingabe des Fußballvereins "Sparta" an die Stadt Emden über Bitte um Einwirken auf das Emder Schützenkorps zur Weiterverpachtung des Geländes am Schützenplatz an den Verein zur Gewährleistung des Spielbetriebes, Dezember 1910

- Einräumung eines Platzes am Hafenausschnitt für Spiele des Fußballvereins "Sparta" nach Kündigung des Pachtvertrages durch das Schützenkorps, Dezember 1910 - Januar 1911

$1910-1911$

Klassifikation Teil B: 00761

Trägermaterial: Papier

Alte Reg.-Sig.: IV Fi 126

Bestell-Nr.: IV 00761

701 Fußballverein "Sparta"

1908-1913

- Gesuch des Fußballvereins "Sparta" um Mitbenutzung des von Senator Brons für Turnzwecke zur Verfügung gestellten Geländes, August 1908

- Druckschrift des Norddeutschen Fußballverbandes über Werbung für den Fußballsport, 1910

- Zeitweise Überlassung des Platzes des Fußballvereins "Sparta" an Angehörige der Marine, Mai 1911

- Gesuch des Fußballvereins "Sparta" um Unterstützung durch die Stadt Emden, August 1913

$1908-1913$

Klassifikation Teil B: 00762

Trägermaterial: Papier

Alte Reg.-Sig.: IV Fi 115

Bestell-Nr.: IV 00762

702 Deutsch - evangelischer Frauenbund

- Gesuch des deutsch-evangelischen Frauenbundes um Überlassung eines Raumes durch die Stadt Emden zur Lagerung und Verteilung der Gaben einer Brockensammlung, September - Oktober 1911 - Gesuch des deutsch-evangelischen Frauenbundes um Befreiung von der Vergnügungssteuer für seine Wohltätigkeitsveranstaltung, März 1912

- Bericht über Erlös des Verkaufs von Gaben aus der

Brockensammlung, November 1912

- Einladung zur Einweihung der Säuglingskrippe des

deutsch-evangelischen Frauenbundes, Februar 1913

- Gesuch um Unterstützung der Stadt Emden zum Betrieb der

Säuglingskrippe, Mai - Dezember 1913

- Liste der von der Krippe aufgenommenen Kinder, Februar 1914

$1911-1914$

Klassifikation Teil B: 00763

Trägermaterial: Papier

Alte Reg.-Sig.: IV Fi 128

Bestell-Nr.: IV 00763 
IV

05

05.03

05.03.03

05.03.03.02

05.03.03.02.09

Stadtverwaltung

Aufgabenbereiche der Stadtverwaltung

Öffentliche Ordnung und Sicherheit

Schutz der öffentlichen Ordnung

Vereine

Lfd. Nr. Titel

Laufzeit

703 Katholischer Jünglingsverein

1911-1913

- Anträge des Katholischen Jünglingsvereins auf Erlass der

Vergnügungssteuer für seine Veranstaltungen, November 1911 -

November 1913

$1911-1913$

Klassifikation Teil B: 00764

Trägermaterial: Papier

Alte Reg.-Sig.: IV Fi 129

Bestell-Nr.: IV 00764

704 Gründung eines welfischen Kriegervereins

1911

- Bericht des Polizeipräsidenten von Hannover über Begründung eines Hannoverschen Kriegervereins durch Welfen-Anhänger und

Notwendigkeit der weiteren Beobachtung, Juli 1911

- Bericht des Oberbürgermeisters Fürbringer an den

Regierungspräsidenten in Aurich über Nichtvorhandensein von

Bestrebungen zur Gründung eines welfischen Kriegervereins in

Emden, Oktober 1911

1911

Klassifikation Teil B: 00765

Trägermaterial: Papier

Alte Reg.-Sig.: IV Fi 130

Bestell-Nr.: IV 00765

705 Dürer-Verein Ostfriesland

$1911-1912$

- Initiative des Dürer-Vereins zur Wiedereinführung des

Choralabspielens vom Emder Rathausturm am Heiligen Abend und den anderen hohen christlichen Festen, Dezember 1911 - Januar 1912

$1911-1912$

Klassifikation Teil B: 00766

Trägermaterial: Papier

Alte Reg.-Sig.: IV Fi 133

Bestell-Nr.: IV 00766

706 Deutscher Centralverband für Rettungswesen

$1906-1912$

- Satzung des Deutschen Centralverbands für Rettungswesen, 1906

- Plakat: "Rettung Ertrinkender", 1908

- Erlass des preußischen Innenministers über Funktion des

Deutschen Centralverbands für Rettungswesen als Informationsstelle für die Organisation des Rettungswesens, April 1912

$1906-1912$

Klassifikation Teil B: 00767

Trägermaterial: Papier

Alte Reg.-Sig.: IV Fi 134

Bestell-Nr.: IV 00767 
IV

05

05.03

Stadtverwaltung

05.03 .03

05.03.03.02

05.03.03.02.09

Aufgabenbereiche der Stadtverwaltung

Öffentliche Ordnung und Sicherheit

Schutz der öffentlichen Ordnung

Vereine

Lfd. Nr. Titel

Laufzeit

707 Oelberg-Verein

1912

- Werbung um Eintritt in den Oelberg-Verein, Juli 1912

- Eintritt des Oberbürgermeisters Fürbringer in den Oelberg-Verein mit einen Beitrag von 10 Mark pro Jahr, Juli 1912

- Druckschrift "Der Oelberg-Verein" mit Schilderung der Aufgabe der Erhaltung der Einrichtung des Johanniter-Ordens auf dem Oelberg in Jerusalem, 1912

1912

Klassifikation Teil B: 00768

Trägermaterial: Papier

Bestell-Nr.: IV 00768

708 Internationaler Verein der Freundinnen junger Mädchen

- Informationen über den Verein mit der Aufgabe der Bekämpfung des Mädchenhandels und dem Schutz der im Ausland arbeitenden deutschen Dienstmädchen, 1912 - 1913

$1912-1913$

Klassifikation Teil B: 00769

Trägermaterial: Papier

Alte Reg.-Sig.: IV Fi 137

Bestell-Nr.: IV 00769

709 Bürgervorsteher-Vereinigung der Provinz Hannover

- Satzung der Bürgervorsteher-Vereinigung der Provinz Hannover, 1912

- Werbung für den von der Bürgervorsteher-Vereinigung der Provinz Hannover herausgegebenen Hannoverschen Städtekalender, 1912

- Tagung der Bürgervorsteher-Vereinigung in Emden, Mai 1914

$1912-1914$

Klassifikation Teil B: 00770

Trägermaterial: Papier

Alte Reg.-Sig.: IV Fi 138

Bestell-Nr.: IV 00770

710 Niedersächsischer Herbergsverband

- Werbeschrift des Niedersächsischen Herbergsverbands, Dezember 1912

- Beitritt der Stadt Emden zum Niedersächsischen Herbergsverband, Januar 1913

- Satzung des Niedersächsischen Herbergsverbands, 1912

$1912-1914$

Klassifikation Teil B: 00771

Trägermaterial: Papier

Alte Reg.-Sig.: IV Fi 139

Bestell-Nr.: IV 00771 
IV

05

05.03

05.03.03

05.03.03.02

05.03.03.02.09

Stadtverwaltung

Aufgabenbereiche der Stadtverwaltung

Öffentliche Ordnung und Sicherheit

Schutz der öffentlichen Ordnung

Vereine

Lfd. Nr. Titel

Laufzeit

711 Deutscher Musikpädagogischer Verband

1913

- Einladung zum I. Internationalen Kongress des Deutschen

Musikpädagogischen Verbandes in Berlin, Februar 1913

1913

Klassifikation Teil B: 00772

Trägermaterial: Papier

Alte Reg.-Sig.: IV Fi 140

Bestell-Nr.: IV 00772

712 Gardeverein für Emden und Umgegend

- Satzung des Gardevereins für Emden und Umgegend für ehemalige

Soldaten von Gardekorps, Juni 1913

- Bestätigung des Vereins durch den preußischen

Landes-Kriegerverband, Mai 1913

- Mitgliederliste, 1913

- Antrag des Gardevereins für Emden und Umgegend auf Verleihung

des Rechts zum Tragen einer Fahne, Februar 1914

$1913-1914$

Klassifikation Teil B: 00773

Trägermaterial: Papier

Alte Reg.-Sig.: IV Fi 141

Bestell-Nr.: IV 00773

713 Verein für Handlungs-Commis

$1911-1914$

- Druckschrift über Arbeitslosenversicherung für Handlungsgehilfen und Kaufleute, 1910

- Jahresberichte des Vereins für Handlungs-Commis, 1911 - 1913

- Druckschrift über Dienst- und Vertragsverhältnisse kaufmännischer Angestellter, 1913

- Antrag des Vereins für Handlungs-Commis auf Genehmigung eines Feuerwerks auf seinem im August geplanten Sommerfest, Juni 1914 - Werbung für öffentliche, paritätische Stellennachweise für kaufmännische Angestellte, Oktober 1914

$1911-1914$

Klassifikation Teil B: 00774

Trägermaterial: Papier

Alte Reg.-Sig.: IV Fi 142

Bestell-Nr.: IV 00774 
05

05.03

05.03.03

05.03.03.02

05.03.03.02.09
Stadtverwaltung

Aufgabenbereiche der Stadtverwaltung

Öffentliche Ordnung und Sicherheit

Schutz der öffentlichen Ordnung

Vereine

Lfd. Nr. Titel

Laufzeit

714 Deutscher Luftflotten-Verein

1912-1915

- Satzungen des Deutschen Luftflottenvereins mit dem Ziel der

Förderung der Luftfahrt, 1912

- Publikation "Die Luftflotte" des Deutschen Luftflottenvereins, 1914

- Gesuch des Deutschen Luftflottenvereins über Bitte um

Unterstützung durch die Stadt Emden bei der Begründung eines

Emder Ortsvereins des Deutschen Luftflottenvereins, Januar 1914

- Liste der Emder Mitglieder des Deutschen Luftflottenvereins, Januar

1914

- Initiative des Deutschen Luftflottenvereins zum Anstoß der

Errichtung ziviler Flugplätze nach dem Ende des Krieges, Januar 1915

$1912-1915$

Klassifikation Teil B: 00775

Trägermaterial: Papier

Alte Reg.-Sig.: IV

Bestell-Nr.: IV 00775

715 Emder Hafenbetriebsverein

1913-1914

- Lohntarifvertrag zwischen dem Emder Hafenbetriebsverein und dem

Zentralverein christlicher Fabrik-, Verkehrs- und Hilfsarbeiter

Deutschlands zur Entlohnung von Hafenarbeiter dieser Gewerkschaft, Juli 1913

- Anzeige über Einstellung des Dr. O. Nübel als Geschäftsführer des

Emder Hafenbetriebsvereins, Januar 1914

- Satzungsänderung des Emder Hafenbetriebsvereins, Februar 1914

$1913-1914$

Klassifikation Teil B: 00776

Trägermaterial: Papier

Alte Reg.-Sig.: IV Fi 144

Bestell-Nr.: IV 00776

716 Ortsverein Emden des Verbandes der Deutschen Buchdrucker

1914-1915

- Leserbrief in der "Rhein-Ems-Zeitung" über Kritik an der Verweigerung einer Beihilfe durch die Stadt Emden zum Besuch der Buchdruckerkunstausstellung in Leipzig durch Mitglieder des Verbandes der Deutschen Buchdrucker, Ortsverein Emden, Mai 1914 - Antrag des Verbandes der Deutschen Buchdrucker, Ortsverein Emden bei der Stadt Emden um eine Beihilfe für die Entsendung von Mitgliedern zur Internationalen Ausstellung des Druckgewerbes und Graphik in Leipzig, April - Mai 1914

- Antrag auf Genehmigung von Versammlungen des Verbandes der

Deutschen Buchdrucker, Ortsverein Emden, März 1915

$1914-1915$

Klassifikation Teil B: 00777

Trägermaterial: Papier

Alte Reg.-Sig.: IV Fi 145

Bestell-Nr.: IV 00777 
IV

05

Stadtverwaltung

05.03

05.03.03

05.03.03.02

05.03.03.02.09

Aufgabenbereiche der Stadtverwaltung

Öffentliche Ordnung und Sicherheit

Schutz der öffentlichen Ordnung

Vereine

Lfd. Nr. Titel

Laufzeit

717 Fördergesellschaft des Instituts für Seeverkehr und Weltwirtschaft der Universität Kiel

1915

- Denkschrift von Prof. Dr. Bernhard Harms über Wiederanknüpfung und Pflege der wirtschaftlichen Beziehungen Deutschlands, 1915

- Werbeschrift der Fördergesellschaft des Instituts für Seeverkehr und Weltwirtschaft der Universität Kiel, 1915

1915

\author{
Klassifikation Teil B: 00778 \\ Trägermaterial: Papier \\ Alte Reg.-Sig.: IV Fi 146 \\ Bestell-Nr.: IV 00778
}

718 Zentralverein für Deutsche Binnenschiffahrt

- Einladung zur Wanderausstellung des Zentralvereins für deutsche Binnenschiffahrt, August 1901

- Einladung zur Mitarbeit in einem Unterausschuss des Zentralvereins wegen Novellierung des preußischen Wassergesetzes, 1908

$1901-1908$

Klassifikation Teil B: 02145

Trägermaterial: Papier

Alte Reg.-Sig.: IV Fi 014

Bestell-Nr.: IV 02145 
IV

05

05.03

05.03.03

05.03.03.02

05.03.03.02.10
Stadtverwaltung

Aufgabenbereiche der Stadtverwaltung

Öffentliche Ordnung und Sicherheit

Schutz der öffentlichen Ordnung

Überwachung der Presse

Lfd. Nr. Titel

Laufzeit

719 Ausführung des Gesetzes über die Presse

1867-1891

- Streit zwischen dem Schriftsetzer Martin van der Linde als Anhänger der Lassalleaner und der "Offenbacher Zeitung" als

sozialdemokratisches Blatt um die programmatische Ausrichtung,

1876

- Klage des Martin van der Linde gegen die "Offenbacher Zeitung" wegen Beleidigung, 1877

- Erlasse und Urteile über die Ausführung des preußischen Gesetzes über die Presse, 1868 - 1880

- Verbot sozialdemokratischer Publikationen, 1878 - 1891

- Ankündigung über die Herausgabe der "Emder Zeitung,

Ostfriesisches Organ für Politik, Volkswirtschaft und literarische

Unterhaltung", September 1876

- Kaution für die Herausgabe der "Ostfriesischen Zeitung" durch den

Verlag "Hahn Wwe.", 1869 - 1874

- Bei Hahn Wwe. gedruckter Aufruf mit Forderung der Eingliederung

Ostfrieslands nach Westfalen, Mai 1868

- Liste verbotener Schriften und Bücher, 1874

- Vorgehen gegen unzüchtige Schriften, 1878 - 1879

- Bericht des Hauptzollamts über Beschlagnahme

sozialdemokratischer Schriften, Januar 1883

$1868-21891$

Klassifikation Teil B: 00779, 01

Trägermaterial: Papier

Alte Reg.-Sig.: IV Fk 7 a

Bestell-Nr.: IV 00779 a

720 Ausführung des Gesetzes über die Presse

$1880-1891$

- Bekanntmachung des Verbots und Beschlagnahme von

Druckschriften, 1882 - 1891

- Verbot sozialdemokratischer Publikationen, 1880 - 1891

- Verbot erotischer Literatur, 1881 - 1890

- Erlass des preußischen Innenministers über Neubewertung des

Verbots sozialdemokratischer Schriften nach Auslaufen des

Sozialistengesetzes, September 1890

- Verbot antisemitisch - rassistischer Literatur, September 1890

- Bekanntmachung über gerichtliche Aufhebungsurteile des Verbots

von Schriften wegen Unzucht, 1889 - 1890

$1880-1891$

Klassifikation Teil B: 00779, 02

Trägermaterial: Papier

Alte Reg.-Sig.: IV Fk 7 b

Bestell-Nr.: IV 00779 b 
IV

05

Stadtverwaltung

05.03

05.03.03

05.03.03.02

05.03.03.02.10

Aufgabenbereiche der Stadtverwaltung

Öffentliche Ordnung und Sicherheit

Schutz der öffentlichen Ordnung

Überwachung der Presse

Lfd. Nr. Titel

Laufzeit

721 Jubiläum der "Ostfriesischen Zeitung"

1912-1914

- Zeitungsberichte über 10-jährges Bestehen der "Ostfriesischen

Zeitung", 1912

- Bericht des Oberbürgermeisters Fürbringer an den

Regierungspräsiden in Aurich über Geschichte des Verlages "Th.

Hahn Wwe." als Herausgeber der "Ostfriesischen Zeitung", Januar

1912

- Schreiben des Zeitungsverlegers Wilhelm Hahn an den

Oberbürgermeister Fürbringer über Bitte um Verfassung eines

Beitrages für die Jubiläumsausgabe der "Ostfriesischen Zeitung",

Januar 1912

- Antrag des Oberbürgermeisters Fürbringer auf Verleihung des

Kronenordens IV. Klasse an den Verleger Wilhelm Hahn, Januar -

Februar 1912

- Jubiläumsausgabe der "Ostfriesischen Zeitung", 19. Februar 1912

- Wechsel in der Geschäftsleitung und dem Aufsichtsrat des Verlages der "Ostfriesischen Zeitung" nach dem Rücktritt Wilhelm Hahn von der Geschäftsleitung, Februar 1914

1912 / 1914

Klassifikation Teil B: 00780

Trägermaterial: Papier

Alte Reg.-Sig.: IV Fk 9

Bestell-Nr.: IV 00780 
05

\subsection{3}

05.03.03

05.03.03.02

05.03.03.02.11
Stadtverwaltung

Aufgabenbereiche der Stadtverwaltung

Öffentliche Ordnung und Sicherheit

Schutz der öffentlichen Ordnung

Bettelei und Bettler

Lfd. Nr. Titel

Laufzeit

722 Überweisung arretierter Bettler an die Landespolizei

1867-1899

- Einweisung von wegen Bettlerei und Förderung der Bettlerei und Landstreicherei sowie wegen Prostitution und Diebstahlsdelikten verurteilter Personen in Haftanstalten, dem Werkshaus zu Moringen und Himmelsthür sowie der provinzialständischen Correctionsanstalt zu Wunstorf, 1867 - 1899

$1867-1899$

Klassifikation Teil B: 00597

Trägermaterial: Papier

Alte Reg.-Sig.: IV Ed 51

Bestell-Nr.: IV 00597

723 Vorschriften zu Verfahren gegen Bettler

- Verfügungen des Oberpräsidenten der Provinz Hannover, des preußischen Landdrosten in Aurich und des Regierungspräsidenten in Aurich über Regelung der Verfahren wegen Bettlerei und damit verbundener Delikte sowie der Einweisung in Arbeitshäuser, 1868 1893

- Erlasse des preußischen Innenministers über Kriterien zur Verhängung einer "correctionellen Nachhaft" in Arbeitshäuser, 1872 1902

- Erlass des preußischen Innenministers über Verhängung einer Sicherheitshaft gegen Landstreicher, Februar 1916

$1868-1916$

Klassifikation Teil B: 00598

Trägermaterial: Papier

Alte Reg.-Sig.: IV Ed

Bestell-Nr.: IV 00598 
IV

05

Stadtverwaltung

05.03

Aufgabenbereiche der Stadtverwaltung

05.03.03

05.03.03.02

05.03.03.02.12

Öffentliche Ordnung und Sicherheit

Schutz der öffentlichen Ordnung

Erlaubte Sammlungen und Sammlungen für wohltätige

Zwecke

Lfd. Nr. Titel

724 Sammlungen und Kollekten

Laufzeit

- Umsetzung der Verfügung des Oberpräsidenten der Provinz

Hannover zur Regulierung des Kollektenwesens, Oktober 1893 - März

1906

- Ermittlungen gegen den Tischlergesellen Carl Bigitschke wegen

unerlaubter Sammlungen, April - Mai 1897

- Berichte des Magistrats der Stadt Emden über genehmigte

Sammlungen für soziale Zwecke, Dezember 1904

$1897-1914$

Klassifikation Teil B: 00346

Trägermaterial: Papier

Alte Reg.-Sig.: IV Fm 4

Bestell-Nr.: IV 00346 
IV

05

Stadtverwaltung

05.03

05.03.03

05.03.03.02

05.03.03.02.13

Aufgabenbereiche der Stadtverwaltung

Öffentliche Ordnung und Sicherheit

Schutz der öffentlichen Ordnung

Prostitution

Lfd. Nr. Titel

Laufzeit

725 Unkonzessionierte Prostituierte

1867-1907

- Bericht der Polizeidirektion in Emden über Syphillis-Erkrankung

zweier unkonzessionierter Prostituierter, April 1867

- Schreiben des Obersten von Weyde, Kommandeur des

Ostfriesischen Infanterie-Regiments Nr. 78 an die Emder

Polizeidirektion über Bitte um Überwachung von Häusern mit

Wohnungen von der Prostitution Verdächtigen zur Verhinderung des

Besuches durch Soldaten, Mai 1868

- Schaffung einer besonderen Abteilung im Gasthaus zur

Untersuchung und Behandlung geschlechtskranker Prostituierter

außerhalb des Krankenhauses, Oktober 1878 - Februar 1879

- Verfolgung unkonzessionierter Prostituierter und ihrer Zuhälter

(Kuppler), 1888 - 1907

$1867-1907$

Klassifikation Teil B: 00592

Trägermaterial: Papier

Alte Reg.-Sig.: IV Fa 03

Bestell-Nr.: IV 00592 
IV

05

Stadtverwaltung

05.03

Aufgabenbereiche der Stadtverwaltung

05.03.03

05.03.03.02

05.03.03.02.14

Öffentliche Ordnung und Sicherheit

Schutz der öffentlichen Ordnung

Tierschutz

Lfd. Nr. Titel

Laufzeit

726 Tierschutz

$1881-1910$

- Hundeschlachtung zum Verzehr durch den Arbeiter Buss in Emden,

Oktober 1881

- Ministerialerlasse zum Tierschutz, Februar 1898

- Druckschrift des Hannoverschen Tiervereins über

Schutzbemühungen für Zugpferde, 1903

- Ermittlungen aufgrund eines Presseberichtes über tierquälerisches

Treiben eines verletzten Schafes zum Schlachthaus, September 1904

- Polizeiverordnung der Stadt Emden über Verbot des Ausknobelns

lebender Tiere, Oktober 1906

- Vorschriften zum Schutz der Zugtiere, 1910

- Druckschriften gegen Tier- und Menschenversuche, 1910

$1881-1910$

Klassifikation Teil B: 00782

Trägermaterial: Papier

Alte Reg.-Sig.: IV Fv 1

Bestell-Nr.: IV 00782 
IV

05

Stadtverwaltung

05.03

Aufgabenbereiche der Stadtverwaltung

05.03.03

05.03.03.02

05.03.03.02.15

Öffentliche Ordnung und Sicherheit

Schutz der öffentlichen Ordnung

Gemeingefährliche Handlungen

Lfd. Nr. Titel

Laufzeit

727 Waffenbesitz und gefährliche Handlungen mit Feuerwerk

$1881-1913$

- Waffenrechtliche Vorschriften in Preußen, 1881 - 1911

- Zertrümmerung einer Fensterscheibe des Particuliers Peter

Valentien in der Wilhelmsstraße durch einen Schuss, Mai 1883

- Verbot der sogenannten "Reifflinge" zur Benutzung als

Kinderspielzeug wegen Verletzungsgefahr, September 1884

- Unerlaubtes Abbrennen von Pulver-Schrot-Kartuschen unter

Gefährdung spielender Kinder, Oktober 1884

- Antrag des G. Stracke auf Erlaubnis zum Erschießen von auf seinem

Grundstück streunenden Katzen, Mai 1891

- Antrag des Obertelegraphen-Assistenten Johannes Schröder auf

Erlaubnis des Schießens von Krähen, November 1894

- Beschwerden gegen das verzögerte Eingreifen der Polizei gegen

Lärm von Schüssen und Feuerwerkskörper, Februar 1898

- Antrag des Arbeiters Fritz Schutt auf Genehmigung des Tragens

eines Revolvers wegen seiner Funktion als Nachtwächter am

Zungenkai im Bereich des WTAG-Schuppens, Mai 1902

- Antrag des M.A. Willemsen auf Erlaubnis zum Schießen von

Sperlingen in einem Getreidefeld, Juli 1903

- Mitteilungen über waffenrechtliche Vorschriften im Ausland, 1910 -

1911

- Abgabe beschlagnahmter Waffen, 1913

$1881-1913$

Klassifikation Teil B: 00781

Trägermaterial: Papier

Alte Reg.-Sig.: IV Fr 1

Bestell-Nr.: IV 00781 
05

\subsection{3}

05.03.04

05.03.04.01

05.03.04.01.01

\section{Stadtverwaltung}

Aufgabenbereiche der Stadtverwaltung

Öffentliches Gesundheitswesen

Aufgabenbereiche des öffentlichen Gesundheitswesens

Einrichtungen der Gesundheitsförderung

Lfd. Nr. Titel

Laufzeit

728 Organisation des Turnwesens

1868-1879

- Antrag des Vorstands des Männerturnvereins beim Magistrat auf Anordnung an den Schulen zur Abstellung einer größeren Schülerzahl zum Turnunterricht zwecks Unterhaltssicherung des vom Verein eingestellten Turnlehrers, Mai - Dezember 1868

- Stellungnahme der Schulen zur Einführung eines verbindlichen

Turnunterrichts, September - November 1868

- Verhandlungen zwischen dem Magistrat und den Schulvorständen wegen Neueinstellung eines Turnlehrers, Dezember 1868 - Januar 1869

- Ankündigung von Fortbildungskursen für Turnlehrer durch das kgl. Konsistorium in Aurich, März 1871 - Mai 1872

- Delegation Emder Turnlehrer zu Fortbildungskursen, Juni 1871 Juni 1847

- Anforderung von Berichten zum Turnunterricht in Emden durch den preußischen Landdrosten in Aurich, Juli - September 1879

$1868-1879$

Klassifikation Teil B: 01657

Trägermaterial: Papier

Alte Reg.-Sig.: IV Pa 3

Bestell-Nr.: IV 01657

- Ankündigung von Veranstaltungen des Männerturnvereins (z.B. Schauturnen, Festumzüge), August 1882 - August 1893

- Änderungen der Statuten (Grundgesetz) des Männerturnvereins Emden, 1886 - 1914

- Antrag des Mänerturnvereins beim Magistrat auf Erlaubnis zum Bau einer Turnhalle im Roten-Mühlen-Zwinger, April - Mai 1888

- Antrag des Mänerturnvereins beim Magistrat auf Befreiung von der Entrichtung der Einschreibgebühr für ein von inm erworbenes Grundstück zum Turnhallenbau, September1888

- Kostenvoranschlag zum Bau einer Kinderbewahranstalt mit Turnhalle für den Männerturnverein, 1888

- Antrag des Männerturnvereins beim preußischen Innenminister auf Verleihung der Korporationsrechte, April - September 1891

- Geschäftsberichte des Männerturnvereins, Februar 1892 - Februar 1895

$1882-1914$

Klassifikation Teil B: 01658

Band: 1

Trägermaterial: Papier

Alte Reg.-Sig.: IV Pa 5

Bestell-Nr.: IV 01658 
IV

05

Stadtverwaltung

05.03

05.03.04

Aufgabenbereiche der Stadtverwaltung

05.03.04.01

05.03.04.01.01

Öffentliches Gesundheitswesen

Aufgabenbereiche des öffentlichen Gesundheitswesens

Einrichtungen der Gesundheitsförderung

Lfd. Nr. Titel

Laufzeit

730 Männerturnverein, Bd. 2

1895-1914

: Ankündigungen von Veranstaltungen des Männerturnvereins

(Schauturnen, Umzüge, Stiftungsfeste), Juni 1895 - Januar 1911

- Jahresberichte des Männerturnvereins, 1896 - 1899

- Anträge des Männerturnvereins beim Regierungspräsidenten in

Aurich durch die Hand des Magistrats auf Genehmigung von

Statutenänderungen (u.a. Etablierung einer Frauenabteilung), März

1897 - Juli 1914

- Initiative zur Ehrung des verstorbenen Hannoverschen Turnlehrers

Franz Wilhelm Metz, Oktober - Dezember 1901

- Organisation des Kreisturnfestes in Emden, Juni - Juli 1902

- Verhandlungen des Männerturnvereins mit dem Magistrat wegen

Überlassung eines Grundstückes zum Bau einer Turnhalle mit

Spielplatz, Oktober 1904 - Januar 1905

- Feier der Grundsteinlegung der Turnhalle des Männerturnvereins,

Oktober 1909

- Anzeige über Neuwahl des Vorstands des Männerturnvereins,

September 1910

- Festschrift zum 50-jährigen Bestehen des Männerturnvereins, 1911

- Initiative des Männerturnvereins zur Etablierung eines

Sedan-Turnfestes in Emden, August 1913

$1895-1914$

Klassifikation Teil B: 01659

Band: 2

Trägermaterial: Papier

Alte Reg.-Sig.: IV Pa 5

Bestell-Nr.: IV 01659

731 Anlage von Kinderspielplätzen

$1909-1910$

- Antrag des Meinhard Akkermann im Namen der Bewohner der VI. Wyck beim Magistrat auf Anlage eines Spielplatzes, Oktober 1909 . Juni 1912

$1909-1910$

Klassifikation Teil B: 01660

Trägermaterial: Papier

Alte Reg.-Sig.: IV Pa 7

Bestell-Nr.: IV 01660 
IV

05

Stadtverwaltung

05.03

05.03.04

05.03.04.01

05.03.04.01.01

Aufgabenbereiche der Stadtverwaltung

Öffentliches Gesundheitswesen

Aufgabenbereiche des öffentlichen Gesundheitswesens

Einrichtungen der Gesundheitsförderung

Lfd. Nr. Titel

Laufzeit

732 Baden an erlaubten und verbotenen Stellen

- Verfügungen des Magistrats über Badeverbote an gefährlichen

Gewässern, Brücken, Verlaaten und Schiffahrtswegen, (1838) 1878 -

1911

- Bekanntmachungen über verbotene Badestellen, 1839 - 1852

- Entwurf einer Polizeiverordnung über Regelungen zum Baden im

Freien innerhalb des Stadtgebiets und der öffentlichen Badeanstalten, Juni - Juli 1876

- Bekanntmachung über Haftung der Badenden für Beschädigungen

von Weidezäunen am Treckfahrtstief, Juli 1912

(1838 - 1852) 1876 - 1912

Klassifikation Teil B: 01661

Trägermaterial: Papier

Alte Reg.-Sig.: IV Pb 1

Bestell-Nr.: IV 01661

733 Badekommission, Bd. 1

- Einladungen zu den Sitzungen der Badekommission mit

Tagesordnung

- Protokolle der Sitzungen der Badekommission über Ausgestaltung

und Finanzierung der Badeanstalten

$1878-1906$

Klassifikation Teil B: 01662

Band: 1

Trägermaterial: Papier

Alte Reg.-Sig.: IV Pb 5

Bestell-Nr.: IV 01662 
05

\subsection{3}

05.03.04

05.03.04.01

05.03.04.01.01

\section{Stadtverwaltung}

Aufgabenbereiche der Stadtverwaltung

Öffentliches Gesundheitswesen

Aufgabenbereiche des öffentlichen Gesundheitswesens

Einrichtungen der Gesundheitsförderung

Lfd. Nr. Titel

Laufzeit

734 Badekommission, Bd. 2

1876-1882

- Eingabe des Männerturnvereins an den Magistrat über Anregung der

Errichtung einer städtischen Badeanstalt, August 1868

- Beschluss der städtischen Kollegien über Errichtung einer

städtischen Badeanstalt und Konstituierung einer für das Badewesen

verantwortlichen städtischen Badekommission, Juni 1876

- Ausstattung der städtischen Badeanstalten, Juni 1876

- Badeordnung für die städtischen Badeanstalten, Juni 1876 / Juni

1878 / Juni 1880

- Werbeschreiben für das neue Bad, Juli 1876

- Verhandlungen zwischen der Badekommission und dem Sergeanten Hermann Hawich über die Annahme von Bademeisterdiensten und

Durchführung von Schwimmunterricht, Juli 1876

- Rechnungswesen der städtischen Schwimm- und Badeanstalt, 1876

$-1879$

- Kostenvoranschläge wegen Verbesserrung der städtischen

Schwimm- und Badeanstalt, Januar 1877 - Mai 1879

- Tarif der städtischen Schwimm- und Badeanstalt, Juni 1877

- Etat der städtischen Schwimm- und Badeanstalt, 1878 - 1880

- Haushaltsprüfung bei der Badekommission, März 1878

- Beschädigung des Bassins der städtischen Schwimm- und

Badeanstalt durch einen Erdrutsch, Juni 1878

- Abwicklung der Rechnungen der städtischen Schwimm- und

Badeanstalt, September 1879

- Verpachtung der städtischen Schwimm- und Badeanstalt, Juni 1880

- Kassenprüfung der städtischen Schwimm- und Badeanstalt durch

die Badekommission, August 1886

- Beschluss der städtischen Kollegien über Errichtung einer

Badeanstalt im Eisenbahndock, Juni 1881

- Verhandlungen der Badekommission wegen Planung einer

Badeanstalt im Eisenbahndock, Juni 1881

- Vergabe der Aufträge zum Bau der Badeanstalt im Eisenbahndock, Juni 1881

- Vertrag zwischen dem Magistrat und dem Feldwebel Hermann

Hawich und seiner Frau Arnoldine, geb. Gröneveld über

Betriebsführung der schwimmenden Badeanstalt im Eisenbahndock,

Juli 1881

- Vertrag über die Umwandlung der Badeanstalt am Thranwarft

(Wolthuser Tief) in eine Frauenbadeanstalt, April 1882

- Reglement für die Badeanstalt für Frauen am Thranwarft, Juni 1882

- Reglement für die Badeanstalt für Männer im Eisenbahndock, Juni 1882

- Darlehen der Stadt Emden in Höhe von 10.000 Mark an die Eheleute

Hawich zur Finanzierung der Ausstattung der städtischen

Badeanstalten, Dezember 1882

$1876-1882$

Klassifikation Teil B: 01663

Band: 2

Trägermaterial: Papier

Alte Reg.-Sig.: IV Pb 5

Bestell-Nr.: IV 01663 
- Inventar der Badeanstalt am Eisenbahndock, November 1882

- Versicherung des Inventars der städtischen Badeanstalten, Februar 1883 - Mai 1889

- Rechnungswesen der Badeanstalten, Februar - August 1883

- Anfrage des Garnisonskommandeurs wegen Benutzung der städtischen Badeanstalt für Männer durch Soldaten, Juni 1883 / Mai 1884

- Badeordnung für die städtische Badeanstalt für Männer, 1883

- Bericht der Badekommission über negative Auswirkungen des künftigen Ems-Jade-Kanals auf die Badeanstalt für Frauen am Wolthuser Tief und anzumeldende Schadensersatzansprüche, Juli 1883

- Visitation der Badeanstalt für Frauen und der Badeanstalt für Männer, Juni 1884 / August 1890

- Bekanntmachung der drohenden Schließung der Badeanstalt für Männer im Eisenbahndock wegen Beschädigung von Bahnwaggons durch von dort kommende Jugendliche, Juli 1884

- Drohung der Eisenbahnverwaltung mit der Schließung der Badeanstalt für Männer im Eisenbahndock bei weiterem Unfug und Sachbeschädigung durch Jugendliche, Juni 1885

- Neuwahlen zur Badekommission, Januar 1886 / August 1890

- Verhandlungen der Badekommissiom wegen notwendige Sanierung der Badeanstalt für Frauen, Februar 1886 - Juli 1887

- Projekt: Admiralsgartenbad Berlin, 1886

- Unfug des Schülers Warnke auf dem Bahnhofsgelände während des Gangs zum Freibad im Eisenbahndock, Mai - Juni 1889

- Benutzung verbotener Wege zum Bad am Eisenbahndock durch Schüler, Juni 1886 - Dezember 1891

- Kostenvoranschlag des Stadtbaumeisters Wiggers über Sanierung der Badeanstalt für Frauen, Mai 1892

- Polizeivordnung zum Schutz der Badeanstalt für Frauen, Juni 1892

$1882-1896$

Klassifikation Teil B: 01664

Band: 3

Trägermaterial: Papier

Alte Reg.-Sig.: IV Pb 5

Bestell-Nr.: IV 01664 
IV

05

Stadtverwaltung

05.03

05.03.04

Aufgabenbereiche der Stadtverwaltung

05.03.04.01

05.03.04.01.01

Öffentliches Gesundheitswesen

Aufgabenbereiche des öffentlichen Gesundheitswesens

Einrichtungen der Gesundheitsförderung

Lfd. Nr. Titel

Laufzeit

736 Badekommission, Bd. 4

1876-1892

- Ankündigung der Freibadöffnung gegen Zahlung einer

Eintrittsgebühr, Juni 1876 / Juni 1877 / Mai 1882

- Bewerbungen um die Stelle eines Bademeisters bei der Emder

Bade- und Schwimmanstalt, Juni - Juli 1876

- Vertrag zwischen der Badekommission und dem Badbetreiber

Hermann Hawich über Bademeisterdienste, Juli 1876 / Juni 1881

- Finanzierung der Unterhaltung der Badeanstalten , Dezember 1876

- Visitation der Badeanstalten, Juni 1877 / August 1890

- Beschlüsse der städtischen Kollegien über Bewilligung von

Zuschüssen für die Badeanstalten, August 1875 - Dezember 1882

- Verfügung des Magistrats an die Badekommission über Erlaubnis der Investition laufender Einnahmen in die Verbesserung der

Badeanstalten und Anordnung der Aufstellung eines ordentlichen

Etats, Mai 1879

- Bericht des Stadtbaumeisters Wiggers über Sanierung der

Badeanstalt für Männer und der Errichtung eines Frauenbades, Mai

1881

- Errichtung der Badeanstalt für Männer im Eisenbahndock und der für

Frauen am Wolthuser Tief, April 1881 - Dezember 1882

- Vermögensstand der Einquartierungskasse (Finanzierungsquelle der

Freibäder), Mai 1881

- Darlehen an das Ehepaar Hermann und Arnoldine Hawich als

Betreiber der Freibäder, Dezember 1882

- Anschaffung von Badeeinrichtuingen, Dezember 1882

- Bescheid des preußischen Ministers der öffentlichen Arbeiten über Ablehnung einer Haftung für die Verschlechterung der Wasserqualität im Freibad für Frauen am Wolthuser Tief infolge des Baus des

Ems-Jade-Kanals, April 1886

$1876-1892$

Klassifikation Teil B: 01665

Band: 4

Trägermaterial: Papier

Alte Reg.-Sig.: IV Pb 5

Bestell-Nr.: IV 01665 
IV

05

Stadtverwaltung

05.03

05.03.04

05.03.04.01

05.03.04.01.01

Aufgabenbereiche der Stadtverwaltung

Öffentliches Gesundheitswesen

Aufgabenbereiche des öffentlichen Gesundheitswesens

Einrichtungen der Gesundheitsförderung

Lfd. Nr. Titel

Laufzeit

737 Errichtung einer Warmbadeanstalt, Bd. 1

$1881-1911$

- Pläne und Kostenanschläge des Oldenburger Architekten C. Spieske über Warmbadeanstalt in Emden, August 1881 - März 1896

- Material über öffentliche Warmbadeanstalt in Oldenburg, 1881 -

1890

- Angebot der Firma Börne \& Co in Berlin wegen Einrichtung einer

Warmbadeanstalt in Emden, November 1888

- Verhandlungen der städtischen Kollegien wegen Warmbadeanstalt, März 1890

- Verhandlungen des Magistrats mit der Garnison wegen Interesse am ehemaligen Lazarett als Warmbadeanstalt, September 1890

- Verhandlungen des Magistrats mit dem Restaurateur und Konditor Jacobus Gottfried Warring sowie dem Badeunternehmer Karl Kirchner wegen Aufbau einer Warmbadeanstalt in Emden, Februar - April 1893 - Angebot der Fa. Göhrmann und Eichhorn wegen Ausstattung des Warmbades, September - November 1896

- Antrag des Warmbadbetreibers Fritz Eitel beim Magistrat auf

Gewährung einer Beihilfe zum Badebetrieb, Februar 1911

$1881-1911$

Klassifikation Teil B: 01666

Band: 1

Trägermaterial: Papier

Alte Reg.-Sig.: IV Pb 6

Bestell-Nr.: IV 01666 
- Verhandlungen des Restaurateurs Karl Kruspe aus Halle / S. mit dem Magistrat wegen Errichtung einer Warmbadeanstalt, Juni 1876 November 1877

- Stellungnahme des Medizinalrats und Kreisphysicus Dr. Stöhr und des Sanitätsrats Dr. Norden zum Projekt einer Warmbadeanstalt in Emden, Juli 1876

- Bericht in der "Ostfriesischen Zeitung" über Plädoyer für eine von der Stadt Emden betriebene Warmbadeanstalt, Oktober 1883

- Material über Warmbade-Unternehmen in anderen Städten, 183

- Beschluss des Magistrats über Vertragsabschluss mot dem Oldenburger Architekten C. Spieske wegen Errichtung einer Warmbadeanstalt, August 1883

- Verhandlungen des Magistrats mit der Garnisonsverwaltung wegen Überlassung eines Flügels der alten Kaserne für eine städtische Warmbadeanstalt, August 1883

- Sicherheitsleistungen des Ehepaars Hermann und Arnoldine Hawich als Betreiber der städtischen Warmbadeanstalt, 1883

- Verhandlungen des Magistrats mit dem Ehepaar Hawich wegen

Betrieb der städtischen Warmbadeanstalt, 1883

- Plan des Architekten C. Spieske zu einer Warmbadeanstalt im ehemaligen Lazarettgebäude der Garnison, 1890

$1876-1890$

Klassifikation Teil B: 01667

Band: 2

Trägermaterial: Papier Alte Reg.-Sig.: IV Pb 6

Bestell-Nr.: IV 01667 
05

05.03

05.03.04

05.03.04.01 05.03.04.01.01
Stadtverwaltung

Aufgabenbereiche der Stadtverwaltung

Öffentliches Gesundheitswesen

Aufgabenbereiche des öffentlichen Gesundheitswesens Einrichtungen der Gesundheitsförderung

Lfd. Nr. Titel

Laufzeit

739 Errichtung eines Brausebades in der städtischen Volksschule

1896-1909

- Initiative des Oberbürgermeisters Fürbringer zur Errichtung eines

Brausebades in der städtischen Volksschule nach dem Vorbild auf der Berliner Gewerbeausstellung, Februar 1896

- Vorlage der Schulkommission der städtischen Volksschule über Angebote und Kosten der Errichtung eines Brausebades, Dezember 1896 / Januar 1897

- Beschluss der städtischen Kollegien über Vertagung des Projektes, März 1897

- Eingabe des Vereins die Nationalsocialen Emdens an den Magistrat über Bitte um Einrichtung eines Brausebades in der städtischen Volksschule, Dezember 1899

- Angebote und Kostenvoranschläge für das Brausebad, Oktober 1899 - Juli 1904

- Abrechnung der Fa. Dose \& Middendorf, Hamburg über Errichtung des Brausebades, Dezember 1905 - Januar 1906

- Plan der Nutzung des Brausebades, 1906

- Eingabe von Hafenarbeitern an den Magistrat über Bitte um Erlaubnis zur Benutzung des Brausebades in der städtischen Volksschule, Januar 1909

$1896-1909$

Klassifikation Teil B: 01668

Trägermaterial: Papier

Alte Reg.-Sig.: IV Pb 8

Bestell-Nr.: IV 01668

740 Badeanstalt des Kaufmanns Max Wendisch

- Anzeige der Auktionatoren Schmidt \& Meyer im Auftrag des Kaufmanns Max Wendisch über Absicht ihres Mandanten zur Errichtung einer Warmbadeanstalt in einem erworbenen Gebäude am Apfelmarkt, März - April 1897

- Antrag des Max Wendisch berim Magistrat auf Ermäßigung des Wasserpreises und auf Betriebsbeihilfe für seine Warmbadeanstalt, Oktoberr 1898 - Dezember 1903

- Antrag des Nachfolgers des M. Wendisch, Max Eitel, auf

Betriebsbeihilfe, März 1904 - Januar 1913

$1897-1913$

Klassifikation Teil B: 01669

Trägermaterial: Papier

Alte Reg.-Sig.: IV Pb 9

Bestell-Nr.: IV 01669 
IV

05

Stadtverwaltung

05.03

05.03.04

Aufgabenbereiche der Stadtverwaltung

05.03.04.01

05.03.04.01.01

Öffentliches Gesundheitswesen

Aufgabenbereiche des öffentlichen Gesundheitswesens

Einrichtungen der Gesundheitsförderung

Lfd. Nr. Titel

Laufzeit

741 Lebensrettung von Personen

$1869-1890$

- Gewährung von Belohnungen für Lebensrettungen

(1854-1865)

- Berichte über Lebensrettungen (Rettung von Ertrinkenden, Rettung

Schiffsbrüchiger, Eisrettungen)

- Verleihung der Verdienstmedaille für Rettung aus Gefahr

(1854 - 1865) 1869 - 1890

Klassifikation Teil B: 01670

Trägermaterial: Papier

Alte Reg.-Sig.: IV Pc 2

Bestell-Nr.: IV 01670

742 Öffentliche Rettungsgeräte

$1891-1912$

- Anbringung von Rettungsgeräten an verschiedenen Punkten am

Rats- und Falderndelft, Juli - Oktober 1891

- Verzeichnis der Rettungsutensilien, Oktober 1891

- Polizeiverordnung über Schutz der öffentlichen Rettungsgeräte,

November 1891

- Bericht über Nichtnutzung von Rettungsutensilien am Roten Siel beim tödlichen Unglücksfall des 11-jährigen Knaben Schade wegen Unwissenheit über Lage des Rettungskastens, Juni 1895

- Fehlende Utensilien im Rettungskasten am Ems-Jade-Kanal,

September - November 1896 / Juni 1906

- Zeitschrift "Der Samariter", Organ der Lebensrettungsgesellschaft, 1907

- Anbringung eines Rettungskasten bei der Landungsbrücke am Delft, März 1912

$1891-1912$

Klassifikation Teil B: 01671

Trägermaterial: Papier

Alte Reg.-Sig.: IV Pc 3

Bestell-Nr.: IV 01671 
05

05.03

05.03.04

05.03.04.01

05.03.04.01.02

\section{Stadtverwaltung}

Aufgabenbereiche der Stadtverwaltung

Öffentliches Gesundheitswesen

Aufgabenbereiche des öffentlichen Gesundheitswesens Lebensmittelüberwachung

Lfd. Nr. Titel

Laufzeit

743 Qualitätskontrolle von Wein

- Erlass des preußischen Ministers für geistliche, Unterrichts- und Medizinalsachen über Gebührenfestsetzung für die Weinkontrolle, November 1909 - März 1910

- Liste der Weinhändler in Emden, 1905 - 1910

- Erlass des preußischen Ministers für geistliche, Unterrichts- und Medizinalsachen über Kontrollen von Flaschenwein, August 1910

- Streit um die Definition von Apfel-Champagner als weinähnliches

Getränk, Januar 1911

- Votum des Amtsleiters Dr. Bruns für die Vornahme aller Untersuchungen von Wein im Regierungsbezirk Aurich durch das Untersuchungsamt der Stadt Emden, November 1910 - April 1911 - Festlegung der Untersuchungsgebühren für die Weinkontrolle, Juni 1911

$1909-1911$

Klassifikation Teil B: 00174

Trägermaterial: Papier

Alte Reg.-Sig.: IV Ge 35

Bestell-Nr.: IV 00174

744 Vorschriften für den Knochenhandel

1891-1899

- Verfügung des Magistrats der Stadt Emden an den Fuhrmann Nicolaus van Detten über Aufforderung zum Abtransport gelagerter Knochen wegen Seuchengefahr, September 1891

- Beschwerde gegen den Kaufmann H. van der Wall wegen Geruchsbelästigung durch Einlagerung von Knochen, Juli 1896

- Verfügung des Magistrats der Stadt Emden an den Tischler Harm van der Walde über Anordnung zum Abriss einer ohne Erlaubnis errichteten Holzbaracke mit Knochenlager, Juli 1899

$1891-1899$

Klassifikation Teil B: 00797

Trägermaterial: Papier

Alte Reg.-Sig.: IV Ga 01

Bestell-Nr.: IV 00797

745 Einfuhrbestimmungen für Fleisch

- Polizeiverordnung der Stadt Emden über vetärinär- und sanitätspolizeiliche Vorschriften bei Fleischeinfuhren, 1878

1878

Klassifikation Teil B: 00800

Trägermaterial: Papier

Alte Reg.-Sig.: IV Ga 12

Bestell-Nr.: IV 00800 
05

\subsection{3}

05.03.04

05.03.04.01

05.03.04.01.02
Stadtverwaltung

Aufgabenbereiche der Stadtverwaltung

Öffentliches Gesundheitswesen

Aufgabenbereiche des öffentlichen Gesundheitswesens Lebensmittelüberwachung

Lfd. Nr. Titel

Laufzeit

746 Untersuchung des Schweinefleisches auf Trichinen etc., Bd. 1

- Beratungen im Magistrat und Bürgervorsteherkollegium in Emden über Organisation der Trichinenschau und Kosten, Dezember 1865 Februar 1882

- Diskussion einer flächendeckenden mikroskopischen

Trichinenuntersuchung durch von der Stadt Emden angestellte Sachverständige, 1875

- Ausschreibung der Stelle eines Fleischbeschauers durch die Stadt Emden, 1877

- Verschiedene Fleischbeschauordnungen als Muster für die Stadt

Emden, 1877

- Bericht des Kreisphysikus und Sanitätsrat Dr. Stöhr über Eignung von Bewerbern um das Fleischbeschaueramt, Juli 1877

- Vereidigung der Emder Fleischbeschauer, April 1877

- Statistik der untersuchten Schweine, 1877 - 1894

- Polizeiverordnung des preußischen Landdrosten in Aurich über Untersuchungspflicht für geschlachtete Schweine auf Trichinen und Finnen, Mai 1878

- Regelung der Untersuchung von amerikanischem Importfleisch, 1872 - 1892

- Festlegung der Fleischbeschaugebühren, Oktober 1879 - Dezember 1885

- Fleischbeschauordnung der Stadt Emden, März 1880

- Instruktionen für Fleischbeschauer, März 1880

- Streit zwischen den Fleischbeschauern, Tierarzt Dr. Mansholt und Barbier Aldert Bakker wegen Verletzung der Schaubezirksgrenzen, $1883-1884$

- Bestellung und Vereidigung des Baders A. J. Voortmann als

Fleischbeschauer, Mai 1885 - Januar 1886

$1865-1895$

Klassifikation Teil B: 00801

Band: 1

Trägermaterial: Papier

Alte Reg.-Sig.: IV Ga 13

Bestell-Nr.: IV 00801 
IV

05

Stadtverwaltung

05.03

05.03.04

05.03.04.01

05.03.04.01.02

Aufgabenbereiche der Stadtverwaltung

Öffentliches Gesundheitswesen

Aufgabenbereiche des öffentlichen Gesundheitswesens

Lebensmittelüberwachung

Lfd. Nr. Titel

Laufzeit

747 Untersuchung des Schweinefleisches auf Trichinen etc., Bd. 2

1895-1910

- Bestellung von Fleischbeschauer, 1877

(1877)

- Statistik der untersuchten Schweine, 1895 - 1902

- Polizeiverordnungen des preußischen Regierungspräsidenten in

Aurich über Organisation der Fleischbeschau, Juli 1895 - Februar

1910

- Untersuchung vom amerikanischem Importfleisch, 1896 - 1904

- Festlegung der Fleischbeschaubezirke der Stadt Emden, November 1898

- Erlasse des preußischen Ministers für geistliche, Unterrichts- und Medizinalangelegenheiten über Regelung des Fleischbeschauwesens, 1896 - 1897

- Statistik der im Emder Schlachthaus auf Trichinen untersuchten Schweine, Juli 1897 - Juli 1899

- Anzeige gegen die Firma Thiele \& Freese wegen Vertreibung nicht auf Trichinen untersuchten Schweinefleisches, März - April 1908

$1895-1910$

Klassifikation Teil B: 00802

Band: 2

Trägermaterial: Papier

Alte Reg.-Sig.: IV Ga 13

Bestell-Nr.: IV 00802 
05

\subsection{3}

05.03.04

05.03.04.01

05.03.04.01.02
Stadtverwaltung

Aufgabenbereiche der Stadtverwaltung

Öffentliches Gesundheitswesen

Aufgabenbereiche des öffentlichen Gesundheitswesens Lebensmittelüberwachung

Lfd. Nr. Titel

Laufzeit

748 Lebensmittelüberwachung, Bd. 1

$1879-1910$

- Umsetzung des Reichsgesetzes über den Verkehr mit Lebensmittel durch den Aufbau eines Lebensmitteluntersuchungsamtes bei der Stadt Emden, 1879 - 1883

- Streit zwischen Emden und Wilhelmshaven um die vom Lebensmitteluntersuchungsamt erhobenen Gebühren für die von Wilhelmshaven in Auftrag gegebene Untersuchung einer Weinprobe, Juni - Juli 1881

- Verfügung des Regierungspräsidenten in Aurich über Kontrolle der auf Märkten angebotenen Butter und Milch, März 1882

- Verhandlungen der Stadt Emden mit dem Amtsgericht in Emden wegen Abführung von Strafgeldern zur Unterhaltung des Lebensmitteluntersuchungsamtes wegen dessen Funktion als Beschaffer von Beweismittel, April - August 1893

- Statistik der Untersuchungen des Lebensmitteluntersuchungsamtes, 1884 - 1888

- Verfügung des Regierungspräsidenten in Aurich über Festlegung der Untersuchungsbezirke der Lebensmitteluntersuchungsämter Emden und Leer, August 1885

- Bericht des Lebensmitteluntersuchungsamtes über Untersuchungsaufträge durch verschiedene Kommunal- und Kreisbehörden Ostfrieslands, Mai 1886

- Instruktion für das Lebensmitteluntersuchungsamt über

Zuständigkeiten und Gebührensätze, Januar 1887

- Erlass des preußischen Ministers der geistlichen Unterrichts- und Medizinalangelegenheiten über Regelung der Lebensmittelüberwachung, Oktober 1896

- Antrag der Stadt Emden beim Regierungspräsidenten in Aurich auf Zuerkennung des Status einer "Öffentlichen Anstalt" für das Lebensmittelüberwachungsamt, November 1900

$1879-1900$

Klassifikation Teil B: 00803

Band: 1

Trägermaterial: Papier

Alte Reg.-Sig.: IV Ga 20

Bestell-Nr.: IV 00803 
05

05.03

05.03.04

05.03.04.01

05.03.04.01.02
Stadtverwaltung

Aufgabenbereiche der Stadtverwaltung

Öffentliches Gesundheitswesen

Aufgabenbereiche des öffentlichen Gesundheitswesens Lebensmittelüberwachung

Lfd. Nr. Titel

Laufzeit

749 Lebensmittelüberwachung, Bd. 2

1880-1902

- Schreiben der Stadt Emden an den Landgerichtspräsidenten über

Bitte um Anerkennung des Lebensmitteluntersuchungsamtes als

Stelle zur Überprüfung von verdächtigen Lebensmittelproben zur

Beweissicherung und Bitte um Unterstützung des Amtes durch

Zuwendungen aus den eingenommenen Strafgeldern, Februar 1880

- Antrag des Leiters des Lebensmitteluntersuchungsamtes, Apotheker

C. Hermann, auf eine Verbesserung der technischen Ausstattung,

August 1893

- Bescheid des preußischen Ministers der geistlichen Unterrichts- und Medizinalangelegenheiten über Ablehnung der Anerkennung des Lebensmitteluntersuchungsamtes Emden als öffentlich-rechtliche Anstalt wegen Fehlens eines eigenen Labors und nicht vorhandener hauptberuflicher Leitungskräfte, März - Oktober 1902

- Antrag der Firma Maggi bei der Polizeiverwaltung der Stadt Emden auf regelmäßige Prüfung ihrer Produkte zur Verhinderung von

Pantschereien, September 1902

$1880-1902$

Klassifikation Teil B: 00805

Band: 2

Trägermaterial: Papier

Alte Reg.-Sig.: IV Ga 20

Bestell-Nr.: IV 00805

750 Lebensmittelüberwachung, Bd. 3

$1879-1912$

- Antrag der Stadt Emden beim Kreisarzt auf Untersuchung von

Zisternen wegen Infektionsgefahr (Cholera), 1879

- Untersuchung von Schnaps (Genever) durch das

Lebensmitteluntersuchungsamt, 1883

- Untersuchung von Wassereis als Kühlmittel durch das

Lebensmitteluntersuchungsamt, 1885

- Antrag der Fa. Maggi auf regelmäßige Tests ihrer Produkte, Januar

1903

- Gebührenrückstände der Polizeiverwaltung beim

Lebensmitteluntersuchungsamt, Juli - August 1909

$1879-1912$

Klassifikation Teil B: 00806

Band: 3

Trägermaterial: Papier

Alte Reg.-Sig.: IV Ga 21

Bestell-Nr.: IV 00806 
IV

05

05.03

05.03.04

05.03.04.01

05.03.04.01.02
Stadtverwaltung

Aufgabenbereiche der Stadtverwaltung

Öffentliches Gesundheitswesen

Aufgabenbereiche des öffentlichen Gesundheitswesens

Lebensmittelüberwachung

Lfd. Nr. Titel

Laufzeit

751 Krankheiten und Vergiftungen durch Miesmuschelgenuss

1885

- Verfügung des Regierungspräsidenten in Aurich über Meldung von

Vergiftungsfällen durch den Genuss von Miesmuscheln, Oktober 1885

- Erhebungsbogen zur evtl. Anzeige, Oktober 1885

1885

Klassifikation Teil B: 00807

Trägermaterial: Papier

Alte Reg.-Sig.: IV Ga 22

Bestell-Nr.: IV 00807

752 Ausführung des Gesetzes über die Fleischbeschau

$1900-1915$

- Ausführungsbestimmungen zum Gesetz über die Fleischbeschau, Juni 1900 - Juli 1902

- Erlasse des preußischen Ministers für Landwirtschaft, Domänen und

Forsten über Ausführung des Gesetzes über die Fleischbeschau,

1902 - 1915

- Erlasse des preußischen Ministers für geistliche, Unterrichts- und

Medizinalangelegenheiten über Ausführung des Gesetzes über die

Fleischbeschau, 1902

- Gebührensatzung des Emder Schlachthauses, Juli 1902

- Bericht des Oberbürgermeisters Fürbringer an den

Regierungspräsidenten in Aurich über Plädoyer gegen die

Beschneidung der kommunalen Rechte bei der Fleischbeschau,

Januar 1903

- Verfügung des Regierungspräsidenten in Aurich über Festlegung der

Fleischbeschaugebühren, Februar - März 1903

- Regelung der Untersuchung von ausländischem Importfleisch, 1902

$-1915$

- Formulare zur Fleischbeschau, 1903

- Wünsche der Kommunen zur Novellierung des Gesetzes über die

Fleischbeschau, Juli 1904

- Statistische Erhebung über vom Emder Schlachthaus

eingenommenen Gebühren, 1906

$1900-1915$

Klassifikation Teil B: 00810

Trägermaterial: Papier

Alte Reg.-Sig.: IV Ga 38 a

Bestell-Nr.: IV 00810 
IV

05

05.03

05.03.04

05.03.04.01

05.03.04.01.02
Stadtverwaltung

Aufgabenbereiche der Stadtverwaltung

Öffentliches Gesundheitswesen

Aufgabenbereiche des öffentlichen Gesundheitswesens Lebensmittelüberwachung

Lfd. Nr. Titel

Laufzeit

753 Verkehr mit Blei und zinkhaltigen Gegenständen

1898-1907

- Ausführung des Gesetzes über den Verkehr mit Blei und zinkhaltigen Gegenständen, 1898 - 1907

- Verfügung des Regierungspräsidenten in Aurich über Anweisung zur Beobachtung des Verkaufes von Metallpfeifen mit unzulässigem

Bleigehalt, April 1898

$1898-1907$

Klassifikation Teil B: 00811

Trägermaterial: Papier

Alte Reg.-Sig.: IV Ga 41

Bestell-Nr.: IV 00811

754 Wert der Milch als Nahrungsmittel

- Verbreitung eines Merkblattes der Ärztekammer für die Rheinprovinz und die hohenzollernschen Lande über den Wert der Milch als Nahrungsmittel, September 1912

1912

Klassifikation Teil B: 00812

Trägermaterial: Papier

Alte Reg.-Sig.: IV Ga 51

Bestell-Nr.: IV 00812

755 Kuhmilch als Nahrungsmittel

$1911-1913$

- Verschiedene Polizeiverordnungen über Verkehr mit Milch als Nahrungsmittel als Vorbild für Emden, 1911

- Erlass des preußischen Ministers der geistlichen Unterrichts- und Medizinalangelegenheiten über Richtlinien für den Verkehr mit Kuhmilch als Nahrungsmittel, Juli 1912

- Denkschrift des Landwirtschaftlichen Hauptvereins für Ostfriesland über Grundsätze der Behandlung und des Vertriebs von Milch als Nahrungsmittel, Oktober 1912

- Gutachten der Molkereigenossenschaft Emden zur Denkschrift, Dezember 1912

- Verhandlungen über den Entwurf einer Polizeiverordnung des Regierungspräsidenten in Aurich über Verkehr mit Milch als Nahrungsmittel, Juli 1913

$1911-1913$

Klassifikation Teil B: 00813

Trägermaterial: Papier

Alte Reg.-Sig.: IV Ga 52

Bestell-Nr.: IV 00813 
05

05.03

05.03 .04

05.03.04.01

05.03.04.01.02

Lfd. Nr. Titel
IV

Stadtverwaltung

Aufgabenbereiche der Stadtverwaltung

Öffentliches Gesundheitswesen

Aufgabenbereiche des öffentlichen Gesundheitswesens

Lebensmittelüberwachung

Laufzeit

1879

- Bericht des Leiters des Nahrungsmitteluntersuchungsamtes,

Apotheker C. Hermann, über Bedarf des Untersuchungsamtes an

Geräten mit Kostenvoranschlag, November 1879

1879

Klassifikation Teil B: 00836

Trägermaterial: Papier

Alte Reg.-Sig.: IV Gr 10

Bestell-Nr.: IV 00836 
05

\subsection{3}

05.03.04

05.03.04.01

05.03.04.01.03
Stadtverwaltung

Aufgabenbereiche der Stadtverwaltung

Öffentliches Gesundheitswesen

Aufgabenbereiche des öffentlichen Gesundheitswesens Gesundheitsvorsorge

Lfd. Nr. Titel

Laufzeit

757 Gesundheitspolizeiliche Anordnungen

1871-1914

- Regelung der Anzeige ansteckender Krankheiten, 1871 - 1919

- Anzeige über den Ausbruch ansteckender Krankheiten in Emden, 1871

- Maßnahmen zur Bekämpfung der Cholera, 1871

- Vermerk des Senators Metger über hygienische Maßregel zur

Verbesserung der gesundheitlichen Verhältnisse uin der Stadt Emden, September 1871

- Berichte des Polizeikommissars und des Medizinalrats Dr. Stöhr als Kreisphysikus über gesundheitsgefährdende, infektiöse Stellen in der Stadt Emden und Vermerke über Beseitigungsmaßnahmen. 1871 1893

- Maßnahmen zur Bekämpfung der Genickstarre, November 1888 -

Februar 1902

- Vom Regierungspräsidenten in Aurich erlassene

Ausführungsbestimmungen zur Polizeiverordnung zur Bekämpfung ansteckender Krankheiten, Juni 1889

- Bericht des Oberbürgermeisters der Stadt Emden, Fürbringer, und des Sanitätsrats Dr. Norden als Kreisphysikus über Durchführbarkeit der Ausführungsbestimmungen, Juli 1889

- Polizeiverordnung über Anzeigenpflicht von Unterleibstyphus,

Oktober 1902

- Programm des "hygienischen Kurses für Verwaltungsbeamte" von Prof. Dr. Fränkel, Direktor des hygienischen Instituts der Universität Halle, Mai 1903

- Gesundheitspolizeiliche Erlasse des preußischen Ministers der geistlichen, Unterrichts- und Medizinalangelegenheiten, 1901 - 1910

- Anschaffung eines staubbindenden Fußbodenpräparats durch die Emder Stadtverwaltung und Schulen, Januar 1905

- Ankündigung des IV. Kongresses für Hygiene und Demographie in Berlin, März 1907

- Anzeige gegen den Arbeiter Spannhoff wegen Verwanzung seiner Wohnung, Juni - Juli 1907

- Anzeige einer Krätzeerkrankung, August 1910

1871 - 1914 (1919)

Klassifikation Teil B: 00798

Trägermaterial: Papier

Alte Reg.-Sig.: IV Ga 07

Bestell-Nr.: IV 00798 
05

05.03

05.03.04

05.03.04.01

05.03.04.01.03
Stadtverwaltung

Aufgabenbereiche der Stadtverwaltung

Öffentliches Gesundheitswesen

Aufgabenbereiche des öffentlichen Gesundheitswesens

Gesundheitsvorsorge

Lfd. Nr. Titel

Laufzeit

758 Lagerung von Tierfellen

1871-1903

- Beschwerden wegen Geruchsbelästigung durch eingelagerte alte Knochen und zum Trocknen aufgehangene Schaffelle im von den Geschäftsleuten Schönberg und Neumark genützten Packhaus in der Kranstr., Mai 1871

- Beschwerden gegen den Pelzhändler Aaron Gans wegen Geruchsbelästigung von in seinem Packhaus gelagerter Felle und Schweinshaar, Juli 1873 - Oktober 1874 / März - April 1875/ September - Oktober 1882 / November 1889 / Oktober 1901 - Beschwerden gegen den Getreidehändler Schönberg wegen Geruchsbelästigung durch von inm im Packhaus an der Kleinen Osterstr. eingelagerter Lumpen und Tierhäute, Juni 1876

- Übersicht über gelagertes Gut im von Aaron Gans genutzten Lagerhaus, März - Mai 1875 / März 1898

- Verhängung einer Geldstrafe gegen den Kaufmann Joseph Neumark wegen Offenlassung einer Luke seines Packhauses an der Kleinen Osterstr. und daraus resultierender Geruchsbelästigung durch eingelagerte Felle und Häute, April 1879

- Anzeige gegen den Kaufmann Wilhelm Philippstein wegen Geruchsbelästigung durch in seinem Packhaus eingelagerte Felle, Häute und Knochen, August - September 1892 / Dezember 1893

$1871-1903$

Klassifikation Teil B: 00799

Trägermaterial: Papier

Alte Reg.-Sig.: IV Ga 11

Bestell-Nr.: IV 00799

759 Bekämpfung der Säuglingssterblichkeit, Bd. 1

- Initiative der Deutschen Berufsvormünder zur Ausweitung der öffentlichen Säuglingsbetreuung, September 1916

- Verhandlungen über den Fortbestand der vom Emder

Erziehungsverein und dem Evangelischen Frauenbund getragenen Kinderkrippe in Emden, Juni 1914 - Mai 1915

- Statistik der Säuglingssterblichkeit in Emden, 1913 - 1915

- Initiative des Kaiserin Auguste Viktoria-Hauses zur Bekämpfung der

Säuglingssterblichkeit im Deutschen Reiche für Maßnahmen zum

Ausbau der Mutter-, Säuglings- und Kleinkinderfürsorge, Juni 1916

- Vereinbarung über Maßnahmen zur Verringerung der

Säuglingssterblichkeit in Emden, August 1916

- Planung und Organisation der Einrichtung einer Kinderkrippe mit

Mütterberatungsstelle in Emden, Dezember 1916

- Plan einer Säuglingskrippe im Emder Gasthaus, 1916

$1914-1916$

Klassifikation Teil B: 00828

Band: 1

Trägermaterial: Papier

Alte Reg.-Sig.: IV Gk 30 a

Bestell-Nr.: IV 00828 
05

\subsection{3}

05.03.04

05.03.04.01

05.03.04.01.03
Stadtverwaltung

Aufgabenbereiche der Stadtverwaltung

Öffentliches Gesundheitswesen

Aufgabenbereiche des öffentlichen Gesundheitswesens

Gesundheitsvorsorge

Lfd. Nr. Titel

Laufzeit

760 Bekämpfung der Säuglingssterblichkeit, Bd. 2

- Verfügung des Oberpräsidenten der Provinz Hannover über

Anordnung zur Einrichtung von Kreisstellen für Säuglings- und

Kleinkinderfürsorge, Januar 1917

- Organisation der Säuglings- und Kleinkinderfürsorge in

Gelsenkirchen als Vorbild für Emden, 1917

- Anlegung und Organisation der Kinderkrippe in Emden, Februar -

Mai 1917

Beiträge verschiedener Emder Firmen zur Einrichtung der

Kinderkrippe, Mai 1917

- Festsetzung der Tagespflegesätze in der Kinderkrippe, Juli 1917

- Organisation der Eröffnungsfeier der Emder Kinderkrippe, Oktober

1917

- Verfügung des Regierungspräsidenten in Aurich über Weisung zur Beseitigung aufgezählter Mängel bei der Emder Kinderkrippe, Oktober 1917

- Wohltätigkeitskonzert zugunsten der Kinderkrippe in Emden, März -

April 1918

$1917-1918$

Klassifikation Teil B: 00829

Band: 2

Trägermaterial: Papier

Alte Reg.-Sig.: IV Gk $30 \mathrm{~b}$

Bestell-Nr.: IV 00829

761 Wanderausstellung zur Säuglingsfürsorge

$1916-1918$

- Gedruckter Führer zur Wanderausstellung zur Säuglingsfürsorge des Vaterländischen Frauenvereins, 1916

- Werbung für die Wanderrausstellung, Juli 1917

- Kostenüberschlag der Wanderausstellung, Juli 1917

- Organisation der Wanderausstellung in Emden, Oktober 1917 - April

1918

- Notizheft mit Angaben über Zustände in der Kinderkrippe im Emder

Gasthaus, ca. 1918

1916 - 1918

Klassifikation Teil B: 00830

Trägermaterial: Papier

Alte Reg.-Sig.: IV Gk 30 c

Bestell-Nr.: IV 00830 
IV

05

Stadtverwaltung

05.03

Aufgabenbereiche der Stadtverwaltung

05.03.04

05.03.04.02

Öffentliches Gesundheitswesen

Stadtphysikat und Stadtchirurgen

Lfd. Nr. Titel

Laufzeit

762 Stadtphysikat

- Erlass des Hannoverschen Ministeriums des Innern über

Verpflichtung der Verankerung der Stelle des Stadtphysici in das

Ortsstatut der Stadt Emden, März 1855

- Verfügung des Hannoverschen Landdrosten in Aurich über

Heranziehung der Wundärzte zur Prüfung der Bader, Juni 1856

- Vertretung des abwesenden, für die Stadt Emden zuständigen

Landphysicus, Sanitätsrat Dr.Stöhr, Oktober 1860

- Vertretung des Medizinalrats Stöhr durch den späteren Sanitätsrat

Dr. Norden, Mai 1867 / Juli 1868 / Juni 1888

- Gesetzliche Regelung der Besoldung der Medizinalbeamten, März

1872

- Bewerbung des Sanitätsrates und Kreiswundarztes Dr. Norden um die Stelle des Kreisphysici in Emden, September 1885

- Ernennung des Sanitätsrats Dr. Norden zum Kreisphysicus durch den Regierungspräsidenten in Aurich, April 1886

- Bewerbung des Dr. Tergast um die Zulassung zur Physicatsprüfung,

Februar 1890

- Entlassung des Sanitätsrats Dr. Norden aus dem Dienst als

Kreisphysicus, August 1890

- Ernennung des Dr. Tergast zum Kreisphysicus mit der Zuständigkeit

für die Stadt Emden, August 1891

- Gesetzliche Regelung der Dienststellung des Kreisarztes,

September 1899

- Regelung der Kompetenzen des Kreisarztes, 1902

- Vertretung des Kreisarztes Dr. Tergast, August 1901 - Juni 1907

- Polizeiverordnung des Regierungspräsidenten in Aurich über Pflicht der niedergelassenen Ärzte zur Vorlage ihrer Prüfungszeugnisse und ihrer Approbation beim Kreisarzt, September 1902

- Dienstanweisung für die Kreisärzte, September 1909

- Vertretung des Kreisarztes Dr. Zibell, Juni 1913

(1855 - 1866) 1867 - 1914

Klassifikation Teil B: 0814

Trägermaterial: Papier

Alte Reg.-Sig.: IV Gb 1

Bestell-Nr.: IV 00814 
IV

05

05.03

05.03.04

05.03.04.03

05.03.04.03.01
Stadtverwaltung

Aufgabenbereiche der Stadtverwaltung

Öffentliches Gesundheitswesen

Medizinische Berufe und Betriebe

Hebammen

Lfd. Nr. Titel

Laufzeit

763 Hebammen-Institut, Bd. 1

1867-1895

- Festsetzung der Hebammengebühren, Januar 1855 - Februar 1858

$(1855-1866)$

- Antrag der Hebamme Catharina Maria Stes, geb. Bicker auf

Erlaubnis zum Schröpfen und Blutegelsetzen, November - Dezember

1855

- Zulassung der Errichtung einer Entbindungsanstalt durch den jüdischen Schlachters A.D. Fulda unter Auflagen, März - Oktober 1856

- Verfügung des Hannoverschen Landdrosten in Aurich über

Aufforderung der Entsendung Schwangerer zur Entbindungsanstalt nach Emden zur Sicherung der praktischen Hebammenausbildung, Oktober 1858

- Bericht der Stadt Emden über Tod des Medizinalrats Dr. Delaporte und Betrauung des Sanitätsrats Dr. Stöhr mit der interimistischen Leitung der Entbindungsanstalt, April 1859

- Verfügung des Hannoverschen Landdrosten in Aurich über Bau einer zentralen Entbindungsanstalt in Aurich als Ersatz für das ungünstig gelegene Emder Etablissement, Mai 1859

- Zulassungen zur Hebammenausbildung, 1859 - 1897

- Verfügung des Hannoverschen Landdrosten in Aurich über

Aufforderung der Entsendung Schwangerer zur zentralen

Entbindungsanstalt nach Aurich zur Sicherung der

Hebammenausbildung, November 1864

- Zulassung von Hebammen, 1864 - 1895

- Verfügung des Magistrats der Stadt Emden über Verpflichtung der Hebammen zur dreimonatlichen Abgabe ihrer Diensttagebücher zur Kontrolle der Amtsführung, Oktober 1872

- Revision der Hebammen, Mai 1876

- Statistische Nachweisung der Hebammen in Emden, Februar 1878

- Auswanderung der Hebamme Schiele nach Amerika, April 1887

- Regelung der vom Kreisphysicus vorzunehmenden Nachprüfung der Hebammen, Juli 1888

- Erlasse des preußischen Ministers der geistlichen, Unterrichts- und Medizinalangelegenheiten über Fortbildung der Hebammen, 1894 1895

(1855 - 1866) 1867 - 1895

Klassifikation Teil B: 00815

Band: 1

Trägermaterial: Papier

Alte Reg.-Sig.: IV Gh 1

Bestell-Nr.: IV 00815 
IV

05

05.03

05.03.04

05.03.04.03

05.03.04.03.01
Stadtverwaltung

Aufgabenbereiche der Stadtverwaltung

Öffentliches Gesundheitswesen

Medizinische Berufe und Betriebe

Hebammen

Lfd. Nr. Titel

Laufzeit

764 Hebammen-Institut, Bd. 2

1898-1918

- Delegierungen zum Fortbildungskurs für Hebammen in der

Provinzialhebammenschule Osnabrück, 1898 - 1914

- Erlass des Oberpräsidenten der Provinz Hannover über Erhebung von Daten zur erwarteten Zahl an Hebammenschülerinnen für die Schaffung der Grundlagen der Planungen zum Bau einer

Provinzialhebammenschule, Mai 1899

- Erlasse des preußischen Ministers der geistlichen, Medizinal- und Unterrichtsangelegenheiten über Organisation des Hebammenwesens und Ausbildungsfragen im Geburtshilfebereich, 1900 - 1908

- Nachprüfungen von Hebammen beim Kreisarzt, 1900 - 1903

- Festlegung einer Gebührenordnung für Hebammen, Februar 1901 -

August 1906

- Festschrift zur Eröffnung der Provinzial-Hebammenlehranstalt zu Hannover, April 1903

- Angebot der Firma Middendorf über Hebammentasche mit Inhalt, Januar 1905

- Regelung der Altersversorgung für praktizierende Hebammen, Mai 1908

- Zulassung der frei praktizierenden Hebamme Abeldine Kramer, Mai 1909

- Entzug der Zulassung als Hebamme für Neelke Penning wegen unsittlicher Lebensführung, 1912

- Dienstanweisung für Hebammen im Kgr. Preußen, September 1912

- Erlasse des preußischen Innenministers zum Hebammenwesen, März 1913 - Juni 1917

- Antrag der Stadt Emden beim kgl. Hauptzollamt in Emden auf Befreiung des für Desinfektionszwecken von den Hebammen benutzten Alkohols von Zoll- und Steuern, Mai - August 1913

$1898-1914$

Klassifikation Teil B: 00816

Band: 2

Trägermaterial: Papier

Alte Reg.-Sig.: IV Gh 1

Bestell-Nr.: IV 00816 
IV

05

05.03

05.03.04

05.03.04.03

05.03.04.03.01
Stadtverwaltung

Aufgabenbereiche der Stadtverwaltung

Öffentliches Gesundheitswesen

Medizinische Berufe und Betriebe

Hebammen

Lfd. Nr. Titel

Laufzeit

765 Kindbettfieber

$1881-1900$

- Anzeige des Arztes Dr. Brinckmann über Tod der Frau des

(1917-1918) Kornmessers Jann Peters am Kindbettfieber, Februar 1881

- Bericht des Kreisphysikus Dr. Stöhr über Unsauberkeit der Hebamme Ites als Ursache für tödliche Kindbettfiebererkrankungen,

Februar 1881

- Verfügung des Regierungspräsidenten in Aurich über Pflicht der sofortigen Meldung von Kindbettfiebererkrankungen an den zuständigen Medizinalbeamten zur Aufdeckung des Infektionsherdes, November 1888

- Erlass des preußischen Ministers der geistlichen, Medizinal- und Unterrichtsangelegenheiten über Pflicht zur ausreichenden Desinfektion der Hebammengerätschaften zur Verhütung des Kindbettfiebers, November 1888

- Verhandlungen im Magistrat der Stadt Emden über Bereitstellung von Mittel zur Beschaffung von Desinfektionsmittel für Hebammen, Januar 1889

- Bericht des Sanitätsrats Dr. Norden als Kreisphysicus über Umsetzung des Ministerialerlasses zur Bekämpfung des

Kindbettfiebers in Emden, Oktober 1889

- Erkrankung der Katharina van Dyken am Kindbettfieber, Oktober 1892

- Tödliche Kindbettfiebererkrankung der Frau des Böttchermeisters

Borgmann, Oktober 1892

- Tödliche Kindbettfiebererkrankung der Bertha Fiesler, November 1892

- Tödliche Kindbettfiebererkrankungen in Emden, 1895 - 1900

- Vermerk des Bürgermeisters Dr. Wilhelm Mützelburg über Vorschläge des Kreisarztes Dr. Zibell zur Reform des Hebammenwesens in Emden, Oktober - Dezember 1917 - Erhöhung der Bezüge der Hebammen in Emden, Februar September 1918

1881 - 1900 (1917 - 1918)

Klassifikation Teil B: 00824

Trägermaterial: Papier

Alte Reg.-Sig.: IV Gk 24

Bestell-Nr.: IV 00824 
05

05.03

05.03.04

05.03.04.03

05.03.04.03.02

Lfd. Nr. Titel
IV

Stadtverwaltung

Aufgabenbereiche der Stadtverwaltung

Öffentliches Gesundheitswesen

Medizinische Berufe und Betriebe

Bader

Laufzeit

1868

- Zulassung von Chirurgen, Badern und Barbieren, 1868

1868

Klassifikation Teil B: 00834

Trägermaterial: Papier

Alte Reg.-Sig.: IV Gq 1

Bestell-Nr.: IV 00834 
IV

05

Stadtverwaltung

05.03

05.03.04

Aufgabenbereiche der Stadtverwaltung

05.03.04.03

05.03.04.03.03

Öffentliches Gesundheitswesen

Medizinische Berufe und Betriebe

Apotheken und Arzneiwesen

Lfd. Nr. Titel

Laufzeit

767 Arzneimittelhandel

$1872-1914$

- Verfügungen des Regierungspräsidenten in Aurich über Regulierung des Arzneimittel- und Heilmittelhandels, 1872 - 1888

- Bekämpfung des Verkaufs von Geheimmittel als Arznei, 1887 - 1890

- Berichte der Stadt Emden über Bestrafungen wegen des Verkaufs von Geheimmittel als Arznei, Mai 1890 - Dezember 1898

- Urteil des Oberlandesgerichtes in Celle über Apothekenpflichtigkeit der sogenannten Wachsmuth'schen Hühneraugenringe, Mai 1895 -

August 1897

- Erlasse des preußischen Ministers der geistlichen, Medizinal- und Unterrichtsangelegenheiten über Regulierung des Vertriebs und der

Qualität der Arzneimittel, 1903 - 1910

- Warnungen vor schädlichen oder unwirksamen Präparate, 1907 -

1914

- Vertrieb verbotener Mittel durch Johann Bruntgen in der Boltentorstr., Juni 1911

- Erlasse des preußischen Innenministers über Bekämpfung des

Vertriebs gefährlicher Mittel durch ausländische Firmen, 1911 - 1912

$1872-1914$

Klassifikation Teil B: 00833

Trägermaterial: Papier

Alte Reg.-Sig.: IV Gr 03

Bestell-Nr.: IV 00833 
IV

05

05.03

05.03.04

05.03.04.03

05.03.04.03.03
Stadtverwaltung

Aufgabenbereiche der Stadtverwaltung

Öffentliches Gesundheitswesen

Medizinische Berufe und Betriebe

Apotheken und Arzneiwesen

Lfd. Nr. Titel

Laufzeit

768 Überwachung der Drogerien und des Arzneimittelvertriebs

1888-1913

- Polizeiverordnung des Regierungspräsidenten über Aufbewahrung und Verabfolgung von Giftwaren, November 1888

- Verfügung des Regierungspräsidenten in Aurich über Definition von giftigen Farben, Februar 1889 / Juni 1889

- Bericht des Polizeikommissars Bracke über revisionspflichtige

Drogerien in Emden, November 1889

- Kgl. Verordnung über zugelassene Arzneimittel, Kategorisierung und

Überwachung der gelagerten Schädlingsvertilgungsmittel, Januar

1890

- Verfügung des Regierungspräsidenten in Aurich über Revision der

Drogerien wegen gelagerter Gifte und Arzneimittel, Mai 1890

- Gemeinsamer Erlass des preußischen Innenministers und des

Ministers der geistlichen, Medizinal- und Unterrichtsangelegenheiten über Revision der Drogerien, Februar 1894

- Erstellung einer Polizeiverordnung der Stadt Emdem über Verkehr mit Giften, Februar 1898

- Erlasse des preußischen Ministers der geistlichen, Medizinal- und Unterrichtsangelegenheiten über Regelung des Vertriebs von

Arzneimittel und Revision der Drogerien, November 1901 - Januar

1911

- Verfügung des Regierungspräsidenten in Aurich über Verbot der

Abfüllung von Gift in leere Bierflaschen, September 1908

- Bericht über die Revision der Hansa-Drogerie (Besitzer Louis

Brüggemann) in Emden, August 1907

- Erlass des preußischen Innenministers über Prüfung von Drogisten und anderer Händler mit Giftstoffen, Juni 1913

$1888-1913$

Klassifikation Teil B: 00835

Trägermaterial: Papier

Alte Reg.-Sig.: IV Gr 09

Bestell-Nr.: IV 00835 
IV

05

Stadtverwaltung

05.03

Aufgabenbereiche der Stadtverwaltung

05.03.04

05.03.04.04

Öffentliches Gesundheitswesen

Bekämpfung von Epidemien

Lfd. Nr. Titel

Laufzeit

769 Bekämpfung übertragbarer Krankheiten

1906

- Erlass des preußischen Ministers der geistlichen, Unterrichts- und

Medizinalangelegenheiten über Anforderung eines statistischen

Berichts über Auftreten von Cholerafällen zur Feststellung der

Cholera-Verbreitung in Preußen, September 1906

- Erlass des preußischen Ministers der geistlichen, Unterrichts- und

Medizinalangelegenheiten über Verteilung einer Broschüre zur

Information über Vorbeugung des Kindbettfiebers, 1906

- Bekanntmachung der Anzeigepflicht von Scharlach, Oktober 1906

- Anzeige eines Todesfalls durch Genickstarre in Emden, Januar 1906

- Statistische Erhebung über Scharlachfälle, September 1906

1906

\author{
Klassifikation Teil B: 00796 \\ Trägermaterial: Papier \\ Alte Reg.-Sig.: IV Ga 01 \\ Bestell-Nr.: IV 00796
}

770 Heilmittel gegen Tuberkulose

$1890-1911$

- Presseberichte über das von Prof. Dr. Robert Koch hergestellte

Heilmittel gegen Tuberkulose (Tuberkulin), November 1890

- Schreiben des Magistrats der Stadt Emden an Prof. Dr. R. Koch über

Bitte um Überlassung einer Mege an Tuberkulin für das städtische

Krankenhaus, November 1890 - September 1891

- Publikation des Deutschen Zentralkomitees zur Bekämpfung der

Tuberkulose über Stand der Tbc-Bekämpfung, 1909

- Geschäftsbericht des Deutschen Zentralkomitees zur Bekämpfung

der Tuberkulose, 1911

- Schriften des Hannoverschen Provinzialvereins zur Bekämpfung der

Tuberkulose, $1907-1908$

$1890-1911$

Klassifikation Teil B: 00808

Trägermaterial: Papier

Alte Reg.-Sig.: IV GA 30

Bestell-Nr.: IV 00808 
IV

05

Stadtverwaltung

05.03

Aufgabenbereiche der Stadtverwaltung

05.03.04

05.03.04.04

Öffentliches Gesundheitswesen

Lfd. Nr. Titel

Bekämpfung von Epidemien

771 Bekämpfung der Diphterie

Laufzeit

1894-1904

- Erlass des preußischen Ministers der geistlichen Unterrichts- und Medizinalangelegenheiten über Anzeige der Erfahrungen mit dem

Behringschen Serum gegen Diphterie, Dezember 1894

- Erlass des preußischen Ministers der geistlichen Unterrichts- und

Medizinalangelegenheiten über Alleinvertrieb des Beringschen

Serums durch Apotheken, Februar - November 1895 / Mai 1904

- Bestimmung der Einhorn-Apotheke des Apothekers C. Hermann in

Emden zur zentralen Abgabestelle für das Beringsche Serum, Mai

1895

- Bericht des Kaiserlichen Gesundheitsamts über erfolgreiche Wirkung des Behringschen Serums, April 1895

$1894-1904$

Klassifikation Teil B: 00809

Trägermaterial: Papier

Alte Reg.-Sig.: IV Ga 33

Bestell-Nr.: IV 00809 
05

05.03

05.03.04

05.03.04.04
Stadtverwaltung

Aufgabenbereiche der Stadtverwaltung

Öffentliches Gesundheitswesen

Bekämpfung von Epidemien

Lfd. Nr. Titel

Laufzeit

772 Maßnahmen gegen Cholera

- Erlasse des preußischen Ministers für geistliche, Medizinal- und Unterrichtsangelegenheiten über Maßnahmen zur Bekämpfung der Cholera (Lepra, Pocken), Juli 1884 - Oktober 1910

- Veröffentlichungen des Kaiserlichen Gesundheitsamtes über Verbreitung der Cholera, September 1892

- Bildung von Gesundheitskommissionen in den Wyken der Stadt

Emden zur Verbesserung der hygienischen Verhältnisse als Mittel zur

Bekämpfung der Cholera, September 1892

- Anweisung der kgl. Eisenbahndirektion in Köln wegen Maßnahmen zur Bekämpfung der Cholera, September 1892

- Erlass des preußischen Innenministers über Abweisung einreisender Cholera-Verdächtiger an der Grenze, September 1892

- Desinfizierung über der Ems einfahrender Schiffe und Reisegepäck, September 1892

- Vereinbarung über Dienst der Diakonissen im Fall eines

Cholera-Ausbruches, April 1893

- Antrag des Polizeisergeanten Lech auf Entschädigung für seine bei der Desinfektion von Gepäck und Kleidung Reisender beschädigter Kleidung, April - Mai 1893

- Erlass des preußischen Ministers der öffentlichen Arbeiten über

Cholera-Schutzmaßnahmen bei der Eisenbahn, Juli 1893

- Berichte über Auftreten der Cholera in den Niederlanden, August 1993 - Dezember 1894

- Verfügung des Regierungspräsidenten in Aurich über Maßnahmen zur Bekämpfung der Cholera, September 1908 / Juli 1910

- Vorsorgemaßnahmen der Stadt Emden wegen drohender Cholera-Einschleppung aus Russland, September - Oktober 1908

- Nominierung zweier Diakonissen für den Dienst in der

Quarantäne-Station auf Nesserland im Falle einer drohenden

Cholera-Epidemie, Oktober 1908

- Berichte über Ausbruch von Cholera-Epidemien, 1911 - 1913

- Erlass des preußischen Innenministers über Impfaktion gegen

Cholera, September 1915

Klassifikation Teil B: 00817

Trägermaterial: Papier

Alte Reg.-Sig.: IV Gk 18

Bestell-Nr.: IV 00817 
Lfd. Nr. Titel

Laufzeit

773 Pocken (Blattern)

- Ausbruch der Pocken in Emden und Verhängung von

Quarantänemaßnahmen, März 1859

- Verdacht auf Pockenerkrankung des Gastwirts Schepker, Dezember 1866

- Infektionen mit Pocken in Emden, Dezember 1866 - Januar 1867

- Gesuch des an Pocken erkrankten J.F. Reinders um Aufhebung der über sein Haus verhängten Quarantäne mit Ausgehverbot wegen Genesung von der Krankheit, April - Mai 1867

- Erkrankung des Malergesellen Tjark Heyen an Pocken, April 1868

- Erkrankung des Handschuhmachergesellen Hermann Schack an den Pocken, Juni 1869

- Bericht des Senators Metger an den preußischen Landdrosten in Aurich über geplante Impfaktion gegen Pocken und Verzögerung durch das Fehlen von Impfstoff, März 1871

- Bericht des Magistrats der Stadt Emden über Pockenepidemie und Maßnahmen zur Bekämpfung, April 1871

- Verhängung der Quarantäne über das Schiff "Bertha" wegen

Erkrankung des Kapitäns Däne an Pocken in England, Januar 1877

(1859) $1866-1877$

Klassifikation Teil B: 00818

Trägermaterial: Papier

Alte Reg.-Sig.: IV Gk 02

Bestell-Nr.: IV 00818

774 Sanitätspolizeiliche Aufgaben

- Angeordnete bauliche Veränderungen in der Abwasserabführung des Hauses des Schneidermeisters Koehorn nach mehreren Typhuserkrankungen in seiner Familie, November 1878 - Juli 1879 - Typhuserkrankung der Familie des Schusters Volmer, Kranstr., August 1894

- Anzeigen über Typhuserkrankungen, 1893 - 1894

- Bericht des Kreisarztes Dr. Tergast über schmutzige Zisternen als Ursache für Typhuserkrankungen und Anweisung an den Zimmermeister Sievert Wurps zu ihrer Entfernung, Oktober 1893

$1878-1894$

Klassifikation Teil B: 00819

Trägermaterial: Papier Alte Reg.-Sig.: IV Gk 12

Bestell-Nr.: IV 00819 
Lfd. Nr. Titel

Laufzeit

775 Maßnahmen gegen die Pest

- Verfügung des Hannoverschen Landdrosten in Aurich über

Verhängung von Quarantäne gegen aus dem Mittelmeer einfahrende Schiffe wegen Pest in der Türkei, Ägypten und Nordafrika, September 1835

- Verfügung des Hannoverschen Landdrosten in Aurich

Desinfektions-Vorschrift für aus Smyrna einfahrende Schiffe wegen

Pestgefahr, April - Dezember 1837

- Verfügung des Hannoverschen Landdrosten in Aurich über Verhängung von Quarantäne von aus New Orleans einlaufender Schiffe wegen Gelbfieber, Seotember 1858 - Oktober 1859

- Verfügung des preußischen Landdrost in Aurich über Desinfektion von aus Russland eingeführte Schaffelle durch schweflige Säure und brennendem Schwefel, Februar 1879

- Kontrolle von Schiffe und Mannschaften aus Russland wegen

Pestgefahr, März - Mai 1879

- Nachricht über Gelbfieber-Epidemie auf Kuba und Brasilien, Juni

1885 - Juni 1891

- Anzeige über Pestausbruch in Südchina, 1893

- Erlass des preußischen Ministers für Handel und Gewerbe und des Ministers der geistlichen, Medizinal- und Unterrichtsangelegenheiten über Einfuhrbeschränkungen wegen aufgetretener Pest in überseeischen Staaten, Mai 1897 - Oktober 1912

- Anzeige über Pest in Alexandrien (Ägypten), Juni 1899

- Verfügung des Regierungspräsidenten in Aurich über Anzeigenpflicht des Auftretens der Pest, September 1899

- Anzeige über Pest in Paraguay, Oktober 1899

- Anzeige über Pest in Glasgow und Liverpool, November 1901

- Anzeige über Pest in Chile, Juni 1906

- Anzeige über Pockenerkrankungen in der Niederlanden, Mai 1906

(1835 - 1859) 1879 -1913

Klassifikation Teil B: 00820

Trägermaterial: Papier

Alte Reg.-Sig.: IV Gk 15

Bestell-Nr.: IV 00820 
IV

05

Stadtverwaltung

05.03

Aufgabenbereiche der Stadtverwaltung

05.03.04

05.03.04.04

Öffentliches Gesundheitswesen

Bekämpfung von Epidemien

Lfd. Nr. Titel

Laufzeit

776 Ansteckende Augenkrankheit

$1880-1912$

- Verfügung des Hannoverschen Landdrosten in Aurich über Anzeigenpflicht der Ansteckenden Augenkrankheit und Bekämpfung der Seuche durch Verbesserung der Hygiene, November 1841

- Bericht des Emder Stadtphysicus Laporte über angelaufene

Bekämpfungsmaßnahmen, November 1841

- Bericht des Kreisarztes Dr. Tergast über Auftreten der Ägyptischen

Augenkrankheit in Emden, November 1880 - April 1881

- Aufstellung über an der Ägyptischen Augenkrankheit erkrankte

Kinder, April 1881

- Schulbefreiung des an einer Augeninfektion (Körnerkrankheit) erkrankten Schülers Anton Brunner, 1912

(1841) $1881-1912$

Klassifikation Teil B: 00821

Trägermaterial: Papier

Alte Reg.-Sig.: IV Gk 18

Bestell-Nr.: IV 00821

777 Maßnahmen gegen die Cholera

$1892-1903$

- Mitteilungen über Ausbruch von Cholera in Nordamerika, Kuba,

Asien und europäische Staaten, Oktober 1892

- Erlass des preußischen Ministers der geistlichen, Medizinal- und

Unterrichtsangelegenheiten über Vorschrift zur Desinfektion von

Waren aus Hamburg wegen dortiger Choleraepidemie, Oktober 1892

- Erlass des Hamburger Senats über Regelung der Ein- und Ausfuhr von Waren angesichts der Choleraepidemie, September - November 1892

- Vergütung des städtischen Krankenhauses in Emden für Lieferung von Verpflegung an die Quarantänestation, Dezember 1892

- Verfügung des Regierungspräsidenten in Aurich über Verbot des

Viehimports aus den Niederlanden wegen Choleragefahr, Dezember 1892

- Bericht des Magistrats der Stadt Emden über Regelung der Wasserversorgung für die im Hafen festgemachten Seeschiffe, März 1903

$1892-1903$

Klassifikation Teil B: 00822

Trägermaterial: Papier

Alte Reg.-Sig.: IV Gk 19

Bestell-Nr.: IV 00822 
IV

05

05.03

05.03.04

05.03.04.04
Stadtverwaltung

Aufgabenbereiche der Stadtverwaltung

Öffentliches Gesundheitswesen

Bekämpfung von Epidemien

Lfd. Nr. Titel

Laufzeit

778 Seuchenschutzbestimmungen

$1872-1899$

- Russische Einfuhrbestimmungen für Baumwolle mit

(1836-1853)

Quarantänebestimmungen, 1836 - 1840

- Bestimmungen für nach Portugal einlaufende Schiffe hinsichtlich

Gesundheitspass und Quarantänebestimmungen, Februar 1846

- Verfügung des Hannoverschen Landdrosten in Aurich über

Verhängung von Quarantäne über Schiffe aus Hamburg und Holstein

wegen dort ausgebrochener Cholera, August 1853

- Verfügung des preußischen Landdrosten in Aurich über Verhängung

von Quarantäne für Schiffe aus der Ostsee wegen dort

ausgebrochener Cholera, Februar 1872

- Nachricht über Flecktyphus in Russland, März 1892

- Erlass des preußischen Ministers für Landwirtschaft, Domänen und

Forsten über Aufhebung der Importbeschränkungen für Wolle aus den

Niederlanden wegen der beendeten Seuchengefahr, Januar 1894

- Verbot der Einfuhr von Textilien aus Paraguay wegen dortiger Pest, 1899

(1836 - 1853) 1872 - 1899

Klassifikation Teil B: 00823

Trägermaterial: Papier

Alte Reg.-Sig.: IV Gk 22

Bestell-Nr.: IV 00823

779 Bekämpfung der Tuberkulose

- Umsetzung der Verfügung des Oberpräsidenten der Provinz

Hannover über Schaffung von Sonderstationen für TBC-Kranke in den Krankenhäusern, 1902

- Einladungen zu Versammlungen des Deutschen Zentral-Komites zur Errichtung von Heilanstalten für Lungenkranke, Januar 1903 - August 1904

- Fragebogen des Deutschen Zentral-Komites zur Errichtung von Heilanstalten für Lungenkranke über Stand der Bekämpfung der Tuberkulose, 1903 - 1904

$1902-1904$

Klassifikation Teil B: 00825

Trägermaterial: Papier

Alte Reg.-Sig.: IV Gk 25

Bestell-Nr.: IV 00825 
IV

05

Stadtverwaltung

05.03

Aufgabenbereiche der Stadtverwaltung

05.03.04

05.03.04.04

Öffentliches Gesundheitswesen

Bekämpfung von Epidemien

Lfd. Nr. Titel

Laufzeit

780 Wanderausstellung zur Tuberkulose-Aufklärung

1908-1913

- Vorstellung des Wandermuseums über Tuberkulose durch den

Hauptverein für Volkswohlfahrt in Hannover, April 1908

- Verfügung des Regierungspräsidenten in Aurich über Anregung zur

Veranstaltung der Ausstellung des Wandermuseums über

Tuberkulose in den größeren Orten Ostfrieslands, Juli 1908 / Juli 1910

- Verhandlungen über einen Zuschuss der Stadt Emden für die

Veranstaltung der Wanderausstellung für Tuberkulose in Emden,

August - September 1910

- Stellung der Turnhalle in der Wilhelmstraße für die Ausstellung,

November 1910

- Druckschrift über das Wandermuseum für Tuberkulose, 1910

- Antrag der städtischen Fürsorgestelle auf Zuschuss der Stadt

Emden für die Wanderausstellung über Tuberkulose, August 1912

- Organisation der Wanderausstellung in Emden, Dezember 1912 -

Februar 1913

- Feststellung und Kompensierung des Defizits der

Wanderausstellung, April . Mai 1913

$1908-1913$

Klassifikation Teil B: 00826

Trägermaterial: Papier

Alte Reg.-Sig.: IV Gk 26

Bestell-Nr.: IV 00826 
Lfd. Nr. Titel

- Verordnungen und Erlasse des Reichssekretärs des Innern und des preußischen Ministers der geistlichen, Medizinal- und Unterrichtsangelegenheiten über Maßnahmen im Seeverkehr, Warenhandel und Rattenbekämpfung zur Verhinderung des

Eindringens der Pest nach Deutschland, 1899 - 1909

- Kostenaufstellung über Instandsetzung der Wache beim Nordertor in Emden für bakteriologische Arbeiten, Oktober 1899

- Herstellung eines Laboratoriums im Städtischen Krankenhaus für Untersuchungen von Proben auf Pest, Oktober 1899

- Kampagne der Stadt Emden zur Vernichtung von Ratten und Mäusen zur Bekämpfung des Pesterregers

- Druck des Kaiserlichen Gesundheitsamtes über Belehrung über die Pest, 1900

- Aufstellung über Schuppen und Baracken mit Namen der Besitzer, Februar 1900

- Verfügung des Regierungspräsidenten in Aurich über Formulare zur

Erfassung etwaiger Pestkranker, August 1901

- Verfügung der Quarantäne über das englische Schiff

"Heurstadale"wegen Pest in Glasgow, August 1903

- Verfügung des Regierungspräsidenten über Vorstellung des

Rattenvertilgungsverfahren des Hamburger Hafenarztes Dr. Nocht, Mai 1904

- Bericht des Magistrats der Stadt Emden über Maßnahnmen zur Kontrolle der Seeschiffe auf Ratten und deren Vertilgung, Mai 1904

$1899-1909$

Klassifikation Teil B: 00827

Trägermaterial: Papier

Alte Reg.-Sig.: IV Gk 27

Bestell-Nr.: IV 00827

782 Maßnahmen zur Verhinderung der Verbreitung von ansteckenden Krankheiten

- Gebührenordnung für die Benutzung der Quarantänestation in Emden und für Desinfizierung von Seeschiffen, September 1894 - Erlasse des preußischen Ministers für Handel und Gewerbe und des Ministers der geistliche, Medizinal- und Unterrichtsangelegenheiten über Maßnahmen zur Desinfizierung von Seeschiffen und Behandlung von seuchenverdächtiger oder an Seuchen erkrankter Personen auf Schiffen, 1892 - 1900

- Verfügungen des Regierungspräsidenten in Aurich über Verhängung besonderer gesundheitspolizeilicher Auflagen gegen Schiffe aus Südamerika, Mittelmeerhafenorte und aus Loruient (Frankreich) wegen Cholera-Gefahr, April 1883 - Juni 1893

- Bericht über Cholera in den Niederlanden, Oktober 1893

$1883-1900$

Klassifikation Teil B: 00831

Trägermaterial: Papier

Alte Reg.-Sig.: IV Gk 01

Bestell-Nr.: IV 00831 
IV

05

Stadtverwaltung

05.03

Aufgabenbereiche der Stadtverwaltung

05.03.04

05.03.04.04

Öffentliches Gesundheitswesen

Bekämpfung von Epidemien

Lfd. Nr. Titel

Laufzeit

783 Quarantänestation in Emden

$1899-1900$

- Verhandlungen des dänischen Viehexporteurs A. C. Gebhard mit Oberbürgermeister Fürbringer über Terrain für die Errichtung einer Quaranränestation in Emden für Exportvieh nach Westfalen,

November 1899 - Januar 1900

- Vom Stadtbaumeister Wiggers erstellter Plan einer

Vieh-Quarantäne-Anstalt in Emden, 1899

- Kritischer Artikel in der "Jade-Zeitung", Varel, über Plan einer

Quarantänestation für dänisches Exportvieh in Emden, Dezember

1899

- Presseartikel über das Projekt der Quarantänestation für Exportvieh in Emden, Dezember 1899 - Januar 1900

- Erlass des preußischen Ministers für Landwirtschaft, Domänen und Forsten über Nichtgenehmigung der geplanten Quarantänestation wegen fehlendem Bedarf, Februar 1900

- Denkschrift über Einrichtung einer Seequarantänestation in Emden, Februar 1900

$1899-1900$

Klassifikation Teil B: 00832

Trägermaterial: Papier

Alte Reg.-Sig.: IV Gk 21

Bestell-Nr.: IV 00832 
IV

05

Stadtverwaltung

05.03

Aufgabenbereiche der Stadtverwaltung

05.03.04

05.03.04.05

Öffentliches Gesundheitswesen

Öffentliche Schlachthäuser

Lfd. Nr. Titel

Laufzeit

784 Anlage des Schlachthofes, Bd. 1

1893

- Korrespondenz der Stadt Emden mit anderen Städten über

Austausch von Normen für die Anlage eines Schlachthofes, Oktober 1893

1893

Klassifikation Teil B: 00837

Band: 1

Trägermaterial: Papier

Alte Reg.-Sig.: IV Gs 01

Bestell-Nr.: IV 00837

785 Schlachthofstatistik, Bd. 1

1898-1900

- Statistische Berichte über Betrieb, Einnahmen und Ausgaben des

Emder Schlachthofes

$1898-1900$

Klassifikation Teil B: 00838

Band: 1

Trägermaterial: Papier

Alte Reg.-Sig.: IV Gs 02

Bestell-Nr.: IV 00838

786 Schlachthofstatistik, Bd. 2

1901

- Statistische Berichte über Betrieb, Einnahmen und Ausgaben des Emder Schlachthofes

1901

\author{
Klassifikation Teil B: 00839 \\ Band: 2 \\ Trägermaterial: Papier \\ Alte Reg.-Sig.: IV Gs 02 \\ Bestell-Nr.: IV 00839
}

787 Schlachthofstatistik, Bd. 3

- Statistische Berichte über Betrieb, Einnahmen und Ausgaben des Emder Schlachthofes

1895

Klassifikation Teil B: 00840

Band: 3

Trägermaterial: Papier

Alte Reg.-Sig.: IV Gs 02

Bestell-Nr.: IV 00840 
IV

05

Stadtverwaltung

05.03

Aufgabenbereiche der Stadtverwaltung

05.03.04

05.03.04.05

Öffentliches Gesundheitswesen

Öffentliche Schlachthäuser

Lfd. Nr. Titel

Laufzeit

788 Schlachthofstatistik, Bd. 4

1896

- Statistische Berichte über Betrieb, Einnahmen und Ausgaben des

Emder Schlachthofes

1896

\author{
Klassifikation Teil B: 00841 \\ Band: 4 \\ Trägermaterial: Papier \\ Alte Reg.-Sig.: IV Gs 02
}

Bestell-Nr.: IV 00841

789 Schlachthofstatistik, Bd. 5

1897

- Statistische Berichte über Betrieb, Einnahmen und Ausgaben des Emder Schlachthofes

1897

\author{
Klassifikation Teil B: 00842 \\ Band: 5 \\ Trägermaterial: Papier \\ Alte Reg.-Sig.: IV Gs 17 \\ Bestell-Nr.: IV 00842
}

790 Schlachthofstatistik, Bd. 6

- Statistische Berichte über Betrieb, Einnahmen und Ausgaben des Emder Schlachthofes

1898
Klassifikation Teil B: 00843
Band: 6
Trägermaterial: Papier
Alte Reg.-Sig.: IV Gs 17
Bestell-Nr.: IV 00843

791 Schlachthofstatistik, Bd. 7

- Statistische Berichte über Betrieb, Einnahmen und Ausgaben des Emder Schlachthofes

1902

Klassifikation Teil B: 00844

Band: 7

Trägermaterial: Papier

Alte Reg.-Sig.: IV Gs 17

Bestell-Nr.: IV 00844 
IV

05

Stadtverwaltung

05.03

Aufgabenbereiche der Stadtverwaltung

05.03.04

05.03.04.05

Öffentliches Gesundheitswesen

Öffentliche Schlachthäuser

Lfd. Nr. Titel

Laufzeit

792 Schlachthofstatistik, Bd. 8

1903

- Statistische Berichte über Betrieb, Einnahmen und Ausgaben des

Emder Schlachthofes

1903

\author{
Klassifikation Teil B: 00845 \\ Band: 8 \\ Trägermaterial: Papier \\ Alte Reg.-Sig.: IV Gs 17
}

Bestell-Nr.: IV 00845

793 Anlage des Schlachthofes, Bd. 2

1893

- Korrespondenz der Stadt Emden mit anderen Städten über

Austausch von Normen für die Anlage eines Schlachthofes, Oktober 1893

1893

Klassifikation Teil B: 00846

Band: 2

Trägermaterial: Papier

Alte Reg.-Sig.: IV Gs 01

Bestell-Nr.: IV 00846

794 Emder Schlachthof

$1877-1900$

- Beschluss über Einführung des Schlachthauszwanges in Emden, April 1877

- Protest der jüdischen Schlachter gegen die Einführung des

Schlachthauszwanges, April 1877

- Beschlussfassung des Magistrats über Erhöhung der

Schlachthofgebühren und Etat des Schlachthofes, Oktober 1899

$1877-1899$

Klassifikation Teil B: 00847

Trägermaterial: Papier

Alte Reg.-Sig.: IV Gs 18

Bestell-Nr.: IV 00847 
IV

05

Stadtverwaltung

05.03

Aufgabenbereiche der Stadtverwaltung

05.03.04

05.03.04.05

Öffentliches Gesundheitswesen

Öffentliche Schlachthäuser

Lfd. Nr. Titel

Laufzeit

795 Schlachthof

$1880-1883$

- Aufstellung über Schlachter in Emden, 1890

- Verhandlungen der städtischen Kollegien wegen Errichtung eines städtischen Schlachthofes, 1891

- Konflikt zwischen Magistrat und Bürgervorsteherkollegium wegen

Aufsichtsrechte über den Schlachthof, 1891 - 1893

- Übersicht des Stadtbaumeisters Wiggers über Schlachtviehmengen,

Aufbau des Schlachthofes und Kostenschätzungen des

Schlachthofbaues, März 1891

- Korrespondenz des Oberbürgermeisters Fürbringer mit dem

oldenburgischen Schlachthofleiter Ostfoff über Schlachthofsachen,

$1880-1883$

$1880-1893$

Klassifikation Teil B: 01683

Trägermaterial: Papier

Alte Reg.-Sig.: IV Gs 1

Bestell-Nr.: IV 01683 
05

05.03

05.03.05

05.03.05.01
Stadtverwaltung

Aufgabenbereiche der Stadtverwaltung

Aufsicht über die Landwirtschaft

Organisierung der Landwirtschaft

Lfd. Nr. Titel

Laufzeit

796 Landwirtschaftliche Vereine

- Werbung für den Eintritt der Stadt Emden in den neugebildeten

Landwirtschaftlichen Verein für Ostfriesland, April 1850

- Statuten des Landwirtschaftlichen Vereins für Ostfriesland, 1850

- Protokolle der Generalversammlungen des landwirtschaftlichen

Provinzialvereins, 1853 - 1854

- Material für die Festschrift zum 100. Stiftungsfest der kgl.

Hannoverschen Landwirtschaftsgesellschaft, 1861 - 1865

- Gesuche des B.G. Tammens im Auftrag des Landwirtschaftlichen

Zweigvereins Emden um Stellung eines Platzes auf dem Neuen Markt

für eine Viehausstellung, Juli 1878 / Juni 1882

- Statuten des Hannoverschen Obstbauvereins, November 1887 /

1894 / 1899

- Druckschriften über Veranstaltungen des Hannoverschen

Obstbauvereins, 1888 - 1889

- Einladung zur Winterversammlung der kgl. landwirtschaftlichen

Gesellschaft, Oktober 1890 / November 1895

- Ausstellung des Hannoverschen Obstbauvereins in Leer, September 1891

- Werbung zum Beitritt zur Deutschen Dendrologischen Gesellschaft

(Baumkunde), Januar 1893

- Preisausschreiben zu Projekten der Wasserklärung von der

Deutschen Landwirtschaftlichen Gesellschaft, 1894

- Statuten der kgl. landwirtschaftlichen Gesellschaft, 1899

- Jahresbericht des Hannoverschen Obstbauvereins, 1900 - 1901

- Ankündigung der "Nordwestdeutschen Obstbauausstellung" in

Hannover, Mai 1905

$(1850-1865) 1879-1905$

Klassifikation Teil B: 00848

Trägermaterial: Papier

Alte Reg.-Sig.: IV Ha 04

Bestell-Nr.: IV 00848

797 Körungen

- Verzeichnis der gekörten Deck - Hengste im Regierungsbezirk

Aurich, 1912 - 1915

- Termine der Eber - und Schafbockkörung, 1912

- Verfügung des Regierungspräsidenten in Aurich über Bestimmungen

zur Organisation der Körungen angesichts der drohenden Maul- und

Klauenseuche, März 1912

- Temine der Kreisstutenschau, 1913

- Bekanntmachung der Hengstkörung. November 1913

- Kreisstutenschau in Ostfriesland, Januar 1914

- Termine der Stierkörungen, März 1913 / März 1914 / März 1915

$1912-1915$

Klassifikation Teil B: 00851

Trägermaterial: Papier

Alte Reg.-Sig.: IV Ha 09

Bestell-Nr.: IV 00851 
IV

05

Stadtverwaltung

05.03

Aufgabenbereiche der Stadtverwaltung

05.03.05

Aufsicht über die Landwirtschaft

05.03.05.01

Organisierung der Landwirtschaft

Lfd. Nr. Titel

Laufzeit

798 Gemüsebauverein

1878-1894

- Anzeige über Gründung des Emder Gemüsebauvereins, März 1878

- Statuten des Emder Gemüsebauvereins, März 1878 / April 1885

- Anzeige über Veränderung im Vorstand des Emder

Gemüsebauvereins, Januar 1894

$1878-1894$

Klassifikation Teil B: 00852

Trägermaterial: Papier

Alte Reg.-Sig.: IV Ha 10

Bestell-Nr.: IV 00852

799 Errichtung von Landwirtschaftskammern

1891-1912

- Preußisches Gesetz über die Errichtung von

Landwirtschaftskammern, Juni 1891

- Beitragserhebung der Landwirtschaftskammer für die Provinz

Hannover, 1903 - 1912 (1921)

- Erhebung der Beiträge zur Landwirtschaftskammer von den Erben

der Witwe Brons wegen Besitzes von zwei Höfen in Groothusen und

Charlottenpolder, September 1903

- Erhebung von Landwirtschaftskammerbeiträgen auf außerhalb der

Stadt gelegene Besitzungen Emder Bürger, 1904 - 1912

$1891-1912(1921)$

Klassifikation Teil B: 00860

Trägermaterial: Papier

Alte Reg.-Sig.: IV Ha 11

Bestell-Nr.: IV 00860 
Lfd. Nr. Titel

Laufzeit

800 Geflügelausstellungen

- Statuten des Vereins für Geflügelzucht und Tierschutz, 1903

- Erlass des Oberpräsidenten der Provinz Hannover über

Genehmigung einer Verlosung auf der Geflügelausstellung des Emder

Vereins für Geflügelzucht und Tierschutz, September 1903

- Seuchenpolizeiliche Bestimmungen als Auflage für

Geflügelausstellungen, November 1903

- Antrag des Vereins für Geflügelzucht und Tierschutz auf

Genehmigung einer Geflügelausstellung, November 1904 - November 1913

- Gedruckte Ausstellungsbestimmungen des Vereins für Geflügelzucht und Tierschutz, 1905 - 1913

- Stiftung eines Ehrenpreises der Stadt Emden für die

Hauptvereins-Junggeflügelausstellung des Vereins für Geflügelzucht und Tierschutz, November 1909

- Antrag des Vereins auf Erlass der Schanksteuer auf während der

Geflügelausstellung gereichte Getränke, November 1910

- Verfügung der Stadt Emden über Rauchverbot auf der

Geflügelausstellung, November 1910

$1903-1913(1921)$

Klassifikation Teil B: 00863

Trägermaterial: Papier

Alte Reg.-Sig.: IV Ha 17

Bestell-Nr.: IV 00863

- Stiftung eines Ehrenpreises der Stadt Emden zur Prämierung von ausgestellten Stücken im Rahmen der Wanderversammlung Hannoverscher Bienenzüchter, August 1904

- Erlass des Oberpräsidenten der Provinz Hannover über Genehmigung einer Verlosung von Preisen auf der Ausstellung im

Rahmen der Wanderversammlung Hannoverscher Bienenzüchter, Juli 1904

- Programm der Wanderversammlung Hannoverscher Bienenzüchter, September 1904

- Presseberichte über die Ausstellung der Wanderversammlung Hannoverscher Bienenzüchter, September - Oktober 1904

1904

Klassifikation Teil B: 00864

Trägermaterial: Papier

Alte Reg.-Sig.: IV Ha 18

Bestell-Nr.: IV 00864 
05

05.03

05.03.05

05.03.05.01
Stadtverwaltung

Aufgabenbereiche der Stadtverwaltung

Aufsicht über die Landwirtschaft

Organisierung der Landwirtschaft

Lfd. Nr. Titel

Laufzeit

802 Errichtung einer landwirtschaftlichen Winterschule

- Etablierung einer landwirtschaftlichen Winterschule für den Kreis

Emden in der Stadt Emden, 1909 - 1910

- Ausschreibung der Bauarbeiten zur Einrichtung der

landwirtschaftlichen Winterschule in den Räumen der früheren

Töchterschule in Emden, September 1910

- Vertrag über bauliche Maßnahmen an der früheren Töchterschule

zur Einrichtung der landwirtschaftlichen Winterschule, Oktober 1910

- Nominierung des Stadtsyndicus Leinberger als Mitglied des

Kuratoriums für die landwirtschaftliche Winterschule, Januar 1911

- Gedruckte Jahresberichte der landwirtschaftlichen Winterschule des

Kreises Emden, 1912 - 1914

- Vermerk des Bürgermeisters Dr. Wilhelm Mützelburg über

Notwendigkeit der Kompensation der Kosten der landwirtschaftlichen

Winterschule durch den Kreis Emden, November 1913

- Streit zwischen der Stadt Emden und dem Landkreis Emden wegen

Räumlichkeiten für die landwirtschaftliche Winterschule, Mai 1919 -

April 1921

1909 - 1914 (1919 - 1921)

Klassifikation Teil B: 00865

Trägermaterial: Papier

Alte Reg.-Sig.: IV Ha 19

Bestell-Nr.: IV 00865

803 Anregungen zur Hebung des Gemüsebaus

1902-1911

- Einberufung einer Versammlung zur Gründung einer

Genossenschaft zur Errichtung einer Konserven- und

Sauerkrautfabrik, Februar - April 1902

- Bericht der Ostfriesischen Zeitung über Gründung einer

Gemüsebauschule in Ostfriesland, März 1908

- Einladung des Oberbürgermeisters Fürbringer zu einer

Versammlung der Emder Gemüsebaugenossenschaft, März 1911

- Protokoll der Versammlung der Emder Gemüsebaugenossenschaft, März 1911

- Antrag der landwirtschaftlichen Winterschule des Kreises Emden auf

Beihilfe der Stadt für den Aufbau eines Winterkursusses für

Gemüsebauern, November 1911

- Erlass des preußischen Ministers für Landwirtschaft, Domänen und Forsten über Angebot der Verpachtung eines Domänenlandstückes an die landwirtschaftliche Winterschule als Versuchsfeld, September 1911

- Verhandlungen über den Bau eines Kohllagerschuppens im Emder Kohlanbaubezirk, November 1911

$1902-1911(1915)$

Klassifikation Teil B: 00866

Trägermaterial: Papier

Alte Reg.-Sig.: IV Ha 20

Bestell-Nr.: IV 00866 
05

05.03

05.03.05

05.03.05.01
Stadtverwaltung

Aufgabenbereiche der Stadtverwaltung

Aufsicht über die Landwirtschaft

Organisierung der Landwirtschaft

Lfd. Nr. Titel

Laufzeit

804 Viehversicherungen, Bd. 1

1877-1903

(1839-1864)

- Verfügung des Hannoverschen Landdrosten in Aurich über

Grundsätze zur Bildung von Viehversicherungsanstalten, Januar 1839

- Statuten der "Kuh-Casse" in Emden, März 1849

- Statuten der Viehversicherungsanstalt Emden, März 1864

- Anpassung der Statuten der Viehversicherung an das preußische

Viehseuchenrecht wegen Entschädigung des Staates für auf

Anordnung getötetes Vieh, November 1877 - November 1878

- Mustersatzung für Viehversicherungen des kaiserlichen

Aufsichtsamt für Privatversicherung, März 1903

(1839 - 1864) 1877 - 1903

Klassifikation Teil B: 00887

Band: 1

Trägermaterial: Papier

Alte Reg.-Sig.: IV Hh 1

Bestell-Nr.: IV 00887

805 Viehversicherungen, Bd. 2

$1873-1905$

- Statuten der Vieh-Versicherungsbank der Provinz Hannover, 1873

- Verfügung des Magistrats der Stadt Emden über Anforderung eines Jahresberichtes vom Emder Viehversicherungs-Verein, Mai 1884 /

März 1905

- Verfügungen des Regierungspräsidenten in Aurich über Regulierung des Betriebs der Viehversicherungsanstalten, 1898 - 1904

- Erlasse des preußischen Ministers für Landwirtschaft, Domänen und Forsten über Regulierung der Viehversicherungsanstalten, Mai 1893 Juli 1902

- Verfügung des Magistrats der Stadt Emden an den

Versicherungsagenten $\mathrm{H}$. Dirks über Aufforderung zur Einreichung der Statuten der von ihm vertretenen Sächsischen

Vieh-Versicherungs-Bank, Juni 1893

- Bericht der Stadt Emden an den Regierungspräsidenten in Aurich über nicht vorhandenen Versicherungsschutz für Schweine, Juni 1893 - Bericht der Stadt Emden über einwandfreie Geschäftsführung der

Viehversicherungs AG Schwerin in Emden, März 1894

- Bericht der Stadt Emden über nicht bestehende

Schlachtviehversicherungen, September 1902

- Antrag des Vorstands der Viehversicherungsgesellschaft Emden auf Anerkennung als "kleiner Verein" zur Erleichterung der

Geschäftsführung und Beibehaltung der Statuten, April 1903 - März

1904

- Werbung der Vaterländischen Viehversicherungsgesellschaft

Dresden, Dezember 1903

- Änderung der Statuten der Emder Viehversicherungsanstalt, November 1904

- Jahresbericht der Viehversicherungsgesellschaft Emden, 1905

$1873-1905$

Klassifikation Teil B: 00888

Band: 2

Trägermaterial: Papier

Alte Reg.-Sig.: IV Hh 1

Bestell-Nr.: IV 00888 
Lfd. Nr. Titel

Laufzeit

806 Viehversicherungen, Bd. 3

- Verfügungen des Regierungspräsidenten in Aurich über Regulierung der Viehversicherungen, 1903 - 1907

- Gedruckte, vom Kaiserlichen Aufsichtsamt für Privatversicherung herausgegebene Mustersatzung für Viehversicherungsanstalten, März 1903

- Erlasse des preußischen Ministers für Landwirtschaft, Domänen und Forsten über Bestimmungen zur Regulierung der

Schlachtviehversicherungen, Oktober 1905 - Januar 1911

- Jahresbericht der Viehversicherungsgesellschaft Emden für das

Geschäftsjahr 1919, 1920

$1903-1911(1920)$

Klassifikation Teil B: 00889

Band: 3

Trägermaterial: Papier

Alte Reg.-Sig.: IV Hh 1

Bestell-Nr.: IV 00889

807 Viehversicherungen, Bd. 4

- Jahresberichte der Emder Viehversicherungsanstalt, 1906 - 1909

- Anfrage der Vaterländischen Viehversicherung Dresden nach geeigneten Persönlichkeiten als Vertreter, Dezember 1906 - Januar 1907

- Datenerhebung der Landwirtschaftskammer für die Provinz

Hannover zu Viehversicherungen, Juni 1908

- Bericht über schlachtviehversicherungsähnlichen Verein von 9

Schweineschlachtern in Emden, Oktober 1908

- Initiative des Oberpräsidenten der Provinz Hannover zur Bildung einer Viehversicherung auf Provinzialebene, 1913

$1906-1913$

Klassifikation Teil B: 00890

Band: 4

Trägermaterial: Papier

Alte Reg.-Sig.: IV Hh 1

Bestell-Nr.: IV 00890

808 Benennung von Gutachtern zur Viehschätzung

- Ernennung von Gutachtern zur Viehschätzung durch den Stadtausschuss des Stadtkreises Emden nach den Bestimungen des preußischen Viehseuchengesetzes

$1886-1914$

Klassifikation Teil B: 03812

Trägermaterial: Papier

Alte Reg.-Sig.: XI IX Nr. 01

Vorprovenienz: Stadtausschuss d. Stadtkreises Emden

Bestell-Nr.: IV 03812 
05

\subsection{3}

05.03.05

05.03.05.02
Stadtverwaltung

Aufgabenbereiche der Stadtverwaltung

Aufsicht über die Landwirtschaft

Gemeinheitsteilungen

Lfd. Nr. Titel

Laufzeit

809 Ausführung des preußischen Feld- und Forstpolizeigesetzes

- Verfügung des preußischen Landdrosten in Aurich über Bitte um gutachterliche Stellungnahme zur Feld- und Forstpolizeiordnung in der Rheinprovinz, November 1870 - Januar 1871

- Preußisches Feld- und Forstpolizeigesetz, April 1878 / April 1880

- Novellierung und Umsetzung des preußischen Feld- und

Forstpolizeigesetzes, Januar 1880 - Januar 1885

- Eingaben des Emder Gemüsebauvereins an die Stadt Emden über Bitte um Publizierung eines Betretungsverbots für Gemüsefelder zur Verhinderung von Diebstahl, September 1891 - Oktober 1898

- Anzeige des Polizeisergeanten Battermann über Diebstahl von Möhren durch Schuljungen, Juni 1910

$1870-1914$

Klassifikation Teil B: 00850

Trägermaterial: Papier

Alte Reg.-Sig.: IV Ha 08

Bestell-Nr.: IV 00850

810 Gemeinheitsteilungs- und Verkupplungssachen

- Verfügungen des Hannoverschen Landdrosten in Aurich über

Umsetzung des Gemeinheitsteilungs- und Verkupplungsgesetzes, November 1844 - Mai 1853

- Verzeichnis der Feldmarken im Bereich der Stadt Emden, Mai 1853

- Verfügung des preußischen Landdrosten in Aurich über Angabe der

Zahl der Verkoppelungen zur Regulierung der Grundsteuer, März

1867

- Erlasse der preußischen Generalkommission über Regeln für die

Durchführung von Verkoppelungen und Gemeinheitsteilungen, 1867 .

1884

- Bericht des Magistrats der Stadt Emden über nichtvorliegende

Verfahren von Verkoppelungen und Gemeinheitsteilungen, März 1869

- Erlass der Generalkommission über Berichtigung der

Grundsteuerkataster, November 1876 - Februar 1877

- Erlass des preußischen Ministers für Landwirtschaft, Domänen und

Forsten über Aufgaben der Meliorationstechniker, April 1880

- Verfügung des Regierungspräsidenten über Aufforderung zur

Forcierung der als notwendig erachteten Verkoppelungen, Juli 1887

(1844 - 1853) $1867-1887$

Klassifikation Teil B: 00882

Trägermaterial: Papier

Alte Reg.-Sig.: IV Hb 2

Bestell-Nr.: IV 00882 
IV

05

Stadtverwaltung

05.03

Aufgabenbereiche der Stadtverwaltung

05.03.05

05.03.05.02

Aufsicht über die Landwirtschaft

Gemeinheitsteilungen

Lfd. Nr. Titel

Laufzeit

811 Realgemeinden

1886

- Gesetzliche Bestimmungen über Organisation und Verfassung von

Realgemerinden, 1886

1886

Klassifikation Teil B: 00883

Trägermaterial: Papier

Alte Reg.-Sig.: IV Hb 3

Bestell-Nr.: IV 00883

812 Lasten bei Gemeinheitsteilungen und Anlage neuer Straßen

1887-1912

(1913-1914)

- Ausführung des Gesetzes über Verteilung der öffentlichen Lasten bei Gemeinheitsteilungen und Anlage neuer Siedlungen in der Provinz Hannover, November 1887 - Juni 1900

- Aufstellung über Kirchen-, Pfarr-, Schul- und Gemeindeverbände im Landkreis und Stadtkreis Emden, August 1888

- Anzeige der Emder Nachbargemeinden über private Bauvorhaben und Grundstücksveränderungen in der Nähe der Emder Feldmark, $1891-1897$

- Geschäftsbericht der Hannoverschen Gemeinnützigen

Ansiedlungsgesellschaft, 1910

- Verfügung des Regierungspräsidenten in Aurich über Regelung der kirchlichen Verhältnisse in neuen Ansiedlungen und Kolonien, Februar 1912

1887 - $1912(1913-1914)$

Klassifikation Teil B: 00884

Trägermaterial: Papier

Alte Reg.-Sig.: IV Hb 4

Bestell-Nr.: IV 00884 
05

05.03

05.03.05

05.03.05.02
Stadtverwaltung

Aufgabenbereiche der Stadtverwaltung

Aufsicht über die Landwirtschaft

Gemeinheitsteilungen

Lfd. Nr. Titel

Laufzeit

813 Anlegung der Arbeiterkolonie "Friesland"

1913-1915

- Lageplan der von der Deutsch-Luxemburgischen Bergwerks- und

Hütten AG als Besitzerin der Nordseewerke projektierten

Werftarbeiterkolonie als Teil des Baugenehmiogungsverfahrens,

Januar 1913

- Bebauungsplan für die Arbeiterkolonie, Januasr 1913

- Stellungnahme der Evangelisch lutherischen Gemeinde Emden über

nicht vorhandene Kapazitäten zur kirchlichen Versorgung der

Einwohner in der geplanten Arbeiterkolonie und Bitte um

Berücksichtigung ihrer Interessen bei Verwirklichung des Projektes,

Februar 1913

- Auflagen für den Aufbau der Kolonie hinsichtlich Wasserversorgung,

Straßenanbindung, Schullasten und Polizeikosten, März 1913

- Verhandlungen der Stadt Emden mit der Regierung in Aurich über

Anpassung des Emder Schulsystems an die Anforderungen dzurch die geplante Arbeiterkolonie, Mai 1913 - Oktober 1914

- Angebot der Nordseewerke, Deutsch-Luxemburgische Bergwerksund Hütten AG, über Abfindungen der Schul- und Kirchenlasten,

Beteiligung an den Kosten für Polizei und Erstellung einer

Wasserversorgung, Juni 1913

- Bescheid des Magistrats der Stadt Emden als Ortspolizeibehörde

über Genehmigung der Anlage der Kolonie "Friesland" unter Auflagen, Juli 1913

- Konflikt der Stadt Emden mit dem Konsistorium in Aurich wegen

Genehmigung der Anlage der Arbeiterkolonie ohne Klärung der

kirchlichen Versorgung, Oktober 1913 - April 1914

- Vertrag zwischen der Stadt Emden und der

Deutsch-Luxemburgischen Bergwerks- und Hütten AG,

Nordseewerke, über Anlage der Kolonie "Friesland", Dezember 1913

- Aufstellung über Bewohner der Kolonie, Zahl der Kinder und

Konfessionszugehörigkeit, 1914

$1913-1915$

Klassifikation Teil B: 00885

Trägermaterial: Papier

Alte Reg.-Sig.: IV Hb 5

Bestell-Nr.: IV 00885 
IV

05

Stadtverwaltung

05.03

Aufgabenbereiche der Stadtverwaltung

05.03.05

05.03.05.03

Aufsicht über die Landwirtschaft

Schädlingsbekämpfung

Lfd. Nr. Titel

Laufzeit

814 Bekämpfung von schädlichen Insekten

1875-1914

- Vorschriften wegen Bekämpfung der Reblaus, 1875 - 1913

- Vorschriften wegen Bekämpfung des Kartoffelkäfers

(Coloradokäfer), 1875 - 1914

- Schreiben der Kaufmännischen Deputation über Vorschlag zur

Verhinderung der Einschleppung des Coloradokäfers (Kartoffelkäfer)

durch schärfere Kontrolle von Ladungen aus den USA, Dezember

1876

- Plakat über Kartoffelkäfer, 1877

- Vorschriften wegen Bekämpfung des Kohlweißlings, 1876 - 1877

- Vorschriften wegen Bekämpfung der Blutlaus, 1883

- Verdacht des Reblausbefalls der Reben des Amtsgerichtsrats

Lohskötter, März - Juni 1885

- Vorschriften wegen Bekämpfung der Dasselfliege, Januar 1896

$1875-1914$

Klassifikation Teil B: 00867

Trägermaterial: Papier

Alte Reg.-Sig.: IV Hc 3

Bestell-Nr.: IV 00867 
IV

05

Stadtverwaltung

05.03

Aufgabenbereiche der Stadtverwaltung

05.03.05

Aufsicht über die Landwirtschaft

05.03.05.04

Statistische Berichte aus der Landwirtschaft

Lfd. Nr. Titel

Laufzeit

815 Landwirtschaftsstatistik

$1900-1915$

- Erhebung von Daten zu Schäden durch Hagel oder

Überschwemmungen, 1900 - 1909 / 1911

- Statistischer Bericht über Bodennutzung im Emder Stadtgebiet, 1900

- Berichte der Stadt Emden über bebaute Ackerflächen, Juli 1902

- Verfügungen des preußischen statistischen Landesamts (kgl.

Statistisches Büro) über Datenerhebungen zur

Landwirtschaftsstatistik, November 1901 - August 1914

- Statistische Korrespondenz über Bodennutzung, 1913 - 1914

- Bericht der Gemüsebaugenossenschaft Emden über

Ernteaussichten im Gemüse - und Kohlanbau, Juli 1915

- Druckschriften: Die Ernte in Preußen, 1912 - 1913

$1900-1915$

Klassifikation Teil B: 00849

Trägermaterial: Papier

Alte Reg.-Sig.: IV Ha 06

Bestell-Nr.: IV 00849 
IV

05

Stadtverwaltung

05.03

Aufgabenbereiche der Stadtverwaltung

05.03.05

05.03.05.05

Aufsicht über die Landwirtschaft

Lfd. Nr. Titel

Be- und Entwässerung

816 Be- und Entwässerung

Laufzeit

1867-1881

(1857)

- Gedruckter Erlass des preußischen Ministers für Landwirtschaft,

Domänen und Forsten über Anweisung für die Bildung von Ent- und

Bewässerungsgenossenschaften, Oktober 1857 / Juli 1867

- Angebot von zinsgünstigen Krediten an Meliorationsverbände durch die Preußische Central-Boden-Credit Actien-Gesellschaft, Juni /

August 1881

(1857) / 1867 / 1881

Klassifikation Teil B: 00886

Trägermaterial: Papier

Alte Reg.-Sig.: IV Hc 1

Bestell-Nr.: IV 00886 
IV

05

Stadtverwaltung

05.03

Aufgabenbereiche der Stadtverwaltung

05.03.05

Aufsicht über die Landwirtschaft

05.03.05.06

Pflanzenkrankheiten und Missernten

Lfd. Nr. Titel

Laufzeit

817 Pflanzenkrankheiten und -Schädlinge

1898-1914

- Bekämpfung der Monilia (Pilzerkrankung an Kirschbäumen), Juli -

September 1898

- Verfügung des Regierungspräsidenten in Aurich über

Berichterstattung beim Auftreten von Schädlingen in Pflanzenkulturen, Januar 1899

- Verfügung des Regierungspräsidenten in Aurich über Anzeige des

Vorkommens von Franzosenkraut, März 1902

- Druckschrift der kaiserlichen biologischen Anstalt für Land- und

Forstwirtschaft über Amerikanischen Mehltau als neue

Pflanzenkrankheit, Juli 1905

- Schrift des landwirtschaftlichen Hauptvereins für Ostfriesland über

Bekämpfung der Spargelschädlinge, 1907

- Biologische Bekämpfung von Mäuse und Ratten durch Bakterien des

Mäusetyphus und des Rattentyphus (Rattin), 1907

- Bekämpfung der gelben Wucherblume, Juni 1907

- Anzeige des Auftretens von Kartoffelpilzkrankheiten, 1909

- Bekämpfung des Amerikanischen Mehltau, 1909 - 1913

$1898-1914$

Klassifikation Teil B: 00861

Trägermaterial: Papier

Alte Reg.-Sig.: IV Ha 12

Bestell-Nr.: IV 00861 
IV

05

Stadtverwaltung

05.03

Aufgabenbereiche der Stadtverwaltung

05.03.05

05.03.05.07

Aufsicht über die Landwirtschaft

Jagd und Fischerei

Lfd. Nr. Titel

Laufzeit

818 Fischereiwesen der Stadt Emden

- Verpachtung der Fischerei auf den Wasserflächen der Stadt Emden, $1836-1892$

(1836 - 1865) 1866 - 1892

Klassifikation Teil B: 00868

Trägermaterial: Papier

Alte Reg.-Sig.: IV Hg 02

Bestell-Nr.: IV 00868

819 Jagd in den Emder Stadtherrlichkeiten

$1869-1900$

- Verhandlungen der Stadt Emden mit der kgl. Forstinspektion in

Aurich wegen Abgrenzung der städtischen Feldmark zum

Domanialland wegen Jagdpachteinnahmen, Januar - Mai 1869

- Ermittlungen wegen verbotener Jagd auf dem Königspolder,

November - Dezember 1900

$1869-1900$

Klassifikation Teil B: 00869

Trägermaterial: Papier

Alte Reg.-Sig.: IV Hg 07

Bestell-Nr.: IV 00869

820 Verpachtung der Jagd im städtischen Teil des Kaiser-Wilhelm-Polder

$1870-1911$

- Bedingungen für die Verpachtung der Jagd, August 1870 / Juli 1881

- Ausschreibung der Pacht, 1870 - 1904

- Anspruch des Eisenbahnfiskus auf einen Anteil an der Jagdpacht wegen Querung der Eisenbahnlinie durch den Kaiser-Wilhelm-Polder, Juli 1890

- Antrag des Jagdpächters J. Penaat auf Pachtermäßigung wegen

Rückgang der Jagderträge nach dem Bau der Einrichtungen der

Heringsfischerei im Kaiser-Wilhelm-Polder, Juni 1894 - August 1895

- Ermäßigung der Jagdpacht auf dem Kaiser-Wilhelm-Polder wegen

Rückgang der Jagdstrecke nach dem Bau von Arbeitersiedlungen in der Nähe, April 1900

$1870-1911$

Klassifikation Teil B: 00870

Trägermaterial: Papier

Alte Reg.-Sig.: IV Hg 08

Bestell-Nr.: IV 00870 
05

05.03

05.03.05

05.03.05.07
IV

\section{Stadtverwaltung}

Aufgabenbereiche der Stadtverwaltung

Aufsicht über die Landwirtschaft

Jagd und Fischerei

Lfd. Nr. Titel

Laufzeit

821 Beihilfe zur Beschaffung eines Fischerbootes

$1911-1912$

(1919)

- Antrag des Fischers B. Buisker auf Unterstützung zum Kauf eines größeren Fischerbootes wegen Verlust seiner nahe Emden befindlichen Fischgründe durch Industriebauten, September 1911 Juni 1912 (1919)

1911 - 1912 (1919)

Klassifikation Teil B: 00871

Trägermaterial: Papier

Alte Reg.-Sig.: IV Hg 18

Bestell-Nr.: IV 00871 
- Erlass des Ministers für öffentliche Arbeiten über Bestrafung von Verkehrsabgabenhinterziehung, August 1897 / Januar 1898 / Mai 1900

$1897-1900$

Klassifikation Teil B: 00035

Trägermaterial: Papier

Alte Reg.-Sig.: IV Cb 16

Bestell-Nr.: IV 00035

823 Unrat auf den Straßen

- Anzeigen wegen Ablegung von Mist, Asche und Unrat auf den städtischen Straßen, (1851) 1871

- Antrag des Gemüsebauern Otto Uilderks auf Erlaubnis der Abstellung seines Dungwagens bei seiner Stallung in der Grasstraße, Dezember 1897

- Antrag des C. - J. Dirksen auf Genehmigung des Verbleibs seines Misthaufens bis zum Juli wegen besserer Verkaufschance für den Mist an Gemüsebauern, Mai 1875

(1851) $1871-1897$

Klassifikation Teil B: 00892

Trägermaterial: Papier

Alte Reg.-Sig.: IV Ja 02

Bestell-Nr.: IV 00892

824 Aufgeschüttetes Vieh

- Protokolle über eingefangenes (aufgeschüttetes) herrenloses Vieh, $1855-1887$

- Festlegung des Schüttgeldes, Oktober 1858

- Erteilung der Schüttstallkonzession an die Schankwirtin Metha

Baumann, Dezember 1858

- Bewerbung des Landgebräuchers J.G. Kiewiet um die Konzession zur Betreibung eines Schüttstalles, Januar 1861

- Streit zwischen dem Schlachter Moses Pels und der Witwe Schaad wegen Schaden durch seine auf ihre Weide geratene Kuh, September 1876

- Kündigung des Schüttstallhalters J.G. Kiewiet , September 1878

- Ernennung des Schankwirts Harm de Vries zum Schüttstallhalter, Juni 1876

(1855 - 1866) 1866 - 1887

Klassifikation Teil B: 00895

Trägermaterial: Papier

Alte Reg.-Sig.: IV Ja 05

Bestell-Nr.: IV 00895 
- Verlegung des Areals für Misthaufen (Dreckwarf) vom Neuen Tor zut Peldemühle, 1844

- Aufstellung über Misthaufen-Plätze bei der Peldemühle, 1844

- Antrag der Gasthaus-Direktion auf ein erweitertes Areal für ihre Misthaufen wegen Vergrößerung des Viehbestandes, April 1853

- Kündigung der Pächter für die Misthaufenareale auf der

Herrentor-Dreckwarf durch die Stadt Emden, Oktober - November 1854

- Aufstellungen über Nutzer des Misthaufenareals am Boltentor, 1856

- 1868

- Beitreibung ausstehender Pachtgelder für Misthaufenareale, 1863 -

1905

- Beschwerden gegen die Misthaufen verschiedener Fuhrleute nahe des Boltentors, September 1865

- Aufstellungen über Nutzer des Misthaufenareals auf der städtischen Dreckwarf am Herrentor, 1868 - 1870

- Aufstellungen über Nutzer des Misthaufenareals auf der städtischen Dreckwarf am Beckhofstor, 1869 - 1878

- Verhandlungen zwischen dem Magistrat und dem

Bürgervorsteherkollegium wegen der Anlage eines Misthaufenareals am Beckhofstor und der Schließung der Plätze innerhalb der Stadt, Februar 1874

- Nutzung des Meister-Geerds-Zwinger für Mist- und Heuhaufen durch die Landgebräucher Lüppe und Garrelt Janssen, 1873 - 1875

- Aufstellungen über Nutzer der städtischen Misthaufenareale, 1876 1879

- Bedingungen für die Verpachtung von Misthaufenplätzen auf den städtischen Misthaufenarealen, 1876 - 1902

- Ausschreibung der Verpachtung der Misthaufenareale am

Beckhofstor, 1878 - 1902

- Pachtberechnungen für städtische Misthaufenareale, 1884 - 1899

- Beschwerde des L. van Senden gegen Geruchsberlästigung durch auf dem städtischen Mistareal am Beckhofstor abgeladene

Schlachtabfälle, Oktober 1891 / Oktober - November 1892

- Auflösung der Düngelagerplätze bei der Knochenmühle, Dezember 1897

- Aufstellungen des Auktionators J.D. Woortman über verpachtete Misthaufenplätze, 1895 - 1908

$(1844-1865) 1868-1911$

Klassifikation Teil B: 00896

Band: 1

Trägermaterial: Papier

Alte Reg.-Sig.: IV Ja 08

Bestell-Nr.: IV 00896 
- Anträge auf Genehmigung der Anlage von Misthaufen, 1908

- Beschwerde des Weinhändlers G. Stracke gegen die von seinem Nachbarn angelegte Jauchegrube, März 1909

- Unvorschriftsmäßiger Misthaufen des Produktenhändlers Abraham van der Walde, April -Mai 1910

$1909-1910$

Klassifikation Teil B: 00897

Band: 2

Trägermaterial: Papier

Alte Reg.-Sig.: IV Ja 07

Bestell-Nr.: IV 00897

827 Regelung von Viehtransporten

- Organisation des Transportes von Vieh zur Landwirtschaftlichen Ausstellung für Ostfriesland in Esens, Juli 1883

- Polizeiverordnung der Stadt Emden über Verbot des Treibens von

Vieh durch die Straßen der Stadt Emden zum Bahnhof, Juli 1885

- Erörterung von Maßnahmen zum Schutz der Bevölkerung beim

Transport von Bullen, Oktober - Dezember 1885

- Polizeiverordnung über Maßregel beim Transport von Bullen, Januar 1886

- Ermittlungen wegen Schäden durch Treiben von Schweinen durch die Stadt zum Schlachthof, November 1897

$1883-1897$

Klassifikation Teil B: 00898

Trägermaterial: Papier

Alte Reg.-Sig.: IV Ja 08

Bestell-Nr.: IV 00898

828 Einfriedungen an den Straßen

- Anträge auf Genehmigung von Zäunen und sonstigen Einfriedungen von Grundstücken an den Straßen, 1856 / 1882 - 1899

- Beseitigung von Hindernissen baulicher Art auf den Fußwegen, 1865

/ 1866 - 1900

- Antrag des Unternehmers August Jasper bei der Stadt Emden auf Senkung der Recognitions-Gebühr für sein an der Straße aufgestelltes Firmenschild, November 1896

- Anträge auf Reparatur schadhafter, von derr Stadt Emden zu unterhaltender Einfriedungen, 1880 - 1902

(1855 - 1865) 1866 - 1902

Klassifikation Teil B: 00899

Trägermaterial: Papier

Alte Reg.-Sig.: IV Ja 13

Bestell-Nr.: IV 00899 
05

\subsection{3}

05.03.06
Stadtverwaltung

Aufgabenbereiche der Stadtverwaltung

Öffentliche Anlagen, Straßenpolizei und Organisation der Ver- und Entsorgung

Straßenpolizei

05.03.06.01

Lfd. Nr. Titel

Laufzeit

829 Umänderung von Straßennamen
$1869-1913$

- Umbenennung der Straße "Hinter dem alten Schlachthaus" in

"Bismarckstraße", Juni - August 1869

- Umbenennung der Straße "Außer dem alten Neutor" in

"Wilhelmsstraße" wegen Einzugs des preußischen Königs Wilhelm I.

über diese Straße in die Stadt, Juni - August 1569

- Erlass des preußischen Ministers für Handel, Gewerbe und

öffentliche Arbeiten über Kriterien der Umbenennung von Straßen

nach Mitgliedern der kaiserlichen und königlichen Familie und Bedarf

der persönlichen Genehmigung des Kaisers, Juli 1874

- Benennung des Platzes vor dem Telegrafenamt mit "Stephans-Platz"

nach dem Staatssekretär für das Postwesen, Januar - April 1883

- Vergrößerung des Stephansplatzes, Juni 1888

- Vergrößerung des inneren Stadtgebiets und Benennung der dortigen

Straßen mit "Außer dem Nordertor" und "Außer dem Neuen Tor",

Februar - Mai 1894

- Festlegung der Namen neuer Straßen: "Ringstraße", "Hafenstraße",

"Neptunstraße" und "Emsstraße" als Verlängerung der Kirchstraße,

Oktober 1896

- Umbenennung der Straße "Hinter der Emsmauer" in

"Emsmauerstraße", Oktober 1896

- Benennung der Verlängerung der Petkumer Straße als

"Faberstraße", August 1898 - März 1899

- Benennung der Parallelstraße der Bahnhofsstraße als

"Parallelstraße", März - April 1900

- Benennung der Straßen im Kaiser Wilhelm-Polder, April 1900

- Benennung der Straße zwischen der Wolthuser Landstraße und dem

Treckfahrtsweg als "Seume - Straße", Juli 1900

- Benennung eines Stückes der Nesserlander Straße als

"Schweckendieckstraße", September 1901

- Eingabe verschiedener Bürger der Stadt Emden über Bitte um

Benennung einer Straße nach dem Erfinder des Buchdrucks,

Gutenberg, 1900

- Benennung der Straße über die Foget'sche Bleiche als

"Gartenstraße", Oktober 1900

- Straßenverzeichnis zum Brandkataster der Stadt Emden, Dezember 1900

- Umbenennung der Straße "Hinter dem Deich" in "Brandenburger

Straße", August 1904

- Benennung der Verbindungstraße zwischen Nesserlander Straße und Schweckendieckstraße als "Küstenbahnstraße", August 1904

- Benennung der Verlängerung der Großen Straße als

"Abdena-Straße", August 1905

- Benennung der von der Kirchstraße in Richtung Küstenbahn abzweigenden Straße als "Annastraße", September 1905

- Benennung zweier Straßen über die Foget'sche Bleiche als

"Ulrich-Str." und "Edzard-Str.", September 1905

- Benennung von Straßen der Arbeitersiedlung im

Kaiser-Wilhelm-Polder als "Fletumer Str.", "Küstenbahnstraße", und

"Franz-Merkensstr.", Mai 1906

- Benennung von Straßen außerhalb des Neuen Tores in

"Bolardus-Straße", "Eggena-Straße" und "Celos-Straße", Juni 1906

- Benennung der Parallelstraße der Ulrichstraße als "Theda-Straße", Juni 1906

- Antrag der Bewohner der Judenstraße auf Umbenennung ihrer 
05

05.03

05.03.06
Stadtverwaltung

Aufgabenbereiche der Stadtverwaltung

Öffentliche Anlagen, Straßenpolizei und Organisation der Ver- und Entsorgung

Straßenpolizei

Lfd. Nr. Titel

Laufzeit

Straße wegen schwieriger Vermietung ihrer Wohnungen aufgrund negativer Assoziationen mit dem Straßennamen, November 1907 - Protest der Gesellschaft für bildende Kunst und vaterländische Altertümer gegen die Umbenennung der St. Joris-Str. und des Hofes von Holland in "Blücherstraße", Februar 1907

- Protokoll der gemeinsamen Sitzung von Magistrat und Bürgervorsteherkollegium über Ablehnung der Bezeichnung "Transvaal" und "Port Arthur" als offiziellen Stadtteilsnamen der Arbeitersiedlung im Kaiser-Wilhelm-Polder, März 1907

- Umbenennung des Neutorsbreitergang un "Elisabethstraße", Dezember 1910 - Januar 1911

- Umbenennung der Straße Außer dem neuen Tor in "Auricher Straße", Dezember 1911

- Straßenbenennungen in der von den Nordseewerken errichteten Kolonie "Friesland", 1913

$1869-1913$

Klassifikation Teil B: 00900

Trägermaterial: Papier

Alte Reg.-Sig.: IV Ja 24

Bestell-Nr.: IV 00900

830 Straßenpolizeiliche Regelungen

1878-1891

- Verfügung der Stadt Emden über Bestrafung der absichtlichen

Scheumachung der Kutschpferde, Juli 1835 / März 1859

- Bericht des Sanitätsrats Dr. Stöhr über Schlagen von Kutschpferden oder Pferden mit Reitern durch Gassenjungen, April 1860

- Beschädigung des Fußweges durch Pferde beim Ziehen von Schiffen, Mai 1876

- Verbot des Abstellens von Kutschpferden ohne Beaufsichtigung, 1878

- Beschwerde des Premierleutnants v. Hake gegen Scheumachung seines Pferdes durch Peitschenknallen von Gassenjungen, Oktober 1879

- Polizeiverordnung der Stadt Emden gegen Musterung von Pferden auf öffentlichen Straßen, April 1884

- Polizeiverordnungen der Stadt Emden gegen zu schnelles Fahren der Torf- und Kalkfahrer sowie Fuhrleute, (1808) 1885

- Beschwerde des Senators Ysaac Brons gegen Reiten von Offizieren auf dem Fußweg, April 1886

- Anzeige gegen Torffahrer wegen Versperrung des Fußwegs an der Großen Brückstraße, Juli 1891

(1835 - 1860) 1878 - 1891

Klassifikation Teil B: 00901

Trägermaterial: Papier

Alte Reg.-Sig.: IV Ja 14

Bestell-Nr.: IV 00901 
IV

05

05.03

Stadtverwaltung

05.03.06

Aufgabenbereiche der Stadtverwaltung

05.03.06.01

Öffentliche Anlagen, Straßenpolizei und Organisation der

Ver- und Entsorgung

Lfd. Nr. Titel

Straßenpolizei

831 Wanderplätze und Bänke

Laufzeit

- Anordnung zur Räumung der Bänke auf der Straße "Zwischen den

Märkten" wegen Pflasterung des Fußweges, Juli - August 1854

- Polizeiverordnung der der Stadt Emden über Verhängung eines

Ausgehverbots ohne Laterne nach 23 Uhr zur Verhinderung der

Zerstörung von Bänken und Vandalismus, Februar 1856

- Anzeige wegen Zerstörung von Bänken und Einwerfen von

Scheiben, 1856

- Schmälerung der Straße durch die "Wanderung" vor dem

neugebauten Haus des Senators van Ness, August 1856

- Schmälerung der Straße durch die "Wanderung" vor dem Haus der Jungfer Maria Halsman, Dezember 1861

- Schmälerung der Straße durch die "Wanderung" vor dem Haus des Joseph A. Pels, Dezember 1874

- Schadhafte "Wanderung" des Konditormeisters Lefermann "Am

Neuen Markt", April 1876

- Schmälerung der Straße durch die "Wanderung" vor dem Haus des

Tierarztes Mansholt, September 1883 - April 1884

- Antrag des Hoteliers Louis Heine, Hotel "Zur Sonne", auf

Genehmigung der Höherlegung der "Wanderung" vor dem Hotel

wegen Gewinnung einer Fläche für ein Straßencafé, April - Mai 185

- Verfügung der Stadt Emden über Anordnung der Reparatur der

"Wanderung" vor dem Haus des Kaufmanns Johann Peters, Juli -

August 1905

(1854 - 1861) 1874 - 1905

Klassifikation Teil B: 00902

Trägermaterial: Papier

Alte Reg.-Sig.: IV Ja 16

Bestell-Nr.: IV 00902 
- Regelung der Anbringung von Geschäfts- und Namensschildern zur Verhinderung der Beeinträchtigung der Straßenbeleuchtung und Vermeidung von Verkehrsbehinderungen, 1866 - 1906

- Angebot der Emailleschilder-Fabrik Ch. Schweizer \& Söhne über Hausnummernschilder für die Stadt Emden, Dezember 1882

- Ersetzung eines den Verkehr der Pferdeeisenbahn des Reint Reints Poppinga gefährdenden Telegrafenmastes durch einen am Haus des Klempnermeisters Bruns anzubringenden Isolator, Juli 1884

- Verfügung des Regierungspräsidenten in Aurich über die Gestaltungsrichtlinien für Firmen- und Geschäftsschilder, Oktober 1896

- Verzeichnis der in Emden zu tief angebrachten Firmenschilder, Januar 1898

- Anträge auf Genehmigung des Aufstellens von Werbetafeln, 1898 1908

- Forderung des Emder Detaillisten-Vereins nach Angabe des

Geschäftsinhabers auf jeder Firmentafel, Juli 1899

- Anzeige gegen den Maurer und Kräutner Otto Völtzke wegen

Nichtanbringens eines Hausnummernschildes, März 1907

- Anzeigen gegen Geschäftsinhaber wegen fehlerhafter Schilder, 1890

$-1913$

- Aufstellung wegen ungenehmigt angebrachter Schaukästen, Oktober 1908

$1866-1913$

Klassifikation Teil B: 00903

Trägermaterial: Papier

Alte Reg.-Sig.: IV Ja 21

Bestell-Nr.: IV 00903

- Anfrage der niederländischen Regierung wegen Regelungen zu Hundefuhrwerken in Deutschland, März - April 1889

- Diskussion des Erlasses einer Polizeiverordnung der Provinz Hannover zu Hundefuhrwerken unter dem Aspekt des Tierschutzes, September - Dezember 1891

- Druckschrift zum Schutz der Ketten- und Zughunde, 1892

$1889-1892$

Klassifikation Teil B: 00904

Trägermaterial: Papier

Alte Reg.-Sig.: IV Ja 30

Bestell-Nr.: IV 00904 
834 Eigentumsrechte an den Wanderplätzen (Umzäunte Rondelle vor den Häusern)

- Gutachten des Bürgermeisters Ernst Hantelmann über

Eigentumsrechte an den Wanderplätzen vor den Häusern, 1859

- Beseitigung von Wanderplätzen vor den Häusern bei Behinderung des Straßenverkehrs und Freihaltung der Fußwege (Trottoirs) von Hindernissen, 1859

- Protest der Eheleute Dinkelmann gegen die Nichteinzeichning der zu ihrem Grundstück gehörenden Wanderung in den Katasterplan, Februar - Oktober 1885 / April - Mai 1889

- Gemeinsamer Erlass des preúßischen Innenministers und des Ministers der öffentlichen Arbeiten über Verpflichtung der

Grundeigentümer zur Unterhaltung des Fußwegs vor ihrem Besitz. Mai 1885

- Streit zwischen der Stadt Emden und dem Commissionärsgehilfen Christian Pool um die Eigentumsrechte an der Wanderung vor dem Pool'schen Haus, März - Juli 1886

- Streit zwischen der Stadt Emden und der Witwe des Konsuls Ysaac Brons um die Eigentumsrechte an der Wanderung vor ihrem Haus Am Alten Markt, November 1901

- Abtretungen von gepflasterten Terrains vor Grundstücken an die Stadt Emden wegen Unterhaltung, 1904 - 1907

- Anspruch des Gastwirts J. Dirks auf Nutzung der Wanderung vor seinem Haus, Januar 1907

- Streit zwischen der Stadt Emden und dem Kaufmann Otto W.

Buscher um die Eigentumsrechte an der Wanderung vor seinem Haus, Juni -Oktober 1908

- Streit zwischen der Stadt Emden und R. Janssen um die

Eigentumsrechte an der Wanderung vor seinem Haus, 1908

(1859) $1885-1911$

Klassifikation Teil B: 00905

Trägermaterial: Papier

Alte Reg.-Sig.: IV Ja 19

Bestell-Nr.: IV 00905 
- Anträge auf Genehmigung der Überfahrt über das Neupfortssiel durch Anlieger, 1858 - 1864

- Anzeigen wegen Gefährdung der Brücke über das Neupfortssiel und der Zerstörung des ungepflasterten Agterums durch die schweren Fuhrwerke des Fuhrmanns Heinrich Bordeaux, Juni 1868 - Februar 1869

- Unerlaubtes Befahren der Brücke über dem Neupfortssiel durch die schweren Fuhrwerke der Familie Bordeaux, Juni 1874 - Januar 1879 - Antrag des Kaufmanns F.J. Duis auf Erlaubnis zur Überfahrt über das Neupfortssiel wegen drohender Unerreichbarkeit seines Packhauses, Februar 1878

- Polizeiverordnung der Stadt Emden über Verbot des Befahrens der Neupfortssielbrücke, Dezember 1878

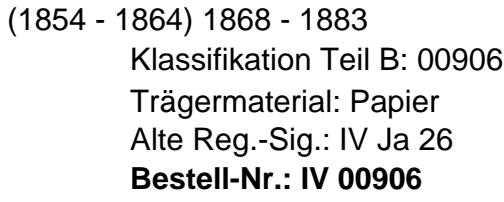

836 Städtische Straßen und Wege

- Protest des H.J. Hoth gegen das Verbot des Reitens, Fahrens und Viehtreibens in der Schonhovenstraße im Bereich seines Anwesens wegen Erschwerung seines landwirtschaftlichen Betriebs, Juli Oktober 1875

- Antrag des Fuhrmanns Hieronymus Dallinga auf freie Durchfahrt zu seinem Haus in der Schonhovenstraße, Juli - September 1875

- Beschwerden gegen Unpassierbarkeit von Straßen und Wegen, 1889 - 1905

- Streit um die Verpflichtung zur Reparatur des vom Fuhrmann Freerk Pommer zerfahrenen Fußweges im Neutorsbreitergang, Januar - Juli 1900

- Antrag auf Verbesserung der Straßenanbindung der Arbeitersiedlungen Transvaal und Port Arthur, Januar - Februar 1908

$1875-1909$

Klassifikation Teil B: 00907

Trägermaterial: Papier Alte Reg.-Sig.: IV Ja 27 Bestell-Nr.: IV 00907 
837 Aufstellung einer Annoncenuhr auf dem Fußweg neben der Hauptwache

- Antrag der Firma Annoncenuhr AG auf Erlaubnis zur Aufstellung einer Annoncenuhr mit meteorologischen Messteilen, August 1886 - Angebot der Firma Urania-Uhr GmbH über Aufstellung einer Urania-Uhr (Uhr mit Werbeanzeigen), November 1892

- Reparatur der Annoncenuhr neben dem Rathaus, Juli 1899

- Beseitigung der Annoncenuhr, Juni 1901

$1886-1901$

Klassifikation Teil B: 00908

Trägermaterial: Papier

Alte Reg.-Sig.: IV Ja 31

Bestell-Nr.: IV 00908

838 Straßenordnung der Stadt Emden

- Zu beseitigende Hindernisse auf Straßen und Wegen, 1897 - 1914 - Ungenehmigtes Aufkleben von Wahlplakaten der SPD durch den Tischler Karl August Bigitschke, Mai 1898

- Erlaubnis zur Lagerung von Baumaterial auf dem Fußweg vor Baustellen, 1900 - 1904

- Beschwerde des Helmer von Baden Foget gegen den Lärm spielender Kinder, März 1903 / März 1904

- Zertrümmerung eines Schaufensters des Schlachters van der Walde in der Großen Faldernstr. durch einen ausgebrochenen Bullen, August 1903

- Verkehrswidriges Abstellen von Fuhrwerken durch den Fuhrmann Johann Dallinga auf der Fahrstraße vor seinem Haus, Oktober 1903 - Verpflichtung der Anlieger zur Straßenreinigung und Verstöße gegen diese Pflicht, 1904 - 1914

- Schäden durch Scheuen eines Fuhrwerk-Pferdes, Mai 1904

$1897-1914$

Klassifikation Teil B: 00909

Trägermaterial: Papier Alte Reg.-Sig.: IV Ja 35

Bestell-Nr.: IV 00909 
IV

05

Stadtverwaltung

05.03

Aufgabenbereiche der Stadtverwaltung

05.03.06

Öffentliche Anlagen, Straßenpolizei und Organisation der Ver- und Entsorgung

05.03.06.01 Straßenpolizei

Lfd. Nr. Titel

Laufzeit

839 Reinigung öffentlicher Wege

- Streit zwischen der Stadt Emden und dem Emder Schützencorps um die Zuständigkeit für die Reinigung der Straße zum Schützenplatz

(Zwischen Beiden Bleichen), Januar 1912 - März 1913

- Preußisches Gesetz über die Reinigung öffentlicher Wege, Juli 1912

- Ausführungsbestimmungen zum Gesetz über die Reinigung öffentlicher Wege, Juli 1912 - April 1914

- Angebote verschiedener Versicherungsgesellschaften über Sammelhaftpflichtversicherungen für streu- und reinigungspflichtige Anlieger öffentlicher Straßen, November - Dezember 1912

- Urteil des Kammergerichts Berlin zur Streu- und Untehaltungspflicht von Anliegern öffentlicher Straßen, Mai 1914

1912 - 1914

Klassifikation Teil B: 00910

Trägermaterial: Papier

Alte Reg.-Sig.: IV Ja 35

Bestell-Nr.: IV 00910 
05

05.03

05.03.06
Stadtverwaltung

Aufgabenbereiche der Stadtverwaltung

Öffentliche Anlagen, Straßenpolizei und Organisation der Ver- und Entsorgung

Straßenpolizei

Lfd. Nr. Titel

Laufzeit

840 Straßenordnung der Stadt Emden

1901-1912

- Erlaubnisse zur Lagerung von Baumaterial und Errichtung von

Gerüsten vor Baustellen an öffentlichen Straßen, 1901 - 1910

- Eingabe des Innungsausschusses für die Stadt Emden an den

Magistrat der Stadt Emden über Bitte um Auslegung der

Straßenordnung zugunsten der Schmiede und Schlosser wegen

Lagerung von Material und Abfertigung von Kunden an der Straße

wegen mangelndem Platz vor ihren Werkstätten, November 1901 -

April 1902

- Anträge verschiedener Schmiede und Schlosser auf weitere

Erlaubnis zur Nutzung des Raumes an der Straße vor ihrer Werkstatt

für ihr Gewerbe, 1902 - 1907

- Anträge auf Genhmigung von Straßenumzügen, 1902 - 1908

- Anträge auf Erlaubnis zum Aufstellen von

Wäschetrocknungsgestellen an der Straße bei Häusern ohne

Trockenboden und Garten, 1904

- Beschwerde der Anlieger der Straße "Am Alten Markt" über

Verschmutzung der Straße durch die elektrische Straßenbahn, Juni

1904

- Unfallbericht: Überfahren eines Fahrradfahrers durch ein Fuhrwerk,

Februar 1905

- Blockierung der Fußwege und Gefährdung der Fußgänger in der

Bahnhofsstraße, 1905

- Anzeigen wegen Blockierung der Straßen durch Baumaterial und dergleichen, 1905 - 1909

- Anzeigen wegen Anbringung von Firmenschildern und

Geschäftsschildern mit laternenlichtbehindernder Wirkung, 1906

- Anzeigen wegen Nichtanbringung von Hausnummern, 1906

- Berichte über durchgehende Fuhrwerke, 1906 - 1907

- Eingabe der Emder Fuhrleute an die Stadt Emden über Bitte um

Veränderung der Verkehrsführung über die neue Drehbrücke wegen

Unfallgefahr, August - September 1906

- Anzeigen wegen Versperrung von Straßen durch Wäscheständer, 1906

- Gefährlicher Zaun um die Grundstücke der Witwe Gertrudt

Helmdeich und der Witwe Hylle Dycken, November 1906

- Anzeige gegen den Viehhändler Isidor Gossels wegen Treibens von

Bullen durch die Stadt trotz Verbotes, September 1907

- Anzeigen wegen Verschmutzung der Straßen, 1906 - 1912

- Gefährdung von Passanten durch Radfahrer, Juni 1910

$1901-1912$

Klassifikation Teil B: 00911

Trägermaterial: Papier

Alte Reg.-Sig.: IV Ja 35

Bestell-Nr.: IV 00911 
05

05.03

05.03.06
Stadtverwaltung

Aufgabenbereiche der Stadtverwaltung

Öffentliche Anlagen, Straßenpolizei und Organisation der Ver- und Entsorgung

Straßenpolizei

Lfd. Nr. Titel

Laufzeit

841 Unbefugtes Beweiden der Uferböschungen des Stadtgrabens

1903

- Anzeigen wegen unbefugtes Beweiden der Böschungen des

Stadtgrabens durch Schafe, 1903

1903

Klassifikation Teil B: 00912

Trägermaterial: Papier

Alte Reg.-Sig.: IV Ja 37

Bestell-Nr.: IV 00912

842 Aufstellung von Telefonzellen

1911

- Antrag des Zivil-Ingenieurs P.J.M. Tollner in Frankfurt/M. auf Genehmigung zur Aufstellung neuerr, vom Reichspostamt privilegierter Telefonzellen, Januar / Juli 1911

- Verhandlungen zwischen P.J.M. Tollner und der Stadt Emden wegen der Modalitäten der Aufstellung der Telefonzellen (z.B. Größe der

Werbetafeln), Juli - September 1911

- Vertrag über die Aufstellung der Telefonzellen, November 1911

1911

Klassifikation Teil B: 00913

Trägermaterial: Papier

Alte Reg.-Sig.: IV Ja 41

Bestell-Nr.: IV 00913

843 Grenzkonflikte bei Grundstücken

- Blockade von Wegen durch Schranken, 1825 - 1847

- Streitigkeiten um Grundstücksgrenzen, 1835 - 1836

- Anträge auf Erlaubnis von Setzung von Düngehaufen, 1836

- Beschwerde wegen Beeinträchtigung des Grundeigentums durch

Anlegung eines Fußweges, 1837

- Illegale Düngerhaufen, 1838

- Gefahr der Blockade von Straßen durch baufällige Häuser, 1841

- Streit um Fahr- und Passagerechte, 1844

- Illegale Ableitung von Fäkalien im Graben am Philosophenweg beim

Grundstück des Landschaftsrat Kluge, Juni - November 1876

- Anzeige über Grenzverletzung des Uildert Uilderks durch Anlage eines Tores, Oktoberr 1876

- Anzeige des Kaufmanns und Konsuls Bernhard Brons wegen Ableitung von Fäkalien in den Graben am Bentincksweg, Mai Oktober 1877

- Festlegung der Grenzen des Brons'schen Grundstücks am

Bentincksweg, 1885 - 1886

- Streit zwischen dem Kaufmann Ysaac Brons und der Stadt Emden wegen der Grenze seines Grundstücks am Grünen Weg anlässlich der Anlage eines Hühnersteges, Juli - Oktober 1889

(1824 - 1848) 1876 - 1886

Klassifikation Teil B: 01131

Trägermaterial: Papier

Alte Reg.-Sig.: IV Jh 01

Bestell-Nr.: IV 01131 
IV

05

Stadtverwaltung

05.03

Aufgabenbereiche der Stadtverwaltung

05.03.06

Öffentliche Anlagen, Straßenpolizei und Organisation der Ver- und Entsorgung

05.03.06.01 Straßenpolizei

Lfd. Nr. Titel

Laufzeit

844 Verbot des Radfahrens

- Verhandlungen des Magistrats über Diskussion eines

Radfahrverbots in der Stadt Emden wegen Unfallverhütung, Juni 1896

- Anzeige des Polizeisergeanten Friedrichs über Fahren des gehbehinderten Johann Klaassen mit einem dreirädrigen Wagen auf dem Bürgersteig, Oktober 1912

$1896-1912$

Klassifikation Teil B: 01219

Trägermaterial: Papier

Alte Reg.-Sig.: IV Ja 33

Bestell-Nr.: IV 01219

845 Straßenordnung

- Verhandlungen der städtischen Kollegien wegen Straßenordnung,

Dezember 1874

- Verzeichnis der Straßen und Plätze in Emden, 1894

- Entwurf einer Straßenordnung, 1894

1894

Klassifikation Teil B: 01821

Trägermaterial: Papier

Alte Reg.-Sig.: IV Ja 07

Bestell-Nr.: IV 01821 
05

05.03

05.03.06

05.03.06.02

05.03.06.02.01
Stadtverwaltung

Aufgabenbereiche der Stadtverwaltung

Öffentliche Anlagen, Straßenpolizei und Organisation der

Ver- und Entsorgung

Straßenreinigung und öffentliche Hygiene

Straßenreinigung und -Unterhaltung durch die Anlieger

Lfd. Nr. Titel

Laufzeit

846 Unterhaltung des "Siebengangs"

- Eingabe der Bewohner des Siebengangs auf Erlaubnis zur

$1867-1908$

(1839-1858)

nächtlichen Abschließung des Ganges wegen Diebstahlsgefahr,

Februar 1839

- Antrag des Rentmeisters de Haas auf Verlegung des Siebenganges,

Januar 1842

- Gestörte Abwässeung im Siebengang, August 1842

- Anträge des G.I. Italiener auf Öffnung der Tür zum Siebengang an

der Hofmauer seines Hauses zur Erleichterung der Abfuhr von

Fäkalien, Dezember 1858 / 1878

- Anträge verschiedener Anlieger des Siebengangs auf Erlaubnis zur

Anbringung einer Tür im Gang zur Verhinderung von Verschmutzung,

Juli 1867

- Beschwerde des Viehhändlers Joseph van Oss wegen Unrat im

Siebengang, Mai - Juli 1879

- Weigerung des Schlachters V.M. Valk und des Bäckermeisters Magnus Valk zur Reinigung eines Teils des Siebenganges wegen behaupteter Zuständigkeit der Stadt Emden, Mai - Juli 1893

- Anzeige gegen den Schlachter Isaak Fulda wegen Nichtreinhaltung seines Anteils am Siebengang, November 1906

- Streit der Anlieger um Reinigung des Siebengangs und Reparatur der Tür zum Gang, Mai 1908

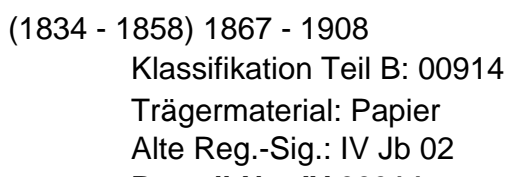

847 Unterhaltung des Gangs am Grundstück des Fritz Meyer

- Antrag des Fritz Meyer auf Erlaubnis zur Errichtung einer Mauer am

Gang entlang seines Grundstücks, Juli 1829

- Streit um die Zulässigkeit des Transports von Mist durch den Gang, Oktober 1840

- Beschwerden über Verschmutzung des Ganges, Oktober 1843

- Streit um die Reinigungspflicht bezüglich des Ganges, Januar 1844

- Streit zwischen Fritz Meyer und dessen Nachbarn W.J.Stevens wegen Reparatur und Unterhaltung des Ganges zwischen ihren Grundstücken, Juni 1852 - August 1854

- Streit zwischen dem Holzhändler Gerhard Smeding und dem Schlachter Jacob de Beer wegen der Unterhaltung des Ganges zwischen ihren Grundstücken, 1870

(1829 - 1854) 1870

Klassifikation Teil B: 00915

Trägermaterial: Papier

Alte Reg.-Sig.: IV Jb 03

Bestell-Nr.: IV 00915 
05

05.03

05.03.06

05.03.06.02

05.03.06.02.01
Stadtverwaltung

Aufgabenbereiche der Stadtverwaltung

Öffentliche Anlagen, Straßenpolizei und Organisation der

Ver- und Entsorgung

Straßenreinigung und öffentliche Hygiene

Straßenreinigung und -Unterhaltung durch die Anlieger

Lfd. Nr. Titel

Laufzeit

848 Unterhaltung des Gangs zwischen Neutorstraße und Apfelmarkt

- Rechnung über Instandsetzungsarbeiten des des Gangs zwischen

1876-1878

(1831-1862)

Neutorstraße und Apfelmarkt, 1831

- Streit um die Unterhaltungspflicht der Anlieger des Ganges, April

1836 - September 1840

- Wiederherstellung der zerbrochenen Tür zum Gang durch die

Anlieger, November 1862

- Schlechter Zustand des Gangs zwischen Neutorstraße und

Apfelmarkt, Oktober 1876 - April 1877

- Verhandlungen wegen Herstellung eines Abflusses (Riele) zwischen dem lutherischen Predigerhaus, dem Haus des Bruin und dem Stall des Senators de Pottere im Gang zwischen der Neutorstraße und dem Apfelmarkt, Mai - Oktober 1878

(1831 - 1862) $1876-1878$

Klassifikation Teil B: 00916

Trägermaterial: Papier

Alte Reg.-Sig.: IV Jb 05

Bestell-Nr.: IV 00916

849 Übergang der Unterhaltung von Straßen von privater in städtischer Hand

- Vorschlag des Kämmerers Abegg zur Abschaffung des

Straßengeldes wegen geringem Ertrag, November 1841

- Initiative des Stadtbaumeisters Martens zur Übernahme der

Zuständigkeit für die Unterhaltung aller Straßen durch die Stadt wegen

Verbesserung der Straßenpflege, Juni - OKtober 1842

- Verfügung des Hannoverschen Landdrosten in Aurich über

Genehmigung der Übernahme der Unterhaltung von Privatstraßen

durch die Stadt Emden und Erhebung einer Steuer zur Unterhaltung

von den Anliegern, November 1842 / Oktober 1847

- Verhandlungen der städtischen Kollegien über Abschaffung des

Straßengeldes, 1844 - 1847

- Verbesserung der Straßenanbindung des Gasthauses "Belvedere", 1854 - 1855

- Antrag des Albert Tholen, Direktor der Mühlensocietät, auf Herstellung einer befestigten Zuwegung zur Weizenmühle, Juni 1866

- Eingabe des Maurergesellen Gottlieb Wildeboer über Gesuch um

Verbesserung der Pflasterung auf dem Kattewall, März 1870

(1841 - 1866) 1870

Klassifikation Teil B: 00917

Trägermaterial: Papier

Alte Reg.-Sig.: IV Jb 10

Bestell-Nr.: IV 00917 
05

05.03

05.03.06

05.03.06.02

05.03.06.02.01
Stadtverwaltung

Aufgabenbereiche der Stadtverwaltung

Öffentliche Anlagen, Straßenpolizei und Organisation der

Ver- und Entsorgung

Straßenreinigung und öffentliche Hygiene

Straßenreinigung und -Unterhaltung durch die Anlieger

Lfd. Nr. Titel

Laufzeit

850 Unterhaltung des Ganges von der Straße "Am Burggraben" bis zum Kasernenplatz

- Beschwerde des Leiters der Gewerbeschule, H.E. Müller, wegen Unbelüftbarkeit der Räume der " Am Burggraben" gelegenen Räume wegen Aborte der Kinderbewahranstalt an der einen und des Aborts der Kaserne an der anderen Fensterseite sowie über Unrat auf dem Gang, Januar 1881

- Beschwerde des Leiters der Taubstummenanstalt gegen die von der Stadt Emden geplante Abschließung des Ganges wegen Blockade des Haupteingangs der Anstalt, November 1881

- Antrag der Taubstummenanstalt auf Herstellung einer befestigten und beleuchteten Zuwegung über den Kasernenplatz und Schließung des Ganges, November 1882 - Januar 1883

- Antrag der Handelsschule auf Beibehaltung des Ganges und Reinigung vom Müll durch die Stadt Emden sowie auf Entfernung von Nischen wegen dort begünstigter "unsittlicher Handlungen", 1881 1886

$1881-1886$

Klassifikation Teil B: 00918

Trägermaterial: Papier

Alte Reg.-Sig.: IV Jb 11

Bestell-Nr.: IV 00918

851 Übernahme der Reinigung von Straßen durch die Stadt

1878-1909
$1881-1886$

\footnotetext{
- Aufstellung über Straßen und Plätze in Emden, Dezember 1878

- Verhandlungen der Stadt Emden mit dem Abfuhrunternehmer Uffe

Fokken wegen Übernahme der Straßenreinigung, 1878 - 1879

- Pressebericht über Enge der Emder Fußwege und Blockade durch missbräuchliche Nutzung für gewerbliche und private Zwecke, August 1879

- Abfuhr- und Tonnenordnung der Stadt Emden, 1879

- Verhandlungen wegen Anschaffung einer Kehrmaschine zur Reinigung der Straßen beim Bahnhof, Oktober 1889 - Januar 1890

- Ablehnung von Entschädigungsforderungen des Fuhrunternehmers Uffe Fokken wegen Reinigung der Straßen am Bahnhof, September Oktober 1889

- Anschaffung eines Sprengwagens, 1889

- Angebote über Sprengwagen und Abfuhrwagen, 1909
}

$1878-1909$

Klassifikation Teil B: 00919

Trägermaterial: Papier

Alte Reg.-Sig.: IV Jb 12

Bestell-Nr.: IV 00919 
05

\subsection{3}

05.03.06

05.03.06.02

05.03.06.02.01

\section{Stadtverwaltung}

Aufgabenbereiche der Stadtverwaltung

Öffentliche Anlagen, Straßenpolizei und Organisation der

Ver- und Entsorgung

Straßenreinigung und öffentliche Hygiene

Straßenreinigung und -Unterhaltung durch die Anlieger

Lfd. Nr. Titel

Laufzeit

852 Unterhaltung des Grannemann's Gang

- Beschwerde des Helmer von Baden Foget gegen die Verweigerung des Durchlassses von Baumaterial durch den Gang zwischen dem Haus des Kaufmanns Smeding und dem Haus des Viehhändlers de Beer zu seinem Grundstück und Ansicht über öffentlichen Charakter des Ganges mit daraus resultierender Verpflichtung der Stadt Emden zur Unterhaltung, Dezember 1899 - Februar 1900

- Verfügung der Stadt Emden an den Viehhändler Isaac de Beer und den Kaufmann Smeding über Aufforderung zur freien Passage des Baumaterials des Helmer van Baden Foget durch den Gang, Januar 1900

- Eingabe des Rechtsanwalts Bode über Bitte um Erklärung des sogenannten "Grannemann's Gang" zur offentlichen Straße und Herstellung der freien Passage für das Baumaterial seines Mandanten Helmer von Baden Foget zu dessen Grundstück, Januar 1900

- Anzeige gegen den Arbeiter Halle wegen Blockade von Grannemann's Gang durch Lagerung von Holz und Mist vor seinem dortigen Haus, Januar 1900

- Einspruch des Viehhändlers Isaac de Beer und der Holzhändler Gerhard und Lüppo Smeding gegen die Erklärung des Grannemann's Gang zur öffentlichen Straße, Januar - Februar 1900

- Anzeige gegen Schiffer wegen Verschmutzung des Grannemann's Ganges durch Erde, Januar 1900

- Bericht des Polizeikommissars Lauter über Verschmutzung des Grannemann's Gang durch Erdtransporte des Helmer von Baden Foget, Februar 1900

- Verfügung der Stadt Emden über Einschränkung der Benutzung des Grannemann's Gang für Transporte des H. von Baden Foget wegen Verschmutzung, Februar - März 1900

- Klage des Gerhard Smeding u.a. vor dem Bezirksausschuss in Aurich und dem Oberverwaltungsgericht Berlin gegen die Erklärung von Grannemann's Gang zur öffentlichen Straße, März 1901 -

Oktober 1904

$1899-1904$

Klassifikation Teil B: 00920

Trägermaterial: Papier

Alte Reg.-Sig.: IV Jb 13

Bestell-Nr.: IV 00920 
05

05.03

05.03.06

05.03.06.02

05.03.06.02.01
Stadtverwaltung

Aufgabenbereiche der Stadtverwaltung

Öffentliche Anlagen, Straßenpolizei und Organisation der

Ver- und Entsorgung

Straßenreinigung und öffentliche Hygiene

Straßenreinigung und -Unterhaltung durch die Anlieger

Laufzeit

853 Reinigung der Bahnhofsstraße

1899-1902

(1913)

- Beschwerde des Berend J. Meyer gegen Verpflichtung zur Reinigung der Bahnhofsstraße, Juni 1899

- Verfügung der Stadt Emden über Verpflichtung der Anlieger der Bahnhofsstraße zur Reinigung der Straße, Juli 1899 / Oktober 1899

- Vermerk des Syndicus Werthen über Schwierigkeiten bei der

Verpflichtung der Anlieger der Bahnhofsstraße zur Straßenreinigung wegen vertraglicher Verpflichtung der Stadt Emden zur Reinigung mit der Übernahme des Terrains des Bahnhofs aus dem eisenbahnfiskalischen Besitz, September 1899

- Beschwerde des Rentners Oscar Ruthenberg beim

Regierungspräsidenten in Aurich gegen seine Verpflichtung als

Anlieger zur Reinigung der Bahnhofsstraße, November 1899 - Januar 1900

- Beschwerde der Anlieger der Bahnhofsstraße beim Oberpräsidenten der Provinz Hannover gegen die vom Regierungspräsidenten in Aurich bestätigte Verfügung der Stadt Emden zur Heranziehung zur Reinigung der Bahnhofsstraße, Juli 1900

- Klage der Anlieger der Bahnhofsstraße gegen die der Verfügung der Stadt Emden bestätigende Entscheidung des Oberpräsidenten der Provinz Hannover beim Oberverwaltungsgericht Berlin, März 1901 März 1902

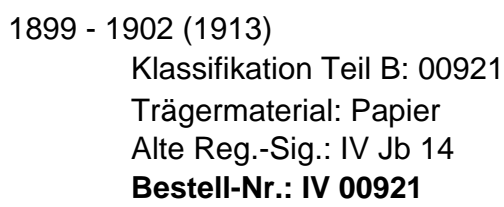

854 Reinigung der Stigte

- Anzeigen gegen Stigt-Aufseher wegen unterlassener Reinigung der Stigte (öffentliche Schiffsanleger), 1898 - 1902

- Gewährung eines Zusatzhonorars an die Stigtaufseher für die Reinigung der öffentlichen Stigte, Juni 1902

- Dienstverträge zwischen der Stadt Emden und den Stigt-Aufsehern mit der Verpflichtung zur Reinigung der Stigte, Jui 1903

- Streitigkeiten um Reinigung der Stigte, Oktober 1903 - Januar 1913

- Anzeige des Polizeisergeanten Thuller über Weigerung der Anwohner der Parallelstraße (heute: Courbierestr.) zur Reinigung des Stigts am Herrentor und daraus entstehende Anhäufung von Schmutz, Mai 1908

- Verbot der Ablagerung von Dünger am Stigt beim Herrentor, Juni 1903

- Organisation der Reinigung der Stigte an der Larrelter Straße, März Oktober 1908

$1898-1913$

Klassifikation Teil B: 00922

Trägermaterial: Papier

Alte Reg.-Sig.: IV Jb 15

Bestell-Nr.: IV 00922 
05

05.03

05.03.06

05.03.06.02

05.03.06.02.01
Stadtverwaltung

Aufgabenbereiche der Stadtverwaltung

Öffentliche Anlagen, Straßenpolizei und Organisation der

Ver- und Entsorgung

Straßenreinigung und öffentliche Hygiene

Straßenreinigung und -Unterhaltung durch die Anlieger

Lfd. Nr. Titel

Laufzeit

855 Unterhaltung des Ganges zwischen den Häusern Rademacherstr. 14 / 15

1904-1906

- Beschwerde des J.S. Regendorp gegen die Einstufung des Ganges zwischen den Häusern Rademacherstr. 14 / 15 als öffentliche Straße, Juni - Juli 1904 / September 1904

- Beschwerde des Kaufmanns Helmer von Baden Foget gegen die Aufhebung der Einstufung des Ganges zwischen den Häusern Rademacherstr. 14 / 15 als öffentliche Straße wegen daraus resultierender Reinigungsverpflichtungen, August 1904

- Antrag des J.S. Regendorp auf Einstufung des Ganges zwischen den Häusern Rademacherstr. 14 / 15 als Privatweg mit

Communionsnutzung, Mai 1905

- Beschluss der städtischen Kollegien über Einstufung des Ganges zwischen den Häusern Rademacherstr. 14 / 15 als Privatweg mit Communionsnutzung, Juni 1905

- Protest des Kaufmanns Helmer von Baden Foget gegen die Einstufung, Juni 1905

- Klage des Helmer von Baden Foget beim Bezirksausschuss in Aurich gegen die Einstufung des Ganges zwischen den Häusern Rademacherstr. 14 / 15 als Privatweg, August 1905 - März 1906 - Verfügung der Stadt Emden über Verbot der Sperrung des Ganges zwischen den Häusern Rademacherstr. 14 / 15 durch J.S.Regendorp, September 1905

$1904-1906$

Klassifikation Teil B: 00923

Trägermaterial: Papier

Bestell-Nr.: IV 00923

856 Reinigung der Bahnhofsstraße

1906-1908

- Anzeige des Polizeisergeanten de Boer über Weigerung des Arztes Dr. Hugo Langhoff zur Reinigung des an seinem Grundstück angrenzenden Teils der Bahnhofsstraße, November - Dezember 1906 - Klage des Dr. H. Langhoff gegen die Stadt Emden beim Bezirksausschuss in Aurich wegen Bestreitung der Pflicht zur Reinigung der Bahnhofsstraße, Dezember 1906 - Juli 1907 - Berufung des Dr. Langhoff gegen den für ihn negativen Bescheid des Bezirksausschusses in Aurich beim Oberverwaltungsgericht Berlin, August 1907 - August 1908

$1906-1908$

Klassifikation Teil B: 00924

Trägermaterial: Papier

Alte Reg.-Sig.: IV Jb 17

Bestell-Nr.: IV 00924 
05

05.03

05.03.06

05.03.06.02 05.03.06.02.01

\section{Stadtverwaltung}

Aufgabenbereiche der Stadtverwaltung

Öffentliche Anlagen, Straßenpolizei und Organisation der Ver- und Entsorgung

Straßenreinigung und öffentliche Hygiene

Straßenreinigung und -Unterhaltung durch die Anlieger

Laufzeit

857 Reinigung der Hafenstraße und Bahnhofsstraße

1906-1908

(1911)

- Anzeige und Strafverfahren gegen den Landwirt Djurke Ulferts wegen Verweigerung der Reinigung der an seinem Grundstück angrenzenden Strecken der Hafenstraße und Bahnhofsstraße, Juni Dezember 1906

- Klage des Djurke Ulferts gegen die Stadt Emden beim Bezirksausschuss in Aurich gegen die Stadt Emden auf Außerkraftsetzung der Verfügung über Verpflichtung zur Straßenreinigung, Dezember 1906 - August 1907

- Berufung des Djurke Ulferts beim Oberverwaltungsgericht in Berlin gegen das für die Stadt Emden vorteilhafte Urteil des Bezirksausschusses, August 1907 - August 1908

$1906-1908(1911)$

Klassifikation Teil B: 00925

Trägermaterial: Papier

Alte Reg.-Sig.: IV Jb 18

Bestell-Nr.: IV 00925

858 Verweigerung der Straßenreinigung

1908-1909

(1911)

- Strafverfahren gegen den Fischhändler Johann Wessels wegen Verweigerung der Straßenreinigung, Oktober 1908 - Dezember 1909

$1908-1909$

Klassifikation Teil B: 00926

Trägermaterial: Papier

Alte Reg.-Sig.: IV Jb 19

Bestell-Nr.: IV 00926

859 Verweigerung der Straßenreinigung

- Klage des Fuhrunternehmers Haye $\mathrm{H}$. Ubbens gegen die Stadt Emden beim Bezirksausschuss in Aurich gegen die Auferlegung einer Straßenreinigungspflicht bezüglich eines von ihm gepachteten Grundstücks, November 1909 - September 1910

- Berufung des Fuhrunternehmers H.H. Ubbens gegen den Entscheid des Bezirksausschusses beim Oberverwaltungsgericht Berlin,

Oktober 1910 - Juni 1911

$1909-1911$

Klassifikation Teil B: 00927

Trägermaterial: Papier

Alte Reg.-Sig.: IV Jb 20

Bestell-Nr.: IV 00927 
IV

05

Stadtverwaltung

05.03

Aufgabenbereiche der Stadtverwaltung

05.03.06

Öffentliche Anlagen, Straßenpolizei und Organisation der

Ver- und Entsorgung

05.03.06.02

05.03.06.02.01

Straßenreinigung und öffentliche Hygiene

Straßenreinigung und -Unterhaltung durch die Anlieger

Lfd. Nr. Titel

Laufzeit

860 Reinigung der Petkumer Landstraße

- Anzeige des Polizeisergeanten Feuerhehn über Unterbleiben der Straßenreinigung im Bereich der Petkumer Landstraße östlich der

Parallelstraße (Courbierestraße), Januar 1910

- Verfügung der Stadt Emden über Pflicht der Anlieger östlich der

Parallelstraße zur Reinigung des betr. Bereiches der Petkumer

Landstraße, Januar / März 1910

- Klage der Anlieger beim Bezirksausschuss in Aurich gegen die Stadt

Emden auf Außerkraftsetzung der Verfügung über Verpflichtung zur

Straßenreinigung, März - September 1910

1910

Klassifikation Teil B: 00928

Trägermaterial: Papier

Alte Reg.-Sig.: IV Jb 21

Bestell-Nr.: IV 00928 
05

05.03

05.03.06

05.03.06.02 05.03.06.02.02
IV

\section{Stadtverwaltung}

Aufgabenbereiche der Stadtverwaltung

Öffentliche Anlagen, Straßenpolizei und Organisation der Ver- und Entsorgung

Straßenreinigung und öffentliche Hygiene

Straßenreinigung durch die Stadt Emden

Laufzeit

861 Anschaffung von Geräten zur Straßenreinigung

1889-1896

- Angebote über Straßenreinigungsmaschinen von verschiedenen Firmen, November 1889 - Juli 1896

- Beschluss der Bau-Commission der Stadt Emden über Anschaffung eines Sprengwagens der Firma C. Beermann in Berlin, Dezember 1896

$1889-1896$

Klassifikation Teil B: 00316

Trägermaterial: Papier

Bestell-Nr.: IV 00316 
05

05.03

05.03.06

05.03.06.02 05.03.06.02.03

\section{Stadtverwaltung}

Aufgabenbereiche der Stadtverwaltung

Öffentliche Anlagen, Straßenpolizei und Organisation der

Ver- und Entsorgung

Straßenreinigung und öffentliche Hygiene

Stadtentwässerung und Abfallentsorgung

Lfd. Nr. Titel

Laufzeit

862 Entwässerungskanal von der Entbindungsanstalt zur alten Kaserne

- Bau eines unterirdischen Entwässerungskanals von der

1876-1884

(1830-1856)

Entbindungsanstalt zur alten Kaserne, Juli 1830

- Verbesserung der Ableitung der Niederschlagswässer im Gebiet der

alten Kaserne, März 1845 - November 1852

- Verhandlungen wegen der notwendigen Reparatur der Riele

(Entwässeruingskanal) unter dem Friedhof der Großen Kirche, Mai

1845 - August 1856

- Veränderung der Abwässerung durch den Bau der neuen

Deichanlagen vor der alten Emsmauer, März 1846

- Aufstellung über zum Beitrag zur Unterhaltung der

Abwässerungsanlagen verpflichtete Anwohner der Kirchstraße, 1851

- Verseuchung des Burggrabens durch eingeleitete Abwässer und

Fäkalien, Juli 1876

- Überschwemmung des Kirchhofs der Großen Kirche durch

Verstopfung des Entwässerungsrohrs bei der Taubstummenanstalt, Dezember 1878

- Erneuerungsbedürftigkeit der Riele vor dem Haus des Auktionators van Heuvel in der Kirchstraße, September 1887

- Aufstellung über Interessenten der "Communions-Wasserlosung" am Friedhof der Großen Kirche, Februar 1882

(1830 - 1856) 1876 - 1884

Klassifikation Teil B: 00929

Trägermaterial: Papier

Alte Reg.-Sig.: IV Jc 02

Bestell-Nr.: IV 00929

863 Entsorgung des Straßenkots und der Abfälle, Bd. 1

$1905-1912$

- Erlöse aus dem Verkauf von Straßenkot, 1905 - 1910

- Angebot der Firma M. Kori über Müllverbrennungsöfen, Oktober 1907

- Terminierung des Verkaufs von Straßenkot und- Kehricht auf die Monate April, Juni, August bis Oktober zum Schutz der Schiffer vor Infektionen, April 1908

- Angebot eines Wasserreinigungssystems der Firma F.Stötzel, Thorn (Westpreußen), 1909

- Angebot über Verwertung von Altmetall aus Müll, März 1909

- Angebote von Müllwagen, Mülltonnen und

Abfallbeseitigungssystemen, 1910 - 1912

$1905-1912$

Klassifikation Teil B: 00930

Band: 1

Trägermaterial: Papier

Alte Reg.-Sig.: IV Jc 03

Bestell-Nr.: IV 00930 
05

05.03

05.03.06

05.03.06.02

05.03.06.02.03

\section{Stadtverwaltung}

Aufgabenbereiche der Stadtverwaltung

Öffentliche Anlagen, Straßenpolizei und Organisation der

Ver- und Entsorgung

Straßenreinigung und öffentliche Hygiene

Stadtentwässerung und Abfallentsorgung

Laufzeit

864 Entsorgung des Straßenkots und der Abfälle, Bd. 2

$1882-1885$

(1852-1864)

- Verkauf von Straßenkot, 1882 - 1885

- Organisation der Entsorgung des Gassenkots, der Fäkalien,

Tierkadaver und Schlachtabfälle, 1852 - 1865

- Ausschreibung der Reinigung der öffentlichen Plätze der Stadt

Emden, September 1864

(1852 - 1864) 1882 - 1885

Klassifikation Teil B: 00931

Band: 2

Trägermaterial: Papier

Alte Reg.-Sig.: IV Jc 03

Bestell-Nr.: IV 00931

865 Entsorgung des Straßenkots und der Abfälle, Bd. 3

1867-1906

- Organisation der Entsorgung des Gassenkots, der Fäkalien,

Tierkadaver und Schlachtabfälle, 1867 - 1906

- Vorstellung des Medizinalrats Dr.Stöhr über Nützlichkeit der Anlage eines Strauchgürtels um die Dreckwarf am Beckhofstor zur Abwehr von Gerüche, Februar 1867

- Anzeigen von Verstößen gegen die Abfuhrpflicht von Fäkalien und Mist, 1869 - 1876

- Verhandlungen der Gassenkot-Kommission über Möglichkeiten der Steigerung der Einnahmen aus dem Verkauf von Gassenkot, Januar 1872

- Anzeigen wegen unterlassener Straßenreinigung, 1870 - 1886

- Anlage einer zentralen Dreckwarf am Beckhofstor, Juli 1875 -

September 1876

- Angebote von Abfuhrgeräten für Fäkalien und Hausmüll, 1897 - 1906

- Berichte der "Rhein-Ems-Zeitung" über mangelhafte Anbindung der

Arbeiterkolonie "Transvaal" an die städtische Müllabfuhr, Mai 1901

$1867-1906$

Klassifikation Teil B: 00932

Band: 3

Trägermaterial: Papier

Alte Reg.-Sig.: IV Jc 03

Bestell-Nr.: IV 00932 
- Abortanlage im Emder Rathaus, 1877

- Reparatur des Abwässerungskanals von der Lookvenne bis zur

Großen Straße, Juni 1880

- Pläne von Toilettenanlagen, 1877 - 1880

- Vermessung der Dreckwarfe am Beckhofstor und Herrentor,

Dezember 1875

- Organisation der Abfuhr des Straßenkots, Mülls und Fäkalien, 1873 -

1878

- Bericht über das städtische Abfuhrwesen in Groningen als Vorbild für Emden, 1873

- Anlage einer Dreckwarf am Herrentor und Schaffung einer schiffbaren Verbindung zur Dreckwarf am Beckhofstor, 1878

- Bau eines Düngerschuppens am Herrentor, Oktober 1878

$1873-1880$

Klassifikation Teil B: 00933

Band: 1

Trägermaterial: Papier

Alte Reg.-Sig.: IV Jc 04

Bestell-Nr.: IV 00933

867 Abfuhrwesen, Bd. 2

- Organisation der Abfuhr von Gassenkot, Müll und Fäkalien

- Bau eines Jaucheschuppens am Herrentor

- Anlegung einer Dreckwarf beim Herrentor

- Verzeichnis der Abnehmer von Delfter Tonnen für Fäkalienabfuhr

1879

\author{
Klassifikation Teil B: 00934 \\ Band: 2 \\ Trägermaterial: Papier \\ Alte Reg.-Sig.: IV Jc 04 \\ Bestell-Nr.: IV 00934
}

- Aufstellung über Abnehmer der Delfter Tonnen für Fäkalienabfuhr, 1879

- Bericht über Entwicklung des Emder Abfuhrwesens, 1879

- Mateial des Oberbürgermeisters Fürbringer über Verbesserung des

Abfuhrwesens, 1876 - 1879

$1876-1879$

Klassifikation Teil B: 00935

Band: 3

Trägermaterial: Papier

Alte Reg.-Sig.: IV Jc 04

Bestell-Nr.: IV 00935 
05

05.03

05.03.06

05.03.06.02

05.03.06.02.03

\section{Stadtverwaltung}

Aufgabenbereiche der Stadtverwaltung

Öffentliche Anlagen, Straßenpolizei und Organisation der

Ver- und Entsorgung

Straßenreinigung und öffentliche Hygiene

Stadtentwässerung und Abfallentsorgung

Lfd. Nr. Titel

Laufzeit

869 Neuregelung des Abfuhrwesens, Bd. 1

1869-1885

- Bericht über Abfuhrwesen in der niederländischen Provinz

Groningen als Vorbild für Emden, 1869

- Situationsplan der Dreckwarf am Herrentor, 1879

- Ausgaben für die Neuregelung des Abfuhrwesens in Emden, 1879 -

1885

- Verbesserung der Abortanlagen im Gasthaus, 1880

- Austausch der Stadt Emden mit anderen Städten wegen des

Abfuhrwesens, Juli 1880 - März 1882

- Einführung des Delfter und Heidelberger Tonnensystems für die

Entsorgung der Fäkalien, 1880 - 1882

- Streit um die Reinigung der Abfallschächte an Brunnen, November 1880

- Verkauf von Straßenkot, März - April 1881

- Bau eines Jauchereservoirs auf der Dreckwarf am Herrentor, 1881/

$1883-1884$

- Verhandlungen des Magistrats und der Abfuhr-Commission über die Organisation des Abfuhrwesens, 1881 - 1885

- Verhandlungen über Verbesserung der Absatzmöglichkeit für Straßendung in den Fehn- und Moorgebieten in Ostfriesland, April 1882

- Organisation der Latrinenabfuhr der Kaserne, 1882

- Polizeiverordnung der Stadt Emden über Einrichtung sanitärer Anlagen und Entsorgung der Fäkalien, September 1883 / September Oktober 1885

- Analyse des Emder Straßenkots auf seinen Düngerwert durch die Moorversuchsstation in Bremen, Januar - Februar 1885

- Bau eines Düngerschuppens an der Schiefen Tille, Juli 1885

$1869-1885$

Klassifikation Teil B: 00936

Band: 1

Trägermaterial: Papier

Alte Reg.-Sig.: IV Jc 04

Bestell-Nr.: IV 00936 
05

05.03

05.03.06

05.03.06.02

05.03.06.02.03

\section{Stadtverwaltung}

Aufgabenbereiche der Stadtverwaltung

Öffentliche Anlagen, Straßenpolizei und Organisation der

Ver- und Entsorgung

Straßenreinigung und öffentliche Hygiene

Stadtentwässerung und Abfallentsorgung

Lfd. Nr. Titel

Laufzeit

870 Neuregelung des Abfuhrwesens, Bd. 2

- Aufbau der Kanalisation in Emden, 1886

- Vergrößerung des Düngerschuppens auf der Dreckwarf am

Herrentor, 1886 - 1887

- Verhandlungen des Magistrats und der Abfuhr-Commission über

Abfuhrwesen, 1886 - 1888

- Einführung des Tonnensystems in Emden, 1886 - 1887

- Errichtung eines Wagen- und Tonnenschuppens am Herrentor, 1886

- Aufnahme von Krediten bei der städtischen Leih- und Sparkasse zur

Finanzierung der Neuerungen im Abfuhrwesen, 1887

- Spezial-Etat der Stadtreinigung und des städtischen

Tonnen-Abfuhrwesens, April 1887 - März 1887

- Einführung des Tonnensystems im Lazarett der Garnison zu Emden, April 1887

- Revision der Aborte in der Emdener Papierfabrik und im Bereich der Auricher Straße, April 1888

- Anzeige über unvorschriftsmäßigen Abort des Fuhrmanns Peter van Dettum, Juli 1888

- Angebote über Abpumpgeräte für Fäkalien, 1888 - 1889

- Anbringung von Aborten in den Gotteskammern in der Strohstraße,

Mai 1889 - Januar 1891

- Plan über Räumung von Wohnungen mit ordnungswidrig angelegten

Aborten, 1889

- Anfragen über Erfahrungen mit dem Tonnensystem in Emden, 1888

- 1894

- Anzeige über eine zu kleine Aborttonne für ein Haus mit fünf

Familien, Juli 1892

$1886-1894$

Klassifikation Teil B: 00937

Band: 2

Trägermaterial: Papier

Alte Reg.-Sig.: IV Jc 04

Bestell-Nr.: IV 00937 
IV

05

Stadtverwaltung

05.03

Aufgabenbereiche der Stadtverwaltung

05.03.06

Öffentliche Anlagen, Straßenpolizei und Organisation der

Ver- und Entsorgung

05.03.06.02

05.03.06.02.03

Straßenreinigung und öffentliche Hygiene

Stadtentwässerung und Abfallentsorgung

Lfd. Nr. Titel

Laufzeit

871 Abfuhrwesen, Bd. 4

1876-1882

- Aufstellung über öffentliche Aborte in der Stadt Emden, März 1876

- Verkauf des Straßenkots und des Stadtdüngers (Fäkalien), 1880 -

1881

- Regulierung des Abfuhrvertragsverhältnisses zwischen der Stadt

Emden und dem Führunternehmer Uffe Fokken, Oktober 1880 -

Dezember 1881

- Verhandlungen der Abfuhr-Commission über Regelung der

Entsorgung von Straßenkot, Fäkalien und Müll, 1881 - 1882

- Verkauf von Stadtdünger nach Holland, 1881 - 1882

- Aufstellung der von Uffe Fokken benutzten und in den Eigentum der

Stadt übergegangene Abfuhrgerätschaften, September 1881

- Beschwerde des Postdirektors Albrecht über ausgebliebene

Tonnenleerung durch U. Fokken und Anspruch auf Schadensersatz

wegen Überlaufen der Tonne, Dezember 1881

$1876-1882$

Klassifikation Teil B: 00938

Band: 4

Trägermaterial: Papier

Alte Reg.-Sig.: IV Jc 04

Bestell-Nr.: IV 00938 
05

05.03

05.03.06

05.03.06.02

05.03.06.02.03

\section{Stadtverwaltung}

Aufgabenbereiche der Stadtverwaltung

Öffentliche Anlagen, Straßenpolizei und Organisation der

Ver- und Entsorgung

Straßenreinigung und öffentliche Hygiene

Stadtentwässerung und Abfallentsorgung

Lfd. Nr. Titel

Laufzeit

872 Neuregelung des Abfuhrwesens, Bd. 3

- Austausch der Stadt Emden mit anderen Städten wegen Organisation des Abfuhrwesens, 1894 - 1907

- Bericht des Kreisphysicus und Sanitätsrats Dr. Tergast über

Zusammenhang zwischen Unterleibstyphus und Mängel des

Abfuhrwesens, Oktober 1895

- Verhandlungen der Abfuhr-Commissiom über Organisation des

Abfuhrwesens, 1892 - 1900

- Angebote über Abfuhrgeräte, Fäkalientonnen und Abfuhrsysteme, $1895-1908$

- Anschaffung neuer Wagen für die Abfuhr der Fäkalientonnen,

Oktober 1896

- Angebote über Maschinen und Geräte zur Straßenreinigung, 1897

- Angebot der Firma M. Friedrich \& Co, Leipzig über Kläranlagen für Spül-Closetts (WC's), 1897

- Anzeigen über unvorschriftmäßig angelegte Aborte und zu kleine

Tonnen, Oktober 1897 - Juni 1905

- Bericht des Oberbürgermeisters der Stadt Emden an den

Regierungspräsidenten in Aurich über angestellte Versuche zur

Bindung von Fäkalien mit Torfmüll, Oktober 1897

- Denkschrift des Medizinalrats Dr. Reincke und des Oberingenieurs

F. Andreas Meyer über Beseitigung des Straßenkehrichts und andere städtische Abfälle durch Verbrennung, 1895

- Denkschriften über Verwertung der städtischen Abfälle, 1900

- Verkauf von Stadtdung (Fäkalien), 1900 - 1901

- Leserbrief in der Rhein Ems Zeitung über Diskriminierung der

Bewohner der Arbeiterkolonie Transvaal bei der

Fäkalientonnenabfuhr, Juni 1901

- Streit zwischen der Rentnerin Antonie Rodewyk und der Stadt

Emden um die Höhe der Abfuhrgebühr für Fäkalientonnen, Februar

1906 - Januar 1907

$1894-1908$

Klassifikation Teil B: 00939

Band: 3

Trägermaterial: Papier

Alte Reg.-Sig.: IV Jc 04

Bestell-Nr.: IV 00939 
05

05.03

05.03.06

05.03.06.02

05.03.06.02.03
Stadtverwaltung

Aufgabenbereiche der Stadtverwaltung

Öffentliche Anlagen, Straßenpolizei und Organisation der

Ver- und Entsorgung

Straßenreinigung und öffentliche Hygiene

Stadtentwässerung und Abfallentsorgung

Lfd. Nr. Titel

Laufzeit

873 Änderung der Vorschriften zur Einrichtung der Aborte

- Bekämpfung der zu Unterleibstyphus führenden Missstände im Fäkalienabfuhrwesen und Abortwesen, Oktober 1895 - August 1896

- Revision der Fäkalientonnenabfuhr durch den Stadtbauaufseher Schultz, Dezember 1895 - Mai 1896

- Neufassung der städtischen Polizeiverordnung zur Regelung des Abortwesens über Normen zum Bau und zur Beschaffenheit der Aborte, Januar 1897 - März 1909

- Organisation der Spülung der Aborttonnen nach dem vom Regierungspräsidenten in Aurich verfügten Verbot der Einleitung des mit Fäkalien verseuchten Spülwassers in das Fehntjer Tief, August 1900

- Verhandlungen der Abfuhr-Commission wegen Schließung der Dreckwarf am Herrentor, April 1907

- Bericht des Polizeisergeanten Gehrs über unhygienische Verhältnisse und Gefährdung der Sittlichkeit durch die Unterbringung von "Schlafleuten" auf zwei holländische Wohnschiffe ohne genügende Räumlichkeiten, Juli 1910

- Anfertigung einer Überdachung für gelagerte Fäkalientonnen, Juni 1910

$1895-1910$

Klassifikation Teil B: 00940

Trägermaterial: Papier

Alte Reg.-Sig.: IV Jc 04

Bestell-Nr.: IV 00940

874 Abortanlagen von Privatpersonen

- Revision der Abortanlagen von Privatleuten durch den städtischen Abfuhraufseher Huismann, November 1897 - Juli 1899

- Verfügungen der Stadt Emden an Hausbesitzer mit mangelhaften Abortanlagen über Aufforderung zur Behebung der Mängel, Dezember 1897 - Juni 1906

- Anzeigen über fehlerhafte Abortanlagen, Mai 1898 - Juni 1906

- Streit zwischen dem Hausbesitzer und Gemüsebauern Bonne Peters und dem Abfuhraufseher Huismann wegen angeblicher

Unbrauchbarkeit der Fäkalientonne im Haus des B. Peters, Juli -

September 1899

- Mangelhafte Abortanlagen in den Mietshäusern des Helmer von

Baden Foget, Juli 1899 - Oktober 1906

- Anzeige über Überbelegung der Baubude des Bauunternehmers

Carl Löschen mit 26 Italienern bei nur einer Aborttonne, April -

September 1906

$1897-1906$

Klassifikation Teil B: 00941

Band: 1

Trägermaterial: Papier

Alte Reg.-Sig.: IV Jc 05

Bestell-Nr.: IV 00941 


\section{5}

05.03

05.03.06

05.03.06.02 05.03.06.02.03

\section{IV}

Stadtverwaltung

Aufgabenbereiche der Stadtverwaltung

Öffentliche Anlagen, Straßenpolizei und Organisation der

Ver- und Entsorgung

Straßenreinigung und öffentliche Hygiene

Stadtentwässerung und Abfallentsorgung

Laufzeit

875 Abortanlagen von Privatpersonen, Bd. 2

$1907-1911$

- Anzeigen über fehlerhafte Abortanlagen, Januar 1907 - Oktober

1910

- Streit zwischen dem Hausbesitzer Bach und dem

Abfuhrunternehmer Meyer wegen Abfuhrgebühr für eine

Fäkalientonne, Februar - März 1907

- Verfügungen der Stadt Emden an Hausbesitzer mit mangelhaften

Abortanlagen über Aufforderung zur Behebung der Mängel, Mai 1907

- September 1911

- Mangelhafte Abortanlagen in den Mietshäusern des Helmer von

Baden Foget, Oktober 1908 - Oktober 1911

$1907-1911$

Klassifikation Teil B: 00942

Band: 2

Trägermaterial: Papier

Alte Reg.-Sig.: IV Jc 05

Bestell-Nr.: IV 00942 
05

\subsection{3}

05.03.06

05.03.06.02 05.03.06.02.03

\section{Stadtverwaltung}

Aufgabenbereiche der Stadtverwaltung

Öffentliche Anlagen, Straßenpolizei und Organisation der Ver- und Entsorgung

Straßenreinigung und öffentliche Hygiene

Stadtentwässerung und Abfallentsorgung

Lfd. Nr. Titel

Laufzeit

876 Verpachtung der Fäkalien- und Müllabfuhr

- Vertrag zwischen der Stadt Emden und dem Abfuhrunternehmer Uffe Fokken über Abfuhr der Fäkalien, des Mülls und des

Straßenkehrichs aus dem Emder Stadtgebiet, Oktober 1878

- Vertragliche Regelung der Fäkalienabfuhr auf Basis des

Heidelberger Tonnensystems, November 1878

- Kauf der Düngervorräte und der sich im städtischen Besitz befindlichen Geräte für Fäkalien- und Müllabfuhr durch Uffe Fokken, November 1879

- Bericht des Kämmerers über unvollständig entrichteter Kaufpreis für den städtischen Düngervorrat und Abfuhrgeräte durch U. Fokken,

November 1879

- Rückstand des Uffe Fokken bei den Pachtgeldern für den städtischen Dünger, Mai 1880 - Juli 1881

- Verhandlungen der städtischen Kollegien über Modifikation des Abfuhrvertrages mit Fokken durch erine Kopplung der Pachtsumme an den erzielbaren Verkaufspreis für den städtischen Dünger, August 1880 - Juli 1881

- Übernahme des Düngerverkaufs durch die Geschwister Jürrina und Franziska Höbarth, Oktober 1880 - Februar 1881

- Liquiditätsschwierigkeiten des Fuhrunternehmers Uffe Fokken,

Februar 1881

- Antrag des Uffe Fokken auf Kompensation seines Defizits wegen der Abfuhr, Juni 1881

- Abrechnung des U. Fokken über Erlöse aus dem Düngerverkauf zwischen 1881 und 1882 sowie zwischen 1889 und 1892, Mai 1882 /

Mai 1892

- Rechnung des Stadtbaumeisters Wiggers über Erlöse aus dem Düngerverkauf zwischen 1883 und 1884, 1884

- Nachträge zum Abfuhrvertrag zwischen der Stadt Emden und dem Abfuhrunternehmer Uffe Fokken, 1881 / 1887 / 1888 / 1889

- Vertrag zwischen der Stadt Emden und dem Abfuhrunternehmer Berend J. Meyer über Abfuhr der Fäkalien, des Mülls und des Straßenkehrichs aus dem Emder Stadtgebiet, April 1899

$1878-1899$

Klassifikation Teil B: 00943

Trägermaterial: Papier Alte Reg.-Sig.: IV Jc 09

Bestell-Nr.: IV 00943 
05

05.03

05.03.06

05.03.06.02

05.03.06.02.03

\section{Stadtverwaltung}

Aufgabenbereiche der Stadtverwaltung

Öffentliche Anlagen, Straßenpolizei und Organisation der

Ver- und Entsorgung

Straßenreinigung und öffentliche Hygiene

Stadtentwässerung und Abfallentsorgung

Lfd. Nr. Titel

Laufzeit

877 Beschwerden über das Abfuhrwesen, Bd. 1

- Anzeige des Fuhrunternehmers Fokken über Unterwanderung seines Monopols durch Nichtablieferung von Mist und Kehricht und deren Verkauf durch Hausbesitzer, 1879

- Beschwerden gegen den Fuhrunternehmer Fokken wegen mangelhafter Fäkalienabfuhr, 1880 - 1899

- Anzeige gegen den Fuhrunternehmer Fokken wegen unterlassener Straßenreinigung, 1889 - 1898

- Streit zwischen dem Schiffsbaumeister Cassens und dem

Fuhrunternehmer Fokken wegen Wechsel der Fäkalientonnen, Januar 1896

- Beschwerde des Fuhrunternehmers Fokken wegen unvorschriftsmäßiger Fäkalientonnen in Privathäusern, 1896

- Verhängung einer Konventionalstrafe gegen den Fuhrunternehmer

U. Fokken wegen Nichtabholung von Fäkalientonnen, August 1896

- Mangelhafte Aborte in den Mietshäusern des Helmer von Baden

Foget, 1899

- Beschwerden gegen den Fuhrunternehmer Berend J. Meyer wegen mangelhafter Fäkalienabfuhr, 1899 - 1909

- Beschwerden gegen den Fuhrunternehmer Meyer wegen mangelhafter Straßenreinigung, August 1901

- Beschwerden gegen den Fuhrunternehmer Meyer wegen

mangelhafter Abfuhr des Kehrrichts, 1906 - 1907

$1879-1909$

Klassifikation Teil B: 00944

Band: 1

Trägermaterial: Papier

Alte Reg.-Sig.: IV Jc 10

Bestell-Nr.: IV 00944

878 Beschwerden über das Abfuhrwesen, Bd. 2

$1909-1915$

- Beschwerden gegen den Fuhrunternehmer Berend J. Meyer wegen mangelhafter Fäkalienabfuhr, 1910 - 1915

- Vertrag zwischen der Stadt Emden und dem Abfuhrunternehmer Berend J. Meyer über Abfuhr der Fäkalien, des Mülls und des Straßenkehrichs aus dem Emder Stadtgebiet, Februar 1909 - Beschwerde des Wykvereins der VI. Wyk über ruhestörenden Lärm der Fäkalienabfuhrtonnenwagen als Schädigung für Hotels, Oktober 1909

$1909-1915$

Klassifikation Teil B: 00945

Band: 2

Trägermaterial: Papier

Alte Reg.-Sig.: IV Jc 10

Bestell-Nr.: IV 00945 
05

05.03

05.03.06

05.03.06.02

05.03.06.02.03
Stadtverwaltung

Aufgabenbereiche der Stadtverwaltung

Öffentliche Anlagen, Straßenpolizei und Organisation der

Ver- und Entsorgung

Straßenreinigung und öffentliche Hygiene

Stadtentwässerung und Abfallentsorgung

Lfd. Nr. Titel

Laufzeit

879 Beschwerden gegen den Dreckwarf am Herrentor

- Beschwerde der Bewohner am Herrentor gegen die Geruchsbelästigung durch die Anfuhr und Lagerung von Fäkalien auf der Dreckwarf am Herrentor, Juli - September 1884 / Mai - August 1885 / Juli - Oktober 1887 / August - September 1892 / Juli 1899 / Juli 1903 - September 1903 / März 1907 / August 1910

- Gutachten des Sanitätsrats Dr. Norden über von der Dreckwarf ausgehende Seuchengefahr (Typhus) für die Anwohner, August 1885

- Verfügung des Regierungspräsidenten in Aurich an die Bewohner des Herrentorviertels über Bestätigung des Standpunkts der Stadt Emden zur Unbedenklichkeit der Dreckwarf, November 1885 - Gutachten des Regierungs- und Medizinalrats Dr. Reiche über grundsätzliche Unbedenklichkeit des Dreckwarfs am Herrentor und Empfehlung von Modifikationen durch Vermeidung privater Misthaufen auf der Dreckwarf und Verbesserung des Düngerschuppens, November 1885

- Aufstellung über Bewohner des Gebiets am Herrentor, 1893

- Beschwerde des Fußgendarms Bernhard Hartrampf im Namen der Bewohner des Herrentorviertels beim Regierungspräsidenten in Aurich gegen die Dreckwarf wegen Gesundheitsgefährdung, August Dezember 1899

- Gutachten des Kreisphysicus und Sanitätsrats Dr. Tergast über Unbedenklichkeit der Dreckwarf und Empfehlung von Maßnahmen gegen die Verseuchung des Fehntjer Tiefs, Oktober 1899 / Juli 1904 / Januar 1907

- Verfügung des Regierungspräsidenten in Aurich an die Stadt Emden über Aufforderung zur Berichtserstattung hinsichtlich der Beseitigung der Missstände auf der Dreckwarf am Herrentor, Oktober 1899 - Verfügung des Regierungspräsidenten in Aurich an die Stadt Emden über Maßnahmen zur Vermeidung der Bodenverseuchung durch Fäkalienlagerung auf der Dreckwarf am Herrentor, Oktober 1899 / Juli 1904 / Januar 1907

- Bau einer wasserdichten Grube für die Fäkalienlagerung auf der Dreckwarf am Herrentor, Mai 1900

- Eingabe des Wykvereins der VI. Wyk an den Regierungspräsidenten in Aurich und den Oberpräsidenten in Hannover über Beantragung einer unangemeldeten Revision der Dreckwarf am Herrentor, Juli 1904

- Verhandlungen der Kanalisations-Commission über Alternativen zur Fäkalienlagerung auf dem Dreckwarf am Herrentor, Mai 1906 - Leserbriefe in der "REZ" und der "EZ" über Wunsch nach Stilllegung der Deckwarf am Herrentor, 1900 - 1907

$1885-1910$

Klassifikation Teil B: 00946

Trägermaterial: Papier

Alte Reg.-Sig.: IV Jc 12

Bestell-Nr.: IV 00946 
05

05.03

05.03.06

05.03.06.02

05.03.06.02.03
Stadtverwaltung

Aufgabenbereiche der Stadtverwaltung

Öffentliche Anlagen, Straßenpolizei und Organisation der

Ver- und Entsorgung

Straßenreinigung und öffentliche Hygiene

Stadtentwässerung und Abfallentsorgung

Lfd. Nr. Titel

Laufzeit

880 Wasser-Closetts und Entsorgung von Fäkalien über die Kanalisation, Bd. 1

- Verhandlungen der Kanalisations-Commission über Gestattung des Anschlusses der WC's an die Kanalisation und Einleitung der Abwässer in die Ems, Mai - Juni 1896

- Korrespondenz der Stadt Emden mit anderen Städten wegen Vorschriften zum Anschluss der WC' an das Kanalnetz und dem Auspumpen von Abortgruben, 1896

- Angebote von Wagen und Geräte zum Auspumpen der Abortgruben, 1896

- Anträge und Genehmigung des Einbaus von WC's in Emder

Häusern mit Abortgruben, September 1897 - November 1907

- Prospekt über WC-Anlage, 1897

- Verweigerung der Zahlung einer Recognitionsgebühr für die Duldung des Anschlusses seiner WC-Anlage an die Kanalisation durch den Hausbesitzer Helmer von Baden Foget, Januar - Juli 1903

$1896-1903$

Klassifikation Teil B: 00947

Band: 1

Trägermaterial: Papier

Alte Reg.-Sig.: IV Jc 13

Bestell-Nr.: IV 00947

881 Wasser-Closetts und Entsorgung von Fäkalien über die Kanalisation, Bd. 2

- Installation der WC-Anlage des städtischen Krankenhauses,

September 1902 - Dezember 1903

- Protest des Installateurs Max Kaune gegen die

Nichtberücksichtigung seines Angebots für die WC-Anlage des

Krankenhauses, Oktober 1903

- Genehmigung der Anschlüsse von WC-Anlagen an die Kanalisation, Oktober 1903 - Dezember 1908

- Aufstellung über Häuser mit WC-Anlagen, 1904 - 1911

- Angebote über WC-Anlagen und Kläranlagen, Mai - September 1904

- Streit zwischen der Stadt Emden und Helmer von Baden Foget wegen der Höhe der Recognitionsgebühr für den Anschluss seiner WC-Anlage an die Kanalisation, Mai - Dezember 1905

- Bericht des Magistrats der Stadt Emden an den

Regierungspräsidenten in Aurich über Stand des Ausbaus der

Kanalisation, Februar 1912

$1892-1912$

Klassifikation Teil B: 00948

Band: 2

Trägermaterial: Papier

Alte Reg.-Sig.: IV Jc 13

Bestell-Nr.: IV 00948
1896-1903

1892-1912 
05

05.03

05.03.06

05.03.06.02

05.03.06.02.03

\section{Stadtverwaltung}

Aufgabenbereiche der Stadtverwaltung

Öffentliche Anlagen, Straßenpolizei und Organisation der

Ver- und Entsorgung

Straßenreinigung und öffentliche Hygiene

Stadtentwässerung und Abfallentsorgung

Lfd. Nr. Titel

Laufzeit

882 Aufseher der Stadtreinigung

- Dienstanweisung für Aufseher der Stadtreinigung mit der

Zuständigkeit für das Abort- und Fäkalienabfuhrwesen, März 1897 /

September 1902

- Bewerbung der Nachtwächter um das Amt des Aufsehers, August 1897

- Einstellung des P. Huismann als Aufseher der Stadtreinigung,

August 1897

- Ernennung des Tjade Dirksen zum Aufseher der Stadtreinigung, Mai

1901

- Bewerbungen um das Amt des Aufsehers der Stadtreinigung, Juli -

August 1902

- Ernennung des Wagenwärters H. Driehaus zum Aufseher der

Stadtreinigung, September 1902

- Ernennung des Invaliden Hinderk Bakker zum Aufseher der

Stadtreinigung nach dem Tode des H. Driehaus, April 1910

- Ernennung des Arbeiters Harm Dirksen zum Aufseher der

Stadtreinigung, Mai 1911

$1897-1913$

Klassifikation Teil B: 00949

Trägermaterial: Papier

Alte Reg.-Sig.: IV Jc 14

Bestell-Nr.: IV 00949

883 Abortverhältnisse bei der Baustelle des Müllerschen Hauses an der

Bahnhofsstraße

- Unvorschriftsmäßige Abortanlage für die vom Bauunternehmer Geerd Tjaden auf der Baustelle des Müllerschen Hauses

beschäftigten Arbeiter, Juni 1905

- Beschwerde des Bauunternehmers Geerd Tjaden gegen die

Verfügung der Stadt Emden über Pflicht zur Anschaffung einer weiteren Fäkalientonne für die Abortanlage für die Arbeiter auf seiner Baustelle, Juli - August 1905

1905

Klassifikation Teil B: 00950

Trägermaterial: Papier

Alte Reg.-Sig.: IV Jc 16

Bestell-Nr.: IV 00950 
05

\subsection{3}

05.03.06

05.03.06.02 05.03.06.02.03

\section{Stadtverwaltung}

Aufgabenbereiche der Stadtverwaltung

Öffentliche Anlagen, Straßenpolizei und Organisation der Ver- und Entsorgung

Straßenreinigung und öffentliche Hygiene

Stadtentwässerung und Abfallentsorgung

Lfd. Nr. Titel

Laufzeit

884 Verbotene WC's im Haus des A. Schortau

- Bericht des Stadtbaumeisters Wiggers über ungenehmigt an die Kanalisaion angeschlossene WC-Anlage im Haus des A. Schortau, Oktober 1908

- Verfügung der Stadt Emden über Anordnung zur Beseitigung der WC-Anlage, November 1908 - Mai 1910

$1908-1910$

Klassifikation Teil B: 00951

Trägermaterial: Papier

Alte Reg.-Sig.: IV Jc 19

Bestell-Nr.: IV 00951

885 Städtische Abfuhrkommission

1874-1908

(1911)

- Wahl der Mitglieder der städtischen Abfuhrkommission, Februar

1876 - Januar 1908

- Beschluss des Magistrats über Stimmrecht des Vorsitzenden der

Abfuhrkommission bei Pattsituationen in Abstimmungen, April 1893

1874 - 1908 (1911)

Klassifikation Teil B: 00956

Trägermaterial: Papier

Alte Reg.-Sig.: IV Jc 06

Bestell-Nr.: IV 00956

886 Herausgabe einer Druckschrift zum Abfuhr- und Tonnenwesen

1886-1900

(1907)

- Manuskript einer Druckschrift zur Aufklärung über das Abfuhr- und Tonnenwesen der Stadt Emden, 1885

- Verhandlungen der Stadt Emden mit dem Club der Landwirte in

Berlin wegen Gewinnung des Geheimen Oberregierungsrats Dr.

Eulenburg für die Abfassung einer Einleitung der Druckschrift, Februar

- März 1885

- Plan zur Verteilung der Druckschrift, Mai 1885

- Dankschreiben verschiedener Institutionen für die Übersendung der

Druckschrift, Mai 1885

- Versendung der Druckschrift auf Nachfrage, Januar 1890 - April

1900

- Druckschriften zum Abfuhrwesen aus anderen Städten, 1893 - 1897

$1885-1900$ (1907)

Klassifikation Teil B: 00957

Trägermaterial: Papier

Alte Reg.-Sig.: IV Jc 08

Bestell-Nr.: IV 00957 
05

05.03

05.03.06

05.03.06.02

05.03.06.02.03

\section{Stadtverwaltung}

Aufgabenbereiche der Stadtverwaltung

Öffentliche Anlagen, Straßenpolizei und Organisation der

Ver- und Entsorgung

Straßenreinigung und öffentliche Hygiene

Stadtentwässerung und Abfallentsorgung

Laufzeit

887 Aufseher für die Kontrolle der Fäkalientonnenreinigung

- Anonyme Beschwerden über mangelhafte Reinigung der

Fäkalientonnen, September 1883

- Verhandlungen über die vom Magistrat vorgeschlagene Einstellung

des E. Jakobs zum Aufseher über die Fäkalientonnenreinigung,

Oktober 1883

- Instruktionen für den Aufseher über die Fäkalientonnenabfuhr- und

Reinigung, Oktober - November 1883

- Vernachlässigung der Reinigung der öffentlichen Aborte, Januar 1886

- Bewerbung des G. von Diepenbrock um die Stelle des Aufsehers über die Fäkalientonnenabfuhr- und Reinigung, Juni 1893

- Anzeige des Polizeisergeanten Brüning über unterlassene Reinigung und Desinfizierung von Fäkalientonnen, November 1895 - Januar 1896

$1883-1896$

Klassifikation Teil B: 00958

Trägermaterial: Papier

Alte Reg.-Sig.: IV Jc 07

Bestell-Nr.: IV 00958 
05

\subsection{3}

05.03.06

05.03.06.02 05.03.06.02.03

\section{Stadtverwaltung}

Aufgabenbereiche der Stadtverwaltung

Öffentliche Anlagen, Straßenpolizei und Organisation der

Ver- und Entsorgung

Straßenreinigung und öffentliche Hygiene

Stadtentwässerung und Abfallentsorgung

Lfd. Nr. Titel

Laufzeit

888 Entwässerungsleitungen und Riolen

- Anzeige über schadhafte Entwässerungsleitungen in der kleinen Deichstraße, Oktober 1870

- Reparaturbedürftigkeit von Gossen an Emder Straßen, 1872 - 1877

- Reparaturbedürftigkeit und Verstopfung von Riolen, 1872 - 1879

- Anzeigen und Klagen wegen übelriechender oder stagnierender Abwässerungsgräben, 1872

- Schäden durch aufgestautes Wasser infolge unerlaubter

Tieferlegung oder Beseitigung von Riolen, 1873 - 1878

- Streit zwischen der Stadt Emden und dem Hausbesitzer Samuel Isaac Italjener um die Tragung der Kosten für die notwendige

Aufgrabung der an seinem Haus vorbeiführenden und durch Fäkalien verstopften Riole, OKtober 1873 - April 1874

- Beschwerden wegen Geruchsbelästigung durch in den Gossen geleitete Jauche aus Viehställen, 1873 - 1876

- Bericht des Landphysicus und Medizinalrats Dr. Stöhr über

Gesundheitsgefährdung durch in die Gossen abgeleitete

Schlachtabfälle und Fäkalien, August 1874

- Beschwerden über unterlassene Gossenreinigung, 1873 - 1879

- Beschwerde der Witwe des R. Rodewyck über Unbrauchbarkeit ihrer Regenbacke wegen einströmendes Abwasser aus einer städtischen Riole, Januar - März 1876

- Beschwerde des Arztes Dr. Brinckmann wegen Geruchsbelästigung aus dem Aborthaus des Nachbarn, März 1876

- Beschwerden wegen Überflutung der Fußweges durch

Abflusswasser aus Gärten, 1875 - 1876

- Schäden durch Verstopfung oder ungenehmigte Zuschüttung von

Abzugsgräben, 1875 - 1877

- Beschwerden wegen mangelhafter Entwässerung des Neuen Marktes, August 1878

- Riolen-Verzeichnis des Stadtbaumeisters Wiggers mit Karte des

Gebietes östlich des Rathauses, 1879

$1870-1879$

Klassifikation Teil B: 00959

Trägermaterial: Papier

Alte Reg.-Sig.: IV Je 08

Bestell-Nr.: IV 00959 
05

05.03

05.03.06

05.03.06.02

05.03.06.02.03

\section{Stadtverwaltung}

Aufgabenbereiche der Stadtverwaltung

Öffentliche Anlagen, Straßenpolizei und Organisation der

Ver- und Entsorgung

Straßenreinigung und öffentliche Hygiene

Stadtentwässerung und Abfallentsorgung

Laufzeit

889 Communions-Wasserleitung hinter dem Alten Fleischhaus

1867-1874

(1828-1865)

- Erhebung des Beitrags von den Bewohnern des Gebietes um das Alte Fleischhaus zur Unterhaltung der Abwasserleitung mit Pumpen, 1828 - 1838

- Streit um den Beitrag zur Unterhsltung der Abwasserleitung,

September - Dezember 1835

- Antrag des J. Mülder an die Stadt Emden auf Untersuchung der

Pumpe der Communions-Wasserleitung wegen Eindringen von

Wasser in seinen Keller, Juli - November 1865

- Beschwerde des J. Mülder an die Stadt Emden wegen Nichthandeln trotz Schadhaftigkeit der Communions-Wasserleitung (Riole) am Alten

Fleischhaus, Januar 1867

- Bericht des Landphysicus und Medizinalrats Dr. Stöhr über

Gesundheitsgefährdung durch aufstauendes Abwasser und Fäkalien

an der Riole beim Alten Fleischhaus, April 1867

- Verstopfung der Gosse an der Bismarckstraße, Juli 1871 - März

1874

(1828 - 1865) 1867 - 1874

Klassifikation Teil B: 00960

Trägermaterial: Papier

Alte Reg.-Sig.: IV Je 09

Bestell-Nr.: IV 00960

890 Riole vor den Häusern an der Oldersumer Straße

- Antrag des Kräutners Johannes C. Tergast auf Erlaubnis zur Anlegung einer Riole zur Ableitung der Abwässer von seinem Haus an der Oldersumer Straße, September 1856

- Antrag des Kaufmanns W. Brons auf Erlaubnis zur Anlegung einer

Riole zur Ableitung der Abwässer von seinem Haus an der

Oldersumer Straße, September 1856

- Beschwerde der Nachbarn gegen den Bau der Riole wegen

Blockade ihrer Grundstücke, Oktober - Dezember 1856

- Kostenanschlag für die Anlegung einer Riole hinter dem Rathaus, 1867

(1856) 1867

Klassifikation Teil B: 00961

Trägermaterial: Papier

Alte Reg.-Sig.: IV Je 10

Bestell-Nr.: IV 00961 
05

05.03

05.03.06

05.03.06.02

05.03.06.02.03

\section{Stadtverwaltung}

Aufgabenbereiche der Stadtverwaltung

Öffentliche Anlagen, Straßenpolizei und Organisation der

Ver- und Entsorgung

Straßenreinigung und öffentliche Hygiene

Stadtentwässerung und Abfallentsorgung

Laufzeit

891 Graben an der Sleedrieverstraße

$1870-1882$

(1838-1852)

- Aufstellung über Beitragspflichtige wegen der Unterhaltung des Grabens an der Sleedrieverstraße, März - Mai 1838

- Aufstellung über Beitragspflichtige wegen der Unterhaltung der Riole mit Pumpe an der Sleedrieverstraße, März 1845 / August 1852

- Anzeige über Unterlassung der Reinigung des Grabens an der Sleedrieverstraße, März 1870

- Verfügung der Stadt Emden an die Anlieger der Sleedrieverstraße über Pflicht zur Reinigung des dortigen Grabens, März - April 1870 - Verfügung der Stadt Emden über Verbot der Einleitung von Fäkalien in die Riolen, Mai 1870 / Juni 1882 / Juni 1883

- Ablehnung der Kontrolle der Riolen auf verbotene Zuleitungen von Aborten (Fäkalien) durch den Stadtbaumeister Wiggers wegen Überbeanspruchung durch andere Aufgaben, Juni 1882

- Aufstellung über in den Graben an der Sleedrieverstraße einmündende Riolen, März 1883

(1845 - 1852) 1870 - 1883

Klassifikation Teil B: 00964

Trägermaterial: Papier

Alte Reg.-Sig.: IV Je 13

Bestell-Nr.: IV 00964

892 Gosse vom Schlachthaus des G. Hunmmerich nach dem Alten Markt

1874-1884

(1846)

- Klage des Konsuls Abegg wegen Geruchsbelästigung aus einem Graben des Schlachters J. H. Hummerich, Oktober 1846 - Beschwerde wegen Verstopfung einer Riole durch Schlachtabfälle des Schlachters Gerhard Hummerich, August 1874 - November 1880

(1846) $1874-1884$

Klassifikation Teil B: 00967

Trägermaterial: Papier

Alte Reg.-Sig.: IV Je 15

Bestell-Nr.: IV 00967 
05

05.03

05.03.06

05.03.06.02

05.03.06.02.03

\section{Stadtverwaltung}

Aufgabenbereiche der Stadtverwaltung

Öffentliche Anlagen, Straßenpolizei und Organisation der

Ver- und Entsorgung

Straßenreinigung und öffentliche Hygiene

Stadtentwässerung und Abfallentsorgung

Lfd. Nr. Titel

Laufzeit

893 Herstellung einer Abwässerung für die Grundstücke beim Herrentor

1880-1907

- Kostenanschlag der Herstellung einer Parallelstraße zur

Bahnhofsstraße (heutige Courbierestraße) mit Pflasterung und

Entwässerungsleitung, September - Oktober 1880

- Verhandlungen der städtischen Kollegien über Heranziehung der

Hauseigentümer in der Parallelstraße zu den Kosten des Baus der

Straße und der Entwässerungsleitung, November 1881 - Januar 1882

- Korrespondenz des Stadtbaumeisters Wiggers mit verschiedenen

Firmen wegen Lieferung der Röhre für die Kanalisation der

Parallelstraße, April - Mai 1881

- Verhandlungen des Oberbürgermeisters Fürbringer mit den

Anliegern der Parallelstraße wegen Herstellung der Hausanschlüsse zur Kanalisation, Juni 1881

- Anzeige über Zuschüttung eines Entwässerungsgrabens am Herrentor durch Bernhard Onken und dadurch verhinderte Ableitung des Abwassers, Juni 1881

- Herstellung einer Kanalisation am Herrentor, Juli - August 1881

- Revision der fertig gestellten Kanalisation in der Parallelstraße, April 1882

- Antrag der Witwe des Hoteliers T.H. Heeren auf Genehmigung des

Anschlusses ihrer Jauchegrube und Abwasserleitung an die

Kanalisation, März 1891

- Beschwerden wegen Verstopfung des Kanals in der Parallelstraße,

Juni 1899 / April - Juni 1901

- Bericht des Oberbürgermeisters Fürbringer an den

Regierungspräsidenten in Aurich über Abwassersystem in der

Parallelstraße, Juli 1907

$180-1907$

Klassifikation Teil B: 00968

Trägermaterial: Papier

Alte Reg.-Sig.: IV Je 16

Bestell-Nr.: IV 00968 
05

05.03

05.03.06

05.03.06.02

05.03.06.02.03
Stadtverwaltung

Aufgabenbereiche der Stadtverwaltung

Öffentliche Anlagen, Straßenpolizei und Organisation der

Ver- und Entsorgung

Straßenreinigung und öffentliche Hygiene

Stadtentwässerung und Abfallentsorgung

Lfd. Nr. Titel

Laufzeit

894 Kanalisation des Königspolders und der Petkumer Landstraße

- Denkschrift des Wasserbau-Inspektors Dannenberg über notwendige Veränderung des Entwässerungssystems in Emden wegen Bau des Ems-Jade-Kanals, September 1881

- Verhandlungen zwischen der kgl. Wasserbau-Inspektion Emden und der Stadt Emden wegen erforderlicher

Veränderung dfes Entwässerungssystems im Königspolder wegen

des Basus des Ems-Jade-Kanals, 1882 - 1884

- Plan: Gebiet des Emder Bahnhofs mit Königspolder, 1886

- Beeinträchtigung der Entwässerung der Bahnhofsstraße durch die

Erhöhung des Hafenwasserstands, Mai 1888

- Eingabe von Anliegern der Bahnhofsstraße, Parallelstraße und

Petkumer Landstraße an den Regierungspräsidenten in Aurich über

Bitte um Verbesserung der durch die Herstellung eines gleichmäßigen

Wasserstands im Hafen beeinträchtigten Entwässerung, Februar

1890

- Bericht über volllaufende Keller in der Parallelstraße wegen

unzureichender Entwässerung über einen Graben tzum Königspolder,

Oktober 1890

- Gutachten des Stadtbaumeisters Wiggers über mangelhafte

Ausmessungen der Entwässerungsgräben im Königspolder, März

1891

- Kostenanschlag für die Kanalisierung des Grabens an der Petkumer

Landstraße zur Abführung der städtischen Abwässer, November 1909

$1881-1909$

Klassifikation Teil B: 00970

Band: 1

Trägermaterial: Papier

Alte Reg.-Sig.: IV Je 18

Bestell-Nr.: IV 00970

895 Kanalisation des Königspolders und der Petkumer Landstraße, Bd. 2

- Beschwerde der Leitung der Hohenzollernhütte über

Geruchbelästigung durch den Abwasser führenden Graben an der

Petkumer Landstraße und dadurch verursachte

Gesundheitsgefährdung für ihre Arbeiter auf dem Weg zur Schicht,

August 1910

- Verfügung des Regierungspräsidenten in Aurich über unrechtmäßige

Einleitung von Abwasser in fiskalische Gräben durch die Stadt

Emden, August 1910

- Verfügung des der kgl, Wasserbau-Inspektion Emden über

Ansetzung einer Spülung des fiskalischen Grabens an der Petkumer

Landstraße, August - September 1910

1910

Klassifikation Teil B: 00971

Band: 2

Trägermaterial: Papier

Alte Reg.-Sig.: IV Je 18

Bestell-Nr.: IV 00971 
05

05.03

05.03.06

05.03.06.02

05.03.06.02.03
Stadtverwaltung

Aufgabenbereiche der Stadtverwaltung

Öffentliche Anlagen, Straßenpolizei und Organisation der

Ver- und Entsorgung

Straßenreinigung und öffentliche Hygiene

Stadtentwässerung und Abfallentsorgung

Lfd. Nr. Titel

Laufzeit

896 Entwässerungsverhältnisse im Bereich der Bahnhofsstraße

- Antrag der Anlieger der Parallelstraße auf Anlage einer Kanalisation, Juni 1890

- Votum der Bau-Commission für die Kanalisierung der Parallelstraße,

Juli 1890

- Plan der Kanalisierung des Bereichs Bahnhofsstraße /

Parallelstraße, 1890 - 1891

- Gutachten des Syndicus Metger zur juristischen Regelung der

Zuständigkeit für die Entwässerung des Gebietes zwischen

Bahnhofsstraße und Parallelstraße, Dezember 1890

- Geruchsbelästigung der Bewohner der Parallelstraße durch

Abwässer im fiskalischen Grenzgraben, 1891 - 1892

$1890-1901$

Klassifikation Teil B: 00974

Trägermaterial: Papier

Alte Reg.-Sig.: IV Je 21

Bestell-Nr.: IV 00974

897 Entwässerungsverhältnisse des Grundstücks der Emder Heringsfischerei AG

- Beschwerde des Brückenwärters Berend Bottmeyer wegen Geruchsbelästigung durch die Abwässer der Emder Heringsfischerei AG, Juli 1890

- Verfügung des Regierungspräsidenten in Aurich an die Stadt Emden über Anforderung eines Berichtes über Maßnahmen gegen die

Einleitung gesundheitsgefährdender Abwässer durch die Emder Heringsfischerei AG, Dezember 1890

- Schreiben der Emder Heringsfischerei AG an die Stadt Emden über tideunabhängiger Hafen als Ursache der Probleme der Entwässerung und Bestreitung einer Gesundheitsgefährdung durch die Abwässer des Werkes, April 1891

- Schreiben der Emder Heringsfischerei AG an die Stadt Emden über technische Maßnahmen zur Abfallentsorgung und Verbesserung der Entwässerung, Oktober 1891

- Verfügung des Regierungspräsidenten in Aurich an die Emder Heringsfischerei AG über Empfehlung der Verbesserung der Abfallund Abwasserentsorgung wegen drohender polizeilicher Maßnahmen wegen Gesundheitsgefährdung durch Ableitung der Abwässer in die Entwässerungsgräben, November 1892

- Korrespondenz der Stadt Emden mit dem kgl. Landratsamt wegen Abwässerung der Emder Heringsfischerei AG, 1898 - 1899

- Anzeige des städtischen Bauhofsvorstehers Eberhard wegen Geruchsbelästigung durch Abwässer der Emder Heringsfischerei AG, April 1905

$1896-1905$

Klassifikation Teil B: 00975

Trägermaterial: Papier

Alte Reg.-Sig.: IV Je 22

Bestell-Nr.: IV 00975
1894-1905 


\section{5}

05.03

05.03.06

05.03.06.02 05.03.06.02.03

\section{IV}

Stadtverwaltung

Aufgabenbereiche der Stadtverwaltung

Öffentliche Anlagen, Straßenpolizei und Organisation der

Ver- und Entsorgung

Straßenreinigung und öffentliche Hygiene

Stadtentwässerung und Abfallentsorgung

Lfd. Nr. Titel

Laufzeit

898 Entwässerung der Baugrundstücke des Landwirts H. Weitz

- Verfügung des Regierungspräsidenten in Aurich über Genehmigung der Einleitung von Abwässern der geplanten Häuser des H. Weitz unter Auflagen in den Treckfahrtskanal, April 1902

1902

Klassifikation Teil B: 00976

Trägermaterial: Papier

Alte Reg.-Sig.: IV Je 24

Bestell-Nr.: IV 00976

899 Entwässerung der Baugrundstücke des Landwirts de Boer

- Verfügung des Regierungspräsidenten in Aurich über Genehmigung der Einleitung von Abwässern aus den Mietshäusern des Landwirts de Boer in Wolthusen in den Ems-Jade-Kanal, September 1901

1901

Klassifikation Teil B: 00977

Trägermaterial: Papier

Alte Reg.-Sig.: IV Je 23

Bestell-Nr.: IV 00977 
05

05.03

05.03.06

05.03.06.02

05.03.06.02.03

\section{Stadtverwaltung}

Aufgabenbereiche der Stadtverwaltung

Öffentliche Anlagen, Straßenpolizei und Organisation der

Ver- und Entsorgung

Straßenreinigung und öffentliche Hygiene

Stadtentwässerung und Abfallentsorgung

Lfd. Nr. Titel

Laufzeit

900 Entwässerung des Stadt- und Hafengebiets, Bd. 1

- Protokoll der Sitzungen der Kanalisationskommission über Entwässerung des Stadtgebiets (Wasserläufe, Kanalisationsführung), $1875-1887$

- Verhandlungen des Magistrats der Stadt Emden mit dem preußischen Landdrosten / Regierungspräsidenten in Aurich wegen Anlage und Finanzierung der Kanalisation, 1885 - 1887

- Austausch mit anderen Städten wegen Anlage der Kanalisation, $1885-1889$

- Verhandlungen des Magistrats über Entwässerungsfragen, 1885

- Verhandlungen der Baukommission über bauliche Maßnahmen und Regelungen hinsichtlich der Kanalisation, 1885

- Verhandlungen der städtischen Kollegien über Maßnahmen der Stadtentwässerung (teilweise Zuschüttung des Rathausdelfts, Zuschüttung des Graupferdtiefs), 1885

- Bekanntmachungen über Kanalisation und Hausanschlüsse der Kanalisation, September 1885 - September 1887

- Regelung der Entwässerung des Stadtviertels am Bahnhof, 1887 1896

- Zuschüttung des Ratsdelfts bis zur Rathausbrücke und verbundene bauliche und entwässerungstechnische Maßnahmen, 1886 - 1887

- Ermittlungen des Vorstandes des Verbandes deutscher Architektenund Ingenieur-Vereine über Niederschlagsmengen und Auslastung der Kanalnetze, November - Dezember 1895

- Gedruckte Protokolle der Verhandlungen der Regierungs- und städtischen Kommissare über Entwässerungs- und

Kanalisationsfragen, August 1884 - Juni 1885

$1884-1896$

Klassifikation Teil B: 01132

Band: 1

Trägermaterial: Papier

Alte Reg.-Sig.: IV Ji 01

Bestell-Nr.: IV 01132

901 Entwässerung des Stadt- und Hafengebiets, Bd. 2

$1884-1885$

- Gedruckte Protokolle der Verhandlungen der Regierungs- und städtischen Kommissare über Entwässerungs- und Kanalisationsfragen, August 1884 - Juni 1885

$1884-1896$

Klassifikation Teil B: 01133

Band: 2

Trägermaterial: Papier

Alte Reg.-Sig.: IV Ji 01

Bestell-Nr.: IV 01133 
05

05.03

05.03.06

05.03.06.02

05.03.06.02.03

\section{Stadtverwaltung}

Aufgabenbereiche der Stadtverwaltung

Öffentliche Anlagen, Straßenpolizei und Organisation der

Ver- und Entsorgung

Straßenreinigung und öffentliche Hygiene

Stadtentwässerung und Abfallentsorgung

Lfd. Nr. Titel

Laufzeit

902 Entwässerung des Stadt- und Hafengebiets, Bd. 3

- Druckschrift: Deichrichter T. Freerksen, Larrelt: Ansichten über die durch die Anlegung des Ems-Jade-Kanals und den Hafenbau sich ändernden Entwässerungsverhältnisse der Stadt Emden - Gutachten des Geheimen Baurats Henoch zu Gotha über Entwässerung der Stadt Emden

- Konzipierung und Kostenschätzung der Erstellung einer Kanalisation in Emden

- Presseberichte über Kanalisations- und Entwässerungsfragen

- Verhandlungen des Magistrats der Stadt Emden mit dem

Regierungspräsidenten in Aurich über Finanzierung der

Entwässerungsanlagen

1884

Klassifikation Teil B: 01134

Band: 3

Trägermaterial: Papier

Alte Reg.-Sig.: IV Ji 01

Bestell-Nr.: IV 01134

903 Entwässerung des Stadt- und Hafengebiets, Bd. 4

- Verhandlungen des Magistrats zur Organisation der Entwässerung

- Massenberechnungen zum Kostenvoranschlag für die Kanalisation

- Gutachten des Wasserbauinspektors Suadicani über Kanalisation in

Emden nach Anpassung des Wasserspiegels in den Delften an das (ordinäre) Hochwasser (der Ems)

- Gutachten des Deichrichters T. Freerksen zu Larrelt über Maßnahmen zur Erhaltung einer Spülung in den Emder Sielen nach dem Bau des Ems-Jade-Kanals

- Gutachten des Regierungs- und Baurats A. Tolle über

Entwässerungssystem in Emden nach der Nesserlander Schleuse

- Stellungnahme des Regierungs- und Baurats A. Tolle zum

Entwässerungsplan des Stadtbaurats Wiggers

- Kostenvoranschläge des Regierungsbaumeisters Germelmann zur

Erneuerung des Emder Entwässerungssystems

- Kostenvoranschlag des Regierungsbaumeisters Germelmann über

Anlage eines Klappsiels bei Nesserland

1884

Klassifikation Teil B: 01135

Band: 4

Trägermaterial: Papier

Alte Reg.-Sig.: IV Ji 01

Bestell-Nr.: IV 01135 
05

\subsection{3}

05.03.06

05.03.06.02 05.03.06.02.03

\section{Stadtverwaltung}

Aufgabenbereiche der Stadtverwaltung

Öffentliche Anlagen, Straßenpolizei und Organisation der Ver- und Entsorgung

Straßenreinigung und öffentliche Hygiene

Stadtentwässerung und Abfallentsorgung

Lfd. Nr. Titel

Laufzeit

904 Entwässerung des Stadt- und Hafengebiets, Bd. 5

1884-1885

- Stellungnahme des Regierungs- und Baurats A. Tolle zum

Gutachten des Geheimen Baurats Henoch, 1884

- Gutachten des Wasserbauinspektors Suadicani zur Kanalisation der Stadt Emden bei Anpassung des Wasserspiegels der Delfte an das ordinäre Hochwasser der Ems, 1884

- Verhandlungen des Magistrats über Organisation der Entwässerung, Mai - Juli 1884

- Verhandlungen des Bürgervorsteherkollegiums über Organisation der Entwässerung, Mai 1884

- Verhandlungen der städtischen Kollegien über Organisation der

Entwässerung, Mai - Dezember 1884

- Stellungnahme des Stadtbaumeisters Wiggers zur Kritik des

Regierungs- und Baurats A. Tolle an seinem Kanalisations-Konzept, Mai 1884

- Resolution des Bürgervorsteherkollegiums an den preußischen Landdrosten in Aurich über finanzielle Überforderung bei Umsetzung einer Vollkanalisation in Emden, Juni 1884

- Bescheid des preußischen Landdrosten in Aurich über Ankündigung einer hochrangigen Delegation aus dem Ministerium für geistliche, Medizinal- und Schulangelegenheiten, dem Ministerium für öffentliche Arbeiten und dem Innenministerium zur Beratung von

Entwässerungskonzepten, Juli - August 1884

- Protokoll der Besprechung zwischen der Ministerialdelegation und der Stadt Emden über die Organisation der Kanalisierung des Stadtund Hafengebiets, August / Dezember 1884

- Verhandlungen der Kanalisations- und Entwässerungskommission über Organisation der Kanalisierung, Dezember 1884 - Februar 1885 - Kostenvoranschläge und Massenberechnungen der Kanalisation, 1884

- Erläuterungen zum Kanalisationsplan, 1884

$1884-1885$

Klassifikation Teil B: 01136

Band: 5

Trägermaterial: Papier

Alte Reg.-Sig.: IV Ji 01

Bestell-Nr.: IV 01136 
05

\subsection{3}

05.03.06

05.03.06.02 05.03.06.02.03

\section{Stadtverwaltung}

Aufgabenbereiche der Stadtverwaltung

Öffentliche Anlagen, Straßenpolizei und Organisation der Ver- und Entsorgung

Straßenreinigung und öffentliche Hygiene

Stadtentwässerung und Abfallentsorgung

Lfd. Nr. Titel

Laufzeit

905 Entwässerung des Stadt- und Hafengebiets, Bd. 6

- Verhandlungen des Magistrats über Organisation der Entwässerung, September 1885 - Juni 1905

- Verhandlungen der städtischen Kollegien über Organisation der Entwässerung, März - September 1885

- Austausch mit anderen Städten wegen Kanalisierung, 1903 - 1910

- Grundstückskäufe der Stadt Emden füpr Kanalisationszwecke, 1904

- Verhandlungen der Stadt Emden mit der Garnisonsverwaltung wegen Notwendigkeit der Legung von Kanalröhren durch das Gelände der alten Kaserne, September 1885

- Durchführung der Arbeiten zur Erstellung der Hausanschlüsse der Kanalisation und Abstimmung mit dem Regierungsbaumeister Germelmann, September 1885 - Juni 1886

- Verhandlungen der Kanalisations- und Entwässerungskommission über Organisation der Kanalisierung, April 1885 - Mai 1886

- Planzeichnungen: Kanalisation der Stadt Emden, 1885

- Werbeschriften von Kanalbaufirmen und Herstellern von Röhren und Kanalbauteilen, 1885 - 1902

Auflassung von Grundstücken für Kanalbauzwecke, 1908

$1885-1910$

Klassifikation Teil B: 01137

Band: 6

Trägermaterial: Papier

Alte Reg.-Sig.: IV Ji 01

Bestell-Nr.: IV 01137 
IV

05

05.03

Stadtverwaltung

05.03 .06

Aufgabenbereiche der Stadtverwaltung

05.03.06.02

Öffentliche Anlagen, Straßenpolizei und Organisation der

Ver- und Entsorgung

05.03.06.02.03

Straßenreinigung und öffentliche Hygiene

Stadtentwässerung und Abfallentsorgung

Lfd. Nr. Titel

Laufzeit

906 Durchführung der Kanalisierungsarbeiten

1885-1889

- Ausschreibung der Kanalisierungsarbeiten, April 1885

- Korrespondenz des Oberbürgermeisters Fürbringer mit dem

Geheimen Baurat Henoch über Beurteilung der sich an der

Ausschreibung beteiligenden Firmen, Mai 1885

- Beurteilung eingegangener Angebote durch den

Regierungsbaumeister Germelmann, Juni - Oktober 1885

- Verhandlungen der Kanalisations- und Entwässerungskommission

über Auftragsvergabe bei der Kanalisierung, Juni 1885 - September

1887

- Verhandlungen des Magistrats über Auftragsvergabe bei der

Kanalisierung, Juni 1885 - Dezember 1886

- Verhandlungen des Bürgervorsteherkollegiums über

Auftragsvergabe bei der Kanalisierung, Juli 1885

- Genehmigung der mit den günstigstbietenden Firmen avisierten

Verträge durch den Regierungspräsidenten in Aurich, Oktober 1885

- Kaution der mit der Arbeit betrauten Firmen, November 1885 - Mai 1889

- Beseitigung der infolge der Kanalisierung entstandener

Straßenschäden, Februar - Oktober 1887

- Antrag der Firma Habich \& Goth auf Sonderentschädigung wegen Schwierigkeiten bei der Kanalisierung wegen im Bodenverborgener

Steine etc., Januar - Dezember 1889

$1885-1889$

Klassifikation Teil B: 01138

Trägermaterial: Papier

Alte Reg.-Sig.: IV Ji 02

Bestell-Nr.: IV 01138 
IV

05

\subsection{3}

05.03.06

05.03.06.02

05.03.06.02.03
Stadtverwaltung

Aufgabenbereiche der Stadtverwaltung

Öffentliche Anlagen, Straßenpolizei und Organisation der

Ver- und Entsorgung

Straßenreinigung und öffentliche Hygiene

Stadtentwässerung und Abfallentsorgung

Lfd. Nr. Titel

Laufzeit

907 Anschluss der Papierfabrik an die Kanalisation

- Vorschläge der Kanalisationskommission zum Anschluss der Papierfabrik an die Kanalisation, Februar 1885

- Polizeiverordnungen über Verbot der Verschnutzung der Gewässer und über Anschluss an die Kanalisation, Dezember 1885

- Verhandlungen des Magistrats mit der Emdener Papierfabrik AG wegen Anschluss der Fabrik an die Kanalisation, Februar 1885 - März 1888

- Verhandlungen der Kanalisationskommission über Anschluss der Papierfabrik an die Kanalisation, Februar - November 1885

- Verhandlungen des Magistrates über Anschluss der Papierfabrik an die Kanalisation, März 1885 - Juli 1886

- Verhandlungen der städtischen Kollegien über Anschluss der

Papierfabrik an die Kanalisation, August - September 1885

- Verfügung des Regierungspräsidenten in Aurich über Verbot der Ableitung ungeklärter Abwässer der Emder Papierfabrik in die Kanalisation, April / Juni 1885

- Berechnung des Regierungsbaumeisters Germelmann über Anteil der Papierfabrik an den Kosten der Kanalisation, August 1885

- Vertrag zwischen der Stadt Emden und der Emder Papierfabrik über Bedingungen für den Anschluss der Papierfabrik an die Kanalisation, Mai 1886

- Bericht des Magistrats an den Regierungspräsidenten in Aurich über den Stand ihrer Verhandlungen mit der Emder Papierfabrik über Anschluss an die Kanalisation, August - September 1886

- Kläranlage der Emder Papierfabrik, August 1887

- Verlängerung der Kanalisationsleitung zur Emder Papierfabrik, Februar - Mai 1896

- Antrag der Emder Papierfabrik auf Befreiung von weiteren Kanalbaubeiträgen, August 1899 - Januar 1900

$1885-1900$

Klassifikation Teil B: 01139

Trägermaterial: Papier Alte Reg.-Sig.: IV Ji 03

Bestell-Nr.: IV 01139 
05

\subsection{3}

05.03.06

05.03.06.02 05.03.06.02.03

\section{Stadtverwaltung}

Aufgabenbereiche der Stadtverwaltung

Öffentliche Anlagen, Straßenpolizei und Organisation der Ver- und Entsorgung

Straßenreinigung und öffentliche Hygiene

Stadtentwässerung und Abfallentsorgung

Lfd. Nr. Titel

Laufzeit

908 Finanzierung der Kanalisierung

1885-1891

(1897)

- Verhandlungen des Magistrats über Finanzierung der Kanalisation und Organisation des Zahlungsverkehrs, Juni 1885

- Aufnahme eines Kassenkredits über 25.000 Mark mit sechsmonatiger Laufzeit bei der städtischen Spar- und Leihkasse zur Zwischenfinanzierung der Kanalisierungsarbeiten, September 1885

- Antrag des Magistrats an den Bezirksausschuss in Aurich auf Erlaubnis zur Aufnahme einer Anleihe in Höhe von 300.000 Mark zur Finanzierung der Kanalisation, Oktober - November 1885

- Abwicklungen der Zahlung der Kanalisationsarbeiten, Dezember 1885 - Juli 1891

- Verfügung des Regierungspräsidenten in Aurich über Zahlung des Staatszuschusses zu den Kosten der Kanalisation an die Stadt Emden, März 1886 - Juli 1888

- Verhandlungen der Kanalisierungskommission über Abwicklung der Zahlungen für die Kanalisierungsarbeiten, Mai 1886

- Nachweis des Wasserbauinspektors Germelmann über Ausgaben für die Kanalisierungsarbeiten und die Zuschüttung des kleinen Tiefs, Oktober 1887

- Gewährung eines Honorars an den Stadtbaumeisters Wiggers und andere Beamte für den Einsatz bei der Kanalisation, Mai - Oktober 1890

$1885-1891(1897)$

Klassifikation Teil B: 01140

Trägermaterial: Papier

Alte Reg.-Sig.: IV Ji 05

Bestell-Nr.: IV 01140 
IV

05

\subsection{3}

05.03.06

05.03.06.02

05.03.06.02.03
Stadtverwaltung

Aufgabenbereiche der Stadtverwaltung

Öffentliche Anlagen, Straßenpolizei und Organisation der

Ver- und Entsorgung

Straßenreinigung und öffentliche Hygiene

Stadtentwässerung und Abfallentsorgung

Lfd. Nr. Titel

Laufzeit

909 Neues oder Stadtsiel

- Bericht des Stadtbaumeisters Wiggers über Baufälligkeit des Neuen oder Stadtsiels und Vorschlag zur Beseitigung des Siels und Umwandlung in eine Kammerschleuse, Februar - April 1885

- Planzeichnung: Projekt einer Kammerschleuse am Neuen Siel, April 1885

- Kostenberechnung für das Projekt, April 1885

- Kostenberechnung einer Wiederherstellung des Neuen Siels, April

1885

- Verhandlungen der Kanalisationskommission über das von

Stadtbaumeister Wiggers vorgeschlagene Projekt, Mai 1885 / August 1886

- Protokoll der Bürgervorsteherkollegiumssitzung über Bewilligung von 1000 Mark für Wiederherstellung des Neuen Siels und Favorisierung seiner Umwandlung in eine Kammerschleuse nach dem Projekt des Stadtbaumeisters, April 1887 / Dezember 1889

- Diskussion der Möglichkeit der Kreuzung des Neuen Siels durch einen Düker, Juni - Juli 1887

- Kostenvoranschlag der Firma Börner \& Herzberg über Zuschüttung und Kanalisierung des Oster- und Brauerspiepentiefs, Juli 1907 - Angebot des Ingenieurs Heinrich Reissig über Pumpsysteme für Kanalisation, November 1907

$1885-1907$

Klassifikation Teil B: 01141

Trägermaterial: Papier

Alte Reg.-Sig.: IV Ji 06

Bestell-Nr.: IV 01141

910 Legung eines Entwässerungssiels in den Flügeldeich bei Nesserland

- Plan des Regierungsbaumeisters Germelmann über Legung eines Entwässerungssiels in den Flügeldeich bei Nesserland, Juli 1885

- Genehmigung des Plans durch den Magistrat und den

Regierungspräsidenten in Aurich, August 1885

1885

Klassifikation Teil B: 01142

Trägermaterial: Papier

Alte Reg.-Sig.: IV Ji 07

Bestell-Nr.: IV 01142 
05

05.03

05.03.06

05.03.06.02

05.03.06.02.03

\section{Stadtverwaltung}

Aufgabenbereiche der Stadtverwaltung

Öffentliche Anlagen, Straßenpolizei und Organisation der

Ver- und Entsorgung

Straßenreinigung und öffentliche Hygiene

Stadtentwässerung und Abfallentsorgung

Lfd. Nr. Titel

Laufzeit

911 Bei der Kanalisierung beschäftigte Beamte

- Bewerbung des Ingenieurs Siegmund Oestreicher aus Kolbergsmunde um den Posten eines Bauleiters bei der Kanalisierung der Stadt Emden, Dezember 1884

- Verhandlungen des Magistrats über Beschäftigung technischer

Fachkräfte bei der Kanalisierung Emdens, April - Juni 1885

- Betrauung des Regierungsbaumeisters Germelmann mit der Leitung der Kanalisierung Emdens und REgelung seiner Stellung gegenüber der Stadt Emden, August - September 1885

- Festsetzung einer Entschädigung für den Kämmerer Ernst August Gebest wegen seiner Tätigkeit als Buch- und Rechnungsführer bei der Kanalisierung Emdens, Oktober 1885

- Abberufung des Regierungsbaumeisters Germelmann durch den

Regierungspräsidenten in Aurich wegen Bedarf in seinem

Geschäftsbereich, Juli 1887

- Vertretung des Wasserbauinspektors Germelmann, Juli 1887

- Erhöhung des Honorars des Wasserbauinspektors Germelmann, September 1887

- Ersetzung des Wasserbauinspektors Germelmann durch den

Regierungsbaumeister Stosch, Oktober 1887

- Ablösung des Regierungsbaumeisters Stosch durch den

Wasserbauinspektor Dannenberg, Oktober 1887

- Festlegung des Honorars für den Regierungsbaumeister Stosch, Juli 1888

$1884-1888$

Klassifikation Teil B: 01144

Trägermaterial: Papier

Alte Reg.-Sig.: IV Ji 09

Bestell-Nr.: IV 01144

912 Umverlegung von Gasleitungen wegen Kanalisierung

- Organisation der wegen der Kanalisierung notwendigen

Umverlegung von Gasleitungen

- Regelung der Beleuchtung der Baugruben der Kanalisation

- Beschädigung von Gasleitungen durch die Kanalisierung

$1885-1886$

Klassifikation Teil B: 01145

Trägermaterial: Papier

Alte Reg.-Sig.: IV Ji 10

Bestell-Nr.: IV 01145 
05

\subsection{3}

05.03.06

05.03.06.02 05.03.06.02.03

\section{Stadtverwaltung}

Aufgabenbereiche der Stadtverwaltung

Öffentliche Anlagen, Straßenpolizei und Organisation der Ver- und Entsorgung

Straßenreinigung und öffentliche Hygiene

Stadtentwässerung und Abfallentsorgung

Lfd. Nr. Titel

Laufzeit

913 Abtretung städtischer Ländereien für die Kanalisierung

- Kündigung von Verpachtungen städtischer Ländereien wegen Abtretung für Kanalisierung, August - Oktober 1885

- Verhandlungen der Kanalisationskommission über Beschluss zur Schätzung des Werts der abzutretenden städtischen Grundstücke durch eine Sachverständigengruppe, Oktober 1885

- Verpachtung des zu Kanalisationszwecken benötigten Landes an die Kanalisationskommission, Oktober 1885

1885

Klassifikation Teil B: 01146

Trägermaterial: Papier

Alte Reg.-Sig.: IV Ji 11

Bestell-Nr.: IV 01146

914 Drucksachen wegen Kanalisierung

$1883-1885$

- Gedrucktes Gutachten des Wasserbauinspektors Suadicani über die Kanalisation in Emden unter Berücksichtigung der Herstellung eines Wasserspiegels in den Delften in Höhe des ordinären

Emshochwassers, Dezember 1883

- Sonderdruck: Aktenstücke zur Beschreibung des

Kanalisationsprojektes und Kostenvoranschläge, 1884 - 1885

- Gedrucktes Gutachten Geheimen Baurats Henoch in Gotha über

Entwässerung der Stadt Emden, März 1884

- Druck: Vorschläge (Propositionen) der Kanalisationskommission für die Entwässerung der Emder Papierfabrik, Februar 1885

- Druck: Deichrichter T. Freerksen: Ansichten über die durch die

Anlegung des Ems-Jade-Kanals und den Hafenbau sich ändernden

Entwässerungsverhältnisse der Stadt Emden, 1885

- Druck: Erläuterungsbericht und Kostenvoranschlasg nebst

Massenberechnung für die Zuschüttung des nordöstlichen Teils des

Rathausdelfts und der beiden Sieltiefe zwischen dem Gasthaussiel, dem Neutorssiel und dem Alten Graben, 1885

- Druck: Anlage eines Spülgrabens vom Emder Binnenfahrwasser nach dem offenen Entwässerungsgraben im Kaiser-Wilhelm-Polder, 1885

$1883-1885$

Klassifikation Teil B: 01147

Trägermaterial: Papier

Alte Reg.-Sig.: IV Ji 12

Bestell-Nr.: IV 01147 
05

\subsection{3}

05.03.06

05.03.06.02

05.03.06.02.03

\section{Stadtverwaltung}

Aufgabenbereiche der Stadtverwaltung

Öffentliche Anlagen, Straßenpolizei und Organisation der

Ver- und Entsorgung

Straßenreinigung und öffentliche Hygiene

Stadtentwässerung und Abfallentsorgung

Lfd. Nr. Titel

Laufzeit

915 Abtransport des Erdaushubs und des Schutts aus den Kanalisationsarbeiten

- Verhandlungen des Magistrats der Stadt Emden mit der Garnisonsverwaltung wegen Transport von Erdaushub zur Zuschüttung des Burggrabens bei der Kaserne, September November 1885

- Verwendung der Aushubmassen aus den Kanalisierungsarbeiten für die Zuschüttung des nördlichen Teils des Ratsdelfts, September 1885 - Verfügung des Regierungspräsidenten in Aurich über Erlaubnis zur Verwendung von Erdmassen aus der Baggerung zur Vertiefung des Emder Fahrwassers für die Zuschüttung des nördlichen Teils des Ratsdelfts, November 1885

- Verhandlungen des Magistrats mit dem Regierungspräsidenten in Aurich über Verwendung der Erdmassen aus der Hafenvertiefung zur Zuschüttung des nördlichen Teils des Ratsdelfts, November 1885 Januar 1886

- Bericht des Wasserbauinspektors Germelmann über Schwierigkeiten bei der Zuschüttung des Graupferdstiefs wegen mangelnder Erdmassen und Transportprobleme bei der Heranschaffung benötigter Erde, November 1886 - Verhandlungen des Magistrats mit dem Regierungspräsidenten in Aurich und dem Ems-Jade.Kanalbaubezirk über Beschaffung von Aushuberde zur Zuschüttung des Burggrabens, März - Oktober 1887 - Verhandlungen des Magistrats mit dem Regierungspräsidenten in Aurich und dem Ems-Jade.Kanalbaubezirk über Verwendung der Aushubmassen aus der Hafen- und Fahrwasservertiefung sowie dem Kanalbau für die Aufhöhung des Stadtpolders und des Bahnhofsgebiets, März 1887

- Beschluss der städtischen Kollegien über Lagerplätze für Aushuberde, August 1885

- Entschädigung für das Armen-Kollegium für die Verwendung des Armenhausgartens als Lagerplatz für Erdaushub, Oktober 1885 - Festlegung von Lagerplätzen für Kanalisationsaushub, September 1886

$1885-1887$

Klassifikation Teil B: 01148

Trägermaterial: Papier Alte Reg.-Sig.: IV Ji 13

Bestell-Nr.: IV 01148 
05

05.03

05.03.06

05.03.06.02

05.03.06.02.03

\section{Stadtverwaltung}

Aufgabenbereiche der Stadtverwaltung

Öffentliche Anlagen, Straßenpolizei und Organisation der

Ver- und Entsorgung

Straßenreinigung und öffentliche Hygiene

Stadtentwässerung und Abfallentsorgung

Lfd. Nr. Titel

Laufzeit

916 Bei den Kanalisationsgrabungen gefundene Altertümer

- Beschluss der Kanalisationskommission und des Magistrats über Abgabe von bei der Kanalisation gefundene Altertümer an die Gesellschaft für bildende Kunst und vaterländische Altertümer, September - Oktober 1885

- Bericht des Wasserbauinspektors Germelmann über Fund von vier volleisernen Kanonenkugeln, November 1885

- Listen der Fundstücke bei Kanalisationsarbeiten, Mai 1886 - April

1887

- Angebot des Magistrats an die Gesellschaft für bildende Kunst und vaterländische Altertümer über Abgabe von bei der Kanalisierung gefundener Fossilien, August 1886

- Übersendung eines bei der Kanalisierung gefundenen Skelettes an das anatomische Institut des Universität Straßburg, Januar 1887

$1885-1887$

Klassifikation Teil B: 01149

Trägermaterial: Papier

Alte Reg.-Sig.: IV Ji 14

Bestell-Nr.: IV 01149 
05

05.03

05.03.06

05.03.06.02

05.03.06.02.03

\section{Stadtverwaltung}

Aufgabenbereiche der Stadtverwaltung

Öffentliche Anlagen, Straßenpolizei und Organisation der

Ver- und Entsorgung

Straßenreinigung und öffentliche Hygiene

Stadtentwässerung und Abfallentsorgung

Lfd. Nr. Titel

Laufzeit

917 Übergang von Sielen und Entwässerungsanlagen in den Besitz der Stadt Emden

- Verhandlungen des Magistrats mit der Regierung in Aurich über Übergang des Gasthaussiels und des Neutorssiels (Neupfortssiel) in den Besitz der Stadt Emden zur ermöglichung der Zuschüttung des nördlichen Teils des Ratsdelftes (heutiger Stadtgarten), September 1885 - August 1886

- Gutachten des Wasserbauinspektors Suadicani über Möglichkeit der Beseitigung der beiden Stadtsiele und der Zuschüttung des nördlichen Teils des Ratsdelftes, November 1885

- Gutachten des Stadtsekretärs Hein über Eigentumsverhältnisse der Stadtsiele, November 1885

- Verhandlungen der Stadt Emden mit den Sielachten der Stadtsiele über Außerfunktionssetzung der Siele und Entschädigung der

Sielachtsinteressenten, Februar - August 1886

- Verhandlungen des Magistrats über städtische Inbesitznahme der beiden Stadtsiele, März 1886

- Klage der Oldersumer und Petkumer Sielacht gegen die Stadt

Emden beim Bezirksauschuss auf Erhalt der Stadtsiele und

Verhinderung der Zuschüttung des nördlichen Ratsdelfts, September -

Oktober 1886

- Schreiben des ehemaligen Sielrichters T.M. Tannens an die Stadt Emden über Bitte um Anweisung der Kaufsumme für die Stadtsiele an die ehemaligen Sielachtsinteressenten, Oktober 1887

- Verhandlungen des Magistrats mit dem Regierungspräsidenten in Aurich über Finanzierung der Niedrigerlegung des Gasthaussiels und der damit verbundenen Straßenbauarbeiten, Oktober 1888

$1885-1888$

Klassifikation Teil B: 01150

Trägermaterial: Papier

Alte Reg.-Sig.: IV Ji 15

Bestell-Nr.: IV 01150

918 Beschwerden wegen Kanalisationsanschlüssen, Bd. 1

$1885-1886$

- Formulare für Antworten auf Beschwerden, 1885

- Beschwerden gegen Heranziehung zu den Kosten der Herstellung des Hausanschlusses zur Kanalisation, 1885 - 1886

- Beschwerden gegen Anschlusszwang, 1885 - 1886

$1885-1886$

Klassifikation Teil B: 01151

Band: 1

Trägermaterial: Papier

Alte Reg.-Sig.: IV Ji 16

Bestell-Nr.: IV 01151 
05

05.03

05.03.06

05.03.06.02

05.03.06.02.03

\section{Stadtverwaltung}

Aufgabenbereiche der Stadtverwaltung

Öffentliche Anlagen, Straßenpolizei und Organisation der

Ver- und Entsorgung

Straßenreinigung und öffentliche Hygiene

Stadtentwässerung und Abfallentsorgung

Lfd. Nr. Titel

Laufzeit

919 Beschwerden wegen Kanalisationsanschlüssen, Bd. 2

- Beschwerden wegen Funktionsstörungen (z.B. Verstopfungen) der Kanalisation

- Verhandlungen der Kanalisationskommision über die Beschwerden

$1885-1888$

Klassifikation Teil B: 01152

Band: 2

Trägermaterial: Papier

Alte Reg.-Sig.: IV Ji 16

Bestell-Nr.: IV 01152

920 Beschwerden über Störungen der Kanalisation

- Beschwerden über Beeinträchtigungen durch Kanalarbeiten, Straßenschäden durch Kanalisation, Schmutz, Geruchsbelästigung durch Kanalisation, unzureichende Abwässerung, mangelhafte Hausanschlüsse, Beschädigung von Brunnen durch Leckagen der Kanalisation, Verstopfungen, 1886 - 1895

- Verhandlungen des Magistrats über die Beschwerden, 1886 - 1895 - Bericht des Stadtbaumeisters Wiggers über Außerfunktionssetzung des Gasthaussiels durch Beginn der Zuschüttung des nördlichen Teils des Ratsdelftes und Zuständigkeit der Kanalisationsbauverwaltung für Beschwerden wegen Entwässerung, September 1886

- Beschädigung des Kanalrohrs durch Auflaufen eines Torfschiffes bei der Rathausbrücke, August 1887

- Schäden an Gebäuden durch Kanalisierung und Zuschüttung von Wasserläufen, 1886 - 1889

$1886-1889$

Klassifikation Teil B: 01153

Trägermaterial: Papier

Alte Reg.-Sig.: IV Ji 17

Bestell-Nr.: IV 01153

921 Lokalitäten für das Kanalisationsbüro

- Finanzierung und Einrichtung eines Büros für die Bauleitung der Kanalisierung

$1885-1887$

Klassifikation Teil B: 01154

Trägermaterial: Papier

Alte Reg.-Sig.: IV Ji 18

Bestell-Nr.: IV 01154 
05

05.03

05.03.06

05.03.06.02

05.03.06.02.03

\section{Stadtverwaltung}

Aufgabenbereiche der Stadtverwaltung

Öffentliche Anlagen, Straßenpolizei und Organisation der

Ver- und Entsorgung

Straßenreinigung und öffentliche Hygiene

Stadtentwässerung und Abfallentsorgung

Laufzeit

922 Einlegung eines Durchlasses in den Fahrwasserdeich

$1885-1886$

- Vom Regierungsbaumeister Germelmann erstellter Plan eines

Durchlasses für den Spülgraben im Kaiser-Wilhelm-Polder durch den

Deich bei Nesserland, Juli 1885

- Verfügung des Regierungspräsidenten über Genehmigung des

Durchlasses, September 1885

- Bericht des Wasserbauinsperktors Germelmann über schadhaftes

Zementrohr für den Deichdurchlass, Mai - Juni 1886

$1885-1886$

Klassifikation Teil B: 01155

Trägermaterial: Papier

Alte Reg.-Sig.: IV Ji 19

Bestell-Nr.: IV 01155

923 Durchführung des Stammsiels der Kanalisation durch den Bahnkörper der ostfriesischen Küstenbahn

- Durch Wasserbauinspektor Germelmann erstellter Plan,

Massenberechnung und Kostenvoranschlag der Durchführung des

Stammsiels der Kanalisation durch die Trasse der Küstenbahn, Juli

1885

- Verhandlungen der Stadt Emden mit dem kgl. Eisenbahnbetriebsamt Münster-Emden über Durchführung des Projektes, März - November 1886

- Verhandlungen der Stadt Emden mit dem kgl. Eisenbahnbetriebsamt Münster-Emden über Verlegung des Durchlasses wegen Anschluss der Nesserland-Hafenbahn an die Kleinbahn Emden-Pewsum, September 1899 - Februar 1900

$1886-1900$

Klassifikation Teil B: 01156

Trägermaterial: Papier

Alte Reg.-Sig.: IV Ji 20

Bestell-Nr.: IV 01156
$1886-1900$ 
05

05.03

05.03.06

05.03.06.02

05.03.06.02.03

\section{Stadtverwaltung}

Aufgabenbereiche der Stadtverwaltung

Öffentliche Anlagen, Straßenpolizei und Organisation der

Ver- und Entsorgung

Straßenreinigung und öffentliche Hygiene

Stadtentwässerung und Abfallentsorgung

Laufzeit

924 Führung (Düker) der Kanalisation durch die Helling bei der Kettenbrücke und den Falderndelft

$1885-1896$

(1904)

- Vom Wasserbauinspektor Germelmann erstellter Plan des Dükers der Kanalisation über die Helling bei der Kettenbrücke durch den Falderndelft, Dezember 1885

- Verhandlungen der Stadt Emden mit dem Besitzer der Helling (Abegg'sche Erbengemeinschaft) über Entschädigung wegen Beeinträchtigung der Besitzung durch den geplanten Düker, Dezember 1885 - Februar 1886

- Klage des Kaufmanns Carl Vocke als Vertreter der Abeggschen Erbengemeinschaft gegen die Stadt Emden beim Bezirksausschuss in Aurich auf Aufhebung der städtischen Verfügung über Duldungspflicht zur Führung der Kanalisierung durch einen Düker über ihre Helling durch den Falderndelft, Februar - Mai 1886

- Verhandlungen der Stadt Emden mit dem Schiffsbauer Johann Janssen als Erwerber des Abeggschen Grundstücks über Entschädigung für die Anlage des Dükers und Führung der Kanalisierung über die Helling bei der Kettenbrücke durch den Falderndelft, Januar 1886 - Juli 1887

- Antrag der Kaufleute Thiele \& Freese auf Tieferlegung des Kanalrohrs im Falderndelft zur Herstellung eines tieferen Fahrwassers zu ihrem Anleger, August 1896

- Eingabe des Wykvereins der IV. Wyk an die Stadt Emden über Bitte um städtische Erwerbung der Abeggschen Helling zur Gewinnung von Raum für die notwendige Verbreiterung der Straße am Falderntor, November 1904

$1885-1896$ (1904)

Klassifikation Teil B: 01157

Trägermaterial: Papier

Alte Reg.-Sig.: IV Ji 20

Bestell-Nr.: IV 01157

925 Durchlass unter der Küstenbahn

$1886-1887$

- Verhandlungen der Stadt Emden mit der Eisenbahnverwaltung über Erlaubnis zur Anlage eines Durchlasses für die Kanalisation durch die Küstenbahn, Januar 1886 - Februar 1887

$1886-1887$

Klassifikation Teil B: 01158

Trägermaterial: Papier

Alte Reg.-Sig.: IV Ji 21

Bestell-Nr.: IV 01158 
IV

05

05.03

05.03.06

05.03.06.02

05.03.06.02.03

\section{Stadtverwaltung}

Aufgabenbereiche der Stadtverwaltung

Öffentliche Anlagen, Straßenpolizei und Organisation der

Ver- und Entsorgung

Straßenreinigung und öffentliche Hygiene

Stadtentwässerung und Abfallentsorgung

Lfd. Nr. Titel

Laufzeit

926 Anschluss des Gasthauses an die Kanalisation

- Planzeichnung des Wasserbauinspektors Germelmann, 1886

- Verhandlungen des Magistrats über den Anschluss des Gasthauses an die Kanalisation, Juli - August 1886

- Verhandlungen der Kanalisationskommission über den Anschluss des Gasthauses an die Kanalisation, August 1886

1886

\author{
Klassifikation Teil B: 01159 \\ Trägermaterial: Papier \\ Alte Reg.-Sig.: IV Ji 22 \\ Bestell-Nr.: IV 01159
}

927 Kanalisierung des Grabens am Schwarzen Weg

- Verhandlungen der Stadt Emden mit der Eisenbahnverwaltung wegen Kanalisierung des an der Eisenbahnlinie am Schwarzen Weg entlanglaufenden Grabens am Schwarzen Weg, August 1886 - Juni 1887

- Korrespondenz zwischen dem Magistrat der Stadt Emden und dem Ems-Jade-Kanalbaubezirk wegen Entwässerung des Stadtpolders und der Beschaffung von Aushuberde für die Zuschüttung des Grabens am Schwarzen Weg, Februar - März 1887

$1886-1887$

Klassifikation Teil B: 01160

Trägermaterial: Papier

Alte Reg.-Sig.: IV Ji 23

Bestell-Nr.: IV 01160
1886

$1886-1887$ 
05

05.03

05.03.06

05.03.06.02

05.03.06.02.03
Stadtverwaltung

Aufgabenbereiche der Stadtverwaltung

Öffentliche Anlagen, Straßenpolizei und Organisation der

Ver- und Entsorgung

Straßenreinigung und öffentliche Hygiene

Stadtentwässerung und Abfallentsorgung

Lfd. Nr. Titel

Laufzeit

928 Abflussgraben der Kanalisation im Kaiser-Wilhelm-Polder

- Geruchsbelästigung durch das Reservoir der Kanalisation bei der Nesserlander Schleuse, September 1888 - Juli 1889

- Verpflichtung der mit der Kanalisierung beauftragten Firma Habich \&

Goth zur Reparatur der Pflasterung des Abflussgrabens der

Kanalisation wegen Gewährleistungsverpflichtung, Mai - Juli 1889

- Gutachten des Wasserbauinspektors Germelmann über

Möglichkeiten zum Ersatz des offenen Kanalisations-Abflussgrabens

durch eine unterirdische Röhrenleitung, Juni 1891

- Projekt des Stadtbaumeisters Wiggers über Kanalisierung des

offenen Abflussgrabens, Apil 1898 / Juli 1900

- Vergütung für den Schleusenwärter auf Nesserland für die Kontrolle und Instandhaltung des Klappsiels der Kanalisation, November 1897 -

Februar 1900

- Projekt der Vergrößerung des Reservoirs der Kanalisation,

November 1897

- Belästigung der Bewohner der Arbeitersiedlung Transvaal durch den

Gestank aus dem Abflussgraben der Kanalisation, September 1903

- Erörterung des Einsatzes von Windturbinen der Deutschen

Windturbinen-Werke Dresden zum Abpumpen des

Kanalisationswassers in die Ems, November 1903

- Beschwerden über vollgelaufene Keller auf Transvaal wegen hoher

Wasserstände im Kanalisationsabflussgraben aufgrund der

Schließung des Klappsiels auf Nesserland, Juli 1909

$1888-1901$

Klassifikation Teil B: 01161

Trägermaterial: Papier

Alte Reg.-Sig.: IV Ji 24

Bestell-Nr.: IV 01161

929 Verbot der Verunreinigung öffentlicher Gewässer

1885-1902

- Konzept einer Polizeiverordnung über das Verbot der Verunreinigung öffentlicher Gewässer und des Einführung eines Zwanges zur Nutzung städtischer unterirdischer Entwässerungsanlagen (Kanalisation), November - Dezember 1885

- Genehmigung des Entwurfs der Polizeiverordnung durch den

Regierungspräsidenten in Aurich, Januar 1886

- Veröffentlichung der Polizeiverordnung, Februar 1886

- Ergänzung der Polizeiverordnung durch die Bestimmung über regelmäßige Reinigung der Kanalhausanschlüsse durch die Hausbesitzer und deren regelmäßige Kontrolle, November 1886 Januar 1887

- Anzeigen über Verunreinigung der Kanalisation durch Einleitung von Speiseresten etc., April 1902

$1885-1902$

Klassifikation Teil B: 01162

Trägermaterial: Papier

Alte Reg.-Sig.: IV Ji 25

Bestell-Nr.: IV 01162 
05

05.03

05.03.06

05.03.06.02

05.03.06.02.03

\section{Stadtverwaltung}

Aufgabenbereiche der Stadtverwaltung

Öffentliche Anlagen, Straßenpolizei und Organisation der

Ver- und Entsorgung

Straßenreinigung und öffentliche Hygiene

Stadtentwässerung und Abfallentsorgung

Laufzeit

930 Statut über die Anlage unterirdischer Entwässerungskanäle

1885-1886

- Material aus anderen Städten zur Anlage von Kanalisation und

Hausanschlüssen, 1885

- Entwurf eines Statuts über die Anlage unterirdischer

Entwässerungskanäle für Emden, Dezember 1885

- Veröffentlichung einer Polzeiverordnung über die Anlage

unterirdischer Entwässerungskanäle, Februar 1886

$1885-1886$

Klassifikation Teil B: 01163

Trägermaterial: Papier

Alte Reg.-Sig.: IV Ji 26

Bestell-Nr.: IV 01163

931 Verstöße gegen die Reinigungspflicht der Hausanschlüsse der Kanalisation

$1886-1888$

- Bericht des Wasserbauinspektors Germelmann über Revision der Hausanschlüsse an die Kanalisation und Feststellung zweier Verstöße gegen die Reinigungspflicht, Mai - Juni 1886

- Bekanntmachung über Pflicht zur Reinigung der Kanalanschlüsse zu den einzelnen Häusern (Schlammfang), September 1886

- Bericht des Wasserbauinspektors Germelmann über Mängel bei Kanalanschlüssen und Verweigerung der Kontrolle durch den autorisierten Angestellten, Februar - April 1887

- Anordnung über Reinigung der Straßenstückkästen (Schlammfang) durch den Abfuhrunternehmer Uffe Fokken zur Vermeidung von Kanalverstopfungen, März 1888

$1886-1888$

Klassifikation Teil B: 01164

Trägermaterial: Papier

Alte Reg.-Sig.: IV Ji 27

Bestell-Nr.: IV 01164

932 Festsetzung der Kanalgebühren

$1885-1914$

- Konzept für ein Regulativ zur Erhebung einer Abgabe für die bEnutzung städtischer Kanäle der Stadt Emden, 1885

- Gemeinsamer Erlass des preußischen Innenministers und des preußischen Finanzministers über Anforderung von Berichte zur Erhebung der Kanalbebühren, Januar 1892

- Gerichtsurteil zur Heranziehung von Mietern zur Kanalgebühr, September 1913

$1885-1914$

Klassifikation Teil B: 01165

Trägermaterial: Papier

Alte Reg.-Sig.: IV Ji 28

Bestell-Nr.: IV 01165 
05

05.03

05.03.06

05.03.06.02

05.03.06.02.03

\section{Stadtverwaltung}

Aufgabenbereiche der Stadtverwaltung

Öffentliche Anlagen, Straßenpolizei und Organisation der

Ver- und Entsorgung

Straßenreinigung und öffentliche Hygiene

Stadtentwässerung und Abfallentsorgung

Laufzeit

933 Abnahme der Kanalisationsbauten

- Antrag des Magistrats der Stadt Emden beim Regierungspräsidenten in Aurich auf Abordnung einer Regierungskommission zur Abnahme der Kanalisationsbauten, Juni - Juli 1887

- Revision der vom Unternehmer Liesenhoff ausgeführten

Kanalisationsbauten, Juli 1887

- Verhandlungen der Kanalisationskommission wegen der Abnahme der Kanalisationsbauten, September 1887

- Antrag der Firma Habich \& Goth auf Abnahme der von inr fertiggestellten Kanalisationsbauten im Kaiser-Wilhelm-Polder, September 1887

1887

Klassifikation Teil B: 01166

Trägermaterial: Papier

Alte Reg.-Sig.: IV Ji 29

Bestell-Nr.: IV 01166

934 Weitere Zuschüttung des Ratsdelftes

1888-1896

- Ablehnung des Projektes des Stadtbaumeisters Wiggers über

Zuschüttung des gesamten Rathausdelftes durch den

Regierungspräsidenten in Aurich, Juli - August 1888

- Anregung der Zuschüttung des Ratsdelftes bis zur neuen

Militärwache durch die Gesellschaft für bildende Kunst und

vaterländische Altertümer, September 1888

- Kostenvoranschlag des Stadtbaumeisters Wiggers über Anlage einer Kajung am offen bleibenden Teil des Ratsdelftes, Oktober 1888

- Verhandlungen des Magistrats mit dem Regierungspräsidenten in Aurich über weitere Zuschüttung des Ratsdelftes und Anlage einer Kajung, Mai 1889 - Mai 1891

- Projekt des Stadtbaumeisters Wiggers mit Kostenvoranschlag und Zeichnung, November 1890

- Vertragsentwurf zur Ausführung der Arbeiten zur Ausführung der Arbeiten zum Bau der Bootstreppe am Ratsdelft, 1896

$1888-1896(1924)$

Klassifikation Teil B: 01167

Trägermaterial: Papier

Alte Reg.-Sig.: IV Ji 30

Bestell-Nr.: IV 01167 
05

05.03

05.03.06

05.03.06.02

05.03.06.02.03

\section{Stadtverwaltung}

Aufgabenbereiche der Stadtverwaltung

Öffentliche Anlagen, Straßenpolizei und Organisation der

Ver- und Entsorgung

Straßenreinigung und öffentliche Hygiene

Stadtentwässerung und Abfallentsorgung

Laufzeit

935 Genehmigungen zur Veränderung bestehender Kanalisationseinrichtungen

1887-1910

- Anträge auf Anschlüsse von Straßen und Gängen an die Kanalisation, 1887 - 1910

- Anträge auf Änderung der Abwässerungszuleitungen, 1889 / 1903

- Streit zwischen der Stadt Emden und dem Fuhrmann J. Ubbens wegen Kostenträgerschaft für den Anschluss seines Pferdestalles an die Kanalisation, August - Dezember 1895

- Projekt des Stadtbaumeisters Wiggers über Entwässerung des Stadtgrabens, Juni 1895

- Genehmigung der kgl. Eisenbahnbetriebsinspektion zur Durchführung von Kanalleitungen durch den Bahnkörper der Nesserlandbahn zum Anschluss der Emder Heringsfischerei AG an die Kanalisation, Januar - April 1901

$1887-1910$

Klassifikation Teil B: 01168

Trägermaterial: Papier

Alte Reg.-Sig.: IV Ji 31

Bestell-Nr.: IV 01168

936 Kanalisierung des Boltentorviertels

1893-1894

- Projektbeschreibung des Stadtbaumeisters Wiggers und Kostenvoranschlag zur Kanalisierung des Boltentorviertels, Oktober 1893

- Verhandlungen der Stadt Emden mit dem Schachtmeister E. Mierig über Ausführung der Arbeiten zum Bau der Kanalisation im Boltentorviertel, Februar 1894

- Sperrungen von Straßen und Wasserzügen im Zuge der Kanalisierung, April - Mai 1894

- Festlegung der Anschlussgebühren für die Hausanschlüsse, Mai 1894

- Streit zwischen den Hausbesitzern J.T. Mentjes. Bernhard Brons, Jr. und Senator Dreesmann-Penning um die Beteiligung des Mentjes an der Instandhaltung alter Entwässerungsanlagen nach dessen Anschluss an die Kanalisation, Mai 1894

- Verhandlungen mit dem Hausbesitzer Bordeaux über Führung des Kanalrohrs zum Anschluss seiner Nachbarn über sein Grundstück, Mai - Juni 1894

- Anträge auf Anschluss an der Kanalisation, Juni - Juli 1894

- Abnahme der Kanalisationsbauten im Boltentorviertel, Juli 1894

- Kosten der Hausanschlüsse, 1894

$1893-1894$

Klassifikation Teil B: 01169

Trägermaterial: Papier

Alte Reg.-Sig.: IV Ji 32

Bestell-Nr.: IV 01169 
05

05.03

05.03.06

05.03.06.02

05.03.06.02.03

\section{Stadtverwaltung}

Aufgabenbereiche der Stadtverwaltung

Öffentliche Anlagen, Straßenpolizei und Organisation der

Ver- und Entsorgung

Straßenreinigung und öffentliche Hygiene

Stadtentwässerung und Abfallentsorgung

Lfd. Nr. Titel

Laufzeit

937 Beschwerden über Kanalisations- und Entwässerungsanlagen

- Beschwerden wegen Verstopfung der Kanalisation, mangelnde Reinigung der Anschlüsse, Geruchsbelästigung, Eindringen von Wasser aus der Kanalisation in Keller, Verseuchung von Trinmkwasserbrunnen durch eingedrungenes Kanalisationswasser, Verseuchung des Hinter Tiefs durch aus dem Notauslass strömendes Kanalisationswasser und schadhafte Gullys, 1893 - 1914

- Illegale Einleitung von Abwässer in die Tiefs, April 1904

- Gasexplosion in der Kanalisation an der Großen Deichstraße, November 1910

$1893-1914$

Klassifikation Teil B: 01170

Trägermaterial: Papier

Alte Reg.-Sig.: IV Ji 33

Bestell-Nr.: IV 01170

- Vorlage der Baukommission über Plan der Kanalisierung der Nesserlander Straße und Festlegung der Anschlussbeiträge für die anliegenden Firmen, Oktober 1900

- Beschluss des Magistrats über Ausführung des Projektes, 1900

- Projektplan mit Planzeichnung, Oktober 1900

- Genehmigung der Eisenbahnverwaltung zur Führung der

Kanalleitung durch die Trasse der Hafenbahn, April 1900

- Anträge auf Stundung oder Erlass von Kanalanschlussgebühren, April - Juni 1901

- Kanalisationsanschluss des Hauses des Bauunternehmers Hempel an der Nesserlander Straße, November 1901 - März 1902

- Verwendung eines Überschusses aus eingezahlten

Kanalanschlussgebühren, Mai 1902 / März - April 1904

- Kanalisationsanschluss der Cassens'schen Bauten am 2.

Hafenbecken, Juli - September 1902

$1900-1904$

Klassifikation Teil B: 01171

Trägermaterial: Papier

Alte Reg.-Sig.: IV Ji 34

Bestell-Nr.: IV 01171 
05

\subsection{3}

05.03.06

05.03.06.02 05.03.06.02.03

\section{Stadtverwaltung}

Aufgabenbereiche der Stadtverwaltung

Öffentliche Anlagen, Straßenpolizei und Organisation der Ver- und Entsorgung

Straßenreinigung und öffentliche Hygiene

Stadtentwässerung und Abfallentsorgung

Lfd. Nr. Titel

Laufzeit

939 Kanalisierung eines Teils der Provinzial-Chaussee Emden-Aurich

1901-1905

- Vorlage der Baukommission über Kosten der Kanalisierung und

Festlegung der Kanalanschlussgebühr, März 1901

- Antrag des Magistrats bei der Bezirksbauinspektion Aurich auf

Erlaubnis zur Legung der Kanalrohre in den Straßenkörpers der

Chaussee, Juni - Juli 1901

- Planzeichnung, 1901

- Finanzielle Abwicklung des Projektes, Mai 1904 - März 1905

$1901-1905$

Klassifikation Teil B: 01172

Trägermaterial: Papier

Alte Reg.-Sig.: IV Ji 35

Bestell-Nr.: IV 01172

940 Kanalisierung der Nordertorstraße

- Verhandlungen des Bürgervorsteherkollegiums über Klagen wegen Gestank aus dem Graben an der Nordertorstraße, Juni 1893

- Vorlage der Baukommission über Kosten der Kanalisierung und Festlegung der Kanalanschlussgebühren, Juli 1893 / Mai 1900 - Mai 1901

Bericht des Stadtbaumeisters Wiggers über Verursacher der

Verschmutzung des Grabens am Gelben Mühlenzwinger, Mai 1900

- Strafbefehl an den Landwirt H.J. Joth wegen Ablassung von Jauche

in den Graben am Gelben Mühlenzwinger, Juli 1901

$1893-1901$

Klassifikation Teil B: 01173

Trägermaterial: Papier

Alte Reg.-Sig.: IV Ji 36

Bestell-Nr.: IV 01173

941 Kanalisierung eines Teils der Bahnhofsstraße

1900

- Anordnung des Magistrats an die Kämmereikasse über Freigabe von Mitteln für die Kanalisierung eines Teils der Bahnhofsstraße, Februar 1900

- Kostenvoranschlag des Stadtbaumeisters Wiggers über die Kanalisierung, Februar 1900

1900

Klassifikation Teil B: 01174

Trägermaterial: Papier

Alte Reg.-Sig.: IV Ji 38

Bestell-Nr.: IV 01174 
05

05.03

05.03.06

05.03.06.02

05.03.06.02.03

\section{Stadtverwaltung}

Aufgabenbereiche der Stadtverwaltung

Öffentliche Anlagen, Straßenpolizei und Organisation der

Ver- und Entsorgung

Straßenreinigung und öffentliche Hygiene

Stadtentwässerung und Abfallentsorgung

Laufzeit

942 Kanalisierung des östlichen Teils des Bentincksweges und des Grünen Weges

- Vorlage der Baukommission über Kanalisierung des östlichen Teils des Bentincksweges und des Grünen Weges mit Kostenvoranschlag, September 1902

- Genehmigung des Projektes durch den Magistrat, September 1902

- Festsetzung und Erhebung der Kanalanschlussgebühren,

September 1902

- Anordnung des Magistrats an die Kämmereikasse über Freigabe der Mittel für die Kanalisierung, September 1902

- Probleme bei der Spezifizierung des Anleihetitels zur Deckung der

Kosten der Kanalisierung, März 1903

- Projektbeschreibung über Kanalisierung des Bentincksweges,

November 1904 / Februar 1906

- Kanalanschluss des Grundstücks des Bernhard Brons am Grünen

Weg, März 1906

$1902-1906$

Klassifikation Teil B: 01175

Trägermaterial: Papier

Alte Reg.-Sig.: IV Ji 39

Bestell-Nr.: IV 01175

943 Kanalisierung des Neutorsbreitergang

1903

(1904)

- Finanztechnische Abwicklung des Projektes, September 1903

- Vermerk des Stadtbaumeisters Wiggers über Bedingungen an den

Bauwilligen Conradi zur Erteilung der Baugenehmigung für sein

Grundstück am Neutorsbreitergang wegen der Kostenträgerschaft für den Kanalanschluss, Januar 1903

- Vorlage der Baukommission und Kostenvoranschlag für die

Kanalisierung, Januar 1903

- Festlegung der Kanalanschlussbeiträge, Januar - März 1903

1903 (1904)

Klassifikation Teil B: 01176

Trägermaterial: Papier

Alte Reg.-Sig.: IV Ji 40

Bestell-Nr.: IV 01176 
- Angebot zum Bau einer Kläranlage durch den Ingenieur Dr. Hunsoth aus Hannover, August 1903

- Bescheid des Magistrats über Ablehnung des Angebots we gen hygienischer Probleme, Oktober 1903

- Vortrag des Ingenieurs Dr. Hunsoth über sein Kläranlagen-System, November 1903

- Angebot des Ingenieurs David Grove über biologisches

Klärverfahren, November 1903 - Januar 1904

- Angebot des Ingenieurs F. Deselaer aus Neuss über Kläranlage, Dezember 1903 - März 1904

$1903-1904$

Klassifikation Teil B: 01177

Band: 1

Trägermaterial: Papier

Alte Reg.-Sig.: IV Ji 41

Bestell-Nr.: IV 01177

- Analyse der Emder Abwässer bei der Moorversuchsanstalt Bremen, Februar 1904

- Angebote über Kläranlage, 1904 - 1908

$1904-1908$

Klassifikation Teil B: 01178

Band: 2

Trägermaterial: Papier

Alte Reg.-Sig.: IV Ji 41

Bestell-Nr.: IV 01178

946 Kanalisierung der Nesserlander Str.

- Anschluss der Heringsfischereigesellschaft "Großer Kurfürst" an die Kanalisation durch Führung der Kanalrohre über die Nesserlander Straße, April - Oktober 1904

1904

Klassifikation Teil B: 01179

Trägermaterial: Papier

Alte Reg.-Sig.: IV Ji 42

Bestell-Nr.: IV 01179 
05

\subsection{3}

05.03.06

05.03.06.02 05.03.06.02.03

\section{Stadtverwaltung}

Aufgabenbereiche der Stadtverwaltung

Öffentliche Anlagen, Straßenpolizei und Organisation der Ver- und Entsorgung

Straßenreinigung und öffentliche Hygiene

Stadtentwässerung und Abfallentsorgung

Lfd. Nr. Titel

Laufzeit

947 Kanalisierung der Schweckendieckstraße und der Nesserlander Straße

- Vorlage der Baukommission über Projekt der Kanalisierung und Kostenvoranschlag, September 1904

- Freigabe der Mittel für das Projekt, Oktober 1904

- Verhandlungen des Magistrats mit der kgl.

Eisenbahnbetriebsinspektion wegen Erlaubnis zur Legung der Kanalisation durch die Eisenbahntrasse der Küstenbahn, Oktober 1904 - April 1905

$1904-1905$

Klassifikation Teil B: 01180

Trägermaterial: Papier

Alte Reg.-Sig.: IV Ji 43

Bestell-Nr.: IV 01180

948 Verbesserung der Kanalisation, Bd. 1

$1905-1908$

- Überlassung des Entwurfs eines Kanalisierungsprojekts der Firma Börner \& Herzberg an die Wasserbauinspektion, Dezember 1905 März 1906

- Antrag des Magistrats beim Regierungspräsidenten in Aurich auf Genehmigung der Umgestaltung der Kanalisation nach dem Projekt der Firma Börner \& Herzberg unter Erlaubnis von Spülklosetts, März 1906 - Juli 1908

- Bericht des Abfuhrunternehmers Berend J. Meyer über Missstände im Tonnensystem, November 1906

- Technisches Gutachten des Regierungs- und Baurats Reisse über das Kanalisierungsprojekt von Börner \& Herzberg, November 1906 - Verhandlungen des Oberbürgermeisters Fürbringer als Landtagsabgeordneter beim preußischen Minister für Handel und Gewerbe wegen Staatszuschuss für das Kanalprojekt, März 1907

$1905-1908$

Klassifikation Teil B: 01181

Band: 1

Trägermaterial: Papier

Alte Reg.-Sig.: IV Ji 44

Bestell-Nr.: IV 01181

949 Verbesserung der Kanalisation, Bd. 2

$1899-1900$

- Korrespondenz des Magistrats mit den Zivilingenieur Pfaffe aus Halle/Saale über Umgestaltung der Kanalisation, November 1899 April 1904

- Kanalisierung des Boltentorviertels, 1899 - 1904 (1912)

$1899-1904(1912)$

Klassifikation Teil B: 01182

Band: 2

Trägermaterial: Papier

Alte Reg.-Sig.: IV Ji 44

Bestell-Nr.: IV 01182

1904-1905 
05

05.03

05.03.06

05.03.06.02

05.03.06.02.03
Stadtverwaltung

Aufgabenbereiche der Stadtverwaltung

Öffentliche Anlagen, Straßenpolizei und Organisation der

Ver- und Entsorgung

Straßenreinigung und öffentliche Hygiene

Stadtentwässerung und Abfallentsorgung

Lfd. Nr. Titel

Laufzeit

950 Verbesserung der Kanalisation, Bd. 3

- Gemeinsamer Erlass der preußischen Ministerien des Inneren, der öffentlichen Arbeiten und der Geistlichen, Medizinal- und Unterrichtsangelegenheiten über Weisung um Vorlage aller Projektunterlagen zur Genehmigung der Kanalisierung als Umsetzung des Gesetzes zur Verhinderung unnötiger

Gewässerverschmutzungen, März 1896

- Korrespondenz der Stadt Emden mit der Firma Börner \& Herzberg wegen Ausbau der Kanalisation, Juni 1908 - Dezember 1911

- Kostenvoranschlag der Firma Börner \& Herzberg über Ausbau der Emder Kanalisation, März 1908

- Kostenvoranschlag der Baukommission über Ergänzung des vorliegenden Projektes von Börner \& Herzberg durch Kanalisierung der äußeren Stadtviertel, April 1909 / Mai 1909

- Bescheid der Regierungspräsidenten in Aurich über Ablehnung eines Staatszuschusses für das Emder Kanalisationsprojekt durch den Minister für öffentliche Arbeiter, Juli 1908

- Verhandlungen der Kanalisationskommission über Ausbau der Kanalisation, Juli 1908 - Oktober 1910

- Antrag des Magistrats der Stadt Emden beim Regierungspräsidenten in Aurich auf Gewährung einer Staatsbeihilfe für das vorgelegte revidierte Kanalisierungsprojekt, August 1909 - September 1912 - Projektbeschreibung: III. Projekt der Kanalisierung Emdens, 1909 - Gutachten der kgl. Versuchs- und Prüfungsanstalt für Wasserversorgung und Abwasserbeseitigung über Verbesserung der Abwasserentsorgung in Emden und Diskussion der Modifikation durch Börner \& Herzberg, Juni 1911

- Zeugnis für die Firma Börner \& Herzberg, 1909

- Bemerkungen des kgl. Wasserbauamts über Verlegung einer Druckrohrleitung der Kanalisation über den Nesserlander Deich, Februar 1912

- Einleitung eines Ausschreibungsverfahrens über Kanalisationsarbeiten, März - Mai 1912

- Honorar für die Firma Börner \& Herzberg, 1913

$1896-1913$

Klassifikation Teil B: 01183

Band: 3

Trägermaterial: Papier

Alte Reg.-Sig.: IV Ji 44

Bestell-Nr.: IV 01183

951 Verbesserung der Kanalisation, Bd. 4

$1909-1912$

- Kanalisationsanlagen anderer Städte als Muster der Organisation der Kanalisation in Emden

$1909-1912$

Klassifikation Teil B: 01184

Band: 4

Trägermaterial: Papier

Alte Reg.-Sig.: IV Ji 44

Bestell-Nr.: IV 01184 
05

05.03

05.03.06

05.03.06.02

05.03.06.02.03

\section{Stadtverwaltung}

Aufgabenbereiche der Stadtverwaltung

Öffentliche Anlagen, Straßenpolizei und Organisation der

Ver- und Entsorgung

Straßenreinigung und öffentliche Hygiene

Stadtentwässerung und Abfallentsorgung

Laufzeit

952 Anschluss der Gemeinde Wolthusen an die Emder Kanalisation

1906-1913

- Verhandlungen wegen Anschluss der Gemeinde Wolthusen an die Emder Kanalisation, 1906 - 1913

- Kostenvoranschlag über Bau einer Kanalisation in Wolthusen mit

Anschluss an das Emder Kanalnetz, 1913

$1906-1913$

Klassifikation Teil B: 01185

Trägermaterial: Papier

Alte Reg.-Sig.: IV Ji 45

Bestell-Nr.: IV 01185

953 Herstellung eines Notauslasses zwischen Großer Brückstraße und

1907-1908

Bollwerkspiepe

- Verhandlungen der Stadt Emden mit der kgl. Wasserbauinspektion in Emden über Erdbeschaffung zur Zuschüttung des Brauersgrabens und der Osterpiepe zur Behebung der Geruchsbelästigung des

Telegraphen- und Postamtes, Juli - September 1907

- Beseitigung des Notauslasses beim Postamt als Auslöser der Geruchsbelästigung, Oktober 1907

- Kostenvoranschlag der Firma Börner \& Herzberg über Herstellung eines Regenwasserkanals im Bereich des Postamtes zur Vermeidung der Auslösung des Notauslasses wegen Überlastung der Kanalisation durch Regenwasser, November 1907 / April 1908

- Von der Baukommission erarbeitete Bedingungen zur Vergabe der Arbeiten, Dezember 1907

1907 - 1908 (1913)

Klassifikation Teil B: 01186

Trägermaterial: Papier

Alte Reg.-Sig.: IV Ji 46

Bestell-Nr.: IV 01186

954 Kanalisierung des Grabens an der Südseite des Berntincksweges

- Antrag des A.F.Brons auf Kanalisierung des an seinem Grundstück entlang führenden Grabens an der Südseite des Bentincksweges, Juli - Oktober 1905

1905

Klassifikation Teil B: 01187

Trägermaterial: Papier

Alte Reg.-Sig.: IV Ji 47

Bestell-Nr.: IV 01187 
05

05.03

05.03.06

05.03.06.02

05.03.06.02.03

\section{Stadtverwaltung}

Aufgabenbereiche der Stadtverwaltung

Öffentliche Anlagen, Straßenpolizei und Organisation der

Ver- und Entsorgung

Straßenreinigung und öffentliche Hygiene

Stadtentwässerung und Abfallentsorgung

Lfd. Nr. Titel

Laufzeit

955 Eignung der Ermscher Brunnen als Klärelement der Emder Kanalisation

- Gutachten der Firma Börner \& Herzberg über Nachteile der

Ermscher Brunnen, September / Dezember 1910

- Beschluss der Kanalisationskommission über Entsendung von

Senator Boerma, Stadtbaumester Wiggers und

Bürgervorsteherkollegiumssprecher Holtmann nach Essen zur

Besichtigung einer Kanalisationsanlage mit Ermscher Brunnen,

November 1910

- Austausch mit anderen Kommunen über Eignung der Ermscher

Brunnen, Oktober 1910 - Januar 1911

- Druckschrift des Ingenieurs Heinrich Schevers über Ermscher

Brunnen, 1911

$1910-1911$

Klassifikation Teil B: 01188

Trägermaterial: Papier

Alte Reg.-Sig.: IV Ji 48

Bestell-Nr.: IV 01188

956 Anschluss des Bahnhofs West und des Kleinbahnhofs an die

Kanalisation

- Erörterung der Kanalisierung der Bahnhöfe im Westen Emdens wegen Geruchsbelästigung durch Ableitung ihrer Abwässer in die Gräben, Juni 1907

- Verhandlungen des Magistrats mit dem Bezirksausschuss in Aurich über dioe Kostenträgerschaft für den Kanalanschluss der beiden

Bahnhöfe, Juni - November 1907

- Kostenvoranschlag des Stadtbaumeisters Wiggers über

Kanalisierung des Gebietes des Bahnhofes West und des

Kleinbahnhofes mit Planzeichnung, Juni 1907

1907 (1911)

Klassifikation Teil B: 01189

Trägermaterial: Papier

Alte Reg.-Sig.: IV Ji 49

Bestell-Nr.: IV 01189 
IV

05

Stadtverwaltung

05.03

Aufgabenbereiche der Stadtverwaltung

05.03.06

Öffentliche Anlagen, Straßenpolizei und Organisation der

Ver- und Entsorgung

05.03.06.02

05.03.06.02.03

Straßenreinigung und öffentliche Hygiene

Stadtentwässerung und Abfallentsorgung

Lfd. Nr. Titel

Laufzeit

957 Kanalisation der Gartenstraße

1911-1913

- Bericht des Stadtbaumeisters Wiggers über Tiefe der Keller als Ursache der Abflussprobleme der Kanalisation in der Gartenstraße,

November 1911

- Beschwerde des Hausbesitzers Helmer von Baden-Foget beim

Bezirksausschuss in Aurich gegen die Verfügung der Stadt Emden zur

Entfernung seiner Abortanschlüsse von der Kanalisation, November

1911 - März 1913

- Bericht des Stadtbaumeisters Wiggers über Missstände im

Sanitärbereich der Foget'schen Mietshäuser (6 Toiletten für 40

Bewohner), Dezember 1911 - Januar 1912

$1911-1913$

Klassifikation Teil B: 01190

Trägermaterial: Papier

Alte Reg.-Sig.: IV Ji 50

Bestell-Nr.: IV 01190

958 Kanalisierung der Stadttiefs

- Verträge über Lieferung von Tonröhren für die Kanalisierung und

Kostenvoranschläge für die Kanalisierung

- Verträge über Ausführung des Baus der Entwässerungsanlagen im

Kaiser-Wilhelm-Polder

- Verträge über Zuschüttung und Kanalisierung des Graupferdstiefs

1885

Klassifikation Teil B: 01525

Trägermaterial: Papier

Alte Reg.-Sig.: IV Me 20

Bestell-Nr.: IV 01525 
IV

05

05.03

Stadtverwaltung

05.03 .06

Aufgabenbereiche der Stadtverwaltung

05.03.06.02

Öffentliche Anlagen, Straßenpolizei und Organisation der

Ver- und Entsorgung

05.03.06.02.03

Straßenreinigung und öffentliche Hygiene

Stadtentwässerung und Abfallentsorgung

Lfd. Nr. Titel

Laufzeit

959 Kanalisierung des Grabens am Bentincksweg

- Projektbeschreibung des Stadtbaumeisters Wiggers über Kanalisierung des Grabens am Bentincksweg, August 1902

- Verfügungen des Magistrats an die Anlieger des Grabens am

Benticksweg über Anordnung von Maßnahmen, u.a. Kanalisierung zur

Beseitigung der Seuchengefahr durch die Ausdunstungen des

Grabens am Bentincksweg, September 1902 - Januar 1905

- Beschwerden gegen die Verfügung des Magistrats, September 1902

- April 1903

- Bericht des Magistrats an den Regierungspräsidenten in Aurich über rechtliche Hindernisse zur Verwirklichung der Kanalisierung,

September 1902

- Antrag des Magistrats beim Regierungspräsidenten auf

Genehmigung eines Enteignungsverfahren gegen Ysaac Brons wegen

seinem Grundstück am Graben am Bentincksweg, Februar 1903

$1902-1905$

Klassifikation Teil B: 01529

Trägermaterial: Papier

Alte Reg.-Sig.: IV Me 24

Bestell-Nr.: IV 01529

960 Zweiter Entwässerungsverband

- Konstituierung des Zweiten Entwässerungsverbandes

1895

Klassifikation Teil B: 01530

Trägermaterial: Papier

Alte Reg.-Sig.: IV Me 26

Bestell-Nr.: IV 01530 
05

05.03

05.03.06

05.03.06.02

05.03.06.02.04

\section{Stadtverwaltung}

Aufgabenbereiche der Stadtverwaltung

Öffentliche Anlagen, Straßenpolizei und Organisation der

Ver- und Entsorgung

Straßenreinigung und öffentliche Hygiene

Öffentliche Bedürfniseinrichtungen

Laufzeit

961 Öffentliche Aborte

1871-1906

(1856-1864)

- Ansicht der öffentlichen Abortanlage an der Emsmauer, 1856

- Bau der öffentlichen Abortanlage an der Emsmauer, 1856

- Anzeige gegen den Aschkarrenfuhrmann Enke Jacobs wegen

Vernachlässigung seiner Pflicht zur Reinigung des öffentlichen Aborts

an der Emsmauer, Juni 1861

- Neubau der öffentlichen Abortanlage an der Emsmauerstraße,

August 1863 - Mai 1864

- Beschwerde des P.M. Heeren wegen Belästigung durch die

Ausdünstungen der Abortanlage an der Emsmauerstraße und ständige Verstopfung durch Müll und Unrat, Juni 1871

- Anzeige wegen verbotener Leerung des Aborts an der

Emsmauerstraße am Tage, Juni 1876

- Ansicht der öffentlichen Abortanlage an der Osterbutvenne, 1876

- Neuorganisation des öffentlichen Abortwesens und Etatplanung,

1883

- Verbesserung des öffentlichen Aborts an der Emsstraße, Oktober 1884 - April 1885

- Organisation der Leerung der Fäkalientonnen in öffentlichen

Aborten, August 1886

- Votum des Abfuhrunternehmers Uffe Focken gegen die Beseitigung

des öffentlichen Aborts am Falderntor, September 1892

- Ersetzung des baufälligen Aborts am Kattewall, Oktober 1897

- Antrag des Bezirksvorstehers des zweiten Bezirks der I. Wyk,

Sauerkraurfabrikant Heinrich Dammeyer, auf Beseitigung der

öffentlichen Abortanlage an der Emsstraße, Januar 1898

- Beschwerden wegen Unverschließbarkeit von Kabinen in

öffentlichen Abortanlagen, Februar 1888 - Oktober 1889

- Antrag von Anliegern des Neutorsteges auf Verlegung der

öffentlichen Abortanlage an der Neutorsbrücke, August - September 1901

- Reparatur der öffentlichen Abortanlage an der Neuen Reihe, 1906

(1856 - 1864) 1871 - 1906

Klassifikation Teil B: 00952

Trägermaterial: Papier

Alte Reg.-Sig.: IV Jd 1

Bestell-Nr.: IV 00952 
05

05.03

05.03.06

05.03.06.02

05.03.06.02.04

\section{Stadtverwaltung}

Aufgabenbereiche der Stadtverwaltung

Öffentliche Anlagen, Straßenpolizei und Organisation der

Ver- und Entsorgung

Straßenreinigung und öffentliche Hygiene

Öffentliche Bedürfniseinrichtungen

Laufzeit

962 Reinhaltung öffentlicher Aborte

1866-1911

(1855-1865)

- Organisation der Reinigung öffentlicher Aborte, 1855 - 1911

- Umsetzung des Hannoverschen Gesetzes über Anlage von

Abortgruben in Städten und städtisch gebauten Orten, 1860 - 1864

- Erlass des kgl. Oberschul-Kollegiums über Pflicht zur regelmäßigen

Revision der Schul-Aborte zur Verhinderung des Ausbruchs einer

Cholera-Epidemie, August 1866

- Antrag des Manufakturwarenhändlers P. Hamer auf Beseitigung der

öffentlichen Abortanlage an der Bunten Piepe, Mai 1870

- Antrag des Hausbesitzers A. Klaassen auf Beseitigung des

öffentlichen Pissoirs vor seinem Haus, Juli 1873 - November 1874

- Beschwerden wegen Unsauberkeit des öffentlichen Aborts am

Rosentief, Juni 1875

- Errichtung einer öffentlichen Abortanlage in der Bismarckstraße, Juli

- November1876

- Errichtung eines öffentlichen Pissoirs am Schreyers Hoek, März

1879

- Anzeige wegen mangelhafter Reinigung öffentlicher Abortanlagen,

Dezember 1880

- Antrag des Simon J. Pels und der Witwe des Kapitän Egberts auf

Beseitigung des öffentlichen Pissoirs vor ihren Häusern wegen

Geruchsbelästigung, Januar 1884

- Erlass des preußischen Ministers der Geistlichen, Unterrichts- und

Medizinalangelegenheiten über Kriterien wegen Zulassung von WC's,

Dezember 1887

$(1855-1865) 1866-1911$

Klassifikation Teil B: 00953

Trägermaterial: Papier

Alte Reg.-Sig.: IV Jd 2

Bestell-Nr.: IV 00953

963 Öffentlicher Abort bei der Wevers Piepe

1876-1909

- Anlage eines öffentlichen Aborts an der Wevers Piepe, 1876

- Beseitigung des öffentlichen Aborts an der Wevers Piepe, 1909

$1876-1909$

Klassifikation Teil B: 00954

Trägermaterial: Papier

Alte Reg.-Sig.: IV Jd 3

Bestell-Nr.: IV 00954 
05

05.03

05.03.06

05.03.06.02

05.03.06.02.04

\section{Stadtverwaltung}

Aufgabenbereiche der Stadtverwaltung

Öffentliche Anlagen, Straßenpolizei und Organisation der

Ver- und Entsorgung

Straßenreinigung und öffentliche Hygiene

Öffentliche Bedürfniseinrichtungen

Lfd. Nr. Titel

Laufzeit

964 Öffentliche Pissoirs und Aborte

- Bericht des Polizeisergeanten Walkenroth über Fehlen eines

Pissoirs am Rathaus als Mangel wegen häufiger

Menschenansammlungen durch Musterungen für Militär unf

Heringslogger, Juni 1880

- Unregelmäßigkeiten bei der Reinigung der Fäkalientonnen in

öffentlichen Aborten, Mai 1885

- Angebote über öffentliche Abortanlagen, 1888 - 1905

- Beschwerde des Hausbesitzers Adolph Schröder gegen die geplante

Errichtung eines Pissoirs neben seinem Grundstück, Mai - Juni 1889

- Errichtung eines Pissoirs auf dem Neuen Markt, 1890 - 1903

- Errichtung eines Pissoirs mit Abortanlage am Lotsenturm, 1895

- Errichtung eines Pissoirs auf den Wallanlagen, 1896

- Errichtung eines Pissoirs im Stadtgarten, 1901 - 1903

- Errichtung eines Pissoirs am Rosentief und der Bunten Piepe, 1903

- Errichtung eines Pissoirs am Beckhof, 1904

$1888-1905$

Klassifikation Teil B: 00955

Trägermaterial: Papier

Alte Reg.-Sig.: IV Jd 4

Bestell-Nr.: IV 00955

965 Heranziehung der Hausbesitzer zur Unterhaltung der öffentlichen Bedürfnisanstalten

- Aufstellung über Mieteinnahmen von Häusern ohne eigenem Abort, Februar 1889 - April 1905

- Aufstellung über Aufwändungen für öffentliche Aborte, 1897

- Denkschrift über Kostendeckung für den Betrieb öffentlicher Aborte durch Verpflichtung der Besitzer von Häusern ohne Abort zur

Unterhaltung öffentlichjer Bedürfnisanstalten, Mai 1897

- Antrag des Hausbesitzers W. Preuß auf Rückzahlung der von inm entrichteten "Closett-Gebühr" wegen Einbau eines Aborts in seinem Haus, Dezember 1897 - Januar 1898

- Anträge verschiedener Hausbesitzer auf Befreiung von der "Closett-Gebühr" wegen erfolgtem Einbau von Abortanlagen in ihren Häusern, März 1898 - Juli 1904

- Aufstellung über Häuser ohne Abort und Festsetzung der

"Closett-Gebühr", Februar 1903

$1889-1905$

Klassifikation Teil B: 00966

Trägermaterial: Papier

Alte Reg.-Sig.: IV Jd 6

Bestell-Nr.: IV 00966
1888-1905

$1889-1905$ 
- Antrag des Architekten L. Stieger auf Erlaubnis zur Passage nach seiner Baustelle über die Rasenflächen am Wall, April 1914 - Ersetzung abgängiger Ulmen im Marienwehrster Zwinger, Dezember 1914

- Herstellung einer Einfriedung für die Wallböschung an der Doelestr., März 1915

- Beschneidung von Ulmen zur Belichtung von Gemüseäcker am Norder Tor und anderer Grundstücke, April 1915 - Mai 1916

- Anzeige gegen zwei Schuljungen wegen Beschädigung des Walles durch Herausreißen von Gras, Juli 1916

- Einstellung des Invaliden Hinrich Lottmann als Wallwärter, Dezember 1916 - Januar 1917

1914 - 1916 (1917 - 1920)

Klassifikation Teil B: 00437

Trägermaterial: Papier

Alte Reg.-Sig.: G III 27 / 3

Bestell-Nr.: IV 00437

- Bericht des Polizeisergeanten Friedrichs über unbefugte Benutzung der Böschung am Roten-Mühlen-Zwinger als Weg durch die Arbeiter bei der im Bau befindlichen Kesselschleuse, Mai 1912

- Initiative der Vereins für Geflügelzucht und Tierschutz zur Aufstellung von Vogelhäuschen auf dem Wall, Januar 1913

- Etat der Verschönerungs-Kommission für 1913, Oktober 1912

- Anlegung von Gehölzen zum Vogelschutz, 1913

- Plan zur Errichtung von Kleinwohnhäusern am Herrentor-Tief, 1914

- Aufstellung von Papierkörben auf dem Wall, Mai 1914

- Anschaffung eines Flachsprengwagens zur Bewässerung des Walls, Juli 1914

1912 - 1914 (1920)

Klassifikation Teil B: 00564

Trägermaterial: Papier

Bestell-Nr.: IV 00564 
- Eingabe der Anlieger der Daalerstraße und der Kleinen Osterstraße über Bitte um Beseitigung der mit Fäkalien verseuchten Roste in den Gossen wegen Gesundheitsgefährdung, Juli 1866

- Etatisierung und Beteiligung der Anlieger an den Kosten zur Anlage einer Riole in der Kleinen Osterstraße, Januar 1869 - Januar 1870

- Unbrauchbarkeit der Gosse in der Oldersumer Straße, Mai 1870

- Eingabe der Anlieger der Oldersumer Straße über Bitte um Anlegung einer Riole unter dem Fußweg unter Beseitigung der Gosse,

November 1871

- Etatisierung der Anlage einer Riole in der Kleinen Osterstraße, Dezember 1872

- Verhandlungen der städtischen Kollegien über die Anlage einer Riole in der Kleinen Osterstraße, März 1873

- Verfügung der Stadt Emden an die Anlieger der Kleinen Osterstraße und der Oldersumer Straße über Aufforderung zur Anlage von

Zuleitungen zur Riole (Hausanschlüsse), Juni - September 1873

- Polizeiliche Ermittlungen wegen Einleitung von Fäkalien und

Schlachtabfälle in die Riole an der Oldersumer Straße, Mai 1875 -

April 1876

- Karte: Riolen und Zuleitungen (Hausanschlüsse) in der Kleinen

Osterstraße, Wallstraße und Daalerstraße, Mai 1876

- Verfügungen der Stadt Emden an die Hausbesitzer über Verbot des Anschlusses von Aborten an und der Einleitung von Schlachtabfällen in die Riolen, März - August 1876

- Anzeige über Verstopfung der Gosse in der Wallstraße, Mai 1880

$1866-1880$

Klassifikation Teil B: 00962

Trägermaterial: Papier

Alte Reg.-Sig.: IV Je 11

Bestell-Nr.: IV 00962

\section{Riole an der Emsmauer}

- Ermittlung gegen den Maurermeister Niemeyer wegen Verwendung von schlechtem Mörtel bei der Anlage der Riole an der Emsmauer, November 1855 - Juli 1856

- Reinigung des Grabens an der Emsmauer, Mai - Juli 1887

(1855 - 1856) 1887

Klassifikation Teil B: 00963

Trägermaterial: Papier

Alte Reg.-Sig.: IV Je 12

Bestell-Nr.: IV 00963 
- Vertiefung einer Riole in der Lookvenne, September 1875

- Anzeige über Reparaturbedürftigkeit einer Riole in der Lookvenne wegen Stauung des Abwassers, Juni 1877

- Wahl eines Pumpenaufsehers für die Pumpe bei der Riole an den Hinterhäusern des Gastwirts Hassebroek und des Sattlers Bödecker, Juni 1877

- Aufstellung über Zuleitungen zur Riole in der Lookvenne, 1877

- Verfügung der Stadt Emden über Aufforderung der Bewohner der Lookvenne zur Umwandlung ihrer Gosse in eine unterirdische Riole, Juli 1877

- Anonymer Leserbrief in der "Emder Zeitung" über Warnung vor dem Betreten der Lookvenne wegen Gesundheitsgefährdung durch Überschwemmung durch stinkendes Wasser aus der verstopften Gosse, Juli 1877

- Bericht des Kreisphysicus und Medizinalrats Dr. Stöhr über Typhuserkrankungen in der Lookvenne, Oktober 1879

- Weigerung von Hausbesitzern in der Lookvenne zum Bau einer Riole, Juni 1880

- Karte zum Ableitungssystem Lookvenne - Neuer Markt, 1880

- Verstopfung einer Riole in der Lookvenne, Juli - Oktober 1881

- Verfügung der Stadt Emden über Erhebung eines Beitrages von den Bewohnern der Lookvenne zur Reparatur und Reinigung der Riole, Dezember 1881

$1875-1882$

Klassifikation Teil B: 00965

Trägermaterial: Papier Alte Reg.-Sig.: IV Je 14

Bestell-Nr.: IV 00965

- Antrag des Senators Ysaac Brons auf Erlaubnis der Anlage einer Riole an seinem Grundstück am Philosophengang unter Schließung des bisherigen Grabens, Juli - August 1883

- Widerspruch der Nachbarn H. Klug, und W. Poelders gegen das Vorhaben, August 1883

- Antrag des Gastwirts Gerd Albert Menthe auf Erlaubnis zur Zuschüttung des Grenzgrabens an seinem Grundstück am Philosophengang, April - Mai 1898

$1883-1898$

Klassifikation Teil B: 00969

Trägermaterial: Papier Alte Reg.-Sig.: IV Je 18 Bestell-Nr.: IV 00969 
IV

05

Stadtverwaltung

05.03

Aufgabenbereiche der Stadtverwaltung

05.03.06

Öffentliche Anlagen, Straßenpolizei und Organisation der

Ver- und Entsorgung

05.03.06.03

Wasserleitungen

Lfd. Nr. Titel

Laufzeit

972 Unterirdischer Kanal von der Mühlenstraße zum Falderndelft

- Beitrag der Anlieger der Mühlenstraße zur Unterhaltung der Pumpe an der Mühlenstraße, 1845 - 1848 / 1885

- Übertragung der Kanalanlage von der Mühlenstraße bis zum

Falderndelft mit Pumpe auf die Stadt Emden, November 1885

(1845 - 1848) 1885

Klassifikation Teil B: 00972

Trägermaterial: Papier

Alte Reg.-Sig.: IV Je 19

Bestell-Nr.: IV 00972

973 Unterhaltung des Hauptpumpenzuges am Boltentor

- Verstopfung der Hauptriole im Boltentorviertel, November -

Dezember 1889

- Verfügung der Stadt Emden an die Hausbesitzer des

Boltentorviertels über Verpflichtung zur Reparatur der Hauptriole auf ihre Kosten, Dezember 1889

- Plankarte: Riolen im Boltentorviertel, 1889

1889

Klassifikation Teil B: 00973

Trägermaterial: Papier

Alte Reg.-Sig.: IV Je 20

Bestell-Nr.: IV 00973 
- Antrag des Hoteliers Johann Albers auf Neubau eines Fußweges vor seinem Hotel wegen gefährlicher Stolperstellen, Januar 1878

- Gutachten des Stadtbaumeisters Wiggers zum Bau des Fußwegs, Februar 1878

- Verhandlungen zur Festlegung der Anliegerbeiträge zum Bau des

Fußweges, März 1878

- Beschluss des Magistrats zur Durchführung des Baues, Mai 1878

- Bereitstellung von Mitteln zur Fußwegbepflasterung, Oktober 1879

$1878-1879$

Klassifikation Teil B: 00612

Trägermaterial: Papier

Alte Reg.-Sig.: IV Ff 11

Bestell-Nr.: IV 00612

975 Anlegung eines Fußweges mit Baumbepflanzung an der Südseite des Neuen Marktes

- Eingabe der Anlieger an der Südseite des Neuen Marktes über Beantragung eines neuen Fußweges und Maßnahmen zur Verbesserung der Abwässerung, März 1877

- Gutachten des Stadtbaumeisters Wiggers über Neubau eines Fußweges mit Baumpflanzung an der Südseite des Neuen Marktes, Februar 1878

- Gutachten des Stadtbaumeisters Wiggers über wegen Verrückung der Baumreihe verursachte Veränderung der Fußwegtrasse, März 1878 / August 1878

- Einleitung eines Enteignungsverfahrens gegen den Medizinalrat Dr.Stöhr wegen Weigerung zur Abtretung eines Teils seines Grundstücks für den geplanten Fußweg, März 1878

- Eingabe der Anlieger an der Südseite des Neuen Marktes über Bitte um Verbesserung der Abwässerung, Mai 1878

- Weigerung des Konditormeisters F. Lefermann zur Zahlung seines zugesagten Anliegerbeitrags, Juni 1878

- Planzeichnung: Fußweg-Projekt am Neuen Markt, Dezember 1880

- Ausschreibung der Arbeiten, Juni 1881

$1877-1881$

Klassifikation Teil B: 00613

Trägermaterial: Papier

Alte Reg.-Sig.: IV Ff 12

Bestell-Nr.: IV 00613 
IV

05

Stadtverwaltung

05.03

Aufgabenbereiche der Stadtverwaltung

05.03.06

Öffentliche Anlagen, Straßenpolizei und Organisation der Ver- und Entsorgung

05.03.06.04 Straßenbau

Lfd. Nr. Titel

Laufzeit

976 Bau eines Fußweges in der Olivenstraße

- Verhandlungen zwischen der Baukommission und den Anliegern der Olivenstraße eines neuen Fußweges, Juni 1882

- Antrag der Abegg'schen Erben auf Genehmigung einer von ihnen finanzierten und vorzunehmenden Pflasterung des Fußweges vor ihren Packhäusern an der Olivenstraße mit Kopfsteinen, September Oktober 1884

- Bericht der Baukommission über Nichtdurchführung des Baus eines Fußweges an der Olivenstraße wegen Opposition der Anlieger und nicht vorhandener Dringlichkeit, Januar 1886

$1882-1886$

Klassifikation Teil B: 00618

Trägermaterial: Papier

Alte Reg.-Sig.: IV Jf 17

Bestell-Nr.: IV 00618 
977 Fußweg an der Petkumer Landstraße und der Parallelstraße zum Bahnhof

- Antrag des Grundstücksbesitzers und Bauunternehmers Kistenmacher auf Genehmigung der Anlage eines Fußweges an seinem Grundstück an der Petkumer Landstraße, April 1883 - Januar 1884

- Eingabe der Anlieger der Petkumer Landstraße an den Magistrat der Stadt Emden über Bitte um Anschluss ihrer Straße an die städtische Straßenbeleuchtung und Verbesserung der Abwässerung, Mai 1888 / Januar 1889

- Gutachten des Stadtbaumeisters Wiggers über Bau eines Fußweges in der Parallelstraße zur Bahnhofsstraße mit Kostenvoranschlag,

Februar 1889

- Streit zwischen der Baukommission und den Anliegern der Parallelstraße wegen Beitrag zur Finanzierung des Fußwegebaus, März 1889

- Verfügung der Stadt Emden über Zahlungsanordnung an die Anlieger der Parallelstraße, August 1889

- Genehmigung des Baus des Fußweges und des Kanals an der Parallelstraße zur Bahnhofsstraße durch den Magistrats und Vermerk des Stadtbaumeister Wiggers über Abschluss der Arbeit, Oktober 1892 - April 1893

- Klage der Witwe F. Finkenbrink gegen die Stadt Emden vor dem Bezirksausschuss in Aurich gegen die Heranziehung zur Finanziehung des Fußweges, Dezember 1892 - Juni 1893

- Gutachten des Stadtbaumeisters Wiggers über Anlage eines Fußweges an der Nordseite der Petkumer Landstraße, Dezember 1899

- Heranziehung der Anlieger zur Finanzierung des Fußwegbaus, Februar 1900 - Februar 1901

- Beitrag der Indo-European Telegraph u. Co zur Anlage eines Fußweges an ihr Grundstück an der Petkumer Landstraße, November 1903 - Oktober 1907

$1883-1907$

Klassifikation Teil B: 00619

Trägermaterial: Papier Alte Reg.-Sig.: IV Jf 18

Bestell-Nr.: IV 00619 
978 Klage gegen die Heranziehung zur Finanzierung der Anlegung eines Fußweges, Bd. 1

- Beschwerde des Vizekonsuls O.C.J. Lindemann beim Regierungspräsidenten in Aurich gegen die Heranziehung zur Finanzierung des Baus des Fußweges am Bentincksweg, Oktober 1889

- Klage des Vizekonsuls O.C.J. Lindemann beim Bezirksausschuss in Aurich gegen die Heranziehung zur Finanzierung des Baus des Fußweges am Bentincksweg, Dezember 1889 - September 1890

$1889-1890$

Klassifikation Teil B: 00620

Band: 1

Trägermaterial: Papier

Alte Reg.-Sig.: IV Jf 19

Bestell-Nr.: IV 00620

979 Klage gegen die Heranziehung zur Finanzierung der Anlegung eines Fußweges, Bd. 1

Laufzeit

- Revisionsklage des Vizekonsuls O.C.J. Lindemann gegen das Urteil des Bezirksausschusses in Aurich wegen der Heranziehung zur Finanzierung des Baus des Fußweges am Bentincksweg beim preußischen Oberverwaltungsgericht in Berlin, Dezember 1890 Januar 1893

$1890-1893$

Klassifikation Teil B: 00621

Band: 2

Trägermaterial: Papier

Alte Reg.-Sig.: IV Jf 19

Bestell-Nr.: IV 00621

980 Anlegung eines Fußweges in der Großen Brückstraße

- Übergang von Wanderungen an der Großen Brückstraße in das Eigentum der Stadt Emden zur Anöegung eines Bürgersteiges (Trottoir), 1868 - 1880

$1868-1880$

Klassifikation Teil B: 00978

Trägermaterial: Papier Alte Reg.-Sig.: IV Jf 07 Bestell-Nr.: IV 00978 
981 Anlegung eines Bürgersteiges in der Klunderburgstraße und der Pelzerstraße

- Projektbeschreibung über Anlegung eines Bürgersteiges in der Klunderburgstraße und der Pelzerstraße, Juni 1879

- Verfügung der Stadt Emden an die Anlieger der Klunderburg- und Pelzerstraße über Entzug der Rechte an den Wanderungen, Juni 1879

- Heranziehung der Anlieger zur Finanzierung der Anlage einer Riole, November - Dezember 18789

1879

Klassifikation Teil B: 00979

Trägermaterial: Papier

Alte Reg.-Sig.: IV Jf 07

Bestell-Nr.: IV 00979

982 Beseitigung einer Zisternenmündung wegen Verkehrsgefährdung

- Beschwerde des Arztes Dr. Wychgram über Verletzung des Beines durch Stolpern über eine in den Bürgersteig der kleinen Osterstraße hineinragende Zisternenmündung am Haus des Raseurs Bakker, Mai 1875

- Verfügung der Stadt Emden an den Raseur Bakker über Aufforderung zur Beseitigung seiner verkehrsgefährdenden Zisternenmündung, Juni 1876 - September 1878 - Verfügung des preußischen Landdrosten in Aurich über Abweisung der Beschwerde des Raseurs A. Bakker gegen die Verfügung der Stadt Emden zur Beseitigung der Zisternenmündung, Juli 1876 - Bescheid des preußischen Innenministers über Rechtmäßigkeit der Verfügungen der Stadt Emden und des Landdrosten in Aurich gegen A. Bakker, September 1876

- Gewährung einer Beihilfe an den Raseur A. Bakker zur Beseitigung der verkehrsgefährdenden Zisternenmündung, März 1879

$1875-1879$

Klassifikation Teil B: 00980

Trägermaterial: Papier Alte Reg.-Sig.: IV Jf 10

Bestell-Nr.: IV 00980 
IV

05

05.03

Stadtverwaltung

05.03 .06

Aufgabenbereiche der Stadtverwaltung

05.03.06.04

Offentliche Anlagen, Straßenpolizei und Organisation der

Ver- und Entsorgung

Lfd. Nr. Titel Straßenbau

983 Anlegung eines Bürgersteiges am Bentincksweg

Laufzeit

- Gesuch der Anlieger des Bentinckweges an die Stadt Emden über Bitte um Anlegung eines gepflasterten Bürgersteiges, Dezember 1888

/ Oktober 1890

- Kostenanschlag und Plan des Stadtbaumeisters Wiggers zur

Anlegung des Bürgersteigs, Januar 1889

- Beteiligung der Anlieger an den Kosten des Bürgersteigs, August

1889 - November 1892

- Gesuch der Anlieger des Bentincksweges über Bitte um Pflasterung

ihrer Straße, Januar 1898 / August 1902

- Kostenanschläge und Plan des Stadtbaumeisters Wiggers über

Pflasterung des Bentincksweges, Januar 1898 - Mai 1902

- Heranziehung der Anlieger zu den Kosten der Pflasterung, Oktober 1900 - Januar 1902

- Plan der Kanalisierung des Bentincksweges, 1899

- Katasterauszug über enteignete Grundfläche für die Anlage eines

Bürgersteiges am Bentincksweg, 1902

- Beschwerde der Brons Erben gegen die Höherlegung des

Bentincksweges wegen Erschwerung des Zugangs zu ihrem

Grundstück und Erschwerung der Entwässerung, September 1902

$1888-1902$

Klassifikation Teil B: 00981

Trägermaterial: Papier

Alte Reg.-Sig.: IV Jf 20

Bestell-Nr.: IV 00981

984 Heranziehung der Anlieger des Bentincksweges zu den Kosten der Pflasterung des Weges

- Verfügung des Magistrats über Heranziehung der Anlieger des Bentincksweges zu den Kosten der Pflasterung des Weges gemäß dem Beschluss des Bürgervorsteherkollegiums, Dezember 1902 - Ermittlung der Beiträge der einzelnen Beiträge, Januar - März 1902 - Einsprüche gegen die Erhebung der Anlieger-Beiträge, Oktober Dezember 1902

- Urteil des Bezirksausschusses in Aurich über Abweisung der Klage von Anliegern des Bentincksweges gegen die Heranziehung zu den Kosten der Pflasterung des Weges und der Kanalisierung, Juli 1903

$1902-1903$

Klassifikation Teil B: 00982

Trägermaterial: Papier

Alte Reg.-Sig.: IV Jf 20

Bestell-Nr.: IV 00982 
05

\subsection{3}

05.03.06

05.03.06.04

\section{Stadtverwaltung}

Aufgabenbereiche der Stadtverwaltung

Öffentliche Anlagen, Straßenpolizei und Organisation der Ver- und Entsorgung

Straßenbau

Lfd. Nr. Titel

Laufzeit

985 Beseitigung der Uptrapp (Freitreppe) vor dem Haus Neutorstraße 14 wegen Verkehrsgefährdung

- Vertrag zwischen der Stadt Emden und den Anliegern der Neutorstraße über Beseitigung der Wanderungen und Treppenaufgänge bei Behinderung des Verkehrs, September 1872 - Polizeiverordnung der Stadt Emden zum Schutz des Stadtgartens u.a. durch Verbot von Überbauten, Mai 1891

- Verfügung der Stadt Emden an die Erben des Kaufmanns Simon Valk über Anordnung der Beseitigung der Freitreppe vor dem Haus Neutorstraße 14, Februar / März 1893

- Vergleich zwischen dem Magistrat der Stadt Emden und Jakob S. Valk als Vertreter der Erbengemeinschaft über Beseitigung der Freitreppe, März 1893 / März 1895

- Streit zwischen der Stadt Emden und der Firma J.M. Valk \& Söhne wegen des Verbotes der Passage des Stadtgartens mit Waren für ihr Geschäft an der Straße Zwischen beiden Sielen, Januar 1910

1872 - 1895 (1910)

Klassifikation Teil B: 00983

Trägermaterial: Papier Alte Reg.-Sig.: IV Jf 21

Bestell-Nr.: IV 00983

986 Anlegung eines Bürgersteiges in der Parallelstraße (Courbierestraße)

- Heranziehung der Anlieger der Parallelstraße zu den Kosten der Anlage des Bürgersteiges, Juni - November 1894 / Juni - Jui 1898

$1894-1898$

Klassifikation Teil B: 00984

Trägermaterial: Papier

Alte Reg.-Sig.: IV Jf 22

Bestell-Nr.: IV 00984 
05

\subsection{3}

05.03.06
Stadtverwaltung

Aufgabenbereiche der Stadtverwaltung

Öffentliche Anlagen, Straßenpolizei und Organisation der Ver- und Entsorgung

Straßenbau

05.03.06.04

Lfd. Nr. Titel

Laufzeit

987 Anlegung einer Straße vom Lotsenturm zum Übergang der Küstenbahn im Kaiser-Wilhelm-Polder

- Etatisierung der Anlegung einer Straße vom Lotsenturm zum Bahnübergang im Kaiser-Wilhelm-Polder, April 1893

- Plan der Straße, April 1893 - April 1896

- Verhandlungen der Stadt Emden mit der kgl. Eisenbahndirektion wegen Anlage der Straße vom Lotsenturm, August 1893

- Verfügung des Regierungspräsidenten in Aurich über Genehmigung der Straßentrasse, Januar 1894

- Planung von Baumanpflanzungen an der neuen Straße, Februar 1894

- Ausschreibung des Straßenbaus, Mai 1894

- Verhandlungen der Stadt Emden mit der kgl. Eisenbahnbetriebsamt über Herstellung eines gepflasterten Bahnübergangs im Kaiser-Wilhelm-Polder, Oktober 1894 - Oktober 1895

- Angebote über Straßenbäume, März - Dezember 1895

- Antrag der Nutzer der Petroleumsschuten auf Erlaubnis zur Nutzung der neuen Straße vom Lotsenturm zum Transport von Petroleum, März 1898

Klassifikation Teil B: 00985

Trägermaterial: Papier

Alte Reg.-Sig.: IV Jf 23

Bestell-Nr.: IV 00985

988 Beteiligung der Anlieger an den Kosten des Fußwegebaues

- Antrag der Stadt Emden beim Regierungspräsidenten als vorsitzenden des Bezirksausschusses auf Genehmigung der Änderung der Bauordnung hinsichtlich der Beteiligung der Anlieger an den Kosten zum Fußwegebau, Februar - März 1891

- Beschwerde der Stadt Emden beim Provinzialrat gegen die Ablehnung der Änderung der Bauordnung durch den

Bezirksausschuss in Aurich, März - Mai 1891

- Erlass eines Ortsstatuts der Stadt Emden wegen Beteiligung der Anlieger an den Kosten des Fußwegebaues, Juli 1891 - Oktober 1892 - Genehmigung des Statuts der Stadt Emden über Beteiligung der Anlieger an den Kosten des Fußwegebaues durch den preußischen Innenminister, September 1892

- Heranziehung des H.Ubbens zu den Kosten des Fußweges vor seinem Haus in der Larrelter Straße, Januar 1898

- Austausch der Stadt Emden mit anderen Städten wegen Beteiligung der Anlieger an den Kosten des Fußwegebaues, 1897 - 1905

$1891-1905$

Klassifikation Teil B: 00986

Trägermaterial: Papier

Alte Reg.-Sig.: IV Jf 24

Bestell-Nr.: IV 00986 
05

05.03

05.03.06
Stadtverwaltung

Aufgabenbereiche der Stadtverwaltung

Öffentliche Anlagen, Straßenpolizei und Organisation der Ver- und Entsorgung

Straßenbau

05.03.06.04

Lfd. Nr. Titel

Laufzeit

989 Niedrigerlegung und Verlängerung der Bahnhofsstraße zum

Stadtpolder

1896-1897

- Kostenanschlag und Plan der Niedrigerlegung der Bahnhofsstraße,

Mai 1896

- Angebote über die notwendigen Erdarbeitn, August 1896

- Abrechnung der Arbeiten, 1897

$1896-1897$

Klassifikation Teil B: 00987

Trägermaterial: Papier

Alte Reg.-Sig.: IV Jf 25

Bestell-Nr.: IV 00987

990 Niedrigerlegung der Larrelter Straße

$1895-1900$

- Plan und Kostenanschlag über Anlegung eines Bürgersteigs zur

Larrelter Haltestelle der Küstenbahn, Dezember 1895

- Projektbeschreibung über Niedrigerlegung der Larrelter Straße zur

Verbesserung des Zugangs zum Schlachthof und der Bebauung des

Terrains, Dezember 1895

- Angebote zur Bauausführung, Juli 1896

- Ausführungsbestimmungen für die Bauarbeiten, Juli 1896

- Beschwerde des Landrats des Landkreises Emden, v. Frese, über

Gefahr wegen ungesicherter Baustelle der Larrelter Straße,

September 1896

- Auspflasterung der Larrelter Straße, 1899 - 1900

$1895-1900$

Klassifikation Teil B: 00988

Trägermaterial: Papier

Alte Reg.-Sig.: IV Jf 26

Bestell-Nr.: IV 00988

991 Anlegung einer neuen Straße am Neuen Tor

1896-1898

- Kalkulation und Etatisierung der Kosten für den Bau der Straße zum Neuen Tor und zum Vogelsangzwinger, Januar 1896

- Projektbeschreibung: Straße zum Neuen Tor und Vogelsangzwinger, 1897

- Angebote über Bauleistungen, März 1897

- Heranziehung der Anlieger der Neutorstraße zu den Kosten des

Straßenbaus, 1897 - 1898

- Einsprüche der Anlieger gegen die Heranziehung zur

Straßenbaufinanzierung beim Regierungspräsidenten in Aurich,

September - November 1897

$1896-1898$

Klassifikation Teil B: 00989

Trägermaterial: Papier

Alte Reg.-Sig.: IV Jf 27

Bestell-Nr.: IV 00989 
992 Anlegung eines Bürgersteigs an der Straße "Außer dem Nordertor" und Neupflasterung der Fahrstraße

Laufzeit

- Kalkulation und Etatisierung des Vorhabens, März 1897

- Projektbeschreibung über Anlegung eines Bürgersteigs und

Neupflasterung der Fahrstraße, März 1897

- Beteiligung der Anlieger an der Straßenbaufinanzierung, März 1897 -

November 1902

- Ausführungsbestimmungen für die Arbeiten der Anlegung eines

Bürgersteigs und Neupflasterung der Fahrstraße, Mai 1902

$1897-1902$

Klassifikation Teil B: 00990

Trägermaterial: Papier

Alte Reg.-Sig.: IV Jf 28

Bestell-Nr.: IV 00990

- Verhandlungen der Stadt Emden mit dem Regierungspräsidenten in Aurich über Abtragung des Strohdeiches bei der Kettenbrücke zur Anlegung von Lösch- und Landeplätzen am Ems-Jade-Kanal, 1894 1897

- Projektbeschreibung der Abtragung des Strohdeiches, 1896 / 1898 - Verhandlungen der Stadt Emden mit der kgl. Wasserbauinspektion wegen Überlassung eines städtischen Grundstückes für das geplante neue Amtsgebäude der Inspektion und dessen Anbindung an die Kranstraße durch Niederlegung des Strohdeiches an der Kettenbrücke, August 1897

- Angebote über Bauleistungen zur Abtragung des Strohdeiches und Anlegung der Hafenstraße, August 1898

- Lieferung von Baumaterial und Rechnungen, Juni - August 1898

$1894-1897$

Klassifikation Teil B: 00991

Trägermaterial: Papier

Alte Reg.-Sig.: IV Jf 30

Bestell-Nr.: IV 00991 
05

\subsection{3}

05.03.06
Stadtverwaltung

Aufgabenbereiche der Stadtverwaltung

Öffentliche Anlagen, Straßenpolizei und Organisation der Ver- und Entsorgung

05.03.06.04 Straßenbau

Lfd. Nr. Titel

Laufzeit

994 Heranziehung der Anlieger an den Kosten der Anlegung der Hafenstraße

- Verhandlungen der städtischen Kollegien über Heranziehung der Anlieger der anzulegenden Hafenstraße zur Finanzierung des Straßenbaus, März 1897 - September 1898

- Kalkulation des Anliegerbeitrags, September 1898

- Denkschrift zur Veränderung der Struktur des südlichen Teils der Stadt Emden durch den Bedeutungsverlust des Strohdeiches am Falderndelft und Favorisierung der Heranziehung der Anlieger zu den Straßenbaukosten, Mai 1899

- Heranziehung der Anlieger zur Straßenbaufinanzierung, Mai 1899

- Beschwerden von Anliegern beim Bezirksausschuss in Aurich, Juli 1899 - August 1900

$1897-1900$

Klassifikation Teil B: 00992

Trägermaterial: Papier

Alte Reg.-Sig.: IV Jf 31

Bestell-Nr.: IV 00992

995 Anlegung eines Bürgersteigs am Delft, Bd. 1

- Projektplanung und Kalkulation der Kosten, Dezember 1900

- Kalkulation der Kosten zur Besitigung der Wanderungen am Delft, Dezember 1900

- Etatisierung der Anlegung eines Bürgersteigs am Delft, 1901 - 1902

- Erhebung über Bereitschaft der Anlieger des Delftes zur Beseitigung der Wanderungen, Dezember 1900 - Februar 1901

- Verhandlungen der Stadt Emden mit den Hausbesitzern am Delft über Beseitigung der Wanderungen und Anlegung des Bürgersteigs, April 1901

- Verfügungen der Stadt Emden an die Hausbesitzer über Anordnung zur Beseitigung der Wanderungen, Mai 1901 - Juli 1901

- Anträge von Hausbesitzern auf Beihilfe zur Beseitigung der Wanderungen vor ihren Häusern, Mai 19014 - Juni 1905

- Klage des Kaufmanns F. Uffen gegen die zwangsweise erfolgte

Entfernung der Wanderung vor seinem Haus am Delft, Juli -

November 1901

- Kalkulation der Kosten für die Anlegung des Bürgersteigs am Delft,

Februar 1902

- Plan des Bürgersteigs, 1902 / 1904

$1900-1905$

Klassifikation Teil B: 00993

Band: 1

Trägermaterial: Papier

Alte Reg.-Sig.: IV Jf 32

Bestell-Nr.: IV 00993 
IV

05

Stadtverwaltung

05.03

Aufgabenbereiche der Stadtverwaltung

05.03.06

Öffentliche Anlagen, Straßenpolizei und Organisation der

Ver- und Entsorgung

05.03.06.04

Straßenbau

Lfd. Nr. Titel

Laufzeit

996 Anlegung eines Bürgersteigs am Delft, Bd. 2

1901

- Klage des Kaufmanns H. Dinkelmann gegen die Stadt Emden beim

Bezirksausschuss in Aurich auf Aufhebung der Verfügung zur

Entfernung der Wanderung vor seinem Haus am Delft, Mai - Juli

1901

1901

Klassifikation Teil B: 00994

Band: 2

Trägermaterial: Papier

Alte Reg.-Sig.: IV Jf 32

Bestell-Nr.: IV 00994

997 Anlegung eines Bürgersteigs am Delft, Bd. 3

- Klage des Kaufmanns H. Dinkelmann gegen die Stadt Emden beim Bezirksausschuss in Aurich auf Aufhebung der Verfügung zur

Entfernung der Wanderung vor seinem Haus am Delft, Juli 1901 Mai 1903

1901

Klassifikation Teil B: 00995

Band: 3

Trägermaterial: Papier

Alte Reg.-Sig.: IV Jf 32

Bestell-Nr.: IV 00995 
IV

05

Stadtverwaltung

05.03

Aufgabenbereiche der Stadtverwaltung

05.03.06

Öffentliche Anlagen, Straßenpolizei und Organisation der Ver- und Entsorgung

05.03.06.04 Straßenbau

Lfd. Nr. Titel

Laufzeit

998 Umgestaltung der Straßen in der Emder Innenstadt

- Plan des kgl. Baurats J. Stübbe über Erweiterung der Stadt- und Hafenanlage in Richtung des Kaiser-Wilhelm-Polder, 1896

- Kostenkalkulation und Planung der Straßen, der Beleuchtung und der Gasversorgung im Bereich der projektierten Stadterweiterung,

Oktober 1896

- Verhandlungen der städtischen Kollegien über Bewilligung der Mittel

für die Straßenerschließung des neuen Stadtareals, November 1896

- Kalkulation und Plan der Verlängerung der Großen Straße bis zur

Larrelter Straße, 1896 - 1903

- Eingabe der Bürger der II. Wyk an die Stadt Emden über Bitte um

Verlängerung der Großen Straße nach Westen, März 1899 -

September 1903

- Eingabe der Anlieger der Emsstraße an die Stadt Emden über Bitte um Anschluss ihres Gebiets an die neuen Stadtteile am Hafen,

September 1899

- Kanalisierung der Großen Straße, 1901

- Projekt der Abtragung des Mittelwalls von der Volksschule bis zur

Larrelter Straße, 1901 - 1902

- Zuschüttung des Burggrabens in Emden, 1901 - 1906

- Bebauungsplan der Ringstraße im Bereich des Burggrabens,

Dezember 1902

- Verwaltung der Anleihen zur Finanzierung der Straßenbauprojekte, 1903 - 1905

- Pflasterung der Burg- und Schweckendiekstraße, 1905

$1896-1905$

Klassifikation Teil B: 00996

Trägermaterial: Papier

Alte Reg.-Sig.: IV Jf 33

Bestell-Nr.: IV 00996

999 Beseitigung verkehrsbehindernder Zisternenanlagen

- Verfügungen der Stadt Emden über Anordnung der Beseitigung oder Veränderung von Zlsternen wegen Behinderung und Gefährdung des Verkehrs

$1897-1907$

Klassifikation Teil B: 00997

Trägermaterial: Papier

Alte Reg.-Sig.: IV Jf 34

Bestell-Nr.: IV 00997 
05

05.03

05.03.06
Stadtverwaltung

Aufgabenbereiche der Stadtverwaltung

Öffentliche Anlagen, Straßenpolizei und Organisation der Ver- und Entsorgung

Straßenbau

Lfd. Nr. Titel

Laufzeit

1000 Heranziehung der Anlieger der Parallelstraße (Courbierestraße) zu den Straßenausbaukosten

1901-1902

- Verhandlungen der städtischen Kollegien über Heranziehung der Anlieger der Parallelstraße (Courbierestraße) zu den

Straßenausbaukosten, Januar - Februar 1902

- Verfügungen der Stadt Emden an die einzelnen Anlieger der

Parallelstraße über zu zahlemde Beiträge zum Straßenausbau,

Februar 1902

- Einsprüche von Anliegern gegen die Heranziehung zur Finanzierung

des Straßenausbaus, März 1902 - Februar 1903

- Stellungnahme der Stadt Emden zur Klage des Bauzeichners

Heubült etc. gegen die Heranziehung zur Finanzierung des

Straßenausbaus vor dem Bezirksausschuss in Aurich, August -

September 1902

- Kostenanschlag über Ausbau der Parallelstraße, Dezember 1901

- Gesuche verschiedener Anlieger über Bitte um Genehmigung der

Zahlung des Straßenausbaubeitrags in Raten, Februar - Mai 1902

$1901-1903$

Klassifikation Teil B: 00998

Trägermaterial: Papier

Alte Reg.-Sig.: IV Jf 35

Bestell-Nr.: IV 00998

1001 Heranziehung der Anlieger der Straße "Am Hundepfad" zu den

$1900-1901$ Straßenausbaukosten

- Beschluss des Magistrats über Heranziehung der Anlieger der Straße "Am Hundepfad" zu den Straßenausbaukosten, Juli 1900

- Plan und Kostenanschlag des Ausbaus der Straße "Am Hundepfad", Dezember 1900

- Verfügung der Stadt Emden an den Anlieger der Straße, J.H. Luiken, über Höhe des zu leistenden Beitrags zum Straßenausbau, November 1900

- Klage des J.H. Luiken gegen die Stadt Emden beim Bezirksausschuss in Aurich auf Aufhebung der Zahlungsanordnung des Beitrags zum Straßenausbaus, September 1901

$1900-1901$

Klassifikation Teil B: 00999

Trägermaterial: Papier

Alte Reg.-Sig.: IV Jf 36

Bestell-Nr.: IV 00999 
05

05.03

05.03.06

05.03.06.04
Stadtverwaltung

Aufgabenbereiche der Stadtverwaltung

Öffentliche Anlagen, Straßenpolizei und Organisation der Ver- und Entsorgung

Straßenbau

Lfd. Nr. Titel

Laufzeit

1002 Heranziehung der Anlieger zu den Kosten der Anlegung eines Bürgersteiges an der Auricher Chaussee

- Kostenanschlag und Plan eines Bürgersteigs an der Auricher Chaussee, Februar 1902

- Verfügungen der Stadt Emden an die Anlieger der Auricher Chaussee über Heranziehung zu den Kosten der Anlegung eines Bürgersteiges, August 1902

- Einspruch des Maschinenbauers H. Bartels gegen die Heranziehung zu den Kosten der Anlegung eines Bürgersteiges, September 1902 - Einspruch des Commerzienrats G. Schnedermann gegen die Heranziehung zu den Kosten der Anlegung eines Bürgersteiges, September 1902 - März 1903

- Verteilung der Kosten für die Anlegung des Bürgersteiges auf die einzelnen Anlieger der Auricher Chaussee, März 1903

$1902-1903$

Klassifikation Teil B: 01000

Trägermaterial: Papier

Alte Reg.-Sig.: IV Jf 37

Bestell-Nr.: IV 01000

1003 Heranziehung von Grundeigentümer und Gewerbetreibende zu den Kosten zur Anlegung von Bürgersteigen

- Erlass eines besonderen Gemeindebeschlusses zum Ortstatut der Stadt Emden zur Schaffung der rechtlichen Möglichkeit der Heranziehung von Gewerbetreibenden und Besitzern von nicht selst genutzten Grundstücken zur Finanzierung der Anlegung von Bürgersteigen und der Anlegung sowie des Ausbaus von Straßen

$1899-1901$

Klassifikation Teil B: 01001

Trägermaterial: Papier

Alte Reg.-Sig.: IV Jf 38

Bestell-Nr.: IV 01001 
05

\subsection{3}

05.03.06
Stadtverwaltung

Aufgabenbereiche der Stadtverwaltung

Öffentliche Anlagen, Straßenpolizei und Organisation der Ver- und Entsorgung

05.03.06.04 Straßenbau

Lfd. Nr. Titel

Laufzeit

1004 Heranziehung des Restaurantbesitzers H. Mahlstede zu den Kosten des Ausbaus des Neutors Breitergang

1898-1900

- Plan und Kostenanschlag für den Ausbau des Platzes vor dem "Tivoli" (Neutors Breitergang), 1898

- Eingabe des J. Onneken an die Stadt Emden über Bitte um Höherlegung und Pflasterung des Bürgersteiges im Neutors Breitergang, Oktober 1898

- Verhandlungen der städtischen Kollegien über Erörterung der Möglichkeit der Heranziehung des Besitzers des "Tivoli", $\mathrm{H}$. Mahlstede, zu den Kosten des Ausbaus des Neutors Breitergang, $1898-1900$

- Klage des Restaurantbesitzers H. Malstede gegen die Stadt Emden beim Bezirksausschuss in Aurich auf Aufhebung der verfügten Heranziehung zur Finanzierung des Ausbaus des Neutors Breitergang, Oktober - November 1900 - Plan der Neupflasterung des Neutors Breitergang, 1905

$1898-1900(1905)$ Klassifikation Teil B: 01002

Trägermaterial: Papier Alte Reg.-Sig.: IV Jf 39

Bestell-Nr.: IV 01002

1005 Heranziehung der Anlieger zu den Kosten der Abtragung des Südfalderndeiches, der Anlegung einer Holzkajung und eines Bürgersteiges

- Kostenanschlag und Plan des Projektes, Oktober 1900

- Verhandlungen der Stadt Emden mit den Anliegern des Südfalderndeiches über Heranziehung zu den Kosten der Abtragung des Südfalderndeiches, der Anlegung einer Holzkajung und eines Bürgersteiges, August 1902 - Juni 1903

- Einsprüche von Anliegern des Südfalderndeiches gegen die Heranziehung zu den Kosten der Abtragung des Südfalderndeiches, der Anlegung einer Holzkajung und eines Bürgersteiges, SEptember 1902 - Juni 1903

- Beschluss der städtischen Kollegien zur Heranziehung der Anlieger zu den Kosten der Abtragung des Südfalderndeiches, der Anlegung einer Holzkajung und eines Bürgersteiges wegen wirtschaftlicher Vorteile für die Betroffenen, März 1902 - Februar 1903

- Angebote zur Durchführung der Arbeiten zur Abtragung des Südfalderndeiches, der Anlegung einer Holzkajung und eines Bürgersteiges, Dezember 1903

$1900-1903$

Klassifikation Teil B: 01003

Trägermaterial: Papier

Alte Reg.-Sig.: IV Jf 40

Bestell-Nr.: IV 01003 
05

\subsection{3}

05.03.06

05.03.06.04
Stadtverwaltung

Aufgabenbereiche der Stadtverwaltung

Öffentliche Anlagen, Straßenpolizei und Organisation der Ver- und Entsorgung

Straßenbau

Lfd. Nr. Titel

Laufzeit

1006 Bürgersteig an der Beuljenstraße

- Verhandlungen der Baukommission mit den Anliegern der

Beuljenstraße über Heranziehung zu den Kosten der Anlegung eines

Bürgersteiges, Juli 1903

- Verfügung der Stadt Emden an den Böttcher A. Bakker über

Anordnung zur Zahlung des Anliegerbeitrages zur Anlegung eines

Bürgersteiges an der Beuljenstraße, September 1903

1903

\author{
Klassifikation Teil B: 01004 \\ Trägermaterial: Papier \\ Alte Reg.-Sig.: IV Jf 41 \\ Bestell-Nr.: IV 01004
}

1007 Beseitigung der Stufen am Haus Große Straße 10

1903-1904

- Verfügung der Stadt Emden an den Hausbesitzer M. Rosenfeld über Verbot eines Treppenteils an seinem Haus Große Str. 10 wegen Verletzung der Baufluchtlinie, Dezember 1903 - Februar 1904

\author{
$1903-1904$ \\ Klassifikation Teil B: 01005 \\ Trägermaterial: Papier \\ Alte Reg.-Sig.: IV Jf 42 \\ Bestell-Nr.: IV 01005
}

1008 Anlegung eines Bürgersteigs an der Straße "Am Pannewarf"

1904-1905

1903

- Plan der Anlegung des Bürgersteigs, März 1904

- Heranziehung der Anlieger zur Finanzierung des Bürgersteigs,

September 1904

- Beseitigung der Wanderungen in der Straße "Am Pannewarf", 1904

- Verhandlungen der Stadt Emden mit dem Gemüsebauern J. Dirksen über Erhalt der Möglichkeit zur Mistabfuhr von seinem Grundstück nach Anlage des Bürgersteiges, November - Dezember 1904

- Beschwerde des Carl Pels gegen die Anlegung des Bürgersteiges wegen Abschneidens des tiefer gelegenen Verbindungsweges zum Haus seiner von inm betreuten Schwester, März 1905

$1904-1905$

Klassifikation Teil B: 01006

Trägermaterial: Papier

Alte Reg.-Sig.: IV Jf 43

Bestell-Nr.: IV 01006 
- Initiative zur Verbreiterung der Straße "Am Falderntor" zur

Erleichterung des Durchgangsverkehrs zum Bahnhof, Mai 1905

- Verhandlungen der Baukommission mit Anliegern der Straße zum Ankauf ihrer Grundstücke zum Erhalt von Raum zur Verbreiterung der Straße, Juni - August 1905

- Anträge des Haus- und Grundbesitzer-Vereins Emden an die Stadt Emden und den Regierungspräsidenten in Aurich auf Freigabe der Straße "Am Falderntor" für den beidseitigen Durchgangsverkehr, Dezember 1906 / April 1909

$1905-1909$

Klassifikation Teil B: 01007

Trägermaterial: Papier

Alte Reg.-Sig.: IV Jf 45

Bestell-Nr.: IV 01007

1010 Verknüpfung einer Baugenehmigung mit der Tragung von Kanalisationskosten

- Klage des Bauunternehmers H. van der Linde gegen die Stadt Emden beim Bezirksausschuss in Aurich auf Rücknahme der Verknüpfung der Tragung der Kanalisationskosten mit der Baugenehmigung für seinen Neubau in der Nordertorstraße 2, Januar 1906 - Januar 1907

$1906-1907$

Klassifikation Teil B: 01008

Trägermaterial: Papier Alte Reg.-Sig.: IV Jf 46

Bestell-Nr.: IV 01008 
05

05.03

05.03.06
Stadtverwaltung

Aufgabenbereiche der Stadtverwaltung

Öffentliche Anlagen, Straßenpolizei und Organisation der Ver- und Entsorgung

Straßenbau

Lfd. Nr. Titel

Laufzeit

1011 Heranziehung der Anlieger zu den Kosten der Anlage einer Kayung 1906-1908 anstelle der beseitigen Janßenschen Helling und anderen straßenbaulichen Maßnahmen im Bereich Kettenbrücke Mühllenstraße

- Plan einer Kayung an der Stelle der beseitigten Janßen'schen , Februar - April 1906

- Angebote von Baumaterial für die Kayung, April 1906

- Beteiligung der Anlieger an den Baukosten der Kayung, Dezember 1906 - April 1907

- Einsprüche von Anliegern gegen die Heranziehung zu den

Baukosten, Mai 1907

- Klage der Anlieger gegen die Stadt Emden beim Bezirksausschuss in Aurich auf Rücknahme der Heranziehung zu den Baukosten, Juni September 1907

- Beschwerde der Anlieger gegen die die Stadt Emden begünstigende Entscheidung des Bezirksausschusses beim Provinzialrat in Hannover, Dezember 1907 - April 1908

$1906-1908$

Klassifikation Teil B: 01009

Trägermaterial: Papier

Alte Reg.-Sig.: IV Jf 47

Bestell-Nr.: IV 01009

1012 Heranziehung der Anlieger zu den Kosten des Ausbaus der Westseite der Nordertorstr.

- Plan des Ausbaus der Westseite der Nordertorstr., Februar 1904 Januar 1907

- Einspruch des Telegraphendirektors W. Ficker, des Rentiers H.

Baumann und des Telegraphen-Sekretärs Johann Tiemann gegen die Heranziehung zu den Kosten des Ausbaus der Westseite der Nordertorstr. wegen ihrer dort gelegenen Grundstücke, März 1904 - Erteilung der Bauerlaubnis an den Telegraphendirektor W. Ficker für ein Wohngebäude an der Nordertorstraße, Januar 1907

- Heranziehung der Anlieger des westlichen Teil der Nordertorstraße zu den Straßenausbaukosten, Juni - Juli 1908

- Einspruch des Telegraphendirektors Ficker gegen die Heranziehung zu den Kosten des Straßenausbaus, August 1908

$1904-1908$

Klassifikation Teil B: 01010

Trägermaterial: Papier

Alte Reg.-Sig.: IV Jf 48

Bestell-Nr.: IV 01010 
1013 Antrag auf Genehmigung einer Privatstraße

- Antrag des Architekten G. Lüpnitz auf Erlaubnis zum Bau einer

Privatstraße zur Verbindung seiner Wohngebäude mit der Straße "Am

Sandpfad", Dezember 1908 - Juli 1909

- Plan und Zeichungen der Straße, 1908

$1908-1909$

Klassifikation Teil B: 01011

Trägermaterial: Papier

Alte Reg.-Sig.: IV Jf 49

Bestell-Nr.: IV 01011

1014 Sicherstellung der ortsstatuarischen Lasten

- Modus der Hinterlegung von Sicherheiten der anliegenden Hausbesitzer für entstehende Kosten der Kanalisierung und für den Straßenbau, Juli 1910 - Oktober 1911

$1910-1911$

Klassifikation Teil B: 01012

Trägermaterial: Papier

Alte Reg.-Sig.: IV Jf 50

Bestell-Nr.: IV 01012

1015 Petkumer Landstraße

- Vereinbarung zwischen der Stadt Emden und dem Eisenbahnfiskus über Abtretung bahnfiskalischer Bodenflächen zum Bau der Petkumer Landstraße, 1875

$1875-1879$

Klassifikation Teil B: 01112

Trägermaterial: Papier

Alte Reg.-Sig.: IV I

Bestell-Nr.: IV 01112 
05

\subsection{3}

05.03.06

05.03.06.05 05.03.06.05.01

\section{Stadtverwaltung}

Aufgabenbereiche der Stadtverwaltung

Öffentliche Anlagen, Straßenpolizei und Organisation der Ver- und Entsorgung

Versorgung der Stadt Emden mit Energie

Organisation der Straßenbeleuchtung

Lfd. Nr. Titel

Laufzeit

1876-1897

(1841-1865)

- Aufstellungen über Straßenlaternen in der Stadt Emden, 1845 - 1849

- Meldungen über nicht brennende Straßenlaternen, 1845 - 1850 /

1894

- Austausch und Erneuerung von Straßenlaternen, (1847 - 1848)

$1876-1896$

- Anzeigen über Beschädigung von Laternen, (1843 - 1861) 1877 -

1897

- Angebote von Laternen, 1894 - 1896

- Anschaffung von Laternen, 1891- 1897

(1841 - 1865) 1876 - 1897

Klassifikation Teil B: 01013

Band: 1

Trägermaterial: Papier

Alte Reg.-Sig.: IV Jg 03

Bestell-Nr.: IV 01013

1017 Stadtbeleuchtung, Bd. 2

- Anlage einer mit Gas betriebenen Straßenbeleuchtung in den geplanten Straßen der Stadterweiterung, April 1897

- Anzeigen über Beschädigung von Straßenlaternen, 1898 - 1905

- Anträge auf Aufstellung von Straßenlaternen, 1898 - 1907

- Ersetzung von Petroleumlaternen durch Gaslaternen, 1898

- Aufstellung über die ganze Nacht brennende Straßenlaternen, 1898 -

1907

- Festlegung der Ausgaben für die Straßenbeleuchtung, Oktober 1899

- Verhandlungen des Oberbürgermeisters Leo Fürbringer mit der WTAG über Verbesserung der Beleuchtung der Verbindung zwischen Stadt und Hafen im Bereich des Zungenkais, Oktober - November 1900

- Verbesserung der Beleuchtung des Stadtgartens, 1903

$1897-1907$

Klassifikation Teil B: 01014

Band: 2

Trägermaterial: Papier

Alte Reg.-Sig.: IV Jg 03

Bestell-Nr.: IV 01014 
05

05.03

05.03.06

05.03.06.05 05.03.06.05.01

\section{Stadtverwaltung}

Aufgabenbereiche der Stadtverwaltung

Öffentliche Anlagen, Straßenpolizei und Organisation der Ver- und Entsorgung

Versorgung der Stadt Emden mit Energie

Organisation der Straßenbeleuchtung

Lfd. Nr. Titel

Laufzeit

1018 Stadtbeleuchtung, Bd. 3

- Anzeigen über Beschädigung von Straßenlaternen, 1911

- Anträge auf Aufstellung von Straßenlaternen, 1908 - 1910

- Aufstellung von die ganze Nacht brennenden Straßenlaternen, 1908

- 1911

$1908-1911$

Klassifikation Teil B: 01015

Band: 3

Trägermaterial: Papier

Alte Reg.-Sig.: IV Jg 03

Bestell-Nr.: IV 01015

1019 Organisation der Stadtbeleuchtung und der Gasproduktion

- Brennkalender der Emder Straßenlaternen (Betriebszeiten,

Gasverbrauch), 1886 - 1892

- Verschiedene Angebote von Beleuchtungssystemen, 1887 - 1889

- Erlass des preußischen Ministers für Handel und Gewerbe über

Verbot der Wasser- und Halbwassergase (Gemisch aus $\mathrm{H}$ und $\mathrm{CO}$ ) wegen Giftigkeit, Mai 1889

- Austausch der Stadt Emden mit anderen Städten wegen Betriebs der Gaswerke, 1890 - 1904

- Angebot eines Kleinbahnsystems für das Gaswerk zum

Kohlentransport, Mai 1898

- Publikation zur Jahrestagung des Deutschen Vereins von Gas- und

Wasserfachmännern in Mainz über Gasversorgung in Mainz, Juni

1900

- Beschwerde der kgl. Eisenbahnbetriebs-Inspektion wegen schlechter

Leuchtqualität der Straßenlaternen am Güterbahnhof, Februar 1909

$1886-1909$

Klassifikation Teil B: 01016

Trägermaterial: Papier

Alte Reg.-Sig.: IV Jg 26

Bestell-Nr.: IV 01016 
05

05.03

05.03.06

05.03.06.05 05.03.06.05.01

\section{Stadtverwaltung}

Aufgabenbereiche der Stadtverwaltung

Öffentliche Anlagen, Straßenpolizei und Organisation der Ver- und Entsorgung

Versorgung der Stadt Emden mit Energie

Organisation der Straßenbeleuchtung

Lfd. Nr. Titel

Laufzeit

1020 Beleuchtung der Zugangswege zum Bahnhof

- Berichte des Polizeisergeanten Preuß über ungenügende Beleuchtung des Zugangsweges zum Bahnhof, Dezember 1881 Januar 1882

- Verhandlungen des Magistrats mit der kgl.

Eisenbahn-Bau-Inspektion über Verbesserung der Beleuchtung des

Zugangsweges zum Bahnhof, Januar 1882 - August 1891

- Eingabe der Kaufmännischen Deputation an die Stadt Emden über

Bitte um Aufhebung von Mängeln bei der Straßenbeleuchtung, Januar

- Februar 1882

- Schreiben des kgl. Eisenbahn-Betriebs-Amts Münster - Emden an die Stadt Emden über nicht vorliegende Verpflichtung der

Eisenbahnverwaltung zur Unterhaltung einer Straßenbeleuchtung auf dem Zufahrtsweg zur Bahnhaltestelle Larrelt, Oktober - November 1883

- Organisation der Unterhaltung der Beleuchtung des Weges zur Larrelter Haltestelle, Oktober - November 1883

- Gutachten des Syndicus Metger über Zuständigkeit der Bahnverwaltung für die Straßenbeleuchtung zwischen Bahnhof und Zollgebäude, Juli 1891

- Installation von Straßenlaternen am Zugangsweg zum Bahnhof durch die Stadt Emden, August 1891

- Rechnungen über Füllung und Betrieb der petroleumbetriebenen

Straßenlaternen am Bahnhof, 1891 - 1896

$1881-1897$

Klassifikation Teil B: 01021

Trägermaterial: Papier

Alte Reg.-Sig.: IV Jg 30

Bestell-Nr.: IV 01021 
05

05.03

05.03.06

05.03.06.05 05.03.06.05.01

\section{Stadtverwaltung}

Aufgabenbereiche der Stadtverwaltung

Öffentliche Anlagen, Straßenpolizei und Organisation der Ver- und Entsorgung

Versorgung der Stadt Emden mit Energie

Organisation der Straßenbeleuchtung

Laufzeit

1021 Umstellung der Straßenbeleuchtung auf Gaslicht

1895-1912

(1917)

- Angebote von automatischen Zündsystemen für Gaslaternen, 1898 1901

- Vergleich: Betriebssysteme verschiedener Gasanstalten, 1896

- Korrespondenz des Oberbürgermeisters Fürbringer mit der Firma

Gebrüder Körting wegen Bau eines elektrischen Kraftwerks, 1896 -

1902

- Verschiedene Presseartikel zu Gaswerken, elektrischen Kraftwerken und Gasbeleuchtung, 1896 - 1899

- Aufstellung über Straßenlaternen in Emden, 1897

- Angebote über Gasleitungsrohre, Gaskohle und Gaslaternen mit Zubehör, 1895 - 1899

- Austausch mit anderen Städten über Nutzen der Gasbeleuchtung, $1896-1898$

- Verhandlungen der Gaswerkskommission über Anschaffung von Gaslaternen mit Zubehör, 1898 - 1912

- Antrag des Nachtwachtmeisters Diepenbrock auf Vergütung der Erstellung eines Brennkalenders und die Kontrolle der Gaslaternen, August 1898

- Angebot der Deutschen Elektrizitätsgesellschaft über Bau eines elektrischen Kraftwerks, April 1899

- Plan der Aufstellung eines Kandelabers in der Neutorstraße, 1905

1895 - $1912(1917)$

Klassifikation Teil B: 01060

Trägermaterial: Papier

Alte Reg.-Sig.: IV Jg 56

Bestell-Nr.: IV 01060 
05

05.03

05.03.06

05.03.06.05

05.03.06.05.01
Stadtverwaltung

Aufgabenbereiche der Stadtverwaltung

Öffentliche Anlagen, Straßenpolizei und Organisation der

Ver- und Entsorgung

Versorgung der Stadt Emden mit Energie

Organisation der Straßenbeleuchtung

Lfd. Nr. Titel

Laufzeit

1022 Beschädigung von Gaslaternen

1900-1907

- Anzeige über Beschädigung einer Gaslaterne an der Auricher Straße durch ein Strohfuhrwerk, März 1900

- Anzeige über Beschädigung einer Gaslaterne an der

Boltentorstraße, April 1900

- Anzeige über Beschädigung einer Gaslaterne an der

Wilhelmsstraße, Mai 1900

- Anzeige über Beschädigung einer Gaslaterne an der Wolthuser

Straße, September 1900

- Weigerung des Fuhrunternehmers H. Ubbens zur Regulierung des

von seinen Fuhrknechten angerichteten Schadens an einer Laterne,

Oktober 1900

- Anzeige über Beschädigung einer Gaslaterne an der Wilhelmsstraße durch ein Fuhrwerk, September 1901

- Klage der Stadt Emden gegen den Fuhrunternehmer H. Ubbens beim Amtsgericht auf Schadensersatz wegen einer von den Ubbens'schen Fuhrknechten beschädigten Gaslaterne, November 1901 - Januar 1902

- Revisionsverhandlung beim Landgericht Aurich wegen der Berufungsklage des $\mathrm{H}$. Ubbens gegen das Urteil des Amtsgerichts

Emden, April - November 1902

- Beschädigung einer Gaslaterne durch ein Fuhrwerk des B.

Schoneboom, Juli 1906

- Klage der Stadt Emden gegen den Fuhrunternehmer B.

Schoneboom beim Amtsgericht auf Schadensersatz wegen einer von seinem Fuhrwerk beschädigten Gaslaterne, August 1907

Klassifikation Teil B: 01064

Trägermaterial: Papier

Alte Reg.-Sig.: IV Jg 61

Bestell-Nr.: IV 01064

1023 Beleuchtung der Borssumer Landstraße

- Kalkulation der Anlage einer Straßenbeleuchtung im

Kaiser-Wilhelms- und Königspolder, Oktober 1900 - Oktober 1907

- Verhandlungen der Gaswerkskommission über Straßenbeleuchtung der Borssumer Landstraße, November 1900

- Bereitstellung von Etatmittel für die Straßenbeleuchtung an der Borssumer Landstraße von der Prallelstraße bis zum Manntz'schen Haus, November 1900

- Lageplan: Anlage der straßenbeleuchtung, 1900

- Antrag der Hohenzollernhütte auf Anlage der Straßenbeleuchtung an der Borssumer Landstraße zum Schutz ihrer Arbeiter auf dem Arbeitsweg, Oktober - November 1907

- Kostenvoranschlag der Hanseatischen Siemens Schuckert Werke über Straßenbeleuchtung an der Borssumer Landstraße, November 1907

$1900-1907$

Klassifikation Teil B: 01085

Trägermaterial: Papier

Alte Reg.-Sig.: IV Jg 69

Bestell-Nr.: IV 01085 
05

05.03

05.03.06

05.03.06.05 05.03.06.05.01

\section{Stadtverwaltung}

Aufgabenbereiche der Stadtverwaltung

Öffentliche Anlagen, Straßenpolizei und Organisation der Ver- und Entsorgung

Versorgung der Stadt Emden mit Energie

Organisation der Straßenbeleuchtung

Lfd. Nr. Titel

Laufzeit

1024 Beleuchtung von Brücken über öffentliche Gewässer

- Erlass des Ministers der öffentlichen Arbeiten über Richtlinien für die Beleuchtung von Brücken über öffentliche Gewässer, November 1909 - Antrag der Witwe Franssen auf Installation einer Beleuchtung auf der Brücke "am Eiland", Oktober 1913

$1909-1913$

Klassifikation Teil B: 01087

Trägermaterial: Papier

Alte Reg.-Sig.: IV Jg 71

Bestell-Nr.: IV 01087

1025 Übernahme städtischer Laternen durch das Gaswerk

- Aufnahme einer Anleihe durch das Gaswerk zum Erwerb der städtischen Straßenlaternen, April 1914

1914 (1918)

Klassifikation Teil B: 01130

Trägermaterial: Papier

Alte Reg.-Sig.: IV Jg 76

Bestell-Nr.: IV 01130 
05

\subsection{3}

05.03.06

05.03.06.05 05.03.06.05.02

\section{Stadtverwaltung}

Aufgabenbereiche der Stadtverwaltung

Öffentliche Anlagen, Straßenpolizei und Organisation der Ver- und Entsorgung

Versorgung der Stadt Emden mit Energie

Emder Gaswerk

Lfd. Nr. Titel

Laufzeit

1026 Gutachten des Ingenieurs Schaar über das Emder Gaswerk

1896

(1897-1898)

- Empfehlungsschreiben verschiedener Stadtverwaltungen zur gutachterlichen Tätigkeit des Civil-Ingenieurs Georg F. Schaar im Gaswerkbereich, 1896

- Gutachten des Civilingenieurs Georg F. Schaar aus Altona über Verbesserungsmöglichkeiten der Organisation und der technischen Ausstattung des Emder Gaswerks, 1896

$1896(1897-1898)$

Klassifikation Teil B: 01017

Trägermaterial: Papier

Alte Reg.-Sig.: IV Jg 31

Bestell-Nr.: IV 01017

1027 Übernahme des Gaswerks durch die Stadt Emden

$1880-1881$

- Verhandlungen der Stadt Emden mit der Pächterin des Gaswerks, Witwe Louise Spreng und ihren Rechtsvertretern über die Beendigung des Pachtverhältnisses, 1880 - 1881

- Prospekt der Fa. August Klönne, Dortmund, über Gaswerksanlagen, 1880

- Bewerbung des Ingenieurs Carl Müller aus Karlsruhe um die Stelle des Gaswerksdirektors in Emden, Februar 1881

$1880-1881$

Klassifikation Teil B: 01018

Trägermaterial: Papier

Alte Reg.-Sig.: IV Jg 27

Bestell-Nr.: IV 01018

1028 Verlegung der Gasrohre wegen Umwandlung der Brücke über das Rote Siel in eine Drehbrücke

- Übermittlung von Daten zum Brückenumbau durch die Ems-Jade-Canalbau, Emden an den Gaswerksdirektor Carl Müller, Januar - März 1881

- Plan zur Verlegung der Gasrohre im Bereich der Rote-Siel-Brücke, Januar - Februar 1881

- Bericht des Gaswerksdirektors Müller über Voraussetzungen für schnelle Leitungsverlegung und Bereitschaft zur eigenverantwortlichen Übernahme der Arbeit, April 1882

$1881-1883$

Klassifikation Teil B: 01019

Trägermaterial: Papier

Alte Reg.-Sig.: IV Jg 28

Bestell-Nr.: IV 01019 
IV

05

05.03

05.03.06

05.03.06.05

05.03.06.05.02

\section{Stadtverwaltung}

Aufgabenbereiche der Stadtverwaltung

Öffentliche Anlagen, Straßenpolizei und Organisation der

Ver- und Entsorgung

Versorgung der Stadt Emden mit Energie

Emder Gaswerk

Lfd. Nr. Titel

Laufzeit

1029 Verhandlungen wegen Verpachtung des Gaswerks

- Verhandlungen der Stadt Emden mit verschiedenen Interessenten wegen Verpachtung des Gaswerks, August 1896 - April 1897

- Entwurf eines Pachtvertrages zwischen der Stadt Emden und dem

Gas-Ingenieur Carl Francke aus Bremen, November 1896

- Erkundigungen der Stadt Emden über die Tätigkeit und den

Leumund des Gas-Ingenieurs Carl Francke, November 1896

- Entwurf eines Pachtvertrages zwischen der Stadt Emden und dem

Gasdirektor Emil Neiß aus Schaffhausen, Januar 1897

$1896-1897$

Klassifikation Teil B: 01022

Trägermaterial: Papier

Alte Reg.-Sig.: IV Jg 32

Bestell-Nr.: IV 01022

1030 Beendigung des Verpachtungsverhältnisses über das Gaswerk mit der Familie Spreng

- Verzeichnis der als Kaution hinterlegten Anleihen des

Gaswerkspächters Emil Spreng, 1896

- Verhandlungen der Stadt Emden mit der Gaswerkspächterin Louise Spreng und ihren Rechtsvertretern wegen Behebung bestehender Mängel in der Geschäftsführung und der technischen Ausstattung des Gaswerks, Dezember 1896 - Februar 1897

- Verhandlungen zur Erzielung einers Vergleichs mit der Gaswerkspächterin Louise Spreng über Beendigung des

Pachtverhältnisses, Entschädigung für am Gaswerk vorgenommene Investitionen sowie Rückerstattung der Kaution, April - August 1897

$1896-1897$

Klassifikation Teil B: 01023

Trägermaterial: Papier

Alte Reg.-Sig.: IV Jg 33

Bestell-Nr.: IV 01023 
05

05.03

05.03.06

05.03.06.05

05.03.06.05.02

\section{Stadtverwaltung}

Aufgabenbereiche der Stadtverwaltung

Öffentliche Anlagen, Straßenpolizei und Organisation der

Ver- und Entsorgung

Versorgung der Stadt Emden mit Energie

Emder Gaswerk

Lfd. Nr. Titel

Laufzeit

1031 Aus- und Umbau des Gaswerkes

1895-1898

(1904)

- Plan: Neue Kohleschuppen für das Gaswerk in Emden, 1895

- Kosten der geplanten Erweiterung des Emder Gaswerks, 1896

- Verhandlungen der Stadt Emden mit der Gaswerksbaufirma August

Klönne, Dortmund, über notwendige bauliche und technische

Maßnahmen bei Erweiterung des Emder Gaswerks, Oktober 1897

- Erwerb von Grundstücken zur Erweiterung des Emder Gaswerks,

Oktober 1897

- Verhandlungen der Gaswerkskommission wegen Anschaffung technischer Anlagen und Geräte für das Gaswerk und bauliche

Maßnahmen, November 1897 - August 1898

- Erkundigungen über das Geschäftsgebaren und den Leumund der

Fa. August Klönne, Dortmund, Januar 1898

- Korrespndenz zwischen dem Oberbürgermeister Leo Fürbringer und dem Direktor des Hannoverschen Gaswerks, Korting, über

Organisation und technische Ausstattung des Emder Gaswerks, März

- Mai 1898

- Gutachten des Gaswerksdirektors Korting zur Erweiteruing des

Emder Gaswerks, März 1898

- Vertrag zwischen der Stadt Emden und der Fa. August Klönne, Dortmund, über Ausführung der Arbeiten zur Erweiterung und dem Umbau des Emder Gaswerks, März 1898 / Januar 1899

$1895-1899(1904)$

Klassifikation Teil B: 01024

Trägermaterial: Papier

Alte Reg.-Sig.: IV Jg 34

Bestell-Nr.: IV 01024 
05

05.03

05.03.06

05.03.06.05

05.03.06.05.02

\section{Stadtverwaltung}

Aufgabenbereiche der Stadtverwaltung

Öffentliche Anlagen, Straßenpolizei und Organisation der

Ver- und Entsorgung

Versorgung der Stadt Emden mit Energie

Emder Gaswerk

Lfd. Nr. Titel

Laufzeit

1032 Umbau der Emder Gasanstalt

- Kostenvoranschlag des Ingenieurs Carl Francke zum

Gaswerksumbau, April / Dezember 1897

- Beschreibungen und Planzeichnungen von technischen Anlagen zur

Gasgewinnung aus Kohle, 1897 - 1898

- Verhandlungen der Gaswerkskommission über Umbau des

Gaswerks zur Erzielung eines besseren Betriebsergebnisses,

Dezember 1896 - Mai 1897

- Gutachten des Leeraner Stadtbaumeisters Jipp zum Projekt des

Umbaus des Emder Gaswerks des Ingenieurs Carl Francke aus

Bremen, 1897

- Angebote über Bauleistungen und technische Anlagen, 1897 - 1898

- Bedingungen für die Auftragsvergabe des Gaswerksumbaus, Mai

1897

- Verhandlungen des Oberbürgermeisters L. Fürbringer mit dem Ingenieur Carl Francke aus Bremen wegen Abschluss eines Vertrages zum Umbau des Emder Gaswerks, Mai - Juni 1897

- Lieferung und Einbau der Ofenanlage für das Gaswerk durch die Fa.

Gustav Horn in Braunschweig, Juni 1897 - November 1898

- Beschwerde Johannes Mustert und Ysaac Brons über schlechte

Qualität des vom Gaswerk produzierten Leuchtgases, Dezember 1897

- Rechnungen des Ingenieurs Carl Francke, Dezember 1897

- Verteidigung des Carl Francke gegen Kritik der von ihm beschafften

Öfen für das Emder Gaswerk, Januar 1898

- Verhandlungen des Oberbürgermeisters Leo Fürbringer mit dem Ingenieur Carl Francke wegen Rechnungsabwicklung und erforderlicher Mehrarbeiten, Februar 1898 - Januar 1899

$1897-1899$

Klassifikation Teil B: 01025

Trägermaterial: Papier

Alte Reg.-Sig.: IV Fg 35

Bestell-Nr.: IV 01025

1033 Anschaffung einer Kohlenbrechmaschine für das Gaswerk

$1898-1902$

- Angebote über Kohlenbrechmaschinen, 1898

- Verhandlungen der Gaswerkskommission über Anschaffung einer

Kohlenbrechmaschine für das Gaswerk, Juni 1898 - Juli 1899

- Genehmigung der Anschaffung durch den Magistrat, Juli 1899

- Anschaffung einer handbetriebenen Kohlenbrechmaschine, 1902

1898

Klassifikation Teil B: 01026

Trägermaterial: Papier

Alte Reg.-Sig.: IV Jg 37

Bestell-Nr.: IV 01026 
05

05.03

05.03.06

05.03.06.05

05.03.06.05.02

\section{Stadtverwaltung}

Aufgabenbereiche der Stadtverwaltung

Öffentliche Anlagen, Straßenpolizei und Organisation der

Ver- und Entsorgung

Versorgung der Stadt Emden mit Energie

Emder Gaswerk

Lfd. Nr. Titel

Laufzeit

1034 Bauten auf dem Gaswerksgelände

1900-1909

- Verhandlungen der Gaswerkskommission über Bau eines

Schutzdaches für gelagerte Kohle, Januar 1900

- Antrag des Gasmeisters August Wolff auf Installation eines

Gasherdes in seiner Werkswohnung, März - April 1900

- Antrag des Gasmeisters August Wolff auf Installation eines

Windfanges vor dem Eingang seiner Werkswohnung, Januar - März

1901

- Verhandlungen der Gaswerkskommission über Bau eines weiteren

Kohleschuppens, August - September 1902

- Vergrößerung des Arbeiteraufenthaltsraums auf dem Gaswerk, 1906

- Erweiterung des Kohlenlagerplatzes auf dem Gaswerk, 1909

$1900-1909$

Klassifikation Teil B: 01027

Trägermaterial: Papier

Alte Reg.-Sig.: IV Jg 38

Bestell-Nr.: IV 01027

1035 Erbauung weiterer Öfen im Gaswerk

1898-1903

(1917)

- Angebot der Fa. G. Horn, Braunschweig, über Erweiterung der Ofenanlage im Emder Gaswerk, September 1898 - Januar 1899 - Angebot der Fa. August Klönne, Dortmund, über Erweiterung der Ofenanlage im Emder Gaswerk, Oktober - November 1898

- Korrespondenz des Oberbürgermeisters L. Fürbringer mit dem Direktor des Hannoverschen Gaswerks, Korting, über

Ofenausstattung des Emder Gaswerks, November 1898 - Januar

1899

- Einbau der Ofenanlage der Firma G. Horn, Braunschweig, März -

April 1899

- Streit um Gewährleistung wegen Schaden an der von der Fa. G.

Horn gelieferten Ofenanlage, Juli - August 1900

- Verhandlungen der Gaswerkskommission über Ofenausstattung des

Gaswerks, Juni 1901 - Mai 1902

- Darlehen der Stadtkasse an das Gaswerk zur Reparatur von Öfen,

April - Mai 1903

- Gutachten des J Heinderks über Verbesserung der Ofenanlagen und

Rationalisierungsmöglichkeiten auf dem Gaswerk, 1917

1898 - 1903 (1917)

Klassifikation Teil B: 01028

Trägermaterial: Papier

Alte Reg.-Sig.: IV Jg 39

Bestell-Nr.: IV 01028 
05

05.03

05.03.06

05.03.06.05

05.03.06.05.02
Stadtverwaltung

Aufgabenbereiche der Stadtverwaltung

Öffentliche Anlagen, Straßenpolizei und Organisation der

Ver- und Entsorgung

Versorgung der Stadt Emden mit Energie

Emder Gaswerk

Lfd. Nr. Titel

Laufzeit

1036 Einstellung von Personal für das Gaswerk

1897-1912

(1915-1918)

- Verhandlungen der Gaswerkskommission über Einstellung technischer Angestellte für das Gaswerk und Festlegung der Gehälter, Oktober 1897 - Dezember 1898

- Bewerbungen um die Stelle eines Gasmeisters im Emder Gaswerk, Dezember 1898

- Überlassung des technischen Angestellten des Hannoverschen

Gaswerk, August Wolff, an das Emder Gaswerk, Dezember 1898

- Dienstanweisung für den Gasmeister August Wolff, 1898

- Bewerbungen um die Stelle des Technikers im Emder Gaswerk, April 1904

- Instruktion für Laternenanzünder, 1899

- Gewährung des Gemeindebeamtenstatus an den Gasmeister

August Wolff, Juni 1903

- Bewerbungen um die Stelle des Röhrenmeisters beim Gaswerk,

September 1902

- Einstellung eines Röhrenmeisters, 1909 - 1911

- Gasmeister Friedrich Strohbach, 1907 - 1910

- Gasmeister Paul Steinbach, 1910 - 1915

Antrag des Gaswerksbuchhalters L. H. Lindemann auf Gewährung des Beamtenstatus, November 1917

1890 - 1912 (1915 - 1918)

Klassifikation Teil B: 01029

Trägermaterial: Papier

Alte Reg.-Sig.: IV Jg 40

Bestell-Nr.: IV 01029

1037 Bevollmächtigter des Gaswerkspächters Emil Spreng

1866-1873

(1861-1865)

- Bestimmung des Ingenieurs Conrad Lang zum Bevollmächtigten des Gaswerkspächters Emil Spreng aus Nürnberg, Mai 1861 - November 1863

- Bestimmung des Ingenieurs Adolph Morstädt zum Bevollmächtigten des Gaswerkspächters Emil Spreng aus Nürnberg, November 1863 Juli 1864

- Bestimmung des Ingenieurs Wilhelm Hartmann zum

Bevollmächtigten der Gaswerkspächterin Louise Spreng als

Nachfolgerin ihres verstorbenen Mannes, Juli 1864 - Januar 1873

- Bestimmung des Ingenieurs H. Ebert zum Bevollmächtigten der

Gaswerkspächterin Louise Spreng als Nachfolgerin ihres

verstorbenen Mannes, Mai 1866

- Bestimmung des Ingenieurs P. Brochier zum Bevollmächtigten der

Gaswerkspächterin Louise Spreng als Nachfolgerin ihres

verstorbenen Mannes, Januar 1873

(1861 - 1865) 1866 - 1873

Klassifikation Teil B: 01030

Trägermaterial: Papier

Alte Reg.-Sig.: IV Jg 24

Bestell-Nr.: IV 01030 
05

05.03

05.03.06

05.03.06.05

05.03.06.05.02

\section{Stadtverwaltung}

Aufgabenbereiche der Stadtverwaltung

Öffentliche Anlagen, Straßenpolizei und Organisation der

Ver- und Entsorgung

Versorgung der Stadt Emden mit Energie

Emder Gaswerk

Lfd. Nr. Titel

Laufzeit

1038 Entlohnung der durch den Gaswerkspächter Spreng angestellten Arbeiter

- Vergütung der durch Arbeiter des Gaswerkspächter durchgeführten Arbeiten am Kanalnetz der Stadt Emden, Januar - Oktober 1863 / Januar 1891

- Vergütung der Reparaturen der Straßenlaternen durch Arbeiter des Gaswerkspächters, September - Dezember 1879

- Haftung der Täter für Beschädigung der Straßenlaternen, Juni 1880 September 1896

(1863) 1879 - 1880

Klassifikation Teil B: 01031

Trägermaterial: Papier

Alte Reg.-Sig.: IV Jg 22

Bestell-Nr.: IV 01031

1039 Beitreibung offener Gasrechnungen

- Beitreibung offener Gasrechnungen des Kaufmanns J. A. Huisman,

- Beschwerde des Kaufmanns J. A. Huismann beim Hannoverschen Landdrosten in Aurich gegen die von der Stadt Emden verfügte Exerkution zur Beitreibung der offenen Gasrechnung wegen privatrechtliche Natur des Streits, Juni - August 1862

- Schiedsgerichtsverfahren in der Streitsache des J. A. Huismann gegen den Gaswerkspächter, August 1862 - Januar 1863

- Beitreibung offener Gasrechnungen beim Gastwirt H. G. Thiele, Gaststätte "Zur Hoffnung", Juni 1864 - April 1866 / April 1867

- Beitreibung offener Gasrechnungen beim Bäckermeister Thein, November 1866

- Beitreibung offener Gasrechnungen beim Schmiedemeister Nolting, September 1867

$(1862-1866) 1866-1874$

Klassifikation Teil B: 01032

Trägermaterial: Papier

Alte Reg.-Sig.: IV Jg 21

Bestell-Nr.: IV 01032 
IV

05

\subsection{3}

05.03.06

05.03.06.05 05.03.06.05.02

\section{Stadtverwaltung}

Aufgabenbereiche der Stadtverwaltung

Öffentliche Anlagen, Straßenpolizei und Organisation der Ver- und Entsorgung

Versorgung der Stadt Emden mit Energie

Emder Gaswerk

Lfd. Nr. Titel

Laufzeit

1881-1897

(1861-1864)

- Bestimmungen wegen Installation und Betrieb von Gasbeleuchtung in Privathäusern, März 1861 - November 1864

- Streit zwischen dem Wirt L. de Ruyter und dem Emder

Gaswerkspächter E. Spreng wegen der Installation von Gasuhren, Februar - März 1862

- Antrag des Installateurs J. Baumgarten auf Anerkennung als Installateur für Gasleitungen und - Anschlüsse, April - Mai 1876

- Zulassung und Abnahme von durch Private erstellte Gasleitungen und - Anschlüsse, 1881 - 1884 / 1881 - 1897

- Antrag des Gaswerksdirektors Carl Müller an die

Gaswerkskommission auf Festsetzung einer Gebühr für die Abnahme und Inspektion privater Gasanschlüsse- und Leitungen, Januar 1895

(1861 - 1864) $1876-1897$

Klassifikation Teil B: 01033

Trägermaterial: Papier

Alte Reg.-Sig.: IV Jg 18

Bestell-Nr.: IV 01033

- Beschädigungen von gasbetriebenen Straßenlaternen durch

Fuhrwerke, September 1861 - Dezember 1871

- Kontrolle der Tätigkeit der Laternenanzünder, Oktober 1861

- Antrag des Gaswerkpächters Emil Spreng auf Genehmigung einer Rohrleitung zur Entsorgung der bei der Kohlenvergasung entstehenden Ammoniaklösung in die Ems, Dezember 1861

- Bildung eines Schiedsgerichtes zur Schlichtung von Streitigkeiten zwischen Gaswerpächter und Gaskunden, Juli 1862

- Beschwerden gegen die Ableitung von bei der Kohlevergasung entstehender Ammoniaklösung in das Rosentief durch das Gaswerk wegen Geruchsbelästigung, Januar 1864

- Regelung der Bestrafung bei eigenmächtiger und unautorisierter Veränderung der Gasuhr durch Kunden, Dezember 1868

- Kampagne gegen geplante Leuchtgassteuer, Mai - Juni 1869

- Beschädigung der Gasleitung während Reparaturarbeiten an einer Kayung, Februar 1870

- Verwaltung der Kaution des Gaswerkspächters, September 1884 -

August 1888

- Brand auf dem Gelände des Gaswerks, August 1893

$(1861-1865) 1866-1893$

Klassifikation Teil B: 01034

Trägermaterial: Papier

Alte Reg.-Sig.: IV Jg 20

Bestell-Nr.: IV 01034 
05

05.03

05.03.06

05.03.06.05

05.03.06.05.02

\section{Stadtverwaltung}

Aufgabenbereiche der Stadtverwaltung

Öffentliche Anlagen, Straßenpolizei und Organisation der

Ver- und Entsorgung

Versorgung der Stadt Emden mit Energie

Emder Gaswerk

Lfd. Nr. Titel

Laufzeit

1042 Gaswerk: Anschlüsse und Gasabsatz

1897-1914

(1915-1917)

- Verkauf des bei der Kohlevergasung anfallenden Teers und Asche, Mai - Dezember 1898 / Juni 1900

- Verhandlungen der Gaswerkskommission über Anregung zur Anlegung einer Gasleitung zur kgl. Wasserbau-Verwaltung zum Betrieb eines Dynamos für die Hafenbeleuchtung, August 1898 - Anträge von Hausbesitzern auf Herstellung enes Gasanschlusses zur Hausbeleuchtung und zum Kochgasbezug, 1897 - 1915 - Bekanntmachung des Gaswerksdirektors Müller über Verbot der unsachgemäßen Veränderung von Gasuhren, Oktober 1897 - Polizeiverordnung der Stadt Emden über Prüfung der Anlage und des Betriebs von Gasanlagen, März 1898 - Dezember 1899 - Druckschrift: Bedingungen für die Ausführung von Gasleitungen, die Abgabe von Leuchtgas, Koch,- Heiz- und Motorengas vom städtischen Gaswerk, August 1897 / August 1899 / Dezember 1899

- Bekanntmachung über Gaspreise, August 1897 - Juni 1901

- Aufstellung über Gasanschluss beantragende Haushalte, 1896

- Anträge auf Gaspreisermäßigung, 1898 - 1906

- Anzeigen von unautorisierter Vornahme von Veränderungen an Gasleitungen durch Hausbesitzer, 1899

- Aufstellung über Besitzer von gasbetriebenen Motoren, November 1899

- Rückständige Gasrechnungen der Nordseewerke, Juli 1907

- Protest der Metallarbeiter-Zwangsinnung Emden bei der Handwerkskammer Osnabrück gegen die Ausführung von Installationsarbeiten an Gasleitungen ausschließlich durch Angestellte des Gaswerks, Juni 1907

- Beitreibung offener Gasrechnungen, 1913

- Streit zwischen dem Mietshausbesitzer Helmer von Baden Foget und dem Gaswerk wegen der Regelung der Belieferung seiner Mieter mit "Münzgas" (Gasuhr mit Münzeinwurf), August - Dezember 1915

1897 - 1915 (1915 - 1917)

Klassifikation Teil B: 01035

Trägermaterial: Papier

Alte Reg.-Sig.: IV Jg 41

Bestell-Nr.: IV 01035

1043 Genehmigung der Gaswerkserweiterung

1898-1899

(1902)

- Genehmigungsverfahren zur Aufstellung eines Gaskessels auf dem Gaswerksgelände, September - Dezember 1898

- Bescheid des Gewerbeinspektors Dr. Jungck über erforderliche aber unterbliebene Genehmigung der Um- und Neubauten von Anlagen des Emder Gaswerks, Dezember 1898

- Verfahren zur nachträglichen Genehmigung der Erweiterung des

Emder Gaswerks, Dezember 1898 - April 1899

$1898-1899$

Klassifikation Teil B: 01036

Trägermaterial: Papier

Alte Reg.-Sig.: IV Jg 42

Bestell-Nr.: IV 01036 
05

\subsection{3}

05.03.06

05.03.06.05

05.03.06.05.02
Stadtverwaltung

Aufgabenbereiche der Stadtverwaltung

Öffentliche Anlagen, Straßenpolizei und Organisation der

Ver- und Entsorgung

Versorgung der Stadt Emden mit Energie

Emder Gaswerk

Lfd. Nr. Titel

Laufzeit

1044 Anschaffung eines Teerkochbehälters

- Angebot eines Teerkochbehälters von der Firma August Klönne, Dortmund, September 1898

- Ansichtsplan und Kostenrechnung, Oktober 1898

- Auftragsvergabe an die Fa. August Klönne, November 1898

- Erstellung des Fundaments des Teerkochbehälters, Dezember 1898

- Januar 1899

$1898-1899$

Klassifikation Teil B: 01037

Trägermaterial: Papier

Alte Reg.-Sig.: IV Jg 43

Bestell-Nr.: IV 01037

1045 Ankauf von Kohle für das Gaswerk

- Bericht des Gaswerksdirektors Carl Müller an Oberbürgermeister

Fürbringer über Verhandlungen zum Kohlenkauf und Analyse

verschiedener Kohlensorten auf ihre Eignung als Gaskohle, März

1897

- Angebot der Deutschen Kohlenhandelsgesellschaft über Gaskohle,

Juni 1897 - März 1904

- Verhandlungen des Oberbürgermeisters Fürbringer mit der Deutschen Kohlenhandelsgesellschaft über Bezug der vom Gaswerk benötigten Kohle über den Dortmund-Ems-Kanal, Januar 1899

- Angebote über Transportraten für Kohle, Februar - Oktober 1899

- Angebot englischer Gaskohle der Fa. Bessler, Waechter \& Co,

Newcastle, Oktober - November 1899

- Vermerk über Verzögerung weiterer Kohlenkäufe wegen hoher

Kohlenpreise, Februar 1912

$1897-1912$

Klassifikation Teil B: 01038

Trägermaterial: Papier

Alte Reg.-Sig.: IV Jg 44

Bestell-Nr.: IV 01038 
05

05.03

05.03.06

05.03.06.05

05.03.06.05.02
Stadtverwaltung

Aufgabenbereiche der Stadtverwaltung

Öffentliche Anlagen, Straßenpolizei und Organisation der

Ver- und Entsorgung

Versorgung der Stadt Emden mit Energie

Emder Gaswerk

Lfd. Nr. Titel

Laufzeit

1046 Personal des Gaswerks

1897-1911

(1917)

- Abschrift: Instruktion für die Laternenanzünder von 1861 und 1881, 1897

- Antrag des Werkmeisters des Gaswerks, Okke Post, auf

Übernahme im städtischen Dienst, November 1897

- Antrag der Stadt Emden an das Hauptmeldeamt in Aurich auf

Rückstellung des Heizers van Hollen von einer Militärübung wegen

Unabkömmlichkeit vom Gaswerk, August 1898

- Anhebung der Löhne der Gaslaternenanzünder, Oktober 1898

- Novellierung der Arbeitsordnung des Gaswerks, Februar - April 1899

- Kaution des Gaskassierers J. C. Waalkes, Dezember 1901

- Erhöhung des Gehaltes des Gaswerksbuchhalters Rusch wegen

Vermehrung der Aufgaben, März 1902

- Neubesetzung der Buchhakterstelle im Gaswerk, 1905

- Antrag des Gaskassierers Waalkes auf Gehaltserhöhung, Mai -

August 1905

- Anzeige des Polizeisergeanten Buscher über verspätetes Anzünden der Laternen in der 6. Wyck, Oktober 1900

- Geldgeschenk und Diplom zum 50 jährigen Dienstjubiläum des

Gaswerksarbeiters Okke Post, April - Mai 1911

- Wahl des Arbeiterausschusses im Gas- und Elektrizitätswerk, Juni Juli 1917

1897 - 1911 (1917)

Klassifikation Teil B: 01039

Trägermaterial: Papier

Alte Reg.-Sig.: IV Jg 45

Bestell-Nr.: IV 01039

1047 Etat des Gaswerks, Bd, 1

1897-1905

- Druckschrift: Etat des Gaswerks, 1897 / 1898

- Spezialetat der städtischen Kämmerei zum Umbau und zur

Erweiterung des Gaswerks, Februar 1899

- Denkschrift über Betriebsergebnisse des Gaswerks und Vorschläge

von Maßnahmen zur Verbesserung der Betriebsorganisation, 1898

- Berichte des Gaswerksdirektors Carl Müller zum Betriebsergebnis des Gaswerks, September 1898

- Etats des Gaswerks, 1898 - 1907

- Verhandlungen des Bürgervorsteherkollegiums über den Etat des

Gaswerkes, 1902 - 1903

- Anleihe der Stadt Emden für das Gaswerk zum Bau einer Anlage zur Gewinnung von Ammoniumsulfat, 1905

$1897-1905$

Klassifikation Teil B: 01040

Band: 1

Trägermaterial: Papier

Alte Reg.-Sig.: IV Jg 46

Bestell-Nr.: IV 01040 
05

\subsection{3}

05.03.06

05.03.06.05 05.03.06.05.02
Stadtverwaltung

Aufgabenbereiche der Stadtverwaltung

Öffentliche Anlagen, Straßenpolizei und Organisation der Ver- und Entsorgung

Versorgung der Stadt Emden mit Energie

Emder Gaswerk

Lfd. Nr. Titel

Laufzeit

1048 Etat des Gaswerks, Bd, 2

1904-1914

- Etats des Gaswerks, 1904 - 1914

$1904-1914$

Klassifikation Teil B: 01041

Band: 2

Trägermaterial: Papier

Alte Reg.-Sig.: IV Jg 46

Bestell-Nr.: IV 01041

1049 Betrieb des Gaswerks

$1898-1900$

- Statistische Monatsberichte über Produkte, Lagerbestand,

Materialverbrauch und Rohstoffumsatz, Juli 1897 - Dezember 1900

$1897-1900$

Klassifikation Teil B: 01042

Trägermaterial: Papier

Alte Reg.-Sig.: IV Jg 47

Bestell-Nr.: IV 01042

1050 Verwaltungsordnung für das Gaswerk

$1897-1912$

- Konzeption einer Verwaltungsordnung für das Gaswerk, Juli -

September 1897

- Denkschrift: Verwaltungsordnung, Tarife und Bedingungen für die

Herstellung von Gasanschlüssen, 1897

- Diskussion einer Eintragung des Gaswerks in das Handelsregister,

März - Oktober 1901

- Verbot der unautorisierten Vornahme von Änderungen an den

Gasleitungen durch Kunden, Februar 1904

- Verwaltungsordnung des Gaswerks, Januar 1905 / Februar 1906

- Aufnahme der Position eines Rohrmeisters in die

Verwaltungsordnung, April - Mai 1911

- Gedruckte Sammlung aller Verordnungen zum Betrieb des

Gaswerks, 1911

- Verhandlungen der Gaswerkskommission über die Bilanz des

Gaswerks, 1912

$1897-1912$

Klassifikation Teil B: 01043

Trägermaterial: Papier

Alte Reg.-Sig.: IV Jg 48

Bestell-Nr.: IV 01043 
IV

05

Stadtverwaltung

05.03

Aufgabenbereiche der Stadtverwaltung

05.03.06

Öffentliche Anlagen, Straßenpolizei und Organisation der

Ver- und Entsorgung

05.03.06.05

05.03.06.05.02

Versorgung der Stadt Emden mit Energie

Emder Gaswerk

Lfd. Nr. Titel

Laufzeit

1051 Gaswerksdirektor, Bd. 1

1896-1908

- Verhandlungen der Gaswerkskommission über Übernahme des Gaswerksdirektors Carl Müller in den Dienst der Stadt Emden nach Übernahme des Gaswerks durch die Stadt, Dezember 1896 - April 1897

- Dienstanweisung für den Gaswerksdirektor, Juli 1897

- Vereidigung des Gaswerksdirektors Carl Müller, Oktober 1897

- Verwaltung der als Kaution hinterlegten Anleihepapiere des

Gaswerksdirektors Müller, 1891 - 1902

- Verbeamtung des Gaswerksdirektors Müller, August 1903

- Antrag des Gaswerkdirektors Müller auf Pensionierung, Oktober

1904 - Januar 1905

- Todesanzeige: Gaswerksdirektor a.D. Carl Müller, Mai 1908

$1896-1908$

Klassifikation Teil B: 01044

Band: 1

Trägermaterial: Papier

Alte Reg.-Sig.: IV Fg 49

Bestell-Nr.: IV 01044

1052 Gaswerksdirektor, Bd. 2

- Empfehlung des Direktors des Hannoverschen Gaswerks Korting zugunsten des Ingenieurs August Wolff als Gaswerksdirektor,

November 1904

- Bewerbungen um das Amt des Gaswerksdirektors in Emden,

Dezember 1904 - Januar 1905

- Genehmigung des Urlaubsgesuches des Gaswerksdirektors

Kleindieck, September 1911

$1904-1911$

Klassifikation Teil B: 01045

Band: 2

Trägermaterial: Papier

Alte Reg.-Sig.: IV Fg 49

Bestell-Nr.: IV 01045 
05

\subsection{3}

05.03.06

05.03.06.05 05.03.06.05.02
Stadtverwaltung

Aufgabenbereiche der Stadtverwaltung

Öffentliche Anlagen, Straßenpolizei und Organisation der Ver- und Entsorgung

Versorgung der Stadt Emden mit Energie

Emder Gaswerk

Lfd. Nr. Titel

Laufzeit

1053 Beseitigung von Leckstellen an Gasleitungen

1899

(1901)

- Angebot des Ingenieurs Johann Göpfert aus Offenburg über Prüfung des Emder Gasnetz auf Leckagen, Juni - Juli 1899

- Zahlung eines Abschlages an den Ingenieur Göpfert, September 1899

- Von Göpfert erstelltes Verzeichnis der Leckstellen im Emder

Gasleitungsnetz, Oktober 1899

- Korrespondenz zwischen Ingenieur J. Göpfert und dem

Oberbürgermeister Fürbringer über Kontrolle und Schadensbehebung am Emder Gasnetz, Oktober 1899

1899 (1901)

Klassifikation Teil B: 01046

Trägermaterial: Papier

Alte Reg.-Sig.: IV Jg 50

Bestell-Nr.: IV 01046

1054 Bilanzen des Gaswerks, Bd. 1 a

- Teilweise gedruckte Bilanzen des Gaswerks, 1898 - 1904

$1898-1904$

Klassifikation Teil B: 01047,01

Band: 1

Trägermaterial: Papier

Alte Reg.-Sig.: IV Jg 51

Bestell-Nr.: IV 01047 a

1055 Bilanzen des Gaswerks, Bd. 1 b

$1905-1912$

- Statistische Betriebsberichte über Produktion und Verbrauch des

Gaswerks, 1905 - 1912

- Verhandlungen der Gaswerkskommission über Verteilung des

Betriebsgewinns des Gaswerks, Juni 1907 - Juni 1910

$1905-1912$

Klassifikation Teil B: 01047,02

Band: 1

Trägermaterial: Papier

Alte Reg.-Sig.: IV Jg 51

Bestell-Nr.: IV 01047 b 
05

\subsection{3}

05.03.06

05.03.06.05 05.03.06.05.02

\section{Stadtverwaltung}

Aufgabenbereiche der Stadtverwaltung

Öffentliche Anlagen, Straßenpolizei und Organisation der

Ver- und Entsorgung

Versorgung der Stadt Emden mit Energie

Emder Gaswerk

Lfd. Nr. Titel

Laufzeit

1056 Bilanzen des Gaswerks, Bd. 2

$1912-1913$

(1921)

- Teilweise gedruckte Bilanzen des Gaswerks, 1912 / 1913

- Verhandlungen der Gaswerkskommiassion über Verteilung des

Betriebsgewinns, Juli 1913

1912 - $1913(1921)$

Klassifikation Teil B: 01048

Band: 2

Trägermaterial: Papier

Alte Reg.-Sig.: IV Jg 51

Bestell-Nr.: IV 01048

1057 Rechnungsführung des Emder Gaswerks

$1897-1914$

(1918)

- Vereinbarung zwischen dem Gaswerksdirektor Müller und dem Kämmerer Gebest über Abwicklung des Zahlungsverkehrs des Gaswerks, Juni 1897

- Anmerkungen zum Rechnungsabschluss des Gaswerks, 1898 1903

- Bilanzen des Gaswerks, 1898 - 1908

- Gewinnabführung des Gaswerks an die Kämmereikasse, 1898 1908

- Zahlungsverkehr zwischen Gaswerk und Kämmereikasse, 1899 -

1908

- Veranlagung des Gaswerks zur Gewerbesteuer, 1900 - 1905

- Verhandlungen der Gaswerkskommission über die Bilanzen des

Gaswerks, 1900 - 1906

- Bescheid des Vorsitzenden des Steuerausschusses für

Gewerbesteuer in Aurich über Neuwahl der Mitglieder des

Gewerbesteuerausschusses, 1899 - 1902

- Verhandlungen der städtischen Kollegien über den Gaswerks-Etat, März 1903

- Aufnahme einer Anleihe zum Erwerb von Gasmesser, Dezember 1904

- Festlegung des Preises des vom Gaswerk zu verkaufenden überschüssigen Gaskokses aus Beständen der Nordseewerke, Januar 1905

- Kassenrevision beim Gaswerk durch die Gaswerkskommission, 1906 - 1914 (1918)

- Anträge auf Bezahlung kleinerer Gebäuderenovierungen beim

Gaswerk aus dessen laufenden Betriebsmitteln, 1906 - 1912

- Verhandlungen des Magistrats der Stadt Emden mit dem Wasserwerk für das nördliche westfälische Kohlenrevier als Betreiber des Emder Wasserwerks über Senkung der Wasserpreise für das Gaswerk, Mai - Juli 1909

- Eintreibung offener Gasrechnungen des Schuhmachermeisters Joachim Dupree, Februar 1910

$1897-1914$ (1918)

Klassifikation Teil B: 01049

Trägermaterial: Papier

Alte Reg.-Sig.: IV Jg 52

Bestell-Nr.: IV 01049 
05

\subsection{3}

05.03.06

05.03.06.05

05.03.06.05.02
Stadtverwaltung

Aufgabenbereiche der Stadtverwaltung

Öffentliche Anlagen, Straßenpolizei und Organisation der

Ver- und Entsorgung

Versorgung der Stadt Emden mit Energie

Emder Gaswerk

Lfd. Nr. Titel

Laufzeit

1058 Erweiterung des Gasleitungsnetzes, Bd. 1

1897-1904

- Bericht des Gaswerksdirektors Müller an den Oberbürgermeister Fürbringer über Erfordernisse für die Gasleitungserweiterung, Januar Mai 1897

- Kostenvoranschalag der Gasleitungserweiterung, Mai - Dezember 1897

- Verhandlungen der Gaswerkskommission über die

Gasleitungserweiterung, Juni 1897 - Juni 1902

- Ausschreibung der Rohrverlegungs- und Pflastererarbeiten zur

Gasleitungserweiterung, Juli 1897

- Angebote für die Arbeiten, Juli 1897

- Bedingungen für die Gasrohrverlegungsarbeiten, August 1897 -

Januar 1900

- Verhandlungen des Magistrats der tadt Emden mit der kgl.

Eisenbahnbetriebs-Direktion wegen Gasbeleuchtung der

Bahnhaltestelle Larrelter Straße, August - September 1897

- Verhandlungen des Magistrats über Organisation der

Gasleitungsnetzerweiterung, Oktober 1897

- Veranlagung der Ausgaben für die Gasleitungsnetzerweiterung im extraordinären Haushalt des Gaswerks, Februar 1898

- Verhandlungen des Magistrats mit dem Landesbau-Direktor über Anlage einer Gasbeleuchtung in der Auricher Chaussee bis zum lutherischen Friedhof, Dezember 1899 - Februar 1900

- Verhandlungen der Gaswerkskommission mit verschiedenen Firmen und Behörden über Anschluss an das Gasnetz zur Herstellung einer Gasbeleuchtung, April - Mai 1900

- Anschluss des erweiterten Hafengebiets an das Gasleitungsnetz, Mai 1900 - April 1902

- Angebote über Gasrohre und Armaturen, 1900 - 1902

- Abwicklung der Zahlungen für die Erweiterungsarbeiten, 1900 - 1904

- Erweiterung des Gasleitungsnetzes in der Wester- und

Osterbutvenne, Kleinfaldern und südlich der großen Straße, 1902

- Verlegung einer Gasleitung durch den Falderndelft und vom

Gaswerk zum Rathaus, 1902 - 1903

- Antrag des Wykvereins für die III. Wyck auf Herstellung einer gasbetriebenen Straßenbeleuchtung im Boltentorsviertel, Oktober November 1902

- Verhandlungen der Stadt Emden und des Kreises Emden mit der Eisenbahnbetriebs-Direktion wegen Anschluss des Kleinbahnhofs an der Larrelter Straße an das Gasleitungsnetz, Januar - April 1903

- Herstellung einer gasbetriebenen Beleuchtung in der Straße

"Zwischen beiden Bleichen", 1903

- Anschluss des Mietshauses des Beamten-Bau- und

Wohnungsvereins zu Emden an das Gasleitungsnetz, April - Juni 1903

- Bescheid des Bezirksausschusses in Aurich über Genehmigung einer Anleihe für die Gasnetzerweiterung, Mai 1903

$1897-1904$

Klassifikation Teil B: 01050

Band: 1

Trägermaterial: Papier

Alte Reg.-Sig.: IV Jg 53

Bestell-Nr.: IV 01050 
05

\subsection{3}

05.03.06

05.03.06.05 05.03.06.05.02

\section{Stadtverwaltung}

Aufgabenbereiche der Stadtverwaltung

Öffentliche Anlagen, Straßenpolizei und Organisation der

Ver- und Entsorgung

Versorgung der Stadt Emden mit Energie

Emder Gaswerk

Lfd. Nr. Titel

Laufzeit

1059 Erweiterung des Gasleitungsnetzes, Bd. 2

1904-1909

- Verlegung von Gasrohren mit größerem Durchmesser von der

Faldernbrücke zum Neuen Markt, Juni - Juli 1904

- Aufstellung über Haushalte mit Gasflammen (Beleuchtung und

Ofen), Juni 1904

- Anschluss der geplanten Arbeiterhäuser an das Gasnetz, August -

November 1905

- Kostenvoranschläge für Gasrohrverlegungsarbeiten, 1905

- Herstellung der Straßenbeleuchtung in der Ring- und

Schweckendieckstraße, 1905 - 1906

- Zahlungsabwicklung der Erweiterungsarbeiten, 1907 - 1909

$1904-1909$

Klassifikation Teil B: 01051

Band: 2

Trägermaterial: Papier

Alte Reg.-Sig.: IV Jg 53

Bestell-Nr.: IV 01051

1060 Feuerversicherung der Gebäude und Anlagen des Gaswerks

1897-1908

(1911)

- Verhandlungen des Magistrats der Stadt Emden mit dem ostfriesischen Landschaftskollegium über Feuerversicherung des Gaswerks bei der Landschaft, Juni 1897

- Angebot der Vaterländischen Versicherungs AG über

Feuerversicherung des Gaswerks, Juni 1897

- Versicherung des Inventars des Gaswerks bei der Vaterländischen

Versicherungs AG, Dezember 1897 - Dezember 1898

1897 - 1908 (1911)

Klassifikation Teil B: 01052

Trägermaterial: Papier

Alte Reg.-Sig.: IV Jg 54

Bestell-Nr.: IV 01052

1061 Verwaltungskommission des Gaswerks

$1895-1911$

- Konstituierung der Gaswerkskommission nach Übernahme des Gaswerks in die direkte Verwaltung durch die Stadt Emden infolge der Beendigung des Pachtverhltnisses mit der Familie Spreng, Dezember 1895 - Januar 1896

- Wahl der Mitglieder der Gaswerkskommission aus Mitgliedern des Magistrats und drei Mitgliedern des Bürgervorsteherkollegiums, Januar 1896 - Oktober 1911

$1895-1911$

Klassifikation Teil B: 01053

Trägermaterial: Papier

Alte Reg.-Sig.: IV Jg 55

Bestell-Nr.: IV 01053 
- Protokolle der Sitzungen der Gaswerkskommission über betriebstechnische Angelegenheiten des Gaswerks, deren Bilanzen und Organisation der Gasversorgung und Straßenbeleuchtung

$1896-1905$

Klassifikation Teil B: 01054

Band: 1

Trägermaterial: Papier

Alte Reg.-Sig.: IV Jg 55

Bestell-Nr.: IV 01054

1063 Sitzungen der Gaswerkskommission, Bd. 2

- Protokolle der Sitzungen der Gaswerkskommission über betriebstechnische Angelegenheiten des Gaswerks, deren Bilanzen und Organisation der Gasversorgung und Straßenbeleuchtung

$1902-1905$

Klassifikation Teil B: 01055

Band: 2

Trägermaterial: Papier

Alte Reg.-Sig.: IV Jg 55

Bestell-Nr.: IV 01055

1064 Sitzungen der Gaswerkskommission, Bd. 3

- Protokolle der Sitzungen der Gaswerkskommission über betriebstechnische Angelegenheiten des Gaswerks, deren Bilanzen und Organisation der Gasversorgung und Straßenbeleuchtung

$1906-1908$

Klassifikation Teil B: 01056

Band: 3

Trägermaterial: Papier

Alte Reg.-Sig.: IV Jg 55

Bestell-Nr.: IV 01056

- Protokolle der Sitzungen der Gaswerkskommission über betriebstechnische Angelegenheiten des Gaswerks, deren Bilanzen und Organisation der Gasversorgung und Straßenbeleuchtung

$1909-1912$

Klassifikation Teil B: 01057

Band: 4

Trägermaterial: Papier

Alte Reg.-Sig.: IV Jg 55

Bestell-Nr.: IV 01057 
05

\subsection{3}

05.03.06

05.03.06.05 05.03.06.05.02

\section{Stadtverwaltung}

Aufgabenbereiche der Stadtverwaltung

Öffentliche Anlagen, Straßenpolizei und Organisation der

Ver- und Entsorgung

Versorgung der Stadt Emden mit Energie

Emder Gaswerk

Lfd. Nr. Titel

Laufzeit

1066 Sitzungen der Gaswerkskommission, Bd. 5

- Protokolle der Sitzungen der Gaswerkskommission über betriebstechnische Angelegenheiten des Gaswerks, deren Bilanzen und Organisation der Gasversorgung und Straßenbeleuchtung

1913

\author{
Klassifikation Teil B: 01058 \\ Band: 5 \\ Trägermaterial: Papier \\ Alte Reg.-Sig.: IV Jg 55 \\ Bestell-Nr.: IV 01058
}

1067 Sitzungen der Gaswerkskommission, Bd. 6

- Protokolle der Sitzungen der Gaswerkskommission über betriebstechnische Angelegenheiten des Gaswerks, deren Bilanzen und Organisation der Gasversorgung und Straßenbeleuchtung

$1914-1917$

Klassifikation Teil B: 01059

Band: 6

Trägermaterial: Papier

Alte Reg.-Sig.: IV Jg 55

Bestell-Nr.: IV 01059

1068 Plan der Anlage einer Wassergasfabrik

1892-1899

(1911)

- Erlasse des preußischen Ministers für Handel und Gewerbe über Schutzmaßnahmen gegen die Gefahren des Wassergases wegen seines Gehalts an CO, Juli 1892 / Dezember 1896

- Gedruckte Vorträge des Dr. Hugo Stracke, Wien, über Stand der Technik der Wassergasproduktion und Vorteile einer Wassergasfabrik durch Einsetzbarkeit des Gases in der Straßenbeleuchtung nach Erfindung des Glühkörpers, 1898

- Druckschrift: Beleuchtung mit Wassergas, 1897 - 1898

- Anfrage der Stadt Emden bei verschiedenen Fachfirmen über Kosten für Wassergasproduktionsanlage in Emden, Januar - März 1899

- Presseberichte über Planung des Baus von Wassergasanlagen in anderen Städten, 1899

- Schreiben der Städte Bremen, Königsberg und Hamburg über

Planungen zum Bau von Wassergasproduktionsanlagen, Januar 1899

- Kostenvoranschlag der Deutschen

Wassergas-Beleuchtungsgesellschaft $\mathrm{GmbH}$ über

Wassergasproduktionsanlage in Emden, Mai 1899

- Planzeichnung einer Wassergasproduktionsanlage, Mai 1899

$1892-1899(1907)$

Klassifikation Teil B: 01061

Trägermaterial: Papier

Alte Reg.-Sig.: IV Jg 58

Bestell-Nr.: IV 01061
1913 
05

05.03

05.03.06

05.03.06.05

05.03.06.05.02

\section{Stadtverwaltung}

Aufgabenbereiche der Stadtverwaltung

Öffentliche Anlagen, Straßenpolizei und Organisation der

Ver- und Entsorgung

Versorgung der Stadt Emden mit Energie

Emder Gaswerk

Lfd. Nr. Titel

Laufzeit

1069 Kleine Anschaffungen für das Gaswerk

1899-1912

- Anschaffungen von Gasometern und Laborgeräten zur

Gasqualitätssicherung sowie Ofenzubehör und Waagen, 1898 - 1899

- Beschwerde der Emder Korbmachermeister gegen die Bevorzugung

Auswärtiger bei der Lieferung von Kohlekörben für das Gaswerk,

November - Dezember 1905 / Juni - Juli 1910

- Verhandlungen der Gaswerkskommission über Anschaffung einer

Koksbrechmaschine, Oktober 1912

$1899-1912$

Klassifikation Teil B: 01062

Trägermaterial: Papier

Alte Reg.-Sig.: IV Jg 59

Bestell-Nr.: IV 01062

1070 Mitgliedschaft des Gaswerks in Vereinen und Verbänden

$1897-1913$

- Beitritt des Gaswerks zum Deutschen Verein von Gas- und

Wasserfachmännern, September 1897

- Mitgliedschaft des Gaswerks in der Berufsgenossenschaft der Gas-

und Wasserwerke, August 1897

- Einladungen und Protokolle zu den Versammlungen der

Berufsgenossenschaft der Gas- und Wasserwerke, 1898

- Erhebungen zu Betriebsunfällen und Gefahrentarif der

Berufsgenossenschaft der Gas- und Wasserwerke, 1897 / 1913

- Protokolle der Jahresversammlungen des Deutschen Vereins von

Gas- und Wasserfachmännern und des niedersächsische Vereins von

Gas- und Wasserfachmännern, 1899 - 1905

- Kampagne des Deutschen Vereins von Gas- und

Wasserfachmännern zur ausreichenden Haftpflichtversicherung ihrer Mitglieder, Juli 1898

- Satzung der Wirtschaftlichen Vereinigung deutscher Gaswerke, Juli 1897

- Beitritt des Gaswerks zur Wirtschaftlichen Vereinigung deutscher

Gaswerke, Oktober 1899

- Verwaltungs- und Rechenschaftsberichte der Berufsgenossenschaft der Gas- und Wasserwerke, 1904 - 1906

- Kampagne gegen eine Reichsgassteuer, 1908

- Protokoll der Mitgliederversammlung der Zentrale für Gasverwertung

e.V., 1910

$1897-1910$

Klassifikation Teil B: 01063

Trägermaterial: Papier

Alte Reg.-Sig.: IV Jg 60

Bestell-Nr.: IV 01063 
IV

05

05.03

05.03.06

05.03.06.05

05.03.06.05.02

\section{Stadtverwaltung}

Aufgabenbereiche der Stadtverwaltung

Öffentliche Anlagen, Straßenpolizei und Organisation der

Ver- und Entsorgung

Versorgung der Stadt Emden mit Energie

Emder Gaswerk

Lfd. Nr. Titel

Laufzeit

1071 Revision des Gaswerks

1903-1909

- Monita der Berufsgenossenschaft der Gas und Wasserwerke nach der Revision des Gaswerks in Emden, August 1903

- Verfügung einer Revision des Emder Gaswerks durch die

Berufsgenossenschaft der Gas- und Wasserwerke, Juli 1909

$1903-1909$

Klassifikation Teil B: 01065

Trägermaterial: Papier

Alte Reg.-Sig.: IV Jg 62

Bestell-Nr.: IV 01065

1072 Errichtung einer Anlage zur Herstellung von Ammoniumsulfat

1899-1906

- Vertrag zwischen dem Gaswerk und der Actiengesellschaft für

Chemische Industrie, Mannheim über Abnahme des bei der

Kohlenvergasung anfallenden Ammoniaks, Dezember 1899

- Berichte von Gaswerken anderer Städte über Erfahrung mit der

Zusammenarbeit mit der Actiengesellschaft für Chemische Industrie,

August 1899

- Entwurf und Kostenvoranschlag der Firma August Klönne, Dortmund

über Anlage zur Konzentrierung des Ammoniakgases, Oktober 1899

- Stellungnahme des Hannoverschen Gaswerksdirektors Korting zum

Projekt der Errichtung einer Anlage zur Herstellung von

Ammoniumsulfat, Dezember 1899

- Verhandlungen der Gaswerkskommission über Errichtung einer

Anlage zur Herstellung von Ammoniumsulfat, 1902 - 1903

- Genehmigungsverfahren beim Bezirksausschuss in Aurich wegen

Errichtung einer Anlage zur Herstellung von Ammoniumsulfat durch

das Gaswerk Emden, Juli - November 1903

- Angebote über Bestandteile einer Anlage zur Herstellung von

Ammoniumsulfat, 1903

- Abnahme der Anlage durch den Verein zur Überprüfung von

Dampfmaschinen in Hannover, März - April 1904

1899 - 1906 (1913)

Klassifikation Teil B: 01066

Trägermaterial: Papier

Alte Reg.-Sig.: IV Jg 63

Bestell-Nr.: IV 01066 
05

\subsection{3}

05.03.06

05.03.06.05 05.03.06.05.02

\section{Stadtverwaltung}

Aufgabenbereiche der Stadtverwaltung

Öffentliche Anlagen, Straßenpolizei und Organisation der Ver- und Entsorgung

Versorgung der Stadt Emden mit Energie

Emder Gaswerk

Lfd. Nr. Titel

Laufzeit

1073 Ausbau des Gaswerks

1905-1909

(1914)

- Statistik der Gasproduktion des Gaswerks, 1905

- Gutachten des Hannoverschen Gaswerksdirektors Korting über

Vergrößerung und Ausbau der Gasanstalt, Januar 1906

- Korrespondenz des Hannoverschen Gaswerksdirektors Korting mit

dem Vorsitzenden der Gaswerkskommission, Senator Klaassen, über

Diskussion der Zweckmäßigkeit einer Gaswerkserweiterung bzw.

eines völligen Neubaus auf einem anderen Gelände, Januar 1906

- Angebot der Fa. August Klönne, Dortmund, über neue Anlagen für das Emder Gaswerk, März 1906

- Bescheid des Bezirksausschusses in Aurich über Genehmigung der geplanten Anleihe der Stadt Emden zum Ausbau des Gaswerks, April 1906 / April 1907

- Errichtung einer Mauer um das Gaswerksgelände, Juli 1906

- Übersicht über Zahlungen und Zahlungsempfänger wegen der

Gaswerkserweiterung, Oktober 1906

- Verhandlungen der Gaswerkskommission über Feststellung des finanziellen Mehrbedarfs für die Erweiterung des Gaswerks, Oktober 1906

- Verhängung einer Konventionalstrafe gegen die Kölnische Maschinenbau AG wegen Nichteinhaltung der Lieferfristen für bestellte Anlageteile, Oktober - November 1906

- Antrag des Arztes Dr. Langhoff auf Kauf seines neben dem Gaswerksgelände befindlichen Hauses durch die Stadt Emden wegen der Geruchsbelästigung durch Schwefelwasserstoff und Ammoniak sowie der Explosionsgefahr der Anlage verursachten Wertminderung seines Anwesens, März 1907

- Planzeichnungen der Erweiterungsbauten, 1908 - 1909

- Ausschreibungsverfahren der für 1909 geplanten

Erweiterungsbauten, Februar 1909

- Presseberichte über Ausbau des Gaswerks, 1906

1905 - 1909 (1914)

Klassifikation Teil B: 01067

Trägermaterial: Papier

Alte Reg.-Sig.: IV Jg 64

Bestell-Nr.: IV 01067 
05

05.03

05.03.06

05.03.06.05 05.03.06.05.02

\section{Stadtverwaltung}

Aufgabenbereiche der Stadtverwaltung

Öffentliche Anlagen, Straßenpolizei und Organisation der Ver- und Entsorgung

Versorgung der Stadt Emden mit Energie

Emder Gaswerk

Lfd. Nr. Titel

Laufzeit

1074 Anlage eines Elektrizitätswerkes und Aufbau eines elektrischen Leitungsnetzes, Bd. 1

- Austausch mit anderen Städten wegen Aufbau von E-Werken und über Erfahrungen mit konzessionierten Kraftwerksbetreibern, 1905 1911

- Druckschrift: Statistik des Elektrizitätswerk der Stadt Dortmund 1903 - 1904, 1905

- Angebote der Rheinisch Westfälischen Elektrizitätswerke, der Hessischen Elektrizitätswerke und des Elektrizitätswerkes Siegerland über Errichtung eines Kraftwerkes in Emden, 1907

- Druckschrift: Jahresbericht des Elerktrizitätswerkes der Stadt Siegen 1903 - 1904, 1905

$1905-1911$

Klassifikation Teil B: 01068

Band: 1

Trägermaterial: Papier

Alte Reg.-Sig.: IV Jg 65

Bestell-Nr.: IV 01068 
05

\subsection{3}

05.03.06

05.03.06.05 05.03.06.05.02

\section{Stadtverwaltung}

Aufgabenbereiche der Stadtverwaltung

Öffentliche Anlagen, Straßenpolizei und Organisation der Ver- und Entsorgung

Versorgung der Stadt Emden mit Energie Emder Gaswerk

Lfd. Nr. Titel

Laufzeit

1075 Gewerbepolizeiliche Genehmigung der Erweiterungsbauten des Gaswerks

- Beschluss der Gaswerkskommission über Erweiterung des

Gaswerks, Januar 1906 / März 1909

- Verfügung des Regierungspräsidenten in Aurich über Übertragung des Genehmigungsverfahrens über Erweiterung des Emder Gaswerks auf den Kreisausschuss des Kreises Emden, Februar 1906

- Beschreibung der neuen Anlagen des Gaswerks durch die Kölnische Maschinenbau-Actien-Gesellschaft, März 1906

- Entschließung der Gaswerkskommission über Notwendigkeit der Gaswerkserweiterung und Appell an das Bürgervorsteherkollegium zur Bezwichtigung der Erweiterungsgegner, April 1906

- Verhandlungen der Gaswerkskommission über Kosten der

Erweiterung des Gaswerks, Mai 1906

- Einspruch des Arztes Dr. Langhoff und des Fischereidirektors Zimmermann beim Kreisausschuss Emden gegen die Erweiterung des Gaswerks wegen Explosionsgefahr und Umweltbelastung durch Schwefelwasserstoff und andere Gase sowie Lärmbelästigung, Mai 1906

- Einspruch des Arztes Dr. Langhoff und des Fischereidirektors Zimmermann beim Regierungspräsidenten in Aurich gegen die Erweiterung des Gaswerks wegen Explosionsgefahr und Umweltbelastung durch Schwefelwasserstoff und andere Gase sowie Lärmbelästigung, Mai 1906

- Empfehlung des Gewerbeinspektors in Aurich über Maßnahmen zum Schutz der Anwohner vor Gas-, Stau- und Lärmbelästigung im Rahmen des Ausbaus des Gaswerks, Mai 1906

- Beschluss des Kreisausschusses des Kreises Emden über Auflagen zur Genehmigung der Eweiterung des Emder Gaswerks, Juni 1906 - Klage des Dr. Langhoff gegen die Stadt Emden beim Landgericht in Aurich auf Einstellung der Gaswerkserweiterung, August - November 1907

- Beschwerde des Stadtbaumeisters Wiggers beim Kreisausschuss gegen die weitere Vergrößerung des Gaswerks wegen Belästigung durch Kohlenstaub, April 1909

$1906-1909$

Klassifikation Teil B: 01082

Trägermaterial: Papier

Alte Reg.-Sig.: IV Jg 66

Bestell-Nr.: IV 01082
1906-1909 
IV

05

\subsection{3}

05.03.06

05.03.06.05

05.03.06.05.02
Stadtverwaltung

Aufgabenbereiche der Stadtverwaltung

Öffentliche Anlagen, Straßenpolizei und Organisation der

Ver- und Entsorgung

Versorgung der Stadt Emden mit Energie

Emder Gaswerk

Lfd. Nr. Titel

Laufzeit

1076 Ausführung der Erweiterungsbauten am Gaswerk

- Entwurf eines Vertrages zwischen der Stadt Emden und der Kölnischen Maschinenbau Actien-Gesellschaft über Durchführung der

Erweiterungsbauten, Mai 1905

- Verhandlungen der Gaswerkskommission über Bestimmungen des

Vertrages, März - Mai 1906

- Verhandlungen zwischen dem Magistrat und der Kölnischen

Maschinenbau Actien-Gesellschaft über Bestimmungen des

Vertrages, April - Mai 1906

- Verhandlungen der Gaswerkskommission über Rechnungen der

Kölnischen Maschinenbau Actien-Gesellschaft, Mai 1907

- Rückzahlung der von der Firma hinterlegten Kaution und

Sichtwechsel, 1909

- Abnahme der gelieferten Anlagen der Kölnischen Maschinenbau

Actien-Gesellschaft, November 1909

- Beschwerde des Fischereidirektors Zimmermann beim

Regierungspräsidenten in Aurich gegen den Bau eines weiteren

Gebäudes auf dem Gaswerksgelände wegen drohender

Lärmbelästigung, August - September 1913

$1905-1913$

Klassifikation Teil B: 01083

Trägermaterial: Papier

Alte Reg.-Sig.: IV Jg 67

Bestell-Nr.: IV 01083

1077 Auskunft über das Gaswerk

- Anfrage des Magistrats der Stadt Papenburg wegen Gastarife des

Emder Gaswerks, Dezember 1906

1906

Klassifikation Teil B: 01084

Trägermaterial: Papier

Alte Reg.-Sig.: IV Jg 68

Bestell-Nr.: IV 01084

1078 Prozessführungsberechtigung des Gaswerks

- Beschluss der städtischen Kollegien über Gewährung der Prozessführungsberechtigung an das Gaswerk als juristische Person, November 1910 / Juni 1914

$1910 / 1914$

Klassifikation Teil B: 01088

Trägermaterial: Papier

Alte Reg.-Sig.: IV Jg 72

Bestell-Nr.: IV 01088 
05

05.03

05.03.06

05.03.06.05

05.03.06.05.02

\section{Stadtverwaltung}

Aufgabenbereiche der Stadtverwaltung

Öffentliche Anlagen, Straßenpolizei und Organisation der

Ver- und Entsorgung

Versorgung der Stadt Emden mit Energie

Emder Gaswerk

Lfd. Nr. Titel

Laufzeit

1079 Erlaubnis zur Benutzung einer Pforte auf dem Gaswerksgelände

- Antrag des Gemüsebauern Georg Voß auf Erlaubnis zur Benutzung einer Pforte an der Einfriedung des Gaswerksgeländes zur Erreichung seiner Fenster zum Reinigen und auf Prüfung der Einfriedung wegen zu großer Nähe zu seiner Grundstücksgrenze, Juni - Oktober 1911

1911

Klassifikation Teil B: 01127

Trägermaterial: Papier

Alte Reg.-Sig.: IV Jg 73

Bestell-Nr.: IV 01127

1080 Beschwerden gegen das Gaswerk

- Beschwerde des M. Oostermann wegen Geruchsbelästigung und Verschmutzungen durch die Abgase des Gaswerks, September 1913 - Beschwerde des Vereins Emder Baugewerksmeister, Gruppe Klempnermeister gegen die verbilligte Lieferung von Badeöfen und andere Sanitärteile durch das Gaswerk in die Wohnungen des Emder Beamtenbauvereins, März 1914

$1913-1914$

Klassifikation Teil B: 01128

Trägermaterial: Papier

Alte Reg.-Sig.: IV Jg 74

Bestell-Nr.: IV 01128

1081 Durchführung von Handwerkerarbeiten durch das Gaswerk

- Beschwerde der Handwerkskammer in Aurich gegen die Vornahme von Handwerksarbeiten beim Gaswerk durch von ihm eingestellte Arbeiter unter Umgehung Emder Handwerksbetriebe, Oktober 1913

1913

Klassifikation Teil B: 01129

Trägermaterial: Papier

Alte Reg.-Sig.: IV Jg 75

Bestell-Nr.: IV 01129 
IV

05

Stadtverwaltung

05.03

Aufgabenbereiche der Stadtverwaltung

05.03.06

Öffentliche Anlagen, Straßenpolizei und Organisation der

Ver- und Entsorgung

05.03.06.05

Versorgung der Stadt Emden mit Energie

05.03.06.05.03

Aufbau eines elektrischen Kraftwerks und eines

Leitungsnetzes

Lfd. Nr. Titel

Laufzeit

1082 Elektrifizierung

$1882-1912$

- Schreiben des kaiserlichen Oberpostdirektors in Oldenburg an die

Stadt Emden über Bitte um Berücksichtigung der

Telegraphenleitungen bei der Planung von elektrischen Leitungen,

Oktober 1882

- Gemeinsamer Erlass des preußischen Ministers der öffentlichen

Arbeiten und des Innenministers über Schutz der

Telegraphenleitungen vor elektrischen Leitungen durch deren

Isolierung, März 1886

- Werbung für elektrische Beleuchtung, 1890 / 1898

- Werbung für Errichtung von Stromkraftwerken, 1894 - 1912

- Werbung für elektrischen Straßenbeleuchtungssysteme, Juli 1905

- AEG-Zeitung über elektrotechnische Anlagen der AEG, 1910 - 1911

- Erlass des preußischen Ministers für Handel und Gewerbe über

Ausbau der Überlandzentralen (Kraftwerke) und Regelung des

Wettbewerbs bei Anlage der Anschlussleitungen, Februar 1912

$1882-1912$

Klassifikation Teil B: 01020

Trägermaterial: Papier

Alte Reg.-Sig.: IV Jg 29

Bestell-Nr.: IV 01020 
05

05.03

05.03.06

05.03.06.05

05.03.06.05.03
Stadtverwaltung

Aufgabenbereiche der Stadtverwaltung

Öffentliche Anlagen, Straßenpolizei und Organisation der

Ver- und Entsorgung

Versorgung der Stadt Emden mit Energie

Aufbau eines elektrischen Kraftwerks und eines

Leitungsnetzes

Lfd. Nr. Titel

Laufzeit

1083 Anlage eines Elektrizitätswerkes und Aufbau eines elektrischen Leitungsnetzes, Bd. 2

1907-1908

- Verhandlungen der Elektrizitätskommission über Anschluss der Stadt Emden an ein im ostfriesischen Moor geplantes zentrales Kraftwerk (Überlandzentrale), Februar 1907 - April 1908

- Kritischer Bericht der Deutschen Bergwerkszeitung über Gewinnung elektrischer Energie aus Torf, Februar 1907

- Schreiben des Oberbürgermeisters Fürbringer an den Oberingenieur Brunhaber von den Hanseatischen Siemens Schuckert Werken über Bereitschaft der Stadt Emden zur Unterstützung der geplanten Überlandzentrale in Marcardsmoor bei Verknüpfung mit der Anlage einer elektrischen Kleinbahn in Emden, März 1907

- Erlass des preußischen Ministers der öffentlichen Arbeiten über Organisation der Aufsicht über die Überlandzentrale und Kleinbahn, Mai 1907

- Pressebericht über geplante Überlandzentrale in Marcardsmoor / Voßbarg, 1907 - 1908

- Kostenvoranschlag der Hanseatischen Siemens - Schuckert - Werke über Ausbau des Emder Straßenbahnnetzes, 1907

- Mitteilung der kgl. Wasserbauinspektion über Energieversorgung der Emder Hafenanlagen aus der Überlandzentrale in Wiesmoor, März 1908

- Betrauung des Ingenieurs Hubert Förster, Direktor des

Elektrizitätswerkes Mühlheim / Ruhr, mit der Funktion eines Beraters der Stadt Emden in Fragen der Elektrizitätsversorgung, April 1908

- Formular der Stadt Emden zur Erfassung anschlusswilliger Stromkunden, Mai 1908

- Stadtplan Emden mit Einzeichnung von Leitungsanschlüssen für elektrische Energie, 1908

- Gutachten des Ingenieurs Hubert Förster über Versorgung der Stadt Emden mit elektrischer Energie, April 1908

- Gutachten des Oberingenieurs Dr. Thorbeck von den Hanseatischen Siemens Schuckert Werken über Versorgung der Stadt Emden mit elektrischer Energie, April 1908

- Verhandlungen der Stadt Emden mit den Hanseatischen Siemens Schuckert Werken über Anschluss Emdens an die Überlandzentrale in Wiesmoor, 1908

1907 - 1908

Klassifikation Teil B: 01069

Band: 2

Trägermaterial: Papier

Alte Reg.-Sig.: IV Jg 65

Bestell-Nr.: IV 01069 
05

\subsection{3}

05.03.06

05.03.06.05

05.03.06.05.03

\section{Stadtverwaltung}

Aufgabenbereiche der Stadtverwaltung

Öffentliche Anlagen, Straßenpolizei und Organisation der

Ver- und Entsorgung

Versorgung der Stadt Emden mit Energie

Aufbau eines elektrischen Kraftwerks und eines

Leitungsnetzes

Lfd. Nr. Titel

1084 Anlage eines Elektrizitätswerkes und Aufbau eines elektrischen Leitungsnetzes, Bd. 3

- Gedruckter Entwurf eines Vertrages zwischen dem Hanseatischen Siemens Schuckert Werk und der Stadt Emden sowie anderen Kommunen im Versorgungsgebiet der Überlandzentrale Wiesmoor über Belieferung mit elektrischem Strom, 1908

- Angebote über Stromzähler, April - Oktober 1908

- Rentabilitätsberechnung über Anschluss der Stadt Emden an die Überlandzentrale Wiesmoor, Oktober 1908

- Stellungnahme des beratenden Ingenieurs und Direktors des Mülheimer Elerktrizitätswerks, Förster, zum Vertragsangebot des Hanseatischen Siemens Schuckert Werkes, Oktober / Dezember 1908

- Kostenanschlag über Anschluss der Stadt Emden an die Überlandzentrale Wiesmoor in der Variante Gleichstrom und der Variante Drehstrom, Oktober 1908

- Gutachten des Sachverständigen, Oberingenieur Richard Sturm aus Brandenburg, zum Vertragsangebot des Hanseatischen Siemens Schuckert Werks an die Stadt Emden, Oktober 1908

- Entwürfe eines Vertrages zwischen dem Hanseatischen Siemens Schuckert Werk und der Stadt Emden über Belieferung mit elektrischem Strom, November 1908

- Gespräche des Oberbürgermeisters Leo Fürbringer als Landtagsabgeordneter mit anderen Kraftwerksbetreibern über Stromlieferungsverträge, Dezember 1908

Klassifikation Teil B: 01070

Band: 3

Trägermaterial: Papier

Alte Reg.-Sig.: IV Jg 65

Bestell-Nr.: IV 01070 
05

05.03

05.03.06

05.03.06.05

05.03.06.05.03
Stadtverwaltung

Aufgabenbereiche der Stadtverwaltung

Öffentliche Anlagen, Straßenpolizei und Organisation der

Ver- und Entsorgung

Versorgung der Stadt Emden mit Energie

Aufbau eines elektrischen Kraftwerks und eines

Leitungsnetzes

Laufzeit

1085 Anlage eines Elektrizitätswerkes und Aufbau eines elektrischen Leitungsnetzes, Bd. 4

- Gedruckter Entwurf eines Vertrages zwischen dem Hanseatischen Siemens Schuckert Werk und der Stadt Emden über Belieferung mit elektrischem Strom, Dezember1908

- Gutachten des beratenden Ingenieurs und Direktors des Mülheimer Elerktrizitätswerks, Förster, zum Vertragsangebot des Hanseatischen Siemens Schuckert Werkes, Dezember 1908

- Verhandlungen der Elektrizitätskommission über Anschluss der Stadt Emden an die Überlandzentrale Wiesmoor, Januar 1909 - Juni 1911

- Plan der elektrischen Fernleitung von Wiesmoor nach Emden, 1909 - Presseberichte über geplante Kraftwerke zur Stromerzeugung in anderen Städten, 1909

- Vertrag zwischen dem Hanseatischen Siemens Schuckert Werk und der Stadt Emden über Belieferung mit elektrischem Strom, Oktober 1909

- Gespräch des Oberbürgermeisters Fürbringer mit dem Siemens-Oberingenieur Nielsen über Richtlinien eines Stromlieferungsvertrages und des Anschlusses des Stadt Emden an die Überlandzentrale Wiesmoor, Dezember 1910 $1908-1911$

Klassifikation Teil B: 01071

Band: 4

Trägermaterial: Papier

Alte Reg.-Sig.: IV Jg 65

Bestell-Nr.: IV 01071

1086 Anlage eines Elektrizitätswerkes und Aufbau eines elektrischen Leitungsnetzes, Bd. 5

- Angebote von Kraftwerksbaufirmen und Kraftwerksbetreibern über Anlage eines elektrischen Kraftwerks in Emden

$1905-1907$

Klassifikation Teil B: 01072

Trägermaterial: Papier

Alte Reg.-Sig.: IV Jg 65

Bestell-Nr.: IV 01072 
05

\subsection{3}

05.03.06

05.03.06.05

05.03.06.05.03
Stadtverwaltung

Aufgabenbereiche der Stadtverwaltung

Öffentliche Anlagen, Straßenpolizei und Organisation der

Ver- und Entsorgung

Versorgung der Stadt Emden mit Energie

Aufbau eines elektrischen Kraftwerks und eines

Leitungsnetzes

Lfd. Nr. Titel

Laufzeit

1087 Anlage eines Elektrizitätswerkes und Aufbau eines elektrischen Leitungsnetzes, Bd. 6

1908

- Beratungstätigkeit des Ingenieurs Dr. Bruno Thierbach zu Verhandlungen zwischen ostfriesischen Städten und dem Hanseatischen Siemens Schuckert Werk wegen Stromlieferungsverträge, April 1908

- Angebote verschiedener Ingenieurbüros über Beratung in oder Ausführung von Kraftwerksbauten, Lieferung von Transformatoren, Leitungsmaterial und Stromzähler, 1908

- Angebote verschiedener Firmen zum Bau von elektrischen

Kleinbahnen, 1908

1908

\author{
Klassifikation Teil B: 01073 \\ Band: 6 \\ Trägermaterial: Papier \\ Alte Reg.-Sig.: IV Jg 65 \\ Bestell-Nr.: IV 01073
}

1088 Anlage eines Elektrizitätswerkes und Aufbau eines elektrischen Leitungsnetzes, Bd. 6

- Angebote verschiedener Ingenieurbüros über Beratung in oder Ausführung von Kraftwerksbauten, Lieferung von Transformatoren, Leitungsmaterial und Stromzähler,

- Angebote verschiedener Firmen zum Bau von elektrischen

Kleinbahnen

$1909-1911$

Klassifikation Teil B: 01074

Band: 7

Trägermaterial: Papier

Alte Reg.-Sig.: IV Jg 65

Bestell-Nr.: IV 01074 
05

\subsection{3}

05.03.06

05.03.06.05

05.03.06.05.03

\section{Stadtverwaltung}

Aufgabenbereiche der Stadtverwaltung

Öffentliche Anlagen, Straßenpolizei und Organisation der

Ver- und Entsorgung

Versorgung der Stadt Emden mit Energie

Aufbau eines elektrischen Kraftwerks und eines

Leitungsnetzes

Lfd. Nr. Titel

Laufzeit

1089 Anlage eines Elektrizitätswerkes und Aufbau eines elektrischen Leitungsnetzes, Bd. 8

- Anmeldungsformular für die Bereitstellung eines elektrischen Hausanschlusses, 1912

- Bedingungen für die Belieferung mit elektrischer Energie, Juli 1912

- Meldung über Bedarf an elektrischer Energie von Behörden und

Kirchen in Emden, August - Dezember 1912

- Ablehnung der Herstellung einer elektrischen Leitung zur Sägemühle am Herrentor wegen zu hoher Leitungsbaukosten und eines erwarteten zu geringen Verbrauchs, April 1913

- Ablehnung des Antrags der Seemannsmission auf Anschluss des Seemannsheims an die elektrische Zentrale am Außenhafen (Nesserland), November 1913

- Vereinbarung der Stadt Emden mit der Verwaltung der Kaserne über Anschluss der Kasernenbauten an das Stromnetz, März 1914

$1912-1914$

Klassifikation Teil B: 01075

Band: 8

Trägermaterial: Papier

Alte Reg.-Sig.: IV Jg 65

Bestell-Nr.: IV 01075

1090 Anlage eines Elektrizitätswerkes und Aufbau eines elektrischen Leitungsnetzes, Bd. 9

- Anschluss städtischer Amtsgebäude und Schulen an das Stromleitungsnetz

1912

Klassifikation Teil B: 01076

Band: 9

Trägermaterial: Papier

Alte Reg.-Sig.: IV Jg 65

Bestell-Nr.: IV 01076

1091 Anlage eines Elektrizitätswerkes und Aufbau eines elektrischen Leitungsnetzes, Bd. 10

- Rentabilitätsberechnung des Oberingenieurs und Projektberaters Richard Sturm aus Brandenburg bzgl. des Stromleitungsnetzes der Stadt Emden

1912

Klassifikation Teil B: 01077

Band: 10

Trägermaterial: Papier

Alte Reg.-Sig.: IV Jg 65

Bestell-Nr.: IV 01077 
05

05.03

05.03.06

05.03.06.05

05.03.06.05.03

Stadtverwaltung

Aufgabenbereiche der Stadtverwaltung

Öffentliche Anlagen, Straßenpolizei und Organisation der

Ver- und Entsorgung

Versorgung der Stadt Emden mit Energie

Aufbau eines elektrischen Kraftwerks und eines

Leitungsnetzes

Laufzeit

Lfd. Nr. Titel

1092 Hochspannungsleitung vom kgl. Wasserbauamt zu den Nordseewerken

1912

- Schreiben der kaiserl. Oberpostdirektion in Oldenburg über Unbedenklichkeit der geplanten Hochspannungsleitung für das

Telegraphennetz, September 1912

- Erlass des Ministers für öffentlichen Arbeiten über Bestimmungen

zum Schutz der Telegraphenanlagen beim Bau elektrischer

Hochspannungsleitungen, Oktobrt 1912

- Antrag der Nordseewerke auf Genehmiging einer

Hochspannungsleitung vom Transformatorenhaus beim $\mathrm{kgl}$.

Wasserbauamt zum Umformer auf uhrem Gelände, November 1912

- Lageplan der Hochspannungsleitung, 1912

1912

Klassifikation Teil B: 01078

Trägermaterial: Papier

Alte Reg.-Sig.: IV Jg 65

Bestell-Nr.: IV 01078

1093 Anschluss der Besitzungen der Gebrüder Lange und der Witwe K.

Poppinga an das Wolthuser Leitungsnetz

- Antrag des Stadtwerkedirektors Kleindiek auf Prüfung der Gemeindezugehörigkeit des Besitzes der Gebrüder Lange und der Witwe Poppinga zu Wolthusen wegen Unstatthaftigkeit des Strombezugs vom Netz der Überlandzentrale in Wiesmoor bei Zugehörigkeit der betr. Besitzungen zur Stadt Emden, Oktober 1912 - Beschluss der Elektrizitätskommission über Erlaubnis zur Führung von elektrischen Leitungen der Überlandzentrale Wiesmoor von Wolthusen über städtisches Gebiet zum Anschluss des auf Wolthuser Gebiet liegenden Grundstücks der Gebrüder Lange (Gärtnerei), November 1912

$1912-1913$

Klassifikation Teil B: 01079

Trägermaterial: Papier

Alte Reg.-Sig.: IV Jg 65

Bestell-Nr.: IV 01079

1094 Umlage der Kosten des Baus elektrischer Leitungen

- Einrechnung des Kosten für den Stromleitungsbau in den Erschließungskosten für Grundstücke und der Anliegerbeiträge, April 1914

1914

Klassifikation Teil B: 01080

Trägermaterial: Papier

Alte Reg.-Sig.: IV Jg 65

Bestell-Nr.: IV 01080 
05

\subsection{3}

05.03.06

05.03.06.05

05.03.06.05.03

\section{Stadtverwaltung}

Aufgabenbereiche der Stadtverwaltung

Öffentliche Anlagen, Straßenpolizei und Organisation der

Ver- und Entsorgung

Versorgung der Stadt Emden mit Energie

Aufbau eines elektrischen Kraftwerks und eines

Leitungsnetzes

Lfd. Nr. Titel

Laufzeit

1095 Störung der deutsch-englischen Telegraphenleitung durch Hochspannungsleitung

- Vermerk über Bewilligung der Mittel für die Verlegung der Hochspannungsleitung am Philosophenweg unter der Erde zur Behebung von Störungen der deutsch-englischen Telegraphenleitung, Juli 1914

1914

Klassifikation Teil B: 01081

Trägermaterial: Papier

Alte Reg.-Sig.: IV Jg 65

Bestell-Nr.: IV 01081

1096 Antrag auf Genehmigung der Führung einer Starkstromleitung der

- Antrag der Hanseatischen Siemens Schuckert Werke als Betreiber der Überlandzentrale Wittmund bei der Stadt Emden auf

Genehmigung der Führung einer Starkstromleitung über Emder

Gebiet, März - August 1909

- Verhandlungen der Stadt Emden mit der Oberpostdirektion

Oldenburg wegen evtl Auflagen zum Schutz der

Telegraphenleitungen, Mai - Juli 1909

- Planzeichnung der projektierten Hochspannungsleitung über Emder Stadtgebiet, 1909

- Einberaumung eines Erörterungstermins über das Projekt beim

Regierungspräsidenten in Aurich, Juli 1909

- Verfügung des Regierungspräsidenten in Aurich über

Schutzmaßnahmen beim Betrieb der Leitung, August 1909

- Genehmigung der Leitung durch die Stadt Emden, Dezember 1909

1909 - 1910 (1911)

Klassifikation Teil B: 01086

Trägermaterial: Papier

Alte Reg.-Sig.: IV Jg 70

Bestell-Nr.: IV 01086 
05

05.03

05.03.06

05.03.06.05

05.03.06.05.03
Stadtverwaltung

Aufgabenbereiche der Stadtverwaltung

Öffentliche Anlagen, Straßenpolizei und Organisation der

Ver- und Entsorgung

Versorgung der Stadt Emden mit Energie

Aufbau eines elektrischen Kraftwerks und eines

Leitungsnetzes

Lfd. Nr. Titel

Laufzeit

1097 Anlage eines Elektrizitätswerkes und Aufbau eines elektrischen Leitungsnetzes, Bd. 11

- Antrag der Westfälischen Transport Aktiengesellschaft (WTAG) bei der Stadt Emden auf Genehmigung einer Stromleitung von ihrem Kraftwerk zu ihrem Abnehmer, der Cassenswerft, über städtisches Gebiet, September - November 1905

- Angebot der WTAG über Einspeisung von elektrischem Strom aus ihrer Zentrale in ein von der Stadt zu unterhaltenes Leitungsnetz, Februar 1906

- Verhandlungen der Kommission für die Beratung der Errichtung eines Elektrizitätswerkes über das Angebot der WTAG, März -

Oktober 1906

- Antrag des Juweliers Franz Richter auf Genehmigung der Installation elektrischer Lichtleitung in seinem Haus zur Vorbereitung der

Elektrifizierung, Juli 1908

- Antrag des Juweliers Franz Richter auf Genehmigung des

Strombezugs vom Apollo-Lichttheater, Oktober 1910

$1905-1911$

Klassifikation Teil B: 01089

Band: 11

Trägermaterial: Papier

Alte Reg.-Sig.: IV Jg 65

Bestell-Nr.: IV 01089

1098 Anlage eines Elektrizitätswerkes und Aufbau eines elektrischen

$1906-1912$ Leitungsnetzes, Bd. 12

- Kostenvoranschlag der AEG für den Bau eines Kraftwerks in Emden, 1906

- Schriftwechsel zwischen dem Magistrat der Stadt Emden und der AEG wegen des Angebots zum Bau und Betrieb eines Kraftwerks in Emden, April - Juni 1906 / Juli 1907 - August 1908 / Mai 1911

- Verhandlungen der Elektrizitätskommission über das Angebot und die Bedingungen der AEG zum Bau und Betrieb eines Kraftwerks in Emden sowie zum Aufbau und Unterhaltung eines Stromleitungsnetzes, März 1908 / Mai - Juni 1911

- Angebot der AEG über Vertrag zum Bau eines Kraftwerks und Betrieb eines Stromnetzes für den Zeitraum von 50 Jahren, 1911 - Bescheid der Stadt Emden an die AEG über Ablehnung des Angebotes, Mai 1912

$1906-1912$

Klassifikation Teil B: 01090

Band: 12

Trägermaterial: Papier

Alte Reg.-Sig.: IV Jg 65

Bestell-Nr.: IV 01090 
05

05.03

05.03.06

05.03.06.05

05.03.06.05.03
Stadtverwaltung

Aufgabenbereiche der Stadtverwaltung

Öffentliche Anlagen, Straßenpolizei und Organisation der

Ver- und Entsorgung

Versorgung der Stadt Emden mit Energie

Aufbau eines elektrischen Kraftwerks und eines

Leitungsnetzes

Laufzeit

1099 Anlage eines Elektrizitätswerkes und Aufbau eines elektrischen Leitungsnetzes, Bd. 13

- Empfehlung des Projektberaters und Oberingenieurs Richard Sturm über zu empfehlende Unternehmen zum Bau und Betrieb eines Stromnetzes, Juni 1912

- Angebote verschiedener Firmen über Installationen von

Stromleitungen und Anschlüssen, Juni 1912

- Verhandlungen der Elektrizitätskommission über Vergabe der

Arbeiten, Juli 1912

- Beschluss der städtischen Kollegien über Auftragsvergabe an die Hanseatischen Siemens Schuckert Werke, Juli 1912

- Verhandlungen zwischen der Stadt Emden und den Hanseatischen Siemens Schuckert Werken über Vertragsabschluss wegen Bau eines Stromleitungsnetzes mit Hausanschlüssen, Juli - September 1912

1912

\author{
Klassifikation Teil B: 01091 \\ Band: 13 \\ Trägermaterial: Papier \\ Alte Reg.-Sig.: IV Jg 65 \\ Bestell-Nr.: IV 01091
}

1100 Anlage eines Elektrizitätswerkes und Aufbau eines elektrischen Leitungsnetzes, Bd. 14

- Zeitungsannoncen zu Stromtarifen, 1908

- Angebote von Ingenieuren über Beratertätigkeit bei der Errichtung eines Stromleitungsnetzes, 1911 - 1912

- Angebot der Abnahme elektrotechnischer Anlagen durch den Dampfkessel-Überwachungsverein zu Hannover, Februar 1912 - Erlass des preußischen Innenministers über Empfehlung und Information über die Tätigkeit des Beratungsvereins "Elektrizität" zu Berlin, Juni 1912

- AEG-Broschüre "Die Elektrizität im Hafen- und Wasserbau", 1912

- AEG-Zeitung, 1912

- Gemeinsamer Erlass der preußischen Minister des Handels und Gewerbe, der Landwirtschaft und des Innenministers über Missbilligung von langfristigen Konzessionen für Stromnetzbetreiber zur Verhinderung eines Wettbewerbs zum Vorteil der Stromkunden, Juli 1912

- Agitation für und gegen Überlandzentralen, 1912 - 1915

$1908-1916$

Klassifikation Teil B: 01092

Band: 14

Trägermaterial: Papier

Alte Reg.-Sig.: IV Jg 65

Bestell-Nr.: IV 01092 
05

05.03

05.03.06

05.03.06.05

05.03.06.05.03
Stadtverwaltung

Aufgabenbereiche der Stadtverwaltung

Öffentliche Anlagen, Straßenpolizei und Organisation der

Ver- und Entsorgung

Versorgung der Stadt Emden mit Energie

Aufbau eines elektrischen Kraftwerks und eines

Leitungsnetzes

Laufzeit

1101 Anlage eines Elektrizitätswerkes und Aufbau eines elektrischen Leitungsnetzes, Bd. 15

- Organisation der elektrischen Energieversorgung des Emder Amtsgerichtsgebäudes, Dezember 1910 - März 1911

$1910-1911$

Klassifikation Teil B: 01093

Band: 15

Trägermaterial: Papier

Alte Reg.-Sig.: IV Jg 65

Bestell-Nr.: IV 01093

1102 Anlage eines Elektrizitätswerkes und Aufbau eines elektrischen Leitungsnetzes, Bd. 16

- Erhebung über Interessenten für den Anschluss an das Stromleitungsnetz, 1908 / 1911

$1908 / 1911$

Klassifikation Teil B: 01094

Band: 16

Trägermaterial: Papier

Alte Reg.-Sig.: IV Jg 65

Bestell-Nr.: IV 01094

1103 Anlage eines Elektrizitätswerkes und Aufbau eines elektrischen Leitungsnetzes, Bd. 17

- Konzessionsvertrag mit den Hanseatischen Siemens Schukert Werken über Einrichtung eines Stromleitungsnetzes in Emden und Anschluss an die Überlandzentrale Wiesmoor, Oktober 1907 - Gutachten des Ingenieurs und Direktors der Mülheimer Elektrizitätswerke, H. Förster, über Versorgung der Stadt Emden mit elektrischer Energie, 1908

- Material: Errichtung und Betrieb von Kraftwerken in anderen Städten, 1911

- Druck: Vorschriften für die Herstellung elektrischer Anlagen zum Anschluss an das Leitungsnetz der Stadt Emden, Juli 1912

- Stromleitungsnetzplan der Stadt Emden, 1910

- Vertragsentwürfe mit Stromnetzbetreibern, 1911 - 1912

Klassifikation Teil B: 01095

Band: 17

Trägermaterial: Papier

Alte Reg.-Sig.: IV Jg 65

Bestell-Nr.: IV 01095 
05

05.03

05.03.06

05.03.06.05

05.03.06.05.03
Stadtverwaltung

Aufgabenbereiche der Stadtverwaltung

Öffentliche Anlagen, Straßenpolizei und Organisation der

Ver- und Entsorgung

Versorgung der Stadt Emden mit Energie

Aufbau eines elektrischen Kraftwerks und eines

Leitungsnetzes

Laufzeit

1104 Anlage eines Elektrizitätswerkes und Aufbau eines elektrischen Leitungsnetzes, Bd. 18

- Beratertätigkeit des Oberingenieurs Richard Sturm aus Brandenburg

/ Havel über Aufbau eines Kraftwerks und eines elektrischen

Stromleitungsnetzes in Emden, August 1908 - November 1911

- Gutachten des Oberingenieurs Richard Sturm zu Angeboten und

Kostenschätzungen potenzieller Netzbetreiber, Januar 1909

$1908-1911$

Klassifikation Teil B: 01096

Band: 18

Trägermaterial: Papier

Alte Reg.-Sig.: IV Jg 65

Bestell-Nr.: IV 01096

1105 Anlage eines Elektrizitätswerkes und Aufbau eines elektrischen

Leitungsnetzes, Bd. 19

- Beratertätigkeit des Direktors des Bremer Elektrizitätswerkes, Fritz

Süchting, über Aufbau eines Kraftwerks und eines elektrischen

Stromleitungsnetzes in Emden, August - Dezember 1911

1911

\author{
Klassifikation Teil B: 01097 \\ Band: 19 \\ Trägermaterial: Papier \\ Alte Reg.-Sig.: IV Jg 65 \\ Bestell-Nr.: IV 01097
}

1106 Anlage eines Elektrizitätswerkes und Aufbau eines elektrischen Leitungsnetzes, Bd. 20

- Verhandlungen der Elektrizitätskommission über Aufbau eines Stromleitungsnetzes, April - Juni 1912

- Beratungstätigkeit des Oberingenieurs Richard Sturm beim Aufbau eines Stromleitungsnetzes, April 1912 - April 1913

- Verhandlungen mit der Eisenbahnverwaltung wegen Verlegung von Stromleitungen über Bahngelände, Mai 1912

- Ausschreibung der Arbeiten zur Einrichtung eines

Stromleitungsnetzes, Juni 1912

- Beschwerde des J. de Ruyter über zu dicht an seinem Haus angelegte Stromleitung, November 1912

- Beschädigung einer Stromleitung durch unautorisierte Arbeiten des

Bauunternehmers Conradi, November 1912

$1912-1913$

Klassifikation Teil B: 01098

Band: 20

Trägermaterial: Papier

Alte Reg.-Sig.: IV Jg 65

Bestell-Nr.: IV 01098 
05

\subsection{3}

05.03.06

05.03.06.05

05.03.06.05.03
Stadtverwaltung

Aufgabenbereiche der Stadtverwaltung

Öffentliche Anlagen, Straßenpolizei und Organisation der

Ver- und Entsorgung

Versorgung der Stadt Emden mit Energie

Aufbau eines elektrischen Kraftwerks und eines

Leitungsnetzes

Lfd. Nr. Titel

Laufzeit

1107 Anlage eines Elektrizitätswerkes und Aufbau eines elektrischen Leitungsnetzes, Bd. 21

- Verhandlungen der Elektrizitätskommission über Aufbau eines

Stromleitungsnetzes, April 1912 - Februar 1913

- Verhandlungen der städtischen Kollegien über Aufbau eines

Stromleitungsnetzes, Juli - Oktober 1912

- Schutz der Telegraphenleitungen vor Störungen durch

Starkstromleitungen, August 1912 - Februar 1913

- Verzeichnis der elektrischen Anschlüsse in Emden, 1912 - 1913

- Querriss: Verkabelung einer Straße und Anlage von Hochmasten,

1912

- Stromleitungsplan der Stadt Emden, 1913

$1912-1913$

Klassifikation Teil B: 01099

Band: 21

Trägermaterial: Papier

Alte Reg.-Sig.: IV Jg 65

Bestell-Nr.: IV 01099

1108 Anlage eines Elektrizitätswerkes und Aufbau eines elektrischen

Leitungsnetzes, Bd. 22

- Zusammenarbeit zwischen der Stadt Emden und der kgl.

Wasserbauverwaltung wegen der Verlegung von Unterwasserkabel im

Bereich Eisenbahndock, Falderndelft und Binnenhafen

- Durchführung der Kabelverlegung durch die Hanseatischen Siemens

Schuckert Werke

1912

Klassifikation Teil B: 01100

Band: 22

Trägermaterial: Papier

Alte Reg.-Sig.: IV Jg 65

Bestell-Nr.: IV 01100 
05

\subsection{3}

05.03.06

05.03.06.05

05.03.06.05.03

\section{Stadtverwaltung}

Aufgabenbereiche der Stadtverwaltung

Öffentliche Anlagen, Straßenpolizei und Organisation der

Ver- und Entsorgung

Versorgung der Stadt Emden mit Energie

Aufbau eines elektrischen Kraftwerks und eines

Leitungsnetzes

Lfd. Nr. Titel

Laufzeit

1109 Anlage eines Elektrizitätswerkes und Aufbau eines elektrischen

1910-1913

Leitungsnetzes, Bd. 23

- Verhandlungen der Stadt Emden mit der Eisenbahnverwaltung wegen Verlegung von Stromleitungen über Bahngelände, Mai 1910 Mai 1912 - Febr. 1913

- Plan: Stromleitungskabel auf Bahngelände, 1913

- Feststellungsklage der Stadt Emden beim Reichsgericht über Frage der Duldung von städtischen Stromleitungen auf Bahngelände durch den Eisenbahnfiskus, 1913 - 1915

$1910-1913$ (1915)

Klassifikation Teil B: 01101

Band: 23

Trägermaterial: Papier

Alte Reg.-Sig.: IV Jg 65

Bestell-Nr.: IV 01101

1110 Anlage eines Elektrizitätswerkes und Aufbau eines elektrischen Leitungsnetzes, Bd. 24

- Verhandlungen der Stadt Emden mit dem kgl. Wasserbauamt über Führung von Stromleitungen über wasserbaufiskalisches Gebiet,

Oktober 1912 - Januar 1913

- Plan einer Kabeltrasse über wasserbaufiskalisches Gebiet, 1912

$1912-1913$

Klassifikation Teil B: 01102

Band: 24

Trägermaterial: Papier

Alte Reg.-Sig.: IV Jg 65

Bestell-Nr.: IV 01102

1111 Anlage eines Elektrizitätswerkes und Aufbau eines elektrischen Leitungsnetzes, $\mathrm{Bd} .25$

- Rechnung des kgl. Wasserbauamts über Anschluss des städtischen Stromleitungsnetzes an die fiskalische Transformatorenstation im Königspolder, Juni 1912 - Juli 1913

$1912-1913$

Klassifikation Teil B: 01103

Band: 25

Trägermaterial: Papier

Alte Reg.-Sig.: IV Jg 65

Bestell-Nr.: IV 01103 
05

\subsection{3}

05.03.06

05.03.06.05

05.03.06.05.03

\section{Stadtverwaltung}

Aufgabenbereiche der Stadtverwaltung

Öffentliche Anlagen, Straßenpolizei und Organisation der

Ver- und Entsorgung

Versorgung der Stadt Emden mit Energie

Aufbau eines elektrischen Kraftwerks und eines

Leitungsnetzes

Lfd. Nr. Titel

Laufzeit

1112 Anlage eines Elektrizitätswerkes und Aufbau eines elektrischen Leitungsnetzes, Bd. 31

- Vergabe der Pflastererarbeiten im Gefolge des Aufbaus der Stromleitungsmasten, September - Oktober 1912

1912

Klassifikation Teil B: 01104

Trägermaterial: Papier

Alte Reg.-Sig.: IV Jg 65

Bestell-Nr.: IV 01109

1113 Anlage eines Elektrizitätswerkes und Aufbau eines elektrischen

Leitungsnetzes, Bd. 26

- Aufbau und Einrichtung von Transformatoren-Stationen durch die Hanseatischen Siemens Schuckert Werke, Juli 1912

- Aufbringung der benötigten Finanzmittel für die Trafostationen durch die städtischen Kollegien, August 1912

- Verhandlungen der Stadt Emden mit den Hanseatischen Siemens

Schukert Werken wegen der Mehrkosten der Trafos, August 1912

1912
Klassifikation Teil B: 01104
Band: 26
Trägermaterial: Papier
Alte Reg.-Sig.: IV Jg 65
Bestell-Nr.: IV 01104

1114 Anlage eines Elektrizitätswerkes und Aufbau eines elektrischen Leitungsnetzes, $\mathrm{Bd}$. 27

- Aufbau und Einrichtung des elektrischen Stromleitungsnetzes durch die Hanseatischen Siemens Schuckert Werke, Juli - August 1912

- Verhandlungen der Elektrokommission über Einrichtung der

Transformationsstationen, Juli - August 1912

1912

Klassifikation Teil B: 01105

Band: 27

Trägermaterial: Papier

Alte Reg.-Sig.: IV Jg 65

Bestell-Nr.: IV 01105 
05

\subsection{3}

05.03.06

05.03.06.05

05.03.06.05.03

\section{Stadtverwaltung}

Aufgabenbereiche der Stadtverwaltung

Öffentliche Anlagen, Straßenpolizei und Organisation der

Ver- und Entsorgung

Versorgung der Stadt Emden mit Energie

Aufbau eines elektrischen Kraftwerks und eines

Leitungsnetzes

Lfd. Nr. Titel

Laufzeit

1115 Anlage eines Elektrizitätswerkes und Aufbau eines elektrischen Leitungsnetzes, Bd. 28

- Antrag des Gärtners August Rackebrandt auf Erlaubnis der Anbringung eines Hinweises auf seine Gärtnerei auf der seinen Eingang verdeckenden Trafosäule, November 1912

- Verlegung der Trafosäule im Stadtgarten wegen ungünstiger

Platzierung, November 1912 - April 1913

$1912-1913$

Klassifikation Teil B: 01106

Band: 28

Trägermaterial: Papier

Alte Reg.-Sig.: IV Jg 65

Bestell-Nr.: IV 01106

1116 Anlage eines Elektrizitätswerkes und Aufbau eines elektrischen

Leitungsnetzes, Bd. 29

- Verhandlungen der Elektrokommission wegen Aufbau der Masten für die oberirdischen Stromleitungen, Oktober 1912

1912
Klassifikation Teil B: 01107
Band: 29
Trägermaterial: Papier
Alte Reg.-Sig.: IV Jg 65
Bestell-Nr.: IV 01107

1117 Anlage eines Elektrizitätswerkes und Aufbau eines elektrischen Leitungsnetzes, Bd. 30

- Verhandlungen der Elektrokommission wegen Aufbau der Masten für die oberirdischen Stromleitungen, August 1912

- Schreiben der Hanseatischen Siemens Schuckert Werke über Unmöglichkeit der Beschaffung der im Auftrag vorgegebenen Mannensmannrohrmasten, Juli 1912

1912

Klassifikation Teil B: 01108

Band: 30

Trägermaterial: Papier

Alte Reg.-Sig.: IV Jg 65

Bestell-Nr.: IV 01108 
1118 Anlage eines Elektrizitätswerkes und Aufbau eines elektrischen Leitungsnetzes, Bd. 32

- Beschwerde des Stadtbauführers Schultz über mangelhafte Aushebung der Kabelgrube durch den Bauunternehmer Neemann, September 1912

- Anzeige über Verkehrsgefährdung durch einen bei den Leitungsverlegungsarbeiten zu Tage geforderten Sandsteinblock, Oktober 1912

1912

\author{
Klassifikation Teil B: 01110 \\ Band: 32 \\ Trägermaterial: Papier \\ Alte Reg.-Sig.: IV Jg 65 \\ Bestell-Nr.: IV 01110
}

1119 Anlage eines Elektrizitätswerkes und Aufbau eines elektrischen Leitungsnetzes, Bd. 33

- Beschwerden verschiedener Grund- und Hausbesitzer gegen die Beeinträchtigung ihres Besitzes durch elektrische Stromleitungen

Klassifikation Teil B: 01111

Band: 33

Trägermaterial: Papier

Alte Reg.-Sig.: IV Jg 65

Bestell-Nr.: IV 01111 
05

05.03

05.03.06

05.03.06.05

05.03.06.05.03
Stadtverwaltung

Aufgabenbereiche der Stadtverwaltung

Öffentliche Anlagen, Straßenpolizei und Organisation der

Ver- und Entsorgung

Versorgung der Stadt Emden mit Energie

Aufbau eines elektrischen Kraftwerks und eines

Leitungsnetzes

Lfd. Nr. Titel

Laufzeit

1120 Anlage eines Elektrizitätswerkes und Aufbau eines elektrischen Leitungsnetzes, Bd. 34

- Stromleitungspläne, 1912

- Nachrichten über Gerichtsverfahren und Publikationen zur

Kostenträgerschaft bei besonderen Maßnahmen zum Schutz der

Telegraphenleitungen vor Stromleitungen, 1912 - 1914

- Verhandlungen der Elektrizitätskommission wegen

Kostenträgerschaft bei besonderen Maßnahmen zum Schutz der

Telegraphenleitungen vor Stromleitungen, März 1913

- Vermerk des Oberbürgermeisters Dr. Mützelburg über

Vorgehensweise gegen das Telegraphenamt in der Frage der

Kostenträgerschaft für den Schutz der Telegraphenleitungen,

November 1913

- Schreiben des Telegrafenamts an die Stadt Emden über

Verweigerung einer Kostenmitträgerschaft für Schutzmaßnahmen für

die Telegraphenleitungen, Februar 1914

- Antrag der Stadt Emden beim Regierungspräsidenten in Aurich auf

Festsetzung der Entschädigung für von der Stadt vorgenommene

Schutzmaßnahmen für die Telegraphenleitung, Dezember 1914 - Juni 1915

$1912-1915$

Klassifikation Teil B: 01113

Band: 34

Trägermaterial: Papier

Alte Reg.-Sig.: IV Jg 65

Bestell-Nr.: IV 01113

1121 Anlage eines Elektrizitätswerkes und Aufbau eines elektrischen

$1912-1913$ Leitungsnetzes, $\mathrm{Bd}$. 35

- Beratertätigkeit des Oberingenieurs Richard Sturm wegen

Angeboten zu Stromtarifen und Aufbau eines Stromleitungsnetzes, Dezember 1911 - August 1912

- Angebot des Oberingenieurs Richard Sturm über Konzept für ein Stromnetz in Emden und über Beratung bei der Durchführung der Arbeiten, Februar - März 1912

- Verhandlungen der städtischen Kollegien über Bewertung der Leistung des Oberingenieurs Sturm sowie Bestellung des Emil

Panthöfer zum Elektrotechniker im Dienst der Stadt Emden, August 1912

- Krankheitsvertretung des Oberingenieurs R. Sturm durch den

Zivilingenieur Paul Peltzer, September - Dezember 1912

- Zeugnis für den Oberingenieur Richard Sturm, Februar 1913

$1912-1913$

Klassifikation Teil B: 01114

Band: 35

Trägermaterial: Papier

Alte Reg.-Sig.: IV Jg 65

Bestell-Nr.: IV 01114 
05

\subsection{3}

05.03.06

05.03.06.05

05.03.06.05.03

\section{Stadtverwaltung}

Aufgabenbereiche der Stadtverwaltung

Öffentliche Anlagen, Straßenpolizei und Organisation der

Ver- und Entsorgung

Versorgung der Stadt Emden mit Energie

Aufbau eines elektrischen Kraftwerks und eines

Leitungsnetzes

Lfd. Nr. Titel

Laufzeit

1122 Anlage eines Elektrizitätswerkes und Aufbau eines elektrischen Leitungsnetzes, Bd. 36

- Anschaffung und Installierung von Stromzählern in an das Stromnetz angeschlossene Emder Häuser, Februar 1912

- Angebote verschiedener Firmen über Stromzähler

1912

\author{
Klassifikation Teil B: 01115 \\ Band: 36 \\ Trägermaterial: Papier \\ Alte Reg.-Sig.: IV Jg 65 \\ Bestell-Nr.: IV 01115
}

1123 Anlage eines Elektrizitätswerkes und Aufbau eines elektrischen

Leitungsnetzes, Bd. 37

- Verhandlungen der Elektrizitätskommission über Aufbau eines Stromleitungsnetzes und der Anschlüsse sowie des dazu erforderliochen technischen Material, April - August 1912

- Konzept der Bedingungen für die Lieferung von elektrischem Strom aus dem Leitungsnetz der Stadt Emden, April - Juli 1912

- Protest der Emder Geschäftsleute und Gewerbetreibenden gegen

hohe Strompreise, Juli - August 1912

- Schutz der Telegraphenleitung durch geerdete Nullleiter in

Stromleitungen, Aeptember - Oktober 1912

1912

\author{
Klassifikation Teil B: 01116 \\ Band: 37 \\ Trägermaterial: Papier \\ Alte Reg.-Sig.: IV Jg 65 \\ Bestell-Nr.: IV 01116
}

1124 Anlage eines Elektrizitätswerkes und Aufbau eines elektrischen Leitungsnetzes, Bd. 38

- Anträge auf Ermäßigung der Strompreise für Gewerbetreibende und Schlachthof

$1914-1915$

Klassifikation Teil B: 01117

Band: 38

Trägermaterial: Papier

Alte Reg.-Sig.: IV Jg 65

Bestell-Nr.: IV 01117 
05

\subsection{3}

05.03.06

05.03.06.05

05.03.06.05.03

\section{Stadtverwaltung}

Aufgabenbereiche der Stadtverwaltung

Öffentliche Anlagen, Straßenpolizei und Organisation der

Ver- und Entsorgung

Versorgung der Stadt Emden mit Energie

Aufbau eines elektrischen Kraftwerks und eines

Leitungsnetzes

Lfd. Nr. Titel

Laufzeit

1125 Anlage eines Elektrizitätswerkes und Aufbau eines elektrischen Leitungsnetzes, Bd. 39

- Angebote über Leistungen zur Herstellung eines elektrischen Stromleitungsnetzes in Emden, 1912

- Kostenanschlag der Hanseatischen Siemens Schuckert Werke über

Aufbau eines Stromleitungsnetzes, 1912

- Verhandlungen der Elektrizitätskommission und der städtischen

Kollegien über Vergabe der Arbeiten zur Herstellung eines

Stromleitungsnetzes, Juli - August 1912

- Vertrag mit den Hanseatischen Siemens Schuckert Werken über

Aufbau eines Stromleitungsnetzes, Juli - August 1912

1912

\author{
Klassifikation Teil B: 01118 \\ Band: 39 \\ Trägermaterial: Papier \\ Alte Reg.-Sig.: IV Jg 65 \\ Bestell-Nr.: IV 01118
}

1126 Anlage eines Elektrizitätswerkes und Aufbau eines elektrischen Leitungsnetzes, Bd. 40

- Verhandlungen der Stadt Emden mit den Hanseatischen Siemens Schuckert Werken über Ermittlung der Kupferpreise zur Feststellung der Kosten des Stromleitungsbaus, Juli - August 1912

1912

\author{
Klassifikation Teil B: 01119 \\ Band: 40 \\ Trägermaterial: Papier \\ Alte Reg.-Sig.: IV Jg 65 \\ Bestell-Nr.: IV 01119
}

1127 Anlage eines Elektrizitätswerkes und Aufbau eines elektrischen Leitungsnetzes, Bd. 41

- Verhandlungen der Hanseatischen Siemens Schuckert Werke mit der Stadt Emden über Verschiebung der Lieferfristen wegen Schwierigkeiten bei der Materialbeschaffung und nicht vorhersehbare Änderungen der Kabeltrasse, August - September 1912

1912

Klassifikation Teil B: 01120

Band: 41

Trägermaterial: Papier

Alte Reg.-Sig.: IV Jg 65

Bestell-Nr.: IV 01120 
1128 Anlage eines Elektrizitätswerkes und Aufbau eines elektrischen Leitungsnetzes, Bd. 42

- Verhandlungen der Stadt Emden mit den Hanseatischen Siemens Schuckert Werken über Erstellung der Hausanschlüsse an das Stromleitungsnetz, April - Mai 1913

- Verhandlungen der Stadt Emden mit den Hanseatischen Siemens Schuckert Werken über Rückkauf von unverbrauchten Kupferkabeln, April 1913

1913

\author{
Klassifikation Teil B: 01121 \\ Band: 42 \\ Trägermaterial: Papier \\ Alte Reg.-Sig.: IV Jg 65 \\ Bestell-Nr.: IV 01121
}

1129 Anlage eines Elektrizitätswerkes und Aufbau eines elektrischen Leitungsnetzes, Bd. 43

- Verhandlungen der städtischen Kollegien über Organisation der Herstellung der Hausanschlüsse an das Stromleitungsnetz, Juli August 1912

- Kostenvoranschlag der Hanseatischen Siemens Schuckert Werke, Juli 1912

- Prüfung der Angebote zur Herstellung der Hausanschlüsse durch den Projektberater, Oberingenieur Richard Sturm, Juli 1912

1912

Klassifikation Teil B: 01122

Band: 43

Trägermaterial: Papier

Alte Reg.-Sig.: IV Jg 65

Bestell-Nr.: IV 01122 
05

05.03

05.03.06

05.03.06.05

05.03.06.05.03
Stadtverwaltung

Aufgabenbereiche der Stadtverwaltung

Öffentliche Anlagen, Straßenpolizei und Organisation der

Ver- und Entsorgung

Versorgung der Stadt Emden mit Energie

Aufbau eines elektrischen Kraftwerks und eines

Leitungsnetzes

Laufzeit

1130 Anlage eines Elektrizitätswerkes und Aufbau eines elektrischen Leitungsnetzes, Bd. 44

- Beschwerde des Verbands der Elektrotechnischen Installationsfirmen beim Regierungspräsidenten in Aurich gegen den Ausschluss freier Installateure bei der Erstellung der elektrischen Hausanschlüsse in Emden durch Exklusivvertrag mit den

Hanseatischen Siemens Schuckert Werken, Februar - Mai 1909

- Verhandlungen der Elektrizitätskommission über Zulassung freier

Elektroinstallateure zur Erstellung der elektrischen Hausanschlüsse,

August - September 1912

- Anträge verschiedener Elektroinstallateure auf Zulassung zur

Einrichtung elektrischer Hausanschlüsse, Juli1912 - Juni 1914

- Auszahlung der zur Zulassung erhobenen Kaution des insolventen

Elektroinstallateurs E. Fokuhl an seinem Konkursverwalter, Juli 1914 Juli 1915

$1914-1915$

Klassifikation Teil B: 01123

Band: 44

Trägermaterial: Papier

Alte Reg.-Sig.: IV Jg 65

Bestell-Nr.: IV 01123

1131 Anlage eines Elektrizitätswerkes und Aufbau eines elektrischen

1911-1912 Leitungsnetzes, Bd. 45

- Ernennung des Senators Thiele zum Mitglied der

Elektrizitätskommission, Oktober 1911

- Betrauung der Elektrizitätskommission mit der Organisation und

Überwachung der Anlage eines Stromnetzes in Emden, August 1912

$1911-1912$

Klassifikation Teil B: 01124

Band: 45

Trägermaterial: Papier

Alte Reg.-Sig.: IV Jg 65

Bestell-Nr.: IV 01124 
1132 Anlage eines Elektrizitätswerkes und Aufbau eines elektrischen Leitungsnetzes, Bd. 46

- Einstellung eines Elektromonteurs- oder Technikers zur Überwachung der Erstellung der elektrischen Hausanschlüsse, Juni August 1912

- Bewerbung des Ernst Panthöfer um die Stelle eines

Elektrotechnikers, Juli - August 1912

- Unfallversicherung des Elektrotechnikers Ernst Panthöfer, Januar 1913

1912 - 1913

Klassifikation Teil B: 01125

Band: 46

Trägermaterial: Papier

Alte Reg.-Sig.: IV Jg 65

Bestell-Nr.: IV 01125

1133 Anlage eines Elektrizitätswerkes und Aufbau eines elektrischen Leitungsnetzes, Bd. 47

- Bekanntmachungen zur Planung eines Kraftwerks, Errichtung des Stromnetzes Informationen für Anschlusswillige und Stromtarife

$1912-1913$

Klassifikation Teil B: 01126

Band: 47

Trägermaterial: Papier Alte Reg.-Sig.: IV Jg 65

Bestell-Nr.: IV 01126 
IV

05

05.03

05.03.07

05.03.07.01

05.03.07.01.01

\section{Stadtverwaltung}

Aufgabenbereiche der Stadtverwaltung

Baupolizei

Organisation der Baupolizei

Baugesetzgebung und Bauvorschriften

Lfd. Nr. Titel

Laufzeit

1134 Ortsstatut über die Anlegung und Veränderung von Straßen und Plätzen, Bd. 1

1876-1888

- Statuten über Anlegung und Veränderung von Straßen und Plätzen aus anderen Städten als Vorbild für Emden, 1876

- Konzipierung des Ortsstatuts über Anlegung und Veränderung von

Straßen und Plätzen in Emden, 1876 - 1888

- Verhandlungen des Magistrats und des Bürgervorsteherkollegiums über Heranziehung der Anlieger zu den Straßenbaukosten, November 1880

- Bekanntmachung über die Einführung fester Hausnummern in Emden, Februar 1887

- Stellungnahme des Bezirksausschusses in Aurich zum Entwurf des Ortsstatuts über die Anlegung und Veränderung von Straßen und Plätzen, August 1887 / August 1888

$1876-1888$

Klassifikation Teil B: 00855

Band: 1

Trägermaterial: Papier

Alte Reg.-Sig.: IV Ka 20

Bestell-Nr.: IV 00855

1135 Ortsstatut über Anlegung und Veränderung von Straßen und Plätzen,

$1894-1913$ Bd. 2

- Novellierung des Ortsstatuts über Anlegung und Veränderung von Straßen und Plätzen, 1894

- Antrag der S. Fischer und F. van Ahrens auf Genehmigung des Baus von Arbeiterhäuser am Hinter Tief, Oktober - Dezember 1899

- Antrag des Zimmermeisters Jacobus Fritzen auf Genehmigung des Baus eines Doppelhauses bei der Papierfabrik, Dezember 1900 -

Dezember 1901

- Plan des Baus einer Arbeitersiedlung am Boltentor, November 1901

- Korrespondenz der Stadt Emden mit anderen Städten wegen Ortsstatut über Anlegung und Veränderung von Straßen und Plätzen, 1901 - 1911

- Abgelehnter Antrag des Grundeigentümers Helmer von Baden Voget auf Anlage einer Sackstraße auf seinem Grundstück im

Boltentorviertel, Dezember 1901 - Januar 1902

- Streit um den gemäß Ortsstatut vom Zimmermeister Jacobus Fritzen erhobenen Anliegerbeitrag wegen Straßenanbindung seiner

Arbeiterhäuser, Dezember 1901 - Januar 1902

$1894-1913$

Klassifikation Teil B: 00856

Band: 2

Trägermaterial: Papier

Alte Reg.-Sig.: IV Ka 20

Bestell-Nr.: IV 00856 
IV

05

05.03

05.03.07

05.03.07.01

05.03.07.01.01

Lfd. Nr. Titel

\section{Stadtverwaltung}

\section{Aufgabenbereiche der Stadtverwaltung}

Baupolizei

Organisation der Baupolizei

Baugesetzgebung und Bauvorschriften

1136 Bestimmungen über bauliche Beschaffenheit von Warenhäusern, Geschäftshäusern etc.

Laufzeit

- Erlasse des preußischen Ministers der öffentlichen Arbeiten über baulichen Auflagen für Warenhäuser mit teilweiser Lagerung von brennbaren Stoffen als Verkaufsware, Mai 1891 - Juli 1908

- Umsetzung des Erlasses in Emden, August 1901 - Mai 1902

- Verbot der Gaslichtbeleuchtung der Schaufenster des Kaufhauses Schönberg wegen Feuergefahr, September 1909 - Februar 1910 - Aufstellung über Geschäfte mit verbotener Gasbeleuchtung der Schaufenster, Februar 1910

- Durchsetzung des Verbotes von Gasbeleuchtung der Schaufenster in Emden, Februar - März 1910

$1891-1910$

Klassifikation Teil B: 00858

Trägermaterial: Papier Alte Reg.-Sig.: IV Ka 23

Bestell-Nr.: IV 00858 
IV

05

05.03

05.03.07

05.03.07.01

05.03.07.01.01
Stadtverwaltung

Aufgabenbereiche der Stadtverwaltung

Baupolizei

Organisation der Baupolizei

Baugesetzgebung und Bauvorschriften

Lfd. Nr. Titel

Laufzeit

1137 Bauordnung der Stadt Emden, Bd. 1

1875-1887

- Verhandlungen der städtischen Kollegien über Erlass einer

Bauordnung für die Stadt Emden, Dezember 1875 - September 1876

- Gedruckte Musterbauordnung gemäß den Richtlinien des Erlasses

des preußischen Ministers für Handel, Gewerbe und öffentliche

Arbeiten, Januar 1878

- Verfügung des preußischen Landdrosten in Aurich über Informierung zur Umsetzung der Musterordnung des preußischen Ministers, März -

Mai 1878

- Gedruckte Musterbauordnung des preußischen Ministeriums der

öffentlichen Arbeiten mit Kommentierung, August 1880

- Bericht des Stadtbaumeisters Wiggers über Umsetzbarkeit der

Musterbauordnung, März 1881

- Entwurf der Bekanntmachung des Magistrats über vollständige

Einreichung aller Anlagen zum Bauvorhaben als Bedingung für

Genehmigungserteilung, April 1883

- Verschiedene baupolizeiliche Einzelanordnungen der Stadt Emden,

Oktober 1883 - November 1884

- Verfügung des preußischen Landdrosten in Aurich über

Notwendigkeit einer allgemeinen Baupolizeiordnung in der Stadt

Emden, September 1884

- Anfragen der Stadt Emden bei anderen Städten der Provinz

Hannover wegen Baupolizeiordnung, 186

- Verhandlungen des Magistrats über Baupolizeiordnung, Oktober

1886

- Gedruckte Entwürfe einer Baupolizeiordnung der Stadt Emden,

November 1886

- Manuskript: Entwurf einer Baupolizeiordnung der Stadt Emden,

November 1886

- Verhandlungen der Baukommission über Erlass einer

Baupolizeiordnung, Juni - Juli 1887

$1875-1887$

Klassifikation Teil B: 01199

Band: 1

Trägermaterial: Papier

Alte Reg.-Sig.: IV Ka 12

Bestell-Nr.: IV 01199 
IV

05

05.03

05.03.07

05.03.07.01

05.03.07.01.01
Stadtverwaltung

\section{Aufgabenbereiche der Stadtverwaltung}

Baupolizei

Organisation der Baupolizei

Baugesetzgebung und Bauvorschriften

Lfd. Nr. Titel

Laufzeit

1138 Bauordnung der Stadt Emden, Bd. 2

1887-1897

- Angebot des Buchdruckers W. Schwalbe wegen Druck der

Baupolizeiordnung, August 1887

- Mitteilung des Oberbürgermeisters Fürbringer an das

Bürgervorsteherkollegium über nicht vorliegende Verpflichtung zur

Zustimmung des Kollegiums zur Baupolizeiordnung, April 1888

- Von den Bürgervorstehern ergänzter und geändeter Entwurf der

Baupolizeiordnung, Mai 1888

- Polizeiverordnung über Pflicht zur Sicherung von Wasserbacken

unter Bürgersteigen zum Schutz der Passanten, September 1888

- Publikation der Baupolizeiordnung, September 1888

- Verteilung der gedruckten Baupolizeiordnung, September 1888

- Bitte anderer Städte um Zusendung der Emder Baupolizeiordnung, 1891 - 1896

- Erlasse des preußischen Ministers der öffentlichen Arbeiten über baupolizeiliche Regelungen zu Baugenehmigungsverfahren, 1893 1896

- Modifikation der Baupolizeiordnung zur Anpassung der baupolizeilichen Regelungen an technische Veränderungen, 1896 1897

$1887-1897$

Klassifikation Teil B: 01200

Band: 2

Trägermaterial: Papier

Alte Reg.-Sig.: IV Ka 12

Bestell-Nr.: IV 01200 
IV

05

05.03

05.03.07

05.03.07.01

05.03.07.01.01
Stadtverwaltung

Aufgabenbereiche der Stadtverwaltung

Baupolizei

Organisation der Baupolizei

Baugesetzgebung und Bauvorschriften

Lfd. Nr. Titel

Laufzeit

1139 Bauordnung der Stadt Emden, Bd. 3

1897-1903

- Baupolizeiliche Regelungen zur Genehmigung des Baus von Schweineställen und der Erlaubnis zur Schweinehaltung, Dezember 1897 - Mai 1902

- Erlass des preußischen Ministers der öffentlichen Arbeiten über Nichtzuständigkeit der Ortsbaupolizeibehörden für die die Genehmigungsverfahren von Staatsbauten, Mai / Dezember 1898 - Ergänzung der Baupolizeiordnung durch die Polizeiverordnung über die Prüfung der Gasleitungen, April 1898

- Verfügung des Regierungspräsidenten in Aurich über Empfehlung der Novellierung der Baupolizeiordnung der Stadt Emden, August / Dezember 1898

- Erlasse des preußischen Ministers für Handel und Gewerbe über baupolizeiliche Regelung von Roh- und Neubauabnahmen, Juni / Juli 1895

- Erlasse des preußischen Ministers der öffentlichen Arbeiten über baulichen Brandschutz, Grenzveränderungen bei Grundstücken, Fluchtlinienpläne und Staatsbauten, Untersuchung von Kalkzement, April 1898 - Mai 1903

- Polizeiverordnung der Stadt Emden über Sicherung von Kellerluken zum Schutz von Passanten, Dezember 1899 / Januar 1900

- Polizeiverordnung über Vorschriften zur Arbeiterfürsorge auf Baustellen, Februar 1900

- Nachträge zur Baupolizeiordnung über Zeichnungen und Schlussabnahme von Neubauten, Februar - Oktober 1901

- Schutzmaßregeln bei der Bauausführung, August 1902

- Revision der Baupolizeibehörde der Stadt Emden durch die

Regierung in Aurich, März 1903

$1897-1903$

Klassifikation Teil B: 01201

Band: 3

Trägermaterial: Papier

Alte Reg.-Sig.: IV Ka 12

Bestell-Nr.: IV 01201 
IV

05

05.03

05.03.07

05.03.07.01

05.03.07.01.01
Stadtverwaltung

Aufgabenbereiche der Stadtverwaltung

Baupolizei

Organisation der Baupolizei

Baugesetzgebung und Bauvorschriften

Lfd. Nr. Titel

Laufzeit

1140 Baupolizeiliche Vorschriften zum Brandschutz in Theatern und öffentlichen Versammlungsräumen, Bd. 1

1881-1897

- Polizeiverordnung der Regierung in Aurich über baupolizeiliche Vorschriften zum Brandschutz in Theatern, November 1889

- Verhandlungen des Magistrats der Stadt Emden über aus Anlass des Theaterbrandes in Wien zu treffende baupolizeiliche Maßnahmen zum Brandschutz im Emder Theater (Hotel "Zur Sonne", Neuer Markt), Dezember 1881 - Januar 1882

- Erlasse des preußischen Innenministers über Anordnung der Revision der Theaterbauten, Zirkusse und Varietes auf bauliche Brandschutzmaßnahmen, November 1881 - September 1894

- Verhandlungen der Baukommission über Revision der

Theater-Lokale in Emden und zu treffende baupolizeiliche Maßnahmen im Brandschutz, Januar 1882

- Bauliche Brandschutzmaßnahmen in der Aula des

Kaiser-Wilhelms-Gymnsiums, 1882

- Verhandlungen der Baukommission über baulichen Brandschutz in

Sälen, Schulen und Kirchen, Februar 1882

- Revision der Tanzsäle wegen Brandschutz, Oktober 1882 -

Dezember 1890

- Antrag des Saalbesitzers H. Simmering auf Befreiung von der Pflicht der feuersicheren Imprägnierung seiner Theaterbühnenteile,

November 1886

- Verfügung des Magistrats der Stadt Emden an den Saalbesitzer H. Hawich über Anweisung zur feuersicheren Imprägnierung seiner Theaterutensilien, Mai 1887

- Anzeige des Polizeisergeanten Bachmann über fehlende Notausgänge im Nordheimer'schen Tanzsaal, Januar 1887 - Verweigerung der Schaffung eines Notausgangs über die Treppe zu seinem Tanzsaal durch den Wirt Gerd Giesen, Juni 1882 - Mai 1889

- Revision des Saals der "Herberge zur Heimat" in der Großen

Faldernstraße, März 1889

- Erlasse des preußischen Ministers der öffentlichen Arbeiten über baupolizeiliche Regelungen zur Feuersicherheit von Theaterbauten,

Oktober 1889 - April 1890

- Verfügung des Regierungspräsidenten in Aurich über

Berichtsanforderung über Umsetzung der novellierten

Polizeiverordnung der Regierung über baupolizeilichen Brandschutz in Sälen und Versammlungsstätten, Mai 1891

- Festsetzung der höchstzulässigen Personenzahl in Sälen in Emden, März 1895

$1881-1897$

Klassifikation Teil B: 01202

Band: 1

Trägermaterial: Papier

Alte Reg.-Sig.: IV Ka 16

Bestell-Nr.: IV 01202 
IV

05

05.03

05.03.07

05.03.07.01

05.03.07.01.01
Stadtverwaltung

Aufgabenbereiche der Stadtverwaltung

Baupolizei

Organisation der Baupolizei

Baugesetzgebung und Bauvorschriften

Lfd. Nr. Titel

Laufzeit

1141 Baupolizeiliche Vorschriften zum Brandschutz in Theatern und öffentlichen Versammlungsräumen, Bd. 2

1897-1909

- Erlasse des preußischen Ministers der öffentlichen Arbeiten über baupolizeiliche Regelungen wegen Feuersicherheit der

Theaterbauten und der Säle mit großer Publikumskapazität,

September 1897 - April 1909

- Festsetzung der zulässigen Personenzahl in Emder Sälen,

September 1898

- Verzeichnis der Saalbesitzer in Emden, März 1899

- Auflagen zur Wiederzulassung des Saalbetriebs des Simon Joseph

Pels, Mai 1899

- Revision und Zulassung der baulichen Feuerschutzmaßnahm,en

(Pläne) in den Emder Gaststätten mit Saalbetrieb u.a.: "Heeren

Logement"; "Zu den drei Kronen"; Schankwirtschaft G. A. Menthe;

"Börse"; "Herberge zur Heimat"; Gastwirtschaft Simon Nordheimer;

Hotel "Union"; Gastwirtschaft Saathoff; Hotel "Bellevue", 1890 - 1907

- Anordnung der feuerfesten Imprägnierung der Kulissen der Theater im "Tivoli" und im Hotel "Union", Februar 1899 - Dezember 1900

- Revision der Versammlungssäle in Emden, August 1889 - 1905

$1897-1909$

Klassifikation Teil B: 01203

Band: 2

Trägermaterial: Papier

Alte Reg.-Sig.: IV Ka 16

Bestell-Nr.: IV 01203

1142 Baupolizeiliche Vorschriften zum Brandschutz in Theatern und öffentlichen Versammlungsräumen, Bd. 3

$1909-1913$

- Erlasse des preußischen Ministers der öffentlichen Arbeiten über baupolizeiliche Regelungen wegen Feuersicherheit der

Theaterbauten und der Säle mit großer Publikumskapazität, August 1909 - Januar 1913

- Polizeiverordnung der Regierung in Aurich über baupolizeiliche

Auflagen für die Brandsicherheit in Theatern und

Versammlungsräumen, Juni 1909

- Revision der Versammlungs- und Theatersäle in Emden, September

1911 - Oktober 1912

$1909-1913$

Klassifikation Teil B: 01204

Band: 3

Trägermaterial: Papier

Alte Reg.-Sig.: IV Ka 16

Bestell-Nr.: IV 01204 
IV

05

05.03

05.03.07

05.03.07.01

05.03.07.01.01
Stadtverwaltung

Aufgabenbereiche der Stadtverwaltung

Baupolizei

Organisation der Baupolizei

Baugesetzgebung und Bauvorschriften

Lfd. Nr. Titel

Laufzeit

1143 Bauordnung der Stadt Emden, Bd.4

1885-1888

- Materialien zum Entwurf einer Bauordnung

$1885-1888$

Klassifikation Teil B: 01208

Band: 4

Trägermaterial: Papier

Alte Reg.-Sig.: IV Ka 12

Bestell-Nr.: IV 01208

1144 Beratung des Entwurfs einer neuen Bauordnung, Bd. 1

1908

- Verfügung des Regierungspräsidenten in Aurich über Weisung zur Beschleunigung des Beschlussverfahrens für eine novellierte Bauordnung der Stadt Emden, April 1908

- Verfügung des Regierungspräsidenten in Aurich über Mitteilung einer Musterbauordnung aus Berlin, Mai 1908

- Rohentwürfe einer Bauordnung, 1908

- Bauordnungen aus anderen Städten als Unterlage für die novellierte Emder Bauordnung, 1908

1908

Klassifikation Teil B: 01228

Band: 1

Trägermaterial: Papier

Alte Reg.-Sig.: IV Ka 34

Bestell-Nr.: IV 01228

1145 Beratung des Entwurfs einer neuen Bauordnung, Bd. 2

1908-1909

- Beratung der novellierten Bauordnung durch die Kommission für Beratung der neuen Bauordnung, September - Oktober 1908

- Von der Kommission für Beratung der neuen Bauordnung beschlossene Anlage zur Bauordnung über Verlegung von Gasleitungen und Erstellung der Hausanschlüsse für Gas, September 1908

- Gedruckter Entwurf der novellierten Bauordnung mit handschriftlichen Änderungs- und Ergänzungsvermerken, September 1908

- Verfügung des Regierungspräsidenten in Aurich über Ergänzungen zur Emder Bauordnung und Betonung der alleinigen Zuständigkeit des Magistrats für die Bauordnung, Oktober 1908 / Februar 1909

- Streit um die Finanzierung der Veröffentlichung der Bauordnung, April - Mai 1909

- Polizeiverordnung über Wasserleitungen und Hausanschlüsse als Anhang der Bauordnung, September - Oktober 1909

$1908-1909$

Klassifikation Teil B: 01229

Band: 2

Trägermaterial: Papier

Alte Reg.-Sig.: IV Ka 34

Bestell-Nr.: IV 01229 
IV

05

05.03

05.03.07

05.03.07.01

05.03.07.01.01
Stadtverwaltung

\section{Aufgabenbereiche der Stadtverwaltung}

Baupolizei

Organisation der Baupolizei

Baugesetzgebung und Bauvorschriften

Lfd. Nr. Titel

Laufzeit

1146 Gesetz über Sicherung der Bauforderungen

1909-1911

- Publikation des Gesetzes über Sicherung der Bauforderungen vom

1. Juni 1909, 1909

- Durchsetzung der im Gesetz vorgeschriebenen Führung von

Baubücher, Oktober 1910 - April 1911

$1910-1911$

Klassifikation Teil B: 01255

Trägermaterial: Papier

Alte Reg.-Sig.: IV Ka 63

Bestell-Nr.: IV 01255

1147 Gesetzliche Regelung der Untersagung der Ausübung des

Baugewerbes

- Gesetz über Veränderung der Gewerbeordnung betr. Untersagung der Ausübung des Baugewerbes und dessen Umsetzung, 1907 - 1911

- Antrag des Stadtbauführers Schulz auf Verhängung eines

Berufsverbots gegen den Bauunternehmer Dinkela wegen unfachmännischer Bauausführung der Schornsteine in den Häusern des Helmer von Baden - Foget und dadurch verursachter Brand, November - Dezember 1911

- Ernennung von Bausachverständige für die Stadt Emden, 1911 1912

$1907-1912$

Klassifikation Teil B: 01259

Trägermaterial: Papier

Alte Reg.-Sig.: IV Ka 67

Bestell-Nr.: IV 01259 
IV

05

05.03

05.03.07

05.03.07.01

05.03.07.01.02
Stadtverwaltung

Aufgabenbereiche der Stadtverwaltung

Baupolizei

Organisation der Baupolizei

Baupolizeiliche Zuständigkeiten

Lfd. Nr. Titel

Laufzeit

1148 Zuschüttung des Burggrabens

1887

- Bericht des Wasserbau-Inspektors Germelmannan die Stadt Emden über Möglichkeit der Verwendung der bei den Baggerungen im Hafengebiet ausgehobenen Erdmassen für die Zuschüttung des Burggrabens und zur Terrainaufhöhung am Küstenbahndamm, Februar 1887

- Verfügung des Ems-Jade-Canal-Bauamts an die Stadt Emden über Verwendung der beim Kanalbau anfallenden Erdmassen, Mai 1887

1887

Klassifikation Teil B: 00167

Trägermaterial: Papier

Bestell-Nr.: IV 00167

1149 Anlegung der Kolonie Friesland durch die Nordseewerke

- Bescheid des Magistrats der Stadt Emden an die Nordseewerke über Verpflichtung der Nordseewerke zur Zahlung einer Pauschalsumme für die Schullasten und die Besoldung eines zusätzlichen Polizeibeamten als Auflage zur Genehmigung des Siedlungsbaus, Juli 1913

- Vertrag zwischen der Nordseewerke und der Stadt Emden über Anlage der Kolonie Friesland als Werftarbeitersiedlung, Januar 1914

$1913-1914$

Klassifikation Teil B: 00313

Trägermaterial: Papier

Alte Reg.-Sig.: II F 14

Bestell-Nr.: IV 00313

1150 Anbringung eines Wetterkastens im Rathausdurchgang

$1904-1911$

- Verhandlungen zwischen der Stadt Emden und dem

Telegraphenamt wegen Anbringung eines Aushangskastens für

Wetterberichte im Rathausdurchgang, Januar - März 1904

- Wetterkastenmodell, 1906

- Unterhaltung des Wetterkastens, 1906 - 1911

$1904-1911$

Klassifikation Teil B: 00440

Trägermaterial: Papier

Alte Reg.-Sig.: IV Cb

Bestell-Nr.: IV 00440 
IV

05

05.03

05.03.07

05.03.07.01

05.03.07.01.02
Stadtverwaltung

Aufgabenbereiche der Stadtverwaltung

Baupolizei

Organisation der Baupolizei

Baupolizeiliche Zuständigkeiten

Lfd. Nr. Titel

Laufzeit

1151 Haus am Neupfortssiel

1871-1888

- Bauantrag des Seilers H. N. Reints wegen Absicht des Umbaus seines Hauses am Neupfortssiel, April 1871

- Verhandlungen wegen Bauauflagen der Stadt Emden an H. N.

Reints, April - August 1871

- Verhandlungen der Stadt Emden mit dem Seilerwarenhändler

Siegfried Pels wegen Absicht der Stadt zum Kauf des Hauses

Neutorstr. 45 (Neupfortssiel), August 1885

- Ermittlungen wegen unerlaubter Umbauten am Haus Neutorstr. 45

(Neupfortssiel), Juli 1887

$1871-1888$

Klassifikation Teil B: 00853

Trägermaterial: Papier

Alte Reg.-Sig.: IV Ka 18

Bestell-Nr.: IV 00853

1152 Straßen-, Fluchtlinien- und Bebauungspläne

- Alphabetisches Straßenverzeichnis mit Angaben zu Fluchtlinien und Bebauungsplänen, 1911

1911

Klassifikation Teil B: 00854

Trägermaterial: Papier

Alte Reg.-Sig.: IV Ka 19

Bestell-Nr.: IV 00854

1153 Schlussabnahme von Bauten

- Ablehnung der Schlussabnahme der Neubauten des

Obertelegraphenassistenten Klug und des Helmer von Baden Voget wegen nicht genügender Austrocknung der Gebäude, April 1901

1901

Klassifikation Teil B: 00857

Trägermaterial: Papier

Alte Reg.-Sig.: IV Ka 21

Bestell-Nr.: IV 00857

1154 Baustil der Fassaden öffentlicher Gebäude

- Initiative der Gesellschaft für bildende Kunst und vaterländische

Altertümer für die Rückbesinnung auf traditionelle niederländische und flämische Gestaltung der Fassaden öffentlicher Gebäude zur

Erhaltung des überkommenden Emder Stadtbildes, Dezember 1899

1899

Klassifikation Teil B: 00859

Trägermaterial: Papier

Alte Reg.-Sig.: IV Ka 24

Bestell-Nr.: IV 00859 
IV

05

05.03

05.03.07

05.03.07.01

05.03.07.01.02
Stadtverwaltung

Aufgabenbereiche der Stadtverwaltung

Baupolizei

Organisation der Baupolizei

Baupolizeiliche Zuständigkeiten

Lfd. Nr. Titel

Laufzeit

1155 Genehmigung baulicher Veränderungen

1866-1896

- Verfügungen des Magistrats der Stadt Emden über Anordnung zur

$(1825-1865)$

Beseitigung gefährlicher oder verkehrshemmender baulicher

Veränderungen oder Maßnahmen an Gebäuden, z.B. Pflanzen von

Bäumen an der Straße, Aufschlagen der Fenster und Türen nach

außen, 1825 - 1896

- Anträge auf Genehmigung baulicher Veränderungen an Gebäuden, 1827 - 1873

- Aufstellung über an den Straßen stehende Bäume und Gamstöcke, 1835

- Regelung des Pflanzens von Bäumen und des Aufstellens von

Gamstöcken vor den Häusern, 1841 - 1850

(1825 - 1865) 1866 - 1896

Klassifikation Teil B: 00891

Trägermaterial: Papier

Alte Reg.-Sig.: IV Ja 01

Bestell-Nr.: IV 00891

1156 Schweine- und Schafhaltung, Bd. 1

1875-1896

- Protokoll über Verpflichtung von Schweine- und Schafhaltern zur

(1834-1865)

Beseitigung ihrer unreinen und gesundheitsschädlichen Stallungen und Einstellung der Schweine- und Schafhaltung, September 1834

- Erhebung einer Gebühr für die Beaufsichtigung der Schweineställe durch den Polizeidiener, Mai 1835 - Februar 1839

- Anzeige gegen den Kräutner Creutzenberg wegen unerlaubtes

Weiden seines Schweines in öffentlichen Anlagen, August 1843

- Anzeige gegen den jüdischen Schlachter Siemon Heymann Glos wegen ungenehmigter Anlage eines Schafstalles, Juli 1858

- Aufstellung über Schweinehalter in der Stadt Emden, 1875

- Anzeige wegen unerlaubter Anlegung eines Misthaufens, August

1876

- Anzeigen wegen Errichtung ungenehmigter und nicht den

Hygienevorschriften entsprechender Schweineställe, (1837 - 1865)

1877 - 1896

- Bericht des Sanitätsrats Dr. Norden über unerträgliche hygienische

Zustände durch Schweinehaltung des Bäckermeisters Sanen in der Neutorstraße, Juli 1877

- Unhygienische und gesundheitsgefährdende Schweinehaltung der

Frau Lierbrock, 1877

- Anträge auf Genehmigung zur Errichtung von Schweineställen im bebauten Stadtgebiet, 1878 - 1893

- Anzeigen wegen unerlaubter Schafweidung auf öffentlichen Plätzen, $1878-1895$

(1834 - 1865) 1875 - 1896

Klassifikation Teil B: 00893

Band: 1

Trägermaterial: Papier

Alte Reg.-Sig.: IV Ja 04

Bestell-Nr.: IV 00893 
IV

05

05.03

05.03.07

05.03.07.01

05.03.07.01.02
Stadtverwaltung

Aufgabenbereiche der Stadtverwaltung

Baupolizei

Organisation der Baupolizei

Baupolizeiliche Zuständigkeiten

Lfd. Nr. Titel

Laufzeit

1157 Schweine- und Schafhaltung in der Stadt, Bd. 2

1897-1912

- Beschwerden wegen Geruchsbelästigung durch Schweinehaltung, 1897 - 1911

- Anzeigen wegen ungenehmigter und unvorschriftmäßig errichteter Schweineställe, 1897 - 1911

- Anzeige gegen den Fuhrmann Harm Störk wegen unerlaubten Weidens seines Pferdes im Roten-Mühlen-Zwinger, September 1897

- Anzeige gegen den Bauunternehmer Balduin Hempel wegen

Geruchsbelästigung und Rattenplage durch seinen Hühnerstall, November - Dezember 1906

- Beschwerde des Telegraphensekretärs Thiemens gegen

Lärmbelästigung durch das Krähen der Hähne des Schuldieners

Leeling, Oktober 1908 - Januar 1910

- Geruchsbelästigung durch einen Ziegenstall, Mai 1911

- Anträge auf Genehmigung der Errichtung oder des Betriebs von

Schweineställen, 1911 - 1912

- Aufstellung über Schweinehalter in Emden, 1912

$1897-1912$

Klassifikation Teil B: 00894

Band: 2

Trägermaterial: Papier

Alte Reg.-Sig.: IV Ja 04

Bestell-Nr.: IV 00894

1158 Unvorschriftsmäßige Markisen und Hausnummernbretter

1871-1909

(1836)

- Antrag des Kaufmanns Joseph Abraham Pels auf Genehmigung einer Markise, April - Juli 1836

- Anzeigen über zu tief angebrachte und zu weit in den Bürgersteig hineinragende Markisen, 1871 - 1909

- Anzeigen über zu niedrig angebrachte Hausnummernbretter,

Oktober 1873 - Februar 1874

- Polizeiverordnung der Stadt Emden über Festlegung der Ablasshöhe von Markisen bei zwei Metern über den Boden, August 1875

(1836) 1871 - 1909

Klassifikation Teil B: 01194

Trägermaterial: Papier

Alte Reg.-Sig.: IV Ka 06

Bestell-Nr.: IV 01194 
IV

05

05.03

05.03.07

05.03.07.01

05.03.07.01.02
Stadtverwaltung

\section{Aufgabenbereiche der Stadtverwaltung}

Baupolizei

Organisation der Baupolizei

Baupolizeiliche Zuständigkeiten

Lfd. Nr. Titel

Laufzeit

1159 Neubauten und Reparaturen von Privatkajungen und Stigte, Bd. 1

1869-1901

(1843-1864)

- Antrag des W. W. Becker auf Genehmigung zum Bau einer neuen

Kajung auf einer Linie mit seinem Nachbarn, Juli 1843

- Antrag des Meinhardus Becker auf Genehmigung eines Abtritts an der Südostecke seines am Delft gelegenen Gartens, September 1843

- Antrag des J. Elckjens auf Genehmigung der Errichtung einer

"Wusche" (Holzbude) zum Trocknen des Tabaks seines

Schwiegersohns auf seinem Grundstück am Delft, November 1844

- Antrag des J. G. van Ameren auf Genehmigung einer "Wusche" auf seinem Grundstück in der Osterbutvenne, Mai 1845

- Entfernung aler Pfähle vor der neuen Kajung des Hutfabrikanten Hennings, Juli 1852

- Antrag des J. B. Campen auf Genehmigung zur Anlegung einer Kajung vor seinem Grundstück an der Straße Zwischen beiden Bleichen, Februar - November 1852

- Anzeigen über Reparaturen an privaten Kajungen, (1854 - 1864)

August 1869 - April 1876

- Anlage eines Fisch- und Kartoffelstigts, Februar - Mai 1856

- Verfügungen des Magistrats über Anordnung der Reparatur von

Privatkajungen, Juni 1858 - April 1899

- Antrag des Simon Valk auf Genehmigung der Anlage einer Kajung bei seinem Grundstück in Zwischen beiden Sielen, Februar 1860

- Antrag der Witwe des B. A. Duin auf Genehmigung der Anlage einer Kajung vor ihrem Grundstück am Delft, Mai - September 1860

- Aufstellung über schadhafte und reparaturbedürftige Kajungen, April 1876

- Berichte des Stadtbaumeisters Wiggers über schadhafte Kajungen, $1876-1879$

- Streit wegen der vom Schiffszimmermeister Johann Janssen vor seiner Helling eingeschlagenen Pfähle, 1886 - 1887

- Ungenehmigt angelegte Kajung des Schiffszimmermeisters Johann Janssen, 1887 - 1888

- Reparatur der Kajungen an der Osterbutvenne, März - Juni 1899

$(1843-1864) 1869-1901$

Klassifikation Teil B: 01195

Band: 1

Trägermaterial: Papier

Alte Reg.-Sig.: IV Ka 08

Bestell-Nr.: IV 01195 
IV

05

05.03

05.03.07

05.03.07.01

05.03.07.01.02
Stadtverwaltung

Aufgabenbereiche der Stadtverwaltung

Baupolizei

Organisation der Baupolizei

Baupolizeiliche Zuständigkeiten

Lfd. Nr. Titel

Laufzeit

1160 Neubauten und Reparaturen von Privatkajungen und Stigte, Bd. 2

1910-1912

- Eingabe der Schiffervereinigung der verbündeten Fehne an den Magistrat über Auiflistung schadhafter Kajungen und Stigten an den

Emder Kanälen und Graften, Juli - August 1910

- Beschwerde des Grundstücksbesitzers Valk Gossels gegen die unbefugte Benutzung seiner Kajung durch fremde Schiffer, Mai 1911

$1910-1912$

Klassifikation Teil B: 01196

Band: 2

Trägermaterial: Papier

Alte Reg.-Sig.: IV Ka 08

Bestell-Nr.: IV 01196

1161 Zuständigkeit der städtischen Baupolizei betr. Staatsgebäude

$1870-1900$

(1852-1853)

- Bericht des Stadtbaumeisters Berg über gegen die städtische Bauordnung verstoßende Ausführung eines Torfschuppens auf dem Gelände des Amtshauses, September - November 1852

- Verhandlungen des Magistrats mit der Amtsverwaltung wegen des

Torfschuppens auf dem Amtshausgelände, Januar - August 1853

- Erlass des preußischen Ministers der öffentlichen Arbeiten über Umsetzung des Urteils des kgl. Obertribunals in Berlin über Nichtgültigkeit von örtlichen Bauordnungen für die Errichtung von

Bahngebäuden, Juli 1870

- Erlass des preußischen Mlnisters der öffentlichen Arbeiten über Nichtzuständigkeit von Ortsbaupolizeibehörden für die Genehmigung bahnfiskalischer Bauten, Oktober 1872 / Mai 1898

- Errichtung des Anbaus des Amtsgerichtsgebäudes ohne

Genehmigung der Baupolizeibehörde der Stadt Emden, März 1884

- Mitteilung der kgl. Eisenbahninspektion über Bau eines Wohnhauses für Weichensteller beim Bahnhof, Mai 1888

- Verstoß des mit Staatsbauten im Nesserlander Polder betrauten

Bauunternehmers Schorttau aus Wilhelmshaven gegen die

Sicherheitsvorschriften beim Gerüstbau, Oktober - November 1900

- Bescheid der Wasserbauinspektion über nicht vorliegende

Zuständigkeit der städtischen Baupolizei für die Staatsbauten auf Nesserland und daraus resultierende Nichtigkeit der Strafe gegen Schorttau, Oktober 1900

(1852 - 1853) 1870 - 1900 Klassifikation Teil B: 01197

Trägermaterial: Papier Alte Reg.-Sig.: IV Ka 10

Bestell-Nr.: IV 01197 
IV

05

05.03

05.03.07

05.03.07.01

05.03.07.01.02
Stadtverwaltung

\section{Aufgabenbereiche der Stadtverwaltung}

Baupolizei

Organisation der Baupolizei

Baupolizeiliche Zuständigkeiten

Lfd. Nr. Titel

Laufzeit

1881

(1839-1857)

- Verfügung des Hannoverschen Landdrosten in Aurich in Aurich über Anordnung zur Mitteilung der Praxis der Baugenehmigungserteilung unter dem Kriterium der Verhinderung von Haushaltsgründungen Unbemittelter, Mai 1839 / Dezember 1843 / Februar 1844

- Reisebericht des Stadtbaumeisters Berg über Pflasterungen in den Niederlanden und Belgien, November 1851

- Verhandlungen der Baukommission über Erlass einer

Baupolizeiordnung in Emden, Juni 1881

(1839 - 1851) 1881

Klassifikation Teil B: 01206

Trägermaterial: Papier

Alte Reg.-Sig.: IV Ka 12

Bestell-Nr.: IV 01206

1163 Staatliche Organisation der Bauverwaltung

1870-1914

- Erhebung der preußischen Landdrostei in Aurich über Fuhrwesen, Oktober - November 1870

- Umorganisation der Bauverwaltung bei der Landdrostei / Regierung in Aurich, Januar 1871 - April 1907

- Aufstellung über Landmesser in Emden, Februar 1889 / Februar 1905

- Antrag der Stadt Emden beim preußischen Minister der öffentlichen Arbeiten auf Belassung des Wasserbauinspektors Stosch in Emden bis zum Abschluss des Hafenausbaus, November 1898

- Bewerbung des Landvermessers Fritz Lottmann um städtische Vermessungsaufträge, Oktober 1905

- Gedruckte Bittschrift der Vereinigung selbständiger, in Preußen vereidigter Landmesser an den preußischen Landtag über Bitte um Beteiligung an das Grundsteuerfestsetzungsverfahren, Oktober 1906

$1870-1914$

Klassifikation Teil B: 01209

Trägermaterial: Papier

Alte Reg.-Sig.: IV Ka 14

Bestell-Nr.: IV 01209 
IV

05

05.03

05.03.07

05.03.07.01

05.03.07.01.02
Stadtverwaltung

Aufgabenbereiche der Stadtverwaltung

Baupolizei

Organisation der Baupolizei

Baupolizeiliche Zuständigkeiten

Lfd. Nr. Titel

Laufzeit

1164 Aufstellung von Verzeichnissen über erteilte Baugenehmigungen und ausgeführte Bauten

1881-1909

- Anfertigung der Statistik über von der Stadt Emden erteilte

Baugenehmigungen durch das Katasteramt, März 1881 - Januar 1882

- Nachweisungen über Veränderung des Gebäudebestandes in

Emden, 1881 - 1906

- Erlass des preußischen Finanzministers über Vorschriften zur

Führung der zur Gebäudesteuerveranlagung notwendigen

Gebäudebestandslisten, März 1892

- Rüge von seiten der Regierung in Aurich gegen die Stadt Emden

wegen Einreichung fehlerhafter Gebäudebestandslisten, Februar 1897

$1881-1909$

Klassifikation Teil B: 01210

Trägermaterial: Papier

Alte Reg.-Sig.: IV Ka 25

Bestell-Nr.: IV 01210

1165 Anbindung der Seumestraße

$1900-1903$

- Antrag der Bau- und Holzhandlung Geerds, Schelten und Boerma auf Aufnahme ihrer Grundstücke an der Seumestraße in den Bebauungsplan und auf Festlegung der Baufluchtlinie wegen Anlage der Straße, Januar 1900

- Verhandlungen der städtischen Kollegien wegen Festlegung der

Baufluchtlinie zur Anlage einer öffentlichen Straße zu den

Grundstücken der Bau- und Holzhandlung Geerds, Schelten und

Boerma, Anlage der Kanalisation und Installation der

Straßenbeleuchtung, Februar - März 1900

- Verhandlungen der Stadt Emden mit der Bau- und Holzhandlung

Geerds, Schelten und Boerma wegen Anlegung der Straße,

Anschluss an die Kanalisation und Straßenbeleuchtung, April 1900

- Öffentliche Auslegung des Straßen- und Baufluchtlinienplanes für die

Seumestraße, April - Mai 1900

- Einreichung eines Wechsels der Bau- und Holzhandlung Geerds,

Schelten und Boerma zur Sicherstellung der Beteiligung an die

Finanzierung der Straßenanlage, Juli 1900 - Oktober 1901

- Mängel bei der Straßenpflasterung, April 1901

- Streit um die von der Stadt Emden verlangten Mietzahlungen für

Hydranten an der Seumestraße, April - Juli 1901

$1900-1903$

Klassifikation Teil B: 01211

Trägermaterial: Papier

Bestell-Nr.: IV 01211 
IV

\section{5}

05.03

05.03.07

05.03.07.01

05.03.07.01.02

\section{Stadtverwaltung}

Aufgabenbereiche der Stadtverwaltung

Baupolizei

Organisation der Baupolizei

Baupolizeiliche Zuständigkeiten

Lfd. Nr. Titel

Laufzeit

1166 Klage des Kaufmanns Hermann C. van Jindelt gegen eine baupolizeiliche Weisung

- Antrag des Kaufmanns Hermann C. van Jindelt auf Genehmigung von baulichen Veränderungen seines Lagerbäudes im Bereich "Hinter der Halle", Dezember 1899 - März 1900

- Verfügung des Magistrats an Hermann C. van Jindelt über Weisung zur Entfernung ordnungswidrig nach außen schlagender Fenster in seinem Lagergebäude, März 1900 / Mai 1900

- Klage des Hermann Cornelius van Jindelt gegen die Stadt Emden beim Bezirksausschuss in Aurich auf Aufhebung der Weisung zur

Entfernung nach außen schlagender Fenster in seinem

Lagergebäude, Mai - November 1900

- Berufung der Stadt Emden gegen das Urteil des

Bezirksausschusses beim Oberverwaltungsgericht Berlin, Februar

1901 - August 1902

$1900-1903$

Klassifikation Teil B: 01212

Trägermaterial: Papier

Alte Reg.-Sig.: IV Ka 28

Bestell-Nr.: IV 01212

1167 Vornahme von Tiefbohrungen

1903-1912

- Arbeitspläne der kgl. Geologischen Landesanstalt und

Bergakademie, 1905 - 1908

- Anfrage des Bohrunternehmers Otto Junge, Hameln, nach

Vorkommen von weiß brennendem Ton, Juli - August 1906

- Erlasse des preußischen Ministers der öffentlichen Arbeiten über

Anordnung der Informierung der kgl. Geologischen Landesanstalt und

Bergakademie über Befunde bei Tiefbohrungen, 1903 - 1908

- Erhebung der Landesanstalt für Gewässerkunde über

Grundwasserverhältnisse, Oktober - November 1909 / Januar 1911

- Erlass des preußischen Innenministers über Weisung der

Heranziehung der Geologischen Landesanstalt und der kgl.

Bergverwaltung zu Regelungen zur Grundwassererschließung und der

Bodenanalyse, September 1912

$1903-1912$

Klassifikation Teil B: 01241

Trägermaterial: Papier

Alte Reg.-Sig.: IV Ka 39

Bestell-Nr.: IV 01241 
IV

05

05.03

05.03.07

05.03.07.01

05.03.07.01.02
Stadtverwaltung

\section{Aufgabenbereiche der Stadtverwaltung}

Baupolizei

Organisation der Baupolizei

Baupolizeiliche Zuständigkeiten

Lfd. Nr. Titel

Laufzeit

1168 Beschwerde des Oberpostschaffners Carl Montigny gegen die Pflicht zur Hinterlegung der ortsstatutarischen Kosten

1906-1907

- Antrag des Oberpostschaffners Carl Montigny auf Genehmigung zum Bau eines Vierfamilienhauses, April 1906

- Erklärung des Carl Montigny über Zahlung der ortsstatutarischen Kosten (Kanalisation, Straßenbeleuchtung) unter Vorbehalt, April 1906 - Klage des Oberpostschaffners Carl Montigny gegen die Stadt Emden beim Bezirksausschuss in Aurich auf Aufhebung der Anordnung zur Hinterlegung der ortsstatutarischen Kosten für sein Bauvorhaben, Mai - November 1906

- Dienstaufsichtsbeschwerde des Carl Montigny gegen die Stadt Emden beim Regierungspräsidenten in Aurich wegen der Anordnung zur Zahlung der ortsstatutarischen Kosten, Mai 1906 - Januar 1907

$1906-1907$

Klassifikation Teil B: 01246

Trägermaterial: Papier

Alte Reg.-Sig.: IV Ka 45

Bestell-Nr.: IV 01246

1169 Beschwerde gegen die Genehmigung des Bauvorhabens des Schlossers Karl Gayck

- Antrag des Schlossers Karl Gayck beim Magistrat auf Genehmigung des Umbaus seines Wohnhauses, Juli 1905

- Antrag des Schlossers Karl Gayck beim Magistrat auf Genehmigung des Baus eines Zweifamilienhauses im Boltentorsbreitergang östlicher Teil Nr. 13, Mai - Juni 1906

- Beschwerde der Grundstücksnachbarn gegen die Erteilung der Baugenehmigung wegen zweifelhaftem sittlichen Ruf des schon bestehenden Hauses, Juni 1906

- Beschwerde des Karl Gayck gegen die Stadt Emden beim Bezirksausschuss in Aurich wegen Verhängung eines Bauverbots, Juli 1906

$1905-1906$

Klassifikation Teil B: 01247

Trägermaterial: Papier

Alte Reg.-Sig.: IV Ka 46

Bestell-Nr.: IV 01247 
IV

05

05.03

05.03.07

05.03.07.01

05.03.07.01.02
Stadtverwaltung

Aufgabenbereiche der Stadtverwaltung

Baupolizei

Organisation der Baupolizei

Baupolizeiliche Zuständigkeiten

Lfd. Nr. Titel

Laufzeit

1170 Verweigerung der Erschließung des Grundstücks des Viehhändlers Isaak de Beer

1906-1907

- Antrag des Viehhändlers Isaac de Beer auf Erschließung (=Anbindung an Kanalisierung, Straßenbeleuchtung) seines Grundstücks an der Straße "Außer dem Neuen Tor" und Aufnahme in den Bebauungsplan zum Bau von Wohnhäusern, November -

Dezember 1906

- Entwurf eines Vertrages zwischen der Stadt Emden und Isaac de Beer über Erschließung seines Grundstücks "Außer dem Neuen Tor", Dezember 1906

- Klage des Isaac de Beer gegen die Stadt Emden beim Bezirksausschuss in Aurich auf Durchführung der Erschließung seines Grundstücks, Januar 1907

$1906-1907$

Klassifikation Teil B: 01248

Trägermaterial: Papier

Alte Reg.-Sig.: IV Ka 47

Bestell-Nr.: IV 01248

1171 Erbauung von Häusern am Grünen Weg

- Antrag der Firma Frerichs \& Mehrings auf Genehmigung des Baus eines Wohnhauses am Grünen Weg, Mai 1906

- Einspruch der Firma Frerichs \& Mehrings gegen die Auferlegung der ortsstatutarischen Kosten (Kanalisationsanschluss,

Straßenbeleuchtung, Straßenanbindung), Mai 1906

- Klage der Firma Frerichs \& Mehrungs gegen die Stadt Emden beim Bezirksausschuss auf Aufhebung der Auferlegung der Hinterlegung der ortsstatutarischen Kosten als Auflage für die Baugenehmigung, Mai - Oktober 1906

- Hinterlegung der ortsstatutarischen Kosten durch die Firma Frerichs \& Mehrings, Januar - Februar 1907

$1906-1907$

Klassifikation Teil B: 01249

Trägermaterial: Papier

Alte Reg.-Sig.: IV Ka 49

Bestell-Nr.: IV 01249 
IV

05

05.03

05.03.07

05.03.07.01

05.03.07.01.02
Stadtverwaltung

Aufgabenbereiche der Stadtverwaltung

Baupolizei

Organisation der Baupolizei

Baupolizeiliche Zuständigkeiten

Lfd. Nr. Titel

Laufzeit

1172 Erschließung eines Baugeländes "Außer dem Herrentor"

1905-1911

- Antrag des Friseurs Wilhelm Emil Sohnemann beim Magistrat auf

Erlaubnis zum Bau von Straßen zur Erschließung eines Baugeländes

"Außer dem Herrentor", Mai 1905 - Februar 1906

- Antrag des Friseurs Wilhelm Emil Sohnemann beim Magistrat auf

Verringerung der Auflagen und der Standarts des Straßenbaus wegen

Planung von Arbeiter- und Beamtenhäusern, November 1905

- Eingabe des W.E. Sohnemann an Oberbürgermeister Leo

Fürbringer über Bitte um Entgegenkommen bei den Auflagen für sein

Bauprojekt wegen Liquiditätsprobleme, April 1908

- Angebot des W.E. Sohnemann zum Verkauf der zu erschließenden

Grundstücke "Außer dem Herrentor" an die Stadt Emden, Mai 1908

- Antrag des Baumaterialienhändlers J. Neeland beim Magistrat auf

Genehmigung seines Bauprojekts "Außer dem Herrentor", November

1910 - März 1911

$1905-1911$

Klassifikation Teil B: 01250

Trägermaterial: Papier

Alte Reg.-Sig.: IV Ka 54

Bestell-Nr.: IV 01250

1173 Verweigerung der Erschließung eines Grundstückes

- Planzeichnung des Bauprojekts des Albert Jens, 1907

- Antrag des Albert Jens beim Magistrat auf Genehmigung des

Ausbaus des Treckfahrtsweges zur Erschließung seines

Grundstückes, März 1908

- Beschwerde des Albert Jens gegen die Stadt Emden beim

Regierungspräsidenten in Aurich gegen die Verweigerung der

Genehmigung des Ausbaus des Treckfahrtsweges zur Erschließung

seines Grundstückes, März - Juli 1907

1907 (1910)

Klassifikation Teil B: 01251

Trägermaterial: Papier

Alte Reg.-Sig.: IV Ka 55

Bestell-Nr.: IV 01251

1174 Statistik über Bauunfälle bei Eisenbetonbauten

- Erlass des preußischen Ministers der öffentlichen Arbeiten über

Einführung einer Statistik über Bauunfälle bei Eisenbetonbauten,

September 1911

1911

Klassifikation Teil B: 01258

Trägermaterial: Papier

Alte Reg.-Sig.: IV Ka 66

Bestell-Nr.: IV 01258 
IV

05

05.03

05.03.07

05.03.07.02
Stadtverwaltung

\section{Aufgabenbereiche der Stadtverwaltung}

Baupolizei

Baukommission

Lfd. Nr. Titel

Laufzeit

1175 Beseitigung einer Rampe vor dem Packhause der Witwe Johannes Brons an der Boltentorstraße

- Antrag der Baukommission auf Erlass einer Polizeiverordnung der Stadt Emden zur Entfernung der Rampe vor dem Packhaus der Witwe Brons an der Boltentorstraße wegen Gefährdung von Passanten, Juni 1876

- Verfügung des preußischen Landdrosten in Aurich über Ablehnung des Widerspruchs der Witwe gegen die Anordnung der Stadt Emden zum Abbruch der Rampe, August 1876

1876

Klassifikation Teil B: 00614

Trägermaterial: Papier

Alte Reg.-Sig.: IV Jf 13

Bestell-Nr.: IV 00614

1176 Beseitigung einer vor dem Mateling'schen Hause an der Neutorstraße befindlichen Kellereinfassung

- Bericht des Stadtbaumeisters Wiggers über Notwendigkeit der Beseitigung der eisernen Gitter vor einem Kelleraufgang und den Abschluss des Kellers durch eine Luke wegen Schutz der Fußgänger vor einem Sturz in den Keller des Hauses, März 1876

- Verfügung der Stadt Emden an die Hausbesitzerin Johanna Mateling über Anordnung zur Beseitigung der vor dem Keller angebrachten Anlagen, Mai 1876

- Ablehnung des Widerspruchs der Johanna Mateling gegen die städtische Verfügung durch den preußischen Landdrosten in Aurich, Juli 1876

1876

Klassifikation Teil B: 00615

Trägermaterial: Papier

Alte Reg.-Sig.: IV Jf 14

Bestell-Nr.: IV 00615 
IV

05

\subsection{3}

05.03.07

05.03.07.02
Stadtverwaltung

Aufgabenbereiche der Stadtverwaltung

Baupolizei

Baukommission

Lfd. Nr. Titel

Laufzeit

1177 Beseitigung von Vorbauten neben dem Rodewyk'schen Haus (Kleine 1880-1881 Brückstraße/Torfmarkt)

- Bericht der Baukommission über Notwendigkeit zur Entfernung der Vorbauten neben dem Rodewyk'schen Haus zum Bau eines

Fußweges von der Oldersumer Straße zur Brückstraße, Juni 1880

- Ablehnung der Entfernung der Vorbauten durch die Rodewyk'schen Erben, Juni - August 1880

- Situationsplan, 1880

- Verfahren vor dem Amtsgericht wegen des Streits zwischen der Stadt Emden und den Rodewyk'schen Erben wegen der Vorbauten an ihrem Haus, August 1880

- Bewilligung der Mittel für die Anlage des Fußweges von der Oldersumer Straße zur Brückstraße durch die städtischen Kollegien, Dezember 1880 / April 1881

- Vergleich zwischen der Stadt Emden und den Rodewyk'schen Erben wegen der Beseitigung der Vorbauten vor ihrem Haus zur Anlegung des Fußweges, März 181

$1880-1881$

Klassifikation Teil B: 00616

Trägermaterial: Papier

Alte Reg.-Sig.: IV Jf 15

Bestell-Nr.: IV 00616

1178 Beseitigung von Pfählen und Prellsteinen vor dem Hause des Gasthofbesitzers Fritz Meyer (Neuer Markt)

- Verfügung der Stadt Emden an den Hotelier Fritz Meyer über Anordnung zur Entfernung einer ungenehmigt errichteten Bretterwand bei seinem Hotel wegen Versperrung des Fußweges, Juli - Oktober 1882

- Verhandlungen zwischen dem Stadtbaumeister Wiggers und dem Hotelier Meyer wegen Abtretung der "Wanderung" vor seinem Hotel an die Stadt zur Verbreiterung des Fußweges, Januar 1883 - Beschwerde des Hoteliers Fritz Meyer beim preußischen Landdrosten in Aurich gegen die Anordnung der Stadt Emden zur Entfernung seiner Bretterwand (Pfähle), Mai - September 1883 - Beschwerde des Wasserbauinspektors H. Dannenberg gegen die Blockade des Fußweges vor dem "Hotel zur Sonne" (Fritz Meyer), Juli 1883

$1882-1884$

Klassifikation Teil B: 00617

Trägermaterial: Papier

Alte Reg.-Sig.: IV Jf 16

Bestell-Nr.: IV 00617 
IV

05

\subsection{3}

05.03.07

05.03.07.02
Stadtverwaltung

Aufgabenbereiche der Stadtverwaltung

Baupolizei

Baukommission

Lfd. Nr. Titel

Laufzeit

1179 Bau eines Hauses durch den Landgebräucher Asmus Hinderks

- Baugesuch des Landgebräuchers Asmus Hinderks für ein Haus auf dem Grundstück beim Neuen Tor, November 1880 - Januar 1881

- Verhandlungen der Baukommission über das Baugesuch hinsichtlich

Planungen mit der Führung des Bentincksweges, Juli 1881

- Antrag des Asmus Hinderks auf Genehmigung des Baus eines

Kornschuppens, Juli 1881

- Antrag der Baukommission auf Anweisung an Menne Dirks auf

Zurücksetzung eines Stacketts wegen Grenzverletzung, November 1893

- Ankauf eines kleinen städtischen Grünstreifens durch Menne Dirks und seine Ehefrau, Februar 1902

- Grenzfeststellung des Dirck'schen Grundstücks, 1906

$1880-1906$

Klassifikation Teil B: 01198

Trägermaterial: Papier

Alte Reg.-Sig.: IV Ka 11

Bestell-Nr.: IV 01198

1180 Ausbau des Hauses Große Faldernstraße

- Antrag der Hausbsitzerin J. A. Munnichen Witwe bei der

Baukommission auf Genehmigung des Ausbaus ihres Hauses an der

Großen Faldernstraße, Februar - März 1870

- Beschwerde der Witwe des J. A. Munnichen beim

Regierungspräsidenten in Aurich wegen der Verweigerung der

Baugenehmigung zum Ausbau ihres Hauses durch die

Baukommission, Mai - Juni 1870

- Ausbau des von der Stadt Emden angekauften Hauses an der

Großen Faldernstraße, Dezember 1884

$1870-1884$

Klassifikation Teil B: 01205

Trägermaterial: Papier

Alte Reg.-Sig.: IV Ka 17

Bestell-Nr.: IV 01205 
IV

05

\subsection{3}

05.03.07

05.03.07.02
Stadtverwaltung

Aufgabenbereiche der Stadtverwaltung

Baupolizei

Baukommission

Lfd. Nr. Titel

Laufzeit

1181 Errichtung von Häusern am Strohdeich

- Antrag des Zimmermeisters Johann Theilen bei der Baukommission auf Genehmigung des Baues eines Wohnhauses am Strohdeich (Lienbahnstraße / Bonnesse), März 1872

- Bericht des Magistrats an den preußischen Landdrosten in Aurich über Unbedenklichkeit einer Baugenehmigung für Theilen wegen nicht mehr bestehender Schutzfunktion des Deiches, Juni 1872

- Verfügung des preußischen Landdrosten an Johann Theilen über Weisung der Einhaltung eines größeren Abstandes zwischen dem Strohdeich und seinem projektierten Bau, Juni 1872

- Erklärung des Johann Theilen über Verpflichtung der jederzeitigen Beseitigung der Brücke über den Strohdeich zu seinem Haus, September 1872

- Antrag des Johann Theilen bei der Baukommission auf

Genehmigung des Baus eines weiteren Wohnhauses auf seinem Grundstück am Strohdeich, Dezember 1878

- Bescheid der Baukommission über Ablehnung der Baugenehmigung wegen eines fehlenden Haupteingangs des geplanten zweiten Hauses zur Hauptstraße, Januar - Februar 1879

$1872-1879$

Klassifikation Teil B: 01207

Trägermaterial: Papier

Alte Reg.-Sig.: IV Ka 13

Bestell-Nr.: IV 01207

1182 Genehmigung des Neubaus eines Packhauses

- Antrag des Zimmermeisters W. Bruns im Auftrag des Kaufmanns Georg Ennen beim Magistrat auf Genehmiung des Baus eines Packhauses anstelle des abgerissenen Wohnhauses des Georg Ennen, Oktober 1897- Februar 1898

$1897-1898$

Klassifikation Teil B: 01213

Trägermaterial: Papier

Alte Reg.-Sig.: IV Ka 29

Bestell-Nr.: IV 01213 
IV

05

\subsection{3}

05.03.07

05.03.07.02
Stadtverwaltung

Aufgabenbereiche der Stadtverwaltung

Baupolizei

Baukommission

Lfd. Nr. Titel

Laufzeit

1183 Bau von Wohnhäusern durch die kgl. Staatsbauverwaltung

- Plan des Baugebiets, 1909

- Bericht des Polizeisergeanten Buscher über ordnungswidrige

Zustände auf der Baustelle der Staatsbauverwaltung, November 1901

- Plan für Beamten- und Arbeiterhäuser beim fiskalischen Bauhof, 1901

- Votum der Baukommission gegen den Bau von Wohnhäusern für Handwerker und Arbeiter der staatlichen Bauverwaltung wegen fehlender Straßenanbindung, Dezember 1901

- Mitteilung der kgl. Wasserbauinspektion über geplante weitere Arbeiter- und Beamtenwohnungen auf dem Gelände des staatlichen Bauhofes, März - April 1903

$1901-1909$

Klassifikation Teil B: 01214

Trägermaterial: Papier

Alte Reg.-Sig.: IV Ka 30

Bestell-Nr.: IV 01214

1184 Klage des Konsuls Friedrich Brons gegen das Verbot nach außen aufschlagender Fenster

- Bericht des Stadtbaumeisters Wiggers als Vorsitzender der Baukommission über Unzulässigkeit von nach außen aufschlagender Fenster im Haus des Konsuls Friedrich Brons, Mai 1903

- Verfügung des Magistrats an den Konsul F. Brons über Verbot nach außen aufschlagender Fenster in seinem Haus am alten Markt wegen Gefährdung von Passanten, Mai 1903

- Klage des Konsuls Friedrich Brons gegen die Stadt beim Bezirksausschuss in Aurich auf Aufhebung der Verfügung über das Verbot nach außen aufschlagender Fenster, Juni 1903 - Januar 1904

$1903-1904$

Klassifikation Teil B: 01215

Trägermaterial: Papier

Alte Reg.-Sig.: IV Ka 31

Bestell-Nr.: IV 01215 
IV

05

05.03

05.03.07

05.03.07.02
Stadtverwaltung

\section{Aufgabenbereiche der Stadtverwaltung}

Baupolizei

Baukommission

Lfd. Nr. Titel

Laufzeit

1185 Ausführung eines ungenehmigten Neubaus durch Helmer von Baden Foget

1903-1904

- Verfügung des Magistrats über Verhängung eines Baustopps gegen den Neubau des Helmer von Baden Foget wegen nicht vorliegender Baugenehmigung, Juni 1903

- Klage des H. von Baden Foget gegen die Stadt Emden beim

Bezirksausschuss in Aurich auf Aufhebung des Baustopps, Juni -

Oktober 1903

- Mit Auflagen versehene Baugenehmigungen der Stadt Emden für drei Neubauten des Helmer von Baden Foget in der Gartenstraße,

August 1903

- Bericht des Kreisbauinspektors Heyder über Besichtigung der

Baustellen des Helmer von Baden Foget, Oktober 1903

- Weigerung des $\mathrm{H}$. von Baden Foget zur Zahlung der

Aufwandsentschädigung für den Kreisbauinspektor Heyder,

September 1904

$1903-1904$

Klassifikation Teil B: 01216

Trägermaterial: Papier

Alte Reg.-Sig.: IV Ka 32

Bestell-Nr.: IV 01216

1186 Weisung an den Hausbesitzer Helmer von Baden Foget zur

1903-1907

Beseitigung eines Schuppens im Innenhof seines Miethauses

- Bericht des Stadtbauführers Schultz über zu geringen Abstand eines Holzschuppens im Innenhof des Miethauses des $\mathrm{H}$. von Baden Foget von den Fenstern seiner Mieter und Brandgefahr durch einen unvorschriftsmäßigen Ofen im Schuppen, Juni 1903 - Verfügung des Magistrats an H. von Baden Foget über Anordnung zur Beseitigung des ungenemigt errichteten Schuppens, Juni 1903 - Klage des H. von Baden Foget gegen die Stadt Emden beim Bezirksausschuss auf Aufhebung der Abrissverfügung gegen seinen Schuppen, Juni - August 1903

- Bericht des Stadtbauführers Schultz über feuchte Keller und durchbrochene Fußboden im Mietshaus des H. von Baden Foget, Juni 1903

- Verfügung des Magistrats an H. von Baden Foget über Anordnung zur Reparatur der Kellerdecke seines Mietshauses in der

Gartenstraße, Juli 1907

- Klage des H. von Baden Foget gegen die Stadt Emden beim Bezirksausschuss auf Aufhebung der Anordnung wegen Reparatur der Kellerdecke, Juli - August 1907

- Bericht des Kreisarztes über gesundheitsschädliche Zustände in den Mietshäusern des H. von Baden Foget, August 1907

$1903-1907$

Klassifikation Teil B: 01217

Trägermaterial: Papier

Alte Reg.-Sig.: IV Ka 33

Bestell-Nr.: IV 01217 
IV

05

\subsection{3}

05.03.07

05.03.07.02

\section{Stadtverwaltung}

\section{Aufgabenbereiche der Stadtverwaltung}

Baupolizei

Baukommission

Lfd. Nr. Titel

Laufzeit

1187 Beseitigung eines ungenehmigten Anbau am Haus des Helmer von Baden Foget, Bd. 1

- Mitteilung des Hausbesitzers Helmer von Baden Foget an Syndicus Riese über Bau einer Veranda vor seinem Haus in der Gartenstraße 18, Februar 1905

- Verfügung des Magistrats über Anordnung der Beseitigung der ungenehmigten Veranda, März 1905

- Antrag des Helmer von Baden Foget auf Genehmigung der bereits teilweise fertiggestellten Veranda im Haus Gartenstraße 18, März 1905

- Bericht der Baukommission über neben der Veranda bereits teilweise fertig gestellte weitere Einbauten im Haus Gartenstraße 18, April 1905

- Klage des H. von Baden Foget gegen die Stadt Emden beim Bezirksausschuss in Aurich auf Rücknahme der Verfügung über Anordnung der Beseitigung der ungenehmigten Veranda, April 1905 Mai 1908

$1905-1908$

Klassifikation Teil B: 01230

Band: 1

Trägermaterial: Papier

Alte Reg.-Sig.: IV Ka 36

Bestell-Nr.: IV 01230

1188 Beseitigung eines ungenehmigten Anbau am Haus des Helmer von Baden Foget, Bd. 2

- Stellungnahme des Magistrats der Stadt Emden gegenüber dem Regierungspräsidenten in Aurich zur Klage des Helmer von Baden Foget gegen die Verfügung über Anordnung zur Entfernung einer ungenehmigten Veranda u.a. Einbauten im Haus Gartenstraße 18, November 1905

1905

Klassifikation Teil B: 01231

Band: 2

Trägermaterial: Papier

Alte Reg.-Sig.: IV Ka 36

Bestell-Nr.: IV 01231 
IV

05

\subsection{3}

05.03.07

05.03.07.02
Stadtverwaltung

Aufgabenbereiche der Stadtverwaltung

Baupolizei

Baukommission

Lfd. Nr. Titel

Laufzeit

1189 Beseitigung eines ungenehmigten Anbau am Haus des Helmer von 1906 Baden Foget, Bd. 3

- Verfügung des Magistrats an Helmer von Baden Foget über Anordnung der Beseitigung einer ungenehmigten Bretterwand am Haus Gartenstraße 18, Juni 1906

- Beschwerde des $\mathrm{H}$. von Baden Foget beim Magistrat gegen die Verfügung zur Beseitigung der Bretterwand, Juni 1906

- Beschwerde des H. von Baden Foget beim Regierungspräsidenten in Aurich gegen die Verfügung zur Beseitigung der Bretterwand, Juni 1906 / September 1906

1906

Klassifikation Teil B: 01232

Band: 3

Trägermaterial: Papier

Alte Reg.-Sig.: IV Ka 36

Bestell-Nr.: IV 01232

1190 Beseitigung eines ungenehmigten Anbau am Haus des Helmer von Baden Foget, Bd. 4

- Verfügung des Magistrats über Anordnung der Beseitigung der ungenehmigten Veranda im Haus Gartenstraße 18, Januar / März 1907

- Stellungnahme des Magistrats zur Klage des Helmer von Baden Foget gegen die Abrissverfügung bzgl. seiner ungenehmigten Veranda, Oktober 1906 - Januar 1907

- Bescheid des Ministers der öffentlichen Arbeiten an Helmer von

Baden Foget über Abweisung seiner Beschwerde gegen Abrissverfügungen des Magistrats und deren Bestätigung durch den Regierungspräsidenten in Aurich, November 1906

- Beschwerde des Helmer von Baden Foget gegen die Verfügungen des Magistrats zur Einstellung ungenehmigter Arbeiten in seinem Haus Gartenstraße 18, Januar - Dezember 1907

- Bericht des Stadtbauaufsehers Schulz über Auseinandersetzung mit $\mathrm{H}$. von Baden Foget bei der Besichtigung des Kellers des Hauses Gartenstraße 18 und Feststellung baulicher Mängel, August 1907

$1906-1907$

Klassifikation Teil B: 01233

Band: 4

Trägermaterial: Papier

Alte Reg.-Sig.: IV Ka 36

Bestell-Nr.: IV 01233 
IV

05

\subsection{3}

05.03.07

05.03.07.02
Stadtverwaltung

Aufgabenbereiche der Stadtverwaltung

Baupolizei

Baukommission

Lfd. Nr. Titel

Laufzeit

1191 Beseitigung eines ungenehmigten Anbau am Haus des Helmer von Baden Foget, Bd. 5

- Antrag des Hausbesitzers Helmer von Baden Foget an den Magistrat auf nachträgliche Genehmigung seines Anbauprojekts an seinem Haus in der Gartenstraße 18, Juli - August 1905

- Schlichtungsversuch des Regierungs- und Baurats Niemann im Streit zwischen Helmer von Baden Foget und der Stadt Emden, August 1905

- Verfügung des Magistrats über Anordnung der Beseitigung der ungenehmigten Anbauten, September 1905 / Januar 1906 / Februar 1906 / April 1906

- Bericht der Baukommission über Unzulässigkeit des von Baden Foget eingereichten Kanalisationsplans für seine Anbauten am Haus Gartenstraße 18, April 1905

- Planzeichnung über Veranda am Haus Gartenstraße 18, 1905

- Mit Auflagen versehene Genehmigung des Gründungsplans für den Anbau Gartenstraße 18, Februar 1906

$1905-1906$

Klassifikation Teil B: 01234

Band: 5

Trägermaterial: Papier

Alte Reg.-Sig.: IV Ka 36

Bestell-Nr.: IV 01234

1192 Bebauungsplan: Mietwohnungen der Bahnverwaltung

- Planzeichnung der projektierten Mietshäuser der Bahnverwaltung an der Petkumer Landstraße, östlich der Parallelstraße, Juli 1905 - Mitteilung der Eisenbahnverwaltung an die Stadt Emden über Projekt und Anfrage zur Datenermittlung für Erschließung der Parzellen, September 1904 - Mitteilung des Magistrats an die Eisenbahnverwaltung über Zustimmung der städtischen Kollegien zum Bauprojekt der Bahnverwaltung, Mai 1905

$1904-1905$

Klassifikation Teil B: 01235

Trägermaterial: Papier

Alte Reg.-Sig.: IV Ka 37

Bestell-Nr.: IV 01235 
IV

05

05.03

05.03.07

05.03.07.02
Stadtverwaltung

Aufgabenbereiche der Stadtverwaltung

Baupolizei

Baukommission

Lfd. Nr. Titel

Laufzeit

1193 Ungenehmigter Bauschuppen des Helmer von Baden Foget

1904-1905

- Bericht der Baukommission zum weiteren Verfahren wegen des ungenehmigten Bauschuppens des Helmer von Baden Foget in der Gartenstraße, September 1904

- Verfügung des Magistrats an Helmer von Baden Foget über Aufforderung zum Abriss des ungenehmigten Bauschuppens im Innenhof des Hauses Gartenstr. 18 wegen zu geringer Hoffläche, Juli

- August 1905

- Beschwerde des H. von Baden Foget gegen die Abrissverfügung, August 1905

- Klage des Helmer von Baden Foget gegen die Stadt Emden beim Bezirksausschuss in Aurich auf Aufhebung der Abrissverfügung,

August - September 1905

$1904-1905$

Klassifikation Teil B: 01236

Trägermaterial: Papier

Alte Reg.-Sig.: IV Ka 38

Bestell-Nr.: IV 01236

1194 Hintergebäude Gartenstraße 18

- Antrag des Hausbesitzers Helmer von Baden Foget beim Magistrat auf Genehmigung eines Hintergebäudes bai dem Haus Gartenstraße 18, Juni 1906

- Bauzeichnungen

- Verfügung des Magistrats über Ablehnung des Bauantrages wegen

zu geringem Hofraum beim Gebäude Gartenstr. 18, Juni 1906

1906

Klassifikation Teil B: 01237

Trägermaterial: Papier

Alte Reg.-Sig.: IV Ka 38

Bestell-Nr.: IV 01237

1195 Bauzeichnung Gartenstraße 18

1902

1902

Klassifikation Teil B: 01238

Trägermaterial: Papier

Alte Reg.-Sig.: IV Ka 39

Bestell-Nr.: IV 01238

1196 Situationsplan des Hauses Gartenstraße 18

1902

Klassifikation Teil B: 01239

Trägermaterial: Mikrofiche

Alte Reg.-Sig.: IV Ka 39

Bestell-Nr.: IV 01239 
IV

05

05.03

05.03.07

05.03.07.02
Stadtverwaltung

Aufgabenbereiche der Stadtverwaltung

Baupolizei

Baukommission

Lfd. Nr. Titel

Laufzeit

1197 Beschwerde der Brons'schen Erben gegen Nichtgenehmigung eines Neubaus am Bentincksweg

- Antrag der Witwe Brons an die Baukommission auf Genehmigung eines Neubaus am Bentincksweg, Februar - März 1905

- Antrag der Baukommission beim Magistrat auf Beschleunigung der Kanalisierung des Bentincksweges als Grundlage zur Genehmigung des Brons'schen Bauantrags, März 1905

- Beschwerde der Erbengemeinschaft der Witwe des Bernhard Brons beim Regierungspräsidenten in Aurich gegen die Verweigerung der Baugenehmigung durch die Baukommission wegen nicht vorhandener Erschließung hinsichtlich Beleuchtung und Kanalisierung des östlichen Teils des Bentincksweges, April - September 1905

- Beschwerde der Erbengemeinschaft der Witwe des Bernhard Brons beim Oberpräsidenten der Provinz Hannover gegen die Entscheidung der Stadt Emden stützenden Bescheid des Regierungspräsidenten in Aurich, Oktober - November 1905

1905

Klassifikation Teil B: 01242

Trägermaterial: Papier

Alte Reg.-Sig.: IV Ka 41

Bestell-Nr.: IV 01242

1198 Beschwerde des Buchdruckereibesitzers Anton Gerhard gegen die Verweigerung der Baugenehmigung für sein Grundstück bei der "Doele", Bd. 1

- Antrag des Buchdruckereibesitzers Anton Gerhard beim Magistrat auf Genehmigung eines Neubaus für das zum Abriss bestimmte Doelehaus auf dem von inm erworbenen Grundstück an der Doolestraße, September - Dezember 1905

- Votum der Baukommission gegen die Genehmigung wegen nicht herstellbarer Straßenanbindung ohne Beschädigung der Wallanlage, Oktober 1905 / November 1905 / April 1906

- Stellungnahme des Magistrats zur Beschwerde des Anton Gerhard beim Regierungspräsidenten in Aurich gegen die Verweigerung der Baugenehmigung, Dezember 1905

- Beschwerde des Anton Gerhard beim Regierungspräsidenten in Aurich gegen die Verweigerung der Baugenehmigung durch die Stadt Emden, November 1905 - April 1908

- Gescheiterter Versuch zum Verkauf des Grundstücks des A.

Gerhard an der Doele, Januar 1907

- Eingabe des A. Gerhard beim Reichskanzler über Bitte um Hilfe gegen die Verweigerung der Baugenehmigung, Februar 1908 - Antrag des A. Gerhard beim Magistrat auf Genehmigung eines modifizierten Bebauungsplans für sein Grundstück an der Doele mit der Anbindung über die Straßen "Sack" und "Hose", April 1909

$1905-1909$

Klassifikation Teil B: 01243

Band: 1

Trägermaterial: Papier

Alte Reg.-Sig.: IV Ka 43

Bestell-Nr.: IV 01243 
05

05.03

05.03.07

05.03.07.02
Stadtverwaltung

\section{Aufgabenbereiche der Stadtverwaltung}

Baupolizei

Baukommission

Lfd. Nr. Titel

Laufzeit

1199 Beschwerde des Buchdruckereibesitzers Anton Gerhard gegen die 1906-1911

Verweigerung der Baugenehmigung für sein Grundstück bei der "Doele", Bd. 2

- Antrag des Buchdruckereibesitzers Anton Gerhard beim Magistrat auf Genehmigung eines Neubaus für das zum Abriss bestimmte Doelehaus auf dem von inm erworbenen Grundstück an der Doolestraße, Oktober 1906

- Beschwerde des Anton Gerhard beim Regierungspräsidenten in Aurich gegen die Verweigerung der Baugenehmigung durch die Stadt Emden, November 1906 - Februar 1907

- Strellungnahme des Magistrats zur Beschwerde des A. Gerhard: Verweigerung der Baugenehmigung wegen Absicht des Gerhard zur Spekulation mit dem Grundstück, Januar 1907

- Klage des A. Gerhard beim Bezirksausschuss in Aurich gegen die Verwerfung seiner Beschwerde wegen Veweigerung der

Baugenehmigung durch die Stadt Emden vom

Regierungspräsidenten, Juni - Dezember 1907

- Berufungsklage des A. Gerhard beim Oberverwaltungsgericht Berlin gegen die für ihn ungünstige Entscheidung des Bezirksausschusses, Januar 1908 - Februar 1909

- Anklage der Staatsanwaltschaft gegen A. Gerhard wegen

Beleidigung des Magistrats, Mai 1909 - April 1911

$1906-1911$

Klassifikation Teil B: 01244

Band: 2

Trägermaterial: Papier

Alte Reg.-Sig.: IV Ka 43

Bestell-Nr.: IV 01244

1200 Beschwerde des Bauunternehmers Balduin Hempel gegen

1905-1906 Verweigerung einer Baugenehmigung

- Antrag des Bauunternehmers Balduin Hempel auf Genehmigung zweier Neubauten auf seinem Grundstück an der Friesenstraße / Am Heuzwinger, Oktober 1905

- Weigerung des Balduin Hempel zur Zahlung der ortsstatutarischen Lasten (Kanalisation, Straßenbeleuchtung, Versorgungsleitungen), Oktober 1905

- Genehmigung eines der beantragten Neubauten des Balduin Hempel, April 1906

$1905-1906$

Klassifikation Teil B: 01245

Trägermaterial: Papier

Alte Reg.-Sig.: IV Ka 44

Bestell-Nr.: IV 01245 
IV

05

05.03

05.03.07

05.03.07.02
Stadtverwaltung

\section{Aufgabenbereiche der Stadtverwaltung}

Baupolizei

Baukommission

Lfd. Nr. Titel

Laufzeit

1201 Ungenehmigter Wohnungsbau des Helmer von Baden Foget

- Bericht der Baukommission über ungenehmigten Umbau der alten Butterfabrik an der Rademacherstraße durch $\mathrm{H}$. von Baden Foget, Februar - März 1910

- Streit zwischen der Baukommission und Helmer von Baden Foget wegen der Genehmigungspflicht der Umbauten an der alten Butterfabrik, März - April 1910

- Planzeichnung des Umbaus, 1910

- Klage des Helmer von Baden Foget gegen die Stadt Emden beim Bezirksausschuss in Aurich auf Genehmigung der Umbauten in der alten Butterfabrik, Juni 1910 - Mai 1911

$1910-1911$

Klassifikation Teil B: 01252

Trägermaterial: Papier

Alte Reg.-Sig.: IV Ka 59

Bestell-Nr.: IV 01252

1202 Streit um das Doelehaus

- Klage des Buchdruckereibesitzers A. Gerhard gegen die Stadt Emden beim Bezirksausschuss auf Aufhebung der Verfügung über Anordnung des Abbruchs oder Umbaus des Doelehauses nach Verweigerung der Genehmigung eines Neubaus, Juni - Dezember 1908

- Berufungsklage des A. Gerhard beim Oberverwaltungsgericht in Berlin gegen das die Auffassung der Stadt Emden stützende Urteil des Bezirksausschusses, Dezember 1908 - März 1910

$1908-1910$

Klassifikation Teil B: 01253

Trägermaterial: Papier

Alte Reg.-Sig.: IV Ka 61

Bestell-Nr.: IV 01253 
IV

05

05.03

05.03.07

05.03.07.02
Stadtverwaltung

\section{Aufgabenbereiche der Stadtverwaltung}

Baupolizei

Baukommission

Lfd. Nr. Titel

Laufzeit

1203 Vom Bauunternehmer Adolf Janssen ausgeführter Neubau der Anna 1910-1911 Garrelts

- Antrag der Anna Garrelts an das Stadtbauamt auf Genehmigung des Baus eines Zweifamilienhauses an der Graf Edzard Straße, Juni - Juli 1910

- Bescheid des Magistrats an Anna Garrelts über Möglichkeit der Aufhebung des verhängten Bauverbots bei Einreichung von

Dokumenten und Belegen über Oberflächenwasser- und

Abwassernetzanschluss, Juni 1910

- Anzeige des Stadtbaumeisters Wiggers über Einrammung von zu wenigen Pfählen zur Grundung des Hauses der Anna Garrelts, Juli 1910

- Verhängung eines Bauverbotes beim Haus der Anna Garrelts wegen Verstoß gegen Bauauflagen hinsichtlich Statik, September 1910 /

Februar 1911

- Strafverfahren gegen den Bauunternehmer Adolf Janssen wegen Verstöße gegen Bauauflagen beim Hausbau für Anna Garrelts, April Mai 1911

$1910-1911$

Klassifikation Teil B: 01254

Trägermaterial: Papier

Alte Reg.-Sig.: IV Ka 62

Bestell-Nr.: IV 01254

1204 Einfriedung des Hauses des Helmer von Baden Foget in der

$1910-1911$ Gartenstraße

- Ungenehmigter Bau einer Einfriedung beim Haus des Helmer von Baden Foget in der Gartenstraße, Juli 1910

- Klage des Helmer von Baden Foget gegen die Stadt Emden beim Bezirksausschuss auf Rücknahme der Verfügung über Anordnung der Beseitigung der ungenehmigten Einfriedung an seinem Haus in der Gartenstraße, August - September 1910 / Juli 1911

- Verfügung des Regierungspräsidenten in Aurich an Helmer von Baden Foget über Aufforderung zur Durchführung des beim Bezirksausschuss erzielten Vergleichs über Modifizierung der Einfriedung seines Hauses an der Gartenstraße, Dezember 1910 - Bescheid des preußischen Ministers der öffentlichen Arbeiten über Ablehnung der Beschwerde des $\mathrm{H}$. von Baden Foget wegen der Einfriedung, April 1911

- Protest des Helmer von Baden Foget gegen den Abriss der Einfriedung durch den Stadtbauführer Schultz, Juni 1911

$1910-1911$

Klassifikation Teil B: 01256

Trägermaterial: Papier

Alte Reg.-Sig.: IV Ka 64

Bestell-Nr.: IV 01256 
IV

05

05.03

05.03.07

05.03.07.02
Stadtverwaltung

\section{Aufgabenbereiche der Stadtverwaltung}

Baupolizei

Baukommission

Lfd. Nr. Titel

Laufzeit

1205 Ungenehmigt angelegte Pforte zum Grundstück des Rentiers Heinrich 1908 W Schelten

- Anzeige des Stadtbaumeisters Wiggers über ungenehmigt angelegte und das Nachbargrundstück versperrende Pforte zum Grundstück des H.W. Schelten, April 1908

- Verfügung des Magistrats der Stadt Emden an H. W. Schelten über Anordnung zur Beseitigung der ungenehmigten Pforte, Mai 1908 - Klage des Rentiers H. W. Schelten gegen die Stadt Emden beim Bezirksausschuss auf Aufhebung der Abbruchsverfügung wegen seiner ungenehmigten Pforte, Mai - November 1908

1908 (1911)

Klassifikation Teil B: 01257

Trägermaterial: Papier

Alte Reg.-Sig.: IV Ka 65

Bestell-Nr.: IV 01257

1206 Personal der Baukommission

- Ernennung von Mitgliedern der Baukommission

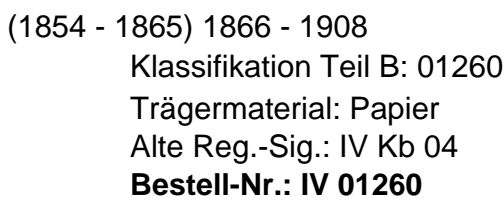

1207 Handakte Oberbürgermeister Fürbringer: Organisation der Baukommission

- Einstellung und Besoldung der Stadtbauaufseher

- Organisation der Baukommission

1876

Klassifikation Teil B: 01261

Trägermaterial: Papier

Alte Reg.-Sig.: IV Kb 04

Bestell-Nr.: IV 01261 
IV

05

05.03

05.03.07

05.03.07.02
Stadtverwaltung

Aufgabenbereiche der Stadtverwaltung

Baupolizei

Baukommission

Lfd. Nr. Titel

Laufzeit

1208 Organisation und Zuständigkeiten der Baukommission $1880-1904$

(1854-1857)

- Druckschrift: Instruction über die Wirksamkeit der Bau-Commission, 1854

- Organisation und Zuständigkeiten der Baukommission, 1854 - 1857

- Beschluss der städtischen Kollegien über Ermächtigung der

Baukommission zur Ausführung kleinerer Reparaturen ohne vorherige

Genehmigung der Kollegien, März 1880

- Festlegung einer Norm für die Höhe von Laden-Fenstern und

Balkonen, April - Mai 1881

- Austausch mit anderen Städten über Organisation der

Baukommission, 1892 - 1904

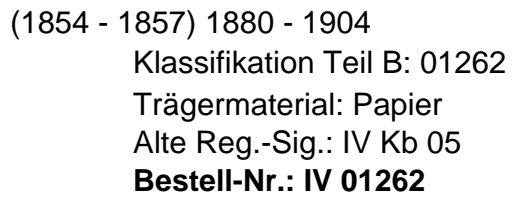

1209 Geschäftsgang der Baukommission

- Organisation des Geschäftsgangs der Baukommission, (1854 -

1865) 1872 - 1874

- Einzelfälle aus dem Zuständigkeitsbereich der Baukommission, 1872

$-1874$

(1854 - 1865) 1872 - 1874

Klassifikation Teil B: 01263

Trägermaterial: Papier

Alte Reg.-Sig.: IV Kb 06

Bestell-Nr.: IV 01263

1210 Bauten auf dem Bahnhofsgelände

- Genehmigungsverfahren für verschiedene Bauten der Bahnverwaltung auf dem Bahngelände

$1910-1911$

Klassifikation Teil B: 02521

Trägermaterial: Papier

Alte Reg.-Sig.: IV Ka 02

Bestell-Nr.: IV 02521 
IV

05

05.03

05.03.07

05.03.07.03
Stadtverwaltung

\section{Aufgabenbereiche der Stadtverwaltung}

Baupolizei

Bauliche Missstände

Lfd. Nr. Titel

Laufzeit

1211 Fehlerhafte Schornsteine, Ofenrohre und sonstige feuergefährliche 1868-1871 Anlagen, Bd. 1

- Berichte des Stadtbauaufsehers A.D. Gisberts über falsch angelegte oder feuergefährliche Schornsteine, Januar - Mai 1868

- Anzeigen verschiedener Polizeisergeanten über fehlerhafte

Schornsteine, Februar 1868 - Juni 1870

- Berichte des Schornsteinfegermeisters J. J. Solaro über fehlerhafte

Schornsteine, März 1868 - Mai 1871

- Beschwerde des Dr. Wychgram über durch mangelhaft ausgeführte

Reinigung des Schornsteinfegers Solaro verursachter

Schornsteinbrand, Mai 1868

- Verfügungen des Magistrats an betroffene Hausbesitzer über

Anordnung der Beseitigung von Schäden bzw. Baufehlern an

Schornsteinen, 1868 - 1871

$1868-1871$

Klassifikation Teil B: 01191

Band: 1

Trägermaterial: Papier

Alte Reg.-Sig.: IV Ka 05

Bestell-Nr.: IV 01191

1212 Fehlerhafte Schornsteine, Ofenrohre und sonstige feuergefährliche Anlagen, Bd. 2

- Antrag des Hausbesitzers L. P. D. Pfannenschmidt an den Magistrat auf Erlass einer verhängten Geldstrafe wegen nicht beseitigter baulicher Mängel am Schornstein seines Hauses infolge Verzögerung wegen Überlastung des mit der Ausführung der Arbeit betrauten Unternehmers, Mai 1872

- Anzeigen verschiedener Polizeisergeanten über fehlerhafte Schornsteine, April 1872 - Mai 1878

- Verfügungen des Magistrats an betroffene Hausbesitzer über Anordnung der Beseitigung von Schäden bzw. Baufehlern an Schornsteinen, 1872 - 1877

- Anzeigen über Schornsteinbrände, November 1872 - Dezember 1878

- Anzeigen über gefährliche Feuerstellen (Öfen, Kochapparate), 1872

$-1878$

- Unvorschriftsmäßige Schornsteine im neuen Gymnasium, April Juni 1877

- Anzeige des Schornsteinfegermeisters Richard Schneider über unvorschriftsmäßigen Neubau eines Schornsteins durch Helmer von Baden Foget, Januar 1878

$1872-1878$

Klassifikation Teil B: 01192

Band: 2

Trägermaterial: Papier

Alte Reg.-Sig.: IV Ka 05

Bestell-Nr.: IV 01192 
IV

05

05.03

05.03.07

05.03.07.03
Stadtverwaltung

\section{Aufgabenbereiche der Stadtverwaltung}

Baupolizei

Bauliche Missstände

Lfd. Nr. Titel

Laufzeit

1213 Fehlerhafte Schornsteine, Ofenrohre und sonstige feuergefährliche 1879-1907 Anlagen, Bd. 3

- Anzeigen verschiedener Polizeisergeanten über fehlerhafte Schornsteine, 1881 - 1895

- Anzeigen der Feuerinspektoren über fehlerhafte Schornsteine,1896

- Verfügungen des Magistrats an betroffene Hausbesitzer über Anordnung der Beseitigung von Schäden bzw. Baufehlern an Schornsteinen, 1879 - 1906

- Anzeigen über Schornsteinbrände, 1879 - 1901

- Anzeigen über feuergefährliche Anlagen, 1879 - 1906

- Beschwerden verschiedener Hausbesitzer gege Belästigungen durch den Rauch aus den Schornsteinen ihrer Nachbarn, 1887 - 1907

- Berichte des Stadtbaumeisters Wiggers über baufällige

Schornsteine, 1893 - 1896

- Verfügung des Magistrats an den Porzellanbrenner Alfred Baumann über bauliche Auflagen am Schornstein zur Erlaubnis des Betriebs seiner Porzellanbrennerei, Dezember 1896

- Feuergefahr durch Schornstein der Dampfsägerei des

Schiffsbaumeisters Cassens, Dezember 1896

- Anträge auf Erlaubnis zur Errichtung von Räucherkammern, 1902 1904

$1879-1907$

Klassifikation Teil B: 01193

Band: 3

Trägermaterial: Papier

Alte Reg.-Sig.: IV Ka 05

Bestell-Nr.: IV 01193

1214 Einfassungen der Brunnen und Regenwasserbacken

1869-1890

- Anzeigen über unvorschriftsmäßige Einfassungen von Brunnen und

(1840-1853)

Regenwasserbacken als Gefährdung des öffentlichen Verkehrs, (1840

- 1853) 1869 - 1895

- Anzeige über Verschmutzung des Brunnens des Schlachters

Gerhard Hummerich durch den Blaufärber Peter Baalmann, April 1869

(1840 - 1853) 1869 - 1895

Klassifikation Teil B: 01264

Trägermaterial: Papier

Alte Reg.-Sig.: IV Kc 46

Bestell-Nr.: IV 01264 
IV

05

05.03

05.03.07

05.03.07.03
Stadtverwaltung

Aufgabenbereiche der Stadtverwaltung

Baupolizei

Bauliche Missstände

Lfd. Nr. Titel

Laufzeit

1879-1888

(1816-1846)

- Stacket (Zaun) vor dem Haus der Kaufmanns Johannes Joachim

Schüürmann und seines Nachfolgers, des Kaufmanns Lambertus

Heyl, (1816 - 1846) 1879

- Anzeige über erhöhte, ungesicherte Plattform zum Be- und Entladen

beim Heyl'schen Haus, Dezember 1878 - März 1879

- Projekt einer schmiedeeisernen Umfriedung in der Neutorstraße vom

Heyl'schen Haus aus, 1879 - 1888

(1816 - 1846) 1878 - 1879

Klassifikation Teil B: 01265

Trägermaterial: Papier

Alte Reg.-Sig.: IV Kc 52

Bestell-Nr.: IV 01265

1216 Beseitigung baulicher Missstände, Bd. 1

- Anzeigen über bauliche Mängel bis zur Einsturzgefahr von

Gebäuden und vorgeschlagene Maßnahmen zu deren Beseitigung

(1864 - 1865) $1866-1872$

Klassifikation Teil B: 01266

Band: 1

Trägermaterial: Papier

Alte Reg.-Sig.: IV Kc 55

Bestell-Nr.: IV 01266

1217 Beseitigung baulicher Missstände, Bd. 2

- Anzeigen über bauliche Mängel bis zur Einsturzgefahr von

Gebäuden und vorgeschlagene Maßnahmen zu deren Beseitigung

$1872-1879$

Klassifikation Teil B: 01267

Band: 2

Trägermaterial: Papier

Alte Reg.-Sig.: IV Kc 55

Bestell-Nr.: IV 01267

1218 Beseitigung baulicher Missstände, Bd. 3

- Anzeigen über bauliche Mängel bis zur Einsturzgefahr von

Gebäuden und vorgeschlagene Maßnahmen zu deren Beseitigung

$1908-1912$

Klassifikation Teil B: 01268

Band: 3

Trägermaterial: Papier

Alte Reg.-Sig.: IV Kc 55

Bestell-Nr.: IV 01268 
IV

05

05.03

05.03.07

05.03.07.03
Stadtverwaltung

\section{Aufgabenbereiche der Stadtverwaltung}

Baupolizei

Bauliche Missstände

Lfd. Nr. Titel

Laufzeit

1219 Baufälligkeit des Hauses des Spirituosenhändlers Bruno Odinga

- Streit zwischen dem Hausbesitzer und Spirituosenhändler Bruno

Odinga und dem Magistrat der Stadt Emden wegen der

Abrissverfügung für sein baufälliges Haus in der Judenstraße

$1871-1874$

Klassifikation Teil B: 01269

Trägermaterial: Papier

Alte Reg.-Sig.: IV Kc 60

Bestell-Nr.: IV 01269

1220 Beseitigung des ordnungswidrigen Schuppens des Schiffsbauers J.

1883-1884

Janssen

- Beschwerde der Nachbarn des J. Janssen gegen einen zu nah an der Grundstücksgrenze errichteten und sichtversperrenden Schuppen, Oktober - Dezember 1883

- Verfügung des Magistrats an J. Janssen über Anordnung zur Beseitigung des Schuppens wegen Feuergefahr, November 1883 / Januar - April 1884

- Drängen der Falderndeichacht auf Beseitigung des Schuppens wegen Feuergefahr und Eingriff in das Deichrecht, Dezember 1883 April 1884

- Eingabe des Schiffbauers Johann Janssen an den Magistrat über Bitte um Rücknahme der Abrissverfügung, November 1883 - Januar 1884

$1883-1884(1901)$

Klassifikation Teil B: 01270

Trägermaterial: Papier

Alte Reg.-Sig.: IV Kc 61

Bestell-Nr.: IV 01270

1221 Reparatur schadhafter Kellerluken

- Anzeigen über schadhafte Kellerluken als Gefährdung der öffentlichen Verkehrssicherheit

- Verfügungen über Anordnung zur Reparatur oder Beseitigung schadhafter Kellerluken

$1901-1913$

Klassifikation Teil B: 01271

Trägermaterial: Papier

Alte Reg.-Sig.: IV Kc 62

Bestell-Nr.: IV 01271 
IV

05

\subsection{3}

05.03.07

05.03.07.03

\section{Stadtverwaltung}

Aufgabenbereiche der Stadtverwaltung

Baupolizei

Bauliche Missstände

Lfd. Nr. Titel

Laufzeit

1222 Illegaler Hühnerstall auf städtischem Gelände 1906

- Verfügung des Magistrats der Stadt Emden an den Maler Jan Bruns über Anordnung zum Abriss eines ungenehmigten, auf städtischem Gelände errichteten Hühnerstalls, April 1906 - Beschwerde des J. Bruns beim Regierungspräsidenten in Aurich gegen die Abrissverfügung der Stadt Emden, Mai - Juni 1906

1906

Klassifikation Teil B: 01272

Trägermaterial: Papier

Alte Reg.-Sig.: IV Kc 63

Bestell-Nr.: IV 01272

1223 Verstöße gegen Schutzbestimmungen für Bauarbeiter

- Berichte des Vorsitzenden der Bauarbeiterschutzkommission, Maurer H. Babiel, über Verstöße gegen Schutzbestimmungen für Bauarbeiter durch mangelhafte und gefährliche Gerüstbauten und mangelhafte sanitäre Anlagen auf Baustellen, 1906 - 1907

- Fotografische Dokumentation der Verstöße, 1906

- Berichte des Baurats Meentz über Verstöße von Bauunternehmen gegen Schutzbestimmungen, Februar 1909

$1906-1909$

Klassifikation Teil B: 01273

Trägermaterial: Papier

Alte Reg.-Sig.: IV Kc 64

Bestell-Nr.: IV 01273

1224 Bestrafungen von Übertretungen baupolizeilicher Vorschriften

- Anzeigen und Verhängung von Strafen wegen baupolizeiliche Verstöße (Verletzung der Baunormen, ungenehmigte Bauten)

- Revision der Neubauten in Emden, Februar 1908

$1906-1913$

Klassifikation Teil B: 01274

Trägermaterial: Papier

Alte Reg.-Sig.: IV Kc 65

Bestell-Nr.: IV 01274

1225 Brand im Haus des Steuereinnehmers Konter

- Anzeige über Schornsteinbrand im Haus des pensionierten

Steuereinnehmers Konter, März 1868

1868

Klassifikation Teil B: 01347

Trägermaterial: Papier

Alte Reg.-Sig.: IV Lc 071

Bestell-Nr.: IV 01347 
Lfd. Nr. Titel

- Ziele des Comites für Arbeiterwohnungen der Gesellschaft tot nut van't algemeen, April - Oktober 1873

- Revision der Arbeiterwohnungen in Emden, Mai 1874

- Aufstellung über von Arbeitern und Kleinverdienern bewohnte Häuser mit Angaben über Größe der Haushaltungen, 1890 - Antrag der kgl. Eisenbahndirektion beim Magistrat auf Erstellung einer Bescheinigung über Mangel an Arbeiterwohnungen als Begründungshilfe für den Bau einer Dienstwohnung für den Brückenwärter der Drehbrücke über den Delft, Januar 1896 - Anzeigen über Missstände in Emder Arbeiterwohnungen: Zu hohe Belegung; Kostgänger; Unbenutzbarkeit der Wohnung, mangelhafte sanitäre Anlagen, 1907 / 1910

\author{
$1873-1910$ \\ Klassifikation Teil B: 01275 \\ Trägermaterial: Papier \\ Alte Reg.-Sig.: IV Kd 01 \\ Bestell-Nr.: IV 01275
}

1227 Wohnungsnotstand

- Bericht des Komitees für Arbeiterwohnungen der Gesellschaft tot nut van't algemeen über Missstände in Arbeiterwohnungen: zu klein, unhygienische Verhältnisse, 1873

- Protokoll des Magistratsbeschlusses über Evaluierung der Möglichkeit der Stellung von städtischem Grundbesitz zum Bau von Arbeiterwohnungen, Januar 1882

- Anfrage des Agenten C. Harms nach Arbeiterwohnungen, April 1896 - Dementierung von Berichten über Wohnungsmangel in Emden in der Rheinisch-Westfälischen Zeitung und der Weserzeitung, August 1896

- Meldungen über drohende Obdachlosigkeit von Arbeitern wegen Wohnungsmangel und Bitten um Wohnungsvermittlung durch die Stadt Emden, April 1897 - Mai 1900

- Antrag des Jacobus Backband auf Zulassung als Wohnungsmakler, Juli 1909

- Bericht des Gewerkschaftskartells Emden über Misstände auf den Wohnschiffen der Heringsfischerei Neptun AG, Oktober 1903

- Meldungen gesundheitsschädlicher Arbeiterwohnungen, April 1906

- Eingabe des Maschinenmeisters S. Weißgeier und anderer Arbeiter der Emder Brikettfabrik und der Nordseewerke an den Magistrat über Bitte um Abgabe von Land auf dem Königspolder zum Bau von Wohnungen in der Nähe ihres Arbeitsplatzes, Mai 1911

- Presseberichte über Wohnungsnot in Emden, 1913 - 1914

- Schreiben des Hausbesitzers Helmer von Baden Foget über Dementierung einer Wohnungsnot und Gegnerschaft gegen Eingriffe der Stadt Emden in den Wohnungsmarkt durch Bau von Arbeitersiedlungen, Januar 1913

$1873-1914$

Klassifikation Teil B: 01276

Trägermaterial: Papier

Alte Reg.-Sig.: IV Kd 02

Bestell-Nr.: IV 01276 
05

05.03

05.03.07

05.03.07.04
Stadtverwaltung

Aufgabenbereiche der Stadtverwaltung

Baupolizei

Bekämpfung der Wohnungsnot

Lfd. Nr. Titel

Laufzeit

1228 Beschaffung von Arbeiterwohnungen, Bd. 1

1887-1902

- Verein "Arbeiterheim", Gründung des Bethel'schen Stiftes, Februar

1887 - Dezember 1903

- Presseberichte über Wohnungsnot der Arbeiter, 1887 - 1901

- Initiative des Magistrats zur Einbeziehung des Bauvereins "Eigenes Heim" in ein Kreditprogramm der Invaliditäts- und Altersversicherung zum Bau von Arbeiterwohnungen, Januar - Juli 1893

- Kreditprogramm der Invaliditäts- und Alterversicherungsanstalt Hannover zum Bau von Arbeiterwohnungen, September 1892

- Bericht der Gesellschaft tot nut van't algemeen über ihr Wirken zur Lösung der Arbeiterwohnungsfrage: Alkoholmissbrauch als Ursache von Arbeiterarmut, September 1893

- Publikationen zur Arbeiterwohnungsfrage, 1892 - 1899

- Bericht des Oberbürgermeisters Fürbringer an den

Regierungspräsidenten in Aurich über Absicht der Stadt Emden zum

Bau von Arbeiterwohnhäuser für Hafenarbeiter und Arbeiter der

Heringsfischerei und Bltte um Abgabe von domänenfiskalisches Land,

Oktober 1899

- Protest der Anwohner der Neptun- und Nesserlander Str. gegen den

Bau von Arbeiterwohnungen in ihrer Nachbarschaft, November 1899

- Angebote über Baumaterial für Arbeiterwohnungen, 1899

- Drängen verschiedener Hafenbetriebsfirmen zur Forcierung des

Arbeiterwohnungsbaus, 1899 - 1900

- Bericht des Regierungsbaurats Böhmer über Planungen zum Aufbau der Arbeitersiedlung im Kaiser-Wilhelm-Polder, (Transvaal), Januar 1900

- Schreiben des Erziehungsvereins an den Magistrat über Bitte zum von Arbeiterwohnungen mit Kleingärten zur Hebung der Moral der Arbeiter, Juni 1900

- Kriterien des Deutschen Vereins für öffentliche Gesundheitspflege hinsichtlich der Einrichtung von Arbeiterwohnungen, Dezember 1901

- Konzept eines Schreibens des Magistrats an die

Hamburg-Amerika-Linie über Beschreibung der projektierten

Arbeiterwohnungen im Kaiser-Wilhelm-Polder (Transvaal), Oktober

1901

- Gemeinsamer Erlass der preußischen Ministerien für Handel und

Gewerbe; der geistlichen, Unterrichts- und Medizianalangelegenheiten und des Innern über Vorschlag von Maßnahmen zur Förderung des

Arbeiterwohnungsbaus, April 1901

- Mietpegel in Emden, Dezember 1901

- Aufstellung des Stadtbaumeisters Wiggers über Wohnungsbauten, 1901

- Bericht des Magistrats über Maßnahmen zur Behebung der Missstände im Arbeiterwohnungswesen und Schilderung der Arbeitersiedlung "Transvaal", Dezember 1901

- Berichte über Wohnungsverhältnisse in den Emder Polizeibezirkern, 1902

$1887-1902$

Klassifikation Teil B: 01277

Band: 1

Trägermaterial: Papier

Alte Reg.-Sig.: IV Kd 03

Bestell-Nr.: IV 01277 
IV

05

05.03

05.03.07

05.03.07.04
Stadtverwaltung

\section{Aufgabenbereiche der Stadtverwaltung}

Baupolizei

Bekämpfung der Wohnungsnot

Lfd. Nr. Titel

Laufzeit

1229 Beschaffung von Arbeiterwohnungen, Bd. 2

- Jahresberichte der Deutschen Vereins "Arbeiterheim", Bielefeld, April

1903 - September 1906

- Erlass des preußischen Ministers für Handel und Gewerbe über

Anforderung von Daten zur Förderung des Arbeiterwohnungsbaus in

den preußischen Provinzen, Juni 1903

- Stellungnahme des Magistrats der Stadt Emden zum geplanten

preußischen Gesetz zur Verbesserung der Wohnverhältnisse der

Arbeiter, Juli 1903

- Aufstellung des Stadtbaumeisters Wiggers über Wohnungsbauten, 1903

- Diskussion gesetzlicher Regelungen des Arbeiterwohnungsbaus, $1901-1908$

- Gründung einer Gemeinnützigen Baugesellschaft für Aurich und

Umgegend, 1908

$1901-1908$

Klassifikation Teil B: 01278

Band: 2

Trägermaterial: Papier

Alte Reg.-Sig.: IV Kd 03

Bestell-Nr.: IV 01278

1230 Beschaffung von Arbeiterwohnungen, Bd. 3

$1901-1908$

- Drucksachen zur Fördeung des Arbeiterwohnungsbaus und der

Behebung der Missstände im Arbeiterwohnungswesen

$1901-1908$

Klassifikation Teil B: 01279

Band: 3

Trägermaterial: Papier

Alte Reg.-Sig.: IV Kd 03

Bestell-Nr.: IV 01279 
IV

05

05.03

05.03.07

05.03.07.04
Stadtverwaltung

Aufgabenbereiche der Stadtverwaltung

Baupolizei

Bekämpfung der Wohnungsnot

Lfd. Nr. Titel

Laufzeit

1231 Beschaffung von Arbeiterwohnungen, Bd. 4

- Datenerhebung des Kaiserlichen Statistischen Amtes über

Arbeiterwohnungen, April 1909

- Druckschrift des Westfälischen Vereins zur Förderung des

Kleinwohnungswesens über Wohnungsbaumaßnahmen in

westfälischen Städten, 1908

- Verfügung des Regierungspräsidenten in Aurich über Auforderung eines Berichtes über Missstände bei der Unterbringung von Arbeitern in Massenquartieren, August 1908

- Bericht der Ostfriesischen Zeitung über Wohnungsfürsorge des

Staates für seine Beamten und Arbeiter in Ostfriesland und Emden, Juli 1909

- Jubiläumsbericht: 25 Jahre Deutscher Verein "Arbeiterheim",

Bielefeld, 1910

- Flugschrift: Werbung des Deutschen Vereins "Arbeiterheim",

Bielefeld, 1911

- Erhebung über leer stehende Wohnungen in den Emder

Polizeibezirken, 1909

- Anfrage der Stadt Paris über Situation des Arbeiterwohnungswesens

in Emden, Oktober 1911

$1909-1911$

Klassifikation Teil B: 01280

Band: 4

Trägermaterial: Papier

Alte Reg.-Sig.: IV Kd 03

Bestell-Nr.: IV 01280

1232 Landabtretungen für Arbeiterwohnungen im Königspolder und im Kaiser-Wilhelm-Polder

- Verhandlungen der Stadt Emden mit dem Regierungspräsidenten in Aurich wegen Erwerb von domänenfiskalischen Ländereien im Königspolder und im Kaiser-Wilhelm-Polder zum Bau einer Arbeitersiedlung (Transvaal), Oktober 1899 - Mai 1901

$1899-1901$

Klassifikation Teil B: 01281

Trägermaterial: Papier

Alte Reg.-Sig.: IV Kd 04

Bestell-Nr.: IV 01281

1233 Beteiligung der Hamburg-Amerika-Linie an einer Baugenossenschaft für Arbeiterwohnungen in Emden

- Verhandlungen zwischen dem Magistrat und der

Hamburg-Amerika-Linie über Beteiligung an der Finanzierung einer

Baugenossenschaft für Arbeiterwohnungen

1899

Klassifikation Teil B: 01282

Trägermaterial: Papier

Alte Reg.-Sig.: IV Kd 05

Bestell-Nr.: IV 01282 
IV

05

05.03

05.03.07

05.03.07.04
Stadtverwaltung

\section{Aufgabenbereiche der Stadtverwaltung}

Baupolizei

Bekämpfung der Wohnungsnot

Lfd. Nr. Titel

Laufzeit

1234 Anschluss der Arbeitersiedlung im Kaiser-Wilhelm-Polder (Transvaal) 1899-1909 an die Wasserleitung

- Verhandlungen zwischen der Stadt Emden und dem Wasserwerk in Emden, Tochter des Wasserwerks für das nördliche westfälische Kohlenrevier, Gelsenkirchen, über Anschluss der Arbeitersiedlung im Kaiser-Wilhelm-Polder an das Wasserleitungsnetz, November 1899 Dezember 1900

- Rechnung des Wasserwerks über Leitungsreparaturen und Wasserverbrauch, März 1909

- Streit zwischen der Stadt Emden und dem Wasserwerk wegen der Tragung der Reparaturkosten für eine durchgerostete Wasserleitungsstelle an der Torumer Straße (Arbeitersiedlung Transvaal), Mai - September 1909

$1899-1909$

Klassifikation Teil B: 01283

Trägermaterial: Papier Alte Reg.-Sig.: IV Kd 06

Bestell-Nr.: IV 01283

1235 Beamten-Bau- und Wohnungsverein

- Antrag des Beamten-Bau und Wohnungsvereins bei der Alters- und Invaliditätsversicherungsanstalt Hannover auf Zuweisung eines Baudarlehens für Beamtenwohnungen, Februar - März 1902 - Antrag des Beamten-Bau und Wohnungsvereins beim Magistrat der Stadt Emden auf Gewährung eines Baudarlehens aus Mitteln des Staatshaushalts nach dem Erlass des preußischen Innenministers vom 14. Juni 1902, August - November 1902

- Antrag des Beamten-Bau und Wohnungsvereins beim Magistrat auf Baugenehmigung für ein Haus auf dem Grundstück Bentincks /

Grüner Weg, Juli - Oktober 1902

- Genehmigung des Baus eines Sechsfamilienhauses des

Beamten-Bau- und Wohnungsvereins an der Nesserlanderstr. /

Schweckendiekstr., Oktober 1902

- Geschäftsberichts des Beamten-Bau- und Wohnungsvereins, 1903 1914

- Probleme bei der Herstellung der Straßen- und Kanalanbindung der neu gebauten Häuser des Beamten-Bau- und Wohnungsvereins,

Februar - Juli 1903

- Beschwerde des Beamten-Bau- und Wohnungsvereins wegen Unregelmäßigkeiten bei der Fäkalientonnenabfuhr, Dezember 1903 - Bestellung des Ludwig Gittermann, Vorstandsbeamter der Emder Gewerbebank, zum Revisor des Beamten-Bau- und Wohnungsvereins, Dezember 1903 - Beschwerde des Haus- und Grundbesitzervereins gegen Vergabe von Wohnungen des Beamten-Bau- und Wohnungsvereins an Nichtmitglieder und daraus resultierenden unlauteren Wettbewerb, Februar 1909

$1902-1914$

Klassifikation Teil B: 01284

Trägermaterial: Papier

Alte Reg.-Sig.: IV Kd 08

Bestell-Nr.: IV 01284 
IV

05

\subsection{3}

05.03.07

05.03.07.04
Stadtverwaltung

Aufgabenbereiche der Stadtverwaltung

Baupolizei

Bekämpfung der Wohnungsnot

Lfd. Nr. Titel

Laufzeit

1236 Gewährung staatlicher Baudarlehen an Baugenossenschaften

1902-1905

- Druckschrift: Bedingungen für die Gewährung von staatlichen

Baudarlehen an Baugenossenschaften, Juni 1902

- Erlass des preußischen Innenministers über Kriterien für die

Darlehensvergabe, April 1905

- Einreichung von Abschriften des Vertrages des Beamten-Bau- und

Wohnungsvereins mit der kgl. Eisenbahndirektion Köln wegen

staatlicher Darlehen für den Wohnungsbau, November - Dezember

1904

$1902-1905$

Klassifikation Teil B: 01286

Trägermaterial: Papier

Alte Reg.-Sig.: IV Kd 10

Bestell-Nr.: IV 01286

1237 Errichtung von besseren Arbeiterwohnhäusern an der Nesserlander

$1901-1902$ Str.

- Protokoll der Magistratssitzung über Beschluss des Angebots von städtischem Land im Kaiser-Wilhem-Polder zur Durchführung eines Bauprojekts von Arbeiterwohnungen der Hamburg-Amerika-Linie, Januar 1901

- Antrag des Bauunternehmers Balduin Hempel auf Abtretung von städtischem Land für Arbeiterwohnhäuser, April 1901

- Grundriss und Ansichtszeichnung der Arbeiterwohnhäuser, April /

Oktober 1901

- Verhandlungen der Baukommission über Abtretung von städtischem Grundbesitz für Arbeiterwohnhäuser und Erschließung des Geländes, Mai 1901

- Antrag der Bauunternehmer Balduin Hempel und Franz Mehlhorn auf Baudarlehen der Landesversicherungsanstalt, Oktober 1901 - Januar 1902

- Projekt: Arbeiterwohnhäuser der Heringsfischerei Neptun AG,

Oktober 1901

- Streit um eine Garantie der Hamburg-Amerika-Linie über 5\% des

Baupreises für die Arbeiterwohnhäuser an der Nesserlander Straße, Januar 1902

- Verhandlungen der Stadt Emden mit den Bauunternehmern Balduin Hempel und Franz Mehlhorn wegen der Finanzierung der Arbeiterwohnhäuser an der Nesserlander Straße, Januar 1902

$1901-1902$

Klassifikation Teil B: 01287

Trägermaterial: Papier

Alte Reg.-Sig.: IV Kd 11

Bestell-Nr.: IV 01287 
IV

05

Stadtverwaltung

05.03

Aufgabenbereiche der Stadtverwaltung

05.03.07

Baupolizei

05.03.07.04

Bekämpfung der Wohnungsnot

Lfd. Nr. Titel

Laufzeit

1238 Allgemeiner Deutscher Wohnungskongress in Frankfurt/Main

1904-1914

- Verhandlungen auf dem Allgemeinen Deutschen

Wohnungskongress in Frankfurt/Main des Deutschen Vereins für

Wohnungsreform

- Druckschriften zur Wohnungsfrage

$1904-1914$

Klassifikation Teil B: 01288

Trägermaterial: Papier

Alte Reg.-Sig.: IV Kd 12

Bestell-Nr.: IV 01288

1239 Vereinbarungen mit dem Gemeinnutzigen Bauverein Emden wegen

Bau von Arbeiterwohnungen

- Material für die Verhandlungen der Baukommission wegen

Vereinbarung der Abtretung von städtischem Grundbesitz und

Darlehen der Landesversicherungsanstalt für den Gemeinnutzigen

Bauverein zum Bau von Arbeiterwohnungen

- Verschiedene Risszeichnungen und Ansichten von

Arbeiterwohnhäuser

$1901-1902$

Klassifikation Teil B: 01289

Trägermaterial: Papier

Alte Reg.-Sig.: IV Kd 13

Bestell-Nr.: IV 01289 
IV

05

05.03

05.03.07

05.03.07.04
Stadtverwaltung

Aufgabenbereiche der Stadtverwaltung

Baupolizei

Bekämpfung der Wohnungsnot

Lfd. Nr. Titel

Laufzeit

1240 Geplante Gründung einer Genossenschaft zum Bau von Arbeiterwohnungen

- Material über Genossenschaftsgründungen in anderen Städten: Rüstringen, Frankfurt / Main, Leipzig, 1895 - 1902

- Denkschrift über Organisation von Baugenossenschaften, 1894

- Verhandlungen der städtischen Kollegien über Plan zur Gründung einer Genossenschaft zum Bau von Arbeiterwohnungen wegen Arbeitereinstellungen bei den Nordseewerken, März - Mai 1905 - Anregung der Nordseewerke zur Einrichtuing einer Fährverbindung durch den Binnenhafen zur Werft zur besseren Anbindung der geplanten Arbeitersiedlung, Mai 1905

- Verhandlungen der Wohnungskommission über Plan zur Gründung einer Genossenschaft zum Bau von Arbeiterwohnungen auf Basis einer Hypothekenvergabe durch die Landesversicherungsanstalt Hannover, Mai - Juni 1905

- Verhandlungen der Wohnungskommission mit der Landesversicherungsanstalt wegen Hypothek für die Bauten der geplanten Baugenossenschaft, Juli 1905

- Verhandlungen des Gemeinnutzigen Bauvereins mit der Landesversicherungsanstalt wegen Hypothek für Wohnungen, Mai 1905

$1894-1905$

Klassifikation Teil B: 01290

Trägermaterial: Papier

Alte Reg.-Sig.: IV Kd 13

Bestell-Nr.: IV 01290

1241 Preisgekrönte Entwürfe und Modelle von Arbeiterwohnhäusern in einer Ausstellung im Rathaussaal

- Organisation einer Ausstellung des Ernst-Ludwig-Vereins, hessischer Zentralverein zur Errichtung billiger Wohnungen, Darmstadt, über preisgekrönte Entwürfe und Modelle von Arbeiterwohnhäuser

1905

\author{
Klassifikation Teil B: 01291 \\ Trägermaterial: Papier \\ Alte Reg.-Sig.: IV Kd 13 \\ Bestell-Nr.: IV 01291
}

1242 Ausstellung von Bauplänen von Arbeiterwohnhäusern

- Bewerbung der Stadt Emden um eine Ausstellung von Bauplänen von Arbeiterwohnhäusern des Hauptvereins für Arbeiterwohlfahrt in Hannover und der Landesversicherungsanstalt Oldenburg

1906

Klassifikation Teil B: 01292

Trägermaterial: Papier

Alte Reg.-Sig.: IV Kd 15

Bestell-Nr.: IV 01292 
IV

05

05.03

05.03.07

05.03.07.04
Stadtverwaltung

\section{Aufgabenbereiche der Stadtverwaltung}

Baupolizei

Bekämpfung der Wohnungsnot

Lfd. Nr. Titel

Laufzeit

1243 Bildung von Arbeiterrentgüter

- Abschrift einer Verfügung des preußischen Ministers für Landwirtschaft, Domänen und Forsten an die Generalkommission über Kriterien zur Förderung der Gründung kleiner Stellen für Landund Industriearbeiter zu deren Sesshaftmachung

1907

Klassifikation Teil B: 01293

Trägermaterial: Papier

Alte Reg.-Sig.: IV Kd 16

Bestell-Nr.: IV 01293

1244 Zweite Hypotheken für Kleinwohnungsbau

- Material aus anderen Städten und Zeitungsberichte über Problem der Erhaltung von Zweithypotheken für den Kleinwohnungsbau

$1912-1914$

Klassifikation Teil B: 01294

Trägermaterial: Papier

Alte Reg.-Sig.: IV Kd 17

Bestell-Nr.: IV 01294

1245 Bescheinigungen für Staatsbeamte über leer stehende Wohnungen

- Ausstellung von Bescheinigungen an Staatsbeamte über ihre infolge Versetzung vor Ende der Mietsvertragszeit verlassene Wohnung zur Neuzuweisung und zur Feststellung des Mietenausfalls für die

Vermieter

$1868-1898$

Klassifikation Teil B: 01673

Trägermaterial: Papier

Alte Reg.-Sig.: IV Qu 13

Bestell-Nr.: IV 01673 
Lfd. Nr. Titel

- Bericht des Magistrats an den Regierungspräsidenten in Aurich über Notwendigkeit des Baus einer Arbeitersiedlung zur Unterbringung von Arbeitern der HAPAG und der Hafenbetriebe, Oktober 1899

- Bestimmung des Standorts für eine Arbeitersiedlung, November 1899

- Verhandlungen der Kommission für Arbeiterwohnungen über Bau der Arbeitersiedlung, Januar 1900

- Kostenvoranschlag des Regierungs- und Baurats Bohnen über

Errichtung der Arbeiterwohnhäuser-Anlage der Stadt Emden, 1900

- Durchführung der Erschließungsarbeiten zum Bau der

Arbeitersiedlung im Kaiser-Wilhelm-Polder, März - Oktober 1900

- Ausschreibung der Bauarbeiten, März - April 1900

- Kostenvoranschlag für Kanalisation und Straßen in der

Arbeitersiedlung, Mai 1900

- Bau der Arbeiterwohnhäuser durch die Fa. Stöver \& Arends, Mai Juni 1900

- Feuerversicherung der Arbeiterwohnhäuser im KW-Polder, Juli 1900

$1899-1900$

Klassifikation Teil B: 02473

Trägermaterial: Papier

Alte Reg.-Sig.: St XVIII 150

Bestell-Nr.: IV 02473

1247 Erbauung von Arbeiterwohnhäusern auf Transvaal

- Beschaffung und Abrechnung von Material für die Arbeiterhäuser auf Transvaal, 1900

- Abrechnung der Planungskosten, 1900

- Kosten des Arbeiterwohnungsbaus, 1900

- Bebauungsplan der Arbeitersiedlung im Kaiser-Wilhelm-Polder, 1900

- Abrechnung der Arbeitsleistungen zum Bau der Arbeiterwohnhäuser, 1900 - 1901

- Beschaffung von Kochherden und Stubenöfen für die

Arbeiterhäuser, 1901

- Herstellung der Straßen in der Arbeitersiedlung, 1901

- Aufstellung über Bewohner der Siedlung Transvaal mit Angaben zum

Viehbesitz, 1901

- Bericht des Magistrats an den Regierungspräsidenten über

Finanzierung des Arbeiterwohnungsbau durch ein Darlehen der Landesversicherungsanstalt Hannover, März 1902

$1900-1902$

Klassifikation Teil B: 02523

Trägermaterial: Papier

Alte Reg.-Sig.: VIII A 2 b 069

Bestell-Nr.: IV 02523 
IV

05

05.03

05.03.08

05.03.08.01

05.03.08.01.01
Stadtverwaltung

Aufgabenbereiche der Stadtverwaltung

\section{Brandschutz}

Organisation des Brandschutzes

Feuerpolizeiliche Vorschriften

Lfd. Nr. Titel

Laufzeit

1248 Sicherheitsvorschriften für elektrische Hochspannungsnetze und 1887-1913 Starkstromanlagen

- Erlass des preußischen Ministers für Handel und Gewerbe über Sicherheitsvorkehrungen beim Betrieb von Starkstromanlagen, September 1897 / Februar 1902

- Erlass des preußischen Ministers für Handel und Gewerbe über Sicherheitsvorkehrungen beim Betrieb von Starkstromleitungen, März 1898

- Runderlass des preußischen Ministers der öffentlichen Arbeiten über Sicherung von Telefonleitungen gegenüber Starkstromleitungen, April 1909 / Dezermber 1909

- Mitteilungen über Verhandlungen zu einem Starkstromwegegesetz, April 1910

- Verfügung des Regierungspräsidenten in Aurich über Anbringung von Warntafeln an Hochspannungsleitungsmasten zur Verhinderung des Kletterns an solchen Masten, Oktober 1910

$1887-1913$

Klassifikation Teil B: 00575

Trägermaterial: Papier

Alte Reg.-Sig.: IV Ea 21

Bestell-Nr.: IV 00575

1249 Vorschriften zur Brandverhütung: Heuhaufen auf Böden und Blöcken

- In zu kleinem Abstand zum Wohnhaus abgelagerter Heuhaufen des Landgebräuchers Hinderk A. Hinderks, August 1902 - August 1905

- Anträge verschiedener Landgebräucher auf Duldung von neben ihren Häusern abgelagerter Heuhaufen, August 1904 - Juni 1905 - Polizeiverordnung der Stadt Emden über Festlegung eines Mindestabstands von sechs Metern zwischen einem Heuhaufen und Wohnhäusern bzw. Straßen, Juni 1905

- Kontrolle eingelagerter Heumengen durch Vertrauensleute der ostfriesischen Feuerversicherungsgesellschaften, 1909

$1902-1909$

Klassifikation Teil B: 01218

Trägermaterial: Papier

Alte Reg.-Sig.: IV La 07

Bestell-Nr.: IV 01218 
IV

05

05.03

05.03.08

05.03.08.01

05.03.08.01.01

\section{Stadtverwaltung}

Aufgabenbereiche der Stadtverwaltung

\section{Brandschutz}

Organisation des Brandschutzes

Feuerpolizeiliche Vorschriften

Lfd. Nr. Titel

Laufzeit

1872-1903

(1850-1859)

- Bericht des Stadtbaumeisters Berg über Anwendung von

Brandschutzvorschriften bei der Genehmigung von Darren, November 1850

- Diskussion einer Vorschrift des Verbotes hölzerner Darren und ihre

Ersetzung durch Eisenblechkonstruktionen nach Entstehung eines

Brandes bei Einsatz einer Holzdarre, März 1855

- Verfügung des Hannoverschen Landdrosten in Aurich über brandschutztechnische Kriterien bei Zulassung von Darren, April 1858

- Bericht des Stadtbaumeisters Robbelen über Anwendung brandschutztechnischer Kriterien bei Zulassung von Darren, November 1858

- Anträge auf Zulassung von Darren, u.a. für Fisch, Tabaktrocknung und Hopfenzubereitung, (1853 - 1859) 1873 - 1893

- Beschwerde der Nachbarn über Belästigung und

Gesundheitsschäden durch Schwefeldämpfe aus der Korndarre im Packhaus des Getreidekaufmanns J. de Vries, August - November 1877 / August 1879

- Beschwerde der Nachbarn über Belästigung und

Gesundheitsschäden durch Schwefeldämpfe aus der Korndarre im Packhaus des Commerzienrats Reemtsma, September 1882 - April 1883

- Verfügungen des Magistrats an verschiedene Kaufleute über Anordnung von Maßnahmen zur Brandverhütung beim Einsatz von hölzernen Darren, 1903

(1850 - 1859) 1872 - 1903

Klassifikation Teil B: 01220

Trägermaterial: Papier

Alte Reg.-Sig.: IV La 12

Bestell-Nr.: IV 01220

1251 Brandordnung für Ostfriesland

$1886-1905$

- Bekanntmachung der novellierten Brandordnung für Ostfriesland im Regierungsamtsblatt, August 1901

- Gesetzliche Regelung der Zuständigkeit für die Organisation des

Feuerlöschwesens, Dezember 1880 - Februar 1881

- Diskussion einer vom ostfriesischen Landschaftskollegium gewünschten Polizeiverordnung des Regierungspräsidenten (Landdrosten) in Aurich über Regelung der auswärtigen Löschhilfe für eine Gemeinde im Brandfall, Januar 1881 - August 1855

- Beantragung des Verbots von Petroleumleuchtern in

Dreschkammern , April - Mai 1905

$1886-1905$

Klassifikation Teil B: 01296

Trägermaterial: Papier

Alte Reg.-Sig.: IV La 26

Bestell-Nr.: IV 01296 
IV

05

05.03

05.03.08

05.03.08.01

05.03.08.01.01
Stadtverwaltung

Aufgabenbereiche der Stadtverwaltung

\section{Brandschutz}

Organisation des Brandschutzes

Feuerpolizeiliche Vorschriften

Lfd. Nr. Titel

Laufzeit

1252 Brandschutz bei Häusern an Eisenbahnlinien

1871-1898

- Polizeiverfügung des preußischen Landdrosten /

Regierungspräsidenten in Aurich über Regelung des Brandschutzes bei Häusern an Eisenbahnlinien, 1873 - 1898

- Erlasse der preußischen Minister des Innern und des Ministers der öffentliche Arbeiten über Brandschutz bei Häusern an

Eisenbahnlinien, Juni 1871 / April 1891

$1871-1898$

Klassifikation Teil B: 01297

Trägermaterial: Papier

Alte Reg.-Sig.: IV La 27

Bestell-Nr.: IV 01297

1253 Brandschutzbestimmungen beim Verkauf von Petroleum

$1882-1904$

- Gesetzliche Regelung zur Prüfung von Petroleum auf seine

Entflammbarkeit, $1882-1897$

- Revision der Petroleumanlagen, 1883 - 1885

- Bericht über Petroleumhandel in Emden, April 1904

$1882-1904$

Klassifikation Teil B: 01298

Trägermaterial: Papier

Alte Reg.-Sig.: IV La 28

Bestell-Nr.: IV 01298

1254 Seetransport feuergefährlicher Güter

$1886-1914$

- Diskussion einer allgemeinen Verordnung zum Seetransport feuergefährlicher Güter nach dem Vorbild einer Polizeiverordnung der Stadt Lübeck, April 1886 - Februar 1889

- Novellierung des Erlasses des preußischen Ministers für Handel und Gewerbe vom 30. März 1912 über Seetransport feuergefährlicher Güter hinsichtlich der Klassifizierung der Feuergefährlichkeit, April 1913 - Oktober 1914

$1886-1914$

Klassifikation Teil B: 01303

Trägermaterial: Papier

Alte Reg.-Sig.: IV La 31

Bestell-Nr.: IV 01303 
IV

05

05.03

05.03.08

05.03.08.01

05.03.08.01.02
Stadtverwaltung

Aufgabenbereiche der Stadtverwaltung

\section{Brandschutz}

Organisation des Brandschutzes

Feuerpolizeiliche Zuständigkeiten

Lfd. Nr. Titel

Laufzeit

1255 Einrichtung und Betrieb von Fahrstühlen

1900-1913

- Umsetzung der Polizeiverordnung des Oberpräsidenten der Provinz Hannover über die Überwachung des Einbaus und Betriebs von

Fahrstühlen im Regierungsbezirk Aurich, 1900 - 1908

- Erlass des preußischen Ministers für Handel und Gewerbe über

Beauftragung des Dampfkesselüberwachungsvereins mit der Inspektion von Aufzugsanlagen, Januar 1907

- Aufstellung über betriebene Aufzüge und sonstige elektrische

Anlagen in der Stadt Emden, 1908

- Aufstellung über betriebene Lastenaufzüge in der Stadt Emden, 1900

- Anträge an den Magistrat der Stadt Emden auf Abnahme eingebauter Fahrstühle und Lastenaufzüge, 1902 - 1908

- Abnahmeberichte des Dampfkesselüberwachungsvereins über

Aufzugsanlagen verschiedener Emder Firmen, 1910 - 1913

$1900-1913$

Klassifikation Teil B: 00576

Trägermaterial: Papier

Alte Reg.-Sig.: IV Ea 23

Bestell-Nr.: IV 00576

1256 Sicherung der Bodenluken in Gebäuden und Mühlen

1886

- Verfügungen des Regierungspräsideenten in Aurich über Sicherung der Bodenluken als Maßnahme des Unfallschutzes, 1886

1886

Klassifikation Teil B: 00577

Trägermaterial: Papier

Alte Reg.-Sig.: IV Ea 24

Bestell-Nr.: IV 00577

1257 Feuergefährliche Handlungen

- Berichte über Ausbruch von Wohnungsbränden, 1867 - 1879

- Feuergefährliches Lagern von Stroh durch den Papierhersteller

Pottkemper, 1871 - 1874

- Anzeigen wegen feuergefährlicher Handlungen (z.B. Kaffeebrennen), 1874 - 1902

- Ermittlungen gegen Schüler wegen Brandstiftung, Februar 1896

$1867-1896$

Klassifikation Teil B: 01223

Trägermaterial: Papier

Alte Reg.-Sig.: IV La 18

Bestell-Nr.: IV 01223 
IV

05

05.03

05.03.08

05.03.08.01

05.03.08.01.02
Stadtverwaltung

Aufgabenbereiche der Stadtverwaltung

\section{Brandschutz}

Organisation des Brandschutzes

Feuerpolizeiliche Zuständigkeiten

Lfd. Nr. Titel

Laufzeit

1258 Verheimlichung von Hausbränden

1876

- Stellungnahme des Magistrats zum Entwurf einer Polizeiverordnung des preußischen Landdrosten in Aurich über Bestrafung der

Verheimlichung von Hausbränden, April 1876

1876

Klassifikation Teil B: 01225

Trägermaterial: Papier

Alte Reg.-Sig.: IV La 21

Bestell-Nr.: IV 01225

1259 Schauung von Feuerungsanlagen

$1877-1883$

- Mängel am neugenauten Schornstein im Gebäude des Clubs zum

Guten Endzweck, März - April 1877

- Bekanntmachung der Revision der Feuerungsanlagen in Emden,

Oktober 1878 - Mai 1882

- Verfügungen über Verbot der Benutzung feuergefährlich aufgebauter

Öfen, 1877 - 1883

- Aufstellung über Mängel an Feuerungsanlagen, 1881 - 1882

$1877-1883$

Klassifikation Teil B: 01226

Trägermaterial: Papier

Alte Reg.-Sig.: IV La 23

Bestell-Nr.: IV 01226

1260 Bestände an Schießpulver in Emden

$1897-1918$

- Gemeinsamer Erlass des preußischen Innenministers und des

Ministers für Handel und Gewerbe über Vorschriften zum Verkehr mit

Schießpulver und Sprengstoffen, Oktober 1893

- Erlass des preußischen Innenministers über Erfassung der

Schwarzpulverbestände, Dezember 1892

- Aufstellungen über gelagerte Schwarzpulvermengen und Patronen

(Gewehrmunition) in Emden, 1902 - 1918

$1897-1918$

Klassifikation Teil B: 01240

Trägermaterial: Papier

Alte Reg.-Sig.: IV La 17

Bestell-Nr.: IV 01240 
IV

05

05.03

05.03.08

05.03.08.01

05.03.08.01.02

Lfd. $\mathrm{Nr}$ Titel
Stadtverwaltung

Aufgabenbereiche der Stadtverwaltung

\section{Brandschutz}

Organisation des Brandschutzes

Feuerpolizeiliche Zuständigkeiten

1261 Blitzableiter auf Schulgebäude

Laufzeit

- Nachweisung über Blitzableiter auf Emder Schulgebäuden, April

1885 / April - November 1902

- Erlass des Ministers der geistlichen- Unterrichts- und

Ministeialangelegenheiten über Anordnung zur Installation von

Blitzableitern an den Gebäuden höherer Schulen, August 1903

- Installation von Blitzableitern an der Kaiser-Friedrich-Realschule und

der städtischen Volksschule, Oktober 1903

- Angebote über Blitzableiter und Installation, 1903

- Antrag der Stadt Emden beim Landschaftskollegium auf eine Beihilfe zur Finanzierung der Blitzableiterinstallation, April - Mai 1904

- Antrag der Stadt Emden beim Landschaftskollegium auf eine Beihilfe zur Finanzierung der Blitzableiterinstallation am Ofenhaus des städtischen Gaswerks, April 1910

- Blitzableiteranlage auf dem Fußartillerie - Kasernement, Januar 1911

$1885-1911$

Klassifikation Teil B: 01299

Trägermaterial: Papier

Alte Reg.-Sig.: IV La 29

Bestell-Nr.: IV 01299 
IV

05

05.03

05.03.08

05.03.08.01

05.03.08.01.02
Stadtverwaltung

Aufgabenbereiche der Stadtverwaltung

\section{Brandschutz}

Organisation des Brandschutzes

Feuerpolizeiliche Zuständigkeiten

Lfd. Nr. Titel

Laufzeit

1262 Schornsteinfegerwesen, Bd. 1

1867-1873

- Beschwerden über schlechte Reinigung von Schornsteinen, (1851 -

(1851-1866) 1866) 1867 - 1873

- Gesuch des Schornsteinfegers Johann Joseph Solaro um Zulassung als Schornsteinfegermeister in Nachfolge des L. Heyl, Oktober 1858

- Bewerbungen um Schornsteinfegerstellen in Emden, (1859 - 1866)

$1868-1871$

- Streit um Honorar des Schornsteinfegers J.J. Solaro für das

Reinigen der Schornsteine des städtischen Krankenhauses, Juni 1861

- Polizeiverordnung der Stadt Emden über Festlegung der

Reinigungsintervalle für Schornsteine und Einführung des

Schornsteinfegerzwangs, Januar 1867

- Verweigerung der Konzessionierung des Schornsteinfegers Edmund

Gräf aus Eisenach durch die Stadt Emden, 1868 - 1869

- Instruktionen für die Bezirksschornsteinfeger in Emden:

Fegebezirksaufteilung; Reinigungsintervalle; Eintreibung der

Fegegebührenrückstände, Mai 1869 / September 1871

- Konflikt zwischen den Schornsteinfegern Johann Solaro und

Edmund Gräf, 1868 - 1871

- Bekanntmachung über den Umfang der Schornsteinfegerbezirke,

Dezember 1869

- Aufstellung des Schornsteinfegers E. Gräf über

schornsteinfegedienstverweigernde Hausbesitzer, August / Dezember 1870

- Entzug der Konzession des Schornsteinfegermeisters E, Gräf wegen Diebstahl, Dezember 1870 - März 1871

- Vermittlung eines neuen Schornsteinfegers als Ersatz für den entlassenen E. Gräf, Mai - Juni 1871

- Anzeigen über Schornsteinbrände, 1870 - 1873

(1851 - 1866) 1867 - 1873

Klassifikation Teil B: 01300

Band: 1

Trägermaterial: Papier

Alte Reg.-Sig.: IV La 02

Bestell-Nr.: IV 01300 
05

\subsection{3}

05.03.08

05.03.08.01

05.03.08.01.02
Stadtverwaltung

Aufgabenbereiche der Stadtverwaltung

Brandschutz

Organisation des Brandschutzes

Feuerpolizeiliche Zuständigkeiten

Lfd. Nr. Titel

Laufzeit

1263 Schornsteinfegerwesen, Bd. 2

1873-1906

- Instruktion für Bezirksschornsteinfeger in der Stadt Emden,

November 1876 / August 1877

- Erlasse und Verfügungen zum Schornsteinfegerwesen, (1843) 1867

- 1903

- Bewerbungen um Schornsteinfegerstellen in Emden, 1873 - 1905

- Schornsteinbrände infolge nachlässiger Reinigung, 1873 - 1880

- Weiterführung des Betriebs des verstorbenen

Schornsteinfegermeisters Johann Joseph Solaro durch seine Witwe

mit Hilfe eines Werkführers, 1873 - 1876

- Übernahme des Betriebes des Johann Joseph Solaro durch den Schornsteinfegermeister Johann Cicon aus Siegen, Januar - Februar

1877

- Einstellung des Robert Düker aus Detern als zweiten

Schornsteinfegermeister in Emden, August 1877

- Antrag der Ehefrau des Schornsteinfegermeisters Richard Schneider auf Genehmigung zur Weiterführung des Schornsteinfegerbetriebes nach der Flucht ihres Mannes wegen Wechselfälschung, Juni - Juli 1882

- Entzug der Konzession des Schornsteinfegermeisters Richard

Schneider wegen Verurteilung wegen Wechselfälschung, August 1882

- September 1883

- Anzeigen über feuergefährliche Schornsteine in Emden, Mai 1883 -

Oktober 1885

- Einstellung des Schornsteinfegermeisters Modesto Laloli aus Italien anstelle des R. Schneider, September 1883

- Belästigung des Goldschmieden Janssen durch den undichten

Schornstein seines Nachbarn P. van Hoorn, Januar 1884

- Anfrage des Provinzialschulkollegiums in Hannover wegen der Häufigkeit der Reinigung der Schornsteine und Öfen im

Kaiser-Wilhelm-Gymnasium, Juni - Juli 1884

- Antrag des Schornsteinfegermeisters Modesto Laloli beim Magistrat auf Zuteilung der Reinigung der Schornsteine in der Höheren

Töchterschule, der städtischen Volksschule und im Arbeitshaus,

September 1888

- Verfügung des preußischen Ministers für Handel und Gewerbe über Anordnung zur Mitteilung von Daten wegen Schornsteinfegerwesen und Qualifikationsanforderungen für Schornsteinfeger, November 1890 / Juni 1906

- Bekanntmachung über Festlegung der Schornsteinfegerbezirke in Emden, Dezember 1891

- Verfügung des Regierungspräsidenten in Aurich über von den Hausbesitzern zu treffe3nde bauliche Maßnahmen zur Verbesserung des Unfallschutzes der Schornsteinfeger, Oktober 1900 - Januar 1901 - Musterordnung für Schornsteinfeger in der Provinz Hannover, Juni 1902

- Polizeiverordnung der Stadt Emden über Einrichtung von

Schornsteinfegerbezirken und Aufhebung der Wahlfreiheit über den Schornsteinfeger von Seiten der Hausbesitzer nach der Vorgabe einer Polizeiverordnung des Regierungspräsidenten, April 1903 - April 1904 - Verfügung des Regierungspräsidenten in Aurich über Ernennung des Stadtbaumeisters Wiggers zum stellvertretenden Vorsitzenden der Meisterprüfungskommission für das Schornsteinfegerhandwerk, Oktober 1904 
05

05.03

05.03.08

05.03.08.01

05.03.08.01.02

Lfd. Nr. Titel

\section{IV}

Stadtverwaltung

Aufgabenbereiche der Stadtverwaltung

\section{Brandschutz}

Organisation des Brandschutzes

Feuerpolizeiliche Zuständigkeiten

$1873-1906$

Klassifikation Teil B: 01301

Band: 2

Trägermaterial: Papier

Alte Reg.-Sig.: IV La 02

Bestell-Nr.: IV 01301

Laufzeit 
IV

05

05.03

05.03.08

05.03.08.01

05.03.08.01.02
Stadtverwaltung

Aufgabenbereiche der Stadtverwaltung

\section{Brandschutz}

Organisation des Brandschutzes

Feuerpolizeiliche Zuständigkeiten

Lfd. Nr. Titel

Laufzeit

1264 Schornsteinfegerwesen, Bd. 3

1907-1916

- Übersendung von Verordnungen und Bestimmungen für das

(1921-1922)

Schornsteinfegergewerbe in Emden für ein Veröffentlichungsprojekt, Januar 1907

- Gemeinsamer Erlass der preußischen Minister für Handel und

Gewerbe und des Innern über Organisierung von

Schornsteinfegerbezirken, Februar 1907 / Juli 1907 / Mai 1908

- Gemeinsamer Erlass der preußischen Minister für Handel und

Gewerbe und des Innern über Ausnahme der Fabrikschornsteine vom

Kehrzwang, April 1907

- Ermittlung des Versicherungsschutzes der Emder Schornsteinfeger, September 1907

- Konzept einer Polizeiverordnung der Stadt Emden über Reinigung der Schornsteine in den Bezirken der Stadt Emden, Oktober 1907

- Ernennung des Stadtbaumeisters Wiggers zum stellvertretenden

Vorsitzenden der Meisterprüfungskommission für das

Schornsteinfegerhandwerk, Oktober 1907

- Festlegung der Kehrtaxe in Emden (Schornsteinfegergebühr),

Oktober 1907 / Dezember 1909

- Eingaben der Schornsteinfegermeister Modesto Laloli und Robert

Düker an den Regierungspräsidenten in Aurich über Bitte um

Zulassung als Bezirksschornsteinfegermeister in Emden, Oktober

1907

- Einrichtung von Zwangskehrbezirken in Emden, Mai 1908 - Januar

1909

- Antrag des Bezirksschornsteinfegermeisters Raith auf Festlegung des Schornsteinfegeintervalles auf vier Mal im Jahr zur Herstellung einheitlicher Verhältnis in Stadt und Landkreis Emden, November 1908 - Januar 1909

- Stellungnahme des Regierungspräsidenten in Aurich zur

Polizeiverordnung der Stadt Emden zur Organisation des

Schornsteinfegerwesens, März 1909

- Streit zwischen dem Hausbesitzer Helmer von Baden - Foget und den Bezirksschornsteinfegermeister Robert Düker wegen Entrichtung der Kehrtaxe, Juli 1911 - März 1913

- Rückstellung der Schornsteinfeger vo Kriegsdienst, September 1914

- September 1916

- Weiterführung des Schornsteinfegerbetriebs des Modesto Laloli

durch seine Witwe, August - September 1921

- Wiederbesetzung der Bezirksschornsteinfegerstelle des

verstorbenen Modesto Laloli, 1922

1907 - 1916 (1921 - 1922)

Klassifikation Teil B: 01302

Band: 3

Trägermaterial: Papier

Alte Reg.-Sig.: IV La 02

Bestell-Nr.: IV 01302 
IV

05

05.03

05.03.08

05.03.08.01

05.03.08.01.02
Stadtverwaltung

Aufgabenbereiche der Stadtverwaltung

\section{Brandschutz}

Organisation des Brandschutzes

Feuerpolizeiliche Zuständigkeiten

Lfd. Nr. Titel

Laufzeit

1265 Petroleumschuppen der Firmen Barth \& Co und Krah \& Hoffmann

1892-1906

- Von der Kaufmännischen Deputation unterstütztes Gesuch

verschiedener Firmen über Bitte um Abtretung städtischen

Grundbesitzes zur Errichtung eines neuen Petroleumschuppens, Juni

- Juli 1892

- Genehmigung des Projekts zum Bau eines neuen

Petroleumschuppens durch den Regierungspräsidenten in Aurich,

September 1892

- Eingabe der Kaufmännischen Deputation an den Magistrat der Stadt

Emden über Bitte um Aussetzung des von der kgl.

Eisenbahnbau-Inspektion geforderten Abrisses des

Petroleumschuppens bis zum Verkauf aller Petroleumvorräte im

Winter, November 1892

- Verpachtung eines städtischen Grundstücks an die Firma Barth \& Co zum Bau eines Petroleumschuppens, 1892 - 1893

- Verpachtung eines städtischen Grundstücks im

Kaiser-Wilhelm-Polder an die Firma Krah \& Hoffmann zum Bau eines

Petroleumschuppens, 1892 - 1893

- Vertrag der Stadt Emden mit einem Firmenkonsortium zur

Verpachtung eines Grundstücks im Kaiser-Wilhelm-Polder zum Bau

eines Petroleumschuppens, April 1893

- Antrag des Firmenkonsortiums auf Genehmigung zum Bau eines

Schuppens für $10.000 \mathrm{~kg}$. Petroleum, Dezember 1893 - Oktober 1894

- Gesuch des Firmenkonsortiums um Verlängerung des

Pachtvertrages, Dezember 1900

- Verfügung des Magistrats über Anordnung zum Abriss des

Petroleumschuppens an der Nesserlander Straße, September 1904 /

März 1905 / Oktober 1906

- Genehmigungsverfahren: Bau eines Petroleumschuppens der Firma

A. ter Vehn \& Co auf dem Gelände der Deutsch-Amerikanischen

Petroleumsgesellschaft, Juni - Oktober 1906

$1892-1906$

Klassifikation Teil B: 01304

Trägermaterial: Papier

Alte Reg.-Sig.: IV La 32

Bestell-Nr.: IV 01304 
IV

05

05.03

05.03.08

05.03.08.01

05.03.08.01.02
Stadtverwaltung

Aufgabenbereiche der Stadtverwaltung

\section{Brandschutz}

Organisation des Brandschutzes

Feuerpolizeiliche Zuständigkeiten

Lfd. Nr. Titel

Laufzeit

1266 Internationale Ausstellung über Feuerschutz- und Feuerrettungswesen

1900-1901

- Anfrage des Regierungspräsidenten nach Exponaten für die

Internationale Ausstellung über Feuerschutz- und

Feuerrettungswesen, August 1900

- Fragebogenaktion zum Feuerschutz anlässlich der Internationalen

Ausstellung über Feuerschutz- und Feuerrettungswesen, Februar -

März 1901

- Einladung an die Emder Stadtverwaltung zur Internationalen

Ausstellung über Feuerschutz- und Feuerrettungswesen in Berlin anlässlich des 50 jährigen Jubiläums der Berliner Berufsfeuerwehr, April 1901

$1900-1901(1910)$

Klassifikation Teil B: 01305

Trägermaterial: Papier

Alte Reg.-Sig.: IV La 34

Bestell-Nr.: IV 01305

1267 Verfahren zur Rauch- und Kohlengasverbrennung

- Werbeschrift für die Erfindung des Ingenieurs Gustav Adolph

Doebbel über Anlage und Verfahren zur nutzbaren

Rauchgasverbrennung

1905

Klassifikation Teil B: 01307

Trägermaterial: Papier

Alte Reg.-Sig.: IV La 39

Bestell-Nr.: IV 01307

1268 Teeröltankanlage im Emder Außenhafen

- Genehmigungsverfahren bei der Regierung in Aurich hinsichtlich eines von der Firma Rütgers Werke geplanten Tanklagers für zum Export nach den USA bestimmtes Steinkohlenteeröl, Januar 1905

1905

Klassifikation Teil B: 01308

Trägermaterial: Papier

Alte Reg.-Sig.: IV La 40

Bestell-Nr.: IV 01308 
IV

05

05.03

05.03.08

05.03.08.01

05.03.08.01.02

Lfd. Nr. Titel
Stadtverwaltung

\section{Aufgabenbereiche der Stadtverwaltung}

\section{Brandschutz}

Organisation des Brandschutzes

Feuerpolizeiliche Zuständigkeiten

1269 Feuergefährliche Häuser in Emden

Laufzeit

- Beschluss des Magistrats der Stadt Emden über Aufstellung einer Liste feuergefährlicher Häuser in Emden und Erstellung durch die Kommission zur Organisation des Feuerlöschwesens, Juni 1904

- Liste feuergefährlicher Häuser in den einzelnen Polizeibezirken der Stadt Emden

- Berichte über Wohnverhältnisse in Emden (Kostgänger,

Raumgrößen, Raumqualität)

1904

Klassifikation Teil B: 01309

Trägermaterial: Papier

Alte Reg.-Sig.: IV La 41

Bestell-Nr.: IV 01309

1270 Feuerlöschordnung für die fiskalischen Hafenanlagen

- Druckschrift mit Plan: Feuerlöschanlagen bei den fiskalischen

Anlagen am Zungenkai und dem Emder Außenhafen mit Alarm- und Löschplan

1912

Klassifikation Teil B: 01310

Trägermaterial: Papier

Alte Reg.-Sig.: IV La 42

Bestell-Nr.: IV 01310 
IV

05

\subsection{3}

05.03.08

05.03.08.02

\section{Stadtverwaltung}

Aufgabenbereiche der Stadtverwaltung

Brandschutz

Feuerversicherungen

Lfd. Nr. Titel

Laufzeit

1271 Beaufsichtigung der Privat-Feuerversicherungen

- Verfügung des Hannoverschen Landdrosten in Aurich über Kriterien zur Beaufsichtigung privater Feuerversicherungen, April 1855

- Diskussion innerhalb der städtischen Kollegien über eine Verordnung der Hannoverschen Regierung über Beaufsichtigung privater Feuerversicherungen, August 1855

- Bericht des Magistrats der Stadt Emden an den preußischen Landdrosten in Aurich über Ausübung der Aufsicht über private Feuerversicherungen in Emden, Mai 1877

- Bestellung vereidigter Schätzer zur Feststellung der Höhe von Brandschäden im Auftrag privater Feuerversicherungen, September 1889

- Verfügung des Regierungspräsidenten in Aurich über Modalitäten der Kündigung privater Feuerversicherungen, Januar 1899

- Werbung des Deutschen Feuerversicherungs-Schutzverbandes, September 1903

(1855) 1877 - 1903

Klassifikation Teil B: 01221

Trägermaterial: Papier

Alte Reg.-Sig.: IV La 08

Bestell-Nr.: IV 01221

1272 Feuerversicherung, Bd. 1

- Aufstellung über bei der Landschaftlichen Brandkasse versicherte Emder Häuser

- Feststellung (Taxation) des Feuerversicherungswertes Emder

Häuser

- Anträge auf Berichtigung der Brandkataster

- Novellierung der Feuerschutzbestimmungen hinsichtlich der

Schaufensterbeleuchtung von Warenhäusern

- Neben-Brandkataster (Zweitregister)

1906

Klassifikation Teil B: 01311

Band: 1

Trägermaterial: Papier

Alte Reg.-Sig.: IV Lb 1

Bestell-Nr.: IV 01311 
IV

05

05.03

05.03.08

05.03.08.02
Stadtverwaltung

Aufgabenbereiche der Stadtverwaltung

\section{Brandschutz}

\section{Feuerversicherungen}

Lfd. Nr. Titel

Laufzeit

1273 Feuerversicherung, Bd. 2

1904-1905

- Festsetzung der Feuerversicherungsbeiträge für Gebäude der Stadt Emden, 1905

- Feststellung (Taxation) des Feuerversicherungswertes Emder

Häuser, 1904

- Feststellung des Feuerversicherungswertes des Gebäudes mit

chemischer Reiniging des B. Barghoorn, November - Dezember 1905

- Berichtigung der Brandkataster, 1904 -1905

- Gesamtverzeichnis der Neuversicherungen und

Versicherungsänderungen bei der landschaftlichen Brandkasse, 1904

- 1905

- Anzeigen über Besitzveränderungen bei feuerversicherten

Immobilien, 1904 - 1905

- Prüfung von Kalksandstein auf Brandfestigkeit, 1905

$1904-1905$

Klassifikation Teil B: 01312

Band: 2

Trägermaterial: Papier

Alte Reg.-Sig.: IV Lb 1

Bestell-Nr.: IV 01312

1274 Feuerversicherung der Nordseewerke

1866-1876

(1853-1865)

- Versicherungspolice der Leipziger Feuerversicherungsanstalt für die Nordseewerke, Emder Werft und Dock AG mit Angaben über den Feuerversicherungswert

$1906-1911$

Klassifikation Teil B: 01313

Trägermaterial: Papier

Alte Reg.-Sig.: IV Lb 1

Bestell-Nr.: IV 01313

1275 Beiträge der Ostfriesischen Provinzial Feuerversicherungskasse, Bd.

- Neu in die Feuerversicherung aufgenommene Immobilien

- Festsetzung und Einziehung der Versicherungsbeiträge

- Aufstellung über bezahlte und rückständige Versicherungsbeiträge

(1853 - 1865) 1866 - 1876

Klassifikation Teil B: 01314

Band: 1

Trägermaterial: Papier

Alte Reg.-Sig.: IV Lb 2

Bestell-Nr.: IV 01314 
IV

05

05.03

05.03.08

05.03.08.02
Stadtverwaltung

\section{Aufgabenbereiche der Stadtverwaltung}

Brandschutz

\section{Feuerversicherungen}

Lfd. Nr. Titel

Laufzeit

1276 Beiträge der Ostfriesischen Provinzial Feuerversicherungskasse, Bd. 2

1877-1913

- Neu in die Feuerversicherung aufgenommene Immobilien

- Festsetzung und Einziehung der Versicherungsbeiträge

- Änderungsanzeigen für das Brandkataster, 1895 - 1909

- Protest der Auktionatoren Schmidt \& Meyer gegen die Verweigerung

des Einblicks in das Brandkaster durch die Stadt Emden, Juli - August

1911

- Verzeichnis der Neuversicherungen und Versicherungsänderungen, 1911 - 1912

$1877-1913$

Klassifikation Teil B: 01315

Band: 2

Trägermaterial: Papier

Alte Reg.-Sig.: IV Lb 2

Bestell-Nr.: IV 01315

1277 Versicherung der Immobilien bei der Ostfriesischen Provinzial

Feuerversicherungskasse, Bd. 1

- Aufnahme von Immobilien in die Ostfriesische Provinzial

Feuerversicherungskasse

- Festsetzung der Versicherungswerte

- Änderungsanzeigen für das Brandkataster

$1875-1879$

Klassifikation Teil B: 01316

Band: 1

Trägermaterial: Papier

Alte Reg.-Sig.: IV Lb 1, 1

Bestell-Nr.: IV 01316

1278 Versicherung der Immobilien bei der Ostfriesischen Provinzial

Feuerversicherungskasse, Bd. 2

- Aufnahme von Immobilien in die Ostfriesische Provinzial

Feuerversicherungskasse

- Festsetzung der Versicherungswerte

- Änderungsanzeigen für das Brandkataster

$1879-1884$

Klassifikation Teil B: 01317

Band: 2

Trägermaterial: Papier

Alte Reg.-Sig.: IV Lb 1, 1

Bestell-Nr.: IV 01317 
IV

05

05.03

05.03.08

05.03.08.02
Stadtverwaltung

\section{Aufgabenbereiche der Stadtverwaltung}

Brandschutz

\section{Feuerversicherungen}

Lfd. Nr. Titel

Laufzeit

1279 Versicherung der Immobilien bei der Ostfriesischen Provinzial

Feuerversicherungskasse, Bd. 3

1885-1892

- Aufnahme von Immobilien in die Ostfriesische Provinzial

Feuerversicherungskasse

- Festsetzung der Versicherungswerte

- Änderungsanzeigen für das Brandkataster

$1885-1892$

Klassifikation Teil B: 01318

Band: 3

Trägermaterial: Papier

Alte Reg.-Sig.: IV Lb 1, 1

Bestell-Nr.: IV 01318

1280 Versicherung der Immobilien bei der Ostfriesischen Provinzial

Feuerversicherungskasse, Bd. 4

- Aufnahme von Immobilien in die Ostfriesische Provinzial

Feuerversicherungskasse

- Festsetzung der Versicherungswerte

- Änderungsanzeigen für das Brandkataster

$1893-1895$

Klassifikation Teil B: 01319

Band: 4

Trägermaterial: Papier

Alte Reg.-Sig.: IV Lb 1, 1

Bestell-Nr.: IV 01319

1281 Versicherung der Immobilien bei der Ostfriesischen Provinzial

Feuerversicherungskasse, Bd. 5

- Aufnahme von Immobilien in die Ostfriesische Provinzial

Feuerversicherungskasse

- Festsetzung der Versicherungswerte

- Änderungsanzeigen für das Brandkataster

$1896-1898$

Klassifikation Teil B: 01320

Band: 5

Trägermaterial: Papier

Alte Reg.-Sig.: IV Lb 1, 1

Bestell-Nr.: IV 01320 
IV

05

05.03

05.03.08

05.03.08.02
Stadtverwaltung

\section{Aufgabenbereiche der Stadtverwaltung}

Brandschutz

Feuerversicherungen

Lfd. Nr. Titel

Laufzeit

1282 Versicherung der Immobilien bei der Ostfriesischen Provinzial

Feuerversicherungskasse, Bd. 6

1899-1903

- Aufnahme von Immobilien in die Ostfriesische Provinzial

Feuerversicherungskasse

- Festsetzung der Versicherungswerte

- Änderungsanzeigen für das Brandkataster

$1899-1903$

Klassifikation Teil B: 01321

Band: 6

Trägermaterial: Papier

Alte Reg.-Sig.: IV Lb 1, 1

Bestell-Nr.: IV 01321

1283 Revision der Brandkataster

- Druckschrift: Erneuerte Verordnung für die

Feuerschaden-Versicherungsgesellschaften füpr die Städte und

Flecken und das platte Land des Fürstentums Ostfriesland und des

Harlingerlandes, Juli 1832

- Verfügungen des Hannoverschen Landdrosten in Aurich über

Ausfertigung der Brandkataster, März 1853

- Revision der Brandkataster. (1853 - 1865) 1866 - 1908

- Vereidigung der Taxatoren (Schätzer der Versicherungswerte der feuerversicherten Gebäude), (1853 - 1865) 1866 - 1902

- Veränderungsanzeigen zu feuerversicherten Gebäuden, (1854 1865) 1866 - 1908

- Liquidation der Taxatoren-Honorare, (1863 - 1865) 1866 - 1883

- Wahl von Vertrauensmännern für die Revision der Brandkataster,

Mai 1883 - April 1902

- Bescheide an Hausbesitzer über Anordnung zur Beseitigung

brennbarer Gegenstände an Schornsteinen, 1903

- Einsprüche gegen das Ergebnis der Schätzungen des

Versicherungswertes durch Revisoren der Feuerversicherung, 1903

(1832 - 1865) 1866 - 1908

Klassifikation Teil B: 01322

Trägermaterial: Papier

Alte Reg.-Sig.: IV Lbl 3

Bestell-Nr.: IV 01322 
IV

05

05.03

05.03.08

05.03.08.02
Stadtverwaltung

Aufgabenbereiche der Stadtverwaltung

Brandschutz

Feuerversicherungen

Lfd. Nr. Titel

Laufzeit

1284 Hilfsfonds der Provinzial-Brandkassen zur Verbesserung der 1867-1869

Feuerlöscheinrichtungen, Bd. 1

(1860-1865)

- Beihilfe der Hannoverschen Landdrostei in Aurich für die

Verbesserung der Feuerspritzen in Emden, Oktober - Dezember 1860

- Berichte des Magistrats der Stadt Emden an die Hannoversche

Landdrostei über nicht vorliegende Anträge auf Unterstützung zur

Verbesserung des Feuerlöschwesens aus dem Hilfsfonds der

Provinzialbrandkassen, 1860 - 1862

- Antrag der Stadt Emden auf Beihilfe zum Bau eines neuen

Spritzenhauses, November 1861

- Antrag der Stadt Emden auf Beihilfe für den Betrieb eines

Spritzenhauses, März 1863

- Antrag der Stadt Emden auf Beihilfe für Instandhaltung der

Feuerlöschschläuche, März 1864 - März 1867

- Antrag der Stadt Emden auf Beihilfe für Instandhaltung der

Feuerlöschschläuche und Personalkosten der Feuerwehr, März 1868

- Dezember 1880

- Antrag der freiwilligen Feuerwehr Emden auf Unterstützung aus dem Hilfsfonds der Brandkasse wegen Bedarfs an wasserfester Kleidung, März 1884

- Beihilfe für die Stadt Emden zur Anschaffung einer Druckspritze,

Oktober 1885

- Antrag der Stadt Emden auf Beihilfe zur Installation von Hydranten, April 1897 - April 1899

(1860 - 1865) $1867-1899$

Klassifikation Teil B: 01323

Band: 1

Trägermaterial: Papier

Alte Reg.-Sig.: IV Lbl 5

Bestell-Nr.: IV 01323

1285 Hilfsfonds der Provinzial-Brandkassen zur Verbesserung der Feuerlöscheinrichtungen, Bd. 2

$1890-1913$

- Hannoversches Gesetz über Einrichtung eines Reservefonds der ostfriesischen Feuerschadensversicherung für Beihilfen zur Verbesserung der Feuerlöscheinrichtungen, Juli 1858

- Verfügung des preußischen Regierungspräsidenten in Aurich über Beihilfen zur Anschaffung von Feuerlöschgeräten aus dem Hilfsfonds der Feuerversicherungen, Februar 1890

- Anträge der Stadt Emden auf Beihilfe aus dem Hilfsfonds zur Verbesserung der städtischen Feuerlöscheinrichtungen, Juni 1900 -

Mai 1913

- Erlass des preußischen Innenministers über Anordnung zur

Berichterstattung über vorhandene Hilfsfonds der

Feuerversicherungsgesellschaften wegen geplanter gesetzlicher

Regelungen zu Hilfsfonds, April 1902

(1858) $1890-1913$

Klassifikation Teil B: 01324

Band: 2

Trägermaterial: Papier

Alte Reg.-Sig.: IV LbI 5

Bestell-Nr.: IV 01324 
IV

05

05.03

05.03.08

05.03.08.02
Stadtverwaltung

Aufgabenbereiche der Stadtverwaltung

Brandschutz

Feuerversicherungen

Lfd. Nr. Titel

Laufzeit

1286 Vereinigte Landschaftliche Brandkasse in Hannover

- Ernennung des Stadtbaumeisters Robbelen zum Schätzer der

(1864-1865)

Vereinigten Landschaftlichen Brandkasse in Hannover, Dezember 1864

- Verfügung des Hannoverschen Landdrosten in Aurich über Funktion von Bautechnikern als Schätzer der Vereinigten Landschaftlichen Brandkasse in Hannover, 1864 - 1865

- Jahresabschlüsse der Vereinigten Landschaftlichen Brandkasse in Hannover, 1868 - 1891

- Verordnung über Feuerversicherung von Gebäuden der Landesbehörden in der Provinz Hannover bei der Vereinigten Landschaftlichen Brandkasse in Hannover, 1915

(1864 - 1865) 1868 - 1915 Klassifikation Teil B: 01325

Trägermaterial: Papier

Alte Reg.-Sig.: IV Lbl 6

Bestell-Nr.: IV 01325

1287 Feuerversicherung in Ostfriesland, Bd. 1

1867-1893

- Gedruckte Verordnung über die

(1832-1865)

Feuerschaden-Versicherungs-Gesellschaften für die Städte und Flecken und das platte Land des Fürstentums Ostfriesland und des Harlingerlandes, Juli 1832

- Antrag der Stadt Emden auf Modifikation der Einrichtung der Feuerschadenversicherung hinsichtlich der Deckung der Versicherungssummen im Großschadensfall (Stadtbrand) und auf Vereinigung der beiden ostfriesischen Versicherunge für Städte und Flecken und das platte Land, (1862 - 1865) 1867

- Diskussion der Bildung eines Reservefonds und Rückversicherung der Feuerschadenversicherung, 1863

- Verordnung der preußischen Königs über Vereinigung der beiden ostfriesischen ständischen Brandkassen, 1869

- Neuklassifizierung der bei der Feuerversicherung für Städte und

Flecken versicherten Gebäude, September 1871 - Januar 1872

- Klassifizierung der Gebäude in Emden, Januar 1872

- Nachtrag zu den Statuten der Feuerschadenversicherungen hinsichtlich der Revision der Brandkataster, Mai 1890 . Juli 1893

(1832 - 1865) 1866 - 1893

Klassifikation Teil B: 01326

Band: 1

Trägermaterial: Papier

Alte Reg.-Sig.: IV Lbl 7

Bestell-Nr.: IV 01326 
IV

05

05.03

05.03.08

05.03.08.02
Stadtverwaltung

Aufgabenbereiche der Stadtverwaltung

Brandschutz

Feuerversicherungen

Lfd. Nr. Titel

Laufzeit

1288 Feuerversicherungen in Ostfriesland, Bd. 2

1891-1908

- Forderungen der ostfriesischen Städte hinsichtlich der Vereinigung beider ostfriesischer Feuerversicherungen wegen Statutenänderung und Hilfsfonds, 1891 - 1894

- Druckschrift: Statuten der Feuerversicherung, (1832) 1894 - 1908

- Regelung der Entziehung der Versicherungsgelder bei Brandstiftung durch den Versicherungsnehmer, 1895

- Bitte der Inselgemeinde Borkum um Unterstützung der Stadt Emden bei ihrem Gesuch um Aufnahme in die Feuerversicherung für Städte und Flecken, November 1901

$1891-1908$

Klassifikation Teil B: 01327

Band: 2

Trägermaterial: Papier

Alte Reg.-Sig.: IV Lbl 7

Bestell-Nr.: IV 01327

1289 Vereinigung der ostfriesischen provinzialständischen

$1904-1907$ Feuerversicherungen

- Votum der städtischen Kollegien gegen die Vereinigung der ostfriesischen provinzialständischen Feuerversicherungen, Juli 1904 - An den Leeraner Bürgermeister Diekmann versandtes Gutachteb des Syndicus Dr. Riese über Zulässigkeit der Vereinigung der ostfriesischen provinzialständischen Feuerversicherungen, Juli 1904 - Stellungnahme verschiedener ostfriesischer Kommunen und der Städte Esens und Aurich zur Ablehnung der Vereinigung der ostfriesischen provinzialständischen Feuerversicherungen durch die Stadt Emden, August 1904

- Gutachten des Leeraner Bürgermeisters Diekmann über Rechtmäßigkeit der Vereinigung der ostfriesischen provinzialständischen Feuerversicherungen, September 1904

- Besprechung des Magistrats der Stadt Emden mit Vertretern ostfriesischer Flecken und Städte über Diskussion der Zweckmäßigkeit der Vereinigung der ostfriesischen provinzialständischen Feuerversicherungen, Juni 1905 / Februar 1906 - Resolution der Magistrate und Fleckensvorstände über Ablehnung der Vereinigung der ostfriesischen provinzialständischen Feuerversicherungen und Votum für enge Kooperation, Juni 1905 - Denkschrift des Senators L. van Senden über Organisation der beiden provinzialständischen Feuerversicherungen wegen Notwendigkeit zur Bildung eines Reservefonds für Großschäden und Rückversicherung, März 1906

- Aufstellung über Bewertung Emder Häuser hinsichtlich des

Feuerversicherungswertes, Juni 1907

- Aufnahmen in die Feuerversicherung, 1907

- Anzeigen von Besitzwechseln von Immobilien zur Aktualisierung der Brandkataster, März 1907

$1904-1907$

Klassifikation Teil B: 01328

Trägermaterial: Papier

Alte Reg.-Sig.: IV LbI 9

Bestell-Nr.: IV 01328 
IV

05

05.03

05.03.08

05.03.08.02
Stadtverwaltung

Aufgabenbereiche der Stadtverwaltung

Brandschutz

Feuerversicherungen

Lfd. Nr. Titel

Laufzeit

1290 Druckschriften der Feuerversicherung 1904-1906

- Jahresbericht der landschaftlichen Brandkassen-Verwaltung, 1904 1905

- Jahresbericht der Ostfriesischen Sparkasse, 1906

- Relationen des ostfriesischen Landschaftskollegiums über u.a.,

Brandkassenrechnungen, 1904 / 1906

- Plan der Vereinigung der landschaftlichen ostfriesischen

Brandkassen, 1904

$1904-1906$

Klassifikation Teil B: 01329

Trägermaterial: Papier

Alte Reg.-Sig.: IV LbI 9

Bestell-Nr.: IV 01329

1291 Versicherung der Gebäude bei der Ostfriesischen

$1907-1911$

Provinzialbrandkasse, Bd. 1

- Anzeigen über Besitzwechsel von Immobilien zur Aktualisierung des

Brandkatasters, 1907 - 1911

- Gebäude - Taxationen (Feststellung der Versicherungswerte), 1908 -

1910

- Aufnahmen in die Feuerversicherung, 1908 - 1911

$1907-1911$

Klassifikation Teil B: 01330

Band: 1

Trägermaterial: Papier

Alte Reg.-Sig.: IV Lbl 1

Bestell-Nr.: IV 01330

1292 Versicherung der Gebäude bei der Ostfriesischen

Provinzialbrandkasse, Bd. 2

1907-1909

- Verzeichnis der Neuversicherungen und Versicherungsänderungen

$1907-1909$

Klassifikation Teil B: 01331

Band: 2

Trägermaterial: Papier

Alte Reg.-Sig.: IV Lbl 1

Bestell-Nr.: IV 01331 
IV

05

\subsection{3}

05.03.08

05.03.08.03
Stadtverwaltung

Aufgabenbereiche der Stadtverwaltung

Brandschutz

Brände

Lfd. Nr. Titel

Laufzeit

1293 Nachrichten über Brände

- Anzeigen über Brände in Wohnungen, Lagegebäuden etc., Oktober 1878

- Berichte von Polizeisergeanten über Feuergefahr wegen ordnungswidrig abgelagerter Stroh - und Heuhaufen, 1867 - 1904

- Verfügung des Regierungspräsidenten über Maßnahmen zur Verhinderung der Selbstentzündung von Heu und Stroh, April 1890 - Beschluss des Magistrats über Anordnung der Beseitigung des ordnungswidrigen Strohhaufens des Landgebräuchers Dirks, September 1898

- Anträge auf Duldung von mit unvorschriftsmäßigem Abstand zur Straße und Gebäuden abgelagerter Stroh- und Heuhaufen, 1902 1903

- Verfügungen des preußischen Landdrosten / Regierungspräsidenten in Aurich an die Stadt Emden über Weisung zur Einsendung von Akten zu Bränden an die Kronanwaltschaft in Aurich, 1872 - 1889

- Bericht über Brände, 1903

- Erlasse des preußischen Innenministers über Berichterstattung in Brandfällen, 1898 - 1908

$1867-1908$

Klassifikation Teil B: 01222

Trägermaterial: Papier

Alte Reg.-Sig.: IV La 11

Bestell-Nr.: IV 01222

1294 Brandstatistik

- Statistische Angaben zu Bränden in Emden für das preußische Statistische Büro

$1900-1912$

Klassifikation Teil B: 01295

Trägermaterial: Papier

Bestell-Nr.: IV 01295

1295 Brand im Haus des Actuars Kopp

- Bericht des Polizeisergeanten Schnur über Brand im Haus des Actuars Christian Friedrich Kopp in der Großen Faldernstraße,

Oktober 1875

- Feststellung des Feuerversicherungswertes des Gebäudes, Oktober 1875

1875

Klassifikation Teil B: 01332

Trägermaterial: Papier

Alte Reg.-Sig.: IV Lc 086

Bestell-Nr.: IV 01332 
IV

05

05.03

05.03.08

05.03.08.03
Stadtverwaltung

Aufgabenbereiche der Stadtverwaltung

Brandschutz

Brände

Lfd. Nr. Titel

Laufzeit

1296 Brand im Haus des Kräutner Kolhoff

- Bericht des Polizeikommissars Carl Gottlieb Lubich über Brand im Haus des Kräutners Kolhoff, Dezember 1874

- Bericht des Brandmeisters des "Anbringers G über

Funktionsprobleme bei der Spritze während der Löscharbeiten bei Kolhoff, Dezember 1874

- Aufstellung über Versicherungsschaden, Januar 1875

- Feststellung des Feuerversicherungswertes des Gebäudes, Oktober 1875

1875

Klassifikation Teil B: 01333

Trägermaterial: Papier

Alte Reg.-Sig.: IV Lc 085

Bestell-Nr.: IV 01333

1297 Schaden am Haus Neutorstr. 22 durch einen "kalten" Blitzschlag

- Bericht des Polizeisergeanten Wildhagen über Schaden am Haus des Zigarrenfabrikanten T. Beneken in der Neutorstr. 22 durch

"kalten" Blitzschlag, Juli 1873

- Bericht des Polizeisergeanten Schnur über Schaden an

Nachbarhäusern, Juli 1873

1873

Klassifikation Teil B: 01334

Trägermaterial: Papier

Alte Reg.-Sig.: IV Lc 084

Bestell-Nr.: IV 01334

1298 Brand im Haus des Tischlers Johann Visser

- Bericht des Polizeikommissars Carl Gottlieb Lubich über Brand im Haus des Tischlers Johann Visser in der Kleinen Brückstraße, Juli 1873

- Feststellung des Feuerversicherungsschadens des Gebäudes, Juli 1873

1875

Klassifikation Teil B: 01335

Trägermaterial: Papier

Alte Reg.-Sig.: IV Lc 083

Bestell-Nr.: IV 01335 
IV

05

\subsection{3}

05.03.08

05.03.08.03
Stadtverwaltung

\section{Aufgabenbereiche der Stadtverwaltung}

Brandschutz

Brände

Lfd. Nr. Titel

Laufzeit

1299 Brand im Haus des Weißgerbers Simon de Beer

- Bericht des Polizeikommissars Carl Gottlieb Lubich über Brand im Packhaus des Schlachters Michel de Beer durch eine Verpuffung beim Fettschmelzen und Schäden am Haus seines Bruders Simon de Beer in der Daalerstr., Mai 1873

- Feststellung des Feuerversicherungsschadens des Gebäudes, Mai 1873

1875

\author{
Klassifikation Teil B: 01336 \\ Trägermaterial: Papier \\ Alte Reg.-Sig.: IV Lc 082 \\ Bestell-Nr.: IV 01336
}

1300 Brand im Haus des Zimmergesellen Lubbertus de Vries

- Bericht des Polizeikommissars Carl Gottlieb Lubich über Brand im Haus des Zimmergesellen Lubbertus de Vries in der Brückstraße und dramatische Rettung der Kinder der Mieterfamilie Dinkela, März 1873 - Feststellung des Feuerversicherungsschadens des Gebäudes, März 1873

- Bericht des Sanitätsrats Dr. Norden über schwere

Brandverletzungen eines der Töchter des Dinkela, März 1873

1873

\author{
Klassifikation Teil B: 01337 \\ Trägermaterial: Papier \\ Alte Reg.-Sig.: IV Lc 081 \\ Bestell-Nr.: IV 01337
}

1301 Brand in der Holzbude des J.G. van Ameren

- Anzeige über die bei Löscharbeiten während des Brandes angerichteten Schäden am Nachbarhaus, Juli 1872

- Feststellung des Feuerversicherungsschadens des Gebäudes, Juli 1872

1872

Klassifikation Teil B: 01338

Trägermaterial: Papier

Alte Reg.-Sig.: IV Lc 080

Bestell-Nr.: IV 01338 
IV

05

\subsection{3}

05.03.08

05.03.08.03
Stadtverwaltung

Aufgabenbereiche der Stadtverwaltung

Brandschutz

Brände

Lfd. Nr. Titel

Laufzeit

1302 Brand im Haus des Holzstaplers B. J. de Vries

- Bericht des Polizeikommissars Carl Gottlieb Lubich über Brand im Haus des Holzstaplers B. J. de Vries durch Selbstentzündung von Heu auf dem Boden, Juni 1872

- Feststellung des Feuerversicherungsschadens des Gebäudes, Juni 1872

1872

Klassifikation Teil B: 01339

Trägermaterial: Papier

Alte Reg.-Sig.: IV Lc 079

Bestell-Nr.: IV 01339

1303 Brand im Kaffeehaus "Belvedere"

- Feststellung des Feuerversicherungsschadens des Gebäudes, April 1872

1872

Klassifikation Teil B: 01340

Trägermaterial: Papier

Alte Reg.-Sig.: IV Lc 078

Bestell-Nr.: IV 01340

1304 Schaden an zwei Häusern durch einen "kalten" Blitzschlag

- Bericht des Polizeisergeanten Wildhagen über Einschlag eines

Blitzes im Giebel des Wohnhauses des Kaufmanns Hector Tapper am

Delft, September 1871

- Feststellung des Versicherungsschadens, September 1871

- Schaden durch einen Blitzschlag im Haus des Obergerichtsrats a.D.

Schnedermann im Boltentorsbreitergang, September 1871

1871

\author{
Klassifikation Teil B: 01341 \\ Trägermaterial: Papier \\ Alte Reg.-Sig.: IV Lc 077 \\ Bestell-Nr.: IV 01341
}

1305 Brand im Haus der Deverna van Ehsen

$1870-1871$

- Bericht des Fußgendarms Nußhorn über Brand im Haus der

Deverna van Ehsen in der Großen Brückstraße, August 1870

- Feststellung des Versicherungsschadens des Gebäudes, August

1870

- Rechnung über Taxationsgebühren, Januar 1871

$1870-1871$

Klassifikation Teil B: 01342

Trägermaterial: Papier

Alte Reg.-Sig.: IV Lc 076

Bestell-Nr.: IV 01342 
IV

05

\subsection{3}

05.03.08

05.03.08.03
Stadtverwaltung

Aufgabenbereiche der Stadtverwaltung

Brandschutz

Brände

Lfd. Nr. Titel

Laufzeit

1306 Brand im Bahnhofsgebäude

- Bericht des Polizeisergeanten Wildhagen über Brand in einem

Gebäude auf dem Bahnhofsgelände, Dezember 1869

- Feststellung des Versicherungsschadens, Januar 1870 / Juni 1874

- Verletzung eines Schornsteinfegergesellen beim Löscheinsatz am

Bahnhof, Januar 1870

- Vernehmung von Zeugen zur Ermittlung der Brandursache, Januar

1870

- Bericht des Polizeikomissars Carl Gottlieb Lubich über Brand im

Bahnhof, Juni 1874

$1869-1874$

Klassifikation Teil B: 01343

Trägermaterial: Papier

Alte Reg.-Sig.: IV Lc 075

Bestell-Nr.: IV 01343

1307 Brand im Haus des Kommerzienrats Reemtsma

- Bericht des Polizeisergeanten Wildhagen über Brand in der

Vierkantkaserne (Besitzer: Kommerzienrat R. Reemtsma), Mai 1869

1869

Klassifikation Teil B: 01344

Trägermaterial: Papier

Alte Reg.-Sig.: IV Lc 074

Bestell-Nr.: IV 01344

1308 Brand in der Peldermühle

1869

- Anzeige des Schornsteinfegemeisters Solaro über Schornsteinbrand im Müllerhaus der Peldemühle, März 1868

- Anzeige über Brand auf der Peldermühle durch Blitzschlag, August 1868

- Zahlung der Taxationsgebühren und der Schäden am

Schlauchmaterial der Feuerwehr, September 1868

1868

\author{
Klassifikation Teil B: 01345 \\ Trägermaterial: Papier \\ Alte Reg.-Sig.: IV Lc 073 \\ Bestell-Nr.: IV 01345
}

- Bericht des Polizeikommissars Carl Gottlieb Lubich über Scheunenbrand im Haus des Particuliers H. Bruns, April 1868

- Feststellung des Versicherungsschadens, April 1868

1868

Klassifikation Teil B: 01346

Trägermaterial: Papier

Alte Reg.-Sig.: IV Lc 072

Bestell-Nr.: IV 01346 
IV

05

05.03

05.03.08

05.03.08.03
Stadtverwaltung

Aufgabenbereiche der Stadtverwaltung

Brandschutz

Brände

Lfd. Nr. Titel

Laufzeit

1310 Brand im Haus des Pastors Leesekamp

- Bericht des Polizeisergeanten Wildhagen über Brand im Haus des

Pastors Leesekamp an der Emsstr., September 1867

- Feststellung des Versicherungsschadens, September 1867

1867
Klassifikation Teil B: 01348
Trägermaterial: Papier
Alte Reg.-Sig.: IV Lc 070
Bestell-Nr.: IV 01348

1311 Brand im Haus des Tischlergesellen Friedrich Grabbe

1867

- Bericht des Polizeikommissars Carl Gottlieb Lubich über Brand im Haus des Tischlergesellen Friedrich Grabbe durch fahrlässigem Umgang mit Feuer und Licht sowie über Tod der Ehefrau des Grabbe in den Flammen, Juni 1867

- Ermittlungen wegen der Brandursache, Juni 1867

- Feststellung des Versicherungsschadens, Juni 1867

1867

Klassifikation Teil B: 01349

Trägermaterial: Papier

Alte Reg.-Sig.: IV Lc 069

Bestell-Nr.: IV 01349

1312 Brand im Haus der Witwe des Fuhrmanns H. E. Müller

- Bericht des Stadtbauführers A. Gisberts über Brand im Haus der Witwe des Fuhrmanns H. E. Müller, März 1867

1867

Klassifikation Teil B: 01350

Trägermaterial: Papier

Alte Reg.-Sig.: IV Lc 068

Bestell-Nr.: IV 01350

1313 Brand im Haus der Aaltje Janssen, geb. Behrens

- Anzeige über von der Bettstelle ausgegangener Brand im Haus der Aaltje Janssen, geb. Behrens, Mai 1867

- Vernehmungen des Syndicus Metger zur Ermittlung der

Brandursache, Mai 1867

- Feststellung des Versicherungsschadens, Juni 1867

1867

Klassifikation Teil B: 01351

Trägermaterial: Papier

Alte Reg.-Sig.: IV Lc 067

Bestell-Nr.: IV 01351 
IV

05

05.03

05.03.08

05.03.08.03
Stadtverwaltung

Aufgabenbereiche der Stadtverwaltung

Brandschutz

Brände

Lfd. Nr. Titel

Laufzeit

1314 Brand im Armen-Arbeitshaus

- Bericht des Polizeisergeanten Wildhagen über Brand im Torfkeller des Armen-Arbeitshauses, November 1875

- Feststellung des Versicherungsschadens, November 1875

1875

Klassifikation Teil B: 01352

Trägermaterial: Papier

Alte Reg.-Sig.: IV Lc 087

Bestell-Nr.: IV 01352

1315 Brand in der alten Kaserne

- Anzeige über Brand im Teerschuppen in der alten Kaserne, April 1878

- Feststellung des Versicherungsschadens, April 1878

- Antrag des Magistrats beim preußischen Landdrosten in Aurich auf

Erlaubnis zum Verzicht auf den Wiederaufbau des Teerschuppens als

Bedingung für die Auszahlung der Versicherungssumme, April -

September 1878

1878
Klassifikation Teil B: 01353
Trägermaterial: Papier
Alte Reg.-Sig.: IV Lc 088
Bestell-Nr.: IV 01353

1316 Brand im Haus des Kräutners Jacobus Bakker

- Feststellung des Versicherungsschadens, Mai 1878

1878

Klassifikation Teil B: 01354
Trägermaterial: Papier
Alte Reg.-Sig.: IV Lc 089

Bestell-Nr.: IV 01354

1317 Blitzschlag in einem Packhaus

- Bericht des Polizeisergeanten Waltemath über Blitzschlag im

Packhaus des Kräutners Wiard Poelders, Zwischen beiden Bleichen,

August 1878

- Feststellung des Versicherungsschadens, August 1878

1878

Klassifikation Teil B: 01355

Trägermaterial: Papier

Alte Reg.-Sig.: IV Lc 090

Bestell-Nr.: IV 01355 
IV

05

\subsection{3}

05.03.08

05.03.08.03
Stadtverwaltung

Aufgabenbereiche der Stadtverwaltung

Brandschutz

Brände

Lfd. Nr. Titel

Laufzeit

1318 Brand im Haus des Kräutners Wiard Poelders

- Bericht über Brand im gemieteten Zimmer der Ehefrau Stern im Haus des Kräutners Wiard Poelders, Zwischen beiden Bleichen, Februar 1879

- Feststellung des Versicherungsschadens, März 1879

1879

Klassifikation Teil B: 01356

Trägermaterial: Papier

Alte Reg.-Sig.: IV Lc 091

Bestell-Nr.: IV 01356

1319 Brand im Hinterhaus des Hotels "Zur Sonne"

- Bericht des Stadtbauaufsehers P. Stuur an den Branddirektor, Senator Foget, über Löscheinsatz beim Hotel des Fritz Meyer am Neuen Markt und über entstandene Schäden an den Schläuchen, Februar 1879

- Bericht des Polizeisergeanten Wildhagen über Brand im Hinterhaus des Hotels "Zur Sonne", Besitzer: Fritz Meyer, Februar 1879

- Feststellung des Versicherungsschadens, Februar 1879

- Abwicklung des Versicherungsschadens, März 1879

1879

Klassifikation Teil B: 01357

Trägermaterial: Papier

Alte Reg.-Sig.: IV Lc 092

Bestell-Nr.: IV 01357

1320 Brand bei der Emder Heringsfischerei AG

- Bericht des Polizeisergeanten Schnür über Brand im Lager der Emder Heringsfischerei AG, April 1879

- Feststellung des Versicherungsschadens, April 1879

1879

Klassifikation Teil B: 01358

Trägermaterial: Papier

Alte Reg.-Sig.: IV Lc 093

Bestell-Nr.: IV 01358

1321 Brand im Haus der Witwe des Kapitäns Hero Friedrich Müller

- Bericht des Polizeisergeanten Waltemath über Brand im Haus der Elisabeth Müller, Witwe des Kapitäns Hero Friedrich Müller in der Großen Osterstraße, Juli 1879

- Feststellung des Versicherungsschadens, August 1879

1879

Klassifikation Teil B: 01359

Trägermaterial: Papier

Alte Reg.-Sig.: IV Lc 094

Bestell-Nr.: IV 01359 
IV

05

05.03

05.03.08

05.03.08.03
Stadtverwaltung

Aufgabenbereiche der Stadtverwaltung

Brandschutz

Brände

Lfd. Nr. Titel

Laufzeit

1322 Brand in einem Packhaus an der Großen Brückstraße

1876

- Bericht des Stadtbauaufseher Stuur an den Branddirektor, Senator

Foget über Brand im Packhaus des Seilermeisters Duentjes, Februar 1876

- Feststellung des Versicherungsschadens, Februar 1876

- Bericht des Stadtbaumeisters Wiggers über zu erfüllende

brandschutztechnische Auflagen beim Wiederaufbau des

Packhauses, Februar 1876

1876

Klassifikation Teil B: 01360

Trägermaterial: Papier

Alte Reg.-Sig.: IV Lc 095

Bestell-Nr.: IV 01360

1323 Brand in den Häusern am Alten Bollwerk

1877

- Feststellung des Versicherungsschaden im Haus des Kräutners van Dycken, Januar 1877

- Ermittlungsverfahren gegen den Kräutner Hermannus van Dycken wegen Brandstiftung, Januar - April 1877

1877

Klassifikation Teil B: 01361

Trägermaterial: Papier

Alte Reg.-Sig.: IV Lc 096

Bestell-Nr.: IV 01361

1324 Brand im Haus der Gebrüder Zeeborg

1878

- Feststellung des Versicherungsschadens im Haus der Gebrüder

Zeeborg, Zwischen beiden Sielen, August 1878

1878

\author{
Klassifikation Teil B: 01362 \\ Trägermaterial: Papier \\ Alte Reg.-Sig.: IV Lc 098 \\ Bestell-Nr.: IV 01363
}

1325 Brand im Haus des Bäckermeisters F. H. Peterssen

- Feststellung des Versicherungsschadens im Haus des

Bäckermeisters F. H. Peterssen in der Großen Straße, Januar 1878

- Feststellung des Versicherungsschadens in den Nachbarhäusern, Januar 1878

1878

Klassifikation Teil B: 01362

Trägermaterial: Papier

Alte Reg.-Sig.: IV Lc 097

Bestell-Nr.: IV 01362 
IV

05

05.03

05.03.08

05.03.08.03
Stadtverwaltung

Aufgabenbereiche der Stadtverwaltung

Brandschutz

Brände

Lfd. Nr. Titel

Laufzeit

1326 Brand im Haus des Fuhrmanns Schröder

1879

- Bericht des Polizeisergeanten Schnür über Brand im Haus des

Fuhrmanns Schröder in der Meister-Geerds-Str. durch

Heuselbstentzündung, August 1879

- Feststellung des Versicherungsschadens, August 1879

1879

Klassifikation Teil B: 01364

Trägermaterial: Papier

Alte Reg.-Sig.: IV Lc 099

Bestell-Nr.: IV 01364

1327 Brand im Offizierskasino der Alten Kaserne

1879

- Feststellung des Versicherungsschadens, August - September 1879

1879

Klassifikation Teil B: 01365

Trägermaterial: Papier

Alte Reg.-Sig.: IV Lc 100

Bestell-Nr.: IV 01365

1328 Brand im Haus des Spiegelfabrikanten R. Becker

- Bericht des Polizeisergeanten Schnür über Brand im Haus des Spiegelfabrikanten Rudolph Becker, Zwischen beiden Sielen,

Dezember 1879

- Feststellung des Versicherungsschadens, Dezember 1879

1879

Klassifikation Teil B: 01366

Trägermaterial: Papier

Alte Reg.-Sig.: IV Lc 100

Bestell-Nr.: IV 01366

1329 Brand im Haus des Manufakturisten Abraham Joseph Meyer

$1880-1881$

- Feststellung des Versicherungsschadens am Haus des Manufakturisten Abraham Joseph Meyer in der Neutorstraße, Juli 1880 / März 1881

- Anforderung der Angabe des Versicherungswertes durch das Amtsgericht Emden im Zuge des Untersuchungsverfahrens gegen A.J. Meyer wegen Brandstiftung, August 1881

$1880-1881$

Klassifikation Teil B: 01367

Trägermaterial: Papier

Alte Reg.-Sig.: IV Lc 102

Bestell-Nr.: IV 01367 
IV

05

05.03

05.03.08

05.03.08.03
Stadtverwaltung

Aufgabenbereiche der Stadtverwaltung

Brandschutz

Brände

Lfd. Nr. Titel

Laufzeit

1330 Beschädigung des Hauses des Kaufmanns Donderikus Meyer durch 1880 Blitzschlag

- Bericht des Polizeisergeanten Waltemath über Schäden durch Blitzschlag am Haus des Kaufmanns Donderikus Meyer, Juli 1880

- Feststellung des Versicherungsschadens, Juli 1880

1880

Klassifikation Teil B: 01368

Trägermaterial: Papier

Alte Reg.-Sig.: IV Lc 103

Bestell-Nr.: IV 01368

1331 Brand im Fabrikgebäude des Kalkbrenners Johann G. van Letten

1880

- Feststellung des Versicherungsschadens, August 180

1880

Klassifikation Teil B: 01369

Trägermaterial: Papier

Alte Reg.-Sig.: IV Lc 104

Bestell-Nr.: IV 01369

1332 Brand im Haus der Nona Garrels

- Bericht des Polizeisergeanten Schnür über Brand im Haus der Nona Garrels durch umgestürzte Petroleumlampe, November 1880

- Feststellung des Versicherungsschadens, Dezember 1880

1880
Klassifikation Teil B: 01370
Trägermaterial: Papier
Alte Reg.-Sig.: IV Lc 105
Bestell-Nr.: IV 01370

1333 Brand im Haus des Kaufmanns Carl Vocke

- Bericht des Polizeisergeanten Waltemath über Brand im Haus des Kaufmanns Carl Vocke durch ein aus dem Kachelofen herausgefallenes brennendes Torfstück, Januar 1881

- Bericht des Stadtbaumeisters Wiggers über provisorische Sicherung des Kachelofens, Januar 1881

- Feststellung des Versicherungsschadens, Januar 1881

1881

Klassifikation Teil B: 01371

Trägermaterial: Papier

Alte Reg.-Sig.: IV Lc 106

Bestell-Nr.: IV 01371 
IV

05

Stadtverwaltung

05.03

05.03.08

05.03.08.03

Aufgabenbereiche der Stadtverwaltung

Brandschutz

Brände

Lfd. Nr. Titel

Laufzeit

1334 Brand im Haus des Particuliers J. G. H. Tholen

1881

- Bericht des Polizeisergeanten Waltemath über Brand im Haus des

Particuliers J. G. H. Tholen, Februar 1881

- Feststellung des Versicherungsschadens, März 1881

1881

Klassifikation Teil B: 01372

Trägermaterial: Papier

Alte Reg.-Sig.: IV Lc 107

Bestell-Nr.: IV 01372

1335 Leichte Brandschäden an Gebäuden, Bd. 1

- Anzeigen und Feststellung des Versicherungsschadens bei leichten Bränden

$1880-1887$

Klassifikation Teil B: 01373

Band: 1

Trägermaterial: Papier

Alte Reg.-Sig.: IV Lc 108

Bestell-Nr.: IV 01373

1336 Leichte Brandschäden an Gebäuden, Bd. 2

1888-1898

- Anzeigen und Feststellung des Versicherungsschadens bei leichten Bränden

$1888-1898$

Klassifikation Teil B: 01374

Band: 2

Trägermaterial: Papier

Alte Reg.-Sig.: IV Lc 108

Bestell-Nr.: IV 01374

1337 Leichte Brandschäden an Gebäuden, Bd. 3

1888-1898

- Anzeigen und Feststellung des Versicherungsschadens bei leichten Bränden

$1888-1898$

Klassifikation Teil B: 01375

Band: 3

Trägermaterial: Papier

Alte Reg.-Sig.: IV Lc 108

Bestell-Nr.: IV 01375 
IV

05

05.03

05.03.08

05.03.08.03
Stadtverwaltung

Aufgabenbereiche der Stadtverwaltung

Brandschutz

Brände

Lfd. Nr. Titel

Laufzeit

1338 Leichte Brandschäden an Gebäuden, Bd. 4

- Anzeigen und Feststellung des Versicherungsschadens bei leichten Bränden

$1888-1898$

Klassifikation Teil B: 01376

Band: 4

Trägermaterial: Papier

Alte Reg.-Sig.: IV Lc 108

Bestell-Nr.: IV 01376

1339 Brand im Packhaus der Firma Ysaac \& Bernhard Brons

1893

- Bericht des Branddirektors über Löscheinsatz beim Brand im

Packhaus der Firma Ysaac \& Bernhard Brons, Januar 1893

- Anzeige des Polizeisergeanten Schnur über Gefahr eines weiteren Brandes durch die Einlagerung des aus dem Packhaus geborgenen, noch heißen Getreide, Januar 1893

- Feststellung des Versicherungsschadens, Januar 1893

Bericht des Polizeisergeanten Schnür über Brand im Packhaus der

Firma Ysaac \& Bernhard Brons, Januar 1893

1893

Klassifikation Teil B: 01377

Trägermaterial: Papier

Alte Reg.-Sig.: IV Lc 109

Bestell-Nr.: IV 01377

1340 Schäden durch Blitzschläge

- Schreiben des Magistrats an den Gefängnisvorsteher des

Amtsgerichtsgefängnisses über Angaben von Schäden durch

Blitzeinschläge (Evaluierung der Anschaffung eines Blitzableiters für das Amtsgerichtsgefängnis), November 1886

1886

Klassifikation Teil B: 01378

Trägermaterial: Papier

Alte Reg.-Sig.: IV Lc 110

Bestell-Nr.: IV 01378 
IV

05

\subsection{3}

05.03.08

05.03.08.03
Stadtverwaltung

Aufgabenbereiche der Stadtverwaltung

Brandschutz

Brände

Lfd. Nr. Titel

Laufzeit

1341 Brand im Haus der Sophie W. Barghoorn

- Aufstellung des Syndicus Metger über Versicherungsschäden zur Regulierung durch die Landschaftliche Brandkasse infolge des Brandes im Haus der Sophie W. Barghoorn und betroffener Nachbarhäuser, September 1887

- Bericht des Branddirektors über eingesetzte Löschgeräte und Schäden an denselben, September 1887

- Regulierung der Versicherungsschäden, September 1887

1887

\author{
Klassifikation Teil B: 01379 \\ Trägermaterial: Papier \\ Alte Reg.-Sig.: IV Lc 111 \\ Bestell-Nr.: IV 01379
}

1342 Brand des Mühlenhauses Nr. 3 am Mühlenwarf

- Bericht des Stadtbaumeisters Wiggers als Branddirektor über Löscheinsatz beim Brand im Haus des Müllers Bronkena am Kattewall, Januar 1888

- Bescheid des Mühlenbrandsocietät für Ostfriesland und Harlingerland über Nichtzahlung einer Löschprämie an die Feuerwehr wegen Wegfall dieser Bestimmung in den revidierten Versicherungsstatuten, Febr. 1888

- Verhandlungen des Magistrats mit dem Landschaftskollegium wegen der Löschprämie, April - Mai 1888

1888
Klassifikation Teil B: 01380
Trägermaterial: Papier
Alte Reg.-Sig.: IV Lc 112
Bestell-Nr.: IV 01380

1343 Brand in der Wagenremise des Posthalters Nanno de Wall

- Feststellung und Regulierung des Versicherungsschadens des Brandes in der Wagenremise des Posthalters Nanno de Wall, Oktober 1888 - Februar 1889

- Antrag des Branddirektors auf Zahlung einer Löschprämie an die

Feuerwehr, März 1889

$1888-1889$

Klassifikation Teil B: 01381

Trägermaterial: Papier

Alte Reg.-Sig.: IV Lc 113

Bestell-Nr.: IV 01381 
IV

05

05.03

05.03.08

05.03.08.03
Stadtverwaltung

Aufgabenbereiche der Stadtverwaltung

Brandschutz

Brände

Lfd. Nr. Titel

Laufzeit

1344 Brand in der Mühle "de goede Verwagting"

- Feststellung und Regulierung des Versicherungsschadens durch den Brand in der Mühle "de goede Verwagting", Oktober 1888 - Februar 1889

- Antrag des Branddirektors auf Zahlung einer Löschprämie an die Feuerwehr, März 1889

$1888-1889$

Klassifikation Teil B: 01382

Trägermaterial: Papier

Alte Reg.-Sig.: IV Lc 114

Bestell-Nr.: IV 01382

1345 Brand im Haus des Fuhrunternehmers und Posthalters B. Ubbens

- Feststellung des Versicherungsschadens durch den Brand im Haus des Fuhrunternehmers und Posthalters B. Ubbens in der Larrelter Straße, August - September 1890

1890

Klassifikation Teil B: 01383

Trägermaterial: Papier

Alte Reg.-Sig.: IV Lc 118

Bestell-Nr.: IV 01383

1346 Brand im Haus des Landwirts H. H. Aalfs

- Feststellung des Versicherungsschadens durch den Brand im Haus des Landwirts H. H. Aalfs an der Auricher Chaussee in Harsweg, August 1891 - März 1892

$1891-1892$

Klassifikation Teil B: 01384

Trägermaterial: Papier

Alte Reg.-Sig.: IV Lc 119

Bestell-Nr.: IV 01384

1347 Brand in den Häusern des Kaufmanns H. Dammeyer in der Kirchstraße

- Feststellung des Versicherungsschadens durch den Brand $\mathrm{n}$ den Häusern des Kaufmanns H. Dammeyer in der Kirchstraße, Februar Mai 1892

1892

Klassifikation Teil B: 01385

Trägermaterial: Papier

Alte Reg.-Sig.: IV Lc 120

Bestell-Nr.: IV 01385 
IV

05

05.03

05.03.08

05.03.08.03
Stadtverwaltung

Aufgabenbereiche der Stadtverwaltung

Brandschutz

Brände

Lfd. Nr. Titel

Laufzeit

1348 Brand im Packhaus und Wohngebäude des Kaufmanns K. A. Kruse

1892

- Feststellung des Versicherungsschadens durch den Brand im Packhaus und Wohngebäude des Kaufmanns K. A. Kruse, Juni -

August 1893

1893

Klassifikation Teil B: 01386

Trägermaterial: Papier

Alte Reg.-Sig.: IV Lc 121

Bestell-Nr.: IV 01386

1349 Brand im am Neuen Markt gelegenen Haus des L. R. Hesse aus Weener

- Feststellung des Versicherungsschadens durch den Brand im am Neuen Markt gelegenen Haus des L. R. Hesse aus Weener, November 1895 - März 1896

$1895-1896$

Klassifikation Teil B: 01388

Trägermaterial: Papier

Alte Reg.-Sig.: IV Lc 123

Bestell-Nr.: IV 01388

1350 Brand im Haus der Witwe des Müllers Roelf Mülders

1895

- Feststellung des Versicherungsschadens durch den Brand im Haus der Witwe des Müllers Roelf Mülders an der Auricher Chaussee infolge Blitzschlages, Juli 1895

1895

Klassifikation Teil B: 01389

Trägermaterial: Papier

Alte Reg.-Sig.: IV Lc 124

Bestell-Nr.: IV 01389

1351 Brand im Haus des H. A, Brüggemann

- Feststellung des Versicherungsschadens durch den Brand im Haus des H. A. Brüggemann an der Lilienstraße, November 1895 - Januar 1896

$1895-1896$

Klassifikation Teil B: 01390

Trägermaterial: Papier

Alte Reg.-Sig.: IV Lc 125

Bestell-Nr.: IV 01390 
IV

05

\subsection{3}

05.03.08

05.03.08.03
Stadtverwaltung

Aufgabenbereiche der Stadtverwaltung

Brandschutz

Brände

Lfd. Nr. Titel

Laufzeit

1352 Brand im Haus des Schiffsführers H. A. Lange

1896

- Feststellung des Versicherungsschadens durch den Brand im Haus des Schiffsführers H. A. Lange, Am Delft, Februar - April 1896

1896

Klassifikation Teil B: 01391

Trägermaterial: Papier

Alte Reg.-Sig.: IV Lc 126

Bestell-Nr.: IV 01391

1353 Brand in den Häusern des Kaufmanns J. Graepel

- Feststellung des Versicherungsschadens durch den Brand $\mathrm{n}$ den Häusern des Kaufmanns J. Graepel an der Lookvenne, Oktober November 1896

1896

Klassifikation Teil B: 01392

Trägermaterial: Papier

Alte Reg.-Sig.: IV Lc 127

Bestell-Nr.: IV 01392

1354 Brände verschiedener Häuser im Bereich Zwischen Beiden Märkten

- Festsetzung des Versicherungsschadens durch die Brände verschiedener Häuser im Bereich Zwischen Beiden Märkten,

November 1896 - Mai 1896

- Presseberichte über den Flächenbrand, November 1896

- Verhandlungen des Magistrats über Brandursache und Folgerungen für das Löschwesen, November 1896

- Bericht des Polizeisergeanten Brüning über die Löscharbeiten, November 1896

- Bericht des Polizeisergeanten Strippelmann über Bergung der Leichen der Brandopfer, November 1896

- Bericht des Branddirektors über Brand der Häuser Zwischen beiden Märkten am 17.11.1896, November 1896

- Bericht des Magistrats an den Regierungspräsidenten in Aurich über Brandablauf und Widerlegung der Presseberichte sowie angestrebte Verbesserung des Feuerlöschwesens, Januar 1897

$1896-1897$

Klassifikation Teil B: 01393

Trägermaterial: Papier

Alte Reg.-Sig.: IV Lc 128

Bestell-Nr.: IV 01393 
IV

05

\subsection{3}

05.03.08

05.03.08.03
Stadtverwaltung

\section{Aufgabenbereiche der Stadtverwaltung}

Brandschutz

Brände

Lfd. Nr. Titel

Laufzeit

1355 Brand des Eisschuppens des Rentiers J. E. Hayen

- Feststellung des Versicherungsschadens durch den Brand des Eisschuppens des Rentiers J. E. Hayen auf dem Schützenplatz, September 1898

- Antrag des Rentiers J. E. Hayen beim Magistrat auf Erlaubnis zur Verwendung der ausgezahlten Versicherungssumme zum Bau eines Wohnhauses, Juni - Juli 1899

$1898-1899$

Klassifikation Teil B: 01394

Trägermaterial: Papier

Alte Reg.-Sig.: IV Lc 129

Bestell-Nr.: IV 01394

1356 Brand im Haus des Fuhrunternehmers W. Ubbens

1889

- Feststellung des Versicherungsschadens durch den Brand im Haus des Fuhrunternehmers W. Ubbens, September - Dezember 1889

1889

Klassifikation Teil B: 01395

Trägermaterial: Papier

Alte Reg.-Sig.: IV Lc 130

Bestell-Nr.: IV 01395

1357 Brand im Haus des Ysaac Brons in der Westerbutvenne

- Feststellung des Versicherungsschadens durch den Brand im Haus des Ysaac Brons in der Westerbutvenne, Januar - März 1895

1895

Klassifikation Teil B: 01395

Trägermaterial: Papier

Alte Reg.-Sig.: IV Lc 122

Bestell-Nr.: IV 01387

1358 Brand des Bahnhofshauptgebäudes

- Feststellung des Versicherungsschadens durch den Brand des Bahnhofshauptgebäudes, Februar - April 1900

- Antrag des Magistrats beim Regierungspräsidenten in Aurich auf

Zahlung einer Löschprämie für die Feuerwehr, Februar - März 1900

1900

Klassifikation Teil B: 01396

Trägermaterial: Papier

Alte Reg.-Sig.: IV Lc 131

Bestell-Nr.: IV 01396 
IV

05

05.03

05.03.08

05.03.08.03
Stadtverwaltung

Aufgabenbereiche der Stadtverwaltung

Brandschutz

Brände

Lfd. Nr. Titel

Laufzeit

1359 Brand im Haus des Landwirts Jan Dirksen am Torfmarkt 1900

- Feststellung des Versicherungsschadens durch den Brand im Haus des Landwirts Jan Dirksen am Torfmarkt, Juli 1900

1900

\author{
Klassifikation Teil B: 01397 \\ Trägermaterial: Papier \\ Alte Reg.-Sig.: IV Lc 132 \\ Bestell-Nr.: IV 01397
}

1360 Brand im Haus des Uhrmachers E. Warner am Neuen Markt

- Feststellung des Versicherungsschadens durch den Brand im Haus des Uhrmachers E. Warner am Neuen Markt, Dezember 1900 -

Februar 1901

$1900-1901$

Klassifikation Teil B: 01398

Trägermaterial: Papier

Alte Reg.-Sig.: IV Lc 133

Bestell-Nr.: IV 01398

1361 Brand im Haus der Ehefrau des R. Schneider, geb. Kruithoff

- Feststellung des Versicherungsschadens durch den Brand im Haus der Ehefrau des R. Schneider, geb. Kruithoff, März - Mai 1901

1901

Klassifikation Teil B: 01399

Trägermaterial: Papier

Alte Reg.-Sig.: IV Lc 134

Bestell-Nr.: IV 01399

1362 Brand im Haus des Kräutners Friedrich Wilhelm Pocker in der

$1900-1901$ Wallstraße

- Feststellung des Versicherungsschadens durch den Brand im Haus des Kräutners Friedrich Wilhelm Pocker in der Wallstraße,

1896

Klassifikation Teil B: 01400

Trägermaterial: Papier

Alte Reg.-Sig.: IV Lc 135

Bestell-Nr.: IV 01400 
IV

05

05.03

05.03.08

05.03.08.03
Stadtverwaltung

Aufgabenbereiche der Stadtverwaltung

Brandschutz

Brände

Lfd. Nr. Titel

Laufzeit

1363 Brand im Haus des Kräutners G. W. Scherz

1900-1901

- Feststellung des Versicherungsschadens durch den Brand im Haus des Kräutners G. W. Scherz in der Boltentorstraße, Dezember 1900 Januar 1901

$1900-1901$

Klassifikation Teil B: 01401

Trägermaterial: Papier

Alte Reg.-Sig.: IV Lc 136

Bestell-Nr.: IV 01401

1364 Brand im Haus des Gastwirts A. Jens

$1901-1902$

- Feststellung des Versicherungsschadens durch den Brand im Haus des Gastwirts A. Jens in der Bahnhofsstraße, November 1901 -

Februar 1902

$1901-1902$

Klassifikation Teil B: 01402

Trägermaterial: Papier

Alte Reg.-Sig.: IV Lc 137

Bestell-Nr.: IV 01402

1365 Brand im Haus des Fischereidirektors G. Zimmermann

1902

- Feststellung des Versicherungsschadens durch den Brand im Haus des Fischereidirektors G. Zimmermann in der Bahnhofsstraße, September 1902

1902

Klassifikation Teil B: 01403

Trägermaterial: Papier

Alte Reg.-Sig.: IV Lc 138

Bestell-Nr.: IV 01403

1366 Brand im Haus des Rentiers G. C. Wagener

- Feststellung des Versicherungsschadens durch den Brand im Haus des Rentiers G. C. Wagener im Boltentorsbreitergang, September Oktober 1902

1902

Klassifikation Teil B: 01404

Trägermaterial: Papier

Alte Reg.-Sig.: IV Lc 139

Bestell-Nr.: IV 01404 
IV

05

\subsection{3}

05.03.08

05.03.08.03
Stadtverwaltung

Aufgabenbereiche der Stadtverwaltung

Brandschutz

Brände

Lfd. Nr. Titel

Laufzeit

1367 Gasexplosion im Haus Kleine Brückstraße

1902

- Feststellung des Versicherungsschadens durch die Gasexplosion im Haus Kleine Brückstraße, November - Dezember 1902

1902

Klassifikation Teil B: 01405

Trägermaterial: Papier

Alte Reg.-Sig.: IV Lc 140

Bestell-Nr.: IV 01405

1368 Brand im Haus des Gastwirts A. Jens (Gaststätte "Bellevue")

- Berichte über Brand der Gaststätte "Bellevue" in der Bahnhofsstraße und Verdacht auf Brandstiftung, Dezember 1902

- Feststellung des Versicherungsschadens durch den Brand im Haus des Gastwirts A. Jens (Gaststätte "Bellevue"), Dezember 1902

- Ermittlungsverfahren wegen Verdachts der Brandstiftung, Dezember 1902 - Januar 1903

$1902-1903$

Klassifikation Teil B: 01406

Trägermaterial: Papier

Alte Reg.-Sig.: IV Lc 141

Bestell-Nr.: IV 01406

1369 Brand im Haus des L. Griepel

- Feststellung des Versicherungsschadens durch den Brand im Haus des L. Griepel in der Pottgießerstraße, Dezember 1903

1903

Klassifikation Teil B: 01407

Trägermaterial: Papier

Alte Reg.-Sig.: IV Lc 142

Bestell-Nr.: IV 01407

1370 Brand im Geschäftshaus des Ferdinand Jünemann

- Bericht des Polizeikommissars Lauter über Brand im Geschäftshaus des F. Jünemann in der Neutorstraße mit fünf Todesopfern, Februar 1904

- Ermittlungen wegen der Brandursache, Februar - März 1904

- Feststellung des Versicherungsschadens durch den Brand im

Geschäftshaus des Ferdinand Jünemann in der Neutorstraße,

Februar - März 1904

- Bewilligung einer Beihilfe durch den Magistrat für G. de Werth zur Wiederbeschaffung von durch die Rettung und Erstversorgung verletzter Personen unbrauchbar gewordener Kleidung, März 1904

1904

Klassifikation Teil B: 01408

Trägermaterial: Papier

Alte Reg.-Sig.: IV Lc 143

Bestell-Nr.: IV 01408 
IV

05

\subsection{3}

05.03.08

05.03.08.03
Stadtverwaltung

\section{Aufgabenbereiche der Stadtverwaltung}

Brandschutz

Brände

Lfd. Nr. Titel

Laufzeit

1371 Brand im Haus des R. Hagen

1904

- Bericht des Polizeiwachtmeisters Strippelmann über Brand im Haus des Bäckers und Konditors Reinhard Hagen in der Neutorstraße, April 1904

- Feststellung des Versicherungsschadens durch den Brand im Haus des Bäckers und Konditors Reinhard Hagen in der Neutorstraße, April 1904

- Widerspruch des Kaufmanns L. Buss gegen die festgestellte Schadenssume für sein vom Brand mitbetroffenes Haus, April - Mai 1904

$1904-1906$

Klassifikation Teil B: 01409

Trägermaterial: Papier

Alte Reg.-Sig.: IV Lc 144

Bestell-Nr.: IV 01409

1372 Brand im Haus des H. König

- Feststellung des Versicherungsschadens durch den Brand im Haus des Zimmermeisters H. König in der Wilhelmsstraße, August 1904

1904

Klassifikation Teil B: 01410

Trägermaterial: Papier

Alte Reg.-Sig.: IV Lc 145

Bestell-Nr.: IV 01410

1373 Brand im Lagerhaus des J. Graepel

- Feststellung des Versicherungsschadens durch den Brand im Lagerhaus des J. Graepel in der Klunderburgstraße, Juni 1905 - Widerspruch des Kaufmanns J. Graepel gegen die festgestellte Schadenssumme, Juni 1905 - Januar 1906

$1905-1906$

Klassifikation Teil B: 01411

Trägermaterial: Papier

Alte Reg.-Sig.: IV Lc 146

Bestell-Nr.: IV 01411

1374 Brand im Kaufhaus des Friedrich G. Janssen

- Feststellung des Versicherungsschadens durch den Brand im Kaufhaus des Friedrich G. Janssen, Februar 1906

1906

Klassifikation Teil B: 01412

Trägermaterial: Papier

Alte Reg.-Sig.: IV Lc 147

Bestell-Nr.: IV 01412 
IV

05

\subsection{3}

05.03.08

05.03.08.03
Stadtverwaltung

Aufgabenbereiche der Stadtverwaltung

Brandschutz

Brände

Lfd. Nr. Titel

Laufzeit

1375 Brand im Packhaus des Peter H. Geelvink

1906-1907

- Feststellung des Versicherungsschadens durch den Brand im

Packhaus des Peter H. Geelvink, Dezember 1906 - Januar 1907

$1906-1907$

Klassifikation Teil B: 01413

Trägermaterial: Papier

Alte Reg.-Sig.: IV Lc 148

Bestell-Nr.: IV 01413

1376 Brand im Wohn- und Geschäftshaus des Kaufmanns Hermann

1908 Scherz

- Bericht des Polizeikommissars Lauter über Brand im Wohn- und Geschäftshaus des Kaufmanns Hermann Scherz, Mai 1908

- Feststellung des Versicherungsschadens durch den Brand im Wohnund Geschäftshaus des Kaufmanns Hermann Scherz, Mai 1908

1908

Klassifikation Teil B: 01414

Trägermaterial: Papier

Alte Reg.-Sig.: IV Lc 149

Bestell-Nr.: IV 01414

1377 Brand in Häusern an der Boltentorstraße und dem Kattewall

1907

- Feststellung des Versicherungsschadens durch den Brand in den Häusern des Rentiers Haye Fokken an der Boltentorstraße und dem Kattewall, September 1907

1907
Klassifikation Teil B: 01415
Trägermaterial: Papier
Alte Reg.-Sig.: IV Lc 150
Bestell-Nr.: IV 01415

1378 Brand des Stallgebäudes des Viehhändlers Salomon Seligmann

- Feststellung des Versicherungsschadens durch den Brand des Stallgebäudes des Viehhändlers Salomon Seligmann, November 1911

- Löschprämie an die freiwillige Feuerwehr, März 1912

$1911-1912$

Klassifikation Teil B: 01416

Trägermaterial: Papier

Alte Reg.-Sig.: IV Lc 151

Bestell-Nr.: IV 01416 
IV

05

05.03

05.03.08

05.03.08.03
Stadtverwaltung

Aufgabenbereiche der Stadtverwaltung

Brandschutz

Brände

Lfd. Nr. Titel

Laufzeit

1379 Brand im Haus des Senators a. D Tamme Dreesmann - Penning

1911

- Feststellung des Versicherungsschadens durch den Brand im Haus des Senators a. D Tamme Dreesmann - Penning, September 1911

1911

\author{
Klassifikation Teil B: 01417 \\ Trägermaterial: Papier \\ Alte Reg.-Sig.: IV Lc 152 \\ Bestell-Nr.: IV 01417
}

1380 Brand im Haus des Peter Campen

- Feststellung des Versicherungsschadens durch den Brand im Haus des Peter Campen, Februar - März 1912

1912

Klassifikation Teil B: 01418

Trägermaterial: Papier

Alte Reg.-Sig.: IV Lc 153

Bestell-Nr.: IV 01418

1381 Brand im Packhaus des Kräutners F. G. Janssen

- Feststellung des Versicherungsschadens durch den Brand im Packhaus des Kräutners F. G. Janssen, Dezember 1888 - Februar 1889

$1888-1889$

Klassifikation Teil B: 01425

Trägermaterial: Papier

Alte Reg.-Sig.: IV Lc 115

Bestell-Nr.: IV 01425

1382 Brand im Etablissement im Neutorsbreitergang

- Feststellung des Versicherungsschadens im Haus des Gastwirts Simon Pels, Neutorsbreitergang, August - September 1889

1889

Klassifikation Teil B: 01426

Trägermaterial: Papier

Alte Reg.-Sig.: IV Lc 116

Bestell-Nr.: IV 01426 
IV

05

05.03

05.03.08

05.03.08.03
Stadtverwaltung

\section{Aufgabenbereiche der Stadtverwaltung}

Brandschutz

Brände

Lfd. Nr. Titel

Laufzeit

1383 Brand im Tabakfabrik-Gebäude des Kaufmanns J. C. Bertram

1889

- Feststellung des Versicherungsschadens durch den Brand im

Tabakfabrik-Gebäude des Kaufmanns J. C. Bertram und Schäden an

den Nachbargebäuden in der Neutorstraße, November 1889

1889

Klassifikation Teil B: 01427

Trägermaterial: Papier

Alte Reg.-Sig.: IV Lc 117

Bestell-Nr.: IV 01427 
IV

05

05.03

05.03.08

05.03.08.04
Stadtverwaltung

Aufgabenbereiche der Stadtverwaltung

Brandschutz

Städtische Brandordnungen

Lfd. Nr. Titel

Laufzeit

1384 Umsetzung der Bestimmungen der Brandordnung

- Nachweise über vereinnahmte und verausgabte

(1846-1865)

Spritzenprämien-Gelder, (1854 - 1865) 1882 - 1904

- Vorschläge zur Verbesserung des Löschwesens, 1846 - 1850

- Listen der Bedienungen der Emder Feuerwehr-Spritzen, 1850

- Anträge der Bedienungen der am schnellsten zur Brandstelle gelangten Spritzen auf Auszahlung der Spritzenprämie, 1854 - 1864

- Beschluss der Volksschulkommission über Auszahlung einer Prämie an den Schulwart der städtischen Volksschule wegen vorbildlichem Einsatz beim Löschen eines Brandes in der Volksschule, Dezember 1897

(1846 - 1865) 1882 - 1904

Klassifikation Teil B: 01419

Trägermaterial: Papier

Alte Reg.-Sig.: IV Ld 3

Bestell-Nr.: IV 01419

1385 Novellierung der städtischen Brandordnung

1866-1903

- Vorschläge zur Verbesserung des Löschwesens, 1855 - 1900

(1855-1865)

- Stellungnahme des Stadtbaumeisters Berg zum Entwurf einer novellierten Brandordnung, April 1855

- Verhandlungen des Magistrats über Novellierung der Brandordnung, $1855-1897$

- Austausch mit anderen Städten wegen Brandordnung, 1858 - 1864

- Entwürfe einer Brandordnung, 1865 / 1866

- Polizeiverordnung der Stadt Emden über Verbot des unbefugten

Betretens von Brandstellen, September 1894

- Bewilligung von Mitteln zur Verbesserung des Löschwesens, Juni 1895

- Antrag des Stadtbaumeisters Wiggers in seiner Funktion als Branddirektor auf Erlaubnis einer Abwesenheit von Brandstellen wegen gesundheitlicher Probleme, Dezember 1898

- Angebot der Firma Stober über Fernmeldeeinrichtungen, 1903

\author{
(1855 - 1865) 1866 - 1903 \\ Klassifikation Teil B: 01420 \\ Trägermaterial: Papier \\ Alte Reg.-Sig.: IV Ld 4 \\ Bestell-Nr.: IV 01420
}

1386 Spritzenprämien für die Hydranten-Abteilung

$1897-1911$

- Anträge des Magistrats der Stadt Emden bei der landschaftlichen Feuerversicherung auf Auszahlung von Spritzenprämien für die zuerst an den Brandstellen erschienenden Bedienungen von Schläuchen mit Hydrantenanschluss (Hydranten-Abteilung)

- Auszahlung der Prämien

$1897-1911$

Klassifikation Teil B: 01421

Trägermaterial: Papier

Alte Reg.-Sig.: IV Ld 6

Bestell-Nr.: IV 01421 
05

05.03

05.03 .08

05.03.08.04

\section{IV}

Stadtverwaltung

Aufgabenbereiche der Stadtverwaltung

Brandschutz

Städtische Brandordnungen

Lfd. Nr. Titel

Laufzeit

1387 Installierung von Feuerlöscheinrichtungen

1869-1913

- Feuerwarnorganisation und Feuerlöscheinrichtungen im Emder Rathaus, 1869 - 1907

- Anschaffung von MINIMAX-Handfeuerlöschgeräten, 1904 - 1913

- Angebote von Feuerlöschsystemen, 1904

- Anschaffung von Rettungssäcken zur Evakuierung von Akten im

Brandfall, Juli - November 1906

$1869-1913$

Klassifikation Teil B: 01422

Trägermaterial: Papier

Alte Reg.-Sig.: IV Ld 5

Bestell-Nr.: IV 01422 
IV

05

\subsection{3}

05.03.08

05.03.08.05

\section{Stadtverwaltung}

Aufgabenbereiche der Stadtverwaltung

Brandschutz

Feuerwehr-Personal

Lfd. Nr. Titel

Laufzeit

1867-1869

(1862-1863)

- Angebot der Emder Turner zur Stellung einer Feuerlöschtruppe, August 1862

- Verhandlungen des Männerturnvereins mit der Stadt Emden über Einreihung der Turner-Feuerlöschtruppe in die Feuerwehr, Mai November 1863

- Verhandlungen der städtischen Kollegien über Ausstattung der

Feuerwehr, Juni 1866 - Juli 1868

- Angebote über Löschgerät, 1869

- Kosten der benötigten Ausrüstung der Feuerwehr, 1867 - 1868

- Einzeichnungsliste der Feuerwehrmitglieder, 1868

- Unterstützung der Turnerfeuerwehr durch die Stadt Emden, 1863 1869

- Aufstellung der Turnerfeuerwehr, September 1868

(1862 - 1863) 1867 - 1869

Klassifikation Teil B: 01224

Trägermaterial: Papier

Alte Reg.-Sig.: IV La 19

Bestell-Nr.: IV 01224

1389 Bildung einer freiwilligen Feuerwehr

- Verfügung des Regierungspräsidenten in Aurich über

Musterortsstatut für Pflichtfeuerwehren, Juli 1907

- Beschwerde gegen die Emder freiwillige Feuerwehr wegen

Mltführens eines mit Cognac gefüllten Zierbeils zum Feuerwehrtag

durch ein Feuerwehrmitglied, August 1908

- Einsätze der freiwilligen Feuerwehr bei Großbränden in Petkum und Uphusen, September 1908

- Unerlaubter Aufenthalt des Lazarus Pels auf einer Brandstelle, Januar - Februar 1909

- Antrag der freiwilligen Feuerwehr auf Befreiung von der

Vergnügungssteuer wegen ihres Stiftungsfestes, Januar 1909

Februar 1914

- Erlasse des preußischen Innenministers wegen Organisation des

Feuerwehrwesens, November 1910 - April 1912

- Unterstützung der Stadt Emden für Delegationen der freiwilligen

Feuerwehr zu Feuerwehrverbandstagen, 1911

- Statistische Übersicht über die Tätigkeit der freiwilligen Feuerwehren des Feuerwehrverbands der Provinz Hannover, 1910 - 1913

$1907-1914$

Klassifikation Teil B: 01227

Trägermaterial: Papier

Alte Reg.-Sig.: IV La 24

Bestell-Nr.: IV 01227 
IV

05

\subsection{3}

05.03.08

05.03.08.05
Stadtverwaltung

Aufgabenbereiche der Stadtverwaltung

Brandschutz

Feuerwehr-Personal

Lfd. Nr. Titel

Laufzeit

1390 Abzeichen für die Feuerwehren

- Anschaffung von Abzeichen für die Emder Feuerwehr nach den Vorschriften einer Allerhöchsten Kabinettsorder vom Juli 1900, Mai September 1901

- Angebote verschiedener Firmen über Feuerwehrabzeichen, 1901

- Erlasse des preußischen Innenministers über Form der

Feuerwehrabzeichen und Feuerwehruniformen, Januar 1902 /

Dezember 1906 / Juni 1909

- Bericht des Magistrats über Uniformierung der Emder Feuerwehr,

Februar 1907

- Erlass des Oberpräsidenten der Provinz Hannover über Abzeichen der Feuerwehren in der Provinz Hannover, Juni 1908

$1901-1909$

Klassifikation Teil B: 01306

Trägermaterial: Papier

Alte Reg.-Sig.: IV La 35

Bestell-Nr.: IV 01306

1391 Angestellte im Löschwesen, Bd. 1

- Einstellung von Personal zur Bedienung der Feuerlöschspritzen,

(1852 - 1865) 1866 - 1869

- Vereidgung der Bedienten im Feuerlöschwesen, (1853 - 1865) 1866

- 1869

- Liste der Kornmesser und Torfträger zum Einsatz an der

Feuerlöschspritze, 1852

- Wahl der Brandmeister, 1853

- Liste der Zunftgesellen zum Einsatz an der Feuerlöschspritze, 1853

- Liste der Totenbitter und Totenträger zum Einsatz an der

Feuerlöschspritze, 1853

- Anträge auf Befreiung vom Feuerlöschdienst. 1854

- Liste des Stadtbaumeisters Berg über im Brandfall zum

Wasserschöpfen vorgesehene Arbeiter, 1855

- Verfügung des Magistrats über Verhängung einer Geldstrafe gegen zwei zum Feuerlöschdienst verpflichtete Maurergesellen wegen

Fernbleiben von einer Brandstelle, Januar 1855

- Entlassungsgesuche von Angestellten beim Brandwesen, (1857 -

1865) $1867-1869$

(1852 - 1865)1866 - 1869

Klassifikation Teil B: 01423

Band: 1

Trägermaterial: Papier

Alte Reg.-Sig.: IV Le 4

Bestell-Nr.: IV 01423 
IV

05

05.03

05.03.08

05.03.08.05
Stadtverwaltung

Aufgabenbereiche der Stadtverwaltung

Brandschutz

Feuerwehr-Personal

Lfd. Nr. Titel

Laufzeit

1392 Angestellte im Löschwesen, Bd. 2

- Einstellung von Personal zur Bedienung der Feuerlöschspritzen, $1870-1883$

- Vereidgung der Bedienten im Feuerlöschwesen, 1870 - 1884

- Entlassungsgesuche von Angestellten beim Brandwesen, 1870 1886

- Einspruch des Brandmeisters der Spritze A gegen die Benennung des Kaufmanns Jung anstelle des von inm vorgeschlagenen Ingenieurs Starcke, Januar 1876

$1870-1886$

Klassifikation Teil B: 01424

Band: 2

Trägermaterial: Papier

Alte Reg.-Sig.: IV Le 4

Bestell-Nr.: IV 01424

1393 Angestellte im Löschwesen, Bd. 3

- Einstellung von Personal zur Bedienung der Feuerlöschspritzen

- Vereidgung der Bedienten im Feuerlöschwesen

- Entlassungsgesuche von Angestellten beim Brandwesen

- Verhängung einer Geldstrafe gegen den Rohrmeister Ahrends

wegen Ungehorsam, November 1896 - Januar 1897

- Gedruckte Instruktionen für die Hydrantenabteilungen, September 1896

$1887-1907$

Klassifikation Teil B: 01428

Band: 3

Trägermaterial: Papier

Alte Reg.-Sig.: IV Le 4

Bestell-Nr.: IV 01428

1394 Rechnungslegung der Feuerwehr

- Vergütungen an Feuerwehrangehörige

- Rechnungsprüfung

- Verhandlungen der städtischen Kollegien über Rechnungslegung

(1863 - 1865) 1866 - 1891

Klassifikation Teil B: 01429

Trägermaterial: Papier

Alte Reg.-Sig.: IV Le 7

Bestell-Nr.: IV 01429 
05

05.03

05.03 .08

05.03.08.05

fd. Nr. Tite

\section{IV}

Stadtverwaltung

Aufgabenbereiche der Stadtverwaltung

Brandschutz

Feuerwehr-Personal

Laufzeit

1395 Bestrafung von Bediensteten der Feuerwehr

1876-1896

- Verhängung von Geldbußen gegen Feuerwehrmänner wegen unentschulgtem Fehlen bei Einsätzen

$1876-1896$

Klassifikation Teil B: 01430

Trägermaterial: Papier

Alte Reg.-Sig.: IV Le 8

Bestell-Nr.: IV 01430 
IV

05

\subsection{3}

05.03.08

05.03.08.06
Stadtverwaltung

Aufgabenbereiche der Stadtverwaltung

Brandschutz

Ausrüstung der Feuerwehr

Lfd. Nr. Titel

Laufzeit

1396 Feuerlöschspritzen

1868-1911

(1856-1861)

- Angebote über Feuerlöschspritzen und -Systeme, (1856 - 1861)

1868 - 1911

- Feststellung eines geeigneten Raums zur Stationierung einer

Feuerlöschspritze, (Mai 1860) Oktober 1878 - Juni 1894

- Antrag des Magistrats beim Hannoverschen Landdrosten in Aurich auf Beihilfe zur Reparatur und Verbesserung von Feuerlöschspritzen aus dem Provinzialhülfsfonds, Februar 1861

- Verkauf ausrangierter Feuerlöschspritzen durch die Stadt Emden, April 1880 - August 1911

- Angebot der Benzwerke Gaggenau über Feuerwehrkraftwagen, 1911

(1856 - 1861) 1868 - 1911

Klassifikation Teil B: 01431

Trägermaterial: Papier

Alte Reg.-Sig.: IV Lf 2

Bestell-Nr.: IV 01431

1397 Feuerlöschspritzen

1867-1909

- Prospekt der Fa. Louis Tidow, Hannover für Feuerlöschgeräte, 1876

- Angebote über Feuerlöschspritzen, 1867 - 1909

- Verhandlungen des Stadtbaumeisters Wiggers als Branddirektor mit der Fa. Louis Tidow wegen Anschaffung von Feuerlöschspritzen,

September - Oktober 1877

- Verkauf ausrangierter Feuerlöschspritzen durch die Stadt Emden, 1897

- Erwerb eines Schlauchwagens für die Emder Feuerwehr von der Fa. Clausing \& Co, Minden, März - April 1897

- Ausschreibung der Anschaffung einer Feuerlösch-Druckspritze, August - November 1879 / April 1885 - November 1887

- Antrag des Magistrats beim preußischen Landdrosten in Emden auf Beihilfe zur Anschaffung von Feuerlöschschläuchen, April 1885 Januar 1886

- Beihilfen zum Ausbau der Feuerwehr und ihrer Ausrüstung von

Feuerversicherungen, 1885 - 1886

- Bericht des Stadtbaumeisters Wiggers als Branddirektor über Einsatz der Feuerwehr bei einem Brand auf der Mühlenwarf und Unterstützung des Ausbaus der freiwilligen Feuerwehr, Februar 1888

$1867-1909$

Klassifikation Teil B: 01432

Trägermaterial: Papier

Alte Reg.-Sig.: IV Lf 5

Bestell-Nr.: IV 01432 
IV

05

Stadtverwaltung

05.03

05.03.08

05.03.08.06

Aufgabenbereiche der Stadtverwaltung

Brandschutz

Lfd. Nr. Titel

Ausrüstung der Feuerwehr

1398 Feuerlöschgeräte

Laufzeit

1879-1904

- Ausschreibung der Anfertigung von Löscheimern, August -

November 1840

- Diebstahl eines Brandhakens bei der Weizenmühle, März 1855

- Bericht über fehlende Feuerlöscheimer, Juli 1856

- Anschaffung eines Rettungsschlauches, September 1879 / April

1880

- Angebot über Feuerlöschgeräte, 1880 - 1904

- Ersatz beschädigter Löschgeräte, Dezember 1885

- Löschprobe mit neuartigen Feuerlöschmaterialien, 1886 - 1891

(1840 - 1856) $1879-1904$

Klassifikation Teil B: 01433

Trägermaterial: Papier

Alte Reg.-Sig.: IV Lg 1

Bestell-Nr.: IV 01433

1399 Löschproben

- Anordnung von Revisionen und Funktionsprüfungen von

Feuerlöschgeräten durch den preußischen Landdrosten /

Regierungspräsidenten in Aurich, Dezember 1873 - November 1890

- Durchführung von Funktionstests bei Feuerlöschschläuchen, (1855 -

1861) 1867 - 1907

- Berichte des Stadtbaumeisters als Branddirektor über Schäden an

Feuerlöschschläuchen, (1855 - 1857) Oktober 1867 - Mai 1891

- Schreiben des preußischen Garnisonskommandanten Oberst von

Wedell über Mängel im Emder Feuerlöschwesen und seiner

Ausrüstung, Juni - Oktober 1867

- Verhängung einer Geldstrafe gegen bei den Funktionstests der

Feuerlöschspritzen fehlenden Bedienungsmannschaften, 1872 - 1878

(1855 - 1861) 1867 - 1907

Klassifikation Teil B: 01434

Trägermaterial: Papier

Alte Reg.-Sig.: IV Lh 1

Bestell-Nr.: IV 01434 
IV

05

\subsection{3}

05.03.08

05.03.08.07

\section{Stadtverwaltung}

Aufgabenbereiche der Stadtverwaltung

Brandschutz

Besonders feuergefährliche Einrichtungen

Lfd. Nr. Titel

Laufzeit

1867-1896

(1822-1862)

- Lagerung der Pulvervorräte der Hannoverschen Garnison und der Stadt Emden in einem Schuppen am Herrentor, Dezember 1822 April 1824

- Antrag des Magistrats beim Hannoverschen Landdrosten in Aurich auf Erbauung eines besonderen Magazins für die Munition der Hannoverschen Garnison, April - August 1824

- Polizeiverordnung der Stadt Emden über Regelung der Entnahme von Schwarzpulver aus dem städtischen Teil des Pulvermagazins am Herrentor, Oktober 1833

- Antrag des Kaufmanns Johann G. Doden auf Erlaubnis zum Handel mit Schießpulver, Mai 1839

- Polizeiverordnung des Hannoverschen Landdrosten in Aurich über Begrenzung der von Kaufleuten in ihren Häusern aufbewahrten Schießpulvermengen, Oktober 1840 / März 1841

- Handelskonzessionen für Schießpulver für Emder Kaufleute, Mai 1841 - Februar 1842

- Revision der Pulvervorräte Emder Kaufleute wegen Feuergefahr, Oktober 1841 - Februar 1855

- Inspektion des Pulvermagazins am Herrentor, August 1847

- Umlagerung der Munition der Hannoverschen Garnison in ein Depot bei der Nesserlander Schleuse, Juli 1851

- Anlegeverbot für Schiffe in der Nähe des Pulvermagazins am Herrentor, März 1862

- Beschluss der städtischen Kollegien über Anlage eines zweiten

Pulvermagazins beim Nordertor, Januar 1867

- Verstöße gegen die Transsportrichtlinien für Schwarzpulver, 1868

- Aufstellung über Pulvervorräte Emder Kaufleute, August 1873

- Gebührensatzung für das Pulvermagazin, November 1874

- Vermietung des alten Pulverschuppens am Herrentor, Mai 1877 -

September 1896

- Plan der Errichtung eines Pulvermagazins im Kaiser-Wilhelm Polder unter Schließung des Magazins am Nordertor, Juni 1896

(1822 - 1862) 1867 - 1896

Klassifikation Teil B: 01435

Trägermaterial: Papier

Alte Reg.-Sig.: IV Li 1

Bestell-Nr.: IV 01435 
05

05.03

05.03.09

05.03.09.01 05.03.09.01.01
Stadtverwaltung

Aufgabenbereiche der Stadtverwaltung

Wasser- und Schifffahrtssachen

Schifffahrts- und Schifffahrtsverkehrseinrichtungen

Schifffahrt und Schiffsverkehrseinrichtungen

Lfd. Nr. Titel

Laufzeit

1401 Seeschifffahrtsstatistik

1896-1897

- Verzeichnis der Emder Heringslogger und ihre Fahrten, 1896 - 1897

- Erlass des preußischen Ministers für Handel und Gewerbe über die

Kategorisierung von Schifffahrtsstatistiken, September 1897

$1896-1897$

Klassifikation Teil B: 00040

Trägermaterial: Papier

Alte Reg.-Sig.: IV Cd 46

Bestell-Nr.: IV 00040

1402 Schiffsregistrierungen, Bd. 1

$1872-1890$

- Schiffsregisterauszüge mit Angaben über Schiffssignalnummern,

Schiffseigentümern, Kapitänen und teilweise über Schiffsschicksale

- Aufstellung über gesunkene oder verschollene Schiffe

- Nachrichten über Löschungen und Veränderungen im Schiffsregister

$1872-1890$

Klassifikation Teil B: 01436

Band: 1

Trägermaterial: Papier

Alte Reg.-Sig.: IV Ma 13

Bestell-Nr.: IV 01436

1403 Schiffsregistrierungen, Bd. 2

$1881-1891$

- Schiffsregisterauszüge mit Angaben über Schiffssignalnummern,

Schiffseigentümern, Kapitänen und teilweise über Schiffsschicksale

- Aufstellung über gesunkene oder verschollene Schiffe

- Nachrichten über Löschungen und Veränderungen im Schiffsregister

$1872-1890$

Klassifikation Teil B: 01437

Band: 2

Trägermaterial: Papier

Alte Reg.-Sig.: IV Ma 13

Bestell-Nr.: IV 01437

1404 Schiffsmeldungen bei den deutschen Konsulaten

$1880-1883$

- Gesetz über Schiffsmeldungen bei den deutschen Konsulaten mit Meldeformulare, September 1880

- Verfügung des preußischen Landdrosten in Aurich über Anordnung von Berichten über Bedarf an Formularen, Mai 1881

- Ermittlung des Aufenthalts des Kapitäns B. Swart wegen nicht erfolgter Abgabe einer Schiffsmeldung, Mai - August 1883

$1880-1883$

Klassifikation Teil B: 01447

Trägermaterial: Papier

Alte Reg.-Sig.: IV Ma 22

Bestell-Nr.: IV 01447 
05

\subsection{3}

05.03.09

05.03.09.01

05.03.09.01.01

\section{Stadtverwaltung}

Aufgabenbereiche der Stadtverwaltung

Wasser- und Schifffahrtssachen

Schifffahrts- und Schifffahrtsverkehrseinrichtungen

Schifffahrt und Schiffsverkehrseinrichtungen

Laufzeit

1405 Verhinderung von Schiffskollisionen

1880-1912

- Prüfung von Nebelhörnern durch die Deutsche Seewarte, Dezember 1880

- Einführung der Nebelhornpflicht für Dampfschiffe, Februar 1881

- Klärung der Nebelhornpflicht für den Flussdampfer "Wilhelm I" der

Emder Dampfschifffahrtsgesellschaft "Concordia", März 1881

- Nachrichten über neue britische Regelungen wegen Beleuchtung

von Fischereifahrzeugen, August 1881 - November 1882

- Regelungen über Beleuchtung, Notsignale und Signalformen, 1882 -

1912

- Verstöße gegen die Beleuchtungsvorschriften, 1882 - 1883

- Stellungnahme des Magistrats zu einer internationalen Neufassung

der Regeln zur Verhinderung von Schiffskollisionen nach Anhörung

Emder Reedereien und Schifffahrtsgesellschaften, März - August

1891

- Diskussion einer schärferen Ahndung von Verstößen gegen die

Schiffsverkehrsregeln und Unfallflucht nach einer Kollision, 1891

- Reichsgesetz über Vorschriften zur Schiffsbeleuchtung und

Maßregel zur Verhinderung von Zusammenstößen, Mai 1897

- Druckschrift: Vorschriften des Deutschen Reiches über

Seestraßenrecht, 1906

$1880-1912$

Klassifikation Teil B: 01448

Trägermaterial: Papier

Alte Reg.-Sig.: IV Ma 23

Bestell-Nr.: IV 01448

1406 Wissenschaftliche Untersuchung der deutschen Meere

$1871-1887$

- Erstellung einer Fischereistatistik durch die Commission der

Wissenschaftliche Untersuchung der deutschen Meere, 1871

- Erstellung der Fischereistatistik für den Emder Bereich, 1887

$1871-1887$

Klassifikation Teil B: 01449

Trägermaterial: Papier

Alte Reg.-Sig.: IV Ma 24

Bestell-Nr.: IV 01449 
05

05.03

05.03.09

05.03.09.01

05.03.09.01.01
Stadtverwaltung

Aufgabenbereiche der Stadtverwaltung

Wasser- und Schifffahrtssachen

Schifffahrts- und Schifffahrtsverkehrseinrichtungen

Schifffahrt und Schiffsverkehrseinrichtungen

Lfd. Nr. Titel

Laufzeit

1407 Klassifikation der See- und Küstenschiffe

1881

- Verfügung des preußischen Landdrosten in Aurich über Anordnung der Erstellung eines Registers über alle bei einer Versicherung klassifizierten Schiffe zur Ermittlung unversicherter Fahrzeuge, Februar 1881

- Aufstellung über bei der Ruven-Veritas klassifizierten Emder Schiffe, Februar 1881

- Verzeichnis in Emden beheimateter Emder Schiffe, 1881

1881

Klassifikation Teil B: 01450

Trägermaterial: Papier

Alte Reg.-Sig.: IV Ma 25

Bestell-Nr.: IV 01450

1408 Verhinderung der Abwerbung von Seeleuten

- Mitteilung über ein geplantes Gesetz über Verbot des Betretens eines Schiffes vor Abmusterung der Mannschaft zur Verhinderung von Abwerbung, Februar 1881

- Stellungnahme des Magistrats zur Zweckmäßigkeit der Übernahme des britischen Gesetzes gegen Matrosenabwerbung, April 1881

1881

Klassifikation Teil B: 01451

Trägermaterial: Papier

Alte Reg.-Sig.: IV Ma 26

Bestell-Nr.: IV 01451

1409 Abgrenzung der Seeschifffahrt von der Binnenschifffahrt

- Verfügung des preußischen Landdrosten in Aurich über Neufestlegung der Bereiche Seeschifffahrt und Binnenschifffahrt, Januar 1884

- Gutachten der kgl. preußischen Musterungsbehörde und der Kaufmännischen Deputation zur Neufestlegung der Bereiche, Februar - März 1884

1884

Klassifikation Teil B: 01452

Trägermaterial: Papier

Alte Reg.-Sig.: IV Ma 28

Bestell-Nr.: IV 01452 
05

05.03

05.03.09

05.03.09.01

05.03.09.01.01
Stadtverwaltung

Aufgabenbereiche der Stadtverwaltung

Wasser- und Schifffahrtssachen

Schifffahrts- und Schifffahrtsverkehrseinrichtungen

Schifffahrt und Schiffsverkehrseinrichtungen

Laufzeit

1885

- Diskussion einer gesetzlichen Revision der Seeschiffe zur

Gewährleistung der Seetüchtigkeit

- Gutachten der Kaufmännischen Deputation zur Einführung einer

gesetzlichen Revision, Juli 1885

1885

Klassifikation Teil B: 01453

Trägermaterial: Papier

Alte Reg.-Sig.: IV Ma 29

Bestell-Nr.: IV 01453

1411 Anzeigen von Unglücksfällen auf Flussschiffen und Flößen

- Erlass des preußischen Innenministrers über Einführung einer Meldepflicht von Unglücksfällen auf Flussschiffen und Flößen, Juli 1882

1882

Klassifikation Teil B: 01454

Trägermaterial: Papier

Alte Reg.-Sig.: IV Ma 27

Bestell-Nr.: IV 01454

1412 Seezeichen

$1878-1891$

- Bekanntmachungen über Seezeichen, 1878 - 1891

- Verfügung des Regierungspräsidenten in Aurich über Informationen und Mitteilungen über Erfahrungen aus Schifffahrtskreisen mit dem Leuchtbojenversuch im englischen South Forthend, Juli 1885 - März 1886

$1878-1891$

Klassifikation Teil B: 01455

Trägermaterial: Papier

Alte Reg.-Sig.: IV Ma 31

Bestell-Nr.: IV 01455

1413 Nachrichten über Hochwasserstände in Ems und Haase

$1886-1909$

- Umsetzung eines Erlasses des preußischen Ministers der öffentlichen Arbeiten über Regelung der Nachrichtenübermittlung über Hochwasserstände in Ems und Haase, Februar 1886 - Juni 19089 - Wasserstandstelegramme von der Nesserlander Schleuse, 1891 1899

$1886-1909$

Klassifikation Teil B: 01456

Trägermaterial: Papier

Alte Reg.-Sig.: IV Ma 32

Bestell-Nr.: IV 01456 
05

05.03

05.03.09

05.03.09.01 05.03.09.01.01
Stadtverwaltung

Aufgabenbereiche der Stadtverwaltung

Wasser- und Schifffahrtssachen

Schifffahrts- und Schifffahrtsverkehrseinrichtungen

Schifffahrt und Schiffsverkehrseinrichtungen

Laufzeit

fd. Nr. Titel

1414 Rettungsgeräte auf Schiffen

$1875-1912$

- Festlegung der Zahl der mitzuführenden Rettungsboote auf Seeschiffen, 1875 - 1901

- Festlegung der Zahl der mitzuführenden Rettungsboote auf

Heringsloggern, 1891

- Umsetzung der Regelung zur Mitführung von Rettungsringen und

Schwimmwesten auf Heringsloggern, 1912

$1875-1912$

Klassifikation Teil B: 01457

Trägermaterial: Papier

Alte Reg.-Sig.: IV Ma 35

Bestell-Nr.: IV 01457

1415 Stellung des Schiffers gegenüber dem Zwangslotsen

1888

- Reichseinheitliche Regelung über Stellung des Schiffers gegenüber dem Zwangslotsen

- Stellungnahme des Lotsenkommandeurs Laarmann über Funktion des Lotsen und seine Beziehung zum Schiffskapitän, September 1888

1888

Klassifikation Teil B: 01459

Trägermaterial: Papier

Alte Reg.-Sig.: IV Ma 37

Bestell-Nr.: IV 01459

1416 IX. Internationaler Schiffahrtskongress in Düsseldorf

1901-1902

- Einladung des Central-Vereins für Hebung der deutschen Fluß- und Kanalschiffahrt zum IX. Internationalen Schiffahrtskongress in

Düsseldorf und Bitte um Spende für den Kongress-Fonds, November 1901

- Eintritt des Oberbürgermeisters Fürbringer in den Ehrenauschuiss des Kongresses, Januar 1902

- Programm des Kongresses, Juni 1902

$1901-1902$

Klassifikation Teil B: 01494

Trägermaterial: Papier

Alte Reg.-Sig.: IV Ma 40

Bestell-Nr.: IV 01494 
05

\subsection{3}

05.03.09

05.03.09.01

05.03.09.01.01
Stadtverwaltung

Aufgabenbereiche der Stadtverwaltung

Wasser- und Schifffahrtssachen

Schifffahrts- und Schifffahrtsverkehrseinrichtungen

Schifffahrt und Schiffsverkehrseinrichtungen

Laufzeit

1417 Beobachtungen und Nachrichten über die Eisverhältnisse an der deutschen Küste

- Erhebung der Deutschen Seewarte über die Eisverhältnisse an der deutschen Küste, Februar 1903

- Schreiben des Magistrats an den Lotsenkommandanten, die kgl.

Wasserbauinspektion und die Naturforschende Gesellschaft über Bitte um Mitteilung von Daten über Eisverhältnisse im Bereich Dollart -

Borkum, Februar 1903

- Berichte des Lotsenkommandeurs Laarmann und der kgl.

Wasserbauinspektion über die Eisverhältnisse im Bereich Dollart -

Borkum, Februar 1903

1903

Klassifikation Teil B: 01495

Trägermaterial: Papier

Alte Reg.-Sig.: IV Ma 42

Bestell-Nr.: IV 01495

1418 Herausgabe eines Wegweisers für die Schifffahrt auf der Ems

1899-1909

- Beschluss des Magistrats zur Bewilligung eines jährlichen Beitrags von 150 Mark zur Herstellung eines Wegweisers für die Schifffahrt auf der Ems, Juni 1898

- Antrag der Handelskammer für Ostfriesland und Papenburg beim Regierungspräsidenten in Aurich auf Beihilfe aus dem Ministerium für öffentliche Arbeiten zu den Druckkosten des Wegweisers, Mai 1899 - Überreichung der III. Auflage des Wegweisers "Aus See nach Emden, Leer, Weener und Papenburg", 1909

$1899-1909$

Klassifikation Teil B: 01496

Trägermaterial: Papier

Alte Reg.-Sig.: IV Ma 43

Bestell-Nr.: IV 01496

1419 Jahresberichte der Reedereien

$1913-1918$

- Anforderungen von Jahresberichten der Reedereien durch den

Magistrat auf Verfügung des Regierungspräsidenten in Aurich

$1913-1918$

Klassifikation Teil B: 01499

Trägermaterial: Papier

Alte Reg.-Sig.: IV Ma 47

Bestell-Nr.: IV 01499 
05

\subsection{3}

05.03.09

05.03.09.01

05.03.09.01.01
Stadtverwaltung

Aufgabenbereiche der Stadtverwaltung

Wasser- und Schifffahrtssachen

Schifffahrts- und Schifffahrtsverkehrseinrichtungen

Schifffahrt und Schiffsverkehrseinrichtungen

Lfd. Nr. Titel

Laufzeit

1420 Desinfektion verseuchter Flussschiffe

- Erlasse des preußischen Innenministers über Desinfektion verseuchter Flussschiffe

$1912-1914$

Klassifikation Teil B: 01501

Trägermaterial: Papier

Alte Reg.-Sig.: IV Ma 59

Bestell-Nr.: IV 01501

1421 Konferenz wegen Rheinschifffahrtsabgabe

1908

- Anfrage des Ministerialdirektors im Ministerium für öffentliche Arbeiten, geheimer Oberregierungsrat Max Peters beim Oberbürgermeister Fürbringer über Möglichkeit von Emden als Veranstaltungsort einer Konferenz der Rheinanrainerländer über die Rheinschifffahrtsabgabe, August - September 1908

1908

Klassifikation Teil B: 01503

Trägermaterial: Papier

Alte Reg.-Sig.: IV Ma 57

Bestell-Nr.: IV 01503

1422 Schiffsversicherungsanstalten

- Nachweisung über Tätigkeit der Emder Schiffsversicherungen

$1870-1871$

Klassifikation Teil B: 01505

Trägermaterial: Papier

Alte Reg.-Sig.: IV Ma 60

Bestell-Nr.: IV 01505

1423 Meldedienst über via Borkum einfahrende Schiffe

- Anregung der Erzimportfirma Possehl \& Co aus Lübeck zur Einrichtung eines Meldedienstes zur Beschleunigung des Verkehrs zum und der Abfertigung im Emder Hafen, November 1905 - Mitteilung der kgl. Wasserbauinspektion und des Telegraphenamts über Mehraufwand bei Vermittlung des Meldedienstes ab Borkum, November - Dezember 1905

- Schreiben der Fa. Possehl \& Co über Verweigerung einer Kostenträgerschaft für den Meldedienst, Januar 1906

- Konferenz über Einrichtung eines Meldedienstes über via Borkum einfahrende Schiffe, Februar 1906

$1905-1906$

Klassifikation Teil B: 01506

Trägermaterial: Papier

Alte Reg.-Sig.: IV Ma 51

Bestell-Nr.: IV 01506 
05

\subsection{3}

05.03.09

05.03.09.01
05.03.09.01.01

Stadtverwaltung

Aufgabenbereiche der Stadtverwaltung

Wasser- und Schifffahrtssachen

Schifffahrts- und Schifffahrtsverkehrseinrichtungen

Schifffahrt und Schiffsverkehrseinrichtungen

Laufzeit

Lfd. Nr. Tite
1905-1912

Handelsschiffen

- Reichsgesetz über Vorschriften über sanitäre Anlagen und Mannschaftsräume auf Handelsschiffen, Juli 1905

- Erlass des preußischen Ministers für Handel und Gewerbe über Umsetzung des Reichsgesetzes über Vorschriften sanitäre Anlagen und Mannschaftsräume auf Handelsschiffen, März 1906 - März 1908 - Problem der Umsetzung der Vorschriften zu Sanitäreinrichtungen auf Schleppdampfern, Dezember 1906 - Januar 1907

- Liste der Passagier- und Schleppdampfer in Emden, 1906

- Regelung über Auffüllung von Schiffsapotheken durch approbierte deutsche Apotheker auf dem Gebiet des Deutschen Reiches,

September 1912

Klassifikation Teil B: 01507

Trägermaterial: Papier

Alte Reg.-Sig.: IV Ma 50

Bestell-Nr.: IV 01507

1425 Schiffsgasmaschine

1904-1905

- Diskussion um die Anwendung der Patente der Schiffsgasmaschine von Emile Capitaine

$1904-1905$

Klassifikation Teil B: 01508

Trägermaterial: Papier

Alte Reg.-Sig.: IV Ma 49

Bestell-Nr.: IV 01508

1426 Einrichtung eines Zeitballs im Emder Hafen

1904-1908

- Antrag des Bürgervorsteherkollegiums auf Anregung der kgl.

Wasserbauinspektion zur Einrichtung eines Zeitballs zur Justierung

der Schiffsuhren zum interkontinentalen Verkehr, Januar 1904

- Schreiben der kgl. Wasserbauinspektion über nicht vorhandenem

Bedarf eines Zeitballs, Februar 1904

- Initiative der Hapag zur Errichtung eines Zeitballs, April 1908

$1904-1908$

Klassifikation Teil B: 01509

Trägermaterial: Papier

Alte Reg.-Sig.: IV Ma 47

Bestell-Nr.: IV 01509 
IV

05

Stadtverwaltung

05.03

Aufgabenbereiche der Stadtverwaltung

05.03.09

Wasser- und Schifffahrtssachen

05.03.09.01

05.03.09.01.01

Schifffahrts- und Schifffahrtsverkehrseinrichtungen

Schifffahrt und Schiffsverkehrseinrichtungen

Lfd. Nr. Titel

Laufzeit

1427 Schiffsregister

$1865-1875$

- Eintragungen in das Schiffsregister wegen Änderung der

Besitzverhältnisse, Umbenenung und Neu- sowie Umbau von Schiffen

in alphabetischer Folge der Schiffsnamen

$1865-1875$

Klassifikation Teil B: 01513

Trägermaterial: Papier

Alte Reg.-Sig.: IV Md 4

Bestell-Nr.: IV 01513

1428 Nutzung des Emder Hafens durch den Norddeutschen Lloyd

- Ablehnung einer förmlichen Vereinbarung über Nutzung des Emder Hafens durch den Norddeutschen Lloyd wegen Unsicherheit der Anschlüsse der nordwestdeutschen Kanäle an den Emder Hafen, April 1907

1907

Klassifikation Teil B: 02470

Trägermaterial: Papier

Alte Reg.-Sig.: IV T6 170

Bestell-Nr.: IV 02470 
05

05.03

05.03.09

05.03.09.01

05.03.09.01.02

Lfd. Nr. Titel
IV

Stadtverwaltung

Aufgabenbereiche der Stadtverwaltung

Wasser- und Schifffahrtssachen

Schifffahrts- und Schifffahrtsverkehrseinrichtungen

Wasserbauten und Hafenanlagen

Laufzeit

1429 Aufsätze über den Emder Hafen

$1912-1914$

- Aufsätze in der Deutschen Bauzeitung zu den Emder Hafenbauten

$1912-1914$

Klassifikation Teil B: 00023

Trägermaterial: Papier

Bestell-Nr.: IV 00023 
05

05.03

05.03.09

05.03.09.01

05.03.09.01.02
Stadtverwaltung

Aufgabenbereiche der Stadtverwaltung

Wasser- und Schifffahrtssachen

Schifffahrts- und Schifffahrtsverkehrseinrichtungen

Wasserbauten und Hafenanlagen

Lfd. Nr. Titel

Laufzeit

1430 Verbesserung der Schifffahrtsanlagen und Korrektur der Ems

1870-1914

- Eingabe der Handelskammer an den Magistrat über Notwendigkeit der Verbesserung der Emder Hafenanlagen wegen infolge Verschlammung des Hafenbeckens unmöglicher Anfahrt beladener Schiffe, Juni 1870 / Juli 1871

- Erlass des preußischen Ministers für Handel, Gewerbe und öffentliche Arbeiten über Beauftragung des Oberlandesbaudirektors Gotthilf Hagen mit einem Gutachten über die Situation des Emder Hafens, Juli 1870

- Verfügung des preußischen Landdrosten in Aurich an den Magistrat über Terminierung einer Besprechung mit Sachverständigen zur Erstellung eines Kostenvoranschlages der Herstellung modernisierter Hafenanlagen nach den Gutachten des Oberlandesbaudirektors Gotthilf Hagen, Januar 1871

- Korrespondenz des Senators und Holzhändlers Carl Dantziger über Hafenverhältnisse in Danzig und Memel, Januar / Februar 1871

- Verhandlungen der städtischen Kollegien mit Sachverständigen der staatlichen Wasserbauverwaltung über Maßnahmen zur

Verbesserung der Emder Hafenzufahrt und über anfallende Kosten und deren Trägerschaft, Februar - September 1871

- Verhandlungen der städtischen Kollegien über Verbesserung der Emder Hafenanlagen, März 1871 - August 1874

- Plan einer neuen Schiffsschleuse an der Nesserlander Schleuse und eines Kanals zum Hafen, April 1871 - März 1872

- Eingaben der Kaufmännischen Deputation und des

Seemanns-Collegiums über dringende Notwendigkeit zur Vertiefung des Emsfahrwassers und der Verbesserung der Hafenzufahrten, Januar 1872 - März 1875

- Votum der Kaufmännischen Deputation für die Übertragung der Hafenanlagen mit den Schleusen und dem Fahrwasser auf den preußischen Staat zur Einleitung der Verbesserungsmaßnahmen aus allgemeinen Steuermitteln, Februar 1872

- Bericht des Magistrats an den preußischen Landdrosten in Aurich über Erfordernisse hinsichtlich der Emsvertiefung und Verbesserung der Hafenanlagen wegen zunehmendem Güterverkehr und größerem Tiefgangs der Schiffe, April 1872

- Ablehnung sofortiger Korrekturmaßnahmen durch das Ministerium für Handel, Gewerbe und öffentliche Arbeiten, Juni 1872

- Rescript des preußischen Landdrosten in Aurich über weiteren Beitrag der Stadt Emden zur Hafenunterhaltung als Bedingung für die Übernahme des Hafens durch den preußischen Staat, November 1872 / Februar 1873

- Ankündigung der Emsvertiefung, Juni 1902 - Juni 1914

$1870-1914$

Klassifikation Teil B: 01438

Trägermaterial: Papier

Alte Reg.-Sig.: IV Ma 13

Bestell-Nr.: IV 01438 
05

\subsection{3}

05.03.09

05.03.09.01

05.03.09.01.02
Stadtverwaltung

Aufgabenbereiche der Stadtverwaltung

Wasser- und Schifffahrtssachen

Schifffahrts- und Schifffahrtsverkehrseinrichtungen Wasserbauten und Hafenanlagen

Lfd. Nr. Titel

Laufzeit

1431 Verbesserung der Emder Hafenanlagen

- Verfügung des preußischen Landdrosten in Aurich an den Magistrat über Aufforderung zur Veräußerung städtischer Grundflächen zum Bau des Ems-Jade-Kanals, Mai 1875

- Kostenvoranschlag zum Bau des Ems-Jade-Kanals auf dem Gebiet der Stadt Emden, 1875

- Verfügung des preußischen Landdrosten in Aurich über Einsetzung des Regierungs- und Baurats Müller und des Regierungsassessors Schweckendieck als Bauleiter der Hafen- und Kanalprojekte in Emden, Mai 1875

- Verhandlungen zwischen der Stadt Emden und dem Ministerium der öffentlichen Arbeiten über Unterhaltung des Emder Hafens und Übergang der Hafenanlagen in das Eigentum des preußischen Staates, Dezember 1879

\author{
$1875-1882$ \\ Klassifikation Teil B: 01439 \\ Trägermaterial: Papier \\ Alte Reg.-Sig.: IV Ma 20 \\ Bestell-Nr.: IV 01439
}

1432 Fortentwicklung der deutschen Seehäfen

$1876-1903$

- Staatswissenschaftliche Arbeit des Bergassessors Schultz über Vergleich zwischen Rotterdam und Emden hinsichtlich der Bedeutung für das rheinisch-westfälische Industriegebiet, ca. 1895

- Korrespondenz Bürgermeister Fürbringer mit Carl Schweckendieck über Erweiterung des Emder Hafens, 1876 - 1877

- Konzept des Emder Bürgermeisters Fürbringer für Verhandlungen wegen der Übernahme der Emder Hafenanlagen durch den preußischen Staat, 1877

- Konzept Schrift Oberbürgermeister Fürbringer: Fortentwicklung der Seehäfen in Deutschland, 1903

- Abschriften verschiedener Dokumente zur Emder Hafengeschichte, 1903

$1876-1903$

Klassifikation Teil B: 01440

Trägermaterial: Papier

Alte Reg.-Sig.: IV Ma 20

Bestell-Nr.: IV 01440 
05

05.03

05.03.09

05.03.09.01

05.03.09.01.02
Stadtverwaltung

Aufgabenbereiche der Stadtverwaltung

Wasser- und Schifffahrtssachen

Schifffahrts- und Schifffahrtsverkehrseinrichtungen

Wasserbauten und Hafenanlagen

Lfd. Nr. Titel

Laufzeit

1433 Emder Hafenanlagen und Ems-Jade-Kanal, Bd. 1

$1879-1883$

- Vertrag zwischen der Stadt Emden und dem Kgr. Preußen wegen Übergang der Hafenanlagen in Emden in den Besitz des preußischen Staates, November - Dezember 1879

- Verhandlungen der städtischen Kollegien wegen Übergang der

Hafenanlagen in Emden in den Besitz des preußischen Staates, Mai 1879

- Verhandlungen des Magistrats mit dem preußischen Landdrosten in Aurich und dem Minister der öffentlichen Arbeiten wegen Übergang der Hafenanlagen in Emden in den Besitz des preußischen Staates, Mai - November 1879

- Beiträge der Stadt Emden zum Bau des Ems-Jade-Kanals, 1880 1882

- Feststellung des Plans des Ems-Jade-Kanals mit Anschluss zur Nesserlander Schleuse, 1880

- Umsetzung des Übergangs der Hafenanlagen in Emden in den Besitz des preußischen Staates, 1880

- Ausbau der Nesserlander Schleuse, 1880 - 1881

- Regulierung des Schleusenwasserstandes der Nesserlander Schleuse zum Schutz der Baugrube des Ems-Jade-Kanals, 1880 1881

- Wartung und Erneuerung der Tore der Nesserlander Schleuse, 1881

$-1882$

- Eingabe des Sägereibesitzers J. Remmerssen an den Magistrat über Forderung von ausreichend lange Verlaate zum Ems-Jade-Kanal wegen Holztransporterfordernisse, Oktober 1881

- Eingaben der Kaufmännischen Deputation und der Vereinigten Torfschiffer aus den ostfriesischen Fehnen über Forderung nach ausreichenden Verlaaten vom städtischen Kanalsystem zum

Ems-Jade-Kanal, Dezember 1881 - Juli 1882

- Grundbuchveränderungen wegen der von der Stadt Emden an den preußischen Staat abgegebenen Grundstücke, 1881 - 1883 Initiative des Oberbürgermeisters Fürbringer zur Herstellung eines Anschlusses zwischen dem Ems-Jade-Kanal und dem

Rhein-Ems-Kanal, Juli 1882

- Handzeichnung der Kesselschleuse, 1882

- Maßnahmen zur Lenkung des Schiffsverkehrs und der Schaffung von Umschlagsmöglichkeiten für Seeschiffe wegen Sperrung des

Emsfahrwassers aufgrund von Arbeiten am Ems-Jade-Kanal, Januar Februar 1883

$1879-1883$

Klassifikation Teil B: 01441

Band: 1

Trägermaterial: Papier

Alte Reg.-Sig.: IV Ma 20

Bestell-Nr.: IV 01441 
05

05.03

05.03.09

05.03.09.01

05.03.09.01.02

Stadtverwaltung

Aufgabenbereiche der Stadtverwaltung

Wasser- und Schifffahrtssachen

Schifffahrts- und Schifffahrtsverkehrseinrichtungen

Wasserbauten und Hafenanlagen

Lfd. Nr. Titel

Laufzeit

1434 Handakte Fürbringer: Übergang der Hafenanlagen in Emden in den

Besitz des preußischen Staates

$1875-1882$

- Planzeichnung der Nesserlander Schleuse, 1875

- Entwurf einer Resolution des Oberbürgermeisters Fürbringer über

Verhandlungsleitlinien der Stadt Emden wegen Übergang der

Hafenanlagen in Emden in den Besitz des preußischen Staates, 1878

- Entwurf einer Denkschrift des Oberbürgermeisters Fürbringer für den

Übergang der Hafenanlagen in Emden in den Besitz des preußischen

Staates, 1878

- Festschrift zum Ems-Jade-Kanal, 1882

$1875-1882$

Klassifikation Teil B: 01442

Trägermaterial: Papier

Alte Reg.-Sig.: IV Ma 20

Bestell-Nr.: IV 01442

1435 Emder Hafenanlagen und Ems-Jade-Kanal, Bd. 2

1883-1887

- Presseberichte über Emder Hafenanlagen und

Entwässerungsprobleme, 1884

- Grundbuchänderungen wegen der von der Stadt Emden an den preußischen Staat abgegebenen Grundstücke in Nesserland,

Dezember 1883

- Anlage des Binnenfahrwassers, 1884

- Verfügungen des preußischen Landdrosten in Aurich an den Magistrat über von der Stadt Emden zu treffende Maßnahmen gegen die Verschlammung des Emder Hafens, Januar - Februar 1885

- Beitrag der Stadt Emden zum Bau des Ems-Jade-Kanals, 1886

- Enteignung von Grundstücken für den Bau des Ems-Jade-Kanals, 1886

- Umsetzung des Übergangs der Hafenanlagen in Emden in den

Besitz des preußischen Staates, 1886 - 1887

$1883-1887$

Klassifikation Teil B: 01443

Band: 2

Trägermaterial: Papier

Alte Reg.-Sig.: IV Ma 20

Bestell-Nr.: IV 01443 
05

05.03

05.03.09

05.03.09.01

05.03.09.01.02
Stadtverwaltung

Aufgabenbereiche der Stadtverwaltung

Wasser- und Schifffahrtssachen

Schifffahrts- und Schifffahrtsverkehrseinrichtungen

Wasserbauten und Hafenanlagen

Lfd. Nr. Titel

Laufzeit

1436 Emder Hafenanlagen und Ems-Jade-Kanal, Bd. 3

1887-1888

- Votum der Kaufmännischen Deputation für gebührenfreie

Schleusungen durch die im Bau befindliche Kesselschleuse, Februar

1887

- Verhandlungen der städtischen Kollegien wegen Umstrukturierung

des Hafens und Bau neuer Anlagen, 1887

- Verfügung des Regierungspräsidenten in Aurich über Pflicht der

Stadt Emden zur Beseitigung der Schlammmassen aus dem Emder

Hafen bis zur Übernahme des Hafens durch den preußischen Staat,

April 1887

- Eingabe des Magistrats an den preußischen Minister der öffentlichen Arbeiten über Bitte um eine Beihilfe zur Entschlammung des Emder Hafens, April 1887

- Planzeichnung: Binnenfahrwasser, 1887

- Konzept des Oberbürgermeisters Fürbringer über

Verhandlungsleitlinien über Vorschläge des Regierungspräsidenten

wegen Änderung der Hafenanlagen, Mai 1887

- Gespräch des Senators Ihnen mit dem Minister der öffentlichen

Arbeiten in Berlin wegen Hafenanlagen, Mai 1887

- Verhandlungen des Magistrats wegen Hafenanlagen, 1887

- Initiative des Oberbürgermeisters Fürbringer beim Minister der öffentlichen Arbeiten zum Anschluss des Emder Hafens an den geplanten Dortmund-Ems-Kanal und Erweiterung der Hafenanlagen in Richtung des Kaiser-Wilhelm-Polders, Juni 1887

- Bericht der Wasserbauinspektore Dannenberg und Germelmann über starke Verschlammung des Emder Hafens entgegen des Berichts des Magistrats, Juni 1887

-Widerlegung der Angaben der Wasserbauinspektore durch den Stadtbaumeister Wiggers, Juni 1887

- Konzept eines Schreibens des Oberbürgermeisters Fürbringer an den Regierungspräsidenten wegen Festsetzung der Wassertiefe im Hafen, Juli 1887

- Gutachten des Wasserbauinspektors H. Dannenberg im Auftrag des Sielamts über Zustand der Nesserlander Schleusentores, Oktober 1887

- Umsetzung des Übergangs der Hafenanlagen in Emden in den Besitz des preußischen Staates im Spiegel der Presse, 1887 - 1888

- Gutachten des Regierungs- und Baurats Schelten über Zustand der Fluttore der Nesserlander Schleuse, Dezember 1887

- Umsetzung des Übergangs der Hafenanlagen in Emden in den Besitz des preußischen Staates, September 1887 - Mai 1888

- Liste der in Staatsbesitz übergehenden Hafenanlagen in Emden, November 1887

$1887-1888$

Klassifikation Teil B: 01444

Trägermaterial: Papier

Alte Reg.-Sig.: IV Ma 20

Bestell-Nr.: IV 01444 
05

05.03

05.03.09

05.03.09.01

05.03.09.01.02
Stadtverwaltung

Aufgabenbereiche der Stadtverwaltung

Wasser- und Schifffahrtssachen

Schifffahrts- und Schifffahrtsverkehrseinrichtungen

Wasserbauten und Hafenanlagen

Lfd. Nr. Titel

Laufzeit

1437 Emder Hafenanlagen und Ems-Jade-Kanal, Bd. 4

1887-1912

- Presseberichte über Übergang der Hafenanlagen in Emden in den Besitz des preußischen Staates, 1887 - 1888

- Liste der in den Staatsbesitz übergehenden Hafenanlagen, 1887

- Gutachten des Regierungs- und Baurats Schelten über Zustand der

Fluttore der Nesserlander Schleuse, Dezember 1887

- Feier zur Übergabe der Hafenanlagen in Emden in den Besitz des preußischen Staates, März 1888

- Programm der Einweihungsfeier des Ems-Jade-Kanals, April 1888

- Geplante Verleihung des Ehrenbürgerrechts der Stadt Emden an den preußischen Minister der öffentlichen Arbeiten, Maybach, anlässlich der Einweihung des Ems-Jade-Kanals, Juli 1888

- Negativer Kommentar des Wasserbauinspektors beim Sielamt über einen in der Zeitschrift "Hanse" erschienenden Aufsatz "Wassernot in Ostfriesland", 1889

- Berichte des Vorstands des Hafenamts (Oberbürgermeister Fürbringer, Wasserbauinspektor Dannenberg) über Baggerungen und Spülungen im Emder Hafen, Juni 1889

- Verbindung des Bauhofs der staatlichen Wasserbau-Verwaltung durch ein Gleis mit dem Bahnhof, April - Juni 1890

- Katasterauszüge über Grundstücke im Hafengebiet, 1890 - 1896

- Planzeichnung: Güterschuppen der Deutschen Küstenschifffahrt AG am Ratsdelft, 1891

- Klagen über Geruchsbelästigungen im Ratsdelft, August 1891

- Nachrichten über Sperrungen oder Senkung des Wasserpegels des

Ems-Jade-Kanals wegen Bauarbeiten, 1892 - 1893

- Forderung der Kaufmännischen Deputation nach Einbau eines zweiten Fluttores in der Nesserlander Schleuse, Februar 1893 - März 1893

- Erlass des preußischen Ministers der öffentlichen Arbeiten über Gebührensätze für Schleusungen durch die Kesselschleuse, Februar 1895

- Umschreibung von Grundstücken im Hafengebiet auf den preußischen Staat als Umsetzung des Überganges der Hafenanlagen in Emden in den Besitz des preußischen Staates, 1889 - 1897

- Anregung der Kaufmännischen Deputation zum Bau einer neuen

Seeschleuse im Emder Hafen, November 1891

- Nachweis der Stadt Emden über Aufwendungen für die

Nesserlanderschleuse seit dem Übergang der Hafenanlagen in

Emden in den Besitz des preußischen Staates, 1901

- Nachrichten über Verkehrsbehinderungen im Ems-Jade-Kanal, 1912

$1887-1912$

Klassifikation Teil B: 01445

Band: 4

Trägermaterial: Papier

Alte Reg.-Sig.: IV Ma 20

Bestell-Nr.: IV 01445 
05

\subsection{3}

05.03.09

05.03.09.01

05.03.09.01.02
Stadtverwaltung

Aufgabenbereiche der Stadtverwaltung

Wasser- und Schifffahrtssachen

Schifffahrts- und Schifffahrtsverkehrseinrichtungen Wasserbauten und Hafenanlagen

Lfd. Nr. Titel

Laufzeit

1438 Verbesserung der Emder Hafenanlagen

- Schreiben des Präsidenten der Kaufmännischen Deputation, F. D. Ihnen und des Kaufmanns Remmerssen an den Bürgermeister Fürbringer über Situation des Schiffsverkehrs im Emder Hafen und Problem der Verschlammung, April - Mai 1876

- Liste der für die Emder Hafenanlagen zu tiefgängigen Schiffe, 1876

- Schreiben der Kaufleute Dantziger und Barghoorn über Probleme beim Löschen ihrer Schiffe an der Reede, April 1876

- Schreiben verschiedener Sachverständiger über Notwendigkeit der Verbesserung der Emder Hafenanlagen, 1876

- Zusammenstellung des Emder Bürgermeisters Fürbringer über historische Entwicklung des Emder Hafens, 1876

1876

Klassifikation Teil B: 01446

Trägermaterial: Papier

Alte Reg.-Sig.: IV Ma 20

Bestell-Nr.: IV 01446

1439 Zuständigkeit für wasser- und deichpolizeiliche Angelegenheiten

- Erlass des preußischen Ministers der öffentlichen Arbeiten über Zuständigkeit für wasser- und deichpolizeiliche Angelegenheiten im Sinne des preußischen Deichgesetzes von 1848, Seeptember 1887 / April 1907

$1887-1907$

Klassifikation Teil B: 01458

Trägermaterial: Papier

Alte Reg.-Sig.: IV Ma 36

Bestell-Nr.: IV 01458 
05

05.03

05.03.09

05.03.09.01

05.03.09.01.02
Stadtverwaltung

Aufgabenbereiche der Stadtverwaltung

Wasser- und Schifffahrtssachen

Schifffahrts- und Schifffahrtsverkehrseinrichtungen

Wasserbauten und Hafenanlagen

Lfd. Nr. Titel

Laufzeit

1440 Erweiterung des Emder Hafens, Bd. 1

1904-1914

- Beschluss der Kollegien der Stadt Emden über Bewilligung einer Summe von 500.000 Mark als Beteiligung der Stadt Emden an einer Hafenerweiterung, Juli 1904

- Protokoll der Besprechung zwischen Vertretern der Regierung in Aurich, dem geheimen Oberregierungsrat im Ministerum für öffentliche Arbeiten, Carl Schweckendieck und Vertretern der Stadt Emden über Projekt der Hafenerweiterung und des Schleusenbaus sowie der finanziellen Beteiligung der Stadt Emden, Oktober 1904 - Verhandflungen zwischen der Stadt Emden und der preußischen Regierung in Aurich über Nutzung des vor dem Königspolder einzudeichenden Areals zur Hafenerweiterung und Festlegung des Nutzungsanteils der Stadt Emden, Dezember 1905 - April 1906 - Bereitstellung der Mittel für Hafenerweiterung und Schleusenbau in Emden im preußischen Haushaltsplan, 1905 / 1906

- Bericht in der Emder Zeitung über Grundsteinlegung der Seeschleuse, Februar 1910

- Aufstellung über Einnahmen und Ausgaben wegen der gemeinsam von der Stadt Emden und dem preußischen Fiskus genutzten Flächen im Hafengebiet (Königspolder), 1906 - 1917

$1904-1910(1917)$

Klassifikation Teil B: 01490

Band: 1

Trägermaterial: Papier

Alte Reg.-Sig.: IV Ma 52

Bestell-Nr.: IV 01490

1441 Erweiterung des Emder Hafens, Bd. 2

- Streit zwischen den Nordseewerken, Deutsch-Luxemburgische Bergbau und Hüttengesellschaft AG und der Stadt Emden wegen Nutzung der Flächen im Königspolder, Februar 1912

- Verhandlungen des Magistrats mit der preußischen Regierung in Aurich über Anteil der Stadt Emden am Erlös der Vererbpachtung eines Areals im Königspolder an die Nordseewerke, Juli 1912 - Entschädigungsanspruch der Stadt Emden wegen einseitigen Verkauf von Flächen im Königspolder an die Nordseewerke durch den preußischen Fiskus, Februar - Dezember 1914

1912 - 1914 (1916 - 1935)

Klassifikation Teil B: 01491

Band: 2

Trägermaterial: Papier Alte Reg.-Sig.: IV Ma 52

Bestell-Nr.: IV 01491 
05

\subsection{3}

05.03.09

05.03.09.01

05.03.09.01.02
Stadtverwaltung

Aufgabenbereiche der Stadtverwaltung

Wasser- und Schifffahrtssachen

Schifffahrts- und Schifffahrtsverkehrseinrichtungen

Wasserbauten und Hafenanlagen

Lfd. Nr. Titel

Laufzeit

1442 Erweiterung des Emder Hafens

- Schreiben der Hannoverschen Bank an Oberbürgermeister

Fürbringer über Probleme der Kreditgewährung für den weiteren

Ausbau der Emder Hafenanlagen, Juni 1902 / August 1903

- Verhandlungen der Stadt Emden mit der Regierung in Aurich und

Vertretern des preußischen Ministeriums der öffentlichen Arbeiten wegen Ausbau der Emder Hafenanlagen, Juni 1903

- Konstituierung einer städtischen Kommission für die

Hafenerweiterungsangelegenheiten, Juni 1903

- Vertrauliche Vorlage des Oberbürgermeisters Fürbringer über Kosten der Anlagen im erweiterten Hafengebiet und Verteilung der Trägerschaft zwischen der Stadt Emden und dem preußischen Fiskus, August 1903

- Verhandlungen zwischen dem Magistrat und der preußischen Staatsregierung wegen Verteilung der Kosten zur Erweiterung des Emder Hafens, August 1903

- Ablehnung eines finanziellen Engagements bei der Gründung einer Hafenbetriebs- und Lagerhausgesellschaft in Emden durch die Deutsche Bank u.a., September - Oktober 1903

$1902-1903$ (1904 - 1907)

Klassifikation Teil B: 01492

Trägermaterial: Papier

Alte Reg.-Sig.: IV Ma 49

Bestell-Nr.: IV 01492

1443 Errichtung einer Brikettfabrik im fiskalischen Königspolder

1903-1908

- Plan der Emder Hafenanlagen, 1903

- Erbpachtsvertrag zwischen der preußischen Regierung in Aurich und dem Rheinisch-Westfälischen Kohlensyndikat über fiskalisches

Gelände im Königspolder zum Bau einer Kokerei (Brikettfabrik),

September 1904

- Gedrucktes Verhandlungsprotokoll mit Plan zur Vereinbarung

zwischen der Stadt Emden und der preußischen Staatsregierung über

Erweiterung des Emder Hafens, 1906

- Beschluss des kgl. Wasserbauamts über Genehmigung der

Verpachtung fiskalischer Flächen im Königspolder an der

Hohenzollern-Hütte AG, September 1908

$1903-1908$

Klassifikation Teil B: 01493

Trägermaterial: Papier

Alte Reg.-Sig.: IV Ma 53

Bestell-Nr.: IV 01493 
05

\subsection{3}

05.03.09

05.03.09.01

05.03.09.01.02
Stadtverwaltung

Aufgabenbereiche der Stadtverwaltung

Wasser- und Schifffahrtssachen

Schifffahrts- und Schifffahrtsverkehrseinrichtungen Wasserbauten und Hafenanlagen

Lfd. Nr. Titel

Laufzeit

1444 Einweihung des neuen Sehafens zu Leer

1907

- Schreiben des Oberbürgermeisters Fürbringer an den Bürgermeister von Leer über Gratulation und beste Wünsche zum neuen Seehafen in Leer sowie Bedauern über Nichtteilnahme an der Einweihungsfeier wegen Verhinderung, September 1907

1907

Klassifikation Teil B: 01497

Trägermaterial: Papier

Alte Reg.-Sig.: IV Ma 44

Bestell-Nr.: IV 01497

1445 Plan der Anlage eines Seehafens an der Unterems

- Initiative der Handelskammer zu Emden zur Anlage eines Seehafens an der Knock, Juli 1868

- Karte von den Emsmündungen, 1868

- Eingabe des Magistrats an den preußischen Minister für Handel, Gewerbe und der öffentlichen Arbeiten über Bitte um Förderung des Plans zum Bau eines Hafens an der Knock (Unterems), Oktober 1868 - Verhandlungen der städtischen Kollegien über das Hafenprojekt an der Unterems mit Votum für die Anlage eines Seehafens bei Logum, Oktober 1868

1868

\author{
Klassifikation Teil B: 01498 \\ Trägermaterial: Papier \\ Alte Reg.-Sig.: IV Ma 48 \\ Bestell-Nr.: IV 01498
}

1446 Zuschuss der Stadt Emden zum Bau der Großen Seeschleuse

- Beschluss des Magistrats über Bewilligung eines Zuschusses von 100.000 Mark zum Bau der Großen Seeschleuse, Oktober 1902 - Schreiben des Magistrats an die kgl. Wasserbauinspektion über Notwendigkeit einer zweiten Seeschleuse wegen Zunahme des Schiffsverkehrs und Erfordernisse des Strurmflutschutzes, Oktober 1902

- Einziehung einer Rate von 300.000 Mark als Anteil der Stadt Emden für die Hafenerweiterung durch die Regierungshauptkasse in Aurich, September 1911

$1902-1911$

Klassifikation Teil B: 01500

Trägermaterial: Papier Alte Reg.-Sig.: IV Ma 46

Bestell-Nr.: IV 01500 
05

05.03

05.03.09

05.03.09.01

05.03.09.01.02
Stadtverwaltung

Aufgabenbereiche der Stadtverwaltung

Wasser- und Schifffahrtssachen

Schifffahrts- und Schifffahrtsverkehrseinrichtungen

Wasserbauten und Hafenanlagen

Lfd. Nr. Titel

Laufzeit

1447 Elbvertiefung

1908

- Materialakte über Verhandlungen zwischen Hamburg und Preußen über Vertiefung des Elbfahrwassers zur Hebung der Seeschifffahrt nach Hamburg, Altona und Harburg

1908

Klassifikation Teil B: 01502

Trägermaterial: Papier

Alte Reg.-Sig.: IV Ma 58

Bestell-Nr.: IV 01502

1448 Entwässerungsverhältnisse in Ostfriesland

$1905-1908$

- Diskussion eines Artikels über Folgen der Moorentwässerung im Landwirtschaftlichen Zentralblatt für Ostfriesland, Dezember 1905 - Gutachten über Folgen einer Änderung der Deich- und Sielordnung wegen Ableitung von Moorwasser durch Trockenlegung der Moore, $1906-1907$

- Widerstand der Stadt Emden gegen einen Kanal von Doerpen nach Oldenburg wegen Schädigung der Emsschifffahrt, 1906 - 1907

- Erlass des Ministers der öffentlichen Arbeiten über Anordnung der Mitteilung von Daten wegen geplanter Reform der

Wasserstraßenbeiräte, September 1912

$1905-1912$

Klassifikation Teil B: 01504

Trägermaterial: Papier

Alte Reg.-Sig.: IV Ma 56

Bestell-Nr.: IV 01504

1449 Gleisanschluss des Emder Hafens

- Bericht des Eisenbahnbau-Inspektors Haarbach über Planung des Gleisanschlusses zum Emder Hafen, September 1881

- Kosten des Gleisanschlusses, 1881

1881

Klassifikation Teil B: 01510

Trägermaterial: Papier

Alte Reg.-Sig.: IV Ma 48

Bestell-Nr.: IV 01510 
05

05.03

05.03.09

05.03.09.01

05.03.09.01.02
Stadtverwaltung

Aufgabenbereiche der Stadtverwaltung

Wasser- und Schifffahrtssachen

Schifffahrts- und Schifffahrtsverkehrseinrichtungen

Wasserbauten und Hafenanlagen

Lfd. Nr. Titel

Laufzeit

1450 Anlage eines der Anforderungen der modernen Schiffen genügenden Hafens

1868-1891

- Denkschrift des Senators Carl Dantziger als Vorsitzender der Handelskammer über Anforderungen der modernen Schifffahrt an den Hafen, 1868 - 1877

- Verhandlungen der Handelskammer Emden - Papenburg mit dem Magstrat wegen Hafenerweiterung und Hafenmodernisierung, 1868 1871

- Eingabe der Handelskammer an das preußische Abgeordnetenhaus über Notwendigkeit der Modernisierung und Erweiterung des Emder Hafens, November 1868

- Reaktionen von Kaufmannsverbänden auf die Denkschrift Dantzigers, Novermber 1868

- Korrespondenz der Emder Handelskammer mit dem Centralverein zur Hebung der Deutschen Fluss- und Kanalschifffahrt wegen der Emder Hafenproblematik, März 1870

- Beschwerden wegen Unmöglichkeit der Erreichung des zollfreien Anliegers und Löschplatzes im Emder Hafen durch beladene Schiffe, Mai 1870

- Verschiedene Beschwerden von Kaufleuten an die Handelskammer wegen zu geringer Fahrwassertiefe beim Emder Hafen, 1871

- Eingabe der Kaufmännischen Deputation an den preußischen Minister der Öffentlichen Arbeiten über Notwendigkeit der

Verbesserung der Emder Hafen. und Fahrwasserverhältnisse, Januar

- Februar 1872

- Eingabe der Kaufmännischen Deputation an den Magistrat über notwendiges Vorgehen gegen die Verschlammung des Emder Hafens und Fahrwassers, Mai 1874 - November 1875

- Pegelungen des Emder Fahrwassers, 1869 - 1876

- Petition der Kaufmännischen Deputation an den preußischen Minister der öffentlichen Arbeiten über Bitte um Verstaatlichung des

Emder Hafens, Dezember 1876

- Hafenbauprojekt des Bauunternehmers Theilen, 1879 - 1881

$1868-1891$

Klassifikation Teil B: 01566

Trägermaterial: Papier

Alte Reg.-Sig.: IV Mh 25

Bestell-Nr.: IV 01566

1451 Seeschleuse und Hafenanlage in Papenburg

- Feier der Eröffnung der Seeschleuse und Hafenanlage in

Papenburg, September 1902

- Festnummer der Emszeitung zur Eröffnungsfeier mit Beschreibung der Papenburger Hafen- und Schleusenanlage, September 1902

1902

Klassifikation Teil B: 02468

Trägermaterial: Papier

Alte Reg.-Sig.: IV Ma 41

Bestell-Nr.: IV 02468 
05

05.03

05.03.09

05.03.09.01

05.03.09.01.02
Stadtverwaltung

Aufgabenbereiche der Stadtverwaltung

Wasser- und Schifffahrtssachen

Schifffahrts- und Schifffahrtsverkehrseinrichtungen

Wasserbauten und Hafenanlagen

Lfd. Nr. Titel

Laufzeit

1452 Einweihung der neuen Seeschleuse in Emden

1913

- Organisation der Feier der Schleuseneinweihung, Oktober 1913

- Presseberichte über Einweihungsfeier, Oktober 1913

1913

Klassifikation Teil B: 02469

Trägermaterial: Papier

Alte Reg.-Sig.: IV Ma 61

Bestell-Nr.: IV 02469

1453 Anschluss des Emder Hafens an den Dortmund-Ems-Kanal

- Beschreibung des Anschlusses des Emder Hafens an den

Dortmund-Ems-Kanal und der geplanten gewerblichen Anlagen

1891

Klassifikation Teil B: 02522

Trägermaterial: Papier

Alte Reg.-Sig.: IV T6 061

Bestell-Nr.: IV 02522 
05

\subsection{3}

05.03.09

05.03.09.01

05.03.09.01.03
Stadtverwaltung

Aufgabenbereiche der Stadtverwaltung

Wasser- und Schifffahrtssachen

Schifffahrts- und Schifffahrtsverkehrseinrichtungen Werftanlagen

Lfd. Nr. Titel

Laufzeit

1454 Nordseewerke, Bd. 1

1899-1903

- Besprechung des Oberbürgermeisters Fürbringer mit dem

Zivilingenieur Hans Schultz wegen dessen Angebot zur Errichtung einer Werft in Emden, April 1899

- Verhandlungen der Bau- und Verpachtungskommission wegen des

Angebots des Zivilingenieurs Hans Schultz, April 1899

- Korrespondenz des Oberbürgermeisters Fürbringer mit dem

Zivilingenieur Hans Schultz wegen Angebot zur Errichtung einer Werft

in Emden, April 1899 - September 1902

- Angebot der Eisenbahnfabrik A. Renner, Braunschweig über Anlage einer Hafenbahn in Emden, Werftmaschinen und

Schwimmdock-Anlage, Juli 1899

- Verschiedene Artikel und Aufsätze über Werftanlagen, 1899 - 1900

- Angebot der Deutsch-Holländischen Baugesellschaft zum Bau einer Werft in Emden, Mai - November 1899

- Verhandlungen des Magistrats mit der Stettiner Maschinenbau AG

Vulcan wegen Bau einer Werft als Filiale des Unternehmens in

Emden, August 1899

- Angebot der Union AG für Bergbau, Eisen- und Stahlindustrie, Dortmund, über Errichtung eines Schwimmdocks in Emden, August 1899

- Bericht des Magistrats an den Regierungspräsidenten in Aurich über Notwendigkeit ausreichender Werft- und Dockanlagen im Emder

Hafen, August 1899

- Verhandlungen des Oberbürgermeisters Fürbringer und des

Ausschusses für Gründung einer Schiffswerft mit Dock über

Werftansiedlung, Oktober 1902

- Errichtung der Werft der Nordseewerke Emder Werft und Dock AG,

April 1903

- Festschrift über Hafenerweiterung und Werftbau in Emden,

September 1902

$1899-1903$

Klassifikation Teil B: 01460

Band: 1

Trägermaterial: Papier

Alte Reg.-Sig.: IV Ma 39

Bestell-Nr.: IV 01460 
05

\subsection{3}

05.03.09

05.03.09.01

05.03.09.01.03
Stadtverwaltung

Aufgabenbereiche der Stadtverwaltung

Wasser- und Schifffahrtssachen

Schifffahrts- und Schifffahrtsverkehrseinrichtungen

Werftanlagen

Lfd. Nr. Titel

Laufzeit

1455 Nordseewerke, Bd. 2

1902-1905

- Verhandlungen der städtischen Kollegien über Beteiligung der Stadt Emden an der projektierten Werft in Emden, August 1902 -

September 1903

- Gedrucktes Statut der Nordseewerke, Emder Werft und Dock AG,

März 1903

- Planzeichnungen der projektierten Werft, 1902 - 1903

- Zahlung des Kapitalanteils der Stadt Emden an die Nordseewerke,

März - April 1903

- Verhandlungen der Kommission für die Werft- und

Schwimmdockanlage zu Emden wegen Beteiligung der Stadt Emden an der Werft, April 1903

- Extrablatt der Rhein-Ems-Zeitung mit Bericht über Konstituierung der Nordseewerke Emder Werft und Dock AG, Juli 1903

- Gedruckter Antrag des Magistrats an die preußische Staatsregierung auf Abtretung von fiskalischem Terrain im Königspolder für den

Werftbau und weitere Unterstützung des Projektes vom Oktober 1902, 1903

- Eintragung der Nordseewerke in das Handelsregister, September 1903

- Bericht in der Zweiten Generalversammlung der Aktionäre der Nordseewerke über Stand der Werftbauten, Juni 1904

- Betriebseröffnung der Nordseewerke, Januar 1905

$1902-1905$

Klassifikation Teil B: 01461

Band: 2

Trägermaterial: Papier

Alte Reg.-Sig.: IV Ma 39

Bestell-Nr.: IV 01461

1456 Nordseewerke, Bd. 3

$1902-1910$

- Bewerbungen um Positionen bei den Nordseewerken, Dezember 1902

- Angebote von Waren und Dienstleistungen für die Werft, März 1903

- Oktober 1909

- Rückgabe zweier vom Barmer Bankverein ausgestellter Wechsel zur

Finanzierung der ortstatutarischen Kosten der Werfthäuser für

Arbeiter der Nordseewerke, März 1910

$1902-1910$

Klassifikation Teil B: 01462

Band: 3

Trägermaterial: Papier

Alte Reg.-Sig.: IV Ma 39

Bestell-Nr.: IV 01462 
Übersicht über Einnahmen und Ausgaben der Nordseewerke

$1910-1912$

Klassifikation Teil B: 01463

Band: 4

Trägermaterial: Papier

Alte Reg.-Sig.: IV Ma 39

Bestell-Nr.: IV 01463

1458 Nordseewerke, Bd. 5

- Pressebericht über Stand der Werftbauten der Nordseewerke, 1903

- 1904

- Protokoll der Sitzung des Gründungsausschusses der Nordseewerke Emder Werft und Dock AG über Beschluss der Statuten der AG, März 1903

- Angebote von Maschinen für die Nordseewerke, 1903

- Bericht des Werftdirektors, Hans L. Schultz, über Probleme beim Grunderwerb für die Werft und Unterzeichnung der Aktien als Ursache für Finanzprobleme, Mai 1903

- Liste der Aktionäre der Nordseewerke, 1903

- Einladung an Oberbürgermeister Fürbringer als Mitglied des

Aufsichtsrat zu einer Aufsichtsratssitzung der Nordseewerke nach

Dortmund, September 1903

- Wahl des Ingenieurs Hans L. Schultz zum Werftdirektor der Nordseewerke, September 1903

- Protokolle der Aufsichtsratssitzungen der Nordseewerke, 1903 1904

$1903-1904$

Klassifikation Teil B: 01464

Band: 5

Trägermaterial: Papier

Alte Reg.-Sig.: IV Ma 39

Bestell-Nr.: IV 01464 
05

\subsection{3}

05.03.09

05.03.09.01

05.03.09.01.03
Stadtverwaltung

Aufgabenbereiche der Stadtverwaltung

Wasser- und Schifffahrtssachen

Schifffahrts- und Schifffahrtsverkehrseinrichtungen

Werftanlagen

Lfd. Nr. Titel

Laufzeit

1459 Nordseewerke, Bd. 6

1903-1904

- Eingabe der Kaufmännischen Deputation an den

Regierungspräsidenten über Bitte um Förderung des Baus eines

Trockendocks in Emden, Januar 1901

- Konzept eines Schreibens des Oberbürgermeisters Fürbringer an

preußische Ministerien und Reichsmarinestellen über Bitte um

Förderung des Baus einer Werft mit Schwimmdock in Emden, Juni -

Oktober 1902

- Schreiben des Reeders Paul G. Roer an Oberbürgermeister

Fürbringer über Bildung eines Gründerausschusses für eine Werft in

Emden durch namhafte Industrielle des Ruhrgebiets, August 1902

- Eingabe des Ausschusses für die Errichtung eines Schwimmdocks und Werftanlage an den Regierungspräsidenten in Aurich über notwendige bauliche Veränderungen im Emder Hafen und an den Schleusen für den erfolgreichen Betrieb einer Werft in Emden,

September 1902

- Initiative des Oberbürgermeisters Fürbringer zur Förderung der

Nordseewerke durch die preußische Staatsregierung, September -

November 1902

-Korrespondenz zwischen dem Ausschuss für Gründung einer

Schiffswerft mit Dock an der Nordsee und dem Oberbürgermeister

Fürbringer über Grunderwerb für die Nordseewerke, November 1902 -

März 1903

- Verfügung des Regierungspräsidenten in Aurich an den Magistrat über Anordnung der Mitteilung von Informationen über die Kreditgeber und Investoren bei der Werft und Leumund der Initiatoren des

Projekts, Dezember 1902

- Auskunft über die Westfälische Bankkomandite als Kreditgeberin der Nordseewerke, Dezember 1902

- Presseberichte über Werftgründung, 1903

- Schiffsbauten der Nordseewerke, 1904 - 1908

$1902-1908$

Klassifikation Teil B: 01465

Band: 6

Trägermaterial: Papier

Alte Reg.-Sig.: IV Ma 39

Bestell-Nr.: IV 01465 
05

\subsection{3}

05.03.09

05.03.09.01

05.03.09.01.03
Stadtverwaltung

Aufgabenbereiche der Stadtverwaltung

Wasser- und Schifffahrtssachen

Schifffahrts- und Schifffahrtsverkehrseinrichtungen

Werftanlagen

Lfd. Nr. Titel

Laufzeit

1460 Nordseewerke, Bd. 7

1906-1907

- Regelung des Postverkehrs zwischen Magistrat und Nordseewerken, Januar - Februar 1905

- Gedruckter Bericht über die Dritte ordentliche Generalversammlung der Nordseewerke Emder Weft und Dock AG, Juni 1905

- Deponierung der im Besitz der Stadt Emden befindlichen Aktien der Nordseewerke, 1905

- Notwendigkeit der Vergrößerung der Dockanlage der Nordseewerke, Februar 1906

- Ablehnung eines weiteren Ausbaus der Beteiligung der Stadt Emden an den Nordseewerken durch die Kommission für Förderung industrieller Anlagen am hiesigen Platz, Mai 1906

- Geheimes Schreiben des Oberpräsidenten der Provinz Hannover an den Oberbürgermeister Fürbringer über bevorstehende Ablehnung des Antrages an die preußische Staatsregierung auf Überlassung fiskalischer Grundstücke am Hafen an die Nordseewerke, Juni 1907 - Beschluss des Magistrats über weitere Kapitalinvestition der Stadt Emden zur Behebung der Zahlungsschwierigkeiten der Nordseewerke, Juni 1907

- Ablehnung des Verkaufs ihrer Nordseewerke-Aktien durch die Stadt Emden, Juli 1907

- Berichte des Oberbürgermeisters Fürbringer an den

Oberpräsidenten der Provinz Hannover über Ursachen der

Zahlungsschwierigkeiten der Nordseewerke, Folgen ihres Konkurses

für die Hafen- und Werftwirtschaft Emdens und Vorschläge zur

Sanierung, Juni - Juli 1907

- Verhandlungen des Magistrats über Beteiligung der Stadt Emden an einer Kapitalaufstockung bei den Nordseewerken zur Vermeidung des Konkurses, August 1907

- Berichte der Prüfungskommission über wirtschaftliche und finanzielle Lage der Nordseewerke und Vorstellung eines Konzeptes der

Sanierung der Werft, Juli - August 1907

- Bericht des Magistrats an den Regierungspräsidenten in Aurich über Lage der Nodseeewerke und Sanierungsplan, August - Oktober 1907

- Presseberichte über Lage der Nordseewerke, September 1907

- Sanierungsvorschläge des Ingenieurs M. Freitag aus Ahlefeld,

Oktober 1907

- Vertrag über Verpachtung des Terrains und des Schwimmdocks der Nordseewerke an den Oberingenieur von Klitzig aus Kiel, Juli 1910

$1906-1907$ (1910)

Klassifikation Teil B: 01466

Band: 7

Trägermaterial: Papier

Alte Reg.-Sig.: IV Ma 39

Bestell-Nr.: IV 01466 
05

\subsection{3}

05.03.09

05.03.09.01

05.03.09.01.03
Stadtverwaltung

Aufgabenbereiche der Stadtverwaltung

Wasser- und Schifffahrtssachen

Schifffahrts- und Schifffahrtsverkehrseinrichtungen

Werftanlagen

Lfd. Nr. Titel

Laufzeit

1461 Nordseewerke, Bd. 8

1905-1907

- Mitteilungen über Aktienkurse der Nordseewerke, November 1904 Juni 1906

- Ankauf von im Besitz der Stadt Emden befindlichen Aktien der Nordseewerke durch die Handelsfirma Heinrich Ende \& Co, Berlin, Juli - Oktober 1905

- Erwerb von Aktien der Nordseewerke durch die Stadt Emden, Juli 1905

- Beschluss des Magistrats zum Verkauf der Nordseewerke-Aktien der Stadt Emden, Juli - August 1905 / Februar 1907

- Kaufangebote für Aktien der Nordseewerke im Besitz der Stadt Emden, Juli 1905 - Juli 1907

- Tilgung der von der Stadt Emden zum Ankauf von

Nordseewerke-Aktien aufgenommenen Anleihen bei der

Ostfriesischen Sparkasse durch den Verkaufserlös der Aktien,

Oktober 1905

- Verkauf ihrer Aktien der Nordseewerke an die

Rheinisch-Westfälische Disconto-Gesellschaft, November 1905

- Kommissionsverkauf von im Besitz der Stadt Emden befindlichen

Aktien der Nordseewerke durch die Emder Bank AG, September November 1905

- Übersicht über Erlös der Nordseewerkeaktien-Verkäufe der Stadt Emden, November - Dezember 1905

- Verkauf von im Besitz der Stadt Emden befindlichen Aktien der Nordseewerke an den Barmer Bankverein, Dezember 1905 -

September 1906

- Konzept einer Vorlage des Oberbürgermeisters Fürbringer über Verkaufsstopp von Aktien der Nordseewerke wegen besserer Zukunftsaussichten der Werft, Dezember 1905

- Verkauf von im Besitz der Stadt Emden befindlichen Aktien der Nordseewerke an die Firma Walter Hammerstein, Mühlheim, Juni 1905 - Dezember 1907

- Verhandlungen des Magistrats mit Paul G. Roer über sein Angebot zum Kauf von Nordseewerke-Aktien der Stadt Emden, Dezember 1906 - März 1907

- Beschluss eines Sanierungsplans durch die Generalversammlung der Nordseewerke, Oktober 1907

$1905-1907$

Klassifikation Teil B: 01467

Band: 8

Trägermaterial: Papier

Alte Reg.-Sig.: IV Ma 39

Bestell-Nr.: IV 01467 
05

\subsection{3}

05.03.09

05.03.09.01

05.03.09.01.03
Stadtverwaltung

Aufgabenbereiche der Stadtverwaltung

Wasser- und Schifffahrtssachen

Schifffahrts- und Schifffahrtsverkehrseinrichtungen

Werftanlagen

Lfd. Nr. Titel

Laufzeit

1462 Nordseewerke, Bd. 9

1904-1908

- Protokoll der Aufsichtsratssitzung der Nordseewerke über Angebot zum Bau von Heringsloggern, Finanzsituation und Raumbedarf der Werft, September 1904

- Boykott der Betriebseinweihungsfeier der Nordseewerke durch die Kollegien der Stadt Emden wegen nicht erfolgter formaler Einladung durch den Aufsichtsratsvorsitzenden Paul G. Roer, Januar 1905

- Angebote zum Ankauf von Nordseewerke-Aktien, April 1906 - Juli 1908

- Gedruckter Bericht der Kommission zur Prüfung der wirtschaftlichen und finanziellen Situation der Nordseewerke über Lage der Werft und Sanierungsvorschläge, August 1907

- Beteiligung der Stadt Emden an der Kapitalerhöhung bei den Nordseewerken, Dezember 1907

- Jahresbilanz der Nordseewerke, Juli 1907 / Juli 1908

- Plan der Herabsetzung des Grundkapitals der Nordseewerke zur

Gewinnung flüssiger Mittel zur Verlustabdeckung, Januar 1908

- Antrag der Nordseewerke auf hypothekarische Belastung ihres Grundbesitzes zur Sicherung der Forderungen ihrer Gläubiger, Juli 1908

- Aufnahme eines Wechselkredits durch die Stadt Emden bei der kgl. Seehandlung (Preußische Staatsbank) zur Finanzierung des Anteils der Stadt Emden an der Verlustabdeckung bei den Nordseewerken, Juli 1907 - Dezember 1908

- Beschlüsse des Magistrats über Beteiligung in Höhe von 150.000

Mark an eine Anleihe für die Nordseewerke, Juli 1908

- Aufstellung über Auftragslage der Nordseewerke, Januar - April 1908

- Einnahme und Ausgasbebilanz der Nordseewerke, 1908

$1904-1908$

Klassifikation Teil B: 01468

Band: 9

Trägermaterial: Papier

Alte Reg.-Sig.: IV Ma 39

Bestell-Nr.: IV 01468

1463 Nordseewerke, Bd. 10

- Korrespondenz des Magistrats mit potenziellen Investoren wegen

Zeichnung von Aktien der Nordseewerke

1903

Klassifikation Teil B: 01469

Band: 10

Trägermaterial: Papier

Alte Reg.-Sig.: IV Ma 39

Bestell-Nr.: IV 01469 
05

\subsection{3}

05.03.09

05.03.09.01

05.03.09.01.03
Stadtverwaltung

Aufgabenbereiche der Stadtverwaltung

Wasser- und Schifffahrtssachen

Schifffahrts- und Schifffahrtsverkehrseinrichtungen Werftanlagen

Lfd. Nr. Titel

Laufzeit

1464 Nordseewerke, Bd. 11

1902-1903

- Korrespondenz zwischen dem Generaldirektor der

Württembergischen Transportversicherung, Paul G. Roer, und dem

Ingenieur Hans L. Schultz über den Aufbau einer Großwerft in Emden

$1902-1903$

Klassifikation Teil B: 01470

Band: 11

Trägermaterial: Papier

Alte Reg.-Sig.: IV Ma 39

Bestell-Nr.: IV 01470

1465 Nordseewerke, Bd. 12

$1903-1910$

- Antrag des Magistrats bei der Landesversicherungsanstalt in Hannover auf Darlehen zur Finanzierung von Häusern für Werftarbeiter der Nordseewerke, März 1903

- Planung einer Werftarbeitersiedlung der Nordseewerke, April 1903 -

August 1906

- Vertrag zwischen der Stadt Emden und den Nordseewerken über

Erschließung eines Terrains im Königspolder auf Kosten der

Nordseewerke zum Bau einer Werftarbeitersiedlung, September 1906

- Bericht des Magistrats an den Regierungspräsidenten in Aurich über

Rechtsstandpunkt der Sicherstellung der Erschließungskosten für die

Werftarbeitersiedlung trotz Besitzrechte des preußischen Fiskus am

Königspolder, Januar 1907

- Kassierung der von den Nordseewerken eingesandten Wechsel zur Sicherstellung der Erschließungskosten, 1907 - 1910

$1907-1910$

Klassifikation Teil B: 01471

Band: 12

Trägermaterial: Papier

Alte Reg.-Sig.: IV Ma 39

Bestell-Nr.: IV 01471 
05

05.03

05.03.09

05.03.09.01

05.03.09.01.03
Stadtverwaltung

Aufgabenbereiche der Stadtverwaltung

Wasser- und Schifffahrtssachen

Schifffahrts- und Schifffahrtsverkehrseinrichtungen

Werftanlagen

Lfd. Nr. Titel

Laufzeit

1466 Nordseewerke, Bd. 13

$1908-1910$

- Bilanz der Nordseewerke, 1908

- Bericht des Magistrats an den Regierungspräsidenten in Aurich über Krise bei den Nordseewerken, Dezember 1908

- Konzept eines Schreibens der drei Hauptgläubiger der

Nordseewerke an den preußischen Minister der öffentlichen Arbeiten über Vorschläge von Maßnahmen der Staatshilfe zur Rettung der

Werft der Nordseewerke und ihrer Kreditfähigkeit, Januar 1909

- Ankaufsangebote für Aktien der Nordseewerke. Januar - Mai 1909

- Antrag des Aufsichtsrates der Nordseewerke an den preußischen

Minister der öffentlichen Arbeiten auf Erlaubnis der hypothekarischen

Belastung des von den Nordseewerken genutzten, in Erbpacht

erhaltenen fiskalischen Terrains im Königspolder zur Abwendung des

Konkurses, Februar 1909

- Stundung eines von der Stadt Emden für die Nordseewerke aufgenommenen Wechselkredits der kgl. Seehandlung (preußische

Staatsbank), Februar - März 1909

- Regulierung der Forderungen der Ottenser Maschinenfabrik gegen die Nordseewerke, März 1909

- Kündigung seiner Kredite an die Nordseewerke durch den Barmer

Bankverein, April 1909

- Stellungnahme der Rheinisch-Westfälischen Discontogesellschaft zum Plan der Stadt Emden zur Umwandlung der Schulden der Nordseewerke in eine Realhypothek auf das Betriebsvermögen, Mai 1909

- Schreiben des Magistrats an die Nordseewerke über Aufforderung zur Zahlung offen stehender Darlehen und Mietforderungen, Mai 1909

- Schreiben des Barmer Bankvereins an den Magistrat über

Einverständnis mit dem Plan der Stadt Emden und der Rheinisch-Westfälischen Discontogesellschaft als Mithauptgläubigerin über Kündigung der Hypotheken der Nordseewerke, August 1909

- Verhandlungen der Hauptgläubiger der Nordseewerke über Strategie zur Realisierung ihrer Schuldforderungen, Oktober 1909

- Verhandlungen der Stadt Emden mit der Fa. Seelman Gebrüder, Hamburg, über Verkauf des Schwimmdocks der Nordseewerke,

Dezember 1909 - Januar 1910

$1908-1910$

Klassifikation Teil B: 01472

Band: 13

Trägermaterial: Papier

Alte Reg.-Sig.: IV Ma 39

Bestell-Nr.: IV 01472 
05

\subsection{3}

05.03.09

05.03.09.01

05.03.09.01.03
Stadtverwaltung

Aufgabenbereiche der Stadtverwaltung

Wasser- und Schifffahrtssachen

Schifffahrts- und Schifffahrtsverkehrseinrichtungen

Werftanlagen

Lfd. Nr. Titel

Laufzeit

1467 Nordseewerke, Bd. 14

1908-1911

- Verhandlungen der Nordseewerke mit ihren Gläubigern zur Erzielung einer Vereinbarung der Hypothekarisierung von Verbindlichkeiten und der Stundung von Forderungen, Mai - September 1909

- Bilanz der Nordseewerke für 1908, Juni 1909

- Bericht des Kämmerers Gebest über Forderungen der Stadt Emden gegenüber den Nordseewerken, September 1909

- Antrag der Nordseewerke an ihre Hauptgläubiger auf Vorstreckung des Versicherungsbeitrags für ihre Kraftstation, September 1909

- Vom Aufsichtsrat der Nordseewerke vorgeschlagener

Sanierungsplan für die Nordseewerke auf Basis einer neuen

Kapitalspritze, September 1909

- Verhandlungen der Hauptgläubiger der Nordseewerke über

Möglichkeit des Verkaufs der Werft an eine Investorengruppe,

Oktober 1909 - September 1911

- Beschluss der Kommission für die Nordseewerke über Ablehnung eines Plans des Barmer Bankvereins zur Gewinnung eines Investors für die Nordseewerke wegen Verluste für die Stadt Emden und über Stellung eines Konkursantrages über das Vermögen der Nordseewerke bei Nichterfüllung städtischer Forderungen, Oktober 1909

- Eröffnung des Konkursverfahrens gegen die Nordseewerke auf Antrag des Magistrats der Stadt Emden, Oktober 1909 - April 1911 - Bericht des Syndicus Leinberger über Verhandlungen mit verschiedenen potenziellen Investoren wegen Verkauf der Nordseewerke, März 1910

$1908-1911$

$1908-1911$

Klassifikation Teil B: 01473

Band: 14

Trägermaterial: Papier

Alte Reg.-Sig.: IV Ma 39

Bestell-Nr.: IV 01473 
05

\subsection{3}

05.03.09

05.03.09.01

05.03.09.01.03
Stadtverwaltung

Aufgabenbereiche der Stadtverwaltung

Wasser- und Schifffahrtssachen

Schifffahrts- und Schifffahrtsverkehrseinrichtungen

Werftanlagen

Lfd. Nr. Titel

Laufzeit

1468 Nordseewerke, Bd. 15

1910-1911

- Anfrage des Oberingenieurs Philipp von Klitzing aus Kiel nach den Konditionen zum Erwerb der Nordseewerke wegen Absicht des

Aufbaus einer Werft, Juni 1910

- Verhandlungen des Barmer Bankvereins als einer der

Hauptgläubiger der Nordseewerke mit dem Oberingenieur P. von

Klitzing wegen Pachtung der Weftanlage und des Schwimmdocks, Juli

- August 1910

- Verhandlungen der Hauptgläubiger der Nordseewerke mit der Fa.

August Klönne, Dortmund, über Pachtung der Werftanlagen, April

1911

- Angebot des Oberingenieurs P. von Klitzing als Chef der

Howaldtswerke über Kauf der Nordseewerke für 600.000 Mark, Juli -

August 1911

- Schreiben des Generalkonsuls John Kothe, Hamburg an der

Oberbürgermeister Fürbringer über Suche nach Investoren für die

Nordseewerke, Februar - Juli 1910

- Schreiben des Generalkonsuls John Kothe, Hamburg, über Konzept der Gründung einer Groß-Rheederei in Verbindung mit den

Nordseewerken zur Sicherung einer Grundauslastung für die Werft, August 1910

$1910-1911$

Klassifikation Teil B: 01474

Band: 15

Trägermaterial: Papier

Alte Reg.-Sig.: IV Ma 39

Bestell-Nr.: IV 01474

1469 Nordseewerke, Bd. 16

1907-1909

- Verhandlungen des Magistrats mit der Sparkasse des Landkreises Emden und der Ostfriesischen Sparkasse in Aurich über Abwicklung der Anleihen für die Nordseewerke, Oktober 1907 - Juni 1908

- Berichte des Magistrats der Stadt Emden an den

Regierungspräsidenten in Aurich über Liquiditätskrise der

Nordseewerke und Sanierungsverhandlungen, Juni 1908

- Verhandlungen der städtischen Kollegien über Sanierung der

Nordseewerke, Juni 1908

- Aufnahme von Wechselkrediten bei der kgl. Seehandlung (preußische Staatsbank) durch die Stadt Emden zum Erhalt der

Zahlungsfähigkeit der Nordseewerke, Juni 1908

- Hypotekarische Belastung der Werftanlage wegen der

Liquiditätskredite, Juli 1908 - August 1909

$1907-1909$

Klassifikation Teil B: 01475

Trägermaterial: Papier

Alte Reg.-Sig.: IV Ma 39

Bestell-Nr.: IV 01475 
05

\subsection{3}

05.03.09

05.03.09.01

05.03.09.01.03
Stadtverwaltung

Aufgabenbereiche der Stadtverwaltung

Wasser- und Schifffahrtssachen

Schifffahrts- und Schifffahrtsverkehrseinrichtungen

Werftanlagen

Lfd. Nr. Titel

Laufzeit

1470 Nordseewerke, Bd. 17

1910-1911

- Verhandlungen des Oberbürgermeisters Fürbringer mit dem Ingenieur H. Dammann wegen Vermittlung von Käufern für die Nordseewerke, August - September 1910

- Verhandlungen der Werftkommission wegen Vermitlungsdienste des Ingenieurs Dammann zum Verkauf der Nordseewerke, August 1910

- Korrespondenz des Magistrats mit den anderen Hauptgläubigern der Nordseewerken wegen Vermittlung eines Verkaufs der

Nordseewerke, September 1910

- Berichte des Ingenieurs Dammann über Vermittlungsbemühungen zum Verkauf der Nordseewerke, November 1910 - Juni 1911

- Verhandlungen der Hauptgläubiger der Nordseewerke über

Festsetzung eines Verkaufspreises für die Nordseewerke, Juni -

Oktober 1911

- Kaufangebot des Chemikers und Fabrikanten Dr. Arnold Rahtjes aus

Hamburg für die Nordseewerke, September - Oktober 1911

$1910-1911$

Klassifikation Teil B: 01476

Band: 17

Trägermaterial: Papier

Alte Reg.-Sig.: IV Ma 39

Bestell-Nr.: IV 01476

1471 Nordseewerke, Bd. 18

- Eintragung von Hypotheken in das Schiffsregister auf die Hebeschute und das Schwimmdock der Nordseewerke und von Hypotheken auf den Grundbesitz der Werft

1910

\author{
Klassifikation Teil B: 01477 \\ Band: 18 \\ Trägermaterial: Papier \\ Alte Reg.-Sig.: IV Ma 39 \\ Bestell-Nr.: IV 01477
}

1472 Nordseewerke, Bd. 19

- Weiterbeschäftgung der technischen Angestellten bei den in Konkurs geratenen Nordseewerken, November 1909 - Mai 1910

- Arbeitsunfall des Maschinenmeisters Gustav Notke, 1911

$1909-1911$

Klassifikation Teil B: 01478

Band: 19

Trägermaterial: Papier

Alte Reg.-Sig.: IV Ma 39

Bestell-Nr.: IV 01478 
- Organisation und Kostenträgerschaft der Instandhaltung der Anlagen und Gebäude der insolventen Nordseewerke

$1910-1911$

Klassifikation Teil B: 01479

Band: 20

Trägermaterial: Papier

Alte Reg.-Sig.: IV Ma 39

Bestell-Nr.: IV 01479

- Protokolle der Verhandlungen der vom Magistrat eingerichteten Werftkommission über Regelung des Betriebs der insolventen Nordseewerke und des Verkaufs oder der Verpachtung der Werft sowie Abwicklung des Konkursverfahrens

$1910-1911$

Klassifikation Teil B: 01480

Band: 21

Trägermaterial: Papier

Alte Reg.-Sig.: IV Ma 39

Bestell-Nr.: IV 01480

- Verhandlungen des Oberbürgermeisters Fürbringer mit dem Oberingenieur Sombeck aus Nordenham wegen einer Verpachtung der Nordseewerke, Juli - September 1911

- Stellungnahme der übrigen Hauptgläubiger der Nordseewerke zu den Verhandlungen Fürbringers, Juli - September 1911

1911

Klassifikation Teil B: 01481

Band: 22

Trägermaterial: Papier

Alte Reg.-Sig.: IV Ma 39

Bestell-Nr.: IV 01481 
05

\subsection{3}

05.03.09

05.03.09.01

05.03.09.01.03
Stadtverwaltung

Aufgabenbereiche der Stadtverwaltung

Wasser- und Schifffahrtssachen

Schifffahrts- und Schifffahrtsverkehrseinrichtungen

Werftanlagen

Lfd. Nr. Titel

Laufzeit

1476 Nordseewerke, Bd. 23

1911

- Geheimes Schreiben der Kaiserlichen Werft in Wilhelmshaven über Absicht der Inbetriebnahme der Werftanlagen der Nordseewerke durch die Marinewerft als Reparaturwerft für Kriegsfahrzeuge bei Ausbruch eines Krieges, März 1911

- Angebot des Oberbürgermeisters Fürbringer an die Marinewerft zur Pachtung bzw. Erwerb der Nordseewerke, März 1911

- Antrag des Magistrats an Großadmiral Alfred von Tirpitz,

Staatsminister des Reichsmarineamts, auf Vergabe von

Marineaufträgen an die Nordseewerke, September - Dezember 1911

1911

Klassifikation Teil B: 01482

Band: 23

Trägermaterial: Papier

Alte Reg.-Sig.: IV Ma 39

Bestell-Nr.: IV 01482

1477 Nordseewerke, Bd. 24

$1911-1912$

- Verhandlungen der Werftkommission über Stand der Gespräche zum Verkauf der Nordseewerke, Oktober 1911

- Verhandlungen des Magistrats mit den übrigen Hauptgläubigern der Nordseewerken über Erstattung der von ihr vorgeschossenern Gelder zur Aufrechterhaltung des Werftbetriebs, Oktober 1911

- Vertrag über Verkauf der Nordseewerke an den Industriellen Hugo Stinnes als Vertreter des anonymen Käufers

(Deutsch-Luxemburgische Bergwerks- und Hüttengesellschaft),

Oktober 1911

- Schreiben des Industriellen Hugo Stinnes an Oberbürgermeister

Fürbringer über Bitte um Wahrung der Anonymität des Käufers der Nordseewerke und Regelung des Werftbetriebs während der Übergangsphase, Oktober 1911

- Übergabe der Nordseewerke an den Oberingenieur Philipp von Klitzing als den vom Käufer eingesetzten Wertftdirektor, November 1911

- Bericht der Rhein-Ems-Zeitung über den Erwerb der Nordseewerke durch die Deutsch Luxemburgische Bergwerks- und Hütten AG,

Dezember 1911

- Abwicklung der Kaufpreiszahlung, Dezember 1911 - Januar 1912

$1911-1912$

Klassifikation Teil B: 01483

Band: 24

Trägermaterial: Papier

Alte Reg.-Sig.: IV Ma 39

Bestell-Nr.: IV 01483 
- Erstattung der von der Stadt Emden vorgeschossenen Gelder zur Sicherstellung des Betriebs bei den Nordseewerken von den beiden Hauptgläubigerbanken (Barmer Bankverein, Rheinisch-Westfälische Discontogesellschaft), 1912 - 1913

- Verhandlungen der Werftkommission über Schlussabrechnung der Nordseewerke, März - Juni 1912

- Prüfung der Schlussabrechnung auf Drängen der Hauptgläubigerbanken der Nordseewerke, November - Dezember 1912

- Klage der Hauptgläubigerbanken der Nordseewerke gegen die Stadt Emden beim Landgericht Aurich auf Zahlung von 8.000 Mark als jeweiligen Anteil an der Überschusssumme der Abschlussrechnung, September 1913

$1912-1913$

Klassifikation Teil B: 01484

Band: 25

Trägermaterial: Papier

Alte Reg.-Sig.: IV Ma 39

Bestell-Nr.: IV 01484

- Bilanzierung der zur Sicherung des Betriebs der Nordseewerke zu leistenden Vorschüsse der Hauptgläubiger

- Betriebsbilanz der Nordseewerke

$1911-1913$

Klassifikation Teil B: 01485

Band: 26

Trägermaterial: Papier

Alte Reg.-Sig.: IV Ma 39

Bestell-Nr.: IV 01485 
05

\subsection{3}

05.03.09

05.03.09.01

05.03.09.01.03
Stadtverwaltung

Aufgabenbereiche der Stadtverwaltung

Wasser- und Schifffahrtssachen

Schifffahrts- und Schifffahrtsverkehrseinrichtungen

Werftanlagen

Lfd. Nr. Titel

Laufzeit

1480 Nordseewerke, Bd. 27

1910-1912

- Verfügung des Regierungspräsidenten in Aurich über Einsetzung der Hauptgläubiger der Nordseewerke (Stadt Emden, Barmer Bankverein, Rheinisch-Westfälische Discontogesellschaft) in die Erbpacht über das Terrain der Nordseewerke, April 1910

- Erbpachtvertrag zwischen der preußischen Staatsregierung und den Hauptgläubigern der Nordseewerken über das Terrain der

Nordseewerke, Oktober 1910

- Verteilung der Erbpachtszahlungen auf die Hauptgläubiger der Nordseewerke, Juni - September 1910

- Memorial des Syndicus Leinberger über Erbpacht als Hindernis zum Verkauf der Nordseewerke, August 1910

- Verhandlungen der Werftkommission über Erbpachtsproblem der Nordseewerke, Juni 1910 - Januar 1911

- Zahlung der Erbpachtszinsen durch die drei Hauptgläubiger der Nordseewerke, 1910 - 1911

- Antrag des Magistrats beim Regierungspräsidenten in Aurich auf Ermäßigung oder Stundung der Erbpachtzinszahlungen zur

Erleichterung des Verkaufs der Nordseewerke, Juli - August 1911

- Erlass des preußischen Mlnisters der öffentlichen Arbeiten über Ablehnung einer Ermäßigung, Oktober 1911

- Verfügung des Regierungspräsidenten in Aurich über Anordnung der Zahlung der Erbpachtzinsraten bis zum Übergang der Nordseewerke an die Deutsch Luxemburgische Bergwerksgesellschaft und Hüttenwerke und des Eintritts des neuen Besitzers in den Erbpachtsvertrag, November 1911 / März 1912

$1910-1912$

Klassifikation Teil B: 01486

Band: 27

Trägermaterial: Papier

Alte Reg.-Sig.: IV Ma 39

Bestell-Nr.: IV 01486

1481 Nordseewerke, Bd. 28

$1910-1911$

- Verhandlungen zur Erzielung eines Vertrages zwischen der Stadt Emden, dem Barmer Bankverein und der Rheinisch-Westfälischen Discontogesellschaft als Hauptgläubiger der Nordseewerke über gemeinsarnen Erwerb der Werft, Oktober 1910 - Januar 1911

$1910-1911$

Klassifikation Teil B: 01487

Band: 28

Trägermaterial: Papier

Alte Reg.-Sig.: IV Ma 39

Bestell-Nr.: IV 01487 
05

05.03

05.03.09

05.03.09.01

05.03.09.01.03
Stadtverwaltung

Aufgabenbereiche der Stadtverwaltung

Wasser- und Schifffahrtssachen

Schifffahrts- und Schifffahrtsverkehrseinrichtungen

Werftanlagen

Lfd. Nr. Titel

Laufzeit

1482 Nordseewerke, Bd. 29

1910-1911

- Abwicklung der Zahlung von Versicherungsbeiträgen zur

Aufrechterhaltung des Versicherungsschutzes der Betriebsanlagen

der im Konkurs befindlichen Nordseewerke

- Verlängerung von Versicherungsverträgen zur Aufrechterhaltung des

Versicherungsschutzes der Betriebsanlagen der im Konkurs

befindlichen Nordseewerke

$1910-1911$

Klassifikation Teil B: 01488

Band: 29

Trägermaterial: Papier

Alte Reg.-Sig.: IV Ma 39

Bestell-Nr.: IV 01488

1483 Nordseewerke, Bd. 30

$1910-1911$

- Plan des Schwimmdocks der Nordseewerke, 1910

- Schreiben des Prof. Ing. Hans Diekhoff an Oberbürgermeister

Fürbringer über Ansprüche gegen die Nordseewerke wegen der

Verwendung seiner Patente beim Bau des Schwimmdocks, August

1910

- Verhandlungen der Werftkommission über Frage der Anerkennung

der Ansprüche des Prof. Diekhoff, August 1910 - Juli 1911

- Patentrechtsgutachten zugunsten der Nordseewerke, Dezember

1910

$1910-1911$

Klassifikation Teil B: 01489

Band: 30

Trägermaterial: Papier

Alte Reg.-Sig.: IV Ma 39

Bestell-Nr.: IV 01489

1484 Übernahme der Nordseewerke durch die Deutsch-Luxemburgische Bergwerks- und Hütten AG, Bd. 1

- Verkauf eines Deichstückes an die Nordseewerke zur Erweiterung des Betriebsgeländes, Dezember 1911

- Presseberichterstattung über die Übernahme der Nordseewerke durch die Deutsch-Luxemburgische Bergwerks- und Hütten AG des Ruhrindustriellen Hugo Stinnes, 1912

- Nachricht über die Einstellung des Oberingenieurs Dr. Schmidt als Direktor der Nordseewerke nach dem Ausscheiden des Direktors von Klitzing, Dezember 1912

$1911-1912$

Klassifikation Teil B: 02136

Band: 1

Trägermaterial: Papier

Alte Reg.-Sig.: IV T6 183

Bestell-Nr.: IV 02136 
IV

05

05.03

05.03.09

05.03.09.01

05.03.09.01.03

Lfd. Nr. Titel
Stadtverwaltung

Aufgabenbereiche der Stadtverwaltung

Wasser- und Schifffahrtssachen

Schifffahrts- und Schifffahrtsverkehrseinrichtungen

Werftanlagen

Laufzeit

1913-1917

1485 Übernahme der Nordseewerke durch die Deutsch-Luxemburgische

Bergwerks- und Hütten AG, Bd. 2

- Eintragung der Übernahme der Nordseewerke durch die

Deutsch-Luxemburgische Bergwerks- und Hütten AG in das

Handelsregister, Januar - Februar 1913

- Veränderungsmitteilungen betr. Nordseewerke aus dem

Handelsregister, Oktober 1913 - Dezember 1917

- Geschäftsberichte der Deutsch-Luxemburgischen Bergwerks- und

Hütten AG mit Angaben zu den Nordseewerken, 1913 - 1917

- Zur Teilnahme an der Hauptversammlung der

Deutsch-Luxemburgischen Bergwerks- und Hütten AG angemeldete

Aktionäre, November 1914 - Oktober 1917

$1913-1917$

Klassifikation Teil B: 02137

Band: 2

Trägermaterial: Papier

Alte Reg.-Sig.: IV T6 183

Bestell-Nr.: IV 02137 
IV

05

\subsection{3}

05.03.09

05.03.09.02
Stadtverwaltung

Aufgabenbereiche der Stadtverwaltung

Wasser- und Schifffahrtssachen

Pegelkommission

Lfd. Nr. Titel

Laufzeit

1486 Pegel- und Windverhältnisse auf Nesserland

1898-1899

- Jahresbericht des Schleusenmeisters W. de Haan über

Pegelstände, Windverhältnisse und Schiffsverkehr bei der

Nesserlander Schleuse

$1898-1899$

Klassifikation Teil B: 01511

Trägermaterial: Papier

Alte Reg.-Sig.: IV Mb 1

Bestell-Nr.: IV 01511

1487 Pegel-Directions-Commission

1866-1883

- Konstituierung und Aufgaben der Pegel-Directions-Commission, Juni

(1844-1865)

- Dezember 1854

- Verfügungen des Magistrats der Stadt Emden über Kontrolle und Markierung des Fahrwassers im Faldern- und Rathausdelft, 1844 /

1851

- Aufteilung der Kosten für die Aufgaben der Pegelkommission

zwischen der Stadt Emden und den Sielachten im Emder Stadtgebiet, April 1855 - März 1875

- Streit zwischen der Pegelkommission und dem Magistrat wegen dessen Anordnung zur Schließung der Schleusentore trotz Ebbe und hohem Binnenwasserstand zur Erzielung einer besseren Spülwirkung zur Entschlammung der Fahrrinnen, Januar - Februar 1861

- Konflikt zwischen der Pegelkommission und dem Magistrat wegen dessen Duldung einer zu dichten Zusammendrängung von

Torfschiffen auf den Emder Binnerntiefen, 1865 - 1866

- Pegelmessung der Emder Binnentiefs, Juni 1870

- Konflikt zwischen der Pegelkommission und der Stadt Emden wegen unterbliebener Ausräumung der Binnentiefs, November 1870 - März

1872

- Bestätigung der Wahl der Mitglieder der Pegelkommission durch den preußischen Landrosten in Aurich, August 1871- Juni 1875

- Einberufung der Versammlungen der Pegelkommission, 1872 - 1882

- Verschiedene Beschwerden von Schiffern an den Magistrat wegen zu geringer Wassrstände in den Delften und Binnentiefs aufgrund der Öffnung der Siel- und Schleusentore, März 1883

(1844 - 1865) $1866-1883$

Klassifikation Teil B: 01512

Trägermaterial: Papier

Alte Reg.-Sig.: IV Mb 2

Bestell-Nr.: IV 01512 
IV

05

05.03

05.03.09

05.03.09.03
Stadtverwaltung

Aufgabenbereiche der Stadtverwaltung

Wasser- und Schifffahrtssachen

Siele, Verlaate und Kajungen

Lfd. Nr. Titel

Laufzeit

1488 Verlaate

- Unerlaubtes Öffnen der "Speyter" von Verlaaten durch

(1832-1864)

Verlaatswärter zur Durchfahrt der Torfschiffe, 1832

- Beschwerde des Sielrichters Iderhoff wegen unerlaubten Öffnen von

Verlaaten durch Schiffer während der Einleitung von Seewasser, Juli 1838

- Forderungen der Witwe des Verlaatswärters Klaas Meints Klaassen wegen noch nicht beglichener Honorare für das Öffnen und Schließen des Larrelter Verlaats, Dezember 1839 - Januar 1840

- Instruktionen für die Verlaatswärter, Juli 1859

- Bewerbung des Wilm Tromp um die Stelle des Verlaatswärters beim Verlaat am Boltentor mit Dienstwohnung, Oktober 1863

- Vereidigung der Verlaatswärter Geike Jacobs und Hindrich Daniels, Mai 1864

- Streit zwische Magistrat und Pegelkommission wegen Zustellung des Larrelter Verlaats, März 1866

- Konflikt des Magistrats mit dem kgl. Wasserbauamt wegen dessen Anordnung zur Beseitigung der Emder Verlaate zur Verbesserung der Abwässerung, April - September 1890

- Eingabe der Witwe Anna Bartmann, Verlaatswärterin des Larrelter Verlaats, an die Stadt Emden über Bitte um Unterstützung wegen ungenügendem Verdienst in Folge zurückgehender Kanalschifffahrt, September 1888 - August 1891

(1832 - 1864) $1866-1891$

Klassifikation Teil B: 01516

Trägermaterial: Papier

Alte Reg.-Sig.: IV Md 6

Bestell-Nr.: IV 01516

1489 Sielpflichtige Grundstücke zur Falden-, Gastgaus und

$1883-1884$ Neupfortssielacht

- Bedingungen für die Veranlagung der Sielpflichtigen zum

Sielachtsbeitrag, 1883

- Verfügung des preußischen Landdrosten in Aurich über Anordnung der Angabe des Flächenumfangs der Emder Sielachten, März 1884

- Verfügung des kgl. Sielamts über Auslegung der Sielrollen, Juni 1884

$1883-1884$

Klassifikation Teil B: 01518

Trägermaterial: Papier

Alte Reg.-Sig.: IV Md 8

Bestell-Nr.: IV 01518 
05

05.03

05.03.09

05.03.09.04
Stadtverwaltung

Aufgabenbereiche der Stadtverwaltung

Wasser- und Schifffahrtssachen

Wasserläufe

Lfd. Nr. Titel

Laufzeit

1490 Reinigung der Stadtgräben

- Rechtsstandpunkt der Stadt Emden, dokumentiert durch verschiedene Abschriften von Dokumenten aus dem 18. Jahrhundert, im Streit mit den Sielinteressenten wegen der Reinigung der Stadtgräben, 1841 - 1843

- Streit zwischen dem Magistrat und den Hannoverschen Wasserbaudirektor Kettler wegen der behaupteten Verantwortung des städtischen Schließbaums am Wolthuser Tief für die Verschlammung des Gewässers, 1841 - 1843

- Verfügungen des Hannoverschen Landdrosten in Aurich an die Stadt Emden über Aufforderung zur Ausbaggerung der Sieltiefe im Stadtgebiet zur Verbesserung der Entwässerung, 1841 - 1843

- Besichtigung der Stadtsiele durch den Hannoverschen

Wasserbaudirektor Kettler, 1841 - 1843

- Verschlammung des "toten Tiefs" beim Herrentor, April 1846

- Organisation und Verdingung der Ausbaggerung der Emder

Stadtgräben und Abtransport der Schlickmassen, 1853

- Berichte des Stadtbaumeisters Berg über notwendige

Ausbaggerungen, 1851 - 1854

- Pegelungen der Stadtgräben, (1853 - 1855) 1868 - 1874

- Beschluss der städtischen Kollegien über Vorgehen gegen das

Einwerfen von Abfällen in die Kanäle, August 1867

- Schreiben der Pegelkommision an den Magistrat über Empfehlung der Baggerungen der Stadtgräben zur Einhaltung der vorgeschriebenen Pegeltiefe, November 1867 - September 1874 - Beschwerden wegen Verschlammung des Gasthaussieltiefs, September 1871

- Polizeiverordnung des preußischen Landdrosten in Aurich über Verbot des Einwerfens von Erde und Unrat in Wasserläufe und Kanäle, September 1871

- Schreiben des Magistrats an das kgl. Sielamt über Bitte um Anordnung der Reparatur des Gasthaussiels und des Neupfortssiels, Juli 1873

- Undichtigkeit des Faldern- und Gashaussiels als Ursache für Verschlammung, Juni 1870

- Beschwerden wegen Verschlammung des Judentiefs, Mai 1910

(1841 - 1855) 1867 - 1910

Klassifikation Teil B: 01519

Trägermaterial: Papier

Alte Reg.-Sig.: IV Me 09

Bestell-Nr.: IV 01519 
05

05.03

05.03.09

05.03.09.04

IV

\section{Stadtverwaltung}

\section{Aufgabenbereiche der Stadtverwaltung}

Wasser- und Schifffahrtssachen

Wasserläufe

Lfd. Nr. Titel

Laufzeit

1491 Bau einer Brücke neben der Jungfernbrücke

- Antrag der Fa. Brill \& Harms beim Magistrat auf Erweiterung der Jungfernbrücke zur Verbesserung der Zufahrt zu ihrem Grundstück, August 1872

- Vereinbarung zwischen der Stadt Emden und der Fa. Brill \& Harms zum Bau einer Nebenbrücke zur Jungfernbrücke, Oktober 1872

$1872(1888)$

Klassifikation Teil B: 01520

Trägermaterial: Papier Alte Reg.-Sig.: IV Me 18

Bestell-Nr.: IV 01520 
05

05.03

05.03.09

05.03.09.04
Stadtverwaltung

Aufgabenbereiche der Stadtverwaltung

Wasser- und Schifffahrtssachen

Wasserläufe

Lfd. Nr. Titel

Laufzeit

1492 Zuschüttung von Gewässern

- Votum des Landphysicus und Medizinalrats Dr. Stöhr für die

Zuschüttung des Stinktiefs und seiner Nebenarme wegen

Verschlammung und Seuchengefahr, Januar 1867

- Verhandlungen des Magistrats und der Baukomission über

Maßnahmen zur Beseitigung der Nebenarme des Stinktiefs, 1867

- Berichte des Magistrats an den preußischen Landdrosten in Aurich über Fortgang der Verhandlungen mit den Anliegern des Stinktiefs und der Großen Ee wegen der Zuschüttung und Kanalisierung der Gewässer sowie über den Fortgang der Arbeiten, Februar 1867 - Mai 1868

- Gutachten des Landphysicus und Medizinalrats Dr. Stöhr über Verschlammung und Verseuchung der Großen Ee mit Fäkalien und Notwendigkeit der Zuschüttung und Riolisierung (Kanalisierung), Mai 1865

- Weigerung der Anlieger der Großen Ee zur Kostenträgerschaft der Kanalisierung, April 1868

- Verhandlungen der städtischen Kollegien über Organisation der Kanalisierung der Großen Ee und Kostenträgerschaft, Februar 1868

- Denkschrift des Dr Prestel über gesundheitliche Folgen der

Ausdünstungen der Großen Ee, Februar 1868

- Verfügung des Magistrats an die Anlieger der Großen Ee über Anordnung der Beseitigung der in die Ee einmündenden Aborte, August 1868

- Beschwerde des Vorstands der Großen Ee über Qualität der Riole, September 1868

- Berichte des Vorstands der Großen Ee über Mängel an der Riole, März / September 1869

- Streit um die Beteiligung der Anlieger der Großen Ee an den Kosten der Riole, 1868 - 1896

- Beitreibung der Beiträge zur Unterhaltung der Riole, 1870 - 1887

- Verfügung des Magistrats an den Vorstand der Großen Ee über Anordnung zur Beseitigung baulicher Mängel an der Riole, Juli 1876 / Juni 1878

- Missstände im Vorstand der Großen Ee, April - November 1881

- Übersicht über an der Riole an der Großen Ee beteiligten Häuser, 1882

1867 - 1896 (1906 - 1907)

Klassifikation Teil B: 01521

Trägermaterial: Papier

Alte Reg.-Sig.: IV Me 19

Bestell-Nr.: IV 01521 
IV

05

05.03

05.03.09

05.03.09.04
Stadtverwaltung

Aufgabenbereiche der Stadtverwaltung

Wasser- und Schifffahrtssachen

Wasserläufe

Lfd. Nr. Titel

Laufzeit

1493 Reinigung der Binnentiefs und der Stadtgräben

- Baufälligkeit der Kajungen am Gasthaussiel, 1841

(1841-1844)

- Protokoll der Besichtigung der Emder Stadtsiele wegen Hindernisse der Abwässerung, Mai 1842 / Oktober 1842 / Februar 1843

- Feststellung der Unzulässigkeit der Schaffung (Anpolderung) der Hahn'schen Insel, Oktober - Dezember 1878

- Planzeichnung der Hahn'schen Insel, 1878

- Genehmigung der durch Louis Hahn vorgenommenen Anpflanzung von Linden auf der Schusterinsel, Oktober 1882

- Verunreinigung des Burggrabens in der Nähe des Kattewalls durch Schutt, Juni 1888

(1841 - 1844) 1878 - 1888

Klassifikation Teil B: 01522

Trägermaterial: Papier

Alte Reg.-Sig.: IV Me 06

Bestell-Nr.: IV 01522

1494 Reinigung der Binnentiefs und Stadtgräben

1875-1901

- Verbreiterung des Stadtgrabens, 1835 - 1838

(1835-1846)

- Reinigung der Binnenkanäle der Stadt Emden, 1837

- Rescript des kgl. Hannoverschen Amts und Wasserbauinspektion an den Magistrat über Anordnung der Entschlammung des

Neupfortssiels, Mai 1838

- Anordnung des Magistrats über Beseitigung des Schilfs im Hinter

Tief durch die Anlieger, Mai 1838

- Verfügung des Hannoverschen Landdrosten in Aurich über

Anordnung der Entschlammung des Falderndelfts und des Roten

Siels, November 1838

- Bericht des kgl. Wasserbaudirektors Kettler über Verschlammung der Emder Binnenkanäle und des Hafens wegen nachlässiger

Reinigung durch die Stadt Emden, Juli 1839

- Pegelungen der Binnentiefs, 1838 - 1840

- Beschwerden über Verschlammung der Stadtgräben, 1875

- Sperrung des Sieltiefs zwischen dem Roten Siel und dem

Burggraben, Oktober 1886

- Verfügung des kgl. Sielamts über Anordnung zur Beseitigung eines

Damms bei der Mündung des Stadtgrabens in das Wolthuser Tief,

Dezember 1897 - März 1898

- Antrag des L. Katzenstein auf Erlaubnis zum Bau einer Brücke über den Stadtgraben bei der Roten Mühle, April - Mai 1901

(1835 - 1840) 1875 - 1901

Klassifikation Teil B: 01523

Trägermaterial: Papier

Alte Reg.-Sig.: IV Me 08

Bestell-Nr.: IV 01523 
05

\subsection{3}

05.03.09

05.03.09.04
Stadtverwaltung

Aufgabenbereiche der Stadtverwaltung

Wasser- und Schifffahrtssachen

Wasserläufe

Lfd. Nr. Titel

Laufzeit

1495 Zuschüttung von Gewässern

- Kostenvoranschlag: Zuschüttung der Seitengräben des Stinktiefs,

Juli 1867

- Schreiben des Syndicus Metger an den Bürgervorsteher J. E. Ennen über Notwendigkeit der Kanalisierung des Stinktiefs und seiner Seitengräben nach einem vom Landdrosten angeforderten Gutchten des Kreisphysicus Dr. Stöhr, September 1867

- Beschluss der Anlieger des Stinktiefs und seiner Seitengräben über Mitkostenträgerschaft der Kanalisierung, Oktober 1867

- Vorlage des Syndicus Metger über Vorgehen bei der Kanalisierung und Heranziehung der Anlieger zu den Kosten, Februar 1868

- Verfügungen des Magistrats über Heranziehung der Anlieger zu den Kanalisierungskosten, Mai 1868 - September 1869

- Angebot der Anlieger wegen der Kostenträgerschaft für die Kanalisierung, Januar - März 1869

- Verhandlungen des Magistrats mit den Anliegern wegen Kostenträgerschaft für die Kanalisierung, April - September 1869

- Beitreibung der Kanalbeiträge, 1869 -1874

- Visitation der Aborte der Häuser in der Kranstr. und der Mühlenstr durch den Polizeisergeanten Wildhagen, Oktober 1870

- Verfügung des Magistrats als Umsetzung eines Erlasses des Innenministers über Anordnung des Baus wasserdichter Aborte und Sammlung der Fäkalien in wasserdichten Tonnen zur Verhinderung von Seuchen, Oktober - Dezember 1870

- Kostenaufstellung wg. Kanalisierung des Stinktiefs, 1870 - 1873

- Genehmigung der Benutzung des Gangs zwischen Kranstr. und Mühlenstr.,Oktober 1893

$1867-1893$

Klassifikation Teil B: 01524

Trägermaterial: Papier

Alte Reg.-Sig.: IV Me 19

Bestell-Nr.: IV 01524

1496 Kajung des Dr. Rodewyk am Graupferdstief

1876-1880

(1843)

- Baufälligkeit der Kajung des Dr. Rodewyk am Graupferdstief, (1843)

1876 - 1877

- Widerspruch der Witwe des Dr. Johann Theodor Rodewyk gegen die Verfügung der Stadt Emden über Anordnung der Rückverlegung der

Kajung, April 1877

- Streit um die Grenzlinie des Rodewyk'schen Grundstücks am

Graupferdstief, März - Juni 1877

- Beseitigung der Pfähle vor der Rodewyk'schen Kajung wegen

Schifffahrtsbeeinträchtigung, April - August 1880

(1843) 1876 - 1880

Klassifikation Teil B: 01526

Trägermaterial: Papier

Alte Reg.-Sig.: IV Me 21

Bestell-Nr.: IV 01526 
IV

05

05.03

05.03.09

05.03.09.04
Stadtverwaltung

Aufgabenbereiche der Stadtverwaltung

Wasser- und Schifffahrtssachen

Wasserläufe

Lfd. Nr. Titel

Laufzeit

1497 Osterpiepe (Brücke über den Brauersgraben zwischen Kleiner und 1870-1900 Großer Osterstr.)

- Kostenvoranschlag des Stadtbauaufsehers Giesberts für die Senkung der Osterpiepe, 1870

- Projektbeschreibung des Stadtbaumeisters Wiggers, 1878 / 1899

- Beschluss des Magistrats über Verteilung der Kostenträgerschaft zwischen den Anliegern der Osterpiepe und der Stadt Emden, März 1878

- Eingabe der Bewohner der Kleinen und Großen Oststraße an den Magistrat über Bitte um Abenkung der Osterpiepe zur Verbesserung der Passage der Osterstraße, Oktober 1880 / April 1895

- Brückengeländer für die Osterpiepe, 1900

- Autounfall auf der Osterpiepe und Beschädigung des Geländers, 1922

1870 - $1900(1921-1922)$

Klassifikation Teil B: 01527

Trägermaterial: Papier

Alte Reg.-Sig.: IV Me 22

Bestell-Nr.: IV 01527

1498 Reinhaltung des Grabens am Grünen Weg

- Antrag des Oberlehrers Dr. Lüpkes auf Kanalisierung des Grabens am Grünen Weg, Oktober 19025

- Verfügung des Regierungspräsidenten in Aurich an den Magistrat über Anordnung der Gewährleistung der Reinigung des Grabens, November 1902

- Verfügung des Magistrats an die Anlieger des Grabens über Anordnung zu dessen Reinigung, Dezember 1902

- Bericht der Baukommission über Anteil der Kanalisationskosten für die Anlieger des Grabens am Grünen Weg, April 1903

$1902-1903$

Klassifikation Teil B: 01528

Trägermaterial: Papier

Alte Reg.-Sig.: IV Me 24

Bestell-Nr.: IV 01528

1499 Absperrung dünner Eisflächen

- Diskussion einer Absperrung dünner Eisflächen, Januar 1912

- Warnung vor zu dünnem Eis auf dem Stadtgraben, Januar 1914

$1912-1914$

Klassifikation Teil B: 01531

Trägermaterial: Papier

Alte Reg.-Sig.: IV Me 36

Bestell-Nr.: IV 01531 
05

05.03

05.03.09

05.03.09.04

Lfd. Nr. Titel
IV

Stadtverwaltung

Aufgabenbereiche der Stadtverwaltung

Wasser- und Schifffahrtssachen

Wasserläufe

Laufzeit

1906-1908

- Beschwerde des Magistrats gegen den Bebauungsplan wegen

Beeinträchtigung der Emder Wasserläufe durch Einleitung ungeklärter

Abwässer durch die nicht geplante Klärungsmöglichkeit in Wolthusen

$1906-1908$

Klassifikation Teil B: 01532

Trägermaterial: Papier

Alte Reg.-Sig.: IV Me 38

Bestell-Nr.: IV 01532 
IV

05

05.03

05.03.09

05.03.09.05
Stadtverwaltung

Aufgabenbereiche der Stadtverwaltung

Wasser- und Schifffahrtssachen

Rats- und Falderndelft

Lfd. Nr. Titel

Laufzeit

1501 Kajungen an der Wester- und Osterbutvenne

- Unstatthafte Nutzung der Kajung beim Haus des Steinhauers G. F. Stockhorst an der Osterbutvenne als Steinlagerplatz und daherige Unbrauchbarkeit als Schiffsanlegemöglichkeit, Oktober 1876

- Instandsetzungsbedürftigkeit der Kajung an der Westerbutvenne, April 1901

$1876-1901$

Klassifikation Teil B: 01533

Trägermaterial: Papier

Alte Reg.-Sig.: IV Mf 07

Bestell-Nr.: IV 01533

1502 Streit um die Instandsetzung der Kajung "Hinter der Halle"

- Verfügung des Magistrats an den Kaufmann Hermann Cornelius van Jindelt über Anordnung der Instandsetzung der Kajung "Hinter der Halle", Januar 1901

- Bericht des Magistrats an den Regierungspräsidenten in Aurich über Rechtsstandpunkt der Stadt Emden in der Verwaltungsstreitsache mit Hermann Cornelius van Jindelt wegen Instandsetzung der Kajung "Hinter der Halle", Februar 1901

- Klage des Kaufmanns Hermann Cornelius van Jindelt gegen die Stadt Emden beim Bezirksausschuss in Aurich auf Aufhebung der Verfügung wegen Instandsetzung der Kajung "Hinter der Halle",

Februar 1901 - Oktober 1903

- Fotografie der betroffenen Kajung (Falderndelft), 1903

- Revisionsklage des Magistrats gegen das für van Jindelt günstige Urteil des Bezirksausschusses beim Oberverwaltungsgericht Berlin, Dezember 1903 - Januar 1906

$1901-1907$

Klassifikation Teil B: 01546

Trägermaterial: Papier

Alte Reg.-Sig.: IV Mf 13

Bestell-Nr.: IV 01546 
Lfd. Nr. Titel

- Verhandlungen des Magistrats mit Eigentümern von Privatkajungen wegen Abtretung der Kajungen an den Staat, Mai 1888 - September 1899

- Aufstellung über Besitzer von Kajungen an der Westerbutvenne, 1891

- Streitsache: Benutzung der Kajung "Hinter der Halle" als Lagerplatz durch den Blockmacher J. de Boer, Januar 1895 - März 1896

- Entwurf eines Berichtes des Magistrats an den

Regierungspräsidenten in Aurich über Beschreibung des

Kajungswesens in Emden, März 1897

- Bescheid des Regierungspräsidenten in Aurich über fehlendes öffentliches Interesse an einer Übernahme der Privatkajungen "Hinter der Halle" durch den Staat, Dezember 1898

- Kostenrechnungen des Stadtbaumeisters Wiggers für Reparatur der Privatkajungen, Dezember 1898 / Januar 1901

- Verhandlungen des Magistrats mit den Besitzern der Privatkajungen wegen Reparaturkostenträgerschaft, Januar - Juni 1899

- Anzeige des Hafenmeisters Zeemann gegen Hermann Cornelius van Jindelt und Kaufmann Kreutzberg wegen unstatthafter Benutzung ihrer Kajungen als Lagerplatz, Februar 1900

- Verfügungen des Magistrats an die Eigentümer der Privatkajungen "Hinter der Halle" über Anordnung zur Reparatur der Kajungen, Januar - April 1901

- Streit um die Eigentumsrechte an den Kajungen "Hinter der Halle", 1903

$1888-1903$

Klassifikation Teil B: 01547

Trägermaterial: Papier

Alte Reg.-Sig.: IV Mf 12

Bestell-Nr.: IV 01547

1504 Lagerung von Baumaterialien auf der Kajung an der Osterbutvenne

- Blockade der Kajung an der Osterbutvenne für den Schiffsverkehr durch die Lagerung von Holz des Holzhändlers J. van Ameren, Juni Juli 1892

- Beschwerde des J. van Ameren beim Regierungspräsidenten gegen eine Strafverfügung der Stadt Emden wegen Lagerung von Holz auf der Kajung an der Osterbutvenne, November 1892 - August 1893

$1892-1893$

Klassifikation Teil B: 01548

Trägermaterial: Papier

Alte Reg.-Sig.: IV Mf 12

Bestell-Nr.: IV 01548 
Lfd. Nr. Titel

- Verfügungen des preußischen Landdrosten in Aurich über Verhaltensmaßregeln beim Wunsch fremder Kriegsschiffe zum Einlaufen in preußische Häfen, Februar 1873 / Oktober 1873

- Mitteilung von Daten der Schiffsversicherer über zulässige

Tieferladung von Schiffen, Juli 1873

- Eingabe der Kaufmännischen Deputation an den Magistrat über Notwendigkeit der Verbesserung der städtischen Hafenpolizei, September 1873

- Verfügung des Magistrats über Signalkode für die Sperrung der Nesserlander Schleuse und das Spülen der Fahrrinne, Juni 1876 - Verstöße gegen die Hafenordnung durch unerlaubtes Schlickfahren und ungenehmigtes Fahren mit voller Ladung bei tiefem Hafenwasserstand, Juni 1879 / November 1882

- Bekanntmachung der Kaufmännischen Deputation über Löschzeiten für Seeschiffe im Emder Hafen, Mai 1904

- Antrag der Fa. Lehnkering \& Cie AG auf Genehmigung des Überladens von Sprengstoff auf den Dampfer "Tinos" von der Bahn über den Kai, März 1912

$1873-1912$

Klassifikation Teil B: 01534

Trägermaterial: Papier

Alte Reg.-Sig.: IV Mg 7

Bestell-Nr.: IV 01534

1506 Benutzung der Landungsbrücke am Schreyers Hoek durch Dampfschiffe

- Blockade der Landungsbrücke durch den Dampfer "Norderney" wegen Weigerung der Räumung des Platzes durch den Dampferkapitän aus Wut gegen den Hafenmeister Zeemann, Juni 1880

1880

Klassifikation Teil B: 01536

Trägermaterial: Papier

Alte Reg.-Sig.: IV Mg 04

Bestell-Nr.: IV 01536 
Lfd. Nr. Titel Hafenpolizei und Hafenordnung

1507 Zusammensetzung des kgl. Hafenamtes

Laufzeit

- Antrag des Magistrats beim Regierungspräsidenten in Aurich auf Änderung der Zusammensetzuung des kgl. Hafenamtes im Hinblick auf die Stellung des Landrates des Kreises Emden nach dem Übergang des Emder Hafens in staatliche Verwaltung, Januar März 1887

- Beschluss des Magistrats über Antrag beim Regierungspräsidenten auf Stellung der Spitze des Hafenamtes mit einem $\mathrm{kgl}$. Wasserbaubeamten und einem Angehörigen des Magistrats (Oberbürgermeister Fürbringer), Mai - Juni 1888

$1887-1888$

Klassifikation Teil B: 01537

Trägermaterial: Papier Alte Reg.-Sig.: IV Mg 06

Bestell-Nr.: IV 01537

- Erlass einer Hafenordnung für den Emder Hafenbezirk, 1888

- Dienstanweisungen für Hafenpolizei-Aufseher und

Hafenpolizei-Wachtmeister, 1901 / 1904

- Hafenpolizeiliche Verfügungen des Regierungspräsidenten und

Erlasse des preußischen Ministers für Handel und Gewerbe, 1908 -

1914

$1888-1914$

Klassifikation Teil B: 01538

Trägermaterial: Papier

Alte Reg.-Sig.: IV Mg 07

Bestell-Nr.: IV 01538

1509 Schifffahrtspolizeiverordnung betr. den Dortmund-Ems-Kanal

- Veröffentlichung der Polizeiverordnung über Verkehrsregelungen auf dem Dortmund-Ems-Kanal im Amtsblatt der kgl. Regierung zu Aurich

1902

Klassifikation Teil B: 01539

Trägermaterial: Papier

Alte Reg.-Sig.: IV Mg 08

Bestell-Nr.: IV 01539 
Lfd. Nr. Titel Hafenpolizei und Hafenordnung

1510 Erstellung von Hafenplänen

Laufzeit

- Angebot des Lithographischen Instituts Wilhelm Greve, Berlin zur Erstellung eines Plans der neuen Hafenanlagen in Emden, April 1900 - Beschluss der städtischen Kollegien über Auftragsvergabe der Erstellung eines neuen Hafenplans, Mai 1900

- Angebot der Lithographischen Anstalt Bogdan Gisovius, Berlin zur Erstellung eines Plans der neuen Hafenanlagen in Emden, Mai 1900 - Korrespondenz zwischen der Lithographischen Anstalt Bodgan Gisevius und dem Oberbürgermeister Fürbringer wegen

Abrechnungsfragen und Aktualisierung der Hafenpläne, September 1901 - November 1902

- Angebote über Vervielfäligungen von Hafenplänen, 1903 - 1908

- Hafenpläne, 1903 - 1907

$1900-1908$

Klassifikation Teil B: 01540

Trägermaterial: Papier Alte Reg.-Sig.: IV Mg 09

Bestell-Nr.: IV 01540

1511 Schiffsverkehrsstatistik, Bd. 1

- Statistische Berichte zum Schiffsverkehr im Emder Hafen

(1861 - 1865) 1866 - 1902

Klassifikation Teil B: 01541

Band: 1

Trägermaterial: Papier

Alte Reg.-Sig.: IV Mg 10

Bestell-Nr.: IV 01541

1512 Schiffsverkehrsstatistik, Bd. 2

- Statistische Berichte zum Schiffsverkehr im Emder Hafen

1903

Klassifikation Teil B: 01542

Band: 2

Trägermaterial: Papier

Alte Reg.-Sig.: IV Mg 10

Bestell-Nr.: IV 01542

1513 Schiffsverkehrsstatistik, Bd. 3

- Statistische Berichte zum Schiffsverkehr im Emder Hafen

$1903-1906$

Klassifikation Teil B: 01543

Band: 3

Trägermaterial: Papier

Alte Reg.-Sig.: IV Mg 10

Bestell-Nr.: IV 01543 
IV

05

Stadtverwaltung

05.03

Aufgabenbereiche der Stadtverwaltung

05.03.09

05.03.09.06

Wasser- und Schifffahrtssachen

Hafenpolizei und Hafenordnung

Lfd. Nr. Titel

Laufzeit

1514 Register der Schiffsankünfte und -Abfahten im Emder Hafen, Bd. 1 1866

- Register mit Angaben zu Schiffseignern, Herkunft und Zielort des Schiffes sowie Einlauf und Ablegedatum

1866
Klassifikation Teil B: 01544
Band: 1
Trägermaterial: Papier
Alte Reg.-Sig.: IV Mg 10

Bestell-Nr.: IV 01544

1515 Register der Schiffsankünfte und -Abfahten im Emder Hafen, Bd. 2

- Register mit Angaben zu Schiffseignern, Herkunft und Zielort des Schiffes sowie Einlauf und Ablegedatum

$1866-1867$

Klassifikation Teil B: 01545

Band: 2

Trägermaterial: Papier

Alte Reg.-Sig.: IV Mg 10

Bestell-Nr.: IV 01545

1516 Schiffspassagen durch die Nesserlander Schleuse, Bd. 1

- Statistik der Schiffspassagen durch die Nesserlander Schleuse zum Ein und Auslaufen in und aus dem Emder Hafen

$1866-1867$
Klassifikation Teil B: 01549
Band: 1
Trägermaterial: Papier
Alte Reg.-Sig.: IV Mg 10
Bestell-Nr.: IV 01549

1517 Schiffspassagen durch die Nesserlander Schleuse, Bd. 2

- Statistik der Schiffspassagen durch die Nesserlander Schleuse zum Ein und Auslaufen in und aus dem Emder Hafen

$1866-1867$

Klassifikation Teil B: 01550

Band: 2

Trägermaterial: Papier

Alte Reg.-Sig.: IV Mg 10

Bestell-Nr.: IV 01550 
IV

05

05.03

05.03.09

05.03.09.06
Stadtverwaltung

Aufgabenbereiche der Stadtverwaltung

Wasser- und Schifffahrtssachen

Hafenpolizei und Hafenordnung

Lfd. Nr. Titel

Laufzeit

1518 Schiffspassagen durch die Nesserlander Schleuse, Bd. 3

$1869-1870$

- Statistik der Schiffspassagen durch die Nesserlander Schleuse zum

Ein und Auslaufen in und aus dem Emder Hafen

$1869-1870$

Klassifikation Teil B: 01551

Band: 3

Trägermaterial: Papier

Alte Reg.-Sig.: IV Mg 10

Bestell-Nr.: IV 01551

1519 Schiffspassagen durch die Nesserlander Schleuse, Bd. 4

- Statistik der Schiffspassagen durch die Nesserlander Schleuse zum

Ein und Auslaufen in und aus dem Emder Hafen

$1870-1871$

Klassifikation Teil B: 01552

Band: 4

Trägermaterial: Papier

Alte Reg.-Sig.: IV Mg 10

Bestell-Nr.: IV 01552

1520 Schiffspassagen durch die Nesserlander Schleuse, Bd. 5

- Statistik der Schiffspassagen durch die Nesserlander Schleuse zum Ein und Auslaufen in und aus dem Emder Hafen

1873

Klassifikation Teil B: 01553

Band: 5

Trägermaterial: Papier

Alte Reg.-Sig.: IV Mg 10

Bestell-Nr.: IV 01553

1521 Schiffspassagen durch die Nesserlander Schleuse, Bd. 6

- Statistik der Schiffspassagen durch die Nesserlander Schleuse zum Ein und Auslaufen in und aus dem Emder Hafen

$1873-1874$

Klassifikation Teil B: 01554

Band: 6

Trägermaterial: Papier

Alte Reg.-Sig.: IV Mg 10

Bestell-Nr.: IV 01554 
IV

05

05.03

05.03.09

05.03.09.06
Stadtverwaltung

Aufgabenbereiche der Stadtverwaltung

Wasser- und Schifffahrtssachen

Hafenpolizei und Hafenordnung

Lfd. Nr. Titel

Laufzeit

1522 Schiffspassagen durch die Nesserlander Schleuse, Bd. 7

- Statistik der Schiffspassagen durch die Nesserlander Schleuse zum

Ein und Auslaufen in und aus dem Emder Hafen

$1874-1875$

Klassifikation Teil B: 01555

Band: 7

Trägermaterial: Papier

Alte Reg.-Sig.: IV Mg 10

Bestell-Nr.: IV 01555

1523 Schiffspassagen durch die Nesserlander Schleuse, Bd. 8

1876

- Statistik der Schiffspassagen durch die Nesserlander Schleuse zum

Ein und Auslaufen in und aus dem Emder Hafen

1876

Klassifikation Teil B: 01556

Band: 8

Trägermaterial: Papier

Alte Reg.-Sig.: IV Mg 10

Bestell-Nr.: IV 01556

1524 Passagegebühren für Binnenschiffer, Bd. 1

- Liste der passage- und torflöschgebührenpflichtigen Schiffe mit Angaben zum Schiffsnamen, Schiffeseigner, Kapitän, Ladung und Bestimmungsort

1872

\author{
Klassifikation Teil B: 01557 \\ Band: 1 \\ Trägermaterial: Papier \\ Alte Reg.-Sig.: IV Mg 10 \\ Bestell-Nr.: IV 01557
}

1525 Passagegebühren für Binnenschiffer, Bd. 2

- Liste der passage- und torflöschgebührenpflichtigen Schiffe mit Angaben zum Schiffsnamen, Schiffeseigner, Kapitän, Ladung und Bestimmungsort

1878 - 1879

Klassifikation Teil B: 01557

Band: 2

Trägermaterial: Papier

Alte Reg.-Sig.: IV Mg 10

Bestell-Nr.: IV 01558 
IV

05

05.03

05.03.09

05.03.09.06
Stadtverwaltung

Aufgabenbereiche der Stadtverwaltung

Wasser- und Schifffahrtssachen

Hafenpolizei und Hafenordnung

Lfd. Nr. Titel

Laufzeit

1526 Passagegebühren für Binnenschiffer, Bd. 3

1884-1885

- Liste der passage- und torflöschgebührenpflichtigen Schiffe mit Angaben zum Schiffsnamen, Schiffeseigner, Kapitän, Ladung und Bestimmungsort

$1884-1885$

Klassifikation Teil B: 01559

Band: 3

Trägermaterial: Papier

Alte Reg.-Sig.: IV Mg 10

Bestell-Nr.: IV 01559

1527 Emder Hafenstatistik

1899-1903

- Nachweisungen über Schiffsverkehr im Emder Hafen

$1899-1903$

Klassifikation Teil B: 01560

Trägermaterial: Papier

Alte Reg.-Sig.: IV Mg 10

Bestell-Nr.: IV 01560

1528 Emder Hafenbetrieb

1904-1912

- Hafenstatistik, 1904

- Verschiedene Einzelvorgänge zu Problemen des Hafenbetriebs,

1904 - 1912

- Materialien zum Betrieb deutscher und europäischer Häfen, 1904 -

1912

- Kampagne gegen den Emder Hafen durch schwedische

Erzexporteure, Dezember 1904

$1904-1912$

Klassifikation Teil B: 01561

Trägermaterial: Papier

Alte Reg.-Sig.: IV Mg 11

Bestell-Nr.: IV 01561

1529 Übertragung der Hafenamtsgeschäfte auf das kgl. Wasserbauamt

- Übergabe der Akten des aufgelösten Hafenamts an das kgl.

Wasserbauamt, Juni 1914

- Verfügung des Regierungspräsidenten an Bürgermeister Dr.

Mützelburg über Einstellung der Honorarzahlungen wegen Erlöschen

seiner Funktion als Hafenamtsleiter, Juli 1914

1914

Klassifikation Teil B: 01562

Trägermaterial: Papier

Alte Reg.-Sig.: IV Mg 13

Bestell-Nr.: IV 01562 
Lfd. Nr. Titel

1530 Verlegung und Bedeichung des Emder Fahrwassers sowie Neubau 1866 einer Schutzschleuse

- Rechnungsbuch über Einnahmen (öffentliche Zuschüsse und Mittel aus dem Stadthaushalt) und Ausgaben für Verlegung und Bedeichung des Emder Fahrwassers sowie Neubau einer Schutzschleuse

1866

Klassifikation Teil B: 01564

Trägermaterial: Papier

Alte Reg.-Sig.: IV Mh 24

Bestell-Nr.: IV 01564

1531 Zustand der Emder Hafenwerke

- Gutachten eines unbekannten Ingenieurs über Zustand des Emder Hafens und Fahrwassers sowie über Maßnahmen zu deren Verbesserung

1869

Klassifikation Teil B: 01565

Trägermaterial: Papier

Alte Reg.-Sig.: IV Mh 24

Bestell-Nr.: IV 01565

1532 Grabung eines neuen Fahrwassers

- Verhandlungen des Magistrats mit der Kleinen Stadtdeichacht wegen Abtretung eines Anwachses vor den Deichen der Stadt zur Grabung eines neuen Fahrwassers, Oktober 1844 - Oktober 1846

- Vehandlungen des Magistrats mit der Hannoverschen Landdrostei in Aurich wegen Abmachung mit der Stadtdeichacht hinsichtlich des Erwerbs des Anwachses, März 1845 - September 1846

- Eintragung der Deichlasten der von der Stadt Emden erworbenen Flächen in das Hypothekenbuch, (1854 - 1864) 1874 - 1886

(1844 - 1864) 1874 - 1886

Klassifikation Teil B: 01567

Trägermaterial: Papier Alte Reg.-Sig.: IV Mh 12

Bestell-Nr.: IV 01567 
05

\subsection{3}

05.03.09

05.03.09.07

\section{Stadtverwaltung}

Aufgabenbereiche der Stadtverwaltung

Wasser- und Schifffahrtssachen

Fahrwasser und Nesserländer Schleuse

Lfd. Nr. Titel

Laufzeit

1533 Nesserlander Schleuse und Fahrwasserdeich

- Unterhaltung und Verstärkung des Fahrwasserdeiches, 1854 - 1858

- Unterhaltung des Binnenfahrwassers, 1854 - 1860

- Reparatur des durch eine Sturmflut beschädigten

Fahrwasserdeiches, Dezember 1863 - September 1864

- Verkehrsregelungen für das Binnenfahrwasser, (1864 - 1865) 1866 -

1873

- Einbau neuer Fluttore in die Nesserlander Schleuse, Juni 1875

- Denkschrift des Senators Carl Dantziger über Projekt eines

Schleusensystems zur Verhinderung der Verschlammung des Emder

Hafens, Januar 1876

- Ausschreibung des Einbaus neuer Ebbetore in die Nesserlander

Schleuse, April - November 1876

- Reparatur der schadhaften Kajung an der Nesserlander Schleuse,

Januar - Oktober 1877

- Beschwerden über Verschlammung des Binnenfahrwassers, 1883 -

1884

- Ausbaggerung des Fahrwassers, 1883 - 1885

- Abgrabung und Planierung des Fahrwasserdeiches, 1892 - 1893

(1854 - 1865) 1866 - 1893

Klassifikation Teil B: 01568

Trägermaterial: Papier

Alte Reg.-Sig.: IV Mh 33

Bestell-Nr.: IV 01568

1534 Beschädigung der Nesserlander Schleuse durch Schiffe

- Anzeigen über Schäden an den Schleusentoren durch Rammen durch Schiffe aufgrund unaufmerksamer Fahrweise und infolge plötzlicher Windstöße

$1873-1878$

Klassifikation Teil B: 01569

Trägermaterial: Papier

Alte Reg.-Sig.: IV Mh 44

Bestell-Nr.: IV 01569

1535 Unfall des Schiffes des H. Litmeyer bei der Nesserlander Schleuse

- Sinken der mit Mauersteinen beladenen Pünte des H. Litmeyer durch Auftreiben auf einen unter Wasser befindlichen Pfahl bei der Nesserlander Schleuse, 1888

- Kostenrechnung für die Hebung der Pünte, 1888

- Entschädigungsanspruch der Versicherungsgesellschaft Amisia gegen die Stadt Emden wegen Nichtbeseitigung der Pfähle als Unterwasserhindernis, 1888 - 1889

- Klage des Schiffers Hermann Litmeyer gegen die Stadt Emden beim Landgericht in Aurich auf Entschädigung, 1890 - 1892

$1888-1892$

Klassifikation Teil B: 01570

Trägermaterial: Papier

Bestell-Nr.: IV 01570 
IV

05

05.03

05.03.09

05.03.09.08
Stadtverwaltung

Aufgabenbereiche der Stadtverwaltung

Wasser- und Schifffahrtssachen

Deichwesen

Lfd. Nr. Titel

Laufzeit

1536 Stadtdeiche, Falderndeich und Stadtsiele, Bd. 1

- Protokolle der Schauungen der Stadtdeiche, (1854 - 1864) 1867 -

1883

- Protokolle der Besichtigungen des Roten- oder Faldernsiels, 1854

- Protokolle der Schauungen des Königspolderdeichs, 1856 - 1890

- Verfügung des Stadtbaumeisters Robbelen an die Interessenten des

Südfalderndeiches über Anordnung zur Besichtigung der

Deichschäden, Juli 1861

- Konflikt um die Höhe der Deichlast für den Südfalderndeich, 1862 -

1863

- Eintreibung der Beiträge zur Unterhaltung des Südfalderndeiches,

$1870-1884$

- Nachweis der Deichverbände, Sielverbände sowie

Meliorationsgenossenschaften in Emden, 1872

- Bericht der Südfaldern-Deichacht an den Magistrat über Wahl eines

Pumpenziehers, Dezember 1872

- Anfertigung neuer Nottüren für das Stadtsiel, 1875

- Verfügung des preußischen Landdrosten in Aurich an den Magistrat über Erlaubnis zur Niederlegung des entbehrlichen Mittelwalldeiches, November 1878

- Streit um die Heranziehung des Bauinspektors Schramme zu den

Deichlasten der Südfalderndeichacht, 1878 - 1879

- Beschluss der städtischen Kollegien über Zustimmung zur

Niederlegung eines Teils des Fahrwasserdamms wegen Anlage der

Küstenbahn, Juni 1882 - Dezember 1883

- Beschädigung des Deiches am Königspolder und Bruch des

Fangdammes an der neuen Nesserlander Schleuse durch die

Sturmflut vom 12./ 13. Dezember 1883, Dezember 1883

- Antrag der Kaufmännischen Deputation an die Stadt Emden auf ausreichenden Verschluss des Eisenbahndurchlasses am Fahrwasser zum Schutz des Stadtgebiets vor hohen Fluten, Januar 1884

(1854 - 1864) $1866-1884$

Klassifikation Teil B: 01514

Band: 1

Trägermaterial: Papier

Alte Reg.-Sig.: IV Md 5

Bestell-Nr.: IV 01514 
Lfd. Nr. Titel

\section{Deichwesen}

1537 Stadtdeiche, Falderndeich und Stadtsiele, Bd. 2

- Durchschneidung des Fahrwasserdamms durch die Pferdebahn, Juli 1883 - Juni 1884

- Widerspruch des Wasserbauinspektors Suadicani gegen eine Hausbebauung an der Bahnhofstraße im Bereich des Falderndeiches, März - Mai 1885

- Protokolle der Schauung der städtischen Deiche, 1885 - 1889

- Verfügung des Regierungspräsidenten in Aurich über Anordnung einer Sonderschauung des Oldersumer und Petkumer Siels und ihrer Gewässer wegen Verschlammung, August 1888

- Beschluss der städtischen Kollegien wegen Abtragung des Fahrwasserdammes, August 1889

- Antrag des Maschinenbauingenieurs Friedrich Barth auf Erlaubnis zur Durchstechung des Falderndeiches wegen Verlegung der Einfahrt zu seinem Grundstück, Juli 1893

- Antrag der Interessenten der Südfalderndeichacht auf Aufhebung des vom Deichrichter Schneidt verfügten Deichschoßes wegen unvertretbarer Härte angesichts der Funktion des Deiches als Schlafdeich, Juni - August 1894

- Niederlegung des Mittelwalldeiches, 1896

- Verhandlungen des Magistrats mit der Südfalderndeichacht wegen Abtragung des Südfalderndeiches und Auflösung der Deichacht, Mai Juli 1897

- Beschreibung des Falderndeiches, seiner Geschichte und Eigentumsverhältnisse, 1897

- Genehmigung der Abtragung des Südfalderndeiches durch den Regierungspräsidenten in Aurich, Januar 1898

- Abtragung der Reste des Fahrwasserdammes, 1899 - 1900

- Antrag der Anlieger des Südfalderndeiches beim Magistrat auf Abtragung der Reste des Deiches, Juli 1900

$1887-1900$

Klassifikation Teil B: 01515

Band: 2

Trägermaterial: Papier

Alte Reg.-Sig.: IV Md 5

Bestell-Nr.: IV 01515

1538 Südfalderndeich

- Statuten der der Deputation des Südfalderndeichs, April 1868

1868

Klassifikation Teil B: 01517

Trägermaterial: Papier

Alte Reg.-Sig.: IV Md 7

Bestell-Nr.: IV 01517 
05

\subsection{3}

05.03.09

05.03.09.08

Stadtverwaltung

Aufgabenbereiche der Stadtverwaltung

Wasser- und Schifffahrtssachen

Deichwesen

Lfd. Nr. Titel

Laufzeit

1539 Flächen der Kleinen Stadtdeichacht

1900-1904

- Aufhebung des Vergleichs zwischen der Stadt Emden und der Stadtdeichacht über Abtretung des Anwachses vor dem Deich der Deichacht an die Stadt Emden gegen Unterhaltung der Deiche durch die Stadt vom April 1846 wegen Fortfalls der Grundlagen (Abtragung der nunmehrigen Schlafdeiche am Mittelwall etc.), 1900 - Verhandlungen der Stadt Emden mit der Kleinen Stadtdeichacht über Verkauf der ehemaligen Deichflächen der Acht an die Stadt, Dezember 1901 - Oktober 1904

- Planzeichnungen der ehemaligen Deichflächen, 1903 - 1904

- Schreiben des Magistrats an das Amtsgericht über Organisation der zur ehemaligen Kleinen Stadtdeichacht gehörigen Landflächen als genossenschaftliche Feldmark, November 1914

$1900-190481914)$

Klassifikation Teil B: 01563

Trägermaterial: Papier

Alte Reg.-Sig.: IV Mh 11

Bestell-Nr.: IV 01563

1540 Deichverband des Königs- und Kaiser-Wilhelm-Polders

- Statut des Deichverbandes des Königs- und Kaiser-Wilhelm-Polders, 1876

- Protokolle der Versammlungen des Deichverbandes mit

Beschlussfassungen über Deichunterhaltungsarbeiten, Etatfragen und Festsetzung des Deichschoßes, 1900 - 1912

- Memorial über Struktur des Deichverbandes, Beschaffenheit seiner Deiche und Grundsätze für die Deichrolle, 1901

$1876-1912$

Klassifikation Teil B: 01573

Trägermaterial: Papier

Alte Reg.-Sig.: IV Mi 01

Bestell-Nr.: IV 01573

1541 Deichrolle des Deichverbandes des Königs- und Kaiser-Wilhelm-Polder

- Verhandlungen über Struktur des Deichverbandes, Beschaffenheit der Deiche und Grundsätze für die Deichrolle

- Deichrolle: Grundstücke, Besitzer und Höhe des Deichschoßes

1892

Klassifikation Teil B: 01574

Trägermaterial: Papier

Alte Reg.-Sig.: IV Mi 02

Bestell-Nr.: IV 01574 
IV

05

Stadtverwaltung

05.03

Aufgabenbereiche der Stadtverwaltung

05.03.09

05.03.09.08

Wasser- und Schifffahrtssachen

Lfd. Nr. Titel

Deichwesen

1542 Deichschutz

Laufzeit

1867-1890

(1835-1860)

- Bekanntmachungen des Verbotes des Reitens und des Fahrens auf dem Deich, (1835 - 1847) 1890

- Verfolgung undf Bestrafungen der Übertretungen des Verbots, (1837

- 1860) 1867

- Ausnahmeregelung zur Deichpassage bei Frost oder

lebenswichtigen Arztbesuchen, 1846 - 1849

(1835 - 1860) 1867 - 1890

Klassifikation Teil B: 01575

Trägermaterial: Papier

Alte Reg.-Sig.: IV Mi 04

Bestell-Nr.: IV 01575

1543 Niederemsische Deichsachen

1885-1907

(1914)

- Gefahr durch einen zugewachsenen Graben am Deich des

Königspolders, 1885

- Erlass des preußischen Ministers der öffentlichen Arbeiten über

Deichschutz bei Eisgang, April 1888

- Initiative des Senators Metger zum Bau einer Rampe zum Schutz

des Strohdeiches bei der Passage, September 1888

- Etat der Niederemsischen Deichacht, 1890 - 1908

- Verfügung des Regierungspräsidenten in Aurich an das kgl. Deichund Sielamt über Anordnung zur Einwirkung auf die Deichachten zur Beschäftigung verheirateter Deicharbeiter zur Behebung des Landarbeitermangels, Januar 1907

$1885-1907$ (1914)

Klassifikation Teil B: 01576

Trägermaterial: Papier

Alte Reg.-Sig.: IV Mi 06

Bestell-Nr.: IV 01576 
05

05.03

05.03.09

05.03.09.08
Stadtverwaltung

Aufgabenbereiche der Stadtverwaltung

Wasser- und Schifffahrtssachen

Deichwesen

Lfd. Nr. Titel

Laufzeit

1544 Verstühlung der Deiche des Königs- und Kaiser-Wilhelm-Polder, Bd. 1

1872-1892

- Statut für den Deichverstuhls-Verband zu Emden als Vorläufer des

Deichverbands des Königspolders, 1872

- Statut für den Deichverband des Kaiser-Wilhelm-Polders, 1876

- Gedrucktes Gutachten des Deichrichters P. Freerksen über

Maßnahmen zur Verstärkung des Deiches vor dem

Kaiser-Wilhelm-Polder, Juni 1882

- Stellungnahme des Deichrichters Freerksen über Vor- und Nachteile der Verstühlung der Deiche des Königs- und Kaiser-Wilhelm-Polders an die Niederemsische Deichacht, Mai 1886

- Verhandlungen zwischen der Stadt Emden, der Niederemsischen

Deichacht, der Oberemsischen Deichacht und des

Wasserbauinspektors Suadicani wegen der Verstühlung der

Stadtemdischen Deiche und der Deiche des Königs- und

Kaiser-Wilhelm-Polders, August - September 1886

- Profil der Deiche des Königs- und Kaiser-Wilhelm-Polders, 1886 /

1888

- Bericht des Magistrats an den Regierungspräsidenten in Aurich über

Beschluss der städtischen Kollegien zur Beantragung der Verstühlung der Deiche im Königs- und Kaiser-Wilhelm-Polders unter Erhebung zu Hauptschutzdeichen, November 1887 / Januar 1888

- Bericht des Niederemsischen Deichrichters P. Freerksen an den Amtmann des Amtes Emden über grundsätzliche Bereitschaft der Niederemsichen Deicht zur Billigung der Verstühlung der Deiche des Königs- und Kaiser-Wilhelm-Polder unter der Bedingung der Kostenrentabilität und der Verstärkung des Polderdeiches, Dezember 1887

- Bericht des Magistrats an den Regierungspräsidenten über unrichtige Darstellung der Niederemsischen Deichacht hinsichtlich der Verstärkung der Polderdeiche, Februar 1888

- Verhandlungen der städtischen Kollegien über Tragung der Kosten der Verstühlung der Deiche des Königs- und Kaiser-Wilhelm-Polders, April 1888

- Vereinbarung über Modalitäten der Verstühlung der Polderdeiche, April 1890

- Entwurf eines Statuts für den neuen Deichverband des Königs- und Kaiser-Wilhelm-Polders, Oktober 1890 - März 1891

- Übernahme der Deichunterhaltung durch den neuen Verband, April Oktober 1891

- Erhebung des Deichschoßes und Erstellung einer Deichrolle des neuen Deichverbandes, 1892

$1872-1892$

Klassifikation Teil B: 01577

Band: 1

Trägermaterial: Papier

Alte Reg.-Sig.: IV Mi 11

Bestell-Nr.: IV 01577 
Lfd. Nr. Titel

\section{Deichwesen}

1545 Verstühlung der Deiche des Königs- und Kaiser-Wilhelm-Polders, Bd. 2

- Vorbericht zur Deichrolle des Deichverbands des Königs- und Kaiser-Wilhelm-Polders: Deichbeschreibung und Verteilung der Deichlast (Deichschoß), 1892

- Beteiligung der Stadt Emden an den Kosten für die Verstärkung der Polderdeiche, März 1893

- Protokolle der Versammlungen des Deichverbands des Königs- und Kaiser-Wilhelm-Polders, April 1893 - Oktober 1899

- Etat des Deichverbands des Königs- und Kaiser-Wilhelm-Polders, April 1894 - April 1900

- Ausdehnung der Deichlast auf alle Grundstücke und Häuser außerhalb des Herrentorviertels, Mai 1893

- Protokolle der Deichschauungen des Deichverbands des Königsund Kaiser-Wilhelm-Polders, 1893 - 1898

- Anteil der Stadt Emden an den Kosten zur Beseitigung der Sturmflutschäden an den Deichen des Königs- und Kaiser-Wilhelm-Polders, März - April 1904

- Heranziehung der Grundstücksbesitzer im Bereich des

Deichverbands des Königs- und Kaiser-Wilhelm-Polders zur

Deichlast, April 1895 - Juli 1900

- Aktualisierung der Deichrolle des Deichverbands des Königs- und Kaiser-Wilhelm-Polders, 1897 - 1900

- Einstellung eines Sielwärters für das Larrelter und das Kaiser-Wilhelm-Poldersiel, 1898

$1892-1900$

Klassifikation Teil B: 01578

Band: 2

Trägermaterial: Papier

Alte Reg.-Sig.: IV Mi 11

Bestell-Nr.: IV 01578

Laufzeit

1892-1900 
05

\subsection{3}

05.03.09

05.03.09.08
Stadtverwaltung

Aufgabenbereiche der Stadtverwaltung Wasser- und Schifffahrtssachen

\section{Deichwesen}

Lfd. Nr. Titel

Laufzeit

1546 Verstühlung der Deiche des Königs- und Kaiser-Wilhelm-Polders, Bd. 3

- Gedrucktes Statut des Deichverbands des Königs- und

Kaiser-Wilhelm-Polders, 1891

- Etat des Deichverbands des Königs- und Kaiser-Wilhelm-Polders, 1901 - 1908

- Heranziehung der Grundstücksbesitzer zur Deichlast, 1901 - 1906

- Wiederwahl des Oberbürgermeisters Fürbringer zum protokollführenden Deichrichter des Deichverbands des Königs- und Kaiser-Wilhelm-Polders, März 1901

- Protokolle der Versammlungen des Deichverbands des Königs- und Kaiser-Wilhelm-Polders, 1901 - 1907

- Tod des niederemsischen Deichrichters Petrus Freerksen, April 1901

- Etat der Niederemsischen Deichacht, 1901 - 1906

- Deichschauungen im Königs- und Kaiser-Wilhelm-Polder, 1901 1907

- Bescheid des preußischen Landwirtschaftsministers über alleinige Kostenträgerschaft des Deichverbands des Königs- und Kaiser-Wilhelm-Polders für die Unterhaltung der Polderdeiche, Juni 1901

- Antrag des Deichverbands des Königs- und Kaiser-Wilhelm-Polders beim kgl. Deich- und Sielamt auf Anhaltung der Ablagerung von Baggerschlick im Fischers Gat wegen drohender Verschlammung der Abwässerungssiele, September 1903

- Aktualisierung der Deichrolle, 1903 - 1907

(1891) $1901-1908$

Klassifikation Teil B: 01579

Band: 3

Trägermaterial: Papier

Alte Reg.-Sig.: IV Mi 11

Bestell-Nr.: IV 01579

1547 Eindeichung der Leybucht

- Projekt- und Kostenbeschreibung des V. A. Fegter aus Dammhusen zur Eindeichung der Leybucht, (1864) 1886

- Eingabe einer Landschaftskommission unter Vorsitz von Landschaftsrat Graf von Knyphausen und dem Oberbürgermeister Fürbringer (Textfassung) an den preußischen Landwirtschaftsminister Dr. Lucius über Antrag auf Förderung der Eindeichung der Leybucht zur Gewinnung neuer landwirtschaftlicher Nutzfläche, August 1886

(1864) 1886

Klassifikation Teil B: 01580

Trägermaterial: Papier

Alte Reg.-Sig.: IV Mi 12

Bestell-Nr.: IV 01580 
05

05.03

05.03.09

05.03.09.08
Stadtverwaltung

Aufgabenbereiche der Stadtverwaltung

Wasser- und Schifffahrtssachen

Deichwesen

Lfd. Nr. Titel

Laufzeit

1548 Eintragung eines Grundstücks in das Grundbuch als Eigentum der Oberemsischen Deichacht

$1900-1901$

- Antrag der Oberemsischen Deichacht auf Eintragung der Parzelle 281/90 (Deich nach Borssum) als ihr Eigentum in ein neues

Grundbuchblatt, Mai 1900 - März 1901

- Urteil des Landgerichts in Aurich über Nichtigkeit der Beschwerde der Stadt Emden gegen die Eintragung der Parzelle 281/90 als

Eigentum der Oberemsischen Deichacht in das Grundbuch wegen

nicht belegbarer Eigentumsansprüche der Stadt Emden, März 1901

$1900-1901$

Klassifikation Teil B: 01581

Trägermaterial: Papier

Alte Reg.-Sig.: IV Mi 13

Bestell-Nr.: IV 01581

1549 Ankauf der Erbpachtsgerechtsame der Oberemsischen Deichacht auf

$1896-1911$ ein Grundstück bei der Westfälischen Eisenbahn

- Kaufgebot des Auktionators Barth auf ein Grundstück mit altem Deichstück und Erbpachtgerechtigkeit aus dem Besitz des

Gemüsebauern Markus, Juli - August 1896

- Schreiben des oberemsischen Deichrichters M. Hülsebus, Petkum über Eigentumsrechte der Oberemsischen Deichacht auf das von Markus genützte Deichstück, August 1896

- Bescheid des Regierungspräsidenten über nicht nachweisbare Eigentumsansprüche der Deichacht, September 1896

- Verkaufsangebot der Oberemsischen Deichacht über die von Markus genützte Deichstrecke, Dezember 1899 - März 1911

- Planzeichnung der betr. Deichstrecke, 1901

- Durch den Arzt Dr. Langhoff vermitteltes Angebot verschiedener Besitzer einer Deichstrecke über Verkauf ihrer Deichstrecken an die Stadt Emden, 1905

- Verhandlungen mit der Oberemsischen Deichacht über Verkauf einer Schlafdeichstrecke, Januar - Februar 1907

$1896-1911$

Klassifikation Teil B: 01582

Trägermaterial: Papier

Alte Reg.-Sig.: IV Mi 14

Bestell-Nr.: IV 01582

1550 Unterhaltung einer Einfriedung beim Borssumer Deich

- Streit zwischen der Stadt Emden, der staatlichen Bauverwaltung und dem Landwirt Wyckhoff in Borssum um die Unterhaltung einer Einfriedung beim Borssumer Deich zur Abgrenzung der Borssumer Landstraße zum Deich

1880 - 1903 (1927 - 192 9)

Klassifikation Teil B: 01583

Trägermaterial: Papier

Alte Reg.-Sig.: IV Mi 15

Bestell-Nr.: IV 01583 
IV

05

05.03

05.03.09

05.03.09.08
Stadtverwaltung

Aufgabenbereiche der Stadtverwaltung

Wasser- und Schifffahrtssachen

Deichwesen

Lfd. Nr. Titel

Laufzeit

1551 Übersichtskarte über Deiche und Siele im Regierungsbezirk Aurich

1904

- Verfügung des Regierungspräsidenten über Anordnung der

Übermittlung von Daten zur Erstellung der Übersichtskarte über

Deiche und Siele im Regierungsbezirk Aurich, Februar August 1904

1904

Klassifikation Teil B: 01584

Trägermaterial: Papier

Alte Reg.-Sig.: IV Mi 16

Bestell-Nr.: IV 01584

1552 Verstühlung des vor dem Königspolderwatt errichteten Seedeichs

- Verfügung des Regierungspräsidenten an den Magistrat über Anordnung zur Auslegung der Antragsunterlagen des Bauamts für Hafenerweiterung über Verstühlung des vor dem Königspolderwatt errichteten Seedeichs und Einsendung von Einwänden, August 1907

- Lageplan und Profilzeichnung des Deiches, 1907

- Gutachten des geh. Oberbaurats Tenge, Oldenburg über Eignung des Seedeichs als Schau- und Hauptdeich, Juli 1907

- Stellungnahme des Oberbürgermeisters Fürbringer für die Erklärung des Seedeichs zum Kampfdeich, August 1907

1907

Klassifikation Teil B: 01585

Trägermaterial: Papier

Alte Reg.-Sig.: IV Mi 17

Bestell-Nr.: IV 01585

1553 Abtragung eines Teils des Larrelter Deiches

- Kosten der Abtragung eines Teils des Larrelter Deiches an der Larrelter Landstraße wegen Errichtung einer Molkerei, März 1910

- Planzeichnung des Stadtbaumeisters Wiggers, März 1910

- Angebote von Baufirmen über Ausführung der Abtragungsarbeiten,

März - April 1910

- Verdingungsvertragsentwurf über die Abtragungsarbeiten, April 1910

1910

Klassifikation Teil B: 01586

Trägermaterial: Papier

Alte Reg.-Sig.: IV Mi 17

Bestell-Nr.: IV 01586 
IV

05

05.03

05.03.09

05.03.09.08
Stadtverwaltung

Aufgabenbereiche der Stadtverwaltung

Wasser- und Schifffahrtssachen

Deichwesen

Lfd. Nr. Titel

Laufzeit

1554 Anwachs zwischen Larrelt und Nesserland

1873-1876

- Vereinbarung zwischen der Stadt Emden, dem preußischen

Domänenfiskus und der Niederemsischen Deichacht über

Eindeichung des Anwachses zwischen Larrelt und Nesserland, April

1873 / Juni 1875

- Beschluss des Magistrats über Abnahme des neuen Deiches vor

dem Neuland zwischen Larrelt und Nesserland und Bedingungen zur

Annahme des Statuts der Einpolderungsgesellschaft, September 1875

- Verhandlungen der städtischen Kollegien über Statut der

Einpolderungsgesellschaft, September 1875 - Mai 1876

$1873-1876$

Klassifikation Teil B: 01587

Trägermaterial: Papier

Alte Reg.-Sig.: IV Mi 20

Bestell-Nr.: IV 01587 
IV

05

Stadtverwaltung

05.03

Aufgabenbereiche der Stadtverwaltung

05.03.09

05.03.09.09

Wasser- und Schifffahrtssachen

Überströmungen

Lfd. Nr. Titel

Laufzeit

1555 Überschwemmung infolge des Bruches der Nottüren des Neuen Siels

1875

- Schadensersatzanspruch des Schlachters Moses Stein, des

Fuhrmanns Hajo Hinderks u.a. Landbesitzer und Pächter wegen

Unbrauchbarkeit ihres Weidelandes wegen Überschwemmung mit

Salzwasser, September - Oktober 1875

- Bericht des Stadtbaumeisters Wiggers über Bruch der Nottüren des

Neuen Siels wegen altersbedingter magelnder Wasserdruckfestigkeit,

September 1875

1875

Klassifikation Teil B: 01588

Trägermaterial: Papier

Alte Reg.-Sig.: IV Mk 12

Bestell-Nr.: IV 01588

1556 Überschwemmungen

$1877-1916$

- Berichte über Überschwemmungen bei der Nesserlander Schleuse, Januar 1877

- Überflutung von Keller durch Einlassung von Seewasser zur Spülung der Delfte, September 1880 / November 1883 / Oktober 1884

- Schadensersatzforderung des Fuhrmanns Peter Bordeaux wegen

Überschwemmung seines Pachtlandes Außer dem Boltentor durch den Bau des Ems-Jade-Kanals, November 1888

- Richtlinien für die Stellung militärischer Kommandos für Hilfeleistung bei Überschwemmungen, März 1889

- Druckschrift: Maßnahmen zum Hochwasserschutz im Ems- und

Wesereinzugsgebiet, 1902

- Anregung der städtischen Kollegien zur Anbringung von Fluttoren in den Schleusen zur Erhöhung des Hochwasserschutzes, März 1906

- Bericht über die Sturmflut vom 12. März 1906

- Hilfe für Überschwemmungsopfer in der Provinz Hannover, Februar

1909

- Telegraphische Wasserstandsmeldungen, 1907 - 1912

$1877-1916$

Klassifikation Teil B: 01589

Trägermaterial: Papier

Alte Reg.-Sig.: IV Mk 13

Bestell-Nr.: IV 01589 
Lfd. Nr. Titel

Laufzeit

1557 Zolltarife für den Gütertransport durch die Schweiz nach Frankreich

- Antrag der Stadt Danzig beim Reichstag auf Zustimmung zum deutsch-russischen Handelsvertrages unter Neufestsetzung des Zolltarifs, 1893

- Regelungen der französischen Regierung hinsichtlich Verzollung über die Schweiz eingeführter Waren, 1894

$1893-1894$

Klassifikation Teil B: 01590

Trägermaterial: Papier Alte Reg.-Sig.: IV Ml 15

Bestell-Nr.: IV 01590

1558 Schifffahrtsvertrag zwischen dem Norddeutschen Bund und Italien

- Regelung der Schifffahrtsabgaben für italienische Schiffe in Deutschland und für deutsche Schiffe in Italien auf Basis der Schiffsgröße, Dezember 1867 - Dezember 1868

- Nachweisung in Italien vermessener Emder Schiffe, Dezember 1868

/ Januar 1869

- Regelung er Schiffsvermessungen in Italien, 1869 - 1890

$1867-1890$

Klassifikation Teil B: 01592

Trägermaterial: Papier Alte Reg.-Sig.: IV MI 16

Bestell-Nr.: IV 01592 
Lfd. Nr. Titel

- Bericht des Magistrats an den preußischen Landdrosten in Aurich über Hafentarif in Emden, Oktober 1873

- Neufassung der Hafenabgabentarife in Emden aufgrund einer Verfügung des preußischen Landdrosten in Aurich, März - Dezember 1874

- Monita des kgl. Prozinzial-Steuer-Direktors in Hannover zu den Hafenabgaben in Emden, September - Oktober 1874

- Initiative der Kaufmännischen Deputation zur Befreiung der am Bahnhofskai und im Eisenbahndock liegenden Schiffe von den Hafengebühren, Juni 1881 - November 1883

- Ermäßigung der Hafenabgaben bei Fluss-, Watt-, und kleinen Schiffen, Oktober 1881 - April 1886

- Streitigkeiten um die Entrichtung der Hafenabgaben, 1884 - 1886

- Antrag der Kaufmännischen Deputation auf Ermäßigung der Hafengebühren für Schiffe mit Kohlenladung, September 1886 - Eintreibung rückständiger Hafen- und Kajungsgebühren, 1888 - Anfragen des kgl. Hauptzollamts wegen Ausnahmeregelungen der Stadt Emden bei der Erhebung der Hafenabgaben, 1889 - 1893

$1873-1893$

Klassifikation Teil B: 01535

Trägermaterial: Papier

Alte Reg.-Sig.: IV Mg 03

Bestell-Nr.: IV 01535

1560 Ostfriesisches Lastengeld

- Gutachten des Oberbürgermeisters Fürbringer für die Aufhebung des ostfriesischen Lastengeldes als Fördermaßnahme für die Schifffahrt, Februar 1889

- Eingabe der Handelskammer für Ostfriesland und Papenburg an den Regierungspräsidenten über Bitte um Aufhebung des Lastengeldes als Hemmnis der Schifffahrt, Mai 1889

1889

Klassifikation Teil B: 01591

Trägermaterial: Papier Alte Reg.-Sig.: IV MI 01

Bestell-Nr.: IV 01591 
IV

05

05.03

05.03.09

05.03.09.11
Stadtverwaltung

Aufgabenbereiche der Stadtverwaltung

Wasser- und Schifffahrtssachen

Schifffahrtsabgaben

Lfd. Nr. Titel

Laufzeit

1561 Ermäßigung der Abgaben der Küstenschfffahrt

1873-1909

- Gemeinsamer Erlass der preußischen Minister der Finanzen, Handel und Gewerbe sowie der öffentlichen Arbeiten über Festlegung eines neuen Abgabentarifs zur Entlastung der Küstenschifffahrt, März 1873

- Bericht des Magistrats über Umsetzung der neuen Tarife in Emden, Juli - Oktober 1873

- Verfügung des Regierungspräsidenten in Aurich über Abgaben niederländischer Leichter in Emden, September - Dezember 1882

- Wiederzulassung niederländischer Schiffe zur deutschen

Küstenschifffahrt, Januar 1885 - Januar 1886

- Erlass des Ministers für Handel und Gewerbe über Erfassung der im außerdeutschen Küstenhandel involvierten deutschen Schiffe, März 1897

- Gemeinsamer Erlass der preußischen Minister des Innern und für öffentliche Arbeiten über Forderung der deutschen Küstenschifffahrt durch Transportmonopol für Staatsbaustellen, November 1899 / Mai Juni 1909

$1873-1909$

Klassifikation Teil B: 01593

Trägermaterial: Papier

Alte Reg.-Sig.: IV MI 17

Bestell-Nr.: IV 01593 
Lfd. Nr. Titel

- Abschaffung der Abgabe des Torf- und Torabwurfs (Abgabe für die

Entladung von Torf u.a. Material), 1847 - 1856

- Bekanntmachung der Neuregelung der Kanalabgabe und des

Torfabwurfs in Emden, (April 1856 - April 1859) März 1866 -

September 1879

- Beschwerden von Fehnschiffen gegen die Emder Kanalabgabe,

(1856 - 1858) 1898

- Verhandlung der städtischen Kollegien über Ausdehnung der

Kanalabgabe auf Dorfschiffe und durchfahrende Torfschiffe, 1873

- Vergütung an den Aufseher Hobarth für die Hebung der

Kanalabgabe, September 1874

- Dienstaufgaben des Kanalabgabeneinnehmers, Dreckwarfaufsehers und Verwalters des Herrentorkrans, September 1876

- Erlass des preußischen Mlnisters der öffentlichen Arbeiten über Befreiung von mit Stadtdung beladenen Schiffen von der Kanalabgabe, Juli 1881

- Einstellung des Packhausmeisters Johannes Böse als Kanalabgabeneinnehmer und Verwalter des Herrentorkrans, Dezember 1883 - Januar 1884

- Wahrnehmung der Aufgaben des Kanalabgabeneinnehmers durch seine Witwe Tibina Böse, geb. de Vries, 1885 - 1888

- Antrag der Witwe Böse auf Nachlass der Pacht für die Kanalabgabe wegen rückläufiger Einnahmen durch die Verringerung der

Schiffspassagen beim Herrentor, Januar 1887 - Februar 1888

(1847 - 1866) 1873 - 1898

Klassifikation Teil B: 01594

Band: 1

Trägermaterial: Papier

Alte Reg.-Sig.: IV Mm 1

Bestell-Nr.: IV 01594

1563 Kanalabgabe, Bd. 2

$1900-1912$

(1932)

- Bewerbungen um die Stelle eines Kanalabgabeneinnehmers, April 1900

- Einstellung des Maschinisten Geerd Klaasen als

Kanalabgabeneinnehmer am Herrentor, Mai 1900

- Antrag des Kanalabgabeneinnehmers Geerd Klaasen auf Anschluss seiner Dienstwohnung im Pförtnerhaus am Herrentor an die Wasserleitung, Juni 1907

- Bescheid des Regierungspräsidenten über nicht vorliegenden Rechtsanspruch der Stadt Emden auf Entschädigung für entgehende Einnahmen aus der Kanalabgabe bei Sperrung des Fehntjer Tiefs und Vorschlag der Verlegung der Hebestelle sowie der Abgabeneinziehung durch den Schleusenwärter der Kesselschleuse, April 1908

$1900-1912$

Klassifikation Teil B: 01595

Band: 2

Trägermaterial: Papier

Alte Reg.-Sig.: IV Mm 1

Bestell-Nr.: IV 01595 
05

05.03

05.03.09

05.03.09.11

Lfd. Nr. Titel

1564 Umgehung der Kanalabgabe

Stadtverwaltung

Aufgabenbereiche der Stadtverwaltung

Wasser- und Schifffahrtssachen

Schifffahrtsabgaben

IV

Anzeigen gegen Schiffer wegen Umgehung der Kanalabgabe

(1856 - 1862) 1868 - 1897

Klassifikation Teil B: 01596

Trägermaterial: Papier

Alte Reg.-Sig.: IV Mm 2

Bestell-Nr.: IV 01596
Laufzeit

1868-1897

(1856-1862) 
Lfd. Nr. Titel

1565 Befähigungszeugnisse für Schiffer und Steuermänner

- Erteilung von Befähigungszeugnissen für Schiffer und Steuermänner

$1867-1879$

Klassifikation Teil B: 01597

Trägermaterial: Papier

Alte Reg.-Sig.: IV Mn 1

Bestell-Nr.: IV 01597

1566 Steuermänner und Seeschiffer

- Aufstellung über in Emden wohnende Seeschiffer und Steuermänner

$1867-1872$

Klassifikation Teil B: 01598

Trägermaterial: Papier

Alte Reg.-Sig.: IV Mn 4

Bestell-Nr.: IV 01598

1567 Eignung der Schiffer und Steuermänner

- Beschwerde des Seemannskollegiums wegen Ausstellung von

Zeugnissen der Befähigung zur Küstenfahrt an unqualifizierte

Personen, Mai 1877 - Juli 1879

- Regelungen auf Reichsebene wegen Qualifikationsnachweise für Schiffer und Steuermänner, 1874 - 1910

- Stellungnahme der Kaufmännischen Deputation und des

Seemannskollegiums zur Novellierung der Prüfungsordnung für

Steuermänner, Dezember 1883 - Januar 1884

- Neufestsetzung der Fahrgrenzen für Küstenfahrer (Patent für "Kleine

Fahrt"), Februar - März 1884

- Verfügung des preußischen Landdrosten in Aurich über vorliegenden Straftatbestand bei Umgehung der Vorschriften zur Qualifikation von

Schiffsführern, März 1884

- Stellungnahme der kgl. Navigationsschule Emden zu

Qualifikationsrichtlinien von Kapitänen auf Dampfschiffen im Maschinistenfach, Juni 1887

- Erlass des Ministers für Handel und Gewerbe über Verbot der Fahrt großer Seeschiffe ohne qualifizierte Steuermänner, Mai 1887

- Antrag der Emder Heringsfischereien an den Magistrat auf

Zulassung niederländischer Schiffsführer und Steuermänner wegen

Mangel an geeignetem deutschen Personal, Mai - Juni 1906

- Regelung des Führens von Fahrtenbüchern durch Schiffspersonal, $1908-1913$

$1877-1915$

Klassifikation Teil B: 01599

Trägermaterial: Papier

Alte Reg.-Sig.: IV Mn 2

Bestell-Nr.: IV 01599 
05

05.03

05.03.09

05.03.09.12
Stadtverwaltung

Aufgabenbereiche der Stadtverwaltung

Wasser- und Schifffahrtssachen

Qualifizierung der Schiffsführer und -Offiziere

Lfd. Nr. Titel

Laufzeit

1568 Ausstellung von Befähigungszeugnissen

- Anträge von Schiffsführer auf Erstellung von Messbriefen zur Belegung ihrer Qualifizierung zur Führung von Schiffen

(1861 - 1862) 1867 - 1892

Klassifikation Teil B: 01600

Trägermaterial: Papier

Alte Reg.-Sig.: IV Mn 5

Bestell-Nr.: IV 01600

1569 Prüfungsvorschriften für Seedampfschiffs-Maschinisten

- Diskussion der Ausdehnung der Befugnisse der

Seedampfschiffs-Maschinisten III. Klasse, 1882 - 1883

- Neuregelung der Vorschriften wegen Befähigung zum Maschinisten auf größeren Seeschiffen, 1886

- Verhandlungen der technischen Kommission für Seeschifffahrt über Reform der Ordnung über Maschinisten auf Seeschiffen und deren

Befähigung, Januar - Februar 1889

- Diskussion der Änderung der Prüfungsordnung für Seemaschinisten hinsichtlich der Erstellung von Maschinenzeichnungen, Mai 1889

$1882-1889$

Klassifikation Teil B: 01601

Trägermaterial: Papier

Alte Reg.-Sig.: IV Mn 6

Bestell-Nr.: IV 01601 
IV

05

Stadtverwaltung

05.03

Aufgabenbereiche der Stadtverwaltung

05.03.09

05.03.09.13

Wasser- und Schifffahrtssachen

Lfd. Nr. Titel

Seepasssachen und Schiffsstatistik

1570 Schiffsstatistik, Bd. 1

Laufzeit

1872-1896

- Erhebungen über Ladungen und Reiseziele Emder Schiffe

$1872-1896$

Klassifikation Teil B: 01602

Band: 1

Trägermaterial: Papier

Alte Reg.-Sig.: IV Mo 01

Bestell-Nr.: IV 01602

1571 Schiffsstatistik, Bd. 2

1900-1902

- Erhebungen über Ladungen und Reiseziele Emder Schiffe

$1900-1902$

Klassifikation Teil B: 01603

Band: 2

Trägermaterial: Papier

Alte Reg.-Sig.: IV Mo 01

Bestell-Nr.: IV 01603

1572 Führung der Schiffsregister

- Reichsgesetz über Registrierung und Bezeichnung der Kauffahrteischiffe, Juni 1879

- Umflaggung des niederländischen Schiffes "Nil Desperandum" wegen Erwerb durch einen deutschen Schiffer, Juni 1902

- Polizeiverordnung über Führung eines Schiffstagebuches, Februar 1904

$1879-1904$

Klassifikation Teil B: 01604

Trägermaterial: Papier

Alte Reg.-Sig.: IV Mo 11

Bestell-Nr.: IV 01604 
IV

05

Stadtverwaltung

05.03

Aufgabenbereiche der Stadtverwaltung

05.03.09

05.03.09.14

Wasser- und Schifffahrtssachen

Lfd. Nr. Titel

\section{Flaggennummern}

1573 Recht zum Führen der Flagge mit dem Eisernen Kreuz

Laufzeit

Ausführungsbestimmungen des Reichsmarineamts zur

Allerhöchsten Order über das Recht zum Führen der Flagge mit dem

Eisernen Kreuz

1903

Klassifikation Teil B: 01610

Trägermaterial: Papier

Alte Reg.-Sig.: IV Mp 3

Bestell-Nr.: IV 01610 
IV

05

05.03

05.03.09

05.03.09.15
Stadtverwaltung

Aufgabenbereiche der Stadtverwaltung

Wasser- und Schifffahrtssachen

Schiffsmusterungen

Lfd. Nr. Titel

Laufzeit

1574 Schiffsmusterungen

1868-1912

- Einstellung und Entlassung von Seeleuten

- Verfahren gegen desertierte Seeleute wegen Vertragsbruch

- Abwicklung des Nachlasses verstorbener Seeleute

- Veränderungen im Schiffsregister

$1868-1912$

Klassifikation Teil B: 01611

Trägermaterial: Papier

Alte Reg.-Sig.: IV Ms 2

Bestell-Nr.: IV 01611

1575 Seemanns-Ordnung

- Organisation der Vollstreckung von Strafen gegen Seeleute durch die Seemannsämter, August 1897

- Diskussion der vom Handelsministerium angeregten Einführung

eines Fahrtenbuches für Küstenfischer, November 1903

- Eingabe des Konservenfabrikanten Heinrich Dammeyer an den

Magistrat über Bitte um Aufklärung von Reedereien und

Heringsfischereien zur Ausrüstung ihrer Schiffe mit

Gemüsekonserven zur Verhütung von Skorbut, Juni 1905

- Erlass des Reichskanzlers über Behandlung geschlechtskranker niederländischer Seeleute, Juni 1914

$1897-1914$

Klassifikation Teil B: 01613

Trägermaterial: Papier

Alte Reg.-Sig.: IV Ms 7

Bestell-Nr.: IV 01613 
IV

05

05.03

05.03.09

05.03.09.15
Stadtverwaltung

Aufgabenbereiche der Stadtverwaltung

Wasser- und Schifffahrtssachen

Schiffsmusterungen

Lfd. Nr. Titel

Laufzeit

1576 Auseinandersetzungen wegen Heuer für Seeleute

- Anzeigen von Seeleuten wegen Vorenthaltung von Heuerzahlungen, 1868

- Heuerforderungen der schiffsbrüchigen Matrosen Heinrich Preuß und Jan Wiards Bruns aus Emden, Mai 1868

- Hilfeersuchen des von einem niederländischen Schiff entlassenen Schiffsjungen Anton Heyen aus Elsfleth, Juli - August 1869

- Überweisung des Nachlasses versorbener Seeleute an ihre

Verwandten, 1867 - 1903

- Verfügung des preußischen Innenministers über Hilfeleistung für Mitglieder preußischer Schiffsbesatzungen im Fall der Heimreise nach Schiffsbruch, Februar 1869

- Schreiben der Handelskammer über nicht vorliegende Verpflichtung der Reedereien zur Bezahlung der Heimreise schiffsbrüchiger, gestrandeter Seeleute, April 1869

- Anfrage der Polizeiverwaltung in Geestemünde nach der Herkunft eines geisteskranken Seemanns, Juni 1869

- Ausstellung eines Heimatsscheins für den 16-jährigen Seemann

Alexander Meinke, Juni 1870

- Finanzierung der Heimreise erkrankter deutscher Seeleute im Ausland, 1876 - 1891

$1868-1891$

Klassifikation Teil B: 01614

Trägermaterial: Papier

Alte Reg.-Sig.: IV Ms 8

Bestell-Nr.: IV 01614

1577 Schiffsmusterungen

$1869-1890$

- Antrag des Magistrats der Stadt Papenburg auf Modifikation der Abmeldepflicht von auf Handelsschiffen anmusternder

Marinereservisten, Februar - März 1869

- Neuregelung der Nachmusterung von Seeleuten für Ostasienfahrten und Regelung der Eintragung in die Musterrolle, Oktober - November 1890

$1869-1890$

Klassifikation Teil B: 01615

Trägermaterial: Papier

Alte Reg.-Sig.: IV Ms 3

Bestell-Nr.: IV 01612

1578 Schiffsmusterrolle

1873-1975

- Musterrolle für das Schiff "Antje Dirks"

$1873-1875$

Klassifikation Teil B: 01615

Trägermaterial: Papier

Alte Reg.-Sig.: IV Ms 9

Bestell-Nr.: IV 01615 
Lfd. Nr. Titel Navigationsschule

1579 Rechnungsführung der kgl. Navigationsschule

Laufzeit

- Verfügungen des preußischen Landdrosten und des

Regierungspräsidenten in Aurich über Richtlinien der

Rechnungsführung in den Navigationsschulen, Mai 1870 - April 1912

- Festlegung der Prüfungsgebühren der Navigationsschule, August 1870

- Erlasse des preußischen Handelsministers, Innenimnisters und Finanzministers über Normen der Rechnungsführung, 1870 - 1917

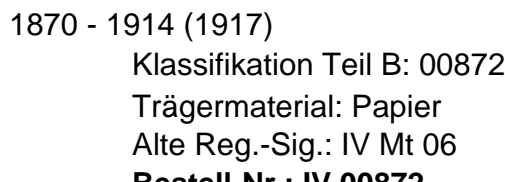

- Abnahmeprotokolle der Rechnungen der Navigationsschule in Emden, 1870 - 1875

- Verhandlungen über Anmerkungen zur Rechnung der Navigationsschule, 1872 - 1898

- Schulgeld der Navigationsschule in Emden, 1883 - 1887

$1870-1898$

Klassifikation Teil B: 00873

Trägermaterial: Papier Alte Reg.-Sig.: IV Mt 06

Bestell-Nr.: IV 00873

- Vermerk des Bürgermeisters Dr. Mützelburg über Argumente für Emden als Seefahrtsschulstandort, Oktober 1917

- Schreiben des Bürgermeisters Dr. Mützelburg an den preußischen Minister für Handel und Gewerbe über Bitte um Erhalt des

Seefahrtsschulstandorts Emden, Oktober 1917

- Verhandlungen des Landtagsabgeordneten und ehemaligen Emder Oberbürgermeister, Leo Fürbringer, beim Handelsministerium über Möglichkeiten zum Erhalt der Emder Seefahrtsschule und Rat zum Erwerb des Hansahauses in der Ringstraße als neues Schulgebäude, November 1917

- Bescheid des preußischen Handelsministers über Ablehnung des Emder Angebotes bezüglich des Hansa-Hauses, Januar 1918 - Initiative des Landtagsabgeordneten Leo Fürbringer zum Erhalt der Emder Seeschiffahrtsschule, Januar - Februar 1918

$1917-1918$

Klassifikation Teil B: 00874

Trägermaterial: Papier Alte Reg.-Sig.: IV Mt 07

Bestell-Nr.: IV 00874 
IV

05

05.03

05.03.09

05.03.09.16
Stadtverwaltung

Aufgabenbereiche der Stadtverwaltung

Wasser- und Schifffahrtssachen

Navigationsschule

Lfd. Nr. Titel

Laufzeit

1582 Lehrer der Seefahrtsschule in Emden, Bd. 1

- Erlass des preußischen Ministers für Handel, Gewerbe und

öffentliche Arbeiten über Genehmigung des Entlassungsgesuches des

Navigationslehrers Adolph Bermpohl, November 1870

- Erlass des preußischen Ministers für Handel, Gewerbe und

öffentliche Arbeiten über Einstellung des Navigationslehrers Kuhn,

Dezember 1870

- Verfügung der preußischen Landdrostei in Aurich über Ablehnung eines Extra-Gehalts für die Erteilung von Englisch-Unterricht durch den Navigationslehrer Kuhn, Februar 1871

- Erlass des preußischen Ministers für Handel, Gewerbe und öffentliche Arbeiten über Einstellung des Navigationslehrers Wendtland an die Navigationsschule in Emden, August 1871

- Einstellung des Gymnasial-Oberlehrers Wiarda als Englisch-Lehrer an der Navigationsschule, Oktober 1871

$1870-1871$

Klassifikation Teil B: 00875

Band: 1

Trägermaterial: Papier

Alte Reg.-Sig.: IV Mt 09

Bestell-Nr.: IV 00875

1583 Lehrer der Seefahrtsschule in Emden, Bd. 2

- Beleidigung der Navigationsschüler urch den Gymnasiallehrer Dr.

Graeser, Januar 1893

- Gesuch des Navigationslehrers beim Kuratorium der

Navigationsschule um Unterstützung wegen hohen

Unterrichtsengagement, Februar 1893

- Vertretung für den erkrankten Navigationslehrer Müller, März 1895

$1893-1895$

Klassifikation Teil B: 00876

Band: 2

Trägermaterial: Papier

Alte Reg.-Sig.: IV Mt 09

Bestell-Nr.: IV 00876 
IV

05

05.03

05.03.09

05.03.09.16
Stadtverwaltung

Aufgabenbereiche der Stadtverwaltung

Wasser- und Schifffahrtssachen

Navigationsschule

Lfd. Nr. Titel

Laufzeit

1584 Lehrer an der Seefahrtsschule in Emden, Bd. 3

- Urlaubsgesuche des Navigationslehrers Kuhn, April 1905 -

November 1907

- Versetzung des Navigationslehrers Bolwin von Emden nach

Stralsund, Juli 1904

- Entsendung des Navigationslehrers als zusätzliche Lehrkraft zur

Navigationsschule Leer, September - November 1905

- Erlass des preußischen Ministers für Handel und Gewerbe über

Neufestlegung der Gehälter der Navigationsschullehrer, April 1907

- Persönliche Verhältnisse des Navigationslehrers Johannes Gerhard

Kühne, 1907

- Genehmigung der Betreuung der Wetterstation und der Seewarte in

Emden durch den Navigationsschullehrer Mennenga, November 1909

- November 1912

- Urlaubsgesuch des Navigationslehrers Mennenga, Januar 1911

- Versetzung des Navigationslehrers Christian Lange von Leer nach

Emden, Juni 1913

- Urlaubsgesuch des Navigationslehrers Lange, März 1914

- Einberufung des Navigationslehrers Lange zur Flotte, November

1915

- Versetzung des Seefahrtsschullehrers Christian Lange nach Barth b.

Danzig, September 1916

$1905-1916(1918)$

Klassifikation Teil B: 00878

Band: 3

Trägermaterial: Papier

Alte Reg.-Sig.: IV Mt 09

Bestell-Nr.: IV 00878

1585 Rechnungsführung der Navigationsschule. Bd. 1

$1872-1890$

- Verfügung des preußischen Landdrosten in Aurich über Richtlinien zur Rechnungsführung der Navigationsschule, Januar - März 1872

- Revision der Rechnungen der Navigationsschule, Januar 1872 -

Dezember 1890

- Nota zur Rechnung der Navigationsschule, Mai 1876

- Ernennung des Steuereinnehmers Düvel zum Kassenführer der

Navigationsschule, Januar 1884

$1872-1894$

Klassifikation Teil B: 00879

Band: 1

Trägermaterial: Papier

Alte Reg.-Sig.: IV Mt 06

Bestell-Nr.: IV 00879 
IV

05

Stadtverwaltung

05.03

Aufgabenbereiche der Stadtverwaltung

05.03.09

05.03.09.16

Wasser- und Schifffahrtssachen

Navigationsschule

Lfd. Nr. Titel

Laufzeit

1586 Rechnungsführung der Navigationsschule, Bd. 2

1893

- Etat der Navigationsschule Emden, 1893

1893

\author{
Klassifikation Teil B: 00880 \\ Band: 2 \\ Trägermaterial: Papier \\ Alte Reg.-Sig.: IV Mt 06 \\ Bestell-Nr.: IV 00880
}

1587 Steuermannsklasse der Navigationsschule

- Ankündigungen über Steuermannskurse an der Navigationsschule, August 1870

- Aufnahmeprüfungen für die Absolventen der Steuermannsklasse zur

Steuermannsschule in Jever, April 1870 / Dezember 1870

- Aufstellung über Schüler der Steuermannsklasse, 1871

$1870-1871$

Klassifikation Teil B: 00881

Trägermaterial: Papier

Alte Reg.-Sig.: IV Mt 08

Bestell-Nr.: IV 00881

1588 Navigationsschule, Bd. 1

$1871-1895$

- Anmeldungen und Zulassungen zu den Steuermannskursen der

Navigationsschule, 1871 - 1895

- Schülerverzeichnisse (Steuermannskurse), 1871 - 1891

- Stundenpläne der Steuermannskurse, 1875 - 1876

- Ankündigung der Steuermannskurse der Navigationsschule, 1877 -

1894

- Ernennung der Navigationsschullehrer Matthies, Emden und Reuter, Leer zu Mitgliedern der Prüfungskommission für Steuermänner in der

Provinz Hannover, Mai 1895

$1871-1895$

Klassifikation Teil B: 01605

Band: 1

Trägermaterial: Papier

Alte Reg.-Sig.: IV Mt 10

Vorprovenienz: Kuratorium der Navigationsschule

Bestell-Nr.: IV 01605 
Lfd. Nr. Titel

- Verhandlungen des Kuratoriums der kgl. Navigationsschule mit dem Magistrat wegen Mitnutzung von Räumen der Navigationsschule durch Klassen der Handelsschule, April 1872

- Anschaffung aktueller Seekarten für die Navigationsschule, 1875

- Stundenpläne der Steuermannskurse, 1876 - 1895

- Genehmigung der Mitnutzung von Räumen der Navigationsschule durch Klassen der Lateinschule (Höhere Bürgerschule) durch den Rektor der Navigationsschulen in der Provinz Hannover, Januar 1888

- Ergebnis der Steuermannsprüfungen in der Emder Navigationsschule, Juni 1889

- Kündigung des Abonnements einer niederländischen Zeitschrift für Meteorologie wegen Sprachunkenntnis der Navigationsschullehrer, Dezember 1891

$1872-1895$

Klassifikation Teil B: 01606

Band: 2

Trägermaterial: Papier

Alte Reg.-Sig.: IV Mt 10

Vorprovenienz: Kuratorium der Navigationsschule

Bestell-Nr.: IV 01606

1590 Ergebnisse der Schifferprüfungen für "Kleine Fahrt"

- Statistische Berichte über Ergebnisse der Schifferprüfungen für

"Kleine Fahrt"

$1974-1888$

Klassifikation Teil B: 01607

Trägermaterial: Papier

Alte Reg.-Sig.: IV Mt 11

Vorprovenienz: Kuratorium der Navigationsschule

Bestell-Nr.: IV 01607

1591 Korrespondenz zwischen den Navigationsschulen der Provinz Hannover

- Informationen über Zurückweisung von Bewerbern um Kurse der Navigationsschulen wegen mangelhafter Kenntnisse, 1870 - 1897

- Berufung von Navigationsschullehrern in die Prüfungskommission für Schiffer und Steuermänner, 1878 - 1896

- Verzeichnis der wegen mangelhafter Leistungen zeitweilig von Steuermanns- und Schifferprüfungen ausgeschlossenen Schüler, 1897 - 1909

$1870-1909$

Klassifikation Teil B: 01608

Trägermaterial: Papier Alte Reg.-Sig.: IV Mt 12

Vorprovenienz: Kuratorium der Navigationsschule

Bestell-Nr.: IV 01608 
IV

05

Stadtverwaltung

05.03

Aufgabenbereiche der Stadtverwaltung

05.03.09

05.03.09.16

Wasser- und Schifffahrtssachen

Navigationsschule

Lfd. Nr. Titel

Laufzeit

1592 Navigationsschulgebäude

1880-1894

- Ausführung des Regulativs über Dienstwohnungen wegen der

Wohnungen der Navigationsschullehrer, 1880 - 1881

- Besichtigung des Navigationsschulgebäudes zur Feststellung von

Baumängeln, März 1883

- Erlass des Ministers für Handel und Gewerbe über Bewilligung einer

Beihilfe zur Renovierung des Navigationsschulgebäudes in Emden,

August 1885

- Verfügung des Regierungspräsidenten in Aurich über Anordnung der

Beseitigung von Bauschäden unter 500 Mark durch die

Navigationsschulen des Bezirks in eigener Regie, Juli 1885

- Finanzierung und Organisation der Bauunterhaltung der

Navigationsschule, 1886 - 1894

$1880-1894$

Klassifikation Teil B: 01609

Trägermaterial: Papier

Alte Reg.-Sig.: IV Mt 13

Vorprovenienz: Kuratorium der Navigationsschule

Bestell-Nr.: IV 01609

1593 Bibliothek der Navigationsschule

- Inventar der Navigantionsschulbibliothek

1870

Klassifikation Teil B: 01616

Trägermaterial: Papier

Alte Reg.-Sig.: IV Mt 01

Vorprovenienz: Kuratorium der Navigationsschule

Bestell-Nr.: IV 01616 
Lfd. Nr. Titel Navigationsschule

1594 Schulwärterdienst in der Navigationsschule

Laufzeit

- Anmietung des dem Gymnasium gehörenden Gebäudes an der Steinstraße (Comp. 1, Nr. 40) durch die Navigationsschulkommission zur Nutzung als Navigationsschule, Mai 1875

- Erhöhung der Vergütung für den Schulwärter der Navigationsschule wegen Vergrößerung der Schulräume, Januar 1880

- Entlassungsgesuch des Navigationsschuldieners Evert Ross, Januar 1880

- Einstellung der Witwe L. Wurtzema als Navigationsschulwärterin, Januar - April 1880

- Verpflichtung des Navigationsschullehrers Kruse zur Reinigung der Straße vor seiner Dienstwohnung, Juni 1880

- Beschwerden der Navigationsschullehrer Matthies und Müller über mangelhafte Arbeitsleistung der Navigationsschulwärterin Wurtzema, Mai 1892

- Ausschreibung der Navigationsschulwärterstelle, Januar 1894

- Einstellung der Tyake Lose als Navigationsschulwärterin, März 1894

- Antrag der Navigationsschulwärterin Tyake Lose an das Kuratorium der Navigationsschule auf Erhöhung ihrer Vergütung, Februar - Mai 1895

- Senkung der Vergütung der Navigationsschulwärterin wegen

Verringerung der Zahl der zu reinigenden Schulräume, Juni - Juli 1897 - Übernahme des Schulwärterdienstes durch das Dienstmädchen des Navigationsschullehrers Kühne, Juli - August 1905

$1875-1905$

Klassifikation Teil B: 01617

Trägermaterial: Papier

Alte Reg.-Sig.: IV Mt 02

Vorprovenienz: Kuratorium der Navigationsschule

Bestell-Nr.: IV 01617

- Gewährung eines Beitrages zur Unterstützung bedürftger Navigationsschüler durch die Stadt Emden, Mai - Juni 1893

- Anträge von Navigationsschüler auf Unterstützung (Localzulage),

Oktober 1893 - September 1896

- Beiträge der Stadt Emden, der Kaufmännischen Deputation und der Heringsfischereien zur Unterstützung bedürftiger Navigationsschüler, Mai 1895

$1893-1896$

Klassifikation Teil B: 01618

Band: 1

Trägermaterial: Papier

Alte Reg.-Sig.: IV Mt 03

Vorprovenienz: Kuratorium der Navigationsschule

Bestell-Nr.: IV 01618 
05

05.03

05.03.09

05.03.09.16
Stadtverwaltung

Aufgabenbereiche der Stadtverwaltung

Wasser- und Schifffahrtssachen

Navigationsschule

Lfd. Nr. Titel

Laufzeit

1596 Unterstützung für Navigationsschüler, Bd. 2

- Verwaltung der Mittel für die Unterstützung bedürftiger

Navigationsschüler, Februar 1894 - März 1896

- Anträge von Navigationsschüler auf Unterstützung (Localzulage),

Juni 1894 - November 1895

$1894-1896$

Klassifikation Teil B: 01619

Band: 2

Trägermaterial: Papier

Alte Reg.-Sig.: IV Mt 03

Vorprovenienz: Kuratorium der Navigationsschule

Bestell-Nr.: IV 01619

1597 Kuratorium der kgl. Navigationsschule zu Emden

$1870-1910$

- Verfügung des preußischen Landdrosten in Aurich über Instruktionen für die Navigationsschulkuratorien des Bezirks hinsichtlich ihrer

Zuständigkeiten, März 1870

- Ernennung der Mitglieder des Kuratorium der kgl. Navigationsschule zu Emden durch den preußischen Landdrosten, später

Regierungspräsidenten in Aurich, März 1870 - November 1892

- Verzicht des Kaufmanns Bernhard Brons auf die Mitgliedschaft im

Kuratorium der Emder Navigationsschule, März 1870

- Mitteilung der Prüfungsaufgaben für das Examen

(Steuermannsprüfung) der Navigationsschule durch den preußischen

Minister für Handel und Gewerbe, November 1870 - Januar 1871

- Verhandlungen des Kuratoriums mit dem Regierungsrat Braun

wegen Rücktrittsabsicht des Bürgermeisters Hantelmann als

Vorsitzender des Kuratoriums, November 1870

- Ernenung von Ersatzmännern für die

Steuermannsprüfungskommission, November 1872 - Februar 1873

- Ernennung der Mitglieder der Prüfungskommission für Schiffer auf

kleine Fahrt, Mai 1873 - Juli 1878

- Übernahme des Amtes des Kuratoriumsvorsitzenden durch den

Bürgermeister Leo Fürbringer, Juli 1876

- Niederlegung der Mitgliedschaft im Kuratorium durch den Kaufmann und Konsul Bernhard Brons, Dezember 1880

- Mitglieder des Kuratoriums der kgl. Navigationsschule, 1904

- Versetzung des Navigationsschuldirektors Kornmehl nach

Geestemünde, August 1910

$1870-1910$

Klassifikation Teil B: 01620

Trägermaterial: Papier

Alte Reg.-Sig.: IV Mt 04

Vorprovenienz: Kuratorium der Navigationsschule

Bestell-Nr.: IV 01620 
IV

05

05.03

05.03.09

05.03.09.16
Stadtverwaltung

Aufgabenbereiche der Stadtverwaltung

Wasser- und Schifffahrtssachen

Navigationsschule

Lfd. Nr. Titel

Laufzeit

1598 Fortbildung der schulentlassenen Schifferjugend

1908

- Anregung der Schaffung einer Einrichtung zur Fortbildung der schulentlassenen Schifferjugend als Schule für die Binnenschifffahrt, Oktober 1908

1908

\author{
Klassifikation Teil B: 01621 \\ Trägermaterial: Papier \\ Alte Reg.-Sig.: IV Mt 05 \\ Vorprovenienz: Kuratorium der Navigationsschule
}

Bestell-Nr.: IV 01621

1599 Mitteilungen an die Navigationsschule über Zulassung für Schiffer, Steuerleute und Maschinisten, Bd. 1

- Verzeichnis von Schiffern mit entzogener Zulassung zur

Gewerbeausübung, 1881

- Erlasse des preußischen Ministers für Handel und Gewerbe über

Entzug der Zulassung zur Gewerbeausübung von Schiffern und

Steuerleuten nach Verurteilung durch Seeämter, Juli 1882 -

Dezember 1883

- Mitteilungserlasse des preußischen Ministers für Handel und

Gewerbe über Wiederzulassung der Gewerbeausübung von Schiffern und Steuerleuten durch Entscheidung des Reichskanzlers, Mai 1882 November 1883

$1881-1883$

Klassifikation Teil B: 01622

Band: 1

Trägermaterial: Papier

Alte Reg.-Sig.: IV Mt 14

Vorprovenienz: Kuratorium der Navigationsschule

Bestell-Nr.: IV 01622

1600 Mitteilungen an die Navigationsschule über Zulassung für Schiffer, Steuerleute und Maschinisten, Bd. 2

- Erlasse des preußischen Ministers für Handel und Gewerbe über Entzug der Zulassung zur Gewerbeausübung von Schiffern und Steuerleuten nach Verurteilung durch Seeämter, Januar 1884 September 1885

- Mitteilungserlasse des preußischen Ministers für Handel und Gewerbe über Wiederzulassung der Gewerbeausübung von Schiffern und Steuerleuten durch Entscheidung des Reichskanzlers, Januar 1884 - August 1885

$1884-1885$

Klassifikation Teil B: 01623

Band: 2

Trägermaterial: Papier

Alte Reg.-Sig.: IV Mt 14

Vorprovenienz: Kuratorium der Navigationsschule

Bestell-Nr.: IV 01623 
IV

05

05.03

05.03.09

05.03.09.16
Stadtverwaltung

Aufgabenbereiche der Stadtverwaltung

Wasser- und Schifffahrtssachen

Navigationsschule

Lfd. Nr. Titel

Laufzeit

1601 Mitteilungen an die Navigationsschule über Zulassung für Schiffer, Steuerleute und Maschinisten, Bd. 3

$1886-1890$

- Erlasse des preußischen Ministers für Handel und Gewerbe über Entzug der Zulassung zur Gewerbeausübung von Schiffern und Steuerleuten nach Verurteilung durch Seeämter, Januar 1886 - April 1890

- Mitteilungserlasse des preußischen Ministers für Handel und Gewerbe über Wiederzulassung der Gewerbeausübung von Schiffern und Steuerleuten durch Entscheidung des Reichskanzlers, März 1886 - Mai 1890

$1886-1890$

Klassifikation Teil B: 01624

Band: 3

Trägermaterial: Papier

Alte Reg.-Sig.: IV Mt 14

Vorprovenienz: Kuratorium der Navigationsschule

Bestell-Nr.: IV 01624

1602 Mitteilungen an die Navigationsschule über Zulassung für Schiffer, Steuerleute und Maschinisten, Bd. 4

- Erlasse des preußischen Ministers für Handel und Gewerbe über Entzug der Zulassung zur Gewerbeausübung von Schiffern und Steuerleuten nach Verurteilung durch Seeämter, Juli 1890 - Januar 1894

- Mitteilungserlasse des preußischen Ministers für Handel und Gewerbe über Wiederzulassung der Gewerbeausübung von Schiffern und Steuerleuten durch Entscheidung des Reichskanzlers, Juli 1890 September 1894

$1890-1894$

Klassifikation Teil B: 01625

Band: 4

Trägermaterial: Papier

Alte Reg.-Sig.: IV Mt 14

Vorprovenienz: Kuratorium der Navigationsschule

Bestell-Nr.: IV 01625 
IV

05

05.03

05.03.09

05.03.09.16
Stadtverwaltung

Aufgabenbereiche der Stadtverwaltung

Wasser- und Schifffahrtssachen

Navigationsschule

Lfd. Nr. Titel

Laufzeit

1603 Mitteilungen an die Navigationsschule über Zulassung für Schiffer, Steuerleute und Maschinisten, Bd. 5

1895-1903

- Erlasse des preußischen Ministers für Handel und Gewerbe über Entzug der Zulassung zur Gewerbeausübung von Schiffern und

Steuerleuten nach Verurteilung durch Seeämter, Januar 1895 - Juni 1903

- Mitteilungserlasse des preußischen Ministers für Handel und Gewerbe über Wiederzulassung der Gewerbeausübung von Schiffern und Steuerleuten durch Entscheidung des Reichskanzlers, Juli 1895 Juni 1903

$1895-1903$

Klassifikation Teil B: 01626

Band: 5

Trägermaterial: Papier

Alte Reg.-Sig.: IV Mt 14

Vorprovenienz: Kuratorium der Navigationsschule

Bestell-Nr.: IV 01626

1604 Hundertjähriges Jubiläum der Navigationsschule

- Beschluss des Magistrats zur Unterstützung der Jubiläumsprojekte der Navigationsschule, September 1887

- Verhandlungen des Magistrats über Plan zur Errichtung einer

Sommerschule für Vorbereitung der Ausbildung in der Handels- und Kriegsmarine, September 1887

1887

Klassifikation Teil B: 01627

Trägermaterial: Papier

Alte Reg.-Sig.: IV Mt 15

Vorprovenienz: Kuratorium der Navigationsschule

Bestell-Nr.: IV 01627 
IV

05

05.03

05.03.09

05.03.09.16
Stadtverwaltung

Aufgabenbereiche der Stadtverwaltung

Wasser- und Schifffahrtssachen

Navigationsschule

Lfd. Nr. Titel

Laufzeit

1605 Maßnahmen zur Erhöhung der Schülerzahlen der Navigationsschule

$1875-1914$

- Verfügung des preußischen Landdrosten in Aurich über Ablehnung der Errichtung einer weiteren Wohnung für Navigationsschullehrer mit dem Hinweis auf sinkende Schülerzahlen und der daraus resultierenden Bestandsgefahr für die Emder Navigationsschule, August 1875

- Plan der Verlegung der Navigationsschule in das Gebäude des ehemaligen Gymnasiums, August 1876

- Finanzierung von Freistellen in der Navigationsschule durch die Kaufmännische Deputation zur Erhöhung der Schülerzahl in der Einrichtung, September 1876 - Juli 1877

- Antrag des Kuratoriums der Navigationsschule beim preußischen Landdrosten in Aurich auf Benutzung des Regierungsdampfers fur Schulzwecke, September - November 1876

- Angebote von möblierten Zimmern für Navigationsschüler, September 1876

- Verfügung des preußischen Landdrosten in Aurich über Ablehnung der Einrichtung eines Observatoriums auf dem Dach der Navigationsschule unter Hinweis auf eine solche Einrichtung beim Gymnasium, November 1876

- Antrag des Navigationsschullehrers Kruse auf Beihilfe für bedürftige Navigationsschüler, Dezember 1876

- Diskussion des Neubaus einer Navigationsschule vor dem Hintergrund der Konkurrenz zum Schulstandort Leer, Januar 1877 März 1878

- Unterstützungsgesuche von Navigationsschülern, März - Juli 1877

- Ankündigung neuer Steuermannskurse an der Navigationsschule

Emden, 1880 - 1890

- Werbekampagne zur Sicherung der Navigationsschule in Emden angesichts sinkender Schülerzahlen, 1913

$1875-1914$

Klassifikation Teil B: 01628

Trägermaterial: Papier

Alte Reg.-Sig.: IV Mt 16

Vorprovenienz: Kuratorium der Navigationsschule

Bestell-Nr.: IV 01628

1606 Alters- und Invaliditätsversicherung der Navigationsschulangestellten

- Versicherung der Navigationsschulwartin Wurtzema bei der Altersund Invaliditätsversicherung, 1891 - 1893

- Verfügungen des Regierungspräsidenten in Aurich wegen der

Durchführung der Alters- und Invaliditätsversicherung, 1891 - 1893

- Ministerialerlasse wegen Durchführung der Alters- und

Invaliditätsversicherung, 1891 - 1903

$1891-1903$

Klassifikation Teil B: 01629

Trägermaterial: Papier

Alte Reg.-Sig.: IV Mt 17

Vorprovenienz: Kuratorium der Navigationsschule

Bestell-Nr.: IV 01629 
IV

05

05.03

05.03.09

05.03.09.16
Stadtverwaltung

Aufgabenbereiche der Stadtverwaltung

Wasser- und Schifffahrtssachen

Navigationsschule

Lfd. Nr. Titel

Laufzeit

1607 Untersuchung der Seeleute auf Farbenblindheit

- Statistische Nachweise über Farbsichtigkeitsuntersuchungen der

Navigationsschulen, Januar 1893 - April 1909

- Erlasse des preußischen Ministers für Handel und Gewerbe über Nachweis der Farbsichtigkeit als Bedingung für Prüfungszulassung der Steuerleute und Schiffsführer, April 1893 / Juni 1895

- Verfügung des regierungspräsidenten in Aurich über Zusendung und Anordnung der Verwendung von Formularen zum Nachweis der

Farbsichtigkeit der Navigationsschüler, Mai 1892

- Reichsstatistik über Farbblindheit von Seeleuten, 1896 - 1904

- Vorschriften über Durchführung der Farbsichtigkeitstests, 1895 1914

$1893-1914$

Klassifikation Teil B: 01630

Trägermaterial: Papier

Alte Reg.-Sig.: IV Mt 18

Vorprovenienz: Kuratorium der Navigationsschule

Bestell-Nr.: IV 01630

1608 Prüfungsstatistik, Bd. 1

1898-1899

- Statistik über Prüfungen im Schifferfach, Ergebnisse der Prüfungen und Zahl der Prüflinge

$1898-1899$

Klassifikation Teil B: 01631

Band: 1

Trägermaterial: Papier

Alte Reg.-Sig.: IV Mt 19

Vorprovenienz: Kuratorium der Navigationsschule

Bestell-Nr.: IV 01631

1609 Prüfungsstatistik, Bd. 3

1905-1906

- Statistik über Prüfungen im Schifferfach, Ergebnisse der Prüfungen und Zahl der Prüflinge

$1905-1906$

Klassifikation Teil B: 01631

Band: 3

Trägermaterial: Papier

Alte Reg.-Sig.: IV Mt 19

Vorprovenienz: Kuratorium der Navigationsschule

Bestell-Nr.: IV 01633 
IV

05

05.03

05.03.09

05.03.09.16
Stadtverwaltung

Aufgabenbereiche der Stadtverwaltung

Wasser- und Schifffahrtssachen

Navigationsschule

Lfd. Nr. Titel

Laufzeit

1610 Prüfungsstatistik, Bd. 2

1900-1904

- Statistik über Prüfungen im Schifferfach, Ergebnisse der Prüfungen und Zahl der Prüflinge

$1900-1904$

Klassifikation Teil B: 01632

Band: 2

Trägermaterial: Papier

Alte Reg.-Sig.: IV Mt 19

Vorprovenienz: Kuratorium der Navigationsschule

Bestell-Nr.: IV 01632

1611 Prüfungsstatistik, Bd. 4

$1909-1911$

- Statistik über Prüfungen im Schifferfach, Ergebnisse der Prüfungen und Zahl der Prüflinge

$1909-1911$

Klassifikation Teil B: 01634

Band: 4

Trägermaterial: Papier

Alte Reg.-Sig.: IV Mt 19

Vorprovenienz: Kuratorium der Navigationsschule

Bestell-Nr.: IV 01634

1612 Prüfungsstatistik, Bd. 5

- Statistik über Prüfungen im Schifferfach, Ergebnisse der Prüfungen und Zahl der Prüflinge

$1912-1914$

Klassifikation Teil B: 01635

Band: 5

Trägermaterial: Papier

Alte Reg.-Sig.: IV Mt 19

Vorprovenienz: Kuratorium der Navigationsschule

Bestell-Nr.: IV 01635

1613 Prüfungsstatistik, Bd. 1

- Statistik über Prüfungen im Schifferfach, Ergebnisse der Prüfungen und Zahl der Prüflinge

$1915-1917$

Klassifikation Teil B: 01636

Band: 6

Trägermaterial: Papier

Alte Reg.-Sig.: IV Mt 19

Vorprovenienz: Kuratorium der Navigationsschule

Bestell-Nr.: IV 01636 
IV

05

Stadtverwaltung

05.03

Aufgabenbereiche der Stadtverwaltung

05.03.09

05.03.09.16

Wasser- und Schifffahrtssachen

Navigationsschule

Lfd. Nr. Titel

Laufzeit

1614 Tauglichkeitsuntersuchungen von Seeleuten

1905

- Bestimmungen für die Durchführung von

Tauglichkeitsuntersuchungen von Seeleuten

1905

Klassifikation Teil B: 01639

Trägermaterial: Papier

Alte Reg.-Sig.: IV Mt 20

Vorprovenienz: Kuratorium der Navigationsschule

Bestell-Nr.: IV 01639

1615 Fremdnutzung von Räumen der Navigationsschule

1913-1917

(1919)

- Schreiben des evangelischen Arbeiterinnenvereins für Emden und Umgegend an das Kuratorium der Navigationsschule über Bitte um Erlaubnis der Nutzung eines Klassenzimmers der Schule für Vereinszwecke wegen Raumnot, Januar - Februar 1913 - Zuständigkeitsregelung für die bauliche Unterhaltung des vom evangelischen Arbeiterinnenverein genutzten Raumes, Februar - Mai 1913

- Vereinbarung zwischen dem Kuratorium der Navigationsschule und dem evangelischen Arbeiterinnenverein wegen Nutzung eines leer stehenden Klassenzimmers, Mai 1913

- Anordnung des Kuratoriums der Navigationsschule an den evangelischen Arbeiterinnenverein zur Zahlung ihres von den vertraglichen Abmachungen abweichenden Gasverbrauchs, Oktober 1913 - April 1915

$1913-1917$ (1919)

Klassifikation Teil B: 01640

Trägermaterial: Papier

Alte Reg.-Sig.: IV Mt 21

Vorprovenienz: Kuratorium der Navigationsschule

Bestell-Nr.: IV 01640

1616 Einziehung von Beamten in den Heeresdienst

- Material der Navigationsschule: Gesetzliche Bestimmungen wegen

Einziehung von Beamten in den Heeresdienst

$1914-1917$

Klassifikation Teil B: 01641

Trägermaterial: Papier

Alte Reg.-Sig.: IV Mt 22

Vorprovenienz: Kuratorium der Navigationsschule

Bestell-Nr.: IV 01641 
Lfd. Nr. Titel Navigationsschule

- Erlass des preußíschen Ministers für Handel, Gewerbe und öffentliche Arbeiten über Versetzung des Navigationsschullehrers Kruse von Timmel nach Emden und des Navigationsschullehrers Wendtland von Emden nach Leer, Juli 1874

- Antrag des Navigationsschullehrers Kruse auf Einrichtung eines Observatoriums für die Navigationsschule Emden und der Umwandlung der ehemaliogen Wohnung des Gymnasialdirektors in eine Dienstwohnung für Navigationsschullehrer, Juli 1875

- Verfügung des preußischen Landdrosten in Aurich über Erlaubnis der Nebentätigkeit der Navigationsschullehrer als Agenten der Deutschen Seewarte, Oktober 1875

- Vertretung des erkrankten Navigationsschullehrers Kruse, März April 1881

- Beurlaubung des Navigationsschullehrers Kruse wegen Antritt einer Kur, Juni 1881

- Gesundheitszustand des Navigationsvorschullehrers Müller, Oktober 1881 - Dezember 1882

- Antrag des Kuratoriums der Navigationsschule beim preußischen Landdrosten in Aurich auf Erlaubnis der Vertretung des in Utrecht zu einer Augenbehandlung weilenden Navigationsvorschullehrers Müller durch seinen Sohn, Dezember 1882

- Verfügung des Landdrosten in Aurich über Pflicht zur Anzeige von Nebenerwerbstätigkeiten von Navigationsschullehrern, August 1875 /

Oktober 1883

- Erhöhung des Wohngeldzuschusses für den Navigationsvorschullehrer Müller, Oktober 1887

- Anzeige der Vorladung des Navigationsschullehrers Kruse als Zeuge vor Gericht in einem Verfahren wegen eines Tötungsdeliktes,

Dezember 1890

- Verschiedene Ministerialerlasse über beamtenrechtliche und gehaltstechnische Bestimmungen mit Bezug auf die Lehrer der Navigationsschule, 1891 - 1894

- Anzeige des Todes des Navigationsschullehrers Kruse, August 1891

- Antrag des Kuratoriums der Navigationsschule beim

Regierungspräsidenten in Aurich auf Erstattung der Kosten für die Inseration eines Nachrufs auf den Navigationsschullehrer Kruse, November 1891 - Juli 1892

$1875-1894$

Klassifikation Teil B: 01642

Trägermaterial: Papier

Alte Reg.-Sig.: IV Mt 23

Vorprovenienz: Kuratorium der Navigationsschule

Bestell-Nr.: IV 01642 
IV

05

05.03

05.03.09

05.03.09.16
Stadtverwaltung

Aufgabenbereiche der Stadtverwaltung

Wasser- und Schifffahrtssachen

Navigationsschule

Lfd. Nr. Titel

Laufzeit

1618 Etatverwaltung der Navigationsschule

- Etats der Navigationsschule, 1874 - 1883

- Ausgabeanweisungen der Navigationsschule für den Schulbetrieb,

$1879-1896$

$1874-1896$

Klassifikation Teil B: 01643

Trägermaterial: Papier

Alte Reg.-Sig.: IV Mt 24

Vorprovenienz: Kuratorium der Navigationsschule

Bestell-Nr.: IV 01643

1619 Preußischer Landdrost, später Regierungspräsident als

$1870-1911$

Aufsichtsbehörde der Navigationsschule

- Mitteilung der Ministerialerlasse zur Betriebsführung der Navigationsschule und zu Schifffahrtsfragen durch den preußischen Landdrosten, später Regierungspräsidenten in Aurich an das

Kuratorium der Navigationsschule

$1870-1911$

Klassifikation Teil B: 01644

Trägermaterial: Papier

Alte Reg.-Sig.: IV Mt 24

Vorprovenienz: Kuratorium der Navigationsschule

Bestell-Nr.: IV 01644

1620 Rechnungsführung der Navigationsschule

- Verhandlungen zwischen dem Kuratorium der Navigationsschule und dem Regierungspräsidenten in Aurich wegen Abnahme der

Rechnungen der Navigationsschule: Monita des

Regierungspräsidenten und übergeordneter Behörden

$1902-1914$

Klassifikation Teil B: 01645

Trägermaterial: Papier

Alte Reg.-Sig.: IV Mt 25

Vorprovenienz: Kuratorium der Navigationsschule

Bestell-Nr.: IV 01645 
05

\subsection{3}

05.03.09

05.03.09.16
Stadtverwaltung

Aufgabenbereiche der Stadtverwaltung

Wasser- und Schifffahrtssachen

Navigationsschule

Lfd. Nr. Titel

Laufzeit

1621 Prüfung zur Erlangung der Berechtigung eines Schiffers auf Kleiner $1870-1900$ Fahrt

- Ausführungsbestimmungen zur vom Norddeutschen Bund erlassenen Prüfungsordnung für Schiffer auf Kleiner Fahrt, Juli 1870

- Verzeichnisse der Prüflinge, 1873 - 1899

- Ankündigung der Prüfungstermine, 1875 - 1900

- Protokolle der Prüfung, 1876 - 1897

- Verzeichnis zeitweilig von der Prüfung ausgeschlossener

Kandidaten, 1898

$1870-1900$

Klassifikation Teil B: 01646

Trägermaterial: Papier

Alte Reg.-Sig.: IV Mt 25

Vorprovenienz: Kuratorium der Navigationsschule

Bestell-Nr.: IV 01646

1622 Bauliche Unterhaltung der Navigationsschule

- Reparaturen und Instandsetzungsarbeiten am Gebäude der Navigationsschule und ihre Finanzierung, 1895 - 1918

- Anträge des Kuratoriums der Navigationsschule beim Regierungspräsidenten auf Zuweisung von Mittel für bauliche Instandsetzungsarbeiten, 1895 - 1918

- Renovierung der Navigationsschullehrerdienstwohnung nach Wegzug des Navigationsschullehrers Matthies und Übernahme durch seinen Nachfolger Bolwin, Januar - Februar 1898

- Gasanschluss für die Dienstwohnung des Navigationsschullehrers, Oktober 1909

- Ministerialerlasse wegen Bauunterhaltung staatlicher Gebäude und Dienstwohnungen, 1895 - 1918

$1895-1918$

Klassifikation Teil B: 01647

Trägermaterial: Papier

Alte Reg.-Sig.: IV Mt 25

Vorprovenienz: Kuratorium der Navigationsschule

Bestell-Nr.: IV 01647 
IV

05

05.03

05.03.09

05.03.09.16
Stadtverwaltung

Aufgabenbereiche der Stadtverwaltung

Wasser- und Schifffahrtssachen

Navigationsschule

Lfd. Nr. Titel

Laufzeit

1623 Hundertjähriges Bestehen der Navigationsschule

- Bitte des Kuratoriums der Navigationsschule um Akteneinsicht beim preußischen Landdrosten und bei der Kaufmännischen Deputation zur Ermittlung von Daten zur Geschichte der Schule seit 1782, Dezember 1880

- Verhandlungen des Kuratoriums der Navigationsschule über Organisation der Jubiläumsfeier der Navigationsschule, Februar 1881 - Eingabe des Kuratoriums der Navigationsschule an den preußischen Landdrosten in Aurich über Bitte um Beförderung seines Antrags auf Erhebung der Emder Navigationsschule in den Rang einer vollen Navigationsschule mit Schifferklasse, September 1881

- Glückwunschtelegramme zum Jubiläum der Navigationsschule, Dezember 1882

- Statistisches Material über Schülerzahlentwicklung in den Navigationsschulen der Provinz Hannover, 1882

- Antrag des Navigationsschullehrers Kruse auf Vergütung seiner Arbeit am Manuskript der Jubiläumsschrift, August 1885

- Antrag des Kuratoriums der Navigationsschule beim preußischen Minister für Handel und Gewerbe auf Förderung der Drucklegung der Jubiläumsschrift und Vergütung für den Navigationsschullehrer Kruse als Autor, August - September 1885

$1880-1885$

Klassifikation Teil B: 01648

Trägermaterial: Papier

Alte Reg.-Sig.: IV Mt 25

Vorprovenienz: Kuratorium der Navigationsschule

Bestell-Nr.: IV 01648

1624 Erste-Hilfe- und Gesundheitsprüfungen an der Navigationsschule

- Regelungen zur Organisation der Erste-Hilfe- und

Gesundheitsprüfungen für Navigationsschüler

$1910-1917$

Klassifikation Teil B: 01649

Trägermaterial: Papier

Alte Reg.-Sig.: IV Mt 25

Vorprovenienz: Kuratorium der Navigationsschule

Bestell-Nr.: IV 01649 
Lfd. Nr. Titel

- Initiative der Kaufmännischen Deputation zur Errichtung einer

Binnenschifferschule in Emden, Mai 1913

- Bescheid des Regierungspräsidenten an das Kuratorium der Navigationsschule über Favorisierung des Standorts Leer für die Binnenschifferschule wegen günstigerer Verkehrslage für die Schifferbevölkerung (Fehngebiet), Juni 1913

- Bekanntmachung des Landrates des Kreises Leer über Eröffnung einer Binnenschifferschule in Leer, Dezember 1913

1913

Klassifikation Teil B: 01650

Trägermaterial: Papier

Alte Reg.-Sig.: IV Mt 25

Vorprovenienz: Kuratorium der Navigationsschule

Bestell-Nr.: IV 01650

1626 Auflösung der Navigationsschule in Emden

- Verfügung des Regierungspräsidenten in Aurich über Auflösung der Navigationsschule in Emden wegen Etatkürzungen im Staatshaushalt, August 1918

- Verfügung des Regierungspräsidenten in Aurich über Einziehung der Schulsiegel und Stempel der Navigationsschule in Emden zur Vernichtung, August 1918

- Erlass des preußischen Ministers für Handel und Gewerbe über Auflösung der Prüfungskommission für Seeleute auf Kleiner Fahrt bei der aufgelösten Navigationsschule in Emden, September 1918

- Verzeichnis der Akten des Kuratoriums der Navigationsschule, Oktober 1918

- Anfrage des preußischen Staatsarchivs in Aurich wegen Aktenverzeichnis des Kuratoriums der Navigationsschule, Februar 1919

1918 (1919) Klassifikation Teil B: 01651

Trägermaterial: Papier Alte Reg.-Sig.: IV Mt 28

Vorprovenienz: Kuratorium der Navigationsschule Bestell-Nr.: IV 01651

- Ausführungsbestimmungen für die Navigationsschullehrer hinsichtlich des Regulativs: Lehrmittel, Lehrgegenstände und Lernziele

1894

Klassifikation Teil B: 01652

Trägermaterial: Papier

Alte Reg.-Sig.: IV Mt 29

Vorprovenienz: Kuratorium der Navigationsschule

Bestell-Nr.: IV 01652 
Lfd. Nr. Titel

- Antrag des Schiffsbesitzers Wiardus H. Fisser beim Magistrat auf Erteilung eines Attestes zur Bestätigung der Seetüchtigkeit seines bei Panembuco gestrandeten Schiffes "Margaretha", Oktober 1875 Januar 1876

- Mitteilungen des englischen Board of Trade über Seeunfälle Emder Schiffe, 1876

- Mitteilung der niederländischen Regierung über Seeunfälle Emder Schiffe vor der niederländischen Küste, 1876 - 1877

- Mitteilungen der dänischen Regierung über Seeunfälle Emder Schiffe vor der dänischen Küste, 1878 - 1880

- Mitteilung der Strandung des Emder Schiffes "Johanna" vor Rio Grande de Sul (Argentinien), Dezember 1879

- Mitteilung über Strandung und Tod der Besatzung des Schiffes

"Aphrodite" vor der englischen Küste bei Eastburne, März 1881

- Mitteilung der Strandung des Emder Schiffes "Maja" vor der irischen Küste, März 1881

- Mitteilung der Strandung des Emder Schiffes "Etta" vor Jamaica, November 1883

- Mitteilung der Strandung des Emder Schiffes "Hilke" vor der schwedischen Küste, September 1886

- Mitteilung der Strandung des Emder Schiffes "Eduard" vor der französischen Küste bei Bayonne, Januar 1887

- Mitteilung der Strandung des Emder Schiffes "Jacobus" vor der englischen Küste, Februar 1887

- Verhandlung wegen Kollision des Emder Heringsloggers "AE 7" mit einem englischen Fischerboot, August - September 1889

- Mitteilung der Strandung des Emder Schiffes "Catharine" vor der

Einfahrt des englischen Hafens Faynmuoth, April 1890

- Mitteilung der Strandung des Emder Schiffes "Cornelia" vor

Göteborg (Schweden), September 1890

- Verhandlungen wegen Seeunfalls des Loggers "Braunschweig",

September - Oktober 1895

- Strandung des Emder Schiffes "Rose" vor der brasilianischen Küste, Dezember 1897

- Kollision der Emder Brigg "Freude" mit einem englischen Segelschiff, März 1898

- Mitteilung über Seeunfall der Emder Schonerbrigg "Margarethe", April 1900

$1875-1900$

Klassifikation Teil B: 01571

Trägermaterial: Papier

Alte Reg.-Sig.: IV Mu 2

Bestell-Nr.: IV 01571

- Regelung der statistischen Erfassung der Schiffsunfälle

$1912-1913$

Klassifikation Teil B: 01572

Trägermaterial: Papier

Alte Reg.-Sig.: IV Mu 6

Bestell-Nr.: IV 01572 
Lfd. Nr. Titel

\section{Strandungen}

1630 Einnahmen aus Strandungsgut

Laufzeit

- Verfügung des preußischen Landdrosten in Aurich über Anordnung der Abführung der Einnahmen aus Strandungsgut, August 1870 - Mai 1871

- Antrag des Magistrats beim preußischen Landdrosten auf Erlaubnis zur Verwendung von Einnahmen aus Strandungsgut für die Seemannskasse zur Unterstützung mittelloser Matrosen, Februar März 1881

$1870-1881$

Klassifikation Teil B: 01637

Trägermaterial: Papier

Alte Reg.-Sig.: IV Mu 5

Bestell-Nr.: IV 01637

1631 Reichskommissar beim Seeamt

- Übernahme der Geschäfte des Reichskommissars beim kgl. Seeamt in Emden durch den Oberbürgermeister Fürbringer, Juli 1878

- Negative Stellungnahme des Reichskanzleramts zu einer vom Reichskommissar Fürbringer eingereichten Eingabe des Seemannskollegiums über Wunsch der Novellierung des Gesetzes über Seeunfälle, Januar - Februar 1879

- Bescheid des Reichskanzleramts an das Seemannskollegium über Ablehnung eines antrages auf Entlassung des Reichskommissars Fürbringer, März 1879

- Vertretung des Reichskommissars Fürbringer, Juli 1879 / März 1880

- Entlassungsgesuch des Reichskommissars Fürbringer, Juni -

Oktober 180

- Vergütung der Dienste des Reichskommissars, 1880

$1878-1880$

Klassifikation Teil B: 01638

Trägermaterial: Papier Alte Reg.-Sig.: IV Mu 9 Vorprovenienz: Seeamt Bestell-Nr.: IV 01638 
IV

05

\subsection{3}

05.03.10

05.03.10.01

Stadtverwaltung

Aufgabenbereiche der Stadtverwaltung

Bestattungswesen

Leichenhalle

Laufzeit

1632 Städtische Leichenhalle

$1880-1910$

- Verhandlungen des Verwaltungsrates des Krankenhauses über Bau einer Leichenhalle, September 1880

- Verhandlungen des Magistrats wegen Bau einer Leichenhalle, November - Dezember 1900

- Protest der Anlieger gegen den angeblichen Bau einer Leichenhalle beim Bauhof, Dezember 1900

- Erlass des preußischen Innenministers über Verbot der Leichenobduktion in Kirchen, Juni 1901

- Plan und Kostenvoranschlag des Stadtbaumeisters Wiggers zum Bau einer Leichenhalle beim städtischen Krankenhaus, März - Mai 1901

- Bericht des Polizeiverwaltungsbeamten Wiards über Notwendigkeit einer separaten Polizeileichenhalle, März 1910

- Kostenvoranschlag für den Anbau eines Raumes an der Leichenhalle des städtischen Krankenhauses zum Zweck einer Polizeileichenhalle mit Planzeichnung, Mai 1910 - Ausschreibungsbedingungen für den Ausbau der Leichenhalle am städtischen Krankenhaus mit separatem Raum für Polizeizwecke, Juni 1910

$1880-1910$

Klassifikation Teil B: 01653

Trägermaterial: Papier

Alte Reg.-Sig.: IV Na 3

Bestell-Nr.: IV 01653 
IV

05

\subsection{3}

05.03.10

05.03.10.02

Stadtverwaltung

Aufgabenbereiche der Stadtverwaltung

Bestattungswesen

Friedhöfe

Lfd. Nr. Titel

1633 Kirchhöfe der deutsch-reformierten Gemeinde

Laufzeit

1871

- Einführung eines Friedhofsregulativs für die deutsch-reformierte

(1859-1860)

Kirchengemeinde, Oktober 1859

- Druckschrift: Friedhofsregulativ für die deutsch-reformierte

Kirchengemeinde, 1860

- Verfügung des preußischen Landdrosten in Aurich an den Magistrat über Anordnung der Prüfung der Aushebungstiefe der Gräber auf dem Friedhof der Neuen Kirche wegen Beschwerden über

Verwesungsgeruch und Seuchengefahr, Juni 1871

(1859 - 1860) 1871

Klassifikation Teil B: 01654

Trägermaterial: Papier

Alte Reg.-Sig.: IV Nb 6

Bestell-Nr.: IV 01654

1634 Begräbnisgebühren und Leichenpässe

- Anschaffung eines Leichenwagens durch die deutsch-reformierte Kirchengemeinde und Festsetzung der Benutzungsgebühren Mai 1867 - Juni 1918

- Festlegung der Zahl der Leichenträger pro Sargtyp, Mai - August 1868

- Gesetzliche Regelung der Ausstellung von Leichenpässen und des Leichentransports, 1873 - 1886

- Festlegung der Gebühr für die Ausstellung von Leichenpässen, März 1876

- Antrag der deutsch-reformierten Kirche beim Magistrat auf Erhöhung der Gebühren für Armenbegräbnisse, Mai 1897 - Juni 1908

$1867-1918(1919-1922)$

Klassifikation Teil B: 01655

Trägermaterial: Papier

Alte Reg.-Sig.: IV Nb 6

Bestell-Nr.: IV 01655 
05

05.03

05.03.10

05.03.10.03

Lfd. Nr. Titel

1635 Ausstellung von Leichenpässen

Stadtverwaltung

Aufgabenbereiche der Stadtverwaltung

Bestattungswesen

Leichenpässe

IV

Regelung der Ausstellung von Leichenpässen und des Leichentransports

1905 - 1909 (1925)

Klassifikation Teil B: 01656

Trägermaterial: Papier

Alte Reg.-Sig.: IV Nd 3

Bestell-Nr.: IV 01656
Laufzeit

1905-1909

(1925) 
IV

05

05.03

05.03.11

05.03.11.01

05.03.11.01.01
Stadtverwaltung

Aufgabenbereiche der Stadtverwaltung

Sozialfürsorge

Institutionen zur Verbesserung der Wohlfahrt

Arbeits- und Unterstützungsvereine

Lfd. Nr. Titel

Laufzeit

1636 Vereine zur Förderung von Arbeiterkolonien

$1882-1913$

- Bekanntmachungen des preußischen Landdrosten, später

Regierungspräsidenten in Aurich zu Vereinen zur Förderung von

Arbeiterkolonien, 1882 - 1893

- Werbeschriften und Nachrichten von verschiedenen Vereinen zur

Förderung von Arbeiterkolonien, 1883 - 1913

- Zeitschrift "Die Arbeiterkolonie", herausgegeben vom Zentralverband

deutscher Arbeiterkolonien, 1884

- Diskussion über die Errichtung von Verpflegungsstationen für

durchziehende Arbeiter, Mai - Juni 1884 / Juli 1888

- Erhebung des kgl. preußischen statistischen Büros über

Verpflegungsstationen für durchziehende Arbeiter und über

Arbeiterkolonien, August 1885

- Denkschrift des Oberregierungsrats von Massow über Organisation der Verpflegungsstationen für durchziehende Arbeiter, 1887

- Unterstützung und Beschäftigung des unter Epilepsie leidenden, wohnungslosen Buchbinders Johann Simmering nach seinem

Krankenhausaufenthalt, März - September 1892

- Erhebung von Daten zu Verpflegungsstationen für durchziehende

Arbeiter, Febr. 1893 - Juli 1894

- Protokoll des Gesamtverbandes deutscher Verpflegungsstationen, 1893

- Initiative des Pastors F. Bodelschwingh für ein Gesetz über Arbeitsund Wanderordnung, Mai 1901

$1882-1913$

Klassifikation Teil B: 01684

Trägermaterial: Papier

Alte Reg.-Sig.: IV Rc 6

Bestell-Nr.: IV 01684 
IV

05

05.03

05.03.11

05.03.11.01

05.03.11.01.02

Stadtverwaltung

Lfd. Nr. Titel

Aufgabenbereiche der Stadtverwaltung

Sozialfürsorge

Institutionen zur Verbesserung der Wohlfahrt

Kranken- und Versicherungskassen

1637 Maurergesellen-Totenkasse

Laufzeit

- Verfahren zur Zulassung der Maurergesellen-Totenkasse als

Geschäftsbetrieb im Sinne des Privatversicherungsgesetzes,

Dezember 1903 - Februar 1906

- Bilanzen der Maurergesellen-Totenkasse, Januar 1904

- Jahresberichte der Maurergesellen-Totenkasse, 1905 - 1911

- Versicherungstechnisches Gutachten über die

Maurergesellen-Totenkasse, 1910

$1903-1911$

Klassifikation Teil B: 01685

Trägermaterial: Papier

Alte Reg.-Sig.: IV Re 011

Bestell-Nr.: IV 01685

1638 Zimmerleute-Totenlade

1902-1918

- Satzungen der Zimmerleute-Totenlade, 1902 - 1904

- Bericht des Versicherungsrevisors an den Regierungspräsidenten in

Aurich über wirtschaftliche Lage der Versicherung

"Zimmerleute-Totenlade", Oktober 1903

- Verfahren zur Zulassung der Zimmerleute-Totenlade als

Geschäftsbetrieb nach den Bestimmungen des

Privatversicherungsgesetzes, Juli 1903 - September 1904

- Versicherungstechnisches Gutachten zur Lage der

Zimmerleute-Totenkasse, August 1904 / November 1909

- Satzungsänderungen der Zimmerleute-Totenlade, Juli - Oktober

1904

- Rechnungsabschlüsse und Jahresberichte der

Zimmerleute-Totenlade, Februar 1906 - Februar 1918

1902 - 1918 (1922)

Klassifikation Teil B: 01686

Trägermaterial: Papier

Alte Reg.-Sig.: IV Re 012

Bestell-Nr.: IV 01686 
IV

05

05.03

05.03.11

05.03.11.01

05.03.11.01.02
Stadtverwaltung

Aufgabenbereiche der Stadtverwaltung

Sozialfürsorge

Institutionen zur Verbesserung der Wohlfahrt

Kranken- und Versicherungskassen

Lfd. Nr. Titel

Laufzeit

1639 Landgebräucher-Beerdigungsverein, Bd. 1

1866-1918

- Eingabe der Landgebräucher-Beerdigungskasse beim

Hannoverschen Landdrosten in Aurich über Bitte um Zulassung zum

Leichentragen für ihre Mitglieder, April - Oktober 1852

- Statuten der Landgebräucher-Beerdigungskasse, 1866 - 1905

- Berichte des Versicherungsrevisors an den Regierungspräsidenten

in Aurich über notwendige Anpassung der

Landgebräucher-Beerdigungskasse an die Bestimmungen des

Privatversicherungsgesetzes, September 1903 - Januar 1905

- Versicherungstechnisches Gutachten zur Lage der

Landgebräucher-Beerdigungskasse, 1904 / 1912

- Jahresberichte der Landgebräucher-Beerdigungskasse, Januar 1906

- März 1918

(1852) 1866 - 1918 (1922)

Klassifikation Teil B: 01687

Band: 1

Trägermaterial: Papier

Alte Reg.-Sig.: IV Re 013

Bestell-Nr.: IV 01687

1640 Landgebräucher-Beerdigungsverein, Bd. 2

$1904-1911$

- Verfügung des Regierungspräsidenten über Anordnung der Anpassung der Statuten der Landgebräucher-Beerdigungskasse an die Bestimmungen des Privatversicherungsgesetzes, Februar -

August 1904

- Versicherungstechnisches Gutachten zur Lage der

Landgebräucher-Beerdigungskasse, 1904

- Verfügung des Regierungspräsidenten über Anordnung zur

Einführung des Kapitaldeckungsverfahrens bei der

Landgebräucher-Beerdigungskasse, März 1905

- Vom Regierungspräsidenten verfügte Satzungsänderungen, 1905 -

1906

- Monita des Regierungspräsidenten wegen Monita des

Regierungspräsidenten zur Rechnungsführung der

Landgebräucher-Beerdigungskasse, Mai 1908 - März 1910

$1904-1911$

Klassifikation Teil B: 01688

Band: 2

Trägermaterial: Papier

Alte Reg.-Sig.: IV Re 013

Bestell-Nr.: IV 01688 
05

05.03

05.03.11

05.03.11.01

05.03.11.01.02

\section{Stadtverwaltung}

Aufgabenbereiche der Stadtverwaltung

Sozialfürsorge

Institutionen zur Verbesserung der Wohlfahrt

Kranken- und Versicherungskassen

Lfd. Nr. Titel

Laufzeit

1641 Kornmesser-Totenkasse

1879-1906

(1840-1862)

- Statuten der Kornmesser-Totenkasse, (1844 - 1847) 1879 - 1892

- Errichtung einer Totenlade der Kornmesser, Februar 1844

- Erhöhung der Versicherungssumme bei der

Kornmesser-Totenkasse im Sterbefall, Juni 1847

- Rechnungsprüfungen bei der Kornmesser-Totenkasse, März 1850 -

März 1862

- Antrag des Armendieners Schonenboom auf Erhalt des

Versicherungsschutzes der Kornmesser-Totenkasse trotz Austritts

aus der Kornmesser-Gilde, Oktober 1869

- Streit um die Mitversicherung der zweiten Ehefrau des H. Swart in der Kornmesser-Totenkasse, Mai - Juni 1879

- Beitragssteigerung bei der Kornmesser-Totenkasse, 1897

- Bescheid des Regierungspräsidenten in Aurich über

Nichtanerkennung der Kornmesser-Totenkasse als Geschäftsbetrieb nach den Bestimmungen des Privatversicherungsgesetzes, Februar 1904

- Verfügung des Regierungspräsidenten über Anordnung zur

Anpassung der Statuten der Kornmesser-Totenkasse an die

Bestimmungen des Privatversicherungsgesetzes, Mai 1904

- Mitglieder der Kornmesser-Totenkasse, 1905 - 1906

(1844 - 1862) 1879 - 1906

Klassifikation Teil B: 01689

Trägermaterial: Papier

Alte Reg.-Sig.: IV Re 037

Bestell-Nr.: IV 01689

1642 Rechnungsbuch der Kornmesser-Totenlade

- Einnahmen und Ausgaben der Kornmesser-Totenlade

$1883-1907$

Klassifikation Teil B: 01690

Trägermaterial: Papier

Alte Reg.-Sig.: IV Re 038

Bestell-Nr.: IV 01690

1643 Rechnungsbuch der Totenkasse der Schmiede- und

1866-1902

Kupferschmiedezunft

(1834-1866)

- Einnahmen und Ausgaben der der Totenkasse der Schmiede- und Kupferschmiedezunft

(1834 - 1864) 1866 - 1902

Klassifikation Teil B: 01691

Trägermaterial: Papier

Alte Reg.-Sig.: IV Re 039

Bestell-Nr.: IV 01691 
IV

05

05.03

05.03.11

05.03.11.01

05.03.11.01.02
Stadtverwaltung

Aufgabenbereiche der Stadtverwaltung

Sozialfürsorge

Institutionen zur Verbesserung der Wohlfahrt

Kranken- und Versicherungskassen

Lfd. Nr. Titel

Laufzeit

1644 Lehrerbeerdigungsverein "Concordia", Bd. 1

$1875-1912$

- Statuten des Lehrerbeerdigungsvereins "Concordia", (1862) 1875 -

1905

- Deponierung der Wertpapiere des Lehrerbeerdigungsvereins

"Concordia" bei der Stadt Emden, 1893 - 1912

- Monita des Regierungspräsidenten in Aurich wegen nicht mit dem

Privatversicherungsgesetz konform gehender Bestimmungen

geänderter Satzungen des Lehrerbeerdigungsvereins "Concordia" und

wegen Beitragserhöhungen des Vereins, März 1904 - März 1905

- Versicherungstechnisches Gutachten zur Lage des

Lehrerbeerdigungsvereins "Concordia", Oktober 1904

- Jahresberichte des Lehrerbeerdigungsvereins "Concordia", 1905 -

1911

(1862) $1875-1912$

Klassifikation Teil B: 01692

Band: 1

Trägermaterial: Papier

Alte Reg.-Sig.: IV Re 047

Bestell-Nr.: IV 01692

1645 Lehrerbeerdigungsverein "Concordia", Bd. 2

1903-1918

- Statuten des Lehrerbeerdigungsvereins "Concordia", (1862) 1877 -

(1919-1920) 1905 (s. 1692)

- Anpassung der Statuten des Lehrerbeerdigungsvereins "Concordia" an die Bestimmungen des Privatversicherungsgesetzes, Juni 1903 -

Oktober 1904

- Anerkennung des Lehrerbeerdigungsvereins "Concordia" als "Kleiner

Verein" im Sinne des Privatversicherungsgesetzes, September 1903

- Bericht des Versicherungsrevisors an den Regierungspräsidenten über notwendiges versicherungstechnisches Gutachten über die Lebensfähigkeit des Lehrerbeerdigungsvereins "Concordia",

November 1903

- Versicherungstechnische Gutachten über den

Lehrerbeerdigungsverein "Concordia", Oktober 1904 / Mai 1914

- Jahresberichte des Lehrerbeerdigungsvereins "Concordia", 1905 -

1918 (1919 - 1920)

1903 - 1918 (1919 - 1920)

Klassifikation Teil B: 01693

Band: 2

Trägermaterial: Papier

Alte Reg.-Sig.: IV Re 047

Vorprovenienz: Regierung zu Aurich

Bestell-Nr.: IV 01693 
IV

05

05.03

05.03.11

05.03.11.01

05.03.11.01.02

Stadtverwaltung

Aufgabenbereiche der Stadtverwaltung

Sozialfürsorge

Institutionen zur Verbesserung der Wohlfahrt

Kranken- und Versicherungskassen

Lfd. Nr. Titel

Laufzeit

1646 Beerdigungskasse der Schneidergesellen, Bd. 1

$1882-1911$

- Statuten der Beerdigungskasse der Schneidergesellen, 1882 - 1904

- Deponierung der Wertpapiere der Beerdigungskasse der

Schneidergesellen bei der Stadt Emden, Januar 1900 - Januar 1906

- Anpassung der Statuten der Beerdigungskasse der

Schneidergesellen an die Bestimmungen des

Privatversicherungsgesetzes, September 1903 - Februar 1904

- Bilanz der Beerdigungskasse der Schneidergesellen, April 1904

- Monita des Regierungspräsidenten wegen nicht mit dem

Privatversicherungsgesetz konform gehenden Bestimmungen der

Satzung der Beerdigungskasse der Schneidergesellen, April -

September 1904

- Versicherungstechnisches Gutachten über die Beerdigungskasse der Schneidergesellen, Juni 1904

- Jahresberichte der Beerdigungskasse der Schneidergesellen, 1905 -

1911

- Monita des Regierungspräsidenten wegen der Jahresberichte der

Beerdigungskasse der Schneidergesellen, März 1906 - März 1910

- Antrag der Beerdigungskasse der Schneidergesellen beim

Regierungspräsidenten auf Verlängerung der Intervalle der

technischen Überprüfung der Kasse durch einen

Versicherungsmathematiker von 5 auf 10 Jahre, Februar 1911

$1882-1911$

Klassifikation Teil B: 01694

Band: 1

Trägermaterial: Papier

Alte Reg.-Sig.: IV Re 049

Bestell-Nr.: IV 01694 
IV

05

05.03

05.03.11

05.03.11.01

05.03.11.01.02

Stadtverwaltung

Aufgabenbereiche der Stadtverwaltung

Sozialfürsorge

Institutionen zur Verbesserung der Wohlfahrt

Kranken- und Versicherungskassen

Lfd. Nr. Titel

Laufzeit

1647 Beerdigungskasse der Schneidergesellen, Bd. 2

- Zulassung der Totenlade der Schneidergesellen in Emden, 1863

(1863-1920)

- Vereinigung der Krankenkasse mit der Beerdigungskasse der

Schneidergesellen, 1869

- Satzungen der Beerdigungskasse der Schneidergesellen, 1878 -

1911

- Satzungen der Krankenkasse der Schneidergesellen, 1879

- Auflösung der Krankenkasse der Schneidergesellen in Ausführung

des Krankenversicherungsgesetzes (AOK), Januar 1885

- Bilanz der Beerdigungskasse der Schneidergesellen, 1904

- Monita des Regierungspräsidenten wegen nicht mit dem

Privatversicherungsgesetz konform gehender Satzungsänderungen

der Beerdigungskasse der Schneidergesellen, Juni 1904 / Dezember 1910

- Versicherungstechnisches Gutachten über die Beerdigungskasse der Schneidergesellen, Juni 1904 / Mai 1910

- Jahresberichte der Beerdigungskasse der Schneidergesellen, 1905 -

1916

- Monita des Regierungspräsidenten zum Jahresbericht der

Beerdigungskasse der Schneidergesellen, Dezember 1909

(1863) 1869 - 1916 (1920)

Klassifikation Teil B: 01695

Band: 2

Trägermaterial: Papier

Alte Reg.-Sig.: IV Re 049

Vorprovenienz: Regierung zu Aurich

Bestell-Nr.: IV 01695 
05

05.03

05.03.11

05.03.11.01

05.03.11.01.02

\section{Stadtverwaltung}

Aufgabenbereiche der Stadtverwaltung

Sozialfürsorge

Institutionen zur Verbesserung der Wohlfahrt

Kranken- und Versicherungskassen

Lfd. Nr. Titel

Laufzeit

1648 Begräbnisverein zu Emden

$1869-1915$

(1855-1925)

- Genehmigung der novellierten Statuten des Begräbnisvereins zu

Emden, September 1858 - Januar 1859

- Genehmigung von Statutenänderungen des Begräbnisvereins zu

Emden, Februar 1860 - Mai 1862

- Neugründung eines Begräbnisvereins zu Emden, März - Mai 1861

- Statuten des Begräbnisvereins zu Emden, (1861) 1871 - 1904

- Vereinigung der beuiden Emder Begräbnisvereine zu einem Verein,

Dezember 1869 - Januar 1870

- Statutenänderungen des Begräbnisvereins zu Emden, 1873 - 1907

- Zulassung des Begräbnisvereins zu Emden als "Kleiner Verein" nach den Bestimmungen des Privatversicherungsgesetzes, Juni 1903

- Anpassung der Satzungen des Begräbnisvereins zu Emden an die Bestimmungen des Privatversicherungsgesetzes, Oktober 1903 - April 1904

- Versicherungstechnisches Gutachten über den Begräbnisverein zu

Emden, September 1904 / Dezember 1913

- Monita des Versicherungsrevisors wegen der Satzungen des

Begräbnisvereins zu Emden, Dezember 1904

- Jahresberichte des Begräbnisvereins zu Emden, 1905 - 1920

- Protest des Abel Sikken gegen hohe Beiträge des Begräbnisvereins zu Emden, Januar - April 1906

- Monita des Regierungspräsidenten wegen der Jahresrechnungen der Begräbnisvereins zu Emden, Mai 1908 - März 1914

- Monita des Versicherungsrevisors wegen der Kassenführung des

Begräbnisvereins zu Emden, Juli 1908 - Dezember 1914

(1858 - 1862) 1869 - 1918 (1919 - 1925)

Klassifikation Teil B: 01696

Trägermaterial: Papier

Alte Reg.-Sig.: IV Re 050

Vorprovenienz: Regierung zu Aurich

Bestell-Nr.: IV 01696

1649 Maurergesellen-Totenkasse

$1899-1917$

- Satzungen der Maurergesellen-Totenkasse, 1899 - 1905

(1920)

- Zulassung der Maurergesellen-Totenkasse als "Kleiner Verein" nach den Bestimmungen des Privatversicherungsgesetzes, November 1903 - März 1905

- Monitum des Versicherungsrevisors gegen die unterschiedliche Festlegung der Versicherungsleistungen für verheiratete und ledige Maurergesellen, Dezember 1904

- Versicherungstechnisches Gutachten über die

Maurergesellen-Totenkasse, September 1904 / Januar 1910

- Jahresberichte der Maurergesellen-Totenkasse, 1906 - 1917

- Statutenänderungen der Maurergesellen-Totenkasse, 1910 - 1913

$1899-1917(1920)$

Klassifikation Teil B: 01697

Trägermaterial: Papier

Alte Reg.-Sig.: IV Re 054

Vorprovenienz: Regierung zu Aurich

Bestell-Nr.: IV 01697 
IV

05

\subsection{3}

05.03.11

05.03.11.01

05.03.11.01.02

\section{Stadtverwaltung}

Aufgabenbereiche der Stadtverwaltung

Sozialfürsorge

Institutionen zur Verbesserung der Wohlfahrt

Kranken- und Versicherungskassen

Lfd. Nr. Titel

Laufzeit

1650 Provinzial-Witwen- und Waisenkasse, Bd. 1

1876-1889

- Initiative des Landesdirektoriums der Provinz Hannover zur

Gründung einer Provinzial-Witwen- und Waisenkasse für Kommunalund Staatsbeamte in der Provinz Hannover, März 1876 - August 1877 - Liste der Emder Stadtbedienstete als Versicherungsberechtigte für die Provinzial-Witwen- und Waisenkasse, April 1876

- Ordnung der Provinzial-Witwen- und Waisenkasse, 1877

- Verhandlungen der städtischen Kollegien wegen Beitritt der Stadt Emden zur Provinzial-Witwen- und Waisenkasse, September 1877 / September 1881 - März 1885

- Verhandlungen des Magistrats mit dem Landesdirektorium wegen Beitritts der Stadt Emden zur Provinzial-Witwen- und Waisenkasse, 1877 - 1883

- Nachrichten von der Provinzial-Witwen- und Waisenkasse, 1880 1889

- Rescript des preußischen Landdrosten in Aurich über Unmöglichkeit der Revision des ablehnenden Votums des

Bürgervorsteher-Kollegiums gegen die Versicherung der städtischen Bediensteten bei der Provinzial-Witwen- und Waisenkasse auf Kosten der Stadt Emden durch eine Anordnung seinerseits gemäß der Hannoverschen Gemeindeordnung, April 1883

$1876-1889$

Klassifikation Teil B: 01698

Band: 1

Trägermaterial: Papier

Alte Reg.-Sig.: IV Re 055

Bestell-Nr.: IV 01698 
IV

05

05.03

05.03.11

05.03.11.01

05.03.11.01.02
Stadtverwaltung

Aufgabenbereiche der Stadtverwaltung

Sozialfürsorge

Institutionen zur Verbesserung der Wohlfahrt

Kranken- und Versicherungskassen

Lfd. Nr. Titel

Laufzeit

1651 Provinzial-Witwen- und Waisenkasse, Bd. 2

$1891-1895$

- Satzungen der Provinzial-Witwen- und Waisenkasse, 1891n - 1908

(1906-1921)

(1921)

- Beitragsberechnung für die städtischen Beamten, 1890

- Aufstellung über bei der Provinzial-Witwen- und Waisenkasse

versicherte städtische Bedienstete, 1890

- Auszahlung von Versicherungsleistungen der Provinzial-Witwen- und

Waisenkasse an die Witwe des Polizeiboten Abko Uphoff,

Geerardine, geb. Visser, Juli 1890

- Statutenänderungen bei der Provinzial-Witwen- und Waisenkasse,

1891

- Beitritt des Kämmerers Ernst August Gebest zur Provinzial-Witwenund Waisenkasse nach seiner Heirat, Juli 1891

- Beitragsanpassungen wegen Gehaltsveränderungen, 1891 - 1895

- Verhandlungen des Brandenburgischen Städtetages zur

Hinterbliebenenabsicherung bei Kommunalbeamten, Mai 1892

- Beitritte zur Provinzial-Witwen- und Waisenkasse, 1893 - 1894

- Auszahlung von Versicherungsleistungen der Provinzial-Witwen- und

Waisenkasse an die Witwe des Nachtwachtmeisters van

Diepenbroek, Talina Wobbina, geb. Brouer, Oktober 1895

$1891-1895$

Klassifikation Teil B: 01699

Band: 2

Trägermaterial: Papier

Alte Reg.-Sig.: IV Re 055

Bestell-Nr.: IV 01699

1652 Provinzial-Witwen- und Waisenkasse, Bd. 3

$1896-1900$

- Beitritte zur Provinzial-Witwen- und Waisenkasse, 1896 - 1900

- Antrag der städtischen Beamten auf Übernahme der Beiträge zur

Provinzial-Witwen- und Waisenkasse durch die Stadt Emden als

Arbeitgeberin, März 1896

- Ablehnung der Übernahme der Beiträge zur Provinzial-Witwen- und

Waisenkasse von seiten der Stadt durch das

Bürgervorsteher-Kollegium, März 1896

- Beitragsanpassung wegen Gehaltsveränderungen, 1899 - 1900

- Auszahlung von Versicherungsleistungen der Provinzial-Witwen- und

Waisenkasse an die Waisen des Nachtwachtmeisters van

Diepenbroek, Februar 1900

$1896-1900$

Klassifikation Teil B: 01700

Band: 3

Trägermaterial: Papier

Alte Reg.-Sig.: IV Re 055

Bestell-Nr.: IV 01700 
IV

05

05.03

05.03.11

05.03.11.01

05.03.11.01.02
Stadtverwaltung

Aufgabenbereiche der Stadtverwaltung

Sozialfürsorge

Institutionen zur Verbesserung der Wohlfahrt

Kranken- und Versicherungskassen

Lfd. Nr. Titel

Laufzeit

1653 Provinzial-Witwen- und Waisenkasse, Bd. 4

1901-1909

- Statuten der Provinzial-Witwen- und Waisenkasse, 1877 / 1889/

(1877-1889) $1901 / 1908$

- Beitritte zur Provinzial-Witwen- und Waisenkasse, 1901 - 1903

- Auszahlung von Versicherungsleistungen der Provinzial-Witwen- und Waisenkasse an hinterbliebene Witwen und Waisen von gestorbenen Versicherungsnehmern, 1901 - 1903

- Versicherung der Lehrer der Kaiser-Friedrich-Realschule bei der Provinzial-Witwen- und Waisenkasse, August 1900 - April 1901

- Verhandlungen des Magistrats mit der Provinzial-Witwen- und Waisenkasse wegen Übernahme der Beitragszahlungen für die Bediensteten der Stadt Emden durch die asrbeitgeberin, Januar 1907 - Listen der bei der Provinzial-Witwen- und Waisenkasse versicherten Bediensteten der Stadt Emden, 1901 - 1903

- Versicherung der Lehrer der Kaiserin-Auguste-Victoria-Schule bei der Provinzial-Witwen- und Waisenkasse, 1909

- Plädoyer des Syndicus Werthen und des Kämmerers Gebest für eine städtische Witwen und Waisenkasse, April / Juni 1901

1901 - 1909 (1877 - 1889)

Klassifikation Teil B: 01701

Band: 4

Trägermaterial: Papier

Alte Reg.-Sig.: IV Re 055

Bestell-Nr.: IV 01701

1654 Provinzial-Witwen- und Waisenkasse, Bd. 5

- Beiträge zur Provinzial-Witwen- und Waisenkasse, 1904 - 1907

- Beitritte zur Provinzial-Witwen- und Waisenkasse, 1904 - 1907

- Liste der bei der Provinzial-Witwen- und Waisenkasse versicherten

Stadtbediensteten, 1904 - 1907

- Anpassung der Beiträge an geänderte Gehälter, 1904 - 1907

- Auszahlung von Versicherungsleistungen der Provinzial-Witwen- und Waisenkasse an hinterbliebene Witwen und Waisen verstorbener Versicherungsnehmer, 1905 - 1907

- Versicherung des Bautechnikers Braa als Nichtruhegeldberechtigter bei der Provinzial-Witwen- und Waisenkasse, September 1905 - April 1906

$1904-1906$

Klassifikation Teil B: 01701

Band: 5

Trägermaterial: Papier

Alte Reg.-Sig.: IV Re 055

Bestell-Nr.: IV 01702 
IV

05

05.03

05.03.11

05.03.11.01

05.03.11.01.02
Stadtverwaltung

Aufgabenbereiche der Stadtverwaltung

Sozialfürsorge

Institutionen zur Verbesserung der Wohlfahrt

Kranken- und Versicherungskassen

Lfd. Nr. Titel

Laufzeit

1655 Provinzial-Witwen- und Waisenkasse, Bd. 6

1907-1910

- Beitritte zur Provinzial-Witwen- und Waisenkasse, 1907 - 1909

- Anpassung der Beiträge zur Provinzial-Witwen- und Waisenkasse an geänderte Gehälter, 1908 - 1910

- Liste der bei der Provinzial-Witwen- und Waisenkasse versicherten

Stadtbediensteten, 1908 - 1910

- Auszahlung der Versicherungsleistungen der Provinzial-Witwen- und Waisenkasse an hinterbliebene Witwen und Waisen verstorbener Versicherungsnehmer, 1908 - 1910

- Beiträge der Provinzial-Witwen- und Waisenkasse, 1908 - 1910

- Versicherung von Lehrer Emder Schulen bei der Provinzial-Witwenund Waisenkasse, Mai 1909

$1907-1910$

Klassifikation Teil B: 01703

Band: 6

Trägermaterial: Papier

Alte Reg.-Sig.: IV Re 055

Bestell-Nr.: IV 01703

1656 Provinzial-Witwen- und Waisenkasse, Bd. 7

$1911-1915$

- Anpassung der Beiträge der Provinzial-Witwen- und Waisenkasse an geänderte Gehaltsverhälnisse, 1911 - 1915

- Beitritte zur Provinzial-Witwen- und Waisenkasse, 1911 - 1915

- Antrag des Gasthausvaters Johann Georg Panzer auf Versicherung bei der Provinzial-Witwen- und Waisenkasse wegen der Gefährlichkeit seiner Position, Mai - Juni 1911

- Liste der bei der Provinzial-Witwen- und Waisenkasse versicherten Stadtbediensteten, 1911 - 1915

- Auszahlung von Versicherungsleistungen der Provinzial-Witwen- und Waisenkasse an hinterbliebene Witwen und Waisen verstorbener Versicherungsnehmer (u.a. Witwe des Landrabbiners Dr. Löb, Jenny geb. Löb), 1911 - 1915

- Versicherung des bei den Emder Kanalisierungsarbeiten beschäftigten Regierungsbaumeister Baege, September 1914

$1911-1915$

Klassifikation Teil B: 01704

Band: 7

Trägermaterial: Papier

Alte Reg.-Sig.: IV Re 055

Bestell-Nr.: IV 01704 


\section{IV}

05

Stadtverwaltung

05.03

05.03.11

Aufgabenbereiche der Stadtverwaltung

05.03.11.01

05.03.11.01.02

Sozialfürsorge

Institutionen zur Verbesserung der Wohlfahrt

Kranken- und Versicherungskassen

Lfd. Nr. Titel

Laufzeit

1657 Provinzial-Witwen- und Waisenkasse, Bd. 8

1916-1918

- Auszahlung der Versicherungsleistungen der Provinzial-Witwen- und

(1919-1921)

Waisenkasse an hinterbliebene Witwen und Waisen verstorbener

Versicherungsnehmer, 1916 - 1918

- Anpassung der Beiträge der Provinzial-Witwen- und Waisenkasse

an veränderte Gehaltsverhältnisse, 1916 - 1918

- Liste der bei der Provinzial-Witwen- und Waisenkasse versicherten

Stadtbediensteten, 1916 - 1918

- Beitritt zur Provinzial-Witwen- und Waisenkasse, 1916 - 1918

- Todeserklärung des bei der Provinzial-Witwen- und Waisenkasse versicherten Oberlehrers Dittmers, verschollen Oktober 1916 an der Westfront, Dezember 1918

1916 - 1918 (1919 - 1921)

Klassifikation Teil B: 01704

Band: 8

Trägermaterial: Papier

Alte Reg.-Sig.: IV Re 055

Bestell-Nr.: IV 01705

1658 Ausführung des Unfallverhütungsgesetzes vom 06.Juli 1884

- Ernennung von Vertrauensärzten zur Unfall- und

Invaliditätsversicherung, Januar 1910

- Erlass des Ministers für Handel und Gewerbe über

Ausführungsbestimmungen zum Unfallverhütungsgesetz für den

Baubereich, April - Juli 1910

1910

Klassifikation Teil B: 01706

Trägermaterial: Papier

Alte Reg.-Sig.: IV Re 060

Bestell-Nr.: IV 01706 
05

\subsection{3}

05.03.11

05.03.11.01

05.03.11.01.02
Stadtverwaltung

Aufgabenbereiche der Stadtverwaltung

Sozialfürsorge

Institutionen zur Verbesserung der Wohlfahrt

Kranken- und Versicherungskassen

Lfd. Nr. Titel

Laufzeit

1659 Krankenunterstützungsverein und Sterbekasse für weibliche Dienstboten

1905-1908

- Satzungen des Krankenunterstützungsvereins und Sterbekasse für weibliche Dienstboten, (1855) / 1905

- Antrag des Krankenunterstützungsvereins und Sterbekasse für weibliche Dienstboten auf Zulassung als "Kleiner Verein" im Sinne des

Privatversicherungsgesetzes, November 1903 - März 1906

- Bericht des Vereinssekretärs Theodor H. M. Behrends über Auflösung des Krankenunterstützungsvereins und Sterbekasse für weibliche Dienstboten durch den aufsichtsführenden Mutterverein "Matschappij tot nut vant Allgemeen", Oktober - November 1906 - Bescheid des Magistrats über notwendige Mitgliederversammlung des Krankenunterstützungsverein und Sterbekasse für weibliche Dienstboten zur rechtmäßigen Auflösung, Dezember 1906 - Bericht der Direktion der "Matschappij tot nut vant Allgemeen" über vollzogene Auflösung des Krankenunterstützungsvereins und Sterbekasse für weibliche Dienstboten und Übernahme der Vereinskasse, März 1908

$1905-1908$

Klassifikation Teil B: 01707

Trägermaterial: Papier

Alte Reg.-Sig.: IV Re 061

Bestell-Nr.: IV 01707

1660 Mitgliedschaft der Stadt Emden in der Hannoverschen

$1887-1913$ Baugewerks-Berufsgenossenschaft

- Statuten der der Hannoverschen

Baugewerks-Berufsgenossenschaft, 1893 - 1913

- Unfallverhütungsvorschriften der der Hannoverschen

Baugewerks-Berufsgenossenschaft, 1887 - 1906

- Beiträge der Stadt Emden zur Hannoverschen

Baugewerks-Berufsgenossenschaft, 1886 - 1913

- Datenerhebung zur Neuklassifizierung des Gefahrentarifs der

Mitglieder der Hannoverschen Baugewerks-Berufsgenossenschaft,

Oktober 1890 - Januar 1891

- Statistische Auflistung der von der Hannoverschen

Baugewerks-Berufsgenossenschaft unterstützten Unfallopfer aus dem

Baugewerbe, Mai 1903 - Mai 1912

- Vorschläge des Ministeriums der öffentliche Arbeiten zur

Abänderung und Ergänzung der in Preußen geltenden

Unfallverhütungsvorschriften der Baugewerksgenossenschaften, April 1907

$1887-1913$

Klassifikation Teil B: 01708

Trägermaterial: Papier

Alte Reg.-Sig.: IV Re 076

Bestell-Nr.: IV 01708 
IV

05

05.03

05.03.11

05.03.11.01

05.03.11.01.02
Stadtverwaltung

Aufgabenbereiche der Stadtverwaltung

Sozialfürsorge

Institutionen zur Verbesserung der Wohlfahrt

Kranken- und Versicherungskassen

Lfd. Nr. Titel

Laufzeit

1661 Beschwerde der Anna Janßen, geb. Garrelts gegen die Heranziehung 1911-1912 zur Baugewerks-Berufsgenossenschaft

- Pfändung rückständiger Beiträge des Bauunternehmers Adolf Janßen zur Hannoverschen Baugewerksgenossenschaft, September 1911

- Pfändung rückständiger Beiträge der Anna Janßen, geb. Garrelts zur Hannoverschen Baugewerks-Berufsgenossenschaft wegen ihrer Rolle als Bauauftraggeberin, Oktober 1911

- Beschwerde der Anna Janßen gegen die Pfändung, Oktober 1911 April 1912

$1911-1912$

Klassifikation Teil B: 01709

Trägermaterial: Papier

Alte Reg.-Sig.: IV Re 083

Bestell-Nr.: IV 01709

1662 Mitgliedschaft der Stadt Emden bei der

$1890-1898$ Tiefbau-Berufsgenossenschaft, Bd. 1

- Mitgliedschaft der Stadt Emden bei der

Tiefbau-Berufsgenossenschaft wegen Beschäftigung von

Kanalarbeitern, Juni 1891

- Unfallverhütungsvorschriften der Tiefbau-Berufsgenossenschaft,

1890

- Etat- und Verwaltungsberichte der Tiefbau-Berufsgenossenschaft, $1890-1898$

- Beiträge der Stadt Emden zur Tiefbau-Berufsgenossenschaft, 1890 1895

- Klassifizierung der Gefahrengruppe für die Beschäftigten der Stadt

Emden bei der Tiefbau-Berufsgenossenschaft, 1890 - 1898

- Diskussion einer stärkeren Beteiligung der Kommunen an der

Tiefbau-Berufsgenossenschaft wegen der Klassifizierung der

Gefahrengruppen, 1891 - 1892

- Jahreslohnnachweise der Stadt Emden für ihre Kanalarbeiter wegen der Beitragsbemessung der Tiefbau-Berufsgenossenschaft, 1891 -

1898

- Klärung der Berufsgenossenschaftszugehörigkeit der

Straßenbauarbeiter der Stadt Emden, 1892 - 1893

- Statuten der Tiefbau-Berufsgenossenschaft, 1896

$1890-1898$

Klassifikation Teil B: 01711

Band: 1

Trägermaterial: Papier

Alte Reg.-Sig.: IV Re 086

Bestell-Nr.: IV 01711 
IV

05

Stadtverwaltung

05.03

05.03.11

Aufgabenbereiche der Stadtverwaltung

05.03.11.01

05.03.11.01.02

Sozialfürsorge

Institutionen zur Verbesserung der Wohlfahrt

Kranken- und Versicherungskassen

Lfd. Nr. Titel

Laufzeit

1663 Mitgliedschaft der Stadt Emden bei der

Tiefbau-Berufsgenossenschaft, Bd. 2

- Jahreslohnnachweise für Kanalarbeiter der Stadt Emden zur

Beitragsbemessung der Tiefbau-Berufsgenossenschaft, 1899 - 1910

- Unfallverhütungsvorschriften der Tiefbau-Berufsgenossenschaft,

1902

- Etat- und Verwaltungsberichte der Tiefbau-Berufsgenossenschaft, $1900-1910$

- Verzeichnis der gewerblichen Mitglieder der

Tiefbau-Berufsgenossenschaft, 1903

- Eingruppierung der städtischen Kanal- und Straßenarbeiter in die

Gefahrenklassen der Tiefbau-Berufsgenossenschaft, 1903 - 1908

$1899-1912$

Klassifikation Teil B: 01712

Band: 2

Trägermaterial: Papier

Alte Reg.-Sig.: IV Re 086

Bestell-Nr.: IV 01712

1664 Mitgliedschaft der Stadt Emden bei der

$1911-1915$

Tiefbau-Berufsgenossenschaft, Bd. 3

- Etat- und Verwaltungsberichte der Tiefbau-Berufsgenossenschaft, 1911 - 1915

- Jahreslohnnachweis für Kanalarbeiter und Straßenbauarbeiter der

Stadt Emden zur Beitragsbemessung zur

Tiefbau-Berufsgenossenschaft, 1911

$1911-1915$

Klassifikation Teil B: 01713

Band: 3

Trägermaterial: Papier

Alte Reg.-Sig.: IV Re 086

Bestell-Nr.: IV 01713 
- Statuten der Betriebskrankenkasse des Bauunternehmens Habich \& Goth, 1890 - 1892

- Verfahren zur Umwandlung der Betriebskrankenkasse des Bauunternehmens Habich \& Goth in eine Krankenkasse nach den Bestimmungen des Gesetzes über die Krankenversicherung, Juli 1890 - Oktober 1891

- Material der Betriebskrankenkasse des Bauunternehmens Habich \& Goth: Mitglieder, Versicherungsfälle, Kassenlage, 1889 - 1890

- Aufsicht über die Betriebskrankenkasse des Bauunternehmens Habich \& Goth durch den Regierungspräsidentwen in Aurich, Juni 1891 - Januar 1902

- Verzeichnis der Mitglieder der Betriebskrankenkasse des Bauunternehmens Habich \& Goth, Juli 1892

- Protokoll der Generalversammlung der Betriebskrankenkasse des Bauunternehmens Habich \& Goth, Februar 1894

- Beschwerde des Mitglieds der Betriebskrankenkasse des Bauunternehmens Habich \& Goth, A. Biller wegen zu geringer Krankengeldzahlungen, November 1894

- Anträge der Betriebskrankenkasse des Bauunternehmens Habich \& Goth beim Magistrat auf Ausgabe ihrer bei der Stadt Emden deponierten Wertpapiere zur Einnahme der Zinsen, 1896 - 1901 - Beiträge zur Betriebskrankenkasse des Bauunternehmens Habich \& Goth, Oktober 1901

$1889-1902$

Klassifikation Teil B: 01714

Trägermaterial: Papier Alte Reg.-Sig.: IV Re 089

Bestell-Nr.: IV 01714 
05

05.03

05.03.11

05.03.11.01

05.03.11.01.02
Stadtverwaltung

Aufgabenbereiche der Stadtverwaltung

Sozialfürsorge

Institutionen zur Verbesserung der Wohlfahrt

Kranken- und Versicherungskassen

Lfd. Nr. Titel

Laufzeit

1666 Arbeiterfürsorge auf Baustellen

$1899-1913$

- Bekanntmachung über Vorschriften zur Arbeiterfürsorge auf

Baustellen, Februar 1906 / September 1907

- Erlass des Ministers der öffentlichen Arbeiten über Möglichkeit der

Regelung der Arbeiterfürsorge auf Baustellen durch Polizeiverfügung,

Juli 1899 / Juli 1907

- Polizeiverordnung des Magistrats wegen Arbeiterfürsorge auf

Baustellen in Emden, Februar 1900

- Anzeigen der Hannoverschen Baugewerks-Berufsgenossenschaft

über Sicherheitsmängel auf Emder Baustellen, November 1900 -

Dezember 1910

- Anzeigen der Polizei über Sicherheitsmängel auf Emder Baustellen, April 1901 - Juni 1909

- Datenerhebung zu Kontrollen von Baustellen aufgrund eines

Erlasses des Ministers der öffentlichen Arbeiten, August 1901

- Beschwerde des Zentralverbandes der Maurer, Zweigstelle Emden gegen den städtischen Bauführer Schulz wegen Sicherheitsmängel beim Bau der Schule in der Wilhelmstraße, Dezember 1901

- Polizeiverordnung des Regierungspräsidenten über

Sicherheitsvorkehrungen beim Arbeiten mit offenem Koksfeuer in

Räumen (Schmiede), April 1903

- Berichte des Stadtbaumeisters Wiggers über Einhaltung der Bestimmungen zum Arbeiterschutz auf Emder Baustellen, April 1903 Juli 1905

- Novellierung der Unfallverhütungsvorschriften der Hannoverschen

Baugewerks-Berufsgenossenschaft, Mai 1906

Organisation der Basustellenkontrollen in Emden, November 1910

- Erlass des Ministers der öffentlichen Arbeiten über

Vorsichtsmaßnahmen bei der Trocknung von Gebäuden durch

Koksöfen, Juli 1913

$1899-1913$

Klassifikation Teil B: 01715

Trägermaterial: Papier

Alte Reg.-Sig.: IV Re 109

Bestell-Nr.: IV 01715

1667 Ausstellungen zum Unfallschutz

$1903-1913$

- Ankündigungen von Ausstellungen zum Unfallschutz, 1903 - 1913

- Beteiligung der Stadt Emden an der Umfrageaktion des

Regierungspräsidenten zur Organisation des Rettungs- und

Krankentransportwesens, Dezember 1903

- Umfrage der Zentralstelle für das Rettungswesen an Binnen- und

Küstengewässer, Berlin, Februar 1909

- Erlasse des Innenministers und des Ministers für öffentliche Arbeiten zur Organisation des Rettungswesens, Dezember 1912 - Juli 1913

$1903-1913$

Klassifikation Teil B: 01716

Trägermaterial: Papier

Alte Reg.-Sig.: IV Re 110

Bestell-Nr.: IV 01716 
IV

05

05.03

05.03.11

05.03.11.01

05.03.11.01.02

Stadtverwaltung

Lfd. Nr. Titel

Aufgabenbereiche der Stadtverwaltung

Sozialfürsorge

Institutionen zur Verbesserung der Wohlfahrt

Kranken- und Versicherungskassen

1668 Gesetz über Privatversicherungsunternehmen, Bd. 1

Laufzeit

- Bestimmungen und Ausführungsbestimmungen des Gesetzes über

Privatversicherungsunternehmen

$1901-1906$

Klassifikation Teil B: 01717

Band: 1

Trägermaterial: Papier

Alte Reg.-Sig.: IV Re 111

Bestell-Nr.: IV 01717

1669 Gesetz über Privatversicherungsunternehmen, Bd. 2

1910-1918

- Nachrichten über die Zulassung von Versicherungen nach dem

Gesetz über Privatversicherungsunternehmen, Februar 1910 -

Oktober 1918

$1910-1918$

Klassifikation Teil B: 01718

Band: 2

Trägermaterial: Papier

Alte Reg.-Sig.: IV Re 111

Bestell-Nr.: IV 01718

1670 Gesetz über Privatversicherungsunternehmen, Bd. 3

- Ausführungsbestimmungen zum Gesetz über

Privatversicherungsunternehmen, 1910 - 1914

- Nachrichten über Zulassung von Privatversicherungen, 1915

- Verzeichnis der Sterbe- und Pensionskassen in der Stadt Emden, 1913

- Bestimmung über Geheimhaltung von Feuerversicherungsdaten wegen Gefahr für die Landesverteidigung bei Weitergabe von Daten an ausländische Rückversicherungen, 1915

$1913-1915$

Klassifikation Teil B: 01719

Band: 3

Trägermaterial: Papier

Alte Reg.-Sig.: IV Re 111

Bestell-Nr.: IV 01719 
IV

05

05.03

05.03.11

05.03.11.01

05.03.11.01.02
Stadtverwaltung

Aufgabenbereiche der Stadtverwaltung

Sozialfürsorge

Institutionen zur Verbesserung der Wohlfahrt

Kranken- und Versicherungskassen

Lfd. Nr. Titel

Laufzeit

1671 Gesetz über Privatversicherungsunternehmen, Bd. 4

$1902-1913$

- Satzungen des Israelitischen Frauenvereins (Kranken- und

Beerdigungsverein), Januar 1904

- Verfügung des Regierungspräsidenten über Anerkennung der

Totenkassen der Torfträger und Torfträgerinnen als

Versicherungsvereine, Februar 1904

- Ausschreibung der versicherungsmathematische Prüfung der Emder

Sterbekassen, April - Mai 1904

- Satzungen des Emder Militärvereins mit Sterbekasse, 1902

- Anpassung der Satzungen der Emder Beerdigungskassen an die

Bestimmungen des Privatversicherungsgesetzes, 1905 - 1907

- Statistische Aufstellung über Beerdigungskassen und Waisen- und

Witwenunterstützungskassen in Emden, 1907

- Versicherung von Kindern bei Sterbekassen, 1909 - 1910

$1902-1913$

Klassifikation Teil B: 01720

Band: 4

Trägermaterial: Papier

Alte Reg.-Sig.: IV Re 111

Bestell-Nr.: IV 01720

1672 Allgemeine Handwerker-Witwenkasse für den Stadt- und Landkreis

1877-1918 Emden

- Statuten der Allgemeinen Handwerker-Witwenkasse für den Stadtund Landkreis Emden , 1877 - 1907

- Beschwerde des R.D. Stuck gegen den Vorstand der Allgemeinen Handwerker-Witwenkasse für den Stadt- und Landkreis Emden wegen Verweigerung von Pensionszahlungen an seine bei der Kasse versicherten, verwitweten Schwester, Juni - September 1884 - Antrag der Allgemeinen Handwerker-Witwenkasse für den Stadtund Landkreis Emden auf Genehmigung der Veranstaltung einer Lotterie, Februar - März 1895

- Anerkennung der Allgemeinen Handwerker-Witwenkasse für den Stadt- und Landkreis Emden als "Kleiner Verein" im Sinne des Privatversicherungsgesetzes, Juni - Oktober 1903

- Kassenberichte der Allgemeinen Handwerker-Witwenkasse für den Stadt- und Landkreis Emden, 1905 - 1918

- Monita des Regierungspräsidenten zu den Kassenberichten, 1907

- Mitgliederverzeichnis und Verzeichnis der von der Allgemeinen Handwerker-Witwenkasse für den Stadt- und Landkreis Emden unterstützten Witwen, 1913

$1877-1918$ (1922)

Klassifikation Teil B: 01721

Trägermaterial: Papier

Alte Reg.-Sig.: IV Re 112

Vorprovenienz: Regierung zu Aurich

Bestell-Nr.: IV 01721 
IV

05

05.03

05.03.11

05.03.11.01

05.03.11.01.02
Stadtverwaltung

Aufgabenbereiche der Stadtverwaltung

Sozialfürsorge

Institutionen zur Verbesserung der Wohlfahrt

Kranken- und Versicherungskassen

Lfd. Nr. Titel

Laufzeit

1673 Versicherungsamtssache

1918

- Beschwerde des J. van de Velde gegen die Allgemeine

Ortskrankenkasse wegen Verweigerung der Bezahlung der vom Arzt verschriebenen Milch, Dezember 1918

1918

Klassifikation Teil B: 01722

Trägermaterial: Papier

Alte Reg.-Sig.: IV Re 113

Bestell-Nr.: IV 01722

1674 Fürsorge für Beamte nach Betriebsunfällen

$1902-1906$

- Vom Innenminister angeordnete Datenerhebung zur Notwendigkeit der gesetzlichen Regelung der Fürsorge für Beamte nach

Betriebsunfällen, Dezember 1902 - Januar 1903

- Werbung des Allgemeinen Deutschen Versicherungs-Vereins in

Stuttgart für eine Unfallversicherung für Gemeindebeamte, November 1903

- Anfrae des Magistrats der Stadt Lüneburg wegen Unfallversicherung der Kommunalbeamten in Emden, Januar - Februar 1906

$1902-1906$

Klassifikation Teil B: 01723

Trägermaterial: Papier

Alte Reg.-Sig.: IV Re 114

Bestell-Nr.: IV 01723

1675 Zimmerleute-Totenlade

1904-1911

- Satzungen der Zimmerleute-Totenlade, 1904

- Verfahren zur Anerkennung der Zimmerleute-Totenlade als

lebensfähige Versicherung nach dem Privatversicherungsgesetz,

November 1903 - Dezember 1904

- Versicherungstechnisches Gutachten über die

Zimmerleute-Totenlade, August 1904

- Monita des Regierungspräsidenten zur Satzung der

Zimmerleute-Totenlade, Oktober 1904

- Kassenberichte der Zimmerleute-Totenlade, 1906 - 1911

$1904-1911$

Klassifikation Teil B: 01724

Trägermaterial: Papier

Alte Reg.-Sig.: IV Re 117

Bestell-Nr.: IV 01724 
IV

05

05.03

05.03.11

05.03.11.01

05.03.11.01.02

Stadtverwaltung

Aufgabenbereiche der Stadtverwaltung

Sozialfürsorge

Institutionen zur Verbesserung der Wohlfahrt

Kranken- und Versicherungskassen

Lfd. Nr. Titel

Laufzeit

1676 Gesetz über den Versicherungsvertrag

1908

- Bestimmungen des Gesetzes über den Versicherungsvertrag

1908

Klassifikation Teil B: 01725

Trägermaterial: Papier

Alte Reg.-Sig.: IV Re 119

Bestell-Nr.: IV 01725

1677 Abonnenten-Versicherungen

- Erlasse des Ministers für Handel und Gewerbe und des Innenministers über Anordnung der Berichterstattung zu Vorschlägen wegen Resolution des Reichstages über Verbot von Abonnentenversicherungen (Verbindung einer Zeitschriften-Abo mit einer Versicherung), Juli 1912 / August 1914

- Bericht des Magistrats an den Regierungspräsidenten über in Emden verbreitete Zeitschriftentitel in Verbindung mit einer Versicherung, August 1911 / Juli 1914

- Zeitschriftentitel, $1911 / 1914$

$1911-1914$

Klassifikation Teil B: 01726

Trägermaterial: Papier

Alte Reg.-Sig.: IV Re 121

Bestell-Nr.: IV 01726

1678 Ziegen-Versicherungsverein

- Verfahren zur Zulassung des Ziegen-Versicherungsvereins, Januar April 1913

- Statuten des Ziegen-Versicherungsvereins (Versicherung für Ziegenhalter), 1913

- Jahresberichte des Ziegen-Versicherungsvereins, 1913 - 1915

- Bericht des Vereinsvorsitzenden G. Drescher über Ruhen der Tätigkeit des Ziegen-Versicherungsverein wegen Kriegsteilnahme seiner Mitglieder, Mai 1917

$1913-1917$

Klassifikation Teil B: 01727

Trägermaterial: Papier

Alte Reg.-Sig.: IV Re 122

Bestell-Nr.: IV 01727 
IV

05

05.03

05.03.11

05.03.11.01

05.03.11.01.02
Stadtverwaltung

Aufgabenbereiche der Stadtverwaltung

Sozialfürsorge

Institutionen zur Verbesserung der Wohlfahrt

Kranken- und Versicherungskassen

Lfd. Nr. Titel

Laufzeit

1679 Beschwerden gegen die Allgemeine Ortskrankenkasse

- Verschiedene Beschwerden beim Versicherungsamt der Stadt

Emden gegen die AOK wegen zu geringer Krankengeldzahlungen,

Februar 1918 - Januar 1919

1918 (1919)

Klassifikation Teil B: 01728

Trägermaterial: Papier

Alte Reg.-Sig.: IV Re 123

Bestell-Nr.: IV 01728

1680 Vertrauensmännerwahlen für die Angestelltenversicherung

$1912-1913$

(Rentenversicherung)

- Erlass des Ministers für Handel und Gewerbe über WAhl der

Vertzrauensmänner für die Angestelltenversicherung, Juli 1912

- Reichsgesetz über Ordnung der Vertrauensmännerwahlen für die

Angestelltenversicherung (Rentenversicherung), Juli 1912

- Wahl der Vertrauensmänner für die Angestelltenversicherung im

Stadtkreis Emden, September 1912 - Februar 1913

- Wahllisten der Vertrauensmännerwahlen, Oktober 1912

$1912-1913$

Klassifikation Teil B: 01729

Trägermaterial: Papier

Alte Reg.-Sig.: IV Re 124

Bestell-Nr.: IV 01729

1681 Kriegsversicherung für Angehörige eingezogener Emder Bürger

- Mitgliederlisten

1914

Klassifikation Teil B: 01730

Trägermaterial: Papier

Alte Reg.-Sig.: IV Re 125

Bestell-Nr.: IV 01730

1682 Arbeitgeberanteil zur Krankenversicherung

- Weigerung des Kaufmanns Helmer von Baden-Foget zur Zahlung des Arbeitgeberbeitrags in die Krankenversicherung für den von ihm beschäftigten Arbeiter Hinderk Smidt

1912

Klassifikation Teil B: 01751

Trägermaterial: Papier

Alte Reg.-Sig.: IV RI 16

Bestell-Nr.: IV 01751 
IV

05

Stadtverwaltung

05.03

Aufgabenbereiche der Stadtverwaltung

05.03.11

Sozialfürsorge

05.03.11.01

05.03.11.01.02

Institutionen zur Verbesserung der Wohlfahrt

Kranken- und Versicherungskassen

Lfd. Nr. Titel

Laufzeit

1683 Invaliden- und Hinterbliebenenversicherung

1912

- Vorgänge bei der Landesversicherungsanstalt Hannover wegen

Einstellung von Zahlungen an Invaliden- oder Hinterbliebenenrente

wegen Wegfalls der Voraussetzung (Arbeitsfähigkeit)

1912

Klassifikation Teil B: 01752

Trägermaterial: Papier

Alte Reg.-Sig.: IV RI 28

Bestell-Nr.: IV 01752

1684 Ostfriesische Reformierte Pfarrtöchterkasse, Emden

- Statuten der Ostfriesischen Reformierten Pfarrtöchterkasse, Emden, 1901 / 1904 / 1907

- Anpassung der Statuten an das Privatversicherungsgesetz, August November 1904

- Jahresberichte der Ostfriesischen Reformierten Pfarrtöchterkasse,

Emden, 1905 - 1916 (1920 - 1925)

1901 - 1916 (1920 - 1925)

Klassifikation Teil B: 01820

Trägermaterial: Papier

Alte Reg.-Sig.: IV Fi 058

Vorprovenienz: Regierung zu Aurich

Bestell-Nr.: IV 01820 
IV

05

05.03

05.03.11

05.03.11.01

05.03.11.01.03
Stadtverwaltung

Aufgabenbereiche der Stadtverwaltung

Sozialfürsorge

Institutionen zur Verbesserung der Wohlfahrt

Krankenhospitale

Lfd. Nr. Titel

Laufzeit

1685 Städtisches Krankenhaus, Bd. 1

1894-1900

- Gedruckte Krankenhausordnung, November 1882

- Regelung der Nutzung des Krankenhauses durch Belegärzte

(Hausärzte), Juli 1891

- Bericht über Ermittlungen zu Vorwürfen gegen Krankenhausarzt und

Schwestern wegen Unregelmäßigkeiten und unsittlicher

Lebensführung, März 1884

- Streit zwischen dem leitenden Krankenhausarzt Dr. Bakker und dem Vorsitzenden des Krankenhausaufsichtsrates, Senator Brons, wegen einer von Brons angeordneten Illumination des Krankenhauses, April 1895

- Streit zwischen Dr. Bakker und dem Aufsichtsratsvorsitzenden Brons um Disziplinargewalt gegenüber den Schwestern, Februar - März 1896

- Spannungsverhältnis zwischen Dr. Bakker und den

Krankenschwestern, Februar 1896 - Februar 1897

- Regelung der Stellung der Krankenhausärzte und der leitenden

Schwester, Februar 1897

- Ausschreibung der Stelle eines leitenden Arztes im städtischen

Krankenhaus, Februar - Mai 1897

- Ministerialerlasse und Verfügungen zum Krankenhauswesen, 1897

- Statut des Emder Krankenhauses, 1897

- Hausordnung des Emder Krankenhauses, 1897

- Jahresberichte des städtischen Krankenhauses, 1894 - 1897

- Errichtung einer zweiten Zelle für Tobsüchtige, September - Oktober 1897

- Kündigung der Schwester Elma, Mai - Juni 1898

- Antrag des Gemüsebauers Hilderich Störk auf Ermäßigung der Verpflegungskosten während seiner Krankenhausbehandlung wegen wirtschaftlicher Schwierigkeiten, Februar 1898

- Statistik der Krankenhausbelegung, 1895 - 1897

- Krankenhausetat, 1899

- Elektrifizierung des städtischen Krankenhauses, 1899

- Antrag der Ortskrankenkasse für gewerbliche Arbeiter und Hilfsarbeiter beim Magistrat auf Verrechnung der Benutzung des

Röntgenapparates und der medizinischen Geräte mit der allgemeinen Taxe für die Nutzung des städtischen Krankenhauses, Oktober 1899

- Instruktionen für den Desinfektor der städtischen

Desinfektionsanstalt zu Emden, Mai 1900

- Maßnahmen zur Abwehr einer drohenden Pestepidemie, Dezember 1899 - März 1900

$1897-1900$

Klassifikation Teil B: 01731

Band: 1

Trägermaterial: Papier

Alte Reg.-Sig.: IV Rf 02

Bestell-Nr.: IV 01731 
IV

05

05.03

05.03.11

05.03.11.01

05.03.11.01.03
Stadtverwaltung

Aufgabenbereiche der Stadtverwaltung

Sozialfürsorge

Institutionen zur Verbesserung der Wohlfahrt

Krankenhospitale

Laufzeit

1903-1914

(1915-1918)

- Datenerhebung des Vorstandes des Provinzialvereins vom Roten Kreuz über Sanitätspersonal mit Eignung zum Kriegseinsatz und freie Bettenkapazitäten der Krankenhäuser für den Kriegsfall, Juli 1903 / März 1906

- Emder Krankenhausstatistik, 1903

- Antrag des Magistrats beim Regierungspräsidenten in Aurich auf Beihilfe zur Einrichtung einer Unterhaltungsbibliothek im städtischen Krankenhaus, Januar 1904

- Verfügung des Magistrats über Aufnahme mittelloser Kranke in das Krankenhaus gegen Bürgschaftserklärung eines Kostenträgers, März 1905

- Neugestaltung des Krankenhausgartens mit Obstbäumen, Mai 1907

- Klagen über Feuchtigkeit in den Räumen der Krankenschwestern, September 1908

- Datenerhebung des Innenministeriums über Verpflegungssätze in städtischen Krankenhäusern, Juli - August 1909

- Einladung des Gewerbeinspektors zur Besichtigung der neuen Wäschereianlage des städtischen Krankenhauses, Februar - Mai 1910

- Verzögerter Transport eines schwerverletzten Arbeiters aus dem Hafen ins Krankenhaus, Juli - August 1913

- Angebote über die Lieferung von Radium (Röntgen), November -

Dezember 1913

- Erlass des Innenministers über Anordnung zur Mitteilung von zur Behandlung verwundeter freier Krankenhauskapazitäten, August 1914

- Ersatz des natürlichen Kamphers durch ein synthetisches Produkt, Oktober 1914

1903 - 1914 (1915 - 1918)

Klassifikation Teil B: 01732

Band: 2

Trägermaterial: Papier

Alte Reg.-Sig.: IV Rf 02

Bestell-Nr.: IV 01732 
IV

05

05.03

05.03.11

05.03.11.01

05.03.11.01.03
Stadtverwaltung

Aufgabenbereiche der Stadtverwaltung

Sozialfürsorge

Institutionen zur Verbesserung der Wohlfahrt

Krankenhospitale

Lfd. Nr. Titel

Laufzeit

1687 Krankenhausbau, Bd. 1

1884-1893

- Kostenvoranschlag des Stadtbaumeisters Wiggers zum Bau eines neuen Krankenhauses, mit Zeichnung, 1884

- Krankenhausprojekt des Vaterländischen Frauenvereins Emden,

August 1884 - Mai 1890

- Weigerung des Bürgervorsteherkollegiums zur Billigung einer

Beteiligung der Stadt Emden am Krankehausprojekt des

Vaterländischen Frauenvereins, April 1888

- Entwurf eines Vertrages zwischen der Stadt Emden und dem

Landkreis Emden über Beteiligung des Kreises am Bau und

Unterhaltung eines Krankenhauses in Emden, Dezember 1889

- Verhandlungen der Krankenhausbau-Kommission wegen

Krankenhausbauprojekt, 1890 - 1893

- Grundsteinlegung und Einweihungsfeier für das neue Krankenhaus

in Emden, 1892 - 1893

$1884-1893$

Klassifikation Teil B: 01733

Band: 1

Trägermaterial: Papier

Alte Reg.-Sig.: IV Rf 05

Bestell-Nr.: IV 01733

1688 Krankenhausbau, Bd. 2

1890-1895

- Projekt des Neubaus eines Krankenhauses in Emden

$1890-1895$

Klassifikation Teil B: 01734

Band: 2

Trägermaterial: Papier

Alte Reg.-Sig.: IV Rf 05

Bestell-Nr.: IV 01734

1689 Krankenhausbau, Bd. 3

1891-1896

- Projekt des Neubaus eines Krankenhauses: Bau einer

Heizungsanlage, 1891 - 1896

- Malerarbeiter im städtischen Krankenhauses, 1904

$1891-1904$

Klassifikation Teil B: 01735

Band: 3

Trägermaterial: Papier

Alte Reg.-Sig.: IV Rf 05

Bestell-Nr.: IV 01735 
IV

05

05.03

05.03.11

05.03.11.01

05.03.11.01.03

Lfd. Nr. Titel
Stadtverwaltung

Aufgabenbereiche der Stadtverwaltung

Sozialfürsorge

Institutionen zur Verbesserung der Wohlfahrt

Krankenhospitale

Laufzeit

1690 Gründung eines Johanniter - Hospitals

$1882-1883$

- Sondierung des Oberbürgermeisters Fürbringer beim Johanniterorden wegen Gründung eines Krankenhauses deas Ordens in Emden

$1882-1883$

Klassifikation Teil B: 01736

Trägermaterial: Papier

Alte Reg.-Sig.: IV Rf 07

Bestell-Nr.: IV 01736

1691 Behandlung von Krankenhauspatienten durch Hausärzte

$1890-1891$

- Antrag des Ärztevereins Emden beim Magistrat auf Erlaubnis der Behandlung und Operationen von Patienten durch Hausärzte im Krankenhaus, Dezember 1890

- Beschluss des Verwaltungsrates des städtischen Krankenhauses über Schaffung von Möglichkeiten der Behandlung von Krankenhauspatienten durch Hausärzte (Belegarztsystem), Mai 1891 - Votum des Krankenhausarztes und Sanitätsrats Dr. Lohmeyer gegen die Behandlung von Krankenhauspatienten durch Hausärzte, Juni 1891

- Beschluss des Magistrats über Schaffuing von Möglichkeiten zur Behandlung von Krankenhauspatienten durch Hausärzte und Benutzung von Operationssälen durch Hausärzte nach Rücksprache mit dem Krankenhausarzt, Juli 1891

- Materialien: Behandlung von Krankenhauspatienten durch Hausärzte in anderen Städten, 1891

$1890-1891$

Klassifikation Teil B: 01737

Trägermaterial: Papier

Alte Reg.-Sig.: IV Rf 09

Bestell-Nr.: IV 01737

1692 Baracken für das Krankenhaus

1906-1907

- Prospekte von Barackenherstellern

$1906-1907$

Klassifikation Teil B: 01738

Trägermaterial: Papier

Alte Reg.-Sig.: IV Rf 10

Bestell-Nr.: IV 01738 
IV

05

05.03

05.03.11

05.03.11.01

05.03.11.01.03
Stadtverwaltung

Aufgabenbereiche der Stadtverwaltung

Sozialfürsorge

Institutionen zur Verbesserung der Wohlfahrt

Krankenhospitale

Lfd. Nr. Titel

Laufzeit

1693 Beitritt der Stadt Emden zum Provinzialverein vom Roten Kreuz

1902-1917

- Mustervertrag des Central-Comites des preußischen Landesvereins vom Roten Kreuz über Lieferung von Baracken zur Errichtung von Quarantänestationen bei Ausbruch von Seuchen, 1905

- Bestellung von Baracken vom preußischen Landesverein vom Roten

Kreuz durch Oberbürgermeister Fürbringer, April 1902

- Erlass des Ministers der geistlichen, Unterrichts- und

Medizinalangelegenheiten über Genehmigung der Lieferung von

Baracken durch den preußischen Landesverein vom Roten Kreuz als Notbehelf, Juni 1902

- Erlass des Ministers der geistlichen, Unterrichts- und

Medizinalangelegenheiten über Normen und Ausstattung der

Baracken für Isolierpatienten (Infektionskranke), Juni 1902

- Beitrittsbedingungen des Roten Kreuzes für Gemeinden, 1902

- Beitritt der Stadt Emden zum Provinzialverein vom Roten Kreuz, November 1902

- Gemeinsamer Erlass des Ministers der geistlichen, Unterrichts- und Medizinalangelegenheiten und des Innenministers über Grundsätze der Stellung von Baracken und deren Ausstattung durch das Rote Kreuz im Epidemiefall, April 1905

- Prospekte von Barackenherstellerfirmen, 1907

- Beschluss des Magistrats über Abschluss eines Vertrages mit dem Provinzialverein vom Roten Kreuz wegen Stellung einer Baracke für den Seuchenfall, Oktober 1908

- Verfügungen des Regierungspräsidenten über gemäß eines

Erlasses des Innenministers notwendige Errichtung eines Lazarettes für die Auswandererstation in Emden und Organisation der Versorgung infektionskranker Auswanderer, August 1913 - August 1916

- Verhandlungen zwischen dem Magistrat, der HAPAG-Lloyd und der Regierung in Aurich wegen Aufbau medizinischer Versorgungseinrichtungen für Auswanderer, Isolation Seuchenkranker und Tragung der Behandlungskosten, 1914

- Verhandlungen des Magistrats mit der HAPAG-Lloyd wegen

Finanzierung der Behandlung kranker Auswanderer, Januar - März

1917

- Nutzung der Isolierbaracken wegen drohender Pockenepidemie, 1917

$1902-1917$ (1919)

Klassifikation Teil B: 01739

Trägermaterial: Papier

Alte Reg.-Sig.: IV Rf 11

Bestell-Nr.: IV 01739 
05

05.03

05.03.11

05.03.11.01

05.03.11.01.03

Lfd. Nr. Titel

\section{Stadtverwaltung}

Aufgabenbereiche der Stadtverwaltung

Sozialfürsorge

Institutionen zur Verbesserung der Wohlfahrt

Krankenhospitale

Laufzeit

1694 Streit wegen Kostenträgerschaft für Verpflegung und Behandlung einer erkrankten Dienstmagd im Krankenhaus

- Unterstützung der mittellosen Dienstmagd Hindertje Janßen, 1902

- Verfügung des Magistrats an den Landwirt Thyssen in Constantia über Anordnung zur Tragung der Verpflegungs- und

Behandlungskosten für seine ins Krankenhaus eingelieferte

Dienstmagd H. Janßen, Oktober 1902

- Klage des Landwirts J. Thyssen gegen den Magistrat beim Amtsgericht auf Rücknahme der Verfügung wegen Trägerschaft der Behandlungs- und Verflegungskosten für die Dienstmagd H. Janßen, April - Juli 1903

$1902-1903$

Klassifikation Teil B: 01740

Trägermaterial: Papier

Alte Reg.-Sig.: IV Rf 14

Bestell-Nr.: IV 01740

1695 Streit wegen Trägerschaft der Behandlungs- und Verpflegungskosten für die erkrankte Dienstmagd Apke Theessen

- Unterstützung der mittellose Dienstmagd Apke Theessen, 1903 - Aufforderung des Magistrats an die Armenverwaltung in Larrelt zur Trägerschaft der Verpflegungskosten für die wegen Scharlach ins Krankenhaus eingewiesene Dienstmagd Apke Theessen, Mai 1903 - Weigerung des Vaters der Apke Theessen zur Übernahme der Krankenhauskosten wegen Einweisung seiner Tochter in das Krankenhaus durch ihren Arbeitgeber P. Regendorp, September 1903 - Klage des Kaufmanns P. Regendorp gegen den Magistrat beim Amtsgericht auf Rücknahme der Heranziehung zur Trägerschaft der Behandlungs- und Verpflegungskosten für seine ehemalige Dienstmagd Apke Theessen, April - Juli 1903

1903

Klassifikation Teil B: 01741

Trägermaterial: Papier

Alte Reg.-Sig.: IV Rf 15

Bestell-Nr.: IV 01741
1902-1903

1903 
IV

05

05.03

05.03.11

05.03.11.01

05.03.11.01.03
Stadtverwaltung

Aufgabenbereiche der Stadtverwaltung

Sozialfürsorge

Institutionen zur Verbesserung der Wohlfahrt

Krankenhospitale

Lfd. Nr. Titel

Laufzeit

1696 Transportable Isolierbaracke für das Krankenhaus

1904-1906

- Kostenanschläge und Planzeichnung für Isolierbaracke, Juli 1905

- Angebote von Barackenbaufirmen, 1905 - 1906

- Bericht des Magistrats an den Regierungspräsidenten über Absicht

der Anschaffung einer transportablen Isolierbaracke für das

Krankenhaus wegen Planung einer Krankenhauserweiterung, Juni

1906

- Bericht des Verwaltungsrates des städtischen Krankenhauses über

Standort für eine Isolierbaracke und Empfehlung der Stationierung der Isolierbaracke außerhalb der Stadt, Mai 1906

- Anschaffung der transportablen Holzbaracke, November 1906 -

Januar 1907

$1905-1907$

Klassifikation Teil B: 01742

Trägermaterial: Papier

Alte Reg.-Sig.: IV Rf 16

Bestell-Nr.: IV 01742

1697 Geplante massive Isolierbaracke und Umfriedung des

1904-1906

Krankenhausgartens

- Austausch des Magistrats mit anderen Städten über Isolierbaracken zur Seuchenbekämpfung, Mai 1904 - Febr 1905

- Planung der Einfriedung des Grundstücks und des neuen Gartens des städtischen Krankenhauses, 1905

- Kostenvoranschlag des Stadtbaumeisters Wiggers über Einfriedung,

Mai 1905

- Verhandlungen des Verwaltungsrates des städtischen

Krankenhauses wegen Isolierbaracke, Juli 1905

- Verfügung des Regierungspräsdidenten über hygienische Auflagen

für die Isolierbaracke am Krankenhaus, November 1905

- Angebote von Barackenbaufirmen, 1905

- Proteste von Anlieger gegen den Bau der Isolierbaracke an der verkehrsreichen Großen Straße, Februar - März 1906

- Abrechnung der Bauarbeiten für die Isolierbaracke, 1906

$1904-1906$

Klassifikation Teil B: 01743

Trägermaterial: Papier

Alte Reg.-Sig.: IV Rf 17

Bestell-Nr.: IV 01743 
IV

05

05.03

05.03.11

05.03.11.01

05.03.11.01.03
Stadtverwaltung

Aufgabenbereiche der Stadtverwaltung

Sozialfürsorge

Institutionen zur Verbesserung der Wohlfahrt

Krankenhospitale

Lfd. Nr. Titel

Laufzeit

1698 Krankenhausanbau

1907-1908

- Votum des Verwaltungsrates des städtischen Krankenhauses für den Krankenhausanbau mit Isolierbereich, u.a. für

Tuberkulosepatienten, Juni 1906 / Februar 1907

- Kostenvoranschlag des Anbaus mit Isolierabteilung für TBC-Kranke,

1907

- Planzeichnungen, 1907

- Finanzierung des Bauprojektes, 1907

- Annehmerbedingungen für den Krankenhausanbau, April -

September 1907

- Streit um mangelhafte Malerarbeiten an der Veranda des

Krankenhausanbaus, Dezember 1907

- Senkung der Garantiebürgschaftssumme des ausführenden

Bauunternehmers R. J. Neeland, Januar 1908

$1907-1908$

Klassifikation Teil B: 01744

Trägermaterial: Papier

Alte Reg.-Sig.: IV Rf 18

Bestell-Nr.: IV 01744

1699 Heizungsanlage im Krankenhaus

1907

- Einbau einer zentralen Dampfheizungsanlage im Krankenhaus

1907

Klassifikation Teil B: 01745

Trägermaterial: Papier

Alte Reg.-Sig.: IV Rf 15

Bestell-Nr.: IV 01745

1700 Dampfwäscherei für das Krankenhaus

1909-1910

(1911-1915)

- Anschaffung und Einbau einer Dampfwäschereianlage für das Krankenhaus

1909 - 1910 (1911 - 1915)

Klassifikation Teil B: 01746

Trägermaterial: Papier

Alte Reg.-Sig.: IV Rf 32

Bestell-Nr.: IV 01746

1701 Verwaltungsausschuss des städtischen Krankenhauses

- Protokolle der Sitzungen des Verwaltungsausschusses des städtischen Krankenhauses

1894

Klassifikation Teil B: 01747

Trägermaterial: Papier

Alte Reg.-Sig.: IV Rf 37

Bestell-Nr.: IV 01747 
IV

05

Stadtverwaltung

05.03

Aufgabenbereiche der Stadtverwaltung

05.03.11

Sozialfürsorge

05.03.11.01

05.03.11.01.03

Institutionen zur Verbesserung der Wohlfahrt

Krankenhospitale

Lfd. Nr. Titel

Laufzeit

1702 Krankenhausärzte

$1902-1913$

- Erlass des Ministers der geistlichen, Unterrichts- und

Medizinalangelegenheiten über Beschäftigung von Praktikanten in

Krankenhäusern, April 1902

- Richtlinien der Einstellung von Praktikanten (Ärzte in der Ausbildung)

im städtischen Krankenhaus, Juni - Juli 1913

- Einstellung des Dr. Kercker als leitender Krankenhausarzt, 1919

1902 - 1913 (1911 - 1935)

Klassifikation Teil B: 01748

Trägermaterial: Papier

Alte Reg.-Sig.: IV Rf 38

Bestell-Nr.: IV 01748 
IV

05

05.03

05.03.11

05.03.11.01

05.03.11.01.04
Stadtverwaltung

Aufgabenbereiche der Stadtverwaltung

Sozialfürsorge

Institutionen zur Verbesserung der Wohlfahrt

Waisenfürsorge

Lfd. Nr. Titel

Laufzeit

1703 Waisenrats-Kollegium

1875-1913

- Einführung des Amtes eines Waisenrates, 1875

- Bestellung und Wahl der Waisenräte in Emden, April 1875 - März

1913

- Regelung der Zusammenarbeit zwischen Waisenräten und dem

Gasthaus Emden in der Betreuung der im Gasthaus untergebrachten

Waisenkinder, März 1876

- Festlegung der Aufgaben der Waisenräte, Mai 1876

- Ablehnung seiner Nominierung zum Waisenrat durch den Kaufmann

B. Brons, Februar 1882

- Erlasse des preußischen Innenministers über verstärkte Beteiligung von Geistlichen an der Arbeit der Waisenräte bzw. deren Bestellung zu Waisenräten sowie Bestellung von Frauen zu Waisennräten, November 1895 / November 1905

- Bekämpfung der Prostitution minderjähriger Mädchen durch

Anwendung der Fürsorgeerziehung, September 1902

- Erteilung von Vormundschaften, 1907

- Vergütung von Botengängen im Auftrag des Waisenrats, März 1909

$1875-1913$

Klassifikation Teil B: 00007

Trägermaterial: Papier

Bestell-Nr.: IV 00007

1704 Waisenrats-Kollegium

1914-1923

- Bestellung des Magistratsassistenten R. Blikslager zum Generalund Berufsvormund über die Waisen in Emden durch das

Amtsgericht, Januar 1914

- Ausscheiden des Kaufmanns J.C. Hennings aus dem

Waisenrats-Kollegium, Januar 1914

- Beschimpfung des Waisenrats J.C.Hayen bei der Ausübung seiner

Funktion, April 1914

- Bestellung von Ersatz für ausscheidende Waisenräte, 1915 - 1923

$1914-1923$

Klassifikation Teil B: 00008

Trägermaterial: Papier

Bestell-Nr.: IV 00008

1705 Mündelregister

$1878-1889$

- Register der vom Waisenrats-Kollegium betreuten Mündel (Waisen) mit Vormünder, 1878 - 1889

$1878-1889$

Klassifikation Teil B: 00009

Trägermaterial: Papier

Bestell-Nr.: IV 00009 
IV

05

Stadtverwaltung

05.03

05.03.11

Aufgabenbereiche der Stadtverwaltung

05.03.11.01

05.03.11.01.04

Sozialfürsorge

Institutionen zur Verbesserung der Wohlfahrt

Waisenfürsorge

Lfd. Nr. Titel

Laufzeit

1706 Rettungsanstalt zu Großefehn

1867-1887

- Werbung des preußischen Landdrosten in Aurich für die

Rettungsanstalt zu Großefehn für verwahrloste Kinder, 1867

- Einweisung des wegen Diebstahls verurteilten Jungen Dirk

Lindenstädt in die Rettungsanstalt zu Großefehn nach Verbüßung

seiner Gefängnisstrafe, Juni 1868

- Genehmigung von Werbeaktionen und Spendensammlungen für die

Rettungsanstalt zu Großefehn durch den preußischen Landdrosten, 1867 - 1871

- Aufnahmebedingungen der Rettungsanstalt zu Großefehn, Februar 1877

- Einweisung der Kinder der Witwe Reinders, Alide und Dietrich, in die Rettungsanstalt zu Großefehn wegen unsittlichen Lebenswandel der Mutter, Februar 1877

- Einweisung des Schülers Heinrich Brinkmann in die Rettungsanstalt zu Großefehn auf Antrag seines Vaters wegen wiederholtem Schulschwänzen und Straftaten, September - Oktober 1887

$1867-1887$

Klassifikation Teil B: 01785

Trägermaterial: Papier

Alte Reg.-Sig.: IV Sh 12

Bestell-Nr.: IV 01785 
IV

05

05.03

05.03.11

05.03.11.02

05.03.11.02.01

Stadtverwaltung

Lfd. Nr. Titel

Aufgabenbereiche der Stadtverwaltung

Sozialfürsorge

Armenpflege und Milde Stiftungen

Diakonie der Haussitzenden Armen

1707 Diakonie der Haussitzenden Armen

Laufzeit

- Kostgeldschulden der Diakonie der Haussitzenden Armen

1871-1872

(1853-1854) gegenüber der Gasthausverwaltung, 1853 - 1854

- Gesuch des mittellosen B. Woortman bei der Diakonie der Haussitzenden Armen um Gewährung einer Unterstützung für den Winter, November 1871

- Nachrichten über zur Entlassung aus diversen Haftanstalten vorgesehene Emder Strafgefangene, 1871 - 1872

- Gesuch der kranken und pflegebedürftigen Matrosenwitwe Johanna de Vries, geb. Bruns um eine Unterstüttzung, Januar 1872

- Gesuch der kranken Witwe W. H. Janssen um Unterstützung,

November 1871

(1853 - 1854) 1871 - 1872

Klassifikation Teil B: 01753

Trägermaterial: Papier

Alte Reg.-Sig.: IV Sb 4

Bestell-Nr.: IV 01753

1708 Rechnungen der Diakonie der Haussitzenden Armen und des

$1871-1874$

Gasthauses

- Verfügungen des preußischen Landdrosten in Aurich über Anordnung zur Einsendung einer nach systematischen Vorgaben geordneten Rechnung der Diakonie der Haussitzenden Armen und des Gasthauses, Februar 1871 /August 1872 - August 1874

$1871-1874$

Klassifikation Teil B: 01754

Trägermaterial: Papier

Alte Reg.-Sig.: IV Sb 20

Bestell-Nr.: IV 01754 
IV

05

05.03

05.03.11

05.03.11.02

05.03.11.02.02

Stadtverwaltung

Aufgabenbereiche der Stadtverwaltung

Sozialfürsorge

Armenpflege und Milde Stiftungen

Gasthaus

Laufzeit

1709 Insassen des Gasthauses

1866-1871

- Verzeichnisse der im Gasthaus untergebrachten mittellosen

Personen

$1866-1871$

Klassifikation Teil B: 01755

Trägermaterial: Papier

Alte Reg.-Sig.: IV Sc 01

Bestell-Nr.: IV 01755

1710 Schule des Gasthauses

1869

- Einstellung eines Kustos zur Beaufsichtigung und Ausbildung der

Gasthauskinder, (Juli 1850 - April 1862) Juli 1869

- Dienstordnung für den Gasthauslehrer und seine Frau, (Februar

1851 - April 1862)

- Gehaltsfestsetzung für die Lehrer der Gasthausschule, 1869

(1850 - 1862) 1869

Klassifikation Teil B: 01756

Trägermaterial: Papier

Alte Reg.-Sig.: IV Sc 21

Bestell-Nr.: IV 01756

1711 Sargmonopol des Gasthauses

$1868-1871$

- Anfrage des Handwerkervereins wegen Rechtmäßigkeit des

Sargmonopols des Gasthauses vor dem Hintergrund der

Bestimmungen des Gewerbegesetzes, August / November 1868

- Beharrung des Gasthausvorstandes auf das Sargmonopol als

wirtschaftliches Standbein der Institution, August 1868

- Entschädigung des Gasthauses für die Aufgabe des Sargmonopols,

Dezember 1868 - Dezember 1871

- Preise für Särge aus der Produktion des Gasthauses, März 1869

$1868-1871$

Klassifikation Teil B: 01757

Trägermaterial: Papier

Alte Reg.-Sig.: IV Sc 29

Bestell-Nr.: IV 01757 
IV

05

05.03

05.03.11

05.03.11.02

05.03.11.02.02
Stadtverwaltung

Aufgabenbereiche der Stadtverwaltung

Sozialfürsorge

Armenpflege und Milde Stiftungen

Gasthaus

Lfd. Nr. Titel

Laufzeit

1712 Unterhaltung der Gasthauskirche

1912-1918

- Verschiedene Gutachten zum Streit zwischen der Stadt Emden und der Reformierten Kirche um die Unterhaltung der Gasthauskirche - Gutachten des Senators Bollhuis-Smeding für die Auflösung der Waisenabteilung des Gasthauses und Überführung der dort untergebrachten Kinder in Pflegefamilien, 1912

- Diskussion der Auflösung der Institution des Gasthauses, 1917

$1912-1918$

Klassifikation Teil B: 01758

Trägermaterial: Papier

Alte Reg.-Sig.: IV Sc 35

Bestell-Nr.: IV 01758

1713 Gasthaus-Direktion

1872-1918

(1919-1926)

- Ablehnung der Wahl zum Mitglied der Gasthaus-Direktion durch die Kaufleute N. Sielmann und David Swartte, Januar 1872

- Widerspruch der Gasthaus-Direktion gegen die von der

Gasthaus-Direktion verfügte Auflösung, Januar 1872

- Vereidigung neuer Mitglieder der Gasthaus-Direktion, Mai 1872

- Neuwahl von Mitglieder der Gasthaus-Direktion, Mai 1872 - Februar 1918 (1919 - 1926)

- Mitglieder der Gasthaus-Direktion, 1912 - 1914 (1919)

1872 - 1918 (1919 - 1926)

Klassifikation Teil B: 01899

Trägermaterial: Papier

Alte Reg.-Sig.: IV SkIV 002

Bestell-Nr.: IV 01899 b

1714 Ankauf von Immobilien durch die Gasthaus-Direktion

1871-1872

- Bericht der Gasthaus-Direktion an den Magistrat über Erwerb eines Hauses in der Nachbarschaft der Gasthauskirche, November 1871

- Billigung des Ankaufs durch das Bürgervorsteherkollegium unter Missbilligung der Unterlassung einer Anzeige von der Kaufabsicht der Gasthaus-Direktion vor dem Abschluss der Verkaufsverhandlungen, Januar 1872

$1871-1872$

Klassifikation Teil B: 01900

Trägermaterial: Papier

Alte Reg.-Sig.: IV SkIV 003

Bestell-Nr.: IV 01900 
IV

05

05.03

05.03.11

05.03.11.02

05.03.11.02.02
Stadtverwaltung

Aufgabenbereiche der Stadtverwaltung

Sozialfürsorge

Armenpflege und Milde Stiftungen

Gasthaus

Lfd. Nr. Titel

Laufzeit

1715 Zuständigkeit der Gasthaus-Direktion

$1872-1875$

- Eingabe der Roesina Eikens an den Magistrat über Bitte um

Veranlassung der Gasthaus-Direktion zur Ergreifung von

Schutzmaßnahmen wegen nach Abriss einer Mauer der

Gasthauskirche verursachte Einsturzgefahr ihres Hauses, August

1872

- Verhandlungen der städtischen Kollegien wegen Reparatur der

Gasthauskirche, Mai 1873 - Februar 1874

- Sanierung der Außenmauer der Gasthauskirche, Mai 1873 - März

1874

- Bekämpfung einer unter den Gasthausbewohnern ausgebrochenen

Typhus-Epidemie, Dezember 1879

- Kosten der Dachsanierung am Gasthaus-Gebäude, 1875

$1872-1875$

Klassifikation Teil B: 01901

Trägermaterial: Papier

Alte Reg.-Sig.: IV SkIV 006

Bestell-Nr.: IV 01901

1716 Gasthausinspektoren und Hilfslehrer

$1869-1910$

- Schreiben des Gasthaus-Direktions-Vorsitzenden Johannes Mustert an den Magistrat über Notwendigkeit der Einstellung eines

Gasthaus-Inspektors zur Verbesserung der Waisenfürsorge, Januar

1868 / August 1869

- Personalvorschläge der Gasthaus-Direktion für die Funktion des

Hilfslehrers im Gasthaus, August 1869

- Verhandlungen der städtischen Kollegien wegen Einstellung eines

Gasthaus-Inspektors, April 1869

- Einstellung des Friedrich Jakob Lobenbrück aus Lüdenscheid als

Gasthaus-Inspektor, Oktober 1869

- Instruktionen für den Gasthaus-Inspektor, Oktober 1869 / September 1905

- Gewährung eines festen Jahresgehalts für den Gasthaus-Inspektor, April 1876 - Oktober 1897

- Anzeige des Gerbers Jacob de Beer gegen den Gasthaus-Inspektor wegen antisemitischer Äußerungen, Dezember 1877 - Februar 1878

- Erhöhung des Gehalts des Gasthaus-Inspektors, Januar 1879 / März 1892 / Juli 1928

- Teilnahme des Gasthaus-Inspektors an Weiterbildungskursen, 1880

- Gewährung einer Alterszulage und Witwengeld für die Witwe des

verstorbenen Gasthaus-Inspektors Lobenbrück, Januar - März 1901

- Einstellung eines Gasthaushilfslehrers, 1872 - 1902

- Gewährung einer Altersunterstützung für die in den Ruhestand getretene Pflegemutter des Gasthauses, Juli 1905

- Einstellung des Georg Blikslager als Gasthaus-Inspektor, Juli -

Oktober 1910

$1872-1910$

Klassifikation Teil B: 01902

Trägermaterial: Papier

Alte Reg.-Sig.: IV SkIV 006

Bestell-Nr.: IV 01902 
IV

05

05.03

05.03.11

05.03.11.02

05.03.11.02.02
Stadtverwaltung

Aufgabenbereiche der Stadtverwaltung

Sozialfürsorge

Armenpflege und Milde Stiftungen

Gasthaus

Lfd. Nr. Titel

Laufzeit

1717 Bewirtschaftung des Ländereien des Gasthauses außerhalb Emdens $1871-1872$

- Vorschlag des Kreishauptmanns des Kreises Emden zur Bestellung eines Bevollmächtigten für die Ländereien des Gasthauses in der Gemeinde Larrelt, Dezember 1871

- Bestellung des Landwirts K. Ohling als Bevollmächtigter für die Ländereien des Gasthauses in der Gemeinde Larrelt, März 1872

$1871-1872$

Klassifikation Teil B: 01903

Trägermaterial: Papier

Alte Reg.-Sig.: IV SkIV 007

Bestell-Nr.: IV 01903

1718 Sargmonopol des Gasthauses

1873

- Schreiben der Gasthaus-Monopols über Notwendigkeit der Aufrecherhaltung des Sargmonopols wegen Rolle als wirtschaftliches Standbein, Oktober 1873

- Votum des Magistrats für eine allmähliche Ablösung des Sargmonopols des Gasthauses, Dezember 1873

1873

Klassifikation Teil B: 01904

Trägermaterial: Papier

Alte Reg.-Sig.: IV SkIV 008

Bestell-Nr.: IV 01904

1719 Abgaben auf die Ländereien des Gasthauses in Hinte

1902-1907

- Verfügung des Kreishauptmanns des Amtes Emden über Pflicht des Gasthauses zur Zahlung von Kirchenabgaben für seine Ländereiemn in der Gemeinde Hinte, Januar 1902

- Bericht des Kämmerers der Stadt Emden über nicht nachgewiesene Pflicht des Gasthauses zur Zahlung der Kirchenabgaben, Mai 1902

- Beharren der Kirchengemeinde Hinte auf Pflicht des Gasthauses zur Zahlung der Kirchenabgaben für seine Ländereien in Hinte, Juni 1906 - Streit um die Zugehörigkeit der zur Kirchensteuer in Hinte veranlagten Ländereien des Gasthauses, Oktober - November 1906 - Von der Kirchengemeinde in Hinte betriebenes Zwangsverfahren gegen das Gasthaus zur Einziehung der Kirchenabgaben, Februar Dezember 1907

$1902-1907$

Klassifikation Teil B: 01905

Trägermaterial: Papier Alte Reg.-Sig.: IV SkIV 010

Bestell-Nr.: IV 01905 
IV

05

05.03

05.03.11

05.03.11.02

05.03.11.02.02
Stadtverwaltung

Aufgabenbereiche der Stadtverwaltung

Sozialfürsorge

Armenpflege und Milde Stiftungen

Gasthaus

Lfd. Nr. Titel

Laufzeit

1720 Magistrats- und Bürgervorsteher-Stuhl in der Gasthauskirche

1874-1884

- Antrag der Gasthaus-Direktion beim Magistrat auf Nutzungserlaubnis für die dem Magistrat und dem Bürgervorsteherkollegium Sitze auf ihrem Stuhl in der Gasthauskirche, März - Mai 1874

- Reservierung der Plätze auf dem Magistrats- und

Bürgervorsteher-Stuhl in der Gasthauskirche für Mitglieder der

Garnison in Emden, Januar 1884

$1874-1884$

Klassifikation Teil B: 01906

Trägermaterial: Papier

Alte Reg.-Sig.: IV SkIV 012

Bestell-Nr.: IV 01906

1721 Übertragung von Grundstücke an der westlichen Seite des

Gasthauses an Hausbesitzer in der Faldernstraße

- Verfügung des Mafgistrats über Anordnung der Vermessung und Bezeichnung des von Privatpersonen gepachteten Landes an der Gasthauskirche, Dezember 1873

- Verkauf der Grundstücke westlich des Gasthauses, November 1874

- November 1875 / Mai - Juni 1881

- Festlegung der Einfriedung der Grundstücke westlich des

Gasthauses, 1906

$1873-1906$

Klassifikation Teil B: 01907

Trägermaterial: Papier

Alte Reg.-Sig.: IV SkIV 013

Bestell-Nr.: IV 01907

1722 Ermächtigung der Gasthaus-Direktion zur Prozessführung

- Ermächtigung der Gasthaus-Direktion zur Prozessführung in ihrer Klage gegen Maria Schröder wegen Rückforderung von Pflegegeld

1875

Klassifikation Teil B: 01908

Trägermaterial: Papier

Alte Reg.-Sig.: IV SkIV 015

Bestell-Nr.: IV 01908 
IV

05

05.03

05.03.11

05.03.11.02

05.03.11.02.02
Stadtverwaltung

Aufgabenbereiche der Stadtverwaltung

Sozialfürsorge

Armenpflege und Milde Stiftungen

Gasthaus

Lfd. Nr. Titel

Laufzeit

1723 Rechnungsprüfung bei der Gasthaus-Direktion

1873-1912

- Monita des Bürgervorsteherkollegiums zu den Rechnungen der

Gasdthaus-Direktion

- Statistiken zum Gasthaus-Betrieb

- Revision der Rechnungen der Gasthaus-Direktion durch den

Magistrat

$1873-1912$

Klassifikation Teil B: 01909

Trägermaterial: Papier

Alte Reg.-Sig.: IV SkIV 016

Bestell-Nr.: IV 01909

1724 Möbilien des Gasthauses

1877-1885

- Übergabe antiker Möbel des Gasthauses an die Gesellschaft für bildende Kunst und vaterländische Altertümer, Oktober - November 1877

- Öffentlicher Verkauf von Bettstellen und Bettwäsche aus dem Gasthaus, August 1878

- Anschaffung eines Dampfkochkessels für die Gasthausküche,

Dezember 1880

- Verkauf des dem Gasthaus gehörenden Gemäldes "de

Boitermoeders", Juli 1884 - September 1885

- Restaurierung des dem Gasthaus gehörenden Gemäldes

"Regententafel", April 1885

$1877-1885$

Klassifikation Teil B: 01910

Trägermaterial: Papier

Alte Reg.-Sig.: IV SkIV 018

Bestell-Nr.: IV 01910

1725 Gasthausschule, Bd. 1

$1878-1912$

- Verfügung des kgl. Konsistoriums in Aurich über Ernennung eines Lokalschulinspektors für die Gasthausschule, Oktober 1875

- Ernennung des Rektors der Höheren Töchterschule, Zwitzers, zum Lokalschulinspektor für die Gasthausschule, November 1878

- Übersicht über Werkzeug und Material für den handwerklichen

Unterricht in der Gasthausschule, 1902 - 1903

- Festgestellte Mängel in der Gasthausschule, 1902 - 1903

- Ernennung des Pastors Conrad zum Aufseher der Gasthausschule, Juli 1907

$1875-1912$

Klassifikation Teil B: 01911

Band: 1

Trägermaterial: Papier

Alte Reg.-Sig.: IV SkIV 022

Bestell-Nr.: IV 01911 
IV

05

05.03

05.03.11

05.03.11.02

05.03.11.02.02
Stadtverwaltung

Aufgabenbereiche der Stadtverwaltung

Sozialfürsorge

Armenpflege und Milde Stiftungen

Gasthaus

Lfd. Nr. Titel

Laufzeit

1726 Gasthausschule, Bd. 2

$1885-1900$

- Revision der Gasthausschule durch den kgl. Schulrat, 1885 - 1895

- Ernennung des Pastor Haenisch zum Aufseher über die

Gasthausschule, August 1897

- Umorganisation der Gasthausschule, 1900 - 1902 / 1917 - 1918

- Instruktion für den Gasthausschullehrer, September 1869

- Verpflegung der Waisenkinder im Gasthaus, 1900

(1869) $1885-1900$

Klassifikation Teil B: 01912

Band: 2

Trägermaterial: Papier

Bestell-Nr.: IV 01912

1727 Gasthausstiftungen

1879-1909

- Angebot des Lotsenkommandeurs Graefenhain über Erwerb der

Gotteskammern, Juli 1879

- Klärung des Rechtsstatus der Gotteskammern als Teil der

Gasthausstiftungen, Juli 1879 - August 1880

- Baufälligkeit der Gotteskammern, Oktober 1891

- Stiftung der Gertruida Osterkamp, geb Zyden an das Gasthaus zur

Unterstützung lutherischer Armen (Stiftung von 1784), 1886

- Verwertung des zur Alimentierung der geisteskranken Witwe Annette

Visser, geb. Lorentz dem Gasthaus gestifteten Geldbetrags, August -

September 1898

- Einrichtung eines Turnraums im Gasthaus und Anschaffung eines

Harmoniums, März 1909

$1879-1909$

Klassifikation Teil B: 01913

Trägermaterial: Papier

Alte Reg.-Sig.: IV SkIV 024

Bestell-Nr.: IV 01913

1728 Rechnungsführung des Gasthausvermögens

$1880-1904$

- Revision der Rechnungsführung über das Gasthausvermögen, 1880

$-1909$

- Verwaltung der Stiftung der Gertruda Stein, geb. Zyden, 1880

- Liste der Anleihescheine der Stadt Emden im Besitz des

Gasthauses, Juli 1905 / März - August 1912

$1880-1912$

Klassifikation Teil B: 01914

Trägermaterial: Papier

Alte Reg.-Sig.: IV SkIV 025

Bestell-Nr.: IV 01914 
IV

05

05.03

05.03.11

05.03.11.02

05.03.11.02.02
Stadtverwaltung

Aufgabenbereiche der Stadtverwaltung

Sozialfürsorge

Armenpflege und Milde Stiftungen

Gasthaus

Lfd. Nr. Titel

Laufzeit

1729 Vermietung und Verpachtung von Gasthaus-Immobilien und Ländereien, Bd. 1

- Pachtverträge des Gasthauses mit u.a. Emdener Papierfabrik, 1880

$-1903$

- Vermietung die dem Gasthaus gehörenden Häuser an der

Gasthauskirche, 1878 - 1904

- Verzeichnis der Pächter der Gasthausländereien, 1878 - 1902

- Organisation der Pachterhebung und Beitreibung von

Pachtrückständen, 1878 - 1902

- Ausschreibung der Verpachtung von Gasthausländereien, 1879 -

1904

$1878-1904$

Klassifikation Teil B: 01915

Band: 1

Trägermaterial: Papier

Alte Reg.-Sig.: IV SkIV 026

Bestell-Nr.: IV 01915

1730 Vermietung und Verpachtung von Gasthaus-Immobilien und Ländereien, Bd. 2

- Vermietung die dem Gasthaus gehörenden Häuser an der Gasthauskirche, 1904 - 1908

- Organisation der Pachterhebung und Beitreibung von

Pachtrückständen, 1905 - 1906

- Organisation der Verpachtung der Gasthausländereien, 1893 - 1907

- Ausschreibung der Verpachtung von Gasthausländereien, 1905 -

1909

$1893-1909$

Klassifikation Teil B: 01916

Band: 2

Trägermaterial: Papier

Alte Reg.-Sig.: IV SkIV 026

Bestell-Nr.: IV 01916 
IV

05

\subsection{3}

05.03.11

05.03.11.02

05.03.11.02.02

Stadtverwaltung

Lfd. Nr. Titel

Aufgabenbereiche der Stadtverwaltung

Sozialfürsorge

Armenpflege und Milde Stiftungen

Gasthaus

Laufzeit

1731 Verpachtung von Ländereien des Gasthauses an die Emdener Papierfabrik

- Verhandlungen zwischen dem Magistrat und der Emdener Papierfabrik wegen Vererbpachtung eines Landstücks zur Anlage einer Arbeitersiedlung, März - Juni 1882

- Verhandlungen der städtischen Kollegien wegen der Vererbpachtung eines Landstücks zur Anlage einer Arbeitersiedlung der Emdener

Papierfabrik, Mai 1882

- Verfügung des preußischen Landdrosten in Aurich über

Genehmigung der Vererbpachtung eines Landstückes des

Gasthauses östlich der Auricher Straße zur Anlage einer

Arbeitersiedlung, Juni 1882

- Vermessung des betr. Landstückes, November 1882

- Erbpachtvertrag zwischen dem Magistrat und dem Vorstand der Emdener Papierfabrik über ein Grundstück des Gasthauses östlich der Auricher Straße zur Anlegung einer Arbeitersiedlung, Dezember 1882

- Nachweis der Besitzrechte an dem Landstück durch das Emder

Gasthaus, Januar - Februar 1883

- Feststellung der Grenze des Erbpachtsgrundstücks, April - Mai 1884

- Abwässerung des Grundstückes, OKtober 1892

- Löschung der Eintragung eines Ablösekapitals über das vererbpachtete Landstück des Gasthauses im Grundbuch, Februar September 1904

$1882-1904$

Klassifikation Teil B: 01917

Trägermaterial: Papier

Alte Reg.-Sig.: IV SkIV 027

Bestell-Nr.: IV 01917 
IV

05

05.03

05.03.11

05.03.11.02

05.03.11.02.02
Stadtverwaltung

Aufgabenbereiche der Stadtverwaltung

Sozialfürsorge

Armenpflege und Milde Stiftungen

Gasthaus

Lfd. Nr. Titel

Laufzeit

1732 Auflösung des Gasthauses

1913-1914

- Statistische Erhebung über im Gasthaus untergebrachte

Waisenkinder, Mai - Dezember 1913

- Bedingungen und Kostenangaben der Pestalozzi-Stiftung Hannover

für die Aufnahme von Waisenkindern in Familienpflege, Mai 1913

- Denkschrift des Senators Bollhuis-Smeding für die Unterbringung der Waisenkinder in Emden bei der Pestalozzi-Stiftung und für die

Auflösung des Gasthauses, 1913

- Votum des Kirchenrats der evangelisch reformierten Gemeinde gegen die Auflösung des Gasthauses und die auswärtige Unterbringung der Waisenkinder in Familienpflege, Dezember 1913

- Material über Waisenfürsorge in den Nachbarstädten Emdens, Januar 1914

- Kampagne gegen die Aufhebung des Gasthauses, Januar - Juli

1914

- Votum des Pastors Bachhausen, Hannover, für den Bau eines

Waisenhauses außerhalb des Wallgürtels in Emden, Februar 1914

- Bericht des Gasthausinspektors Georg Blikslager über Verhältnisse

in der Gasthausschule, Februar 1914

- Veränderung der Besetzung der Gasthaus-Direktion, April - Mai 1914

- Verhandlungen des Gasthaus-Direktoriums über den Erhalt der

Gasthausschule, Juli 1914

- Druckschriften zur Waisenhausorganisation, 1863 - 1915

$1913-1914$

Klassifikation Teil B: 01918

Trägermaterial: Papier

Alte Reg.-Sig.: IV SkIV 033

Bestell-Nr.: IV 01918 
IV

05

05.03

05.03.11

05.03.11.02

05.03.11.02.03

Stadtverwaltung

Lfd. Nr. Titel

Aufgabenbereiche der Stadtverwaltung

Sozialfürsorge

Armenpflege und Milde Stiftungen

Armensteuer

Laufzeit

1733 Armen-Abgabe, Bd. 1

1890-1895

- Regulativ über Armen-Abgabe auf öffentliche Lustbarkeiten, Januar 1890

- Novelle der Ordnung betr. Erhebung der Lustbarkeitssteuer im Bezirk der Stadt Emden unter Erhöhung der Steuersätze, Oktober 1894 - Dezember 1895

$1890-1895$

Klassifikation Teil B: 01759

Band: 1

Trägermaterial: Papier

Alte Reg.-Sig.: IV Sd 078

Bestell-Nr.: IV 01759

1734 Armen-Abgabe auf öffentliche Lustbarkeiten (Lustbarkeitsteuer), Bd. 2

- Verfügung des Regierungspräsidenten in Aurich über Interpretation der Ministerialerlasse bei der Neufassung von

Lustbarkeitssteuerordnungen, Juni 1907

- Novellierung der Lustbarkeitssteuerordnung in Emden, September 1907 - September 1908

- Protest der Inhaber von Konnzert- und Gesellschaftssälen gegen eine geplante Erhöhung der Lustbarkeitsteuer, Oktober 1907

- Anträge auf Ermäßigung der Lustbarkeitssteuer, September 1908

- Antrag des Wirtevereins auf Ermäßigung der Lustbarkeitssteuer auf Musikautomaten, September 1908

- Erlass des Innenministers über Begrenzung der Belastung der

Musikautomaten durch Lustbarkeitssteuer, Dezember 1909

Einführung einer Kartensteuer in Emden, 1913

$1907-1913$

Klassifikation Teil B: 01760

Trägermaterial: Papier

Alte Reg.-Sig.: IV Sd 078

Bestell-Nr.: IV 01760

1735 Armen-Abgabe auf öffentliche Lustbarkeiten (Lustbarkeitssteuer), Bd. 3

- Gesetzliche Bestimmungen und Ministerialerlasse als rechtliche Grundlage für die Erhebung der Lustbarkeitssteuer

$1890-1903$

Klassifikation Teil B: 01761

Band: 3

Trägermaterial: Papier

Alte Reg.-Sig.: IV Sd 078

Bestell-Nr.: IV 01761 
IV

05

05.03

05.03.11

05.03.11.02

05.03.11.02.03

Stadtverwaltung

Aufgabenbereiche der Stadtverwaltung

Sozialfürsorge

Armenpflege und Milde Stiftungen

Armensteuer

Laufzeit

1736 Etat der Armenverwaltung der protestantischen Kirche

1867-1868

- Vorlage des Etats der Diakonie der Haussitzenden Armen und des

Gasthauses zur Genehmigung durch die städtischen Kollegien,

Oktober 1867 - Januar 1868

- Antrag des Magistrats beim preußischen Landdrosten in Aurich auf

Genehmigung einer Umlage der protestantischen Gemeinden in

Emden zur Schließung der Deckungslücke des Etats der

Armenhilfeeinrichtungen, November 1867

$1867-1868$

Klassifikation Teil B: 01762

Trägermaterial: Papier

Alte Reg.-Sig.: IV Sd 117

Bestell-Nr.: IV 01762

1737 Armen - Umlage, Bd. 1

1867

- Rechnungsbuch über Einnahmen zur Armen-Umlage

1867

Klassifikation Teil B: 01763

Band: 1

Trägermaterial: Papier

Alte Reg.-Sig.: Sd 118

Bestell-Nr.: IV 01763

1738 Armen - Umlage, Bd. 2

1868

- Rechnungsbuch über Einnahmen zur Armen-Umlage

1868

Klassifikation Teil B: 01764

Band: 2

Trägermaterial: Papier

Alte Reg.-Sig.: Sd 118

Bestell-Nr.: IV 01764

1739 Armen - Umlage, Bd. 3

- Rechnungsbuch über Einnahmen zur Armen-Umlage

1867

Klassifikation Teil B: 01765

Band: 3

Trägermaterial: Papier

Alte Reg.-Sig.: Sd 118

Bestell-Nr.: IV 01765 
IV

05

05.03

05.03.11

05.03.11.02

05.03.11.02.03

Stadtverwaltung

Aufgabenbereiche der Stadtverwaltung

Sozialfürsorge

Armenpflege und Milde Stiftungen

Armensteuer

Lfd. Nr. Titel

Laufzeit

1740 Armen - Umlage, Bd. 4

1871

- Rechnungsbuch über Einnahmen zur Armen-Umlage

1871

Klassifikation Teil B: 01766

Band: 4

Trägermaterial: Papier

Alte Reg.-Sig.: Sd 124

Bestell-Nr.: IV 01766

1741 Armen - Umlage, Bd. 5

1871

- Rechnungsbuch über Einnahmen zur Armen-Umlage

1871

Klassifikation Teil B: 01767

Band: 5

Trägermaterial: Papier

Alte Reg.-Sig.: Sd 123

Bestell-Nr.: IV 01767

1742 Quittungsbuch über mit den Armenbeiträgen bestrittene Ausgaben

- Quittungen über mit Armenbeiträgen bestrittene Ausgaben

- Restanten der Armenbeiträge

1867

Klassifikation Teil B: 01768

Trägermaterial: Papier

Alte Reg.-Sig.: IV Sd 125

Bestell-Nr.: IV 01768

1743 Armenbeitrags-Zahlungspflichtige, Bd. 1

1870

- Hauptrolle der Armenbeitragszahlungspflichtigen

1870
Klassifikation Teil B: 01769
Band: 1
Trägermaterial: Papier
Alte Reg.-Sig.: IV Sd 125
Bestell-Nr.: IV 01769

1744 Armenbeitrags-Zahlungspflichtige, Bd. 2

- Hauptrolle der Armenbeitragszahlungspflichtigen

1868

Klassifikation Teil B: 01770

Band: 2

Trägermaterial: Papier

Alte Reg.-Sig.: IV Sd 125

Bestell-Nr.: IV 01770 
IV

05

05.03

05.03.11

05.03.11.02

05.03.11.02.03

Stadtverwaltung

Aufgabenbereiche der Stadtverwaltung

Sozialfürsorge

Armenpflege und Milde Stiftungen

Armensteuer

Lfd. Nr. Titel

Laufzeit

1745 Armenbeitrags-Zahlungspflichtige, Bd. 3

1869

- Hauptrolle der Armenbeitragszahlungspflichtigen

1869

Klassifikation Teil B: 01771

Band: 3

Trägermaterial: Papier

Alte Reg.-Sig.: IV Sd 125

Bestell-Nr.: IV 01771

1746 Armenbeiträge

1867

- Rechnung über Einnahmen aus den Armenbeiträgen und Ausgaben für die Hebung

1867

Klassifikation Teil B: 01772

Trägermaterial: Papier

Alte Reg.-Sig.: IV Sd 119

Bestell-Nr.: IV 01772

1747 Etat der Armenverwaltung der protestantischen Kirche

- Vorlage des Etats der Diakonie der Haussitzenden Armen und des Gasthauses zur Genehmigung durch die städtischen Kollegien,

Oktober 1868 - April 1869

1868.1869

Klassifikation Teil B: 01773

Trägermaterial: Papier

Alte Reg.-Sig.: IV Sd 120

Bestell-Nr.: IV 01773

1748 Erhebung der Armenbeiträge

- Beschwerde des Telegrafensekretärs Borchert gegen die Form der Erhebung der Armenbeiträge und gegen die Entrichtung einer

Hebegebühr, Mai - September 1868

- Beschwerde des Obertelegraphensekretärs Vollmer gegen die Form der Hebung und Untransparenz des Armenbeitragssystems, Juli 1868

1868

Klassifikation Teil B: 01774

Trägermaterial: Papier

Alte Reg.-Sig.: IV Sd 122

Bestell-Nr.: IV 01774 
05

05.03

05.03.11

05.03.11.02

05.03.11.02.04

\section{IV}

Stadtverwaltung

Aufgabenbereiche der Stadtverwaltung

Sozialfürsorge

Armenpflege und Milde Stiftungen

Klementiner- Brüderschaft

Laufzeit

1875-1892

- Bericht über die Geschichte der Seemannskasse

(Clementiner-Brunderschaft) in Emden, Januar 1875

- Statut der Seemannskasse, September 1875

- Rechnungsprüfung bei der Seemannskasse, 1877 -1892

$1875-1892$

Klassifikation Teil B: 01777

Trägermaterial: Papier

Alte Reg.-Sig.: IV Sg 2

Bestell-Nr.: IV 01777

1750 Sammlung der Clementiner - Bruderschaft

- Antrag der Clementiner-Bruderschaft beim Magistrat auf Erlaubnis einer Spendensammlung

1913

Klassifikation Teil B: 01779

Trägermaterial: Papier

Alte Reg.-Sig.: IV Sg 4

Bestell-Nr.: IV 01779 
05

05.03

05.03.11

05.03.11.02

05.03.11.02.05

Lfd. Nr. Titel

\section{IV}

Stadtverwaltung

Aufgabenbereiche der Stadtverwaltung

Sozialfürsorge

Armenpflege und Milde Stiftungen

Fremdelingen-Diakonie

1751 Fremdelingen Armen Diaconie

Laufzeit

- Rechnungsprüfung bei der Fremdelingen Armen Diaconie

$1867-1891$

Klassifikation Teil B: 01775

Trägermaterial: Papier

Alte Reg.-Sig.: IV Sf 1

Bestell-Nr.: IV 01775 
IV

05

05.03

05.03.11

05.03.11.02

05.03.11.02.06
Stadtverwaltung

Aufgabenbereiche der Stadtverwaltung

Sozialfürsorge

Armenpflege und Milde Stiftungen

Schifferwitwen- und -Waisenkasse

Lfd. Nr. Titel

Laufzeit

1752 Schiffer-Witwen- und Waisenkasse "Eendragt"

1904-1906

- Gedruckte Statuten der Schiffer-Witwen- und Waisenkasse

"Eendragt", 1864

- Berichte der Schiffer-Witwen- und Waisenkasse "Eendragt" über ihre

Kassenlage, Febraur - Dezember 1904

- Bericht der Schiffer-Witwen- und Waisenkasse "Eendragt" an den

Magistrat über Probleme bei der Anpassung ihrer Satzung an die

Bestimmungen des Privatversicherungsgesetzes, März 1905

- Verfügung des Regierungspräsidenten in Aurich über Verpflichtung

der Schiffer-Witwen- und Waisenkasse "Eendragt" zur Anpassung

ihrer Satzung an das Privatversicherungsgesetz, März 1905

- Protokoll der Hauptversammlung der Schiffer-Witwen- und

Waisenkasse "Eendragt"über formalen Beschluss der Nichtaufnahme neuer Mitglieder zur Umgehung der Anpassungspflicht der Satzung an das Privatversicherungsgesetz, Januar 1906

(1864) 1904 - 1907

Klassifikation Teil B: 01776

Trägermaterial: Papier

Alte Reg.-Sig.: IV Sg 1

Bestell-Nr.: IV 01776

1753 Sammlung für die Hinterbliebenen der Besatzung des

1874 untergegangenen Lotsenschoners "Ems"

- Organisation einer Spendensammlung für die Hinterbliebenen der Besatzung des untergegangenen Lotsenschoners "Ems" durch die Lotsenbruderschaft und den Magistrat, März - Oktober 1878

- Aufstellungen über vom Untergang betroffene Lotsen und ihre Familien, März - Juli 1878

- Aufstellung über eingegangene Spenden, April 1878

- Verschiedene Briefe von Spendern, März - Juni 1878

- Bericht des Polizeisergeanten Schnur über Lage der Hinterbliebenen der Besatzung des untergegangenen Lotsenschoners "Ems", September 1878

1878

Klassifikation Teil B: 01778

Alte Reg.-Sig.: IV Sg 4

Bestell-Nr.: IV 01778

1754 Schiffer-Gilden-Witwen-Kasse, Bd. 1

$1870-1881$

- Statuten der Schiffer-Gilden-Witwen-Kasse, 1870

- Vermögensverwaltung der Schiffer-Gilden-Witwenkasse, 1874 -

1881

$1870-1881$

Klassifikation Teil B: 01780

Band: 1

Trägermaterial: Papier

Alte Reg.-Sig.: IV Sg 5

Bestell-Nr.: IV 01780 
IV

05

Stadtverwaltung

05.03

Aufgabenbereiche der Stadtverwaltung

05.03.11

05.03.11.02

05.03.11.02.06

\section{Sozialfürsorge}

Armenpflege und Milde Stiftungen

Schifferwitwen- und -Waisenkasse

Lfd. Nr. Titel

Laufzeit

1755 Schiffer-Gilden-Witwen-Kasse, Bd. 2

1901-1911

- Statuten der Schiffer-Gilden-Witwen-Kasse, 1906

- Deponierung der Wertpapiere der Schiffer-Gilden-Witwenkasse bei

der Stadtverwaltung, 1901

- Kassenbericht der Schiffer-Gilden-Witwen-Kasse, Januar 1904

- Anpassung der Satzung der Schiffer-Gilden-Witwen-Kasse an die

Bestimmungen des Privatversicherungsgesetzes, 1904 - 1906

- Versicherungstechnisches Gutachten zur Lage der

Schiffer-Gilden-Witwen-Kasse, Mai 1905 / Februar 1910

- Monita des Regierungspräsidenten in Aurich zu den Jahresberichten der Schiffer-Gilden-Witwen-Kasse, 1906 - 1911

- Jahresberichte der Schiffer-Gilden-Witwen-Kasse, 1906 - 1911

$1901-1911$

Klassifikation Teil B: 01781

Band: 2

Trägermaterial: Papier

Alte Reg.-Sig.: IV Sg 5

Bestell-Nr.: IV 01781 
IV

05

05.03

05.03.11

05.03.11.02

05.03.11.02.06
Stadtverwaltung

Aufgabenbereiche der Stadtverwaltung

Sozialfürsorge

Armenpflege und Milde Stiftungen

Schifferwitwen- und -Waisenkasse

Lfd. Nr. Titel

Laufzeit

1756 Schiffer-Gilden-Witwen-Kasse, Bd. 3

1903-1918

- Statuten der Schiffer-Gilden-Witwen-Kasse, (1870 / 1885) 1906

Verfügung des Regierungspräsidenten in Aurich über Anordnung der

Einsendung der Jahresberichte der Schiffer-Gilden-Witwen-Kasse

nach den Bestimmungen des Privatversicherungsgesetzes,

September 1903

- Jahresberichte der Schiffer-Gilden-Witwen-Kasse, 1904 - 1918

(1921)

- Antrag der Schiffer-Gilden-Witwen-Kasse auf

Ausnahmegenehmigung hinsichtlich der Anpassung der Satzung an das Privatversicherungsgesetz wegen ihres Charakters als geschlossene Gesellschaft, Februar - April 1905

- Anpassung der Satzung der Schiffer-Gilden-Witwen-Kasse an die Bestimmungen des Privatversicherungsgesetzes, 1905 - 1906

- Versicherungstechnisches Gutachten zur Lage der

Schiffer-Gilden-Witwen-Kasse, Mai 1905 / Februar 1910

- Monita des Regierungspräsidenten in Aurich zum Jahresbericht der

Schiffer-Gilden-Witwen-Kasse, 1911

- Verzeichnis der von der Schiffer-Gilden-Witwen-Kasse unterstützten

Schifferwitwen, 1911 - 1912

- Prüfung der Schiffer-Gilden-Witwen-Kasse durch den

Versicherungsrevisor, 1911 - 1914

- Erhöhung des Rentensatzes der Schiffer-Gilden-Witwen-Kasse, Mai 1912

- Auflösung der Schiffer-Gilden-Witwen-Kasse

$1903-1918(1921)$

Klassifikation Teil B: 01782

Band: 3

Trägermaterial: Papier

Alte Reg.-Sig.: IV Sg 5

Bestell-Nr.: IV 01782

1757 Unterstützungskasse "Verbrüderung" für Schifferwitwen und -Waisen

- Monita des preußischen Landdrosten in Aurich wegen der Statuten der Unterstützungskasse "Verbrüderung" für Schifferwitwen und -Waisen, Februar - Juli 1879 / Oktober 1880

- Liste der Mitglieder der Unterstützungskasse "Verbrüderung" für

Schifferwitwen und -Waisen, 1901

- Protokoll der Mitgliederversammlung über Auflösung der

Unterstützungskasse "Verbrüderung" für Schifferwitwen und -Waisen, Februar 1901

$1879-1901$

Klassifikation Teil B: 01783

Trägermaterial: Papier

Alte Reg.-Sig.: IV Sg 8

Bestell-Nr.: IV 01783 
05

05.03

05.03.11

05.03.11.02

05.03.11.02.06

Lfd. Nr. Titel
IV

\section{Stadtverwaltung}

Aufgabenbereiche der Stadtverwaltung

Sozialfürsorge

Armenpflege und Milde Stiftungen

Schifferwitwen- und -Waisenkasse

Laufzeit

1900-1904

- Datenerhebung des Regierungspräsidenten über

Wohlfahrtseinrichtungen für Seefischer, Mai 1900

- Geldsammlung für notleidende Binnenschiffer durch den

Central-Verein zur Hebung der Deutschen Fluß- und Kanalschiffahrt,

1904

$1900-1904$

Klassifikation Teil B: 01784

Trägermaterial: Papier

Alte Reg.-Sig.: IV Sg 8

Bestell-Nr.: IV 01784 
IV

05

05.03

05.03.11

05.03.11.03

05.03.11.03.01
Stadtverwaltung

Aufgabenbereiche der Stadtverwaltung

Sozialfürsorge

Ortsarmenverband

Organisation des Armenwesens

Lfd. Nr. Titel

Laufzeit

1759 Zweifelhafter Unterstützungswohnsitz

1873

- Streit zwischen Emden und Geestemünde um den

Unterstützungswohnsitz des Seemanns Joseph König, geboren in

Emden, März - April 1873

1873

Klassifikation Teil B: 00317

Trägermaterial: Papier

Alte Reg.-Sig.: IV Bb 4, 33

Bestell-Nr.: IV 00317

1760 Anschluss der Feldmark Emden an das städtische Armenwesen

- Verhandlungen des Magistrats mit dem Kreishauptmann des Amtes Emden wegen Anschluss der Emder Feldmark an das städtische Armenwesen, 1871 - 1873

- Beschwerde des Pächters der Mühle "Zeldenrüst", P. J. Poets, gegen die Heranziehung zu den Armenlasten der Stadt Emden wegen Zugehörigkeit seiner Mühle zur Gemeinde Wolthusen, März - August 1872

$1871-1873$

Klassifikation Teil B: 01786

Trägermaterial: Papier

Alte Reg.-Sig.: IV Sk 03

Bestell-Nr.: IV 01786

1761 Beschulung der Armenkinder

$1871-1875$

- Umsetzung der Vereinbarung zwischen dem Magistrat und den Kirchenräten der katholischen, der baptistischen und dem Vorstand der Israelitischen Gemeinde über Beschulung der Armenkinder in der jeweiligen Schule ihrer Konfession und Erstattung des Schulgeldes durch die Stadt Emden nach der Abschaffung des konfessionell gebundenen Armenhilfesystems

$1871-1875$

Klassifikation Teil B: 01787

Trägermaterial: Papier

Alte Reg.-Sig.: IV Sk 09

Bestell-Nr.: IV 01787

1762 Kirchensitze der ehemaligen Diakonie der Haussitzenden Armen

- Verhandlungen zwischen dem Magistrat und den Kirchenrat der deutsch reformierten Kirche über Status der Kirchensitze der ehemsligen Diakonie der Haussitzenden Armen in der Großen Kirche

$1872-1873$

Klassifikation Teil B: 01790

Trägermaterial: Papier

Alte Reg.-Sig.: IV Sk 18

Bestell-Nr.: IV 01790 
IV

05

05.03

05.03.11

05.03.11.03

05.03.11.03.01

Lfd. Nr. Titel
Stadtverwaltung

Aufgabenbereiche der Stadtverwaltung

Sozialfürsorge

Ortsarmenverband

Organisation des Armenwesens

1763 Gesetz über den Unterstützungswohnsitz, Bd. 1

Laufzeit

- Ausführungsbestimmungen des Gesetzes über den

Unterstützungswohnsitz

$1870-1909$

Klassifikation Teil B: 01791

Band: 1

Trägermaterial: Papier

Alte Reg.-Sig.: IV SkI, 02

Bestell-Nr.: IV 01791

1764 Gesetz über den Unterstützungswohnsitz, Bd. 2

1871

- Umsetzung des Gesetzes über den Unterstützungswohnsitz auf örtlicher Ebene

- Auflösung der konfessionellen Armenverbände in Emden

1871

Klassifikation Teil B: 01792

Band: 2

Trägermaterial: Papier

Alte Reg.-Sig.: IV Skl, 02

Bestell-Nr.: IV 01792

1765 Gesetz über den Unterstützungswohnsitz, Bd. 3

- Ausführung des Gesetzes über den Unterstützungswohnsitz auf örtlicher Ebene

- Statut der öffentlichen Armenverwaltung der Stadt Emden,

Dezember 1871

1871
Klassifikation Teil B: 01793
Band: 3
Trägermaterial: Papier
Alte Reg.-Sig.: IV Skl, 02
Bestell-Nr.: IV 01793

1766 Gesetz über den Unterstützungswohnsitz, Bd. 4

$1871-1877$

- Ausführung des Gesetzes über den Unterstützungswohnsitz auf örtlicher Ebene

- Hilfen zur Auslegung des Gesetzes über den

Unterstützungswohnsitz

$1871-1877$

Klassifikation Teil B: 01794

Band: 4

Trägermaterial: Papier

Alte Reg.-Sig.: IV SkI, 02

Bestell-Nr.: IV 01794 
IV

05

05.03

05.03.11

05.03.11.03

05.03.11.03.01

Stadtverwaltung

Lfd. Nr. Titel

Aufgabenbereiche der Stadtverwaltung

Sozialfürsorge

Ortsarmenverband

Organisation des Armenwesens

1767 Gesetz über den Unterstützungswohnsitz, Bd. 5

Laufzeit

- Ausführung des Gesetzes über den Unterstützungswohnsitz vor Ort

- Ausgaben für die Unterstützung fremder Armen in Emden

- Verzeichnis der in der Armen-Arbeits-Anstalt Emden verpflegten

Personen, 1872 - 1876

- Verzeichnis der im Gasthaus verpflegten Personen, 1872 - 1876

$1872-1881$

Klassifikation Teil B: 01795

Band: 5

Trägermaterial: Papier

Alte Reg.-Sig.: IV Skl, 02

Bestell-Nr.: IV 01795

1768 Gesetz über den Unterstützungswohnsitz, Bd. 6

1881-1889

- Ausführungsbestimmungen des Gesetzes über den

Unterstützungswohnsitz

- Drucksache: Organisation des Armenwesens

$1881-1889$

Klassifikation Teil B: 01796

Band: 6

Trägermaterial: Papier

Alte Reg.-Sig.: IV Skl, 02

Bestell-Nr.: IV 01796

1769 Gesetz über den Unterstützungswohnsitz, Bd. 7

1894-1909

- Ausführungsbestimmungen des Reichsgesetzes über den

Unterstützungswohnsitz

$1894-1909$

Klassifikation Teil B: 01797

Band: 7

Trägermaterial: Papier

Alte Reg.-Sig.: IV Skl, 02

Bestell-Nr.: IV 01797

1770 Gesetz über den Unterstützungswohnsitz, Bd. 8

1908-1912

- Ausführungsbestimmungen des Reichsgesetzes über den

Unterstützungswohnsitz

$1908-1912$

Klassifikation Teil B: 01798

Band: 8

Trägermaterial: Papier

Alte Reg.-Sig.: IV Skl, 02

Bestell-Nr.: IV 01798 
IV

05

05.03

05.03.11

05.03.11.03

05.03.11.03.01

Stadtverwaltung

Lfd. Nr. Titel

Aufgabenbereiche der Stadtverwaltung

Sozialfürsorge

Ortsarmenverband

Organisation des Armenwesens

1771 Armenverbände

Laufzeit

1771 Armenverbände

$1869-1870$

- Datenerhebung des preußischen Landdrosten in Aurich über

Armenverbände, November 1869 - März 1870

- Übersicht über die von den christlichen Konfessionen und der

jüdischen Gemeinde organisierten Armenverbände, März 1870

$1869-1870$

Klassifikation Teil B: 01799

Trägermaterial: Papier

Alte Reg.-Sig.: IV Skl 01

Bestell-Nr.: IV 01799

1772 Übergang der konfessionellen Armeneinrichtungen auf die Stadt

1867-1874

Emden

- Übernahme der Einrichtungen des Armenfürsorge der katholischen und der jüdischen Gemeinde durch die Armenverwaltung der Stadt

Emden infolge Kommunalisierung des Armenwesens

- Verhandlungen des Magistrats mit der katholischen

Kirchengemeinde über Entschädigung der Gemeinde wegen

Übergangs des katholischen Armenvermögens an die Stadt Emden

$1867-1874(1882)$

Klassifikation Teil B: 01800

Trägermaterial: Papier

Alte Reg.-Sig.: IV Skl 04

Bestell-Nr.: IV 01800

1773 Übergang des jüdischen Armenvermögens an die Stadt Emden

- Verhandlungen des Magistrats mit der Israelitischen Gemeinde wegen Entschädigung der Gemeinde für den Übergang ihres

Armenvermögens an die Stadt Emden infolge Kommunalisierung des Armenwesens

$1870-1872$

Klassifikation Teil B: 01801

Trägermaterial: Papier

Alte Reg.-Sig.: IV Skl 06

Bestell-Nr.: IV 01801 
IV

05

05.03

05.03.11

05.03.11.03

05.03.11.03.01

Stadtverwaltung

Lfd. Nr. Titel

Aufgabenbereiche der Stadtverwaltung

Sozialfürsorge

Ortsarmenverband

Organisation des Armenwesens

1774 Neuorganisation des Emder Armenwesens, Bd. 1

Laufzeit

- Verhandlungen der Armendeputation über Neuorganisation des

Emder Armenwesens: Aufgaben der Armenverwaltung,

Zusammensetzung der Armendeputation, September - Oktober 1871

- Gutachten des Syndicus Metger zur Organisation des

Armenwesens, 1871

- Entwurf eines Armenregulativs der Stadt Emden: u.a.

Zwangsarbeitshaus, Struktur des Gasthauses, 1871

- Materialien: Organisation des Armenwesens in anderen Städten der

Provinz Hannover, 1871

1871

\author{
Klassifikation Teil B: 01802 \\ Band: 1 \\ Trägermaterial: Papier \\ Alte Reg.-Sig.: IV Skl 14
}

Bestell-Nr.: IV 01802

1775 Neuorganisation des Emder Armenwesens, Bd. 2

- Nominierung der vom Bürgervorsteherkollegium zu stellenden

Mitglieder der Armenverwaltung, Dezember 1871 - Januar 1872

- Widerspruch der Kaufleute Sielmann und Geelvink gegen die Wahl zu Mitgliedern der Armenverwaltung, März - April 1872

$1871-1872$

Klassifikation Teil B: 01803

Band: 2

Trägermaterial: Papier

Alte Reg.-Sig.: IV SkI 14

Bestell-Nr.: IV 01803

1776 Neuorganisation des Emder Armenwesens, Bd. 3

- Verfügung des kgl. Consistoriums in Aurich über Erlaubnis zur Verwendung von Erträgen aus Schulländereien zur Finanzierung der Armenverwaltung, Juni 1876

1876

Klassifikation Teil B: 01804

Band: 3

Trägermaterial: Papier

Alte Reg.-Sig.: IV Skl 14

Bestell-Nr.: IV 01804 
IV

05

05.03

05.03.11

05.03.11.03

05.03.11.03.01
Stadtverwaltung

Aufgabenbereiche der Stadtverwaltung

Sozialfürsorge

Ortsarmenverband

Organisation des Armenwesens

Lfd. Nr. Titel

Laufzeit

1777 Hilfe für die Besatzung des gesunkenen italienischen Schiffes "Adelchi Bignami"

- Bericht über Strandung des Schiffes "Adelchi Bignami" vor Borkum, März 1874

- Benachrichtigung des für die Besatzung zuständigen italienischen Konsulats von der Strandung, März 1874

- Verfügung des preußischen Landdrosten in Aurich über Verpflegung der schiffsbrüchigen Mannschaft durch die Armenverwaltung, April Mai 1874

- Verhandlungen des Magistrats mit dem Landdrosten wegen Kostenträgerschaft der Verpflegung für die schiffsbrüchige Besatzung der "Adelchi Bignami", März - Oktober 1874

- Quittungen wegen Verpflegung der Schiffsbrüchigen, 1874

1874

Klassifikation Teil B: 01806

Trägermaterial: Papier

Alte Reg.-Sig.: IV SkI 20

Bestell-Nr.: IV 01806

1778 Armensärge

- Beschwerden wegen zu kleiner Armensärge, April 1887

- Votum des Armenkollegiums gegen die Abschaffung der

Armensärge mit plattem Deckel, Mai 1887

- Beschwerde des Emder Bürgervereins beim Armenkollegium gegen die Bestattung verstorbener Armer in platten Kisten, August 1893

- Verfügung des Magistrats über Anordnung zur Verwendung gewölbter Särge für Armenbestattungen nach Bewilligung der Mittel zu ihrer Beschaffung durch das Bürgervorsteherkollegium, Oktober 1893

$1887-1893$

Klassifikation Teil B: 01807

Trägermaterial: Papier

Alte Reg.-Sig.: IV SkI 26

Bestell-Nr.: IV 01807

1779 Datenerhebung zum Armenwesen

- Datenerhebung des Innenministeriums zum Armenwesen in

Preußen

- Statistik der Em,der Armenpflege

- Aufstellung von aus Armenmitteln unterstützter Emder Bewohner

1894

Klassifikation Teil B: 01808

Trägermaterial: Papier

Alte Reg.-Sig.: IV SkI 31

Bestell-Nr.: IV 01808 
IV

05

05.03

05.03.11

05.03.11.03

05.03.11.03.01

Lfd. $\mathrm{Nr}$ Titel
Stadtverwaltung

Aufgabenbereiche der Stadtverwaltung

Sozialfürsorge

Ortsarmenverband

Organisation des Armenwesens

1780 Vertretung des zum Militärdienst einberufenen Gasthaus-Inspektors

Laufzeit

- Einstellung eines Ersatzes für den zum Kriegsdienst einberufenen

Gasthausinspektor Georg Blikslager

$1917-1918$

Klassifikation Teil B: 01809

Trägermaterial: Papier

Alte Reg.-Sig.: IV SkI 32

Bestell-Nr.: IV 01809

1781 Finanzierung des Armenhausbaues

- Verhandlungen der städtischen Kollegien über Finanzierung des

Baus eines Armenarbeitshauses aus den Mitteln des

Armenvermögens, Januar 1873

- Genehmigung der Finanzierung des Baus aus dem Armenvermögen

durch den preußischen Landdrosten in Aurich, Februar 1873

- Übersicht über Stand des Armenvermögens, Februar 1873

1873

Klassifikation Teil B: 01818

Trägermaterial: Papier

Alte Reg.-Sig.: IV SkIII 05

Bestell-Nr.: IV 01818

1782 Ausbau des Armenhauses

1814

- Plan des Ausbaues des Armenhauses

1884

Klassifikation Teil B: 01819

Trägermaterial: Papier

Alte Reg.-Sig.: IV SkIII 07

Bestell-Nr.: IV 01819

1783 Rechnungsbuch der städtisdchen Armenverwaltung, Bd. 1

- Einnahmen und Ausgaben der städtischen Armenverwaltung

1871

Klassifikation Teil B: 01822

Band: 1

Trägermaterial: Papier

Alte Reg.-Sig.: IV SkIII 10

Bestell-Nr.: IV 01822 
IV

05

Stadtverwaltung

05.03

05.03.11

Aufgabenbereiche der Stadtverwaltung

05.03.11.03

05.03.11.03.01

Sozialfürsorge

Ortsarmenverband

Organisation des Armenwesens

Lfd. Nr. Titel

Laufzeit

1784 Rechnungsbuch der städtisdchen Armenverwaltung, Bd. 2

- Einnahmen und Ausgaben der städtischen Armenverwaltung

1872

Klassifikation Teil B: 01822

Band: 2

Trägermaterial: Papier

Alte Reg.-Sig.: IV SkIII 10

Bestell-Nr.: IV 01823

1785 Rechnungsbuch der städtisdchen Armenverwaltung, Bd. 3

1873

- Einnahmen und Ausgaben der städtischen Armenverwaltung

1873

Klassifikation Teil B: 01824

Band: 3

Trägermaterial: Papier

Alte Reg.-Sig.: IV SkIII 10

Bestell-Nr.: IV 01824

1786 Rechnungsbuch der städtisdchen Armenverwaltung, Bd. 4

- Einnahmen und Ausgaben der städtischen Armenverwaltung,

Zweitschrift

1873

Klassifikation Teil B: 01825

Band: 4

Trägermaterial: Papier

Alte Reg.-Sig.: IV SkIII 10

Bestell-Nr.: IV 01825

1787 Rechnungsbuch der städtisdchen Armenverwaltung, Bd. 5

- Einnahmen und Ausgaben der städtischen Armenverwaltung

1874

Klassifikation Teil B: 01826

Band: 5

Trägermaterial: Papier

Alte Reg.-Sig.: IV SkIII 10

Bestell-Nr.: IV 01826 


\section{IV}

05

05.03

05.03.11

05.03.11.03

05.03.11.03.01

Lfd. Nr. Titel
Stadtverwaltung

Aufgabenbereiche der Stadtverwaltung

Sozialfürsorge

Ortsarmenverband

Organisation des Armenwesens

1788 Rechnungsbuch der städtisdchen Armenverwaltung, Bd. 6

Laufzeit

- Einnahmen und Ausgaben der städtischen Armenverwaltung

1875

Klassifikation Teil B: 01827

Band: 6

Trägermaterial: Papier

Alte Reg.-Sig.: IV SkIII 10

Bestell-Nr.: IV 01827

1789 Rechnungsbuch der städtisdchen Armenverwaltung, Bd. 7

1874

- Einnahmen und Ausgaben der städtischen Armenverwaltung,

Zweitschrift

1874

Klassifikation Teil B: 01828

Band: 7

Trägermaterial: Papier

Alte Reg.-Sig.: IV SkIII 10

Bestell-Nr.: IV 01828

1790 Rechnungsbuch der städtisdchen Armenverwaltung, Bd. 8

- Einnahmen und Ausgaben der städtischen Armenverwaltung,

Zweitschrift

1875
Klassifikation Teil B: 01829
Band: 8
Trägermaterial: Papier
Alte Reg.-Sig.: IV SkIII 10
Bestell-Nr.: IV 01829

1791 Rechnungsbuch der städtisdchen Armenverwaltung, Bd. 9

- Einnahmen und Ausgaben der städtischen Armenverwaltung

$1876-1877$

Klassifikation Teil B: 01830

Band: 9

Trägermaterial: Papier

Alte Reg.-Sig.: IV SkIII 10

Bestell-Nr.: IV 01830 
IV

05

05.03

05.03.11

05.03.11.03

05.03.11.03.01

Lfd. Nr. Titel
Stadtverwaltung

Aufgabenbereiche der Stadtverwaltung

Sozialfürsorge

Ortsarmenverband

Organisation des Armenwesens

1792 Rechnungsbuch der städtisdchen Armenverwaltung, Bd. 10

Laufzeit

- Einnahmen und Ausgaben der städtischen Armenverwaltung, Zweitschrift

$1876-1877$

Klassifikation Teil B: 01831

Band: 10

Trägermaterial: Papier

Alte Reg.-Sig.: IV SkIII 10

Bestell-Nr.: IV 01831

1793 Rechnungsbuch der städtisdchen Armenverwaltung, Bd. 11

- Einnahmen und Ausgaben der städtischen Armenverwaltung

$1877-1878$

Klassifikation Teil B: 01832

Band: 11

Trägermaterial: Papier

Alte Reg.-Sig.: IV SkIII 10

Bestell-Nr.: IV 01832

1794 Rechnungsbuch der städtisdchen Armenverwaltung, Bd. 12

- Einnahmen und Ausgaben der städtischen Armenverwaltung,

Zweitschrift

$1877-1878$

Klassifikation Teil B: 01833

Band: 12

Trägermaterial: Papier

Alte Reg.-Sig.: IV SkIII 10

Bestell-Nr.: IV 01833

1795 Rechnungsbuch der städtisdchen Armenverwaltung, Bd. 12

- Einnahmen und Ausgaben der städtischen Armenverwaltung

$1878-1879$

Klassifikation Teil B: 01834

Band: 12

Trägermaterial: Papier

Alte Reg.-Sig.: IV SkIII 10

Bestell-Nr.: IV 01834 
IV

05

05.03

05.03.11

05.03.11.03

05.03.11.03.01

Lfd. Nr. Titel
Stadtverwaltung

Aufgabenbereiche der Stadtverwaltung

Sozialfürsorge

Ortsarmenverband

Organisation des Armenwesens

1796 Rechnungsbuch der städtisdchen Armenverwaltung, Bd. 14

Laufzeit

- Einnahmen und Ausgaben der städtischen Armenverwaltung

$1880-1881$

Klassifikation Teil B: 01835

Band: 14

Trägermaterial: Papier

Alte Reg.-Sig.: IV SkIII 10

Bestell-Nr.: IV 01835

1797 Rechnungsbuch der städtisdchen Armenverwaltung, Bd. 15

$1880-1881$

- Einnahmen und Ausgaben der städtischen Armenverwaltung,

Zweitschrift

$1880-1881$

Klassifikation Teil B: 01835

Band: 15

Trägermaterial: Papier

Alte Reg.-Sig.: IV SkIII 10

Bestell-Nr.: IV 01836

1798 Rechnungsbuch der städtisdchen Armenverwaltung, Bd. 16

- Einnahmen und Ausgaben der städtischen Armenverwaltung

$1881-1882$

Klassifikation Teil B: 01837

Band: 16

Trägermaterial: Papier

Alte Reg.-Sig.: IV SkIII 10

Bestell-Nr.: IV 01837

1799 Rechnungsbuch der städtisdchen Armenverwaltung, Bd. 17

- Einnahmen und Ausgaben der städtischen Armenverwaltung,

Zweitschrift

$1881-1882$

Klassifikation Teil B: 01838

Band: 17

Trägermaterial: Papier

Alte Reg.-Sig.: IV SkIII 10

Bestell-Nr.: IV 01838 


\section{IV}

05

05.03

05.03.11

05.03.11.03

05.03.11.03.01

Lfd. Nr. Titel
Stadtverwaltung

\section{Aufgabenbereiche der Stadtverwaltung}

Sozialfürsorge

Ortsarmenverband

Organisation des Armenwesens

1800 Rechnungsbuch der städtisdchen Armenverwaltung, Bd. 18

Laufzeit

- Einnahmen und Ausgaben der städtischen Armenverwaltung

$1882-1883$

Klassifikation Teil B: 01839

Band: 18

Trägermaterial: Papier

Alte Reg.-Sig.: IV SkIII 10

Bestell-Nr.: IV 01839

1801 Rechnungsbuch der städtisdchen Armenverwaltung, Bd. 19

- Einnahmen und Ausgaben der städtischen Armenverwaltung,

Zweitschrift

$1882-1883$

Klassifikation Teil B: 01840

Band: 19

Trägermaterial: Papier

Alte Reg.-Sig.: IV SkIII 10

Bestell-Nr.: IV 01840

1802 Rechnungsbuch der städtisdchen Armenverwaltung, Bd. 20

- Einnahmen und Ausgaben der städtischen Armenverwaltung

$1883-1884$

Klassifikation Teil B: 01841

Band: 20

Trägermaterial: Papier

Alte Reg.-Sig.: IV SkIII 10

Bestell-Nr.: IV 01841

1803 Rechnungsbuch der städtisdchen Armenverwaltung, Bd. 21

- Einnahmen und Ausgaben der städtischen Armenverwaltung,

Zweitschrift

$1883-1884$

Klassifikation Teil B: 01842

Band: 21

Trägermaterial: Papier

Alte Reg.-Sig.: IV SkIII 10

Bestell-Nr.: IV 01842 


\section{IV}

05

05.03

05.03.11

05.03.11.03

05.03.11.03.01

Lfd. Nr. Titel
Stadtverwaltung

Aufgabenbereiche der Stadtverwaltung

Sozialfürsorge

Ortsarmenverband

Organisation des Armenwesens

1804 Rechnungsbuch der städtisdchen Armenverwaltung, Bd. 22

Laufzeit

- Einnahmen und Ausgaben der städtischen Armenverwaltung

$1884-1885$

Klassifikation Teil B: 01843

Band: 22

Trägermaterial: Papier

Alte Reg.-Sig.: IV SkIII 10

Bestell-Nr.: IV 01843

1805 Rechnungsbuch der städtisdchen Armenverwaltung, Bd. 23

1884-1885

- Einnahmen und Ausgaben der städtischen Armenverwaltung,

Zweitschrift

$1884-1885$

Klassifikation Teil B: 01844

Band: 23

Trägermaterial: Papier

Alte Reg.-Sig.: IV SkIII 10

Bestell-Nr.: IV 01844

1806 Rechnungsbuch der städtisdchen Armenverwaltung, Bd. 24

1885-1886

- Einnahmen und Ausgaben der städtischen Armenverwaltung

$1885-1886$

Klassifikation Teil B: 01845

Band: 24

Trägermaterial: Papier

Alte Reg.-Sig.: IV SkIII 10

Bestell-Nr.: IV 01845

1807 Rechnungsbuch der städtisdchen Armenverwaltung, Bd. 25

- Einnahmen und Ausgaben der städtischen Armenverwaltung,

Zweitschrift

$1885-1886$

Klassifikation Teil B: 01846

Band: 25

Trägermaterial: Papier

Alte Reg.-Sig.: IV SkIII 10

Bestell-Nr.: IV 01846 


\section{IV}

05

05.03

05.03.11

05.03.11.03

05.03.11.03.01

Lfd. Nr. Titel
Stadtverwaltung

\section{Aufgabenbereiche der Stadtverwaltung}

Sozialfürsorge

Ortsarmenverband

Organisation des Armenwesens

1808 Rechnungsbuch der städtisdchen Armenverwaltung, Bd. 26

Laufzeit

- Einnahmen und Ausgaben der städtischen Armenverwaltung

$1886-1887$

Klassifikation Teil B: 01847

Band: 26

Trägermaterial: Papier

Alte Reg.-Sig.: IV SkIII 10

Bestell-Nr.: IV 01847

1809 Rechnungsbuch der städtisdchen Armenverwaltung, Bd. 27

- Einnahmen und Ausgaben der städtischen Armenverwaltung,

Zweitschrift

$1886-1887$

Klassifikation Teil B: 01848

Band: 27

Trägermaterial: Papier

Alte Reg.-Sig.: IV SkIII 10

Bestell-Nr.: IV 01848

1810 Rechnungsbuch der städtisdchen Armenverwaltung, Bd. 28

- Einnahmen und Ausgaben der städtischen Armenverwaltung

$1887-1888$

Klassifikation Teil B: 01849

Band: 28

Trägermaterial: Papier

Alte Reg.-Sig.: IV SkIII 10

Bestell-Nr.: IV 01849

1811 Rechnungsbuch der städtisdchen Armenverwaltung, Bd. 29

- Einnahmen und Ausgaben der städtischen Armenverwaltung,

Zweitschrift

$1887-1888$

Klassifikation Teil B: 01850

Band: 29

Trägermaterial: Papier

Alte Reg.-Sig.: IV SkIII 10

Bestell-Nr.: IV 01850 


\section{IV}

05

05.03

05.03.11

05.03.11.03

05.03.11.03.01

Lfd. Nr. Titel
Stadtverwaltung

Aufgabenbereiche der Stadtverwaltung

Sozialfürsorge

Ortsarmenverband

Organisation des Armenwesens

1812 Rechnungsbuch der städtisdchen Armenverwaltung, Bd. 30

Laufzeit

- Einnahmen und Ausgaben der städtischen Armenverwaltung

$1888-1889$

Klassifikation Teil B: 01851

Band: 30

Trägermaterial: Papier

Alte Reg.-Sig.: IV SkIII 10

Bestell-Nr.: IV 01851

1813 Rechnungsbuch der städtisdchen Armenverwaltung, Bd. 31

- Einnahmen und Ausgaben der städtischen Armenverwaltung,

Zweitschrift

1888- 1890

Klassifikation Teil B: 01852

Band: 31

Trägermaterial: Papier

Alte Reg.-Sig.: IV SkIII 10

Bestell-Nr.: IV 01852

1814 Rechnungsbuch der städtisdchen Armenverwaltung, Bd. 32

$1889-1890$

- Einnahmen und Ausgaben der städtischen Armenverwaltung

$1889-1890$

Klassifikation Teil B: 01853

Band: 32

Trägermaterial: Papier

Alte Reg.-Sig.: IV SkIII 10

Bestell-Nr.: IV 01853

1815 Rechnungsbuch der städtisdchen Armenverwaltung, Bd. 33

- Einnahmen und Ausgaben der städtischen Armenverwaltung,

Zweitschrift

$1889-1890$

Klassifikation Teil B: 01854

Band: 33

Trägermaterial: Papier

Alte Reg.-Sig.: IV SkIII 10

Bestell-Nr.: IV 01854 
IV

05

05.03

05.03.11

05.03.11.03

05.03.11.03.01

Lfd. Nr. Titel
Stadtverwaltung

Aufgabenbereiche der Stadtverwaltung

Sozialfürsorge

Ortsarmenverband

Organisation des Armenwesens

1816 Rechnungsbuch der städtisdchen Armenverwaltung, Bd. 34

Laufzeit

- Einnahmen und Ausgaben der städtischen Armenverwaltung

$1890-1891$

Klassifikation Teil B: 01855

Band: 34

Trägermaterial: Papier

Alte Reg.-Sig.: IV SkIII 10

Bestell-Nr.: IV 01855

1817 Rechnungsbuch der städtisdchen Armenverwaltung, Bd. 35

- Einnahmen und Ausgaben der städtischen Armenverwaltung,

Zweitschrift

$1890-1891$

Klassifikation Teil B: 01856

Band: 35

Trägermaterial: Papier

Alte Reg.-Sig.: IV SkIII 10

Bestell-Nr.: IV 01856

1818 Rechnungsbuch der städtisdchen Armenverwaltung, Bd. 36

- Einnahmen und Ausgaben der städtischen Armenverwaltung

$1891-1892$

Klassifikation Teil B: 01857

Band: 36

Trägermaterial: Papier

Alte Reg.-Sig.: IV SkIII 10

Bestell-Nr.: IV 01857

1819 Rechnungsbuch der städtisdchen Armenverwaltung, Bd. 37

- Einnahmen und Ausgaben der städtischen Armenverwaltung,

Zweitschrift

$1891-1892$

Klassifikation Teil B: 01858

Band: 37

Trägermaterial: Papier

Alte Reg.-Sig.: IV SkIII 10

Bestell-Nr.: IV 01858 


\section{IV}

05

05.03

05.03.11

05.03.11.03

05.03.11.03.01

Lfd. Nr. Titel
Stadtverwaltung

Aufgabenbereiche der Stadtverwaltung

Sozialfürsorge

Ortsarmenverband

Organisation des Armenwesens

1820 Rechnungsbuch der städtisdchen Armenverwaltung, Bd. 38

Laufzeit

- Einnahmen und Ausgaben der städtischen Armenverwaltung

$1892-1893$

Klassifikation Teil B: 01859

Band: 38

Trägermaterial: Papier

Alte Reg.-Sig.: IV SkIII 10

Bestell-Nr.: IV 01859

1821 Rechnungsbuch der städtisdchen Armenverwaltung, Bd. 39

- Einnahmen und Ausgaben der städtischen Armenverwaltung,

Zweitschrift

$1892-1893$

Klassifikation Teil B: 01860

Band: 39

Trägermaterial: Papier

Alte Reg.-Sig.: IV SkIII 10

Bestell-Nr.: IV 01860

1822 Rechnungsbuch der städtisdchen Armenverwaltung, Bd. 40

1893-1894

- Einnahmen und Ausgaben der städtischen Armenverwaltung

$1893-1894$

Klassifikation Teil B: 01861

Band: 40

Trägermaterial: Papier

Alte Reg.-Sig.: IV SkIII 10

Bestell-Nr.: IV 01861

1823 Rechnungsbuch der städtisdchen Armenverwaltung, Bd. 41

- Einnahmen und Ausgaben der städtischen Armenverwaltung,

Zweitschrift

$1893-1894$

Klassifikation Teil B: 01861

Band: 41

Trägermaterial: Papier

Alte Reg.-Sig.: IV SkIII 10

Bestell-Nr.: IV 01862 


\section{IV}

05

05.03

05.03.11

05.03.11.03

05.03.11.03.01

Lfd. Nr. Titel
Stadtverwaltung

Aufgabenbereiche der Stadtverwaltung

Sozialfürsorge

Ortsarmenverband

Organisation des Armenwesens

1824 Rechnungsbuch der städtisdchen Armenverwaltung, Bd. 42

Laufzeit

- Einnahmen und Ausgaben der städtischen Armenverwaltung

$1894-1895$

Klassifikation Teil B: 01863

Band: 42

Trägermaterial: Papier

Alte Reg.-Sig.: IV SkIII 10

Bestell-Nr.: IV 01863

1825 Rechnungsbuch der städtisdchen Armenverwaltung, Bd. 43

1894-1895

- Einnahmen und Ausgaben der städtischen Armenverwaltung,

Zweitschrift

$1894-1895$

Klassifikation Teil B: 01864

Band: 43

Trägermaterial: Papier

Alte Reg.-Sig.: IV SkIII 10

Bestell-Nr.: IV 01864

1826 Rechnungsbuch der städtisdchen Armenverwaltung, Bd. 44

1895-1896

- Einnahmen und Ausgaben der städtischen Armenverwaltung

$1895-1896$

Klassifikation Teil B: 01865

Band: 44

Trägermaterial: Papier

Alte Reg.-Sig.: IV SkIII 10

Bestell-Nr.: IV 01865

1827 Rechnungsbuch der städtisdchen Armenverwaltung, Bd. 45

- Einnahmen und Ausgaben der städtischen Armenverwaltung,

Zweitschrift

$1895-1896$

Klassifikation Teil B: 01866

Band: 45

Trägermaterial: Papier

Alte Reg.-Sig.: IV SkIII 10

Bestell-Nr.: IV 01866 
IV

05

05.03

05.03.11

05.03.11.03

05.03.11.03.01

Lfd. Nr. Titel
Stadtverwaltung

Aufgabenbereiche der Stadtverwaltung

Sozialfürsorge

Ortsarmenverband

Organisation des Armenwesens

1828 Rechnungsbuch der städtisdchen Armenverwaltung, Bd. 46

Laufzeit

- Einnahmen und Ausgaben der städtischen Armenverwaltung

$1896-1897$

Klassifikation Teil B: 01867

Band: 46

Trägermaterial: Papier

Alte Reg.-Sig.: IV SkIII 10

Bestell-Nr.: IV 01867

1829 Rechnungsbuch der städtisdchen Armenverwaltung, Bd. 47

1896-1897

- Einnahmen und Ausgaben der städtischen Armenverwaltung,

Zweitschrift

$1896-1897$

Klassifikation Teil B: 01868

Band: 47

Trägermaterial: Papier

Alte Reg.-Sig.: IV SkIII 10

Bestell-Nr.: IV 01868

1830 Rechnungsbuch der städtisdchen Armenverwaltung, Bd. 48

1901-1902

- Einnahmen und Ausgaben der städtischen Armenverwaltung

$1901-1902$

Klassifikation Teil B: 01869

Band: 48

Trägermaterial: Papier

Alte Reg.-Sig.: IV SkIII 10

Bestell-Nr.: IV 01869

1831 Rechnungsbuch der städtisdchen Armenverwaltung, Bd. 49

- Einnahmen und Ausgaben der städtischen Armenverwaltung

$1902-1903$

Klassifikation Teil B: 01870

Band: 49

Trägermaterial: Papier

Alte Reg.-Sig.: IV SkIII 10

Bestell-Nr.: IV 01870 
IV

05

05.03

05.03.11

05.03.11.03

05.03.11.03.01

Lfd. Nr. Titel
Stadtverwaltung

Aufgabenbereiche der Stadtverwaltung

Sozialfürsorge

Ortsarmenverband

Organisation des Armenwesens

1832 Rechnungsbuch der städtisdchen Armenverwaltung, Bd. 50

Laufzeit

- Einnahmen und Ausgaben der städtischen Armenverwaltung,

Zweitschrift

$1902-1903$

Klassifikation Teil B: 01871

Band: 50

Trägermaterial: Papier

Alte Reg.-Sig.: IV SkIII 10

Bestell-Nr.: IV 01871

1833 Rechnungsbuch der städtisdchen Armenverwaltung, Bd. 51

1903-1904

- Einnahmen und Ausgaben der städtischen Armenverwaltung

$1903-1904$

Klassifikation Teil B: 01872

Band: 51

Trägermaterial: Papier

Alte Reg.-Sig.: IV SkIII 10

Bestell-Nr.: IV 01872

1834 Rechnungsbuch der städtisdchen Armenverwaltung, Bd. 52

1903-1904

- Einnahmen und Ausgaben der städtischen Armenverwaltung,

Zweitschrift

$1903-1904$

Klassifikation Teil B: 01873

Band: 52

Trägermaterial: Papier

Alte Reg.-Sig.: IV SkIII 10

Bestell-Nr.: IV 01873

1835 Rechnungsbuch der städtisdchen Armenverwaltung, Bd. 53

1904-1905

- Einnahmen und Ausgaben der städtischen Armenverwaltung

$1904-1905$

Klassifikation Teil B: 01874

Band: 53

Trägermaterial: Papier

Alte Reg.-Sig.: IV SkIII 10

Bestell-Nr.: IV 01874 
IV

05

05.03

05.03.11

05.03.11.03

05.03.11.03.01

Lfd. Nr. Titel
Stadtverwaltung

Aufgabenbereiche der Stadtverwaltung

Sozialfürsorge

Ortsarmenverband

Organisation des Armenwesens

1836 Rechnungsbuch der städtisdchen Armenverwaltung, Bd. 54

Laufzeit

- Einnahmen und Ausgaben der städtischen Armenverwaltung,

Zweitschrift

$1904-1905$

Klassifikation Teil B: 01875

Band: 54

Trägermaterial: Papier

Alte Reg.-Sig.: IV SkIII 10

Bestell-Nr.: IV 01875

1837 Rechnungsbuch der städtisdchen Armenverwaltung, Bd. 55

1905-1906

- Einnahmen und Ausgaben der städtischen Armenverwaltung

$1905-1906$

Klassifikation Teil B: 01876

Band: 55

Trägermaterial: Papier

Alte Reg.-Sig.: IV SkIII 10

Bestell-Nr.: IV 01876

1838 Rechnungsbuch der städtisdchen Armenverwaltung, Bd. 56

1905-1906

- Einnahmen und Ausgaben der städtischen Armenverwaltung,

Zweitschrift

$1905-1906$

Klassifikation Teil B: 01877

Band: 56

Trägermaterial: Papier

Alte Reg.-Sig.: IV SkIII 10

Bestell-Nr.: IV 01877

1839 Rechnungsbuch der städtisdchen Armenverwaltung, Bd. 57

- Einnahmen und Ausgaben der städtischen Armenverwaltung

$1906-1907$

Klassifikation Teil B: 01878

Band: 57

Trägermaterial: Papier

Alte Reg.-Sig.: IV SkIII 10

Bestell-Nr.: IV 01878 
IV

05

05.03

05.03.11

05.03.11.03

05.03.11.03.01

Lfd. Nr. Titel
Stadtverwaltung

\section{Aufgabenbereiche der Stadtverwaltung}

Sozialfürsorge

Ortsarmenverband

Organisation des Armenwesens

1840 Rechnungsbuch der städtisdchen Armenverwaltung, Bd. 58

Laufzeit

- Einnahmen und Ausgaben der städtischen Armenverwaltung, Zweitschrift

$1906-1907$

Klassifikation Teil B: 01879

Band: 58

Trägermaterial: Papier

Alte Reg.-Sig.: IV SkIII 10

Bestell-Nr.: IV 01879

1841 Rechnungsbuch der städtisdchen Armenverwaltung, Bd. 59

1907-1908

- Einnahmen und Ausgaben der städtischen Armenverwaltung

$1907-1908$

Klassifikation Teil B: 01880

Band: 59

Trägermaterial: Papier

Alte Reg.-Sig.: IV SkIII 10

Bestell-Nr.: IV 01880

1842 Rechnungsbuch der städtisdchen Armenverwaltung, Bd. 60

1907-1908

- Einnahmen und Ausgaben der städtischen Armenverwaltung,

Zweitschrift

$1907-1908$

Klassifikation Teil B: 01881

Band: 60

Trägermaterial: Papier

Alte Reg.-Sig.: IV SkIII 10

Bestell-Nr.: IV 01881

1843 Rechnungsbuch der städtisdchen Armenverwaltung, Bd. 61

- Einnahmen und Ausgaben der städtischen Armenverwaltung

$1908-1909$

Klassifikation Teil B: 01882

Band: 61

Trägermaterial: Papier

Alte Reg.-Sig.: IV SkIII 10

Bestell-Nr.: IV 01882 
IV

05

05.03

05.03.11

05.03.11.03

05.03.11.03.01

Lfd. Nr. Titel
Stadtverwaltung

Aufgabenbereiche der Stadtverwaltung

Sozialfürsorge

Ortsarmenverband

Organisation des Armenwesens

1844 Rechnungsbuch der städtisdchen Armenverwaltung, Bd. 62

Laufzeit

- Einnahmen und Ausgaben der städtischen Armenverwaltung,

Zweitschrift

$1908-1909$

Klassifikation Teil B: 01883

Band: 62

Trägermaterial: Papier

Alte Reg.-Sig.: IV SkIII 10

Bestell-Nr.: IV 01883

1845 Rechnungsbuch der städtisdchen Armenverwaltung, Bd. 63

$1909-1910$

- Einnahmen und Ausgaben der städtischen Armenverwaltung

$1909-1910$

Klassifikation Teil B: 01884

Band: 63

Trägermaterial: Papier

Alte Reg.-Sig.: IV SkIII 10

Bestell-Nr.: IV 01884

1846 Rechnungsbuch der städtisdchen Armenverwaltung, Bd. 64

- Einnahmen und Ausgaben der städtischen Armenverwaltung

$1910-1911$

Klassifikation Teil B: 01885

Band: 64

Trägermaterial: Papier

Alte Reg.-Sig.: IV SkIII 10

Bestell-Nr.: IV 01885

1847 Rechnungsbuch der städtisdchen Armenverwaltung, Bd. 65

- Einnahmen und Ausgaben der städtischen Armenverwaltung

$1897-1898$

Klassifikation Teil B: 01886

Band: 65

Trägermaterial: Papier

Alte Reg.-Sig.: IV SkIII 10

Bestell-Nr.: IV 01886 
IV

05

05.03

05.03.11

05.03.11.03

05.03.11.03.01

Lfd. Nr. Titel
Stadtverwaltung

Aufgabenbereiche der Stadtverwaltung

Sozialfürsorge

Ortsarmenverband

Organisation des Armenwesens

1848 Rechnungsbuch der städtisdchen Armenverwaltung, Bd. 66

Laufzeit

- Einnahmen und Ausgaben der städtischen Armenverwaltung,

Zweitschrift

$1897-1898$

Klassifikation Teil B: 01887

Band: 66

Trägermaterial: Papier

Alte Reg.-Sig.: IV SkIII 10

Bestell-Nr.: IV 01887

1849 Rechnungsbuch der städtisdchen Armenverwaltung, Bd. 67

1898-1899

- Einnahmen und Ausgaben der städtischen Armenverwaltung

$1898-1899$

Klassifikation Teil B: 01888

Band: 67

Trägermaterial: Papier

Alte Reg.-Sig.: IV SkIII 10

Bestell-Nr.: IV 01888

1850 Rechnungsbuch der städtisdchen Armenverwaltung, Bd. 68

1898-1899

- Einnahmen und Ausgaben der städtischen Armenverwaltung,

Zweitschrift

$1898-1899$

Klassifikation Teil B: 01889

Band: 67

Trägermaterial: Papier

Alte Reg.-Sig.: IV SkIII 10

Bestell-Nr.: IV 01889

1851 Rechnungsbuch der städtisdchen Armenverwaltung, Bd. 69

- Einnahmen und Ausgaben der städtischen Armenverwaltung

$1899-1900$

Klassifikation Teil B: 01890

Band: 69

Trägermaterial: Papier

Alte Reg.-Sig.: IV SkIII 10

Bestell-Nr.: IV 01890 
IV

05

05.03

05.03.11

05.03.11.03

05.03.11.03.01

Lfd. Nr. Titel
Stadtverwaltung

\section{Aufgabenbereiche der Stadtverwaltung}

Sozialfürsorge

Ortsarmenverband

Organisation des Armenwesens

1852 Rechnungsbuch der städtisdchen Armenverwaltung, Bd. 70

Laufzeit

- Einnahmen und Ausgaben der städtischen Armenverwaltung,

Zweitschrift

$1899-1900$

Klassifikation Teil B: 01891

Band: 70

Trägermaterial: Papier

Alte Reg.-Sig.: IV SkIII 10

Bestell-Nr.: IV 01891

1853 Rechnungsbuch der städtisdchen Armenverwaltung, Bd. 71

1900-1901

- Einnahmen und Ausgaben der städtischen Armenverwaltung

$1900-1901$

Klassifikation Teil B: 01892

Band: 71

Trägermaterial: Papier

Alte Reg.-Sig.: IV SkIII 10

Bestell-Nr.: IV 01892

1854 Rechnungsbuch der städtisdchen Armenverwaltung, Bd. 72

1900-1901

- Einnahmen und Ausgaben der städtischen Armenverwaltung,

Zweitschrift

$1900-1901$

Klassifikation Teil B: 01893

Band: 72

Trägermaterial: Papier

Alte Reg.-Sig.: IV SkIII 10

Bestell-Nr.: IV 01893

1855 Rechnungsbuch der städtisdchen Armenverwaltung, Bd. 73

- Einnahmen und Ausgaben der städtischen Armenverwaltung

$1910-1911$

Klassifikation Teil B: 01894

Band: 73

Trägermaterial: Papier

Alte Reg.-Sig.: IV SkIII 10

Bestell-Nr.: IV 01894 
IV

05

05.03

05.03.11

05.03.11.03

05.03.11.03.01

Lfd. Nr. Titel
Stadtverwaltung

Aufgabenbereiche der Stadtverwaltung

Sozialfürsorge

Ortsarmenverband

Organisation des Armenwesens

1856 Rechnungsbuch der städtisdchen Armenverwaltung, Bd. 74

Laufzeit

- Einnahmen und Ausgaben der städtischen Armenverwaltung,

Zweitschrift

$1910-1911$

Klassifikation Teil B: 01895

Band: 74

Trägermaterial: Papier

Alte Reg.-Sig.: IV SkIII 10

Bestell-Nr.: IV 01895

1857 Rechnungsbuch der städtisdchen Armenverwaltung, Bd. 75

1911-1912

- Einnahmen und Ausgaben der städtischen Armenverwaltung

$1911-1912$

Klassifikation Teil B: 01896

Band: 75

Trägermaterial: Papier

Alte Reg.-Sig.: IV SkIII 10

Bestell-Nr.: IV 01896

1858 Rechnungsbuch der städtisdchen Armenverwaltung, Bd. 76

- Einnahmen und Ausgaben der städtischen Armenverwaltung,

Zweitschrift

$1911-1912$

Klassifikation Teil B: 01897

Band: 76

Trägermaterial: Papier

Alte Reg.-Sig.: IV SkIII 10

Bestell-Nr.: IV 01897

1859 Belege zu den Armenrechnungen, Bd. 1

1870

Klassifikation Teil B: 01898

Band: 1

Trägermaterial: Papier

Alte Reg.-Sig.: IV SkIII 10

Bestell-Nr.: IV 01898

1860 Belege zu den Armenrechnungen, Bd. 2

1873

Klassifikation Teil B: 01899

Band: 2

Trägermaterial: Papier

Alte Reg.-Sig.: IV SkIII 10

Bestell-Nr.: IV 01899 a 
IV

05

05.03

05.03.11

05.03.11.03

05.03.11.03.02
Stadtverwaltung

Aufgabenbereiche der Stadtverwaltung

Sozialfürsorge

Ortsarmenverband

Zentral-Armendeputation

Lfd. Nr. Titel

Laufzeit

1861 Bildung der Central-Armen-Deputation

1871

- Bildung der Central-Armen-Deputation aus Mitgliedern des

Bürgervorsteherkollegiums, Diakonen der Diakonie der

Haussitzenden Armen und der Gasthausverwaltung, Juni 1871

1871

Klassifikation Teil B: 01788

Trägermaterial: Papier

Alte Reg.-Sig.: IV Sk 10

Bestell-Nr.: IV 01788

1862 Central-Armen-Deputation

1871

- Übernahme der Bediensteten der bisherigen Organisationen des Armenwesens in die Dienste der Central-Armen-Deputation zu ihren bisherigen Gehaltsbedingungen

1871

Klassifikation Teil B: 01789

Trägermaterial: Papier

Alte Reg.-Sig.: IV Sk 12

Bestell-Nr.: IV 01789

1863 Beschwerden gegen Entscheidungen des Ortsarmenverbandes

$1872-1900$

- Beschwerden gegen die Central-Armen-Deputation wegen

Verweigerung von Armenunterstützung

$1872-1900$

Klassifikation Teil B: 01805

Trägermaterial: Papier

Alte Reg.-Sig.: IV Skl 16

Bestell-Nr.: IV 01805

1864 Central-Armen-Deputation

$1871-1913$

- Gedrucktes Statut der Armenverwaltung der Stadt Emden, 1871

- Gedruckte Waisenratsordnung der Stadt Emden, 1875

- Mitglieder der Central-Armen-Deputation, 1878 - 1913

- Protokolle der Sitzungen der Central-Armen-Deputation, 1898

- Mitglieder des Waisenrates, 1900

$1871-1913$

Klassifikation Teil B: 01810

Trägermaterial: Papier

Alte Reg.-Sig.: IV Skll 01

Bestell-Nr.: IV 01810 
05

05.03

05.03.11

05.03.11.03

05.03.11.03.02

Lfd. $\mathrm{Nr}$ Titel
IV

Stadtverwaltung

Aufgabenbereiche der Stadtverwaltung

Sozialfürsorge

Ortsarmenverband

Zentral-Armendeputation

Laufzeit

1865 Sitzungen der Central-Armen-Deputation

1873-1882

- Protokoll der Sitzungen der Central-Armen-Deputation

$1873-1882$

Klassifikation Teil B: 01813

Trägermaterial: Papier

Alte Reg.-Sig.: IV Skll 03

Bestell-Nr.: IV 01813

1866 Central-Armen-Deputation

1888-1904

- Protokolle der Sitzungen der Central-Armen-Deputation, 1888 - 1898

- Bestellung eines Armenarztes, 1890 - 1897

- Mitglieder der Central-Armen-Deputation, 1890 - 1904

- Instruktionen für den Armenarzt Dr. Sternberg, Januar 1893

$1888-1904$

Klassifikation Teil B: 01814

Trägermaterial: Papier

Alte Reg.-Sig.: IV SkII 04

Bestell-Nr.: IV 01814 
IV

05

05.03

05.03.11

05.03.11.03

05.03.11.03.03
Stadtverwaltung

Aufgabenbereiche der Stadtverwaltung

Sozialfürsorge

Ortsarmenverband

Armenkollegium

Lfd. Nr. Titel

Laufzeit

1867 Rechnungslegung der Armenkommission, Bd. 1

1871-1872

- Bilanz über Einnahmen und Ausgaben der Armenkommission,

November 1871

- Verschiedene Berichte des Kämmerers van Buiren zur Kassenlage

der Armenkommission, 1871 - 1872

$1871-1872$

Klassifikation Teil B: 01811

Band: 1

Trägermaterial: Papier

Alte Reg.-Sig.: IV Skll 02

Bestell-Nr.: IV 01811

1868 Rechnungslegung der Armenkommission, Bd. 2

1875

- Bilanz über Einnahmen und Ausgaben der Armenkommission

1875

Klassifikation Teil B: 01812

Band: 2

Trägermaterial: Papier

Alte Reg.-Sig.: IV Skll 02

Bestell-Nr.: IV 01812

1869 Beamte des Armenkollegiums

- Einstellung des Johann Christian Panzer als Hausvater des Armen-Arbeitshauses, August 1872

- Antrag der Armenärzte Dr. Norden und Dr. van Senden auf Erhöhung des Honorars für Armenbehandlungen, Dezember 1873 Januar 1874

- Antrag des Hausvaters des Armen-Arbeitshauses, Johann Christian Panzer, auf Erhöhung seines Gehaltes wegen Vermehrung der Arbeitslast, März - April 1878

- Anzeige der Witwe Friederike van Cleef gegen den Armenvogt Marten Vogt wegen Hausfriedensbruch, Januar - Februar 1879 - Glücjkwünsche und Gratifikation zum 25-jährigen Dienstjubiläum des Armenhausvaters Johann Christian Panzer, August - September 1897 - Gewährung einer Teuerungszulage für den Armenhausvater, Juli 1908

- Pensionierungsgesuch des Armenhausvaters Panzer, Juni - Juli 1909

- Neubesetzung der Armenhausvaterstelle durch Johann Georg

Panzer aus Frankfurt / M., Neffe des Johann Christian Panzer, August 1909 - Januar 1910

$1872-1910$

Klassifikation Teil B: 01815

Trägermaterial: Papier Alte Reg.-Sig.: IV SkIII 05

Bestell-Nr.: IV 01815 
IV

05

05.03

05.03.11

05.03.11.03

05.03.11.03.03

Lfd. Nr. Titel

\section{Stadtverwaltung}

Aufgabenbereiche der Stadtverwaltung

Sozialfürsorge

Ortsarmenverband

Armenkollegium

1870 Bildung des Armenkollegiums

Laufzeit

$1872-1918$

(1919-1928)

- Ablehnung der Wahl zum Mitglied des Armenkollegiums durch verschiedene Nominierte, 1872

- Rücktrittsgesuche verschiedener Armenpfleger, 1872 - 1904

- Veränderung der Struktur des Armenkollegiums (Zahl der

Mitglieder), 1872 - 1873

- Wahl neuer Armenpfleger, 1873 - 1880

- Ablehnungen der Wahl zum Armenpfleger, 1880

- Rücktrittsgesuch des Armenkollegiumsvorsitzenden H. A. C. Apetz,

Dezember 1882

- Wahl der Mitglieder des Armenkollegiums, 1882 - 1918 (1919 -

1928)

- Wahl des Senators Gittermann zum Vorsitzenden des

Armenkollegiums, April 1883

- Wahl des Senators Franz D. Ihnen zum Vorsitzenden des

Armenkollegiums, April 1887

- Diskussion der Ernennung von Frauen zu Armenpflegerinnen, Juli -

Dezember 1913

1872 - 1918 (1919 - 1928)

Klassifikation Teil B: 01816

Trägermaterial: Papier

Alte Reg.-Sig.: IV SkIII 01

Bestell-Nr.: IV 01816

1871 Rechningsprüfung beim Armenkollegium

- Rechnungslegung durch das Armenkollegium und

Rechnungsprüfung durch das Bürgervorsteherkollegium

$1873-1914$

Klassifikation Teil B: 01817

Trägermaterial: Papier

Alte Reg.-Sig.: IV SkIII 03

Bestell-Nr.: IV 01817 
IV

05

05.03

05.03.11

05.03.11.03

05.03.11.03.03
Stadtverwaltung

Aufgabenbereiche der Stadtverwaltung

Sozialfürsorge

Ortsarmenverband

Armenkollegium

Lfd. Nr. Titel

Laufzeit

1872 Verschiedene Armensachen

1913-1915

- Vermittlung von schulentlassenen Jungen aus dem Gasthaus zur Lehre bei auswärtigen Handwerksmeistern, 1913

- Jahresbericht der Pestalozzistiftung, 1913

- Gebühren für die Bestattung einer im Hafen aufgefundenen unbekannten Leiche, 1913

- Kosten der Krankenhausbehandlung der mittellosen Gepke Wilms, $1913-1914$

- Statistik der Kinderkrippe des evangelischen Frauenbundes,

Dezember 1913

- Anforderung von Ausgleichszahlungen für die Unterstützung Emder Hilfsbedürftiger durch auswärtige Gemeinde wegen dortigen

Aufenthalts, 1913 - 1914

- Unterbringung des Alkoholikers Georg Markus in das

Armen-Arbeitshaus, Februar 1914

- Einweisung des aus Österreich-Ungarn stammenden jüdischen Damenschneider Hirsch Leizer Leinwohl in das Armen-Arbeitshaus wegen Mittellosigkeit, August 1914

- Heranziehung des Sohnes des Lazarus Pels zur Unterhaltung seines mittellosen Vaters, Oktober 1914

- Mitteilungen über Gewährung von Kriegswaisen- und Witwenrente,

1915

- Entrichtung der Hebammengebühren für die Niederkunft mittelloser

Frauen, 1913 - 1915

- Unterstützungsfälle, 1914 - 1915

$1913-1915$

Klassifikation Teil B: 01920

Trägermaterial: Papier

Alte Reg.-Sig.: IV Sm 001

Vorprovenienz: Armenamt der Stadt Emden

Bestell-Nr.: IV 01920

1873 Unterstützungsfall: Matrose Hermann Hans Jacob

- Behandlungskosten des bei einer Schlägerei verletzten

Heringslogger-Matrosen Hermann Hans Jacob

1913

Klassifikation Teil B: 01921

Trägermaterial: Papier

Alte Reg.-Sig.: IV Sm 011

Vorprovenienz: Armenamt

Bestell-Nr.: IV 01921 
IV

05

05.03

05.03.11

05.03.11.03

05.03.11.03.03
Stadtverwaltung

Aufgabenbereiche der Stadtverwaltung

Sozialfürsorge

Ortsarmenverband

Armenkollegium

Lfd. Nr. Titel

Laufzeit

1874 Unterstützungsfall: Elisabeth Janssen, verw. Tiemann, geb. Decker

1913-1916

- Unterstützung der Elisabeth Janssen, verw. Tiemann, geb. Decker wegen Mittellosigkeit

- Tragung der Bestattungskosten für ihren Sohn Johannes Tiemann

- Versuch der Heranziehung ihres Sohns Wilhelm Janssen zum

Unterhalt seiner Mutter

$1913-1916$

Klassifikation Teil B: 01922

Trägermaterial: Papier

Alte Reg.-Sig.: IV Sm 013

Vorprovenienz: Armenamt

Bestell-Nr.: IV 01922

1875 Unterstüzungsfall: Agge Janssen

1914

- Behandlungskosten: Chronische Handgelenksentzündung und TBC

- Unterbringung des todkranken Agge Janssen in das Armenhaus

1914

Klassifikation Teil B: 01923

Trägermaterial: Papier

Alte Reg.-Sig.: IV Sm 014

Vorprovenienz: Armenamt

Bestell-Nr.: IV 01923

1876 Unterstüzungsfall: Schiffsbauer Johann Heinrich Friedrich Jarks

- Vorschuss aus der Armenkasse für die Krankenhausbehandlung der Ehefrau des Schiffsbauers Johann Heinrich Friedrich Jarks

$1914-1915$

Klassifikation Teil B: 01924

Trägermaterial: Papier

Alte Reg.-Sig.: IV Sm 015

Vorprovenienz: Armenamt

Bestell-Nr.: IV 01924

1877 Unterstüzungsfall: Witwe Alberta Jacobs, geb. Janssen

- Antrag der mittellosen Witwe Alberta Jacobs auf Hilfe für sich und ihre Kinder

1914

Klassifikation Teil B: 01925

Trägermaterial: Papier

Alte Reg.-Sig.: IV Sm 016

Vorprovenienz: Armenamt

Bestell-Nr.: IV 01925 
IV

05

\subsection{3}

05.03.11

05.03.11.03

05.03.11.03.03
Stadtverwaltung

Aufgabenbereiche der Stadtverwaltung

Sozialfürsorge

Ortsarmenverband

Armenkollegium

Lfd. Nr. Titel

Laufzeit

1878 Unterstüzungsfall: Witwe Johanna Cornelia Janßen, geb. Boer

- Anforderung der Kosten für die Heilbehandlung des Matrosen Jelmer Steinhuizen in Emden von der Reederei W. Kunstmann durch die Stadt Emden, Februar - März 1912

- Unterstützung des mittellosen Jelmer Steinhuizen und seiner Frau Johanna Steinhuizen, verwtwete Janßen, geb. Boer, März 1912

- Vermisste Daten zu Jelmer Steinhuizen, Juli - August 1912

- Ermittlungen zum Aufenthaltsort des Vaters des unehelichen Kindes der Johanna Steinhuizen, verw. Janßen, geb. Boer, Februar 1914 - Unterstützung für Johanna Steinhuizen, verw. Janßen, geb. Boer, ihre ehelichen Kinder und ihrer unehelichen Tochter, Juli 1914

$1912-1914$

Klassifikation Teil B: 01926

Trägermaterial: Papier

Alte Reg.-Sig.: IV Sm 017

Vorprovenienz: Armenamt

Bestell-Nr.: IV 01926

1879 Unterstüzungsfall: Matrose Johann Jetses

$1914-1915$

- Unterstützungsantrag der Familie des in den USA festsitzenden

Matrosen Johann Jetses

$1914-1915$

Klassifikation Teil B: 01927

Trägermaterial: Papier

Alte Reg.-Sig.: IV Sm 019

Vorprovenienz: Armenamt

Bestell-Nr.: IV 01927

1880 Unterstüzungsfall: Maurer Wilhelm Jacobs

- Ermittlung des Unterstützungswohnsitzes des Maurers Wilhelm Jacobs mit Familie

1914

Klassifikation Teil B: 01928

Trägermaterial: Papier

Alte Reg.-Sig.: IV Sm 020

Vorprovenienz: Armenamt

Bestell-Nr.: IV 01928 
IV

05

05.03

05.03.11

05.03.11.03

05.03.11.03.03
Stadtverwaltung

Aufgabenbereiche der Stadtverwaltung

Sozialfürsorge

Ortsarmenverband

Armenkollegium

Lfd. Nr. Titel

Laufzeit

1881 Unterstüzungsfall: Alma Hedwig Johanna Jungk

1915-1917

- Antrag der Betreuerin des Kindes Else Jungk auf Gewährung eines Pflegegeldes wegen ausbleibender Zahlungen der Mutter Alma Jungk aufgrund schwangerschaftsbedingter Arbeitslosigkeit, Februar 1915 - Zahlung des Pflegegeldes durch die Bremische Armenverwaltung wegen Status der Hansestadt Bremen als Unterstützungswohnsitz, $1915-1917$

- Einweisung der schwangeren Alma Jungk in das Armenhaus zur

Entbindung wegen Mittellosigkeit, Juli 1915

- Übernahme des Kindes Else Jungk durch die Bremische

Armenverwaltung, August 1915

$1915-1917$

Klassifikation Teil B: 01929

Trägermaterial: Papier

Alte Reg.-Sig.: IV Sm 021

Vorprovenienz: Armenamt

Bestell-Nr.: IV 01929

1882 Unterstützungsfall: Hutmacher Conrad Janssen

1898-1917

- Anträge des Gasthauses auf Übertragung der Invalidenrente für den taubstummen, beinamputierten Hutmacher Conrad Janssen auf sein Konto wegen Unterbringung im Gasthaus

$1898-1917$

Klassifikation Teil B: 01930

Trägermaterial: Papier

Alte Reg.-Sig.: IV Sm 022

Vorprovenienz: Armenamt

Bestell-Nr.: IV 01930

1883 Dienstmagd Johanne Sophie Janssen

- Ermittlung des Unterhaltspflichtigen für die Kosten der

Gasthausunterbringung der aus ihrer Stelle entlassenen, mittellosen

Dienstmagd Johanne Sophie Janssen

1915

Klassifikation Teil B: 01931

Trägermaterial: Papier

Alte Reg.-Sig.: IV Sm 023

Vorprovenienz: Armenamt

Bestell-Nr.: IV 01931 
IV

05

\subsection{3}

05.03.11

05.03.11.03

05.03.11.03.03
Stadtverwaltung

Aufgabenbereiche der Stadtverwaltung

Sozialfürsorge

Ortsarmenverband

Armenkollegium

Lfd. Nr. Titel

Laufzeit

1884 Dienstmagd Johanne Antonette Janssen

1915-1917

- Ermittlungen gegen die Dienstmagd Johanne A. Janssen wegen Ansteckung eines Marinesoldaten mit einer Geschlechtskrankheit (Tripper), Oktober - November 1915

- Antrag der Johanne A. Janssen auf Unterstützung wegen notwendiger Tripper-Behandlung, November 1915 / Februar 1917

- Verfügung des Regierungspräsidenten über Kostenträgerschaft der Stadt Emden für die Zwangsheilbehandlung der Dienstmagd Johanne Antonette Janssen wegen Geschlechtskrankheit, April 1917

$1915-1917$

Klassifikation Teil B: 01932

Trägermaterial: Papier

Alte Reg.-Sig.: IV Sm 024

Vorprovenienz: Armenamt

Bestell-Nr.: IV 01932

1885 Arbeiter Johann Ivens

$1916-1918$

- Einweisung der vier Kinder des an der Front stehenden Arbeiters Johann Ivens in das Gasthaus wegen Versterbens ihrer Mutter an den Folgen einer Fehlgeburt, März 1916

- Verpflegungskosten , 1916 - 1917

$1916-1918$

Klassifikation Teil B: 01933

Trägermaterial: Papier

Alte Reg.-Sig.: IV Sm 025

Vorprovenienz: Armenamt

Bestell-Nr.: IV 01933

1886 Sattler und Tapezierer Hinderk Janssen

- Inschutzhaftnahme des Sattlers und Tapezierers Hinderk Janssen wegen Geisteskrankheit, Oktober 1916

- Trägerschaft der Krankenhausbehandlungskosten für den als geheilt zum Militärdienst entlassenen Hinderk Janssen, Oktober - November 1916

1916

Klassifikation Teil B: 01934

Trägermaterial: Papier

Alte Reg.-Sig.: IV Sm 029

Vorprovenienz: Armenamt

Bestell-Nr.: IV 01934 
IV

05

05.03

05.03.11

05.03.11.03

05.03.11.03.03
Stadtverwaltung

Aufgabenbereiche der Stadtverwaltung

Sozialfürsorge

Ortsarmenverband

Armenkollegium

Lfd. Nr. Titel

Laufzeit

1887 Arbeiter Everhardus Ites

1916-1918

- Unterstützungsantrag des Arbeiters Everhardus Ites wegen Mittellosigkeit, Dezember 1916

- Vernachlässigung seiner Unterhaltspflicht gegenüber seiner Familie durch den auf einem Heringslogger tätigen E. Ites, Juni 1918

- Bericht über tödlichen Unfall des E. Ites durch Seeminenexplosion,

August 1918

Enthält auch:

Unterstützungsantrag seiner Ehefrau wegen Mittellosigkeit aufgrund einer gegen Johann Ivens verhängten Haftstrafe, Januar 1917

$1916-1918$

Klassifikation Teil B: 01935

Trägermaterial: Papier

Alte Reg.-Sig.: IV Sm 029

Vorprovenienz: Armenamt

Bestell-Nr.: IV 01935

1888 Dienstmagd Helene Isecke

- Festnahme der minderjährigen, aus Polleben, Mansfelder Seekreis, geflohenen Dienstmagd Helene Isecke und Einweisung in eine Fürsorgeanstalt, Februar - April 1918

1918

Klassifikation Teil B: 01936

Trägermaterial: Papier

Alte Reg.-Sig.: IV Sm 032

Vorprovenienz: Armenamt

Bestell-Nr.: IV 01936

1889 Fürsorgeerziehungsverfahren: Friedrich Tönjes

- Einweisung des Minderjährigen Friedrich Tönjes in

Fürsorgeerziehung wegen Herumtreiberei, Faulheit und

Gewalttätigkeit gegen Mutter und Geschwister nach dem Kriegstod

des Vaters, Juni 1917

1917

Klassifikation Teil B: 01937

Trägermaterial: Papier

Alte Reg.-Sig.: IV Sm 126

Vorprovenienz: Armenamt

Bestell-Nr.: IV 01937 
IV

05

05.03

05.03.11

05.03.11.03

05.03.11.03.03
Stadtverwaltung

Aufgabenbereiche der Stadtverwaltung

Sozialfürsorge

Ortsarmenverband

Armenkollegium

Lfd. Nr. Titel

Laufzeit

1890 Kartoffellieferung für das Armen-Arbeitshaus

1886-1914

- Angebote verschiedener Händler über Kartoffellieferung für das

Armen-Arbeitshaus, 1886 - 1914

- Lieferverträge der Armenkommission mit verschiedenen Händlern

über Kartoffellieferungen für das Armen-Arbeitshaus, November 1899

- Oktober 1911

$1886-1914$

Klassifikation Teil B: 01938

Trägermaterial: Papier

Alte Reg.-Sig.: IV Sm 130

Vorprovenienz: Armenamt

Bestell-Nr.: IV 01938

1891 Verpflegungskosten von kranken Armen im Krankenhaus

1914

- Initiative des Armenkollegiums zur Senkung der Verpflegungskosten

für kranke Arme im Krankenhaus, April 1914

- Umfrage des Magistrats an die Nachbarstädte in der Provinz

Hannover wegen Festsetzung der Pflegesätze für kranke Arme im

Krankenhaus, Juni - Juli 1914

1914

Klassifikation Teil B: 01939

Trägermaterial: Papier

Alte Reg.-Sig.: IV Sm 131

Vorprovenienz: Armenamt

Bestell-Nr.: IV 01939

1892 Brotlieferiung für das Armen-Arbeitshaus

- Ausschreibungsbedingungen der Armenkommission für die Brotlieferungen für das Armen-Arbeitshaus, Juni 1881 - September 1913

- Angebote verschiedener Bäckereien über Brotlieferung für das

Armen-Arbeitshaus, 1882 - 1914

$1882-1914$

Klassifikation Teil B: 01940

Trägermaterial: Papier

Alte Reg.-Sig.: IV Sm 132

Vorprovenienz: Armenamt

Bestell-Nr.: IV 01940 
IV

05

Stadtverwaltung

05.03

Aufgabenbereiche der Stadtverwaltung

05.03.11

Sozialfürsorge

05.03.11.04

Landarmenverband

Lfd. Nr. Titel

Laufzeit

1893 Beitrag der Stadt Emden zum Landarmenverband

$1872-1905$

- Verfügungen des Landesdirektoriums der Provinz Hannover über Festsetzung des Beitrags der Stadt Emden zu den Ausgaben des Landarmenverbands der Provinz, Januar 1872 - März 1900

- Aufstellungen über Ausgaben der Stadt Emden für den

Landarmenverband der Provinz Hannover, 1872 - 1897

- Konzept einer Denkschrift des Oberbürgermeisters Fürbringer über Auswirkungen der geplanten Reform des Armenbeitragswesens auf den Etat der Stadt Emden, März 1894

- Entrichtung der Provinzialabgabe für den Landarmenverband auf

Basis der eingenommenen Betriebs-, Grund- und Einkommenssteuer, $1900-1905$

$1872-1905$

Klassifikation Teil B: 01919

Trägermaterial: Papier

Alte Reg.-Sig.: IV SI 2

Bestell-Nr.: IV 01919 
IV

05

05.03

05.03.12

05.03.12.01

05.03.12.01.01

Stadtverwaltung

Aufgabenbereiche der Stadtverwaltung

Handels- und Gewerbeförderung

Wirtschaftsförderung

Wirtschaftsstatistik

Lfd. Nr. Titel

Laufzeit

1894 Baustatistik

1881

- W. Houselle: Denkschrift zur Statistik des Bauwesens, 1881

- Antrag des Verbandes deutscher Architekten- und Ingenieur-Vereine auf Übernahme der von inm entwickelten Kategorien der Baustatistik, Dezember 1881

1881
Klassifikation Teil B: 00041
Trägermaterial: Papier
Alte Reg.-Sig.: IV Cd 48
Bestell-Nr.: IV 00041

1895 Statistische Berichte: Werftbetriebe und Schiffsversicherungsanstalten

- Statistik: Schiffsversicherungswesen, 1871 - 1872

- Verfügungen des preußischen Landdrosten in Aurich über

Einsendung von Statistiken von Schiffsversicherungen und

Schiffswerften, 1871 - 1885

- Statistischer Berichte zum Werftbetrieb in Emden, 1874 - 1884

$1871-1885$

Klassifikation Teil B: 00298

Trägermaterial: Papier

Alte Reg.-Sig.: II B 6

Bestell-Nr.: IV 00298

1896 Statistische Berichte der Städtische Spar- und Leihbank

- Statistische Bilanz-Berichte der Spar- und Leihbank der Stadt

Emden, 1871 - 1880

$1871-1880$

Klassifikation Teil B: 00299

Trägermaterial: Papier

Alte Reg.-Sig.: II B 8

Bestell-Nr.: IV 00299

1897 Statistische Berichte der Städtische Spar- und Leihbank

- Statistische Bilanz-Berichte der Spar- und Leihbank der Stadt

Emden, 1881 - 1890

$1881-1890$

Klassifikation Teil B: 00300

Trägermaterial: Papier

Alte Reg.-Sig.: II B 8

Bestell-Nr.: IV 00300 
05

\subsection{3}

05.03.12

05.03.12.01

05.03.12.01.01
Stadtverwaltung

Aufgabenbereiche der Stadtverwaltung

Handels- und Gewerbeförderung

Wirtschaftsförderung

Wirtschaftsstatistik

Lfd. Nr. Titel

Laufzeit

1898 Statistische Berichte der Städtische Spar- und Leihbank

$1891-1900$

- Statistische Bilanz-Berichte der Spar- und Leihbank der Stadt

Emden, 1891 - 1900

$1891-1900$

Klassifikation Teil B: 00301

Trägermaterial: Papier

Alte Reg.-Sig.: II B 8

Bestell-Nr.: IV 00301

1899 Statistische Berichte der Städtische Spar- und Leihbank

- Statistische Bilanz-Berichte der Spar- und Leihbank der Stadt

Emden, 1901 - 1902

$1901-1902$

Klassifikation Teil B: 00302

Trägermaterial: Papier

Alte Reg.-Sig.: II B 8

Bestell-Nr.: IV 00302

1900 Statistik über Aktiengesellschaften

- Verfügung des preußischen Landdrosten über Datenerhebung zu Aktiengesellschaften, Januar - Februar 1868 / Juni 1873

- Übersicht über in Emden ansässige Aktiengesellschaften, Februar 1868 / Juli 1868 / Juli 1873

- Schreiben der Emsloots-Gesellschaft an den Magistrat über

Ablehnung der Charackterisierung als Aktiengesellschaft, Juli 1868

- Beschreibung der Emdener Papierfabrik, 1872

- Fabrik-Reglement der Emdener Papierfabrik (Verhaltensrichtlinien für Arbeiter), 1872

- Statuten der Emder Assecuranz-Compagnie für Seegefahr, 1870

- Statuten des Brandversicherungsvereins, (1866) 1870

- Statuten und Geschäftsbericht der Zweiten Assecuranz-Compagnie,

1870

- Neues Statut der Emder Häringsfischerei AG, 1873

- Statuten der Dampfspinnerei- Weberei und Färberei

Actien-Gesellschaft, 1873

- Datenerhebung über Versicherungsgesellschaften, Januar 1887

$1868-1887$

Klassifikation Teil B: 02046

Trägermaterial: Papier

Alte Reg.-Sig.: IV T6 107

Bestell-Nr.: IV 02046 
IV

05

05.03

05.03.12

05.03.12.01

05.03.12.01.01
Stadtverwaltung

Aufgabenbereiche der Stadtverwaltung

Handels- und Gewerbeförderung

Wirtschaftsförderung

Wirtschaftsstatistik

Lfd. Nr. Titel

Laufzeit

1901 Geschäftsberichte verschiedener Emder Firmen

- Verwaltungsbericht der Reichsbank, 1902

- Jahresbericht der Deutsch-Luxemburgischen Bergwerks- und Hütten

AG (Nordseewerke), 1914 / 15

- Jahresbericht der AG Ems, 1914 - 1918 / 19

- Jahresbericht der WTAG, 1913 - 1914 / 1917 - 1918

- Jahresbericht der preußischen Central-Bodenkredit AG, 1917

- Jahresbericht der Disconto-Gesellschaft, Berlin, 1916

- Jahresbericht der Borkumer Kleinbahn- und Dampfschiffahrt AG,

$1913-1914$

- Jahresbericht des Rheinisch-Westfälischen Kohlensyndicats, 1912 -

1916

- Jahresbericht der See- und Kanalschiffahrt Wilhelm Hamsoth AG,

$1911-1914$

- Jahresbericht der Hohenzollernhütte, 1915

1911 - 1918 (1919)

Klassifikation Teil B: 02142

Trägermaterial: Papier

Alte Reg.-Sig.: IV T6 188

Bestell-Nr.: IV 02142 
05

05.03

05.03.12

05.03.12.01

05.03.12.01.02
Stadtverwaltung

Aufgabenbereiche der Stadtverwaltung

Handels- und Gewerbeförderung

Wirtschaftsförderung

Gesetzliche Regelung von Handel und Gewerbe

Lfd. Nr. Titel

Laufzeit

1902 Feststellung von Preisen und Löhnen

1901-1916

- Mitteilungen über Vorräte an Lebensmittel und deren Preise, 1915 -

1916

- Runderlass des preußischen statistischen Landesamts über

Erhebung der Daten zu Preisen von Lebensmitteln und Gütern,

Oktober 1909 / Dezember 1912

- Erlass des preußischen Landwirtschaftsministers über Feststellung

der Großhandelspreise für Getreide, Juli 1901 / Dezember 1912

- Mitteilungen an die Stadt Emden über Fleischpreise, 1911

$1901-1916$

Klassifikation Teil B: 00037

Trägermaterial: Papier

Alte Reg.-Sig.: IV Cd 39

Bestell-Nr.: IV 00037

1903 Feststellung von Preisen und Löhnen

- Runderlass des preußischen statistischen Landesamts über Erhebung der Daten zu Preisen von Lebensmitteln und Gütern, November 1901 / August 1904 / Dezember 1909

- Mitteilungen an die Stadt Emden über Fleischpreise, Oktober -

Dezember 1902

$1901-1916$

Klassifikation Teil B: 00038

Trägermaterial: Papier

Alte Reg.-Sig.: IV Cd 39

Bestell-Nr.: IV 00038 
05

\subsection{3}

05.03.12

05.03.12.01

05.03.12.01.02
Stadtverwaltung

Aufgabenbereiche der Stadtverwaltung

Handels- und Gewerbeförderung

Wirtschaftsförderung

Gesetzliche Regelung von Handel und Gewerbe

Lfd. Nr. Titel

Laufzeit

1904 Feststellung der Preise für Lebensmittel und Güter des täglichen Bedarfs

$1866-1900$

- Erlasse des preußischen Innenministers über Anordnung der Anfertigung von Berichten über Preise für Lebensmittel und Artikel des täglichen Bedarfs, März 1872 - April 1897

- Verfügung des preußischen Landdrosten in Aurich über Durchführung der Feststellung der Preise für Lebensmittel und Güter des täglichen Bedarfs mit Definition der betreffenden Ware, April 1872 - September 1875

- Verfügung des preußischen Regierungspräsidenten über Durchführung Feststellung der Preise für Lebensmittel und Güter des täglichen Bedarfs, März 1891

- Rundverfügung des kgl. statistischen Büros über Durchführung Feststellung der Preise für Lebensmittel und Güter des täglichen Bedarfs, September 1872 - November 1900

- Mitteilungen verschiedener Firmen und Behörden an die Stadt Emden über Preise für Lebensmittel und Güter des täglichen Bedarfs, 1880 - 1886

- Statistische Berichte der Stadt Emden über Preise für Lebensmittel und Güter des täglichen Bedarfs, 1874 - 1883

- Mitteilungen der Stadt Emden an den Verein "Concordia, Verein zur Forderung des Wohls der Arbeiter" über Löhne und Preise in Emden, $1880-1884$

- Torfpreise, 1881 - 1897

- Brennstoffpreise, 1866 - 1900

$1866-1900$

Klassifikation Teil B: 00040

Trägermaterial: Papier

Alte Reg.-Sig.: IV Cd 39

Bestell-Nr.: IV 00039

1905 Ausführung der Gewerbeordnung

- Erlass der preußischen Minister der Justiz, des Handels und Gewerbes und des Inneren über Regelungen zur Gewerbeordnung und Definition der Begriffe im Sinne der Verordnung, 1906 - 1913

$1906-1913$

Klassifikation Teil B: 00694

Trägermaterial: Papier

Alte Reg.-Sig.: IV Fi 032

Bestell-Nr.: IV 00694 
IV

05

05.03

05.03.12

05.03.12.01

05.03.12.01.02
Stadtverwaltung

Aufgabenbereiche der Stadtverwaltung

Handels- und Gewerbeförderung

Wirtschaftsförderung

Gesetzliche Regelung von Handel und Gewerbe

Lfd. Nr. Titel

Laufzeit

1906 Handels- und gewerbliche Angelegenheiten, Bd. 1

$1881-1910$

- Erlasse und Verfügungen des Ministers für Handel und Gewerbe und nachgeordneter Behörden auf Provinz- und Bezirksebene über

Regelungen für Handels- und Gewerbetreibende wegen

Preisgestaltung und Warenqualität, 1881 - 1890

- Verbot der Verwendung gebrauchter, nicht desinfizierter Watte für

Matratzeneinlagen, 1881

- Verfügung des Regierungspräsidenten in Aurich über Erstellung

einer Datenerhebung über Handwerkerfachvereine, Juni 1888

- Antrag des Bezirksvorstehers der Emder Bäcker, R. R. Janssen, beim Magistrat auf Verbot des Hausierhandels mit Backwaren, Juli 1888

- Material zu verschiedenen Gewerbeausstellungen des In- und

Auslandes, 1895 - 1903

- Anfrage der kgl. Kanal-Kommission zu Münster wegen eines Emder

Bebauungsplans zur Verwendung für eine Ausstellung zur

Fertigstellung des Dortmund-Ems-Kanals, April 1896

- Denkschrift des preußischen Ministers für Handel und Gewerbe über Stand der Gewerbeförderung in Preußen, 1903

- Einladung an den Oberbürgermeister Fürbringer zur Gewerbeschau

in Groningen, Juni - Juli 1903

- Erlass des Ministers für Handel und Gewerbe über Förderung von

Gewerbeausstellungen, 1904 - 1905

- Bekämpfung von Scheinausstellungen, 1905 - 1906

$1881-1910$

Klassifikation Teil B: 01941

Band: 1

Trägermaterial: Papier

Alte Reg.-Sig.: IV T1 26

Bestell-Nr.: IV 01941

1907 Handels- und gewerbliche Angelegenheiten, Bd. 2

$1910-1913$

- Materialien zu verschiedenen Gewerbeausstellungen des In- und

Auslandes, 1910 - 1912

- Ausstellung zur Jahrhundertfeier der Freiheitskriege in Breslau, 1913

$1910-1913$

Klassifikation Teil B: 01942

Band: 2

Trägermaterial: Papier

Alte Reg.-Sig.: IV T1 26

Bestell-Nr.: IV 01942 
05

\subsection{3}

05.03.12

05.03.12.01

05.03.12.01.02
Stadtverwaltung

Aufgabenbereiche der Stadtverwaltung

Handels- und Gewerbeförderung

Wirtschaftsförderung

Gesetzliche Regelung von Handel und Gewerbe

Lfd. Nr. Titel

Laufzeit

1908 Vorschriften für beeidigte Auktionatoren

1899-1911

- Zulassung der Auktionatoren Schmidt und Meyer, 1899

- Ermittlungen gegen die Auktionatoren Schmidt und Meyer wegen

Unterschlagung von Stempelsteuer, Januar 1899

- Vorschriften für beeidigte Auktionatoren als Abdruck im Amtsblatt der Regierung zu Aurich, Juli 1902

- Zulassung der Auktionatoren J. Bergmann und P. de Vries in

Emden, 1905 - 1911

- Betriebsführung der Auktionatoren Schmidt und Meyer, 1908

- Verfügung des Regierungspräsidenten über Verbot des gemeinsamen Auktionatorenbetriebs der J. Bergmann und P. de

Vries, Oktober 1909

- Beschwerde der Emder Auktiionatoren Dieckmann und Woortmann gegen die weitere Berufsausübung des Auktionators Bergmann in Emden, Juni 1910

$1899-1910$

Klassifikation Teil B: 01943

Trägermaterial: Papier

Alte Reg.-Sig.: IV T1 27

Bestell-Nr.: IV 01943

1909 Abhaltung von Fleischauktionen an der städtischen Waage

1883-1902

- Votum der Marktkommission für die Abhaltung von Auktionen von

Schweinefleisch an der städtischen Waage, August 1883

- Beschluss des Magistrats über Verbot des Verkaufs von

Schweinefleisch im Gebäude der städtischen Waage, Juli 1883

- Bericht des Polizeisergeanten Schnur über Verkauf von verdorbenen

Schweineschinken durch den Schlachter Gerhard A. Hummerich an der Waage, August 1883

- Beschwerde des Schlachtermeisters Gerhard A. Hummerich gegen

Verkauf von Schweinefleisch an der Waage durch unorganisierte

Schlachter, Februar 1884

- Aufstellung über Fleischverkäufe an der Waage, Dezember 1883 -

Februar 1884 / 1887 - 1888

- Anzeige des Schlachtermeisters Diedrich A. Hummerich wegen verbotene Auktionen von Schweinefleisch in der Waage, Juni 1885

- Beschwerde der vereinigten Schlachter Emdens gegen

Fleischauktionen an der Waage, Februar - April 1888

- Beschwerde des Emder Detaillisten-Vereins gegen Versteigerungen von Lebensmittel an der Waage, November 1902

$1883-1902$

Klassifikation Teil B: 01952

Trägermaterial: Papier

Alte Reg.-Sig.: IV T1 37

Bestell-Nr.: IV 01952 
- Rescript des preußischen Landdrosten in Aurich an den Magistrat über nicht vorliegende Voraussetzung für einen Ministerialerlass wegen Regelung des Wanderlagerbetriebes in Zollgrenzbezirken, April 1888

- Ermittlungen gegen nicht versteuerte Wanderlager-Betriebe, Januar 1898 - September 1909

- Antrag des Emder Detaillisten-Vereins auf hohe Besteuerung einer Auktion von Manufakturwaren einer auswärtigen Firma, August 1900 - Initiative der Emder Gewerbevereine zur Begrenzung der Auktionen auswärtiger Waren, November 1902

- Verschiedene Anträge auf Genehmigung von Auktionen, Januar März 1912

$1888-1912$

Klassifikation Teil B: 01953

Trägermaterial: Papier Alte Reg.-Sig.: IV T1 35

Bestell-Nr.: IV 01953

- Vorlage: Gesetzentwurf über Bekämpfung des Wuchers durch

Einschränkung der Wechselfähigkeit, August 1880

- Stellungnahme des Oberbürgermeisters Fürbringer zum

Gesetzentwurf, September 1880

1880

Klassifikation Teil B: 01954

Trägermaterial: Papier

Alte Reg.-Sig.: IV T1 36

Bestell-Nr.: IV 01954 
IV

05

05.03

05.03.12

05.03.12.01

05.03.12.01.03

Lfd. $\mathrm{Nr}$ Titel
Stadtverwaltung

Aufgabenbereiche der Stadtverwaltung

Handels- und Gewerbeförderung

Wirtschaftsförderung

Bankwesen
Laufzeit

1896

- Konzept eines Schreibens des Oberbürgermeisters Leo Fürbringer an den Direktor der Reichsbankstelle Emden über Bitte um Rücknahme der geplanten Schließung der Reichsbankstelle, Dezember 1896

1896

Klassifikation Teil B: 00315

Trägermaterial: Papier

Alte Reg.-Sig.: II C 46

Bestell-Nr.: IV 00315

1913 Sparkassenbücher, Bd. 1

$1860-1871$

- Bilanzen der städtischen Sparkasse

(1861 - 1865) 1868 - 1871

Klassifikation Teil B: 01674

Band: 1

Trägermaterial: Papier

Alte Reg.-Sig.: IV Ra 03

Bestell-Nr.: IV 01674

1914 Sparkassenbücher, Bd. 2

1904-1913

- Bilanzen der städtischen Sparkasse

$1904-1913$

Klassifikation Teil B: 01675

Band: 2

Trägermaterial: Papier

Alte Reg.-Sig.: IV Ra 03

Bestell-Nr.: IV 01675

1915 Kreditzinsen und Schreibgebühren der städtischen Pfandleihkasse

- Regelungen hinsichtlich Schreibgebühren und Kreditzinsen für

Darlehen der städtischen Pfandleihkasse

(1855 - 1864) $1867-1917$

Klassifikation Teil B: 01676

Trägermaterial: Papier

Alte Reg.-Sig.: IV Ra 04

Bestell-Nr.: IV 01676 
IV

05

\subsection{3}

05.03.12

05.03.12.01

05.03.12.01.03
Stadtverwaltung

Aufgabenbereiche der Stadtverwaltung

Handels- und Gewerbeförderung

Wirtschaftsförderung

Bankwesen

Lfd. Nr. Titel

Laufzeit

1916 Kredite der städtischen Sparkasse an Genossenschaften

1898-1916

- Erlasse des preußischen Innenministers über Kriterien zur

Gewährung von Sparkassenkrediten an Genossenschaften, Januar

1898 / Oktober - November 1901

- Verfügung des Oberpräsidenten der Provinz Hannover über

Regelung der Kreditvergabe der Sparkassen an Genossenschaften, Juli 1898

- Diskussion der Gründung einer Hannoverschen komunalen

Pfandbriefanstalt, Deze,ber 1916

$1898-1916(1920)$

Klassifikation Teil B: 01677

Trägermaterial: Papier

Alte Reg.-Sig.: IV Ra 19

Bestell-Nr.: IV 01677

1917 Statuten und Satzungen der städtischen Sparkasse

- Statuten der städtischen Sparkasse, 1874

- Verhandlungen des Aufsichtsrates der Sparkasse mit dem Magistrat wegen Modernisierung der Sparkassensatzung, März - Oktober 1901 / Januar - November 1903

- Gedruckter Entwurf der Statuten der städtischen Sparkasse, 1901 /

1903

- Verfügung des Regierungspräsidenten über Anordnung zur

Anpassung der Sparkassensatzung an die im Erlass des Oberpräsidenten genannten Richtlinien, Oktober 1901 / Dezember 1901 / Februar 1902

- Monita des Regierungspräsidenten in Aurich zur Neufassung der Sparkassensatzung, Januar 1904

- Ablehnung des revidierten Sparkassenstatuts durch den

Oberpräsidenten der Provinz Hannover, August 1904 / April 1906

- Mustersatzung für die Sparkassen in der Provinz Hannover, 1904

$1874-1906$

Klassifikation Teil B: 01678

Trägermaterial: Papier

Alte Reg.-Sig.: IV Ra 05

Bestell-Nr.: IV 01678 
IV

05

\subsection{3}

05.03.12

05.03.12.01

05.03.12.01.03
Stadtverwaltung

Aufgabenbereiche der Stadtverwaltung

Handels- und Gewerbeförderung

Wirtschaftsförderung

Bankwesen

Lfd. Nr. Titel

Laufzeit

1918 Dispositionsfonds der Sparkasse

1871-1909

- Verhandlungen der städtischen Kollegien wegen Verwendung der Überschüsse der Sparkasse (Dispositionsfonds), Januar 1871 - Juli 1887

- Aufstellung der Überschüsse der Sparkasse, Januar - Juni 1871

- Anträge des Kämmerers auf Zuweisung der Überschüsse der Sparkasse an die Kämmereikasse, Februar 1871 - Januar 1904

- Erlass des preußischen Innenministers über Verwendung der Sparkassenüberschüsse, Juli 1902

$1871-1909$

Klassifikation Teil B: 01679

Trägermaterial: Papier

Alte Reg.-Sig.: IV Ra 14

Bestell-Nr.: IV 01679

1919 Sparkasse

$1881-1912$

- Erlasse des preußischen Innenministers und des Oberpräsidenten der Provinz Hannover zum Sparkassenwesen, 1881 - 1912

- Verfügungen des Regierungspräsidenten zum Sparkassenwesen, $1881-1910$

- Errichtung einer Sparkasse bei der Emder Genossenschaftsbank unter Förderung der Regierung in Aurich, 1886

- Stellungnahme des Sparkassenvorstands zum novellierten

Sparkassengesetz, Mai 1893 / Dezember 1895

$1881-1912$

Klassifikation Teil B: 01680

Trägermaterial: Papier

Alte Reg.-Sig.: IV Ra 14

Bestell-Nr.: IV 01680

1920 Bildung eines zentralen Geldinstituts der kommunalen preußischen Sparkassen

1901-1902

(1920)

- Projekt eines zentralen Geldinstituts der kommunalen preußischen Sparkassen

- Negative Stellungnahme des Vorstands der städtischen Sparkasse zum zentralen Geldinstitut der kommunalen preußischen Sparkassen, April 1901

$1901-1902$

Klassifikation Teil B: 01681

Trägermaterial: Papier

Alte Reg.-Sig.: IV Ra 18

Bestell-Nr.: IV 01681 
IV

05

\subsection{3}

05.03.12

05.03.12.01

05.03.12.01.03
Stadtverwaltung

Aufgabenbereiche der Stadtverwaltung

Handels- und Gewerbeförderung

Wirtschaftsförderung

Bankwesen

Lfd. Nr. Titel

Laufzeit

1921 Spar- und Darlehenskassen

1895-1904

- Allgemeine Ministerialerlasse und Verfügungen zum

Genossenschaftsbankwesen

- Denkschrift: Das Scherl'sche Prämiensparen

$1895-1904$

Klassifikation Teil B: 01682

Trägermaterial: Papier

Alte Reg.-Sig.: IV Rd 5

Bestell-Nr.: IV 01682

1922 Dienstgebäude für die Reichsbankstelle

1876-1904

- Verhandlungen zwischen der Reichbank und der Stadt Emden wegen Vermietung eines städtischen Gebäudes zur Aufrechterhaltung der Emder Reichsbankfiliale, Mai - August 1876

- Erwerb eines Grundstücks für das neue Dienstgebäude der

Reichsbankstelle Emden, Juni 1887

- Verlängerung des Mietvertrages über Räume im Rathaus zwischen

der Reichsbank und der Stadt Emden, April - August 1896

- Widerstand gegen den Bau eines Reichsbankgebäudes am

Stadtgarten, Mai - Juni 1896

- Erwerb eines Grundstückes an der Schweckendieckstraße zur

Errichtung eines neuen Dienstgebäudes für die Reichsbankfiliale

Emden, Januar - April 1904

$1876-1904$

Klassifikation Teil B: 02035

Trägermaterial: Papier

Alte Reg.-Sig.: IV T6 089

Bestell-Nr.: IV 02035

1923 Geschäftsberichte Emder Banken

- Geschäftsbericht der Emder Gewerbebank, 1902

- Geschäftsbericht der Emder Bank AG

1902

Klassifikation Teil B: 02143

Trägermaterial: Papier

Alte Reg.-Sig.: IV T6 189

Bestell-Nr.: IV 02143 
IV

05

05.03

05.03.12

05.03.12.02

05.03.12.02.01

Stadtverwaltung

Aufgabenbereiche der Stadtverwaltung

Handels- und Gewerbeförderung

Förderung des Handwerks

Organisiertes Handwerk

Lfd. Nr. Titel

Laufzeit

1924 Gewerbehalle

1866-1903

- Neuwahl des Vorstands des Vereins der Gewerbehalle zu Emden, Januar 1872

- Nominierung des städtischen Vertreters im Verwaltungsrat der

Gewerbehalle, 1872 - 1900

- Statistische Übersicht über Betrieb der Gewerbehalle, März 1876

- Anzeige gegen den Geschäftsführer der Gewerbehalle, Heinrich

Ziegler, wegen Unterschlagung, November 1876

- Beschwerde verschiedener Tischler gegen den Geschäftsführer der

Gewerbehalle wegen Wirtschaften in eigener Tasche, Juli 1878

- Ablehnung einer Nutzung von Räumen der Gewerbehalle zu

Schulzwecken durch den Verwaltungsrat des Vereins für die

Gewerbehalle, Dezember 1880

- Bericht über wirtschaftliche Krise der Halle, Februar 1881

- Antrag verschiedener Handwerker auf Übernahme der Gewerbehalle

durch die Stadt Emden, März 1881

- Verlegung einer Klasse der städtischen Volksschule in die

Gewerbehalle, Mai 1881

- Liquidation des Vereins der Gewerbehalle wegen Unwirtschaftlichkeit

der Gewerbehalle, 1903

$1872-1903$

Klassifikation Teil B: 00635

Trägermaterial: Papier

Alte Reg.-Sig.: IV Fi 005

Bestell-Nr.: IV 00635

1925 Verkauf von Eiern nach Gewicht

$1880-1904$

- Diskussion einer Verordnung zur Regelung und Erlaubnis des

Verkaufs von Eiern u.a. Lebensmittel nach Gewicht, 1880 - 1904

- Ergänzung der Wochenmarktsordnung der Stadt Emden über

Verkauf von Kartoffeln und grüne Bohnen nach Gewicht, 1881

$1880-1904$

Klassifikation Teil B: 01944

Trägermaterial: Papier

Alte Reg.-Sig.: IV T1 29

Bestell-Nr.: IV 01944 
IV

05

\subsection{3}

05.03.12

05.03.12.02

05.03.12.02.01
Stadtverwaltung

Aufgabenbereiche der Stadtverwaltung

Handels- und Gewerbeförderung

Förderung des Handwerks

Organisiertes Handwerk

Lfd. Nr. Titel

Laufzeit

1926 Organisation des Handwerks

1893-1912

- Vorschläge des Ministers für Handel und Gewerbe zur Organisation des Handwerks, August 1893

- Stellungnahme verschiedener Handwerkerorganisationen in Emden zu den Vorschlägen des Ministers, Oktober - November 1893

- Diskussion des geplanten Innungs- und Handwerksgesetzes in der

Presse, 1897

- Diskussion einer gesetzlichen Regulierung der pro Betrien

zulässigen Lehrlingszahl, 1899

- Diskussion eines Projektes des Pastors Bode aus Egestorf über

Schaffung einer Genossenschaftskreditkasse für das Handwerk, 1897

- Verhandlungen des 10. Deutschen Handwerker- und

Gewerbekammertages, August 1909

- Gründung eines Nordwestdeutschen Handwerkerbundes, 1912

$1893-1912$

Klassifikation Teil B: 01955

Trägermaterial: Papier

Alte Reg.-Sig.: IV T1 40

Bestell-Nr.: IV 01955

1927 Kupferschmiedezunft

- Konstituierung des Vorstands der Kupferschmiedezunft, Januar Juni 1872

- Verkauf des Gildehauses der Kupferschmiedezunft, 1870

$1870-1872$

Klassifikation Teil B: 01956

Trägermaterial: Papier

Alte Reg.-Sig.: IV T2 45

Bestell-Nr.: IV 01956

1928 Fuhrmanns-Sachen

1880-1894

- Anträge verschiedener Fuhrmänner auf Aufnahme in die

Fuhrmannsgilde nach dem Erwerb einer Fuhrmannschaft

$1880-18891$

Klassifikation Teil B: 02013

Trägermaterial: Papier

Alte Reg.-Sig.: IV T6 021

Bestell-Nr.: IV 02013 
05

05.03

05.03 .12

05.03.12.02

05.03.12.02.01

Lfd. Nr. Titel
IV

Stadtverwaltung

Aufgabenbereiche der Stadtverwaltung

Handels- und Gewerbeförderung

Förderung des Handwerks

Organisiertes Handwerk

1929 Fuhrmannsgilde

Laufzeit

- Rückständige Gildegebühren des Fuhrmanns Wilke Roelf Steen,

Oktober 1866 - März 1867

- Geldstrafe gegen den Fuhrmann Jan Wübben wegen Trunkenheit im

Dienst, Februar 1867

- Geldstrafen gegen Fuhrleute wegen Verstoß gegen die Gildestatuten wegen Einsatz von zwei Gespannen zur gleichen Zeit, April 1867 -

Februar 1868

- Beschwerden wegen Umgehung des Dienstes der Fuhrleutegilde, 1867

- Geldstrafen wegen ordnungswidrigen Aufstellens von Fuhrwerken, Juni 1868

- Geldstrafen wegen Verstöße gegen die Gildestatuten, 1870 - 1888

$1866-1888$

Klassifikation Teil B: 02018

Trägermaterial: Papier

Alte Reg.-Sig.: IV T6 041

Bestell-Nr.: IV 02018 
IV

05

05.03

05.03.12

05.03.12.02

05.03.12.02.01
Stadtverwaltung

Aufgabenbereiche der Stadtverwaltung

Handels- und Gewerbeförderung

Förderung des Handwerks

Organisiertes Handwerk

Lfd. Nr. Titel

Laufzeit

1930 Fuhrleute-Ordnung

1866-1913

- Konflikt um die in einer Denkschrift des Syndicus Metger verfochtene Aufhebung des Monopols der Fuhrmannsgilde wegen Widerspruchs zu den Bestimmmungen des Gewerbegesetzes, August 1866 - Juni 1867

- Beauftragung des Obergerichtsanwalts Vissering in Aurich mit der Abfassung eines Gutachtens über die Zulässigkeit des Monopols der Fuhrmannsgilde, November 1868 - Januar 1869

- Neufestlegung der Fuhrtaxen in Emden, Dezember 1867 - Juni 1901

/ Mai 1913

- Streit zwischen der Fuhrmannsgilde und der Kornmessergilde wegen Begrenzung der jeweiligen Tätigkeitsfelder, Februar 1869

- Übersicht über Besitzer von Fuhrmannschaften, Mai 1870

- Einsetzung eines städtischen Kommissars über das

Fuhrmannswesen, 1872 - 1877

- Anträge auf Löschung von hypothekarischen Schulden auf

Fuhrmannschaften, 1878 - 1879

- Festlegung der Fuhrtaxe von der Altstadt nach Nesserland und dem Anschluss der Küstenbahn, September 1884 - Mai 1895

- Streit des Kaufmanns J. Smidt mit der Fuhrmannsgilde wegen der Höhe des Fuhrlohns für den Transport seines Getreides, Juli - August 1894

- Fuhrmannschaft als pfändbarer Besitztitel: Fall Fuhrmann H. Störk, Januar - März 1899

- Erlass des Innenministers über Einführung der

Kennzeichnungspflicht von Fuhrwerken zur Bekämpfung des

Zigeuner-Unwesens, März 1901

- Verfügungen des Regierungspräsidenten in Aurich zum

Fuhrmannswesen, 1901 - 1902

- Polizeiverordnungen wegen Sicherheitseinrichtungen bei

Fuhrwerken (Beleuchtung), 1901 - 1909

$1866-1913$

Klassifikation Teil B: 02039

Trägermaterial: Papier

Alte Reg.-Sig.: IV T6 099

Bestell-Nr.: IV 02039

1931 Änderung der Gewerbeordnung

1894-1896

- Umsetzung des Gesetzes über die Änderung der Gewerbeordnung auf Reichs- und kommunaler Ebene durch Reform der Handwerksordnungen

$1894-1896$

Klassifikation Teil B: 02226

Trägermaterial: Papier

Alte Reg.-Sig.: IV T13 01

Bestell-Nr.: IV 02226 
IV

05

05.03

05.03.12

05.03.12.02

05.03.12.02.01

Stadtverwaltung

Aufgabenbereiche der Stadtverwaltung

Handels- und Gewerbeförderung

Förderung des Handwerks

Organisiertes Handwerk

Lfd. Nr. Titel

Laufzeit

1932 Maler-Innung

1873-1889

- Antrag der neugegründeten Maler-Innung für Emden und Umgegend an den Magistrat auf Genehmigung der Statuten, August - Oktober

1879

- Statuten der Maler-Innenug, 1879

- Werbung des Bundes Deutscher Glaserinnungen für den Deutschen

Glaser-Tag in Hannover, August 1882

- Bericht des Polizeisergeanten Deters über Struktur der

Maler-Innung, Juli 1887

- Selbstauflösung der Maler-Innung, August - September 1887 / April Juli 1889

- Wiederaufrichtung der Maler-Innung nach dem Reichsgesetz über die Gewerbeordnung von 1881, Oktober 1887

- Anpassung der Statuten der Maler-Innung an die Vorgaben der

Gewerbeordnung von 1881, März 1888

$1879-1889$

Klassifikation Teil B: 02227

Trägermaterial: Papier

Alte Reg.-Sig.: IV T13 02

Bestell-Nr.: IV 02227

1933 Schuhmacher-Innung

$1879-1892$

- Gründung einer Schuhmacher-Innung in Emden, Februar 1879

- Statuten der Schuhmacher-Innung für Stadt und Amt Emden, 1879 /

1885

- Monita des Regierungspräsidenten in Aurich wegen der

Statutenänderung der Schuhmacher-Innung, Juni 1885

- Antrag der Schuhmacher-Innung beim Regierungspräsidenten auf

Verleihung des Rechts zur Regelung der Lehrlingsausbildung,

Oktober 1887 - Oktober 1891

- Statuten der Witwenunterstützungskasse der Schuhmacher-Innung,

Juli 1889

- Entwicklung der Mitgliederzahlen der Innung, 1889 - 1891

- Vorstand der Schuhmacher-Innung, 1892

$1879-1892$

Klassifikation Teil B: 02228

Trägermaterial: Papier

Alte Reg.-Sig.: IV T13 04

Bestell-Nr.: IV 02228 
IV

05

05.03

05.03.12

05.03.12.02

05.03.12.02.01
Stadtverwaltung

Aufgabenbereiche der Stadtverwaltung

Handels- und Gewerbeförderung

Förderung des Handwerks

Organisiertes Handwerk

Lfd. Nr. Titel

Laufzeit

1934 Kleidermacher-Innung

1879-1889

- Gründung der Kleidermacher-Innung für Emden, 1879

- Statuten der Kleidermacher-Innung, 1880

- Verfügung des Regierungspräsidenten in Aurich über Auflösung der Kleidermacher-Innung wegen verweigerter Anpassung der Statuten an die novellierte Gewerbeordnung, März 1889

$1879-1889$

Klassifikation Teil B: 02229

Trägermaterial: Papier

Alte Reg.-Sig.: IV T13 05

Bestell-Nr.: IV 02229

1935 Barbier-Innung

1880

- Statuten der Barbier-Innung

1880

Klassifikation Teil B: 02230

Trägermaterial: Papier

Alte Reg.-Sig.: IV T13 06

Bestell-Nr.: IV 02230

1936 Innungswesen

$1880-1890$

- Anfrage des Magistrats an andere Städte über Stand der

Wiederbelebung des Innungswesens, Februar - März 1880

- Verhandlungen im Reichstag zur Reform des Innungswesens, 1880

- Nachricht des Regierungspräsidenten in Aurich über

Statutengenehmigungen für Handwerkerdachverbände, April 1887 /

August 1888

$1880-1890$

Klassifikation Teil B: 02231

Trägermaterial: Papier

Alte Reg.-Sig.: IV T13 07

Bestell-Nr.: IV 02231

1937 Schlosser- und Schmiedeinnung

$1885-1891$

- Gründung der Schlosser- und Schmiedeinnung, Mai 1885

- Statuten der Schlosser- und Schmiedeinnung, 1885

- Wahl des Vorstandes der Schlosser- und Schmiedeinnung, Februar

1886 / Januar 1888 / April 1891

- Statut der Sterbekasse der Schlosser- und Schmiedeinnung, Mai

1888

$1885-1891$

Klassifikation Teil B: 02232

Trägermaterial: Papier

Alte Reg.-Sig.: IV T13 07

Bestell-Nr.: IV 02232 
IV

05

05.03

05.03.12

05.03.12.02

05.03.12.02.02

05.03.12.02.02.01
Stadtverwaltung

Aufgabenbereiche der Stadtverwaltung

Handels- und Gewerbeförderung

Förderung des Handwerks

Gewerbliche Konzessionen

Freies Gewerbe

Lfd. Nr. Titel

Laufzeit

1938 Streit um die Anlage einer Schlachterei in der Großen Straße

- Klage des Schlachters Nathan M. Karßeboom gegen die Stadt Emden beim preußischen Landdrosten in Aurich wegen Verweigerung der Genehmigung des Betriebs einer Schlachterei im Anbau des Hauses Große Straße 40, Mai - Juli 1878

1878

Klassifikation Teil B: 00165

Trägermaterial: Papier

Bestell-Nr.: IV 00165

1939 Konzessionierung von Gewerbebetrieben

1902

- Erlaubnis für den Kaufmann Adolph Kampe in Wolthusen zum

Verkauf von Alkohol in Flaschen

1902

Klassifikation Teil B: 00469

Trägermaterial: Papier

Vorprovenienz: Landkreis Emden

Bestell-Nr.: IV 00469

1940 Konzessionierung von Gewerbebetrieben

1909

- Erlaubnis für den "Club zum Guten Endzweck" zum Betrieb einer Schankwirtschaft im Clubgebäude

1909

Klassifikation Teil B: 00470

Trägermaterial: Papier

Alte Reg.-Sig.: IV Eb 12

Bestell-Nr.: IV 00470

1941 Konzessionierung von Gewerbebetrieben

- Erlaubnis für Wilko Folts und Carl van Dyken zum Betrieb einer Kantine am Zungenkai in der Gemeinde Borssum

1900

Klassifikation Teil B: 00471

Trägermaterial: Papier

Vorprovenienz: Landkreis Emden

Bestell-Nr.: IV 00471 
IV

05

05.03

05.03.12

05.03.12.02

05.03.12.02.02

05.03.12.02.02.01
Stadtverwaltung

Aufgabenbereiche der Stadtverwaltung

Handels- und Gewerbeförderung

Förderung des Handwerks

Gewerbliche Konzessionen

Freies Gewerbe

Lfd. Nr. Titel

Laufzeit

1942 Konzessionierung von Gewerbebetrieben

1892-1893

- Nach Verfügung des Regierungspräsidenten in Aurich erfolgte gutachterliche Entscheidung des Stadtausschusses des Stadtkreises Emden im Streit um den Antrag des Gastwirts A.H. Schröder auf Konzessionierung seiner Gaststätte "Ratskeller" im neuen Rathaus zu Leer, 1892 - 1893

$1892-1893$

Klassifikation Teil B: 00472

Trägermaterial: Papier

Alte Reg.-Sig.: IV Ba 53

Bestell-Nr.: IV 00472

1943 Fuhrmannschaft

1880-1894

- Zulassung des Landgebräuchers Wilm Eilers als Fuhrmann nach dem Kauf der Fuhrmannsstelle des verstorbenen Fuhrmanns Roelf de Wall, Januar 1894

- Besetzung freigewordener Fuhrmannsstellen, 1880 - 1891

$1880-1894$

Klassifikation Teil B: 00877

Trägermaterial: Papier

Alte Reg.-Sig.: IV T6 021

Bestell-Nr.: IV 00877

1944 Kunstdrechsler-Gewerbe

1866

(1853-1864)

- Gesuche verschiedener Handwerker über Bitte um Zulassung zur

Ausübung des Kunstdrechsler-Handwerks

$(1852-1864) 1866$

Klassifikation Teil B: 01957

Trägermaterial: Papier

Alte Reg.-Sig.: IV T3 14

Bestell-Nr.: IV 01957

1945 Steinhauergewerbe

1866-1867

- Gesuch des G. Neerbeck um Zulassung zur Ausübung des

Steinhauerhandwerks, 1851

- Beschwerde der Witwe Neerbeck und des Steinhauers W. P. Thielke gegen die Zulassung des J. W. Niehaus als Steinhauer wegen mangelhafter Auftragslage, Dezember 1866 - Januar 1867

(1851) 1866 - 1867

Klassifikation Teil B: 01958

Trägermaterial: Papier

Alte Reg.-Sig.: IV T3 15

Bestell-Nr.: IV 01958 
IV

05

05.03

05.03.12

05.03.12.02

05.03.12.02.02

05.03.12.02.02.01
Stadtverwaltung

Aufgabenbereiche der Stadtverwaltung

Handels- und Gewerbeförderung

Förderung des Handwerks

Gewerbliche Konzessionen

Freies Gewerbe

Lfd. Nr. Titel

Laufzeit

1946 Betrieb einer Verkaufsbude auf dem Rathausplatz

- Antrag der Händler Thomas Mustert, H. L. Hennings und Franz Heyl

1868-1897

(1852-1859) auf Entfernung der hölzernen Verkaufsbude vor dem Rathaus, Februar 1856

- Verhandlungen der städtischen Kollegien über Verpachtung eines städtischen Geländes auf dem Rathausplatz zum Betrieb einer Verkaufsbude, April 1856 / Januar - Februar 1873

- Verbot des Verkaufs von Süßigkeiten an Gasthauskinder durch die Verkaufsbudenbetreiber Berend Wilken und Peter Boerheide, Mai 1857 / Juni 1859

- Antrag des Berend Wilken auf Erlaubnis zum Verkauf von Bier und Milchgetränken in der Verkaufsbude, Januar - Februar 1858

- Gesuch des Peter Boerheide um Übernahme der Pachtung des städtischen Geländes mit der Verkaufsbude auf dem Rathausplatz von seinem verstorbenen Stiefvater Berend Wilken, Mai 1859 - Übernahme der Pachtung des verstorbenen P. Boerheide durch seine Mutter, März 1868

- Votum verschiedener Bürger für den Erhalt der Verkaufsbude auf dem Rathausplatz, Oktober - November 1872

- Gesuch des Fruchthändlers Reinder Huismann um Übernahme des Verkaufsbude seiner verstorbenen Tante, der Witwe des Berend Wilken, Februar 1876

- Berechnung der Pachtgelder für die Verkaufsbude auf städtischem

Gelände am Rathaus (Rathausplatz), 1878 - 1895

- Pachtgebote des Reindert Huismann, 1877 - 1882

- Verpachtung des Geländes mit der Verkaufsbude an die

Gemüsehandelsfirma S. J. Italjener \& Sohn, 1883 - 1898

- Antrag der Firma S. Italjener \& Sohn auf Vergrößerung der

Verkaufsbude, März 1883 / August 1889

- Votum der Bau-Commission für Abriss der Verkaufsbude wegen Neugestaltung des Stadtgartens und Verbesserung der Ästhetik, Juni 1896

- Neubau der Verkaufsbude auf dem "Landje" am Rathaus, 1896 1897

(1852 - 1859) 1868 - 1896

Klassifikation Teil B: 01959

Trägermaterial: Papier

Alte Reg.-Sig.: IV T5 19

Bestell-Nr.: IV 01959 
IV

05

05.03

05.03.12

05.03.12.02

05.03.12.02.02

05.03.12.02.02.01
Stadtverwaltung

Aufgabenbereiche der Stadtverwaltung

Handels- und Gewerbeförderung

Förderung des Handwerks

Gewerbliche Konzessionen

Freies Gewerbe

Lfd. Nr. Titel

Laufzeit

1947 Dienstmannswesen

1872-1918

(1864)

- Mitteilung über Regulierung des Dienstmanns - Betriebs in

Osnabrück, 1864

- Konzessionierung des Dienstmanns-Instituts des C.A.G. Brauwer, 1864

- Anfrage der Stadt Emden wegen Datenerhebung zum

Dienstmannswesen in anderen Städten der Provinz Hannover, 1872

- Beschwerden über bissige Hunde der Dienstmänner Peter

Koningshoff und Jacobus Bronjes, November 1878

- Antrag der Fuhrleute-Gilde auf Entfernung der Dienstmänner vom

Platz vor der Börse wegen unzulässiger Konkurrenz, Mai 1880

- Beschwerden gegen Dienstmänner wegen überhöhter

Transporttarife und Verlust von Gepäckstücken, 1882

- Zulassungen zum Dienstmänner-Gewerbe, 1882 - 1911

- Inkraftsetzung der Polizeiverordnung der Stadt Emden über

Regulierung des Gewerbetriebs der Dienstmänner, Juli - August 1883

- Verfügung des Magistrats über Verhaltensmaßregel für die vor der

Börse und der oberen Rathausbrücke stationierten Dienstmänner, April 1887

- Entzug der Zulassung des Dienstmannes Daniel Duif wegen fehlender Kaution, 1891

- Nichtzulassung des jüdischen Schlachters Gossel Gossels als

Dienstmann wegen unhygienischem Lebenswandel und

Geistesschwäche, September 1892

- Beschwerde gegen die Assistierung des Dienstmanns Bronjes durch seinen Sohn wegen Verstoßes gegen die Zulassungsauflagen des

Magistrats, Mai - Juni 1895

- Modifikation der Polizeiverordnung über die Dienstmänner über

Begrenzung der Standzeiten am Bahnhof, März 1918

(1864) $1872-1918$

Klassifikation Teil B: 01960

Trägermaterial: Papier

Alte Reg.-Sig.: IV T5 21

Bestell-Nr.: IV 01960

1948 Ausübung des Viehverschnitts

- Verfügung des preußischen Landdrosten in Aurich über

Prüfungsordnung für Viehverschneider (Kastrationen)

1867

Klassifikation Teil B: 01961

Trägermaterial: Papier

Alte Reg.-Sig.: IV T5 22

Bestell-Nr.: IV 01961 
IV

05

05.03

05.03.12

05.03.12.02

05.03.12.02.02

05.03.12.02.02.01
Stadtverwaltung

Aufgabenbereiche der Stadtverwaltung

Handels- und Gewerbeförderung

Förderung des Handwerks

Gewerbliche Konzessionen

Freies Gewerbe

Lfd. Nr. Titel

Laufzeit

1949 Zulassung zum Handel mit Spirituosen, Bd. 1

1869

- Zulassung des Kräutners J.M. Luiken zum Kleinhandel mit

Spirituosen

1869

Klassifikation Teil B: 01962

Band: 1

Trägermaterial: Papier

Alte Reg.-Sig.: IV T5 23

Bestell-Nr.: IV 01962

1950 Zulassung zum Handel mit Spirituosen, Bd. 2

1866-1886

- Zulassung des Agenten B. A. G. Ruyter und seiner Söhne zum

(1856-1857)

Spirituosenhandel

(1856 - 1857) 1877 - 1886

Klassifikation Teil B: 01962

Band: 2

Trägermaterial: Papier

Alte Reg.-Sig.: IV T5 23

Bestell-Nr.: IV 01963

1951 Ausübung des Hufbeschlagsgewerbes

$1887-1891$

- Anordnung des Regierungspräsidenten in Aurich über kostenlose Inserierung der Prüfungsordnung für Hufschmiede in den

Kreisblättern, 1888 - 1891

- Erlass des Ministers für Handel und Gewerbe über

Zulassungskriterien für Hufschmiede, Februar 1891

$1888-1891$

Klassifikation Teil B: 01964

Trägermaterial: Papier

Alte Reg.-Sig.: IV T5 26

Bestell-Nr.: IV 01964

1952 Ergebnisse des Motorbootsbetriebs

$1907-1918$

- Einnahmen aus dem Motorbootbetrieb, 1903 - 1916

- Jahresbericht der Firma Gebrüder Körting als Betreiberin des

Motorbootsbetriebs, 1902

- Bilanz des Motorbootsbetriebs, 1902 - 1913

- Monatliche Übersichten über Betriebseinnahmen, 1903 - 1914

- Fahrplan der Motorbootslinie im Emder Binnenhafen, 1913

$1903-1918$

Klassifikation Teil B: 01999

Trägermaterial: Papier

Alte Reg.-Sig.: IV T5 46

Bestell-Nr.: IV 01999 
IV

05

05.03

05.03.12

05.03.12.02

05.03.12.02.02

05.03.12.02.02.02
Stadtverwaltung

Aufgabenbereiche der Stadtverwaltung

Handels- und Gewerbeförderung

Förderung des Handwerks

Gewerbliche Konzessionen

Straßenbahnbetrieb

Lfd. Nr. Titel

Laufzeit

1953 Bau einer Pferdebahn vom Bahnhof nach Nesserland, Bd. 1

1883-1884

- Zeichnung der Wagenremise und der Stallungen der Pferdebahn, 1883

- Zeichnung der Bahntrasse, 1883

- Vertrag zwischen der Stadt Emden und dem Bäckermeister R. R.

Poppinga über Anlage und Betrieb einer Pferdebahn vom Bahnhof nach Nesserland (Außenhafen), Oktober 1883

- Antrag des Bäckermeisters R. R. Poppinga auf Verleihung des

Grundstücks für die Wagenremise in Erbpacht und auf Genehmigung

zum Einbau zweier Wohnungen in der Remise, Januar 1884

- Antrag des Bäckermeisters R. R. Poppinga auf Erlaubnis des

Betriebes der Bahn mit Lokomotiven, Februar 1884

- Festlegung der Streckenführung der Pferdebahn vom Lotsenturm bis zur Nesserlander Schleuse, Februar 1884

- Genehmigungsverfahren der Stadt Emden und des kgl,

Eisenbahnbetriebsamts zur Anlage der Pferdebahn, Januar - April

1884

- Polizeiverordnung der Stadt Emden über Betrieb der Pferdebahn, 1884

- Stellung einer Bürgschaft für ein Darlehen der Stadt Emden an den

Pferdebahnbetreiber, März 1884

$1883-1884$

Klassifikation Teil B: 01965

Band: 1

Trägermaterial: Papier

Alte Reg.-Sig.: IV T5 27

Bestell-Nr.: IV 01965

1954 Bau einer Pferdebahn vom Bahnhof nach Nesserland, Bd. 2

- Verhandlungen der städtischen Kollegien wegen der vom Magistrat angestrebten Klageerhebung gegen den Bahnbetreiber R. R.

Poippinga wegen Verletzung des Vertrages über Anlage einer

Pferdebahn vom Bahnhof nach Nesserland durch Nichtvorlage genügender Planzeichnungen, Juli - Oktober 1885

- Klage der Stadt Emden gegen den Bäckermeister R. R. Poppinga beim Landgericht in Aurich auf Schadensersatz wegen

Vertragsverletzung, Februar - Oktober 1886

- Revisionsklage der Stadt Emden gegen das Urteil des Landgerichts Aurich beim Oberlandesgericht Celle, 1887

- Gutachten des Anwalts Dr. Gustav Meyer wegen Erfolgsaussichten der Revisionsklage, Januar - Februar 1887

- Revisionsklage der Stadt Emden gegen das Urteil des

Oberlandesgerichts Celle beim Reichsgericht Berlin, Juni - Juli 1887

$1885-1887$

Klassifikation Teil B: 01966

Band: 2

Trägermaterial: Papier

Alte Reg.-Sig.: IV T5 27

Bestell-Nr.: IV 01966 
IV

05

05.03

05.03.12

05.03.12.02

05.03.12.02.02

05.03.12.02.02.02
Stadtverwaltung

Aufgabenbereiche der Stadtverwaltung

Handels- und Gewerbeförderung

Förderung des Handwerks

Gewerbliche Konzessionen

Straßenbahnbetrieb

Lfd. Nr. Titel

Laufzeit

1955 Bau einer Pferdebahn vom Bahnhof nach Nesserland, Bd. 3

1884-1889

- Streit zwischen der Stadt Emden und dem Pferdebahnbetreiber R. R. Poppinga wegen Zinsforderungen der Stadt aus einem Darlehen von 20.000 Mark, Oktober 1884 - April 1894

- Besichtigung der Pferdebahn durch die als Schiedsrichter in dem Vertragsstreit zwischen der Stadt Emden und dem

Pferdebahnbetreiber R. R. Poppinga fungierenden Landgerichtsrat Siemens, Wasserbauinspektor Suadicani und Deichrichter Freerksen, Februar 1885

- Klage der Stadt Emden gegen den Bauunternehmer K. J. de Vries als Bürge für R. R. Poppinga beim Landgericht Aurich auf Zahlung der ausstehenden Zinsen des Darlehens an Janssen, Januar 1885 Januar 1899

$1884-1899$

Klassifikation Teil B: 01967

Band: 3

Trägermaterial: Papier

Alte Reg.-Sig.: IV T5 27

Bestell-Nr.: IV 01967

1956 Bau einer Pferdebahn vom Bahnhof nach Nesserland, Bd. 4

- Ansprüche der Stadt Emden an die Konkursmasse des R. R.

Poppinga, 1892 - 1895

- Korrespondenz des Pferdebahnbetreibers R. R. Poppinga mit

Oberbürgermeister Fürbringer wegen Abwicklung des

Genehmigungsverfahrens, November 1883

- Gedruckter Betriebs- und Konzessionierungsvertrag für die

Pferdebahn vom Bahnhof nach Nesserland, Oktober 1883

- Sachstandsinformation zum Streit zwischen R. R. Poppinga und der Stadt Emden an den als Vorsitzenden des Schiedsgerichts zwischen den Streitparteien fungierenden Leeraner Bürgermeister Diekmann, Dezember 1890

- Prozessunterlagen zur Klage der Stadt Emden gegen R. R. Poppinga auf Schadensersatz wegen Vertragsverletzung, Dezember 1890 - März 1891

- Schiedsgerichtsverfahren im Vertragsstreit zwischen der Stadt

Emden und R. R. Poppinga, Juni 1891 - Februar 1892

- Gutachten des Direktors der Hagener Straßenbahn von Stulpnagel und des Vorsitzenden des Georgs-Marien Bergwerks- und Hüttenvereins, Haarmann, über Zustand der Pferdebahn, Juli 1885

$1891-1895$

Klassifikation Teil B: 01968

Band: 4

Trägermaterial: Papier

Alte Reg.-Sig.: IV T5 27

Bestell-Nr.: IV 01968 
IV

05

\subsection{3}

05.03.12

05.03.12.02

05.03.12.02.02

05.03.12.02.02.02
Stadtverwaltung

Aufgabenbereiche der Stadtverwaltung

Handels- und Gewerbeförderung

Förderung des Handwerks

Gewerbliche Konzessionen

Straßenbahnbetrieb

Lfd. Nr. Titel

Laufzeit

1957 Anlage einer elektrischen Kleinbahn (Straßenbahn), Bd. 1

- Verhandlungen des Magistrats mit der Phoebus Elektrizitäts AG wegen Anlage einer elektrischen Kleinbahn (Straßenbahn), Oktober 1900 - Februar 1901

- Verschiedene Eingaben an den Magistrat wegen der Linienführung der geplanten elektrischen Kleinbahn, 1901

- Preesseberichte und abgedruckte Leserbriefe zum Kleinbahnprojekt, 1901

- Material aus anderen Städten zu elektrischen Kleinbahnen, 1901

- Verschiedene Prospekte und Musteraufnahmen von Straßenbahnen, 1901

- Kostenvoranschlag der Firma Siemens \& Halske über Anlage einer elektrischen Kleinbahn in Emden, Dezember 1900

- Verhandlungen des Magistrats mit der Firma Siemens \& Halske wegen Anlage einer elektrischen Kleinbahn, November - Dezember 1900

$1900-1901$

Klassifikation Teil B: 01969

Band: 1

Trägermaterial: Papier

Alte Reg.-Sig.: IV T5 25

Bestell-Nr.: IV 01969

1958 Anlage einer elektrischen Kleinbahn (Straßenbahn), Bd. 2

$1900-1901$

- Festlegung der Verhandlungslinie des Magistrats wegen Anlage einer elektrischen Kleinbahn, April - Dezember 1900

- Angebote verschiedener Firmen wegen Anlage einer elektrischen Kleinbahn, Oktober 1900 - März 1901

- Protokoll einer Konferenz in Emden mit Teilnehmern aus dem Ministerium der öffentlichen Arbeiten, dem Regierungspräsidium, Eisenbahnverwaltung, Magistrat und Bürgervorsteherkollegium über Realisierung und Finanzierung des Straßenbahnprojektes, Dezember 1900

$1900-1901$

Klassifikation Teil B: 01970

Band: 2

Trägermaterial: Papier

Alte Reg.-Sig.: IV T5 25

Bestell-Nr.: IV 01970
1900-1901 
IV

05

\subsection{3}

05.03.12

05.03.12.02

05.03.12.02.02

05.03.12.02.02.02
Stadtverwaltung

Aufgabenbereiche der Stadtverwaltung

Handels- und Gewerbeförderung

Förderung des Handwerks

Gewerbliche Konzessionen

Straßenbahnbetrieb

Lfd. Nr. Titel

Laufzeit

1959 Elektrische Kleinbahnen in anderen Städten

1900

- Material zu elektrischen Kleinbahnen (Straßenbahnen) in anderen

Städten Deutschlands und Österreichs: Betriebskosten, Aufbau,

Elektrizitätsversorgung

1900

Klassifikation Teil B: 01971

Trägermaterial: Papier

Alte Reg.-Sig.: IV T5 29

Bestell-Nr.: IV 01971

1960 Betrieb der elektrischen Kleinbahn (Straßenbahn), Bd. 1

1902-1905

- Rentabilitätsberechnung für die elektrische Kleinbahn Emden,

November - Dezember 1902

- Kapitalerhöhungen bei der Emder elektrischen Kleinbahn, Dezember

1902 - Oktober 1903

- Bericht der Firma Gebrüder Körting als Betreiberin der Emder

elektrischen Kleinbahn über Anschaffungen für die Straßenbahn,

Dezember 1902

- Verhandlungen des Magistrats mit dem Regierungspräsidenten in

Aurich und dem Landesdirektorium der Provinz Hannover wegen

Darlehen für die Anschaffung eines weiteren Triebwagens und den

Bau einer Waggonhalle für die elektrische Kleinbahn, Dezember 1902

- Dezember 1903

- Vergrößerung des Finanzierungsbedarf wegen notwendiger

Verlegung der geplanten Waggonhalle, Februar 1903

- Beschluss der Kommission für die elektrische Kleinbahn über

Anschaffung des vierten Triebwagens und Bau eines

Waggonschuppens, März 1903 / Oktober 1903

- Planzeichnung des Triebwagens, 1903

- Planzeichnung der Waggonhalle, 1903

- Kostenplan für die Erweiterung der elektrischen Kleinbahn Emden,

1903

- Planung des Wartehäuschens an der Haltestelle Transvaal, 1904

- Herstellung einer Überdachung für die Kaistraße im Außenhafen

(Endstation), Oktober 1904

$1902-1904$

Klassifikation Teil B: 01972

Band: 1

Trägermaterial: Papier

Alte Reg.-Sig.: IV T5 30

Bestell-Nr.: IV 01972 
IV

05

05.03

05.03.12

05.03.12.02

05.03.12.02.02

05.03.12.02.02.02
Stadtverwaltung

Aufgabenbereiche der Stadtverwaltung

Handels- und Gewerbeförderung

Förderung des Handwerks

Gewerbliche Konzessionen

Straßenbahnbetrieb

Lfd. Nr. Titel

Laufzeit

1961 Betrieb der elektrischen Kleinbahn (Straßenbahn), Bd. 2

1908-1910

- Ausrüstung der Straßenbahn mit verbesserten, durchgängigen

Bremsen, Dezember 1908 - Februar 1909

- Antrag der Betriebsleitung der Elektrischen Kleinbahn Emden -

Außenhafen beim Magistrat auf Anschaffung eines weiteren

Triebwagens wegen hoher Frequentierung der Bahn, Erweiterung der

Waggonhalle und Umgestaltung des Bürogebäudes, Dezember 1908

- März 1909

- Aufnahme eines Darlehens über 35032 Mark zur Finanzierung des

weiteren Triebwagens, der Erweiterung der Waggonhalle und der

Umgestaltung des Bürogebäudes der Elektrischen Kleinbahn Emden -

Aißenhafen, April 1909 - März 1910

- Planzeichnungen: Triebwagen der Straßenbahn, 1909

$1908-1910$

Klassifikation Teil B: 01973

Band: 2

Trägermaterial: Papier

Alte Reg.-Sig.: IV T5 30

Bestell-Nr.: IV 01973

1962 Betrieb der elektrischen Kleinbahn (Straßenbahn), Bd. 3

- Abwicklung der Zahlungen für Beschaffung von Material zum Bau der Kleinbahn, rollendes Material etc

- Abrechnungen der Bahnbetreiber, Fa Gebrüder Korting und AEG, über Bauleistungen

$1901-1906$

Klassifikation Teil B: 01974

Band: 3

Trägermaterial: Papier

Alte Reg.-Sig.: IV T5 30

Bestell-Nr.: IV 01974

1963 Betrieb der elektrischen Kleinbahn (Straßenbahn), Bd. 4

- Festlegung des Beginns des Rechnungsjahres der Elektrischen

Kleinbahn Emden - Außenhafen zur Bestimmung der Amortisation der Anleihen der Bahn

$1902-1903$

Klassifikation Teil B: 01975

Band: 4

Trägermaterial: Papier

Alte Reg.-Sig.: IV T5 30

Bestell-Nr.: IV 01975 
IV

05

05.03

05.03.12

05.03.12.02

05.03.12.02.02

05.03.12.02.02.02
Stadtverwaltung

Aufgabenbereiche der Stadtverwaltung

Handels- und Gewerbeförderung

Förderung des Handwerks

Gewerbliche Konzessionen

Straßenbahnbetrieb

Lfd. Nr. Titel

Laufzeit

1964 Verträge wegen elektrischer Kleinbahn (Straßenbahn)

1900-1902

- Bürgschafts- und Garantieverträge zum Betrieb der elektrischen

Kleinbahn, 1902

- Verhandlungen des Magistrats mit verschiedenen Firmen (WTAG,

HAPAG, Siemens) über Abschluss von Bürgschafts- und

Garantieverträgen zum Betrieb der elektrischen Kleinbahn, November

1900 - Juni 1902

$1900-1902$

Klassifikation Teil B: 01976

Trägermaterial: Papier

Alte Reg.-Sig.: IV T5 32

Bestell-Nr.: IV 01976

1965 Elektrisches Leitungsnetz für die elektrische Kleinbahn (Straßenbahn)

1900-1904

- Verhandlungen des Magistrats mit der kgl. Staatsbauverwaltung über Genehmigung zur Nutzung von durch den Fiskus beschaffte Leitungsmasten für die Oberleitung der Straßenbahn, 1900 - 1902 - Mitbenutzung der fiskalischen Masten für eine Stromleitung der WTAG, 1903 - 1904

$1900-1904$

Klassifikation Teil B: 01977

Trägermaterial: Papier

Alte Reg.-Sig.: IV T5 34

Bestell-Nr.: IV 01977

1966 Bezug elektrischer Energie für den Straßenbahnbetrieb

1901-1914

(1920)

- Vertrag zwischen der WTAG als Pächterin des staatlichen

Elektrizitätswerkes auf Nesserland und dem Magistrat über Bezug elektrischer Energie für die Straßenbahn, Oktober 1901

- Verhandlungen des Magistrats mit der WTAG mit dem Ziel einer Strompreissenkung, März - August 1905

- Widerstand der Betreibergesellschaft der elektrischen Kleinbahn, AEG, gegen eine Strompreiserhöhung, April 1914

$1901-1914$ (1920)

Klassifikation Teil B: 01978

Trägermaterial: Papier

Alte Reg.-Sig.: IV T5 35

Bestell-Nr.: IV 01978 
05

\subsection{3}

05.03.12

05.03.12.02

05.03.12.02.02

05.03.12.02.02.02
Stadtverwaltung

Aufgabenbereiche der Stadtverwaltung

Handels- und Gewerbeförderung

Förderung des Handwerks

Gewerbliche Konzessionen

Straßenbahnbetrieb

Lfd. Nr. Titel

Laufzeit

1967 Betriebsabläufe bei der elektrischen Kleinbahn (Straßenbahn), Bd. 1

1902-1907

- Besetzung der Komission für die elektrische Kleinbahn

(Straßenbahn), 1902

- Denkschrift des Wirklichen Geheimen Oberregierungsrats

Schweckendieck über Maßnamen zur Verbesserung des Betriebs der

Elektrischen Kleinbahn Emden-Außenhafen und Organisation der

Finanzierung, März 1901

- Fahrpläne der Elektrischen Kleinbahn Emden-Außenhafen, 1902 -

1907

- Tarife der Elektrischen Kleinbahn Emden-Außenhafen, 1902 - 1906

- Festlegung von Sondertarife zur Benutzung der Straßenbahn für

Angehörige der Zollverwaltung, 1902

- Erteilung der Betriebsgenehmigung für die Elektrische Kleinbahn

Emden-Außenhafen und Genehmigung der Bahntarife sowie des

Fahrplans durch den Regierungspräsidenten, März 1902

- Gütertarif der Elektrischen Kleinbahn Emden-Außenhafen, 1902

- Verfügung des Regierungspräsidenten in Aurich über Zuständigkeit der Stadt Emden sls Ortspolizeibehörde für die Festlegung des

Fahrplans der elektrischen Kleinbahn und seine Koordinierung mit dem Motorbootsbetrieb im Binnenhafen, Februar 1903

- Antrag des Unternehmens Gebrüder Körting, Hannover als Betreiber der Elektrischen Kleinbahn Emden-Außenhafen auf Verkürzung des

Bahntaktes auf 20 Minuten, April 1902

- Beschwerde des Bürgervorsteherkollegiums wegen Verpachtung der Straßenbahn an Mayer zu Laathen, August 1902

- Einsetzung einer Kommission für den Fahrplan der Elektrischen

Kleinbahn Emden-Außenhafen, April 1902

- Bahnpreisvergünstigung für Schulkinder, Januar - März 1903

- Verhandlungen der Kommission für die elektrische Kleinbahn über

Festlegung der Fahrpläne, 1905 - 1906

- Bericht der Betriebsleitung der Elektrischen Kleinbahn

Emden-Außenhafen über Ursache von Bahnverspätungen und

Verschmutzung der Bahn durch Arbeiter, April 1905

- Antrag zweier Hebammen auf Ermäßigung des Fahrpreises für ihre

Diensttouren mit der Straßenbahn, Juni 1905

- Eingabe Emder Hafenarbeiter an den Magistrat über Bitte um

Verlängerung der Gültigkeit ihrer ermäßigten Arbeiterkarten auf

Nachtfahrten zur Arbeit, Juli 1906

- Eingabe Emder Hafenarbeiter an den Magistrat über Bitte um

Verbesserung des Mittagstaktes der Elektrischen Kleinbahn

Emden-Außenhafen, September - Oktober 1907

$1902-1909$

Klassifikation Teil B: 01979

Band: 1

Trägermaterial: Papier

Alte Reg.-Sig.: IV T5 36

Bestell-Nr.: IV 01979 
IV

05

05.03

05.03.12

05.03.12.02

05.03.12.02.02

05.03.12.02.02.02
Stadtverwaltung

Aufgabenbereiche der Stadtverwaltung

Handels- und Gewerbeförderung

Förderung des Handwerks

Gewerbliche Konzessionen

Straßenbahnbetrieb

Lfd. Nr. Titel

Laufzeit

1968 Betriebsabläufe bei der elektrischen Kleinbahn (Straßenbahn), Bd. 2

1902-1917

- Neufestsetzung der Arbeitertarife der Elektrischen Kleinbahn

Emden-Außenhafen, 1902 - 1909

- Festsetzung der Tarife der Elektrischen Kleinbahn

Emden-Außenhafen, 1905 - 1915

- Vereinbarung zwischen dem kgl. Zollamt und der Elektrischen

Kleinbahn Emden-Außenhafen über Zahlung eines Pauschalbetrages

zur Finanzierung der Freifahrt der Zollbeamten bei dienstlichen

Aufträgen, 1902 - 1905

- Fahrpläne der Elektrischen Kleinbahn Emden-Außenhafen, 1908 -

1917

- Verhandlungen wegen Ausdehnung des Schüler-Tarifs der

Elektrischen Kleinbahn Emden-Außenhafen auf Schüler der höheren

Schulen, Mai - Juni 1914

1902 - 1914 (1919)

Klassifikation Teil B: 01980

Band: 2

Trägermaterial: Papier

Alte Reg.-Sig.: IV T5 36

Bestell-Nr.: IV 01980

1969 Beschwerden gegen die Betriebsleitung der Elektrischen Kleinbahn

1902-1913

Emden-Außenhafen

- Beschwerden verschiedener Bahnnutzer gegen die Betriebsleitung der Elektrischen Kleinbahn Emden-Außenhafen wegen

Nichtmitnahme, Überfüllung der Straßenbahn, Verspätungen, 1902 1909

- Anzeige des Hilfsschaffners Jürren Waalkes gegen den Techniker Heinrich Baunemann wegen Beleidigung bei der Fahrkartenkontrolle, Mai - Juni 1913

$1902-1913$ (1919)

Klassifikation Teil B: 01981

Trägermaterial: Papier

Alte Reg.-Sig.: IV T5 37

Bestell-Nr.: IV 01981

1970 Sitzungen der Kommission für die Herstellung und Betrieb der elektrischen Kleinbahn, Bd. 1

1900-1909

- Protokolle der Verhandlungen der Kommission für die Herstellung und Betrieb der elektrischen Kleinbahn über Probleme beim Bau der Straßenbahn, Finanzierungsfragen und Betriebsorganisation

$1900-1909$

Klassifikation Teil B: 01982

Band: 1

Trägermaterial: Papier

Alte Reg.-Sig.: IV T5 38

Bestell-Nr.: IV 01982 
IV

05

05.03

05.03.12

05.03.12.02

05.03.12.02.02

05.03.12.02.02.02
Stadtverwaltung

Aufgabenbereiche der Stadtverwaltung

Handels- und Gewerbeförderung

Förderung des Handwerks

Gewerbliche Konzessionen

Straßenbahnbetrieb

Lfd. Nr. Titel

Laufzeit

1971 Sitzungen der Kommission für die Herstellung und Betrieb der elektrischen Kleinbahn, Bd. 2

1905-1915

- Einladungen zu den Sitzungen der Kommission für die Herstellung und Betrieb der elektrischen Kleinbahn mit Tagesordnung

$1905-1915$

Klassifikation Teil B: 01982

Band: 2

Trägermaterial: Papier

Alte Reg.-Sig.: IV T5 38

Bestell-Nr.: IV 01983

1972 Sitzungen der Kommission für die Herstellung und Betrieb der

elektrischen Kleinbahn, Bd. 3

- Protokolle der Verhandlungen der Kommission für die Herstellung und Betrieb der elektrischen Kleinbahn über Probleme beim Bau der Straßenbahn, Finanzierungsfragen und Betriebsorganisation

$1910-1913$

Klassifikation Teil B: 01984

Band: 3

Trägermaterial: Papier

Alte Reg.-Sig.: IV T5 38

Bestell-Nr.: IV 01984

1973 Sitzungen der Kommission für die Herstellung und Betrieb der

1914-1918

elektrischen Kleinbahn, Bd. 4

(1919)

- Protokolle der Verhandlungen der Kommission für die Herstellung und Betrieb der elektrischen Kleinbahn über Probleme beim Bau der Straßenbahn, Finanzierungsfragen und Betriebsorganisation

$1914-1918$ (1919)

Klassifikation Teil B: 01985

Band: 4

Trägermaterial: Papier

Alte Reg.-Sig.: IV T5 38

Bestell-Nr.: IV 01985 
IV

05

\subsection{3}

05.03.12

05.03.12.02

05.03.12.02.02

05.03.12.02.02.02
Stadtverwaltung

Aufgabenbereiche der Stadtverwaltung

Handels- und Gewerbeförderung

Förderung des Handwerks

Gewerbliche Konzessionen

Straßenbahnbetrieb

Lfd. Nr. Titel

Laufzeit

1974 Polizeiverordnung über Betrieb der Elektrischen Kleinbahn

Emden-Außenhafen

1902-1913

(1919)

- Entwurf einer Polizeiverordnung über Betrieb der Elektrischen

Kleinbahn Emden-Außenhafen, März - Mai 1902

- Verfügung des Regierungspräsidenten in Aurich über Genehmigung

der Polizeiverordnung über Betrieb der Elektrischen Kleinbahn

Emden-Außenhafen, April 1902

- Mitteilung über Betriebsstörungen bei der elektrischen Kleinbahn, Juni - Juli 1902

- Novellierung der Polizeiverordnung über Betrieb der Elektrischen

Kleinbahn Emden-Außenhafen, 1907 - 1908 / 1913 (1919)

1902 - 1913 (19189)

Klassifikation Teil B: 01986

Trägermaterial: Papier

Alte Reg.-Sig.: IV T5 40

Bestell-Nr.: IV 01986

1975 Regulativ für den Erneuerungsfonds der Elektrischen Kleinbahn

Emden-Außenhafen

- Forderung einer Satzung für den Erneuerungsfonds durch die AEG als Betreiberin der Elektrischen Kleinbahn Emden-Außenhafen,

Februar 1912

- Verhandlungen der Kommission für die Elektrische Kleinbahn über Neugestaltung des Erneuerungsfonds, März 1912

- Genehmigung der Neugestaltung des Erneuerungsfonds der

Elektrischen Kleinbahn Emden-Außenhafen durch den

Regierungspräsdidenten in Aurich und dem Landesdirektorium der Provinz Hannover, Mai - Juni 1912

- Regulativ über Verwendung der Mittel des durch Rücklagen und Betriebsgewinnen gebildeten Erneuerungsfonds der Elektrischen Kleinbahn Emden-Außenhafen, Juni 1912

1912 - 1917 (1919 - 1925)

Klassifikation Teil B: 01987

Trägermaterial: Papier

Alte Reg.-Sig.: IV T5 41

Bestell-Nr.: IV 01987 
IV

05

05.03

05.03.12

05.03.12.02

05.03.12.02.02

05.03.12.02.02.02
Stadtverwaltung

Aufgabenbereiche der Stadtverwaltung

Handels- und Gewerbeförderung

Förderung des Handwerks

Gewerbliche Konzessionen

Straßenbahnbetrieb

Lfd. Nr. Titel

Laufzeit

1976 Betriebszwischenfälle bei der Elektrischen Kleinbahn

1896-1910

- Firmenjubiläum der Gebrüder Körting als Betreibergesellschaft der

Elektrischen Kleinbahn Emden-Außenhafen, 1896

- Beinaheunfall der Straßenbahn wegen mangelhafter Signalanlage, Juni - Juli 1902

- Unfälle der Straßenbahn mit Personenschäden, September 1902 -

Juni 1905

- Beschädigung von Straßen durch den Bahnbetrieb, 1902

- Sabotage gegen die Straßenbahn durch auf die Gleise gelegte

Steine, 1903

- Schreiben des Ingenieurs Stegemann an Oberbürgermeister

Fürbringer über Bitte um Beförderung seiner Bewerbung als

technischer Direktor bei der elektrischen Kleinbahn, Februar 1903

- Gesuch verschiedener Einwohner Nesserlands um Einrichtung einer

Haltestelle der Straßenbahn bei der Eisenbahnlinie in Nesserland,

Februar - März 1903

- Beschwerden gegen die elektrische Kleinbahn: u.a.

Fahrgelderhebung , 1903

- Betriebsstörungen der Straßenbahn, Dezember 1904

- Angebote über Material für die Straßenbahn, 1905 - 1910

$1896-1910$

Klassifikation Teil B: 01988

Trägermaterial: Papier

Alte Reg.-Sig.: IV T5 42

Bestell-Nr.: IV 01988

1977 Betriebsergebnis der Elektrischen Kleinbahn Emden-Außenhafen

- Übersichten über monatliche Betriebsergebnisse der Elektrischen Kleinbahn Emden-Außenhafen, 1902

- Übersichten über Betriebseinnahmen der Elektrischen Kleinbahn

Emden-Außenhafen, 1903 - 1915

$1902-1915$

Klassifikation Teil B: 01989

Trägermaterial: Papier

Alte Reg.-Sig.: IV T5 43

Bestell-Nr.: IV 01989 
IV

05

05.03

05.03.12

05.03.12.02

05.03.12.02.02

05.03.12.02.02.02
Stadtverwaltung

Aufgabenbereiche der Stadtverwaltung

Handels- und Gewerbeförderung

Förderung des Handwerks

Gewerbliche Konzessionen

Straßenbahnbetrieb

Lfd. Nr. Titel

Laufzeit

1978 Rechnungslegung der Elektrischen Kleinbahn Emden-Außenhafen, Bd. 1

- Geschäftsbericht der Elektrischen Kleinbahn Emden-Außenhafen, 1902 - 1903 / 1903 - 1904

- Monita der WTAG als Bürgin der Elektrischen Kleinbahn

Emden-Außenhafen wegen der Jahresrechnung 1902/03, August

1903

- Verfügung des Regierungspräsidenten in Aurich an den Magistrat über Rechnungsprüfung für die Elektrischen Kleinbahn

Emden-Außenhafen durch die kgl. Eisenbahndirektion und Festlegung eines Stichtages der Einreichung der Jahresrechnung, August 1903

- Entlastung der Firma Gebrüder Körting als Betreibergesellschaft der

Elektrischen Kleinbahn Emden-Außenhafen, September 1903

- Prüfung der Jahresrechnung der Elektrischen Kleinbahn

Emden-Außenhafen durch die kgl. Eisenbahn-Direktion Münster,

Dezember 1903

- Monita des Regierungspräsidenten zur Jahresrechnung der

Elektrischen Kleinbahn Emden-Außenhafen für das Geschäftsjahr 1902/03, April 1904

- Jahresrechnung der Elektrischen Kleinbahn Emden-Außenhafen für das Geschäftsjahr 1903/04, Juli 1904

- Beschwerde der WTAG gegen die Höhe des zu entrichtenden Anteils am Defizit der Elektrischen Kleinbahn Emden-Außenhafen, August 1904

- Monita des Magistrats zur Jahresrechnung der Elektrischen Kleinbahn Emden-Außenhafen für das Geschäftsjahr 1903/04, August 1904

- Monita der WTAG als Bürgin wegen der Jahresrechnung 1903/04

- Protokoll der Versammlung zur Rechnungslegung der Elektrischen

Kleinbahn Emden-Außenhafen, September 1904 / November 1904

- Stellungnahme der Firma Gebrüder Körting als Betreiberin der

Elektrischen Kleinbahn Emden-Außenhafen zu den Monita des

Regierungspräsidenten, der Bürgen und des Magistrats, Oktober -

November 1904

$1903-1904$

Klassifikation Teil B: 01990

Band: 1

Trägermaterial: Papier

Alte Reg.-Sig.: IV T5 45

Bestell-Nr.: IV 01990 
IV

05

\subsection{3}

05.03.12

05.03.12.02

05.03.12.02.02

05.03.12.02.02.02
Stadtverwaltung

Aufgabenbereiche der Stadtverwaltung

Handels- und Gewerbeförderung

Förderung des Handwerks

Gewerbliche Konzessionen

Straßenbahnbetrieb

Lfd. Nr. Titel

Laufzeit

1979 Rechnungslegung der Elektrischen Kleinbahn Emden-Außenhafen, Bd. 2

- Vorlage der Jahresrechnung der Elektrischen Kleinbahn Emden-Außenhafen für das Geschäftsjahr 1903/04 durch die

Betreiberfirma Gebrüder Körting, Dezember 1904

- Rechnungsprüfung des Jahresabschlusses 1903/04 der Elektrischen Kleinbahn Emden-Außenhafen durch die kgl. Eisenbahn-Direktion Münster, März 1905

- Protokoll der Versammlung im Rathaus zur Rechnungslegung der Elektrischen Kleinbahn Emden-Außenhafen, März 1905 / Dezember 1905

- Protokoll der Versammlung zur Rechnungslegung der Elektrischen Kleinbahn Emden-Außenhafen bei der kgl. Eisenbahn-Direktion in Münster, April 1905

- Stellungnahme der Firma Gebrüder Körting als Betreiberin der Elektrischen Kleinbahn Emden-Außenhafen zu den Monita des Regierungspräsidenten, der Eisenbahn-Direktion und des Magistrats sowie der Bürgen, Juni - Juli 1905

- Billigung des Jahresabschlusses der Elektrischen Kleinbahn emden-Außenhafen für 1904/05 durch den Regierungspräsidenten, Februar 1906

- Neufeststellung des Defizits der elektrischen Kleinbahn Emden-Außenhafen aus dem Geschäftsjahr 1902/03 und Verteilung unter den Bürgen, April 1906

$1904-1906$

Klassifikation Teil B: 01991

Band: 2

Trägermaterial: Papier

Alte Reg.-Sig.: IV T5 45

Bestell-Nr.: IV 01991 
IV

05

\subsection{3}

05.03.12

05.03.12.02

05.03.12.02.02

05.03.12.02.02.02
Stadtverwaltung

Aufgabenbereiche der Stadtverwaltung

Handels- und Gewerbeförderung

Förderung des Handwerks

Gewerbliche Konzessionen

Straßenbahnbetrieb

Lfd. Nr. Titel

Laufzeit

1980 Rechnungslegung der Elektrischen Kleinbahn Emden-Außenhafen, Bd. 3

- Vorlage der Jahresrechnung der Elektrischen Kleinbahn Emden-Außenhafen für das Geschäftsjahr 1904/05 und 1905/06 sowie 1907/08 durch die Betreiberfirma AEG, September 1906 - Protokoll der Versammlung im Rathaus zur Rechnungslegung der Elektrischen Kleinbahn Emden-Außenhafen, Oktober 1906 / März / Juli 1907

- Bilanz der Elektrischen Kleinbahn Emden-Außenhafen, 1905 - 1912

- Verteilung des Betriebsdefizits der Elektrischen Kleinbahn

Emden-Außenhafen auf die Bürgen, November 1906 - Juli 1907

- Monita der kgl. Eisenbahn-Direktion Münster zu den Jahresabschlüssen der Elektrischen Kleinbahn Emden-Außenhafen für die Geschäftsjahre 1904/05 und 1905/06, Februar / September 1907

- Rechnungsprüfung des Jahresabschlusses 1905/06 der Elektrischen Kleinbahn Emden-Außenhafen durch die kgl. Eisenbahn-Direktion Münster, März 1907

- Stellungnahme der AEG als Betreiberin der Elektrischen Kleinbahn

Emden-Außenhafen zu den Monita, Mai 1907

- Bericht des Magistrats an den Regierungspräsidenten über

Bemerkungen zu den Jahresabschlüssen der Elektrischen Kleinbahn-Außenhafen für 1904/05 und 1905/06, November 1907

$1906-1912$

Klassifikation Teil B: 01992

Band: 3

Trägermaterial: Papier

Alte Reg.-Sig.: IV T5 45

Bestell-Nr.: IV 01992 
IV

05

05.03

05.03.12

05.03.12.02

05.03.12.02.02

05.03.12.02.02.02
Stadtverwaltung

Aufgabenbereiche der Stadtverwaltung

Handels- und Gewerbeförderung

Förderung des Handwerks

Gewerbliche Konzessionen

Straßenbahnbetrieb

Lfd. Nr. Titel

Laufzeit

1981 Rechnungslegung der Elektrischen Kleinbahn Emden-Außenhafen, Bd. 4

- Monitum des Regierungspräsidenten wegen Registrierung einer Zinszahlung unter dem Erneuerungsfonds der Elektrischen Kleinbahn Emden-Außenhafen durch die Betreiberin AEG, November 1908

- Vorlage der Jahresrechnung der Elektrischen Kleinbahn Emden-Außenhafen für die Geschäftsjahre 1906/07 und 1907/08 durch die Betreiberfirma AEG, Mai - Juni 1908

- Monitum der kgl. Eisenbahn-Direktion über Zinszahlungen der Elektrischen Kleinbahn Emden-Außenhafen an ihre Betreiberfirma AEG, Juni 1908

- Verteilung des Defizits der Elektrischen Kleinbahn

Emden-Außenhafen auf die Bürgen, Juni 1908 - März 1909

- Bilanzen der Elektrischen Kleinbahn Emden-Außenhafen, 1906 -

1909

- Monita der Kommission für die Revision der Jahresrechnungen der Elektrischen Kleinbahn Emden-Außenhafen zum Jahresabschluss 1907/08 und 1908/09, Juli 1908/März 1909

- Verhandlungen der Kommission für die Elektrische Kleinbahn Emden-Außenhafen wegen Differenzen bei der Rechnungsführung der Betreiberfirma AEG, Januar 1909

- Monita der kgl. Eisenbahn-Direktion wegen der Rechnungsführung der Betreiberfirma der Elektrischen Kleinbahn Emden-Außenhafen, Dezember 1908

- Stellungnahme der AEG als Betreiberin der Elektrischen Kleinbahn Emden-Außenhafen zu den Monita der kgl. Eisenbahn-Direktion, März 1909

- Verhandlung der Kommission für die Elektrische Kleinbahn

Emden-Außenhafen über Rechnungsabschluss für 1908/09, März

1909

- Monita des Regierungspräsidenten zur Jahresrechnung der elektrischen Kleinbahn Emden-Außenhafen für 1908/09, Mai 1909

$1908-1909$

Klassifikation Teil B: 01993

Band: 4

Trägermaterial: Papier

Alte Reg.-Sig.: IV T5 45

Bestell-Nr.: IV 01993 


\section{IV}

05

\subsection{3}

05.03.12

05.03.12.02

05.03.12.02.02

05.03.12.02.02.02

\section{Stadtverwaltung}

Aufgabenbereiche der Stadtverwaltung

Handels- und Gewerbeförderung

Förderung des Handwerks

Gewerbliche Konzessionen

Straßenbahnbetrieb

Lfd. Nr. Titel

Laufzeit

1982 Rechnungslegung der Elektrischen Kleinbahn Emden-Außenhafen, Bd. 5

- Verfügung des Regierungspräsidenten in Aurich über Entlastung der AEG als Betreiberin der Elektrischen Kleinbahn Emden-Außenhafen für die Jahresabschlüsse 1906/07 und 1907/08, Mai 1909

- Vorlage der Jahresrechnung der Elektrischen Kleinbahn Emden-Außenhafen für das Geschäftsjahr 1908/09 durch die Betreiberfirma AEG, Juli 1909

- Bilanz der Elektrischen Kleinbahn Emden-Außenhafen für 1908/09, April 1909

- Verhandlungen der Rechnungsprüfungskommission über Rechnungsabschluss der Elektrischen Kleinbahn Emden-Außenhafen für 1908/09, September 1909

- Verhandlungen der Kommission für die Elektrische Kleinbahn Emden-Außenhafen über Rechnungsabschluss der Elektrischen Kleinbahn Emden-Außenhafen für 1908/09, Oktober 1909 - Stellungnahme der AEG als Betreiberin der Elektrischen Kleinbahn Emden-Außenhafen zu den Prüfungsberichten der Kommissionen, Oktober 1909

- Bericht des Magistrats an den Regierungspräsidenten über Rechnungsabschluss der Elektrischen Kleinbahn Emden-Außenhafen für das Geschäftsjahr 1908/09, November 1909 / Juli 1910

- Verteilung des Betriebsdefizits der Elektrischen Kleinbahn Emden-Außenhafen auf die Bürgen, November 1910 - Monita der kgl. Eisenbahn-Direktion Münster zum Rechnungsabschluss der Elektrischen Kleinbahn Emden-Außenhafen für das Jahr 1908/09, März 1910 / Dezember 1910

- Stellungnahme der AEG als Betreiberin der Elektrischen Kleinbahn Emden-Außenhafen zu den Monita der kgl. Eisenbahn-Direktion, März 1910

- Monita des Regierungspräsiden zur Jahresrechnung der Elektrischen Kleinbahn Emden-Außenhafen für das Geschäftsjahr 1908/09, August 1910

$1909-1910$

Klassifikation Teil B: 01994

Band: 5

Trägermaterial: Papier Alte Reg.-Sig.: IV T5 45

Bestell-Nr.: IV 01994
$1909-1910$ 
IV

05

\subsection{3}

05.03.12

05.03.12.02

05.03.12.02.02

05.03.12.02.02.02
Stadtverwaltung

Aufgabenbereiche der Stadtverwaltung

Handels- und Gewerbeförderung

Förderung des Handwerks

Gewerbliche Konzessionen

Straßenbahnbetrieb

Lfd. Nr. Titel

Laufzeit

1983 Rechnungslegung der Elektrischen Kleinbahn Emden-Außenhafen, Bd. 6

- Monita des Regierungspräsidenten zum Rechnungsabschluss der Elektrischen Kleinbahn Emden-Außenhafen für das Geschäftsjahr 1908/09, August 1910

- Vorlage der Jahresrechnung der Elektrischen Kleinbahn Emden-Außenhafen für das Geschäftsjahr 1909/10 durch die Betreiberfirma AEG, September 1910

- Bilanz der Elektrischen Kleinbahn Emden-Außenhafen für das

Geschäftsjahr 1909/10, September 1910

- Verfügung des Landesdirektoriums für die Provinz Hannover über Erhöhung der Zinsen für die Darlehen des Staates und der Provinz für die Elektrische Kleinbahn Emden-Außenhafen wegen Erzielung eines Betriebsgewinns, Oktober 1910 - Januar 1911

- Rechnungsprüfung des Jahresabschlusses 1909/10 der Elektrischen Kleinbahn Emden-Außenhafen durch die Kommission für die Rechnungsprüfung der Elektrischen Kleinbahn Emden-Außenhafen, Oktober 1910

- Verhandlung der Kommission für die Elektrische Kleinbahn Emden-Außenhafen über Rechnungsabschluss 1909/10 und Investitionen für die Straßenbahn, Oktober 1910

- Bericht des Magistrats an den Regierungspräsidenten über Rechnungsabschluss der Elektrischen Kleinbahn Emden-Außenhafen für das Geschäftsjahr 1909/10, November 1910

- Monita der kgl. Eisenbahn-Direktion wegen der Jahresrechnung der Elektrischen Kleinbahn Emden-Außenhafen für 1909/10, Dezember 1910

$1910-1911$

Klassifikation Teil B: 01995

Band: 6

Trägermaterial: Papier

Alte Reg.-Sig.: IV T5 45

Bestell-Nr.: IV 01995 
IV

05

\subsection{3}

05.03.12

05.03.12.02

05.03.12.02.02

05.03.12.02.02.02
Stadtverwaltung

Aufgabenbereiche der Stadtverwaltung

Handels- und Gewerbeförderung

Förderung des Handwerks

Gewerbliche Konzessionen

Straßenbahnbetrieb

Lfd. Nr. Titel

Laufzeit

1984 Rechnungslegung der Elektrischen Kleinbahn Emden-Außenhafen, Bd. 7

- Verfügung des Regierungspräsidenten über Registrierung einer Abschreibung in den Jahresabschluss der Elektrischen Kleinbahn Emden-Außenhafen für das Geschäftsjahr 1908/09, April -Mai 1911 - Vorlage der Jahresrechnung der Elektrischen Kleinbahn Emden-Außenhafen für das Geschäftsjahr 1909/10 durch die Betreiberfirma der Elektrischen Kleinbahn Emden-Außenhafen, AEG, August 1911

- Bilanz der Elektrischen Kleinbahn Emden-Außenhafen, August 1911 - Rechnungsprüfung der Elektrischen Kleinbahn Emden-Außenhafen für das Geschäftsjahr 1910/11 durch die Kommission für die Rechnungsprüfung der Elektrischen Kleinbahn Emden-Außenhafen, Oktober 1911

- Verfügung des Landesdirektoriums für die Provinz Hannover über Erhöhung der Zinsen für die Darlehen des Staates und der Provinz für die Elektrische Kleinbahn Emden-Außenhafen wegen Erzielung eines Betriebsgewinns, Oktober 1911 - März 1912

- Monita der kgl. Eisenbahn-Direktion wegen der Jahresrechnung der Elektrischen Kleinbahn Emden-Außenhafen für 1910/11, Januar 1912 - Stellungnahme der AEG als Betreiberin der Elektrischen Kleinbahn Emden-Außenhafen zu den Monita der kgl. Eisenbahn-Direktion, Februar 1912

- Antrag des Magistrats beim Regierungspräsidenten in Aurich auf Entlastung der Betreibergesellschaft der Elektrischen Kleinbahn hinsichtlich des Jahresaabschlusses 1910/11, April 1912

- Hinterlegung von Wertpapieren für den Erneuerungsfonds der Elektrischen Kleinbahn Emden-Außenhafen bei der Stadt Emden, Juli 1912

$1911-1912$

Klassifikation Teil B: 01996

Band: 7

Trägermaterial: Papier

Alte Reg.-Sig.: IV T5 45

Bestell-Nr.: IV 01996 
IV

05

05.03

05.03.12

05.03.12.02

05.03.12.02.02

05.03.12.02.02.02
Stadtverwaltung

Aufgabenbereiche der Stadtverwaltung

Handels- und Gewerbeförderung

Förderung des Handwerks

Gewerbliche Konzessionen

Straßenbahnbetrieb

Lfd. Nr. Titel

Laufzeit

1985 Rechnungslegung der Elektrischen Kleinbahn Emden-Außenhafen,

Bd. 8

- Vorlage der Jahresrechnung der Elektrischen Kleinbahn

Emden-Außenhafen für das Geschäftsjahr 1914/15 durch die

Betreiberfirma AEG, Juni 1915

- Bilanz der Elektrischen Kleinbahn Emden-Außenhafen, Juni 1915

- Monita des Regierungspräsidenten zur Jahresrechnung der

Elektrischen Kleinbahn Emden-Außenhafen, November 1915.

- Stellungnahme der AEG als Betreiberin der Elektrischen Kleinbahn

Emden-Außenhafen zu den Monita, November 1915

- Monita der kgl. Eisenbahn-Direktion Münster zur Jahresrechnung der

Elektrischen Kleinbahn Emden-Außenhafen für 1914/15, Februar

1916

- Stellungnahme der AEG als Betreiberin der Elektrischen Kleinbahn

Emden-Außenhafen zu den Monita, März 1916

$1915-1916$

Klassifikation Teil B: 01997

Band: 8

Trägermaterial: Papier

Alte Reg.-Sig.: IV T5 45

Bestell-Nr.: IV 01997

1986 Rechnungslegung der Elektrischen Kleinbahn Emden-Außenhafen,

Bd. 9

- Vorlage der Jahresrechnung der Elektrischen Kleinbahn

Emden-Außenhafen für das Geschäftsjahr 1917/18 durch die

Betreiberfirma AEG, September 1918

- Bilanz der Elektrischen Kleinbahn Emden-Außenhafen, September

1918

- Monita der kgl. Eisenbahn-Direktion Münster zur Jahresrechnung der

Elektrischen Kleinbahn Emden-Außenhafen für 1917/18, März / Juli

1919

- Verfügung des Landesdirektoriums für die Provinz Hannover über

Erhöhung der Zinsen für die Darlehen des Staates und der Provinz für die Elektrische Kleinbahn Emden-Außenhafen wegen Erzielung eines Betriebsgewinns, November 1918 / Juni 1919

- Stellungnahme der AEG als Betreiberin der Elektrischen Kleinbahn

Emden-Außenhafen zu den Monita, Mai 1919

$1918-1919$

Klassifikation Teil B: 01998

Band: 9

Trägermaterial: Papier

Alte Reg.-Sig.: IV T5 45

Bestell-Nr.: IV 01998 
IV

05

\subsection{3}

05.03.12

05.03.12.02

05.03.12.02.02

05.03.12.02.02.02

\section{Stadtverwaltung}

Aufgabenbereiche der Stadtverwaltung

Handels- und Gewerbeförderung

Förderung des Handwerks

Gewerbliche Konzessionen

Straßenbahnbetrieb

Lfd. Nr. Titel

Laufzeit

1987 Konzessionierungsantrag wegen Betrieb einer Straßenbahn vom Königspolder über den Hauptbahnhof zur Stadtmitte

1904

- Antrag des Versicherungsdirektors Paul G. Roer aus Münster auf Konzessionierung einer Straßenbahnlinie vom Königspolder über den Hauptbahnhof zur Stadtmitte, Mai - Dezember 1904

1904

Klassifikation Teil B: 02000

Trägermaterial: Papier

Alte Reg.-Sig.: IV T5 47

Bestell-Nr.: IV 02000

1988 Vervielfältigung von Aktenstücken über die Elektrische Kleinbahn Emden-Außenhafen

- Verschiedene Kopien und Abschriften von Aktenstücken zur Gründungsgeschichte der Elektrischen Kleinbahn Emden-Außenhafen

$1901-1904$

Klassifikation Teil B: 02001

Trägermaterial: Papier

Alte Reg.-Sig.: IV T5 48

Bestell-Nr.: IV 02001

1989 Städtisches Reservelager der Elektrischen Kleinbahn

Emden-Außenhafen

- Benutzung eines städtischen Lagergebäudes durch die Firma

Gebrüder Körting als Betreiberin der Elektrischen Kleinbahn

Emden-Außenhafen, November 1904

- Inventar der eingelagerten Gegenstände der Elektrischen Kleinbahn

Emden-Außenhafen, November 1904 / März 1909

- Inventar des Betriebslagers der Elektrischen Kleinbahn

Emden-Außenhafen, Dezember 1904

- Vereinbarung zwischen dem Magistrat und der Betreibergesellschaft der Elektrischen Kleinbahn Emden-Außenhafen über Nutzung des

städtischen Reservelagers, Januar 1905

1904 - 1909

Klassifikation Teil B: 02002

Trägermaterial: Papier

Alte Reg.-Sig.: IV T5 49

Bestell-Nr.: IV 02002 
IV

05

05.03

05.03.12

05.03.12.02

05.03.12.02.02

05.03.12.02.02.02
Stadtverwaltung

Aufgabenbereiche der Stadtverwaltung

Handels- und Gewerbeförderung

Förderung des Handwerks

Gewerbliche Konzessionen

Straßenbahnbetrieb

Lfd. Nr. Titel

Laufzeit

1990 Geplante Erweiterung der Elektrischen Kleinbahn Emden-Außenhafen

1907

- Kostenvoranschlag der AEG als Betreiberin der Elektrischen

Kleinbahn Emden-Außenhafen für eine Erweiterung der Straßenbahn

in Richtung Hauptbahnhof und Larrelt, Februar 1907

- Verhandlungen der Kommission für die Elektrische Kleinbahn

Emden-Außenhafen über Erweiterungsplan, März 1907

- Beschluss des Magistrats über Verschiebung des Projektes wegen

mangelnder Rentabilität, April 1907

1907

Klassifikation Teil B: 02003

Trägermaterial: Papier

Alte Reg.-Sig.: IV T5 50

Bestell-Nr.: IV 02003

1991 Wartehallen für die Elektrische Kleinbahn Emden-Außenhafen

$1904-1910$

- Verhandlungen des Magistrats mit dem Regierungspräsidenten in

Aurich und der Kommission für die Elektrische Kleinbahn

Emden-Außenhafen über Anlage und Platzierung von Wartehallen an

Straßenbahnhaltestellen, 1904

- Verhandlungen des Magistrats mit der kgl. Eisenbahnverwaltung wegen Aufbau von Wartehäuschen, 1904

- Lageplan des Wartehäuschens an der Haltestelle Außenhafen, 1904

/ 1905

- Ausschreibung der Arbeiten zum Aufbau des Wartehäuschens,

November - Januar 1905

- Lagepläne für Wartehäuschen, 1905

- Verhandlungen der Kommission für die Elektrische Kleinbahn

Emden-Außenhafen über Maßnahmen gegen mutwillige

Beschädigung der Wartehäuschen an Straßenbahnhaltestellen, Mai

1906 - August 1907

- Regelung der Anbringung von Werbetafeln an den Wartehäuschen,

Dezember 1907

- Antrag der Betriebsleitung der Elektrischen Kleinbahn

Emden-Außenhafen auf Abbruch des Wartehäuschens an der

Haltestelle Außenhafen wegen Vandalismus, Oktober - Dezember

1910

$1904-1910$

Klassifikation Teil B: 02004

Trägermaterial: Papier

Alte Reg.-Sig.: IV T5 51

Bestell-Nr.: IV 02004 
IV

05

05.03

05.03.12

05.03.12.02

05.03.12.02.02

05.03.12.02.02.02
Stadtverwaltung

Aufgabenbereiche der Stadtverwaltung

Handels- und Gewerbeförderung

Förderung des Handwerks

Gewerbliche Konzessionen

Straßenbahnbetrieb

Lfd. Nr. Titel

Laufzeit

1992 Vorschriften für den Straßenbahnbetrieb

1902-1917

- Umsetzung von Sicherheitsvorschriften für den Straßenbahnbetrieb, $1903-1907$

- Inspektion der Straßenbahnen und Feststellung von Mängeln, März -

Juni 1904

- Erlasse des Ministers der öffentlichen Arbeiten über Verbot des

Alkoholgenusses für Bedienstete der Straßenbahnen, November 1905

- Januar 1906 / Januar 1907

- Betriebsvorschriften für Straßenbahnen, 1905 - 1914

- Erhebung der kgl. Eisenbahn-Direktion über Sehfähigkeit der

Straßenbahnbediensteten, Dezember 1906

- Ausrüstung der Emder Straßenbahn mit durchgängigen Bremsen,

Mai - Oktober 1907

- Sicherheitsbestimmungen und Verhaltensregeln für die Bediensteten

der Elektrischen Kleinbahn Emden-Außenhafen, 1902

- Einstellung des Ingenieurs Kurt Bandt als Betriebsleiter der

Elektrischen Kleinbahn Emden-Außenhafen, Dezember 1912

- Beabsichtigte Angleichung der Gehälter der Bediensteten der

Elektrischen Kleinbahn Emden-Außenhafen mit denen der staatlichen

Eisenbahn, 1917

$1902-1917(1921)$

Klassifikation Teil B: 02005

Trägermaterial: Papier

Alte Reg.-Sig.: IV T5 53

Bestell-Nr.: IV 02005

1993 Geplanter Ausbau der Emder Straßenbahn nach Borssum und zur neuen Seeschleuse, Bd. 1

- Besprechung des Direktors der Bremisch-Hannoverschen Kleinbahnen, Köhler, mit Oberbürgermeister Fürbringer über Möglichkeit des Ausbaus der Emder Straßenbahn nach Borssum und zur neuen Seeschleuse, September 1907

1907

Klassifikation Teil B: 02006

Band: 1

Trägermaterial: Papier

Alte Reg.-Sig.: IV T5 54

Bestell-Nr.: IV 02006 
IV

05

05.03

05.03.12

05.03.12.02

05.03.12.02.02

05.03.12.02.02.02
Stadtverwaltung

Aufgabenbereiche der Stadtverwaltung

Handels- und Gewerbeförderung

Förderung des Handwerks

Gewerbliche Konzessionen

Straßenbahnbetrieb

Lfd. Nr. Titel

Laufzeit

1994 Geplanter Ausbau der Emder Straßenbahn nach Borssum und zur neuen Seeschleuse, Bd. 2

1912-1914

- Vermerk des Oberbürgermeisters Fürbringer über Notwendigkeit des

Ausbaus der Straßenbahn, April 1912

- Verhandlungen der Kommission für die Elektrische Kleinbahn

Emden-Außenhafen über Ausbau der Emder Straßenbahn nach

Borssum und zur neuen Seeschleuse, April 1912 - November 1914

- Material zur Organisation der Straßenbahnen in anderen Städten,

1913

- Konzept und Kostenvoranschlag der AEG als Betreiberin der

Elektrischen Kleinbahn Emden-Außenhafen über Ausbau des

Straßenbahnnetzes, Dezember 1913

- Vermerk des Bürgermeisters Dr. Mützelburg über Gespräch mit dem

Direktor der Rheinisch Westfälischen Elektrizitätsgesellschaft,

Goldberg, über Straßenbahnausbau, Februar 1914

- Entwurf eines Vertrages zwischen der Stadt Emden und der

Rheinisch-Westfälischen Elektrizitätsgesellschaft über Ausbau der

Emder Straßenbahn, April 1914

$1912-1914$

Klassifikation Teil B: 02007

Band: 2

Trägermaterial: Papier

Alte Reg.-Sig.: IV T5 54

Bestell-Nr.: IV 02007

1995 Bildung eines Spezialreservefonds für die Elektrische Kleinbahn

Emden-Außenhafen

(1915-1916)

- Verfügung des Regierungspräsidenten in Aurich über Anordnung zur Bildung eines Spezialreservefonds für die Elektrische Kleinbahn

Emden-Außenhafen als Vorsorge für außergewöhnliche Ereignisse, Januar 1914 / April 1914

- Beschluss des Kleinbahn-Ausschusses zur Bildung eines

Spezialreservefonds, Februar 1914

- Regulativ des Spezialreservefonds für die Elektrische Kleinbahn

Emden-Außenhafen, Mai 1914

- Stellungnahme der AEG als Betreiberin der Elektrischen Kleinbahn

Emden-Außenhafen gegen die Bildung eines Spezialreservefonds,

März - Juli 1914

1914 (1915 - 1916)

Klassifikation Teil B: 02008

Trägermaterial: Papier

Alte Reg.-Sig.: IV T5 56

Bestell-Nr.: IV 02008 
IV

05

05.03

05.03.12

05.03.12.02

05.03.12.02.02

05.03.12.02.02.02
Stadtverwaltung

Aufgabenbereiche der Stadtverwaltung

Handels- und Gewerbeförderung

Förderung des Handwerks

Gewerbliche Konzessionen

Straßenbahnbetrieb

Lfd. Nr. Titel

Laufzeit

1996 Straßenbahnverbindung von Emden in die Krummhörn

1880-1882

- Korrespondenz des Oberbürgermeisters Fürbringer mit den

Zivilingenieuren Geseling und Birnbaum in Berlin wegen Realisierung

einer Straßenbahnverbindung von Emden in die Krummhörn, 1880 -

1882

- Materialien zu verschiedenen auswärtigen Straßenbahnprojekten,

1881

- Korrespondenz des Oberbürgermeisters Fürbringer mit dem

Zivilingenieur Dr. H. Zerener wegen Realisierung einer

Straßenbahnverbindung von Emden in die Krummhörn, Dezember

1881

$1880-1882$

Klassifikation Teil B: 02010

Trägermaterial: Papier

Alte Reg.-Sig.: IV T6 001

Bestell-Nr.: IV 02010

1997 Bilanz der Elektrischen Kleinbahn Emden-Außenhafen, Bd. 1

- Jahresabschluss der Elektrischen Kleinbahn Emden-Außenhafen

1902 - 1918 (1919 - 1922)

Klassifikation Teil B: 02064

Band: 1

Trägermaterial: Papier

Alte Reg.-Sig.: IV T6 125

Bestell-Nr.: IV 02064

1998 Bilanz der Elektrischen Kleinbahn Emden-Außenhafen, Bd. 2

1905-1908

- Rechnungsabnahme der Elektrischen Kleinbahn

Emden-Außenhafen

$1905-1908$

Klassifikation Teil B: 02065

Band: 2

Trägermaterial: Papier

Alte Reg.-Sig.: IV T6 125

Bestell-Nr.: IV 02065

1999 Schulden der Elektrischen Kleinbahn Emden-Außenhafen

$1901-1912$

- Schuldverschreibungen der Stadt Emden für die Elektrische

Kleinbahn Emden-Außenhafen

$1901-1912$

Klassifikation Teil B: 02066

Trägermaterial: Papier

Alte Reg.-Sig.: IV T6 125

Bestell-Nr.: IV 02066 
05

05.03

05.03.12

05.03.12.02

05.03.12.02.02

05.03.12.02.02.02

Lfd. Nr. Titel
Stadtverwaltung

Aufgabenbereiche der Stadtverwaltung

Handels- und Gewerbeförderung

Förderung des Handwerks

Gewerbliche Konzessionen

Straßenbahnbetrieb

2000 Elektrische Kleinbahn Emden - Außenhafen

Laufzeit

- Sammlung verschiedener Aktenstücke zur Konzessionierung der Straßenbahn

1904

Klassifikation Teil B: 02807

Trägermaterial: Papier

Alte Reg.-Sig.: IV T5

Bestell-Nr.: IV 02807 
05

\subsection{3}

05.03.12

05.03.12.03

05.03.12.03.01

05.03.12.03.01.01

\section{Stadtverwaltung}

Aufgabenbereiche der Stadtverwaltung

Handels- und Gewerbeförderung

Förderung von Handel und Industrie

Förderung von Handel und Verkehr

Maßnahmen zur Handels- und Verkehrsförderung

Lfd. Nr. Titel

Laufzeit

2001 Zentralverein zur Hebung der Fluss- und Kanalschifffahrt, Bd. 1

1904

- Planung und Durchführung der Versammlung des Zentralvereins zur Hebung der Fluss- und Kanalschifffahrt in Emden (Sommerausflug), März - Juni 1904

- Einladung zum Verbandstag der Deutsch-Östereichisch-Ungarischen

Gesellschaft für Binnenschifffahrt in München, August 1903

(1903) 1904

Klassifikation Teil B: 00649

Band: 1

Trägermaterial: Papier

Alte Reg.-Sig.: IV Fi 014

Bestell-Nr.: IV 00649

2002 Zentralverein zur Hebung der Fluss- und Kanalschifffahrt, Bd. 2

1904

- Planung und Durchführung der Versammlung des Zentralvereins zur Hebung der Fluss- und Kanalschifffahrt in Emden (Sommerausflug), März - Juni 1904

- Rede des Emder Oberbürgermeisters Leo Fürbringer über "Zweck, Bedeutung und Erweiterung des Emder Hafens", Juni 1904

- Vorschlagung neuer Mitglieder für den Zentralverein zur Hebung der Fluss- und Kanalschifffahrt, Oktober 1904

1904

\author{
Klassifikation Teil B: 00650 \\ Band: 2 \\ Trägermaterial: Papier \\ Alte Reg.-Sig.: IV Fi 014 \\ Bestell-Nr.: IV 00650
}

2003 Zentralverein zur Hebung der Fluss- und Kanalschifffahrt, Bd. 3

- Veröffentlichung der auf der Versammlung des Zentralvereins zur Hebung der Fluss- und Kanalschifffahrt gehaltenen Rede des Emder Oberbürgermeisters Leo Fürbringer über "Zweck, Bedeutung und Erweiterung des Emder Hafens", Februar - April 1905

- Wahl Leo Fürbringer in den "Großen Ausschuss" des Zentralvereins zur Hebung der Fluss- und Kanalschifffahrt, Juni 1905

1905

Klassifikation Teil B: 00651

Band: 3

Trägermaterial: Papier

Alte Reg.-Sig.: IV Fi 014

Bestell-Nr.: IV 00651 
05

05.03

05.03.12

05.03.12.03

05.03.12.03.01

05.03.12.03.01.01
Stadtverwaltung

Aufgabenbereiche der Stadtverwaltung

Handels- und Gewerbeförderung

Förderung von Handel und Industrie

Förderung von Handel und Verkehr

Maßnahmen zur Handels- und Verkehrsförderung

Lfd. Nr. Titel

Laufzeit

2004 Zentralverein zur Hebung der Fluss- und Kanalschifffahrt, Bd. 4

1907

- Sonderdruck über den Emder Hafen nach seiner Erweiterung in der

"Zeitschrift für Binnenschifffahrt", Vereinszeitschift des Zentralvereins

zur Hebung der Fluss- und Kanalschifffahrt, 1907

- Gedruckte Satzung des Zentralvereins zur Hebung der Fluss- und

Kanalschifffahrt, November 1907

1907

\author{
Klassifikation Teil B: 00652 \\ Band: 4 \\ Trägermaterial: Papier \\ Alte Reg.-Sig.: IV Fi 014
}

Bestell-Nr.: IV 00652

2005 Küstenbahn Emden-Norden Wittmund

- Denkschrift über Streckenführung und Wirtschaftlichkeit, 1877

- Initiative der Ostfriesischen Landschaft zum Bau der Küstenbahn,

1878

- Plan des sächsischen Oberbaurats Busseck über eine

Schmalspurbahn Emden-Aurich-Wittmund, Dezember 1878

- Plan des sächsischen Oberbaurats Busseck über eine

Schmalspurbahn Norden - Esens, Dezember 1878

- Finanzierung diverser Gutachten zum Bahnbau, 1879 - 1883

$1877-1883$

Klassifikation Teil B: 00783

Band: 1

Trägermaterial: Papier

Alte Reg.-Sig.: IV T6 056

Bestell-Nr.: IV 00783 
05

\subsection{3}

05.03.12

05.03.12.03

05.03.12.03.01

05.03.12.03.01.01
Stadtverwaltung

Aufgabenbereiche der Stadtverwaltung

Handels- und Gewerbeförderung

Förderung von Handel und Industrie

Förderung von Handel und Verkehr

Maßnahmen zur Handels- und Verkehrsförderung
Lfd. Nr. Titel

Laufzeit

2006 Küstenbahn Emden-Norden Wittmund

- Korrespondenz des Oberbürgermeisters Fürbringer mit verschiedenen Bahnsachverständigen wegen Planungen für die Küstenbahn, 1878

- Verhandlungen der von der Küstenbahn betroffenen Landkreise, Städte und Gemeinden wegen Verwirklichung des Projektes, 1878

- Diätenrechnung des Eisenbahn-Betriebsdirektors Voss wegen

Gutachtertätigkeit, 1877 - 1878

- Eingabe des Eisenbahn-Comitees in Emden an den preußischen Minister für Handel, Gewerbe und öffentliche Arbeitenüber Bitte um Umsetzung des Projektes Küstenbahn, März 1878

- Gedruckter Aufsatz des sächsischen Baurats Plasser über

Rentabilität der Küstenbahn, 1878

- Korrespondenz des Oberbürgermeisters Fürbringer mit

Bürgermeistern der an der Küstenbahn interessierten Orte über

Fortgang und Probleme des Projekts, Januar - April 1878

- Bewerbungen verschiedener Unternehmen um die Durchführung des

Projektes, Mai 1878

- Vereinbarung zwischen den Kaufmanns-Korporationen in Emden und Norden über koordinierte Schritte zur schnellen Abwicklung des Bahnprojekts, Dezember 1877

$1877-1878$

\author{
Klassifikation Teil B: 00784 \\ Band: 2 \\ Trägermaterial: Papier \\ Alte Reg.-Sig.: IV T6 056 \\ Bestell-Nr.: IV 00784
}

2007 Küstenbahn Emden-Norden Wittmund

$1869-1878$

- Denkschrift des sächsischen Oberbaurats Busseck über

Realisierungsmöglichkeit der Küstenbahn, 1869

- Verhandlungen im Magistrat und Bürgevoprsteherkollegium der

Stadt Emdenüber Umsetzung des Projektes, November 1869 -

Februar 1878

- Rentabilitätsberechnung für die Küstenbahn, 1872

- Korrespondenz des Oberbürgermeisters Fürbringer mit verschiedenen Bahnsachverständigen wegen Planungen für die Küstenbahn, 1877

- Korrespondenz des Oberbürgermeisters Fürbringer mit

Bürgermeistern der an der Küstenbahn interessierten Orte über

Fortgang und Probleme des Projekts, Februar 1878

$1869-1878$

Klassifikation Teil B: 00785

Band: 3

Trägermaterial: Papier

Alte Reg.-Sig.: IV T6 056

Bestell-Nr.: IV 00785 
05

\subsection{3}

05.03.12

05.03.12.03

05.03.12.03.01

05.03.12.03.01.01
Stadtverwaltung

Aufgabenbereiche der Stadtverwaltung

Handels- und Gewerbeförderung

Förderung von Handel und Industrie

Förderung von Handel und Verkehr

Maßnahmen zur Handels- und Verkehrsförderung

Lfd. Nr. Titel

Laufzeit

2008 Küstenbahn Emden-Norden Wittmund
1878-1892

- Korrespondenz des Oberbürgermeisters Fürbringer mit verschiedenen Bahnsachverständigen wegen Planungen für die Küstenbahn, 1878 - 1879

- Verhandlungen im Magistrat und Bürgevorsteherkollegium der Stadt Emden über Umsetzung des Projektes, Oktober 1878 - Februar 1890

- Korrespondenz des Oberbürgermeisters Fürbringer mit der Kaufmännischen Deputation wegen Realisierung des

Küstenbahn-Projektes, November 1878 - Dezember 1889

- Gedruckte Aufforderung zur Beteiligung an einer Bahn von Leer nach Aurich, November 1878

- Zuschüsse aus Mittel der Landschaft für die Küstenbahn, Januar 1879

- Ermittlung des Flächenbedarfs für die Bahn auf Emder Stadtgebiet, Mai 1879

- Verhandlungen der Stadt Emden mit den an der Küstenbahn interessierten Orte über Fortgang und Probleme des Projekts, 1888

- Erlass des preußischen Ministers der öffentlichen Arbeiten über Notwendigkeit der bedingungslosen Abgabe von Landflächen der Stadt Emden für den Bahnbau, September 1888

- Entwurf eines Vertrages zwischen der Stadt Emden und der kgl. Eisenbahndirektion Köln über Betrieb der Anlagen der Küstenbahn in Emden und Verantwortlichkeiten bei der Unterhaltung, 1889

- Vertrag zwischen der Stadt Emden und der kgl. Eisenbahndirektion Köln über Gleisverbindung von der Küstenbahn zum rechten Ufer des Ems-Jade-Kanals, April 1892

$1877-1878$

Klassifikation Teil B: 00786

Band: 4

Trägermaterial: Papier

Alte Reg.-Sig.: IV T6 056

Bestell-Nr.: IV 00786 
05

\subsection{3}

05.03.12

05.03.12.03

05.03.12.03.01

05.03.12.03.01.01
Stadtverwaltung

Aufgabenbereiche der Stadtverwaltung

Handels- und Gewerbeförderung

Förderung von Handel und Industrie

Förderung von Handel und Verkehr

Maßnahmen zur Handels- und Verkehrsförderung

Lfd. Nr. Titel

Laufzeit

2009 Küstenbahn Emden Norden Wittmund

- Verfügung des Regierungspräsidenten in Aurich über Prüfung der Sicherheit der Lagerhäuser im Bereich der Küstenbahn auf Emder Hafengebiet, Januar - April 1883

- Parzellen für den Bau der Küstenbahn, Februar 1883

- Organisation der Einweihung der Küstenbahn, Mai - Juni 1883

- Antrag der Stadt Emden beim kgl. Eisenbahnbetriebsamt auf

Verbesserung des Fahrplans, September -Oktober 1883

- Ausbau des Fußweg zur Haltestelle Larrelter Str., Oktober 1883

- Anträge verschiedener Handelskammern auf Erhöhung der

Fahrgeschwindigkeit der Küstenbahn, September - Dezember 1883

- Verhandlungen der Stadt Emden mit der kgl. Eisenbahndirektion in

Köln wegen Verbesserung des Fahrplans der Küstenbahn, Januar -

Februar 1884

- Verzeichnis der Bahnübergänge im Emder Stadtgebiet, 1885

- Entschädigung der Grundeigentümer für Landabtretungen für

Bahnbauzwecke, Februar 1889 - Februar 1895

- Rescript des preußischen Ministers der Öffentlichen Arbeiten über Ablehnung einer Trassenänderung der Küstenbahn zur Ermöglichung einer freien Schiffspassage durch den Emder Binnenhafen durch Aufgabe der Drehbrücke, Mai 1896

- Öffnungszeiten der Drehbrücke über den Emder Binnenhafen für den Schiffsverkehr, 1897 - 1907

- Bahnunfall mit einem spielenden Kind, Juli 1903

- Tragung der Behandlungskosten für die bei einem Sturz vom

Zugtrittbrett verunglückte Witwe Janna Reinhold, August 1903

- Rede des Landtagsabgeordneten Dr. Iderhoff in der Debatte zum

Eisenbahnetat über Plädoyer für eine verbesserte Anbindung Aurichs an der Küstenbahn, März 1905

- Antrag der Stadt Emden bei der kgl. Eisenbahndirektion auf Herstellung eines Übergangs an der Schweckendiekstr., August 1905

- Antrag der Stadt Emden bei der kgl. Eisenbahninspektion auf

Befestigung der Übergänge an de Nesserlander Str- zum Schutz der Verkehrsteilnehmer, Februar - August 1906

- Antrag der Stadt Emden bei der kgl. Eisenbahninspektion auf Einfriedung der Gleise der Küstenbahn auf Emder Stadtgebiet, Mai 1907

- Initiative der Kaufmännischen Deputation zur Anlage eines Nebengleises von der Küstenbahn zum rechten Ufer des Emder Fahrwassers zur Verbesserung des Hafenumschlags, Juni 1907 - Initiative der Kaufmännischen Deputation zur Einrichtung eines weiteren Schnellzugs von Emden nach Westfalen, September 1908

$1882-1908$

Klassifikation Teil B: 00787

Band: 5

Trägermaterial: Papier

Alte Reg.-Sig.: IV T6 056

Bestell-Nr.: IV 00787
1882-1908 
05

\subsection{3}

05.03.12

05.03.12.03

05.03.12.03.01

05.03.12.03.01.01
Stadtverwaltung

Aufgabenbereiche der Stadtverwaltung

Handels- und Gewerbeförderung

Förderung von Handel und Industrie

Förderung von Handel und Verkehr

Maßnahmen zur Handels- und Verkehrsförderung

Lfd. Nr. Titel

Laufzeit

2010 Küstenbahn Emden Norden Wittmund

- Entschädigung der Grundeigentümer für Landabtretungen für Aufbau eines Gewerbegebiets am Emder Hafen mit Anschlussgleis zur Küstenbahn aus Mitteln der Ostfriesischen Landschaft, Februar -

September 1887

- Übersichtsplan des betroffenen Gebietes, 1883

- Verhandlungen der Stadt Emden mit dem preußischen Minister der öffentlichen Arbeiten, dem Regierungspräsidenten in Aurich und der kgl. Eisenbahndirektion in Köln wegen Herstellung eines

Gleisanschlusses der neuen Hafenanlagen mit der Küstenbahn,

September 1886 - April 1892

- Wünsche der Kaufmännischen Deputation hinsichtlich des

Anschlusses des Hafengebiets an die Küstenbahn, November 1886 April 1887

- Verhandlungen im Bürgervorsteherkollegium über die Forderung des preußischen Ministers der öffentlixchen Arbeiten nach einer unentgeltlichen Abgabe von städtischem Land für die Gleisanbindung des Emder Hafens, Dezember 1887 / Februar 1890

- Kataster der von der Stadt Emden an die Eisenbahnverwaltung abgetretenen Ländereien, August 1893

- Abtretung weiterer Ländereien an die Eisenbahnverwaltung durch die Stadt Emden, Mai - Juni 1897

$1883-1897$

Klassifikation Teil B: 00788

Band: 6

Trägermaterial: Papier

Alte Reg.-Sig.: IV T6 056

Bestell-Nr.: IV 00788 
05

05.03

05.03.12

05.03.12.03

05.03.12.03.01

05.03.12.03.01.01
Stadtverwaltung

Aufgabenbereiche der Stadtverwaltung

Handels- und Gewerbeförderung

Förderung von Handel und Industrie

Förderung von Handel und Verkehr

Maßnahmen zur Handels- und Verkehrsförderung

Lfd. Nr. Titel

Laufzeit

2011 Küstenbahn Emden Norden Wittmund

- Verhandlungen im Bürgervorsteherkollegium und Magistrat der Stadt Emden über Küstenbahnfragen, Mai 1879 - Mai 1881

- Verhandlungen der Stadt Emden mit dem preußischen Minister der öffentlichen Arbeiten, dem Regierungspräsidenten in Aurich und der $\mathrm{kgl}$. Eisenbahndirektion in Köln wegen Herstellung eines Gleisanschlusses der neuen Hafenanlagen mit der Küstenbahn, Januar 1880 - Dezember 1882

- Plan einer Brücke als Verbindungsteil des Emder Bahnhofs mit der Küstenbahn, Januar 1880

- Konferenz der Stadt Emden, des preußischen Landdrosten in Aurich, der Eisenbahnverwaltung und eines Vertreters des preußischen Ministeriums der öffentlichen Arbeiten im Emder Rathaus über Planung der Anbindung Emdens an die Küstenbahn, Juni 1880 - Diskussion der Delftquerung der Küstenbahn, Juni 1880 - Zuschuss der Ostfriesischen Landschaft zum Bau der Küstenbahn, Juli 1880 - Januar 1882

- Kostenvoranschlag über Anbindung der Emder Hafenanlagen an die Küstenbahn, März 1881

- Verzeichnis der in Folge des Baus der Bahnanlagen zu bauenden neuen Wege, Juni 1881

- Feststellung des Planes für die Trasse der Küstenbahn, September 1881 - März 1882

- Verschiedene Pläne zur Anlage der Küstenbahn, 1881

- Akquirierung der Landflächen für die Trasse der Küstenbahn, September - Dezember 1881

- Gesuche verschiedener Bürger über Bitte um Anlegung einer Bahnhaltestelle im Kaiser-Wilhelm-Polder, November - Dezember 1881

$1879-1882$

Klassifikation Teil B: 00789

Band: 7

Trägermaterial: Papier

Alte Reg.-Sig.: IV T6 056

Bestell-Nr.: IV 00789

2012 Bahnverbindung Emden - Münster

1901-1908

- Erwerb von Wasserflächen durch die Eisenbahnverwaltung wegen geplanter Erweiterung des Emder Bahnhofs, August 1905

- Eingaben der Kaufmännischen Deputation und anderer Organisationen an die kgl. Eisenbahn-Direktion in Münster und den preußischen Minister für offentliche Arbeiten über Bitte um Verbesserung der Schnellzugverbindungen von Münster, Oktober 1907 - Dezember 1908

$1901-1908$

Klassifikation Teil B: 00790

Trägermaterial: Papier

Alte Reg.-Sig.: IV T6 051

Bestell-Nr.: IV 00790 
05

\subsection{3}

05.03.12

05.03.12.03

05.03.12.03.01

05.03.12.03.01.01
Stadtverwaltung

Aufgabenbereiche der Stadtverwaltung

Handels- und Gewerbeförderung

Förderung von Handel und Industrie

Förderung von Handel und Verkehr

Maßnahmen zur Handels- und Verkehrsförderung

Lfd. Nr. Titel

Laufzeit

2013 Ausbau von Bahnverbindungen

- Denkschrift für einen Ausbau der Strecke Bremen - Frankfurt, 1908

- Unterstützung des Ausbaus der Strecke

Osnabrück-Bielefeld-Paderborn durch die Stadt Emden, Februar 1910

- Projekt des Ausbaus der Strecke Münster - Bielefeld, April 1910

- Rede des Oberbürgermeisters Fürbringer als nationalliberaler Abgeordneter im preußischen Landtag für eine Verbesserung der Eisenbahnanbindung Emdens an Westfalen und das Ruhrgebiet sowie nach Berlin, April 1913

- Schreiben des H. C. van Jindelt an den Oberbürgermeister

Fürbringer über Plädoyer für Verhinderung eines Ausbaus der

Eisenbahnverbindung Bremen - Frankfurt / Main wegen Nachteile für

Emden, November 1913

$1908-1913$

Klassifikation Teil B: 00791

Trägermaterial: Papier

Alte Reg.-Sig.: IV T6 051

Bestell-Nr.: IV 00791

2014 Eisenbahnen

$1881-1885$

- Verfügungen des preußischen Landdrosten in Aurich zum

Eisenbahnwesen, 1881 - 1884

- Mitteilungen der Großherzoglichen Eisenbahndirektion (Oldenburg)

über Öffnungszeiten der Eisenbahnbrücke in Weener, Mai 1881 - Mai

1884

- Beschluss des Magistrats der Stadt Emden über Antrag an die kgl.

Eisenbahndirektion in Köln auf Verbesserung der

Eisenbahnverbindungen nach Emden, September 1881 - Oktober

1882

- Eingabe des Magistrats der Stadt Emden an den preußischen

Minister der öffentlichen Arbeiten über Antrag auf auf

Weitergewährung eines ermäßigten Frachttarifs für Emder

Gemüsebauern, September 1881 - März 1885

- Denkschrift des sächsischen Baurats F. Plessner über Anlage

landwirtschaftlicher Bahnen, 1882

- Verhandlungen zwischen der Ems-Dampfschifffahrts-Gesellschaft

"Concordia" und der kgl. Eisenbahndirektion in Köln über Organisation

des Reiseverkehrs nach Borkum, April 1884

- Reichsgesetzblatt: Bahnpolizei-Reglement für die Eisenbahnen

Deutschlands, Dezember 1885

$1881-1885$

Klassifikation Teil B: 00792

Trägermaterial: Papier

Alte Reg.-Sig.: IV T6 051

Bestell-Nr.: IV 00792 
05

\subsection{3}

05.03.12

05.03.12.03

05.03.12.03.01

05.03.12.03.01.01
Stadtverwaltung

Aufgabenbereiche der Stadtverwaltung

Handels- und Gewerbeförderung

Förderung von Handel und Industrie

Förderung von Handel und Verkehr

Maßnahmen zur Handels- und Verkehrsförderung

Lfd. Nr. Titel

Laufzeit

1897

(1855-1857)

- Verhandlungen der Stadt Emden mit der Eisenbahndirektion in Hannover über Anbindung der Ortschaften am linken Emsufer an die Westbahn, März - Juli 1855

- Eingabe der Bewohner des Dorfes Petkum und Umgebung an die Stadt Emden über Bitte um Unterstützung ihrer Initiative zur Anlegung einer Bahnhaltestelle bei Petkum, Februar - September 1857

- Antrag des Gemeindevorstehers von Petkum an die Stadt Emden auf Verlegung der Bahnhaltestelle bei Petkum nach einem näher beim Dorf gelegenen Ort, August 1897

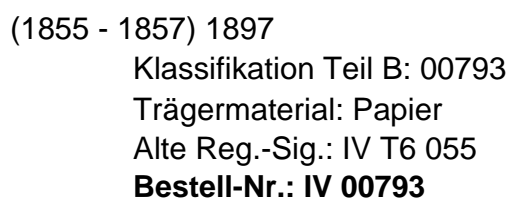

2016 Kranordnung

- Übersendung der Kranordnung der Stadt Emden an das kgl.

Hauptzollamt, 1868 - 1869

- Mitteilung über Einnahmen und Ausgaben für die freiwillige

Benutzung der städtischen Kräne zu Emden, 1876 - 1887

- Mitteilung des kgl. Hauptzollamts über Senkung der Krangebühren,

Oktober 1881

- Krangeldtarif der Stadt Emden, Juli 1882

- Verfügung des preußischen Landdrosten in Aurich über

Genehmigung der Neufestsetzung des Krangeldtarifs, Juli 1882

- Beschwerde der Kaufmännischen Deputation gegen zu hohe Krangeldgebühren, September - Oktober 1886

- Vorschlagung der Senkung des Honorars an die Tochter des verstorbenen Verwalters des Krans am Herrentor, Hobarth, für die

Verwaltung des Krans wegen Abnahme der Frequentierung, Juni - Juli 1887

- Beseitigung des Krans am Herrentor wegen Nichtbenutzung,

September 1902

$1868-1902$

Klassifikation Teil B: 00794

Trägermaterial: Papier

Alte Reg.-Sig.: IV T6 044

Bestell-Nr.: IV 00794 
05

05.03

05.03.12

05.03.12.03

05.03.12.03.01

05.03.12.03.01.01
Stadtverwaltung

Aufgabenbereiche der Stadtverwaltung

Handels- und Gewerbeförderung

Förderung von Handel und Industrie

Förderung von Handel und Verkehr

Maßnahmen zur Handels- und Verkehrsförderung

Lfd. Nr. Titel

Laufzeit

2017 Dampfschifffahrt nach Borkum und Norderney

1873-1907

- Anzeige des Norddeutschen Lloyd über Eröffnung einer Dampferlinie von Emden nach Norderney und Borkum, April 1873

- Gleichstellung der Leeraner Dampfschiffgesellschaft mit dem

Norddeutschen Lloyd hinsichtlich der Hafengebühren in Emden, Mai

1873

- Beschwerde des Justizrats Baron von Dayna über über Aussetzen seiner Familie und anderen Passagieren eines Dampfers der Leeraner Dampfschiffgesellschaft an der Nesserlander Schleuse, Juli 1877

- Denkschrift über die Situation der Dampferlinien von Emden nach

Borkum und Norderney, 1898

- Denkschrift der Vereinigten Dampfschiffrhedereien Norden und

Norderney wegen Situation der Linie Norddeich - Norderney und der

Erwiderung auf Vorwürfe des unerlaubten Monopols, 1907

$1873-1907$

Klassifikation Teil B: 00795

Trägermaterial: Papier

Alte Reg.-Sig.: IV T6 049

Bestell-Nr.: IV 00795

2018 Eisenbahnen

$1872-1907$

- Verhandlungen zwischen dem Magistrat der Stadt Emden und der kgl. Eisenbahnverwaltung über Benutzung und Bebauung der Straße zum Bahnhof, April - Mai 1872

- Besichtigung der neuen Bahnanlagen im Emder Bahnhofsbereich, 1907

$1872-1907$

Klassifikation Teil B: 02009

Trägermaterial: Papier

Alte Reg.-Sig.: IV T6 002

Bestell-Nr.: IV 02009 
05

05.03

05.03.12

05.03.12.03

05.03.12.03.01

05.03.12.03.01.01
Stadtverwaltung

Aufgabenbereiche der Stadtverwaltung

Handels- und Gewerbeförderung

Förderung von Handel und Industrie

Förderung von Handel und Verkehr

Maßnahmen zur Handels- und Verkehrsförderung

Lfd. Nr. Titel

Laufzeit

2019 Vorschriften wegen Räder der Fuhrwerke

1879-1897

- Vorschriften der kgl. Hannoverschen Landdrostei in Aurich wegen

(1836-1843)

Räder von Fuhrwerken, 1836 - 1845

- Gesuche um Straßenverbreiterungen nach Einführung der breiten

Wagenspur im Kgr. Hannover, 1842

- Ausführungsbestimmungen zum Gesetz über die

Radfelgenbeschläge der Fuhrwerke in der Provinz Hannover, Februar

1879

- Radnormen für Fuhrwerke im Großherzogtum Oldenburg, August

1897

- Diskussion einer Verschärfung der Vorschriften über

Radfelgenbeschläge bei Fuhrwerken, März - September 1897

(1836 - 1845) 1879 - 1897

Klassifikation Teil B: 02016

Trägermaterial: Papier

Alte Reg.-Sig.: IV T6 030

Bestell-Nr.: IV 02016

2020 Weg vor dem Boltentor

- Unterhaltung des Weges vor dem Boltentor, (1840 - 1847) 1881

$(1840-1847)$

- Erhebung einer mit der Witwe des Amtmanns Telting vereinbarten

Abgabe zur Unterhaltung des Weges vor dem Boltentor von den

Rechtsnachfolgern, Juli 1881

- Ausbau des Weges vor dem Boltentor, 1896

(1840 - 1847) 1881 - 1896

Klassifikation Teil B: 02017

Trägermaterial: Papier

Alte Reg.-Sig.: IV T6 040

Bestell-Nr.: IV 02017 
05

\subsection{3}

05.03.12

05.03.12.03

05.03.12.03.01

05.03.12.03.01.01
Stadtverwaltung

Aufgabenbereiche der Stadtverwaltung

Handels- und Gewerbeförderung

Förderung von Handel und Industrie

Förderung von Handel und Verkehr

Maßnahmen zur Handels- und Verkehrsförderung

Lfd. Nr. Titel

Laufzeit

2021 Dortmund-Ems-Kanal, Bd. 1

1882-1883

(1865)

- Austausch des Magistrats mit der Kaufmännischen Deputation wegen eines vom preußischen Wasserbaurat Michaelis vorgeschlagenen Projektes eines Rhein-Weser-Kanals, 1865

- Berichterstattung über das Projekt des Dortmund-Ems-Kanals, 1882

- Diskussion von Maßnahmen gegen die Antikanalpropaganda, April -

Mai 1882

- Verteilung der Kosten der Agitation für das Kanalprojekt auf die interessierten Kommunen und Städte an der Ems, Mai 1882

- Resolution der am Bau des Dortmund-Ems-Kanals interessierten Gemeinden und Städte an den preußischen Landtag über Forderung nach Verwirklichung des Kanalprojektes, Mai 1882

- Konstituierung eines Spezialkomitees für den Bau eines

Rhein-Ems-Kanals, November 1882

- Verhandlungen des Spezialkomitees wegen Maßnahmen zur

Verwirklichung des Kanalprojektes, Januar 1883

- Petition des Spezialkomitees an den preußischen Landtag über Bitte um Verwirklichung des Dortmund-Ems-Kanal als Teil des

Rhein-Ems-Kanals, Januar / April 1883

- Verhandlungen der städtischen Kollegien über das

Dortmund-Ems-Kanal-Projekt, April - Dezember 1883

- Erstellung einer Denkschrift für das Dortmund-Ems-Kanal-Projekt

und Verteilung der Kosten auf die interessierten Städte und

Gemeinden, April - Dezember 1883

- Beratung des Gesetzes betr. Bau eines Schiffahrtskanals von

Dortmund (...) nach der unteren Ems, 1883

- Kosten des Kanalprojektes, 1883

- Plan der "Neuen Emdener Seeschleuse", 1883

- Pläne der Häfen von Leer und Papenburg, 1883

(1865) $1882-1883$

Klassifikation Teil B: 02019

Band: 1

Trägermaterial: Papier

Alte Reg.-Sig.: IV T6 061

Bestell-Nr.: IV 02019 
IV

05

Stadtverwaltung

05.03

05.03.12

Aufgabenbereiche der Stadtverwaltung

05.03.12.03

05.03.12.03.01

Handels- und Gewerbeförderung

Förderung von Handel und Industrie

Förderung von Handel und Verkehr

05.03.12.03.01.01

Maßnahmen zur Handels- und Verkehrsförderung

Lfd. Nr. Titel

Laufzeit

2022 Dortmund-Ems-Kanal, Bd. 2

1885-1889

- Agitation des Executiv-Ausschusses für den Kanal

Dortmund-Emshäfen für die Ausführung des Kanalprojektes, 1885 -

1886

- Verhandlungen der städtischen Kollegien wegen Umsetzung des

Dortmund-Ems-Kanal-Projektes, April 1886

- Petitionen der Ostfriesischen Landschaft, der Stadt Emden und des

Ostfriesischen Landwirtschaftlichen Hauptvereins an den preußischen

Landtag über Bitte um Realisierung des

Dortmund-Ems-Kanal-Projektes als nationale Aufgabe, April 1886

- Verhandlungen des Executiv-Ausschusses für den Kanal

Dortmund-Emshäfen über Probleme des Kanalprojektes (Technische

Fragen, Grunderwerb), Juli 1886 - August 1887

- Finanzierung der Vorarbeiten für das Planfeststellungsverfahren des

Dortmund-Ems-Kanals, September 1886 - Januar 1889

- Petition des Executiv-Ausschusses an den preußischen Landtag

über Bitte um Realisierung des Kanalprojektes, Dezember 1886

$1885-1889$

Klassifikation Teil B: 02020

Band: 2

Trägermaterial: Papier

Alte Reg.-Sig.: IV T6 061

Bestell-Nr.: IV 02020 
05

\subsection{3}

05.03.12

05.03.12.03

05.03.12.03.01

05.03.12.03.01.01
Stadtverwaltung

Aufgabenbereiche der Stadtverwaltung

Handels- und Gewerbeförderung

Förderung von Handel und Industrie

Förderung von Handel und Verkehr

Maßnahmen zur Handels- und Verkehrsförderung

Lfd. Nr. Titel

Laufzeit

2023 Dortmund-Ems-Kanal, Bd. 3

- Gesuch des Magistrats an den Minister der öffentlichen Arbeiten über Bitte um Verlegung der Bauleitung für den Dortmund-Ems-Kanal nach Emden zur Kompensation der negativen Folgen der Auflösung der Emder Garnison, März 1889

- Finanzierung der Grunderwerbskosten für den Dortmund-Ems-Kanal und Anteil der Stadt Emden, 1889 - 1890

- Planung des Seitenkanals zum Dortmund-Ems-Kanal bei Oldersum, Dezember 1889 - Januar 1890

- Organisation der Arbeiterfürsorge beim Bau des Seitenkanals zwischen Oldersum und Emden, 1890

- Enteignungsverfahren beim Bau des Dortmund-Ems-Kanal, 1889

- Gescheiterte Versuche der Stadt Emden zur Ansiedlung von

Werftindustrie mit dem Hinweis auf den Anschluss an das Ruhrgebiet durch den Dortmund-Ems-Kanal, 1890

- Denkschrift des Stadtbaumeisters Wiggers über Gestaltung der Einmündung des Dortmund-Ems-Kanals in den Emder Hafen, Juli 1890

- Verhandlungen des Magistrats über die Hafenerweiterung in Emden im Zuge des Anschlusses an den Dortmund-Ems-Kanal, juli 1890 - Verhandlungen des Magistrats mit der kgl. Kanalkommission in Münster wegen Ausbau des Emder Hafens, Juli 1890 - Januar 1891 - Übersichtskarte: Anschluss Emdens an den Dortmund-Ems-Kanal, Seitenkanal bei Oldersum und Vorflutkanäle, 1891

- Beschwerde der Landwirtschaftsverbände gegen den Dortmund-Ems-Kanal wegen drohender Vermehrung der Getreideund Kartoffeleinfuhr, 1891

$1890-1891$

Klassifikation Teil B: 02021

Band: 3

Trägermaterial: Papier

Alte Reg.-Sig.: IV T6 061

Bestell-Nr.: IV 02021 
05

05.03

05.03.12

05.03.12.03

05.03.12.03.01

05.03.12.03.01.01
Stadtverwaltung

Aufgabenbereiche der Stadtverwaltung

Handels- und Gewerbeförderung

Förderung von Handel und Industrie

Förderung von Handel und Verkehr

Maßnahmen zur Handels- und Verkehrsförderung

Lfd. Nr. Titel

Laufzeit

2024 Dortmund-Ems-Kanal, Bd. 4

1884-1886

- Finanzierung der Grunderwerbskosten für den

Dortmund-Ems-Kanal, 1884 - 1885

- Schinkel-Preis des Architekten-Vereins zu Berlin für die Aufgabe:

Anschluss des Emder Hafens an den Dortmund-Ems-Kanal

(Rhein-Ems-Kanal), 1885

- Flugschrift des Th. Springmann gegen den Dortmund-Ems-Kanal,

Mai 1884

- Plan zur Verteilung der Kosten des Grunderwerbs für den Kanal

Dortmund-Emshäfen auf dem Gebiet der Provinz Hannover, 1884

- Presseberichte über das Kanalprojekt, 1884 - 1885

- Gedruckte Landtagsprotokolle über Verhandlungen zum

Kanalprojekt, März 1885 - Juni 1886

- Korrespondenz des Oberbürgermeisters Fürbringer mit dem Grafen von Knyphausen und dem Grafen von Wedel wegen Verhandlungen der Kanalvorlage im preußischen Herrenhaus (Adelskammer des Landtages), Mai - Juni 1886

$1884-1886$

Klassifikation Teil B: 02022

Band: 4

Trägermaterial: Papier

Alte Reg.-Sig.: IV T6 061

Bestell-Nr.: IV 02022 
05

\subsection{3}

05.03.12

05.03.12.03

05.03.12.03.01

05.03.12.03.01.01
Stadtverwaltung

Aufgabenbereiche der Stadtverwaltung

Handels- und Gewerbeförderung

Förderung von Handel und Industrie

Förderung von Handel und Verkehr

Maßnahmen zur Handels- und Verkehrsförderung

Lfd. Nr. Titel

Laufzeit

2025 Dortmund-Ems-Kanal, Bd. 5

1891-1893

(1897)

- Festschrift des Wasserbauingenieurs Matthies zum Dortmunder Hafen, 1897

- Eingabe des Magistrats an den Minister der öffentlichen Arbeiten über Notwendigkeit von den aktuellen Schiffsgrößen angepasster Schleusen und Brücken des Dortmund-Ems-Kanals als Vorsorge für den Kriegsfall, Februar 1891

- Verhandlungen der städtischen Kollegien über Ausbau der Emder Hafenanlagen und Anschluss an den Dortmund-Ems-Kanal sowie Änderung des Vertrages über den Königspolder, Februar - Dezember 1891

- Bescheid des Bezirksausschusses in Aurich über Charakterisierung des Passusses über Nichtzulassung einer gewerblichen Nutzung des Königspolders als revidierbare Vertragsbestimmung, März 1891 - Verfügung des Regierungspräsidenten über Genehmigung der Aufheibung der vertraglichen Bestimmungen von 1845 über Gewerbebeschränkungen im Königspolder, April 1891

- Bericht des Stadtbaumeisters Wiggers über ausgelegte Hafenausbaupläne der kgl. Kanalbaukommission, August 1891 - Änderungswünsche des Magistrats hinsichtlich des geplanten Hafenausbaus, November 1891

- Eingabe verschiedener Sielrichter und Gemeindevorsteher der Emder Nachbarkommunen an den Minister der öffentlichen Arbeiten über Bitte um Verzicht auf den Seitenkanal bei Oldersum wegen Entwässerungsprobleme, Oktober 1891

- Presseberichterstattung über das Dortmund-Ems-Kanal-Projekt, 1892

- Protokoll einer Konferenz in Emden unter Teilnahme des Geh. Regierungsrats Schweckendieck, Vertreter der kgl.

Wasserbauverwaltung, der Regierung in Aurich, der kgl. Kanalkommission, der Bauleitung des Dortmund-Ems-Kanals und Vertretern aus Wirtschaft und Politik über Ausbau des Emder Hafens und Anschluss an den Dortmund-Ems-Kanal, November 1892

$1891-1893$ (1897)

Klassifikation Teil B: 02023

Band: 5

Trägermaterial: Papier

Alte Reg.-Sig.: IV T6 061

Bestell-Nr.: IV 02023 
05

\subsection{3}

05.03.12

05.03.12.03

05.03.12.03.01

05.03.12.03.01.01
Stadtverwaltung

Aufgabenbereiche der Stadtverwaltung

Handels- und Gewerbeförderung

Förderung von Handel und Industrie

Förderung von Handel und Verkehr

Maßnahmen zur Handels- und Verkehrsförderung

Lfd. Nr. Titel

Laufzeit

2026 Dortmund-Ems-Kanal, Bd. 6

1893-1897

- Votum des Borssumer Gemeindevorstehers H. Gresemann für eine

Schleuse im Dortmund-Ems-Kanal bei Borssum, Juli 1897

- Festlegung der Entschädigung für zum Kanalbau abgegebene

Landflächen, Juli 1893 - Dezember 1894

- Presseberichte über den Dortmund-Ems-Kanal, 1893 - 1897

- Eingabe verschiedener Rhein-Schifffahrts-Gesellschaften an die preußische Staatsregierung über Bitte um Verwirklichung des

Dortmund-Ems-Kanals in größeren Abmessungen wegen

zunehmender Schiffsgrößen, Februar 1894

- Vertrauliche Denkschrift des Oberbürgermeisters Fürbringer über

Stand der Hafenerweiterung, November 1894

- Reisebericht einer Kommission der Kaufmännischen Deputation über Daten zum erwarteten Verkehrsaufkommen im

Dortmund-Ems-Kanal, Dezember 1894

- Planfeststellungsverfahren zur Emder Hafenerweiterung und

Anschluss an den Dortmund-Ems-Kanal, Dezember 1894 - März 1895

- Anfrage des B.A. Baruch wegen des geplanten Petroleumhafens in

Emden, April - Juni 1895

- Anfrage des Rheinisch-Westfälischen Kohlensyndicats wegen der geplanten Emder Hafenanlagen, Juli 1895

- Gutachten des Kanalvereins über wirtschaftliche Bedeutung des

Rhein-Weser-Elbe-Kanals, 1895

- Plan: Gleisanschluss im Kaiser-Wilhelm-Polder, 1895

- Verhandlungen über Gleisanschlüsse der projektierten

Hafenanlagen, Oktober 1895

- Anfrage des Centralvereins für Hebung der deutschen Fluss- und

Kanalschiffahrt wegen des Dortmund-Ems-Kanals und der neuen

Emder Hafenanlagen, Dezember 1895 - Januar 1896

- Protokoll einer Versammlung von Ruhrindustriellen,

Handelskammervertretern, Vertreter der Stadt Dortmund, des Emder

Magistrats und der kgl. Kanalverwaltung über Organisation des

künftigen Kanalverkehrs und notwendige Einrichtungen im Emder

Hafen, September 1896

Festlegung des Kanaltarifs, Juni 1895 - April 1897

$1893-1897$

Klassifikation Teil B: 02024

Band: 6

Trägermaterial: Papier

Alte Reg.-Sig.: IV T6 061

Bestell-Nr.: IV 02024 
05

\subsection{3}

05.03.12

05.03.12.03

05.03.12.03.01

05.03.12.03.01.01
Stadtverwaltung

Aufgabenbereiche der Stadtverwaltung

Handels- und Gewerbeförderung

Förderung von Handel und Industrie

Förderung von Handel und Verkehr

Maßnahmen zur Handels- und Verkehrsförderung

Lfd. Nr. Titel

Laufzeit

2027 Dortmund-Ems-Kanal, Bd. 7

- Regelung der Kanal-, Strom und Schifffahrtspolizei auf dem

Dortmund-Ems-Kanal, April - Dezember 1899

- Auslegung des Plans einer Schleuse zwischen dem Vorflutkanal des

Ems-Jade-Kanals und dem Fehntjer Tief, April 1898

- Erläuterungsbericht der Wasserbauinspektion Emden zur

landespolizeilichen Prüfung des Planes einer Schleuse, März 1898

- Planzeichnung der Schleuse, 1898

- Presseberichte zum Dortmund-Ems-Kanal, 1898 - 1913

- Petition der städtischen Kollegien an den preußischen Landtag über Bitte um Bewilligung der Mittel zum Ausbau des Emder Hafens und des Dortmund-Ems-Kanals, Februar 1901

- Verkehrsstatistik des Dortmund-Ems-Kanals, 1901 - 1908

- Diskussion der Fördeung des Verkehrs auf dem

Dortmund-Ems-Kanal, 1901 - 1909

- Erlass des Ministers der öffentlichen Arbeiten über Anordnung der

Abgabe regelmäßiger Berichte über die Verkehrsentwicklung auf dem

Dortmund-Ems-Kanal, August 1909

- Verfügung des Regierungspräsidenten in Aurich über Anordnung einer Datenerhebung über den Dortmund-Ems-Kanal zur Erstellung einer Denkschrift des Ministers der öffentlichen Arbeiten, November 1912

- Folgen der Sperrung des Dortmund-Ems-Kanals wegen des Bruches des Oberhaupts der Meppener Schleuse für den Emder Hafen,

September 1904

- Statistik des Hafens von Münster, 1899 - 1903

- Geschäftsbericht der WTAG zum Kanalbetrieb des

Dortmund-Ems-Kanals, 1909

$1898-1913$

Klassifikation Teil B: 02025

Band: 7

Trägermaterial: Papier

Alte Reg.-Sig.: IV T6 061

Bestell-Nr.: IV 02025

2028 Dortmund-Ems-Kanal, Bd. 8

- Konferenz von Vertretern des Ministriums der öffentlichen Arbeiten, der kgl. Wasserbauverwaltung, der Dortmund-Ems-Kanal-Kommission, des Magistrats, der HAPAG, der Hafenbetriebe und Transportfirmen über Maßnahmen zum Ausbau des Emder Hafens und Förderung des Dortmund-Ems-Kanals, September 1899

1899

Klassifikation Teil B: 02026

Band: 8

Trägermaterial: Papier

Alte Reg.-Sig.: IV T6 061

Bestell-Nr.: IV 02026 
IV

05

Stadtverwaltung

05.03

05.03.12

Aufgabenbereiche der Stadtverwaltung

05.03.12.03

05.03.12.03.01

Handels- und Gewerbeförderung

Förderung von Handel und Industrie

Förderung von Handel und Verkehr

05.03.12.03.01.01

Maßnahmen zur Handels- und Verkehrsförderung

Lfd. Nr. Titel

Laufzeit

2029 Dortmund-Ems-Kanal, Bd. 9

1895-1896

- Verhandlungen des Magistrats und der Bau- und

Verpachtungskommission über Aushebung von Erde zum

Hafenausbau aus städtischen Grundflächen, April 1895 - Januar 1896

- Verhandlungen des Magistrats mit der kgl. Wasserbauverwaltung und der kgl. Kanalkommission wegen des Erdaushubs, 1895 - 1896

- Kostenträgerschaft für die Befestigung des städtischen

Hafendamms, 1896

$1895-1896$

Klassifikation Teil B: 02027

Band: 9

Trägermaterial: Papier

Alte Reg.-Sig.: IV T6 061

Bestell-Nr.: IV 02027

2030 Dortmund-Ems-Kanal, Bd. 10

1911-1913

- Installierung eines staatlichen Schleppmonopols auf der Ems und

Widerstand dagegen von Seiten der Schifffahrtsorganisationen und

-Firmen wegen drohender hoher Tarifsätze

- Lobbyarbeit der Magistrate von Dortmund und Emden gegen das

Schleppmonopol im preußischen Landtag

$1911-1913$

Klassifikation Teil B: 02028

Band: 10

Trägermaterial: Papier

Alte Reg.-Sig.: IV T6 061

Bestell-Nr.: IV 02028 
05

05.03

05.03.12

05.03.12.03

05.03.12.03.01

05.03.12.03.01.01
Stadtverwaltung

Aufgabenbereiche der Stadtverwaltung

Handels- und Gewerbeförderung

Förderung von Handel und Industrie

Förderung von Handel und Verkehr

Maßnahmen zur Handels- und Verkehrsförderung

Lfd. Nr. Titel

Laufzeit

2031 Straßenbau-Verwaltung

- Verfügungen des Hannoverschen und des preußischen Landdrosten

1867-1878

$(1842-1864)$

in Aurich über Organisation der Straßenbauverwaltung und des

Abrechnungswesens zur Straßen- und Wegeunterhaltung, (1842 -

1864) 1867 - 1874

- Hannoversche Ministerialerlasse wegen Bau und Unterhaltung von

Landstraßen, 1842 - 1855

- Erlass des Landesdirektoriums der Provinz Hannover über

Geschäftsanweisung für die Landstraßenaufseher in der Provinz

Hannover, Oktober 1874

- Erlass des preußischen Finanzministers über Wegegeldfreiheit für

Dienstreisen der Bediensteten der staatlichen Straßenbauverwaltung, Juni 1874

- Regelung der Wegegelderhebung auf Landstraßen, Oktober 1874

- Dienstanweisung für den provinzialständischen Wegbau-Inspektor, Januar 1875

- Initiative zum Ausbau des Landstraßennetzes im Rheiderland, 1873

- Statistik: Umlage zum Straßenbau

(1842 - 1864) 1867 - 1878

Klassifikation Teil B: 02029

Trägermaterial: Papier

Alte Reg.-Sig.: IV T6 065

Bestell-Nr.: IV 02029

- Denkschrift des C. H. Metger für den Anschluss des Kgr. Hannover an den deutschen Zollverein, Mai 1862

- Diskussion über den Anschluss des Kgr. Hannover an den deutschen Zollverein, 1842 - 1851

- Befreiung der Zollbediensteten der Zollvereinsstaaten von persönlichen Steuern und Kommunalabgaben, 1853 - 1874

- Befreiung von Handelsreisenden aus den Zollvereinsstaaten von der Gewerbesteuer, 1854 - 1868

- Verkehrserleichterungen und Zollbestimmungen für Händler aus den Zollvereinsstaaten, 1859 - 1906

(1842 - 1866) 1867 - 1906

Klassifikation Teil B: 02030

Trägermaterial: Papier

Alte Reg.-Sig.: IV T6 069

Bestell-Nr.: IV 02030 
05

05.03

05.03.12

05.03.12.03

05.03.12.03.01

05.03.12.03.01.01
Stadtverwaltung

Aufgabenbereiche der Stadtverwaltung

Handels- und Gewerbeförderung

Förderung von Handel und Industrie

Förderung von Handel und Verkehr

Maßnahmen zur Handels- und Verkehrsförderung

Lfd. Nr. Titel

Laufzeit

2033 Beteiligung der Stadt Emden am Landstraßenbau im Amtsbezirk Emden, Bd. 1

1867-188

- Verhandlungen zwischen dem Amt und der Stadt Emden über finanzielle Beteiligung der Stadt Emden an Straßenverbindungen von der Stadt ins Amtsgebiet, 1867 - 1880

- Verhandlungen der städtischen Kollegien über Beteiligung der Stadt an der Finanzierung von Straßenbauprojekten im Amt Emden, 1867 1881

- Denkschrift des Oberbürgermeisters Ernst Hantelmann über Verpflichtung der Stadt Emden zur Unterhaltung von Wegen ins Amtsgebiet (z.B. Straße nach Nesserland), September 1869

- Beihilfe der Provinz Hannover für Straßenbauprojekte des Amtes und der Stadt Emden, März 1872

- Kosten des Baues einer Landstraße von Emden nach Larrelt, 1873

- Verhandlungen zwischen Amt und der Stadt Emden wegen

Finanzierung des Landstraßenbaus Emden - Larrelt, 1873 - 1878

- Verhandlungen der städtischen Kollegien über Finanzierung des Landstraßenbaus Emden - Larrelt, 1873 - 1876

- Eingabe Emder Bürger an den Magistrat über Bitte um Führung des Anschlusses an die Larrelter Landstraße in einem südlichen Bogen und Vorschlagung eines Ortes für ein Kriegerdenkmal, Dezember 1873

- Verdingung der Arbeiten für den Anschluss an die Larrelter Landstraße, Februar - März 1876

- Ausführung des Projektes, 1876

$1867-1881$

Klassifikation Teil B: 02040

Band: 1

Trägermaterial: Papier

Alte Reg.-Sig.: IV T6 100

Bestell-Nr.: IV 02040 
05

05.03

05.03.12

05.03.12.03

05.03.12.03.01

05.03.12.03.01.01
Stadtverwaltung

Aufgabenbereiche der Stadtverwaltung

Handels- und Gewerbeförderung

Förderung von Handel und Industrie

Förderung von Handel und Verkehr

Maßnahmen zur Handels- und Verkehrsförderung

Lfd. Nr. Titel

Laufzeit

2034 Beteiligung der Stadt Emden am Landstraßenbau im Amtsbezirk

Emden, Bd. 2

1872-1909

- Verhandlungen zwischen Stadt und Amt Emden wegen Beteiligung der Stadt am Bau und an der Unterhaltung der Landstraße nach Petkum, Februar 1872 - Juli 1875

- Verhandlungen der städtischen Kollegien über Beteiligung der Stadt Emden am Bau der Landstraße nach Petkum, März 1872 - November 1874

- Festlegung der Trasse der Petkumer Landstraße, 1873 - 1875

- Kostenvoranschläge für den Bau der Petkumer Landstraße, 1874 1875

- Ausschreibung der Straßenbauarbeiten, Januar - Februar 1876

- Übergabe des von der Stadt Emden hergestellten Teils der

Petkumer Landstraße, Juni 1878

- Heranziehung der Anlieger zur Unterhaltung der Petkumer

Landstraße, 1895 / 1909

- Beschwerden über schlechten Zustand der Petkumer Landstraße, November - Dezember 1904

$1872-1909$

Klassifikation Teil B: 02041

Band: 2

Trägermaterial: Papier

Alte Reg.-Sig.: IV T6 100

Bestell-Nr.: IV 02041

2035 Beteiligung der Stadt Emden am Landstraßenbau im Amtsbezirk Emden, Bd. 3

- Verhandlungen der städtischen Kollegien über Beteiligung an den Straßenprojekten Emden-Larrelt und Emden-Petkum, April -

Dezember 1875

- Ankauf von Steinen für den Landstraßenbau, Januar - August 1876

- Kostenanschläge und technische Beschreibungen der

Straßenbauprojekte, 1876

- Bestellung eines Rendanten für den Wegeverband der Stadt Emden, April 1876

- Ausschreibung von Pflastererarbeiten, Mai 1876

- Auszahlung der vom Landesdirektorium der Provinz Hannover bewilligten Beihilfen zum Straßenbau, 1876

- Bepflanzung der Straßenränder mit Alleebäumen, April 1876

- Beschwerden über Unpassierbarkeit der Landstraße von Emden nach Petkum, Dezember 1888 - Januar 1889

$1875-1889$

Klassifikation Teil B: 02042

Band: 3

Trägermaterial: Papier

Alte Reg.-Sig.: IV T6 100

Bestell-Nr.: IV 02042

$1875-1889$ 
05

05.03

05.03.12

05.03.12.03

05.03.12.03.01

05.03.12.03.01.01
Stadtverwaltung

Aufgabenbereiche der Stadtverwaltung

Handels- und Gewerbeförderung

Förderung von Handel und Industrie

Förderung von Handel und Verkehr

Maßnahmen zur Handels- und Verkehrsförderung

Lfd. Nr. Titel

Laufzeit

2036 Errichtung einer Zweigstation der Norddeutschen Seewarte

1869

- Antrag der Handelskammer beim Magistrat auf Beihilfe zur

Errichtung einer Zweigstation der Norddeutschen Seewarte, Oktober -

November 1869

1869

Klassifikation Teil B: 02043

Trägermaterial: Papier

Alte Reg.-Sig.: IV T6 102

Bestell-Nr.: IV 02043

2037 Herstellung einer unterirdischen Telegrafenleitung von Emden nach

$1871-1910$ Greetsiel

- Mitteilung der kaiserlichen Telegraphen-Direktion über Trasse der Telegrafenlinie von Emden nach Greetsiel als Anschluss an die

Telegrafenleitung zur englischen Küste, September 1871

- Plan der Trasse durch Emder Stadtgebiet, 1871

- Vereinbarung zwischen der Stadt Emden und der Vereinigten

Deutschen Telegraphengesellschaft wegen der Trassenführung der

Telegrafenleitung durch Emder Gebiet, November 1871

- Beschwerde der Vereinigten Deutschen Telegraphengesellschaft gegen eine unbefugte Veränderung der Lage von

Telegrafenleitungskabeln auf Privatgrundstücken, Juni 1872

- Festlegung der Trasse einer Telegrafenleitung von Emden über

Greetsiel nach Nordamerika, September 1881

- Ankauf der Vereinigten Deutschen Telegraphengesellschaft und ihres Netzes durch die kaiserliche Postverwaltung, Januar -

September 1888

- Trassenführung einer Telegrafenleitung nach England über Emder

Stadtgebiet, Juni - Juli 1881

- Presseberichte über Telegrafenleitungen, 1891 / 1896

- Planzeichnungen von Telegrafenleitungen, 1892 - 1902

- Herstellung einer Telegrafenlinie von Emden über Greetsiel nach USA, 1894 - 1895

- Ausbau der Telegrafenverbindung von Deutschland nach England, $1895-1896$

- Festlegung der Trasse der Telegrafenleitung nach den USA auf

Emder Stadtgebiet, 1896

- Verhandlungen des Magistrats mit den kaiserlichen Telegrafenamt wegen Tieferlegung von Telegrafenleitungen, März - April 1900

- Plan einer oberirdischen Telegrafenleitung durch Emder Stadtgebiet, Januar 1901

- Beschädigung von Telegrafenleitungen durch Verlegung von

Gasrohren, 1902

- Regulierung von Schäden durch die Verlegung von

Telegrafenleitungen, 1904 - 1909

1871 - 1909

Klassifikation Teil B: 02045

Trägermaterial: Papier

Alte Reg.-Sig.: IV T6 104

Bestell-Nr.: IV 02045 
IV

05

Stadtverwaltung

05.03

05.03.12

Aufgabenbereiche der Stadtverwaltung

05.03.12.03

05.03.12.03.01

Handels- und Gewerbeförderung

Förderung von Handel und Industrie

Förderung von Handel und Verkehr

05.03.12.03.01.01

Maßnahmen zur Handels- und Verkehrsförderung

Lfd. Nr. Titel

Laufzeit

2038 Schauungen der Gemeindewege

1874-1901

- Verfügung des preußischen Landdrosten in Aurich über Organisation der Schauung von Gemeindewegen, November 1874 / Dezember 1876

- Schauungsprotokolle über Zustand der Wege auf Emder Gebiet, Juli 1875 - Juli 1901

- Beschwerden über schlechten Zustand der Wege in der Emder Feldmark, 1876

- Protest des Landwirts Fokke Bakker gegen die Verhängung einer Geldstrafe wegen Unterlassung der Wegeunterhaltung vor seinem Besitz, September - Oktober 1890

- Protest des H. Rosingh gegen die Verhängung einer Geldstrafe wegen Unterlassung der Wegeunterhaltung vor seinem Besitz, Oktober 1897

$1874-1901$

Klassifikation Teil B: 02048

Trägermaterial: Papier

Alte Reg.-Sig.: IV T6 110

Bestell-Nr.: IV 02048 
05

\subsection{3}

05.03.12

05.03.12.03

05.03.12.03.01

05.03.12.03.01.01

\section{Stadtverwaltung}

Aufgabenbereiche der Stadtverwaltung

Handels- und Gewerbeförderung

Förderung von Handel und Industrie

Förderung von Handel und Verkehr

Maßnahmen zur Handels- und Verkehrsförderung

Lfd. Nr. Titel

Laufzeit

2039 Verbesserung der Fährverbindung an der Unterems

- Bericht des Magistrats an den preußischen Landdrosten in Aurich 1883-1890 über Notwendigkeit der Verbesserung der Fährverbindungen an der Ems, Januar 1883

- Erstellung einer Statistik über Gütertransporte mit Fähren zum und vom Rheiderland, Februar 1883

- Bericht des Magistrats an den preußischen Landdrosten in Aurich über Statistik des Gütertransports zum Rheiderland per Fähre, April 1883

- Bericht des Wasserbauinspektors Suadicani über Kosten und Rentabilität der Anlegung einer Fähre von Petkum über die Ems, April 1883

- Gesuch des Landwirtschaftlichen Zweigvereins Emden über Bitte um Anlegung einer Püntfähre über die Unterems, April 1883

- Bericht des Lotsenkommandeurs Graefenhain über fehlgeschlagene Versuche zur Etablierung einer Fährlinie von Emden nach Ditzum, Juli 1883

- Diskussion der Errichtung einer Fährlinie zwischen Oldersum und Hatzum, März - Juli 1885

- Verhandlungen wegen Finanzierung einer Fährlinie von Petkum nach Ditzum, Oktober 1885 - Oktober 1890

- Angebot des Erwerbs des Dampfers "Norderney" für den Fährdienst Petkum - Ditzum, Oktober 1889

- Versammlung der Fährinteressenten in Ditzum über Beschluss zur Planung einer Fährverbindung von Hatzum nach Rorichum, Dezember 1890

$1883-1890(1906)$

Klassifikation Teil B: 02050

Trägermaterial: Papier

Alte Reg.-Sig.: IV T6 112

Bestell-Nr.: IV 02050 
05

\subsection{3}

05.03.12

05.03.12.03

05.03.12.03.01

05.03.12.03.01.01
Stadtverwaltung

Aufgabenbereiche der Stadtverwaltung

Handels- und Gewerbeförderung

Förderung von Handel und Industrie

Förderung von Handel und Verkehr

Maßnahmen zur Handels- und Verkehrsförderung

Lfd. Nr. Titel

Laufzeit

2040 Gemeindeweg von Emden nach Uphusen und Verlängerung nach Riepe

$1876-1890$

- Verhandlungen zwischen dem Amtshauptmann von Weyhe und dem Magistrat wegen Beteiligung der Stadt Emden wegen Verlängerung des Gemeindeweges von Emden nach Uphusen in Richtung Riepe, April 1876 - Oktober 1879

- Kostenanschlag über den Ausbau des Gemeindeweges von Emden nach Uphusen, 1877 / 1879

- Kollekte zur Finanzierung des Wegebaues, 1877

- Verhandlungen des Magistrats über Beteiligung der Stadt Emden an der Wegebaufinanzierung, April 1877 - August 1878

- Verhandlungen der städtischen Kollegien über Beteiligung der Stadt

Emden an der Wegebaufinanzierung, Juni 1877 - Oktober 1879

- Bescheid des Landesdirektoriums der Provinz Hannover an den Kreishauptmann von Weyhe über Nichtbewilligung einer Beihilfe zum Ausbau des Gemeindeweges von Emden nach Uphusen Richtung Riepe, August 1878

- Plan des projektierten Weges von Emden nach Uphusen, 1879 - Antrag der Stadt Emden an das Landesdirektorium der Provinz Hannover auf Gewährung einer Beihilfe zum Bau des städtischen Teil des Weges von Emden nach Uphusen, Oktober 1879 - Januar 1881 - Ausschreibung der Wegebauarbeiten im Gebiet der Stadt Emden, November 1879 - Februar 1880

- Beschwerde der Gemeindevorsteher von Uphusen und Wolthusen gegen die zu schmale Ausführung des Gemeindeweges von Emden nach Uphusen, Mai 1880

- Antrag des Magistrats an den preußischen Landdrosten in Aurich auf Einbeziehung des Anschlusses des Gemeindeweges nach Uphusen an die Landstraße nach Riepe in den Straßenbauetat, Juni 1884 - Verhandlungen über den Anschluss des Gemeindeweges nach Uphusen an die Landstraße nach Riepe, 1889 - 1890

$1876-1890$

Klassifikation Teil B: 02051

Trägermaterial: Papier

Alte Reg.-Sig.: IV T6 115

Bestell-Nr.: IV 02051

2041 Ausstellung von Lehrlingsarbeiten

- Organisation einer Ausstellung von Lehrlingsarbeiten durch den Handwerker-Verein in Emden, 1881 - 1882

- Übersicht über prämierte Arbeiten von Lehrlingen, April 1882

$1881-1882$

Klassifikation Teil B: 02053

Trägermaterial: Papier

Alte Reg.-Sig.: IV T6 117

Bestell-Nr.: IV 02053 
05

05.03

05.03.12

05.03.12.03

05.03.12.03.01

05.03.12.03.01.01
Stadtverwaltung

Aufgabenbereiche der Stadtverwaltung

Handels- und Gewerbeförderung

Förderung von Handel und Industrie

Förderung von Handel und Verkehr

Maßnahmen zur Handels- und Verkehrsförderung

Lfd. Nr. Titel

Laufzeit

2042 Bahnwesen

1881-1897

- Erlasse des Ministers der öffentlichen Arbeiten über Regulierung und Normierung des Bahnwesens, 1881 - 1897

- Verfügungen des preußischen Landdrosten/Regierungspräsidenten

in Aurich über Regulierung des Bahnwesens, 1883 - 1897

- Materialien zur Konzessionierung von Pferdebahnen in den

Nachbarstädten Emdens, 1884

- Erlass einer Polizeiverordnung der Stadt Emden zum Betrieb einer

Pferdebahn, Juli 1884

$1881-1897$

Klassifikation Teil B: 02054

Trägermaterial: Papier

Alte Reg.-Sig.: IV T6 118

Bestell-Nr.: IV 02054

2043 Geplante Dampfschiffverbindung von Emden nach England

- Initiative der Speditionsfirma Leichtentritt \& Bollenstein (Möbius) beim Oberbürgermeister Fürbringer zur Anregung der Errichtung einer Dampferlinie von Emden nach England, Juni 1883 - September 1884 - Verhandlungen des Magistrats über Förderung der Errichtung einer Dampfschiffverbindung von Emden nach England, Januar 1884 - April 1885

- Petition des Magistrats an die Minister für Handel und Verkehr, der Finanzen und an den Staatssekretär des Reichspostamts über Bitte um Förderung einer Dampfschiffverbindung von Emden nach England, Januar - Februar 1884

- Befürwortung der Förderung einer Dampfschiffverbindung von Emden nach England durch die Kaufmännische Deputation, März 1884

- Schreiben des Agenten H. Diekenga an den Magistrat über Interesse einer englischen Firma an der Errichtung einer Dampfschiffverbindung von Emden nach England, April 1887

- Schreiben der HAPAG über Unwirtschaftlichkeit einer

Dampfschiffverbindung von Emden nach England, November 1900

- Anregung der Husumer Firma J.K. Hanssen zum Anschluss Emdens als Zubringer einer Dampferlinie von Husum nach Hull (England), Oktober 1906

$1883-1906$

Klassifikation Teil B: 02056

Trägermaterial: Papier

Alte Reg.-Sig.: IV T6 120

Bestell-Nr.: IV 02056 
05

05.03

05.03.12

05.03.12.03

05.03.12.03.01

05.03.12.03.01.01
Stadtverwaltung

Aufgabenbereiche der Stadtverwaltung

Handels- und Gewerbeförderung

Förderung von Handel und Industrie

Förderung von Handel und Verkehr

Maßnahmen zur Handels- und Verkehrsförderung

Lfd. Nr. Titel

Laufzeit

2044 Bau einer Landungsbrücke und einer Inselbahn auf Borkum

1883-1901

- Planung einer Landungsbrücke und Pferdebahn auf der Insel

Borkum, Juli 1883 - Januar 1884

- Vertrag zwischen den Reedereien F. D. Ihnen und M. H. Schönberg

sowie dem Magistrat über Finanzierung der Landungsbrücke auf

Borkum, August 1883

- Protest des Hermann Russell als Vertreter der

Weser-Dampfschifffahrtsgesellschaft gegen die Exklusivrechte von

Emder Reedereien bei der Nutzung der geplanten Landungsbrücke

auf Borkum, September 1883

- Konzessionierung der Pferdebahn auf Borkum, November 1883

- Planzeichnungen der Landungsbrücke, 1883

- Rammen der Nesserländer Schleuse durch den Dampfer

"Borkumriff", November 1883 - Mai 1884

- Eingabe des Bauunternehmens Habich \& Goth an den Magistrat über Bitte um ein Darlehen zum Bau einer Landungsbrücke und einer Inselbahn auf Borkum, November 1887 - Februar 1888

- Verhandlungen des Magistrats mit der Kaufmännischen Deputation über Subventionierung des Projektes, Dezember 1887 - Februar 1888

- Anfrage des Regierungspräsidenten über Beteiligung der Stadt Emden an die in einer Aktiengesellschaft umgewandelte Inselbahn, August 1901

- Übernahme der Kleinbahn auf Borkum durch eine

Aktiengesellschaft, gebildet von Kommerzienrat Metger, Kaufmann

Philippstein und Kaufmann Russell, November 1901

$1883-1901$

Klassifikation Teil B: 02058

Trägermaterial: Papier

Alte Reg.-Sig.: IV T6 122

Bestell-Nr.: IV 02058

2045 Herstellung einer regelmäßigen Verkehrsverbindung von Emden nach Wilhelmshaven über den Ems-Jade-Kanal

- Fahrplan und Tarif einer Motobootslinie von Emden nach

Wilhelmshaven über den Ems-Jade-Kanal, Dezember 1892

Enthält auch:

- Plan der Errichtung einer Motorbootslinie im Emder Hafen zum

Transport der Arbeiter zu ihren Arbeitsstellen im Hafengebiet, 1899 1900

$1892(1899-1900)$

Klassifikation Teil B: 02059

Trägermaterial: Papier

Alte Reg.-Sig.: IV T6 124

Bestell-Nr.: IV 02059 
05

05.03

05.03.12

05.03.12.03

05.03.12.03.01

05.03.12.03.01.01
Stadtverwaltung

Aufgabenbereiche der Stadtverwaltung

Handels- und Gewerbeförderung

Förderung von Handel und Industrie

Förderung von Handel und Verkehr

Maßnahmen zur Handels- und Verkehrsförderung

Lfd. Nr. Titel

Laufzeit

2046 Kleinbahnen

- Gesetze Ministerialerlasse und Verfügungen zum Kleinbahnwesen, 1888 - 1912

- Material zum Kleinbahnwesen, 1888 - 1917

- Aufstellung über Kleinbahnlinien in Ostfriesland, 1893

- Angebote von Firmen über Baumaterial bei Einrichtung sowie

Fahrzeuge einer Kleinbahn, 1894 - 1911

- Anfragen wegen Konzessionierung von Kleinbahnunternehmen, 1894

- Verhandlungen des Provinzialausschusses wegen Zulassung von

Kleinbahnen, 1894 - 1896

- Verhandlungen wegen Errichtung einer Kleinbahn Borkum AG,

Oktober 1897

$1888-1897$

Klassifikation Teil B: 02060

Trägermaterial: Papier

Alte Reg.-Sig.: IV T6 125

Bestell-Nr.: IV 02060

2047 Nachweisungen über Kleinbahnen, Bd. 1

$1900-1914$

- Erlass des Ministers der öffentlichen Arbeiten über Datenerhebung (Nachweise) zu Kleinbahnen, November 1900 - Juli 1904

- Eingesandte Nachweise über Kleinbahnen auf Emder Stadtgebiet (Elektrische Kleinbahn Emden-Außenhafen), 1902 - 1914

- Monita des Regierungspräsidenten in Aurich wegen der vom

Magistrat in den Nachweisen gemachten Angaben zur Elektrischen

Kleinbahn Emden-Außenhafen, 1902 - 1909

$1900-1914$

Klassifikation Teil B: 02061

Band: 1

Trägermaterial: Papier

Alte Reg.-Sig.: IV T6 125

Bestell-Nr.: IV 02061

2048 Nachweisungen über Kleinbahnen, Bd. 2

$1915-1918$

(1919-1922)

- Eingesandte Nachweise über Kleinbahnen auf Emder Stadtgebiet (Elektrische Kleinbahn Emden-Außenhafen)

1915 - 1918 (1919 - 1922)

Klassifikation Teil B: 02062

Band: 2

Trägermaterial: Papier

Alte Reg.-Sig.: IV T6 125

Bestell-Nr.: IV 02062 
05

05.03

05.03.12

05.03.12.03

05.03.12.03.01

05.03.12.03.01.01
Stadtverwaltung

Aufgabenbereiche der Stadtverwaltung

Handels- und Gewerbeförderung

Förderung von Handel und Industrie

Förderung von Handel und Verkehr

Maßnahmen zur Handels- und Verkehrsförderung

Lfd. Nr. Titel

Laufzeit

1915-1918

(1919-1923)

- Erlasse des Ministers der öffentlichen Arbeiten über Regelung des Kleinbahnbetriebs (z.B. Sicherheitsvorschriften), Juli 1915 - Oktober 1918 (1919 - 1923)

- Verzeichnis der Bediensteten der Elektrischen Kleinbahn

Emden-Außenhafen, Oktober 1916

1915 - 1918 (1919 - 1923)

Klassifikation Teil B: 02063

Trägermaterial: Papier

Alte Reg.-Sig.: IV T6 125

Bestell-Nr.: IV 02063

2050 Bau einer Vollbahn von Emden nach Norden

1895-1896

- Einladung des Ausschusses für den Bau einer Vollbahn von Emden nach Norden an den Oberbürgermeister Fürbringer zur Mitgliedschaft, Dezember 1895

- Verhandlungen des Ausschusses für den Bau einer Vollbahn von Emden nach Norden über Strategien zur Verwirklichung des

Projektes, Dezember 1895

- Eingabe des Ausschusses für den Bau einer Vollbahn von Emden nach Norden an den Minister der Öffentlichen Arbeiten über Bitte zum Ausbau der ostfriesischen Küstenbahn zu einer Vollbahn, August 1896

$1895-1896$

Klassifikation Teil B: 02067

Trägermaterial: Papier

Alte Reg.-Sig.: IV T6 127

Bestell-Nr.: IV 02067 
05

\subsection{3}

05.03.12

05.03.12.03

05.03.12.03.01

05.03.12.03.01.01
Stadtverwaltung

Aufgabenbereiche der Stadtverwaltung

Handels- und Gewerbeförderung

Förderung von Handel und Industrie

Förderung von Handel und Verkehr

Maßnahmen zur Handels- und Verkehrsförderung

Lfd. Nr. Titel

Laufzeit

2051 Westfälische Transport Aktiengesellschaft

1896-1910

- Verhandlungen der Interessenten des Dortmund-Ems-Kanals mit der Staatsregierung und Industriellen über die Beschaffung von Kanalschiffen zur Nutzung des Kanals, 1896

- Eingabe der Kaufmännischen Deputation an den Minister der Öffentlichen Arbeiten über Bitte um Förderung des Baues der notwendigen Ladeeinrichtung zur Güterverladung von Seeschiffen in Kanalschiffen, Oktober 1896

- Bildung der Westfälischen Transport Aktiengesellschaft, November 1896 - August 1897

- Korrespondenz des Oberbürgermeisters Fürbringer mit verschiedenen Ruhrindustriellen wegen Ausbaus des Emder Hafens, der Ladeeinrichtungen und Förderung der Schifffahrt auf dem Dortmund-Ems-Kanal, November 1896 - Juli 1897

- Werbung des Oberbürgermeisters Fürbringer in Schweden für einen Erzumschlag über den Emder Hafen, 1897

- Geschäftsberichte der Westfälischen Transport Aktiengesellschaft, 1900 - 1909

- Presseberichte über Verkehrsentwicklung auf dem

Dortmund-Ems-Kanal, 1910

$1896-1910$

Klassifikation Teil B: 02068

Trägermaterial: Papier

Alte Reg.-Sig.: IV T6 129

Bestell-Nr.: IV 02068

2052 Motorbootsverbindung zwischen Emden und Greetsiel

- Eingabe des Seefahrers F. de Boer, Greetsiel, an den Magistrat über Bitte um Vertiefung der Wasserläufe nach Greetsiel im Bereich der stadt Emden zur Ermöglichung einer Motorbootsverbindung von Emden nach Greetsiel, Januar 1897

- Eingabe des Seefahrers F. de Boer an den Magistrat über Bitte um Verbesserung der Anlegemöglichkeit für die Motorboote seiner Linie nach Greetsiel, Juni - Juli 1897

1897

Klassifikation Teil B: 02074

Trägermaterial: Papier

Alte Reg.-Sig.: IV T6 132

Bestell-Nr.: IV 02074 
05

05.03

05.03.12

05.03.12.03

05.03.12.03.01

05.03.12.03.01.01
Stadtverwaltung

Aufgabenbereiche der Stadtverwaltung

Handels- und Gewerbeförderung

Förderung von Handel und Industrie

Förderung von Handel und Verkehr

Maßnahmen zur Handels- und Verkehrsförderung

Lfd. Nr. Titel

Laufzeit

2053 Herstellung einer Telefonleitung von Emden nach Oldenburg

- Mitteilung der kaiserl. Oberpostdirektion Oldenburg über

Genehmigung des Baus einer Telefonleitung von Emden nach

Oldenburg und Bekanntgabe der von Emden telefonisch erreichbarten

Orte, März 1881

- Bericht der Weserzeitung über Fernsprechverbindungen in

Ostfriesland, Februar 1899

$1881-1899$

Klassifikation Teil B: 02075

Trägermaterial: Papier

Alte Reg.-Sig.: IV T6 133

Bestell-Nr.: IV 02075

2054 Bau eines Kanals vom Rhein zur Weser, Bd. 1

$1892-1898$

- Presseberichte über verschiedene Kanalprojekte (Mittellandkanal, Küstenkanal, Rhein-Elbe-Kanal), 1892 - 1898

- Presseberichte über Schiffahrts-Congress in Paris: Diskussion des Ausbaus von Kanälen und der Binnenschifffahrt , Juli - August 1892

- Konferenz in Berlin über das Projekt eines Weser-Elbekanals, November 1895

$1892-1898$

Klassifikation Teil B: 02077

Band: 1

Trägermaterial: Papier

Alte Reg.-Sig.: IV T6 135

Bestell-Nr.: IV 02077

2055 Bau eines Kanals vom Rhein zur Weser, Bd. 2

1899-1900

- Presseberichte über verschiedene Kanalprojekte (Mittellandkanal, Küstenkanal, Rhein-Elbe-Kanal), 1899 - 1900

- Petition Hannoverscher Abgeordneter im preußischen Landtag über Bitte um Verabschiedung von Maßnahnen zur Verbesserung des Wasserstraßennetzes in der Provinz Hannover unter Berücksichtigung landwirtschaftlicher Interessen, Juni 1899

- Druck: Kanalvorlage des preußischen Abgeordnetenhauses, 1899

$1899-1900$

Klassifikation Teil B: 02078

Band: 2

Trägermaterial: Papier

Alte Reg.-Sig.: IV T6 135

Bestell-Nr.: IV 02078

$1881-1899$ 
05

05.03

05.03.12

05.03.12.03

05.03.12.03.01

05.03.12.03.01.01
Stadtverwaltung

Aufgabenbereiche der Stadtverwaltung

Handels- und Gewerbeförderung

Förderung von Handel und Industrie

Förderung von Handel und Verkehr

Maßnahmen zur Handels- und Verkehrsförderung

Lfd. Nr. Titel

Laufzeit

2056 Bau eines Kanals vom Rhein zur Weser, Bd. 3

1900

- Presseberichte über verschiedene Kanalprojekte (Mittellandkanal, Küstenkanal, Rhein-Elbe-Kanal) und Konkurrenz zur Eisenbahn

- Druckschrift: Bedeutung des Rhein-Weser-Kanals und seine

Verlängerung zur Elbe

- Jahresbericht der Handelskammer zu Altona mit Kritik am

Rhein-Weser-Elbe-Kanalprojekt

1900

Klassifikation Teil B: 02079

Band: 3

Trägermaterial: Papier

Alte Reg.-Sig.: IV T6 135

Bestell-Nr.: IV 02079

2057 Bau eines Kanals vom Rhein zur Weser, Bd. 4

1900-1901

- Presseberichte über verschiedene Kanalprojekte (Mittellandkanal, Küstenkanal, Rhein-Elbe-Kanal), 1900 - 1901

- Petitionen der Handelskammer für Ostfriesland und Papenburg und der städtischen Kollegien Emdens an den preußischen Landtag über Bitte um weitere Förderung des Ausbaus des Dortmund-Ems-Kanals und seiner Häfen und Verladeeinrichtungen, Januar 1901

- Konzept der Petition der städtischen Kollegien an den preußischen Landtag gegen den Bau eines Rhein-Elbe-Kanals, Januar 1901

- Verhandlungen der Landtagskommission für Kanalprojekte über Bau eines Dortmund-Rhein-Kanals, März 1901

$1900-1901$

Klassifikation Teil B: 02080

Band: 4

Trägermaterial: Papier

Alte Reg.-Sig.: IV T6 135

Bestell-Nr.: IV 02080

2058 Dampfschiffsverbindung zwischen Emden und Delfzyl

1900-1901

(1907)

- Interesse der Groninger-Rotterdammer Stoomboot-Matschappij an einer Dampfschiffsverbindung zwischen Emden und Delfzyl, Oktober 1900

- Ankündigung eines regelmäßigen Liniendienstes zwischen Emden und Delfzyl durch die Groninger Firma W.A. Scholten, April 1901

Enthält auch:

- Errichtung einer Frachtschiffslinie von Emden nach Hamburg durch die Firma Lehnkering, Juni 1907

$1900-1901(1907)$

Klassifikation Teil B: 02082

Trägermaterial: Papier

Alte Reg.-Sig.: IV T6 137

Bestell-Nr.: IV 02082 
05

\subsection{3}

05.03.12

05.03.12.03

05.03.12.03.01

05.03.12.03.01.01
Stadtverwaltung

Aufgabenbereiche der Stadtverwaltung

Handels- und Gewerbeförderung

Förderung von Handel und Industrie

Förderung von Handel und Verkehr

Maßnahmen zur Handels- und Verkehrsförderung

Lfd. Nr. Titel

Laufzeit

2059 Bau eines neuen Personenbahnhofs

- Bericht des Magistrats an den Regierungspräsidenten in Aurich über Agitation für den Bau einer Kleinbahn von Emden nach Aurich und Notwendigkeit der Verlegung des Anfangsteils der Küstenbahn in den Osten der Stadt zur Vermeidung der den Binnenhafen versperrenden Eisenbahnbrücke, August 1895

- Ablehnung der Verlegung der Küstenbahn durch den Minister der öffentlichen Arbeiten, Mai 1896

- Niederschrift des Oberbürgermeisters Fürbringer über Verhandlungen mit der Eisenbahnverwaltung und der Wasserbauverwaltung im Beisein des Geheimen Oberregierungsrats Schweckendieck über Anlage eines Personenbahnhofs im Kaiser-Wilhelm-Polder und der Streckenführung der Eisenbahn im Außenhafen, Juni - Juli 1896

- Grunderwerb für den geplanten Bahnhof, Februar 1901

- Verhandlungen der städtischen Kollegien über das Bahnhofsprojekt, Februar - April 1901

- Presseberichte über Bürgerversammlung wegen geplanten Verlegung des Personenbahnhofs, Februar 1901

- Planzeichnung einer Bahnhaltestelle an der Larrelter Straße, Februar 1901

- Stellungnahme des Senators T. Dreesmann-Penning zum Projekt eines Personenbahnhofs auf dem Kaiser-Wilhelm-Polder, März 1901 - Bescheid der kgl Eisenbahndirektion Münster über Vertagung des Bahnhofsprojekts aus Kostengrunden, Juni 1901

- Bürgerbegehren gegen die Verlagerung der Trasse der Küstenbahn nach Osten, 1903 - 1904

- Rede des Oberbürgermeisters L. Fürbringer als Landtagsabgeordneter im preußischen Abgeordnetenhaus über Plädierung für eine Verlegung der ostfriesischen Küstenbahn und gegen die Beibehaltung der Eisenbahnbrücke am Binnenhafen, März 1906

$1895-1906$

Klassifikation Teil B: 02083

Trägermaterial: Papier

Alte Reg.-Sig.: IV T6 139

Bestell-Nr.: IV 02083
1895-1906 
IV

05

05.03

05.03.12

05.03.12.03

05.03.12.03.01

05.03.12.03.01.01
Stadtverwaltung

Aufgabenbereiche der Stadtverwaltung

Handels- und Gewerbeförderung

Förderung von Handel und Industrie

Förderung von Handel und Verkehr

Maßnahmen zur Handels- und Verkehrsförderung

Lfd. Nr. Titel

Laufzeit

2060 Stationierung von Schleppdampfern auf der Ems

1899-1904

- Verhandlungen des Magistrats über Anschaffung von

Schleppdampfern, Oktober 1901

- Verhandlungen der städtischen Kollegien über Anschaffung von

Schleppdampfern, Oktober 1901

- Angebote über Schleppdampfer, Dezember 1899

- Verhandlungen des Oberbürgermeisters Fürbringer mit den

Oderwerken, Maschinenbaufabrik und Schiffswerft AG, Stettin, über

Anschaffung zweier Schleppdampfer, November 1899

- Bewerbung um die Stelle des Schleppdampferkapitäns, 1899

- Protokoll einer Verhandlung im Ministerium der öffentlichen Arbeiten unter Vorsitz des Geheimen Oberregierungsrats C. Schweckendieck über Anschaffung und Finanzierung von Schleppdampfern auf der

Ems, November 1899

- Entwurf eines Vertrages zwischen der HAPAG und der Vereinigten

Bugsier- und Frachtschifffahrtsgesellschaft über Schlepperdienste für nach Emden einlaufende Schiffe der HAPAG, Dezember 1899

- Verhandlungen wegen Eintritt der Stadt Emden in den Vertrag,

Dezember 1899 - August 1900

- Beteiligung der Stadt Emden an den Kosten des Schleppdienstes,

August 1900

- Beschwerden über mangelhafte Schlepperdienste der Vereingite Bugsier- und Frachtschifffahrtsgesellschaft AG, Januar 1902 - Januar 1904

$1899-1904$

Klassifikation Teil B: 02084

Trägermaterial: Papier

Alte Reg.-Sig.: IV T6 141

Bestell-Nr.: IV 02084 
05

\subsection{3}

05.03.12

05.03.12.03

05.03.12.03.01

05.03.12.03.01.01
Stadtverwaltung

Aufgabenbereiche der Stadtverwaltung

Handels- und Gewerbeförderung

Förderung von Handel und Industrie

Förderung von Handel und Verkehr

Maßnahmen zur Handels- und Verkehrsförderung
Lfd. Nr. Titel

Laufzeit

2061 Status des Emder Hafens als zollfreies Gebiet

- Verhandlungen zur Etablierung einer zollfreien Zone im Emder Hafen, April - Mai 1900

- Eingabe der HAPAG an den Minister der öffentlichen Arbeiten über

Bitte um Einrichtung einer zollfreien Zone im Emder Hafen zur

Erleichterung des Umschlagsverkehrs, Juni 1900

- Erlass des Ministers der öffentlichen Arbeiten über Einrichtung einer zollfreien Zone im Emder Hafen unter Beteiligung der Stadt Emden an den Kosten, Oktober 1900

- Abwicklung der Emder Beitragszahlung in Höhe von 20.000 Mark, Mai - Juni 1902

- Eingabe der Handelskammer für Ostfriesland und Papenburg an den Finanzminister über Bitte um Ausdehnung des Status der Zollfreiheit auf das gesamte Emder Hasfengebiet, Dezember 1902

- Dankschreiben des Magistrats an den Geheimen Oberregierungsrat Carl Schweckendieck für seinen Einsatz für den Status des Emder Hafens als zollfreies Gebiet, Januar 1904

- Berichterstattung über die Zollfreiheit des Emder Hafens, Januar Februar 1904

$1900-1905$

Klassifikation Teil B: 02085

Trägermaterial: Papier

Alte Reg.-Sig.: IV T6 142

Bestell-Nr.: IV 02085

2062 Telegrafischer Schiffsmeldedienst auf der Ems

$1901-1902$

- Ermittlung des Bedürfnisses für einen telegrafischen

Schiffsmeldedienst, Juni - August 1901

- Mitteilung des kaiserlichen Telegrafenamtes über Kosten dieses

Dienstes, Oktober 1901

- Bestimmungen für die Teilnahme am telegrafischen

Schiffsmeldedienst, März 1902

$1901-1902$

Klassifikation Teil B: 02086

Trägermaterial: Papier

Alte Reg.-Sig.: IV T6 143

Bestell-Nr.: IV 02086 
05

\subsection{3}

05.03.12

05.03.12.03

05.03.12.03.01

05.03.12.03.01.01
Stadtverwaltung

Aufgabenbereiche der Stadtverwaltung

Handels- und Gewerbeförderung

Förderung von Handel und Industrie

Förderung von Handel und Verkehr

Maßnahmen zur Handels- und Verkehrsförderung

Lfd. Nr. Titel

Laufzeit

2063 Kleinbahn von Emden nach Pewsum

- Presseberichte über Kleinbahninitiativen in der Krummhörn, 1895

- Antrag des Fleckensvorstehers von Pewsum, H. W. Lüpkes als

Vorsitzender des Ausschusses zum Bau einer Kleinbahn

Pewsum-Emden beim Magistrat auf Förderung des Baus einer

Kleinbahn von Emden nach Pewsum, März - Juli 1895

- Druckschrift: Verkehrsverhältnisse in der Krummhörn, 1895

- Konzept eines Berichtes des Magistrats an den

Regierungspräsidenten in Aurich über Notwendigkeit des Baus einer Kleinbahn von Emden nach Pewsum in Verbindung mit einer

Ostverlagerung des Anschlusses von Emden an die Küstenbahn,

August 1895

- Planfeststellung über die Trasse der geplanten Kleinbahn von

Emden nach Pewsum, Februar 1898 - März 1899

- Kompetenzstreit zwischen dem Magistrat und dem Kreisausschuss des Kreises Emden wegen Verpachtung von Land auf dem niedergelegten kleinen Stadtdeich für die Kleinbahn Emden-Pewsum, Februar - Mai 1900

$1895-1900$

Klassifikation Teil B: 02087

Trägermaterial: Papier

Alte Reg.-Sig.: IV T6 145

Bestell-Nr.: IV 02087

2064 Kanalnetz der Wasserschaftsgenossenschaft

- Konsequenzen des geplanten Ausbaus des Kanalnetzes der Wasserschaftsgenossenschaft auf die Sicherheit der Polder auf der deutschen Seite des Dollarts

1971

Klassifikation Teil B: 02088

Trägermaterial: Papier

Alte Reg.-Sig.: IV T6 146

Bestell-Nr.: IV 02088
$1895-1900$ 
05

05.03

05.03.12

05.03.12.03

05.03.12.03.01

05.03.12.03.01.01
Stadtverwaltung

Aufgabenbereiche der Stadtverwaltung

Handels- und Gewerbeförderung

Förderung von Handel und Industrie

Förderung von Handel und Verkehr

Maßnahmen zur Handels- und Verkehrsförderung

Lfd. Nr. Titel

Laufzeit

2065 Kleinbahnprojekt: Emden-Riepe-Ostgroßefehn, Bd. 1

- Beteiligung der Stadt Emden am Kleinbahnprojekt Ditzum-Bunde mit einer Bürgschaftssumme von 500 Mark, Dezember 1899

- Memorandum des Oberbürgermeisters Leo Fürbringer über Votum

für eine städtische Beteiligung am Kleinbahnprojekt

Emden-Riepe-Ostgroßefehn und anderer Vorhaben in Richtung

aurich, März 1900

- Angebote der der Firma Vering \& Waechter, Berlin und der

Aktiengesellschaft für Feld- und Kleinbahnen, Berlin über Bau und

Betrieb der Kle8inbahn Emden-Riepe-Ostgroßefehn, Juni - August

1900

- Verhandlungen der städtischen Kommission für die Kleinbahn

Emden-Riepe-Ostgroßefehn über Stand des Projektes und weiteres

Verfahren, Juni - Dezember 1900

- Entwurf des Oberbürgermeisters L. Fürbringer über

Magistratsbeschluss zur Beteiligung der Stadt Emden am

Kleinbahnprojekt Emden-Riepe-Ostgroßefehn, Juli - Dezember 1900

$1899-1900$

Klassifikation Teil B: 02089

Band: 1

Trägermaterial: Papier

Alte Reg.-Sig.: IV T6 147

Bestell-Nr.: IV 02089

2066 Kleinbahnprojekt: Emden-Riepe-Ostgroßefehn, Bd. 2

1901

- Verhandlungen über Anschluss der Kleinbahn Emden-Großefehn an die Kleinbahn Aurich Wittmund-Wilhelmshaven, Januar 1901

- Verhandlungen der städtischen Kommission für die Kleinbahn

Emden-Riepe-Ostgroßefehn über Stand des Projektes, Januar - Mai

1901

- Vorarbeiten zur Umsetzung des Kleinbahnprojektes durch die Firma Vering \& Waechter nach Bewilligung von 5000 Mark durch den

Magistrat, Februar - April 1901

- Finanzierung des Kleinbahnprojektes, Mai - Juni 1901

- Festlegung der Trasse der Kleinbahn Emden-Riepe-Ostgroßefehn unter Berücksichtung eines Anschlusses nach Wilhelmshaven, Mai Juni 1901

- Ermittelung der Rentabilität der Kleinbahn, Mai - November 1901

- Planzeichnung der Trasse der Kleinbahn

Emden-Riepe-Ostgroßefehn, 1901

1901

Klassifikation Teil B: 02090

Band: 2

Trägermaterial: Papier

Alte Reg.-Sig.: IV T6 147

Bestell-Nr.: IV 02090 
IV

05

Stadtverwaltung

05.03

05.03.12

05.03.12.03

05.03.12.03.01

Aufgabenbereiche der Stadtverwaltung

Handels- und Gewerbeförderung

Förderung von Handel und Industrie

Förderung von Handel und Verkehr

05.03.12.03.01.01

Maßnahmen zur Handels- und Verkehrsförderung

Lfd. Nr. Titel

Laufzeit

2067 Kleinbahnprojekt: Emden-Riepe-Ostgroßefehn, Bd. 3

1901-1910

- Angebote verschiedener Firmen über Lieferung von Material zum

Kleinbahnbau

1901

Klassifikation Teil B: 02091

Band: 3

Trägermaterial: Papier

Alte Reg.-Sig.: IV T6 147

Bestell-Nr.: IV 02091

2068 Kleinbahnprojekt: Emden-Riepe-Ostgroßefehn, Bd. 4

$1904-1910$

- Protokolle der Kommission für die projektierte Kleinbahn

Emden-Riepe-Ostgroßefehn über Verhandlungen zum Stand der

Umsetzung des Projektes und Beschlüsse zur Finanzierung,

Trassenführung etc.

$1904-1910$

Klassifikation Teil B: 02092

Band: 4

Trägermaterial: Papier

Alte Reg.-Sig.: IV T6 147

Bestell-Nr.: IV 02092 
05

05.03

05.03.12

05.03.12.03

05.03.12.03.01

05.03.12.03.01.01
Stadtverwaltung

Aufgabenbereiche der Stadtverwaltung

Handels- und Gewerbeförderung

Förderung von Handel und Industrie

Förderung von Handel und Verkehr

Maßnahmen zur Handels- und Verkehrsförderung

Lfd. Nr. Titel

Laufzeit

2069 Kleinbahnprojekt: Emden-Riepe-Ostgroßefehn, Bd. 5

1901-1904

- Vom Minister der öffentlichen Arbeiten angeordneten und durch die $\mathrm{kgl}$. Eisenbahndirektion in Münster durchgeführte Erhebung über Wichtigkeit von Kleinbahnverkehrsverbindungen in Ostfriesland,

Dezember 1901 - März 1902

- Protokoll des Oberbürgermeisters Leo Fürbringer über seine

Besprechung mit dem Eisenbahndirektor Sannuer von der kgl.

Eisenbahndirektion über Kleinbahnprojekt Emden-Ostgroßefehn, ihr

Anschluss an die Trasse nach Wilhelmshaven und

Fördermöglichkeiten, Februar 1902

- Verhandlungen der städtischen Kommission für die Kleinbahn

Emden-Riepe-Ostgroßefehn über Stand des Projektes, Februar 1902

- Dezember 1904

- Finanzierung der von der Firma Vering \& Waechter durchgeführten

Erschließungsarbeiten für die Kleinbahn Emden-Ostgroßefehn,

Oktober 1902 - Oktober 1904

- Genehmigungsverfahren des Kleinbahnprojektes

Emden-Ostgroßefehn, Oktober 1902 - April 1903

- Erwerb von Land für die Kleinbahnlinie Emden-Ostgroßefehn,

Februar 1903

- Presseberichte über das Kleinbahnprojekt, 1902 - 1904

1901- 1904

Klassifikation Teil B: 02093

Band: 5

Trägermaterial: Papier

Alte Reg.-Sig.: IV T6 147

Bestell-Nr.: IV 02093

2070 Kleinbahnprojekt: Emden-Riepe-Ostgroßefehn, Bd. 6

1905-1906

- Abtretung der Rechte der Firma Vering \& Waechter auf Konzession zum Betrieb der Kleinbahn Emden-Riepe-Ostgroßefehn an die Stadt

Emden für 4350 Mark, November 1905 - Juli 1906

- Vergabe der Konzession zum Bau und Betrieb der Kleinbahn

Emden-Osthroßefehn an die Eisenbahnbaugesellschaft Becker \& Co

in Berlin, Dezember 1905 - November 1906

- Anbindung der Kleinbahn Emden-Ostgroßefehn an den Emder Hauptbahnhof, August - Oktober 1906

- Verhandlungen mit den von der Kleinbahn durchquerten Gemeinden wegen Grunderwerb und Trassenführung sowie Festlegung der Haltestellen, September - Oktober 1906

- Verhandlungen der städtischen Kommission für die Kleinbahn Emden-Riepe-Ostgroßefehn über Stand des Projektes, September November 1906

- Protokoll der Besichtigung der geplanten Bahntrasse, Oktober 1906

$1905-1906$

Klassifikation Teil B: 02094

Band: 6

Trägermaterial: Papier

Alte Reg.-Sig.: IV T6 147

Bestell-Nr.: IV 02094 
05

05.03

05.03.12

05.03.12.03

05.03.12.03.01

05.03.12.03.01.01
Stadtverwaltung

Aufgabenbereiche der Stadtverwaltung

Handels- und Gewerbeförderung

Förderung von Handel und Industrie

Förderung von Handel und Verkehr

Maßnahmen zur Handels- und Verkehrsförderung

Lfd. Nr. Titel

Laufzeit

2071 Kleinbahnprojekt: Emden-Riepe-Ostgroßefehn, Bd. 7

1906-1907

- Trassenplan der Kleinbahn Emden-Riepe-Ostgroßefehn, 1907

- Verhandlungen mit den von der Kleinbahn durchquerten Gemeinden wegen Grunderwerb und Trassenführung, Dezember 1906 - April 1907

- Verhandlungen der städtischen Kommission für die Kleinbahn Emden-Riepe-Ostgroßefehn über Stand des Kleinbahnprojektes, Januar 1907

- Konzept einer Denkschrift des Oberbürgermeisters Fürbringer über Notwendigkeit der Kleinbahn zum Transport von Arbeiter des Hafens und der Industrie zu ihren Arbeitsstätten ohne Umzug nach Emden und Vorschlag zur Bildung einer Aktiengesellschaft für den

Kleinbahnbetrieb, Januar 1907

- Entwurf des Vertrages über Bildung einer Aktiengesellschaft für den

Betrieb der Kleinbahn Emden-Ostgroßefehn, Februar 1904

- Statuten verschiedener Kleinbahnbetriebs AG'S als Muster, 1907

- Zeichnung von Aktien der KleinbahnbetriebsAG

Emden-Ostgroßefehn durch Emder Hafenfirmen, März 1907

- Denkschrift und Ertragsberechung betr. Bau einer Kleinbahn

Emden-Riepe-Ostgroßefehn, 1907

- Protokoll über Besichtigung der geplanten Bahntrasse, April 1907

$1906-1907$

Klassifikation Teil B: 02095

Band: 7

Trägermaterial: Papier

Alte Reg.-Sig.: IV T6 147

Bestell-Nr.: IV 02095 
05

\subsection{3}

05.03.12

05.03.12.03

05.03.12.03.01

05.03.12.03.01.01
Stadtverwaltung

Aufgabenbereiche der Stadtverwaltung

Handels- und Gewerbeförderung

Förderung von Handel und Industrie

Förderung von Handel und Verkehr

Maßnahmen zur Handels- und Verkehrsförderung

Lfd. Nr. Titel

Laufzeit

2072 Kleinbahnprojekt: Emden-Riepe-Ostgroßefehn, Bd. 8

- Analyse der Besichtigung der geplanten Bahntrasse, April 1907

- Beschluss des Magistrats zur Zeichnung von 1/3 der Aktien der geplanten Betriebsgesellschaft der Kleinbahn

Emden-Riepe-Ostgroßefehn, Mai 1907

- Erwerb von Landflächen für die Kleinbahn und Widerstand gegen die Landveräußerung in den von der Bahn durchquerten Gemeinden, Mai 1907

- Verhandlungen des Magistrats mit dem Landesdirektorium der Provinz Hannover über Bedingungen zur Förderung des Kleinbahnprojekts durch die Provinz, Mai - November 1907

- Kosten- und Rentabilitätsberechnung der Kleinbahn

Emden-Riepe-Ostgroßefehn, Juni 1907

- Abstimmungen in den Gemeindevertretungen der von der Bahn durchquerten Kommunen über Beiträge zum Bau der Kleinbahn, Juni - Juli 1907

. Antrag des Magistrats beim Regierungspräsidenten in Aurich auf Beteilugung des Staates an der Kleinbahn

Emden-Riepe-Ostgroßefehn in Höhe von einem Drittel des

Aktienkapitals, Juli - Oktober 1907

- Verhandlungen der städtischen Kommission für die Kleinbahn

Emden-Riepe-Ostgroßefehn über Stand des Kleinbahnprojektes, Juni

- November 1907

- Bewerbung verschiedener Zivilingenieure um Bauaufträge für de Kleinban Norden-Ostgroßefehn

1907

Klassifikation Teil B: 02096

Band: 8

Trägermaterial: Papier

Alte Reg.-Sig.: IV T6 147

Bestell-Nr.: IV 02096 
05

\subsection{3}

05.03.12

05.03.12.03

05.03.12.03.01

05.03.12.03.01.01
Stadtverwaltung

Aufgabenbereiche der Stadtverwaltung

Handels- und Gewerbeförderung

Förderung von Handel und Industrie

Förderung von Handel und Verkehr

Maßnahmen zur Handels- und Verkehrsförderung

Lfd. Nr. Titel

Laufzeit

2073 Kleinbahnprojekt: Emden-Riepe-Ostgroßefehn, Bd. 9

- Rentabilitätsberechnung für die Klenbahn

Emden-Riepe-Ostgroßefehn, 1908

- Protokolle der städtischen Kommision für die Kleinbahn

Emden-Riepe über Stand des Projektes, März 1908

- Antrag des Magistrats beim Regierungspräsidenten auf staatliche

Förderung des Kleinbahnprojektes, Februar 1908

- Prüfungsbemerkungen des Wasserbauinspektors Zander über die Klenbahnlinie Emden-Riepe-Ostgroßefehn hinsichtlich der Brücken und Überfahrten über Gewässer, Februar 1908

- Prüfung des Kleinbahnprojektes durch die kgl. Eisenbahndirektion Münster, April 1908

- Planfeststellungsvefahren über die Bahntrasse, Mai 1908 - Januar 1909

- Finanzierung der Bahn auf Basis von Aktien unter Beteiligung der Provinz Hannover und des preußischen Staates, Januar - Dezember 1909

- Wünsche der durch die Kleinbahn gequerten Gemeinden hinsichtlich der Trassenführung, Februar 1909

$1908-1909$

Klassifikation Teil B: 02097

Band: 9

Trägermaterial: Papier

Alte Reg.-Sig.: IV T6 147

Bestell-Nr.: IV 02097

2074 Kleinbahnprojekt: Emden-Riepe-Ostgroßefehn, Bd. 10 1908-1909

- Finanzierung der Bahn auf Basis von Aktien, April 1910 - September 1911

- Plan der Kreuzung der Kleinbahnlinie Emden-Riepe-Ostgroßefehn mit der Staatsbahn im Osten Emdens, 1911

- Anträge des Magistrats beim Landesdirektorium der Provinz Hannover auf Verlängerung der Frist zur Bildung einer Aktiengesellschaft zum Betrieb der Kleinbahn Emden-Riepe-Ostgroßefehn, 1911 - 1916

- Die Bahn wurde nicht verwirklicht -

1910 - 1916 (1918 - 1921)

Klassifikation Teil B: 02098

Band: 10

Trägermaterial: Papier

Alte Reg.-Sig.: IV T6 147

Bestell-Nr.: IV 02098 
05

\subsection{3}

05.03.12

05.03.12.03

05.03.12.03.01

05.03.12.03.01.01
Stadtverwaltung

Aufgabenbereiche der Stadtverwaltung

Handels- und Gewerbeförderung

Förderung von Handel und Industrie

Förderung von Handel und Verkehr

Maßnahmen zur Handels- und Verkehrsförderung

Lfd. Nr. Titel

Laufzeit

2075 Gleisanschluss der Hafenanlagen an die Ostfriesische Küstenbahn

1896

- Bescheid der kgl. Eisenbahn-Direktion in Münster an den

Regierungspräsidenten in Aurich über Konzept der

Eisenbahn-Direktion zum Anschluss des Emder Hafens und des

städtischen Schlachthofes an die ostfriesische Küstenbahn, Mai 1896

- Bericht des Magistrats an den Regierungspräsidenten über

Unzufriedenheit mit dem Konzept der Eisenbahn-Direktion wegen

Ignorierung der örtlichen Verhältnisse, Juni 1896

- Verhandlungen des Magistrats mit der kgl. Eisenbahn-Direktion über

Anschluss der Hafenanlagen an die ostfriesische Küstenbahn, Juli -

Oktober 1896

1896

Klassifikation Teil B: 02101

Trägermaterial: Papier

Alte Reg.-Sig.: IV T6 152

Bestell-Nr.: IV 02101

2076 Anlegung einer Eisenbahnverladestelle für Weißkohl im

1900 Kaiser-Wilhelm-Polder

- Verhandlungen des Magistrats mit der kgl.

Eisenbahnbetriebsinspektion Emden über Anlegung einer

Eisenbahnverladestelle für Weißkohl im Kaiser-Wilhelm-Polder, März

- April 1900

- Eingabe Emder Gemüsebauern an die kgl. Eisenbahndirektion über Bitte um Anlegung einer Eisenbahnverladestelle für Weißkohl im Kaiser-Wilhelm-Polder wegen großer abzutransportierender Mengen an Weißkohl während der Erntesaison, April 1900

- Verhandlungen des Regierungspräsidenten mit der kgl.

Eisenbahndirektion über Anlegung einer Eisenbahnverladestelle für

Weißkohl im Kaiser-Wilhelm-Polder, Juni - Juli 1900

- Bericht des Stadtbaumeisters Wiggers über Fertigstellung der

Verladestelle, August 1900

- Planzeichnung der Verladestelle, 1900

1900

Klassifikation Teil B: 02102

Trägermaterial: Papier

Alte Reg.-Sig.: IV T6 153

Bestell-Nr.: IV 02102

2077 Plan des Baus eines neuen Hafenbeckens in Delfzyl

- Bericht im "Algemeen Handelsblad"zur Planung eines neuen

Hafenbeckens in Delfzyl

1903

Klassifikation Teil B: 02104

Trägermaterial: Papier

Alte Reg.-Sig.: IV T6 155

Bestell-Nr.: IV 02104 
05

\subsection{3}

05.03.12

05.03.12.03

05.03.12.03.01

05.03.12.03.01.01
Stadtverwaltung

Aufgabenbereiche der Stadtverwaltung

Handels- und Gewerbeförderung

Förderung von Handel und Industrie

Förderung von Handel und Verkehr

Maßnahmen zur Handels- und Verkehrsförderung

Lfd. Nr. Titel

Laufzeit

2078 Rhein- Elbe- Kanal

1899

- Presseberichte zum Projekt des Rhein-Elbe-Kanals

- Verhandlungen im preußischen Landtag über das Kanalprojekt

- Petition der Handelskammer für Ostfriesland und Papenburg an den preußischen Landtag über Bitte um Angleichung der Schleusenmaße des geplanten Rhein-Elbe-Kanals mit denen des

Dortmund-Ems-Kanals zur Herstellung gleicher Wettbewerbschancen, April

1899

Klassifikation Teil B: 02105

Trägermaterial: Papier

Alte Reg.-Sig.: IV T6 156

Bestell-Nr.: IV 02105

2079 Getreidespeicher am Außenhafen

1903-1911

- Planzeichnung der Getreidespeicher, 1903

- Schreiben des Oberbürgermeisters Fürbringer an verschiedene

Großbanken über Werbung zur Mitfinanzierung verschiedener

Bauprojekte und Industrieanlagen im Emder Hafen, darunter:

Getreidespeicher, September 1903

- Werbung des Oberbürgermeisters bei verschiedenen Lagerfirmen und Getreidehandlungen um den Bau von Getreidespeichern im

Emder Außenhafen, September 1903

- Antwortschreiben verschiedener Firmen mit negativem Echo,

September - Oktober 1903

- Projekt des H. Neumann, Direktor Filiale der landwirtschaftlichen

Zentralgenossenschaft Dortmund, über Gründung einer

Lagerhausgesellschaft in Emden zum Bau und Betrieb eines

Getreidespeichers, November 1903.- April 1904

- Material mit Informationen über Getreidespeicherbauten, Dezember

1903

- Rücknahme einer Kreditzusage der Deutschen Bank wegen voreiliger Einberufung der Gründungsversammlung der Emder Lagerhausgesellschaft durch Heinrich Neumann, März 1904

- Angebote verschiedener Firmen über Baumaterialien für

Getreidespeicher, Februar - April 1904

$1903-1904$

Klassifikation Teil B: 02110

Trägermaterial: Papier

Alte Reg.-Sig.: IV T6 156

Bestell-Nr.: IV 02110 
05

05.03

05.03.12

05.03.12.03

05.03.12.03.01

05.03.12.03.01.01
Stadtverwaltung

Aufgabenbereiche der Stadtverwaltung

Handels- und Gewerbeförderung

Förderung von Handel und Industrie

Förderung von Handel und Verkehr

Maßnahmen zur Handels- und Verkehrsförderung

Lfd. Nr. Titel

Laufzeit

2080 Gründung einer Reederei "Emder Dampfer-Compagnie"

1904

- Schreiben der Reederei Menzell \& Co, Hamburg, über Ankündigung der Gründung der Emder Dampfer-Compagnie, Januar 1904

1904

Klassifikation Teil B: 02111

Trägermaterial: Papier

Alte Reg.-Sig.: IV T6 157

Bestell-Nr.: IV 02111

2081 Plan der Gründung einer deutschen Orientlinie mit Sitz in Emden

- Plan der Firma F.W. Niemöller in Gütersloh zur Errichtung einer Frachtlinie zur Einfuihr von Getreide aus Osteuropa und Kleinasien über Emden nach Deutschland, Juni 1905

- Stellungnahme Emder Reedereien zur Zweckmäßigkeit der

Einrichtung einer regelmäßigen Frachtlinie von Emden zum

Schwarzen Meer und Kleinasien, Juli - August, 1905

1905

Klassifikation Teil B: 02112

Trägermaterial: Papier

Alte Reg.-Sig.: IV T6 160

Bestell-Nr.: IV 02112

2082 Verbindungskanal zwischen Schottjer Tief und Moortief in Norden

- Eingabe der Handelskammer für Ostfriesland und Papenburg an den Magistrat über Bitte um Förderung des Kanalprojektes wegen

Bedeutung für den Emder Hafen, August 1905

1905

Klassifikation Teil B: 02114

Trägermaterial: Papier

Alte Reg.-Sig.: IV T6 162

Bestell-Nr.: IV 02114 
05

05.03

05.03.12

05.03.12.03

05.03.12.03.01

05.03.12.03.01.01
Stadtverwaltung

Aufgabenbereiche der Stadtverwaltung

Handels- und Gewerbeförderung

Förderung von Handel und Industrie

Förderung von Handel und Verkehr

Maßnahmen zur Handels- und Verkehrsförderung

Lfd. Nr. Titel

Laufzeit

2083 Schiffsverbindung zwischen Emden und Deutsch Ostafrika

1905-1907

- Schreiben des Kommerzienrats Carl Lehnkering an den Wirklichen geh. Oberregierungsrat Carl Schweckendieck über Bitte um Berücksichtigung Emdens bei der Planung einer Frachterverbindung zu den deutschen Kolonien in Afrika, Dezember 1905

- Schreiben der Deutschen Ostafrika-Linie an Oberbürgermeister Fürbringer über Nichtberücksichtigung Emdens als Ausfuhrhafen wegen zu geringen Ausfuhrvolumens, Februar 1906

- Verhandlungen des Oberbürgermeisters Leo Fürbrnger mit der Hamburg-Bremer Afrika-Linie wegen Einbeziehung Emdens in eine Frachterlinie nach Deutsch Ostafrika, April - November 1907

$1905-1907$

Klassifikation Teil B: 02116

Trägermaterial: Papier

Alte Reg.-Sig.: IV T6 164

Bestell-Nr.: IV 02116

2084 Geplante Errichtung einer Schiffahrtsgesellschaft "Westdeutscher Lloyd"

1902

- Abschrift eines Zeitungsberichtes über Konzept der Errichtung einer Schiffahrtsgesellschaft "Westdeutscher Lloyd" in Emden, Juli 1902

- Expose des Paul G. Roer über Errichtung einer

Schiffahrtsgesellschaft "Westdeutscher Lloyd", September 1902

1902

Klassifikation Teil B: 02117

Trägermaterial: Papier

Alte Reg.-Sig.: IV T6 165

Bestell-Nr.: IV 02117

2085 Gründung einer afrikanischen Handelskompanie

- Initiative des Eberhard von Schopp zur Gründung einer afrikanischen Handelskompanie, 1905 - 1906

- Verhandlungen des Magistrats über Beteiligung der Stadt Emden das Projekt, September 1905 - April 1906

- Projekt zur Gründung einer Afrikanischen Compagnie AG, 1906

- Presseberichte zum Projekt, 1906

- Geschäftsbericht der Afrikanischen Kompanie, 1907

$1905-1907$

Klassifikation Teil B: 02118

Trägermaterial: Papier

Alte Reg.-Sig.: IV T6 166

Bestell-Nr.: IV 02118 
05

05.03

05.03.12

05.03.12.03

05.03.12.03.01

05.03.12.03.01.01
Stadtverwaltung

Aufgabenbereiche der Stadtverwaltung

Handels- und Gewerbeförderung

Förderung von Handel und Industrie

Förderung von Handel und Verkehr

Maßnahmen zur Handels- und Verkehrsförderung

Lfd. Nr. Titel

Laufzeit

2086 Kanalprojekte als Gefahr für den Emder Hafen, Bd. 1

1906-1907

- Plan eines Verbindungskanals vom Dortmund-Ems-Kanal nach der Weser über Oldenburg, 1906

- Protest des Magistrats beim Ministerium der öffentlichen Arbeiten gegen das Kanalprojekt wegen Gefahr der Abschnürung des Emder Hafens vom Handelsstrom, April - Dezember 1906

- Koordinierung des Widerstands gegen das Kanalprojekt durch die Städte Emden und Leer, April 1906 - Januar 1907

- Initiative der großherzoglich oldenburgischen Regierung bei der preußischen Staatsregierung für die Verwirklichung des Verbindingskanals vom Dortmund-Ems-Kanal über Oldenburg zur Weser, März - Mai 1906

- Eingabe der Kaufmännischen Deputation an den Minister der öffentlichen Arbeiten über Bitte um Verhinderung des für den Emder Hafen und seine Betriebe gefährlichen Kanalprojekts, Mai / Juli 1906

- Eingabe der Kaufmännischen Deputation an den

Regierungspräsidenten in Aurich über Bitte um Einsatz gegen das

Kanalprojekt, Oktober 1906

- Presseberichte über das Kanalprojekt, 1907 - 1907

- Gutachten der kgl. Wasserbauinspektion über Einfluss des gelanten

Projekt eines Verbindungskanals zwischen Dortmund-Ems-Kanal über

Oldenburg zur Weser auf den Verkehr zum Emder Hafen, November

1906

- Verhandlungen des Magistrats über das Kanalprojekt, Oktober -

Dezember 1906

- Supplication des Magistrats und der Bürgervorsteher der Stadt

Emden an Kaiser und König Wilhelm II. über Bitte um Verhinderung

des Kanalprojekts, Dezember 1906

- Initiative der preußischen Gemeinden an der Unterweser für das

Kanalprojekt, November 1906 - Februar 1907

- Bericht des Magistrats an den Regierungspräsidenten über Audienz beim Oberpräsidenten der Provinz Hannover mit Apellation der

Emshäfen gegen das Kanalprojekt, Dezember 1906

- Petition der Handelskammer für Ostfriesland und Papenburg an den preußischen Landtag über Bitte um Verhinderung des Kanalprojektes, Dezember 1906

- Verhandlungen des Provinzialausschusses gegen das Kanalprojekt, Dezember 1906 - Februar 1907

- Verhandlungen des Etat-Ausschusses des preußischen Landtages über das Kanalprojekt, Februar 1907

- Rede des Oberbürgermeisters und Landtagsabgeordneten

Fürbringer gegen das Projekt, April 1907

$1906-1907$

Klassifikation Teil B: 02119

Band: 1

Trägermaterial: Papier

Alte Reg.-Sig.: IV T6 167

Bestell-Nr.: IV 02119 
05

\subsection{3}

05.03.12

05.03.12.03

05.03.12.03.01

05.03.12.03.01.01
Stadtverwaltung

Aufgabenbereiche der Stadtverwaltung

Handels- und Gewerbeförderung

Förderung von Handel und Industrie

Förderung von Handel und Verkehr

Maßnahmen zur Handels- und Verkehrsförderung

Lfd. Nr. Titel

Laufzeit

2087 Kanalprojekte als Gefahr für den Emder Hafen, Bd. 2

- Koordinierung des Widerstandes der Emshäfen und der Städte Hannover, Minden u.a. gegen das Projekt eines Verbindungskanals zwischen dem Dortmund-Ems-Kanal über Oldenburg und der Weser, $1908-1911$

- Presseberichte über das Kanalprojekt, 1908 - 1910

- Referat des Ersten Bürgermeisters der Stadt Minden, Dr. Johansen, auf der Versammlung des Zentralvereins für deutsche

Binnenschiffahrt gegen das Kanalprojekt wegen zu erwartender hoher Frachtraten, Konkurrenz zum Mittellandkanal und Schädigung der Schifffahrt auf der Oberweser, Juni 1909

- Korrespondenz des Oberbürgermeisters Fürbringer mit dem Oldenburgischen Kommerzienrat August Schulze über Gründung einer nordwestdeutschen Binnenschifffahrtsinteressensgemeinschaft zur Koordinierung von Kanalprojekten und Vertretung der Handelsund Schifffahrtsinteressen der Stadt Emden, Juli - Oktober 1909 - Eingabe des Zentralvereins für deutsche Binnenschiffahrt beim Minister der öffentlichen Arbeiten über Bitte um Realisierung des Kanalprojektes, Mai - August 1909

- Lobbyarbeit des Oberbürgermeisters und Landtagsabgeordneten

Fürbringer im Landtag gegen das Kanalprojekt, Februar - März 1910 - Supplication des Magistrats an den Kaiser und König Wilhelm II. über Bitte um Verhinderung des Kanalprojektes, Februar / Juli 1910 - Eingabe der Kaufmännischen Deputation an den Minister der öffentlichen Arbeiten über Bitte um Verhinderung des Kanalprojektes, Juni 1910

- Resolution der Handelskammer für Ostfriesland und Papenburg gegen das Kanalprojekt, Januar 1911

- Verhandlungen des Abgeordnetenhauses des preußischen Landtages über das Kanalprojekt, Februar 1913

$1909-1913$

Klassifikation Teil B: 02120

Band: 2

Trägermaterial: Papier

Alte Reg.-Sig.: IV T6 167

Bestell-Nr.: IV 02120
$1909-1913$ 
05

05.03

05.03.12

05.03.12.03

05.03.12.03.01

05.03.12.03.01.01
Stadtverwaltung

Aufgabenbereiche der Stadtverwaltung

Handels- und Gewerbeförderung

Förderung von Handel und Industrie

Förderung von Handel und Verkehr

Maßnahmen zur Handels- und Verkehrsförderung

Lfd. Nr. Titel

Laufzeit

2088 Propaganda für die Emder Hafenanlagen

1905-1906

- Sonderdruck über die Emder Hafenanlagen in der Zeitschrift "Stahl und Eisen", 1906

- Zusammenstellung und Übersendung des Materials für den Sonderdruck an den Verlag der Zeitschrift "Stahl und Eisen", November 1905 - April 1906

- Vertrieb des Sonderdruckes an Verbände und Handelskammern, Mai - August 1906

$1905-1906$

Klassifikation Teil B: 02121

Trägermaterial: Papier

Alte Reg.-Sig.: IV T6 168

Bestell-Nr.: IV 02121

2089 Propaganda für den Emder Hafen

- Sonderdruck zum Emder Hafen in der Wochenschrift "Der Rhein", 1907

- Zusammenstellung und Übersendung von Material für den Sonderdruck an den Verlag der Wochenschrift "Der Rhein", Oktober 1906 - März 1907

- Bestellung von 700 Exemplaren des Sonderdrucks durch die Stadt Emden, April 1907

$1906-1907$

Klassifikation Teil B: 02124

Trägermaterial: Papier

Alte Reg.-Sig.: IV T6 171

Bestell-Nr.: IV 02124 
05

05.03

05.03.12

05.03.12.03

05.03.12.03.01

05.03.12.03.01.01
Stadtverwaltung

Aufgabenbereiche der Stadtverwaltung

Handels- und Gewerbeförderung

Förderung von Handel und Industrie

Förderung von Handel und Verkehr

Maßnahmen zur Handels- und Verkehrsförderung

Lfd. Nr. Titel

Laufzeit

2090 Gründung der Frachtdampfer-Gesellschaft Roer-Linie

- Prospekt der Gründung der Roer-Linie mit Ausgangshafen Emden als Werbung für die Zeichnung ihrer Aktien, 1906

- Beschluss des Magistrats über Nichtzeichnung von Aktien der

Roer-Linie durch die Stadt Emden, September 1906

- Antrag des Reeders Paul G. Roer beim Regierungspräsidenten in

Aurich auf Befreiung der Schiffe der Roer-Linie AG vom Lotsenzwang

auf der Ems, September - Dezember 1906

- Statut der Roer-Linie AG, September 1906

- Mitteilung der Absetzung des Vorsitzenden der Roer-Linie, Paul G.

Roer, wegen unautorisierter Handlungen zu Lasten der Gesellschaft, Juli 1907

- Bericht des Magistrats an den Regierungspräsidenten über

Absetzung des Paul G. Roer als Vorsitzender der Roer-Linie, Juli 1907

- Schreiben des Vorsitzenden der Roer-Linie AG, Wilhelm Hemsoth

an Oberbürgermeister Fürbringer über Vorkommnisse bei der

Gesellschaft im Zusammenhang mit der Absetzung des Paul G.

Roer, September 1907

- Pressebericht über die Fusion der Roer-Linie mit der W. Hemsoth

Kanal- und Seeschiffahrts AG, Mai 1909

$1906-1909$

Klassifikation Teil B: 02125

Trägermaterial: Papier

Alte Reg.-Sig.: IV T6 172

Bestell-Nr.: IV 02125

2091 Kleinbahnprojekt Emden - Rysum, - Groothusen

$1907-1914$

- Plan der projektierten Kleinbahnlinie auf Emder Stadtgebiet, 1907

- Streit zwischen den einzelnen interessierten Gemeinden in der

Krummhörn um die Streckenführung, Januar 1907 - Februar 1910

- Rentabilitätsberechnung für die Kleinbahn

Emden-Rysum-Groothusen, August 1907

- Verhandlungen des Magistrats mit dem Domänenfiskus wegen

Grunderwerb für die Bahn, Februar 1908 - März 1912

- Verhandlungen der städtischen Kommission für neue Kleinbahnen

über Beteiligung der Stadt Emden an der projektierten Kleinbahnlinie,

März 1905 - Juli 1912

- Plan der Kleinbahnlinie Emden-Rysum-Groothuien, 1911

- Verhandlungen des Magistrats wegen Förderung der Kleinbahnlinie,

1908 - 1914

$1907-1914$

Klassifikation Teil B: 02126

Trägermaterial: Papier

Alte Reg.-Sig.: IV T6 173

Bestell-Nr.: IV 02126 
05

05.03

05.03.12

05.03.12.03

05.03.12.03.01

05.03.12.03.01.01
Stadtverwaltung

Aufgabenbereiche der Stadtverwaltung

Handels- und Gewerbeförderung

Förderung von Handel und Industrie

Förderung von Handel und Verkehr

Maßnahmen zur Handels- und Verkehrsförderung

Lfd. Nr. Titel

Laufzeit

2092 Dampferlinie Husum-Emden-Hull

1907

- Anfrage des Reeders Wilhelm J. E. Hansen aus Husum an

Oberbürgermeister Fürbringer über Möglichkeit einer

Viehverschickung von Husum über Emden nach Hull wegen

notwendiger Stall- und Verladekapazitäten im Emder Hafen, März

1907

1907

Klassifikation Teil B: 02127

Trägermaterial: Papier

Alte Reg.-Sig.: IV T6 174

Bestell-Nr.: IV 02127

2093 Viehabfertigung auf der Eisenbahnsstation Hude-Harsweg

1907

- Initiative der Kaufmännischen Deputation für eine positive

Stellungnahme des Magistrats zum Antrag des Domänenpächters und Viehhändlers A. J. Stein auf Errichtung einer Viehverladungsstation an der Eisenbahnlinie Emden - Norden, Station Harsweg, Oktober 1907

1907
Klassifikation Teil B: 02128
Trägermaterial: Papier
Alte Reg.-Sig.: IV T6 175
Bestell-Nr.: IV 02128

2094 Planung eines Rhein-Nordseekanals, Bd. 1

- Auftragsvergabe zur Herstellung eines Planes eines

Rhein-Nordseekanals, April - September 1910

- Satzung des Vereins zur Förderung des Baus eines

Großschiffahrtsweges vom Rhein zur deutschen Nordsee, 1912

- Gutachten des geh. Baurats Herzberg zum Rhein-Nordseekanal, 1912

$1910-1912$

Klassifikation Teil B: 02129

Band: 1

Trägermaterial: Papier

Alte Reg.-Sig.: IV T6 176

Bestell-Nr.: IV 02129 
05

05.03

05.03.12

05.03.12.03

05.03.12.03.01

05.03.12.03.01.01
Stadtverwaltung

Aufgabenbereiche der Stadtverwaltung

Handels- und Gewerbeförderung

Förderung von Handel und Industrie

Förderung von Handel und Verkehr

Maßnahmen zur Handels- und Verkehrsförderung

Lfd. Nr. Titel

Laufzeit

2095 Planung eines Rhein-Nordseekanals, Bd. 2

- Finanzierung der Planungsvorarbeiten für den Rhein-Nordseekanal, 1912

- Initiative des Vereins zur Förderung eines Großschiffahrtsweges vom Rhein zur deutschen Nordsee zur Verwirklichung des Kanalprojektes, 1912

- Lobbyarbeit des Oberbürgermeisters Fürbringer als Mitglied des Vorstands des Vereins zur Förderung eines Großschiffahrtsweges vom Rhein zur deutschen Nordsee beim Reichskanzler, Landesministerium und verschiedenen einflussreichen Personen für das Projekt, 1912

1912

Klassifikation Teil B: 02130

Band: 2

Trägermaterial: Papier

Alte Reg.-Sig.: IV T6 176

Bestell-Nr.: IV 02130

2096 Planung eines Rhein-Nordseekanals, Bd. 3

- Verhandlungen des preußischen Landtages über

Rhein.Nordseekanal, 1913

- Initiative des Vereins zur Förderung eines Großschiffahrtsweges vom Rhein zur deutschen Nordsee zur Verwirklichung des Kanalprojektes, 1913 - 1914

- Lobbyarbeit des Oberbürgermeisters Fürbringer als Mitglied des Vorstands des Vereins zur Förderung eines Großschiffahrtsweges vom Rhein zur deutschen Nordsee beim Reichskanzler,

Landesministerium und verschiedenen einflussreichen Personen für das Projekt, 1913 - 1914

$1913-1914$

Klassifikation Teil B: 02131

Band: 3

Trägermaterial: Papier

Alte Reg.-Sig.: IV T6 176

Bestell-Nr.: IV 02131 
05

05.03

05.03.12

05.03.12.03

05.03.12.03.01

05.03.12.03.01.01
Stadtverwaltung

Aufgabenbereiche der Stadtverwaltung

Handels- und Gewerbeförderung

Förderung von Handel und Industrie

Förderung von Handel und Verkehr

Maßnahmen zur Handels- und Verkehrsförderung

Lfd. Nr. Titel

Laufzeit

2097 Luftschifffahrt
1909-1913

- Anfrage des Oberleutnants zur See, Reelitz, über Topographie des Emder Raumes wegen Planung einer Landestation für Zeppeline im Gebiet des Großen Meeres im Rahmen einer internationalen

Ballonwettfahrt, August - September 1909

- Verfügung des Regierungspräsidenten über Förderung des Nordwestdeutschen Vereins für Luftschiffahrt bei der Erstellung von Flugkarten von der Nordseeküste, Dezember 1909

- Initiative des Komitees zur Errichtung von Luftschiffstationen im Reiche zum Aufbau eines Netzes von Stützpunkten zur Förderung des Luftschiffwesens mit Zeppelinen, 1909

- Zeitungsberichte und Zeitschriften zum Luftschifffahrtswesen, 1910 1912

- Gemeinsame Erlasse des Ministers der öffentlichen Arbeiten und des Innenministers über Regelung des Luftfahrtswesens, März 1911 Januar 1912

- Initiative der Deutschen Luftschiffverankerungsgesellschaft zur

Errichtung eines Luftschiffslandeplatzes in Emden, November 1911 -

Oktober 1913

- Evaluierung von Landeplätzen für Flugzeuge durch den

Seeofizier-Luftclub Wilhelmshaven, Februar 1912

- Anträge an den Magistrat auf Erlaubnis zur Veranstaltung von

Luftschautagen, 1911 - 1913

- Luftschautag in Emden, Juli 1913

$1909-1913$

Klassifikation Teil B: 02132

Trägermaterial: Papier

Alte Reg.-Sig.: IV T6 179

Bestell-Nr.: IV 02132

2098 Nationale Flugspende des Deutschen Reiches, Bd. 1

- Aufruf des Komitees für die Nationale Flugspende des Deutschen Reiches zur Teilnahme an der Spendenaktion zur Förderung des deutschen Flugwesens, April 1912

- Organisation der Sammlung für die Nationale Flugspende des

Deutschen Reiches im Regierungsbezirk Aurich und der Stadt Emden, April - Juni 1912

- Spendenlisten, u.a. von Schulen, Mai - Juni 1912

1912

Klassifikation Teil B: 02133

Band: 1

Trägermaterial: Papier

Alte Reg.-Sig.: IV T6 179

Bestell-Nr.: IV 02133 
05

05.03

05.03.12

05.03.12.03

05.03.12.03.01

05.03.12.03.01.01
Stadtverwaltung

Aufgabenbereiche der Stadtverwaltung

Handels- und Gewerbeförderung

Förderung von Handel und Industrie

Förderung von Handel und Verkehr

Maßnahmen zur Handels- und Verkehrsförderung

Lfd. Nr. Titel

Laufzeit

2099 Nationale Flugspende des Deutschen Reiches, Bd. 2

- Spendenzusagen für die nationale Flugspende des deutschen

Reiches, August 1912

- Organisation der Abschlusskundgebung des Komitees der

Nationalen Flugspende des deutschen Reiches, August 1912

1812

Klassifikation Teil B: 02134

Band: 2

Trägermaterial: Papier

Alte Reg.-Sig.: IV T6 179

Bestell-Nr.: IV 02134

2100 Werbung für die Emder Hafenanlagen

- Werbeschriften für verschiedene Häfen, 1912

- Verhandlungen des Magistrats mit verschiedenen Verlagen wegen

Druck und Vertrieb einer Broschüre über den Emder Hafen, März -

Juni 1912

- Korrespondenz des Oberbürgermeisters Fürbringer mit dem

Redakteur König aus Witten wegen Gestaltung einer Bröschüre über den Emder Hafen, April 1912

- Kostenaufstellung

1912

Klassifikation Teil B: 02135

Trägermaterial: Papier

Alte Reg.-Sig.: IV T6 180

Bestell-Nr.: IV 02135 
05

05.03

05.03.12

05.03.12.03

05.03.12.03.01

05.03.12.03.01.01
Stadtverwaltung

Aufgabenbereiche der Stadtverwaltung

Handels- und Gewerbeförderung

Förderung von Handel und Industrie

Förderung von Handel und Verkehr

Maßnahmen zur Handels- und Verkehrsförderung

Lfd. Nr. Titel

Laufzeit

2101 Schnelldampferlinie von Emden nach London

- Prospekt der Fa. Adolf Koch, Internationale Spedition aus Berlin, über Gründung einer Schnelldampferlinie von Emden nach London, Februar 1913

- Information zur Planung der Schnelldampferlinie Emden-London an den Oberbürgermeister Fürbringer durch Friedrich Koth, Juni -

Oktober 1912

- Denkschrift über Rentabilität einer Schnelldampferlinie

Emden-London, 1912

- Bescheid des Staatssekretärs des Reichspostamts über Bereitschaft zur Nutzung der geplanten Schnelldampferlinie durch die Post bei günstigen Konditionen, Oktober 1912

- Material über als Zielort der Linie in Frage kommende Häfen in der Nähe von London, 1912

- Information der Spedition Adolf Koch an Oberbürgermeister Fürbringer und dessen Nachfolger Bürgermeister Dr. Mützelburg über Struktur der geplabnten Schnelldampferlinie, März - september 1913 - Verweigerung der Gewährung eines Sondertarifs für die mit der Schnelldampfer transportierten Güter durch die preußische Staatsbahn, Dezember 1913

$1912-1913$

Klassifikation Teil B: 02138

Trägermaterial: Papier

Alte Reg.-Sig.: IV T6 184

Bestell-Nr.: IV 02138

2102 Transatlantischer Schiffsverkehr von Emden

- Presseberichte über geplante transatlantische Schiffsverkehrslinie der EVAG

1914

Klassifikation Teil B: 02139

Trägermaterial: Papier

Alte Reg.-Sig.: IV T6 187

Bestell-Nr.: IV 02139
1912-1913 
05

\subsection{3}

05.03.12

05.03.12.03

05.03.12.03.01

05.03.12.03.01.01
Stadtverwaltung

Aufgabenbereiche der Stadtverwaltung

Handels- und Gewerbeförderung

Förderung von Handel und Industrie

Förderung von Handel und Verkehr

Maßnahmen zur Handels- und Verkehrsförderung

Lfd. Nr. Titel

Laufzeit

2103 Plan der Anlage einer Luftschiffhalle in der Nähe von Emden, Bd. 1

- Presseartikel über Luftschiffwesen, 1912 - 1913

- Planzeichnung über Standort für eine Luftschiffhalle, 1912 - 1913

- Handschreiben des Vizeadmirals Dick an den Oberbürgermeister

Fürbringer über Bereitschaft des Reichsmarineamts zur

Subventionierung einer Luftschiffhalle unter Bedingung einer Nutzung durch Marineluftschiffe, November 1912

- Angebot der Fa. Max Weinberg Sen., Berlin, über Aufkauf des

Terrains für eine Luftschiffhalle, Oktober - November 1912

- Ermächtigung des Oberbürgermeisters Fürbringer durch den

Magistrat zu Verhandlungen wegen der Luftschiffhalle, Dezember

1912

- Verhandlungen des Oberbürgermeisters Fürbringer mit

verschiedenen Landbesitzer wegen Fläche für die Luftschiffhalle,

Dezember 1912 - Januar 1913

- Vermerk des Oberbürgermeisters Fürbringer über Verwendung einer Fläche der projektierten Kleinbahn Emden--Riepe-Ostgroßefehn für den Aufbau der Luftschiffhalle, Dezember 1912

$1912-1913$

Klassifikation Teil B: 02140

Trägermaterial: Papier

Alte Reg.-Sig.: IV T6 186

Bestell-Nr.: IV 02140

2104 Plan der Anlage einer Luftschiffhalle in der Nähe von Emden, Bd. 2

- Material über Luftschiffhalle in Braunschweig, 1913

- Verhandlungen des Bürgermeisters Dr. Mützelburg mit der

Zeppelin-Hallenbau GmbH, Berlin wegen Aufbau einer Luftschiffhalle, Juni 1913

- LS-Hallen-Projekt der Zeppelin-Hallenbau GmbH, 1913

- Artikel über Luftschiffhallenbau, 1913

- Angebote zum Bau eines Luftschiffhafens, 1914

- Bescheid des Reichsmarineamtes über Rückziehung des Angebotes zur Subventionierung der Errichtung einer Luftschiffhalle in Emden, Januar 1914

$1913-1914$

Klassifikation Teil B: 02141

Band: 2

Trägermaterial: Papier

Alte Reg.-Sig.: IV T6 186

Bestell-Nr.: IV 02141 
IV

05

Stadtverwaltung

05.03

05.03.12

Aufgabenbereiche der Stadtverwaltung

05.03.12.03

05.03.12.03.01

Handels- und Gewerbeförderung

Förderung von Handel und Industrie

Förderung von Handel und Verkehr

05.03.12.03.01.01

Maßnahmen zur Handels- und Verkehrsförderung

Lfd. Nr. Titel

Laufzeit

2105 Handakte Fürbringer: Handels- und Schifffahrtsfragen

1905-1912

- Presseartikel zu Handels- und Schifffahrtsfragen, u.a. Emden als Auswandererhafen, 1905 - 1912

- Dokumente zu einzelnen Firmen, u.a. Hohenzollernhütte, 1905 -

1912

- Geschäftsbericht der Nordseewerke, 1907

- Angebot des Julius Meier, Bremen, zur Errichtung einer

Auswandererlinie von Emden nach Nordamerika, Dezember 1909 -

November 1910

- Antrag der Deutschen Reederei auf Konzessionierung einer

Auswandererlinie, Juni - August 1912

$1905-1912$

Klassifikation Teil B: 02146

Trägermaterial: Papier

Alte Reg.-Sig.: IV T6 192

Bestell-Nr.: IV 02146 
05

\subsection{3}

05.03.12

05.03.12.03

05.03.12.03.01

05.03.12.03.01.01
Stadtverwaltung

Aufgabenbereiche der Stadtverwaltung

Handels- und Gewerbeförderung

Förderung von Handel und Industrie

Förderung von Handel und Verkehr

Maßnahmen zur Handels- und Verkehrsförderung

Lfd. Nr. Titel

Laufzeit

2106 Emden als Auswandererhafen

1910-1914

(1923)

- Verhandlungen des Oberbürgermeisters Fürbringer mit der HAPAG-Lloyd wegen Einrichtung einer Auswandererlinie in Emden, März 1909

Bericht des Oberbürgermeisters an den Regierungspräsidenten in Aurich über Konzessionierungsantrag der Fa. Heinrich \& Wagner zur Einrichtung einer Auswandererlinie von Emden zu den US-Südstaaten und Kanada, Januar 1910

- Verhandlungen der Fa. Heinrich \& Wagner mit dem

Oberbürgermeister Fürbringer wegen Einrichtung einer

Auswandererlinie von Emden nach Galveston (USA), März 1910

- Verhandlungen des Oberbürgermeisters Fürbringer mit dem

Reichskanzler Bethmann-Hollweg wegen Konzessionierung einer

Auswandererlinie von Emden aus, Januar 1911

- Bewerbung der Deutschen Reederei um eine Konzession für eine

Auswandererlinie ab Emden, März - Juni 1912

- Presseberichte über Emden als Auswandererhafen, April - Oktober

1912

- Konzept eines Gesuches der städtischen Kollegien an Kaiser

Wilhelm II. über Bitte um Konzessionierung der Deutschen Reederei für eine Auswandererlinie, April / Mai 1912

- Erlass des Ministers für Handel und Gewerbe über Verleihung der Konzession für eine Auswandererlinie vbon Emden an den Norddeutschen Lloyd und die HAPAG, Juni 1912

- Verhandlungen der städtischen Kollegien über Einrichtung einer Auswandererlinie, Juni - Dezember 1912

- Eingabe des Magistrats an den Handelsminister über Vorstellungen hinsichtlich einer Auswandererlinie ab Emden zur Erreichung einer besseren Auslastung des Emder Hafens, Juni / Juli 1912

- Verhandlungen des Magistrats mit den Emder Hafen- und Verkehsbetrieben sowie der Hafenverwaltung über Einrichtung einer Auswandererlinie, August 1912

- Verhandlungen zwischen dem Handelsministerium, der HAPAG-Lloyd und des Magistrats wegen der Auswandererlinie,

Oktober 1912

- Verpflichtungserklärung der HAPAG- Lloyd gegenüber der preußischen Staatsregierung über Betrieb einer Auswandererlinie ab dem preußischen Staatshafen Emden, November 1912

- Eröffnung der Emder Auswandererhallen und der Auswandererlinie, April 1914

$1910-1914$

Klassifikation Teil B: 02471

Trägermaterial: Papier

Alte Reg.-Sig.: IV T6 180

Bestell-Nr.: IV 02471 
05

\subsection{3}

05.03.12

05.03.12.03

05.03.12.03.01

05.03.12.03.01.02
Stadtverwaltung

Aufgabenbereiche der Stadtverwaltung

Handels- und Gewerbeförderung

Förderung von Handel und Industrie

Förderung von Handel und Verkehr

Institutionen des Handels, Gewerbes und Verkehrs

Lfd. Nr. Titel

Laufzeit

2107 Handelskammer für Ostfriesland und Papenburg, Bd. 1

- Neuorganisation der Handelskammer für die Stadt Emden und Umgebung, Wahl eines Vorstands und Aufnahme neuer Mitglieder, April 1871 - Januar 1872

- Erlass des Ministers für Handel und Gewerbe über Änderung der Wahlbezirke der Handelskammer für Ostfriesland und Papenburg, April 1877

- Rotation des Sitzes der Handelskammer zwischen Emden und Leer, Juli 1882 - Januar 1883 / Februar - August 1906

- Änderung der Wahlbezirke der Handelskammer nach der Kreisreform in Ostfriesland, Januar 1885

- Verfügung des Regierungspräsidenten in Aurich über Festlegung der Mitgliedsbeiträge zur Handelskammer, November 1885 / Juni 1895 - Jahresberichte der Handelskammer für Ostfriesland und Papenburg, Teil I + II, 1903 / 1908

- Nachrichten über Konstituierung von Handelskammern in verschiedenen Regierungsbezirken Preußens, 1906 - 1909

$1871-1909$

Klassifikation Teil B: 01945

Band: 1

Trägermaterial: Papier

Alte Reg.-Sig.: IV T1 33

Bestell-Nr.: IV 01945

2108 Handelskammer für Ostfriesland und Papenburg, Bd. 2

- Jahresberichte der Handelskammer für Ostfriesland und Papenburg, $1910-1912$

- Verhandlungen und Mitteilungen der Handelskammer für

Ostfriesland und Papenburg, November 1910 - Oktober 1914

- Nachrichten aus anderen Handelskammern in Preußen, 1910 - 1914

- Erlass des Ministers für Handel und Gewerbe über Festlegung des

Sitzes der Handelskammer in Emden, Februar 1910

$1910-1914$

Klassifikation Teil B: 01946

Band: 2

Trägermaterial: Papier

Alte Reg.-Sig.: IV T1 33

Bestell-Nr.: IV 01946 
05

05.03

05.03.12

05.03.12.03

05.03.12.03.01

05.03.12.03.01.02
Stadtverwaltung

Aufgabenbereiche der Stadtverwaltung

Handels- und Gewerbeförderung

Förderung von Handel und Industrie

Förderung von Handel und Verkehr

Institutionen des Handels, Gewerbes und Verkehrs

Lfd. Nr. Titel

Laufzeit

2109 Handelskammer für Emden und Umgebung, Bd. 1

1868-1871

- Protokolle der Verhandlungen der Mitglieder (Börse) über gewerbepolitische, steuerrechtliche, verkehrspolitische und verbandspolitische Fragen

$1868-1871$

Klassifikation Teil B: 01947

Band: 1

Trägermaterial: Papier

Alte Reg.-Sig.: IV T1 33

Bestell-Nr.: IV 01947

2110 Handelskammer für Emden und Umgebung, Bd. 2

- Eintreibung rückständiger Mitgliedsbeiträge zur Handelskammer, $1867-1870$

- Beschwerden gegen Pfändung rückständiger Mitgliedsbeiträge, 1867

$-1871$

- Liste wahlberechtigter Kammermitglieder, März 1870

- Aufnahme neuer Mitglieder in die Handelskammer für Emden und

Umgebung, 1871

$1867-1871$

Klassifikation Teil B: 01948

Band: 2

Trägermaterial: Papier

Alte Reg.-Sig.: IV T1 33

Bestell-Nr.: IV 01948

2111 Handelskammer für Emden und Umgebung, Bd. 3

- Festlegung der Mitgliedsbeiträge zur Handelskammer, 1866 - 1870

- Eintreibung rückständiger Mitgliedsbeiträge, 1867

- Antrag der Handelskammer beim Magistrat auf Genehmigung der novellierten Statuten, Juli 1867 - Januar 1871

$1866-1871$

Klassifikation Teil B: 01949

Band: 3

Trägermaterial: Papier

Alte Reg.-Sig.: IV T1 33

Bestell-Nr.: IV 01949 
05

\subsection{3}

05.03.12

05.03.12.03

05.03.12.03.01

05.03.12.03.01.02
Stadtverwaltung

Aufgabenbereiche der Stadtverwaltung

Handels- und Gewerbeförderung

Förderung von Handel und Industrie

Förderung von Handel und Verkehr

Institutionen des Handels, Gewerbes und Verkehrs

Lfd. Nr. Titel

Laufzeit

2112 Einrichtung gewerblicher Schiedsgerichte

- Erlass des Ministers für Handel und Gewerbe und der öffentlichen Arbeiten über Einrichtung gewerblicher Schiedsgerichte zum Erhalt des Betriebs- und Gewerbefriedens, Oktober 1870 / Juli 1871

- Bericht des Magistrats an den preußischen Landdrosten in Aurich über nichtbestehende Notwendigkeit zur Errichtung eines gewerblichen Schiedsgerichts in Emden, Dezember 1871 / Dezember 1871 / November 1872

$1870-1872$

Klassifikation Teil B: 01950

Trägermaterial: Papier

Alte Reg.-Sig.: IV T1 34

Bestell-Nr.: IV 01950

2113 Einrichtung einer Gewerbekammer für den Regierungsbezirk Aurich

- Einladung an den Oberbürgermeister Fürbringer zu einer Konferenz mit dem preußischen Landdrosten von Hepp wegen von der Staatsregierung erwarteten Anordnung der Einrichtung einer Gewerbekammer, Februar 1885

- Vorlage des Oberpräsidenten der Provinz Hannover an den Provinziallandtag wegen Bereitstellung von Haushaltsmittel zur

Einrichtung und Betreibung von Gewerbekammern, Juni 1885

- Verfügung des Regierungspräsidenten in Aurich über Anordnung zur Benennung von zur Besetzung einer Gewerbekammer geeigneten Handwerkern, November 1885

- Verfügung des Regierungspräsidenten an den Magistrat über Anordnung der zur Acquise geeigneter Räume in Emden für die Gewerbekammer, März 1886

- Jahresbericht der Gewerbekammer für den Regierungsbezirk Aurich, 1886

- Protokoll der zweiten Sitzung der Gewerbekammer für den

Regierungsbezirk Aurich, Mai 1887

Klassifikation Teil B: 01951

Trägermaterial: Papier

Alte Reg.-Sig.: IV T1 38

Bestell-Nr.: IV 01951 
05

\subsection{3}

05.03.12

05.03.12.03

05.03.12.03.01

05.03.12.03.01.02
Stadtverwaltung

Aufgabenbereiche der Stadtverwaltung

Handels- und Gewerbeförderung

Förderung von Handel und Industrie

Förderung von Handel und Verkehr

Institutionen des Handels, Gewerbes und Verkehrs

Lfd. Nr. Titel

Laufzeit

2114 Konsuln und Generalkonsuln

- Mitteilungen über Akkreditierung von Konsuln und Generalkonsuln, $1906-1914$

- Verfügung des Regierungspräsidenten in Aurich über Anordnung der Beobachtung des in Emden residierenden argentinischen Konsuls $\mathrm{J}$. J. Visca wegen seiner Werbung für Auswanderung und der Einfuhr argentinischen Rindfleisches, Februar 1914

- Entziehung der Exequatur von Konsuln der gegen Deutschland kriegsführenden Staaten, 1914 - 1916

$1906-1916$

Klassifikation Teil B: 02012

Trägermaterial: Papier

Alte Reg.-Sig.: IV T6 018

Bestell-Nr.: IV 02012

2115 Errichtung einer Kornbörse in Emden

$1892-1903$

- Schreiben der Emder Getreidehändler an die Kaufmännische Deputation über Bildung einer Verhandlungskommission wegen Ausgestaltung der Kornbörse, Dezember 1892

- Benennung von Mitgliedern aus der Bauernschaft für die

Kommission der Kornbörse durch den Landwirtschaftlichen

Zweigverein Emden, Dezember 1892

- Bericht des Oberbürgermeisters Fürbringer an den

Regierungspräsdidenten über Stellungnahme zum Projekt einer Kornbörse in Emden, Dezember 1892

- Bescheid des Regierungspröäsidenten in Aurich über grundsätzliche Billigung der Kornbörse unter der Voraussetzung der Genehmigung durch den Handelsminister, Juni 1893

- Bericht der Kaufmännischen Deputation über Umsatz der Kornbörse, August 1894

- Verfügung des Oberpräsidenten der Provinz Hannover über Anordnung der Übermittlung von Preisnotierungen der Emder Börse an das kaiserliche Statistische Amt, Januar 1897

- Vorschriften über telegraphische Berichte von Preisnotierungen an das kaiserliche Statistische Amt, Januar 1897 - November 1903

- Aufnahme des Landwirtschaftlichen Hauptvereins für Ostfriesland in die Kommission der Kornbörse, Mai 1897

- Reglement für die Kornbörse in der Stadt Emden, August 1897

$1892-1903$

Klassifikation Teil B: 02014

Trägermaterial: Papier

Alte Reg.-Sig.: IV T6 022

Bestell-Nr.: IV 02014 
05

05.03

05.03.12

05.03.12.03

05.03.12.03.01

05.03.12.03.01.02
Stadtverwaltung

Aufgabenbereiche der Stadtverwaltung

Handels- und Gewerbeförderung

Förderung von Handel und Industrie

Förderung von Handel und Verkehr

Institutionen des Handels, Gewerbes und Verkehrs

Lfd. Nr. Titel

Laufzeit

2116 Kornmessergilde

1873-1898

- Bestimmungen über Mess- und Wägelohn für Getreide, Mai 1873

- Druckschrift: Bestimmungen über das Kassen- und

Rechnungswesen des Kornmesser-Instituts, April 1892

- Information des Magistrats der Stadt Aurich über das

Kornmesser-Institut der Stadt Emden, Februar - April 1894

- Beschwerde der Kornmessergilde gegen die Umgehung ihrer

Dienste durch die Getreidehändler, Dezember 1898

$1873-1898$

Klassifikation Teil B: 02015

Trägermaterial: Papier

Alte Reg.-Sig.: IV T6 034

Bestell-Nr.: IV 02015

2117 Schiffsversicherungsgesellschaften

- Geschäftsbericht der Ersten Assecuranz-Compagnie, Emden, 1872

- Gutachten der Handelskammer über nicht vorhandene

Konzessionierungsfähigkeit der Schiffsversicherungsgesellschaft

"Concordia", November 1867

- Gesuche verschiedener Versicherungsgesellschaften um Erhalt der

Konzession als Schiffsversicherung, 1892

- Datenerhebung zum Schiffsversicherungswesen, 1899

- Statutenänderungen der Zweiten Assecuranz-Compagnie,

September 1869 - April 1870

- Geschäftsberichte der Zweiten Assecuranz-Compagnie in Emden, 1867

$1867-1899$

Klassifikation Teil B: 02031

Trägermaterial: Papier

Alte Reg.-Sig.: IV T6 073

Bestell-Nr.: IV 02031 
05

05.03

05.03.12

05.03.12.03

05.03.12.03.01

05.03.12.03.01.02
Stadtverwaltung

Aufgabenbereiche der Stadtverwaltung

Handels- und Gewerbeförderung

Förderung von Handel und Industrie

Förderung von Handel und Verkehr

Institutionen des Handels, Gewerbes und Verkehrs

Lfd. Nr. Titel

Laufzeit

1874-1883

(1854-1857)

- Gesuch des Meindert Dallinga über Bitte um Konzessionierung einer von inm betriebenen Droschkenlinie vom Bahnhof in die Stadt,

Dezember 1854

- Information zum Droschkenreglement in der Residenzstadt

Hannover und in Göttingen, Januar - Mai 1855

- Regulierung des Droschkenwesens in Emden, (Januar 1857) / Mai -

August 1883

- Anzeige des Polizeikommissars von Diepenbrock gegen den

Droschkenbesitzer und Fuhrmann Peter Bordeaux wegen

Beschimpfung und Bedrohung von Fahrgästen wegen

Nichtinanspruchnahme seiner Dienste, August 1874

- Polizeiverordnung des Magistrats über Regelung des Fahrverkehrs der Droschken und Verhaltensrichtlinien für auf Gäste am Bahnhof und am Schiffslandesteg wartende Hotelbedienstete, August 1883

(1854 - 1857) 1874 - 1883

Klassifikation Teil B: 02032

Trägermaterial: Papier

Alte Reg.-Sig.: IV T6 076

Bestell-Nr.: IV 02032

2119 Beurtfahrt von Emden nach Groningen

$1869-1871$

- Diskussion der Abschaffung des Beurtfahrt-Monopols, 1869

- Antrag des Sikke Barghoorn beim Magistrat auf Übertragung der Beurtfahrt von Emden nach Groningen auf seinen Vetter Willem

Barghoorn, Januar 1871

$1869-1871$

Klassifikation Teil B: 02033

Trägermaterial: Papier

Bestell-Nr.: IV 02033

2120 Puntschifffahrt auf der Ems, der Haase und dem

$1889-1912$

Dortmund-Ems-Kanal

- Frachttarife auf der Ems, 1858

- Verhandlungen des Magistrats mit den Nachbarkommunen an der

Ems wegen Neufestlegung der Frachttarife, März - April 1889

- Geplanter Bau einer Brücke bei Leerort, 1912

(1858) $1889-1912$

Klassifikation Teil B: 02034

Trägermaterial: Papier

Alte Reg.-Sig.: IV T6 087

Bestell-Nr.: IV 02034 
05

05.03

05.03.12

05.03.12.03

05.03.12.03.01

05.03.12.03.01.02
Stadtverwaltung

Aufgabenbereiche der Stadtverwaltung

Handels- und Gewerbeförderung

Förderung von Handel und Industrie

Förderung von Handel und Verkehr

Institutionen des Handels, Gewerbes und Verkehrs

Lfd. Nr. Titel

Laufzeit

2121 Emder Hafen

1869-1912

- Gutachten des niederländischen Ingenieurs J. van de Vegt über den

Zustand des Emder Hafens und seiner Anlagen, Oktober 1869

- Regelung der Benutzung des Stigtes am Beckhof, August 1912

$1869 / 1912$

Klassifikation Teil B: 02036

Trägermaterial: Papier

Alte Reg.-Sig.: IV T6 092

Bestell-Nr.: IV 02036

2122 Ems-Lots-Wesen

$1872-1912$

- Statistik der Emslots-Gesellschaft, 1858 - 1903

(1858)

- Feier des 25. jährigen Bestehens der Emslots-Gesellschaft,

Dezember 1883 - Januar 1884

- Tarife der Emslots-Gesellschaft, 1872 / 1903

- Verhältnisse des Lotsenschiffers Rewe Herlyn, Dezember 1883

- Diskussion des Lotsenzwanges, November 1907 - Februar 1908

- Geschäftsberichte der Emslots-Gesellschaft, 1909 - 1912

(1858) 1872 - 1912

Klassifikation Teil B: 02037

Trägermaterial: Papier

Alte Reg.-Sig.: IV T6 093

Bestell-Nr.: IV 02037

2123 Zwangslotsgeld

$1891-1902$

- Streitigkeiten mit verschiedenen Kapitänen und

Schifffahrtsgesellschaften wegen der Erhebung des Zwangslotsgeldes

$1891-1902$

Klassifikation Teil B: 02038

Trägermaterial: Papier

Alte Reg.-Sig.: IV T6 096

Bestell-Nr.: IV 02038 
05

\subsection{3}

05.03.12

05.03.12.03

05.03.12.03.01

05.03.12.03.01.02
Stadtverwaltung

Aufgabenbereiche der Stadtverwaltung

Handels- und Gewerbeförderung

Förderung von Handel und Industrie

Förderung von Handel und Verkehr

Institutionen des Handels, Gewerbes und Verkehrs

Lfd. Nr. Titel

Laufzeit

2124 Wiener Weltausstellung

1873-1874

(1881)

- Erlass des Ministers für Handel und Gewerbe und der öffentlichen Arbeiten über Förderung der Beteiligung an der Wiener

Weltausstellung, Juni 1873

- Empfehlung des Aufsichtsrats der Dampfspnnerei,- Weberei und

-Färberei AG für eine Förderung des Webers $P$. H. Campen zum

Besuch der Wiener Weltausstellung, Juli 1873

- Eingabe des Emder Handwerkervereins an den Magistrat über Bitte um Förderung verschiedener, besonders ausgezeichneter

Handwerker zur Ermöglichung einer Reise zur Wiener

Weltausstellung, Juli 1873

- Vehandlungen der städtischen Kollegien über Förderanträge, August

/ September 1873

$1873-1874$

Klassifikation Teil B: 02047

Trägermaterial: Papier

Alte Reg.-Sig.: IV T6 108

Bestell-Nr.: IV 02047

2125 Allgemeine Gewerbeausstellung der Provinz Hannover

- Aufforderung des Vereins für die Allgemeine Gewerbeausstellung der Provinz Hannover zur Teilnahme an der Ausstellung, Januar 1878

- Aussstellungsordnung, Februar 1878

- Schreiben des ehemaligen Oberbürgermeisters Ernst Hantelmann an seinen Nachfolger Leo Fürbringer über Bitte um Beschickung des kunsthistorischen Teils der Gewerbeausstellung, Januar 1878

- Grundriss der Allgemeinen Gewerbeausstellung der Provinz Hannover, 1878

- Plakat zur Allgemeinen Gewerbeausstellung der Provinz Hannover, 1878

- Verzeichnis der Ausstellungsbeschicker aus Emden, Februar 1878

- Aufstellung über Mitglieder des Lokalausschusses "Emden" für die

Allgemeine Gewerbeausstellung der Provinz Hannover, Februar 1878

- Aufstellung über zur Ausstellung entsandten Stücke der Emder

Rüstkammer, Februar - Juni 1878

- Hannoversche Gewerbe-Ausstellungs-Zeitung, Mai 1878

- Dankesschreiben der Kommission für die Allgemeine

Gewerbeausstellung der Provinz Hannover für die Förderung der

Ausstellung durch die Stadt Emden, Februar 1879

$1878-1879$

Klassifikation Teil B: 02049

Trägermaterial: Papier

Alte Reg.-Sig.: IV T6 111

Bestell-Nr.: IV 02049 


\section{5}

\subsection{3}

05.03.12

05.03.12.03

05.03.12.03.01

05.03.12.03.01.02

\section{Stadtverwaltung}

Aufgabenbereiche der Stadtverwaltung

Handels- und Gewerbeförderung

Förderung von Handel und Industrie

Förderung von Handel und Verkehr

Institutionen des Handels, Gewerbes und Verkehrs

Lfd. Nr. Titel

Laufzeit

2126 Kunstgewerbeausstellung in München

- Entsendung von Kunstgegenständen und Waffen aus der

Rüstkammer zur Kunstgewerbeausstellung nach München, 1876

- Erstattung der Transportkosten und des Aufwands zur Restaurierung der nach München versandten Kunstgegenstände und Waffen, 1877 1878

$1876-1878$

Klassifikation Teil B: 02052

Trägermaterial: Papier

Alte Reg.-Sig.: IV T6 116

Bestell-Nr.: IV 02052

2127 Ostfriesische Ausstellung für Gewerbe und Landwirtschaft

- Organisation der Ausstellung für Gewerbe und Landwirtschaft durch den Emder Handwerkerverein, Juli 1882 - Juli 1883

- Verhandlungen des Magistrats über Förderung der Ausstellung,

August 1883

- Antrag des Comites für die Ostfriesische Ausstellung für Gewerbe und Landwirtschaft beim Regierungspräsidenten in Aurich auf Unterstützung des Projektes der Ostfriesischen Ausstellung für Gewerbe und Landwirtschaft, Januar 1888

- Genehmigungsverfahren zur Veranstaltung einer Verlosung zur Finanzierung der Ostfriesischen Ausstellung für Gewerbe und Landwirtschaft, Januar - März 1888

- Förderung der Ausstellung durch die Stadt Emden, Februar 1888

- Anfrage des Magistrats der Stadt Kiel wegen Organisation der Ausstellung zur Gewinnung von Erfahrungswerten für eine eigene Gewerbeausstellung, März 1903

- Runderlass der preußischen Staatsregierung über Bekämpfung der Auswüchse im Ausstellungswesen, Februar 1902

- Organisation einer Gewerbeausstellung durch den Emder Handwerkerverein, Mai 1912

$1882-1912(1914)$

Klassifikation Teil B: 02057

Trägermaterial: Papier

Alte Reg.-Sig.: IV T6 121

Bestell-Nr.: IV 02057

2128 Pariser Weltausstellung

- Vertrauliche Besprechung über Beteiligung der deutschen Reedereien und Schiffswerfte an der Weltausstellung in Paris mit dem Beschluss einer kollektiven Beteiligung, Dezember 1898

1898 (1902)

Klassifikation Teil B: 02076

Trägermaterial: Papier

Alte Reg.-Sig.: IV T6 134

Bestell-Nr.: IV 02076 
IV

05

05.03

05.03.12

05.03.12.03

05.03.12.03.01

05.03.12.03.01.02
Stadtverwaltung

Aufgabenbereiche der Stadtverwaltung

Handels- und Gewerbeförderung

Förderung von Handel und Industrie

Förderung von Handel und Verkehr

Institutionen des Handels, Gewerbes und Verkehrs

Lfd. Nr. Titel

Laufzeit

2129 Reglement für die vereidigten Emder Wäger

1899-1906

- Eingabe der Kaufmännischen Deputation an den Magistrat über Notwendigkeit der Bestellung vereidigter Wäger für die Abwiegung der durch den Dortmund-Ems-Kanal einkommenden Massengüter,

September - Oktober 1899

- Vorschlag eines Regulativs für vereidigte Wäger nach Hamburger Vorbild durch die Kaufmännische Deputation, Dezember 1899

- Konziperung eines Reglements für die vereidigten Wäger durch den Magistrat, April - Mai 1900

- Bescheid des kgl. Hauptzollamts in Emden über Akzeptierung Wiegescheine der vereidigten Wäger der Stadt Emden, Dezember 1900

- Beschwerden der Münsterischen Lagerhaus AG und anderer Handelsfirmen über falsche Wiegeergebnisse durch ungenau eingestellte Waagen der städtischen Wäger, August 1901 - Juni 1902 - Novellierung des Reglements für die vereidigten Wäger der Stadt Emden unter Neufestsetzung der Wiegegebühren, April 1902 -

Februar 1903

- Streit um die Sonn- und Feiertagsvergütung für Wäger, Mai - Juni 1902

$1899-1903$

Klassifikation Teil B: 02081

Trägermaterial: Papier

Alte Reg.-Sig.: IV T6 136

Bestell-Nr.: IV 02081

2130 Veröffentlichungen über den Emder Hafen

- Beschluss des Magistrats über Erlaubnis zur Erstellung einer Reportage über den Emder Hafen durch den Korrespondenten Dr. E. Franke aus Berlin, Juni 1899

- Bewilligung eines Honorars für die Werbeartikel des Dr. E. Franke über Emden, August - September 1899

1899

Klassifikation Teil B: 02099

Trägermaterial: Papier

Alte Reg.-Sig.: IV T6 149

Bestell-Nr.: IV 02099 
05

05.03

05.03.12

05.03.12.03

05.03.12.03.01

05.03.12.03.01.02
Stadtverwaltung

Aufgabenbereiche der Stadtverwaltung

Handels- und Gewerbeförderung

Förderung von Handel und Industrie

Förderung von Handel und Verkehr

Institutionen des Handels, Gewerbes und Verkehrs

Lfd. Nr. Titel

Laufzeit

2131 Weltausstellung in St. Louis (USA)

1902-1904

- Vorschlag des US-Konsuls Henry W. Diedrich zur Präsentation des Emder Hafens auf der Weltausstellung in St Louis (USA), November 1902

- Herstellung und Finanzierung einer für die Weltausstellung geplanten Reliefkarte der Stadt Emden, Januar - Februar 1903 - Plan der deutschen Exponate für die Weltausstellung in St Louis, Januar 1903

- Beitrag der Stadt Emden zur Weltausstellung, 1903

- Finanzierung der Herstellung der Emder Exponate, 1903 - 1904

$1902-1904$

Klassifikation Teil B: 02100

Trägermaterial: Papier

Alte Reg.-Sig.: IV T6 150

Bestell-Nr.: IV 02100

2132 Geplante Gründung einer Industrie-Landgesellschaft und einer Freibezirk-Lagerhausgesellschaft

- Initiative des Oberbürgermeisters Fürbringer zur Gründung einer Industrie-Landgesellschaft zur Erschließung des Hafengebiets für Industriebetriebe, 1903

- Plan der Gründung einer Emder Lagerhausgesellschaft unter Beteiligung der Deutschen Bank, Mai - Oktober 1904

$1903-1904$

Klassifikation Teil B: 02103

Trägermaterial: Papier

Alte Reg.-Sig.: IV T6 154

Bestell-Nr.: IV 02103

2133 Baufachausstellung in Leipzig

- Prospekt der Baufachausstellung in Leipzig, 1913

- Bewilligung eines Reisezuschusses für den Bauassistenten Braa zum Besuch der Ausstellung, Juni 1913

- Aufstellung der Reisekosten für Mitglieder des Magistrats und Bediensteter des Bauamts zum Besuch der Ausstellung, Oktober 1913

1913

Klassifikation Teil B: 02144

Trägermaterial: Papier

Alte Reg.-Sig.: IV T6 190

Bestell-Nr.: IV 02144 
05

05.03

05.03.12

05.03.12.03

05.03.12.03.01

05.03.12.03.01.02
Stadtverwaltung

Aufgabenbereiche der Stadtverwaltung

Handels- und Gewerbeförderung

Förderung von Handel und Industrie

Förderung von Handel und Verkehr

Institutionen des Handels, Gewerbes und Verkehrs

Lfd. Nr. Titel

Laufzeit

2134 Kaufmännische Deputation, Bd. 1

$1869-1911$

- Vorschläge der Kaufmännischen Deputation zur Beilegung von

Konflikten zwischen Getreidehändlern und Kornmessern, 1869 - 1889

- Verzeichnis der wahlberechtigten Mitglieder der Handelskammer, 1870

- Novellierung des Regulativs und der Statuten der Kaufmännischen

Deputation, (1865) 1870 - 1911

- Regulativ des Börsenvereins, 1872

- Vermögen der Kaufmännischen Deputation, 1872 - 1888

- Vorstandswahlen beim Börsenverein, 1873

- Aufnahme von Mitglieder in die Kaufmännische Deputation, 1875 1876

- Protokoll der Generalversammlung des Börsenvereins, März 1888

- Festlegung des Mitgliedsbeiträge der Kaufmännischen Deputation, Januar 1902

$1869-1911$

Klassifikation Teil B: 02148

Band: 1

Trägermaterial: Papier

Alte Reg.-Sig.: IV T6 202

Bestell-Nr.: IV 02148

2135 Kaufmännische Deputation, Bd. 2

1866-1898

- Einladungen an den Bürgermeister / Oberbürgermeister der Stadt

(1861-1865)

Emden zu den Generalversammlungen der Kaufmännischen

Deputation, (1861 - 1865) 1866 - 1869

- Vorstandswahlen bei der Kaufmännischen Deputation, (Januar 1861

- Februar 1864) April 1866 - März 1868

- Mitglieder der Handelskammer Emden, 1869 - 1871

- Wahlmodus für die Mitgliedschaft bei der Handelskammer, 1866

- Beantragung der Einberufung von Mitgliederversammlungen der

Kaufmännischen Deputation, 1866

- Einberufung der Mitgliederversammlungen der Kaufmännischen

Deputation, 1866 - 1878

- Geschäftsordnung der Kaufmännischen Deputation, 1872

- Generalversammlung des Börsenvereins mit Wahl neuer Mitglieder, 1877 - 1898

- Vermögen der Kaufmännischen Deputation, 1882

(1861 - 1865) $1866-1898$

Klassifikation Teil B: 02149

Band: 2

Trägermaterial: Papier

Alte Reg.-Sig.: IV T6 202

Bestell-Nr.: IV 02149 
IV

05

Stadtverwaltung

05.03

05.03.12

05.03.12.03

05.03.12.03.01

Aufgabenbereiche der Stadtverwaltung

Handels- und Gewerbeförderung

Förderung von Handel und Industrie

Förderung von Handel und Verkehr

05.03.12.03.01.02

Institutionen des Handels, Gewerbes und Verkehrs

Lfd. Nr. Titel

Laufzeit

2136 Westdeutscher Fluß- und Kanalverein

1883-1889

- Veranstaltungen des Westdeutschen Fluß- und Kanalvereins über verschiedene Kanalprojekte, 1883 - 1884

- Gründung des Westdeutschen Fluß- und Kanalvereins, 1883

- Statut des Westdeutschen Fluß- und Kanalvereins, 1884

- Rechnung des Emder Lokalvereins des Westdeutschen Fluß- und

Kanalvereins, 1884

- Konzipierung von Schleppkähnen für den Dortmund-Ems-Kanal,

Oktober - November 1889

$1883-1889$

Klassifikation Teil B: 02150

Trägermaterial: Papier

Alte Reg.-Sig.: IV T6 203

Bestell-Nr.: IV 02150 
05

\subsection{3}

05.03.12

05.03.12.03

05.03.12.03.01

05.03.12.03.01.03
Stadtverwaltung

Aufgabenbereiche der Stadtverwaltung

Handels- und Gewerbeförderung

Förderung von Handel und Industrie

Förderung von Handel und Verkehr

Märkte

Lfd. Nr. Titel

Laufzeit

2137 Pfähle auf dem Viehmarkt

- Einnahmen aus dem Pfahl- oder Stellgeld des Viehmarktes, 1866 -

1878

- Vorschlag der städtischen Marktkommission zur Versetzung der

Pfähle für den Viehmarkt, Februar - April 1883 / Oktober 1893

- Verfügung des Magistrats über Beschluss der Herstellung einer doppelten Pfahlreihe auf dem Neuen Markt zur Anbindung von Vieh, November 1895 - Mai 1896

- Umfahren zweier Pfähle auf dem Neuen Markt durch ein Gespann, November 1904

- Beschluss der Marktkommission zur Anschaffung einer Schranke zur Abgrenzung des Viehmarktes, 1909

- Werbung für Anbindepfähle, 1910

$1866-1910$

Klassifikation Teil B: 02203

Trägermaterial: Papier

Alte Reg.-Sig.: IV T10 01

Bestell-Nr.: IV 02203

2138 Marktkalender, Bd. 1

- Festlegung der Markttage und der Jahrmärkte, 1870 - 1884

- Jahrmärkte in Ostfriesland, 1870 - 1884

- Anträge von Kaufleuten auf Änderung von Markttagen, 1872

- Verfügungen des preußischen Landdrosten über Genehmigung oder

Änderung von Markttagen, 1870 - 1884

- Ablehnung der Datierung des Emder Flachsmarktes suf den 01.11.

wegen des katholischen Feiertages "Allerheiligen", Oktober 1881

$1870-1884$

Klassifikation Teil B: 02204

Band: 1

Trägermaterial: Papier

Alte Reg.-Sig.: IV T10 02

Bestell-Nr.: IV 02204

2139 Marktkalender, Bd. 2

$1885-1896$

- Festlegung der Markttage und der Jahrmärkte

- Jahrmärkte in Ostfriesland

- Anträge von Kaufleuten auf Änderung von Markttagen

- Verfügungen des preußischen Regierungspräsidenten in Aurich über Genehmigung oder Änderung von Markttagen

$1885-1896$

Klassifikation Teil B: 02205

Band: 2

Trägermaterial: Papier

Alte Reg.-Sig.: IV T10 02

Bestell-Nr.: IV 02205 
05

05.03

05.03.12

05.03.12.03

05.03.12.03.01

05.03.12.03.01.03
Stadtverwaltung

Aufgabenbereiche der Stadtverwaltung

Handels- und Gewerbeförderung

Förderung von Handel und Industrie

Förderung von Handel und Verkehr

Märkte

Lfd. Nr. Titel

Laufzeit

2140 Marktkalender, Bd. 3

- Festlegung der Markttage und der Jahrmärkte

- Jahrmärkte in Ostfriesland

- Anträge von Kaufleuten auf Änderung von Markttagen

- Verfügungen des preußischen Regierungspräsidenten in Aurich über

Genehmigung oder Änderung von Markttagen

- Gesetzliche Bestimmungen und Verfügungen des

Regierungspräsidenten zur Regulierung des Marktwesens

$1908-1917$

Klassifikation Teil B: 02206

Band: 3

Trägermaterial: Papier

Alte Reg.-Sig.: IV T10 02

Bestell-Nr.: IV 02206

2141 Städtische Marktkommission

1880

- Protokolle der Sitzungen der Marktkommission über Regulierung von Marktfragen

1880

Klassifikation Teil B: 02207

Trägermaterial: Papier

Alte Reg.-Sig.: IV T10

Bestell-Nr.: IV 02207

2142 Märkte in Emden

1902

- Überschneidung des Viehmarktes in Weener mit den in Emden, Juli 192

- Emder Marktkalender, 1902

1902

Klassifikation Teil B: 02208

Trägermaterial: Papier

Alte Reg.-Sig.: IV T10 02

Bestell-Nr.: IV 02208

2143 Marktpreise

$1881-1896$

- Anfrage des preußischen Landdrosten in Aurich wegen Marktpreise, Mai 1881

- Marktpreise für Butter und Käse, Mai - Juni 1906

$1881 / 1906$.

Klassifikation Teil B: 02209

Trägermaterial: Papier

Alte Reg.-Sig.: IV T10 04

Bestell-Nr.: IV 02209 
05

\subsection{3}

05.03.12

05.03.12.03

05.03.12.03.01

05.03.12.03.01.03
Stadtverwaltung

Aufgabenbereiche der Stadtverwaltung

Handels- und Gewerbeförderung

Förderung von Handel und Industrie

Förderung von Handel und Verkehr

Märkte

Lfd. Nr. Titel

Laufzeit

2144 Gebühren für Marktstände

- Festlegung der Gebühren für Marktstände, März 1868 - Dezember 1909

- Erlasse des Ministers für Handel und Gewerbe über Regulierung der Marktstandsgebühren, März 1871 - August 1874

- Umsetzung gesetzlicher Bestimmungen zu Marktstandsgebühren, Juni - Juli 1872

- Eingabe des Eichmeisters U. I. Balker an den Magistrat über Bitte um Festlegung eines neuen Tarifs der Marktstandsgebühren, Juli 1873

- Neufestlegung des Tarifs der Marktstandsgebühren in Emden nach Auricher Vorbild, April - September 1874

- Umrechnung der Marktgebühren auf Markwährung, Dezember 1875

- März 1876

- Festlegung der Standgebühr für ein mechanisches Theater auf dem Marktplatz, April 1876

- Festlegung der Standgebühren für den Viehmarkt, März 1879

- Eintreibung der rückständigen Standgebühr für das Hippodrom des

Weselers August Schulten, Oktober - November 1908

- Standgebühren für Vergnügungsbuden auf dem Markt, 1908

$1868-1909$

Klassifikation Teil B: 02210

Trägermaterial: Papier

Alte Reg.-Sig.: IV T10 06

Bestell-Nr.: IV 02210

2145 Wochenmärkte

$1876-1911$

1868-1909

- Eingabe der Kaufmännischen Deputation an den Magistrat über Bitte um Einrichtung eines Wochenmarktes in Emden, Mai 1876

- Konzipierung einer Wochenmarktsordnung für Emden, 1876 - 1877

- Verfügung des Magistrats wegen Regelung des Wochenmarktes,

1877

- Verhandlungen der Marktkommission über Regulierung des

Wochenmarktes, April 1877 - September 1909

-Tarif über Standgebühr für den Wochenmarkt, April 1879 -

September 1906

- Regelung des Verkaufs von Gemüse auf dem Wochenmarkt, Juni Juli 1905

- Wochenmarktsordnung der Stadt Emden, August - September 1908

$1876-1908$

Klassifikation Teil B: 02211

Trägermaterial: Papier

Alte Reg.-Sig.: IV T10 07

Bestell-Nr.: IV 02211 
05

05.03

05.03.12

05.03.12.03

05.03.12.03.01

05.03.12.03.01.03
Stadtverwaltung

Aufgabenbereiche der Stadtverwaltung

Handels- und Gewerbeförderung

Förderung von Handel und Industrie

Förderung von Handel und Verkehr

Märkte

Lfd. Nr. Titel

Laufzeit

2146 Jahrmärkte

- Verhinderung von Ausschreitungen auf Jahrmärkten, November 1876 / September - Oktober 1877

- Beschwerden wegen nächtlicher Ruhestörung durch Abbauarbeiten nach Abschluss des Jahrmarktes, September 1896

- Regelung des Aushangs der Marktordnung, August 1900 /

Dezember 1902

- Regelung der Reinigung des Marktplatzes nach Markttagen, Oktober 1904

- Anträge verschiedener Marktbeschicker an den Magistrat auf Verlängerung der Marktzeit, Mai 1909

- Erlass des Finanzministers über Definition steuerrechtlich günstiger zu bewertenden Marktwaren (Marktviktualien), Januar 1910

$1877-1910$

Klassifikation Teil B: 02212

Trägermaterial: Papier

Alte Reg.-Sig.: IV T10 03

Bestell-Nr.: IV 02212

2147 Marktkommission, Bd. 1

1876-1908

- Statut über Bildung einer Marktkommission, Mai 1876 - Mai 1877

- Wahl der Mitglieder der Marktkommission, Mai 1877 - Januar 1908

- Protokoll der Sitzungen der Marktkommission über Organisation des Marktwesens, 1877 - 1908

$1876-1908$

Klassifikation Teil B: 02213

Band: 1

Trägermaterial: Papier

Alte Reg.-Sig.: IV T10 08

Bestell-Nr.: IV 02213

2148 Marktkommission, Bd. 2

- Wahl der Mitglieder der Marktkommission

- Protokoll der Sitzungen der Marktkommission über Organisation des Marktwesens

$1883-1895$

Klassifikation Teil B: 02214

Band: 2

Trägermaterial: Papier

Alte Reg.-Sig.: IV T10 08

Bestell-Nr.: IV 02214 
05

05.03

05.03.12

05.03.12.03

05.03.12.03.01

05.03.12.03.01.03
Stadtverwaltung

Aufgabenbereiche der Stadtverwaltung

Handels- und Gewerbeförderung

Förderung von Handel und Industrie

Förderung von Handel und Verkehr

Märkte

Lfd. Nr. Titel

Laufzeit

1900-1918

(1919-1920)

- Protokoll der Sitzungen der Marktkommission über Organisation des Marktwesens

1900 - 1918 (1919 - 1920)

Klassifikation Teil B: 02215

Band: 3

Trägermaterial: Papier

Alte Reg.-Sig.: IV T10 08

Bestell-Nr.: IV 02215

2150 Markthalle in Emden

1876-1905

- Grundriss einer Markthalle für Emden, 1876

- Anfrage des Magistrats an verschiedene Städte wegen Markthallen und deren Verwaltung, Juli 1905

1876 / 1905

Klassifikation Teil B: 02216

Trägermaterial: Papier

Alte Reg.-Sig.: IV T10 16

Bestell-Nr.: IV 02216

2151 Marktpreise für Roggen und Futtermittel

1886-1889

- Berichte über Marktpreise für Roggen und Futtermittel

$1886-1889$

Klassifikation Teil B: 02217

Trägermaterial: Papier

Alte Reg.-Sig.: IV T10 20

Bestell-Nr.: IV 02217

2152 Butter- und Käsemarkt

1903

- Ordnung für den Emder Butter- und Käsemarkt

1903

Klassifikation Teil B: 02218

Trägermaterial: Papier

Alte Reg.-Sig.: IV T10 21

Bestell-Nr.: IV 02218 
05

05.03

05.03.12

05.03.12.03

05.03.12.03.01

05.03.12.03.01.03
Stadtverwaltung

Aufgabenbereiche der Stadtverwaltung

Handels- und Gewerbeförderung

Förderung von Handel und Industrie

Förderung von Handel und Verkehr

Märkte

Lfd. Nr. Titel

Laufzeit

2153 Fleischpreise im Kleinhandel der Stadt Emden

1913-1915

- Richtlinien für die Feststellung und Berichterstattung über die

Marktpreise für Fleisch an das kgl. preußische statistische

Landesamt, 1913 - 1915

- Organisation der Feststellung der Fleischpreise in Emden, 1914

- Berichte über Fleischpreise, Januar 1914 - DEzember 1915

$1913-1915$

Klassifikation Teil B: 02219

Trägermaterial: Papier

Alte Reg.-Sig.: IV T10 22

Bestell-Nr.: IV 02219

2154 Lebensmittelpreise

1881-1918

- Feststellung der Lebensmittelpreise auf dem Emder Markt

$1881-1918$ (1919)

Klassifikation Teil B: 02220

Trägermaterial: Papier

Alte Reg.-Sig.: IV T10 23

Bestell-Nr.: IV 02220

2155 Butterfässer

1867-1870

- Bestimmungen über die Beschaffenheit der Butterfässer. 1867

- Beschwerde der Handelskammer über nachlässige Kontrolle der

Einhaltung der Normen für Butterfässer, September - Oktober 1869

- Verhandlungen des Bürgervorsteherkollegiums über Normierung der

Butterfässer, September 1870

$1867-1870$

Klassifikation Teil B: 02221

Trägermaterial: Papier

Alte Reg.-Sig.: IV T10 24

Bestell-Nr.: IV 02221 
Lfd. Nr. Titel

- Angebote von Waagen und Wiegevorrichtungen für die städtische Waage, 1882

- Übersicht über Tarife der städtischen Waage, 1867

- Neufassung der Tarife der städtischen Waage, 1885 - 1886

- Anzeigen über unzulässige Gewichte bei der städtischen Waage, Juni 1885 / Oktober 1886

- Zustand der Viehwaage, 1885

- Festlegung der Miete für den von der französisch-reformierten Gemeinde genutzten Raum in der städtischen Waage, März 1896

- Anschaffung einer neuen Viehwaage, Mai 1895 - Januar 1896

- Aichung der Waagen, Juni 1893

- Missstände bei der Lagerung von Molkereiprodukten auf der städtischen Waage, Juli 1894

$1867-1896$

Klassifikation Teil B: 02011

Trägermaterial: Papier

Alte Reg.-Sig.: IV T6 007

Bestell-Nr.: IV 02011

2157 Eichung von Maßen und Messgeräten sowie Maschinen, Bd. 1

- Bekanntmachung der Eichterminen, 1891

- Aufstellung über Eichungen durch den Eichmeister, 1896

$1891-1896$

Klassifikation Teil B: 02222

Band: 1

Trägermaterial: Papier

Alte Reg.-Sig.: IV T11 20

Bestell-Nr.: IV 02222 
05

\subsection{3}

05.03.12

05.03.12.03

05.03.12.03.01

05.03.12.03.01.04
Stadtverwaltung

Aufgabenbereiche der Stadtverwaltung

Handels- und Gewerbeförderung

Förderung von Handel und Industrie

Förderung von Handel und Verkehr

Maße und Gewichte

Lfd. Nr. Titel

Laufzeit

2158 Eichung von Maßen und Messgeräten sowie Maschinen, Bd. 2

$1872-1880$

- Bekanntmachung der Termine für die Eichung (Revision) der Waagen und Messeinrichtungen, 1872 - 1880

- Polizeiberichte über beschlagnahmte unzulässige Waagen und

Gewichte mit deren Nennwert, Januar 1873 - Oktober 1878

- Verfügungen des preußischen Landdrosten in Aurich zur

Organisation des Eichwesens, 1872 - 1878

- Protest der Fa. W. Brons \& Söhne gegen die Beschlagnahme von

Gewichtsstücken, Juli 1878

- Verzeichnis der vogenommenen Maß- und Gewichte-Revision, 1877

- Verbotene Verwendung des "Vierdup" durch Kornmesser, Oktober

1878

- Verhängung einer Geldstrafe gegen die Emdener Papierfabrik wegen Verwendung unzulässiger Waagen, Dezember 1877 -

Dezember 1878

$1872-1880$

Klassifikation Teil B: 02223

Band: 2

Trägermaterial: Papier

Alte Reg.-Sig.: IV T11 23

Bestell-Nr.: IV 02223

2159 Eichung von Maßen und Messgeräten sowie Maschinen, Bd. 3

$1881-1899$

- Bekanntmachung der Termine der Eichung (Revision) der Waagen und Messgeräte, 1899

- Übersichten über Revision der Messgeräte und Waagen in der Provinz Hannover, 1888 - 1893

- Geschäftstätigkeit der Eichbehörde in Emden, 1887 - 1891

- Revision der Messgeräte und Waagen in Emden, 1881 - 1890

- Beschwerden gegen die Beschlagnahme falscher Gewichte, 1881 -

1886

- Verfügungen der Eichinspektion zu Hannover über Organisation des

Eichwesens, 1883 - 1888

- Verfügungen des Magistrats über Kriterien bei der Durchführung der

Revision von Waagen und Messgeräten, 1881 - 1887

- Antrag des kgl. Hauptzollamts Emden auf Eichung seiner Waagen

im Zollgebäude, 1886 - 1888

1881 - 1899

Klassifikation Teil B: 02224

Band: 3

Trägermaterial: Papier

Alte Reg.-Sig.: IV T11 23

Bestell-Nr.: IV 02224 
05

05.03

05.03.12

05.03.12.03

05.03.12.03.01

05.03.12.03.01.04

Lfd. Nr. Titel
Stadtverwaltung

Aufgabenbereiche der Stadtverwaltung

Handels- und Gewerbeförderung

Förderung von Handel und Industrie

Förderung von Handel und Verkehr

Maße und Gewichte

2160 Gebäude für das Eichamt

Laufzeit

- Einrichtung eines Eichamtes im Wohnhaus des Eichmeisters Wienholtz

1894

Klassifikation Teil B: 02225

Trägermaterial: Papier

Alte Reg.-Sig.: IV T11 28

Bestell-Nr.: IV 02225 
05

05.03

05.03.12

05.03.12.03

05.03.12.03.01

05.03.12.03.01.05
Stadtverwaltung

Aufgabenbereiche der Stadtverwaltung

Handels- und Gewerbeförderung

Förderung von Handel und Industrie

Förderung von Handel und Verkehr

Zulassung technischer Anlagen

Lfd. Nr. Titel

Laufzeit

2161 Veränderung gewerblicher Anlagen

1906

- Antrag der Kölnischen Tiefbau-Gesellschaft, Baubüro Emden, beim

Stadtausschuss des Stadtkreises Emden auf Genehmigung zum

Einbau eines Dampfkessels in den Eimerbagger "Colonia", Mai 1906

1906

Klassifikation Teil B: 00373

Trägermaterial: Papier

Alte Reg.-Sig.: VIII A 173

Bestell-Nr.: IV 00373

2162 Genehmigung zur Errichtung und zur Veränderung gewerblicher

1906

Anlagen, Bd. 1

- Antrag der Kölnischen Tiefbau-Gesellschaft, Baubüro Emden auf Genehmigung des Einbaus eines Dampfkessels in dem Eimerbagger "Rhenania"

1906
Klassifikation Teil B: 00451
Band: 1
Trägermaterial: Papier
Alte Reg.-Sig.: VIII A 172
Bestell-Nr.: IV 00451

2163 Genehmigung zur Errichtung und zur Veränderung gewerblicher Anlagen, Bd. 2

- Antrag der kgl. Maschinenbauinspektion Emden auf Genehmigung des Betriebs eines Dampfkessels in dem Eimerbagger "ED 1"

1906
Klassifikation Teil B: 00452
Band: 2
Trägermaterial: Papier
Alte Reg.-Sig.: VIII A 173
Bestell-Nr.: IV 00452

2164 Genehmigung zur Errichtung und zur Veränderung gewerblicher Anlagen, Bd. 3

- Antrag der Heringsfischerei "Großer Kurfürst" AG auf Genehmigung der Ausstattung von zehn Heringsloggern der Gesellschaft mit

Dampfkesseln

1906

Klassifikation Teil B: 00453

Band: 3

Trägermaterial: Papier

Alte Reg.-Sig.: VIII A 175

Bestell-Nr.: IV 00453 
05

05.03

05.03.12

05.03.12.03

05.03.12.03.01

05.03.12.03.01.05
Stadtverwaltung

Aufgabenbereiche der Stadtverwaltung

Handels- und Gewerbeförderung

Förderung von Handel und Industrie

Förderung von Handel und Verkehr

Zulassung technischer Anlagen

Lfd. Nr. Titel

Laufzeit

2165 Genehmigung zur Errichtung und zur Veränderung gewerblicher

Anlagen, Bd. 1

1906

- Antrag der Firma Philipp Holzmann und Co GmbH auf Genehmigung

des Einbaus eines Dampfkessels in eine Lokomotive

1906

Klassifikation Teil B: 00454

Band: 4

Trägermaterial: Papier

Alte Reg.-Sig.: VIII A 176

Bestell-Nr.: IV 00454

2166 Genehmigung zur Errichtung und zur Veränderung gewerblicher Anlagen, Bd. 5

- Antrag der Heringsfischerei AG "Neptun" auf Genehmigung des Einbaus von Dampfkesseln in zwei Heringslogger der Gesellschaft

1906
Klassifikation Teil B: 00455
Band: 5
Trägermaterial: Papier
Alte Reg.-Sig.: VIII A 177
Bestell-Nr.: IV 00455

2167 Genehmigung zur Errichtung und zur Veränderung gewerblicher Anlagen, Bd. 5

- Antrag der Heringsfischerei AG "Neptun" auf Genehmigung des Einbaus eines Dampfkessels in den Dampfer "Vera"

1906
Klassifikation Teil B: 00456
Band: 6
Trägermaterial: Papier
Alte Reg.-Sig.: VIII A 178
Bestell-Nr.: IV 00456

2168 Genehmigung zur Errichtung und zur Veränderung gewerblicher Anlagen, Bd. 7

- Antrag der Emslots-Gesellschaft auf Genehmigung des Einbaus eines Dampfkessels in einen euen Lotsendampfer

1906

Klassifikation Teil B: 00457

Band: 7

Trägermaterial: Papier

Alte Reg.-Sig.: VIII A 179

Bestell-Nr.: IV 00457 
05

05.03

05.03.12

05.03.12.03

05.03.12.03.01

05.03.12.03.01.05
Stadtverwaltung

Aufgabenbereiche der Stadtverwaltung

Handels- und Gewerbeförderung

Förderung von Handel und Industrie

Förderung von Handel und Verkehr

Zulassung technischer Anlagen

Lfd. Nr. Titel

Laufzeit

2169 Genehmigung zur Errichtung und zur Veränderung gewerblicher

Anlagen, Bd. 8

1906

- Antrag der kgl. Maschinenbauinspektion Emden auf Genehmigung des Betriebs eines stationären Dampfkessels auf dem kgl. Bauhof zum Betrieb einer Heizungsanlage

1906
Klassifikation Teil B: 00458
Band: 8
Trägermaterial: Papier
Alte Reg.-Sig.: VIII A 180
Bestell-Nr.: IV 00458

2170 Genehmigung zur Errichtung und zur Veränderung gewerblicher

1906 Anlagen, Bd. 9

- Antrag der Kölnischen Tiefbau-Gesellschaft, Baubüro Emden auf Genehmigung des Einbaus eines Dampfkessels in den Eimerbagger "Colonia"

1906

\author{
Klassifikation Teil B: 00459 \\ Band: 9 \\ Trägermaterial: Papier \\ Alte Reg.-Sig.: VIII A 181 \\ Bestell-Nr.: IV 00459
}

2171 Genehmigung zur Errichtung und zur Veränderung gewerblicher Anlagen, Bd. 10

- Antrag des kgl. Bauamts für die Hafenerweiterung auf Genehmigung des Einbaus einer Dampfschiffskesselanlage für ihren

Schleppdampfer

1906

Klassifikation Teil B: 00460

Band: 10

Trägermaterial: Papier

Alte Reg.-Sig.: VIII A 182

Bestell-Nr.: IV 00460 
IV

05

05.03

05.03.12

05.03.12.03

05.03.12.03.01

05.03.12.03.01.05
Stadtverwaltung

Aufgabenbereiche der Stadtverwaltung

Handels- und Gewerbeförderung

Förderung von Handel und Industrie

Förderung von Handel und Verkehr

Zulassung technischer Anlagen

Lfd. Nr. Titel

Laufzeit

2172 Genehmigung zur Errichtung und zur Veränderung gewerblicher Anlagen, Bd. 11

1898

- Antrag der Emder Heringsfischerei AG auf Genehmigung der

Ausstattung von zwölf Heringsloggern der Gesellschaft mit

Dampfkesseln

1898
Klassifikation Teil B: 00461
Band: 11
Trägermaterial: Papier
Alte Reg.-Sig.: VIII A 80
Bestell-Nr.: IV 00461

2173 Genehmigung zur Errichtung und zur Veränderung gewerblicher

Anlagen, Bd. 12

- Antrag der Emder Heringsfischerei AG auf Genehmigung der Ausstattung von elf Heringsloggern der Gesellschaft mit

Dampfkesseln

1900

\author{
Klassifikation Teil B: 00462 \\ Band: 12 \\ Trägermaterial: Papier \\ Alte Reg.-Sig.: VIII A 100 \\ Bestell-Nr.: IV 00462
}

2174 Genehmigung zur Errichtung und zur Veränderung gewerblicher Anlagen, Bd. 13

- Antrag der Hohenzollernhütte Roer König \& Co AG auf Genehmigung des Einbaus eines Dampfkessels in einen Drehkran

1907

Klassifikation Teil B: 00463

Band: 13

Trägermaterial: Papier

Alte Reg.-Sig.: VIII A 183

Bestell-Nr.: IV 00463 
IV

05

05.03

05.03.12

05.03.12.03

05.03.12.03.01

05.03.12.03.01.05
Stadtverwaltung

Aufgabenbereiche der Stadtverwaltung

Handels- und Gewerbeförderung

Förderung von Handel und Industrie

Förderung von Handel und Verkehr

Zulassung technischer Anlagen

Lfd. Nr. Titel

Laufzeit

2175 Genehmigung zur Errichtung und zur Veränderung gewerblicher

Anlagen, Bd. 14

1907

- Antrag der Kölnischen Tiefbau-Gesellschaft, Baubüro Emden auf

Genehmigung des Einbaus eines Dampfkessels in den Eimerbagger

"Borussia"

1907

Klassifikation Teil B: 00464

Band: 14

Trägermaterial: Papier

Alte Reg.-Sig.: VIII A 184

Bestell-Nr.: IV 00464

2176 Genehmigung zur Errichtung und zur Veränderung gewerblicher

Anlagen, Bd. 15

- Antrag der Heringsfischerei AG "Neptun" auf Genehmigung des

Einbaus von Dampfkesseln in ihre Heringslogger "Borkum", "Consul

Valk" und "Norderney"

1907

Klassifikation Teil B: 00465

Band: 15

Trägermaterial: Papier

Alte Reg.-Sig.: VIII A 190

Bestell-Nr.: IV 00465

2177 Genehmigung zur Errichtung und zur Veränderung gewerblicher Anlagen, Bd. 16

- Antrag der Emder Heringsfischerei AG auf Genehmigung der Ausstattung ihres Heringsloggers "Dortmund" mit einem Dampfkessel

1907

Klassifikation Teil B: 00466

Band: 16

Trägermaterial: Papier

Alte Reg.-Sig.: VIII A 191

Bestell-Nr.: IV 00466 
05

05.03

05.03.12

05.03.12.03

05.03.12.03.01

05.03.12.03.01.05
Stadtverwaltung

Aufgabenbereiche der Stadtverwaltung

Handels- und Gewerbeförderung

Förderung von Handel und Industrie

Förderung von Handel und Verkehr

Zulassung technischer Anlagen

Lfd. Nr. Titel

Laufzeit

2178 Genehmigung zur Errichtung und zur Veränderung gewerblicher

Anlagen, Bd. 17

1907

- Antrag der Kölnischen Tiefbau-Gesellschaft, Baubüro Emden auf

Genehmigung des Einbaus zweier Dampfkessel in den Saugbagger

"Gouda"

1907

Klassifikation Teil B: 00467

Band: 17

Trägermaterial: Papier

Alte Reg.-Sig.: VIII A 192

Bestell-Nr.: IV 00467

2179 Genehmigung zur Errichtung und zur Veränderung gewerblicher

Anlagen, Bd. 18

- Antrag des Schiffsbaumeisters Cassens auf Genehmigung der Ausstattung seines Schleppdampfers "Concurrent" mit einem gebrauchten Dampfkessel

1907

\author{
Klassifikation Teil B: 00468 \\ Band: 18 \\ Trägermaterial: Papier \\ Alte Reg.-Sig.: VIII A 195 \\ Bestell-Nr.: IV 00468
}

2180 Zulassung von Benzinmotorenanlagen und Petroleumtanks

- Antrag des Zimmermeisters Tjado Bensing auf Zulassung eines

Benzinmotors zum Antrieb von Geräten in seiner Werkstatt, Juli 1898

- Juli 1901

- Beschwerden der Nachbarn gegen Lärmbelästigung und

Luftverschmutzung durch die Motorisierung der Werkstatt des Tjado

Bensing, April - Mai 1901

- Zwangsverfahren gegen Tjado Bensing wegen nicht abgestellter

Mängel seiner Motoranlage, Juni 1901

1901

Klassifikation Teil B: 00574

Trägermaterial: Papier

Alte Reg.-Sig.: IV Ea 29

Bestell-Nr.: IV 00574 
05

\subsection{3}

05.03.12

05.03.12.03

05.03.12.03.01

05.03.12.03.01.05
Stadtverwaltung

Aufgabenbereiche der Stadtverwaltung

Handels- und Gewerbeförderung

Förderung von Handel und Industrie

Förderung von Handel und Verkehr

Zulassung technischer Anlagen

Lfd. Nr. Titel

Laufzeit

2181 Fernsprech-Anlagen

1880-1911

(1914)

- Ministerialerlasse und Verfügungen des Landdrosten /

Regierungspräsidenten in Aurich über Regulierung des

Fernsprechwesens, 1880 - 1910

- Plan der Telefonleitung für die Fernsprechanlage des Holzhändlers

Remmerssen, März 1884

- Antrag des Holzhändlers J. Remmerssen auf Zulassung seiner

Fernsprechanlage, März - Mai 1884

- Verhandlungen zwischen dem Magistrat und dem Telegrafenamt wegen Bau einer Telefonleitung von Nesserland über Emden nach

Larrelt, Januar - Februar 1885

- Errichtung einer Telefonleitung von der Wohnung des

Oberbürgermeisters und des Syndicus zum Rathaus und zum

Bauhof, Oktober 1886

- Bau einer Telefonleitung von Emden entlang des Ems-Jade-Kanals nach Wilhelmshaven, November - Dezember 1889

- Antrag der Firma S. Italjener \& Sohn auf Erlaubnis zum Bau einer

Telefonleitung von ihrem Kontor zu ihrem Packhaus, Januar - Februar 1891

- Zeitungsberichte über Diskussion einer

Fernsprechgebührenordnung, 1897 - 1899

- Antrag der Heringsfischerei AG "Neptun" auf Genehmigung einer

Telefonleitung zwischen dem Kontor und den "holländischen

Häusern", März - April 1898

- Allerhöchste Kabinettsordre des Kaisers Wilhelm II. über Festlegung der Fernsprechgebühren, Dezember 1899

- Antrag des kaiserlichen Telegraphenamt beim Magistrat auf

Genehmigung der Legung neuer Telefonleitungen, 1911

$1880-1911$ (1914)

Klassifikation Teil B: 02055

Trägermaterial: Papier

Alte Reg.-Sig.: IV T6 119

Bestell-Nr.: IV 02055 
05

\subsection{3}

05.03.12

05.03.12.03

05.03.12.03.01

05.03.12.03.01.05
Stadtverwaltung

Aufgabenbereiche der Stadtverwaltung

Handels- und Gewerbeförderung

Förderung von Handel und Industrie

Förderung von Handel und Verkehr

Zulassung technischer Anlagen

Lfd. Nr. Titel

Laufzeit

2182 Zulassung gewerblicher Anlagen

1873-1909

- Ablehnung der Genehmigung einer vom Schlachter Gossels geplanten Schlachterei, 1875

- Verfügungen des preußischen Landdrosten und des

Regierungspräsidenten in Aurich über Zuständigkeiten bei der Genehmigung und Überwachung gewerblicher Anlagen, September 1875 - April 1896

- Statistik über gewerbliche Anlagen in Emden, 1876 - 1900

- Erlasse der preußischen Minister für Handel und Gewerbe und der

Öffentlichen Arbeiten über Konzessionierungspflicht für

Fischräuchereien und deren Umsetzung in Emden, Juli 1878 -

November 1888

- Petition des Verbandes der Tierschutzvereine des Deutschen

Reiches an den Reichstag über Bitte um Erlass gesetzlicher

Bestimmungen zum Schutz von Schlachttieren vor grausamer und schmerzvoller Schlachtung (Schächtung), Februar 1882 / Februar 1887

- Diskusssion des Verbots von Schlachtereien im dicht besaiedelten Emder Stadtgebiet, Mai 1883 - Juni 1884

- Erlass des preußischen Ministers für Handel und Gewerbe über Kriterien für eine Ablehnung oder einem Entzug der gewerblichen Konzession, September 1885 - Dezember 1893

- Erlasse des Ministers für Handel und Gewerbe über Kriterien zur Genehmigung gewerblicher Anlagen (Arbeitsschutzauflagen,

Brandschutz, Umweltschutz), August 1886 - Juni 1905

- Erlass des Ministers der geistlichen, Unterrichts- und

Medizinalangelegenheiten über tierschutzgerechte Schlachtung von

Rindern, Mai 1889

- Polizeiverordnung des Regierungspräsidenten über

Schlachtmethoden, Januar 1890

$1875-1909$

Klassifikation Teil B: 02184

Trägermaterial: Papier

Alte Reg.-Sig.: IV T12 17

Bestell-Nr.: IV 02184

2183 Seifensiederei des G. T. Reinders

- Genehmigungsverfahren für die Seifensiederei des Georg T.

Reinders, Januar - März 1881

1881

Klassifikation Teil B: 02185

Trägermaterial: Papier

Alte Reg.-Sig.: IV T12 27

Bestell-Nr.: IV 02185 
05

\subsection{3}

05.03.12

05.03.12.03

05.03.12.03.01

05.03.12.03.01.05
Stadtverwaltung

Aufgabenbereiche der Stadtverwaltung

Handels- und Gewerbeförderung

Förderung von Handel und Industrie

Förderung von Handel und Verkehr

Zulassung technischer Anlagen

Lfd. Nr. Titel

Laufzeit

2184 Beschwerden gegen gewerbliche Anlagen

$1879-1900$

- Beschwerden gegen Schlachter wegen ungesetzlicher Lagerung von Schlachtabfällen, 1879 - 1884

- Zulassung von Schlachtereien im Emder Innenstadtgebiet

(Hartogsohn, Hummerich), 1887 - 1889

- Beschwerde gegen die Schmiedewerkstatt des Alrich Boomgarden

in der Kranstraße wegen Lärmbelästigung, Juni - November 1891

- Bericht des Gewerbeinspektors über unerlaubte Kinderarbeit in der

Eisengießerei und Maschinenfabrik der Gebrüder Barth, Mai 1894

- Beschwerde gegen den Musikdirektor Adami wegen

Lärmbelästigung durch Musikunterricht, Juni 1896

- Beschwerde gegen die Cassens-Werft wegen Lärmbelästigung, Mai

1899 - August 1900

$1879-1900$

Klassifikation Teil B: 02186

Trägermaterial: Papier

Alte Reg.-Sig.: IV T12 22

Bestell-Nr.: IV 02186

2185 Dampfsägerei der Cassenswerft

$1897-1901$

- Genehmigungsverfahren zum Betrieb einer Schiffsmaschine zum

Antrieb des Sägewerks der Cassens-Werft, 1897 - 1900

- Beschwerden wegen Lärmbelästigung durch die Sägerei, 1901

$1897-1901$

Klassifikation Teil B: 02187

Trägermaterial: Papier

Alte Reg.-Sig.: IV T12 37

Bestell-Nr.: IV 02187

2186 Ölkochereianlage für die Herstellung von Firniß bei der Firma G. W. Sikkens

- Genehmigungsverfahren zur Anlage einer Ölkocherei und der Gesamtproduktionsanlage für Firniß der Emder Filiale des Groningers G. W. Sikkens, April 1873 - Januar 1874

- Beschwerden gegen die Anlage wegen Geruchsbelästigung und

Gefahren durch Öldämpfe, Oktober 1873 - Januar 1874

$1873-1874$

Klassifikation Teil B: 02188

Trägermaterial: Papier

Alte Reg.-Sig.: IV T12 05

Bestell-Nr.: IV 02188 
05

05.03

05.03.12

05.03.12.03

05.03.12.03.01

05.03.12.03.01.05
Stadtverwaltung

Aufgabenbereiche der Stadtverwaltung

Handels- und Gewerbeförderung

Förderung von Handel und Industrie

Förderung von Handel und Verkehr

Zulassung technischer Anlagen

Lfd. Nr. Titel

Laufzeit

2187 Genehmigungsverfahren für Gewerbeanlagen

1873-1875

- Informationen u.a. aus Bochum wegen Genehmigungsverfahren für Gewerbeanlagen

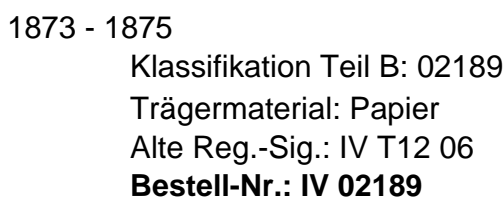

2188 Gewerbliche Zulassungen

- Antrag der Rüttgerswerke an den Stadtausschuss des Stadtkreises Emden auf Genehmigung einer Tankanlage

$<$ Akte unvollständig >

1905

Klassifikation Teil B: 03700

Trägermaterial: Papier

Alte Reg.-Sig.: IX / VIII a 001

Vorprovenienz: Stadtausschuss d. Stadtkreises Emden

Bestell-Nr.: IV 03700

2189 Gewerbliche Zulassungen

- Antrag des Seifensieders C. H. Reinders an den Stadtausschuss des Stadtkreises Emden auf Genehmigung der Veränderung seiner Seifensiederei

1887
Klassifikation Teil B: 03701
Trägermaterial: Papier
Alte Reg.-Sig.: IX / VIII a 010
Vorprovenienz: Stadtausschuss d. Stadtkreises Emden
Bestell-Nr.: IV 03701

- Antrag des kgl. Eisenbahnbetriebsamtes Münster an den Stadtausschuss des Stadtkreises Emden auf Zulassung eines stationären Dampfkessels auf der Betriebswerkstätte Emden

1888

Klassifikation Teil B: 03702

Trägermaterial: Papier Alte Reg.-Sig.: IX / VIII a 014

Vorprovenienz: Stadtausschuss d. Stadtkreises Emden Bestell-Nr.: IV 03702 
05

05.03

05.03.12

05.03.12.03

05.03.12.03.01

05.03.12.03.01.05
Stadtverwaltung

Aufgabenbereiche der Stadtverwaltung

Handels- und Gewerbeförderung

Förderung von Handel und Industrie

Förderung von Handel und Verkehr

Zulassung technischer Anlagen

Lfd. Nr. Titel

Laufzeit

2191 Gewerbliche Zulassungen

1889

- Antrag des Kaufmanns J. E. Ennen an den Stadtausschuss des Stadtkreises Emden auf Zulassung eines stationären Dampfkessels auf seinem Grundstück am Wall

1889

Klassifikation Teil B: 03703

Trägermaterial: Papier

Alte Reg.-Sig.: IX / VIII a 018

Vorprovenienz: Stadtausschuss d. Stadtkreises Emden

Bestell-Nr.: IV 03703

2192 Gewerbliche Zulassungen

- Antrag des Schmiedemeisters P.J. Brillmann an den Stadtausschuss des Stadtkreises Emden auf Zulassung eines Dampfkessels auf seinem Grundstück an der Großen Brückstr. 45

1888

Klassifikation Teil B: 03704

Trägermaterial: Papier

Alte Reg.-Sig.: IX / VIII a 022

Vorprovenienz: Stadtausschuss d. Stadtkreises Emden

Bestell-Nr.: IV 03704

2193 Gewerbliche Zulassungen

- Antrag der AG Ems an den Stadtausschuss des Stadtkreises Emden auf Zulassung eines Schiffsdampfkessels auf dem Dampfschiff "Borkum"

1890

Klassifikation Teil B: 03705

Trägermaterial: Papier

Alte Reg.-Sig.: IX / VIII a 024

Vorprovenienz: Stadtausschuss d. Stadtkreises Emden

Bestell-Nr.: IV 03705

2194 Gewerbliche Zulassungen

- Antrag der Emder Heringsfischerei AG an den Stadtausschuss des Stadtkreises Emden auf Zulassung eines Schiffsdampfkessels auf dem Dampfschiff "Pony"

1890

Klassifikation Teil B: 03706

Trägermaterial: Papier

Alte Reg.-Sig.: IX / VIII a 025

Vorprovenienz: Stadtausschuss d. Stadtkreises Emden

Bestell-Nr.: IV 03706 
05

05.03

05.03.12

05.03.12.03

05.03.12.03.01

05.03.12.03.01.05
Stadtverwaltung

Aufgabenbereiche der Stadtverwaltung

Handels- und Gewerbeförderung

Förderung von Handel und Industrie

Förderung von Handel und Verkehr

Zulassung technischer Anlagen

Lfd. Nr. Titel

Laufzeit

2195 Gewerbliche Zulassungen

1891

- Antrag der Reederei P.W.Wessels Wwe. an den Stadtausschuss des Stadtkreises Emden auf Zulassung eines Schiffsdampfkessels auf dem Dampfschiff "P.W.Wessels"

1890

Klassifikation Teil B: 03707

Trägermaterial: Papier

Alte Reg.-Sig.: IX / VIII a 028

Vorprovenienz: Stadtausschuss d. Stadtkreises Emden

Bestell-Nr.: IV 03707

2196 Gewerbliche Zulassungen

- Antrag der kgl. Staatsbauverwaltung an den Stadtausschuss des Stadtkreises Emden auf Zulassung eines Dampfkessels auf dem Kranbagger Nr. 103

1892

\author{
Klassifikation Teil B: 03708 \\ Trägermaterial: Papier \\ Alte Reg.-Sig.: IX / VIII a 032 \\ Vorprovenienz: Stadtausschuss d. Stadtkreises Emden \\ Bestell-Nr.: IV 03708
}

2197 Gewerbliche Zulassungen

- Antrag der Fa. Habich \& Goth an den Stadtausschuss des Stadtkreises Emden auf Zulassung eines Schiffsdampfkessels auf dem Dampfschiff "Dr. von Stephan"

1892

\author{
Klassifikation Teil B: 03709 \\ Trägermaterial: Papier \\ Alte Reg.-Sig.: IX / VIII a 033 \\ Vorprovenienz: Stadtausschuss d. Stadtkreises Emden \\ Bestell-Nr.: IV 03709
}

2198 Gewerbliche Zulassungen

- Antrag der kgl. Wasserbauinspektion an den Stadtausschuss des Stadtkreises Emden auf Zulassung eines Schiffsdampfkessels auf dem Dampfschiff "Nesserland"

1892

Klassifikation Teil B: 03710

Trägermaterial: Papier

Alte Reg.-Sig.: IX / VIII a 039

Vorprovenienz: Stadtausschuss d. Stadtkreises Emden

Bestell-Nr.: IV 03710 
05

05.03

05.03.12

05.03.12.03

05.03.12.03.01

05.03.12.03.01.05
Stadtverwaltung

Aufgabenbereiche der Stadtverwaltung

Handels- und Gewerbeförderung

Förderung von Handel und Industrie

Förderung von Handel und Verkehr

Zulassung technischer Anlagen

Lfd. Nr. Titel

Laufzeit

2199 Gewerbliche Zulassungen

1892-1893

- Antrag der Fa. Schönberg \& Neumark an den Stadtausschuss des Stadtkreises Emden auf Zulassung einer Trocknungsanlage für ungegerbte Tierfelle im Packhaus Nr. 43 an der Mühlenstraße

$1892-1893$

Klassifikation Teil B: 03711

Trägermaterial: Papier

Alte Reg.-Sig.: IX / VIII a 042

Vorprovenienz: Stadtausschuss d. Stadtkreises Emden

Bestell-Nr.: IV 03711

2200 Gewerbliche Zulassungen

1892-1893

- Antrag der Fa. Schönberg \& Neumark an den Stadtausschuss des Stadtkreises Emden auf Zulassung einer Anlage zur Einsalzung ungegerbter Tierfelle im Packhaus Nr. 5 an der Großen Deichstraße

$1892-1893$

Klassifikation Teil B: 03712

Trägermaterial: Papier

Alte Reg.-Sig.: IX / VIII a 043

Vorprovenienz: Stadtausschuss d. Stadtkreises Emden

Bestell-Nr.: IV 03712

2201 Gewerbliche Zulassungen

1893

- Antrag der AG Ems an den Stadtausschuss des Stadtkreises Emden auf Zulassung eines Schiffsdampfkessels auf dem Raddampfer "Emden"

1893

Klassifikation Teil B: 03713

Trägermaterial: Papier

Alte Reg.-Sig.: IX / VIII a 044

Vorprovenienz: Stadtausschuss d. Stadtkreises Emden

Bestell-Nr.: IV 03713

2202 Gewerbliche Zulassungen

- Antrag der kgl. Wasserbauinspektion an den Stadtausschuss des Stadtkreises Emden auf Zulassung eines Dampfkessels auf dem Dampfeimerbagger "Ems"

1893

Klassifikation Teil B: 03714

Trägermaterial: Papier

Alte Reg.-Sig.: IX / VIII a 045

Vorprovenienz: Stadtausschuss d. Stadtkreises Emden

Bestell-Nr.: IV 03714 
05

05.03

05.03.12

05.03.12.03

05.03.12.03.01

05.03.12.03.01.05
Stadtverwaltung

Aufgabenbereiche der Stadtverwaltung

Handels- und Gewerbeförderung

Förderung von Handel und Industrie

Förderung von Handel und Verkehr

Zulassung technischer Anlagen

Lfd. Nr. Titel

Laufzeit

2203 Gewerbliche Zulassungen

1892-1893

- Antrag der Fa. Schönberg \& Neumark an den Stadtausschuss des Stadtkreises Emden auf Zulassung einer Anlage zur Einsalzung und Trocknung ungegerbter Tierfelle

$1892-1893$

Klassifikation Teil B: 03715

Trägermaterial: Papier

Alte Reg.-Sig.: IX / VIII a 046

Vorprovenienz: Stadtausschuss d. Stadtkreises Emden

Bestell-Nr.: IV 03715

2204 Gewerbliche Zulassungen

- Antrag der kgl. Wasserbauinspektion an den Stadtausschuss des Stadtkreises Emden auf Zulassung eines Schiffsdampfkessels auf dem Eisbrecher "Emden"

1893

Klassifikation Teil B: 03716

Trägermaterial: Papier

Alte Reg.-Sig.: IX / VIII a 049

Vorprovenienz: Stadtausschuss d. Stadtkreises Emden

Bestell-Nr.: IV 03716

2205 Gewerbliche Zulassungen

1893

- Antrag des Maschinenbauers Hermann Bartels an den Stadtausschuss des Stadtkreises Emden auf Zulassung eines beweglichen Dampfkessels in seinem Betrieb

1893

Klassifikation Teil B: 03717

Trägermaterial: Papier

Alte Reg.-Sig.: IX / VIII a 051

Vorprovenienz: Stadtausschuss d. Stadtkreises Emden

Bestell-Nr.: IV 03717

2206 Gewerbliche Zulassungen

- Antrag des Bauunternehmens Habich \& Goth an den Stadtausschuss des Stadtkreises Emden auf Zulassung eines beweglichen Dampfkessels in seinem Betrieb

1893

Klassifikation Teil B: 03718

Trägermaterial: Papier

Alte Reg.-Sig.: IX / VIII a 052

Vorprovenienz: Stadtausschuss d. Stadtkreises Emden

Bestell-Nr.: IV 03718 
05

05.03

05.03.12

05.03.12.03

05.03.12.03.01

05.03.12.03.01.05
Stadtverwaltung

Aufgabenbereiche der Stadtverwaltung

Handels- und Gewerbeförderung

Förderung von Handel und Industrie

Förderung von Handel und Verkehr

Zulassung technischer Anlagen

Lfd. Nr. Titel

Laufzeit

2207 Gewerbliche Zulassungen

1893

- Antrag der Fa. Habich \& Goth und des Kapitäns B. de Vries an den Stadtausschuss des Stadtkreises Emden auf Zulassung eines

Schiffsdampfkessels auf dem Dampfschiff "Varina"

1893

\author{
Klassifikation Teil B: 03719 \\ Trägermaterial: Papier \\ Alte Reg.-Sig.: IX / VIII a 054 \\ Vorprovenienz: Stadtausschuss d. Stadtkreises Emden \\ Bestell-Nr.: IV 03719
}

2208 Gewerbliche Zulassungen

- Antrag des Senffabrikanten Georg Ennen an den Stadtausschuss des Stadtkreises Emden auf Zulassung eines stationären

Dampfkessels auf seinem Grundstück Am Wall 6

1893

\author{
Klassifikation Teil B: 03720 \\ Trägermaterial: Papier \\ Alte Reg.-Sig.: IX / VIII a 055 \\ Vorprovenienz: Stadtausschuss d. Stadtkreises Emden \\ Bestell-Nr.: IV 03720
}

2209 Gewerbliche Zulassungen

1894

- Antrag des Lederfabrikanten R. F. Kortkampf an den

Stadtausschuss des Stadtkreises Emden auf Zulassung eines

stationären Dampfkessels in seinem Fabrikgebäude Hinder dem

Rahmen 5

1894

\author{
Klassifikation Teil B: 03721 \\ Trägermaterial: Papier \\ Alte Reg.-Sig.: IX / VIII a 061 \\ Vorprovenienz: Stadtausschuss d. Stadtkreises Emden \\ Bestell-Nr.: IV 03721
}

2210 Gewerbliche Zulassungen

- Antrag der Fabrikanten Johann Visser und G. M. Danecker an den Stadtausschuss des Stadtkreises Emden auf Zulassung eines stationären Dampfkessels für ihre Sauerkraufabrik am Hof von Holland 1

1894

Klassifikation Teil B: 03722

Trägermaterial: Papier

Alte Reg.-Sig.: IX / VIII a 062

Vorprovenienz: Stadtausschuss d. Stadtkreises Emden

Bestell-Nr.: IV 03722 
05

05.03

05.03.12

05.03.12.03

05.03.12.03.01

05.03.12.03.01.05
Stadtverwaltung

Aufgabenbereiche der Stadtverwaltung

Handels- und Gewerbeförderung

Förderung von Handel und Industrie

Förderung von Handel und Verkehr

Zulassung technischer Anlagen

Lfd. Nr. Titel

Laufzeit

2211 Gewerbliche Zulassungen

1895

- Antrag der kgl. Wasserbauinspektion an den Stadtausschuss des Stadtkreises Emden auf Zulassung eines Schiffsdampfkessels auf der Dampfbarkasse "Theda"

1895

\author{
Klassifikation Teil B: 03723 \\ Trägermaterial: Papier \\ Alte Reg.-Sig.: IX / VIII a 063 \\ Vorprovenienz: Stadtausschuss d. Stadtkreises Emden \\ Bestell-Nr.: IV 03723
}

2212 Gewerbliche Zulassungen

- Antrag der Fischerei AG "Neptun" an den Stadtausschuss des Stadtkreises Emden auf Zulassung eines Schiffsdampfkessels auf dem Logger "Catherina"

1895

\author{
Klassifikation Teil B: 03724 \\ Trägermaterial: Papier \\ Alte Reg.-Sig.: IX / VIII a 064 \\ Vorprovenienz: Stadtausschuss d. Stadtkreises Emden \\ Bestell-Nr.: IV 03724
}

2213 Gewerbliche Zulassungen

1895

- Antrag der Fa. Eisengießerei und Maschinenfabrik Gebr. Barth an den Stadtausschuss des Stadtkreises Emden auf Zulassung eines Dampfkessels auf ihrem Fabrikgrundstück an der Mühlenstr. 57/58

1895

\author{
Klassifikation Teil B: 03725 \\ Trägermaterial: Papier \\ Alte Reg.-Sig.: IX / VIII a 065 \\ Vorprovenienz: Stadtausschuss d. Stadtkreises Emden \\ Bestell-Nr.: IV 03725
}

2214 Gewerbliche Zulassungen

- Antrag des Magistrats an den Stadtausschuss des Stadtkreises Emden auf Zulassung eines Dampfkessels auf dem Gelände des städtischen Schlachthofes

1895

Klassifikation Teil B: 03726

Trägermaterial: Papier

Alte Reg.-Sig.: IX / VIII a 066

Vorprovenienz: Stadtausschuss d. Stadtkreises Emden

Bestell-Nr.: IV 03726 
05

05.03

05.03.12

05.03.12.03

05.03.12.03.01

05.03.12.03.01.05
Stadtverwaltung

Aufgabenbereiche der Stadtverwaltung

Handels- und Gewerbeförderung

Förderung von Handel und Industrie

Förderung von Handel und Verkehr

Zulassung technischer Anlagen

Lfd. Nr. Titel

Laufzeit

2215 Gewerbliche Zulassungen

1895

- Antrag der kgl. Eisenbahn-Maschinen-Inspektion I an den

Stadtausschuss des Stadtkreises Emden auf Zulassung eines

Dampfkessels in der Eisenbahnbetriebsstätte

1895

Klassifikation Teil B: 03727

Trägermaterial: Papier

Alte Reg.-Sig.: IX / VIII a 067

Vorprovenienz: Stadtausschuss d. Stadtkreises Emden

Bestell-Nr.: IV 03727

2216 Gewerbliche Zulassungen

1896

- Antrag der Emder Heringsfischerei AG an den Stadtausschuss des Stadtkreises Emden auf Zulassung eines Schiffsdampfkessels auf dem Logger "Fortuna"

1896

Klassifikation Teil B: 03728

Trägermaterial: Papier

Alte Reg.-Sig.: IX / VIII a 069

Vorprovenienz: Stadtausschuss d. Stadtkreises Emden

Bestell-Nr.: IV 03728

2217 Gewerbliche Zulassungen

1896

- Antrag des niederländischen Bauunternehmers S. ten Bokkel an den Stadtausschuss des Stadtkreises Emden auf Zulassung von

Dampfkesseln auf den Baggern "Nieuwe Maasmond II, IV, VIII, IX"

1896

Klassifikation Teil B: 03729

Trägermaterial: Papier

Alte Reg.-Sig.: IX / VIII a 070

Vorprovenienz: Stadtausschuss d. Stadtkreises Emden

Bestell-Nr.: IV 03729

2218 Gewerbliche Zulassungen

- Antrag der Fischerei AG "Neptun" an den Stadtausschuss des Stadtkreises Emden auf Zulassung von Schiffsdampfkesseln auf den Loggern "Allard", "Jennie", "Magarethe", "Johannes" und "Phoenix"

1896

Klassifikation Teil B: 03730

Trägermaterial: Papier

Alte Reg.-Sig.: IX / VIII a 071

Vorprovenienz: Stadtausschuss d. Stadtkreises Emden

Bestell-Nr.: IV 03730 
05

05.03

05.03.12

05.03.12.03

05.03.12.03.01

05.03.12.03.01.05
Stadtverwaltung

Aufgabenbereiche der Stadtverwaltung

Handels- und Gewerbeförderung

Förderung von Handel und Industrie

Förderung von Handel und Verkehr

Zulassung technischer Anlagen

Lfd. Nr. Titel

Laufzeit

2219 Gewerbliche Zulassungen

1897

- Antrag des Schiffsbaumeisters C. Cassens an den Stadtausschuss des Stadtkreises Emden auf Zulassung eines Dampfkessels auf seinem Grundstück an der Großen Brückstr.

1897

Klassifikation Teil B: 03731

Trägermaterial: Papier

Alte Reg.-Sig.: IX / VIII a 072

Vorprovenienz: Stadtausschuss d. Stadtkreises Emden

Bestell-Nr.: IV 03731

2220 Gewerbliche Zulassungen

- Antrag der kgl. Wasserbauinspektion an den Stadtausschuss des Stadtkreises Emden auf Zulassung von Dampfkesseln auf den Dampfbaggerprähmen Emden 1 und Emden 2

1897

Klassifikation Teil B: 03732

Trägermaterial: Papier

Alte Reg.-Sig.: IX / VIII a 073

Vorprovenienz: Stadtausschuss d. Stadtkreises Emden

Bestell-Nr.: IV 03732

2221 Gewerbliche Zulassungen

- Antrag der Emder Heringsfischerei AG an den Stadtausschuss des Stadtkreises Emden auf Zulassung von Schiffsdampfkesseln auf den Loggern "Stella", "Oberbürgermeister Fürbringer", "Bückeburg" und "Osnabrück"

1897

\author{
Klassifikation Teil B: 03733 \\ Trägermaterial: Papier \\ Alte Reg.-Sig.: IX / VIII a 074 \\ Vorprovenienz: Stadtausschuss d. Stadtkreises Emden \\ Bestell-Nr.: IV 03733
}

2222 Gewerbliche Zulassungen

- Antrag der Fa. Habich \& Goth an den Stadtausschuss des Stadtkreises Emden auf Zulassung eines Schiffsdampfkessels auf dem Personenschraubendampfer "Kaiser Wilhelm II."

1896

Klassifikation Teil B: 03734

Trägermaterial: Papier

Alte Reg.-Sig.: IX / VIII a 075

Vorprovenienz: Stadtausschuss d. Stadtkreises Emden

Bestell-Nr.: IV 03734 
05

05.03

05.03.12

05.03.12.03

05.03.12.03.01

05.03.12.03.01.05
Stadtverwaltung

Aufgabenbereiche der Stadtverwaltung

Handels- und Gewerbeförderung

Förderung von Handel und Industrie

Förderung von Handel und Verkehr

Zulassung technischer Anlagen

Lfd. Nr. Titel

Laufzeit

2223 Gewerbliche Zulassungen

1897

- Antrag des Maschinenbauers H. Barth an den Stadtausschuss des Stadtkreises Emden auf Zulassung eines Dampfkessels auf seinem Fabrikgrundstück an der Mühlenstr. 57/58

1897

Klassifikation Teil B: 03735

Trägermaterial: Papier

Alte Reg.-Sig.: IX / VIII a 076

Vorprovenienz: Stadtausschuss d. Stadtkreises Emden

Bestell-Nr.: IV 03735

2224 Gewerbliche Zulassungen

- Antrag der Fa. Eisengießerei und Maschinenfabrik Gebr. Barth an den Stadtausschuss des Stadtkreises Emden auf Zulassung eines Dampfkessels auf ihrem Fabrikgrundstück an der Mühlenstr. 57/58

1897

Klassifikation Teil B: 03736

Trägermaterial: Papier

Alte Reg.-Sig.: IX / VIII a 077

Vorprovenienz: Stadtausschuss d. Stadtkreises Emden

Bestell-Nr.: IV 03736

2225 Gewerbliche Zulassungen

1898

- Antrag des Schiffsbaumeisters C. Cassens an den Stadtausschuss des Stadtkreises Emden auf Zulassung eines Schiffsdampfkessels auf dem Schleppdampfer "Hedwig"

1898

Klassifikation Teil B: 03737

Trägermaterial: Papier

Alte Reg.-Sig.: IX / VIII a 079

Vorprovenienz: Stadtausschuss d. Stadtkreises Emden

Bestell-Nr.: IV 03737

2226 Gewerbliche Zulassungen

- Antrag der kgl. Wasserbauinspektion an den Stadtausschuss des Stadtkreises Emden auf Zulassung von Dampfkesseln auf den Pumpenbaggern "121", "122", "123"

1898

Klassifikation Teil B: 03738

Trägermaterial: Papier

Alte Reg.-Sig.: IX / VIII a 081

Vorprovenienz: Stadtausschuss d. Stadtkreises Emden

Bestell-Nr.: IV 03738 
05

05.03

05.03.12

05.03.12.03

05.03.12.03.01

05.03.12.03.01.05
Stadtverwaltung

Aufgabenbereiche der Stadtverwaltung

Handels- und Gewerbeförderung

Förderung von Handel und Industrie

Förderung von Handel und Verkehr

Zulassung technischer Anlagen

Lfd. Nr. Titel

Laufzeit

2227 Gewerbliche Zulassungen

1898

- Antrag des Unternehmers O. Nederlof an den Stadtausschuss des Stadtkreises Emden auf Zulassung eines Dampfkessels auf dem Dampfbagger "Concurrent"

1898

\author{
Klassifikation Teil B: 03739 \\ Trägermaterial: Papier \\ Alte Reg.-Sig.: IX / VIII a 083 \\ Vorprovenienz: Stadtausschuss d. Stadtkreises Emden \\ Bestell-Nr.: IV 03739
}

2228 Gewerbliche Zulassungen

- Antrag der Fa. Sebern Bokkel-Huisink an den Stadtausschuss des Stadtkreises Emden auf Zulassung eines Dampfkessels auf dem Elevator "Polder"

1892

\author{
Klassifikation Teil B: 03740 \\ Trägermaterial: Papier \\ Alte Reg.-Sig.: IX / VIII a 084 \\ Vorprovenienz: Stadtausschuss d. Stadtkreises Emden \\ Bestell-Nr.: IV 03740
}

2229 Gewerbliche Zulassungen

1898

- Antrag der kgl. Kanalkommission in Aurich an den Stadtausschuss des Stadtkreises Emden auf Zulassung von Dampfkesseln auf den schwimmenden Dampfkränen Nr. 1 und Nr.2 im Emder Hafen

1898

\author{
Klassifikation Teil B: 03741 \\ Trägermaterial: Papier \\ Alte Reg.-Sig.: IX / VIII a 086 \\ Vorprovenienz: Stadtausschuss d. Stadtkreises Emden \\ Bestell-Nr.: IV 03741
}

2230 Gewerbliche Zulassungen

- Antrag der kgl. Wasserbauinspektion an den Stadtausschuss des Stadtkreises Emden auf Zulassung von Dampfkesseln auf dem Tonnenlegerdampfer und dem Schlickbagger

1898

Klassifikation Teil B: 03742

Trägermaterial: Papier

Alte Reg.-Sig.: IX / VIII a 086

Vorprovenienz: Stadtausschuss d. Stadtkreises Emden

Bestell-Nr.: IV 03742 
05

05.03

05.03.12

05.03.12.03

05.03.12.03.01

05.03.12.03.01.05
Stadtverwaltung

Aufgabenbereiche der Stadtverwaltung

Handels- und Gewerbeförderung

Förderung von Handel und Industrie

Förderung von Handel und Verkehr

Zulassung technischer Anlagen

Lfd. Nr. Titel

Laufzeit

2231 Gewerbliche Zulassungen

1899

- Antrag der kgl. Kanalkommission in Aurich an den Stadtausschuss des Stadtkreises Emden auf Zulassung von Dampfkesseln in der elektrischen Zentralstation zu Nesserland

1899

Klassifikation Teil B: 03743

Trägermaterial: Papier

Alte Reg.-Sig.: IX / VIII a 087

Vorprovenienz: Stadtausschuss d. Stadtkreises Emden

Bestell-Nr.: IV 03743

2232 Gewerbliche Zulassungen

- Antrag der kgl. Wasserbauinspektion an den Stadtausschuss des Stadtkreises Emden auf Zulassung eines Dampfkessels auf dem Greifbagger "Krabbe"

1899

Klassifikation Teil B: 03744

Trägermaterial: Papier

Alte Reg.-Sig.: IX / VIII a 088

Vorprovenienz: Stadtausschuss d. Stadtkreises Emden

Bestell-Nr.: IV 03744

- Antrag der kgl. Wasserbauinspektion an den Stadtausschuss des Stadtkreises Emden auf Zulassung eines Dampfkessels auf dem Greifbagger "Granat"

1899

Klassifikation Teil B: 03745

Trägermaterial: Papier

Alte Reg.-Sig.: IX / VIII a 089

Vorprovenienz: Stadtausschuss d. Stadtkreises Emden

Bestell-Nr.: IV 03745 
05

05.03

05.03.12

05.03.12.03

05.03.12.03.01

05.03.12.03.01.05
Stadtverwaltung

Aufgabenbereiche der Stadtverwaltung

Handels- und Gewerbeförderung

Förderung von Handel und Industrie

Förderung von Handel und Verkehr

Zulassung technischer Anlagen

Lfd. Nr. Titel

Laufzeit

2234 Gewerbliche Zulassungen

- Antrag der Emder Heringsfischerei AG und der Fischerei AG "Neptun" an den Stadtausschuss des Stadtkreises Emden auf Zulassung von Schiffsdampfkesseln auf den Loggern:

"Neptun" AG: Logger "David", "Arnoldine Marie", "Wilhelmine", "Heinrich Daniel", "Jacob"

Emder Heringsfischerei AG: Logger "Ostfriesland", "Stadt Leer", "Köln", "Westfalen", "Bückeburg", "Minister Dr. Lucius", "Fürst von Bismarck", "Osnabrück", "Anna und Emma", "Stadt Emden",

"Oldenburg", "Catharina Christina"

1899

Klassifikation Teil B: 03746

Trägermaterial: Papier

Alte Reg.-Sig.: IX / VIII a 090

Vorprovenienz: Stadtausschuss d. Stadtkreises Emden

Bestell-Nr.: IV 03746

2235 Gewerbliche Zulassungen

- Antrag der Fischerei AG "Neptun" an den Stadtausschuss des Stadtkreises Emden auf Zulassung von Schiffsdampfkesseln auf den Loggern "Doggerbank" und "Ida"

1899

\author{
Klassifikation Teil B: 03747 \\ Trägermaterial: Papier \\ Alte Reg.-Sig.: IX / VIII a 091 \\ Vorprovenienz: Stadtausschuss d. Stadtkreises Emden \\ Bestell-Nr.: IV 03747
}

- Antrag des Maschinenbauers H. Barth an den Stadtausschuss des Stadtkreises Emden auf Zulassung eines Dampfkessels auf seinem Fabrikgrundstück an der Mühlenstr. 57/58

1899

Klassifikation Teil B: 03748

Trägermaterial: Papier

Alte Reg.-Sig.: IX / VIII a 092

Vorprovenienz: Stadtausschuss d. Stadtkreises Emden

Bestell-Nr.: IV 03748 
05

05.03

05.03.12

05.03.12.03

05.03.12.03.01

05.03.12.03.01.05
Stadtverwaltung

Aufgabenbereiche der Stadtverwaltung

Handels- und Gewerbeförderung

Förderung von Handel und Industrie

Förderung von Handel und Verkehr

Zulassung technischer Anlagen

Lfd. Nr. Titel

Laufzeit

2237 Gewerbliche Zulassungen

1899

- Antrag der kgl. Wasserbauinspektion an den Stadtausschuss des Stadtkreises Emden auf Zulassung eines Schiffsdampfkessels auf der Peil-Barkasse

1899

Klassifikation Teil B: 03749

Trägermaterial: Papier

Alte Reg.-Sig.: IX / VIII a 093

Vorprovenienz: Stadtausschuss d. Stadtkreises Emden

Bestell-Nr.: IV 03749

2238 Gewerbliche Zulassungen

1900

- Antrag der kgl. Wasserbauinspektion an den Stadtausschuss des Stadtkreises Emden auf Zulassung von Dampfkesseln auf einem Dampfprahm und zwei schwimmenden Dampfkränen

1900

Klassifikation Teil B: 03750

Trägermaterial: Papier

Alte Reg.-Sig.: IX / VIII a 094

Vorprovenienz: Stadtausschuss d. Stadtkreises Emden

Bestell-Nr.: IV 03750

2239 Gewerbliche Zulassungen

1900

- Antrag der Reederei P.W.Wessels Wwe. an den Stadtausschuss des Stadtkreises Emden auf Zulassung eines Schiffsdampfkessels auf dem Dampfer "Justine Wessels"

1900

Klassifikation Teil B: 03751

Trägermaterial: Papier

Alte Reg.-Sig.: IX / VIII a 095

Vorprovenienz: Stadtausschuss d. Stadtkreises Emden

Bestell-Nr.: IV 03751

2240 Gewerbliche Zulassungen

1900

- Antrag der kgl. Wasserbauinspektion an den Stadtausschuss des Stadtkreises Emden auf Zulassung eines Dampfkessels auf dem Greifbagger "Krabbe"

1900

Klassifikation Teil B: 03752

Trägermaterial: Papier

Alte Reg.-Sig.: IX / VIII a 096

Vorprovenienz: Stadtausschuss d. Stadtkreises Emden

Bestell-Nr.: IV 03752 
05

05.03

05.03.12

05.03.12.03

05.03.12.03.01

05.03.12.03.01.05
Stadtverwaltung

Aufgabenbereiche der Stadtverwaltung

Handels- und Gewerbeförderung

Förderung von Handel und Industrie

Förderung von Handel und Verkehr

Zulassung technischer Anlagen

Lfd. Nr. Titel

Laufzeit

2241 Gewerbliche Zulassungen

1900

- Antrag des Schiffsbaumeisters C. Cassens an den Stadtausschuss des Stadtkreises Emden auf Genehmigung der Errichtung einer Werft im II. (städtischen) Hafeneinschnitt

1900

Klassifikation Teil B: 03753

Trägermaterial: Papier

Alte Reg.-Sig.: IX / VIII a 096

Vorprovenienz: Stadtausschuss d. Stadtkreises Emden

Bestell-Nr.: IV 03753

2242 Gewerbliche Zulassungen

1900

- Antrag des Schiffsbaumeisters C. Cassens an den Stadtausschuss des Stadtkreises Emden auf Zulassung eines Schiffsdampfkessels auf der Barkasse "Bernard"

1900

Klassifikation Teil B: 03755

Trägermaterial: Papier

Alte Reg.-Sig.: IX / VIII a 101

Vorprovenienz: Stadtausschuss d. Stadtkreises Emden

Bestell-Nr.: IV 03755

2243 Gewerbliche Zulassungen

1900

- Antrag der Fischerei AG "Neptun" an den Stadtausschuss des Stadtkreises Emden auf Zulassung von Schiffsdampfkesseln auf den Loggern "Dollart", "Catharina Maria", "Ems", "Johanna Theodora", "Phoenix", "Nella", "Nesserland"

1900

\author{
Klassifikation Teil B: 03756 \\ Trägermaterial: Papier \\ Alte Reg.-Sig.: IX / VIII a 102 \\ Vorprovenienz: Stadtausschuss d. Stadtkreises Emden \\ Bestell-Nr.: IV 03756
}

2244 Gewerbliche Zulassungen

1900

- Antrag der Emder Maschinenfabrik Wilhelm Heuer Söhne an den Stadtausschuss des Stadtkreises Emden auf Zulassung eines stationären Dampfkessels auf dem Fabrikgelände am Ersten Hafeneinschnitt

1900

Klassifikation Teil B: 03757

Trägermaterial: Papier

Alte Reg.-Sig.: IX / VIII a 103

Vorprovenienz: Stadtausschuss d. Stadtkreises Emden

Bestell-Nr.: IV 03757 
05

05.03

05.03.12

05.03.12.03

05.03.12.03.01

05.03.12.03.01.05
Stadtverwaltung

Aufgabenbereiche der Stadtverwaltung

Handels- und Gewerbeförderung

Förderung von Handel und Industrie

Förderung von Handel und Verkehr

Zulassung technischer Anlagen

Lfd. Nr. Titel

Laufzeit

2245 Gewerbliche Zulassungen

1900

- Antrag des Bauunternehmers W. Rogge an den Stadtausschuss des Stadtkreises Emden auf Zulassung eines beweglichen Dampfkessels für seine Baustellen

1900

Klassifikation Teil B: 03758

Trägermaterial: Papier

Alte Reg.-Sig.: IX / VIII a 104

Vorprovenienz: Stadtausschuss d. Stadtkreises Emden

Bestell-Nr.: IV 03758

2246 Gewerbliche Zulassungen

1900

- Antrag der Kölnischen Tiefbaugesellschaft m.b.H. an den Stadtausschuss des Stadtkreises Emden auf Zulassung eines Dampfkessels auf dem Dampfbagger "AG Heykes"

1900

Klassifikation Teil B: 03759

Trägermaterial: Papier

Alte Reg.-Sig.: IX / VIII a 105

Vorprovenienz: Stadtausschuss d. Stadtkreises Emden

Bestell-Nr.: IV 03759

2247 Gewerbliche Zulassungen

1900

- Antrag der Kölnischen Tiefbaugesellschaft m.b.H. an den

Stadtausschuss des Stadtkreises Emden auf Zulassung von

Schiffsdampfkesseln auf den Dampfschleppbooten "Ada" und "Kitty"

1900

Klassifikation Teil B: 03760

Trägermaterial: Papier

Alte Reg.-Sig.: IX / VIII a 106

Vorprovenienz: Stadtausschuss d. Stadtkreises Emden

Bestell-Nr.: IV 03760

2248 Gewerbliche Zulassungen

1900

- Antrag der Kölnischen Tiefbaugesellschaft m.b.H. an den Stadtausschuss des Stadtkreises Emden auf Zulassung eines Dampfkessels auf dem Dampfbagger "Nieuwe Maatmond II"

1900

Klassifikation Teil B: 03761

Trägermaterial: Papier

Alte Reg.-Sig.: IX / VIII a 107

Vorprovenienz: Stadtausschuss d. Stadtkreises Emden

Bestell-Nr.: IV 03761 
05

05.03

05.03.12

05.03.12.03

05.03.12.03.01

05.03.12.03.01.05
Stadtverwaltung

Aufgabenbereiche der Stadtverwaltung

Handels- und Gewerbeförderung

Förderung von Handel und Industrie

Förderung von Handel und Verkehr

Zulassung technischer Anlagen

Lfd. Nr. Titel

Laufzeit

2249 Gewerbliche Zulassungen

1900

- Antrag der kgl. Wasserbauinspektion an den Stadtausschuss des Stadtkreises Emden auf Zulassung eines Schiffsdampfkessels auf einem geplanten Schleppdampfer

1900

Klassifikation Teil B: 03762

Trägermaterial: Papier

Alte Reg.-Sig.: IX / VIII a 108

Vorprovenienz: Stadtausschuss d. Stadtkreises Emden

Bestell-Nr.: IV 03762

2250 Gewerbliche Zulassungen

1900

- Antrag der Fa. Schulte \& Bruns an den Stadtausschuss des Stadtkreises Emden auf Zulassung eines Schiffsdampfkessels auf dem Schleppdampfer "Westfalen"

1900

Klassifikation Teil B: 03763

Trägermaterial: Papier

Alte Reg.-Sig.: IX / VIII a 109

Vorprovenienz: Stadtausschuss d. Stadtkreises Emden

Bestell-Nr.: IV 03763

2251 Gewerbliche Zulassungen

1900

- Antrag der kgl. Wasserbauinspektion an den Stadtausschuss des Stadtkreises Emden auf Zulassung von Schiffsdampfkesseln auf 2 schwimmenden Dampfpunten

1900

Klassifikation Teil B: 03764

Trägermaterial: Papier

Alte Reg.-Sig.: IX / VIII a 110

Vorprovenienz: Stadtausschuss d. Stadtkreises Emden

Bestell-Nr.: IV 03764

2252 Gewerbliche Zulassungen

1900

- Antrag der Emdener Papierfabrik an den Stadtausschuss des Stadtkreises Emden auf Zulassung eines stationären Dampfkessels auf dem Fabrikgelände an der Auricher Chaussee

1900

Klassifikation Teil B: 03765

Trägermaterial: Papier

Alte Reg.-Sig.: IX / VIII a 111

Vorprovenienz: Stadtausschuss d. Stadtkreises Emden

Bestell-Nr.: IV 03765 
05

05.03

05.03.12

05.03.12.03

05.03.12.03.01

05.03.12.03.01.05
Stadtverwaltung

Aufgabenbereiche der Stadtverwaltung

Handels- und Gewerbeförderung

Förderung von Handel und Industrie

Förderung von Handel und Verkehr

Zulassung technischer Anlagen

Lfd. Nr. Titel

Laufzeit

2253 Gewerbliche Zulassungen

1901

- Antrag der Emder Maschinenfabrik Wilhelm Heuer Söhne an den

Stadtausschuss des Stadtkreises Emden auf Zulassung eines

stationären Dampfkessels auf dem Fabrikgelände am Ersten

Hafeneinschnitt

1901

Klassifikation Teil B: 03766

Trägermaterial: Papier

Alte Reg.-Sig.: IX / VIII a 112

Vorprovenienz: Stadtausschuss d. Stadtkreises Emden

Bestell-Nr.: IV 03766

2254 Gewerbliche Zulassungen

1901

- Antrag der Fischerei AG "Neptun" an den Stadtausschuss des

Stadtkreises Emden auf Zulassung von Schiffsdampfkesseln auf den

Loggern "Clara" und "Louise"

1901

Klassifikation Teil B: 03767

Trägermaterial: Papier

Alte Reg.-Sig.: IX / VIII a 113

Vorprovenienz: Stadtausschuss d. Stadtkreises Emden

Bestell-Nr.: IV 03767

2255 Gewerbliche Zulassungen

1901

- Antrag der Kölnischen Tiefbaugesellschaft m.b.H. an den

Stadtausschuss des Stadtkreises Emden auf Zulassung eines

Dampfkessels auf dem Elevator "Kaiser-Wilhelm-Polder"

1901

Klassifikation Teil B: 03768

Trägermaterial: Papier

Alte Reg.-Sig.: IX / VIII a 114

Vorprovenienz: Stadtausschuss d. Stadtkreises Emden

Bestell-Nr.: IV 03768

2256 Gewerbliche Zulassungen

1901

- Antrag der Bremer Baugesellschaft Volker Bos, Ficke \& Co an den Stadtausschuss des Stadtkreises Emden auf Zulassung zweier

Dampfkessel auf einem Pumpenbagger

1901

Klassifikation Teil B: 03768

Trägermaterial: Papier

Alte Reg.-Sig.: IX / VIII a 115

Vorprovenienz: Stadtausschuss d. Stadtkreises Emden

Bestell-Nr.: IV 03769 
05

05.03

05.03.12

05.03.12.03

05.03.12.03.01

05.03.12.03.01.05
Stadtverwaltung

Aufgabenbereiche der Stadtverwaltung

Handels- und Gewerbeförderung

Förderung von Handel und Industrie

Förderung von Handel und Verkehr

Zulassung technischer Anlagen

Lfd. Nr. Titel

Laufzeit

2257 Gewerbliche Zulassungen

1901

- Antrag des Schiffsbaumeisters C. Cassens an den Stadtausschuss des Stadtkreises Emden auf Zulassung eines stationären

Dampfkessels auf dem Werftgelände am II. Hafeneinschnitt

1901

Klassifikation Teil B: 03770

Trägermaterial: Papier

Alte Reg.-Sig.: IX / VIII a 116

Vorprovenienz: Stadtausschuss d. Stadtkreises Emden

Bestell-Nr.: IV 03770

2258 Gewerbliche Zulassungen

1901

- Antrag der kgl. Wasserbauinspektion an den Stadtausschuss des Stadtkreises Emden auf Zulassung von Schiffsdampfkesseln auf Dampfbaggerprähmen

1901

\author{
Klassifikation Teil B: 03771 \\ Trägermaterial: Papier \\ Alte Reg.-Sig.: IX / VIII a 117 \\ Vorprovenienz: Stadtausschuss d. Stadtkreises Emden \\ Bestell-Nr.: IV 03771
}

2259 Gewerbliche Zulassungen

1901

- Antrag der Emder Heringsfischerei "Dollart" AG an den

Stadtausschuss des Stadtkreises Emden auf Zulassung eines

Dampfkessels zum Betrieb einer Tranerei auf ihrem Betriebsgelände

1901

\author{
Klassifikation Teil B: 03772 \\ Trägermaterial: Papier \\ Alte Reg.-Sig.: IX / VIII a 118 \\ Vorprovenienz: Stadtausschuss d. Stadtkreises Emden \\ Bestell-Nr.: IV 03772
}

2260 Gewerbliche Zulassungen

- Antrag der Deutsch-Holländischen-Kanal- und Seeschiffahrts GmbH. an den Stadtausschuss des Stadtkreises Emden auf Zulassung eines Schiffsdampkessels auf dem Dampfer "Hans Hensoth"

1911

Klassifikation Teil B: 03773

Trägermaterial: Papier

Alte Reg.-Sig.: IX / VIII a 228

Vorprovenienz: Stadtausschuss d. Stadtkreises Emden

Bestell-Nr.: IV 03773 
05

05.03

05.03.12

05.03.12.03

05.03.12.03.01

05.03.12.03.01.05
Stadtverwaltung

Aufgabenbereiche der Stadtverwaltung

Handels- und Gewerbeförderung

Förderung von Handel und Industrie

Förderung von Handel und Verkehr

Zulassung technischer Anlagen

Lfd. Nr. Titel

Laufzeit

2261 Gewerbliche Zulassungen

1901

- Antrag der Emslots-Gesellschaft an den Stadtausschuss des Stadtkreises Emden auf Zulassung eines Schiffsdampfkessels auf einem Lotsenversetzungsdampfer

1901

\author{
Klassifikation Teil B: 03774 \\ Trägermaterial: Papier \\ Alte Reg.-Sig.: IX / VIII a 118 \\ Vorprovenienz: Stadtausschuss d. Stadtkreises Emden \\ Bestell-Nr.: IV 03774
}

2262 Gewerbliche Zulassungen

- Antrag der Reederei P.W.Wessels Wwe. an den Stadtausschuss des Stadtkreises Emden auf Zulassung eines Schiffsdampfkessels auf dem Schleppdampfer "Sophie Wessels"

1900

\author{
Klassifikation Teil B: 03775 \\ Trägermaterial: Papier \\ Alte Reg.-Sig.: IX / VIII a 122 \\ Vorprovenienz: Stadtausschuss d. Stadtkreises Emden \\ Bestell-Nr.: IV 03775
}

2263 Gewerbliche Zulassungen

1902

- Antrag der kgl. Wasserbauinspektion an den Stadtausschuss des Stadtkreises Emden auf Zulassung eines stationären Dampfkessels in der elektrischen Zentralstation "Nesserland"

1902

\author{
Klassifikation Teil B: 03776 \\ Trägermaterial: Papier \\ Alte Reg.-Sig.: IX / VIII a 123 \\ Vorprovenienz: Stadtausschuss d. Stadtkreises Emden \\ Bestell-Nr.: IV 03776
}

2264 Gewerbliche Zulassungen

- Antrag des Schiffsbaumeisters C. Cassens an den Stadtausschuss des Stadtkreises Emden auf Zulassung eines Schiffsdampfkessels auf dem Dampfboot "Bernhard"

1902

Klassifikation Teil B: 03777

Trägermaterial: Papier

Alte Reg.-Sig.: IX / VIII a 124

Vorprovenienz: Stadtausschuss d. Stadtkreises Emden

Bestell-Nr.: IV 03777 
05

05.03

05.03.12

05.03.12.03

05.03.12.03.01

05.03.12.03.01.05
Stadtverwaltung

Aufgabenbereiche der Stadtverwaltung

Handels- und Gewerbeförderung

Förderung von Handel und Industrie

Förderung von Handel und Verkehr

Zulassung technischer Anlagen

Lfd. Nr. Titel

Laufzeit

2265 Gewerbliche Zulassungen

1902

- Antrag der Emdener Papierfabrik an den Stadtausschuss des

Stadtkreises Emden auf Zulassung eines stationären Dampfkessels

auf dem Fabrikgelände an der Auricher Chaussee

1902

Klassifikation Teil B: 03778

Trägermaterial: Papier

Alte Reg.-Sig.: IX / VIII a 125

Vorprovenienz: Stadtausschuss d. Stadtkreises Emden

Bestell-Nr.: IV 03778

2266 Gewerbliche Zulassungen

- Antrag der Emder Heringsfischerei "Dollart" AG an den

Stadtausschuss des Stadtkreises Emden auf Zulassung zweier

Schiffsdampfkessel auf dem Dampfer "Remulus"

1902

Klassifikation Teil B: 03779

Trägermaterial: Papier

Alte Reg.-Sig.: IX / VIII a 127

Vorprovenienz: Stadtausschuss d. Stadtkreises Emden

Bestell-Nr.: IV 03779

2267 Gewerbliche Zulassungen

1902

- Antrag der Fischerei AG "Neptun" an den Stadtausschuss des Stadtkreises Emden auf Zulassung von Schiffsdampfkesseln auf den Loggern "Ocean" etc,

1902

Klassifikation Teil B: 03780

Trägermaterial: Papier

Alte Reg.-Sig.: IX / VIII a 128

Vorprovenienz: Stadtausschuss d. Stadtkreises Emden

Bestell-Nr.: IV 03780

2268 Gewerbliche Zulassungen

- Antrag der Fischerei AG "Neptun" an den Stadtausschuss des Stadtkreises Emden auf Zulassung von Schiffsdampfkesseln auf dem Logger "Ora et Labora"

1902

Klassifikation Teil B: 03781

Trägermaterial: Papier

Alte Reg.-Sig.: IX / VIII a 129

Vorprovenienz: Stadtausschuss d. Stadtkreises Emden

Bestell-Nr.: IV 03781 
05

05.03

05.03.12

05.03.12.03

05.03.12.03.01

05.03.12.03.01.05
Stadtverwaltung

Aufgabenbereiche der Stadtverwaltung

Handels- und Gewerbeförderung

Förderung von Handel und Industrie

Förderung von Handel und Verkehr

Zulassung technischer Anlagen

Lfd. Nr. Titel

Laufzeit

2269 Gewerbliche Zulassungen

1902

- Antrag des Badeanstaltsbesitzers Max Wendisch an den

Stadtausschuss des Stadtkreises Emden auf Zulassung eines

stationären Dampfkessels in der Badeanstalt Am Apfelmarkt 6 - 7

1902

Klassifikation Teil B: 03782

Trägermaterial: Papier

Alte Reg.-Sig.: IX / VIII a 130

Vorprovenienz: Stadtausschuss d. Stadtkreises Emden

Bestell-Nr.: IV 03782

2270 Gewerbliche Zulassungen

- Antrag der kgl. Wasserbauinspektion an den Stadtausschuss des Stadtkreises Emden auf Zulassung von Schiffsdampfkesseln auf zwei ihrer Schiffe

1902

Klassifikation Teil B: 03783

Trägermaterial: Papier

Alte Reg.-Sig.: IX / VIII a 131

Vorprovenienz: Stadtausschuss d. Stadtkreises Emden

Bestell-Nr.: IV 03783

2271 Gewerbliche Zulassungen

$1902-1903$

- Antrag des Kaufmanns und Fellhändlers S. D. de Beer an den Stadtausschuss des Stadtkreises Emden auf Zulassung einer Anlage zum Einsalzen und Trocknen ungegerbter Tierfelle auf dem Grundstück Außer dem Neuen Tor

$1902-1903$

Klassifikation Teil B: 03784

Trägermaterial: Papier

Alte Reg.-Sig.: IX / VIII a 132

Vorprovenienz: Stadtausschuss d. Stadtkreises Emden

Bestell-Nr.: IV 03784

2272 Gewerbliche Zulassungen

1903

- Antrag der Fa. Schulte \& Bruns an den Stadtausschuss des Stadtkreises Emden auf Zulassung eines Schiffsdampfkessels auf dem Dampfer "Westfalen"

1903

Klassifikation Teil B: 03785

Trägermaterial: Papier

Alte Reg.-Sig.: IX / VIII a 133

Vorprovenienz: Stadtausschuss d. Stadtkreises Emden

Bestell-Nr.: IV 03785 
05

05.03

05.03.12

05.03.12.03

05.03.12.03.01

05.03.12.03.01.05
Stadtverwaltung

Aufgabenbereiche der Stadtverwaltung

Handels- und Gewerbeförderung

Förderung von Handel und Industrie

Förderung von Handel und Verkehr

Zulassung technischer Anlagen

Lfd. Nr. Titel

Laufzeit

2273 Gewerbliche Zulassungen

1903

- Antrag der Kölnischen Tiefbaugesellschaft m.b.H. an den

Stadtausschuss des Stadtkreises Emden auf Zulassung eines

Schiffsdampfkessels auf dem Dampfer "Rheinland"

1903

Klassifikation Teil B: 03786

Trägermaterial: Papier

Alte Reg.-Sig.: IX / VIII a 134

Vorprovenienz: Stadtausschuss d. Stadtkreises Emden

Bestell-Nr.: IV 03786

2274 Gewerbliche Zulassungen

- Antrag der Fa. Schulte \& Bruns an den Stadtausschuss des Stadtkreises Emden auf Zulassung eines Schiffsdampfkessels auf dem Dampfer "Ostfriesland"

1903

Klassifikation Teil B: 03787

Trägermaterial: Papier

Alte Reg.-Sig.: IX / VIII a 135

Vorprovenienz: Stadtausschuss d. Stadtkreises Emden

Bestell-Nr.: IV 03787

2275 Gewerbliche Zulassungen

1903

- Antrag der Fa. Habich \& Goth an den Stadtausschuss des Stadtkreises Emden auf Zulassung eines Schiffsdampfkessels auf dem Dampfer "Kaiser Wilhelm II"

1903

Klassifikation Teil B: 03788

Trägermaterial: Papier

Alte Reg.-Sig.: IX / VIII a 136

Vorprovenienz: Stadtausschuss d. Stadtkreises Emden

Bestell-Nr.: IV 03788

2276 Gewerbliche Zulassungen

- Antrag der Emder Heringsfischerei "Dollart" AG an den Stadtausschuss des Stadtkreises Emden auf Zulassung von

Schiffsdampfkesseln auf den Loggern "Stettin", "Rostock", "Danzig",

"Memel", "Vesta", "Juno", "Cera", "Pallas"

1903

Klassifikation Teil B: 03789

Trägermaterial: Papier

Alte Reg.-Sig.: IX / VIII a 137

Vorprovenienz: Stadtausschuss d. Stadtkreises Emden

Bestell-Nr.: IV 03789 
05

05.03

05.03.12

05.03.12.03

05.03.12.03.01

05.03.12.03.01.05
Stadtverwaltung

Aufgabenbereiche der Stadtverwaltung

Handels- und Gewerbeförderung

Förderung von Handel und Industrie

Förderung von Handel und Verkehr

Zulassung technischer Anlagen

Lfd. Nr. Titel

Laufzeit

2277 Gewerbliche Zulassungen

1903

- Antrag der Fischerei AG "Neptun" an den Stadtausschuss des

Stadtkreises Emden auf Zulassung von Schiffsdampfkesseln auf den

Loggern "Betty", "Gerhardine", "Fanny", "Y. Brons", "Cornelia"

1903

Klassifikation Teil B: 03790

Trägermaterial: Papier

Alte Reg.-Sig.: IX / VIII a 138

Vorprovenienz: Stadtausschuss d. Stadtkreises Emden

Bestell-Nr.: IV 03790

2278 Gewerbliche Zulassungen

- Antrag der kgl. Wasserbauinspektion an den Stadtausschuss des Stadtkreises Emden auf Zulassung eines Dampfkessels auf dem schwimmenden Dampfkran Nr. 5

1903

Klassifikation Teil B: 03791

Trägermaterial: Papier

Alte Reg.-Sig.: IX / VIII a 139

Vorprovenienz: Stadtausschuss d. Stadtkreises Emden

Bestell-Nr.: IV 03791

2279 Gewerbliche Zulassungen

1903

- Antrag der Emder Heringsfischerei "Dollart" AG an den Stadtausschuss des Stadtkreises Emden auf Zulassung von Schiffsdampfkesseln auf den Loggern "Susanna Henriette" und "Henry \& Markus"

1903

\author{
Klassifikation Teil B: 03792 \\ Trägermaterial: Papier \\ Alte Reg.-Sig.: IX / VIII a 140 \\ Vorprovenienz: Stadtausschuss d. Stadtkreises Emden \\ Bestell-Nr.: IV 03792
}

2280 Gewerbliche Zulassungen

- Antrag der kgl. Wasserbauinspektion an den Stadtausschuss des Stadtkreises Emden auf Zulassung zweier Schiffsdampfkessel zum Betrieb einer Compoundmaschine

1903

Klassifikation Teil B: 03793

Trägermaterial: Papier

Alte Reg.-Sig.: IX / VIII a 141

Vorprovenienz: Stadtausschuss d. Stadtkreises Emden

Bestell-Nr.: IV 03793 
05

05.03

05.03.12

05.03.12.03

05.03.12.03.01

05.03.12.03.01.05
Stadtverwaltung

Aufgabenbereiche der Stadtverwaltung

Handels- und Gewerbeförderung

Förderung von Handel und Industrie

Förderung von Handel und Verkehr

Zulassung technischer Anlagen

Lfd. Nr. Titel

Laufzeit

2281 Gewerbliche Zulassungen

1903

- Antrag der Reederei P. W. Wessels an den Stadtausschuss des Stadtkreises Emden auf Zulassung eines Schiffsdampfkessels auf dem Schiff Nr. 433 "Peter Wessels Witwe"

1903

Klassifikation Teil B: 03794

Trägermaterial: Papier

Alte Reg.-Sig.: IX / VIII a 142

Vorprovenienz: Stadtausschuss d. Stadtkreises Emden

Bestell-Nr.: IV 03794

2282 Gewerbliche Zulassungen

- Antrag der kgl. Wasserbauinspektion an den Stadtausschuss des Stadtkreises Emden auf Zulassung eines

Austausch-Schiffsdampfkessels auf dem Dampfer "Nesserland"

1904

\author{
Klassifikation Teil B: 03795 \\ Trägermaterial: Papier \\ Alte Reg.-Sig.: IX / VIII a 144 \\ Vorprovenienz: Stadtausschuss d. Stadtkreises Emden \\ Bestell-Nr.: IV 03795
}

2283 Gewerbliche Zulassungen

1904

- Antrag der Nordseewerke an den Stadtausschuss des Stadtkreises Emden auf Zulassung eines beweglichen Dampfkessels auf einem fahrbaren Kran

1904

\author{
Klassifikation Teil B: 03796 \\ Trägermaterial: Papier \\ Alte Reg.-Sig.: IX / VIII a 145 \\ Vorprovenienz: Stadtausschuss d. Stadtkreises Emden \\ Bestell-Nr.: IV 03796
}

2284 Gewerbliche Zulassungen

- Antrag der Emder Dampfschiffreederei AG an den Stadtausschuss des Stadtkreises Emden auf Zulassung zweier Schiffsdampfkessel auf dem Frachtdampfer "Amisia"

1904

Klassifikation Teil B: 03797

Trägermaterial: Papier

Alte Reg.-Sig.: IX / VIII a 146

Vorprovenienz: Stadtausschuss d. Stadtkreises Emden

Bestell-Nr.: IV 03797 
05

05.03

05.03.12

05.03.12.03

05.03.12.03.01

05.03.12.03.01.05
Stadtverwaltung

Aufgabenbereiche der Stadtverwaltung

Handels- und Gewerbeförderung

Förderung von Handel und Industrie

Förderung von Handel und Verkehr

Zulassung technischer Anlagen

Lfd. Nr. Titel

Laufzeit

2285 Gewerbliche Zulassungen

1904

- Antrag der Emder Heringsfischerei "Dollart" AG an den

Stadtausschuss des Stadtkreises Emden auf Zulassung eines

Schiffsdampfkessels auf dem Dampfer "Ostfriesland"

1904

Klassifikation Teil B: 03798

Trägermaterial: Papier

Alte Reg.-Sig.: IX / VIII a 147

Vorprovenienz: Stadtausschuss d. Stadtkreises Emden

Bestell-Nr.: IV 03798

2286 Gewerbliche Zulassungen

- Antrag der Emder Heringsfischerei "Dollart" AG an den

Stadtausschuss des Stadtkreises Emden auf Zulassung von

Schiffsdampfkesseln auf den Loggern "Wega", "Altair" und "Orion"

1903

Klassifikation Teil B: 03799

Trägermaterial: Papier

Alte Reg.-Sig.: IX / VIII a 148

Vorprovenienz: Stadtausschuss d. Stadtkreises Emden

Bestell-Nr.: IV 03799

2287 Gewerbliche Zulassungen

1904

- Antrag der Fischerei AG "Neptun" an den Stadtausschuss des Stadtkreises Emden auf Zulassung von Schiffsdampfkesseln auf den Loggern "Heinrich Daniel" und "Ingwalde"

1904

Klassifikation Teil B: 03800

Trägermaterial: Papier

Alte Reg.-Sig.: IX / VIII a 149

Vorprovenienz: Stadtausschuss d. Stadtkreises Emden

Bestell-Nr.: IV 03800

2288 Gewerbliche Zulassungen

- Antrag der Fischerei AG "Neptun" an den Stadtausschuss des Stadtkreises Emden auf Zulassung von Schiffsdampfkesseln auf den Loggern "Bahrenfeld" und "Altona"

1904

Klassifikation Teil B: 03801

Trägermaterial: Papier

Alte Reg.-Sig.: IX / VIII a 150

Vorprovenienz: Stadtausschuss d. Stadtkreises Emden

Bestell-Nr.: IV 03801 
05

05.03

05.03.12

05.03.12.03

05.03.12.03.01

05.03.12.03.01.05
Stadtverwaltung

Aufgabenbereiche der Stadtverwaltung

Handels- und Gewerbeförderung

Förderung von Handel und Industrie

Förderung von Handel und Verkehr

Zulassung technischer Anlagen

Lfd. Nr. Titel

Laufzeit

2289 Gewerbliche Zulassungen

1905

- Antrag des Reeders Franz Pansch an den Stadtausschuss des

Stadtkreises Emden auf Zulassung eines neuen Schiffsdampfkessels auf dem Dampfer "Mentje"

1905

Klassifikation Teil B: 03802

Trägermaterial: Papier

Alte Reg.-Sig.: IX / VIII a 156

Vorprovenienz: Stadtausschuss d. Stadtkreises Emden

Bestell-Nr.: IV 03802

2290 Gewerbliche Zulassungen

- Antrag der kgl. Wasserbauinspektion an den Stadtausschuss des Stadtkreises Emden auf Zulassung zweier neuer Schiffsdampfkessel zum Betrieb von Expansionsschrauben-Schiffsmaschinen

1905

Klassifikation Teil B: 03803

Trägermaterial: Papier

Alte Reg.-Sig.: IX / VIII a 157

Vorprovenienz: Stadtausschuss d. Stadtkreises Emden

Bestell-Nr.: IV 03803

2291 Gewerbliche Zulassungen

1905

- Antrag der Kölnischen Tiefbaugesellschaft m.b.H. an den

Stadtausschuss des Stadtkreises Emden auf Zulassung eines

Schiffsdampfkessels auf dem Eimerbagger "Britannia"

1905

Klassifikation Teil B: 03804

Trägermaterial: Papier

Alte Reg.-Sig.: IX / VIII a 159

Vorprovenienz: Stadtausschuss d. Stadtkreises Emden

Bestell-Nr.: IV 03804

2292 Gewerbliche Zulassungen

- Antrag der Fischerei AG "Neptun" AG an den Stadtausschuss des Stadtkreises Emden auf Zulassung eines Schiffsdampfkessels auf dem Logger "Sirius"

1905

Klassifikation Teil B: 03805

Trägermaterial: Papier

Alte Reg.-Sig.: IX / VIII a 160

Vorprovenienz: Stadtausschuss d. Stadtkreises Emden

Bestell-Nr.: IV 03805 
05

05.03

05.03.12

05.03.12.03

05.03.12.03.01

05.03.12.03.01.05
Stadtverwaltung

Aufgabenbereiche der Stadtverwaltung

Handels- und Gewerbeförderung

Förderung von Handel und Industrie

Förderung von Handel und Verkehr

Zulassung technischer Anlagen

Lfd. Nr. Titel

Laufzeit

2293 Gewerbliche Zulassungen

1905

- Antrag der Fischerei AG "Neptun" AG an den Stadtausschuss des Stadtkreises Emden auf Zulassung eines Schiffsdampfkessels auf dem Logger "Finkenwarder"

1905

Klassifikation Teil B: 03806

Trägermaterial: Papier

Alte Reg.-Sig.: IX / VIII a 165

Vorprovenienz: Stadtausschuss d. Stadtkreises Emden

Bestell-Nr.: IV 03806

2294 Gewerbliche Zulassungen

- Antrag der Heringsfischerei AG "Großer Kurfürst" an den

Stadtausschuss des Stadtkreises Emden auf Zulassung eines

Dampfkessels auf der Pumpanlage ihres Betriebsgeländes am II.

Hafeneinschnitt

1905

Klassifikation Teil B: 03807

Trägermaterial: Papier

Alte Reg.-Sig.: IX / VIII a 168

Vorprovenienz: Stadtausschuss d. Stadtkreises Emden

Bestell-Nr.: IV 03807

2295 Gewerbliche Zulassungen

- Antrag der Emder Heringsfischerei "Dollart" AG an den

Stadtausschuss des Stadtkreises Emden auf Zulassung eines

Schiffsdampfkessels auf dem stählernen Segellogger "Satorius"

1908

Klassifikation Teil B: 03808

Trägermaterial: Papier

Alte Reg.-Sig.: IX / VIII a 201

Vorprovenienz: Stadtausschuss d. Stadtkreises Emden

Bestell-Nr.: IV 03808 
05

05.03

05.03.12

05.03.12.03

05.03.12.03.01

05.03.12.03.01.05
Stadtverwaltung

Aufgabenbereiche der Stadtverwaltung

Handels- und Gewerbeförderung

Förderung von Handel und Industrie

Förderung von Handel und Verkehr

Zulassung technischer Anlagen

Lfd. Nr. Titel

Laufzeit

2296 Gewerbliche Zulassungen

1905

- Antrag der Emder Heringsfischerei "Dollart" AG an den

Stadtausschuss des Stadtkreises Emden auf Zulassung von

Schiffsdampfkesseln auf den Loggern "Friedrich Wilhelm",

"Brandenburg", "Oranien", "Marie", "Prinz Ludwig" und "Louise

Henriette"

1905

Klassifikation Teil B: 03809

Trägermaterial: Papier

Alte Reg.-Sig.: IX / VIII a 161

Vorprovenienz: Stadtausschuss d. Stadtkreises Emden

Bestell-Nr.: IV 03809

2297 Gewerbliche Zulassungen

1905

- Antrag der Heringsfischerei AG "Großer Kurfürst" an den

Stadtausschuss des Stadtkreises Emden auf Zulassung von

Schiffsdampfkesseln auf den Loggern "Morian", "Spanien",

"Windhund", und "Kurprinz"

1905

Klassifikation Teil B: 03810

Trägermaterial: Papier

Alte Reg.-Sig.: IX / VIII a 164

Vorprovenienz: Stadtausschuss d. Stadtkreises Emden

Bestell-Nr.: IV 03810

2298 Gewerbliche Zulassungen

- Antrag des Schiffsbaumeisters C. Cassens an den Stadtausschuss des Stadtkreises Emden auf Zulassung eines Schiffsdampfkessels auf der Pinasse "Bernard"

1905

Klassifikation Teil B: 03811

Trägermaterial: Papier

Alte Reg.-Sig.: IX / VIII a 167

Vorprovenienz: Stadtausschuss d. Stadtkreises Emden

Bestell-Nr.: IV 03811 
05

05.03

05.03.12

05.03.12.03

05.03.12.03.01

05.03.12.03.01.05
Stadtverwaltung

Aufgabenbereiche der Stadtverwaltung

Handels- und Gewerbeförderung

Förderung von Handel und Industrie

Förderung von Handel und Verkehr

Zulassung technischer Anlagen

Lfd. Nr. Titel

Laufzeit

2299 Gewerbliche Zulassungen

1908

- Antrag der Kölnischen Tiefbaugesellschaft m.b.H. an den

Stadtausschuss des Stadtkreises Emden auf Zulassung eines

Dampfkessels auf dem Bagger "Borussia"

1905

Klassifikation Teil B: 03813

Trägermaterial: Papier

Alte Reg.-Sig.: IX / VIII a 196

Vorprovenienz: Stadtausschuss d. Stadtkreises Emden

Bestell-Nr.: IV 03813

2300 Gewerbliche Zulassungen

- Antrag der Emder Heringsfischerei "Dollart" AG an den Stadtausschuss des Stadtkreises Emden auf Zulassung eines Schiffsdampfkessels auf einem nicht benannten stählernen Segellogger

1908

Klassifikation Teil B: 03814

Trägermaterial: Papier

Alte Reg.-Sig.: IX / VIII a 197

Vorprovenienz: Stadtausschuss d. Stadtkreises Emden

Bestell-Nr.: IV 03814

2301 Gewerbliche Zulassungen

- Antrag der Reederei P. W. Wessels an den Stadtausschuss des Stadtkreises Emden auf Zulassung eines Schiffsdampfkessels auf dem Schiffsneubau Nr. 491

1908

\author{
Klassifikation Teil B: 03815 \\ Trägermaterial: Papier \\ Alte Reg.-Sig.: IX / VIII a 198 \\ Vorprovenienz: Stadtausschuss d. Stadtkreises Emden \\ Bestell-Nr.: IV 03815
}

2302 Gewerbliche Zulassungen

1908

- Antrag der Nordseewerke an den Stadtausschuss des Stadtkreises Emden auf Zulassung eines Dampfkessels zum Betrieb auf der schwimmenden Kraftstation "Kraft"

1908

Klassifikation Teil B: 03816

Trägermaterial: Papier

Alte Reg.-Sig.: IX / VIII a 199

Vorprovenienz: Stadtausschuss d. Stadtkreises Emden

Bestell-Nr.: IV 03816 
05

05.03

05.03.12

05.03.12.03

05.03.12.03.01

05.03.12.03.01.05
Stadtverwaltung

Aufgabenbereiche der Stadtverwaltung

Handels- und Gewerbeförderung

Förderung von Handel und Industrie

Förderung von Handel und Verkehr

Zulassung technischer Anlagen

Lfd. Nr. Titel

Laufzeit

2303 Gewerbliche Zulassungen

1908

- Antrag der Emder Heringsfischerei "Dollart" AG an den

Stadtausschuss des Stadtkreises Emden auf Zulassung eines

Schiffsdampfkessels auf dem stählernen Segellogger "Lübeck"

1908

Klassifikation Teil B: 03817

Trägermaterial: Papier

Alte Reg.-Sig.: IX / VIII a 202

Vorprovenienz: Stadtausschuss d. Stadtkreises Emden

Bestell-Nr.: IV 03817

2304 Gewerbliche Zulassungen

- Antrag der Kölnischen Tiefbaugesellschaft m.b.H. an den Stadtausschuss des Stadtkreises Emden auf Zulassung eines Schiffsdampfkessels auf dem Saugbagger "Germania II"

1908

Klassifikation Teil B: 03818

Trägermaterial: Papier

Alte Reg.-Sig.: IX / VIII a 203

Vorprovenienz: Stadtausschuss d. Stadtkreises Emden

Bestell-Nr.: IV 03818

2305 Gewerbliche Zulassungen

1908

- Antrag der Kölnischen Tiefbaugesellschaft m.b.H. an den Stadtausschuss des Stadtkreises Emden auf Zulassung eines Schiffsdampfkessels auf dem Saugbagger "Peking"

1908

Klassifikation Teil B: 03819

Trägermaterial: Papier

Alte Reg.-Sig.: IX / VIII a 204

Vorprovenienz: Stadtausschuss d. Stadtkreises Emden

Bestell-Nr.: IV 03819

2306 Gewerbliche Zulassungen

- Antrag der Rutgerswerke an den Stadtausschuss des Stadtkreises Emden auf Zulassung eines Schiffsdampfkessels auf dem

Teeröldampferneubau Nr. 229

1908

Klassifikation Teil B: 03820

Trägermaterial: Papier

Alte Reg.-Sig.: IX / VIII a 205

Vorprovenienz: Stadtausschuss d. Stadtkreises Emden

Bestell-Nr.: IV 03820 
05

05.03

05.03.12

05.03.12.03

05.03.12.03.01

05.03.12.03.01.05
Stadtverwaltung

Aufgabenbereiche der Stadtverwaltung

Handels- und Gewerbeförderung

Förderung von Handel und Industrie

Förderung von Handel und Verkehr

Zulassung technischer Anlagen

Lfd. Nr. Titel

Laufzeit

2307 Gewerbliche Zulassungen

1908

- Antrag der Emder Heringsfischerei "Dollart" AG an den

Stadtausschuss des Stadtkreises Emden auf Zulassung von

Schiffsdampfkesseln auf den Loggern "Königsberg" und "Frankfurt"

1908

Klassifikation Teil B: 03821

Trägermaterial: Papier

Alte Reg.-Sig.: IX / VIII a 207

Vorprovenienz: Stadtausschuss d. Stadtkreises Emden

Bestell-Nr.: IV 03821

2308 Gewerbliche Zulassungen

- Antrag der Emder Heringsfischerei "Dollart" AG an den

Stadtausschuss des Stadtkreises Emden auf Zulassung eines

Schiffsdampfkessels auf dem Logger "Venus"

1908

Klassifikation Teil B: 03822

Trägermaterial: Papier

Alte Reg.-Sig.: IX / VIII a 206

Vorprovenienz: Stadtausschuss d. Stadtkreises Emden

Bestell-Nr.: IV 03822

2309 Gewerbliche Zulassungen

1908

- Antrag der Fischerei AG "Neptun" an den Stadtausschuss des Stadtkreises Emden auf Zulassung eines Schiffsdampfkessels auf dem Segellogger "Cornelia"

1908

Klassifikation Teil B: 03823

Trägermaterial: Papier

Alte Reg.-Sig.: IX / VIII a 208

Vorprovenienz: Stadtausschuss d. Stadtkreises Emden

Bestell-Nr.: IV 03823

2310 Gewerbliche Zulassungen

- Antrag der Fischerei AG "Neptun" an den Stadtausschuss des Stadtkreises Emden auf Zulassung eines Schiffsdampfkessels auf dem Segellogger "Nesserland"

1908

Klassifikation Teil B: 03824

Trägermaterial: Papier

Alte Reg.-Sig.: IX / VIII a 208

Vorprovenienz: Stadtausschuss d. Stadtkreises Emden

Bestell-Nr.: IV 03824 
05

05.03

05.03.12

05.03.12.03

05.03.12.03.01

05.03.12.03.01.05
Stadtverwaltung

Aufgabenbereiche der Stadtverwaltung

Handels- und Gewerbeförderung

Förderung von Handel und Industrie

Förderung von Handel und Verkehr

Zulassung technischer Anlagen

Lfd. Nr. Titel

Laufzeit

2311 Gewerbliche Zulassungen

1908

- Antrag der Kölnischen Tiefbaugesellschaft m.b.H. an den

Stadtausschuss des Stadtkreises Emden auf Zulassung eines

Schiffsdampfkessels auf dem Eimerbagger "Barbarossa"

1908

Klassifikation Teil B: 03825

Trägermaterial: Papier

Alte Reg.-Sig.: IX / VIII a 211

Vorprovenienz: Stadtausschuss d. Stadtkreises Emden

Bestell-Nr.: IV 03825

2312 Gewerbliche Zulassungen

1908

- Antrag des Kaufmanns O. Ahlrichs an den Stadtausschuss des Stadtkreises Emden auf Zulassung eines Schiffsdampfkessels auf dem Schleppdampfer "Dollart"

1908

Klassifikation Teil B: 03826

Trägermaterial: Papier

Alte Reg.-Sig.: IX / VIII a 217

Vorprovenienz: Stadtausschuss d. Stadtkreises Emden

Bestell-Nr.: IV 03826

2313 Gewerbliche Zulassungen

1908

- Antrag der Kölnischen Tiefbaugesellschaft m.b.H. an den

Stadtausschuss des Stadtkreises Emden auf Zulassung eines

Schiffsdampfkessels auf dem Hoppesaugbagger "Berlin"

1908

Klassifikation Teil B: 03827

Trägermaterial: Papier

Alte Reg.-Sig.: IX / VIII a 213

Vorprovenienz: Stadtausschuss d. Stadtkreises Emden

Bestell-Nr.: IV 03827

2314 Gewerbliche Zulassungen

1908

- Antrag der Nordseewerke an den Stadtausschuss des Stadtkreises Emden auf Zulassung zweier Schiffsdampfkessel auf dem Dampfer "Wilhelm Hansoth"

1908

Klassifikation Teil B: 03828

Trägermaterial: Papier

Alte Reg.-Sig.: IX / VIII a 214

Vorprovenienz: Stadtausschuss d. Stadtkreises Emden

Bestell-Nr.: IV 03828 
05

05.03

05.03.12

05.03.12.03

05.03.12.03.01

05.03.12.03.01.05
Stadtverwaltung

Aufgabenbereiche der Stadtverwaltung

Handels- und Gewerbeförderung

Förderung von Handel und Industrie

Förderung von Handel und Verkehr

Zulassung technischer Anlagen

Lfd. Nr. Titel

Laufzeit

2315 Gewerbliche Zulassungen

1908

- Antrag der Fischerei AG "Neptun" an den Stadtausschuss des Stadtkreises Emden auf Zulassung eines Schiffsdampfkessels auf dem Segellogger "Ysaac Brons"

1908

Klassifikation Teil B: 03829

Trägermaterial: Papier

Alte Reg.-Sig.: IX / VIII a 209

Vorprovenienz: Stadtausschuss d. Stadtkreises Emden

Bestell-Nr.: IV 03829

2316 Gewerbliche Zulassungen

1908

- Antrag der kgl. Maschinenbauinspektion an den Stadtausschuss des Stadtkreises Emden auf Zulassung von Schiffsdampfkesseln auf dem Bereisungsdampfer "Ems" und dem Dampfprahm II

1908

Klassifikation Teil B: 03830

Trägermaterial: Papier

Alte Reg.-Sig.: IX / VIII a 215

Vorprovenienz: Stadtausschuss d. Stadtkreises Emden

Bestell-Nr.: IV 03830

2317 Gewerbliche Zulassungen

1909

- Antrag der kgl. Maschinenbauinspektion an den Stadtausschuss des Stadtkreises Emden auf Zulassung eines Schiffsdampfkessels auf dem Dampfer "Tender"

1909

Klassifikation Teil B: 03831

Trägermaterial: Papier

Alte Reg.-Sig.: IX / VIII a 216

Vorprovenienz: Stadtausschuss d. Stadtkreises Emden

Bestell-Nr.: IV 03831

2318 Gewerbliche Zulassungen

- Antrag der Borkumer Kleinbahn- und Dampfschiffahrt AG an den Stadtausschuss des Stadtkreises Emden auf Zulassung eines Schiffsdampfkessels auf dem Dampfer "Prinz Heinrich"

1909

Klassifikation Teil B: 03832

Trägermaterial: Papier

Alte Reg.-Sig.: IX / VIII a 217

Vorprovenienz: Stadtausschuss d. Stadtkreises Emden

Bestell-Nr.: IV 03832 
05

05.03

05.03.12

05.03.12.03

05.03.12.03.01

05.03.12.03.01.05
Stadtverwaltung

Aufgabenbereiche der Stadtverwaltung

Handels- und Gewerbeförderung

Förderung von Handel und Industrie

Förderung von Handel und Verkehr

Zulassung technischer Anlagen

Lfd. Nr. Titel

Laufzeit

2319 Gewerbliche Zulassungen

1910

- Antrag der kgl. Maschinenbauinspektion an den Stadtausschuss des Stadtkreises Emden auf Zulassung eines Schiffsdampfkessels auf dem Dampfer "Logum"

1909

Klassifikation Teil B: 03833

Trägermaterial: Papier

Alte Reg.-Sig.: IX / VIII a 218

Vorprovenienz: Stadtausschuss d. Stadtkreises Emden

Bestell-Nr.: IV 03833

2320 Gewerbliche Zulassungen

- Antrag der Emder Heringsfischerei "Dollart" AG an den

Stadtausschuss des Stadtkreises Emden auf Zulassung eines

Schiffsdampfkessels auf dem Segellogger "Münster"

1908

Klassifikation Teil B: 03834

Trägermaterial: Papier

Alte Reg.-Sig.: IX / VIII a 219

Vorprovenienz: Stadtausschuss d. Stadtkreises Emden

Bestell-Nr.: IV 03834

2321 Gewerbliche Zulassungen

- Antrag der Emder Heringsfischerei "Dollart" AG an den

Stadtausschuss des Stadtkreises Emden auf Zulassung eines

Schiffsdampfkessels auf dem Segellogger "Dortmund"

1910

Klassifikation Teil B: 03835

Trägermaterial: Papier

Alte Reg.-Sig.: IX / VIII a 220

Vorprovenienz: Stadtausschuss d. Stadtkreises Emden

Bestell-Nr.: IV 03835

2322 Gewerbliche Zulassungen

- Antrag der kgl. Maschinenbauinspektion an den Stadtausschuss des Stadtkreises Emden auf Zulassung eines Schiffsdampfkessels auf dem Eimerbagger E.D.V.

1910

Klassifikation Teil B: 03836

Trägermaterial: Papier

Alte Reg.-Sig.: IX / VIII a 221

Vorprovenienz: Stadtausschuss d. Stadtkreises Emden

Bestell-Nr.: IV 03836 
05

05.03

05.03.12

05.03.12.03

05.03.12.03.01

05.03.12.03.01.05
Stadtverwaltung

Aufgabenbereiche der Stadtverwaltung

Handels- und Gewerbeförderung

Förderung von Handel und Industrie

Förderung von Handel und Verkehr

Zulassung technischer Anlagen

Lfd. Nr. Titel

Laufzeit

2323 Gewerbliche Zulassungen

1910

- Antrag der Fischerei AG "Neptun" an den Stadtausschuss des Stadtkreises Emden auf Zulassung eines Schiffsdampfkessels auf dem Segellogger "Heinrich Daniel"

1910

Klassifikation Teil B: 03837

Trägermaterial: Papier

Alte Reg.-Sig.: IX / VIII a 222

Vorprovenienz: Stadtausschuss d. Stadtkreises Emden

Bestell-Nr.: IV 03837

2324 Gewerbliche Zulassungen

- Antrag der Bauunternehmer C.A. und J. van der Linde an den Stadtausschuss des Stadtkreises Emden auf Zulassung eines

Dampfkessels auf ihrem Firmengelände

1910

Klassifikation Teil B: 03838

Trägermaterial: Papier

Alte Reg.-Sig.: IX / VIII a 224

Vorprovenienz: Stadtausschuss d. Stadtkreises Emden

Bestell-Nr.: IV 03838

2325 Gewerbliche Zulassungen

- Antrag der kgl. Maschinenbauinspektion an den Stadtausschuss des Stadtkreises Emden auf Zulassung eines Schiffsdampfkessels auf dem Dampfer "Leda"

1910

Klassifikation Teil B: 03839

Trägermaterial: Papier

Alte Reg.-Sig.: IX / VIII a 224

Vorprovenienz: Stadtausschuss d. Stadtkreises Emden

Bestell-Nr.: IV 03839

2326 Gewerbliche Zulassungen

- Antrag der kgl. Maschinenbauinspektion an den Stadtausschuss des Stadtkreises Emden auf Zulassung eines Schiffsdampfkessels auf dem Feuerschiff "Borkumriff"

1910

Klassifikation Teil B: 03840

Trägermaterial: Papier

Alte Reg.-Sig.: IX / VIII a 225

Vorprovenienz: Stadtausschuss d. Stadtkreises Emden

Bestell-Nr.: IV 03840 
05

05.03

05.03.12

05.03.12.03

05.03.12.03.01

05.03.12.03.01.05

\section{IV}

Stadtverwaltung

Aufgabenbereiche der Stadtverwaltung

Handels- und Gewerbeförderung

Förderung von Handel und Industrie

Förderung von Handel und Verkehr

Zulassung technischer Anlagen

Lfd. Nr. Titel

Laufzeit

2327 Gewerbliche Zulassungen

1910

- Antrag der kgl. Maschinenbauinspektion an den Stadtausschuss des

Stadtkreises Emden auf Zulassung eines Schiffsdampfkessels auf

dem Dampfer "Emden"

1910

Klassifikation Teil B: 03841

Trägermaterial: Papier

Alte Reg.-Sig.: IX / VIII a 226

Vorprovenienz: Stadtausschuss d. Stadtkreises Emden

Bestell-Nr.: IV 03841 
05

05.03

05.03.12

05.03.12.03

05.03.12.03.01

05.03.12.03.01.06
Stadtverwaltung

Aufgabenbereiche der Stadtverwaltung

Handels- und Gewerbeförderung

Förderung von Handel und Industrie

Förderung von Handel und Verkehr

Bildungseinrichtungen für Handel und Gewerbe

Lfd. Nr. Titel

Laufzeit

2328 Bildungsanstalten für Gewerbe, Handel und Verkehr, Bd. 1

1869-1879

- Anträge auf Befreiung von Handelslehrlingen von der Pflicht zum

Besuch der Handelsschule, 1869 - 1879

- Erlass einer Polizeiverordnung über Handelsschulpflicht für

Handelslehrlinge, März - Mai 1869

- Jahresbericht der Emder Handelsschule, 1869

- Statut der Unterrichtsanstalt für Handelslehrlinge (Handelsschule),

Mai 1869

- Rückständige Schulgeldzahlungen und Verstöße gegen die

Handelsschulpflicht, April 1869 - April 1879

- Antrag des Vorstands der Handelsschule an den Magistrat auf

Erhöhung der Unterstützung der Handelsschule wegen Notwendigkeit des Ausbaus des Schulgebäudes, Dezember 1870

- Mitwirkung der Handelskammer im Vorstand der Handelsschule,

Oktober 1871

- Ausdehnung der Ausdehnung der Handelsschulpflicht auf die

Kellnerlehrlinge, 1878

$1869-1879$

Klassifikation Teil B: 02152

Band: 1

Trägermaterial: Papier

Alte Reg.-Sig.: IV T7 01

Bestell-Nr.: IV 02152 


\section{IV}

05

\subsection{3}

05.03.12

05.03.12.03

05.03.12.03.01

05.03.12.03.01.06
Stadtverwaltung

Aufgabenbereiche der Stadtverwaltung

Handels- und Gewerbeförderung

Förderung von Handel und Industrie

Förderung von Handel und Verkehr

Bildungseinrichtungen für Handel und Gewerbe

Lfd. Nr. Titel

Laufzeit

2329 Bildungsanstalten für Gewerbe, Handel und Verkehr, Bd. 2

$1866-1871$

- Festlegung des Etats der Gewerbeschule, 1866 - 1870

- Inserierung der Anmeldefrist für die Gewerbeschule, 1867 - 1871

- Schulgeldrückstände und Verstöße gegen die Gewerbeschulpflicht, 1867 - 1870

- Lehr- und Stundenplan der Gewerbeschule, 1867 - 1869

- Auswahl von Schülerarbeiten für eine Gewerbeschulausstellung in

Hannover, März 1868

- Gewährung einer Staatsunterstützung zum Betrieb der Emder

Gewerbeschule, Dezember 1868 - Dezember 1869

- Prüfung der Jahresrechnungen der Gewerbeschule durch die kgl.

Verwaltungs-Commission für Gewerbeschulen in Hannover, 1869 -

1870

- Ersatzwahl für das ausscheidende Gewerbeschulvorstandsmitglied

Senator Graepel, September 1869

- Beihilfe für die Gewerbeschule aus der Dispositionskasse der

Ostfriesischen Landschaft, April 1870

- Erlass des Ministers für Handel und Gewerbe und der öffentlichen

Arbeiten über Verlagerung der Aufsicht auf die Landdrosteien der

Provinz Hannover, Dezember 1870

- Anträge auf Befreiung von der Gewerbeschulpflicht, 1870

- Beschwerde des Gewerbeschullehrers C. Hesse gegen einen

Gewerbeschüler wegen Disziplinlosigkeit, Februar 1871

- Gewerbeschulstatistik, 1868 - 1870

- Monita des preußischen Landdrosten in Aurich zu den

Rechnungsunterlagen der Gewerbeschule, Juli 1871

- Rechnungslegung der Gewerbeschule, 1869 - 1871

$1866-1871$

Klassifikation Teil B: 02153

Band: 2

Trägermaterial: Papier

Alte Reg.-Sig.: IV T7 01

Bestell-Nr.: IV 02153 
05

05.03

05.03.12

05.03.12.03

05.03.12.03.01

05.03.12.03.01.06
Stadtverwaltung

Aufgabenbereiche der Stadtverwaltung

Handels- und Gewerbeförderung

Förderung von Handel und Industrie

Förderung von Handel und Verkehr

Bildungseinrichtungen für Handel und Gewerbe

Lfd. Nr. Titel

Laufzeit

2330 Bildungsanstalten für Gewerbe, Handel und Verkehr, Bd. 3

$1873-1880$

- Festsetzung des Etats der Gewerbeschule, 1873 - 1880

- Aufgabenverteilung bei der Gewerbeschule, 1873

- Protokoll der Übergabe der Bücher und Utensilien der

Gewerbeschule an den neuen dirigierenden Lehrer H. E. Müller,

November 1873

- Staatsbeihilfe für die Gewerbeschule, 1874

- Berichte über Unterrichtsstörungen durch Gewerbeschüler, 1874 -

1875

- Neuwahl von Mitgliedern des Vorstands der Gewerbeschule, Februar

1874 / September 1876 / Dezember 1877

- Vorschläge des J. G. Visser zur Verbesserung der Gewerbeschule,

Oktober 1876 - Januar 1877

- Lehrplan der Gewerbeschule, 1877 - 1878

- Problem der Überschneidung zwischen Konfirmanden- und

Gewerbeschulunterricht, November 1877

- Verstöße gegen die Gewerbeschulpflicht, 1877

- Errichtung einer vierten Klasse in der Gewerbeschule, 1878

$1873-1880$

Klassifikation Teil B: 02154

Band: 3

Trägermaterial: Papier

Alte Reg.-Sig.: IV T7 01

Bestell-Nr.: IV 02154 
05

\subsection{3}

05.03.12

05.03.12.03

05.03.12.03.01

05.03.12.03.01.06
Stadtverwaltung

Aufgabenbereiche der Stadtverwaltung

Handels- und Gewerbeförderung

Förderung von Handel und Industrie

Förderung von Handel und Verkehr

Bildungseinrichtungen für Handel und Gewerbe

Lfd. Nr. Titel

Laufzeit

2331 Bildungsanstalten für Gewerbe, Handel und Verkehr, Bd. 4

1879-1884

- Unterhaltung des Gewerbeschulgebäudes am Burgplatz, 1879

- Festlegung des Etats der Gewerbeschule, 1879 - 1884

- Lehr- und Stundenpläne der Gewerbeschule, 1879 - 1884

- Rückständige Schulgeldzahlungen und Verstöße gegen die

Gewerbeschulpflicht, 1879 - 1883

- Krankmeldungen von Lehrern der Gewerbeschule, 1879

- Wahl von Mitgliedern des Gewerbeschulvorstands, 1879

- Rechnungslegung der Gewerbeschule, 1879

- Monita des preußischen Landdrosten in Aurich zu den Rechnungen der Gewerbeschule, 1879

- Antrag des dirigierenden Lehrers der Gewerbeschule, Harmen E. Müller, beim Gewerbeschulvorstand auf Abschaffung der öffentlichen mündlichen Prüfung der Gewerbeschüler und Gewährung von

Prämien an besonders fleißige Absolventen, Januar - Februar 1880

- Anträge auf Schulgeldbefreiung, 1880 - 1881

- Erstellung eines Inventars der Gewerbeschule, Mai - Juni 1880

- Anträge auf Befreiung von der Gewerbeschulpflicht, 1880 - 1883

- Antrag des dirigierenden Lehrers der Gewerbeschule, Harmen E. Müller, beim Gewerbeschulvorstand auf Einrichtung einer fünften Klasse wegen Erhöhung der Schülerzahlen, Dezember 1880

- Prämierung besonders fleißiger Gewerbeschüler, Februar 1881

- Vertretung erkrankter Gewerbeschullehrer, 1881 - 1882

- Unterstützung der Stadt Emden für die Gewerbeschule, 1880 - 1883

- Zeugnis für den dirigierenden Lehrer der Gewerbeschule, Harmen E. Müller, Dezember 1883

. Erlass des Ministers der geistlichen, Unterrichts und Medizinalangelegenheiten über Unterrichtsinhalte der

Gewerbeschulen, Januar 1884

$1879-1884$

Klassifikation Teil B: 02155

Band: 4

Trägermaterial: Papier

Alte Reg.-Sig.: IV T7 01

Bestell-Nr.: IV 02155 
05

\subsection{3}

05.03.12

05.03.12.03

05.03.12.03.01

05.03.12.03.01.06
Stadtverwaltung

Aufgabenbereiche der Stadtverwaltung

Handels- und Gewerbeförderung

Förderung von Handel und Industrie

Förderung von Handel und Verkehr

Bildungseinrichtungen für Handel und Gewerbe

Lfd. Nr. Titel

Laufzeit

2332 Bildungsanstalten für Gewerbe, Handel und Verkehr, Bd. 5

- Wahl des Bürgervorstehers Niemeyer in den Vorstand der

Gewerbeschule, Januar 1880

- Inserierung der Anmeldefristen für die Gewerbeschule, 1880 - 1894

- Beschwerden gegen heimkehrende Gewerbeschüler wegen

Lärmens und "Unfug", April 1880 - September 1887

- Verstöße gegen die Gewerbeschulpflicht und rückständige

Schulgeldzahlungen, 1880 - 1885

- Beschwerde des dirigierenden Gewerbelehrers Müller gegen den

Schüler Reelf B. W. Gronewold wegen Beleidigung, September 1880

- Lehr- und Stundenpläne der Gewerbeschule, 1880 - 1884

- Antrag des Gewerbeschullehrers Höls beim Vorstand der

Gewerbeschule auf Einrichtung einer separaten Modellierklasse für angehende Bauhandwerker, September - Oktober 1880

- Nachweisung der Lehrer an der Gewerbeschule Emden, 1880 - 1886

- Anträge auf Befreiung von der Gewerbeschulpflicht,1881 - 1882

- Streit zwischen Handwerksmeistern und Gewerbeschule wegen

Unterrichtsinhalte, 1882 - 1883

- Unterhaltung des Gewerbeschulgebäudes, 1882

- Festlegung des Etats der Gewerbeschule, 1884 - 1895

- Vom Gewerbeverein Hannover organisierte Ausstellung von Arbeiten von Gewerbeschülern, November 1886 - Mai 1887 / August 1891

- Delegierung zweier Mitglieder des Bürgervorsteherkollegiums in den

Vorstand der Gewerbeschule, Januar 1890

- Erlasse des Ministers für Handel und Gewerbe über Regelung der

Fortbildung der Gewerbeschullehrer, Februar 1891 - Juli 1895

- Teilnahme von Gewerbeschullehrern an

Fortbildungsveranstaltungen, 1891 - 1898

- Anträge von Gewerbeschullehrern auf Honorarerhöhung, 1891

- Anschaffung neuer Lampen für die Gewerbeschule, September 1892

- Organisation des Zeichenunterrichts an der Gewerbeschule, Mai

1896

- Staatsbeihilfe für die Gewerbeschule zur Anschaffung notwendiger

Lehrmittel, Mai 1898

1880 - 1898

Klassifikation Teil B: 02156

Band: 5

Trägermaterial: Papier

Alte Reg.-Sig.: IV T7 01

Bestell-Nr.: IV 02156
1880-1898 
05

05.03

05.03.12

05.03.12.03

05.03.12.03.01

05.03.12.03.01.06
Stadtverwaltung

Aufgabenbereiche der Stadtverwaltung

Handels- und Gewerbeförderung

Förderung von Handel und Industrie

Förderung von Handel und Verkehr

Bildungseinrichtungen für Handel und Gewerbe

Lfd. Nr. Titel

Laufzeit

2333 Bildungsanstalten für Gewerbe, Handel und Verkehr, Bd. 6

$1899-1911$

- Inspektion der Emder Gewerbeschule durch eine vom Minister für

Handel und Gewerbe ernannte Delegation, Januar - Mai 1899

- Teilnahme von Gewerbeschullehrern an

Fortbildungsveranstaltungen, 1899 - 1904

- Mängel im Unterricht der Gewerbeschule, August 1899

- Lehrplan der Gewerbeschule, 1899

- Delegierung zweier Mitglieder des Bürgervorsteherkollegiums in den

Vorstand der Gewerbeschule, Januar 1900 - August 1911

- Antrag der freien Emsinnung an den Vorstand der Gewerbeschule auf Einschulung von Lehrlingen aus den Emder Umlandgemeinden in der Emder Gewerbeschule, Oktober - November 1900

- Forderungen der Handwerksverbände gegenüber dem Unterricht der Gewerbeschule, Dezember 1900

- Diskussion um eine Vorverlegung der Unterrichtszeiten der

Gewerbeschule, April - Mai 1901

- Geschäftsbericht des Provinzialverbandes Hannoverscher

Gewerbelehrer, 1905

- Ersatzwahl für das verstorbene Mitglied des

Gewerbeschulvorstands, J. D. Theilen, April 1904

$1899-1911$

Klassifikation Teil B: 02157

Band: 6

Trägermaterial: Papier

Alte Reg.-Sig.: IV T7 01

Bestell-Nr.: IV 02157

2334 Vorstand der Gewerbeschule Emden, Bd. 1

1891-1894

- Protokolle der Vorstandssitzungen über Etatfragen, Anschaffung von Lehrmittel, Einstellung und Kündigung von Gewerbeschullehrern sowie Unterrichtsfragen und Fortbildung

$1891-1894$

Klassifikation Teil B: 02158

Band: 1

Trägermaterial: Papier

Alte Reg.-Sig.: IV T7 02

Bestell-Nr.: IV 02158

2335 Vorstand der Gewerbeschule Emden, Bd. 2

- Protokolle der Vorstandssitzungen über Etatfragen, Anschaffung von Lehrmittel, Einstellung und Kündigung von Gewerbeschullehrern sowie Unterrichtsfragen und Fortbildung

$1895-1899$

Klassifikation Teil B: 02159

Band: 2

Trägermaterial: Papier

Alte Reg.-Sig.: IV T7 02

Bestell-Nr.: IV 02159 
IV

05

Stadtverwaltung

05.03

05.03.12

05.03.12.03

05.03.12.03.01

Aufgabenbereiche der Stadtverwaltung

05.03.12.03.01.06

Handels- und Gewerbeförderung

Förderung von Handel und Industrie

Förderung von Handel und Verkehr

Bildungseinrichtungen für Handel und Gewerbe

Lfd. Nr. Titel

Laufzeit

2336 Vorstand der Gewerbeschule Emden, Bd. 3

1900-1904

- Protokolle der Vorstandssitzungen über Etatfragen, Anschaffung von Lehrmittel, Einstellung und Kündigung von Gewerbeschullehrern sowie Unterrichtsfragen und Fortbildung

$1900-1904$

Klassifikation Teil B: 02160

Band: 3

Trägermaterial: Papier

Alte Reg.-Sig.: IV T7 02

Bestell-Nr.: IV 02160

2337 Vorstand der Gewerbeschule Emden, Bd. 4

- Protokolle der Vorstandssitzungen über Etatfragen, Anschaffung von Lehrmittel, Einstellung und Kündigung von Gewerbeschullehrern sowie Unterrichtsfragen und Fortbildung

$1905-1908$

Klassifikation Teil B: 02161

Band: 4

Trägermaterial: Papier

Alte Reg.-Sig.: IV T7 02

Bestell-Nr.: IV 02161

2338 Bibliothek der Gewerbeschule

- Ordnung der Bibliothek der Gewerbeschule

1872

Klassifikation Teil B: 02162

Trägermaterial: Papier

Alte Reg.-Sig.: IV T7 05

Bestell-Nr.: IV 02162 
05

\subsection{3}

05.03.12

05.03.12.03

05.03.12.03.01

05.03.12.03.01.06
Stadtverwaltung

Aufgabenbereiche der Stadtverwaltung

Handels- und Gewerbeförderung

Förderung von Handel und Industrie

Förderung von Handel und Verkehr

Bildungseinrichtungen für Handel und Gewerbe

Lfd. Nr. Titel

Laufzeit

2339 Gewerbeschule: Schulversäumnisse und Unterrichtsbefreiungen

1915-1918

- Anträge der Nordseewerke auf Befreiumg ihrer Lehrlinge vom

Gewerbeschulunterricht wegen Einsatz für kriegswirtschaftliche

Aufträge, April 1915 - April 1916

- Aufstellung über aus kriegswirtschaftlichen Gründen vom

Gewerbeschulunterricht befreite Lehrlinge, April - September 1915

- Erlass des Ministers für Handel und Gewerbe und des

Kriegsministers über Kriterien für die Unterrichtsbefreiung von

Gewerbeschülern, September 1915 / Januar 1916

- Antrag der Nordseewerke auf Befreiung von Schulgeldzahlungen für ihre vom Gewerbeschulunterricht dispensierten Lehrlinge und jugendlichen Arbeiter, Oktober 1915

- Verfügung des Magistrats an die Nordseewerke über Pflicht ihrer

Lehrlinge zur Teilnahme an den Gewerbeschulunterricht und

militärischen Übungen, Januar 1918

$1915-1918$

Klassifikation Teil B: 02163

Trägermaterial: Papier

Alte Reg.-Sig.: IV T7 05

Bestell-Nr.: IV 02163

2340 Einrichtung technischer Lehranstalten

1868-1897

- Material zu Baugewerbeschulen in der Provinz Hannover, 1868 -

1876

- Vom Regierungspräsidenten in Aurich angeordnete Datensammlung

zu Baugewerbeschulen, Mai - Juni 1881

- Presseberichte über Baugewerbeschulen, 1896 - 1897

- Antrag des Handwerkervereins Emden auf Einrichtung einer

Baugewerbeschule, Januar - März 1892 / November 1896 - März

1897

- Berichte des Magistrats an den Regierungspräsidenten in Aurich

über Notwendigkeit einer Baugewerbeschule, Juli 1895 - Dezember 1896

$1868-1897$

Klassifikation Teil B: 02164

Trägermaterial: Papier

Alte Reg.-Sig.: IV T7 08

Bestell-Nr.: IV 02164 
05

05.03

05.03.12

05.03.12.03

05.03.12.03.01

05.03.12.03.01.06
Stadtverwaltung

Aufgabenbereiche der Stadtverwaltung

Handels- und Gewerbeförderung

Förderung von Handel und Industrie

Förderung von Handel und Verkehr

Bildungseinrichtungen für Handel und Gewerbe

Lfd. Nr. Titel

Laufzeit

2341 Ausbildung der Handelslehrlinge, Bd. 1

$1864-1890$

Antrag der Kaufmännischen Deputation an den Magistrat auf Einrichtung einer Handelsschule zur Hebung der Ausbildung der Handelslehrlinge, Dezember 1864 - Januar 1865 / August 1865 / Mai 1867

- Entwurf der Kaufmännischen Deputation über Statut einer Handelsschule, August 1865 - Mai 1867

- Einwände der Handelskammer gegen ein vom Magistrat vorgelegtes Statut einer Emder Handelsschule, Januar - Februar 1868

- Nominierung von Mitgliedern der Handelskammer für den Vorstand der Handelsschule, Februar 1888

- Rückständige Schulgeldzahlungen von Schülern der Handelsschule, Oktober 1868 - Mai 1890

- Versöße gegen die Handelsschulpflicht, Oktober 1868 - Januar 1869

- Antrag des Vorstands der Handelsschule an den Magistrat auf eine

Beihilfe für den Schulbetrieb, Oktober 1880 - April 1890

- Boykott des Unterrichts durch Handelsschüler wegen durch die Mitbenutzung der Schulräume der Handelsschule durch Volksschüler eingeschlepptes Ungeziefer, November - Dezember 1882

- Sachbeschädigungen durch Handelsschüler, Dezember 1882 Januar 1883

- Antisemitische Äußerungen und Tätlichkeiten gegen die jüdischen Handelsschüler Isaac und Simon de Beer, Februar - März 1885

$1864-1890$

Klassifikation Teil B: 02165

Band: 1

Trägermaterial: Papier

Alte Reg.-Sig.: IV T7 07

Bestell-Nr.: IV 02165 
05

\subsection{3}

05.03.12

05.03.12.03

05.03.12.03.01

05.03.12.03.01.06
Stadtverwaltung

Aufgabenbereiche der Stadtverwaltung

Handels- und Gewerbeförderung

Förderung von Handel und Industrie

Förderung von Handel und Verkehr

Bildungseinrichtungen für Handel und Gewerbe

Lfd. Nr. Titel

Laufzeit

2342 Ausbildung der Handelslehrlinge, Bd. 2

- Festlegung des Etats der Handelsschule, 1891 - 1912

- Rückständige Schulgeldzahlungen von Handelsschülern, 1891

- Anträge auf Erlass von Schulgeldzahlungen, 1891

- Anträge des Vorstands der Handelsschule auf an den Magistrat auf

Gewährung einer Beihilfe zum Schulbetrieb, Februar 1892 - Februar

1906

- Erlass des Ministers für Handel und Gewerbe über Mängel im

Lehrplan der Handelsschule und deren Beseitigung, Oktober -

Dezember 1892

- Beihilfe der Stadt Emden an die Handelsschule zur Einrichtung einer Schulbibliothek, Mai - Dezember 1892

- Antrag des Vorstandes der Handelsschule auf Ausdehnung der Handelsschulpflicht wegen sinkender Schülerzahlen und

zurückgehender Schulgeldeinnahmen, Mai 1894

- Presseartikel zum Handelsschulwesen, 1895 - 1897

- Gewährung einer Staatsbeihilfe zum Betrieb der Handelsschule,

März 1897 - November 1903

- Übersicht über kaufmännische Unterrichtsanstalten in Preußen, 1898

- Stundenplan der Handelsschule, (1889) 1895 - 1900

- Statistik über Organisation und Unterricht der Handelsschule, 1901 1912

- Planzeichnung des Handelsschulgebäudes in der alten Kaserne am Burggraben, 1906

- Erweiterung der Handelsschule unter Einbeziehung von Räumen der Höheren Töchterschule, 1906

- Erlass des Ministers für Handel und Gewerbe über fremdsprachlichen Unterricht an der Handelsschule, November 1906 - Antrag des Vorstands der Handelsschule beim Magistrat auf Mittel zur Anschaffung von Schreibmaschinen für Unterrichtszwecke,

Dezember 1906

- Materialien über Vereine für gewerbliche Ausbildung, 1909 - 1910

- Erlass des Ministers für Handel und Gewerbe über Regelung der Aufsicht über die Handelsschule in kommunaler Trägerschaft, April 1910

- Eingabe des Deutschnationalen Handlungsgehilfenverbandes an den Magistrat über Bitte um Nichteinrichtung einer

Handelsschulklasse für weibliche Lehrlinge und Gehilfinnen, Mai 1913

- Anzeigen gegen Emder Kaufleute wegen Nichtanmeldung ihrer weiblichen Lehrlinge zur Handelsschule, Juli 1913

$1891-1913$

Klassifikation Teil B: 02166

Band: 2

Trägermaterial: Papier

Alte Reg.-Sig.: IV T7 07

Bestell-Nr.: IV 02166
1864-1880 
05

05.03

05.03.12

05.03.12.03

05.03.12.03.01

05.03.12.03.01.06
Stadtverwaltung

Aufgabenbereiche der Stadtverwaltung

Handels- und Gewerbeförderung

Förderung von Handel und Industrie

Förderung von Handel und Verkehr

Bildungseinrichtungen für Handel und Gewerbe

Lfd. Nr. Titel

Laufzeit

2343 Ortsstatut für die Handels- und Gewerbeschule

1869-1914

- Einführung der Gewerbeschulpflicht in der Provinz Hannover, 1869

- Statuten der Gewerbeschule in Emden, Oktober 1869 / Januar 1892

/ September 1914

- Verstöße gegen die Gewerbeschulpflicht und Handelsschulpflicht, 1890

- Anpassung der Statuten der Gewerbeschule an die novellierte

Reichsgewerbeordnung, August - Oktober 1891

- Ausdehnung der Gewerbeschulpflicht auf Lehrlinge und Gehilfen bis zum vollendeten 18. Lebensjahr, Oktober - November 1891

- Monita des Bezirksausschusses gegen die Neufassung des Statuts der Emder Gewerbeschule, Dezember 1891

- Handelsschulpflicht für Lehrlinge und Gehilfen im Handelsbereich, Juni 1891 - Februar 1892

- Gutachten des dirigierenden Handelsschullehrer Enkelstroth über Ausdehnung der Handelsschulpflicht bis zum 18. Lebensjahr, November 1891

- Ortsstatut der Handelsschule in Emden, Februar 1892 - Januar 1893

- Ausdehnung der Handelsschulpflicht auf weibliche Gehilfinnen und

Lehrmädchen, September 1912

- Ausdehnung der Gewerbeschulpflicht auf Arbeiterinnen unter 18

Jahren, Juni 1914

$1869-1914$

Klassifikation Teil B: 02167

Trägermaterial: Papier

Alte Reg.-Sig.: IV T7 10

Bestell-Nr.: IV 02167 
05

\subsection{3}

05.03.12

05.03.12.03

05.03.12.03.01

05.03.12.03.01.06
Stadtverwaltung

Aufgabenbereiche der Stadtverwaltung

Handels- und Gewerbeförderung

Förderung von Handel und Industrie

Förderung von Handel und Verkehr

Bildungseinrichtungen für Handel und Gewerbe

Lfd. Nr. Titel

Laufzeit

2344 Teilnahme von Gewerbeschullehrer an Fortbildungsveranstaltungen

1904-1914

- Teilnahme von Gewerbeschullehrern an Zeichenkursen u.a. in Hannover, 1904 - 1914

- Ankündigung von Fortbildungskursen im Zeichen, 1905 - 1906

- Teilnahme des Handelsschullehrers Theodor Behrends am

Oberkurs für Handelsschullehrer in Berlin, März - April 1906

- Teilnahme des Lehrers Rösing am Unterkurs für Handelsschullehrer, August - Oktober 1906

- Vom Leeraner Stadtbaumeister Jipp an Anweisung der Regierung in

Aurich durchgeführte Revision der Gewerbeschule in Emden mit

Beurteilung der Leistungen der Zeichenlehrer zur Feststellung des

Fortbildungsbedarfs, Februar 1908

- Teilnahme des Lehrers Ohling an einen Unterkurs für

Gewerbeschullehrer in Berlin, Oktober 1908 - Februar 1909

- Erlasss des Ministers für Handel und Gewerbe über Eröffnung neuer

Gewerbeschulen nur bei genügender Anzahl von qualifizierten

Lehrern, Januar 1910

- Delegierung des Gewerbelehrers und Malermeisters H. Susemiehl zur Malerausstellung "Bemalte Räume" in Hamburg zur Aufnahme neuer Trends, Juli - August 1911

$1904-1914$

Klassifikation Teil B: 02168

Trägermaterial: Papier

Alte Reg.-Sig.: IV T7 22

Bestell-Nr.: IV 02168

2345 Handfertigkeits- und Werkunterricht

$1887-1914$

- Angebote von Fortbildungskursen für Lehrer im Fach Handfertigkeit und Werken, 1897 - 1913

- Teilnahme von Lehrern an den Fortbildungskursen für

Handfertigkeit, 1897

- Initiative des Deutschen Vereins für Knabenhandarbeit zur

Einführung von Handfertigkeitsunterricht an Volks- und

Gewerbeschulen, 1897

- Denkschrift des Deutschen Vereins für Knabenhandarbeit über

"erziehliche Knabenhandarbeit" in Volks- und Gewerbeschulen, 1904

- Statistik über Handfertigkeitsunterricht in Emder Schulen, Januar

1907

- Antrag des Lehrers D. Ihmels, Mitglied des Vereins für Handfertigkeit und Hausfleiß, auf Beihilfe zur Beschaffung einer Hobelbank für die vom Verein organisierten Handfertigkeitsunterrichtskurse, September 1912

$1897-1912$

Klassifikation Teil B: 02169

Trägermaterial: Papier

Alte Reg.-Sig.: IV T7 12

Bestell-Nr.: IV 02169 
05

\subsection{3}

05.03.12

05.03.12.03

05.03.12.03.01

05.03.12.03.01.06
Stadtverwaltung

Aufgabenbereiche der Stadtverwaltung

Handels- und Gewerbeförderung

Förderung von Handel und Industrie

Förderung von Handel und Verkehr

Bildungseinrichtungen für Handel und Gewerbe

Lfd. Nr. Titel

Laufzeit

2346 Beihilfen für die Gewerbeschule, Bd. 1

1874-1914

- Erlass des Ministers der geistlichen, Unterrichts- und

Medizinalangelegenheiten über Kriterien für die Gewährung von

Staatsbeihilfen zum Betrieb von Gewerbeschulen, Juni 1874

- Monita des des Ministers der geistlichen, Unterrichts- und

Medizinalangelegenheiten zum Lehrplan der Emder Gewerbeschule,

März 1881

- Beihilfe der Ostfriesischen Landschaft für die Emder

Gewerbeschule, Juli 1885 - Juni 1886

- Monita des Ministers für Handel und Gewerbe zur Organisation der

Gewerbeschule, Juni 1889 - April 1890

- Statistik der Gewerbeschule, 1889

- Erlass des Ministers für Handel und Gewerbe über Kriterien für die

Gewährung von Staatsbeihilfen zum Betrieb von Gewerbeschulen,

März 1891 - Dezember 1914

- Vordrucke der Anträge auf Staatsbeihilfe, 1894

- Verfügungen des Regierungspräsidenten in Aurich über Form der Anträge auf Beihilfe, Daten und Fristen der Antragsstellung, 1892 1908

$1874-1914$

Klassifikation Teil B: 02170

Band: 1

Trägermaterial: Papier

Alte Reg.-Sig.: IV T7 14

Bestell-Nr.: IV 02170

2347 Beihilfen für die Gewerbeschule, Bd. 2

$1880-1911$

- Beihilfe der Ostfriesischen Landschaft für die Emder

Gewerbeschule, 1880 - 1884

- Anträge der Gewerbeschule an den Minister für Handel und

Gewerbe durch die Hand des Magistrats und des

Regierungspräsidenten auf Gewährung von Staatsbeihilfe, 1881 -

1911

- Erlass des Ministers für Handel und Gewerbe über Anordnung der

Einrichtung einer fünften Zeichenklasse an der Gewerbeschule alsd Bedingung für eine Staatsbeihilfe, Oktober 1881

- Auszahlung der Staatsbeihilfe an die Gewerbeschule, 1882 - 1906

- Quittung des Magistrats über Empfang der Staatsbeihilfe und

Weiterleitung an den Vorstand der Gewerbeschule, 1882 - 1895

- Verfügungen des Regierungspräsidenten in Aurich über Form der Anträge auf Beihilfe, Daten und Fristen der Antragsstellung, 1882 1907

$1874-1914$

Klassifikation Teil B: 02171

Band: 2

Trägermaterial: Papier

Alte Reg.-Sig.: IV T7 14

Bestell-Nr.: IV 02171 
05

\subsection{3}

05.03.12

05.03.12.03

05.03.12.03.01

05.03.12.03.01.06
Stadtverwaltung

Aufgabenbereiche der Stadtverwaltung

Handels- und Gewerbeförderung

Förderung von Handel und Industrie

Förderung von Handel und Verkehr

Bildungseinrichtungen für Handel und Gewerbe

Lfd. Nr. Titel

Laufzeit

2348 Beihilfen für die Gewerbeschule, Bd. 3

1912-1918

(1919)

- Erlass des Ministers für Handel und Gewerbe über Form der Anträge auf Gewährung von Staatsbeihilfen zum Betrieb von Gewerbeschulen, April 1912 - April 1914

- Verfügungen des Regierungspräsidenten in Aurich über Form der Anträge auf Beihilfe, Daten und Fristen der Antragsstellung, 1912 1918

- Anträge der Gewerbeschule an den Minister für Handel und Gewerbe durch die Hand des Magistrats und des

Regierungspräsidenten auf Gewährung von Staatsbeihilfe, 1912 -

1914

- Auszahlung der Staatsbeihilfe an die Gewerbeschule, 1912

- Schreiben der Handelskammer über zuzhohe Belastung ihrer Mitgliedsbetriebe durch Schulgeld für Lehrlinge in der Gewerbeschule und Plädierung für eine höhere Staatsbeihilfe, Juli 1912

1912 - 1918 (1919)

Klassifikation Teil B: 02172

Band: 3

Trägermaterial: Papier

Alte Reg.-Sig.: IV T7 14

Bestell-Nr.: IV 02172

2349 Private Gewerbeschule

$1892-1894$

- Projekt des Malermeisters Marten Peters über eine private gewerbliche Lehranstalt für Maler, Bauhandwerker und Maschinisten, 1892

- Protest des reformierten Kirchenrates gegen die parallel zum

Gottesdienst einberaumten Unterrichtszeiten der "gewerblichen Fortbildungsschule" am Sonntag, März 1893

- Lehrplan und Stundenplan der gewerbliche Lehranstalt für Maler,

Bauhandwerker und Maschinisten, April 1893

- Finanzierung einer Freistelle an der gewerbliche Lehranstalt für Maler, Bauhandwerker und Maschinisten für mittellose Lehrlinge durch die Stadt Emden, April - August 1893

$1892-1894$

Klassifikation Teil B: 02173

Trägermaterial: Papier

Alte Reg.-Sig.: IV T7 16

Bestell-Nr.: IV 02173 


\section{5}

05.03

05.03.12

05.03.12.03

05.03.12.03.01

05.03.12.03.01.06
Stadtverwaltung

Aufgabenbereiche der Stadtverwaltung

Handels- und Gewerbeförderung

Förderung von Handel und Industrie

Förderung von Handel und Verkehr

Bildungseinrichtungen für Handel und Gewerbe

Lfd. Nr. Titel

Laufzeit

2350 Zeichenunterricht an der Gewerbeschule

1897-1914

- Erlass des Ministers für Handel und Gewerbe, Verfügungen des Oberpräsident der Provinz Hannover und Regierungspräsidenten in Aurich über Kriterien der Beaufsichtigung des Zeichenunterrichts an Gewerbeschulen, Januar 1897 - März 1913

- Besichtigung des Zeichenunterrichts der Emder Gewerbeschule, 1887 - 1914

- Anordnung einer Revision des Zeichenunterrichts an der Emder Gewerbeschule durch den Regierungspräsidenten in Aurich, Januar 1909

$1897-1914$

Klassifikation Teil B: 02174

Trägermaterial: Papier

Alte Reg.-Sig.: IV T7 17

Bestell-Nr.: IV 02174

2351 Tagesfachklassen für Bauhandwerker

1898-1900

(1921)

- Verhandlungen zwischen dem Magistrat und dem

Regierungspräsidenten in Aurich wegen Einrichtung einer

Tagesfachklasse für Bauhandwerker zur Hebung des

Ausbildungsstandes, Juni 1898 - Januar 1900

- Eingabe des Handwerkervereins Emden an den Magistrat über Bitte um Zahlung eines ausreichenden Gehaltes an den Leiter der geplanten Tagesfachklasse für das Bauhandwerk zur Vermeidung von Nebentätigkeiten, August 1898

- Erlass des Ministers für Handel und Gewerbe über Genehmigung der Tagesfachklasse für das Bauhandwerk in Emden, August 1898 - Konzipierung eines Lehrplanes für die Tagesfachklasse für das Bauhandwerk, September 1898 - Mai 1899

- Bewerbung des Baugewerksführers und Architekten Claus Busse um die Stelle des Leiters der Tagesfachklasse für das Bauhandwerk in Emden, Februar - September 1899

- Haushaltsplan der Tagesfachklasse für das Bauhandwerk, 1899

- Auseinandersetzung um die Mietforderungen des Unternehmers Kappelhoff gegen den als Leiter der Tagesfachklasse für das Bauhandwerk vorgesehenen Claus Busse nach dem Scheitern des Projektes, Oktober 1899 - April 1900

- Erlass des Ministers für Handel und Gewerbe über Datenerhebung zur Notwendigkeit der Errichtung von Tagesfachklassen für das Bauhandwerk, Juni 1900

$1898-1900(1921)$

Klassifikation Teil B: 02175

Trägermaterial: Papier

Alte Reg.-Sig.: IV T7 18

Bestell-Nr.: IV 02175 
05

\subsection{3}

05.03.12

05.03.12.03

05.03.12.03.01

05.03.12.03.01.06
Stadtverwaltung

Aufgabenbereiche der Stadtverwaltung

Handels- und Gewerbeförderung

Förderung von Handel und Industrie

Förderung von Handel und Verkehr

Bildungseinrichtungen für Handel und Gewerbe

Lfd. Nr. Titel

Laufzeit

2352 Lehrer der Gewerbeschule

- Kündigungsschreiben von Gewerbeschullehrern, 1895 - 1908

- Bewerbung des Klassenlehrers Theodor H. M. Behrens um eine neue Lehrerstelle an der Gewerbeschule, März - April 1899

- Einstellung des Malermeisters Heinrich Susemihl als Zeichenlehrer an der Gewerbeschule, April 1902

- Einstellung von Zeichenlehrern, 1908 - 1913

- Entlassungsgesuch des Gewerbeschuldirektors Müller, September -

Oktober 1905

- Bewilligung von Mitteln für Dienstreisen des Gewerbeschuldirektors Müller, 1907

- Zeugnis für den Gewerbeschullehrer Behrens wegen seiner auswärtigen Bewerbung, Januar 1910

- Urlaubsbewilligungen für Gewerbeschullehrer, 1911

- Vergütung von Vertretungslehrerdiensten, 1917

$1895-1917$

Klassifikation Teil B: 02176

Trägermaterial: Papier

Alte Reg.-Sig.: IV T7 23

Bestell-Nr.: IV 02176

2353 Schuldiener der Gewerbeschule und der Handelsschule

$1880-1918$

(1919-1926)

- Einstellung des Maurergesellen Ignatz Joseph Marschall zum

Schuldiener der Gewerbeschule und der Handelsschule, April 1888

- Dienstanweisung für den Schuldiener der Gewerbeschule und der

Handelsschule, Mai 1888 / Mai 1912 / Mai 1918

- Gewährung einer Gehaltserhöhung für den Schuldiener Marschall, Mai 1906 / November 1911

- Ausschreibung der Schuldienerstelle nach dem Tode des

Schuldieners Marschall, April - Mai 1912

- Einstellung des Maurers Hieronymus Schölzchen zum Schuldiener der Gewerbeschule und der Handelsschule, August 1912

- Beurlaubung des Schuldieners Schölzchen wegen Aufenthalt in einem Lungensanatorium, Oktober 1916

- Bewerbung um das amt eines Schulwärters (Schuldieners) an der

Gewerbe- und Handelsschule, 1918

1888 - $1918(1919-1926)$

Klassifikation Teil B: 02177

Trägermaterial: Papier

Alte Reg.-Sig.: IV T7 23

Bestell-Nr.: IV 02177 


\section{IV}

05

05.03

05.03.12

05.03.12.03

05.03.12.03.01

05.03.12.03.01.06
Stadtverwaltung

Aufgabenbereiche der Stadtverwaltung

Handels- und Gewerbeförderung

Förderung von Handel und Industrie

Förderung von Handel und Verkehr

Bildungseinrichtungen für Handel und Gewerbe

Lfd. Nr. Titel

Laufzeit

2354 Lehrplan der Gewerbeschule

1897-1917

- Erlass des Ministers für Handel und Gewerbe über Richtlinien für die Lehrpläne der Gewerbeschule, 1897 - 1917

- Lehrplan der Gewerbeschule Emden, 1911

$1897-1917$

Klassifikation Teil B: 02178

Trägermaterial: Papier

Alte Reg.-Sig.: IV T7 28

Bestell-Nr.: IV 02178

2355 Gewerbeschulpflicht für jugendliche Arbeiter

1908-1916

- Berichtsanforderung des Regierungspräsidenten in Aurich über

Folgen der Ausdehnung der Gewerbeschulpflicht auf jugendliche

Arbeiter für die Emder Gewerbeschule, Juli 1908 / März 1910

- Aufstellung über jugendliche Arbeiter in Emden, 1908 / 1913

- Bericht des Magistrats an den Regierungspräsidenten über

Notwendigkeit der Einrichtung zweier zusätzlicher Klassen in der

Gewerbeschule bei Ausdehnung der Gewerbeschulpflicht, September

1908 / Dezember 1910

- Bericht des Magistrats an den Regierungspräsidenten über

Nichtnotwendigkeit der Ausdehnung der Gewerbeschulpflicht,

November 1908 / September 1912

- Erlass des Ministers für Handel und Gewerbe über Ausdehnung der

Gewerbeschulpflicht auf die jugendlichen Arbeiter beiderlei

Geschlechts, Februar 1910

- Denkschrift des Gewerbeschuldirektors Müller über Auswirkungen der Ausdehnung der Gewerbeschulpflicht auf den Schulbetrieb, Juli 1913

- Stellungnahme von Arbeitgebern jugendlicher Arbeiter, November 1913 - März 1914

$1908-1916$

Klassifikation Teil B: 02179

Trägermaterial: Papier

Alte Reg.-Sig.: IV T7 29

Bestell-Nr.: IV 02179

2356 Ostfriesischer Fortbildungsverein

1913-1917

(1922-1928)

- Unterstützung des Ostfriesischen Fortbildungsverein durch die Stadt

Emden, April - Mai 1913

- Mitgliedschaft der Stadt Emden im Ostfriesischen

Fortbildungsverein, 1913 - 1916

- Jahresbericht des Ostfriesischen Fortbildungsvereins, 1917

1913 - 1917 (1922 - 1928)

Klassifikation Teil B: 02180

Trägermaterial: Papier

Alte Reg.-Sig.: IV T7 31

Bestell-Nr.: IV 02180 
IV

05

05.03

05.03.12

05.03.12.03

05.03.12.03.01

05.03.12.03.01.06
Stadtverwaltung

Aufgabenbereiche der Stadtverwaltung

Handels- und Gewerbeförderung

Förderung von Handel und Industrie

Förderung von Handel und Verkehr

Bildungseinrichtungen für Handel und Gewerbe

Lfd. Nr. Titel

Laufzeit

2357 Praktischer Unterricht für Fleischerlehrling

- Antrag der Fleischerinnung Emden auf Erteilung von praktischen

Unterricht für Fleischerlehrlinge auf dem Schlachthof

1912 (1926)

Klassifikation Teil B: 02181

Trägermaterial: Papier

Alte Reg.-Sig.: IV T7 30

Bestell-Nr.: IV 02181

2358 Erhebung des Gewerbeschulbeitrags

- Gesetz zur Erhebung von Beiträgen zur Unterhaltung der Gewerbeschule über Festlegung der Beitragspflicht der Arbeitgeber der Lehrlinge, August 1909 / Juli 1916

- Verhandlungen des Vorstands der Gewerbeschule über Probleme bei der Erhebung des Gewerbeschulbeitrags, Oktober 1911

- Statutenänderung hinsichtlich der Beitragserhebung von den

Arbeitgebern, 1912 - 1918

1909 - 1918 (1922 - 1928)

Klassifikation Teil B: 02182

Trägermaterial: Papier

Alte Reg.-Sig.: IV T7 32

Bestell-Nr.: IV 02182

2359 Vorstand der Gewerbeschule

- Protokolle der Sitzungen des Gewerbeschulvorstandes über Verhandlungen über Organisationsfragen der Gewerbeschule

1908

Klassifikation Teil B: 02183

Trägermaterial: Papier

Alte Reg.-Sig.: IV T7 50

Bestell-Nr.: IV 02183 
IV

05

05.03

05.03.12

05.03.12.03

05.03.12.03.02
Stadtverwaltung

Aufgabenbereiche der Stadtverwaltung

Handels- und Gewerbeförderung

Förderung von Handel und Industrie

Förderung der Industrie

Lfd. Nr. Titel

Laufzeit

2360 Anlage eines Hochofenwerkes, Bd. 1

1905-1906

- Korrespondenz des Oberbürgermeisters Fürbringer mit dem Senator und Kommerzienrat Metger über Plan zur Ansiedlung eines

Hochofenwerkes im Emder Hafengebiet, März 1905

- Verhandlungen des Oberbürgermeisters mit verschiedenen Firmen und Verbandsrepräsentanten wegen Ansiedlung eines

Hochofenwerkes, März - August 1905

- Korrespondenz des Oberbürgermeisters mit der Beratungsfirma

"Hüttentechnisches Büro" in Berlin über Hochofenwerk in Emden, April

1905 - Februar 1906

- Verhandlungen in Emden unter Anwesenheit des wirklichen geheimen Oberregierungsrates Schweckendieck über Veräußerung domänenfiskalischen Landes (Königspolder) zum Bau eines Hochofenwerkes, August 1905

- Verschiedene Planzeichnungen des Diplomingenieurs F. Wiegand aus Siegen mit Kostenvoranschlägen zum Hochofenwerk, 1906

- Korrespondenz zwischen Oberbürgermeister Fürbringer und Paul G.

Roer über Aufbau der Hohenzollernhütte in Emden, März 1906

$1905-1906$

Klassifikation Teil B: 02106

Band: 1

Trägermaterial: Papier

Alte Reg.-Sig.: IV T6 161

Bestell-Nr.: IV 02106 
05

05.03

05.03.12

05.03.12.03

05.03.12.03.02
Stadtverwaltung

Aufgabenbereiche der Stadtverwaltung

Handels- und Gewerbeförderung

Förderung von Handel und Industrie

Förderung der Industrie

Lfd. Nr. Titel

Laufzeit

2361 Anlage eines Hochofenwerkes, Bd. 2

1905-1909

- Angebote verschiedener Firmen zur Lieferung von Material zum Bau eines Hochofenwerkes im Wert von 1.000000 Mark, August 1905 -

Januar 1908

- Zeichnung von Aktien der Hohenzollernhütte auf Anleihebasis durch die Stadt Emden, Januar 1906 - Dezember 1907

- Presseberichte über schwierige Kapitalbeschaffung für die

Hohenzollernhütte in Emden, Februar - März 1906

- Expose: Errichtung eines Hüttenwerkes in Emden unter dem Namen Hohenzollernhütte AG, März 1906

- Gründung der Hohenzollernhütte AG, Juni 1906

- Rentabilitätsberechnung für die in Emden geplante Hochofenanlage, 1906

- Pfändungsbeschluss des Amtsgerichts Emden gegen das Aktienvermögen des Reeders Paul G. Roer, Vorsitzender der Hohenzollernhütte AG wegen Verbindlichkeiten gegenüber der Roer-Linie, Charlottenburg, über 100.000 Mark, September 1907

- Rechtsgutachten des Syndicus Riese über Möglichkeit der Verweigerung einer Auskehrung von 100 im Besitz der Stadt Emden befindlichen Aktien der Hohenzollernhütte AG als Honorar für Paul G. Roer für den Aufbau des Werkes, September 1907

- Verhandlungen des Magistrats mit dem Roer-Gläubigeranwalt Rudolf Metger wegen Auskehrung von 100 Aktien der Hohenzollernhütte,

September 1907 - März 1908

- Genehmigungsverfahren zum Bau der Hochofenanlage, Oktober November 1907

- Angebote zum Kauf von Aktien der Hohenzollernhütte, Juli 1908

- Streit zwischen Paul G. Roer und dem Magistrat wegen ein

Gründungsprämie von 100.000 Mark in Aktien der Hohenzollernhütte, 1906 - 1908

- Antrag der Hohenzollernhütte AG beim Regierungspräsidenten in Aurich auf Senkung der Erbpacht auf das von ihr benutzte

Betriebsgelände, November 1908 - Juni 1909

$1905-1909$

Klassifikation Teil B: 02107

Band: 2

Trägermaterial: Papier

Alte Reg.-Sig.: IV T6 161

Bestell-Nr.: IV 02107 
05

05.03

05.03.12

05.03.12.03

05.03.12.03.02
Stadtverwaltung

Aufgabenbereiche der Stadtverwaltung

Handels- und Gewerbeförderung

Förderung von Handel und Industrie

Förderung der Industrie

Lfd. Nr. Titel

Laufzeit

2362 Anlage eines Hochofenwerkes, Bd. 3

$1910-1911$

- Einsetzung einer städtischen Kommission zur Verhandlung des

Gesuches der Hohenzollernhütte AG um kaufweise Überlassung ihres

in Erbpacht genutzten Betriebsgeländes, November 1910

- Korrespondenz zwischen dem Oberbürgermeister Fürbringer und dem Anwalt der Hohenzollernhütte, Dr. Küstermann, wegen Absicht der Hohenzollernhütte zum Kauf ihres Betriebsgeländes, November 1910 - April 1911

- Schreiben des Magistrats an den Unterstaatssekretär des

Ministeriums der öffentlichen Arbeiten über Befürwortung des

Verkaufs des in Erbpacht genutzten Betriebsgeländes durch die

Hohenzollernhütte wegen Notwendigkeit einer florierenden Industrie in

Emden, April 1911

- Bericht der "Kölnischen Zeitung" über Hauptversammlung der

Aktionäre der Hohenzollernhütte über Erklärung zur Ermäßigung der

Erbpacht für das Betriebsgelände und Beschluss der Beschaffung neuer Kapitalmittel, Juli 1911

- Schreiben der Hohenzollernhütte über Scheitern des

Sanierungskonzeptes durch die Verweigerung der Genehmigung des

Baus eines weiteren Hochofens durch das Roheisensyndicat, Juli

1911

- Schreiben der Hohenzollernhütte über Verweigerung größerer

Roheisenkontingente für einen weiteren Hochofen durch das

Roheisensyndicat, August 1911

$1910-1911$

Klassifikation Teil B: 02108

Band: 2

Trägermaterial: Papier

Alte Reg.-Sig.: IV T6 161

Bestell-Nr.: IV 02108 
05

05.03

05.03.12

05.03.12.03

05.03.12.03.02
Stadtverwaltung

Aufgabenbereiche der Stadtverwaltung

Handels- und Gewerbeförderung

Förderung von Handel und Industrie

Förderung der Industrie

Lfd. Nr. Titel

Laufzeit

2363 Anlage eines Hochofenwerkes, Bd. 4

1908-1911

- Protokoll der Erklärung des Oberbürgermeisters Fürbringer über Nichtbeteiligung an der Gründung der Hohenzollernhütte AG sowie dem Vorgehen der Gläubiger des Paul G. Roer sowie über Nichtvorliegen eines Anlasses für die Beleidigungen des Paul G. Roer, Mai 1908

- Ermittlungen der Staatsanwaltschaft beim Landgericht Berlin gegen den Reeder und Eisenhüttendirektor Paul G. Roer wegen Untreue, Juli 1908

- Schreiben der Anwälte des Oberbürgermeisters Fürbringer über Vorgehen gegen Paul G. Roer, April 1909

- Übernahme der Prozesskosten durch die Stadtkasse, April 1909

- Ablehnung der Einleitung eines Verfahrens wegen Beleidigung gegen Paul G. Roer durch die Staatsanwaltschaft in Osnabrück wegen nicht vorliegender polizeilicher Meldung des Paul G. Roer in

Bentheim, Juli - August 1909

- Festsetzung der Prozesskosten für die Klage des

Oberbürgermeisters Fürbringer gegen Paul G. Roer wegen

Beleidigung, April 1911

- Korrespondenz des Magistrats mit seinen Berliner Anwälten Dr. Paul Krause, Dr. Ernst Beer und Dr. Karl Kiesel über Vorgehen im Prozess gegen Paul G. Roer, April - August 1911

$1908-1911$

Klassifikation Teil B: 02109

Band: 4

Trägermaterial: Papier

Alte Reg.-Sig.: IV T6 161

Bestell-Nr.: IV 02109 
05

05.03

05.03.12

05.03.12.03

05.03.12.03.02

05.03.12.03.02.01
Stadtverwaltung

Aufgabenbereiche der Stadtverwaltung

Handels- und Gewerbeförderung

Förderung von Handel und Industrie

Förderung der Industrie

Fabriken

Lfd. Nr. Titel

Laufzeit

2364 Statistische Berichte über Lage der Industrie in Emden

1881-1909

- Erlass des preußischen Ministers für Handel und Gewerbe und

Verfügungen des preußischen Landdrosten in Aurich, später des

Regierungspräsidenten in Aurich über Gestaltung der statistischen

Berichte zur Lage der Industrie, 1881 - 1909

- Statistische Berichte der Stadt Emden über Lage der Industrie in

Emden, 1881 - 1909

- Verschiedene Geschäftsberichte Emder Firmen (Nordseewerke,

Emder Papierfabrik, Brikettfabrik, Hammerwerk Emden, Städtische

Gaswerke), 1906 - 1909

$1881-1909$

Klassifikation Teil B: 00017

Trägermaterial: Papier

Alte Reg.-Sig.: IV Cd 17

Bestell-Nr.: IV 00017

2365 Statistische Berichte über Lage der Industrie in Emden

$1881-1900$

- Statistische Berichte der Stadt Emden über Lage der Industrie in

Emden, 1881 - 1900

- Verschiedene Geschäftsberichte Emder Firmen (C. Cassens,

Schiffsbauerei und Holzhandlung, Emder Papierfabrik, 1881 - 1900

$1881-1900$

Klassifikation Teil B: 00018

Trägermaterial: Papier

Alte Reg.-Sig.: IV Cd 13

Bestell-Nr.: IV 00018

2366 Statistische Berichte über Lage der Industrie in Emden

- Statistische Berichte der Stadt Emden über Lage der Industrie in Emden, 1900 - 1906

- Verschiedene Geschäftsberichte Emder Firmen (Nordseewerke , Emder Papierfabrik, Cassens-Werft, Emder Maschinenfabrik), 1900 1906

$1900-1906$

Klassifikation Teil B: 00019

Trägermaterial: Papier

Alte Reg.-Sig.: IV Cd 13

Bestell-Nr.: IV 00019 
05

\subsection{3}

05.03.12

05.03.12.03

05.03.12.03.02

05.03.12.03.02.01
Stadtverwaltung

Aufgabenbereiche der Stadtverwaltung

Handels- und Gewerbeförderung

Förderung von Handel und Industrie

Förderung der Industrie

Fabriken

Lfd. Nr. Titel

Laufzeit

2367 Arbeiterstatistik

1903

- Erhebung über in den größeren Betrieben Emdens beschäftigte

Arbeiter, 1903

1903

Klassifikation Teil B: 00020

Trägermaterial: Papier

Bestell-Nr.: IV 00020

2368 Verwaltungsbericht der Stadt Emden

- Statistische Berichte über Tätigkeit der Verwaltung der Stadt Emden, $1905-1906$

- Preisindex

- Statistischer Bericht: Städtisches Bauwesen, 1905

- Schulstatistik

- Statistischer Bericht: Brandversicherung, elektrische Kleinbahn

- Statistische Berichte von städtischen Betrieben (Schlachthaus, Sparund Leihkasse)

- Statistischer Bericht: Emder Gesundheitswesen (Städtisches

Krankenhaus)

- Statistik: Emder Hafenverkehr

$1900-1906$

Klassifikation Teil B: 00294

Trägermaterial: Papier

Alte Reg.-Sig.: IV Cd 13

Bestell-Nr.: IV 00294

- Anregung des Hüttendirektors König zur Höherlegung von Bahnhof, Bahndamm und Eisenbahndrehkreuz zur Beseitigung der Behinderungen für den Verkehr auf der Pewsumer Straße in Richtung des östlichen Hafens, Juli 1910

- Pfändung von Aktien der Hohenzollernhütte auf grund eines

Pfändungsbeschlusses des Amtsgerichts wegen Schuldforderungen gegen Paul G. Roer als Hauptaktionär der Hütte, August 1909 - Mai 1911

- Anspruch des Hüttendirektors König auf 17 Aktien der Hohenzollernhütte, September 1909 - Januar 1910

- Anspruch der Ida Wilhelmine Roer, geb. Bach auf 100 Aktien der Hohenzollernhütte, Juli 1910 - Juli 1911

$1909-1910$

Klassifikation Teil B: 00606

Trägermaterial: Papier

Alte Reg.-Sig.: IV F 6

Bestell-Nr.: IV 00606 
IV

05

05.03

05.03.12

05.03.12.03

05.03.12.03.02

05.03.12.03.02.01

\section{Stadtverwaltung}

Aufgabenbereiche der Stadtverwaltung

Handels- und Gewerbeförderung

Förderung von Handel und Industrie

Förderung der Industrie

Fabriken

Lfd. Nr. Titel

Laufzeit

2370 Industrieansiedlung, Bd. 1

1896-1901

- Korrespondenz des Oberbürgermeisters Fürbringer mit veerschiedenen in- und ausländischen Persönlichkeiten über

Werbung für Industrieansiedlung in Emden, 1896 - 1901

- Gescheiterte Ansiedlung der AG Land und Seekabel in Emden,

August - Dezember 1898

$1896-1901$

Klassifikation Teil B: 02069

Band: 1

Trägermaterial: Papier

Alte Reg.-Sig.: IV T6 131

Bestell-Nr.: IV 02069

2371 Industrieansiedlung, Bd. 2

1902-1912

- Korrespondenz des Oberbürgermeisters Fürbringer mit

(1916)

veerschiedenen in- und ausländischen Persönlichkeiten über

Werbung für Industrieansiedlung in Emden, 1902 - 1912

$1902-1912(1916)$

Klassifikation Teil B: 02070

Band: 2

Trägermaterial: Papier

Alte Reg.-Sig.: IV T6 131

Bestell-Nr.: IV 02070

2372 Industrieansiedlung, Bd. 3

$1896-1899$

- Material zum Dortmunder Hafen als Ausgangspunkt des

Dortmund-Ems-Kanals, 1896

- Korrespondenz des Oberbürgermeisters Fürbringer mit veerschiedenen in- und ausländischen Persönlichkeiten über Werbung für Industrieansiedlung in Emden, 1896 - 1899

- Anzeigenkampagne der Stadt Emden über Angebot von Flächen im

Hafengebiet zur Industrieansiedlung, August - Dezember 1896

$1896-1899$

Klassifikation Teil B: 02071

Band: 3

Trägermaterial: Papier

Alte Reg.-Sig.: IV T6 131

Bestell-Nr.: IV 02071 
05

05.03

05.03.12

05.03.12.03

05.03.12.03.02

05.03.12.03.02.01
Stadtverwaltung

Aufgabenbereiche der Stadtverwaltung

Handels- und Gewerbeförderung

Förderung von Handel und Industrie

Förderung der Industrie

Fabriken

Lfd. Nr. Titel

Laufzeit

2373 Industrieansiedlung, Bd. 4

1906-1907

- Bildung einer städtischen Kommission zur Förderung der Industrieansiedlung, 1906 - 1907

- Verhandlung der Kommission für Förderung industrieller Anlagen am hiesigen Platz über Erwerb weiterer Aktien der Hohenzollernhütte des

Paul G. Roer und der Nordseewerke, Mai 1906

$1906-1907$

Klassifikation Teil B: 02072

Band: 4

Trägermaterial: Papier

Alte Reg.-Sig.: IV T6 131

Bestell-Nr.: IV 02072

2374 Betriebsgelände für die Hohenzollernhütte AG

1906-1910

- Verhandlungen des Beirats für die Hafenerweiterung über

Ansiedlung und Betriebsgelände für die Hohenzollernhütte AG, 1906 -

1910

- Erbpachtsvertrag zwischen der Hohenzollernhütte AG und der preußischen Staatsregierung über Gelände im Hafengebiet für den Hüttenbetrieb, 1907 / 1910

$1906-1910$

Klassifikation Teil B: 02113

Trägermaterial: Papier

Alte Reg.-Sig.: IV T6 161

Bestell-Nr.: IV 02113

2375 Prozesse gegen den Reeder und Direktor Paul G. Roer

1905-1911

- Dokumente zum Prozess der Roer-LInie gegen Paul G. Roer wegen Schuldforderungen, 1905 - 1907

- Dokumente zum Prozess des Oberbürgermeisters Fürbringer gegen

Paul G. Roer wegen Beleidigung und Schadensersatz, 1910 - 1911

$1905-1911$

Klassifikation Teil B: 02115

Trägermaterial: Papier

Alte Reg.-Sig.: IV T6 163

Bestell-Nr.: IV 02115 
IV

05

05.03

05.03.12

05.03.12.03

05.03.12.03.02

05.03.12.03.02.01

\section{Stadtverwaltung}

Aufgabenbereiche der Stadtverwaltung

Handels- und Gewerbeförderung

Förderung von Handel und Industrie

Förderung der Industrie

Fabriken

Lfd. Nr. Titel

Laufzeit

2376 Deutsche Norgine-Gesellschaft, Bd. 1

1905

- Werbung der für den Aufbau einer Fabrik zur Verarbeitung von Tang zur Jodproduktion

1905

Klassifikation Teil B: 02122

Band: 1

Trägermaterial: Papier

Alte Reg.-Sig.: IV T6 169

Bestell-Nr.: IV 02122

2377 Deutsche Norgine-Gesellschaft, Bd. 2

1905-1906

- Werbung für aus Tang gewonnenes Algin, 1905

- Erhebung über wirtschaftlich zu nutzende Tangbestände, 1905

- Werbung des Regierungsrats a.D. Paschke für eine Norgine-Fabrik

in Emden, April 1906

- Bericht des Kommissionärs B. Hosky in Prag über Rentabilität einer französische Norgine-Fabrik, März 1906

$1905-1906$

1905
Klassifikation Teil B: 02123
Band: 2
Trägermaterial: Papier
Alte Reg.-Sig.: IV T6 169
Bestell-Nr.: IV 02123

2378 Mühlen auf dem Wall

- Kappung von Bäumen auf dem Stadtwall zur Erhaltung eines

Windfeldes für die Wallmühlen, (1816 - 1866) 1867 - 1921

- Stiftungsurkunde der Vereinigten Mühlen-Societät zu Emden, 1816

(1816 - 1866) 1866 - 1918 (1919 - 1925)

Klassifikation Teil B: 02191

Trägermaterial: Papier

Alte Reg.-Sig.: IV T9 15

Bestell-Nr.: IV 02191 
IV

05

05.03

05.03.12

05.03.12.03

05.03.12.03.02

05.03.12.03.02.01

Stadtverwaltung

Aufgabenbereiche der Stadtverwaltung

Handels- und Gewerbeförderung

Förderung von Handel und Industrie

Förderung der Industrie

Fabriken

Lfd. Nr. Titel

Laufzeit

2379 Umwandlung der Sägemühle "Zeldenrüst" in eine Kornmühle

1866-1888

- Genehmigungsverfahren zur Umwandlung der Mühle "Zeldenrüst" von einer Sägemühle in eine Kornmühle, April 1866 - Dezember 1867

- Schadensersatzforderung des Müllers F.T. Loning gegen den

Staatsfiskus wegen Schädigung der Mühle "Zeldenrüst" durch den

Bau des Ems-Jade-Kanals, August - Oktober 1888

1866 .- 1888

Klassifikation Teil B: 02192

Trägermaterial: Papier

Alte Reg.-Sig.: IV T9 23

Bestell-Nr.: IV 02192

2380 Ostfriesische Molkereigerätefabrik T. Bartels \& Co

1900-1909

- Genehmigungsverfahren: Errichtung der Ostfriesische

Molkereigerätefabrik T. Bartels \& Co, 1903 - 1911

- Genehmigungsverfahren: Anbau der Fabrik, JUli 1903 - August 1904

/ April 1909

$1900-1909$

Klassifikation Teil B: 02200

Trägermaterial: Papier

Alte Reg.-Sig.: IV T9 40

Bestell-Nr.: IV 02200

2381 Emder Brikettfabrik

1901-1904

- Genehmigungsverfahren zur Errichtung der Emder Brikettfabrik

$1901-1904$

Klassifikation Teil B: 02202

Trägermaterial: Papier

Alte Reg.-Sig.: IV T9 41

Bestell-Nr.: IV 02202 
IV

05

Stadtverwaltung

05.03

05.03.12

Aufgabenbereiche der Stadtverwaltung

05.03.12.03

05.03.12.03.02

05.03.12.03.02.02

Handels- und Gewerbeförderung

Förderung von Handel und Industrie

Förderung der Industrie

Überwachung des produzierenden Gewerbes

Lfd. Nr. Titel

Laufzeit

2382 Arbeiterschutz

1872-1904

- Reichs- und landesgesetzliche Bestimmungen und Verfügungen zum Arbeiterschutz, Jugendarbeitsschutz, Frauenarbeit,

Gesundheitsschutz und Einschränkungen der Kinderarbeit, 1872 -

1904

- Datenerhebung zur Lage der Arbeiterschaft in Preußen, 1874

- Statistik der Arbeiterinnen und jugendlichen Arbeiter in Emden, 1874

- Ermittlungen über Arbeitszeiten der Bäckerlehrlinge in Emden, März

1892

- Änderung des Reichsgesetzes über Kontrolle der Arbeitsbücher, 1893

- Revisionen der Betriebe mit Beschäftigung von Frauen und jugendlichen Arbeiter, Februar - März 1893

- Verzeichnis der Emder Betriebe mit jugendlichen Arbeitern und

Arbeiterinnen, Dezember 1894

- Umsetzung eines Erlasses des Innenministers über

Arbeitszeitrahmen im Bäckergewerbe, Februar - März 1895

- Prüfung der Umsetzung der Arbeiterschutzbestimmungen im

Ziegeleigewerbe, Mai - Oktober 1898

- Besichtigung der Emdener Papierfabrik durch den

Gewerbeinspektor, Januar 1896

- Erhebung über Gewerbebetriebe mit Dampfkesseln, März 1897

- Erhebung über eingesetzte Kraftmaschinen und Motoren in Emder

Gewerbebetrieben, Mai 1898 / Dezember 1900 - Januar 1901

- Erhebung über gewerbliche Tätigkeit von Schulkindern in Emden,

1899

- Polizeiverordnung der Stadt Emden über Regelung der

Beschäftigung von Schulkindern im Gewerbe, Februar 1900

$1872-1904$

Klassifikation Teil B: 02190

Trägermaterial: Papier

Alte Reg.-Sig.: IV T12 07

Bestell-Nr.: IV 02190 
IV

05

Stadtverwaltung

05.03

05.03.12

Aufgabenbereiche der Stadtverwaltung

05.03.12.03

05.03.12.03.02

Handels- und Gewerbeförderung

Förderung von Handel und Industrie

Förderung der Industrie

05.03.12.03.02.02

Überwachung des produzierenden Gewerbes

Lfd. Nr. Titel

Laufzeit

2383 Arbeiterentlassungen größerer Betriebe

1875-1909

- Bericht des Bürgermeisters Fürbringer an den preußischen Landdrosten in Aurich über bevorstehende oder erwartete größere

Entlassungen von Arbeitern, Oktober 1875

- Bericht des Polizeikommissars Lubich über Beschäftigtenstand größerer Emder Betriebe, Januar 1876 / April 1876

- Berichte des Oberbürgermeisters Fürbringer an den preußischen Landdrosten in Aurich über Beschäftigtenstand größerer Emder

Betriebe, Januar 1876 - März 1883

- Aufstellung über Arbeiterzahlen in Emder Betrieben, Oktober 1876 -

März 1883

- Maßnahmen gegen hohe Arbeitslosigkeit in Preußen, 1901 - 1902

- Bericht des Polizeisergeanten Buscher über Entlassung von 300

Arbeitern der Nordseewerke, November 1907

- Resolution des Gewerkschaftskartells Emden über Aufforderung zur

Anbietung von Notstandsarbeiten zur Bekämpfung der durch die

Schließung der Nordseewerke und der Hohenzollernhütte

entstandenen Arbeitslosigkeit, Dezember 1908 - Februar 1909

$1875-1909$

Klassifikation Teil B: 02193

Trägermaterial: Papier

Alte Reg.-Sig.: IV T9 28

Bestell-Nr.: IV 02193 
05

\subsection{3}

05.03.12

05.03.12.03

05.03.12.03.02

05.03.12.03.02.02
Stadtverwaltung

Aufgabenbereiche der Stadtverwaltung

Handels- und Gewerbeförderung

Förderung von Handel und Industrie

Förderung der Industrie

Überwachung des produzierenden Gewerbes

Lfd. Nr. Titel

Laufzeit

2384 Verunreinigung der Binnentiefs durch die Abwässer der Emdener Papierfabrik, Bd. 1

$1872-1884$

- Berichte und Anzeigen über Verunreinigung des Hinter Tiefs durch die Abwässer der Emdener Papierfabrik, Juli 1872 - August 1884

- Stellungnahme der Direktion der Emdener Papierfabrik zu den Verunreinigungen, November 1872

- Erwerb eines Stücklabndes des Emder Gasthauses durch die Emdener Papierfabrik, Dezember 1872 - Juli 1873

- Gutachten des Landphysicus und Medizinalrats Dr. Stöhr über gesundheitsgefährdenden Zustand des Hinter Tiefs durch die Einleitung der Abwässer der Emdener Papierfabrik, September 1873

- Verfügungen des preußischen Landdrosten / Regierungspräsidenten in Aurich über Verbot der weiteren Einlassung von Abwässern der Emdener Papierfabrik in das Hinter Tief, Oktober 1873 - August 1884 - Vermerk des Stadtbaumeisters Wiggers über Auflagen zur Abwasserentsorgung für die Emdener Papierfabrik, Juli 1876 - Revision der Abwasseraufbereitungsanlagen der Emdener Papierfabrik, JUli 1876

- Verhängung einer Geldstrafe gegen den Vorstand der Emdener Papierfabrik wegen Beschäftigung jugendlicher Arbeiter in der Nacht, Dezember 1876

- Berichte des Magistrats an den preußischen Landdrosten in Aurich über Besichtigung der Abwasseraufbereitungsanlage der Emdener Papierfabrik wegen Überprüfung der Umsetzung der Auflagen zur Abwasserreinigung, Januar 1878 - Juli 1880

- Ermittlungen der Baukommission wegen Ursache der Verschmutzung des Hinter Tiefs, August 1880 - Erläuterung des Abwasserproblems der Emdener Papierfabrik auf der Versammlung des Internationalen Vereins gegen die Verunreinigung der Flüsse, 1880

- Beschwerde der Emdener Papierfabrik beim Minister für Handel und Gewerbe gegen das Einleitungsverbot von Abwässer in das Hinter Tief, Januar - Juli 1884

- Plan einer Kläranlage der Emdener Papierfabrik, 1884

- Vorstellung des Magistrats beim Reichskanzler Otto von Bismarck in seiner Eigenschaft als preußischer Minister für Handel und Gewerbe über Bitte um Genehmigung der Einleitung teilweise ungeklärter Abwässer der Emdener Papierfabrik in das Hinter Tief wegen drohender Schließung des Betriebes, September 1884

$1872-1884$

Klassifikation Teil B: 02194

Band: 1

Trägermaterial: Papier

Alte Reg.-Sig.: IV T9 29

Bestell-Nr.: IV 02194 


\section{5}

\subsection{3}

05.03.12

05.03.12.03

05.03.12.03.02

05.03.12.03.02.02

\section{Stadtverwaltung}

Aufgabenbereiche der Stadtverwaltung

Handels- und Gewerbeförderung

Förderung von Handel und Industrie

Förderung der Industrie

Überwachung des produzierenden Gewerbes

Lfd. Nr. Titel

Laufzeit

2385 Verunreinigung der Binnentiefs durch die Abwässer der Emdener Papierfabrik, Bd. 2

1885-1896

- Anzeige und Berichte über Verunreinigung des Hinter Tiefs durch die Abwässer der Emdener Papierfabrik, Februar 1885 - April 1896

- Verhängung einer Geldstrafe von 600 Mark gegen die Direktion der Emdener Papierfabrik wegen Verunreinigung des Hinter Tiefs,

Februar - April 1885

- Analyse der Abwässer der Emdener Papierfabrik durch den Leiter des chemischen Untersuchungsamtes C. Herrmann, Januar 1885 Juli 1886

- Eingabe der von der Emdener Papierfabrik entlassenen Arbeiter an den Magistrat über Bitte um Aufhebung des

Abwassereinleitungsverbotes gegen die Papierfabrik zur

Wiederaufnahme des Betriebes, Januar 1885

- Verfügung des preußischen Landdrosten über Verbot der Einleitung der Abwässer der Emdener Papierfabrik in das Hinter Tief, Februar März 1885

- Ermittlung des geeigneten Verfahrens der Abwässerreinigung bei der Emdener Papierfabrik, Januar - Februar 1885

- Klage der Emdener Papierfabrik gegen die Stadt Emden auf Schadensersatz wegen Verbot der Einleitung von Abwasser in das Hinter Tief, Juni - Oktober 1885

$1885-1896$

Klassifikation Teil B: 02195

Band: 2

Trägermaterial: Papier

Alte Reg.-Sig.: IV T9 29

Bestell-Nr.: IV 02195

2386 Produktion von Zigarren

- Erlasse des Ministers für Handel und Gewerbe über Regulierung des Betriebs von Zigarrenfabriken, März 1886 - Februar 1907

- Bericht des Polizeisergeanten Schnur über Produktionsstätten für

Zigarren in Emden, Msi 1886 / Januar 1889

- Verfügung des Regierungspräsidenten in Aurich über Erlaubnis für die Emder Zigarrenmacher Warner A. Beencken, Andreas Beencken und Hermann $\mathrm{H}$. Janßen zur Weiternutzung ihrer in der Höhe von den Richtlinien des Ministeriaslerlasses abweichenden Räume bei guter Ventilation, Februar 1889 / Dezember 1895

- Aufstellung über Tabaks- und Zigarrenfabriken in Emden, Juli 1903

$1886-1912$

Klassifikation Teil B: 02196

Trägermaterial: Papier

Alte Reg.-Sig.: IV T9 30

Bestell-Nr.: IV 02196 
IV

05

Stadtverwaltung

05.03

05.03.12

Aufgabenbereiche der Stadtverwaltung

05.03.12.03

05.03.12.03.02

Handels- und Gewerbeförderung

Förderung von Handel und Industrie

Förderung der Industrie

05.03.12.03.02.02

Überwachung des produzierenden Gewerbes

Lfd. Nr. Titel

Laufzeit

2387 Herstellung von Bürsten

$1899-1910$

- Gesetzliche Regelung des Betriebs von Rosshaarspinnereien, Haarund Bürstenzurichtereien sowie der Bürsten- und Pinselmachereien, Januar 1899 - Juni 1909

- Bericht des Magistrats an den Regierungspräsidenten in Aurich über Bürsten- und Pinselmachereien in Emden, September 1899 / Januar

1905

- Bericht des Polizeisergeanten Strippelmann über von den

Bürstenmachern angewandtes Herstellungsverfahren von Bürsten aus rohen Tierhaaren, Januar 1900

- Kontrolle der Führung eines für die Bürstenmacher

vorgeschriebenen Materialbuches, Januar 1904

- Erlass des Ministers der geistlichen, Unterrichts- und

Medizinalangelegenheiten über Anordnung einer Pockenimpfung für

Bürstenmacher wegen eines erhöhten Infektionsrisikos, August 1907 /

März 1909

$1899-1910$

Klassifikation Teil B: 02197

Trägermaterial: Papier

Alte Reg.-Sig.: IV T9 31

Bestell-Nr.: IV 02197

2388 Teermagazin-Miete

1874-1879

- Umrechnung der Teermagazin-Miete in die Mark-Währung

- Rückständige Miete für das städtische Teermagazin

$1874-1879$

Klassifikation Teil B: 02198

Trägermaterial: Papier

Alte Reg.-Sig.: IV T9 32

Bestell-Nr.: IV 02198 
05

05.03

05.03.12

05.03.12.03

05.03.12.03.02

05.03.12.03.02.02
Stadtverwaltung

Aufgabenbereiche der Stadtverwaltung

Handels- und Gewerbeförderung

Förderung von Handel und Industrie

Förderung der Industrie

Überwachung des produzierenden Gewerbes

Lfd. Nr. Titel

Laufzeit

2389 Fabriken: Revisionen und Arbeitsordnungen

- Erlasse des Ministers für Handel und Gewerbe über Richtlinien für Arbeitsordnungen, JUni 1892 - Dezember 1910

- Arbeitsordnung der Emdener Papierfabrik, 1892 - 1893

- Arbeitsordnung für die Brikettfabrik Emden, 1906 / 1909

- Arbeitsordnung der Schiffswerft zum Preußischen Adler (C.

Cassens), April 1892

- Arbeitsordnung der Emdener Maschinen Fabrik,1900

- Arbeitsordnung der Druckerei Anton Gerhard, 1900

- Besichtigung Emder Betriebe durch den Gewerbeinspektor mit

Angabe von Mängeln und deren Behebung, Juli 1895 - November 1904

- Arbeitsordnung der Ostfriesischen Molkereigerätefabrik T. Bartels \&

Co., November 1901

- Arbeitsordnung der Maschinenfabrik Ernst Hoeppner \& Co,

Dezember 1901 - Dezember 1906

- Arbeitsordnung der Werft für Eisernen Schiffbau, C. Cassens, 1903 1904

- Arbeitsordnung der Nordseewerke Emder Werft und Dock AG, 1905

- Revision gewerblicher Anlagen durch die Stadt Emden, 1905 - 1906

- Arbeitsordnung der Hohenzollernhütte AG, 1907

$1892-1910$

Klassifikation Teil B: 02199

Trägermaterial: Papier

Alte Reg.-Sig.: IV T9 34

Bestell-Nr.: IV 02199

2390 Sauggasanlagen

$1902-1911$

- Genehmigungsverfahren für Sauggasanlagen, 1903 - 1911

- Gesetzliche Bestimmung wegen Genehmigung von

Sauggasanlagen, 1902 - 1904

$1902-1911$

Klassifikation Teil B: 02201

Trägermaterial: Papier

Alte Reg.-Sig.: IV T9 40

Bestell-Nr.: IV 02201
$1892-1910$ 
Lfd. Nr. Titel

Laufzeit

2391 Von der Stadt Emden erworbene Ölgemälde der Familie Loesing

- Vererbung von Ölgemälden an das Gasthaus durch J.C. Loesing, August 1885

- Verschiedene testamentarische Verfügungen zu den Ölgemälden der Familie Loesing, 1838 - 1862

- Vertrag über Aufbewahrung der Gemälde im Gemäldesaal des

Vereins für bildende Kunst und vaterländische Altertümer, Mai 1894

- Verzeichnis der Gemälde, 1907

$1885-1907$

Klassifikation Teil B: 00026

Trägermaterial: Papier

Bestell-Nr.: IV 00026

2392 Stiftung des Geh. Oberregierungsrat Schweckendieck für ein

- Stiftung eines Geldbetrages durch den Geh. Oberregierungsrat Carl Schweckendieck zur Anschaffung eines bemalten Glasfensters für das Rathaus, Juli 1901

1901

Klassifikation Teil B: 00028

Trägermaterial: Papier

Alte Reg.-Sig.: IV C 09

Bestell-Nr.: IV 00028

2393 Mitteilung von Aktenstücken über Wassergeusen in Emden aus dem belgischen Staatsarchiv

- Verhandlungen der Stadt Emden mit dem belgischen Staatsarchiv in Brüssel und der belgischen Regierung über Erhalt von Informationen aus archivierten Aktenstücken zu Beziehungen zwischen der Stadt Emden und den niederländischen Wassergeusen (Piraten), Februar 1883 - August 1887

- Abschriften von Aktenstücken aus dem belgischen Staatsarchiv Brüssel zu Wassergeusen und Beziehungen der Stadt Emden zum ostfriesischen Fürstenhaus, 1887

$1883-1887$

Klassifikation Teil B: 00304

Trägermaterial: Papier

Alte Reg.-Sig.: II E 61

Bestell-Nr.: IV 00304 
IV

05

Stadtverwaltung

05.03

05.03.13

Aufgabenbereiche der Stadtverwaltung

Kunst- und Kulturpflege

Lfd. Nr. Titel

Laufzeit

2394 Stephansdenkmal

- Entwurf eines Denkmals für den Generalpostmeister Dr. von

Stephan, 1894

- Verhandlungen wegen der Ehrung des Dr. von Stephan durch ein

Ehrenmal wegen seiner Verdienste um die Einbindung Deutschlands

in das Welttelegrafennetz und der Wahl Emdens als Schnittpunkt,

1894

- Vertrag zwischen dem Komitee für das Stephans-Denkmal, vertreten durch Oberbürgermeister Leo Fürbringer, und dem Bildhauer Georg

Küsthardt über Errichtung des Stephansdenkmals, November 1894

- Spendenaufruf des Komitees für das Stephans-Denkmal, Januar

1895

- Eingang von Spenden, 1894 - 1895

- Antrag des Komitees für das Stephans-Denkmals auf Zuweisung

eines Platzes für das Denkmal, November 1895

- Entwurf des Urkundentextes für in den Sockel des geplanten

Denkmals einzulassendes Pergament, 1895

- Feier der Denkmalsenthüllung, April 1896

- Schreibendes Staatssekretärs des Reichspostamtes, v. Stephan, an den Oberbürgermeister Fürbringer über Danksagung für die gelungene Denkmalsenthüllungsfeier und für die Aufmerksamkeit durch das Denkmal, März 1896

- Kostenabrechnung: Denkmalsbau und Enthüllungsfeier, Juni 1896

- Kondolenzschreiben der Stadt Emden zunm Tode des

Staatssekretärs Dr. v. Stephan, April 1897

$1894-1897$

Klassifikation Teil B: 00323

Trägermaterial: Papier

Alte Reg.-Sig.: II E 65

Bestell-Nr.: IV 00323 
05

05.03

05.03.13
Stadtverwaltung

Aufgabenbereiche der Stadtverwaltung

Kunst- und Kulturpflege

Lfd. Nr. Titel

Laufzeit

2395 Denkmäler

1873-1917

- Verfügung des Oberpräsidenten der Provinz Hannover über

Aufstellung eines Katasters über vorchristliche Altertümer, August -

Oktober 1872 / März 1892

- Erlass des Ministers der Geistlichen, Unterrichts- und

Medizinalangelegenheiten über Zuständigkeit der Regierungen für die

Denkmalspflege und Erhaltung der Altertümer, November 1881

- Antrag der Gesellschaft für bildende Kunst und vaterländische

Altertümer an den Magiststrat auf Überprüfung der

Erhaltungswürdigkeit der Deckengemälde in der Klunderburg, August

1888

- Erlasse des Ministers der Geistlichen, Unterrichts- und

Medizinalangelegenheiten über Regelung der Denkmalspflege, Juli

1876 - Januar 1909

- Verfügung des Magistrats über Erhaltung des Uko-Grabmals in der

Gasthauskirche, Juli 1892

- Antrag des Prof. Friedrich Ritter als Schriftführer der Gesellschaft für bildende Kunst und vaterländische Altertümer auf Erhaltung des historischen Giebels des Gasthauses "Goldener Adler" am Delft mit einem "Alba-Kopf" wegen Gefährdung durch Bauarbeiten, Mai 1902 - Bericht über Wirksamkeit der Denkmalspflege in der Provinz Hannover, 1904 - 1913

- Vertrag des Magistrats mit Gladenbeck's Institut für Denkmalspflege wegen Kontrolle und Pflege der städtischen Bronzedenkmäler, Juni 1906

- Erfassung der Baudenkmäler der Stadt Emden in den

"Kunstdenkmälern der Provinz Hannover", Oktober 1907 / März 1908

- Benennung des Apothekers C. Hermann als Emder Mitglied des

Bezirkskomitees für Naturdenkmalspflege, Dezember 1907

- Vortrag des Landeskonservators a.D. Dr. Reimers über Funktion historischer Vereine in der staatlichen Denkmalspflege, Dezember 1907

- Entdeckung eines vorreformatorischen Altartisches auf dem

Nesserlander Friedhof, Dezember 1910 - Februar 1911

- Erlass des Ministers der Geistlichen, Unterrichts- und

Medizianalangelegenheiten über Kriterien der Ablieferung von

Brinzedenkmälern zu Kriegszwecken, Januar 1916

- Bericht des Magistrats über Nichtabgabe der Bronzestatuen der Hohenzollernherrscher im Stadtgarten und der Statue des

Reichspostsekretärs Dr. Stephan wegen enger Verbundenheit mit der Emder Stadtgeschichte, Februar 1916

$1873-1917(1919)$

Klassifikation Teil B: 02233

Trägermaterial: Papier

Alte Reg.-Sig.: IV U 01

Bestell-Nr.: IV 02233 
05

05.03

05.03.13
Stadtverwaltung

Aufgabenbereiche der Stadtverwaltung

Kunst- und Kulturpflege

Lfd. Nr. Titel

Laufzeit

2396 Museen, Sammlungen und Archive

- Erlass des Ministers der Geistlichen, Unterrichts- und Medizinalangelegenheiten über Erfassung der Bestände in Museen und Sammlungen, März 1884

- Aufstellung über historische Sammlungen in der Stadt Emden, April 1884

- Erlass des Ministers der Geistlichen, Unterrichts- und

Medizinalangelegenheiten über Berichterstattung über archäologische Funde zur Verhinderung der Veräußerung von Fundstücken in das Ausland, Februar 1887 / Oktober 1892 / Dezember 1893 / April 1908 - Bericht des Magistrats an den Regierungspräsidenten in Aurich über Kosten der Errichtung eines Museums der Rüstkammer und der städtischen Sammlungen, September 1890

- Fund von zwei Schwertern, einer Kette und acht Schlüssel bei Baggerarbeiten im Emder Hafen, Januar - Mai 1893

- Aufstellung über Sammlungen und Kataloge der Gesellschaft für bildende Kunst und vaterländische Altertümer, 1893

- Erlass des Innenministers über Einreichung von Archivbauplanungen zur Prüfung, März 1900

- Abgabe von Glocken für die Kriegswirtschaft, 1917

$1884-1917$

Klassifikation Teil B: 02234

Trägermaterial: Papier

Alte Reg.-Sig.: IV U 02

Bestell-Nr.: IV 02234

2397 Renaissance-Giebel des früheren Brinkmannschen Hauses, Am Delft 24

- Schreiben des Oberbürgermeisters Fürbringer an den Bremer Dombaumeister Ehrhardt über Bitte um fachmännische Unterstützung der Restaurierung des Renaissance-Giebels des früheren Brinkmannschen Hauses, Februar 1899

- Antrag des Magistrats beim Landesdirektorium der Provinz Hannover auf Beihilfe zur Finanzierung der Restaurierung des Renaissance-Giebels des früheren Brinkmannschen Hauses, Februar 1899 - April 1901

- Verhandlungen des Magistrats mit der Gesellschaft für bildende Kunst und vaterländische Altertümer wegen Beteiligung der Kunst an der Finanzierung der Restaurierung, Februar - Juni 1899- Bericht über die Rettung des Brinkmann'schen Hauses in der Zeitschrift "Die Denkmalspflege", Juni 1899

- Verhandlungen zwischen dem Magistrat und dem Hotelier Johann Albers über Erhalt des Renaissance-Giebels des früheren Brinkmannschen Hauses und Änderung der Umbaupläne seines Hotels "Zum Weißen Haus" gegen eine Unterstützung von 5.000 Mark, April 1899

- Planzeichnung: Renaissance-Fassade des Brinkmann'schen Hauses, 1900

1899 - 1901 (1910) Klassifikation Teil B: 02235

Trägermaterial: Papier Alte Reg.-Sig.: IV U 04

Bestell-Nr.: IV 02235 
05

05.03

05.03.13
Stadtverwaltung

Aufgabenbereiche der Stadtverwaltung

Kunst- und Kulturpflege

Lfd. Nr. Titel

Laufzeit

2398 Konkurrenzen für Bildhauer-Kunst

- Denkschrift der Bildhauer-Vereinigung des Vereins Berliner Künstler und des Künstlerverbandes Deutscher Bildhauer über Richtlinien bei Wettbewerbsausstellungen von Bildhauern, 1904

- Erlass des Ministers der Geistlichen, Unterrichts- und

Medizinalangelegenheiten über Verfahren bei

Wettbewerbsausstellungen von Bildhauern, Juni 1914

$1904-1914$

Klassifikation Teil B: 02236

Trägermaterial: Papier

Alte Reg.-Sig.: IV U 08

Bestell-Nr.: IV 02236

2399 Kaufangebot über Schiffsmodelle des Schiffbauers Friedrich Stark

- Angebot des Schiffsbaumeisters Friedrich Stark über Verkauf von inm gefertigter Modelle des Schiffes des Klaas Störtebeker und des Hanseschiffes "Bunte Kuh" an die Stadt Emden, Januar - März 1908

1908

Klassifikation Teil B: 02237

Trägermaterial: Papier

Alte Reg.-Sig.: IV U 10

Bestell-Nr.: IV 02237 
06.01 Städtisches Vermögen

06.01.01

Lfd. Nr. Titel

Laufzeit

2400 Enteignung von Grundeigentum

- Erlasse des Finanzministers und des Ministers der öffentlichen Arbeiten über Regelung von Enteignungen privater Grundstücke sowie Entschädigung der Besitzer

$1890-1899$

Klassifikation Teil B: 02507

Trägermaterial: Papier

Alte Reg.-Sig.: VIII 2 a 05

Bestell-Nr.: IV 02507

2401 Lagerbuch über städtisches Vermögen

1866

- Regelungen zur Anlage und Führung eines Lagerbuches über Grundbesitz und sonstige Vermögenswerte der Stadt Emden

(1865) 1866

Klassifikation Teil B: 02508

Trägermaterial: Papier

Alte Reg.-Sig.: VIII A1 01

Bestell-Nr.: IV 02508

2402 Grenzgräben zwischen städtischen und privaten Grundstücken

$1881-1909$

- Festlegung der Grenzen städtischer Grundstücke, 1881 - 1910

- Reinigung der Grenzgräben und Streitigkeiten um die Verpflichtung zur Reinigung, 1881 - 1902

- Antrag des Landgebräuchers H. Hooten beim Magistrat auf

Erlaubnis zur Zuschüttung des Grenzgrabens zwischen seinem

Grundstück und einem der Stadt Emden, Dezember 1909

$1881-1910$

Klassifikation Teil B: 02509

Trägermaterial: Papier

Alte Reg.-Sig.: VIII 2 a 03

Bestell-Nr.: IV 02509

2403 Eintragung städtischer Grundstücke in das Grundbuch

$1877-1910$

- Regelung der Eintragung städtischer Grundstücke in das Grundbuch durch das Katasteramt

- Prüfung von Grundbucheintragungen

- Auszüge aus dem Grundbuch zu städtischen Grundstücken

$1877-1906$

Klassifikation Teil B: 02510

Trägermaterial: Papier

Bestell-Nr.: IV 02510 
06.01 Städtisches Vermögen

06.01.01 Städtische Gebäude und Grundstücke

06.01.01.01 Unterhaltung städtischen Eigentums

Lfd. Nr. Titel

Laufzeit

2404 Ausverdingung städtischer Baumaterialien

- Jährliche Ausschreibungen für zur Unterhaltung städtischer

Gebäude und für Bauarbeiten benötigte Materialien

$1871-1912$

Klassifikation Teil B: 02525

Trägermaterial: Papier

Alte Reg.-Sig.: VIII A 2 b 025

Bestell-Nr.: IV 02525

2405 Unterhaltung städtischer Gebäude

- Etat über Aufwendungen zur Bauunterhaltung städtischer

Wohnungen, Gebäude, Kajungen und Entwässerungssystems sowie Straßen

(1857 -1865) 1866 - 1875

Klassifikation Teil B: 02526

Trägermaterial: Papier

Alte Reg.-Sig.: VIII A 2 b 024

Bestell-Nr.: IV 02526

2406 Bauunterhaltung städtischer Wohnungen

- Regelung der Reinigung der Dachrinnen städtischer Wohnhäuser, 1841

- Reparatur städtischer Wohnungen, (1853) 1881

- Brandversicherung städtischer Wohnhäuser, 1902

- Veranlagung städtischer Wohnungen zur Gebäudesteuer, 1903

(1841 - 1853) $1881-1903$

Klassifikation Teil B: 02527

Trägermaterial: Papier

Alte Reg.-Sig.: VIII A 2 b 028

Bestell-Nr.: IV 02527

2407 Ausverdingung von Fuhren für das städtische Bauwesen

- Ausschreibung von Fuhren von Baumaterial zu den Baustellen städtischer Gebäude und Straßen und des Abtransports von Bauschutt

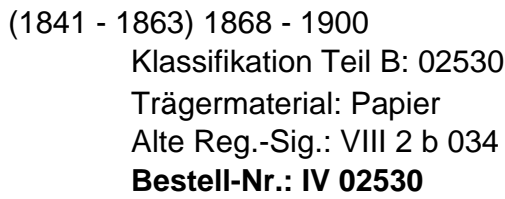


Lfd. Nr. Titel

Laufzeit

2408 Verdingungswesen

- Regelung der Verfahren zur Ausschreibung von Bauleistungen für die Stadt Emden, 1882 - 1908

- Eingabe Emder Maler an den Magistrat über Beschwerde gegen den Gewinner der Ausschreibung der Anstricharbeiten von Brücken, Johann de Jonge, wegen unsachgemäßer Ausführung der Arbeiten, Oktober - November 1884

- Verfügung des Regierungspräsidenten in Aurich über Prüfung von Kalksteinen vor ihrer Verwendung, Dezember 1898

- Verhandlungen auf der Versammlung des Hannoverschen

Städtetages über Organisation des Verdingungswesens, August 1899

- Initiative des Arbeitgeberverbandes Berlin und Umgebung zur

Änderung der Ausschreibungsverfahren für öffentliche Arbeiten, September 1902

- Eingabe der Handwerkskammer Osnabrück-Ostfriesland an den Regierungspräsidenten in Aurich über Bitte um ausschließliche Betrauung von Handwerksmeistern mit öffentlichen Aufträgen, September 1895

- Erlass des Innenministers über Gültigkeit eines neuen Ausschreibungsverfahrens auch für die Gemeinden, März 1906 - Erlass des Innenministers über Regelung der Sicherheitsleistungen bei öffentlichen Aufträgen, November 1907

- Initiative des Deutschen Arbeitgeberbundes für das Baugewerbe zur Modernisierung des Submissionswesens und Einführung einer Streikklausel zur Verlängerung der Auftragsfrist um die Dauer eines Arbeitskampfes, 1909

- Erlass des Innenministers über statistische Erhebung zu

Ausschreibungen öffentlicher Arbeiten, August 1911 - März 1911

- Erlass des Innenministers über Preisgestaltung bei

Ausschreibungsverfahren, November 1912 / Januar 1913

$182-1913$

Klassifikation Teil B: 02548

Trägermaterial: Papier

Alte Reg.-Sig.: VIII a 2 b 064

Bestell-Nr.: IV 02548 
- Bau und Ausbau des Zollamtsgebäudes durch die Stadt Emden für die staatliche Zollverwaltung

$1902-1912$

Klassifikation Teil B: 02472

Trägermaterial: Papier

Alte Reg.-Sig.: St XX 159

Bestell-Nr.: IV 02472

\section{Bauhof der Stadt Emden}

- Pfandsachen auf dem Boden des Bauhofes, 1837 - 1838

- Streit um die Abwässerung der Nachbargrundstücke des Bauhofes über dessen Gelände, April - Mai 1838

- Streit um die Grenze zwischen dem Bauhofsgrundstück und dem Grundstück der Schiffsbauwerft v. Ness, August 1838 - März 1839 - Lagerung von Seetonnen und sonstigem Gerät des kgl. Wasserbauamtes auf dem Bauhof, (1837 - 1859) 1869 - 1879

- Verkauf von Brennholz auf dem Bauhof, 1854 - 1857

- Anfrage des Sanitätsrates Dr. Norden wegen eines Raumes auf dem Bauhof zur Unterstellung seiner Kutsche und seines Pferdes, Juni 1889

- Lagerung von Booten des Kaiser-Friedrich-Realgymnasiums auf dem Bauhof, 1907 - 1909

(1877 - 1889) 1869 - 1909

Klassifikation Teil B: 02512

Trägermaterial: Papier

Alte Reg.-Sig.: VIII A 2 b 015

Bestell-Nr.: IV 02512 
- Renovierung der Gewölbe des Rathauses, 1849

- Reparaturarbeiten an den Schornsteinen und dem Gebäude des

Rathauses, (1853 - 1865) 1866 - 1888

- Organisation des Schließdienstes und der Aufbewahrung der

Schlüssel des Rathauses, Februar 1865

- Antrag des Stockmeisters Diepenbroek beim Magistrat auf Beibehaltung eines separaten Eingang zum Gefängnis im Rathaus, Juli 1867

- Beschädigung des Rathausbogens durch den Transport eines

Dampfkessels vom Bahnhof zur Emder Papierfabrik, September 1872

- Organisation der 300 Jahresfeier der Grundsteinlegung des

Rathauses, Mai - Juni 1874

- Antrag des Polizeikommissars Lubich beim Magistrat auf

Rücknahme der Räumung seiner Wohnung im Rathaus wegen

Wanzenbefall, September 1726

- Verlegung und Veränderung von Büroräumen und Sitzungszimmern, 1874 - 1889

- Antrag des Fotografen Heinrich Schröder auf Genehmigung der Anbringung eines Bilderkastens im Rathausbogen, Juli 1879

- Verbesserung des Brandschutzes im Rathaus, 1884

- Anschaffung von Markisen für das Rathaus, Juni 1885

- Modernisierung der Abortanlage im Rathaus, 1885

- Restaurierung der Innenräume des Rathauses, 1888

- Rattenbefall des Rathauses, 1892

- Anlegung neuer Fußböden im Rathaus, 1895 - 1897

- Anlegung einer neuen Klingelanlage im Rathaus, 1897

(1849 - 1865) 1866 - 1897

Klassifikation Teil B: 02513

Band: 1

Trägermaterial: Papier

Alte Reg.-Sig.: VIII A 2 b 016

Bestell-Nr.: IV 02513 
- Reparaturarbeiten an den Schornsteinen und dem Gebäude des

Rathauses, 1899 - 1912

- Gebäudeversicherung des Rathauses, 1899

- Vergrößerung der Abortanlage des Rathauses, 1900 - 1902

- Verbesserung des Treppenaufgangs zur Rüstkammer, 1900

- Einrichtung einer Werkstatt für den Rüstmeister mit Arbeitszimmer, 1902

- Sicherung des Baupläne des Rathauses vor Brandeinwirkung, 1906

- Herstellung einer Treppenverbindung zwischen Rummel und

Erdgeschoss des Rathauses, 1909

- Instandsetzung der Rüstkammer-Werkstatt und der Räume der alten

Registratur, 1909 - 1910

$1899-1910$

Klassifikation Teil B: 02514

Band: 2

Trägermaterial: Papier

Alte Reg.-Sig.: VIII A 2 b 016

Bestell-Nr.: IV 02514

2413 Büroräume im südlichen Flügel des Rathauses

- Umstrukturierung der Räume im südlichen Flügel des Rathauses wegen Wegzug der Reichsbankfiliale aus dem Rathaus, 1907 - 1909 - Grundriss: Etage der Rüstkammer mit Museum und Registraturen, 1907

- Umbau der Alten Wache beim Rathaus, 1907 - 1908

- Grundriss der Alten Wache, 1908

- Einrichtung der Registratur in den Räumen der weggezogenen

Reichsbank, 1908

- Umwandlung von Türen im Westflügel des Rathauses in Fensrtern, 1908

- Markisen für das Rathaus, 1908

1907 - 1909

Klassifikation Teil B: 02515

Trägermaterial: Papier

Alte Reg.-Sig.: VIII A 2 b 016

Bestell-Nr.: IV 02515

- Umstrukturierung der Räume im nördlichen Flügel des Rathauses wegen Wegzug der Reichsbankfiliale aus dem Rathaus

- Einrichtung der Bibliothek des Oberbürgermeisters

- Vergrößerung und Neueinrichtuing des Büros des

Oberbürgermeisters

1909

Klassifikation Teil B: 02516

Trägermaterial: Papier

Alte Reg.-Sig.: VIII A 2 b 16

Bestell-Nr.: IV 02516 
- Erbauung und Vermietung des städtischen Kommissionshauses und anderer Gebäude auf Nesserland an die Zollbehörde und Bedienstete sowie Schleusenwärter und Lotsen, (1848 - 1865) 1867 1876

- Risszeichnungen der städtischen Miethäuser auf Nesserland, 1849 - Anträge des G. Giesen und des M. Heinholtz an den Magistrat auf Erlaubnis zur Errichtung einer Speiseanstalt mit Getränkebude auf Nesserland zur Versorgung von Deicharbeiter, März 1874

- Verpachtung des Nesserlander Hammrichs und des Hammrichshauses, März 1874 - Oktober 1875

- Antrag des H. Stosch beim Magistrat auf Verlängerung des Mietvertrages für das Hammrichshauses zur Verpflegung der Deicharbeiter, Februar 1875

- Verpachtung des Nesserlander Pfarrhauses und der Armenwarf an den Restaurateur Johann Conrad Suchsland, März 1874

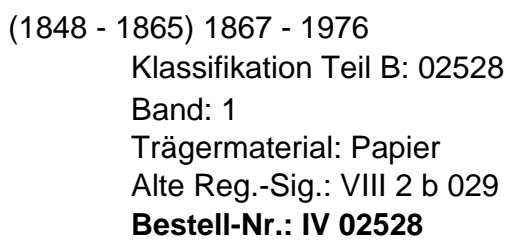

- Pachtvertrag zwischen dem Magistrat und dem Oekonom und Sielrichter Johasnn Conrad Suchsland über Verpachtung von Gebäude und Stallungen auf der Armen- und Kirchwarf von Nesserland, Juni 1878

- Bau eines Hofgebäudes auf der Kirch- und Armenwarf von Nesserland, 1878 - 1901

- Verpachtung des Klingenborg'schen Hauses auf Nesserland an den Oekonom und Schankwirt Johann Conrad Suchsland, 1877 - 1901 - Angebot des Conrad Suchsland über Erwerb der verwertbaren Materialien aus dem Abbruch des Menting'schen Hauses auf Nesserland, Mai - Juni 1895 Klassifikation Teil B: 02529

Band: 2

Trägermaterial: Papier Alte Reg.-Sig.: VIII 2 b 029

Bestell-Nr.: IV 02529 
2417 Vermietung von Räumen im Rathaus an die kgl. Polizei-Direktion

Laufzeit

2417 Vermietung von Răumen im Rathaus an die kgl. Polizei-Direktion

- Beschluss der städtischen Kollegien über Vermietung von Räumen im Rathaus an die kgl. Polizei-Direktion für eine Jahresmiete von 80 Rthlr., März 1860

- Mietvertrag zwischen der Stadt Emden und der kgl. Polizei-Direktion, Juni 1860

- Verlegung der Büros der Polizei-Direktion in die Nordseite des Rathauses zur Nutzung ihrer bisherigen Räume durch eine Filiale der Preußischen Staatsbank, März - April 1867

(1860) 1867

Klassifikation Teil B: 02531

Trägermaterial: Papier

Alte Reg.-Sig.: VIII A 2 b 034

Bestell-Nr.: IV 02531

\title{
2418 Vermietung von Räumen in der Ratelerwache
}

- Vermietung von Räumen in der Ratelerwache an die Zollbehörde und die kgl. Polizei-Direktion sowie daraus resultierende Notwendigkeit baulicher Veränderungen, (1855 - 1865) 1866 - 1868

- Einrichtung der Ratelerwache für Garnisonszwecke, Mai 1867

- Vermietung von Räumen des von der Stadt Emden gemieteten Abegg'schen Hauses an die Zollverwaltung, 1872 - 1903

- Verhandlungen zwischen dem Magistrat und der Kaufmännischen Deputation über Tragung der Mietkosten für das Abegg'sche Haus an der Westerbutvenne, Mai 1878

- Grundriss der Zollabfertigungsstelle am Schreyers Hoek, 1895

- Ausbau der Zollabfertigungshalle am Schreyers Hoek, 1895

- Streit um die Kündigung des Mietverhältnisses über das Abegg'sche Haus durch die Zollverwaltung, Januar 1903 - Mai 1904

\author{
(1855 - 1865) 1866 - 1904 \\ Klassifikation Teil B: 02532 \\ Trägermaterial: Papier \\ Alte Reg.-Sig.: VIII 2 b 036 \\ Bestell-Nr.: IV 02532
}


- Antrag des Buchbinders Poelders an den Magistrat auf

Genehmigung des Anschlusses seines Ladens im Rathaus an die Gasbeleuchtung, März 1861

- Anschluss der Ratelerwache an die Gasbeleuchtung, 1861 - 1862

- Anschluss der Büros im Rathaus an die Gasbeleuchtung, (1861 -

1862) 1879

- Nachforschungen wegen erhöhten Gasverbrauchs in der

Ratelerwache, Februar 1867

- Kosten des Anschlusses der Räume des Polizeikommissars, der

Registratur und des Büros des Assessors Metger an die

Gasbeleuchtung und Kosten für Lampen mit Zubehör, Februar 1869

- Beschaffung einer größeren Gasuhr für das Rathaus, 1884 - 1885

- Streit des Stadtbaumeisters Wiggers mit der Firma Schaffer \&

Walcher wegen Bezahlung eines Gasfernzünders, 1896 - 1897

\author{
(1861 - 1862) 1867 - 1887 \\ Klassifikation Teil B: 02535 \\ Trägermaterial: Papier \\ Alte Reg.-Sig.: VIII A 2 b 039 \\ Bestell-Nr.: IV 02535
}

2420 Verkauf des städtischen Postgebäudes an die staatliche

$1866-1868$ Postverwaltung

- Verkauf des städtischen Postgebäudes an die kgl. hannoversche Postverwaltung und ihrer preuißischen Rechtsnachfolgerin für 4.500 / 5000 Rthlr., April 1866 - September 1867

- Ankauf eines Grundstückes des Gasthauses an der Faldernstraße durch die Stadt Emden zur Weiterveräußerung an die Postverwaltung zum Zwecke der Vergrößerung des Grundstückes für ein

Postgebäude, Juli 1866 - November 1868

$1866-1868$

Klassifikation Teil B: 02536

Trägermaterial: Papier

Alte Reg.-Sig.: VIII A 2 b 042

Bestell-Nr.: IV 02536

2421 Verkauf eines städtischen Kiekerhauses

- Verkauf des städtischen Kiekerhauses am Judenfriedhof an den Israelitischen Begräbnisverein, Oktober 1872 - Februar 1873

- Inkorporierung des Grundstücks des Kiekerhauses in den jüdischen Friedhof, August 1882

$1871-1883$

Klassifikation Teil B: 02537

Trägermaterial: Papier

Alte Reg.-Sig.: VIII A 2 b 044

Bestell-Nr.: IV 02537 
- Übergang eines Miethauses der Israelitischen Gemeinde an den städtischen Armenverband wegen Kommunalisierung des Armenwesens, Januar 1873

- Auflassung der Grundstücke der an den städtischen Armenverband übergegangenen Häuser der katholischen und der Israelitischen Gemeinde am Pottgang und der Judenstraße, Januar 1873 - Verkauf der Objekte durch die Stadt Emden, April 1873 - Oktober 1874

- Verfügung des Magistrats an den Vorstand der Israelitischen Gemeinde über Aufforderung zur Zahlung der vom November 1872 bis Mai 1873 erzielten Mieteinnahmen aus dem an den Armenverband der Stadt Emden übergegangenen Haus in der Judenstraße, Juli September 1873

- Vermietung der Wohnungen des von der katholischen Gemeinde der Stadt Emden übereigneten Hauses im Pottgang, November -

Dezember 1873

- Eintragungen zu dem übereigneten Gebäude der katholischen Gemeinde im Grundbuch, 1886

$1873-1886$

Klassifikation Teil B: 02538

Trägermaterial: Papier

Alte Reg.-Sig.: VIII 2 b 046

Bestell-Nr.: IV 02538

- Vermietung des Hauses Burgstraße 19 an Bürgermeister Fürbringer alsw Nachfolger des Oberbürgermeisters Ernst Hantelmann, 1875 1880

- Modernisierung des Aborts der Bürgermeisterwohnung, April November 1876

- Erneuerung der Öfen in der Wohnung des Oberbürgermeisters Fürbringer in der Burgstraße, September 1877

- Vermietung des Hauses große Burgstraße 19 nach dem Umzug des Oberbürgermeisters Fürbringer, 1877 - 1905

- Gasanschluss des Hauses Große Burgstraße 19, März - April 1901

$1875-1905$

Klassifikation Teil B: 02539

Trägermaterial: Papier

Alte Reg.-Sig.: VIII A 2 b 047

Bestell-Nr.: IV 02539 
2424 Rückkauf der Gebäude des Alten Gymnasiums durch die Stadt Emden

Laufzeit

- Planzeichnung der zum Alten Gymnasium gehörenden Gebäude an der Kirchstraße, 1878

- Eingabe des Magistrats an den Minister der Geistlichen, Unterrichtsund Medizinalangelegenheiten über Bitte um Überlassung der nicht mehr zu Schulzwecke genutzten Gebäude des Alten Gymnasiums, Mai 1876 - Juli 1877

- Verhandlungen des Magistrats mit dem Provinzialschul-Kollegium über Rückkauf der Gebäude des Alten Gymnasiums, April 1876 Januar 1880

- Beschluss des Magistrats über Einsetzung einer Kommission zur Prüfung des Rückkaufs der Gebäude des Alten Gymnasiums zur Unterbringung von Garnisonssoldaten, November 1876

- Verhandlungen der Kommission zur Prüfung des Rückkaufs der Gebäude des Alten Gymnasiums, November - Dezember 1876

- Erlass des Ministers der Geistlichen, Unterrichts- und Medizinalangelegenheiten über notwendige Erhöhung des Kaufpreises im Verhältnis zum Wert der Gebäude des Alten Gymnasiums, Juli 1877

- Einrichtung des Alten Gymnasiums als Kaserne, 1878

- Regelung der Finanzierung des Rückkaufs des Alten Gymnasiums, September 1879 - August 1880 (1889)

$1876-1889$

Klassifikation Teil B: 02540

Trägermaterial: Papier

Alte Reg.-Sig.: VIII A 2 b 049

Bestell-Nr.: IV 02540

2425 Abbruch des Hammrichshauses auf Nesserland

- Beschluss des Magistrats über Abbruch des baufälligen Hammrichshauses auf Nesserland, Dezember 1875 / Januar 1876

- Verkauf des Nesserlander Hammrichshauses auf Abbruch, Januar 1876

- Ausschreibung der Planierungsarbeiten und Entfernung des

Fundaments, Januar - Februar 1876

$1875-1876$

Klassifikation Teil B: 02541

Trägermaterial: Papier

Alte Reg.-Sig.: VIII A 2 b 050

Bestell-Nr.: IV 02541 
2426 Künstlerische Ausschmückung des Rathauses

Laufzeit

- Antrag des Magistrats beim Minister der geistlichen, Medizinal- und Unterrichtsangelegenheiten auf Unterstützung aus dem staatlichen Kulturfonds zur Anschaffung von Gemälden und Skulpturen für das Rathaus, August 1884 - Dezember 1885

- Gutachten des geheimen Regierungsrats von Dehn-Rotfelsen über Notwendigkeit der künstlerischen Ausgestaltung der Innenräume des Rathauses mit Vorschlägen, April 1885

- Antrag des Magistrats beim Landesdirektorium der Provinz Hannover auf Förderung der künstlerischen Ausgestaltung des Rathauses, Oktober 1885

- Angebot von Antikmöbeln für das Magistratszimmer durch die Kunstund Antiquittätenhandlung M van Cleef, Emden, Oktober 1892 - Angebot des Prof. Henrici aus Aachen über architektonische Beratung für einen Ausbau des Rathauses, Juli - August 1895

1884 - 1895 (1897) Klassifikation Teil B: 02542

Trägermaterial: Papier

Alte Reg.-Sig.: VIII A 2 b 057

Bestell-Nr.: IV 02542

- Erwerb des Bentinckshofes von Eckhoff's Erben durch die Stadt emden für 5500 Rthlr., April - November 1872

- Beschluss der städtischen Kollegien über Neubau des Wilhelms-Gymnasiums auf dem Grundstück des Bentinckshofes, Februar 1873

- Verpachtung eines Teils des Bentinckshofes nebst Garten, Januar 1874 - Oktober 1892

$1872-1892$

Klassifikation Teil B: 02543

Trägermaterial: Papier

Alte Reg.-Sig.: VIII 2 b 048

Bestell-Nr.: IV 02543 
- Beschluss des Magistrats über Umbau des Wachthäuschens am Boltentor zum Stallgebäude für Major Gronemann vom Ostfriesischen Infanterie-Regiment Nr. 18 als Mieter zur Unterbringung seines Reitpferdes, September 1878

- Risszeichnung und Kostenvoranschläge des Umbaus des Wachthäuschens am Boltentor zum Stallgebäude, September 1878 - Eintritt des Hauptmanns von Puttkamer in den Mietvertrag des Majors Gronemann, Dezember 1879

- Planung einer Funktion des Wachthäuschens am Boltentor als Leichenhaus für den Fall des Ausbruchs einer Cholera-Epidemie, August 1884

- Vermietung des Wachthäuschens am Boltentor als Lagergebäude an den Kaufmann Peter de Jonge, 1882 - 1891

$1878-1891$

Klassifikation Teil B: 02544

Trägermaterial: Papier

Alte Reg.-Sig.: VIII 2 b 051

Bestell-Nr.: IV 02544

2429 Vermietung des Anbaus des Alten Gymnasiums

- Vermietung des Anbaus des Alten Gymnasiums an den

Zimmermann Johann G. Jürgens, 1879 - 1890

- Grundrisszeichnung des Grundstücks des Alten Gymnasiums, 1879

- Vermietung des Anbaus des Alten Gymnasiums an den Briefträger

W. Buurmann, Juni 1891

$1879-1891$

Klassifikation Teil B: 02545

Trägermaterial: Papier

Alte Reg.-Sig.: VIII 2 b 054

Bestell-Nr.: IV 02545

2430 Wachthaus am Nordertor

- Kündigung des Mietverhältnisses mit der Garnison zur Nutzung des Wachthauses am Nordertor als Pulvermagazin, Juni - Juli 1886

- Einrichtung des Wachthauses als Leichenkammer für gefundene Leichen, August 1887 - Januar 1888

- Erlass des Innenministers über Pflicht der Kommunen zur Stellung von Räumen für Leichenschauen und Obduktionen, November 1890

- Räumung des als Notdomizil der Familie des Arbeiters Friedrich

Brinkmann genutzten Wachthauses am Nordertor, November 1897

- Abbruch des Wachthauses am Nordertor, 1899 - 1900

$1886-1900$

Klassifikation Teil B: 02546

Trägermaterial: Papier

Alte Reg.-Sig.: VIII 2 b 059

Bestell-Nr.: IV 02546 
- Verkauf der Gebäude des Alten Gymnasiums an den Partikulier Wilhelm Buurmann für 16.000 Mark, Juli 1889 - Juli 1890

- Interesse der Gesellschaft für bildende Kunst und vaterländische Altertümer am Erwerb der Gedenksteine der Lateinschule am Alten Gymnasium, April - Juni 1890

- Löschung der auf dem Grundstück des Alten Gymnasiums liegenden Hypothek des Kaufpreises wegen Veräußerung des Objektes durch Wilhelm Buurmann, 1907 (1914)

$1889-1914$

Klassifikation Teil B: 02547

Trägermaterial: Papier

Alte Reg.-Sig.: VIII 2 b 060

Bestell-Nr.: IV 02547

- Eingabe der Kaufmännischen Deputation an den Magistrat über Bitte um Angabe der Mietbedingungen für die geplanten Arbeiterhäuser im Kaiser-Wilhelm-Polder, Juli 1900

- Erläuterungen des Architekten Schmidt vom Baubüro Cuxhaven der Hamburg-Amerika-Linie zum von inm vorgelegten Bebauungsplan für die Arbeitersiedlung im Kaiser-Wilhelm-Polder, September 1900

- Plan der Vermietung der fertig gestellten Arbeiterwohnungen, August 1900

- Mitteilung der Mietbedingungen für die Arbeiterwohnungen an die Direktion der Hamburg-Amerika-Linie, September 1900

- Telegrafische Nachricht der Hamburg-Amerika-Linie über Anmietung von Wohnungen für ihre Beschäftigten ab Frühjahr 1901,

November1900

- Beauftragung des Auktionators Woortmann mit der Vermietung der Arbeiterhäuser im Kaiser-Wilhelm-Polder, Februar 1901 - Februar 1905

- Aufstellung über Mieter der Arbeiterhäuser im

Kaiser-Wilhelm-Polder, März / Mai 1901

- Berechnung der Mieteinnahmen aus den Arbeiterhäusern im Kaiser-Wilhelm-Polder, März 1901 - Februar 1908

- Kündigung von Mietern wegen vertragswidriger Nutzung ihrer Wohnungen und Mietrückständen, 1902 - 1905

- Genehmigung des Magistrats zur Errichtung einer Kinderbewahranstalt in einem leerstehenden Haus an der Wilgumer Str. (Transvaal), November 1902

$1900-1908$

Klassifikation Teil B: 02550

Trägermaterial: Papier

Alte Reg.-Sig.: VIII A 2 b 070

Bestell-Nr.: IV 02550 
2433 Vermietung von Räumen in der alten Kaserne und dem ehemaligen Krankenhaus

Laufzeit

- Verschiedene Mietverträge für Räume in der Alten Kaserne, 1889 1891

- Vermietung von Räumen in der Alten Kaserne an den Schlachter Geerd Hummerich zur Einrichtung einer Schlachterei, Februar 1880 September 1892

- Vermietung der Feldwebelwohnung in der Alten Kaserne an den Arbeiter Joseph Zeinpel, Januar 1890

- Vermietung der Feldwebelwohnung in der Alten Kaserne an den Sattlermeister W. Orth, April 1889 - Oktober 1890

- Mietbedingungen für das ehemaligen Krankenhaus mit Garten, November 1899

- Vermietung von Wohnungen im ehemaligen Krankenhaus, Februar 1891 - Mai 1909

$1889-1909$

Klassifikation Teil B: 02551

Trägermaterial: Papier

Alte Reg.-Sig.: VIII A 2 b 071

Bestell-Nr.: IV 02551

2434 Bau eines Wohnhauses für den Ersten Nachwachtmeister und Gefangenenwärter

- Planzeichnung eines Dienstwohnhauses für den Ersten Nachtwachtmeister an der kleinen Faldernstraße, Juli 1901

- Beschluss des Magistrats zum Bau eines Wohnhauses für den Ersten Nachwachtmeister und Gefangenenwärter auf dem Gasthauskirchhof, Februar - August 1901

- Kostenvoranschlag des Baues, 1901

- Ausschreibung der Bauarbeiten, September 1901

- Veranlagung des Grundstücks Gasthauskirchhof 8 zur Grundsteuer, 1903

$1901-1903$

Klassifikation Teil B: 02552

Trägermaterial: Papier

Alte Reg.-Sig.: VIII A 2 b 072

Bestell-Nr.: IV 02552 
2435 Bau und Vermietung eines Vierfamilienhauses durch die Stadt Emden 1901-1909 in der Dollartstraße

- Bescheid der Landesversicherungsanstalt Hannover über Bereitstellung von 6000 Mark als Darlehen für den Bau des Hauses, April 1901

- Bauzeichnung des Hauses, Mai 1902

- Ausschreibung des Baus eines Arbeiterwohnhauses für vier

Familien, Mai - Juli 1902

- Angebote von Arbeits- und Materialleistungen für den Hausbau,

Februar - Juli 1902

- Berechnung des Mietpreises für das Vierfamilienhaus an der

Dollartstraße, September 1902

- Vermietungsbedingungen, September 1902

- Vermietung der Wohnungen im Haus durch den Auktionator D.

Woortmann, 1902 - 1908

- Beschwerde der Mieter wegen Wassereinbrüche im Keller, Februar 1905

- Streitigkeiten der Mietparteien im Haus, Juli 1908 - Februar 1909

$1901-1905$

Klassifikation Teil B: 02553

Trägermaterial: Papier

Alte Reg.-Sig.: VIII A 2 b 074

Bestell-Nr.: IV 02553

2436 Arbeiterwohnhäuser an der Küstenbahn

- Veranlagung der Arbeits- und Materialleistungen für die geplanten ASrbeiterwohnhäuser, Juli 1905

- Kostenvoranschlag für die Arbeiterwohnhäuser, Juli - Oktober 1905

- Wertschätzung der für den Bau der Arbeiterwohnhäuser vorgesehenen, von der Stadt Emden verpachteten Gemüseländereien an der Küstenbahn, Oktober 1905

- Ausschreibung der Arbeits- und Materiallieferungen für die Arbeiterwohnhäuser, August - Oktober 1905

- Angebote von Arbeits- und Materialleistungen, Oktober 1905 - April 1906

- Risszeichnung der Arbeiterwohnhäuser, 1905

- Kritik der kgl. Wasserbauinspektion an die zu schwache Ausführung der Fundamente der Arbeiterwohnhäuser, Januar 1906

- Regelung der Übernahme der Arbeiterwohnhäuser an der Küstenbahn durch die Nordseewerke zur Vermietung an ihre Arbeiter, Mai 1906

- Festsetzung der von den Nordseewerken zu entrichtenden Mietzahlungen für die Arbeitewrwohnhäuser an der Küstenbahn, September 1906

$1905-1906$

Klassifikation Teil B: 02554

Trägermaterial: Papier

Alte Reg.-Sig.: VIII A 2 b 074

Bestell-Nr.: IV 02554 
- Antrag des Vorstands der Kinderbewahranstalten an den Magistrat auf Bau einer verbesserten Kinderbewahranstalt auf Transvaal und Finanzierung aus den Resten einer Anleihe für Arbeiterwohnhäuser, November 1903

- Risszeichnung einer Kleinkinderschule an der Dollartstraße (Transvaal), Dezember 1903

- Ausschreibung der Bauarbeiten und Materiallieferungen für die Kleinkinderschule (Kinderbewahranstalt), Februar 1904

- Übergabe des neugebauten Gebäudes an den Vorstand der Kinderbewahranstalt, August - September 1904

- Kleinere Reparaturen in der Wohnung der Lehrerin der Kleinkinderschule (Kinderbewahranstalt), März - August 1906

$1903-1906$

Klassifikation Teil B: 02555

Trägermaterial: Papier

Alte Reg.-Sig.: VIII A 2 b 078

Bestell-Nr.: IV 02555

- Bewrbungen um Pachtung des nicht mehr genutzten

Polizeiwachtgebäudes (Alte Militärwache)

1905

Klassifikation Teil B: 02558

Trägermaterial: Papier

Alte Reg.-Sig.: VIII A 2 b 083

Bestell-Nr.: IV 02558

2439 Vermietung und späterer Verkauf des Hauses kleine Holzsägerstraße 16 durch die Stadt Emden

- Kaufinteressenten für das Haus kleine Holzsägerstraße 16, Oktober 1906

- Illegale Benutzung des Hauses durch den Niederländer Pieter de Jong und Familie, Juni - Juli 1907

- Vermietung des Hauses an den Kaufmann Nikolaus Holthuis, September 1907 - September 1910

- Kostenvoranschlag des Stadtbaumeisters Wiggers über Renovierung des Hauses kleine Holzsägerstraße 16, November 1907 - Umschreibung des Besitztitels des Hauses im Grundbuch auf die Stadt Emden wegen Herrenlosigkeit wegen nicht vorhandener Erben des verstorbenen Besitzers, 1909 - 1910

- Verkauf des Hauses an den Kaufmann Holthuis, November 1911

$1906-1911$

Klassifikation Teil B: 02560

Trägermaterial: Papier

Alte Reg.-Sig.: VIII A 2 b 088

Bestell-Nr.: IV 02560 
2440 Verpachtung eines städtischen Grundstücks an die Firma Schönberg 1905 und Neumark

- Eingabe der Getreidehändler Schönberg und Neumark an den Magistrat der Stadt Emden über Bitte um Verpachtung eines Geländestreifens aus städtischem Besitz bei ihrem Getreidesilo an der Nesserländer Str. wegen Raumbedarf, Februar 1905

- Pachtvertrag zwischen der Stadt Emden und der Firma Neumark und Schönberg über Geländestreifen an der Nesserlander Str., April 1905

- Pachterhöhungen, 1914 - 1924

- Streit um Erhebung von Grundsteuer auf das von Neumark und Schönberrg gepachtete Gelände, 1925 - 1927

1905 (1925 - 1944)

Klassifikation Teil B: 00441

Trägermaterial: Papier

Alte Reg.-Sig.: VIII A 2 c

Bestell-Nr.: IV 00441

2441 Städtische Grundstücke

- Grundbuchauszüge über städtische Grundstücke

$1899-1903$

Klassifikation Teil B: 02506

Trägermaterial: Papier

Alte Reg.-Sig.: VIII A 2 a 04

Bestell-Nr.: IV 02506

- Festlegung der Grenzen der Grundstücke der Faldernsielacht nach dem Bau eines Anliegers durch die Stadt Emden, Juni - August 1872 - Antrag des Konsuls Helm auf Erlaubnis zum Bau eines Weges über ein Grundstück der Stadt Emden südlich des Roten Sieles und Erwerb des Grundstückes auf Erbpacht, März - Mai 1888

$1872-1888$

Klassifikation Teil B: 02511

Trägermaterial: Papier

Alte Reg.-Sig.: VIII A 2 e 59

Bestell-Nr.: IV 02511 
- Aufmessung der Grundstücke der Weizenmühle zur Feststellung der

Grenze zu städtischen Grundstücken, 1820

- Verhandlungen des Magistrats mit der Mühlen-Societät wegen Grundstückstausch zwischen der Stadt Emden und der Mühlen-Societät als Besitzerin der Weizenmühle, April - Juni 1820

- Aufnahme städtischer Gebäude in das Brandkataster, 1833

- Besitztitel der Stadt Emden über ein Grundstück am Kattewall, 1840

- Feststellung der Grenze zwischen einem städtischen Anwuchs am Nordertor und Domanialland, 1841

- Aufstellung über Grund- und Immobilienbesitz der Stadt Emden, 1847

- Erstattung erhobener Grundsteuer von dem städtischen Besitz 1885

( 1820 - 1847) 1885

Klassifikation Teil B: 02533

Trägermaterial: Papier

Alte Reg.-Sig.: VIII A 2 b 037

Bestell-Nr.: IV 02533

2444 Kauf der Maiboom'schen Seilerbahn

- Beschluss der städtischen Kollegien zum Kauf der Maiboom'schen Seilerbahn mit Arbeiterwohnungen, Mai 1874

- Original-Vergleich von 1798 wegen Festlegung der

Grundstücksgrenze der Maiboom'schen Seilerbahn, November 1881

- Ankauf der Maiboom'schen Seilerbahn durch den Zimmermeister H. Sanders im Auftrag der Stadt Emden, Dezember 1891

- Vermietung der Arbeiterwohnungen im Seilerhaus der von der Stadt

Emden erworbenen Maiboom'schen Seilerbahn, 1882 - 1890

- Eintragung des Besitztitels der Stadt Emden über die

Maiboom'sdche Seilerbahn in das Grundbuch, Juni 1882

- Verhandlungen wegen Verkaufs der baufälligen Maiboom'schen

Seilerbahn auf Abbruch, 1891 - 1893

- Risszeichnung des Seilerhauses, 1891

- Risszeichnung des Seilerhauses mit Arbeiterwohnungen und

Remisen, 1889

$1874-1893$

Klassifikation Teil B: 02534

Trägermaterial: Papier

Alte Reg.-Sig.: VIII A 2 b 045

Bestell-Nr.: IV 02534 
2445 Ankauf der am Brauers Graben gelegenen van Letten'schen

Laufzeit Besitzung

- Abbruch der Holzbude auf dem van Letten'schen Grundstück, 1901 - Beschluss des Magistrats zum Erwerb des Grundstücks für 17.000 Mark, September 1901

- Eingetragene Hypotheken auf dem van Letten'schen Grundstück, $1901 / 1902$

-Verpachtung des Grundstücks, Januar 1902 - November 1908

- Ablösung der Erbpachten auf dem van Letten'schen Grundstück, 1902

. Nutzung des Grundstücks für das Kaiser-Friedrich-Realgymnasium, Oktober 1903

$1901-1908$

Klassifikation Teil B: 02549

Trägermaterial: Papier

Alte Reg.-Sig.: VIII A 2 b 061

Bestell-Nr.: IV 02549

2446 Kauf des Grundstücks des Drahtseilfabrikanten Diedrich Cramer durch die Stadt Emden

- Angebot des Grundstücks des Drahtseilfabrikanten Diedrich Cramer durch die Auktionatoren Schmidt \& Meyer zum Kauf, Juli 1904

- Beschluss des Magistrats üner Preisgebot über 6000 Mark für das Grundstück, August 1904

- Kaufvertrag über das Grundstück des Drahtseilfabrikanten Diedrich Cramer zum Preis von 8000 Mark zwischen den Auktionatoren und der Stadt Emden, September 1904

- Auflassung des von der Stadt Emden erworbenen Grundstücks des Drahtseilfabrikanten Diedrich Cramer, September - Oktober 1905

$1904-1905$

Klassifikation Teil B: 02556

Trägermaterial: Papier

Alte Reg.-Sig.: VIII A 2 b 079

Bestell-Nr.: IV 02556

2447 Verkauf und Wiederverkauf des Baugrundstücks Pottgießstraße 1 durch die Stadt Emden

- Beschluss des Magistrats zum Kauf des Brandgrundstücks des Gropel'schen Hauses in der Pottgießerstraße 1, Dezember 1903 - Ankauf des Grundstücks zum Abbruch der Brandruine, Januar 1904 - Verkauf des Grundstücks durch die Stadt Emden an den Bäckermeister Tjark Woydt, Juli - Oktober 1904

$1903-1904$

Klassifikation Teil B: 02557

Trägermaterial: Papier

Alte Reg.-Sig.: VIII A 2 b 080

Bestell-Nr.: IV 02557 
- Beschluss des Magistrats über Kauf des Janssen'schen Hellings durch die Stadt Emden, Dezember 1905

- Verhandlungen des Magistrats mit dem Auktionator D. Woortmann wegen Kauf des Janssen'schen Hellings durch die Stadt Emden, Juli 1905

- Eintragung des Besitzerwechsels im Grundbuch, August 1905

- Pachtung des Grundstücks durch den Vorbesitzer,

Schiffsbaumeister Jacob Janssen, Dezember 1905 - Februar 1909

$1905-1909$

Klassifikation Teil B: 02559

Trägermaterial: Papier

Alte Reg.-Sig.: VIII A 2 b 084

Bestell-Nr.: IV 02559

2449 Verpachtung der Thranenwarf

- Verpachtung der Thranenwarf an verschiedene Schiffsbaumeister zur Nutzung als Holzstapelplatz

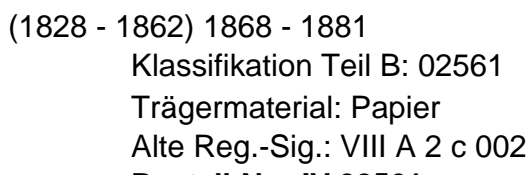

2450 Nutzung der von der Stadt Emden erworbenen Grundstücke der ehemaligen Heringsfischerei-Kompanie

- Reparatur der Kajung vor den "Kupen", 1835 - 1836

- Nutzung einer Grundfläche am Strohdeich durch Heringsfischereien als Netzstellfläche zum Trocknen der Fangnetze, 1823 - 1853

- Grenzstreit zwischen den Grundbesitzern Janssen und Wychgram

Erben an der Lienbahnstraße, 1845

- Verpachtung der von der Stadt erworbenen Grundstücke der Heringsfischerei-Kompanie ("Kupen", Strohdeich), (1853 - 1862) 1873

- Risszeichnung der verpachteten Grundstücke, 1874

- Streit um die Instandsetzung der Gräben um die städtischen

Grundstücke, 1875

(1823 - 1862) 1873 - 1875

Klassifikation Teil B: 02562

Trägermaterial: Papier

Alte Reg.-Sig.: VIII A 2 c 003

Bestell-Nr.: IV 02562 
06.01 Städtisches Vermögen

06.01.01

06.01.01.03

Städtische Gebäude und Grundstücke

Städtische Grundstücke

Lfd. Nr. Titel

Laufzeit

2451 Verpachtung der städtischen Grundstücke im Meister-Geerds-Zwinger

- Verpachtung der städtischen Grundstücke im

Meister-Geerds-Zwinger an Landgebräucher Roolf Willms, dessen

Erben u.a., (1805 - 1865) 1866 - 1903

- Regelung des Grenzverlaufs zwischen den städtischen

Grundstücken im Meister-Geerds-Zwinger und dem Grundstück der

R. Willms Erben, 1842

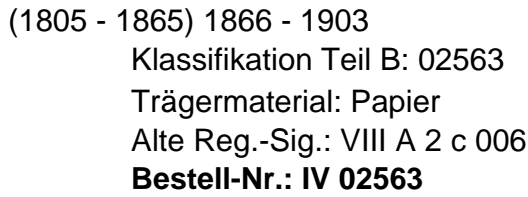

2452 Verpachtung des Vorlandes zwischen dem Deich und dem

- Verzeichnis der verpachteten Flächen des Vorlandes zwischen dem Deich und dem Beckhofstor (Quellergras), (1860 - 1865) 1866 - 1871 - Pachtbedingungen für das Vorland zwischen dem Deich und dem Beckhofstor, 1866

- Bewerbungen um die Pachtung des Vorlandes zwischen dem Deich und dem Beckhofstor, 1866 - 1870

- Jährliche Verpachtung des Vorlandes zwischen dem Deich und dem Beckhofstor, 1866 - 1873

(1860 - 1865), 1866 - 1873

Klassifikation Teil B: 02564

Trägermaterial: Papier

Alte Reg.-Sig.: VIII A 2 c 007

Bestell-Nr.: IV 02564 
- Bedingungen der Verpachtung der Ländereien der Stadt Emden an den Stadtgräben, dem Larrelter Deich, der ehemaligen Langen Brücke und der Emsmauer, 1874 - 1889

- Verpachtung der Ländereien, 1880 - 1887

- Berechnung der Pachten, 1880 - 1889

- Aufstellung über Pächter der Ländereien, 1880 - 1884

- Pachtgesuch des Gendarm Hartrampf um ein Grundstück an der

Parallelstraße / Am Herrentor, Februar - November 1884

- Verpachtung von städtischen Grundstücken am Herrentor, 1883 1884

- Verpachtung der Anwuchsflächen am Stadtwall, 1874 - 1878

- Kündigung der Verpachtung der Anwuchsflächen durch den Magistrat wegen notwendiger Deponierung von Schlick aus dem Binnenhafen, 1875

- Antrag des Pächters Jacob Remmers an den Magistrat auf Erlass einer Konventionalstraße wegen verspäteter Pachtzahlung, November - Dezember 1877

$1874-1889$

Klassifikation Teil B: 02565

Trägermaterial: Papier

Alte Reg.-Sig.: VIII A 2 c 010

Bestell-Nr.: IV 02565

2454 Verpachtung der städtischen Grundstücke am Wall, am Hinter Tiefs-Verlaat und am Kasernenplatz, Bd. 1

- Pachtbedingungen für die städtischen Grundstücke am Wall, am Hinter Tiefs-Verlaat und am Kasernenplatz, 1866 - 1893

- Öffebntliche Ausschreibung der Pachtung, 1869 - 1872

- Pächter der städtischen Grundstücke am Wall, am Hinter

Tiefs-Verlaat und am Kasernenplatz, 1866 - 1893

- Antrag des Pächters G. H. Hebarth beim Magistrat auf Minderung seiner Pacht wegen Beeinträchtigung der von inm gepachteten Landstücke am Herrentor durch die Anlage einer Dreckwarf, November 1866

- Eintreibung rückständiger Pachten, Dezember 1866 - Januar 1869

- Verpachtung der Grasmahd auf den Wallgrundstücken, 1867 - 1871

- Verpachtung von Grundstücken am Hinter Tiefs-Verlaat an die

Emdener Papierfabrik zur Nutzung als Strohlagerplatz, 1867 - 1870

- Verpachtung der Grasmahd am Grünen Weg beim Hinter

Tiefs-Verlaat, 1870

$1866-1893$

Klassifikation Teil B: 02566

Band: 1

Trägermaterial: Papier

Alte Reg.-Sig.: VIII A 2 c 011

Bestell-Nr.: IV 02566 
- Verpachtung der Grasmahd auf den Wallgrundstücken

$1894-1911$

Klassifikation Teil B: 02567

Band: 2

Trägermaterial: Papier

Alte Reg.-Sig.: VIII A 2 c 011

Bestell-Nr.: IV 02567

2456 Verpachtung der städtischen Grundstücke am Mittelwall, am Deich nach Nesserland und an der Deichstracke östlich des Fahrwassers und der Nesserlander Schleuse, Bd. 1

- Pachtbedingungen für die Grundstücke, (1860 - 1865) 1866 - 1893

- Ausschreibung der Pachtung für die Grundstücke, 1866 - 1893

- Pächter der Grundstücke, 1866 - 1893

- Promemoria der Verpachtungskommission über Verpachtung städtischer Deichstrecken als Schafweide, April 1866

- Eingabe des Fuhrmanns Barteld Ziemann an den Magistrat über Bitte um Niederschlagung einer Strafe wegen unerlaubten Weidens seiner Kühe am Fahrwasserdeich, Oktober 1867

- Anträge auf Pachtermäßigung wegen Nutzungsbeschränkungen durch Militär oder Hafenbau, 1868 - 1873

- Bewerbungen um Pachtung von Grundstücken am Mittelwall ec. unter der Hand, 1869

(1860 - 1865) 1866 - 1893

Klassifikation Teil B: 02568

Band: 1

Trägermaterial: Papier

Alte Reg.-Sig.: VIII A 2 c 012

Bestell-Nr.: IV 02568 
06.01

06.01.01

06.01.01.03
Städtisches Vermögen

Städtische Gebäude und Grundstücke

Städtische Grundstücke

Lfd. Nr. Titel

Laufzeit

2457 Verpachtung der städtischen Grundstücke am Mittelwall, am Deich nach Nesserland und an der Deichstracke östlich des Fahrwassers 1895-1909 und der Nesserlander Schleuse, Bd. 2

- Pachtbedingungen für die Grundstücke

- Ausschreibung der Pachtung für die Grundstücke

- Pächter der Grundstücke

- Anträge auf Pachtermäßigung wegen Nutzungsbeschränkungen durch Militär oder Hafenbau

- Anzeige gegen den Pächter Groustra wegen unerlaubter Beweidung seiner gepachteten Fläche mit Schafen und daraus resultierende Lärmbelästigung der Nachbarn durch Schafsgeblöke, Juli -

September 1905

$1895-1909$

Klassifikation Teil B: 02569

Band: 2

Trägermaterial: Papier

Alte Reg.-Sig.: VIII A 2 c 012

Bestell-Nr.: IV 02569

2458 Veräußerung eines städtischen Grundstücks auf Nesserland zum Bau eines Zollgebäudes

- Verhandlungen der kgl- Hannoverschen Zollverwaltung mit dem Magistrat wegen Veräußerung eines städtischen Grundstücks auf Nesserland zum Bau eines Zollgebäudes im Tausch mit einem fiskalischen Grundstücks im Königspolder, 1852 - 1856

- Verhandlungen des kgl. Hauptzollamts mit dem Magistrat wegen Erwerb von städtischem Grund auf Nesserland zur Errichtung eines Wohngebäudes für Zöllner, Dezember 1894 - Dezember 1900

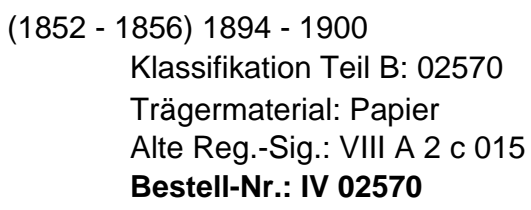

2459 Verpachtung städtischer Ländereien auf Nesserland

- Pachtbedingungen für städtische Ländereien auf Nesserland, 1866 / 1870 / 1876

- Pächter der Ländereien, 1866 - 1881

- Ausschreibung der Pachtung der städtischen Ländereien aufg Nesserland, 1866 - 1881

- Vermietung des Hammrichshauses auf Nesserland, 1866 - 1871

- Verpachtung von Ländereien der Stadt Emden auf Nesserland "unter der Hand", 1867 - 1875

- Rückständige Pachten auf Nesserland, 1868

$1866-1881$

Klassifikation Teil B: 02571

Trägermaterial: Papier

Alte Reg.-Sig.: VIII A 2 c 018

Bestell-Nr.: IV 02571 
2460 Verpachtung der städtischen Ländereien vor dem Strohdeich im

Laufzeit Königspolder, Bd. 1

- Situationsplan der Ländereien, 1862

- Pachtbedingungen für die städtischen Ländereien vor dem

Strohdeich im Königspolder, (1862 - 1865) 1866 - 1897

- Pächter der städtischen Ländereien vor dem Strohdeich im Königspolder, (1862 - 1865) 1866 - 1897

- Ausschreibung der Verpachtung der städtischen Ländereien vor dem Strohdeich im Königspolder, (1862 - 1865) 1866 - 1897

- Anträge verschiedener Pächter auf Gewährung einer Zahlungsfrist zur Entrichtung ihrer Pachtrückstände, (Juni 1863 - Mai 1866) / Juni 1867 - Juli 1872

- Aufstellung über Pachtrückstände, (1863 - 1865) 1866 - 1871

- Verpachtung der städtischen Ländereien zwischen Bahnhof und Strohdeich, 1866 - 1867

- Bürgschaftserklärungen für Pächter, 1866

- Kündigung von Pachtungen, 1885 - 1891

(1862 - 1865) 1866 - 1897

Klassifikation Teil B: 02572

Band: 1

Trägermaterial: Papier

Alte Reg.-Sig.: VIII A 2 c 019

Bestell-Nr.: IV 02572

2461 Verpachtung der städtischen Ländereien vor dem Strohdeich im Königspolder, Bd. 2

- Pachtbedingungen für die städtischen Ländereien im Königspolder und bei der ehemaligen Emsmauer, (1860 - 1865) 1866 - 1880 - Pächter der städtischen Ländereien im Königspolder und bei der ehemaligen Emsmauer, (1860 - 1865) 1866 - 1880

- Ausschreibung der Verpachtung der städtischen Ländereien im Königspolder und bei der ehemaligen Emsmauer, (1860 - 1865) 1866

$-1880$

- Anträge verschiedener Pächter auf Gewährung einer Zahlungsfrist zur Entrichtung ihrer Pachtrückstände, (Mai 1862 - Februar 1866) / Februar 1867 - Februar 1877

- Kündigung von Pachtungen wegen Verwendung der Ländereien für Hafenbauzwecke, Juli 1872 - Juni 1873

- Aufstellung über Pachtrückstände, 1876 - 1878

- Antrag der Eisenbahnverwaltung an den Magistrat über Bitte um Verpachtung städtischer Ländereien im Königspolder an den Bahnfiskus, September 1881 - März 1883

(1862 - 1865) $1866-1897$

Klassifikation Teil B: 02573

Band: 2

Trägermaterial: Papier

Alte Reg.-Sig.: VIII A 2 c 019

Bestell-Nr.: IV 02573 
06.01

06.01.01

06.01.01.03

- Pachtbedingungen für die städtischen Ländereien vor dem Strohdeich im Königspolder, 1897 - 1904

- Pächter der städtischen Ländereien vor dem Strohdeich im Königspolder, 1897 - 1904

- Ausschreibung der Verpachtung der städtischen Ländereien vor dem Strohdeich im Königspolder, 1897 - 1904

- Anträge des Pächters H. Strohdiek auf Gewährung einer

Zahlungsfrist zur Entrichtung seiner Pachtrückstände, September 1898 - Mai 1903

- Kündigung von Pachtungen im Stadtpolder wegen Badarf zum

Hafenbau, 1902 - 1903

- Kündigung eines Pachtverhältnisses mit der Stadt Emden durch die

Pächterin Wwe. Ammersken, März 1900

$1897-1904$

Klassifikation Teil B: 02574

Band: 3

Trägermaterial: Papier

Alte Reg.-Sig.: VIII A 2 c 019

Bestell-Nr.: IV 02574

2463 Entschädigung von Pächtern

- Verhandlungen des Magistrats mit Pächtern städtischer Grundstücke auf Nesserland wegen Entschädigung wegen Verlust der Nutzung durch Abgrabung von Land zu Deichbauzwecken, (Mai 1855 - Mai 1866) Dezember 1866 - September 1873

(1855 - 1865) 1866 - 1873

Klassifikation Teil B: 02576

Trägermaterial: Papier

Alte Reg.-Sig.: VIII A 2 c 020

Bestell-Nr.: IV 02575

2464 Verpachtung von städtischen Grundstücken im Herrengarten

- Gesuch des Berend Redmers an den Magistrat über Bitte um Überlassung eines städtischen Grundstücks am Herrengarten in Erbpacht, Dezember 1854 - Oktober 1855

- Verpachtung des Grundstücks an B. Redmers auf 12 Jahre, Mai 1855

- Antrag des Jacob Redmers auf Übernahme der Pachtung von seinem verstorbenen Vater, November 1867

- Antrag der Witwe des Jacob Redmers auf Übernahme der Pachtung von ihrem verstorbenen Mann, Dezember 1877

- Verpachtung des Grundstücks an den Fuhrmann Adolf Mentzen, Januar 1878 - Dezember 1897

(1854 - 1855) 1867 - 1897

Klassifikation Teil B: 02576

Trägermaterial: Papier

Alte Reg.-Sig.: VIII 2 c 024

Bestell-Nr.: IV 02576 
- Enteignung von Ländereien zum Bau von militärischen

Befestigungen an der Nesserlander Schleuse und Regelung der

Entschädigung, 1857 - 1860

- Gesuch des Magistrats an die Garnisonsverwaltung über Bitte um

Entfernung eines Stacketts um das Gelände der ehemaligen Batterie wegen Weghindernis, April - Juni 1868

- Verhandlungen des Magistrats mit der Garnisonsverwaltung wegen Störung der Aussicht vom Suchsland'schen Lokals durch einen Deichbau vor der ehemaligen Batterie, April 1874

- Rescript der Garnisonsverwaltung über Beibehaltung des Besitzes des Batteriegeländes durch den Militärfiskus, April 1874

- Verhandlungen des Magistrats mit der Garnisonsverwaltung wegen

Erwerb des Batteriegeländes durch die Stadt, Juni 1874 - Mai 1875

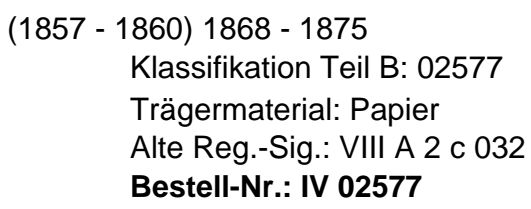

2466 Abtretung eines städtischen Grundstücks an der Osterpiepe

- Abtretung eines städtischen Grundstücks an der Osterpiepe an den Maurermeister Otto Niemeyer unter der Bedingung der Reparatur der dort befindlichen Kajung, März - November 1856

- Prüfung des Zustands der Kajung nach Ablauf der zwölfjährigen Garantiezeit im Überlassungsvertrag mit Otto Niemeyer, Juli 1869 - Vertragswidrige Errichtung einer Bude auf dem von Niemeyer erworbenen Grundstück, April - Mai 1873

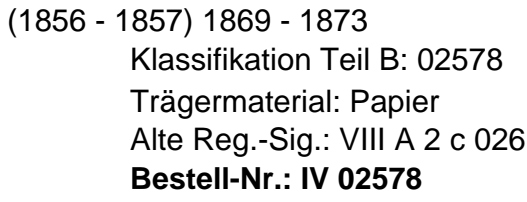

2467 Veräußerung von städtischen Grundstücken an der Bahnhofsstraße

- Gesuche um Erwerb von städtischen Grundstücken an der

Bahnhofsstraße zur Nutzung als Bauplaätze, (1854 - 1855) 1872 -

1878

- Öffentlicher Verkauf von Bauplätzen an der Bahnhofsstraße, 1872 1873

(1854 - 1855) 1872 - 1878

Klassifikation Teil B: 02579

Trägermaterial: Papier

Alte Reg.-Sig.: VIII A 2 c 028

Bestell-Nr.: IV 02579 
2468 Veräußerung eines städtischen Grundstücks zum Bau einer Werft

Laufzeit

2468 Verăußerung eines stădtischen Grundstücks zum Bau einer Wert

- Veräußerung eines städtischen Grundstücks am Fahrwasser an den

Schiffsbauer R. J. Rieke aus Papenburg, 1855 - 1859

- Konkurs der Schiffswerft des Reinhard Joseph Rieke und

Forderungen der Stadt Emden, 1859 - 1861

- Verpachtung des von der Stadt wieder übernommenen Grundstücks an verschiedene Emder Firmen zum Aufbau einer Werft, (1862 -

1865) 1866 - 1874

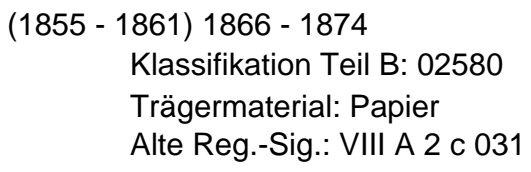

2469 Verkauf eines Grundstücks bei der Nesserlander Schleuse

- Verkauf eines Grundstücks bei der Nesserlander Schleuse an die

Emslotsgesellschaft zur Errichtung einer Lotsenstation für 166 Rthlr., Februar 1859 - Januar 1860

- Tausch des Grundstücks mit einem anderen der Stadt Emden wegen Bedarf des Geländes für Kanalbauzwecke, April 1880 - Januar 1881

- Beschluss des Magistrats zum Erwerb eines Geländes am

Ems-Jade-Kanal zum Bau einer Lotsenstation durch die

Emslotsgesellschaft, Juni 1880

(1859 - 1860) 1880 - 1881

Klassifikation Teil B: 02581

Trägermaterial: Papier

Alte Reg.-Sig.: VIII A 2 c 037

Bestell-Nr.: IV 02581 
- Pachtbedingungen, 1861 - 1862

- Ausschreibung der Pachtung des Welgenlandjes, (1861 - 1865)

$1872-1882$

- Pächter des Welgenlandjes am Stadtgraben, (1861 - 1865) 1866 -

1882

- Risszeichnung des Welgenlandjes, 1862

- Bewerbung des Kräutners E. J. Boerma um die Übernahme der Pachtung eines Stücks des Welgenlandjes von seiner verstorbenen Schwiegermutter, der Witwe Knapp, März 1872

- Pachtung eines Stückes des Welgenlandjes durch die Firma G. W. Sikkens \& Co zur Anlage einer Oelkocherei, 1882 - 1891

- Verpachtung des Geländes der ehemaligen Meiboom'schen

Seilbahn an den Mühlenbaumeister Bernhard Dirks, 1893

- Pachtung eines Stück des Welgenlandjes durch Bäckermeister J. C. Hagen zur Einrichtung eines Eiskellers, 1887 - 1893

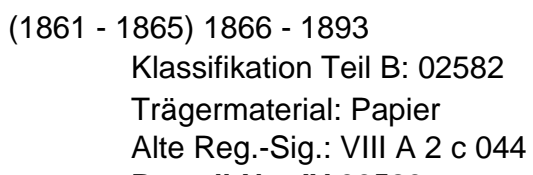

2471 Kauf der Nesserlander Armenländereien durch die Stadt Emden

- Kauf der Nesserlander Armenländereien durch die Stadt Emden,

$1865-1866$

- Registrierung der von der Stadt Emden erworbenen Grundstücke in das Hypothekenbuch, 1867

(1865) 1866 - 1867

Klassifikation Teil B: 02583

Trägermaterial: Papier

Alte Reg.-Sig.: VIII A 2 c 049

Bestell-Nr.: IV 02583

2472 Eigentumsanspruch der Stadt Emden am Vogelsangzwinger

- Kläerung der Eigentumsverhältnisse des Grundstücks mit dem von der katholischen Gemeinde vermieteten Wohnhaus am Vogelsangzwinger, Mai 1864 - Mai 1868

- Bedingungen der Verpachtung eines städtischen Grundstücks am Vogelsangzwinger, 1869 - 1872

- Ausschreibung der Verpachtung, 1869 - 1872

(1864 - 1865) 1866 - 1872

Klassifikation Teil B: 02584

Trägermaterial: Papier

Alte Reg.-Sig.: VIII A 2 c 051

Bestell-Nr.: IV 02584 
2473 Graben zwischen dem Stadtgarten am Wall und Privatgrundstücken 1869-1893 am Nordertor

- Unerlaubter Ausbau und Aufstauung des Grabens zwischen dem Stadtgarten am Wall und Privatgrundstücken am Nordertor durch den Kaufmann Bernhard Bertram zur Anlage eines Schwanenteiches bei seinem als Park gestalteten Grundstück, 1869

- Beschwerde des Landgebräuchers Hoote Hooten gegen den Kaufmann B. Bertram wegen zu hoher Aufstauung des Grabens zwischen dem Stadtgarten am Wall und Privatgrundstücken am Nordertor, März - September 1870

- Beeinträchtigung des Stadtgartens durch die Ausdunstungen des verunreinigten, aufgestauten Grabens, Mai 1870 - Juli 1893 - Streit um die Reinigung des Grabens zwischen dem Stadtgarten am Wall und Privatgrundstücken am Nordertor, 1877 - 1889

$1869-1893$

Klassifikation Teil B: 02585

Trägermaterial: Papier

Alte Reg.-Sig.: VIII A 2 c 053

Bestell-Nr.: IV 02585

2474 Verpachtung eines städtischen Grundstücks zum Bau einer Zementfabrik

- Bewerbung des Kalkbrenners Johann Diedrich Folkerts um die Pachtung des städtischen Grundstücks mit der ehemaligen Rieke'schen Werft am Fahrwasser zur Anlage einer Zementfabrik, April - Mai 1869

- Ausschreibung des Verkaufs der ehemaligen Rieke'schen Immobilien durch den Kaufmann R. W. Schulte, April 1869

1869

Klassifikation Teil B: 02586

Trägermaterial: Papier

Alte Reg.-Sig.: VIII A 2 c

Bestell-Nr.: IV 02586

2475 Abtretung von Grundstücken der Eisenbahnverwaltung an die Stadt Emden

- Verhandlungen zwischen der kgl. Eisenbahnbetriebs-Inspection, der kgl. Direktion der Westfälischen Eisenbahn und dem Magistrat wegen Abtretung der nicht zum Eisenbahnbau benötigten Grundflächen an der geplanten Petkumer Straße an die Stadt Emden, 1872 - 1876 - Reinigung der Gräben an den bahnfiskalischen Grundstücken, 1888 $-1889$

$1872-1889$

Klassifikation Teil B: 02587

Trägermaterial: Papier

Alte Reg.-Sig.: VIII A 2 c 060

Bestell-Nr.: IV 02587 

(Kaiser-Wilhelm-Polder), Bd. 1

- Verhandlungen des Magistrats mit der Niederemsischen Deichacht wegen Bedeichung des Anwachses zwischen Nesserland und Larrelt, 1869 - 1872

- Regelung der Kostenträgerschaft des neu zu erbauenden Deiches vor dem Kaiser-Wilhelm-Polder, Dezember 1871 - Januar 1890

- Beschreibung des Deichprojektes zur Eindeichung des Anwachses zwischen Nesserland und Larrelt, Januar 1873 / Mai 1874

- Kalkulation der Deichbaukosten durch Deichrichter Freerksen, November 1873

- Konstituierung einer Baukommission für die Eindeichung des Anwachses zwischen Nesserland und Larrelt, Februar 1874

- Verfügung des geh. Regierungsrats Roloff von der Regierung in Aurich über Benennung des neuen Polders mit Kaiser.Wilhelm-Polder, Oktober 1874

- Verhandlungen der Baukommission für die Einpolderung über Organisation des Deichbaues, November - Dezember 1874

- Parzellierung des Kaiser-Wilhelm-Polder durch den Geometer Goepel, April - Juli 1875

- Bericht des Stadtbaumeisters Wiggers über Prüfung des Deichbaus hinsichtlich der Vorgaben des Bauanschlages, September 1875

- Entwässerung des Kaiser-Wilhelm-Polders, Juli 1876

- Bemerkungen des Oberbürgermeisters Fürbringer zum ostfriesischen Anwachsrecht hinsichtlich des Eigentums am Kaiser-Wilhelm-Polder, 1878

- Verbesserung der Wege des Kaiser-Wilhelm-Polders durch

Pflasterung, Februar 1878

- Etat des Deichverbandes des Kaiser-Wilhelm-Polders

$1867-1890$

Klassifikation Teil B: 02588

Band: 1

Trägermaterial: Papier

Alte Reg.-Sig.: VIII A 2 c 061

Bestell-Nr.: IV 02588 
(Kaiser-Wilhelm-Polder), Bd. 2

- Etat des Deichverbandes des Kaiser-Wilhelm-Polders, 1881 - 1901 - Übertragung des Nutzungsrechtes am Anwachs vor dem Polder auf den Deichverband für den Kaiser-Wilhelm-Polder für 40 Jahre, 1881

- Schauungsberichte des Kaiser-Wilhelm-Polder-Deiches, März 1882 September 1891

- Bemerkungen der Bauräte Schramm und Dannenberg zur

Rechnungslegung über Unterhaltung des

Kaiser-Wilhelm-Polder-Deiches, 1882 / 1890

- Risszeichnung: Profil des Kaiser-Wilhelm-Polder-Deiches,

Dezember 1883

- Plan zur Erhöhung und Verstärkung des

Kaiser-Wilhelm-Polder-Deiches, 1884

- Protokolle der Verhandlungen des

Kaiser-Wilhelm-Polder-Deichverbandes, 1884

- Ersatzwahlen zur Führung des

Kaiser-Wilhelm-Polder-Deichverbandes, 1889

- Katasterkarte des Kaiser-Wilhelm-Polders, 1891

- Protokoll der Besichtigung des Watts vor dem

Kaiser-Wilhelm-Polder-Deich wegen Gutachten zur Entwicklung des

Anwachses hinsichtlich Bedeichungsfähigkeit, Juni 1870

- Verpachtung der Grasung auf dem Kaiser-Wilhelm-Polder-Deich, März 1901 - Juni 1908

$1891-1908$

Klassifikation Teil B: 02589

Band: 2

Trägermaterial: Papier

Alte Reg.-Sig.: VIII A 2 c 061

Bestell-Nr.: IV 02589

2478 Einpolderung des Anwachses zwischen Nesserland und Larrelt (Kaiser-Wilhelm-Polder), Bd. 3

- Verhandlungen des Magistrats mit dem Regierungs- und Baurat Beckmann wegen Tragung der Kosten für die Verkoppelung des Kaiser-Wilhelm-Polders mit Nesserland, Dezember 1874 - Juli 1875

- Rechenschaftsbericht der Baukommission für die Eindeichung des Kaiser-Wilhelm-Polders über Organisation und Fortschritt des

Deichbaus, Januar 1877

- Bemerkungen der Rechnungs-Revisions-Commission zu den

Deichbaurechnungen, März 1877 - Juli 1887

- Festlegung der Kaution des Deichrentmeisters Tholen, Mai 1877

- Protokoll der Verhandlungen zur Revision der Deichbaurechnung,

August 1877

- Revision der Deichbaurechnung durch die Oberrechnungskammer in Potsdam, 1877 - 1879

$1874-1887$

Klassifikation Teil B: 02590

Band: 3

Trägermaterial: Papier

Alte Reg.-Sig.: VIII A 2 c 061

Bestell-Nr.: IV 02590 
2479 Einpolderung des Anwachses zwischen Nesserland und Larrelt (Kaiser-Wilhelm-Polder), Bd. 4

- Klage des Schachtmeisters Johann Carl Gottlieb Scholz aus Wilhelmshaven gegen die ausführenden Stellen des Deichbaus im Kaiser-Wilhelm-Polder beim kgl. Obergericht in Aurich auf Auszahlung der als Caution hinterlegten Gelder nach Ablehnung einer weiteren Beschäftigung in 1875, August 1876 - Oktober 1877

-- Klage des Bauunternehmers Rens gegen die ausführenden Stellen des Deichbaus im Kaiser-Wilhelm-Polder beim kgl. Obergericht in Aurich auf Auszahlung der als Caution hinterlegten Gelder nach Ablehnung einer weiteren Beschäftigung, Oktober 1876 - Februar 1878

$1876-1878$

Klassifikation Teil B: 02591

Band: 4

Trägermaterial: Papier

Alte Reg.-Sig.: VIII A 2 c 061

Bestell-Nr.: IV 02591

2480 Einpolderung des Anwachses zwischen Nesserland und Larrelt (Kaiser-Wilhelm-Polder), Bd. 5

- Katastrierung der neugewonnenen Flächen im

Kaiser-Wilhelm-Polder, Juli 1881 - April 1888

- Festlegung der auf den Landflächen zu legenden Beiträge zur

Finanzierung des Deichbaus und zur Deich- und Sielunterhaltung,

September 1881 - Juli 1882

- Streit zwischen dem Magistrat und dem kgl. Deichamt Emden wegen ungünstiger Festlegung des städtischen Beitrags zur Finanzierung und Unterhaltung des Kaiser-Wilhelm-Polderdeiches, März 1882 August 1888

$1881-1882$

Klassifikation Teil B: 02592

Band: 5

Trägermaterial: Papier

Alte Reg.-Sig.: VIII A 2 c 061

Bestell-Nr.: IV 02592 
06.01

06.01.01

06.01.01.03

Städtisches Vermögen

Ifd. $\mathrm{Nr}$. Titel

\title{
Städtische Gebäude und Grundstücke
}

Städtische Grundstücke

Laufzeit

\author{
2481 Kuperei am Strohdeich \\ - Festlegung der Grenze des Grundstücks Kuperei am Strohdeich, \\ Besitzer: Abegg'sche Erben, mit Packhaus und den benachbarten \\ städtischen Grundstücken, (1865) 1866 - 1900 \\ - Genehmigungsverfahren über auf dem Grundstück Kuperei am \\ Strohdeich geplante Zuckerfabrik des Reemt Janssen, Dezember \\ 1865 - Januar 1866 \\ - Antrag des Reemt Janssen an den Magistrat auf Überlassung eines \\ kleinen Streifens städtischen Grundes an der Grenze des von ihm \\ erworbenen Grundstücks Kuperei am Strohdeich, Januar 1866 - \\ Januar 1867 \\ - Ansprüche der Stadt Emden aus Erbpachtforderungen auf die \\ Konkursmasse des Reemt Janssen, Februar 1869 \\ - Genehmigung baulicher Veränderungen am Haus des Actuars Knop \\ trotz Beeinträchtigung eines städtischen Geländestreifens im Bereich \\ des Grundstücks Kuperei am Strohdeich, 1874 - 1878 \\ - Risszeichnung des Grundstücks Kuperei am Strohdeich am \\ Falderndelft, 1878 \\ (1865) 1866 - 1900 \\ Klassifikation Teil B: 02593 \\ Trägermaterial: Papier \\ Alte Reg.-Sig.: VIII A 2 c 062 \\ Bestell-Nr.: IV 02593
}

2482 Verpachtung eines städtischen Grundstücks an der Nesserlander Schleuse

- Gesuch des Kaffeehausbesitzers C. Suchsland an den Magistrat um Erlaubnis zur Errichtung eines Pavillons auf dem Schleusendeich in Nesserland zur Nutzung der Aussicht für touristische Zwecke, (1857 1859) 1866 - 1870

- Verpachtung eines städtischen Grundstücks an der Nesserlander Schleuse an den Gastwirt C. Suchsland zur Errichtung eines

Gaststättengebäudes, 1874 - 1894

(1857 - 1859) 1866 - 1894

Klassifikation Teil B: 02594

Trägermaterial: Papier

Alte Reg.-Sig.: VIII A 2 c 063

Bestell-Nr.: IV 02594 

Schleuse

- Gesuch des Bauunternehmers G.B. Dose beim Magistrat um die Pachtung eines städtischen Grundstücks an der Nesserlander Schleuse zur Errichtung einer Bude zur Unterbringung von Arbeitern der Wasserbauprojekte, Mai - Juni 1873

- Verfügung des Magistrats an den Bauunternehmer Dose über Aufforderung zum Abbruch der hölzernen Bude an der Nesserlander Schleuse, Juni 1877

- Gesuch des Bauunternehmers W. Heubült an den Magistrat über Bitte um Überlassung der hölzernen Bude des G. B. Dose für die Unterbringung seiner Arbeiter, Juli 1877

- Verpachtung des Grundstücks mit der Bude an den Bauunternehmer W. Heubült, August 1877

$1873-1877$

Klassifikation Teil B: 02595

Alte Reg.-Sig.: VIII A 2 c 064

Bestell-Nr.: IV 02595

2484 Verpachtung eines Geländestreifens östlich des Hafenfahrwassers

- Gesuch der Emder Heringsfischerei AG an den Magistrat über Bitte um Verpachtung eines städtischen Geländestreifens östlich des Hafenfahrwassers zur Anlegung einer Fähre zu ihren an der Westseite des Fahrwassers befindlichen Lagerhäusern, Mai - Juni 1873

- Gesuch der Emder Heringsfischerei AG an den Magistrat über Bitte um Vererbpachtung eines städtischen Geländestreifens südöstlich des Hafenfahrwassers zur Errichtung einer Landungsbrücke für ihre vergrößerte Heringsloggerflotte, November 1873 - Juli 1874

- Pachtkontrakt zwischen der Stadt Emden und der Emder Heringsfischerei AG über Geländestreifen östlich des Hafenfahrwassers mit einer Laufzeit von 20 Jahren, ab dem 01.01.1875, Juli 1874

- Kündigung des Pachtcontrakts durch die Stadt Emden wegen Bedarf der Fläche für Schleusenbauzwecke, August 1880

- Beschwerde des Emder Heringsfischerei AG wegen Beschädigung ihrer Landungsbrücke durch vorbeifahrende Schiffe, Juli 1885 - Übergang des des verpachteten Geländestreifens in dem Gebiet östlich des Fahrwassers auf Preußen, 1888

$1873-1888$

Klassifikation Teil B: 02596

Trägermaterial: Papier

Alte Reg.-Sig.: VIII A 2 c 065

Bestell-Nr.: IV 02596 
2485 Abtretung eines städtischen Grundstücks an der Schoonhovenpipe

Laufzeit

- Kauf eines städtischen Grundstücks an der Schoonhovenpipe durch den Senator R. Reents zur Arrondierung seines Gartens, Dezember 1872 - Januar 1873

- Umgestaltung der Fläche durch den Senator Reents als Parkfläche, August 1874 - Januar 1876

\section{$1872-1876$}

Klassifikation Teil B: 02597

Trägermaterial: Papier

Alte Reg.-Sig.: VIII A 2 c 066

Bestell-Nr.: IV 02597

2486 Kauf der Nesserlander Kirchen- und Pfarrländereien durch die Stadt

- Verzeichnis der Nesserlander Kirchen- und Pfarrländereien, 1865

- Verhandlungen des Magistrats mit dem kgl. Konsistorium wegen Ankauf der Nesserlander Kirchen- und Pfarrländereien durch die Stadt Emden, August 1865 - Dezember 1868

- Verkauf von Teilen der nunmehr städtischen Ländereien an den Staatsfiskus wegen Hafen- und Kanalbau, August 1887

- Ablösung von Hypotheken auf den ehemaligen Nesserlander Kirchen- und Pfarrländereien durch die Erlöse des Teilverkaufs, 1887 $-1888$

(1865) 1866 - 1888

Klassifikation Teil B: 02598

Trägermaterial: Papier

Alte Reg.-Sig.: VIII A 2 c 067

Bestell-Nr.: IV 02598

- Ermittlung der Eigentumsverhältnisse des Grundstücks der Sielbude, 1875

- Weigerung der Sielrichter der Neupforts- und Gasthaussielacht zur Tragung der Kosten des Abbruchs der Sielbude, Februar - Mai 1875

1875

Klassifikation Teil B: 02599

Trägermaterial: Papier

Alte Reg.-Sig.: VIII A 2 c 069

Bestell-Nr.: IV 02599 
- Verhandlungen des Magistrats mit der Oberpostdirektion in Oldenburg über Grundstückstausch zur Herstellung einer einheitlichen Fluchtlinie für das Postamtsgebäude in der Großen Brückstraße,

Dezember 1871 - April 1875

- Gebäuderissplan: Postamt in der Großen Brückstraße, Januar 1875

- Verhandlungen des Magistrats mit der Oberpostdirektion in Oldenburg über von der Post angeregte Aufhöhung des Platzes vor der Graupferdstraße zur Erweiterung des Postamtsgebäudes, Mai Juni 1876

$1874-1876$

Klassifikation Teil B: 02600

Trägermaterial: Papier

Alte Reg.-Sig.: VIII A 2 c 070

Bestell-Nr.: IV 02600

2489 Ankauf eines Landstücks außer dem Herrentor durch die Stadt Emden

- Beschluss der städtischen Kollegien zum Ankauf eines Landstücks außer dem Herrentor von den Erben des Nittert Janssen, November 1873 - Februar 1874

- Ausfertigung des Kaufvertrages, Dezember 1873

- Verschiedene Verträge über Veräußerung von Teilen des Janssen'schen Besitzes, 1874

$1873-1875$

Klassifikation Teil B: 02601

Trägermaterial: Papier

Alte Reg.-Sig.: VIII A 2 c 072

Bestell-Nr.: IV 02601

2490 Ankauf eines Landstücks außer dem Boltentor durch die Stadt Emden

- Verhandlungen des Magistrats mit den Auktionator Hilkes über Ankauf eines Landstücks außer dem Boltentor durch die Erben des Lübbert Holtkamp, November - Dezember 1871

- Abwicklung der Finanzierung, 1872

- Änderung des Besitztitels im Hypothekenbuch durch das Amtsgericht, Juli 1872

- Schadensersatzforderung des Fuhrmanns H. A. Hinderks wegen Überströmung seines Landes mit Seewasser infolge der Aufschlickung der ehemals Holtkamp'schen Ländereien, Juli 1874

1871 - 1874 (1885) Klassifikation Teil B: 02602

Trägermaterial: Papier Alte Reg.-Sig.: VIII A 2 c 073

Bestell-Nr.: IV 02602 
- Pachtvertrag zwischen der Stadt Emden und dem jüdischen Schlachter Max Stein über Grundstück am Beckhoffstor, März 1872

- Bedingungen der Verpachtung des von der Stadt Emden erworbenen Grundstücks von Holtkamps Erben am Beckhoffstor, 1871

- Risszeichnung des Landstücks (Flurname "Geerds"), 1871

- Berechnung der Pachtgelder für das Landstück, 1874

- Pachtermäßigung für das Landstück außer dem Herrentor wegen Überströmung durch Seewasser, September 1875

- Bedingungen der Verpachtung der Ländereien außer dem Boltentor und außer dem Herrentor, 1876 - 1903

- Pächter der Ländereien, 1876 - 1899

- Pachtberechnung der Ländereien außer dem Boltentor und außer dem Herrentor, 1877 - 1894

- Verpachtung der von der Stadt Emden erworbenen Spannhoffschen Ländereien, 1878 - 1904

- Verpachtung des Grasschnitts auf den Spannhoffschen Ländereien, 1896

- Kündigung der Pachtung eines Teils der Ländereien außer dem Boltentor und dem Herrentor wegen Anlage der Kleinbahn Emden Pewsum, Oktober 1898

$1871-1904$

Klassifikation Teil B: 02603

Band: 1

Trägermaterial: Papier

Alte Reg.-Sig.: VIII A 2 c 074

Bestell-Nr.: IV 02603 
- Pachtermäßigung wegen Beeinträchtigung der Nutzung der Ländereien außer dem Boltentor durch die Anlage einer Kleinbahn und Überschlickung, 1899 - 1900

- Verhandlungen des Magistrats mit dem Kreisausschuss des Kreises Emden wegen Abgrenzung des Bahndamms der Kleinbahn von den städtischen Ländereien außer dem Boltentor, Juli - September 1899 - Pachtberechnung der zum Gemüsebau genutzten Ländereien außer dem Boltentor, Januar 1899 - Januar 1907

- Pachtberechnung der zum Gemüsebau genutzten Ländereien am Herrentor, Januar 1899 - April 1906

- Verpachtung der Ländereien außer dem Boltentor und am Herrentor durch den Auktionator J. D. Woortman, April 1899 - Dezember 1905

- Pächter der Ländereien, 1899 - 1905

- Anträge verschiedener Pächter auf Pachtverlängerung oder

Pachtübernahme, Juni 1899 - Juni 1907

- Kündigung der Pachtung eines Teils der Spannhoffschen Ländereien wegen Verlegung einer Dreckwarf, 1909

- Verpachtung der von der Stadt Emden erworbenen Spannhoffschen Ländereien, 1912

$1871-1904$

Klassifikation Teil B: 02604

Band: 2

Trägermaterial: Papier

Alte Reg.-Sig.: VIII A 2 c 074

Bestell-Nr.: IV 02604 
- Verfügung der Magistrats an die Verpachtungs-Commission über Vorbereitung der Verpachtung des parzellierten Polderlandes, April 1874

- Antrag des Senators Carl Dantziger an den Magistrat auf Erlaubnis zur Errichtung von Baracken im Kaiser-Wilhelm-Polder zur Unterbringung der Deicharbeiter bei der Eindeichung des Polders, November - Dezember 1874 / April 1875

- Regelung der Beaufsichtigung der Quellerwiesen vor dem Kaiser-Wilhelm-Polder, Februar 1875

- Pachtgebote für Felder im Kaiser-Wilhelm-Polder, Mai - Juli 1875

- Pachtgeldberechnung für die Parzellen, 1875

- Kündigung der Pachtung einer Parzelle wegen Bedarfs für einen

Militärschießstand,September - Dezember 1875

- Pachtbedingungen und Verpachtung von Parzellen des Kaiser-Wilhelm-Polders, 1876 - 1897

- Neuverpachtung der vom Kaufmann Helmer von Baden-Foget gepachteten Ländereien im Polder wegen Konkurs, Juni 1878

- Pachten und Pachtraten, 1879 - 1885

- Aufstellung über Kosten von Meliorationsarbeiten im

Kaiser-Wilhelm-Polder, Dezember 1884

- Verpachtung von Ländereien hinter der Emsmauer, 1881 - 1904

$1874-1904$

Klassifikation Teil B: 02605

Band: 1

Trägermaterial: Papier

Alte Reg.-Sig.: VIII A 2 c 076

Bestell-Nr.: IV 02605 
- Verhandlungen des Magistrats mit dem Deichrichter Freerksen wegen Melioration des Kaiser-Wilhelm-Polders, Mai - Juli 1884 - Aufstellung über Pächter und Nutzung des Polderlandes mit Risszeichnung des Kaiser-Wilhelm-Polders, Januar 1890 - Pachtbedingungen und Verpachtung von Parzellen des Kaiser-Wilhelm-Polders, 1886 - 1896

- Pachten und Pachtraten, 1886 - 1896

- Aufstellung über zum Kanalbau vorgesehenen Polderflächen und Entschädigung der Pächter, 1887

- Antrag des Fuhrmanns Haye H. Ubbens an den Magistrat auf Vererbpachtung einer Parzelle nahe seines Hauses im Kaiser-Wilhelm-Polder, Februar - Mai 1889

- Verpachtung der Grasung an den Polderwegen, 1886 - 1893

- Verpachtung der Grasung auf dem Polderdeich, 1894

- Entschädigung von Pächtern wegen Kündigung von Pachtungen durch den Bau des Hafenausschnitts im Kaiser-Wilhelm-Polder, Juni November 1895

$1884-1896$

Klassifikation Teil B: 02606

Band: 2

Trägermaterial: Papier

Alte Reg.-Sig.: VIII A 2 c 076

Bestell-Nr.: IV 02606

2495 Verpachtung der Parzellen im Kaiser-Wilhelm-Polder, Bd. 3

- Ertragsberechnung und Berechnung eines Verkaufspreises für Parzellen im Kaiser-Wilhelm-Polder, Dezember 1895

- Pachten und Pachtraten, 1895 - 1900

- Verpachtung der Grasung auf dem Polderdeich, 1896

- Entschädigung von Pächtern wegen Kündigung von Pachtungen durch Hafen- und Bahnbau im Kaiser-Wilhelm-Polder, 1897 - 1901 - Antrag der Gemüsebaugenossenschaft Emden an den Magistrat auf Beschleunigung der Pflasterung der Polderwege zur Gewährleistung der Erreichbarkeit der von ihren Mitgliedern gepachteten Felder, März 1898

- Verhängung von Konventionalstrafen gegen Pächter wegen Nichtreinigung der Gräben, Juni 1898

$1895-1901$

Klassifikation Teil B: 02607

Band: 3

Trägermaterial: Papier

Alte Reg.-Sig.: VIII A 2 c 076

Bestell-Nr.: IV 02607 
06.01

06.01 .01

06.01.01.03

Städtisches Vermögen

Id. Nr. Tite

\section{Städtische Gebäude und Grundstücke}

Städtische Grundstücke

2496 Abtretung eines Streifens städtischen Grundes am Falderndelft

Laufzeit

- Antrag des Holzhändlers J. Remmerssen an den Magistrat auf Erwerb eines städtischen Geländestreifens wegen Notwendigkeit zur Reparatur und Verbreiterung seiner Kajung am Falderndelft, Mai Juni 1878

- Risszeichnung des Kajungsprojektes, Juli 1878

1878
Klassifikation Teil B: 02608
Trägermaterial: Papier
Alte Reg.-Sig.: VIII A 2 c 095
Bestell-Nr.: IV 02608

2497 Verpachtung städtischer Flächen am Vogelsangzwinger

- Verpachtung städtischer Flächen am Vogelsangzwinger an den Zimmermann Brian etc.

1876
Klassifikation Teil B: 02609
Trägermaterial: Papier
Alte Reg.-Sig.: VIII A 2 c 090
Bestell-Nr.: IV 02609

2498 An- und Verkauf von Erde

- Verkauf von Erde aus städtischen Grundstücken zu Aufhöhungsund Meliorationszwecken, (1856 - 1860) 1874 - 1910

- Kauf von Erde auis der Vertiefung des Liegehafens der Heringsfischerei AG Neptun durch die Stadt Emden zur Aufhöhung städtischer Grundstücke, 1900 - 1906

(1856 - 1860) 1874 - 1910

Klassifikation Teil B: 02610

Trägermaterial: Papier

Alte Reg.-Sig.: VIII A 2 c 084

Bestell-Nr.: IV 02610

- Pachtbedingungen und Berechnung der Pachtraten für den Grasschnitt auf städtischen Grundstücken (Wall, Deiche, Wege etc.)

1879

Klassifikation Teil B: 02611

Trägermaterial: Papier

Alte Reg.-Sig.: VIII A 2 c 094

Bestell-Nr.: IV 02611 
- Verpachtung des Löschplatzes am Hinter Tief an Schiffer etc. zur Lagerung von Bauschutt und anderer Materialien

$1879-1909$

Klassifikation Teil B: 02612

Trägermaterial: Papier

Alte Reg.-Sig.: VIII A 2 c 093

Bestell-Nr.: IV 02612

2501 Grundstückstausch zwischen der Stadt Emden und der Gemeinde der

- Antrag der Verwaltung der Großen Kirche an den Magistrat auf Tausch eines Streifens des südlichen Friedhofs der Großen Kirche gegen einen Streifen städtischen Grundes, April - November 1877

1877
Klassifikation Teil B: 02613
Trägermaterial: Papier
Alte Reg.-Sig.: VIII A 2 c 092
Bestell-Nr.: IV 02613

2502 Platz zwischen beiden Bleichen und der Haarlemer Bleiche

- Anzeigen des Polizeisergeanten Schnür gegen die Witwe Wever und gegen den Kaufmann Heyl wegen unerlaubten Abstechens von Soden von einem städtischen Gelände (ehemalige Seilbahn), Mai - Juni 1870

- Votum der Verpachtungskommission für eine Einfriedung des Grundstücks zwischen beiden Bleichen und der Haarlemer Bleiche und Nutzung als städtischer Obstgarten, Mai 1876

- Unerlaubte Aufstellung von Pfählen auf dem Gelände durch den Seilermeister J. H. Schmeding, Oktober 1881 - Februar 1882

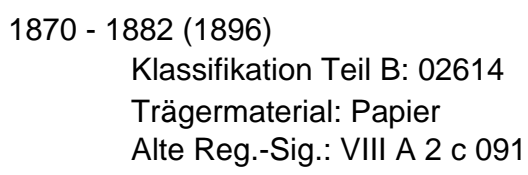

2503 Abtretung eines städtischen Geländestreifens an der Nesserlander Schleuse

-Abtretung eines städtischen Geländestreifens an der Nesserlander Schleuse an die Deutsche Seewarte zur Errichtung eines Signalmastes, 1876

- Verlegung des Signalmastes wegen Verlegung des Deiches an der Nesserlander Schleuse, 1902

$1876-1902$ 
- Verpachtung einer Schloothälfte am Herrentor an den Holzhändler Johann van Ameren

$1876-1901$

Klassifikation Teil B: 02616

Trägermaterial: Papier

Alte Reg.-Sig.: VIII A 2 c 088

Bestell-Nr.: IV 02616

2505 Verpachtung eines städtischen Landstücks an der Auricher Chaussee

- Verpachtung eines städtischen Landstücks an der Auricher Chaussee an den Gemüsebauern Bette Raveling

$1877-1882$

Klassifikation Teil B: 02617

Trägermaterial: Papier

Alte Reg.-Sig.: VII A 2 c 082

Bestell-Nr.: IV 02617

2506 Verpachtung eines städtischen Geländestreifens an der Schoonhovenstraße

- Antrag des Fuhrmanns Hieronymus Dallinga an den Magistrat auf Pachtung eines städtischen Grundstreifens zur Arrondierung seines Grundstücks, April - Juli 1875

- Beeinträchtigung städtischen Grundbesitzes durch ungenehmigte Veränderung des Eingangsbereiches des Dallinga'schen

Grundstücks, Januar - April 1876

- Verfügung des Magistrats über Verpachtung eines städtischen Geländestreifens an der Schoonhovenstraße an H. Dallinga gegen eine jährliche Recognition, April 1875

- Verpachtung eines weiteren städtischen Geländestreifens an H. Dallinga zur Aufstellung von Tischen und Stühlen für den Außenbereich seiner Gaststätte, Juli - September 1877

- Antrag des H. Dallinga auf Umwandlung seiner Pachtung in eine Erbpachtung, Dezember 1877 - Januar 1878

- Verhandlungen des Magistrats mit H. Dallinga über

Grundstückstausch zur Arrondierung des städtischen und des

Besitzes des H. Dallinga, Februar - Mai 1878

$1875-1878$

Klassifikation Teil B: 02618

Trägermaterial: Papier

Alte Reg.-Sig.: VIII A 2 c 079

Bestell-Nr.: IV 02618 
2507 Grenzziehung zwischen einem städtischen Grundstück und den Besitz des Uffe Fokken am Herrentor

- Regelung des Grenzverlaufes zwischen dem Grundstück des Uffe Fokken und des städtischen Grundbesitzes am Herrentor wegen Beeinträchtigung des städtischen Grundbesitzes durch eine vorspringende Treppe des Uffen'schen Hauses, 1875

- Eintragung der neuen Grenzverhältnisse in das Grundbuch, Dezember 1885 - Juni 1886

$1875-1886$

Klassifikation Teil B: 02619

Trägermaterial: Papier

Alte Reg.-Sig.: VIII A 2 c 080

Bestell-Nr.: IV 02619

2508 Veräußerung eines Bauplatzes aus der städtischen Besitzung

Bentinckshof

- Angebote zum Kauf eines Bauplatzes aus der städtischen Besitzung Bentinckshof, Mai - Dezember 1875

1875
Klassifikation Teil B: 02620
Trägermaterial: Papier
Alte Reg.-Sig.: VIII A 2 c 079
Bestell-Nr.: IV 02620

2509 Beabsichtigte Landkäufe

- Verhandlungen des Magistrats mit Grundbesitzern über Grundstücksverkäufe an die Stadt Emden

$1871-1896$

Klassifikation Teil B: 02621

Trägermaterial: Papier

Alte Reg.-Sig.: VIII A 2 c 078

Bestell-Nr.: IV 02621 
- Klage des Holzhändlers Luto van Senden gegen den Magistrat der Stadt Emden vor dem Amtsgericht wegen Beeinträchtigung seines Eigentumsrecht an einem Grundstück an der Boltentorstraße durch einen von der Stadt Emden angelegten Weg unter Missachtung seiner Wegegerechtigkeit, Dezember 1875 - März 1877

- Berufung des Holzhändlers L. van Senden beim Obergericht Aurich gegen das für inn ungünstige Urteil des Amtsgerichts Emden, April 1877 - Juni 1880

- An den Syndicus Metger gesandtes Vergleichsangebot des L. van Senden, Mai - Juni 1879

- Abrechnungen über Gerichts und Anwaltskosten, 1880 - 1881

$1875-1881$

Klassifikation Teil B: 02622

Band: 1

Trägermaterial: Papier

Alte Reg.-Sig.: VIII A 2 c 098

Bestell-Nr.: IV 02622

2511 Rechtsstreit um das Eigentum an einem Grundstück an der Boltentorstraße, Bd. 2

- Handakte des Syndicus Metger zum Rechtsstreit Holzhändlers Luto van Senden gegen den Magistrat der Stadt Emden wegen Beeinträchtigung seines Eigentumsrecht an einem Grundstück an der Boltentorstraße durch einen von der Stadt Emden angelegten Weg unter Missachtung seiner Wegegerechtigkeit zur Führung des Berufungsverfahrens vor dem Obergericht

$1877-1881$

Klassifikation Teil B: 02623

Band: 2

Trägermaterial: Papier

Alte Reg.-Sig.: VIII A 2 c 098

Bestell-Nr.: IV 02623

2512 Rechtsstreit um das Eigentum an einem Garten am Bentincksweg

- Klage des Gärtners J. Boekwinkel gegen den Magistrat beim Amtsgericht Emden wegen Beeinträchtigung seiner Eigentumsrechte durch Magistratsverfügung über Unterlassung einer Grabenreinigung, Oktober 1874 - Januat 1876

- Verhandlungen zwischen beiden Parteien zur Erzielung eines Vergleiches, Mai - November 1876

- Berufungsklage des Magistrats gegen das Urteil des Amtsgerichtes beim Obergericht Aurich, Dezember 1876 - Februar 1877

$1874-1877$

Klassifikation Teil B: 02624

Trägermaterial: Papier

Alte Reg.-Sig.: VIII A 2 c 096

Bestell-Nr.: IV 02624 
2513 Rechtsstreit um das Eigentum am Grundstück am alten Bollwerk, Bd. 1

- Verhandlungen zwischen dem Holzhändler J. G. van Letten und dem Magistrat wegen Grenzfestsetzung zwuschen dem Grundstück des Holzhändlers und dem städtischen Gelände am Bollwerk zur Klärung der Lage umstrittener Holzpfähle vor seiner Hiolzbude, Juli - Oktober 1877

- Widerspruchsvefahren wegen der Verfügung des Magistrats zur Beseitigung der Pfähle vor dem preußischen Landdrosten in Aurich, Juni 1877 - Juli 1878

- Klage des Holzhändlers J. G. van Letten gegen den Magistrat beim Amtsgericht Emden gegen Beeinträchtigung seiner Eigentumsrechte durch die Magistratsverfügung über Anordnung zur Entfernung von Holzpfählen vor seiner Holzbude auf seinem Grundstück am alten Bollwerk, Juli 1878 - Dezember 1880

- Berufungsklage des Magistrats gegen das Urteil des Amtsgerichts Emden beim Landgericht Aurich, Januar 1880 - Dezember 1881

$1877-1881$

Klassifikation Teil B: 02625

Band: 1

Trägermaterial: Papier

Alte Reg.-Sig.: VIII A 2 c 099

Bestell-Nr.: IV 02625

2514 Rechtsstreit um das Eigentum am Grundstück am alten Bollwerk, Bd. 2

- Handakte des Rechtsanwalts Vissering als Vertreter des Magistrats in der Berufungsklage Magistrats gegen das Urteil des Amtsgerichts Emden beim Landgericht Aurich in der Grundeigentumsstreitsache zwischen dem Holzhändler J. G. van Letten gegen die Stadt Emden

$1880-1881$

Klassifikation Teil B: 02626

Band: 2

Trägermaterial: Papier

Alte Reg.-Sig.: VIII A 2 c 099

Bestell-Nr.: IV 02626 
2515 Kauf einer Landfläche im Kaiser-Wilhelm-Polder durch die Stadt Emden

- Verhandlungen des Magistrats über Angebot des Landwirts Groenhagen aus Wolthusen zum Verkauf von vier Morgen Land im Kaiser-Wilhelm-Polder gegen 2840 Mark/Morgen, Februar - Juli 1880 - Eintragung der Stadt Emden als neue Besitzerin der Ländereien des Landwirts Groenhagen im Kaiser-Wilhelm-Polder in das Grundbuch, November 1880

- Abwicklung der Finanzierung des Landkaufs, Januar - März 1881

$1880-1881$

Klassifikation Teil B: 02627

Trägermaterial: Papier

Alte Reg.-Sig.: VIII A 2 c 100

Bestell-Nr.: IV 02627

2516 Platz an der Wilhelmstraße

- Streit zwischen dem Kräutner Wiard Poelders und dem Magistrat wegen Besitzansprüche des W. Poelders auf dem Platz an der Wilhelmstraße

1879

Klassifikation Teil B: 02628

Trägermaterial: Papier

Alte Reg.-Sig.: VIII A 2 c 101

Bestell-Nr.: IV 02628

2517 Verpachtung des städtischen Grundstückes an der Westseite der Schlichte

- Verpachtung des städtischen Grundstückes an der Westseite der Schlichte an den Sielwärter Johann H. Henning, August - September 1879

- Pachtberechnung, Oktober 1879

- Antrag des Sielwärters Henning an den Magistrat auf Überlassung des gepachteten Grundstücks an der Schlichte in Erbpacht, Februar 1881

- Rückerstattung zuviel gezahlter Pachtbeträge an den Auktionator Woortmann wegen Verkauf des Grundstückes, 1905

$1879-1905$

Klassifikation Teil B: 02629

Trägermaterial: Papier

Alte Reg.-Sig.: VIII A 2 c 102

Bestell-Nr.: IV 02629 
2518 Ankauf eines Grundstücks an der Boltentorstraße durch die Stadt Emden und Verkauf durch die Stadt

- Angebot des Holzhändlers Luto van Senden über Verkauf seines Grundstücks an der Boltentorstraße an die Stadt Emden zur Vermeidung einer Enteignung wegen der Lage seines Grundstücks auf der geplanten Trasse der Chaussee nach Larrelt, Mai 1873 - Verhandlungen des Magistrats mit den vom Chausseebau betroffenen Grundbesitzern über Erwerb ihrer Grundstücke, Januar Juli 1874

- Anfrage des Holzhändlers Luto van Senden wegen Erwerb eines Teils des Dungerplatzes am Beckhoffstor wegen beabsichtigter Anlage eines Lagerplatzes, Januar 1875

- Verhandlungen des Magistrats mit Luto van Senden wegen Grundstückstausch: Holzbude an der Boltentorstraße gegen Teil des Dungerplatzes am Beckhoffstor, November 1875 - Mai 1876

- Eintragung der neuen Besitztitel in das Grundbuch, Mai 1881

- Vermessung der Grundstücke, April 1882

$1877-1882$

Klassifikation Teil B: 02630

Trägermaterial: Papier

Alte Reg.-Sig.: VIII A 2 c 103

Bestell-Nr.: IV 02630

2519 Grundstückstausch zwischen der Stadt Emden und dem Kalkbrenner J. D. Folkerts

- Tausch des Grundstücks des Kalkbrenners J. D. Folkerts gegen das städtische Nachbargrundstück zur Arrondierung des Fabrikgeländes, November 1875

- Zeichnung der ausgetauschten Grundstücke, 1875

- Genehmigung des Grundstückstausches durch den preußischen Landdrosten in Aurich, Januar 1876

- Eintragung der neuen Besitztitels in das Grundbuch, März 1876

$1875-1876$

Klassifikation Teil B: 02631

Trägermaterial: Papier

Alte Reg.-Sig.: VIII A 2 c 104

Bestell-Nr.: IV 02631 
2520 Ankauf eines Grundstücks am Bentincksweges durch die Stadt Emden

- Beschluss der städtischen Kollegien über Ankauf eines Grundstücks am Bentincksweges zur Weiterführung des Weges bis zum Wall, Februar 1878 / April 1880

- Gutachten des Stadtbaumeisters Wiggers über Wert und

Beschaffenheit des vom Kaufmann Wiard Poelders abzukaufenden

Grundstücks am Bentincksweg, Januar 1880

- Kaufvertrag zwischen Wiard Poelders und der Stadt Emden, Juni

1880

- Planung der Verlängerung des Bentincksweges zum Wall, Dezember 1880 - Juni 1881

- Katastervermessung des Grundstücks des W. Poelders und

Änderung des Besitztitels im Grundbuch, 1881 - 1882

$1878-1882$

Klassifikation Teil B: 02632

Trägermaterial: Papier

Alte Reg.-Sig.: VIII A 2 c 106

Bestell-Nr.: IV 02632

- Anzeige des Polizeisergeanten Wildhagen gegen den Kaufmann Aaron Gans wegen Versperrung des öffentlichen Münnickeganges, November 1874

- Verpachtung eines Bereichs des Münnickeganges an den Schlachter G. H. Thyssen zur Nutzung als Schweineschlachtplatz, Juli 1880 -

Oktober 1883

- Regelung der Reinigung des Münnickeganges, 1884

$1874-1884$

Klassifikation Teil B: 02633

Trägermaterial: Papier

Alte Reg.-Sig.: VIII A 2 c 108

Bestell-Nr.: IV 02633 
- Schadensersatzforderung des C. Pantekoek gegen die Stadt Emden wegen Beschädigung seiner Obstbäume durch herabfallende morsche Äste von Bäumen am Wall, August 1878

- Grenzregulierung des Pantekoek'schen Grundstücks am Albringwehrster Zwinger, Januar - Juli 1879

- Streit um die Einfriedung des Pantekoekschen Grundstück durch eine Hecke, August 1879 - März 1880

- Streit um die Weidung von Schafen auf dem Weg vor dem

Pantekoekschen Erbpachtsgrundstück, April 1880

- Verschiedene Anzeigen gegen C. Pantekoek wegen Beschädigung von Wallbäumen am Weg vor seinem Grundstück, 1881

- Klage des Carl Pantekoek gegen die Stadt Emden vor dem Amtsgericht wegen Verletzung seines Eigentumsrechtes am Weg vor seinem Haus, Oktober 1881

- Berufungsverfahren gegen das für Pantekoek ungünstige Urteil des Amtsgerichts vor dem Landgericht Aurich, November 1881 -

Dezember 1884

$1878-1884$

Klassifikation Teil B: 02634

Trägermaterial: Papier

Alte Reg.-Sig.: VIII A 2 c 109

Bestell-Nr.: IV 02634

2523 Gesuche um Pachtung städtischer Grundstücke

- Verschiedene Gesuche um Pachtung städtischer Grundstücke

$1881-1912$

Klassifikation Teil B: 02635

Trägermaterial: Papier

Alte Reg.-Sig.: VIII A 2 c 111

Bestell-Nr.: IV 02635

2524 Erwerb einer Moorfläche durch die Stadt Emden

- Verhandlungen des Magistrats über Erwerb einer Moorfläche bei Moordorf vom Domänenfiskus in Erbpacht zur Kultivierung, Mai 1881 - Schreiben des Regierungsrats Buchholtz an den Magistrat über Bedingungen der Moorkultivierung und der Verkehrsanbindung, Mai Juni 1881

- Werbung des Vereins für innere soziale Kolonialisierung, 1912

1881 (1912)

Klassifikation Teil B: 02636

Trägermaterial: Papier

Alte Reg.-Sig.: VIII A 2 c 113

Bestell-Nr.: IV 02636 
06

Finanzverwaltung der Stadt Emden

06.01

06.01.01

06.01.01.03

Städtisches Vermögen

Städtische Gebäude und Grundstücke

Städtische Grundstücke

Lfd. Nr. Titel

Laufzeit

2525 Grünstreifen an der Boltentorstraße

- Streit um die Eigentumsrechte an der Wanderung vor dem Haus Boltentorstraße 56 zwischen dem Hausbesitzer H. Visser und dem Magistrat, Oktober 1880 - April 1881

$1880-1881$

Klassifikation Teil B: 02637

Trägermaterial: Papier

Alte Reg.-Sig.: VIII A 2 c 114

Bestell-Nr.: IV 02637

2526 Abtretung eines städtischen Grundstücks an der kleinen

1879

Faldernstraße

- Abtretung eines Streifens städtischen Grundes an der kleinen

Faldernstraße an die Witwe Uffen nach Verlegung des Pissoirs am

Postamts zur Vermeidung von Verschmutzungen

1879

Klassifikation Teil B: 02638

Trägermaterial: Papier

Alte Reg.-Sig.: VIII A 2 c 112

Bestell-Nr.: IV 02638

2527 Streit um die Eigentumsrechte an einem Grundstück außerhalb der langen Brücke

- Verfügung des Magistrats an den Kräutner S. P. Kolhoff über Aufforderung zur Beendigung der Anmaßung von Eigentumsrechten am Grundstück Nr. 46, außerhalb der langen Brücke und Behinderung des städtischen Pächters, November 1884

- Klage des Magistrats gegen den Kräutner S. P. Kolhoff beim

Landgericht Aurich wegen Besitzstörung, April - Juli 1884

- Berufungsverfahren vor dem Oberlandesgericht Celle gegen das für die Stadt Emden ungünstige Urteil des Landgerichts Aurich, Juli 1885 - April 1886

$1884-1885$

Klassifikation Teil B: 02639

Trägermaterial: Papier

Alte Reg.-Sig.: VIII A 2 c 117

Bestell-Nr.: IV 02639 
06

Finanzverwaltung der Stadt Emden

06.01

06.01 .01

06.01.01.03

Städtisches Vermögen

Städtische Gebäude und Grundstücke

Städtische Grundstücke

Lfd. Nr. Titel

Laufzeit

2528 Grundstück an der Boltentorstraße

- Beschwerde des Oltmann H. Oltmanns gegen die Anlegung einer neuen Tür am ehemaligen Wachthäuschen am Wall an der Boltentorstraße wegen Eigentumsansprüche am Grundstück des Wachthäuschens, Oktober 1878

- Klärung der Eigentumsverhältnisse des Grundstücks des alten Wachthäuschens, November 1878 - März 1881

$1878-1881$

Klassifikation Teil B: 02640

Trägermaterial: Papier

Alte Reg.-Sig.: VIII A 2 c 115

Bestell-Nr.: IV 02640

2529 Abtretung eines städtischen Grundstücks an die kgl.

1885-1896

Wasserbau-Inspektion

- Suche nach einem geeigneten städtischen Grundstück im Hafengebiet für ein Dienstgebäude der kgl. Wasserbau-Inspektion wegen Protest der Emder Heringsfischerei AG gegen einen Bau in unmittelbarer Nähe zu ihrem Betriebsgelände, Dezember 1885 November 1892

- Verhandlungen des Magistrats mit der Regierung in Aurich wegen Austausch eines städtischen Grundstücks gegen fiskalisches Land zum Bau des Dienstgebäudes für die kgl. Wasserbau-Inspektion, August 1890 - September 1896

$1885-1896(1897)$

Klassifikation Teil B: 02641

Alte Reg.-Sig.: VIII A 2 c 118

Bestell-Nr.: IV 02641 
2530 Klärung der Eigentumsverhältnisse des Terrains zwischen dem Wall 1882-1889 und der Vrouw-Johanna-Mühle

- Beschwerde des Müllers A. A, Foget gegen Beeinträchtigung seines Mühlenbetriebes durch Wegebau und Pflanzungen auf dem Terrain zwischen dem Wall und der Vrouw-Johanna-Mühle unter Behauptung seiner Eigentümerrechte, Mai 1882

- Regelung der Grundstücksgrenze der Vrouw-Johanna-Mühle, Dezember 1882 - Dezember 1888

- Risszeichnung: Grundstück der Vrouw-Johanna-Mühle, 1886

- Klage des Müllers Hinderk Foget gegen den Magistrat beim Amtsgericht wegen Beschneidung seines Wegerechtes durch Anlage von Parkanlagen am Wall, September - Dezember 1887

- Vergleich zwischen Hinderk H. Foget und dem Magistrat über Regelung der Wegegerechtigkeit im Zuge der Anlegung eines Reitweges, Dezember 1887

- Katastvermessuing des Terrains zwischen dem Wall und der Vrouw-Johanna-Mühle, 1889

$1882-1889(1908)$

Klassifikation Teil B: 02642

Trägermaterial: Papier

Alte Reg.-Sig.: VIII A 2 c 119

Bestell-Nr.: IV 02642

- Abtretung einer kleinen Grundfläche seines Grundstückes an die Stadt Emden durch Otto G. van Senden, September - Oktober 1885 - Vermessung der neuen Fluchtlinie, 1886

1885.- 1886

Klassifikation Teil B: 02643

Trägermaterial: Papier Alte Reg.-Sig.: VIII A 2 c 121

Bestell-Nr.: IV 02643 
- Vermerk des Oberbürgermeisters Fürbringer über Kaufpreis für den Erwerb von Grundstücken zum Bau- und Ausbau des Post- und Telegraphenamtes, Dezember 1887

- Verhandlungen mit Grundstücksbesitzern über Verkauf ihrer

Liegenschaften, Dezember 1887 - November 1891

- Verhandlungen des Magistrats mit der kaiserlichen

Oberpostdirektion in Oldenburg wegen Ankauf von Grundstücken zum

Bau des Post- und Telegraphenamtes, Dezember 1887 - Mai 1896

- Eintragung der neuen Besitztitel für die angekauften Grundstücke in das Grundbuch, 1888 / 1892

- Finanzielle Abwicklung der Grundstückskäufe, Mai 1888

- Vermietung der von der Stadt Emden (ursprünglich für den

Postfiskus) erworbenen Rodewykschen Häuser, 1889 - 1890

- Abriss der Rodewykschen Häuser, 1890

- Vermietung des von der Stadt Emden (ursprünglich für den

Postfiskus) erworbenen Hauses Große Osterstraße 25, 1891 - 1894

- Abriss der von der Stadt erworbenen Häuser Große Osterstraße 23 /

24 und 25, Mai 1894

\author{
$1887-1896$ \\ Klassifikation Teil B: 02644 \\ Trägermaterial: Papier \\ Alte Reg.-Sig.: VIII A 2 c 122 \\ Bestell-Nr.: IV 02644
}

2533 Verpachtung eines städtischen Grundstücks Außer dem Beckhofftor

- Antrag des Holzhändlers Luto van Senden beim Magistrat auf Pachtung eines städtischen Grundstücks Außer dem Beckhofftor zur Lagerung von Baumaterialien, Juni - Oktober 1889

- Verpachtung eines städtischen Grundstücks Außer dem Beckhofftor an den Holzhändler Luto van Senden, November 1889 - April 1899

- Beschwerde des Holzändlers Luto van Senden gegen die Höhe der Pachtrate, Januar 1890

- Verpachtung des Grundstücks an die Fa. Busche \& Mühlenbruch, Februar 1891 - Juni 1902

$1889-1902$

Klassifikation Teil B: 02645

Trägermaterial: Papier

Alte Reg.-Sig.: VIII A 2 c 124

Bestell-Nr.: IV 02645

2534 Grenzregulierungen und Grundbucheintragungen

- Grenzregulierungen zwischen privaten und städtischen Grundstücken am Neuen Markt und Eintragungen der Korrekturen in das Grundbuch

$1885-1888$

Klassifikation Teil B: 02646

Trägermaterial: Papier

Alte Reg.-Sig.: VIII A 2 c 126

Bestell-Nr.: IV 02646 
2535 Abtretung der im Besitz der Eisenbahnverwaltung befindlichen Grundstücke im Bereich der Bahnhofsstraße an die Stadt Emden

- Verhandlungen zwischen dem Magistrat und der kgl.

Staatseisenbahn-Verwaltung über Abtretung der im Besitz der Eisenbahnverwaltung befindlichen Grundstücke im Bereich der Bahnhofsstraße gegen Anschluss des Bahnhofsgebäudes an die Kanalisation und der Übertragung städtischer Ländereien an der

Petkumer Straße an den Bahnfiskus, Juli 1893

- Eintragung der neuen Besitztitel in das Grundbuch, 1894

$1893-1894$

Klassifikation Teil B: 02647

Trägermaterial: Papier

Alte Reg.-Sig.: VIII A 2 c 127

Bestell-Nr.: IV 02647

2536 Korrektur irrtümlich erfolgter Eintragung bahnfiskalischer Grundstücke unter dem Besitztitel der Stadt Emden in das Grundbuch

- Spezifikation der irrtümlich unter dem Besitztitel der Stadt Emden in das Grundbuch eingetragene bahnfiskalische Grundstücke, April 1895 - Neueintragung der Grundstücke in das Grundbuch, Mai 1895 Januar 1896

$1895-1896$

Klassifikation Teil B: 02648

Trägermaterial: Papier

Alte Reg.-Sig.: VIII A 2 c 201

Bestell-Nr.: IV 02648

\section{Bahnhofsstraße}

- Organisation der Reinigung der Bahnhofsstraße, 1888

- Verhandlungen des Magistrats mit der Eisenbahnverwaltung über Erwerb des eisenbahnfiskalischen Teils der Bahnhofsstraße durch die Stadt Emden, Februar 1888 - März 1895

- Eintragung der von der Stadt erworbenen bahnfiskalischen Grundstücke unter dem neuen Besitztitel in das Grundbuch, April 1895

- Anschluss des Bahnhofs und der bahnfiskalischen Anlagen an die Kanalisation, 1891 - 1894

- Planzeichnung: Bahnhof und Bahnhofsstraße, 1891

$1888-1895$

Klassifikation Teil B: 02649

Trägermaterial: Papier

Alte Reg.-Sig.: VIII A 2 c 127

Bestell-Nr.: IV 02649 
06.01

06.01 .01

06.01.01.03

Städtisches Vermögen

Ifd. $\mathrm{Nr}$. Titel

\section{Städtische Gebäude und Grundstücke}

Städtische Grundstücke

2538 Verpachtung eines städtischen Grundstücks als Lagerplatz

Laufzeit

2538 Verpachtung eines städtischen Grundstücks als Lagerplatz

- Verpachtung eines städtischen Grundstücks an der Larrelter

Landstraße als Lagerplatz an den Baumaterialienhändler Hayo

Folkerts, 1889 - 1896

- Risszeichnung des Grundstücks, 1889

$1889-1896$

Klassifikation Teil B: 02650

Trägermaterial: Papier

Alte Reg.-Sig.: VIII A 2 c 128

Bestell-Nr.: IV 02650

2539 Klärung der Eigentumsrechte an einer Parzelle an der Spiegelstraße

- Klärung der Eigentumsrechte an einer Parzelle und einem Gang an der Spiegelstraße

1885
Klassifikation Teil B: 02651
Trägermaterial: Papier
Alte Reg.-Sig.: VIII A 2 c 130
Bestell-Nr.: IV 02651

2540 Grenzregulierung zwischen dem Grundstück des H. Brongers und der Straße Zwischen Beiden Bleichen II. Teil

- Feststellung der Grenze des Grundstücks des Hermannus Brongers gegenüber der Straße Zwischen Beiden Bleichen II. Teil

$1887-1889$

Klassifikation Teil B: 02652

Trägermaterial: Papier

Alte Reg.-Sig.: VIII A 2 c 131

Bestell-Nr.: IV 02652

2541 Verpachtung einer städtischen Grundfläche an die Emdener Papierfabrik

- Pachtung einer städtischen Grundfläche durch die Emdener Papierfabrik zur Herstellung einer Einfriedung um das Fabrikgelände, 1889 - 1914

- Feststellung der Grenze des Grundstücks der Emdener Papierfabrik, September 1889 -- März 1890

$1889-1914$

Klassifikation Teil B: 02653

Trägermaterial: Papier

Alte Reg.-Sig.: VIII A 2 c 133

Bestell-Nr.: IV 02653 
06.01 Städtisches Vermögen

06.01.01

06.01.01.03

Städtische Gebäude und Grundstücke

Städtische Grundstücke

Lfd. Nr. Titel

Laufzeit

2542 Plan des Ankaufs des ehemaligen Lazaretts und des Exerzierplatzes 1889-1892 durch die Stadt Emden

- Feststellung des Wertes der Grundstücke des ehemaligen Lazaretts und des Exerzierplatzes, 1889

- Verhandlungen des Magistrats mit der Intendantur des 10.

Armeekorps wegen Kauf des ehemaligen Lazaretts und des

Exerzierplatzes durch die Stadt Emden, April 1889 - Oktober 1892

$1889-1892$

Klassifikation Teil B: 02655

Trägermaterial: Papier

Alte Reg.-Sig.: VIII A 2 c 135

Bestell-Nr.: IV 02655

2543 Verpachtung einer Grünfläche am Terrain des zugeschütteten Neupfortssieltiefes

- Bewerbung des Kaufmanns Siegfried Pels um die Pachtung einer Grünfläche am Terrain des zugeschütteten Neupfortssieltiefes,

Oktober 1892

- Verpachtung einer Grünfläche am Terrain des zugeschütteten Neupfortssieltiefes an den Kaufmann Siegfried Pels und seine Witwe, $1893-1901$

$1892-1901$

Klassifikation Teil B: 02656

Trägermaterial: Papier

Alte Reg.-Sig.: VIII A 2 c 140

Bestell-Nr.: IV 02656 
- Verkauf des Exerzierplatzes durch das kgl. Hannoversche

Kriegsministerium an die Stadt Emden, 1840 - 1841

- Gesuch des Magistrats an das preußische Kriegsministerium um Genehmigung des Baues eines Krankenhauses auf dem Hofgelände der alten Kaserne, Dezember 1890 - Februar 1891 - Mitteilung des Regierungspräsidenten in Aurich über Kaufpreisforderung des Kriegsministeriums über das Gelände der alten Kaserne über 21.000 Mark, Februar 1891

- Verhandlungen des Magistrats mit dem Vaterländischen Frauenverein Emden über Erwerb des Grundstück für ein Krankenhaus unter Trägerschaft des Vereins, Mai - Juni 1891

- Verhandlungen der städtischen Kollegien über den von der Regierung in Aurich vorgelegten Vertragsentwurf zum Ankauf des Kasernenplatzes, August 1891

- Konflikt zwischen dem Magistrat und der Regierung wegen eines von ihr verfochtenen Eigentumsvorbehaltes über den Kasernenplatz, September - Oktober 1891

- Eingabe des Magistrats an den preußischen Minister für Landwirtschaft. Domänen und Forsten über Bitte um Weglassung des Eigentumsvorbehaltes im Kaufvertrag über das Kasernengelände, Oktober 1891

- Vollzug des Kaufvertrages, Dezember 1891 - Juni 1892

- Eintragung des neuen Besitztitels im Grundbuch, August 1892

(1840 - 1841) 1890 - 1892 (1894 / 1935)

Klassifikation Teil B: 02657

Trägermaterial: Papier

Alte Reg.-Sig.: VIII A 2 c 140

Bestell-Nr.: IV 02657

2545 Grundstückstausch zwischen der Stadt Emden und der Wwe. Brons

- Tausch des städtischen Teils der Tholenwarf am Alten Markt gegen ein Gartengrundstück der Wwe. Brons

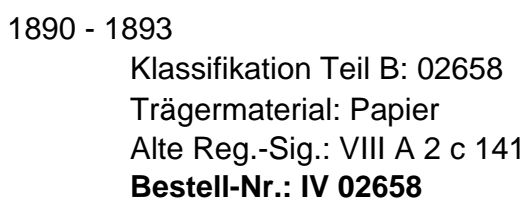

2546 Grenzregulierung: Abegg'sche Helling

- Regulierung der Grenze des Grundstücks der Abegg'schen Helling gegenüber städtischen Grundstücken

$1885-1886$

Klassifikation Teil B: 02659

Trägermaterial: Papier

Alte Reg.-Sig.: VIII A 2 c 142

Bestell-Nr.: IV 02659 
- Abtretung eines Grünstreifens am zugeschütteten Lindengraben im Bereich des Friedhofs der Neuen Kirche an die reformierte Gemeinde

1888

\author{
Klassifikation Teil B: 02660 \\ Trägermaterial: Papier \\ Alte Reg.-Sig.: VIII A 2 c 146 \\ Bestell-Nr.: IV 02660
}

2548 Verpachtung eines städtischen Grünstreifens an der Neutorstraße

- Verpachtung eines städtischen Grünstreifens an der Neutorstraße an den Hotelier Louis Schoy wegen Raumbedarf zum Bau eines Pferdestalls mit Remise

$1896-1902$

Klassifikation Teil B: 02661

Trägermaterial: Papier

Alte Reg.-Sig.: VIII A 2 c 147

Bestell-Nr.: IV 02661

- Streit um die Instandsetzung einer Kajung am Schullegang wegen unklarer Eigentumsverhältnisse, 1873 / 1890

- Ankauf des Schaaf'schen Brandgrundstücks (Besitzerin: Kaufmannswitwe Gesina Klaassen) durch die Stadt Emden zur Verbreiterung der Straße Zwischen beiden Märkten und Sicherung der Fluchtlinie, Dezember 1896 - Juli 1897

- Verhandlungen des Magistrats mit dem landschaftlichen Kollegium wegen Auszahlung der Brandversicherungssumme für das angebrannte Haus der Witwe Klaassen an die Stadtkasse, Dezember 1896 - Mai 1897

- Kauf der Grundstücke des Kaufmanns G. Geerds und der Gebrüder R. und J. Schaudy durch die Stadt Emden, Dezember 1896

- Situationsplan, 1894 - 1896

$1873-1897$

Klassifikation Teil B: 02662

Trägermaterial: Papier

Alte Reg.-Sig.: VIII A 2 c 150

Bestell-Nr.: IV 02662 
- Verpachtung städtischer Ländereien außerhalb der Langen Brücke an die Holz- und Baumaterialienhandlung Geerdes, Schelten und Boerma zur Erweiterung ihres Lagerplatzes, November 1896 November 1901

- Entschädigung der Pächter wegen Beeinträchtigung der

Pachtflächen durch den Bau der Emder Straßenbahn, 1901

$1896-1901$

Klassifikation Teil B: 02663

Trägermaterial: Papier

Alte Reg.-Sig.: VIII A 2 c 151

Bestell-Nr.: IV 02663

2551 Verpachtung eines städtischen Grundstücks im Kaiser-Wilhelm-Polder

- Antrag der Deutsch-Russischen Naphtha-Import-Gesellschaft auf Kauf oder Pachtung einer Fläche von 600 - 1200 Quadratmeter im Kaiser-Wilhelm-Polder Zur Errichtung eines Tanklagers für Erdöl, September 1897 / Juli 1904 - Januar 1905

- Angebot der Verpachtung von 159 Quadratmeter des gewünschten Geländes an die Deutsch-Russische Naphtha-Import-Gesellschaft, September 1897

- Presseberichte über Expansion des russischen Petroleumhandels, Dezember 1897 - Januar 1898

- Verhandlungen des Oberbürgermeisters Fürbringer mit der Deutsch-Russischen Naphtha-Import-Gesellschaft wegen Pachtung eines Areals im Kaiser-Wilhelm-Polder, Juli - September 1900 - Planzeichnungen über das projektierte Areal für Tankanlagen der Deutsch-Russischen Naphtha-Import-Gesellschaft, 1904

$1897-1905$

Klassifikation Teil B: 02665

Trägermaterial: Papier

Alte Reg.-Sig.: VIII A 2 c 155

Bestell-Nr.: IV 02665

2552 Abtretung eines städtischen Grundstücks an den Staatsfiskus

- Verhandlungen der kgl. Wasserbau-Inspektion und dem Magistrat über Abtretung eines städtischen Grundstücks nahe der Nesserlander Schleuse zum Bau eines Kraftwerks, Mai - November 1898 - Änderung des Besitztitels des Grundstückes im Grundbuch, Februar 1900

- Bau einer Zuwegung zum von der Stadt veräußerten Grundstück, April 1901

- Plan einer elektrischen Zentrale auf Nesserland, 1909

1898 - 1909

Klassifikation Teil B: 02666

Trägermaterial: Papier

Alte Reg.-Sig.: VIII A 2 c 161

Bestell-Nr.: IV 02666 
06.01 Städtisches Vermögen

06.01.01

06.01.01.03

Städtische Gebäude und Grundstücke

Städtische Grundstücke

Lfd. Nr. Titel

Laufzeit

2553 Ankauf eines Grundstücks an der Nordertorstraße

- Ankauf des Grundstücks des Landgebräuchers H. J. Heeren an der Nordertorstraße durch den Magistrat für 20000 Mark, März 1903 März 1904

$1903-1904$

Klassifikation Teil B: 02667

Trägermaterial: Papier

Alte Reg.-Sig.: VIII A 2 c 163

Bestell-Nr.: IV 02667

2554 Verpachtung städtischen Terrains zwischen dem I. und II.

$1900-1904$ Hafeneinschnitt

- Verhandlungen zwischen der Holzindustrie Albert Maasie AG und dem Magistrat wegen Verpachtung städtischen Terrains zwischen dem I. und II. Hafeneinschnitt zur Errichtung einer Holzverarbeitungsfabrik, Mai 1900 - März 1901 - Neuverpachtung des Geländes nach Auflösung der Emder Filiale der Holzindustrie Albert Maasie AG, September 1902 - Mai 1903

- Kündigung des Pachtvertrags durch die Holzindustrie Albert Maasie AG, Mai 1903 - Januar 1904

- Zahlung der Gebühren für das Anschlussgleis zum geplanten

Fabrikgelände an die Eisenbahnverwaltung, Januar - Februar 1904

$1900-1904$

Klassifikation Teil B: 02668

Trägermaterial: Papier

Alte Reg.-Sig.: VIII A 2 c 165

Bestell-Nr.: IV 02668

2555 Verkauf von städtischem Land an der Bahnhofsstraße

- Beschluss des Magistrats zur Anbietung von städtischen Grundflächen an den Pastor Middendorff und dem Bauaufseher Heubült, April 1899

- Aktualisierung des Katasterblattes zu den Grundflächen, April -

August 1899

- Verkauf der städtischen Grundfläche an der Bahnhofsstraße an den

Pastor Middendorff, Dezember 1899 - Oktober 1900

$1899-1900$

Klassifikation Teil B: 02669

Trägermaterial: Papier

Alte Reg.-Sig.: VIII A 2 c 166

Bestell-Nr.: IV 02669 
2556 Verpachtung eines städtischen Grundstücks an der Wolthuser 1901-1903 Landstraße

- Kündigung der Pachtung des städtischen Grundstücks an der Wolthuser Landstraße durch den Bauunternehmer A. Kruithoff, April Mai 1901

- Verpachtung des städtischen Grundstücks an der Wolthuser Landstraße, Mai 1901 - Mai 1903

$1901-1903$

Klassifikation Teil B: 02670

Trägermaterial: Papier

Alte Reg.-Sig.: VIII A 2 c 174

Bestell-Nr.: IV 02670

2557 Grenzverletzung eines städtischen Grundstücks durch den Schulbau der Lutherischen Gemeinde

- Verfügung des Stadtbaumeisters Wiggers an die Lutherische Baukommission über Verbot des Weiterbaus der Lutherischen Schule wegen Verletzung der Grenze städtischen Grundes an der Seite des Alten Grabens, September 1901

- Situationsplan des Schulbaus, 1901

- Beschluss des Magistrats über Duldung der Grenzverletzung gegen Zahlung von 100 Mark, September 1901

1901

Klassifikation Teil B: 02671

Trägermaterial: Papier

Alte Reg.-Sig.: VIII A 2 c 176

Bestell-Nr.: IV 02671

2558 Verpachtung eines städtischen Grundstücks an der Nesserlander Straße

- Verpachtung eines städtischen Grundstücks an der Nesserlander Straße in der Nähe des Ölschuppens an den Bildhauer Heinrich Borgstädt, Mai 1901 - September 1902

- Übegang der Pachtung auf die Wilhelmshavener Bildhauer Colussi \& Paomnit, September 1902 - Juli 1903

$1901-1903$

Klassifikation Teil B: 02672

Trägermaterial: Papier

Alte Reg.-Sig.: VIII A 2 c 178

Bestell-Nr.: IV 02672 
- Verpachtung einer städtischen Grundfläche am Torfmarkt an den Kaufmann Salomon Katzenstein zum Bau eines Verkaufspavillons, Juni 1901 - August 1903

- Verpachtung einer städtischen Grundfläche am Torfmarkt an den Lithographen August Wagner, März 1904 - Juli 1908

$1901-1908$

\author{
Klassifikation Teil B: 02673 \\ Trägermaterial: Papier \\ Alte Reg.-Sig.: VIII A 2 c 179 \\ Bestell-Nr.: IV 02673
}

2560 Austausch von Grundflächen am Fahrwasser zwischen der Stadt

- Verhandlungen der Staatsbauverwaltung mit dem Magistrat über Erwerb von städtischem Gelände im Watt am Fahrwasserdeich egen fiskalisches Land, August 1895 - Februar 1897

- Vertrag über den Grundflächenaustausch zwischen der

Staatsbauverwaltung und der Stadt Emden, März 1897

- Planzeichnung der fiskalischen Flächen am Dortmund-Ems-Kanal, 1897

1895 - 1897 (19019

Klassifikation Teil B: 02674

Trägermaterial: Papier

Alte Reg.-Sig.: VIII A 2 c 180

Bestell-Nr.: IV 02674

2561 Abtretung städtischer Grundflächen an die Kleinbahn Emden -Pewsum

- Verhandlungen des Magistrats mit dem Kreisausschuss des Kreises Emden über Abtretung städtischer Grundflächen am Boltentor an die Kleinbahn Emden -Pewsum, September 1898 - Juli 1900

- Katastervermessung der abzutretenden Grundstücke, Juli - August 1899

- Eintragung der neuen Besitztitel der abgetretenen Grundstücke in das Grundbuch, Dezember 1900

- Reklamierung zuviel gezahlter Pachtgelder für den Grünen Weg durch die Eisenbahnbetriebs-Inspektion Emden, Dezember 1901 . Januar 1902

$1898-1902$

Klassifikation Teil B: 02675

Trägermaterial: Papier

Alte Reg.-Sig.: VIII A 2 c 186

Bestell-Nr.: IV 02675 
- Angebot des Kaufmanns Poelders zum Verkauf des Grundstücks seiner Frau am Bentincksweg an die Stadt Emden, September 1900 . Januar 1901

- Katastervermessung des Grundstücks, Juni - Juli 1901

- Kaufvertrag zwiischen W. Poelders und der Stadt Emden, Oktober 1901

- Kündigung eines Teils der Pachtungen über die Grundfläche wegen notwendiger Abtretung des gepachteten Landes wegen Begradigung des Bentincksweges, März 1902

- Verpachtung des Grundstücks, 1902 - 1904

$1900-1904$

Klassifikation Teil B: 02676

Trägermaterial: Papier

Alte Reg.-Sig.: VIII A 2 c 181

Bestell-Nr.: IV 02676

2563 Verpachtung des von der Stadt Emden erworbenen Poelderschen Grundstücks

- Verpachtung des von der Stadt Emden erworbenen Poelderschen Grundstücks, März 1901 - August 1904

- Kündigung der Pachtverträge wegen Bedarfs eines Teils der

Parzellen durch die Stadt, August 1902 - November 1903

- Verpachtung des verkleinerten Grundstücks, 1904 - 1906

$1901-1906$

Klassifikation Teil B: 02677

Trägermaterial: Papier

Alte Reg.-Sig.: VIII A 2 c 182

Bestell-Nr.: IV 02677

- Antrag des Rentiers Friedrich Janssen an den Magistrat auf Pachtung eines städtischen Grundstreifens an der Bahnhofsstraße, Mai 1900

- Antrag des Rentiers Friedrich Janssen an den Magistrat auf

Pachtung eines städtischen Grundstreifens an der Bahnhofsstraße zur Arrondierung seines Grundstückes, April - Mai 1901

- Pachtvertrag, Januar 1902

- Kündigung des Pachtvertrages durch den Magistrat, Juli - August 1906

$1900-1906$

Klassifikation Teil B: 02678

Trägermaterial: Papier

Alte Reg.-Sig.: VIII A 2 c 190

Bestell-Nr.: IV 02678 
- Verhandlungen zwischen dem Magistrat und der

Eisenbahnbetriebs-Direktion wegen Abtretung von städtischen

Grundstücken an der Nesserlander Straße zum Bau von

Wohnhäusern für Bahnbedienstete und für Eisenbahnliniern,

September 1901 - November 1904

- Grenzregulierung zwischen den von der Bahnverwaltung gewünschten städtischen Grundstücken und denen der Wasserbauverwaltung an der Nesserlander Straße, August 1904 Januar 1905

- Genehmigung der Abtretung von städtischen Grundstücken an der Nesserlander Straße an die Eisenbahnverwaltung durch den Bezirksausschuss in Aurich, März 1903

$1901-1905$

Klassifikation Teil B: 02679

Trägermaterial: Papier

Alte Reg.-Sig.: VIII A 2 c 192

Bestell-Nr.: IV 02679

2566 Grundstückstausch zwischen der Stadt Emden und dem Domänenfiskus

- Verhandlungen der Zollverwaltung und dem Magistrat über Abtretung eines städtischen Grundstücks am Elektrizitätswerk auf Nesserland gegen eine domänenfiskalische Parzelle im Königspolder wegen notwendiger Vergrößerung des Zollgebäudes infolge des vergrößerten Hafens, Mai 1900 - Oktober 1905

- Verfügung des Regierungspräsidenten in Aurich an den Magistrat über Verweigerung der Abtretung einer domänenfiskalischen Parzelle an die Stadt Emden im Zuge eines Grundstücktausches mit der Zollverwaltung wegen des großen Wertes der fiskalischen Parzellen, März 1901

- Katasteramtliche Vermessung der zu tauschenden Grundstücke, Mai 1905

- Genehmigung des Grundstückstausch durch den Bezirksausschuss in Aurich, November 1905

$1900-1905$

Klassifikation Teil B: 02680

Trägermaterial: Papier Alte Reg.-Sig.: VIII A 2 c 193

Bestell-Nr.: IV 02680 
2567 Grenzregulierung zwischen einem städtischen Grundstück und dem

Laufzeit

Grundstück der Witwe Brons

- Verhandlungen wegen Festlegung der Grenze des Grundstücks der Witwe Brons gegenüber dem städtischen Grundstück am Schullegang am Stadtgarten, November 1900 - November 1901

- Streit um die Lage des Aborts zum Grundstück des Kaufmanns

Theodor Drost am Schullegang, 1910 - 1911

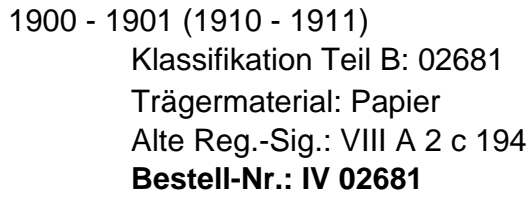

2568 Berichtigung im Grundbuch

- Berichtigung der Angaben zu den Parzellen 378 / 276 - 292 an der Gasthauskirche im Grundbuch

1899
Klassifikation Teil B: 02682
Trägermaterial: Papier
Alte Reg.-Sig.: VIII A 2 c 195
Bestell-Nr.: IV 02682

2569 Verpachtung eines städtischen Grundstücks an der Nesserlander Straße

- Verpachtung eines städtischen Grundstücks an der Nesserlander Straße an die Fa. Busche \& Mühlenbruch zur Anlage eines Holzlagerplatzes, April 1902 - Februar 1906

$1902-1906$

Klassifikation Teil B: 02683

Trägermaterial: Papier

Alte Reg.-Sig.: VIII A 2 c 196

Bestell-Nr.: IV 02683

2570 Grundstückstausch zwischen der Stadt Emden und dem Schmiedemeister G. Boomgaarden

- Gesuch des Schmiedemeisters G. Boomgaarden an den Magistrat über Bitte um Genehmigung der Erweiterung seiner Schmiede an der Mühlenstraße, Januar - Februar 1898

- Tausch einer städtischen Fläche an der Mühlenstraße gegen ein Stück des Boomgaaden'schen Grundstücks, Februar - Juni 1898 - Eintragung der neuen Besitztitel in das Grundbuch, Juli - Dezember 1898

1898

Klassifikation Teil B: 02684

Trägermaterial: Papier

Alte Reg.-Sig.: VIII A 2 c 197

Bestell-Nr.: IV 02684 
2571 Abtretung eines kleinen Grundstreifens von der Stadt Emden an Kapitän Huizinga

- Bauantrag des Bauunternehmers R. B. Heits wegen Ausbau des Hauses des Kapitäns H. Huizinga, April 1897

- Verfügung des Magistrats an Kapitän H. Huizinga über Anordnung des Rückbaus wegen nicht genehmigter Verletzung der Straßenfluchtlinie durch den Hausausbau, Juli - August 1897

- Beschwerde des H. Huizinga gegen die Verfügung, August 1897

- Erwerb des von ihm bebauten städtischen Geländes durch Kapitän Huizinga für 350 Mark, August - September 1897

- Neufeststellung der Grenze des Huizingaschen Grundstücks,

Dezember 1897 - Februar 1898

$1897-1898$

Klassifikation Teil B: 02685

Trägermaterial: Papier

Alte Reg.-Sig.: VIII A 2 c 202

Bestell-Nr.: IV 02685

- Katastervermessung des Scheltenschen Grundstücks am Rosentief mit dem Ergebnis einer um 9 Quadratmetern zu großen Fläche auf Kosten des städtischen Besitzes, April - Juni 1899

- Abtretung dieser Fläche an den Zimmermeister Schelten für 48 Mark, Juni - Juli 1899

- Eintragung der Änderung in das Grundbuch, Juli - Oktober 1899

1899

Klassifikation Teil B: 02686

Trägermaterial: Papier

Alte Reg.-Sig.: VIII A 2 c 205

Bestell-Nr.: IV 02686 
2573 Grundstückstausch zwischen der Stadt Emden und dem 1896 Schiffsbaumeister Janssen

- Beschwerden gegen die Anlegung von Holzläger und anderer Anlagen am Südfalderndeich durch den Schiffsbaumeister Janssen, Februar / Mai 1896

- Verfügung des Magistrats an den Schiffsbaumeister Janssen über Aufforderung zur Freimachung des Südfalderndeiches, März / April 1896

- Antrag des Schiffsbaumeisters Janssen auf Feststellung der Grenzen seines Werftgrundstücks durch Katastervermessung, April 1896

- Abtretung eines Teils des Werftgrundstücks durch Schiffsbaumeister Janssen an die Stadt Emden gegen Erhalt einiger Flächen am Südfalderndeich, Juli 1896

- Genehmigung des Tausches durch den Bezirksausschuss, August 1896

1896

Klassifikation Teil B: 02687

Trägermaterial: Papier

Alte Reg.-Sig.: VIII A 2 c 206

Bestell-Nr.: IV 02687

- Verkauf des Gangs am Falderntor an den Kaufmann Jacob Pels und die Witwe Egberts, Oktober 1893 - Januar 1894

- Risszeichnung der Lage des Gangs, Dezember 1893

- Einverständnis der Anlieger des Ganges zum Verkauf des Anteils der verstorbenem Witwe Egberts am Gang an Jacob Pels, August 1897

$1893-1897$

Klassifikation Teil B: 02688

Trägermaterial: Papier

Alte Reg.-Sig.: VIII A 2 c 207

Bestell-Nr.: IV 02688 
- Eingabe der Kaufmännischen Deputation an das Hafenamt über Bitte um Übergang des Ufers des Falderndelftes an die Staatsbauverwaltung wegen Bedarf an Löschplätzen durch den zunehmenden Schiffsverkehr, Mai 1896

- Eingabe des Magistrats an den Regierungspräsidenten in Aurich über Bitte um Förderung des Übergangs des Ufers des Falderndelftes an die Staatsbauverwaltung, Juni 1896

- Antrag des Magistrats beim Katasteramt auf Vermessung des Ufers des Falderndelfts nach dem Einverständnis der Eisenbahnverwaltung zur Abtretung der Flächen am Falderndelft an die

Staatsbauverwaltung, September 1896

1896

Klassifikation Teil B: 02689

Trägermaterial: Papier

Alte Reg.-Sig.: VIII A 2 c 209

Bestell-Nr.: IV 02689

2576 Verpachtung eines städtischen Grundstücks an der Straße zu den Lagerplätzen (Hafenstraße)

- Verpachtung eines städtischen Grundstücks an der Straße zu den Lagerplätzen (Hafenstraße) an den Generalagenten H. Dinkelmann, November 1901 - August 1906

$1901-1906$

Klassifikation Teil B: 02690

Trägermaterial: Papier

Alte Reg.-Sig.: VIII A 2 c 212

Bestell-Nr.: IV 02690

2577 Feststellung der Entschädigung für einen von der Fa. Kappelhoff Wwe \& Sohn an die Stadt Emden abgetretenen Grundstücksstreifen

- Abtretung eines Streifens des Grundstücks der Fa. Kappelhoff, Wwe. \& Sohn an der Neutorstraße zur Erhaltung der Fluchtlinie, Januar - Februar 1902

- Feststellung des Wertes des abzutretenden Grundstücksstreifens, April 1902 - September 1903

- Risszeichnung des betr. Grundstücks an der Neutorstraße / Altes

Bollwerk, November 1902

- Eintragung der neuen Besitztitel in das Grundbuch, Oktober 1903

$1902-1903$

Klassifikation Teil B: 02691

Trägermaterial: Papier

Alte Reg.-Sig.: VIII A 2 c 213

Bestell-Nr.: IV 02691 
2578 Feststellung der Entschädigung für einen vom Obertelegrafen-Assistenten Tiemens an die Stadt Emden abgetretenen Grundstücksstreifen

- Bauantrag des J. Tiemens für ein Wohnhaus an der Nordertorstraße, April - Mai 1901

- Risszeichnung des Grundstücks mit dem an die Stadt Emden zur Einheitichkeit der Fluchtlinie abzutretenden Grundstücksstreifen, 1901

- Beschwerde des Obertelegrafen-Assistenten J. Tiemens beim Bezirksauasschuss wegen Verweigerung einer Entschädigung für seinen abzutretenden Grundstücksstreifen durch die Stadt Emden, Juni 1901

- Klage des Obertelegrafen-Assistenten J. Tiemens gegen den Magistrat beim Bezirksausschuss wegen Verweigerung einer Entschädigung für seinen abzutretenden Grundstücksstreifen, Mai 1902

- Klage des Obertelegrafen-Assistenten J. Tiemens gegen den Magistrat beim Bezirksausschuss wegen Heranziehung zur Finanzierung des Bürgersteigs vor seinem Grundstück, Mai 1902 - Enteignungsverfahren wegen des Grundstückstreifens, Januar 1903 - Januar 1904

$1901-1904$

Klassifikation Teil B: 02692

Trägermaterial: Papier

Alte Reg.-Sig.: VIII A 2 c 215

Bestell-Nr.: IV 02692

2579 Abtretung eines Streifens des Grundstücks des Zimmermeisters Jacob Visser an die Stadt Emden

- Vereinbarung des Magistrats mit dem Zimmermeister Jacob Visser über Abtretung eines Streifens seines Grundstücks an der Stiefelstraße an die Stadt Emden zur Anlegung eines Bürgersteiges, August 1903 - Februar 1904

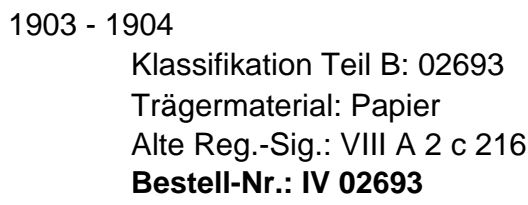

- Verpachtung einer städtischen Grundfläche Außer dem Nordertor an den Rentier E. Goljenboom

$1903-1904$

Klassifikation Teil B: 02694

Trägermaterial: Papier

Alte Reg.-Sig.: VIII A 2 c 221

Bestell-Nr.: IV 02694 
2581 Feststellung der Entschädigung für einen vom Telegrafen-Direktor Ficker an die Stadt Emden abgetretenen Grundstücksstreifen

Laufzeit

- Feststellung der Entschädigung für einen vom Telegrafen-Direktor Ficker an die Stadt Emden abgetretenen Grundstücksstreifen an der Nordertorstraße zur Sicherung der Fluchtlinie

- Situationsplan

$1902-1903$

Klassifikation Teil B: 02695

Trägermaterial: Papier

Alte Reg.-Sig.: VIII A 2 c 223

Bestell-Nr.: IV 02695

2582 Verpachtung einer städtischen Grundfläche an der Nesserlander Straße

- Verpachtung einer städtischen Grundfläche an der Nesserlander Straße an den Seilermeister H. Smeding

$1904-1909$

Klassifikation Teil B: 02696

Trägermaterial: Papier

Alte Reg.-Sig.: VIII A 2 c 232

Bestell-Nr.: IV 02696

2583 Verpachtung einer städtischen Grundfläche bei der Roten Mühle

- Verpachtung einer städtischen Grundfläche bei der Roten Mühle an den Müller D. A. Staal

$1904-1916$ (1921)

Klassifikation Teil B: 02697

Trägermaterial: Papier

Alte Reg.-Sig.: VIII A 2 c 234

Bestell-Nr.: IV 02697

2584 Verpachtung eines städtischen Grundstücks zwischen Nesserlander Str. und dem Dritten Hafeneinschnitt

- Verpachtung eines städtischen Grundstücks zwischen Nesserlander Str. und dem Dritten Hafeneinschnitt an die Fa. Vellmer \& Rasmussen zur Einrichtung eines Holzlagers

$1905-1913$

Klassifikation Teil B: 02698

Trägermaterial: Papier

Alte Reg.-Sig.: VIII A 2 c 236

Bestell-Nr.: IV 02698 
06.01

Städtisches Vermögen

06.01.01

06.01.01.03

Städtische Gebäude und Grundstücke

Städtische Grundstücke

Lfd. Nr. Titel

Laufzeit

2585 Verpachtung von Grundstücken der Stadt Emden

. Erhebung der Pachtraten bei zeitverpachteten städtischen

Grundstücken

- Aufstellung über Zeitpächter

$1905 / 1912$

Klassifikation Teil B: 02699

Trägermaterial: Papier

Alte Reg.-Sig.: VIII A 2 c 239

Bestell-Nr.: IV 02699

2586 Verpachtung eines städtischen Grundstücks beim Schlachthof, Bd. 1

- Verpachtung eines städtischen Grundstücks beim Schlachthof an den Färber N. S. Barghoorn für seinen Fabrikbetrieb

$1905-1906$

Klassifikation Teil B: 02700

Band: 1

Trägermaterial: Papier

Alte Reg.-Sig.: VIII A 2 c 241

Bestell-Nr.: IV 02700

2587 Verpachtung eines städtischen Grundstücks beim Schlachthof, Bd. 2

- Weiterverpachtung eines städtischen Grundstücks beim Schlachthof an das Bauunternehmen Hagen \& Benjamins

$1906-1910$

Klassifikation Teil B: 02701

Band: 2

Trägermaterial: Papier

Alte Reg.-Sig.: VIII A 2 c 241

Bestell-Nr.: IV 02701

2588 Verpachtung eines städtischen Grundstücks am Stadtgraben

- Verpachtung eines städtischen Grundstücks am Stadtgraben an den Bootsbauer Rudolf van Jindelt zur Anlage einer Bootswerft, 1907 1910

- Antrag des Bootsbauers Rudolf van Jindelt an den Magistrat auf Umwandlung der Zeitpacht in eine Erbpacht, Februar 1910

$1907-1910$

Klassifikation Teil B: 02702

Trägermaterial: Papier

Alte Reg.-Sig.: VIII A 2 c 247

Bestell-Nr.: IV 02702 
2589 Verpachtung eines städtischen Grundstücks am Dritten Hafeneinschnitt

- Verpachtung eines städtischen Grundstücks am Dritten Hafeneinschnitt an die Kölnische Tiefbau-Gesellschaft, Baubüro

Emden zur Verwendung als Lagerplatz

$1904-1910$

Klassifikation Teil B: 02703

Trägermaterial: Papier

Alte Reg.-Sig.: VIII A 2 c 249

Bestell-Nr.: IV 02703

2590 Anlage von Schrebergärten

1907-1909

- Verschiedene Werbeschriften des Zentralverbandes Deutscher

Arbeiter- und Schrebergärtner für die Einrichtung von Schrebergärten

1907 - 1909 (1923)

Klassifikation Teil B: 02704

Trägermaterial: Papier

Alte Reg.-Sig.: VIII A 2 c 251

Bestell-Nr.: IV 02704

2591 Überlassung von Gelände am Ems-Jade-Kanal

- Antrag des Emder Bürgerpark-Vereins an den Magistrat auf pachtweise Überlassung von Gelände am Ems-Jade-Kanal zur Errichtung eines Spielplatzes

1909

Klassifikation Teil B: 02705

Trägermaterial: Papier

Alte Reg.-Sig.: VIII A 2 c 264

Bestell-Nr.: IV 02705

2592 Enteignung von Grundstücken am Heuzwinger

- Verhandlungen des Magistrats mit Grundbesitzern im Heuzwinger wegen freiwilliger Abtretung oder Enteignung von Teilen ihrer Grundstücke zugunsten der Stadt Emden zur Anlage von Wegen und Bürgersteigen, 1907 - 1913

- Klage des Helmut Bitter gegen den Magistrat beim Bezirksausschuss auf Aufhebung der Enteignung eines Teils seines Grundstücks, Januar - Juli 1910

$1907-1910$

Klassifikation Teil B: 02706

Trägermaterial: Papier

Alte Reg.-Sig.: VIII A 2 c 266

Bestell-Nr.: IV 02706 
- Angebot des Zimmermeisters Jacques Fritzen zum Kauf des unbebauten städtischen Grundstücks An der Schlichte zum Bau eines Wohnhauses, Februar - März 1906

- Verkauf des Grundstücks an Malermeister Reinhard Peters, März Juli 1906

1906

\author{
Klassifikation Teil B: 02707 \\ Trägermaterial: Papier \\ Alte Reg.-Sig.: VIII A 2 c 271 \\ Bestell-Nr.: IV 02707
}

- Verhandlungen zwischen dem Emder Turnverein, Grundstücksbesitzer Bernhard Brons und dem Magistrat wegen Erwerb des Brons'schen Grundstücks zur Anlage eines Turn- und Spielplatzes, Dezember 1907 - Oktober 1910

- Karte: Bebauungsplan des Stadtteils "Zwischen Beiden Bleichen", 1908

- Verpachtung des früheren Brons'schen Gartens, Juni 1909

- Entwurf eines Schenkungsvertrages über das Brons'sche Grundstück mit dem Zweck der Einrichtung eines Turn- und Spielplatzes, Juli 1909 - April 1910

- Anschaffungen zur Anlage des Spiel- und Turnplatzes, Oktober 1909

- Oktober 1910

$1907-1912$

Klassifikation Teil B: 02708

Trägermaterial: Papier

Alte Reg.-Sig.: VIII A 2 c 281

Bestell-Nr.: IV 02708

2595 Verpachtung eines Lagerplatzes am III. Hafeneinschnitt

- Verpachtung eines städtischen Grundstücks am Dritten Hafeneinschnitt an die Abwrackfirma Ateliers de Transformation societé anonyme aus Gent (Belgien) zur Lagerung von Teilen des abzuwrackenden Schulschiffs "Stosch", 1907 - 1909

- Klage des Magistrats gegen die Firma Ateliers de Transformation auf Zahlung von Pachtrückständen, September - November1909

- Abwicklung der rückständigen Pachtsumme, Mai 1911 - Januar 1912

$1907-1912$

Klassifikation Teil B: 02709

Trägermaterial: Papier

Alte Reg.-Sig.: VIII A 2 c 282

Bestell-Nr.: IV 02709 
2596 Streit um die Eigentumsrechte an einem Terrain "Zwischen beiden $1906-1910$ Bleichen"

- Klage des Schankwirts H. C. Wienrank gegen den Magistrat beim Landgericht Aurich wegen Verletzung seiner Eigentumsrechte an der Parzelle neben seinem Grundstück in "Zwischen beiden Bleichen"

$1906-1910$

Klassifikation Teil B: 02710

Trägermaterial: Papier

Alte Reg.-Sig.: VIII A 2 c 283

Bestell-Nr.: IV 02710

2597 Grundstückstausch zwischen der Stadt Emden und der Fa. Ysaac \&

\section{Bernhard Brons}

- Grundstückstausch zwischen der Stadt Emden und der Fa. Ysaac \& Bernhard Brons am alten Markt zur Herstellung eines Durchgangs zum Stadtgarten, 1891

- Angebot der Fa Ysaac \& Bernhard Brons zu einem

Grundstückstausch am Stadtgarten, 1902

$1891-1902$

Klassifikation Teil B: 02711

Trägermaterial: Papier

Alte Reg.-Sig.: VIII A 2 c 284

Bestell-Nr.: IV 02711

2598 Erwerb eines kleinen Grundstücks an der Kranstraße durch die Stadt Emden

- Antrag des Gastwirts Klaas Poppinga an den Magistrat auf Genehmigung des Abrisses eines alten Hauses auf seinem Grundstück und dessen Ersatz durch einen größeren Neubau, Februar 1904

- Abtretung eines Grundstücks an der Kranstraße an die Stadt Emden durch den Gastwirt Klaas Poppinga zur Erhaltung der Konzession für zwei Lichtschächte, September 1904

- Eintragung der neuen Besitztitel in das Grundbuch, November 1904 Oktober 1906

$1904-1906$

Klassifikation Teil B: 02712

Trägermaterial: Papier

Alte Reg.-Sig.: VIII A 2 c 286

Bestell-Nr.: IV 02712 
- Antrag des Gastwirts Eggers an den Magistrat auf Grundstückstausch wegen notwendiger Arrondierung seines Grundstückes an der Boltentorstraße zum Ausbau seiner Gaststätte, April - Juli 1906

- Eintragung der neuen Besitztitel in das Grundbuch, Juli 1908 Januar 1912

$1906-1912$

Klassifikation Teil B: 02713

Trägermaterial: Papier

Alte Reg.-Sig.: VIII A 2 c 287

Bestell-Nr.: IV 02713

2600 Grenzregulierung: Grundstück der Staatsbauverwaltung und Grundstück der Elektrischen Kleinbahn (Straßenbahn)

- Antrag der kgl. Wasserbau-Inspektion an den Magistrat auf Grenzregulierung zwischen den Grundtücken der kgl.

Staatsbauverwaltung und der Straßenbahn wegen vermuteter Lage des Waggonschuppens in den fiskalischen Bereich, Oktober 1904 - Streit zwischen der Stadt Emden und der kgl. Wasserbau-Inspektion wegen angeblicher Grenzverletzung des fiskalischen Grundstücks durch den Bau der Waggonhalle, September 1906 - August 1910 - Verhandlungen des Magistrats mit der kgl. Wasserbau-Inspektion über Erwerb der mit dem Waggonschuppen überbauten fiskalischen Grundfläche durch die Stadt Emden, August 1910 - März 1911 - Neuvermessung der Grundstücksgrenze und Eintragung in das Grundbuch, Mai 1912

$1904-1912$

Klassifikation Teil B: 02714

Trägermaterial: Papier

Alte Reg.-Sig.: VIII A 2 c 290

Bestell-Nr.: IV 02714

2601 Prozess wegen Grundbucheintragung betr. Wiederverkaufsrecht am Grundstück der ehemaligen Heringsfischerei Neptun AG

- Klage der Stadt Emden gegen den Kaufmann Carl Meentzen, Bremen beim Landgericht in Aurich wegen dessen Nichtanerkennung des Erbbaurechts der Stadt Emden am Grundstück der ehemaligen Heringsfischerei Neptun AG und Behauptung eines Wiederverkaufsrechtes

$1915-1917$

Klassifikation Teil B: 02715

Trägermaterial: Papier

Alte Reg.-Sig.: VIII A 2 c 298

Bestell-Nr.: IV 02715 
2602 Klage des Kaufmanns C. Meentzen wegen Versicherungsgelder der abgebrannten Gebäude der Heringsfischerei Neptun AG

Laufzeit

- Klage des Kaufmanns C. Meentzen gegen den Magistrat beim Landgericht Aurich auf Auszahluntg der Versicherungsgelder für die 1913 abgebrannten Gebäude der Heringsfischerei AG Neptun, 1915 1916

- Berufungsverfahren vor dem Oberlandesgericht Celle wegen des für Meentzen ungünstigen Urteils des Landgerichts Aurich, 1917 - 1918

$1915-1918$

Klassifikation Teil B: 02716

Trägermaterial: Papier

Alte Reg.-Sig.: VIII A 2 c 299

Bestell-Nr.: IV 02716

2603 Plan des Ankaufs einer domänenfiskalischen Moorfläche am Ems-Jade-Kanal

- Anfertigung von Kstasterzeichnungen über für die Stadt Emden interessante Moorflächen, Oktober 1894 - Mai 1895

- Verhandlungen des Magistrats mit der Regierung in Aurich über Erwerb von domänenfiskalischen Moorflächen am Ems-Jade-Kanal durch die Stadt Emden, Oktober 1894 - Juli 1895

- Grundsteuer-Mutterrollen-Auszüge über die von der Stadt Emden gewünschten Moorflächen, 1894

- Schreiben des Direktors des Wasserwerks für das nördliche westfälische Kohlerevier, Schmidt, an Oberbürgermeister Fürbringer über Bedarf der Moorflächen für ein geplantes Wasserwerk, Januar 1895

- Eingabe des Magistrats an den preußischen Minister für Domänen, Forsten und Landwirtschaft über Bildung eines Konsortiums durch die Stadt Emden zur Kultivierung von Moorflächen am Ems-Jade-Kanal (Marcardsmoor) und Bitte um Verkauf der gewünschten Moorflächen (Marcardsmoor), Mai 1895

- Streit um die Entwässerung des Auricher Wiesmoores I von Aurich über das Fehntjer und Petkumer Tief in Richung Emden, 1899 - 1902 - Besichtigung der ostfriesischen Moore durch die preußischen Minister für Finanzen und Landwirtschaft, 1905

$1894-1905$

Klassifikation Teil B: 02864

Trägermaterial: Papier

Alte Reg.-Sig.: VIII 2 c 152

Bestell-Nr.: IV 02664 
IV

06

Finanzverwaltung der Stadt Emden

06.01

Städtisches Vermögen

06.01.01

Städtische Gebäude und Grundstücke

06.01.01.03

Städtische Grundstücke

Lfd. Nr. Titel

Laufzeit

2604 Verkauf städtischer Grundstücke am Neutor und im Vogelsangzwinger

- Beschluss des Magistrats zum Verkauf des von der katholischen Gemeinde erworbenen städtischen Hauses am Neutor und des

Grundstücks im Vogelsangzwinger, November 1889 - Januar 1891

- Angebot: Abriss des Hauses am Neutor, 1889

- Verkauf des Grundstücks am Vogelsangzwinger an die

Indo-European-Telegraph, April 1889

$1889-1891$

Klassifikation Teil B: 2654

Trägermaterial: Papier

Alte Reg.-Sig.: VIII A 2 c 135

Bestell-Nr.: IV 02654 
Lfd. Nr. Titel

- Bestellung von australichem Jamah-Holz zur Restaurierung der

Rathausbrücke, Mai 1914

- Zeichnung der Rathausbrücke mit Gründung, 1914

1914 (1936)

Klassifikation Teil B: 02524

Trägermaterial: Papier

Alte Reg.-Sig.: B IV a 12. I

Bestell-Nr.: IV 02524

2606 Rüstkammer der Stadt Emden

- Beschreibung der Rüstkammer in der Zeitschrift für historische Waffenkunde, 1900

- Kondolenz zum Tode des Ehrenvorsitzenden des Vereins für historische Waffenkunde, Wendelin Boheim, Wien, November 1900

- Verhandlungen der Kommission für die Rüstkammer über Beauftragung des Dr. Othmar Baron Potier des Echelles aus Wien mit der Ordnung der Rüstkammer, Oktober - Dezember 1900

- Bericht des Dr. Potier an die Kommission für die Rüstkammer über Plan der Katalogisierung der historischen Waffen in der Rüstkammer, Dezember 1900

- Gutachten des Dr. Potier über Zustand der Rüstkammer, Dezember 1900

- Kostenvoranschlag des Stadtbaumeisters Wiggers für die Unterbringung der Rüstkammer in der Klunderburg, Januar 1901

- Korrespondenz zwischen Oberbürgermeister Fürbringer und Dr.

Potier wegen Organisation der Rüstkammer, 1900 / 1910

- Nachruf auf Dr. Rudolf Baron Potier des Echelles, 1912

- Datierung und Beschreibung von Meistersiegeln in der Rüstkammer, 1912

$1900-1912$

Klassifikation Teil B: 02719

Trägermaterial: Papier

Alte Reg.-Sig.: VIII A3 04 a

Bestell-Nr.: IV 02719 
Lfd. Nr. Titel

- Verhandlungen des Magistrats mit der Gesellschaft für bildende Kunst und vaterländische Altertümer und der Naturforschenden Gesellschaft über Errichtung eines Museums für die Rüstkammer und die Bestände der Gesellschaften, Juni - Juli 1900 / Oktober 1908 November 1909

- Bericht des Magistrats an den Regierungspräsidenten in Aurich über Stand der Verhandlungen über die Errichtung eines zentralen Museums für die öffentlichen Sammlungen in der Klunderburg und Frage der Finanzierung, November 1900

- Berechnung des Raumbedarfs für ein ostfriesisches Landesmuseum durch den Stadtbaumeister Wiggers, Dezember 1909

- Plan eines Museums an der Ringstraße, 1909

$1900-1909$

Klassifikation Teil B: 02720

Trägermaterial: Papier

Alte Reg.-Sig.: VIII A3 $04 \mathrm{~b}$

Bestell-Nr.: IV 02720

2608 Restaurierung, Neuordnung und Katalogisierung der Rüstkammer

- Zeichnung des Rathauses mit Markierung der Etage der

Rüstkammer, 1901

- Eingabe des Vorsitzenden der Gesellschaft für bildende Kunst und vaterländische Altertümer, Schweckendiek,an den Magistrat über Bitte um Herausgabe eines Kataloges über die Bestände der Rüstkammer, April 1882

- Gutachten des Dr. Othmar, Baron Potier des Echelles über den

Zustand der Rüstkammer, Dezember 1900

- Antrag des Magistrats beim Landesdirektorium der Provinz

Hannover auf Beihilfe für die Restaurierung des Rathauses und

Neuordnung der Rüstkammer, Februar - Juli 1901

- Verhandlung des Antrages der Stadt Emden vor dem

Provinziallandtag, Februar 1901

- Vorschläge des Dr. Othmar Baron Potier über Neuordnung,

Katalogisierung und Unterbringung der Rüstkammer, April 1901

- Kostenvoranschlag des Stadtbaumeisters Wiggers über Instandsetzung der Rüstkammer, Dezember 1901

- Kostenvoranschlag über Verbesserung der Beleuchtung der

Rüstkammer, Juni 1902

$1882-1902$

Klassifikation Teil B: 02721

Trägermaterial: Papier

Alte Reg.-Sig.: VIII A3 04 c

Bestell-Nr.: IV 02721 
06

IV

06.01

Finanzverwaltung der Stadt Emden

06.01 .02

Städtisches Vermögen

Lfd. Nr. Titel

Sonstiges städtisches Eigentum

2609 Restaurierung der Rüstkammer

Laufzeit

- Verhandlungen der Kommission für die Rüstkammer über Neuorganisation der Rüstkammer, Umsiedlung in die Klunderburg und Katalogisierung der Rüstkammer, Oktober 1900 / Juni 1902

- Bericht des Magistrats an den Regierungspräsidenten in Aurich über Neuordnung der Rüstkammer, Januar - August 1902

- Auszahlung der Staatsbeihilfe zur Restaurierung der Rüstkammer, Februar 1902

- Genehmigungsverfahren für eine weitere Staatsbeihilfe zur

Restaurierung der Rüstkammer, März - Juni 1902

- Durchführung der Arbeiten zur Restaurierung der Rüstkammer,

Februar - März 1902

- Bescheid des Landesdirektoriums über Nichtgewährung einer Beihilfe zum Umzug der Rüstkammer in die Klunderburg wegen Nichtgewährung einer Staatsbeihilfe durch die preußische Staatsregierung, Juni 1902

- Konzipierung von Schränken für die historischen Waffen der Rüstkammer, Juli 1902

- Beschwerde des Dr. Othmar Baron Potier gegen die Hinausweisung aus der Rüstkammer durch einen Arbeiter, August 1902

- Vortrag des Barons Potier über die Rüstkammer vor der Gesellschaft für bildende Kunst und vaterländische Altertümer, November 1902

- Zeugnis des Magistrats für die Tätigkeit des Dr. Othmar Baron Potier des Echelles, August 1902

$1900-1902$

Klassifikation Teil B: 02722

Trägermaterial: Papier

Alte Reg.-Sig.: VIII A3 $04 \mathrm{~g}$

Bestell-Nr.: IV 02722 
06.01

Lfd. Nr. Titel

Laufzeit

2610 Erwerb und Verkauf von Waffen der Rüstkammer, Bd. 1

- Beschluss des Magistrats zum Verkauf von Gewehren der Emder Bürgerwehr von 1848 /49, März 1882

- Anfrage des Bürgermeisters der Stadt Dillenburg a. d. Lahn nach Rüstungen aus der Zeit von Wilhelm von Oranien mit der Absicht des Erwerbs, August 1897

- Angebot des Waffenhändlers Moritz Magnus aus Hamburg zum Erwerb von Steinschloss- und Perkussions-Gewehren. August 1897

- Anfragen nach und Anbietung antiker Waffen, 1900 - 1906

- Verkauf antiker Waffen aus der Rüstkammer an den Architekten Weber, Dezember 1902 - März 1903

- Erwerb französischer Beutewaffen von 1870/71 für die Rüstkammer aus Beständen des kgl. Zeughauses Berlin, Mai - Oktober 1903

- Liste der erworbenen Waffen, Oktober 1903

- Erwerb von Waffen und Waffenteilen für die Rüstkammer von durch Dr. O. Baron Potier empfohlenen Firmen, Januar - März 1904

- Erwerb eines Helms passend zu einer französischen Kurasse,

Februar - April 1904

$1882-1906$

Klassifikation Teil B: 02723

Band: 1

Trägermaterial: Papier

Alte Reg.-Sig.: VIII A3 $04 \mathrm{f}$

Bestell-Nr.: IV 02723

2611 Erwerb und Verkauf von Waffen der Rüstkammer, Bd. 2

- Anfragen nach und Anbietung antiker Waffen durch verschiedene Waffenhändler, 1907 - 1914 (1920 - 1922)

- Initiative der Gesellschaft für bildende Kunst und vaterländische

Altertümer zum Erwerb von gefundenen Geschützteilen der

Friedeburg (Oldenburg), April - Mai 1908

- Auktionskatalog über Waffen und Waffenteilen, Mai 1908

- Antrag des Magistrats beim preußischen Kriegsministerium auf

Überlassung von Beutewaffen aus dem Weltkrieg an die

Rüstkammer, Oktober 1915 - Dezember 1918

$1882-1906$

Klassifikation Teil B: 02724

Band: 2

Trägermaterial: Papier

Alte Reg.-Sig.: VIII A3 $04 \mathrm{f}$

Bestell-Nr.: IV 02724 
06.01

Lfd. Nr. Titel

Laufzeit

2612 Restaurierung der Rüstkammer

- Aufstellung über bewilligte Mittel der preußischen Staatsregierung, der Provinz Hannover und der Stadt Emden zur Restaurierung der Rüstkammer, November 1903

- Angebote und Kostenvoranschläge für einen Rüstkammer-Katalog, 1902

- Korrespondenz des Dr. Othmar Baron Potier mit dem

Oberbürgermeister Fürbringer über Erstellung eines Kataloges zur

Rüstkammer, Januar - April 1903

- Gestaltung des Inventars, Geleitworte, Stichwortverzweichnis und Index, 1903

- Druckfahne des Kataloges, 1905

- Entwurf des Druckauftrages für den Katalog, Mai 1903

- Versendung und Verteilung der fertigen Kataloge, 1903 - 1904

$1902-1904$

Klassifikation Teil B: 02725

Trägermaterial: Papier

Alte Reg.-Sig.: VIII A 304 i

Bestell-Nr.: IV 02725

- Beschluss der Kommission für die Rüstkammer über Sondierungen bei staatlichen Sammlungen in Süddeuitschland und den Nachbarstaaten zum Erwerb der dort ausgesonderten alten Waffen für die Rüstkammer, Oktober 1905

- Schreiben an verschiedene Institutionen mit historischen Waffensammlungen über Möglichkeit der Abgabe von Waffen an die Emder Rüstkammer, Januar 1906

- Bescheide aus den angeschriebenen Institutionen, Februar Oktober 1906

- Liste der aus preußischen Heeresbeständen an die Rüstkammer abgegebenen Beutewaffen von 1871, 1906

- Nachweis der vom Artilleriedepot Oldenburg für die Rüstkammer angekauiften historischen Waffen (!870/71), Oktober 1906

- Angebot des niederländischen Kriegsministeriums zum Tausch von Waffen ihrer historischen Sammlung gegen Stücke aus der Rüstkammer, Juli - August 1906

- Erwerb von Waffen für die Rüstkammer aus den historischen Beständen des niederländischen Kriegsministeriums, Januar -

Februar 1907

- Tausch von Waffen der Rüstkammer mit historischen Stücken aus der Sammlung des bayerischen Kriegsministeriums, Oktober 1906 Februar 1907

1905 - 1907 (1912 - 1913)

Klassifikation Teil B: 02726

Trägermaterial: Papier

Alte Reg.-Sig.: VIII A3 $04 \mathrm{~g}$

Bestell-Nr.: IV 02726 
06.01

Lfd. Nr. Titel

- Gedruckte Aufsätze und Abhandlungen über die Rüstkammer

- Werbeschriften von Händlern über Waffen und Munition

- Werbeschriften übe Ausstellungsschränke für Waffen

$1903-1905$

Klassifikation Teil B: 02727

Trägermaterial: Papier

Alte Reg.-Sig.: VIII A3 $04 \mathrm{~h}$

Bestell-Nr.: IV 02727

2615 Nebeninventar der Rüstkammer

- Aufstellung über in das Hauptinventar nachzutragende Waffen - Aufstellung über Fahnen, Standarten, Fackeln und Trommeln in der Rüstkammer

- Anordnung des Magistrats über Aufnahmen in das Nebeninventar der Rüstkammer

$1880-1903$

Klassifikation Teil B: 02728

Trägermaterial: Papier

Alte Reg.-Sig.: VIII A3 04 j

Bestell-Nr.: IV 02728

2616 Rüstmeister-Werkstatt

- Beschluss der Kommission für die Rüstkammer zur Einrichtung einer Rüstmeister-Werkstatt, September 1902

- Kostenvoranschlag des Stadtbaumeisters Wiggers zur Einrichtung einer Rüstmeisterwerkstatt, September 1902

- Verlegung der Werkstatt für den Aufbau einer Schmiede-Asse, Januar - Juli 1903

- Holzwurmbekämpfung durch Petroleumbad, Juli 1903

$1902-1903$

Klassifikation Teil B: 02729

Trägermaterial: Papier

Alte Reg.-Sig.: VIII A3 04 k1

Bestell-Nr.: IV 02729 
06.01 Städtisches Vermögen

06.01.02 Sonstiges städtisches Eigentum

Lfd. Nr. Titel

Laufzeit

2617 Rüstkammer: Bauliche Angelegenheiten 1906-1911

- Einbau von Glastüren in von der Höheren Töchterschule der Rüstkammer zur Verfügung gestellte Kleiderschränke zur Ausstellung von Uniformen, September - November 1906

- Unterbringung neu erworbener Waffen und der Sammlung des kleinen Stadtmuseums, Mai - Juni 1908

- Verlegung und Modernisierung der Rüstmeister-Werkstatt, Juli 1908

- Mai 1911

- Vergitterung der Treppe zur Rüstkammer, 1920

$1906-1911(1920)$

Klassifikation Teil B: 02730

Trägermaterial: Papier

Alte Reg.-Sig.: VIII A3 04 k2

Bestell-Nr.: IV 02730

2618 Fahnen in der Rüstkammer

- Aufstellungen über Fahnen und Flaggen in der Rüstkammer, 1858 /

1862

- Reataurierung von Fahnen und Flaggen nach den Empfehlungen von Dr. Othmar Baron Potier, Mai 1902 - Februar 1904

Enthält auch:

- Rechenschaftsbericht des Dr. Othmar Baron Potier über seine Tätigkeit in der Rüstkammer, 1901

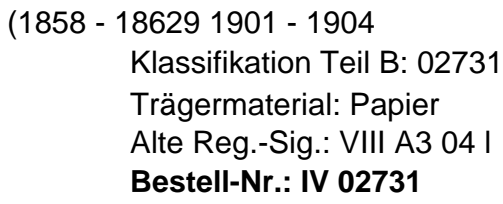

2619 Bildatlas der Rüstkammer

- Aufstellung des Konzeptes eines Bildatlasses zur Rüstkammer

$1901-1906$

Klassifikation Teil B: 02732

Trägermaterial: Papier

Alte Reg.-Sig.: VIII A3 $04 \mathrm{~m}$

Bestell-Nr.: IV 02732 
06.01

Lfd. Nr. Titel

Laufzeit

2620 Inventar der Rüstkammer

- Schenkung eines Gemäldes mit dem Bildnis von Kaiser Wilhelm I. an die Stadt Emden und Platzierung in den Rathaussal, April 1871 - Initiative des Kaufmanns Bernhard Brons zur Weiterführung der Waffensammlung in der Rüstkammer durch Erwerb von Beutewaffen aus dem deutsch-französischen Krieg, März 1871

- Verhandlungen des Magistrats mit dem preußischen Kriegsministerium wegen Wunsch des Erwerbs von Beutewaffen und Waffen des deutschen Heeres aus dem deutsch-französischen Krieg für die Emder Rüstkammer, Mai 1871 - Februar 1872

- Bestandsübersichten zu französischen Beutewaffen in den Artilleriedepots Mainz und Oldenburg, Oktober 1871

- Aufstellung über nach Emden abgegebene Beutewaffen aus dem Artilleriedepot Mainz, März 1872

- Aufstellung über nach Emden abgegebene Beutewaffen aus dem Artilleriedepot Oldenburg, März 1872

- Anfrage des Germanischen Nationalmuseums Nürnberg wegen Überlassung von Waffen aus der Emder Rüstkammer als Dauerleihgabe, November - Dezember 1875

- Inventar der Rüstkammer, 1880

- Anfrage des Vereins Berliner Künstler wegen Überlassung von Uniformen aus dem Dreißigjährigen Krieg, Januar 1881

- Schenkungen von Waffen, Fahnen etc. an die Rüstkammer, 1881 1885

- Anfrage des Magistrats beim preußischen Kriegsministerium wegen Überlassung von deutschen Waffen aus dem Deutsch-Französischen Krieg zur Ergänzung der Waffensammlung der Rüstkammer, Februar - Mai 1889

- Erwerbungen für die Rüstkammer (1858 - 1865) 1868 - 1907

- Ausleihe von Fahnen und Waffen aus der Rüstkammer an den Emder Turnverein, Emder Schützencorps und Emder Kriegerverein, 1882 - 1906

(1858 - 1865) 1866 - 1907

Klassifikation Teil B: 02733

Trägermaterial: Papier

Alte Reg.-Sig.: VIII A3 04 n

Bestell-Nr.: IV 02733 
06.01

Lfd. Nr. Titel

Laufzeit

2621 Rüstkammer: Druck und Verkauf eines Führers

- Artikel über die Rüstkammer in der Zeitschrift Überall, Illustrierte Wocheschrift für Heer und Marine, Nr. 6, 1902 / 1903

- Artikel über die Rüstkammer in der Antiquitätenzeitung, Januar 1904

- Organisation des Verkaufs des Führers der Rüstkammer, 1904 1908

- Bereitschaft der Gesellschaft für bildende Kunst und vaterländische Altertümer zur Bewerbung des Rüstkammerführers in ihrem Jahrbuch, April 1904

- Versendung von Exemplaren des Führers an Mitglieder des Provinziallandtages, der Provinziallandtagsbibliothek und an die Mitglieder der ostfriesischen Landrechnungsversammlung, Februar März 1905

$1902-1908$

\author{
Klassifikation Teil B: 02734 \\ Trägermaterial: Papier \\ Alte Reg.-Sig.: VIII A3 $04 \mathrm{p}$ \\ Bestell-Nr.: IV 02734
}

- Rücktritt des Senators van Ness von der Aufsicht über die

Rüstkammer, Februar 1862

- Restaurierung von Münzprägestempeln in der Rüstkammer, August 1876 - Juni 1878

- Anfragen wegen Besichtigung der Rüstkammer, 1874

- Aufstellung über zum Tausch geeignete Waffen der Rüstkammer, 1878

- Austausch von Doppelexemplaren von Waffen mit anderen, 1880 -

1881

- Planung einer Publikation über die Rüstkammer, 1882

- Beschwerde der Gesellschaft für bildende Kunst und vaterländische Altertümer gegen die Erhebung von Eintritt zur Rüstkammer von ihren Mitgliedern für den Besuch zu Studienzwecken, April 1883

- Tätigkeitsbericht des seit 1847 amtierenden Rüstmeisters Georg Janßen, Dezember 1887

- Anträge verschiedener Vereine auf Ermäßigung der Eintrittspreise für Besichtigungen der Rüstkammer anlässlich Verbandstagungen $u$. dgl., 1880 - 1901

- Gebührenordnung für Besucher der Rüstkammer, September 1901

(1862) 1874 - 1901

Klassifikation Teil B: 02735

Trägermaterial: Papier

Alte Reg.-Sig.: VIII A3 04

Bestell-Nr.: IV 02735 
06.01

Lfd. Nr. Titel

- Artikel über die Rüstkammer in der Antiquitätenzeitung, Juli 1908

- Diebstahl eines Prüfgerätes aus der Rüstkammer, 1911

- Instandhaltung von Rüstungen und Waffen, 1912 - 1913

- Restaurierung des Gobelins "Urteil des Kambyses", 1912 - 1916

$1908-1906$

Klassifikation Teil B: 02736

Trägermaterial: Papier

Alte Reg.-Sig.: VIII A3 04

Bestell-Nr.: IV 02736

2624 Neuauflage des Rüstkammerführers

1908-1916

- Vorschlag einer durchgehenden Inventarnummerierung der

Rüstkammer zur Verbesserung des Führers, September 1908 -

Oktober 1909

- Aufstellung über Zugänge an Waffen für die Rüstkammer, 1908

- Beschluss der Kommission für die Rüstkammer zum Druck einer

Neuauflage des Rüstkammerführers, Oktober 1908

- Schreiben des Oberbürgermeisters Fürbringer an Dr. Othmar Baron

Potier über Bitte um sachkundige Unterstützung der Arbeit an der Neuauflage des Rüstkammerführers, Oktober 1908

- Organisation der Bearbeitung der Neuauflage, Dezember 1908

- Stellungnahme des Dr. Othmar Baron Potier zur Neuauflage des

Rüstkammerführers, November 1908 - Februar 1909

1908 - 1909 (1910 - 1920)

Klassifikation Teil B: 02737

Trägermaterial: Papier

Alte Reg.-Sig.: VIII A3 $04 \mathrm{q}$

Bestell-Nr.: IV 02737

2625 Liste der Mobilien im Rathaus, Bd. 1

$1868-1880$

- Aufstellung über Möbel, Gemälde, Modette etc. im Rathaus

$1868 / 1880$

Klassifikation Teil B: 02738

Band: 1

Trägermaterial: Papier

Bestell-Nr.: IV 02738

2626 Liste der Mobilien im Rathaus, Bd. 2

- Anschaffungen für die Polizeiverwaltung und andere

Verwaltungsabteilungen im Rathaus

- Inventarien der Mobilien im Rathaus

- Reparaturen, Renovierngen und Neuanschaffungen von Möbel,

Gefängnisausstattung, Gemälde und Gebrauchsgegenstände

1852 - 1865) 1865 - $19161868 / 1880$

Klassifikation Teil B: 02739

Band: 2

Trägermaterial: Papier

Bestell-Nr.: IV 02739 
06.01

Lfd. Nr. Titel

Laufzeit

2627 Städtisches Torfwesen, Bd. 1

- Regulativ über das Torfwesen der Stadt Emden (Erhebung der

Torfakzise, Regelung der Torfeinfuhr und des Verkaufs), 1894

- Ausverdingung der Torffuhren, (1860 - 1865) 1866 - 1890

- Änderung der Aufsicht über das Torfwesen, Mai 1877

- Revision der Torfmesskörbe, Juli 1878 - Dezember 1879

- Aufstellung über Torfmesserinnen und Anzahl ihrer Messkörbe, Juli -

Dezember 1878

- Anzeige des Polizeisergeanten Widhagen über Zunahme des

verbotenen Sitzens der Torffahrer auf den Torfkörben, Oktober 1879

- Vergabe der Unterhaltung der Torfwaagen an den Schmied P.J.

Brillmann, März 1883 - April 1895

- Ausschreibung der Ausbesserung und Instandhaltung der städtischen Torfkörbe, Februar 1884 - April 1896

- Ausschreibung der Lieferung neuer Torfkörbe, April 1884 - März 1899

(1860 - 1865) 1866 - 1899

Klassifikation Teil B: 02740

Band: 1

Trägermaterial: Papier

Alte Reg.-Sig.: VIII A3 11

Bestell-Nr.: IV 02740

2628 Städtisches Torfwesen, Bd. 2

- Ausverdingung der Torffuhren, 1900 - 1913

- Beschwerde des Buchdruckereibesitzers A. Gerhard gegen

Verschmutzung des Gehweges vor seinem Geschäft durch

Pferdemist der Torfgespanne, Juli 1902

- Ausschreibung der Ausbesserung und Instandhaltung der städtischen Torfkörbe, 1902

- Bericht des Kämmerers Gebest über Defizit des städtischen

Torfwesens, August 1905 / August 1906

- Verkauf von Torfwagen, Oktober 1905 - Oktober 1906

- Auflösung des städtischen Torfwesens, Dezember 1913 - Juli 1914

$1900-1914$

Klassifikation Teil B: 02741

Band: 2

Trägermaterial: Papier

Alte Reg.-Sig.: VIII A3 11

Bestell-Nr.: IV 02741 
06

IV

06.01

Finanzverwaltung der Stadt Emden

06.01.02

Städtisches Vermögen

Lfd. Nr. Titel

Sonstiges städtisches Eigentum

2629 Anfertigung eines Kataloges der Rüstkammer

Laufzeit

- Anfertigung eines Kataloges der Rüstkammer durch den

Amtsassessor Rolffs und Druck durch den Buchdrucker H. Woortman, $1857-1860$

- Antrag des Buchdruckers $\mathrm{H}$. Woortman beim Magistrat auf Fortsetzung des Katalogverkaufs in der Rüstkammer, Juli - August 1868

- Antrag des Buchdruckers H. Woortman auf Übernahme der Restauflage des Kataloges durch die Stadt Emden, Dezember 1875

(1857 - 1860) 1868 - 1875

Klassifikation Teil B: 02742

Trägermaterial: Papier

Alte Reg.-Sig.: VIII A3 13

Bestell-Nr.: IV 02742

2630 Silbersachen im Rathaus, Bd. 1

1878-1898

- Angebot des Händlers G. Goldschmidt aus Frankfurt/M. zum Kauf des Emder Ratssilbers, Mai 1860

- Schätzung des Wertes des Ratssilbers durch P. van Hoorn, Mai 1860 / Juni 1861

- Verhandlungen der städtischen Kollegien über Verkauf des Emder

Ratssilbers, Mai - Juni 1860 / Januar - Februar 1881

- Protest der Gesellschaft für bildende Kunst und vaterländische

Altertümer gegen den beabsichtigten Verkauf des Emder Ratssilbers, Mai 1860

- Anfrage des preußischen Kronprinzen wegen Ausleihung einer Silberschale des Ratssilbers zur Anfertigung einer Reproduktion, September 1878 - Mai 1879

- Angebot der Gebrüder Löwenstein aus Frankfurt/M zum Kauf des

Emder Ratssilbers, Februar - April 1880 / Januar - Februar 1881

- Angebot der Fa. J. \& S. Goldschmidt zum Kauf des Emder

Ratssilbers, Februar - April 1881

- Anfragen verschiedener Museen wegen Ausleihe von Stücken des

Ratssilbers, 1884

- Erwähnung des Emder Ratssilbers in einer Publikation von Egon

Rosenberg, Eine vergessene Goldschmiedestadt, 1886

- Ausleihe von Geschirr aus dem Emder Ratssilber für ein vom hannoverschen Provinziallandtag veranstaltetes Festbankett für Kaiser Wilhelm II., Juli - September 1889

- Ausleihe von Stücken des Emder Ratssilbers für die Jubiläumsfeier des Emder Schützencorps, August - September 1898

$(1860-1861) 1878-1898$

Klassifikation Teil B: 02743

Band: 1

Trägermaterial: Papier

Alte Reg.-Sig.: VIII A3 13

Bestell-Nr.: IV 02743 
06.01

Lfd. Nr. Titel

Laufzeit

2631 Silbersachen im Rathaus, Bd. 2

- Anfragen verschiedener Museen wegen Ausleihe von Stücken des

Ratssilbers, 1902

- Artikel über das Emder Ratssilber in der Zeitschrift "Daheim", Nr. 1, 1902

- Ausleihe von Geschirr aus dem Emder Ratssilber für ein vom hannoverschen Provinziallandtag veranstaltetes Festbankett für Kaiser Wilhelm II., Juni - September 1907

- Übernahme einer Dankmünze auf die Stadt Emden vom Großherzog von Oldenburg, August 1907

- Feststellung der Reparaturbedürftigkeit von Stücken des Emder Ratssilbers, November 1907

- Verzeichnis des Emder Ratssilbers, 1907

- Reparatur von Stücken des Emder Ratssilbers durch den Juwelier und Goldschmied Franz Richter, 1907 - 1908

$1902-1908(1919-1921)$

\author{
Klassifikation Teil B: 02744 \\ Band: 2 \\ Trägermaterial: Papier \\ Alte Reg.-Sig.: VIII A3 13 \\ Bestell-Nr.: IV 02744
}

2632 Ölgemälde im Rathaus

- Restaurierung der Gemälde "Graf Enno II. zu Ostfriesland" und

"Gräfin Anna" durch den Oldenburger Maler Diederichs, September Oktober 1865

- Aufstellung über restaurierungsbedürftige Ölgemälde und Schätzung der Kosten einer Restaurierung, November 1865

- Restaurierung der Gemälde von Graf Enno II. und Gräfin Anna durch Diederichs, September.- Dezember 1866

- Klärung des irrigen Titels eines Bolardus-Gemäldes als Bildnis eines Oranier-Prinzen, November 1885

- Erwerb des Bildes "Großer Kurfürst" des Historienmalers Paul

Stankiewicz, 1895 - 1896

- Versicherungswert der Ölgemälde, 1898

- Restaurierung von Gemälden des Kunstmalers L. Fischbeck aus

Oldenburg, 1901 - 1902

1866 - 1912 (1865 / 1922)

Klassifikation Teil B: 02745

Trägermaterial: Papier

Alte Reg.-Sig.: VIII A3 16

Bestell-Nr.: IV 02745

2633 Verpachtung der Regenwasserbacke an der Waage

- Verpachtung der Zisterne an der Waage

(1840 - 1854) 1868 - 1869

Klassifikation Teil B: 02746

Trägermaterial: Papier

Bestell-Nr.: IV 02746 
06.01

Lfd. Nr. Titel

Laufzeit

2634 Verpachtung von Regenwasser-Zisternen

- Anlage einer Regenwasser-Zisterne an der Neuen Kirche durch die Stadt Emden zur Behebung des Trinkwassermangels der preußischen Garnison, Juli 1869 - August 1870

- Anlage einer Regenwasser-Zisterne an der lutherischen Kirche und Vereinbarung der lutherischen Gemeinde mit dem Magistrat über Nutzung der Zisterne, Dezember 1870 - Januar 1872

- Verrechnung der Geldeinnahmen aus der Abgabe von Wasser aus den Zisternen, Juli 1875 - Mai 1910

- Plan der Anlage einer Regenwasser-Zisterne an der städtischen Volksschule, Dezember 1883 - März 1884

- Plan der Anlage einer Regenwasser-Zisterne an der Gasthauskirche, Mai - September 1886

- Plan der Anlage einer Regenwasser-Zisterne an der Großen Kirche, April - Juni 1887

- Plan der Anlage einer Regenwasser-Zisterne an der Höheren

Bürgerschule, Oktober - November 1888

- Kostenanschlag des Stadtbaumeisters Wiggers für eine Zisterne an der Höheren Töchterschule, November 1891

- Antrag der Heringsfischerei AG Neptun an den Magistrat auf Erlaubnis einer unentgeltlichen Wasserentnahme aus der städtischen Zisterne für ihre Arbeiterwohnungen, Mai 1895

- Antrag des Wäschereibesitzers Simon D. de Beer auf Gewährung eines Pauschalpreises für aus der Zisterne an der

Kaiser-Friedrichs-Schule entnommenen Wassers, März - Mai 1900

- Anlage einer Zisterne an der Klunderburg, 1887 - 1903

- Antrag der lutherischen Gemeinde auf Nutzung der Zisterne an der lutherischen Schule für ihr Altersheim, Februar - März 1904

$1869-1910$

Klassifikation Teil B: 02747

Trägermaterial: Papier

Alte Reg.-Sig.: VIII A3 16

Bestell-Nr.: IV 02747

2635 Rüstkammer - Kommission

$1901-1914$

(1920)

- Protokolle der Verhandlungen der Kommission für die Rüstkammer über Organisation der Rüstkammer und Herstellung eines

Rüstkammer - Kataloges

1901 - 1914 (1920 - 1921)

Klassifikation Teil B: 02749

Trägermaterial: Papier

Alte Reg.-Sig.: VIII A3 04y

Bestell-Nr.: IV 02749 
06.01 Städtisches Vermögen

06.01.02

Sonstiges städtisches Eigentum

Lfd. Nr. Titel

Laufzeit

2636 Rüstkammer: Neuordnung durch Dr. Othmar Baron von Potier 1901

- Rechenschaftsbericht des Dr. Othmar Baron von Potier über seine Tätigkeit zur Neuordnung der Rüstkammer

1901

Klassifikation Teil B: 02750

Trägermaterial: Papier

Alte Reg.-Sig.: VIII A3 04

Bestell-Nr.: IV 02750

2637 Rüstkammer: Verschiedenes

- Bericht des Magistrats über Reorganisation der Rüstkammer, 1903

- Organisation des Kartenverkaufs zur Besichtigung der Rüstkammer, November 1902 - Januar 1903

- Publikationen über die Rüstkammer, 1902 - 1903

- Anträge von Vereinen auf Ermäßigung des Eintritts zur Besichtigung der Rüstkammer, 1903 - 1904

- Restaurierung von Hellebarden der Rüstkammer, September -

Oktober 1903

- Anbietung einer Schützentafel von 1748 für die Rüstkammer durch das Emder Schützencorps, November 1903

- Restaurierung der Baselisken in der Rüstkammer, Dezember 1903 -

September 1904

- Niederdeutsche Beschreibung der Glasmalereien im Rathaus

(Transkripte), 1903

- Ausstellung von Bildern (Photographien) des Kaiserbesuches von

1902, Dezember 1903 - Februar 1904

- Bericht über Führer durch die Rüstkammer in der

"Antiquitäten-Zeitung", Januar 1904

$1903-1904$

Klassifikation Teil B: 02751

Trägermaterial: Papier

Alte Reg.-Sig.: VIII A3 04

Bestell-Nr.: IV 02751 
06.01

Lfd. Nr. Titel

Laufzeit

2638 Rüstkammer: Verschiedenes

- Statistik: Verkaufte Eintrittskarten, Rüstkammerführer und

Ansichtskarten, 1904 - 1905

- Verweigerung der Zahlung eines Eintrittsgeldes zum Besuch der

Rüstkammer durch Dr. Sternberg ünter Hinweis auf sein Bürgerrecht,

August - Oktober 1904

- Ermäßigung des Eintritts zur Rüstkammer für Emder Einwohner, Januar 1905

- Anträge von Vereinen auf Ermäßigung des Eintritts zur Besichtigung der Rüstkammer, 1905 - 1907

- Gewährung freien Eintritts in die Rüstkammer für Militärpersonen, Juli 1905

- Öffnungszeiten der Rüstkammer, 1905 - 1907

- Angebot des Goldschmiedes und Juweliers Franz Rütter zur

Renovierung der Waffenstände, Oktober 1907

- Zustand der Waffen in der Rüstkammer, 1907 - 1914

$1904-1907$

Klassifikation Teil B: 02752

Trägermaterial: Papier

Alte Reg.-Sig.: VIII A3 04

Bestell-Nr.: IV 02752

2639 Archivalien

1901

- Verzeichnis der Akten im Ratsarchiv

1901

Klassifikation Teil B: 02753

Trägermaterial: Papier

Alte Reg.-Sig.: VIII A3

Bestell-Nr.: IV 02753

2640 Einquartierungskasse, Bd. 1

- Rechnungslegung über den Zinsertrag der der Einquartierungskasse gehörenden Wertpapiere unter Hinterlegung der Papiere beim städtischen Depositum und der städtischen Spar- und Leihkasse

(1860 - 1865) 1866 - 1899

Klassifikation Teil B: 02754

Band: 1

Trägermaterial: Papier

Alte Reg.-Sig.: VIII A3 07

Bestell-Nr.: IV 02754 
06.01

Lfd. Nr. Titel

Laufzeit

2641 Einquartierungskasse, Bd. 2

- Rechnungslegung über den Zinsertrag der der Einquartierungskasse gehörenden Wertpapiere unter Hinterlegung der Papiere beim städtischen Depositum und der städtischen Spar- und Leihkasse

$1900-1904$

Klassifikation Teil B: 02755

Band: 2

Trägermaterial: Papier

Alte Reg.-Sig.: VIII A3 07

Bestell-Nr.: IV 02755

2642 Inventar der Rüstkammer

- Anfrage des Kriegervereins Emden wegen Ausleihe von Waffen aus der Rüstkammer zur Aufführung von "Lebenden Bildern" anlässlich des Kaisergeburtstages, Januar 1908

- Stiftung einer Silbermünze für die Münzsammlung in der

Rüstkammer durch Kapitän Peter Templin, Hamburger Bugsier- und

Frachtschifffahrtsgesellschaft, April - Mai 1908

- Antrag des Rüstmeisters Mundt an die Kommission für die

Rüstkammer auf Erlaubnis auf Entfernung nachträglich angebrachter

Teile an Originalrüstungen zur Herstellung der Urzustandes,

September - Oktober 1908

- Erfolgloser Versuch der Anwendung eines von Rudolf Schiele,

Restaurator am Provinzialmuseum Hannover, entwickelten

Härtungsverfahrens an Gewehrschäften aus der Rüstkammer, August

1909 - April 1910

- Antrag der Gesellschaft für bildende Kunst und vaterländische

Altertümer auf Übertragung ausgesonderter Teile der Rüstkammer auf ihre Sammlung, Februar 1910

- Rechnungsprüfung: Einnahmen und Ausgaben der Rüstkammer, $1912-1913$

$1908-1913$

Klassifikation Teil B: 02756

Trägermaterial: Papier

Alte Reg.-Sig.: VIII A3 04 r

Bestell-Nr.: IV 02756

2643 Rüstkammer: Fremdenbesuch

- Verfügung des Magistrats über Regelung der Fremdenführungen durch die Rüstkammer, April - Mai 1908

- Festlegung der Besichtigungszeiten der Rüstkammer, Mai 1908

- Anmeldung von Gruppen zur Besichtigung der Rüstkammer, 1908 -

1914

- Änderung des Gebührentarifs zur Besichtigung der Rüstkammer, 1911

$1908-1914$

Klassifikation Teil B: 02757

Trägermaterial: Papier

Alte Reg.-Sig.: VIII A3 $04 \mathrm{~s}$

Bestell-Nr.: IV 02757 
06

06.01

06.01 .02

Sonstiges städtisches Eigentum

Lfd. Nr. Titel

Laufzeit

2644 Rüstkammer: Aufseher

- Diskussion um Öffnungszeiten der Rüstkammer, August 1902

- Bewerbung des pensionierten Lokomotivführers Louis Müller um die Stelle eines Rüstmeisters, August 1902

- Verfügung des Magistrats über Einstellung des Louis Müller als

Rüstkammer-Aufseher, August 1902

- Entlassung des L. Müller wegen Trunkenheit im Dienst, September 1903

- Einstellung zweier Aufseher der Rüstkammer für den Dienst am Sonntag und bei Abwesenheit des Rüstmeisters, September 1903 /

März 1908 / Mai 1914 (1920 - 1922)

1902 - 1914 (1920 - 1922)

Klassifikation Teil B: 02758

Trägermaterial: Papier

Alte Reg.-Sig.: VIII A3 $04 \mathrm{t}$

Bestell-Nr.: IV 02758

2645 Rüstkammer: Rüstmeister

- Verfahren zur Besetzung der vakanten Rüstmeister-Stelle, Juni 1902

- April 1903 / August 1906 - Februar 1907

- Von Dr. Othmar Baron Potier erstellte Dienstanweisung für den

Rüstmeister, Dezember 1902

$1902-1907$

Klassifikation Teil B: 02759

Trägermaterial: Papier

Alte Reg.-Sig.: VIII A3 $04 \mathrm{u}$

Bestell-Nr.: IV 02759

2646 Rüstkammer: Etat

- Entwurf des Etats der Rüstkammer, 1903 - 1911

- Übernahme von Defiziten des Rüstkammer-Etats durch die

Kämmereikasse, 1903 / 1908 - 1913

- Festgestellte Etats der Rüstkammer, 1904 - 1912

- Beihilfe des Landesdirektoriums der Provinz Hannover zur

Unterhaltung der Rüstkammer, 1914 - 1917

$1903-1917$

Klassifikation Teil B: 02760

Trägermaterial: Papier

Alte Reg.-Sig.: VIII A3 04 v

Bestell-Nr.: IV 02760 
06.01

Lfd. Nr. Titel

Laufzeit

2647 Rüstkammer: Ansichtskarten

- Herstellung und Verkauf von Ansichtskarten von der Rüstkammer, 1904 - 1912

- Ansichtskarten der Rüstkammer, 1904 / 1906

- Verhandlungen der Kommission für die Rüstkammer über

Gestaltung der Ansichtskarten, 1905

- Angebote zur Herstellung von Ansichtskarten von der Rüstkammer, 1906

$1904-1912$

Klassifikation Teil B: 02761

Trägermaterial: Papier

Alte Reg.-Sig.: VIII A3 $04 \mathrm{v}$

Bestell-Nr.: IV 02761

2648 Rüstkammer: Kommission

- Bildung einer Kommission für die Rüstkammer, 1882 / 1899

- Bestellung der Mitglieder der Kommission für die Rüstkammer, Januar 1900

- Ersatzwahlen zur Kommission für die Rüstkammer, November 1900

- Nov. 1908 (1920 - 1921)

- Verhandlungen der Kommission für die Rüstkammer über

Organisation der Rüstkammer, 1902

1882 - 1908 (1920 - 1921)

Klassifikation Teil B: 02762

Trägermaterial: Papier

Alte Reg.-Sig.: VIII A3 $04 \mathrm{w}$

Bestell-Nr.: IV 02762

2649 Rüstkammer: Feuerversicherung

- Versicherung der Rüstkammer gegen Feuersgefahr bei der Westdeutschen Versicherungs-Aktienbank, Essen über 556.200 Mk

$1900-1907$

Klassifikation Teil B: 02763

Trägermaterial: Papier

Alte Reg.-Sig.: VIII A3 $04 \mathrm{x}$

Bestell-Nr.: IV 02763 
Lfd. Nr. Titel

Laufzeit

2650 Stühle für Magistratsangehörige und Bürgervorsteher in den Emder 1866-1885 evangelischen Kirchen

- Verhandlungen wegen Einräumung von Stühlen für Magistratsangehörige und Bürgervorsteher in der lutherischen Kirche gemäß dem Regulativ von 1772, 1815 - 1847

- Antrag des Kirchenrats der deutsch-reformierten Gemeinde auf Erlaubnis der Nutzung der Stühle für den Magistrat in der Großen Kirche durch Offiziere, Dezember 1866 - September 1867 / Februar 1885

- Verfügung des Magistrats an die evangelischen Kirchen über Aufforderung zur Verhinderung unbefugter Benutzung des Gestühls für den Magistrat, Mär - Mai 1880

- Antrag des Kirchenrats der deutsch reformierten Gemeinde auf Verzicht des Magistrats auf das Gestühl für seine Mitglieder in der Großen Kirche, Mai 1885

(1815 - 1847) 1866 - 1885

Klassifikation Teil B: 02764

Trägermaterial: Papier

Alte Reg.-Sig.: VIII A3 03

Bestell-Nr.: IV 02764

- Kostenvoranschlag zur Anlegung eines neuen städtischen Brunnens, Januar 1842

- Anlage öffentlicher Brunnen, (1842 - 1859) 1875 - 1895

- Anzeigen wegen fehlender Einfassung von Brunnen, August 1844

(1842 - 1859) 1875 - 1895

Klassifikation Teil B: 02765

Trägermaterial: Papier

Alte Reg.-Sig.: VIII A3 06

Bestell-Nr.: IV 02765

2652 Anlage eines Röhrenbrunnens

- Angebote von Pumpen und Bohrer, 1877

- Angebot der Fa. Breymann \& Tiller wegen Bohrung eines

Trinkwasserbrunnens in der Stadt Emden, Mai - Juli 1877

- Angebot der Fa. W. Kramer, Gütersloh zur Bohrung eines Brunnens

in Emden, Juli 1877

- Ergebnis von Bohrversuichen der Fa. Kramer bei der Waage, August 1877

- Bericht des Stadtbaumeisters Wiggers über Stand der Bohrung,

Dezember 1877

- Anschaffung einer Saugpumpe für den Tiefbrunnen bei der Waage,

Dezember 1877 - Januar 1878

$1877-1878$

Klassifikation Teil B: 02766

Trägermaterial: Papier

Alte Reg.-Sig.: VIII A3 22

Bestell-Nr.: IV 02766 
06.01

Lfd. Nr. Titel

Laufzeit

2653 Verpachtung der städtischen Waage und des Marktmeisterdienstes, $1877-1910$ Bd. 1

- Ausschreibung der Verpachtung des Marktmeisterdienstes, 1877 1878 / 1881 - 1882

- Verhandlungen der Marktkommission mit dem Magistrat über Vereinigung der Funktionen des Marktmeisters mit denen des Waage-Meisters, März 1878

- Bedingungen der Verpachtung der Stadtwaage und der Erhebung der Marktstandsgebühr für Vieh, März 1878 - Mai 1879

- Vereidigung des Markt- und Waage-Meisters Nagel, April 1885

- Beschwerde des Marktbeschickers G. Engelhardt gegen den Marktmeister wegen Nichtfreihaltung des von inm bestellten und bezahlten Marktstandes, September - OKtober 1885

- Tarif der Waage-Nutzung, 1886

- Diskussion einer Polizeiverordnung über das Verbot des Viehhandels außerhalb des Marktes an Markttagen, April - Mai 1890 - Beschwerde des Emder Colonialwaaren- und Detaillisten-Vereins gegen den Marktmeister wegen der Abhaltung von Auktionen bei der Waage und anderer Missstände, August / Dezember 1898 - Verpachtung Stadtwaage und des Marktmeisterdienstes an J. Nagel und seiner Witwe, 1884 - 1909

$1877-1910$

Klassifikation Teil B: 02767

Band: 1

Trägermaterial: Papier

Alte Reg.-Sig.: VIII A3 24

Bestell-Nr.: IV 02767

2654 Verpachtung der städtischen Waage und des Marktmeisterdienstes,

- Bedingungen der Verpachtung der Stadtwaage und des

Marktmeisterdienstes, Dezember 1909

- Ausschreibung der Verpachtung, Januar 1910 / 1918 (1919)

- Übergabe der Waage-Utensilien an den Waage-Pächter S. Siemens,

März 1910

- Einnahmen der städtischen Waage, 1910 / 1912

- Eingabe des Waagenpächters Siemens an den Magistrat über Bitte um Senkung der Waagen-Pacht wegen Einnahmeverluste durch Viehseuche, Juli 1911 - März 1912 / September 1915

- Beschwerden der Anwohner des Neuen Marktes wegen

Lärmbelästigung durch Karussels und Musikapparate, März 1913

$1909-1918(1919)$

Klassifikation Teil B: 02768

Band: 2

Trägermaterial: Papier

Alte Reg.-Sig.: VIII A3 24

Bestell-Nr.: IV 02768 
Lfd. Nr. Titel

- Eingabe einer Aktiengesellschaft, bestehend aus dem

Stadtbaumeister Berg, Dr.med. Lange und M. Neumark an den Magistrat über Bitte um Verkauf einer Strecke des Walles am Heuzwinger zur Anlegung eines Eiskellers, Oktober 1851 - August 1853

- Planskizze des Eiskellers, Oktober 1851

- Klärung der Eigentumsverhältnisse des Eiskellers, Oktober Dezember 1872

- Wechsel der Eigentümer des Eiskellers, 1872 - 1879

- Übernahme der Aktien der Eiskeller-Gesellschaft durch die Stadt Emden, März 1879 - August 1880

- Pachtung des Eiskellers durch den Bäckermeister Jan Iden Hagen, April 1879 - Mai 1905

- Verfügung des Magistrats an Jan I. Hagen über Aufforderung zur Instandsetzung des baufälligen Eiskellers, März 1901

- Beseitigung des Eiskellers, 1913

(1851 - 1853) 1872 - 1913

Klassifikation Teil B: 02769

Trägermaterial: Papier

Alte Reg.-Sig.: VIII A3 26

Bestell-Nr.: IV 02769

2656 Ölgemälde der Hohenzollernkaiser als Geschenk des preußischen Kultusministers an die Stadt Emden

- Gesuch des Magistrats an das kaiserliche Zivilkabinett über Bitte um Zusendung eines Gemäldes des Kaisers Wilhelm II. zur Vervollständigung der städtischen Sammlung, Mai 1888 - Korrespondenz des Oberbürgermeisters Fürbringer mit dem Historienmaler Paul Stankiewicz wegen Kauf eines Gemäldes des Kaisers Wilhelm I., Mai 1888

- Anschaffung der passenden Rahmen für das Gemälde, Juni 1888 - Bescheid des Ministers der geistlichen, Unterrichts- und Medicinalangelegenheiten über Schenkung der vom Historienmaler Stankiewicz gefertigten Gemälde vom Kaiser Wilhelm I,und Kaiser Friedrich III, Juli 1888

- Schreiben des Historienmalers P. Stankiewicz an OB Fürbringer über Rahmen für die Gemälde, Juli 1889

- Angebot eines Gemäldes von der kaiserlichen Familie von P. Stankiewcz für 100 Mark, März 1890

- Künstlerische Anfertigung von Namensschilder für die Gemälde im Rathaus, 1907

$1888-1907$

Klassifikation Teil B: 02770

Trägermaterial: Papier

Alte Reg.-Sig.: VIII A3 28

Bestell-Nr.: IV 02770 
- Votum der städtischen Kollegien für ein Profilgemäldes des Großen Kurfürsten Friedrich Wilhelm von Brandenburg, Dezember 1894 - Anfertigung des Gemäldes vom Großen Kurfürsten durch den Historienmaler Paul Stankiewicz, 1894 - 1895

- Anfertigung der Rahmen für das Gemälde in Abstimmung mit $P$. Stankiewicz, Februar - März 1895

- Aufhängung des Gemäldes im Rathaus, Mai 1895

$1894-1895$

Klassifikation Teil B: 02771

Trägermaterial: Papier

Alte Reg.-Sig.: VIII A3 31

Bestell-Nr.: IV 02771

- Gutachten des Professors H. Linnemann über Restaurierung der

Glasmalereien des Rathauses, Juni 1899

- Angebote über Ausführung der Restaurationsarbeiten, März 1900 Oktober 1901

- Notarbeiten an den Glasmalereien anlässlich des bevorstehenden Kaiserbesuches, 1900

- Bescheid des Regierungspräsidenten in Aurich über Bewilligung einer Staatsbeihilfe in Höhe von 3000 Mark zur Restaurierung der Glasmalereien, Juni 1901

- Ausführung der Restaurationsarbeiten durch den Architekten und Glasmaler Prof H. Linnemann, 1900 - 1901

- Planskizze der Fenster für die Glasmalereien, 1901 - 1902

- Bericht des Rüstmeisters Jung über Sturmschäden an den bemalten Glasfenstern im Rathaus, Oktober 1903

- Diskussion von Maßnahmen zum Schutz der Glasmalereien, Juni 1907

- Auftreten neuer Schäden an den bemalten Glasfenstern, Februar März 1910

- Reparatur der Scheiben durch Einfügung der Glasmalereien zwischen zwei Scheiben, Mai - Juli 1910

$1899-1910$

Klassifikation Teil B: 02772

Trägermaterial: Papier

Alte Reg.-Sig.: VIII A3 32

Bestell-Nr.: IV 02772 
06

Finanzverwaltung der Stadt Emden

06.01

Städtisches Vermögen

06.01 .02

Sonstiges städtisches Eigentum

Lfd. Nr. Titel

Laufzeit

2659 Nachbildung des Convoyer-Schiffsmodells "Emden" im Rummel des 1905 Rathauses

- Anfrage der Teltowkanal-Bauverwaltung in Willmersdorf / Berlin wegen Möglichkeit der Nachbildung des Convoyer-Schiffsmodells

"Emden", Juli 1905

- Nachbau des Modells für die Teltowkanal-Bauverwaltung durch den

Schiffsbaumeister Friedrich Stark, 1905

1905

Klassifikation Teil B: 02773

Trägermaterial: Papier

Alte Reg.-Sig.: VIII A3 36

Bestell-Nr.: IV 02773 
IV

06

Finanzverwaltung der Stadt Emden

06.01

06.01 .03

Städtisches Vermögen

Lfd. Nr. Titel

Renten und Gerechtigkeiten

2660 Berechnung der An- und Abfahrtsgelder bei Veräußerung von

Laufzeit

Grundstücken

- Grundsatzklage wegen rechtlicher Grundlagen der Berechnung der

An- und Abfahrtsgelder bei Veräußerung von Grundstücken als

Ausfluss der Feudallast "Beheerdischheit"

$1873-1880$

Klassifikation Teil B: 02775

Trägermaterial: Papier

Alte Reg.-Sig.: VIII A4 08

Bestell-Nr.: IV 02775

2661 Anmeldung städtischer Rechte bei der Subhastation

1886-1911

(Zwangsversteigerung) von Immobilien

- Aneldung städtischer Rechte aus Erbpachten, Abgaben und

Feudallasten bei Zwangsversteigerungen

$1886-1911$

Klassifikation Teil B: 02776

Trägermaterial: Papier

Alte Reg.-Sig.: VIII A4 09

Bestell-Nr.: IV 02776 
06.01

Lfd. Nr. Titel

Laufzeit

2662 Kruggeld in Uphusen 1880

- Antrag des Gastwirts G. Middents aus Uphusen an den Magistrat auf Löschung der auf seinem Gasthof "In't Emder Waapen" eingetragene Reallast des Kruggeldes für die Stadt Emden als Besitzerin der Herrlichkeit Uphusen, November 1880

1880

Klassifikation Teil B: 02777

Trägermaterial: Papier

Alte Reg.-Sig.: VIII A5 12

Bestell-Nr.: IV 02777

2663 Herrlichkeitsgefälle

- Erhebung der Feudallast "Kuhschatz" aus Uphusen durch den Magistrat wegen Rechtstitel aus dem Besitz der Herrlichkeit Uphusen durch die Stadt Emden, 1867 - 1893

- Ablösung der Feudallast des "Torfgeldes" und des "Hofdienstes" auf dem Grundstück der Gesina Maria Peterssen, geb. Helmers zu Uphusen, Dezember 1908

$1867-1909$

Klassifikation Teil B: 02778

Trägermaterial: Papier

Alte Reg.-Sig.: VIII A5 10

Bestell-Nr.: IV 02778

2664 Herrlichkeitsgefälle, Bd. 1

- Anträge auf Ablösung der auf Grundstücken in den Emder Herrlichkeiten Borssum, Oldersum, Uphusen und Wolthusen ruhenden Feudallast "Hofdienst" als Reallast aus dem Grundbuch, $1886-1899$

- Einziehung des "Hofdienstgeldes" von Grundbesitzern in Oldersum durch die Stadt Emden als Herrlichkeitsbesitzerin, 1887 - 1893

- Weigerung des Magistrats zur Löschung der auf Oldersumer Grundstücken ruhenden Feudallast "Auffütterung eines Jagdhundes" zugunsten der Stadt Emden als Herrlichkeitsbesitzerin ohne die Vereinbarung einer Kapitalablösung, April 1889

$1886-1899$

Klassifikation Teil B: 02779

Band: 1

Trägermaterial: Papier

Alte Reg.-Sig.: VIII A5 11

Bestell-Nr.: IV 02779 
06

06.01

Lfd. Nr. Titel

Laufzeit

2665 Herrlichkeitsgefälle, Bd. 2

- Klärung des Umfangs der als Reallast auf Grundstücken in Borssum, Gandersum, Jarssum, Oldersum, Rorichum und Widdelswehr liegenen Feudalabgaben ("Hofdienst" etc.) zugunsten der Stadt Emden, 1900

- Anträge auf Ablösung von Feudallasten, 1900 - 1906

$1900-1906$

Klassifikation Teil B: 02780

Band: 2

Trägermaterial: Papier

Alte Reg.-Sig.: VIII A5 11

Bestell-Nr.: IV 02780

2666 Patronat der Stadt Emden über ihre Herrlichkeiten

- Beschluss des Kirchen- und Schulvorstandes zu Tergast über Ablehnung einer Gehaltserhöhung für den Schullehrer unter Verweisung der Zuständigkeit an die Stadt Emden als Patronin der Herrlichkeit Oldersum, Juni - Oktober 1876

- Streit um die vom Kirchenvorstand zu Wolthusen und dem Kreishauptmann des Amtes Emden beabsichtigte Heranziehung der Stadt Emden als Patronin zur Finanzierung der Reparatur der Wolthuser Kirche, Juli 1877 - April 1882

$1876-1882$

Klassifikation Teil B: 02781

Trägermaterial: Papier

Alte Reg.-Sig.: VIII A5 41

Bestell-Nr.: IV 02781

- Plan der Trockenlegung des Uphuser Meeres, 1887

- Ermittlung der Eigentumsverhältnisse über das Uphuser Meer, 1885

- Plankarte des Uphuser Meeres mit Profilbohrungsergebnissen, 1885

$1885-1889$

Klassifikation Teil B: 02782

Trägermaterial: Papier

Alte Reg.-Sig.: VIII A5 50

Bestell-Nr.: IV 02782

2668 Prozess um Feudallast "Hofdienst" in Oldersum

- Klage des Kirchenvorstandes zu Oldersum gegen den Magistrat beim Landgericht in Aurich wegen Bestreitung des Rechtes des Magistrats zur Erhebung der Feudallast "Hofdienst"von Kirchenland

$1886-1889$

Klassifikation Teil B: 02783

Trägermaterial: Papier

Alte Reg.-Sig.: VIII A5 51

Bestell-Nr.: IV 02783 
06

06.01

- Verkauf der Oldersumer Burg durch die Stadt Emden, (1856) 1867 -

1872

- Beschreibung des Burggebäudes und Geländes, Mai 1871

- Rechtsstreit zwischen dem Magistrat und Roelt Coners aus

Simonswolde wegen Verweigerung der Entrichtung der Feudallast

"Hofdienst" von seinem Grundstück, Oktober 1878

(1856) 1867 - 1878

Klassifikation Teil B: 02786

Trägermaterial: Papier

Alte Reg.-Sig.: VIII A5 40

Bestell-Nr.: IV 02786

2670 Eintragung des bei Simonswolde liegenden "Sandwaters" auf den Namen der Stadt Emden in das Grundbuch

- Nicht vollzogener Verkauf des "Sandwaters" durch die Stadt Emden an verschiedene Interessenten, Juni - Juli 1882

- Auflassung und Neuvermessung des "Sandwaters", August 1882 /

August 1905

- Denkschrift des Oberbürgermeisters L. Fürbringer über

Eigentumsrechte der Stadt Emden am "Sandwater" in Simonswolde als Teil der Herrlichkeit Oldersum, Dezember 1882

- Antrag des Magistrats beim Kgl. Grundbuchamt in Aurich auf

Eintragung der Besitzrechte der Stadt Emden in das Grundbuch, November 1887

- Klage der Stadt Emden gegen das kgl. Grundbuchamt beim Landgericht in Aurich auf Eintragung ihrer Besitzrechte am

"Sandwater" in das Grundbuch, 1888 - 1889

$1882-1905$

Klassifikation Teil B: 02787

Trägermaterial: Papier

Alte Reg.-Sig.: VIII A5 52

Bestell-Nr.: IV 02787

2671 Gefälle aus den Emder Herrlichkeiten

- Register der Einnahmen aus Gefälle (Feudalabgaben) für die Stadt Emden aus den Herrlichkeiten Borssum, Jarssum und Up- und Wolthusen

$1910-1914$

Klassifikation Teil B: 02788

Trägermaterial: Papier

Alte Reg.-Sig.: VIII A5 60

Bestell-Nr.: IV 02788 
06

Finanzverwaltung der Stadt Emden

06.01

Städtisches Vermögen

06.01.04

Einnahmen aus den Emder Herrlichkeiten

Lfd. Nr. Titel

Laufzeit

2672 Feudalabgabe des "Windgeldes" von den Mühlen

1869-1872

- Antrag des Müllers H. S. Mülders auf Aufhebung der Abgabe

"Windgeld", November 1870 / November 1871

- Anfrage der kgl. Finanz-Direktion wegen Recognitions-Gelder von

Emder Mühlen, 1869

- Gutachten des Obergerichtsanwalts Vissering über Zulässigkeit der

Abgabe "Windgeld", Juli 1872

$1869-1872$

Klassifikation Teil B: 02789

Trägermaterial: Papier

Alte Reg.-Sig.: VIII A5 61

Bestell-Nr.: IV 02789

2673 Gefälle aus der Emder Herrlichkeit Oldersum

1907-1916

- Register der Einnahmen aus Gefälle (Feudalabgaben) für die Stadt

Emden aus der Herrlichkeit Oldersum

$1907-1916$

Klassifikation Teil B: 02790

Trägermaterial: Papier

Alte Reg.-Sig.: VIII A5 62

Bestell-Nr.: IV 02790 
06

Finanzverwaltung der Stadt Emden

06.01

Städtisches Vermögen

06.01 .05

Städtische Forderungen

Lfd. Nr. Titel

Laufzeit

2674 Prozesse der Stadt Emden wegen Forderungen aus Zöllen u.a. Gerechtsamen

1866-1871

(1865)

- Handakten des Obergerichtsanwalts Sindelmann zu Klagen der

Stadt Emden gegen den Hannoverschen und preußischen Fiskus auf

Entschädigung von Forderungen aus den der Stadt Emden

entzogenen Zöllen und Gerechtsamen

(1865) $1866-1871$

Klassifikation Teil B: 02791

Trägermaterial: Papier

Alte Reg.-Sig.: VIII A6 027

Bestell-Nr.: IV 02791 
Lfd. Nr. Titel

Laufzeit

2675 Vermietung städtischer Gebäude und Grundstücke

- Verpachtung städtischer Marktbuden, 1844 - 1856

1866-1909

(1844-1864)

- Pachtbedingungen für die städtischen Kiekerhäuser, 1845 - 1853

- Beschreibung der städtischen Kiekerhäuser, 1845

- Verpachtung städtischer Grundstücke, (1846 - 1864) 1866 - 1909

- Beitreibung rückständiger Mieten von städtischen Gebäuden, (1864) $1866-1878$

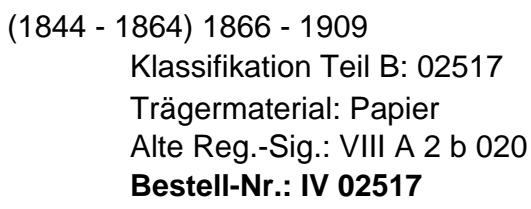

2676 Vermietung städtischer Wohngebäude

- Vermietung der Pförtnerhäuschen am Beckhofstor, am Boltentor und am Nordertor, (1855 - 1863) 1866 - 1896

- Vermietung städtischer Wohnhäuser, (1857 - 1860) 1866 - 1904

- Eintreibung rückständiger Hausmieten, (1863) 1872

- Anträge auf Mietminderung oder -Stundung, (1863 - 1864) 1871

- Antrag des Mieters Dreesing bei der Baukommission auf Vergütung für den von inn in dem gemieteten Wohnhaus der Stadt Emden vorgenommenen Einbau eines Abortes, November 1876 - Januar 1877

- Verschiedene Anträge von Mietern städtischer Wohnungen auf Verlängerung der Mietkontrakte ohne Neuausschreibung, 1898

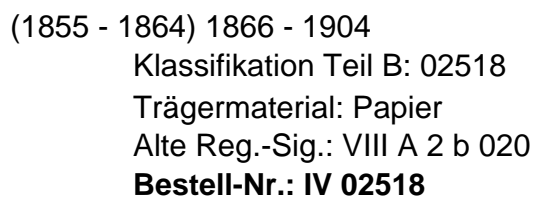

2677 Vererbpachtungen

- Eintreibung von Erbpachtsrückständen, (1857 - 1864) 1870 - 1904

- Gesuche um Überlassung städtischer Grundstücke in Erbpacht, (1860) 1869 - 1895

- Umwidmung der vererbpachteten Geländes der Reents'schen Seilbahn in Gartenland, Januar - April 1875

- Rechte der Stadt Emden aus der Erbpacht auf dem Grundstück der Vrouw Johanna - Mühle im Marienwehrster Zwinger, Oktober 1875 - Gesuch des Posthalters A. G. Oltmanns an den Magistrat über Bitte um Überlassung von Räumen im Bauhof zur Einrichtung eines Postbüros der kaiserlichen Post, Februar 1876

- Grundbucheintragung über Erbpacht für das städtische Grundstück am Gelben Mühlenzwinger, 1898

(1857 - 1864) 1869 - 1904 Klassifikation Teil B: 02784

Trägermaterial: Papier Alte Reg.-Sig.: VIII A8 002

Bestell-Nr.: IV 02784 
Lfd. Nr. Titel

Laufzeit

2678 Vererbpachtungen

- Vererbpachtung des im Besitz der Stadt Emden befindlichen de

Bruynschen und Rodewyk'schen Grundstücks

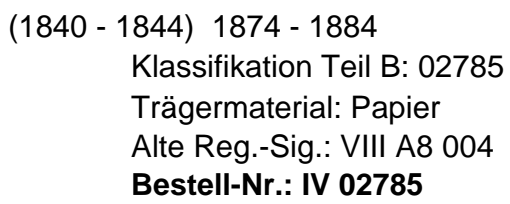

2679 Vererbpachtung städtischer Grundstücke

- Vererbpachtung eines städtischen Anwachses an den Kaufmann F.G.H. Ringius zur Anlage einer Glasfabrik bis zu seinem Konkurs, $1827-1832$

- Klärung der Erbpachtsverhältnisse des Grundstücks wegen nie erfolgter Löschung des Erbpächters F.G.H. Ringius aus dem Grundbuch, September 1884 - Januar 1885

(1827 - 1832) 1884 - 1885

Klassifikation Teil B: 02792

Trägermaterial: Papier

Alte Reg.-Sig.: VIII A8 005

Bestell-Nr.: IV 02792

2680 Vererbpachtung städtischer Grundstücke

- Vererbpachtung eines Geländes am Falderndelft für den

Werftbetrieb "Zum preußischen Adler" (Cassens-Werrft)
(1814 - 1859) 1875 - 1914 (1931 - 1932$)$
Klassifikation Teil B: 02793
Trägermaterial: Papier
Alte Reg.-Sig.: VIII A8 006
Bestell-Nr.: IV 02793

- Genehmigung des Umbaus des Packhauses "Vissers Hoep" durch den Magistrat wegen daraus resultierender Veränderung des Erbpachtsobjektes durch den Posthalter A.G. Oltmanns, Februar Juni 1878

1878

Klassifikation Teil B: 02794

Trägermaterial: Papier

Alte Reg.-Sig.: VIII A8 007

Bestell-Nr.: IV 02794 
06

06.01

06.01 .06

Finanzverwaltung der Stadt Emden

Städtisches Vermögen

Vererbpachtung, Verkauf und Veräußerung städtischer Grundstücke

Lfd. Nr. Titel

Laufzeit

2682 Vererbpachtung städtischer Grundstücke

- Vererbpachtung des städtischen Grundstücks an der Boltentorstraße an den Holzhändler E. van Senden und Genehmigung von

Baumaßnahmen auf dem Grundstück

(1838 - 1839) 1914

Klassifikation Teil B: 02795

Trägermaterial: Papier

Alte Reg.-Sig.: VIII A8 008

Bestell-Nr.: IV 02795

2683 Vererbpachtung städtischer Grundstücke

$1889-1891$

- Vererbpachtung des städtischen Grundstücks in Comp. 18 Nr. 109

(1838-1849)

(Am Nordertor) an den Mühlenbesitzer Carl Richtering, dessen Erben, an Wildhändler Dirk Hinderks und seine Witwe sowie an seiner

Tochter Tjalke Heerma, geb. Hinderks

- Katastervermessung und Auflassung des Grundstücks, 1890 / 1891

(1838 - 1849) 1889 - 1891

Klassifikation Teil B: 02796

Trägermaterial: Papier

Alte Reg.-Sig.: VIII A8 009

Bestell-Nr.: IV 02796

2684 Vererbpachtung städtischer Grundstücke

-Vererbpachtung eines städtischen Geländes am Wall für eine

Seilerbahn und ein Teerhaus

(1816 - 1855) 1874

Klassifikation Teil B: 02797

Trägermaterial: Papier

Alte Reg.-Sig.: VIII A8 014

Bestell-Nr.: IV 02797

2685 Vererbpachtung städtischer Grundstücke

- Vererbpachtung des städtischen Grundstücks "Spannhoff'sche Land" an den Kalkbrenner Johann Diederich Folkerts zur Anlegung eines Kalkofens, später an Hayo Folkerts, Baumaterialienhandlung - Ablösung der Erbpacht, 1911

(1855 - 1865) 1880 - 1911

Klassifikation Teil B: 02798

Trägermaterial: Papier

Alte Reg.-Sig.: VIII A8 018

Bestell-Nr.: IV 02798 
Lfd. Nr. Titel

Laufzeit

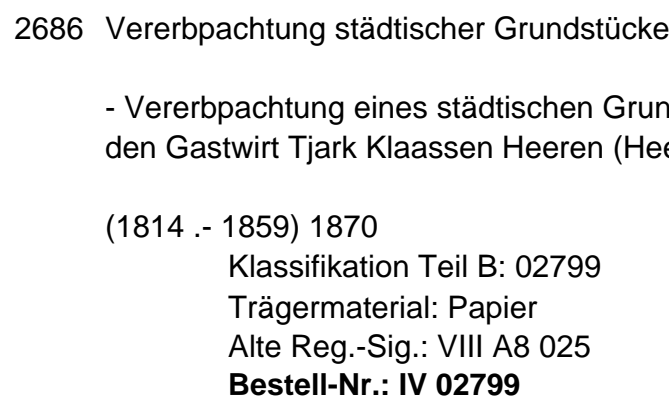

2686 Vererbpachtung städtischer Grundstücke

- Vererbpachtung eines städtischen Grundstücks Am Herrentor an den Gastwirt Tjark Klaassen Heeren (Heeren's Hotel)

2687 Vererbpachtung städtischer Grundstücke

- Vererbpachtung von städtischen Grundstücken im Königspolder an die Emder Heringsfischerei AG

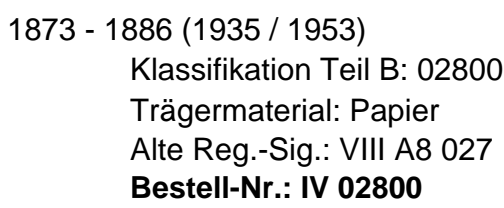

2688 Vererbpachtung städtischer Grundstücke

- Vererbpachtung eines städtischen Grundstückes an der Bahnhofstraße an den Restaurateur Carl Hoffmeister (Hotel "Bellevue")

$1876-1897$

$$
\begin{aligned}
& \text { Klassifikation Teil B: } 02801 \\
& \text { Trägermaterial: Papier } \\
& \text { Alte Reg.-Sig.: VIII A8 } 030
\end{aligned}
$$

Bestell-Nr.: IV 02801

2689 Vererbpachtung städtischer Grundstücke

- Erlaubnis zur Anlegung einer Kajung am vom Konsul Ysaac Brons geerbpachteten Grundstück am Alten Markt

1868
Klassifikation Teil B: 02802
Trägermaterial: Papier
Alte Reg.-Sig.: VIII A8 024
Bestell-Nr.: IV 02802

2690 Vererbpachtung städtischer Grundstücke

- Erlaubnis zum Anbau einer Kajung am von Buchhändler W. Heynel geerbpachteten Grundstück am Neuen Markt

1871

Klassifikation Teil B: 02803

Trägermaterial: Papier

Alte Reg.-Sig.: VIII A8 026

Bestell-Nr.: IV 02803 
Lfd. Nr. Titel

- Vererbpachtung eines städtischen Grundstücks an der Bahnhofsstraße an Senator Carl Dantziger und seinem

Rechtsnachfolger O. Buterberg, 1872 - 1918

- Einräumung eines Wegerechts über das Grundstücks für die

Bahnverwaltung zur Erreichung des Bahnkörpers, 1873

- Ablösung der Erbpacht, 1918

$1872-1918$

Klassifikation Teil B: 02804

Trägermaterial: Papier

Alte Reg.-Sig.: VIII A8 028

Bestell-Nr.: IV 02804

2692 Vererbpachtung städtischer Grundstücke

- Vererbpachtung eines städtischen Grundstückes am Neuen Tor (Vogelsangzwinger) an den Zimmermann J. Brian

$1876-1879$

Klassifikation Teil B: 02805

Trägermaterial: Papier

Alte Reg.-Sig.: VIII A8 031

Bestell-Nr.: IV 02805

2693 Vererbpachtung städtischer Grundstücke

- Vererbpachtung eines städtischen Grundstückes an den

Bauunternehmer K.J. de Vries (Hotel "Union")

- Neubewertung und Ablösung der Erbpacht, 1928 - 1933

1879 - 1910 (1928 - 1933)

Klassifikation Teil B: 02806

Trägermaterial: Papier

Alte Reg.-Sig.: VIII A8 032

Bestell-Nr.: IV 02806

2694 Vererbpachtung städtischer Grundstücke

- Vererbpachtung eines städtischen Grundstücks an der

Bahnhofsstraße an den Bauinspektor, später Baurat Schramme

- Plan eines "herrschaftlichen Gebäudes" für Baurat Schramme

- Ablösung der Erbpacht, 1899

$1879-1899$

Klassifikation Teil B: 02808

Trägermaterial: Papier

Alte Reg.-Sig.: VIII A8 033

Bestell-Nr.: IV 02808 
Lfd. Nr. Titel

2695 Vererbpachtung städtischer Grundstücke

- Vererbpachtung eines städtischen Grundstücks Am Herrentor an Schlachter Simon Heimann Gloes

- Ablösung der Erbpacht, 1891

$1880-1891$

Klassifikation Teil B: 02809

Trägermaterial: Papier

Alte Reg.-Sig.: VIII A8 034

Bestell-Nr.: IV 02809

- Vererbpachtung eines städtischen Grundstücks an der Petkumer Landstraße an den Telegraphenleitungs-Aufseher Karl Ackmann, später seine Witwe und Erben

- Plan des Wohnhauses der Familie Ackmann

$1872-1918$

Klassifikation Teil B: 02810

Trägermaterial: Papier

Alte Reg.-Sig.: VIII A8 035

Bestell-Nr.: IV 02810

2697 Vererbpachtung städtischer Grundstücke

- Vererbpachtung eines städtischen Grundstücks am Bentincksweg an Particulier Rudolf Rulffes, später Heringsfischerei-Direktor O.

Lindemann, 1874 - 1887

- Ablösung der Erbpacht, 1888

$1874-1888$

Klassifikation Teil B: 02811

Trägermaterial: Papier

Alte Reg.-Sig.: VIII A8 037

Bestell-Nr.: IV 02811

2698 Vererbpachtung städtischer Grundstücke

- Vererbpachtung eines städtischen Grundstücks Am Herrentor an

Gemüsebauer Bernhard Onken, 1880 - 1881

- Lageplan der projektierten Straße Am Herrentor

- Aufwertung und Ablösung der Erbpacht, 1928 - 1929

$1880-1881$ (1928 - 1929)

Klassifikation Teil B: 02812

Trägermaterial: Papier

Alte Reg.-Sig.: VIII A8 038

Bestell-Nr.: IV 02812 
Lfd. Nr. Titel

2699 Vererbpachtung städtischer Grundstücke

- Vererbpachtung eines städtischen Grundstücks Am Herrentor an

Fußgendarm Carl Hertrampf, 1880 - 1883

$1880-1883$

Klassifikation Teil B: 02813

Trägermaterial: Papier

Alte Reg.-Sig.: VIII A8 039

Bestell-Nr.: IV 02813

2700 Vererbpachtung städtischer Grundstücke

- Vererbpachtung eines städtischen Grundstücks Am Neuen Tor für eine Seilerbahn an den Fabrikanten G. F. Metger, später:

Reepschläger R. Dupree

- Aufwertung der Erbpacht, 1928 - 1933

1867 - 1887 (1928 - 1933)

Klassifikation Teil B: 02814

Trägermaterial: Papier

Alte Reg.-Sig.: VIII A8 040

Bestell-Nr.: IV 02814

2701 Vererbpachtung städtischer Grundstücke

- Vererbpachtung eines städtischen Grundstücks Am Herrentor an den Bauaufseher J. E. Heubült

$1880-1883$

Klassifikation Teil B: 02815

Trägermaterial: Papier

Alte Reg.-Sig.: VIII A8 041

Bestell-Nr.: IV 02815

2702 Vererbpachtung städtischer Grundstücke

- Vererbpachtung eines städtischen Grundstücks Am Herrentor an Zimmermeister Hinderk Theessen aus Wolthusen

- Ablösung der Erbpacht, 1881

$1880-1881$

Klassifikation Teil B: 02816

Trägermaterial: Papier

Alte Reg.-Sig.: VIII A8 042

Bestell-Nr.: IV 02816 
06.01

Lfd. Nr. Titel

2703 Vererbpachtung städtischer Grundstücke

- Vererbpachtung eines städtischen Grundstücks Am Herrentor an Maurerpolier, später Maurermeister Heinrich Stöver

1880 - 1881 (1928 - 1929)

Klassifikation Teil B: 02817

Trägermaterial: Papier

Alte Reg.-Sig.: VIII A8 043

Bestell-Nr.: IV 02817

2704 Vererbpachtung städtischer Grundstücke

- Festlegung der Erbpachtsbedingungen und Veräußerung städtischer Grundstücke

$1880-1913$

Klassifikation Teil B: 02818

Trägermaterial: Papier

Alte Reg.-Sig.: VIII A8 044

Bestell-Nr.: IV 02818

2705 Vererbpachtung städtischer Grundstücke

- Vererbpachtung eines städtischen Grundstücks am Strohdeich an Stadtbaumeister Heinrich Wiggers zur Errichtung eines Wohnhauses, 1881 - 1895

- Ablösung der Erbpacht, 1896 - 1898

$1881-1898$

Klassifikation Teil B: 02819

Trägermaterial: Papier

Alte Reg.-Sig.: VIII A8 045

Bestell-Nr.: IV 02819

2706 Vererbpachtung städtischer Grundstücke

- Vererbpachtung eines städtischen Grundstücks Am Herrentor an

Zimmermeister Hinderk Theesen aus Wolthusen, später Freerk

Seebens

- Ablösung der Erbpacht, 1889 - 1890

$1880-1890$

Klassifikation Teil B: 02820

Trägermaterial: Papier

Alte Reg.-Sig.: VIII A8 046

Bestell-Nr.: IV 02820 
Lfd. Nr. Titel

- Vererbpachtung eines städtischen Grundstücks an der Petkumer Landstraße an den Heizer Johann Heinrich Röpke

- Ablösung der Erbpacht, 1894

$1881-1894$

Klassifikation Teil B: 02821

Trägermaterial: Papier

Alte Reg.-Sig.: VIII A8 048

Bestell-Nr.: IV 02821

2708 Vererbpachtung städtischer Grundstücke

- Vererbpachtung eines städtischen Grundstücks an der Auricher

Chaussee an Kaufmann J. G. Gerken, Emdener Papierfabrik

- Ablösung der Erbpacht, 1904

$1877-1904$

Klassifikation Teil B: 02822

Trägermaterial: Papier

Alte Reg.-Sig.: VIII A8 049

Bestell-Nr.: IV 02822

2709 Vererbpachtung städtischer Grundstücke

- Vererbpachtung eines städtischen Grundstreifens am Gemeindeweg nach Wolthusen an den Wildhändler D. Hinderks

- Ablösung der Erbpacht, 1882

$1881-1882$

Klassifikation Teil B: 02823

Trägermaterial: Papier

Alte Reg.-Sig.: VIII A8 050

Bestell-Nr.: IV 02823

2710 Vererbpachtung städtischer Grundstücke

- Vererbpachtung eines städtischen Grundstücks im Heuzwinger an Petrus Niemann, später Reepschläger Reinhard Diepen zum Betrieb einer Seilerei (Reeperbahn)

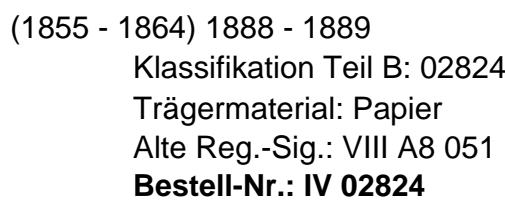


Lfd. Nr. Titel

- Vererbpachtung eines städtischen Grundstücks an der Larrelter Straße im Kaiser-Wilhelm-Polder an Fuhrmann Haye H. Ubbens zur Errichtung eines Wohn- und Stallgebäudes

- Ablösung der Erbpacht, 1890 - 1897

$1881-1897$

Klassifikation Teil B: 02825

Trägermaterial: Papier

Alte Reg.-Sig.: VIII A8 052

Bestell-Nr.: IV 02825

2712 Vererbpachtung städtischer Grundstücke

- Vererbpachtung eines städtischen Grundstücks Am Herrentor an Fuhrmann Berend J. Meyer nach dem Verzicht des W. de Boer aus Wolthusen auf die Erbpachtung

$1882-1884$

Klassifikation Teil B: 02826

Trägermaterial: Papier

Alte Reg.-Sig.: VIII A8 053

Bestell-Nr.: IV 02826

2713 Vererbpachtung städtischer Grundstücke

- Vererbpachtung eines städtischen Grundstücks Am Herrentor an Schlachter Ludwig Hummerich zum Bau eines Wohnhauses mit Schlachterei

$1883-1884$

Klassifikation Teil B: 02827

Trägermaterial: Papier

Alte Reg.-Sig.: VIII A8 055

Bestell-Nr.: IV 02827

2714 Vererbpachtung städtischer Grundstücke

- Vererbpachtung eines städtischen Grundstücks an der Nesserlander Schleuse an Bäckermeiser R. R. Poppinga zur Errichtung eines

Restaurationsgebäudes

$1883-1885$

Klassifikation Teil B: 02828

Trägermaterial: Papier

Alte Reg.-Sig.: VIII A8 057

Bestell-Nr.: IV 02828 
06.01

06.01 .06

Lfd. Nr. Titel

2715 Vererbpachtung städtischer Grundstücke

- Vererbpachtung eines städtischen Grundstücks an der Ostseite der Bahnhofsstraße an den Kräutner Hindericus Hermannus Bomfleur zur

Errichtung eines Wohnhauses

\section{5}

Klassifikation Teil B: 02828,01

Trägermaterial: Papier

Alte Reg.-Sig.: VIII A8 058

Bestell-Nr.: IV 02828 a

2716 Vererbpachtung städtischer Grundstücke

- Vererbpachtung eines städtischen Grundstücks an der Bahnhofsstr. an den Amtsgerichtsrat Thomsen

$1885-1903$

Klassifikation Teil B: 02829

Trägermaterial: Papier

Alte Reg.-Sig.: VIII A8 059

Bestell-Nr.: IV 02829

2717 Vererbpachtung städtischer Grundstücke

- Vererbpachtung eines städtischen Grundstücks an der Parallelstraße zur Bahnhofsstraße an Zimmermeister Claas P. Schelten, 1884 -

1895

- Ablösung der Erbpacht, 1895 - 1900

$1881-1897$

Klassifikation Teil B: 02830

Trägermaterial: Papier

Alte Reg.-Sig.: VIII A8 060

Bestell-Nr.: IV 02830

2718 Vererbpachtung städtischer Grundstücke

- Antrag von Erbpächtern an den Magistrat und Regieung auf Erlaubnis zur Veräußerung ihrer Erbpachtgrundstücke

1884

Klassifikation Teil B: 02831

Trägermaterial: Papier

Alte Reg.-Sig.: VIII A8 061

Bestell-Nr.: IV 02831 
06.01

06.01 .06

Lfd. Nr. Titel

- Vererbpachtung eines städtischen Grundstücks an der Bahnhofsstr. an den Oberbürgermeister Leo Fürbringer zur Errichtung eines repräsentativen Woihnhauses, 1885 - 1903

- Ablösung der Erbpacht, 1904 - 1908

$1885-1908$

Klassifikation Teil B: 02832

Trägermaterial: Papier

Alte Reg.-Sig.: VIII A8 062

Bestell-Nr.: IV 02832

2720 Vererbpachtung städtischer Grundstücke

- Vererbpachtung eines städtischen Grundstücks an der projektierten Parallelstraße zur Bahnhofsstr. an den Eisenbahnschaffner Carl

Finkenbrink zur Errichtung eines Woihnhauses, 1884 - 1888

- Ablösung der Erbpacht, 1895

$1884-1895$

Klassifikation Teil B: 02833

Trägermaterial: Papier

Alte Reg.-Sig.: VIII A8 063

Bestell-Nr.: IV 02833

2721 Vererbpachtung städtischer Grundstücke

- Vererbpachtung eines städtischen Grundstücks am Bentincksweg an den Telegraphen-Assistenten Julius Behrendt

$1885-1908$

Klassifikation Teil B: 02834

Trägermaterial: Papier

Alte Reg.-Sig.: VIII A8 064

Bestell-Nr.: IV 02834

- Vererbpachtung eines städtischen Grundstücks an der Petkumer Straße an den Eisenbahn-Packmeister G. Hotsch, 1886 - 1897

- Ablösung der Erbpacht, 1899

$1886-1899$

Klassifikation Teil B: 02835

Trägermaterial: Papier

Alte Reg.-Sig.: VIII A8 067

Bestell-Nr.: IV 02835 
06.01

06.01 .06

Lfd. Nr. Titel

Laufzeit

2723 Vererbpachtung städtischer Grundstücke

- Vererbpachtung eines städtischen Grundstücks an der Bahnhofsstr. an den Senator Franz D. Ihnen

$1885-1903$

Klassifikation Teil B: 02836

Trägermaterial: Papier

Alte Reg.-Sig.: VIII A8 068

Bestell-Nr.: IV 02836

2724 Vererbpachtung städtischer Grundstücke

- Vererbpachtung eines städtischen Grundstücks an der Petkumer Landstraße an Johanne Schaper, geb. Günther, Ehefrau des Weichenstellers Christian Schaper, später: Holzhändler Johann van Ameren; Johann Heinrich Melles

$1885-1908$

Klassifikation Teil B: 02837

Trägermaterial: Papier

Alte Reg.-Sig.: VIII A8 069

Bestell-Nr.: IV 02837

2725 Vererbpachtung städtischer Grundstücke

- Vererbpachtung eines städtischen Grundstücks am Bentincksweg an den Bürgerschullehrer F. Schaper, 1887 - 1889

- Ablösung der Erbpacht, 1898

$1887-1898$

Klassifikation Teil B: 02838

Trägermaterial: Papier

Alte Reg.-Sig.: VIII A8 070

Bestell-Nr.: IV 02838

2726 Vererbpachtung städtischer Grundstücke

- Vererbpachtung eines städtischen Grundstücks am Vierkant an den Vollziehungsbeamten Carl Martini, 1886 - 1890

- Ablösung der Erbpacht, 1891 - 1892

$1886-1892$

Klassifikation Teil B: 02839

Trägermaterial: Papier

Alte Reg.-Sig.: VIII A8 071

Bestell-Nr.: IV 02839 
Lfd. Nr. Titel

Laufzeit

2727 Vererbpachtung städtischer Grundstücke

- Vererbpachtung eines städtischen Grundstücks an der projektierten Parallelstraße zur Bahnhofsstr. an den Zimmermann Geerd Tapken, $1887-1910$

- Ablösung der Erbpacht, 1911

$1887-1911$

Klassifikation Teil B: 02840

Trägermaterial: Papier

Alte Reg.-Sig.: VIII A8 072

Bestell-Nr.: IV 02840

2728 Vererbpachtung städtischer Grundstücke

$1888-1892$

- Vererbpachtung eines städtischen Grundstücks an der projektierten Parallelstraße zur Bahnhofsstr. an den Zimmermeister Carl P.

Schelten, 1887 - 1891

- Ablösung der Erbpacht, 1892

$1888-1892$

Klassifikation Teil B: 02841

Trägermaterial: Papier

Alte Reg.-Sig.: VIII A8 073

Bestell-Nr.: IV 02841

2729 Vererbpachtung städtischer Grundstücke

- Vererbpachtung eines städtischen Grundstücks im Vogelsangzwinger / Neues Tor an den Landgebräucher (Gemüsebauer) H. B. Hooten zum Bau eines Bauernhauses

$1888-1891$

Klassifikation Teil B: 02842

Trägermaterial: Papier

Alte Reg.-Sig.: VIII A8 075

Bestell-Nr.: IV 02842

2730 Vererbpachtung städtischer Grundstücke

- Vererbpachtung eines städtischen Grundstücks im Vogelsangzwinger / Neues Tor an den Landgebräucher (Gemüsebauer) Jan Störk zum Bau eines Bauernhauses

$1888-1891$

Klassifikation Teil B: 02843

Trägermaterial: Papier

Alte Reg.-Sig.: VIII A8 076

Bestell-Nr.: IV 02843 
06.01

06.01 .06

\section{Städtisches Vermögen}

Vererbpachtung, Verkauf und Veräußerung städtischer Grundstücke

Lfd. Nr. Titel

Laufzeit

2731 Vererbpachtung städtischer Grundstücke

- Vererbpachtung eines städtischen Grundstücks am Bentincksweg an den Bauaufseher J. E. Heubült

$1888-1891$

Klassifikation Teil B: 02844

Trägermaterial: Papier

Alte Reg.-Sig.: VIII A8 077

Bestell-Nr.: IV 02844

2732 Vererbpachtung städtischer Grundstücke

- Vererbpachtung eines städtischen Grundstücks am Bentincksweg an den Kassenschreiber Franz Hinderks zur Errichtung eines Wohnhauses

$1888-1891$

Klassifikation Teil B: 02845

Trägermaterial: Papier

Alte Reg.-Sig.: VIII A8 078

Bestell-Nr.: IV 02845

2733 Vererbpachtung städtischer Grundstücke

- Vererbpachtung eines städtischen Grundstücks am Bentincksweg an den Amtsgerichtssekretär Paul Dreyschuch zum Bau eines

Wohnhauses

$1890-1891$

Klassifikation Teil B: 02846

Trägermaterial: Papier

Alte Reg.-Sig.: VIII A8 079

Bestell-Nr.: IV 02846

- Vererbpachtung eines städtischen Grundstücks am Vierkant an den Verein "Eignes Heim" e.V., Vorsitzender: Zimmergeselle Jakob Gerd van Dyken

$1890-1891$

Klassifikation Teil B: 02847

Trägermaterial: Papier

Alte Reg.-Sig.: VIII A8 080

Bestell-Nr.: IV 02847 
Lfd. Nr. Titel

- Vererbpachtung eines städtischen Grundstücks im Vogelsangzwinger / Neues Tor an den Landgebräucher und Fuhrmann J. M. Bakker zum Bau eines Bauernhauses, später:

Particulier Sieffried H. Burmeister

$1890-1897$

Klassifikation Teil B: 02848

Trägermaterial: Papier

Alte Reg.-Sig.: VIII A8 081

Bestell-Nr.: IV 02848

- Vererbpachtung eines städtischen Grundstücks im Vogelsangzwinger / Neues Tor an den Telegrafen-Assistenten Max Dreger, 1890 - 1891

- Ablösung der Erbpacht, 1891

- Erwerb des Grundstücks durch Prof. Friedrich Ritter, 1907

$1890-1907$

\author{
Klassifikation Teil B: 02849 \\ Trägermaterial: Papier \\ Alte Reg.-Sig.: VIII A8 082 \\ Bestell-Nr.: IV 02849
}

2737 Vererbpachtung städtischer Grundstücke

1890-1899

- Vererbpachtung des Terrains des zugeschütteten Lindengrabens an den Verein "Eignes Heim" e.V., 1890 - 1898

- Ablösung der Erbpacht, 1899 (1921

$1890-1899(1921)$

Klassifikation Teil B: 02850

Trägermaterial: Papier

Alte Reg.-Sig.: VIII A8 083

Bestell-Nr.: IV 02850

2738 Vererbpachtung städtischer Grundstücke

- Vererbpachtung eines städtischen Grundstücks an der "Langen

Brücke" (Emsmauerstraße) an den Vizekonsul Lindemann,

Fischhändler Johann Klaassen und Witwe P. W. Wessels zur Anlage einer Fischfabrik

1891 - $1904(1921-1922)$

Klassifikation Teil B: 02851

Trägermaterial: Papier

Alte Reg.-Sig.: VIII A8 084

Bestell-Nr.: IV 02851 
Lfd. Nr. Titel

2739 Vererbpachtung städtischer Grundstücke

- Vererbpachtung des Terrains des zugeschütteten Gasthaussiels an den Senator C. H. Metger

$1889-1893$

Klassifikation Teil B: 02852

Trägermaterial: Papier

Alte Reg.-Sig.: VIII A8 085

Bestell-Nr.: IV 02852

2740 Vererbpachtung städtischer Grundstücke

- Vererbpachtung des Terrains des zugeschütteten Teils des

Ratsdelfts an den Drogisten Johann Bruins zum Bau einer kunstvoll gestalteten Veranda vor seinem Haus, 1890 - 1897

- Ablösung der Erbpacht, 1921 - 1922

$1890-1897(1921-1922)$

Klassifikation Teil B: 02853

Trägermaterial: Papier

Alte Reg.-Sig.: VIII A8 086

Bestell-Nr.: IV 02853

2741 Vererbpachtung städtischer Grundstücke

- Vererbpachtung eines städtischen Grundsreifens an der Straße "Zwischen beiden Bleichen, 1. Teil" an Senator Heinrich Christoph Barth, 1891 - 1906

- Ablösung der Erbpacht, 1907 - 1908

$1891-1908$

Klassifikation Teil B: 02854

Trägermaterial: Papier

Alte Reg.-Sig.: VIII A8 087

Bestell-Nr.: IV 02854

2742 Vererbpachtung städtischer Grundstücke

- Vererbpachtung eines städtischen Grundstreifenss Am Kattewall an den Müller Hinricus Pannenborg und seiner Frau Alberta, geb. de Ruyter, 1892

- Ablösung der Erbpacht, 1928 - 1929

$1892(1928$ - 1929)

Klassifikation Teil B: 02855

Trägermaterial: Papier

Alte Reg.-Sig.: VIII A8 088

Bestell-Nr.: IV 02855 
Lfd. Nr. Titel

- Vererbpachtung des städtischen Bentickshofes an Zimmermeister Claas Peters Schelten, 1890 - 1893

- Ablösung der Erbpacht, 1894 - 1895

$1890-1895$

Klassifikation Teil B: 02856

Trägermaterial: Papier

Alte Reg.-Sig.: VIII A8 089

Bestell-Nr.: IV 02856

2744 Vererbpachtung städtischer Grundstücke

- Vererbpachtung eines städtischen Geländes im Binnenhafen an den Heringsfischerei-Unternehmer Johannes Reijnvaarn aus Amsterdam zur Etablierung eines dritten Heringsfischerei-Unternehmens ("Neptun AG") in Emden mit Gruindstücken für Arbeitersiedlung

$1894-1914$

Klassifikation Teil B: 02857

Trägermaterial: Papier

Alte Reg.-Sig.: VIII A8 090

Bestell-Nr.: IV 02857

2745 Vererbpachtung städtischer Grundstücke

- Vererbpachtung städtischer Grundstücke an der neuen Straße iom Kaiser-Wilhelm-Polder (Emsmauerstr.) an die Fa. Gerrits, Schelten \& Boerma zur Errichtung von Wohnungen für Arbeiter der

Heringsfischerei AG "Neptun"

$1894-1911$

Klassifikation Teil B: 02858

Trägermaterial: Papier

Alte Reg.-Sig.: VIII A8 091

Bestell-Nr.: IV 02858

2746 Vererbpachtung städtischer Grundstücke

- Vererbpachtung eines städtischen Grundstücks an der Wolthuser Landstraße an Ziegeleibesitzer C. Suchwold

$1895-1897$

Klassifikation Teil B: 02859

Trägermaterial: Papier

Alte Reg.-Sig.: VIII A8 092

Bestell-Nr.: IV 02859 
06.01

06.01 .06

Lfd. Nr. Titel

Laufzeit

2747 Vererbpachtung städtischer Grundstücke

- Vererbpachtung eines städtischen Grundstücks an der Neptunstraße an Taubstummenlehrer Hermann Müller

- Ablösung der Erbpacht

$1896-1897$

Klassifikation Teil B: 02860

Trägermaterial: Papier

Alte Reg.-Sig.: VIII A8 093

Bestell-Nr.: IV 02860

2748 Vererbpachtung städtischer Grundstücke

1896-1898

- Vererbpachtung eines städtischen Grundstücksan der

Lienbahnstraße an den Verein "Eignes Heim" e. V.

- Ablösung der Erbpacht, 1921

$1896-1898$ (1921)

Klassifikation Teil B: 02861

Trägermaterial: Papier

Alte Reg.-Sig.: VIII A8 094

Bestell-Nr.: IV 02861

2749 Vererbpachtung städtischer Grundstücke

- Vererbpachtung eines städtischen Grundstücks an der Neptun- und Nesserlander Str. an Zimmermeister Jürjen Sanders, 1896 - 1897

- Ablösung der Erbpacht, 1898

$1896-1898$

Klassifikation Teil B: 02862

Trägermaterial: Papier

Alte Reg.-Sig.: VIII A8 095

Bestell-Nr.: IV 02862

2750 Vererbpachtung städtischer Grundstücke

- Vererbpachtung eines städtischen Grundstücks an der Neptunstraße an Zimmermeister Bernhard Jürgens, 1896 - 1897

- Ablösung der Erbpacht, 1898

$1896-1898$

Klassifikation Teil B: 02863

Trägermaterial: Papier

Alte Reg.-Sig.: VIII A8 096

Bestell-Nr.: IV 02863 
06.01

06.01 .06

\section{Städtisches Vermögen}

Vererbpachtung, Verkauf und Veräußerung städtischer Grundstücke

Lfd. Nr. Titel

Laufzeit

2751 Vererbpachtung städtischer Grundstücke

- Vererbpachtung eines städtischen Grundstücks an der Nesserlander Str. an den Bauunternehmer R. G. Heits,1897 - 1909

- Ablösung der Erbpacht, 1910

1897 - 1910 (1920 - 1930)

Klassifikation Teil B: 02864

Trägermaterial: Papier

Alte Reg.-Sig.: VIII A8 097

Bestell-Nr.: IV 02864

2752 Vererbpachtung städtischer Grundstücke

- Vererbpachtung eines städtischen Grundstücks an der Larrelter

Straße an Kaufmann Leonhard Lindemann, 1899

- Ablösung der Erbpacht, 1920

1899 (1920)

Klassifikation Teil B: 02865

Trägermaterial: Papier

Alte Reg.-Sig.: VIII A8 098

Bestell-Nr.: IV 02865

2753 Vererbpachtung städtischer Grundstücke

- Vererbpachtung eines städtischen Grundstücks an der

Bahnhofsstraße an Kaufmann Heinrich Wilhelm Schelten

1897
Klassifikation Teil B: 02866
Trägermaterial: Papier
Alte Reg.-Sig.: VIII A8 099
Bestell-Nr.: IV 02866

2754 Verkauf städtischer Grundstücke

- Verkauf eines städtischen Grundstücks an die Lotsen Hindericus van der Wyk und Engelbert Coners

$1897-1899$

Klassifikation Teil B: 02867

Trägermaterial: Papier

Alte Reg.-Sig.: VIII A8 100

Bestell-Nr.: IV 02867 
06.01

Lfd. Nr. Titel

2755 Verkauf städtischer Grundstücke

- Verkauf eines städtischen Grundstücks an der Petkumer Landstraße an den Eisenbahnstations-Assistenten B. Smid

1899

\author{
Klassifikation Teil B: 02868 \\ Trägermaterial: Papier \\ Alte Reg.-Sig.: VIII A8 102 \\ Bestell-Nr.: IV 02868
}

2756 Verkauf städtischer Grundstücke

- Verkauf eines städtischen Grundstücks an der Petkumer Landstraße an den Lehrer Jacob G. Kiewiet

$1899-1900$

Klassifikation Teil B: 02869

Trägermaterial: Papier

Alte Reg.-Sig.: VIII A8 103

Bestell-Nr.: IV 02869

2757 Vererbpachtung städtischer Grundstücke

- Vererbpachtung eines städtischen Grundstücks an der

Claas-Tholen-Straße an den Zimmermeister Barthold G. Meyer, 1900

$-1902$

- Ablösung der Erbpacht, 1903

$1900-1903$

\author{
Klassifikation Teil B: 02870 \\ Trägermaterial: Papier \\ Alte Reg.-Sig.: VIII A8 105 \\ Bestell-Nr.: IV 02870
}

2758 Vererbpachtung städtischer Grundstücke

- Vererbpachtung eines städtischen Grundstücks an der Neptunstraße an den Zimmermeister Christian Warners

$1900-1902$

Klassifikation Teil B: 02871

Trägermaterial: Papier Alte Reg.-Sig.: VIII A8 107

Bestell-Nr.: IV 02871 
06.01

06.01 .06

Lfd. Nr. Titel

- Verkauf eines städtischen Grundstücks an der Nesserlander Str / Neptunstraße an Kapitän Friedrich Kellenberg

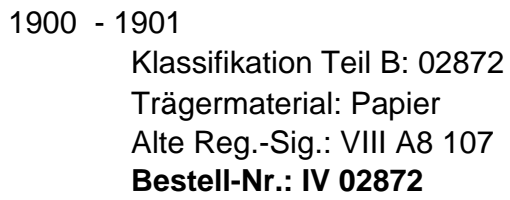

2760 Verkauf städtischer Grundstücke

- Verkauf eines städtischen Grundstücks an der Nesserlander Str. / Neptunstraße an den Kaufmann Hermann C. van Jindelt

$1899-1901$

Klassifikation Teil B: 02873

Trägermaterial: Papier Alte Reg.-Sig.: VIII A8 108

Bestell-Nr.: IV 02873

- Regularien für den Abschluss von Erbpachtsverträgen

- Bewerbungen um Erbpachten

- Anfrage des Bundes der Bodenreformer wegen Veröffentlichung eines Aufsatzes über die Praxis der Erbpacht in Emden, 1907 - 1910 - Verhandlungen über Vererbpachtung städtischen Bodens zum Bau eines Eisenwerks in Emden, 1909 - 1910

$1901-1911$

Klassifikation Teil B: 02874

Trägermaterial: Papier

Bestell-Nr.: IV 02874

2762 Verkauf städtischer Grundstücke

- Verkauf eines städtischen Grundstücks an der Neptunstraße an den Lotsen Dirk Bleeker

$1900-1901$

Klassifikation Teil B: 02875

Trägermaterial: Papier

Alte Reg.-Sig.: VIII A8 110

Bestell-Nr.: IV 02875 
06.01

06.01 .06

Lfd. Nr. Titel

2763 Vererbpachtung städtischer Grundstücke

- Vererbpachtung eines städtischen Grundstücks an der Dollartstraße an den Kaufmann Johann Heinrich Peters

$1900-1903$

Klassifikation Teil B: 02876

Trägermaterial: Papier

Alte Reg.-Sig.: VIII A8 112

Bestell-Nr.: IV 02876

2764 Vererbpachtung städtischer Grundstücke

$1899-1901$

- Vererbpachtung eines städtischen Grundstücks an der Larrelter

Straße an den Klubwirt Friedrich Hippen

$1899-1901$

Klassifikation Teil B: 02877

Trägermaterial: Papier

Alte Reg.-Sig.: VIII A8 113

Bestell-Nr.: IV 02877

2765 Verkauf städtischer Grundstücke

$1900-1901$

- Verkauf eines städtischen Grundstücks an der Neptunstraße an die Gebrüder Minold und Willem Minolds

(Zimmermann/Magistratskanzlist)

$1900-1901$

Klassifikation Teil B: 02878

Trägermaterial: Papier

Alte Reg.-Sig.: VIII A8 114

Bestell-Nr.: IV 02878

2766 Verkauf städtischer Grundstücke

$1891-1901$

- Verkauf eines städtischen Grundstücks an der Larrelter Landstraße an die Fa. Visser \& Danecker zum Bau einer Sauerkrautfabrik

$1899-1901$

Klassifikation Teil B: 02879

Trägermaterial: Papier

Alte Reg.-Sig.: VIII A8 116

Bestell-Nr.: IV 02879

2767 Verkauf städtischer Grundstücke

- Verkauf eines städtischen Grundstücks an der Neptunstraße an den Zimmermeister Wurpt Wurpts

$1898-1901$

Klassifikation Teil B: 02880

Trägermaterial: Papier

Alte Reg.-Sig.: VIII A8 117

Bestell-Nr.: IV 02880 
06.01

Städtisches Vermögen

06.01.06

Vererbpachtung, Verkauf und Veräußerung städtischer Grundstücke

Lfd. Nr. Titel

Laufzeit

2768 Verkauf städtischer Grundstücke

- Verkauf eines städtischen Grundstücks an der Bismarckstraße an die Emder Bank AG

1899

\author{
Klassifikation Teil B: 02881 \\ Trägermaterial: Papier \\ Alte Reg.-Sig.: VIII A8 118 \\ Bestell-Nr.: IV 02881
}

2769 Verkauf städtischer Grundstücke

- Verkauf eines städtischen Grundstücks zwischen der Pelzerstraße und der Emsmauerstraße an den Bauunternehmer Balduin Hempel

1899
Klassifikation Teil B: 02882
Trägermaterial: Papier
Alte Reg.-Sig.: VIII A8 119
Bestell-Nr.: IV 02882

2770 Verkauf städtischer Grundstücke

- Verkauf eines städtischen Grundstücks an der Wolthuser Landstraße an die Deutsch-Atlantische Telegrafiegesellschaft zum Bau eines Verwaltungsgebäudes

1901
Klassifikation Teil B: 02883
Trägermaterial: Papier
Alte Reg.-Sig.: VIII A8 120

Bestell-Nr.: IV 02883

2771 Vererbpachtung städtischer Grundstücke

- Vererbpachtung eines städtischen Grundstücks an der Hühnerkäuferstraße an den Kaufmann Helmer von Baden Foget
$1899-1904$
Klassifikation Teil B: 02884
Trägermaterial: Papier
Alte Reg.-Sig.: VIII A8 121
Bestell-Nr.: IV 02884 
06.01

06.01 .06

Lfd. Nr. Titel

2772 Unentgeltliche Übertragung eines städtischen Grundstücks

- Unentgeltliche Übertragung eines städtischen Grundstücks an der Schweckendieckstraße / Ringstraße an die Westfälische Transport AG (WTAG) zum Bau eines Verwaltungsgebäudes

$1902-1904$

Klassifikation Teil B: 02885

Trägermaterial: Papier

Alte Reg.-Sig.: VIII A8 122

Bestell-Nr.: IV 02885

2773 Vererbpachtung städtischer Grundstücke

1900-1902

- Vererbpachtung eines städtischen Grundstücks an der Neptunstraße an den Bauunternehmer Balduin Hempel zum Bau von Wohnhäusern (Mietshäuser)

- Ablösung der Erbpacht, 1902

$1900-1902$

Klassifikation Teil B: 02886

Trägermaterial: Papier

Alte Reg.-Sig.: VIII A8 123

Bestell-Nr.: IV 02886

2774 Verkauf städtischer Grundstücke

- Verkauf eines städtischen Grundstücks an der Wolthuser Landstraße an den Zimmermeister Gerhardus J. Elsen

$1900-1902$

Klassifikation Teil B: 02887

Trägermaterial: Papier

Alte Reg.-Sig.: VIII A8 124

Bestell-Nr.: IV 02887

2775 Verkauf städtischer Grundstücke

- Verkauf eines städtischen Grundstücks an der Wolthuser Landstraße / Seumestraße an den Zimmermeister Barthold G. Meyer

$1900-1902$

Klassifikation Teil B: 02888

Trägermaterial: Papier

Alte Reg.-Sig.: VIII A8 125

Bestell-Nr.: IV 02888 
06.01

Lfd. Nr. Titel

2776 Vererbpachtung städtischer Grundstücke

- Vererbpachtung eines städtischen Grundstücks am Bentincksweg an Konsul O.C.J. Lindemann

$1893-1896$

Klassifikation Teil B: 02889

Trägermaterial: Papier

Alte Reg.-Sig.: VIII A8 125

Bestell-Nr.: IV 02889

2777 Vererbpachtung städtischer Grundstücke

- Vererbpachtung eines städtischen Grundstücks an der Neutorstraße / Stadtgarten an den Drogisten Johann Bruns

- Austausch eines Streifens des vererbpachten Grundstücks

$1893-1895$

Klassifikation Teil B: 02890

Trägermaterial: Papier

Alte Reg.-Sig.: VIII A8 127

Bestell-Nr.: IV 02890

2778 Unentgeltliche Übertragung eines städtischen Grundstücks

- Unentgeltliche Übertragung eines städtischen Grundstreifens am Lindengraben an die Reformierte Gemeinde zur Herstellung einer Abschlussmauer im Nordwesten des Neuen Kirchhofs

$1896-1897$

Klassifikation Teil B: 02891

Trägermaterial: Papier

Alte Reg.-Sig.: VIII A8 128

Bestell-Nr.: IV 02891

2779 Verkauf städtischer Grundstücke

- Verkauf eines städtischen Grundstücks an der Straße Zwischen Beiden Bleichen an die Witwe Wiepke Visser, geb. Hemius

$1899-1901$

Klassifikation Teil B: 02892

Trägermaterial: Papier

Alte Reg.-Sig.: VIII A8 129

Bestell-Nr.: IV 02892 
06.01

Lfd. Nr. Titel

2780 Vererbpachtung städtischer Grundstücke

- Vererbpachtung eines städtischen Grundstücks zwischen der Neutorstraße / Agterum an den Hotelier L. Schoy zum Bau eines Hotels ("Central-Hotel")

$1896-1899$

Klassifikation Teil B: 02893

Trägermaterial: Papier

Alte Reg.-Sig.: VIII A8 130

Bestell-Nr.: IV 02893

2781 Verkauf städtischer Grundstücke

- Verkauf zweier städtischer Grundstücke an der Wolthuser Landstraße an die Baustoffirma Gerrits, Schelten \& Boerma sowie den Zimmermeister W. Bruns und M. Hollander

$1896-1898$

Klassifikation Teil B: 02894

Trägermaterial: Papier

Alte Reg.-Sig.: VIII A8 131

Bestell-Nr.: IV 02894

2782 Vererbpachtung städtischer Grundstücke

- Vererbpachtung eines städtischen Grundstücks an der Nesserlander Str. an den Bauunternehmer Balduin Hempel

- Ablösung der Erbpacht

$1902-1909$

Klassifikation Teil B: 02895

Trägermaterial: Papier

Alte Reg.-Sig.: VIII A8 133

Bestell-Nr.: IV 02895

2783 Verkauf städtischer Grundstücke

- Verkauf des Terrains des zugeschütteten Brauerspiepentiefs an die Anlieger H. Docquier etc.

$1893-1908$

Klassifikation Teil B: 02896

Trägermaterial: Papier

Alte Reg.-Sig.: VIII A8 134

Bestell-Nr.: IV 02896 
06.01

06.01 .06

Lfd. Nr. Titel

2784 Vererbpachtung städtischer Grundstücke

- Vererbpachtung eines städtischen Grundstücks an der Wolthuser Landstraße / Seumestraße an den Restaurateur Hinnerikus Aalfs (Gaststätte "Prinz Heinrich"), später: Geerd Siept van Brethorst, 1901 $-1907$

- Ablösung der Erbpacht, 1907

$1901-1907$

Klassifikation Teil B: 02897

Trägermaterial: Papier

Alte Reg.-Sig.: VIII A8 136

Bestell-Nr.: IV 02897

- Grundstückstausch zwischen der Stadt Emden und dem Bauunternehmer F. C.. Dettmers sowie Kaufmann H. Bauermann (Nordertorstr. / Schonhovenstr.)

$1901-1904$

Klassifikation Teil B: 02898

Trägermaterial: Papier

Alte Reg.-Sig.: VIII A 138

Bestell-Nr.: IV 02898

- Kauf eines Grundstücks des Bildhauers B. Nanninga aus Leer an der Großen Straße durch die Stadt Emden

1901

Klassifikation Teil B: 02899

Trägermaterial: Papier

Alte Reg.-Sig.: VIII A8 139

Bestell-Nr.: IV 02899

- Grundstreifentausch zwischen der Stadt Emden und dem Kunstgärtner Carl Schrage ( Am Stadtgarten)

1901 - 1903

Klassifikation Teil B: 02900

Trägermaterial: Papier

Alte Reg.-Sig.: VIII A 140

Bestell-Nr.: IV 02900 
Lfd. Nr. Titel

- Verkauf eines städtischen Grundstreifens an der Kirchstr /

Emsmauerstr. an den Zimmermeister Hinrich J. de Boer

$1900-1902$

Klassifikation Teil B: 02901

Trägermaterial: Papier

Alte Reg.-Sig.: VIII A8 143

Bestell-Nr.: IV 02901

2789 Verkauf städtischer Grundstücke

- Verkauf eines städtischen Grundstreifens an der Schlichte an den Kaufmann Geerd Siept van Brethorst

$1900-1902$

Klassifikation Teil B: 02902

Trägermaterial: Papier

Alte Reg.-Sig.: VIII A8 144

Bestell-Nr.: IV 02902

2790 Verkauf städtischer Grundstücke

- Verkauf eines städtischen Grundstücks an der Bahnhofsstraße an den Privatier Friedrich G. Janßen

$1899-1906$

Klassifikation Teil B: 02903

Trägermaterial: Papier

Alte Reg.-Sig.: VIII A8 145

Bestell-Nr.: IV 02903

2791 Verkauf städtischer Grundstücke

- Verkauf des Ganges zwischen der Mühlenwarf und der

Pottbackerstraße an den Kaufmann G. W. Scherz und den Müller H.

Pannenborg und dessen Ehefrau

$1899-1902$

Klassifikation Teil B: 02904

Trägermaterial: Papier

Alte Reg.-Sig.: VIII A8 146

Bestell-Nr.: IV 02904

2792 Verkauf städtischer Grundstücke

- Verkauf eines städtischen Grundstücks an der Bahnhofsstraße /

Martin - Faber - Str. an den Fischereidirektor G. F. Zimmermann

$1900-1902$

Klassifikation Teil B: 02905

Trägermaterial: Papier

Alte Reg.-Sig.: VIII A8 147

Bestell-Nr.: IV 02905 
06.01

06.01 .06

Lfd. Nr. Titel

Laufzeit

2793 Vererbpachtung städtischer Grundstücke 1900-1901

- Vererbpachtung eines städtischen Grundstücks an der

Schweckendieckstraße an den Bauunternehmer Ernst Miese

- Ablösung der Erbpacht

$1900-1901(1918)$

Klassifikation Teil B: 02906

Trägermaterial: Papier

Alte Reg.-Sig.: VIII A8 148

Bestell-Nr.: IV 02906

2794 Verkauf städtischer Grundstücke

- Verkauf eines städtischen Grundstücks an der Ringstr. / Große

Straße an den Agenten R. G. Meyer

$1902-1904(1956)$

Klassifikation Teil B: 02907

Trägermaterial: Papier

Alte Reg.-Sig.: VIII A8 150

Bestell-Nr.: IV 02907

2795 Verkauf städtischer Grundstücke

- Verkauf des Terrains des zugeschütteten Gasthaussieltiefs an die Anlieger

1902

Klassifikation Teil B: 02908

Trägermaterial: Papier

Alte Reg.-Sig.: VIII A8 153

Bestell-Nr.: IV 02908

2796 Verkauf städtischer Grundstücke

- Verkauf eines städtischen Grundstücks an der Ringstraße /

Emsstraße an den Buchhalter Johann Heinrich Kleine

$1902-1904$

Klassifikation Teil B: 02909

Trägermaterial: Papier

Alte Reg.-Sig.: VIII A8 154

Bestell-Nr.: IV 02909

2797 Verkauf städtischer Grundstücke

- Verkauf eines städtischen Grundstücks an der Dollartstraße an den Kaufmann Johann H. Peters

1902

Klassifikation Teil B: 02910

Trägermaterial: Papier

Alte Reg.-Sig.: VIII A8 155

Bestell-Nr.: IV 02910 
Lfd. Nr. Titel

- Verkauf eines städtischen Grundstücks an der

Schweckendieckstraße an den Beamten-Bau-und -Wohnungsverein

$1902-1903$

Klassifikation Teil B: 02911

Trägermaterial: Papier

Alte Reg.-Sig.: VIII A8 155

Bestell-Nr.: IV 02911

2799 Grundstückstausch

- Grundstückstausch zwischen der Stadt Emden und der reformierten Schulgemeinde in der Schonhovenstr.

$1902-1903$

Klassifikation Teil B: 02912

Trägermaterial: Papier

Alte Reg.-Sig.: VIII A 158

Bestell-Nr.: IV 02912

- Grundstückstausch zwischen der Stadt Emden und dem Fiskus

(Hafenamt) über ein fiskalische Grundstück an der

Martin-Faber-Straße gegen ein städtisches an der Hafenstraße

$1902-1903$

Klassifikation Teil B: 02913

Trägermaterial: Papier

Alte Reg.-Sig.: VIII A 159

Bestell-Nr.: IV 02913

2801 Vererbpachtung städtischer Grundstücke

- Vererbpachtung eines städtischen Grundstücks am Bentincksweg an den Bauunternehmer Johann Neeland

$1902-1903$

Klassifikation Teil B: 02914

Trägermaterial: Papier

Alte Reg.-Sig.: VIII A8 160

Bestell-Nr.: IV 02914

2802 Vererbpachtung städtischer Grundstücke

- Vererbpachtung eines städtischen Grundstücks an der

Martin-Faber-Straße an den Kanzleirat a.D. Kopp

$1902-1903$

Klassifikation Teil B: 02915

Trägermaterial: Papier

Alte Reg.-Sig.: VIII A8 161

Bestell-Nr.: IV 02915 
06.01

06.01 .06

Lfd. Nr. Titel

- Grundstückstausch zwischen der Stadt Emden und dem Hotelier Louis Schoy über einen Grundstückstreifen zwischen seinem Hotelgrundstück und einer städtischen Fläche

1902

\author{
Klassifikation Teil B: 02916 \\ Trägermaterial: Papier \\ Alte Reg.-Sig.: VIII A 162 \\ Bestell-Nr.: IV 02916
}

2804 Verkauf städtischer Grundstücke

- Verkauf eines städtischen Grundstücks am Bentincksweg an den Lehrer Albert van der Laan

$1902-1904$

Klassifikation Teil B: 02917

Trägermaterial: Papier

Alte Reg.-Sig.: VIII A8 164

Bestell-Nr.: IV 02917

2805 Verkauf städtischer Grundstücke

- Verkauf eines städtischen Grundstücks am Wall an den Stadtdiener Onno Alberts

$1903-1904$

Klassifikation Teil B: 02918

Trägermaterial: Papier

Alte Reg.-Sig.: VIII A8 167

Bestell-Nr.: IV 02918

2806 Verkauf städtischer Grundstücke

- Verkauf eines städtischen Grundstreifensam Bentincksweg an

Pastor Gerhard Cöper und Stadtsekretär Ernst H. Böse

1903

Klassifikation Teil B: 02919

Trägermaterial: Papier

Alte Reg.-Sig.: VIII A8 168

Bestell-Nr.: IV 02919 
Lfd. Nr. Titel

- Vererbpachtung eines städtischen Grundstücks am Bentincksweg / Wall an den Baumaterialienhändler Jan Neeland

- Ablösung der Erbpacht

$1903-1906$

Klassifikation Teil B: 02920

Trägermaterial: Papier

Alte Reg.-Sig.: VIII A8 169

Bestell-Nr.: IV 02920

2808 Verkauf städtischer Grundstücke

- Verkauf eines städtischen Grundstücks an der Straße Außer dem Nordertor an Zimmermeister Gerhardus J. Elsen

$1903-1905$

Klassifikation Teil B: 02921

Trägermaterial: Papier

Alte Reg.-Sig.: VIII A8 170

Bestell-Nr.: IV 02921

2809 Verkauf städtischer Grundstücke

- Verkauf eines städtischen Grundstücks an der Ringstraße an die Fa. Wohlgemuth \& Kenold

$1902-1904$

Klassifikation Teil B: 02922

Trägermaterial: Papier

Alte Reg.-Sig.: VIII A8 171

Bestell-Nr.: IV 02922

2810 Verkauf städtischer Grundstücke

- Verkauf eines städtischen Grundstücks an der Sleedrieverstraße an den Kommissionär H. Bokelmann

$1904-1905$

Klassifikation Teil B: 02923

Trägermaterial: Papier

Alte Reg.-Sig.: VIII A8 172

Bestell-Nr.: IV 02923

2811 Verkauf städtischer Grundstücke

- Verkauf eines städtischen Grundstücks an der Nesserlander Str. /

Schweckendieckstraße an die Gebrüde Lüppe und Jan Visser

$1904-1905$

Klassifikation Teil B: 02924

Trägermaterial: Papier

Alte Reg.-Sig.: VIII A8 173

Bestell-Nr.: IV 02924 
06.01

06.01 .06

\title{
Städtisches Vermögen
}

Vererbpachtung, Verkauf und Veräußerung städtischer Grundstücke

Lfd. Nr. Titel

Laufzeit

2812 Verkauf städtischer Grundstücke

- Verkauf eines städtischen Grundstücks am Wall an den Maschinenbauer Hermann Bartels

1904

\author{
Klassifikation Teil B: 02925 \\ Trägermaterial: Papier \\ Alte Reg.-Sig.: VIII A8 176 \\ Bestell-Nr.: IV 02925
}

2813 Verkauf städtischer Grundstücke

1904

- Verkauf eines städtischen Grundstücks am Philosophenweg an den Agenten Casjen Manesse

1904
Klassifikation Teil B: 02926
Trägermaterial: Papier
Alte Reg.-Sig.: VIII A8 177
Bestell-Nr.: IV 02926

2814 Verkauf städtischer Grundstücke

- Verkauf eines städtischen Grundstücks an der Ringstraße /

Emsstraße an Schiffskapitän Jan Rozenboom

1904
Klassifikation Teil B: 02927
Trägermaterial: Papier
Alte Reg.-Sig.: VIII A8 178
Bestell-Nr.: IV 02927

2815 Verkauf städtischer Grundstücke

- Verkauf eines städtischen Grundstücks an der Schonhovenstraße an den Kaufmann Hilrich de Vries

1904
Klassifikation Teil B: 02928
Trägermaterial: Papier
Alte Reg.-Sig.: VIII A8 179
Bestell-Nr.: IV 02928

2816 Verkauf städtischer Grundstücke

- Verkauf eines städtischen Grundstücks an der Bahnhofsstraße an den Gaswerksdirektor a.D. Carl Müller

1904

Klassifikation Teil B: 02929

Trägermaterial: Papier

Alte Reg.-Sig.: VIII A8 180

Bestell-Nr.: IV 02929 
06.01

06.01 .06

\title{
Städtisches Vermögen
}

Vererbpachtung, Verkauf und Veräußerung städtischer Grundstücke

Lfd. Nr. Titel

Laufzeit

2817 Verkauf städtischer Grundstücke 1905-1908

- Verkauf eines städtischen Grundstücks an der verlängerten Großen Straße an den Bauaufseher Nicolaus Barghoorn

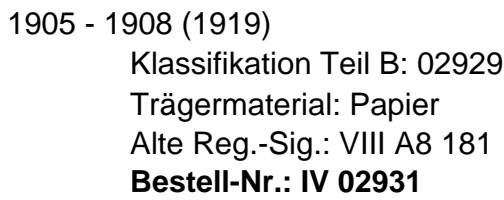

2818 Abtretung städtischer Grundstücke

- Unentgeltliche Abtretung eines städtischen Grundstücks am Wall ("Mudderpaal") an den Verein für Diakonissen-Krankenpflege zum Bau eines Siechenhauses

1904

\author{
Klassifikation Teil B: 02930 \\ Trägermaterial: Papier \\ Alte Reg.-Sig.: VIII A8 181 \\ Bestell-Nr.: IV 02930
}

2819 Verkauf städtischer Grundstücke

- Verkauf des Terrains des zugeschütteten Graupferdspiepentiefs an die Anlieger

1902
Klassifikation Teil B: 02932
Trägermaterial: Papier
Alte Reg.-Sig.: VIII A8 183

Bestell-Nr.: IV 02932

2820 Abtretung städtischer Grundstücke

- Abtretung städtischer Ländereien im Kaiser-Wilhelm-Polder an den preußischen Staat wegen Ausbau des Emder Hafens und Anlegung einer Hafenbahn

$1897-1902$

Klassifikation Teil B: 02933

Trägermaterial: Papier

Alte Reg.-Sig.: VIII A8 184

Bestell-Nr.: IV 02933 
06.01

Lfd. Nr. Titel

2821 Abtretung städtischer Grundstücke

- Verhandlungen des gemeinnutzigen Bauvereins Emden mit dem Magistrat wegen Abtretung städtischer Ländereien zum Bau einer Arbeitersiedlung

$1905-1906$

Klassifikation Teil B: 02934

Trägermaterial: Papier

Alte Reg.-Sig.: VIII A8 185

Bestell-Nr.: IV 02934

2822 Abtretung städtischer Grundstücke

1905

- Unentgeltliche Abtretung eines städtischen Grundstücks an die lutherische Kirchengemeinde zum Bau einer zweiten Kirche

1905

Klassifikation Teil B: 02935

Trägermaterial: Papier

Alte Reg.-Sig.: VIII A8 186

Bestell-Nr.: IV 02935

2823 Abtretung städtischer Grundstücke

- Verhandlungen der Maschinenfabrik, Eisen- und Stahlgießerei AG mit dem Magistrat wegen Abtretung städtischer Ländereien zum Bau einer Arbeitersiedlung auf Port Arthur / Transvaal

$1905-1916$

Klassifikation Teil B: 02936

Trägermaterial: Papier

Alte Reg.-Sig.: VIII A8 187

Bestell-Nr.: IV 02936

2824 Käufe von Grundstücken durch die Stadt Emden

- Verschiedene Grundstückskäufe durch die Stadt Emden

$1906-1911$

Klassifikation Teil B: 02937

Trägermaterial: Papier

Alte Reg.-Sig.: VIII A8 188

Bestell-Nr.: IV 02937 
06.01

06.01 .06

Lfd. Nr. Titel

2825 Verkauf städtischer Grundstücke

- Verhandlungen des Beamten-Bau-und-Wohnungsverein mit dem Magistrat wegen Kauf von städtischen Grundstücken an der Martin-Faber-Str. / Hafenstr. als Bauland

1904

Klassifikation Teil B: 02938

Trägermaterial: Papier

Alte Reg.-Sig.: VIII A8 189

Bestell-Nr.: IV 02938

- Verhandlung zwischen der Stadt Emden und der kgl.

Bahnverwaltung wegen eines Grundstuckstausches an der Petkumer Landsraße

$1902-1903$

Klassifikation Teil B: 02939

Trägermaterial: Papier

Alte Reg.-Sig.: VIII A8 190

Bestell-Nr.: IV 02939

2827 Abtretung städtischer Grundstücke

- Abtretung städtischer Ländereien an die Staatsbauverwaltung und die Eisenbahnverwaltung nach dem Vertrag von 18 / 22. Dezember 1879

$1894-1905$

Klassifikation Teil B: 02940

Trägermaterial: Papier

Alte Reg.-Sig.: VIII A8 191

Bestell-Nr.: IV 02940

2828 Verkauf städtischer Grundstücke

$1907-1911$

(1919)

- Verkauf zweier städtischer Grundstücke an den Bauunternehmer Diedrich Pieper, Kaufmann Franz Habich und Kaufmann Peter Haut

$1907-1911$

Klassifikation Teil B: 02941

Trägermaterial: Papier

Alte Reg.-Sig.: VIII A8 192

Bestell-Nr.: IV 02941 
06.01

06.01 .06

Lfd. Nr. Titel

2829 Vererbpachtung und Verkauf städtischer Grundstücke

- Verkauf eines städtischen Grundstücks "Außer dem Neuen Tore" an die Deutsch-Reformierte Gemeinde

- Vererbpachtung eines städtischen Grundstücks "Außer dem Neuen Tore" an den Verein "Eignes Heim"

$1904-1905$

Klassifikation Teil B: 02942

Trägermaterial: Papier

Alte Reg.-Sig.: VIII A8 193

Bestell-Nr.: IV 02942

2830 Vererbpachtung städtischer Grundstücke

- Vererbpachtung eines städtischen Grundstücks an der Nesserlander Str. / Schweckendieckstraße an den Malermeister Heinrich Susemiehl und Kaufmann Ewald Schröder

$1905-1907$

Klassifikation Teil B: 02943

Trägermaterial: Papier

Alte Reg.-Sig.: VIII A8 194

Bestell-Nr.: IV 02943

2831 Verkauf städtischer Grundstücke

- Verkauf eines städtischen Grundstücks an der Abdenastraße an das Bauunternehmen Hagen \& Benjamins

1904

\author{
Klassifikation Teil B: 02944 \\ Trägermaterial: Papier \\ Alte Reg.-Sig.: VIII A8 197 \\ Bestell-Nr.: IV 02944
}

2832 Vererbpachtung städtischer Grundstücke

- Vererbpachtung eines städtischen Grundstücks an der Jansumstraße an den Bäckermeister Carl Siemering

- Ablösung der Erbpacht

1905 - 1907

Klassifikation Teil B: 02945

Trägermaterial: Papier

Alte Reg.-Sig.: VIII A8 199

Bestell-Nr.: IV 02945 
Lfd. Nr. Titel

2833 Verkauf städtischer Grundstücke

- Verkauf eines städtischen Grundstücks an der Bahnhofsstraße an den Privatier Jan Hinrichs Hanssen

1905

\author{
Klassifikation Teil B: 02946 \\ Trägermaterial: Papier \\ Alte Reg.-Sig.: VIII A8 200 \\ Bestell-Nr.: IV 02946
}

2834 Verkauf städtischer Grundstücke

- Verkauf eines städtischen Grundstücks an der Nesserlander Straße / Küstenbahn an den Kapitän Karl Schröder

$1904-1905$

Klassifikation Teil B: 02947

Trägermaterial: Papier

Alte Reg.-Sig.: VIII A8 201

Bestell-Nr.: IV 02947

2835 Verkauf städtischer Grundstücke

- Verkauf eines städtischen Grundstücks an der Jansumer Straße /

Emsstraße an den Zimmermann Ernst-Heinrich Meyer

$1905-1908$

Klassifikation Teil B: 02948

Trägermaterial: Papier

Alte Reg.-Sig.: VIII A8 202

Bestell-Nr.: IV 02948

2836 Vererbpachtung städtischer Grundstücke

- Vererbpachtung eines städtischen Grundstücks an der Ringstraße / Mittelwallstraße an den Zimmermeister Christian Warners

- Ablösung der Erbpacht

$1905-1907$

Klassifikation Teil B: 02949

Trägermaterial: Papier

Alte Reg.-Sig.: VIII A8 203

Bestell-Nr.: IV 02949

2837 Verkauf städtischer Grundstücke

- Verkauf eines städtischen Grundstücks an der Jansumer Straße an den Böttcher Johann Siemens

1905 - 1908

Klassifikation Teil B: 02950

Trägermaterial: Papier

Alte Reg.-Sig.: VIII A8 204

Bestell-Nr.: IV 02950 
06.01

06.01 .06

Lfd. Nr. Titel

2838 Verkauf städtischer Grundstücke

- Verkauf eines städtischen Grundstücks an der Ringstraße an Fa.

Ludwig R. Hesse Bierbrauerei $\mathrm{GmbH}$, Weener zum Aufbau einer

Filial-Bierhandlung unter Bierhändler Johann van Hove

$1905-1907$

Klassifikation Teil B: 02951

Trägermaterial: Papier

Alte Reg.-Sig.: VIII A8 205

Bestell-Nr.: IV 02951

2839 Verkauf städtischer Grundstücke

- Verkauf eines städtischen Grundstücks an der Fürbringerstrraße an Bauunternehmer August Schortau

$1906-1907$

Klassifikation Teil B: 02952

Trägermaterial: Papier

Alte Reg.-Sig.: VIII A8 208

Bestell-Nr.: IV 02952

2840 Verkauf städtischer Grundstücke

- Verkauf eines städtischen Grundstücks an der Nesserlander Str. /

Schweckendieckstraße an den Architekten Gustav Lüppens aus

Wilhelmshaven - Bant

$1906-1908$

Klassifikation Teil B: 02953

Trägermaterial: Papier

Alte Reg.-Sig.: VIII A8 209

Bestell-Nr.: IV 02953

2841 Verkauf städtischer Grundstücke

- Verkauf eines städtischen Grundstücks an der

Schweckendieckstraße an Bauunternehmer August Schortau

1906

Klassifikation Teil B: 02954

Trägermaterial: Papier

Alte Reg.-Sig.: VIII A8 211

Bestell-Nr.: IV 02954 
Lfd. Nr. Titel

2842 Vererbpachtung städtischer Grundstücke

- Vererbpachtung eines städtischen Grundstücks an der

Schweckendieckstraße an den Dachdeckermeister Wilhelm Langheim

$1905-1908$

Klassifikation Teil B: 02955

Trägermaterial: Papier

Alte Reg.-Sig.: VIII A8 213

Bestell-Nr.: IV 02955

2843 Vererbpachtung und Verkauf städtischer Grundstücke

- Verkauf eines städtischen Grundstücks "Außer dem Nordertor" an die Gärtner Gebrüder Johann und Heinrich Lange

1905

Klassifikation Teil B: 02956

Trägermaterial: Papier

Alte Reg.-Sig.: VIII A8 214

Bestell-Nr.: IV 02956

- Tausch von Grundstücken in der Straße "Hose" zwischen der Stadt Emden und Zimmermann Jan van Hont

1906

Klassifikation Teil B: 02957

Trägermaterial: Papier

Alte Reg.-Sig.: VIII A8 215

Bestell-Nr.: IV 02957

2845 Verkauf städtischer Grundstücke

- Verkauf eines städtischen Grundstücks an der Ringstraße an den Zimmermeister Christian Harms

$1906-1909$

Klassifikation Teil B: 02958

Trägermaterial: Papier

Alte Reg.-Sig.: VIII A8 216

Bestell-Nr.: IV 02958

- Vererbpachtung eines städtischen Grundstücks an der Nesserlander Str. an den Kaufmann August Jasper - Ablösung der Erbpacht, 1923

1908 (1923)

Klassifikation Teil B: 02959

Trägermaterial: Papier

Alte Reg.-Sig.: VIII A8 217

Bestell-Nr.: IV 02959 
06.01

06.01 .06

Lfd. Nr. Titel

2847 Käufe von Grundstücken durch die Stadt Emden

- Verhandlungen zwischen der Viehhandelsfirma A. Stein und der Stadt Emden wegen Abtretung eines Streifens ihres Grundstücks an der Straße Zwischen Beiden Bleichen an die Stadt Emden

$1899-1911$

Klassifikation Teil B: 02960

Trägermaterial: Papier

Alte Reg.-Sig.: VIII A8 219

Bestell-Nr.: IV 02960

2848 Vererbpachtung städtischer Grundstücke

- Vererbpachtung eines städtischen Grundstücks an der Larrelter Straße an den Fuhrunternehmer Heyo J. Ubbens

- Ablösung der Erbpacht

$1890-1901$

Klassifikation Teil B: 02961

Trägermaterial: Papier

Alte Reg.-Sig.: VIII A8 223

Bestell-Nr.: IV 02961

2849 Grundstückstausch

1904

- Tausch eines städtischen Grundstücks an der Burgstraße mit dem A. Menten und seiner Frau

1904

Klassifikation Teil B: 02962

Trägermaterial: Papier

Alte Reg.-Sig.: VIII A8 225

Bestell-Nr.: IV 02962

2850 Verkauf städtischer Grundstücke

- Verkauf eines städtischen Grundstücks an der Martin-Faber-Straße an den Architekten Georg Lüpnitz

$1906-1913$

Klassifikation Teil B: 02963

Trägermaterial: Papier

Alte Reg.-Sig.: VIII A8 225

Bestell-Nr.: IV 02963 
06.01

Städtisches Vermögen

06.01 .06

Vererbpachtung, Verkauf und Veräußerung städtischer Grundstücke

Lfd. Nr. Titel

Laufzeit

2851 Verkauf städtischer Grundstücke

- Verkauf eines städtischen Grundstücks an der Hafenstraße an den Architekten Georg Lüpnitz

$1906-1911$

Klassifikation Teil B: 02964

Trägermaterial: Papier

Alte Reg.-Sig.: VIII A8 226

Bestell-Nr.: IV 02964

2852 Verkauf städtischer Grundstücke

- Verkauf eines städtischen Grundstücks an der Nordertorstraße /

Philosophenweg an den Schankwirt A. Menthe

$1904-1906$

Klassifikation Teil B: 02965

Trägermaterial: Papier

Alte Reg.-Sig.: VIII A8 227

Bestell-Nr.: IV 02965 
06.01

06.01.07

Städtisches Vermögen

Lfd. Nr. Titel

2853 Ablösung von Reallasten an Kirchen- und Schulinstituten

Laufzeit

1880

- Verfügung der kgl. Generalkommission über Erfassung nicht abgelöster Reallasten, Februar - März 1880

- Registrierung der nicht abgelösten Reallasten zugunsten von

Stiftungen, Kirchen und Schulen in Emden, März 1880

1880

Klassifikation Teil B: 00314

Trägermaterial: Papier

Alte Reg.-Sig.: VIII Ag 9

Bestell-Nr.: IV 00314

2854 Ablösungen

$1858-1913$

- Ausführung des Ablösungsgesetzes des Kgr. Hannover bezüglich der Ablösung von Feudalabgaben und - Lasten, 1858 - 1913

$1858-1913$

Klassifikation Teil B: 00379

Trägermaterial: Papier

Alte Reg.-Sig.: III Bb 09

Bestell-Nr.: IV 00379

2855 Ablösung der Herrlichkeitsgefälle

- Anträge verschiedener Grundstücksbesitzer der Emder Herrlichkeiten Borssum, Oldersum, Widdelswehr und Wolthusen auf Ablösung monetarisierter Feudallasten (Hofdienstgeld, Torfgeld, Kuhschatz)

$1874-1894$

Klassifikation Teil B: 02966,01

Trägermaterial: Papier

Alte Reg.-Sig.: VIII A9 08

Bestell-Nr.: IV 02966 a

2856 Ablösung der Herrlichkeitsgefälle

- Anträge verschiedener Grundstücksbesitzer der Emder Herrlichkeiten Borssum, Oldersum, Widdelswehr und Wolthusen auf Ablösung monetarisierter Feudallasten (Hofdienstgeld, Torfgeld, Kuhschatz)

$1894-1911$

Klassifikation Teil B: 02966,02

Trägermaterial: Papier

Alte Reg.-Sig.: VIII A9 08

Bestell-Nr.: IV 02966 b 
06.01

06.01.07

Städtisches Vermögen

Lfd. Nr. Titel

Ablösungen

2857 Ablösung von Reallasten

Laufzeit

1869-1899

(1838-1862)

- Anträge verschiedener Grundstücksbesitzer auf Ablösung von auf ihrem Besitz liegenden Reallasten (Grundrenten, Erbpachten)

(1838 - 1862) $1869-1899$

Klassifikation Teil B: 02967

Trägermaterial: Papier

Alte Reg.-Sig.: VIII A9 03

Bestell-Nr.: IV 02967

2858 Ablösungen

- Verhandlungen des Landrats des Kreises Emden als Ablösungskommissar mit dem Magistrat über Regelung der

Ablösungen und Festlegung des Ablösekapitals

- Berichtigungen in den Grundbüchern nach erfolgter Ablösung

$1867-1911$

Klassifikation Teil B: 02968

Trägermaterial: Papier

Alte Reg.-Sig.: VIII A9 08

Bestell-Nr.: IV 02968

2859 Verwendung der Ablösegelder

- Übersicht über Anlage und Verwendung der von der Stadt Emden eingenommenen Ablösegelder

$1904-1909$

Klassifikation Teil B: 02969

Trägermaterial: Papier

Alte Reg.-Sig.: VIII A8 010

Bestell-Nr.: IV 02969

2860 Ablösungen unter Vermittlung des kgl. Ablösungskommissar, Bd. 1

- Vermittlung des kgl. Ablösungskommissars bei Streitigkeiten zwischen dem Magistrat und Antragsstellern um die Ablösung von Feudallasten auf Grundstücken in den Emder Herrlichkeiten - Ablösung von Feudallasten auf Grundstücken der Großen Kirche

$1871-1886$

Klassifikation Teil B: 02970

Band: 1

Trägermaterial: Papier

Alte Reg.-Sig.: VIII A9 12

Bestell-Nr.: IV 02970 
06

Finanzverwaltung der Stadt Emden

06.01

06.01.07

Städtisches Vermögen

Lfd. Nr. Titel

Ablösungen

2861 Ablösungen unter Vermittlung des kgl. Ablösungskommissar, Bd. 2

Laufzeit

- Vermittlung des kgl. Ablösungskommissars bei Streitigkeiten zwischen dem Magistrat und Antragsstellern um die Ablösung von

Feudallasten auf Grundstücken in den Emder Herrlichkeiten

- Ablösung von Feudallasten auf Grundstücken der Großen Kirche

$1871-1886$

Klassifikation Teil B: 02971

Band: 2

Trägermaterial: Papier

Alte Reg.-Sig.: VIII A9 12

Bestell-Nr.: IV 02971 
IV

06

Finanzverwaltung der Stadt Emden

06.02

06.02.01

06.02.01.01

Steuern und Abgaben

Lfd. Nr. Titel

Direkte und indirekte Steuern

Direkte Steuern

2862 Persönliche Steuer

Laufzeit

1905

- Geburtsregisterauszug des Jahrgangs 1888 zur Feststellung der

Pflicht zur Entrichtung der Persönlichen Steuer

1905

Klassifikation Teil B: 02237

Trägermaterial: Papier

Alte Reg.-Sig.: VI B 041

Bestell-Nr.: IV 02238

2863 Einführung einer Branntweinvertriebsabgabe als direkte Steuer

- Umsetzung des Erlasses des Finanzministers über Einführung einer Branntweinvertriebsabgabe als direkte Steuer zur Eindämmung der Vermehrung der Branntweinverkaufsstellen, August 1870

- Statistische Übersicht: Branntweinverkaufsstellen in Emden, 1878 / 1880

- Erlass des Finanzministers über Datenerhebung wegen geplanter Novellierung des Gesetzes über Branntweinvertriebsabgabe, März 1888

$1870-1888$

Klassifikation Teil B: 02239

Trägermaterial: Papier

Alte Reg.-Sig.: VI C 08

Bestell-Nr.: IV 02239

2864 Veranlagung zur Klassensteuer, Bd. 1

- Gewährung von Befreiungen von der Klassensteuer wegen Armut oder geringem Einkommen

$1869-1873$

Klassifikation Teil B: 02240

Band: 1

Trägermaterial: Papier

Alte Reg.-Sig.: VI C 12

Bestell-Nr.: IV 02240

2865 Veranlagung zur Klassensteuer, Bd. 2

- Veranlagung der Lehrer und Beamten zur Klassensteuer

1873

Klassifikation Teil B: 02241

Band: 2

Trägermaterial: Papier

Alte Reg.-Sig.: VI C 12

Bestell-Nr.: IV 02241 
06

Finanzverwaltung der Stadt Emden

06.02

06.02.01

06.02.01.01

Steuern und Abgaben

Direkte und indirekte Steuern

Lfd. Nr. Titel

Direkte Steuern

2866 Veranlagung zur Klassensteuer, Bd. 3

Laufzeit

1877-1888

- Allgemeine Veranlagung zur Klassensteuer

- Aufstellung über Verbindlichkeiten von Steuerpflichtigen

- Anträge auf Befreiung von oder Ermäßigung der Klassensteuer

- Heranziehung der Beamten und Staatsdiener zur Klassensteuer

$1877-1888$

Klassifikation Teil B: 02242

Band: 3

Trägermaterial: Papier

Alte Reg.-Sig.: VI C 12

Bestell-Nr.: IV 02242

2867 Veranlagung zur Klassensteuer, Bd. 4

- Allgemeine Veranlagung zur Klassensteuer

- Aufstellung über Verbindlichkeiten von Steuerpflichtigen

- Anträge auf Befreiung von oder Ermäßigung der Klassensteuer

- Heranziehung der Beamten und Staatsdiener zur Klassensteuer

- Statistische Übersicht über Klassensteuerpflichtige in Emden

$1882-1883$

Klassifikation Teil B: 02243

Band: 4

Trägermaterial: Papier

Alte Reg.-Sig.: VI C 12

Bestell-Nr.: IV 02243

2868 Veranlagung zur Klassensteuer, Bd. 5

$1885-1886$

- Allgemeine Veranlagung zur Klassensteuer

- Aufstellung über Verbindlichkeiten von Steuerpflichtigen

- Anträge auf Befreiung von oder Ermäßigung der Klassensteuer

- Heranziehung der Beamten und Staatsdiener zur Klassensteuer

- Übersicht über Ertrag der Klassensteuer in Emden

$1885-1886$

Klassifikation Teil B: 02244

Band: 5

Trägermaterial: Papier

Alte Reg.-Sig.: VI C 12

Bestell-Nr.: IV 02244 
06.02

2869 Veranlagung zur Klassensteuer, Bd. 6

Laufzeit

- Allgemeine Veranlagung zur Klassensteuer

- Aufstellung über Verbindlichkeiten von Steuerpflichtigen

- Anträge auf Befreiung von oder Ermäßigung der Klassensteuer

- Heranziehung der Beamten und Staatsdiener zur Klassensteuer

- Übersicht über Ertrag der Klassensteuer in Emden

$1889-1890$

Klassifikation Teil B: 02245

Band: 6

Trägermaterial: Papier

Alte Reg.-Sig.: VI C 12

Bestell-Nr.: IV 02245

2870 Klassifizierte Einkommenssteuer des Rentiers Oskar Butenberg

- Veranlagung des Rentiers Oskar Butenberg zur klassifizierten Einkommenssteuer nach den geschätzten Pachteinnahmen der Ländereien und Einnahmen aus Aktienbesitz aus dem Erbe von seiner verstorbenen Mutter

- Ermittlung des Vermögens der verstorbenen Mutter der Gebrüder Oskar und Alfons Butenberg

$1875-1881$

Klassifikation Teil B: 02246

Trägermaterial: Papier

Alte Reg.-Sig.: VI C 13

Bestell-Nr.: IV 02246

2871 Veranlagung der Offiziere zur Klassensteuer

- Nachweisung der Einkommen der Offiziere und Unteroffiziere der Garnison Emden

- Zu- und Abgang von Offizieren der Emder Garnison

$1867-1870$

Klassifikation Teil B: 02247

Trägermaterial: Papier

Alte Reg.-Sig.: VI C 15

Bestell-Nr.: IV 02247

2872 Veranlagung zur Klassensteuer

- Schreiben des Magistrats an andere Städte und Gemeinden über Veranlagung von deren Bewohnern zur Klassensteuer wegen

Besitzungen in Emden und daraus resultierender Miet- und Pachteinnahmen

$1867-1886$

Klassifikation Teil B: 02248

Trägermaterial: Papier

Alte Reg.-Sig.: VI C 16

Bestell-Nr.: IV 02248 
IV

06

Finanzverwaltung der Stadt Emden

06.02

06.02.01

06.02.01.01

Steuern und Abgaben

Direkte und indirekte Steuern

Lfd. Nr. Titel

Laufzeit

2873 Einführung des preußischen Steuersystems

1867

- Umsetzung der Bestimmungen zur Einführung des preußischen

Steuersystems in der Provinz Hannover durch die Stadt Emden

1867

Klassifikation Teil B: 02249

Trägermaterial: Papier

Alte Reg.-Sig.: VI C 21

Bestell-Nr.: IV 02249

2874 Veranlagung zur Klassensteuer

- Einziehung der Klassensteuer: Einzelfälle

1885

Klassifikation Teil B: 02250

Trägermaterial: Papier

Alte Reg.-Sig.: VI C 21

Bestell-Nr.: IV 02250

2875 Ergänzungssteuergesetz

1893

- Bestimmungen des Ergänzungssteuergesetzes (Ergänzungssteuer zur klassifizierten Einkommenssteuer)

1893

Klassifikation Teil B: 02251

Trägermaterial: Papier

Alte Reg.-Sig.: VI C 25

Bestell-Nr.: IV 02251

2876 Ermittlung von Einkommenssteuerpflichtigen

- Verschiedene Nachweisungen zur Ermittlung der

Einkommenssteuerpflicht, darin: LIsten von Kirchenlandpächtern;

Armenunterstützungsempfänger

- Nachrichten aus anderen Städten und Gemeinden über Besitzungen

Emder Bürger in deren Bezirk zur Ermittlung der

Einkommenssteuerpflicht

- Nachrichten über Erbschaften Emder Bürger

- Nachrichten über Nachlässe Emder Bürger

$1867-1891$

Klassifikation Teil B: 02252

Trägermaterial: Papier

Alte Reg.-Sig.: VI C 30

Bestell-Nr.: IV 02252 
IV

06

Finanzverwaltung der Stadt Emden

06.02

Steuern und Abgaben

06.02.01

06.02.01.01

Direkte und indirekte Steuern

Lfd. Nr. Titel

Direkte Steuern

2877 Veranlagung zur Klassifizierten Einkommenssteuer

Laufzeit

- Verzeichnis der zur Klassifizierten Einkommenssteuer veranlagten

Personen in Emden

- Bearbeitung der Widersprpüche zur Veranlagung zur Klassifizierten

Einkommenssteuer durch dier Einschätzungskommission zur

Klassifizierten Einkommenssteuer

1885

Klassifikation Teil B: 02253

Trägermaterial: Papier

Alte Reg.-Sig.: VI C 30

Bestell-Nr.: IV 02253

2878 Einziehung von Einkommenssteuerrückständen

- Zahlungsaufforderung an säumige Einkommenssteuerpflichtige, 19081914

- Klage der Stadt Emden gegen Ehefrau Dalhoff auf Zahlung rückständiger Einkommenssteuern aus ihren Gewerbegewinnen (Bauunternehmung ihres Mannes), Januar 1908 - April 1909

- Klage des Konkursverwalters des Kaufmanns Egbert Mansholt gegen die Stadt Emden auf Rücknahme einer Pfändung von $50 \mathrm{~kg}$ Tee wegen Steuerforderungen, Februar - Juli 1913

$1908-1913$

Klassifikation Teil B: 02254

Trägermaterial: Papier

Alte Reg.-Sig.: VI C 32

Bestell-Nr.: IV 02254 
06.02

\author{
Steuern und Abgaben
}

06.02.01

Direkte und indirekte Steuern

06.02.01.02

Grundsteuer und Wertzuwachssteuer

Lfd. Nr. Titel

Laufzeit

2879 Katasteramt als Feststellungsbehörde der Grundsteuer

- Ernennung des Katasteramtsleiters durch die Regierung in Aurich, Januar 1886

- Regelung des Diensteinkommens der Katasterkontrolleure, 1890

- Verfügungen des Regierungspräsidenten über Organisation der

Katasterverwaltung, 1890 - 1910

- Koordination der Zusammenarbeit zwischen Katasteramt und der Stadtverwaltung bei der Grundsteuerverwaltung, 1895 - 1913

- Geschäftsanweisung für die Katasterbehörden hinsichtlich der Grundsteuerfestsetzung, März 1895

- Mitwirkung des Stadtbaumeisters an der Feststellung der

Katastervermessungen, 1904

$1890-1913$

Klassifikation Teil B: 02255

Trägermaterial: Papier

Alte Reg.-Sig.: VI D 11

Bestell-Nr.: IV 02255

2880 Ergänzung der Katasterkarten

- Aktualisierung der Katasterkarten bei Umgemeimndungen, Aufbau der Arbeitersiedlung im Kaiser-Wilhelm-Polder, Besitzveränderungen - Zusendung aktualisierter Katasterkarten an die Stadtverwaltung zur Festsetzung der Grundsteuern

$1890-1913$

Klassifikation Teil B: 02256

Trägermaterial: Papier

Alte Reg.-Sig.: VI D 13

Bestell-Nr.: IV 02256

2881 Wertzuwachssteuer als Reichssteuer

- Entwurf und Ausführung des Gesetzes über die Erhebung einer Wertzuwachssteuer auf die bei der Veräußerung von Grundstücken und Betriebsvermögen erzielten Mehrerlöse gegenüber dem ursprünglichen Wert zur Erschwerung der Grundstücksspekulation

$1911-1916$

Klassifikation Teil B: 02257

Trägermaterial: Papier

Alte Reg.-Sig.: VI D 14

Bestell-Nr.: IV 02257 
06

Finanzverwaltung der Stadt Emden

06.02

Steuern und Abgaben

06.02.01

Direkte und indirekte Steuern

06.02.01.02

Grundsteuer und Wertzuwachssteuer

Lfd. Nr. Titel

Laufzeit

2882 Reichsgesetz über Wertzuwachssteuer

1913

- Bestimmungen des Reichsgesetzes über die

Wertzuwachsbesteuerung

1913

Klassifikation Teil B: 02258

Trägermaterial: Papier

Alte Reg.-Sig.: VI D 15 a

Bestell-Nr.: IV 02258

2883 Wertzuwachssteuer: Feststellung der Steuerpflicht

- Mitteilungen des Katasteramtes über Veränderung von Eigentum an Grundstücken zur Feststellung der Pflicht zur Entrichtung der

Wertzuwachssteuer

1916

Klassifikation Teil B: 02259

Trägermaterial: Papier

Alte Reg.-Sig.: VI D 15 b

Bestell-Nr.: IV 02259

2884 Klagen gegen die Heranziehung zur Wertzuwachssteuer, Bd. 1

- Beschwerde der Deutsch-Luxemburgischen Bergwerks- und Hütten AG (Nordseewerke) gegen die Heranziehung zur Wertzuwachssteuer nach dem Erwerb von Ländereien des Johann Marto Schnedermann

1913
Klassifikation Teil B: 02260
Band: 1
Trägermaterial: Papier
Alte Reg.-Sig.: VI D 16
Bestell-Nr.: IV 02260

2885 Klagen gegen die Heranziehung zur Wertzuwachssteuer, Bd. 2

- Beschwerde des Kaufmanns Ferdinand van der Brelie gegen die Heranziehung zur Wertzuwachssteuer

$1917-1918$

Klassifikation Teil B: 02261

Band: 2

Trägermaterial: Papier

Alte Reg.-Sig.: VI D 17

Bestell-Nr.: IV 02261 
06.02

Steuern und Abgaben

06.02.01

Direkte und indirekte Steuern

06.02.01.02

Grundsteuer und Wertzuwachssteuer

Lfd. Nr. Titel

Laufzeit

2886 Klagen gegen die Heranziehung zur Wertzuwachssteuer, Bd. 3

- Beschwerde der Emdener Papierfabrik AG gegen die Heranziehung zur Wertzuwachssteuer wegen Erlöse aus der Liquidation des

Firmenvermögens

$1913-1914$

Klassifikation Teil B: 02262

Band: 3

Trägermaterial: Papier

Alte Reg.-Sig.: VI D 18

Bestell-Nr.: IV 02262

2887 Veranlagung zur Wertzuwachssteuer, Bd. 1

- Veranlagung des Gastwirts Hinrich Eggen zur Wertzuwachssteuer wegen der Erlöse aus der Veräußerung seines Hauses in der

Boltentorstr. 27/28

$1914-1915$

Klassifikation Teil B: 02263

Band: 1

Trägermaterial: Papier

Alte Reg.-Sig.: VI D 19

Bestell-Nr.: IV 02263

2888 Veranlagung zur Wertzuwachssteuer, Bd. 2

Veranlagungen zur Wertzuwachssteuer und Beschwerden dagegen

$1914-1915$

Klassifikation Teil B: 02264

Band: 2

Trägermaterial: Papier

Alte Reg.-Sig.: VI D 19

Bestell-Nr.: IV 02264

2889 Veranlagung zur Wertzuwachssteuer, Bd. 3

- Veranlagung des Viehhändlers Isaac de Beer zur

Wertzuwachssteuer wegen der Erlöse aus der Veräußerung von Land bei Borssum an die Eisenbahnverwaltung

$1914-1918$

Klassifikation Teil B: 02265

Band: 3

Trägermaterial: Papier

Alte Reg.-Sig.: VI D 19

Bestell-Nr.: IV 02265 
06.02

Lfd. Nr. Titel

Laufzeit

2890 Zolltarif

- Agitation der Reedereien und des Deutschen Nautischen Vereins für eine Revision des Zolltarifs im Sinne des Freihandels, 1879

- Verhandlungen des Deutschen Städtetages wegen der Zolltariffrage, 1879

- Anforderung von Daten zur Preisentwicklung der Lebensmittel und Gebrauchsgüter durch die preußische Landdrostei in Aurich,

Dezember 1879 - Juni 1880

- Erhöhung der Getreidezollsätze, 1885 - 1892

- Petition des Magistratas an den Bundesrat über Bitte um Ersetzung direkter durch direkte Steuern auf Güter des nicht lebenswichtigen Bedarfes (z.B. Alkohol), Dezember 1894

$1879-1894$ (1899)

Klassifikation Teil B: 02266

Trägermaterial: Papier

Alte Reg.-Sig.: VI G 09

Bestell-Nr.: IV 02266

- Regelung der Verteilung der Überschüsse aus Zolleinnahmen an die Kommunalverbände

$1885-1902$

Klassifikation Teil B: 02267

Trägermaterial: Papier

Alte Reg.-Sig.: VI G 09

Bestell-Nr.: IV 02267

- Anfrage des Magistrats bei Nachbarstädten wegen Praxis der

Erhebung der Torfakzise, 1907

- Verfügungen des Magistrats wegen Tarife beim Torftransport,

Gebühren für Entladung u.a., (1856 / 1861) 1867 - 1906

- Umgegung des Monopols angestellter Torfträger durch die

Engagierung freier Lohnarbeiter durch Torfabnehmer, 1905 - 1907

- Tarif der Torfakzise, 1894

(1856 / 1861) 1867 - 1907

Klassifikation Teil B: 02774

Trägermaterial: Papier

Alte Reg.-Sig.: VIII A4 03

Bestell-Nr.: IV 02774 
06.02

\section{Steuern und Abgaben}

06.02 .02

06.02.02.01

Gewerbesteuer

Lfd. Nr. Titel

\section{Besteuerung des Wandergewerbes}

2893 Besteuerung des Wandergewerbes, Bd. 1

Laufzeit

- Bestimmungen über Regulierung des Wandergewerbes durch Besteuerung und Polizeiverordnungen, u.a. gegen Kinderarbeit

$1874-1876$

Klassifikation Teil B: 02268

Band: 1

Trägermaterial: Papier

Alte Reg.-Sig.: VI J1 01

Bestell-Nr.: IV 02268

2894 Besteuerung des Wandergewerbes, Bd. 2

- Bestimmungen über Regulierung des Wandergewerbes durch Besteuerung und Polizeiverordnungen, u.a. gegen Kinderarbeit

$1898-1912$

Klassifikation Teil B: 02269

Band: 2

Trägermaterial: Papier

Alte Reg.-Sig.: VI J1 01

Bestell-Nr.: IV 02269

2895 Wandergewerbescheine, Bd. 1

- Übersicht über an reisende Personen mit Emder Wohnsitz ausgegebene Wandergewerbescheine

- Anträge auf Gewährung von Wandergewerbescheinen

$1910-1911$

Klassifikation Teil B: 02270

Band: 1

Trägermaterial: Papier

Alte Reg.-Sig.: VI J1 02

Bestell-Nr.: IV 02270

2896 Wandergewerbescheine, Bd. 2

- Übersicht über an reisende Personen mit Emder Wohnsitz ausgegebene Wandergewerbescheine

- Anträge auf Gewährung von Wandergewerbescheinen

$1911-1912$

Klassifikation Teil B: 02271

Band: 2

Trägermaterial: Papier

Alte Reg.-Sig.: VI J1 02

Bestell-Nr.: IV 02271 
06.02

\section{Steuern und Abgaben}

06.02 .02

06.02.02.01

Gewerbesteuer

Lfd. Nr. Titel

\section{Besteuerung des Wandergewerbes}

2897 Gewerbetrieb der Handelsreisenden

Laufzeit

1866-1901

(1864-1865)

- Vorschriften zur Regelung des Gewerbebetriebs der Handelsreisenden mit Zollbestimmungen, (1865) 1867 - 1901

- Verzeichnis der erteilten Gewerbe-Legitimations-Karten

(Wandergewerbescheine) für Emder Handelsreisende, 1864

- Ausstellung einer Gewerbelegitimation für den Emder

Handlungsreisenden Benjamin C. van Clef

(1664 - 1865) 1866 - 1901

Klassifikation Teil B: 02272

Trägermaterial: Papier

Alte Reg.-Sig.: VI J1 02

Bestell-Nr.: IV 02272

2898 Gewerbe-Legitimationskarten

1907-1909

- Regelung der Ausgabe von Gewerbe-Legitimationskarten

- Berichte des Magistrats an den Regierungspräsidenten in Aurich über ausgefertigte Gewerbe-Legitimationskarten

$1907-1909$

Klassifikation Teil B: 02273

Trägermaterial: Papier

Alte Reg.-Sig.: VI J1 05

Bestell-Nr.: IV 02273

2899 Vertrieb von Früchteeis

$1904-1913$

- Erteilung der Erlaubnis zum Vertrieb von Früchteeis in Emden als Saisongewerbe

Enthält auch:

Erteilung der Erlaubnis zum Vertrieb religiöser Flugschriften und

Bibeln etc. (Mission)

$1904-1913$

Klassifikation Teil B: 02274

Trägermaterial: Papier

Alte Reg.-Sig.: VI J1 06

Bestell-Nr.: IV 02274 
06

Finanzverwaltung der Stadt Emden

06.02

Steuern und Abgaben

06.02.02

06.02.02.02

Gewerbesteuer

Lfd. Nr. Titel

Besteuerung von Gewerbebetrieben

2900 Gewerbliche Abgaben

Laufzeit

- Aufstellung über Art der Abgabe auf den Betrieb eines Gewerbes, 1866

- Erlass des preußischen Innenministers über Abschaffung aller

Abgaben für den Betrieb eines Gewerbes, Juli 1869

- Aufstellung über Grundbucheintragungen von "Windgeld" auf Mühlen

in Up- und Wolthusen, 1872

- Verhandlungen des Magistrats und des Bürgervorsteherkollegiums

über Abschaffung des "Windgeldes", November 1872

- Löschungen der Grundbucheintragungen "Windgeld" auf

Mühlengrundstücke in Emden, 1879 - 1897

$1866-1897$

Klassifikation Teil B: 00804

Trägermaterial: Papier

Alte Reg.-Sig.: IV T1

Bestell-Nr.: IV 00804

2901 Gewerbesteuer, Bd. 1

- Gewerbesteuerrolle mit Namen der Gewerbesteuerpflichtigen,

Gewerbe und Steuertarifierung

1875

Klassifikation Teil B: 02275

Band: 1

Trägermaterial: Papier

Alte Reg.-Sig.: VI J2 01

Bestell-Nr.: IV 02275

2902 Gewerbesteuer, Bd. 2

- Gewerbesteuerrolle mit Namen der Gewerbesteuerpflichtigen,

Gewerbe und Steuertarifierung

1876

Klassifikation Teil B: 02276

Band: 2

Trägermaterial: Papier

Alte Reg.-Sig.: VI J2 01

Bestell-Nr.: IV 02276 
06

Finanzverwaltung der Stadt Emden

06.02

Steuern und Abgaben

06.02.02

06.02.02.02

Gewerbesteuer

Besteuerung von Gewerbebetrieben

Lfd. Nr. Titel

Laufzeit

2903 Gewerbesteuer, Bd. 3

- Gewerbesteuerrolle mit Namen der Gewerbesteuerpflichtigen,

Gewerbe und Steuertarifierung

- Bestimmungen über Erhebung der Gewerbesteuer

- Widersprüche gegen die Veranlagung zur Gewerbesteuer

$18779-1880$

Klassifikation Teil B: 02277

Band: 3

Trägermaterial: Papier

Alte Reg.-Sig.: VI J2 01

Bestell-Nr.: IV 02277

2904 Veranlagung der Mühlen zur Gewerbesteuer

- Verfügung des kgl. Obersteuerkollegiums in Hannover über Regel ung der Veranlagung von Mühlen zur Gewerbesteuer, September 1867

- Auszug aus der Gewerbesteuerrolle: Gewerbesteuerpflichtige

Mühlen, 1867

- Erlass des Finanzministers über Besteuerung des Mühlengewerbes,

Februar 1870

$1867-1870$

Klassifikation Teil B: 02278

Trägermaterial: Papier

Alte Reg.-Sig.: VI J2 03

Bestell-Nr.: IV 02278

2905 Gewerbesteuerreklamationen

- Widersprüche gegen die Veranlagung zur Gewerbesteuer

1871

Klassifikation Teil B: 02279

Trägermaterial: Papier

Alte Reg.-Sig.: VI J2 04

Bestell-Nr.: IV 02279 
06.02

Lfd. Nr. Titel

Laufzeit

2906 Verstöße gegen das Gewerbesteuerrecht

- Mitteilungen des Amtmanns / Kreishauptmanns des Amtes / Kreises Emden über Verhängung von Geldstrafen wegen Verstöße gegen das Gewerbesteuerrecht, 1868 / 1871

- Mitteilungen aus anderen Kommunen und Städten über Verstöße

Emder Handelsreisender gegen das Gewerbesteuerrecht, 1868 -

1869

- Anzeigen über Verstöße gegen das Gewerbesteuerrecht, 1868 1884

- Anzeige und Ermittlungen gegen Mitglieder der Regimentskapelle der Emder Garnison wegen "Schwarzspielens", Oktober 1869

$1868-1884$

Klassifikation Teil B: 02280

Trägermaterial: Papier

Alte Reg.-Sig.: VI J2 06

Bestell-Nr.: IV 02280

2907 Gewerbesteuer

- Erlasse des Finanzministers über Regelung des

Gewerbesteuerwesens

$1896-1908$

Klassifikation Teil B: 02281

Trägermaterial: Papier

Alte Reg.-Sig.: VI J2 08

Bestell-Nr.: IV 02281

2908 Einführung besonderer Gewerbesteuern

- Erlasse des Finanzministers über Regelung der Einführung besonderer Gewerbesteuern mit Gewerbesteuermusterordnungen zur Vermeidung unzumutbarer Belastungen der

Gewerbesteuerpflichtigen, Januar 1895 - Juli 1908

- Erlass des Innenministers über Richtlinien zur Abfassung von

Gewerbesteuerordnungen, Juni 1897

- Denkschrift: Gewerbesteuerordnung, 1897

- Richtlinien des Finanzministeriums über Veranlagung zur

Betriebssteuer, März 1894

- Protest der Emder Wirte gegen die Heranziehung zur Betriebssteuer, Mai 1898

$1894-1908$

Klassifikation Teil B: 02282

Trägermaterial: Papier

Alte Reg.-Sig.: VI J2 10

Bestell-Nr.: IV 02282 
06.02

Lfd. Nr. Titel

Laufzeit

2909 Warenhaussteuer 1900-1908

- Gesetz über die Einführung einer Warenhaussteuer für Kaufhäuser und Filialketten als Gemeindesteuer, Juli 1900

- Erlasse des Ministers für Handel und Gewerbe über Definition der Warenhaussteuerpflicht, u.a. durch Handel mit Luxuswaren, Oktober 1900 - Juli 1908

$1900-1908$

Klassifikation Teil B: 02283

Trägermaterial: Papier Alte Reg.-Sig.: VI J2 11

Bestell-Nr.: IV 02283

2910 Einführung einer Filial-Gewerbesteuer

- Anfrage des Magistrats an andere Städte über Erfahrungen mit der Filial-Gewerbesteuer, Juli 1907 - August 1913

- Gemeinsamer Erlass des Finanzministers und des Innenministers über Zulässigkeit der Filial-Gewerbesteuer zur Besteuerung von Filialbetrieben, Juli 1908

- Urteil des preußischen Oberverwaltungsgerichts über

Nichtzulässigkeit der Filial-Gewerbesteuer mit Kommentar, 1908

- Entwurf einer Gewerbesteuerordnung der Stadt Emden mit

Besteuerung von Filialbetrieben, November 1912 - September 1913

- Gewerbesteuerordnung der Stadt Emden, April 1914

$1907-1914$

Klassifikation Teil B: 02284

Trägermaterial: Papier

Alte Reg.-Sig.: VI J2 12

Bestell-Nr.: IV 02284

2911 Gas- und Elektrizitätssteuer

- Kampagne gegen die Gas- und Elektrizitätssteuer

1908

Klassifikation Teil B: 02285

Trägermaterial: Papier

Alte Reg.-Sig.: VI J2 13

Bestell-Nr.: IV 02285 
IV

06

Finanzverwaltung der Stadt Emden

06.02

Steuern und Abgaben

06.02.03

Städtische Abgaben

06.02.03.01

Stüber- und Straßengeld

Lfd. Nr. Titel

Laufzeit

2912 Stübergeld

1868-1893

- Organisation der Erhebung von Stübergeld als direkte städtische Steuer auf Immobilien, 1868 - 1874

- Anträge auf Niederschlagung von Stübergeld - Rückständen, 1881

- Gutachten des Justizrates Vissering über Rechtmäßigkeit der

Erhebung des Stübergelds, September 1861

- Heranziehung des Garnisonslazaretts zum Stübergeld, März - Juli

1887

- Klärung der Abzugsfähigkeit des Stübergelds von der

Einkommenssteuer, August - September 1893

$1868-1893$

Klassifikation Teil B: 02972

Trägermaterial: Papier

Alte Reg.-Sig.: VIII B1 33

Bestell-Nr.: IV 02972

2913 Widerspruch gegen Stübergeld-Festsetzung

- Widerspruch des Kaufmanns M. N. Kruckenberg und anderer Mühleninteressenten gegen die Heranziehung zum Stübergeld wegen Nichtberücksichtigung der Mühlentriebwerke bei der Festlegung der Stübergeldhöhe

$1867-1885$

Klassifikation Teil B: 02973

Trägermaterial: Papier

Alte Reg.-Sig.: VIII B1 39

Bestell-Nr.: IV 02973 
06

Finanzverwaltung der Stadt Emden

06.02

Steuern und Abgaben

06.02 .03

Städtische Abgaben

06.02.03.03

Städtische Akzise auf Waren und Dienstleistungen

Lfd. Nr. Titel

Laufzeit

2914 Akzise der Stadt Emden, Bd. 1

$1867-1878$

- Beschwerden verschiedener Handelstreibender und Handwerker gegen die Neufassung der Akziseordnung wg. Ungerechtigkeit der

Tarife der Akzise, Mai 1867

- Neufassung der Akzise-Tarife, Dezember 1867 / September 1874 -

Januar 1875

- Streitigkeiten um die Erhebung der Akzise, Februar 1868 - Juni 1876

- Verhandlungen der städtischen Kollegien über Erhebung einer Torf -

Akzise, März 1870 - März 1877

- Entwurf einer städtischen Verordnung über Neufassung der

Torf-Akzise unter Ausdehnung der Akzise auf Presstorf, September

1876 - Oktober 1878

- Gedruckte Akziseordnung der Stadt Emden, 1883

$1867-1878$

Klassifikation Teil B: 02974

Band: 1

Trägermaterial: Papier

Alte Reg.-Sig.: VIII A3 38

Bestell-Nr.: IV 02974 
06

IV

06.02

Finanzverwaltung der Stadt Emden

06.02 .03

06.02.03.03

Steuern und Abgaben

Städtische Abgaben

Lfd. Nr. Titel

Städtische Akzise auf Waren und Dienstleistungen

2915 Akzise der Stadt Emden, Bd. 2

Laufzeit

1879-1909

- Beschwerden gegen eine Akzise-Erhöhung und das

Akzise-Tarifsystem, 1879 - 1899

- Novellierungen der Akzise-Ordnung, 1879 - 1894

- Verhandlungen der städtischen Kollegien über Organisation des

Akzisewesens, Dezember 1879 - März 1891

- Antrag des Kaufmanns G. Graepel beim Magistrat auf Aufhebung

der Akzise auf Speck und Schmalz, März - Juni 1887

- Druckschrift für den Hannoverschen Städtetages über Beschreibung

des Emder Akzisewesens, 1884

- Ausdehnung der Akzise auf Roggenmehl, Mai - Juni 1886

- Anzeige gege4n Pewasumer Schiffer wegen Verstoß gegen die

Akziseordnung durch Nichtanmeldung akzisepflichtiger Waren, Juni

1889

- Verfügung des Magistrats über Pflicht der Fuhrleute zur Anmeldung transportierter akzisepflichtiger Waren, März 1890

- Protokolle der Sitzungen der Akzise-Kommission über Organisation des Akzisewesens, August 1890 - Juli 1899

- Initiative des Emder Bürgervereins zur Aufhebung der Akzise,

Februar 1892

- Gesuch der Bäcker-Innung an den Magistrat über Bitte um

Aufhebung der Akzise auf Getreide, Mehl und Torf, Dezember 1892 -

Dezember 1895

- Beschwerde des Emder Detailisten-Vereins gegen die Einführung

von Fleischwaren und Lebensmittel durch Bahnbeamte unter

Umgehung der Akzise, Januar 1902

- Übersicht über Ertrag der Akzise auf Fleisch, Getreide und

Lebensmittel, 1900

- Diskussion über Aufhebung der Fleischsteuer, 1909

$1879-1909$

Klassifikation Teil B: 02975

Band: 2

Trägermaterial: Papier

Alte Reg.-Sig.: VIII B3 38

Bestell-Nr.: IV 02975

2916 Torfschiffe

$1882-1887$

- Register der nach Emden fahrenden und Torf löschenden Torfschiffe zur Erfassung der Akzisepflichtigen

$1882-1887$

Klassifikation Teil B: 02976

Trägermaterial: Papier

Alte Reg.-Sig.: VIII B3 42

Bestell-Nr.: IV 02976 
06.02

Lfd. Nr. Titel

- Anträge auf Erlass der Torfakzise, 1867 - 1901

- Verhandlungen der städtischen Kollegien über Befreiung von

Fabriken (z.B. Kalkbrennereien) von der Torfakzise, Dezember 1867 -

September 1868 / November 1900

- Antrag der Präsidentin des Frauenvereins für verschämte Arme, J. Hesse, auf Befreiung Mittelloser von der Torfakzise, Dezember 1867 - Anzeigen der Akzise-Einnehmer über nicht gezahlte Torf-Akzisen durch Schiffer, 1892

- Verfügung des Regierungspräsidenten in Aurich an den Magistrat über Unzulässigkeit der Befreiung von Fabriken von der Torfakzise wg. Verstoß gegen die eigene Akziseordnung, Oktober 1900

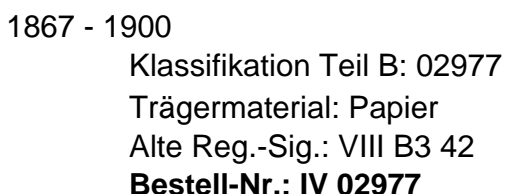

- Beschlüsse der städtischen Kollegien über Einführung einer Akzise auf Spirituosen, November 1867 - Februar 1868 / März 1877 /

Dezember 1879

- Entwurf einer Akzise-Ordnung für Spirituosen, Dezember 1867 - Juli 1868

- Eingabe der Emder Schankwirte an den preußischen Landdrosten in Aurich über Bitte um Aufhebung der Spirituosen-Akzise der Stadt Emden, Januar 1868

- Genehmigungsverfahren für die Akzise auf Spirituosen der Stadt Emden beim preußischen Landdrosten in Aurich, Mai - Juli 1868

$1867-1879$

Klassifikation Teil B: 02978

Trägermaterial: Papier

Alte Reg.-Sig.: VIII B3 43

Bestell-Nr.: IV 02978 
06.02

Lfd. Nr. Titel

- Angaben des Verbrauchs von Fleisch durch die Mannschaften der Emder Garnison zur Rückerstattung der von ihr gezahlten Fleisch-Akzise, Januar 1868 - März / Dezember 1874

- Verfügung des preußischen Landdrosten in Aurich über Methode zur Bestimmung der Höhe der der Garnison zurückzuerstattenden Akzise auf Schlachtvieh, Februar 1868

- Verfügung des preußischen Landdrosten in Aurich über generelle Befreiung der Garnison von der Akzise, Juli 1868

- Allerhöchste Kabinettsordre des preußischen Königs Friedrich Wilhelm IV. über Befreiung der preußischen Garnisonen von der Schlacht- und Fleisch-Akzise, 1824 (1874)

- Zurückerstattung von Schlachtakzise an die Garnison, 1868 - 1881

- Zurückerstattung von Schlachtakzise an die Verwaltung des

Garnisons-Lazaretts, 1872 - 1873

$1878-1881$

Klassifikation Teil B: 02980

Trägermaterial: Papier

Alte Reg.-Sig.: VIII A3 045

Bestell-Nr.: IV 02980

2920 Verpachtung der Branntwein- und Spirituosen-Akzise

- Ausschreibung der Verpachtung der Branntwein- und Spirituosen-Akzise und Vergabeverfahren, 1882 - 1883

- Pachtverträge über Branntwein- und Spirituosen-Akzise, 1887 / 1888

- Statut zur Einführung der Branntwein- und Spirituosen-Akzise, 1883

- Beschwerde der Wirtin Wwe. Hartmann gegen den Akzisepächter

Schröder wg. Erhebung überhöhter Akzise-Sätze, Mai 1889

- Beschwerde ehemaliger Akzisepächter beim Magistrat wegen

Nichtauszahlung von Teilen ihrer Kaution wegen geforderter

Rückzahlungen von Akzise, Mai 1889

- Novellierung der Statuten der Branntwein- und Spirituosen-Akzise, $1884-1910$

$1882-1910$

Klassifikation Teil B: 02981

Trägermaterial: Papier

Alte Reg.-Sig.: VIII B3 45

Bestell-Nr.: IV 02981

- Anträge verschiedener Spediteure an den Magistrat auf Befreiung ihrer eingelagerten Alkoholbestände von der Akzise

1883 - 1905

Klassifikation Teil B: 02982

Trägermaterial: Papier

Alte Reg.-Sig.: VIII B3 49

Bestell-Nr.: IV 02982 
IV

06

Finanzverwaltung der Stadt Emden

06.02

Steuern und Abgaben

06.02.03

06.02.03.03

Städtische Abgaben

Lfd. Nr. Titel

Städtische Akzise auf Waren und Dienstleistungen

2922 Verstöße gegen die Satzung der Spirituosen-Akzise

Laufzeit

1883-1902

- Verstöße gegen die Satzung der Spirituosen-Akzise durch nicht angemeldete Alkohollager und Hinterziehung der Akzise

$1883-1902$

Klassifikation Teil B: 02983

Trägermaterial: Papier

Alte Reg.-Sig.: VIII B3 50

Bestell-Nr.: IV 02983

2923 Hilfskräfte der Pächter der Spirituosen-Akzise

$1887-1901$

- Einstellung von Hilfskräften der Pächter der Spirituosen-Akzise durch den Magistrat und deren Vereidigung (Akzise-Controlleure)

$1887-1901$

Klassifikation Teil B: 02984

Trägermaterial: Papier

Alte Reg.-Sig.: VIII B3 51

Bestell-Nr.: IV 02984

2924 Kommission für Verwaltung der Akzise-Angelegenheiten

$1889-1906$

- Wahl der Mitglieder der Akzise-Kommission

$1889-1906$

Klassifikation Teil B: 02985

Trägermaterial: Papier

Alte Reg.-Sig.: VIII B3 54

Bestell-Nr.: IV 02985

2925 Rechnungslegung der Akzisenverwaltung

- Vorlage der Rechnungen der Akzisenverwaltung mit teilweisen Angaben der Akzisenerträge

1891 - 1913

Klassifikation Teil B: 02986

Trägermaterial: Papier

Alte Reg.-Sig.: VIII B3 56

Bestell-Nr.: IV 02986 
IV

06

Finanzverwaltung der Stadt Emden

06.02

Steuern und Abgaben

06.02.03

06.02.03.03

Städtische Abgaben

Städtische Akzise auf Waren und Dienstleistungen

Lfd. Nr. Titel

Laufzeit

2926 Ausdehnung der Akziseordnung auf weitere Warengruppen

- Einführung einer Bier- und Obstweinsteuer, Oktober 1894 - August 1895

- Erlasse des preußischen Innenministers über Regelung des

kommunalen Akzisewesens (indirekte Steuern), 1895 - 1911

- Musterordnung für eine Biersteuer als Kommunalabgabe, 1900

- Verfügung des Magistrats an die Emder Bierhändler über

Verpflichtung zur Offenlegung der Bücher über Ein- und Ausfuhr von

Bier, September 1902

- Resolution des Bürgervorsteherkollegiums über Abschaffung der

Obstweinsteuer, März 1907

- Einführung der Bier-Akzise, 1895 - 1909

- Einnahmen aus der Bier- und Obstweinakzise, 1900 - 1911

- Erhebung der Bierakzise während des Ersten Weltkriegs, 1915 -

1917

$1894-1917$

Klassifikation Teil B: 02987

Trägermaterial: Papier

Alte Reg.-Sig.: VIII B3 57

Bestell-Nr.: IV 02987

2927 Heranziehung der Bewohner der Feldmark und Nesserlands zur Akzise

- Beschluss der Akzise-Kommission über Heranziehung der Bewohner Nesserlands zur Torfakzise, September 1895

- Anzeigen gegen Bewohner Nesserlands wegen Nichtzahlung der

Torfakzise, 1895 - 1896

- Entrichtung der Mehl-Akzise von der Mühle "Zeldenrüst" in der

Feldmark, November 1895

$1895-1897$

Klassifikation Teil B: 02988

Trägermaterial: Papier

Alte Reg.-Sig.: VIII B3 58

Bestell-Nr.: IV 02988

2928 Akzisevereinbarung mit Bäckern aus Wolhusen, Bd. 1

- Ferstlegung einer Pauschalsumme der Akzise für nach Emden eingeführter Backwaren Wolhuser Bäcker

- Anträge verschiedener Wolhuser Bäcker auf Ermäßigung der

Pauschal-Akzise

$1900-1903$

Klassifikation Teil B: 02989

Band: 1

Trägermaterial: Papier

Alte Reg.-Sig.: VIII B3 59

Bestell-Nr.: IV 02989 
IV

06

Finanzverwaltung der Stadt Emden

06.02

Steuern und Abgaben

06.02 .03

06.02.03.03

Städtische Abgaben

Lfd. Nr. Titel

Städtische Akzise auf Waren und Dienstleistungen

2929 Akzisevereinbarung mit Bäckern aus Wolhusen, Bd. 1

Laufzeit

1904-1907

- Ferstlegung einer Pauschalsumme der Akzise für nach Emden eingeführter Backwaren Wolhuser Bäcker

- Anträge verschiedener Wolhuser Bäcker auf Ermäßigung der

Pauschal-Akzise

$1904-1907$

Klassifikation Teil B: 02990

Band: 2

Trägermaterial: Papier

Alte Reg.-Sig.: VIII B3 59

Bestell-Nr.: IV 02990

2930 Regelung der Akziseerhebung bei Müllern

1904-1908

- Vereinbarungen des Magistrats mit den Emder Mühlenbetreibern über Erhebung eines Pauschalsatzes bei der Mehlakzise, März 1906 - Erhebung der Mehlakzise von den Emder Mühlenbetreibern, 1904 1907

- Verhandlungen zwischen dem Magistrat und den Emder Müllern über Erleichterungen für die Mühlenbetriebe bei der Akzise, August 1904 - Februar 1905 (1907 - 1908)

- Anträge auf Ermäßigung der pauschalierten Mehlakzise, 1907

- Neufestsetzung der pauschalierten Mehlakzise, 1908

$1904-1908$

Klassifikation Teil B: 02991

Trägermaterial: Papier

Alte Reg.-Sig.: VIII B3 60

Bestell-Nr.: IV 02991 
IV

06

Finanzverwaltung der Stadt Emden

06.02

Steuern und Abgaben

06.02.03

06.02.03.04

Städtische Abgaben

Sonstige städtische Abgaben

Lfd. Nr. Titel

Laufzeit

2931 Erhebung der Hundesteuer, Bd. 1

- Befreiung der Hunde von Militärpersonen von der Hundesteuer, 1867

$-1869$

- Angebot der Fa. Ed. Kraft Witwe über Hundesteuermarken, 1868 -

1889

- Bekanntmachungen über Zahlungstermine der Hundesteuer, Januar

1868 - Dezember 1883

- Beschlüsse der städtischen Kollegien über Erhöhung der

Hundesteuer, Januar 1870 - November 1873

- Erlasse des Innenministers über Erhebung der Hundesteuer und ihre

Verwaltungsorganisation, 1878 - 1879

- Anträge auf Befreiung von der Hundesteuer, 1881

- Listen der Hundesteuerpflichtigen, 1881

- Hinterziehung von Hundesteuer, 1881 - 1884

- Polizeiverordnung über Hundesteuererhebung in der Stadt Emden, November 1886

$1867-1889$

Klassifikation Teil B: 01749

Band: 1

Trägermaterial: Papier

Alte Reg.-Sig.: IV Rh 1

Bestell-Nr.: IV 01749

2932 Erhebung der Hundesteuer, Bd. 2

- Statut über die Erhebung der Hundesteuer in Emden, 1893 - 1896

- Anträge auf Befreiung von der Hundesteuer, 1893

- Hinterziehung der Hundesteuer, 1893

- Bekanntmachungen über Zahlungstermine der Hundesteuer, 1893 -

1893

- Neufestsetzung und Erhöhung der Hundesteuer für große

Hunderassen, Januar 1895

- Votum des Bezirksausschusses gegen die Staffelung der Emder

Hundesteuer nach Rassen, Oktober - Dezember 1896

$1893-1898$

Klassifikation Teil B: 01750

Band: 2

Trägermaterial: Papier

Alte Reg.-Sig.: IV Rh 1

Bestell-Nr.: IV 01750

2933 Hundesteuer

- Entwurf der Statuten über Erhebung der Hundesteuer in Emden

$1892-1893$

Klassifikation Teil B: 02286

Trägermaterial: Papier

Alte Reg.-Sig.: VI Rh 1

Bestell-Nr.: IV 02286 
IV

06

Finanzverwaltung der Stadt Emden

06.02

Steuern und Abgaben

06.02.03

06.02.03.04

Städtische Abgaben

Sonstige städtische Abgaben

Lfd. Nr. Titel

Laufzeit

2934 Hafen- und Kaygeld

- Ermäßigung des Hafen- und Kaygelds für Schiffe mit dem Ziel

Eisenbahndock, Februar 1871 / Juli 1885

- Befreiung US-amerikanischer Schiffe vom Hafen- und Kaygeld nach Maßgabe des preußisch-amerikanischen Handelsvertrages, Januar Juli 1873

- Bekanntmachung des preußischen Landdrosten in Aurich über

Berechnung der Hafengebühren für französische Schiffe, August 1873

- Erhebung von Kaygeld von bei der Großen Seeschleuse ankernden

Schiffen, März 1881

$1871-1885$

Klassifikation Teil B: 02992

Trägermaterial: Papier

Alte Reg.-Sig.: VIII B6 10

Bestell-Nr.: IV 02992

2935 Abgaben für die Nützung städtischen Grundeigentums

- Gebühren für die Nutzung städtischen Grundeigentums zu

Lagerzwecken, April 1887 / Juni 1895

- Festlegung einer Gebühr für die Nützung städtischen

Grundeigentums, September 1873

- Anträge auf Nutzung von städtischen Grundstücken für

Lagerzwecke, 1881 - 1901

$1873-1901$

Klassifikation Teil B: 02993

Trägermaterial: Papier

Alte Reg.-Sig.: VIII B6 17

Bestell-Nr.: IV 02993

2936 Erhebung von Verkehrsabgaben

$1882-1910$

- Gemeinsamer Erlass des preußischen Finanzministers, des Handelsministers und des Ministers für öffentliche Arbeiten über Festlegung der Höhe der Verkehrsabgabe in Relation zur Höhe der Baukosten der Verkehrswege, Dezember 1882 / Mai 1895 / Februar 1901 / Juni - Juli 1909/ Dezember 1910

- Aufstellung über städtische und fiskalische Verkehrsabgaben in

Emden, März 1885

- Erlass des Ministers der öffentliche Arbeiten in Emden über

Beseitigung der Verkehrsabgabe an fiskalischen Brücken, November 1884

$1882-1910$

Klassifikation Teil B: 02994

Trägermaterial: Papier

Alte Reg.-Sig.: VIII B6 20

Bestell-Nr.: IV 02994 
IV

06

Finanzverwaltung der Stadt Emden

06.02

Steuern und Abgaben

06.02 .03

06.02.03.04

Städtische Abgaben

Lfd. Nr. Titel

Sonstige städtische Abgaben

2937 Aufbringung der Gemeindeabgaben

Laufzeit

1877

- Beratungen im preußischen Landtag über einen gemeinsamen

Gesetzentwurf des Innenministers und des Finanzministers wegen

Aufbringung der Gemeindeabgaben (Gewerbesteuer, Akzise)

1877

Klassifikation Teil B: 02995

Trägermaterial: Papier

Alte Reg.-Sig.: VIII B6 21

Bestell-Nr.: IV 02995

2938 Umsatzsteuer (Steuer bei Verkauf von Immobilien)

1896-1908

- Anträge auf Befreiung von der Umsatzsteuer

$1896-1908$

Klassifikation Teil B: 02996

Trägermaterial: Papier

Alte Reg.-Sig.: VIII B6 23

Bestell-Nr.: IV 02996

2939 Umsatzsteuer (Steuer bei Verkauf von Immobilien)

$1910-1911$

-Klage der Fa. Schmidt \& Meyer gegen den Magistrat vor dem Oberlandesgericht gegen die Veranlagung zur Umsatzsteuer im

Rahmen eines Grundstücksgeschäftes

$1910-1911$

Klassifikation Teil B: 02997

Trägermaterial: Papier

Alte Reg.-Sig.: VIII B6 23

Bestell-Nr.: IV 02997

2940 Stadtsiegelgeld, Bd. 1

1897-1899

- Abnahme der Rechnung wegen Stadtsiegelgeld ( Abgabe bei Umschreibung der Besitztitel von Grundstücken)

$1897-1899$

Klassifikation Teil B: 02998

Band: 1

Trägermaterial: Papier

Alte Reg.-Sig.: VIII B6 24

Bestell-Nr.: IV 02998 
06.02

Lfd. Nr. Titel

Laufzeit

2941 Stadtsiegelgeld, Bd. 2

- Abnahme der Rechnung wegen Stadtsiegelgeld ( Abgabe bei Umschreibung der Besitztitel von Grundstücken)

$1901-1912$

Klassifikation Teil B: 02999

Band: 2

Trägermaterial: Papier

Alte Reg.-Sig.: VIII B6 24

Bestell-Nr.: IV 02999

2942 Gebühren für die Nutzung der städtischen Lagerplätze

- Einnahmen aus Gebühren für die Nutzung der städtischen

Lagerplätze durch Bauunternehmer, Schiffsbauer, Spediteure etc.

$1901-1911$

Klassifikation Teil B: 03000

Trägermaterial: Papier

Alte Reg.-Sig.: VIII B6 25

Bestell-Nr.: IV 03000

2943 Rechnung über Stadtsiegelgeld, Bd. 1

- Einnahmen aus dem Stadtsiegelgeld ( Abgabe bei Umschreibung der Besitztitel von Grundstücken)

1902

Klassifikation Teil B: 03001

Band: 1

Trägermaterial: Papier

Alte Reg.-Sig.: VIII B6 26

Bestell-Nr.: IV 03001

2944 Rechnung über Stadtsiegelgeld, Bd. 2

- Einnahmen aus dem Stadtsiegelgeld ( Abgabe bei Umschreibung der Besitztitel von Grundstücken)

1907

Klassifikation Teil B: 03002

Band: 2

Trägermaterial: Papier

Alte Reg.-Sig.: VIII B6 26

Bestell-Nr.: IV 03002 
IV

06

Finanzverwaltung der Stadt Emden

06.02

Steuern und Abgaben

06.02.03

06.02.03.04

Städtische Abgaben

Sonstige städtische Abgaben

Lfd. Nr. Titel

Laufzeit

2945 Rechnung über Stadtsiegelgeld, Bd. 3

1908

- Einnahmen aus dem Stadtsiegelgeld ( Abgabe bei Umschreibung der Besitztitel von Grundstücken) und der Wertzuwachssteuer (Steuer bei Verkauf von Grundstücken)

1902

Klassifikation Teil B: 03003

Band: 3

Trägermaterial: Papier

Alte Reg.-Sig.: VIII B6 26

Bestell-Nr.: IV 03003

2946 Rechnung über Stadtsiegelgeld, Bd. 4

1909

- Einnahmen aus dem Stadtsiegelgeld ( Abgabe bei Umschreibung der Besitztitel von Grundstücken) und der Wertzuwachssteuer (Steuer bei Verkauf von Grundstücken)

1909

Klassifikation Teil B: 03004

Band: 4

Trägermaterial: Papier

Alte Reg.-Sig.: VIII B6 26

Bestell-Nr.: IV 03004

2947 Umsatz- und Wertzuwachssteuer

$1896-1914$

(1918)

- Erlasse des preußischen Innenministers und des Finanzministers zur Erhebung der Umsatz- und Wertzuwachssteuer be

Immobiliengeschäften in Städten und Gemeinden, 1896 . 1914

- Ordnung der Wertzuwachs- und Umsatzsteuer in Emden, Juni 1904

- Novellierung der Wertzuwachs- und Umsatzsteuerordnung in

Emden, 1906 - 1908

- Genehmigung der novellierten Wertzuwachs- und

Umsatzsteuerordnung in Emden durch den Bezirksausschuss in

Aurich, April 1907

- Daten über Ordnung der Wertzuwachssteuer in anderen Städten,

$1907-1912$

- Monita des preußischen Innenministeriums gegen die Wertzuwachsund Umsatzsteuerordnung in Emden, Juli 1907

- Monita des Bezirksausschusses gegen die Wertzuwachs- und

Umsatzsteuerordnung in Emden, November 1907

$1896-1914(1918)$

Klassifikation Teil B: 03005

Trägermaterial: Papier

Alte Reg.-Sig.: VIII B6 27

Bestell-Nr.: IV 03005 
IV

06

Finanzverwaltung der Stadt Emden

06.02

Steuern und Abgaben

06.02.03

06.02.03.04

Städtische Abgaben

Sonstige städtische Abgaben

Lfd. Nr. Titel

Laufzeit

2948 Vergütung der Nutzung städtischen Grundbesitzes

- Regelung der Vergütung der Nutzung städtischen Grundbesitzes,

1909

- Erhebung der Geldsummen zur Vergütung der Nutzung städtischen

Grundbesitzes, 1909 - 1911

$1909-1911$

Klassifikation Teil B: 03006

Trägermaterial: Papier

Alte Reg.-Sig.: VIII B6 29

Bestell-Nr.: IV 03006

2949 Erhebung der Wertzuwachssteuer, Bd. 1

$1907-1916$

- Veranlagung verschiedener Emder Hausbesitzer zur

Wertzuwachssteuer wegen Veräußerung oder Erwerb von Immobilien

$1907-1916$

Klassifikation Teil B: 03007

Band: 1

Trägermaterial: Papier

Alte Reg.-Sig.: VIII B6 37

Bestell-Nr.: IV 03007

2950 Erhebung der Wertzuwachssteuer, Bd. 2

1914

- Veranlagung verschiedener Emder Hausbesitzer zur

Wertzuwachssteuer wegen Veräußerung oder Erwerb von Immobilien:

Nr. 1 - Nr.9

1914

Klassifikation Teil B: 03008

Band: 2

Trägermaterial: Papier

Alte Reg.-Sig.: VIII B6 37

Bestell-Nr.: IV 03008

2951 Erhebung der Wertzuwachssteuer, Bd. 3

- Veranlagung verschiedener Emder Hausbesitzer zur

Wertzuwachssteuer wegen Veräußerung oder Erwerb von Immobilien:

Nr.10 - Nr.19

1914

Klassifikation Teil B: 03009

Band: 3

Trägermaterial: Papier

Alte Reg.-Sig.: VIII B6 37

Bestell-Nr.: IV 03009 
06

Finanzverwaltung der Stadt Emden

06.02

Steuern und Abgaben

06.02.03

06.02.03.04

Städtische Abgaben

Sonstige städtische Abgaben

Lfd. Nr. Titel

Laufzeit

2952 Erhebung der Wertzuwachssteuer, Bd. 4

1914

- Veranlagung verschiedener Emder Hausbesitzer zur

Wertzuwachssteuer wegen Veräußerung oder Erwerb von Immobilien:

Nr.20 - Nr.29

1914

Klassifikation Teil B: 03010

Band: 4

Trägermaterial: Papier

Alte Reg.-Sig.: VIII B6 37

Bestell-Nr.: IV 03010

2953 Erhebung der Wertzuwachssteuer, Bd. 5

- Veranlagung verschiedener Emder Hausbesitzer zur

Wertzuwachssteuer wegen Veräußerung oder Erwerb von Immobilien:

Nr.30 - Nr.39

1914

Klassifikation Teil B: 03011

Band: 5

Trägermaterial: Papier

Alte Reg.-Sig.: VIII B6 37

Bestell-Nr.: IV 03011

2954 Erhebung der Wertzuwachssteuer, Bd. 6

- Veranlagung verschiedener Emder Hausbesitzer zur

Wertzuwachssteuer wegen Veräußerung oder Erwerb von Immobilien:

$\mathrm{Nr} .40$ - Nr.49

1914

Klassifikation Teil B: 03012

Band: 6

Trägermaterial: Papier

Alte Reg.-Sig.: VIII B6 37

Bestell-Nr.: IV 03012

2955 Erhebung der Wertzuwachssteuer, Bd. 7

- Veranlagung verschiedener Emder Hausbesitzer zur

Wertzuwachssteuer wegen Veräußerung oder Erwerb von Immobilien:

Nr.50 - Nr.59

1914

Klassifikation Teil B: 03013

Band: 7

Trägermaterial: Papier

Alte Reg.-Sig.: VIII B6 37

Bestell-Nr.: IV 03013 
IV

06

Finanzverwaltung der Stadt Emden

06.02

Steuern und Abgaben

06.02.03

06.02.03.04

Städtische Abgaben

Sonstige städtische Abgaben

Lfd. Nr. Titel

Laufzeit

2956 Recognitionsgebühren

1916-1918

(1919)

- Regelung der Hebung von Recognitionsgebühren auf Spültoiletten und Bauten auf städtischem Grund (Einfriedungen, Lichtschächte)

$1916-1918$ (1919)

Klassifikation Teil B: 03013

Trägermaterial: Papier

Alte Reg.-Sig.: VIII B6 33

Bestell-Nr.: IV 03014

2957 Erhebung der Wertzuwachssteuer, Bd. 8

- Veranlagung verschiedener Emder Hausbesitzer zur

Wertzuwachssteuer wegen Veräußerung oder Erwerb von Immobilien:

Nr.60 - Nr.69

1914

Klassifikation Teil B: 03015

Band: 8

Trägermaterial: Papier

Alte Reg.-Sig.: VIII B6 37

Bestell-Nr.: IV 03015

2958 Erhebung der Wertzuwachssteuer, Bd. 9

1914

- Veranlagung verschiedener Emder Hausbesitzer zur

Wertzuwachssteuer wegen Veräußerung oder Erwerb von Immobilien:

$\mathrm{Nr} .70$ - Nr.79

1914
Klassifikation Teil B: 03016
Band: 9
Trägermaterial: Papier
Alte Reg.-Sig.: VIII B6 37

Bestell-Nr.: IV 03016

2959 Erhebung der Wertzuwachssteuer, Bd. 10

- Veranlagung verschiedener Emder Hausbesitzer zur

Wertzuwachssteuer wegen Veräußerung oder Erwerb von Immobilien:

Nr.80 - Nr.89

1914

Klassifikation Teil B: 03017

Band: 10

Trägermaterial: Papier

Alte Reg.-Sig.: VIII B6 37

Bestell-Nr.: IV 03017 
06 Finanzverwaltung der Stadt Emden

06.02 Steuern und Abgaben

06.02 .03 06.02.03.04 Städtische Abgaben Sonstige städtische Abgaben

Lfd. Nr. Titel

Laufzeit

2960 Erhebung der Wertzuwachssteuer, Bd. 11 1914

- Veranlagung verschiedener Emder Hausbesitzer zur Wertzuwachssteuer wegen Veräußerung oder Erwerb von Immobilien: Nr.90 - Nr.100

1914

Klassifikation Teil B: 03018

Band: 11

Trägermaterial: Papier

Alte Reg.-Sig.: VIII B6 37

Bestell-Nr.: IV 03018

2961 Erhebung der Wertzuwachssteuer, Bd. 12

- Veranlagung verschiedener Emder Hausbesitzer zur

Wertzuwachssteuer wegen Veräußerung oder Erwerb von Immobilien:

Nr.101 - Nr.109

1914

Klassifikation Teil B: 03019

Band: 12

Trägermaterial: Papier

Alte Reg.-Sig.: VIII B6 37

Bestell-Nr.: IV 03019

2962 Erhebung der Wertzuwachssteuer, Bd. 13

- Veranlagung verschiedener Emder Hausbesitzer zur

Wertzuwachssteuer wegen Veräußerung oder Erwerb von Immobilien: Nr.111 - Nr.119

$1914-1915$

Klassifikation Teil B: 03020

Band: 13

Trägermaterial: Papier

Alte Reg.-Sig.: VIII B6 37

Bestell-Nr.: IV 03020

- Veranlagung verschiedener Emder Hausbesitzer zur

Wertzuwachssteuer wegen Veräußerung oder Erwerb von Immobilien: Nr.120 - Nr.122

1914

Klassifikation Teil B: 03021

Band: 14

Trägermaterial: Papier

Alte Reg.-Sig.: VIII B6 37

Bestell-Nr.: IV 03021 
06

Finanzverwaltung der Stadt Emden

06.02

Steuern und Abgaben

06.02 .03

06.02.03.04

Städtische Abgaben

Sonstige städtische Abgaben

Lfd. Nr. Titel

Laufzeit

2964 Erhebung der Wertzuwachssteuer, Bd. 15

1914-1915

- Veranlagung verschiedener Emder Hausbesitzer zur

Wertzuwachssteuer wegen Veräußerung oder Erwerb von Immobilien:

Nr. 95

$1914-1915$

Klassifikation Teil B: 03022

Band: 15

Trägermaterial: Papier

Alte Reg.-Sig.: VIII B6 37

Bestell-Nr.: IV 03022

2965 Erhebung der Wertzuwachssteuer, Bd. 16

- Veranlagung verschiedener Emder Hausbesitzer zur

Wertzuwachssteuer wegen Veräußerung oder Erwerb von Immobilien:

Nr. 1 - Nr.9

1915

Klassifikation Teil B: 03023

Band: 16

Trägermaterial: Papier

Alte Reg.-Sig.: VIII B6 37

Bestell-Nr.: IV 03023

2966 Erhebung der Wertzuwachssteuer, Bd. 17

- Veranlagung verschiedener Emder Hausbesitzer zur

Wertzuwachssteuer wegen Veräußerung oder Erwerb von Immobilien:

Nr. 10 - Nr.19

1915

\author{
Klassifikation Teil B: 03024 \\ Band: 17 \\ Trägermaterial: Papier \\ Alte Reg.-Sig.: VIII B6 37 \\ Bestell-Nr.: IV 03024
}

2967 Erhebung der Wertzuwachssteuer, Bd. 18

- Veranlagung verschiedener Emder Hausbesitzer zur

Wertzuwachssteuer wegen Veräußerung oder Erwerb von Immobilien:

Nr. 20 - Nr.29

1915

Klassifikation Teil B: 03025

Band: 18

Trägermaterial: Papier

Alte Reg.-Sig.: VIII B6 37

Bestell-Nr.: IV 03025 
06 Finanzverwaltung der Stadt Emden

06.02 Steuern und Abgaben

06.02 .03

06.02.03.04

Städtische Abgaben

Sonstige städtische Abgaben

Lfd. Nr. Titel

Laufzeit

2968 Erhebung der Wertzuwachssteuer, Bd. 19

- Veranlagung verschiedener Emder Hausbesitzer zur

Wertzuwachssteuer wegen Veräußerung oder Erwerb von Immobilien:

Nr. 30 - Nr. 39

1915

Klassifikation Teil B: 03029

Band: 19

Trägermaterial: Papier

Alte Reg.-Sig.: VIII B6 37

Bestell-Nr.: IV 03029

2969 Erhebung der Wertzuwachssteuer, Bd. 20

- Veranlagung verschiedener Emder Hausbesitzer zur

Wertzuwachssteuer wegen Veräußerung oder Erwerb von Immobilien:

Nr. 40 - Nr. 49

1915

Klassifikation Teil B: 03030

Band: 20

Trägermaterial: Papier

Alte Reg.-Sig.: VIII B6 37

Bestell-Nr.: IV 03030

2970 Erhebung der Wertzuwachssteuer, Bd. 21

- Veranlagung verschiedener Emder Hausbesitzer zur

Wertzuwachssteuer wegen Veräußerung oder Erwerb von Immobilien: Nr. 50 - Nr. 51

1916

\author{
Klassifikation Teil B: 03031 \\ Band: 21 \\ Trägermaterial: Papier \\ Alte Reg.-Sig.: VIII B6 37 \\ Bestell-Nr.: IV 03031
}

2971 Erhebung der Wertzuwachssteuer, Bd. 22

- Veranlagung verschiedener Emder Hausbesitzer zur

Wertzuwachssteuer wegen Veräußerung oder Erwerb von Immobilien: Nr. 1 - Nr. 9

1917

Klassifikation Teil B: 03032

Band: 22

Trägermaterial: Papier

Alte Reg.-Sig.: VIII B6 37

Bestell-Nr.: IV 03032 
06

Finanzverwaltung der Stadt Emden

06.02

06.02.03

06.02.03.04

Steuern und Abgaben

Städtische Abgaben

Lfd. Nr. Titel

\section{Sonstige städtische Abgaben}

2972 Erhebung der Wertzuwachssteuer, Bd. 23

Laufzeit

- Veranlagung verschiedener Emder Hausbesitzer zur

Wertzuwachssteuer wegen Veräußerung oder Erwerb von Immobilien:

Nr. 10 - Nr. 19

1917

Klassifikation Teil B: 03033

Band: 23

Trägermaterial: Papier

Alte Reg.-Sig.: VIII B6 37

Bestell-Nr.: IV 03033

2973 Erhebung der Wertzuwachssteuer, Bd. 24

- Veranlagung verschiedener Emder Hausbesitzer zur

Wertzuwachssteuer wegen Veräußerung oder Erwerb von Immobilien:

Nr. 20 - Nr. 29

1917

Klassifikation Teil B: 03034

Band: 24

Trägermaterial: Papier

Alte Reg.-Sig.: VIII B6 37

Bestell-Nr.: IV 03034

2974 Erhebung der Wertzuwachssteuer, Bd. 25

- Veranlagung verschiedener Emder Hausbesitzer zur

Wertzuwachssteuer wegen Veräußerung oder Erwerb von Immobilien:

Nr. 30 - Nr. 39

1917
Klassifikation Teil B: 03035
Band: 25
Trägermaterial: Papier
Alte Reg.-Sig.: VIII B6 37
Bestell-Nr.: IV 03035

2975 Erhebung der Wertzuwachssteuer, Bd. 26

- Veranlagung verschiedener Emder Hausbesitzer zur

Wertzuwachssteuer wegen Veräußerung oder Erwerb von Immobilien: Nr. 40 - Nr. 49

1917

Klassifikation Teil B: 03036

Band: 26

Trägermaterial: Papier

Alte Reg.-Sig.: VIII B6 37

Bestell-Nr.: IV 03036 
06

Finanzverwaltung der Stadt Emden

06.02

Steuern und Abgaben

06.02 .03

06.02.03.04

Städtische Abgaben

Lfd. Nr. Titel

Laufzeit

2976 Erhebung der Wertzuwachssteuer, Bd. 24

1917

- Veranlagung verschiedener Emder Hausbesitzer zur

Wertzuwachssteuer wegen Veräußerung oder Erwerb von Immobilien:

Nr. 50 - Nr. 59

1917

Klassifikation Teil B: 03037

Band: 27

Trägermaterial: Papier

Alte Reg.-Sig.: VIII B6 37

Bestell-Nr.: IV 03037

2977 Veranlagung der Deutsch - Luxemburgischen Bergwerks- und Hütten AG zur Umsatzsteuer (Wertzuwachssteuer)

- Bescheide über Höhe der von der Deutsch - Luxemburgischen

Bergwerks- und Hütten AG wegen Grunderwerbungen und

Veräußerungen für die Nordseewerke zu entrichtenden Umsatzsteuer

$1913-1913$

Klassifikation Teil B: 03038

Trägermaterial: Papier

Alte Reg.-Sig.: VIII B6 44

Bestell-Nr.: IV 03038 
06.02

- Regelung der Besteuerung von Einkommen aus Grundbesitz durch die Kommunen und Städte, 1870 - 1880

- Verhandlungen der städtischen Kollegien über Erhebung der Kommunalsteuer in Emden, August 1871 - Januar 1872

- Statut der Kommunalsteuer in Emden als direkte Steuer, Mai 1871

- Richtlinien zur Befreiung von der Kommunalsteuerpflicht, November 1872

- Novellierung der Statuten der Kommunalsteuer, 1873 - 1893

- Korrespondenz des Magistrats mit Nachbarstädten wegen der Ausgestaltung der Kommunalsteuer, 1874 - 1885

- Regelung der Heranziehung auswärtiger Schulkinder zur

Kommunalsteuer, April 1881

- Regelung der Ausgestaltung der Kommunalsteuer, 1873 - 1891

- Verfügung des Magistrats über Definition der Widerspruchsfrist nach

Erhalt des Kommunalsteuerbescheides, März 1885

- Organisation der Erhebung der Kommunalsteuer, 1890

$1870-1893$

Klassifikation Teil B: 03026

Trägermaterial: Papier

Alte Reg.-Sig.: VIII B7 01

Bestell-Nr.: IV 03026

- Einnahmen aus der Kommunalsteuer, 1884 - 1887

- Kommunalsteuer - Restanten, 1884 - 1887

. Beratungen der städtischen Kollegien über Höhe der zu erhebenden Kommunalsteuer, 1884 - 1886

$1884-1887$

Klassifikation Teil B: 03027

Trägermaterial: Papier

Alte Reg.-Sig.: VIII B7 02

Bestell-Nr.: IV 03027

- Anträge verschiedener Steuerschuldner beim Magistrat auf Freigabe ihnen zum, Ausgleich der Kommunalsteuerschuld gepfändeter Güter

1872 - 1902

Klassifikation Teil B: 03028

Trägermaterial: Papier

Alte Reg.-Sig.: VIII B7 07

Bestell-Nr.: IV 03028 
IV

06

Finanzverwaltung der Stadt Emden

06.02

Steuern und Abgaben

06.02 .03

06.02.03.06

Städtische Abgaben

Direkte Gemeindesteuern

Lfd. Nr. Titel

Laufzeit

2981 Ausführung des Kommunalabgabengesetzes vom 14. Juli 1893, Bd. 1

1886-1894

- Widerspruch der Kleinen Stadtdeichacht gegen die Heranziehung ihrer Grundstücke in der Emder Feldmark zur Kommunalabgabe,

1886 - 1890

- Beratungen und Verhandlungen im Landtag wegen der Einführung

einheitlicher Kommunalabgaben, 1891 - 1892

- Bestimmungen zu Kommunalabgaben zur Vorbereitung einer

Steuerstrukturreform, 1891 - 1892

- Petition der städtischen Kollegien an den Landtag über Bitte um

Beibehaltung des bisherigen Kommunalsteuer- und Abgabensystems wegen drohender Einnahmeausfälle, Dezember 1892

- Text des Kommunalabgabengesetzes vom 14. 07. 1893 über

Definition der kommunalen Steuern und Abgaben, Juli 1893

- Erlasse des preußischen Innenministers über

Ausführungsbestimmungen des Kommunalabgabengesetzes v.

14.07.1893, August 1893 / Dezember 1894

- Regelung der Heranziehung des Wandergewerbes zu den

Kommunalabgaben nach dem Gesetz vom 14.07.1893, September

1893

- Verhandlungen der städtischen Kollegien über Ausführung des

Kommunalabgabengesetzes, September 1894

- Konzept des Oberbürgermeisters Fürbringer: Plan der Ausführung des Kommunalabgabengesetzes, 1894

$1886-1894$

Klassifikation Teil B: 03039,01

Band: 1

Trägermaterial: Papier

Alte Reg.-Sig.: VIII B8 001

Bestell-Nr.: IV 03039 a 
IV

06

Finanzverwaltung der Stadt Emden

06.02

Steuern und Abgaben

06.02.03

06.02.03.06

Städtische Abgaben

Direkte Gemeindesteuern

Lfd. Nr. Titel

Laufzeit

2982 Ausführung des Kommunalabgabengesetzes vom 14. Juli 1893, Bd. 2

1895-1913

- Urteile des Oberverwaltungsgerichts Berlin zu

Ausführungsbestimmungen des Kommunalabgabengesetzes, 1895

- Erlasse des preußischen Innenministers über Ausführung des

Kommunalabgabegesetzes, Januar - April 1895

- Regelungen hinsichtlich städtischen Gebühren und Abgaben aus

Basis des Kommunalabgabengesetzes, 1895

- Erhebung der klassifizierten Einkommenssteuer, 1895

- Erlasse der preußischen Minister des Inneren, der öffentlichen

Arbeiten und der Finanzen über Regelung der Erhebung von

Gebühren auf Basis des Kommunalabgabengesetzes, 1895 - 1907

- Verwaltungsgebührensatzung der Stadt Emden, 1895

- Novellierung des Kommunalabgabengesetzes, Juni 1907

- Datenerhebung über Steuerverhältnisse von Forensen und juristischen Personen in Emden auf Anweisung des

Regierungspräsidenten in Aurich, November 1911

- Genehmigungsverfahren für den Tarif zur Benutzung der städtischen

Kanäle und Wasserläufe durch Schiffer, Juli 1913

$1895-1913$

Klassifikation Teil B: 03039,02

Band: 2

Trägermaterial: Papier

Alte Reg.-Sig.: VIII B8 001

Bestell-Nr.: IV 03039 b

2983 Ausführung des Kommunalabgabengesetzes vom 14. Juli 1893, Bd. 3

- Novellierung des Kommunalabgabengesetzes, März 1912 - Juli 1914

- Umsetzung des Kommunalabgabengesetzes in Emden, 1894 - 1913

$1894-1914$

Klassifikation Teil B: 03039,03

Band: 3

Trägermaterial: Papier

Alte Reg.-Sig.: VIII B8 001

Bestell-Nr.: IV 03039 c 
IV

06

Finanzverwaltung der Stadt Emden

06.02

Steuern und Abgaben

06.02.03

06.02.03.06

Städtische Abgaben

Direkte Gemeindesteuern

Lfd. Nr. Titel

Laufzeit

2984 Diskussion der Erhebung einer besonderen Steuer auf Grundbesitz

1899-1914

- Grundsteuerordnung verschiedener Städte über

Grundstücksbesteuerung nach dem Nutzwert, 1904 - 1914

- Erlass des preußischen Innenministers über Modus der

Grundbesteuerung (besondere Steuier), Oktober 1899

- Vermerk des Emder Kämmerers Ernst-August Gebest über

Begutachtung einer besonderen Steuer auf Grundbesitz als Ersatz für das Stübergeld mit Ertragsberechnung, Juni 1900

- Denkschrift des preußischen Innenministers und des

Finanzministers über Organisation der Grundbesteuerung nach der Veranlagung nach dem "gemeinen Wert", 1904

- Pressebericht über Diskussion der besonderen Besteuerung des

Grundbesitzes, 1905

- Verhandlungen der städtischen Kollegien über Erhebung einer besonderen Steuer auf den Grundbesitz, März 1906 - August 1908

- Entwurf einer Haus- und Landsteuerordnung für die Stadt Emden, 1907

- Antrag des Magistrats an den Bezirksausschuss in Aurich auf

Zulassung der Haus- und Landsteuer, Januar - März 1908

- Monita des Regierungspräsidenten in Aurich über Monita zur Hausund Landsteuerordnung der Stadt Emden, April 1908

- Protest des Haus- und Grundbesitzer-Vereins Emden gegen die geplante Haus- und Landsteuer auf Grundlage der Bemessung nach dem gemeinen Wert, September 1913

- Drucksachen zum Grundsteuerrecht, 1907 - 1914

$1899-1914$

Klassifikation Teil B: 03040

Trägermaterial: Papier

Alte Reg.-Sig.: VIII B8 004

Bestell-Nr.: IV 03040

- Ordnung der direkten Grundsteuer in der Stadt Emden

1895

Klassifikation Teil B: 03041

Trägermaterial: Papier

Alte Reg.-Sig.: VIII B8 005

Bestell-Nr.: IV 03041 
IV

06

Finanzverwaltung der Stadt Emden

06.02

Steuern und Abgaben

06.02.03

06.02.03.07

Städtische Abgaben

Schankerlaubnissteuer

Lfd. Nr. Titel

Laufzeit

2986 Schankkonzessionssteuer

1907-1914

- Kreis- und Provinzialabgabengesetz als gesetzliche Grundlage für die Schankkonzessionssteuer, 1909

- Erhebung des Magistrats über Handhabung der

Schankkonzessionssteuer in anderen Städten, 1906

- Beschwerde des Emder Wirtevereins gegen die Erhebung einer

Schankkonzessionssteuer, Januar - Februar 1907

- Entwurf einer Schankkonzessioonssteuerordnung für Emden,

Oktober 1907

- Verhandlungen der Kommission für indirekte Steuern über

Einführung einer Schankkonzessionssteuer in Emden, Januar 1908

- Monita des Bezirksausschusses wegen der

Schankkonzessionssteuerordnung in Emden, Februar 1908 -

September 1909

- Verhandlungen der städtischen Kollegien über Einführung einer

Schankkonzessionssteuer in Emden, April 1908

- Verhandlungen der Schankkonzessionissteuerkommission über

Fassung der Schankkonzessionssteuerordnung, November 1908

- Klage des Gastwirts Johannes Klöffkorn beim Bezirksausschuss

gegen die Heranziehung zur Schankkonzessionssteuer, Januar - April

1910

- Anträge auf Ermäßigung der Schankkonzessionssteuer, 1909 - 1911

- Beschwerden gegen die Heranziehung zur

Schankkonzessionssteuer, 1910 - 1912

$1906-1914$

Klassifikation Teil B: 03042

Trägermaterial: Papier

Alte Reg.-Sig.: VIII B8 008

Bestell-Nr.: IV 03042

2987 Befreiung von der Schankerlaubnissteuer

Verschiedene Anträge auf Befreiung von der Schankerlaubnissteuer

1912

Klassifikation Teil B: 03042,01

Trägermaterial: Papier

Alte Reg.-Sig.: VIII B8 008

Bestell-Nr.: IV 03042 a 
Lfd. Nr. Titel

2988 Erhebungen über den Vermögens- und Schuldenstand der Stadt

Emden

- Ausgefüllte Fragebögen zum Stand des Vermögens und der Verbindlichkeiten der Stadt Emden, 1905

- Vermögen und Schulden der Stadt Emden, 1905 - 1906

- Rundverfügung des preußischen statistischen Landesamts zur

Erhebung der Daten zu Vermögen und Verschuldung der Kommunen,

September 1906 - November 1909

$1905-1909$

Klassifikation Teil B: 00042

Trägermaterial: Papier

Alte Reg.-Sig.: IV Cd 81

Bestell-Nr.: IV 00042

2989 Anleihen der Stadt Emden bei der städtischen Spar- und Leihkasse

- Aufnahme einer Anleihe über 12.700 Rthlr. durch die

Kämmereikasse von der städtischen Spar- und Leihkasse nach

Genehmigung durch die städtischen Kollegien zur Finanzierung von

Grundstückskäufen der Stadt Emden, April - Juni 1872

- Aufnahme einer Anleihe über 50.000 Rthlr. durch die

Kämmereikasse von der städtischen Spar- und Leihkasse nach

Genehmigung durch die städtischen Kollegien als Teilbetrag zur

Finanzierung der Eindeichung des Larrelter Polders, März - Oktober

1874

- Aufnahme einer Anleihe über 30.000 Rthlr. durch die

Kämmereikasse von der städtischen Spar- und Leihkasse nach

Genehmigung durch die städtischen Kollegien zur Finanzierung der

Eindeichung des Larrelter Polders, Juli 1875

- Aufnahme einer Anleihe über 12.700 Rthlr. durch die

Kämmereikasse von der städtischen Spar- und Leihkasse nach

Genehmigung durch die städtischen Kollegien zur Finanzierung von

Einquartierungen, Januar 1867

- Aufnahme von Kassenkrediten bei der städtischen Spar- und

Leihkasse durch die Kämmereikasse, 1868 - 1900

- Übersicht über Guthaben und Verbindlichkeiten der Stadt Emden bei der städtiisschen Spar- und Leihkasse, März 1896 / Februar 1902

- Einlösung von Wertpapieren der Stadt Emden zur Tilgung ihrer

Verbindlichkeiten bei der städtischen Spar- und Leihkasse, September

- November 1902

$1868-1902$

Klassifikation Teil B: 03067

Trägermaterial: Papier

Alte Reg.-Sig.: VIII C 023

Bestell-Nr.: IV 03067 
Lfd. Nr. Titel

Laufzeit

1866-1887

(1864-1865)

- Ablösung städtischer Obligationen durch neue Papiere oder

Barauszahlung

- Verwaltung der Schuldpapiere der Stadt Emden

(1864 - 1865) 1866 - 1867

Klassifikation Teil B: 03068

Trägermaterial: Papier

Alte Reg.-Sig.: VIII C 026

Bestell-Nr.: IV 03068

2991 Finanzangelegenheiten der Stadt Emden

1866-1881

- Kassenführung der Kämmereikasse und Verwaltung der

Geldbestände

- Verwaltung der Wertpapiere im Besitz der Stadt Emden:

Kündigungen, Umschreibungen, Neuerwerb

- Statistische Übersichten über Zahlungsverkehr der Kämmereikasse

- Statistiken über Vermögen und Verbindlichkeiten der Stadt Emden

- Aufnahme von Kassenkrediten bei der Spar- und Leihkasse

$1866-1881$

Klassifikation Teil B: 03069

Trägermaterial: Papier

Alte Reg.-Sig.: VIII C 027

Bestell-Nr.: IV 03069

2992 Finanzangelegenheiten der Stadt Emden

1873-1909

- Platzierung einer städtischen Anleihe über 200.000 Rthlr. = 600-000

Mk., 1873 - 1875

- Tilgungsplan der Anleihe, 1875

- Tilgung (Auslösung) der Anleihe, 1876 - 1909

$1873-1909$

Klassifikation Teil B: 03070

Trägermaterial: Papier

Alte Reg.-Sig.: VIII C 028

Bestell-Nr.: IV 03070

2993 Gebührenpflichtige Eintragung städtischer Grundstücke ins

Grundbuch

- Entrichtung von Gebühren für die durch gesetzliche Vorgaben

notwendige Eintragung städtischer Grundstücke in das Grundbuch

1874

Klassifikation Teil B: 03071

Trägermaterial: Papier

Alte Reg.-Sig.: VIII C 032

Bestell-Nr.: IV 03071
1874 
Lfd. Nr. Titel

- Aufnahme einer Anleihe über 250.000 Mk durch die Stadt Emden bei der Spar- und Leihkasse unter Verpfändung der vom Staat gezahlten Zollerntschädigungsrente

\author{
$1879-1888$ \\ Klassifikation Teil B: 03072 \\ Trägermaterial: Papier \\ Alte Reg.-Sig.: VIII C 037
}

Bestell-Nr.: IV 03072

2995 Umschreibung der städtischen Anleihen "B", "D", "E"

- Angebot der Oldenburgischen Spar- und Leihbank über Anleihen von 500.000 Mk. oder 200.000 Mk. per Emission von

Schuldverschreibungen, Juni 1888

- Umschreibung alter Anleihen der Stadt Emden in ein neues, zinsgünstigeres Papier, Juni 1888

- Verhandlungen des Magistrats mit der Ostfriesischen Sparkasse in Aurich über eine weitere Anleihe von 500.000 Mk., Juni - September 1888

- Beschwerde des Magistrats beim Regierungspräsidenten in Aurich und dem Provinzialrat der Provinz Hannover gegen eine Auflage des Bezirksausschuses im Bescheid über Genehmigung der zweiten Anleihe über 500.000 Mk, Juli - Oktober 1888

- Bericht des Magistrats an den Regierungspräsidenten über Tilgungsplan für die Anleihen über insgesamt 1 Million Mk. (Laufzeit bis 1933), November 1888

- Genehmigung der Anleihe durch den Regierungspräsidenten nach Erteilung eines Allerhöchsten Privilegiums durch den preußischen König, Februar 1889

- Nachweisung über von der Stadt Emden gezahlte Schuldzinsen und getilgte Anleihen, 1887 - 1890

$1888-1890$

Klassifikation Teil B: 03073

Trägermaterial: Papier Alte Reg.-Sig.: VIII C 039

Bestell-Nr.: IV 03073

2996 Umschreibung städtischer Anleihepapiere

- Antrag des Magistrats an den Regierungspräsidenten in Aurich auf Genehmigung einer Herabsetzung des Zinsfußes bei den laufenden Anleihen "B", "D", "E" nach den Bestimmungen des Allerhöchsten Privilegiums, Juni - September 1888

- Tilgungspläne nach einem Zinsfuß von $4 \%$ und von $3 \%, 1888$ - Verhandlungen der Finanz-Commission über Modalitäten der Umschreibung der Anleihe auf geringerem Zinsfuß, September 1888

- Bekanntmachung der Zinsfußsenkung der städtiischen Anleihen, September 1888 - Mai 1889

$1888-1889$

Klassifikation Teil B: 03074

Trägermaterial: Papier

Alte Reg.-Sig.: VIII C 040

Bestell-Nr.: IV 03074 
Lfd. Nr. Titel

Laufzeit

2997 Tilgung der Anleihepapiere "B", "'E", "F" und "G"

- Tilgung der Anleihepapiere "B", "'E", "F" und "G" nach einem Losverfahren

- Verzeichnis der getilgten Anleihepapiere

$1896-1915$ (1919)

Klassifikation Teil B: 03075

Trägermaterial: Papier

Alte Reg.-Sig.: VIII C 041

Bestell-Nr.: IV 03075

2998 Anleihen für städtische Bauprojekte

- Verhandlungen der städtischen Kollegien über Finanzierun g des Baues eines Nebengebäudes zum Armenarbeitshaus durch eine Anleihe von 16.450 Mk bei der Spar- und Leihkasse, Juni 1892 - Antrag des Magistrats beim Bezirksausschuss in Aurich auf Genehmigung der Anleihe, Juli - September 1892

- Verwendung der Anleihesumme als Kassenkredit für illiquide Kämmereikasse, März 1893

- Antrag des Magistrats an den Bezirksausschuss in Aurich auf Genehmigung einer Anleihe bei der städtischen Spar- und Leihkasse zur Finanzierung des geplanten Schlachthauses mit Kühleinrichtung, August 1894

$1892-1894$

Klassifikation Teil B: 03076

Trägermaterial: Papier

Alte Reg.-Sig.: VIII C 042

Bestell-Nr.: IV 03076

2999 Anleihe zum Bau eines Krankenhauses

- Verhandlungen der städtischen Kollegien über Finanzierung des Krankenhausbaues durch eine Anleihe, März 1892

- Antrag des Magistrats beim Bezirksausschuss auf Genehmigung einer Anleihe von 170.000 Mk. zum Bau eines städtischen

Krankenhauses, Oktober 1892 - Januar 1893

- Flüssigmachung der Anleihesumme aus der Anleihe der städtischen Spar- und Leihkasse, Juli 1893

- Antrag des Magistrats an den Bezirksausschuss auf Genehmigung einer weiteren Anleihe von 16.500 Mk. zum Krankenhausbau,

Dezember 1897

$1892-1897$

Klassifikation Teil B: 03077

Trägermaterial: Papier

Alte Reg.-Sig.: VIII C 043

Bestell-Nr.: IV 03077 
Lfd. Nr. Titel

- Antrag des Magistrats an den Bezirksausschuss auf Genehmigung einer Anleihe über 52.700 Mk zur Planierung eines Teiles des

Fahrwasserdeiches und zum Bau einer Straße an der Küstenbahn, Mai - Juli 1895

1895

\author{
Klassifikation Teil B: 03078 \\ Trägermaterial: Papier \\ Alte Reg.-Sig.: VIII C 045
}

Bestell-Nr.: IV 03078

3001 Anleihen zum Bau des städtisachen Schlachthauses

- Aufstellung über Kosten des Schlachthausbaues, April 1896

- Antrag des Magistrats an den Bezirksausschuss auf Genehmigung einer Anleihe über 44250 Mk zur Finanzierung des

Schlachthausbaues, April - Juni 1897

- Bericht des Magistrats an den Bezirksausschuss über Summe der Anleihen (278550 Mk) für den Schlachthausbau, Dezember 1897

$1896-1897$

Klassifikation Teil B: 03079

Trägermaterial: Papier

Alte Reg.-Sig.: VIII C 047

Bestell-Nr.: IV 03079

3002 Anleihe zum Ankauf eines Brandgrundstückes

- Anrag des Magistrats an den Bezirksausschuss auf Genehmigung einer Anleihe über 5.000 Mk. zum Ankauf des Grundstückes mit dem abgebrannten Haus der Witwe Klaassen Am Alten Markt, Dezember 1896 - Januar 1897

$1896-1897$

Klassifikation Teil B: 03080

Trägermaterial: Papier

Alte Reg.-Sig.: VIII C 054

Bestell-Nr.: IV 03080

3003 Anleihen für das städtische Gaswerk

- Aufnahme von Anleihen durch die Stadt Emden zur Finanzierung des Ausbaus des städtischen Gaswerks

$1896-1904$

Klassifikation Teil B: 03081

Trägermaterial: Papier

Alte Reg.-Sig.: VIII C 070

Bestell-Nr.: IV 03081 
06

Lfd. Nr. Titel

- Verhandlungen der städtischen Kollegien über Aufnahme einer Anleihe in Höhe von 210.000 Mk. bei der Spar- und Leihkasse zum Bau der Höheren Töchterschule, November 1903

- Antrag des Magistrats an den Bezirksausschuss in Aurich auf

Genehmigung der Anleihe, Dezember 1903 - Januar 1904

- Kostenvoranschlag zum Bau der Höheren Töchterschule mit

Lehrerinnen-Seminar, 1903

- Tilgungsplan der Anleihe, 1906

- Aufnahme einer Zusatz-Anleihe über 34.750 Mk. zur Finanzierung von Mehrkosten beim Bau der Höheren Töchterschule, Oktober November 1906

- Rückzahlung eines durch Einsparungen erwirtschafteten Betrages zu

Teiltilgung der Zusatz-Anleihe, Dezember 1909

$1903-1909$

Klassifikation Teil B: 03082

Trägermaterial: Papier

Alte Reg.-Sig.: VIII C 083

Bestell-Nr.: IV 03082

3005 Anleihe für Einbau von WC's im städtischen Krankenhaus

- Aufnahme einer Anleihe durch die Stadt Emden für Einbau von WC's im städtischen Krankenhaus

1903

Klassifikation Teil B: 03084

Trägermaterial: Papier

Alte Reg.-Sig.: VIII C 085

Bestell-Nr.: IV 03084

3006 Anleihe für Feuermeldeanlage

- Aufnahme einer Anleihe durch die Stadt Emden in Höhe von 8847 Mk zum Bau einer Feuermeldeanlage

$1906-1907$

Klassifikation Teil B: 03085

Trägermaterial: Papier Alte Reg.-Sig.: VIII C 091

Bestell-Nr.: IV 03085

- Aufnahme einer Anleihe über 10.315 Mk durch die Stadt Emden zur Anlage eines verlängerten Notdurchlasses bis zum Puntschloot

$1906-1907$

Klassifikation Teil B: 03086

Trägermaterial: Papier

Alte Reg.-Sig.: VIII C 093

Bestell-Nr.: IV 03086 
IV

06

Finanzverwaltung der Stadt Emden

06.03

Städtische Schuldenverwaltung

Lfd. Nr. Titel

Laufzeit

3008 Geldvermittlungsstelle des Deutschen Städtetages

$1911-1915$

- Tätigkeit der Geldvermittlungsstelle des Deutschen Städtetages als Kreditvermittlerin

$1911-1915$

Klassifikation Teil B: 03087

Trägermaterial: Papier

Alte Reg.-Sig.: VIII C 100

Bestell-Nr.: IV 03087

3009 Zinskoupons

- Vordrücke von Zinskoupons für städtische Schuldverschreibungen

1912

Klassifikation Teil B: 03088

Trägermaterial: Papier

Alte Reg.-Sig.: VIII C 101

Bestell-Nr.: IV 03088

3010 Ausgesetzte Anleihen

- Aufstellung über Anleihen der Stadt Emden mit ausgesetzter Tilgung

1917

Klassifikation Teil B: 03099

Trägermaterial: Papier

Alte Reg.-Sig.: VIII C 102

Bestell-Nr.: IV 03089 
06.04

Lfd. Nr. Titel

3011 Nachbewilligungen zum Etat

- Nachbewilligungen zum Etat 1873

1873

Klassifikation Teil B: 03083

Trägermaterial: Papier

Alte Reg.-Sig.: VIII D1 022

Bestell-Nr.: IV 03083

3012 Aufstellung des städtischen Haushaltsplans

- Festlegung des Berichtsmodus für die Haushaltspläne der Stadt

Emden gegenüber dem preußischen Landdrosten in Aurich, 1867

- Bemerkungen des Kämmerers zu Haushaltsposten des

Kämmerei-Etats, 1873 - 18888

- Neufestsetzung des Haushaltsjahres auf den Zeitraum vom 1. April bis zum 31. März, September 1876

- Auszüge der Kämmereirechnung, 1877

$1867-1888 \quad$ (1915)

Klassifikation Teil B: 03090

Trägermaterial: Papier

Alte Reg.-Sig.: VIII D1 008

Bestell-Nr.: IV 03090

3013 Gestaltung der Haushaltsrubriken

1866-1867

- Richtlinien des Hannoverschen, später preußischen Landdrosten in

Aurich über formale Gestaltung der Rubriken im Haushaltsplan

1866 - 1867 (1881)

Klassifikation Teil B: 03091

Trägermaterial: Papier

Alte Reg.-Sig.: VIII D1 020

Bestell-Nr.: IV 03091

3014 Etatfestsetzung

- Feststellung des Etatplans der Stadt Emden für 1867

- Verhandlungen der städtischen Kollegien über Etat für 1867

- Berichterstattung des Magistrats an den preußischen Landdrosten in

Aurich zum Etat für 1867

- Nachbewilligungen für verschiedene Etatposten

$1866-1867$

Klassifikation Teil B: 03092

Trägermaterial: Papier

Alte Reg.-Sig.: VIII D1 021

Bestell-Nr.: IV 03092 
06.04

Lfd. Nr. Titel

- Feststellung des Etatplans der Stadt Emden für 1868

- Verhandlungen der städtischen Kollegien über Etat für 1868

- Berichterstattung des Magistrats an den preußischen Landdrosten in

Aurich zum Etat für 1868

- Nachbewilligungen für verschiedene Etatposten

1868

Klassifikation Teil B: 03092

Trägermaterial: Papier

Alte Reg.-Sig.: VIII D1 022

Bestell-Nr.: IV 03093

- Feststellung des Etatplans der Stadt Emden für 1870

- Verhandlungen der städtischen Kollegien über Etat für 1870

- Berichterstattung des Magistrats an den preußischen Landdrosten in Aurich zum Etat für 1870

- Nachbewilligungen für verschiedene Etatposten

$1870-1871$

Klassifikation Teil B: 03094

Trägermaterial: Papier

Alte Reg.-Sig.: VIII D1 024

Bestell-Nr.: IV 03094

- Verhandlungen der städtischen Kollegien über Etat der Kämmerei

- Feststellung des Kämmereietats

- Berichterstattung an den preußischen Landdrosten, später

Regierungspräsidenten in Aurich zum Kämmereietat

$1871-1875$

Klassifikation Teil B: 03095

Trägermaterial: Papier

Alte Reg.-Sig.: VIII D1 026

Bestell-Nr.: IV 03095

- Feststellung des Etatplans der Stadt Emden für 1876 und I.Quartal 1877

- Verhandlungen der städtischen Kollegien über Etat für 1876 / 77 nach Umstellung des Haushaltsjahres auf 1. April bis zum 31. März

- Berichterstattung des Magistrats an den preußischen

Regierungspräsidenten in Aurich zum Etat für 1876 / 1877

- Nachbewilligungen für verschiedene Etatposten

$1876-1877$

Klassifikation Teil B: 03096

Trägermaterial: Papier

Alte Reg.-Sig.: VIII D1 030

Bestell-Nr.: IV 03096 
06.04

Lfd. Nr. Titel

- Verhandlungen der städtischen Kollegien über Etat der Kämmerei

- Feststellung des Kämmereietats

- Berichterstattung an den preußischen Regierungspräsidenten in

Aurich zum Kämmereietat

$1876-1877$

Klassifikation Teil B: 03097

Trägermaterial: Papier

Alte Reg.-Sig.: VIII D1 031

Bestell-Nr.: IV 03097

3020 Kämmereietat 1878/79

- Verhandlungen der städtischen Kollegien über Etat der Kämmerei

- Feststellung des Kämmereietats

- Berichterstattung an den preußischen Regierungspräsidenten in

Aurich zum Kämmereietat

1878

Klassifikation Teil B: 03098

Trägermaterial: Papier

Alte Reg.-Sig.: VIII D1 092

Bestell-Nr.: IV 03098

3021 Kämmereietat 1879/80

- Verhandlungen der städtischen Kollegien über Etat der Kämmerei

- Feststellung des Kämmereietats

- Berichterstattung an den preußischen Regierungspräsidenten in

Aurich zum Kämmereietat

$1879-1880$

Klassifikation Teil B: 03099

Trägermaterial: Papier

Alte Reg.-Sig.: VIII D1 033

Bestell-Nr.: IV 03099

- Verhandlungen der städtischen Kollegien über Etat der Kämmerei

- Feststellung des Kämmereietats

- Berichterstattung an den preußischen Regierungspräsidenten in

Aurich zum Kämmereietat

$1880-1881$

Klassifikation Teil B: 03100

Trägermaterial: Papier

Alte Reg.-Sig.: VIII D1 034

Bestell-Nr.: IV 03100 
06.04

Lfd. Nr. Titel

Laufzeit

3023 Kämmereietat 1881/82

- Verhandlungen der städtischen Kollegien über Etat der Kämmerei

- Feststellung des Kämmereietats

- Berichterstattung an den preußischen Regierungspräsidenten in

Aurich zum Kämmereietat

$1881-1882$

Klassifikation Teil B: 03101

Trägermaterial: Papier

Alte Reg.-Sig.: VIII D1 035

Bestell-Nr.: IV 03101

3024 Kämmereietat 1882/83

- Verhandlungen der städtischen Kollegien über Etat der Kämmerei

- Feststellung des Kämmereietats

- Berichterstattung an den preußischen Regierungspräsidenten in

Aurich zum Kämmereietat

$1882-1883$

Klassifikation Teil B: 03102

Trägermaterial: Papier

Alte Reg.-Sig.: VIII D1 036

Bestell-Nr.: IV 03102

3025 Kämmereietat 1883/84

- Verhandlungen der städtischen Kollegien über Etat der Kämmerei

- Feststellung des Kämmereietats

- Berichterstattung an den preußischen Regierungspräsidenten in

Aurich zum Kämmereietat

$1883-1884$

Klassifikation Teil B: 03103

Trägermaterial: Papier

Alte Reg.-Sig.: VIII D1 038

Bestell-Nr.: IV 03103

3026 Kämmereietat 1885/86

- Verhandlungen der städtischen Kollegien über Etat der Kämmerei

- Feststellung des Kämmereietats

- Berichterstattung an den preußischen Regierungspräsidenten in

Aurich zum Kämmereietat

$1885-1886$

Klassifikation Teil B: 03104

Trägermaterial: Papier

Alte Reg.-Sig.: VIII D1 039

Bestell-Nr.: IV 03104 
06.04

Lfd. Nr. Titel

Laufzeit

3027 Kämmereietat 1886/87

- Verhandlungen der städtischen Kollegien über Etat der Kämmerei

- Feststellung des Kämmereietats

- Berichterstattung an den preußischen Regierungspräsidenten in

Aurich zum Kämmereietat

$1886-1887$

Klassifikation Teil B: 03105

Trägermaterial: Papier

Alte Reg.-Sig.: VIII D1 040

Bestell-Nr.: IV 03105

3028 Kämmereietat 1886/87

1888

- Antrag des Kämmerers Ernst August Gebest an den Magistrat auf Nachbewilligung von 1054,52 Mk zum Etatausgleich für 1886/87,

Oktober 1888

1888

Klassifikation Teil B: 03106

Trägermaterial: Papier

Alte Reg.-Sig.: VIII D1 041

Bestell-Nr.: IV 03106

3029 Kämmereietat 1888/89

1888-1889

- Verhandlungen der städtischen Kollegien über Etat der Kämmerei

- Feststellung des Kämmereietats

- Berichterstattung an den preußischen Regierungspräsidenten in

Aurich zum Kämmereietat

$1888-1889$

Klassifikation Teil B: 03107

Trägermaterial: Papier

Alte Reg.-Sig.: VIII D1 043

Bestell-Nr.: IV 03107

3030 Kämmereietat 1890/91

$1890-1891$

- Verhandlungen der städtischen Kollegien über Etat der Kämmerei

- Feststellung des Kämmereietats

- Berichterstattung an den preußischen Regierungspräsidenten in

Aurich zum Kämmereietat

1890 - 1891

Klassifikation Teil B: 03108

Trägermaterial: Papier

Alte Reg.-Sig.: VIII D1 044

Bestell-Nr.: IV 03108 
06.04

Lfd. Nr. Titel

Laufzeit

3031 Kämmereietat 1891/92

- Verhandlungen der städtischen Kollegien über Etat der Kämmerei

- Feststellung des Kämmereietats

- Berichterstattung an den preußischen Regierungspräsidenten in

Aurich zum Kämmereietat

$1891-1892$

Klassifikation Teil B: 03109

Trägermaterial: Papier

Alte Reg.-Sig.: VIII D1 045

Bestell-Nr.: IV 03109

3032 Kämmereietat 1892/93

- Verhandlungen der städtischen Kollegien über Etat der Kämmerei

- Feststellung des Kämmereietats

- Berichterstattung an den preußischen Regierungspräsidenten in

Aurich zum Kämmereietat

$1892-1893$

Klassifikation Teil B: 03110

Trägermaterial: Papier

Alte Reg.-Sig.: VIII D1 046

Bestell-Nr.: IV 03110

3033 Kämmereietat 1893/94

- Verhandlungen der städtischen Kollegien über Etat der Kämmerei

- Feststellung des Kämmereietats

- Berichterstattung an den preußischen Regierungspräsidenten in

Aurich zum Kämmereietat

$1893-1894$

Klassifikation Teil B: 03111

Trägermaterial: Papier

Alte Reg.-Sig.: VIII D1 047

Bestell-Nr.: IV 03111

3034 Kämmereietat 1894/95

- Verhandlungen der städtischen Kollegien über Etat der Kämmerei

- Feststellung des Kämmereietats

- Berichterstattung an den preußischen Regierungspräsidenten in

Aurich zum Kämmereietat

$1894-1895$

Klassifikation Teil B: 03112

Trägermaterial: Papier

Alte Reg.-Sig.: VIII D1 048

Bestell-Nr.: IV 03112 
06.04

Lfd. Nr. Titel

Laufzeit

3035 Kämmereietat 1895/96

- Verhandlungen der städtischen Kollegien über Etat der Kämmerei

- Feststellung des Kämmereietats

- Berichterstattung an den preußischen Regierungspräsidenten in

Aurich zum Kämmereietat

$1895-1896$

Klassifikation Teil B: 03113

Trägermaterial: Papier

Alte Reg.-Sig.: VIII D1 049

Bestell-Nr.: IV 03113

3036 Kämmereietat 1896/97

- Verhandlungen der städtischen Kollegien über Etat der Kämmerei

- Feststellung des Kämmereietats

- Berichterstattung an den preußischen Regierungspräsidenten in

Aurich zum Kämmereietat

- Antrag des Magistrats an den Regierungspräsidenten auf

Genehmigung von Nachbewilligungen zum Ausgleich des Etats

1896/97, Juni 1898

$1896-1898$

Klassifikation Teil B: 03114

Trägermaterial: Papier

Alte Reg.-Sig.: VIII D1 050

Bestell-Nr.: IV 03114

3037 Kämmereietat 1898/99

- Verhandlungen der städtischen Kollegien über Etat der Kämmerei

- Feststellung des Kämmereietats

- Berichterstattung an den preußischen Regierungspräsidenten in

Aurich zum Kämmereietat

$1898-1899$

Klassifikation Teil B: 03115

Trägermaterial: Papier

Alte Reg.-Sig.: VIII D1 052

Bestell-Nr.: IV 03115

3038 Kämmereietat 1900/01

$1900-1901$

- Verhandlungen der städtischen Kollegien über Etat der Kämmerei

- Feststellung des Kämmereietats

- Berichterstattung an den preußischen Regierungspräsidenten in

Aurich zum Kämmereietat

$1900-1901$

Klassifikation Teil B: 03116

Trägermaterial: Papier

Alte Reg.-Sig.: VIII D1 054

Bestell-Nr.: IV 03116 
06.04

Lfd. Nr. Titel

Laufzeit

3039 Kämmereietat 1901/02

- Verhandlungen der städtischen Kollegien über Etat der Kämmerei

- Feststellung des Kämmereietats

- Berichterstattung an den preußischen Regierungspräsidenten in

Aurich zum Kämmereietat

$1901-1902$

Klassifikation Teil B: 03117

Trägermaterial: Papier

Alte Reg.-Sig.: VIII D1 055

Bestell-Nr.: IV 03117

3040 Kämmereietat 1902/03

- Verhandlungen der städtischen Kollegien über Etat der Kämmerei

- Feststellung des Kämmereietats

- Berichterstattung an den preußischen Regierungspräsidenten in

Aurich zum Kämmereietat

$1902-1903$

Klassifikation Teil B: 03118

Trägermaterial: Papier

Alte Reg.-Sig.: VIII D1 056

Bestell-Nr.: IV 03118

3041 Kämmereietat 1903/04

- Verhandlungen der städtischen Kollegien über Etat der Kämmerei

- Feststellung des Kämmereietats

- Berichterstattung an den preußischen Regierungspräsidenten in

Aurich zum Kämmereietat

$1903-1904$

Klassifikation Teil B: 03119

Trägermaterial: Papier

Alte Reg.-Sig.: VIII D1 057

Bestell-Nr.: IV 03119

3042 Kämmereietat 1904/05

- Verhandlungen der städtischen Kollegien über Etat der Kämmerei

- Feststellung des Kämmereietats

- Berichterstattung an den preußischen Regierungspräsidenten in

Aurich zum Kämmereietat

$1904-1905$

Klassifikation Teil B: 03120

Trägermaterial: Papier

Alte Reg.-Sig.: VIII D1 058

Bestell-Nr.: IV 03120 
06 Finanzverwaltung der Stadt Emden

06.04

Rechnungswesen

06.04.01

Haushaltspläne

Lfd. Nr. Titel

Laufzeit

3043 Kämmereietats

1906-1911

- Kämmereietats (Haushaltspläne)

$1906-1911$

Klassifikation Teil B: 03121

Trägermaterial: Papier

Alte Reg.-Sig.: VIII D1 059

Bestell-Nr.: IV 03121

3044 Haushaltsplan der Stadt Emden

1869

- Bauetat: Bauverwaltung, Verwaltung städtischer Parkanlagen

1869.

Klassifikation Teil B: 03123

Trägermaterial: Papier

Alte Reg.-Sig.: VIII D1 060

Bestell-Nr.: IV 03123

3045 Haushaltsplan der Stadt Emden

- Kämmerei- und Bauetat

1870

Klassifikation Teil B: 03124

Trägermaterial: Papier

Alte Reg.-Sig.: VIII D1 061

Bestell-Nr.: IV 03124

3046 Haushaltsplan der Stadt Emden

- Kämmereietat

1871

Klassifikation Teil B: 03125

Trägermaterial: Papier

Alte Reg.-Sig.: VIII D1 062

Bestell-Nr.: IV 03125

3047 Haushaltsplan der Stadt Emden

- Kämmereietat

1872

Klassifikation Teil B: 03126

Trägermaterial: Papier

Alte Reg.-Sig.: VIII D1 063

Bestell-Nr.: IV 03126 
06 Finanzverwaltung der Stadt Emden

06.04

06.04.01

Rechnungswesen

Haushaltspläne

Lfd. Nr. Titel

Laufzeit

3048 Haushaltsplan der Stadt Emden 1891-1892

- Kämmereietat: Außerordentliche Ausgaben (Extraordinarium)

$1891 / 92$

Klassifikation Teil B: 03127

Trägermaterial: Papier

Alte Reg.-Sig.: VIII D1 064

Bestell-Nr.: IV 03127

3049 Haushaltsplan der Stadt Emden

$1892-1893$

- Kämmereietat

$1892-1893$

Klassifikation Teil B: 03128

Trägermaterial: Papier

Alte Reg.-Sig.: VIII D1 065

Bestell-Nr.: IV 03128

3050 Haushaltsplan der Stadt Emden

$1893-1894$

- Kämmereietat

$1893-1894$

Klassifikation Teil B: 03129

Trägermaterial: Papier

Alte Reg.-Sig.: VIII D1 066

Bestell-Nr.: IV 03129

3051 Haushaltsplan der Stadt Emden

1894-1895

- Kämmereietat

$1894-1895$

Klassifikation Teil B: 03130

Trägermaterial: Papier

Alte Reg.-Sig.: VIII D1 066

Bestell-Nr.: IV 03130

3052 Haushaltsplan der Stadt Emden

1895-1904

- Gedruckte Haushaltspläne

$1895-1904$

Klassifikation Teil B: 03131

Trägermaterial: Papier

Alte Reg.-Sig.: VIII D1 067

Bestell-Nr.: IV 03131 
06 Finanzverwaltung der Stadt Emden

06.04

06.04.01

Rechnungswesen

Haushaltspläne

Lfd. Nr. Titel

Laufzeit

3053 Haushaltsplan der Stadt Emden 1895-1896

- Kämmereietat

$1895-1896$

Klassifikation Teil B: 03132

Trägermaterial: Papier Alte Reg.-Sig.: VIII D1 068

Bestell-Nr.: IV 03132

3054 Haushaltsplan der Stadt Emden

1896-1897

- Kämmereietat

$1896-1897$

Klassifikation Teil B: 03133

Trägermaterial: Papier

Alte Reg.-Sig.: VIII D1 069

Bestell-Nr.: IV 03133

3055 Haushaltsplan der Stadt Emden

1897-1898

- Kämmereietat

$1897-1898$

Klassifikation Teil B: 03134

Trägermaterial: Papier

Alte Reg.-Sig.: VIII D1 070

Bestell-Nr.: IV 03134

3056 Haushaltsplan der Stadt Emden

1898-1899

- Kämmereietat

$1898-1899$

Klassifikation Teil B: 03135

Trägermaterial: Papier

Alte Reg.-Sig.: VIII D1 071

Bestell-Nr.: IV 03135

3057 Haushaltsplan der Stadt Emden

$1899-1900$

- Kämmereietat

$1899-1900$

Klassifikation Teil B: 03136

Trägermaterial: Papier

Alte Reg.-Sig.: VIII D1 072

Bestell-Nr.: IV 03136 
06.04

Rechnungswesen

06.04.01

\section{Haushaltspläne}

Lfd. Nr. Titel

Laufzeit

3058 Haushaltsplan der Stadt Emden 1900-1901

- Kämmereietat

$1900-1901$

Klassifikation Teil B: 03136

Trägermaterial: Papier

Alte Reg.-Sig.: VIII D1 073

Bestell-Nr.: IV 03137

3059 Haushaltsplan der Stadt Emden

1901-1902

- Kämmereietat

$1901-1902$

Klassifikation Teil B: 03138

Trägermaterial: Papier

Alte Reg.-Sig.: VIII D1 074

Bestell-Nr.: IV 03138

3060 Haushaltsplan der Stadt Emden

1902-1903

- Kämmereietat

$1902-1903$

Klassifikation Teil B: 03139

Trägermaterial: Papier

Alte Reg.-Sig.: VIII D1 075

Bestell-Nr.: IV 03139

3061 Haushaltsplan der Stadt Emden

1903-1904

- Kämmereietat

$1903-1904$

Klassifikation Teil B: 03140

Trägermaterial: Papier

Alte Reg.-Sig.: VIII D1 076

Bestell-Nr.: IV 03140

3062 Haushaltsplan der Stadt Emden

- Kämmereietat

$1904-1905$

Klassifikation Teil B: 03141

Trägermaterial: Papier

Alte Reg.-Sig.: VIII D1 077

Bestell-Nr.: IV 03141 
06.04

Rechnungswesen

06.04.01

Haushaltspläne

Lfd. Nr. Titel

3063 Haushaltsplan der Stadt Emden 1905-1906

- Kämmereietat

1905 - 1906

Klassifikation Teil B: 03142

Trägermaterial: Papier Alte Reg.-Sig.: VIII D1 098

Bestell-Nr.: IV 03142

3064 Haushaltsplan der Stadt Emden

- Kämmereietat

$1906-1907$

Klassifikation Teil B: 03143

Trägermaterial: Papier

Alte Reg.-Sig.: VIII D1 099

Bestell-Nr.: IV 03143

3065 Haushaltsplan der Stadt Emden

1907-1908

- Kämmereietat

1907 - 1908

Klassifikation Teil B: 03144

Trägermaterial: Papier

Alte Reg.-Sig.: VIII D1 100

Bestell-Nr.: IV 03144

3066 Haushaltsplan der Stadt Emden

1909-1910

- Kämmereietat

$1909-1910$

Klassifikation Teil B: 03145

Trägermaterial: Papier Alte Reg.-Sig.: VIII D1 101

Bestell-Nr.: IV 03145

3067 Haushaltsplan der Stadt Emden

- Kämmereietat

$1910-1911$

Klassifikation Teil B: 03146

Trägermaterial: Papier Alte Reg.-Sig.: VIII D1 102

Bestell-Nr.: IV 03146 
06 Finanzverwaltung der Stadt Emden

06.04 06.04.01 Rechnungswesen

Lfd. Nr. Titel Haushaltspläne

3068 Haushaltsplan der Stadt Emden Laufzeit

- Kämmereietat

1911 - 1912

Klassifikation Teil B: 03147

Trägermaterial: Papier Alte Reg.-Sig.: VIII D1 103

Bestell-Nr.: IV 03147

3069 Haushaltsplan der Stadt Emden

- Kämmereietat

$1912-1913$

Klassifikation Teil B: 03148

Trägermaterial: Papier

Alte Reg.-Sig.: VIII D1 104

Bestell-Nr.: IV 03148

3070 Haushaltsplan der Stadt Emden

- Kämmereietat

$1913-1914$

Klassifikation Teil B: 03149

Trägermaterial: Papier

Alte Reg.-Sig.: VIII D1 105

Bestell-Nr.: IV 03149

3071 Haushaltsplan der Stadt Emden

- Kämmereietat

$1914-1915$

Klassifikation Teil B: 03150

Trägermaterial: Papier

Alte Reg.-Sig.: VIII D1 106

Bestell-Nr.: IV 03150

3072 Haushaltsplan der Stadt Emden

- Kämmereietat

$1915-1916$

Klassifikation Teil B: 03151

Trägermaterial: Papier

Alte Reg.-Sig.: VIII D1 107

Bestell-Nr.: IV 03151 
06

Finanzverwaltung der Stadt Emden

06.04

06.04.01

Rechnungswesen

Lfd. Nr. Titel

Haushaltspläne

3073 Haushaltsplan der Stadt Emden

Laufzeit

1916-1917

- Kämmereietat

$1916-1917$

Klassifikation Teil B: 03152

Trägermaterial: Papier

Alte Reg.-Sig.: VIII D1 108

Bestell-Nr.: IV 03152

3074 Haushaltsplan der Stadt Emden

1917-1918

- Kämmereietat

1917 - 1918

Klassifikation Teil B: 03153

Trägermaterial: Papier

Alte Reg.-Sig.: VIII D1 109

Bestell-Nr.: IV 03153 
06

06.04

Rechnungswesen

06.04.02

Rechnungsabnahme

Lfd. Nr. Titel

Laufzeit

3075 Rechnungsabnahme: Etat der Stadt Emden

- Vorlage der Rechnungen und der Rechnungslegung zu städtischen

Einrichtungen durch Kämmerer Ernst August Gebest

- Verhandlungen der städtischen Kollegien über Rechnungslegung

zum Etat der Stadt Emden

- Bemerkungen des Magistrats zu Rechnungsmonita des

Bürgervorsteherkollegiums wegen des Etats der Stadt Emden

$1880-1912$

Klassifikation Teil B: 03122

Trägermaterial: Papier

Alte Reg.-Sig.: VIII D2 04

Bestell-Nr.: IV 03122

3076 Rechnungsabnahme verschiedener Etatjahre

- Aktenreste: Verhandlungen zur Rechnungslegung der Etats 1880/81; 1882/83; 1885/86; 1906/1907; 1912

$1880-1912$

Klassifikation Teil B: 03154

Trägermaterial: Papier

Alte Reg.-Sig.: VIII D2 04

Bestell-Nr.: IV 03154

3077 Rechnungslegung

Aktenreste:

- Verhandlungen über Rechnungslegung zum Etat 1884 / 85; Etat

1904 / 05

- Vorschriften aus dem preußisschen Innenministerium und vom

Regierungaspräsidenten in Aurich über Rechnungslegung

$1884-1914$

Klassifikation Teil B: 03155

Trägermaterial: Papier

Alte Reg.-Sig.: VIII D2 07

Bestell-Nr.: IV 03155

3078 Ausgabe - Beläge Etatsjahr 1902/03

- Rechnungen und Quittungen über Ausgaben im Etatsjahr 1902/03, Bd. 9

(Bd. 1 - 8 nicht vorhanden)

$1902-1903$

Klassifikation Teil B: 03156

Trägermaterial: Papier

Alte Reg.-Sig.: VIII D2 09

Bestell-Nr.: IV 03156 
06.04

Lfd. Nr. Titel

Laufzeit

3079 Einnahmen und Ausgaben für das Etatjahr 1899/1900 1899-1900

- Mannual der Kämmerei über Einnahme- und Ausgabeposten im Etatjahr 1899/1900

$1899-1900$

Klassifikation Teil B: 03157

Trägermaterial: Papier Alte Reg.-Sig.: VIII D2 09

Bestell-Nr.: IV 03157

3080 Kämmerei: Kassenführung

1917-1918

- Tagesabschlüsse, Mai 1917 - August 1919

1917 - 1918 (1919)

Klassifikation Teil B: 03158

Trägermaterial: Papier

Alte Reg.-Sig.: VIII D2 11

Bestell-Nr.: IV 03158

3081 Kämmerei: Hauptjournal für das Etatjahr 1902/03

- Tageseinnahmen und -Ausgaben der Kämmereikasse

$1902-1903$

Klassifikation Teil B: 03159

Trägermaterial: Papier

Alte Reg.-Sig.: VIII D2 11

Bestell-Nr.: IV 03159

3082 Kämmerei: Hauptjournal für das Etatjahr 1889/90

- Einnahmen und -Ausgaben der Kämmereikasse

$1889-1890$

Klassifikation Teil B: 03160

Trägermaterial: Papier

Alte Reg.-Sig.: VIII D2 11

Bestell-Nr.: IV 03160

3083 Kämmerei: Hauptjournal für das Etatjahr 1893/94

- Einnahmen und -Ausgaben der Kämmereikasse

$1893-1894$

Klassifikation Teil B: 03161

Trägermaterial: Papier

Alte Reg.-Sig.: VIII D2 11

Bestell-Nr.: IV 03161 
07.01

Lfd. Nr. Titel

Laufzeit

3084 Plan der Verlegung der Emder Garnison

- Petition der städtischen Kollegien an Kaiser Wilhelm I. über Bitte um

Verbleib des in Emden stationierten 1. Bataillon des 78.

(Ostfriesischen) Infanterie-Regiments, Dezember 1877

- Korrespondenz zwischen Oberbürgermeister Fürbringer und dem

Reichstagsabgeordneten Jan ten Doornkaat-Koolman, Norden wegen

Maßnahmen zur Verhinderung der Verlegung des es in Emden

stationierten 1. Bataillon des 78. (Ostfriesischen)

Infanterie-Regiments, Mai 1877

- Nachrichten über Bemühungen zum Erhalt der preußischen

Garnison in Emden, Dezember 1877

- Verhandlungen des Magistrats mit dem Garnisonskommando über

Maßnahmen zur Verbesserung der Entwässerung des

Exerzierplatzes, Dezember 1877 - Januar 1878

- Verhandlungen des Magistrats mit dem Kriegsministerium über

Verhinderung der Verlegung der preußischen Garnison, Dezember

1877 - Januar 1878

1877 - 1878 (1879)

Klassifikation Teil B: 02287

Trägermaterial: Papier

Alte Reg.-Sig.: VII A 1

Bestell-Nr.: IV 02287

3085 Exerzierplatz

$1866-1881$

- Anlage eines Exerzierplatzes mit Schießstand durch das in Emden stationierte 1. Bataillon des 78. (Ostfriesischen) Infanterie-Regiments, Dezember 1866 .- Mai 1881

- Planzeichnung: Exerzierplatz, 1881

- Plan des Stadtbaumeisters Wiggers über Anlage eines

Exerzierplatzes, August 1878

- Verhandlungen wegen Anlage eines Schießplatzes im Königspolder, August 1873 - Januar 1874

$1866-1874$

Klassifikation Teil B: 02288

Trägermaterial: Papier

Alte Reg.-Sig.: VII A 10

Bestell-Nr.: IV 02288

- Verhandlungen des Magistrats mit dem reformierten Kirchenrat über Organisation der Militärseelsorge für reformierte Soldaten der preußischen Garnison in Emden, 1867 - 1871

- Ernennung des Pastors Hesse zum reformierten Militärseelsorger, 1867

- Organisation der Militärseelsorge im Fußartillerie-Regiment Hintersin Nr.2, 1911

$1867-1911$

Klassifikation Teil B: 02289

Trägermaterial: Papier

Alte Reg.-Sig.: VII A 18

Bestell-Nr.: IV 02289 
07.01

Lfd. Nr. Titel

- Verhandlungen zwischen dem Kriegsministerium und dem Magistrat über Neuaufbau einer preußischen Garnison in Emden, 1905 - 1908 - Verhandlungen zwischen der Intendantur des X. Armeekorps in Hannover und dem Magistrat über den Bau einer Kaserne für ein Fuß-Artillerie-Bataillon auf städtischem Grund und Boden auf Kosten der Stadt bei Vermietung der fertigen Kasernengebäude an den Militärfiskus, August 1908

- Persönliche Verhandlungen des des Oberbürgermeisters Fürbringer in Berlin wegen Neuaufbau einer preußischen Garnison in Emden, $1908-1909$

- Entwurfsskizze einer Kaserne, 1908

- Verhandlungen des Magistrats mit Landbesitzern zum Erwerb von Ländereien für die geplante Kaserne, Januar 1908

- Bildung einer städtischen Kommission für den Kasernenbau, Januar 1908

- Anfrage der "Osnabrücker Zeitung" wegen Stand der Verhandlungen über den Aufbau einer preußischen Garnison in Emden, Februar 1908 - Rüge des Regierungspräsidenten gegen den Magistrat wegen Geheimhaltung der Verhandlungen vor seiner Behörde, März 1908 - Betrauung des Architekten Fritzen von der Firma Hartmann \& Schlenzig, Atelier für Architektur und Bauausführung, mit der Bauleitung der Kaserne in Emden, Januar 1909

- Festsetzung der Miete für die Kaserne, 1912

$1908-1912$

Klassifikation Teil B: 02332

Trägermaterial: Papier Alte Reg.-Sig.: VII G 125

Bestell-Nr.: IV 02332

3088 Stationierung des Minensuchschiffes "Arcona" in Emden

- Mitteilung des Fregattenkapitäns Wilhelm von Hippel über

Stationierung des von inm befehligten Minensuchschiffes "Arcona" in Emden, November 1912

- Organisation einer Empfangsfeier für die "Arcona" und ihre Besatzung, November 1912

- Antworttelegramm des Kaisers Wilhelm II. auf das Danktelegramm der städtischen Kollegien wegen der Stationierung der "Arcona" in

Emden, November 1912

- Presseberichte über Empfang der "Arcona", November 1912

- Antrag des Autors Alfred G Nagel an den Magistrat über Bitte um Gewährung einer Druckkostenbeihilfe zur Herstellung eines Buches über die "Arcona"in Form der Verpflichtung zur Abnahmne von 100 Büchern, Oktober 1913

$1911-1913$

Klassifikation Teil B: 02344

Trägermaterial: Papier

Alte Reg.-Sig.: VII G 143

Bestell-Nr.: IV 02344 
07.01

\section{Preußische Garnison in Emden}

Lfd. Nr. Titel

Laufzeit

3089 Feier des 25 jährigen Bestehens des Infanterie-Regiments Herzog Friedrich Wilhelm von Braunschweig (ostfr.)

- Zusage des Oberbürgermeisters Leo Fürbringer zur Teilnahme an der Feier des 25 jährigen Bestenens des Infanterie-Regiments (Nr. 18) Herzog Friedrich Wilhelm von Braunschweig (ostfr.) zu

Osnabrück, August 1891

- Ablehnung eines Magistratsantrags auf Organisation einer Jubiläumsfeier für das Infanterie-Regiment Nr. 18 wegen langjähriger Stationierung in Emden durch das Bürgervorsteherkollegium, September 1891

- Vorlage des Oberbürgermeisters Fürbringer über Schenkung eines Gemäldes des Emder Rathauses an das Regiment, September 1891 - Einladung zum 100 jährigen Jubiläum des Infabnterieregiments, August 1913

$1891-1913(1914)$

Klassifikation Teil B: 02480

Trägermaterial: Papier

Alte Reg.-Sig.: VII M 23

Bestell-Nr.: IV 02480

3090 Reitweg für die Garnison in Emden

- Verhandlungen über die Anlegung eines Reitweges von Emden nach Suurhusen zur Nutzung durch Offiziere der Garnison zu Emden

1914

Klassifikation Teil B: 02482

Trägermaterial: Papier

Alte Reg.-Sig.: VII M 34

Bestell-Nr.: IV 02482

3091 Militär-Brieftauben

- Gesetze und Erlasse zum Brieftaubenwesen im Militärbereich

$1894-1914$

Klassifikation Teil B: 02483

Trägermaterial: Papier

Alte Reg.-Sig.: VII M 26

Bestell-Nr.: IV 02483 
07.02

\section{Aushebung und Rekrutierung}

Lfd. Nr. Titel

Laufzeit

3092 Bildung der Kreis-Ersatz-Kommission

- Bildung und Aufgaben der Kreis-Ersatz-Kommission bei der

Erfassung und Einziehung von Rekruten, November 1866

- Bestellung von Mitgliedern der Kreis-Ersatz-Kommission, Dezember 1866 - Juli 1918

$1866-1918$

Klassifikation Teil B: 02290

Trägermaterial: Papier

Alte Reg.-Sig.: VII B 30

Bestell-Nr.: IV 02290

3093 Erfassung der Wehrpflichtigen, Bd. 1

- Bestimmungen zur Erfassung der Wehrpflichtigen nach

Geburtsjahrgängen, 1876 - 1878

- Von den Kirchen erstellte Listen der männlichen Geburtsjahrgänge von 1865 - 1868, 1886

$1876-1886$

Klassifikation Teil B: 02291

Band: 1

Trägermaterial: Papier

Alte Reg.-Sig.: VII B 41

Bestell-Nr.: IV 02291

3094 Erfassung der Wehrpflichtigen, Bd. 2

- Register der männlichen Geburtsjahrgänge zur Erfassung der Wehrpflichtigen, 1893 - 1900

- Anträge auf Erlass der Wehrpflicht, 1906 - 1911

$1893-1911$

Klassifikation Teil B: 02292

Band: 2

Trägermaterial: Papier

Alte Reg.-Sig.: VII B 41

Bestell-Nr.: IV 02292

3095 Musterungen, Bd. 1

- Register über gemusterte Wehrpflichtige und ihre Klassifizierung nach Diensttauglichkeit

1901

Klassifikation Teil B: 02293

Band: 1

Trägermaterial: Papier

Alte Reg.-Sig.: VII B 56

Bestell-Nr.: IV 02293 
07.02

\title{
Aushebung und Rekrutierung
}

Lfd. Nr. Titel

Laufzeit

3096 Musterungen, Bd. 2

1902

- Register über gemusterte Wehrpflichtige und ihre Klassifizierung nach Diensttauglichkeit

1902

\author{
Klassifikation Teil B: 02294 \\ Band: 2 \\ Trägermaterial: Papier \\ Alte Reg.-Sig.: VII B 56 \\ Bestell-Nr.: IV 02294
}

3097 Musterungen, Bd. 3

1904

- Register über gemusterte Wehrpflichtige und ihre Klassifizierung nach Diensttauglichkeit

1904
Klassifikation Teil B: 02295
Band: 3
Trägermaterial: Papier
Alte Reg.-Sig.: VII B 56
Bestell-Nr.: IV 02295

3098 Musterungen, Bd. 4

1905

- Register über gemusterte Wehrpflichtige und ihre Klassifizierung nach Diensttauglichkeit

1905
Klassifikation Teil B: 02296
Band: 4
Trägermaterial: Papier
Alte Reg.-Sig.: VII B 56
Bestell-Nr.: IV 02296

3099 Musterungen, Bd. 5

- Register über gemusterte Wehrpflichtige und ihre Klassifizierung nach Diensttauglichkeit

1905
Klassifikation Teil B: 02297
Band: 5
Trägermaterial: Papier
Alte Reg.-Sig.: VII B 56
Bestell-Nr.: IV 02297

3100 Wehrpflichtige

- Musterungsscheine verschiedener Wehrpflichtiger

$1902-1914$

Klassifikation Teil B: 02299

Trägermaterial: Papier

Alte Reg.-Sig.: VII B 58

Bestell-Nr.: IV 02299 
07

Militärangelegenheiten (1866 - 1914)

07.03

Freiwillige

Lfd. Nr. Titel

Laufzeit

3101 Einjährig-Freiwillige

1896

- Antrag des Bautechnikers Wilhelm Niemeyer auf Rückgabe seines

Berechtigtenscheines als Einjährig-Freiwiilliger nach dessen

Einziehung wegen einer Straftat

1896

Klassifikation Teil B: 02300

Trägermaterial: Papier

Alte Reg.-Sig.: VII C 20

Bestell-Nr.: IV 02300

3102 Beförderung Einjährig-Freiwilliger zu Reserveoffizieren

- Leumundsatteste für zur Beförderung zum Reserveoffizier vorgesehene Einjährig-Freiwillige

$1878-1910$

Klassifikation Teil B: 02301

Trägermaterial: Papier

Alte Reg.-Sig.: VII C 18

Bestell-Nr.: IV 02301 
07.04

\section{Entlassung aus dem Wehrdienst}

Lfd. Nr. Titel

Laufzeit

3103 Vorzeitige Entlassungen aus dem Militärdienst 1906-1913

- Anlage auf vorzeitige Entlassung aus dem Militärdienst, 1906 - 1913

$1906-1913$

Klassifikation Teil B: 00356

Alte Reg.-Sig.: E 593

Bestell-Nr.: IV 00356

3104 Entlassung vom Wehrdienst, Bd. 1

- Anträge auf Entlassung aus dem Wehrdienst

$1910-1914$

Klassifikation Teil B: 02302

Trägermaterial: Papier

Alte Reg.-Sig.: VII D 53

Bestell-Nr.: IV 02302

3105 Entlassung vom Wehrdienst, Bd. 2

- Anträge auf Entlassung aus dem Wehrdienst

$1907-1910$

Klassifikation Teil B: 02308

Band: 2

Trägermaterial: Papier

Alte Reg.-Sig.: VII D 53

Bestell-Nr.: IV 02308

3106 Unterstützung hilfsbedürftiger Veteranen

- Unterstützung mittelloser Veteranen aus den Befreiungskriegen aus einem Fonds des Innenministeriums, 1869 - 1876

- Zahlung einer Unterstützung aus dem Fonds an den Veteranen Alje Buschmann, April 1869

- Unterstützung zur Finanzierung der Bestattung des

Befreungskriegsveteranen Dedde Lolling aus dem Fonds, Februar

1870

- Listen der hilfsbedürftigen Veteranen aus den Befreiungskriegen in der Stadt Emden, 1871 - 1876

- Antrag des Klassenlehrers Dirksen an den Magistrat auf

Unterstützung für den 84 jährigen Befreiungskriegsveteranen Wolter

Harms Wolters, September 1876

$1869-1876$

Klassifikation Teil B: 02475

Trägermaterial: Papier

Alte Reg.-Sig.: VII M 13

Bestell-Nr.: IV 02475 
07.04

\section{Entlassung aus dem Wehrdienst}

Lfd. Nr. Titel

Laufzeit

3107 Besetzung von Stellen in der Stadtverwaltung mit Militärinvaliden

- Regelung der Klassensteuerpflicht für aus dem Militärdienst ausgeschiedene Veteranen und Invaliden, 1867 - 1875

- Erlass des Innenministers über Einstellung von Veteranen in

Zivilverwaltungsstellen, November 1897

- Erlass des Reichsamtes des Innern über Nichtausstellung eines

Zivilversorgungsscheines an Frauen in der freiwilligen Krankenpflege

in Lazaretten, Januar 1907

- Verhandlungen des Magistrats mit verschiedenen

Bezirkskommandos wegen Besetzung einer Kanzleistelle mit einem

Zivilversorgungsscheininhaber, Juli - November 1911

- Ausschreibung einer Verwaltungsstelle bei der Stadt Emden in der

Vakanzenliste für Militäranwärter und Inhaber eines

Zivilversorgungsscheins, September 1912

- Stellen bei der Stadtverwaltung für Zivilversorgungsscheininhaber, $1912-1914$

$1867-1914$

Klassifikation Teil B: 02479

Trägermaterial: Papier

Alte Reg.-Sig.: VII M 22

Bestell-Nr.: IV 02479

3108 Stellen für Veteranen (Zivilversorgungsscheininhaber) in der städtischen Kanzlei

- Verzeichnis der mit Zivilversorgungscheininhabern besetzbaren Stellen des einfachen und mittleren Kanzleidienstes bei der Stadt Emden

1907

Klassifikation Teil B: 02481

Trägermaterial: Papier

Alte Reg.-Sig.: VII M 24

Bestell-Nr.: IV 02481 
07 Militärangelegenheiten (1866 - 1914)

07.05

\section{Militärlasten}

Lfd. Nr. Titel

Laufzeit

3109 Servis-Kasse, Bd. 1

- Entschädigung durch Einquartierung betroffener Hausbesitzer aus der Servis-Kasse

$1875-1886$

Klassifikation Teil B: 02314

Band: 1

Trägermaterial: Papier

Alte Reg.-Sig.: VII G 002

Bestell-Nr.: IV 02314

3110 Servis-Kasse, Bd. 2

- Entschädigung durch Einquartierung betroffener Hausbesitzer aus der Servis-Kasse

$1888-1889$

Klassifikation Teil B: 02315

Band: 2

Trägermaterial: Papier

Alte Reg.-Sig.: VII G 002

Bestell-Nr.: IV 02315

3111 Einquartierungen anlässlich des Besuches des Kaisers Wilhelm II. in Emden

- Organisation der Einquartierung der Ehrenkompagnien des (Ostfriesischen) Infanterie-Regiments 78 und der 2. Abt. der I. Marinedivision Wilhelmshaven

- Entschädigung der von der Einquartierung betroffenen Hausbesitzer

$1901-1902$

Klassifikation Teil B: 02316

Trägermaterial: Papier

Alte Reg.-Sig.: VII G 063

Bestell-Nr.: IV 02316 
Lfd. Nr. Titel

Laufzeit

3112 Vergütung von gelieferten Naturalien und Verpflegung für einquartierte 1866-1879 Soldaten

- Abrechnungen über gelieferte Fourage an einquartierte Truppen, $1866-1878$

- Verhandlungen des Magistrats mit dem Kommando des (Ostfr.) Infanterie-Regiments 78 über Organisation der Vergütung von Verpflegung und Fourage für einquartierte Soldaten und Pferde, 1866

- 1879

- Verhandlungen des Magistrats mit dem preußischen Generalgouvernements-Department für Finanzen in Hannover über Erstattung verausgabter Gelder zur Verpflegung der einquartierten Soldaten, Dezember 1866 - Februar 1867

- Verhandlungen des Magistrats mit der Intendantur des X. Armeekorps in Hannover über Rückerstattung verausgabter Gelder zur Verpflegung einquartierter Soldaten des (Ostfriesischen) Infanterie-Regiments 78, Januar 1868 - Juli 1879

$1866-1879$

Klassifikation Teil B: 02324

Trägermaterial: Papier

Alte Reg.-Sig.: VII G 083

Bestell-Nr.: IV 02324

3113 Einquartierung 1876

1876

- Einquartierungslisten: Belegungsquoten

1876

Klassifikation Teil B: 02325

Trägermaterial: Papier

Alte Reg.-Sig.: VII G 083

Bestell-Nr.: IV 02325

3114 Vergütung für Kriegslieferungen

- Korrespondenz des Magistrats mit den Magistraten von Hildesheim, Hannover und Aurich über Verteilung der Belastungen durch

Kriegslieferungen und Einquartierungen, April 1871

- Erlass des Innenministers über Vergütung für requrierte Gespanne und Fuhrwerke, April 1871

- Gemeinsamer Erlass des Kriegsministers, des Innenministers und des Finanzministers über Vergütung für requirierte Fuhrwerke, Mai 1871 / Januar 1872

- Bericht des Magistrats an den Regierungspräsidenten in Aurich über Notwendigkeit einer Entschädigung für Kriegslieferungen und

Einquartierungen, Mai 1871

- Erlass des Innenministers über Anordnung einer Datenerhebung über Kriegslieferungen und Einquartierungen. Februar 1872

$1871-1872$

Klassifikation Teil B: 02326

Trägermaterial: Papier

Alte Reg.-Sig.: VII G 085

Bestell-Nr.: IV 02326 
Lfd. Nr. Titel

Laufzeit

3115 Einquartierungslisten

- Einquartierungslisten: Belegung pro quartierpflichtigem Haushalt und Mängelbemerkungen

$1866-1867$

Klassifikation Teil B: 02327

Trägermaterial: Papier

Alte Reg.-Sig.: VII G 085

Bestell-Nr.: IV 02327

3116 Rechnung der Einquartierungskasse

- Rechnung über Einnahmen (Staatsmittel) und Ausgaben

(Entschädigung für Einquartierungen) der Einquartierungskasse

$1888-1889$

Klassifikation Teil B: 02329

Trägermaterial: Papier

Alte Reg.-Sig.: VII G 086

Bestell-Nr.: IV 02329

3117 Regulierung des Mietsverhältnisses der preußischen Garnison mit der

- Gestaltung des Mietsverhältnisses zwischen der Garnison und der Stadt Emden wegen Funktionsräume (Montierungskammer, Werkstätten etc.)

$1873-1889$

Klassifikation Teil B: 02330

Trägermaterial: Papier Alte Reg.-Sig.: VII G 110

Bestell-Nr.: IV 02330

3118 Unterbringung von Soldaten in der alten Kaserne

- Vergütung der Unterbringung der Soldaten in der alten Kaserne, 1874

- Vergütung der Stellung von Gespannen und Sachleistungen für die preußische Garnison, 1874

- Betrieb der alten Kaserne durch den Briefträger W. Burman, 1885 -

1888

- Plan des Stadtbaumeisters Wiggers über notwendige bauliche Veränderungen der alten Kaserne zur Unterbringung der Soldaten des (Ostfr.) Infanterie-Regiments 78, April 1887

$1874-1888$

Klassifikation Teil B: 02331

Trägermaterial: Papier

Alte Reg.-Sig.: VII G 115

Bestell-Nr.: IV 02331 
07

Militärangelegenheiten (1866 - 1914)

07.05

Militärlasten

Lfd. Nr. Titel

Laufzeit

3119 Servis-Kasse, Bd. 3

1884-1885

- Entschädigung durch Einquartierung betroffener Hausbesitzer aus der Servis-Kasse

$1884-1885$

Klassifikation Teil B: 02345

Band: 3

Trägermaterial: Papier

Alte Reg.-Sig.: VII G 002

Bestell-Nr.: IV 02345

3120 Servis-Kasse, Bd. 4

1897-1898

- Entschädigung durch Einquartierung betroffener Hausbesitzer aus der Servis-Kasse

$1897-1898$

Klassifikation Teil B: 02346

Band: 4

Trägermaterial: Papier

Alte Reg.-Sig.: VII G 002

Bestell-Nr.: IV 02346 
Lfd. Nr. Titel

Laufzeit

3121 Kaserne in Emden

- Aufforderung der Hannoverschen Kriegskanzlei an die Stadt Emden zur Tragung der Kosten der Kasernenrenovierung, Oktober 1818

- Angebote zur Stellung von Quartieren für Soldaten, Oktober 1866

- Vehandlungen des Magistrats mit dem Kommandeur des

(Ostfriesischen) Infanterie-Regiments 78 über Standorte für eine

Kaserne, Dezember 1866 - März 1867

- Plan des Stadtbaumeisters Wiggers über projektierte

Kasernenbauten, 1867

(1818) $1866-1867$

Klassifikation Teil B: 02317

Trägermaterial: Papier

Alte Reg.-Sig.: VII G 065

Bestell-Nr.: IV 02317

3122 Klunderburg als Kaserne, Bd. 1

- Verpachtung der Kaserne Klunderburg an D. J. Dirksen, Dez. 1866 April 1870

- Ausstattung der Kaserneneinrichtung, März 1867

- Übersicht über Belegung der Kaserne Klunderburg, 1867 - 1868

- Streit zwischen dem Magistrat und dem Kasernenpächter D.J.

Dirksen wegen Entschädigung der nicht im Pachtvertrag

vorgesehenen Mehrkosten für die Kaserneneinrichtung, 1868 - 1869

$1866-1870$

Klassifikation Teil B: 02318

Band: 1

Trägermaterial: Papier

Alte Reg.-Sig.: VII G 068

Bestell-Nr.: IV 02318

- Verpachtung der Kaserne Klunderburg an B. J. Engberts, 1871 1876

- Ausstattung der Kaserneneinrichtung, 1872 - 1877

- Weigerung des Kasernenpächters zur Bereitstellung von

Brennmaterial für die Zubereitung von Mahlzeiten für außerhalb der

Kaserne einquartierte Soldaten, Dezember 1873 - Januar 1874

- Revision der Kaserne Klunderburg, Oktober 1874

$1871-1877$

Klassifikation Teil B: 02319

Band: 2

Trägermaterial: Papier

Alte Reg.-Sig.: VII G 068

Bestell-Nr.: IV 02319 
07.06

\section{Kaserne in Emden}

Lfd. Nr. Titel

Laufzeit

3124 Klunderburg als Kaserne, Bd. 3

- Finanzierung der Kasernenausstattung, November 1866

- Verpachtungsbedingungen der Kaserne, 1866 - 1886 (1889 - 1907)

- Erwerb der Klunderburg durch die Stadt Emden vom Landwirt N. A.

Schmidt aus Oldersum, April 1867

- Untersuchung der Klunderburg auf ihre Eignung als Kaserne, März

1867 / November 1868 / August 1876

- Mäuse- und Rattenplage in der Klunderburg, August 1867 /

November 1868 / November 1871

- Vermietung von Räumlichkeiten der Klunderburg an die

Garnisonsverwaltung, Juni 1881

1866 - 1889 (1896 - 1907)

Klassifikation Teil B: 02320

Trägermaterial: Papier

Alte Reg.-Sig.: VII G 068

Bestell-Nr.: IV 02320

3125 Vom Konsul Willibald Helm betriebene Kaserne

- Angebot des Konsuls Willibald Helm über Einrichtung einer Kaserne für 50 Soldaten in seinem Haus, Oktober 1866

- Vereinbarung zwischen dem Magistrat und dem Konsul Willibald

Helm über Nutzung seines Hauses als Kaserne, März 1867

- Zahlung des Nutzungsentgelts an Konsul Helm aus der

Servis-Kasse, Juni - November 1867

- Verhandlungen zwischen dem Magistrat und dem Kommando des

Ostfriesischen Infanterie-Regiments Nr. 78 über Erhalt der

Helm'schen Kaserne, August 1867

- Ausstattung der Kaserne des Konsuls Helm, 1867 - 1870

- Forderung nach einer Erhöhung des Nutzungsentgelts für die Kaserne "Neuvorpommern" durch Konsul W. Helm, Februar - April 1868

- Mängel in der Helm'schen Kaserne, 1869 - 1870

$1866-1870$

Klassifikation Teil B: 02321

Trägermaterial: Papier

Alte Reg.-Sig.: VII G 070

Bestell-Nr.: IV 02321 
Lfd. Nr. Titel

- Belegung der vom Senator Reemtsma betriebenen Kaserne, 1867 1868

- Antrag des Senators Reemtsma an den Magistrat asuf Befreiung der Torflieferungen für seine Kaserne von der Akzise, Dezember 1868

- Plan der Einrichtung eines Lazaretts in einer Stube der

Reemtsma'schen Kaserne, April - Mai 1869

- Schlechte Wasserqualität des Brunnens der Vierkant-Kaserne, 1872

$-1875$

- Forderung der Erhöhung des Nutzungsentgelts für die

Vierkant-Kaserne durch den Senator Reemtsma, Februar 1873

- Mängel der Vierkant-Kaserne hinsichtlich der Einrichtung und Hygiene der Vierkant-Kaserne, 1873 - 1885

- Vereinbarung zwischen dem Magistrat und dem Senator und Kommerzienrat R. Reemtsma über die Nutzung seines Gebäudes "Vierkant" als Kaserne, 1873 - 1880

- Ausbruch von Typhus unter den Soldaten der Vierkant-Kaserne, Juni 1878

- Verlegung der Soldaten der Kaserne Vierkant in das leer stehende Alte Gymnasium, Juni 1878

- Streit um die Verpflichtung des Senators Reemtsma zur

Finanzierung neuer Schränke in der Kaserne Vierkant, September 1887 - März 1888

- Schließung der Kaserne wegen Verlegung des Infanterie-Regiments 78 , März - April 1889

- Rechtsstreit zwischen dem Magistrat und Senator Reemtsma wegen von der Stadt Emden geforderter Herausgabe der Schränke aus der ehemaligen Kaserne Vierkant, Juni 1889 - März 1891

$1867-1891$

Klassifikation Teil B: 02322

Trägermaterial: Papier

Alte Reg.-Sig.: VII G 071

Bestell-Nr.: IV 02322 
07.06

\section{Kaserne in Emden}

Lfd. Nr. Titel

Laufzeit

3127 Militärische Einrichtungen in den Emder Kasernen

- Anmietung von Räumen für militärische Werkstätte, Lager und Ausbildungszwecke, 1871 - 1887

- Beschwerde des Kommandeurs des Ersatzbataillons des (ostfriesischen) Infanterie-Regiments 78 und der Garnisonsverwaltung wegen mangelhafter Räume für militärische Zwecke, Dezember 1871

- Januar 1879

- Verhandlungen zwischen Magistrat und Garnisonsverwaltung wegen Beschaffung von Räumen für militärische Zwecke, 1873 - 1875

- Anschaffung von Einrichtungsgegenständen für die militärischen Werkstätten durch den Magistrat, Dezember 1875 - Februar 1876

- Revision des Pulvermagazins am Herrentor, November 1876

- Renovierung der Montierungskammer in der alten Kaserne, Januar September 1878

- Umbau von Kammern in der alten Kaserne zu Handwerkerstuben für die Garnison, 1881

- Benutzung von Räumen der Gewerbeschule für militärische Ausbildungszwecke, 1885 - 1886

$1871-1887$

Klassifikation Teil B: 02323

Trägermaterial: Papier

Alte Reg.-Sig.: VII G 075

Bestell-Nr.: IV 02323 
07.06

\section{Kaserne in Emden}

Lfd. Nr. Titel

Laufzeit

3128 Bau einer neuen Kaserne in Emden, Bd. 1

- Auflagen des Kriegsministerium hinsichtlich der Baustoffe und der Baunormen für die neue Kaserne in Emden, 1909 - 1910

- Mitteilungen des Kriegsministeriums über Ausschluss von

Bautechnikern von der Auftragsvergabe wegen Unterschlagungen,

Betrug, Unzuverlässigkeit und Vertragsbruch, 1909 - 1910

- Aussperrung von Bauarbeitern während des Kasernenbaus wegen eines Tarifkonfliktes, April - Juni 1910

- Verfügung der Stadt Emden an die Bauunternehmer Oortgiese \& Meyer, Hagen \& Benjamins sowie R.G. Heits über Aufforderung zur sofortigen Wiederaufnahme der arbeit an der Kaserne nach Ende der Aussperrungen, Juni 1910

- Prüfung der Bauentwürfe für die Kaserne in Emden durch die Intendantur des X. Armeekorps in Hannover, Dezember 1908 - Januar 1909

- Ausschreibungen und Bedingungen für Materiallieferungen und Werkleistungen zum Kasernenbau, 1908 - 1909

- Beschreibungen unsd Kostenvoranschläge des Kasernenbaus, März 1908 - Januar 1910

- Streit zwischen der Bauleitung und den bauausführenden Firmen wegen Verantwortung für Verzögerungen bei der Fertigstellung der Kaserne, August - Dezember 1910

- Abnahme des Kaserneneubaus und festgestellte Mängel, Juni 1911 - Mai 1912

- Rechnungslegung über den Kasernenbau, September - Dezember 1912

$1908-1912$

Klassifikation Teil B: 02333

Band: 1

Trägermaterial: Papier

Alte Reg.-Sig.: VII G 128

Bestell-Nr.: IV 02333

3129 Bau einer neuen Kaserne in Emden, Bd. 2

- Bericht des Stadtbaurats Wiggers über Zusammenarbeit mit der Fa. Hartmann \& Schlenzig, Atelier für Architektur und Bauausführung als Bauleiterin des Kasernenbaus

- Vorgaben der Intendantur des X. Armeekorps zum Kasernenbau

- Korrespondenz mit Lieferfirmen zum Kasernenbau

$19089-1911$

Klassifikation Teil B: 02334

Band: 2

Trägermaterial: Papier

Alte Reg.-Sig.: VII G 128

Bestell-Nr.: IV 02334 
07.06

\section{Kaserne in Emden}

Lfd. Nr. Titel

Laufzeit

3130 Bau einer neuen Kaserne in Emden, Bd. 3

- Ausschreibungsverfahren über Materiallieferungen und

Werkleistungen zum Kasernenbau, 1909 - 1911

- Protest der Hauptvereinigung der Binnen-, Fluss- und Küstenfahrer

Ostfrieslands gegen die Nichtheranziehung der Verbandsmitglieder zu

Materiallieferungen zum Kasernenbau, August - September 1910

$1909-1911$

Klassifikation Teil B: 02335

Band: 2

Trägermaterial: Papier

Alte Reg.-Sig.: VII G 128

Bestell-Nr.: IV 02335

3131 Wasserversorgung für die Kaserne

- Verhandlungen des Magistrats mit dem Wasserwerk für das nördliche westfälische Kohlenrevier als Betreiberin des Wasserwerkes in Emden wegen Anschluss der Kaserne an die Wasserleitung, April -

August 1910

- Verhandlungen des Magistrats mit der Intendantur des X.

Armeekorps in Hannover wegen Anschluss der Kaserne an die

Wasserleitung, April - Juli 1910

- Klärung der Zuständigkeit für die Zahlung des Wassergeldes, 1911

$1910-1911$

Klassifikation Teil B: 02336

Trägermaterial: Papier

Alte Reg.-Sig.: VII G 131

Bestell-Nr.: IV 02336

3132 Entwässerungsanlage der Kaserne

- Verhandlungen des Magistrats mit der Intendantur des X. Armeekorps über Gestaltung des Entwässerungssystems für die Kaserne, Dezember 1908 - Juli 1909

- Prüfung des geplanten Entwässerungssystems für die Kaserne durch die Baukommission, Mai 1909

- Entwurf der Kläranlage für die Kaserne durch die Fa Hartmann \& Schlenzig, Atelier für Architektur und Bauausführung, August 1909

- Konflikt zwischen dem Magistrat und dem Landrat des Kreises Emden wegen der vom Magistrat verfügten Bedingungen für die Einleitung des Kasernenabwassers in das Hinter Tief, Mai 1910 . Februar 1911

$1908-1911$

Klassifikation Teil B: 02337

Trägermaterial: Papier

Alte Reg.-Sig.: VII G 130

Bestell-Nr.: IV 02337 
Lfd. Nr. Titel

Laufzeit

3133 Einfriedung des Kasernengeländes

- Antrag des Magistrats beim Landesdirektorium der Provinz Hannover auf Genehmigung der Zuschüttung des Grabens an der Chaussee nach Aurich im Bereich der Kaserne wegen notwendiger Einbeziehung des Grabens in die Kaserneneinfriedigung, August 1909

- Verhandlungen des Magistrats mit der Intendantur des X. Armeekorps wegen Einfriedung der Kaserne, 1909 - 1911

$1909-1911$

Klassifikation Teil B: 02338

Trägermaterial: Papier

Alte Reg.-Sig.: VII G 132

Bestell-Nr.: IV 02338

3134 Schießstand für die Garnison

- Bau eines Schießstandes durch die Stadt Emden nach Vorgaben der Intendantur des X. Armeekorps und des Militärbauamtes in

Oldenburg, 1908 - 1910

- Bewachung der Anlage vor der Übergabe an das

Fußartillerie-Regiment, Juni 1910 - Januar 1911

- Pachtung des Geländes des Schießstandes durch die Stadt Emden, $1911-1913$

$1908-1913$

Klassifikation Teil B: 02339

Trägermaterial: Papier

Alte Reg.-Sig.: VII G 134

Bestell-Nr.: IV 02339

3135 Bau der Kaserne

- Feuerversicherung der Kasernengebäude, 1910 - 1911

- Einstellung eines Nachtwächters zur Überwachung des

Kasernengeländes, 1911

- Anfragen aus anderen Städten wegen Kasernenprojekt in Emden, 1910 - 1911

- Angebote verschiedener Firmen für das Kasernenbauprojekt, 1909 1911

1909 - 1911

Klassifikation Teil B: 02340

Trägermaterial: Papier

Alte Reg.-Sig.: VII G 137

Bestell-Nr.: IV 02340 
Lfd. Nr. Titel

- Verhandlungen zwischen dem Magistrat und der Intendantur des X. Armeekorps über Verschiebung des Übergabetermins der Kaserne wegen Bauverzögerungen, Januar - Juli 1911

- Verhandlungen des Oberbürgermeisters Fürbringer mit dem Kriegsministerium über Verlegung des Übergabetermins der Kaserne, Januar 1911

- Erlass des Kriegsministers über Festsetzung des Übergabetermis der Kaserne auf dem 2. Juni 1911, März 1911

1911

Klassifikation Teil B: 02341

Trägermaterial: Papier

Alte Reg.-Sig.: VII G 138

Bestell-Nr.: IV 02341

3137 Feier des Einrückens des 2. Bataillons des Fußartillerie-Regiments von Hindemis - 1. Pommersches Nr. 2

- Organisation der Feier des Einrückens des 2. Bataillons des Fußartillerie-Regiments von Hindemis - 1. Pommersches Nr. 2 in die neue Kaserne, Mai - Juni 1911

- Einladungen zur Feier des Einrückens des 2. Bataillons des

Fußartillerie-Regiments von Hindemis - 1. Pommersches Nr. 2, Juni 1911

- Danktelegramm der städtischen Kollegien an den Kaiser Wilhelm II. wegen Wiederbegründung einer preußischen Garnison in Emden, Juni 1911

- Antrag des Magistrats auf Vergrößerung der Garnison,September 1913

1911 (1913)

Klassifikation Teil B: 02342

Trägermaterial: Papier

Alte Reg.-Sig.: VII

Bestell-Nr.: IV 02342

3138 Grundstück der Kaserne

- Vermessung des Kasernengründstücks durch das Katasteramt, Juli September 1909

- Katasterplanzeichnung des auf dem Namen der Stadt Emden eingetragenen Grundstücks der Kaserne, September 1909

- Streit zwischen der Stadt Emden und der deutsch-reformierten

Gemeinde wegen des Grenzverlaufes zwischen dem

Kasernengrundstück und dem benachbarten Landstück der Großen

Kirche, 1910 - 1912

$1909-1912$

Klassifikation Teil B: 02343

Trägermaterial: Papier Alte Reg.-Sig.: VII G 140

Bestell-Nr.: IV 02343 
08.01

\section{Mobilmachung}

Lfd. Nr. Titel

Laufzeit

3139 Anträge auf Rückstellung vom Kriegsdienst

- Anträge von Ehefrauen und Verwandten von Firmeninhabern und

Gewerbetreibenden auf Rückstellung ihrer Ehemänner und

Angehörigen vom Kriegseinsatz wegen wichtiger

Betriebsangelegenheiten, 1915 - 1917

$1915-1917$

Klassifikation Teil B: 00238

Trägermaterial: Papier

Bestell-Nr.: IV 00238

3140 Musterung zum Landsturm

- Plakat über Aufforderung an die Landsturmpflichtigen zur Musterung,

August 1914

- Anträge der Nordseewerke, der Cassens-Werft und des

Telegrafenamts auf Rückstellung inrer Bediensteten vom

Landsturmdienst, August - September 1914

- Unabkömmlichkeitsatteste für Telegrafenbeamte, August 1914

1914

Klassifikation Teil B: 02298

Trägermaterial: Papier

Alte Reg.-Sig.: VII B 57

Bestell-Nr.: IV 02298

3141 Rückstellung vom Kriegsdienst, Bd. 1

- Anträge auf Rückstellung vom Kriegsdienst wegen Sicherung des Gewerbebetriebs und Unterhalt der Familie

$1914-1918$

Klassifikation Teil B: 02303

Band: 1

Trägermaterial: Papier

Alte Reg.-Sig.: VII D 54

Bestell-Nr.: IV 02303

3142 Rückstellung vom Kriegsdienst, Bd. 2

- Unabkömmlichkeit städtischer Beamter und Bediensteter

- Regelung der Einziehung Beamter zum Kriegsdienst

$1914-1918$

Klassifikation Teil B: 02304

Band: 2

Trägermaterial: Papier

Alte Reg.-Sig.: VII D 54

Bestell-Nr.: IV 02304 
08.01

\section{Mobilmachung}

Lfd. Nr. Titel

Laufzeit

3143 Rückstellung vom Kriegsdienst, Bd. 3

- Anträge auf Rückstellung vom Kriegsdienst wegen Sicherung des Gewerbebetriebs und Unterhalt der Familie

$1915-1918$

Klassifikation Teil B: 02305

Band: 3

Trägermaterial: Papier

Alte Reg.-Sig.: VII D 54

Bestell-Nr.: IV 02305

3144 Rückstellung vom Kriegsdienst, Bd. 4

- Anträge auf Rückstellung vom Kriegsdienst wegen Sicherung des Gewerbebetriebs und Unterhalt der Familie

$1916-1918$

Klassifikation Teil B: 02306

Band: 4

Trägermaterial: Papier

Alte Reg.-Sig.: VII D 54

Bestell-Nr.: IV 02306

3145 Rückstellung vom Kriegsdienst, Bd. 5

- Anträge auf Rückstellung vom Kriegsdienst wegen Sicherung des Gewerbebetriebs und Unterhalt der Familie

$1916-1918$

Klassifikation Teil B: 02307

Band: 5

Trägermaterial: Papier

Alte Reg.-Sig.: VII D 54

Bestell-Nr.: IV 02307

3146 Erster Weltkrieg Bd. 1

- Aufruf des Kaisers Wilhelm II. zum Ausbruch des Ersten

Weltkrieges, August 1914

- Anordnungen und Erlasse zur Organisation der Kriegswirtschaft,

Organisation des Gerichtswesens, Behandlung Angehöriger

feindlicher Staaten und Maßnahmen zur Aufrechterhaltung der

öffentlichen Sicherheit, August 1914 - Januar 1915

- Ernennung des Oberbürgermeisters a.D L. Fürbringer zum

kommissarischen Bürgermeister nach der Einziehung von

Bürgermeister Dr. Wilhelm Mützelburg zum Kriegsdienst, August 1914

$1914-1915$

Klassifikation Teil B: 02312

Band: 1

Trägermaterial: Papier

Alte Reg.-Sig.: VII J 025

Bestell-Nr.: IV 02312 
08.01

\section{Mobilmachung}

Lfd. Nr. Titel

Laufzeit

3147 Erster Weltkrieg Bd. 2

- Anordnungen und Erlasse zur Organisation der Kriegswirtschaft, Organisation des Gerichtswesens, Behandlung Angehöriger feindlicher Staaten und Maßnahmen zur Aufrechterhaltung der öffentlichen Sicherheit, 1915 - 1918

- Verzeichnis der Einquartierungsquote in Emder Häusern, 1917

- Propagandaplakate, 1915 - 1918

$1915-1918$

Klassifikation Teil B: 02313

Band: 2

Trägermaterial: Papier

Alte Reg.-Sig.: VII J 025

Bestell-Nr.: IV 02313

3148 Der Erste Weltkrieg, Bd. 2

- Erfassung von Pferdeausrüstungen für Kriegszwecke, Dezember 1914 - Mai 1915

- Kriegsmaßnahmen im Reichsgebiet und den besetzten Gebieten, $1915-1916$

- Erfassung von Reifenmaterial zu Heereszwecken, Januat 1915

- Antrag des Magistrats an den Regierungspräsidenten in Aurich auf Erstattung der Verpflegungskosten für internierte Engländer und Franzosen, Februar 1915

- Internierung von Angehörigen der Feindmächte in Emden, 1914 -

1915

- Zensurbestimmungen für die Presse, 1915 - 1916

- Aufruf des Kaisers Wilhelm II zum ersten Jahrestag des

Kriegsausbruchs, August 1915

- Einführung eines Erlaubnisscheins zum Betreten des Emder

Hafengebiets, Dezember 1915

$1914-1916$

Klassifikation Teil B: 02350

Band: 2

Trägermaterial: Papier

Alte Reg.-Sig.: VII J 023

Bestell-Nr.: IV 02350 
08.01

\section{Mobilmachung}

Lfd. Nr. Titel

Laufzeit

3149 Einquartierung in Ersten Weltkrieg, Bd. 1

- Anbietung von Häusern und Einrichtungen für Einquartierungs- und Lazarettzwecke, August 1914

- Bekanntmachung der Einquartierungen, August 1914

- Verhandlungen des Magistrats mit der Intendantur des X.

Armeekorps über Einquartierungen in Emden, August 1914

- Von der Stadt Emden gelieferte Verpflegung an die

Versorgungsstelle der Ems (Marine), August 1914

- Abrechnungen über Kosten der Verpflegung für das zweite Batailloin des Infanterie-Regiments 78, August 1914

- Schreiben des Landsturm-Oberleutnants Strange an den Magistrat über Weg seiner Kompanie von Einquartierung in Emden bis zum

Einsatz an der Westfront bei Lille, November 1914

1914

Klassifikation Teil B: 02351

Band: 1

Trägermaterial: Papier

Alte Reg.-Sig.: VII J 024

Bestell-Nr.: IV 02351

3150 Einquartierung in Ersten Weltkrieg, Bd. 2

- Regelungen der Einquartierungen und Kompensation der Aufwendungen für die Quartierpflichtigen, 1914 - 1915

- Regelungen über Unterstützung der Familien der zum Kriegsdienst Eingezogenen, 1914 - 1915

- Abrechnungen über Verpflegungskosten für das in Emden einquartierte Landsturm Fußartillerie-Bataillon Nr. 2, August -

Dezember 1914

- Einquartierungslisten, 1914

$1914-1915$

Klassifikation Teil B: 02352

Band: 2

Trägermaterial: Papier

Alte Reg.-Sig.: VII J 024

Bestell-Nr.: IV 02352 
08.01

\section{Mobilmachung}

Lfd. Nr. Titel

Laufzeit

3151 Mobilmachung 1914-1916

- Vorbereitung der allgemeinen Mobilisierung (Geheimbestimmungen), (1918) Juli 1914

- Spendenaufruf des Roten Kreuzes für Liebesgaben an ausrückende Soldaten und dier Verwundetenfürsorge, August 1914

- Plakate mit Anordnungen zur Mobilisierung, 1914

- Verfügung des Magistrats über Verbot des Verkaufs von Alkohol während der Mobilisierung, August 1914

- Anträge auf Befreiung vom Kriegsdienst wegen Unabkömmlichkeit, August 1914 - November 1915

- Erfassung von Pferden und Mauleseln für Kriegszwecke, Oktober November 1914

- Erlass des Kriegsministers über Heranziehung aktiver Landsturmoffiziere als Ersatz für gefallene Heeresoffiziere, November 1914

- Aufruf des Kriegsministeriums zur Erfassung aller tauglichen Männer zum Kriegsdienst, März 1916

- Freistellung von Ärzten aus dem Heer zur Dämpfung des

Ärztemangels im Heimatgebiet, März 1916

$1914-1916$

Klassifikation Teil B: 02353

Trägermaterial: Papier

Alte Reg.-Sig.: VII J 025

Bestell-Nr.: IV 02353

3152 Schutz strategischer Einrichtungen

- Organisation des Bahnschutzes in Emden, August 1914 - Februar 1915

- Bewachung des Gaswerks und der Wassertürme, Dezember 1914 Oktober 1916

$1914-1916$

Klassifikation Teil B: 02358

Trägermaterial: Papier

Alte Reg.-Sig.: VII G 029

Bestell-Nr.: IV 02358 
08.01

\section{Mobilmachung}

Lfd. Nr. Titel

Laufzeit

3153 Feststellung der Unabkömmlichkeit städtischer Bediensteter zum Kriegsdienst

- Antrag des Magistrats beim Bezirkskommando in Aurich auf Entlassung benötigter Beamte vom Kriegsdienst, August 1914 - Anträge des Magistrats an den Regierungspräsidenten und verschiedenen Armeestellen auf Entlassung des Syndicus Trommershausen aus dem Landsturmregiment 81, Dezember 1914 Februar 1915

- Verhandlungen des Magistrats mit dem Regierungspräsidenten wegen Erreichung der Unabkömmlichkeit der städtischen Polizeibeamten, November - Dezember 1914

- Organisation der Stadtverwaltung bei der Abwesenheit des kommissarischen Oberbürgermeisters Fürbringer zur Wahrnehmung seines Landtagsmandats, Februar 1915

- Verhandlungen des Magistrats mit dem Generalkommando des X. Armeekorps in Hannover wegen Entlassung des Steuersekretärs Otto Neuhaus aus dem Kriegsdienst, September - November 1914

- Verhandlungen des Magistrats mit dem Generalkommando des X. Armeekorps in Hannover wegen Entlassung des Steuerassistenten Ebendorff aus dem Kriegsdienst, September - Oktober 1914 - Erlasse des Innenministers und des Kriegsministers über Richtlinien zur Bewilligung der Unabkömmlichkeit zum Kriegsdienst, Dezember 1914 - Mai 1916

$1914-1916$

Klassifikation Teil B: 02361

Trägermaterial: Papier

Alte Reg.-Sig.: VII J 035

Bestell-Nr.: IV 02361

3154 Einrichtung einer öffentlichen Kriegsschreibstube

- Verhandlungen des Reichspostamts mit dem Magistrat wegen

Einrichtung einer öffentlichen Kriegsschreibstube in einem

Schulgebäude zur Verpackung und Adressierung von Feldpostbriefen

$1914-1915$

Klassifikation Teil B: 02380

Trägermaterial: Papier

Alte Reg.-Sig.: VII J 052

Bestell-Nr.: IV 02380

3155 Spionageverdacht

- Bekanntmachung des Stellvertretenden Generalkommandos des X. Armeekorps über Erklärung des Kriegszustandes und Außerkraftsetzung von Grundrechten der Verfassung zur Bekämpfung der Spionage, Oktober 1914

- Fahndungsausschreiben nach Spionageverdächtigen, Dezember

1914

- Mitteilungen zur Spionageabwehr, 1915

$1914-1915$

Klassifikation Teil B: 02384

Trägermaterial: Papier

Alte Reg.-Sig.: VII J 057

Bestell-Nr.: IV 02384 
08.01

Lfd. Nr. Titel

- Regelung der Bildung und des Einsatzes von Bürgerwehren, August 1914 - Februar 1915

- Bericht des Magistrats an den Regierungspräsidenten über Einsaatz des Schützen-Corps als Bürgerwehr, August 1914

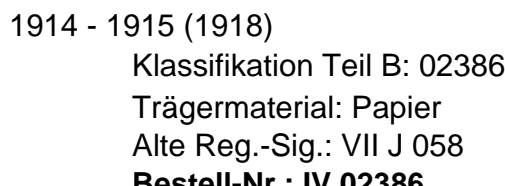

3157 Verlegung eines elektrischen Kabels von der Zentrale Nesserland nach der Treiböfversorgung der Marine

- Verlegung eines elektrischen Kabels von der Zentrale Nesserland nach der Treiböfversorgung der Marine unter Einbeziehung städtischen Grundes, Dezember 1916 - Januar 1917

- Verhandlungen des Marinebauamts mit dem Magistrat über Bedingungen zur Nutzung städtischen Bodens für die Kabeltrasse, Dezember 1916 - Mai 1917

$1916-1917$

Klassifikation Teil B: 02404

Trägermaterial: Papier

Alte Reg.-Sig.: VII J 084 a

Bestell-Nr.: IV 02404

3158 Delegierung von Verwaltungsbeamten zur Verwaltung der von Deutschland besetzten Gebiete

- Erlass des Innenministers über Erfassung und Meldung von geeigneten Beamten für die Verwaltung der von Deutschland besetzten Gebiete, April 1915

1915

Klassifikation Teil B: 02407

Trägermaterial: Papier

Alte Reg.-Sig.: VII J 086

Bestell-Nr.: IV 02407

3159 Missbräuchliche Sammlung von Feldadressen

- Verordnung des Kommandierenden Generals des X. Armeekorps über Verbot der Anlegung oder Veröffentlichung von Sammlungen von Feldpostadressen von Soldaten, Mai 1915

- Erlass des Innenministers über Verbot der Veröffentlichung von

Feldpostadressen, Mai 1915

- Erlass des Innenministers über Anordnung zur Abgabe bereits angelegter Sammlungen von Feldpostadressen an das

Generalkommando, Mai / Juni 1916

$1915-1916$

Klassifikation Teil B: 02408

Trägermaterial: Papier

Alte Reg.-Sig.: VII J 087

Bestell-Nr.: IV 02408 
08.01

\section{Mobilmachung}

Lfd. Nr. Titel

Laufzeit

3160 Anträge auf Rückstellung vom Kriegsdienst, Bd. 1

- Anträge auf Rückstellung vom Kriegsdienst wegen

Unabkömmlichkeit

$1914-1917$

Klassifikation Teil B: 02476

Band: 1

Trägermaterial: Papier

Alte Reg.-Sig.: VII Kn 2

Bestell-Nr.: IV 02476

3161 Anträge auf Rückstellung vom Kriegsdienst, Bd. 2

- Anträge auf Rückstellung vom Kriegsdienst wegen

Unabkömmlichkeit

$1917-1918$

Klassifikation Teil B: 02477

Band: 2

Trägermaterial: Papier

Alte Reg.-Sig.: VII Kn 2

Bestell-Nr.: IV 02477

3162 Reklamationen

- Anträge auf Beurlaubung vom Kriegsdienst

$1916-1918$

Klassifikation Teil B: 02478

Trägermaterial: Papier

Alte Reg.-Sig.: VII L 18

Bestell-Nr.: IV 02478

3163 Mobilmachung

- Bekanntmachungen zur Mobilmachung, 1914 - 1916

- Regelung der Erstattung der von der Stadt Emden ausgelegten Insertionskosten für die Bekanntmachungen zur Mobilmachung,

November 1914 -März 1916

- Verhandlungen des Magistrats mit den Besitzern der in Emden erscheinenden Zeitungen wegen Insertiomspreise für

Bekanntmachungen zur Mobilisierung, 1915

$1914-1916$

Klassifikation Teil B: 02484

Trägermaterial: Papier

Alte Reg.-Sig.: IV N 01

Bestell-Nr.: IV 02484 
08.01

\section{Mobilmachung}

Lfd. Nr. Titel

Laufzeit

3164 Pferdemusterung für die Armee

- Ernennung der Mitglieder der Pferdeaushebungskommission, März 1909 - Februar 1918

- Meldung des Magistrats über Ernennung des Landwirts Jan Dirksen zum Futterlieferanten für die zur Armee eingezogenen und abzutransportierenden Pferde, März 1910

- Bekanntmachung der Musterung von Pferden in Emden, Juni 1910 August 1913

- Anträge verschiedener Pferdebesitzer auf Befreiung von der

Musterungspflicht, Juli 1910

- Berichte über die Pferdemusterung, Juli 1910 - Juni 1912

- Statistische Übersicht zur Pferdemusterung, 1910 - 1913

- Übersicht über Zielorte der zur Armee aus Emden eingezogenen

Pferde nach Mobilisierungstagen, 1911 - 1912

- Verzeichnis der Emder Ziviltierärzte zur Mitwirkung bei der

Pferdemusterung, 1911 - 1913

- Erlass des Kriegsministers über Befreiung der tragenden Stuten von der Musterung, August 1914

- Regelung der Erfassung kriegsdienstfähiger Pferde, Mai 1918

$1909-1918$

Klassifikation Teil B: 02485

Trägermaterial: Papier

Alte Reg.-Sig.: IV N 02

Bestell-Nr.: IV 02485

3165 Demobilisierung der Pferde bei der Armee

1916-1918

(1919)

- Planung der Organisation der Demobilisierung von Armeepferden,

Dezember 1916 / Oktober 1917

- Übersicht über Zahl der für den Armeedienst gemusterten Pferde in Emden, Dezember 1916

- Organisation der Demobilisierung und Verteilung der Armeepferde, November 1918 - Oktober 1919

$1916-1918$ (1919)

Klassifikation Teil B: 02486

Trägermaterial: Papier

Alte Reg.-Sig.: IV N 04

Bestell-Nr.: IV 02486

3166 Beschlagnahme von Baracken des Emder Hafenbetriebs für

- Festlegung der Entschädigung für den Emder Hafenbetrieb wegen Beschlagnahme seiner Baracken zur Unterbringung von Landsturmmännern, Dezember 1915 - August 1916

1915 - 1916 (1917 - 1918)

Klassifikation Teil B: 02487

Trägermaterial: Papier

Alte Reg.-Sig.: VII N 04

Bestell-Nr.: IV 02487 
08.01

\section{Mobilmachung}

Lfd. Nr. Titel

Laufzeit

3167 Entschädigung von Kriegssachleistungen

- Festlegung von Entschädigungsleistungen für Hafenwirtschaftsunternehmen und andere Firmen für die Benutzung ihrer Betriebseinrichtungen für militärische Zweecke

$1914-1917$

Klassifikation Teil B: 02488

Trägermaterial: Papier

Alte Reg.-Sig.: IV N 04

Bestell-Nr.: IV 02488

3168 Entschädigung nach dem Kriegsleistungsgesetz

- Regelung der Entschädigung nach dem Kriegsleistungsgesetz für Unternehmen und Privatpersonen für Militärdienstleistungen, 1876 $1880 / 1914-1918$

- Eidesformel für Mitglieder der Entschädigungskommission für Militärdienstleistungen, 1880

- Ermittlungen der Marktpreise für vom Kriegsleistungsgesetz erfasste Naturalien zur Bildung eines Entschädigungssatzes, 1879 - 1900

- Wahl der Mitglieder der Kommission für Abschätzung der Entschädigung nach dem Kriegsleistungsgesetz, März 1885 - Februar 1915

- Verfügung des Regierungspräsidenten in Aurich über Errichtung eines Reservelazaretts in Mahlstede's Tivoli bei Eintritt der Mobilmachung und Ernennung des Senators Metger zum Kommissar der Landesregierung zur Ausführung des Kriegsleistungsgesetzes, September 1909

- Erlass des Finanzminisrters über Regulierung von Kriegsschäden, März 1917 - Mai 1918

$1876-1918(1919-1920)$

Klassifikation Teil B: 02489

Trägermaterial: Papier

Alte Reg.-Sig.: VII N 04

Bestell-Nr.: IV 02489

3169 Zustellung von Gestellungsordres

- Organisation der Zustellung von Einberufungsbescheiden zum Militärdienst im Mobilmachungsfall

- Benennung von Boten zur Zustellung der Einberufungsbescheide

$1902-1908$

Klassifikation Teil B: 02490

Trägermaterial: Papier Alte Reg.-Sig.: VII Nn 08

Bestell-Nr.: IV 02490 
08.01

\section{Mobilmachung}

Lfd. Nr. Titel

Laufzeit

3170 Schiffsrequisitions-Kommission

- Bekanntmachungen des Kommandos der Marinestation der Nordsee in Wilhelmshaven über Ernennung der Mitglieder der Schiffsrequisitions-Kommission zur Erfassung und Beschlagnahmung von Schiffen für die Marine im Kriegsfall

$1896-1907$

Klassifikation Teil B: 02491

Trägermaterial: Papier

Alte Reg.-Sig.: VII N 13

Bestell-Nr.: IV 02491

3171 Im Mobilmachungsfall zu erfolgende Heranziehung von Personal für Luftschifferzwecke

- Datensammlung des Generalkommandos des X. Armeekorps über Anlagen zum Luftschiffsbetrieb und im Mobilmachungsfall verfügbares Personal zum Betrieb dieser Anlagen, Juni - Juli 1901

1901

Klassifikation Teil B: 02492

Trägermaterial: Papier

Alte Reg.-Sig.: VII N 15

Bestell-Nr.: IV 02492

3172 Reservelazarette für den Fall der Mobilmachung

- Inspizierung der für Zwecke eines Reservelazaretts vorgesehenen

Räume des "Tivoli" durch die Intendantur des X. Armeekorps, Februar

- September 1900

- Ermittlung der Örtlichkeit einer Quarantäne-Station für den

Mobilisierungsfall, September 1900 - August 1902

- Organisation der Lieferung von Betten, Sanitätsmaterial und

Lebensmittel für das Reservelazarett im Mob.-Fall, August 1902 -

August 1903

- Benennung von Standorten für Reservelazarette in Emden, 1905 .

1912

$1900-1912$

Klassifikation Teil B: 02493

Trägermaterial: Papier

Alte Reg.-Sig.: VII N 05

Bestell-Nr.: IV 02493 
08.01

\section{Mobilmachung}

Lfd. Nr. Titel

Laufzeit

3173 Ausbildung von Krankenpflegern für den Mobilisierungsfall

- Kampagne des kaiserlichen Kommissars und Inspektors für freiwillige Krankenpflege zur Erhöhung der Zahl der ausgebildeten Krankenpfleger für den Kriegsfall, Februar 1901

- Umsetzung der Kampagne in Emden, April 1901

- Geheimverfügungen des Oberpräsidenten der Provinz Hannover über Erstellung eines Kriegsbereitschaftsplans für die freiwillige Krankenpflege in der Provinz Hannover, April 1905 - August 1913

- Umsetzung der Verfügungen in Emden, 1905 - 1913

- Geheimer Kriegsbereitschaftsplan des Roten Kreuzes der Provinz Hannover, 1906 - 1911

$1901-1913$

Klassifikation Teil B: 02494

Trägermaterial: Papier

Alte Reg.-Sig.: VII N 16

Bestell-Nr.: IV 02494

3174 Beschlagnahmung von Sprengmitteln aus Privatbesitz im Mobilisierungsfall

- Geheime Anordnung des X. Armeekorps wegen Beschlagnahmung von Sprengmitteln aus Privatbesitz im Mobilisierungsfall, Januar 1902 - Geheime Verfügung des Oberpräsidenten der Provinz Hannover über Beschlagnahmung von Sprengmitteln aus Privatbesitz im Mobilisierungsfall und bei inneren Unruhen, November 1909 - Umsetzung der Verfügung in Emden: Regelung über Kaserne als Lagerungsort von Pulver und Sprengstoff aus Privatbesitz, Januar 1910 / März 1913

- Genehmigung der Abgabe von beschlagnahmter Jagdmunition an die Besitzer zu Jagdzwecken, Dezember 1914

$1902-1914$

Klassifikation Teil B: 02495

Trägermaterial: Papier

Alte Reg.-Sig.: VII N 18

Bestell-Nr.: IV 02495

3175 Räume zur Einkleidung eingezogener Landsturmmänner

- Ermittlung von geeigneten Räumen zur Einkleidung eingezogener Landsturmmänner

$1907-1909$

Klassifikation Teil B: 02496

Trägermaterial: Papier

Alte Reg.-Sig.: VII N 21

Bestell-Nr.: IV 02496 
08.01

\section{Mobilmachung}

Lfd. Nr. Titel

Laufzeit

3176 Taxatoren für die Pferdeaushebung

- Wahl der Taxatoren zur Einschätzung des Wertes der vom Militär eingezogenen Pferde, Januar 1903 - Februar 1915

- Verfügung des Magistrats über Pflichten der Taxatoren für die

Pferdeaushebung, Februar 1903

- Erhebung bei den Mitgliedern der Taxatoren-Kommission über Erhalt der geheimen Verfügung wegen ihrer Dienstpflichten, April 1903 -

April 1914

$1903-1905$

Klassifikation Teil B: 02497

Trägermaterial: Papier

Alte Reg.-Sig.: VII N 22

Bestell-Nr.: IV 02497

3177 Postprüfungskommission für den Kriegsfall

1914

- Bestellung der Mitglieder einer Postprüfungskommission für den Kriegsfall, Mai 1914

- Erhebung über potenzielle Mitglieder einer Postprüfungskommission für den Kriegsfall unter Angabe ihrer Fremdsprachenkenntnisse, Juni 1914

- Aufstellung über Emder Firmen mit Auslandskontakten, 1914

1914

Klassifikation Teil B: 02498

Trägermaterial: Papier

Alte Reg.-Sig.: VII N 24

Bestell-Nr.: IV 02498

3178 Verhaltensrichtlinien für Beamte im Fall einer feindlichen Besetzung

- Erlass der preußischen Staatsregierung über Verhaltensrichtlinien für Beamte im Fall einer feindlichen Besetzung

1914

Klassifikation Teil B: 02499

Trägermaterial: Papier

Alte Reg.-Sig.: VII N 25

Bestell-Nr.: IV 02499

3179 Überwachung der Presse im Mobilmachungsfall

- Anordnung des Kommandos des X. Armeekorps über Verhängung einer Pressezensur im Mobilmachungsfall und ihre Durchührung

- Merkblatt des Kriegsministerium über Pressezensur

$1909 / 1914$

Klassifikation Teil B: 02500

Trägermaterial: Papier

Alte Reg.-Sig.: VII N 26

Bestell-Nr.: IV 02500 
08.01

\section{Mobilmachung}

Lfd. Nr. Titel

Laufzeit

3180 Reklamationen

- Anträge auf Befreiung vom Kriegsdienst wegen familiärer und gewerblicher Gründe

$1915-1918$

Klassifikation Teil B: 02501

Trägermaterial: Papier Alte Reg.-Sig.: VII N 57

Bestell-Nr.: IV 02501

3181 Befreiung städtischer Beamter vom Kriegsdienst

- Anträge auf Befreiung städtischer Beamter vom Kriegsdienst wegen dienstlicher Dringlichkeit

$1914-1918$

Klassifikation Teil B: 02502

Trägermaterial: Papier

Alte Reg.-Sig.: VII N 54 I

Bestell-Nr.: IV 02502

3182 Reklamationen

- Anträge auf Befreiung vom Kriegsdienst wegen familiärer und gewerblicher Gründe

$1917-1918$

Klassifikation Teil B: 02503

Trägermaterial: Papier

Alte Reg.-Sig.: VII N 54 II

Bestell-Nr.: IV 02503

3183 Reklamation des Kriminalpolizeibeamten Krebs

- Anträge auf Befreiung des Kriminalpolizeibeamten Krebs wegen Wichtigkeit seiner Funktion

$1916-1918$

Klassifikation Teil B: 02504

Trägermaterial: Papier

Alte Reg.-Sig.: VII N 55

Bestell-Nr.: IV 02504

3184 Anträge auf Entlassung aus dem Kriegsdienst

- Anträge auf Entlassung aus dem Kriegsdienst wegen familiärer und gewerblicher Gründe

$1917-1918$

Klassifikation Teil B: 02505

Trägermaterial: Papier

Alte Reg.-Sig.: VII N 58

Bestell-Nr.: IV 02505 
Lfd. Nr. Titel

Laufzeit

3185 Unterstützungen für Familien von Kriegsteilnehmern

- Regelung der Unterstützung hilfsbedürftiger Familien von zum Kriegsdienst Mobilisierter, August 1914

- Anträge auf Unterstützung, September 1914

- Regelung der Stadt Emden über Mietbeihilfen für Familien eingezogener Soldaten, September 1914

- Listen der Quartierzettel wegen Einquartierung, September 1914

1914

\author{
Klassifikation Teil B: 00347 \\ Trägermaterial: Papier \\ Bestell-Nr.: IV 00347
}

3186 Spenden für heimkehrende Kriegsgefangene

- Aufruf des Magistrats zur Spende für heimkehrende Kriegsgefangene, April 1918

1918
Klassifikation Teil B: 02059
Trägermaterial: Papier
Alte Reg.-Sig.: VII J 150 a
Bestell-Nr.: IV 02459

3187 Kriegsunterstützungsausschuss

- Bildung und Funktion des Kriegsunterstützungsausschusses zur Unterstützung bedürftiger Familien von zum Kriegsdienst eingezogener Emder

$1914-1915$

Klassifikation Teil B: 02310

Trägermaterial: Papier

Alte Reg.-Sig.: VII J 03

Bestell-Nr.: IV 02310

3188 Emder Kriegstote im Ersten Weltkrieg

- Verzeichnis der im Ersten Weltkrieg umgekommenen Emder Bürger

$1914-1917$

Klassifikation Teil B: 02311

Trägermaterial: Papier

Alte Reg.-Sig.: VII J 020

Bestell-Nr.: IV 02311 
Lfd. Nr. Titel

3189 Hinterbliebenenversorgung nach dem Ersten Weltkrieg

- Gesetzliche Regelung der Hinterbliebenenversorgung

(Militärversorgungsgesetze)

- Erlasse des Kriegsministers über Kriegshinterbliebenenversorgung

- Fragebögen zur Feststellung der Versorgungsbedürftigkeit

- Verfügung des Bezirkskommando in Aurich über Regelung der

Versorgung der Familien vermisster und kriegsgefangener Soldaten

$1914-1918$

Klassifikation Teil B: 02348

Trägermaterial: Papier

Alte Reg.-Sig.: VII H 011

Bestell-Nr.: IV 02348

3190 Gedenkblatt für Kriegsopfer

- Übergabe der Gedenkblätter für Kriegsopfer an die Angehörigen, 1914 - 1917

- Liste der Emder Kriegsopfer zur Verteilung der für sie bestimmten Gedenkblätter, 1916 - 1918

$1914-1918$

Klassifikation Teil B: 02349

Trägermaterial: Papier

Alte Reg.-Sig.: VII Ha 28

Bestell-Nr.: IV 02349 
Lfd. Nr. Titel

- Aufbau eines Nationalen Frauendienstes durch den Bund Deutscher Frauenvereine zur Beteiligung an der Kriegsfürsorge, August 1914 - Bildung eines Kriegsfürsorgeausschusses in Emden, August 1914 Januar 1915

- Ausbildung und Einsatz von Rotkreuzschwestern, 1914

- Anfrage der Torpedobootsflottille in Emden an den Magistrat wegen Stellung von Bade- und Waschmöglichkeiten, August 1914

- Ausschreibung einer Prämien für wegen Tapferkeit vor dem Feind ausgezeichnete Emder Soldaten, August 1914

- Organisation der Sammlung und des Versands von Liebesgaben für die Front, September 1914 - März 1915

- Dankschreiben des Oberbürgermeisters der ostpreußischen Hauptstadt Königsberg für Hilfslieferungen aus Emden für das kriegszerstörte Ostpreußen, Oktober 1914

- Spenden von Amerika-Ostfriesen für Notleidende des Krieges in Ostfriesland, Februar - Mai 1915

- Spendenaufrufe verschiedener Organisationen, 1915

- Beschluss des Magistrats zur Durchführung einer Spendenaktion für Kriegsfürsorge, Juli 1915

- Material aus anderen Städten für eine "eiserne Figur" zur Anregung der Spendentätigkeit, August - November 1915

- Feier des Vaterländischen Frauen-Zweigvereins zur Einweihung des "Isdern Kerl", August 1915

- Beschreibung des Isdern Kerl, August 1915

- Spendenaufruf des Territorialdelegierten für freiwillige Krankenpflege, November 1915

$1914-1915$

Klassifikation Teil B: 02354

Band: 1

Trägermaterial: Papier

Alte Reg.-Sig.: VII J 026

Bestell-Nr.: IV 02354 
Lfd. Nr. Titel

- Spendenaktionen für die Kriegsfürsorge, 1915 - 1918

- Spende von Amerika-Ostfriesen für Kriegsnotleidende in

Ostfriesland, Februar - August 1915

- Streit um den Empfang der Amerika-Spende, April - August 1915

- Organisation der Versendung von Liebesgaben an deutsche Kriegsgefangene in Russland, September 1915

- Organisation der Belieferung des Feldheeres und der Marine mit Liebesgaben zu Weihnachten, November 1915 - Oktober 1917

- Verteilung des Erbes des in Russland gefallenen Soldaten Campen an den Verband mittlerer Reichspost- und Telegraphenbeamten, November - Dezember 1915

- Organisation der Kriegsfürsorge, 1915 - 1916

- Organisation der Fürsorge für kriegsgefangene deutsche Soldaten, $1915-1917$

- Regulierung der freiwilligen Krankenpflege durch Integration in das Lazarettwesen der Heeresverwaltung, 1916

- Schlussabrechnung des Kriegsfürsorgeausschusses und Entlastung der Kommissionsmitglieder, Juni 1920

$1915-1918$ (1920)

Klassifikation Teil B: 02355

Band: 2

Trägermaterial: Papier

Alte Reg.-Sig.: VII J 026

Bestell-Nr.: IV 02355

3193 Unterstützung der Stadt Emden für die Kriegsfürsorge

- Spendenaufrufe verschiedener Organisationen für Kriegsfürsorge,

August 1914 - OKtober 1918

- Erlass des Innenministers über Förderung des Betriebs von

Säuglingsheimen während des Krieges, August 1914

- Förderung der Kinderkrippe am Kattewall durch die Stadt Emden,

August - September 1914

- Unterstützung der Stadt Emden für das kriegsverwüstete

Ostpreußen, September 1914

- Sammlung von Kleidung und Geld für die Winterausrüstung der deutschen Armee, September 1914

- Spende der Stadt Emden für die Weihnachtsfeier in Emder

Lazaretten, Oktober 1915

- Unterstützung der Stadt Emden für die Kinderspeiseanstalt des

Vaterländischen Frauenvereins, Oktober 1916

$1914-1918$

Klassifikation Teil B: 02356

Trägermaterial: Papier

Alte Reg.-Sig.: VII J 027

Bestell-Nr.: IV 02356 
Lfd. Nr. Titel

- Festlegung von Höchstpreisen für Lebensmittel, September 1914 -

März 1916

- Regelungen über Ausnützung des Getreides für Ernährungszwecke, Januar 1915

- Bewirtschaftung der Zuckerbestände, Oktober 1916

- Bewerbung des Wolf Valk um die Funktion eines Sammlers von Knochen zur Belieferung des Kregsausschusses für Öle und Fette, August 1916

- Regelung der Bewirtschaftung von Lebensmittel und Förderung des Anbaus von Ölpflanzen zur Öl- und Fettgewinnung, 1915 - 1916

- Erfassung der Dreschmaschinen im Regierungsbezirk Aurich, Juni 1916

- Flugblätter und Plakate zur Fördeung des Anbaus von Ölsaaten und Ersatzstoffpflanzen, 1916

- Verstöße Emder Händler gegen die Höchstpreisverordnung, Februar 1915 - Juni 1916

- Informationsschriften zur kriegsmäßigen Gestaltung der Landwirtschaft, 1916

- Antrag des Kaiser's Kaffeegeschäft, Filiale Emden, auf Beorderung eines Polizeibeamten vor dem Geschäftshaus wegen großem Andrang beim Verkauf von Margarinezuteilungen, März 1916

$1914-1916$

Klassifikation Teil B: 02359

Band: 1

Trägermaterial: Papier

Alte Reg.-Sig.: VII J 030

Bestell-Nr.: IV 02359

3195 Familienunterstützung

- Anträge auf Familienunterstützung für Angehörige

Kriegsdienstleistender, 1914 - 1916

- Regelung der Unterstützung von Soldatenfamilien, 1914 - 1915

- Datenerhebung der Stadt Emden bei Nachbarstädten wegen

Finanzierung der Familienunterstützung, Dezember 1915 - Januar 1916

$1914-1916$

Klassifikation Teil B: 02360

Trägermaterial: Papier

Alte Reg.-Sig.: VII J 033

Bestell-Nr.: IV 02360 
Lfd. Nr. Titel

- Regelung der Unterbringung und Verpflegung von Kriegsgefangenen in der Kaserne, August 1914

- Vermerk des Magistrats über bevorstehende Ankunft englischer Kriegsgefangener in Emden, August 1914

- Anordnung der Intendantur des X. Armeekorps über Unterbringung von Kriegsgefangenen in Barackenlagern, September 1914

- Erlass des Innenministers über Verpflegung von Kriegsgefangenen mit Haferflocken, Dezember 1914

- Erlass des Innenministers über medizinische Behandlung russischer Kriegsgefangene wegen Seuchengefahr, 1915

- Mitteilungen über Flucht von Kriegsgefangenen und deren

Festnahme, 1915 - 1916

- Erlasse des Kriegsministers über Verfolgung flüchtiger

Kriegsgefangener,1915 - 1917

$1914-1917$

Klassifikation Teil B: 02362

Trägermaterial: Papier

Alte Reg.-Sig.: VII J 036

Bestell-Nr.: IV 02362

3197 Mieten und Hypotheken während des Krieges

- Verfügung des Magistrats über Fortbestand der

Zahlungsverpflichtungen von Mietern nach Kriegsausbruch

- Bericht des Polizeisergeanten Schünemann über Praktiken des

Hausbesitzers Helmer von Baden-Foget zur Eintreibung der

rückständigen Mietzahlungen seiner Mieter, September 1914

- Wassergeldrückstende des Helmer von Baden-Foget, September 1914

- Erlass des Innenministers über Wohnraumsicherung als Aufgabe der Kriegsfürsorge, März 1915

- Antrag des Hausbesitzers Helmer von Baden-Foget an den

Magistrat auf Erstattung seiner kriegsbedingten Mietausfälle, Juli 1917

/ April 1918

$1914-1918$

Klassifikation Teil B: 02363

Trägermaterial: Papier

Alte Reg.-Sig.: VII J 037

Bestell-Nr.: IV 02363

3198 Bekämpfung kriegsbedingter Seuchengefahr

- Schutz der Wassertürme zur Sicherung der Versorgung mit sauberem Wasser als Schutz gegen Seuchen

1914

Klassifikation Teil B: 02364

Trägermaterial: Papier

Alte Reg.-Sig.: VII J 038

Bestell-Nr.: IV 02364 
Lfd. Nr. Titel

Laufzeit

3199 Sammlung für die Nationalstiftung für Hinterbliebene gefallener Soldaten

- Gründung eines Provinzialverbandes der Nationalstiftung für Hinterbliebene gefallener Soldaten unter dem Vorsitz des Oberpräsidenten der Provinz Hannover, August 1914

- Organisation einer Sammlung für die Nationalstiftung für Hinterbliebene gefallener Soldaten durch den Magistrat, August 1914 Januar 1915 / April - Juli 1918

- Erlasse des Innenministers über Organisation und Aufgaben der Nationalstiftung für Hinterbliebene gefallener Soldaten, Oktober 1914 Juli 1916

- Satzung der Nationalstiftung für Hinterbliebene gefallener Soldaten, $1915 / 1916$

- Satzung des Provinzialverbandes der Nationalstiftung für

Hinterbliebene gefallener Soldaten, Hannover, August 1916

- Bericht des Magistrats an den Regierungspräsidenten in Aurich über Ergebnis einer Spendenaktion für die Nationalstiftung für Hinterbliebene gefallener Soldaten und Zuschuss von 1000 Mark aus der Kämmereikasse, Dezember 1915

- Nachweis über Klassifizierung der Unterstützungszahlungen und Tarife der Unterstützung der Nationalstiftung an die Kriegshinterbliebenen, 1916

- Erlass des Kriegsministers über Form des Verkehrs der Beamten mit Hinterbliebenen gefallener Soldaten und der Bearbeitung von Untersützungsanträgen, Juli 1916

- Protokolle der Sitzungen der amtlichen Fürsorge für Kriegsteilnehmer und Hinterbliebene der Stadt Emden über Beschlüsse zu Unterstützungsanträgen, Oktober 1916 .

$1914-1918$

Klassifikation Teil B: 02366

Trägermaterial: Papier Alte Reg.-Sig.: VII J 040

Bestell-Nr.: IV 02366 
Lfd. Nr. Titel

- Erlasse des Ministers für Handel und Gewerbe über Organisation der Vermittlung von freigewordenen und nicht zum Kriegsdienst eingezogenen Arbeitskräften zur Erntearbeit, August 1914

- Mobilisierung von Schülern zum Ernteeinsatz, August 1914 - Juni 1915

- Einrichtung einer Arbeitsvermittlung für landwirtschaftliche Arbeiter im Landkreis und in der Stadt Emden, August 1914 - Januar 1915

- Erlasse des Innenministers über Maßnahmen zur Verhinderung von Arbeitslosigkeit, August 1914

- Vereinfachung des Enteignungsrechts zur Förderung arbeitsschaffender Projekte, September 1914 - April 1915

- Erlass des Ministers für Landwirtschaft und Domänen über

Förderung des Frischgemüseanbaus zur Entspannung der

Ernährungslage, Februar 1915

- Verwendung polnischer und russischer Arbeitskräfte zum

Ernteeinsatz, 1915 - 1916

- Flugblätter über Förderung des Kriegsgemüseanbaus, 1916

$1914-1916$

Klassifikation Teil B: 02367

Trägermaterial: Papier

Alte Reg.-Sig.: VII J 028

Bestell-Nr.: IV 02357

3201 Bestattung in Emden gestorbener Soldaten

- Einladung des Emder Magistrats zur Bestattungsfeier für die bei Untergängen von Torpedobooten und anderer Kriegsschiffe ums Leben gekommener Matrosen, September 1914 - Oktober 1915 - Anträge des Kriegervereins Emden und des Militärvereins Emden an den Magistrat auf Ubernahme der Kosten für Musik und Kränze zur Bestattung getöteter Matrosen, Oktober 1914 / Oktober 1915 - Erlass des Innenministers über Wegfall der Gebühren für die Erstellung von Leichenpässen gefallener Soldaten, OKtober 1914 - Bestattung eines russischen Kriegsgefangenen mit militärischen Ehren, November 1915

$1914-1916$

Klassifikation Teil B: 02374

Trägermaterial: Papier Alte Reg.-Sig.: VII J 047

Bestell-Nr.: IV 02374 
Lfd. Nr. Titel

- Mitteilung der Borkumer Kommandantur über Plan der Evakuierung von Frauen und Kinder von Borkum im Fall einer Beschießung, November 1914

- Schreiben der HAPAG an den Magistrat über Unmöglichkeit der Unterbringung Evakuierter aus Borkum in den Emder Auswandererhallen wegen Funktion als Lazarett, November 1914

1914

\author{
Klassifikation Teil B: 02375 \\ Trägermaterial: Papier \\ Alte Reg.-Sig.: VII J 048 \\ Bestell-Nr.: IV 02375
}

- Hilfeaufruf für die Flüchtlinge aus den ostpreußischen

Kampfgebieten, September 1914

- Erlass des Innenministers über Rückführung der ostpreußischen

Flüchtlinge, Oktober 1914

- Erlass des Staatskommissars für das Flüchtlingswesen über

Festlegung der zur Flüchtlingsrückführung zugelassenen Gebiete in

Ostpreußen, Oktober 1914 / November 1914

- Unterbringung ostpreußischer Flüchtlinge in Emden, November 1914

- Verfügung des Magistrats über Beschäftigung der ostpreußischen

Flüchtlinge in Emden, November - Dezember 1914

- Erlass des Innenministers über Anweisung der Rückkehr von aus den von Deutschland besetzten Gebieten Polens Geflüchteten in ihre Heimat und Gewährung von Freifahrkarten für Rückkehrer, August 1915

- Antrag der aus Goldap / Ostpreußen geflüchteten Johanna Zick an den Magistrat auf Genehmigung der Rückkehr in ihre Heimat, Mai 1915

- Suche nach der bei der Flucht aus Ostpreußen vermissten 10-jährigen Ottilie Kempf, September 1915

- Erlass des Kriegsministers über Aufnahme und Beschäftigung aus Russland rückgewanderter Deutsche, November 1915

- Antrag des Stellvertretenden Generalkommando des X. Armeekorps über Anordnung einer zurückhaltenden Presseberichtserstattung über deutsche Rückwanderer aus Russland, Juni 1916

$1914-1916$

Klassifikation Teil B: 02377

Trägermaterial: Papier

Alte Reg.-Sig.: VII J 050

Bestell-Nr.: IV 02377 
08.02

Lfd. Nr. Titel

Laufzeit

3204 Einigungsämter

- Bekanntmachung des Bundesrates über Einrichtung von

Einigungsämtern zur außergerichtlichen Beilegung von zivilrechtlichen Stretfällen, September - Dezember 1914

- Erlass des Innenministers über Anordnung der Einrichtung von

Einigungsämtern zur Beilegung von Mietstreitigkeiten als Beitrag zur

Erhaltung der öffentlichen Kriegsmoral, August 1917 / November 1917

- Eirrichtung eines Einigungsamtes in Emden, September - Oktober 1917

- Ausdehnung der Kompetenz der Einigungsämter auf Schlichtung von Streitigkeiten wegen Sammelheizung und Warmwasserversorgung,

Dezember 1917 - März 1918

- Projekt der Einrichtung eines Hypotheken-Einigungsamtes, Fenruar März 1918

- Bestellung der Mitglieder des Einigungsamtes /Mieteinigungsamt, April - Juni 1918 (1919)

$1914-1918(1919)$

Klassifikation Teil B: 02381

Trägermaterial: Papier

Alte Reg.-Sig.: VII J 053

Bestell-Nr.: IV 02381

3205 Kriegsbeschädigtenfürsorge

- Maßnahmen zur beruflichen Reintegration von Kriegsbeschädigten,

$1915-1916$

- Aufstellung über aus dem Heeresdienst entlassene

Kriegsbeschädigte in Emden, Dezember 1915

$1915-1916$

Klassifikation Teil B: 02387

Trägermaterial: Papier

Alte Reg.-Sig.: VII J 059

Bestell-Nr.: IV 02387

3206 Unfallfürsorge für Schiffsbesatzungen

- Regelung der Unfallfürsorge für Besatzungen ziviler Handelsschiffe während des Weltkrieges

1915

Klassifikation Teil B: 02388

Trägermaterial: Papier

Alte Reg.-Sig.: VII J 060

Bestell-Nr.: IV 02388 
Lfd. Nr. Titel

Laufzeit

3207 Anlage von Soldatenfriedhöfen 1915-1917

- Erlass des Innenministers über Ehrung der Kriegstoten durch die Anlage von Ehrenhainen, Juli 1915

- Bericht der lutherischen Gemeinde Emden über Kriegsgräber auf ihrem Friedhof und Plan der Errichtung eines Ehrenhains nach

Kriegsende, Januar 1917

1915 - 1917 (1920)

Klassifikation Teil B: 02389

Trägermaterial: Papier

Alte Reg.-Sig.: VII J 061

Bestell-Nr.: IV 02389

3208 Fürsorge für Angehörige eingezogener Mannschaften

- Vorstellung von Organisationen der Kriegsfürsorge

1915
Klassifikation Teil B: 02399
Trägermaterial: Papier
Alte Reg.-Sig.: VI J 078
Bestell-Nr.: IV 02399

3209 Fahrbare Kriegsbüchereien für die Front

- Vorstellung einer fahrbaren Kriegsbücherei durch den Ausschuss für fahrbare Kriegsbüchereien, Februar 1916

- Beteiligung der Stadt Emden an den Kosten für einen Bücherwagen "Ostfriesland", März 1916

1916

Klassifikation Teil B: 02400

Trägermaterial: Papier

Alte Reg.-Sig.: VII J 079

Bestell-Nr.: IV 02400 
08.02

Lfd. Nr. Titel

Laufzeit

3210 Schutz gegen Fliegerangriffe

- Aufbau eines Luftalarmsystems in Absprache zwischen Magistrat und Garnisonskommando, Oktober 1915

- Bekanntmachung des Garnisonskommandos über

Verhaltensrichtlinien im Falle eines feindlichen Luftangriffs, Oktober

1915

- Mitteilung des Stellvertretenden Generalkommandos des X.

Armeekorps über Methode zur Ablöschung von Brandbomben, August 1916

- Geheimbericht des Emder Garnisonskommandos an das

Stellvertretende Generalkommando des X. Armeekorps über

Maßnahmen der Verdunkelung bei nächtlichen Luftangriffen, August

1916

- Anordnung des Stellvertretenden Generalkommandos des X.

Armeekorps über Informierung der Bevölkerung über zivilen

Luftschutz, April 1918

$1915-1918$

Klassifikation Teil B: 02401

Trägermaterial: Papier

Alte Reg.-Sig.: VII J 080

Bestell-Nr.: IV 02401

3211 Kriegskinderfürsorge

- Erlass des Ministers für geistliche und Unterrichtsangelegenheiten über Information zur Kregskinderpflegeeinrichtung des

Centralkomitees vom Roten Kreuz, August 1915

1915

Klassifikation Teil B: 02402

Trägermaterial: Papier

Alte Reg.-Sig.: VII J 082

Bestell-Nr.: IV 02402

3212 Bau von Kriegerheimstätten

- Initiative des Vorstands des Hauptausschusses für Kriegerheimstätte für den Bau von Kriegerheimstätten für zurückkehrende Soldaten und ihre Familien zur Bekämpfung der Bodenspekulation, 1915

- Entschließung des Arbeitervereins Emden für den Bau von

Kriegerheimstätten, Oktober 1916

$1915-1916$

Klassifikation Teil B: 02405

Trägermaterial: Papier

Alte Reg.-Sig.: VII J 084

Bestell-Nr.: IV 02405 
08.02

Lfd. Nr. Titel

- Modell der Stadtküche in Köln mit fahrbarer Kücheneinrichtung, 1916

- Angebote über fahrbare Kochküchen (Feldküchen), 1916

- Anfrage des Magistrats an andere Städte wegen Praktikabilität fahrbarer Volksküchen, Mai 1906

- Vermerk des Bürgermeisters Dr. Mützelburg über Abwarten eines Antrages des vaterländischen Frauenvereins wegen Einrichtung einer Volksküche, Juni 1916

1916

\author{
Klassifikation Teil B: 02409 \\ Trägermaterial: Papier \\ Alte Reg.-Sig.: VII J 088 \\ Bestell-Nr.: IV 02409
}

3214 Verwendung vaterländischer Spenden

- Erlass des Innenministers über Plan der Verwendung vaterländischer Spenden zur Förderung des Wohnungsbaus für kinderreiche Familien und heimkehrende Soldaten, April 1916

1916

\author{
Klassifikation Teil B: 02410 \\ Trägermaterial: Papier \\ Alte Reg.-Sig.: VII J 089 \\ Bestell-Nr.: IV 02410
}

- Audruf des Reichstagspräsidenten Dr. Kämpf zur Teilnahme an der U-Boot-Spende zugunsten der U-Boot-Besatzungen, März 1917

- Erlass des Innenministers über Anordnung zur Werbung für die U-Boot-Spende, April 1917

- Organisation der U-Boot-Spende in Emden, April - Mai 1917

- Aufruf des Magistrats zur U-Boot-Spende, Mai 1917

- Liste der Sammlerinnen für die U-Boot-Spende, Mai 1917

- Plakate zur U-Boot-Spende, u.a.: Motiv des Marinemalers Willy

Stöver, 1917

- Sammellisten für die Stadt Emden, 1917

1917

Klassifikation Teil B: 02452

Trägermaterial: Papier

Alte Reg.-Sig.: VII J 130

Bestell-Nr.: IV 02452

- Plakate mit Aufrufen zur Spende für deutsche Soldatenheime, 1917

- Emder Sammellisten für Spenden für Soldatenheime, August 1917

1917

Klassifikation Teil B: 02453

Trägermaterial: Papier

Alte Reg.-Sig.: VII J 131

Bestell-Nr.: IV 02453 
08.02

Lfd. Nr. Titel

Laufzeit

3217 Kriegsopfer

- Mitteilungen über gefallene Soldaten aus Emden zur Überreichung von Gedenkblättern an die Hinterbliebenen mit Quittungen

$1915-1918$

Klassifikation Teil B: 02454

Trägermaterial: Papier

Alte Reg.-Sig.: VII J 132

Bestell-Nr.: IV 02454

3218 Löhnungsgesuche für vermisste oder gefallene Soldaten

- Aufstellung des Magistrats über Gesuche Hinterbliebener gefallener oder vermisster Soldaten aus Emden um Weiterzahlung des Soldes oder Familienhilfe mit Wertung der Bedürftigkeit

$1917-1918$

Klassifikation Teil B: 02455

Trägermaterial: Papier

Alte Reg.-Sig.: VII J 133

Bestell-Nr.: IV 02455

- Aufruf zur nach dem Generalquartiermeister Ludendorff benanmnten Spende für Kriegsinvalide, März 1918

- Organisation der Spendenaktion, März - Mai 1918

- Durchführung der Spendenaktion in Emden, April - August 1918

- Aufruf des Magistrats zur Ludendorffspende, Mai 1918

- Plakate über Aufruf zur Ludendorffspende, Mai 1918

- Aufstellungen über Ertrag der Ludendorffspende in Emden, Juni

1918

- Mitteilungen über Spenden von Emder Firmen und Verwaltungen, Juni 1918

1918

Klassifikation Teil B: 02457

Band: 1

Trägermaterial: Papier

Alte Reg.-Sig.: VII J 150

Bestell-Nr.: IV 02457

3220 Ludendorffspende, Bd. 2

- Sammellisten zur Ludendorffspende

1918

Klassifikation Teil B: 02458

Band: 2

Trägermaterial: Papier

Alte Reg.-Sig.: VII J 150

Bestell-Nr.: IV 02458 
08 Der Erste Weltkrieg (1914 - 1918)

08.02 Kriegsfürsorge

Lfd. Nr. Titel

Laufzeit

3221 Opfertag für Säuglings- und Kleinkinderschutz

- Organisation des Opfertages für Säuglings- und Kleinkinderschutz durch den Hauptverein für Volkswohlfahrt in Hannover, Juli - Oktober 1917 (April 1918)

- Aufstellung zum Ertrag des Opfertages in Emden, September 1917

$1917(1918)$

Klassifikation Teil B: 02460

Trägermaterial: Papier

Alte Reg.-Sig.: VII J 151

Bestell-Nr.: IV 02460 
Lfd. Nr. Titel

- Erhebung über Viehbestand in der Stadt Emden, 1916

1916
Klassifikation Teil B: 00010
Trägermaterial: Papier
Bestell-Nr.: IV 00010

3223 Viehzählung

- Erhebung über Viehbestand in der Stadt Emden, 1917

1917
Klassifikation Teil B: 00011
Trägermaterial: Papier
Bestell-Nr.: IV 00011

3224 Viehzählung

- Erhebung über Viehbestand in der Stadt Emden, 1917

1917
Klassifikation Teil B: 00012
Trägermaterial: Papier
Bestell-Nr.: IV 00012

3225 Viehzählung

- Erhebung über Viehbestand in der Stadt Emden, 1917

1917

Klassifikation Teil B: 00013

Trägermaterial: Papier

Bestell-Nr.: IV 00013

1917

Klassifikation Teil B: 00014

Trägermaterial: Papier

Bestell-Nr.: IV 00014

- Erhebung über Viehbestand in der Stadt Emden, 1917

1917

Klassifikation Teil B: 00015

Trägermaterial: Papier

Bestell-Nr.: IV 00015 
Lfd. Nr. Titel

Laufzeit

3228 Viehzählung 1918

- Erhebung über Viehbestand in der Stadt Emden, 1918

1918

Klassifikation Teil B: 00016

Trägermaterial: Papier

Bestell-Nr.: IV 00016

3229 Teuerungszulagen für Beamte im Kriegsdienst

- Rechtliche Bestimmungen zur Gewährung von Teuerungszulagen, 1917 - 1918

- Berechnung der Teuerungszulagen, 1917 - 1918

- Gewährung einmaliger Teuerungszulagen, 1917 - 1918

- Anträge auf Teuerungszulagen durch sich im Kriegseinsatz befindliche Angestellte und Beamte der Stadt Emden, 1917 - 1918

$1917-1918$

Klassifikation Teil B: 00186

Trägermaterial: Papier

Alte Reg.-Sig.: III C 16 a

Bestell-Nr.: IV 00186

3230 Kaffeegrund-Sammlung

- Verfügung des Reichskanzlers über Kaffeegrundsammlung durch die Trockenfuttermittel GmbH zwecks Trocknung zur

Tierfuttergewinnung, Oktober - November 1916

- Umsetzung der Verfügung in Emden, November 1916 - März 1918

$1916-1918$

Klassifikation Teil B: 00357

Trägermaterial: Papier

Bestell-Nr.: IV 00357

3231 Bewegung zur Einführung einer Sommerzeit

- Initiative der "Sommerzeit-Zentrale Sarotti" zur Einführng der

Sommerzeit, Juli 1912

- Erlass des Reichskanzlers über Einführung der Sommerzeit, April

1916

- Erfolgsberichte über Einführung der Sommerzeit, August 1916

$1912-1916$

Klassifikation Teil B: 00399

Trägermaterial: Papier

Alte Reg.-Sig.: III Dg 10

Bestell-Nr.: IV 00399 
Lfd. Nr. Titel

- Anfrage des Deutschen Seefischerei-Vereins nach dem Schicksal der Heringsfischerei AG "Neptun", März 1914

- Stellungnahme des Direktors der Heringsfischerei AG, Carl Strüfing, zum Projekt des Reichsmarineamts der Stationierung von

Fischdampfern in Emden und Rolle Emdens als Fischereihafen,

Dezember 1916 / August 1917

- Vermerk des Bürgermeisters Dr. Mützelburg über Instruktion zur Gründung einer Hochseefischerei AG unter Übernahme der vom Reichsmarineamt in Emden stationierten Fischdampfer mit Kommentierung durch den pensionierten Oberbürgermeister Fürbringer, November 1916 / Januar 1917

- Konzept einer Eingabe des Magistrats an den Staatssekretär des Reichsmarineamt, Admiral von Kapelle, über Bitte um Überlassung der von der Marine in Emden stationierten Fischdampfer an einer Emder Hochseefischerei AG, Dezember 1916

- Bescheid des Reichsamts des Innern an den pensionierten Oberrbürgermeister Fürbringer über Nichtgewährung einer Unterstützung an die Stadt Emden zum Ankauf von Fischdampfern wegen fehlender Haushaltsansätze, März 1917

- Initiative des Fischereidirektors Strüfing zur Gründung einer Emder Fischmarkt AG, Dezember 1917

- Denkschrift des Fischereidirektors Strüfing über Gründung einer Hochseefiascherei AG in Emden, Dezember 1917

- Stellungnahmen verschiedener westdeutscher Städte über Notwendigkeit einer Versorgung mit Fisch von Emden, November Dezember 1917

- Vertrag zwischen der Stadt Emden und dem Fischereidirektor Carl Strüfing über Gründung einer Emder Hochseefischerei AG mit Beteiligung der Stadt Emden am Aktienkapital und durch die Vererbpachtung des Betriebsgeländes der ehemaligen Heringsfischerei "Neptun" AG, Januar 1918

- Prospekt der Hochseefischerei und Fischmarkt AG Emden, März 1918

- Bescheid des Ministers für Handel und Gewerbe über Nichtgenehmigung der Gründung der Emder Hochseefischerei AG wegen fehlendem Betriebsplans und unsichere Planung mit den Marinefischdampfern, Mai 1918

$1914-1918$

Klassifikation Teil B: 02151

Trägermaterial: Papier

Alte Reg.-Sig.: IV T6 204

Bestell-Nr.: IV 02151

- Bestimmungen über die Heranziehung von Zivilflugzeugen für den Kriegseinsatz

1912

Klassifikation Teil B: 02309

Trägermaterial: Papier

Alte Reg.-Sig.: VII N 23

Bestell-Nr.: IV 02309 
Lfd. Nr. Titel

- Erlass des Innenministers über Schaffung von Mechanismen und Ausnützung satzungsmäßiger Möglichkeiten zu Beleihung von Hypotheken zur Erfüllung der Kriegserfordernisse, August 1914

1914

\author{
Klassifikation Teil B: 02367 \\ Trägermaterial: Papier \\ Alte Reg.-Sig.: VII J 041 \\ Bestell-Nr.: IV 02367
}

- Zeichnung von Kriegsanleihen durch den Magistrat der Stadt Emden, September 1914 - März 1916

- Erlasse des Innenministers über Aufforderung zur Zeichnung der Kriegsanleihe, September 1914 - September 1916

- Aufrufe zur Zeichnung der Kriegsanleihe, September 1914

- Kampagne der Sadt Emden zur Zeichnung der Kriegsanleihe mit einer Zielvorgabe von 3,5 Millionen Mark, September 1914

- Mitteilungen über Zeichnung von Kriegsanleihen, September 1914 -

Mai 1916

$1914-1916$

Klassifikation Teil B: 02368

Band: 1

Trägermaterial: Papier

Alte Reg.-Sig.: VII J 042

Bestell-Nr.: IV 02368 
Lfd. Nr. Titel

- Bilanz der von der Stadt Emden gezeichneten Kriegsanleihen, 1916

- Zeichnung von Kriegsanleihen durch den Magistrat der Stadt Emden, September 1916 - März 1917

- Erlasse des Innenministers über Aufforderung zur Zeichnung der Kriegsanleihe, September 1916 - März 1917

- Aufrufe zur Zeichnung der Kriegsanleihe, September 1916 / Februar 1917

- Vertrauliche Verfügung des Regierungspräsidenten in Aurich über Bitte um Einwirkung der Gewährsträger auf die kommunalen Sparkassen zur Erhöhung ihrer Zeichnungen auf die V. Kriegsanleihe, September 1916

- Bescheid des Bezirksausschusses Aurich über Genehmigung einer Anleihe der Stadt Emden bei der städtischen Leih- und Sparkasse zur Zeichnung der V. Kriegsanleihe, Februar - März 1917

- Protest des Sparkassenverbandes gegen eine vom Innenmister angeordnete Abwertung der im Besitz der Sparkassen befindlichen Kriegsanleihen und Wertpapiere, Februar - März 1917

- Grundsätze der Werbung für die Kriegsanleihe, 1917

- Verfügung des Magistrats über zweijährige Rückzahlfrist für Gehaltsvorauszahlungen zur Zeichnung der VI. Kriegsanleihe, März 1917

- Erlass des Reichsschatzamtes über Vorzugszinsen für für geliehenes Kapital der Reichsdarlehenskasse zur Zeichnung der VI. Kriegsanleihe, März 1917

- Mitteilung des Präsidenten des Oberlandesgerichts Celle über Möglichkeit der Hypothekarisierung von Grundbesitz zur Zeichnung der VI. Kriegsanleihe, März 1917

- Werbeplakate für die VI. Kriegsanleihe, 1917

- Mitteilung über Zeichnung der V. uind VI. Kriegsanleihe in Emden, September 1916 / März - April 1917

- Propaganda für die VI. Kriegsanleihe: "Gebt Geld für Hindenburg", März 1917

- Bericht des Konsuls August Jasper über Werbung für die VI.

Kriegsanleihe in Emden, April 1917

$1916-1917$

Klassifikation Teil B: 02369

Band: 2

Trägermaterial: Papier

Alte Reg.-Sig.: VII J 042

Bestell-Nr.: IV 02369 
Lfd. Nr. Titel

- Zeichnungen der VII. Kriegsanleihe in der Stadt Emden, August -

September 1917

- Informationen der Reichsbank zur VII. Kriegsanleihe, August -

September 1917

- Werberichtlinien für die VII. Kriegsanleihe, August - Oktober 1917

- Bericht des Generalkommandos des X. Armeekorps über

Kriegslage, August 1917

- Aufrufe zur Zeichnung der VII. Kriegsanleihe, August 1917

- Organisation der Werbung für die VI. und VII. Kriegsanleihe in

Emden, Januar - Oktober 1917

- Mitteilungen über Zeichnungen der VII. Kriegsanleihe in Emden,

Oktober 1917

1917

Klassifikation Teil B: 02370

Band: 2

Trägermaterial: Papier

Alte Reg.-Sig.: VII J 042

Bestell-Nr.: IV 02370

3238 Linderung der Kriegslast des gewerblichen Mittelstands

- Erlass des Ministers für Handel und Gewerbe über Maßnahmen zur Linderung der Kreditnot des Mittelstands wegen des Kriegsausbruchs, August - September 1914

- Kreditprogramm der preußischen Central-Genossenschafts-Kasse, September - November 1914

- Gründung einer Kriegskreditkasse für den deutschen Mittelstand, November 1914

1914

\author{
Klassifikation Teil B: 02371 \\ Trägermaterial: Papier \\ Alte Reg.-Sig.: VII J 043 \\ Bestell-Nr.: IV 02371
}

- Festsetzung von Höchstsätzen für die Vergütung

Getreidelieferungen für die Armee, 1914 / 1915

- Erlass des Innenministers über Organisation der Getreidelieferungen für das Heer, August 1914

- Vergütung der von der Stadt Emden erbrachten Leistungen zum

Aufbau von Lazaretten, August 1914

- Angebote über Lebensmittellieferungen für Lazarette etc.,

September 1914

- Erlass des Innenministers über Vergütung von

Kriegsdienstleistungen, Oktober 1915 - März 1916

$1914-1917$

Klassifikation Teil B: 02372

Trägermaterial: Papier

Alte Reg.-Sig.: VII J 044

Bestell-Nr.: IV 02372 
Lfd. Nr. Titel

- Erlass des Innenministers über Anregung der Einsammlung von Goldgeldmünzen in ländlichen Gebieten im Umtausch gegen Papiergeld, September 1914

- Aufruf zum Umtausch von Goldgeldmünzen gegen Banknoten, September 1914

- Anordnung des Stellvertretenden Generalkommandos X. Armeekorps zur Beobachtung der drei als Goldaufkäufer verdächtigten Niederländer: Kaufmann Voss, Viehhändler Herz und Goldschmied Reents, Februar 1915

- Erlass des Innenministers über Ersatz der Nickelmünzen durch Münzen aus Eisen, Dezember 1915 - Januar 1916

$1914-1916$

Klassifikation Teil B: 02373

Trägermaterial: Papier

Alte Reg.-Sig.: VII J 046

Bestell-Nr.: IV 02373

- Bericht der Emder Wirtschaftsverbände über Einwirkung des Krieges auf Gewerbe, Handel und Landwirtschaft, November 1914

- Verordnung des Bundesrats über Verlängerung der Zahlungsfristen für Hypotheken etc. wegen des Kriegsausbruchs, Dezember 1914

1914

Klassifikation Teil B: 02376

Trägermaterial: Papier

Alte Reg.-Sig.: VII J 049

Bestell-Nr.: IV 02376 
Lfd. Nr. Titel

Laufzeit

3242 Sammlungen

- Sammlung von Ferngläsern und Armeepistolen, September 1914 -

März 1915

- Organisation einer Reichswollwoche zur Sammlung von Wollsachen für Frontsoldaten, Januar 1915

- Bericht des Vaterländischen Frauenzweigvereins Emden über Ablauf der Reichswollwoche in Emden, Januar 1915

- Erlass des Kriegsministers über Erfassung und Sammlung von

Waffen und Munition aus Privatbesitz, März 1915

- Aufstellung über Emder Waffen- und Munitionsbesitzer, März 1915

- Organisation einer reichseinheitlichen Metallsammlung, März 1915 -

August 1918

- Sammlung von Obstkernen zur Ölgewinnung, Mai 1915 - Mai 1918

- Erfassung und Beschlagnahmung von Gummireifen, Mai 1915 - April 1918

- Beschlagnahmung und Ablieferung von Messing und Nickel gegen

Entschädigung zu kriegswirtschaftlichen Zwecken, Juli 1915

- Sammlung von Weihnachtsgaben für Frontsoldaten, Oktober -

November 1915 / Oktober 1916

- Werbung der Gesellschaft für Deutsches Kraftfutter GmbH

Sammlung und Verwertung von Küchenabfällen zur Produktion von

Kraftfutter, Januar 1917

- Organisation einer Sammlung von Heringsköpfen u.a. Fischabfälle zur Gewinnung von Ölen und Fetten durch den Kriegsausschuss für Öle und Fette, November 1916 - Januar 1917

- Organisation der Sammlung von Flaschen als U-Boot-Spende, Mai 1917

- Ersatzstoffe für Tee und Kaffee, Juni - Juli 1917

- Sammlung von Kolbenschilf zur Tau- und Gurtherstellung durch die

Deutsche Typhagesellschaft mbH., Juni 1917 - März 1918

$1915-1918$

Klassifikation Teil B: 02379

Trägermaterial: Papier

Alte Reg.-Sig.: VII J 054

Bestell-Nr.: IV 02379 
Lfd. Nr. Titel

- Aufkauf von Roggen durch die Stadt Emden, Dezember 1914 Januar 1915

- Bekanntmachungen von Anordnungen zur Getreidebewirtschaftung, Dezember 1914 - Januar 1916

- Antrag des Magistrats an den Regierungspräsidenten über Bitte um Erlaubniserteilung an den Landrat des Kreises Emden zur Beschlagnahmung von Roggen für den Bedarf der Stadt Emden, Januar 1915

- Mahlgenehmigung für den Müller Buismann (Weizenmühle) für Mischmehl aus Weizen und Roggen, Januar 1915

- Widerspruch der Brotfabrik Staal und Cramer gegen die Anordnung zum Verbacken von Kartoffelmehl im Schwarzbrot, Januar 1915

- Erfassung der Getreidevorräte in Emden, Januar - März 1915

- Anträge verschiedener Bäckermeister auf Erlaubnis zum Schroten von Roggen, Februar 1915

- Prüfung der Roggenmehlpreise, März 1915

- Betrauung die Fa. Ysaac \& Bernhard Brons mit der Vertretung der Kriegsgetreidegesellschaft, März 1915

- Vereinigung der Stadt Emden mit dem Landkreis Emden zu einem Getreideversorgungsgebiet, März 1915

$1914-1916$

Klassifikation Teil B: 02382

Trägermaterial: Papier

Alte Reg.-Sig.: VII J 055

Bestell-Nr.: IV 02382

- Anforderung von Hafer durch die Zentralstelle zur Beschaffung der Heeresverpflegung, Mai - Juni 1917

- Bekanntmachung der Herabsetzung der Haferration für Zivilpferde und Zuchtbullen, Juni 1917 / September 1917 / November 1917

- Bestimmungen zur Festlegung und Verteilung der Haferration für Pferde, 1917 - 1918

- Monierung des Preises und des Untergewichts einer Haferlieferung des Proviantamtes Verden / Aller durch den Magistrat, Juni - August 1914

- Zuteilung einer Lieferung von Hafer und Gerstenschrot nach Emden, November 1917

- Antrag des Magistrats an die Reichsfuttermittelstelle auf Sonderzuteilung von Hafer an die Emder Gemüsebauern wegen Bestellung der Äcker zur Sicherung der Volksernährung, März 1918 - Aufstellung über kriegswirtschaftlich tätige Pferde in Emden, Juli 1918

$1917-1918$

Klassifikation Teil B: 02383

Trägermaterial: Papier

Alte Reg.-Sig.: VII J 056

Bestell-Nr.: IV 02383 
Lfd. Nr. Titel

- Erlasse des Ministers für Landwirtschaft, Domänen und Forsten über Stützung der Schweinepreise durch Schlachtungsaktionen und Konservierung des Fleisches zur Sicherung der Kriegsernährung, August 1914 / Januar 1915

- Erlass des Innenministers über Lieferungsanforderungen des Heeres für Lebensmittel, Futter u.a., August 1914

- Erlass des Innenministers über Erfassung der Vorräte an Nitraten und Salpeter, Oktober 1914

- Erlass des Handelsministers über Preisregulierung für Erdöl, November 1914

- Erlass des Innenministers über Erfassung der Vorräte an Kakao und Kakaoprodukten, November 1914

- Erlass des Innenministers über Vorbereitung der Bevölkerung auf die Lebensmittelbewirtschaftung, Dezember 1914

- Erlass des Handelsministers über Anordnung der Streckung des Brotgetreides durch Kartoffelmehl und Empfehlung von angepassten Backverfahren, Dezember 1914

- Vereinbarung mit Österreich-Ungarn über Einfuhr von Futtermitteln, Dezember 1914

- Bewirtschaftung von Fetten (Butter, Margarine), März 1916 -

September 1917

- Bildung einer Reichsstelle zur Versorgung mit Vieh und Fleisch, April 1916

- Erlass des Innenministers über Regelung der Zusammenarbeit zwischen zivilen und militärischen Stellen bei der Orgasnisation der Heeresversorgung, Mai 1916

- Einführung einer Fleischkarte, Mai 1916

- Beihilfe für die Einrichtung einer Volksküche in Emden, September November 1916

- Erlass des Landwirtschaftsministers über Einsatz von Rüben bei der Schweinemast, Oktober 1916

- Regelung von Käse- und Viehimporten aus den Niederlanden,

Dezember 1916

- Bekämpfung von Pflanzenkrankheiten, 1918

- Bestellung eines Reichskommissars für Volksernährung, Februar

1917

- Bestellung eines Staatskommissars für Volksernährung in Preußen, März 1917

$1914-1918$

Klassifikation Teil B: 02385

Trägermaterial: Papier

Alte Reg.-Sig.: VII J 058

Bestell-Nr.: IV 02385 
Lfd. Nr. Titel

3246 Erfassung und Beschlagnahmung von Buntmetall für die

Kriegswirtschaft

- Erlass des Kriegsministers über Beschlagnahmung von Kupfer, Nickel und Messing für Zwecke der Kriegswirtschaft, Juli 1915

- Übersicht über abgelieferte Buntmetallmengen aus Emden, Oktober 1915

- Befreiung von Gegenständen aus Buntmetall von der

Beschlagnahmung wegen ihrer kulturhistorischen Bedeutung,

November 1915

1915

Klassifikation Teil B: 02390

Trägermaterial: Papier

Alte Reg.-Sig.: VII J 062

Bestell-Nr.: IV 02390

3247 Beschlagnahmung von Buntmetall für die Kriegswirtschaft

- Anweisung des Kriegsministers an die Kommunalverbände wegen

Beschlagnahmung von Buntmatall und Berichterstattung an die

Metallmobilmachungsstelle im Kriegsministerium und die Kriegsmetall

AG, August 1915

- Berichte des Magistrats an die Kriegsmetall AG und die

Metallmobilmachungsstelle im Kriegsministerium über Erfassung von

Buntmetall und über Vorschüsse aus der Kämmereikasse für

Entschädigungszahlungen an die Besitzer des Buntmetalls,

September 1915

- Rückerstattung der von der Kämmereikasse vorgeschossenen

Eigentümerentschädigungen für beschlagnahmtes Buntmetall durch die Kriegsmetall AG, September - November 1915

1915

Klassifikation Teil B: 02391

Trägermaterial: Papier

Alte Reg.-Sig.: VII J 064

Bestell-Nr.: IV 02391

3248 Ablieferung von Buntmetall

- Aufstellung über Ablieferung von Buntmatall Emder Bürger

1915

Klassifikation Teil B: 02392

Trägermaterial: Papier

Alte Reg.-Sig.: VII J 065

Bestell-Nr.: IV 02392 
Lfd. Nr. Titel

- Bekanntmachung über Erfassung, Beschlagnahmung und Einziehung von Kupfer und Buntmetall, November - Dezember 1915

- Anweisung des Stellvertretenden Generalkommando des X.

Armeekorps an die Kommunalverbände über Erfassung,

Beschlagnahmung und Einziehung von Kupfer und Buntmetall,

Dezember 1915

- Organisation der Ablieferung von Kupfer und Buntmetall in Emden,

Dezember 1915 - Oktober 1916

- Rückerstattung der von der Kämmereikasse vorgeschossenen

Entschädigungszahlungen für die Eigentümer des beschlagnahmten

Kupfers durch die Kriegsmetall AG, Januar 1916

- Aufstellung über beim Norddeutschen Lloyd beschlagnahmte

Kupfergeräte, Oktober 1916

$1915-1916$

Klassifikation Teil B: 02394

Band: 1

Trägermaterial: Papier

Alte Reg.-Sig.: VII J 074

Bestell-Nr.: IV 02394

3250 Ablieferung von Kupfer und Buntmetall, Bd. 2

- Scheine über Ablieferung von Kupfer, Messing und Nickel

1916

Klassifikation Teil B: 02395

Band: 2

Trägermaterial: Papier

Alte Reg.-Sig.: VII J 074

Bestell-Nr.: IV 02395

- Aufstellung über Ablieferung von Kupfer, Messing und Nickel

1916

Klassifikation Teil B: 02396

Band: 3

Trägermaterial: Papier

Alte Reg.-Sig.: VII J 074

Bestell-Nr.: IV 02396 
Lfd. Nr. Titel

3252 Ablieferung von Kupfer und Buntmetall, Bd. 4

- Aufstellung über Ablieferung von Kupfer, Messing und Nickel

1916

\author{
Klassifikation Teil B: 02397 \\ Band: 4 \\ Trägermaterial: Papier \\ Alte Reg.-Sig.: VII J 074 \\ Bestell-Nr.: IV 02397
}

3253 Ablieferung von Kupfer und Buntmetall, Bd. 5

- Organisation der Ablieferung von Kupfer und Buntmetall in Emden

- Rückerstattung der von der Kämmereikasse vorgeschossenen

Entschädigungszahlungen für die Eigentümer des beschlagnahmten

Kupfers durch die Kriegsmetall AG

1916

\author{
Klassifikation Teil B: 02398 \\ Band: 1 \\ Trägermaterial: Papier \\ Alte Reg.-Sig.: VII J 077 \\ Bestell-Nr.: IV 02398
}

3254 Förderung der Kleinviehhaltung

- Erlass des Landwirtschaftsministers über Förderung der Kleinviehund Kaninchenzucht im Dienst der Kriegswirtschaft, März / Mai 1916 - Mitteilung des Magistrats an die Leiter der Emder Schulen über Angebot von Kleeheu und Futter für kaninchenzüchtende Schüler gegen einen günstigen Preis durch die Kriegshilfe, August 1916

1916 (1918)

Klassifikation Teil B: 02403

Trägermaterial: Papier

Alte Reg.-Sig.: VII J 083

Bestell-Nr.: IV 02403

3255 Brandschutz für kriegswichtige Großbetriebe

- Anordnung des Stellvertretenden Generalkommandos des X. Armeekorps über Organisation des Brandschutzes kriegswichtiger Betriebe, Läger etc., Oktober 1915

1915

Klassifikation Teil B: 02406

Trägermaterial: Papier

Alte Reg.-Sig.: VII J 085

Bestell-Nr.: IV 02406 
Lfd. Nr. Titel

Laufzeit

3256 Beschlagnahmung von Bierkrugdeckeln aus Zinn und anderer

Zinnsachen für die Kriegswirtschaft, Bd.

- Anordnung des Stellvertretenden Generalkommandos des X. Armeekorps über Beschlagnahmung von Bierkrugdeckel aus Zinn und anderer Sachen aus Zinn für kriegswirtschaftliche Zwecke, September 1916

- Umsetzung der Anordnung, September 1916 - November 1917

- Rückerstattung der von der Kämmereikasse vorgeschossenen

Entschädigungszahlungen für die Besitzer von Zinn durch die

Kriegsmetall AG, April 1917

$1916-1917$

Klassifikation Teil B: 02411

Band: 1

Trägermaterial: Papier

Alte Reg.-Sig.: VII J 090

Bestell-Nr.: IV 02411

3257 Beschlagnahmung von Bierkrugdeckeln aus Zinn und anderer Zinnsachen für die Kriegswirtschaft, Bd. 2

- Abgabescheine: Zinn

1917

Klassifikation Teil B: 02412

Band: 2

Trägermaterial: Papier

Alte Reg.-Sig.: VII J 090

Bestell-Nr.: IV 02412

3258 Beschlagnahmung von Bierkrugdeckeln aus Zinn und anderer Zinnsachen für die Kriegswirtschaft, Bd. 3

- Abgabescheine: Zinn

1917

Klassifikation Teil B: 02413

Band: 3

Trägermaterial: Papier

Alte Reg.-Sig.: VII J 090

Bestell-Nr.: IV 02413

3259 Beschlagnahmung von Orgelprospekten wegen ihres Zinngehalts, Bd.

- Abgabe von Prospekten Emder Kirchenorgeln wegen Zinngehalt

1917

Klassifikation Teil B: 02414

Band: 1

Trägermaterial: Papier

Alte Reg.-Sig.: VII J 091

Bestell-Nr.: IV 02414 
Lfd. Nr. Titel

3260 Beschlagnahmung von Orgelprospekten wegen ihres Zinngehalts, Bd. 2

- Abgabe von Prospekten Emder Kirchenorgeln wegen Zinngehalt

1917

Klassifikation Teil B: 02415

Band: 2

Trägermaterial: Papier

Alte Reg.-Sig.: VII J 091

Bestell-Nr.: IV 02415

3261 Beschlagnahmung von Aluminium und anderen Metallen, Bd. 1

- Anordnung des Stellvertretenden Generalkommandos des X. Armeekorps über Erfassung und Beschlagnahmung von

Aluminium-Gegenständen für kriegswirtschaftliche Zwecke, Februar / Mai 1917

- Umsetzung der Anordnung durch die Kommunalverbände der

Provinz Hannover, März - April 1917

- Merldung von $1060 \mathrm{~kg}$ Aluminium durch den Magistrat an die

Kriegsmetall AG, März / Juli 1917

- Erlasse des Kriegsministers über Ablieferung von Aluminium, Juni

1917 / August 1917

- Rückerstattung der von der Kämmereikasse vorgeschossenen

Entschädigungszahlungen für Aluminiumbesitzer durch die

Kriegsmetall AG, August 1917

- Aufstellung über Verstöße gegen die Abgabepflicht von Aluminium,

Oktober 1917

- Ermittlungsverfahren wegen Nichtablieferung von Aluminium, November 1917

- Liste über abgegebenes Aluminium, 1917

1917

Klassifikation Teil B: 02416

Trägermaterial: Papier

Bestell-Nr.: IV 02416

3262 Beschlagnahmung von Aluminium und anderen Metallen, Bd. 2

- Listen: Abgabe von Aluminium

1917

Klassifikation Teil B: 02417

Trägermaterial: Papier

Bestell-Nr.: IV 02417 
Lfd. Nr. Titel

- Beschlagnahmung von Orgelpfeifen für die Kriegswirtschaft wegen Zinngehalt, 1917

- Verhandlungen des städtischen Metallausschusses über Organisation der Erfassung und Abgabe von Metallen für die Kriegswirtschaft, März 1917 - Oktober 1918

$1917-1918$

Klassifikation Teil B: 02418

Trägermaterial: Papier

Alte Reg.-Sig.: VII J 092

Bestell-Nr.: IV 02418

- Alphabetische Liste von Besitzern angegebener Aluminiumsachen

1917

\author{
Klassifikation Teil B: 02419 \\ Trägermaterial: Papier \\ Alte Reg.-Sig.: VII J 093 \\ Bestell-Nr.: IV 02419
}

3265 Ablieferung von Glocken für die Kriegswirtschaft, Bd. 1

- Anordnung des Stellvertretenden Generalkommandos des X.

Armeekorps über Beschlagnahmung und Ausbau von Glocken zur

Gewinnung von Bronze für die Kriegswirtschaft, Februar 1917 / Juni

1917

- Anweisung des Kriegsministeriums an die Kommunalverbände wegen Ablieferung der Glocken, Februar 1917

- Erlass des Ministers der geistlichen und Unterrichtsangelegenheiten über Befreiung kulturhistorisch wertvoller Glocken von der

Abgabepflicht und Feststellung der Wertigkeit durch

Sachverständigengutachten, Februar 1917 / April 1918

- Meldung von Bronzeglocken an die Kriegsmetall AG und die Metallmobilmachungsstelle im Kriegsministerium mit Angaben zur kulturhistorischen Bedeutung durch den Magistrat, März - August 1917 / September 1918

- Beleg über Ablieferung der Glocke der Gasthauskirche, August 1918

$1917-1918$ (1919)

Klassifikation Teil B: 02420

Band: 1

Trägermaterial: Papier

Alte Reg.-Sig.: VII J 093

Bestell-Nr.: IV 02420 
Lfd. Nr. Titel

3266 Ablieferung von Glocken für die Kriegswirtschaft, Bd. 2

- Nachweisung der abgegebenen Glocken

1917

Klassifikation Teil B: 02421

Band: 2

Trägermaterial: Papier

Alte Reg.-Sig.: VII J 093

Bestell-Nr.: IV 02421

- Anordnung des Stellvertretenden Generalkommandos des X. Armeekorps über Beschlagnahmung von Kupfer, Platin und Zink für die Kriegswirtschaft, April 1917

- Bekanntmachung des Stellvertretenden Generalkommandos des X. Armeekorps über Höchstpreise für abgabepflichtiges Zink, Januar 1917

1917

Klassifikation Teil B: 02422

Trägermaterial: Papier

Alte Reg.-Sig.: VII J 094

Bestell-Nr.: IV 02422

3268 Beschlagnahmung von Kupfer für die Kriegswirtschaft, Bd. 1

- Verfügung des Magistrats über Meldepflicht für Kupfer zur kriegswirtschaftlichen Verwendung, Januar 1917

- Anordnung des Stellvertretenden Generalkommandos des X. Armeekorps über Beschlagnahmung von Kupfer und Platin für die Kriegswirtschaft, März - April 1917 / Juni 1918

- Ausdehnung der Abgabepflicht auf Blitzableiter aus Kupfer, April 1917

- Meldung von Dachkupfer zur Abgabe, Juli 1917 / Oktober 1917 / März 1918

- Befreiung der Mühlen von der Abgabepflicht ihrer Blitzableiter wegen Brandgefahr, November 1917 - Juni 1918

- Rückerstattung der von der Kämmereikasse vorgeschossenen Entschädigungszahlungen für die Besitzer des beschlagnahmten Kupfers durch die Kriegsmetall AG, Januar 1918 - Oktober 1918

$1917-1918$

Klassifikation Teil B: 02423

Band: 1

Trägermaterial: Papier

Alte Reg.-Sig.: VII J 095

Bestell-Nr.: IV 02423 
Lfd. Nr. Titel

3269 Beschlagnahmung von Kupfer für die Kriegswirtschaft, Bd. 2

- Anmeldung von abgabepflichtigem Kupfer

1917

\author{
Klassifikation Teil B: 02424 \\ Band: 2 \\ Trägermaterial: Papier \\ Alte Reg.-Sig.: VII J 095 \\ Bestell-Nr.: IV 02424
}

3270 Beschlagnahmung von Dachkupfer für die Kriegswirtschaft, Bd. 1

- Anträge auf Befreiung von der Abgabepflicht wegen Alters des Dachkupfers vor 1859, Mai 1917

- Organisation der Abgabe des Dachkupfers für kriegswirtschaftliche

Zwecke, Mai - September 1918

- Meldescheine für abgegebenes Dachkupfer, 1915 - 1918

$1915-1918$

Klassifikation Teil B: 02425

Band: 1

Trägermaterial: Papier

Alte Reg.-Sig.: VII J 095

Bestell-Nr.: IV 02425

3271 Beschlagnahmung von Dachkupfer für die Kriegswirtschaft, Bd. 2

- Ablieferungsscheine und Entschädigungsquittungen für abgegebenes Dachkupfer

$1917-1918$

Klassifikation Teil B: 02426

Band: 2

Trägermaterial: Papier

Alte Reg.-Sig.: VII J 095

Bestell-Nr.: IV 02426

3272 Beschlagnahmung von Dachkupfer für die Kriegswirtschaft, Bd. 3

- Ablieferungsscheine und Entschädigungsquittungen für abgegebenes Dachkupfer

$1917-1918$

Klassifikation Teil B: 02427

Band: 3

Trägermaterial: Papier

Alte Reg.-Sig.: VII J 095

Bestell-Nr.: IV 02427 
Lfd. Nr. Titel

Laufzeit

3273 Beschlagnahmung von Destllationsapparaten aus Kupfer und

Kupferlegierung für die Kriegswirtschaft

- Bekanntmachung des Stellvertretenden Generalkommandos des X. Armeekorps über Beschlagnahmung von Destllationsapparaten aus Kupfer und Kupferlegierung für die Kriegswirtschaft, Mai 1917

- Meldung von Destllationsapparaten aus Kupfer und Kupferlegierung an die Kriegsmetallmobilisierungsstelle, Juni - Juli 1917

- Anträge auf Befreiung von der Abgabepflicht, Juni - Juli 1917

- Ausführungsbestimmungen der Kriegsmetallmobilisierungsstelle zur Ablieferung von Destllationsapparaten aus Kupfer und Kupferlegierung für die Kriegswirtschaft, Oktober 1917 - Mai 1918

- Rückerstattung der aus der Kämmereikasse vorgeschossenen

Entschädigungszahlungen für abgelieferte Destllationsapparate aus

Kupfer und Kupferlegierung, durch die Kriegsmetall AG, August 1918

$1917-1918$

Klassifikation Teil B: 02428

Trägermaterial: Papier

Alte Reg.-Sig.: VII J 096

Bestell-Nr.: IV 02428

3274 Beschlagnahmung von Blitzableitern aus Kupfer für die Kriegswirtschaft, Bd. 1

- Anträge auf Stellung von Ersatz und höhere Entschädigungen für abgelieferte Blitzableiter aus Kupfer

$1916-1918$

Klassifikation Teil B: 02429

Band: 1

Trägermaterial: Papier

Alte Reg.-Sig.: VII J 096

Bestell-Nr.: IV 02429

3275 Beschlagnahmung von Blitzableitern aus Kupfer für die

Kriegswirtschaft, Bd. 2

- Bekanntmachung des Stellvertretenden Generalkommandos des X. Armeekorps über Beschlagnahmung von Blitzableitern aus Kupfer und Kupferlegierung für die Kriegswirtschaft, Juni 1917

- Meldung von Blitzableitern aus Kupfer und Kupferlegierung an die Kriegsmetallmobilisierungsstelle, Oktober 1917

Klassifikation Teil B: 02430

Band: 2

Trägermaterial: Papier

Alte Reg.-Sig.: VII J 096

Bestell-Nr.: IV 02430 
Lfd. Nr. Titel

3276 Beschlagnahmung von Kupfer und Kupferlegierungen für die Kriegswirtschaft, Bd.1

- Bekanntmachung des Stellvertretenden Generalkommandos des X. Armeekorps über Beschlagnahmung von Kupfer und Kupferlegierung für die Kriegswirtschaft, Juni 1917

- Bestellung des Kaufmanns L. Heerma zum Sachverständigen bei der Organisation der Abgabe von Kupfer und Kupferlegierungen, Juli 1917

- Organisation der Abgabe von Kupfer und Kupferlegierungen in Emden, Juli - Oktober 1917

1917

Klassifikation Teil B: 02431

Band: 1

Trägermaterial: Papier

Alte Reg.-Sig.: VII J 096

Bestell-Nr.: IV 02431

3277 Beschlagnahmung von Kupfer und Kupferlegierungen für die Kriegswirtschaft, Bd.2

- Abgabelisten über Kupfer und Kupferlegierungen

1917

Klassifikation Teil B: 02432

Band: 2

Trägermaterial: Papier

Alte Reg.-Sig.: VII J 096

Bestell-Nr.: IV 02432

3278 Beschlagnahmung von Kupfer und Kupferlegierungen für die Kriegswirtschaft, Bd.3

- Abgabelisten über Kupfer und Kupferlegierungen

1917

Klassifikation Teil B: 02432,01

Band: 3

Trägermaterial: Papier

Alte Reg.-Sig.: VII J 096

Bestell-Nr.: IV 02432 a

3279 Portofreiheit für den Briefverkehr mit der

Kriegsmetallmobilmachungsstelle und anderen Dienststellen

- Verfügung des Kriegsministers über Portofreiheit für den Briefverkehr mit der Kriegsmetallmobilmachungsstelle und anderen Dienststellen

1917

Klassifikation Teil B: 02433

Trägermaterial: Papier

Alte Reg.-Sig.: VII J 098

Bestell-Nr.: IV 02433 
Lfd. Nr. Titel

- Aufstellung mit Personen mit Genehmigung zur Nutzung eines Fahrrades zur beruflichen Nutzung und Befreiung von der Ablieferungspflicht von Fahrradreifen, 1916

- Bekanntmachung des Stellvertretenden Generalkommandos des X. Armeekorps über Beschlagnahmung von Fahrradreifen aus Gummi für die Kriegswirtschaft, März 1916 / September 1916 / November 1916 / Februar 1917

- Anordnung des Kriegsministers über Beschlagmnahmung von Fahrradreifen aus Gummi, Juli 1916

- Anträge auf Nutzungserlaubnis von Fahrräder mit Gummireifen, Juni - August 1916

- Bekanntmachung des Magistrats über Beschlagnahmung von Fahrradreifen aus Gummi und Zahlung eines Einheitspreises zur Entschädigung der Eigentümer bei freiwilliger Abgabe, August 1916 - Meldung der in Emden gesammelten Gummibereifungen an die Gummisammelstelle Neuenhagen, November 1916 / Februar 1917 - Anordnung des des Stellvertretenden Generalkommandos des X. Armeekorps über Enteignung von Fahrradreifen aus Gummi, Februar 1917

- Liste der Eigentümer der zur Enteignung anstehenden

Fahrrad-Gummireifen, März 1917

- Erlass des Ministers der öffentlichen Arbeiten über Ersatz von

Gummireifen durch ein Federsystem, Oktober 1918

$1916-1918$

Klassifikation Teil B: 02434

Trägermaterial: Papier

Alte Reg.-Sig.: VII J 100

Bestell-Nr.: IV 02434

- Erlass des Innenministers über Errichtung eines Eisenkommissariats als Koordinierungsstelle zur Erfassung von Alteisen für die Kriegswirtschaft, März 1918

1918

Klassifikation Teil B: 02435

Trägermaterial: Papier

Alte Reg.-Sig.: VII J 101

Bestell-Nr.: IV 02435

3282 Höchstpreise für Schuhe sowie für Web- und Strickwaren

- Verordnung des Bundesrates über Höchstpreise für Schuhe sowie für Web- und Strickwaren, März 1916

- Umsetzung der Verordnung über Höchstpreise für Schuhe sowie für Web- und Strickwaren, 1916 - 1918

$1916-1918$

Klassifikation Teil B: 02436

Trägermaterial: Papier

Alte Reg.-Sig.: VII J 103

Bestell-Nr.: IV 02436 
Lfd. Nr. Titel

Laufzeit

3283 Beschaffung von Arbeitskleidung für die minderbemittelte 1917-1918 Bevölkerung, Bd. 1

- Bekanntmachung der Reichsbekleidungsstelle über Verteilung von Männersocken und Frauenstrümpfen sowie schwarzen Kinderstrümpfen an die Kommunalverbände zur Weitergabe an die Bevölkerung, Januar 1917

- Bestellung von 900 Paar Männer-, Frauen- und Kindersocken bei der Reichsbekleidungsstelle durch den Magistrat, März 1917

- Verhandlungen der städtischen Bekleidigungskommission über Organisation der Versorgung der minderbemittelten Bevölkerung mit Arbeitskleidung und Überzeug sowie Preisfestsetzung der von der Stadt verkauften Textilien, April 1917 - November 1918

- Erwerb des Textilienlagers des Eduard Block durch den Magistrat, April 1917

- Reisen des J. Valk zum Ankauf von Arbeitsbekleidung für Minderbemittelte, Mai - Juni 1917

- Angebot der Fa. Max Märkle, Frankfurt / Main über Arbeitskleidung, Juni 1917

- Angebot der Fa. Kröger über Warenlager von Kindergarderoben und Damen-Konfektionskleidung, Juni - August 1917

- Datensammlung wegen Kleiderverteilung in anderen Städten, Juni 1917

- Angebot der Reichsbekleidungsstelle über Hosen, Anzüge,

Damenmäntel, Röcke und Blusen, 1917

- Übersicht über Ausgaben für das städtische Manufakturwarenlager (Verteilungsstelle für Textilien), 1917

- Bekanntmachung über von der Verteilungsstelle angebotene Kleidung, Februar - August 1918

$1917-1918$

Klassifikation Teil B: 02437

Band: 1

Trägermaterial: Papier

Alte Reg.-Sig.: VII J 104

Bestell-Nr.: IV 02437

3284 Beschaffung von Arbeitskleidung für die minderbemittelte Bevölkerung, Bd. 2

- Rechnungen über angeschaftte Kleidungsstücke und Reisekosten der Kleideraufkäufer sowie Lagerkosten

$1917-1918$

Klassifikation Teil B: 02438

Band: 2

Trägermaterial: Papier

Alte Reg.-Sig.: VII J 104

Bestell-Nr.: IV 02438 
Lfd. Nr. Titel

Laufzeit

3285 Kleiderversorgung 1916-1918

- Bekanntmachung des Magistrats zur Bewirtschaftung von Schuhen und Textilien

1916 - 1918 (1919)

Klassifikation Teil B: 02439

Trägermaterial: Papier

Alte Reg.-Sig.: VII J 108

Bestell-Nr.: IV 02439

3286 Manufakturwarenlager der Stadt Emden (Kleiderlager)

$1916-1918$

- Anmietung der Geschäftsräume des Händlers Polack zum Zweck eines Manufakturwarenlagers, Mai 1917

- Vertrag zwischen der Stadt Emden und dem Norddeutschen Lloyd über Anmietung von Räumen der Auswandererhalle zum Zweck eines Manufakturwarenlagers, Mai 1917

- Vermietung der Lloyd-Hallen als Durchgangslager für entlassene und heimkehrende deutsche Kriegsgefangene, Juni 1919

1917 (1919)

Klassifikation Teil B: 02440

Trägermaterial: Papier

Alte Reg.-Sig.: VII J 109

Bestell-Nr.: IV 02440

3287 Bekleidungsausschuss der Stadt Emden

- Verhandlungen des Bekleidungsausschusses wegen der

Bewirtschaftung von Textilien und Schuhe

1916 - 1918 (1919 - 1920)

Klassifikation Teil B: 02441

Trägermaterial: Papier

Alte Reg.-Sig.: VII J 111

Bestell-Nr.: IV 02441

3288 Rechnungslegung: Manufakturwarenlager (Kleiderlager)

- Einnahmen und Ausgaben des Manufakturwarenlagers

1918

Klassifikation Teil B: 02442

Trägermaterial: Papier

Alte Reg.-Sig.: VII J 109

Bestell-Nr.: IV 02442 
Lfd. Nr. Titel

Laufzeit

3289 Angestellte im städtischen Manufakturwarenlager $1917-1918$

- Einstellung der Verkäuferin Frauke Kruse als Lageristin im Manufakturwarenlager, Mai 1917

- Gesuche der Angestellten um Gehaltserhöhung, Oktober 1917 Januar 1918

1917 - 1918 (1919)

Klassifikation Teil B: 02443

Trägermaterial: Papier

Alte Reg.-Sig.: VII J 112

Bestell-Nr.: IV 02443

3290 Zurückstellung der beim Bekleidungsamt beschäftigten

$1916-1918$

Wehrpflichtigen vom Kriegsdienst

- Anträge des Magistrats auf Zurückstellung der beim Bekleidungsamt beschäftigten Wehrpflichtigen vom Kriegsdienst

$1916-1918$

Klassifikation Teil B: 02444

Trägermaterial: Papier

Alte Reg.-Sig.: VII J 113

Bestell-Nr.: IV 02444

3291 Beschlagnahmung von Sonnenvorhängen aus Stoff für die

Kriegswirtschaft

- Listen über Besitzer abgabepflichtiger Sonnenvorhänge aus Stoff,

1918

- Bekanntmachung der Beschlagnahmung von Sonnenvorhängen aus

Stoff für die Kriegswirtschaft, Juli 1918

1918

Klassifikation Teil B: 02445

Trägermaterial: Papier

Alte Reg.-Sig.: VII J 114

Bestell-Nr.: IV 02445

- Erlasse des Innenministers über Anordnung Sammlung von

Arbeitskleidung für Rüstungsarbeiter, Mai / August 1918

- Organisation der Sammlung durch die Zentrale für

Kleiderverarbeitung für Ostfriesland mit Hilfe von Schulen, Mai 1918

- Aufruf zur Abgabe von Anzügen und Oberbekleidung zu Gunsten von Rüstungsarbeitern, Mai / August 1918

- Anträge auf Befreiung von einer Abgabepflicht von Kleidung, Juni August 1918

- Aufstellung über Ergebnis der Kleidersammlung in Emden, August 1918

1918

Klassifikation Teil B: 02446

Trägermaterial: Papier

Alte Reg.-Sig.: VII J 115

Bestell-Nr.: IV 02446 
Lfd. Nr. Titel

- Erlass des Innenministers über Abgabe von Uniformstücken,

Februar 1917

- Anordnung der Reichsbekleidungsstelle über Versorgung der

Beamten von Verwaltungen mit Uniformen, April 1917

1917 (1919)

Klassifikation Teil B: 02447

Trägermaterial: Papier

Alte Reg.-Sig.: VII J 115

Bestell-Nr.: IV 02447

- Anbietung von Kursen für Frauen unter Leitung der Fortbildungsschullehrerin Kopp über Techniken zur Herstellung leichter Schuhe aus Segeltuch und Lederersatz sowie Flicken beschädigter Schuhe, Oktober 1917

- Angebote von Holzsohlen u.a. Lederersatzstoffen zur

Schuhherstellung, Dezember 1917 - Mai 1918

$1917-1918$

Klassifikation Teil B: 02448

Trägermaterial: Papier

Alte Reg.-Sig.: VII J 116

Bestell-Nr.: IV 02448

- Eingang von Sohlen aus Lederersatzstoff zur Schuhreparatur, 1917

- Aufklärungsschrift der Kriegsledergesellschaft: Wo bleibt unser

Leder, 1917

- Bericht des Magistrats an den Regierungspräsidenten in Aurich über Schuhmangel in Emden und drohende Unruhe unter der

Arbeiterschaft weiterem Fortbestand des Mangels an Arbeitsschuhen, Oktober 1917

- Gesuche Emder Polizisten um Zuteilung von Schuhen und

Schuhleder, Januar 1918

- Eingabe des Magistrats an den Hauptverteilungsausschuss des

Schuhhandels über Bitte um Zuteilung von Schuhwerk für

Rüstungsarbeiter und Polizisten, Januar 1918

- Mitteilung der Reichsstelle für Schuhversorgung über

Schuhbewirtschaftung, 1918 (1919)

- Antrag der Arbeiter des städtischen Abfuhrbetriebs auf Zuteilung von Lederschuhen wegen Unmöglichkeit der Arbeitsverrichtung mit

Schuhen mit Holzsohlen, Juni 1918

1918 (1919)

Klassifikation Teil B: 02449

Trägermaterial: Papier

Alte Reg.-Sig.: VII J 117

Bestell-Nr.: IV 02449 
Lfd. Nr. Titel

Laufzeit

3296 Versorgung der Bevölkerung mit Holzschuhen

- Liste der Bestellungen von Holzschuhen für die Stadt und den

Landkreis Emden, 1917

- Ankauf von Holzschuhen durch die Bekleidungskommission der

Stadt Emden, August 1917 - April 1918

- Organisation des Vertriebs von Holzschuhen, September -

November 1917

- Beschwerde der Gutachterkommission für Schuhwarenpreise über zu hohe Verkaufspreise für Holzschuhe in Emden, November 1917

- Abrechnungen über Einkauf und Transport von Holzschuhen, 1918

1917 - 1918 (1919 - 1920)

Klassifikation Teil B: 02450

Trägermaterial: Papier

Alte Reg.-Sig.: VII J 118

Bestell-Nr.: IV 02450

3297 Neunte Kriegsanleihe

- Werbung für die IX. Kriegsanleihe u.a. im Rahmen des

Nationaljugendtages. Juni - September 1918

- Erlass des Innenministers über Zeichnung der IX. Kriegsanleihe,

September 1918

- Erlass des Innenministers über Heranziehung der Beamten zur

Zeichnung der IX. Kriegsanleihe, Oktober 1918

1918

Klassifikation Teil B: 02451

Trägermaterial: Papier

Alte Reg.-Sig.: VII J 129

Bestell-Nr.: IV 02451

3298 Heulieferungen für das Heer

- Verordnung des Kriegsernährungsamtes über Bewirtschaftung und Ablieferung von Heu an das Heer, Mai 1918

- Umsetzung der Verordnung in Emden, Juni 1918

- Verordnung des preußischen Kriegsamtes für Futtermittel über Heubewirtschaftung, Preise für Heereslieferungen oder für

Zwangsablieferungen, Mai 1918

- Aufstellung über Besitzer von Wiesen in Emden, Mai / Juni 1918

- Anordnung der Kriegswirtschaftsstelle der Stadt Emden über

Ablieferungsmengen für Heu, Juni 1918

- Anträge auf Befreiung von den Heuablieferungen, Juni - August 1918

- Aufstellungen über Heuablieferungen aus Emden, August -

September 1918

- Telegrafischer Erlass des Oberpräsidenten der Provinz Hannover über Einstellung der Heulieferungen an das Heer, Dezember 1918

1918

Klassifikation Teil B: 02461

Trägermaterial: Papier

Alte Reg.-Sig.: VII J 152

Bestell-Nr.: IV 02461 
Lfd. Nr. Titel

- Aufstellung über abgabepflichtige Getreidemengen aus Emden, 1917 / 1918

- Verfügung des Magistrats an die Emder Getreidehändler über Verbot des ungenehmigten Weiterverkaufs des von den Bauern des Landkreises Emden erworbenen Getreides und Hülsenfrüchten, August - September 1917

- Erfassung der Getreidevorräte im Landkreis Emden, Januar - April 1918

- Anzeige gegen den Viehhändler Moses Seligmann wegen unerlaubten Hortens und Weiterverhandelns von Hülsenfrüchten, Februar 1918

- Ernteberichte, 1918

$1917-1918$

Klassifikation Teil B: 02462

Band: 1

Trägermaterial: Papier

Alte Reg.-Sig.: VII J 153

Bestell-Nr.: IV 02462

3300 Bewirtschaftung von Getreide

- Aufstellung über ausgedroschenes Getreide

$1917-1918$

Klassifikation Teil B: 02463

Band: 2

Trägermaterial: Papier

Alte Reg.-Sig.: VII J 154

Bestell-Nr.: IV 02463

3301 Ablieferung von Metallen für die Kriegswirtschaft

- Regelung der Ablieferung von Metallen für die Kriegswirtschaft, 1915

- 1916

- Plakate über Anordnung der Ablieferung von Metallen für die

Kriegswirtschaft, 1917 / 1918

$1915-1918$

Klassifikation Teil B: 02464

Trägermaterial: Papier

Alte Reg.-Sig.: VII J 155

Bestell-Nr.: IV 02464 
Lfd. Nr. Titel

Laufzeit

3302 Bewirtschaftung von Stroh

- Anordnung des Kriegsamtes für Futtermittel über Ablieferungsmenge von Stroh für die Kriegswirtschaft, Juni 1918

- Feststellung der abzuliefernden Strohmenge für die Stadt Emden, Juni - Juli 1918

- Bestellungen von Futterstroh, Juli - August 1918

- Aufstellung der von der Stadt Emden abgelieferten Strohmengen, November 1918

1918

Klassifikation Teil B: 02465

Trägermaterial: Papier

Alte Reg.-Sig.: VII J 156

Bestell-Nr.: IV 02465

- Regelung der Benutzung von Kraftwagen, 1918 (1919)

- Bewirtschaftung von Lebensmitteln und Futter, 1918

- Anträge auf Bezug kriegswichtiger Rohstoffe (Dachpappe etc.), 1918

- Einsatz von Gespannen für militärische Zwecke, September 1918

- Demobilisierung: Entlassung von Kriegsgefangenen, November

1918 (Januar 1919)

- Aufstellung über gewerblich eingesetzte Pferde in Emden, Februar 1918

- Demobilisierung: Planung des Ersatzes von Kriegsgefangenen durch demobilisierte Soldaten, Juni 1918

1918

Klassifikation Teil B: 02466

Trägermaterial: Papier

Alte Reg.-Sig.: VII J 157

Bestell-Nr.: IV 02466

3304 Bewirtschaftung von Textilwaren

- Mitteilungen der Reichsbekleidungsstelle und der Kriegswirtschafts AG über Bewirtschaftung von Textilien

$1917-1918$

Klassifikation Teil B: 02474

Trägermaterial: Papier

Alte Reg.-Sig.: VII J 156

Bestell-Nr.: IV 02474 
Lfd. Nr. Titel

- Erlass des Landwirtschaftsministers über Preisgestaltung bei

Kartoffeln, Januar - Februar 1916

- Verhandlungen zwischen Magistrat und Kartoffelhändlern wegen

Kartoffellieferungen, Februar - August 1916

- Rechtsstreit um eine im Dezember 1915 eingelaufene Lieferung

verfaulter Kartoffeln vom Gut des Majors v. Heydebeck aus Bärwalde /

Pommern, Februar - März 1916

- Organisation der Kartoffellieferungen nach Emden über die

Reichskartoffelstelle und die Provinzialkartoffelstelle, Januar - August

1916

- Importe von Kartoffeln aus den Niederlanden, Januar - Juli 1916

- Erfassung der Kartoffelbestände bei den Emder Händlern, Januar -

Februar 1916

- Bekanntmachung des Reichskanzlers und des Bundesrats über

Organisatiion der Versorgung mit Kartoffeln: u.a. Enteignung privater

Bestände, Februar / Juni 1916

- Bericht des Magistrats an den Regierungspräsidenten über

Kartoffelbestände und nicht notwendige Enteignungen, März 1916

- Bericht des Magistrats an den Regierungspräsidenten über

Organisation der Kartoffelrationierung in Emden, März 1916

- Anforderung von Kartoffeln aus benachbarten Kommunalverbänden durch den Magistrat wegen akutem Bedarf, März 1916

- Antrag der Gemüsebaugenossenschaft Emden an den Magistrat auf

Erhöhung der festgesetzten Erzeiugerpreise für Kartoffeln, Juli 1916

- Bericht des Kriminalpolizei-Sergeanten Schünemann über unerlaubte Preistreiberei der Emder Gemüsebauern beim

Kartoffelverkauf, Juli 1916

- Verfügung des Magistrats über Erfassung und Beschlagnahme der Kartoffellbestände der Erzeger, Juli 1916

- Erlass des Innenministers über Subventionierung des

Kartoffelpreises zugunsten Minderbemittelter, Juli 1916

1916

Klassifikation Teil B: 03842

Trägermaterial: Papier

Vorprovenienz: Lebensmittelamt der Stadt Emden

Bestell-Nr.: IV 03842

- Ankauf und Abgabe der benötigten Rüben durch die städtische Kartoffelgechäftsstelle (Fa. Bernhard Polak)

- Angebote von Steckrübenlieferanten

- Verfahren der Fa. Johnsen, Hamburg zur Aufbereitung von Rüben für den menschlichen Verzehr, Mai 1918

1918 (1919) Klassifikation Teil B: 03843

Trägermaterial: Papier

Vorprovenienz: Lebensmittelamt der Stadt Emden

Bestell-Nr.: IV 03843 
Lfd. Nr. Titel

- Verordnungen der preußischen Zentralbehörden über Verwendung und Bewirtschaftung von Milch- und Milchprodukten,

- Milchbezugskarte

- Bericht des Magistrats an den Regierunspräsidenten in Aurich über

Entwicklung des Milchangebots in Emden, Oktober 1915

- Bericht der Molkerei Emden über ausbleibende Milchlieferungen, Juni 1916

- Berichte der Landwirte Ohling und Boerma über Motive für die Nichtbelieferung der Molkerei in Emden, Juni 1916

- Bericht des Polizeisergeanten Buscher über Milchknappheit, August 1916

- Einführung der Milbewirtschaftung, August - November 1916

- Sonderzuteilung von Milch an Kranke auf ärztlichem Attest, Oktober 1916

Anträge auf Mehrzuteilungen von Milch und Verbeserung der

Verteilung, November 1916

- Ermittlung des Eigenverbrauchs von Milcherzeugern, November -

Dezember 1916

1916

\author{
Klassifikation Teil B: 03844 \\ Trägermaterial: Papier \\ Vorprovenienz: Lebensmittelamt der Stadt Emden \\ Bestell-Nr.: IV 03844
}

3308 Versorgung mit Kohl

- Ankauf von Weißkohl aus den Niederlanden, April 1917 / Februar 1918

- Bewirtschaftung von Kohl, 1917 - 1918 (1919)

- Angebot der Fa. Jäger und Co aus Wesselbühren über Lieferung von Weißkohl gegen Mineraldünger, Oktober 1917 / März 1918

- Anordnungen der Reichsstelle für Gemüse und Obst zur Kohlbewirtschaftung, Oktober 1917

- Bericht des Magistras an die Reichsstelle für Obst und Gemüse über Ernteausfälle bei Kohl wegen Wetterunbilden (Dürre, Daueregen) und Felddiebstahl, Oktober 1917 / Januar 1918

- Antrag ddes Gemüsehändlers Johann Klaassen, Mitinhaber der Fa. Joh. Klaassen, beim Magistrat auf Erhalt der Funktion der Kreis- und Bezirksstelle für Obst und Gemüse unter Ablösung des bisherigen Betreibers, Gemüsegroßhändler Bernhard Polak, April 1918

- Anordnung der Kriegsgesellschaft für Sauerkraut über

Absatzordnung für Sauerkraut und Rübensauerkraut, März 1917

- Ermittlungen gegen den Gemüsehändler Johann Klaassen wegen

Verstoß gegen die Höchstpreisverordnung für Sauerkraut, Juni -

November 1918

$1917-1918$

Klassifikation Teil B: 03845

Trägermaterial: Papier

Vorprovenienz: Lebensmittelamt der Stadt Emden

Bestell-Nr.: IV 03845 
Lfd. Nr. Titel

- Produktion und Anschaffung sowie Einlagerung von

Fleischdauerware (Pökelfleisch, Salzfleisch) durch die Stadt Emden zur Sicherung der Fleischversorgung, Januar - Februar 1915

- Festsetzuung eines Höchstpreises für Schweinefleisch, April 1915 /

Februar 1916

- Organisation der Bewirtschaftung von Schweinefleisch, Februar 1915

- Erlasse von Reichs- und preußischer Staatsregierung zur

Fleischbewirtschaftung, 1915 - 1916

- Antrag des Schlachtermeisters Heymann Glös an den Magistrat auf Berücksichtigung der am Samstag schließenden jüdischen

Schlachtereigeschäfte (Sabbat) bei der Fleischverteilung vom

Schlachthof, Mai 1916

- Organisation der Fleischbewirtschaftung, 1916

- Aufkauf von Schlachtvieh durch die Stadt Emden, 1915 - 1916

$1915-1916$

Klassifikation Teil B: 03846

Trägermaterial: Papier

Vorprovenienz: Lebensmittelamt der Stadt Emden

Bestell-Nr.: IV 03846

3310 Abgabe von Buntmetall aus Dachrinnen

- Geheimer Erlass des Kriegsministers über Erfassung und Abgabe von Kupfer und anderes Buntmetall aus Dachrinnen, Fallrohren etc. für kriegswirtschaftliche Zwecke, August 1915

- Erlass des Innenministers über Erfassung kupferner Dachrinnen etc., September 1915

Aufstellungen über kupferne oder mit Kupfer beschlagene Dachrinnen etc. an Emder Gebäuden, September - Dezember 1915

- Anträge auf Befreiung von der Ablieferung wegen hohen Alters der betr. kupfernen Dachrinnen und schwieriger Ausbau des Kupfers,

September - Dezember 1915

- Entschädigungszahlungen an die Eigentümer der beschlagnahmten Kupferteile und Rückerstattung der von der Kämmereikasse vorgeschossenen Gelder duch die Metallmobilmachungsstelle im Kriegsministerium, September 1915 - Mai 1916

- Organisation der Abgabe des Kupfers aus Dachrinnen etc., September 1915 - Mai 1916

$1915-1916$

Klassifikation Teil B: 2393

Trägermaterial: Papier

Alte Reg.-Sig.: VII J 068

Bestell-Nr.: IV 02393 
Lfd. Nr. Titel

Laufzeit

3311 Deutsche Vaterlandspartei

- Agitation und Programm der Deutschen Vaterlandspartei für einen

Siegfrieden

- Mitglieder der Deutschen Vaterlandspartei in Emden

- Ludendorffspende

- Vermögensabwicklung der Deutschen Vaterlandspartei

$1917-1918(1920)$

Klassifikation Teil B: 02328

Trägermaterial: Papier

Alte Reg.-Sig.: VII J 010

Bestell-Nr.: IV 02328

- Aufruf zur Unterstützung der Deutschen in den (verlorenen) Kolonien

- Ertrag der Haussammlung zur Kolonialspende

1918

Klassifikation Teil B: 02347

Trägermaterial: Papier

Alte Reg.-Sig.: VII H 010

Bestell-Nr.: IV 02347

- Bestimmungen zur Pressezensur und der Kriegsberichtserstattung

- Regelung des Postverkehrs im Weltkrieg

- Kriegswirtschaftliche Bekanntmachungen

$1914-1917$

Klassifikation Teil B: 02365

Trägermaterial: Papier

Alte Reg.-Sig.: VII J 037

Bestell-Nr.: IV 02365

3314 Hindenburg-Gabe anlässlich des Geburtstags des

Generalfeldmarschalls von Hindenburg

- Organisation der Spende für deutsche Soldatenheime, Dezember 1916 - Februar 1917

- Aufruf zur Teilnahme an der Hindenburg-Spende anlässlich des 70.

Geburtstags des Generalfeldmarschalls von Hindenburg, August -

Oktober 1917

- Organisation der Hindenburg - Feier, September - Oktober 1917

- Feier zum 70. Geburtstag des Generalfeldmarschals von

Hindenburg, Oktober 1917

$1916-1917$

Klassifikation Teil B: 02378

Trägermaterial: Papier

Alte Reg.-Sig.: VII J 051

Bestell-Nr.: IV 02378 
Lfd. Nr. Titel

Laufzeit

3315 Aufrufe und Plakate, Flugschriften

- Flugschriften zur Ostpreußenhilfe, 1915

- Werbung für Kriegsbüchereien

- Schrift des Verbandes deutscher Eisen- und Stahlindustrieller über

Notwendigkeit der Annexion französischer Eisenerzgebiete in

Lothringen, Mai 1918

- Druckschriften zur Kriegswohlfahrt, 1917 - 1918

- Deutsche Kriegswochenschau, Mai - Oktober 1918

- Werbung für die IX. Kriegsanleihe, September - Oktober 1918

$1915-1918$ (1919)

Klassifikation Teil B: 02456

Trägermaterial: Papier

Alte Reg.-Sig.: VII J 134

Bestell-Nr.: IV 02456 
09

09.01
Kirchen

\section{Aufsicht über die Kirchen}

Lfd. Nr. Titel

Laufzeit

3316 Patronatsrecht der Stadt Emden über die Prediger-, Küster- und Organistenstelle der Kirchengemeinde Wolthusen

- Gesuch des Antonius Fegter, Zweiter Prediger in Wolthusen, über Bitte um Unterstützung für die hinterlassenen Kinder des verstorbenen Predigers Dreesmann, April - September 1837

- Besetzung der durch den Tod des Pastors Dreesmann vakanten Ersten Predigerstelle in Wolthusten unter dem Patronat der Stadt Emden durch den Prediger Warner Janssen, August 1837 - Oktober 1838

- Berichte der Kirchen-Commission der Stadt Emden Gehalt des Predigers in Wolthusen, Mai 1882

- Wahl eines Predigers in Wolthusen, Juni 1882 - Oktober 1916 - Scheitern einer Initiative des Wolthuser Kirchenvorstandes zum Ankauf des Wahlrechts zur Predigerwahl von der Stadt Emden als Patron, Dezember 1882

$1837-1915$

Klassifikation Teil B: 00318

Trägermaterial: Papier

Alte Reg.-Sig.: IV B 19

Bestell-Nr.: IV 00318

3317 Überweisung von Gräbern der früheren Weberzunft auf dem Friedhof der Neuen Kirche an die Stadt Emden

- Eingabe des Webers Johannes Bachmann an den Magistrat der Stadt Emden über Antrag auf Benutzungserlaubnis für drei Gräber der erloschenen Weberzunft durch seine Familie, Februar 1899

- Antrag des Magistrats der Stadt Emden beim Regierungspräsidenten in Aurich auf Genehmigung der Übertragung der Gräber der erloschenen Weberzunft in den Besitz der Stadt Emden, Mai - August 1899

- Schreiben des Magistrats der Stadt Emden an den reformierten Kirchenrat über Bitte um Mitteilung seiner Haltung zur Absicht der Stadt zur Übernahme der Grabstellen der ehemaligen Weberzunft, Juli 1899

- Veräußerung der Grabstellen durch die Stadt Emden, September 1907 - August 1909

$1899-1909$

Klassifikation Teil B: 00381

Trägermaterial: Papier

Alte Reg.-Sig.: IV Tz 69

Bestell-Nr.: IV 00381 
IV

09 Kirchen

09.01

09.01.01

Organisation des Kirchenwesens

Lfd. Nr. Titel

Laufzeit

3318 Umzugskosten der Prediger

- Finanzierung von Reise- und Umzugskosten für Prediger im Consistorialbereich Emden durch die Kämmereikasse der Stadt

Emden (Akte unvollständig)

$1887-1911$

Klassifikation Teil B: 03162

Trägermaterial: Papier

Alte Reg.-Sig.: IX A1 011

Bestell-Nr.: IV 03162

3319 Form der Berichterstattung aus der Kirchenverwaltung

- Regelung der Form der Berichtserstattung zu Angelegenheiten der Kirchenverwaltung an die beaufsichtigende Konsistorialbehörde der Stadt Emden und der Landdrostei (Regierung) zu Aurich, 1866 - 1891

Enthält auch:

- Erlasse der preußischen MInister der geistlichen UNterichts- und Medizinalangelegenheiten über Beihilfen für Kirchen- und Schulbauten, April - Juli 1892

$1866-1892$

Klassifikation Teil B: 03163

Trägermaterial: Papier

Alte Reg.-Sig.: IX A1 013

Bestell-Nr.: IV 03163

3320 Kirchenvisitationen und Anordnungen des Konsistoriums

- Organisation der Kirchen und Schulvisitationen durch die Konsistorialbehörden

- Bestimmungen des kgl. Konsistoriums über Vertretung der Kirchen bei Gerichtsprozessen, Funktion von Geistlichen als Gutachter bei Gericht, Verwaltung und Einlösung von Wertpapieren in Kirchenbesitz und über Gehalt der Geistlichen

- Abschaffung der Festmahle bei der Einführung von Geistlichen in ein Pfarramt, 1910 - 1911

$1871-1911$

Klassifikation Teil B: 03164

Trägermaterial: Papier

Alte Reg.-Sig.: IX A1 015

Bestell-Nr.: IV 03164 
IV

09 Kirchen

09.01

Aufsicht über die Kirchen

09.01 .01

Organisation des Kirchenwesens

Lfd. Nr. Titel

Laufzeit

3321 Rechtlicher Status der Kirchen- und Schullasten 1871-1906

- Regelung der Heranziehung von kirchlichem Grundbesitz und Nutznießungen zu Realsteuern und Deichlasten sowie monetarisierten feudalen Dienstleistungen (Hand- und Spanndienste)

Enthält auch:

- Regelung der Heranziehung zur Kirchensteuer

$1871-1906$

Klassifikation Teil B: 03165

Trägermaterial: Papier

Alte Reg.-Sig.: IX A1 020

Bestell-Nr.: IV 03165

3322 Kirchenverhältnisse der preußischen Garnison in Emden

- Regelung der kirchlichen und seelsorgerlichen Betreuung der preußischen Garnison in Emden

1866

Klassifikation Teil B: 03166

Trägermaterial: Papier

Alte Reg.-Sig.: IX A1 022

Bestell-Nr.: IV 03166

3323 Kirchen-. und Schulgebäude unter Oberaufsicht des kgl. Konsistorium

- Beaufsichtigung von Kirchen- und Schulgebäude durch das kgl.

Konsistorium

1870

Klassifikation Teil B: 03167

Trägermaterial: Papier

Alte Reg.-Sig.: IX A1 023

Bestell-Nr.: IV 03167

3324 Jesuiten-Gesetz

- Ausführung der Bestimmungen des Gesetzes über das Verbot des Jesuiten-Ordens

$1872-1873$

Klassifikation Teil B: 03168

Trägermaterial: Papier

Alte Reg.-Sig.: IX A1 024

Bestell-Nr.: IV 03168 
IV

09

09.01

09.01.01

\section{Kirchen}

Aufsicht über die Kirchen

Organisation des Kirchenwesens

Lfd. Nr. Titel

Laufzeit

3325 Beihilfe der Stadt Emden zur Besoldung der reformierten Prediger, Bd. 1

- Bericht des Kämmerers van Buiren über Leistungen aus der Stadtkasse für die Beihilfe der Stadt Emden zur Besoldung der reformierten Prediger, Februar 1869

- Verhandlungen der städtischen Kollegien über Weiterführung der Beihilfe der Stadt Emden zur Besoldung der reformierten Prediger, Januar 1872 - Oktober 1873 / April 1877 - März 1878

- Gutachten des Magistrats über Grundlage für die Beihilfe der Stadt

Emden zur Besoldung der reformierten Prediger, 1873

- Gutachten des Prof. John, Universität Göttingen, über

Rechtsanspruch der reformierten Prediger auf die Beihilfe der Stadt

Emden zu ihrer Besoldung, 1888 / 1889

$1869-1889$

Klassifikation Teil B: 03169

Band: 1

Trägermaterial: Papier

Alte Reg.-Sig.: IX A1 025

Bestell-Nr.: IV 03169

3326 Beihilfe der Stadt Emden zur Besoldung der reformierten Prediger, Bd. 2

- Denkschrift Oberbürgermeister Fürbringer über historische Grundlagen für die Beihilfe der Stadt Emden zur Besoldung der reformierten Prediger, 1893

- Verhandlungen der städtischen Kollegien über Weiterführung der Beihilfe der Stadt Emden zur Besoldung der reformierten Prediger, 1894

$1893-1894$

Klassifikation Teil B: 03170

Band: 2

Trägermaterial: Papier

Alte Reg.-Sig.: IX A1 025

Bestell-Nr.: IV 03170

3327 Qualifikation der Geistlichen

- Ausführung des Gesetzes über die Vorbildung und Anstellung der Geistlichen v. 11. Ma 1873

$1873-1879$

Klassifikation Teil B: 03171

Trägermaterial: Papier

Alte Reg.-Sig.: IX A1 026

Bestell-Nr.: IV 03171 
IV

09

09.01

09.01.01
Kirchen

Aufsicht über die Kirchen

Organisation des Kirchenwesens

Lfd. Nr. Titel

Laufzeit

$1879-1885$

(1913)

- Erlass des preußischen Ministers für geistiche Unterrichts und Medizinalangelenheiten über Regelung der Beaufsichtigung der Kirchen durch den Staat, September 1874 / April 1885

- Bericht des Magistrats über Praxis der Kirchenaufsicht in Emden, März 1875

$1874-1885$ (1913)

Klassifikation Teil B: 03172

Trägermaterial: Papier

Alte Reg.-Sig.: IX A 1028

Bestell-Nr.: IV 03172

3329 Kirchenheizung

$1881-1882$

- Einrichtung einer Gasofenheizung in der lutherischen Kirche zu Emden nach dem Vorbild der St. Thomas - Kirche zu Leipzig

$1881-1882$

Klassifikation Teil B: 03173

Trägermaterial: Papier

Alte Reg.-Sig.: IX A1 029

Bestell-Nr.: IV 03173

3330 Abgrenzung der Kirchenbezirke

- Feststellung der Zugehörigkeit der Feldmark zum Stadtkreis Emden und der Zugehörigkeit des dort wohnenden Lutheraners,

Regierungsrat Borchling, zur lutherischen Gemeinde Emden, Januar 1902

- Umpfarrung eines Teils der Gemeinde Wolthusen zu dfen evangelischen Kirchengemeinden der Stadt Emden, 1907

- Neufestsetzung der reformierten Pfarrbezirke, 1897 - 1901

- Klärung der Gemeindezugehörigkeit der in Borssum wohnenden Lutheraner, April 1914

- Festlegung der Parochialgrenze zwischen Emden und Hinte, 1896 1905

- Zugehörigkeit Nesserlands zur reformierten Kirchengemeinde

Emden, 1903

$1896-1914$

Klassifikation Teil B: 03174

Trägermaterial: Papier

Alte Reg.-Sig.: IX A1 031

Bestell-Nr.: IV 03174 


\section{9}

09.01

09.01.01

\section{Kirchen}

Aufsicht über die Kirchen

Organisation des Kirchenwesens

Lfd. Nr. Titel

3331 Gebühren für Kirchenbesichtigungen 1901

- Erlass des preußischen Ministers der geistlichen, Unterrichts- und Medizinalangelegenheiten über Richtlinien zur Erhebung von

Gebühren für Kirchenbesichtigungen, August 1901

- Berichte aus Emder Kirchengemeinden über kostenlose

Kirchenbesichtigungen, September 1901

1901

Klassifikation Teil B: 03176

Trägermaterial: Papier

Alte Reg.-Sig.: IX A1 033

Bestell-Nr.: IV 03176

3332 Staatliche Beihilfen zu Kirchen- und Pfarrhausbauten

- Erlass des preußischen Ministers der geistlichen, Unterrichts- und Medizinalangelegenheiten über formale Gestaltung der Anträge auf Gewährung staatlicher Beihilfen zu Kirchen- und Pfarrhausbauten

1910

Klassifikation Teil B: 03181

Trägermaterial: Papier

Alte Reg.-Sig.: IX A1 039

Bestell-Nr.: IV 03181

3333 Zuschuss zur Besoldung niederer Kirchendiener

- Erlass des Oberpräsidenten der Provinz Hannover über Einrichtung eines landeskirchlichen Fonds für Zuschüsse zur Besoldung niederer Kirchendiener

1911
Klassifikation Teil B: 03182
Trägermaterial: Papier
Alte Reg.-Sig.: IX A1 040

Bestell-Nr.: IV 03182

3334 Gesetze und Erlasse zum Kirchenwesen

- Gesetze und Erlasse zur Organisation des Kirchenwesens (unvollständig)

$1882-1909$

Klassifikation Teil B: 03183

Trägermaterial: Papier

Alte Reg.-Sig.: IX A 1a 01

Bestell-Nr.: IV 03183 
IV

09 Kirchen

09.01

Aufsicht über die Kirchen

09.01 .01

Organisation des Kirchenwesens

Lfd. Nr. Titel

Laufzeit

3335 Einpfarrung des Königspolders nach Borssum 1889

- Ablehnung einer vom reformierten Synodalverband diskutierten Einpfarrung des Königspolders nach Borssum durch den Magistrat

1889

Klassifikation Teil B: 03184

Trägermaterial: Papier

Alte Reg.-Sig.: IX A 2a 03

Bestell-Nr.: IV 03184

3336 Vorschriften über das Kirchen- und Schulrechnungswesen

- Verfügungen des kgl. Konsistoriums über Regelung des Kirchenund Schulrechnungswesen

$1867-1884$

Klassifikation Teil B: 03185

Trägermaterial: Papier

Alte Reg.-Sig.: IX A 2a 06

Bestell-Nr.: IV 03185

3337 Kirchen- und Schulpflichtigkeit der Bewohner der Emder Feldmark

1885-1901

- Gutachten des Magistrats über die kirchliche und schulische

Zuordnung der Bewohner der Emder Feldmark nach Emden, Hinte und Borssum, Januar 1885

- Regulierung der Parochialgrenze in der Emder Feldmark, 1887 1901

$1885-1901$

Klassifikation Teil B: 03186

Trägermaterial: Papier

Alte Reg.-Sig.: IX A 2a 12

Bestell-Nr.: IV 03186

3338 Kollekten

1899-1901

- Kollekte zum Bau einer Kirche in Dar-es-Salaam (Deutsch

Ostafrika), 1899 - 1900

- Formblatt für eine Hauskollekte, 1901

$1899-1901$

Klassifikation Teil B: 03187

Trägermaterial: Papier

Alte Reg.-Sig.: IX A 2a 15

Bestell-Nr.: IV 03187 
09

09.01

09.01.01

\section{Kirchen}

\section{Aufsicht über die Kirchen}

Organisation des Kirchenwesens

Lfd. Nr. Titel

Laufzeit

3339 Befreiung kirchlicher Beamter mit Mindestpension von der 1904 Versicherungspflicht

- Datenerhebung des Ministeriums der geistlichen Unterrichts- und Medizinalangelegenheiten über Anzahl der kirchlichen Beamten mit Mindestpension zur Förderung einer Initiative des evangelischen Oberkirchenrats in Berlin zur Befreiung dieses Personenkreises von der Versicherungspflicht

1904

Klassifikation Teil B: 03188

Trägermaterial: Papier

Alte Reg.-Sig.: IX A 2a 16

Bestell-Nr.: IV 03188

3340 Festlegung der Emder Parochialgrenze

- Verhandlungen zwischen dem weltlichen Kirchenkommissar, Syndicus Dr. Riese, der reformierten Kirchenkommission und dem kgl. Konsistorium über Umpfarrung von Gebieten der Nachbarkirchengemeinden nach Emden, 1902

- Antrag des lutherischen Kirchenrats an das kgl. Konsistorium auf Einpfarrung der Lutheraner in Borssum, Hinte, Larrelt und Wolthusen zur lutherischen Kirchengemeinde Emden, Dezember 1905 -

September 1908 / September 1913

- Regulierung der Parochialgrenze zwischen Emden und Borssum, $1913-1914$

- Regelung der Kirchengemeindenzugehörigkeit der Arbeiterkolonie Friesland, 1913

$1902-1914$

Klassifikation Teil B: 03189

Trägermaterial: Papier

Alte Reg.-Sig.: IX A 2a 17

Bestell-Nr.: IV 03189

3341 Einschränkung der Tanzveranstaltungen während der Passionszeit

- Antrag des Pastors G. H. Stockmann in Borssum an das kgl. Konsistorium auf Einschränkung der Tanzveranstaltungen während der Passionszeit wegen Anstieg der unehelichen Geburten und Gefahr der sozialdemokratischen Indoktrination, April 1908 - Bericht des Kirchenrats der reformierten Gemeinde an die Kirchenkommission der reformierten Gemeinden über Notwendigkeit der Einschränkung der Tanzveranstaltungen während der Passionszeit zum Schutz der Moral, Mai 1908

1908

Klassifikation Teil B: 03190

Trägermaterial: Papier

Alte Reg.-Sig.: IX A 2a 19

Bestell-Nr.: IV 03190 
IV

09 Kirchen

09.01

Aufsicht über die Kirchen

09.01.01

Organisation des Kirchenwesens

Lfd. Nr. Titel

Laufzeit

3342 Gemeindezugehörigkeit der Lutheraner in Nesserland

1908-1909

- Verfügung des kgl. Konsistoriums an die Kirchenkommission der evangelischen Kirchen über Einpfarrung der Lutheraner auf Nesserland in die lutherische Gemeinde Emden, Juli 1908

- Bekanntmachung der Einpfarrung durch den Stadtsyndicus

Leinberger als weltlichen Kirchenkommissar, Juli 1908

- Liste der Lutheraner auf Nesserland, 1908

- Einpfarrungsurkunde, April 1909

$1908-1909$

Klassifikation Teil B: 03191

Trägermaterial: Papier

Alte Reg.-Sig.: IX A 2a 19

Bestell-Nr.: IV 03191 
IV

\section{9}

\subsection{1}

09.01 .02

\section{Kirchen}

Aufsicht über die Kirchen

Kirchensteuer

Lfd. Nr. Titel

Laufzeit

3343 Heranziehung von Grundstücken in der Emder Feldmark zur Kirchensteuer der Gemeinde Wolthusen

- Einspruch des Magistrats gegen die Heranziehung von Grundstücken in der Emder Feldmark zur Kirchensteuer der Gemeinde Wolthusen, Dezember 1898 - Dezember 1899

- Feststellung der Zugehörigkeit der Grundstücke in der Feldmark zur Stadtgemeinde Emden, Dezember 1898

- Heranziehung von Ländereien des Gasthauses in der Emder

Feldmark zur Kirchensteuer der Gemeinde Wolthusen, April 1904

$1898-1904$

Klassifikation Teil B: 03175

Trägermaterial: Papier

Alte Reg.-Sig.: IX A1 032

Bestell-Nr.: IV 03175

3344 Kirchen- und Schulsteuern in Emden

- Ernennung des städtischen Einnehmers B. Schröder zum Einnehmer der Kirchen- und Schulsteuer für die lutherische Kirchengemeinde, Dezember 1883 - April 1884

- Bewerbungen um die Stelle eines Kirchen- und

Schulsteuereinnehmers für die katholische Gemeinde, Januar .-

Februar 1885

- Übernahme der Hebung der Kirchen- und Schulsteuer für die lutherische Gemeinde durch Kämmerer Ernst August Gebest, August 1897 - November 1907

- Streit um die Erhebung von Kirchen- und Schulsteuern von

Bewohnern der Straße Außer dem neuen Tor, März 1900

$1883-1907$

Klassifikation Teil B: 03177

Trägermaterial: Papier

Alte Reg.-Sig.: IX A1 034

Bestell-Nr.: IV 03177

3345 Kirchen- und Schulsteuern

- Streit um die Heranziehung der Bewohner des Nordertores zur

Kirchen- und Schulsteuer der Gemeinde Wolthusen

$1903-1905$

Klassifikation Teil B: 03178

Trägermaterial: Papier

Alte Reg.-Sig.: IX A1 035

Bestell-Nr.: IV 03178 
IV

\section{9}

09.01

09.01 .02

\section{Kirchen}

Aufsicht über die Kirchen

Kirchensteuer

Lfd. Nr. Titel

Laufzeit

3346 Kirchensteuer - Gesetz

- Bestimmungen der Gemeindeverfassung der lutherischen Gemeinde Emdens zur Kirchensteuer, 1893

- Ausführungsbestimmungen des Gesetzes zur Erhebung der Kirchensteuer in den lutherischen und reformierten Gemeinden der

Provinz Hannover, April 1906

- Antrag Ysaac Brons an den lutherischen Kirchenvorstand auf

Gewährung des vollen Stimmrechts für seine Kirchensteuer zahlende

Ehefrau und andere Frauen, Oktober 1906

$1893-1906$

Klassifikation Teil B: 03179

Trägermaterial: Papier

Alte Reg.-Sig.: IX A1 036

Bestell-Nr.: IV 03179

3347 Kirchensteuer

1907-1909

- Streit um die Heranziehung der Bewohner Außer dem Neuen Tor zur Kirchensteuer der Gemeinde Hinte

$1907-1909$

Klassifikation Teil B: 03180

Trägermaterial: Papier

Alte Reg.-Sig.: IX A1 038

Bestell-Nr.: IV 03180

3348 Erhebung der kirchlichen Umlagen

- Erlass des preußischen Ministers der geistlichen, Unterrichts- und Medizinalangelegenheiten über Form und Erhebung kirchlicher Umlagen

$1885-1886$

Klassifikation Teil B: 03201

Trägermaterial: Papier

Alte Reg.-Sig.: IX A2b 30

Bestell-Nr.: IV 03201 
IV

09 Kirchen

09.02

Evangelische Kirchen

09.02.01

Kirchenkommissionen der evangelischen Gemeinden

09.02.01.01

Kirchenkommission der Reformierten Gemeinde

Lfd. Nr. Titel

Laufzeit

3349 Kirchenkommission der evangelischen Kirchen

1874-1918

(1919)

- Organisation der Kirchenkommission für die lutherische und reformierten Gemeinde Emdens

$1874-1918$ (1919)

Klassifikation Teil B: 03192

Trägermaterial: Papier

Alte Reg.-Sig.: IX A 2b 01

Bestell-Nr.: IV 03192

3350 Bearbeitete Sachen der Kirchenkommission für die reformierte Gemeinde

- Widersprüche gegen die Heranziehung zur Schulsteuer der reformierten Gemeinde

- Unterstützungsgesuche von reformierten Predigerwitwen

- Heranziehung von Kirchenland zu den Deich- und Siellasten

- Verwendung eines neuen Kirchengesangbuches in der reformierten

Volksschule

- Erhebung übe Mitgliedschaften in der reformierten

Schullehrer-Witwen und Sterbekasse

- Einzelne Inventar-Veränderungsanzeigen aus der deutsch reformierten Gemeinde

- Aufwendungen für die Kirchenbibliothek

$1869-1910$

Klassifikation Teil B: 03245

Trägermaterial: Papier

Alte Reg.-Sig.: IX BI 24

Bestell-Nr.: IV 03245 
IV

09

Kirchen

09.02

Evangelische Kirchen

09.02.01

Kirchenkommissionen der evangelischen Gemeinden

09.02.01.02

Kirchenkommission der evangelisch lutherischen Kirche

Lfd. Nr. Titel

Laufzeit

3351 Ehe- und Verlöbnissachen in der lutherischen Gemeinde

1868-1875

- Anträge auf Befreiung von der Aufgebotspflicht für Eheschließungen,

Februar 1868 - Mai 1874

- Bericht der lutherischen Kirchenkommission über Absicht der

Verhinderung des Übertritts der Johanne Margarethe Müller und der

Berendine Smeding zur jüdischen Religion wegen ihrer beabsichtigten

Heirat mit Juden, Mai 1868

$1868-1875$

Klassifikation Teil B: 00121

Trägermaterial: Papier

Alte Reg.-Sig.: C I 10

Bestell-Nr.: IV 00121 
09 Kirchen

09.03

Evangelische Kirchengemeinden

09.03.01

09.03.01.01

Evangelisch Reformierte Kirchengemeinden

Deutsch reformierte Gemeinde

Lfd. Nr. Titel

Laufzeit

3352 Witwen- und Waisenkasse für die reformierten Prediger

- Bei der Stadtkasse hinterlegte Wertpapiere der Witwen- und

Waisenkasse für die reformierten Prediger

- Rechnungsprüfung bei der der Witwen- und Waisenkasse für die reformierten Prediger

$1866-1887$

Klassifikation Teil B: 03194

Trägermaterial: Papier

Alte Reg.-Sig.: IX A2b 19

Bestell-Nr.: IV 03194

3353 Kirchliches Gesetz- und Verordnungsblatt

- Bekanntmachung des kgl. Konsistoriums in Aurich über Zulassung des kirchlichen Gesetz- und Verordnungsblattes für die reformierte Kirche

1884

Klassifikation Teil B: 03200

Trägermaterial: Papier

Alte Reg.-Sig.: IX A2b 29

Bestell-Nr.: IV 03200

3354 Streit um Zuschüsse der Stadt Emden zu den Gehältern der

Geistlichen der Deutsch Reformierten Gemeinde Emden. Bd. 1

- Beschwerde des Kirchenrats der Deutsch Reformierten Gemeinde an den Regieungspräsidenten in Aurich gegen die Streichung des

Zuschusses zu den Gehältern der Geistlichen der Deutsch

Reformierten Gemeinde Emden durch den Magistrat der Stadt

Emden, April - Juli 1887

- Beschwerde des Kirchenrats der Deutsch Reformierten Gemeinde an den Oberpräsidenten in Hannover gegen die Streichung des Zuschusses zu den Gehältern der Geistlichen der Deutsch

Reformierten Gemeinde Emden durch den Magistrat der Stadt

Emden, Juli 1887 - Februar 1888

$1887-1888$

Klassifikation Teil B: 03204

Band: 1

Trägermaterial: Papier

Alte Reg.-Sig.: IX A2b 35

Bestell-Nr.: IV 03204 
- Revisionsverfahren vor dem kgl. Oberverwaltungsgericht in Celle wegen der Klage der Deutsch Reformierten Kirche gegen den Magistrat der Stadt Emden auf Aufhebung der Streichung des Zuschusses zu den Gehältern der Geistlichen der Deutsch Reformierten Gemeinde Emden durch den Magistrat der Stadt Emden

1894

\author{
Klassifikation Teil B: 03205 \\ Band: 2 \\ Trägermaterial: Papier \\ Alte Reg.-Sig.: IX A2b 36
}

Bestell-Nr.: IV 03205

3356 Streit um Zuschüsse der Stadt Emden zu den Gehältern der Geistlichen der Deutsch Reformierten Gemeinde Emden. Bd. 3

- Revisionsverfahren vor dem kgl. Oberverwaltungsgericht in Celle wegen der Klage der Deutsch Reformierten Kirche gegen den Magistrat der Stadt Emden auf Aufhebung der Streichung des Zuschusses zu den Gehältern der Geistlichen der Deutsch Reformierten Gemeinde Emden durch den Magistrat der Stadt Emden

1894

\author{
Klassifikation Teil B: 03206 \\ Band: 3 \\ Trägermaterial: Papier \\ Alte Reg.-Sig.: IX A2b 36
}

Bestell-Nr.: IV 03206

3357 Streit um Zuschüsse der Stadt Emden zu den Gehältern der Geistlichen der Deutsch Reformierten Gemeinde Emden. Bd. 4

- Revisionsverfahren vor dem kgl. Oberverwaltungsgericht in Celle wegen der Klage der Deutsch Reformierten Kirche gegen den Magistrat der Stadt Emden auf Aufhebung der Streichung des Zuschusses zu den Gehältern der Geistlichen der Deutsch Reformierten Gemeinde Emden durch den Magistrat der Stadt Emden: Material des Magistrats zum Prozess

1891 - 1894

Klassifikation Teil B: 03207

Band: 4

Trägermaterial: Papier Alte Reg.-Sig.: IX A2b 36

Bestell-Nr.: IV 03207 
- Revisionsverfahren vor dem kgl. Oberverwaltungsgericht in Celle wegen der Klage der Deutsch Reformierten Kirche gegen den Magistrat der Stadt Emden auf Aufhebung der Streichung des Zuschusses zu den Gehältern der Geistlichen der Deutsch Reformierten Gemeinde Emden durch den Magistrat der Stadt Emden: Material des Magistrats zum Prozess

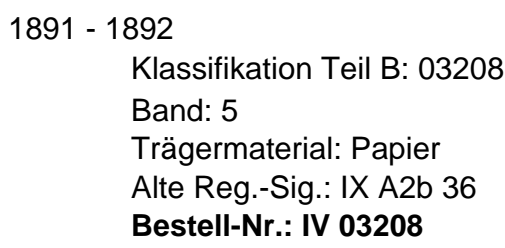

3359 Streit um Zuschüsse der Stadt Emden zu den Gehältern der

- Revisionsverfahren vor dem kgl. Oberverwaltungsgericht in Celle wegen der Klage der Deutsch Reformierten Kirche gegen den Magistrat der Stadt Emden auf Aufhebung der Streichung des Zuschusses zu den Gehältern der Geistlichen der Deutsch Reformierten Gemeinde Emden durch den Magistrat der Stadt Emden: Urteil des Gerichts zugunsten Magistrats

1898

Klassifikation Teil B: 03209

Band: 6

Trägermaterial: Papier

Alte Reg.-Sig.: IX A2b 36

Bestell-Nr.: IV 03209

3360 Streit um Zuschüsse der Stadt Emden zu den Gehältern der Geistlichen der Deutsch Reformierten Gemeinde Emden. Bd. 7

- Urteil des Reichsgerichts in Leipzig über Zulassung des Revisionsantrag der Deutsch Reformierte Kirche über ihre Klage gegen den Magistrat der Stadt Emden auf Aufhebung der Streichung des Zuschusses zu den Gehältern der Geistlichen der Deutsch Reformierten Gemeinde Emden durch den Magistrat der Stadt Emden und Rückverweisung des Verfahrens an das kgl. Oberverwaltungsgericht in Celle, November 1894

1894

Klassifikation Teil B: 03210

Band: 7

Trägermaterial: Papier

Alte Reg.-Sig.: IX A2b 36

Bestell-Nr.: IV 03210 
- Urteil des kgl. Oberverwaltungsgericht in Celle wegen der Klage der Deutsch Reformierten Kirche gegen den Magistrat der Stadt Emden auf Aufhebung der Streichung des Zuschusses zu den Gehältern der Geistlichen der Deutsch Reformierten Gemeinde Emden durch den Magistrat der Stadt Emden: Fragment

1895

\author{
Klassifikation Teil B: 03211 \\ Band: 8 \\ Trägermaterial: Papier \\ Alte Reg.-Sig.: IX A2b 36
}

Bestell-Nr.: IV 03211

3362 Streit um Zuschüsse der Stadt Emden zu den Gehältern der Geistlichen der Deutsch Reformierten Gemeinde Emden. Bd. 9

\footnotetext{
- Material zum Prozess vor dem kgl. Oberverwaltungsgericht in Celle wegen der Klage der Deutsch Reformierten Kirche gegen den Magistrat der Stadt Emden auf Aufhebung der Streichung des Zuschusses zu den Gehältern der Geistlichen der Deutsch Reformierten Gemeinde Emden durch den Magistrat der Stadt Emden:
}

Darin:

Kirchenverfassung der reformierten Gemeinden Ostfrieslands 1897

\author{
Klassifikation Teil B: 03212 \\ Band: 9 \\ Trägermaterial: Papier \\ Alte Reg.-Sig.: IX A2b 36 \\ Bestell-Nr.: IV 03212
}

3363 Streit um Zuschüsse der Stadt Emden zu den Gehältern der Geistlichen der Deutsch Reformierten Gemeinde Emden. Bd. 10

- Revisionsbegründung des Anwalts des Magistrats der Stadt Emden beim Reichsgericht

1898

Klassifikation Teil B: 03213

Band: 10

Trägermaterial: Papier

Alte Reg.-Sig.: IX A2b 36

Bestell-Nr.: IV 03213 
- Korrespondenz des Magistrats mit seinem Anwalt, Rechtsanwalt Müller in Aurich

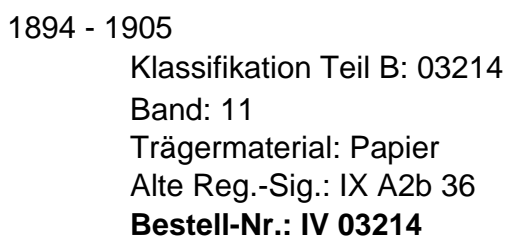

3365 Streit um Zuschüsse der Stadt Emden zu den Gehältern der

- Urteil des kgl. Oberverwaltungsgericht in Celle zugunsten der Deutsch Reformierten Gemeinde Emden wegen der Klage der Deutsch Reformierten Kirche gegen den Magistrat der Stadt Emden auf Aufhebung der Streichung des Zuschusses zu den Gehältern der Geistlichen der Deutsch Reformierten Gemeinde Emden durch den Magistrat der Stadt Emden

1904

\author{
Klassifikation Teil B: 03215 \\ Band: 12 \\ Trägermaterial: Papier \\ Alte Reg.-Sig.: IX A2b 36 \\ Bestell-Nr.: IV 03215
}

3366 Streit um Zuschüsse der Stadt Emden zu den Gehältern der Geistlichen der Deutsch Reformierten Gemeinde Emden. Bd. 13

- Urteil des Reichsgerichts zugunsten der Stadt Emden in der Revisionsklage wegen des Streits mit der Deutsch Reformierten Gemeinde Emden

1898

\author{
Klassifikation Teil B: 03216 \\ Band: 13 \\ Trägermaterial: Papier \\ Alte Reg.-Sig.: IX A2c 37 \\ Bestell-Nr.: IV 03216
}

3367 Streit um Zuschüsse der Stadt Emden zu den Gehältern der Geistlichen der Deutsch Reformierten Gemeinde Emden. Bd. 14

- Prozessrrelevante Schriftstücke des Magistrats im Gerichtsstreit mit der Deutsch Reformierten Gemeinde

1890

Klassifikation Teil B: 03217

Band: 14

Trägermaterial: Papier

Alte Reg.-Sig.: IX A2c 38

Bestell-Nr.: IV 03217 
- Prozessschriftstücke: Begründung der Revisionsklage des Magistrats gegen Urteile zugunsten der Deutsch Reformierten Kirchengemeinde

$1890-1895$

Klassifikation Teil B: 03218

Band: 15

Trägermaterial: Papier

Alte Reg.-Sig.: IX A2c 39

Bestell-Nr.: IV 03218

3369 Streit um Zuschüsse der Stadt Emden zu den Gehältern der

- Prozessschriftstücke: Begründung der Revisionsklage des Magistrats gegen Urteile zugunsten der Deutsch Reformierten Kirchengemeinde

1894

\author{
Klassifikation Teil B: 03219 \\ Band: 16 \\ Trägermaterial: Papier \\ Alte Reg.-Sig.: IX A2c 40 \\ Bestell-Nr.: IV 03219
}

3370 Streit um Zuschüsse der Stadt Emden zu den Gehältern der

- Unterlagen des Magistrats im Streit mit der Deutsch Reformierten Kirchengemeinde für den Rechtsanwalt Dr. Meyer, Aurich

1895

\author{
Klassifikation Teil B: 03220 \\ Band: 17 \\ Trägermaterial: Papier \\ Alte Reg.-Sig.: IX A2b 40
}

Bestell-Nr.: IV 03220

3371 Streit um Zuschüsse der Stadt Emden zu den Gehältern der Geistlichen der Deutsch Reformierten Gemeinde Emden. Bd. 18

- Prozessunterlagen zur Stützung des Rechtsstandpunktes des Magistrats im Rechtssttreit mit der Deutsch Reformierten Gemeinde Emden

1891 - 1898

Klassifikation Teil B: 03221

Band: 18

Trägermaterial: Papier

Alte Reg.-Sig.: IX A2c 40

Bestell-Nr.: IV 03221 
3372 Streit um Zuschüsse der Stadt Emden zu den Gehältern der 1898 Geistlichen der Deutsch Reformierten Gemeinde Emden. Bd. 19

- Urteil des kgl. Oberlandesgerichts Celle zugunsten der Deutsch Reformierten Gemeinde Emden im Rechtsstreit mit dem Magistrat der Stadt Emden

1898

\author{
Klassifikation Teil B: 03222 \\ Band: 19 \\ Trägermaterial: Papier \\ Alte Reg.-Sig.: IX A2c 40 \\ Bestell-Nr.: IV 03222
}

3373 Streit um Zuschüsse der Stadt Emden zu den Gehältern der

Geistlichen der Deutsch Reformierten Gemeinde Emden. Bd. 20

- Aktenstücke und Dokumente zur Stützung des Rechtsstandpunktes des Magistrats im Rechtssttreit mit der Deutsch Reformierten Gemeinde Emden

1898

\author{
Klassifikation Teil B: 03223,1 \\ Band: 20 \\ Trägermaterial: Papier \\ Alte Reg.-Sig.: IX A2c 40 \\ Bestell-Nr.: IV 03223 a
}

3374 Streit um Zuschüsse der Stadt Emden zu den Gehältern der Geistlichen der Deutsch Reformierten Gemeinde Emden. Bd. 21

- Rechtsstandpunkt der Deutsch Reformierten Gemeinde Emden im Rechtssttreit mit dem Magistrat

1891

\author{
Klassifikation Teil B: 03224 \\ Band: 21 \\ Trägermaterial: Papier \\ Alte Reg.-Sig.: IX A2c 40
}

Bestell-Nr.: IV 03224

3375 Streit um Zuschüsse der Stadt Emden zu den Gehältern der Geistlichen der Deutsch Reformierten Gemeinde Emden. Bd. 22

- Prozessunterlagen zur Stützung des Rechtsstandpunktes des Magistrats im Rechtssttreit mit der Deutsch Reformierten Gemeinde Emden

1891

Klassifikation Teil B: 03225

Band: 22

Trägermaterial: Papier

Alte Reg.-Sig.: IX A2c 40

Bestell-Nr.: IV 03225 
IV

09 Kirchen

09.03

Evangelische Kirchengemeinden

09.03.01

09.03.01.01

Evangelisch Reformierte Kirchengemeinden

Deutsch reformierte Gemeinde

Lfd. Nr. Titel

Laufzeit

3376 Streit um Zuschüsse der Stadt Emden zu den Gehältern der

Geistlichen der Deutsch Reformierten Gemeinde Emden. Bd. 23

1894-1904

(1924)

- Urteil des Reichsgerichts im Revisionsverfahren zum Rechtsstreit zwischen dem Magistrat und der Deutsch Reformierten Gemeinde wg. Gehaltszuschüsse für Geistliche, November 1894

- Neuverhandlung der Streitsache beim kgl. Landgericht in Aurich und dem kgl. Oberlandesgericht in Celle, 1895 - 1904

1894 - 1904 (1924)

Klassifikation Teil B: 03226

Band: 23

Trägermaterial: Papier

Alte Reg.-Sig.: IX A2c 41

Bestell-Nr.: IV 03226

3377 Streit um Zuschüsse der Stadt Emden zu den Gehältern der

Geistlichen der Deutsch Reformierten Gemeinde Emden. Bd. 24

- Unterlagen zu den Prozessen und Dokumentenabschriften zur Untermauerung des Rechtsstandpunktes des Magistrats

$1894-1904$

Klassifikation Teil B: 03227

Band: 24

Trägermaterial: Papier

Alte Reg.-Sig.: IX A2c 42

Bestell-Nr.: IV 03227 


\section{IV}

09

Kirchen

09.03

Evangelische Kirchengemeinden

09.03.01

09.03.01.01

Evangelisch Reformierte Kirchengemeinden

Deutsch reformierte Gemeinde

Lfd. Nr. Titel

Laufzeit

3378 Prediger der evangelisch reformierten Gemeinde

1874-1910

- Gesuch des reformierten Kirchenrats N. Vietor um Pensionierung als

Prediger, Februar - Mai 1874

- Urlaubsgesuche des Kirchenrats N. Vietor zur Kur im Nordseebad

Norderney, 1877 - 1879

- Teilweise Entbindung des Predigers Veenhuis von seinem Amt wegen fortgeschrittenen Alters, Dezember 1878 - Januar 1879

- Einstellung eines Ersatzes für den Pastor Veenhuis, Februar - Juni

1879

- Pensionierung des Pastors Veenhuis, September 1879

- Wahl des Pastors Justus Heinrich Middendorf zum Prediger der deutsch reformierten Gemeinde, August - Dezember 1879

- Vereidigung und Amtseinführung des Pastors Justus Heinrich

Middendorf als Prediger der deutsch reformierten Gemeinde,

Dezember 1879

- Wahl des Pastors Otto Zillessen aus Dussel (Rheinprovinz) zum

Prediger in der deutsch reformierten Gemeinde, Juli 1880

- Anträge der Pastoren Middendorf und Zillessen an den

Kirchenkommissar auf Erlaubnis zur Übernahme von

Vormundschaften über uineheliche Kinder, 1882 - 1884

- Wahl und Einführung des Pastors Carl Johann Peter Prumers aus

Unna in das Amt eines Predigers der deutsch reformierten Gemeinde, Juni - Juli 1887

- Wahl und Einführung des Pastors J. Müntinga aus Großwolde in das Amt eines Predigers der deutsch reformierten Gemeinde, April - Mai 1891

- Gehaltsverhältnisse der Prediger, 1894 - 1895

- Kritik des Pastors Müntinga in seiner Buß- und Bettagspredigt an den sozialen Verhältnissen in Deutschland im allgemeinen und in Emden im besonderen, November 1894 - Mai 1895

- Wahl und Einführung des Pastors Friedrich Voget aus Bunde in das Amt eines Predigers der deutsch reformierten Gemeinde mit Vereidigung, August - Oktober 1892

Wahl und Einführung des Pastors Gotthilf Kind aus der Rheinprovinz in das Amt eines Predigers der deutsch reformierten Gemeinde,

Februar - März 1899

- Wahl und Vereidigung des Pastors Hänisch aus Grimersum als Prediger der deutsch reformierten Gemeinde, März - Mai 1895

- Wahl und Vereidigung des Pastors Gerhard Cöper aus Grimersum als Prediger der deutsch reformierten Gemeinde, Januar - Februar 1898

- Wahl und Vereidigung des Pastors Johannes Conrad aus Nümbrecht als Prediger der deutsch reformierten Gemeinde, Januar 1907

- Wahl und Vereidigung des Pastors Ernst Koch aus Hattingen als Prediger der deutsch reformierten Gemeinde, August - September 1907

- Wahl und Vereidigung des Pastors Erich Riedlin aus Larrelt als

Prediger der deutsch reformierten Gemeinde, Februar - April 1910

$1874-1910$

Klassifikation Teil B: 03228

Trägermaterial: Papier

Alte Reg.-Sig.: IX BI 03

Bestell-Nr.: IV 03228 
- Regelung der Organistenbesoldung, Juli 1868 - Jasnuar 1869

- Erhöhung der Gehälter der Totengräber, Februar 1868

- Gewährung einer freien Wohnung für den Küster der Neuen Kirche, November 1871

- Erhöhung des Gehalts des Küsters an der Großen Kirche, Dezember 1873 / März 1881

- Besetzung der Küsterstellen an der Großen und Neuen Kirche, Januar - März 1883

- Gehaltserhöhung für den Vorleser- und Sänger an der Neuen Kirche, Dezember 1883

- Gehaltserhöhung für den Kirchvogt der Großen Kirche, Mai 1885

- Gehaltserhöhung für den Totengräber und Küster an der Neuen

Kirche, 1887 - 1888

- Besetzung der Organistenstellen an der Großen und Neuen Kirche, April - Juni 1893

- Gehaltserhöhung für die Türsteherinnen an der Großen und Neuen

Kirche, Oktober - November 1904

Enthält auch:

- Unfallversicherung der Totengräber der lutherischen Gemeinde, November 1911

$1868-1911$

Klassifikation Teil B: 03229

Trägermaterial: Papier

Alte Reg.-Sig.: IV BI 05

Bestell-Nr.: IV 03229

3380 Diensteinnahmen der Prediger

- Satzungen über Alterszulage für evangelische Geistliche im Kgr. Preußen, 1909

- Verfügung des kgl. Konsistoriums in Aurich an die deutsch reformierte Gemeinde über Beschaffung von Dienstwohnungen für ihre Geistlichen, Mai 1912 / September 1913

$1909-1913$

Klassifikation Teil B: 03231

Trägermaterial: Papier

Alte Reg.-Sig.: IX BI 07

Bestell-Nr.: IV 03231

3381 Rechnungsabnahme der Neuen Kirche

- Prüfung und Abnahme der Rechnung der Neuen Kirche durch die Kirchenkommission der reformierten Gemeinde

- Stellungnahme des kgl. Konsistoriums zur Rechnungsprüfung

$1867-1902$

Klassifikation Teil B: 03233

Trägermaterial: Papier

Alte Reg.-Sig.: IX BI 10

Bestell-Nr.: IV 03233 
09 Kirchen

09.03

Evangelische Kirchengemeinden

09.03.01

09.03.01.01

Evangelisch Reformierte Kirchengemeinden

Deutsch reformierte Gemeinde

Lfd. Nr. Titel

Laufzeit

3382 Wertpapiere der deutsch reformierten Gemeinde

- Anträge der deutsch reformierten Gemeinde an das kgl.

Konsistorium auf Erlaubnis zum Erwerb oder zur Einlösung von

Staatsschuldverschreibungen

$1870-1885$

Klassifikation Teil B: 03234

Trägermaterial: Papier

Alte Reg.-Sig.: IX BI 11

Bestell-Nr.: IV 03234

3383 Streit um die Trägerschaft von Kirchenlasten, Bd. 1

- Gerichtliche Auseinandersetzung zwischen der deutsch reformierten

Gemeinde und dem Magistrat vor dem Amtsgericht, dem kgl.

Landgericht Aurich und dem kgl. Oberlandesgericht Celle um die

Auffassung der Gemeinde über Verpflichtung des Magistrats zur

Mittragung der Kirchenlasten (Kirchenbauunterhaltung,

Predigergehälter, Schullasten etc.)

$1890-1894$

Klassifikation Teil B: 03236

Band: 1

Trägermaterial: Papier

Alte Reg.-Sig.: IX BI 43

Bestell-Nr.: IV 03236

3384 Streit um die Trägerschaft von Kirchenlasten, Bd. 2

- Gerichtliche Auseinandersetzung zwischen der deutsch reformierten Gemeinde und dem Magistrat vor dem Amtsgericht, dem kgl. Landgericht Aurich und dem kgl. Oberlandesgericht Celle um die Auffassung der Gemeinde über Verpflichtung des Magistrats zur Mittragung der Kirchenlasten (Kirchenbauunterhaltung,

Predigergehälter, Schullasten etc.)

1890

Klassifikation Teil B: 03237

Band: 2

Trägermaterial: Papier

Alte Reg.-Sig.: IX BI 43

Bestell-Nr.: IV 03237 
- Gerichtliche Auseinandersetzung zwischen der deutsch reformierten Gemeinde und dem Magistrat vor dem Amtsgericht, dem kgl. Landgericht Aurich und dem kgl. Oberlandesgericht Celle um die Auffassung der Gemeinde über Verpflichtung des Magistrats zur Mittragung der Kirchenlasten (Kirchenbauunterhaltung, Predigergehälter, Schullasten etc.)

$1899-1900$

Klassifikation Teil B: 03238

Band: 3

Trägermaterial: Papier

Alte Reg.-Sig.: IX BI 43

Bestell-Nr.: IV 03238

3386 Streit um die Trägerschaft von Kirchenlasten, Bd. 4

- Gerichtliche Auseinandersetzung zwischen der deutsch reformierten Gemeinde und dem Magistrat vor dem Amtsgericht, dem kgl. Landgericht Aurich und dem kgl. Oberlandesgericht Celle um die Auffassung der Gemeinde über Verpflichtung des Magistrats zur Mittragung der Kirchenlasten (Kirchenbauunterhaltung,

Predigergehälter, Schullasten etc.)

$1887-1893$

Klassifikation Teil B: 03239

Band: 4

Trägermaterial: Papier

Alte Reg.-Sig.: IX BI 43

Bestell-Nr.: IV 03239

3387 Inventarium über die Mittel der neuen Kirche

- Bericht des Kirchenrats der reformierten Gemeinde Emdens an das $\mathrm{kgl}$. Konsistorium in Aurich über Veränderungen im Inventarium über die Mittel der Neuen Kirche (Besitzstände und Vermögen)

- Stellungnahme und Monita des kgl. Konsistoriums zu den Anzeigen

$1868-1910$

Klassifikation Teil B: 03240

Trägermaterial: Papier

Alte Reg.-Sig.: IX BI 13

Bestell-Nr.: IV 03240 
09.03

Lfd. Nr. Titel

3388 Annahme von Schenkungen und Vermächtnissen in Kirchensachen

- Legat der Witwe Ebeling, geb. Hayenga zugunsten der deutsch reformierten Gemeinde, 1871

- Legat der Witwe Doncker zugunsten der deutsch reformierten Gemeinde, November 1872

- Legat der Witwe des Kräutners Eisse Janssen Eissen zugunsten der deutsch reformierten Gemeinde, 1872

- Anträge des reformierten Kirchenrats an die Kommission für die deutsch reformierte Gemeinde auf Genehmigung der Annahme von Legaten und Geldmittel für die Unterhaltung von Gräbern auf den Friedhofen der Großen und Neuen Kirche, 1871 - 1918

- Schenkung des Fräuleins Jakoba Douwes über 9.750 Mark zur Errichtung eines Frauenheims durch die reformierte Gemeinde, September 1902

- Schenkung des Kaufmanns Peter Geelvink für denselben Zweck, November 1908

$1871-1918$

Klassifikation Teil B: 03241

Trägermaterial: Papier

Alte Reg.-Sig.: IX BI 15

Bestell-Nr.: IV 03241

3389 Führung der Kirchenbücher der deutsch reformierten Gemeinde

- Regelung der nachträglichen Eintragung von Geburten in das Kirchenbuch, 1867 - 1868

- Anträge auf Änderung von Kirchenbucheintragungen (z.B. bei Adoptionen), 1871 - 1896

$1867-1896$

Klassifikation Teil B: 03242

Trägermaterial: Papier

Alte Reg.-Sig.: IX BI 17

Bestell-Nr.: IV 03242 
- Verfügung des kgl. Konsistoriums in Aurich über Aufhebung der Gebühren für kirchliche Aufgebote (Trauungen) in den reformierten Gemeinden Ostfrieslands unter Gleichstellung mit den Lutheranern, November 1875

- Verfügung des kgl. Konsistoriums in Aurich über Möglichkeit einer freiwilligen Recognitionszahlung von Brautpaaren anstelle der Aufgebotsgebühr, Juni 1876

- Umsetzung der gesetzliche Bestimmungen über Aufhebung von "Stolgebühren" bei Trauungen, Taufen und kirchlichen Aufgeboten, März - Mai 1893

- Einführung einer Traugebühr für geschlossene Trauungen (=außerhalb des gewöhnlichen Gottesdienstes) in der deutsch reformierten Gemeinde, 1904 - 1905

$1875-1905$

Klassifikation Teil B: 03243

Trägermaterial: Papier

Alte Reg.-Sig.: IX BI 22

Bestell-Nr.: IV 03243

3391 Ablösung von der reformierten Kirche zustehenden Erbpachten

- Anträge verschiedener Grundbesitzer an den Kirchenkommissar für die reformierte Gemeinde auf Ablösung der Erbpachten und anderer Reallasten zugunsten der reformierten Kirche auf ihren Grundstücken

$1869-1876$

Klassifikation Teil B: 03244

Trägermaterial: Papier

Alte Reg.-Sig.: IX BI 23

Bestell-Nr.: IV 03244

3392 Grundstücke der deutsch reformierten Gemeinde in der Feldmark

- Tausch von Grundstücken der Großen Kirche in der Feldmark gegen städtische Grundstücke

- Heranziehung der Grundstücke zu den Schullasten der reformierten Volksschule,

1877 / 1897

Klassifikation Teil B: 03246

Trägermaterial: Papier

Alte Reg.-Sig.: IX BI 25

Bestell-Nr.: IV 03246 
09 Kirchen

09.03

Evangelische Kirchengemeinden

09.03.01

09.03.01.01

Evangelisch Reformierte Kirchengemeinden

Deutsch reformierte Gemeinde

Lfd. Nr. Titel

Laufzeit

3393 Verkauf eines Hauses der deutsch reformierten Gemeinde

1901-1902

- Verkauf eines Hauses der deutsch reformierten Gemeinde in der

Burgstraße 16 an den Zimmermann Carl Poppinga

$1901-1902$

Klassifikation Teil B: 03247

Trägermaterial: Papier

Alte Reg.-Sig.: IX BI 26

Bestell-Nr.: IV 03247

3394 Deutsch reformierter Gemeindefonds

$1881-1884$

- Verwaltung des deutsch reformierten Gemeindefonds zur Zahlung von Wohngeldzuschüssen für reformierte Prediger der deutsch reformierten Gemeinde

$1881-1884$

Klassifikation Teil B: 03248

Trägermaterial: Papier

Alte Reg.-Sig.: IX BI 27

Bestell-Nr.: IV 03248

3395 Regulativ für die Friedhöfe der reformierten Gemeinde

- Entwurf eines Regulativs für die Friedhöfe der reformierten

Gemeinde, 1881 / 1888/ 1892/ 1893

- Friedhofsordnung für die Friedhöfe der reformierten Gemeinde, 1896

$1881-1896$

Klassifikation Teil B: 03249

Trägermaterial: Papier

Alte Reg.-Sig.: IX BI 28

Bestell-Nr.: IV 03249

3396 Gebühren für Armenbegräbnisse

- Erwerb von Armengräbern auf den Friedhöfen der deutsch reformierten Gemeinde durch den kommunalen Ortsarmenverband nach der Verstaatlichung des Armenwesens und REgelung der an die Gemeinde zu zahlenden Gebühren bei Armenbegräbnissen

$1882-1883$

Klassifikation Teil B: 03250

Trägermaterial: Papier

Alte Reg.-Sig.: IX BI 29

Bestell-Nr.: IV 03250 
IV

09 Kirchen

09.03

Evangelische Kirchengemeinden

09.03.01

09.03.01.01

Evangelisch Reformierte Kirchengemeinden

Deutsch reformierte Gemeinde

Lfd. Nr. Titel

Laufzeit

3397 Ausführung der Gemeinde-Synodalordnung

- Meldung über Vollzähligkeit der Gemeindeorgane der reformierten

Gemeinden

$1888-1910$

Klassifikation Teil B: 03251

Trägermaterial: Papier

Alte Reg.-Sig.: IX BI 30

Bestell-Nr.: IV 03251

3398 Etat für die Neue Kirche

- Meldungen über Ausgaben aus den Mitteln der Neuen Kirche

- Aufwendungen für Bauunterhaltung, Orgelreparatur und - Pflege

- Aufwendungen für die Heizungsanlage

- Etatvorberichte

$1870-1908$

Klassifikation Teil B: 03252

Trägermaterial: Papier

Alte Reg.-Sig.: IX BI 32

Bestell-Nr.: IV 03252

3399 Kirchenvisitationen

$1898-1911$

- Ausführung der Kirchenvisitationen nach dem Kirchengesetz vom 8.

August 1898

Enthält auch:

- Bautechnisches Gutachten über den Zustand der Großen Kirche und der Neuen Kirche,September 1910

$1898-1911$

Klassifikation Teil B: 03253

Trägermaterial: Papier

Alte Reg.-Sig.: IX BI 35

Bestell-Nr.: IV 03253

3400 Einführung der Pfarrkassen-Rechnungsführung

- Verfügung des kgl. Konsistoriums in Aurich über Einführung der Pfarrkassen-Rechnungsführung, März 1901

- Umsetzung der Verfügung bei der deutsch reformierten Gemeinde, April 1901

1901

Klassifikation Teil B: 03254

Trägermaterial: Papier

Alte Reg.-Sig.: IX BI 36

Bestell-Nr.: IV 03254 
09

09.03

09.03.01

09.03.01.01
Kirchen

Evangelische Kirchengemeinden

Evangelisch Reformierte Kirchengemeinden

Deutsch reformierte Gemeinde

Lfd. Nr. Titel

Laufzeit

3401 Schließung des Nesserlander Friedhofes

1901

- Bericht des kgl. Kirchenkommissars für die reformierte Gemeinde an das kgl. Konsistorium über Befürwotung des Antrages des reformierten Kirchenrats auf Schließung des Nesserlander Friedhofes wegen Einverleibung Nesserlands in das Hafengebiet, Mai 1901

1901

Klassifikation Teil B: 03255

Trägermaterial: Papier

Alte Reg.-Sig.: IX BI 39

Bestell-Nr.: IV 03255

3402 Bewilligung von Beihilfen zur Pastorenbesoldung

$1902-1913$

- Verfügung des kgl. Konsistoriums in Aurich über Bewilligung einer Beihilfe über 4.000 Mark an die deutsch reformierte Gemeinde zur Besoldung ihrer Pastoren, März 1902

- Verfügung des kgl. Konsistoriums über Rückziehung der Beihilfe und Aufforderung an die reformierte Gemeinde zur Beschaffung fehlender Mittel zur Pastorenbesoldung aus Umschichtungen im Etat oder Ausschreibung einer Umlage, März 1903

- Anträge der deutsch reformierten Gemeinde an das kgl.

Konsistorium auf Weitergewährung einer Beihilfe zur

Pastorenbesoldung wegen Bedürftigkeit, Mai 1903 / Januar 1904 /

Juni 1906 / Oktober 1913

- Erlass des preußischen Ministers der geistlichen, Unterrichts- und Medizinalangelegenheiten über Gewährung einer Beihilfe von 2.000 Mark zur Pastorenbesoldung der deutsch reformierten Gemeinde, November 1903

$1902-1903$

Klassifikation Teil B: 03256

Trägermaterial: Papier

Alte Reg.-Sig.: IX BI 38

Bestell-Nr.: IV 03256

3403 Anlage eines neuen Begräbnisplatzes

$1910-1913$

- Beschluss der Versammlung der vereinigten Gemeindeorgane der reformierten Kirche über Anlage eines neuen Friedhofs auf zwei kirchlichen Grundstücken "Außer dem Neuen Tor" am Wallgraben, November 1910

- Gutachten des geh. Medizinalrats und Kreisarztes Dr. Tergast über Eignung des Geländes zur Anlage eines Friedhofes, Februar 1911 - Antrag des Fuhrunternehmers H. H. Uffens an das kgl. Konsistorium in Aurich auf Verhinderung eines angestrebten Monopols für Leichentransporte zum neuen Friedhof für den Leichenwagen der reformierten Gemeinde, Februar 1913

1910 - 1913

Klassifikation Teil B: 03257

Trägermaterial: Papier

Alte Reg.-Sig.: IX BI 39

Bestell-Nr.: IV 03257 
IV

09

Kirchen

09.03

Evangelische Kirchengemeinden

09.03.01

09.03.01.01

Evangelisch Reformierte Kirchengemeinden

Deutsch reformierte Gemeinde

Lfd. Nr. Titel

Laufzeit

3404 Eheangelegenheiten von reformierten Gemeindemitgliedern

- Anträge auf Verkürzung der Aufgebotsfrist, 1867 - 1874

- Verfügung des kgl. Konsistoriums in Aurich über weitere Gültigleit der Vorschrift der dreimaligen Aufgebotsproklamation vor der

kirchlichen Trauung trotz Inkrafttreten der Zivilehe, Oktober 1874

$1867-1874$

Klassifikation Teil B: 03258

Trägermaterial: Papier

Alte Reg.-Sig.: IX B| 41

Bestell-Nr.: IV 03258

3405 Reformierte Prediger in Emden

1890

- Liste der reformierten Prediger in Emden von 1537 - 1837, Abschrift, ca. 1890

1890
Klassifikation Teil B: 03260
Trägermaterial: Papier
Alte Reg.-Sig.: IX BI 51
Bestell-Nr.: IV 03260

3406 Hauptinventarium der Neuen Kirche

- Verzeichnis des Grundbesitzes und des Kapitalvermögens der Neuen Kirche sowie ihrer Verbindlichkeiten

1897
Klassifikation Teil B: 03261
Trägermaterial: Papier
Alte Reg.-Sig.: IX BI 52
Bestell-Nr.: IV 03261

3407 Angelegenheiten der deutsch reformierten Gemeinde

- Änderung des Statuts der deutsch reformierten Gemeinde, Juni 1895 - März 1896

- Wahl eines Lehrers für die IV. Klasse der reformierten Volksschule, Januar 1877

$1877-1896$

Klassifikation Teil B: 03263

Trägermaterial: Papier

Alte Reg.-Sig.: IX BI 54

Bestell-Nr.: IV 03263 
IV

09 Kirchen

09.03

09.03.01

09.03.01.01

Evangelische Kirchengemeinden

Lfd. Nr. Titel

Evangelisch Reformierte Kirchengemeinden

Deutsch reformierte Gemeinde

3408 Hauptinventarium der Großen Kirche

Laufzeit

- Verzeichnis des Grundbesitzes und des Kapitalvermögens der

Großen Kirche sowie inrer Verbindlichkeiten

1897

Klassifikation Teil B: 03264

Trägermaterial: Papier

Alte Reg.-Sig.: IX BI 52

Bestell-Nr.: IV 03264

3409 Rechtsanspruch der reformierten Gemeinde auf die Gasthauskirche

- Streit zwischen der Gasthausdirektion und der reformierten

Gemeinde um das Verfügungsrecht über die Gasthauskirche, 1871 -

1873

- Verfügung des kgl. Konsistoriums in Aurich über Zuständigkeit der Stadt Emden für die bauliche Unterhaltung und Restaurierung der

Gasthauskirche, August 1896

$1871-1896$

Klassifikation Teil B: 03265

Trägermaterial: Papier

Alte Reg.-Sig.: IX BI 20

Bestell-Nr.: IV 03265 
IV

09

Kirchen

09.03

Evangelische Kirchengemeinden

09.03.01

09.03.01.02

Evangelisch Reformierte Kirchengemeinden

Rechnung der Großen Kirche

Lfd. Nr. Titel

Laufzeit

3410 Inventar unsd Haushaltsmittel der Großen Kirche

- Anzeigen an das kgl. Konsistorium über Veränderungen im Inventar und den Haushaltsmitteln der Großen Kirche

$1877-1897$

Klassifikation Teil B: 03193

Trägermaterial: Papier

Alte Reg.-Sig.: IX A2b 12

Bestell-Nr.: IV 03193

3411 Grabsteine in der Großen Kirche

$1883-1884$

- Schutz der historisch wertvollen Grabsteine in der Großen Kirche

$1883-1884$

Klassifikation Teil B: 03199

Trägermaterial: Papier

Alte Reg.-Sig.: IX A2b 28

Bestell-Nr.: IV 03199

3412 Grabmal des Grafen Enno II. in der Großen Kirche

- Restaurierung und Erhaltung des Grabmals des Grafen Enno II. in der Großen Kirche

- Klärung der Zuständigkeit für die Finanzierung der Erhaltung des

Grabmals aus der Renaissance

$1874-1903$

Klassifikation Teil B: 03230

Trägermaterial: Papier

Alte Reg.-Sig.: IX BI 06

Bestell-Nr.: IV 03230

3413 Kasse der Großen Kirche

- Einnahmen und Ausgaben der Kasse der Großen Kirche mit

Verwendungszweck

$1891-1898$

Klassifikation Teil B: 03235

Trägermaterial: Papier

Alte Reg.-Sig.: IX B| 11

Bestell-Nr.: IV 03235 
IV

09 Kirchen

09.03

Evangelische Kirchengemeinden

09.03.01

09.03.01.02

Lfd. Nr. Titel

Evangelisch Reformierte Kirchengemeinden

Rechnung der Großen Kirche

3414 Ablösung von Grundpachten

Laufzeit

- Ablösungen der der Großen Kirche zustehenden Grundpachten auf Antrag der betroffenen Grundbesitzer

1876

Klassifikation Teil B: 03262

Trägermaterial: Papier

Alte Reg.-Sig.: IX BI 54

Bestell-Nr.: IV 03262 
- Antrag der französisch reformierten Gemeinde an den Magistrat auf Beihilfe zur Anschaffung zweier Öfen für ihre Kirchenräume in der Waage am Neuen Markt, Oktober 1871

- Verhandlungen der städtischen Kollegien über den städtischen Etat: Diskussion der Verpflichtung zur Unterhaltung der Kirchenräume der französisch-reformierten Gemeinde, Januar 1873

- Erhebung der Abgabe durch den Magistrat für die Nutzung von Räumen in der Waage am Neuen Markt für den Gottesdienstbetrieb der französisch-reformierten Gemeinde, 1895 - 1896 - Vereinbarung zwischen dem Magistrat und der französisch-reformierten Gemeinde über Nutzung von Räumen in der Waage für Gottesdienste etc., Januar - April 1897

- Zeitungsberichte über Fusionierung der frasnzösisch-reformierten Gemeinde mit der deutsch-reformierten Gemeinde, April - Mai 1897

$1871-1897$

Klassifikation Teil B: 03223,2

Trägermaterial: Papier

Alte Reg.-Sig.: IX D II 05

Bestell-Nr.: IV 03223 b

3416 Unterstützung zum Gehalt des Predigers der französisch-reformierten Gemeinde

- Gewährung einer staatlichen Beihilfe zum Gehalt des Predigers der französisch-reformierten Gemeinde

$1883-1888$

Klassifikation Teil B: 03320

Trägermaterial: Papier

Alte Reg.-Sig.: IX D II 02

Bestell-Nr.: IV 03320

3417 Inventarium der französisch-reformierte Gemeinde

- Anzeigen der Inventarien der französisch-reformierten Gemeinde (aktives und passives Vermögen)

(1860) $1869-1895$

Klassifikation Teil B: 03322

Trägermaterial: Papier

Alte Reg.-Sig.: IX D II 04

Bestell-Nr.: IV 03322 
09

09.03

09.03.01

09.03.01.03
Kirchen

Evangelische Kirchengemeinden

Evangelisch Reformierte Kirchengemeinden

Französisch Reformierte Gemeinde

Lfd. Nr. Titel

Laufzeit

3418 Französisch-reformierte Gemeinde

- Antrag der französisch-reformierten Gemeinde beim Magistrat auf Beihilfe zur Anschaffung zweier Öfen für ihre Kirchenräume in der Waage am Neuen Markt, Oktober 1871

- Verhandlungen der städtischen Kollegien: Diskussion der Verpflichtung zur Unterhaltung der Kirchenräume der französisch-reformierten Gemeinde durch die Stadt Emden, Januar 1873

- Erhebung einer Abgabe durch den Magistrat für die Nutzung von Räumen in der Waage am Neuen Markt durch die französisch-reformierte Gemeinde, 1895 - 1896

- Vereinbarung zwischen Magistrat und französisch-reformierter Gemeinde wegen Nutzung der Räume in der Waage, Januar - April 1897

- Zeitungsberichte über Fusion der französisch-reformierten

Gemeinde mit der deutsch-reformierten Gemeinde, April - Mai 1897

$1871-1897$

Klassifikation Teil B: 03323

Trägermaterial: Papier

Alte Reg.-Sig.: IX D II 05

Bestell-Nr.: IV 03323

3419 Prediger der französisch-reformierten Gemeinde

- Datenerhebung des kgl. Konsistoriums über Diensteinkommen der Prediger der französisch-reformierten Gemeinde, Juli 1871 / April 1872 / Juni 1895 / Januar - März 1896

- Diensteinkommen des Predigers der französisch-reformierten

Gemeinde, August 1871 / April 1872 / Juli 1895

- Erhöhung des Diensteinkommens des Predigers der französisch-reformierten Gemeinde, Mai 1872 / November 1872 April 1873

Einstellung des Predigerkandidaten Medenwold als Prediger der französisch-reformierten Gemeinde, März 1894

$1871-1897$

Klassifikation Teil B: 03324

Trägermaterial: Papier

Alte Reg.-Sig.: IX D II 05

Bestell-Nr.: IV 03324

3420 Fusion der französisch-reformierten mit der deutsch-reformierten Gemeinde

Etat der französisch-reformierten Gemeinde, 1894 / 1895

(Akte unvollständig)

$1894-1897$

Klassifikation Teil B: 03325

Trägermaterial: Papier

Alte Reg.-Sig.: IX D II 33

Bestell-Nr.: IV 03325 
IV

09 Kirchen

09.03

09.03.01

09.03.01.03

Evangelische Kirchengemeinden

Lfd. $\mathrm{Nr}$. Titel

Evangelisch Reformierte Kirchengemeinden

Französisch Reformierte Gemeinde

3421 Prediger-Witwenkasse der französisch-reformierten Gemeinde

Laufzeit

3421 Prediger-Witwenkasse der französisch-reformierten Gemeinde

$1898-1913$

- Rechnungslegung der Prediger-Witwenkasse der

französisch-reformierten Gemeinde nach der Auflösung der

Gemeinde und Eingliederung in die Deutsch-reformierte Gemeinde,

1898 - 1913

- Novellierung der Statuten der Prediger-Witwenkasse der

französisch-reformierten Gemeinde nach Auflösung der

französisch-reformierten Gemeinde, Dezember 1899 - Mai 1900

- Statuten der Prediger-Witwenkasse der französisch-reformierten

Gemeinde: Versorgung noch lebender Witwen und Waisen

französisch-reformierter Prediger, April 1900

$1898-1913$

Klassifikation Teil B: 03326

Trägermaterial: Papier

Alte Reg.-Sig.: IX D II 34

Bestell-Nr.: IV 03326

3422 Etat der französisch-reformierten Gemeinde

$1886-1893$

- Einreichung der Etats der französisch-reformierten Gemeinde, 1886

$-1887$

- Etatentwürfe, 1887 - 1893

$1886-1893$

Klassifikation Teil B: 03327

Trägermaterial: Papier

Alte Reg.-Sig.: IX D II 12

Bestell-Nr.: IV 03327 
09 Kirchen

09.03

Evangelische Kirchengemeinden

09.03.01

09.03.01.04

Evangelisch Reformierte Kirchengemeinden

Gasthauskirche

Lfd. Nr. Titel

Laufzeit

3423 Kommission für die Verwaltung der Gasthauskirche, Bd. 1

- Gemeindeverordnung über Übertragung der Verwaltung des

Gasthauses mit Kirche auf den Magistrat, Dezember 1871 / Januar

1872

- Verhandlungen wegen Entschädigung der reformierten

Kirchengemeinde für die verlorenen Rechte an der

Gasthausverwaltung, 1873 - 1878

- Bestellung der Mitglieder der Kommission für die Verwaltung der

Gasthauskirche, 1876 - 1915

$1871-1915$

Klassifikation Teil B: 03195

Band: 1

Trägermaterial: Papier

Alte Reg.-Sig.: IX A2b 25

Bestell-Nr.: IV 03195

3424 Kommission für die Verwaltung der Gasthauskirche, Bd. 2

- Verhandlungen der Kommission für die Verwaltung der

Gasthauskirche über Organisation des Gasthauses

Darin auch:

- Inventar der Gasthauskirche, 1876

- Ländereien des Gasthauses, 1876

- Etat der Gasthauskirche, 1877 - 1887

- Vermietung der Sitzstellen der Gasthauskirche, 1879 - 1883

- Reinigung und Restaurierung der Orgel in der Gasthauskirche, 1881

$-1883$

$1876-1887$

Klassifikation Teil B: 03195

Band: 2

Trägermaterial: Papier

Alte Reg.-Sig.: IX A2b 25

Bestell-Nr.: IV 03196

3425 Kommission für die Verwaltung der Gasthauskirche, Bd. 3

- Protokolle der Sitzungen der Kommission für die Verwaltung der Gasthauskirche, 1875 - 1917

$1875-1917$

Klassifikation Teil B: 03197

Band: 3

Trägermaterial: Papier

Alte Reg.-Sig.: IX A2b 25

Bestell-Nr.: IV 03197 
- Gutachten des Syndicus Metger über Verpflichtung der Stadt Emden zur Übernahme der Aufwändungen für Gottesdienste und Instandhaltung der Gasthauskirche, Februar 1891

- Vermietung der Sitzplätze in der Gasthauskirche, 1876 - 1890

- Restaurierung der Kronleuchter in der Gasthauskirche, 1878

- Nachbewilligung von Etatmitteln zur Reparatur von Sturmschäden an der Gasthauskirche, Oktober 181

- Ablösung von Reallasten zugunsten der Gasthauskirche auf

Grundstücken von Privatpersonen, 1880 - 1882

- Feuerversicherung der Gasthauskirche, 1883

- Modernisierung der Heizungsanlage der Gasthauskirche, 1883 -

1887

- Feststellung der Restaurierungsbedürftigkeit der Gasthauskirche durch Stadtbaumeister Wiggers, Januar 1884

- Streit um die Benutzung der Gasthauskirche zum Gottesdienst, 1885

- Genehmigung des Etats der Gasthauskirche, 1880 - 1891

$1876-1891$

Klassifikation Teil B: 03198

Trägermaterial: Papier

Alte Reg.-Sig.: IX A2b 26

Bestell-Nr.: IV 03198

3427 Organisten- und Vorsängerdienst in der Gasthauskirche

- Einstellung eines Organisten und Vorsängers für die

Gasthauskirche, 1887 - 1912

- Honorierung / Gehalt für den Organisten- und Vorsängerdienst in der

Gasthauskirche, 1887 - 1913

- Dienstanweisung für den Vorsänger und Vorleser der

Gasthauskirche, 1888

- Dienstanweisung für den Organisten der Gasthauskirche, 1888 /

1902 / 1911

1887 - $1913(1919-1930)$

Klassifikation Teil B: 03202

Trägermaterial: Papier

Alte Reg.-Sig.: IX A2b 31

Bestell-Nr.: IV 03202

3428 Sitze der Magistratsmitglieder und der Mitglieder des

Bürgervorsteherkollegiums in der Gasthauskirche

- Reservations- und Nutzungsrecht an Sitzplätzen in der Gasthauskirche durch Mitglieder der städtischen Kollegien

1902

Klassifikation Teil B: 03203

Trägermaterial: Papier

Alte Reg.-Sig.: IX A2b 34

Bestell-Nr.: IV 03203 
IV

09

Kirchen

09.03

Evangelische Kirchengemeinden

09.03.01

09.03.01.04

Evangelisch Reformierte Kirchengemeinden

Lfd. $\mathrm{Nr}$. Titel

Gasthauskirche

3429 Küsterstelle an der Gasthauskirche

Laufzeit

- Bewerbungen um die Küsterstelle an der Gasthauskirche

- Plan der Küsterwohnung

1905

Klassifikation Teil B: 03259

Trägermaterial: Papier

Alte Reg.-Sig.: IX BI 50

Bestell-Nr.: IV 03259

3430 Sitzstellen in der Gasthauskirche

- Umschreibung der Sitzstellen in der Gasthauskirche auf neue Nutzer wegen Vererbung oder Neuvermietung

(1805 - 1856) 1875 - $1913(1919-1921)$

Klassifikation Teil B: 03266

Trägermaterial: Papier

Alte Reg.-Sig.: IX A2b 12

Bestell-Nr.: IV 03266 
3431 Beschaffung einer Kirchenorgel für die lutherische Gemeinde

- Antrag der lutherischen Gemeinde Emden bei der Kirchenkommission auf Genehmigung einer Anleihe zur Anschaffung einer neuen Orgel als Ersatz für die abgängige alte Orgel, Dezember 1890 - Mai 1892

- Antrag der lutherischen Gemeinde Emden bei der

Kirchenkommission auf Genehmigung einer Anleihe zur Finanzierung der notwendigen Orgelreparatur, Mai - August 1902

$1890-1902$

Klassifikation Teil B: 00122

Trägermaterial: Papier

Alte Reg.-Sig.: CI 35

Bestell-Nr.: IV 00122

3432 Kirchenkasse der lutherischen Gemeinde, Bd. 1

- Abnahme der Kirchenkassenrechnung der lutherischen Gemeinde durch das kgl. Konsistorium in Aurich

$1890-1899$

Klassifikation Teil B: 03268

Band: 1

Trägermaterial: Papier

Alte Reg.-Sig.: IX CI 03

Bestell-Nr.: IV 03268

3433 Kirchenkasse der lutherischen Gemeinde, Bd. 2

- Abnahme der Kirchenkassenrechnung der lutherischen Gemeinde durch das kgl. Konsistorium in Aurich

$1903-1914$

Klassifikation Teil B: 03269

Band: 2

Trägermaterial: Papier

Alte Reg.-Sig.: IX Cl 03

Bestell-Nr.: IV 03269

3434 Abnahme der Rechnungen des zweiten lutherischen Predigerfonds

- Abnahme der Rechnungen des zweiten lutherischen Predigerfonds durch das kgl. Konsistorium in Aurich

$1868-1871$

Klassifikation Teil B: 03270

Trägermaterial: Papier

Alte Reg.-Sig.: IX Cl 04

Bestell-Nr.: IV 03270 
Lfd. Nr. Titel

Laufzeit

3435 Abnahme der Rechnungen der Nellnerschen Predigerwitwen-Kasse

- Abnahme der Rechnungen der Nellnerschen Predigerwitwen-Kasse durch das kgl. Konsistorium in Aurich

$1868-1914$

Klassifikation Teil B: 03271

Trägermaterial: Papier

Alte Reg.-Sig.: IX Cl 05

Bestell-Nr.: IV 03271

3436 Inventarium der Nellnerschen Predigerwitwen-Stiftung

- Immobilien- und Geldvermögen der Nellnerschen

Predigerwitwen-Stiftung

1899

Klassifikation Teil B: 03272

Trägermaterial: Papier

Alte Reg.-Sig.: IX CI 05

Bestell-Nr.: IV 03272

3437 Abnahme der Rechnungen der lutherischen Friedhofskasse

1898-1901

- Abnahme der Rechnungen der lutherischen Friedhofskasse durch das kgl. Konsistorium in Aurich

$1898-1901$

Klassifikation Teil B: 03273

Trägermaterial: Papier

Alte Reg.-Sig.: IX CI 06

Bestell-Nr.: IV 03273

3438 Organisation der lutherischen Gemeinde

- Vom kgl. Konsistorium angeordnete Datensammlung zur Finanzlage der lutherischen Gemeinden zur Ermittlung ihres Beitrages zur Landessynode, August 1869

- Verordnung über die Regelung der staatlichen Aufsicht über die lutherischen Gemeinden in der Provinz Hannover, Juni 1885

- Kirchengesetz in der Provinz Hannover über Regelung der Visitationen der lutherischen Kirchengemeinden, September 1891

- Abshriften von Dokumenten zur Beihilfe der Stadt Emden zu den Gehältern der lutherischen Geistlichen von 1774 - 1876, 1891

$1869-1891$

Akte unvollständig

Klassifikation Teil B: 03274

Trägermaterial: Papier

Alte Reg.-Sig.: IX CI 10

Bestell-Nr.: IV 03274 
Lfd. Nr. Titel

Laufzeit

3439 Inventar der lutherischen Gemeinde

- Anzeige über Veränderungen im Vermögensstatus und der

Verbindlichkeiten der lutherischen Gemeinde und ihrer Stiftungen an das kgl. Konsistorium

- Monita des kgl. Konsistoriums zu den Anzeigen

$1891-1914$ (1919)

Klassifikation Teil B: 03275

Trägermaterial: Papier

Alte Reg.-Sig.: IX CI 07

Bestell-Nr.: IV 03275

3440 Plan zum Bau eines Turms bei der lutherischen Kirche

- Antrag des Kirchenrats der lutherischen Gemeinde an den Magistrat auf Genehmigung eines Turmbaus trotz Einengung der Straße "Am Bollwerk", März - Mai 1870 / April - Oktober 1886

$1870-1886$

(Akte unvollständig)

Klassifikation Teil B: 03276

Trägermaterial: Papier

Alte Reg.-Sig.: IX CI 07

Bestell-Nr.: IV 03276

3441 Etat der lutherischen Gemeinde

- Verhandlungen zwischen dem Oberbürgermeister Fürbringer als weltlicher Kirchenkommissar für die lutherische Gemeinde und dem $\mathrm{kgl}$. Konsistorium in Aurich über Regelung der Zuständigkeit für die Genehmigung der Etats der lutherischen Kirchengemeinde und der Prüfung ihrer Rechnungen, April - Mai 1892

- Etatvoranschläge der lutherischen Gemeinde, 1894 - 1900

- Besprechungen der Etats in den Gemeindeorganen, 1895 - 1898

- Antrag des Kirchenrats der lutherischen Gemeinde an den weltlichen Kirchenkommissar für die lutherische Gemeinde auf Genehmigung

außerplanmäßiger Ausgaben, August - November 1896

- Bauetats der lutherischen Gemeinde, 1899 - 1914

$1892-1914$

Klassifikation Teil B: 03277

Trägermaterial: Papier

Alte Reg.-Sig.: IX CI 08

Bestell-Nr.: IV 03277 
Lfd. Nr. Titel

- Anträge auf Änderung von Eintragungen im Kirchenbuch der lutherischen Gemeinde

$1868-1892$

Klassifikation Teil B: 03279

Trägermaterial: Papier

Alte Reg.-Sig.: IX Cl 11

Bestell-Nr.: IV 03278

3443 Bildung der Bezirkssynode für die lutherischen Kirchen Ostfrieslands

- Verfügung des kgl. Konsistoriums in Aurich über Eingliederung der lutherischen Gemeinden in eine Bezirkssynode, Januar 1868 / April 1869

- Protokolle der Sitzungen der Bezirkssynode über Verhandlungen von kirchenpolitischen Fragen, 1890 / 1894

$1868-1894$

Klassifikation Teil B: 03279

Trägermaterial: Papier

Alte Reg.-Sig.: IX CI 12

Bestell-Nr.: IV 03279

3444 Bauliche Unterhaltung von lutheranischer Kirche und Schule

- Feststellung des baulichen Zustands der lutheranischen

Kirchengebäude und Pastoreien, 1873 - 1912

- Feuerversicherung von lutheranischer Kirche und Schule, 1897

- Neugestaltung des Sitzungszimmers der lutherischen

Gemeindekollegien, Oktober 1902

- Verfügungen des kgl. Konsistoriums über Verpflichtung der Kirchengemeinden zur Bauunterhaltung ihrer Kirchen und Anordnung einer regelmäßigen Berichterstattung über den baulichen Zustand der Kirchen, November 1872 / März 1837

- Verfügung des kgl. Konsistoriums über regelmäßige Visitation kirchlicher Visitation kirchlicher Gebäude, Dezember 1878

- Bestellung des Baumeisters Theilen zum Aufseher über den

Bauzustand der lutherischen Kirchengebäude, Dezember 1875

- Reparatur der II. Lutherischen Patorei (Wwe. Boumann'sches Haus), 1872 - 1873

- Reparatur der I. Lutherischen Pastorei, 1876 - 1877

- Ankauf eines neuen Gebäudes zur Unterbringung der I. Lutherischen

Pastorei, Januar 1881

$1872-1912$

Klassifikation Teil B: 03281

Trägermaterial: Papier

Alte Reg.-Sig.: IX CI 15

Bestell-Nr.: IV 03281 
- Anlage von Geld der lutherischen Gemeinde, 1875 - 1902

- Bericht des Kirchenrats der lutherischen Gemeinde, A. Frerichs, an die Kirchenkommision für die lutherische Gemeinde über Anschaffung sicherer Schränke zur Verwahrung der Wertgegenstände der lutherischen Gemeinde, Juni 1876

- Übersicht über das Vermögen der lutherischen Gemeinde, September 1888

$1875-1902$

Klassifikation Teil B: 03282

Trägermaterial: Papier

Alte Reg.-Sig.: IX CI 16

Bestell-Nr.: IV 03282

3446 Aufhebung der Gebühren für kirchliche Aufgebote, Trauungen und Taufen

- Kompensation für die Aufhebung der Aufgebotsgebühren, 1875 1892

- Festlegung der Gebühren für Haustrauungen, 1876 - 1877

- Aufhebung der Konfirmationsgebühren in der lutherischen

Gemeinde, April - August 1901

- Ermäßigung der Gebühr für Taufbescheinigungen, September -

Oktober 1904

$1875-1904$

Klassifikation Teil B: 03283

Trägermaterial: Papier

Alte Reg.-Sig.: IX Cl 17

Bestell-Nr.: IV 03283

3447 Kirchenorganisation

1868-1905

- Kollekte für den allgemeinen lutherischen Kirchenfonds für die

Provinz Hannover, 1868 - 1870

- Stempelung der Wertpapiere der lutherischen Gemeinde, 1868

- Regelung der Berechtigung zur Abhaltung von Grabreden, 1901

- Organisation von Gottesdiensten für Taubstumme, 1904

- Anzeigen von Inventar-Veränderungen (aktives und passives

Vermögen) der lutherischen Gemeinde, 1905

1868 - 1905 (1920)

Klassifikation Teil B: 03284

Trägermaterial: Papier

Alte Reg.-Sig.: IX Cl 19

Bestell-Nr.: IV 03284 
09

09.03

09.03.02
Kirchen

Evangelische Kirchengemeinden Evangelisch Lutherische Kirchengemeinde

Lfd. Nr. Titel

Laufzeit

3448 Verkauf der Erbpachten der Nellnerschen Predigerwitwen-Stiftung

- Bericht des Kirchenrats der lutherischen Gemeinde über Absicht des Verkaufs der Erbpachten der Nellnerschen Predigerwitwen-Stiftung wegen schwieriger Eintreibung der Erbpachten von den Landnutzern, 1873

- Verfügungen des kgl. Konsistoriums über Richtlinien zur Ablösung von Erbpachten bei kirchlichen Ländereien, Seoptember 1874 / Januar 1877 / Juli 1878

$1873-1878$ Klassifikation Teil B: 03285

Trägermaterial: Papier

Alte Reg.-Sig.: IX C1 20

Bestell-Nr.: IV 03285

3449 Hebung der unfreiwilligen Kirchenbeiträge (Kirchensteuer)

- Beschlüsse der lutherischen Kirchengemeindekollegien über Hebung der unfreiwilligen KIrchenbeiträge (Kirchensteuer), Januar 1873 / Dezember 1906 / Februar 1910 / Februar 1913 / Februar 1914

- Bericht der Kirchenkommission für die lutherische Gemeinde an das $\mathrm{kgl}$. Konsistorium über Befürwortung der von der lutherischen Gemeinde vorgeschlagenen Kirchensteuer, Januar 1873 / Dezember 1884 / März - April 1910

- Eintreibung der lutherischen Kirchensteuer durch den städtischen Steuereinnehmer, November 1884

$1873-1914$

Klassifikation Teil B: 03286

Trägermaterial: Papier Alte Reg.-Sig.: IX Cl 21

Bestell-Nr.: IV 03286

3450 Regulativ für den Friedhof der lutherischen Gemeinde

- Erlass eines neuen Regulativs für den Friedhof der lutherischen Gemeinde, Januar - November 1878

- Moneta des kgl. Konsistoriums zum Regulativ-Entwurf, September 1878 / Dezember 1891

- Änderungen des Regulativs, Mai 1883 / Januar - November 1891

- Gedrucktes Friedhofsstatut der lutherischen Gemeinde, 1893

- Verfügung des kgl. Konsistoriums über Verlängerung der Totenruhe auf 15 Jahre, Dezember 1904

Enthält auch:

- Bildung eines Kirchenchores in der lutherischen Gemeinde, 1886

$1878-1904$

Klassifikation Teil B: 03287

Trägermaterial: Papier

Alte Reg.-Sig.: IX Cl 25

Bestell-Nr.: IV 03287 
IV

09 Kirchen

09.03

09.03.02

Evangelische Kirchengemeinden

Lfd. Nr. Titel Evangelisch Lutherische Kirchengemeinde

3451 Heizung und Beleuchtung der lutherischen Kirche

Laufzeit

- Anschaffung einer Heizungsanlage für die lutherische Kirche, 1880 1903

- Installation einer Gasbeleuchtung in der lutherischen Kirche, 1895

$1880-1903$

Klassifikation Teil B: 03288

Trägermaterial: Papier

Alte Reg.-Sig.: IX CI 26

Bestell-Nr.: IV 03288

3452 Verwendung der im Klingelbeutel und in der Büchse gesammelten

1882

Gelder von der lutherischen Gemeinde

- Beschluss der Kirchengremien der lutherischen Gemeinde über Verwendung der im Klingelbeutel und in der Büchse gesammelten Gelder für Zwecke der Armenfürsorge, Januar 1882

- Genehmigung des Beschlusses durch das kgl. Konsistorium, März 182

1882

Klassifikation Teil B: 03289

Trägermaterial: Papier

Alte Reg.-Sig.: IX CI 27

Bestell-Nr.: IV 03289

3453 Gebühren wegen Bestattung lutherischer Armer

- Verhandlungen zwischen dem lutherischen Kirchenrat der städtischen Friedhofskommission und dem Magistrat über Festlegung der Gebühren wegen Bestattung lutherischer Armer, Juli 1881 - Juni 1883

- Genehmigung des Vetrages zwischen der lutherischen Gemeinde und dem Magistrat über Gebühren wegen Bestattung lutherischer Armer, Juli 1883

$1881-1883$

Klassifikation Teil B: 03290

Trägermaterial: Papier

Alte Reg.-Sig.: IX CI 28

Bestell-Nr.: IV 03290 
09 Kirchen

09.03

Evangelische Kirchengemeinden

09.03.02 Evangelisch Lutherische Kirchengemeinde

Lfd. Nr. Titel

Laufzeit

3454 Einführung eines neuen Gesangbuches in den lutherischen 1883 Gemeinden der Provinz Hannover

- Datensammlung des kgl. Konsistoriums über Stand der Einführung eines neuen Gesangbuches in den lutherischen Gemeinden der Provinz Hannover, Juli 1883

1883

(Akte unvollständig) Klassifikation Teil B: 03291

Trägermaterial: Papier

Alte Reg.-Sig.: IX VI 29

Bestell-Nr.: IV 03291

3455 Nellnersche Predigerwitwen-Stiftung

- Unterstützungen aus der Nellnersche Predigerwitwen-Stiftung, 1867

- 1901

- Anlage des Stiftungskapitals, 1889

- Definition der Unterstützungsberechtigten unter Einbeziehung der Witwen emeritierter Pastoren, 1902

$1867-1902$

Klassifikation Teil B: 03292

Trägermaterial: Papier

Alte Reg.-Sig.: IX CI 30

Bestell-Nr.: IV 03292 
IV

09 Kirchen

09.03

Evangelische Kirchengemeinden

09.03.02 Evangelisch Lutherische Kirchengemeinde

Lfd. Nr. Titel

Laufzeit

3456 Schenkungen und Vermächtnisse zugunsten der lutherischen Gemeinde

- Legat zur Unterhaltung des Grabes des Medizinalrats Dr. Stöhr, 1885

- Legat der Anna Catharina Frederike Brüggemanns zugunsten der lutherischen Armen, 1885

- Legat des Particuliers Otto Nicolaus Clösser an die lutherische Gemeinde, 1887 - 1889

- Legat der Theda Block an die lutherische Gemeinde, 1891

- Meldungen über Schenkungen und Legate an die lutherische Gemeinde, 1893 - 1914

- Legat zur Unterhaltung der Gräber der Eheleute Reese, 1897

- Legat der Katharina Margaretha Honsberg an die lutherische

Gemeinde, 1898

- Legat der Christiane Brüning an die lutherische Gemeinde, 1900

- Legat des Rentners Johann Cornelius Jutting über 10.000 Mark für geplante Gotteskammern der lutherischen Gemeinde, Agust 1903

- Legat des Rentiers Ferdinand Doden über 2000 Mark an die lutherische Gemeinde, 1904

- Legat der Babetta Merkel an die lutherische Gemeinde, 1905

- Legat der Eheleute de Vries zur Unterhaltung ihrer Gräber auf dem lutherischen Friedhof, 1910

- Legat des Rentiers Daniel van Holten, 1912

$1885-1914$

Klassifikation Teil B: 03293

Trägermaterial: Papier

Alte Reg.-Sig.: IX CI 31

Bestell-Nr.: IV 03293 
09 Kirchen

09.03

Evangelische Kirchengemeinden

09.03.02

Evangelisch Lutherische Kirchengemeinde

Lfd. Nr. Titel

Laufzeit

3457 Gehaltszuschuss an lutherische Geistliche aus der Kämmereikasse

- Antrag des lutherischen Kirchenrats an die Kirchenkommission für die lutherische Gemeinde auf Genehmigung einer Erhöhung der Kirchensteuer nach Streichung des Gehaltszuschusses an lutherische Geistliche aus der Kämmereikasse, März 1887

- Streit zwischen dem kgl. Konsistorium und der Kirchenkommission für die lutherische Gemeinde um Berechtigung zur Genehmigung einer Kirchensteuererhöhung, April 1887

- Antrag des lutherischen Kirchenrats an die Kirchenkommission der lutherischen Gemeinde auf Genehmigung einer Anleihe zur Deckung des Defizits wegen Streichung des Gehaltszuschusses an lutherische Geistliche aus der Kämmereikasse, Oktober 1887

- Bericht des lutherischen Kirchenrats an das kgl. Konsistorium über Anspruch auf den Gehaltszuschuss aus der Kämmereikasse und Weigerung zur Mittragung eines Gehaltszuschusses für reformierte Prediger, Januar 1888

- Genehmigung einer Anleihe der lutherischen Gemeinde zur Deckung der Etatlücken in 1887 / 88 durch den Wegfall des Gehaltszuschusses an lutherische Geistliche aus der Kämmereikasse durch die Kirchenkommission für die lutherische Gemeinde, Mai 1889

$1887-1889$

Klassifikation Teil B: 03294

Trägermaterial: Papier

Alte Reg.-Sig.: IX CI 32

Bestell-Nr.: IV 03294

3458 Immobilien der lutherischen Gemeinde

$1888-1913$

- Ankauf des Seelerschen Besitzung durch die lutherische Gemeinde zu Schulzwecken, November 1888 - März 1889

- Verkauf des lutherischen Schulhauses in Zwischen beiden Bleichen, April - Juli 1889

- Ablösung einer auf dem Grundstück der II. luth. Pastorei liegenden

Erbpacht, Oktober 1893 - Dezember 1896

- Berichtigung der Grundbuchblätter zu den Grundstücken der lutherischen Gemeinde, 1896 - 1897

- Ankauf eines Hauses für die III luth. Pastoreim Oktober 1903

- Zustand der Pfarrhäuser der lutherischen Gemeinde, 1906

- Bauliche Umgestaltung von Gebäuden der lutherischen Gemeinde, $1906-1907$

- Verkauf von Gebäude der lutherischen Gemeinde am Apfelmarkt, 1907 / 1908

- Anschluss des luth. Pfarrhauses an der Jungfernbrückstraße an das elektrische Netz, $1912 / 13$

$1888-1913$

Klassifikation Teil B: 03295

Trägermaterial: Papier

Alte Reg.-Sig.: IV CI 33

Bestell-Nr.: IV 03295 
Lfd. Nr. Titel

Laufzeit

3459 Lutherischer Generalsuperintendent für Ostfriesland

- Vertretung des lutherischen Generalsuperintendenten für

Ostfriesland, 1888 - 1889

- Ernennung des Superintendenten Baring zum lutherischen

Generalsuperintendenten für Ostfriesland, September 1889

$1888-1889$

Klassifikation Teil B: 03296

Trägermaterial: Papier

Alte Reg.-Sig.: IX CI 34

Bestell-Nr.: IV 03296

3460 Kalkulation der lutherischen Kirchenrechnungen

- Organisation der Rechnungsprüfung bei der lutherischen Gemeinde und der Nellnerschen Predigerwitwen-Stiftung

$1891 / 1914$

Klassifikation Teil B: 03297

Trägermaterial: Papier

Alte Reg.-Sig.: IX CI 36

Bestell-Nr.: IV 03297

3461 Verfassung der lutherischen Gemeinde

1866-1897

- Gedrucktes Regulativ (Verfassung) der lutherischen Gemeinde,

1855 / 1866

- Novellierung der Verfassung, 1887 - 1889 / 1891 - 1892

- Regulierung der Gemeindezugehörigkeit der auf Nesserland

wohnenden Lutheraner, 1888

- Aufnahme einer dritten Pfarrstelle in die Gemeindeverfassung, 1897

$1866-1897(1855)$

Klassifikation Teil B: 03298

Trägermaterial: Papier

Alte Reg.-Sig.: IX CI 37

Bestell-Nr.: IV 03298

3462 Lutherische Friedhofskasse

- Plan der Einnahmen und Ausgaben der lutherischen Friedhofskasse, 1894 - 1895

- Antrag des Kirchenrats der lutherischen Gemeinde an die Kirchenkommission für die lutherische Gemeinde auf Genehmigung des Einsatzes von Mitteln aus der Friedhofskasse zur Herstellung einer Einfriedung um den lutherischen Friedhof, August - September 1895

- Vergütung für den Rechnungsführer der lutherischen

Friedhofskasse, Oktober - November 1897

$1894-1897$

Klassifikation Teil B: 03299

Trägermaterial: Papier

Alte Reg.-Sig.: IX CI 38

Bestell-Nr.: IV 03299 
3463 Einführung eines kirchlichen Notfonds für die lutherische Kirche in der 1894-1900 Provinz Hannover

- Ermittlung der Einkommenssteuerrate der lutherischen Gemeindemitglieder in Emden zur Festlegung der Beitragshöhe der Gemeinde zum kirchlichen Notfonds

$1894-1906$

Klassifikation Teil B: 03300

Trägermaterial: Papier

Alte Reg.-Sig.: IX CI 40

Bestell-Nr.: IV 03300

3464 Aufstellung der Kircheninventaria

- Regelungen zur Aufstellung der Kircheninventaria: Fristfestlegungen, Formfragen, Rubiken

$1894-1906$

Klassifikation Teil B: 03301

Trägermaterial: Papier

Alte Reg.-Sig.: IV CI 41

Bestell-Nr.: IV 03301

3465 Honsbergsche Predigerwitwen- und Töchterstiftung

- Abschrift des Testaments der Catharina Margaretha Honsberg über Legat an die lutherische Gemeinde vom März 1873, März 1894

- Errichtung der Honsbergschen Predigerwitwen- und Töchterstiftung, 1894

- Rechnungslegung der Honsbergschen Predigerwitwen- und Töchterstiftung, 1896 - 1914

1894 .- 1914

Klassifikation Teil B: 03302

Trägermaterial: Papier

Alte Reg.-Sig.: IX Cl 41

Bestell-Nr.: IV 03302

3466 III. Pastorei der lutherischen Gemeinde

- Antrag des Kirchenrats der lutherischen Gemeinde an die Kirchenkommission für die lutherische Gemeinde auf Genehmigung der Errichtung einer III. Pastorei wegen Zunahme der Zahl der Lutheraner in Emden, Dezember 1891 - Februar 1895

- Beschwerde des Oberbürgermeisters Fürbringer als weltlicher Kirchenkommissar für die lutherische Gemeinde gegen den Pastor Buck beim kgl. Konsistorium wegen kritischer Äußerungen des Pastors gegen seine Person aus Anlass einer Diskussion wegen der III. Pastorei, November 1892

- Besetzung der III. Pastorei, Juni 1895 - Aug. 1906

$1895-1903$

Klassifikation Teil B: 03303

Trägermaterial: Papier

Alte Reg.-Sig.: IX Cl 42

Bestell-Nr.: IV 03303 
Lfd. Nr. Titel

Laufzeit

3467 Rechnungslegung der Stiftungen der lutherischen Gemeinde

- Revision der Rechnungen der Stiftungen der lutherischen Gemeinde

$1895-1918$

Klassifikation Teil B: 03304

Trägermaterial: Papier

Alte Reg.-Sig.: IX Cl 43

Bestell-Nr.: IV 03304

3468 Gemeinde-Seelsorge

- Verteilung der seelsorgerischen Arbeit unter den Pastoren der lutherischen Gemeinde

$1896-1897$

Klassifikation Teil B: 03305

Trägermaterial: Papier

Alte Reg.-Sig.: IX CI 44

Bestell-Nr.: IV 03305

3469 Nellnersche Stiftung

1904

- Auszug über Vermögen und Ausgaben der Nellnerschen

Predigerwitwen- und Töchterstiftung

1904

Klassifikation Teil B: 03306

Trägermaterial: Papier

Alte Reg.-Sig.: IX Cl 47

Bestell-Nr.: IV 03306

3470 Stiftungen der lutherischen Gemeinde

- Auszug über Vermögen und Ausgaben der Honsbergschen Predigerwitwen- und Töchterstiftung und anderer Stiftungen und Lagate der lutherischen Gemeinde

$1899-1913$

Klassifikation Teil B: 03307

Trägermaterial: Papier

Alte Reg.-Sig.: IX Cl 48

Bestell-Nr.: IV 03307

3471 Einführung der Pfarrkassenrechnungsführung bei der lutherischen Gemeinde

- Verfügungen des kgl. Konsistoriums über Organisation der Kirchenkassen bei den lutherischen Gemeinden nach den Richtlinien Pfarrkassenrechnungsführung, März - Juli 1901

1901

Klassifikation Teil B: 03308

Trägermaterial: Papier

Alte Reg.-Sig.: IX Cl 49

Bestell-Nr.: IV 03308 
3472 Umbau des früheren lutherischen Schulgebäudes am Alten Bollwerk 1903

- Genehmigungsverfahren wegen Umbau des früheren lutherischen Schulgebäudes am Alten Bollwerk zu einem Altenheim mit Küsterwohnung

1903

\author{
Klassifikation Teil B: 03309 \\ Trägermaterial: Papier \\ Alte Reg.-Sig.: IX CI 50 \\ Bestell-Nr.: IV 03309
}

3473 Finanzierung der Pfarrbesoldung in der lutherischen Gemeinde

- Festlegung des von der lutherischen Gemeinde in den Zusatzfonds für Beihilfe zur Pfarrbesoldung zu zahlenden Beitrages, Mai 1887 März 1888

- Einführung einer Kirchensteuer in der lutherischen Gemeinde zur Finanzierung der Pfarrbesoldung, August 1874 - April 1875

- Verbindung von Kirchen- und Schulsteuer zu einer allgemeinen Gemeindesteuer, Dezember 1874

$1874-1888$

Klassifikation Teil B: 03310

Trägermaterial: Papier

Alte Reg.-Sig.: IX CI 53

Bestell-Nr.: IV 03310

3474 Begräbnis verstorbener Kinder in der lutherischen Gemeinde

- Regelung der Mitwirkung von Geistlichen bei der Bestattung verstorbener Babies in der lutherischen Gemeinde

$1905-1908$

Klassifikation Teil B: 03311

Trägermaterial: Papier

Alte Reg.-Sig.: IX CI 53

Bestell-Nr.: IV 03311

3475 Kirchensteuer der lutherischen Gemeinde

- Kirchensteuerlisten der lutherischen Gemeinde

1918 / 1919

Klassifikation Teil B: 03312

Trägermaterial: Papier

Alte Reg.-Sig.: IX Cl 54

Bestell-Nr.: IV 03312 
IV

09 Kirchen

09.03

Evangelische Kirchengemeinden

09.03.02

Evangelisch Lutherische Kirchengemeinde

Lfd. Nr. Titel

Laufzeit

3476 Stitungen der lutherischen Gemeinde 1906

- Inventarien der Stiftungen der lutherischen Gemeinde

1906

Klassifikation Teil B: 03313

Trägermaterial: Papier

Alte Reg.-Sig.: IX CI 55

Bestell-Nr.: IV 03313

3477 Inventar: Mittel der lutherischen Gemeinde

- Aufstellung über Vermögen und Einnahmen sowie Ausgaben der lutherischen Gemeinde

1898

\author{
Klassifikation Teil B: 03314 \\ Trägermaterial: Papier \\ Alte Reg.-Sig.: IX CI 56 \\ Bestell-Nr.: IV 03314
}

3478 Zuschuss zur Besoldung der lutherischen Pastoren

1890

- Gesuch der lutherischen Gemeinde an den Magistrat über Bitte um Gewährung eines Zuschuss zur Pfarrbesoldung, November 1890

1890

Klassifikation Teil B: 03315

Trägermaterial: Papier

Alte Reg.-Sig.: IX CI 57

Bestell-Nr.: IV 03315

3479 Diensteinkommen der Prediger

- Regelung der Einkommen der Pastoren der lutherischen Gemeinde - Anträge auf Erhöhung der Pastorengehälter in der lutherischen Gemeinde sowie auf Gehaltszulagen

$1872-1907$

Klassifikation Teil B: 03316

Trägermaterial: Papier Alte Reg.-Sig.: IX Cl 60

Bestell-Nr.: IV 03316 
09

09.03

09.03.03
Kirchen

Evangelische Kirchengemeinden

Gemeinden in den Emder Herrlichkeiten

Lfd. Nr. Titel

Laufzeit

3480 Prediger in Oldersum

1884-1901

- Verhandlungen zwischen dem Kirchen- und Schulvorstand Oldersum und dem Magistrat wegen Ablösung der Patronatsrechte der Stadt Emden zum Erhalt des freien Predigerwahlrechts, März - Juni 1884 - Schreiben des Rechtsanwalts Bode als Vertreter des Oldersumer Kirchenrats an den Magistrat über Bestreitung des Patronatsrechts über die Kirchen- und Schulgemeinde nach dem Verkauf des Gutes Oldersum, Juni 1900

- Beschwerde des Kirchen- und Schulvorstands Oldersum gegen den Magistrat beim Bezirksausschuss wegen umstrittenes Patronatsrecht der Stadt Emden über die Oldersumer Kirchengemeinde, Januar 1901 - Bewerbungen um die nach dem Tode des Predigers L. Wychgram vakanten Predigerstelle in Oldersum, Mai - Juni 1901

$1884-1901$

Klassifikation Teil B: 03328

Trägermaterial: Papier

Alte Reg.-Sig.: IX A2c 07

Bestell-Nr.: IV 03328

3481 Prediger und Lehrer in Tergast

- Bewerbungen um die Predigerstelle in Tergast, 1886

- Wahl des Pastors H. Duif aus Leer zum Prediger in Tergast und

Bestätigung der Wahl durch den Magistrats als Patron der Gemeinde, Oktober 1886

- Gesetzliche Regelung über Abschaffung des Bestätigungsrecht des Patrons bei der Wahl eines Predigers, 1924

- Ablösung des Patronatsrechtes der Stadt Emden über die Kirchenund Schulgemeinde Tergast gegen eine Ablösesumme von 500 RM, Mai 1924

1886 (1924)
Klassifikation Teil B: 03329
Trägermaterial: Papier
Alte Reg.-Sig.: IX A2c 12
Bestell-Nr.: IV 03329

3482 Ablösung des Patronatsrechts über die Kirchengemeinde in Oldersum

- Abschrift: Historische Grundlagen des Patronatsrechtes der Stadt Emden über die Kirchengemeinde in Oldersum, 1901

- Ablösung des Patrontsrechts gegen eine Ablösesumme von 1.500

M, Mai - September 1901

1901

Klassifikation Teil B: 03330

Trägermaterial: Papier

Alte Reg.-Sig.: IV A2c 15

Bestell-Nr.: IV 03330 
09 Kirchen

09.03

Evangelische Kirchengemeinden

09.03.03

Gemeinden in den Emder Herrlichkeiten

Lfd. Nr. Titel

Laufzeit

3483 Patronat über die Kirchengemeinden Groß- und Kleinborssum

- Anfrage des Amtshauptmann des Amtes Emden an den Magistrat über dessen Haltung zu einer Vereinigung der Kirchengemeinden Groß- und Kleinborssum wegen Patronat, Mai / Juni 1869

- Schreiben des Amtshauptmanns von Weyhe an den Magistrat über Angebot von 400 Rthlr. durch die Gemeinden in Borssum zur Ablösung des Emder Patronats, Oktober 1869

- Verhandlungen über Ablösung des Emder Patronats über Borssum, September 1869 - Mai 1871

- Fusion von Groß- und Kleinborssum, September 1871

$1869-1871$

Klassifikation Teil B: 03331

Trägermaterial: Papier

Alte Reg.-Sig.: IX A2c 11

Bestell-Nr.: IV 03331

3484 Patronat der Stadt Emden über die Gemeinde Uphusen

- Besetzung der Pastorenstelle in Uphusen nach dem Tode des Predigers Anton Fegter, 1876

- Aufstellung über Einkünfte der Pastoren in Uphusen, 1876

- Verhandlungen über Ablösung des Patronatsrechts der Stadt Emden über die Kirchengemeinde Uphusen, Januar - März 1876

1876

\author{
Klassifikation Teil B: 03332 \\ Trägermaterial: Papier \\ Alte Reg.-Sig.: IX A2c 13 \\ Bestell-Nr.: IV 03332
}

3485 Ernennung von Kirchenälteste in den Emder Herrlichkeiten

- Ernennung des Patronvertreters in den Kirchengemeinden Tergast und Wolthusen, April 1902 / Februar - März 1905

- Ernennung von Kirchenältesten in der Kirchengemeinde Wolthusen durch den Magistrat als Patron, April 1890

- Ernennung von Kirchenältesten in der Kirchengemeinde Oldersum durch den Magistrat als Patron, 1890 - 1895

- Ernennung von Kirchenältesten in der Kirchengemeinde Tergast durch den Magistrat als Patron, 1907

- Wahl zweier Kirchenratsmitglieder in Wolthusen, Mai 1890

- Wahl des Kirchenrats in Oldersum, Juli 1884

$1869-1907$

Klassifikation Teil B: 03333

Trägermaterial: Papier

Alte Reg.-Sig.: IX A2c 14

Bestell-Nr.: IV 03333 
IV

09 Kirchen

09.03

Evangelische Kirchengemeinden

09.03.04 Mennonitengemeinde

Lfd. Nr. Titel

Laufzeit

3486 Verleihung der Korporationsrechte an die Mennonitengemeinde 1901-1902

- Gedruckte Satzung der Mennonitengemeinde in Emden mit Mitgliederliste, 1901

- Gesetzliche Bestimmungen über Erteilung der Korporationsrechte an die Mennonitengemeinden, Juni 1874

- Antrag der Mennonitengemeinde an den Magistrat auf Erteilung der Korporationsrechte, April 1904

- Liste der stimmberechtigten Mitglieder der Mennonitengemeinde, April 19041

- Bericht des Magistrats an den Regierungspräsidenten in Aurich über Befürwortung des Antrags der Mennonitengemeinde auf Erteilung der Korporationsrechte, Juli 1901

- Erlass des Ministers der geistlichen, Unterrichts- und Medizinalangelegenheiten über Erteilung der Korporationsrechte an die Emder Mennonitengemeinde, Oktober 1901

$1901-1902$

Klassifikation Teil B: 03334

Trägermaterial: Papier

Alte Reg.-Sig.: IX A4 04

Bestell-Nr.: IV 03334 
IV

09

Kirchen

09.04

Katholische Kirche

09.04.01

Überwachung der katholischen Kirche

Lfd. Nr. Titel

Laufzeit

3487 Armenbeiträge der katholischen Gemeinde

- Festlegung der Armenkassenbeiträge für die Mitglieder der katkolischen Gemeinde, 1867 - 1869

- Heranziehung neu zugezogener Katholiken zu den

Armenkassenbeiträgen, Dezember 1867

- Liste der Beitragszahler zur katholischen Armenkasse, 1867 - 1870

- Widerspruch des Schankwirts G. H. Müller gegen die Heranziehung

zur katholischen Armenkasse, Juli - August 1870

$1867-1870$

Klassifikation Teil B: 03335

Trägermaterial: Papier

Alte Reg.-Sig.: IX A3 11

Bestell-Nr.: IV 03335

3488 Katholische Schule und Kirche

$1872-1892$

- Gesetze und Erlasse des Ministers der geistlichen, Unterrichts- und Medizinalangelegenheiten über Regelungen zur Überwachung der katholischen Kirche (Kulturkampf), 1872

- Verfügung des kgl. katholischen Konsistoriums in Osnabrück über Anweisungen zur Vermögensverwaltung des Schulvorstände der katholischen Gemeinden, April 1875

- Verfügung des kgl. katholischen Konsistoriums in Osnabrück über Haushalts- und Verwaltungsführung der katholischen Gemeinden,

Dezember 1876 - März 1877

- Buchgeschenk des Ministers der geistlichen, Unterrichts- und Medizinalangelegenheiten an die katholische Gemeindeschule in Emden, Juni 1886

- Erlass des Ministers der geistlichen, Unterrichts- und Medizinalangelegenheiten über Erlaubnis einer Spendensammlung für den Bau eines Turms an der katholischen Kirche in Emden, Februar 1890

- Verfügung des Regierungspräsidenten in Aurich über

Datensammlung zur Ermittlung der Höhe der Staatsbeihilfe für die katholische Gemeinde nach Aufhebung der Stol-Gebühren

(fürTraungen, Taufen und Beerdigungen), Juni 1891

- Datensammlung des Ministeriums der geistlichen, Unterrichts- und Medizinalangelegenheiten über Praxis der Vereidigung der Küster von katholischen Gemeinden, Juli 1892

$1872-1892$

Klassifikation Teil B: 03336

Trägermaterial: Papier

Alte Reg.-Sig.: IX A3 12

Bestell-Nr.: IV 03336 
IV

09

Kirchen

09.04

Katholische Kirche

09.04.01

Überwachung der katholischen Kirche

Lfd. Nr. Titel

Laufzeit

3489 Organe der Katholischen Kirchengemeinde

- Germeinsamer Erlass des Innenministers und des Ministers der geistlichen, Unterrichts- und Medizinalangelegenheiten über

Zulässigkeit von Prozessionen und des Aufstellens von Altären auf die

Straße durch katholische Gemeinden, April 1902

- Wahl der Kirchenvorsteher und der Gemeindevertretung der

katholischen Gemeinde Emden, 1902 - 1914

- Grußwort des Magistrats zur Jubiläumsfeier des 100-jährigen

Bestehens der kath. St. Michael-Kirche und der Einweihung des

Turmbaus, September 1906

$1902-1914$

Klassifikation Teil B: 03338

Trägermaterial: Papier

Alte Reg.-Sig.: IX A3 20

Bestell-Nr.: IV 03338

3490 Wahl und Berufung des Vorstands der katholischen Gemeinde

- Erlass des Ministers der geistlichen Unterrichts- und

Medizinalangelegenheiten über Bildung und Wahlordnung der

Vertretungsorgane der katholischen Gemeinde, Juni 1875

- Verfügung des Oberpräsidenten der Provinz Hannover über

Umsetzung des Erlasses, Juli 1875

- Liste der Beitragszahler für die katholische Gemeindekasse (=

Kirchensteuer), 1875

- Verfügung des preußischen Landdrosten in Aurich über Regelung der Bildung und Wahl der Vertretungen der katholischen Gemeinden im Landdrosteibezirk Aurich, Oktober 1875

1875

Klassifikation Teil B: 03339

Trägermaterial: Papier

Alte Reg.-Sig.: IX A3 20a

Bestell-Nr.: IV 03339

3491 Kirchenpolitische Gesetze

- Gesetz über Abänderung der kirchenpolitischen Gesetze:

Gewährung größerer Autonomie an die katholische Kirche,

Veränderung der Aufsicht (Beendigung des "Kulturkampfes")

1886 (1922)

Klassifikation Teil B: 03342

Trägermaterial: Papier

Alte Reg.-Sig.: IX A3 27

Bestell-Nr.: IV 03342 
IV

09 Kirchen

09.04

Katholische Kirche

09.04.01 Überwachung der katholischen Kirche

Lfd. Nr. Titel

Laufzeit

3492 Bildung kirchlicher Hilfsfonds für sich neu errichtende katholische 1904-1906 Pfarrgemeinden

- Erlass des Ministers der geistlichen, Unterrichts- und Medizinalangelegenheiten über Zulassung und Förderung kirchlicher Hilfsfonds für sich neu errichtende katholische Pfarrgemeinden

$1904-1906$

Klassifikation Teil B: 03346

Trägermaterial: Papier

Alte Reg.-Sig.: IX A3 31

Bestell-Nr.: IV 03346

3493 Erhebung von Kirchensteuern in den katholischen Gemeinden

- Gesetz uber Erhebung von Kirchensteuern in den katholischen

Gemeinden, Juli 1905

- Durchführungsbestimmungen, 1905 - 1906

$1905-1906$

Klassifikation Teil B: 03347

Trägermaterial: Papier

Alte Reg.-Sig.: IX A3 32

Bestell-Nr.: IV 03347 
IV

09 Kirchen

09.04

Katholische Kirche

09.04 .02

Katholische Kirchengemeinde

Lfd. Nr. Titel

Laufzeit

3494 Statistik der katholischen Gemeinde $1880-1900$

- Statistische Meldungen über Struktur und Mitglieder der katholischen Gemeinde Emden an den Oberpräsidenten der Provinz Hannover auf Anordnung des Ministers der geistlichen Unterrichts- und Medizinalangelegenheiten, Dezember 1880 - Juni 1900

$1880-1900$

Klassifikation Teil B: 03341

Trägermaterial: Papier

Alte Reg.-Sig.: IX A3 26

Bestell-Nr.: IV 03341

3495 Ambulante Krankenpflege iin der katholischen Gemeinde

- Antrag der katholischen Gemeinde an den Regierungspräsidenten auf Zulassung einer eigenen ambulanten Krankenpflege, August -

Dezember 1902

- Übersicht über im Regierungsbezirk Aurich ansässige

Niederlassungen geistlicher Orden (Schwestern des

Franziskanerorden $=$ Krankenpflege)

$1902-1911$

Klassifikation Teil B: 03344

Trägermaterial: Papier

Alte Reg.-Sig.: IX A3 29

Bestell-Nr.: IV 03344 
09

Kirchen

09.05

\section{Sonstige Kirchen und Sekten}

Lfd. Nr. Titel

Laufzeit

3496 Baptisten

$1875-1913$

(1920)

- Regelung des Erwerbs von Korporationsrechten durch

Baptistengemeinden, 1875 - 1907

- Bericht des Magistrats an den Regierungspräsidenten über Struktur und Tätigkeit der Baptistengemeinde in Emden, Februar 1890

- Druck: Glaubensbekenntnis und Verfassung der Gemeinden getaufter Christen (Baptisten), 1905

- Aufstellung über Mitglieder der Baptisten-Gemeinde und

Steuerzahlungen, 1906

- Anträge der Emder Baptistengemeinde auf Verleihung der

Korporationsrechte, August 1906 - Februar 1908 (4920)

- Beschreibung der Emder Baptistengemeinde durch Prediger Emil

Wederwardt, Juni 1907

- Ermittlung der Steuerverhältnisse der Baptistengemeinde, Oktober -

November 1907

- Satzungen der Baptistengemeinde, Mai 1912 - März 1913

$1875-1913(1920)$

Klassifikation Teil B: 03348

Trägermaterial: Papier

Alte Reg.-Sig.: IX A5 02

Bestell-Nr.: IV 03348

3497 Sekten

$1867-1910$

- Verfügung des preußischen Landdrosten in Aurich über Aufhebung des Verbots der Sektiererei von Ausländern wegen verkündeter

Religionsfreiheit, Dezember 1867

- Bericht des Magistrats an den preußischen Landdrosten über

Verhältnisse der Baptisten in Emden, November 1871

- Erlass des Innenministers über Ausweisung missionierender

Mormonen, Januar 1903 / Juni 1910

$1867-1910$

Klassifikation Teil B: 03349

Trägermaterial: Papier

Alte Reg.-Sig.: IX A5 01

Bestell-Nr.: IV 03349 
09 Kirchen

09.05

\section{Sonstige Kirchen und Sekten}

Lfd. Nr. Titel

Laufzeit

3498 Altreformierte Gemeinde 1869-1905

- Anfrage des ostfriesischen Infanterieregiments Nr. 78 an den Magistrat nach der Berechtigung des altreformierten Pastors Bode zur Abhaltung von Konfirmandenunterricht für unkonfirmierte Rekruten, April 1869

- Anträge der altreformierten Gemeinde auf Erteilung der Korporationsrechte, Oktober 1872 - Januar 1873 / Mai - August 1892 / August 1904 - Mai 1905 (1922)

- Ermittlungen gegen den Prediger Koopmann wegen bezahlter Pastoraltätigkeit trotz Bezugs einer Unfallrente von einer

Eisenbahngesellschaft, Januar - Februar 1882

- Ermittlungen gegen den Prediger Koopmann wegen unbefugter Bestattung, Oktober 1882

- Bericht des Magistrats an den Regierungspräsidenten über Verhältnisse der altreformierten Gemeinde, Februar 1905

- Liste der Mitglieder der altreformierten Gemeinde, 1905

$1869-1905(1922)$

Klassifikation Teil B: 03350

Trägermaterial: Papier

Alte Reg.-Sig.: IX A5 05

Bestell-Nr.: IV 03350 
10.01

Lfd. Nr. Titel

- Kgl. Verordnung über Errichtung einer Elementarlehrer- Witwen- und Waisenkasse für die Provinz Hannover, November 1874

- Umsetzung der Verordnung durch das Provinzialschulkollegium in Hannover, November 1874 - Januar 1875

- Verfügung des Magistrats über Abwicklung des Zahlungsverkehrs an die Elementarlehrer- Witwen- und Waisenkasse über die städtische Steuerkasse, Januar 1875

- Verfügungen des Provinzialschulkollegiums über Organisation des Geschäftsgangs und der Kassenführung der ElementarlehrerWitwen- und Waisenkasse, Juli 1875 - März 1890

- Verfügung des Provinzialschulkollegiums über Regelung der Zahlung von Begräbnisgelder und Definition der Leistungsempfänger der Elementarlehrer- Witwen- und Waisenkasse, November 1875 - Verwaltung der Mitgliedschaften der Elementarlehrer- Witwen- und Waisenkasse in Emden, November 1875 - Mai 1878

- Novellierung der Statuten der Elementarlehrer- Witwen- und Waisenkasse, April 1878 - August 1880

- Definition der Höhe der Pensionszahlungen aus der ElementarlehrerWitwen- und Waisenkasse, März - April 1879

- Statistische Meldungen der Elementarlehrer- Witwen- und Waisenkasse, 1880

- Anträge Emder Volksschullehrer an das Provinzialschulkollegium durch die Hand des Magistrats auf Erlass der Zahlung 20 \%igen Gehaltsverbesserungsgeldes an die Elementarlehrer- Witwen- und Waisenkasse, August / September 1885

$1874-1890$

Klassifikation Teil B: 03351

Trägermaterial: Papier

Alte Reg.-Sig.: IX B1 01

Bestell-Nr.: IV 03351

3500 Gehalt und Versorgung der Volksschullehrer

- Gesetzliche Regelungen zur Volksschullehrerbesoldung und

-Versorgung, 1909 - 1914

- Aufstellung über Volksschullehrer mit Wahlrecht,1909

- Organisation der Zahlung der Volksschullehrergehälter und Zulagen, 1909 - 1911

- Nach Emder Volksschulen gegliederte Aufstellung über Lehrer und

Gehaltszahlungen mit Mietentschädigung, 1909

- Anträge von Volksschullehrern auf Zahlung von Zulagen zum

Grundgehalt, 1910

- Statistiken über Gehaltsaufwändungen Emder Schulverbände, 1910

- 1914

- Gewährung von Staatszuschüssen für die Emder Schulverbände, 1910 - 1912

$1909-1914$

Klassifikation Teil B: 03353

Trägermaterial: Papier Alte Reg.-Sig.: IX BI 06

Bestell-Nr.: IV 03353 
10

\subsection{1}

10.01.01

\section{Schulaufsicht}

Schulsachen

Organisation des Schulwesens

Lfd. Nr. Titel

Laufzeit

3501 Ostfriesische Lehrerwitwen- und Waisenunterstützungskasse

- Verfügungen des preußischen Landdrosten und des $\mathrm{kgl}$. Konsistoriums in Aurich über Orgamnisation der Ostfriesischen Lehrerwitwen- und Waisenunterstützungskasse : Beiträge, Verwaltung, 1870 - 1873

- Verfügung des Magistrats an die Schulverbände über Zahlung von Beiträgen an die Ostfriesische Lehrerwitwen- und Waisenunterstützungskasse, November 1870

- Eintreibung rückständiger Beiträge zur Ostfriesischen Lehrerwitwenund Waisenunterstützungskasse, Januar 1871

- Aufstellungen über bei der Ostfriesischen Lehrerwitwen- und Waisenunterstützungskasse pflichtversicherte Emder Volksschullehrer, 1871 - 1873

- Bildung eines Vorstandes für die Ostfriesische Lehrerwitwen- und Waisenunterstützungskasse im Bereich Emden, Juni - Juli 1871 - Heranziehung der in der Gasthausschule tätigen Lehrer zur Ostfriesischen Lehrerwitwen- und Waisenunterstützungskasse, 1871 1874

- Einziehung der Beiträge zur Provinzial Lehrerwitwen- und Waisenkasse, 1879

$1870-1879$

Klassifikation Teil B: 03354

Trägermaterial: Papier

Alte Reg.-Sig.: IX BI 10

Bestell-Nr.: IV 03354

- Verfügungen des kgl. Konsistoriums über Regelung der

Finanzierung von Volksschulbauten, 1868 - 1869

- Verfügungen des kgl. Konsistoriums über Organisation der

Volksschulen: Lehrmittel, Unterricht, Ferienregelung, Schulbänke, 1869 - 1888

- Organisation des Handarbeitsunterrichts für Mädchen (Näh- und Strickschule), 1870

- Regelung der Einziehung des Schulgeldes für die Schulverbände in Emden, 1870

- Streit um die Eintreibung von Schulgeld für die lutherische Schule trotz Besuchs der Höheren Töchterschule durch die betreffenden Schülerinnen, November 1870 - Dezember 1871

- Instruktion des Landes-Konsistoriums Hannover über Beitrag der Schulen zur Erreichung der Taufe ungetaufter Schüler, Juni - Juli 1973

- Festlegung des Schulbeginns für die unteren Klassen auf 9.00 Uhr während des Winterhalbjahres, 1890

- Dislussion um geplante Novellierung des preußischen

Volksschulgesetzes (Verstaatlichung der Volksschulen), 1891

- Resolution verschiedener Städte der Provinz Hannover gegen die Gestzesnovelle, 1891

$1868-1891$

Klassifikation Teil B: 03355

Trägermaterial: Papier

Alte Reg.-Sig.: IX BI 12

Bestell-Nr.: IV 03355 
IV

10

Schulaufsicht

10.01

Schulsachen

10.01.01

Organisation des Schulwesens

Lfd. Nr. Titel

Laufzeit

3503 Besoldung der Volksschullehrer

- Datenerhebung des kgl. Konsistoriums über Lehrerbesoldung im Regierungsbezirk Aurich, 1869

- Aufstellungen über Besoldung der Lehrer in Emder Volksschulen, 1869

- Bericht des Magistrats an das kgl. Konsistorium über Darstellung der

Gehaltsklassen von Emder Lehrern, November 1889

- Datenerhebung des Ministers der geistlichen Unterrichts- und

Medizinalangelegenheiten zur Lehrerbesoldung, November 1889

- Diskussion eines Gesetzes wegen Alterszulagen für

Volksschullehrer, 1890

$1869-1890$

Klassifikation Teil B: 03356

Trägermaterial: Papier

Alte Reg.-Sig.: IX BI 15

Bestell-Nr.: IV 03356

3504 Gesamt-Schulkommission

- Verhandlungen der städtischen Kollegien über Initiative des Senators Mustert zur Bildung einer Gesamt-Schulkommission

- Anfrage des Magistrats an die Stadt Osnabrück wegen Erfahrungen mit der Zusammenfassung der Schulkommissionen

1878

\author{
Klassifikation Teil B: 03357 \\ Trägermaterial: Papier \\ Alte Reg.-Sig.: IX BI 35 \\ Bestell-Nr.: IV 03357
}

3505 Finanzierung der evangelischen Volksschulen

- Bericht des Magistrats an das kgl. Konsistorium über Finanzierung der evangelischen Volksschulen durch Schulsteuern aufgrund gesetzlicher Bestimmungen der ehemaligen Hannoverschen Landesherrschaft von 1845

1886 / 1890

Klassifikation Teil B: 03358

Trägermaterial: Papier

Alte Reg.-Sig.: IX BI 41

Bestell-Nr.: IV 03358 
10.01

Lfd. Nr. Titel

Laufzeit

3506 Reorganisation des Emder Volksschulwesens

- Votum der der städtischen Kollegien für die Bildung eines einheitlichen Emder Volksschulverbandes, April 1887

- Kalkulation der Belastung des städtischen Haushalts durch die vom preußischen Volksschulgesetz angestrebte Vereinheitlichung des Volksschulwesens, Februar 1889

- Konzept des Oberbürgermeisters Fürbringer für ein einheitliches Volksschulsystem und Neuverteilung der Lasten, Februar 1889

- Druckschrift: Bernhard Brons, Das Emder Schulwesen, Hintergrund: Diskussion um die Einheitsschule, 1904

$1887-1889(1904)$

Klassifikation Teil B: 03359

Trägermaterial: Papier

Alte Reg.-Sig.: IX BI 42

Bestell-Nr.: IV 03359

3507 Ümschülung der Schüler aus einem Teil des Borssumer Hammrichs nach Emden

- Antrag des N. Janssen etc. an den Landrat des Kreises Emden auf Umschulung ihrer Kinder nach Emden wegen großer Entfernung nach Borssum, Dezember 1887

- Verhandlungen der Antragssteller mit dem Magistrat wegen der Umschulung, Feruar 1888

- Einverständnis des lutherischen Schulverbandes mit den

Umschulungen, März 1888

- Weigerung der Aufnahme von reformierten Schülern aus dem Borssumer Hammrich durch den reformierten Schulverband wegen Unsicherheit des Eingangs der Schulsteuer von den betroffenen Eltern, März 1888

- Schreiben des Magistrats an den Landrat des Kreises Emden über Schwierigkeiten einer Umschulung von Schüler aus dem Borssumer Hammrich, April 1888

- Verfügung des Regierungspräsidenten in Aurich über Umschulung der betr. Schüler nach dem Übergang des Borssumer Hammrichs nach Emden, November 1888

- Antrag der reformierten Bewohner der Borssumer Feldmark auf Einpfarrung in die deuitsch-reformierte Gemeinde Emden, Juni 1889 April 1890

- Umschulung der Kinder der Bewohner des zu Emden gehörenden

Teils des Königspolders nach Emden, 1895

$1887-1895$

Klassifikation Teil B: 03360

Trägermaterial: Papier Alte Reg.-Sig.: IX BI 44

Bestell-Nr.: IV 03360 
IV

10 Schulaufsicht

10.01 Schulsachen

10.01.01

Organisation des Schulwesens

Lfd. Nr. Titel

Laufzeit

3508 Technische Lehranstalten 1877-1896

Errichtung einer Baugewerbeschule in Emden, 1877

- Druck: Vorstellung des Handwerkervereins über Förderung einer technischen Lehranstalt, November 1896

1877 / 1896

Klassifikation Teil B: 03361

Trägermaterial: Papier

Alte Reg.-Sig.: IX BI 45

Bestell-Nr.: IV 03361

3509 Aufhebung der Kirchenkommissionen für Schulsachen

- Erlass des Oberpräsidenten der Provinz Hannover über Suspendierung der Tätigkeit der Kirchenkommissionen für Schulsachen, September 1889

- Verfügung des Regierungspräsidenten über Zuständigkeit der Kreisschulinspektoren für die Schulaufsicht, Oktober 1889 - Instruktionen für die Kreisschulinspektoren der Provinz Hannover: Schulaufsicht, Dienstaufsicht über die Lehrer, September 1889

- Aufstellung über Kreisschulinspektoren im Regierungsbezirk Aurich (meist Pastoren und Superintendenten), November 1889

- Einsetzung des lutherischen Pastors Buck als Kreisschulinspektor, Oktober 1896

- Einsetzung des lutherischen Pastors Haenisch als

Kreisschulinspektor, März 1898

- Einsetzung des reformierten Pastors Coper als Kreisschulinspektor, Mai 1899

- Regelung des Geschäftsgangs zwischen Regierung,

Kreisschulinspektor und Magistrat, Juni 1900 / Mai 1914

- Einsetzung des reformierten Pastors Redlin als Kreisschulinspektor, November 1912

- Einsetzung des katholischen Pfarrers Sievers als

Kreisschulinspektor für die katholische Schule, 1917

$1889-1917$

Klassifikation Teil B: 03362

Trägermaterial: Papier

Alte Reg.-Sig.: IX BI 46

Bestell-Nr.: IV 03362 
10.01

Lfd. Nr. Titel

Laufzeit

3510 Supervision der Schulrechnungen

- Verfügung des Regierungspräsidenten über Zuständigkeit des Magistrats für die Rechnungsprüfung bei den Emder Schulverbänden, November 1889 / Januar 1890

- Verfügung des Regierungspräsidenten über Zuständigkeit der kgl. Regierung für die Rechnungsprüfung bei den Emder Schulverbänden und Verpflichtung der Schulverbände zur Einsendung der REchnungsunterlagen nach Aurich, Dezember 1890

- Verfügung des Regierungspräsidenten über Richtlinien der Rechnungslegung bei den Schulverbänden, Mai 1893 / Februar 1897

$1889-1897$

Klassifikation Teil B: 03363

Trägermaterial: Papier Alte Reg.-Sig.: IX BI 47

Bestell-Nr.: IV 03363

3511 Aufstellung der Schuletats

- Verfügung des Regierungspräsidenten über Form der

Etataufstellungen und Fristsetzungen, Januar 1907 / März 1910

$1907-1910$

Klassifikation Teil B: 03364

Trägermaterial: Papier

Alte Reg.-Sig.: IX BI 48

Bestell-Nr.: IV 03364

3512 Schulinventarien

- Verfügung des Regierungspräsidenten über Form der Aufstellung der Schulinventarien

$1891(1915)$

Klassifikation Teil B: 03365

Trägermaterial: Papier

Alte Reg.-Sig.: IX BI 49

Bestell-Nr.: IV 03365 
10.01

Lfd. Nr. Titel

Laufzeit

3513 Gehälter der Volksschullehrer

- Verfügung des Regierungspräsidenten über Formalia und Voraussetzungen für einen Antrag auf Staatsbeihilfe zur Lehrerbesoldung, September 1890

- Bericht der Gasthaus-Direktion an den Magistrat über Unmöglichkeit der von der kgl. Regierung verfügten Erhöhung des Gehalts des Lehrers an der Gasthausschule, Oktober 1890 - März 1891

- Ablehnung einer Staatsbeihilfe zur Lehrerbesoldung durch den Minister der geistlichen, Unterrichts- und Medizinalangelegenheiten, Dezember 1890

- Inkraftsetzung neuer Gehaltsklassen für Völksschullehrer in Emden, Mai - Juni 1891

- Bewilligung einer Staatsbeihilfe zur Lehrerbesoldung durch den Minister der geistlichen, Unterrichts- und Medizinalangelegenheiten für den reformierten Schulverband in Emden, August 1891 / März 1892

- Gewährung einer Alterszulage für Volksschullehrer, 1894 - 1896 - Antrag des Magistrats beim Minister der geistlichen, Unterrichts und Medizinalangelegenheiten auf Gewährung eines Staatszuschusses zur Lehrerbesoldung in der Stadt Emden, Mai - Dezember 1894 - Aufstellung über Volksschullehrer in der Stadt Emden, 1894 - Übernahme der Lehrerbesoldung auf den Etat der Stadt Emden, Dezember 1894 - Januar 1895

$1890-1896$

Klassifikation Teil B: 03366

Trägermaterial: Papier

Alte Reg.-Sig.: IX BI 50

Bestell-Nr.: IV 03366

3514 Ruhegehaltskassen für Lehrerinnen und Lehrer, Bd. 1

- Nachweisungen über ruhegehaltsberechtigte Diensteinkommen für die Inhaber der Lehrer- und Lehrerinnenstellen an den öffentlichen Volksschulen der Emder Schulverbände, 1893 - 1895 - Bemerkungen des Regierungspräsiden zu Gehaltsangaben verschiedener Lehrerinnen und Lehrer wegen fehlender Genehmigung einer Gehaltsänderung durch die Regierung in Aurich, Dezember 1894 / Februar 1895

- Festlegung der Beiträge zur Ruhegehaltskasse, 1895

- Verfügung des Regierungspräsidenten über Form der Nachweisung der Ruhestandsgehälter, Dezember 1893 / Mai 1894

$1893-1895$

Klassifikation Teil B: 03367

Band: 1

Trägermaterial: Papier

Alte Reg.-Sig.: IX BI 51

Bestell-Nr.: IV 03367 
10.01

Lfd. Nr. Titel

Laufzeit

3515 Ruhegehaltskassen für Lehrerinnen und Lehrer, Bd. 2

- Nachweisungen über ruhegehaltsberechtigte Diensteinkommen für die Inhaber der Lehrer- und Leherinnenstellen an den öffentlichen Volksschulen der Emder Schulverbände, 1895 - 1900

- Bemerkungen des Regierungspräsiden zu Gehaltsangaben verschiedener Lehrerinnen und Lehrer wegen fehlender Genehmigung einer Gehaltsänderung durch die Regierung in Aurich, 1896 - 1899

$1895-1900$

Klassifikation Teil B: 03368

Band: 2

Trägermaterial: Papier

Alte Reg.-Sig.: IX BI 51

Bestell-Nr.: IV 03368

3516 Ruhegehaltskassen für Lehrerinnen und Lehrer, Bd. 3

- Nachweisungen über ruhegehaltsberechtigte Diensteinkommen für die Inhaber der Lehrer- und Lehrerinnenstellen an den öffentlichen Volksschulen der Emder Schulverbände, 1903 - 1917

- Preußisches Landesgesetz über die Errichtung und Funktion der Ruhegehaltskassen für Lehrer und Lehrerinnen, Juli 1893 - Festlegung der von den Schulverbänden des Regierungsbezirks Aurich zu entrichtenden Beiträge zur Ruhegehaltskasse für Lehrer und Lehrerinnen durch den Regierungspräsidenten, 1903 - 1908

$1893-1895$

Klassifikation Teil B: 03369

Band: 3

Trägermaterial: Papier

Alte Reg.-Sig.: IX BI 51

Bestell-Nr.: IV 03369

3517 Fürsorge von Lehrerwaisen

- Preußisches Landesgesetz über Regelung der Fürsorge von Lehrerwaisenkinder durch eine beitragsfinanzierte Waisenkasse, Juni 1890

- Nachweisung des an Cornelia Fenna Boeting, hinterlasssene Tochter des Lehrers Hinderikus Boeting, zu zahlende Waisengeldes, Juni 1894

$1890-1894$

Klassifikation Teil B: 03370

Trägermaterial: Papier

Alte Reg.-Sig.: IX BI 52

Bestell-Nr.: IV 03370 
10.01

Lfd. Nr. Titel

Laufzeit

3518 Staatsbeihilfe für Emder Schulverbände, Bd. 1

- Erlass des Ministers der geistlichen, Unterrichts- und

Medizinalangelegenheiten über Regelung der Gewährung von

Staatsbeihilfe zur Lehrerbesoldung, Juni 1896

- Nachweise über finanzielle Situation des evangelisch reformierten

Schulverbandes, 1900 - 1904

- Nachweise über finanzielle Situation des evangelisch - lutherischen

Schulverbandes, 1900 - 1903

- Antrag des lutherischen Schulverbandes auf Gewährung einer

Staatsbeihilfe, September 1900 - Dezember 1901 / Juni 1905

- Antrag des reformieten Schulverbandes auf Gewährung einer

Staatsbeihilfe, September 1900 - Dezember 1901 / Juni 1905

- Stellungnahmen des Magistrats an die Regierung in Aurich zu den

Anträgen der evangelischen Schulverbände auf Staatsbeihilfe,

Oktober 1900

Enthält auch:

- Meldungen über Vermögen und Geschäftsberichte der reformierten

Kirchengemeinden in Emden, 1867 - 1880

1896 - 1905 (1867 - 1880)

Klassifikation Teil B: 03371

Trägermaterial: Papier

Alte Reg.-Sig.: IX BI 63

Bestell-Nr.: IV 03371

3519 Staatsbeihilfe für Emder Schulverbände, Bd. 2

- Erlass des Ministers der geistlichen, Unterrichts- und

Medizinalangelegenheiten über Regelung der Gewährung von

Staatsbeihilfe zur Lehrerbesoldung und Prüfung der Bedürftigkeit, Juni 1899

- Nachweise über finanzielle Situation des evangelisch reformierten

Schulverbandes, 1891 - 1895 / 1907

- Nachweise über finanzielle Situation des evangelisch - lutherischen

Schulverbandes, 1894 - 1895

- Antrag des lutherischen Schulverbandes auf Gewährung einer

Staatsbeihilfe, September 1900 - Dezember 1901 / Juni 1905

- Antrag des reformieten Schulverbandes auf Gewährung einer

Staatsbeihilfe, September 1900 - Dezember 1901 / Juni 1905

- Verfügung des Magistrats über Verteilung der Staatsbeihilfe auf die einzelnen Schulverbände und Festlegung der Schulgeldhöhe auf auf eine Spanne von 50 \% - $61 \%$ der direkten Staatssteuer, September 1894

- Verfügung des Regirtungspräsidenten über Widerruflichkeit der Staatsbeihilfe für die Schulverbände, August 1895

$1894-1907$

Klassifikation Teil B: 03372

Band: 2

Trägermaterial: Papier

Alte Reg.-Sig.: IX BI 63

Bestell-Nr.: IV 03372 
IV

10 Schulaufsicht

10.01 Schulsachen

10.01.01

Organisation des Schulwesens

Lfd. Nr. Titel

Laufzeit

3520 Nachweis der finanziellen Leistungsfähigkeit der Schulverbände 1893-1896

- Regelung der Form und der Kriterien des Nachweises der finanziellen Leistungsfähigkeit der Schulverbände

$1893-1896$

Klassifikation Teil B: 03373

Trägermaterial: Papier

Alte Reg.-Sig.: IX BI 54

Bestell-Nr.: iV 03373

3521 Schulgeld von auswärtigen Schulkindern

$1898-1900$

- Antrag des Schulvorstands der ev. ref. Gemeinde an den Magistrat auf Erlaubnis zur Erhebung eines Schulgeldes von auswärtigen

Schülern, November 1898

- Genehmigung des vom ev. ref. Schulverband vorgeschlagenen Schulgeldsatzes von $20 \mathrm{M}$ / Jahr für jeden auswärtigen Schüler durch die Regierung in Aurich, November 1899

- Bericht des Direktors der Kaiser-Friedrichs Realschule an den Magistrat über Möglichkeit der Einziehung eines höheren Fremden-Schulgeldes von sechs auswärtigen Schülern, Dezember 1900

$1898-1900$

Klassifikation Teil B: 03374

Trägermaterial: Papier

Alte Reg.-Sig.: IX BI 56

Bestell-Nr.: IV 03374

3522 Wert der Lehrer-Dienstwohnungen

$1899-1909$

- Verfügung des Regierungspräsidenten über Kriterien zur

Feststellung des Wertes der Lehrer-Dienstwohnungen , Februar 1899

/ Februar - März 1904

- Aufstellungen über Wert der Lehrer-Dienstwohnungen in den Emder Schulverbänden, 1899 - 1907

- Umbau der Lehrer-Dienstwohnung in der katholischen Schule zum

Klassenraum, Oktober - Dezember 1909

$1899-1909$

Klassifikation Teil B: 03375

Trägermaterial: Papier

Alte Reg.-Sig.: IX BI 57

Bestell-Nr.: IV 03375 
10.01

Lfd. Nr. Titel

3523 Diensteinkommen der Volksschullehrer, Bd. 1

- Bericht des Magistrats an den Regierungspräsidenten über erforderliche Neufestsetzung des Diensteinkommens der Volksschullehrer sowie der Alters- und Teuerungszulagen unter Angabe der daraus entstehenden Belastungen für die Stadtkasse, Oktober 1897

1897

\author{
Klassifikation Teil B: 03376 \\ Band: 1 \\ Trägermaterial: Papier \\ Alte Reg.-Sig.: IX BI 60 \\ Bestell-Nr.: IV 03376
}

\begin{abstract}
- Austausch zwischen den Städten Emden, Aurich, Leer und Wilhelmshaven über die Regelung der Diensteinkommen der Volksschullehrer in den Städten und Gemeinden des Regierungsbezirks Aurich, Juni 1897

- Nachweisung über Diensteinkommen der Volksschullehrer in den einzelnen Emder Schulverbänden, April 1897

- Regelung der Mietentschädigung bei Lehrer ohne Dienstwohnung, April 1897

- Nachweisung über organisch verbundene Lehrer - und

Kirchendienerstellen, 1897

- Sitzungen der Kommission wegen Festsetzung der Besoldung der Lehrer und Lehrerinnen an den städtischen Volksschulen über Neuorganisation der Gehaltsstruktur der Volksschullehrer, April August 1897

- Verfügung des Regierungspräsidenten über Festlegung des

Diensteinkommens der Volksschullehrerinnen, April 1905

- Erlass des Ministers der geistlichen, Unterrichts- und Medizinalangelegenheiten über Festlegung der Teuerungszulagen für Lehrerinnen im Regierungsbezirk Aurich, Juni 1905

- Erhöhung der Alterszulagen für Volksschullehrer, März 1904 -

Oktober 1905
\end{abstract}

$1897-1905$

Klassifikation Teil B: 03377

Band: 2

Trägermaterial: Papier

Alte Reg.-Sig.: IX BI 60

Bestell-Nr.: IV 03377 
10.01

Lfd. Nr. Titel

Laufzeit

3525 Diensteinkommen der Volksschullehrer, Bd. 3

- Preußisches Gesetz zur Regelung der Diensteinkommen der Volksschullehrer mit Ausführungsbestimmungen, März - Mai 1897

- Erhöhung der Alterszulage für Volksschullehrer, April 1905 - Oktober 1908

- Erhöhung der Mietentschädigung für Volksschullehrer ohne

Dienstwohnung, Februar - September 1907

- Gedruckte Petition der Emder Volksschullehrer über Biotte um

Erhöhung des Grundgehalts und der Alterszulage, Juni 1910

- Beschwerde des Rektors der städtischen Volksschule, F. Müller, beim Magistrat gegen die Verkürzung des Unterschiedes zwischen seinem Gehalt als Rektor und den Gehältern der Volksschullehrer durch Gewährung von Zulagen an die Lehrer, Februat 1907

- Erhöhung der Teuerungszulage für Volksschullehrer, April 1908

- Besoldungsordnungen der städtischen Volksschule, der lutherischen Volksschule, der reformierten Volksschule und der Gasthausschule, $1898 / 1908$

$1897-1909$

Klassifikation Teil B: 03378

Band: 3

Trägermaterial: Papier

Alte Reg.-Sig.: IX BI 60

Bestell-Nr.: IV 03378

- Datenerhebung des Ministers der geistlichen, Unterrichts- und Medizinalangelegenheiten zu Schulbauten zur Gewinnung von Informationen über Dringlichkeit einer separaten Schulbaukasse, August - September 1903

- Beschreibung der Schulgebäude der Emder Schulverbände, September 1903 / Juli 1905

- Erlass des Ministers der geistlichen, Unterrichts- und Medizinalangelegenheiten über Gebäudeversicherung von Schulbauten bei der Schulbaukasse, Juni 1905

$1903-1905$

Klassifikation Teil B: 03379

Trägermaterial: Papier

Alte Reg.-Sig.: IX BI 64

Bestell-Nr.: IV 03379 
10.01

Lfd. Nr. Titel

3527 Stadt- und Landgemeinden umfassende Schulverbände 1904

- Datenerhebung des Ministers der geistlichen, Unterrichts- und Medizinalangelegenheiten über Stadt- und Landgemeinden umfassende Schulverbände, Juni 1904

- Angabe des ev. ref. Schulverbands als Stadt- und Landgemeinden umfassenden Schulverband wg. Einbeziehung von Harsweg, Juni 1904

- Angabe des lutherischen Schulverbands als Stadt- und Landgemeinden umfassenden Schulverband wg. Einbeziehung von Borssum, Larrelt und Wolthusen, Juni 1904

1904

Klassifikation Teil B: 03380

Trägermaterial: Papier

Alte Reg.-Sig.: IX BI 67

Bestell-Nr.: IV 03380

3528 Einführung e4iner neuen Zeichenmethode in den Volksschulen

- Angebot von Fortbildungskursen für Zeichenlehrer zum Unterricht von gegenständlichem Zeichnen als neue Methode

1904 / 1906

Klassifikation Teil B: 03381

Trägermaterial: Papier

Alte Reg.-Sig.: IX BI 68

Bestell-Nr.: IV 03381

3529 Schulkinder aus Umlandgemeinden in Emder Volksschulen

- Datenerhebung über auswärtige Schulkinder in Emder Volksschulen

- Datenerhebung über auswärtige Schüler und Schülerinnen an der Kaiser-Friedrichs-Realschule, dem Wilhelms-Gymnasium und der höheren Töchterschule

1905

Klassifikation Teil B: 03382

Trägermaterial: Papier

Alte Reg.-Sig.: IX BI 61

Bestell-Nr.: IV 03382

3530 Bericht über Volksschulwesen

1893-1908

(1911)

- Erlass des Ministers für geistliche, Unterrichts- und Medizinalangelegenheiten über Form und Rubriken der einzureichenden statistischen Berichte zum Volksschulwesen, Mai 1893

- Berichte über Verhältnisse in Emder Volksschulen, November 1893 August 1908

1893 - 1908 (1911)

Klassifikation Teil B: 03383

Trägermaterial: Papier

Alte Reg.-Sig.: IX BI 70

Bestell-Nr.: IV 03383 
IV

10

10.01

10.01 .01

\section{Schulaufsicht}

Schulsachen

Organisation des Schulwesens

Lfd. Nr. Titel

3531 Schülerzahlen der Volksschulen in der Stadt Emden 1906

- Nach Klassen geordnete Statistiken der Schülerzahlen in Emder Volksschulen

1906

Klassifikation Teil B: 03384

Trägermaterial: Papier

Alte Reg.-Sig.: IX BI 71

Bestell-Nr.: IV 03384

3532 Gehaltszulagen für Hilfsschullehrer

- Initiative des Verbandes der Hilfsschullehrer Deutschlands zur Gewährung von Gehaltszulagen für Hilfsschullehrer, 1909

- Antrag des Hilfsschullehrers Harms an den Magistrat auf Gewährung einer pensionsfähigen Gehaltszulage, Januar - Februar 1911

$1909-1911$

Klassifikation Teil B: 03385

Trägermaterial: Papier

Alte Reg.-Sig.: IX BI 74

Bestell-Nr.: IV 03385

3533 Diensteinkommen der Schullehrer, Bd. 1

- Erlass des Ministers der geistlichen, Unterrichts- und Medizinalangelegenheiten über Ausführungsbestimmungen des Haushaltsgesetzes hinsischtlich der Gehaltszulagen für Lehrer, April 1908

- Aufstellung über Schullehrer in Emden mit Angaben zu Gehälter und Zulagen, April 1908 / Oktober 1908

- Material zu den Verhandlungen eines preußischen Lehrerbesoldungsgesetzes, u.a. Finanzierung der Lehrerbesoldung durch die Kom,munen nach Wegfall der Staatsbeihilfe, 1908 - 199 - Korrespondenz des Magistrats mit Nachbarstädten über Strategie zur Wiedererlangung der Staatsbeihilfe zur Lehrerbesoldung, Januar April 1909

- Petition der städtischen Kollegien an die Kammern des preußischen Landtages über Bitte um Modifizierung des geplanten Lehrerbesoldungsgesetzes hinsichtlich der Rücknahme der Streichung der Staatsbeihilfe zur Lehrerbesoldung, Februar 1909 - Gewährung einer Staatsbeihilfe nach dem Lehrerbesoldungsgesetz von 1897 für die Emder Schulverbände, März / April 1909

- Aufstellung über Veränderungen bei der Besoldung Emder Lehrer nach der Novellierung des Lehrerbesoldungsgesetzes von 1897, Mai / Juni 1909

- Gesuch der Emder Volksschullehrer um Erhöhung der Mietentschädigung nach den Bestimmungen des novellierten Lehrerbesoldungsgesetzes, Juli 1909

$1908-1909$

Klassifikation Teil B: 03386

Band: 1

Trägermaterial: Papier

Alte Reg.-Sig.: IX BI 74

Bestell-Nr.: IV 03386 
IV

10 Schulaufsicht

10.01 Schulsachen

10.01.01

Organisation des Schulwesens

Lfd. Nr. Titel

Laufzeit

3534 Diensteinkommen der Schullehrer, Bd. 2

- Ablehnender Bescheid des Provinzialrates zum Antrag des Lehrervereins Emdens auf Erhöhung der Mietentschädigung, Januar 1915

- Auszahlung der Alterszulage für Lehrer aus der Regierungskasse, 1915 - 1918 (1919 - 1920)

- Gesuch der technischen Lehrerinnen der Emder Bezirksschulen auf Gewährung einer Teuerungszulage (Kriegszulage), Oktober 1915 Juni 1917

- Antrag der Volksschullehrerinnen an den Magistrat auf Gewährung eines Entgelts für geleistete Überstunden, Juni - Juli 1917

- Gewährung einer Staatsbeihilfe zur Lehrerbesoldung an die Emder Schulverbände, März 1918 (1919)

1915 - 1918 (1919 - 1920)

Klassifikation Teil B: 03387

Band: 2

Trägermaterial: Papier

Alte Reg.-Sig.: IX BI 74

Bestell-Nr.: IV 03387 
10.01

Lfd. Nr. Titel

Laufzeit

3535 Diensteinkommen der Schullehrer, Bd. 3

- Besprechung von Vertretern niedersächsischer Städte in Hannover über Folgen der Streichung der Staatsbeihilfe zur Lehrerbesoldung nach Verabschiedung der Novelle des Lehrerbesoldungsgesetzes, Juli 1909

- Gesuch der Volksschullehrer und -Lehrerinnen an den Magistrat über Bitte um Gewährung einer Ortszulage, August 1909 - Korrespondenz des Magistrats mit Magistraten der Nachbarstädte über Gewährung einer Amtszulage für Schulrektoren und Ortszulagen an Lehrer, September 1909 - Januar 1910

- Aufstellung über Belastung des städtischen Haushalts durch Gewährung einer Ortszulage für Lehrer, Mai 1910

- Aufstellung über Ortszulage für Volksschullehrer in Emden, 1910

- Bericht des Kreisschulinspektors Blanke über Notwendingkeit der Gewährung einer Ortszulage nach dem Lehrerbesoldungsgesetz von 1909 zur Besetzung neuer oder freiwerdender Lehrerstellen, Juli 1910 - Beschluss der städtischen Schuldeputation über Empfehlung an die städtischen Kollegien zur Gewährung einer Ortszulage für Volksschullehrer, August - September 1910 / Januar 1912 - Denskschrift der Emder Lehrer über Notlage der Emder Volksschullehrer infolge der unzulänglichen Lehrerbesoldung, Dezember 1910

- Gesuche des Lehrervereins Emden an den Magistrat über Bitte um Gewährung einer Ortszulage für die Volksschullehrer wegen

Teuerung, November 1911 / August 1912

- Bescheid der Regierung in Aurich über Gewährung von Ortzulagen für Lehrer zur Gewinnung fähiger Pädagogen, Oktober 1912

- Anträge verschiedener Lehrerinnen und Lehrer an den Magistrat auf Gewährung einer Ortszulage wegen Unterhaltung eines eigenen Hausstandes, 1913 - 1915

$1909-1915$ Klassifikation Teil B: 03388

Band: 3

Trägermaterial: Papier Alte Reg.-Sig.: IX BI 74

Bestell-Nr.: IV 03388 
IV

10 Schulaufsicht

10.01 Schulsachen

10.01.01

Organisation des Schulwesens

Lfd. Nr. Titel

Laufzeit

3536 Besoldungsordnung für Emder Volksschullehrer

- Monita des Regierungspräsidenten zu den eingereichten Entwürfen einer Besoldungsordnung für Emder Volksschullehrer, November 1909

- Überarbeiteter Entwurf einer Besoldungsordnung für Emder

Volksschullehrer, Dezember 1909

- Verfügung des Regierungspräsidenten über Aufforderung an den

Vorstand der jüdischen Volksschule zur Aufstellung einer

Besoldungsordnung für die Lehrer der jüdischen Volksschule,

Dezember 1909

- Monita des Regierungspräsidenten zur eingereichten

Besoldungsordnung für Lehrer der jüdischen Volksschule, Januar

1910

- Nachträge zur Besoldungsordnung für Emder Volksschullehrer:

Gehaltsveränderungen, Oktober 1910 / Juni 1913 (1920)

1909 - 1913 (1920)

Klassifikation Teil B: 03389

Trägermaterial: Papier

Alte Reg.-Sig.: IX BI 74 a

Bestell-Nr.: IV 03389

3537 Errichtung von Vorschulklassen

- Verfügung der kgl. Regierung, Abt. II in Aurich über Anforderung von Stellungnahmen aus den Städsten und Gemenden des Regierungsbezirks Aurich zum Plan der Errichtung von Vorklassen für die höheren Schulen im dritten Schuljahrgang, September 1909

- Stellungnahmen von Emder Schulrektoren zum Plan:

Unpraktizierbarkeit der Einrichtung von besonderen Vorklassen für die höheren Schulen in den Volksschulen, September 1909

- Stellungnahme des Rektors Janssen für eine Sonderklasse als

Vorklasse für die höheren Schulen zur Verkürzung der Schulzeit zum

Abitur, Oktober 1909

- Bericht des Magistrats an die Regierung in Aurich über skeptische Haltung der Schulrektoren und der Schuldeputation zur Einrichtung von Vorklassen für die höheren Schulen und für die Beibehaltung des bisherigen Statusquo, November 1909

1909

Klassifikation Teil B: 03390

Trägermaterial: Papier

Alte Reg.-Sig.: IX BI 77

Bestell-Nr.: IV 03390 
10.01

Lfd. Nr. Titel

Laufzeit

3538 Unterhaltungskosten des Schulverbands Borssum

- Antrag des Gemeindevorstands in Borssum an den Magistrat auf

Zahlung eines Beitrages in Höhe von 2.000 Mark zu den Borssumer Schullasten wegen Berufstätigkeit vieler Schülerväter aus Borssum in Emden, Dezember 1909 - Januar 1910

- Aufstellung über in Emder Betrieben arbeitender Borssumer, 1910

- Beschwerde des Gemeindevorstands in Borssum gegen den

Magistrat beim Bezirksausschuss $n$ Aurich wegen Ablehnung einer

Mittragung der Borssumer Schullasten, Februar 1910 - Oktober 1912

1909 - 1912 (1913)

Klassifikation Teil B: 03391

Trägermaterial: Papier

Alte Reg.-Sig.: IX BI 83

Bestell-Nr.: IV 03391

3539 Schulbaracken

- Angebote über Schulbaracken von der Fa. Christoph \& Unmach AG an den Kreisschulinspektor Pastor Blanke, 1905

- Bericht des Kreisschulinspektors Pastor Blanke an die

Stadtschuldeputation über Unmöglichkeit der Unterbringung weiterer Klassen der Bezirksschule I (ref.) in der Höheren Töchterschule und Vorschlag der Errichtung von Schulbaracken, Juni 1911

- Votum der Baukommission gegen die Anschaffung von

Schulbaracken wegen zu hoher Anschaffungspreise, März /

September 1911

$1905-1911$

Klassifikation Teil B: 03392

Trägermaterial: Papier

Alte Reg.-Sig.: IX BI 83

Bestell-Nr.: IV 03392

3540 Anerkennung von Lehrerzeugnissen

- Gegenseitige Anerkennung von Zeugnissen von Lehrerinnen an Höheren Mädchenschulen durch die Hansestadt Hamburg und das Kgr. Preußen, Juli 1912

- Staatsbertrag über gegenseitige Anerkennung von Lehramts-Abschlüssen durch die Staaten des Norddeutschen Bundes von 1870 / 1896, 1913

1912 - 1913

Klassifikation Teil B: 03393

Trägermaterial: Papier

Alte Reg.-Sig.: IX BI 89

Bestell-Nr.: IV 03393 
10.01

Lfd. Nr. Titel

Laufzeit

3541 Vergehen von Schulkindern

- Ermittlungen gegen Schulkinder wegen verschiedener Delikte, u.a. Sachbeschädigung, kleine Diebstähle, Körperverletzung, grober Unfug, Bettelei, Schmierereien, 1882 - 1914

- Bericht des lutherischen Kreisschulinspektors, Pasor Blanke, über Zunahme unerlaubter Glücksspiele unter den Schülern und daraus resultierende sittliche Gefährdung, Januar 1903

$1882-1914$

Klassifikation Teil B: 03437

Trägermaterial: Papier

Alte Reg.-Sig.: IX B I 39

Bestell-Nr.: IV 03437

3542 Verzeichnisse der Lehrer und Schulkinder der Emder Volksschulen

- Listen der Schülerinnen und Schüler aller Emder Volksschulen mit Heimatadresse und Geburtsdatum

1907

Klassifikation Teil B: 03622

Trägermaterial: Papier

Alte Reg.-Sig.: IX B6 12

Bestell-Nr.: IV 03622

3543 Etats des reformierten Schulverbands

- Kalkulation der Einnahmen und Ausgaben des reformierten

Schulverbandes für 1908/09

1907

\author{
Klassifikation Teil B: 03623 \\ Trägermaterial: Papier \\ Alte Reg.-Sig.: IX B6 13 \\ Bestell-Nr.: IV 03623
}

3544 Volksschuletats

- Entwürfe der Etats der Emder Volksschulen

1918 (1919 - 1923)

Klassifikation Teil B: 03624

Trägermaterial: Papier

Alte Reg.-Sig.: IX B6 13

Bestell-Nr.: IV 03624 
10.01

Lfd. Nr. Titel

Laufzeit

3545 Allgemeine Angelegenheiten der Emder Volksschulen

- Organisation der Belieferung der Emder Volksschulen mit Brennmaterial, 1908

- Kriterien für Richtigkeitsvermerke in Rechnungen, Juni 1909

- Schreiben verschiedener Organisationen für Bildung, Schulwesen und Volksbildung über Aufklärung zur Tätigkeit und Werbung für ihre Produkte, Publikationen, 1909 - 1914

- Anschaffung einer Trittnähmaschine für die Emder Volksschulen zum Handarbeitsunterricht, Januar 1910/ März 1914

- Anschaffung von Fußbodenoel und Reinigungsmittel, 1910

- Aufbau einer Bibliothek der Emder Volksschulen, März 1910

- Anschaffung von Schulbücher, Juni 1911

- Antrag der Stadtschuldeputation auf unentgeltlichen Besuch der Rüstkammer durch Volksschulklassen, Oktober 1911 - Juli 1912

- Schulfeier zum 25. Regierungsjubiäum des Kaisers Wilhelm II, 1913

- Erlass des Ministers der Geistlichen, Unterrichts- und

Medizinalangelegen über Verbot der Anschaffung von

Singer-Nähmaschinen durch Schulen aus der Singer-Fabrik in Wittenberg wegen deutschfeindlicher Agitation der amerikanischen Mutterfirma, Februar 1915

- Protokoll der Sitzung der Schuldeputation über Beschluss zur Erwirkung der Zuteilung größerer Ledermengen für Schuhe der Schüler oder anderer Maßnahmen zur Verhinderung des Erscheinens zum Unterricht ohne festes Schuhwerk, Juni 1915

$1908-1915$

Klassifikation Teil B: 03625

Trägermaterial: Papier

Alte Reg.-Sig.: IX B6 18

Bestell-Nr.: IV 03625

- Anschaffung von Schulbänken, 1908 - 1909

- Antrag der Schulkommission der ev. Bezirksschule I auf regelmäßige Besprengung des Schulspielplatzes im Sommer oder Anlegung eines Hydranten, Juni - Juli 1908

- Verwendung der im Handarbeitsunterricht verfertgten Kleidungsstücke, 1911

$1908-1911$

Klassifikation Teil B: 03626

Trägermaterial: Papier

Alte Reg.-Sig.: IX B6 18

Bestell-Nr.: IV 03626 
10

\subsection{1}

10.01.01

\section{Schulaufsicht}

Schulsachen

Organisation des Schulwesens

Lfd. Nr. Titel

Laufzeit

3547 Konflikt um die Organisation des Emder Volksschulwesens

- Verfügungen der Stadtschuldeputation zur Versetzung von Lehern zu den einzelnen Bezirksschulen zur Erteilung des reformierten Religionsunterrichts, April 1906

- Konflikt zwischen der Stadtschuldeputation und dem Kreisschulinspektor wegen der verfügten Lehrerversetzungen, April Mai 1908

- Verfügung des Regierungspräsidenten über Trennung des Religionsunterrichts nach der Konfession der Schüler und der Möglichkeit der Versetzung geeigneter Lehrer, April / Mai 1908 - Aufstellung über Lehrer in den Emder Bezirksschulen, 1908 - Aufstellung über Schülerzahlung und Klassenverteilungen sowie Konfessionszugehörigkeit, 1908

- Bericht des Rektors B. Janssen über Undurchführbarkeit der Verfügung des Regierungspräsidenten hinsichtlich des nach Konfessionen getrennten Religionsunterrichts, Mai 1908 - Gesuch des Magistrats an den Regierungspräsidenten über Bitte um Aufhebung einer Rüge wegen direkter Eingabe an den Minister der Geistlichen, Unterricts- und Medizinalangelegenheiten in der Frage des getrennten konfessionellen Unterrichts und Verteidigung des Bezirksschulsystems, Juli 1908

- Protest des Magistrats gegen Eingriffe der kgl. Regierung in die Lehrpläne der Emder Volksschulen für den Religionsunterricht, Juli 1908

- Verhandlungen des Magistrats mit Kommissaren des Ministeriums der Geistliche, Unterrichts- und Medizinalangelegenheiten über Organisation der Bezirksschulen entlang der Konfessionen, Oktober 1908

- Votum der Stadtschuldeputaton gegen die Aufteilung der Schüler nach Konfessionen und Abschaffung des Bezirksschulsystems, Dezember 1908

- Verfügung des Regierungspräsidenten über Umsetzung des Schlichterspruchs des Ministerialkommissars Dr. Schwartzkopf wegen Organisation des Emder Volksschulwesens entlang der Konfessionen, April 1909

- Reorganisation der Emder Bezirksschulen nach der Konfession der Schüler, April 1909

- Aufstellung über notwendige Versetzung von Schülern nach Schulen ihrer Konfession, Mai 1909

- Protest verschiedener Eltern beim Minister der Geistlichen, Unterrichts- und Medizinalangelegenhaiten gegen die Abweisung ihrer Kinder durch die Bezirksschule I (paritätisch) wegen ihres Wohnsitz im Bereich einer anderen Bezirksschule, Juli 1909

- Proteste verschiedener konfessionell orientierter Eltern gegen die Zuordnung ihrer Kinder zu einer konfessionell nicht ihreRichtung vertretenden Bezirksschule, 1910 - 1911

- Regelung der Umschulung reformierter Kinder von der Bezirksschule I (paritätisch luth./ref.) zur Bezirksschule III (reformiert), 1911

$1908-1911$

Klassifikation Teil B: 03629

Trägermaterial: Papier

Alte Reg.-Sig.: IX B6 20

Bestell-Nr.: IV 03629 
10

\subsection{1}

10.01.01

\section{Schulaufsicht}

Schulsachen

\section{Organisation des Schulwesens}

Lfd. Nr. Titel

Laufzeit

3548 Einstellung von Turn- und Handarbeitslehrerinnen an den 1908

Bezirksschulen I und II

- Beschlüsse des Magistrats und der Stadtschuldeputation über

Einstellung von Turn- und Handarbeitslehrerinen an den

Bezirksschulen I und II, April - Mai 1908

- Feststellung des Gehalts für die einzustellenden technischen

Lehrerinnen, März - Juni 1908

- Einstellung der Turn- und Handarbeitslehrerinnen Martha

Behrensroth, Matha Vietinghausen und Emma Janssen, August 1908

- Verteilung der Lehrerinnen auf die Bezirksschulen, August /

September 1908

1908

Klassifikation Teil B: 03632

Trägermaterial: Papier

Alte Reg.-Sig.: IX B6 23

Bestell-Nr.: IV 03632

3549 Feuerversicherung der Schulmöbel und -Utensilien

- Feuerversicherung der neuen Bezirksschulen bei der

Hamburg-Bremer-Feuerversicherung, 1912

- Aufstellung über Inventar der Bezirksschule I, März 1912

- Wertangaben zu Mobilien der Bezirksschule III, Januar 1913 / Mai

1914

- Versicherung der Mobilien der Bezirksschulen bei der Ostfriesischen

Mobiliar-Feuerversicherungsanstalt Norden, 1912 - 1914

- Versicherung der Bezirksschulen gegen Einbruchsdiebstahl, 1917

$1912-1917$

Klassifikation Teil B: 03633

Trägermaterial: Papier

Alte Reg.-Sig.: IX B6 24

Bestell-Nr.: IV 03633

3550 Erstattung von Reisekosten der Mitglieder der Stadtschuldeputation

- Regelung der Erstattung von Reisekosten der Mitglieder der Stadtschuldeputation bei informatorischen Reisen wegen Schulsachen, 1902 - 1904

- Vorgelegte Reisekostenrechnungen von Mitgliedern der Stadtschuldeputation, 1908

- Klage des Bürgervorstehers Lindemann gegen den Magistrat beim Bezirksausschuss und dem Amtsgericht auf Rückerstattung von Reisekosten als Mitglied der Stadtschuldeputation wegen Reise zur Begutachtung des Unterrichts eines Lehramtsbewerbers, Dezember 1908 - Mai 1909

- Revisionsklage des Bürgervorstehers Lindemann gegen das für sie nachteilige Urteil des Amtsgerichts Emden beim Landgericht Aurich, Mai - Oktober 1909

$1908-1909$

Klassifikation Teil B: 03634

Trägermaterial: Papier

Alte Reg.-Sig.: IX B6 20

Bestell-Nr.: IV 03634 
IV

10

Schulaufsicht

10.01

Schulsachen

10.01.01

Organisation des Schulwesens

Lfd. Nr. Titel

Laufzeit

3551 Lehrervertretungen 1905-1915

- Vertretungskräfte für dienstunfähige Lehrerinnen und Lehrer oder wegen Heirat ausscheidende Lehrerinnen der städtischen Bezirksschulen

$1905-1915$

Klassifikation Teil B: 03635

Trägermaterial: Papier

Alte Reg.-Sig.: IX B6 29

Bestell-Nr.: IV 03635

3552 Personalakte: Turn-und Handarbeitslehrerin Bernhardine Apel

- Beschäftigung der Bernhardine Apel als Turn- und

Handarbeitslehrerin an der Bezirksschule I

$1912-1914$

Klassifikation Teil B: 03636

Trägermaterial: Papier

Alte Reg.-Sig.: IX B6 30

Bestell-Nr.: IV 03636

3553 Personalakte: Lehrer Thomas Boekhoff

$1909-1912$

- Beschäftigung des Thomas Boekhoff als Lehrer an der

Bezirksschule I

$1909-1912$

Klassifikation Teil B: 03637

Trägermaterial: Papier

Alte Reg.-Sig.: IX B6 30

Bestell-Nr.: IV 03637

3554 Personalakte: Lehrer Hermann Eden

1910-1912

- Beschäftigung des Taubstummenhilfslehrers Hermann Eden als Lehrer an der Bezirksschule I

- Wechsel als Taubstummenlehrer nach Hildesheim

$1910-1912$

Klassifikation Teil B: 03638

Trägermaterial: Papier

Alte Reg.-Sig.: IX B6 30

Bestell-Nr.: IV 03638

3555 Personalakte: Lehrerin Margaretha Kaffka

- Beschäftigung der Margaeha Kaffka als Lehrerin an der

Bezirksschule I

$1912-1915$

Klassifikation Teil B: 03639

Trägermaterial: Papier

Alte Reg.-Sig.: IX B6 30

Bestell-Nr.: IV 03639 
IV

10 Schulaufsicht

10.01 Schulsachen

10.01.01

Organisation des Schulwesens

Lfd. Nr. Titel

Laufzeit

3556 Personalakte: Lehrer Theodor Krieger 1913-1914

- Beschäftigung des Theodor Krieger als Lehrer an der Bezirksschule I

$1912-1914$

Klassifikation Teil B: 03640

Trägermaterial: Papier

Alte Reg.-Sig.: IX B6 30

Bestell-Nr.: IV 03640

3557 Personalakte: Lehrer Wilhelm Neumüller

- Wahl und Beschäftigung des Wilhelm Neumüller als Lehrer an der Bezirksschule I

$1912-1914$

Klassifikation Teil B: 03641

Trägermaterial: Papier

Alte Reg.-Sig.: IX B6 30

Bestell-Nr.: IV 03641

3558 Personalakte: Turn-und Handarbeitslehrerin Helene Westermeyer

- Wahl und Beschäftigung der Helene Westermeyer als Turn- und Handarbeitslehrerin an der Bezirksschule I

1913 - 1918 (1919 - 1920)

Klassifikation Teil B: 03642

Trägermaterial: Papier

Alte Reg.-Sig.: IX B6 30

Bestell-Nr.: IV 03642

3559 Personalakte: Lehrer Johann Wülbers

- Wahl und Beschäftigung des Johann Wülbers als Lehrer an der Bezirksschule I

$1912-1914$

Klassifikation Teil B: 03643

Trägermaterial: Papier

Alte Reg.-Sig.: IX B6 30

Bestell-Nr.: IV 03643

3560 Personalakte: Lehrer Reemt J. Baumann

- Wahl und Beschäftigung des Reemt J. Baumann als Lehrer an der Bezirksschule I

Nachruf auf den verstorbenen Lehrer Reemt J. Baumnn, Juli 1912

$1909-1912$

Klassifikation Teil B: 03644

Trägermaterial: Papier

Alte Reg.-Sig.: IX B6 30

Bestell-Nr.: IV 03644 
IV

10 Schulaufsicht

10.01 Schulsachen

10.01.01

Organisation des Schulwesens

Lfd. Nr. Titel

Laufzeit

3561 Personalakte: Lehrer Harry Baden 1911-1918

- Wahl und Beschäftigung als Lehrer an der Bezirksschule II

- Wechsel nach Hannover, 1920

1911 - 1918 (1920)

Klassifikation Teil B: 03645

Trägermaterial: Papier

Alte Reg.-Sig.: IX B6 31

Bestell-Nr.: IV 03645

3562 Personalakte: Turn- und Handarbeitslehrerin Martha Behrensroth

$1908-1910$

- Wahl und Beschäftigung als Turn- und Handarbeitslehrerin an der Bezirksschule II

$1908-1910$

Klassifikation Teil B: 03646

Trägermaterial: Papier

Alte Reg.-Sig.: IX B6 31

Bestell-Nr.: IV 03646

3563 Personalakte: Lehrer Theodor Behrens

$1889-1917$

- Wahl und Beschäftigung als Lehrer an der e. lutherischen

Klassenschule / Bezirksschule II

$1889-1917$

Klassifikation Teil B: 03647

Trägermaterial: Papier

Alte Reg.-Sig.: IX B6 31

Bestell-Nr.: IV 03647

3564 Personalakte: Lehrer Fritz Bussmann

1910-1914

- Wahl und Beschäftigung als Lehrer an der Bezirksschule II

<gefallen im Ersten Weltkrieg, 1917>

$1910-1914$

Klassifikation Teil B: 03648

Trägermaterial: Papier

Alte Reg.-Sig.: IX B6 31

Bestell-Nr.: IV 03648

3565 Personalakte: Lehrer Heiko Eujen

1906-1917

- Wahl und Beschäftigung als Lehrer an der Bezirksschule II

$1906-1917$

Klassifikation Teil B: 03649

Trägermaterial: Papier

Alte Reg.-Sig.: IX B6 31

Bestell-Nr.: IV 03649 
IV

10 Schulaufsicht

10.01 Schulsachen

10.01.01

Organisation des Schulwesens

Lfd. Nr. Titel

Laufzeit

3566 Personalakte: Lehrer Friedrich Friedewold 1905-1917

- Wahl und Beschäftigung als Lehrer an der Bezirksschule II $<$ vermisst im Ersten Weltkrieg>

$1906-1917$

Klassifikation Teil B: 03650

Trägermaterial: Papier

Alte Reg.-Sig.: IX B6 31

Bestell-Nr.: IV 03650

3567 Personalakte: Lehrer D. Gerjets

1904-1911

- Wahl und Beschäftigung als Lehrer an der Bezirksschule II

$1904-1911$

Klassifikation Teil B: 03651

Trägermaterial: Papier

Alte Reg.-Sig.: IX B6 31

Bestell-Nr.: IV 03651

3568 Personalakte: Lehrer Karl Heyen

$1909-1910$

- Wahl und Beschäftigung als Lehrer an der Bezirksschule II - Ermittlungen gegen den Lehrer Karl Heyen wegen sexuellen Missbrauchs einer Schülerin, 1910

$1906-1917$

Klassifikation Teil B: 03652

Trägermaterial: Papier

Alte Reg.-Sig.: IX B6 31

Bestell-Nr.: IV 03652

3569 Personalakte: Lehrer Gerhard Husmann

$1906-1913$

- Wahl und Beschäftigung als Lehrer an der Bezirksschule II

$1906-1913$

Klassifikation Teil B: 03653

Trägermaterial: Papier

Alte Reg.-Sig.: IX B6 31

Bestell-Nr.: IV 03653

3570 Personalakte: Lehrer Ludwig Jabben

$1911-1918$

- Wahl und Beschäftigung als Lehrer an der Bezirksschule II

$1911-1919$

Klassifikation Teil B: 03654

Trägermaterial: Papier

Alte Reg.-Sig.: IX B6 31

Bestell-Nr.: IV 03654 
IV

10 Schulaufsicht

10.01 Schulsachen

10.01.01

Organisation des Schulwesens

Lfd. Nr. Titel

Laufzeit

3571 Personalakte: Lehrer und Kantor Oncken 1882-1911

- Wahl und Beschäftigung als Lehrer an der ev.. lutherischen Klassenschule / Bezirksschule II

$1882-1911$

Klassifikation Teil B: 03655

Trägermaterial: Papier

Alte Reg.-Sig.: IX B6 31

Bestell-Nr.: IV 03655

3572 Personalakte: Schulamtsanwärter Fritz Schachtebeitz

- Wahl und Beschäftigung als Lehrer an der Bezirksschule II

1914

Klassifikation Teil B: 03656

Trägermaterial: Papier

Alte Reg.-Sig.: IX B6 31

Bestell-Nr.: IV 03656

3573 Personalakte: Lehrer Gerhard Takenberg

$1907-1910$

- Wahl und Beschäftigung als Lehrer an der Bezirksschule II

$1907-1910$

Klassifikation Teil B: 03657

Trägermaterial: Papier

Alte Reg.-Sig.: IX B6 31

Bestell-Nr.: IV 03657

3574 Personalakte: Lehrerin Christine Baumann

$1915-1918$

- Wahl und Beschäftigung als Lehrerin an der Bezirksschule IV

$1915-1921$

Klassifikation Teil B: 03658

Trägermaterial: Papier

Alte Reg.-Sig.: IX B6 32

Bestell-Nr.: IV 03658

3575 Personalakte: Lehrer Christoph de Boer

- Wahl und Beschäftigung als Lehrer an der Bezirksschule IV

1917 - 1918

Klassifikation Teil B: 03659

Trägermaterial: Papier

Alte Reg.-Sig.: IX B6 32

Bestell-Nr.: IV 03659 
IV

10 Schulaufsicht

10.01 Schulsachen

10.01.01

Organisation des Schulwesens

Lfd. Nr. Titel

Laufzeit

3576 Personalakte: Turn- und Handarbeitslehrerin Marie Budde 1915-1918

- Wahl und Beschäftigung als Turn- und Handarbeitslehrerin an der Bezirksschule IV

$1915-1918$ (1921)

Klassifikation Teil B: 03660

Trägermaterial: Papier

Alte Reg.-Sig.: IX B6 32

Bestell-Nr.: IV 03660

3577 Personalakte: Lehrer Nikolaus Buschmann

- Wahl und Beschäftigung als Lehrer an der Bezirksschule IV

$1908-1917$

Klassifikation Teil B: 03661

Trägermaterial: Papier

Alte Reg.-Sig.: IX B6 32

Bestell-Nr.: IV 03661

3578 Personalakte: Lehrer Emil August Buse

$1874-1910$

- Wahl und Beschäftigung als Lehrer an der städtischen Volksschule /

Bezirksschule I

$1874-1910$

Klassifikation Teil B: 03662

Trägermaterial: Papier

Alte Reg.-Sig.: IX B6 32

Bestell-Nr.: IV 03662

3579 Personalakte: Lehrer Julius Denkena

- Wahl und Beschäftigung als Lehrer an der Bezirksschule IV

$<$ Akte unvollständig >

$1884-1923$

Klassifikation Teil B: 03663

Trägermaterial: Papier

Alte Reg.-Sig.: IX B6 32

Bestell-Nr.: IV 03663

3580 Personalakte: Lehrerin Emma Diekmann

- Wahl und Beschäftigung als Lehrerin an der Bezirksschule IV

$1913-1916$

Klassifikation Teil B: 03664

Trägermaterial: Papier

Alte Reg.-Sig.: IX B6 32

Bestell-Nr.: IV 03664 
IV

10 Schulaufsicht

10.01 Schulsachen

10.01.01

Organisation des Schulwesens

Lfd. Nr. Titel

Laufzeit

3581 Personalakte: Rektor Folkert Dinkela $1868-1910$

- Wahl und Amtszeit als Rektor an der reformierten Klassenschule /

Bezirksschule III

$1868-1910$

Klassifikation Teil B: 03665

Trägermaterial: Papier

Alte Reg.-Sig.: IX B6 32

Bestell-Nr.: IV 03665

3582 Personalakte: Lehrerin Alma Dittmer

1912-1918

- Wahl und Beschäftigung als Lehrerin an der Bezirksschule III

$1912-1919$

Klassifikation Teil B: 03666

Trägermaterial: Papier

Alte Reg.-Sig.: IX B6 32

Bestell-Nr.: IV 03666

3583 Personalakte: Lehrer Wiard Folkerts

1913-1918

(1919)

- Wahl und Beschäftigung als Lehrer an der Bezirksschule III

$1913-1919$

Klassifikation Teil B: 03666

Trägermaterial: Papier

Alte Reg.-Sig.: IX B6 32

Bestell-Nr.: IV 03667

3584 Personalakte: Lehrerin Dorothea Harms

- Wahl als Lehrerin an der Bezirksschule III

- Nichtantritt des Dienstes wegen Heirat

1915
Klassifikation Teil B: 03668
Trägermaterial: Papier
Alte Reg.-Sig.: IX B6 32
Bestell-Nr.: IV 03668

3585 Personalakte: Schulamtsbewerber Johann Heckmann

- Probeweise Beschäftigung des kriegsversehrten Johann Heckmann als Lehrer an der Bezirksschule III

1915

Klassifikation Teil B: 03669

Trägermaterial: Papier

Alte Reg.-Sig.: IX B6 32

Bestell-Nr.: IV 03669 
IV

10 Schulaufsicht

10.01 Schulsachen

10.01.01

Organisation des Schulwesens

Lfd. Nr. Titel

Laufzeit

3586 Personalakte: Lehrer Ontje Hilders 1877-1918

- Wahl und Beschäftigung als Lehrer an der reformierten

Klassenschule / Bezirksschule III

$1878-1919$

Klassifikation Teil B: 03670

Trägermaterial: Papier

Alte Reg.-Sig.: IX B6 32

Bestell-Nr.: IV 03670

3587 Personalakte: Lehrer Hermann Hußmann

$1909-1913$

- Wahl und Beschäftigung als Lehrer an der Bezirksschule III

$1909-1913$

Klassifikation Teil B: 03671

Trägermaterial: Papier

Alte Reg.-Sig.: IX B6 32

Bestell-Nr.: IV 03671

3588 Personalakte: Lehrerin Gertrud Klages

- Wahl und Beschäftigung als Lehrerin an der Bezirksschule III

$1912-1914$

Klassifikation Teil B: 03672

Trägermaterial: Papier

Alte Reg.-Sig.: IX B6 32

Bestell-Nr.: IV 03672

3589 Personalakte: Lehrer Peter Janssen

$1906-1910$

- Wahl und Beschäftigung als Lehrer an der Bezirksschule II

$1906-1910$

Klassifikation Teil B: 03673

Trägermaterial: Papier

Alte Reg.-Sig.: IX B6 32

Bestell-Nr.: IV 03673

3590 Handarbeitslehrerin i.R. D. Hummerich

$1908-1911$

- Unterstützung für die ehemalige Handarbeitslehrerin D. Hummerich aus der Kasse der Bezirksschule III, später aus der Stadtkasse

$1908-1911$

Klassifikation Teil B: 03674

Trägermaterial: Papier

Alte Reg.-Sig.: IX B6 32

Bestell-Nr.: IV 03674 
IV

10 Schulaufsicht

10.01 Schulsachen

10.01.01

Organisation des Schulwesens

Lfd. Nr. Titel

Laufzeit

3591 Personalakte: Lehrerin Maria (Marie) Mohr 1917-1918

- Wahl und Beschäftigung als Lehrerin an der Bezirksschule II

$1917-1918$

Klassifikation Teil B: 03675

Trägermaterial: Papier

Alte Reg.-Sig.: IX B6 32

Bestell-Nr.: IV 03675

3592 Personalakte: Schulamtsanwärter Klaas Müller

- Wahl und Beschäftigung als Lehrer an der Bezirksschule III, 1912 -

1914

- Standesamtsauszug: Tod des Klaas Müller an der Westfront, März

1918

$1912-1918$

Klassifikation Teil B: 03676

Trägermaterial: Papier

Alte Reg.-Sig.: IX B6 32

Bestell-Nr.: IV 03676

3593 Personalakte: Lehrer Berend Ohling

- Wahl und Beschäftigung als Lehrer an der städtischen Volksschule / Bezirksschule I

$1891-1917$

Klassifikation Teil B: 03677

Trägermaterial: Papier

Alte Reg.-Sig.: IX B6 32

Bestell-Nr.: IV 03677

3594 Schule auf Transvaal

- Ablehnung einer eigenständigen Schule auf Transvaal durch die Stadtschuldeputation, Januar 1909

- Gesuch verschiedener Bewohner auf Transvaal an die Stadtschuldeputation über Bitte um Errichtung einer Schule auf Transvaal wegen Überfüllung der Bezirksschulen und zu weite Schulwege, Februar 1912

$1909-1912$

Klassifikation Teil B: 03678

Trägermaterial: Papier

Alte Reg.-Sig.: IX B6 44

Bestell-Nr.: IV 03678 
IV

10 Schulaufsicht

10.01 Schulsachen

10.01.01

Organisation des Schulwesens

Lfd. Nr. Titel

Laufzeit

3595 Personalakte: Lehrer Ernst Bernhardt 1913-1918

- Wahl und Beschäftigung als Lehrer an der Bezirksschule I

$1913-1918$

Klassifikation Teil B: 03679

Trägermaterial: Papier

Alte Reg.-Sig.: IX B6 32

Bestell-Nr.: IV 03679

3596 Personalakte: Lehrerin Annie Niemer

- Wahl und Beschäftigung als Lehrerin an der Hilfsschule

$1914-1918$

Klassifikation Teil B: 03680

Trägermaterial: Papier

Alte Reg.-Sig.: IX B6 32

Bestell-Nr.: IV 03680

3597 Personalakte: Lehreri Otto Legel

- Wahl und Beschäftigung als Lehrer an der Hilfsschule

$<$ Akte unvollständig >

1912

Klassifikation Teil B: 03681

Trägermaterial: Papier

Alte Reg.-Sig.: IX B6 34

Bestell-Nr.: IV 03681

3598 Handarbeitslehrerinnenstelle an der Hilfsschule

- Bewerbungen verschiedener Lehrerinnen um die Stelle einer Handarbeitslehrerin an der Hilfsschule

$1911-1913$

Klassifikation Teil B: 03682

Trägermaterial: Papier

Alte Reg.-Sig.: IX B6 34

Bestell-Nr.: IV 03682

3599 Personalakte: Lehrer Oskar Rape

$1909-1916$

- Wahl und Beschäftigung als Lehrer an der Bezirksschule IV (katholische Volksschule), gefallen im Kriegsdienst 1916

$1909-1916$

Klassifikation Teil B: 03683

Trägermaterial: Papier

Alte Reg.-Sig.: IX B6 33

Bestell-Nr.: IV 03683 
IV

10 Schulaufsicht

10.01 Schulsachen

10.01.01

Organisation des Schulwesens

Lfd. Nr. Titel

Laufzeit

3600 Personalakte: Lehrerin Elisabeth Bachmann

- Wahl und Beschäftigung als Lehrerin an der Bezirksschule IV (katholische Volksschule)

<Akte unvollständig>

$1884-1924$

Klassifikation Teil B: 03684

Trägermaterial: Papier

Alte Reg.-Sig.: IX B6 33

Bestell-Nr.: IV 03684

3601 Personalakte: Lehrer Friedrich Barre

- Wahl und Beschäftigung als Lehrer an der Bezirksschule IV (katholische Volksschule)

$1913-1914$

Klassifikation Teil B: 03685

Trägermaterial: Papier

Alte Reg.-Sig.: IX B6 33

Bestell-Nr.: IV 03685

3602 Personalakte: Rektor Eduard Stähler

- Wahl und Amtszeit als Rektor der Bezirksschule IV (katholische Volksschule), 1914

- Mitteilung über Tod des Rektors Stähler in französischer

Kriegsgefangenschaft, Februar 1916

- Rückforderung von überzahlten Gehältern an den Rektor Stähler vom Zeitpunkt seines festgestellten Todes im Dezember 1914 bis März 1916 von seiner Witwe, Februar 1916 - März 1917

- Überweisung einer Gedenkplatte für den gefallenen Rektor Stähler an die Bezirksschule IV durch seinen Schwiegervater, März 1917

$1914-1917$

Klassifikation Teil B: 03686

Trägermaterial: Papier

Alte Reg.-Sig.: IX B6 33

Bestell-Nr.: IV 03686

3603 Personalakte: Lehrer Adolf Redderberg

- Wahl und Beschäftigung als Lehrer an der Bezirksschule IV (katholische Volksschule)

$1913-1914$

Klassifikation Teil B: 03687

Trägermaterial: Papier

Alte Reg.-Sig.: IX B6 33

Bestell-Nr.: IV 03687 
IV

10 Schulaufsicht

10.01 Schulsachen

10.01.01

Organisation des Schulwesens

Lfd. Nr. Titel

Laufzeit

3604 Personalakte: Lehrer Karl Lüddecke 1913-1918

(1919-1920)

- Wahl und Beschäftigung als Lehrer an der Bezirksschule IV (katholische Volksschule)

$1913-1920$

Klassifikation Teil B: 03688

Trägermaterial: Papier

Alte Reg.-Sig.: IX B6 33

Bestell-Nr.: IV 03688

3605 Personalakte: Lehrer Ernst Hallmann

1914-1918

(1919)

- Wahl und Beschäftigung als Lehrer an der Bezirksschule IV (katholische Volksschule)

$1914-1919$

Klassifikation Teil B: 03689

Trägermaterial: Papier

Alte Reg.-Sig.: IX B6 33

Bestell-Nr.: IV 03689

3606 Personalakte: Schulamtsbewerber Claas Cornelius

$1914-1918$

- Wahl und Beschäftigung als Lehrer an der Bezirksschule IV (katholische Volksschule)

- Erörterung der endgültigen Einstellung des als vermisst geltenden (später als gefallen gemeldeten) Schulamtsbewerber Claas Cornelius, November 1918

1914- 1918

Klassifikation Teil B: 03690

Trägermaterial: Papier

Alte Reg.-Sig.: IX B6 33

Bestell-Nr.: IV 03690

3607 Personalakte: Lehrer Berend Klaaßen

1904-1916

- Wahl und Beschäftigung als Lehrer an der Bezirksschule IV (katholische Volksschule)

$1904-1916$

Klassifikation Teil B: 03691

Trägermaterial: Papier

Alte Reg.-Sig.: IX B6 33

Bestell-Nr.: IV 03691

3608 Personalakte: Lehrerin Irmgard Zippel

- Wahl und Beschäftigung als Lehrer an der Bezirksschule I

1917 - 1918 (1919-1937)

Klassifikation Teil B: 03692

Trägermaterial: Papier

Alte Reg.-Sig.: IX B6 38

Bestell-Nr.: IV 03692 
IV

10 Schulaufsicht

10.01 Schulsachen

10.01.01

Organisation des Schulwesens

Lfd. Nr. Titel

Laufzeit

3609 Personalakte: Turn- und Handarbeitslehrerin Frieda Zipp

1915-1917

- Wahl und Beschäftigung als Lehrer an der Bezirksschule II

$1915-1917$

Klassifikation Teil B: 03693

Trägermaterial: Papier

Alte Reg.-Sig.: IX B6 33

Bestell-Nr.: IV 03693

3610 Personalakte: Turn- und Handarbeitslehrerin Martha Wistinghausen

1908-1914

- Wahl und Beschäftigung als Lehrer an der Bezirksschule I

$1908-1913$

Klassifikation Teil B: 03694

Trägermaterial: Papier

Alte Reg.-Sig.: IX B6 32

Bestell-Nr.: IV 03694

3611 Personalakte: Lehrer Bruno Wilde

1908-1916

- Wahl und Beschäftigung als Lehrer an der Bezirksschule III

$1908-1916$

Klassifikation Teil B: 03695

Trägermaterial: Papier

Alte Reg.-Sig.: IX B6 32

Bestell-Nr.: IV 03695

3612 Personalakte: Technische Lehrerin Elsbeth van Bollhuis-Smeding

- Wahl und Beschäftigung als technische Lehrerin an der

Bezirksschule III

$1917-1918$

Klassifikation Teil B: 03696

Trägermaterial: Papier

Alte Reg.-Sig.: IX B6 32

Bestell-Nr.: IV 03696

3613 Personalakte: Turn- und Handarbeitslehrerin Käthe Schultze

- Wahl und Beschäftigung als Turn- und Handarbeitslehrerin an der Bezirksschule III

$1913-1914$

Klassifikation Teil B: 03697

Trägermaterial: Papier

Alte Reg.-Sig.: IX B6 32

Bestell-Nr.: IV 03697 
10.01

Lfd. Nr. Titel

- Gedruckter Bericht einer Magistratskommission und des Schulvorstandes der deutsch-reformierten Gemeinde über Notwendigkeit einer eigenständigen Mittelschule für Kinder des gewerblichen Mittelstandes, Dezember 1880

- Verhandlungen der städtischen Kollegien über den Plan der

Errichtung einer Mittelschule, Februar - März 1881

- Stellungnahme der Kaufmännischen Deputation für den Plan, März 1881

- Stellungnahme des Kirchenrats der deutsch-reformierten Gemeinde gegen eine Kommunalisierung der reformierten Schulen infolge der Errichtung einer Mittelschule, März 1881

- Stellungnahme des Börsenvereins für die Mittelschule unter Kommunalisierung der evangelischen Volksschulen, Mai 1881 - Stellungnahme des reformierten Schulvorstands gegen die Verschmelzung der städtischen Volksschule mit der reformierten Klassenschule zur Mittelschule, Mai 1881

- Stellungnahme des Handwerkervereins gegen die Mittelschule und für eine Verbesserung des bisherigen Systems, Mai 1881

- Rescript des kgl. Consistoriums in Aurich über Sympathie für den Plan einer Mittelschule durch Fusion der städtischen Volksschule mit der reformierten Klassenschule und einer stufenweise Durchführung des Planes, Juni 1881

- Stellungnahme des Kirchenrats der lutherischen Gemeinde gegen eine Mittelschule und für den Erhalt des konfessionellen Schulsystems, Juli 1881

- Gutachten des Schulvorstands der lutherischen Gemeinde gegen den Mittelschulplan, Juli 1881

- Bericht einer Kommission des deutsch-reformierten Kirchenrats gegen das Schulprojekt und für den Ausbau der reformierten Klassenschule, Juni 1881

$1880-1881$

Klassifikation Teil B: 03698

Band: 1

Trägermaterial: Papier Alte Reg.-Sig.: IV B7 2

Bestell-Nr.: IV 03698 
Lfd. Nr. Titel

- Initiative des Kuratoriums der Kaiser-Friedrich-Realschule zum Ausbau der Schule zur Oberrealschule bei gleichzeitiger Errichtung einer Mittelschule für Knaben, April 1913

- Datenerhebung des Magistrats bei anderen Städten über Erfahrungen mit dem gleichzeitigen Bestehen von Mittelschulen für Kinder des gewerblichen Bürgertums und Oberrealschulen, April 1913 - Verhandlungen des Magistrats über Ausbau des Emder Schulsystems unter dem Aspekt der Errichtung einer Mittelschule und des Ausbaus der Kaiser-Friedrich-Realschule zur Oberrealschule, Juni 1913

- Verhandlungen der Stadtschuldeputation über Plan der Errichtung einer Mittelschule, Julöi 1913 - Juni 1914

- Denkschrift des Bürgermeisters Dr. Mützelburg für die Errichtung einer Mittelschule, 1913

- Presseausschnitte zur Mittelschule, 1913 - 1914

- Votum der Bürgervorsteher Lolling etc. gegen die Mittelschule wegen fehlendem Fremdsprachenunterricht, September 1913

- Aufstellung über Meldung von Schülern für die Mittelschule, Januar 1914

- Votum des Verbands mittlerer Reichspost- und

Telegraphen-Beamter gegen die Mittelschule, Februar 1914

Enthält auch:

- Verhandlungen des Magistrats über Schulsituation in der Arbeiterkolonie Friesland, Mai - Juni 1913

$1913-1914$

Klassifikation Teil B: 03699

Trägermaterial: Papier

Alte Reg.-Sig.: IX B7 3

Bestell-Nr.: IV 03699 
10.01

\section{Schulsachen}

10.01 .02

Kommunalisierung des Schulwesens

Lfd. Nr. Titel

Laufzeit

3616 Gesetz über die Unterhaltung der öffentlichen Volksschulen

- Gesetz über die Unterhaltung der öffentlichen Volksschulen vom 28. Juli 1906 mit Ausführungsbestimmungen, 1906

- Umsetzung in Emden: Trägerschaft der Volksschulen bei der Stadt; Regelung der Zuständigkeit für den Religionsunterricht;

Neustrukturierung der Schulverbände; Bildung einer

Stadtschuldeputation als Verwaltungs-und Kontrollinstanz des

Volksschulwesens, 1906 - 1907

- Vorschläge des Rektors der lutherischen Klassenschule, B. Janssen, zur Neuordnung des Emder Volksschulwesens, November 1907

- Eingabe der reformierten Gemeinde an die kgl. Regierung über Bitte um Abwendung der Nachteile für die reformierten Schulen infolge der Kommunalisierung des Volksschulwesens, November 1907

- Bildung der Stadtschuldeputation, Februar - April 1908

- Bildung der und Verteilung der Schüler auf die neugebildeten Emder Schulbezirke, März - April 1908

- Verfügung der kgl. Regierung in Aurich über Nichtverteilung von Staatsmittel an den jüdischen Schulverband in Emden, März 1908

$1906-1908$

Klassifikation Teil B: 03617

Trägermaterial: Papier

Alte Reg.-Sig.: IX B6 01

Bestell-Nr.: IV 03617

3617 Vorschriften über die Geschäftsführung der Stadtschuldeputation

- Vorschriften (Statuten) über die Geschäftsführung der

Stadtschuldeputation in Emden, Juli 1908

- Konzipierung der Vorschriften über die Geschäftsführung der

Stadtschuldeputation durch Oberbürgermeister Fürbringer nach den

Bestimmungen der Dritten Anweisung zur Durchführung des Gesetzes

zur Unterhaltung der Volksschulen v. November 1907. Mai - Juni 1908

- Antrag des Magistrats an die Regierung über Bitte um Genehmigung der Vorschriften über die Geschäftsführung der Stadtschuldeputation, Mai 1908

- Monita der kgl. Regierung zum eingereichten Entwurf der

Vorschriften über die Geschäftsführung der Stadtschuldeputation, Juli 1908 / Juni 1909

- Verfügung der kgl. Regierung über Befugnisse des Kreisschulinspektors als Schulaufsichtsorgan gegenüber der Stadtschuldeputation, November 1910

- Konflikt zwischen der Stadtschuldeputation und dem Kreissschulinspektor Riedlin wegen Befugnis der Entlassung von Schülern, April - Mai 1914

$1908-1914$

Klassifikation Teil B: 03618

Trägermaterial: Papier

Alte Reg.-Sig.: IX B6 03

Bestell-Nr.: IV 03618 
10.01

\section{Schulsachen}

10.01 .02

Kommunalisierung des Schulwesens

Lfd. Nr. Titel

Laufzeit

3618 Einsetzung einer Kommission zur Reorganisation des Emder 1907-1908 Volksschulwesens

- Bildung einer Kommission zur Reorganisation des Emder Volksschulwesens aus den Städtischen Kollegien nach den Vorgaben des Volksschulunterhaltungsgesetzes, Juli 1907

- Verhandlungen der Kommission über Maßnahmen zur Reorganisation des Emder Volksschulwesens, November 1907 - April 1908

$1907-1908$

Klassifikation Teil B: 03619

Trägermaterial: Papier

Alte Reg.-Sig.: IX B6 04

Bestell-Nr.: IV 03619

3619 Sitzungsprotokolle der Stadtschuldeputation

- Sitzungen der Stadtschuldeputation über Organisation der Emder Volksschulen, Einstellung und Entlassung von Lehrern, Koordinierung des Lehrereinsatzes, konfessionelle Konflikte zwischen Reformierten und Lutheranern, Etatfragen

$1908-1911$

Klassifikation Teil B: 03620

Trägermaterial: Papier

Alte Reg.-Sig.: IX B6 09

Bestell-Nr.: IV 03620 
10.02

Volksschulen

10.02.01

Volksschule der deutsch reformierten Gemeinde

Lfd. Nr. Titel

Laufzeit

3620 Reformierte Klassenschule Emden

- Wahl der Hilfs- und Nebenlehrer, der Lehrer und der Schuldiener der reformierten Klassenschule in Emden, 1852

- Regelung der Lehrerbesoldung, 1852 - 1866

- Kritik des Lehrers Meyer an der Schulaufsicht des kgl.

Konsistoriums, März 1868

(1852 - 1865) $1866-1868$

Klassifikation Teil B: 03232

Trägermaterial: Papier

Alte Reg.-Sig.: IX B3 04

Bestell-Nr.: IV 03232

3621 Schulkasse der reformierten Gemeinde

- Einnahmen und Ausgaben der Schulkasse der reformierten

Gemeinde, 1897 - 1898

Enthält auch:

Abschlussarbeiten von Schülern der Gasthausschule, 1910 / 1912

\author{
1897 - 1898 (1910 - 1912) \\ Klassifikation Teil B: 03267 \\ Trägermaterial: Papier \\ Alte Reg.-Sig.: IX A 2b II 10
}

Bestell-Nr.: IV 03267

- Antrag des Schulvorstands der deutsch-reformierten Gemeinde an den Magistrat auf Mitteilung neuzuziehender reformierter Bewohner zur Erfassung aller Schulsteuerpflichtigen, Oktober 1869

- Neuorganisation der evangelisch reformierten Klassenschule,

Dezember 1891

- Revision der reformierten Klassenschule, 1901 - 1903

- Antrag des Schulvorstandes der reformierten Gemeinde an die Regierung auf Regelung der Möglixchkeit des Verweises von Schüler aus der reformierten Klassenschule, Mai 1902

- Anschaffung eines neuen Dienstsiegels für die reformierten Klassenschule, November 1909

$1869-1909$

Klassifikation Teil B: 03447

Trägermaterial: Papier

Alte Reg.-Sig.: IX B3a 01

Bestell-Nr.: IV 03447 
- Antrag der Kirchen-Commission der deutsch-reformierten Gemeinde an das kgl. Consistorium in Aurich auf Genehmigung der Änderung der Schulordnung der reformierten Klassenschule hinsichtlich der Aufsicht über die Knaben- und Mädchenklassen, Dezember 1877

- Schulordnung der reformierten Klassenschule, 1881

- Novellierung der Schulordnung der reformierten Klassenschule, 1883

$1877-1883$

Klassifikation Teil B: 03448

Trägermaterial: Papier

Alte Reg.-Sig.: IX B3a 01

Bestell-Nr.: IV 03448

3624 Inventarverzeichnis der reformierten Klassenschule

- Schulmobilien und Utensilien

- Bestand der Lehrerbibliothek

- Inventar der Turnhalle und der Schulwärterwohnung

1890

\author{
Klassifikation Teil B: 03449 \\ Trägermaterial: Papier \\ Alte Reg.-Sig.: IX B 3a 02 \\ Bestell-Nr.: IV 03449
}

3625 Schulvorstand der deutsch-reformierten Gemeinde

- Wahl und Verpflichtung der Mitglieder des Schulvorstandes der deutsch-reformierten Gemeinde, 1868 - 1903

- Suspendierung des Kaufmanns R. W. Remmers aus dem

Schulvorstand der deutsch-reformierten Gemeinde wegen

Nichtteilnahme an den Sitzungen, Juni 1871 - Juni 1873

- Regelung der Mitgliedschaft des Hauptlehrers der reformierten

Klassenschule im Schulvorstand der deutsch-reformierten Gemeinde, Mai - Juni 1889

- Streit zwischen dem Schulvorstand der deutsch-reformierten Gemeinde und der deutsch-reformierten Gemeinde um die novellierte Vorstandssatzung insbesondere hinsichtlich der Lehrerwahl, Februar 1902 - Januar 1903

- Druck: Satzung des Schulvorstandes der reformierten Gemeinde, Dezember 1902

$1868-1903$

Klassifikation Teil B: 03450

Trägermaterial: Papier

Alte Reg.-Sig.: IX B3a 03

Bestell-Nr.: IV 03450 
10.02

Volksschulen

10.02.01

Volksschule der deutsch reformierten Gemeinde

Lfd. Nr. Titel

Laufzeit

3626 Schuletat der deutsch-reformierten Gemeinde, Bd. 1

- Deckung der Defizite des Schuletats der deutsch-reformierten

Gemeinde durch die Stadt Emden, April 1867 - Juni 1874

- Eintreibung rückständiger Schulbeiträge, 1868 - 1870

- Widersprüche gegen die Heranziehung zum Schulbeitrag der

reformierten Klassenschule, 1868 - 1869

- Antrag der Kirchenkommission der reformierten Gemeinde beim kgl.

Konsisterium in Aurich auf Genehmigung der ausgeschriebenen

Schulbeiträge für die reformierte Klassenschule, September 1872 -

Dezember 1881

- Monita des Magistrats zum Etat der reformierten Klassenschule, Januar 1869 - Februar 1886

- Erhebung über Schulbeitragseinnahmen der reformierten

Klassenschule, Dezember 1884

- Etat der Schulkasse der deutsch-reformieten Gemeinde, 1885 -

1890

- Unterhaltungskosten der reformierten Klassenschule,1885 - 1890

$1867-1890$

Klassifikation Teil B: 03451

Band: 1

Trägermaterial: Papier

Alte Reg.-Sig.: IX B3a 09

Bestell-Nr.: IV 03451

3627 Schuletat der deutsch-reformierten Gemeinde, Bd. 2

- Etat der Schulkasse der deutsch-reformieten Gemeinde, 1892 -

1907

- Unterhaltungskosten der reformierten Klassenschule, 1902 - 1907

$1891-1907$

Klassifikation Teil B: 03452

Band: 2

Trägermaterial: Papier

Alte Reg.-Sig.: IX B3a 09

Bestell-Nr.: IV 03452

3628 Geschäftsberichte über das Volksschulwesen: Reformierte Klassenschule

- Statistische Geschäftsberichte der reformierten Klassenschule auf Anforderung durch den Regierungspräsidenten in Aurich

$1872-1883$

Klassifikation Teil B: 03453

Trägermaterial: Papier

Alte Reg.-Sig.: IX B 3a 11

Bestell-Nr.: IV 03453 
IV

10

Schulaufsicht

10.02

Volksschulen

10.02.01

Volksschule der deutsch reformierten Gemeinde

Lfd. Nr. Titel

Laufzeit

3629 Schulaufsicht

1869-1888

- Erlasse des Ministers der Geistlichen, Unterrichts- und

Medizinalangelegenheiten über Regelung der Schulaufsicht über die

Volksschulen

$1869-1888$

Klassifikation Teil B: 03454

Trägermaterial: Papier

Alte Reg.-Sig.: IX B 3a 12

Bestell-Nr.: IV 03454

3630 Abnahme der Rechnungen der reformierten Schulkasse

- Antrag des Schulvorstands der reformierten Gemeinde an den Magistrat über Bitte um Erreichung der Vornahme der Rechnungsprüfung der reformierten Schulkasse durch das $\mathrm{kgl}$. Konsistorium zur Vermeidung der Behinderung des Geschäftsgangs, Januar 1868

- Verfügung des kgl. Konsistoriums in Aurich über Vornahme der Rechnungsprüfung der Schulverbände durch den jeweiligen konfessionellen oder staatlichen Träger, Februar 1868

- Rechnungsabnahme der reformierten Schulkasse durch die Kirchenkommission für die reformierte Gemeinde, 1868 - 1908

- Monita des kgl. Konsistoriums / der kgl. Regierung in Aurich zur Rechnungsabnahme, 1868 - 1908

- Inventarium über Vermögen und Inventar der reformierten

Klassenschule sowie der Schuleinrichtung, Oktober 1882

$1868-1908$

Klassifikation Teil B: 03455

Trägermaterial: Papier

Alte Reg.-Sig.: IX B 3a 13

Bestell-Nr.: IV 03455

3631 Heranziehung der Geistlichen und Lehrer zu den Schullasten

- Widerspruch der Pastoren und Lehrer der reformierten Gemeinde gegen die Heranziehung zu den Schullasten, März - April 1868 - Verfügung des kgl. Konsistoriums in Aurich über Rechtmäßigkeit der Heranziehung der Prediger und Lehrer zu den Schullasten, August 1868

1868

Klassifikation Teil B: 03456

Trägermaterial: Papier

Alte Reg.-Sig.: IX 3a 15

Bestell-Nr.: IV 03456 
10.02

Volksschulen

10.02.01

Volksschule der deutsch reformierten Gemeinde

Lfd. Nr. Titel

Laufzeit

3632 Kriegsdienstbefreiung von Lehrern

- Bericht des Schulvorstandes der reformierten Gemeinde an die Kirchenkommission für die reformierte Gemeinde über Unersetzbarkeit des zum Kriegsdienst herangezogenen Lehrers F. Dinkela, Oktober 1870

- Antrag der Kirchenkommission für die reformierte Gemeinde an das $\mathrm{kgl} \mathrm{Konsistorium} \mathrm{auf} \mathrm{Bewirkung} \mathrm{der} \mathrm{Befreiung} \mathrm{des} \mathrm{Lehrers} \mathrm{F.} \mathrm{Dinkela}$ vom Kriegsdienst, Oktober 1871

- Bericht des Schulvorstandes der reformierten Gemeinde an die Kirchenkommission für die reformierte Gemeinde über Notwendigkeit der Befreiung des Hilfslehrers Behrens vom Kriegsdienst zur Aufrechterhaltung eines regulären Schulbetriebs, Januar 1871 - Antrag der Kirchenkommission für die reformierte Gemeinde an das $\mathrm{kgl} \mathrm{Konsistorium} \mathrm{auf} \mathrm{Bewirkung} \mathrm{der} \mathrm{Befreiung} \mathrm{des} \mathrm{Hilfslehrers}$ Behrens vom Kriegsdienst, Januar 1871

$1870-1871$

Klassifikation Teil B: 03457

Trägermaterial: Papier

Alte Reg.-Sig.: IX 3a 16

Bestell-Nr.: IV 03457

- Verfügung des kgl. Konsistoriums über Einführung eines Turnpflichtunterrichts nach einem Erlass des Ministers der Geistlichen, Unterrichts- und Medizinalangelegenheiten, Juni 1869 - Verfügung des kgl. Konsistoriums über Genehmigung der Erhöhung des Gehalts des Turnlehrers an der reformierten Klassenschule, Februar 1880

- Nutzung der Turnhalle der reformierten Klassenschule durch den christlichen Jünglingsverein, März 1904

$1869-1904$

Klassifikation Teil B: 03458

Trägermaterial: Papier

Alte Reg.-Sig.: IX B 3a 18

Bestell-Nr.: IV 03458

3634 Verhandlungen wegen der städtischen Volksschule

- Stellungnahme des Schulvorstands der reformierten Gemeinde gegen den Plan des Magistrats zur Errichtung einer städtischen Volksschule wegen Ausfälle an Schulgeld durch diese neue Schule, Januar 1874

$1873-1874$

Klassifikation Teil B: 03459

Trägermaterial: Papier

Alte Reg.-Sig.: IX B 3a 19

Bestell-Nr.: IV 03459 
IV

10

10.02

10.02 .01
Schulaufsicht

\section{Volksschulen}

Volksschule der deutsch reformierten Gemeinde

Lfd. Nr. Titel

Laufzeit

3635 Errichtung eines neuen Gebäudes für die reformierte Klassenschule

- Antrag des Schulvorstands der reformierten Gemeinde an die kgl. Regierung in Aurich auf Genehmigung der Errichtung eines neuen Gebäudes für die reformierte Klassenschule wegen Mangelhaftigkeit des bisherigen Schullokals, Februar - Juni 1890

- Finanzierung des Neubaus mit einem Darlehen der Hannoverschen Landes-Credit-Anstalt, August - September 1891

- Einweihung des Schulgebäudes an der Beuljenstraße, Oktober 1891

- Antrag des Schulvorstands der reformierten Gemeinde an die kgl. Regierung in Aurich auf Genehmigung der Errichtung eines weiteren Schulgebäudes mit Turnhalle, Februar - Dezember 1894

- Kostenlose Vermietung von Räumen der Gewerbeschule an die reformierte Klassenschule, März - Juni 1897

- Modernisierung der Schuleinrichtung und des Schulhofes der reformierten Klassenschule, Mai 1900 - September 1901

$1890-1901$

Klassifikation Teil B: 03460

Trägermaterial: Papier

Alte Reg.-Sig.: IX B 3a 21

Bestell-Nr.: IV 03460

3636 Stimmrecht bei der Lehrerwahl

- Eingabe von Mitgliedern der reformierten Schulgemeinde an die kgl. Regierung in Aurich über Gesuch um Aufhebung des bisherigen Stimmregisters wegen unrechtmäßiger Abgabe zum Erwerb des Stimmrechts zur Lehrerwahl, Juli - Dezember 1891

1891

Klassifikation Teil B: 03461

Trägermaterial: Papier

Alte Reg.-Sig.: IX B3a 22

Bestell-Nr.: IV 03461 
- Schließung der Lehrerpensionskasse der reformierten Klassenschule und Verteilung der Kapitalzinsen an die beitragszahlenden Lehrer wegen Einrichtung einer Lehrerwitwen- und Waisenkasse auf Bezirksebene als Umsetzung des Lehrerbesoldungsgesetzes, November 1885 - Februar 1886

- Beschwerde des Lehrers M. Wille gegen die Auflösung der Lehrerpensionskasse, Januar 1886

- Statut der Lehrerwitwen- und Waisenkasse der reformierten Gemeinde in Emden, 1886

- Monita der kgl. Regierung in Aurich zur Novellierung der Statuten der Lehrerwitwen- und Waisenkasse der reformierten Gemeinde, April 1887

- Monita der Kirchenkommission für die reformierte Gemeinde zur Rechnungslegung der Lehrerwitwen- und Waisenkasse, September 1889

$1885-1889$

Klassifikation Teil B: 03462

Trägermaterial: Papier

Alte Reg.-Sig.: IX B 3a 23

Bestell-Nr.: IV 03462

- Antrag des Schulvorstands der reformierten Gemeinde an die Kirchenkommission für die reformierte Gemeinde auf Genehmigung einer Erhöhung der Schulgeldsätze, September - Oktober 1882 / Februar 1903 / August 1905

- Verfügung des kgl. Konsistoriums in Aurich über Ablehnung der geplanten Erhöhung der Schulgeldsätze der reformierten Klassenschule, Oktober 1882

- Verfügung des kgl. Konsistoriums in Aurich über Genehmigung der geplanten Erhöhung der Schulgeldsätze der reformierten Klassenschule wegen Einstellung zweier Lehrer, Januar 1883 - Befreiung des 3. und 4. schulpflichtigen Kindes vom Schulgeld der reformierten Klassenschule, 1899

- Weigerung des Zimmermanns Johannes Meinders zur Zahlung einer Schulsteuer, Januar 1907

$1882-1907$

Klassifikation Teil B: 03463

Trägermaterial: Papier

Alte Reg.-Sig.: IX B 3a 23

Bestell-Nr.: IV 03463 
10

10.02

10.02 .01

\section{Schulaufsicht}

Volksschulen

Volksschule der deutsch reformierten Gemeinde

Lfd. Nr. Titel

Laufzeit

3639 Aufbau einer fünften Knaben- und Mädchenklasse an der reformierten $1880-1885$ Klassenschule

- Verfügung des $\mathrm{kgl}$. Konsistoriums über Notwendigkeit der Erweiterung der reformierten Klassenschule wegen großer Schülerzahl, Mai / Oktober 1880

- Bericht der Kirchenkommission für die reformierte Gemeinde an das $\mathrm{kgl}$. Konsistorium über Widerstand des Kirchenrats der Großen Kirche gegen eine Erweiterung der reformierten Klassenschule, März 1881 - Verfügung des kgl. Konsistoriums über nicht vorliegende Notwendigkeit einer Genehmigung der Erweiterung der reformierten Klassenschule durch den Kirchenrat der Großen Kirche, Juni 1881 - Bericht des Schulvorstands der reformierten Gemeinde an die Kirchenkommission für die Reformierte Gemeinde über Beschlussfassung im Einvernehmen mit dem Kirchenrat der Großen Kirche zur Erweiterung der reformierten Klassenschule und Einstellung zweier weiterer Lehrer, Dezember 1881 / Januar 1882

- Wahl der zusätzlichen Lehrer für die erweiterte reformierte Klassenschule, März 1882

- Antrag des Schulvorstands der reformierten Gemeinde an die Kirchenkommission für die reformierte Gemeinde auf Genehmigung einer Anleihe zur Finanzierung der Erweiterung der reformierten Klassenschule, September 1885

$1880-1885$

Klassifikation Teil B: 03464

Trägermaterial: Papier

Alte Reg.-Sig.: IX B 3a 25

Bestell-Nr.: IV 03464

3640 Heranziehung der Mitglieder der französisch reformierten Gemeinde und der Mennoniten zum reformierten Schulverband

- Antrag des Schulvorstands der reformierten Gemeinde an die Kirchenkommission für die reformierte Gemeinde auf Vereinigung des nicht mehr lebensfähigen Schulverbands der französisch reformierten Gemeinde mit dem reformierten Schulverband, November 1872 - April 1873

- Antrag des Schulvorstands der reformierten Gemeinde an die Kirchenkommission für die reformierte Gemeinde auf Heranziehng der Mennoniten zum reformierten Schulverband, Mai - Juni 1879

- Eingabe der Mennonitengemeinde an den Minister der Geistlichen, Unterrichts- und Medizinalangelegenheiten über Bitte um Förderung einer überkonfessionellen städtischen, evangelischen Volksschule, Mai 1880

- Erlass des Ministers der Geistlichen, Unterrichts.- und Medizinalangelegenheiten über Ablehnung des Antrages der Mennonitengemeinde auf Bildung eines eigenen Schulverbandes, Möglichkeit der Wahl eines der in Emden vorhandenen evangelischen Schulverbandes für Mennonitenkinder, Mai / August 1881

$1872-1881$

Klassifikation Teil B: 03465

Trägermaterial: Papier

Alte Reg.-Sig.: IX 3 a 27

Bestell-Nr.: IV 03465 
Lfd. Nr. Titel

Laufzeit

3641 Lehrerinnen - Stelle an der reformierten Klassenschule

- Antrag des Schulvorstandes der reformierten Gemeinde an die kgl. Regierung in Aurich auf Gewährung einer Staatsbeihilfe zur Beschäftigung einer Lehrerin an der reformierten Klassenschule, September - Oktober 1900

- Bericht des Kreisschulinspektors Cöper an die kgl. Regierung in Aurich über Plädoyer für ein Abwarten einer novellierten und vereinfachten Lehrerwahlordnung der deutsch-reformierten Gemeinde zur Erreichung der Weiterbeschäftigung der Lehrerin S. Siefkens als

13. Lehrkraft an der reformierten Klassenschule, Februar 1901 - Beschluss des Schulvorstands der reformierten Gemeinde über Errichtung einer Lehrerinnenstelle an der reformierten Klassenschule, Dezenber 1901

- Beschluss des Schulvorstands der reformierten Gemeinde über Festlegung des Gehalts und der Zulagen für die neue Lehrerinnenstelle, Januar 1902

- Wahl der S. Siefkens zur Lehrerin an der reformierten

Klassenschule, Juni 1902

$1900-1902$

Klassifikation Teil B: 03467

Trägermaterial: Papier

Alte Reg.-Sig.: IX B3a 28

Bestell-Nr.: IV 03467

3642 Neubau eines Schulgebäudes der deutsch-reformierten Gemeinde

- Übereinkunft zwischen dem Schulvorstand der reformierten

Gemeinde und dem Magistrat über Zurverfügungsstellung eines städtischen Grundstücks am Friedhof der Großen Kirche zum Bau eines neuen Schulgebäudes, April - Juni 1902

- Revisionsbericht des Schulrats Runge über mangelhafte Ausstattung und drangvolle Enge der reformierten Klassenschule, März 1902 - Lageplan eines Neubaus der reformierten Klassenschule mit Turnhalle an der Ringstraße, Mai 1902

- Aufnahme einer Anleihe durch die reformirte Gemeinde bei der städtischen Leih- und Sparkasse zur Finanzierung des Schulbaus,

Dezember 1902 - Juli 1903

- Protest des C. G. Janssen gegen die die Einfriedung des

Schulgrundstücks an der Schoonhovenstraße durch eine Mauer zur

Straßenseite, Dezember 1903

- Einweihungsfeier für die neue reformierte Klassenschule an der Schoonhovenstraße, März - April 1904

- Abnahme des Schulneubaus, April 1904

1902 - 1904 (1906 / 1910)

Klassifikation Teil B: 03468

Trägermaterial: Papier

Alte Reg.-Sig.: IX B3a 29

Bestell-Nr.: IV 03468 
Lfd. Nr. Titel

3643 Verzicht des Schulverbandes der reformierten Gemeinde auf ein 1903 kirchliches Schulgebäude bei der Großen Kirche

- Verzicht des Schulverbandes der reformierten Gemeinde auf ein kirchliches Grundstück mit Schulgebäude bei der Großen Kirche und Nutzung durch die Reformierte Gemeinde als Eigentümerin

1903

Klassifikation Teil B: 03469

Trägermaterial: Papier

Alte Reg.-Sig.: IX B3a 30

Bestell-Nr.: IV 03469

3644 Verkauf von Grundbesitz der reformierten Gemeinde an der

Beuljenstraße und am Apfelmarkt

- Antrag des Schulvorstands der reformierten Gemeinde an die kgl.

Regierung auf Genehmigung des Verkaiufs von Grundstücksteilen am

Apfelmarkt und an der Beuljenstraße zur Finanzierung des

Schulneubaus an der Schonhovenstr., Januar - April 1904

- Antrag des Schulvorstands der reformierten Gemeinde an die kgl.

Regierung auf Genehmigung des Abschlusses des Kaufvertrages mit dem Rentier F. Peterssen über die Grundstücke, September 1905

$1904-1905$

Klassifikation Teil B: 03470

Trägermaterial: Papier

Alte Reg.-Sig.: IX B3a 31

Bestell-Nr.: IV 03470

3645 Rendant der reformierten Klassenschule

- Instruktionen zur Amtsführung des Rendanten der reformierten

Klassenschule

1868

Klassifikation Teil B: 03471

Trägermaterial: Papier

Alte Reg.-Sig.: IX B3a 32

Bestell-Nr.: IV 03471 
IV

10

\subsection{2}

10.02.02

\section{Schulaufsicht}

Volksschulen

Volksschule der französisch reformierten Gemeinde

Lfd. Nr. Titel

Laufzeit

3646 Besoldung des Lehrers an der Volksschule der $1867-1871$ französisch-reformierten Gemeinde

- Mitteilungen der französisch reformierten Gemeinde an das kgl. Konsostorium über Gehalt des Lerhrers an ihrer Volksschule als Beitrag zur Datensammlung wg. Verbesserung der Gehälter der Volksschullehrer, 1867 - 1868

- Anträge des Schulverbandes der französisch reformierten Gemeinde an die Kirchenkommission der französisch reformierten Gemeinde auf Beantragung einer Gehaltszulage für den Lehrer Samuel Günther Tapernon aus einem Fonds der kgl. Generalkasse, August 1868 August 1871

- Ausschreibung des preußischen Ministeriums der geistlichen, Unterrichts- und Medizianalangelegenheiten über Staatsbeihilfe zu den Gehältern von Volksschullehrern, November 1868

$1867-1871$

Klassifikation Teil B: 03319

Trägermaterial: Papier

Alte Reg.-Sig.: IX D II 01

Bestell-Nr.: IV 03319

- Antrag der Lehrerin Spangenberg an den Magistrat auf Gleichstellung der französischen Schule mit der Höheren Töchterschule, März 1871

- Verfügung des kgl. Konsistoriums über Bestätigung der Auffassung des Magistrats über Charakter der französischen Schule als Volksschule der französisch-reformierten Gemeinde, April 1871

- Tod des Samuel Günther Tapernon, Lehrer an der französisch-reformierten Volksschule, Februar 1872 - Verfügung des kgl. Konsistoriums über Anordnung zur Klärung des weiteren Bestehens der Volksschule der französisch-reformierten Gemeinde vor Neuwahl eines Lehrers, September 1872

$1871-1872$

Klassifikation Teil B: 03321

Trägermaterial: Papier Alte Reg.-Sig.: IX D II 03

Bestell-Nr.: IV 03321 
IV

10

10.02

10.02 .03
Schulaufsicht

Volksschulen

Volksschule der evangelisch lutherischen Gemeinde

Lfd. Nr. Titel

Laufzeit

3648 Schuldiener an der lutherischen Volksschule 1894

(1852-1855)

- Instruktiomnen für die lutherischen Schulrendanten, 1852

- Ernennung des B. A. Puls zum Rendanten der lutherischen

Volksschule, Juli 1854

- Erhöhung des Gerhalts für die Schulwärterin O. Puls an der lutherischen Volsschule, Mai 1894

$(1852-1854) 1894$

(Akte unvollständig)

Klassifikation Teil B: 03280

Trägermaterial: Papier

Alte Reg.-Sig.: IX Cl 13

Bestell-Nr.: IV 03280

3649 Inventar: Mittel der lutherischen Schule

1881

- Aufstellung über Vermögen und Einnahmen sowie Ausgaben der lutherischen Schule

1881

\author{
Klassifikation Teil B: 03317 \\ Trägermaterial: Papier \\ Alte Reg.-Sig.: IX CII 58 \\ Bestell-Nr.: IV 03317
}

3650 Schullasten der lutherischen Gemeinde

- Festlegung und Erhebung der unfreiwilligen Schulbeiträge für die lutherische Volksschule

$1872-1888$

Klassifikation Teil B: 03318

Trägermaterial: Papier

Alte Reg.-Sig.: IX CII 08

Bestell-Nr.: IV 03318

3651 Schulgeldsätze an der lutherischen Klassenschule

- Verfügung der kgl. Regierung in Aurich über Genehmigung der beantragten Schulgeldsätze für die lutherische Klassenschule, März April 1887

- Antrag des Schulvorstands der lutherischen Gemeinde beim

Bezirksausschuss in Aurich auf Erhaltung des bisherigen

Schulgeldsystems, Dezember 1903 - Februar 1904

- Antrag des Schulvorstands der lutherischen Gemeinde an den Magistrat über Bitte um Genehmigung einer Erhöhung der Schulgeldsätze, April 1905

$1887-1905$

Klassifikation Teil B: 03466

Trägermaterial: Papier

Alte Reg.-Sig.: IX 3b 17

Bestell-Nr.: IV 03466 
10.02

Volksschulen

10.02 .03

Volksschule der evangelisch lutherischen Gemeinde

Lfd. Nr. Titel

Laufzeit

3652 Lehrer an der lutherischen Klassenschule, Bd. 1

- Verfahren zur Wahl der Lehrer an der lutherischen Klassenschule, 1875 / 1886 / 1887 / 1889

- Bericht der Kirchenmkommission der lutherischen Gemeinde in Emden an die kgl. Konsistorium über antrag des Schulvorstands der lutherischen Gemeinde auf Verleihung des Rektortitels an den Lehrer Johann Hermann Rohden, April - Mai 1876

- Vertretung des erkrankten Lehrers Rohden, April 1879 - Januar 1880

- Anstellung eines Hilflehrers an der lutherischen Klassenschule, 1881

$-1882$

- Definitive Einstellung der Lehrerin Johanne Spangenberg nach

25jähriger Dienstzeit, Juli 1883

- Einstellung eines neuen Lehrers als Nachfolger des dauerhaft erkrankten Hauptlehrers Rohden, Mai 1885

- Pensionierung des Hauptlehrers Johann Hermann Rohden, Oktober 1885 - Mai 1886

- Wahl der Lehrer Behrends und Focken als 1. und 2. Lehrer der lutherischen Klassenschule, Juni 1886

- Pensionierung des Lehrers Dirk Janssen Eilts Gerjets, Mai - August 1887

- Pensionierung der Lehrerin Johanne Spangenberg, Juli 1887

- Einstellung der Lehrerin Elisabeth Kruse, Oktober 1887

- Wahl des Mittelschullehrers Friedrich Eilers zum Lehrer der Ersten Mädchenklasse der lutherischen Klassenschule, Januar 1888

- Antrag des Schulvorstands der lutherischen Gemeinde an die Kirchenkommission der lutherischen Gemeinde über Bitte um Bewirkung der ernennung des Hauptlehrers Fokken zum Rektor der lutherischen Klassenschule, März 1888

- Wahl des Lehrers Harm de Vries, November / Dezember 1889

$1875-1889$

Klassifikation Teil B: 03472

Band: 1

Trägermaterial: Papier

Alte Reg.-Sig.: IX B3b 04

Bestell-Nr.: IV 03472 
10.02

Lfd. Nr. Titel

Laufzeit

3653 Lehrer an der lutherischen Klassenschule, Bd. 2

- Gewährung einer Teuerungszulage an den Lehrer Grieshammer, November 1881

- Antrag des Schulvorstands der lutherischen Gemeinde an den Magistrat über Bitte um Vermittlung einer Staatsbeihilfe zur Finanzierung der den Lehrern der lutherischen Klassenschule gewährten Teuerungszulagen, Januar - Februar 1892

- Verfahren zur Wahl der Lehrer an der lutherischen Klassenschule, 1894 / 1907

- Wahl des Johann Peter Lorenz, Lehrer an der Rettungsanstalt Großefehn, zum Lehrer der lutherischen Klassenschule, März 1894 - Pensionierung des Lehrers Eilert Geerdes, September 1894 - Errichtung einer weiteren Lehrerstelle im Zuge der durch die Zunahme der Schülerzahlen notwendigwerdenden Vergrößerung der lutherischen Klassenschule, November - Dezember 1895 / Januar 1901 / Januar 1904 / Januar 1905 / März 1906

- Wahl des Gerhard Hermann Lübben zum Lehrer der lutherischen Klassenschule, März 1896

- Wahl des Lehrers Heinrich Wessel Rickleffs aus Großefehn zum Lehrer der lutherischen Klassenschule, Dezember 1897

- Wahl des Lehrers Berent Janssen Hinrichs aus Loga zum Lehrer der lutherischen Klassenschule, März 1901

- Pensionierung des Lehrers Friedrich Eilers, August 1907

- Wahl des Lehrers Johann Hinrichs aus Ludwigsdorf zum Lehrer der lutherischen Klassenschule, Oktober - November 1907

- Errichtung von vier Lehrerinnenstellen an der lutherischen Klassenschule, Oktober - November 1907

$1891-1907$

Klassifikation Teil B: 03473

Band: 2

Trägermaterial: Papier

Alte Reg.-Sig.: IX B3b 04

Bestell-Nr.: IV 03473

3654 Veränderungsanzeigen zum Schulinventar der lutherischen

$1866-1879$ Klassenschule

- Anzeigen über Änderung der Vermögensverhältnisse, der Verbindlichkeiten, der Schuleinrichtung und der Lehrergehälter an der lutherischen Klassenschule

$1866-1879$

Klassifikation Teil B: 03474

Trägermaterial: Papier Alte Reg.-Sig.: IX B3b 10

Bestell-Nr.: IV 03474 
10.02

Volksschulen

10.02 .03

Volksschule der evangelisch lutherischen Gemeinde

Lfd. Nr. Titel

Laufzeit

3655 Abnahme der Schulkassenrechnung der lutherischen Klassenschule

- Monita des kgl. Konsistoriums zur Rechnungsführung

- Monita der städtischen Kämmerei zur Rechnungsführung

- Entlastung des Rechnungsführers der lutherischen Schulkasse

durch das kgl. Konsistorium

$1867-1908$

\author{
Klassifikation Teil B: 03475 \\ Trägermaterial: Papier \\ Alte Reg.-Sig.: IX B3b 11 \\ Bestell-Nr.: IV 03475
}

3656 Etat der lutherischen Klassenschule

- Genehmigung der vom Schulvorstand der lutherischen Gemeinde vorgelegten Etats der lutherischen Klassenschule durch die

Kirchenkommission der lutherischen Gemeinde

- Etats der lutherischen Klassenschule

$1868-1898$

Klassifikation Teil B: 03476

Trägermaterial: Papier

Alte Reg.-Sig.: IX B3b 12

Bestell-Nr.: IV 03476

3657 Aufsicht über die lutherische Klassenschule

- Verfügung des kgl. Konsistoriums in Aurich über Verteilung der Armenschüler auf die konfessionellen Klassenschulen, Dezember 1871 - Januar 1872

- Organisation der Schulaufsicht, 1879 - 1880

- Verfügungen des kgl. Konsistoriums / kgl. Regierung zur

Schulorganisation, 1880 - 1888

$1871-1888$

Klassifikation Teil B: 03477

Trägermaterial: Papier

Alte Reg.-Sig.: IX B3b 13

Bestell-Nr.: IV 03477

3658 Turnunterricht an der lutherischen Klassenschule

- Einführung des Turnunterrichts als Pflichtfach an der lutherischen Klassenschule

$1869-1870$

Klassifikation Teil B: 03478

Trägermaterial: Papier

Alte Reg.-Sig.: IX B3b 14

Bestell-Nr.: IV 03478 
IV

10

10.02

10.02 .03
Schulaufsicht

Volksschulen

Volksschule der evangelisch lutherischen Gemeinde

Lfd. Nr. Titel

Laufzeit

3659 Bauunterhaltung der lutherischen Klassenschule

- Revision der Schulgebäudes der lutherischen Klassenschule durch das kgl. Konsistorium, 1880

- Verfügung des kgl. Konsistoriums über Bestätigung der

Eigentumsrechte der lutherischen KIrchengemeinde an Gebäude und Grundstück der lutherischen Klassenschule, Januar 1882

- Novelle der Vereinbarung zwischen dem lutherischen Schulvorstand und der lutherischen Kirchengemeinde über Eigentum und

Nutzungsrechte an Schulgrundstück- und Gebäude, März 1882 / April 1889

- Neubau des zweiklassigen Schulgebäudes der lutherischen

Klassenschule, 1885 - 1887

- Finanzierung des Baus durch ein Darlehen der Klosterkammer Hannover, November 1885 - Mai 1886

- Erweiterung des Schulgeländes durch Ankauf des Seckerschen

Grundstücks, Januar - Dezember 1889

- Befreiung des lutherischen Schulverbands von der Gebäudesteuer, August 1890

$1880-1890$

Klassifikation Teil B: 03479

Trägermaterial: Papier

Alte Reg.-Sig.: IX B3b 15

Bestell-Nr.: IV 03479

3660 Geschäftsberichte der lutherischen Klassenschule

- Verlängerung der Schulpflicht für bei der Abschlussprüfung durchgefallene Schüler der lutherischen Klassenschule, Juni 1874

- Statistische Geschäftsberichte der lutherischen Klassenschule, 1873

- 1880

- Änderung der Bezeichnung "lutherische Schulgemeinde" in

"lutherischer Schulverband", April / Mai 1882

- Änderung der Lehrerwahlordnung und Umorganisation

Lehrerstellenplans mit Angebot eines höheren Gehalts zur Gewinnung qualifizierter Lehrer, April / Mai 1882

- Beförderung des Klassenlehrers Focken zum Hauptlehrer, Januar 1887

$1873-1887$

Klassifikation Teil B: 03480

Trägermaterial: Papier

Alte Reg.-Sig.: IX B3b 16

Bestell-Nr.: IV 03480 
10.02

Lfd. Nr. Titel

Laufzeit

3661 Option der Französisch-Reformierten und der Mennoniten zum $1881-1883$ lutherischen Schulverband

- Erlass des Ministers der Geistlichen, Unterrichts- und Medizinalangelegenheiten über Wahlmöglichkeit der Mennoniten für eine konfessionelle Volksschule für ihre Schulkinder, August 1881 - Verfügung des kgl. Konsistoriums in Aurich über für den lutherischen Schulverband optierende Mennonitenfamilien (darunter Fam. Brons) und französisch-reformierte Familien, Januar 1882

- Verfügung des kgl. Konsistoriums in Aurich über für den lutherischen Schulverband optierende Familie des Schiffskapitäns B. J. Swart, Januar 1883

$1881-1883$

Klassifikation Teil B: 03481

Trägermaterial: Papier

Alte Reg.-Sig.: IX B3b 19

Bestell-Nr.: IV 03481

3662 Schulvorstand der lutherischen Klassenschule

- Regelung der Mitgliedschaft von Lehrern im Vorstand der lutherischen Klassenschule

1889

Klassifikation Teil B: 03482

Trägermaterial: Papier

Alte Reg.-Sig.: IX B3b 20

Bestell-Nr.: IV 03482

3663 Widersprüche gegen die Veranlagung zu den Schullasten der lutherischen Klassenschule

- Beschwerden gegen die Veranlagung zu den Schullasten der lutherischen Klassenschule wegen Zahlungsunfähigkeit und Bestreitung der Zugehörigkeit zum lutherischen Schulverbands etc.

$1868-1896$

Klassifikation Teil B: 03483

Trägermaterial: Papier

Alte Reg.-Sig.: IX B3b 18

Bestell-Nr.: IV 03483

- Neuregelung der Gehaltsklassen der Lehrer an der lutherischen Klassenschule, Februar 1893 - Januar 1894

- Gehaltsfestlegung für die neunte Lehrerstelle der lutherischen Klassenschule, April 1896

$1893-1896$

Klassifikation Teil B: 03484

Trägermaterial: Papier

Alte Reg.-Sig.: IX B3b 20

Bestell-Nr.: IV 03484 
Lfd. Nr. Titel

Laufzeit

3665 Schulordnung und Verfassung der lutherischen Klassenschule

- Berücksichtigung der Mennoniten im lutherischen Schulverband bei der Besetzung des Schulvorstands, August - November 1881

- Novellierung der Schulordnung der lutherischen Klassenschule,

Februar - Mai 1887

- Entwurf einer neuen Schulordnung, April 1887

- Entwurf einer Verfassung des lutherischen Schulverbands,

Dezember 1881 / April - Mai 1890

- Dienstanweisung für die Lehrer der lutherischen Klassenschule, April 1890

$1887-1890$

Klassifikation Teil B: 03486

Trägermaterial: Papier

Alte Reg.-Sig.: IX B3b 21

Bestell-Nr.: IV 03486

3666 Neubau der lutherischen Klassenschule mit Turnhalle

- Bericht des Schulvorstands der lutherischen Gemeinde an die Regierung in Aurich über Beschreibung des geplanten Neubaus der lutherischen Klassenschule, Juni 1900

- Genehmigungsverfahren für den Neubau bei der kgl. Regierung, September 1900 - Januar 1901

- Baugenehmigungsverfahren bei der Stadt Emden, Dezember 1900 Mai 1901

- Finanzierung des Schulneubaus durch eine Anleihe des lutherischen Schulverbands bei der städtischen Spar- und Leihkasse, Oktober 1901 - April 1902

- Eingabe des Schulvorstands der lutherischen Gemeinde an den Magistrat über Bitte um Vermittlung einer Staatsbeihilfe für den Schulneubau, November 1901

- Ablehnung einer Staatsbeihilfe durch das Ministerium der

Geistlichen, Unterrichts- und Medizinalangelegenheiten, Januar 1902

- Einweihungsfeier für den Schulneubau, Juli - August 1902

- Ankauf eines Grundstückes durch den lutherischen Schulverband zum Bau einer Turnhalle bei der neuen lutherischen Klassenschule (Neutorschule), Januar 1906 - Februar 1909

- Finanzierung und Bau der Turnhalle der lutherischen Klassenschule, April - Oktober 1907

$1900-1909$

Klassifikation Teil B: 03487

Trägermaterial: Papier

Alte Reg.-Sig.: IX B3b 22

Bestell-Nr.: IV 03487 
10

\subsection{2}

10.02.03

\section{Schulaufsicht}

Volksschulen

Volksschule der evangelisch lutherischen Gemeinde

Lfd. Nr. Titel

3667 Verzicht des lutherischen Schulverbands auf Rechte am ehemaligen Grundstück der lutherischen Klassenschule

- Verzicht des lutherischen Schulverbands auf Rechte am ehemaligen Grundstück der lutherischen Klassenschule zugunsten der lutherischen Gemeinde nach Errichtung des neuen Schulgebäudes an der Wilhelmsstraße

1903

Klassifikation Teil B: 03488

Trägermaterial: Papier

Alte Reg.-Sig.: IX B3b 23

Bestell-Nr.: IV 03488

3668 Diensteinkommen der Lehrer an der lutherischen Klassenschule

- Erhöhung der Diensteinkommen der Lehrer an der lutherischen Klassenschule, (1859 - 1864) 1867 - 1881

- Umwandlung einer Hilfslehrerstelle in eine ordentlichen Stelle unter Anpassung des Gehalts, Juni 1875

- Erhöhung der Diensteinkommen der Lehrer an der Vorschule des lutherischen Klassenschule, März 1883

- Gewährung einer Bedürfniszulage von 150 Mark / Jahr an den Klassenlehrer Fokken, Dezember 1884

- Gewährung einer Bedürfniszulage von 150 Mark / Jahr an den Klassenlehrer Rohden, März 1885

(1859 - 1864) $1867-1885$

Klassifikation Teil B: 03489

Trägermaterial: Papier

Alte Reg.-Sig.: IX B3b 26

Bestell-Nr.: IV 03489 
IV

10

10.02

10.02 .04
Schulaufsicht

Volksschulen

Volksschulen in den Emder Herrlichkeiten

Lfd. Nr. Titel

Laufzeit

3669 Lehrerstelle an der Schule in Wolthusen

1889

- Bewerbungen verschiedener Lehrer um die Stelle an der Schule

Wolthusen, Oktober - November 1889

- Bericht des Vorsitzenden des reformierten Kirche und des

Schulverbands in Wolthusen an den Magistrat als Patron der Kirchen-

und Schulgemeinde über Wahl des Lehrers Meyer aus Jarssum zum

Lehrer, Organist und Küster der Kirche in Wolthusen, Oktober 1889

1889

Klassifikation Teil B: 03490

Trägermaterial: Papier

Alte Reg.-Sig.: IX B3c 01

Bestell-Nr.: IV 03490

3670 Schule in Borssum

- Antrag des Magistrats an die Regierung in Aurich auf Beihilfe zum Betrieb der Schule in Borssum nach der Eingemeindung des Fleckens Borssum, Februar 1915

-. Etat der Volksschule in Borssum , 1915

1915
Klassifikation Teil B: 03491
Trägermaterial: Papier
Alte Reg.-Sig.: IX B3c 02
Bestell-Nr.: IV 03491

3671 Schule in Borssum

1908-1909

- Bau einer zweiklassigen Volksschule in Borssum

$1908-1909$

Klassifikation Teil B: 03492

Trägermaterial: Papier

Alte Reg.-Sig.: IX B3c 02

Bestell-Nr.: IV 03492

3672 Lehrerstelle an der Schule in Oldersum

1888-1889

- Bewerbungen verschiedener Lehrer um die Stelle an der Schule

Oldersum, Dezember 1888 - März 1889

- Bericht des Vorsitzenden des reformierten Kirche und des

Schulverbands in Oldersum an den Magistrat als Patron der Kirchenund Schulgemeinde über Lehrerwahl, März 1889

$1888-1889$

Klassifikation Teil B: 03493

Trägermaterial: Papier

Alte Reg.-Sig.: IX B3c 03

Bestell-Nr.: IV 03493 
10

10.02

10.02.04
Schulaufsicht

Volksschulen

Volksschulen in den Emder Herrlichkeiten

Lfd. Nr. Titel

Laufzeit

3673 Schule und Lehrer in Oldersum 1889

- Versetzung des Lehrers, Küsters und Organisten Oostermann in den Ruhestand: Festlegung und Finanzierung der Pension, September November 1889

- Finanzierung der Lehrer- Küster und Organistenstelle in Oldersum, Oktober 1889

- Ausschreibung der Lehrer- Küster- und Organistenstelle in Oldersum, Oktober 1889

- Bewerbung des Lehrers Geerd W. Meyer um die Lehrer- Küster und Organistenstelle in Oldersum, Oktober 1889

1889

Klassifikation Teil B: 03495

Trägermaterial: Papier

Alte Reg.-Sig.: IX B3c 07

Bestell-Nr.: IV 03495 
IV

10

10.02

10.02 .05
Schulaufsicht

Volksschulen

Städtische Volksschule

Lfd. Nr. Titel

Laufzeit

1873-1891

3674 Protokollbuch der städtischen Volksschule

- Satzung der Schulkommission der städtischen Volksschule, August 1873

- Protokolle der Sitzungen der Schulkommission der städtischen Volksschule über Lehrerpersonalia, Unterrichtsorganisation,

Etatfragen

$1873-1891$

Klassifikation Teil B: 03352

Trägermaterial: Papier

Alte Reg.-Sig.: IX BI 05

Bestell-Nr.: IV 03352

3675 Umwandlung der Diakonieschule in eine städtische Volksschule

- Bericht der Commission für Vorprüfung der Frage der Aufhebung der Diakonieschule über geplante Auflösung der Diakonieschule als Armenschule und Plädoyer für die Verteilung der Schüler auf die vorhandenen Konfessionsschulen, Mai 1873

- Verhandlungen der städtischen Kollegien über Auflösung der Diakonieschule, Juni - September 1873

- Gründung der städtischen Volksschule durch Auflösung der

Diakonieschule, September - Dezember 1873

- Entwurf eines Regulativs für die städtische Volksschule, November

1873 - Juni 1874

$1873-1874$

Klassifikation Teil B: 03494

Trägermaterial: Papier

Alte Reg.-Sig.: IX B3e 04

Bestell-Nr.: IV 03494

3676 Lehrerpersonalakte: Friedrich Bender

$1902-1903$

- Einstellung als Lehrer an der städtischen Volksschule

$1902-1903$

Klassifikation Teil B: 03496

Trägermaterial: Papier

Alte Reg.-Sig.: IX 3B3e 07

Bestell-Nr.: IV 03496

3677 Lehrerpersonalakte: Martha Klingemann

1901-1906

- Einstellung als Lehrerin an der städtischen Volksschule

$1901-1906$

Klassifikation Teil B: 03497

Trägermaterial: Papier

Alte Reg.-Sig.: IX 3B3e 07

Bestell-Nr.: IV 03497 
IV

10

\subsection{2}

10.02 .05
Schulaufsicht

Volksschulen

Städtische Volksschule

Lfd. Nr. Titel

Laufzeit

1886-1918

(1920)

- Einstellung als Lehrer an der städtischen Volksschule

- Versetzung in den Ruhestand wegen Krankheit, 1920

$1886-1918(1920)$

Klassifikation Teil B: 03498

Trägermaterial: Papier

Alte Reg.-Sig.: IX 3B3e 07

Bestell-Nr.: IV 03498

3679 Lehrerpersonalakte: Rektor Focke Janssen Müller

$1871-1917$

(1921)

- Einstellung als Lehrer an der städtischen Volksschule, 1871 - 1894

- Eingabe des Lehrers F. J. Müller an die Schulkommission über Bitte um dauerhafte Betrauung mit der Leitung der städtischen

Volksschule, November 1895

- Ernennung des F.J. Müller zum dirigierenden Lehrer mit der

Verpflichtung zur Ablegung der Rektoratsprüfung, Januar 1896

- Erfolgreiche Absolvierung der Ersten Rektoratsprüfung, Juli 1898

- Erfolgreiche Absolvierung der zweiten Rektoratsprüfung, Juni 1899

- Bestallung des dirigierenden Lehrers F. J. Müller als Rektor der

städtischen Volksschule, Juli - August 1899

- Versetzung in den Ruhestand, 1917

- Nachruf, 1921

$1871-1917(1921)$

Klassifikation Teil B: 03499

Trägermaterial: Papier

Alte Reg.-Sig.: IX 3B3e 07

Bestell-Nr.: IV 03499

3680 Lehrerpersonalakte: Gerhardine Remmerssen

$1906-1911$

- Einstellung der Gerhardine Remmerssen als Lehrerin an der städtischen Volksschule

$1906-1911$

Klassifikation Teil B: 03500

Trägermaterial: Papier

Alte Reg.-Sig.: IX 3B3e 07

Bestell-Nr.: IV 03500

3681 Lehrerpersonalakte: Wilhelm Vogelpohl

$1905-1907$

- Einstellung des Wilhelm Vogelpohl als Lehrer an der städtischen Volksschule

$1906-1911$

Klassifikation Teil B: 03501

Trägermaterial: Papier

Alte Reg.-Sig.: IX 3B3e 07

Bestell-Nr.: IV 03501 
IV

10

\subsection{2}

10.02.05
Schulaufsicht

Volksschulen

Städtische Volksschule

Lfd. Nr. Titel

Laufzeit

3682 Personalakte: Schulwärterin Witwe L. Wurtzema

- Gesuch der Schulwärterin Wwe. L. Wurtzema an die Kommission der städtischen Volksschule über Bitte um Gehaltserhöhung, November 1879 - März 1880

$1879-1880$

$<$ Akte unvollständig>

Klassifikation Teil B: 03502

Trägermaterial: Papier

Alte Reg.-Sig.: IX 3B3e 07

Bestell-Nr.: IV 03502

3683 Handarbeitslehrerinnen an der städtischen Volksschule

- Geschenk über 25 Mark an die Stricklehrerin Elise Meyer zum 25 jährigen Dienstjubiläum, März 1886

- Pensionierung der Stricklehrerin Elise Meyer und Festlegung des

Ruhestandsgehalts, Januar - Februar 1886

- Gesuch der Stricklehrerin J. Thyssen an den Magistrat über Bitte um

Gewährung einer Pension, Dezember 1886 - März 1887

- Bewerbungen um eine Einstellung als Handarbeitslehrerin, 1904 1905

$1886-1905$

Klassifikation Teil B: 03503

Trägermaterial: Papier

Alte Reg.-Sig.: IX 3B3e 07

Bestell-Nr.: IV 03503

3684 Lehrer an der städtischen Volksschule

- Ersetzung des nach Wirdumer Neuland wechselnden Lehrers

Bender durch den Lehrer Wirtjes, 1905

- Verschiedene Gesuche von Lehrern um Unterstützung, 1926 / 1936

1905 (1926 / 1936)

Klassifikation Teil B: 03504

Trägermaterial: Papier

Alte Reg.-Sig.: IX B3e 07

Bestell-Nr.: IV 03504 
IV

10

10.02

10.02 .05
Schulaufsicht

Volksschulen

Städtische Volksschule

Lfd. Nr. Titel

Laufzeit

3685 Verschiedene Lehrerpersonalakten der städtischen Volksschule 1885-1902

- Lehrer Meinhard Dreyer, 1888 - 1902

- Lehrer L. Busemann, 1892

- Lehrer Wessel Klüver, 1886

- Pensionierung des Lehrers Johann Hermann Bruhns wegen

Geisteskrankheit, Februar 1885 - März 1886

- Delegierung der Lehrerin Anna Mordhorst zur städtischen

Volksschule,1902

$1885-1902$

Klassifikation Teil B: 03505

Trägermaterial: Papier

Alte Reg.-Sig.: IX 3B3e 07

Bestell-Nr.: IV 03505

3686 Schulkommission der städtischen Volksschule

1896-1906

- Protokolle der Sitzungen der Schulkommission der städtischen Volksschule über Organisation des Schulbetriebs, Bauunterhaltung, Bau einer Turnhalle, Einrichtung eines Brausebades, Besetzung von Lehrerstellen

$1896-1906$

$<$ Akte unvollständig >

Klassifikation Teil B: 03505

Trägermaterial: Papier

Alte Reg.-Sig.: IX 3B3e 09

Bestell-Nr.: IV 03507

3687 Städtische Volksschule Emden

$1902-1904$

- Mietentschädigung für Lehrer der städtischen Volksschule, 1902 /

1904

- Bewerbungen um eine vakante Lehrerstelle der städtischen

Volksschule, Februar - März 1902

- Etat der städtischen Volksschule, 1902 - 1904

- Anschaffung von 100 Paar Turnschuhen für den Turnunterricht in der städtischen Volksschule, Oktober 1903

$1902-1904$

Klassifikation Teil B: 03506

Trägermaterial: Papier

Alte Reg.-Sig.: IX 3B3e 09

Bestell-Nr.: IV 03506 
IV

10

\subsection{2}

10.02.05
Schulaufsicht

Volksschulen

Städtische Volksschule

Lfd. Nr. Titel

Laufzeit

3688 Rendantur der städtischen Volksschule

- Bestellung des Altschiffers Harm Kievitt zum Rendanten der städtischen Volksschule, August 1874

- Organisation der Rendantur: Hebung des Schulgeldes und Kontrolle der Listen, 1879 - 1880

- Bericht des Kämmerers an den Magistrat über geringe Einnahmen an Schulgeld für die städtische Volksschule durch den Heber $\mathrm{H}$.

Kieviet und Empfehlung zur Umwandlung der städtischen Volksschule in eine allgemeine, schulgeldfreie Anstalt, Juli 1881

$1874-1881$

Klassifikation Teil B: 03508

Trägermaterial: Papier

Alte Reg.-Sig.: IX B3e 10

Bestell-Nr.: IV 03508

3689 Zustand der Räume der städtischen Volksschule

- Einbau eines "russischen" Schornsteins in der städtischen Volksschule, 1880

- Verfügung des kgl. Konsistoriums über Anordnung der Prüfung der gesundheitlichen Verhältnisse im Gebäude der städtischen Volksschule durch den Kreisphysicus Dr. Stöhr und den Baurat Schramme, Juli 1880

- Diskussion der Verwendung von Räumen der Gerwerbeschule für eine Klasse der städtischen Volksschule, Oktober 1880

- Gutachten des Kreisphysicus Dr. Stöhr und des Baurats Schramm über baulichen Zustand des städtischen Volksschulgebäudes, September 1880

1880

Klassifikation Teil B: 03509

Trägermaterial: Papier

Alte Reg.-Sig.: IX 3B3 e

Bestell-Nr.: IV 03509 
IV

10

10.02

10.02 .05
Schulaufsicht

Volksschulen

Städtische Volksschule

Lfd. Nr. Titel

Laufzeit

3690 Lehrmittel für die städtische Volksschule

- Ablösung des bisher genützten Lehrbuches von Quietmeyer, Februar

- März 1875

- Anschaffung von Bibeln und Lehrbücher für die Oberklasse,

November 1875

- Einführung des Lehrbuches von W. u. K. Dietlein, Januar 1876

- Verfügung des Magistrats über Bewilligung eines Betragesvon 900

Mark zur Anschaffung von Lehrbücher durch die städtische

Volksschule, März 1876

- Ablösung des Lehrbuches von W. und K. Dietlein durch ein vom

Lehrerverein Hannover herausgebenes "Lehrbuch für Bürgerschulen", April 1881

- Erlass des Ministers der Geistlichen, Unterrichts- und

Medizinalangelegenheiten über Einführung von Tafeln für den

Kunstunterricht zur verbindlichen Anschaffung, Oktober 1890

$1875-1890$

Klassifikation Teil B: 03510

Trägermaterial: Papier

Alte Reg.-Sig.: IX 3B3 e 13

Bestell-Nr.: IV 03510

3691 Schenkung einer Orgel an die städtische Volksschule

1891

- Schenkung einer Orgel an die städtische Volksschule durch die Mennoniten-Gemeinde

1891

Klassifikation Teil B: 03511

Trägermaterial: Papier

Alte Reg.-Sig.: IX B3B e 17

Bestell-Nr.: IV 03511

3692 Heizung der städtischen Volksschule

$1898-1903$

- Anschaffung einer Dampfzentralheizung der Fa. Gebrüder Körting durch die Städtische Volksschule

$1898-1903$

Klassifikation Teil B: 03512

Trägermaterial: Papier

Alte Reg.-Sig.: IX 3B3 e 18

Bestell-Nr.: IV 03512

3693 Aufbau neuer Klassen in der städtischen Volksschule

- Ausbau des Schulbodens zur Unterbringung einer weiteren Klasse und Errichtung einer Turnhalle bei der städtischen Volksschule

$1899-1900$

Klassifikation Teil B: 03513

Trägermaterial: Papier

Alte Reg.-Sig.: IX B3B 19

Bestell-Nr.: IV 03513 
IV

10

\subsection{2}

10.02.05
Schulaufsicht

Volksschulen

Städtische Volksschule

Lfd. Nr. Titel

Laufzeit

3694 Errichtung einer Turnhalle für die städtische Volksschule 1900-1906

- Planung und Errichtung der Turnhalle für die städtische Volksschule - Antrag der Israelitischen Gemeinde an die Schulkommission der städtischen Volksschule auf kostenlose Mitbenutzung der Turnhalle der städtischen Volksschule durch die jüdische Volksschule,

Dezember 1903

- Anschaffung eines Heizofens für die Turnhalle, 1906

$1899-1906$

Klassifikation Teil B: 03514

Trägermaterial: Papier

Alte Reg.-Sig.: IX B3B e 23

Bestell-Nr.: IV 03514

3695 Bildung eines Bezirksvorstands der Lehrerwitwen- und Waisenkasse für das Stadtgebiet Emden

- Bestellung der Mitglieder des Bezirksvorstands der Lehrerwitwenund Waisenkasse für das Stadtgebiet Emden

$1875-1898$

Klassifikation Teil B: 03515

Trägermaterial: Papier

Alte Reg.-Sig.: IX B3B e 24

Bestell-Nr.: IV 03515

3696 Register der Lehrerwitwen- und Waisenkasse für das Stadtgebiet Emden

- Aufnahme untersützungsberechtigter Lehrerwitwen in das Register - Verzeichnung von Abgängen aus dem Register durch Wegzug oder Tod unterstützungsberechtigter Lehrerwitwen

1894

Klassifikation Teil B: 03516

Trägermaterial: Papier

Alte Reg.-Sig.: IX 3B3 e 24

Bestell-Nr.: IV 03516 
10.02

Volksschulen

10.02 .05

Städtische Volksschule

Lfd. Nr. Titel

Laufzeit

3697 Anlegung eines Registers (Grundbuch) der von der Lehrerwitwen- und $1873-1880$ Waisenkasse für das Stadtgebiet Emden unterstützten Lehrerinnen

- Verfügung des kgl. Konsistoriums über Kriterien für die Gestaltung des Registers, Oktober 1873

- Verfügung des kgl. Konsistoriums über Bescheinigung der Daten der Lehrer vor Eintragung in das Register, November 1873

- Monita des kgl. Konsistoriums zu den Eintragungen in das Register, Januar 1874

- Klärung der Mitgliedschaft der Lehrer der Gasthausschule in der Lehrerwitwen- und Waisenkasse für das Stadtgebiet Emden, 1874

- Aufstellung über bei der Lehrerwitwen- und Waisenkasse für das Stadtgebiet Emden versicherten Lehrer, 1876

- Registerauszug (Grundbuchauszug) zum bei der Lehrerwitwen- und Waisenkasse für das Stadtgebiet Emden versicherten Lehrer Isaac Terveer, 1876

- Erlass des Provinzial-Schulkollegiums über Regelung der Aufsicht über die Wahl der Vorstände der Bezirks-Lehrerwitwen- und Waisenkasse, Juli 1876

- Auflösung der Grundbücher der Lehrerwitwen- und Waisenkasse für das Stadtgebiet Emden, 1880

$1873-1880$

Klassifikation Teil B: 03517

Trägermaterial: Papier

Alte Reg.-Sig.: IX 3B3 e 24

Bestell-Nr.: IV 03517

3698 Register der Lehrerwitwen- und Waisenkasse für das Stadtgebiet Emden

- Register (Grundbuch) mit den Versicherten der Lehrerwitwen- und Waisenkasse für das Stadtgebiet Emden

$1878-1895$

Klassifikation Teil B: 03518

Trägermaterial: Papier

Alte Reg.-Sig.: IX 3B3 e 24

Bestell-Nr.: IV 03518

3699 Kassenrechnung der städtischen Volksschule

- Belege über Ausgaben und Einnahmen der Kasse der städtischen Volksschule

$1877-1878$

Klassifikation Teil B: 03621

Trägermaterial: Papier

Alte Reg.-Sig.: IX B6 05

Bestell-Nr.: IV 03621 
IV

10

10.02

10.02 .05
Schulaufsicht

Volksschulen

Städtische Volksschule

Lfd. Nr. Titel

Laufzeit

3700 Städtische Volksschule

- Einstellung neuer Lehrer, 1876 - 1877

- Gestaltung des Lehrplans und Festlegung der Unterrichtszeiten, 1876 - 1877

- Organisation der Rechnungslegung bei der städtischen Volksschule, 1876

- Ausbau des Handarbeitsunterrichts, August 1876

- Bauliche Unterhaltung der städtischen Volksschule, 1876

- Denkschrift des Rektors Gerhardt über die Situation der städtischen Volksschule hinsichtlich Schule und ihre Defizite, Organisation des Unterrichts und Perspektive der städtischen Volksschule, 1876 - 1878

- Etat der städtischen Volksschule, 1876 - 1878

- Zuschüsse für die städtische Volksschule aus der Stadtkasse zu Augleich des Defizits, 1877

- Schulfeier zum Kaisergeburtstag, 1877

- Instruktionen für den Dirigenten der städtischen Volksschule, 1877

- Prüfungsordnung der städtischen Volksschule, März 1877

- Wahl eines Rektors der städtischen Volksschule, Juni 1877

- Aufstellung über Schulversäumnisse, November 1877 / Februar 1878

- Errichtung einer Schulsparkasse, Januar - Juni 1878

- Aufbau einer Turnhalle an der städtischen Volksschule, April 1878

- Veranlassung der Einweisung der kranken Schülerin Johanna Nathen in das Krankenhaus wegen gesundheitsschädlicher

Wohnbedingungen bei den Eltern, Oktober - November 1878

- Darreichung von Mittagessen für bedürftige Schulkinder durch den Kornvorrat, Dezember 1878

$1876-1878$

Klassifikation Teil B: 03628

Trägermaterial: Papier

Alte Reg.-Sig.: IX B6 19

Bestell-Nr.: IV 03628

3701 Schulkommission der städtischen Volksschule

- Sitzungen der Schulkommission der städtischen Volksschule über Organisation des Schulbetriebs, Etatfragen und Lehrerpersonalsachen

$1891-1901$

Klassifikation Teil B: 03630

Trägermaterial: Papier

Alte Reg.-Sig.: IX B6 21

Bestell-Nr.: IV 03630 
IV

10

\subsection{2}

10.02 .06

Schulaufsicht

Lfd. Nr. Titel

Volksschulen

Katholische Volksschule

3702 Dritte Lehrerstelle an der katholischen Volksschule

Laufzeit

1902

- Antrag des Vorstandes der Katholischen Volksschule beim Magistrat auf Vermittlung einer Beihilfe aus Staatsmitteln zur Einstellung einer dritten Lehrkraft

1902

\author{
Klassifikation Teil B: 02748 \\ Trägermaterial: Papier \\ Alte Reg.-Sig.: X A3 19 \\ Bestell-Nr.: IV 02748
}

3703 Katholische Volksschule

$1875-1888$

- Antrag des G. Jedden und des Zimmermeisters D. Brian an den Magistrat auf Befreiung von der Schulgeldpflicht gegenüber der katholischen Gemeinde wegen Besuchs der lutherischen Schule durch ihre Kinder trotz katholischer Konfessionszugehörigkeit, Februar 1875 / Juli - September 1878

- Liste der Schulgeldrestanden der katholischen Volksschule, 1875

- Beihilfe aus der Stadtkasse für die katholische Volksschule, 1876

- Verfügung des katholischen Konsistoriums in Osnabrück über Anordnung der strengen Kontrolle des Schulbesuchs katholischer Schulkinder, Oktober 1891

- Einrichtung einer weiteren Schulklasse in der katholischen Volksshule in Emden, Dezember 1887 - Januar 1888

- Anträge auf Befreiung von der Schulgeldpflicht gegenüber der katholischen Gemeinde, 1887 - 1888

$1875-1888$

Klassifikation Teil B: 03337

Trägermaterial: Papier

Alte Reg.-Sig.: IX A3 13

Bestell-Nr.: IV 03337 
IV

10

10.02

10.02 .06
Schulaufsicht

Volksschulen

Katholische Volksschule

Lfd. Nr. Titel

Laufzeit

3704 Aufsicht über die katholische Volksschule

- Verfügung des kgl. katholischen Konsistoriums in Osnabrück über die Ernennung des Dechanten Meyer in Leer zum Lokalschulinspektor über die katholische Volksschule in Emden, Dezember 1879 - Verfügung des kgl. katholischen Konsistoriums in Osnabrück über die Ernennung des Vikars Menge zum Lokalschulinspektor über die katholische Volksschule in Emden, Mai 1880

Verfügung des kgl. katholischen Konsistoriums in Osnabrück an den Magistrat über Verpflichtungen der katholischen Schulvorsteher, Dezember 1878

- Verfügung des kgl. katholischen Konsistoriums in Osnabrück an den Magistrat über Einführung des Kaufmanns Henrich Bockwinkel und des Bankdirektors Hölzenbein als Vorstandsmitglieder der katholischen Schule, Januar 1882

- Anfrage des preußischen Landdrosten an den Magistrat wegen Vertraulichkeit des katholischen Geistlichen Ladorff bei der Beaufsichtigung der katholischen Volksschule, Oktober 1884 - Verfügungen des kgl. katholischen Konsistoriums in Osnabrück Bildung und Bestätigung der Vorstände der katholischen Volksschule in Emden, 1884 - 1890

$1878-1890$

Klassifikation Teil B: 03340

Trägermaterial: Papier

Alte Reg.-Sig.: IX A3 25

Bestell-Nr.: IV 03340

3705 Abnahme der Rechnungen der katholischen Schulkasse

- Revision der katholischen Schulkasse und Monita des Regierungspräsidenten zu den Berichten des Magistrats

$1889-1909$

Klassifikation Teil B: 03343

Trägermaterial: Papier

Alte Reg.-Sig.: IX A3 28

Bestell-Nr.: IV 03343

3706 Revision der katholischen Volksschule

- Besichtigung des Gebäudes der katholischen Volksschule durch den Kreisarzt Dr. Tergast, September - Oktober 1902 / November -

Dezember 1907

- Umsetzung der vom Kreisarzt angeoidneten Übeweisung geistig behinderter Kinder der katholischen Volksschule in das katholische Erziehungsheim für geistig zurückgebliebene Kinder in Cloppenburg, Februar 1903

$1902-1907$

Klassifikation Teil B: 03346

Trägermaterial: Papier

Alte Reg.-Sig.: IX A3 30

Bestell-Nr.: IV 03345 
IV

10

Schulaufsicht

10.02

Volksschulen

10.02 .06

Katholische Volksschule

Lfd. Nr. Titel

Laufzeit

3707 Katholische Volksschule 1908-1911

- Ausstattung der Schule u.a. mit Schulbänken, 1908 - 1910

- Etat der katholishen Volksschule, 1908

- Sitzungsprotokoll der Schulkommission für die katholische

Volksschule über Gehaltserhöhung für die Schuldiener, Wahl von

Lehrerinnen, Anschaffung eines Fahnenmastes, August 1909

- Ermittlungsverfahren wegen Einwerfens einer Fensterscheibe im

Abort der katholischen Volksschule, Mai 1911

$1908-1911$

Klassifikation Teil B: 03627

Trägermaterial: Papier

Alte Reg.-Sig.: IX B6 18

Bestell-Nr.: IV 03627 
10

10.02

10.02.07

Lfd. Nr. Titel
IV

Schulaufsicht

Volksschulen

Hilfsschule in Emden 
10

\subsection{2}

10.02.07
Schulaufsicht

Volksschulen

Hilfsschule in Emden

Lfd. Nr. Titel

Laufzeit

3708 Errichtung einer Hilfsschule für schwach begabte Schulkinder

- Anregung der kgl. Regierung in Aurich zur Errichtung einer Hilfsschule für schwach begabte Schulkinder in Emden, September -

Dezember 1900

- Stellungnahme des Vorstands der städtischen Volksschule zur

Errichtung einer Hilfsschule für schwach begabte Schulkinder,

Dezember 1900

- Anfrage des Magistrats bei anderen Städten der Provinz Hannover wegen Einrichtung einer Hilfsschule, Januar - April 1901 / Januar -

Februar 1903

- Erlass des Ministers der Geistlichen, Unterrichts- und Medizinalangelegenheiten über Regelung der Tätigkeit der Hilfsschulen und weitere Förderung ihrer Errichtung, April 1901

- Vefügung der Regierung in Aurich über Genehmigung der Eröffnung der Hilfsschule in Emden als erste Einrichtung ihrer Art im Bezirk und Unterstellung unter der Aufsicht durch Kreisschulinspektor Pastor Blancke, Dezember 1901

- Verhandlungen der Volksschul-Kommission über Errichtung einer Hilfsschule für schwach begabte Schulkinder, Dezember 1901 -

September 1906

- Kostenanschlag des Stadtbaumeisters Wiggers zur Errichtung einer Hilfsschule für "schwach begabte und geistig zurückgebliebene Kinder" im Dachgeschoss der städtischen Volksschule, Januar 1902

- Bericht des Magistrats an die kgl. Regierung über Notwendigkeit eines Staatszuschusses zur Einrichtung der Hilfsschule und Finanzierung der Gehälter der Fachlehrer, Februar 1902

- Verfügung der kgl. Regierung über Betrauung des städtischen

Volksschuldirektors Müller mit der Leitung der "Hülfsclasse", Mai 1902

- Verfügung der kgl. Regierung über Nichtgewährung einer

Staatsbeihilfe für die Hilfsschule in Emden, Mai 1902

- Votum des Magistrats über Trägerschaft einer "Hülfsclasse" nur mit Staatsbeihilfe, Juni 1902

- Einstellung geeigneter Lehrer für die "Hülfsclasse" (Hilfsschule),

August 1902

- Verhandlung des Oberbürgermeisters Fürbringer mit dem Schulrat Runge über Organisation der "Hülfsclasse", Februar - April 1903

- Einstellung des Lehrers Vogelpohl an der "Hülfsclasse", April 1903

- Etats der "Hülfsschulclasse", 1903 - 1907

- Delegierung des Volksschullehrers Harms von der lutherischen

Klassenschule zur "Hülfsschulclasse", April 1903

- Erlass des Ministers der Geistlichen, Unterrichts- und Medizinalangelegenheiten über Gewährung einer Staatsbeihilfe für den Betrieb der "Hülfsclasse", Mai 1903 / Februar 1906

- Aufsatz des Lehrers Harms im "Ostfriesischen Schulblatt" über den Verbandstag deutscher Hilfsschullehrer, Juni - Juli 1903

- Votum des Kreisschulinspektiors Blanke für eine selbständige Hilfsschule, Oktober 1903

- Antrag des Magistrats an das Ostfriesische Landschaftskollegium auf Gewährung einer Beihilfe zum Betrieb der Hilfsschule aus dem Landschaftsfonds, Januar 1903

- Revision der Hilfsschule durch Kreisschulinspektor Blanke, August 1904

- Erlass des Ministers der Geistlichen, Unterrichts- und Medizinalangelegenheiten über Aufnahmekriterien für die Hilfsschule und Kriterien für die Gestaltung des Lehrplanes, Januar 1905 - Werbung des Lehrers Harms für die Weiterentwicklung der Hilfsschule, 1905 
- Datensammlung über Erfahrungen mit dem Ausbau der Hilfsschule in Nachbarstädten der Provinz Hannover, Oktober - Dezember 1905

$1900-1907$

Klassifikation Teil B: 03485

Trägermaterial: Papier

Alte Reg.-Sig.: IX B3e 21

Bestell-Nr.: IV 03485

3709 Hilfsschule für schwachbegabte und geistig zurückgebliebene Kinder

- Konstituierung der Hilfsschule für schwachbegabte und geistig zurückgebliebene Kinder als besondere Schule nach dem System der Emder Volksschulen, November 1907 / April 1908

- Etat der Hilfsschule für schwachbegabte und geistig zurückgebliebene Kinder1908 - 1910

- Denkschrift des an der Hilfsschule tätigen Lehrers J. H. Harms über Bildung einer besonderen Kommission für die Hilfsschule für schwachbegabte und geistig zurückgebliebene Kinder und zur Organisation des Schulbetriebs, 1908

- Überweisung der jüdischen Schüler Max Stein und Henni Weinberg an die Hilfsschule wegen Unfähigkeit zum Lesen und Schreiben sowie Regelung der Schulgeldfrage für diese Schüler, April 1908

- Nominierung des Vertreters für die Belange der Hilfsschule mit Sitz in der Kommission für die städtischen Volksschulen, Mai 1908 - Beantragung der Gewährung einer Staatsbeihilfe zum Betrieb der Hilfsschule für schwachbegabte und geistig zurückgebliebene Kinder, Mai 1908

- Satzungen der Schulkommission der Hilfsschule über Organisation des Schulbetriebs,Juli 1908

- Nachbewilligung von Mitteln aus der Stadtkasse zur Deckung des Etatdefizits der Hilfsschule, Dezember 1908

- Antrag des Hilfsschullehrers J. H. Harms an den Magistrat auf Erstellung eines eigenen Personalbogens für die Hilfsschule, Januar 1910

- Ausstattung der Hilfsschule für schwachbegabte und geistig zurückgebliebene Kinder, 1909 - 1910

- Einrichtung und Finanzierung einer zweiten Lehrerstelle an der Hilfsschule, 1909 - 1911

- Aufstellung über schwachbegabte Schüler, April 1910 - März 1918

- Verhandlungen der Stadtschuldeputation wegen Aufnahmekriterien für die Hilfsschule, 1911

- Datensammlung zu Aufnahmekriterien für Hilfsschulen anderer Städte, 1911

- Erarbeitung einer Dienstanweisung für den Leiter der Hilfsschule, 1911

$1908-1918$

Klassifikation Teil B: 03631

Trägermaterial: Papier

Alte Reg.-Sig.: IX B6 21

Bestell-Nr.: IV 03631 
IV

10

Schulaufsicht

10.03

Höhere Schulen

10.03.01

Organisation des Höheren Schulwesens

Lfd. Nr. Titel

Laufzeit

3710 Hochschulen

1913

- Vorstellung des Programms der Hochschule für Kommunale und Soziale Verwaltung, Köln

1913

Klassifikation Teil B: 03439

Trägermaterial: Papier

Alte Reg.-Sig.: IX B II 44

Bestell-Nr.: IV 03439

3711 Universitätsbund Göttingen e. V.

-Schreiben des Rektors der Georg-August-Universität Göttingen über

Werbung zum Eintritt in den Universitätsbund Göttingen e. V., Juli 1918

1918 (1919)

Klassifikation Teil B: 03440

Trägermaterial: Papier

Alte Reg.-Sig.: IX B || 45

Bestell-Nr.: IV 03440 
IV

10

Schulaufsicht

10.03

Höhere Schulen

10.03.02

Gymnasium in Emden

Lfd. Nr. Titel

Laufzeit

3712 Gymnasium in Emden

1909

- Einstellung des Kapitäns Eckhoff als Rendant und Kassenführer des $\mathrm{kgl}$. Wilhelms-Gymnasiums, 1909

- Ernennung des Gymnasialdirektors Prof. Mudder zum Direktor des kgl. Wilhelms Gymnasiums, September 1909

1909

Klassifikation Teil B: 03398

Trägermaterial: Papier

Alte Reg.-Sig.: IX BII 011

Bestell-Nr.: IV 03398

3713 Gebäude des Gymnasiums

$1869-1884$

- Verhandlungen der Schulkommission des kgl. Gymnasiums zu

Emden mit dem kgl. Provinzial-Schul-Kollegium über Staatsbeihilfe für einen Neubau des Gymnasiums, August 1869 - Dezember 1869

- Verhandlungen des Magistrats mit dem kgl.

Provinzial-Schul-Kollegium über Finanzierung des Baus eines neuen

Gymnasiums in Emden, Dezember 1869 - April 1870

- Verhandlungen der städtischen Kollegien über Beitrag der Stadt

Emden zur Finanzierung des Baus eines neuen Gymnasiums, Aprl

1870

- Eingabe des Magistrats an den Minister der geistlichen, Unterrichtsund Medizinalangelegenheiten über Bitte um Annahme eines

Vergleichs zwischen Staat und Stadt zur Tragung der Kosten des

Neubaus des kgl. Gymnasiums, Mai 1870

- Bescheid des Ministers der geistlichen, Unterrichts- und

Medizinalangelegenheiten über Gewährung einer Staatsbeihilfe zum

Bau des Gymnasiums in Emden unter der Bedingung der Abtretung

eines städtischen Grundstücks für den Bau, September 1871

- Verhandlungen des Magistrats mit dem kgl.

Provinzial-Schul-Kollegium wegen Bau des Gymnasiums in Emden, November 1871 - Oktober 1875

- Erwerb des zum Gymnasiunsbau benötigten Grundstücks durch die Stadt Emden und Abtretung an den Staat, Juli - September 1874

- Erlass des Ministers der geistlichen, Unterrichts- und

Medizinalangelegenheiten über Verleihung des Namens

"Wilhelms-Gymnasium" an die neue Schule durch Allerhöchste

Kabinettsordre, Januar 1877

$1869-1884$

Klassifikation Teil B: 03399

Trägermaterial: Papier

Alte Reg.-Sig.: IX BII 16

Bestell-Nr.: IV 03399 
Lfd. Nr. Titel

Laufzeit

3714 Realschule in Emden

- Initiative der Kaufmännischen Deputation zur Errichtung einer

Realschule zur Ausbildung des kaufmännischen Nachwuchses, 1881

- Denkschrift über Errichtung einer Realschule in Emden, Februar

1881

- Jahresberichte der Lateinlosen höheren Bürgerschule, später

Kaiser-Friedrich-Schule, 1886 - 1889

$1881-1889$

Klassifikation Teil B: 02147

Trägermaterial: Papier

Alte Reg.-Sig.: IX B2 04

Bestell-Nr.: IV 02147

3715 Jahresberichte der Kaiser-Friedrich-Realschule

- Schulstatistik, Lehrpläne, Prüfungen

$1888-1903$

Klassifikation Teil B: 03394

Trägermaterial: Papier

Alte Reg.-Sig.: IX B II 003

Bestell-Nr.: IV 03394

3716 Kuratorium der Kaiser-Friedrichs-Schule, Bd. 1

- Protokolle der Sitzungen des Kuratoriums der

Kaiser-Friedrich-Realschule: Neubau der Schule, Schulgeldsätze und

Ermäßigungen, Etatplanungen, Lehrerpersonalangelegenheiten,

Schulausstattung, Organisation der Einweihungsfeierlichkeiten des

Neubaus der Kaiser-Friedrichs-Schule.

$1885-1890$

Klassifikation Teil B: 03395

Band: 1

Trägermaterial: Papier

Alte Reg.-Sig.: IX BII 001

Bestell-Nr.: IV 03395

3717 Kuratorium der Kaiser-Friedrich-Schule, Bd. 2

- Protokolle der Sitzungen des Kuratoriums der

Kaiser-Friedrich-Realschule: Schulgeldsätze und Ermäßigungen,

Etatplanungen, Lehrerpersonalangelegenheiten, Lehrpläne,

Lehrerstellenbesetzung und -Besoldung

$1885-1890$

Klassifikation Teil B: 03396

Band: 2

Trägermaterial: Papier

Alte Reg.-Sig.: IX BII 001

Bestell-Nr.: IV 03396 
3718 Kuratorium der Kaiser-Friedrich-Schule, Bd. 3

- Protokolle der Sitzungen des Kuratoriums der Kaiser-Friedrich-Realschule: Schulgeldsätze und Ermäßigungen, Etatplanungen, Lehrerpersonalangelegenheiten, Lehrpläne,

Lehrerstellenbesetzung und -Besoldung, Diskussion der Umwandlung

in ein Reform-Gymnasium

$1902-1910$

Klassifikation Teil B: 03397

Band: 3

Trägermaterial: Papier

Alte Reg.-Sig.: IX BII 001

Bestell-Nr.: IV 03397

3719 Lehrerpersonalakte: Dr. Adolf Bullerdieck, Oberlehrer

- Einstellungsverfahren: Oberlehrer Dr. Bullerdieck als Lehrer für Mathematik und Naturwissenschaften an der

Kaiser-Friedrichs-Realschule, 1905 - 1906

- Kündigung des Oberlehrers Dr. Bullerdieck, Dezember 1906 -

Januar 1907

$1905-1907$

Klassifikation Teil B: 03400

Trägermaterial: Papier

Alte Reg.-Sig.: IX BII 19

Bestell-Nr.: IV 03400 
3720 Diensteinkommen der Lehrer an nichtstaatlichen höheren Lehranstalten

- Preußische Gesetzgebung über Regelung der Diensteinkommen der Lehrer an nichtstaatlichen höheren Lehranstalten: Anpassung der Gehälter an die Teuerung, Definition der GehaltsklassenJuli 1892 April 1900

- Festlegung der Gehälter der Lehrer der Höheren Bürgerschule in Emden (später: Kaiser-Friedrichs-Realschule) durch den Magistrat, November 1885 - März 1886

- Verfügung des Provinzial-Schul-Kollegiums über Ablehnung der vom Magistrat definierten Gehaltsklassen für die Lehrer der Höheren Bürgerschule, Juni 1886

- Verhandlungen eines Landesgesetzes zur Regelung der Diensteinkommen der Lehrer an nichtstaatlichen höheren Lehranstalten, April - Mai 1892

- Vorschläge des Rektors der Kaiser-Friedrichs-Realschule über Gehälter und Gehaltsklassen für die Lehrer an der Schule, September 1892

- Monita des Provinzial-Schul-Kollegiums zu den eingereichten Übersichten der Gehälter und Gehaltsklassen für die Lehrer der Kaiser-Friedrichs-Realschule, November - Dezember 1892

- Aufstellung über Mehrausgaben der Kaiser-Friedrichs-Realschule infolge der gesetzlichen Neuregelung der Lehrergehälter (Durchführung des Normaletats), Januar 1893

- Anträge des Magistrats beim Provinzial-Schul-Kollegium auf Gewährung einer Staatsbeihilfe zur Deckung der Mehrausgaben für die Lehrergehälter (Durchführung des Normaletats), Oktober 1893 Juni 1903

- Verfügung des Provinzial-Schul-Kollegiums über Planung einer Staatsbeihilfe zur Lehrerbesoldung für bedürftige nichtstaatliche höhere Schulen, April 1898 / Mai 1902

- Zuschuss aus der Stadtkasse zur Deckung des Normaletats der Kaiaser-Friedrich-Realschule, Juni 1900

- Protokolle der Sitzungen des Kuratoriums für die Kaiser-Friedrich-Realschule über Verhandlungen wegen Aufstellung des Normaletats unter der Bedingung einer Staatsbeihilfe, Mai 1901/ Juni 1903

$1885-1903$

Klassifikation Teil B: 03401

Trägermaterial: Papier

Alte Reg.-Sig.: IX BII 19 b

Bestell-Nr.: IV 03401 
Lfd. Nr. Titel

- Besetzung der Stelle des ausscheidenden Oberlehrers Dr.

Bullerdieck, Januar 1907 - Juni 1908

- Zuweisung von Kandidaten für das höhere Lehramt zur

Beschäftigung ais wissenschaftliche Hilfslehrer an der

Kaiser-Friedrichs-Realschule durch das Provinzial-Schul-Kollegium,

$1907-1916$

- Berichte des Direktors der Kaiser-Friedrichs-Realschule an den Magistrat über Anforderung von wissenschaftlichen Hilfslehrern beim Provinizial-Schul-Kollegium, Juni 1908 - März 1904

- Antrag des Vereins zur Pflege der volkstümlichen Musik an den Magistrat auf Beschäftigung seines Dirigenten als Hilfslehrer für Musik an der Kasiser-Friedrichs-Realschule oder der Höheren

Töchterschule, April 1908

- Anforderung von wissenschaftlichen Hilfslehrern zur Beschäftigung an der Kaiser-Friedrichs-Realschule beim Provinzial-Schul-Kollegium durch den Magistrat, 1909 - 1915

$1907-1916$

Klassifikation Teil B: 03402

Trägermaterial: Papier

Alte Reg.-Sig.: IX BII 19 c

Bestell-Nr.: IV 03402

3722 Versicherung des Gebäudes der Kaiser-Friedrich-Realschule gegen Feuersgefahr

- Abschluss und Verlängerung der Feuerversicherungen für das Schulgebäude und der Schulutensilien

$1895-1908$

Klassifikation Teil B: 03404

Trägermaterial: Papier

Alte Reg.-Sig.: IX B II 19

Bestell-Nr.: IV 03404 
- Erlasse des Ministers der geistlichen, Unterrichts- und Medizinalangelegenheiten über Regelung der Lehrerbesoldung, 1892

- 1900

- Antrag des wissenschaftlichen Hilfslehrer Faber an den Magistrat auf Anpassung seines Gehalts an die von ihm wahrgenommene Funtion des dritten Elementarlehrers, März 1894

- Antrag der Lehrer der Kaiser-Friedrich-Schule an den Magistrat auf Honorierung der wegen der Krankheit des Oberlehrers Dekker geleisteten Vertretungsstunden, März 1901

- Beschluss des Kuratoriums der Kaiser-Friedrich-Realschule über Finanzierung des Mehrbedarfs an Turnstunden wegen Anstieg der Schülerzahlen, April 1901

- Beschluss des Kuratoriums der Kaiser-Friedrich-Realschule über Finanzierung der Vertretungsstunden für den erkrankten Oberlehrer Dekker, Juni 1901

- Deckung des Defizite des Etats der Kaiser-Friedrich-Realschule aus der Stadtkasse, August 1901

- Anträge des Direktors Niemöller an den Magistrat auf Erstattung der Kosten für zu leistende Hilfsunterrichtsstunden aus der Stadtkasse, Juli - Auigust 1902 / Januar 1903 / Mai 1908

- Besetzung von Hilfslehrerstellen in der Kaiser-Friedrch-Realschule, September 1902.- Februar 1903

. Bewerbungen um Hilfslehrerstellen an der

Kaiser-Friedrich-Realschule, 1902 - 1908

$1892-1908$

Klassifikation Teil B: 03405

Band: 1

Trägermaterial: Papier

Alte Reg.-Sig.: IX B II 19 a

Bestell-Nr.: IV 03405

3724 Lehrer und Angestellte der Kaiser-Friedrich-Realschule, Bd. 2

- Ausschreibung von Oberlehrerstellen an der

Kaiser-Friedrich-Realschule, 1889 - 1900

- Erlass des Ministers der geistlichen, Unterrichts- und

Medizinalangelegenheiten über Nichtbestätigung der Einstellung des

Elementarlehrers Jacques Roßkamp als Zeichenlehrer wegen

fehlender Qualifikation, März 1902

- Bewerbung des Lehrers Jacques Roßkamp um eine Stelle als

Zeichenlehrer an der Kaiser-Friedrich-Realschule, Januar - März 1902

- Besetzung der Elementarlehrerstellen an der

Kaiser-Friedrich-Realschule, 1886 - 1903

$1886-1903$

Klassifikation Teil B: 03406

Band: 2

Trägermaterial: Papier

Alte Reg.-Sig.: IX B II 19 a

Bestell-Nr.: IV 03406 
- Erlass des Ministers der geistlichen, Unterrichts- und Medezinalangelegenheiten über Regelung der Besoldung der Lehrer an nichtstaatlichen höheren Schulen, Juni 1907

- Protokolle der Sitzungen des Kuratoriums der Kaiser-Friedrich-

Realschule über Anpassung der Lehrerbesoldung an den Normaletat und entstehende Mehrkosten, Juli 1907

- Antrag des Magistrats Provinzial-Schul-Kollegium auf Staatsbeihilfe zur Deckung der Kosten des Normaletats zur Lehrerbesoldung, Juli November 1907

1907

Klassifikation Teil B: 03407

Band: 1

Trägermaterial: Papier

Alte Reg.-Sig.: IX B II 19 b

Bestell-Nr.: IV 03407 
- Erlass des Ministers der geistlichen, Unterrichts- und

Medizinalangelegenheiten über Kriterien der Aufstellung des

Normaletats (Besoldung der Leiter und Lehrer der nichtstaatlichen höheren Lehranstalten), Juni 1907

- Aufstellungen über Mehraufwändungen aus dem Etat der

Kaiser-Friedrich-Realschule wegen Gehaltserhöhungen bei den Lehrern (Normaletat), 1908 - 1909

- Antrag des Magistrats an das kgl. Provinzial-Schul-Kollegium auf Staatsbeihilfe zur Deckung der Mehrausgaben infolge der Vorgaben des Normaletats, Juli 1909 - Februar 1909

- Anfrage des Magistrats an die Nachbarstädte in der Provinz Hannover über Anwendung des Normaletats im Rechnungsjahr 1908, Juli 1907

- Konferenz von Städten der Provinz Hannover, darunter Emden, in Hannover über Koordinierung der Anwendung des Normaletats,

August 1909

- Verhandlungen des Magistrats über Anwendung des Normaletats,

September 1909

- Regelung der Anrechnung des Dienstalters der Lehrer auf den Normaletat, September - Oktober 1909

- Erhöhung des Wohngeldzuschusses für Lehrer der

Kaiser-Friedrich-Realschule, August / September 1909

- Antrag des Lehrers Lorenz an den Magistrats auf Anpassung seines

Gehalts an die Bestimmungen des Normaletats, Juli - Oktober 1913

- Antrag des Oberbürgermeisters Fürbringer beim

Provinzial-Schul-Kollegium auf Erlaubnis der Heranziehung von

Mitteln des Eigenfonds des Lyzeums der

Kaiserin-Auguste-Voktoria-Schule zur Finanzierung der durch die Umsetzung des Normaletats erforderlichen Gehaltsnachzahlungen für Lehrer der Höheren Töchterschule rückwirkend seit 1908 / 09,

November 1913

- Regelung der Weiterzahlung der Gehälter für die zum Kriegsdienst einberufenen Lehrer, 1915

1909 - 1915 (1919 - 1920)

Klassifikation Teil B: 03408

Band: 2

Trägermaterial: Papier

Alte Reg.-Sig.: IX B II 19 b

Bestell-Nr.: IV 03408

3727 Personalakte: Hermann Büning

- Einstellung des Oberlehrers H. Büning an der

Kaiser-Friedrich-Realschule, 1912

- Versorgung der hinterbliebenen Familienmitglieder des gefallenen

Oberlehrers H. Büning, 1918 ( 1920 - 1921)

1912 - 1918 ( 1920 - 1921)

Klassifikation Teil B: 03409

Trägermaterial: Papier

Alte Reg.-Sig.: IX B II 19

Bestell-Nr.: IV 03409 
3728 Kriegsteuerungszulage und Beihilfen für Lehrer der städtischen 1916-1918 höheren Schulen

- Erlass des Ministers der geistlichen, Unterrichts- und Medizinalangelegenheiten über Regelung der Gewährung von Kriegsteuerungszulagen und besondere Beihilfen für Lehrer, 1916 1917

- Aufstellung über Zahlung der Kriegsteuerungszulage an Lehrern der Kaiser-Friedrich-Realschule und der Kaiserin-Auguste-Viktoria-Schule (Höhere Töchterschule), 1917 - 1918

- Anträge verschiedener Lehrer der Kaiser-Friedrich-Realschule und der Kaiserin-Auguste-Viktoria-Schule (Höhere Töchterschule) auf Gewährung einer Kriegsteuerungszulage, November 1916 - März 1918

- Verhandlungen des Magistrats und des Schulausschusses über Gewährung einer Kriegsteuerungszulage, 1916 - 1917

$1916-1918$

\author{
Klassifikation Teil B: 03410 \\ Trägermaterial: Papier \\ Alte Reg.-Sig.: IX B II 19 \\ Bestell-Nr.: IV 03410
}

- Einstellung des Lehrers Peter Dekker als Oberlehrer an der Kaiser-Friedrich-Realschule, 1887 - 1888

- Bestätigung des Wahl Peter Dekkers zum Oberlehrer durch das

Provinzial-Schulkollegium, September 1889

- Gewährung einer Gehaltszulage an den Oberlehrer P. Dekker, Mai 1903

- Entlassungsgesuch des Oberlehrers Peter Dekker, Januar 1905

$1887-1905$

Klassifikation Teil B: 03411

Trägermaterial: Papier

Alte Reg.-Sig.: IX B II 19

Bestell-Nr.: IV 03411

- Einstellung des Oberlehrers Albert Dittmers an der Kaiser-Friedrich-Realschule, 1908

- Wahl des Albert Dittmers zum Oberlehrer, September 1908

- Bericht des Magistrats an das kgl. Provinzial-Schul-Kollegium über Vermisstenstatus des an der Westfont als Soldat eingesetzten Albert Dittmers seit Oktober 1916 und Bitte um Stellung des Antrages auf Todeserklärung, Mai 1918

$1908-1918$

Klassifikation Teil B: 03412

Trägermaterial: Papier Alte Reg.-Sig.: IX B II 19

Bestell-Nr.: IV 03412 
- Bewerbung und Einstellung des Tischlermeisters und Militärinvaliden Hermann Meyer als Schuldiener an der Kaiser-Friedrich Realschule, Juli - September 1910

- Nicht berücksichtigte Bewerbung des Militärinvaliden Wilhelm Topp um die Stelle des Schuldieners an der Kaiser-Friedrich-Realschule, September 1910

- Dienstanweisung für den Schuldiener der Kaiser-Friedrich-Realschule, September 1910

- Verschiedene Anträge des schuldieners hermann Meyer auf Kostenerstattung für Putzmaterialien und auf Gehaltserhöhung, 1910 1914

1910 - 1914 (1919 - 1921) Klassifikation Teil B: 03413

Trägermaterial: Papier

Alte Reg.-Sig.: IX B II 19

Bestell-Nr.: IV 03413

- Einstellung des Dr. Carl Theodor Müller als wissenschaftlichen Hilfslehrer an der Kaiser-Friedrich-Realschule, Januar - Februar 1890 - Bestellung des Dr. Carl Theodor Müller als ordentlichen Lehrer an der Kaiser-Friedrich-Realschule, April . Mai 1891

- Entlassungsgesuch des Dr. Carl Theodor Müller, September 892

$1890-1892$

Klassifikation Teil B: 03414

Trägermaterial: Papier Alte Reg.-Sig.: IX B II 19

Bestell-Nr.: IV 03414 
- Bewerbung des Gymnasial-Oberlehrers Dr. Friedrich Niemöller um die Stelle des Direktors der Kaiser-Wilhelm-Realschule, September 1895

- Wahl und Bestellung des Dr. Friedrich Niemöller zum Direktor der Kaiser-Friedrich-Realschule, September - Oktober 1895

- Rede des Oberbürgermeisters Leo Fürbringer zur Amtseinführung des Direktors Dr. Friedrich Niemöller, April 1896

- Organisation der Vertretung des scheidenden Schuldirektors Hemmo Suur bis zur Amtseinführung des Dr. Friedrich Niemöller, Oktober 1895 - April 1896

- Urlaubsanträge des Dr. Friedrich Niemöller, 1896 / 1897/ 1898 /

1902 / 1904 / 1907 / 1909 / 1914 / 1915

- Anpassung des Gehalts des Direktors der

Kaiser-Friedrich-Realschule an die Vorgaben des Normaletats, Juli 1907 / Oktober 1909

- Beförderung des Dr. Friedrich Niemöller zum Geheimen Studienrat, Oktober 1918

- Versetzung des Dr. Friedrich Niemöller in den Ruhestand nach

Erreichung der Altersgrenze, März 1921

- Nachruf zum Tode des Dr. Friedrich Niemöller, Februar 1932

1895 - 1918 (1921 - 1932)

Klassifikation Teil B: 03415

Trägermaterial: Papier

Alte Reg.-Sig.: IX B II 19

Bestell-Nr.: IV 03415

- Einstellung des Kandidaten für den höheren Schuldienst Ludwig Riess als wissenschaftlichen Hilfslehrer an der

Kaiser-Friedrich-Realschule, Dezember 1903 - Januar 1904

- Erklärung des Ludwig Riess gegenüber dem kgl.

Provinzial-Schul-Kollegium über seine Bereitschaft zur Ablegung der Oberlehrerprüfung, August 1904

- Entlassungsgesuch des L. Riess, März 1905

$1903-1905$

Klassifikation Teil B: 03416

Trägermaterial: Papier

Alte Reg.-Sig.: IX B II 19

Bestell-Nr.: IV 03416 
Lfd. Nr. Titel

3735 Personalakte: Wissenschaftlicher Hilfslehrer Dr. Otto Rohte 1903

- Einstellung des Kandidaten für den höheren Schuldienst Dr. Otto

Rohte als wissenschaftlichen Hilfslehrer an der Kaiser-Friedrich-Realschule, Februar - März 1903

- Neuausschreibung der Stelle wg. Wechsels des Dr. Rohte zur

Oberverwaltungsschule Hannover, Oktober - Dezember 1903

1903

Klassifikation Teil B: 03417

Trägermaterial: Papier

Alte Reg.-Sig.: IX B II 19

Bestell-Nr.: IV 03417

3736 Personalakte: Zeichenlehrer Friedrich Schaper

- Einstellung des Gymnasial-Vorschullehrers Friedrich Schaper als Elementarlehrer an der Kaiser-Friedrich-Schule, November 1885 April 1888

- Antrag des Zeichenlehrers F. Schaper auf Eingruppierung in die Besoldungsklasse der geprüften Zeichenlehrer, September 1892 / September - November 1895

- Gesuch des Lehrers F. Schaper an das Kuratorium der Kaiser-Friedrich-Realschule über Bitte um Zusicherung der Einstellung als Zeichenlehrer nach Ablegung der Zeichenlehrerprüfung auf seine Kosten, April 1893

- Beurteilung der Fähigkeiten des Lehrers F. Schaper zur Zulassung zum Zeichenlehrerkursus mit anschließender Zeichenlehrerprüfung, 1894 / 1895

$1885-1895$

Klassifikation Teil B: 03418

Trägermaterial: Papier

Alte Reg.-Sig.: IX B II 19

Bestell-Nr.: IV 03418

3737 Personalakte: Oberlehrer Dr. Edmund Staacke

- Einstellung des Oberlehrers Dr. Edmund Staacke als Oberlehrer an der Kaiser-Friedrich-Realschule, Juli 1914

- Versetzung des Dr. E. Staacke in den einstweiligen Ruhestand, 1924 $-1934$

$1914(1924-1934)$

Klassifikation Teil B: 03419

Trägermaterial: Papier

Alte Reg.-Sig.: IX B II 19

Bestell-Nr.: IV 03419 
- Bewerbung des Kandidaten für den höheren Schuldienst, Dr. Heinrich Peter Tjaden, um eine Stelle als wissenschaftlicher Hilfslehrer an der lateinlosen höheren Bürgerschule in Emden, später Kaiser-Friedrichs-Realschule, Januar 1887

- Berufung des Dr. Heinrich Peter Tjaden als wissenschaftlicher Hilfslehrer, Januar - Februar 1887

- Vereidigung des wissenschaftlichen Hilfslehrers Dr. Heinrich Peter Tjaden, Mai 1887

- Einstellung des Dr. Heinrich Peter Tjaden als ordentlicher Lehrer an der Kaiser-Friedrich-Realschule, September 1887

- Rüge des Oberlehrers Dr. Tjaden durch das kgl.

Provinzial-Schulkollegium wegen Mitwirkung an einem Kommentar zu Emder Kommunalverhältnissen mit Kritik an den Ehrungen für Oberbürgermeister Fürbringer in einer auswärtigen Zeitung, September 1900

- Verleihung des Charakters Professor an den Oberlehrer Dr. Heinrich Peter Tjaden, Februar 1906

- Verleihung des Titels "Rat IV. Klasse" an Dr. Tjaden durch Allerhöchste Kabinettsordre des Kaisers, April 1906

- Anpassung des Gehalts des Prof. Dr. Tjaden an den Vorgaben des Normaletats, Oktober 1909 / September 1910

- Ruhegehalt des Studienrats Prof. Dr. Heinrich Peter Tjaden, 1923 1924

1887 - 1910 (1923 - 1924) Klassifikation Teil B: 03420

Trägermaterial: Papier Alte Reg.-Sig.: IX B II 19

Bestell-Nr.: IV 03420

- Einstellung des gebürtigen Ostpreußen Gustav Steffler als wissenschaftlichen Hilfslehrer an der höheren Bürgerschule, später: Kaiser-Friedrich-Realschule, 1885 - 1886

- Einstellung des G. Steffler als ordentlicher Lehrer an der höheren Bürgerschule, November 1887

- Verfügung einer Gehaltspfändung gegen den wissenschaftlichen Lehrer G. Steffler wegen Forderungen des Schneidermeisters Hofer in Königsberg/Pr., Dezember 1886 - Januar 1887

- Antrag des Oberbürgermeisters Fürbringer beim

Provinzial-Schulkollegium auf Beförderung des G. Steffler zum Oberlehrer, November 1891 - Januar 1892

- Neuregelung der Gehaltszulagen für den Oberlehrer Steffler, Juli 1899

- Berufung des G. Steffler als Oberlehrer an der höheren Schule der Stadt Königsberg/Pr., November - Dezember 1902

$1887-1902$

Klassifikation Teil B: 03421

Trägermaterial: Papier Alte Reg.-Sig.: IX B II 19

Bestell-Nr.: IV 03421 
- Bewerbung des Veteranen der Kriege von 1866 und 1870/71 Tischlermeister Carl Walter um die Stelle des Schuldieners im neugebauten Gebäude der Kaiser-Friedrich-Realschule, März 1888 - Ausschreibung einer Schuldiener-Stelle an der Kaiser-Friedrich-Realschule, November 1888 - Februar 1889

- Wahl des Tischlermeisters Carl Walter zum Schuldiener, März 1889

- Dienstanweisungen für den Schuldiener Carl Walter, April 1889

- Gesuche des Schuldieners Carl Walter an das Kuratorium der Kaiser-Friedrich-Realschule über Bitte um Gehaltserhöhung wegen gestiegender Arbeitsbelastung, Februar - März 1902 / März - April 1908

- Antrag des Schuldieners Carl Walter auf Erstattung der Ausgaben für Putzmaterial, Dezember 1909

- Kündigung des Schuldieners C. Walter, Juli 1910

- Bewerbungen um die Nachfolge des C. Walter, Juli - September 1910

$1888-1910$

Klassifikation Teil B: 03422

Trägermaterial: Papier Alte Reg.-Sig.: IX B II 19

Bestell-Nr.: IV 03422

- Abordnung des Kandidaten für den höheren Schuldienst, Wilhelm Wacken, als wissenschaftlicher Hilfslehrer an die

Kaiser-Friedrich-Realschule durch das Provinzial-Schulkollegium, Januar 1905

1905

Klassifikation Teil B: 03423

Trägermaterial: Papier Alte Reg.-Sig.: IX B II 19

Bestell-Nr.: IV 03423 
- Verhandlungen des Kuratoriums der Kaiser-Friedrich-Realschule über Findung einer Persönlichkeit zur Besetzung einer vakanten Stelle als wissenschaftlicher Hilfslehrer, Dezember 1888 - Januar 1889 - Einstellung des Dr. Johann Friedrich August Zietsch als wissenschaftlicher Hilfslehrer, März 1889

- Bericht eines Auskunftsbüros über den Leumund des Dr. Johann Friedrich August Zietsch, März 1889

- Anstellung des Dr. Johann Friiedrich August Zietsch als ordentlicher Lehrer an der Kaiser-Friedrich-Realschule, März 1890

- Beförderung des Dr.Johann Friedrich August Zietsch zum Oberlehrer, März 1905

- Verleihung des Charakters Professor an den Oberlehrer Dr. J. F. A. Zietsch, Juni 1906

- Verleihung des Titels "Rat IV. Klasse" an Oberlehrer Prof. Dr. Zietsch durch Allerhöchste Kabinettsordre des Kaisers, Juli 1906

- Anpassung des Gehalts des Studienrats Prof. Dr. Zietsch an die Vorgaben des Normaletats, September 1910

- Versetzung des Prof. Dr. Zietsch in den Ruhestand, 1923

- Versorgung der Wiwe des Prof. Dr. Zietsch, 1933

1888 - $1910(1923-1933)$

Klassifikation Teil B: 03424

Trägermaterial: Papier

Alte Reg.-Sig.: IX B II 19

Bestell-Nr.: IV 03424

3743 Schulgeld der Kaiser-Friedrich-Realschule

$1899-1918$

- Verhandlungen der städtischen Kollegien über Festlegung der Schulgeldtarife an der Kaiser-Friedrich-Realschule, März 1888 / Dezember 1889

- Eintreibung von Schulgeldrückständen, 1891 - 1893

- Anträge auf Erlass von Schulgeldforderungen, 1899 - 1918 (1919)

- Verfügung des Provinzial-Schulkollegiums über Regelung der Schulgeldzahlungen bei Beamtenkindern im Fall der Versetzung ihrer Väter, März 1905 / November 1905

- Neuregelung der Kriterien für eine Schulgeldbefreiung, Februar März 1907

- Verweisung des Schülers Rasenack von der Kaiser-Friedrich-Realschule wegen Nichtzahlung des Schulgeldes durch seinen Vater, Oktober - November 1909

- Regelungen der Schulgelderhebung während des Ersten Weltkrieges, 1914 - 1916

- Aufnahme eines türkischen Schülers an einer Freistelle der Kaiser-Friedrich-Realschule im Rahmen einer Vereinbarung mit der Deutsch-Türkischen Vereinigung zur Befestigung der Allianz mit der Türkei, September - Oktober 1916

$1899-1918$ (1919) Klassifikation Teil B: 03425

Trägermaterial: Papier Alte Reg.-Sig.: IX B II 20

Bestell-Nr.: IV 03425 
- Verhandlungen der städtischen Kollegien über Etats der Höheren Bürgerschule / Kaiser-Friedrich-Realschule, 1886 - 1892

- Monita des Provinzial-Schulkollegium zu den Etats der Kaiser-Friedrich-Realschule, 1886 - 1896

- Erlass des Ministers der Geistlichen, Unterrichts- und Medizinalangelegenheiten über Kriterien der Aufstellung der Etats der höheren Schulen, u.a.: Übernahme von Ausgabeposten, 1886

- Etatentwürfe der Höheren Bürgerschule /

Kaiser-Friedrich-Realschule, 1887 - 1899

- Genehmigung der Etats der Kaiser-Friedrich-Realschule durch den Minister der Geistlichen, Unterrichts- und Medizinalangelegenheiten, 1889 - 1894

- Anträge des Magistrats an den Minister der Geistlichen, Unterrichts.und Medizinalangelegenheiten auf Staatsbeihilfe für die Kaiser-Friedrich-Realschule, August 1892 - Oktober 1898

$1886-1900$

Klassifikation Teil B: 03426

Band: 1

Trägermaterial: Papier

Alte Reg.-Sig.: IX B II 22

Bestell-Nr.: IV 03426

3745 Verleihung des Namens Kaiser-Friedrich-Realschule an die höhere Bürgerschule

- Eingabe des Magistrats an den Minister der Geistlichen, Unterrichtsund Medizinalangelegenheiten über Bitte um Vermittlung beim Kaiser zur Benennung der Höheren Bürgerschule nach Kaiser Friedrich, April 1887

- Votum der städtischen Kollegien für die Benennung der Höheren Bürgerschule nach Kaiser Friedrich, April 1888

- Urkunde über die Namensgebung "Kaiser-Friedrich-Schule" durch die städtischen Kollegien, April 1888

- Verfügung des Regierungsprsidenten in Aurich an Oberbürgermeister Fürbringer über Aufforderung zur Berichterstattung über die Gründe der beabsichtigten Umbenennung der Höheren Bürgerschule, Juli 1888

- Bescheid des Regierungspräsidenten über Allerhöchsten Erlass über Verleihung des Namens "Kaiser-Friedrich-Schule" an die Höhere Bürgerschule, September 1888

- Abschrift des Allerhöchsten Erlasses des Kaisers Wilhelm II. über Verleihung des Namens Kaiser Friedrich-Schule an die Höhere Bürgershule vom August 1888, 1889

$1888-1889$

Klassifikation Teil B: 03427

Trägermaterial: Papier

Alte Reg.-Sig.: IX B II 26

Bestell-Nr.: IV 03427 
- Feier der Grundsteinlegung des Gebäudes (Rede

Oberbürgermeister Fürbringer; Urkunden zur Grundsteinlegung), April

1888

- Feier der Einweihung des neuen Schulgebäudes, Mai 1889

$1888-1889$

Klassifikation Teil B: 03428

Trägermaterial: Papier

Alte Reg.-Sig.: IX B II 25

Bestell-Nr.: IV 03428

3747 Etat der Kaiser-Friedrich-Realschule, Bd. 2

- Zuschuss für den Betrieb der Kaiser-Friedrich-Realschule aus der Stadtkasse, 1898 - 1899

- Monita des Provinzial-Schulkollegiums zum Etat der

Kaiser-Friedrich-Realschule, September 1898 / Juni 1901

- Antrag des Oberbürgermeisters Fürbringer an den

Regierungspräsidenten in Aurich auf Vermittlung einer Staatsbeihilfe zum Betrieb der Kaiser-Friedrich-Realschule, Oktober 1899

- Verfügung des Ministers der Geistlichen, Unterrichts- und Medizinalangelegenheiten über Bewilligung einer Staatsbeihilfe für die Kaiser-Friedrich-Realschule, September 1900 / Januar 1901

- Bericht des Direktors Dr. Niemöller über Belastung des Etats der Kaiser-Friedrich-Schule durch Mehraufwändung durch eine vom Staatsministerium verordnete Reform des Lehrplanes, Juli 1901 - Antrag des Magistrats an den Minister der Geistlichen, Unterrichts.und Medizinalangelegenheiten auf Staatsbeihilfe für die

Kaiser-Friedrich-Realschule wegen Mehrauswändungen durch die

Reform des Lehrplans, Juli 1901

- Etat der Kaiser-Friedrich-Realschule 1901 - 1903

$1898-1903$

Klassifikation Teil B: 03429

Band: 2

Trägermaterial: Papier

Alte Reg.-Sig.: IX B II 22

Bestell-Nr.: IV 03429 
- Monita des Provinzial-Schulkollegiums zum Etat der

Kaiser-Friedrich-Realschule, Oktober 1902

- Antrag des Oberbürgermeisters Fürbringer an den

Regierungspräsidenten in Aurich auf Vermittlung einer Staatsbeihilfe zum Betrieb der Kaiser-Friedrich-Realschule, Dezember 1902

- Verfügung des Ministers der Geistlichen, Unterrichts- und

Medizinalangelegenheiten über Bewilligung einer Staatsbeihilfe für die Kaiser-Friedrich-Realschule, Oktober 1903

- Bericht des Direktors Dr. Niemöller über Entwicklung des Etats der

Kaiser-Friedrich-Schule, August 1903

- Etatplan der Kaiser-Friedrich-Realschule für 1904 - 1906, 1903

$1902-1903$

Klassifikation Teil B: 03430

Band: 3

Trägermaterial: Papier

Alte Reg.-Sig.: IX B II 22

Bestell-Nr.: IV 03430

3749 Etat der Kaiser-Friedrich-Realschule, Bd. 4

1905-1909

- Monita des Provinzial-Schulkollegiums zum Etat der

Kaiser-Friedrich-Realschule, September 1905

- Verfügung des Ministers der Geistlichen, Unterrichts- und

Medizinalangelegenheiten über Bewilligung einer Staatsbeihilfe für die

Kaiser-Friedrich-Realschule, Juli 1906

- Etatplan der Kaiser-Friedrich-Realschule für 1907 - 1909, 1905

$1902-1903$

Klassifikation Teil B: 03431

Band: 4

Trägermaterial: Papier

Alte Reg.-Sig.: IX B II 22

Bestell-Nr.: IV 03431

3750 Etat der Kaiser-Friedrich-Realschule, Bd. 5

- Monita des Provinzial-Schulkollegiums zum Etat der

Kaiser-Friedrich-Realschule, September 1908

- Anträge des Magistrats an das Provinzial-Schulkollegium auf

Vermittlung von Staatsbeihilfe zum Betrieb der

Kaiser-Friedrich-Realschule, November 1908 - Januar 1912

- Verfügung des Ministers der Geistlichen, Unterrichts- und

Medizinalangelegenheiten über Bewilligung einer Staatsbeihilfe für die

Kaiser-Friedrich-Realschule, August 1909

- Etatplan der Kaiser-Friedrich-Realschule für 1910 - 1912 / 1913 -

1915/ 1916 - 1918, 1909 / 1912 / 1915

1908 - 1915 (1919 - 1926)

Klassifikation Teil B: 03432

Band: 5

Trägermaterial: Papier

Alte Reg.-Sig.: IX B II 22

Bestell-Nr.: IV 03432 
10

\subsection{3}

10.03.03

\section{Schulaufsicht}

Höhere Schulen

Kaiser-Friedrich-Realschule

Lfd. Nr. Titel

Laufzeit

3751 Berechtigung für die Kaiser-Friedrich-Realschule zur Ausstellung von 1891 Zeugnissen für den einjährig-freiwilligen Militärdienst

- Erlass des Ministers der Geistlichen, Unterrichts- und Medizinalangelegenheiten über Verknüpfung der Berechtigung für die Kaiser-Friedrich-Realschule zur Ausstellung von Zeugnissen für den einjährig-freiwilligen Militärdienst mit dem dauerhaften Ausgleich des Schuletats, Mai 1891

- Erlass des Ministers der Geistlichen, Unterrichts- und Medizinalangelegenheiten über Erteilung der Berechtigung für die Kaiser-Friedrich-Realschule zur Ausstellung von Zeugnissen für den einjährig-freiwilligen Militärdienst, Juli 1891

- Schreiben des Magistrats an die Redaktion der Hannoverschen Courier über Bitte um Korrektur des Artikels über Schulen mit Berechtigung zur Ausstellung von Zeugnissen für den einjährig-freiwilligen Militärdienst durch Einfügung des Namens der Kaiser-Friedrich-Realschule, Dezember 1891

1891

Klassifikation Teil B: 03433

Trägermaterial: Papier

Alte Reg.-Sig.: IV B II 30

Bestell-Nr.: IV 03433

3752 Wahl des Direktors der Kaiser-Friedrich-Realschule

- Bewerbungen um die Stelle eines Direktors an der

Kaiser-Friedrich-Realschule, 1888 / 1895

- Vorschlagung geeigneter Bewerber durch das

Provinzial-Schulkollegium, Juni 1888

- Genehmigung einer Interimsleitung der Kaiser-Friedrich-Realschule durch den Direktor der höheren Töchterschule, A. F. Zwitzers vom Minister der Geistlichen, Unterrichts- und Medizinalangelegenheiten, 1886 - 1888

- Verfügung des Provinzial-Schulkollegiums über Genehmigung der Einsetzung des Lehrers Steffler zum Direktor der Kaiser-Friedrich-Realschule, April 1888

- Bestätigung der Amtseinführung des Lehrers Steffler als Schuldirektor durch den Minister der Geistlichen, Unterrichts- und Medizinalangelegenheiten, Juni 1888

- Wahl des gebürtigen Emders und Gymnasiallehrers Hemmo Suur zum Direktor der Kaiser-Friedrich-Realschule, August 1888

- Wechsel des Direktors Hemmo Suur als Leiter des Realgymnasiums nach Iserlohn, September 1895

$1886-1895$

Klassifikation Teil B: 03434

Trägermaterial: Papier

Alte Reg.-Sig.: IX B II 34

Bestell-Nr.: IV 03434 
- Gutachten des Schuldirektors Niemöller über Kosten und Notwendigkeit des Ausbaus der Kaiser-Friedrich-Realschule zur Oberrealschule, Juli 1904

- Ausbau des Schulgebäudes der Kaiser-Friedrich-Realschule zur

Einrichtung einer Oberrealschule, 1907 - 1910

- Verhandlungen des Magistrats über Schaffung der Voraussetzungen zum Ausbau der Kaiser-Friedrich-Realschule zur Oberrealschule, April 1907 - November 1911

- Antrag des Oberbürgermeisters Fürbringer an das Kgl.

Provinzialschul-Kollegium auf Anerkennung der

Kaiser-Friedrich-Realschule als Oberrealschule und auf Genehmigung des geplanten Ausbaus des Schulgebäudes, Oktober 1907

- Antrag des Magistrats beim kgl. Provinzialschul-Kollegium auf

Zuweisung zweier weiterer Lehrkräfte zum Aufbau der

Oberrealschule, Oktober 1908

- Bericht des Realschuldirektors Niemöller an den Magistrat über Kosten der vermehrten Lehrerstunden beim Betrieb der Kaiser-Friedrichs-Schule als Oberrealschule, Oktober 1908

- Erlass des Ministers der Geistlichen, Unterrichts- und Medizinalangelegenheiten über Ablehnung einer Staatsbeihilfe für den Ausbau der Kaiser-Friedrich-Realschule zur Oberrealschule, Juni 1909

- Bericht des Realaschuldirektors Niemöller über Kosten des Ausbaus der Kaiser-Friedrich-Realschule, Oktober 1909

$1904-1911$

Klassifikation Teil B: 03435

Trägermaterial: Papier

Alte Reg.-Sig.: IX B II 37

Bestell-Nr.: IV 03435

- Initiattive des Kuratoriums der Kaiser-Friedrich-Realschule zur

Einrichtung eines Alumnats (Internat) an der

Kaiser-Friedrich-Realschule in Kooperation mit dem

Wilhelms-Gymnasium, Mai 1903

1903

Klassifikation Teil B: 03436

Trägermaterial: Papier

Alte Reg.-Sig.: IX B II 38

Bestell-Nr.: IV 03436 
10

\subsection{3}

10.03.03

\section{Schulaufsicht}

Höhere Schulen

Kaiser-Friedrich-Realschule

Lfd. Nr. Titel

Laufzeit

3755 Teilung von Klassen an der Kaiser-Friedrich-Realschule $1905-1910$

- Verhandlungen des Kuratoriums der Kaiser-Friedrich-Realschule über Teilung von Klassen bei zu großer Schülerzahl, 1905 - 1910 - Antrag des Rektors Dr. Niemöller an den Magistrat auf Teilung von Klassen und Einstellung neuer Oberlehrer und wissenschaftlicher Hilfslehrer, Januar - März 1907 / März 1908 / Januar - Februar 1909 - Einrichtung von Aushilfsklassen der Kaiser-Friedrich-Realschule im van Lettenschen Gebäude, September 1907 - Juli 1908

- Stundentafel der Kaiser-Friedrich-Realschule, 1909

$1905-1910$

Klassifikation Teil B: 03438

Trägermaterial: Papier

Alte Reg.-Sig.: IX B II 43

Bestell-Nr.: IV 03438

3756 Mitglieder des Kuratoriums der Kaiser-Friedrich-Realschule

$1895-1911$

- Bestellung von Mitgliedern des Kuratoriums der

Kaiser-Friedrich-Realschule durch das Bürgervorsteherkollegium

$1895-1911(1921)$

Klassifikation Teil B: 03441

Trägermaterial: Papier

Alte Reg.-Sig.: IX B II 46

Bestell-Nr.: IV 03441

3757 Kuratorium der Kaiser-Friedrich-Realschule

- Gedruckte Schulordnung der Kaiser-Friedrich-Realschule mit

Organisationsbeschreibung des Kuratoriums, 1889

- Stimmrecht des Vorsitzenden des Kuratoriums der

Kaiser-Friedrich-Realschule, April 1893

- Gewährung eines Staatszuschusses für die

Kaiser-Friedrich-Realschule, 1893

- Erlass des Ministers der Geistlichen, Unterrichts- und

Medizinalangelegenheiten über Änderung der Ordnung für die

Reifeprüfung, Februar 1909

- Monita des Magistrats zu den Statuten der

Kaiser-Friedrich-Realschule, Dezember 1909 - Mai 1910

$1893-1910$

Klassifikation Teil B: 03442

Trägermaterial: Papier

Alte Reg.-Sig.: IX B II 47

Bestell-Nr.: IV 03442 
Lfd. Nr. Titel

3758 Etat der Kaiser-Friedrich-Realschule, Bd. 1

- Etatentwürfe der Kaiser-Friedrich-Realschule, 1892 - 1900

- Nachbewilligungen von Zuschüssen zum Etat der Kaiser-

Friedrich-Realschule aus der Stadtkasse, 1895 - 1899

$1892-1900$

Klassifikation Teil B: 03443

Band: 1

Trägermaterial: Papier

Alte Reg.-Sig.: IX B || 47

Bestell-Nr.: IV 03443

3759 Etat der Kaiser-Friedrich-Realschule, Bd. 2

- Etatentwürfe der Kaiser-Friedrich-Realschule

- Nachbewilligungen von Zuschüssen zum Etat der Kaiser-

Friedrich-Realschule aus der Stadtkasse

$1901-1906$

Klassifikation Teil B: 03444

Band: 2

Trägermaterial: Papier

Alte Reg.-Sig.: IX B I| 47

Bestell-Nr.: IV 03444

3760 Versicherung der Gebäude der Kaiser-Friedrich-Realschule gegen

$1886-1890$

Feuersgefahr und Ausstattung der Schule

- Anschaffung von Schulmöbel für die Höhere Bürgerschule /

Kaiser-Friedrich-Realschule, 1886 - 1888

- Feuerversicherung der Kaiser-Friedrich-Realschule mit ihren

Mobilien bei der Feuerversicherungsbank für Deutschland, September

1888 - November 1889

- Aufstellung über benötigte Schulutensilien, Februar 1890

$1886-1890$

Klassifikation Teil B: 03445

Trägermaterial: Papier

Alte Reg.-Sig.: IX BII 49

Bestell-Nr.: IV 03445

3761 Freistellen und Schulgeldermäßigungen an der Kaiser-Friedrich-Realschule

- Aufstellung über Freistellen an der Kaiser-Friedrich-Realschule,

1914 - 1917

- Anträge auf Gewährung von Freistellen und Ermäßigung des

Schulgeldes, 1914 - 1916

$1914--1917$

Klassifikation Teil B: 03446

Trägermaterial: Papier

Alte Reg.-Sig.: IX B II 50

Bestell-Nr.: IV 03446 
IV

10

Schulaufsicht

10.04

Höhere Töchterschule / Kaiserin-Auguste-Viktoria-Schule

Lfd. Nr. Titel

Laufzeit

3762 Höhere Töchterschule, Bd. 1

1872

- Einrichtung einer Vorklasse der Höheren Töchterschule zur

Vorbereitung auf das Unterrichtspensum ab Klasse 6 (sexta)

1872

Klassifikation Teil B: 03519

Band: 1

Trägermaterial: Papier

Alte Reg.-Sig.: IX B4 04

Bestell-Nr.: IV 03519

3763 Höhere Töchterschule, Bd. 2

- Ausbau der Höheren Töchterschule, 1872 - 1876 / 1884 / 1889 -

1890

- Organisation des Schornsteinfegerdienstes an der Höheren

Töchterschule, 1881

- Antrag des Direktors August E. Zwitzers an die Höhere

Töchterschulkommission auf Verbesserung der sanitären Anlagen in der Höheren Töchterschule, November 1886

- Ersetzung des Brunnens der Höheren Töchterschule durch eine

Zisterne, 1891

$1872-1891$

Klassifikation Teil B: 03520

Band: 2

Trägermaterial: Papier

Alte Reg.-Sig.: IX B4 04

Bestell-Nr.: IV 03520 
Lfd. Nr. Titel

- Verhandlungen der städtischen Kollegien über Aufbau einer Höheren

Töchterschule, Juli - August 1872

- Prospekt der städtischen Höheren Töchterschule, März 1876

- Verhandlungen des Oberbürgermeisters Hantelmann mit geeigneten

Lehrerinnen zur Gewinnung fähiger Lehrkräfte für die Höhere

Töchterschule, April - Mai 1872

- Korrespondenz des Oberbürgermeisters Hantelmann mit dem

Direktor der Höheren Töchterschule in Hannover, Dr. Nöldecke, über

Organisation der geplanten Höheren Töchterschule, 1872

- Feier zur Eröffnung der Höheren Töchterschule, Oktober 1872

- Verfügung des kgl. Konsistoriums in Aurich an den Magistrat über

Anordnung der nachträglichen Vorlage der Personaldaten der an der Höheren Töchterschule berufenen Lehrer und Lehrerinnen zur nachträglichen Bestätigung sowie Anforderung des Entwurfs einer Schulordnung, November 1872

- Regelung der Aufsicht über die Höhere Töchterschule, Dezember 1872

- Erweiterung der Höheren Töchterschule, 1873

- Rechnung der Höheren Töchterschule, 1872 - 1875

- Stundentafel der Höheren Töchterschule, 1874

- Antrag der Schulkommission der Höheren Töchterschule an den Magistrat auf Nachbewilligungen auf den Etat der Höheren

Töchterschule, Juni 1874

$1872-1875$

1872

\author{
Klassifikation Teil B: 03521 \\ Band: 3 \\ Trägermaterial: Papier \\ Alte Reg.-Sig.: IX B4 04
}

Bestell-Nr.: IV 03521

3765 Höhere Töchterschulkommission, Bd. 1

- Protokolle der Sitzungen der Töchterschulkommission über:

Organisation des Schulbetriebs, Regelung der Lehrergehälter, Etat der Höheren Töchterschule, Vergabe von Freistellen an Schülerinnen, Ausschreibung der Lehrerstellen, Etat des Lehrerinnen-Seminars an der Höheren Töchterschule, Bauunterhaltung, Einweihungsfeier für das neue Gebäude der Kaiserin-Auguste-Viktoria-Schule (Höhere Töchterschule/Lyzeum) an der Ringstraße, Ausschreibung der Rektorenstelle nach der Pensionierung des Direktors August E. Zwitzers

$1898-1910$

Klassifikation Teil B: 03522

Band: 1

Trägermaterial: Papier

Alte Reg.-Sig.: IX B4 05

Bestell-Nr.: IV 03522 
IV

10 Schulaufsicht

10.04

Höhere Töchterschule / Kaiserin-Auguste-Viktoria-Schule

Lfd. Nr. Titel

Laufzeit

3766 Höhere Töchterschulkommission, Bd. 2

- Protokolle der Sitzungen der Töchterschulkommission (Vorstand der Höheren Töchterschule): Besetzung der Stelle des Dirigierenden

Lehrers

$<$ Unvollständig>

1872

Klassifikation Teil B: 03523

Band: 2

Trägermaterial: Papier

Alte Reg.-Sig.: IX B4 04

Bestell-Nr.: IV 03523

3767 Höhere Töchterschulkommission, Bd. 3

- Protokolle der Sitzungen der Töchterschulkommission über:

Organisation des Schulbetriebs, Etat der Höheren Töchterschule, Vergabe von Freistellen an Schülerinnen, Ausschreibung der Lehrerstellen, Bauunterhaltung

$1872-1879$

Klassifikation Teil B: 03524

Band: 3

Trägermaterial: Papier

Alte Reg.-Sig.: IX B4 05

Bestell-Nr.: IV 03524

3768 Höhere Töchterschulkommission, Bd. 4

- Protokolle der Sitzungen der Töchterschulkommission über:

Organisation des Schulbetriebs, Etat der Höheren Töchterschule, Vergabe von Freistellen an Schülerinnen, Ausschreibung der Lehrerstellen, Bauunterhaltung

$1880-1889$

Klassifikation Teil B: 03525

Band: 4

Trägermaterial: Papier

Alte Reg.-Sig.: IX B4 05

Bestell-Nr.: IV 03525

3769 Höhere Töchterschulkommission, Bd. 5

- Protokolle der Sitzungen der Töchterschulkommission über:

Organisation des Schulbetriebs, Etat der Höheren Töchterschule, Vergabe von Freistellen an Schülerinnen, Ausschreibung der Lehrerstellen, Bauunterhaltung, Novellierung der Schulordnung

$1890-1899$

Klassifikation Teil B: 03526

Band: 5

Trägermaterial: Papier

Alte Reg.-Sig.: IX B4 05

Bestell-Nr.: IV 03526 
IV

10 Schulaufsicht

10.04 Höhere Töchterschule / Kaiserin-Auguste-Viktoria-Schule

Lfd. Nr. Titel

Laufzeit

3770 Höhere Töchterschulkommission (Kaiserin-Auguste-Viktoria-Schule), Bd. 6

- Protokolle der Sitzungen der Töchterschulkommission über: Organisation des Schulbetriebs, Etat der Höheren Töchterschule / Kaiserin-Auguste-Viktoria-Schule, Vergabe von Freistellen an Schülerinnen, Ausschreibung der Lehrerstellen, Bauunterhaltung

$1900-1901$

Klassifikation Teil B: 03527

Band: 6

Trägermaterial: Papier

Alte Reg.-Sig.: IX B4 05

Bestell-Nr.: IV 03527

3771 Höhere Töchterschulkommission (Kaiserin-Auguste-Viktoria-Schule), Bd. 7

- Protokolle der Sitzungen der Töchterschulkommission über: Organisation des Schulbetriebs, Etat der Höheren Töchterschule / Kaiserin-Auguste-Viktoria-Schule, Vergabe von Freistellen an Schülerinnen, Ausschreibung der Lehrerstellen, Bauunterhaltung

$1911-1914$

Klassifikation Teil B: 03528

Band: 7

Trägermaterial: Papier

Alte Reg.-Sig.: IX B4 05

Bestell-Nr.: IV 03528

3772 Gehälter der Lehrerinnen an der Höheren Töchterschule

- Besuche verschiedener Lehrerinnen um Gehaltserhöhung, 1875 1892

- Verfügung der Töchterschulkommission über Genehmigungspflicht zur Erteilung von Unterricht an der Gewerbeschule durch Lehrerinnen und Lehrer der Höheren Töchterschule, Februar 1876

- Neuregelung des Lehrbetriebs nach der Kündigung der Lehrerin Voss, Januar 1887

- Festlegung der Alterszulage und Gehaltsklassen für Lehrerinnen, Januar 1887

$1875-1892$

Klassifikation Teil B: 03529

Trägermaterial: Papier

Alte Reg.-Sig.: IX B4 06

Bestell-Nr.: IV 03529 
IV

10 Schulaufsicht

10.04 Höhere Töchterschule / Kaiserin-Auguste-Viktoria-Schule

Lfd. Nr. Titel

Laufzeit

3773 Besetzung einer Lehrerstelle an der Höheren Töchterschule

- Lehrplan der Höheren Töchterschule, 1875

- Wiederbesetzung der durch den Weggang des Lehrers Vogt vakanten Lehrerstelle, Januar - Februar 1876

$1875-1876$

Klassifikation Teil B: 03530

Trägermaterial: Papier

Alte Reg.-Sig.: IX B4 06

Bestell-Nr.: IV 03530

3774 Technische Lehrerinnen an der Höheren Töchterschule

- Meldung der Handarbeitslehrerin Marie Jeep u.a. zur Weiterbildung, $1887-1890$

- Regelung des Gehalts der Handarbeitslehrerinnen, Januar 1887 -

August 1890

- Bewerbungen um Anstellung als Handarbeitslehrerin oder

Turnlehrerin an der Höheren Töchterschule, 1887 - 1889

$1887-1890$

Klassifikation Teil B: 03531

Trägermaterial: Papier

Alte Reg.-Sig.: IX B4 06

Bestell-Nr.: IV 03531

3775 Lehrerinnen und Lehrer der Höheren Töchterschule

- Gehaltsfestlegungen für Lehrerinnen an der Höheren Töchterschule, 1873 - 1899

- Gewährung des Titels Oberlehrerin und einer Gehaltszulage von 100 Mark / Jahr an die Lehrerin Emilie de Leune zum Anlass ihres 70.

Geburtstags, August - November 1895

- Errichtung einer dauerhaften Oberlehrerinnenstelle an der Höheren

Töchterschule, November 1895

- Bestallungsurkunde für die Lehrerin Emilie de Leune, November

1872

- Bestallungsurkunde für die Lehrerin Elise de Leune, November 1872

$1872-1899$

Klassifikation Teil B: 03532

Trägermaterial: Papier

Alte Reg.-Sig.: IX B4 06

Bestell-Nr.: IV 03532 
Lfd. Nr. Titel

Laufzeit

3776 Anstellung eines wissenschaftlichen Lehrers an der Höheren Töchterschule

- Antrag des Direktors A.E. Zwitzers an den Magistrat auf Anstellung eines wissenschaftlichen Lehrers an der Höheren Töchterschule, Januar - Februar 1889

- Wahl des Lehrers Schulz zum wissenschaftlichen Lehrer an der Höheren Töchterschule, Dezember 1890

- Bewerbung des Emil Biller um die Stelle eines wissenschaftlichen Lehrers an der Höheren Töchterschule, Januar 1891

$1889-1891$

Klassifikation Teil B: 03533

Trägermaterial: Papier

Alte Reg.-Sig.: IX B4 06

Bestell-Nr.: IV 03533

3777 Höhere Töchterschule / Kaiserin-Auguste-Viktoria-Schule,

$1901-1918$

Lehrerpersonalakte: Oberlehrer Karl Johann Behrens

- Personaldaten zum Oberlehrer Karl Johann Behrens, 1901

- Anstellung des Oberlehrers Karl Johann Behrens an der Höheren

Töchterschule, 1901

- Bestallungsurkunde für den Oberlehrer Karl J. Behrens, Februar 1901

- Tadel der mangelhaften Qualifikation und Klage gegen die

Amtsführung des Oberlehrers Karl J. Behrens, März 1904 / März 1905

- Zeugnis des Direktors Zwitzers für Oberlehrer Karl J. Behrens, Juni 1906

- Gesuch des Oberlehrers Behrens um Gehaltserhöhung, Dezember 1906

- Neufestlegung des Gehalts des Oberlehrer Karl J. Behrens,

September 1909 - Februar 1910

- Verleihung des Titels "Professor" an Oberlehrer Behrens, Juni 1911

- Verleihung des Ranges "Rat IV. Klasse" durch Allerhöchste

Kabinettsorder Kaiser Wilhelm II., August 1911

- Versetzung in den Ruhestand, September 1918 - Januar 1919

$1901-1918$ (1919)

Klassifikation Teil B: 03534

Trägermaterial: Papier

Alte Reg.-Sig.: IV B4 06

Bestell-Nr.: IV 03534

3778 Höhere Töchterschule / Kaiserin-Auguste-Viktoria-Schule, Lehrerpersonalakte: Zeichenlehrerin Frieda Bielitz

- Personaldaten zur Zeichenlehrerin Frieda Bielitz, 1913

- Tätigkeit der Zeichenlehrerin Frieda Bielitz an der

Kaiserin--Auguste-Viktoria-Schule, Januar 1913 - Dezember 1918

$(1919-1920)$

$1913-1918$ (1919-1920)

Klassifikation Teil B: 03534

Trägermaterial: Papier

Alte Reg.-Sig.: IV B4 06

Bestell-Nr.: IV 03535 
10

10.04

\section{Schulaufsicht}

Höhere Töchterschule / Kaiserin-Auguste-Viktoria-Schule

Lfd. Nr. Titel

Laufzeit

3779 Höhere Töchterschule / Kaiserin-Auguste-Viktoria-Schule, Lehrerpersonalakte: Lehrerin Paula Conrad

- Personaldaten zur Lehrerin Paula Conrad, 1908

- Tätigkeit als Lehrerin an der Kaiserin-Auguste-Viktoria-Schule, 1909

$-1910$

- Entlassung der Lehrerin Paula Conrad nach dem Ende des

Probejahres wegen Unfähigkeit, Februar 1910

$1908-1910$

Klassifikation Teil B: 03536

Trägermaterial: Papier

Alte Reg.-Sig.: IV B4 06

Bestell-Nr.: IV 03536

3780 Höhere Töchterschule, Lehrerpersonalakte: Lizeallehrer Dittmer

- Personaldaten zum Lizeallehrer Hermann Dittmer, 1876

- Tätigkeit als Lehrer an der Höheren Töchterschule, 1876 - 1884

- Weigerung des Magistrat in Stade zur vorzeitigen Entlassung des in seinem Schuldienst beschäftigten Lehrers H. Dittmer, März 1876

- Weggang des Lehrers H. Dittmer nach Norden infolge Annahme der Rektorenstelle der dortige lutherischen Klassenschule, 1883 - 1884

$1876-1884$

Klassifikation Teil B: 03537

Trägermaterial: Papier

Alte Reg.-Sig.: IV B4 06

Bestell-Nr.: IV 03537

3781 Höhere Töchterschule / Kaiserin-Auguste-Viktoria-Schule, Lehrerpersonalakte: Oberlehrerin Ida Doll

$1909-1914$

- Personaldaten zur Oberlehrerin Ida Doll, 1909

- Tätigkeit als Oberlehrerin an der Auguste-Viktoria-Schule, 1910 -

1914

$1909-1914$

Klassifikation Teil B: 03538

Trägermaterial: Papier

Alte Reg.-Sig.: IV B4 06

Bestell-Nr.: IV 03538

3782 Höhere Töchterschule / Kaiserin-Auguste-Viktoria-Schule,

- Beschäftigung als Schuldiener bei der

Kaiserin-Auguste-Viktoria-Schule, 1907 - 1918

- Geänderte Dienstanweisung für den Schuldiener (Aufgaben und

Verhaltensregeln), Dezember 1906

$1906-1918$

Klassifikation Teil B: 03539

Trägermaterial: Papier

Alte Reg.-Sig.: IV B4 06

Bestell-Nr.: IV 03539 
Lfd. Nr. Titel

3783 Höhere Töchterschule / Kaiserin-Auguste-Viktoria-Schule, Lehrerpersonalakte: Lehrer Heinrich August Enkelstroth

- Bewerbung des Lehrers Heinrich August Enkelstroth um eine Lehrerstelle an der Höheren Töchterschule, Dezember 1873

- Bestallungsurkunde für den Lehrer Heinrich A. Enkelstroth, Februar 1874

- Besoldungserhöhungen, 1880 - 1902

- Verleihung des Kronenordens IV. Klasse an den Lehrer Heinrich A.

Enkelstroth, Oktober 1905

- Pensionierung des Lehrers Heinrich A. Enkelstroth, August 1906

- Streichung des pensionierten Lehrers Heinrich A. Enkelstroth aus der Elemtarlehrer-Witwen- und Waisenkasse wegen Tod seiner Frau, 1914

$1873-1914$

Klassifikation Teil B: 03540

Trägermaterial: Papier Alte Reg.-Sig.: IV B4 06

Bestell-Nr.: IV 03540

3784 Höhere Töchterschule, Personalakte: Schulwärterin Gepke Fink

- Besetzung der Schulwärterinnenstelle an der Höheren

Töchterschule, Oktober 1878

- Contractliche Instruktionen (Aufgaben und Pflichten) für die

Schulwärterin Gepke Fink, November 1878

- Gehaltserhöhungen, 1866 / 1891 / 1895 - 1896

- Entlassung der Schulwärterin G. Fink, Juni 1905

$1878-1905$

Klassifikation Teil B: 03541

Trägermaterial: Papier

Alte Reg.-Sig.: IV B4 06

Bestell-Nr.: IV 03541

3785 Höhere Töchterschule / Kaiserin-Auguste-Viktoria-Schule,

Lehrerpersonalakte:

Elementarlehrer Diedrich Johann Garjets

- Einstellung des Lehrers Diedrich Johann Garjets als Elementarlehrer an der Kaiserin-Auguste-Viktoria-Schule, 1910

- Nachruf auf den kriegsgefallenen Lehrer Diedrich J. Garjets, Juli 1916

$1910-1916$

Klassifikation Teil B: 03542

Trägermaterial: Papier

Alte Reg.-Sig.: IV B4 06

Bestell-Nr.: IV 03542 
IV

10 Schulaufsicht

10.04 Höhere Töchterschule / Kaiserin-Auguste-Viktoria-Schule

Lfd. Nr. Titel

Laufzeit

3786 Höhere Töchterschule / Kaiserin-Auguste-Viktoria-Schule, $1909-1910$ Lehrerpersonalakte:

Töchterschullehrer Friedrich Hoffmeister

- Bestallungsurkunde für Töchterschullehrer Friedrich Hoffmeister, September 1909

- Kündigung des Töchterschullehrers F. Hoffmeister, Juni 1910

$1909-1910$

Klassifikation Teil B: 03543

Trägermaterial: Papier

Alte Reg.-Sig.: IV B4 06

Bestell-Nr.: IV 03543

3787 Höhere Töchterschule, Lehrerpersonalakte: Lehrerin Jeanette

- Beschäftigung als Elementarlehrerin an der Höheren Töchterschule, Februar 1887 - Juni 1889

- Beschäftigung als ordentliche Lehrerin, Juli 1889 - September 1892

- Bestallungsurkunde für die Lehrerin Jeanette Janssen, Mai 1887 /

Juli 1889

- Kündigung des Lehramts durch Jeanette Janssen, Oktober 1892

$1887-1892$

Klassifikation Teil B: 03544

Trägermaterial: Papier

Alte Reg.-Sig.: IV B4 06

Bestell-Nr.: IV 03544

3788 Höhere Töchterschule / Kaiserin-Auguste-Viktoria-Schule, Lehrerpersonalakte:

Hilfslehrerin Hilda Lüpkes, geb. Winter

- Personaldaten zur Hilfslehrerin Hilda Lüpkes, geb. Winter, März

1918

- Einstellung als Wissenschaftliche Hilfslehrerin, April 1918

1918
Klassifikation Teil B: 03545
Trägermaterial: Papier
Alte Reg.-Sig.: IV B4 06
Bestell-Nr.: IV 03545

3789 Lehramtsbewerber für die Höhere Töchterschule

- Erkundigungen über Lehramtsbewerber für die Höhere

Töchterschule: Lehramtsbewerber Dr. Walle

1876

Klassifikation Teil B: 03546

Trägermaterial: Papier

Alte Reg.-Sig.: IX B4 06

Bestell-Nr.: IV 03546 
IV

10 Schulaufsicht

10.04 Höhere Töchterschule / Kaiserin-Auguste-Viktoria-Schule

Lfd. Nr. Titel

Laufzeit

3790 Höhere Töchterschule / Kaiserin-Auguste-Viktoria-Schule, Lehrerpersonalakte: Lehrer Carl Margis

- Einstellung des Lehrers Carl Margis an der Höheren Töchterschule, Juni - September 1885

- Bestallungsurkunde für den Lehrer Carl Margis, Oktober 1885

- Zwangsvollstreckungssache: Buchhandlung Haynel vs. Lehrer Carl Margis, Dezember 1886

- Gehaltserhöhungen für Lehrer Carl Margis, 1888 - 1908

- Pensionierung des Lehrers Carl Margis, September 1913 - Januar 1914

$1885-1914$

Klassifikation Teil B: 03547

Trägermaterial: Papier

Alte Reg.-Sig.: IV B4 06

Bestell-Nr.: IV 03547

3791 Höhere Töchterschule / Kaiserin-Auguste-Viktoria-Schule, Lehrerpersonalakte: Lehrer Sikko Martini

- Beschäftigung des Sikko Martini als Lehrer der Fünften Klasse der Höheren Töchterschule, Dezember 1872 - September 1875

- Bestallungsurkunden für den Lehrer Sikko Martini, Februar 1873 / Juli 1875 / April 1884

- Gehaltsfestlegungen, 1874 - 1875 / 1880 / 1898 / 1902 / 1907 / 1909

- Definitive Einstellung des Lehrers Sikko Martini an der Höheren

Töchterschule, September 1875

- Ablegung der Mittellehrer-Prüfung (Lehrer an Mittelschulen und Höheren Töchterschulen), November 1883

- Zeugnis der Befähigung für das Rektorat an Mittelschulen und Höheren Töchterschulen, April 1887

- Unterstützungszahlungen für die Hinterbliebenen des Lehrers Martini, 1920 - 1921

1872 - 1909 (1920 - 1921)

Klassifikation Teil B: 03548

Trägermaterial: Papier Alte Reg.-Sig.: IV B4 06

Bestell-Nr.: IV 03548 
Lfd. Nr. Titel

3792 Höhere Töchterschule / Kaiserin-Auguste-Viktoria-Schule, 1903 Lehrerpersonalakte: Oberlehrerin Marie Puhlmann

- Bewerbung der Oberlehrerin Marie Puhlmann um eine ausgeschriebene Oberlehrerinnenstelle an der Kaiserin-Auguste-Viktoria-Schule, Januar 1903

- Wahl der Marie Puhlmann zur Oberlehrerin an der Kaiserin-Auguste-Viktoria-Schule, Januar 1903

- Bestallungsurkunde für die Oberlehrerin Marie Puhlmann, Januar 1903

- Ablehnung der Entlassung der Oberlehrerin Marie Puhlmann aus dem Schuldienst in Burg b. Magdeburg durch den dortigen Magistrat, Jabnuar - März 1903

- Zurückziehung der Bewerbung durch M. Puhlmann, April 1903

1903

Klassifikation Teil B: 03549

Trägermaterial: Papier

Alte Reg.-Sig.: IV B4 06

Bestell-Nr.: IV 03549

3793 Höhere Töchterschule / Kaiserin-Auguste-Viktoria-Schule,

Lehrerpersonalakte:

Lehrer Christian Wilhem Schlechtweg

- Wahl und Einstellung des Christian Wilhelm Schlechtweg als Lehrer an der Kaiserin-Auguste-Viktoria-Schule, September 1906 - Januar 1907

- Bestallungsurkunde für den Lehrer Christian Wilhelm Schlechtweg, Januar 1907 / Mai 1909

- Absolvierung der II. Lehrerprüfung (Mittellehrer-Prüfung), Juni 1907

- Kündigung des Lehrer Christian Wilhelm Schlechtweg wegen

Absicht der Absolvierung eines Studiums, August 1909 / März 1910

$1906-1910$

Klassifikation Teil B: 03550

Trägermaterial: Papier

Alte Reg.-Sig.: IV B4 06

Bestell-Nr.: IV 03550

3794 Höhere Töchterschule / Kaiserin-Auguste-Viktoria-Schule,

- Personalblatt zum Oberlehrer Dr. Heinrich Schmidt, 1910

- Bericht über das Probejahr des Dr. Heinrich Schmidt als Oberlehrer an der Kaiser Friedrich-Realschule (1909/1910). 1910

- Wahl und Einstellung des Oberlehrers Dr. Heinrich Schmidt als

Oberlehrer an der Kaiserin-Auguste-Viktoria-Schule, Januar - Februar

1910

- Vereidigung des Oberlehrers Dr. Schmidt, 1910

- Feststellung des Dienstalters des 1918 gefallenen Oberlehrers Dr. H. Schmidt zur Verbesserung der Hinterbliebenenversorgung, 1921

1910 (1921)

Klassifikation Teil B: 03551

Trägermaterial: Papier

Alte Reg.-Sig.: IV B4 06

Bestell-Nr.: IV 03551 
Lfd. Nr. Titel

3795 Höhere Töchterschule / Kaiserin-Auguste-Viktoria-Schule, Personalakte: Schuldiener Heinrich Menno Schuur

- Ausschreibung der Schuldienerstelle an der Kaiserin-Auguste-Viktoria-Schule, März - April 1905

- Bewerbungen um die Schuldienerstelle, April - Mai 1905

- Wahl des Heinrich Menno Schuur zum Schuldiener an der Kaiserin-Auguste-Viktoria-Schule, Juni 1905

- Dienstvorschriftwen für den Schuldiener Heinrich Menno Schuur, Juni / Oktober 1905

- Entlassung des Schuldieners Menno Heinrich Schüür wegen

Vernachlässigung des Dienstes, September 1906

$1905-1906$

Klassifikation Teil B: 03552

Trägermaterial: Papier

Alte Reg.-Sig.: IV B4 06

Bestell-Nr.: IV 03552

3796 Höhere Töchterschule / Kaiserin-Auguste-Viktoria-Schule, Lehrerpersonalakte: Oberlehrerin Cornelia van Senden

- Personaldaten der Oberlehrerin Cornelia van Senden, 1909

- Wahl der Cornelia van Senden zur Lehrerin an der Höheren

Töchterschule, Dezember 1891

- Bestallungsurkunden für die Lehrerin / Oberlehrerin Cornelia van

Senden, Februar 1892 / August 1895 / März 1900

- Vereidigung der Lehrerin Cornelia van Senden, Oktober 1892

- Definitive Einstellung der Lehrerin Cornelia van Senden, August 1895

- Fortbildung zur Oberlehrerin an der Universität Göttingen, 1897 1899

- Ernennung der Cornelia van Senden zur Oberlehrerin mit Sitz im Prüfungsausschuss des Lehrerinnen-Seminars, Februar 1900

- Antrag der Oberlehrerin C. van Senden an den Minister der Geistlichen, Unterrichts- und Medizinalangelegenheiten auf Beihilfe für einen Frankreich-Aufenthalt zur Sprachauffrischung (Forbildung),

März - April 1906

- Verhandlungen des Oberbürgermeisters Fürbringer als Vorsitzender der Töchterschulkommission mit der Oberlehrerin C. van Senden über Bedingungen für ihren Verbleib in Emden, Dezember 1909

- Kündigung der Lehrtätigkeit durch Cornelia van Senden, Dezember 1909 - Januar 1910

$1891-1910$

Klassifikation Teil B: 03553

Trägermaterial: Papier

Alte Reg.-Sig.: IV B4 06

Bestell-Nr.: IV 03553 
Lfd. Nr. Titel

3797 Höhere Töchterschule / Kaiserin-Auguste-Viktoria-Schule, Lehrerpersonalakte: Oberlehrerin Elisabeth Seyfried

- Personaldaten zur Oberlehrerin Elisabeth Seyfried, 1903

- Bestallungsurkunde für Elisabeth Seyfried als Lehrerin /

Oberlehrerin, April 1903

- Vereidigung der Elisabeth Seyfried, Juni 1903

- Kündigung der Lehrtätigkeit durch E. Seyfried, Dezember 1909

$1903-1909$

Klassifikation Teil B: 03554

Trägermaterial: Papier

Alte Reg.-Sig.: IV B4 06

Bestell-Nr.: IV 03554

3798 Höhere Töchterschule / Kaiserin-Auguste-Viktoria-Schule, Lehrerpersonalakte: Lehrer Heinrich Specht

- Personalblatt mit Daten zum Lehrer Heinrich Specht, 1914

- Wahl des Lehrers Specht mit Rektorexamen zum ordentlichen

Lehrer der Kasiserin-Auguste-Viktoria-Schule, Juni 1914

- Kündigung der Lehrtätigkeit durch Lehrer Specht wegen Wahl zum

Rektor der Volksschule in Nordhorn, Juli - September 1917

$1914-1917$

Klassifikation Teil B: 03555

Trägermaterial: Papier

Alte Reg.-Sig.: IV B4 06

Bestell-Nr.: IV 03555

3799 Höhere Töchterschule / Kaiserin-Auguste-Viktoria-Schule, Lehrerpersonalakte: Hilfslehrerin Johanna ter Vehn

- Personalblatt mit Daten zur Hilfslehrerin Johanna ter Vehn, 1916

- Wahl der Johanna ter Vehn zur Hilfslehrerin an der

Kaiserin-Auguste-Viktoria-Schule, Februar 1916

- Gesuch der Hilfslehrerin Johanna ter Vehn um feste Einstellung,

April 1918 (1919 - 1921)

- Tätigkeit als Lehrerin an der Bezirksschule IV, 1923 - 1928

1916 - 1918 (1919 - 1928)

Klassifikation Teil B: 03556

Trägermaterial: Papier

Alte Reg.-Sig.: IV B4 06

Bestell-Nr.: IV 03556

3800 Höhere Töchterschule, Lehrerpersonalakte: Lehrerin Louise Spangenberg

- Bestallungsurkunde für die Lehrerin Louise Spangenberg, November 1872

- Gehaltsfestlegung, 1892 / 1898

$1872-1878$

Klassifikation Teil B: 03557

Trägermaterial: Papier

Alte Reg.-Sig.: IV B4 06

Bestell-Nr.: IV 03557 
Lfd. Nr. Titel

3801 Höhere Töchterschule / Kaiserin-Auguste-Viktoria-Schule, 1914 Lehrerpersonalakte: Hilfslehrerin Elisabeth Rehbock

- Personalblatt mit Daten zur Hilfslehrerin Elisabeth Rehbock, 1914 - Bewerbung der Lehrerin Elisabeth Rehbock um eine Stelle an der Kaiserin-Auguste-Viktoria-Schule, April 1914

- Einstellung als Hilfslehrerin, Juni 1914

1914

Klassifikation Teil B: 03558

Trägermaterial: Papier

Alte Reg.-Sig.: IV B4 06

Bestell-Nr.: IV 03558

3802 Höhere Töchterschule / Kaiserin-Auguste-Viktoria-Schule, Lehrerpersonalakte: Lehrerin Agnes Vocke

- Personalblatt mit Daten zur Lehrerin Agnes Vocke, 1924

- Wahl der Agnes Vocke zur Lehrerin an der

Kaiserin-Auguste-Viktoria-Schule, August 1898

- Bestallungsurkunde für die Lehrerin Agnes Vocke, August 1898

- Tätigkeit als Lehrerin an der Höheren Töchterschule /

Kaiserin-Auguste-Viktoria-Schule, 1899 - 1924 / 1928

1898 - 1918 (1919 - 1928)

Klassifikation Teil B: 03559

Trägermaterial: Papier

Alte Reg.-Sig.: IV B4 06

Bestell-Nr.: IV 03559

3803 Höhere Töchterschule, Lehrerpersonalakte: Turnlehrerin Paula Voss

- Ausschreibung einer Turnlehrerinnen - Stelle an der Höheren

Töchterschule, November - Dezember 1876

- Bestallungsurkunde für die Turnlehrerin Paula Voss, März 1879

- Kündigung der Lehrtätigkeit durch die Turnlehrerin Voss wegen

Versetzung ihres Vaters, Dezember 1879 - Januar 1880

$1878-1880(1885)$

Klassifikation Teil B: 03560

Trägermaterial: Papier

Alte Reg.-Sig.: IV B4 06

Bestell-Nr.: IV 03560 
10

10.04

\section{Schulaufsicht}

Höhere Töchterschule / Kaiserin-Auguste-Viktoria-Schule

Lfd. Nr. Titel

Laufzeit

3804 Höhere Töchterschule / Kaiserin-Auguste-Viktoria-Schule, Lehrerpersonalakte: Lehrerin Sophie Wissmar

- Personalblatt mit Daten zur Lehrerin Sophie Wissmar, 1907

- Bewerbung der Lehrerin Sophie Wissmar um eine vakante Lehrerinnenstelle an der Kaiserin-Auguste-Viktoria-Schule, Juli 1906

- Wahl der Sophie Wissmar zur Lehrerin an der Kaiserin-Auguste-Viktoria-Schule, Oktober 1906

- Bestallungsurkunde für die Lehrerin Sophie Wissmar, Oktober 1906

- Gehaltsfestlegung, Februar 1907

- Kündigung der Lehrtätigkeit durch die Lehrerin Sophie Wissmar wegen Absicht zur Absolvierung des Oberlehrerinnen-Seminars in Göttingen, September 1908

$1906-1908$

Klassifikation Teil B: 03561

Trägermaterial: Papier

Alte Reg.-Sig.: IV B4 06

Bestell-Nr.: IV 03561

3805 Höhere Töchterschule, Lehrerpersonalakte: Rektor Dr. Wulffes

- Wahl des Dr. E. Wulffes aus Hannover zum Rektor der Höheren

Töchterschule, Juni - August 1872

- Bestallungsurkunde für den Rektor Dr. E. Wulffes, November 1872

- Weggang des Dr. E. Wulffes nach Clausthal wegen Wahl zum Archediakon, Oktober - November 1876

- Forderung des Magistrats gegenüber Dr. Wulffes wegen zuviel gezahlter Gehälter durch seinen vorzeitigen Weggang nach Clausthal, März 1877 - Januar 1878

$1872-1878$

Klassifikation Teil B: 03562

Trägermaterial: Papier

Alte Reg.-Sig.: IV B4 06

Bestell-Nr.: IV 03562
1906-1908 
10

10.04

\section{Schulaufsicht}

Höhere Töchterschule / Kaiserin-Auguste-Viktoria-Schule

Lfd. Nr. Titel

Laufzeit

3806 Höhere Töchterschule / Kaiserin-Auguste-Viktoria-Schule, Lehrerpersonalakte: Lehrerin Marie Zander

- Personalblatt mit Daten zur Lehrerin Marie Zander, 1908

- Einstellung der Marie Zander als Vertretungslehrerin an der Höheren Töchterschule, April 1897

- Wahl der Marie Zander zur ordentlichen Lehrerin an der Höheren

Töchterschule, April 1899

- Bestallungsurkunde für die Lehrerin Marie Zander, Juli 1899

- Anrechnung des Vertretungsdienstes auf das Dienstalter, 1900 1901

- Antrag der Marie Zander an den Magistrat auf Gewährung eines einjährigen Urlaubs zur Fortbildung, August 1903

- Gewährung eines Erholungsurlaubs wegen nervöser

Krankheitsbeschwerden, Juni 1906 / 1908

- Sanatoriumsaufenthalt wegen nevöser Erschöpfung, Januar - April 1907

- Kündigung der Lehrtätigkeit durch die Lehrerin Marie Zander wegen

Heirat, Dezember 1908 - Januar 1909

$1897-1909$

Klassifikation Teil B: 03563

Trägermaterial: Papier

Alte Reg.-Sig.: IV B4 06

Bestell-Nr.: IV 03563

3807 Höhere Töchterschule / Kaiserin-Auguste-Viktoria-Schule,

$1877-1911$ Lehrerpersonalakte: Rektor August Ernst Zwitzers

- Personalblatt mit Daten zum Rektor August Ernst Zwitzers, 1910

- Wahl des reformierten Pastors in Hatzum, August Ernst Zwitzers zum Direktor der Höheren Töchterschule, November 1876

- Bestallungsurkunde für den Rektor E.A. Zwitzers, Januar 1877

- Amtsantritt des Direktors A.E. Zwitzers, März 1877

- Antrag des Direktors A. E. Zwitzers an die Töchterschulkommission auf Trennung der Leitung der Höheren Töchterschule von der Leitung der Höhgeren Bürgerschule wegen Überbelastung, Juni 1888 - - Antrag des Direktors A. E. Zwitzers an die Töchterschulkommission auf Anpassung seines Gehaltes an die Mehrbelastungen durch Organisation des Lererinnenseminars an der Höheren Töchterschule u.a. Anforderungen, November 1888

- Feier des 25-jährigen Dienstjubiläums des Direktors A.E.Zwitzers, Februar 1902

- Gehaltsrthöhung nach Anerkennung der Kaiserin-Auguste-Viktoria-Schule als Höhere Mädchenschule nach dem Allerhöchsten Erlass vom 14. August 1908, September 1908

- Versetzung in den Ruhestand, September 1910 - April 1911

- Anbringung einer Ehrentafel für Direktor A.E. Zwitzers, März 1911

- Todesanzeige und Nachruf auf A.E. Zwitzers, Januar 1921

$1877-1911(1921)$

Klassifikation Teil B: 03564

Trägermaterial: Papier

Alte Reg.-Sig.: IV B4 06

Bestell-Nr.: IV 03564 
IV

10 Schulaufsicht

10.04

Höhere Töchterschule / Kaiserin-Auguste-Viktoria-Schule

Lfd. Nr. Titel

Laufzeit

3808 Höhere Töchterschule / Kaiserin-Auguste-Viktoria-Schule, Lehrerpersonalakte: Oberlehrerin Anna Jenssen

- Personalblatt mit Daten zur Oberlehrerin Anna Jenssen, 1914

- Bewerbung der Lehrerin Anna Jenssen mit der Befähigung zur

Oberlehrerin um die dritte Oberlehrerinnenstelle an der

Kaiserin-Auguste-Viktoria-Schule, Mai 1914

- Wahl der Anna Jenssen zur Oberlehrerin an der

Kaiserin-Auguste-Viktoria-Schule, Juni 1914

- Bestallung der Anna Janssen als Oberlehrerin, September - Oktober 1915

- Entlassungsgesuch der Oberlehrerin Jenssen wegen beabsichtigten Wechsels nach Nordhausen, Februar 1918

$1914-1918$

Klassifikation Teil B: 03565

Trägermaterial: Papier

Alte Reg.-Sig.: IV B4 06

Bestell-Nr.: IV 03565

3809 Bewerbungen um die Stelle des Direktors der Höheren Töchterschule

- Anfragen des Bürgermeisters L. Fürbringer zur Gewinnung von Informationen zu Bewerbern um das Amt des Töchterschuldirektors in Emden

1876

Klassifikation Teil B: 03566

Trägermaterial: Papier

Alte Reg.-Sig.: IX B4 06

Bestell-Nr.: IV 03566 
Lfd. Nr. Titel

Laufzeit

3810 Diensteinkommen der Lehrerinnen und Lehrer an der Höheren Töchterschule / Kaiserin Augusta-Viktiria-Schule, Bd. 1

- Promemoria des Direktors Zwitzers über Plädoyer für die Anpassung der Lehrergehälter an der Höheren Töchterschule an die der Realschule, November 1896

- Datensammlung des Magistrats über Gehaltsverhältnisse der Töchterschullehrer in den Städten der Provinz Hannover, November 1896

- Gesuche verschiedener Lehrerinnen und Lehrer um

Gehaltserhöhung, 1887 - 1908

- Beschluss der Töchterschulkommission über Erhöhung der Lehrergehälter bei gleichzeitiger Erhöhung der Schulgeldsätze, Mai Juni 1897

- Bestimmungen über Gehälter der Lehrer und Lehrerinnen der Höheren Töchterschule, August 1898

- Änderungen der Gehaltsbestimmungen / Alterszulage, 1903 - 1908

- Novellierung der Gehaltsbestimmungen, Mai - Juni 1905

- Erhöhung der Gehälter für die Elementarlehrer an der Höheren

Töchterschule, September 1908

$1896-1908$

\author{
Klassifikation Teil B: 03567 \\ Band: 1 \\ Trägermaterial: Papier \\ Alte Reg.-Sig.: IX B4 06b \\ Bestell-Nr.: IV 03567
}

3811 Diensteinkommen der Lehrerinnen und Lehrer an der Höheren Töchterschule / Kaiserin Augusta-Viktiria-Schule, Bd. 2

- Anpassung der Lehrergehälter an die Bestimmungen des staatlichen Besoldungsordnung vom Mai 1909, 1909

- Regelung des Wohngeldzuschusses für Oberlehrerinnen, 1909 1913

- Novellierung der Gehaltsordnung für Lehrerinnen und Lehrer an der Kaiserin-Auguste-Viktoria-Schule, Mai - Juni 1912

- Datensammlung des Magistrats über Besoldungsordnungen für Töchterschullehrer in Städten der Provinz Hannover, 1913

$1909-1914$

Klassifikation Teil B: 03568

Band: 2

Trägermaterial: Papier

Alte Reg.-Sig.: IX B4 06b

Bestell-Nr.: IV 03568 
Lfd. Nr. Titel

Laufzeit

3812 Diensteinkommen der Lehrerinnen und Lehrer an der Höheren Töchterschule / Kaiserin Augusta-Viktiria-Schule, Bd. 3

- Novellierung der Besoldungsordnung für Lehrerinnen und Lehrer der Kaiserin-Auguste-Viktoria-Schule, Oktober 1913

- Regelung der Gehälter für Kandidaten für das Höhere Lehramt, Februar 1914

- Erhöhung der Wohnungszulage für Oberlehrerinnen durch Angleichung der Sätze mit denen der unverheirateten männlichen Oberlehrer, Januar 1914

- Regelung der Ortszulage für Lehrer, 1916

$1913-1916(1919)$

\author{
Klassifikation Teil B: 03569 \\ Band: 3 \\ Trägermaterial: Papier \\ Alte Reg.-Sig.: IX B4 06b \\ Bestell-Nr.: IV 03569
}

3813 Besetzung der Direktorenstelle an der

Kaiserin-Auguste-Viktoria-Schule

- Bewerbungen um die vakante Direktorenstelle an der

Kaiserin-Auguste-Viktoria-Schule nach der Pensionierung des

Direktors Zwitzers, September 1910

- Verfahren zur Wahl des neuen Direktors der

Kaiserin-Auguste-Viktoria-Schule, Oktober 1910

1910

\author{
Klassifikation Teil B: 03570 \\ Trägermaterial: Papier \\ Alte Reg.-Sig.: IX B4 06e
}

Bestell-Nr.: IV 03570

3814 Schulgeld an der Höheren Töchterschule / Kaiserin-Auguste.-Viktoria-Schule, Bd. 1

- Eintreibung rückständiger Schulgeldforderungen, 1876 - 1901

- Neufestsetzung der Schulgeldsätze der Höheren Töchterschule, 1884 - 1904

- Anträge auf Erlass von Schulgeldzahlungen, 1886 - 1905

- Beschluss der städtischen Kollegien über Schulgeldermäßigungen für Töchter von Lehrern an der Höheren Töchterschule, März 1886

- Bekanntmachung über Zahlungsfristen für Schulgeld an der Höheren Töchterschule, März 1895

- Datensammlung über Schulgeldsysteme für Höhere Töchterschulen in Städten der Provinz Hannover, 1896 / 1898 / 1904

$1876-1905$

Klassifikation Teil B: 03571

Band: 1

Trägermaterial: Papier

Alte Reg.-Sig.: IX B4 07

Bestell-Nr.: IV 03571 
IV

10 Schulaufsicht

10.04 Höhere Töchterschule / Kaiserin-Auguste-Viktoria-Schule

Lfd. Nr. Titel

Laufzeit

3815 Schulgeld an der Höheren Töchterschule / $1905-1914$ Kaiserin-Auguste.-Viktoria-Schule, Bd. 2

- Neufestsetzung der Schulgeldsätze der Höheren Töchterschule, $1905-1914$

- Bekanntmachung über Zahlungsfristen für Schulgeld an der Kaiserin-Auguste.-Viktoria-Schule, Januar 1906

- Beschluss der städtischen Kollegien über Rücknahme der Schulgeldermäßigung für Lehrertöchter, Mai 1909

$1905-1914$

Klassifikation Teil B: 03572

Band: 2

Trägermaterial: Papier

Alte Reg.-Sig.: IX B4 07

Bestell-Nr.: IV 03572

3816 Schulgeld an der Höheren Töchterschule /

$1906-1915$

Kaiserin-Auguste.-Viktoria-Schule, Bd. 3

- Anträge auf Erlass oder Ermäßigung von Schulgeldzahlungen

$1906-1915$

Klassifikation Teil B: 03573

Band: 3

Trägermaterial: Papier

Alte Reg.-Sig.: IX B4 07

Bestell-Nr.: IV 03573

3817 Regelung der Ruhegehaltsverhältnisse bei Lehrerinnen und Lehrern an der Höheren Töchterschule / Kaiserin- Auguste-Viktoria-Schule

- Gesetze und Erlasse mit Ausführungsbestimmungen wegen Regelung der Ruhegehaltsverhältnisse an nichtstaatlichen Höheren Schulen, 1894 - 1912

- Umsetzung des Gesetzes über die Regelung der

Ruhegehaltsverhältnisse bei Lehrerinnen und Lehrern vom Juni 1894 auf die Lehrkräfte der Höheren Töchterschule, Juli 1894 - Antrag des Magistrats an das Provinzial-Schul-Kollegium in Hannover auf Erhalt der Mitgliedschaft der Töchterschullehrer bei der Elermentarlehrer-Witwen- und Waisenkasse, März 1909 / Januar 1910

$1894-1912$

Klassifikation Teil B: 03574

Trägermaterial: Papier Alte Reg.-Sig.: IX B4 09

Bestell-Nr.: IV 03574 
IV

10 Schulaufsicht

10.04

Höhere Töchterschule / Kaiserin-Auguste-Viktoria-Schule

Lfd. Nr. Titel

Laufzeit

3818 Etat der Höheren Töchterschule / Kaiserin-Auguste-Viktoria-Schule 1877-1909

- Nachbewilligungen zum Etat der Höheren Töchterschule /

Kaiserin-Auguste-Viktoria-Schule, 1877 - 1909

- Verhandlungen der städtischen Kollegien über Etat der Höheren

Töchterschule, März 1884 / März 1893 / November 1907

$<$ Akte unvollständig $>$

1877 - 1909 (1918)

Klassifikation Teil B: 03575

Trägermaterial: Papier

Alte Reg.-Sig.: IX B4 10

Bestell-Nr.: IV 03575

3819 Rendantur der Höheren Töchterschule

- Ernennung des Johann Hermann Tholen zum Rendanten der Höheren Töchterschule, September 1872

- Instruktion für den Rendanten der Höheren Töchterschule über

Aufgaben und Funktionen, September 1872

- Gesuch des Rendanten Johann Hermann Tholen über Bitte um

Erhöhung seiner Vergütungen wegen Vermehrung der Aufgaben,

März 1874

- Etatberatungen der Kommission für die Höhere Töchterschule, 1875

$-1882$

$<$ Akte unvollständig >

$1872-1882$

Klassifikation Teil B: 03576

Trägermaterial: Papier

Alte Reg.-Sig.: IX B4 10

Bestell-Nr.: IV 03576

3820 Schulgeldhebungslisten der Höheren Töchterschule

- Listen über Schulgeldpflichtige und Zahlungen von Eltern der Schülerinnen der Höheren Töchterschule

$1875-1876$

Klassifikation Teil B: 03577

Trägermaterial: Papier

Alte Reg.-Sig.: IX B4 10

Bestell-Nr.: IV 03577

3821 Schulordnung der Höheren Töchterschule

- Schulordnungen der Höheren Töchterschule mit Ergänzungen

$1875-1895$

Klassifikation Teil B: 03578

Trägermaterial: Papier

Alte Reg.-Sig.: IX B4 10

Bestell-Nr.: IV 03578 
Lfd. Nr. Titel

Laufzeit

3822 Hinterbliebenenversorgung für die Lehrkräfte der Höheren $1880-1913$ Töchterschule / Kaiserin-Auguste-Viktoria-Schule

- Aufnahme von Töchterschullehrer in die

Provinzial-Elementarlehrer-Witwen und Waisenkasse, August 1880

- Aufstellungen über Witwen- und Waisenkassen-Zugehörigkeit von

Töchterschullehrern, 1882 - 1913

- Ruhestandsversetzungen von Töchterschullehrern mit der Folge des

Ausscheidens aus der Witwen- und Waisenkasse, 1898 - 1899 / 1913

- Ausscheiden der Töchterschullehrkräfte aus der

Provinzial-Elementarlehrer-Witwen und Waisenkasse nach

Anerkennung der Höheren Töchterschule /

Kaiserin-Auguste-Viktoria-Schule als Höhere Lehranstalt, April 1910

$1880-1913$

Klassifikation Teil B: 03579

Trägermaterial: Papier

Alte Reg.-Sig.: IX B4 12

Bestell-Nr.: IV 03579

3823 Innere Angelegenheiten der Höheren Töchterschule

- Verfügung des kgl. Konsistoriums in Aurich über Umsetzung eines Ministerialerlasses über Vereinheitlichung der deutschen

Orthographie, Januar 1880

- Inventar: Turngeräte der Höheren Töchterschule, Juli 1880

- Integration der Vorklasse der Höheren Töchterschule in allgemeine

Vorschulklassen für Jungen und Mädchen als Vorbereitung und

Zugang zu den höheren Schulen in Emden, Dezember 1881 - Mai

1883

- Teilung von Klassen der Höheren Töchterschule wegen Zunahme der Zahl der Schülerinnen, 1883

- Stellungnahme des Direktors Zwitzers gegen eine Verstaatlichung der Höheren Töchterschule und gegen zentrale staatliche Vorschriften zu Lehrplänen und Schulorganisation, September 1894

- Anschaffung neuer Schulbänke für die Höhere Töchterschule, 1895 1896

- Stundenplan für die Höhere Töchterschule, 1900 /01

- Verwendung von Schulgeldmehreinnahmen, November - Dezember 1902

$1880-1902$

Klassifikation Teil B: 03580

Trägermaterial: Papier

Alte Reg.-Sig.: IX B4 15

Bestell-Nr.: IV 03580 
Lfd. Nr. Titel

Laufzeit

3824 Beaufsichtigung und Revision der Höheren Töchterschule

- Revision der Organisation und des Unterrichts der Höheren

Töchterschule durch die kgl. Regierung in Aurich, 1888 - 1899

- Unterstellung der Höheren Töchterschule unter die Aufsicht des

Provinzial-Schul-Kollegiums, April 1900 - April 1901

- Revision der Höheren Töchterschule durch die

Provinzial-Schul-Kommission, 1905 - 1906

1888 - 1906 (1928 - 1936)

Klassifikation Teil B: 03582

Trägermaterial: Papier

Alte Reg.-Sig.: IX B4 15

Bestell-Nr.: IV 03582

3825 Benennung der Höheren Töchterschule als

1904-1905 Kaiserin-Auguste-Viktoria-Schule (Patronat)

- Antrag des Magistrats an den Minister der Geistlichen, Unterrichtsund Meduzinalangelegenheiten durch die Hand des Regierungspräsidenten auf Verleihung des Namens Kaiserin-Auguste-Viktoria-Schule für die Höhere Töchterschule, April 1904

- Allerhöchste Kabinettsorder des Kaisers Wilhelm II. über Benennung der Höheren Töchterschule nach seiner Frau Auguste-Viktoria, Januar 1905

$1904-1905$

Klassifikation Teil B: 03583

Trägermaterial: Papier

Alte Reg.-Sig.: IX B4 16

Bestell-Nr.: IV 03583

3826 Stiftung von Glasmalereien und eines Ölgemäldes der Kaiserin

- Bericht des Oberbürgermeisters Fürbringer über Zusage des Kultusministers zur Finanzierung von bemalten Glasfenstern und eines Ölgemäldes von Kaiserin Auguste Viktoria für die Aula der Kaiserin-Auguste-Viktoria-Schule, März 1904

- Antrag des Magistrats an den Minister der Geistlichen, Unterrichtsund Medizinalangelegenheiten auf Beihilfe zur Finanzierung bemalter Glasfenster und Bitte um Vermittlung eines Ölgemäldses der Kaiserin Auguste Viktoria für die Aula der Kaiserin-Auguste-Viktoria-Schule, April - September 1904

- Korrespondenz des Oberbürgermeisters Fürbringer mit Prof Wychgram und Prof. A. Linnemann wegen Motive der Glasmalereien für die Fenster der Aula der Kaiserin-Auguste-Viktoria-Schule, November 1904

1904

Klassifikation Teil B: 03584

Trägermaterial: Papier

Alte Reg.-Sig.: IX B4 17

Bestell-Nr.: IV 03584 
IV

10 Schulaufsicht

10.04 Höhere Töchterschule / Kaiserin-Auguste-Viktoria-Schule

Lfd. Nr. Titel

Laufzeit

3827 Einweihungsfeier des neuen Gebäudes der 1905

Kaiserin-Auguste-Viktoria-Schule

- Programm der Einweihungsfeier, Oktober 1905

- Verhandlungen der Töchterschulkommission über Organisation und Ablauf der Einweihungsfeier, März - Oktober 1905

- Bericht des Oberbürgermeisters Fürbringer an den

Regierungspräsidenten über Planungsstand der Einweihungsfeier Beschreibung der Kaiserin-Auguste-Viktoria-Schule und Statistik, August 1905

- Zu- und Absagen eingeladener Personen zur Einweihungsfeier,

Oktober 1905

- Bekanntmachung der Einweihungsfeier, Oktober 1905

- Glückwunschtelegramm der Kaiserin Auguste Viktoria anlässlich der Einweihungsfeier der nach ihr benannten Höheren Töchterschule, Oktober 1905

- Presseberichte über die Einweihungasfeier, Oktober 1905

1905

Klassifikation Teil B: 03585

Trägermaterial: Papier

Alte Reg.-Sig.: IX B4 18

Bestell-Nr.: IV 03585

3828 Seminar-Übungsschule an der Kaiserin-Auguste-Viktoria-Schule

- Bericht des Rektors Zwitzers an den Magistrat über Notwendigkeit zur Verbesserung der Seminar-Übungsschule an der

Kaiserin-Auguste-Viktoria-Schule, November 1907

- Anfragen aus anderen Städten wegen Organisation der

Seminarübungsschule, 1908 - 1912

- Verfügung des Provinzialschul-Kollegiums über Erlaubnis der Übernahme des Übungsunterrichts des Lehrerinnenseminars auf das Lyzeum (Kaiserin-Auguste-Viktoria-Schule) unter Aufforderung zur Einrichtung einer besonderen Seminar-Übungsschule, März 1912

$1907-1912$

Klassifikation Teil B: 03586

Trägermaterial: Papier

Alte Reg.-Sig.: IX B4 21

Bestell-Nr.: IV 03586

3829 Errichtung von Parallelklassen in der Kaiserin-Auguste-Viktoria-Schule

- Verhandlungen der Töchterschulkommission über Einrichtung von Parallelklassen in der Kaiserin-Auguste-Viktoria-Schule wegen

Zunahme der Zahl der Schülerinnen, April 1908 / März 1912

- Verfügung des Magistrats über Genehmigung der Einrichtung von

Parallelklassen in der Kaiserin-Auguste-Viktoria-Schule, April 1908 /

April 1912

$1908-1912$

Klassifikation Teil B: 03587

Trägermaterial: Papier

Alte Reg.-Sig.: IX B4 22

Bestell-Nr.: IV 03587 
10

10.04
Schulaufsicht

Höhere Töchterschule / Kaiserin-Auguste-Viktoria-Schule

Lfd. Nr. Titel

Laufzeit

1905-1911

- Denkschrift des Rektors A.E. Zwitzers für die Einrichtung einer Mittelschule für Mädchen, Juli 1905

- Aufsatz über Mittelschulen für Mädchen in: Die Mittelsachule und Höhere Mädchenschulen, Pädagogische Zeitschrift, 1904

- Anfrage des Oberbürgermeisters Fürbringer an Nachbarstädte in der Provinz Hannover über Erfahrungen mit Mittelschulen für Mädchen, April 1911

- Daten aus Göttingen, Hameln, Harburg, Hildesheim, Kiel, Linden (Hannover), Lüneburg, Wilhelmshaven über Erfahrung mit Mittelschulen für Mädchen, April / Mai 1911

$1905-1911$

Klassifikation Teil B: 03588

Band: 1

Trägermaterial: Papier Alte Reg.-Sig.: IX B4 23

Bestell-Nr.: IV 03588 
Lfd. Nr. Titel

- Verhandlung der Töchterschulkommission über Einrichtung einer Mittelschule für Mädchen, April - Dezember 1911

- Denkschift des Rektors Dr. Zahrenhusen für Einrichtung einer Mittelschule für Mädchen als Seminar-Übungsschule für die praktische Lehrerausbildung, August / Dezember 1911

- Kalkulation der Einnahmen und Ausgaben nach Einrichtung der Mittelschule für Mädchen, September 1911

- Verhandlungen der Stadtschuldeputation über Einrichtung einer Mittelschule für Mädchen, November 1911

- Datenerhebung über Seminar-Übungsschulen an Höheren

Töchterschulen, November 1911

- Stellungnahme des Innungsausschusses und des Verbandes mittlerer Reichspost - und Telegraphiebeamter, Ortsgruppe Ostfriesland für die Einrichtung einer Mittelschule für Mädchen, Dezember 1911

- Votum des Bürgervorsteherkollegiums gegen die Einrichtung einer Mittelschule für Mädchen und für eine Seminar-Übungsschule, Februar 1912

- Bericht des Direktors Dr. Zahrenhusen über Raumbedarf der Kaiserin-Auguste-Viktoriaschule bei Umsetzung des Projekts Mittelschule für Mädchen, Mai 1912

- Verhandlungen der Schulkommission für die Kaiserin-Auguste-Viktoria-Schule über die Einrichtung einer Seminar-Übungsschule an der Kaiserin-Auguste-Voktoria-Schule, Oktober - Dezember 1912

- Organisationsschema der Kaiserin-Auguste-Viktoria-Schule mit vierklassiger Höherer Mädchenschule (Mittelschule für Mädchen), Januar 1913

- Verhandlungen der städtischen Kollegien über Einrichtung einer Höheren Mädchenschule (Mittelschule für Mädchen) als Seminarübungsschule an der Auguste-Viktoria-Schule, Januar Februar 1913

$1911-1913$

Klassifikation Teil B: 03589

Band: 2

Trägermaterial: Papier

Alte Reg.-Sig.: IX B4 23

Bestell-Nr.: IV 03589 
Lfd. Nr. Titel

Laufzeit

3832 Seminar-Vorschule an der Kaiserin-Auguste-Viktoria-Schule

- Anregung des Direktors Zwitzers zur Einrichtung einer Seminar-Vorschule als Vorbereitung zum Besuch des Lehrerinnenseminars an der Kaiserin-Auguste-Viktoria-Schule und zur Sicherung einer genügenden Zahl von Absolventinnen, September 1908

- Meldungen von Kandidatinnen für die Seminar-Vorschule, Oktober 1908

- Beschluss der Töchterschulkommission zur versuchsweisen

Einrichtung einer Seminar-Vorschule auf zwei Jahre, Oktober 1908

- Beschluss der Töchterschulkommission über Beendigung des

Projektes, Dezember 1908

1908

\author{
Klassifikation Teil B: 03590 \\ Trägermaterial: Papier \\ Alte Reg.-Sig.: IX B4 24 \\ Bestell-Nr.: IV 03590
}

3833 Staatsbeihilfe für die Kaiserin-Auguste-Viktoria-Schule, Bd. 1

- Antrag des Magistrats an den Minister der Geistlichen, Unterrichtsund Medizinalangelegenheiten auf Staatsbeihilfe zum Betrieb des Lehrerinnenseminars an der Kaiserin-Auguste-Viktoria-Schule, Januar 1901 - Dezember 1907

- Verschiedene Anlagen:

- Verfügung der kgl. Regierung in Aurich über Anordnung der Senkung der Klassenfrequenz im Lehrerinnen-Seminar, Juni 1902 - Gutachten des Rektors Zwitzers über Mehrkosten bei der Umsetzung der Verfügung, Juli 1902

- Etat des Lehrerinnen-Seminars an der Kaiserin-Auguste-Viktoria-Schule, 1903 / 1904 / 1907

- Anträge des Magistrats an den Minister der Geistliche, Unterrichtsund Medizinalangelegenheiten auf Staatsbeihilfe für den Betrieb der Kaiserin-Auguste-Viktoria-Schule, 1903 - 1907

- Anlagen: Etats der Kaiserin-Auguste-Viktoria-Schule, 1903 - 1907

$1901-1907$

Klassifikation Teil B: 03591

Band: 1

Trägermaterial: Papier

Alte Reg.-Sig.: IX B4 25

Bestell-Nr.: IV 03591

3834 Staatsbeihilfe für die Kaiserin-Auguste-Viktoria-Schule, Bd. 2

- Anträge und und Gewährung einer Staatsbeihilfe zum Betrieb der Kaiserin-Auguste-Viktoria-Schule

$1915-1917$

Klassifikation Teil B: 03592

Band: 2

Trägermaterial: Papier

Alte Reg.-Sig.: IX B4 25

Bestell-Nr.: IV 03592 
IV

10 Schulaufsicht

10.04 Höhere Töchterschule / Kaiserin-Auguste-Viktoria-Schule

Lfd. Nr. Titel

Laufzeit

3835 Freistellen an der Kaiserin-Auguste-Viktoria-Schule

- Anträge auf Schulgeldbefreiung oder Schulgeldermäßigung

- Vergabe von Freistellen (Schulgeldbefreiung) oder Ermäßigung von

Schulgeldforderungen

$1913-1917$

Klassifikation Teil B: 03593

Trägermaterial: Papier

Alte Reg.-Sig.: IX B4 25

Bestell-Nr.: IV 03593

3836 Disziplinarstrafen gegen Schülerinnen der Höheren Töchterschule

- Bestrafung von Schülerinnen wegen Boykottierung von trotz parallel stattfindender privater Chorproben angesetztem Gesangsunterricht, August 1875

- Plädoyer des Direktors Dr. Wulffes für das Verbot des Besuches der privaten Singakademie des Musikers Hoffmeister durch Schülerinnen der Höheren Töchterschule, September 1875

- Suspendierung der Schülerin Elisabeth Prinz wegen von ihrem Vater aus der Ansicht der Benachteiligung der katholischen Minderheit geduldetem Ungehorsams gegen Weisungen des Direktors, August September 1879

- Streit zwischen dem Lehrer Enkelstroth und der Rechtsanwaltsgattin Russell wegen Bestrafung ihrer Tochter Wilhelmine, November -

Dezember 1882

$<$ Akte unvollständig >

$1875-1890$

Klassifikation Teil B: 03594

Trägermaterial: Papier

Alte Reg.-Sig.: IX B4 25

Bestell-Nr.: IV 03594

3837 Etat der Höheren Töchterschule / Kaiserin-Auguste-Viktoria-Schule

- Haushaltspläne der Höheren Töchterschule /

Kaiserin-Auguste-Viktoria-Schule mit Beilagen

- Beratung der Etats in der Töcherschulkommission /

Schulkommssion der Kaiserin-Auguste-Viktoria-Schule

- Übernahme der Etatdefizite durch die Stadtkasse

1893 - 1918 (1918 - 1921)

Klassifikation Teil B: 03595

Trägermaterial: Papier

Alte Reg.-Sig.: IX B4 26

Bestell-Nr.: IV 03595 
IV

10

Schulaufsicht

10.04

Höhere Töchterschule / Kaiserin-Auguste-Viktoria-Schule

Lfd. Nr. Titel

Laufzeit

3838 Versicherung des Gebäudes der Kaiserin-Auguste-Viktoria-Schule 1893-1907

- Versicherung der Gebäude der Höheren Töchterschule /

Kaiserin-Auguste-Viktoria-Schule gegen Feuer bei der

Vaterländischen Feuerversicherungsvesicherungs AG in Elberfeld,

$1893-1907$

- Verhandlungen wegen Aktualisierung der Feuerversicherungspolice

des Schulgebäudes der Kaiserin-Auguste-Viktoria-Schule in der

Ringstraße, 1906

- Versicherung des Schulgebäudes bei der Ostfriesischen

Brandkasse, 1906

- Versicherung des Gebäudes gegen Wasserleitungsschäden, 1906

$1893-1907$

Klassifikation Teil B: 03596

Trägermaterial: Papier

Alte Reg.-Sig.: IX B4 27

Bestell-Nr.: IV 03596

3839 Kommission der Höheren Töchterschule, Bd. 1

1890-1909

- Schulordnung der Höheren Töchterschule, 1890

- Stimmrecht des Kommissionsvorsitzenden, 1893

$<$ Akte unvollständig >

$1890-1909$

Klassifikation Teil B: 03597

Band: 1

Trägermaterial: Papier

Alte Reg.-Sig.: IX B4 27

Bestell-Nr.: IV 03597

3840 Kommission der Höheren Töchterschule, Bd. 2

$1886-1894$

- Ersatzwahlen für die Kommission der Höheren Töchterschule

$<$ Akte unvollständig >

$1886-1894$

Klassifikation Teil B: 03598

Band: 2

Trägermaterial: Papier

Alte Reg.-Sig.: IX B4 27

Bestell-Nr.: IV 03598 
10

10.04

\section{Schulaufsicht}

Höhere Töchterschule / Kaiserin-Auguste-Viktoria-Schule

Lfd. Nr. Titel

Laufzeit

1874

- Einrichtung einer Siebten Klasse an der Höheren Töchterschule wegen Zunahme der Zahl der Schülerinnen und Einstellung von Lehrer für diese Klasse

1874
Klassifikation Teil B: 03599
Trägermaterial: Papier
Alte Reg.-Sig.: IX B4 28
Bestell-Nr.: IV 03599

3842 Vorschriften zur Staatsbeihilfe zum Neu- und Ausbau von Schulen

1912

- Erlass des Ministers der Geistlichen, Unterrichts- und Medizinalangelegenheiten über Vorschriften zur Staatsbeihilfe zum Neu- und Ausbau von Schulen

1912

\author{
Klassifikation Teil B: 03600 \\ Trägermaterial: Papier \\ Alte Reg.-Sig.: IX B4 28 \\ Bestell-Nr.: IV 03600
}

3843 Einführung des Turnunterrichts an der Höheren Töchterschule

- Verhandlungen der Töchterschulkommission über Errichtung einer

Turnhalle und Einstellung von Turnlehrerinnen an der Höheren

Töchterschule,

- Einarbeitung des Turnunterrichts in den Lehrplan der Höheren

Töchterschule

Enthält auch:

- Errichtung des Lehrerinnen-Seminars an der Höheren Töchterschule

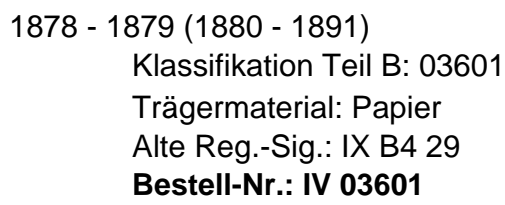

3844 Schulwärter an der Höheren Töchterschule

$<$ Akte unvollständig >

1889

Klassifikation Teil B: 03602

Trägermaterial: Papier

Alte Reg.-Sig.: IX B4 30

Bestell-Nr.: IV 03602 
10

10.04

Schulaufsicht

IV

Höhere Töchterschule / Kaiserin-Auguste-Viktoria-Schule

Lfd. Nr. Titel

Laufzeit

3845 Schulstatistik der Höheren Töchterschule

$1872-1890$

- Statistiken über Schülerinnenzahlen, Jahresberichte,

Schulgeldeinnahmen, Listen der Schülerinnen, Prüfungen und Etats der Höheren Töchterschule

- Kassenrevision bei der Höheren Töchterschule

18721890

Klassifikation Teil B: 03603

Trägermaterial: Papier

Alte Reg.-Sig.: IX B4 45

Bestell-Nr.: IV 03603

3846 Schuletats der Höheren Töchterschule

Haushaltspläne

$1872-1896$

Klassifikation Teil B: 03604

Trägermaterial: Papier

Alte Reg.-Sig.: IX B4 45

Bestell-Nr.: IV 03604 
10

10.05

Lfd. Nr. Titel

- Räumung eines Teils der Alten Kaserne durch die

Kinderbewahranstalt wegen Benötigung des Raums für die

Erweiterung des städtischen Kankenhauses, 1868

- Antrag des Vorstands der Kinderbewahranstalten, Pastor Frerichs, an den Magistrat auf Beihilfe aus der Stadtkasse für die

Kinderbewahranstalten, Februar / Mai 1872

Beihilfe der Stadt Emden zur Finanzierung der Einfriedung der

Kinderbewahranstalt an der Roten Mühle, Juni 1872

- Antrag des Vorstands der Kinderbewahranstalten, Pastor Frerichs, an den Magistrat auf eine dauernde Unterstützung für den Betrieb der Kinderbewahranstalten, November 1872 - Dezember 1884

- Kollekten des Vorstands der Kinderbewahranstalten zum Betrieb der Anstalten, Februar 1875 - März 1881

- Instandsetzung der Kinderbewahranstalt in der Alten Kaserne, Oktober 1877

- Raumnot der Kinderbewahranstalt in der Alten Kaserne nach Anforderung des von ihr genutzten Wagenraumes, März 1878 Jamuar 1879 / Dezember 1885

- Ausbesserung des Fußbodens in den Räumen des von der Kinderbewahranstalt genutzten Teils der Kaserne, April - Mai 1879

- Reglement für die Kinderbewahranstalten in Emden, Mai 1879

- Antrag des Vorstands der Kinderbewahranstalten auf Vergrößerung des Spielplatzes der Kinderbewahranstalt in der Kaserne, August 1879

- Berichte über Zustand, Organisation und Tätigkeit der Kinderbewahranstalten in Emden, 1880 - 1891

- Ausbreitung einer infektiösen Augenkrankheit unter den Kindern in der Kinderbewahranstalt, November - Dezember 1880

- Renovierungsbedarf für die Kinderbewahranstalt in der Großen

Brückstraße, November 1882 - Juli 1883

- Einrichtung einer Küche in der Kinderbewahranstalt in der Alkten

Kaserne, 1882

- Etat der christlichen Kinderschule auf dem Kattewall, 1889 / 1891

$1868-1890$

Klassifikation Teil B: 03605

Trägermaterial: Papier

Alte Reg.-Sig.: IX B5 02

Bestell-Nr.: IV 03605

3848 Private Musikschulen

- Erlasse des Ministers der Geistlichen, Unterrichts- und Medizinalangelegenheiten über Beaufsichtigung privater Musikschulen, Juni / Juli 1913

- Bericht des Syndicus Dr. Riese an den Regierungspräsidenten über private Musikschulen und -Lehrer in Emden, August 1913

1913

Klassifikation Teil B: 03606

Trägermaterial: Papier

Alte Reg.-Sig.: IX B5 06

Bestell-Nr.: IV 03608 
Lfd. Nr. Titel

- Erlass des Ministers der Geistlichen, Unterrichts- und Medizinalangelegenheiten über Meldepflicht von Privatschulen über

Prüfungen für den Einjährig-Freiwilligen Dienst, Juni 1886

- Erlass des Ministers für Handel und Gewerbe über Organisation der

Aufsicht über Privatschulen, 1900 - 1916

- Urteil des Kammergerichts über Zulässigkeit des

Privatschulbesuches, 1900

- Prospekt des H. Stalliing 'schen Heilpädagogiums in

Hannover-Kirchrode (Privatschule für geistig zurückgebliebene Kinder gebildeter Eltern), Juni 1905

- Prospekt der privaten Höheren Töchterhandelsschule in Heilbronn, 1906

- Bericht des Magistrats über zwei ohne Genehmigung tätige

Privatschulen in Emden: Emder Industrieschule für Frauen und

Töchter; The Berlitz School of Languages, Mai 1908

- Nachträgliches Genehmigungsverfahren für beide Schulen, Juni -

Juli 1908

- Erlass des Landwirtschaftsministers über Meldung privater land- und hauswirtschaftlicher Privatschulen, Juli 1908

- Eingabe des deutschnationalen Handlungsgehilfen-Verbandes an den Regierungspräsidenten über Bitte um Verbesserung der Aufsicht über private Handels- und Sprachschulen und Schließung untauglicher Anstalten, September 1908

- Antrag des Rektors der Kaiserin-Auguste-Viktoria-Schule, A.E.

Zwitzers auf Genehmigung einer Mädchen-Fortbildungsschule, März 1909

- Antrag des Dr. Frerichs auf Zulassung der von ihm geplanten privaten Handelsschule in Emden, März - August 1910

- Negatives Gutachten des Kreisschulrats über den Lehrer Dr.

Frerichs, 1910

- Verfügung der kgl. Regierung über Organisation einer einheitlichen Aufsicht über die Privatschulen im Regierungsbezirk Aurich, Januar 1914

- Antrag des Lehrers Wallrich Buttjer an den Magistrat auf Zulassung von inm veranstalteter Handelsschulkurse, Januar 1915

$1886-1916$

Klassifikation Teil B: 03606

Trägermaterial: Papier

Alte Reg.-Sig.: IX B5 03

Bestell-Nr.: IV 03606

3850 Kinderbewahranstalten

- Unterstützung der Kinderbewahranstalten aus der Stadtkasse, 1903

$-1905$

- Etat der Kindebewahranstalt auf Transvaal, 1904 - 1905

- Jahresberichte der Kinderbewahranstalten, 1903 - 1905

$1903-1905$

Klassifikation Teil B: 03607

Trägermaterial: Papier

Alte Reg.-Sig.: IX B5 05

Bestell-Nr.: IV 03607 
10

10.05

Lfd. Nr. Titel

- Antrag des Vorstands des Kindergartens an den Magistrat auf Umwandlung des 1855 von der Matschappij tot nutz van't algemeen gegründeten Kindergartens für Kinder mittlerer und höherer Stände in ein städtisches Institut, Juli 1873

- Anträge des Vorstands des Kindergartens an den Magistrat auf Beihilfe der Stadt für den Kindergartenbetrieb, August 1874 - März 1914

- Antrag des Vorstands des Kindergartens an den Magistrat auf Stellung eines neuen Gebäudes für den Kindergarten, Dezember 1881

- Gutachten des Rektors A. E. Zwitzers über Notwendigkeit eines Kindergartens für die höheren Stände unter städtischer Trägerschaft, Dezember 1881

- Etat des Kindergartens, 1889 - 1909

- Statuten des Kindergartens zu Emden, 1860 / 1889

- Tagesordnung (Stundenplan) für den Kindergarten, ca. 1889

- Anfrage des Magistrats bei der kgl. Regierung hinsichtlich

Unterstützung des Plans zur Einrichtung eines Kindergärtnerinnen -

Seminars in Emden, August 1889

- Medizinische Begutachtung des Kindergartens durch den Kreisarzt

Dr. Tergast, Dezember 1907

- Ehrung der Kindergarten-Vorsteherin Sentina Stomberg zum 40 jährigen Dienstjubiläum, April 1908

$1873-1914$

Klassifikation Teil B: 03609

Trägermaterial: Papier

Alte Reg.-Sig.: IX B5 05

Bestell-Nr.: IV 03609

3852 Errichtung einer Bildungsanstalt für Kindergärtnerinnen

- Promemoria des Oberbürgermeisters Leo Fürbringer über Initiative der Kindergärtnerin Johanna Mecke zur Errichtung einer

Bildungsanstalt für Kindergärtnerinnen, Oktober 1889 / Januar 1890

- Verfügung des Regierungspräsidenten über Nichtgewährung einer Beihilfe für das geplante Kindergärtnerinnen-Seminar und über Genehmigungspflicht des Projektes, September 1889

- Beratung des Projektes in den städtischen Kollegien, November 1889 - Januar 1890

- Initiative und Spendenzusagen verschiedener Emder Bürger (u.a.

Ysaak Brons Wwe., T. Dreesmann-Penning) für die Errichtung einer Bildungsanstalt für Kindergärtnerinnen, Mai 1890

- Antrag des Magistrats an die kgl. Regierung auf Genehmigung der Errichtung einer Bildungsanstalt für Kindergärtnerinnen, Mai 1890

- Prospekt eines Kindergärtnerinnen-Seminars in Emden unter der

Trägerschaft der Matschappij tot nut van't algemeen, März 1890

$1889-1890$

Klassifikation Teil B: 03610

Trägermaterial: Papier

Alte Reg.-Sig.: IX B5 06

Bestell-Nr.: IV 03610 
Lfd. Nr. Titel

- Anträge des Vorstands der Kinderbewahranstalten an den Magistrat auf Unterstützung aus der Stadtkasse zum Betrieb der Kinderbewahranstalten, Januar 1906 - November 1911

- Jahresberichte der Kinderbewahranstalten, 1905 - 1912

- Situationsplan des Kinderbewahranstalt am Kattewall, 1912

- Haushaltspläne der Kinderbewahranstalten, 1906 - 1910

- Bericht des Kreisarztes über Mängel in den Kinderbewahranstalten am Kattewall und in der Alten Kaserne, Dezember 1907 - Januar 1908 - Aufstellung über Besichtigung der Kinderbewahranstalten durch den Kreisarzt, Dezember 1907

$1905-1912$

Klassifikation Teil B: 03611

Trägermaterial: Papier

Alte Reg.-Sig.: IX B5 02

Bestell-Nr.: IV 03611

3854 Umbau und Erweiterung der Kinderbewahranstalt in der Großen Brückstraße (Rote Mühle)

- Antrag des Vorstands der Kinderbewahranstalten an den Magistrat auf Gewährung einer Beihilfe zur Finanzierung des notwendigen Umbaus der Kinderbewahranstalt in der Großen Brückstraße, April 1907

- Planzeichnungen des Bauprojektes, September 1907

- Kostenvoranschlag des Stadtbaumeisters Wiggers zum Umbau der Kinderbewahranstalt in der Großen Brückstraße, September 1907

- Verhandlungen zwischen dem Vorstand der Kinderbewahranstalten und dem Magistrat über Modalitäten der Finanzierung des Projektes (Umschreibung des Baugrundstückes auf die Stadt Emden),

Dezember 1907 - März 1908

- Beschluss des Bürgervorsteherkollegiums über Tragung der Kosten des Umbaus der Kinderbewahranstalt in der Großen Brückstraße, Mai 1908

- Nachbewilligung von Mehrkosten der Baumaßnahme, November 1908

$1907-1908$

Klassifikation Teil B: 03612

Trägermaterial: Papier Alte Reg.-Sig.: IX B6 02

Bestell-Nr.: IV 03612 
10

10.05

\section{Privatschulen}

Lfd. Nr. Titel

Laufzeit

3855 Fortbildungsschule für das weibliche Geschlecht

- Unterstützung der Stadt Emden für die von der Frau des Arztes Dr. de Beer gegründete Fortbildungsschule für das weibliche Geschlecht, September 1872 - März 1873

- Bericht des Magistrats an das kgl. Konsistorium über Fortbildungsschulen, u.a. Fortbildungsschule für das weibliche Geschlecht mit Unterrichtsinhalten, Mai 1873

- Antrag der Matschappij tot nut van't algemeen an den Magistrat auf Unterstützung der von ihr geplante Fortbildungsschule für das weibliche Geschlecht, Mai 1879

- Statuten der geplanten Fortbildungsschule für das weibliche Geschlecht, Mai 1879

- Datenerhebungen des preußischen Handelsministers zu Fortbildungsschulen für das weibliche Geschlecht, 1892 / 1895 / 1901 / 1903

- Zeitungsbericht über Vortrag der Oberlehrerin S. van Senden für die Schaffung einer obligatorischen Fortbildungsschule für das weibliche Geschlecht zur Verbesserung der Haushaltskenntnisse, Februar 1901 - Antrag der Leitung der Emder Industriefortbildungsschule an den Magistrat über Bitte um Sicherung des Bestands der Einrichtung, August 1903

- Bericht des Magistrats an die kgl. Regierung über Nichtgründung einer städtischen Haushaltungsschule, Mai 1907

- Aufstellung über Mädchenfortbildungsschulen der Matschappij tot nut van't algemeen, Mai 1907

- Bericht des Magistrats an den Regierungspräsidenten in Aurich über Stand der Fortbildungsschule für das weibliche Geschlecht, März 1909 / Oktober 1910

$1872-1915$

Klassifikation Teil B: 03613

Trägermaterial: Papier

Alte Reg.-Sig.: IX B5 04

Bestell-Nr.: IV 03613

3856 Errichtung einer Stotterheilanstalt

- Antrag des Stotterheillehrers Otto Juschka an den Magistrat auf Übernahme seiner Stotterheilanstalt durch die Stadr Emden, Juni 1890

- Initiative zur Begründung einer städtischen Stotterheilanstalt, 1890

1890

Klassifikation Teil B: 03614

Trägermaterial: Papier

Alte Reg.-Sig.: IX B5 07

Bestell-Nr.: IV 03614 
Lfd. Nr. Titel

- Antrag des Vorstands des Vaterländischen Frauenzweigvereins Emden an den Magistrat auf Einräumung des ehemaligen Schulgebäudes der Höheren Töchterschule mit Turnhalle für die geplante Kochschule, Oktober 1905

- Kostenanschlag des Stadtbauführers Schultz für die zu Zwecken der Haushaltungsschule notwendigen Baumaßnahmen am ehemaligen Gebäude der Höheren Töchterschule, Februar 1906

- Antrag des Vorstands des Vaterländischen Frauenzweigvereins Emden an den Magistrat auf bauliche Anpassung der für die geplante Haushaltungsschule überwiesenen Räume an den Unterrichtszweck und Bitte um Vermittlung einer Staatsbeihilfe, Dezember 1906

- Verfügung der kgl. Regierung über Genehmigung eines Probebetriebs der Kochschule mit freiwilliger Teilnahme von Volksschülerinnen an deren Kursen zu festgelegten Zeiten, April 1907 - Erlass des Ministers der Geistlichen, Unterrichts- und Medizinalangelegenheiten über Gewährung einer außerordentlichen Staatsbeihilfe für den Betrieb der Kochschule, April 1907 - Vereinbarung zwischen dem Vaterländischen Frauenzweigverein und den Rektoren der Volksschulen über Organisation des Unterrichts in der Haushaltungsschule (Kochschule), April 1907

- Revision des Schulbetriebs durch die kgl. Regierung, Oktober 1907 / März 1910 / Februar 1911

- Reisebericht des Geheimen Oberregierungsrat Simon und des Geheimen Regierungsrat Prof. Gürtler über Situation und Organisation des Haushaltungsunterrichts in Fankreich und Belgien, 1907

- Bescheid der kgl. Regierung über Gewährung einer Staatsbeihilfe für den Betrieb der Haushaltungsschule des Vaterländischen

Frauenzweigvereins Emden, Mai 1909 / April 1917

- Bericht des Vorstands der Haushaltungsschule über Erfolg der

Einrichtung und Bedarf einer besseren finanziellen Ausstattung wegen Vermehrung der Ausgaben, April 1910

- Verfügung des preußischen Landwirtschaftsministers über Staatszuschuss für land- und hauswirtschaftliche Schulen, Februar 1911

- Anträge des Vorstands der Haushaltungsschule an den Magistrat auf Genehmigung einer Beihilfe aus der Stadtkasse zum Schulbetrieb, März 1912 / Dezember 1915

- Verfügung der kgl. Regierung an den Magistrat über Aufforderung zur Gewährung einer städtischen Beihilfe für die Haushaltungsschule des Vaterländischen Frauenzweigvereins, April 1911

- Initiative des Deutsch-nationalen Handlungsgehilfenverbandes Ortsgruppe Emden für die Schaffung einer allgemeinen Pflicht für weibliche Schulentlassene zum Besuch einer Haushaltungsschule zur Verhinderung des Ergreifens von Büroberufen durch Frauen, April 1912

- Statistischer Bericht über Zahl der Schülerinnen sowie der Ausgaben und Einnahmen der Haushaltungsschule, August 1912

- Erlass des Handelsministers über Heranziehung von Haushaltungsschulen zur Ausbildung von Soldaten zum kriegsmäßigen Kochen, Januar 1915

$1905-1917$

Klassifikation Teil B: 03615

Trägermaterial: Papier

Alte Reg.-Sig.: IX B5 06 
Lfd. Nr. Titel

Laufzeit

Bestell-Nr.: IV 03615

3858 Private Handelsschule der Eva Stein

- Zulassung der privaten Handels- und Sprachschule für Englich der Eva Stein in der kleinen Brückstr. 5 (Haus des Kaufmanns und Schankwirts A. Italjener), 1910 - 1911

- Prospekt der Privat-Handelsschule und Sprachschule für Englisch, 1911

- Bericht über Auflösung der Schule infolge des Todes der Betreiberin und Inhaberin Eva Stein, September 1912

$1910-1912$

Klassifikation Teil B: 03616

Trägermaterial: Papier

Alte Reg.-Sig.: IX B5 09

Bestell-Nr.: IV 03616 
IV

Index

\begin{tabular}{|c|c|c|}
\hline \multicolumn{3}{|c|}{ GEOB } \\
\hline Indexbegriff & Laufzeit & Lfd.Nr. \\
\hline \multirow[t]{2}{*}{ Borssum } & $1874-1894$ & 2.855 \\
\hline & $1894-1911$ & 2.856 \\
\hline Borssum, Eingemeindung nach Emden & $1915-1918$ & 242 \\
\hline \multirow[t]{2}{*}{ Borssum, Gemeindevorsteher } & $1892-1895$ & 246 \\
\hline & $1911-1912$ & 247 \\
\hline Borssum, Kanalisation & $1909-1910$ & 251 \\
\hline Borssum, Volksschule & 1915 & 244 \\
\hline Borssum, Zungenkai & 1900 & 1.941 \\
\hline Charlottenpolder & $1891-1912$ & 799 \\
\hline Danzig & $1870-1914$ & 1.430 \\
\hline Delfzyl & 1903 & 2.077 \\
\hline \multirow[t]{2}{*}{ Dortmund, Hafen } & $1891-1893$ & 2.025 \\
\hline & 1896-1899 & 2.372 \\
\hline \multirow[t]{22}{*}{ Dortmund-Ems-Kanal } & $1897-1901$ & 182 \\
\hline & $1895-1914$ & 462 \\
\hline & $1887-1888$ & 1.436 \\
\hline & 1891 & 1.453 \\
\hline & 1902 & 1.509 \\
\hline & $1881-1910$ & 1.906 \\
\hline & $1882-1883$ & 2.021 \\
\hline & $1885-1889$ & 2.022 \\
\hline & $1890-1891$ & 2.023 \\
\hline & 1884-1886 & 2.024 \\
\hline & $1891-1893$ & 2.025 \\
\hline & $1893-1897$ & 2.026 \\
\hline & $1899-1913$ & 2.027 \\
\hline & 1899 & 2.028 \\
\hline & $1895-1896$ & 2.029 \\
\hline & 1911-1913 & 2.030 \\
\hline & $1896-1910$ & 2.051 \\
\hline & 1906-1907 & 2.086 \\
\hline & $1909-1913$ & 2.087 \\
\hline & $1889-1912$ & 2.120 \\
\hline & 1883-1889 & 2.136 \\
\hline & & Vorwort \\
\hline Emden, Abegg'sches Haus & $1866-1904$ & 2.418 \\
\hline Emden, Albringwehrster Zwinger & $1878-1884$ & 2.522 \\
\hline \multirow[t]{6}{*}{ Emden, Alte Kaserne } & $1857-1907$ & 514 \\
\hline & $1876-1884$ & 862 \\
\hline & 1889-1909 & 2.433 \\
\hline & $1874-1888$ & 3.118 \\
\hline & $1871-1887$ & 3.127 \\
\hline & $1868-1890$ & 3.847 \\
\hline Emden, Alte Wache & 1907-1909 & 2.413 \\
\hline \multirow[t]{2}{*}{ Emden, Alter Graben } & $1883-1885$ & 914 \\
\hline & 1901 & 2.557 \\
\hline Emden, Altes Fleischhaus & $1867-1874$ & 889 \\
\hline \multirow[t]{3}{*}{ Emden, Altes Gymnasium } & 1876-1909 & 2.424 \\
\hline & $1879-1891$ & 2.429 \\
\hline & $1885-1914$ & 2.431 \\
\hline Emden, Am Alten Markt & $1901-1912$ & 840 \\
\hline Emden, Am Kattewall & 1888 & 1.342 \\
\hline Emden, Arbeiterkolonie "Friesland" & $1913-1915$ & 813 \\
\hline Emden, Arbeiterkolonie "Transvaal" & 1894-1908 & 872 \\
\hline Emden, Außenhafen & $1900-1901$ & 176 \\
\hline
\end{tabular}


Index

\begin{tabular}{|c|c|c|}
\hline \multicolumn{3}{|c|}{ GEOB } \\
\hline Indexbegriff & Laufzeit & Lfd.Nr. \\
\hline Emden, Außenhafen & $1897-1901$ & 182 \\
\hline Emden, Auswandererhalle & 1916-1918 & 3.286 \\
\hline Emden, Badeanstalt am Thranwarft (Wolthuser Tief) & $1876-1882$ & 734 \\
\hline Emden, Badeanstalt im Eisenbahndock & $1876-1882$ & 734 \\
\hline Emden, Bahnhof West & 1907 & 956 \\
\hline Emden, Bahnhofsstraße & $1901-1912$ & 840 \\
\hline \multirow[t]{2}{*}{ Emden, Beckhofstor } & $1866-1873$ & 2.452 \\
\hline & 1875 & 2.487 \\
\hline Emden, Bentinckshof & $1872-1892$ & 2.427 \\
\hline \multirow[t]{4}{*}{ Emden, Bentincksweg } & 1876-1889 & 843 \\
\hline & 1905 & 954 \\
\hline & 1902-1905 & 959 \\
\hline & 1900-1904 & 2.562 \\
\hline Emden, Bismarckstraße & $1866-1911$ & 962 \\
\hline Emden, Bollwerkspiepe & 1907-1908 & 953 \\
\hline \multirow[t]{2}{*}{ Emden, Boltentor } & $1881-1896$ & 2.020 \\
\hline & $1878-1891$ & 2.428 \\
\hline \multirow[t]{3}{*}{ Emden, Boltentorviertel } & 1893-1894 & 936 \\
\hline & $1899-1900$ & 949 \\
\hline & 1889 & 973 \\
\hline Emden, Borssumer Landstraße & $1900-1907$ & 1.023 \\
\hline Emden, Brauerspiepentief & 1893-1908 & 2.783 \\
\hline Emden, Brinkmannsches Haus & 1899-1901 & 2.397 \\
\hline Emden, Brücke über das Rote Siel & $1881-1883$ & 1.028 \\
\hline Emden, Bunte Piepe & $1866-1911$ & 962 \\
\hline Emden, Burggraben & 1887 & 1.148 \\
\hline \multirow[t]{3}{*}{ Emden, Doelehaus } & $1905-1909$ & 1.198 \\
\hline & $1906-1911$ & 1.199 \\
\hline & $1908-1910$ & 1.202 \\
\hline Emden, Dreckwarf am Beckhofstor & $1868-1911$ & 825 \\
\hline \multirow[t]{2}{*}{ Emden, Dreckwarf am Herrentor } & $1868-1911$ & 825 \\
\hline & $1885-1910$ & 879 \\
\hline Emden, Eisenbahndock & 1891 & 507 \\
\hline Emden, Emsmauer & 1871-1906 & 961 \\
\hline Emden, Falderndeich & $1883-1900$ & 1.537 \\
\hline \multirow[t]{7}{*}{ Emden, Falderndelft } & 1873 & 421 \\
\hline & $1885-1896$ & 924 \\
\hline & $1866-1883$ & 1.487 \\
\hline & $1875-1901$ & 1.494 \\
\hline & 1878 & 2.496 \\
\hline & 1896 & 2.575 \\
\hline & $1875-1914$ & 2.680 \\
\hline \multirow[t]{2}{*}{ Emden, Falderntor } & $1871-1906$ & 961 \\
\hline & 1893-1897 & 2.574 \\
\hline Emden, Foget'sche Bleiche & $1869-1913$ & 829 \\
\hline \multirow[t]{2}{*}{ Emden, Friedhof der Neuen Kirche } & 1871 & 1.633 \\
\hline & 1899-1909 & 3.317 \\
\hline Emden, Gasthaus & 1869-1885 & 869 \\
\hline Emden, Gasthaus "Goldener Adler" & 1873-1917 & 2.395 \\
\hline \multirow[t]{7}{*}{ Emden, Gasthauskirche } & $1872-1875$ & 1.715 \\
\hline & 1874-1884 & 1.720 \\
\hline & $1917-1918$ & 3.265 \\
\hline & $1876-1887$ & 3.424 \\
\hline & $1876-1891$ & 3.426 \\
\hline & $1887-1913$ & 3.427 \\
\hline & 1902 & 3.428 \\
\hline \multirow[t]{2}{*}{ Emden, Gasthaussiel } & 1883-1885 & 914 \\
\hline & $1885-1888$ & 917 \\
\hline
\end{tabular}


Index

\begin{tabular}{|c|c|c|}
\hline \multicolumn{3}{|c|}{ GEOB } \\
\hline Indexbegriff & Laufzeit & Lfd.Nr. \\
\hline \multirow[t]{2}{*}{ Emden, Gasthaussiel } & 1886-1895 & 920 \\
\hline & $1878-1888$ & 1.493 \\
\hline \multirow[t]{2}{*}{ Emden, Gasthaussieltief } & $1867-1910$ & 1.490 \\
\hline & 1902 & 2.795 \\
\hline \multirow[t]{2}{*}{ Emden, Gelber Mühlenzwinger } & $1893-1901$ & 940 \\
\hline & $1869-1904$ & 2.677 \\
\hline Emden, Gewerbehalle & $1866-1903$ & 1.924 \\
\hline Emden, Graupferdspiepentief & 1888-1906 & 2.819 \\
\hline \multirow[t]{3}{*}{ Emden, Graupferdstief } & $1884-1896$ & 900 \\
\hline & 1885 & 958 \\
\hline & $1876-1880$ & 1.496 \\
\hline Emden, Große Ee & $1867-1896$ & 1.492 \\
\hline \multirow[t]{6}{*}{ Emden, Große Kirche } & $1824-1920$ & 433 \\
\hline & $1876-1884$ & 862 \\
\hline & $1872-1873$ & 1.762 \\
\hline & $1898-1911$ & 3.399 \\
\hline & $1877-1897$ & 3.410 \\
\hline & $1883-1884$ & 3.411 \\
\hline \multirow[t]{3}{*}{ Emden, Große Seeschleuse } & $1904-1914$ & 1.440 \\
\hline & $1902-1911$ & 1.446 \\
\hline & & Vorwort \\
\hline Emden, Große Straße & 1878 & 1.938 \\
\hline Emden, Grüner Weg & $1902-1903$ & 1.498 \\
\hline \multirow[t]{3}{*}{ Emden, Hafen } & $1900-1901$ & 180 \\
\hline & $1912-1914$ & 1.429 \\
\hline & 1869 & 1.531 \\
\hline \multirow[t]{2}{*}{ Emden, Hafenanlagen } & $1897-1901$ & 182 \\
\hline & $1868-1891$ & 1.450 \\
\hline Emden, Hahn'sche Insel & $1878-1888$ & 1.493 \\
\hline \multirow[t]{3}{*}{ Emden, Herrentor } & $1867-1896$ & 1.400 \\
\hline & $1900-1912$ & 1.563 \\
\hline & 1868-1902 & 2.016 \\
\hline Emden, Herrentor-Tief & $1912-1914$ & 967 \\
\hline \multirow[t]{2}{*}{ Emden, Heuzwinger } & $1907-1913$ & 2.592 \\
\hline & $1872-1913$ & 2.655 \\
\hline Emden, Judentief & $1867-1910$ & 1.490 \\
\hline Emden, Jüdischer Friedhof & 1847-1902 & 494 \\
\hline Emden, Jüdisches Waisenhaus & $1903-1917$ & 495 \\
\hline Emden, Jungfernbrücke & 1872 & 1.491 \\
\hline \multirow[t]{19}{*}{ Emden, Kaiser-Wilhelm-Polder } & 1904-1908 & 230 \\
\hline & $1883-1911$ & 231 \\
\hline & 1899-1901 & 233 \\
\hline & $1883-1885$ & 914 \\
\hline & 1887 & 933 \\
\hline & 1885 & 958 \\
\hline & 1887-1902 & 1.228 \\
\hline & 1899-1901 & 1.232 \\
\hline & 1899-1909 & 1.234 \\
\hline & $1892-1906$ & 1.265 \\
\hline & $1867-1896$ & 1.400 \\
\hline & 1887-1888 & 1.436 \\
\hline & $1872-1892$ & 1.544 \\
\hline & $1892-1900$ & 1.545 \\
\hline & 1901-1908 & 1.546 \\
\hline & 1879-1882 & 2.011 \\
\hline & 1893-1897 & 2.026 \\
\hline & $1895-1906$ & 2.059 \\
\hline & 1900 & 2.076 \\
\hline
\end{tabular}


Index

\begin{tabular}{|c|c|c|}
\hline \multicolumn{3}{|c|}{ GEOB } \\
\hline Indexbegriff & Laufzeit & Lfd.Nr. \\
\hline \multirow[t]{11}{*}{ Emden, Kaiser-Wilhelm-Polder } & $1900-1908$ & 2.432 \\
\hline & $1867-1890$ & 2.476 \\
\hline & $1881-1901$ & 2.477 \\
\hline & $1874-1887$ & 2.478 \\
\hline & $1876-1878$ & 2.479 \\
\hline & $1881-1888$ & 2.480 \\
\hline & $1874-1904$ & 2.493 \\
\hline & $1884-1896$ & 2.494 \\
\hline & $1896-1901$ & 2.495 \\
\hline & $1880-1881$ & 2.515 \\
\hline & $1857-1905$ & 2.551 \\
\hline Emden, Kajung "Hinter der Halle" & $1901-1907$ & 1.502 \\
\hline \multirow[t]{2}{*}{ Emden, Kattewall } & $1871-1906$ & 961 \\
\hline & 1885 & 2.443 \\
\hline \multirow[t]{3}{*}{ Emden, Kesselschleuse } & $1912-1914$ & 967 \\
\hline & $1879-1883$ & 1.433 \\
\hline & $1887-1912$ & 1.437 \\
\hline \multirow[t]{2}{*}{ Emden, Kettenbrücke } & $1885-1896$ & 924 \\
\hline & 1894-1898 & 993 \\
\hline Emden, Kleinbahnhof & 1907 & 956 \\
\hline \multirow[t]{4}{*}{ Emden, Klunderburg } & $1906-1907$ & 677 \\
\hline & $1866-1870$ & 3.122 \\
\hline & $1871-1877$ & 3.123 \\
\hline & $1866-1889$ & 3.124 \\
\hline Emden, Kolonie Friesland & $1913-1914$ & 1.149 \\
\hline \multirow[t]{20}{*}{ Emden, Königspolder } & $1900-1903$ & 229 \\
\hline & $1883-1911$ & 231 \\
\hline & $1897-1900$ & 232 \\
\hline & $1881-1909$ & 894 \\
\hline & $1899-1901$ & 1.232 \\
\hline & $1904-1914$ & 1.440 \\
\hline & $1912-1914$ & 1.441 \\
\hline & $1903-1908$ & 1.443 \\
\hline & $1903-1910$ & 1.465 \\
\hline & $1867-1890$ & 1.536 \\
\hline & $1885-1907$ & 1.543 \\
\hline & $1872-1892$ & 1.544 \\
\hline & $1892-1900$ & 1.545 \\
\hline & $1901-1908$ & 1.546 \\
\hline & $1891-1893$ & 2.025 \\
\hline & $1866-1897$ & 2.460 \\
\hline & $1866-1883$ & 2.461 \\
\hline & $1897-1904$ & 2.462 \\
\hline & $1873-1886$ & 2.687 \\
\hline & 1889 & 3.335 \\
\hline Emden, Königspolderdeich & $1867-1890$ & 1.536 \\
\hline Emden, Lange Brücke & $1896-1901$ & 2.550 \\
\hline Emden, Lindengraben & 1888 & 2.547 \\
\hline Emden, Lookvenne & $1875-1882$ & 970 \\
\hline Emden, Maiboom'sche Seilerbahn & 1874-1893 & 2.444 \\
\hline \multirow[t]{2}{*}{ Emden, Marienwehrster Zwinger } & 1914-1916 & 966 \\
\hline & $1869-1904$ & 2.677 \\
\hline Emden, Meister-Geerds-Zwinger & $1866-1903$ & 2.451 \\
\hline \multirow[t]{2}{*}{ Emden, Mittelwalldeich } & $1867-1890$ & 1.536 \\
\hline & $1883-1900$ & 1.537 \\
\hline Emden, Mühle "de goede Verwagting" & $1888-1889$ & 1.344 \\
\hline Emden, Mühlenwarf & 1888 & 1.342 \\
\hline Emden, Nesserland & 1877-1885 & 440 \\
\hline
\end{tabular}


Index

\begin{tabular}{|c|c|c|}
\hline \multicolumn{3}{|c|}{ GEOB } \\
\hline Indexbegriff & Laufzeit & Lfd.Nr. \\
\hline \multirow[t]{17}{*}{ Emden, Nesserland } & 1879-1905 & 622 \\
\hline & $1883-1887$ & 1.435 \\
\hline & 1898-1899 & 1.486 \\
\hline & $1867-1876$ & 2.415 \\
\hline & $1878-1901$ & 2.416 \\
\hline & $1875-1876$ & 2.425 \\
\hline & $1894-1900$ & 2.458 \\
\hline & $1866-1881$ & 2.459 \\
\hline & $1866-1873$ & 2.463 \\
\hline & $1867-1890$ & 2.476 \\
\hline & $1881-1901$ & 2.477 \\
\hline & $1874-1887$ & 2.478 \\
\hline & $1876-1878$ & 2.479 \\
\hline & $1881-1888$ & 2.480 \\
\hline & $1866-1894$ & 2.482 \\
\hline & 1908-1909 & 3.342 \\
\hline & 1901 & 3.401 \\
\hline Emden, Nesserland, Armenländereien & $1866-1867$ & 2.471 \\
\hline Emden, Nesserland, Batterie & 1868-1875 & 2.465 \\
\hline \multirow[t]{2}{*}{ Emden, Nesserland, Friedhof } & 1873-1917 & 2.395 \\
\hline & 1901 & 3.401 \\
\hline Emden, Nesserland, Hammrich & 1867-1876 & 2.415 \\
\hline Emden, Nesserland, Kirch- und Armenwarf & 1878-1901 & 2.416 \\
\hline Emden, Nesserlander Deich & $1896-1913$ & 950 \\
\hline \multirow{24}{*}{ Emden, Nesserlander Schleuse } & 1888-1909 & 928 \\
\hline & 1867-1896 & 1.400 \\
\hline & 1886-1909 & 1.413 \\
\hline & $1870-1914$ & 1.430 \\
\hline & $1879-1883$ & 1.433 \\
\hline & 1875-1882 & 1.434 \\
\hline & $1887-1888$ & 1.436 \\
\hline & 1887-1912 & 1.437 \\
\hline & 1873-1912 & 1.505 \\
\hline & $1866-1867$ & 1.516 \\
\hline & 1867-1868 & 1.517 \\
\hline & $1869-1870$ & 1.518 \\
\hline & $1870-1871$ & 1.519 \\
\hline & 1873 & 1.520 \\
\hline & $1873-1874$ & 1.521 \\
\hline & 1874-1875 & 1.522 \\
\hline & 1876 & 1.523 \\
\hline & $1866-1893$ & 1.533 \\
\hline & 1873-1878 & 1.534 \\
\hline & 1888-1892 & 1.535 \\
\hline & $1877-1916$ & 1.556 \\
\hline & 1873-1907 & 2.017 \\
\hline & 1898-1909 & 2.552 \\
\hline & & Vorwort \\
\hline \multirow[t]{2}{*}{ Emden, Neue Kirche } & 1824-1920 & 433 \\
\hline & $1898-1911$ & 3.399 \\
\hline Emden, Neues oder Stadtsiel & 1885-1907 & 909 \\
\hline Emden, Neues Siel & 1875 & 1.555 \\
\hline Emden, Neues Tor & 1896-1898 & 991 \\
\hline \multirow{3}{*}{ Emden, Neupfortssiel } & $1868-1883$ & 835 \\
\hline & $1871-1888$ & 1.151 \\
\hline & $1875-1901$ & 1.494 \\
\hline Emden, Neutorsbrücke & $1871-1906$ & 961 \\
\hline Emden, Neutorssiel & 1883-1885 & 914 \\
\hline
\end{tabular}


Index

\begin{tabular}{|c|c|c|}
\hline \multicolumn{3}{|c|}{ GEOB } \\
\hline Indexbegriff & Laufzeit & Lfd.Nr. \\
\hline Emden, Neutorssiel (Neupfortssiel) & $1885-1888$ & 917 \\
\hline \multirow[t]{2}{*}{ Emden, Nordertor } & 1867-1896 & 1.400 \\
\hline & $1886-1900$ & 2.430 \\
\hline Emden, Oster- und Brauerspiepentief & $1885-1907$ & 909 \\
\hline \multirow[t]{4}{*}{ Emden, Osterbutvenne } & 1871-1906 & 961 \\
\hline & $1869-1901$ & 1.159 \\
\hline & 1876-1901 & 1.501 \\
\hline & $1892-1893$ & 1.504 \\
\hline Emden, Osterpiepe & $1870-1900$ & 1.497 \\
\hline Emden, Petkumer Landstraße & $1872-1909$ & 2.034 \\
\hline \multirow[t]{2}{*}{ Emden, Polizeigefängnis } & $1879-1904$ & 522 \\
\hline & $1899-1913$ & 523 \\
\hline Emden, Port Arthur & 1875-1909 & 836 \\
\hline Emden, Ratelerwache & $1866-1904$ & 2.418 \\
\hline \multirow[t]{6}{*}{ Emden, Rathaus } & 1866-1897 & 2.411 \\
\hline & 1899-1912 & 2.412 \\
\hline & 1907-1909 & 2.413 \\
\hline & 1909 & 2.414 \\
\hline & 1867 & 2.417 \\
\hline & 1867-1897 & 2.419 \\
\hline \multirow[t]{2}{*}{ Emden, Rathausbrücke } & 1888-1902 & 194 \\
\hline & 1914 & 2.605 \\
\hline \multirow[t]{3}{*}{ Emden, Rathausdelft } & 1884-1896 & 900 \\
\hline & $1883-1885$ & 914 \\
\hline & $1866-1883$ & 1.487 \\
\hline Emden, Rathausplatz & 1868-1897 & 1.946 \\
\hline \multirow[t]{5}{*}{ Emden, Ratsdelft } & $1885-1887$ & 915 \\
\hline & $1885-1888$ & 917 \\
\hline & 1886-1895 & 920 \\
\hline & $1888-1896$ & 934 \\
\hline & 1887-1912 & 1.437 \\
\hline \multirow[t]{3}{*}{ Emden, Rosentief } & $1866-1911$ & 962 \\
\hline & $1866-1893$ & 1.041 \\
\hline & 1899 & 2.572 \\
\hline Emden, Rote Mühle & $1875-1901$ & 1.494 \\
\hline Emden, Roter-Mühlen-Zwinger & $1912-1914$ & 967 \\
\hline \multirow[t]{3}{*}{ Emden, Rotes- oder Faldernsiel } & $1891-1912$ & 742 \\
\hline & $1875-1901$ & 1.494 \\
\hline & $1867-1890$ & 1.536 \\
\hline Emden, Rotes Siel & $1872-1888$ & 2.442 \\
\hline Emden, Schoonhovenpipe & $1872-1876$ & 2.485 \\
\hline \multirow{3}{*}{ Emden, Schreyers Hoek } & $1866-1911$ & 962 \\
\hline & 1880 & 1.506 \\
\hline & 1866-1904 & 2.418 \\
\hline Emden, Schusterinsel & $1878-1888$ & 1.493 \\
\hline Emden, Seeschleuse & 1913 & 1.452 \\
\hline Emden, Sleedrieverstraße & $1870-1882$ & 891 \\
\hline Emden, Stadtgarten & 1901 & 181 \\
\hline Emden, Stadtgarten am Wall & $1869-1893$ & 2.473 \\
\hline \multirow[t]{2}{*}{ Emden, Stadtgraben } & 1903 & 841 \\
\hline & $1912-1914$ & 1.499 \\
\hline Emden, Stadtpolder & 1897-1904 & 2.462 \\
\hline \multirow[t]{2}{*}{ Emden, Stinktief } & 1867-1896 & 1.492 \\
\hline & $1867-1893$ & 1.495 \\
\hline Emden, Strohdeich & $1872-1879$ & 1.181 \\
\hline \multirow[t]{3}{*}{ Emden, Südfalderndeich } & $1867-1890$ & 1.536 \\
\hline & 1868 & 1.538 \\
\hline & 1896 & 2.573 \\
\hline
\end{tabular}


IV

Index

\begin{tabular}{|c|c|c|}
\hline \multicolumn{3}{|c|}{ GEOB } \\
\hline Indexbegriff & Laufzeit & Lfd.Nr. \\
\hline Emden, Tholenwarf & $1890-1893$ & 2.545 \\
\hline Emden, Thranenwarf & $1868-1881$ & 2.449 \\
\hline Emden, Torfmarkt & $1901-1908$ & 2.559 \\
\hline \multirow[t]{4}{*}{ Emden, Transvaal } & 1875-1909 & 836 \\
\hline & 1888-1909 & 928 \\
\hline & $1899-1900$ & 1.246 \\
\hline & 1909-1912 & 3.594 \\
\hline Emden, VI. Wyck & $1909-1910$ & 731 \\
\hline Emden, Vierkant-Kaserne & $1867-1891$ & 3.126 \\
\hline \multirow[t]{3}{*}{ Emden, Vogelsangzwinger } & 1866-1872 & 2.472 \\
\hline & 1876 & 2.497 \\
\hline & 1889-1891 & 2.604 \\
\hline Emden, Vrouw -Johanna-Mühle & 1869-1904 & 2.677 \\
\hline Emden, Vrouw-Johanna-Mühle & $1882-1889$ & 2.530 \\
\hline Emden, Wall & 1866-1905 & 2.378 \\
\hline \multirow{2}{*}{ Emden, Wallanlagen } & 1914-1916 & 966 \\
\hline & $1912-1914$ & 967 \\
\hline Emden, Weizenmühle & 1885 & 2.443 \\
\hline Emden, Welgenlandje & $1872-1893$ & 2.470 \\
\hline \multirow[t]{3}{*}{ Emden, Westerbutvenne } & $1876-1901$ & 1.501 \\
\hline & $1888-1903$ & 1.503 \\
\hline & 1866-1904 & 2.418 \\
\hline Emden, Wevers Piepe & 1876-1909 & 963 \\
\hline Emden, Wolthuser Tief & $1875-1901$ & 1.494 \\
\hline Emden, Zwischen den Märkten & 1874-1905 & 831 \\
\hline \multirow[t]{4}{*}{ Emder Feldmark } & $1861-1865$ & 235 \\
\hline & $1867-1907$ & 237 \\
\hline & $1885-1901$ & 3.337 \\
\hline & 1898-1904 & 3.343 \\
\hline Emder Hafen & 1903-1908 & 1.443 \\
\hline \multirow[t]{2}{*}{ Ems } & 1886-1909 & 1.413 \\
\hline & $1889-1912$ & 2.120 \\
\hline Ems, Fischers Gat & $1901-1908$ & 1.546 \\
\hline \multirow[t]{13}{*}{ Ems-Jade-Kanal } & $1891-1912$ & 742 \\
\hline & 1881-1909 & 894 \\
\hline & 1901 & 899 \\
\hline & $1875-1882$ & 1.431 \\
\hline & $1879-1883$ & 1.433 \\
\hline & $1875-1882$ & 1.434 \\
\hline & $1887-1912$ & 1.437 \\
\hline & $1877-1916$ & 1.556 \\
\hline & $1899-1913$ & 2.027 \\
\hline & $1880-1881$ & 2.469 \\
\hline & 1894-1905 & 2.603 \\
\hline & $1875-1888$ & 2.994 \\
\hline & & Vorwort \\
\hline \multirow[t]{3}{*}{ Fehntjer Tief } & $1885-1910$ & 879 \\
\hline & $1900-1912$ & 1.563 \\
\hline & $1899-1913$ & 2.027 \\
\hline Groningen, Gewerbeschau & $1881-1910$ & 1.906 \\
\hline Groothusen & $1891-1912$ & 799 \\
\hline Großfriedrichsburg, Brandenburgische Festung & 1913 & 191 \\
\hline \multirow[t]{2}{*}{ Haase } & 1886-1909 & 1.413 \\
\hline & $1889-1912$ & 2.120 \\
\hline Hinter Tief & $1875-1901$ & 1.494 \\
\hline
\end{tabular}


IV

Index

\begin{tabular}{|c|c|c|}
\hline \multicolumn{3}{|c|}{ GEOB } \\
\hline Indexbegriff & Laufzeit & Lfd.Nr. \\
\hline \multirow[t]{4}{*}{ Hinter Tief } & $1872-1884$ & 2.384 \\
\hline & $1885-1896$ & 2.385 \\
\hline & 1879-1909 & 2.500 \\
\hline & 1908-1911 & 3.132 \\
\hline Hinter Tiefs-Verlaat & $1866-1893$ & 2.454 \\
\hline Jerusalem, Oelberg & 1912 & 707 \\
\hline Karolinen-Inseln & $1908-1910$ & 270 \\
\hline Königsberg, Ostpreußen & 1914-1915 & 3.191 \\
\hline Königspolderwatt & 1907 & 1.552 \\
\hline Krummhörn & 1895-1900 & 2.063 \\
\hline Langensalza, Thüringen & & Vorwort \\
\hline \multirow[t]{5}{*}{ Larrelt } & $1867-1890$ & 2.476 \\
\hline & $1881-1901$ & 2.477 \\
\hline & 1874-1887 & 2.478 \\
\hline & $1876-1878$ & 2.479 \\
\hline & $1881-1888$ & 2.480 \\
\hline Larrelter Deich & 1910 & 1.553 \\
\hline Larrelter Landstraße & 1910 & 1.553 \\
\hline Larrelter Verlaat & $1866-1891$ & 1.488 \\
\hline Leer, Hafen & $1882-1883$ & 2.021 \\
\hline Leer, Neues Rathaus & $1892-1893$ & 1.942 \\
\hline Leer, Seehafen & 1907 & 1.444 \\
\hline Leerort, Brücke & $1889-1912$ & 2.120 \\
\hline Leybucht & 1886 & 1.547 \\
\hline Mailand, Schifffahrtskongress & 1903-1908 & 665 \\
\hline Memel & $1870-1914$ & 1.430 \\
\hline Meppener Schleuse & $1899-1913$ & 2.027 \\
\hline Metz, Soldatengräber & $1895-1910$ & 571 \\
\hline Moordorf & 1881 & 2.524 \\
\hline Moortief & 1905 & 2.082 \\
\hline Münster, Hafen & 1899-1913 & 2.027 \\
\hline \multirow[t]{4}{*}{ Nesserlander Schleuse } & 1868-1875 & 2.465 \\
\hline & $1880-1881$ & 2.469 \\
\hline & 1873-1877 & 2.483 \\
\hline & 1876-1902 & 2.503 \\
\hline \multirow[t]{2}{*}{ Oldersum } & 1874-1894 & 2.855 \\
\hline & $1894-1911$ & 2.856 \\
\hline Oldersum, Burg & 1867-1878 & 2.669 \\
\hline Oldersum, Seitenkanal & $1890-1891$ & 2.023 \\
\hline Oldersumer Siel & $1883-1900$ & 1.537 \\
\hline Ostfriesland & 1912 & 209 \\
\hline Papenburg, Hafen & $1882-1883$ & 2.021 \\
\hline Papenburg, Hafen- und Schleusenanlage & 1902 & 1.451 \\
\hline Petkum, Bahnhaltestelle & 1897 & 2.015 \\
\hline Petkumer Siel & $1883-1900$ & 1.537 \\
\hline Polleben, Mansfelder Seekreis & 1918 & 1.888 \\
\hline Rheinisch-westfälisches Industriegebiet & $1876-1903$ & 1.432 \\
\hline Rotterdam, Hafen & 1903-1908 & 665 \\
\hline Schottjer Tief & 1905 & 2.082 \\
\hline
\end{tabular}


Index

\section{GEOB}

\begin{tabular}{lrr}
\hline Indexbegriff & Laufzeit & Lfd.Nr. \\
\hline Simonswolde, Sandwater & $1882-1905$ & 2.670 \\
Stettin, Gerichtsgefängnis & $1899-1913$ & 523 \\
Tergast, Kirchen- und Schulgemeinde & 1886 & 3.481 \\
Uphuser Meer & & 2.667 \\
Weener & $1885-1889$ & \\
Weener, Eisenbahnbrücke & 1902 & 2.142 \\
Widdelswehr & $1881-1885$ & 2.014 \\
& $1874-1894$ & 2.855 \\
Wiesmoor, Kraftwerk & $1894-1911$ & 2.856 \\
Wirdumer Neuland & $1872-1916$ & 330 \\
Wittenberg, Schlosskirche & $1886-1905$ & 3.684 \\
Wolthusen & $1900-1911$ & 259 \\
& $1890-1910$ & 252 \\
& $1906-1912$ & 253 \\
& $1880-1913$ & 254 \\
Wolthusen, Kirche & $1906-1908$ & 1.500 \\
Wolthusen, Schule & $1874-1894$ & 2.855 \\
& $1894-1911$ & 2.856 \\
& $1876-1882$ & 2.666 \\
& $1908-1909$ & 227
\end{tabular}


Index

\begin{tabular}{|c|c|c|}
\hline \multicolumn{3}{|l|}{ INST } \\
\hline Indexbegriff & Laufzeit & Lfd.Nr. \\
\hline \multirow[t]{6}{*}{ Abfuhr-Commission } & $1869-1885$ & 869 \\
\hline & $1886-1894$ & 870 \\
\hline & $1876-1882$ & 871 \\
\hline & 1894-1908 & 872 \\
\hline & $1895-1910$ & 873 \\
\hline & 1874-1908 & 885 \\
\hline Abgeordnetenhaus des preußischen Landtages & $1909-1913$ & 2.087 \\
\hline Abschätzungs-Kommission, Emden & $1873-1914$ & 592 \\
\hline Actiengesellschaft für Chemische Industrie, Mannheim & $1899-1906$ & 1.072 \\
\hline \multirow{2}{*}{ Adressbuch-Kommission, Stadt Emden } & $1910-1913$ & 331 \\
\hline & $1913-1914$ & 332 \\
\hline \multirow[t]{16}{*}{ AEG, Allgemeine Elektrizitätsgesellschaft } & $1882-1912$ & 1.082 \\
\hline & $1906-1912$ & 1.098 \\
\hline & $1908-1916$ & 1.100 \\
\hline & 1901-1906 & 1.962 \\
\hline & $1901-1914$ & 1.966 \\
\hline & $1912-1917$ & 1.975 \\
\hline & $1906-1912$ & 1.980 \\
\hline & 1908-1909 & 1.981 \\
\hline & $1909-1910$ & 1.982 \\
\hline & $1910-1911$ & 1.983 \\
\hline & 1911-1912 & 1.984 \\
\hline & $1915-1916$ & 1.985 \\
\hline & $1918-1919$ & 1.986 \\
\hline & 1907 & 1.990 \\
\hline & $1912-1914$ & 1.994 \\
\hline & 1914 & 1.995 \\
\hline Afrikanische Compagnie AG & $1905-1907$ & 2.085 \\
\hline AG Bildgießerei Friedrichshagen & $1900-1901$ & 203 \\
\hline \multirow[t]{4}{*}{ AG Ems } & $1895-1914$ & 462 \\
\hline & $1911-1918$ & 1.901 \\
\hline & 1890 & 2.193 \\
\hline & 1893 & 2.201 \\
\hline AG Land und Seekabel & $1896-1901$ & 2.370 \\
\hline Aktiengesellschaft für Feld- und Kleinbahnen, Berlin & $1899-1900$ & 2.065 \\
\hline \multirow[t]{3}{*}{ Akzise-Commission } & $1900-1905$ & 255 \\
\hline & $1879-1909$ & 2.915 \\
\hline & $1895-1897$ & 2.927 \\
\hline Allgem. Handwerker-Witwenkasse f. d. Stadt- u. Landkreis Emden & $1877-1918$ & 1.672 \\
\hline Allgemeine Gewerbeausstellung der Provinz Hannover & $1878-1879$ & 2.125 \\
\hline \multirow[t]{2}{*}{ Allgemeine Ortskrankenkasse } & 1918 & 1.673 \\
\hline & 1918 & 1.679 \\
\hline Allgemeinen Deutschen Versicherungs-Verein & $1902-1906$ & 1.674 \\
\hline Allgemeiner Arbeiterverein für Emden und Umgebung & $1891-1912$ & 632 \\
\hline Allgemeiner Deutscher Wohnungskongress in Frankfurt/Main & $1904-1914$ & 1.238 \\
\hline Allgemeiner Konsumverein für Emden & $1907-1915$ & 694 \\
\hline Allgemeiner lutherischer Kirchenfonds für die Provinz Hannover & $1868-1905$ & 3.447 \\
\hline \multirow[t]{2}{*}{ Alte Kaserne, Emden } & 1878 & 1.315 \\
\hline & 1879 & 1.327 \\
\hline Alten- und Siechenhaus "Bethanien", Emden & $1904-1915$ & 578 \\
\hline Altreformierte Gemeinde, Emden & $1869-1905$ & 3.498 \\
\hline Amtl. Fürsorge f. Kriegsteilnehmer u. Hinterbliebene d. Stadt Emden & $1914-1918$ & 3.199 \\
\hline \multirow[t]{6}{*}{ Amtsgericht Emden } & 1857-1908 & 313 \\
\hline & $1908-1912$ & 365 \\
\hline & $1880-1881$ & 1.329 \\
\hline & $1900-1904$ & 1.539 \\
\hline & 1914-1923 & 1.704 \\
\hline & 1905-1909 & 2.361 \\
\hline
\end{tabular}


Index

\begin{tabular}{|c|c|c|}
\hline \multicolumn{3}{|l|}{ INST } \\
\hline Indexbegriff & Laufzeit & Lfd.Nr. \\
\hline \multirow[t]{8}{*}{ Amtsgericht Emden } & $1875-1881$ & 2.510 \\
\hline & $1874-1877$ & 2.512 \\
\hline & $1877-1882$ & 2.513 \\
\hline & $1878-1884$ & 2.522 \\
\hline & $1890-1894$ & 3.383 \\
\hline & 1890 & 3.384 \\
\hline & $1899-1900$ & 3.385 \\
\hline & $1887-1893$ & 3.386 \\
\hline \multirow[t]{2}{*}{ Amtsgerichtsgefängnis, Emden } & $1869-1917$ & 524 \\
\hline & 1886 & 1.340 \\
\hline Anatomisches Institut des Universität Straßburg & $1885-1887$ & 916 \\
\hline Angestelltenversicherung (Rentenversicherung) & $1912-1913$ & 1.680 \\
\hline Annoncenuhr AG & $1886-1901$ & 837 \\
\hline \multirow[t]{2}{*}{ Antiquitätenzeitung } & $1902-1908$ & 2.621 \\
\hline & $1908-1916$ & 2.623 \\
\hline Antiquitäten-Zeitung & 1903-1904 & 2.637 \\
\hline Apollo-Lichttheater & $1905-1911$ & 1.097 \\
\hline Arbeiterkolonie Friesland & $1913-1914$ & 3.615 \\
\hline Arbeiter-Radfahrer-Verein "Vorwärts" & $1891-1912$ & 632 \\
\hline Arbeiterverein Emden & 1915 & 3.212 \\
\hline Arbeitgeberverband Berlin und Umgebung & $1882-1913$ & 2.408 \\
\hline Arbeitshaus, Emden & 1873-1906 & 1.263 \\
\hline Architekten-Verein zu Berlin & $1884-1886$ & 2.024 \\
\hline \multirow[t]{2}{*}{ Archiv, Stadt Emden } & 1857-1908 & 313 \\
\hline & $1899-1916$ & 315 \\
\hline Armen-Arbeits-Anstalt & $1872-1881$ & 1.767 \\
\hline \multirow[t]{3}{*}{ Armen-Arbeitshaus } & 1875 & 1.314 \\
\hline & $1886-1914$ & 1.890 \\
\hline & $1881-1914$ & 1.892 \\
\hline Armendeputation, Stadt Emden & 1871 & 1.774 \\
\hline \multirow{6}{*}{ Armenkollegium, Emden } & $1891-1912$ & 519 \\
\hline & $1885-1887$ & 915 \\
\hline & 1887-1893 & 1.778 \\
\hline & $1872-1910$ & 1.869 \\
\hline & $1873-1914$ & 1.871 \\
\hline & 1914 & 1.891 \\
\hline \multirow[t]{2}{*}{ Armenkommission } & $1871-1872$ & 1.867 \\
\hline & 1875 & 1.868 \\
\hline Armenverband, Stadt Emden & $1873-1886$ & 2.422 \\
\hline Artilleriedepot Mainz & 1866-1907 & 2.620 \\
\hline Artilleriedepot Oldenburg & $1866-1907$ & 2.620 \\
\hline Ateliers de Transformation societé anonyme, Abwrackfirma & $1907-1912$ & 2.595 \\
\hline Aufstellungs-Commission, Kaiserbesuch & 1902 & 184 \\
\hline Auktionatoren Schmidt \& Meyer & 1904-1905 & 2.446 \\
\hline Ausschuss f. d. Errichtung eines Schwimmdocks u. Werftanlage & 1903-1904 & 1.459 \\
\hline Ausschuss für den Bau einer Vollbahn von Emden nach Norden & $1895-1896$ & 2.050 \\
\hline Ausschuss für fahrbare Kriegsbüchereien & 1916 & 3.209 \\
\hline Ausschuss für Gründung einer Schiffswerft mit Dock & 1899-1903 & 1.454 \\
\hline Ausschuss zum Bau einer Kleinbahn Pewsum-Emden & $1895-1900$ & 2.063 \\
\hline Auswärtiges Amt & $1867-1880$ & 499 \\
\hline Ärztekammer für die Rheinprovinz u. d. hohenzollernschen Lande & 1912 & 754 \\
\hline Ärzteverein Emden & $1890-1891$ & 1.691 \\
\hline Bäcker-Innung & 1879-1909 & 2.915 \\
\hline \multirow[t]{3}{*}{ Badekommission } & $1878-1906$ & 733 \\
\hline & 1876-1882 & 734 \\
\hline & $1876-1892$ & 736 \\
\hline
\end{tabular}


IV

Index

\begin{tabular}{|c|c|c|}
\hline \multicolumn{3}{|l|}{ INST } \\
\hline Indexbegriff & Laufzeit & Lfd.Nr. \\
\hline Baptistengemeinde, Emden & $1875-1913$ & 3.496 \\
\hline Barbier-Innung, Innung & 1880 & 1.935 \\
\hline \multirow[t]{8}{*}{ Barmer Bankverein } & $1902-1910$ & 1.456 \\
\hline & 1905-1907 & 1.461 \\
\hline & $1908-1910$ & 1.466 \\
\hline & 1908-1911 & 1.467 \\
\hline & $1910-1911$ & 1.468 \\
\hline & $1912-1913$ & 1.478 \\
\hline & 1910-1912 & 1.480 \\
\hline & $1910-1911$ & 1.481 \\
\hline Bau- und Holzhandlung Geerds, Schelten und Boerma & $1900-1903$ & 1.165 \\
\hline \multirow[t]{2}{*}{ Bau- und Verpachtungskommission } & 1899-1903 & 1.454 \\
\hline & $1895-1896$ & 2.029 \\
\hline Bauamt für die Hafenerweiterung & 1906 & 2.171 \\
\hline Bauamt für Hafenerweiterung & 1907 & 1.552 \\
\hline Bauamt, Stadtamt & $1912-1913$ & 314 \\
\hline Bauarbeiterschutzkommission & 1906-1909 & 1.223 \\
\hline \multirow{34}{*}{ Bau-Commission, Stadt Emden } & 1902 & 184 \\
\hline & 1889-1896 & 861 \\
\hline & $1890-1901$ & 896 \\
\hline & 1884-1896 & 900 \\
\hline & 1900-1904 & 938 \\
\hline & 1901-1905 & 939 \\
\hline & 1893-1901 & 940 \\
\hline & 1902-1906 & 942 \\
\hline & 1903 & 943 \\
\hline & $1896-1913$ & 950 \\
\hline & 1907-1908 & 953 \\
\hline & 1883-1907 & 977 \\
\hline & 1905-1909 & 1.009 \\
\hline & $1875-1887$ & 1.137 \\
\hline & 1881 & 1.162 \\
\hline & 1876 & 1.175 \\
\hline & $1880-1881$ & 1.177 \\
\hline & $1880-1906$ & 1.179 \\
\hline & $1870-1884$ & 1.180 \\
\hline & $1872-1879$ & 1.181 \\
\hline & 1901-1909 & 1.183 \\
\hline & 1903-1904 & 1.184 \\
\hline & 1905-1906 & 1.191 \\
\hline & 1904-1905 & 1.193 \\
\hline & 1905 & 1.197 \\
\hline & $1906-1911$ & 1.199 \\
\hline & $1910-1911$ & 1.201 \\
\hline & 1866-1908 & 1.206 \\
\hline & 1876 & 1.207 \\
\hline & $1880-1904$ & 1.208 \\
\hline & $1872-1874$ & 1.209 \\
\hline & 1901-1902 & 1.237 \\
\hline & 1901-1902 & 1.239 \\
\hline & $1902-1903$ & 1.498 \\
\hline Baufachausstellung in Leipzig & 1913 & 2.133 \\
\hline Bauhof der Stadt Emden & 1869-1909 & 2.410 \\
\hline Baukommission für die Eindeichung des Kaiser-Wilhelm-Polders & 1874-1887 & 2.478 \\
\hline \multirow[t]{2}{*}{ Bauunternehmen Habich \& Goth } & $1883-1901$ & 2.044 \\
\hline & 1893 & 2.206 \\
\hline \multirow[t]{2}{*}{ Bauunternehmen Hagen \& Benjamins } & $1906-1913$ & 2.587 \\
\hline & 1905 & 2.831 \\
\hline
\end{tabular}


IV

Index

\begin{tabular}{ll}
\hline INST \\
\hline Indexbegriff \\
\hline Bauverein "Eigenes Heim"
\end{tabular}

Bauverein Emden

Bayerisches Kriegsministerium

Beamten-Bau- und Wohnungsverein, Emden

Beamten-Haushaltungsverein

Beerdigungskasse der Schneidergesellen

Begräbnisverein zu Emden

Beirat für die Hafenerweiterung

Bekleidungsamt

Bekleidungsausschuss, Stadt Emden

Bekleidungskommission, Stadt Emden

Belgisches Staatsarchiv in Brüssel

Benzwerke Gaggenau

Beratungsverein "Elektrizität" zu Berlin

Berlin-Dresdener Eisenbahngesellschaft

Berliner Berufsfeuerwehr

Berufsgenossenschaft der Gas- und Wasserwerke

Betriebskrankenkasse des Bauunternehmens Habich \& Goth

Bezirksausschuss, Aurich

\section{Laufzeit}

1887-1902

$1890-1911$

1905-1907

$1902-1914$

1902-1905

1902-1903

1906-1908

1890-1892

1882-1911

$1869-1916$

1869-1915

1906-1910

1916-1918

1916-1918

$1917-1918$

1917-1918

1883-1887

1868-1911

1908-1916

1880-1897

1900-1901

1897-1913

1903-1909

1896-1902

1904-1905

1901-1903

1901-1902

1898

1900-1903

1904-1908

1897-1900

1899-1901

1900

1906-1914

1915-1918

1890

1899-1904

1904-1906

1906-1908

1906-1908

1909-1911

1910

1885-1891

1885-1888

1907

1911-1913

1889-1890

1890-1893

1902-1903

1891-1905

1897-1900

1901

1901-1903

1901-1902

1900-1901

1906-1908

1899-1906

1905-1909
Lfd.Nr.

1.228

687

2.613

1.235

1.236

2.798

2.825

627

1.646

1.647

1.648

2.374

3.290

3.287

3.283

3.296

2.393

1.396

1.100

615

1.266

1.070

1.071

1.665

14

76

77

80

229

230

232

233

234

236

242

354

852

855

856

857

859

860

908

917

956

957

978

979

984

988

994

996

997

1.000

1.001

1.011

1.072

1.073 
IV

Index

\begin{tabular}{|c|c|c|}
\hline \multicolumn{3}{|c|}{ INST } \\
\hline Indexbegriff & Laufzeit & Lfd.Nr. \\
\hline \multirow[t]{31}{*}{ Bezirksausschuss, Aurich } & $1900-1903$ & 1.166 \\
\hline & $1906-1907$ & 1.168 \\
\hline & $1905-1906$ & 1.169 \\
\hline & $1906-1907$ & 1.170 \\
\hline & 1906-1907 & 1.171 \\
\hline & 1903-1904 & 1.184 \\
\hline & $1903-1904$ & 1.185 \\
\hline & 1903-1907 & 1.186 \\
\hline & $1905-1908$ & 1.187 \\
\hline & 1905 & 1.188 \\
\hline & 1904-1905 & 1.193 \\
\hline & $1906-1911$ & 1.199 \\
\hline & $1910-1911$ & 1.201 \\
\hline & $1908-1910$ & 1.202 \\
\hline & $1910-1911$ & 1.204 \\
\hline & 1908 & 1.205 \\
\hline & $1901-1907$ & 1.502 \\
\hline & $1869-1914$ & 2.343 \\
\hline & $1901-1905$ & 2.565 \\
\hline & $1900-1905$ & 2.566 \\
\hline & 1896 & 2.573 \\
\hline & $1893-1898$ & 2.932 \\
\hline & $1888-1890$ & 2.995 \\
\hline & $1892-1894$ & 2.998 \\
\hline & $1892-1897$ & 2.999 \\
\hline & 1895 & 3.000 \\
\hline & $1896-1897$ & 3.001 \\
\hline & $1896-1897$ & 3.002 \\
\hline & 1903-1909 & 3.004 \\
\hline & $1916-1917$ & 3.236 \\
\hline & $1902-1909$ & 3.550 \\
\hline Bezirksbauinspektion Aurich & $1901-1905$ & 939 \\
\hline Bezirkskomitee für Naturdenkmalspflege & $1873-1917$ & 2.395 \\
\hline Bezirkskommando in Aurich & $1914-1916$ & 3.153 \\
\hline \multirow[t]{17}{*}{ Bezirksschule I (ev. reformierte Volksschule) } & $1905-1911$ & 3.539 \\
\hline & 1908 & 3.548 \\
\hline & 1912-1917 & 3.549 \\
\hline & $1912-1914$ & 3.552 \\
\hline & $1909-1912$ & 3.553 \\
\hline & $1910-1912$ & 3.554 \\
\hline & $1912-1915$ & 3.555 \\
\hline & 1913-1914 & 3.556 \\
\hline & $1912-1914$ & 3.557 \\
\hline & 1918 & 3.558 \\
\hline & 1912-1914 & 3.559 \\
\hline & $1909-1912$ & 3.560 \\
\hline & 1874-1910 & 3.578 \\
\hline & $1891-1917$ & 3.593 \\
\hline & $1913-1918$ & 3.595 \\
\hline & $1917-1918$ & 3.608 \\
\hline & $1908-1914$ & 3.610 \\
\hline \multirow[t]{7}{*}{ Bezirksschule II (ev. lutherische Volksschule) } & 1908 & 3.548 \\
\hline & $1911-1918$ & 3.561 \\
\hline & $1908-1910$ & 3.562 \\
\hline & $1889-1917$ & 3.563 \\
\hline & $1910-1914$ & 3.564 \\
\hline & $1906-1917$ & 3.565 \\
\hline & $1905-1917$ & 3.566 \\
\hline
\end{tabular}


IV

Index

\begin{tabular}{|c|c|c|}
\hline \multicolumn{3}{|l|}{ INST } \\
\hline Indexbegriff & Laufzeit & Lfd.Nr. \\
\hline \multirow[t]{10}{*}{ Bezirksschule II (ev. lutherische Volksschule) } & 1904-1911 & 3.567 \\
\hline & $1909-1910$ & 3.568 \\
\hline & $1906-1913$ & 3.569 \\
\hline & $1911-1918$ & 3.570 \\
\hline & $1882-1911$ & 3.571 \\
\hline & 1914 & 3.572 \\
\hline & $1907-1910$ & 3.573 \\
\hline & $1906-1910$ & 3.589 \\
\hline & $1917-1918$ & 3.591 \\
\hline & $1915-1917$ & 3.609 \\
\hline \multirow[t]{14}{*}{ Bezirksschule III (städtische Volksschule) } & $1912-1917$ & 3.549 \\
\hline & $1868-1910$ & 3.581 \\
\hline & $1912-1918$ & 3.582 \\
\hline & 1913-1918 & 3.583 \\
\hline & 1915 & 3.584 \\
\hline & 1915 & 3.585 \\
\hline & 1877-1918 & 3.586 \\
\hline & $1909-1913$ & 3.587 \\
\hline & $1912-1914$ & 3.588 \\
\hline & $1908-1911$ & 3.590 \\
\hline & $1912-1918$ & 3.592 \\
\hline & 1908-1916 & 3.611 \\
\hline & 1917-1918 & 3.612 \\
\hline & 1913-1914 & 3.613 \\
\hline \multirow[t]{16}{*}{ Bezirksschule IV (katholische Volksschule) } & $1915-1918$ & 3.574 \\
\hline & 1917-1918 & 3.575 \\
\hline & $1915-1918$ & 3.576 \\
\hline & $1908-1917$ & 3.577 \\
\hline & 1894 & 3.579 \\
\hline & 1913-1916 & 3.580 \\
\hline & $1909-1916$ & 3.599 \\
\hline & 1884 & 3.600 \\
\hline & 1913-1914 & 3.601 \\
\hline & $1914-1917$ & 3.602 \\
\hline & 1913-1914 & 3.603 \\
\hline & 1913-1918 & 3.604 \\
\hline & 1914-1918 & 3.605 \\
\hline & 1914-1918 & 3.606 \\
\hline & $1904-1916$ & 3.607 \\
\hline & 1916-1918 & 3.799 \\
\hline Bezirkssynode, Lutherische Gemeinden Ostfrieslands & 1868-1894 & 3.443 \\
\hline Bezirksverein f. d. Ostfriesische Küste z. Rettung Schiffsbrüchiger & 1879-1905 & 622 \\
\hline Bezirksverein für den 1. und 2. Bezirk der III Wyk & 1902 & 653 \\
\hline Bildhauer-Vereinigung des Vereins Berliner Künstler & 1904-1914 & 2.398 \\
\hline Blaues Kreuz, Ortsverein Emden & 1903-1914 & 696 \\
\hline Board of Trade & $1875-1900$ & 1.628 \\
\hline \multirow{2}{*}{ Borkumer Kleinbahn- und Dampfschiffahrt AG } & 1911-1918 & 1.901 \\
\hline & 1909 & 2.318 \\
\hline \multirow[t]{3}{*}{ Börsenverein, Emden } & 1869-1911 & 2.134 \\
\hline & $1866-1898$ & 2.135 \\
\hline & $1880-1881$ & 3.614 \\
\hline Brandenburgischer Städtetag & 1891-1895 & 1.651 \\
\hline Bremer Baugesellschaft Volker Bos, Ficke \& Co & 1901 & 2.256 \\
\hline Bremische Armenverwaltung & $1915-1917$ & 1.881 \\
\hline Brotfabrik Staal und Cramer & 1914-1916 & 3.243 \\
\hline Bücherwagen "Ostfriesland" & 1916 & 3.209 \\
\hline Bund der Bodenreformer & $1901-1910$ & 2.761 \\
\hline Bund der Industriellen & 1905 & 674 \\
\hline
\end{tabular}


IV

Index

\begin{tabular}{|c|c|c|}
\hline \multicolumn{3}{|c|}{ INST } \\
\hline Indexbegriff & Laufzeit & Lfd.Nr. \\
\hline Bund Deutscher Frauenvereine & $1914-1915$ & 3.191 \\
\hline Bund Deutscher Gemeindebeamter & $1898-1913$ & 635 \\
\hline Bund Deutscher Glaserinnungen & $1873-1889$ & 1.932 \\
\hline \multirow[t]{3}{*}{ Bundesrat } & 1918 & 461 \\
\hline & 1914-1918 & 3.204 \\
\hline & $1916-1918$ & 3.282 \\
\hline \multirow[t]{52}{*}{ Bürgervorsteher-Kollegium, Stadt Emden } & $1917-1918$ & 2 \\
\hline & $1853-1891$ & 12 \\
\hline & 1904-1905 & 14 \\
\hline & $1854-1914$ & 74 \\
\hline & $1872-1903$ & 75 \\
\hline & $1901-1903$ & 76 \\
\hline & $1901-1902$ & 77 \\
\hline & 1898 & 80 \\
\hline & $1868-1869$ & 84 \\
\hline & $1870-1871$ & 85 \\
\hline & $1872-1873$ & 86 \\
\hline & $1874-1875$ & 87 \\
\hline & $1876-1877$ & 88 \\
\hline & $1878-1879$ & 89 \\
\hline & $1880-1881$ & 90 \\
\hline & $1882-1883$ & 91 \\
\hline & 1884 & 92 \\
\hline & $1885-1886$ & 93 \\
\hline & 1887 & 94 \\
\hline & $1888-1889$ & 95 \\
\hline & $1890-1891$ & 96 \\
\hline & $1892-1893$ & 97 \\
\hline & 1894-1895 & 98 \\
\hline & $1896-1897$ & 99 \\
\hline & $1898-1899$ & 100 \\
\hline & $1900-1901$ & 101 \\
\hline & $1902-1903$ & 102 \\
\hline & 1904 & 103 \\
\hline & 1905 & 104 \\
\hline & 1906 & 106 \\
\hline & 1907 & 107 \\
\hline & 1908 & 108 \\
\hline & 1909 & 109 \\
\hline & 1910 & 110 \\
\hline & $1871-1903$ & 111 \\
\hline & $1854-1890$ & 112 \\
\hline & $1886-1904$ & 113 \\
\hline & 1867 & 114 \\
\hline & 1868 & 115 \\
\hline & 1869 & 116 \\
\hline & 1870 & 117 \\
\hline & 1871 & 118 \\
\hline & 1872 & 119 \\
\hline & 1873 & 120 \\
\hline & 1874 & 121 \\
\hline & 1875 & 122 \\
\hline & 1876 & 123 \\
\hline & 1877 & 124 \\
\hline & 1878 & 125 \\
\hline & 1880 & 126 \\
\hline & 1881 & 127 \\
\hline & $1882-1883$ & 128 \\
\hline
\end{tabular}


IV

Index

\begin{tabular}{|c|c|c|}
\hline \multicolumn{3}{|c|}{ INST } \\
\hline Indexbegriff & Laufzeit & Lfd.Nr. \\
\hline \multirow[t]{46}{*}{ Bürgervorsteher-Kollegium, Stadt Emden } & $1884-1885$ & 129 \\
\hline & 1886 & 130 \\
\hline & 1887 & 131 \\
\hline & 1888 & 132 \\
\hline & 1889 & 133 \\
\hline & 1890 & 134 \\
\hline & 1891 & 135 \\
\hline & 1892 & 136 \\
\hline & $1893-1894$ & 137 \\
\hline & 1895 & 138 \\
\hline & $1896-1897$ & 139 \\
\hline & $1897-1898$ & 140 \\
\hline & $1899-1900$ & 141 \\
\hline & $1900-1902$ & 142 \\
\hline & $1902-1904$ & 143 \\
\hline & 1904-1908 & 144 \\
\hline & $1908-1910$ & 145 \\
\hline & $1910-1912$ & 146 \\
\hline & $1912-1913$ & 147 \\
\hline & $1913-1914$ & 148 \\
\hline & 1914-1917 & 149 \\
\hline & $1917-1919$ & 150 \\
\hline & $1867-1869$ & 155 \\
\hline & $1870-1872$ & 156 \\
\hline & $1873-1874$ & 157 \\
\hline & 1873 & 158 \\
\hline & $1875-1878$ & 159 \\
\hline & $1879-1881$ & 160 \\
\hline & 1882-1884 & 161 \\
\hline & $1885-1888$ & 162 \\
\hline & $1889-1893$ & 163 \\
\hline & 1894-1910 & 164 \\
\hline & $1910-1914$ & 165 \\
\hline & $1915-1919$ & 166 \\
\hline & 1866 & 174 \\
\hline & $1901-1913$ & 187 \\
\hline & 1854-1888 & 335 \\
\hline & $1884-1885$ & 904 \\
\hline & $1885-1910$ & 905 \\
\hline & $1885-1889$ & 906 \\
\hline & $1893-1901$ & 940 \\
\hline & 1876-1889 & 1.650 \\
\hline & $1896-1900$ & 1.652 \\
\hline & $1871-1872$ & 1.775 \\
\hline & 1887-1893 & 1.778 \\
\hline & 1871 & 1.861 \\
\hline Bürgervorsteher-Vereinigung der Provinz Hannover & $1912-1914$ & 709 \\
\hline Cafe "Japan" & $1900-1901$ & 537 \\
\hline Cafe "National" & $1900-1901$ & 537 \\
\hline Cassens-Werft & $1899-1908$ & 527 \\
\hline & $1879-1900$ & 2.184 \\
\hline & $1897-1901$ & 2.185 \\
\hline Central-Armen-Deputation & 1871 & 1.861 \\
\hline & 1871 & 1.862 \\
\hline & $1872-1900$ & 1.863 \\
\hline & $1871-1913$ & 1.864 \\
\hline & $1873-1882$ & 1.865 \\
\hline
\end{tabular}


IV

Index

\begin{tabular}{l}
\hline \\
\hline Indexbegriff \\
\hline Central-Armen-Deputation \\
Centralkomitee vom Roten Kreuz \\
Centralverein der Maurer Deutschlands, Zweig \\
Centralverein für das Wohl der arbeitenden K \\
Central-Verein für Hebung der deutschen Flu \\
\\
Christliche Kinderschule \\
Christlicher Gesangverein, gemischter Chor \\
Christlicher Jünglingsverein \\
Christlicher Jünglingsverein, Emden \\
Clementiner-Bruderschaft \\
Club der Landwirte, Berlin \\
Club "Einigkeit" \\
Club "Typographia" (Buchdrucker) \\
Club zum Guten Endzweck
\end{tabular}

Colussi \& Paomnit, Bildhauerfirma aus Wilhelmshaven Commission d. wissenschaftlichen Untersuchung d. dtsch. Meere Consistorialbereich Emden

Correctionsanstalt, Wunstorf

Dampferlinie Husum-Emden-Hull

Dampfkesselüberwachungsverein

Dampfspinnerei- Weberei und Färberei Actien-Gesellschaft

Deichverband des Kaiser-Wilhelm-Polders

Deichverband des Königs- und Kaiser-Wilhelm-Polders

Deichverband des Königspolders

Deichverstuhls-Verband zu Emden

Deputation des Südfalderndeichs

Desinfektionsanstalt zu Emden

Deutsch Luxemburgische Bergwerks- und Hütten AG

Deutsch reformierte Gemeinde

Deutsch reformierter Gemeindefonds

Deutsch-Amerikanische Petroleumsgesellschaft

Deutsch-Atlantische Telegrafiegesellschaft

Deutsche Bank

Deutsche Bauzeitung

Deutsche Dendrologische Gesellschaft

Deutsche Elektrizitätsgesellschaft

Deutsche Gesellsch. z. Bekämpfung d. Geschlechtskrankheiten

Deutsche Gesellschaft für Milchausschank

Deutsche Gesellschaft zur Rettung Schiffsbrüchiger

Deutsche Kohlenhandelsgesellschaft

Deutsche Kolonialgesellschaft, Abt. Emden

Deutsche Kriegswochenschau

Deutsche Küstenschifffahrt AG

INST

\section{Laufzeit}

1888-1904

1915

1903-1907

1880-1913

1904-1911

1901-1902

1868-1891

1900-1904

1868-1890

1888-1906

1869-1904

1892-1913

1875-1892

1886-1900

1883-1893

1888-1906

1900

1901-1902

1881-1912

1909

1901-1903

1871-1887

1887-1911

1867-1899

1907

1900-1913

1868-1887

1873-1874

1867-1890

1881-1901

1876-1912

1892

1892-1900

1901-1908

1872-1892

1872-1892

1868

1894-1900

1911-1918

1894

1881-1884

1892-1906

1902-1903

1903-1911

1903-1904

1912-1914

1879-1905

$1895-1912$

1905-1914

1906-1908

1879-1905

1897-1912

1905

1915-1919

1887-1912
Lfd.Nr.

1.866

3.211

658

628

456

1.416

1.450

1.758

3.847

672

3.633

516

1.749

1.750

886

617

672

538

543

626

1.940

2.558

1.406

3.318

722

2.092

1.255

1.900

2.124

2.476

2.477

1.540

1.541

1.545

1.546

1.544

1.544

1.538

1.685

1.901

3.355

3.394

1.265

2.770

1.442

2.079

2.132

1.429

796

1.021

688

676

622

1.045 
Index

\begin{tabular}{|c|c|c|}
\hline \multicolumn{3}{|l|}{ INST } \\
\hline Indexbegriff & Laufzeit & Lfd.Nr. \\
\hline Deutsche Luftschiffverankerungsgesellschaft & $1909-1913$ & 2.097 \\
\hline \multirow[t]{2}{*}{ Deutsche Norgine-Gesellschaft } & 1905 & 2.376 \\
\hline & $1905-1906$ & 2.377 \\
\hline Deutsche Ostafrika-Linie & 1905-1907 & 2.083 \\
\hline \multirow{2}{*}{ Deutsche Reederei } & $1905-1912$ & 2.105 \\
\hline & $1910-1914$ & 2.106 \\
\hline \multirow[t]{4}{*}{ Deutsche Seewarte } & $1880-1912$ & 1.405 \\
\hline & 1903 & 1.417 \\
\hline & $1875-1894$ & 1.617 \\
\hline & 1876-1902 & 2.503 \\
\hline Deutsche Typhagesellschaft mbH. & $1915-1918$ & 3.242 \\
\hline Deutsche Vaterlandspartei & $1917-1918$ & 3.311 \\
\hline Deutsche Wassergas-Beleuchtungsgesellschaft $\mathrm{GmbH}$ & $1892-1899$ & 1.068 \\
\hline Deutscher Arbeitgeberbund für das Baugewerbe & $1882-1913$ & 2.408 \\
\hline Deutscher Betonverein & $1909-1912$ & 699 \\
\hline Deutscher Bund & & Vorwort \\
\hline Deutscher Centralverband für Rettungswesen & $1906-1912$ & 706 \\
\hline Deutscher Feuerversicherungs-Schutzverband & 1877-1903 & 1.271 \\
\hline Deutscher Flottenverein & $1898-1914$ & 638 \\
\hline Deutscher Gastwirteverband & 1904-1915 & 667 \\
\hline Deutscher Glaser-Tag & $1873-1889$ & 1.932 \\
\hline Deutscher Handwerker- und Gewerbekammertag & $1893-1912$ & 1.926 \\
\hline Deutscher Hilfsverein in Wien & $1883-1893$ & 617 \\
\hline Deutscher Kolonialverein & $1883-1893$ & 617 \\
\hline \multirow[t]{2}{*}{ Deutscher Kriegerbund } & $1873-1910$ & 598 \\
\hline & $1899-1913$ & 634 \\
\hline Deutscher Luftflotten-Verein & $1912-1915$ & 714 \\
\hline Deutscher Musikpädagogischer Verband & 1913 & 711 \\
\hline Deutscher Nautischer Verein & 1879-1894 & 2.890 \\
\hline Deutscher Samariter-Bund & $1905-1914$ & 589 \\
\hline Deutscher Schulschiffverein & 1903 & 656 \\
\hline Deutscher Seefischerei-Verein & 1914-1918 & 3.232 \\
\hline \multirow[t]{2}{*}{ Deutscher Städtetag } & $1879-1894$ & 2.890 \\
\hline & $1911-1915$ & 3.008 \\
\hline Deutscher Tischlerverband, Zahlstelle Emden & $1892-1893$ & 631 \\
\hline \multirow[t]{2}{*}{ Deutscher Verein "Arbeiterheim", Bielefeld } & $1901-1908$ & 1.229 \\
\hline & $1909-1911$ & 1.231 \\
\hline Deutscher Verein für Gasthausreform & 1867-1909 & 529 \\
\hline Deutscher Verein für Knabenhandarbeit & $1887-1914$ & 2.345 \\
\hline Deutscher Verein für öffentliche Gesundheitspflege & 1887-1902 & 1.228 \\
\hline Deutscher Verein für Wohnungsreform & 1904-1914 & 1.238 \\
\hline Deutscher Verein gegen den Missbrauch geistiger Getränke & 1903-1906 & 646 \\
\hline \multirow[t]{2}{*}{ Deutscher Verein von Gas- und Wasserfachmänner } & 1886-1909 & 1.019 \\
\hline & $1897-1913$ & 1.070 \\
\hline Deutscher Zentralverein z. Fürsorge f. d. schulentlassene Jugend & $1902-1913$ & 660 \\
\hline Deutsches Schriftsteller-Heim & $1899-1903$ & 651 \\
\hline Deutsches Zentralkomitee zur Bekämpfung der Tuberkulose & $1890-1911$ & 770 \\
\hline Deutsch-evangelischer Frauenbund & $1911-1914$ & 702 \\
\hline Deutsch-freisinnige Partei & 1884 & 629 \\
\hline Deutsch-Holländische Baugesellschaft & 1899-1903 & 1.454 \\
\hline Deutsch-Holländische-Kanal- und Seeschiffahrts $\mathrm{GmbH}$. & 1911 & 2.260 \\
\hline \multirow[t]{5}{*}{ Deutsch-Luxemburgische Bergwerks- und Hütten AG } & $1911-1912$ & 1.477 \\
\hline & $1910-1912$ & 1.480 \\
\hline & $1911-1912$ & 1.484 \\
\hline & $1913-1917$ & 1.485 \\
\hline & 1913-1915 & 2.977 \\
\hline Deutsch-Luxemburgische Hütten- und Bergwerks AG & & Vorwort \\
\hline Deutsch-nationaler Handlungsgehilfenverband Ortsgruppe Emden & $1888-1906$ & 672 \\
\hline
\end{tabular}


IV

Index

\begin{tabular}{|c|c|c|}
\hline \multicolumn{3}{|l|}{ INST } \\
\hline Indexbegriff & Laufzeit & Lfd.Nr. \\
\hline \multirow[t]{3}{*}{ Deutsch-nationaler Handlungsgehilfenverband Ortsgruppe Emden } & $1864-1880$ & 2.342 \\
\hline & $1886-1916$ & 3.849 \\
\hline & $1905-1917$ & 3.857 \\
\hline Deutsch-Östereichisch-Ungarische Gesellsch. für Binnenschifffahrt & 1904 & 2.001 \\
\hline Deutsch-Österreich-Ungarischer Verband für Binnenschifffahrt & $1903-1911$ & 663 \\
\hline \multirow{53}{*}{ Deutsch-reformierte Gemeinde } & 1871 & 1.633 \\
\hline & $1867-1918$ & 1.634 \\
\hline & 1904-1905 & 2.829 \\
\hline & $1909-1912$ & 3.138 \\
\hline & $1869-1910$ & 3.350 \\
\hline & $1887-1888$ & 3.354 \\
\hline & 1894 & 3.356 \\
\hline & $1891-1894$ & 3.357 \\
\hline & $1891-1892$ & 3.358 \\
\hline & 1898 & 3.359 \\
\hline & 1894 & 3.360 \\
\hline & 1895 & 3.361 \\
\hline & 1897 & 3.362 \\
\hline & 1898 & 3.363 \\
\hline & $1894-1905$ & 3.364 \\
\hline & 1904 & 3.365 \\
\hline & 1898 & 3.366 \\
\hline & 1890 & 3.367 \\
\hline & $1890-1895$ & 3.368 \\
\hline & 1894 & 3.369 \\
\hline & 1895 & 3.370 \\
\hline & $1891-1898$ & 3.371 \\
\hline & 1898 & 3.372 \\
\hline & 1898 & 3.373 \\
\hline & 1891 & 3.374 \\
\hline & 1891 & 3.375 \\
\hline & 1894-1904 & 3.376 \\
\hline & 1894-1904 & 3.377 \\
\hline & $1874-1910$ & 3.378 \\
\hline & $1868-1911$ & 3.379 \\
\hline & $1909-1913$ & 3.380 \\
\hline & $1870-1885$ & 3.382 \\
\hline & $1890-1894$ & 3.383 \\
\hline & 1890 & 3.384 \\
\hline & $1899-1900$ & 3.385 \\
\hline & $1887-1893$ & 3.386 \\
\hline & $1871-1918$ & 3.388 \\
\hline & $1867-1896$ & 3.389 \\
\hline & $1875-1905$ & 3.390 \\
\hline & $1877-1897$ & 3.392 \\
\hline & $1901-1902$ & 3.393 \\
\hline & $1881-1884$ & 3.394 \\
\hline & $1891-1896$ & 3.395 \\
\hline & $1882-1883$ & 3.396 \\
\hline & $1898-1911$ & 3.399 \\
\hline & 1901 & 3.400 \\
\hline & $1902-1913$ & 3.402 \\
\hline & $1871-1876$ & 3.409 \\
\hline & $1894-1897$ & 3.420 \\
\hline & $1887-1895$ & 3.507 \\
\hline & $1867-1890$ & 3.626 \\
\hline & $1891-1907$ & 3.627 \\
\hline & 1903 & 3.643 \\
\hline
\end{tabular}


IV

Index

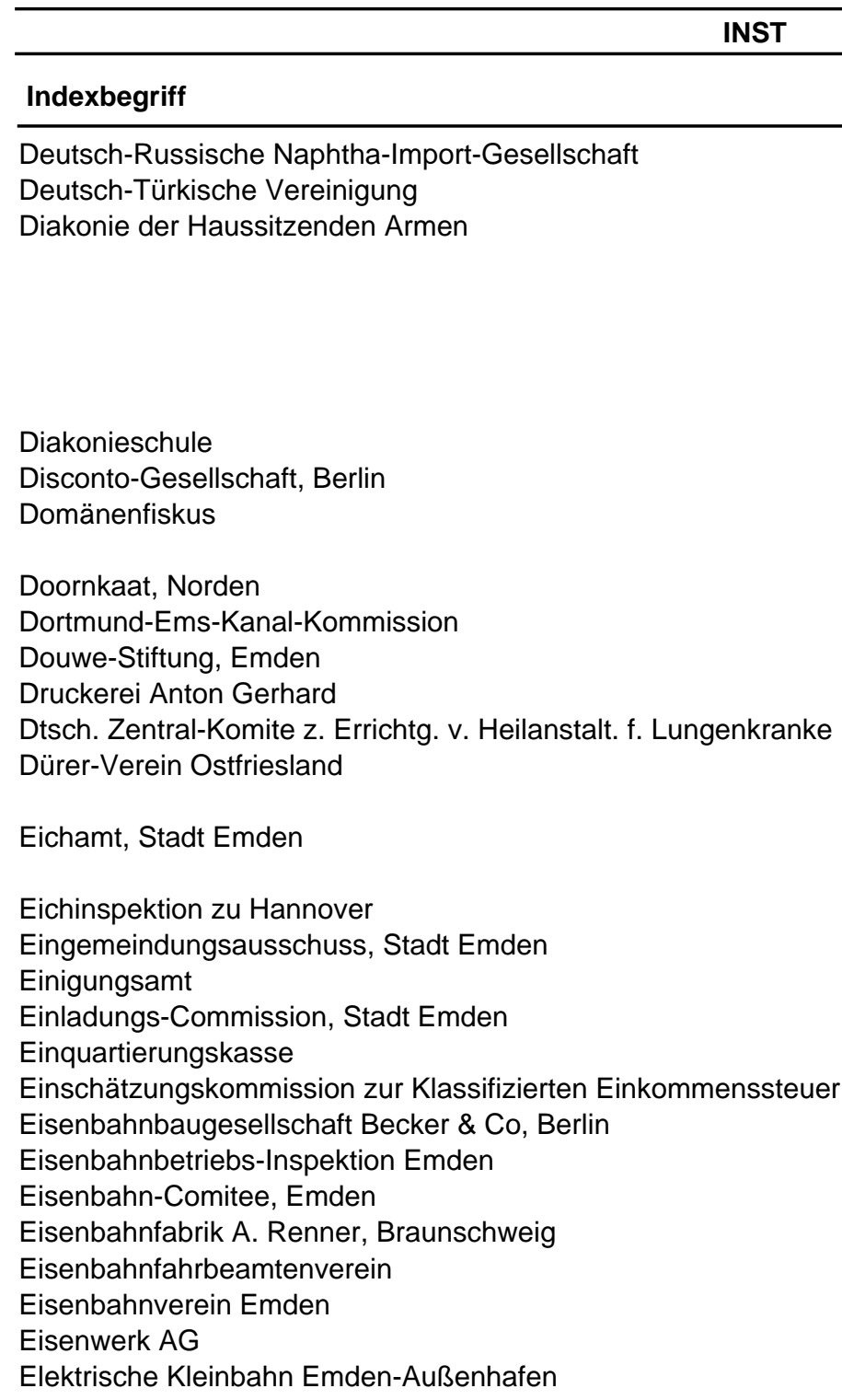


IV

Index

\begin{tabular}{|c|c|c|}
\hline \multicolumn{3}{|l|}{ INST } \\
\hline Indexbegriff & Laufzeit & Lfd.Nr. \\
\hline \multirow[t]{8}{*}{ Elektrische Kleinbahn Emden-Außenhafen } & 1914 & 1.995 \\
\hline & $1902-1918$ & 1.997 \\
\hline & $1905-1908$ & 1.998 \\
\hline & $1901-1912$ & 1.999 \\
\hline & 1904 & 2.000 \\
\hline & $1900-1914$ & 2.047 \\
\hline & $1915-1918$ & 2.048 \\
\hline & $1915-1918$ & 2.049 \\
\hline \multirow[t]{2}{*}{ Elektrische Zentralstation "Nesserland" } & 1899 & 2.231 \\
\hline & 1902 & 2.263 \\
\hline \multirow[t]{14}{*}{ Elektrizitätskommission, Stadt Emden } & 1907-1908 & 1.083 \\
\hline & $1908-1911$ & 1.085 \\
\hline & $1912-1913$ & 1.093 \\
\hline & $1906-1912$ & 1.098 \\
\hline & 1912 & 1.099 \\
\hline & 1912 & 1.106 \\
\hline & $1912-1913$ & 1.107 \\
\hline & 1912 & 1.114 \\
\hline & 1912 & 1.116 \\
\hline & 1912 & 1.117 \\
\hline & $1912-1915$ & 1.120 \\
\hline & 1912 & 1.123 \\
\hline & 1912 & 1.125 \\
\hline & $1911-1912$ & 1.131 \\
\hline Elektrizitätswerk Siegerland & $1905-1911$ & 1.074 \\
\hline Elementarlehrer- Witwen- u. Waisenkasse f. d. Provinz Hannover & $1874-1890$ & 3.499 \\
\hline Elermentarlehrer-Witwen- und Waisenkasse & $1894-1912$ & 3.817 \\
\hline Emailleschilder-Fabrik Ch. Schweizer \& Söhne & $1866-1913$ & 832 \\
\hline Emden, Siedlung Transvaal & $1900-1902$ & 1.247 \\
\hline Emdener Maschinen Fabrik & $1892-1910$ & 2.389 \\
\hline \multirow[t]{17}{*}{ Emdener Papierfabrik AG } & $1886-1894$ & 870 \\
\hline & $1885-1900$ & 907 \\
\hline & $1883-1885$ & 914 \\
\hline & $1878-1904$ & 1.729 \\
\hline & $1882-1904$ & 1.731 \\
\hline & $1868-1887$ & 1.900 \\
\hline & $1872-1880$ & 2.158 \\
\hline & 1900 & 2.252 \\
\hline & 1902 & 2.265 \\
\hline & $1872-1904$ & 2.382 \\
\hline & $1872-1884$ & 2.384 \\
\hline & $1885-1896$ & 2.385 \\
\hline & $1892-1910$ & 2.389 \\
\hline & $1866-1893$ & 2.454 \\
\hline & $1884-1914$ & 2.541 \\
\hline & $1877-1904$ & 2.708 \\
\hline & $1913-1914$ & 2.886 \\
\hline Emder Assecuranz-Compagnie für Seegefahr & $1868-1887$ & 1.900 \\
\hline \multirow[t]{3}{*}{ Emder Bank AG } & $1905-1907$ & 1.461 \\
\hline & 1902 & 1.923 \\
\hline & 1899 & 2.768 \\
\hline Emder Beamtenbauverein & $1913-1914$ & 1.080 \\
\hline Emder Börsenverein & 1905 & 674 \\
\hline \multirow[t]{4}{*}{ Emder Brikettfabrik } & $1873-1914$ & 1.227 \\
\hline & $1901-1904$ & 2.381 \\
\hline & $1892-1910$ & 2.389 \\
\hline & & Vorwort \\
\hline Emder Bürgerpark-Verein & 1909 & 2.591 \\
\hline
\end{tabular}


IV

Index

\begin{tabular}{|c|c|c|}
\hline \multicolumn{3}{|c|}{ INST } \\
\hline Indexbegriff & Laufzeit & Lfd.Nr. \\
\hline \multirow[t]{2}{*}{ Emder Bürgerverein } & $1891-1894$ & 630 \\
\hline & 1879-1909 & 2.915 \\
\hline Emder Bürgerwehr von 1848 /49 & $1882-1906$ & 2.610 \\
\hline Emder Club "Erholung" & $1883-1893$ & 617 \\
\hline \multirow[t]{2}{*}{ Emder Colonialwaren-Detaillisten-Verein } & 1898-1908 & 636 \\
\hline & $1877-1910$ & 2.653 \\
\hline Emder Dampfer-Compagnie & 1904 & 2.080 \\
\hline Emder Dampfschifffahrtsgesellschaft "Concordia" & $1880-1912$ & 1.405 \\
\hline Emder Dampfschiffreederei AG & 1904 & 2.284 \\
\hline \multirow[t]{4}{*}{ Emder Detaillisten-Verein } & $1866-1913$ & 832 \\
\hline & 1883-1902 & 1.909 \\
\hline & $1888-1912$ & 1.910 \\
\hline & 1879-1909 & 2.915 \\
\hline Emder Eisenhütte & 1905 & 674 \\
\hline Emder Erziehungsverein & 1914-1916 & 759 \\
\hline Emder Flachsmarkt & $1870-1884$ & 2.138 \\
\hline Emder Fleischer-Innung & $1868-1913$ & 597 \\
\hline Emder Gemüsebaugenossenschaft & $1902-1911$ & 803 \\
\hline \multirow{2}{*}{ Emder Genossenschaftsbank } & $1895-1914$ & 462 \\
\hline & $1881-1912$ & 1.919 \\
\hline Emder Gesellenverein (Männergesangverein) & $1883-1893$ & 617 \\
\hline \multirow{3}{*}{ Emder Gewerbebank } & $1895-1914$ & 462 \\
\hline & $1902-1914$ & 1.235 \\
\hline & 1902 & 1.923 \\
\hline Emder Hafenbetrieb & $1915-1916$ & 3.166 \\
\hline Emder Hafenbetriebsverein & 1913-1914 & 715 \\
\hline Emder Hafenverein & $1906-1907$ & 677 \\
\hline Emder Handwerkerverein & $1873-1874$ & 2.124 \\
\hline Emder Häringsfischerei AG & $1868-1887$ & 1.900 \\
\hline \multirow[t]{14}{*}{ Emder Heringsfischerei AG } & $1895-1914$ & 462 \\
\hline & 1894-1905 & 897 \\
\hline & $1887-1910$ & 935 \\
\hline & 1879 & 1.320 \\
\hline & 1898 & 2.172 \\
\hline & 1900 & 2.173 \\
\hline & 1907 & 2.177 \\
\hline & 1890 & 2.194 \\
\hline & 1896 & 2.216 \\
\hline & 1897 & 2.221 \\
\hline & 1899 & 2.234 \\
\hline & $1873-1888$ & 2.484 \\
\hline & $1885-1896$ & 2.529 \\
\hline & $1873-1886$ & 2.687 \\
\hline \multirow[t]{14}{*}{ Emder Heringsfischerei "Dollart" AG } & 1901 & 2.259 \\
\hline & 1902 & 2.266 \\
\hline & 1903 & 2.276 \\
\hline & 1903 & 2.279 \\
\hline & 1904 & 2.285 \\
\hline & 1904 & 2.286 \\
\hline & 1908 & 2.295 \\
\hline & 1905 & 2.296 \\
\hline & 1908 & 2.300 \\
\hline & 1908 & 2.303 \\
\hline & 1908 & 2.307 \\
\hline & 1908 & 2.308 \\
\hline & 1910 & 2.320 \\
\hline & 1910 & 2.321 \\
\hline Emder Industriefortbildungsschule & $1872-1915$ & 3.855 \\
\hline
\end{tabular}


Index

\begin{tabular}{|c|c|c|}
\hline \multicolumn{3}{|l|}{ INST } \\
\hline Indexbegriff & Laufzeit & Lfd.Nr. \\
\hline Emder Industrieschule für Frauen und Töchter & $1886-1916$ & 3.849 \\
\hline Emder Kohlanbaubezirk & $1902-1911$ & 803 \\
\hline \multirow{2}{*}{ Emder Kriegerverein } & $1873-1910$ & 598 \\
\hline & 1866-1907 & 2.620 \\
\hline \multirow[t]{2}{*}{ Emder Lagerhausgesellschaft } & $1903-1911$ & 2.079 \\
\hline & 1903-1904 & 2.132 \\
\hline \multirow[t]{2}{*}{ Emder Maschinenfabrik Wilhelm Heuer Söhne } & 1900 & 2.244 \\
\hline & 1901 & 2.253 \\
\hline Emder Militärverein mit Sterbekasse & $1902-1913$ & 1.671 \\
\hline \multirow[t]{2}{*}{ Emder Ratssilber } & $1878-1898$ & 2.630 \\
\hline & $1902-1908$ & 2.631 \\
\hline Emder Reederei AG & $1895-1914$ & 462 \\
\hline \multirow[t]{2}{*}{ Emder Ruderverein von 1906} & $1901-1912$ & 642 \\
\hline & $1909-1912$ & 689 \\
\hline Emder Schach-Club & $1883-1893$ & 617 \\
\hline Emder Schlachthof & $1877-1900$ & 794 \\
\hline \multirow[t]{4}{*}{ Emder Schützencorps } & $1912-1914$ & 839 \\
\hline & $1866-1907$ & 2.620 \\
\hline & $1878-1898$ & 2.630 \\
\hline & 1903-1904 & 2.637 \\
\hline Emder Stadtkapelle & $1912-1914$ & 567 \\
\hline \multirow[t]{3}{*}{ Emder Turnverein } & $1867-1914$ & 576 \\
\hline & $1907-1912$ & 2.594 \\
\hline & $1866-1907$ & 2.620 \\
\hline Emder Viehversicherungsanstalt & $1906-1913$ & 807 \\
\hline Emder Viehversicherungs-Verein & 1873-1905 & 805 \\
\hline \multirow[t]{2}{*}{ Emder Wirteverein } & $1904-1915$ & 667 \\
\hline & $1907-1914$ & 2.986 \\
\hline Emder Zeitung & $1867-1891$ & 719 \\
\hline Ems-Dampfschifffahrts-Gesellschaft "Concordia" & $1881-1885$ & 2.014 \\
\hline Ems-Jade-Canal-Bauamt & 1887 & 1.148 \\
\hline \multirow{2}{*}{ Ems-Jade-Kanalbaubezirk } & $1885-1887$ & 915 \\
\hline & $1886-1887$ & 927 \\
\hline Emsloots-Gesellschaft & $1868-1887$ & 1.900 \\
\hline \multirow[t]{4}{*}{ Emslots-Gesellschaft } & $1872-1912$ & 2.122 \\
\hline & 1906 & 2.168 \\
\hline & 1901 & 2.261 \\
\hline & $1880-1881$ & 2.469 \\
\hline Emszeitung & 1902 & 1.451 \\
\hline Entschädigungskommission für Militärdienstleistungen & $1876-1918$ & 3.168 \\
\hline Ernst-Ludwig-Verein, Darmstadt & 1905 & 1.241 \\
\hline Erste Assecuranz-Compagnie, Emden & $1867-1887$ & 2.117 \\
\hline \multirow[t]{2}{*}{ Erstes Bataillon des 78. (Ostfriesischen) Infanterie-Regiments } & 1877-1878 & 3.084 \\
\hline & $1866-1881$ & 3.085 \\
\hline Erziehungsverein & 1887-1902 & 1.228 \\
\hline Etat-Ausschuss des preußischen Landtages & 1906-1907 & 2.086 \\
\hline EVAG, Emder Verkehrs AG & 1914 & 2.102 \\
\hline \multirow[t]{3}{*}{ Evangelisch - lutherischer Schulverband } & 1896-1905 & 3.518 \\
\hline & $1899-1907$ & 3.519 \\
\hline & 1904 & 3.527 \\
\hline Evangelische Volksschule (Bezirksschule I) & $1908-1914$ & 3.546 \\
\hline \multirow[t]{2}{*}{ Evangelischer Arbeiterinnenverein } & $1888-1915$ & 668 \\
\hline & $1913-1917$ & 1.615 \\
\hline Evangelischer Arbeiterverein & $1888-1915$ & 668 \\
\hline Evangelischer Frauenbund & 1914-1916 & 759 \\
\hline \multirow[t]{3}{*}{ Evangelisch-reformierter Schulverband } & 1896-1905 & 3.518 \\
\hline & 1899-1907 & 3.519 \\
\hline & $1898-1900$ & 3.521 \\
\hline
\end{tabular}


IV

Index

\begin{tabular}{ll}
\hline INST \\
\hline
\end{tabular}

Indexbegriff

Evangelisch-reformierter Schulverband

Executiv-Ausschuss für den Kanal Dortmund-Emshäfen

Fa. Adolf Koch, Internationale Spedition, Berlin

Fa. August Klönne, Dortmund

Fa. Barth \& Co

Fa. Bessler, Waechter \& Co, Newcastle, Kohlenhandel

Fa. Börne \& Co, Berlin

Fa. Börner \& Herzberg

Fa. Breymann \& Tiller

Fa. Brill \& Harms

Fa. Busche \& Mühlenbruch

Fa. Christoph \& Unmach AG

Fa. Clausing \& Co, Minden

Fa. Dose \& Middendorf, Hamburg

Fa. Eisengießerei und Maschinenfabrik Gebr. Barth

Fa. F. Stötzel, Thorn (Westpreußen)

Fa. F.W. Niemöller,. Gütersloh

$\mathrm{Fa}$. Frerichs \& Mehrings

Fa. G. Horn, Braunschweig

Fa. G. W. Sikkens

Fa. Gebrüder Körting

Fa. Gerrits, Schelten \& Boerma

Fa. Göhrmann und Eichhorn

Fa. Habich \& Goth

Fa. Heinrich \& Wagner

Fa. Heio von Norden

Fa. J. \& S. Goldschmidt

Fa. J.K. Hanssen, Husum

Fa. Jäger und Co, Gemüsehandel aus Wesselbühren

Fa. Joh. Klaassen, Gemüsehandel

Laufzeit

1904

1885-1889

1912-1913

1880-1881

1895-1898

1898-1903

1898-1899

$1899-1906$

1905-1909

1910-1911

1892-1906

1897-1912

1881-1911

1885-1907

1905-1908

1896-1913

1907-1908

1910-1911

1877-1878

1872

1889-1902

1902-1906

1905-1911

1867-1909

1896-1909

1895

1897

1905-1912

1905

1906-1907

1898-1903

1873-1874

1872-1893

1907-1918

1902-1905

1901-1906

1902-1907

1896-1910

1903-1904

1904-1906

1898-1903

1894-1911

1896-1898

1881-1911

1885-1889

1888-1909

1887

1892

1893

1897

1903

1910-1914

1901

1878-1898

1883-1906

1917-1918

1917-1918
Lfd.Nr.

3.527

2.022

2.101

1.027

1.031

1.035

1.044

1.072

1.073

1.468

1.265

1.045

737

909

948

950

953

955

2.652

1.491

2.533

2.569

3.539

1.397

739

2.213

2.224

863

2.081

1.171

1.035

2.186

2.470

1.952

1.960

1.962

1.967

1.976

1.978

1.979

3.692

2.745

2.781

737

906

928

933

2.197

2.207

2.222

2.275

2.106

181

2.630

2.043

3.308

3.308 
Index

\begin{tabular}{l}
\hline \\
\hline Indexbegriff \\
\hline Fa. Johnsen, Hamburg \\
Fa. Kappelhoff, Wwe. \& Sohn \\
Fa. Krah \& Hoffmann \\
Fa. Kröger \\
Fa. Lehnkering \\
Fa. Lehnkering \& Cie AG \\
Fa. Louis Tidow, Hannover \\
Fa. Ludwig R. Hesse Bierbrauerei GmbH, Weener \\
Fa. M. Friedrich \& Co, Leipzig \\
Fa. M. Kori \\
Fa. Max Märkle, Frankfurt / Main \\
Fa. Max Weinberg Sen., Berlin, Landaufkauffirma \\
Fa. Otto Fischer Sohn, Berlin \\
Fa. Possehl \& Co, Erzimportfirma aus Lübeck \\
Fa. Rütgers Werke \\
Fa. S. Italjener \& Sohn \\
Fa. Schaffer \& Walcher \\
Fa. Schmidt \& Meyer \\
Fa. Schönberg \& Neumark
\end{tabular}

Fa. Schulte \& Bruns

Fa. Sebern Bokkel-Huisink

Fa. Seelman Gebrüder, Hamburg

Fa. Stober

Fa. Stöver \& Arends

Fa. Urania-Uhr GmbH

Fa. Vellmer \& Rasmussen

Fa. Vering \& Waechter, Berlin

Fa. Visser \& Danecker, Sauerkrautfabrik

Fa. W. Brons \& Söhne

Fa. W. Kramer, Gütersloh

Fa. W.A. Scholten

Fa. Walter Hammerstein, Mühlheim

Fa. Wohlgemuth \& Kenold

Fa. Ysaac \& Bernhard Brons

Falderndeichacht

Faldernsielacht

Familienverein "Ressource"

Feuerversicherungsbank für Deutschland

Filialverein für Vogelzucht, Geflügel- und Singvögelschutz

Finanzkommission für den Kaiserbesuch

Fischerei AG "Neptun"

\section{INST}

INST


IV

Index

\begin{tabular}{|c|c|c|}
\hline \multicolumn{3}{|l|}{ INST } \\
\hline Indexbegriff & Laufzeit & Lfd.Nr. \\
\hline \multirow[t]{24}{*}{ Fischerei AG "Neptun" } & 1895 & 2.212 \\
\hline & 1895 & 2.218 \\
\hline & 1899 & 2.234 \\
\hline & 1899 & 2.235 \\
\hline & 1900 & 2.243 \\
\hline & 1901 & 2.254 \\
\hline & 1902 & 2.267 \\
\hline & 1902 & 2.268 \\
\hline & 1903 & 2.277 \\
\hline & 1904 & 2.287 \\
\hline & 1904 & 2.288 \\
\hline & 1905 & 2.292 \\
\hline & 1905 & 2.293 \\
\hline & 1908 & 2.309 \\
\hline & 1908 & 2.310 \\
\hline & 1908 & 2.315 \\
\hline & 1910 & 2.323 \\
\hline & $1874-1910$ & 2.498 \\
\hline & $1915-1917$ & 2.601 \\
\hline & $1915-1918$ & 2.602 \\
\hline & $1869-1910$ & 2.634 \\
\hline & $1894-1914$ & 2.744 \\
\hline & $1894-1911$ & 2.745 \\
\hline & 1914-1918 & 3.232 \\
\hline Fischmarkt AG, Emden & 1914-1918 & 3.232 \\
\hline Fleischerinnung Emden & 1912 & 2.357 \\
\hline Fleischer-Innung, Emden & $1911-1913$ & 479 \\
\hline Flottenbund deutscher Frauen & $1907-1908$ & 685 \\
\hline Förderges. d. Instituts f. Seeverkehr u. Weltwirtschaft d. Uni. Kiel & 1915 & 717 \\
\hline \multirow[t]{12}{*}{ Französisch-reformierte Gemeinde, Emden } & $1876-1896$ & 328 \\
\hline & $1867-1896$ & 2.156 \\
\hline & $1871-1897$ & 3.415 \\
\hline & $1883-1888$ & 3.416 \\
\hline & $1869-1895$ & 3.417 \\
\hline & $1871-1897$ & 3.418 \\
\hline & $1871-1897$ & 3.419 \\
\hline & $1894-1897$ & 3.420 \\
\hline & $1898-1913$ & 3.421 \\
\hline & $1886-1893$ & 3.422 \\
\hline & $1867-1871$ & 3.646 \\
\hline & $1871-1872$ & 3.647 \\
\hline \multirow[t]{2}{*}{ Französisch-reformierte Predigerwitwenkasse, Emden } & $1876-1896$ & 328 \\
\hline & $1898-1913$ & 3.421 \\
\hline Frauenverein für christliche Armen- und Krankenpflege & $1861-1903$ & 577 \\
\hline Frauenverein für verschämte Arme & 1867-1902 & 2.917 \\
\hline \multirow[t]{4}{*}{ Frauenverein für verwundete und kranke deutsche Krieger } & $1870-1872$ & 593 \\
\hline & 1870 & 594 \\
\hline & 1870 & 595 \\
\hline & $1870-1871$ & 596 \\
\hline Freie Emsinnung & $1899-1911$ & 2.333 \\
\hline Freier Verein vom Roten Kreuz & 1907 & 681 \\
\hline Freimaurer-Loge "Loge zur Ostfriesischen Union, Orient Emden" & $1879-1892$ & 619 \\
\hline Freimaurer-Loge "Zur wahren Treue" & $1879-1892$ & 619 \\
\hline \multirow[t]{2}{*}{ Freiwillige Feuerwehr, Emden } & $1867-1869$ & 1.284 \\
\hline & $1907-1914$ & 1.389 \\
\hline Fremdelingen Armen Diaconie & $1867-1891$ & 1.751 \\
\hline Friedhofskommission, Stadt Emden & $1881-1883$ & 3.453 \\
\hline Fuhrmannsgilde & $1880-1894$ & 1.928 \\
\hline
\end{tabular}


IV

Index

\begin{tabular}{|c|c|c|}
\hline \multicolumn{3}{|l|}{ INST } \\
\hline Indexbegriff & Laufzeit & Lfd.Nr. \\
\hline \multirow[t]{2}{*}{ Fuhrmannsgilde } & $1866-1888$ & 1.929 \\
\hline & $1866-1913$ & 1.930 \\
\hline Fußartillerie - Kasernement, Emden & $1885-1911$ & 1.261 \\
\hline Fußartillerie-Regiment Hintersin Nr.2 & $1867-1911$ & 3.086 \\
\hline Fußartillerie-Regiment von Hindemis - 1. Pommersches Nr. 2 & 1911 & 3.137 \\
\hline \multirow{3}{*}{ Fußballverein "Sparta" } & $1888-1906$ & 672 \\
\hline & $1910-1911$ & 700 \\
\hline & $1908-1913$ & 701 \\
\hline Gabelsbergerscher Stenographenverein & $1901-1913$ & 693 \\
\hline Gardeverein für Emden und Ümgegend & $1913-1914$ & 712 \\
\hline Garnison, Emden & $1868-1881$ & 2.919 \\
\hline Garnisonskommando, Emden & $1915-1918$ & 3.210 \\
\hline \multirow[t]{2}{*}{ Garnisonslazarett, Emden } & $1868-1893$ & 2.912 \\
\hline & $1868-1881$ & 2.919 \\
\hline Gassenkot-Kommission & $1867-1906$ & 865 \\
\hline Gast- und Schankwirtschaft im "Goldenen Adler" & 1902-1904 & 545 \\
\hline Gasthaus "Belvedere" & 1870 & 849 \\
\hline \multirow{34}{*}{ Gasthaus Emden, Armen- und Waisenhaus } & $1855-1896$ & 409 \\
\hline & 1914-1916 & 759 \\
\hline & 1886 & 926 \\
\hline & $1875-1913$ & 1.703 \\
\hline & $1871-1874$ & 1.708 \\
\hline & $1866-1871$ & 1.709 \\
\hline & 1869 & 1.710 \\
\hline & $1868-1871$ & 1.711 \\
\hline & $1912-1918$ & 1.712 \\
\hline & $1872-1918$ & 1.713 \\
\hline & $1871-1872$ & 1.714 \\
\hline & $1872-1875$ & 1.715 \\
\hline & $1869-1910$ & 1.716 \\
\hline & $1871-1872$ & 1.717 \\
\hline & 1873 & 1.718 \\
\hline & $1902-1907$ & 1.719 \\
\hline & $1873-1906$ & 1.721 \\
\hline & 1875 & 1.722 \\
\hline & $1873-1912$ & 1.723 \\
\hline & $1878-1912$ & 1.725 \\
\hline & $1885-1900$ & 1.726 \\
\hline & 1879-1909 & 1.727 \\
\hline & $1880-1904$ & 1.728 \\
\hline & $1878-1904$ & 1.729 \\
\hline & 1893-1909 & 1.730 \\
\hline & 1913-1914 & 1.732 \\
\hline & $1867-1868$ & 1.736 \\
\hline & $1868-1869$ & 1.747 \\
\hline & $1872-1881$ & 1.767 \\
\hline & $1913-1915$ & 1.872 \\
\hline & $1898-1917$ & 1.882 \\
\hline & $1916-1918$ & 1.885 \\
\hline & $1872-1884$ & 2.384 \\
\hline & $1866-1868$ & 2.420 \\
\hline \multirow[t]{2}{*}{ Gasthausdirektion } & $1871-1876$ & 3.409 \\
\hline & $1890-1896$ & 3.513 \\
\hline \multirow[t]{4}{*}{ Gasthauskirche, Emden } & $1871-1876$ & 3.409 \\
\hline & $1876-1887$ & 3.424 \\
\hline & $1876-1891$ & 3.426 \\
\hline & $1887-1913$ & 3.427 \\
\hline
\end{tabular}


IV

Index

\begin{tabular}{|c|c|c|}
\hline \multicolumn{3}{|c|}{ INST } \\
\hline Indexbegriff & Laufzeit & Lfd.Nr. \\
\hline \multirow[t]{3}{*}{ Gasthauskirche, Emden } & 1902 & 3.428 \\
\hline & 1905 & 3.429 \\
\hline & $1879-1913$ & 3.430 \\
\hline \multirow[t]{2}{*}{ Gasthausschule } & $1897-1898$ & 3.621 \\
\hline & $1873-1880$ & 3.697 \\
\hline Gasthof "Frisia" & 1902 & 550 \\
\hline Gasthof "In't Emder Waapen", Uphusen & 1880 & 2.662 \\
\hline Gasthof "Nordstern" & 1902 & 549 \\
\hline \multirow[t]{2}{*}{ Gasthof "Stadt Mastricht" } & $1899-1900$ & 536 \\
\hline & 1902 & 546 \\
\hline \multirow[t]{2}{*}{ Gasthof "Tivoli", Emden } & 1901 & 181 \\
\hline & $1901-1912$ & 643 \\
\hline \multirow[t]{46}{*}{ Gaswerk, Emden } & 1914 & 1.025 \\
\hline & 1896 & 1.026 \\
\hline & $1880-1881$ & 1.027 \\
\hline & 1896-1897 & 1.029 \\
\hline & $1896-1897$ & 1.030 \\
\hline & $1895-1898$ & 1.031 \\
\hline & 1897-1899 & 1.032 \\
\hline & 1898-1902 & 1.033 \\
\hline & 1900-1909 & 1.034 \\
\hline & $1898-1903$ & 1.035 \\
\hline & $1897-1912$ & 1.036 \\
\hline & $1866-1873$ & 1.037 \\
\hline & $1875-1899$ & 1.038 \\
\hline & $1866-1874$ & 1.039 \\
\hline & $1881-1897$ & 1.040 \\
\hline & $1866-1893$ & 1.041 \\
\hline & $1897-1914$ & 1.042 \\
\hline & 1898-1899 & 1.043 \\
\hline & 1898-1899 & 1.044 \\
\hline & 1897-1912 & 1.045 \\
\hline & $1897-1911$ & 1.046 \\
\hline & 1897-1905 & 1.047 \\
\hline & 1904-1914 & 1.048 \\
\hline & $1898-1900$ & 1.049 \\
\hline & 1897-1912 & 1.050 \\
\hline & $1896-1908$ & 1.051 \\
\hline & 1904-1911 & 1.052 \\
\hline & 1899 & 1.053 \\
\hline & 1898-1904 & 1.054 \\
\hline & $1905-1912$ & 1.055 \\
\hline & $1912-1913$ & 1.056 \\
\hline & $1897-1914$ & 1.057 \\
\hline & 1897-1904 & 1.058 \\
\hline & 1897-1908 & 1.060 \\
\hline & $1895-1911$ & 1.061 \\
\hline & 1896-1905 & 1.062 \\
\hline & $1902-1905$ & 1.063 \\
\hline & 1906-1908 & 1.064 \\
\hline & $1909-1912$ & 1.065 \\
\hline & 1913 & 1.066 \\
\hline & 1914-1917 & 1.067 \\
\hline & $1899-1912$ & 1.069 \\
\hline & $1897-1913$ & 1.070 \\
\hline & 1903-1909 & 1.071 \\
\hline & 1899-1906 & 1.072 \\
\hline & 1905-1909 & 1.073 \\
\hline
\end{tabular}


IV

Index

\begin{tabular}{|c|c|c|}
\hline \multicolumn{3}{|c|}{ INST } \\
\hline Indexbegriff & Laufzeit & Lfd.Nr. \\
\hline \multirow[t]{7}{*}{ Gaswerk, Emden } & 1906-1909 & 1.075 \\
\hline & 1906 & 1.077 \\
\hline & $1910-1914$ & 1.078 \\
\hline & 1911 & 1.079 \\
\hline & $1913-1914$ & 1.080 \\
\hline & 1913 & 1.081 \\
\hline & $1896-1904$ & 3.003 \\
\hline \multirow[t]{23}{*}{ Gaswerkskommission, Stadt Emden } & $1895-1912$ & 1.021 \\
\hline & 1895-1898 & 1.031 \\
\hline & $1898-1902$ & 1.033 \\
\hline & $1900-1909$ & 1.034 \\
\hline & $1897-1912$ & 1.036 \\
\hline & $1897-1914$ & 1.042 \\
\hline & 1897-1912 & 1.050 \\
\hline & $1905-1912$ & 1.055 \\
\hline & $1912-1913$ & 1.056 \\
\hline & 1897-1914 & 1.057 \\
\hline & $1897-1904$ & 1.058 \\
\hline & $1895-1911$ & 1.061 \\
\hline & 1896-1905 & 1.062 \\
\hline & 1902-1905 & 1.063 \\
\hline & 1906-1908 & 1.064 \\
\hline & $1909-1912$ & 1.065 \\
\hline & 1913 & 1.066 \\
\hline & 1914-1917 & 1.067 \\
\hline & $1899-1912$ & 1.069 \\
\hline & 1899-1906 & 1.072 \\
\hline & $1905-1909$ & 1.073 \\
\hline & $1906-1909$ & 1.075 \\
\hline & $1905-1913$ & 1.076 \\
\hline Gebrüder Löwenstein aus Frankfurt/M, Edelmetallhandel & 1878-1898 & 2.630 \\
\hline Gehaltsordnungsausschuss, Stadt Emden & 1914 & 442 \\
\hline Geheimes Civil-Kabinett des Kaisers Wilhelm II. & $1900-1901$ & 203 \\
\hline Geldvermittlungsstelle des Deutschen Städtetages & $1911-1915$ & 3.008 \\
\hline Gemeinde Hinte & 1907-1909 & 3.347 \\
\hline \multirow[t]{2}{*}{ Gemeinde Wolthusen } & 1898-1904 & 3.343 \\
\hline & 1903-1905 & 3.345 \\
\hline Gemeindeausschuss, Wolthusen & 1906-1912 & 253 \\
\hline Gemeindeversammlung Borssum & 1893 & 249 \\
\hline Gemeindevorstand in Borssum & 1909-1912 & 3.538 \\
\hline Gemeinnützige Baugesellschaft für Aurich und Umgegend & 1901-1908 & 1.229 \\
\hline \multirow[t]{3}{*}{ Gemeinnutziger Bauverein Emden } & 1901-1902 & 1.239 \\
\hline & 1894-1905 & 1.240 \\
\hline & 1905-1906 & 2.821 \\
\hline Gemischter Chor "Liederkranz" & 1888-1906 & 672 \\
\hline \multirow[t]{3}{*}{ Gemüsebaugenossenschaft Emden } & $1900-1915$ & 815 \\
\hline & $1896-1901$ & 2.495 \\
\hline & 1916 & 3.305 \\
\hline Gemüsebauverein Emden & 1878-1894 & 798 \\
\hline \multirow{4}{*}{ Generalkommando des X. Armeekorps } & 1914-1916 & 3.153 \\
\hline & 1901 & 3.171 \\
\hline & 1917 & 3.237 \\
\hline & 1917 & 3.261 \\
\hline Generalkommission & 1880 & 2.853 \\
\hline \multirow[t]{3}{*}{ General-Ordens-Kommission } & $1900-1911$ & 259 \\
\hline & 1909-1913 & 261 \\
\hline & $1912-1918$ & 263 \\
\hline Geologische Landesanstalt und Bergakademie & 1903-1912 & 1.167 \\
\hline
\end{tabular}


IV

Index

\begin{tabular}{ll}
\hline & INST \\
\hline Indexbegriff &
\end{tabular}

\section{NST}

Georg-August-Universität Göttingen

Gerichtsgefängnis Stettin

Germanisches Nationalmuseum Nürnberg

Ges. Seemannshaus f. Unteroffiziere u. Mannsch. d. Ksl. Marine

Gesamt-Schulkommission

Gesamtverband deutscher Verpflegungsstationen

Gesellen-Krankenkasse, Emden

Gesellschaft für bildende Kunst und vaterländische Altertümer

Gesellschaft für deutsche Erziehungs- und Schulgeschichte

Gesellschaft für Deutsches Kraftfutter $\mathrm{GmbH}$

Gesellschaft für Milchausschank in Nordwestdeutschland

Gesellschaft tot nut van't algemeen

Gesellschaft zur Verbreiterung der Volksbildung

Gewerbekammer für den Regierungsbezirk Aurich

Gewerbeschule Emden

Laufzeit

1914

1899-1913

1866-1907

1906-1915

1878

1882-1913

1884-1896

1853-1891

1879-1880

1900-1911

1867-1901

1899-1916

1869-1913

1885-1887

1888-1896

1899

1877-1885

1873-1917

1884-1917

1899-1901

1885-1914

1900-1909

1882-1902

1907-1912

1902-1908

1874-1901

1878-1898

1908-1913

1893-1913

1915-1918

1906-1908

1867-1909

1873-1910

1873-1914

1887-1902

1899-1905

1907-1913

1885-1887

1881-1886

1866-1871

1873-1880

1879-1884

1880-1898

1899-1911

1891-1894

1895-1899

1900-1904

1905-1908

1872

1915-1918

1869-1914

1874-1914

1880-1911

1912-1918

1897-1914

1895-1917

1880-1918

1897-1917
Lfd.Nr.

3.711

523

2.620

679

3.504

1.636

434

12

193

259

310

315

829

916

934

1.154

1.724

2.395

2.396

2.397

2.431

2.607

2.608

2.611

2.621

2.622

2.630

2.642

633

3.242

676

529

1.226

1.227

1.228

644

690

2.113

850

2.329

2.330

2.331

2.332

2.333

2.334

2.335

2.336

2.337

2.338

2.339

2.343

2.346

2.347

2.348

2.350

2.352

2.353

2.354 
IV

Index

\begin{tabular}{l}
\hline Indexbegriff \\
\hline Gewerbeschule Emden \\
Gewerbeverein Hannover \\
Gewerbliche Lehranstalt f. Maler, Bauhandwerker \\
Gewerkschaftskartell Emden \\
Gladenbeck's Institut für Denkmalspflege \\
Gotteskammer, Emden \\
Groninger-Rotterdammer Stoomboot-Matschappij \\
Große Kirche, Emden
\end{tabular}

Großherzogliche Eisenbahndirektion, Oldenburg

Großherzogliche Hochschule, Darmstadt

Gründungsausschuss d. Nordseewerke Emder Werft u. Dock AG

Gustav-Adolf-Frauenverein, Emden

Gutachterkommission für Schuhwarenpreise

Guttemplerorden, "Durch die Brandung"

Guttemplerorden, Loge Friesland

\section{INST}

Hafenamt

Hafenbautechnische Gesellschaft

Hagen \& Benjamins, Bauunternehmer

Hamburg-Amerika-Linie, HAPAG

INST


IV

Index

\begin{tabular}{|c|c|c|}
\hline \multicolumn{3}{|l|}{ INST } \\
\hline Indexbegriff & Laufzeit & Lfd.Nr. \\
\hline \multirow[t]{3}{*}{ Handelskammer für Ostfriesland und Papenburg } & 1909-1913 & 2.087 \\
\hline & 1871-1909 & 2.107 \\
\hline & $1910-1914$ & 2.108 \\
\hline \multirow[t]{4}{*}{ Handelsschule Emden } & 1905 & 686 \\
\hline & 1869-1879 & 2.328 \\
\hline & $1864-1880$ & 2.342 \\
\hline & $1869-1914$ & 2.343 \\
\hline \multirow[t]{6}{*}{ Handwerkerverein Emden } & $1868-1871$ & 1.711 \\
\hline & $1881-1882$ & 2.041 \\
\hline & 1887-1912 & 2.127 \\
\hline & $1868-1897$ & 2.340 \\
\hline & 1877-1896 & 3.508 \\
\hline & $1880-1881$ & 3.614 \\
\hline Handwerkskammer Aurich & 1913 & 1.081 \\
\hline Handwerkskammer Osnabrück & $1897-1914$ & 1.042 \\
\hline Handwerkskammer Osnabrück-Ostfriesland & $1882-1913$ & 2.408 \\
\hline Hannoversche Bank & $1902-1903$ & 1.442 \\
\hline \multirow{2}{*}{ Hannoversche Baugewerks-Berufsgenossenschaft } & 1887-1913 & 1.660 \\
\hline & 1899-1913 & 1.666 \\
\hline Hannoversche Baugewerksgenossenschaft & 1911-1912 & 1.661 \\
\hline Hannoversche Garnison, Emden & 1867-1896 & 1.400 \\
\hline \multirow[t]{2}{*}{ Hannoversche Gemeinnützige Ansiedlungsgesellschaft } & 1907-1915 & 682 \\
\hline & 1887-1912 & 812 \\
\hline Hannoversche Kriegskanzlei & $1866-1867$ & 3.121 \\
\hline Hannoversche Landes-Credit-Anstalt & $1890-1901$ & 3.635 \\
\hline Hannoversche Landwirtschaftsgesellschaft & 1879-1905 & 796 \\
\hline Hannoverscher Kriegerverein & 1911 & 704 \\
\hline Hannoverscher Obstbauverein & 1879-1905 & 796 \\
\hline Hannoverscher Provinzialverein zur Bekämpfung der Tuberkulose & $1890-1911$ & 770 \\
\hline \multirow[t]{3}{*}{ Hannoverscher Städtetag } & 1876-1907 & 4 \\
\hline & $1882-1913$ & 2.408 \\
\hline & 1879-1909 & 2.915 \\
\hline \multirow[t]{3}{*}{ Hannoverscher Städteverein } & $1888-1893$ & 586 \\
\hline & 1894-1901 & 587 \\
\hline & 1905-1906 & 588 \\
\hline Hannoverscher Tierverein & $1881-1910$ & 726 \\
\hline \multirow[t]{17}{*}{ Hanseatische Siemens Schuckert Werke } & $1900-1907$ & 1.023 \\
\hline & 1907-1908 & 1.083 \\
\hline & 1908 & 1.084 \\
\hline & $1908-1911$ & 1.085 \\
\hline & 1908 & 1.087 \\
\hline & $1909-1910$ & 1.096 \\
\hline & 1912 & 1.099 \\
\hline & 1907-1912 & 1.103 \\
\hline & $1912-1913$ & 1.113 \\
\hline & 1912 & 1.114 \\
\hline & 1912 & 1.117 \\
\hline & 1912 & 1.125 \\
\hline & 1912 & 1.126 \\
\hline & 1912 & 1.127 \\
\hline & 1913 & 1.128 \\
\hline & 1912 & 1.129 \\
\hline & 1909-1915 & 1.130 \\
\hline \multirow[t]{4}{*}{ HAPAG-Lloyd } & $1902-1917$ & 1.693 \\
\hline & 1899 & 2.028 \\
\hline & $1910-1914$ & 2.106 \\
\hline & 1914 & 3.202 \\
\hline Hartmann \& Schlenzig, Atelier für Architektur und Bauausführ & 1908-1912 & 3.087 \\
\hline
\end{tabular}


IV

Index

\begin{tabular}{l}
\hline Indexbegriff \\
\hline Hartmann \& Schlenzig, Atelier für Archite \\
Hauptausschuss für Kriegerheimstätte \\
Hauptmeldeamt, Aurich \\
Hauptverein des evangelischen Bunde \\
Hauptverein für Arbeiterwohlfahrt, Han \\
Hauptverein für Volkswohlfahrt \\
Hauptverein für Volkswohlfahrt, Hanno \\
Hauptvereinigung d. Binnen-, Fluss- u. \\
Hauptverteilungsausschuss des Schuh \\
Hauptzollamt, Emden \\
Haus- und Grundbesitzerverein Emden \\
Henriettenstiftung, Hannover \\
Herberge zur Heimat \\
Herberge zur Heimat, Gaststätte \\
Heringsfischerei AG "Großer Kurfürst"
\end{tabular}

Hessische Elektrizitätswerke

Hilfsfonds der Brandkasse

Hilfsfonds für sich neu errichtende katholische Pfarrgemeinden Hilfsschule f. schwachbegabte u. geistig zurückgebliebene Kinder

Historischer Verein für Niedersachsen

Hochschule für Kommunale und Soziale Verwaltung, Köln

Hochseefischerei AG

Hohenzollernhütte

Hohenzollernhütte AG

Höhere Bürgerschule

Höhere Töchterhandelsschule in Heilbronn Höhere Töchterschule

\section{INST}

\section{Laufzeit}

1909-1911

1908-1911

1915

$1897-1911$

1908

1906

1917

1908-1913

1909-1911

1918

1898-1918

1907-1913

1905-1909

1902-1914

$1899-1914$

1861-1903

1904-1915

1882-1915

1881-1897

1904

1906

1905

1905

1905-1911

1867-1869

1890-1913

1904-1906

1914-1918

1912

1911-1913

1900-1907

1908-1918

1902

1913

1914-1918

1900-1907

1903-1908

1911-1918

1907

1905-1906

1905-1909

1910-1911

1908-1911

1910-1911

1906-1907

1906-1910

1875-1909

1892-1910

1885-1903

1887-1910

1886-1902

1886-1916

1900-1911

1873-1906

1903-1909

1905

1905-1911
Lfd.Nr.

3.129

3.132

3.212

1.046

691

1.242

3.221

780

3.130

3.295

764

602

1.009

1.235

2.984

577

578

618

1.140

946

2.164

2.294

2.297

1.074

1.284

1.285

3.492

3.596

3.597

3.598

3.708

3.709

647

3.710

3.232

Vorwort

1.023

1.443

1.901

2.174

2.360

2.361

2.362

2.363

2.369

2.373

2.374

2.383

2.389

3.720

3.738

3.739

3.849

259

1.263

3.004

3.529

3.539 
IV

Index

\begin{tabular}{|c|c|c|}
\hline \multicolumn{3}{|c|}{ INST } \\
\hline Indexbegriff & Laufzeit & Lfd.Nr. \\
\hline \multirow[t]{58}{*}{ Höhere Töchterschule } & $1907-1916$ & 3.721 \\
\hline & 1872 & 3.762 \\
\hline & $1872-1891$ & 3.763 \\
\hline & 1872 & 3.764 \\
\hline & $1898-1910$ & 3.765 \\
\hline & 1872 & 3.766 \\
\hline & $1872-1879$ & 3.767 \\
\hline & $1880-1889$ & 3.768 \\
\hline & $1890-1899$ & 3.769 \\
\hline & $1900-1910$ & 3.770 \\
\hline & 1911-1914 & 3.771 \\
\hline & $1875-1892$ & 3.772 \\
\hline & $1875-1876$ & 3.773 \\
\hline & $1887-1890$ & 3.774 \\
\hline & $1872-1899$ & 3.775 \\
\hline & $1889-1891$ & 3.776 \\
\hline & $1901-1918$ & 3.777 \\
\hline & 1913-1918 & 3.778 \\
\hline & $1908-1910$ & 3.779 \\
\hline & $1876-1884$ & 3.780 \\
\hline & 1909-1914 & 3.781 \\
\hline & 1906-1918 & 3.782 \\
\hline & 1873-1914 & 3.783 \\
\hline & $1878-1905$ & 3.784 \\
\hline & $1910-1916$ & 3.785 \\
\hline & $1909-1910$ & 3.786 \\
\hline & $1887-1892$ & 3.787 \\
\hline & 1918 & 3.788 \\
\hline & 1876 & 3.789 \\
\hline & $1885-1914$ & 3.790 \\
\hline & $1872-1909$ & 3.791 \\
\hline & 1903 & 3.792 \\
\hline & $1909-1910$ & 3.793 \\
\hline & 1910 & 3.794 \\
\hline & $1905-1906$ & 3.795 \\
\hline & $1891-1910$ & 3.796 \\
\hline & 1903-1909 & 3.797 \\
\hline & 1914-1917 & 3.798 \\
\hline & 1916-1918 & 3.799 \\
\hline & $1872-1898$ & 3.800 \\
\hline & 1914 & 3.801 \\
\hline & 1898-1918 & 3.802 \\
\hline & $1878-1880$ & 3.803 \\
\hline & 1906-1908 & 3.804 \\
\hline & $1872-1878$ & 3.805 \\
\hline & $1897-1908$ & 3.806 \\
\hline & 1877-1911 & 3.807 \\
\hline & 1914-1918 & 3.808 \\
\hline & 1876 & 3.809 \\
\hline & 1896-1908 & 3.810 \\
\hline & 1908-1914 & 3.811 \\
\hline & 1913-1916 & 3.812 \\
\hline & $1872-1882$ & 3.819 \\
\hline & $1875-1876$ & 3.820 \\
\hline & 1875-1895 & 3.821 \\
\hline & $1880-1902$ & 3.823 \\
\hline & 1888-1906 & 3.824 \\
\hline & $1875-1890$ & 3.836 \\
\hline
\end{tabular}


IV

Index

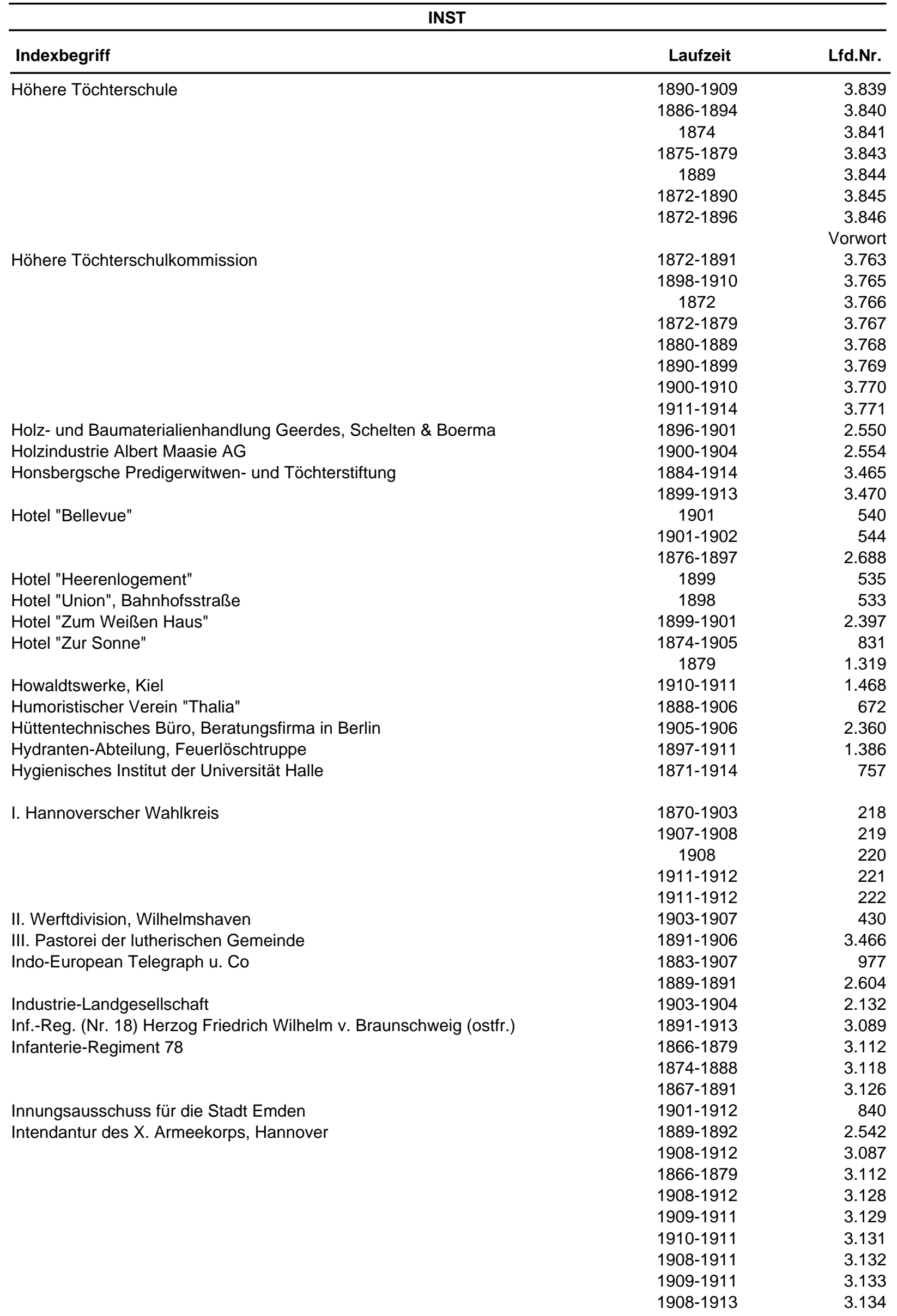


Index

\begin{tabular}{ll}
\hline & INST \\
\hline Indexbegriff &
\end{tabular}

\section{NST}

Intendantur des X. Armeekorps, Hannover

Laufzeit

1911

1914

$1900-1912$

Internationale Ausstellung für Reise und Fremdenverkehr, Berlin Internationaler Verband der Schifffahrtskongresse Internationaler Verein der Freundinnen junger Mädchen Internationaler Verein gegen die Verunreinigung der Flüsse Invaliditäts- und Alterversicherungsanstalt Hannover Israelitische Gemeinde, Emden

Israelitische Kranken- und Beerdigungsanstalt, Emden Israelitische Kranken- und Beerdigungsbruderschaft, Emden Israelitischer Begräbnisverein Israelitischer Frauenverein (Kranken- und Beerdigungsverein) Israelitischer Gemeindemitgliederverein Emden Israelitischer Kranken- und Beerdigungsverein, Emden IV. Kongress für Hygiene und Demographie, Berlin IX. Internationaler Schiffahrtskongress

Jade-Zeitung, Varel

Jesuiten-Orden

Johanniter-Orden

Jüdischer Schulverband, Emden

Kaffeehaus "Belvedere"

Kais. Kommissar und Inspektor für freiwillige Krankenpflege

Kaiser-Friedrich-Realgymnasium

Kaiser-Friedrich-Realschule
1914-1917

1905-1911

1903-1908

$1912-1913$

$1872-1884$

1887-1902

1867-1903

1902-1903

1858-1911

1865-1903

1847-1902

1873-1886

1900-1906

1847-1902

1847-1902

1871-1883

1902-1913

1910-1913

1847-1902

1871-1914

1901-1902

1899-1900

1872-1873

1912

$1882-1883$

1906-1908

1872

$1901-1913$

1869-1909

1901-1908

1885-1911

1901-1909

$1898-1900$

1905

1881-1889

1888-1903

1885-1890

1891-1901

1902-1910

1905-1907

1885-1903

1907-1916

1893-1908

1892-1908

1886-1903

1907

1909-1915

1912-1918

1916-1918

1887-1905

1908-1918

1910-1914
Lfd.Nr.

3.136

3.149

3.172

3.196

673

665

708

2.384

1.228

483

487

489

490

494

2.422

3.694

494

494

2.421

1.671

493

494

757

1.416

783

3.324

707

1.690

3.616

1.303

3.173

2.410

2.445

Vorwort

1.261

1.653

3.521

3.529

3.714

3.715

3.716

3.717

3.718

3.719

3.720

3.721

3.722

3.723

3.724

3.725

3.726

3.727

3.728

3.729

3.730

3.731 
IV

Index

\begin{tabular}{|c|c|c|}
\hline \multicolumn{3}{|c|}{ INST } \\
\hline Indexbegriff & Laufzeit & Lfd.Nr. \\
\hline \multirow[t]{30}{*}{ Kaiser-Friedrich-Realschule } & $1890-1892$ & 3.732 \\
\hline & $1895-1918$ & 3.733 \\
\hline & 1903-1905 & 3.734 \\
\hline & 1903 & 3.735 \\
\hline & $1885-1895$ & 3.736 \\
\hline & 1914 & 3.737 \\
\hline & $1887-1910$ & 3.738 \\
\hline & $1886-1902$ & 3.739 \\
\hline & $1888-1910$ & 3.740 \\
\hline & 1905 & 3.741 \\
\hline & $1887-1910$ & 3.742 \\
\hline & $1899-1918$ & 3.743 \\
\hline & $1886-1900$ & 3.744 \\
\hline & $1888-1889$ & 3.745 \\
\hline & $1888-1889$ & 3.746 \\
\hline & $1898-1903$ & 3.747 \\
\hline & $1902-1903$ & 3.748 \\
\hline & $1905-1909$ & 3.749 \\
\hline & $1908-1918$ & 3.750 \\
\hline & 1891 & 3.751 \\
\hline & $1886-1895$ & 3.752 \\
\hline & $1904-1911$ & 3.753 \\
\hline & 1903 & 3.754 \\
\hline & $1905-1910$ & 3.755 \\
\hline & $1895-1911$ & 3.756 \\
\hline & $1893-1910$ & 3.757 \\
\hline & $1892-1900$ & 3.758 \\
\hline & $1901-1906$ & 3.759 \\
\hline & $1886-1890$ & 3.760 \\
\hline & 1914-1917 & 3.761 \\
\hline \multirow[t]{28}{*}{ Kaiserin-Auguste-Viktoria-Schule (Höhere Töchterschule) } & $1901-1909$ & 1.653 \\
\hline & $1909-1915$ & 3.726 \\
\hline & $1916-1918$ & 3.728 \\
\hline & $1898-1910$ & 3.765 \\
\hline & $1900-1910$ & 3.770 \\
\hline & $1911-1914$ & 3.771 \\
\hline & $1901-1918$ & 3.777 \\
\hline & $1913-1918$ & 3.778 \\
\hline & $1908-1910$ & 3.779 \\
\hline & $1876-1884$ & 3.780 \\
\hline & $1909-1914$ & 3.781 \\
\hline & $1906-1918$ & 3.782 \\
\hline & $1873-1914$ & 3.783 \\
\hline & $1910-1916$ & 3.785 \\
\hline & $1909-1910$ & 3.786 \\
\hline & $1887-1892$ & 3.787 \\
\hline & 1918 & 3.788 \\
\hline & $1885-1914$ & 3.790 \\
\hline & $1872-1909$ & 3.791 \\
\hline & 1903 & 3.792 \\
\hline & $1909-1910$ & 3.793 \\
\hline & 1910 & 3.794 \\
\hline & $1905-1906$ & 3.795 \\
\hline & $1891-1910$ & 3.796 \\
\hline & 1903-1909 & 3.797 \\
\hline & $1914-1917$ & 3.798 \\
\hline & $1916-1918$ & 3.799 \\
\hline & 1914 & 3.801 \\
\hline
\end{tabular}


IV

Index

\begin{tabular}{|c|c|c|}
\hline \multicolumn{3}{|l|}{ INST } \\
\hline Indexbegriff & Laufzeit & Lfd.Nr. \\
\hline 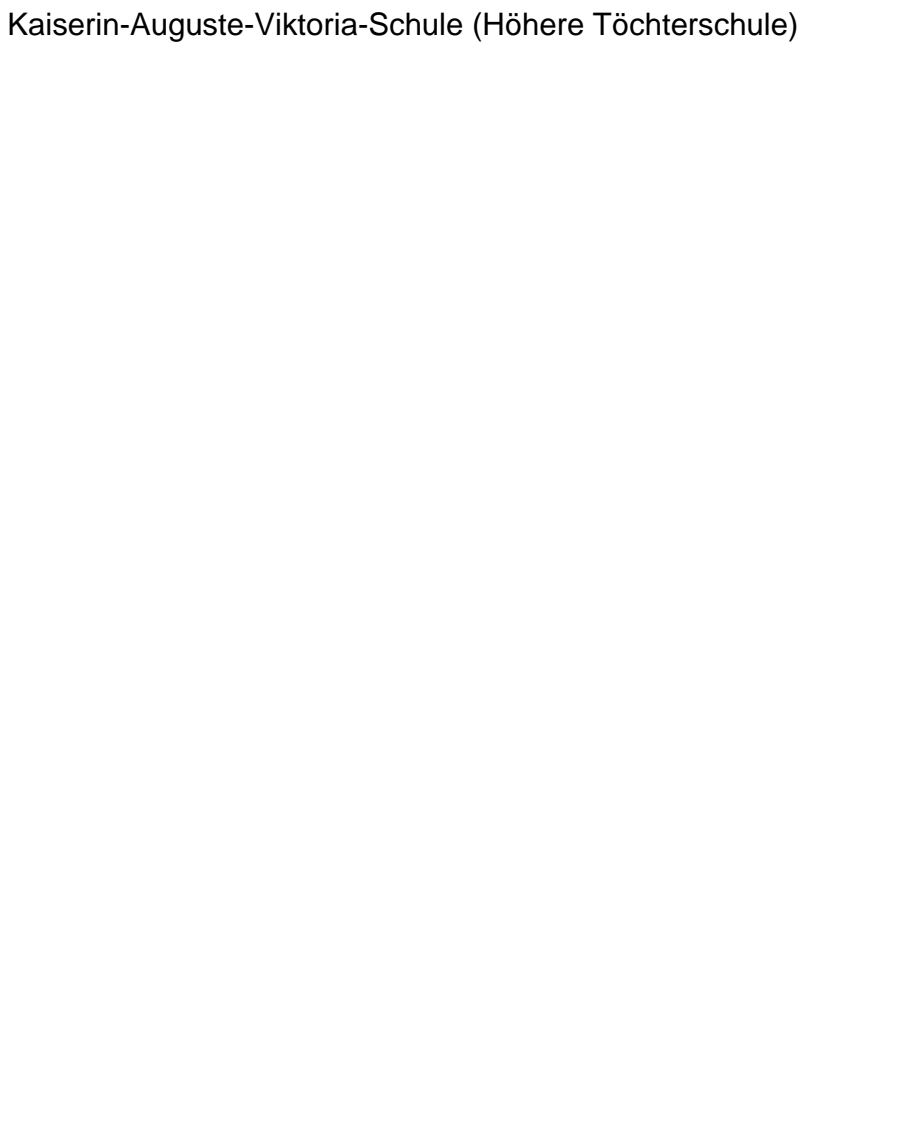 & $\begin{array}{c}1898-1918 \\
1906-1908 \\
1897-1908 \\
1877-1911 \\
1914-1918 \\
1896-1908 \\
1908-1914 \\
1913-1916 \\
1910 \\
1876-1905 \\
1905-1914 \\
1906-1915 \\
1894-1912 \\
1877-1909 \\
1880-1913 \\
1904-1905 \\
1904 \\
1905 \\
1907-1912 \\
1908-1912 \\
1911-1913 \\
1908 \\
1901-1907 \\
1915-1917 \\
1913-1917 \\
1893-1918 \\
1893-1907 \\
1912\end{array}$ & $\begin{array}{r}3.802 \\
3.804 \\
3.806 \\
3.807 \\
3.808 \\
3.810 \\
3.811 \\
3.812 \\
3.813 \\
3.814 \\
3.815 \\
3.816 \\
3.817 \\
3.818 \\
3.822 \\
3.825 \\
3.826 \\
3.827 \\
3.828 \\
3.829 \\
3.831 \\
3.832 \\
3.833 \\
3.834 \\
3.835 \\
3.837 \\
3.838 \\
3.842 \\
\text { Vorwort }\end{array}$ \\
\hline Kaiserliche Gesandtschaft, Den Haag & $1867-1880$ & 499 \\
\hline Kaiserliche Oberpostdirektion, Oldenburg & 1887-1896 & 2.532 \\
\hline Kaiserliche Telegraphen-Direktion & $1871-1910$ & 2.037 \\
\hline Kaiserliche Werft, Wilhelmshaven & 1911 & 1.476 \\
\hline Kaiserliches Aufsichtsamt für Privatversicherung & $\begin{array}{c}1877-1903 \\
1903-1911\end{array}$ & $\begin{array}{l}804 \\
806\end{array}$ \\
\hline Kaiserliches Gesundheitsamt & $\begin{array}{c}1894-1904 \\
1899-1909\end{array}$ & $\begin{array}{l}771 \\
781\end{array}$ \\
\hline Kaiserliches Statistisches Amt & $1892-1903$ & 2.115 \\
\hline Kaiserliches Telegrafenamt & $\begin{array}{l}1871-1910 \\
1901-1902 \\
1880-1911\end{array}$ & $\begin{array}{l}2.037 \\
2.062 \\
2.181\end{array}$ \\
\hline $\begin{array}{l}\text { Kaiser's Kaffeegeschäft, Filiale Emden } \\
\text { Kaiser-Wilhelm-Stiftung f. deutsche Invaliden, Zweigverein Emden }\end{array}$ & $\begin{array}{c}1914-1916 \\
1885 \\
1887 \\
1894-1897 \\
1900 \\
1899-1908 \\
1908-1909 \\
1910 \\
1905-1914 \\
1901-1912 \\
1869-1896 \\
1873-1914 \\
1874-1875 \\
1879 \\
1880-1881 \\
1882-1883 \\
1884-1885\end{array}$ & $\begin{array}{r}3.194 \\
579 \\
580 \\
581 \\
582 \\
583 \\
584 \\
585 \\
589 \\
590 \\
591 \\
592 \\
603 \\
606 \\
607 \\
608 \\
609\end{array}$ \\
\hline
\end{tabular}


IV

Index

\begin{tabular}{|c|c|c|}
\hline \multicolumn{3}{|l|}{ INST } \\
\hline Indexbegriff & Laufzeit & Lfd.Nr. \\
\hline \multirow[t]{2}{*}{ Kaiser-Wilhelm-Stiftung f. deutsche Invaliden, Zweigverein Emden } & $1886-1887$ & 610 \\
\hline & $1901-1903$ & 612 \\
\hline \multirow[t]{12}{*}{ Kämmereikasse } & 1905 & 349 \\
\hline & 1869-1896 & 436 \\
\hline & 1868-1902 & 2.989 \\
\hline & $1866-1881$ & 2.991 \\
\hline & 1892-1894 & 2.998 \\
\hline & 1915 & 3.247 \\
\hline & $1915-1916$ & 3.249 \\
\hline & 1916 & 3.253 \\
\hline & $1916-1917$ & 3.256 \\
\hline & 1917 & 3.261 \\
\hline & 1917-1918 & 3.268 \\
\hline & $1915-1916$ & 3.310 \\
\hline \multirow[t]{2}{*}{ Kammergericht Berlin } & $1912-1914$ & 839 \\
\hline & $1886-1916$ & 3.849 \\
\hline \multirow[t]{15}{*}{ Kanalisations- und Entwässerungskommission, Stadt Emden } & $1896-1903$ & 880 \\
\hline & 1884-1896 & 900 \\
\hline & 1884-1885 & 904 \\
\hline & $1885-1910$ & 905 \\
\hline & $1885-1900$ & 907 \\
\hline & $1885-1907$ & 909 \\
\hline & 1885 & 913 \\
\hline & $1883-1885$ & 914 \\
\hline & 1885-1887 & 915 \\
\hline & $1885-1887$ & 916 \\
\hline & $1885-1886$ & 919 \\
\hline & 1886 & 926 \\
\hline & 1887 & 933 \\
\hline & $1896-1913$ & 950 \\
\hline & $1910-1911$ & 955 \\
\hline Kanalverein & 1893-1897 & 2.026 \\
\hline \multirow[t]{3}{*}{ Kanzlei, Stadt Emden } & 1854-1857 & 336 \\
\hline & 1872-1902 & 340 \\
\hline & 1907 & 3.108 \\
\hline Kartoffelgechäftsstelle, Stadt Emden & 1918 & 3.306 \\
\hline Kaserne "Neuvorpommern" & $1866-1870$ & 3.125 \\
\hline Kasse der Großen Kirche & 1891-1898 & 3.413 \\
\hline \multirow[t]{5}{*}{ Katasteramt } & 1892-1899 & 224 \\
\hline & $1881-1909$ & 1.164 \\
\hline & $1877-1910$ & 2.403 \\
\hline & $1890-1913$ & 2.879 \\
\hline & 1916 & 2.883 \\
\hline \multirow[t]{8}{*}{ Katholische Gemeinde, Emden } & 1873-1886 & 2.422 \\
\hline & 1883-1907 & 3.344 \\
\hline & $1867-1870$ & 3.487 \\
\hline & 1872-1892 & 3.488 \\
\hline & $1902-1914$ & 3.489 \\
\hline & 1875 & 3.490 \\
\hline & $1880-1900$ & 3.494 \\
\hline & $1902-1911$ & 3.495 \\
\hline \multirow[t]{7}{*}{ Katholische Volksschule } & 1908-1909 & 227 \\
\hline & 1913-1915 & 241 \\
\hline & $1899-1909$ & 3.522 \\
\hline & 1902 & 3.702 \\
\hline & $1875-1888$ & 3.703 \\
\hline & $1878-1890$ & 3.704 \\
\hline & 1889-1909 & 3.705 \\
\hline
\end{tabular}


IV

Index

\begin{tabular}{|c|c|c|}
\hline \multicolumn{3}{|c|}{ INST } \\
\hline Indexbegriff & Laufzeit & Lfd.Nr. \\
\hline \multirow[t]{2}{*}{ Katholische Volksschule } & $1902-1907$ & 3.706 \\
\hline & $1908-1911$ & 3.707 \\
\hline Katholischer Arbeiterverein & $1911-1913$ & 698 \\
\hline Katholischer Jünglingsverein & $1911-1913$ & 703 \\
\hline \multirow[t]{42}{*}{ Kaufmännische Deputation, Emden } & $1871-1913$ & 419 \\
\hline & 1900-1902 & 422 \\
\hline & $1905-1906$ & 675 \\
\hline & $1875-1914$ & 814 \\
\hline & $1881-1897$ & 1.020 \\
\hline & 1884 & 1.409 \\
\hline & 1885 & 1.410 \\
\hline & $1870-1914$ & 1.430 \\
\hline & $1879-1883$ & 1.433 \\
\hline & $1887-1888$ & 1.436 \\
\hline & $1887-1912$ & 1.437 \\
\hline & 1876 & 1.438 \\
\hline & 1903-1904 & 1.459 \\
\hline & 1873-1912 & 1.505 \\
\hline & $1867-1890$ & 1.536 \\
\hline & 1873-1893 & 1.559 \\
\hline & $1877-1915$ & 1.567 \\
\hline & 1893-1896 & 1.595 \\
\hline & $1875-1914$ & 1.605 \\
\hline & $1880-1885$ & 1.623 \\
\hline & 1913 & 1.625 \\
\hline & 1878-1892 & 2.008 \\
\hline & $1882-1908$ & 2.009 \\
\hline & 1883-1897 & 2.010 \\
\hline & 1901-1908 & 2.012 \\
\hline & 1868-1902 & 2.016 \\
\hline & 1883-1906 & 2.043 \\
\hline & 1883-1901 & 2.044 \\
\hline & 1906-1907 & 2.086 \\
\hline & 1909-1913 & 2.087 \\
\hline & 1907 & 2.093 \\
\hline & $1892-1903$ & 2.115 \\
\hline & 1899-1906 & 2.129 \\
\hline & $1869-1911$ & 2.134 \\
\hline & $1866-1898$ & 2.135 \\
\hline & $1876-1911$ & 2.145 \\
\hline & $1864-1890$ & 2.341 \\
\hline & 1866-1904 & 2.418 \\
\hline & 1900-1908 & 2.432 \\
\hline & 1896 & 2.575 \\
\hline & $1880-1881$ & 3.614 \\
\hline & $1881-1889$ & 3.714 \\
\hline Kaufmännischer Verein, Emden & $1880-1913$ & 620 \\
\hline Kaufmanns- und Gewerbegericht, Emden & $1907-1911$ & 32 \\
\hline Kgl. Deich- und Sielamt & $1885-1907$ & 1.543 \\
\hline Kgl. Deichamt Emden & $1881-1888$ & 2.480 \\
\hline Kgl. Direktion der Westfälischen Eisenbahn & $1872-1889$ & 2.475 \\
\hline \multirow[t]{3}{*}{ Kgl. Eisenbahnbauinspektion, Emden } & 1891 & 507 \\
\hline & $1881-1897$ & 1.020 \\
\hline & $1892-1906$ & 1.265 \\
\hline Kgl. Eisenbahnbetriebsamt Münster & 1888 & 2.190 \\
\hline \multirow[t]{3}{*}{ Kgl. Eisenbahnbetriebsamt Münster - Emden } & $1886-1900$ & 923 \\
\hline & 1893-1895 & 987 \\
\hline & $1881-1897$ & 1.020 \\
\hline
\end{tabular}


Index

\begin{tabular}{ll}
\hline INST \\
\hline
\end{tabular}

\section{Indexbegriff}

Kgl. Eisenbahnbetriebs-Direktion

Kgl. Eisenbahnbetriebs-Inspection

Kgl. Eisenbahnbetriebsinspektion, Emden

Kgl. Eisenbahndirektion, Köln

Kgl. Eisenbahn-Direktion, Münster

Kgl. Eisenbahninspektion, Münster

Kgl. Eisenbahn-Maschinen-Inspektion I

Kgl. Eisenbahnverwaltung

Kgl. Generalkasse

Kgl. Grundbuchamt, Aurich

Kgl. Hafenamt

Kgl. Hannoversche Amts und Wasserbauinspektion Kgl. Hannoversche Zollverwaltung

Kgl. Hannoversches Kriegsministerium

Kgl. Hauptzollamt

Kgl. Kanalkommission, Aurich

Kgl. Kanalkommission, Aurich

Kgl. Kanalkommission, Münster

Kgl. katholisches Konsistorium in Osnabrück Kgl. Konsistorium, Aurich

Lfd.Nr.

Laufzeit

2.565

1872-1889

1887-1910

2.475

1904-1905

1886-1909

1900

1884-1915

1893-1895

1873-1910

1902-1905

1878-1892

1882-1908

1883-1897

1881-1885

1903-1904

1904-1906

1906-1912

1908-1909

1909-1910

1910-1911

1911-1912

1915-1916

1918-1919

1902-1917

1901-1908

1895-1906

1901-1904

1908-1909

1896

1900

1870-1900

1882-1908

1895

1872-1907

1906-1912

1894-1905

1867-1871

1882-1905

1887-1912

1887-1888

1914

1875-1901

1894-1900

1890-1892

1873-1893

1868-1902

1899-1906

1881-1899

1894-1900

1898

1899

1895-1896

1881-1910

1890-1891

1891-1893

1872-1892

1876-1896

1883
935

947

1.019

2.076

772

987

1.226

1.236

2.008

2.009

2.010

2.014

1.978

1.979

1.980

1.981

1.982

1.983

1.984

1.985

1.986

1.992

2.012

2.059

2.069

2.073

2.075

2.076

1.161

2.009

2.215

2.018

2.826

2.827

3.646

2.670

1.437

1.507

1.529

1.494

2.458

2.544

1.559

2.016

2.129

2.159

2.458

2.229

2.231

2.029

1.906

2.023

2.025

3.488

328

569 
IV

Index

\begin{tabular}{|c|c|c|}
\hline \multicolumn{3}{|c|}{ INST } \\
\hline Indexbegriff & Laufzeit & Lfd.Nr. \\
\hline \multirow[t]{10}{*}{ Kgl. Konsistorium, Aurich } & $1868-1879$ & 728 \\
\hline & 1876 & 1.776 \\
\hline & $1866-1888$ & 2.486 \\
\hline & $1871-1911$ & 3.320 \\
\hline & 1870 & 3.323 \\
\hline & $1867-1884$ & 3.336 \\
\hline & $1902-1914$ & 3.340 \\
\hline & 1908-1909 & 3.342 \\
\hline & $1868-1910$ & 3.387 \\
\hline & 1901 & 3.400 \\
\hline \multirow[t]{2}{*}{ Kgl. Kriegsministerium } & $1907-1912$ & 2.611 \\
\hline & 1866-1907 & 2.620 \\
\hline \multirow[t]{15}{*}{ Kgl. Landgericht Aurich } & 1890 & 354 \\
\hline & $1912-1913$ & 1.478 \\
\hline & 1877-1882 & 2.513 \\
\hline & $1880-1881$ & 2.514 \\
\hline & $1878-1884$ & 2.522 \\
\hline & 1884-1885 & 2.527 \\
\hline & $1906-1910$ & 2.596 \\
\hline & $1915-1917$ & 2.601 \\
\hline & $1886-1889$ & 2.668 \\
\hline & 1894-1904 & 3.376 \\
\hline & 1894-1904 & 3.377 \\
\hline & $1890-1894$ & 3.383 \\
\hline & 1890 & 3.384 \\
\hline & $1899-1900$ & 3.385 \\
\hline & $1887-1893$ & 3.386 \\
\hline Kgl. Landratsamt, Emden & 1894-1905 & 897 \\
\hline \multirow{7}{*}{ Kgl. Maschinenbauinspektion } & 1908 & 2.316 \\
\hline & 1909 & 2.317 \\
\hline & 1910 & 2.319 \\
\hline & 1910 & 2.322 \\
\hline & 1910 & 2.325 \\
\hline & 1910 & 2.326 \\
\hline & 1910 & 2.327 \\
\hline \multirow[t]{23}{*}{ Kgl. Navigationsschule, Emden } & $1877-1915$ & 1.567 \\
\hline & $1870-1914$ & 1.579 \\
\hline & $1870-1898$ & 1.580 \\
\hline & $1870-1871$ & 1.582 \\
\hline & 1893-1895 & 1.583 \\
\hline & $1905-1916$ & 1.584 \\
\hline & $1872-1890$ & 1.585 \\
\hline & 1893 & 1.586 \\
\hline & $1870-1871$ & 1.587 \\
\hline & $1871-1895$ & 1.588 \\
\hline & $1872-1895$ & 1.589 \\
\hline & 1874-1888 & 1.590 \\
\hline & $1880-1894$ & 1.592 \\
\hline & 1870 & 1.593 \\
\hline & 1875-1905 & 1.594 \\
\hline & $1893-1896$ & 1.595 \\
\hline & 1894-1896 & 1.596 \\
\hline & $1870-1910$ & 1.597 \\
\hline & 1887 & 1.604 \\
\hline & $1875-1914$ & 1.605 \\
\hline & 1913-1917 & 1.615 \\
\hline & 1875-1894 & 1.617 \\
\hline & $1874-1896$ & 1.618 \\
\hline
\end{tabular}


Index

\begin{tabular}{ll}
\hline INST \\
\hline Indexbegriff
\end{tabular}

Kgl. Navigationsschule, Leer Kgl. Oberlandesgericht, Celle

Kgl. Oberschul-Kollegium

Kgl. Obersteuerkollegium in Hannover

Kgl. Obertribunal, Berlin

Kgl. Oberverwaltungsgericht, Celle

Kgl. Polizei-Direktion

Kgl. preußische Musterungsbehörde

$\mathrm{Kgl}$. preußisches statistisches Büro

Kgl. preußisches statistisches Landesamt

Kgl. Provinzial-Schul-Kollegium

Kgl. Seeamt Emden

Kgl. Seehandlung, Preußische Staatsbank

Kgl. Sielamt

Kgl. Staatsbauverwaltung

Kgl. Staatseisenbahn-Verwaltung

Kgl. Theater, Hannover

Kgl. Wasserbauamt

Kgl. Wasserbauamt, Emden

Kgl. Wasserbauinspektion

INST

\section{Laufzeit}

1870-1911

1902-1914

1895-1918

1880-1885

1910-1917

1918

1905-1916

1898

1894-1904

1894-1904

1890-1894

1890

1899-1900

1887-1893

1866-1911

1867-1870

1870-1900

1894

1894

1891-1894

1891-1892

1898

1894

1895

1897

1904

1867

1866-1904

1884

1866-1900

1913-1915

1869-1884

1878-1880

1904-1908

1908-1910

1907-1909

1883-1884

1867-1910

1875-1901

1900-1904

1892

1893-1894

1898

1869-1909

1896-1913

1912

1912-1913

1912-1913

1903-1908

1866-1891

1914

1881-1909

1910

1907-1908

1894-1898

1907-1908

1870-1900

1901-1909
Lfd.Nr.

1.619

1.620

1.622

1.623

1.624

1.626

1.584

3.372

3.376

3.377

3.383

3.384

3.385

3.386

962

2.904

1.161

3.355

3.356

3.357

3.358

3.359

3.360

3.361

3.362

3.365

2.417

2.418

1.409

1.904

2.153

3.713

1.631

1.462

1.466

1.469

1.489

1.490

1.494

1.965

2.196

2.535

188

2.410 
IV

Index

\begin{tabular}{|c|c|c|}
\hline \multicolumn{3}{|c|}{ INST } \\
\hline Indexbegriff & Laufzeit & Lfd.Nr. \\
\hline \multirow[t]{29}{*}{ Kgl. Wasserbauinspektion } & 1903 & 1.417 \\
\hline & 1905-1906 & 1.423 \\
\hline & 1904-1908 & 1.426 \\
\hline & 1906-1907 & 2.086 \\
\hline & 1892 & 2.198 \\
\hline & 1893 & 2.202 \\
\hline & 1893 & 2.204 \\
\hline & 1895 & 2.211 \\
\hline & 1897 & 2.220 \\
\hline & 1898 & 2.226 \\
\hline & 1898 & 2.230 \\
\hline & 1899 & 2.232 \\
\hline & 1899 & 2.233 \\
\hline & 1899 & 2.237 \\
\hline & 1900 & 2.238 \\
\hline & 1900 & 2.240 \\
\hline & 1900 & 2.249 \\
\hline & 1900 & 2.251 \\
\hline & 1901 & 2.258 \\
\hline & 1902 & 2.263 \\
\hline & 1902 & 2.270 \\
\hline & 1903 & 2.278 \\
\hline & 1903 & 2.280 \\
\hline & 1904 & 2.282 \\
\hline & 1905 & 2.290 \\
\hline & $1905-1906$ & 2.436 \\
\hline & 1885-1896 & 2.529 \\
\hline & 1898-1909 & 2.552 \\
\hline & $1904-1912$ & 2.600 \\
\hline \multirow[t]{2}{*}{ Kgl. Wasserbauverwaltung } & $1897-1914$ & 1.042 \\
\hline & 1912 & 1.108 \\
\hline Kgl. Zeughaus Berlin & 1882-1906 & 2.610 \\
\hline Kindebewahranstalt auf Transvaal & 1903-1905 & 3.850 \\
\hline Kinderbewahranstalt am Kattewall & $1905-1912$ & 3.853 \\
\hline Kinderbewahranstalt in der Großen Brückstraße & 1907-1908 & 3.854 \\
\hline Kinderkrippe am Kattewall & 1914-1918 & 3.193 \\
\hline Kirchen- und Schulgemeinde Tergast & 1886 & 3.481 \\
\hline Kirchen- und Schulvorstand Oldersum & 1884-1901 & 3.480 \\
\hline Kirchen- und Schulvorstand zu Tergast & $1876-1882$ & 2.666 \\
\hline Kirchen-Commission, Stadt Emden & 1837-1915 & 3.316 \\
\hline Kirchengemeinde in Oldersum & 1901 & 3.482 \\
\hline Kirchengemeinde Oldersum & $1869-1907$ & 3.485 \\
\hline Kirchengemeinde Tergast & 1869-1907 & 3.485 \\
\hline Kirchengemeinde Uphusen & 1876 & 3.484 \\
\hline Kirchengemeinde Wolthusen & 1869-1907 & 3.485 \\
\hline Kirchengemeinden Groß- und Kleinborssum & $1869-1871$ & 3.483 \\
\hline \multirow[t]{2}{*}{ Kirchenkasse der lutherischen Gemeinde } & 1890-1899 & 3.432 \\
\hline & 1903-1914 & 3.433 \\
\hline Kirchenkommision der lutherischen Gemeinde & 1875-1902 & 3.445 \\
\hline \multirow[t]{2}{*}{ Kirchenkommissar für die reformierte Gemeinde } & $1869-1876$ & 3.391 \\
\hline & 1901 & 3.401 \\
\hline \multirow[t]{2}{*}{ Kirchenkommission der evangelischen Kirchen } & 1908-1909 & 3.342 \\
\hline & 1874-1918 & 3.349 \\
\hline Kirchenkommission der französisch reformierten Gemeinde & $1867-1871$ & 3.646 \\
\hline \multirow[t]{3}{*}{ Kirchenkommission der lutherischen Gemeinde } & 1873-1914 & 3.449 \\
\hline & 1887-1889 & 3.457 \\
\hline & 1868-1898 & 3.656 \\
\hline Kirchenkommission der reformierten Gemeinde & $1869-1910$ & 3.350 \\
\hline
\end{tabular}


IV

Index

\begin{tabular}{|c|c|c|}
\hline \multicolumn{3}{|l|}{ INST } \\
\hline Indexbegriff & Laufzeit & Lfd.Nr. \\
\hline \multirow[t]{2}{*}{ Kirchenkommission der reformierten Gemeinde } & 1867-1902 & 3.381 \\
\hline & $1877-1883$ & 3.623 \\
\hline Kirchenkommission der reformierten Gemeinden & 1908 & 3.341 \\
\hline \multirow[t]{3}{*}{ Kirchenrat der deutsch-reformierten Gemeinde } & 1902 & 551 \\
\hline & $1866-1885$ & 2.650 \\
\hline & $1880-1881$ & 3.614 \\
\hline Kirchenrat der Großen Kirche & $1880-1885$ & 3.639 \\
\hline \multirow[t]{2}{*}{ Kirchenrat der lutherischen Gemeinde } & $1870-1886$ & 3.440 \\
\hline & $1880-1881$ & 3.614 \\
\hline \multirow[t]{3}{*}{ Kirchenrat der reformierten Gemeinde } & 1913-1914 & 1.732 \\
\hline & 1908 & 3.341 \\
\hline & $1868-1910$ & 3.387 \\
\hline Kirchenvorstand zu Oldersum & $1886-1889$ & 2.668 \\
\hline Kirchenvorstand zu Wolthusen & 1876-1882 & 2.666 \\
\hline Kirchenvorstand, Wolthusen & $1837-1915$ & 3.316 \\
\hline Kleidermacher-Innung für Emden & 1879-1889 & 1.934 \\
\hline Kleinbahn Borkum AG & $1880-1917$ & 2.046 \\
\hline \multirow[t]{2}{*}{ Kleinbahn Emden-Pewsum } & $1886-1900$ & 923 \\
\hline & 1898-1902 & 2.561 \\
\hline Kleinbahn-Ausschuss & 1914 & 1.995 \\
\hline \multirow[t]{3}{*}{ Kleine Stadtdeichacht } & $1874-1886$ & 1.532 \\
\hline & 1900-1904 & 1.539 \\
\hline & $1886-1894$ & 2.981 \\
\hline Klosterkammer Hannover & $1880-1890$ & 3.659 \\
\hline Kölnische Maschinenbau Actien-Gesellschaft & $1905-1913$ & 1.076 \\
\hline \multirow[t]{2}{*}{ Kölnische Maschinenbau-Actien-Gesellschaft } & 1905-1909 & 1.073 \\
\hline & 1906-1909 & 1.075 \\
\hline \multirow[t]{12}{*}{ Kölnische Tiefbaugesellschaft m.b.H. } & 1900 & 2.246 \\
\hline & 1900 & 2.247 \\
\hline & 1900 & 2.248 \\
\hline & 1901 & 2.255 \\
\hline & 1903 & 2.273 \\
\hline & 1905 & 2.291 \\
\hline & 1908 & 2.299 \\
\hline & 1908 & 2.304 \\
\hline & 1908 & 2.305 \\
\hline & 1908 & 2.311 \\
\hline & 1908 & 2.313 \\
\hline & 1904-1910 & 2.589 \\
\hline \multirow[t]{5}{*}{ Kölnische Tiefbau-Gesellschaft, Baubüro Emden } & 1906 & 2.161 \\
\hline & 1906 & 2.162 \\
\hline & 1906 & 2.170 \\
\hline & 1907 & 2.175 \\
\hline & 1907 & 2.178 \\
\hline Kölnische Zeitung & $1910-1911$ & 2.362 \\
\hline Komission für die elektrische Kleinbahn & 1902-1907 & 1.967 \\
\hline Komitee der Nationalen Flugspende des deutschen Reiches & 1912 & 2.099 \\
\hline Komitee für das Kaiserstandbild, Emden & $1879-1880$ & 193 \\
\hline Komitee für das Stephans-Denkmal, Emden & 1894-1897 & 2.394 \\
\hline Komitee für die Nationale Flugspende des Deutschen Reiches & 1912 & 2.098 \\
\hline Komitee für ein Pariser Heim für deutsche Erzieherinnen & 1883-1893 & 617 \\
\hline Komitee zur Errichtung von Luftschiffstationen im Reiche & $1909-1913$ & 2.097 \\
\hline Kommandantur Borkum & 1914 & 3.202 \\
\hline \multirow[t]{2}{*}{ Kommandierender General des X. Armeekorps } & $1917-1918$ & 199 \\
\hline & $1915-1916$ & 3.159 \\
\hline Kommando des X. Armeekorps & $1909-1914$ & 3.179 \\
\hline \multirow{2}{*}{ Kommission der Höheren Töchterschule } & 1872-1882 & 3.819 \\
\hline & $1890-1909$ & 3.839 \\
\hline
\end{tabular}


IV

Index

\begin{tabular}{l}
\hline INST \\
\hline Indexbegriff \\
\hline Kommission der Höheren Töchterschule \\
Kommission f. d. Beratung d. Errichtung eines Elektrizitätswerkes \\
Kommission f. d. Fahrplan d. Elektr. Kleinbahn Emden-Außenh \\
Kommission f. d. Herstellung u Betrieb d. elektrischen Kleinbah \\
Kommission für Arbeiterwohnungen \\
Kommission für Beratung der neuen Bauordnung \\
Kommission für die elektrische Kleinbahn \\
Kommission für die Elektrische Kleinbahn Emden-Außenhafen
\end{tabular}

Kommission für die Hafenerweiterungsangelegenheiten Kommission für die Kleinbahn Emden-Riepe-Ostgroßefehn

Kommission für die Rüstkammer

Kommission für die städtischen Volksschulen

Kommission für die Verwaltung der Gasthauskirche

Kommission für die Werft- und Schwimmdockanlage zu Emden Kommission für Förderung industrieller Anlagen am hiesigen Platz

Kommission für neue Kleinbahnen

Kommission für Verwaltung der Akzise-Angelegenheiten

Kommission z. Prüfg. d. Rückkaufs d. Gebde d. Alten Gymnasiums

Kommission zur Organisation des Feuerlöschwesens

Kommission zur Reorganisation des Emder Volksschulwesens

Kommission zur Reorganisation des Nachtwachtwesens, Emden

Kommission zur Wahl eines neuen Landrabbiners

Kornbörse, Stadt Emden

\section{Laufzeit}

1886-1894

$1905-1911$

1902-1907

1900-1909

$1905-1915$

1910-1913

1914-1918

1899-1900

1908-1909

1902-1905

1908-1909

1909-1910

1910-1911

1904-1910

1912-1914

1902-1903

1899-1900

1901

1904-1910

1901-1904

1905-1906

1906-1907

1907

1908-1909

1900-1912

1900-1902

1905-1907

1902-1903

1908-1916

1901-1914

1908-1913

1904-1912

1882-1902

1908-1918

1871-1915

1876-1887

1875-1917

1902-1905

1906-1907

1906-1907

1907-1914

1889-1906

1876-1909

1904

1907-1908

1869-1896

1874

1877-1912

1892-1903

1866-1913

1873-1898

1879-1906

1873-1898

1879-1906

1883-1907

1876-1878

1884-1893
Lfd.Nr.

3.840

1.097

1.967

1.970

1.971

1.972

1.973

1.246

1.145

1.960

1.981

1.982

1.983

1.990

1.991

1.994

1.442

2.065

2.066

2.068

2.069

2.070

2.071

2.072

2.073

2.606

2.609

2.613

2.616

2.624

2.635

2.642

2.647

2.648

3.709

3.423

3.424

3.425

1.455

1.460

2.373

2.091

2.924

2.424

1.269

3.618

436

491 
IV

Index

\begin{tabular}{l}
\hline \\
\hline Indexbegriff \\
\hline Krankenkasse der Schneidergesellen \\
Krankenunterstützungsverein u. Sterbek \\
Kregsausschuss für Öle und Fette \\
Kreis- und Bezirksstelle für Obst und Ge \\
Kreisausschuss des Kreises Emden \\
Kreis-Ersatz-Kommission \\
Kreissparkasse Eschwege \\
Kriegerverein Emden \\
Kriegsamt für Futtermittel, Preußen \\
Kriegsausschuss für Öle und Fette \\
Kriegsernährungsamt, Deutsches Reich \\
Kriegsfürsorgeausschuss, Stadt Emden \\
Kriegsgesellschaft für Sauerkraut \\
Kriegsgetreidegesellschaft \\
Kriegshilfe \\
Kriegsledergesellschaft \\
Kriegsmetall AG
\end{tabular}

Kriegsmetallmobilisierungsstelle

Kriegsmetallmobilmachungsstelle

Kriegsunterstützungsausschuss

Kriegsversicherung für Angehörige eingezogener Emder Bürger Kriegswirtschafts AG

Kriegswirtschaftsstelle, Stadt Emden

Kronanwaltschaft, Aurich

Kuh-Casse, Emden

Kunst- und Antiquittätenhandlung $\mathrm{M}$ van Cleef

Kunstdenkmäler der Provinz Hannover

Kunstgewerbeausstellung in München

Kunstgewerbliche Werkstätte Gebr. Küsthardt GmbH

Künstlerverband Deutscher Bildhauer

Kupferschmiedezunft

Kuratorium der Kaiser-Friedrich-Realschule

\section{INST}


IV

Index

\begin{tabular}{|c|c|c|}
\hline \multicolumn{3}{|l|}{ INST } \\
\hline Indexbegriff & Laufzeit & Lfd.Nr. \\
\hline \multirow[t]{3}{*}{ Kuratorium der Navigationsschule } & $1872-1895$ & 1.589 \\
\hline & $1875-1905$ & 1.594 \\
\hline & 1918 & 1.626 \\
\hline Kuratorium für die landwirtschaftliche Winterschule & $1909-1914$ & 802 \\
\hline Küstenbahn & $1886-1887$ & 925 \\
\hline Landarmenverband der Provinz Hannover & $1872-1905$ & 1.893 \\
\hline Landdrostei, Aurich & & Vorwort \\
\hline \multirow[t]{14}{*}{ Landesdirektorium der Provinz Hannover } & $1880-1881$ & 211 \\
\hline & $1876-1889$ & 1.650 \\
\hline & $1910-1911$ & 1.983 \\
\hline & 1911-1912 & 1.984 \\
\hline & $1918-1919$ & 1.986 \\
\hline & $1875-1889$ & 2.035 \\
\hline & $1876-1890$ & 2.040 \\
\hline & 1907 & 2.072 \\
\hline & $1910-1916$ & 2.074 \\
\hline & $1899-1901$ & 2.397 \\
\hline & 1884-1895 & 2.426 \\
\hline & 1882-1902 & 2.608 \\
\hline & $1900-1902$ & 2.609 \\
\hline & $1909-1911$ & 3.133 \\
\hline \multirow[t]{7}{*}{ Landesversicherungsanstalt Hannover } & $1901-1902$ & 1.237 \\
\hline & $1901-1902$ & 1.239 \\
\hline & 1894-1905 & 1.240 \\
\hline & $1900-1902$ & 1.247 \\
\hline & $1903-1910$ & 1.465 \\
\hline & 1912 & 1.683 \\
\hline & 1901-1909 & 2.435 \\
\hline Landesversicherungsanstalt Oldenburg & 1906 & 1.242 \\
\hline \multirow[t]{2}{*}{ Landgebräucher-Beerdigungskasse } & $1866-1918$ & 1.639 \\
\hline & $1904-1911$ & 1.640 \\
\hline Landgemeinde Borssum & $1900-1903$ & 229 \\
\hline \multirow{3}{*}{ Landschaftliche Brandkasse } & 1906 & 1.272 \\
\hline & 1904-1905 & 1.273 \\
\hline & 1887 & 1.341 \\
\hline Landschaftliche Feuerversicherung & $1897-1911$ & 1.386 \\
\hline Landschafts-Büro zur Pflege verwundeter und erkrankter Krieger & 1870 & 594 \\
\hline Landschaftsfonds & $1900-1907$ & 3.708 \\
\hline \multirow[t]{5}{*}{ Landschaftskollegium, Aurich } & 1909 & 208 \\
\hline & $1886-1905$ & 1.251 \\
\hline & $1885-1911$ & 1.261 \\
\hline & 1888 & 1.342 \\
\hline & $1873-1897$ & 2.549 \\
\hline Landsturm & 1914 & 3.140 \\
\hline Landsturm Fußartillerie-Bataillon Nr. 2 & $1914-1915$ & 3.150 \\
\hline Landtagskommission für Kanalprojekte & $1900-1901$ & 2.057 \\
\hline \multirow{2}{*}{ Landwirtschaftliche Winterschule für den Kreis Emden } & $1909-1914$ & 802 \\
\hline & $1902-1911$ & 803 \\
\hline Landwirtschaftliche Zentralgenossenschaft Dortmund & $1903-1911$ & 2.079 \\
\hline \multirow[t]{2}{*}{ Landwirtschaftlicher Hauptverein für Ostfriesland } & $1911-1913$ & 755 \\
\hline & $1892-1903$ & 2.115 \\
\hline Landwirtschaftlicher Provinzialverein & 1879-1905 & 796 \\
\hline Landwirtschaftlicher Verein für Ostfriesland & $1879-1905$ & 796 \\
\hline \multirow[t]{3}{*}{ Landwirtschaftlicher Zweigverein Emden } & $1879-1905$ & 796 \\
\hline & $1883-1890$ & 2.039 \\
\hline & $1892-1903$ & 2.115 \\
\hline Landwirtschaftliches Zentralblatt für Ostfriesland & $1905-1908$ & 1.448 \\
\hline
\end{tabular}


IV

Index

\begin{tabular}{l}
\hline \\
\hline Indexbegriff \\
\hline Landwirtschaftskammer für die Provinz Hannover \\
Lateinlose Höhere Bürgerschule \\
Lebensrettungsgesellschaft \\
Leeraner Dampfschiffgesellschaft \\
Lehrerbeerdigungsverein "Concordia" \\
Lehrerinnen-Seminar an der Kaiserin-Auguste-Viktoria-Schule \\
Lehrerpensionskasse der reformierten Klassenschule \\
Lehrerverein Emden \\
Lehrerwitwen- u. Waisenkasse d. ref. Gemeinde in Emden \\
Lehrerwitwen- und Waisenkasse für das Stadtgebiet Emden \\
Leih- und Sparkasse, Stadt Emden \\
Leipziger Feuerversicherungsanstalt \\
Lithographische Anstalt Bogdan Gisovius, Berlin \\
Lithographische Anstalt M. Wilkens. Leer \\
Lokalverein Emd. z. Pflege i. Felde verwund. dtsch. Krieger
\end{tabular}

Lutherische Baukommission

Lutherische Friedhofskasse

Lutherische Gemeinde, Emden

\section{Laufzeit}

1891-1912

1881-1889

1891-1912

1873-1907

1875-1912

1903-1918

1898-1910

$1891-1910$

1901-1907

1885-1889

1915-1918

1885-1889

1875-1898

1874

1873-1880

1878-1895

1916-1917

1902-1904

1866-1876

1902-1907

1900-1908

1902-1907

1900-1908

1872-1916

1869-1896

1873-1914

1874-1875

1876

1877-1878

1879

1880-1881

1882-1883

1884-1885

1886-1887

1870-1902

1901

1898-1901

1894-1897

1901-1913

1900-1911

1913-1915

1901

1905

1915-1917

1896-1914

1883-1907

1893-1906

1868-1875

1868-1911

1890-1902

1890-1899

1903-1914

1869-1891

1891-1914

1892-1914

1868-1892

1872-1912

1875-1902
Lfd.Nr.

799

3.714

742

2.017

1.644

1.645

3.765

3.796

3.833

3.637

3.534

3.637

3.695

3.696

3.697

3.698

3.236

3.642

1.274

325

1.510

325

1.510

330

591

592

603

604

605

606

607

608

609

610

645

2.557

3.437

3.462

187

259

813

2.557

2.822

3.207

3.330

3.344

3.346

3.351

3.379

3.431

3.432

3.433

3.438

3.439

3.441

3.442

3.444

3.445 
IV

Index

\begin{tabular}{|c|c|c|}
\hline \multicolumn{3}{|l|}{ INST } \\
\hline Indexbegriff & Laufzeit & Lfd.Nr. \\
\hline \multirow[t]{26}{*}{ Lutherische Gemeinde, Emden } & $1875-1904$ & 3.446 \\
\hline & $1868-1905$ & 3.447 \\
\hline & $1873-1914$ & 3.449 \\
\hline & $1878-1904$ & 3.450 \\
\hline & $1880-1903$ & 3.451 \\
\hline & 1882 & 3.452 \\
\hline & $1881-1883$ & 3.453 \\
\hline & 1887-1889 & 3.457 \\
\hline & $1888-1913$ & 3.458 \\
\hline & $1891-1914$ & 3.460 \\
\hline & $1866-1897$ & 3.461 \\
\hline & 1894-1906 & 3.464 \\
\hline & $1884-1914$ & 3.465 \\
\hline & $1891-1906$ & 3.466 \\
\hline & $1895-1918$ & 3.467 \\
\hline & 1896-1897 & 3.468 \\
\hline & $1899-1913$ & 3.470 \\
\hline & 1901 & 3.471 \\
\hline & 1903 & 3.472 \\
\hline & $1874-1888$ & 3.473 \\
\hline & $1905-1908$ & 3.474 \\
\hline & 1918 & 3.475 \\
\hline & 1906 & 3.476 \\
\hline & 1898 & 3.477 \\
\hline & 1890 & 3.478 \\
\hline & $1872-1907$ & 3.479 \\
\hline Lutherische Kirche & $1866-1885$ & 2.650 \\
\hline \multirow{2}{*}{ Lutherische Kirchenkommission, Emden } & $1868-1875$ & 3.351 \\
\hline & 1890-1902 & 3.431 \\
\hline \multirow[t]{15}{*}{ Lutherische Klassenschule } & $1906-1908$ & 3.616 \\
\hline & $1887-1905$ & 3.651 \\
\hline & $1875-1889$ & 3.652 \\
\hline & $1891-1907$ & 3.653 \\
\hline & 1866-1879 & 3.654 \\
\hline & $1867-1908$ & 3.655 \\
\hline & $1872-1888$ & 3.657 \\
\hline & $1869-1870$ & 3.658 \\
\hline & $1880-1890$ & 3.659 \\
\hline & $1873-1887$ & 3.660 \\
\hline & $1868-1896$ & 3.663 \\
\hline & $1893-1896$ & 3.664 \\
\hline & $1887-1890$ & 3.665 \\
\hline & $1900-1909$ & 3.666 \\
\hline & 1903 & 3.667 \\
\hline Lutherische Schulgemeinde & 1873-1887 & 3.660 \\
\hline \multirow[t]{3}{*}{ Lutherische Volksschule } & 1894 & 3.648 \\
\hline & 1881 & 3.649 \\
\hline & $1872-1888$ & 3.650 \\
\hline Lutherischer Generalsuperintendent für Ostfriesland & 1888-1889 & 3.459 \\
\hline Lutherischer Kirchenrat & $1902-1914$ & 3.340 \\
\hline Lutherischer Kirchenvorstand & 1893-1906 & 3.346 \\
\hline \multirow[t]{5}{*}{ Lutherischer Schulverband } & 1873-1887 & 3.660 \\
\hline & $1881-1883$ & 3.661 \\
\hline & $1868-1896$ & 3.663 \\
\hline & $1887-1890$ & 3.665 \\
\hline & 1903 & 3.667 \\
\hline Mädchenfortbildungsschule, Matschappij tot nut van't algemeen & $1872-1915$ & 3.855 \\
\hline
\end{tabular}


IV

Index

\begin{tabular}{|c|c|c|}
\hline \multicolumn{3}{|c|}{ INST } \\
\hline Indexbegriff & Laufzeit & Lfd.Nr. \\
\hline Magistrat der Stadt Papenburg & $1869-1890$ & 1.577 \\
\hline Magistrat, Stadt Emden & $1872-1876$ & 34 \\
\hline & 1878 & 35 \\
\hline & 1879 & 36 \\
\hline & 1880 & 37 \\
\hline & 1881 & 38 \\
\hline & 1882 & 39 \\
\hline & 1885 & 40 \\
\hline & 1883 & 41 \\
\hline & 1884 & 42 \\
\hline & 1886 & 43 \\
\hline & 1887 & 44 \\
\hline & 1888 & 45 \\
\hline & 1889 & 46 \\
\hline & 1890 & 47 \\
\hline & 1891 & 48 \\
\hline & 1893 & 49 \\
\hline & 1892 & 50 \\
\hline & 1894 & 51 \\
\hline & 1895 & 52 \\
\hline & 1896 & 53 \\
\hline & 1897 & 54 \\
\hline & 1898 & 55 \\
\hline & 1899 & 56 \\
\hline & 1900 & 57 \\
\hline & 1901 & 58 \\
\hline & 1902 & 59 \\
\hline & 1906 & 60 \\
\hline & 1903 & 61 \\
\hline & 1903 & 62 \\
\hline & 1904 & 63 \\
\hline & 1905 & 64 \\
\hline & 1907 & 65 \\
\hline & 1911 & 66 \\
\hline & 1912 & 67 \\
\hline & 1914 & 68 \\
\hline & 1916 & 69 \\
\hline & 1915 & 70 \\
\hline & 1919 & 71 \\
\hline & 1920 & 72 \\
\hline & 1910 & 73 \\
\hline & 1854-1914 & 74 \\
\hline & $1867-1869$ & 155 \\
\hline & $1870-1872$ & 156 \\
\hline & 1873-1874 & 157 \\
\hline & 1873 & 158 \\
\hline & $1875-1878$ & 159 \\
\hline & $1879-1881$ & 160 \\
\hline & $1882-1884$ & 161 \\
\hline & $1885-1888$ & 162 \\
\hline & 1889-1893 & 163 \\
\hline & 1894-1910 & 164 \\
\hline & $1910-1914$ & 165 \\
\hline & $1915-1919$ & 166 \\
\hline & 1868-1869 & 318 \\
\hline & $1869-1870$ & 319 \\
\hline & $1870-1871$ & 320 \\
\hline & 1854-1888 & 335 \\
\hline
\end{tabular}


IV

Index

\begin{tabular}{|c|c|c|}
\hline \multicolumn{3}{|l|}{ INST } \\
\hline Indexbegriff & Laufzeit & Lfd.Nr. \\
\hline \multirow[t]{10}{*}{ Magistrat, Stadt Emden } & $1858-1903$ & 506 \\
\hline & $1884-1885$ & 904 \\
\hline & $1885-1910$ & 905 \\
\hline & $1885-1889$ & 906 \\
\hline & $1885-1900$ & 907 \\
\hline & $1885-1887$ & 915 \\
\hline & $1885-1887$ & 916 \\
\hline & 1886 & 926 \\
\hline & $1886-1887$ & 927 \\
\hline & 1902-1906 & 942 \\
\hline \multirow[t]{3}{*}{ Mahlstede's Tivoli, Emden } & $1873-1914$ & 592 \\
\hline & $1876-1918$ & 3.168 \\
\hline & $1900-1912$ & 3.172 \\
\hline Malerausstellung "Bemalte Räume", Hamburg & 1904-1914 & 2.344 \\
\hline Maler-Innung für Emden und Umgegend & 1873-1889 & 1.932 \\
\hline \multirow[t]{5}{*}{ Männerturnverein Emden } & $1891-1898$ & 561 \\
\hline & $1868-1879$ & 728 \\
\hline & $1882-1914$ & 729 \\
\hline & $1895-1914$ & 730 \\
\hline & $1876-1882$ & 734 \\
\hline \multirow[t]{4}{*}{ Manufakturwarenlager, Stadt Emden } & 1917-1918 & 3.283 \\
\hline & $1916-1918$ & 3.286 \\
\hline & 1918 & 3.288 \\
\hline & 1917-1918 & 3.289 \\
\hline Marinebauamt & $1916-1917$ & 3.157 \\
\hline Marinestation der Nordsee & $1896-1907$ & 3.170 \\
\hline Marineverein für Emden und Umgebung & $1905-1913$ & 671 \\
\hline Märkisches Wandertheater & $1912-1914$ & 555 \\
\hline \multirow[t]{9}{*}{ Marktkommission, Stadt Emden } & $1877-1912$ & 324 \\
\hline & 1883-1902 & 1.909 \\
\hline & $1866-1910$ & 2.137 \\
\hline & 1880 & 2.141 \\
\hline & $1876-1911$ & 2.145 \\
\hline & 1876-1908 & 2.147 \\
\hline & 1883-1895 & 2.148 \\
\hline & $1900-1918$ & 2.149 \\
\hline & $1877-1910$ & 2.653 \\
\hline \multirow[t]{2}{*}{ Maschinenbauinspektion Emden } & 1906 & 2.163 \\
\hline & 1906 & 2.169 \\
\hline Maschinenfabrik Ernst Hoeppner \& Co & $1892-1910$ & 2.389 \\
\hline Maschinenfabrik, Eisen- und Stahlgießerei AG & $1905-1916$ & 2.823 \\
\hline \multirow[t]{3}{*}{ Matschappij tot nut van't algemeen } & $1873-1914$ & 3.851 \\
\hline & $1889-1890$ & 3.852 \\
\hline & $1872-1915$ & 3.855 \\
\hline Matschappij tot nut van't allgemeen & 1905-1908 & 1.659 \\
\hline \multirow[t]{2}{*}{ Maurergesellen-Totenkasse } & $1903-1911$ & 1.637 \\
\hline & $1899-1917$ & 1.649 \\
\hline \multirow[t]{2}{*}{ Meisterprüfungskommission für das Schornsteinfegerhandwerk } & 1873-1906 & 1.263 \\
\hline & $1907-1916$ & 1.264 \\
\hline \multirow[t]{2}{*}{ Mennonitengemeinde, Emden } & 1901-1902 & 3.486 \\
\hline & 1891 & 3.691 \\
\hline Metallarbeiter-Zwangsinnung Emden & $1897-1914$ & 1.042 \\
\hline Metallausschuss, Stadt Emden & 1917-1918 & 3.263 \\
\hline \multirow[t]{3}{*}{ Metallmobilmachungsstelle im Kriegsministerium } & 1915 & 3.247 \\
\hline & $1917-1918$ & 3.265 \\
\hline & $1915-1916$ & 3.310 \\
\hline \multirow[t]{2}{*}{ Militärverein Emden } & $1901-1912$ & 643 \\
\hline & 1914-1916 & 3.201 \\
\hline
\end{tabular}


IV

Index

\begin{tabular}{|c|c|c|}
\hline \multicolumn{3}{|l|}{ INST } \\
\hline Indexbegriff & Laufzeit & Lfd.Nr. \\
\hline Missionsfrauenverein, Emden & $1868-1914$ & 557 \\
\hline \multirow[t]{2}{*}{ Mittelschule für Mädchen } & $1905-1911$ & 3.830 \\
\hline & $1911-1913$ & 3.831 \\
\hline Molkereigenossenschaft Emden & $1911-1913$ & 755 \\
\hline Moltke-Comitee, Emden & $1890-1891$ & 565 \\
\hline Moltke-Stiftung & $1890-1891$ & 565 \\
\hline Moorversuchsanstalt Bremen & 1904-1908 & 945 \\
\hline \multirow[t]{3}{*}{ Mühle "Zeldenrüst" } & $1871-1873$ & 1.760 \\
\hline & $1866-1888$ & 2.379 \\
\hline & $1895-1897$ & 2.927 \\
\hline \multirow[t]{2}{*}{ Mühlensocietät } & 1870 & 849 \\
\hline & 1885 & 2.443 \\
\hline Münsterische Lagerhaus AG & 1899-1906 & 2.129 \\
\hline Musikkorps des Ostfriesischen Infanterie-Regiments Nr. 78 & $1871-1875$ & 570 \\
\hline Musikverein Emden & $1902-1909$ & 654 \\
\hline \multirow[t]{2}{*}{ Nationale Flugspende des Deutschen Reiches } & 1912 & 2.098 \\
\hline & 1912 & 2.099 \\
\hline Nationalliberaler Verein für die Stadt Emden & $1879-1880$ & 623 \\
\hline Nationalsozialer Verein & 1900 & 640 \\
\hline Nationalstiftung für Hinterbliebene gefallener Soldaten & $1914-1918$ & 3.199 \\
\hline \multirow[t]{4}{*}{ Naturforschende Gesellschaft, Emden } & $1900-1911$ & 259 \\
\hline & $1912-1918$ & 263 \\
\hline & 1903 & 1.417 \\
\hline & $1900-1909$ & 2.607 \\
\hline Naturpark "Wilseder Berg" (Lüneburger Heide) & $1911-1914$ & 600 \\
\hline Nautischer Verein & 1907 & 678 \\
\hline Navigationsschulkommission & $1875-1905$ & 1.594 \\
\hline Nellnersche Predigerwitwen-Kasse & $1868-1914$ & 3.435 \\
\hline \multirow[t]{5}{*}{ Nellnersche Predigerwitwen-Stiftung } & 1899 & 3.436 \\
\hline & $1873-1878$ & 3.448 \\
\hline & 1867-1902 & 3.455 \\
\hline & $1891-1914$ & 3.460 \\
\hline & 1904 & 3.469 \\
\hline Nesserlander Friedhof & 1901 & 3.401 \\
\hline Nesserlander Schleuse & 1898-1899 & 1.486 \\
\hline Nesserland-Hafenbahn & $1886-1900$ & 923 \\
\hline \multirow[t]{5}{*}{ Neue Kirche zu Emden } & $1868-1911$ & 3.379 \\
\hline & 1867-1902 & 3.381 \\
\hline & $1868-1910$ & 3.387 \\
\hline & $1870-1908$ & 3.398 \\
\hline & 1897 & 3.406 \\
\hline \multirow[t]{4}{*}{ Niederemsische Deichacht } & $1885-1907$ & 1.543 \\
\hline & $1872-1892$ & 1.544 \\
\hline & $1873-1876$ & 1.554 \\
\hline & $1867-1890$ & 2.476 \\
\hline Niederländisches Kriegsministerium & $1905-1907$ & 2.613 \\
\hline Niedersächsischer Ausschuss für Heimatschutz & $1907-1912$ & 695 \\
\hline Niedersächsischer Herbergsverband & $1912-1914$ & 710 \\
\hline Niedersächsischer Stenographenbund & $1901-1913$ & 693 \\
\hline Niedersächsischer Verein von Gas- und Wasserfachmänner & $1897-1913$ & 1.070 \\
\hline Niedersächsischer Vertretertag & $1907-1912$ & 695 \\
\hline Norddeutsche Seewarte & 1869 & 2.036 \\
\hline \multirow[t]{2}{*}{ Norddeutscher Bund } & $1866-1867$ & 216 \\
\hline & $1870-1900$ & 1.621 \\
\hline Norddeutscher Fußballverband & $1908-1913$ & 701 \\
\hline \multirow[t]{2}{*}{ Norddeutscher Lloyd } & 1907 & 1.428 \\
\hline & $1873-1907$ & 2.017 \\
\hline
\end{tabular}


IV

Index

\begin{tabular}{|c|c|c|}
\hline \multicolumn{3}{|l|}{ INST } \\
\hline Indexbegriff & Laufzeit & Lfd.Nr. \\
\hline Norddeutscher Lloyd & $1915-1916$ & 3.249 \\
\hline \multirow[t]{4}{*}{ Nordseewerke, Deutsch-Luxemburgische Bergwerks- und Hütten AG } & $1913-1915$ & 813 \\
\hline & $1912-1914$ & 1.441 \\
\hline & $1915-1918$ & 2.339 \\
\hline & 1913 & 2.884 \\
\hline \multirow[t]{51}{*}{ Nordseewerke, Emder Werft und Dock AG } & $1872-1916$ & 330 \\
\hline & $1905-1910$ & 373 \\
\hline & $1903-1911$ & 666 \\
\hline & $1890-1911$ & 687 \\
\hline & $1897-1914$ & 1.042 \\
\hline & 1912 & 1.092 \\
\hline & $1913-1914$ & 1.149 \\
\hline & $1873-1914$ & 1.227 \\
\hline & 1894-1905 & 1.240 \\
\hline & $1866-1876$ & 1.274 \\
\hline & $1899-1903$ & 1.454 \\
\hline & $1902-1905$ & 1.455 \\
\hline & $1902-1910$ & 1.456 \\
\hline & $1910-1912$ & 1.457 \\
\hline & 1903-1904 & 1.458 \\
\hline & 1903-1904 & 1.459 \\
\hline & $1906-1907$ & 1.460 \\
\hline & $1905-1907$ & 1.461 \\
\hline & 1904-1908 & 1.462 \\
\hline & 1903 & 1.463 \\
\hline & $1902-1903$ & 1.464 \\
\hline & $1903-1910$ & 1.465 \\
\hline & $1908-1910$ & 1.466 \\
\hline & $1908-1911$ & 1.467 \\
\hline & $1910-1911$ & 1.468 \\
\hline & $1907-1909$ & 1.469 \\
\hline & $1910-1911$ & 1.470 \\
\hline & 1910 & 1.471 \\
\hline & $1909-1911$ & 1.472 \\
\hline & $1910-1911$ & 1.473 \\
\hline & $1910-1911$ & 1.474 \\
\hline & 1911 & 1.475 \\
\hline & 1911 & 1.476 \\
\hline & $1911-1912$ & 1.477 \\
\hline & $1912-1913$ & 1.478 \\
\hline & $1910-1911$ & 1.479 \\
\hline & $1910-1912$ & 1.480 \\
\hline & $1910-1911$ & 1.481 \\
\hline & $1910-1911$ & 1.482 \\
\hline & $1910-1911$ & 1.483 \\
\hline & $1911-1912$ & 1.484 \\
\hline & $1913-1917$ & 1.485 \\
\hline & $1905-1912$ & 2.105 \\
\hline & 1904 & 2.283 \\
\hline & 1908 & 2.302 \\
\hline & 1908 & 2.314 \\
\hline & $1906-1907$ & 2.373 \\
\hline & $1875-1909$ & 2.383 \\
\hline & $1892-1910$ & 2.389 \\
\hline & $1905-1906$ & 2.436 \\
\hline & & Vorwort \\
\hline Nordwestdeutsche Obstbauausstellung & $1879-1905$ & 796 \\
\hline Nordwestdeutscher Gabelsbergerscher Stenographenverein & $1901-1913$ & 693 \\
\hline
\end{tabular}


IV

Index

\begin{tabular}{|c|c|c|}
\hline \multicolumn{3}{|l|}{ INST } \\
\hline Indexbegriff & Laufzeit & Lfd.Nr. \\
\hline Nordwestdeutscher Handwerkerbund & 1893-1912 & 1.926 \\
\hline Nordwestdeutscher Verein für Luftschiffahrt & $1909-1913$ & 2.097 \\
\hline Notfonds für die lutherische Kirche in der Provinz Hannover & $1894-1900$ & 3.463 \\
\hline \multirow[t]{3}{*}{ Oberemsische Deichacht } & $1872-1892$ & 1.544 \\
\hline & $1900-1901$ & 1.548 \\
\hline & $1896-1911$ & 1.549 \\
\hline \multirow[t]{3}{*}{ Obergericht Aurich } & $1875-1881$ & 2.510 \\
\hline & $1877-1881$ & 2.511 \\
\hline & 1874-1877 & 2.512 \\
\hline \multirow[t]{3}{*}{ Oberlandesgericht, Celle } & $1908-1912$ & 365 \\
\hline & $1872-1914$ & 767 \\
\hline & 1884-1885 & 2.527 \\
\hline \multirow[t]{4}{*}{ Oberpostdirektion, Oldenburg } & $1876-1908$ & 266 \\
\hline & $1909-1910$ & 1.096 \\
\hline & $1881-1899$ & 2.053 \\
\hline & $1874-1876$ & 2.488 \\
\hline \multirow[t]{14}{*}{ Oberverwaltungsgericht, Berlin } & 1904-1905 & 14 \\
\hline & $1901-1903$ & 76 \\
\hline & 1901-1902 & 77 \\
\hline & 1899-1904 & 852 \\
\hline & $1899-1902$ & 853 \\
\hline & 1906-1908 & 856 \\
\hline & 1906-1908 & 857 \\
\hline & $1909-1911$ & 859 \\
\hline & $1890-1893$ & 979 \\
\hline & $1900-1903$ & 1.166 \\
\hline & $1906-1911$ & 1.199 \\
\hline & $1908-1910$ & 1.202 \\
\hline & 1901-1907 & 1.502 \\
\hline & $1895-1913$ & 2.982 \\
\hline Oberverwaltungsschule Hannover & 1903 & 3.735 \\
\hline Oderwerke, Maschinenbaufabrik und Schiffswerft AG, Stettin & $1899-1904$ & 2.060 \\
\hline Oelberg-Verein & 1912 & 707 \\
\hline Oldenburgische Spar- und Leihbank & $1888-1890$ & 2.995 \\
\hline Oortgiese \& Meyer, Bauunternehmen & $1908-1912$ & 3.128 \\
\hline Ortskrankenkasse für gewerbliche Arbeiter und Hilfsarbeiter & $1894-1900$ & 1.685 \\
\hline Ortsverband der städtischen Beamten, Emden & $1898-1913$ & 635 \\
\hline Ortsverein Emden des Verbandes der Deutschen Buchdrucker & $1914-1915$ & 716 \\
\hline Osnabrücker Zeitung & $1908-1912$ & 3.087 \\
\hline Ostfriesische Ausstellung für Gewerbe und Landwirtschaft & $1887-1912$ & 2.127 \\
\hline Ostfriesische Brandkasse & 1893-1907 & 3.838 \\
\hline Ostfriesische Küstenbahn & 1896 & 2.075 \\
\hline \multirow[t]{9}{*}{ Ostfriesische Landschaft } & 1902 & 206 \\
\hline & $1867-1877$ & 207 \\
\hline & 1909 & 208 \\
\hline & $1878-1892$ & 2.008 \\
\hline & $1883-1897$ & 2.010 \\
\hline & $1879-1882$ & 2.011 \\
\hline & $1885-1889$ & 2.022 \\
\hline & $1874-1914$ & 2.346 \\
\hline & $1880-1911$ & 2.347 \\
\hline Ostfriesische Landschaftliche Brandkasse & 1909 & 208 \\
\hline Ostfriesische Lehrerwitwen- und Waisenunterstützungskasse & $1870-1879$ & 3.501 \\
\hline Ostfriesische Mobiliar-Feuerversicherungsanstalt & $1912-1917$ & 3.549 \\
\hline \multirow[t]{2}{*}{ Ostfriesische Molkereigerätefabrik T. Bartels \& Co. } & $1900-1909$ & 2.380 \\
\hline & $1892-1910$ & 2.389 \\
\hline Ostfriesische Provinzial Feuerversicherungskasse & $1866-1876$ & 1.275 \\
\hline
\end{tabular}


Index

\begin{tabular}{|c|c|c|}
\hline \multicolumn{3}{|l|}{ INST } \\
\hline Indexbegriff & Laufzeit & Lfd.Nr. \\
\hline \multirow[t]{7}{*}{ Ostfriesische Provinzial Feuerversicherungskasse } & $1877-1913$ & 1.276 \\
\hline & $1875-1879$ & 1.277 \\
\hline & 1879-1884 & 1.278 \\
\hline & 1885-1892 & 1.279 \\
\hline & $1893-1895$ & 1.280 \\
\hline & 1896-1898 & 1.281 \\
\hline & $1899-1903$ & 1.282 \\
\hline \multirow[t]{2}{*}{ Ostfriesische Provinzialbrandkasse } & $1907-1911$ & 1.291 \\
\hline & 1907-1909 & 1.292 \\
\hline Ostfriesische reformierte Pfarrtöchterkasse auf Gegenseitigkeit & $1900-1911$ & 650 \\
\hline Ostfriesische Reformierte Pfarrtöchterkasse, Emden & $1901-1916$ & 1.684 \\
\hline Ostfriesische Schulblätter & 1903-1909 & 661 \\
\hline \multirow[t]{3}{*}{ Ostfriesische Sparkasse } & $1867-1877$ & 207 \\
\hline & 1904-1906 & 1.290 \\
\hline & 1907-1909 & 1.469 \\
\hline \multirow[t]{3}{*}{ Ostfriesische Zeitung } & $1866-1913$ & 452 \\
\hline & $1867-1891$ & 719 \\
\hline & $1912-1914$ & 721 \\
\hline Ostfriesischer Fortbildungsverein & 1913-1917 & 2.356 \\
\hline \multirow[t]{2}{*}{ Ostfriesischer Kriegerbund } & $1899-1913$ & 634 \\
\hline & $1901-1912$ & 643 \\
\hline Ostfriesischer Kriegertag & $1872-1913$ & 599 \\
\hline Ostfriesischer Kriegerverein & 1895-1899 & 202 \\
\hline Ostfriesischer Landwirtschaftlicher Hauptverein & $1885-1889$ & 2.022 \\
\hline Ostfriesischer Lehrerverein & 1903-1909 & 661 \\
\hline Ostfriesischer Sängerbund & 1902 & 186 \\
\hline Ostfriesischer Schützenbund & $1886-1914$ & 574 \\
\hline Ostfriesischer Verein zur Rettung Schiffsbrüchiger & $1909-1913$ & 261 \\
\hline Ostfriesisches Infanterie-Regiment Nr. 18 & $1878-1891$ & 2.428 \\
\hline \multirow[t]{2}{*}{ Ostfriesisches Infanterie-Regiment Nr. 78} & $1866-1870$ & 3.125 \\
\hline & 1869-1905 & 3.498 \\
\hline \multirow[t]{3}{*}{ Ostfriesisches Landschaftskollegium } & 1902 & 206 \\
\hline & 1904-1906 & 1.290 \\
\hline & $1900-1907$ & 3.708 \\
\hline Ostfriesisches Schulblatt & $1900-1907$ & 3.708 \\
\hline Packhaus "Vissers Hoep" & 1878 & 2.681 \\
\hline Papierfabrik Heinrich Geldmacher & $1866-1914$ & 317 \\
\hline Pegel-Directions-Commission & $1866-1883$ & 1.487 \\
\hline Pegelkommision & $1867-1910$ & 1.490 \\
\hline \multirow[t]{2}{*}{ Pestalozzi-Stiftung, Hannover } & 1913-1914 & 1.732 \\
\hline & 1913-1915 & 1.872 \\
\hline Pfandleihkasse, Stadt Emden & $1867-1917$ & 1.915 \\
\hline Pferdeaushebungskommission & 1909-1918 & 3.164 \\
\hline Pharusverlag & 1902-1907 & 325 \\
\hline Philipp Holzmann und Co GmbH & 1906 & 2.165 \\
\hline Phoebus Elektrizitäts AG & $1900-1901$ & 1.957 \\
\hline Polizeidirektion Bremen & $1909-1911$ & 387 \\
\hline Polizeidirektion Emden & 1867-1907 & 725 \\
\hline \multirow[t]{2}{*}{ Polizeigefängnis, Emden } & 1879-1904 & 522 \\
\hline & 1899-1913 & 523 \\
\hline Polizeiverwaltung Halle & $1882-1910$ & 501 \\
\hline Postamt & 1907-1908 & 953 \\
\hline Postprüfungskommission für den Kriegsfall & 1914 & 3.177 \\
\hline Preußische Central-Boden-Credit Actien-Gesellschaft & $1867-1881$ & 816 \\
\hline Preußische Central-Bodenkredit AG & 1911-1918 & 1.901 \\
\hline Preußische Central-Genossenschafts-Kasse & 1914 & 3.238 \\
\hline Preußische Lebensversicherungsgesellschaft AG & 1890 & 354 \\
\hline
\end{tabular}


IV

Index

\begin{tabular}{l} 
Indexbegriff \\
\hline Preußische Staatsbahn \\
Preußische Staatsbank \\
Preußischer Domänenfiskus \\
Preußischer Landeskriegerverband \\
Preußischer Landesverband der Haus- und Grundbesitzervereine
\end{tabular}

Preußischer Landtag

\section{Laufzeit}

1912-1913

1904-1908

$1873-1910$

Preußischer Städtetag

Preußisches Abgeordnetenhaus

Preußisches Generalgouvernements-Department für Finanzen

Preußisches Oberverwaltungsgericht

Preußisches Staatsarchiv, Aurich

Preußisches Statistisches Büro

Preußisches statistisches Landesamt

Private Pflegeanstalt für Geisteskranke, Neusandhorst

Proviantamt Verden / Aller

Provinzial Lehrerwitwen- und Waisenkasse

Provinzial Schul-Kollegium, Hannover

Provinzialausschuss, Hannover

Provinzial-Delegierter für die freiwillige Krankenpflege

Provinzial-Elementarlehrer-Witwen und Waisenkasse

Provinzial-Hebammenlehranstalt, Hannover

Provinzialhebammenschule, Osnabrück

Provinzialhülfsfonds

Provinzialkartoffelstelle

Provinziallandtag, Hannover

Provinzialmuseum Hannover

Provinzialrat der Provinz Hannover

Provinzialrat, Hannover

Provinzialschulkollegium Hannover

Provinzialschulkollegium, Hannover

Provinzial-Schul-Kollegium, Hannover

Provinzialverband der hann. Vereine z. Fürsorge f. entl. Häftlinge Provinzialverband der hannoverschen Bürgervereine

Provinzialverband Hannoverscher Gewerbelehrer Provinzialverbd. d. Nationalstiftung f. Hinterbliebene gef. Soldaten Provinzialverein vom Roten Kreuz
1867

1899-1913

1901-1912

$1905-1913$

1913-1914

$1907-1913$

1876-1907

1911

1899

\section{Lfd.Nr.}

2.101

2.417

230

598

634

643

671

712

602

4

226

2.078

1911

1899-1900

1866-1879

1907-1914

1918

1900-1912

1918

Vorwort

1900-1915

1901-1916

1905-1909

1855-1912

1917-1918

1870-1879

$1872-1916$

1915-1918

1880-1917

1906-1907

1870-1872

1880-1913

1898-1918

1898-1918

1868-1911

1916

1898

1867-1915

1878-1898

1902-1908

1908-1913

1888-1890

1900-1903

1906-1908

1873-1906

1874-1890

1887-1905

1894-1912

1888-1906

1899-1908

1848-1915

1903

1899-1911

1914-1918

1905-1914

1903-1914
226

2.055

3.112

2.910

1.626

1.294

461

815

1.902

1.903

2.988

521

3.244

3.501

330

242

2.046

2.086

593

3.822

764

764

1.396

3.305

188

204

2.630

2.631

Vorwort

2.642

2.995

229

1.011

1.263

3.499

3.729

3.817

3.824 
IV

Index

\begin{tabular}{|c|c|c|}
\hline \multicolumn{3}{|l|}{ INST } \\
\hline Indexbegriff & Laufzeit & Lfd.Nr. \\
\hline Provinzialverein vom Roten Kreuz & $1902-1917$ & 1.693 \\
\hline \multirow{8}{*}{ Provinzial-Witwen- und Waisenkasse } & $1876-1889$ & 1.650 \\
\hline & 1891-1895 & 1.651 \\
\hline & $1896-1900$ & 1.652 \\
\hline & $1901-1909$ & 1.653 \\
\hline & 1904-1907 & 1.654 \\
\hline & $1907-1910$ & 1.655 \\
\hline & $1911-1915$ & 1.656 \\
\hline & $1916-1918$ & 1.657 \\
\hline Prüfungsanstalt für Wasserversorgung und Abwasserbeseitigung & $1896-1913$ & 950 \\
\hline Prüfungskomm. über wirtsch. u. finanz. Lage d. Nordseewerke & $1906-1907$ & 1.460 \\
\hline Prüfungskommission für Schiffer und Steuermänner & $1870-1909$ & 1.591 \\
\hline Prüfungskommission für Steuermänner in der Provinz Hannover & 1871-1895 & 1.588 \\
\hline Quarantäne-Station, Nesserland & $1884-1915$ & 772 \\
\hline R.G. Heits, Bauunternehmen & $1908-1912$ & 3.128 \\
\hline Radfahrverein "Emdena" & 1888-1906 & 672 \\
\hline Rateler-Corps, Stadt Emden & 1884-1906 & 413 \\
\hline \multirow[t]{2}{*}{ Ratsbibliothek, Stadt Emden } & $1867-1901$ & 310 \\
\hline & $1901-1913$ & 311 \\
\hline Reederei F. D. Ihnen & $1883-1901$ & 2.044 \\
\hline Reederei M. H. Schönberg & $1883-1901$ & 2.044 \\
\hline Reederei Menzell \& Co, Hamburg & 1904 & 2.080 \\
\hline \multirow[t]{5}{*}{ Reederei P.W.Wessels Wwe. } & 1891 & 2.195 \\
\hline & 1900 & 2.239 \\
\hline & 1902 & 2.262 \\
\hline & 1903 & 2.281 \\
\hline & 1908 & 2.301 \\
\hline Reederei W. Kunstmann & $1912-1914$ & 1.878 \\
\hline \multirow[t]{2}{*}{ Reformierte Gemeinde } & 1888 & 2.547 \\
\hline & $1896-1897$ & 2.778 \\
\hline Reformierte Kirchenkommission & $1902-1914$ & 3.340 \\
\hline \multirow[t]{16}{*}{ Reformierte Klassenschule } & $1868-1910$ & 3.581 \\
\hline & $1877-1918$ & 3.586 \\
\hline & $1866-1868$ & 3.620 \\
\hline & 1869-1909 & 3.622 \\
\hline & $1877-1883$ & 3.623 \\
\hline & 1890 & 3.624 \\
\hline & $1867-1890$ & 3.626 \\
\hline & $1891-1907$ & 3.627 \\
\hline & $1872-1883$ & 3.628 \\
\hline & $1868-1908$ & 3.630 \\
\hline & $1869-1904$ & 3.633 \\
\hline & $1890-1901$ & 3.635 \\
\hline & $1882-1907$ & 3.638 \\
\hline & $1880-1885$ & 3.639 \\
\hline & $1900-1902$ & 3.641 \\
\hline & 1868 & 3.645 \\
\hline Reformierte Schulgemeinde & $1902-1903$ & 2.799 \\
\hline Reformierte Schulkasse & $1868-1908$ & 3.630 \\
\hline Reformierte Schullehrer-Witwen und Sterbekasse & $1869-1910$ & 3.350 \\
\hline Reformierte Volksschule, Emden & $1877-1896$ & 3.407 \\
\hline Reformierter Kirchenrat & $1892-1894$ & 2.349 \\
\hline \multirow[t]{2}{*}{ Reformierter Schulverband } & 1907 & 3.543 \\
\hline & $1872-1881$ & 3.640 \\
\hline Reformierter Schulvorstand & $1880-1881$ & 3.614 \\
\hline Reformierter Synodalverband & 1889 & 3.335 \\
\hline
\end{tabular}


IV

Index

\begin{tabular}{|c|c|c|}
\hline \multicolumn{3}{|c|}{ INST } \\
\hline Indexbegriff & Laufzeit & Lfd.Nr. \\
\hline \multirow[t]{2}{*}{ Registratur, Stadt Emden } & 1857-1908 & 313 \\
\hline & $1912-1913$ & 314 \\
\hline \multirow[t]{2}{*}{ Reichsamt des Innern } & $1867-1914$ & 3.107 \\
\hline & $1914-1918$ & 3.232 \\
\hline \multirow[t]{2}{*}{ Reichsbank } & 1876-1904 & 1.922 \\
\hline & 1917 & 3.237 \\
\hline Reichsbank, Filiale Emden & $1911-1918$ & 1.901 \\
\hline Reichsbankfiliale Emden & $1876-1904$ & 1.922 \\
\hline Reichsbankstelle, Emden & 1896 & 1.912 \\
\hline \multirow[t]{3}{*}{ Reichsbekleidungsstelle } & 1917-1918 & 3.283 \\
\hline & 1917 & 3.293 \\
\hline & $1917-1918$ & 3.304 \\
\hline Reichsdarlehenskasse & $1916-1917$ & 3.236 \\
\hline Reichsfuttermittelstelle & $1917-1918$ & 3.244 \\
\hline \multirow[t]{6}{*}{ Reichsgericht, Leipzig } & $1910-1913$ & 1.109 \\
\hline & 1894 & 3.360 \\
\hline & 1898 & 3.363 \\
\hline & 1898 & 3.366 \\
\hline & 1894-1904 & 3.376 \\
\hline & 1894-1904 & 3.377 \\
\hline \multirow[t]{2}{*}{ Reichskanzleramt } & 1874-1909 & 500 \\
\hline & $1878-1880$ & 1.631 \\
\hline Reichskartoffelstelle & 1916 & 3.305 \\
\hline Reichskommissar für Volksernährung & $1914-1918$ & 3.245 \\
\hline \multirow[t]{4}{*}{ Reichsmarineamt } & 1903 & 1.573 \\
\hline & $1912-1913$ & 2.103 \\
\hline & $1913-1914$ & 2.104 \\
\hline & 1914-1918 & 3.232 \\
\hline Reichsmarineamt, Nachrichtenbüro & 1903-1909 & 312 \\
\hline Reichspostamt & $1914-1915$ & 3.154 \\
\hline Reichsstelle für Gemüse und Obst & $1917-1918$ & 3.308 \\
\hline Reichsstelle für Schuhversorgung & 1918 & 3.295 \\
\hline Reichsstelle zur Versorgung mit Vieh und Fleisch & 1914-1918 & 3.245 \\
\hline \multirow[t]{5}{*}{ Reichstag des Deutschen Reiches } & $1870-1903$ & 218 \\
\hline & 1907-1908 & 219 \\
\hline & 1908 & 220 \\
\hline & $1911-1912$ & 221 \\
\hline & $1911-1912$ & 222 \\
\hline \multirow[t]{3}{*}{ Reichstag des Norddeutschen Bundes } & $1866-1867$ & 216 \\
\hline & 1867-1869 & 217 \\
\hline & $1870-1903$ & 218 \\
\hline Rendantur der städtischen Volksschule & $1874-1881$ & 3.688 \\
\hline \multirow[t]{2}{*}{ Rettungsanstalt Großefehn } & $1867-1887$ & 1.706 \\
\hline & $1891-1907$ & 3.653 \\
\hline Rhein-Ems-Zeitung & $1902-1905$ & 1.455 \\
\hline Rheinisch Westfälische Elektrizitätsgesellschaft & $1912-1914$ & 1.994 \\
\hline Rheinisch Westfälische Elektrizitätswerke & $1905-1911$ & 1.074 \\
\hline \multirow[t]{5}{*}{ Rheinisch-Westfälische Discontogesellschaft } & $1905-1907$ & 1.461 \\
\hline & $1908-1910$ & 1.466 \\
\hline & $1912-1913$ & 1.478 \\
\hline & $1910-1912$ & 1.480 \\
\hline & $1910-1911$ & 1.481 \\
\hline \multirow[t]{4}{*}{ Rheinisch-Westfälisches Kohlensyndikat } & $1895-1914$ & 462 \\
\hline & $1903-1908$ & 1.443 \\
\hline & $1911-1918$ & 1.901 \\
\hline & $1893-1897$ & 2.026 \\
\hline \multirow[t]{2}{*}{ Roer-Linie, Frachtdampfergesellschaft } & 1906-1909 & 2.090 \\
\hline & 1905-1909 & 2.361 \\
\hline
\end{tabular}


IV

Index

\begin{tabular}{|c|c|c|}
\hline \multicolumn{3}{|c|}{ INST } \\
\hline Indexbegriff & Laufzeit & Lfd.Nr. \\
\hline Roheisensyndicat & $1910-1911$ & 2.362 \\
\hline \multirow[t]{3}{*}{ Rotes Kreuz } & $1905-1914$ & 589 \\
\hline & 1901-1912 & 590 \\
\hline & 1914-1916 & 3.151 \\
\hline \multirow[t]{5}{*}{ Rotes Kreuz, Zweigverein Emden } & 1898 & 611 \\
\hline & $1901-1903$ & 612 \\
\hline & 1908 & 613 \\
\hline & $1909-1910$ & 614 \\
\hline & 1870-1902 & 645 \\
\hline Rotes Kreuzes der Provinz Hannover & $1901-1913$ & 3.173 \\
\hline Ruderverein Emden & $1901-1912$ & 642 \\
\hline \multirow[t]{2}{*}{ Ruderverein Ostfriesland } & $1901-1912$ & 642 \\
\hline & $1909-1912$ & 689 \\
\hline \multirow[t]{3}{*}{ Ruhegehaltskassen für Lehrerinnen und Lehrer } & 1893-1895 & 3.514 \\
\hline & $1895-1900$ & 3.515 \\
\hline & $1903-1917$ & 3.516 \\
\hline \multirow[t]{33}{*}{ Rüstkammer, Stadt Emden } & $1878-1879$ & 2.125 \\
\hline & $1876-1878$ & 2.126 \\
\hline & 1884-1917 & 2.396 \\
\hline & $1900-1912$ & 2.606 \\
\hline & $1900-1902$ & 2.609 \\
\hline & 1882-1906 & 2.610 \\
\hline & $1907-1912$ & 2.611 \\
\hline & 1902-1904 & 2.612 \\
\hline & $1905-1907$ & 2.613 \\
\hline & 1903-1905 & 2.614 \\
\hline & $1880-1903$ & 2.615 \\
\hline & $1902-1903$ & 2.616 \\
\hline & $1906-1911$ & 2.617 \\
\hline & 1901-1904 & 2.618 \\
\hline & $1901-1906$ & 2.619 \\
\hline & $1866-1907$ & 2.620 \\
\hline & 1902-1908 & 2.621 \\
\hline & $1874-1901$ & 2.622 \\
\hline & 1908-1916 & 2.623 \\
\hline & $1908-1916$ & 2.624 \\
\hline & $1868-1875$ & 2.629 \\
\hline & $1901-1914$ & 2.635 \\
\hline & 1901 & 2.636 \\
\hline & 1903-1904 & 2.637 \\
\hline & 1904-1907 & 2.638 \\
\hline & $1908-1913$ & 2.642 \\
\hline & 1908-1914 & 2.643 \\
\hline & $1902-1914$ & 2.644 \\
\hline & $1902-1907$ & 2.645 \\
\hline & 1903-1917 & 2.646 \\
\hline & 1904-1912 & 2.647 \\
\hline & 1882-1902 & 2.648 \\
\hline & $1900-1907$ & 2.649 \\
\hline \multirow[t]{2}{*}{ Rüstkammer-Kommission, Stadt Emden } & $1902-1903$ & 429 \\
\hline & 1903-1907 & 430 \\
\hline Rutgerswerke & 1908 & 2.306 \\
\hline Rüttgerswerke & 1905 & 2.188 \\
\hline Ruven-Veritas, Schiffsversicherung & 1881 & 1.407 \\
\hline Sächsische Vieh-Versicherungs-Bank & $1873-1905$ & 805 \\
\hline Schankkonzessionissteuerkommission & 1907-1914 & 2.986 \\
\hline Schankwirtschaft "Delfthalle" & 1901-1902 & 542 \\
\hline
\end{tabular}


Index

\begin{tabular}{|c|c|c|}
\hline \multicolumn{3}{|c|}{ INST } \\
\hline Indexbegriff & Laufzeit & Lfd.Nr. \\
\hline Schankwirtschaft "Delfthalle" & $1903-1906$ & 552 \\
\hline Schiffahrts-Congress, Paris & $1892-1898$ & 2.054 \\
\hline Schiffahrtsgesellschaft "Westdeutscher Lloyd" & 1902 & 2.084 \\
\hline \multirow[t]{3}{*}{ Schiffer-Gilden-Witwen-Kasse } & $1870-1881$ & 1.754 \\
\hline & $1901-1911$ & 1.755 \\
\hline & $1903-1918$ & 1.756 \\
\hline Schiffervereinigung der verbündeten Fehne & $1910-1912$ & 1.160 \\
\hline Schiffer-Witwen- und Waisenkasse "Eendragt" & $1904-1906$ & 1.752 \\
\hline Schifffahrts- und Handelsbörse & $1905-1906$ & 675 \\
\hline Schiffsbautechnische Gesellschaft & $1903-1911$ & 666 \\
\hline Schiffsrequisitions-Kommission & $1896-1907$ & 3.170 \\
\hline Schiffsversicherungsgesellschaft "Concordia" & $1867-1887$ & 2.117 \\
\hline Schiffswerft zum Preußischen Adler (C. Cassens) & $1892-1910$ & 2.389 \\
\hline Schillertheater, Bremen & $1908-1912$ & 556 \\
\hline Schinkel-Preis & $1884-1886$ & 2.024 \\
\hline \multirow[t]{2}{*}{ Schlachthof } & $1880-1883$ & 795 \\
\hline & 1895 & 2.214 \\
\hline Schlosser- und Schmiedeinnung, Emden & $1885-1891$ & 1.937 \\
\hline Schöffengericht, Emden & 1907 & 250 \\
\hline Schönberg und Neumark, Getreidehandelsfirma & 1905 & 2.440 \\
\hline Schuhmacher-Innung für Stadt und Amt Emden & $1879-1892$ & 1.933 \\
\hline Schule für Verwaltungsbeamte, Cottbus & $1898-1913$ & 635 \\
\hline Schülerruderverein "Wiking" & $1901-1912$ & 642 \\
\hline \multirow{2}{*}{ Schulkasse der deutsch-reformieten Gemeinde } & $1867-1890$ & 3.626 \\
\hline & $1891-1907$ & 3.627 \\
\hline Schulkasse der reformierten Gemeinde & 1897-1898 & 3.621 \\
\hline Schulkommission der ev. Bezirksschule I & $1908-1914$ & 3.546 \\
\hline Schulkommission der Höheren Töchterschule & 1872 & 3.764 \\
\hline Schulkommission der Kaiserin-Auguste-Viktoria-Schule & $1911-1913$ & 3.831 \\
\hline \multirow[t]{3}{*}{ Schulkommission der städtischen Volksschule } & $1873-1891$ & 3.674 \\
\hline & $1896-1906$ & 3.686 \\
\hline & $1891-1901$ & 3.701 \\
\hline Schulkommission des kgl. Gymnasiums zu Emden & $1869-1884$ & 3.713 \\
\hline Schulkommission für die katholische Volksschule & $1908-1911$ & 3.707 \\
\hline Schulkommssion der Kaiserin-Auguste-Viktoria-Schule & 1893-1918 & 3.837 \\
\hline Schulverband der französisch-reformierten Gemeinde & $1867-1871$ & 3.646 \\
\hline Schulverband Wolthusen & 1908-1909 & 227 \\
\hline \multirow[t]{7}{*}{ Schulvorstand der deutsch-reformierten Gemeinde } & $1898-1900$ & 3.521 \\
\hline & $1869-1909$ & 3.622 \\
\hline & $1868-1903$ & 3.625 \\
\hline & $1900-1902$ & 3.641 \\
\hline & $1902-1904$ & 3.642 \\
\hline & 1903 & 3.643 \\
\hline & 1904-1905 & 3.644 \\
\hline \multirow[t]{3}{*}{ Schulvorstand der lutherischen Gemeinde } & $1880-1881$ & 3.614 \\
\hline & $1868-1898$ & 3.656 \\
\hline & $1900-1909$ & 3.666 \\
\hline \multirow[t]{5}{*}{ Schützen-Corps, Emden } & 1866 & 509 \\
\hline & $1886-1914$ & 574 \\
\hline & $1870-1908$ & 575 \\
\hline & $1910-1911$ & 700 \\
\hline & $1914-1915$ & 3.156 \\
\hline Schwurgericht, Aurich & $1883-1887$ & 20 \\
\hline See- und Kanalschiffahrt Wilhelm Hamsoth AG & $1911-1918$ & 1.901 \\
\hline Seemanns-Erholungsheim, Emden & $1909-1913$ & 697 \\
\hline \multirow[t]{2}{*}{ Seemannskasse } & $1870-1881$ & 1.630 \\
\hline & $1875-1892$ & 1.749 \\
\hline Seemannskollegium & $1870-1914$ & 1.430 \\
\hline
\end{tabular}


Index

\begin{tabular}{l}
\hline \\
\hline Indexbegriff \\
\hline Seemannskollegium \\
Seemannsmission, Emden \\
Seemaschinistenverein für Emden und Umge \\
Seeofizier-Luftclub Wilhelmshaven \\
Seequarantänestation, Emden \\
Seewarte, Emden \\
Senden van, S., Oberlehrerin \\
Servis-Kasse \\
Siemens \& Halske \\
Singverein "Frohsinn" \\
Singverein "Union" \\
Sozialdemokratischer Arbeiterverein, Emden \\
Sozialdemokratischer Wahlverein, Emden \\
Spar- und Leihbank, Stadt Emden
\end{tabular}

Spar- und Leihkasse, Stadt Emden

Sparkasse

Sparkasse des Landkreises Emden

SPD

Speditionsfirma Leichtentritt \& Bollenstein (Möbius) Spezialkomitee für den Bau eines Rhein-Ems-Kanals Sprachverein

St. Michael-Kirche, Emden

Staatliche Wasserbau-Verwaltung

Staatlicher Kulturfonds

Staatsanwaltschaft beim Amtsgericht in Hamburg

Staatsanwaltschaft, Aurich

Staatsbauverwaltung

Staats-Classen-Lotterie

Staatskommissar für Volksernährung

Stadtausschuss des Stadtkreises Emden

INST

\section{Laufzeit}

1877-1915

1878-1880

$1912-1914$

1903-1908

1909-1913

1899-1900

1905-1916

1872-1915

1875-1886

1888-1889

1884-1885

1897-1898

1866-1870

1900-1901

1877

1883-1893

1891-1912

1883-1893

$1871-1880$

1881-1890

1891-1900

1901-1902

1885-1891

1868-1902

1866-1881

1875-1888

1892-1894

1860-1871

1904-1913

1898-1916

1874-1906

1871-1909

1881-1912

1901-1902

1907-1909

1897-1914

1883-1906

$1882-1883$

1905

1902-1914

1887-1912

1884-1895

1905-1910

1883-1887

1895-1897

1894-1905

1886-1904

1914-1918

1898

1898

1898

1898

1899

1899

1899-1900

1900-1901

1900

\section{Lfd.Nr.}

1.567

1.631

1.089

657

2.097

783

1.584

3.855

3.109

3.110

3.119

3.120

3.125

1.957

652

617

632

617

1.896

1.897

1.898

1.899

908

2.989

2.991

2.994

2.998

1.913

1.914

1.916

1.917

1.918

1.919

1.920

1.469

838

Vorwort

2.043

2.021

686

3.489

1.437

2.426 
IV

Index

\begin{tabular}{|c|c|c|}
\hline \multicolumn{3}{|c|}{ INST } \\
\hline Indexbegriff & Laufzeit & Lfd.Nr. \\
\hline Stadtausschuss des Stadtkreises Emden & 1900 & 539 \\
\hline & 1901 & 540 \\
\hline & 1901 & 541 \\
\hline & $1901-1902$ & 542 \\
\hline & 1901-1902 & 543 \\
\hline & $1901-1902$ & 544 \\
\hline & 1902-1904 & 545 \\
\hline & 1902 & 546 \\
\hline & 1902 & 547 \\
\hline & 1902 & 548 \\
\hline & 1902 & 549 \\
\hline & 1902 & 550 \\
\hline & 1902 & 551 \\
\hline & 1903-1906 & 552 \\
\hline & 1902 & 553 \\
\hline & 1904-1915 & 667 \\
\hline & $1886-1914$ & 808 \\
\hline & $1892-1893$ & 1.942 \\
\hline & 1906 & 2.161 \\
\hline & 1905 & 2.188 \\
\hline & 1887 & 2.189 \\
\hline & 1888 & 2.190 \\
\hline & 1889 & 2.191 \\
\hline & 1889 & 2.192 \\
\hline & 1890 & 2.193 \\
\hline & 1890 & 2.194 \\
\hline & 1891 & 2.195 \\
\hline & 1892 & 2.196 \\
\hline & 1892 & 2.197 \\
\hline & 1892 & 2.198 \\
\hline & $1892-1893$ & 2.199 \\
\hline & $1892-1893$ & 2.200 \\
\hline & 1893 & 2.201 \\
\hline & 1893 & 2.202 \\
\hline & $1892-1893$ & 2.203 \\
\hline & 1893 & 2.204 \\
\hline & 1893 & 2.205 \\
\hline & 1893 & 2.206 \\
\hline & 1893 & 2.207 \\
\hline & 1893 & 2.208 \\
\hline & 1894 & 2.209 \\
\hline & 1894 & 2.210 \\
\hline & 1895 & 2.211 \\
\hline & 1895 & 2.212 \\
\hline & 1895 & 2.213 \\
\hline & 1895 & 2.214 \\
\hline & 1895 & 2.215 \\
\hline & 1896 & 2.216 \\
\hline & 1896 & 2.217 \\
\hline & 1895 & 2.218 \\
\hline & 1897 & 2.219 \\
\hline & 1897 & 2.220 \\
\hline & 1897 & 2.221 \\
\hline & 1897 & 2.222 \\
\hline & 1897 & 2.223 \\
\hline & 1897 & 2.224 \\
\hline & 1898 & 2.225 \\
\hline & 1898 & 2.226 \\
\hline
\end{tabular}


IV

Index

\begin{tabular}{|c|c|c|}
\hline \multicolumn{3}{|c|}{ INST } \\
\hline Indexbegriff & Laufzeit & Lfd.Nr. \\
\hline \multirow[t]{58}{*}{ Stadtausschuss des Stadtkreises Emden } & 1898 & 2.227 \\
\hline & 1892 & 2.228 \\
\hline & 1898 & 2.229 \\
\hline & 1898 & 2.230 \\
\hline & 1899 & 2.231 \\
\hline & 1899 & 2.232 \\
\hline & 1899 & 2.233 \\
\hline & 1899 & 2.234 \\
\hline & 1899 & 2.235 \\
\hline & 1899 & 2.236 \\
\hline & 1899 & 2.237 \\
\hline & 1900 & 2.238 \\
\hline & 1900 & 2.239 \\
\hline & 1900 & 2.240 \\
\hline & 1900 & 2.241 \\
\hline & 1900 & 2.242 \\
\hline & 1900 & 2.243 \\
\hline & 1900 & 2.244 \\
\hline & 1900 & 2.245 \\
\hline & 1900 & 2.246 \\
\hline & 1900 & 2.247 \\
\hline & 1900 & 2.248 \\
\hline & 1900 & 2.249 \\
\hline & 1900 & 2.250 \\
\hline & 1900 & 2.251 \\
\hline & 1900 & 2.252 \\
\hline & 1901 & 2.253 \\
\hline & 1901 & 2.254 \\
\hline & 1901 & 2.255 \\
\hline & 1901 & 2.256 \\
\hline & 1901 & 2.257 \\
\hline & 1901 & 2.258 \\
\hline & 1901 & 2.259 \\
\hline & 1911 & 2.260 \\
\hline & 1901 & 2.261 \\
\hline & 1902 & 2.262 \\
\hline & 1902 & 2.263 \\
\hline & 1902 & 2.264 \\
\hline & 1902 & 2.265 \\
\hline & 1902 & 2.266 \\
\hline & 1902 & 2.267 \\
\hline & 1902 & 2.268 \\
\hline & 1902 & 2.269 \\
\hline & 1902 & 2.270 \\
\hline & $1902-1903$ & 2.271 \\
\hline & 1903 & 2.272 \\
\hline & 1903 & 2.273 \\
\hline & 1903 & 2.274 \\
\hline & 1903 & 2.275 \\
\hline & 1903 & 2.276 \\
\hline & 1903 & 2.277 \\
\hline & 1903 & 2.278 \\
\hline & 1903 & 2.279 \\
\hline & 1903 & 2.280 \\
\hline & 1903 & 2.281 \\
\hline & 1904 & 2.282 \\
\hline & 1904 & 2.283 \\
\hline & 1904 & 2.284 \\
\hline
\end{tabular}


IV

Index

\begin{tabular}{|c|c|c|}
\hline \multicolumn{3}{|c|}{ INST } \\
\hline Indexbegriff & Laufzeit & Lfd.Nr. \\
\hline \multirow[t]{43}{*}{ Stadtausschuss des Stadtkreises Emden } & 1904 & 2.285 \\
\hline & 1904 & 2.286 \\
\hline & 1904 & 2.287 \\
\hline & 1904 & 2.288 \\
\hline & 1905 & 2.289 \\
\hline & 1905 & 2.290 \\
\hline & 1905 & 2.291 \\
\hline & 1905 & 2.292 \\
\hline & 1905 & 2.293 \\
\hline & 1905 & 2.294 \\
\hline & 1908 & 2.295 \\
\hline & 1905 & 2.296 \\
\hline & 1905 & 2.297 \\
\hline & 1905 & 2.298 \\
\hline & 1908 & 2.299 \\
\hline & 1908 & 2.300 \\
\hline & 1908 & 2.301 \\
\hline & 1908 & 2.302 \\
\hline & 1908 & 2.303 \\
\hline & 1908 & 2.304 \\
\hline & 1908 & 2.305 \\
\hline & 1908 & 2.306 \\
\hline & 1908 & 2.307 \\
\hline & 1908 & 2.308 \\
\hline & 1908 & 2.309 \\
\hline & 1908 & 2.310 \\
\hline & 1908 & 2.311 \\
\hline & 1908 & 2.312 \\
\hline & 1908 & 2.313 \\
\hline & 1908 & 2.314 \\
\hline & 1908 & 2.315 \\
\hline & 1908 & 2.316 \\
\hline & 1909 & 2.317 \\
\hline & 1909 & 2.318 \\
\hline & 1910 & 2.319 \\
\hline & 1910 & 2.320 \\
\hline & 1910 & 2.321 \\
\hline & 1910 & 2.322 \\
\hline & 1910 & 2.323 \\
\hline & 1910 & 2.324 \\
\hline & 1910 & 2.325 \\
\hline & 1910 & 2.326 \\
\hline & 1910 & 2.327 \\
\hline Stadtbauamt & $1910-1911$ & 1.203 \\
\hline Stadterweiterungskommission & $1897-1900$ & 232 \\
\hline Stadtgericht, Emden & $1848-1915$ & 1 \\
\hline \multirow[t]{2}{*}{ Städtische Spar- und Leihkasse } & $1866-1899$ & 2.640 \\
\hline & 1900-1904 & 2.641 \\
\hline \multirow[t]{10}{*}{ Städtische Volksschule, Emden } & 1873-1906 & 1.263 \\
\hline & $1882-1904$ & 1.384 \\
\hline & $1874-1910$ & 3.578 \\
\hline & $1891-1917$ & 3.593 \\
\hline & 1873-1891 & 3.674 \\
\hline & $1873-1874$ & 3.675 \\
\hline & $1902-1903$ & 3.676 \\
\hline & 1901-1906 & 3.677 \\
\hline & $1886-1918$ & 3.678 \\
\hline & $1871-1917$ & 3.679 \\
\hline
\end{tabular}


IV

Index

\begin{tabular}{|c|c|c|}
\hline \multicolumn{3}{|c|}{ INST } \\
\hline Indexbegriff & Laufzeit & Lfd.Nr. \\
\hline \multirow[t]{16}{*}{ Städtische Volksschule, Emden } & $1906-1911$ & 3.680 \\
\hline & 1905-1907 & 3.681 \\
\hline & $1879-1880$ & 3.682 \\
\hline & 1886-1905 & 3.683 \\
\hline & 1886-1905 & 3.684 \\
\hline & 1885-1902 & 3.685 \\
\hline & $1902-1904$ & 3.687 \\
\hline & 1880 & 3.689 \\
\hline & $1875-1890$ & 3.690 \\
\hline & 1891 & 3.691 \\
\hline & $1898-1903$ & 3.692 \\
\hline & $1899-1900$ & 3.693 \\
\hline & 1900-1906 & 3.694 \\
\hline & $1877-1878$ & 3.699 \\
\hline & $1876-1878$ & 3.700 \\
\hline & $1891-1901$ & 3.701 \\
\hline \multirow[t]{4}{*}{ Städtische Waage } & 1883-1902 & 1.909 \\
\hline & 1867-1896 & 2.156 \\
\hline & $1877-1910$ & 2.653 \\
\hline & $1909-1918$ & 2.654 \\
\hline \multirow[t]{17}{*}{ Städtisches Krankenhaus, Emden } & $1892-1903$ & 777 \\
\hline & 1899-1909 & 781 \\
\hline & 1894-1900 & 1.685 \\
\hline & $1903-1914$ & 1.686 \\
\hline & $1884-1893$ & 1.687 \\
\hline & 1890-1895 & 1.688 \\
\hline & $1891-1896$ & 1.689 \\
\hline & $1890-1891$ & 1.691 \\
\hline & 1906-1907 & 1.692 \\
\hline & 1904-1906 & 1.696 \\
\hline & 1904-1906 & 1.697 \\
\hline & 1907-1908 & 1.698 \\
\hline & 1907 & 1.699 \\
\hline & $1909-1910$ & 1.700 \\
\hline & 1894 & 1.701 \\
\hline & $1902-1913$ & 1.702 \\
\hline & 1903 & 3.005 \\
\hline Stadtkasse, Stadt Emden & $1867-1880$ & 326 \\
\hline \multirow[t]{9}{*}{ Stadtschuldeputation } & 1908-1915 & 3.545 \\
\hline & $1908-1911$ & 3.547 \\
\hline & $1902-1909$ & 3.550 \\
\hline & 1909-1912 & 3.594 \\
\hline & $1913-1914$ & 3.615 \\
\hline & 1906-1908 & 3.616 \\
\hline & 1908-1914 & 3.617 \\
\hline & $1908-1911$ & 3.619 \\
\hline & 1908-1918 & 3.709 \\
\hline Steindruckerei, Buchhandlung W. Schwalbe, Emden & 1902-1907 & 325 \\
\hline \multirow[t]{10}{*}{ Stellvertretendes Generalkommando des X. Armeekorps } & 1914-1915 & 3.155 \\
\hline & 1914-1916 & 3.203 \\
\hline & $1915-1918$ & 3.210 \\
\hline & $1914-1916$ & 3.240 \\
\hline & $1915-1916$ & 3.249 \\
\hline & 1915 & 3.255 \\
\hline & $1916-1917$ & 3.256 \\
\hline & $1917-1918$ & 3.265 \\
\hline & 1917 & 3.267 \\
\hline & 1917-1918 & 3.268 \\
\hline
\end{tabular}


IV

Index

\begin{tabular}{ll}
\hline INST \\
\hline
\end{tabular}

Indexbegriff
Stellvertretendes Generalkommando des X. Armeekorps

Stellvertretendes Generalkommando des X. Armeekorps

Sterbekasse d. Verbdes dtsch. Eisenbahnhandwerker u. -Arbeiter Stettiner Maschinenbau AG "Vulcan"

Steuerausschuss für Gewerbesteuer, Aurich

Steuerbüro, Stadt Emden

Steuermannsschule, Jever

Stift Isenwald bei Gifhorn, Trinkerheilanstalt

Stiftung "Asyl für altersschwache würdige Israeliten"

Stiftungsfonds d. Frauenvereins für verw. u. kranke dtsch. Krieger

Südfaldern-Deichacht

Swift Packing Company, Gefrierfleischproduzent

Synagogengemeinde Emden

Tagesfachklasse für Bauhandwerker

Tanzgesellschaft "Concordia"

Taubstummenanstalt, Emden

Taxatoren-Kommission

Technikerverein Emden

Technikerverein für Emden und Umgegend

Teermagazin, Emden

Telegrafenamt

Telegraphen-Gehülfen-Verein

Teltowkanal-Bauverwaltung

The Berlitz School of Languages

Thiele \& Freese, Handelsfirma

Tiefbau-Berufsgenossenschaft

Töchterschulkommission

Torpedobootsflottille in Emden

Totenkasse der Schmiede- und Kupferschmiedezunft

Totenkasse der Torfträger

Totenkasse der Torfträgerinnen

Totenlade der Schneidergesellen

Transportarbeiterverband

Trinkerheilstätte für Frauen, Herford

Trockenfuttermittel GmbH

Turnverein "Freie Turnerschaft"
Laufzeit

1917-1918

1917

1917

1916-1918

1900-1912

1899-1903

1897-1914

$1916-1917$

1900-1917

1907-1908

1873-1916

1870-1871

1900-1909

1885-1895

1870-1872

1867-1890

1883-1900

1911-1913

1874

1883-1905

1898-1900

1883-1893

1881-1886

1876-1884

1903-1915

1883-1893

1898-1902

1874-1879

1907-1908

1912-1915

1905-1906

1907

1905

1886-1916

1895-1910

1899-1912

1911-1915

1875-1892

1891-1910

1896-1908

1905

1908-1912

1908

1893-1918

1914-1915

1866-1902

1902-1913

1902-1913

1869-1916

1891-1912

1900-1909

1916-1918

1904-1913

1899-1903

1914
1890-1898

\section{Lfd.Nr.}

3.273

3.275

3.276

3.280

639

1.454

1.057

337

338

342

435

1.587

560

496

593

1.536

1.537

479

491

492

2.351

617

850

862

3.176

617

637

2.388

953

1.120

1.423

683

2.659

3.849

747

1.662

1.663

1.664

3.772

3.796

3.810

3.827

3.829

3.832

3.837

3.191

1.643

1.671

1.671

1.647

632

560

3.230

664

1.454

Universitätsbund Göttingen e. V. 
Index

\begin{tabular}{|c|c|c|}
\hline \multicolumn{3}{|l|}{ INST } \\
\hline Indexbegriff & Laufzeit & Lfd.Nr. \\
\hline Unterstützungskasse "Verbrüderung" f. Schifferwitwen u. -Waisen & $1879-1901$ & 1.757 \\
\hline Untersuchungsamt, Stadt Emden & $1909-1911$ & 743 \\
\hline Überall, Illustrierte Wocheschrift für Heer und Marine & $1902-1908$ & 2.621 \\
\hline \multirow{5}{*}{ Überlandzentrale Wiesmoor } & $1907-1908$ & 1.083 \\
\hline & 1908 & 1.084 \\
\hline & $1908-1911$ & 1.085 \\
\hline & $1912-1913$ & 1.093 \\
\hline & $1907-1912$ & 1.103 \\
\hline Vakanzenliste f. Militäranwärter & $1867-1914$ & 3.107 \\
\hline Vaterländische Feuerversicherungsvesicherungs AG & 1893-1907 & 3.838 \\
\hline Vaterländische Versicherungs AG & 1897-1908 & 1.060 \\
\hline \multirow[t]{2}{*}{ Vaterländische Viehversicherungsgesellschaft Dresden } & 1873-1905 & 805 \\
\hline & 1906-1913 & 807 \\
\hline \multirow[t]{5}{*}{ Vaterländischer Frauenverein Emden } & 1916-1918 & 761 \\
\hline & $1884-1893$ & 1.687 \\
\hline & 1890-1892 & 2.544 \\
\hline & 1914-1918 & 3.193 \\
\hline & 1916 & 3.213 \\
\hline Vaterländischer Frauenverein, Aurich & 1870 & 594 \\
\hline Vaterländischer Frauenverein, Hannover & $1870-1872$ & 593 \\
\hline Vaterländischer Frauenverein, Zweigverein Emden & $1861-1903$ & 577 \\
\hline \multirow[t]{2}{*}{ Vaterländischer Frauenverein, Zweigverein für Emden u. Umgebg. } & $1880-1897$ & 615 \\
\hline & 1882 & 616 \\
\hline \multirow[t]{2}{*}{ Vaterländischer Frauen-Zweigverein Emden } & 1914-1915 & 3.191 \\
\hline & $1905-1917$ & 3.857 \\
\hline Verband der Gemeindebeamten der Provinz Hannover & 1898-1913 & 635 \\
\hline Verband der Tierschutzvereine des Deutschen Reiches & 1873-1909 & 2.182 \\
\hline Verband der Totengräber Deutschlands & 1824-1920 & 433 \\
\hline \multirow[t]{2}{*}{ Verband deutscher Architekten- und Ingenieur-Vereine } & 1884-1896 & 900 \\
\hline & 1881 & 1.894 \\
\hline Verband deutscher Eisen- und Stahlindustrieller & 1915-1919 & 3.315 \\
\hline Verband mittlerer Reichspost - und Telegraphenbeamter & 1911-1913 & 3.831 \\
\hline \multirow[t]{2}{*}{ Verband mittlerer Reichspost- und Telegraphenbeamter } & 1915-1918 & 3.192 \\
\hline & 1913-1914 & 3.615 \\
\hline Verbandstag deutscher Hilfsschullehrer & $1900-1907$ & 3.708 \\
\hline Verein "Arbeiterheim", Bielefeld & $1887-1902$ & 1.228 \\
\hline Verein Berliner Künstler & $1866-1907$ & 2.620 \\
\hline Verein "Concordia, Verein zur Forderung des Wohls der Arbeiter" & $1866-1900$ & 1.904 \\
\hline Verein der Gewerbehalle zu Emden & $1866-1903$ & 1.924 \\
\hline Verein der Maschinisten und Heizer "Volldampf" & 1903-1908 & 657 \\
\hline Verein der Zollbeamten zu Emden & 1888-1906 & 672 \\
\hline Verein deutscher Lokomotivführer und Heizer & $1900-1912$ & 639 \\
\hline Verein die Nationalsocialen Emdens & 1896-1909 & 739 \\
\hline \multirow[t]{4}{*}{ Verein "Eignes Heim" e.V., Wohnungsbauverein } & $1890-1891$ & 2.734 \\
\hline & 1890-1899 & 2.737 \\
\hline & 1896-1898 & 2.748 \\
\hline & 1904-1905 & 2.829 \\
\hline Verein Emder Baugewerksmeister & 1904-1914 & 669 \\
\hline Verein Emder Baugewerksmeister, Gruppe Klempnermeister & 1913-1914 & 1.080 \\
\hline Verein für bildende Kunst und vaterländische Altertümer, Emden & 1885-1907 & 2.391 \\
\hline \multirow[t]{3}{*}{ Verein für Diakonissen-Krankenpflege } & 1861-1903 & 577 \\
\hline & 1904-1915 & 578 \\
\hline & 1904-1905 & 2.818 \\
\hline Verein für Feuerbestattung & 1907-1914 & 680 \\
\hline Verein für Gabelsbergische Stenographie & $1879-1880$ & 623 \\
\hline Verein für Geflügelzucht und Tierschutz & $1903-1913$ & 800 \\
\hline
\end{tabular}


Index

\begin{tabular}{|c|c|c|}
\hline \multicolumn{3}{|l|}{ INST } \\
\hline Indexbegriff & Laufzeit & Lfd.Nr. \\
\hline Verein für Geflügelzucht und Tierschutz & $1912-1914$ & 967 \\
\hline \multirow[t]{3}{*}{ Verein für Großschiffahrtsweg v. Rhein z. dtsch. Nordsee } & $1910-1912$ & 2.094 \\
\hline & 1912 & 2.095 \\
\hline & $1913-1914$ & 2.096 \\
\hline Verein für Handfertigkeit und Hausfleiß & $1887-1914$ & 2.345 \\
\hline Verein für Handlungs-Commis & $1911-1914$ & 713 \\
\hline Verein für hansische Geschichte & $1900-1902$ & 649 \\
\hline Verein für historische Waffenkunde & $1900-1912$ & 2.606 \\
\hline Verein für historische Wappenkunde & $1893-1913$ & 633 \\
\hline Verein für innere soziale Kolonialisierung & 1881 & 2.524 \\
\hline Verein für niedersächsische Sprachforschung & $1900-1902$ & 649 \\
\hline Verein für Trinkerrettung & $1900-1909$ & 560 \\
\hline Verein für volkstümliche Musik & 1914 & 624 \\
\hline Verein gegen das Moorbrennen & $1879-1880$ & 621 \\
\hline Verein gegen Hausbettelei & $1879-1880$ & 623 \\
\hline Verein "Locomotive" (Verbindung von Eisenbahner) & 1888-1906 & 672 \\
\hline Verein "Lokomotive" (Vereinigung von Lokomotivführern) & $1900-1912$ & 639 \\
\hline Verein "Mercur" f. gemütl. Versammlg. junger jüdischer Kaufleute & $1888-1906$ & 672 \\
\hline Verein Naturschutzpark e.V. & $1911-1914$ & 600 \\
\hline Verein ostfriesischer Viehhändler & $1867-1914$ & 576 \\
\hline Verein Seemans-Erholungsheim & $1909-1913$ & 697 \\
\hline Verein z. Erziehung verwaister jüdischer Kinder "Esrath Jersomin" & $1903-1917$ & 495 \\
\hline Verein z. Hebg. d. Fischereibetriebe a. d. ostfriesischen Gewässern & $1879-1880$ & 623 \\
\hline Verein z. Hebung d. religiös-sittlichen Notstands & $1888-1906$ & 672 \\
\hline Verein zur Förderung des Fremdenverkehrs in Emden & $1905-1911$ & 673 \\
\hline Verein zur Förderung handwerklicher u.a. Berufe durch Juden & 1867-1909 & 486 \\
\hline Verein zur Pflege der volkstümlichen Musik & $1907-1916$ & 3.721 \\
\hline Verein zur Überprüfung von Dampfmaschinen & 1899-1906 & 1.072 \\
\hline Verein zur Verbreitung guter volkstümlicher Schriften & $1899-1905$ & 644 \\
\hline Vereinigte Bugsier- und Frachtschifffahrtsgesellschaft & $1899-1904$ & 2.060 \\
\hline Vereinigte Dampfschiffrhedereien Norden und Norderney & 1873-1907 & 2.017 \\
\hline Vereinigte Deutsche Telegraphengesellschaft & $1871-1910$ & 2.037 \\
\hline Vereinigte Gemeindeorgane der reformierten Kirche & $1910-1913$ & 3.403 \\
\hline Vereinigte Landschaftliche Brandkasse in Hannover & $1868-1915$ & 1.286 \\
\hline Vereinigte Mühlen-Societät zu Emden & $1866-1905$ & 2.378 \\
\hline Vereinigte Schlachter Emdens & 1883-1902 & 1.909 \\
\hline Vereinigte Torfschiffer aus den ostfriesischen Fehnen & $1879-1883$ & 1.433 \\
\hline Vereinigung selbständiger, in Preußen vereidigter Landmesser & $1870-1914$ & 1.163 \\
\hline Vereinigung zur Erhaltung deutscher Burgen & 1912 & 601 \\
\hline Verpachtungs-Commission & 1874-1904 & 2.493 \\
\hline Verpachtungskommission, Emden & $1866-1893$ & 2.456 \\
\hline Verschönerungs-Kommission, Stadt Emden & $1912-1914$ & 967 \\
\hline Versicherungsamt, Stadt Emden & 1918 & 1.679 \\
\hline Versicherungsgesellschaft Amisia & $1888-1892$ & 1.535 \\
\hline Versorgungsstelle der Ems (Marine) & 1914 & 3.149 \\
\hline Viehhandelsfirma A. Stein & $1899-1911$ & 2.847 \\
\hline Viehversicherungsanstalt Emden & $1877-1903$ & 804 \\
\hline Vieh-Versicherungsbank der Provinz Hannover & $1873-1905$ & 805 \\
\hline Viehversicherungsgesellschaft Emden & $1903-1911$ & 806 \\
\hline Vierkantkaserne & 1869 & 1.307 \\
\hline \multirow[t]{3}{*}{ Volksschule Borssum } & 1915 & 244 \\
\hline & 1915 & 3.670 \\
\hline & 1908-1909 & 3.671 \\
\hline \multirow[t]{2}{*}{ Volksschule der französisch-reformierten Gemeinde } & $1867-1871$ & 3.646 \\
\hline & $1871-1872$ & 3.647 \\
\hline \multirow[t]{2}{*}{ Volksschulkommission } & $1882-1904$ & 1.384 \\
\hline & $1900-1907$ & 3.708 \\
\hline Vorstand der Großen Ee & $1867-1896$ & 1.492 \\
\hline
\end{tabular}


IV

Index

\begin{tabular}{|c|c|c|}
\hline \multicolumn{3}{|l|}{ INST } \\
\hline Indexbegriff & Laufzeit & Lfd.Nr. \\
\hline Vorstand der Kinderbewahranstalten & $1903-1906$ & 2.437 \\
\hline Vorstand der lutherischen Klassenschule & 1889 & 3.662 \\
\hline W. Hemsoth Kanal- und Seeschiffahrts AG & $1906-1909$ & 2.090 \\
\hline \multirow{2}{*}{ Waage am Neuen Markt } & $1871-1897$ & 3.415 \\
\hline & $1871-1897$ & 3.418 \\
\hline Waisenrat, Stadt Emden & $1871-1913$ & 1.864 \\
\hline \multirow{3}{*}{ Waisenrats-Kollegium } & $1875-1913$ & 1.703 \\
\hline & $1914-1923$ & 1.704 \\
\hline & $1878-1889$ & 1.705 \\
\hline Wandermuseum für Tuberkulose & $1908-1913$ & 780 \\
\hline Wanderversammlung Hannoverscher Bienenzüchter & 1904 & 801 \\
\hline Warmbadeanstalt in Oldenburg & $1881-1911$ & 737 \\
\hline Wasserbauinspektion Emden & $1899-1913$ & 2.027 \\
\hline Wasserschaftsgenossenschaft & 1901 & 2.064 \\
\hline \multirow[t]{3}{*}{ Wasserwerk für das nördliche westfälische Kohlenrevier } & $1872-1916$ & 330 \\
\hline & $1894-1905$ & 2.603 \\
\hline & $1910-1911$ & 3.131 \\
\hline Wasserwerk in Emden & $1899-1909$ & 1.234 \\
\hline Wegeverband der Stadt Emden & $1875-1889$ & 2.035 \\
\hline Wegweiser "Aus See nach Emden, Leer, Weener u. Papenburg" & $1899-1909$ & 1.418 \\
\hline Weltausstellung in Paris & 1898 & 2.128 \\
\hline Weltausstellung in St. Louis & $1902-1904$ & 2.131 \\
\hline Werft für Eisernen Schiffbau, C. Cassens & $1892-1910$ & 2.389 \\
\hline Werftbetrieb "Zum preußischen Adler" & $1875-1914$ & 2.680 \\
\hline \multirow[t]{5}{*}{ Werftkommission } & $1910-1911$ & 1.474 \\
\hline & $1911-1912$ & 1.477 \\
\hline & $1912-1913$ & 1.478 \\
\hline & $1910-1912$ & 1.480 \\
\hline & $1910-1911$ & 1.483 \\
\hline Werkshaus, Himmelsthür & $1867-1899$ & 722 \\
\hline Werkshaus, Moringen & $1867-1899$ & 722 \\
\hline Weser-Dampfschifffahrtsgesellschaft & $1883-1901$ & 2.044 \\
\hline Weserzeitung & $1881-1899$ & 2.053 \\
\hline Westbahn & & Vorwort \\
\hline Westdeutsche Versicherungs-Aktienbank, Essen & $1900-1907$ & 2.649 \\
\hline Westdeutscher Fluß- und Kanalverein & $1883-1889$ & 2.136 \\
\hline Westfälische Bankkomandite & $1903-1904$ & 1.459 \\
\hline \multirow[t]{8}{*}{ Westfälische Transport Aktiengesellschaft (WTAG) } & $1905-1911$ & 1.097 \\
\hline & $1911-1918$ & 1.901 \\
\hline & $1900-1904$ & 1.965 \\
\hline & $1901-1914$ & 1.966 \\
\hline & $1903-1904$ & 1.978 \\
\hline & $1899-1913$ & 2.027 \\
\hline & $1896-1910$ & 2.051 \\
\hline & $1902-1904$ & 2.772 \\
\hline Wiener Weltausstellung & $1873-1874$ & 2.124 \\
\hline \multirow{8}{*}{ Wilhelms-Gymnasium } & $1889-1893$ & 382 \\
\hline & $1873-1906$ & 1.263 \\
\hline & $1872-1892$ & 2.427 \\
\hline & 1905 & 3.529 \\
\hline & 1909 & 3.712 \\
\hline & $1869-1884$ & 3.713 \\
\hline & 1903 & 3.754 \\
\hline & & Vorwort \\
\hline Windthorst - Bund & 1907 & 684 \\
\hline Wirteverein, Emden & $1907-1913$ & 1.734 \\
\hline Wirtschaftlicher Vereinigung deutscher Gaswerke & $1897-1913$ & 1.070 \\
\hline
\end{tabular}


IV

Index

\begin{tabular}{|c|c|c|}
\hline \multicolumn{3}{|l|}{ INST } \\
\hline Indexbegriff & Laufzeit & Lfd.Nr. \\
\hline Wirtschaftsbund Niedersachsen - Kassel & 1902 & 647 \\
\hline Witwen- und Waisenkasse für die reformierten Prediger & $1886-1887$ & 3.352 \\
\hline Wohnungskommission & 1894-1905 & 1.240 \\
\hline WTAG, Westfälische Transport AG & $1897-1907$ & 1.017 \\
\hline Württembergische Transportversicherung & $1902-1903$ & 1.464 \\
\hline Wykverein der IV. Wyk & $1885-1896$ & 924 \\
\hline \multirow[t]{2}{*}{ Wykverein der VI. Wyk } & 1902 & 648 \\
\hline & $1909-1915$ & 878 \\
\hline Wykverein für die III. Wyk & 1904 & 670 \\
\hline \multirow[t]{3}{*}{ X. Armeekorps } & 1870 & 595 \\
\hline & $1873-1910$ & 598 \\
\hline & $1902-1914$ & 3.174 \\
\hline Zeitschrift "Daheim" & $1902-1908$ & 2.631 \\
\hline Zeitschrift "Die Denkmalspflege" & $1899-1901$ & 2.397 \\
\hline Zeitschrift für Binnenschifffahrt & 1907 & 2.004 \\
\hline Zeitschrift für historische Waffenkunde & $1900-1912$ & 2.606 \\
\hline Zeitschrift "Hanse" & $1887-1912$ & 1.437 \\
\hline Zeitung, "Algemeen Handelsblad" & 1903 & 2.077 \\
\hline Zentralauskunftstelle für Auswanderer, Berlin & $1905-1912$ & 450 \\
\hline Zentrale für Gasverwertung e.V. & $1897-1913$ & 1.070 \\
\hline Zentrale für Kleiderverarbeitung für Ostfriesland & 1918 & 3.292 \\
\hline Zentralstelle f. d. Rettungswesen an Binnen- u. Küstengewässer & $1903-1913$ & 1.667 \\
\hline Zentralstelle für Heimatschutz in Niedersachsen & $1907-1912$ & 695 \\
\hline Zentralstelle für Volkswohlfahrt & $1880-1913$ & 628 \\
\hline Zentralstelle zur Beschaffung der Heeresverpflegung & 1917-1918 & 3.244 \\
\hline Zentralver. christl. Fabrik-, Verkehrs- u. Hilfsarbeiter Deutschlands & $1913-1914$ & 715 \\
\hline Zentralverband der Gemeindebeamten Preußens & $1898-1913$ & 635 \\
\hline Zentralverband der Maurer, Zweigstelle Emden & $1899-1913$ & 1.666 \\
\hline Zentralverband der Zimmerer Deutschlands, Zahlstelle Emden & $1901-1907$ & 655 \\
\hline Zentralverband Deutscher Arbeiter- und Schrebergärtner & 1907-1909 & 2.590 \\
\hline Zentralverband deutscher Arbeiterkolonien & $1882-1913$ & 1.636 \\
\hline \multirow[t]{2}{*}{ Zentralverein für deutsche Binnenschiffahrt } & 1901-1908 & 718 \\
\hline & $1909-1913$ & 2.087 \\
\hline \multirow[t]{4}{*}{ Zentralverein zur Hebung der Fluss- und Kanalschifffahrt } & 1904 & 2.001 \\
\hline & 1904 & 2.002 \\
\hline & 1905 & 2.003 \\
\hline & 1907 & 2.004 \\
\hline Zeppelin-Hallenbau GmbH, Berlin & $1913-1914$ & 2.104 \\
\hline Ziegen-Versicherungsverein & $1913-1917$ & 1.678 \\
\hline \multirow[t]{2}{*}{ Zimmerleute-Totenlade } & $1902-1918$ & 1.638 \\
\hline & $1904-1911$ & 1.675 \\
\hline Zionistischer Verein "Lemaan Zion" & 1904 & 485 \\
\hline Zollverein & 1867-1906 & 2.032 \\
\hline Zweigver. d. Unterstzgsvereins d. Bürsten- u. Pinselmacher Dtsld. & $1891-1912$ & 632 \\
\hline Zweigverein der Deutschen Maurer und Steinhauer & $1867-1914$ & 576 \\
\hline Zweigverein der Gustav-Adolf-Stiftung & $1900-1910$ & 641 \\
\hline \multirow[t]{2}{*}{ Zweigverein vom Roten Kreuz, Emden } & $1905-1914$ & 589 \\
\hline & $1901-1912$ & 590 \\
\hline Zweite Assecuranz-Compagnie & $1868-1887$ & 1.900 \\
\hline Zweiter Entwässerungsverband & 1895 & 960 \\
\hline Zweiter lutherischer Predigerfonds & $1868-1871$ & 3.434 \\
\hline
\end{tabular}


Index

PERS

\section{Indexbegriff}

Aalfs, H. H., Landwirt

Aalfs, H.B., Restaurantbesitzer

Aalfs, Hinnerikus, Restaurateur

Abegg, Kämmerer

Abegg, Siebo, Polizeisergeant

Ackmann, Karl, Telegraphenleitungs-Aufseher

Adalbert, Prinz von Preußen

Adami, Ernst, Musikdirektor

Ahlrichs, O., Kaufmann

Ahrends, Rohrmeister

Ahrens van, F., Bauantragssteller

Akkermann, Meinhard, Wyksprecher

Albers, Johann, Hotelier

Alberts, Onno, Stadtdiener

Albrecht, Postdirektor

Albrecht, Prinz von Preußen

Ameren van, J. G., Hausbesitzer

Ameren van, J. G., Sägewerksbesitzer

Ameren van, J., Holzhändler

Ameren van, Johann, Holzhändler

Ammersken, Wwe., Pächterin

Apel, Bernhardine, Turn- und Handarbeitslehrerin

Apetz, H. A. C., Armenkollegiumwsvorsitzender

Apt, B., Lehrer der jüdischen Schule

Auguste Viktoria, Deutsche Kaiserin

Auguste Viktoria, Kronprinzessin von Preußen

Baalmann, Peter, Blaufärber

Babiel, H., Vorsitzender d. Bauarbeiterschutzkommission

Bach, Hausbesitzer

Bachhausen, Pastor in Hannover

Bachmann, Elisabeth, Lehrerin

Bachmann, Johannes, Weber

Backband, Jacobus, Wohnungsmakler

Backhaus, E., Kanzlist-Bewerber

Baden Foget von, Helmer, Mietshausbesitzer

PERS

\section{Lfd.Nr.}

1891-1892

1904

1.346

1901-1907

1870

223

1912-1917

2.784

1876-1909

1866-1868

1881-1890

1879-1900

1908

1887-1907

1894-1913

1909-1910

1878-1879

1899-1901

1903-1904

1876-1882

1874-1911

1869-1901

1872

1892-1893

1876-1901

1886-1891

1897-1904

1912-1914

1872-1918

1895

1898

1903-1906

1904-1905

1904

1905

1874-1911

1869-1890

1906-1909

1907-1911

1913-1914

1884

1899-1909

1873-1914

1872-1902

1897-1914

1899-1904

1904-1906

1897-1906

1907-1911

1879-1909

1896-1903

1892-1912

1911-1913

1897-1914

1894-1913

1907-1912

1901

1903-1904

1903-1907

1905-1908
361

2.696

189

554

2.184

2.312

1.393

1.135

731

974

2.397

2.805

871

190

1.159

1.301

1.504

2.504

2.724

2.462

3.552

1.870

488

188

196

3.825

3.826

3.827

190

1.214

1.223

875

1.732

3.600

3.317

1.227

340

838

852

855

874

875

877

880

881 
Index

\begin{tabular}{|c|c|c|}
\hline \multicolumn{3}{|l|}{ PERS } \\
\hline Indexbegriff & Laufzeit & Lfd.Nr. \\
\hline \multirow[t]{14}{*}{ Baden Foget von, Helmer, Mietshausbesitzer } & 1905 & 1.188 \\
\hline & 1906 & 1.189 \\
\hline & $1906-1907$ & 1.190 \\
\hline & 1905-1906 & 1.191 \\
\hline & 1904-1905 & 1.193 \\
\hline & 1906 & 1.194 \\
\hline & $1910-1911$ & 1.201 \\
\hline & $1910-1911$ & 1.204 \\
\hline & $1872-1878$ & 1.212 \\
\hline & $1873-1914$ & 1.227 \\
\hline & 1912 & 1.682 \\
\hline & 1874-1904 & 2.493 \\
\hline & 1899-1904 & 2.771 \\
\hline & 1914-1918 & 3.197 \\
\hline \multirow[t]{2}{*}{ Baden Foget von, Helmer, Mietshausbesitzer u. Branddirektor } & 1879 & 1.319 \\
\hline & 1876 & 1.322 \\
\hline Baden, Harry, Lehrer & $1911-1918$ & 3.561 \\
\hline Baege, Regierungsbaumeister & $1911-1915$ & 1.656 \\
\hline Bakker, A., Böttcher & 1903 & 1.006 \\
\hline Bakker, A., Raseur & $1875-1879$ & 982 \\
\hline Bakker, Aldert, Barbier und Fleischbeschauer & $1865-1895$ & 746 \\
\hline Bakker, Dr., Leitender Krankenhausarzt & 1894-1900 & 1.685 \\
\hline Bakker, Fokke, Landwirt & 1874-1901 & 2.038 \\
\hline Bakker, Hinderk, Aufseher der Stadtreinigung & 1897-1913 & 882 \\
\hline Bakker, J. M., Fuhrmann und Landgebräucher & 1890-1897 & 2.735 \\
\hline Bakker, Jacobus, Kräutner & 1878 & 1.316 \\
\hline Balker, U. I., Eichmeister & 1868-1909 & 2.144 \\
\hline Bandt, Kurt, Ingenieur und Straßenbahnbetriebsleiter & $1902-1917$ & 1.992 \\
\hline Barfs, Hinrikus, Restaurateur & 1902 & 553 \\
\hline Barghoorn, B., Betreiber einer Chemischen Reinigung & 1904-1905 & 1.273 \\
\hline Barghoorn, Kaufmann & 1876 & 1.438 \\
\hline Barghoorn, N. S., Färber & 1905-1906 & 2.586 \\
\hline Barghoorn, Nicolaus, Betreiber einer chemischen Reinigung & 1905-1908 & 2.817 \\
\hline Barghoorn, Sikke, Schiffer & $1869-1871$ & 2.119 \\
\hline Barghoorn, Sophie W., Hausbesitzerin & 1887 & 1.341 \\
\hline Barghoorn, Willem, Schiffer & $1869-1871$ & 2.119 \\
\hline Baron, Franz, Bahnhofswirt & 1902 & 547 \\
\hline Barre, Friedrich Lehrer & 1913-1914 & 3.601 \\
\hline Bart von, Theodor, Reichstagsabgeordneter & $1870-1903$ & 218 \\
\hline \multirow[t]{3}{*}{ Bartels, Hermann, Maschinenbauer } & 1901-1903 & 1.002 \\
\hline & 1893 & 2.205 \\
\hline & 1904 & 2.812 \\
\hline Barth, Auktionator & $1896-1911$ & 1.549 \\
\hline Barth, Friedrich, Maschinenbauingenieur & $1883-1900$ & 1.537 \\
\hline \multirow[t]{2}{*}{ Barth, H., Maschinenbauer } & 1897 & 2.223 \\
\hline & 1899 & 2.236 \\
\hline Barth, H.C., Senator & $1885-1894$ & 29 \\
\hline Barth, Heinrich Christoph, Senator & 1897-1908 & 2.741 \\
\hline Bartmann, Anna, Verlaatswärterin des Larrelter Verlaat & $1866-1891$ & 1.488 \\
\hline Baruch, B.A., Fragesteller & 1893-1897 & 2.026 \\
\hline Battermann, Polizeisergeant & $1870-1914$ & 809 \\
\hline Bauermann, H., Kaufmann & 1901-1904 & 2.785 \\
\hline Baumann, Alfred, Porzellanbrenner & 1879-1907 & 1.213 \\
\hline Baumann, Christne, Leheriin & $1915-1918$ & 3.574 \\
\hline Baumann, H., Rentier & 1904-1908 & 1.012 \\
\hline Baumann, Julius, Maschinist & $1912-1915$ & 347 \\
\hline Baumann, Metha, Schankwirtin & $1866-1887$ & 824 \\
\hline Baumann, Reemt J., Lehrer & 1909-1912 & 3.560 \\
\hline
\end{tabular}


Index

\begin{tabular}{|c|c|c|}
\hline \multicolumn{3}{|l|}{ PERS } \\
\hline Indexbegriff & Laufzeit & Lfd.Nr. \\
\hline Baumgarten, J. F., Installateur & $1881-1897$ & 1.040 \\
\hline Baunemann, Heinrich, Techniker & $1902-1913$ & 1.969 \\
\hline Becker, Meinhardus, Grundstücksbesitzer & $1869-1901$ & 1.159 \\
\hline Becker, Rudolph, Spiegelfabrikant & 1879 & 1.328 \\
\hline Becker, W. W., Grundstücksbesitzer & $1869-1901$ & 1.159 \\
\hline Beckmann, Regierungs- und Baurat & $1874-1887$ & 2.478 \\
\hline Beencken, Andreas, Zigarrenmacher & $1886-1912$ & 2.386 \\
\hline Beencken, Warner A., Zigarrenmacher & $1886-1912$ & 2.386 \\
\hline Beer de Simon, Weißgerber & 1873 & 1.299 \\
\hline Beer de, Isaac, Jüdischer Handelsschüler & $1864-1890$ & 2.341 \\
\hline \multirow[t]{3}{*}{ Beer de, Isaac, Viehhändler } & $1899-1904$ & 852 \\
\hline & 1906-1907 & 1.170 \\
\hline & 1914-1918 & 2.889 \\
\hline Beer de, Jacob, Gerber & $1869-1910$ & 1.716 \\
\hline Beer de, Jacob, Schlachter & 1870 & 847 \\
\hline Beer de, Mlchel, Schlachter & 1873 & 1.299 \\
\hline Beer de, S. D., Fellhändler & $1902-1903$ & 2.271 \\
\hline Beer de, Simon D., Wäschereibesitzer & $1869-1910$ & 2.634 \\
\hline Beer de, Simon, Jüdischer Handelsschüler & $1864-1890$ & 2.341 \\
\hline Beer de, Simon, Synagogenvorsteher & $1865-1903$ & 490 \\
\hline Beer de, Simon, Vorsteher der Israelitischen Gemeinde & $1865-1903$ & 490 \\
\hline Beer, Dr., Ernst, Anwalt in Berlin & $1908-1911$ & 2.363 \\
\hline Behrends, Lehrer & $1875-1889$ & 3.652 \\
\hline Behrends, Theodor H. M., Vereinssekretär & $1905-1908$ & 1.659 \\
\hline Behrends, Theodor, Handelsschullehrer & 1904-1914 & 2.344 \\
\hline Behrendt, Julius, Telegraphen-Assistent & $1886-1890$ & 2.721 \\
\hline Behrens, Hilfslehrer & $1870-1871$ & 3.632 \\
\hline Behrens, Johann Karl, Oberlehrer an der Höheren Töchterschule & $1901-1918$ & 3.777 \\
\hline Behrens, Theodor H. M., Gewerbeschullehrer & $1895-1917$ & 2.352 \\
\hline Behrens, Theodor, Lehrer & $1889-1917$ & 3.563 \\
\hline \multirow[t]{2}{*}{ Behrensroth, Martha, Turn- und Handarbeitslehrerin } & 1908 & 3.548 \\
\hline & $1908-1910$ & 3.562 \\
\hline Benchmann, Carl Theodor, Maurer & $1867-1914$ & 576 \\
\hline \multirow[t]{2}{*}{ Bender, Friedrich, Lehrer } & $1902-1903$ & 3.676 \\
\hline & 1886-1905 & 3.684 \\
\hline Bensing, Tjado, Zimmermeister & 1898-1909 & 2.180 \\
\hline \multirow[t]{7}{*}{ Berg, Stadtbaumeister } & $1870-1900$ & 1.161 \\
\hline & 1881 & 1.162 \\
\hline & $1872-1903$ & 1.250 \\
\hline & $1866-1903$ & 1.385 \\
\hline & $1868-1869$ & 1.391 \\
\hline & $1867-1910$ & 1.490 \\
\hline & $1872-1913$ & 2.655 \\
\hline Bergmann, J., Auktionator in Emden & $1899-1911$ & 1.908 \\
\hline Bermpohl, Adolph, Navigationslehrer & $1870-1871$ & 1.582 \\
\hline Bernhardt, Ernst, Lehrer & $1913-1918$ & 3.595 \\
\hline Bertram, Bernhard, Kaufmann & $1869-1893$ & 2.473 \\
\hline Bertram, J. C., Kaufmann und Fabrikant & 1889 & 1.383 \\
\hline Best, Heinrich, Polizeisergeant & $1905-1907$ & 377 \\
\hline Bielitz, Frieda, Zeichenlehrerin & 1913-1918 & 3.778 \\
\hline Bigitschke, Carl, Tischlergeselle & $1893-1914$ & 724 \\
\hline Bigitschke, Karl August, Tischler & $1897-1914$ & 838 \\
\hline Bildt, Wilhelm, Untersuchungsgefangener & $1899-1913$ & 523 \\
\hline Biller, Emil, Lehramtsbewerber & $1889-1891$ & 3.776 \\
\hline Bindern, C., Mieterin & $1857-1907$ & 514 \\
\hline Birnbaum, Zivilingenieur & $1880-1882$ & 1.996 \\
\hline \multirow[t]{2}{*}{ Bismarck, Fürst von, Otto, Deutscher Reichskanzler } & 1885 & 564 \\
\hline & $1895-1915$ & 566 \\
\hline
\end{tabular}




\section{Index}

\begin{tabular}{|c|c|c|}
\hline \multicolumn{3}{|l|}{ PERS } \\
\hline Indexbegriff & Laufzeit & Lfd.Nr. \\
\hline Bismarck, Otto, Fürst v., Reichskanzler und Ehrenbürger Emdens & 1904-1908 & 268 \\
\hline Bitter, Helmut, Kläger & $1907-1913$ & 2.592 \\
\hline \multirow[t]{3}{*}{ Blanke, Kreisschulinspektor } & 1909-1915 & 3.535 \\
\hline & $1905-1911$ & 3.539 \\
\hline & $1882-1914$ & 3.541 \\
\hline Blanke, Kreisschulinspektor und Pastor & $1900-1907$ & 3.708 \\
\hline Blaser, Telegraphensekretär & 1907 & 684 \\
\hline \multirow{2}{*}{ Bleeker, Dirk, Lotse } & 1900-1901 & 2.762 \\
\hline & 1899 & 2.768 \\
\hline \multirow[t]{3}{*}{ Blikslager, Georg, Gasthausinspektor } & $1869-1910$ & 1.716 \\
\hline & 1913-1914 & 1.732 \\
\hline & 1917-1918 & 1.780 \\
\hline Blikslager, R., Magistratsassistent & 1914-1923 & 1.704 \\
\hline Block, Eduard, Händler & 1917-1918 & 3.283 \\
\hline Block, Theda, Legatgeberin & $1885-1914$ & 3.456 \\
\hline Blum, Landrabbiner & 1911-1922 & 482 \\
\hline Bockwinkel, Henrich, Mitglied des kath. Schulvorstands & $1878-1890$ & 3.704 \\
\hline Bode, Altreformierter Pastor & 1869-1905 & 3.498 \\
\hline Bode, Pastor aus Egestorf & 1893-1912 & 1.926 \\
\hline \multirow[t]{2}{*}{ Bode, Rechtsanwalt } & 1899-1904 & 852 \\
\hline & 1884-1901 & 3.480 \\
\hline Bodelschwingh, Friedrich, Pastor, Leiter d. Bethel'schen Anstalten & $1882-1913$ & 1.636 \\
\hline Boekhoff, Thomas, Lehrer & $1909-1912$ & 3.553 \\
\hline Boekwinkel, J., Gärtner & 1874-1877 & 2.512 \\
\hline Boer de, Christoph, Lehrer & 1917-1918 & 3.575 \\
\hline Boer de, F., Seefahrer aus Greetsiel & 1897 & 2.052 \\
\hline Boer de, Hinrch J., Zimmermeister & 1900-1902 & 2.788 \\
\hline Boer de, Landwirt und Mietshausbesitzer & 1901 & 899 \\
\hline Boer de, Polizeisergeant & 1906-1908 & 856 \\
\hline Boer de, W., Erbpächter & $1882-1884$ & 2.712 \\
\hline Boerheide, Peter, Verkaufsbudenbetreiber & 1868-1897 & 1.946 \\
\hline Boerma, Landwirt & $1915-1916$ & 3.307 \\
\hline Boerma, Senator & $1910-1911$ & 955 \\
\hline Boeting, Cornelia Fenna, Lehrerwaise & 1890-1894 & 3.517 \\
\hline Boheim, Wendelin, Ehrenvorsitzender Ver. f. hist. Waffenkunde & $1900-1912$ & 2.606 \\
\hline Böhmer, Regierungsbaurat & 1887-1902 & 1.228 \\
\hline Bohnen, Regierungs- und Baurat & $1899-1900$ & 1.246 \\
\hline Bokelmann, H., Gold- und Effektenmakler & $1871-1913$ & 419 \\
\hline Bokelmann, H., Kommissionär & 1904-1905 & 2.810 \\
\hline Bokelmann, Hindrikus, Makler & $1902-1910$ & 420 \\
\hline Bokkel ten, S., Niederländischer Bauunternehmer & 1896 & 2.217 \\
\hline Bollhuis-Smeding van, Elsbeth, Technische Lehrerin & 1917-1918 & 3.612 \\
\hline \multirow[t]{2}{*}{ Bollhuis-Smeding, Senator } & $1912-1918$ & 1.712 \\
\hline & 1913-1914 & 1.732 \\
\hline Bolwin, Navigationsschullehrer & $1905-1916$ & 1.584 \\
\hline Bomfleur, Hindericus Hermannus, Kräutner & 1885 & 2.715 \\
\hline Boomgaarden, G., Schmiedemeister & 1898 & 2.570 \\
\hline Boomgarden, Alrich, Schmiedemeister & $1879-1900$ & 2.184 \\
\hline Borchling, Regierungsrat & $1896-1914$ & 3.330 \\
\hline Bordeaux, Hausbesitzer & 1893-1894 & 936 \\
\hline Bordeaux, Heinrich, Fuhrmann & $1868-1883$ & 835 \\
\hline \multirow[t]{2}{*}{ Bordeaux, Peter, Fuhrmann } & $1877-1916$ & 1.556 \\
\hline & $1874-1883$ & 2.118 \\
\hline Borgstädt, Heinrich, Bildhauer & $1901-1903$ & 2.558 \\
\hline Bornscheuer, Georg, Stadtsekretär & $1912-1918$ & 263 \\
\hline \multirow[t]{2}{*}{ Böse, Ernst H., Stadtsekretär } & $1902-1911$ & 333 \\
\hline & 1903 & 2.806 \\
\hline Böse, geb. de Vries, Tibina, Kanalabgabeneinehmerin & 1873-1898 & 1.562 \\
\hline
\end{tabular}


Index

\begin{tabular}{|c|c|c|}
\hline \multicolumn{3}{|l|}{ PERS } \\
\hline Indexbegriff & Laufzeit & Lfd.Nr. \\
\hline Böse, Johannes, Kanalabgabeneinnehmer und Packmeister & 1873-1898 & 1.562 \\
\hline Bottmeyer, Berend, Brückenwärter & 1894-1905 & 897 \\
\hline Bouman, Kryno, Polizeisergeant & $1893-1899$ & 346 \\
\hline Boysen, Christian, Polizeisergeant & $1912-1915$ & 347 \\
\hline Braa, Bauassistent & 1913 & 2.133 \\
\hline Braa, Bautechniker & 1904-1907 & 1.654 \\
\hline Braa, Harbert, Bauaufseher und Kartenzeichner & $1902-1907$ & 325 \\
\hline \multirow[t]{3}{*}{ Bracke, Carl, Polizeikommissar } & $1887-1888$ & 412 \\
\hline & $1871-1891$ & 416 \\
\hline & $1888-1913$ & 768 \\
\hline Brandt, Hermann, Musikdirektor & $1881-1890$ & 554 \\
\hline Brauer, Grietje, Hausbesitzerin in Borssum & 1907 & 250 \\
\hline Brauwer, C.A.G., Dienstmannsinstitutsbesitzer & $1872-1918$ & 1.947 \\
\hline Brelie van der, Ferdinand, Kaufmann & 1913 & 2.885 \\
\hline Brethorst van, Geerd Siept, Erbpächter & $1901-1907$ & 2.784 \\
\hline Brethorst van, Geerd Siept, Kaufmann & $1900-1902$ & 2.789 \\
\hline Brian, D., Zimmermeister und Katholik & $1875-1888$ & 3.703 \\
\hline Brian, J., Zimmermann & $1876-1879$ & 2.692 \\
\hline Brian, Zimmermann & 1876 & 2.497 \\
\hline Brillmann, P. J., Schmied & 1866-1899 & 2.627 \\
\hline Brillmann, P. J., Schmiedemeister & 1889 & 2.192 \\
\hline \multirow[t]{2}{*}{ Brinckmann, Dr., Arzt } & $1881-1900$ & 765 \\
\hline & $1870-1879$ & 888 \\
\hline Brinkmann, Friedrich, Arbeiter & $1886-1900$ & 2.430 \\
\hline Brinkmann, Heinrich, Eingewiesener in Rettungsanstalt & $1867-1887$ & 1.706 \\
\hline Brochier, P., Ingenieur u. Bevollmächtigter d. Gaswerkspächterin & $1866-1873$ & 1.037 \\
\hline Broer, G., Schiffsmakler & $1852-1875$ & 451 \\
\hline Bronger, Friedrich, Torfbuchhalter & 1894-1913 & 426 \\
\hline Brongers, Hermannus, Hausbesitzer & 1887-1889 & 2.540 \\
\hline Bronjes, Jacobus, Dienstmann & $1872-1918$ & 1.947 \\
\hline Brons jun., Bernhard, Konsul & 1899-1905 & 644 \\
\hline Brons, A.F., Kaufmann & 1905 & 954 \\
\hline Brons, A.F., Kaufmann, Konsul und Senator & $1890-1901$ & 26 \\
\hline Brons, B., Kaufmann & $1875-1913$ & 1.703 \\
\hline Brons, Bernhard Jr., Kaufmann & 1893-1894 & 936 \\
\hline \multirow[t]{2}{*}{ Brons, Bernhard, Kaufmann } & 1902-1906 & 942 \\
\hline & $1866-1907$ & 2.620 \\
\hline \multirow[t]{2}{*}{ Brons, Bernhard, Kaufmann und Konsul } & $1876-1889$ & 843 \\
\hline & $1870-1910$ & 1.597 \\
\hline Brons, Bernhard, Rentier und Konsul a.D. & $1900-1911$ & 259 \\
\hline Brons, Bernhard, Senator & $1907-1912$ & 2.594 \\
\hline Brons, Friedich, Konsul & $1900-1911$ & 259 \\
\hline Brons, Friedrich, Kaufmann und Bürgervorsteher & 1904-1905 & 14 \\
\hline Brons, Friedrich, Kaufmann und Senator & $1912-1918$ & 263 \\
\hline Brons, Friedrich, Konsul & 1903-1904 & 1.184 \\
\hline Brons, Johannes, Kaufmann und Senator & $1866-1872$ & 15 \\
\hline \multirow[t]{2}{*}{ Brons, jun., Bernhard, Kaufmann, Konsul und Senator } & $1877-1911$ & 25 \\
\hline & $1887-1889$ & 3.506 \\
\hline Brons, Senator und Krankenhausaufsichtsratsvorsitzender & 1894-1900 & 1.685 \\
\hline Brons, W., Kaufmann & 1867 & 890 \\
\hline \multirow[t]{2}{*}{ Brons, Witwe } & 1876 & 1.175 \\
\hline & $1900-1901$ & 2.567 \\
\hline \multirow[t]{4}{*}{ Brons, Ysaac, Kaufmann } & $1876-1889$ & 843 \\
\hline & 1902-1905 & 959 \\
\hline & $1897-1899$ & 1.032 \\
\hline & 1895 & 1.357 \\
\hline Brons, Ysaac, Konsul & 1868 & 2.689 \\
\hline Brons, Ysaac, Rentier & $1900-1911$ & 259 \\
\hline
\end{tabular}


Index

\begin{tabular}{|c|c|c|}
\hline \multicolumn{3}{|l|}{ PERS } \\
\hline Indexbegriff & Laufzeit & Lfd.Nr. \\
\hline Brons, Ysaac, Rentier & $1912-1918$ & 263 \\
\hline \multirow[t]{2}{*}{ Brons, Ysaac, Senator } & $1878-1891$ & 830 \\
\hline & 1883-1898 & 971 \\
\hline Brons, Ysaac, Senator und Reichstagskandidat & $1866-1867$ & 216 \\
\hline Brons, Ysaac, Unternehmer & 1893-1906 & 3.346 \\
\hline Bronsema, Jurco, Gefangener & 1902-1907 & 526 \\
\hline Brüggemann, H. A., Hausbesitzer & $1895-1896$ & 1.351 \\
\hline Brüggemann, Louis, Drogist in Emden & $1888-1913$ & 768 \\
\hline Brüggemanns, Anna Catharina Frederike, Legatgeberin & $1885-1914$ & 3.456 \\
\hline Bruhns, Johann Hermann, Lehrer & $1885-1902$ & 3.685 \\
\hline Bruin, Hausbesitzer & 1876-1878 & 848 \\
\hline Bruins, Johann, Drogist & $1890-1897$ & 2.740 \\
\hline Brüning, Christiane, Legatgeberin & $1885-1914$ & 3.456 \\
\hline \multirow[t]{3}{*}{ Brüning, Gerhard, Polizeisergeant } & $1893-1913$ & 388 \\
\hline & 1883-1896 & 887 \\
\hline & 1896-1897 & 1.354 \\
\hline Brunner, Anton, Schüler mit Augeninfektion & $1880-1912$ & 776 \\
\hline Bruns, Antje, Unterstützungsbedürftige in Wolthusen & 1906-1912 & 253 \\
\hline Bruns, Dr., Leiter des Untersuchungsamtes & 1909-1911 & 743 \\
\hline Bruns, Jan Wiards, Matrose & $1868-1891$ & 1.576 \\
\hline Bruns, Jan, Maler & 1906 & 1.222 \\
\hline Bruns, Johann, Drogist & 1893-1895 & 2.777 \\
\hline Bruns, Taddäus Wiardus, Zimmermeister & $1900-1911$ & 259 \\
\hline \multirow[t]{2}{*}{ Bruns, W., Zimmermeister } & 1897-1898 & 1.182 \\
\hline & $1896-1898$ & 2.781 \\
\hline Bruntgen, Johann, Vertreiber verbotener Arzneien & $1872-1914$ & 767 \\
\hline Buchholtz, Regierungsrat & 1881 & 2.524 \\
\hline Buchholz, Dr., Landrabbiner & $1870-1886$ & 481 \\
\hline Buck, Luth. Pastor & 1891-1906 & 3.466 \\
\hline Buck, Luth. Pastor und Kreisschulinspektor & 1889-1917 & 3.509 \\
\hline Budde, Marie,Turn- und Handarbeitslehrerin & $1915-1918$ & 3.576 \\
\hline Buiren van, Gottfried, Akzise-Verwalter & $1866-1912$ & 257 \\
\hline Buiren van, Gottfried, Kämmerer & $1871-1872$ & 1.867 \\
\hline Buiren van, Kämmerer & $1869-1889$ & 3.325 \\
\hline Buisker, B., Fischer & 1911-1912 & 821 \\
\hline Buismann, Müller & 1914-1916 & 3.243 \\
\hline \multirow[t]{2}{*}{ Bullerdieck,Dr., Adolf, Oberlehrer } & 1905-1907 & 3.719 \\
\hline & $1907-1916$ & 3.721 \\
\hline Büning, Hermann, Oberlehrer an der Kaiser-Friedrich-Realschule & $1912-1918$ & 3.727 \\
\hline Burman, W., Briefträger und Kasernenbetreiber & 1874-1888 & 3.118 \\
\hline Burmeister, Sieffried H., Particulier & $1890-1897$ & 2.735 \\
\hline Buscher, Otto W., Kaufmann & $1885-1911$ & 834 \\
\hline Buscher, Polizeisergeant & 1875-1909 & 2.383 \\
\hline Buschmann, Alje, Veteran aus dem Befreiungskrieg & $1869-1876$ & 3.106 \\
\hline Buschmann, Nikolaus, Lehrer & 1908-1917 & 3.577 \\
\hline Buse, Emil - August, Lehrer & $1874-1910$ & 3.578 \\
\hline Busemann, L., Lehrer & 1885-1902 & 3.685 \\
\hline Buss, Arbeiter & $1881-1910$ & 726 \\
\hline Buss, L., Kaufmann & 1904 & 1.371 \\
\hline Busse, Claus, Baugewerksführer und Architekt & $1898-1900$ & 2.351 \\
\hline \multirow[t]{2}{*}{ Busseck, Sächsischer Oberbaurat } & $1877-1893$ & 2.005 \\
\hline & $1869-1878$ & 2.007 \\
\hline Bussmann, Fritz, Lehrer & $1910-1914$ & 3.564 \\
\hline Butenberg, Alfons, Rentier & $1875-1881$ & 2.870 \\
\hline Butenberg, Oskar, Rentier & $1875-1881$ & 2.870 \\
\hline Buterberg, O., Erbpächter & $1872-1918$ & 2.691 \\
\hline Buurmann, W., Briefträger & $1879-1891$ & 2.429 \\
\hline Buurmann, Wilhelm, Partikulier & $1885-1914$ & 2.431 \\
\hline
\end{tabular}


Index

\begin{tabular}{l}
\hline \\
\hline Indexbegriff \\
\hline Cäcilie, Herzogin von Mecklenburg u. Kronprinzessin \\
Campen, Gefallener Soldat \\
Campen, J. B., Hausbesitzer \\
Campen, Peter, Hausbesitzer \\
Capitaine, Emile, Schiffsmotorenbauer \\
Cassens, C., Schiffsbaumeister
\end{tabular}

PERS

Chuden, Kapitän u. Reichskommissar für das Auswandererwesen Cicon, Johann, Schornsteinfegermeister Cleef van, Friederike, Witwe

Clef van, Benjamin C., Handlungsreisender

Clösser, Otto Nicolaus, Legatgeber, Partikulier

Coners, Engelbert, Lotse

Coners, Roelf, Grundbesitzer aus Simonswolde

Conrad, Johannes, Reformierter Pastor

Conrad, Pastor und Aufseher über die Gasthausschule

Conrad, Paula, Lehrerin

Conradi, Bauunternehmer

Conradi, Bauwilliger

Cöper, Gerhard, Reformierter Pastor

Coper, Reformierter Pastor und Kreisschulinspektor

Cornelius, Claas, Schulamtsbewerber

Cramer, Diedrich, Drahtseilfabrikant

Creutzenberg, Kräutner

Dalhoff, Ehefrau

Dallinga, Hieronymus, Fuhrmann

Dallinga, Hieronymus, Fuhrmann und Gastwirt

Dallinga, Johann, Fuhrmann

Dallinga, Meindert, Fuhrmann und Droschkenlinienbetreiber

Dammann, H., Ingenieur

Dammeyer, H., Kaufmann

Dammeyer, Heinrich, Bezirksvorsteher und Sauerkrautfabrikant

Dammeyer, Heinrich, Konservenfabrikant

Dancker, Georg Mathäus, Böttchermeister

Däne, Kapitän und Pockenkranker

Danecker, G. M., Fabrikant

Dänekas, Catharina, Witwe aus Oldenburg

Daniels, Hindrich, Verlaatswärter

Dannenberg, Baurat

Dannenberg, H., Wasserbauinspektor

Dantziger, Carl, Kaufmann und Senator

\begin{tabular}{|c|c|}
\hline 1904-1905 & 197 \\
\hline $1915-1918$ & 3.192 \\
\hline $1869-1901$ & 1.159 \\
\hline 1912 & 1.380 \\
\hline 1904-1905 & 1.425 \\
\hline 1879-1909 & 877 \\
\hline $1879-1907$ & 1.213 \\
\hline 1907 & 2.179 \\
\hline 1897 & 2.219 \\
\hline 1898 & 2.225 \\
\hline 1900 & 2.241 \\
\hline 1900 & 2.242 \\
\hline 1901 & 2.257 \\
\hline 1902 & 2.264 \\
\hline 1905 & 2.298 \\
\hline $1866-1913$ & 452 \\
\hline 1873-1906 & 1.263 \\
\hline $1872-1910$ & 1.869 \\
\hline 1866-1901 & 2.897 \\
\hline $1885-1914$ & 3.456 \\
\hline 1898-1899 & 2.754 \\
\hline $1867-1878$ & 2.669 \\
\hline $1874-1910$ & 3.378 \\
\hline $1878-1912$ & 1.725 \\
\hline $1908-1910$ & 3.779 \\
\hline 1912 & 1.106 \\
\hline 1903 & 943 \\
\hline 1903 & 2.806 \\
\hline $1874-1910$ & 3.378 \\
\hline $1889-1917$ & 3.509 \\
\hline 1900-1902 & 3.641 \\
\hline $1914-1918$ & 3.606 \\
\hline 1904-1905 & 2.446 \\
\hline $1875-1896$ & 1.156 \\
\hline $1908-1914$ & 2.878 \\
\hline $1875-1909$ & 836 \\
\hline $1875-1878$ & 2.506 \\
\hline $1897-1914$ & 838 \\
\hline $1874-1883$ & 2.118 \\
\hline $1910-1911$ & 1.470 \\
\hline 1892 & 1.347 \\
\hline 1871-1906 & 961 \\
\hline $1897-1914$ & 1.575 \\
\hline $1886-1898$ & 258 \\
\hline $1859-1877$ & 773 \\
\hline 1894 & 2.210 \\
\hline $1912-1915$ & 347 \\
\hline 1866-1891 & 1.488 \\
\hline $1881-1901$ & 2.477 \\
\hline $1881-1909$ & 894 \\
\hline 1884-1888 & 911 \\
\hline $1882-1884$ & 1.178 \\
\hline $1887-1888$ & 1.436 \\
\hline $1872-1879$ & 22 \\
\hline 1891 & 201 \\
\hline 1876 & 1.438 \\
\hline
\end{tabular}


Index

\begin{tabular}{|c|c|c|}
\hline \multicolumn{3}{|l|}{ PERS } \\
\hline Indexbegriff & Laufzeit & Lfd.Nr. \\
\hline \multirow[t]{3}{*}{ Dantziger, Carl, Kaufmann und Senator } & $1866-1893$ & 1.533 \\
\hline & 1874-1904 & 2.493 \\
\hline & $1872-1918$ & 2.691 \\
\hline Dantziger, Carl, Senator und Holzhändler & $1870-1914$ & 1.430 \\
\hline Dantziger, Carl, Senator und Vorsitzender der Handelskammer & $1868-1891$ & 1.450 \\
\hline Dauwes, Adolph, Registrator und Stadtsekretär & 1879-1907 & 334 \\
\hline Davids, B., Lotterie-Einnehmer & $1886-1904$ & 558 \\
\hline Dayna, Baron von, Justizrat & 1873-1907 & 2.017 \\
\hline Dehn-Rotfelsen von, Geheimer Regierungsrat & 1884-1895 & 2.426 \\
\hline Dekker, Peter, Oberlehrer & $1887-1905$ & 3.729 \\
\hline Delaporte Dr., Medizinalrat & 1867-1895 & 763 \\
\hline Denkena, Julius, Lehrer & 1894 & 3.579 \\
\hline Deppe, Franz, Polizeisergeant & $1859-1915$ & 369 \\
\hline Deselaer, F., Ingenieur aus Neuss & 1903-1904 & 944 \\
\hline Detten van, Nicolaus, Fuhrmann & $1891-1899$ & 744 \\
\hline Dettmers, F. C., Bauunternehmer & 1901-1904 & 2.785 \\
\hline Dettum van, Peter, Fuhrmann & 1886-1894 & 870 \\
\hline Dick, Vizeadmiral & $1912-1913$ & 2.103 \\
\hline Dieckmann, Auktionator in Emden & $1899-1911$ & 1.908 \\
\hline Diederichs, Maler aus Oldenburg & $1866-1912$ & 2.632 \\
\hline Diedrich, Henry W., US-Konsul & $1902-1904$ & 2.131 \\
\hline Diekenga, $\mathrm{H}_{.}$, Agent & 1883-1906 & 2.043 \\
\hline Diekhoff, Hans, Professor der Ingenieurwissenschaften & $1910-1911$ & 1.483 \\
\hline \multirow[t]{2}{*}{ Diekmann, Bürgermeister von Leer } & 1904-1907 & 1.289 \\
\hline & 1891-1895 & 1.956 \\
\hline Diekmann, Emma, Lehrerin & 1913-1916 & 3.580 \\
\hline Diepen, Petrus, Reepschläger & 1888-1889 & 2.710 \\
\hline Diepenbrock van, Hillrich, Nachtwächter & 1884-1906 & 413 \\
\hline Diepenbrock von, G., Bewerber & $1883-1896$ & 887 \\
\hline Diepenbrock von, Polizeikommissar & 1874-1883 & 2.118 \\
\hline Diepenbrock, Nachtwachtmeister & $1895-1912$ & 1.021 \\
\hline Diepenbroek geb. Brouer, Talina Wobbina, Witwe & 1891-1895 & 1.651 \\
\hline \multirow[t]{2}{*}{ Diepenbroek van, Nachtwachtmeister } & 1891-1895 & 1.651 \\
\hline & $1896-1900$ & 1.652 \\
\hline Diepenbroek van, Nachtwachtmeister und Stockmeister & 1866-1897 & 2.411 \\
\hline Diestel, Wilhelm, Polizeisergeant & 1897-1902 & 359 \\
\hline Dinkela, Bauunternehmer & 1907-1912 & 1.147 \\
\hline Dinkela, F., Beschwerdeführer & $1900-1917$ & 338 \\
\hline Dinkela, F., Lehrer & $1870-1871$ & 3.632 \\
\hline Dinkela, Folkert, Rektor & $1868-1910$ & 3.581 \\
\hline Dinkela, Jacobus, Polizeisergeant & 1902 & 345 \\
\hline Dinkela, Mieterfamilie & 1873 & 1.300 \\
\hline \multirow[t]{2}{*}{ Dinkelmann H., Kaufmann } & 1901 & 996 \\
\hline & 1901-1903 & 997 \\
\hline Dinkelmann, H., Generalagent & 1901-1906 & 2.576 \\
\hline Dirks, Bernhard, Mühlenbaumeister & $1872-1893$ & 2.470 \\
\hline Dirks, J., Gastwirt & $1885-1911$ & 834 \\
\hline Dirks, Landgebräucher & 1867-1908 & 1.293 \\
\hline Dirks, Menne, Hausbesitzer & 1880-1906 & 1.179 \\
\hline Dirksen, C.-J., Bauer & $1871-1897$ & 823 \\
\hline Dirksen, D. J., Kasernenpächter & $1866-1870$ & 3.122 \\
\hline Dirksen, Harm, Aufseher der Stadtreinigung & 1897-1913 & 882 \\
\hline Dirksen, J., Gemüsebauer & 1904-1905 & 1.008 \\
\hline \multirow[t]{2}{*}{ Dirksen, Jan, Landwirt } & 1900 & 1.359 \\
\hline & 1909-1918 & 3.164 \\
\hline Dirksen, Klassenlehrer & 1869-1876 & 3.106 \\
\hline Dirksen, Tjade, Aufseher der Stadtreinigung & 1897-1913 & 882 \\
\hline Dittmer, Alma, Leherin & 1912-1918 & 3.582 \\
\hline
\end{tabular}


Index

\begin{tabular}{|c|c|c|}
\hline \multicolumn{3}{|l|}{ PERS } \\
\hline Indexbegriff & Laufzeit & Lfd.Nr. \\
\hline Dittmer, Alma, Leherin & $1912-1914$ & 3.588 \\
\hline Dittmer, Hermann, Lizeallehrer & 1876-1884 & 3.780 \\
\hline \multirow[t]{2}{*}{ Dittmers, Albert, Oberlehrer } & $1916-1918$ & 1.657 \\
\hline & $1908-1918$ & 3.730 \\
\hline Docquier, H., Anlieger & 1893-1908 & 2.783 \\
\hline Doden, Ferdinand, Legatgeber & $1885-1914$ & 3.456 \\
\hline Doden, Johann G., Kaufmann & 1867-1896 & 1.400 \\
\hline Doebbel, Gustav Adolph, Ingenieur & 1905 & 1.267 \\
\hline Doll, Ida, Oberlehrerin & 1909-1914 & 3.781 \\
\hline Doolmann, Berend Martens, Maurer & $1912-1918$ & 263 \\
\hline Doornkaat-Koolman ten, Jan, Reichstagsabgeordneter & 1877-1878 & 3.084 \\
\hline Dose, G. B., Bauunternehmer & 1873-1877 & 2.483 \\
\hline Dose, Geske, Taubstumme aus Wolthusen & $1880-1913$ & 254 \\
\hline Douwes, Jakoba, Schenkerin für Frauenheim & 1871-1918 & 3.388 \\
\hline Dreesing, Mieter & 1866-1904 & 2.676 \\
\hline Dreesmann, Verstorbener Prediger von Wolthusen & $1837-1915$ & 3.316 \\
\hline Dreesmann-Penning, Senator & 1893-1894 & 936 \\
\hline \multirow{2}{*}{ Dreesmann-Penning, T., Kaufmann und Senator } & $1889-1912$ & 21 \\
\hline & $1895-1906$ & 2.059 \\
\hline Dreesmann-Penning,Tamme, Senator a. D. & 1911 & 1.379 \\
\hline Dreesmann-Penning,Tamme, Senator a.D. & $1900-1911$ & 259 \\
\hline Dreger, Max, Telegrafen-Assistent & 1890-1907 & 2.736 \\
\hline Drescher, G., Vereinsvorsitzender & 1913-1917 & 1.678 \\
\hline Dreyer, Meinhard, Lehrer & 1885-1902 & 3.685 \\
\hline Dreyschuch, Paul, Amtsgerichtssekretär & $1890-1891$ & 2.733 \\
\hline Driehaus, H., Aufseher der Stadtreinigung & $1897-1913$ & 882 \\
\hline Drost, Theodor, Kaufmann & $1900-1901$ & 2.567 \\
\hline Duentjes, Seilermeister & 1876 & 1.322 \\
\hline Duif, Daniel, Dienstmann & $1872-1918$ & 1.947 \\
\hline Duif, H., Prediger in Tergast & 1886 & 3.481 \\
\hline Duin, B. A., Witwe, Hausbesitzerin & 1869-1901 & 1.159 \\
\hline Duis, F.J., Kaufmann & $1868-1883$ & 835 \\
\hline \multirow[t]{2}{*}{ Düker, Robert, Schornsteinfegermeister } & 1873-1906 & 1.263 \\
\hline & 1907-1916 & 1.264 \\
\hline Dupree, S., Reepschläger & $1867-1887$ & 2.700 \\
\hline Düvel, Steuereinnehmer & $1872-1890$ & 1.585 \\
\hline Dycken van, Hermannus, Kräutner & 1877 & 1.323 \\
\hline Dycken, Hille, Grundbesitzerin & $1901-1912$ & 840 \\
\hline Dyken van, Carl, Kantinenwirt & 1900 & 1.941 \\
\hline Dyken van, Jakob Gerd, Zimmergesele u. Vereinsvorsitzender & $1890-1891$ & 2.734 \\
\hline Dyken van, Katharina, Kindbettfieberkranke & $1881-1900$ & 765 \\
\hline Ebeling, geb. Hayenga, Wwe., Legatgeberin & 1871-1918 & 3.388 \\
\hline Ebendorff, Steuerassistent & 1914-1916 & 3.153 \\
\hline Eberhard, Bauhofsvorsteher & 1894-1905 & 897 \\
\hline Ebert, H., Ingenieur und Bevollmächtigter d. Gaswerkspächterin & $1866-1873$ & 1.037 \\
\hline Eckhoff, H., Bürgervorsteher & $1854-1920$ & 81 \\
\hline Eckhoff, Kapitän und Rendant & 1909 & 3.712 \\
\hline Edelmann, Anni, Maschinenschreiberin & 1916-1918 & 339 \\
\hline Eden, August, Schankwirt & 1902 & 549 \\
\hline Eden, August, Zimmermann & 1900 & 539 \\
\hline Eden, Hermann, Taubstummenlehrer & $1910-1912$ & 3.554 \\
\hline \multirow[t]{2}{*}{ Edzard, Fürst von Inn- und Knyphausen, Reichstagsabgeordneter } & $1870-1903$ & 218 \\
\hline & 1907-1908 & 219 \\
\hline Egberts,Witwe & 1893-1897 & 2.574 \\
\hline Eggen, Hinrich, Gastwirt & 1914-1915 & 2.887 \\
\hline Eggers, H., Gastwirt & 1906-1912 & 2.599 \\
\hline Ehsen van, Deverna, Hausbesitzerin & $1870-1871$ & 1.305 \\
\hline
\end{tabular}


Index

\begin{tabular}{|c|c|c|}
\hline \multicolumn{3}{|l|}{ PERS } \\
\hline Indexbegriff & Laufzeit & Lfd.Nr. \\
\hline Eiben, Akzisekontrolleur & $1902-1904$ & 427 \\
\hline Eikens, Roesina, Hausbesitzerin & $1872-1875$ & 1.715 \\
\hline Eilers, Friedrich, Lehrer & $1891-1907$ & 3.653 \\
\hline Eilers, Friedrich, Lehrer der Mittelschule & $1875-1889$ & 3.652 \\
\hline Eilers, Wilm, Landgebräucher und Fuhrmann & $1880-1894$ & 1.943 \\
\hline Eitel, Fritz, Warmbadbetreiber & $1881-1911$ & 737 \\
\hline Eitel, Max, Warmbadbetreiber & $1897-1913$ & 740 \\
\hline Elckjens, J., Hausbesitzer & $1869-1901$ & 1.159 \\
\hline Elma, Krankenschwester & $1894-1900$ & 1.685 \\
\hline \multirow[t]{2}{*}{ Elsen, Gerhardus J., Zimmermeister } & $1900-1902$ & 2.774 \\
\hline & 1903-1905 & 2.808 \\
\hline Engberts, B. J., Kasernenpächter & 1871-1877 & 3.123 \\
\hline Engelbarts, Diedrich, Schuldiener & $1906-1918$ & 3.782 \\
\hline Engelhardt, G., Marktbeschicker & $1877-1910$ & 2.653 \\
\hline Engels, Fregattenkapitän & $1908-1914$ & 271 \\
\hline Enkelstroth, Dirigierender Handelsschullehrer & $1869-1914$ & 2.343 \\
\hline \multirow[t]{2}{*}{ Enkelstroth, Heinrich August, Lehrer } & 1873-1914 & 3.783 \\
\hline & $1875-1890$ & 3.836 \\
\hline Ennen, Georg, Kaufmann & 1897-1898 & 1.182 \\
\hline Ennen, Georg, Senffabrikant & 1893 & 2.208 \\
\hline Ennen, J. E., Bürgervorsteher & $1867-1893$ & 1.495 \\
\hline Ennen, J. E., Kaufmann & 1889 & 2.191 \\
\hline Erdbrink, Otto, Polizeisergeant & 1889-1893 & 382 \\
\hline Erlenmeyer, Dr., Albrecht, Psychiater & 1891-1912 & 519 \\
\hline Eujen, Heiko, Lehrer & $1906-1917$ & 3.565 \\
\hline Eulenburg, Dr., Geheimer Oberregierungsrat & $1886-1900$ & 886 \\
\hline Everard, Theaterdirektor & 1908-1912 & 556 \\
\hline Faber, Wissenschaftl. Hilfslehrer & 1892-1908 & 3.723 \\
\hline Falke, Julius, Polizeisergeant & 1907-1908 & 355 \\
\hline Fecht, Johannes,Turmwächter & 1869-1896 & 436 \\
\hline Fegter, Anton, Prediger in Uphusen & 1876 & 3.484 \\
\hline Fegter, Antonius, Zweiter Prediger in Wolthusen & $1837-1915$ & 3.316 \\
\hline \multirow{2}{*}{ Fegter, Jan, Domänenpächter und Reichstagsabgeordneter } & 1908 & 220 \\
\hline & 1911-1912 & 222 \\
\hline Fegter, V.A., Eindeichungsinitiator & 1886 & 1.547 \\
\hline Fellner, Vorsänger und Schächter der israelitischen Gemeinde & 1883-1905 & 492 \\
\hline Feuerhehn, Polizeisergeant & 1910 & 860 \\
\hline \multirow[t]{2}{*}{ Ficker, W., Telegraphendirektor } & 1904-1908 & 1.012 \\
\hline & $1902-1903$ & 2.581 \\
\hline Fiesler, Bertha, Kindbettfieberkranke & $1881-1900$ & 765 \\
\hline Fink, Gepke, Schulwärterin & 1878-1905 & 3.784 \\
\hline Finkenbrink, Carl, Eisenbahnschaffner & 1884-1895 & 2.720 \\
\hline Finkenbrink, F, Witwe und Hausbesitzerin & 1883-1907 & 977 \\
\hline Fischbeck, L., Kunstmaler aus Oldenburg & 1866-1912 & 2.632 \\
\hline Fischer, S., Bauantragssteller & 1894-1913 & 1.135 \\
\hline Fischer, Willy, Polizeisergeant & 1905 & 349 \\
\hline Fisser, J., Restaurateur & 1902 & 548 \\
\hline Fisser, Karl, Konsul und Kaufmann & 1912-1918 & 263 \\
\hline Fisser, Wiardus H., Schiffsbesitzer & $1875-1900$ & 1.628 \\
\hline Fligge, Friedrich, Polizeisergeant in Emden & 1905 & 352 \\
\hline Flohr, Wilke Dirks, Polizeisergeant & 1880 & 350 \\
\hline Focken, Hauptlehrer & $1875-1889$ & 3.652 \\
\hline Focken, Klassenlehrer & $1873-1887$ & 3.660 \\
\hline Foget, A. A., Müller & $1882-1889$ & 2.530 \\
\hline Foget, Helmer H., Kaufmann und Senator & 1875-1899 & 18 \\
\hline Foget, Hinderk Hinderks, Müller & $1882-1889$ & 2.530 \\
\hline Fokken, Haye, Rentier & 1907 & 1.377 \\
\hline
\end{tabular}


Index

\begin{tabular}{|c|c|c|}
\hline \multicolumn{3}{|l|}{ PERS } \\
\hline Indexbegriff & Laufzeit & Lfd.Nr. \\
\hline \multirow[t]{7}{*}{ Fokken, Uffe, Abfuhrunternehmer } & 1878-1909 & 851 \\
\hline & $1876-1882$ & 871 \\
\hline & 1878-1899 & 876 \\
\hline & 1879-1909 & 877 \\
\hline & $1886-1888$ & 931 \\
\hline & $1871-1906$ & 961 \\
\hline & $1875-1886$ & 2.507 \\
\hline Fokuhl, Emil, Elektroinstallateur & $1909-1915$ & 1.130 \\
\hline Folkers, Gefängniswärter & $1899-1913$ & 523 \\
\hline \multirow[t]{2}{*}{ Folkerts, Hayo, Baumaterialienhändler } & $1889-1896$ & 2.538 \\
\hline & $1880-1911$ & 2.685 \\
\hline \multirow[t]{3}{*}{ Folkerts, Johann Diederich, Kalkbrenner } & 1869 & 2.474 \\
\hline & $1875-1876$ & 2.519 \\
\hline & $1880-1911$ & 2.685 \\
\hline Folkerts, Remmer, Antragssteller & $1908-1916$ & 83 \\
\hline Folkerts, Wiard, Lehrer & 1913-1918 & 3.583 \\
\hline Folts, Wilko, Kantinenwirt & 1900 & 1.941 \\
\hline Forkenbeck, Wilhelm. Gastwirt & 1902 & 550 \\
\hline \multirow[t]{4}{*}{ Förster, Hubert, Direktor des Elektrizitätswerkes Mühlheim / Ruhr } & 1907-1908 & 1.083 \\
\hline & 1908 & 1.084 \\
\hline & $1908-1911$ & 1.085 \\
\hline & 1907-1912 & 1.103 \\
\hline \multirow[t]{2}{*}{ Francke, Carl, Gas-Ingenieur } & $1896-1897$ & 1.029 \\
\hline & 1897-1899 & 1.032 \\
\hline Frank, Johannes, Auslieferungsgefangener & $1902-1907$ & 526 \\
\hline Franke Dr., E., Korrespondent & 1899 & 2.130 \\
\hline Franke, H., Grenzaufseher & 1893 & 249 \\
\hline Fränkel, Prof. Dr., Institutsdirektor & $1871-1914$ & 757 \\
\hline Franssen, Witwe & $1909-1913$ & 1.024 \\
\hline Franz, Robert, Polizeisergeant & 1892 & 351 \\
\hline Franzius, Dr., Jusizrat und Reichstagsabgeordneter & $1870-1903$ & 218 \\
\hline \multirow[t]{2}{*}{ Freerksen, Petrus, Deichrichter der Niederemsischen Deichacht } & $1872-1892$ & 1.544 \\
\hline & 1901-1908 & 1.546 \\
\hline \multirow[t]{5}{*}{ Freerksen, T., Deichrichter in Larrelt } & 1884 & 902 \\
\hline & 1884 & 903 \\
\hline & 1883-1885 & 914 \\
\hline & $1867-1890$ & 2.476 \\
\hline & 1884-1896 & 2.494 \\
\hline Freitag, M., Ingenieur aus Ahlefeld & $1906-1907$ & 1.460 \\
\hline Frerichs Dr., Lehrer & $1886-1916$ & 3.849 \\
\hline \multirow[t]{2}{*}{ Frerichs, A., Kirchenrat } & $1875-1902$ & 3.445 \\
\hline & $1868-1890$ & 3.847 \\
\hline Fresemann, G.V., Antragssteller & $1908-1916$ & 83 \\
\hline Friedewold, Friedrich, Lehrer & $1905-1917$ & 3.566 \\
\hline Friedrich Wilhelm, Kronprinz des deutschen Reiches & 1904-1905 & 197 \\
\hline Friedrich Wilhelm, Kronprinz von Preußen & $1866-1868$ & 189 \\
\hline \multirow[t]{3}{*}{ Friedrichs, Ernst, Polizeisergeant } & $1907-1914$ & 400 \\
\hline & $1896-1912$ & 844 \\
\hline & $1912-1914$ & 967 \\
\hline Fritzen, Architekt & $1908-1912$ & 3.087 \\
\hline Fritzen, Jacobus Zimmermeister & 1894-1913 & 1.135 \\
\hline Fritzen, Jacques, Zimmermeister & 1906 & 2.593 \\
\hline Fulda, A. D., Schlachter u. Betreiber d. Entbindungsanstalt & 1867-1895 & 763 \\
\hline Fulda, Isaak, Schlachter & 1867-1908 & 846 \\
\hline Fülscher, Geheimer Oberbaurat & 1903-1909 & 312 \\
\hline \multirow[t]{3}{*}{ Fürbringer, Leo, Bürgermeister der Stadt Emden } & $1876-1903$ & 1.432 \\
\hline & 1876 & 1.438 \\
\hline & $1870-1910$ & 1.597 \\
\hline
\end{tabular}


IV

Index

\section{PERS}

Indexbegriff

Fürbringer, Leo, kommissarischer Oberbürgermeister

Fürbringer, Leo, Landtagsabgeordneter

Fürbringer, Leo, Oberbürgermeister der Stadt Emden

\section{Laufzeit}

1876

$1915-1918$

1906-1915

1914-1915

1914-1916

1913

1905-1908

1908

1917-1918

1906-1907

1909-1913

1904-1912

1853-1891

1875-1913

1902

1901-1913

1898

1907

1900-1901

1867-1915

1911-1912

1900-1909

1908-1910

1908-1914

1903-1909

1871-1891

1904-1911

1870-1886

1896

1885

1902-1913

1905-1911

1908

1912-1914

1896-1909

1880-1883

1876-1879

1880-1907

1885-1889

1897-1907

1898-1903

1887-1897

1901-1902

1876-1903

1875-1882

1887-1888

1902-1903

1907

1899-1903

1903-1904

1903-1904

1906-1907

1905-1907

1910-1911

1910-1911

1911

1911

1910-1911
Lfd.Nr.

3.809

242

273

3.146

3.153

215

948

1.084

1.581

2.086

2.087

10

12

13

186

187

188

195

203

204

221

264

270

271

312

455

456

481

520

564

659

673

692

721

739

795

868

893

906

1.017

1.035

1.138

1.416

1.432

1.434

1.436

1.442

1.444

1.454

1.458

1.459

1.460

1.461

1.468

1.470

1.475

1.476

1.483 
IV

Index

PERS

\begin{tabular}{|c|c|c|}
\hline Indexbegriff & Laufzeit & Lfd.Nr. \\
\hline \multirow{51}{*}{ Fürbringer, Leo, Oberbürgermeister der Stadt Emden } & $1900-1908$ & 1.510 \\
\hline & $1901-1908$ & 1.546 \\
\hline & 1886 & 1.547 \\
\hline & 1907 & 1.552 \\
\hline & 1889 & 1.560 \\
\hline & $1878-1880$ & 1.631 \\
\hline & $1882-1883$ & 1.690 \\
\hline & 1880 & 1.911 \\
\hline & 1896 & 1.912 \\
\hline & 1907 & 1.993 \\
\hline & $1880-1882$ & 1.996 \\
\hline & 1904 & 2.002 \\
\hline & 1905 & 2.003 \\
\hline & 1907 & 2.004 \\
\hline & $1877-1878$ & 2.006 \\
\hline & $1869-1878$ & 2.007 \\
\hline & 1878-1892 & 2.008 \\
\hline & $1893-1897$ & 2.026 \\
\hline & $1896-1910$ & 2.051 \\
\hline & $1895-1906$ & 2.059 \\
\hline & $1899-1900$ & 2.065 \\
\hline & $1901-1904$ & 2.069 \\
\hline & 1906-1907 & 2.071 \\
\hline & $1903-1911$ & 2.079 \\
\hline & $1905-1907$ & 2.083 \\
\hline & 1912 & 2.095 \\
\hline & $1913-1914$ & 2.096 \\
\hline & 1912 & 2.100 \\
\hline & $1910-1914$ & 2.106 \\
\hline & $1885-1887$ & 2.113 \\
\hline & $1878-1879$ & 2.125 \\
\hline & $1905-1906$ & 2.360 \\
\hline & $1910-1911$ & 2.362 \\
\hline & $1908-1911$ & 2.363 \\
\hline & $1905-1911$ & 2.375 \\
\hline & $1875-1909$ & 2.383 \\
\hline & $1894-1897$ & 2.394 \\
\hline & $1875-1905$ & 2.423 \\
\hline & $1867-1890$ & 2.476 \\
\hline & $1888-1907$ & 2.656 \\
\hline & $1882-1905$ & 2.670 \\
\hline & $1885-1908$ & 2.719 \\
\hline & $1908-1912$ & 3.087 \\
\hline & 1911 & 3.136 \\
\hline & $1897-1898$ & 3.326 \\
\hline & $1887-1889$ & 3.506 \\
\hline & $1895-1918$ & 3.733 \\
\hline & $1891-1910$ & 3.796 \\
\hline & 1904 & 3.826 \\
\hline & $1889-1890$ & 3.852 \\
\hline & & Vorwort \\
\hline \multirow[t]{2}{*}{ Fürbringer, Leo, Oberbürgermeister u. weltl. Kirchenkommissar } & $1892-1914$ & 3.441 \\
\hline & 1891-1906 & 3.466 \\
\hline Fürbringer, Marie, Gattin des Oberbürgermeisters & $1909-1913$ & 261 \\
\hline \multirow[t]{2}{*}{ Gans, Aaron, Jüdischer Kaufmann } & $1871-1903$ & 758 \\
\hline & 1874-1884 & 2.521 \\
\hline Garjets, Diedrich Johann, Lehrer & $1910-1916$ & 3.785 \\
\hline
\end{tabular}


IV

Index

PERS

Gebhard, A. C., Dänischer Viehexporteur Geelvink, Kaufmann

Geelvink, Peter H., Eisenwarenhändler

Geelvink, Peter, Kaufmann und Schenker für Frauenheim

Geerdes, Eilert, Lehrer

Geerds, G., Kaufmann

Gehrs, Franz, Polizeisergeant

Georg V., König von Hannover

Gerhard, Anton, Buchdruckereibesitzer

Gerhardt, Rektor der städtischen Volksschule

Gerjets, D., Lehrer

Gerjets, Dirk Janssen Eilts, Lehrer

Gerken, J. G., Kaufmann

Germelmann, Regierungsbaumeister und Wasserbauinspektor
Gernetzky, Carl Wilhelm, Bewerber als Polizeisergeant

Gerritzen,Turmwächter

Geseling, Zivilingenieur

Giesberts, G.D., Stadtbauaufseher

Giesen, G., Geschäftsmann

Giesen, Gerd, Gastwirt und Saalbesitzer

Gisberts, A. D., Bauaufseher

Gittermann, C.H., Kaufmann und Senator

Gittermann, Ludwig, Vorstandsbeamter der Emder Gewerbebank
Laufzeit

Lfd.Nr.

1880

1910-1911

1905-1906

1900-1911

1909-1913

1891-1892

1900-1902

1884-1888

1897-1914

1908-1911

1891-1895

1901-1909

1899-1914

1880-1912

1883-1907

1899-1900

1871-1872

1906-1907

1871-1918

1891-1907

1873-1897

1908-1912

1895-1910

1905-1909

1906-1911

1908-1910

1900-1914

1876-1878

1904-1911

1875-1889

1877-1904

1884

1885-1910

1885-1889

$1885-1900$

1885-1891

1885

1884-1888

1885-1887

1885-1886

1886-1900

1885-1896

1886

1888-1909

1886-1888

1887-1888

1882

1869-1896

1880-1882

1865-1871

1870-1900

1867-1876

1881-1897

1868-1871

1867

1883-1887

1902-1914
1.332

1.203

1.169

259

261

341

422

911

1.057

1.467

1.651

1.653

2.984

3.075

3.344

783

1.775

1.375

3.388

3.653

2.549

365

873

Vorwort

1.198

1.199

1.202

2.628

3.700

3.567

3.652

903

905

906

907

908

910

911

915

923

924

926

928

931

1.436

370

436

1.996

438

1.497

2.415

1.140

1.211

1.312

20

1.235
2.708

922 
Index

\begin{tabular}{|c|c|c|}
\hline \multicolumn{3}{|l|}{ PERS } \\
\hline Indexbegriff & Laufzeit & Lfd.Nr. \\
\hline Gittermann, Senator und Armenkollegiumwsvorsitzender & $1872-1918$ & 1.870 \\
\hline Gloes, Simon Heimann, Schlachter & $1880-1891$ & 2.695 \\
\hline Glös, Heymann, Schlachtermeister & $1915-1916$ & 3.309 \\
\hline Glos, Siemon Heymann, Schlachter & $1875-1896$ & 1.156 \\
\hline Goepel, Geometer & $1867-1890$ & 2.476 \\
\hline Gohlke, Max, Polizeisergeant & $1906-1907$ & 383 \\
\hline Goldberg, Direktor d. Rheinisch Westfäl. Elektrizitätsgesellschaft & $1912-1914$ & 1.994 \\
\hline Goljenboom, E., Rentier & 1903-1904 & 2.580 \\
\hline Göpfert, Johann, Ingenieur & 1899 & 1.053 \\
\hline Gossels, Gossel, Schlachter & $1872-1918$ & 1.947 \\
\hline Gossels, Isidor, Viehhändler & $1901-1912$ & 840 \\
\hline Gossels, Jüdischer Schlschter & 1873-1909 & 2.182 \\
\hline Gossels, Valk, Grundstücksbesitzer & $1910-1912$ & 1.160 \\
\hline Grabbe, Friedrich, Tischler & 1867 & 1.311 \\
\hline \multirow[t]{2}{*}{ Graefenhain, Lotsenkommandeur } & 1879-1909 & 1.727 \\
\hline & $1883-1890$ & 2.039 \\
\hline Graepel, Friedrich, Kaufmann & $1876-1904$ & 170 \\
\hline Graepel, G., Kaufmann & 1879-1909 & 2.915 \\
\hline \multirow{2}{*}{ Graepel, J., Kaufmann } & 1896 & 1.353 \\
\hline & $1905-1906$ & 1.373 \\
\hline Graepel, Senator u. Gewerbeschulvorstandsmitglied & $1866-1871$ & 2.329 \\
\hline Graeser, Dr., Lehrer am Gymnasium & 1893-1895 & 1.583 \\
\hline Gräf, Edmund, Schornsteinfeger & $1867-1873$ & 1.262 \\
\hline Gresemann, H., Gemeindevorsteher in Borssum & $1893-1897$ & 2.026 \\
\hline Griepel, L., Hausbesitzer & 1903 & 1.369 \\
\hline Grieshammer, Lehrer & $1891-1907$ & 3.653 \\
\hline Grigoleit, Otto, Polizeisergeant & 1907-1908 & 402 \\
\hline Groeneveld, Engelke (Ubben), Landwirt in Borssum & $1911-1912$ & 247 \\
\hline Groeneveld, Ubbe Engelkes, Gemeindevorsteher in Borssum & $1892-1895$ & 246 \\
\hline Groenewold, Meinke, Schleusenmeister & $1877-1885$ & 440 \\
\hline Groenhagen, Landwirt & $1880-1881$ & 2.515 \\
\hline Gronemann, Major & $1878-1891$ & 2.428 \\
\hline Großkopf, Wilhelm, Polizeisergeant & $1907-1911$ & 403 \\
\hline Groustra, Pächter & 1895-1909 & 2.457 \\
\hline Grove, David, Ingenieur & 1903-1904 & 944 \\
\hline Grunert, Baurat & $1902-1903$ & 177 \\
\hline Guttmann, Karl, Vollziehungsbeamter & $1900-1919$ & 353 \\
\hline Haan de, W., Schleusenmeister & 1898-1899 & 1.486 \\
\hline Haarbach, Eisenbahnbau-Inspektor & 1881 & 1.449 \\
\hline Haarmann, Vors. d. Georgs-Marien Bergwerks- u. Hüttenvereins & $1891-1895$ & 1.956 \\
\hline Haas de, Vorsänger d. jüdischen Synagogengemeinde zu Emden & 1883-1905 & 492 \\
\hline Habich, Franz, Kaufmann & $1907-1911$ & 2.828 \\
\hline Habich, Franz, Reeder & $1900-1911$ & 259 \\
\hline Haenisch, Lutherischer Pastor und Kreisschulinspektor & $1889-1917$ & 3.509 \\
\hline Haenisch, Pastor und Aufseher über die Gasthausschule & $1885-1900$ & 1.726 \\
\hline Hagedorn, Dr., Historiker & $1899-1916$ & 315 \\
\hline Hagen, Gotthilf, Oberlandesbaudirektor & $1870-1914$ & 1.430 \\
\hline Hagen, J. C., Bäckermeister & $1872-1893$ & 2.470 \\
\hline Hagen, Jan Iden, Bäckermeister & $1872-1913$ & 2.655 \\
\hline Hagen, Reinhard, Bäcker und Konditor & 1904 & 1.371 \\
\hline Hahlbrock, Hermann, Gastwirt & 1902 & 546 \\
\hline Hahlbrock, Hermann, Oberkellner & $1899-1900$ & 536 \\
\hline \multirow[t]{2}{*}{ Hahn, Louis, Drucker und Zeitungsverleger } & $1868-1914$ & 557 \\
\hline & $1878-1888$ & 1.493 \\
\hline Hahn, Wilhelm, Verleger & $1912-1914$ & 721 \\
\hline Hake von, Premierleutnant & $1878-1891$ & 830 \\
\hline Halle, Arbeiter & $1899-1904$ & 852 \\
\hline
\end{tabular}


IV

Index

\begin{tabular}{l}
\hline PERS \\
\hline Indexbegriff \\
\hline Hallmann, Ernst, Lehrer \\
Halsman, Maria, Jungfer \\
Hamburger, Dr., Landrabbiner \\
Hamer, P., Manufakturwarenhändler \\
Hamphoff, Ausklingler \\
Hänisch, Reformieter Pastor \\
Hansen, Wilhelm J.E., Reeder aus Husum \\
Hanssen, Jan Hinrichs, Privatier \\
Hantelmann, Ernst Heinrich, Bürgermeister u. Oberbürgermeister
\end{tabular}

Harenkamp, Friedrich, Oberkellner

Harms, C., Agent

Harms, Christian, Zimmermeister

Harms, Dorothea, Lehrerin

Harms, Hilfsschullehrer

Harms, Johann H., Hilfsschullehrer

Harms, Prof. Dr., Bernhard, Hochschullehrer der Uni Kiel

Harms, Volksschullehrer

Hartmann Wwe., Wirtin

Hartmann, Wilhelm, Ing. u. Bevollmächtigter d. Gaswerkspächterin

Hartrampf, Bernhard, Fußgendarm

Hartrampf, Carl, Nachtwachtmeister

Haut, Peter, Kaufmann

Hawich, Arnoldine, geb. Gröneveld, Badbetreiberin

Hawich, H., Saalbesitzer

Hawich, Hermann, Sergeant und Badbetreiber

Hayen, J. E., Rentier

Hayen, J.C., Waisenrat

Haynel, W., Buchhändler

Hebarth, G. H., Pächter

Heckmann, Johann, Kriegsversehrter Schulamtsbewerber

Heeren, H. J., Landgebräucher

Heeren, P. M., Beschwerdeführer

Heeren, T.H., Hotelier

Heeren, T.S., Bittsteller

Heeren, Tjark Klaassen, Gastwirt

Heerma, geb. Hinderks, Tjalke, Erbpächterin

Heerma, H., Schiffsbesichtiger

Heerma, H.G., Hafenmeister

Heerma, L., Kaufmann

Hegen, H.P., Getreidemakler

Heiland, O, Bäckermeister

Hein, Stadtsekretär

Heinderks, J., Gutachter

Heine, Louis, Hotelier

Laufzeit

1914-1918

1874-1905

$1870-1886$

1858-1911

1874

1866-1911

1867-1882

1874-1910

1907

1905

1853-1891

1867-1869

1885-1911

$1870-1910$

1867-1881

1878-1879

1875-1905

1872

1903-1906

1873-1914

1906-1909

1915

1909-1911

1908-1918

1915

1900-1907

1882-1910

1866-1873

$1885-1910$

1884-1906

1907-1911

1876-1882

1876-1892

1876-1890

1881-1897

$1876-1882$

1876-1892

$1876-1890$

1898-1899

1914-1923

1867-1901

1866-1893

1915

1903-1904

1871-1906

1880-1907

1867-1909

1870

1889-1891

1900-1902

1857-1885

1917

1871-1913

1824-1920

1885-1888

1898-1903

1874-1905
Lfd.Nr.

3.605

831

481

489

491

962

431

3.378

2.092

2.833

12

217

834

1.597

2.033

2.125

2.423

3.764

Vorwort

552

1.227

2.845

3.584

3.532

3.709

717

3.708

2.920

1.037

879

413

2.828

734

736

738

1.140

734

736

738

1.355

1.704

310

2.454

3.585

2.553

961

893

529

2.686

2.683

422

418

3.276

419

433

917

1.035

831 
Index

\begin{tabular}{|c|c|c|}
\hline \multicolumn{3}{|l|}{ PERS } \\
\hline Indexbegriff & Laufzeit & Lfd.Nr. \\
\hline Heinholtz, M., Geschäftsmann & $1867-1876$ & 2.415 \\
\hline Heinrich, Prinz von Preußen, Admiral & $1874-1911$ & 190 \\
\hline Heise, W.J., Stadtsekretär & $1854-1888$ & 335 \\
\hline Heits, R. B., Bauunternehmer & 1897-1898 & 2.571 \\
\hline Heits, R. G., Bauunternehmer & $1897-1910$ & 2.751 \\
\hline \multirow[t]{2}{*}{ Helm, Willibald, Konsul und Kasernenbetreiber } & $1872-1888$ & 2.442 \\
\hline & $1866-1870$ & 3.125 \\
\hline Helmdeich, Getrudt, Grundbesitzerin & $1901-1912$ & 840 \\
\hline Hemkes, J., Stadtsekretär & $1854-1888$ & 335 \\
\hline Hemkes, J., Stadtverordneter & $1854-1890$ & 112 \\
\hline \multirow[t]{7}{*}{ Hempel, Balduin, Bauunternehmer } & $1900-1904$ & 938 \\
\hline & $1897-1912$ & 1.157 \\
\hline & $1905-1906$ & 1.200 \\
\hline & $1901-1902$ & 1.237 \\
\hline & 1899 & 2.769 \\
\hline & $1900-1902$ & 2.773 \\
\hline & 1901-1909 & 2.782 \\
\hline Hemsoth, Wilhelm, Vorsitzender der Roer-Linie & 1906-1909 & 2.090 \\
\hline Hemstedt, Carl, Polizeisergeant & 1902 & 357 \\
\hline Henning, Johann H., Sielwärter & $1879-1905$ & 2.517 \\
\hline Hennings, H. L., Händler & $1868-1897$ & 1.946 \\
\hline Hennings, Hutfabrikant & $1869-1901$ & 1.159 \\
\hline Hennings, J.C., Waisenrat & 1914-1923 & 1.704 \\
\hline \multirow[t]{3}{*}{ Henoch, Geheimer Baurat zu Gotha } & 1884 & 902 \\
\hline & $1885-1889$ & 906 \\
\hline & $1883-1885$ & 914 \\
\hline Henrici, Prof., Aachen & 1884-1895 & 2.426 \\
\hline Hepp von, Preußischer Landdrost in Aurich & $1885-1887$ & 2.113 \\
\hline Herlyn,, Rewe, Lotsenschiffer & $1872-1912$ & 2.122 \\
\hline Hermann, C, Bürgervorsteherkandidat und Apotheker & $1872-1903$ & 75 \\
\hline \multirow[t]{2}{*}{ Hermann, C., Apotheker } & 1898 & 80 \\
\hline & $1880-1902$ & 749 \\
\hline Hermann, C., Leiter d. Chemischen Untersuchungsamtes & $1885-1896$ & 2.385 \\
\hline \multirow[t]{3}{*}{ Hermann, Carl, Apotheker } & $1912-1918$ & 263 \\
\hline & 1879 & 756 \\
\hline & $1873-1917$ & 2.395 \\
\hline Hertrampf, Carl, Fußgendarm & $1880-1883$ & 2.699 \\
\hline Herz, Niederländischer Viehhändler & 1914-1916 & 3.240 \\
\hline Herzberg, Geh. Baurat & $1910-1912$ & 2.094 \\
\hline Hesse, Carl, Gefangener & $1879-1904$ & 522 \\
\hline Hesse, J., Vereinspräsidentin & 1867-1902 & 2.917 \\
\hline Hesse, L. R., Hausbesitzer aus Weener & $1895-1896$ & 1.349 \\
\hline Hesse, Pastor und Militärseelsorger & $1867-1911$ & 3.086 \\
\hline Heubült, Bauzeichner & $1901-1902$ & 1.000 \\
\hline \multirow[t]{4}{*}{ Heubült, J. E., Bauaufseher } & $1899-1900$ & 2.555 \\
\hline & $1880-1883$ & 2.701 \\
\hline & $1888-1891$ & 2.731 \\
\hline & $1890-1891$ & 2.733 \\
\hline Heubült, W., Bauunternehmer & $1873-1877$ & 2.483 \\
\hline Heydebeck, Gutsbesitzer und Major aus Bärwalde / Pommern & 1916 & 3.305 \\
\hline Heyder, Kreisbauinspektor & $1903-1904$ & 1.185 \\
\hline Heyen, Anton, Schiffsjunge aus Elsfleth & $1868-1891$ & 1.576 \\
\hline Heyen, Tjark, Malergeselle und Pockenkranker & $1859-1877$ & 773 \\
\hline Heyen. Karl, Lehrer & $1909-1910$ & 3.568 \\
\hline Heyer, K., Musikdirektor & $1881-1890$ & 554 \\
\hline Heyl, Franz, Händler & $1868-1897$ & 1.946 \\
\hline Heyl, geb. Brake, Angela & $1886-1898$ & 258 \\
\hline Heyl, Johannes Wilhelm & 1886-1898 & 258 \\
\hline
\end{tabular}


Index

\begin{tabular}{|c|c|c|}
\hline \multicolumn{3}{|l|}{ PERS } \\
\hline Indexbegriff & Laufzeit & Lfd.Nr. \\
\hline Heyl, Kaufmann & $1870-1882$ & 2.502 \\
\hline Heyl, L., Schornsteinfegermeister & $1867-1873$ & 1.262 \\
\hline Heyl, Lambertus, Kaufmann & $1879-1888$ & 1.215 \\
\hline Heynel, W., Buchhändler & 1871 & 2.690 \\
\hline Hiege, August Friedrich Wilhelm, Maurer & $1867-1914$ & 576 \\
\hline Hilders, Ontje, Lehrer & $1877-1918$ & 3.586 \\
\hline Hilkes, Auktionator & $1871-1874$ & 2.490 \\
\hline Hindenburg von, Generalfeldmarschall & 1916-1917 & 3.314 \\
\hline Hinderks, Asmus, Landgebräucher & $1880-1906$ & 1.179 \\
\hline Hinderks, D., Wildhändler & $1881-1882$ & 2.709 \\
\hline Hinderks, Dirk, Wildhändler & $1889-1891$ & 2.683 \\
\hline Hinderks, Franz, Kassenassistent, Akzisekassenschreiber & $1873-1916$ & 435 \\
\hline Hinderks, Franz, Kassenschreiber & 1889-1891 & 2.732 \\
\hline Hinderks, H. A., Fuhrmann & $1871-1874$ & 2.490 \\
\hline Hinderks, Hajo, Fuhrmann & 1875 & 1.555 \\
\hline Hinderks, Hinderk A., Landgebräucher & 1902-1909 & 1.249 \\
\hline Hinrichs, Berent Janssen, Lehrer & $1891-1907$ & 3.653 \\
\hline Hinrichs, Johann, Lehrer & $1891-1907$ & 3.653 \\
\hline Hintze, Otto, Historiker & 1915 & 200 \\
\hline Hippel von, Wilhelm, Fregattenkapitän & $1912-1913$ & 3.088 \\
\hline Hippen, Friedrich, Klubwirt & 1899-1901 & 2.764 \\
\hline Hischer, Ernst, Kanzlist & 1907-1908 & 342 \\
\hline Höbarth, Franziska, Düngerverkäuferin & 1878-1899 & 876 \\
\hline Höbarth, Jürrina, Düngerverkäuferin & $1878-1899$ & 876 \\
\hline Hobarth, Verstorbener Kranverwalter & 1868-1902 & 2.016 \\
\hline Höcke, Albert, Bauaufseher- und Schreiber & 1876-1892 & 437 \\
\hline Hofer, Schneidermeister in Königsberg/Pr. & 1886-1902 & 3.739 \\
\hline Hoffmann, Diedrich Ferdinand, Arbeiter & $1882-1910$ & 501 \\
\hline Hoffmann, Dr., Landrabbiner & 1911-1922 & 482 \\
\hline Hoffmeister, Carl, Restaurateur & $1876-1897$ & 2.688 \\
\hline Hoffmeister, Friedrich, Töchterschullehrer & $1909-1910$ & 3.786 \\
\hline Hoffmeister, Heinz, Bildhauer & $1879-1880$ & 193 \\
\hline Hoffmeister, Musiker & $1875-1890$ & 3.836 \\
\hline Hollander, M., Erbpächter & 1896-1898 & 2.781 \\
\hline Hollen van, Heizer & $1897-1911$ & 1.046 \\
\hline Holten van, Daniel, Legatgeberin & $1885-1914$ & 3.456 \\
\hline Holthuis, Nikolaus, Kaufmann & $1906-1911$ & 2.439 \\
\hline Holtmann, Bürgervorsteherkollegiumsssprecher & $1910-1911$ & 955 \\
\hline Hölzenbein, Bankdirektor u. Mitglied d. kath. Schulvorstands & $1878-1890$ & 3.704 \\
\hline Honsberg, Katharina Margaretha, Legatgeberin & $1885-1914$ & 3.456 \\
\hline Hont van, Jan, Zimmermann & 1906 & 2.844 \\
\hline Hoogklimmer, Heinrich, Gerichtsassessor & 1913 & 428 \\
\hline Hoorn van, P., Hausbesitzer & 1873-1906 & 1.263 \\
\hline Hooten, H. B., Gemüsebauer & $1888-1891$ & 2.729 \\
\hline Hooten, H., Landgebräucher & 1881-1909 & 2.402 \\
\hline Hooten, Hoote, Landgebräucher & $1869-1893$ & 2.473 \\
\hline Hosky, B., Kommissionär aus Prag & $1905-1906$ & 2.377 \\
\hline Hoth, H.J., Landgebräucher & $1875-1909$ & 836 \\
\hline Hotsch, G., Eisenbahn-Packmeister & $1886-1899$ & 2.722 \\
\hline Houselle, W, Autor & 1881 & 1.894 \\
\hline Houtrouw, T. Bürgervorsteherkandidat & $1872-1903$ & 75 \\
\hline Hove van, Johann, Bierhändler & 1906-1907 & 2.838 \\
\hline Huisman, J. A., Kaufmann & $1866-1874$ & 1.039 \\
\hline Huismann, Abfuhraufseher & $1897-1906$ & 874 \\
\hline Huismann, P., Aufseher der Stadtreinigung & $1897-1913$ & 882 \\
\hline Huismann, Reinder, Verkaufsbudenbetreiber & $1868-1897$ & 1.946 \\
\hline Huizenga, Hinderk, Kapitän & $1912-1918$ & 263 \\
\hline Huizinga, H., Kapitän & 1897-1898 & 2.571 \\
\hline
\end{tabular}


Index

\begin{tabular}{|c|c|c|}
\hline \multicolumn{3}{|l|}{ PERS } \\
\hline Indexbegriff & Laufzeit & Lfd.Nr. \\
\hline Hülsebus, M., Deichrichter & $1896-1911$ & 1.549 \\
\hline Hülst van, Theodor, Gutsbesitzer und Reichstagsabgeordneter & $1870-1903$ & 218 \\
\hline Hummerich, D., Handarbeitslehrerin i. R. & $1908-1911$ & 3.590 \\
\hline Hummerich, Diedrich A., Schlachtermeister & 1883-1902 & 1.909 \\
\hline Hummerich, Geerd, Schlachter & $1889-1909$ & 2.433 \\
\hline Hummerich, Gerhard A., Schlachtermeister & $1883-1902$ & 1.909 \\
\hline \multirow[t]{2}{*}{ Hummerich, Gerhard, Schlachter } & $1874-1884$ & 892 \\
\hline & $1869-1890$ & 1.214 \\
\hline Hummerich, J.H., Schlachter & $1874-1884$ & 892 \\
\hline Hummerich, Johann, Schlachter in Borssum & 1914 & 238 \\
\hline Hummerich, Ludwig, Schlachter & $1883-1884$ & 2.713 \\
\hline Hunsoth Dr., Ingenieur aus Hannover & 1903-1904 & 944 \\
\hline Husmann, Gerhard, Lehrer & $1906-1913$ & 3.569 \\
\hline Hußmann, Hermann, Lehrer & $1909-1913$ & 3.587 \\
\hline Iderhoff, Dr., Landtagsabgeordneter & $1882-1908$ & 2.009 \\
\hline Iderhoff, Sielrichter & $1866-1891$ & 1.488 \\
\hline Ihmels, D., Lehrer & $1887-1914$ & 2.345 \\
\hline Ihnen, F. D., Präsident der Kaufmännischen Deputation & 1876 & 1.438 \\
\hline Ihnen, Franz D., Senator & $1885-1903$ & 2.723 \\
\hline Ihnen, Franz D., Senator und Armenkollegiumsvorsitzender & $1872-1918$ & 1.870 \\
\hline Ihnen, Senator & $1887-1888$ & 1.436 \\
\hline Ihnen, Weert, Getreidemakler & $1871-1913$ & 419 \\
\hline Isecke, Helene, Dienstmagd & 1918 & 1.888 \\
\hline Italiener, Albert, Kaufmann & 1899 & 534 \\
\hline Italiener, G.I., Schlachter & $1867-1908$ & 846 \\
\hline Italjener, Joseph, Beschwerdeführer & 1911-1922 & 482 \\
\hline Italjener, Samuel Isaac, Hausbesitzer & $1870-1879$ & 888 \\
\hline Ites, Everhardus, Arbeiter & $1916-1918$ & 1.887 \\
\hline Ivens, Johann, Arbeiter & 1916-1918 & 1.885 \\
\hline Ivens, Johann, Häftling & $1916-1918$ & 1.887 \\
\hline Jabben, Ludwig, Lehrer & $1911-1918$ & 3.570 \\
\hline Jacob, Hermann Hans, Heringsloggermatrose & 1913 & 1.873 \\
\hline Jacobi, Franz, Akzise-Kontrolleur & $1902-1904$ & 427 \\
\hline Jacobs, Enke, Aschkarrenfuhrmann & $1871-1906$ & 961 \\
\hline Jacobs, geb. Janssen, Alberta, Mittellose Witwe & 1914 & 1.877 \\
\hline Jacobs, Jacob, Verlaatswärter & $1866-1891$ & 1.488 \\
\hline Jacobs, Wilhelm, Maurer & 1914 & 1.880 \\
\hline Jakobs, E., Bewerber & $1883-1896$ & 887 \\
\hline Janßen geb. Garrelts, Anna, Bauauftraggeberin & $1911-1912$ & 1.661 \\
\hline \multirow[t]{2}{*}{ Janssen, Adolf, Bauunternehmer } & $1910-1911$ & 1.203 \\
\hline & 1911-1912 & 1.661 \\
\hline Janssen, Agge, Tbc-kranker Mittelloser & 1914 & 1.875 \\
\hline Janssen, B., Rektor & $1908-1911$ & 3.547 \\
\hline Janssen, C. G., Hausbesitzer & $1902-1904$ & 3.642 \\
\hline Janssen, Conrad, Hutmacher & $1898-1917$ & 1.882 \\
\hline Janssen, Emil, Polizeisergeant & $1882-1884$ & 405 \\
\hline Janssen, Emma, Turn- und Handarbeitslehrerin & 1908 & 3.548 \\
\hline Janssen, F. G., Kräutner & $1888-1889$ & 1.381 \\
\hline Janssen, Friedrich G., Kaufhausbesitzer & 1906 & 1.374 \\
\hline Janßen, Friedrich G., Privatier & $1899-1906$ & 2.790 \\
\hline Janssen, Friedrich, Rentier & $1900-1906$ & 2.564 \\
\hline Janssen, Garrelt, Landgebräucher & $1868-1911$ & 825 \\
\hline Janssen, geb. Behrens, Aaltje, Hausbesitzerin & 1867 & 1.313 \\
\hline Janssen, Gemeindevorsteher in Borssum & $1913-1915$ & 241 \\
\hline Janßen, Georg, Rüstmeister & $1874-1901$ & 2.622 \\
\hline Janssen, Goldschmied & 1873-1906 & 1.263 \\
\hline
\end{tabular}


Index

\begin{tabular}{|c|c|c|}
\hline \multicolumn{3}{|c|}{ PERS } \\
\hline Indexbegriff & Laufzeit & Lfd.Nr. \\
\hline Janssen, Harm, Polizeisergeant & $1912-1914$ & 417 \\
\hline Janßen, Hatto G., Restaurateur & $1902-1904$ & 545 \\
\hline Janßen, Hermann A., Zigarrenmacher & $1886-1912$ & 2.386 \\
\hline Janssen, Hinderk, Sattler und Tapezierer & 1916 & 1.886 \\
\hline Janßen, Hindertje, Dienstmagd & $1902-1903$ & 1.694 \\
\hline Janssen, Jacob, Schiffsbaumeister & 1905-1909 & 2.448 \\
\hline Janssen, Jeanette, Lehrerin & 1887-1892 & 3.787 \\
\hline \multirow[t]{2}{*}{ Janssen, Johann, Schiffsbauer } & $1885-1896$ & 924 \\
\hline & $1883-1884$ & 1.220 \\
\hline Janssen, Johann, Schiffszimmermeister & $1869-1901$ & 1.159 \\
\hline Janssen, Johanne Antonette, Dienstmagd & $1915-1917$ & 1.884 \\
\hline Janssen, Johanne Sophie, Dienstmagd & 1915 & 1.883 \\
\hline Janssen, Lüppe, Landgebräucher & $1868-1911$ & 825 \\
\hline Janssen, N., Antragssteller & 1887-1895 & 3.507 \\
\hline Janssen, Peter, Lehrer & $1906-1910$ & 3.589 \\
\hline Janssen, R., Grundstücksbesitzer & $1885-1911$ & 834 \\
\hline Janssen, R.R., Bäckermeister u. Verbandsvorsitzender & $1881-1910$ & 1.906 \\
\hline Janssen, Schiffsbaumeister & 1896 & 2.573 \\
\hline \multirow{2}{*}{ Janssen, Schulrektor } & 1909 & 3.537 \\
\hline & 1906-1908 & 3.616 \\
\hline Janssen, V.R., Bezirksvorsteher & $1865-1877$ & 153 \\
\hline Janssen, verw. Tiemann, geb. Decker, Elisabeth, Mittellose & $1913-1916$ & 1.874 \\
\hline Janssen, W. H., Mittellose Witwe & $1871-1872$ & 1.707 \\
\hline Janssen, W.H., Pastor & $1879-1905$ & 622 \\
\hline Janßen, Wilke Hinrichs, Kanzlist & $1854-1857$ & 336 \\
\hline Janssen,, Reemt, Zuckerfabrikant & $1866-1900$ & 2.481 \\
\hline Jarks, Johann Heinrich Friedrich, Schiffsbauer & $1914-1915$ & 1.876 \\
\hline Jasper, A., Bürgervorsteher & 1913 & 428 \\
\hline Jasper, August, Kaufmann & 1908 & 2.846 \\
\hline Jasper, August, Konsul & $1916-1917$ & 3.236 \\
\hline Jedden, G., Katholik & $1875-1888$ & 3.703 \\
\hline Jeep, Marie, Handarbeitslehrerin & $1887-1890$ & 3.774 \\
\hline Jens, Albert, Bauherr & 1907 & 1.173 \\
\hline \multirow[t]{3}{*}{ Jens, Albert, Gastwirt } & 1901-1902 & 544 \\
\hline & 1901-1902 & 1.364 \\
\hline & $1902-1903$ & 1.368 \\
\hline Jens, Albert, Maurer & 1901 & 540 \\
\hline Jenssen, Anna, Oberlehrerin & 1914-1918 & 3.808 \\
\hline Jetses, Johann, Matrose & 1914-1915 & 1.879 \\
\hline Jhering, Prof., Kandidat für Reichstagswahl & $1866-1867$ & 216 \\
\hline Jindelt van, Cornelius, Turmwächter & $1869-1896$ & 436 \\
\hline \multirow{5}{*}{ Jindelt van, Hermann Cornelius, Kaufmann } & $1900-1903$ & 1.166 \\
\hline & $1901-1907$ & 1.502 \\
\hline & $1888-1903$ & 1.503 \\
\hline & $1908-1913$ & 2.013 \\
\hline & $1899-1901$ & 2.760 \\
\hline Jindelt van, Rudolf, Bootsbauer & $1907-1910$ & 2.588 \\
\hline Jipp, Stadtbaumeister in Leer & 1897-1899 & 1.032 \\
\hline Johansen, Dr., Erster Bürgermeister der Stadt Minden & $1909-1913$ & 2.087 \\
\hline John Prof., Jurist Universität Göttingen & 1869-1889 & 3.325 \\
\hline Jong de, Pieter, Niederländischer Schiffer & $1906-1911$ & 2.439 \\
\hline Jonge de, H., Schiffsbesichtiger & $1900-1902$ & 422 \\
\hline Jonge de, Johann, Malermeister & $1882-1913$ & 2.408 \\
\hline Jonge de, Peter, Kaufmann & $1878-1891$ & 2.428 \\
\hline Joth, H.J., Landwirt & $1893-1901$ & 940 \\
\hline Jünemann, Ferdinand, Manufakturwarenhändler & 1904 & 1.370 \\
\hline Jung, Heinrich, Rüstmeister & 1903-1907 & 430 \\
\hline Jung, Kaufmann & $1870-1886$ & 1.392 \\
\hline
\end{tabular}


Index

\begin{tabular}{|c|c|c|}
\hline \multicolumn{3}{|l|}{ PERS } \\
\hline Indexbegriff & Laufzeit & Lfd.Nr. \\
\hline Jungck, Gewerbeinspektor & $1898-1899$ & 1.043 \\
\hline Junge, Otto, Bauunternehmer aus Hameln & $1903-1912$ & 1.167 \\
\hline Jungk, Alma Hedwig Johanna, Mittellose & $1915-1917$ & 1.881 \\
\hline Jungk, Else, Kind & $1915-1917$ & 1.881 \\
\hline Jürgens, Bernhard, Zimmermeister & $1896-1898$ & 2.750 \\
\hline Jürgens, Johann G., Zimmermann & $1879-1891$ & 2.429 \\
\hline Juschka, Ottto, Stotterheilanstalt & 1890 & 3.856 \\
\hline Jutting, Johann Cornelius, Legatgeber & $1885-1914$ & 3.456 \\
\hline Juzi, Theodor, Kaufmann und Senator & $1869-1905$ & 24 \\
\hline Kaffka, Margaretha, Lehrerin & $1912-1915$ & 3.555 \\
\hline Kampe, Adolph, Kafmann in Wolthusen & 1902 & 1.939 \\
\hline Kämpf, Dr., Reichstagspräsident & 1917 & 3.215 \\
\hline Kannegießer, Ulrich, Polizeisergeant & $1908-1909$ & 375 \\
\hline Kapelle von, Admiral und Staatsskretär im Reichsmarineamt & $1914-1918$ & 3.232 \\
\hline Kappelhoff, Anton, Bankier, Kaufmann und Senator & $1912-1918$ & 263 \\
\hline Kappelhoff, Anton, Senator und Bankier & $1900-1911$ & 259 \\
\hline Karßeboom, Nathan M., Schlachter & 1878 & 1.938 \\
\hline Katzenstein, L., Jüdischer Geschäftsmann & $1875-1901$ & 1.494 \\
\hline Katzenstein, Salomon, Kaufmann & 1901-1908 & 2.559 \\
\hline \multirow[t]{2}{*}{ Katzke, Adolph Otto, Polizeisergeant } & $1868-1872$ & 358 \\
\hline & $1874-1875$ & 404 \\
\hline Kaune, Max, Installateur & $1892-1912$ & 881 \\
\hline Kellenberg, Friedrich, Kapitän & $1900-1901$ & 2.759 \\
\hline Kempf, Ottilie, Vermisstes Flüchtlingskind & $1914-1916$ & 3.203 \\
\hline \multirow[t]{2}{*}{ Kettler, Hannoverscher Wasserbaudirektor } & $1867-1910$ & 1.490 \\
\hline & $1875-1901$ & 1.494 \\
\hline Kiesel, Dr., Karl, Anwalt in Berlin & $1908-1911$ & 2.363 \\
\hline Kievitt, Harm, Altschiffer und Rendant & $1874-1881$ & 3.688 \\
\hline Kiewiet, J.G., Landgebräucher und Schüttstallbetreiber & $1866-1887$ & 824 \\
\hline Kiewiet, Jakob G., Lehrer & $1899-1900$ & 2.756 \\
\hline Kind, Gotthilf, Reformierter Pastor & $1874-1910$ & 3.378 \\
\hline Kirchner, Karl, Badeunternehmer & $1881-1911$ & 737 \\
\hline Klaasen, Geerd, Maschinist und Kanalabgabeneinnehmer & $1900-1912$ & 1.563 \\
\hline Klaassen, A., Hausbesitzer & $1866-1911$ & 962 \\
\hline Klaaßen, Berend, Lehrer & $1904-1916$ & 3.607 \\
\hline Klaassen, Gesina, Kaufmannswitwe & $1873-1897$ & 2.549 \\
\hline Klaassen, Johann, Fischhändler & $1891-1904$ & 2.738 \\
\hline Klaassen, Johann, Gehbehinderter & $1896-1912$ & 844 \\
\hline Klaassen, Johann, Gemüsehändler & 1917-1918 & 3.308 \\
\hline Klaassen, Klaas Meints, Verlaatswärter & $1866-1891$ & 1.488 \\
\hline Klaassen, Senator u. Vorsitzender der Gaswerkskommission & $1905-1909$ & 1.073 \\
\hline Klaassen, W. H., Bezirksvorsteher & $1865-1877$ & 153 \\
\hline Klaassen, Wwe., Hausverkäuferin & $1896-1897$ & 3.002 \\
\hline Klages, Gertrud, Lehrerin & $1912-1914$ & 3.588 \\
\hline \multirow[t]{2}{*}{ Kleindieck, Gaswerksdirektor } & $1904-1911$ & 1.052 \\
\hline & $1912-1913$ & 1.093 \\
\hline Kleine, Johann Heinrich, Buchhalter & $1902-1904$ & 2.796 \\
\hline Klingemann, Martha, Lehrerin & 1901-1906 & 3.677 \\
\hline \multirow[t]{3}{*}{ Klitzing von, Philipp, Oberingenieur } & $1910-1911$ & 1.468 \\
\hline & 1911-1912 & 1.477 \\
\hline & 1911-1912 & 1.484 \\
\hline Klöffkorn, Johann, Gastwirt & $1907-1914$ & 2.986 \\
\hline Klopp, Onno. Geschichtsschreiber & $1900-1901$ & 203 \\
\hline Klug, H., Hausbesitzer & $1883-1898$ & 971 \\
\hline Klug, H., Landschaftsrat und Senator & $1879-1885$ & 27 \\
\hline Klug, Obertelegraphenassistent & 1901 & 1.153 \\
\hline Kluge, Landschaftsrat & 1876-1889 & 843 \\
\hline
\end{tabular}


Index

\begin{tabular}{l}
\hline \\
\hline Indexbegriff \\
\hline Klüver, Wessel, Lehrer \\
Knop, Actuar \\
Knyphausen, Graf von, Landschaftsrat \\
Koch, Carl, Steinsetzer \\
Koch, Ernst, Reform. Pastor \\
Koch, Prof. Dr., Robert, Bakteriologe und Arzt \\
Koehorn, Schneidermeister \\
Koerts, Siegfried, Polizeisergeant \\
Köhler, Direktor der Bremisch-Hannoverschen Kleinbahnen \\
Kolhoff, Kräutner \\
Kolhoff, S. P., Kräutner \\
König, H., Zimmermeister \\
König, Hüttendirektor \\
König, Joseph, Seemann \\
König, Redakteur aus Witten \\
Koningshoff, Peter, Dienstmann \\
Konter, Steuereinnehmer \\
Koopmann, Altreformierter Prediger \\
Kopp, Christian Friedrich, Actuar \\
Kopp, Kanzleirat a.D. \\
Kornmehl, Navigationsschuldirektor \\
Korting, Direktor des Hannoverschen Gaswerks
\end{tabular}

Kortkampf, R. F., Lederfabrikant

Kothe, John, Generalkonsul

Kramer, Abeldine, Hebamme

Krause, Dr., Paul, Anwalt in Berlin

Krebs, Kripobeamter

Kreling, C., Getreidemakler

Kreutzberg, Kaufmann

Krieger, Theodor, Lehrer

Kruckenberg, M. N., Mühlenbetreiber

Krüger, Friedrich, Polizeisergeant

Kruithoff, A., Baunternehmer

Kruse, Elisabeth, Lehrerin

Kruse, Frauke, Lageristin

Kruse, K. A., Kaufmann

Kruse, Navigationsschullehrer

Kruspe, Karl, Restaurateur aus Halle / S.

Kuckuck, Carl Hermann, Polizeisekretär

Kuhn, Navigationslehrer

Kühne, Johannes Gerhard, Navigationsschullehrer

Kuiper, Anton, Veteran der Ersten deutschen Marine

Küstermann, Dr., Anwalt der Hohenzollerhütte

Küsthardt, Georg, Bildhauer

\section{Laufzeit}

1885-1902

$1866-1900$

1886

1898

1874-1910

1890-1911

1878-1894

1909-1911

1907

1874-1875

1884-1885

1902

1910-1911

1873

1912

1872-1918

1868

1869-1905

1875

1902-1903

1870-1910

1895-1898

1898-1903

1904-1911

1899-1906

1905-1909

1894

1910-1911

1898-1918

1908-1911

1916-1918

1871-1913

1888-1903

1913-1914

1867-1885

1905-1912

1901-1903

1875-1889

1917-1918

1892

1875-1905

1875-1914

1875-1894

1880-1885

1876-1890

1863-1892

1879

1870-1871

1905-1916

1905-1916

1875-1905

1909-1913

1888-1902

1894-1897

1902-1904

1888
1910-1911

Lfd.Nr.

3.685

2.481

1.547

530

3.378

770

774

387

1.993

1.296

2.527

1.372

2.369

1.759

2.100

1.947

1.225

3.498

1.295

2.802

1.597

1.031

1.035

1.052

1.072

1.073

2.209

1.468

764

2.363

3.183

419

1.503

3.556

2.913

381

2.556

3.652

3.289

1.348

1.594

1.605

1.617

1.623

738

356

398

1.582

1.584

1.584

1.594

Laarmann, Lotsenkommandeur 
Index

\begin{tabular}{l}
\hline \\
\hline Indexbegriff \\
\hline Laarmann, Lotsenkommandeur \\
Ladorff, Kath. Geistlicher \\
Laermann, Hermann, Lotsenkommandeur \\
Laloli, Modesto, Schornsteinfegermeister \\
Lang, Conrad, Ingenieur u. Bevollmächtigter d. Gaswerkspächters \\
Lange, Christian, Navigationslehrer \\
Lange, Dr. med., Arzt \\
Lange, H. A., Schiffsführer \\
Lange, Heinrich, Gärtner \\
Lange, Johann, Gärtner \\
Lange, Johannes Petrus, Alkoholiker \\
Langheim, Wilhelm, Dachdeckermeister \\
Langhoff, Dr., Hugo, Arzt
\end{tabular}

Lantzius, Friedrich, Lehrer

Laporte, Stadtphysicus

Lauter, Gustav, Polizeikommissar

Lech, Polizeisergeant

Lechtern, Karl, Polizeisergeant

Leck, Konrad, Polizeisergeant

Leeling, Schuldiener

Leesekamp, Pastor

Lefermann, F., Konditormeister

Legel, Otto, Lehrer

Lehnkering, Carl, Kommerzienrat

Leigraf, Schankwirt

Leinberger, Walter, Stadtsyndicus

Leinberger, Walter, Stadtsyndicus u. weltlicher Kirchenkommissar Leinwohl, Hirsch Leizer, Jüdischer Damenschneider

Letten van, J. G., Holzhändler

Letten van, Johann G., Kalkbrenner

Leune de, Elise, Töchterschullehrerin

Leune de, Emilie, Töchterschullehrerin

Leurog, Frauke Heiden, Unterstützungsbedürftige

Lewinsky, Dr., Landrabbiner des Regierungsbezirks Hildesheim

Liegnitz, Architekt

Lier, Franz, Nachtwachtmeister

Lierbrock, Frau, Schweinehalterin

Liesenhoff, Unternehmer

Linde van der, C. A., Bauunternehmer

Linde van der, $\mathrm{H}$., Bauunternehmer

Linde van der, J., Bauunternehmer

Linde van der, Martin, Schriftsetzer und Lassalleaner

Lindemann, Bürgevorsteherin

Lindemann, L. H., Gaswerksbuchhalter

\section{Laufzeit}

1903

1878-1890

1909-1913

1873-1906

1907-1916

1866-1873

1905-1916

1872-1913

1896

1905

1905

1891-1912

1905-1908

1906-1908

1905-1909

1906-1909

1896-1911

1886-1918

1880-1912

1912-1918

1879-1904

1891-1912

1899-1904

1904

1908

1884-1915

1905-1915

1906-1907

1890-1893

1897-1912

1867

1874-1905

1877-1881

1912

1905-1907

1904-1915

1907-1911

1909-1914

1908-1911

1908-1909

1913-1915

1877-1882

1880-1881

1880

1872-1899

1872-1899

1906-1912

1911-1922

1908-1912

1884-1906

1875-1896

1887

1910

1906-1907

1910

1867-1891

1902-1909

1897-1912
Lfd.Nr.

1.417

3.704

261

1.263

1.264

1.037

1.584

2.655

1.352

2.843

2.843

519

2.842

856

1.073

1.075

1.549

3.678

776

263

522

632

852

1.370

1.376

772

364

376

378

1.157

1.310

831

975

3.597

2.083

667

32

802

1.467

3.342

1.872

2.513

2.514

1.331

3.775

3.775

253

482

556

413

1.156

2.324

1.010

2.324

719

3.550

1.036 
Index

\begin{tabular}{|c|c|c|}
\hline \multicolumn{3}{|c|}{ PERS } \\
\hline Indexbegriff & Laufzeit & Lfd.Nr. \\
\hline Lindemann, Leonhard, Kaufmann & 1899 & 2.752 \\
\hline Lindemann, $\mathrm{O}$, Heringsfischerei-Direktor & 1874-1888 & 2.697 \\
\hline \multirow[t]{2}{*}{ Lindemann, O.C.J., Vizekonsul und Hausbesitzer } & $1889-1890$ & 978 \\
\hline & $1890-1893$ & 979 \\
\hline Lindemann, Vizekonsul & $1891-1904$ & 2.738 \\
\hline Lindemann. O. C. J., Konsul & 1893-1896 & 2.776 \\
\hline Lindenstädt, Dirk, Eingewiesener in Rettungsanstalt & $1867-1887$ & 1.706 \\
\hline Linnemann Prof, A., Glasmalereiexperte & 1904 & 3.826 \\
\hline Linnemann Prof, H., Architekt und Glasmaler & $1899-1910$ & 2.658 \\
\hline Litmeyer, Hermann, Schiffer & $1888-1892$ & 1.535 \\
\hline \multirow{3}{*}{ Löb, Dr., Jonas Hermann, Landrabbiner } & $1900-1911$ & 259 \\
\hline & 1911-1922 & 482 \\
\hline & $1911-1915$ & 1.656 \\
\hline Löb, Jenny, Witwe des Landrabbiners & $1911-1915$ & 1.656 \\
\hline Lobenbrück, Friedrich Jacob, Gasthaus-Inspektor & $1869-1910$ & 1.716 \\
\hline Loesing, Familie & $1885-1907$ & 2.391 \\
\hline Loesing, J.C., Erblasser & $1885-1907$ & 2.391 \\
\hline Loesing, Johann Cornelius Particulier und Senator & 1894 & 19 \\
\hline Lohmeyer, Dr., Sanitätsrat und Krankenhausrat & $1890-1891$ & 1.691 \\
\hline Lohmeyer, Sanitätsrat & 1900-1909 & 264 \\
\hline \multirow[t]{2}{*}{ Lohskötter, Amtsgerichtsrat } & $1900-1911$ & 259 \\
\hline & $1875-1914$ & 814 \\
\hline Lolling, Bürgervorsteher & $1913-1914$ & 3.615 \\
\hline Lolling, Dedde, Veteran aus dem Befreiungskrieg & $1869-1876$ & 3.106 \\
\hline Lolling, Rechnungssteller & 1867-1882 & 431 \\
\hline Loning, F. T., Müller & $1866-1888$ & 2.379 \\
\hline Lorenz, Johann Peter, Lehrer & $1891-1907$ & 3.653 \\
\hline Löschen, Carl, Bauunternehmer & 1897-1906 & 874 \\
\hline Lose, Tyake, Navigationsschulwärterin & $1875-1905$ & 1.594 \\
\hline Lottmann, Fritz, Landvermesser & $1870-1914$ & 1.163 \\
\hline Lottmann, Hinrich, Invalide und Wallwärter & $1914-1916$ & 966 \\
\hline Lübben, Gerhard Hermann, Lehrer & $1891-1907$ & 3.653 \\
\hline \multirow[t]{12}{*}{ Lubich, Carl Gottlieb, Polizeikommissar } & $1868-1904$ & 171 \\
\hline & $1855-1896$ & 409 \\
\hline & $1874-1875$ & 1.296 \\
\hline & 1873 & 1.298 \\
\hline & 1873 & 1.299 \\
\hline & 1873 & 1.300 \\
\hline & 1872 & 1.302 \\
\hline & $1869-1874$ & 1.306 \\
\hline & 1868 & 1.309 \\
\hline & 1867 & 1.311 \\
\hline & $1875-1909$ & 2.383 \\
\hline & $1866-1897$ & 2.411 \\
\hline Lubich, geb. Meyer, Bertha, Kommissarswitwe & $1855-1896$ & 409 \\
\hline Lucius, Dr., Preußischer Landwirtschaftsminister & 1886 & 1.547 \\
\hline Lüddecke, Karl, Lehrer & $1913-1918$ & 3.604 \\
\hline Ludendorff, Generalquartiermeister & 1918 & 3.219 \\
\hline Luers, H.A., Schiffsbesichtiger & $1900-1902$ & 422 \\
\hline Luiken, J. H., Kläger & $1900-1901$ & 1.001 \\
\hline Luiken, J. M:, Kräutner & 1869 & 1.949 \\
\hline Lüpkes, Dr., Oberlehrer & $1902-1903$ & 1.498 \\
\hline Lüpkes, geb. Winter, Hilda, Wissenschaftliche Hilfslehrerin & 1918 & 3.788 \\
\hline Lüpkes, H. W., Fleckensvorsteher in Pewsum & $1895-1900$ & 2.063 \\
\hline \multirow[t]{2}{*}{ Lüpnitz, Geoeg, Architekt } & $1881-1912$ & 626 \\
\hline & $1908-1909$ & 1.013 \\
\hline \multirow[t]{2}{*}{ Lüpnitz, Georg, Architekt } & $1906-1913$ & 2.850 \\
\hline & $1906-1911$ & 2.851 \\
\hline
\end{tabular}


Index

\begin{tabular}{|c|c|c|}
\hline \multicolumn{3}{|c|}{ PERS } \\
\hline Indexbegriff & Laufzeit & Lfd.Nr. \\
\hline Lüppens, Gustav, Architekt & $1906-1908$ & 2.840 \\
\hline Luther, Martin, Reformator & 1883 & 569 \\
\hline Lutz, Adolf, Polizeisergeant & $1896-1901$ & 407 \\
\hline Magnus, Moritz, Waffenhändler aus Hamburg & 1882-1906 & 2.610 \\
\hline Mahlmann, Rechtsanwalt und Notar & 1876-1904 & 170 \\
\hline Mahlstede, H., Restaurantbesitzer & $1898-1900$ & 1.004 \\
\hline Manesse, Casjen, Agent & 1904 & 2.813 \\
\hline \multirow[t]{2}{*}{ Mansholt, Dr., Tierarzt und Fleischbeschauer } & $1865-1895$ & 746 \\
\hline & 1874-1905 & 831 \\
\hline Mansholt, Egbert, Kaufmann & $1908-1914$ & 2.878 \\
\hline Mansholt, J., Gemeindevorsteher von Ditzum & 1902 & 345 \\
\hline Margis, Carl, Lehrer & $1885-1914$ & 3.790 \\
\hline Markus, Gemüsebauer & $1896-1911$ & 1.549 \\
\hline Markus, Georg, Alkoholiker & $1913-1915$ & 1.872 \\
\hline Marschall, Ignatz Joseph, Schuldiener & $1880-1918$ & 2.353 \\
\hline Martens, Stadtbaumeister & 1870 & 849 \\
\hline Martini, Carl, Vollziehungsbeamter & 1886-1892 & 2.726 \\
\hline Martini, Sikko, Lehrer & $1872-1909$ & 3.791 \\
\hline Massow von, Oberregierungsrat & $1882-1913$ & 1.636 \\
\hline Mateling, Johanna, Hausbesitzerin & 1876 & 1.176 \\
\hline \multirow[t]{2}{*}{ Matthies, Navigationsschullehrer } & $1871-1895$ & 1.588 \\
\hline & $1875-1905$ & 1.594 \\
\hline Matthies, Wasserbauingenieur & $1891-1893$ & 2.025 \\
\hline Maybach, Preußischer Minister der öffentlichen Arbeiten & $1887-1912$ & 1.437 \\
\hline Mecke, Johanna, Kindergärtnerin & $1889-1890$ & 3.852 \\
\hline Medenwold, Predigerkandidat & $1871-1897$ & 3.419 \\
\hline Meentz, Baurat & 1906-1909 & 1.223 \\
\hline \multirow[t]{2}{*}{ Meentzen, Carl, Kaufmann } & $1915-1917$ & 2.601 \\
\hline & $1915-1918$ & 2.602 \\
\hline Mehlhorn, Franz, Bauunternehmer & $1901-1902$ & 1.237 \\
\hline Meier, Julius, Bremen & $1905-1912$ & 2.105 \\
\hline Meinders, Johannes, Zimmermann & $1882-1907$ & 3.638 \\
\hline Meinecke, Heinrich, Polizeisergeant & $1909-1911$ & 362 \\
\hline Meinke, Alexander, Seemann & $1868-1891$ & 1.576 \\
\hline Melles, Johann Heinrich, Erbpächter & $1886-1891$ & 2.724 \\
\hline Menge, Vikar und Lokalschulinspektor & $1878-1890$ & 3.704 \\
\hline Mennenga, Diedrich, Kellner & 1898 & 531 \\
\hline \multirow[t]{2}{*}{ Mennenga, Dirk, Gastwirt } & $1901-1903$ & 76 \\
\hline & 1901-1902 & 77 \\
\hline Mennenga, Navigationslehrer & $1905-1916$ & 1.584 \\
\hline \multirow[t]{2}{*}{ Mensching, Werner, Syndicus der Stadt Emden } & $1911-1917$ & 33 \\
\hline & 1907-1912 & 695 \\
\hline Menten, A., Grundbesitzer & 1904 & 2.849 \\
\hline Menthe, A., Schankwirt & 1904-1906 & 2.852 \\
\hline Menthe, Gerd Albert, Gastwirt & 1883-1898 & 971 \\
\hline Mentjes, J.T., Hausbesitzer & 1893-1894 & 936 \\
\hline Mentz, Baurat & 1907 & 250 \\
\hline Mentzen, Adolf, Fuhrmann und Pächter & $1867-1897$ & 2.464 \\
\hline Merkel, Babette, Legatgeberin & $1885-1914$ & 3.456 \\
\hline Metger, Assessor & $1867-1897$ & 2.419 \\
\hline Metger, C. H., Senator & $1889-1893$ & 2.739 \\
\hline Metger, G. F., Fabrikant & $1867-1887$ & 2.700 \\
\hline \multirow{5}{*}{ Metger, Gottfried R., Stadtsyndicus } & $1868-1912$ & 30 \\
\hline & $1881-1897$ & 1.020 \\
\hline & 1867 & 1.313 \\
\hline & 1887 & 1.341 \\
\hline & $1867-1893$ & 1.495 \\
\hline
\end{tabular}


Index

\begin{tabular}{|c|c|c|}
\hline \multicolumn{3}{|c|}{ PERS } \\
\hline Indexbegriff & Laufzeit & Lfd.Nr. \\
\hline \multirow[t]{3}{*}{ Metger, Gottfried R., Stadtsyndicus } & $1866-1913$ & 1.930 \\
\hline & $1875-1881$ & 2.510 \\
\hline & $1877-1881$ & 2.511 \\
\hline Metger, Kommerzienrat & 1883-1901 & 2.044 \\
\hline Metger, Kommerzienrat und Senator & $1905-1906$ & 2.360 \\
\hline \multirow[t]{7}{*}{ Metger, Konrad Hermann, Senator und Fabrikdirektor } & $1900-1911$ & 259 \\
\hline & $1909-1913$ & 261 \\
\hline & $1912-1918$ & 263 \\
\hline & $1887-1888$ & 412 \\
\hline & $1871-1914$ & 757 \\
\hline & 1885-1907 & 1.543 \\
\hline & $1867-1906$ & 2.032 \\
\hline Metger, Rudolf, Rechtsanwalt & $1905-1909$ & 2.361 \\
\hline Metger, Senator und Kommissar & 1876-1918 & 3.168 \\
\hline Metger, Syndicus & 1871 & 1.774 \\
\hline Metz, Franz Wilhelm, Turnlehrer & $1895-1914$ & 730 \\
\hline Metzner, Fritz, Rüstmeister & $1902-1903$ & 429 \\
\hline Meyer Dr., Rechtsanwalt in Aurich & 1895 & 3.370 \\
\hline Meyer, Abraham Joseph, Manufakturist & $1880-1881$ & 1.329 \\
\hline Meyer, Amtsgerichtsrat und Landtagsabgeordneter & $1902-1903$ & 205 \\
\hline Meyer, Anton, Auktionator & $1902-1906$ & 168 \\
\hline Meyer, Auktionator & $1877-1913$ & 1.276 \\
\hline Meyer, Auktionator in Emden & $1899-1911$ & 1.908 \\
\hline \multirow[t]{2}{*}{ Meyer, Barthold G., Zimmermeister } & $1900-1903$ & 2.757 \\
\hline & 1901-1902 & 2.775 \\
\hline \multirow[t]{6}{*}{ Meyer, Berend J., Abfuhrunternehmer } & $1907-1911$ & 875 \\
\hline & 1878-1899 & 876 \\
\hline & 1879-1909 & 877 \\
\hline & $1909-1915$ & 878 \\
\hline & 1905-1908 & 948 \\
\hline & $1882-1884$ & 2.712 \\
\hline Meyer, Berend J., Hausbesitzer & 1899-1902 & 853 \\
\hline Meyer, Dechant und Lokalschulinspektor & $1878-1890$ & 3.704 \\
\hline Meyer, Donderikus, Kaufmann & 1880 & 1.330 \\
\hline Meyer, Elise, Stricklehrerin & 1886-1905 & 3.683 \\
\hline Meyer, Ernst-Heinrich, Zimmermann & 1905-1907 & 2.835 \\
\hline Meyer, F. Andreas, Oberingenieur & 1894-1908 & 872 \\
\hline Meyer, Fritz, Grundbesitzer & 1870 & 847 \\
\hline \multirow[t]{2}{*}{ Meyer, Fritz, Hotelier } & $1882-1884$ & 1.178 \\
\hline & 1879 & 1.319 \\
\hline Meyer, Geerd W., Lehrer & 1889 & 3.673 \\
\hline Meyer, Hermann, Schuldiener & $1910-1914$ & 3.731 \\
\hline Meyer, Lehrer & $1866-1868$ & 3.620 \\
\hline Meyer, Lehrer aus Jarssum & 1889 & 3.669 \\
\hline Meyer, R. G., Agent & 1902-1904 & 2.794 \\
\hline Michaelis, Wasserbaurat & $1882-1883$ & 2.021 \\
\hline \multirow[t]{2}{*}{ Middendorf, Justus Heinrich, Reformierter Pastor } & $1899-1900$ & 2.555 \\
\hline & 1874-1910 & 3.378 \\
\hline Middents, G., Gastwirt & 1880 & 2.662 \\
\hline Mierig, E., Schachtmeister & 1893-1894 & 936 \\
\hline Miese, Ernst, Bauunternehmer & $1900-1901$ & 2.793 \\
\hline Milde, Architekt & 1902-1903 & 177 \\
\hline Minolds, Minold, Zimmermann & $1900-1901$ & 2.765 \\
\hline Minolds, Willem, Magistratskanzlist & $1900-1901$ & 2.765 \\
\hline Mohr, Maria (Marie), Lehrerin & 1917-1918 & 3.591 \\
\hline Moltke, Graf von, Hellmuth, Generalfeldmarschall & $1890-1891$ & 565 \\
\hline Monkhorst, Johann Rewert, Kanzlist u. Sekretariatsgehilfe & 1872-1902 & 340 \\
\hline Montigny, Carl, Oberpostschaffner & 1906-1907 & 1.168 \\
\hline
\end{tabular}


IV

Index

\begin{tabular}{rc}
\hline & PERS \\
\hline
\end{tabular}

Indexbegriff

Morstädt, Adolph, Ing. u. Bevollmächtigter d. Gaswerkspächters

Motzkus, Gustav, Polizeisergeant

Mudder, Prof., Gymnasialdirektor

Mülder, J., Hausbesitzer

Mülders, H.S., Müller

Mülders, Müllerwitwe

Müller Dr., Carl Theodor, Lehrer

Müller, Carl, Gaswerksdirektor

\section{Laufzeit}

1885-1902

1866-1873

1902-1907

1909

1867-1874

1869-1872

1895

1890-1892

1881-1883

1881-1897

1897-1914

1897-1912

1897-1905

1896-1908

$1897-1914$

1904-1905

Müller, Carl, Gaswerksdirektor a.D.

Müller, Carl, Ingenieur

Müller, Elisabeth, Witwe des Kapitäns Hero Friedrich Müller

Müller, Exekutor

Müller, Focke Janssen, Rektor der städtischen Volksschule

Müller, G. H., Schankwirt

Müller, H. E., Fuhrmannswitwe

Müller, Harmen E., Dirigierender Lehrer an der Gewerbeschule

$1880-1881$

1879

1884-1896

1897-1909

$1871-1917$

1867-1870

1867

1881-1886
$1873-1880$

1879-1884

1880-1898

$1895-1917$

1908-1916

1896-1897

1868-1875

Müller, Johanne Margarethe, Verlobte eines Juden

Müller, Justizrat

Müller, Klaas, Schulamtsanwärter

Müller, Louis, Rüstkammer-Aufseher

Müller, Navigationsschullehrer

Müller, Navigationsvorschullehrer

Müller, Rechtsanwalt in Aurich

Müller, Regierungs- und Baurat

Müller, Volksschuldirektor

Müller,Turmwächter

Mundt, Rüstmeister

Munnichen, J. A. Witwe, Hausbesitzerin

Müntinga, J., Reformierter Pastor

Mustert, Johannes, Beschwerdeführer

Mustert, Johannes, Kaufmann und Senator

Mustert, Johannes, Vorsitzender der Gasthaus-Direktion

Mustert, Thomas, Händler

Mützelburg, Dr., Wilhelm, Bürgermeister d. Stadt Emden
$1915-1918$

$1912-1918$

$1902-1914$

1893-1895

$1875-1905$

$1875-1894$

1894-1905

$1875-1882$

1900-1907

1869-1896

$1908-1913$

$1870-1884$

$1874-1910$

1897-1899

1872-1890

1869-1910

1868-1897

1917-1918

1913-1914

1914-1915

1913-1915

1913-1922

1868-1914

1913

1914-1918

1881-1900

1909-1914
Lfd.Nr.

3.685

1.037

366

3.712

889

2.672

1.350

3.732

1.028

1.040

1.042

1.045

1.047

1.051

1.057

2.816

1.027

1.321

434

3.525

3.679

3.487

1.312

850

2.330

2.331

2.332

2.352

2.355

2.747

3.351

242

3.592

2.644

1.583

1.594

1.617

3.364

1.431

3.708

436

2.642

1.180

3.378

1.032

17

1.716

1.946

2 
Index

\begin{tabular}{|c|c|c|}
\hline \multicolumn{3}{|l|}{ PERS } \\
\hline Indexbegriff & Laufzeit & Lfd.Nr. \\
\hline Mützelburg, Dr., Wilhelm, Bürgermeister d. Stadt Emden & $\begin{array}{c}1914 \\
1917-1918 \\
1912-1914 \\
1913-1914 \\
1914-1915 \\
1916 \\
1913-1914\end{array}$ & $\begin{array}{r}1.529 \\
1.581 \\
1.994 \\
2.104 \\
3.146 \\
3.213 \\
3.615 \\
\text { Vorwort }\end{array}$ \\
\hline Nagel, Alfred G., Autor & $1912-1913$ & 3.088 \\
\hline Nagel, J., Markt- und Waage-Meister & $1877-1910$ & 2.653 \\
\hline Nanninga, B., Bildhauer aus Leer & 1901 & 2.786 \\
\hline Nathen, Johanne, Schülerin & $1876-1878$ & 3.700 \\
\hline Nederlof, O., Unternehmer & 1898 & 2.227 \\
\hline \multirow[t]{2}{*}{ Neeland, Jan, Baumaterialienhändler } & $1905-1911$ & 1.172 \\
\hline & 1903-1906 & 2.807 \\
\hline Neeland, Johann, Bauunternehmer & $1902-1903$ & 2.801 \\
\hline Neeland, R. J., Bauunternehmer & $1907-1908$ & 1.698 \\
\hline Neerbeck, G., Steinhauer & $1866-1867$ & 1.945 \\
\hline Neiß, Emil, Gasdirektor & $1896-1897$ & 1.029 \\
\hline \multirow[t]{2}{*}{ Ness van, Senator } & 1874-1905 & 831 \\
\hline & 1874-1901 & 2.622 \\
\hline Neufuth, Regierungsrat & 1898-1905 & 394 \\
\hline Neuhaus, Otto, Steuersekretär & 1914-1916 & 3.153 \\
\hline Neumann, Heinrich, Direktor einer landw. Genossenschaft & 1903-1911 & 2.079 \\
\hline Neumark, Joseph, Jüdischer Kaufmann & $1871-1903$ & 758 \\
\hline Neumark, Jüdischer Getreidehändler & 1905 & 2.440 \\
\hline Neumark, M., Händler & $1872-1913$ & 2.655 \\
\hline Neumüller, Wilhelm, Lehrer & $1912-1914$ & 3.557 \\
\hline Niehaus, J. W., Steinhauer & $1866-1867$ & 1.945 \\
\hline Niehofen, Swalina, Alkoholikerin & 1891-1912 & 519 \\
\hline Niemann, Petrus, Erbpächter & 1888-1889 & 2.710 \\
\hline Niemann, Regierungs- und Baurat & 1905-1906 & 1.191 \\
\hline Niemer, Annie, Lehrerin & 1914-1918 & 3.596 \\
\hline Niemeyer, Bürgervorsteher & 1880-1898 & 2.332 \\
\hline Niemeyer, Otto, Maurermeister & $1869-1873$ & 2.466 \\
\hline Niemeyer, Wilhelm, Bautechniker & 1896 & 3.101 \\
\hline \multirow[t]{6}{*}{ Niemöller Dr., Friedrich, Schuldirektor } & 1892-1908 & 3.723 \\
\hline & $1895-1918$ & 3.733 \\
\hline & 1898-1903 & 3.747 \\
\hline & $1902-1903$ & 3.748 \\
\hline & 1904-1911 & 3.753 \\
\hline & $1905-1910$ & 3.755 \\
\hline Nobis, Heinrich Hubert, Polizeisergeant & 1893-1894 & 399 \\
\hline Nocht, Dr., Hamburger Hafenarzt & 1899-1909 & 781 \\
\hline Nöldecke Dr., Töchterschuldirektor & 1872 & 3.764 \\
\hline Nolting, Schmiedemeister & $1866-1874$ & 1.039 \\
\hline Noortmann, Johannes, Maurer & $1867-1914$ & 576 \\
\hline Norden Dr., Armenarzt & $1872-1910$ & 1.869 \\
\hline \multirow[t]{2}{*}{ Norden Dr., Sanitätsrat } & $1876-1890$ & 738 \\
\hline & 1873 & 1.300 \\
\hline \multirow[t]{5}{*}{ Norden, Dr., Sanitätsrat und Kreisphysicus } & $1866-1914$ & 762 \\
\hline & $1881-1900$ & 765 \\
\hline & $1885-1910$ & 879 \\
\hline & $1875-1896$ & 1.156 \\
\hline & 1869-1909 & 2.410 \\
\hline Nordheimer, Abraham, Mitglied der Israelitischen Gemeinde & $1865-1903$ & 490 \\
\hline Notke, Gustav, Maschinenmeister & $1909-1911$ & 1.472 \\
\hline
\end{tabular}


Index

\begin{tabular}{|c|c|c|}
\hline \multicolumn{3}{|c|}{ PERS } \\
\hline Indexbegriff & Laufzeit & Lfd.Nr. \\
\hline Nübel Dr., O., Geschäftsführer & 1913-1914 & 715 \\
\hline Nußhorn, Fußgendarm & $1870-1871$ & 1.305 \\
\hline Odinga, Bruno, Spirituosenhändler und Hausbesitzer & 1871-1874 & 1.219 \\
\hline Oestreicher, Siegmund, Ingenieur & 1884-1888 & 911 \\
\hline Ohling, Berend, Lehrer & $1891-1917$ & 3.593 \\
\hline Ohling, K., Landwirt & 1871-1872 & 1.717 \\
\hline Ohling, Landwirt & $1915-1916$ & 3.307 \\
\hline Ohling, Lehrer & 1904-1914 & 2.344 \\
\hline \multirow[t]{2}{*}{ Oltmanns, A. G., Posthalter } & 1869-1904 & 2.677 \\
\hline & 1878 & 2.681 \\
\hline Oltmanns, Oltmann H., Landbesitzer & $1878-1881$ & 2.528 \\
\hline Oncken, Kantor und Lehrer & $1882-1911$ & 3.571 \\
\hline Onken, Bernhard, Gemüsebauer & $1880-1881$ & 2.698 \\
\hline Onken, Bernhard, Hausbesitzer & 1880-1907 & 893 \\
\hline Onneken, J., Eingabensteller & $1898-1900$ & 1.004 \\
\hline Oostermann, Lehrer, Küster und Organist in Oldersum & 1889 & 3.673 \\
\hline Oostermann, M., Hausbesitzer & 1913-1914 & 1.080 \\
\hline \multirow[t]{2}{*}{ Oppermann, Heinrich Ludwig, Vollziehungsbeamter } & 1890 & 354 \\
\hline & $1885-1890$ & 379 \\
\hline Oppermann, Robert, Polizeisergeant & 1911-1912 & 367 \\
\hline Orth, W., Sattlermeister & 1889-1909 & 2.433 \\
\hline Oss van, Joseph, Viehhändler & 1867-1908 & 846 \\
\hline Osterkamp, geb Zyden, Gertruida, Stifterin & 1879-1909 & 1.727 \\
\hline Ostfoff, Oldenburgischer Schlachthofleiter & $1880-1883$ & 795 \\
\hline Otte, C., Musikdirektor & $1881-1890$ & 554 \\
\hline Pakebusch, Richard, Kanzlist & $1872-1902$ & 340 \\
\hline Pannenborg, geb. de Ruyter, Alberta, Ehefrau & 1892 & 2.742 \\
\hline \multirow[t]{2}{*}{ Pannenborg, Hinricus, Müller } & 1892 & 2.742 \\
\hline & 1899-1902 & 2.791 \\
\hline Pansch, Franz, Reeder & 1905 & 2.289 \\
\hline Pantekoek, Carl, Erbpächter & 1878-1884 & 2.522 \\
\hline Panthöfer, Emil, Elektrotechniker & $1912-1913$ & 1.121 \\
\hline Panthöfer, Ernst, Elektrotechniker & $1912-1913$ & 1.132 \\
\hline \multirow{2}{*}{ Panzer, Johann Christian, Armen- und Arbeitshausvater } & $1909-1913$ & 261 \\
\hline & $1872-1910$ & 1.869 \\
\hline Panzer, Johann Georg, Armenhausvater & $1872-1910$ & 1.869 \\
\hline Panzer, Johann Georg, Gasthausvater & $1911-1915$ & 1.656 \\
\hline Paschke, Regierungsrat a.D. & $1905-1906$ & 2.377 \\
\hline Passow, Robert, Polizeisergeant & 1906 & 386 \\
\hline Pels, Carl, Vormund & 1904-1905 & 1.008 \\
\hline Pels, Jacob, Kaufmann & 1893-1897 & 2.574 \\
\hline \multirow[t]{2}{*}{ Pels, Jacob, Kaufmann und Bürgervorsteher } & $1900-1911$ & 259 \\
\hline & $1912-1918$ & 263 \\
\hline Pels, Joseph Abraham, Kaufmann & $1871-1909$ & 1.158 \\
\hline Pels, Lazarus & $1907-1914$ & 1.389 \\
\hline Pels, Lazarus, Mittelloser & $1913-1915$ & 1.872 \\
\hline Pels, Moses, Schlachter & $1866-1887$ & 824 \\
\hline Pels, Siegfried, Kaufmann & $1892-1901$ & 2.543 \\
\hline Pels, Siegfried, Seilerwarenhändler & $1871-1888$ & 1.151 \\
\hline Pels, Simon J., Antragssteller & $1866-1911$ & 962 \\
\hline Pels, Simon Joseph, Saalbesitzer & $1897-1909$ & 1.141 \\
\hline Pels, Simon, Gastwirt & 1889 & 1.382 \\
\hline Peltzer, Paul, Zivilingenieur und Projektberater & $1912-1913$ & 1.121 \\
\hline Penaat, j., Jagdpächter & $1870-1911$ & 820 \\
\hline Penning, Neelke, Hebamme & $1898-1918$ & 764 \\
\hline Peters, Bonne, Gemüsebauer und Hausbesitzer & 1897-1906 & 874 \\
\hline
\end{tabular}


Index

\begin{tabular}{ll}
\hline & PERS
\end{tabular}

Indexbegriff

Peters, Johann H., Kaufmann

Peters, Johann Heinrich, Kaufmann

Peters, Johann, Kaufmann

Peters, Marten, Malermeister

Peters, Max, Geheimer Oberregierungsrat und Ministerialdirektor

Peters, Reinhard, Malermeister

Peterssen, F. H., Bäckermeister

Peterssen, F., Rentier

Peterssen, geb. Helmers, Gesina Maria, Grundbesitzerin

Peterssen, Gemeindevorsteher in Borssum

Pfaffe, Zivilingenieur aus Halle/Saale

Pfannenschmidt, L. P. D., Hausbesitzer

Philippstein, Wilhelm, Dampfschifffahrtsdirektor

Philippstein, Wilhelm, Jüdischer Kaufmann

Pieper, Diedrich, Bauunternehmer

Pischkalla, Eugen, Polizeisergeant

Plagge, Dr. jur., Bürgervorsteher

Plasser, Sächsischer Baurat

Plessner, F., Sächsischer Baurat

Plooger, Leichenbitter

Pocker, Friedrich Wilhelm, Kräutner

Poelders, Buchbinder

Poelders, W., Hausbesitzer

Poelders, W., Kaufmann

Poelders, Wiard, Kräutner

Laufzeit

1902

1902

1900-1903

1874-1905

1892-1894

1908

1906

1878

1904-1905

1867-1909

1911-1912

1907

1899-1900

1872-1878

1912-1918

1883-1901

1871-1903

1907-1911

1907

1879-1890

1877-1878

1881-1885

1824-1920

1900-1901

1867-1897

1883-1898

1900-1904

1878

1879

1879

1878-1882

1871-1873

1903-1904

1916-1918

1917-1918

1875-1909

1885-1911

1900-1902

1871-1913

1902-1910

1901-1902

1898

1883-1885

1866-1913

1883-1884

1885-1887

1884-1889

1891-1895

1904-1906

1897-1911

1900-1912

1882-1902

1900-1902

1882-1906

1902-1904

1901-1904

1908-1916

1901
Lfd.Nr.

551

2.797

2.763

831

2.349

1.421

2.593

1.325

3.644

2.663

247

250

949

1.212

263

2.044

758

2.828

360

79

2.006

2.014

433

1.362

2.419

971

2.562

1.317

1.318

2.516

2.520

1.760

389

3.286

3.308

836

834

422

419

420

3.393

532

2.714

832

1.953

1.954

1.955

1.956

2.598

1.046

2.606

2.608

2.609

2.610

2.612

2.618

2.624

2.636 
Index

\begin{tabular}{|c|c|c|}
\hline \multicolumn{3}{|c|}{ PERS } \\
\hline Indexbegriff & Laufzeit & Lfd.Nr. \\
\hline Potier des Echelles, Dr., Othmar Baron, Sachverständiger & 1902-1907 & 2.645 \\
\hline Pottere de, Senator & 1876-1878 & 848 \\
\hline Pottkemper, Papierhersteller & 1867-1902 & 1.257 \\
\hline Preiß, August, Polizeisergeant & $1880-1882$ & 371 \\
\hline Prestel, Dr., Arzt & 1867-1896 & 1.492 \\
\hline Preuß, Heinrich, Matrose & $1868-1891$ & 1.576 \\
\hline Preuß, Polizeisergeant & $1881-1897$ & 1.020 \\
\hline Preuß, W., Hausbesitzer & 1889-1905 & 965 \\
\hline Prinz, Elisabeth, Schülerin & $1875-1890$ & 3.836 \\
\hline Prumers, Carl Johann Peter, Reformierter Pastor & $1874-1910$ & 3.378 \\
\hline Puhlmann, Marie, Oberlehrerin & 1903 & 3.792 \\
\hline Puls, B. A., Schulrendant & 1894 & 3.648 \\
\hline Puls, O., Schulwärterin & 1894 & 3.648 \\
\hline Puttkamer von, Hauptmann & $1878-1891$ & 2.428 \\
\hline Rackebrandt, August, Gärtner & $1912-1913$ & 1.115 \\
\hline Rahtjes, Dr., Arnold, Chemiker und Fabrikant & $1910-1911$ & 1.470 \\
\hline Raith, Bezirksschornsteinfegermeister & $1907-1916$ & 1.264 \\
\hline Rape, Oskar, Lehrer & $1909-1916$ & 3.599 \\
\hline Rasenack, Schüler & 1899-1918 & 3.743 \\
\hline Raveling, Bette, Gemüsebauer & $1877-1882$ & 2.505 \\
\hline Redderberg, Adolf, Lehrer & 1913-1914 & 3.603 \\
\hline Redlin, Reformierter Pastor und Kreisschulinspektor & $1889-1917$ & 3.509 \\
\hline Redmers, Berend, Pächter & $1867-1897$ & 2.464 \\
\hline Redmers, Jacob, Pächter & 1867-1897 & 2.464 \\
\hline \multirow[t]{2}{*}{ Reemtsma, R., Kommerzienrat } & $1872-1903$ & 1.250 \\
\hline & 1869 & 1.307 \\
\hline Reemtsma, R., Kommerzienrat und Senator & $1867-1891$ & 3.126 \\
\hline Reents, Niederländischer Goldschmied & 1914-1916 & 3.240 \\
\hline Reents, R., Senator & $1872-1876$ & 2.485 \\
\hline Regendorp, J.S., Grundbesitzer & 1904-1906 & 855 \\
\hline Regendorp, P., Kaufmann & 1903 & 1.695 \\
\hline Rehbock, Elisabeth, Hilfslehrerin & 1914 & 3.801 \\
\hline Rehfuß, Emil, Polizeikommissar & 1899-1928 & 401 \\
\hline Reiche, Dr., Regierungs- und Medizinalrat & $1885-1910$ & 879 \\
\hline Reijnvaarn, Johannes, Heringsfischerei-Unternehmer & 1894-1914 & 2.744 \\
\hline Reimers, Dr., Landeskonservator a.D. & $1873-1917$ & 2.395 \\
\hline Rein, Andreas Matthiesen, Schuhmachergeselle & $1882-1910$ & 501 \\
\hline Reincke, Dr., Medizinalrat & 1894-1908 & 872 \\
\hline Reinders, Alide, Eingewiesene in Rettungsanstalt & $1867-1887$ & 1.706 \\
\hline Reinders, C. H., Seifensieder & 1887 & 2.189 \\
\hline Reinders, Dietrich, Eingewiesener in Rettungsanstalt & $1867-1887$ & 1.706 \\
\hline Reinders, Georg T., Seifenhersteller & 1881 & 2.183 \\
\hline Reinders, J. F., Pockenkranker & 1859-1877 & 773 \\
\hline Reinhold, Janna, Witwe, Sturz & 1882-1908 & 2.009 \\
\hline Reints, H. N., Seiler & 1871-1888 & 1.151 \\
\hline Reisse, Regierungs- und Baurat & 1905-1908 & 948 \\
\hline Reissig, Heinrich, Ingenieur & 1885-1907 & 909 \\
\hline Remmers, Jacob, Pächter & 1874-1889 & 2.453 \\
\hline Remmers, R. W., Kaufmann & 1868-1903 & 3.625 \\
\hline Remmerssen, Gerhardine, Lehrerin & $1906-1911$ & 3.680 \\
\hline \multirow[t]{4}{*}{ Remmerssen, J., Holzhändler und Sägeeibesitzer } & 1879-1883 & 1.433 \\
\hline & 1876 & 1.438 \\
\hline & $1880-1911$ & 2.181 \\
\hline & 1878 & 2.496 \\
\hline Rens, Bauunternehmer & 1876-1878 & 2.479 \\
\hline Rensen van, Peter, Handelskammervorsitzender & $1909-1913$ & 261 \\
\hline Reuter, Navigationsschullehrer & 1871-1895 & 1.588 \\
\hline
\end{tabular}


Index

$\begin{array}{r}\hline \\ \hline\end{array}$

Indexbegriff

Richter, Franz, Goldschmied und Juwelier

Richter, Rudolf, Polizeisergeant

Richtering, Carl, Mühlenbesitzer

Rickleffs, Heinrich W., Lehrer

Riedlin, Erich, Reformierter Pastor

Riedlin, Kreisschulinspektor

Rieke, Reinhard Joseph, Schiffsbaumeister

Riese, Dr., Hans, Stadtsyndicus

Riese, Dr., Hans, Stadtsyndicus u. weltlicher Kirchenkommissar

Riess, Ludwig, Wissenschaftlicher Hilfslehrer

Ringena, Siwert Heyen, Gutsbesitzer

Ringius, F. G. H., Kaufmann

Ritter, Friedrich, Professor, Studienrat

Ritter, Prof., Friedrich, Schriftührer der Kunst

Ritterbusch, Louis, Polizeisergeant

Robbelen, Carl F. C., Ingenieur und Stadtbaumeister

Röben, Johann, Direktor

Rodewyk, Antonie, Rentnerin

Rodewyk, Dr., Johann Theodor, Grundstücks- u. Kajungsbesitzer

Roer, geb. Bach, Ida Wilhelmine

Roer, Paul G., Aufsichtsratsvorsitzender Nordseewerke

Roer, Paul G., Eisenwerksdirektor und Reeder

Roer, Paul G., Hauptaktionär

Roer, Paul G., Reeder und Investor

Roer, Paul G., Versicherungsdirektor

Roer, Paul Gerhard, Versicherungsdirektor

Rogge, W., Bauunternehmer

Rohden, Johann Hermann, Hauptlehrer

Rohte Dr., Otto, Wissenschaftlicher Hilfslehrer

Rolffs, Amtsassessor

Roloff, Geheimer Regierungsrat

Ronda, G.N., Kaufmann und Senator

Röpke, Johann Heinrich, Heizer

Roschmann, Christian, Hotelbesitzer

Rosenberg, Egon, Autor

Rosenfeld, M., Hausbesitzer

Rosenthal, Auguste, Jüdin aus New Orleans

Rösing, Handelsschullehrer

Rosingh, H., Grundbesitzer

Ross, Evert, Navigationsschuldiener

Roßkamp, Jacques, Elementarlehrer

Rothe, Rudolf, Fotograf

Rozenboom, Jan, Schiffskapitän

\section{Laufzeit}

1908-1916

1905-1911

1902-1908

$1905-1910$

1889-1891

1891-1907

1874-1910

1908-1914

1866-1874

1901-1908

1904-1907

1902-1914

1903-1905

1896

1884-1885

1912-1918

1890-1907

1873-1917

1907

1858

$1872-1903$

1868-1915

1867-1890

1909-1913

1894-1908

1876-1880

1910-1911

1904-1908

1905

1905-1906

1905-1909

1908-1911

1906-1907

1905-1911

1910-1911

1903-1904

1902

1906-1909

1900-1911

1902-1903

1904

1900

1875-1889

1903

1868-1875

1867-1890

1866-1872

1881-1894

1898

1878-1898

1903-1904

1903-1917

1904-1914

1874-1901

1875-1905

1886-1903

1902

1904
Lfd.Nr.

83

1.097

2.631

373

2.683

3.653

3.378

3.617

2.468

31

1.289

3.340

3.734

520

2.679

263

2.736

2.395

385

441

1.250

1.286

1.536

261

872

1.496

2.369

1.462

674

2.360

2.361

2.363

2.373

2.375

2.369

1.459

2.084

2.090

259

1.464

1.987

2.245

3.652

3.735

2.629

2.476 
Index

\begin{tabular}{|c|c|c|}
\hline \multicolumn{3}{|l|}{ PERS } \\
\hline Indexbegriff & Laufzeit & Lfd.Nr. \\
\hline Rückwardt, Hermann, Hoffotograf aus Berlin-Lichterfelde & $1867-1901$ & 310 \\
\hline Rugullis, Michael, Polizeisergeant & 1906-1907 & 411 \\
\hline Rulffes, Rudolf, Particulier & $1874-1888$ & 2.697 \\
\hline Ruller, Anton, Bildhauer aus Münster & $1906-1915$ & 273 \\
\hline \multirow[t]{2}{*}{ Runge, Schulrat } & $1902-1904$ & 3.642 \\
\hline & $1900-1907$ & 3.708 \\
\hline Rusch, Gaswerksbuchhalter & $1897-1911$ & 1.046 \\
\hline Russell, Kaufmann & $1883-1901$ & 2.044 \\
\hline Russell, Rechtsanwaltsgattin & $1875-1890$ & 3.836 \\
\hline Russell, Wilhelmine, Schülerin & $1875-1890$ & 3.836 \\
\hline Rust, Annäus, Gastwirt & 1899 & 535 \\
\hline Ruthenberg, Oscar, Rentner & 1899-1902 & 853 \\
\hline Rütter, Franz, Goldschmied und Juwelier & 1904-1907 & 2.638 \\
\hline Ruyen, Louis, Heringsfischereidirektor & $1912-1918$ & 263 \\
\hline Ruyter de, J., Beschwerdeführer & 1912 & 1.106 \\
\hline Ruyter de, L., Wirt & $1881-1897$ & 1.040 \\
\hline Ruyter, B. A. G., Agent & $1866-1886$ & 1.950 \\
\hline Saathoff, Evert, Hausdiener & 1884-1906 & 413 \\
\hline Sander, Wilhelm Restaurateur & 1901-1902 & 542 \\
\hline Sanders, H., Zimmermeister & $1874-1893$ & 2.444 \\
\hline Sanders, Jürjen, Zimmermeister & 1896-1898 & 2.749 \\
\hline Santjer, Jakob, Lotse & 1900-1909 & 264 \\
\hline Saul, Otto, Polizeisergeant & 1907-1909 & 374 \\
\hline Schaad, Witwe & $1866-1887$ & 824 \\
\hline Schaar, Georg F., Civil-Ingenieur & 1896 & 1.026 \\
\hline Schachtebeitz, Fritz, Schulamtsbewerber & 1914 & 3.572 \\
\hline Schack, Hermann, Handschuhmachergeselle u. Pockenkranker & $1859-1877$ & 773 \\
\hline Schaper, Christian, Weichensteller & $1886-1891$ & 2.724 \\
\hline Schaper, F., Bürgerschullehrer & $1887-1898$ & 2.725 \\
\hline Schaper, Friedrich, Lehrer und Zeichenlehrer & $1885-1895$ & 3.736 \\
\hline Schaper, geb. Günther, Johanne, Erbpächterin & $1886-1891$ & 2.724 \\
\hline Schaper, Prof., Künstler & $1900-1901$ & 203 \\
\hline Schaudy, J und R., Gebrüder & $1873-1897$ & 2.549 \\
\hline Schelten, Carl P., Zimmermeister & 1888-1892 & 2.728 \\
\hline \multirow[t]{2}{*}{ Schelten, Claas Peters, Zimmermeister } & 1884-1900 & 2.717 \\
\hline & $1890-1895$ & 2.743 \\
\hline Schelten, Heinrich W., Rentier & 1908 & 1.205 \\
\hline Schelten, Heinrich Wilhelm, Kaufmann & 1897 & 2.753 \\
\hline \multirow[t]{2}{*}{ Schelten, Regierungs- und Baurat } & 1887-1888 & 1.436 \\
\hline & $1887-1912$ & 1.437 \\
\hline Schelten, Zimmermeister & 1899 & 2.572 \\
\hline Schepker, Gastwirt und Pockenkranker & $1859-1877$ & 773 \\
\hline Scherz, G. W., Kaufmann & 1899-1902 & 2.791 \\
\hline Scherz, G. W., Kräutner & $1900-1901$ & 1.363 \\
\hline Scherz, Hermann, Kaufmann & 1908 & 1.376 \\
\hline Schevers, Heinrich, Ingenieur & $1910-1911$ & 955 \\
\hline Schiele, Hebamme & 1867-1895 & 763 \\
\hline Schiele, Rudolf, Restaurator & $1908-1913$ & 2.642 \\
\hline Schiller v., Friedrich, Schriftsteller & 1905 & 568 \\
\hline Schlechtweg, Christian Wilhelm, Lehrer & $1909-1910$ & 3.793 \\
\hline Schmeding,, J.H., Seilermeister & $1870-1882$ & 2.502 \\
\hline Schmid, Dr., Heinrich, Oberlehrer & 1910 & 3.794 \\
\hline Schmidt, A., Amtsgerichtsrat & 1876-1904 & 170 \\
\hline Schmidt, A.S., Totengräber & $1824-1920$ & 433 \\
\hline Schmidt, Architekt & $1900-1908$ & 2.432 \\
\hline Schmidt, Dr., Oberingenieur & $1911-1912$ & 1.484 \\
\hline Schmidt, Georg, Auktionator & $1902-1906$ & 168 \\
\hline
\end{tabular}


Index

\begin{tabular}{|c|c|c|}
\hline \multicolumn{3}{|c|}{ PERS } \\
\hline Indexbegriff & Laufzeit & Lfd.Nr. \\
\hline Schmidt, Georg, Auktionator & $1877-1913$ & 1.276 \\
\hline Schmidt, J.G., Bezirksvorsteher u. Sattlermeister & $1893-1903$ & 154 \\
\hline Schmidt, Johann Friedrich, Kanzlist & $1872-1902$ & 340 \\
\hline Schmidt, N. A., Landwirt aus Oldersum & $1866-1889$ & 3.124 \\
\hline Schmidt, Polizeisergeant & $1905-1907$ & 380 \\
\hline Schmidt, W.J., Klempner & $1879-1890$ & 79 \\
\hline Schmidt, Wasserwerksdirektor & $1894-1905$ & 2.603 \\
\hline Schnedermann, G., Commerzienrat & $1901-1903$ & 1.002 \\
\hline Schnedermann, geb. Brons, Anna Katharina, Stifterin & $1872-1916$ & 330 \\
\hline Schnedermann, Johann Martho, Stifter & $1872-1916$ & 330 \\
\hline Schnedermann, Johann Marto, Landbesitzer & 1913 & 2.884 \\
\hline Schnedermann, Obergerichtsrat a.D. & 1871 & 1.304 \\
\hline \multirow[t]{2}{*}{ Schneider, Richard, Schornsteinfegermeister } & $1872-1878$ & 1.212 \\
\hline & $1873-1906$ & 1.263 \\
\hline Schneider,geb. Kruithoff, Ehefrau & 1901 & 1.361 \\
\hline Schneidt, Deichrichter & $1883-1900$ & 1.537 \\
\hline Schnur, Georg, Polizeibote & $1890-1921$ & 410 \\
\hline \multirow[t]{2}{*}{ Schnur, Polizeidiener } & 1875 & 1.295 \\
\hline & 1873 & 1.297 \\
\hline \multirow[t]{8}{*}{ Schnür, Polizeisergeant } & 1879 & 1.320 \\
\hline & 1879 & 1.326 \\
\hline & 1879 & 1.328 \\
\hline & 1880 & 1.332 \\
\hline & 1893 & 1.339 \\
\hline & 1874 & 1.753 \\
\hline & $1883-1902$ & 1.909 \\
\hline & $1870-1882$ & 2.502 \\
\hline Scholz, Johann Carl Gottlieb, Schachtmeister & $1876-1878$ & 2.479 \\
\hline Schölzchen, Hieronymus, Schuldiener & $1880-1918$ & 2.353 \\
\hline \multirow[t]{2}{*}{ Schönberg, Jüdischer Getreidehändler } & $1871-1903$ & 758 \\
\hline & 1905 & 2.440 \\
\hline Schönburg, Grenzaufseher & 1893 & 249 \\
\hline Schoneboom, Ahlrich, Landwirt in Borssum & $1911-1912$ & 247 \\
\hline Schoneboom, B., Fuhrunternehmer & $1900-1907$ & 1.022 \\
\hline Schoneboom, Christian, Bürogehilfe & $1900-1917$ & 338 \\
\hline Schoneboom, G., Landwirt in Borssum & $1911-1912$ & 247 \\
\hline Schoneboom, Remmer, Gemeindevorsteher in Borssum & $1892-1895$ & 246 \\
\hline Schonenboom, Armendiener & $1879-1906$ & 1.641 \\
\hline Schopp von, Eberhard, Geschäftsmann & $1905-1907$ & 2.085 \\
\hline Schortau, A., Hausbesitzer & $1908-1910$ & 884 \\
\hline \multirow[t]{2}{*}{ Schortau, August, Bauunternehmer } & $1906-1907$ & 2.839 \\
\hline & 1906 & 2.841 \\
\hline Schorttau, Bauunternehmer aus Wilhelmshaven & $1870-1900$ & 1.161 \\
\hline Schott, Georg, Polizeisergeant & 1888 & 390 \\
\hline \multirow[t]{3}{*}{ Schoy, Louis, Hotelier } & $1896-1902$ & 2.548 \\
\hline & 1896-1899 & 2.780 \\
\hline & 1902 & 2.803 \\
\hline Schrage, Carl, Kunstgärtner & $1901-1903$ & 2.787 \\
\hline \multirow[t]{2}{*}{ Schramm, Baurat } & $1881-1901$ & 2.477 \\
\hline & 1880 & 3.689 \\
\hline Schramme, Bauinspektor & $1867-1890$ & 1.536 \\
\hline Schramme, Baurat & $1879-1899$ & 2.694 \\
\hline Schröder, A. H., Gastwirt & $1892-1893$ & 1.942 \\
\hline Schröder, Adolph, Hausbesitzer & 1888-1905 & 964 \\
\hline Schröder, Akzisepächter & $1882-1910$ & 2.920 \\
\hline Schröder, B., Einnehmer & $1883-1907$ & 3.344 \\
\hline Schröder, Ewald, Kaufmann & $1905-1907$ & 2.830 \\
\hline Schröder, Fuhrmann & 1879 & 1.326 \\
\hline
\end{tabular}


IV

Index

\begin{tabular}{l}
\hline \\
\hline Indexbegriff \\
\hline Schröder, Heinrich, Fotograf \\
Schröder, Johannes, Obertelegraphen-Assistent \\
Schröder, Karl, Kapitän \\
Schröder, Lucas, Ausklingler \\
Schröder, Maria, Beklagte \\
Schulte, Friedrich, Bauführer \\
Schulte, Johann Hermann, Schiffsmakler und Vizek \\
Schulte, R. W., Kaufmann \\
Schulten, August, Hippodrombesitzer aus Wesel \\
Schultz, Bergassessor \\
Schultz, Hans L., Direktor der Nordseewerke \\
Schultz, Hans, Zivilingenieur \\
Schultz, Stadtbauaufseher \\
Schultz, Stadtbauführer \\
Schultze, Käthe, Turn- und Handarbeitslehrerin \\
Schultze, W.J., Exekutor \\
Schulz, Bauführer \\
Schulz, Töchterschullehrer \\
Schulze, August, Kommerzienrat \\
Schuppenies, Otto, Polizeisergeant \\
Schürzler, Gymnasialdirektor in Emden \\
Schüte, C.J., Registrator \\
Schutt, Fritz, Arbeiter u. Nachtwächter \\
Schüür, Menno Heinrich, Schuldiener \\
Schüürmann, Johannes Joachim, Kaufmann \\
Schwalbe, W., Buchhändler \\
Schwartzkopf, Dr., Ministerialkommissar \\
Schweckendieck, Carl, Geh. Oberregierungsrat \\
Scher
\end{tabular}

Schweckendieck, Carl, Geh. Oberregierungsrat und Ehrenbürger

\section{PERS}

Schröder, Heinrich, Fotograf

Schröder, Karl, Kapitän

Schröder, Lucas, Ausklingle

Schulte, Friedrich, Bauführe

Schulte, Johann Hermann, Schiffsmakler und Vizekonsul

Schulte, R. W., Kaufmann

Schultz, Bergassessor

Schultz, Hans, Zivilingenieur

Schultz, Stadtbauaufseher

Schultze, W.J., Exekutor

Schulz, Bauführer

Iz, Tochterschullehrer

Schuppenies, Otto, Polizeisergeant

Schürzler, Gymnasialdirektor in Emden

Schutt, Fritz, Arbeiter u. Nachtwächter

Schüür, Menno Heinrich, Schuldiener

Schwalbe, W., Buchhändler

Schweckendieck, Carl, Geh. Oberregierungsrat
Schweckendieck, Carl, Regierungsassessor

Schweckendiek, Vorsitzender der Kunst

Seebens, Freerk, Erbpächter

Seeleute, Einstellung und Entlassung

Selig, W., Hauptlehrer der jüdischen Schule

Seligmann, Moses, Viehhändler

Seligmann, Salomon, Viehhändler

Sello, Georg, Geh. Archivrat aus Oldenburg

Senden van Dr., Armenarzt

Senden van, Cornelia, Oberlehrerin
Lfd.Nr.

1866-1897

2.411

1881-1913

727

1904-1905

2.834

1867-1882

1875

431

1912-1918

1.722

$1912-1918$

1869

263

2.474

1868-1909

2.144

1.432

259

1.458

1.454

1.464

873

1.118

1.186

1.204

3.613

434

1.666

3.776

2.087

348

573

313

727

3.795

1.215

310

3.547

180

202

255

2.059

2.060

2.061

2.083

2.360

2.392

Vorwort

1901-1906 267

1904-1908 268

1906-1915 273

1904-1914 1.440

1902-1907 $\quad 1.967$

$1891-1893 \quad 2.025$

$1875-1882 \quad 1.431$

1876-1903 1.432

$1882-1902 \quad 2.608$

1880-1890 2.706

1868-1912 $\quad 1.574$

$1895 \quad 488$

1917-1918 3.299

$1911-1912 \quad 1.378$

1899-1916 315

$1872-1910 \quad 1.869$

$1891-1910 \quad 3.796$ 
Index

$\begin{array}{r}\hline \text { PERS } \\ \hline\end{array}$

\begin{tabular}{l} 
Indexbegriff \\
\hline Senden van, E., Holzhändler \\
Senden van, L., Beschwerdeführer \\
Senden van, L., Senator \\
Senden van, Luto, Holzhändler
\end{tabular}

Senden van, Otto G., Grundstücksbesitzer Seyfried, Elisabeth, Oberlehrerin

Seyfried, Oberlehrerin

Siebolds, Rudolf, Bürogehilfe

Siebolts, P., Leichenbitter

Siefkens, S., Lehrerin

Sielmann, Kaufmann

Siemens, Johann, Böttcher

Siemens, Landgerichtsrtat

Siemens, S., Marktmeister und Waage-Pächter

Siemering, Carl, Bäckermeister

Siemons, Siegbold Edmund, Getreidemakler

Sievers, Katholischer Pfarrer und Kreisschulinspektor

Sikken, Abel, Beschwerdeführer

Sikken, Johann Hinrich, Getreidemakler

Simmering, H., Saalbesitzer

Simmering, Johann, Buchbinder

Sindelmann, Obergerichtsanwalt

Smeding, Berendine, Verlobte eines Juden

Smeding, Gerhard, Holzhändler

Smeding, H., Seilermeister

Smeding, Lüppo, Holzhändler

Smid, B., Eisenbahnstations-Assistent

Smidt, Hinderk, Arbeiter

Smidt, J., Kaufmann

Sohnemann, Wilhelm Emil, Friseur

Solaro, Johann Joseph, Schornsteinfegermeister

Soldatow, Friedrich, Polizeikommissar

Sombeck, Oberingenieur

Spangenberg, Johanne, Lehrerin

Spangenberg, Lehrerin

Spangenberg, Louise, Lehrerin

Spannhoff, Arbeiter mit verwanzter Wohnung

Specht, Heinrich, Lehrer

Spieske, C., Architekt aus Oldenburg

Sporree, Johanne, Abgeschobene

Spreng, Emil, Gaswerkspächter

Spreng, Louise, Gaswerkspächterin

Springmann, Th., Kanalgegner

\section{Laufzeit}

1914

1868-1911

1904-1907

1875-1881

1877-1881

1873-1882

1889-1902

1885-1886

1903-1909

1907-1908

1916-1917

1824-1920

1900-1902

1871-1872

1906-1907

1884-1889

1909-1918

1905-1907

1905-1907

1871-1913

1889-1917

1869-1915

1871-1913

1881-1897

$1882-1913$

1866-1871

1868-1875

1870

1899-1904

1904-1909

1899-1904

1899

1912

1866-1913

1905-1911

1868-1871

1867-1873

1873-1906

1869

1886-1895

1911

1875-1889

1871-1872

1872-1898

1871-1914

1914-1917

1881-1911

1876-1890

1882-1910

1896-1897

1866-1873

1875-1899

1881-1897

1866-1893

1880-1881

1896-1897

1866-1873

1884-1886
Lfd.Nr.

2.682

825

1.289

2.510

2.511

2.518

2.533

2.531

3.797

685

337

433

3.641

1.775

2.837

1.955

2.654

2.832

2.836

419

3.509

1.648

419

1.140

1.636

2.674

3.351

847

852

2.582

852

2.755

1.682

1.930

1.172

1.211

1.262

1.263

1.308

344

1.475

3.652

3.647

3.800

3.798

737

738

501

1.030

1.037

1.038

1.040

1.041

1.027

1.030

1.037

2.024 
IV

Index

\begin{tabular}{rr}
\hline \\
PERS
\end{tabular}

Indexbegriff

Staacke Dr., Edmund, Oberlehrer

Staal, D. A., Müller

Stähler, Eduard, Rektor

Stankiewicz, Paul, Historienmaler

Starcke, Ingenieur

Stärge, Registrator

Stark, Friedrich, Schiffsbaumeister

Steen, Wilke Roelf, Fuhrmann

Steffler, Gustav, Oberlehrer

Stein, A. J., Viehhändler und Domänenpächter

Stein, Eva, Inhaberin und Betreiberin einer Handelsschule

Stein, geb. Zyden, Gertruda, Stifterin

Stein, Max, Jüdischer Hilfsschüler

Stein, Max, Schlachter und Pächter

Stein, Moses, Schlachter

Stein, Wilhelm, Spendengeldbuchführer d. Israelitischen Gemeinde

Steinbach, Paul, Gasmeister

Steinhuizen, Jelmer, Matrose

Steinhuizen, verw. Janßen, geb. Boer, Johanna, Mittellose

Stephan von, Generalpostmeister und Staatssekretär

Stern, Ehefrau

Sternberg, Dr., Arzt

Sternberg, Dr., Armenarzt

Stes, geb. Bicker, Catharina Maria, Hebamme

Steur, Peter, Stadtbauaufseher

Stevens, W.J., Grundbesitzer

Stieger, L., Architekt

Stinnes, Hugo, Großindustrieller

Stockhorst, G. F., Steinhauer

Stockmann, G. H., Pastor in Borssum

Stoermer, Paul, Polizeisergeant

Stöhr, Dr., Medizinalrat und Kreisphysicus

Stöhr, Dr., Medizinalrat und Landphysicus

Stöhr, Dr., Sanitätsrat

Stöhr, Dr., Sanitätsrat und Kreisphysikus

Stomberg, Sentina, Kindergartenvorsteherin

Stoppel, Geschäftsführer

Störk, Harm, Fuhrmann

Störk, Hilderich, Gemüsebauer

Störk, Jan, Gemüsebauer

Laufzeit

1914

1904-1916

1914-1917

1866-1912

1888-1907

1894-1895

1870-1886

1857-1908

1908

1905

1866-1888

1886-1902

1886-1895

1907

1910-1912

1880-1904

1908-1918

1871-1904

1875

1865-1903

1897-1912

1912-1914

1912-1914

1894-1897

1879

1904-1907

1888-1904

1867-1895

1865-1871

1870

1914-1916

1912-1918

1911-1912

1876-1901

1908

1884

1876-1890

1867-1906

1875-1882

1877-1881

1867-1874

1867-1896

1872-1884

1885-1914

1867-1895

1878-1891

1865-1895

1871-1914

1866-1914

1881-1900

1870-1879

1880

1873-1914

1898-1908

1897-1912

1894-1900

1888-1889
Lfd.Nr.

3.737

2.583

3.602

2.632

2.656

2.657

1.392

313

2.399

2.659

1.929

3.739

3.752

2.093

3.858

1.728

3.709

2.491

1.555

490

1.036

1.878

1.878

2.394

Vorwort

1.318

2.638

1.866

763

438

847

966

263

1.477

1.501

3.341

384

738

865

970

975

889

1.492

2.384

3.456

763

830

746

757

762

765

888

3.689

3.851

1.157

1.685

2.730 
IV

Index

\begin{tabular}{l}
\hline \\
\hline Indexbegriff \\
\hline Stosch, H., Mieter des Hammrichshauses auf Nesserland \\
Stosch, Regierungsbaumeister \\
Stosch, Wasserbauinspektor \\
Stöver, Heinrich, Maurermeister \\
Stöver, Willy, Marinemaler \\
Stracke, G., Weinhändler \\
Strange, Landsturm-Oberleutnant \\
Strippelmann, Gendarm \\
Strippelmann, Polizeisergeant \\
Strippelmann, Polizeiwachtmeister \\
Strohbach, Friedrich, Gasmeister \\
Strohdiek, H., Pächter \\
Strüfing, Carl, Fischereidirektor \\
Stubbe, J., Baurat der Stadt Köln \\
Stübbe, J., kgl. Baurat \\
Stuck, R. D., Beschwerdeführer \\
Stulpnagel von, Direktor der Hagener Straßenbahn \\
Sturm, Richard, Oberingenieur u. Projektberater aus Brandenburg
\end{tabular}

Stuur, Peter, Stadtbauaufseher

Suadicani, Wasserbauinspektor

Suchsland, Bauer

Suchsland, Heinrich,Turmwächter

Suchsland, Johann Conrad, Oekonom, Schankwirt, Sielrichter

Suchsland, Johann Conrad, Restaurateur

Süchting, Fritz, Direktor des Bremer Elektrizitätswerkes

Suchwold, C., Ziegeleibesitzer

Susemiehl, Heinrich, Gewerbeschullehrer und Malermeister

Susemiehl, Heinrich, Malermeister

Suur, D.W., Bürgermeister

Suur, Hemmo, Schuldirektor

Swart, B. J., Schiffskapitän

Swart, B., Kapitän

Takenberg, Gerhard, Lehrer

Tammens, B.G., Mitglied eines landwirtschaftl. Vereins

Tannens, T.M., Sielrichter

Tapernon, Samuel Günther, Volksschullehrer

Tapken, Geerd, Zimmermann

Tapper, Hector, Kaufmann

Tebbens, Peter, Polizeisergerant

Teichgräber, Otto, Polizeisergeant

Templin, Peter, Kapitän

Laufzeit

1867-1876

1884-1888

$1870-1914$

1880-1904

1917

1909-1910

1914

1891-1912

1896-1897

1904

1897-1912

1897-1904

1914-1918

1883-1911

1896-1906

1877-1918

1891-1895

1908

1912

1912

1907-1911

1912

1912-1913

1912

1879

1876

1884

1884-1885

1883-1885

1885-1888

1883-1900

1872-1892

$1883-1890$

1877-1885

1869-1896

1878-1901

1867-1876

1866-1894

1911

1895-1897

1904-1914

1905-1907

1853-1891

1895-1918

1886-1895

1881-1883

1880-1883

1907-1910

1879-1905

1885-1888

1867-1871

1871-1872

1887-1911

1871

1905

1907

1908-1913
Lfd.Nr.

2.415

911

1.163

2.703

3.215

826

3.149

632

1.354

1.371

1.036

2.462

3.232

231

998

1.672

1.956

1.084

1.091

1.099

1.104

1.106

1.121

1.129

1.319

1.322

903

904

914

917

1.537

1.544

2.039

440

436

2.416

2.415

2.482

1.105

2.746

2.344

2.830

1.404

3.573 
Index

$\begin{array}{r}\hline \text { PERS } \\ \hline\end{array}$

\section{Indexbegriff}

Tenge, Geheimer Oberbaurat in Oldenburg

Tergast, Dr., Geh.Medizinalrat und Kreisarzt

Tergast, Dr., Medizinalrat und Kreisarzt

Tergast, Johannes C., Kräutner

Terveer, Isaac, Lehrer

Theesen, Hinderk, Zimmermeister

Theessen, Apke, Dienstmagd

Theessen, Hinderk, Zimmermeister

Theilen, Baumeister

Theilen, Bauunternehmer

Theilen, J. D., Mitglied des Gewerbeschulvorstands

Theilen, Johann, Zimmermeister

Thein, Bäckermeister

Thiele \& Freese, Kaufleute

Thiele, Carl, Kaufmann und Senator

Thiele, H. G., Kaufmann

Thielke, W. P., Steinhauer

Thiemens, Telegraphensekretär

Thierbach, Dr., Bruno, Beratender Ingenieur

Tholen, Albert, Direktor der Mühlensocietät

Tholen, Deichrentmeister

Tholen, J. G. H., Particulier

Thomsen, Amtsgerichtsrat

Thorbeck, Dr., Obering. Hanseatische Siemens Schuckert Werke

Thuller, Polizeisergeant

Thyssen, G. H., Schlachter

Thyssen, J., Landwirt

Thyssen, J., Stricklehrerin

Tiemann, Johann, Telegraphen-Sekretär

Tiemens, Johann, Obertelegrafen - Assistent

Tirpitz v., Alfred, Großadmiral u. Staatsminister d. Reichsmarineamts

Tito, H. Bürgervorsteher und stellvertretender Wahlleiter

Tjaden Prof Dr., Heinrich Peter, Studienrat

Tjaden, Geerd, Bauunternehmer

Tolle, A., Regierungs- und Baurat

Tollner, P.J.M., Zivil-Ingenieur aus Frankfurt/M.

Tönjes, Friedrich, Minderjähriger

Topp, Wilhelm, Militärinvalide

Trommershausen, SYndicus

Trommershausen, Syndicus der Stadt emden

Tromp, Wilm, Verlaatswärterstellenbewerber

Ubbens, B., Posthalter und Fuhrunternehmer

Ubbens, H., Hausbesitzer

Ubbens, Haye H., Fuhrunternehmer

Laufzeit

1907

1910-1913

1902-1907

1873-1914

1867-1901

1857-1907

1866-1914

1878-1894

1880-1912

1894-1908

1885-1910

1867

1873-1880

1880-1890

1903

1880-1881

1872-1912

1868-1891

1899-1911

1872-1879

1866-1874

1885-1896

1912-1918

1911-1912

1866-1874

1866-1867

1897-1912

1908

1870

1874-1887

1881

1885-1903

1907-1908

1898-1913

1874-1884

1902-1903

1886-1905

1904-1908

1901-1904

1908-1910

1908-1914

1911

1867-1869

1887-1910

1905

1884

1884-1885

1911

1917

1910-1914

1914-1916

1914-1915

1866-1891

1890

1891-1905

1909-1911

1900-1907
Lfd.Nr.

1.552

3.403

3.706

3.851

310

514

762

774

776

872

879

890

3.697

2.706

1.695

2.702

3.444

1.450

2.333

1.181

1.039

924

263

1.131

1.039

1.945

1.157

1.087

849

2.478

1.334

2.716

1.083

854

2.521

1.694

3.683

1.012

2.578

270

271

1.476

217

3.738

883

903

904

842

1.889

3.731

3.153

9

1.488

1.345

988

859

1.022 
Index

\begin{tabular}{|c|c|c|}
\hline \multicolumn{3}{|l|}{ PERS } \\
\hline Indexbegriff & Laufzeit & Lfd.Nr. \\
\hline \multirow[t]{3}{*}{ Ubbens, Haye H., Fuhrunternehmer } & 1884-1896 & 2.494 \\
\hline & $1883-1897$ & 2.711 \\
\hline & $1910-1913$ & 3.403 \\
\hline Ubbens, Heyo J., Fuhrunternehmer & $1890-1901$ & 2.848 \\
\hline Ubbens, J., Fuhrmann & $1887-1910$ & 935 \\
\hline Ubbens, W., Fuhrunternehmer & 1889 & 1.356 \\
\hline Ueberschär, Richard, Polizeisergeant & $1905-1906$ & 372 \\
\hline Uffen, F., Kaufmann & $1900-1905$ & 995 \\
\hline Uilderks, Otto, Gemüsebauer & $1871-1897$ & 823 \\
\hline Uilderks, Uildert, Grundstücksbesitzer & $1876-1889$ & 843 \\
\hline Ulferts, Djurke, Landwirt & 1906-1908 & 857 \\
\hline Ulffers, Kapitänleutnant und Kriegsschiffskommandant & 1866 & 509 \\
\hline Unverzagt, D., Grenzaufseher & 1893 & 249 \\
\hline Uphoff geb. Visser, Geerardine, Polizeibotenwitwe & 1891-1895 & 1.651 \\
\hline Uphoff, Abko, Polizeibote & 1891-1895 & 1.651 \\
\hline Uphues, Prof., Künstler & $1900-1901$ & 203 \\
\hline Valentien, Peter, Particulier & $1881-1913$ & 727 \\
\hline Valk, Hinderine Moses, Mittellose Witwe & 1847-1902 & 494 \\
\hline Valk, J., Textilienhändler & 1917-1918 & 3.283 \\
\hline Valk, Jakob S., Kaufmann & $1872-1895$ & 985 \\
\hline Valk, Magnus, Bäckermeister & 1867-1908 & 846 \\
\hline \multirow[t]{2}{*}{ Valk, Simon Moses, Kaufmann } & 1847-1902 & 494 \\
\hline & $1872-1895$ & 985 \\
\hline Valk, Simon, Hausbesitzer & $1869-1901$ & 1.159 \\
\hline Valk, V.M., Schlachter & 1867-1908 & 846 \\
\hline Valk, Wolf, Geschäftsmann & $1914-1916$ & 3.194 \\
\hline Veenhuis, Reformierter Pastor & $1874-1910$ & 3.378 \\
\hline Vegt van der, J., Niederländischer Ingenieur & $1869-1912$ & 2.121 \\
\hline Vehn ter, Johanna, Hilfslehrerin & $1916-1918$ & 3.799 \\
\hline Velde van de, Beschwerdeführer & 1918 & 1.673 \\
\hline Velde van der, Meindert, Nachtwächter & $1874-1875$ & 404 \\
\hline Vellen, Anton, Gastwirt & $1904-1915$ & 667 \\
\hline Veltjes, Theodor, Zimmerlehrling und verurteilter Dieb & $1874-1913$ & 172 \\
\hline Vietinghausen, Martha, Turn- und Handarbeitslehrerin & 1908 & 3.548 \\
\hline Vietor, Nicolaus, Reformierter Kirchenrat & $1874-1910$ & 3.378 \\
\hline Visca, J. J., Argentinischer Konsul & $1906-1916$ & 2.114 \\
\hline Visser, Bernhard, Kämmerer & $1912-1918$ & 263 \\
\hline Visser, geb. Hemius, Wiepke, Witwe & $1899-1901$ & 2.779 \\
\hline Visser, geb. Lorentz, Annette, Witwe & $1879-1909$ & 1.727 \\
\hline Visser, H., Hausbesitzer & $1880-1881$ & 2.525 \\
\hline Visser, J. G., Verbesserungsvorschläge für die Gewerbeschule & $1873-1880$ & 2.330 \\
\hline Visser, Jacob, Zimmermeister & $1903-1904$ & 2.579 \\
\hline Visser, Jan, Grundstückskäufer & 1904-1905 & 2.811 \\
\hline Visser, Johann, Fabrikant & 1894 & 2.210 \\
\hline Visser, Lüppe, Grundstückskäufer & 1904-1905 & 2.811 \\
\hline Visser, Menno, Schiffsbesichtiger & $1900-1902$ & 422 \\
\hline Vissering, Justizrat & $1868-1893$ & 2.912 \\
\hline Vissering, Obergerichtsanwalt & $1869-1872$ & 2.672 \\
\hline Vissering, Obergerichtsanwalt in Aurich & $1866-1913$ & 1.930 \\
\hline Vissering, Rechtsanwalt & $1880-1881$ & 2.514 \\
\hline Vocke, Agnes, Lehrerin & $1898-1918$ & 3.802 \\
\hline Vocke, Carl, Kaufmann & 1881 & 1.333 \\
\hline Vogel, Ernst, Polizeisergeant & $1907-1911$ & 363 \\
\hline Vogelpohl, Wilhelm, Lehrer & $1905-1907$ & 3.681 \\
\hline Vogelpohl, Wilhelm, Lehrer an der Hülfsclasse & $1900-1907$ & 3.708 \\
\hline Voget, Friedrich, Reformierter Pastor & $1874-1910$ & 3.378 \\
\hline Vogt, Lehrer an der Höheren Töchterschule & $1875-1876$ & 3.773 \\
\hline
\end{tabular}


Index

\begin{tabular}{|c|c|c|}
\hline \multicolumn{3}{|l|}{ PERS } \\
\hline Indexbegriff & Laufzeit & Lfd.Nr. \\
\hline Vogt, Marten, Armenhausvogt & $1872-1910$ & 1.869 \\
\hline Völker, Paul, Magistratsassistent & 1914-1915 & 9 \\
\hline Völtzke, Otto, Maurer und Kräutner & $1866-1913$ & 832 \\
\hline Voortmann, A. J., Bader und Fleischbeschauer & $1865-1895$ & 746 \\
\hline \multirow[t]{2}{*}{ Voss, Eisenbahnbetriebsdirektor } & $1877-1878$ & 2.006 \\
\hline & $1869-1878$ & 2.007 \\
\hline Voß, Georg, Gemüsebauer & 1911 & 1.079 \\
\hline Voss, Niederländischer Kaufmann & 1914-1916 & 3.240 \\
\hline Voss, Paula, Turnlehrerin & $1878-1880$ & 3.803 \\
\hline Vries de, Berend, Tagelöhner & $1882-1910$ & 501 \\
\hline Vries de, Diedrich,Turmwächter & $1869-1896$ & 436 \\
\hline Vries de, Enno, Bäcker & $1882-1910$ & 501 \\
\hline Vries de, geb. Bruns, Johanna, Mittellose Witwe & $1871-1872$ & 1.707 \\
\hline Vries de, Harm, Lehrer & $1875-1889$ & 3.652 \\
\hline Vries de, Harm, Schankwirt und Schüttstallbetreiber & $1866-1887$ & 824 \\
\hline Vries de, Hilrich & 1904 & 2.815 \\
\hline Vries de, J., Kornkaufmann & $1872-1903$ & 1.250 \\
\hline Vries de, K. J., Bauunternehmer & $1879-1910$ & 2.693 \\
\hline Vries de, Lübbertus, Zimmergeselle & 1873 & 1.300 \\
\hline Vries de, P., Auktionator in Emden & $1899-1911$ & 1.908 \\
\hline Waalkes, J. C., Gaskassierer & $1897-1911$ & 1.046 \\
\hline Waalkes, Jürren, Hilfsschaffner & $1902-1913$ & 1.969 \\
\hline Wachter, Dr., Geheimer Archivrat und Archivleiter & $1899-1916$ & 315 \\
\hline Wacken, Wilhelm, Wissenschaftlicher Hilfslehrer & 1905 & 3.741 \\
\hline Wagener, G. C., Rentier & 1902 & 1.366 \\
\hline Wagner, August, Lithograph & $1901-1908$ & 2.559 \\
\hline Waldau, Grete, Kunstmalerin & $1915-1919$ & 178 \\
\hline Walde van der, Abraham, Produktenhändler & $1909-1910$ & 826 \\
\hline Walde van der, Harm, Tischlermeister & $1891-1899$ & 744 \\
\hline Walkenroth, Polizeisergeant & $1888-1905$ & 964 \\
\hline Wall de, Nanno, Posthalter & $1888-1889$ & 1.343 \\
\hline Wall de, Roelf, Fuhrmann & $1880-1894$ & 1.943 \\
\hline Wall van der, H., Kaufmann & $1891-1899$ & 744 \\
\hline Walle, Dr., Lehramtsbewerber & 1876 & 3.789 \\
\hline \multirow[t]{5}{*}{ Waltemath, Polizeisergeant } & 1878 & 1.317 \\
\hline & 1879 & 1.321 \\
\hline & 1880 & 1.330 \\
\hline & 1881 & 1.333 \\
\hline & 1881 & 1.334 \\
\hline Walter, Carl, Schuldiener & $1888-1910$ & 3.740 \\
\hline Warner, E., Uhrmacher & $1900-1901$ & 1.360 \\
\hline \multirow[t]{2}{*}{ Warners, Christian, Zimmermeister } & $1900-1902$ & 2.758 \\
\hline & $1905-1907$ & 2.836 \\
\hline Warnke, Schüler & $1882-1896$ & 735 \\
\hline \multirow[t]{2}{*}{ Warring, Jacobus Gottfried, Restaurateur und Konditor } & $1900-1901$ & 537 \\
\hline & $1881-1911$ & 737 \\
\hline Watkes, Johann, Kapitän eines Auswandererschiffes & $1852-1875$ & 451 \\
\hline Weber, Architekt und Waffenkäufer & $1882-1906$ & 2.610 \\
\hline Weber, Otto, Polizeisergeant & $1912-1913$ & 406 \\
\hline Wedell von, Oberst, Garnisonskommandant & $1867-1907$ & 1.399 \\
\hline Wederwardt, Emil, Prediger in der Baptistengemeinde & $1875-1913$ & 3.496 \\
\hline Weert de, Jakob, Korbmacher & $1905-1910$ & 373 \\
\hline Weinberg, Henni, Jüdische Hilfsschülerin & $1908-1918$ & 3.709 \\
\hline Weiß, Aaron, Vorsänger u. Hilfsschächter d. israelit. Gemeinde & 1883-1905 & 492 \\
\hline Weißgeier, S., Maschinenmeister & $1873-1914$ & 1.227 \\
\hline Weitz, H., Landwirt & 1902 & 898 \\
\hline Wendisch, Max, Badeanstaltsbesitzer & $1897-1913$ & 740 \\
\hline
\end{tabular}


IV

Index

$\begin{array}{r}\hline \text { PERS } \\ \hline\end{array}$

Indexbegriff

Wendisch, Max, Badeanstaltsbesitzer

Laufzeit

Lfd.Nr.

Wendt, Friedrich, Polizeisergeant

Wendtland, Navigationsschullehrer

1902

2.269

1902-1903

2.271

1905

368

1870-1871

1875-1894

Wentzel, Carl, Polizeisergeant und Nachtwachtmeister

1901-1902

1.582

Wentzel, Karl Robert, Nachtwachtmeister

1898-1905

1.617

1903-1905

408

Wentzel, Karl Robert, Polizeisergeant

Wenzel, Carl, Polizeisergeant

Werth de, G., Feuerwehrmitglied

Werthen, Syndicus der Stadt Emden

1902

394

396

397

1904

1899-1902

1.370

1901-1909

853

Wessels, Johann, Fischhändler

Wessels, P. W., Witwe, Fischhändlerin

Westermeyer, Helene, Turn- und Handarbeitslehrerin

1908-1909

1.653

1891-1904

858

1918

2.738

Wetsch, Jacob, Restaurateur

1901

3.558

1902-1904

Wever, Witwe

Weyde v., Oberst u. Kommandeur d. Ostfries. Infant.-Reg. Nr. 78

1870-1882

1867-1907

Weyhe v., Kreishauptmann, Schatzmeister d. Frauenvereins

Weyhe von, Kreishauptmann, Landrat des Kreises Emden

1880-1897

1868-1887

1876-1890

$1869-1871$

Wiarda, Gymnasial-Oberlehrer

Wiarda, T.D.H.S., Kaufmann und Senator

1870-1871

1869-1875

Wiards, Polizeiverwaltungsbeamter

Wichtental, Oskar, Künstler

Wiegand, F., Diplomingenieur aus Siegen

$1880-1910$

1908-1910

1905-1906

Wiemkes, Johann, Kaufmann

1909-1913

1912-1918

1894

Wienholtz, Eichmeister

Wienrank, H. C., Schankwirt

Wiers, Wiard Martin, Seemann

1906-1910

$1882-1910$

541

545

2.502

725

615

210

2.040

3.483

1.582

23

1.632

270

2.360

261

263

2.160

Wiggers, Heinrich, Stadtbaumeister

1881-1898

Wiggers, Stadtbaumeister

$1882-1896$
$1880-1883$

2.596 
Index

\section{PERS}

\begin{tabular}{|c|c|c|}
\hline Indexbegriff & Laufzeit & Lfd.Nr. \\
\hline \multirow[t]{38}{*}{ Wiggers, Stadtbaumeister } & $1878-1879$ & 974 \\
\hline & $1877-1881$ & 975 \\
\hline & $1883-1907$ & 977 \\
\hline & $1888-1902$ & 983 \\
\hline & 1906-1909 & 1.075 \\
\hline & $1875-1887$ & 1.137 \\
\hline & 1869-1901 & 1.159 \\
\hline & 1876 & 1.176 \\
\hline & $1882-1884$ & 1.178 \\
\hline & 1903-1904 & 1.184 \\
\hline & $1910-1911$ & 1.203 \\
\hline & 1908 & 1.205 \\
\hline & $1879-1907$ & 1.213 \\
\hline & $1887-1902$ & 1.228 \\
\hline & $1901-1908$ & 1.229 \\
\hline & $1873-1906$ & 1.263 \\
\hline & $1907-1916$ & 1.264 \\
\hline & 1876 & 1.322 \\
\hline & 1881 & 1.333 \\
\hline & 1888 & 1.342 \\
\hline & $1887-1888$ & 1.436 \\
\hline & $1870-1900$ & 1.497 \\
\hline & $1888-1903$ & 1.503 \\
\hline & 1910 & 1.553 \\
\hline & 1875 & 1.555 \\
\hline & $1880-1910$ & 1.632 \\
\hline & $1899-1913$ & 1.666 \\
\hline & 1904-1906 & 1.697 \\
\hline & $1891-1893$ & 2.025 \\
\hline & 1900 & 2.076 \\
\hline & $1872-1884$ & 2.384 \\
\hline & $1867-1897$ & 2.419 \\
\hline & 1906-1911 & 2.439 \\
\hline & $1878-1882$ & 2.520 \\
\hline & 1901 & 2.557 \\
\hline & 1877-1878 & 2.652 \\
\hline & $1866-1881$ & 3.085 \\
\hline & $1866-1867$ & 3.121 \\
\hline \multirow[t]{2}{*}{ Wiggers, Stadtbaumeister und Branddirektor } & $1866-1903$ & 1.385 \\
\hline & $1867-1909$ & 1.397 \\
\hline Wiggers, Stadtbaurat & $1909-1911$ & 3.129 \\
\hline Wilde, Bruno, Lehrer & $1908-1916$ & 3.611 \\
\hline Wildeboer, Gottlieb, Maurergeselle & 1870 & 849 \\
\hline Wildermann, Carl Louis, Schiffsmakler & $1871-1913$ & 419 \\
\hline Wildhagen, W. H., Polizeisergeant & $1874-1884$ & 2.521 \\
\hline \multirow[t]{9}{*}{ Wildhagen, W.H., Polizeisergeant } & $1859-1884$ & 393 \\
\hline & 1873 & 1.297 \\
\hline & 1871 & 1.304 \\
\hline & $1869-1874$ & 1.306 \\
\hline & 1869 & 1.307 \\
\hline & 1867 & 1.310 \\
\hline & 1875 & 1.314 \\
\hline & 1879 & 1.319 \\
\hline & $1867-1893$ & 1.495 \\
\hline \multirow[t]{4}{*}{ Wilhelm I., Deutscher Kaiser und preußischer König } & $1875-1913$ & 13 \\
\hline & $1879-1880$ & 193 \\
\hline & 1888-1902 & 194 \\
\hline & $1895-1899$ & 202 \\
\hline
\end{tabular}


Index

\begin{tabular}{|c|c|c|}
\hline \multicolumn{3}{|c|}{ PERS } \\
\hline Indexbegriff & Laufzeit & Lfd.Nr. \\
\hline \multirow[t]{5}{*}{ Wilhelm I., König von Preußen } & 1866 & 174 \\
\hline & 1869 & 175 \\
\hline & $1866-1868$ & 189 \\
\hline & 1874-1911 & 190 \\
\hline & & Vorwort \\
\hline \multirow[t]{19}{*}{ Wilhelm II., König von Preußen und deutscher Kaiser } & 1901-1908 & 31 \\
\hline & $1907-1911$ & 32 \\
\hline & $1900-1901$ & 176 \\
\hline & $1902-1903$ & 177 \\
\hline & $1915-1919$ & 178 \\
\hline & $1900-1901$ & 180 \\
\hline & 1901 & 181 \\
\hline & $1897-1901$ & 182 \\
\hline & 1902 & 183 \\
\hline & 1902 & 184 \\
\hline & 1902 & 185 \\
\hline & 1902 & 186 \\
\hline & 1913 & 191 \\
\hline & 1903-1906 & 196 \\
\hline & 1913 & 198 \\
\hline & $1917-1918$ & 199 \\
\hline & 1914-1915 & 3.146 \\
\hline & 1914-1916 & 3.148 \\
\hline & & Vorwort \\
\hline Wilken, Berend, Verkaufsbudenbetreiber & $1868-1897$ & 1.946 \\
\hline Wille, M., Lehrer & $1885-1889$ & 3.637 \\
\hline Willemsen, M. A., Landbesitzer & $1881-1913$ & 727 \\
\hline Willms, Roolf, Landgebräucher & $1866-1903$ & 2.451 \\
\hline Willrath, Martin Willrath, Senator & $1859-1870$ & 28 \\
\hline Wilms, Gepke, Mittellose & 1913-1915 & 1.872 \\
\hline Wirtjes, Lehrer & $1886-1905$ & 3.684 \\
\hline Wissmar, Sophie, Lehrerin & $1906-1908$ & 3.804 \\
\hline Wistinghausen, Martha, Turn- und Handarbeitslehrerin & $1908-1914$ & 3.610 \\
\hline \multirow{2}{*}{ Wolff, August, Gasmeister } & $1900-1909$ & 1.034 \\
\hline & 1897-1912 & 1.036 \\
\hline Wolff, August, Ingenieur & $1904-1911$ & 1.052 \\
\hline Wolters, Wolter Harms, Veteran aus dem Befreiungskrieg & $1869-1876$ & 3.106 \\
\hline Woortman, B., Mittelloser & 1871-1872 & 1.707 \\
\hline Woortman, H., Buchdrucker & $1868-1875$ & 2.629 \\
\hline \multirow[t]{7}{*}{ Woortman, J. D., Auktionator } & $1868-1911$ & 825 \\
\hline & $1899-1911$ & 1.908 \\
\hline & $1900-1908$ & 2.432 \\
\hline & 1901-1909 & 2.435 \\
\hline & 1905-1909 & 2.448 \\
\hline & $1899-1912$ & 2.492 \\
\hline & 1879-1905 & 2.517 \\
\hline Woydt, Tjark, Bäckermeister & $1903-1904$ & 2.447 \\
\hline Wübben, Jan, Fuhrmann & 1866-1888 & 1.929 \\
\hline Wülbers, Johann, Lehrer & $1912-1914$ & 3.559 \\
\hline Wulff, Ernst, Industrieller & $1900-1909$ & 560 \\
\hline \multirow[t]{2}{*}{ Wulffes Dr., E., Rektor der Höheren Töchterschule } & $1872-1878$ & 3.805 \\
\hline & $1875-1890$ & 3.836 \\
\hline Wurps, Sievert, Zimmermeister & 1878-1894 & 774 \\
\hline Wurpts, Wurpt, Zimmermeister & $1898-1901$ & 2.767 \\
\hline Wurtzema, L. Wwe., Schulwärterin & $1879-1880$ & 3.682 \\
\hline \multirow[t]{2}{*}{ Wurtzema, L., Navigationsschulwärterin } & 1875-1905 & 1.594 \\
\hline & 1891-1903 & 1.606 \\
\hline Wychgram, Dr. med, Theodor, Arzt und Sanitätsrat & 1886-1898 & 258 \\
\hline
\end{tabular}


IV

Index

\begin{tabular}{|c|c|c|}
\hline \multicolumn{3}{|l|}{ PERS } \\
\hline Indexbegriff & Laufzeit & Lfd.Nr. \\
\hline Wychgram, Dr., Hausbesitzer & $1868-1871$ & 1.211 \\
\hline Wychgram, L., Prediger in Oldersum & 1884-1901 & 3.480 \\
\hline Wychgram, Prof., Glasmalereiexperte & 1904 & 3.826 \\
\hline Wyckhoff, Landwirt in Borssum & $1880-1903$ & 1.550 \\
\hline Wyk van der, Hindericus, Lotse & 1898-1899 & 2.754 \\
\hline Wykhoff, B. J., Gemeindevorsteher in Borssum & 1892-1895 & 246 \\
\hline Zahrenhusen, Dr., Rektor der Kaiserin-Auguste-Viktoria-Schule & 1911-1913 & 3.831 \\
\hline Zander, Marie, Lehrerin & 1897-1908 & 3.806 \\
\hline Zander, Wasserbauinspektor & 1908-1909 & 2.073 \\
\hline Zeeborg, Gebrüder & 1878 & 1.324 \\
\hline \multirow[t]{3}{*}{ Zeemann, Jacob Meindert, Hafenmeister } & 1857-1885 & 418 \\
\hline & $1888-1903$ & 1.503 \\
\hline & 1880 & 1.506 \\
\hline Zeinpel, Joseph, Arbeiter & 1889-1909 & 2.433 \\
\hline Zeiß, M., Kanzlei- und Kämmereischreiber & 1891-1892 & 341 \\
\hline Zeppelin, Graf von, Luftschiffskonstrukteur & $1899-1910$ & 512 \\
\hline Zerener, Dr. H., Zivilingenieur & $1880-1882$ & 1.996 \\
\hline \multirow{2}{*}{ Zibell Dr., Kreisarzt } & $1866-1914$ & 762 \\
\hline & $1881-1900$ & 765 \\
\hline Zick, Johanna, Flüchtling aus Ostpreußen & 1914-1916 & 3.203 \\
\hline Ziegler, Heinrich, Geschäftsführer der Gewerbehalle & $1866-1903$ & 1.924 \\
\hline Ziemann, Barteld, Fuhrmann & $1866-1893$ & 2.456 \\
\hline Zietsch Prof. Dr., Johann Friedrich August, Studienrat & $1887-1910$ & 3.742 \\
\hline Zillessen, Otto, Reformierter Pastor & $1874-1910$ & 3.378 \\
\hline \multirow[t]{5}{*}{ Zimmermann, Gerhard, Heringsfischereidirektor } & $1912-1918$ & 263 \\
\hline & 1906-1909 & 1.075 \\
\hline & $1905-1913$ & 1.076 \\
\hline & 1902 & 1.365 \\
\hline & $1900-1902$ & 2.792 \\
\hline Zipp, Frieda, Turn- und Handarbeitslehrerin & $1915-1917$ & 3.609 \\
\hline Zippel, Irmgard, Lehrerin & 1917-1918 & 3.608 \\
\hline Zopp, August, Vorsitzender des Vereins "Lokomotive" & $1900-1912$ & 639 \\
\hline Zorn, Conrad, Bürgervorsteherkollegiumssprecher & $1900-1911$ & 259 \\
\hline \multirow[t]{13}{*}{ Zwitzers, August Ernst, Direktor der Höheren Töchterschule } & $1878-1912$ & 1.725 \\
\hline & 1886-1895 & 3.752 \\
\hline & $1872-1891$ & 3.763 \\
\hline & $1898-1910$ & 3.765 \\
\hline & 1889-1891 & 3.776 \\
\hline & $1877-1911$ & 3.807 \\
\hline & 1910 & 3.813 \\
\hline & 1880-1902 & 3.823 \\
\hline & $1907-1912$ & 3.828 \\
\hline & 1908 & 3.832 \\
\hline & 1901-1907 & 3.833 \\
\hline & $1886-1916$ & 3.849 \\
\hline & 1873-1914 & 3.851 \\
\hline Zwitzers, August, Schulrat & $1900-1911$ & 259 \\
\hline
\end{tabular}




SACH

\begin{tabular}{l} 
Indexbegriff \\
\hline Abfall, Organisation der Entsorgung
\end{tabular}

Abfall, Organisation der Entsorgung

\section{Laufzeit}

$1882-1885$

1867-1906

$1873-1880$

1879

Abfallbeseitigungssysteme, Angebot Abfälle, Verbrennung

Abfälle, Verwertung

Abfuhr- und Tonnenordnung, Stadt Emden

Abfuhr- und Tonnenwesen, Druckschrift

Abfuhrgeräte, Angebote

Abfuhrgerätschaften, Aufstellung

Abfuhrkommission, Mitgliederwahl

Abfuhrkommission, Stimmrecht des Vorsitzenden

Abfuhrpflicht, Fäkalien und Mist

Abfuhrsysteme, Angebote

Abfuhrvertragsverhältnis, Stadt Emden und Berend J. Meyer

Abfuhrvertragsverhältnis, Stadt Emden und Uffe Fokken

Abfuhrwagen, Anschaffung

Abfuhrwesen, Druckschriften

Abfuhrwesen, Entwicklung

Abfuhrwesen, Groningen

Abfuhrwesen, Konventionalstrafe

Abfuhrwesen, Kredite für Neuerungen

Abfuhrwesen, Monopol des Fuhrunternehmers Fokken

Abfuhrwesen, Neuregelung

Abfuhrwesen, Organisation

Abfuhrwesen, Unterleibstyphus

Abfuhrwesen, Verbesserung

Abfuhrwesen, Verhandlungen über Organisation

Abgabe des Torf- und Torabwurfs, Abschaffung

Abgaben, Betrieb eines Gewerbes

Abgaben, Niederländische Leichter in Emden

Abgeordneter, Mandatsniederlegung

Ablösegelder, Verwendung

Ablösekapital, Festlegung

Ablösungen, Regelung

Ablösungsgesetz, Ausführung

Abonnenten-Versicherungen, Verbotsdiskussion

Abort, Vergütung des Einbaus

Abortanlage, Antrag auf Beseitigung

Abortanlage, Belästigung durch Ausdünstungen

Abortanlage, Emder Rathaus

Abortanlage, Reinigung

Abortanlage, Unvorschriftsmäßige auf einer Baustelle

Abortanlagen, Fehlerhafte

Abortanlagen, Öffentliche in Emden

Abortanlagen, Reinigung

Abortanlagen, Revision

Abortanlagen, Verbesserung

Aborte, Anbringung in den Gotteskammern

Aborte, Belästigung

Aborte, Beseitigungsanordnung
$1905-1912 \quad 863$

1894-1908 872

1894-1908 872

1878-1909 851

$1886-1900 \quad 886$

1867-1906 865

1894-1908 872

1876-1882 871

1874-1908 $\quad 885$

1874-1908 885

$1867-1906 \quad 865$

1894-1908 872

1909-1915 878

$1876-1882 \quad 871$

1878-1909 851

$1886-1900 \quad 886$

1876-1879 868

$1873-1880 \quad 866$

1879-1909 877

1886-1894 870

1879-1909 877

1869-1885 869

1894-1908 872

1894-1908 872

1876-1879 868

1886-1894 $\quad 870$

$1873-1898 \quad 1.562$

1866-1897 2.900

1873-1909 $\quad 1.561$

1867-1869 217

1904-1909 2.859

1867-1911 2.858

1867-1911 2.858

1858-1913 2.854

1911-1914 $\quad 1.677$

1866-1904 $\quad 2.676$

1866-1911 962

1871-1906 961

1873-1880 866

1871-1906 961

$1905 \quad 883$

1897-1906 874

1907-1911 875

1871-1906 961

1866-1911 962

1876-1909 963

1888-1905 964

1866-1911 962

1897-1906 874

1907-1911 875

1869-1885 869

$1886-1894 \quad 870$

$1881-1886 \quad 850$

1867-1896 $\quad 1.492$ 
Index

\section{SACH}

Indexbegriff

Aborte, Öffentliche in Emden

1879-1909

Lfd.Nr.

Aborte, Ordnungswidrige

Aborte, Reinigung öffentlicher Anlagen

1876-1882

Aborte, Revision

1886-1894

871

1883-1896

870

Aborte, Unvorschriftsmäßige Anlage

1866-1911

Aborte, Visitation

$1886-1894$

Abortgruben, Angebote über Auspumpgeräte

1894-1908

870

$1867-1893$

Abortgruben, Gesetzesbestimmungen

Aborthaus, Geruchsbelästigung

Aborttonne, Übernutzung

Aborttonnen, Spülung

Abortwesen, Missstände

Abortwesen, Regelung

Abschätzungs-Kommission, Ernennung der Mitglieder

$1896-1903$

1.495

$1866-1911$

880

$1870-1879$

962

1897-1906

888

$1895-1910$

874

$1895-1910$

873

1895-1910

873

1873-1914

873

Abtritt, Bauantrag

Abwässer, Ableitung in die Tiefs

Abwässer, Einleitung in den Ems-Jade-Kanal

1869-1901

1893-1914

1.159

Abwässer, Einleitung in die Entwässerungsgräben

Abwasser, Einleitung in fiskalische Gräben

Abwässer, Einleitung in Treckfahrtskanal

Abwässer, Geruchsbelästigung

1901

1894-1905

1910

1902

1910

1890-1901

1894-1905

1894-1905

Abwässer, Gesundheitsgefährdung

$1885-1900$

Abwässer, Verbot der Ableitung

Abwasserleitung, Unterhaltung

Abwasserreinigung

1867-1874

1903-1904

Abwässerungsanlagen, Unterhaltung

Abwässerungsgräben, Geruchsbelästigung

1904-1908

$1876-1884$

1870-1879

1873-1880

862

Abwässerungskanal, Reparatur

Abwässerungszuleitungen, Änderungsanträge

Abzugsgräben, Schäden durch Verstopfung

$1887-1910$

$1870-1879$

$1900-1915$

$1869-1916$

1910-1913

1913-1914

1910-1913

1913-1914

1910-1913

1913-1914

1910-1913

1913-1914

1866

Akten, Abgaben

1912-1913

888

866

935

888

815

454

Akten, Evakuierung im Brandfall

Akten, Übergabe

Aktenpläne, Stadtverwaltung

Aktenvernichtung, Auflistung

Aktenvernichtung, Hinzuziehung der Archive

Aktenvernichtung, Stadt Emden

1869-1913

1914

1.387

1857-1908

1.529

1866-1914

Aktenvernichtung, Vorschriften

$1866-1914$

Aktien, Erwerb

Aktien, Pfändung

1906-1907 
Index

\begin{tabular}{|c|c|c|}
\hline \multicolumn{3}{|l|}{ SACH } \\
\hline Indexbegriff & Laufzeit & Lfd.Nr. \\
\hline Aktienvermögen, Pfändung & $1905-1909$ & 2.361 \\
\hline \multirow[t]{2}{*}{ Akzise, Eingeführte Backwaren } & $1900-1903$ & 2.928 \\
\hline & 1904-1907 & 2.929 \\
\hline Akzise, Erhebung & $1867-1878$ & 2.914 \\
\hline Akzise, Erhöhung & 1879-1909 & 2.915 \\
\hline Akzise, Ertrag & 1879-1909 & 2.915 \\
\hline Akzise, Getreide, Mehl und Torf & 1879-1909 & 2.915 \\
\hline Akzise, Hinterziehung & 1883-1902 & 2.922 \\
\hline Akzise, Roggenmehl & 1879-1909 & 2.915 \\
\hline Akzise, Speck und Schmalz & 1879-1909 & 2.915 \\
\hline Akzise, Umgehung & 1879-1909 & 2.915 \\
\hline Akzise, Verpachtung & $1882-1910$ & 2.920 \\
\hline Akzise, Zurückerstattung an Garnison & $1868-1881$ & 2.919 \\
\hline Akzise-Kassenschreiber, Einstellung & $1873-1916$ & 435 \\
\hline Akzise-Kassenschreiber, Pensionierung & $1873-1916$ & 435 \\
\hline Akzise-Kontrolleur, Dienstanweisung & 1902-1904 & 427 \\
\hline Akzise-Kontrolleur, Entlassungsgesuch & $1902-1904$ & 427 \\
\hline Akzise-Kontrolleur, Gnadengehalt für Witwe & $1902-1904$ & 427 \\
\hline Akzise-Kontrolleur, Stellenausschreibung & $1902-1904$ & 427 \\
\hline Akzise-Kontrolleure, Einstellung & $1887-1901$ & 2.923 \\
\hline Akzisenverwaltung, Rechnungslegung & $1891-1913$ & 2.925 \\
\hline Akziseordnung, Ausdehnung & 1894-1917 & 2.926 \\
\hline Akziseordnung, Neufassung & $1867-1878$ & 2.914 \\
\hline Akziseordnung, Novellierung & 1879-1909 & 2.915 \\
\hline Akziseordnung, Spirituosen & $1867-1879$ & 2.918 \\
\hline Akziseordnung, Verstoß gegen & 1879-1909 & 2.915 \\
\hline Akzisepächter, Beschwerde gegen & $1882-1910$ & 2.920 \\
\hline Akzise-Tarife, Neufassung & $1867-1878$ & 2.914 \\
\hline Akzisewesen, Organisation & 1879-1909 & 2.915 \\
\hline Alarm- und Löschplan, Fiskalische Hafenanlagen & 1912 & 1.270 \\
\hline Algin, Werbung & $1905-1906$ & 2.377 \\
\hline Alkohol, Verkaufserlaubnis & 1902 & 1.939 \\
\hline Alkoholausschank, Verbot an Gymnasiasten & 1867-1909 & 529 \\
\hline Alkoholkonsum, Bekämpfung & 1867-1909 & 529 \\
\hline \multirow{3}{*}{ Alkoholmissbrauch, Bekämpfung } & $1899-1905$ & 644 \\
\hline & 1903-1906 & 646 \\
\hline & $1903-1914$ & 696 \\
\hline Alleebäume, Pflanzung & $1875-1889$ & 2.035 \\
\hline Alleen, Schutz & $1907-1912$ & 695 \\
\hline Allgemeiner Arbeiterverein für Emden und Umgebung, Mitglieder & $1891-1912$ & 632 \\
\hline Allgemeiner Arbeiterverein für Emden und Umgebung, Statuten & $1891-1912$ & 632 \\
\hline \multirow[t]{3}{*}{ Allgemeines Ehrenzeichen, Verleihung } & $1900-1911$ & 259 \\
\hline & $1909-1913$ & 261 \\
\hline & $1912-1918$ & 263 \\
\hline Altartisch, Entdeckung & $1873-1917$ & 2.395 \\
\hline Altertümer, Kataster & $1873-1917$ & 2.395 \\
\hline Altmetall, Verwertung & $1905-1912$ & 863 \\
\hline Altpapier, Sammlung & $1866-1914$ & 317 \\
\hline Altreformierte Gemeinde, Korporationsrechte & 1869-1905 & 3.498 \\
\hline Altreformierte Gemeinde, Mitglieder & 1869-1905 & 3.498 \\
\hline \multirow[t]{2}{*}{ Aluminium, Abgabe für Kriegswirtschaft } & 1917 & 3.261 \\
\hline & 1917 & 3.262 \\
\hline Aluminium, Abgabeliste & 1917 & 3.264 \\
\hline Aluminium, Entschädigung & 1917 & 3.261 \\
\hline Amerikanischer Mehltau, Bekämpfung & $1898-1914$ & 817 \\
\hline Ammoniaklösung, Entsorgung & $1866-1893$ & 1.041 \\
\hline Amnestierung, Stellungnahme für einen Verurteilten & 1874-1913 & 172 \\
\hline Amtsanwalt, Aufgabenbereich & $1913-1914$ & 7 \\
\hline
\end{tabular}


IV

Index

\section{SACH}

Indexbegriff

Amtsanwalt, Gehalt

Amtsanwalt, Stellenausschreibung

Amtsbuch, Ein- und Ausgänge der Stadtverwaltung

\section{Laufzeit}

1913-1914

1913-1914

1913-1914

1869

1870

1871

1872

1873

1874

1875

1876

1877

1878

1879

1880

1881

1882

1883

1884

1885

1886

1887

1888

1889

1890

1891

1892

1893

1894

1895

1896

1896

1897

1897

1898

1898

1899

1899

1867

1907-1913

1907-1913

1907-1913

1907-1913

1907-1913

1902-1906

1907-1913

1902-1906

1907-1913

1910-1911

1907-1913

1870-1900

1870-1900

1879-1891

1883

1865-1866

1865-1866

1912-1913

1902-1903
Lfd.Nr.

7


IV

Index

\section{SACH}

\begin{tabular}{|c|c|c|}
\hline Indexbegriff & Laufzeit & Lfd.Nr. \\
\hline Anlagen, Feuergefahr & $1879-1907$ & 1.213 \\
\hline \multirow[t]{18}{*}{ Anlagen, Genehmigung zum Bau oder Veränderung } & 1906 & 2.162 \\
\hline & 1906 & 2.163 \\
\hline & 1906 & 2.164 \\
\hline & 1906 & 2.165 \\
\hline & 1906 & 2.166 \\
\hline & 1906 & 2.167 \\
\hline & 1906 & 2.168 \\
\hline & 1906 & 2.169 \\
\hline & 1906 & 2.170 \\
\hline & 1906 & 2.171 \\
\hline & 1898 & 2.172 \\
\hline & 1900 & 2.173 \\
\hline & 1907 & 2.174 \\
\hline & 1907 & 2.175 \\
\hline & 1907 & 2.176 \\
\hline & 1907 & 2.177 \\
\hline & 1907 & 2.178 \\
\hline & 1907 & 2.179 \\
\hline Anlegemöglichkeit, Motorboote nach Greetsiel & 1897 & 2.052 \\
\hline Anleihe, Angebot & $1888-1890$ & 2.995 \\
\hline Anleihe, Ankauf eines Brandgrundstückes & $1896-1897$ & 3.002 \\
\hline Anleihe, Anlage eines Notdurchlasses & 1906-1907 & 3.007 \\
\hline Anleihe, Aufnahme & $1875-1888$ & 2.994 \\
\hline Anleihe, Ausbau des Gaswerks & $1896-1904$ & 3.003 \\
\hline Anleihe, Bau der Höheren Töchterschule & 1903-1909 & 3.004 \\
\hline Anleihe, Bau eines Krankenhauses & $1892-1897$ & 2.999 \\
\hline Anleihe, Deich- und Straßenbau & 1895 & 3.000 \\
\hline Anleihe, Einbau von WC's im städtischen Krankenhaus & 1903 & 3.005 \\
\hline Anleihe, Feuermeldeanlage & $1906-1907$ & 3.006 \\
\hline Anleihe, Platzierung & 1873-1909 & 2.992 \\
\hline Anleihe, Tilgungsplan & 1873-1909 & 2.992 \\
\hline Anleihe,Tilgung & 1873-1909 & 2.992 \\
\hline Anleihen, Aussetzung der Tilgung & 1917 & 3.010 \\
\hline Anleihen, Schlachthausbau & $1896-1897$ & 3.001 \\
\hline Anleihen, Stadt Emden & 1868-1902 & 2.989 \\
\hline Anleihen, Städtische Bauprojekte & $1892-1894$ & 2.998 \\
\hline Anleihen, Tilgung & $1888-1890$ & 2.995 \\
\hline Anleihen, Tilgungsplan & $1888-1890$ & 2.995 \\
\hline \multirow{2}{*}{ Anleihen, Umschreibung } & $1888-1890$ & 2.995 \\
\hline & 1888-1889 & 2.996 \\
\hline Anleihepapiere, Tilgung & $1896-1915$ & 2.997 \\
\hline Anleihepapiere, Umschreibung & 1888-1889 & 2.996 \\
\hline Anleihepapiere, Zinsfuß & 1888-1889 & 2.996 \\
\hline \multirow[t]{4}{*}{ Anlieger, Heranziehung zu den Straßenbaukosten } & 1906-1908 & 1.011 \\
\hline & 1904-1908 & 1.012 \\
\hline & $1910-1911$ & 1.014 \\
\hline & $1876-1888$ & 1.134 \\
\hline \multirow[t]{2}{*}{ Anliegerbeitrag, Erhebung } & $1897-1900$ & 994 \\
\hline & 1894-1913 & 1.135 \\
\hline \multirow[t]{2}{*}{ Anliegerbeitrag, Fußwegbau } & $1878-1879$ & 974 \\
\hline & $1877-1881$ & 975 \\
\hline Annektion, Königreich Hannover durch Preußen & 1866 & 174 \\
\hline Annoncenuhr, Aufstellung & $1886-1901$ & 837 \\
\hline Annoncenuhr, Beseitigung & $1886-1901$ & 837 \\
\hline Annoncenuhr, Reparatur & $1886-1901$ & 837 \\
\hline Anschlussgleis, Gebühren & $1900-1904$ & 2.554 \\
\hline Ansiedlungen, Förderung & $1907-1915$ & 682 \\
\hline
\end{tabular}


Index

\section{SACH}

Indexbegriff

Ansteckende Augenkrankheit, Anzeigenpflicht

Laufzeit

Lfd.Nr.

Antisemitismus

Antisemitismus, Agitation des Schleusenmeisters M. Groenewold

Antisemitismus, Verbot von Literatur

Anwachs, Abtretung

Anwachs, Bedeichungsfähigkeit

Anwachs, Einpolderung

$1880-1912$

$1880-1912$

776

776

1877-1885

Vorwort

1880-1891

440

1900-1904

720

1881-1901

1.539

$1867-1890$

2.477

1881-1901

2.476

2.477

1874-1887

2.478

1876-1878

2.479

$1881-1888$

2.480

Anwachs, Nutzungsrecht

$1881-1901$

2.477

Apfel-Champagner, Definition

Apothekenpflichtigkeit, Gerichtsurteil

Arbeiter- und Beamtenhäuser, Planung

1909-1911

743

1872-1914

767

$1905-1911$

1.172

Arbeiter- und Beamtenwohnungen, Staatliche Bauverwaltung

1901-1909

1.183

Arbeiter, Entlohnung

$1875-1899$

1.038

Arbeiter, Erhebung über Beschäftigung

1903

2.367

Arbeiter, Unterbringung

Arbeiter, Unterstützung

1873-1877

2.483

1.636

1.046

$1897-1911$

1867-1891

719

Arbeiterbewegung, Streit SPD mit Lassalleanern

1875-1909

2.383

Arbeiterfürsorge, Baustellen

1897-1903

1.139

1899-1913

1.666

Arbeiterhäuser, Ausstattung mit Herden und Öfen

$1900-1902$

1.247

1.135

Arbeiterhäuser, Bauantrag

Arbeiterhäuser, Mieteinnahmen

Arbeiterhäuser, Straßenanbindung

Arbeiterhäuser, Vermietung

Arbeiterinnen, Statistik über Beschäftigung in Emden

Arbeiterkolonie, Anbindung an die städtische Müllabfuhr

894-1913

2.432

1.135

2.432

$1900-1908$

$1872-1904$

2.382

1867-1906 865

Arbeiterkolonie, Anlage

Arbeiterkolonie, Bebauungsplan

Arbeiterkolonie, Bewohner

1913-1915

1913-1915

1913-1915

813

813

813

Arbeiterkolonie, Kirchliche Versorgung

1913-1915

1913-1915

813

813

Arbeiterkolonie, Schullasten

1913-1915

1913-1914

1913-1915

813

3.615

Arbeiterkolonie, Straßenanbindung

Arbeiterkolonie, Wasserversorgung

1913-1915

813

813

1882-1913

1.636

Arbeiterrentgüter, Bildung

1907

1.243

Arbeiterschaft, Datenerhebung über Lage

1872-1904

$1872-1904$

2.382

Arbeiterschutz

Arbeitersiedlung, Anlage

Arbeitersiedlung, Anschluss an die Wasserleitung

Arbeitersiedlung, Aufbau im Kaiser-Wilhelm-Polder

Arbeitersiedlung, Bau

Arbeitersiedlung, Bebauungsplan

Arbeitersiedlung, Grundstücksacquise

$1882-1904$

2.382

1.731

1.234

1.228

1887-1902

1.246

$1899-1900$

2.432

1900-1908

2.821

1905-1906

2.823

$1869-1913$

Arbeitersiedlung, Kaiser-Wilhelm-Polder

1899-1901

1.232

Arbeitersiedlung, Landerwerb

Arbeitersiedlung, Plan

1894-1913

1.135

Arbeitersiedlung, Port Arthur

$1869-1913$

Arbeitersiedlung, Standortbestimmung 
Index

SACH

Indexbegriff

Arbeitersiedlungen, Straßenanbindung

Arbeiter-Stellen, Bewerbungen

Arbeiterturnvereine, Politischer Charakter

Arbeiterverein, Überwachung

Arbeiterwohnhaus, Bau

Arbeiterwohnhaus, Vermietung

Arbeiterwohnhäuser, Ansichten und Risszeichnungen

Arbeiterwohnhäuser, Ausstellung von preisgekrönten Modellen

Arbeiterwohnhäuser, Bau

Arbeiterwohnhäuser, Bauplanausstellung

Arbeiterwohnhäuser, Errichtung an der Nesserlander Str.

Arbeiterwohnhäuser, Finanzierung

Arbeiterwohnhäuser, Kanalisierung

Arbeiterwohnhäuser, Risszeichnungen

Arbeiterwohnungen, Bau

Arbeiterwohnungen, Bauförderung

Arbeiterwohnungen, Datenerhebung

Arbeiterwohnungen, Einrichtungskriterien

Arbeiterwohnungen, Engagement von Vereinen

Arbeiterwohnungen, Hypothekverhandlungen

Arbeiterwohnungen, Mietbedingungen

Arbeiterwohnungen, Missstände

Arbeiterwohnungen, Revision

Arbeiterwohnungen, Seilerhaus

Arbeiterwohnungsbau, Abtretung von städtischem Land

Arbeiterwohnungsbau, Finanzierung

Arbeiterwohnungsbau, Förderung

Laufzeit

Lfd.Nr.

1869-1913

829

$1867-1906$

865

1875-1909

836

$1906-1912 \quad 432$

1904-1913 664

1904-1913 664

1901-1909 2.435

$1901-1909 \quad 2.435$

$1905-1906 \quad 2.436$

1901-1902 1.239

$1905 \quad 1.241$

$1899-1900 \quad 1.246$

$1900-1902 \quad 1.247$

1905-1906 2.436

$1906 \quad 1.242$

1901-1902 $\quad 1.237$

1901-1902 $\quad 1.237$

$1899-1900 \quad 1.246$

1901-1902 $\quad 1.237$

1894-1911 2.745

1873-1914 1.227

$1909-1911 \quad 1.231$

1887-1902 1.228

$1873-1910 \quad 1.226$

$1887-1902 \quad 1.228$

1901-1902 1.239

1894-1905 $\quad 1.240$

1894-1905 $\quad 1.240$

1900-1908 2.432

$1873-1910 \quad 1.226$

1873-1914 1.227

$1873-1910 \quad 1.226$

1874-1893 2.444

$1901-1902 \quad 1.237$

1900-1902 1.247

$1887-1902 \quad 1.228$

1901-1908 1.229

1901-1908 $\quad 1.230$

$1909-1911 \quad 1.231$

$1901-1902 \quad 1.237$

1901-1908 $\quad 1.229$

$1887-1902 \quad 1.228$

1887-1902 1.228

1901-1908 $\quad 1.230$

$1909-1911 \quad 1.231$

$1882-1913 \quad 1.636$

$1902 \quad 397$

Arbeitsangebot, Ablehnung

$1902 \quad 397$

Arbeitsaufnahme, Verpflichtung

Arbeitsbekleidung, Ankauf

1917-1918

3.283

Arbeitsbücher, Kontrolle

1872-1904

2.382

1911-1914 713

Arbeitslosenversicherung, Handlungsgehilfen und Kaufleute

1875-1909

2.383

Arbeitslosigkeit, Bekämpfung

Arbeitslosigkeit, Verhinderung

1914-1916

3.200

1914-1916 $\quad 3.200$

Arbeitsordnungen, Richtlinien

1892-1910

2.389

Arbeitsschuhe, Mangel

1918

Arbeitsverbot, Sonn- und Feiertage

$1891-1898$

3.295 
Index

SACH

Indexbegriff

Archäologie, Meldung von Fundstücken

Archiv, Aktenausleihe

Archiv, Anfragen für Recherchen

Archiv, Eingliederung von Emden nach aurich

Archiv, Gutachten zur Neuorganisation

Archivbauplanung, Prüfung

Archivverhandlungen, Stadt Emden mit Belgien

Arme, Unterstützung Fremder in Emden

Arme, Verpflegte in Emden

Armeedienst, Pferde in Emden

Armeepferde, Demobilisierung

Armen-Abgabe, Regulativ

Armen-Arbeitshaus, Brotlieferung

Armen-Arbeitshaus, Einweisung

Armenarzt, Bestellung

Armenarzt, Instruktionen

Armenärzte, Honorar

Armenbegräbnisse, Gebühren

Armenbeiträge, Ausgaben für die Hebung

Armenbeiträge, Beschwerden

Armenbeiträge, Bestrittene Ausgaben

Armenbeiträge, Einnahmen

Armenbeiträge, Katholische Gemeinde

Armenbeiträge, Restanten

Armenbeitrags-Zahlungspflichtige

Armendeputation, Zusammensetzung

Armenfürsorge, Übernahme durch die Stadt Emden

Armenfürsorge, Verwendung von Geld a. d. Klingelbeutel

Armengräber, Erwerb durch den Ortsarmenverband

Armenhaus, Ausbauplan

Armenhaus, Einweisung zur Entbindung

Armenhausbau, Finanzierung

Armenhausordnung, Stadt Emden

Armenhausvater, Dienstjubiläum

Armenhausvater, Einstellung

Armenhausvater, Gehaltserhöhungswunsch

Armenhausvater, Pensionierungsgesuch

Armenhausvater, Teuerungszulage

Armenhilfeeinrichtungen, Etats

Armenkasse, Vorschuss für die Krankenhausbehandlung

Armenkinder, Beschulung

Armenkollegium, Beamte

Armenkollegium, Mitgliederwahl

Armenkollegium, Rechnungslegung

Armenkollegium, Rechnungsprüfung

Armenkollegium, Rücktritt des Vorsitzenden

Armenkollegium, Vorsitzwahl

Armenkommission, Bilanz

Armenkommission, Kassenlage

Armenländereien, Kauf durch die Stadt Emden

Armenlasten, Heranziehung

Armenpflege, Statistik

Laufzeit

1911-1916

$1884-1917$

1899-1916

1899-1916

1899-1916

1899-1916

1884-1917

1883-1887

1872-1881

1872-1881

1916-1918

1916-1918

1890-1895

1881-1914

1913-1915

1888-1904

1888-1904

1872-1910

1867-1918

1882-1883

1867

1868

1867

1867

1867-1870

1867

1870

1868

1869

1871

1867-1874

1882

1882-1883

1814

1915-1917

1873

1877-1912

1872-1910

1872-1910

1872-1910

1872-1910

$1872-1910$

1867-1868

1868-1869

1914-1915

1871-1875

1872-1910

1872-1918

1873-1914

1873-1914

1872-1918

1872-1918

1871-1872

1875

1871-1872

1866-1867

1871-1873

1894
Lfd.Nr.

563

2.396

315

315

315

315

2.396

2.393

1.767

1.767

3.165

3.165

1.733

1.892

1.872

1.866

1.866

1.869

1.634

3.396

1.746

1.748

1.742

1.746

3.487

1.742

1.743

1.744

1.745

1.774

1.772

3.452

3.396

1.782

1.881

1.781

324

1.869

1.869

1.869

1.869

1.869

1.736

1.747

1.876

1.761

1.869

1.870

1.871

1.871

1.870

1.870

1.867

1.868

1.867

2.471

1.760

1.779 
IV

Index

\section{SACH}

Indexbegriff

Armenpfleger, Nominierung

Armenpfleger, Rücktritt

Armenpflegerinnen, Diskussion der Ernennung

Armenrechnungen, Belege

Armenrecht, Zeugnisse

Armenrechtsantragsteller, Zahlungsfähigkeit

Armenregulativ, Entwurf

Armensache, Bestattungsgebühr für unbekannte Leiche

Armensache, Krankenhausbehandlung

Armensachen, Unterstützungsfälle

Armensärge, Beschaffung gewölbter Särge

Armensärge, Beschwerden

Armenschule, Auflösung

Armenschüler, Verteilung auf die konfessionellen Klassenschulen

Armen-Umlage, Einnahmen

\section{Laufzeit}

1894

$1872-1918$

1872-1918

$1872-1918$

1870

1873

1868-1913

1868-1913

1871

1913-1915

1913-1915

1913-1915

1887-1893

1887-1893

1873-1874

1872-1888

1867

1868

1869

1871

1871

Armenunterstützung, Verweigerung

Armenverbände, Auflösung der Konfessionellen in Emden

Armenverbände, Datenerhebung

Armenverbände, Organisation

Armenvermögen, Emden

Armenvermögen, Übergang auf Stadt Emden

Armenverwaltung, Ausgaben und Einnahmen
$1872-1900$

1871

1869-1870

$1869-1870$

1873

1867-1874

1870-1872

1871

1872

1873

1873

1874

1875

1874

1875

1876-1877

1876-1877

1877-1878

1877-1878

1878-1879

1880-1881

1880-1881

1881-1882

1881-1882

1882-1883

1882-1883

1883-1884

1883-1884

1884-1885

1884-1885

1885-1886

1885-1886

1886-1887

1886-1887

1887-1888

1887-1888

1888-1889
Lfd.Nr.

1.779

1.870

1.870

1.870

1.859

1.860

173

173

1.774

1.872

1.872

1.872

1.778

1.778

3.675

3.657

1.737

1.738

1.739

1.740

1.741

1.863

1.764

1.771

1.771

1.781

1.772

1.773

1.783

1.784

1.785

1.786

1.787

1.788

1.789

1.790

1.791

1.792

1.793

1.794

1.795

1.796

1.797

1.798

1.799

1.800

1.801

1.802

1.803

1.804

1.805

1.806

1.807

1.808

1.809

1.810

1.811

1.812 
IV

Index

SACH

Indexbegriff
Armenverwaltung, Ausgaben und Einnahmen

Laufzeit

1888-1889

1889-1890

1889-1890

1890-1891

1890-1891

1891-1892

1891-1892

1892-1893

1892-1893

1893-1894

1893-1894

1894-1895

1894-1895

1895-1896

1895-1896

1896-1897

1896-1897

1901-1902

1902-1903

1902-1903

1903-1904

1903-1904

1904-1905

1904-1905

1905-1906

1905-1906

1906-1907

1906-1907

1907-1908

1907-1908

1908-1909

1908-1909

1909-1910

1910-1911

1897-1898

1897-1898

1898-1899

1898-1899

1899-1900

1899-1900

1900-1901

1900-1901

1910-1911

1910-1911

1911-1912

1911-1912

1876

1871-1872

1871-1913

1871

1871-1873

1894

1867-1874

1870-1872

1873-1886

1881-1889

1871

1871-1872
Lfd.Nr.

1.813

1.814

1.815

1.816

1.817

1.818

1.819

1.820

1.821

1.822

1.823

1.824

1.825

1.826

1.827

1.828

1.829

1.830

1.831

1.832

1.833

1.834

1.835

1.836

1.837

1.838

1.839

1.840

1.841

1.842

1.843

1.844

1.845

1.846

1.847

1.848

1.849

1.850

1.851

1.852

1.853

1.854

1.855

1.856

1.857

1.858

1.776

1.775

1.864

1.765

1.760

1.779

1.772

1.773

2.422

1.768

1.774

1.775 
Index

SACH

\section{Indexbegriff}

Armenwesen, Organisation

Arzneimittel- und Heilmittelhandel, Regulierung

Arzneimittel, Vertrieb

Arzneimittel, Zulassung und Kategorisierung

Aufenthalt, Mitglieder der kaiserlichen Familie in Emden

Aufenthalt, Unerlaubter in Wolthusen

Aufgebotsgebühren, Streichung

Aufschlickung, Schadensersatzforderung

Aufseher der Stadtreinigung, Bewerbungen

Aufseher der Stadtreinigung, Ernennung

Aufstand, Karolineninseln

Aufstände, Haftung für Schäden

Aufzüge, Aufstellung in Emden

Aufzugsanlagen, Abnahme

Aufzugsanlagen, Inspektion

Augeninfektion, Schulbefreiung

Auktion, Begrenzung

Auktionator, Betriebsführung

Auktionator, Verbot eines gemeinsamen Betriebs

Auktionatoren, Ermittlungsverfahren wegen Unterschlagung

Auktionatoren, Vorschriften

Auktionatoren, Zulassung

Auktionen, Anträge

Auktionskatalog, Waffen und Waffenteilen

Ausgehverbot, Verhinderung von Vandalismus

Ausgewiesene, Aufnahmepflicht der Stadt Emden

Aushuberde, Beschaffung

Aushuberde, Lagerplätze

Auslagerung, Alte Registratur (I. Registratur)

Ausländer, Ausweisung aus dem Ghzgt. Oldenburg

Auslandskontakte, Emder Firmen

Auslieferungen, Grenzorte für Niederlande

Auslieferungsbegehren, Zuständigkeit

Auslieferungsvertrag, Außerkraftsetzung

Auslieferungsvertrag, Preußen mit Niederlanden

Auslieferungsverträge, Bekanntmachung

Ausschreibungsverfahren, Öffentliche Aufträge

Außenhafen, Einweihung

Außenhafen, Einweihungsfeier

Ausstellungen. Landwirtschaftliche Vereine

Auswanderer, Beherbergung

Auswanderer, Errichtung v, Abfertigungshallen

Auswanderer, Liste

Auswanderer, Regelung der Durchreise

Auswanderer, Trägerschaft v. medizinischen Behandlungskosten

Auswanderer, Unterstützung

Auswandereragenten, Bekämpfung

Auswanderererlaubnisscheine, Ausstellung für Juden

Auswandererhafen, Funktion

Auswandererhalle, Eröffnung

Auswandererhallen, Eröffnung

Auswandererlinie, Einrichtung in Emden

Auswandererlinie, Errichtung

Auswandererlinie, Konzessionierung

Auswandererstation, Medizinische Versorgung

Auswandererstatistik

Laufzeit

1876

1872-1914

$1888-1913$

1888-1913

1874-1911

1906-1912

1875-1905

1871-1874

1897-1913

1897-1913

1908-1910

1866

1900-1913

1900-1913

1900-1913

1880-1912

1888-1912

1899-1911

1899-1911

1899-1911

1899-1911

1899-1911

1888-1912

1907-1912

1874-1905

1882-1910

1886-1887

1885-1887

1857-1908

1882-1910

1914

1873-1914

1867-1880

1867-1880

1867-1880

1873-1914

1882-1913

1897-1901

1900-1901

1879-1905

1914

1872-1916

1852-1875

1866-1913

1902-1917

1852-1875

1905-1912

1852-1875

1867-1876

1905-1912

1910-1914

1910-1914

1872-1916

1905-1912

1910-1914

1902-1917

1905-1912
Lfd.Nr.

1.776

767

768

768

190

253

3.390

2.490

882

882

270

509

1.255

1.255

1.255

776

1.910

1.908

1.908

1.908

1.908

1.908

1.910

2.611

831

501

927

915

313

501

3.177

497

499

499

499

497

2.408

182

176

796

453

330

451

452

1.693

451

450

451

484

2.105

Vorwort

2.106

2.106

330

2.105

2.106

1.693

450 
Index

\begin{tabular}{|c|c|c|}
\hline \multicolumn{3}{|l|}{ SACH } \\
\hline Indexbegriff & Laufzeit & Lfd.Nr. \\
\hline Auswandererverkehr, Votum gegen einseitige Förderung & $1852-1875$ & 451 \\
\hline Auswandererwerbungen, Warnung & 1866-1913 & 452 \\
\hline Auswandererwesen, Gesetzliche Regelung & $1866-1913$ & 452 \\
\hline Auswandererwesen, Reichskommissar & 1866-1913 & 452 \\
\hline Auswanderung, Juden & 1867-1876 & 484 \\
\hline Auswanderung, Statistik & 1852-1875 & 451 \\
\hline Auswanderung, Warnung vor & 1905-1912 & 450 \\
\hline Auswanderung, Warnungen & 1866-1913 & 452 \\
\hline Auswanderungserlaubnis, Gebühr & 1852-1875 & 451 \\
\hline Auswanderungsstatistik & 1895-1914 & 462 \\
\hline Auswanderungsstatistik, Emden & 1895-1914 & 462 \\
\hline Ausweisung, Deutsche aus anderen Staaten & $1882-1910$ & 501 \\
\hline Auszeichnungen, Verleihung an Lehrer & $1900-1911$ & 259 \\
\hline Autounfall & 1870-1900 & 1.497 \\
\hline Aviso "Loreley" & & Vorwort \\
\hline Ägyptische Augenkrankheit & 1880-1912 & 776 \\
\hline Ämterhäufung, Oberbürgermeister als Landtagsabgeordneter & 1904-1912 & 10 \\
\hline Ärztemangel, Dämpfung & $1914-1916$ & 3.151 \\
\hline Babies, Bestattung in der lutherischen Gemeinde & 1905-1908 & 3.474 \\
\hline Bäcker und Konditoren, Öffnungszeiten an Sonn- und Feiertagen & 1898-1911 & 562 \\
\hline & 1911-1916 & 563 \\
\hline Bäckergewerbe, Arbeitszeit & 1872-1904 & 2.382 \\
\hline Bäckerlehrlinge, Arbeitszeiten in Emden & 1872-1904 & 2.382 \\
\hline Backwaren, Hausierhandel & $1881-1910$ & 1.906 \\
\hline Badeanstalt für Frauen, Errichtung & 1876-1892 & 736 \\
\hline Badeanstalt für Frauen, Schutz & 1882-1896 & 735 \\
\hline Badeanstalt für Männer, Errichtung & 1876-1892 & 736 \\
\hline Badeanstalt, Ausstattung & 1876-1882 & 734 \\
\hline Badeanstalt, Bademeisterdinst & 1876-1882 & 734 \\
\hline Badeanstalt, Badeordnung & 1876-1882 & 734 \\
\hline Badeanstalt, Bau & 1876-1882 & 734 \\
\hline Badeanstalt, Benutzung durch Soldaten & 1882-1896 & 735 \\
\hline Badeanstalt, Inventar & 1882-1896 & 735 \\
\hline Badeanstalt, Inventarversicherung & 1882-1896 & 735 \\
\hline Badeanstalt, Kassenführung & 1876-1882 & 734 \\
\hline Badeanstalt, Nützung durch Soldaten & 1882-1896 & 735 \\
\hline Badeanstalt, Rechnungswesen & 1876-1882 & 734 \\
\hline Badeanstalt, Reglement & 1876-1882 & 734 \\
\hline Badeanstalt, Sanierung & 1882-1896 & 735 \\
\hline Badeanstalt, Schadensersatz wegen Schäden durch Kanalbau & 1882-1896 & 735 \\
\hline Badeanstalt, Schließungsdrohung & 1882-1896 & 735 \\
\hline Badeanstalt, Schließungsverfügung & 1891 & 507 \\
\hline Badeanstalt, Tarif & 1876-1882 & 734 \\
\hline Badeanstalt, Umwandlung in eine Frauenbadeanstalt & 1876-1882 & 734 \\
\hline Badeanstalt, Verbesserung & 1876-1882 & 734 \\
\hline Badeanstalt, Verpachtung & 1876-1882 & 734 \\
\hline Badeanstalt, Visitation & 1882-1896 & 735 \\
\hline Badeanstalten, Ausgestaltung und Finanzierung & 1878-1906 & 733 \\
\hline Badeanstalten, Finanzierung der Ausstattung & 1876-1882 & 734 \\
\hline Badeanstalten, Zuschüsse & 1876-1892 & 736 \\
\hline Badekommission, Etat & 1876-1892 & 736 \\
\hline Badekommission, Haushaltsprüfung & 1876-1882 & 734 \\
\hline Badekommission, Konstituierung & 1876-1882 & 734 \\
\hline Badekommission, Neuwahlen & 1882-1896 & 735 \\
\hline Badekommission, Sitzungen & 1878-1906 & 733 \\
\hline Bademeister, Bewerbungen & 1876-1892 & 736 \\
\hline
\end{tabular}


Index

\begin{tabular}{|c|c|c|}
\hline \multicolumn{3}{|c|}{ SACH } \\
\hline Indexbegriff & Laufzeit & Lfd.Nr. \\
\hline Baden, Regelungen & $1876-1912$ & 732 \\
\hline Badende, Haftung & $1876-1912$ & 732 \\
\hline Bader, Prüfung & $1866-1914$ & 762 \\
\hline Bader, Zulassung & 1868 & 766 \\
\hline Badestellen, Verbotene & $1876-1912$ & 732 \\
\hline Badeverbote, Verhängung & $1876-1912$ & 732 \\
\hline Bagger "Borussia" & 1908 & 2.299 \\
\hline Bagger "Nieuwe Maasmond II, IV, VIII, IX" & 1896 & 2.217 \\
\hline Baggergut, Verwendung & 1887 & 1.148 \\
\hline Baggerungen, Ems-Jade-Kanal & 1887 & 1.148 \\
\hline Baggerungen, Hafengebiet & 1887 & 1.148 \\
\hline Bahn, Leer nach Aurich & 1878-1892 & 2.008 \\
\hline Bahnanlagen, Besichtigung & $1872-1907$ & 2.018 \\
\hline Bahnbau, Gutachten-Finanzierung & $1877-1893$ & 2.005 \\
\hline Bahnbauten, Genehmigungsverfahren & 1910-1911 & 1.210 \\
\hline Bahnen, Anlage landwirtschaftlicher & $1881-1885$ & 2.014 \\
\hline Bahngebäude, Baupolizeiliche Zuständigkeit & $1870-1900$ & 1.161 \\
\hline Bahnhaltestelle, Anlegung bei Petkum & 1897 & 2.015 \\
\hline Bahnhaltestelle, Bitte um Anlegung & $1879-1882$ & 2.011 \\
\hline Bahnhof, Straßenbebauung & $1872-1907$ & 2.018 \\
\hline Bahnhofsgaststätten, Überwachung & $1867-1909$ & 529 \\
\hline Bahnhofsgebäude, Brand in & $1869-1874$ & 1.306 \\
\hline Bahnhofsstraße, Niedrigerlegung und Verlängerung & 1896-1897 & 989 \\
\hline Bahnpersonal, Propreußische Haltung & 1866 & 509 \\
\hline Bahnpolizei-Reglement & $1881-1885$ & 2.014 \\
\hline Bahnschutz, Organisation & 1914-1916 & 3.152 \\
\hline Bahntrasse, Analyse & 1907 & 2.072 \\
\hline \multirow[t]{2}{*}{ Bahntrasse, Besichtigung } & 1905-1906 & 2.070 \\
\hline & 1906-1907 & 2.071 \\
\hline Bahntrasse, Planfeststellung & 1908-1909 & 2.073 \\
\hline Bahnübergang, Kaiser-Wilhelm-Polder & 1893-1895 & 987 \\
\hline Bahnübergänge, Emden & $1882-1908$ & 2.009 \\
\hline Bahnunfall, Kind & $1882-1908$ & 2.009 \\
\hline Bahnverbindung Emden - Münster & 1901-1908 & 2.012 \\
\hline Bahnverbindungen, Ausbau & $1908-1913$ & 2.013 \\
\hline Bahnverkehr, Gefährdung & 1891 & 507 \\
\hline Bahnwesen, Regulierung & $1881-1897$ & 2.042 \\
\hline Ballon- und Zeppelinwesen, Regelung & $1899-1910$ & 512 \\
\hline Bänke, Räumung wegen Pflasterung & 1874-1905 & 831 \\
\hline Banken, Geschäftsberichte & 1902 & 1.923 \\
\hline Banknoten, Bekämpfung von Fälschungen & $1866-1912$ & 257 \\
\hline Bannerweihe & $1891-1912$ & 632 \\
\hline Baptisten & $1867-1910$ & 3.497 \\
\hline Baptisten, Glaubensbekenntnis & $1875-1913$ & 3.496 \\
\hline Baptistengemeinde, Korporationsrechte & $1875-1913$ & 3.496 \\
\hline Baptistengemeinde, Steuerverhältnisse & $1875-1913$ & 3.496 \\
\hline Baptistengemeinde, Verfassung & $1875-1913$ & 3.496 \\
\hline Baptistengemeinde,Satzungen & $1875-1913$ & 3.496 \\
\hline Baracken, Beschlagnahme für Armeezwecke & $1915-1916$ & 3.166 \\
\hline Barbiere, Zulassung & 1868 & 766 \\
\hline Barbier-Innung, Statuten & 1880 & 1.935 \\
\hline Barkasse "Bernard" & 1900 & 2.242 \\
\hline Batteriegelände, Erwerb durch die Stadt Emden & $1868-1875$ & 2.465 \\
\hline Bauantrag, Ablehnung & 1906 & 1.194 \\
\hline Bauantrag, Doppelhaus & $1894-1913$ & 1.135 \\
\hline Bauantrag, Umbauabsicht & 1871-1888 & 1.151 \\
\hline Bauarbeiter, Aussperrung im Tarifkonflikt & $1908-1912$ & 3.128 \\
\hline Bauarbeiter, Schutzbestimmungen & 1906-1909 & 1.223 \\
\hline
\end{tabular}


Index

\begin{tabular}{|c|c|c|}
\hline \multicolumn{3}{|l|}{ SACH } \\
\hline Indexbegriff & Laufzeit & Lfd.Nr. \\
\hline Bauaufseher- und Schreiber, Bewerbung & $1876-1892$ & 437 \\
\hline Bauaufseher- und Schreiber, Einstellung & $1876-1892$ & 437 \\
\hline Bauaufseher- und Schreiber, Entlassungsgesuch & $1876-1892$ & 437 \\
\hline Bauaufseher- und Schreiber, Gehaltserhöhungsbitte & $1876-1892$ & 437 \\
\hline Bauaufseher- und Schreiber, Nebentätigkeit & 1876-1892 & 437 \\
\hline Bauaufseher- und Schreiber, Soziale Lage & $1876-1892$ & 437 \\
\hline Bauaufseher- und Schreiber, Stellenausschreibung & $1876-1892$ & 437 \\
\hline Bauaufseher, Nebentätigkeit & $1876-1892$ & 437 \\
\hline Bauausführung, Schutzmaßregeln & $1897-1903$ & 1.139 \\
\hline Baubücher, Durchsetzung & $1909-1911$ & 1.146 \\
\hline Baubude, Überbelegung & $1897-1906$ & 874 \\
\hline Baudenkmäler, Erfassung & $1873-1917$ & 2.395 \\
\hline Bauerlaubnis, Erteilung & 1904-1908 & 1.012 \\
\hline Bauetat, Lutherische Kirchengemeinde & $1892-1914$ & 3.441 \\
\hline \multirow[t]{2}{*}{ Bauetat, Stadt Emden } & 1869 & 3.044 \\
\hline & 1870 & 3.045 \\
\hline Baufachausstellung, Prospekt & 1913 & 2.133 \\
\hline Baufachausstellung, Reisekosten & 1913 & 2.133 \\
\hline Baufälligkeit, Abrissverfügung & $1871-1874$ & 1.219 \\
\hline Baufälligkeit, Haus der Grietje Brauer in Borssum & 1907 & 250 \\
\hline Baufluchtlinie, Festlegung & $1900-1903$ & 1.165 \\
\hline Baufluchtlinie, Verletzung & $1903-1904$ & 1.007 \\
\hline Bauforderungen, Sicherung & $1909-1911$ & 1.146 \\
\hline Baugelände, Erschließung & $1905-1911$ & 1.172 \\
\hline Baugenehmigung, Ablehnung & $1872-1879$ & 1.181 \\
\hline Baugenehmigung, Beschwerde gegen & $1905-1906$ & 1.169 \\
\hline Baugenehmigung, Erteilung & $1872-1879$ & 1.181 \\
\hline Baugenehmigung, Ortsstatutarische Kosten & $1906-1907$ & 1.171 \\
\hline Baugenehmigung, Tragung von Kanalisationskosten & $1906-1907$ & 1.010 \\
\hline \multirow[t]{6}{*}{ Baugenehmigung, Verweigerung } & $1870-1884$ & 1.180 \\
\hline & 1905 & 1.197 \\
\hline & $1905-1909$ & 1.198 \\
\hline & $1906-1911$ & 1.199 \\
\hline & $1905-1906$ & 1.200 \\
\hline & $1908-1910$ & 1.202 \\
\hline Baugenehmigung, Widerspruchsverfahren wegen Verweigerung & 1905 & 1.197 \\
\hline Baugenehmigungen, Statistik & $1881-1909$ & 1.164 \\
\hline Baugenehmigungserteilung, Praxis & 1881 & 1.162 \\
\hline Baugenehmigungsverfahren, Baupolizeiliche Richtlinien & $1887-1897$ & 1.138 \\
\hline Baugenossenschaft, Finanzierung & 1899 & 1.233 \\
\hline Baugenossenschaft, Gründung & 1894-1905 & 1.240 \\
\hline \multirow[t]{2}{*}{ Baugenossenschaften, Baudarlehen } & $1902-1905$ & 1.236 \\
\hline & $1901-1902$ & 1.239 \\
\hline Baugenossenschaften, Organisation & 1894-1905 & 1.240 \\
\hline \multirow[t]{2}{*}{ Baugesuche, Wolthusen } & $1890-1910$ & 252 \\
\hline & $1880-1913$ & 254 \\
\hline Baugewerbe, Ausübungsverbot & $1907-1912$ & 1.147 \\
\hline Baugewerbe, Massenaussperrung im Tarifstreit & $1904-1914$ & 669 \\
\hline Baugewerbe, Tarifbewegung & $1904-1914$ & 669 \\
\hline Baugewerbeschule, Einrichtung & $1868-1897$ & 2.340 \\
\hline Baugewerbeschule, Errichtung & 1877-1896 & 3.508 \\
\hline Baugewerks-Berufsgenossenschaft, Beiträge & $1887-1913$ & 1.660 \\
\hline Baugewerks-Berufsgenossenschaft, Beitragspfändung & $1911-1912$ & 1.661 \\
\hline Baugewerks-Berufsgenossenschaft, Gefahrentarifsbestimmung & $1887-1913$ & 1.660 \\
\hline Baugewerks-Berufsgenossenschaft, Statuten & $1887-1913$ & 1.660 \\
\hline \multirow[t]{2}{*}{ Baugewerks-Berufsgenossenschaft, Unfallverhütungsvorschriften } & $1887-1913$ & 1.660 \\
\hline & $1899-1913$ & 1.666 \\
\hline Baugewerks-Berufsgenossenschaft, Unterstützte Unfallopfer & $1887-1913$ & 1.660 \\
\hline
\end{tabular}


Index

\begin{tabular}{|c|c|c|}
\hline \multicolumn{3}{|l|}{ SACH } \\
\hline Indexbegriff & Laufzeit & Lfd.Nr. \\
\hline Baugrundstück, Kauf und Wiederverkauf durch Stadt Emden & 1903-1904 & 2.447 \\
\hline Bauhandwerker, Fortbildung & $1898-1900$ & 2.351 \\
\hline Bauhof, Gleisanschluss & $1887-1912$ & 1.437 \\
\hline Bauhof, Lagerung & $1869-1909$ & 2.410 \\
\hline Bauhofgrundstück, Abgrenzung & 1869-1909 & 2.410 \\
\hline Baukommission, Einzelfälle & $1872-1874$ & 1.209 \\
\hline Baukommission, Geschäftsgang & $1872-1874$ & 1.209 \\
\hline Baukommission, Konstituierung & $1867-1890$ & 2.476 \\
\hline Baukommission, Mitglieder & 1866-1908 & 1.206 \\
\hline Baukommission, Normfestlegung & 1880-1904 & 1.208 \\
\hline \multirow[t]{2}{*}{ Baukommission, Organisation } & 1876 & 1.207 \\
\hline & $1880-1904$ & 1.208 \\
\hline Baukommission, Zuständigkeit & 1880-1904 & 1.208 \\
\hline Bauland, Kaufverhandlungen & 1906-1908 & 2.825 \\
\hline Bauleistungen, Ausschreibungsverfahren & $1882-1913$ & 2.408 \\
\hline Bauleiter, Honorar & 1884-1888 & 911 \\
\hline Baumanpflanzungen, Planung & 1893-1895 & 987 \\
\hline Baumaterial, Ausschreibung der Fuhren & $1868-1900$ & 2.407 \\
\hline Baumaterial, Passage durch Gang & $1899-1904$ & 852 \\
\hline Baumaterial. Lagerung an der Straße & $1901-1912$ & 840 \\
\hline Baumaterialien, Ausschreibungen & $1871-1912$ & 2.404 \\
\hline Bäume, Pflanzregelungen & 1866-1896 & 1.155 \\
\hline Bäume, Schutz & 1907-1912 & 695 \\
\hline \multirow[t]{2}{*}{ Bauordnung, Beratung } & 1908 & 1.144 \\
\hline & 1908-1909 & 1.145 \\
\hline Bauordnung, Erlass & $1875-1887$ & 1.137 \\
\hline Bauordnung, Material für Entwurf & $1885-1888$ & 1.143 \\
\hline Bauordnung, Veröffentlichung & 1908-1909 & 1.145 \\
\hline Bauordnung, Zuständigkeit & 1908-1909 & 1.145 \\
\hline Bauplatz, Kaufangebot & 1875 & 2.508 \\
\hline Bauplätze, Verkauf & $1872-1878$ & 2.467 \\
\hline Baupolizei, Bestrafungen von Verstößen & 1906-1913 & 1.224 \\
\hline Baupolizei, Einzelerlasse des preuß. Ministeriums & 1897-1903 & 1.139 \\
\hline Baupolizeibehörde, Revision & 1897-1903 & 1.139 \\
\hline Baupolizei-Gebühren-Ordnung, Stadt Emden & 1877-1912 & 324 \\
\hline Baupolizeiordnung, Druck & 1887-1897 & 1.138 \\
\hline Baupolizeiordnung, Entwurf & $1875-1887$ & 1.137 \\
\hline Baupolizeiordnung, Ergänzungen & 1897-1903 & 1.139 \\
\hline \multirow[t]{2}{*}{ Baupolizeiordnung, Erlass } & $1875-1887$ & 1.137 \\
\hline & 1881 & 1.162 \\
\hline Baupolizeiordnung, Mitwirkung des Bürgervorsteherkollegiums & 1887-1897 & 1.138 \\
\hline Baupolizeiordnung, Modifikation & $1887-1897$ & 1.138 \\
\hline Baupolizeiordnung, Publikation & 1887-1897 & 1.138 \\
\hline Baupolizeiordnung, Verteilung & 1887-1897 & 1.138 \\
\hline Bausachverständige, Ernennung & 1907-1912 & 1.147 \\
\hline Bauschuppen, Ungenehmigt & 1904-1905 & 1.193 \\
\hline Bauschutt, Abtransport & $1868-1900$ & 2.407 \\
\hline Baustatistik, Kategorien & 1881 & 1.894 \\
\hline Baustellen, Missstände & 1903-1907 & 658 \\
\hline Baustellen, Sicherheitsmängel & 1899-1913 & 1.666 \\
\hline Baustopp, Verhängung & 1903-1904 & 1.185 \\
\hline Bautechniker, Ausschluss von der Auftragsvergabe & 1908-1912 & 3.128 \\
\hline Bauten, Schlussabnahme & 1901 & 1.153 \\
\hline Bauunterhaltung, Gebäude und Straßen der Stadt Emden & $1866-1875$ & 2.405 \\
\hline Bauunterhaltung, Städtische Wohnungen & 1881-1903 & 2.406 \\
\hline Bauverbot, Verhängung & $1910-1911$ & 1.203 \\
\hline Bauverein, Anteilserwerb durch Stadt Emden & $1890-1911$ & 687 \\
\hline Bauverein, Liquidierung & $1890-1911$ & 687 \\
\hline
\end{tabular}


Index

\section{SACH}

\begin{tabular}{|c|c|c|}
\hline Indexbegriff & Laufzeit & Lfd.Nr. \\
\hline Bauverein, Revision & $1890-1911$ & 687 \\
\hline Bauverein, Satzung & $1890-1911$ & 687 \\
\hline Bauverwaltung, Organisation Landdrostei / Regierung in Aurich & $1870-1914$ & 1.163 \\
\hline Bauvorhaben, Anzeige & $1887-1912$ & 812 \\
\hline Bauvorhaben, Ortsstatutarische Kosten & 1906-1907 & 1.168 \\
\hline Bauzeichnung & 1902 & 1.195 \\
\hline Beamte, Amtsverschwiegenheit & $1869-1902$ & 343 \\
\hline Beamte, Anfangs- und Endgehälter & $1909-1911$ & 445 \\
\hline Beamte, Aufstellung für Emden & 1914 & 442 \\
\hline Beamte, Besoldungsordnung & 1914 & 442 \\
\hline Beamte, Bitte um Teuerungszulage & $1909-1911$ & 445 \\
\hline Beamte, Fürsorge nach Betriebsunfällen & $1902-1906$ & 1.674 \\
\hline \multirow[t]{2}{*}{ Beamte, Gehaltszulage } & $1899-1908$ & 444 \\
\hline & $1909-1911$ & 445 \\
\hline Beamte, Gesuche um Gehaltserhöhung & 1914 & 442 \\
\hline Beamte, Heeresdienst & 1914-1917 & 1.616 \\
\hline Beamte, Jahresgehalt von unter 2000 Mark & 1899-1908 & 444 \\
\hline Beamte, Nebeneinkünfte & 1914 & 442 \\
\hline Beamte, Statut über Anstellung und Versorgung & 1914 & 442 \\
\hline Beamte, Unfallversicherung & $1902-1906$ & 1.674 \\
\hline Beamte, Verbot der Anfertigung von Gesuchen & $1869-1902$ & 343 \\
\hline Beamte, Verhalten im Fall einer feindlichen Besetzung & 1914 & 3.178 \\
\hline Beamte, Verzeichnis & $1870-1887$ & 6 \\
\hline \multirow[t]{3}{*}{ Beamtengehälter, Neufestsetzung } & 1898-1899 & 443 \\
\hline & 1899-1908 & 444 \\
\hline & $1909-1911$ & 445 \\
\hline Beamtenwohnungen, Baudarlehen & $1902-1914$ & 1.235 \\
\hline Bebauungsplan, Aufnahme & $1900-1903$ & 1.165 \\
\hline Bebauungsplan, Beschwerde & 1906-1908 & 1.500 \\
\hline Bebauungsplan, Ringstraße im Bereich des Burggrabens & 1896-1906 & 998 \\
\hline Bedürfnisanstalten, Betriebsunterhaltung & 1889-1905 & 965 \\
\hline \multirow[t]{2}{*}{ Beerdigungskasse, Bilanz } & $1882-1911$ & 1.646 \\
\hline & $1869-1916$ & 1.647 \\
\hline \multirow[t]{3}{*}{ Beerdigungskasse, Jahresberichte } & $1866-1918$ & 1.639 \\
\hline & $1882-1911$ & 1.646 \\
\hline & $1869-1916$ & 1.647 \\
\hline Beerdigungskasse, Kapitaldeckungsverfahren & $1904-1911$ & 1.640 \\
\hline Beerdigungskasse, Monita wegen Satzung und Jahresbericht & $1882-1911$ & 1.646 \\
\hline Beerdigungskasse, Rechnungsführung & $1904-1911$ & 1.640 \\
\hline Beerdigungskasse, Satzungen & $1869-1916$ & 1.647 \\
\hline Beerdigungskasse, Satzungsänderungen & $1869-1916$ & 1.647 \\
\hline \multirow[t]{3}{*}{ Beerdigungskasse, Statuten } & $1866-1918$ & 1.639 \\
\hline & $1904-1911$ & 1.640 \\
\hline & $1882-1911$ & 1.646 \\
\hline Beerdigungskasse, Technische Überprüfung & $1882-1911$ & 1.646 \\
\hline Beerdigungskasse, Versicherungstechnisches Gutachten & $1869-1916$ & 1.647 \\
\hline Beerdigungskasse, Wertpapierdeponierung & $1882-1911$ & 1.646 \\
\hline Beerdigungskasse, Zulassung zum Leichentragen & $1866-1918$ & 1.639 \\
\hline Beerdigungskassen, Statistik & $1902-1913$ & 1.671 \\
\hline Beflaggungsvorschriften & $1866-1914$ & 508 \\
\hline Befreiungskriege, Jubiläumsfeiern & $1912-1914$ & 567 \\
\hline Begräbnisbedienung, Beschwerde & $1824-1920$ & 433 \\
\hline Begräbnisplatz, Anlage & $1910-1913$ & 3.403 \\
\hline Begräbnisverein, Beiträge & $1869-1915$ & 1.648 \\
\hline Begräbnisverein, Jahresberichte & 1869-1915 & 1.648 \\
\hline Begräbnisverein, Kassenführung & $1869-1915$ & 1.648 \\
\hline Begräbnisverein, Neugründung & $1869-1915$ & 1.648 \\
\hline Begräbnisverein, Statuten & $1869-1915$ & 1.648 \\
\hline
\end{tabular}


Index

\begin{tabular}{|c|c|c|}
\hline \multicolumn{3}{|l|}{$\mathrm{SACH}$} \\
\hline Indexbegriff & Laufzeit & Lfd.Nr. \\
\hline Begräbnisverein, Zulassung als "Kleiner Verein" & $1869-1915$ & 1.648 \\
\hline Begräbnisvereine, Vereinigung & $1869-1915$ & 1.648 \\
\hline Begräbniswesen, Wolthusen & $1890-1910$ & 252 \\
\hline Behinderte, Überweisung aus Volksschule & $1902-1907$ & 3.706 \\
\hline Bekanntmachungen, Preußischer Landdrost in Aurich & $1867-1870$ & 322 \\
\hline Bekanntmachungen, Preußischer Regierungspräsident in Aurich & $1886-1905$ & 323 \\
\hline Beleidigung, Verfahren gegen Paul G. Roer & $1908-1911$ & 2.363 \\
\hline Beleuchtungssysteme, Angebote & 1886-1909 & 1.019 \\
\hline Beleuchtungsvorschriften, Verstöße & $1880-1912$ & 1.405 \\
\hline Bentinckshof, Erwerb durch Stadt Emden & $1872-1892$ & 2.427 \\
\hline Bentincksweg, Höherlegung & $1888-1902$ & 983 \\
\hline Benzinmotor, Zulassung zum Werkstattbetrieb & 1898-1909 & 2.180 \\
\hline Bereisungsdampfer "Ems" & 1908 & 2.316 \\
\hline Beringsches Serum, Vertrieb & 1894-1904 & 771 \\
\hline Beringsches Serum, Wirkung & 1894-1904 & 771 \\
\hline Berufsschulsystem, Emden & & Vorwort \\
\hline Beschäftigtenstand, Emder Großbetriebe & $1875-1909$ & 2.383 \\
\hline Beschäftigungsstatistik & 1911 & 464 \\
\hline Beschäftigungsstatistik, Emden & $1895-1914$ & 462 \\
\hline Besitztitel, Städtische Grundstücke & 1885 & 2.443 \\
\hline Bestattung, Antrag auf Marsch mit Musik & $1903-1907$ & 658 \\
\hline Bestattung, Gebühren für lutherische Arme & $1881-1883$ & 3.453 \\
\hline Bestattungsfeier, Gefallene Matrosen & 1914-1916 & 3.201 \\
\hline Bestattungswesen, Personal & $1824-1920$ & 433 \\
\hline Besuch, Admiral Prinz Heinrich von Preußen in Emden & $1874-1911$ & 190 \\
\hline Besuch, Prinz Adalbert von Preußen in Emden & $1866-1868$ & 189 \\
\hline Betriebskrankenkasse, Aufsicht & 1896-1902 & 1.665 \\
\hline Betriebskrankenkasse, Beiträge & 1896-1902 & 1.665 \\
\hline Betriebskrankenkasse, Beschwerde wg. Krankengeld & 1896-1902 & 1.665 \\
\hline Betriebskrankenkasse, Generalversammlung & $1896-1902$ & 1.665 \\
\hline Betriebskrankenkasse, Material & 1896-1902 & 1.665 \\
\hline Betriebskrankenkasse, Mitglieder & 1896-1902 & 1.665 \\
\hline Betriebskrankenkasse, Statuten & $1896-1902$ & 1.665 \\
\hline Betriebskrankenkasse, Umwandlungsverfahren & $1896-1902$ & 1.665 \\
\hline Betriebskrankenkasse, Wertpapiere & 1896-1902 & 1.665 \\
\hline Betriebssteuer, Veranlagung & 1894-1908 & 2.908 \\
\hline \multirow[t]{2}{*}{ Bettler, Einweisung in Arbeitshäuser } & 1867-1899 & 722 \\
\hline & $1868-1916$ & 723 \\
\hline Bettler, Verhängung einer "correctionellen Nachhaft" & $1868-1916$ & 723 \\
\hline Bettlerei, Verfahrensregelung zur Verfolgung & $1868-1916$ & 723 \\
\hline Beurtfahrt, Emden nach Groningen & $1869-1871$ & 2.119 \\
\hline Beurtfahrt, Übertragung & $1869-1871$ & 2.119 \\
\hline Beurtfahrt-Monopol, Diskussion & $1869-1871$ & 2.119 \\
\hline \multirow[t]{2}{*}{ Bevölkerungsstatistik } & $1914-1918$ & 463 \\
\hline & 1911 & 464 \\
\hline Bevölkerungsstruktur, Wandel in Emden & & Vorwort \\
\hline Bezirksausschuss, Aurich & $1901-1904$ & 2.578 \\
\hline \multirow[t]{2}{*}{ Bezirksschornsteinfeger, Instruktionen } & $1867-1873$ & 1.262 \\
\hline & 1873-1906 & 1.263 \\
\hline Bezirksschornsteinfegermeister, Zulassung & $1907-1916$ & 1.264 \\
\hline Bezirksschulen, Vertretungslehrkräfte & $1905-1915$ & 3.551 \\
\hline Bezirksschulsystem, Organisation nach Konfessionen & $1908-1911$ & 3.547 \\
\hline Bezirkssynode, Bildung & $1868-1894$ & 3.443 \\
\hline Bezirksvorsteher, Aufstellung & $1865-1877$ & 153 \\
\hline Bezirksvorsteher, Liste & $1892-1912$ & 151 \\
\hline Bezirksvorsteher, Polizeiliche Pflichten & $1908-1916$ & 83 \\
\hline \multirow[t]{2}{*}{ Bezirksvorsteher, Vereidigung } & $1878-1892$ & 152 \\
\hline & $1865-1877$ & 153 \\
\hline
\end{tabular}


Index

\begin{tabular}{l}
\hline \\
\hline Indexbegriff \\
\hline Bezirksvorsteher, Wahl \\
Bezirksvorsteherwahl, Geldstrafe gegen Wahlenthaltung \\
Bezirksvorsteherwahl, Strafe wegen Wahlenthaltung \\
Bezirksvorsteherwahl, Wahlberechtigte \\
Bezirksvorsteherwahlen, Ergebnisse \\
Bienenzüchter, Ausstellung in Emden \\
Bier- und Obstweinsteuer, Einführung \\
Bier-Akzise, Einführung \\
Bierakzise, Erhebung \\
Bilanz-Berichte, Spar- und Leihbank der Stadt Emden
\end{tabular}

Bildhauer, Wettbewerbsausstellungen

Bildungsanstalt für Kindergärtnerinnen, Initiative

Bildungsanstalten, Gewerbe, Handel und Verkehr

Bildungssystem, Emden

Binnenfahrwasser, Ausbaggerung

Binnenfahrwasser, Planzeichnung

Binnenfahrwasser, Unterhaltung

Binnenfahrwasser, Verkehrsregelungen

Binnenfahrwasser, Verschlammung

Binnenkanäle, Reinigung

Binnenschiffer, Geldsammlung für Notleidende

Binnenschiffer, Passagegebühren

Binnenschifferschule, Errichtung in Leer

Binnentief, Pegelungen

Binnentiefs, Pegelmessung

Biographie,Geheimer Oberregierungsrat Carl Schweckendieck

Bleigehalt, Gesetzliche Grenzwerte

Blitzableiter, Befreiung von der Abgabepflicht

Blitzableiter, Installation an Schulgebäuden

Blitzableiter, Öffentliche Gebäude

Blitzableiterinstallation, Beihilfeantrag

Blitzableiterkupfer, Beschlagnahmung für die Kriegswirtschaft

Blitzschlag, Packhaus

Blitzschlag, Peldemühle

Blitzschlag, Schaden

Blitzschlag, Schäden

Blitzschläge, Schäden

Blockade, Gaststätten in Emden wegen Streik bei Doornkaat

Blutlaus, Bekämpfung

Bodenanalyse, Regelungen

Bodenluken, Sicherung

Bodennutzung, Emder Stadtgebiet

\section{SACH}


IV

Index

\begin{tabular}{|c|c|c|}
\hline \multicolumn{3}{|l|}{ SACH } \\
\hline Indexbegriff & Laufzeit & Lfd.Nr. \\
\hline Bodennutzung, Statistik & $1900-1915$ & 815 \\
\hline Bootshaus, Bauverschiebung & $1901-1912$ & 642 \\
\hline Bootstreppe, Bau am Ratsdelft & $1888-1896$ & 934 \\
\hline Börsenverein, Generalversamlmung & $1869-1911$ & 2.134 \\
\hline Börsenverein, Mitgliederwahl & $1866-1898$ & 2.135 \\
\hline Börsenverein, Regulativ & $1869-1911$ & 2.134 \\
\hline Börsenverein, Vorstandswahlen & 1869-1911 & 2.134 \\
\hline Borssum, Eingemeindung nach Emden & 1913-1915 & 241 \\
\hline Böschungen, Unbefugtes Beweiden & 1903 & 841 \\
\hline Botengänge, Vergütung & $1875-1913$ & 1.703 \\
\hline Boykott, Singer-Nähmaschinen & $1908-1915$ & 3.545 \\
\hline Brand, Am Neuen Markt gelegenes Haus des L. R. Hesse & 1895-1896 & 1.349 \\
\hline Brand, Bahnhofshauptgebäude & 1900 & 1.358 \\
\hline Brand, Bericht & 1875 & 1.295 \\
\hline & 1874-1875 & 1.296 \\
\hline & 1873 & 1.298 \\
\hline & 1873 & 1.299 \\
\hline & 1873 & 1.300 \\
\hline & 1872 & 1.302 \\
\hline & $1870-1871$ & 1.305 \\
\hline & 1869 & 1.307 \\
\hline & 1867 & 1.310 \\
\hline & 1867 & 1.311 \\
\hline & 1867 & 1.312 \\
\hline & 1875 & 1.314 \\
\hline & 1878 & 1.315 \\
\hline & 1879 & 1.318 \\
\hline & 1879 & 1.319 \\
\hline & 1879 & 1.320 \\
\hline & 1879 & 1.321 \\
\hline & 1876 & 1.322 \\
\hline & 1879 & 1.326 \\
\hline & 1879 & 1.328 \\
\hline & 1880 & 1.332 \\
\hline & 1881 & 1.333 \\
\hline & 1881 & 1.334 \\
\hline & 1893 & 1.339 \\
\hline Brand, Eisschuppen des Rentiers J. E. Hayen & $1898-1899$ & 1.355 \\
\hline Brand, Etablissement im Neutorsbreitergang & 1889 & 1.382 \\
\hline Brand, Gaststätte "Bellevue" in der Bahnhofsstraße & $1902-1903$ & 1.368 \\
\hline Brand, Geschäftshaus des F. Jünemann in der Neutorstraße & 1904 & 1.370 \\
\hline Brand, Haus d. Bäckers u. Konditors R. Hagen i. d. Neutorstraße & 1904 & 1.371 \\
\hline Brand, Haus der Ehefrau des R. Schneider, geb. Kruithoff & 1901 & 1.361 \\
\hline Brand, Haus der Sophie W. Barghoorn & 1887 & 1.341 \\
\hline Brand, Haus der Witwe des Müllers Roelf Mülders & 1895 & 1.350 \\
\hline Brand, Haus des Fuhrunternehmers und Posthalters B. Ubbens & 1890 & 1.345 \\
\hline Brand, Haus des Fuhrunternehmers W. Ubbens & 1889 & 1.356 \\
\hline Brand, Haus des Gastwirts A. Jens in der Bahnhofsstraße & 1901-1902 & 1.364 \\
\hline Brand, Haus des H. A. Brüggemann an der Lilienstraße & 1895-1896 & 1.351 \\
\hline Brand, Haus des Kräutners Friedr. Wilh. Pocker in der Wallstraße & $1900-1901$ & 1.362 \\
\hline Brand, Haus des Kräutners G. W. Scherz in der Boltentorstraße & $1900-1901$ & 1.363 \\
\hline Brand, Haus des L. Griepel in der Pottgießerstraße & 1903 & 1.369 \\
\hline Brand, Haus des Landwirts H. H. Aalfs & 1891-1892 & 1.346 \\
\hline Brand, Haus des Landwirts Jan Dirksen am Torfmarkt & 1900 & 1.359 \\
\hline Brand, Haus des Müllers Bronkena am Kattewall & 1888 & 1.342 \\
\hline Brand, Haus des Peter Campen & 1912 & 1.380 \\
\hline Brand, Haus des Rentiers G. C. Wagener im Boltentorsbreitergang & 1902 & 1.366 \\
\hline Brand, Haus des Schiffsführers H. A. Lange, Am Delft & 1896 & 1.352 \\
\hline
\end{tabular}


Index

\begin{tabular}{l}
\hline \\
\hline Indexbegriff \\
\hline Brand, Haus des Senators a. D Tamme Dreesmann - Penning, \\
Brand, Haus des Uhrmachers E. Warner am Neuen Markt \\
Brand, Haus des Ysaac Brons in der Westerbutvenne \\
Brand, Haus des Zimmermeisters H. König in der Wilhelmsstraße \\
Brand, Haus Fischereidirektor G. Zimmermann \\
Brand, Häuser an der Boltentorstraße und dem Kattewall \\
Brand, Häuser des Kaufmanns H. Dammeyer in der Kirchstraße \\
Brand, Häuser des Kaufmanns J. Graepel an der Lookvenne \\
Brand, Häuser Zwischen beiden Märkten \\
Brand, Kaufhaus des Friedrich G. Janssen \\
Brand, Lagerhaus des J. Graepel in der Klunderburgstraße \\
Brand, Mühle "de goede Verwagting" \\
Brand, Offizierskasino \\
Brand, Packhaus der Firma Ysaac \& Bernhard Brons \\
Brand, Packhaus des Kräutners F. G. Janssen \\
Brand, Packhaus des P. H. Geelvink \\
Brand, Packhaus und Wohngebäude des Kaufmanns K. A. Kruse \\
Brand, Stallgebäude des Viehhändlers Salomon Seligmann \\
Brand, Tabakfabrik-Gebäude des Kaufmanns J. C. Bertram \\
Brand, Todesopfer \\
Brand, Wagenremise des Posthalters Nanno de Wall \\
Brand, Wohn- u. Geschäftshaus des Kaufmanns Hermann Scherz \\
Brandbomben, Löschung \\
Brände, Berichterstattung \\
Brandgrundstück, Ankauf durch die Stadt Emden \\
Brandhaken, Diebstahl \\
Brandkasse, Jahresabschlüsse \\
Brandkasse, Schätzer \\
Brandkassenrechnungen, RElationen \\
Brandkataster, Aktualisierung \\
Brandkataster, Änderungsanzeigen \\
Banang
\end{tabular}

Brandkataster, Ausfertigung

Brandkataster, Berichtigung

Brandkataster, Einblick

Brandkataster, Revision

Brandkataster, Städtische Gebäude

Brandordnung, Novelle

Brandordnung, Ostfriesland

Brandschäden, Feststellung für private Feuerversicherungen

Brandschäden, Gebäude

Brandschutz, Häuser an Eisenbahnlinien

Brandschutz, Kriegswichtige Betriebe

Brandschutz, Theater und Säle

Brandstatistik, Emden
Laufzeit

Lfd.Nr.

$\begin{array}{cc}1911 & 1.379 \\ 1900-1901 & 1.360 \\ 1895 & 1.357 \\ 1902 & 1.372 \\ 1902 & 1.365 \\ 1907 & 1.377 \\ 1892 & 1.347 \\ 1896 & 1.353\end{array}$

1896-1897 1.354

$1906 \quad 1.374$

1905-1906 1.373

1888-1889 $\quad 1.344$

$1879 \quad 1.327$

$1893 \quad 1.339$

1888-1889 $\quad 1.381$

1906-1907 $\quad 1.375$

$1892 \quad 1.348$

1911-1912 1.378

$1889 \quad 1.383$

$1867 \quad 1.311$

1888-1889 1.343

$1908 \quad 1.376$

$1915-1918 \quad 3.210$

1867-1908 1.293

$1873-1897 \quad 2.549$

1879-1904 1.398

1868-1915 $\quad 1.286$

$1868-1915 \quad 1.286$

1904-1906 1.290

1904-1907 $\quad 1.289$

1907-1911 1.291

$1877-1913 \quad 1.276$

$1875-1879 \quad 1.277$

1879-1884 $\quad 1.278$

1885-1892 1.279

$1893-1895 \quad 1.280$

1896-1898 1.281

$1899-1903 \quad 1.282$

1866-1908 1.283

$1906 \quad 1.272$

1904-1905 $\quad 1.273$

$1877-1913 \quad 1.276$

$1866-1908 \quad 1.283$

$1867-1893 \quad 1.287$

$1885 \quad 2.443$

1866-1903 $\quad 1.385$

1886-1905 $\quad 1.251$

$1877-1903 \quad 1.271$

$1880-1887 \quad 1.335$

1888-1898 $\quad 1.336$

1888-1898 $\quad 1.337$

1888-1898 1.338

1871-1898 1.252

$1915 \quad 3.255$

1881-1897 $\quad 1.140$

1897-1909 1.141

1909-1913 $\quad 1.142$

1900-1912 1.294 
Index

\begin{tabular}{|c|c|c|}
\hline \multicolumn{3}{|l|}{ SACH } \\
\hline Indexbegriff & Laufzeit & Lfd.Nr. \\
\hline Brandstellen, Verbot unbefugten Betretens & $1866-1903$ & 1.385 \\
\hline Brandstiftung, Ermittlungen & 1867-1902 & 1.257 \\
\hline \multirow[t]{2}{*}{ Brandstiftung, Ermittlungsverfahren } & 1877 & 1.323 \\
\hline & $1902-1903$ & 1.368 \\
\hline Brandstiftung, Untersuchungsverfahren & $1880-1881$ & 1.329 \\
\hline Brandursache, Emittlungen & 1867 & 1.313 \\
\hline Brandursache, Ermittlung & 1904 & 1.370 \\
\hline Brandursache, Zeugenvernehmung & $1869-1874$ & 1.306 \\
\hline Brandverhütung, Heuhaufen & $1902-1909$ & 1.249 \\
\hline Brandverhütung, Vorschriften bezgl. Darren & $1872-1903$ & 1.250 \\
\hline \multirow{2}{*}{ Brandverhütung, Vorschriften bezgl. Heulagerung } & 1902-1909 & 1.249 \\
\hline & 1867-1908 & 1.293 \\
\hline Brandversicherung, Städtische Wohnhäuser & $1881-1903$ & 2.406 \\
\hline Brandversicherungssumme, Auszahlung & $1873-1897$ & 2.549 \\
\hline Branntwein- und Spirituosen-Akzise, Statuten & $1882-1910$ & 2.920 \\
\hline Branntwein- und Spirituosen-Akzise, Verpachtung & $1882-1910$ & 2.920 \\
\hline Branntweinverkaufsstellen, Emden & $1870-1888$ & 2.863 \\
\hline Branntweinvertriebsabgabe, Einführung als direkte Steuer & $1870-1888$ & 2.863 \\
\hline Brauersgraben, Plan zur Zuschüttung & 1907-1908 & 953 \\
\hline Brausebad, Benutzung durch Hafenarbeiter & 1896-1909 & 739 \\
\hline Brausebad, Einrichtung in der städtischen Volksschule & 1896-1909 & 739 \\
\hline Brennstoffpreise, Emden & $1866-1900$ & 1.904 \\
\hline Brieftauben. Militärnutzung & $1894-1914$ & 3.091 \\
\hline Brigg "Freude" & $1875-1900$ & 1.628 \\
\hline Brikettfabrik, Errichtung im fiskalischen Königspolder & 1903-1908 & 1.443 \\
\hline Brockensammlung, Lagerung und Verteilung & $1911-1914$ & 702 \\
\hline Bronzebüsten, Ehrenbürger & 1904-1908 & 268 \\
\hline Bronzedenkmäler, Pflege & $1873-1917$ & 2.395 \\
\hline Bronzestatuen, Abgabe zu Kriegszwecken & $1873-1917$ & 2.395 \\
\hline Bröschüre, Emder Hafen & 1912 & 2.100 \\
\hline Brotgetreide, Streckung mit Kartoffelmehl & 1914-1918 & 3.245 \\
\hline Brücke, "am Eiland" & $1909-1913$ & 1.024 \\
\hline Brücke, Bau & 1872 & 1.491 \\
\hline Brücke, Bauantrag & $1875-1901$ & 1.494 \\
\hline Brücke, Plan bei Leerort & $1889-1912$ & 2.120 \\
\hline Brücken, Beleuchtung & $1909-1913$ & 1.024 \\
\hline Brunnen, Bohrung & $1877-1878$ & 2.652 \\
\hline Brunnen, Einfassungen & $1869-1890$ & 1.214 \\
\hline Brunnen, Verschmutzung & $1869-1890$ & 1.214 \\
\hline Buchbestellungen, Rabatt & $1867-1901$ & 310 \\
\hline Buchdruckarbeiten, angebote & 1911-1922 & 327 \\
\hline Buchdruckerkunstausstellung, Beihilfeantrag für Entsendung & 1914-1915 & 716 \\
\hline Bücher, Anschaffung für Mannschaftsbibliothek der SMS "Emden" & $1908-1914$ & 271 \\
\hline \multirow[t]{2}{*}{ Bücher, Verbote } & $1867-1891$ & 719 \\
\hline & $1880-1891$ & 720 \\
\hline Bücher, Verzeichnis der entliehenen & 1903-1909 & 312 \\
\hline Bulle, Ausbruch & $1897-1914$ & 838 \\
\hline Bullen, Treiben durch die Stadt & $1901-1912$ & 840 \\
\hline Bund der Industriellen, Tagung in Emden & 1905 & 674 \\
\hline Bundesschießen, Förderung & $1886-1914$ & 574 \\
\hline \multirow[t]{2}{*}{ Buntmetall, Ablieferung für die Kriegswirtschaft } & 1915 & 3.248 \\
\hline & $1915-1916$ & 3.249 \\
\hline \multirow[t]{2}{*}{ Buntmetall, Beschlagnahmung für die Kriegswirtschaft } & 1915 & 3.246 \\
\hline & 1915 & 3.247 \\
\hline \multirow[t]{3}{*}{ Buntmetall, Entschädigungszahlung } & 1915 & 3.247 \\
\hline & $1915-1916$ & 3.249 \\
\hline & $1915-1916$ & 3.310 \\
\hline Buntmetallmengen, Ablieferung aus Emden & 1915 & 3.246 \\
\hline
\end{tabular}


IV

Index

SACH

Indexbegriff

Burgen, Erhaltung

Bürgergewinngeld, Neufestsetzung

Bürgermeister, Amtseinführung

Bürgermeister, Bewerbung

Bürgermeister, Dienstalterfestsetzung

Bürgermeister, Ruhestand

Bürgermeister, Tod

Bürgermeister, Vereidigung

Bürgermeister, Verzeichnis

Bürgermeister, Wahl

Bürgermeister, Wahl eines Stellvertreters

Bürgermeisterwahl, Antrag auf Verlegung

Bürgermeisterwahl, Verfahren

Bürgerrecht, Erwerb durch Arbeiter

Bürgerrecht, Verleihung an Kriegsteilnehmer

Bürgerrechtsreform, Diskussion

Bürgersteig, Anlegung

Bürgersteig, Anlegung an der Auricher Chaussee

Bürgersteig, Anlegung in d. Klunderburgstraße u. d. Pelzerstraße

Bürgersteig, Finanzierung

Bürgersteig, Finanzierung durch Anlieger

Bürgersteig, Ordnungswidrige Benutzung mit Dreirad

Bürgervorsteher, Akteneinsicht

Bürgervorsteher, Beteiligung an Kommissionen

Bürgervorsteher, Ehrengeschenk

Bürgervorsteher, Ehrenmedaille

Bürgervorsteher, Kommunikation mit Stadt Emden

Bürgervorsteher, Mandatsniederlegung

Bürgervorsteher, Vereidigung

Bürgervorsteher, Versammlungen

Bürgervorsteher, Verzeichnis

Bürgervorsteher, Wahl

Bürgervorsteher, Zuständigkeiten

Bürgervorsteher-Kollegium, Anwesenheitslisten

Laufzeit

1867-1878

1912

1858-1893

1853-1891

1853-1891

1875-1913

1875-1913

$1853-1891$

1853-1891

1853-1891

1875-1913

1870-1887

1875-1913

1853-1891

1853-1891

1853-1891

1917-1918

1917-1918

1917-1918

1876-1907

1868-1880

1888-1902

1895-1900

1897-1902

1900-1905

1904-1905

1901-1903

1879

1888-1902

1894-1898

1901-1903

1899-1901

1900-1903

1903

1904-1905

1896-1912

1848-1915

1854-1914

1854-1920

1854-1920

1854-1914

$1879-1890$

$1872-1903$

1867-1869

$1879-1890$

1903-1911

1854-1914

1870-1887

1848-1915

1872-1903

1901-1902

1867-1869

1879-1890

1898

1908-1916

1903-1911

1872-1903

1871-1903
Lfd.Nr. 2.669 601 
IV

Index

SACH

Indexbegriff
Bürgervorsteher-Kollegium, Funktionsträger

Bürgervorsteher-Kollegium, Geschäftsordnung

Bürgervorsteher-Kollegium, Mitglieder

Bürgervorsteher-Kollegium, Mittel für Bürodienst

Bürgervorsteher-Kollegium, Neuwahl

Bürgervorsteher-Kollegium, Sitzungen

Laufzeit

$1854-1890$

$1854-1914$

1917-1918

1872-1903

$1854-1890$

1917-1918

1868-1869

1870-1871

$1872-1873$

1874-1875

$1876-1877$

$1878-1879$

1880-1881

$1882-1883$

1884

$1885-1886$

1887

1888-1889

1890-1891

1892-1893

1894-1895

1896-1897

1898-1899

1900-1901

1902-1903

1904

1905

1906

1907

1908

1909

1910

1886-1904

1867

1868

1869

1870

1871

1872

1873

1874

1875

1876

1877

1878

1880

1881

1882-1883

1884-1885

1886

1887

1888

1889

1890

1891

1892

1893-1894

1895
Lfd.Nr.

112 
Index

\begin{tabular}{|c|c|c|}
\hline \multicolumn{3}{|l|}{ SACH } \\
\hline Indexbegriff & Laufzeit & Lfd.Nr. \\
\hline \multirow[t]{12}{*}{ Bürgervorsteherkollegium, Sitzungsprotokolle } & $1896-1897$ & 139 \\
\hline & 1897-1898 & 140 \\
\hline & $1899-1900$ & 141 \\
\hline & $1900-1902$ & 142 \\
\hline & $1902-1904$ & 143 \\
\hline & $1904-1908$ & 144 \\
\hline & $1908-1910$ & 145 \\
\hline & $1910-1912$ & 146 \\
\hline & $1912-1913$ & 147 \\
\hline & $1913-1914$ & 148 \\
\hline & $1914-1917$ & 149 \\
\hline & $1917-1919$ & 150 \\
\hline Bürgervorsteher-Kollegium, Stellung v. Kommissionsmitglieder & $1854-1890$ & 112 \\
\hline Bürgervorsteher-Kollegium, Streit mit Magistrat & $1854-1914$ & 74 \\
\hline Bürgervorsteher-Kollegium, Vorsitzender & $1854-1890$ & 112 \\
\hline Bürgervorsteher-Vereinigung, Tagung in Emden & $1912-1914$ & 709 \\
\hline \multirow[t]{2}{*}{ Bürgervorsteherwahl, Anfechtung } & $1901-1903$ & 76 \\
\hline & 1901-1902 & 77 \\
\hline Bürgervorsteherwahl, Klage & 1898 & 80 \\
\hline Bürgervorsteherwahl, Streit & $1872-1903$ & 75 \\
\hline \multirow[t]{3}{*}{ Bürgervorsteherwahl, Wahlberechtigte } & $1872-1903$ & 75 \\
\hline & 1901 & 82 \\
\hline & 1908-1916 & 83 \\
\hline Bürgerwehr, Bildung und Einsatz & $1914-1915$ & 3.156 \\
\hline Burggraben, Verseuchung durch eingeleitete Abwässer & $1876-1884$ & 862 \\
\hline Burggraben, Verunreinigung & 1878-1888 & 1.493 \\
\hline \multirow[t]{3}{*}{ Burggraben, Zuschüttung } & $1885-1887$ & 915 \\
\hline & 1896-1906 & 998 \\
\hline & 1887 & 1.148 \\
\hline Bürogehilfe, Beschäftigung & $1900-1917$ & 338 \\
\hline Bürogehilfe, Dienstvertrag & 1916-1917 & 337 \\
\hline Bürogehilfe, Einstellung & $1916-1917$ & 337 \\
\hline Bürogehilfe, Gehaltsfestsetzung & $1916-1917$ & 337 \\
\hline Bürogehilfe, Nebentätigkeit & $1900-1917$ & 338 \\
\hline Bürsten- und Pinselmachereien, Emden & $1899-1910$ & 2.387 \\
\hline Bürsten- und Pinselmachereien, Regelung des Betriebs & $1899-1910$ & 2.387 \\
\hline Bürsten, Herstellungsverfahren & $1899-1910$ & 2.387 \\
\hline Bürstenmacher, Materialbuch & $1899-1910$ & 2.387 \\
\hline Bürstenmacher, Pockenimpfanordnung & $1899-1910$ & 2.387 \\
\hline Butter- und Käsemarkt, Ordnung & 1903 & 2.152 \\
\hline Butter- und Käsemarktsordnung, Stadt Emden & 1877-1912 & 324 \\
\hline Butter, Kontrolle & $1879-1910$ & 748 \\
\hline Butterfabrik, Ungenehmigter Umbau & $1910-1911$ & 1.201 \\
\hline Butterfässer, Normierung & $1867-1870$ & 2.155 \\
\hline Cämmereischreiber, Einstellung & $1858-1893$ & 5 \\
\hline Central-Armen-Deputation, Bedienstete & 1871 & 1.862 \\
\hline Central-Armen-Deputation, Bildung & 1871 & 1.861 \\
\hline \multirow[t]{2}{*}{ Central-Armen-Deputation, Mitglieder } & $1871-1913$ & 1.864 \\
\hline & $1888-1904$ & 1.866 \\
\hline \multirow[t]{3}{*}{ Central-Armen-Deputation, Sitzungsprotokolle } & $1871-1913$ & 1.864 \\
\hline & 1873-1882 & 1.865 \\
\hline & $1888-1904$ & 1.866 \\
\hline Central-Polizeiblatt & $1896-1914$ & 505 \\
\hline Chausseebau, Grundstückserwerb & $1873-1882$ & 2.518 \\
\hline Chirurgen, Zulassung & 1868 & 766 \\
\hline Cholera, Ausbruch & $1892-1903$ & 777 \\
\hline Cholera, Bekämpfung & $1871-1914$ & 757 \\
\hline
\end{tabular}


Index

SACH

Indexbegriff

Cholera, Epidemie in Hamburg

Cholera, Feststellung der Verbreitung

Cholera, Impfaktion

Cholera, Niederlande

Cholera, Verbesserung der Hygiene

Cholera, Verbreitung

Cholera-Ausbruch, Dienst der Diakonissen

Cholera-Epidemien, Ausbruch

Choleragefahr, Maßnahmen bei einfahrenden Schiffen

Choleragefahr, Regelung Ein- und Ausfuhr

Cholera-Verdächtige, Verweigerung des Grenzübertritts

Choralabspielen, Initiative zur Wiedereinführung

Clementiner-Bruderschaft, Spendensammlungsantrag

Closett-Gebühr, Anträge auf Befreiung

Closett-Gebühr, Erhebung

Dachkupfer, Beschlagnahmung für die Kriegswirtschaft

Dachrinnen, Reinigung

Dampfbagger "AG Heykes"

Dampfbagger "Concurrent"

Dampfbagger "Nieuwe Maatmond II"

Dampfbaggerprahm Emden 1

Dampfbaggerprahm Emden 2

Dampfbarkasse "Theda"

Dampfboot "Bernhard"

Dampfeimerbagger "Ems"

Dampfer "Borkum"

Dampfer "Borkumriff"

Dampfer "Emden"

Dampfer "Hans Hensoth"

Dampfer "Justine Wessels"

Dampfer "Kaiser Wilhelm II"

Dampfer "Leda"

Dampfer "Logum"

Dampfer "Mentje"

Dampfer "Nesserland"

Dampfer "Norderney"

Dampfer "Ostfriesland"

Dampfer "Prinz Heinrich"

Dampfer "Remulus"

Dampfer "Rheinland"

Dampfer "Tender"

Dampfer "Tinos"

Dampfer "Vera"

Dampfer "Westfalen"

Dampfer "Wilhelm Hansoth"

Dampfer, Ausstattung mit Dampfkessel

Dampferlinie, Eröffnung

Dampferlinien, Situation

Dampfkessel, Antrag auf Einbaugenehmigung

Dampfkessel, Betriebsgenehmigung

\section{Laufzeit}

1884-1915

$1892-1903$

1906

1884-1915

1884-1915

1883-1900

1884-1915

1884-1915

1884-1915

1884-1915

1883-1900

1892-1903

1884-1915

1911-1912

1913

1889-1905

1889-1905

1915-1918

1917-1918

1917-1918

1881-1903

1900

1898

1900

1897

1897

1895

1902

1893

1902

1883-1901

1902

1910

1911

1900

1903

1910

1910

1905

1904

1880

1883-1890

1903

1904

1909

1902

1903

1909

1873-1912

1906

1903

1908

1906

1873-1907

1873-1907

1906

1906
Lfd.Nr.

772


IV

Index

\section{SACH}

\begin{tabular}{|c|c|c|}
\hline Indexbegriff & Laufzeit & Lfd.Nr. \\
\hline \multirow[t]{40}{*}{ Dampfkessel, Zulassung } & 1893 & 2.202 \\
\hline & 1895 & 2.213 \\
\hline & 1895 & 2.214 \\
\hline & 1895 & 2.215 \\
\hline & 1896 & 2.217 \\
\hline & 1897 & 2.219 \\
\hline & 1897 & 2.220 \\
\hline & 1897 & 2.223 \\
\hline & 1897 & 2.224 \\
\hline & 1898 & 2.226 \\
\hline & 1898 & 2.227 \\
\hline & 1892 & 2.228 \\
\hline & 1898 & 2.229 \\
\hline & 1898 & 2.230 \\
\hline & 1899 & 2.231 \\
\hline & 1899 & 2.232 \\
\hline & 1899 & 2.233 \\
\hline & 1899 & 2.236 \\
\hline & 1900 & 2.238 \\
\hline & 1900 & 2.240 \\
\hline & 1900 & 2.244 \\
\hline & 1900 & 2.245 \\
\hline & 1900 & 2.246 \\
\hline & 1900 & 2.248 \\
\hline & 1900 & 2.252 \\
\hline & 1901 & 2.253 \\
\hline & 1901 & 2.255 \\
\hline & 1901 & 2.256 \\
\hline & 1901 & 2.257 \\
\hline & 1901 & 2.259 \\
\hline & 1902 & 2.263 \\
\hline & 1902 & 2.265 \\
\hline & 1902 & 2.269 \\
\hline & $1902-1903$ & 2.271 \\
\hline & 1903 & 2.278 \\
\hline & 1904 & 2.283 \\
\hline & 1905 & 2.294 \\
\hline & 1908 & 2.299 \\
\hline & 1908 & 2.302 \\
\hline & 1910 & 2.324 \\
\hline \multirow[t]{9}{*}{ Dampfkessel, Zulassungsantrag } & 1888 & 2.190 \\
\hline & 1889 & 2.191 \\
\hline & 1889 & 2.192 \\
\hline & 1892 & 2.196 \\
\hline & 1893 & 2.205 \\
\hline & 1893 & 2.206 \\
\hline & 1893 & 2.208 \\
\hline & 1894 & 2.209 \\
\hline & 1894 & 2.210 \\
\hline Dampfkran Nr. 1 & 1898 & 2.229 \\
\hline Dampfkran Nr.2 & 1898 & 2.229 \\
\hline Dampfsägerei, Feuergefahr durch Schornstein & $1879-1907$ & 1.213 \\
\hline Dampfschiff "Borkum" & 1890 & 2.193 \\
\hline Dampfschiff "Dr. von Stephan" & 1892 & 2.197 \\
\hline Dampfschiff "Nesserland" & 1892 & 2.198 \\
\hline Dampfschiff "P.W.Wessels" & 1891 & 2.195 \\
\hline Dampfschiff "Pony" & 1890 & 2.194 \\
\hline Dampfschiff "Varina" & 1893 & 2.207 \\
\hline
\end{tabular}


Index

\begin{tabular}{|c|c|c|}
\hline \multicolumn{3}{|c|}{ SACH } \\
\hline Indexbegriff & Laufzeit & Lfd.Nr. \\
\hline Dampfschifffahrt, Borkum und Norderney & 1873-1907 & 2.017 \\
\hline Dampfschiffskapitäne, Qualifikation im Maschinenfach & $1877-1915$ & 1.567 \\
\hline Dampfschiffsverbindung, Emden und Delfzyl & $1900-1901$ & 2.058 \\
\hline Dampfschiffverbindung, Emden nach England & 1883-1906 & 2.043 \\
\hline Dampfschiffverbindung, Errichtung & $1883-1906$ & 2.043 \\
\hline Dampfschiffverbindung, Förderung & 1883-1906 & 2.043 \\
\hline Dampfschiffverbindung, Unwirtschaftlichkeit & 1883-1906 & 2.043 \\
\hline Dampfschleppboot "Ada" & 1900 & 2.247 \\
\hline Dampfschleppboot "Kitty" & 1900 & 2.247 \\
\hline Dankmünze, Übernahme & $1902-1908$ & 2.631 \\
\hline Darren, Zulassung & $1872-1903$ & 1.250 \\
\hline Dasselfliege, Bekämpfung & $1875-1914$ & 814 \\
\hline Datenerhebung, Hagelschäden und Überschwemmungen & $1900-1915$ & 815 \\
\hline Defektenbeschluss & 1890 & 354 \\
\hline Deich- und Sielordnung, Änderung wg. Moorentwässerung & $1905-1908$ & 1.448 \\
\hline Deich- und Sielunterhaltung, Beiträge & $1881-1888$ & 2.480 \\
\hline Deich, Abnahme & $1873-1876$ & 1.554 \\
\hline Deich, Abtragung & 1910 & 1.553 \\
\hline Deich, Beschädigung & $1867-1890$ & 1.536 \\
\hline Deich, Durchlass & $1885-1886$ & 922 \\
\hline Deich, Durchstechung & $1883-1900$ & 1.537 \\
\hline Deich, Einfriedung zur Landstraße & $1880-1903$ & 1.550 \\
\hline Deich, Erhöhung und Verstärkung & $1881-1901$ & 2.477 \\
\hline Deich, Kostenträgerschaft & $1867-1890$ & 2.476 \\
\hline \multirow[t]{2}{*}{ Deich, Niederlegung } & $1867-1890$ & 1.536 \\
\hline & $1883-1900$ & 1.537 \\
\hline Deich, Schauungsberichte & $1881-1901$ & 2.477 \\
\hline Deich, Unterhaltung & $1881-1901$ & 2.477 \\
\hline Deich, Verbot des Befahrens & $1867-1890$ & 1.542 \\
\hline Deich, Verpachtung der Grasung & $1881-1901$ & 2.477 \\
\hline Deich, Verstärkung & $1872-1892$ & 1.544 \\
\hline Deichacht, Auflösung & $1883-1900$ & 1.537 \\
\hline Deichacht, Eigentumsrechte & $1896-1911$ & 1.549 \\
\hline Deichacht, Etat & $1885-1907$ & 1.543 \\
\hline Deicharbeiter, Beschäftigung & $1885-1907$ & 1.543 \\
\hline Deicharbeiter, Unterbringung & 1874-1904 & 2.493 \\
\hline Deicharbeiter, Versorgung & $1867-1876$ & 2.415 \\
\hline Deichbau, Finanzierungsbeiträge & $1881-1888$ & 2.480 \\
\hline Deichbau, Klagen wegen Caution & $1876-1878$ & 2.479 \\
\hline Deichbau, Organisation & $1874-1887$ & 2.478 \\
\hline Deichbau, Prüfung & $1867-1890$ & 2.476 \\
\hline Deichbaurechnungen, Prüfung & $1874-1887$ & 2.478 \\
\hline Deichbeschreibung & $1892-1900$ & 1.545 \\
\hline \multirow[t]{2}{*}{ Deiche, Beschaffenheit } & $1876-1912$ & 1.540 \\
\hline & 1892 & 1.541 \\
\hline Deiche, Schauungen & $1883-1900$ & 1.537 \\
\hline Deiche, Übersichtskarte & 1904 & 1.551 \\
\hline Deiche, Verstärkung & $1892-1900$ & 1.545 \\
\hline \multirow[t]{2}{*}{ Deiche, Verstühlung } & $1872-1892$ & 1.544 \\
\hline & 1907 & 1.552 \\
\hline Deichflächen, Planzeichnung & $1900-1904$ & 1.539 \\
\hline Deichflächen, Verkauf & $1900-1904$ & 1.539 \\
\hline Deichlast, Eintreibung & $1867-1890$ & 1.536 \\
\hline \multirow[t]{2}{*}{ Deichlast, Grundstücksbesitzer } & $1892-1900$ & 1.545 \\
\hline & $1901-1908$ & 1.546 \\
\hline Deichlast, Konflikte & $1867-1890$ & 1.536 \\
\hline Deichlast, Verteilung & $1892-1900$ & 1.545 \\
\hline Deichlasten, Eintragung in das Hypothekenbuch & 1874-1886 & 1.532 \\
\hline
\end{tabular}


Index

\begin{tabular}{|c|c|c|}
\hline \multicolumn{3}{|l|}{ SACH } \\
\hline Indexbegriff & Laufzeit & Lfd.Nr. \\
\hline Deichprojekt, Beschreibung & $1867-1890$ & 2.476 \\
\hline Deichrecht, Zuständigkeitsregelung & $1887-1907$ & 1.439 \\
\hline Deichrentmeister, Kaution & $1874-1887$ & 2.478 \\
\hline Deichrichter, Wahl & $1901-1908$ & 1.546 \\
\hline \multirow{2}{*}{ Deichrolle, Aktualisierung } & $1892-1900$ & 1.545 \\
\hline & $1901-1908$ & 1.546 \\
\hline Deichrolle, Angaben & 1892 & 1.541 \\
\hline Deichrolle, Erstellung & $1872-1892$ & 1.544 \\
\hline \multirow[t]{2}{*}{ Deichrolle, Grundsätze } & $1876-1912$ & 1.540 \\
\hline & 1892 & 1.541 \\
\hline Deichschäden, Beseitigungsanordnung & $1867-1890$ & 1.536 \\
\hline \multirow[t]{2}{*}{ Deichschauungen, Protokolle } & $1892-1900$ & 1.545 \\
\hline & 1901-1908 & 1.546 \\
\hline Deichschoß, Erhebung & 1872-1892 & 1.544 \\
\hline Deichschoß, Widerspruch gegen & $1883-1900$ & 1.537 \\
\hline Deichschutz, Eisgang & $1885-1907$ & 1.543 \\
\hline Deichstrecken, Verkaufsangebote & $1896-1911$ & 1.549 \\
\hline \multirow{2}{*}{ Deichstrecken, Verpactung als Schafweide } & $1866-1893$ & 2.456 \\
\hline & 1895-1909 & 2.457 \\
\hline Deichunterhaltung, Übernahme & 1872-1892 & 1.544 \\
\hline Deichverband, Deichunterhaltungsträgerschaft & $1901-1908$ & 1.546 \\
\hline Deichverband, Ersatzwahlen & $1881-1901$ & 2.477 \\
\hline \multirow{4}{*}{ Deichverband, Etat } & $1892-1900$ & 1.545 \\
\hline & $1901-1908$ & 1.546 \\
\hline & $1867-1890$ & 2.476 \\
\hline & $1881-1901$ & 2.477 \\
\hline \multirow[t]{2}{*}{ Deichverband, Statut } & $1876-1912$ & 1.540 \\
\hline & 1901-1908 & 1.546 \\
\hline \multirow[t]{2}{*}{ Deichverband, Statuten } & 1868 & 1.538 \\
\hline & $1872-1892$ & 1.544 \\
\hline \multirow[t]{2}{*}{ Deichverband, Struktur } & $1876-1912$ & 1.540 \\
\hline & 1892 & 1.541 \\
\hline \multirow[t]{2}{*}{ Deichverband, Versammlungen } & 1876-1912 & 1.540 \\
\hline & $1892-1900$ & 1.545 \\
\hline Deichvorland, Verpachtung & $1866-1873$ & 2.452 \\
\hline Demobilisierung & 1918 & 3.303 \\
\hline Denkmal, Generalpostmeister Dr. von Stephan & 1894-1897 & 2.394 \\
\hline Denkmalsbau, Kostenabrechnung & 1894-1897 & 2.394 \\
\hline Denkmalspflege, Historische Vereine & $1873-1917$ & 2.395 \\
\hline Denkmalspflege, Provinz Hannover & $1873-1917$ & 2.395 \\
\hline Denkmalspflege, Regelung & 1873-1917 & 2.395 \\
\hline Denkmalspflege, Zuständigkeit & $1873-1917$ & 2.395 \\
\hline Desinfektor, Instruktionen & 1894-1900 & 1.685 \\
\hline Deutsche Kolonialgesellschaft, Satzungen & 1905 & 674 \\
\hline Deutsche Vaterlandspartei, Agitation & 1917-1918 & 3.311 \\
\hline Deutsche Vaterlandspartei, Mitglieder in Emden & 1917-1918 & 3.311 \\
\hline Deutscher Tischlerverband, Mitgliederliste für Emden & $1892-1893$ & 631 \\
\hline Deutscher Tischlerverband, Statuten & $1892-1893$ & 631 \\
\hline Deutsch-freisinnige Partei, Mitglieder & 1884 & 629 \\
\hline Deutsch-freisinnige Partei, Statuten & 1884 & 629 \\
\hline Deutsch-Luxembg. Bergwerks- u. Hütten AG, Geschäftsberichte & 1913-1917 & 1.485 \\
\hline Deutsch-Luxembg. Bergwerks- u. Hütten AG, Hauptversammlung & 1913-1917 & 1.485 \\
\hline Diakonie, Unterstützungsgesuche & 1871-1872 & 1.707 \\
\hline Diakonissen-Station, Unterhaltung & $1880-1897$ & 615 \\
\hline Diebstahl, Möhren & $1870-1914$ & 809 \\
\hline Dienstgebäude, Kgl. Wasserbau-Inspektion & $1885-1896$ & 2.529 \\
\hline Dienstmädchen, Schutz im Ausland & $1912-1913$ & 708 \\
\hline Dienstmagd, Tragung von Krankenhauskosten & 1902-1903 & 1.694 \\
\hline
\end{tabular}


Index

\begin{tabular}{|c|c|c|}
\hline \multicolumn{3}{|l|}{ SACH } \\
\hline Indexbegriff & Laufzeit & Lfd.Nr. \\
\hline Dienstmagd, Tragung von Krankenhauskosten & 1903 & 1.695 \\
\hline Dienstmänner, Beschwerden gegen & $1872-1918$ & 1.947 \\
\hline Dienstmänner, Konkurrenz mit Fuhrleuten & $1872-1918$ & 1.947 \\
\hline Dienstmänner, Verhaltensmaßregel & $1872-1918$ & 1.947 \\
\hline Dienstmänner, Zulassung & $1872-1918$ & 1.947 \\
\hline Dienstmanns-Institut, Zulassung & $1872-1918$ & 1.947 \\
\hline Dienstmannswesen, Datenerhebung & $1872-1918$ & 1.947 \\
\hline Dienstmannswesen, Regulierung & $1872-1918$ & 1.947 \\
\hline Dienstwohnung, Straßenreinigungspflicht & 1875-1905 & 1.594 \\
\hline Diphterie, Bekämpfung & 1894-1904 & 771 \\
\hline Direktor, Kaiser-Friedrich-Realschule & $1886-1895$ & 3.752 \\
\hline Direktorenstelle, Kaiserin-Auguste-Viktoria-Schule & 1910 & 3.813 \\
\hline Dispacheur, Einstellung & $1871-1913$ & 419 \\
\hline Dortmund-Ems-Kanal, Ausbauförderung & $1900-1901$ & 2.057 \\
\hline Dortmund-Rhein-Kanal, Bauplanungsdiskussion & $1900-1901$ & 2.057 \\
\hline \multirow[t]{2}{*}{ Dreckwarf, Anlage } & $1873-1880$ & 866 \\
\hline & 1879 & 867 \\
\hline Dreckwarf, Anlage am Beckhofstor & 1867-1906 & 865 \\
\hline Dreckwarf, Anlegung eines Strauchgürtels & 1867-1906 & 865 \\
\hline Dreckwarf, Beschwerden gegen & $1885-1910$ & 879 \\
\hline Dreckwarf, Gutachten zur Seuchengefahr & $1885-1910$ & 879 \\
\hline Dreckwarf, Schließung & $1895-1910$ & 873 \\
\hline Dreckwarf, Situationsplan & $1869-1885$ & 869 \\
\hline Dreckwarf, Vermessung & $1873-1880$ & 866 \\
\hline Drehbrücke, Öffnungszeiten & 1882-1908 & 2.009 \\
\hline Drehkran, Ausstattung mit Dampfkessel & 1907 & 2.174 \\
\hline Dreschmaschinen, Erfassung & 1914-1916 & 3.194 \\
\hline Drogerien, Revision & $1888-1913$ & 768 \\
\hline Drogerien, Revisionspflicht & $1888-1913$ & 768 \\
\hline Drogisten, Prüfung & $1888-1913$ & 768 \\
\hline Droschkenbesitzer, Beleidigung von Fahrgästen & 1874-1883 & 2.118 \\
\hline Droschkenlinie, Konzessionsgesuch & 1874-1883 & 2.118 \\
\hline Droschkenwesen, Regulierung & 1874-1883 & 2.118 \\
\hline Düngehaufen, Setzungserlaubnis & $1876-1889$ & 843 \\
\hline \multirow[t]{2}{*}{ Düngerschuppen, Bau } & 1873-1880 & 866 \\
\hline & 1869-1885 & 869 \\
\hline Düngerschuppen, Vergrößerung & $1886-1894$ & 870 \\
\hline Düngerverkauf, Erlöse & 1878-1899 & 876 \\
\hline Düngerverkauf, Privatisierung & 1878-1899 & 876 \\
\hline Dungwagen, Erlaubnis zum Abstellen & $1871-1897$ & 823 \\
\hline Düppel-Gedächtnisfeier & $1912-1914$ & 567 \\
\hline Durchgangsverkehr, Freigabeantrag & 1905-1909 & 1.009 \\
\hline Durchreise, Königliche und kaiserliche Familie durch Emden & 1874-1911 & 190 \\
\hline Eheangelegenheiten, Aufgebotsfristverkürzungsanträge & 1867-1874 & 3.404 \\
\hline Eheangelegenheiten, Aufgebotsproklamation & $1867-1874$ & 3.404 \\
\hline Eheschließungen, Aufgebotspflicht & $1868-1875$ & 3.351 \\
\hline Eheschließungen, Christen mit Juden & $1868-1875$ & 3.351 \\
\hline Ehrenbürgerbrief, E.H. Hantelmann & 1853-1891 & 12 \\
\hline Ehrenbürgerbrief, Schenkung & 1853-1891 & 12 \\
\hline Ehrenbürgerbrief, Verleihung & 1853-1891 & 12 \\
\hline Ehrenbürgerrecht, Geplante Verleihung & 1887-1912 & 1.437 \\
\hline Ehrenbürgerrecht, Verleihung & 1901-1906 & 267 \\
\hline Ehrenbürgerwürde, Leo Fürbringer & $1875-1913$ & 13 \\
\hline Ehrengeschenk, Reichskanzler von Bismarck & 1885 & 564 \\
\hline Ehrenpreis, Stiftung & 1904 & 801 \\
\hline Ehrentribüne, Bau & 1902 & 184 \\
\hline Ehrenvorsitz, Verein z. Förderung des Fremdenverkehrs in Emden & 1905-1911 & 673 \\
\hline
\end{tabular}


Index

SACH

Indexbegriff

Eichamt, Umzug

Eichbehörde, Geschäftstätigkeit

Eichtermine, Bekanntmachung

Eichung, Termine

Eichung, Waagen und Messeinrichtungen

Eichungen, Aufstellung durch den Eichmeister

Eichwesen, Organisation

Eidesformel

Eier, Verkauf nach Gewicht

Eigentumsrecht, Klage wegen Verletzung

Eigentumsrechte, Klärung

Eigentumsrechte, Streit

Eigentumsverhältnisse, Ermittlung

Eigentumsverhältnisse, Klärung

Eimerbagger "Colonia"

Eimerbagger "Barbarossa"

Eimerbagger "Borussia"

Eimerbagger "Britannia"

Eimerbagger "Colonia"

Eimerbagger E.D.V.

Eimerbagger "Ed 1"

Eimerbagger "Rhenania"

Einbeufungsbescheide, Zustellung bei Mobilmachung

Eindeichung, Anwachs zwischen Larrelt und Nesserland

Eindeichung, Förderantrag

Einfriedung, Grundstücke westlich des Gasthauses

Einfriedung, Ungenehmigter Bau

Einfriedung, Unterhaltung

Einfriedungen, Anträge

Einfriedungen, Reparaturanträge

Eingemeindung, Ablehnung

Eingemeindung, Begründung

Eingemeindung, Borssum nach Emden

Eingemeindung, Denkschrift

Eingemeindung, Einfrierung

Eingemeindung, Kaiser-Wilhelm-Polder

Eingemeindung, Kasernengrundstück nach Emden

Eingemeindung, Königspolder

Eingemeindung, Steuerstreit

Eingemeindung, Verhandlungen

Eingemeindung, Vorland des Königspolders

Eingemeindung, Wolthusen nach Emden

SACH 
Index

\begin{tabular}{|c|c|c|}
\hline \multicolumn{3}{|l|}{ SACH } \\
\hline Indexbegriff & Laufzeit & Lfd.Nr. \\
\hline Eingemeindung,Teile der Gemeinde Wolthusen nach Emden & 1913-1915 & 241 \\
\hline Eingemeindungsvertrag, Verbindlichkeit & $1915-1918$ & 242 \\
\hline Einigungsamt, Mitglieder & 1914-1918 & 3.204 \\
\hline Einigungsämter, Einrichtung & 1914-1918 & 3.204 \\
\hline Einigungsämter, Kompetenz & 1914-1918 & 3.204 \\
\hline Einjährig-Freiwillige & 1896 & 3.101 \\
\hline Einjährig-Freiwillige, Beförderung zu Reserveoffizieren & $1878-1910$ & 3.102 \\
\hline Einjährig-freiwilliger Militärdienst, Zeugnis für & 1891 & 3.751 \\
\hline Einkommenssteuer, Erhebung & $1895-1913$ & 2.982 \\
\hline Einkommenssteuerpflicht, Ermittlung & $1867-1891$ & 2.876 \\
\hline Einkommenssteuerrückstände, Einziehung & $1908-1914$ & 2.878 \\
\hline \multirow[t]{2}{*}{ Einladung, Mitglieder der kgl. Familie nach Emden } & 1866-1868 & 189 \\
\hline & 1874-1911 & 190 \\
\hline Einpfarrung, Königspolder nach Borssum & 1889 & 3.335 \\
\hline Einpolderungsgesellschaft, Statut & $1873-1876$ & 1.554 \\
\hline \multirow[t]{4}{*}{ Einquartierung, Entschädigung } & $1875-1886$ & 3.109 \\
\hline & $1888-1889$ & 3.110 \\
\hline & 1884-1885 & 3.119 \\
\hline & 1897-1898 & 3.120 \\
\hline Einquartierung, Kaiserbesuch & 1901-1902 & 3.111 \\
\hline Einquartierung, Quartierzettel & 1893-1914 & 3.185 \\
\hline Einquartierungen, Entschädigung & 1871-1872 & 3.114 \\
\hline Einquartierungen, Kostenerstattung & $1866-1879$ & 3.112 \\
\hline Einquartierungskasse, Rechnung & 1888-1889 & 3.116 \\
\hline \multirow{2}{*}{ Einquartierungskasse, Rechnungslegung } & 1866-1899 & 2.640 \\
\hline & $1900-1904$ & 2.641 \\
\hline \multirow[t]{2}{*}{ Einquartierungslisten } & 1876 & 3.113 \\
\hline & $1866-1867$ & 3.115 \\
\hline Einquartierungsquote, Emder Häuser & 1915-1918 & 3.147 \\
\hline Einwanderungsbeschränkungen, Kanada & $1866-1913$ & 452 \\
\hline Einweihungsfeier, Jüdisches Waisenhaus & 1903-1917 & 495 \\
\hline Einweihungsfeier, Nichtteilnahme des OB's beim Hafen Leer & 1907 & 1.444 \\
\hline \multirow[t]{2}{*}{ Einweihungsfeier, Planung für den Emder Außenhafen } & 1901 & 181 \\
\hline & $1897-1901$ & 182 \\
\hline Einwohner, Verzeichnis & $1850-1860$ & 458 \\
\hline Eisbrecher "Emden" & 1893 & 2.204 \\
\hline Eisenbahn, Streckenführung im Außenhafen & 1895-1906 & 2.059 \\
\hline Eisenbahnanbindung, Emden an Westfalen, Ruhrgebiet u. Berlin & 1908-1913 & 2.013 \\
\hline Eisenbahnbrücke, Öffnungszeiten & 1881-1885 & 2.014 \\
\hline Eisenbahndurchlass, Verschluss & $1867-1890$ & 1.536 \\
\hline Eisenbahnverbindungen, Verbesserung & 1881-1885 & 2.014 \\
\hline Eisenbahnverein Emden, Satzung & $1900-1912$ & 639 \\
\hline Eisenbahnverladestelle, Anlegung & 1900 & 2.076 \\
\hline Eisenbahnwesen, Verfügungen zum & 1881-1885 & 2.014 \\
\hline Eisenbetonbauten, Unfallstatistik & 1911 & 1.174 \\
\hline Eisenerzgebiete, Annexionsforderung & 1915-1919 & 3.315 \\
\hline Eisflächen, Absperrung & $1912-1914$ & 1.499 \\
\hline Eiskeller, Anlage & $1872-1913$ & 2.655 \\
\hline Eiskeller, Einrichtung & $1872-1893$ & 2.470 \\
\hline Eiskeller, Verpachtung & $1872-1913$ & 2.655 \\
\hline Eisverhältnisse, Bereich Dollart - Borkum & 1903 & 1.417 \\
\hline Eisverhältnisse, Datenerhebung & 1903 & 1.417 \\
\hline Elbvertiefung & 1908 & 1.447 \\
\hline Elektrifizierung, Bekanntmachungen & $1912-1913$ & 1.133 \\
\hline Elektrifizierung, Regelung & $1882-1912$ & 1.082 \\
\hline Elektrifizierung, Werbung & $1882-1912$ & 1.082 \\
\hline Elektrische Energie, Lieferungsbedingungen & $1912-1914$ & 1.089 \\
\hline Elektrische Fernleitung, Emden - Wiesmoor & $1908-1911$ & 1.085 \\
\hline
\end{tabular}


Index

\begin{tabular}{|c|c|c|}
\hline \multicolumn{3}{|l|}{ SACH } \\
\hline Indexbegriff & Laufzeit & Lfd.Nr. \\
\hline Elektrizitätsversorgung, Einstellung eines Beraters & 1907-1908 & 1.083 \\
\hline Elektrizitätswerk, Anlage & $1905-1911$ & 1.074 \\
\hline Elektroinstallateure, Einrichtung elektrischer Hausanschlüsse & $1909-1915$ & 1.130 \\
\hline Elektrotechniker, Bestellung & $1912-1913$ & 1.121 \\
\hline Elektrotechniker, Bewerbung & $1912-1913$ & 1.132 \\
\hline Elektrotechniker, Einstellung & $1912-1913$ & 1.132 \\
\hline Elementarlehrer, Hinterbliebenenversicherung & $1874-1890$ & 3.499 \\
\hline Elementarlehrerstellen, Besetzung & $1886-1903$ & 3.724 \\
\hline Elevator "Kaiser-Wilhelm-Polder" & 1901 & 2.255 \\
\hline Elevator "Polder" & 1892 & 2.228 \\
\hline Emden, Besetzung & & Vorwort \\
\hline Emden, Straßen und Plätze & 1874-1894 & 845 \\
\hline Emder Bürgerverein, Mitglieder & $1891-1894$ & 630 \\
\hline Emder Bürgerverein, Satzung & 1891-1894 & 630 \\
\hline Emder Colonialwaren-Detaillisten-Verein, Mitglieder & 1898-1908 & 636 \\
\hline Emder Colonialwaren-Detaillisten-Verein, Statut & $1898-1908$ & 636 \\
\hline Emder Hafen, Publikationen & 1904-1911 & 456 \\
\hline Emder Haus und Grundbesitzerverein, Satzung & $1907-1913$ & 602 \\
\hline Ems, Emder Bereich & 1900 & 234 \\
\hline Emsfahrwasser, Sperrung & 1879-1883 & 1.433 \\
\hline Emsfahrwasser, Vertiefung & $1870-1914$ & 1.430 \\
\hline Emsmündungen, Karte & 1868 & 1.445 \\
\hline Emsschifffahrt, Negative Folgen eines Kanalprojekts & 1905-1908 & 1.448 \\
\hline Energieversorgung, Emder Hafenanlagen & 1907-1908 & 1.083 \\
\hline Enno-Denkmal, Restaurierung & 1874-1903 & 3.412 \\
\hline Ent- und Bewässerungsgenossenschaften, Bildung & $1867-1881$ & 816 \\
\hline Entbindungsanstalt, Entsendung Schwangerer & 1867-1895 & 763 \\
\hline Entbindungsanstalt, Errichtung & 1867-1895 & 763 \\
\hline Entbindungsanstalt, Leitung & $1867-1895$ & 763 \\
\hline Enteignungsverfahren & 1901-1904 & 2.578 \\
\hline Enteignungsverfahren, Fußwegbau & $1877-1881$ & 975 \\
\hline Enthüllungsfeier, Denkmäler Großer Kurfürst u. Friedrich d. Gr. & $1900-1901$ & 176 \\
\hline Enthüllungsfeier, Kostenabrechnung & 1894-1897 & 2.394 \\
\hline Entmündigung, Antrag gegen Alkoholiker & 1891-1912 & 519 \\
\hline Entmündigungen, Alkoholiker & $1891-1912$ & 519 \\
\hline Entwässerung, Beeinträchtigung & $1881-1909$ & 894 \\
\hline Entwässerung, Bereich Entbindungsanstalt bis zur alten Kaserne & $1876-1884$ & 862 \\
\hline Entwässerung, Gutachten & 1884 & 902 \\
\hline \multirow[t]{3}{*}{ Entwässerung, Organisation } & 1884 & 903 \\
\hline & 1884-1885 & 904 \\
\hline & $1885-1910$ & 905 \\
\hline \multirow[t]{2}{*}{ Entwässerung, Stadtgebiet } & 1884-1896 & 900 \\
\hline & 1884-1885 & 901 \\
\hline Entwässerung, Streit & 1894-1905 & 2.603 \\
\hline Entwässerung, Zuständigkeiten & $1890-1901$ & 896 \\
\hline \multirow[t]{2}{*}{ Entwässerung. Streitigkeiten in Wolthusen } & $1890-1910$ & 252 \\
\hline & $1880-1913$ & 254 \\
\hline Entwässerungsanlagen, Bauverträge & 1885 & 958 \\
\hline Entwässerungsanlagen, Finanzierung & 1884 & 902 \\
\hline Entwässerungsanlagen, Streit um Instandhaltung & 1893-1894 & 936 \\
\hline Entwässerungsanlagen, Übergang in den Besitz der Stadt Emden & $1885-1888$ & 917 \\
\hline \multirow[t]{2}{*}{ Entwässerungsfragen, Verhandlungen } & 1884-1896 & 900 \\
\hline & 1884-1885 & 901 \\
\hline Entwässerungsgraben, Zuschüttung & $1880-1907$ & 893 \\
\hline Entwässerungskanal, Bau & $1876-1884$ & 862 \\
\hline Entwässerungskonzepte, Beratung & 1884-1885 & 904 \\
\hline Entwässerungsleitung, Kostenanschlag & $1880-1907$ & 893 \\
\hline Entwässerungsleitung, Kostenträgerschaft der Anlieger & $1880-1907$ & 893 \\
\hline
\end{tabular}


IV

Index

\section{SACH}

\begin{tabular}{l} 
Indexbegriff \\
\hline Entwässerungsleitungen, Schadhafte \\
Entwässerungssiel, Legung in den Flügeldeich bei Nesserland \\
Entwässerungssystem, Änderung nach Bau Ems-Jade-Kanal \\
Entwässerungssystem, Kostenvoranschlag \\
Entwässerungssystem, Unterhaltungskosten \\
Entwässerungssystem, Veränderung wg. Kanalbau \\
Entwässerungsverband, Konstituierung \\
Entwässerungsverhältnisse, Veränderung \\
Epileptiker, Übersicht \\
Erbpacht, Ablösung
\end{tabular}

Erbpacht, Aufwertung

Erbpacht, Eintreibung von Rückständen

Erbpacht, Gesuche

Erbpacht, Grundbucheintragung

Erbpachten, Ablösung

Erbpachten, Ablösung bei kirchlichen Ländereien

Erbpachten, Ablösungsanträge

\section{Laufzeit}

1870-1879

1885

1884

1884

1866-1875

1881-1909

1895

1884

1896

1880-1911

1872-1918

$1879-1910$

1879-1899

1880-1891

1874-1888

1880-1881

1880-1881

1881-1898

1880-1890

1881-1894

1877-1904

1881-1882

1883-1897

1884-1900

1884

1885-1908

1884-1895

1886-1899

1887-1898

1886-1892

1887-1911

1888-1892

1890-1907

1890-1899

1890-1897

1897-1908

1892

1890-1895

1894-1911

1896-1897

1896-1898

1896-1898

1896-1898

1897-1910

1899

1900-1903

1905-1907

1905-1907

1908

1890-1901

1880-1881

1867-1887

1869-1904

1869-1904

1869-1904

1901-1908

1873-1878

1869-1876
Lfd.Nr.

888

910

903

903

2.405

894

960

902

520

2.685

2.691

2.693

2.694

2.695

2.697

2.698

2.702

2.705

2.706

2.707

2.708

2.709

2.711

2.717

2.718

2.719

2.720

2.722

2.725

2.726

2.727

2.728

2.736

2.737

2.740

2.741

2.742

2.743

2.745

2.747

2.748

2.749

2.750

2.751

2.752

2.757

2.832

2.836

2.846

2.848

2.698

2.700

2.677

2.677

2.677

2.445

3.448

3.391 
Index

\begin{tabular}{l}
\hline \\
\hline Indexbegriff \\
\hline Erbpachtforderungen, Konkursmasse des Reemt Janssen \\
Erbpachtgrundstücke, Veräußerung \\
Erbpachtsbedingungen, Festlegung \\
Erbpachtsgrundstück, Umwidmung \\
Erbpachtsverträge, Regularien \\
Erbschaftssteuerpflicht, Gemeinnutziger Verein \\
Erdaushub, Verwendung \\
Erde, An- und Verkauf \\
Ergänzungssteuergesetz, Bestimmungen \\
Ergebenheitstelegramm, Stadt Emden an Kaiser Wilhelm II. \\
Erholungsheim für Beamte, Beihilfe \\
Erholungsstätten, Werbung \\
Erinnerungsmedaille, Verdienste im Feuerlöschwesen \\
Erinnerungsmedaillen, Überreichung \\
Erlasse, Veröffentlichungsverbot bei Vertraulichkeit \\
Erntearbeit, Einsatz von Polen und Russen \\
Erntearbeit, Vermittlung \\
Ernteaussichten, Gemüse - und Kohlanbau \\
Erntestatistik, Preußen \\
Erste Hilfe, Ausbildungsaufforderung \\
Erweiterungsarbeit, Zahlungsabwicklug \\
Erzumschlag über den Emder Hafen, Werbung \\
Etat, Ausgabe-Beläge \\
Etat, Ausgabeposten \\
Etat, Einnahmen \\
Etat, Französisch-reformierte Gemeinde \\
Etat, Kaiser-Friedrich-Realschule
\end{tabular}

Etat, Lutherische Kirchengemeinde

Etat, Lutherische Klassenschule

Etat, Nachbewilligungen

Etat, Neue Kirche

Etat, Rechnungsabnahme

Etat, Rechnungslegung

Etat, Verschönerungs-Kommission

Etatausgleich, Nachbewilligung

Etatplan, Feststellung

Etatposten, Nachbewilligungen

Evakuierte, Unterbringung

Evakuierungsplan, Frauen und Kinder aus Borkum

Evangelischer Arbeiterverein, Mitglieder

Evangelischer Arbeiterverein, Statuten

Exekutor, Amtsniederlegung

Exekutor, Beitreibung v. Krankenkassen-Restanden

Exekutor, Nebenverdienst

Exekutor, Pensionsantrag

Exekutor, Stellenbesetzung
Lfd.Nr.

1866-1900

2.481

1884

2.718

$1880-1913$

2.704

1869-1904

2.677

1901-1910

2.761

1900-1910

641

1885-1887

915

1874-1910

2.498

1893

1891

2.875

1898-1913

1870-1902

1909-1913

1901-1913

1869-1902

1914-1916

1914-1916

1900-1915

1900-1915

1870-1902

1904-1909

1896-1910

1902-1903

1899-1900

1899-1900

1886-1893

1886-1900

1898-1903

1902-1903

1905-1909

1908-1918

1892-1914

1868-1898

1873

1870-1908

1880-1912

1880-1912

1884-1914

1912-1914

1888

1896-1898

1866-1867

1868

1870-1871

1876-1877

1866-1867

1868

1870-1871

1876-1877

1914

1914

1888-1915

1888-1915

1884-1896

1884-1896

1884-1896

1884-1896

1884-1896
201

635

645

261

187

343

3.200

3.200

815

815

645

1.059

2.051

3.078

3.079

3.079

3.422

3.744

3.747

3.748

3.749

3.750

3.441

3.656

3.011

3.398

3.075

3.076

3.077 
Index

\begin{tabular}{|c|c|c|}
\hline \multicolumn{3}{|l|}{ SACH } \\
\hline Indexbegriff & Laufzeit & Lfd.Nr. \\
\hline Exerzierplatz, Anlage & $1866-1881$ & 3.085 \\
\hline Exerzierplatz, Entwässerung & $1877-1878$ & 3.084 \\
\hline Exerzierplatz, Kaufverhandlungen & $1889-1892$ & 2.542 \\
\hline Fabrik, Aufbau zur Verarbeitung von Tang zur Jodproduktion & 1905 & 2.376 \\
\hline \multirow[t]{2}{*}{ Fabrik, Genehmigungsverfahren } & $1900-1909$ & 2.380 \\
\hline & $1901-1904$ & 2.381 \\
\hline Fabriken, Arbeitsordnungen & $1892-1910$ & 2.389 \\
\hline Fachliteratur, Angebote & $1901-1913$ & 311 \\
\hline Fachliteratur, Erwerb durch die Stadtverwaltung & $1867-1901$ & 310 \\
\hline Fahnenweihe, Antrag & $1868-1913$ & 597 \\
\hline Fahrkartenkontrolle, Beleidigung des Schaffners & $1902-1913$ & 1.969 \\
\hline Fährlinie, Finanzierung & $1883-1890$ & 2.039 \\
\hline \multirow[t]{2}{*}{ Fahrpreisermäßigungen, Verein für Diakonissen-Krankenpflege } & $1861-1903$ & 577 \\
\hline & $1904-1915$ & 578 \\
\hline Fahrradfahrer, Unfall durch Überfahren durch Fuhrwerk & $1901-1912$ & 840 \\
\hline Fahrradreifen, Beschlagnahmung & $1916-1918$ & 3.280 \\
\hline Fahrrinnen, Entschlammung & $1866-1883$ & 1.487 \\
\hline Fahrstraße, Neupflasterung & 1897-1902 & 992 \\
\hline Fahrstühle, Überwachung von Einbau und Betrieb & $1900-1913$ & 1.255 \\
\hline Fährverbindung, Rentabilitätsberechnung & $1883-1890$ & 2.039 \\
\hline Fährverbindung, Verbesserung & $1883-1890$ & 2.039 \\
\hline Fahrwasser, Bedeichung und Verlegung & 1866 & 1.530 \\
\hline Fahrwasser, Erwerb von Landflächen zur Grabung & $1874-1886$ & 1.532 \\
\hline Fahrwasser, Markierung & $1866-1883$ & 1.487 \\
\hline Fahrwasser, Pegelungen & $1868-1891$ & 1.450 \\
\hline Fahrwasser, Zustand & 1869 & 1.531 \\
\hline Fahrwasserdamm, Abtragung & $1883-1900$ & 1.537 \\
\hline Fahrwasserdamm, Durchschneidung & $1883-1900$ & 1.537 \\
\hline Fahrwasserdamm, Niederlegung & $1867-1890$ & 1.536 \\
\hline Fahrwasserdeich, Abgrabung und Planierung & $1866-1893$ & 1.533 \\
\hline \multirow[t]{2}{*}{ Fahrwasserdeich, Übertritt des Beweidungsverbots } & $1866-1893$ & 2.456 \\
\hline & 1895-1909 & 2.457 \\
\hline Fahrwasserdeich, Unterhaltung & $1866-1893$ & 1.533 \\
\hline Fahrwassertiefe, Beschwerden & $1868-1891$ & 1.450 \\
\hline Fäkalien- und Müllabfuhr, Defizit & $1878-1899$ & 876 \\
\hline Fäkalien- und Müllabfuhr, Vertrag & $1878-1899$ & 876 \\
\hline Fäkalien, Abfuhr & 1867-1908 & 846 \\
\hline Fäkalien, Bindung mit Torfmüll & 1894-1908 & 872 \\
\hline \multirow[t]{2}{*}{ Fäkalien, Entsorgung } & $1869-1885$ & 869 \\
\hline & $1886-1894$ & 870 \\
\hline Fäkalien, Entsorgung in Fässer & $1867-1893$ & 1.495 \\
\hline Fäkalien, Entsorgung über die Kanalisation & 1896-1903 & 880 \\
\hline Fäkalien, Illegale Ableitung & $1876-1889$ & 843 \\
\hline \multirow[t]{2}{*}{ Fäkalienabfuhr, Beschwerden } & $1879-1909$ & 877 \\
\hline & $1909-1915$ & 878 \\
\hline \multirow[t]{2}{*}{ Fäkalienabfuhr, Delfter Tonnen } & 1879 & 867 \\
\hline & $1876-1879$ & 868 \\
\hline Fäkalienabfuhr, Heidelberger Tonnensystem & $1878-1899$ & 876 \\
\hline Fäkalienabfuhrtonnenwagen, Beschwerde wegen Lärm & $1909-1915$ & 878 \\
\hline Fäkalienabfuhrwesen, Missstände & $1895-1910$ & 873 \\
\hline Fäkalienlagerung, Geruchsbelästigung & $1885-1910$ & 879 \\
\hline Fäkalienlagerung, Maßnahmen gegen Bodenverseuchung & $1885-1910$ & 879 \\
\hline Fäkalientonne, Abfuhrgebühr & $1907-1911$ & 875 \\
\hline Fäkalientonne, Unbrauchbarkeit & 1897-1906 & 874 \\
\hline Fäkalientonnen, Abfuhr & 1894-1908 & 872 \\
\hline Fäkalientonnen, Abfuhrgebühr & 1894-1908 & 872 \\
\hline Fäkalientonnen, Angebote & 1894-1908 & 872 \\
\hline
\end{tabular}


Index

\begin{tabular}{|c|c|c|}
\hline \multicolumn{3}{|l|}{ SACH } \\
\hline Indexbegriff & Laufzeit & Lfd.Nr. \\
\hline Fäkalientonnen, Lagerung & $1895-1910$ & 873 \\
\hline \multirow[t]{2}{*}{ Fäkalientonnen, Leerung in öffentlichen Aborten } & $1871-1906$ & 961 \\
\hline & 1888-1905 & 964 \\
\hline Fäkalientonnen, Reinigungsmängel & $1883-1896$ & 887 \\
\hline Fäkalientonnen, Unvorschriftsmäßige in Privathäusern & $1879-1909$ & 877 \\
\hline Fäkalientonnenabfuhr- und Reinigung, Aufsicht & $1883-1896$ & 887 \\
\hline Fäkalientonnenabfuhr, Diskriminierung von Transvaal & 1894-1908 & 872 \\
\hline Fäkalientonnenabfuhr, Revision & $1895-1910$ & 873 \\
\hline Fäkalientonnenabfuhr, Unregelmäßigkeit & $1902-1914$ & 1.235 \\
\hline Fäkalientonnenreinigung, Aufsicht & $1883-1896$ & 887 \\
\hline Fäkalientonnenreinigung, Einstellung eines Aufsehers & $1883-1896$ & 887 \\
\hline Falderndelft, Ufer an die Staatsbauverwaltung & 1896 & 2.575 \\
\hline Familienunterstützung, Soldatenfamilien & $1914-1916$ & 3.195 \\
\hline Fangdamm, Bruch & $1867-1890$ & 1.536 \\
\hline Farbsichtigkeitstest, Durchführung & $1893-1914$ & 1.607 \\
\hline Fassaden, Gestaltung an öffentlichen Gebäuden & 1899 & 1.154 \\
\hline Feier, 100. Geburtstag des Fürsten von Bismarck & $1895-1915$ & 566 \\
\hline Feier, 25-Jähriges Bestehen des (Zweiten) deutschen Kaiserreichs & 1896 & 573 \\
\hline Feier, 400. Geburtstag des Reformators Martin Luther & 1883 & 569 \\
\hline Feier, 70. Geburtstag des Reichskanzlers Fürst Otto von Bismarck & 1885 & 564 \\
\hline Feier, 90. Geburtstag des Reichskanzlers Fürst Otto von Bismarck & $1895-1915$ & 566 \\
\hline Feier, Geburtstag d. Generalfeldmarschalls Hellmuth Graf v. Moltke & $1890-1891$ & 565 \\
\hline Feld- und Forstpolizeigesetz, Ausführung & $1870-1914$ & 809 \\
\hline Feld- und Forstpolizeigesetz, Novellierung & $1870-1914$ & 809 \\
\hline Feld- und Forstpolizeiordnung, Diskussion & $1870-1914$ & 809 \\
\hline Feldmark, Abgranzung & $1869-1900$ & 819 \\
\hline Feldmarken, Bereich der Stadt Emden & $1867-1887$ & 810 \\
\hline Feldpostadressen, Verbot der Sammlung & $1915-1916$ & 3.159 \\
\hline Fenster, Verbot des Aufschlagens nach Außen & $1903-1904$ & 1.184 \\
\hline Fensterscheibe, Zertrümmerung durch Schuss & $1881-1913$ & 727 \\
\hline Fernmeldeeinrichtungen, Angebot & $1866-1903$ & 1.385 \\
\hline Fernsprech-Anlagen, Genehmigungsverfahren & $1880-1911$ & 2.181 \\
\hline Fernsprechgebühren, Festlegung & $1880-1911$ & 2.181 \\
\hline Fernsprechverbindungen, Ostfriesland & $1881-1899$ & 2.053 \\
\hline Festbuch, Ostfriesische Lehrerversammlung in Emden & 1903-1909 & 661 \\
\hline Festschrift, Geschichte des Emder Hafens & $1900-1901$ & 180 \\
\hline Festschrift, Materialien & $1900-1901$ & 180 \\
\hline Festschrift, Suscription & $1900-1901$ & 180 \\
\hline Fette, Bewirtschaftung & $1914-1918$ & 3.245 \\
\hline Feudalabgabe "Windgeld" & $1869-1872$ & 2.672 \\
\hline Feudalabgaben und - Lasten, Ablösung & $1858-1913$ & 2.854 \\
\hline Feudalabgaben, Einnahmen aus Emder Herrlichkeiten & $1910-1914$ & 2.671 \\
\hline Feudalabgaben, Einnahmen aus Oldersum & $1907-1916$ & 2.673 \\
\hline Feudalabgaben, Umfang & $1900-1906$ & 2.665 \\
\hline Feudallast "Auffütterung eines Jagdhundes" & $1886-1899$ & 2.664 \\
\hline \multirow[t]{4}{*}{ Feudallast "Hofdienst" } & 1867-1909 & 2.663 \\
\hline & $1886-1899$ & 2.664 \\
\hline & $1886-1889$ & 2.668 \\
\hline & $1867-1878$ & 2.669 \\
\hline Feudallast "Kuhschatz" & 1867-1909 & 2.663 \\
\hline Feudallast "Torfgeld" & 1867-1909 & 2.663 \\
\hline \multirow[t]{2}{*}{ Feudallast, Ablösung } & 1867-1909 & 2.663 \\
\hline & $1886-1899$ & 2.664 \\
\hline Feudallast, An- und Abfahrtsgeld & $1873-1880$ & 2.660 \\
\hline Feudallast, Grundsatzklage & $1873-1880$ & 2.660 \\
\hline Feudallast, "Kruggeld" & 1880 & 2.662 \\
\hline \multirow[t]{2}{*}{ Feudallasten, Ablösung } & $1874-1894$ & 2.855 \\
\hline & $1894-1911$ & 2.856 \\
\hline
\end{tabular}


Index

\begin{tabular}{|c|c|c|}
\hline \multicolumn{3}{|l|}{ SACH } \\
\hline Indexbegriff & Laufzeit & Lfd.Nr. \\
\hline \multirow[t]{2}{*}{ Feudallasten, Ablösung } & $1871-1886$ & 2.860 \\
\hline & 1871-1886 & 2.861 \\
\hline Feudallasten, Ablösungsanträge & 1900-1906 & 2.665 \\
\hline Feuergefährlichkeit, Klassifizierung & $1886-1914$ & 1.254 \\
\hline Feuerlöschanlagen, Fiskalischer Hafenbereich & 1912 & 1.270 \\
\hline Feuerlöschdienst, Fernbleiben & $1868-1869$ & 1.391 \\
\hline Feuerlösch-Druckspritze, Anschaffung & 1867-1909 & 1.397 \\
\hline \multirow{2}{*}{ Feuerlöscheinrichtungen, Beihilfeanträge Stadt Emden } & 1867-1869 & 1.284 \\
\hline & $1890-1913$ & 1.285 \\
\hline Feuerlöscheinrichtungen, Emder Rathaus & $1869-1913$ & 1.387 \\
\hline Feuerlöschgeräte, Angebote & 1867-1909 & 1.397 \\
\hline Feuerlöschgeräte, Anschaffung & 1879-1904 & 1.398 \\
\hline Feuerlöschgeräte, Beihilfen zur Anschaffung & $1890-1913$ & 1.285 \\
\hline Feuerlöschgeräte, Funktionsprüfung & 1867-1907 & 1.399 \\
\hline Feuerlöschmaterialien, Löschprobe & 1879-1904 & 1.398 \\
\hline Feuerlöschschläuche, Beihilfe zur Anschaffung & 1867-1909 & 1.397 \\
\hline Feuerlöschschläuche, Funktionstests & $1867-1907$ & 1.399 \\
\hline Feuerlöschschläuche, Schäden & 1867-1907 & 1.399 \\
\hline \multirow[t]{2}{*}{ Feuerlöschspritzen, Angebote } & $1868-1911$ & 1.396 \\
\hline & $1867-1909$ & 1.397 \\
\hline Feuerlöschspritzen, Anschaffung & 1867-1909 & 1.397 \\
\hline Feuerlöschspritzen, Beihilfeantrag & $1868-1911$ & 1.396 \\
\hline Feuerlöschspritzen, Stationierung & $1868-1911$ & 1.396 \\
\hline \multirow[t]{2}{*}{ Feuerlöschspritzen, Verkauf } & $1868-1911$ & 1.396 \\
\hline & 1867-1909 & 1.397 \\
\hline Feuerlöschsysteme, Angebote & $1869-1913$ & 1.387 \\
\hline Feuerlöschtruppe, Aufstellung durch Turner & $1867-1869$ & 1.388 \\
\hline \multirow[t]{3}{*}{ Feuerlöschwesen, Bestrafung von Bediensteten } & 1887-1907 & 1.393 \\
\hline & 1876-1896 & 1.395 \\
\hline & $1867-1907$ & 1.399 \\
\hline \multirow[t]{3}{*}{ Feuerlöschwesen, Entlassungsgesuche von Bediensteten } & $1868-1869$ & 1.391 \\
\hline & $1870-1886$ & 1.392 \\
\hline & 1887-1907 & 1.393 \\
\hline Feuerlöschwesen, Mängel & 1867-1907 & 1.399 \\
\hline Feuerlöschwesen, Organisation & 1886-1905 & 1.251 \\
\hline Feuerlöschwesen, Verbesserung & 1896-1897 & 1.354 \\
\hline \multirow[t]{3}{*}{ Feuerlöschwesen, Vereidigung der Bediensteten } & $1868-1869$ & 1.391 \\
\hline & $1870-1886$ & 1.392 \\
\hline & 1887-1907 & 1.393 \\
\hline Feuerlöschwesen, Verpflichtung zum Dienst & $1868-1869$ & 1.391 \\
\hline Feuerschadenversicherung, Deckung im Großschadensfall & $1867-1893$ & 1.287 \\
\hline Feuerschaden-Versicherungs-Gesellschaften, Vereinigung & $1867-1893$ & 1.287 \\
\hline Feuerschiff "Borkumriff" & 1910 & 2.326 \\
\hline Feuerschutz- und Feuerrettungswesen, Ausstellung & $1900-1901$ & 1.266 \\
\hline Feuerschutzbestimmungen, Schaufensterbeleuchtung & 1906 & 1.272 \\
\hline \multirow[t]{2}{*}{ Feuerstellen, Anzeigen wegen Gefahr } & $1872-1878$ & 1.212 \\
\hline & $1879-1907$ & 1.213 \\
\hline Feuerungsanlagen, Mängel & $1877-1883$ & 1.259 \\
\hline Feuerungsanlagen, Revision & $1877-1883$ & 1.259 \\
\hline Feuerversicherung für Städte und Flecken, Aufnahme Borkums & $1891-1908$ & 1.288 \\
\hline Feuerversicherung, Änderungen & 1904-1905 & 1.273 \\
\hline Feuerversicherung, Änderungsmeldungen & 1907-1909 & 1.292 \\
\hline \multirow[t]{2}{*}{ Feuerversicherung, Aufnahme } & $1907-1911$ & 1.291 \\
\hline & $1907-1909$ & 1.292 \\
\hline Feuerversicherung, Aufnahmen & 1904-1907 & 1.289 \\
\hline Feuerversicherung, Besitzänderung bei Immobilien & 1904-1905 & 1.273 \\
\hline Feuerversicherung, Druckschriften & $1904-1906$ & 1.290 \\
\hline Feuerversicherung, Emder Häuser & 1906 & 1.272 \\
\hline
\end{tabular}


Index

\begin{tabular}{|c|c|c|}
\hline \multicolumn{3}{|l|}{ SACH } \\
\hline Indexbegriff & Laufzeit & Lfd.Nr. \\
\hline Feuerversicherung, Emder Häuser & 1904-1905 & 1.273 \\
\hline Feuerversicherung, Gebäude der Landesbehörden & $1868-1915$ & 1.286 \\
\hline \multirow[t]{9}{*}{ Feuerversicherung, Neuaufnahmen } & 1904-1905 & 1.273 \\
\hline & $1866-1876$ & 1.275 \\
\hline & $1877-1913$ & 1.276 \\
\hline & 1875-1879 & 1.277 \\
\hline & $1879-1884$ & 1.278 \\
\hline & 1885-1892 & 1.279 \\
\hline & 1893-1895 & 1.280 \\
\hline & $1896-1898$ & 1.281 \\
\hline & 1899-1903 & 1.282 \\
\hline Feuerversicherung, Nordseewerke & $1866-1876$ & 1.274 \\
\hline Feuerversicherung, Statuten & $1891-1908$ & 1.288 \\
\hline \multirow[t]{2}{*}{ Feuerversicherung, Versicherungsbeiträge } & $1866-1876$ & 1.275 \\
\hline & $1877-1913$ & 1.276 \\
\hline \multirow[t]{3}{*}{ Feuerversicherungen, Vereinigung } & $1891-1908$ & 1.288 \\
\hline & 1904-1907 & 1.289 \\
\hline & 1904-1906 & 1.290 \\
\hline Feuerversicherungsbeiträge, Festsetzung & 1904-1905 & 1.273 \\
\hline Feuerversicherungsdaten, Geheimhaltung & $1910-1918$ & 1.670 \\
\hline Feuerversicherungswert, Anlagen der Nordseewerke & $1866-1876$ & 1.274 \\
\hline \multirow[t]{14}{*}{ Feuerversicherungswert, Feststellung } & 1906 & 1.272 \\
\hline & 1904-1905 & 1.273 \\
\hline & $1875-1879$ & 1.277 \\
\hline & 1879-1884 & 1.278 \\
\hline & $1885-1892$ & 1.279 \\
\hline & 1893-1895 & 1.280 \\
\hline & $1896-1898$ & 1.281 \\
\hline & $1899-1903$ & 1.282 \\
\hline & 1866-1908 & 1.283 \\
\hline & $1867-1893$ & 1.287 \\
\hline & 1904-1907 & 1.289 \\
\hline & $1907-1911$ & 1.291 \\
\hline & 1875 & 1.295 \\
\hline & 1874-1875 & 1.296 \\
\hline Feuerwarnorganisation, Emder Rathaus & 1869-1913 & 1.387 \\
\hline Feuerwehr, Abzeichen & 1901 & 1.390 \\
\hline Feuerwehr, Ausbau der freiwilligen & 1867-1909 & 1.397 \\
\hline Feuerwehr, Ausstattung & $1867-1869$ & 1.388 \\
\hline Feuerwehr, Einsatz bei Großbränden in Petkum und Uphusen & 1907-1914 & 1.389 \\
\hline Feuerwehr, Rechnungsprüfung & $1866-1891$ & 1.394 \\
\hline Feuerwehr, Uniform & 1901 & 1.390 \\
\hline Feuerwehrangehörige, Vergütungen & $1866-1891$ & 1.394 \\
\hline Feuerwehren, Tätigkeitsstatistik & $1907-1914$ & 1.389 \\
\hline Feuerwehrkraftwagen, Angebot & 1868-1911 & 1.396 \\
\hline Feuerwehrmitglied, Mitführen eines Zierbeils mit Cognac & 1907-1914 & 1.389 \\
\hline Feuerwehrmitglieder, Einzeichnung & 1867-1869 & 1.388 \\
\hline Feuerwehr-Spritzen, Bedienungen & $1882-1904$ & 1.384 \\
\hline Feuerwehrverbandstage, Unterstützung für Emder Delegation & 1907-1914 & 1.389 \\
\hline Feuerwehrwesen, Organisationserlasse & $1907-1914$ & 1.389 \\
\hline Filialbetriebe, Besteuerung & 1907-1914 & 2.910 \\
\hline Filial-Gewerbesteuer, Einführung & $1907-1914$ & 2.910 \\
\hline Finanz-Commission, Verhandlungen & 1888-1889 & 2.996 \\
\hline Firmen- und Geschäftsschilder, Gestaltungsrichtlinien & $1866-1913$ & 832 \\
\hline Firmen, Geschäftsberichte & 1911-1918 & 1.901 \\
\hline Firmenschild, Recognitions-Gebühr & 1866-1902 & 828 \\
\hline Firmenschilder, Beeinträchtigung der Straßenlaternen & 1901-1912 & 840 \\
\hline Firmenschilder, Unvorschriftmäßige & $1866-1913$ & 832 \\
\hline
\end{tabular}


Index

\begin{tabular}{|c|c|c|}
\hline \multicolumn{3}{|c|}{ SACH } \\
\hline Indexbegriff & Laufzeit & Lfd.Nr. \\
\hline Fisch- und Kartoffelstigt, Anlage & $1869-1901$ & 1.159 \\
\hline Fischerboot, Antrag auf Beschaffungsbeihilfe & 1911-1912 & 821 \\
\hline Fischerei, Verpachtung & 1866-1892 & 818 \\
\hline Fischereifahrzeuge, Beleuchtungsregelung & $1880-1912$ & 1.405 \\
\hline Fischereigerechtigkeit, Einschränkung in Wolthusen & $1880-1913$ & 254 \\
\hline Fischereistatistik, Erstattung & $1871-1887$ & 1.406 \\
\hline Fischgründe, Verlust durch Industriebauten & $1911-1912$ & 821 \\
\hline Fischlieferungen, Angebote & $1911-1913$ & 479 \\
\hline Fischmarkt, Gründung einer Handelsgesellschaft & 1914-1918 & 3.232 \\
\hline Fischräuchereien, Konzessionierungspflicht & $1873-1909$ & 2.182 \\
\hline Fischversorgung, Organisierung von Emden & $1914-1918$ & 3.232 \\
\hline Flächenbrand, Presseberichte & 1896-1897 & 1.354 \\
\hline Flagge, Recht zur Führung des Eisernen Kreuzes & 1903 & 1.573 \\
\hline Flaschenwein, Kontrolle & $1909-1911$ & 743 \\
\hline Flecktyphus, Ausbruch in Russland & 1872-1899 & 778 \\
\hline Fleischauktionen, Abhaltung an der städtischen Waage & $1883-1902$ & 1.909 \\
\hline Fleischbeschau, Gesetz & $1900-1915$ & 752 \\
\hline Fleischbeschau, Organisation & $1895-1910$ & 747 \\
\hline Fleischbeschau, Umsetzung des Gesetzes & $1900-1915$ & 752 \\
\hline Fleischbeschaubezirke, Festlegung & $1895-1910$ & 747 \\
\hline Fleischbeschauer, Bestellung & $1895-1910$ & 747 \\
\hline Fleischbeschauer, Eignung der Bewerber & $1865-1895$ & 746 \\
\hline Fleischbeschauer, Instruktionen & $1865-1895$ & 746 \\
\hline Fleischbeschauer, Stellenausschreibung & $1865-1895$ & 746 \\
\hline Fleischbeschauer, Vereidigung & 1865-1895 & 746 \\
\hline Fleischbeschaugebühren, Festlegung & $1865-1895$ & 746 \\
\hline Fleischbeschaugebühren, Gebührensätze & $1900-1915$ & 752 \\
\hline Fleischbeschauordnung, Stadt Emden & 1865-1895 & 746 \\
\hline Fleischbewirtschaftung & $1915-1916$ & 3.309 \\
\hline Fleischdauerware, Einlagerung & $1915-1916$ & 3.309 \\
\hline Fleischeinfuhren, Vorschriften & 1878 & 745 \\
\hline Fleischerlehrlinge, Unterricht & 1912 & 2.357 \\
\hline Fleischimporte, Angebot aus Argentinien & $1911-1913$ & 479 \\
\hline Fleischkarte, Einführung & 1914-1918 & 3.245 \\
\hline Fleischpreise, Erhebung & 1911-1913 & 479 \\
\hline Fleischpreise, Feststellung & $1913-1915$ & 2.153 \\
\hline \multirow{2}{*}{ Fleischpreise, Mitteilung } & $1901-1916$ & 1.902 \\
\hline & 1901-1909 & 1.903 \\
\hline Fleischsteuer, Aufhebungsdiskussion & 1879-1909 & 2.915 \\
\hline Fleischverteilung, Jüdische Schlachtereien & $1915-1916$ & 3.309 \\
\hline Flottenstärken, Plakat d. Deutschen Flottenvereins & $1898-1914$ & 638 \\
\hline Flottenverein, Förderung & $1898-1914$ & 638 \\
\hline Flottenverein, Vortragsreihe & $1898-1914$ & 638 \\
\hline \multirow[t]{4}{*}{ Fluchtlinie, Sicherung } & $1873-1897$ & 2.549 \\
\hline & $1902-1903$ & 2.577 \\
\hline & 1901-1904 & 2.578 \\
\hline & $1902-1903$ & 2.581 \\
\hline Fluchtlinie, Vermessung & $1885-1886$ & 2.531 \\
\hline Flugplätze, Initiative des Deutschen Luftflottenvereins & $1912-1915$ & 714 \\
\hline Flugschriften, Vertrieb religiöser & $1904-1913$ & 2.899 \\
\hline Flugspende, Abschlusskundgebung & 1912 & 2.099 \\
\hline Flugspende, Zusagen & 1912 & 2.099 \\
\hline Flugwesen, Förderung durch Spendenaktion & 1912 & 2.098 \\
\hline Flussdampfer "Wilhelm I" & $1880-1912$ & 1.405 \\
\hline Flussschiffe, Desinfektion & $1912-1914$ & 1.420 \\
\hline Flussschiffe, Meldepflicht von Unfällen & 1882 & 1.411 \\
\hline Fortbildungsschule für das weibliche Geschlecht, Aufbau & $1872-1915$ & 3.855 \\
\hline Fotografien, Angebote & $1867-1901$ & 310 \\
\hline
\end{tabular}


Index

\begin{tabular}{|c|c|c|}
\hline \multicolumn{3}{|l|}{ SACH } \\
\hline Indexbegriff & Laufzeit & Lfd.Nr. \\
\hline Frachtdampfer "Amisia" & 1904 & 2.284 \\
\hline Frachtdampfer-Gesellschaft, GRündung & 1906-1909 & 2.090 \\
\hline Frachterverbindung, Emden nach Ostafrika & $1905-1907$ & 2.083 \\
\hline Frachtschiffslinie, Emden nach Hamburg & $1900-1901$ & 2.058 \\
\hline Frachttarif, Ermäßigung für Emder Gemüsebauern & $1881-1885$ & 2.014 \\
\hline Frachttarife, Ems & $1889-1912$ & 2.120 \\
\hline Franzosenkraut & $1898-1914$ & 817 \\
\hline Frauenheim, Schenkungen & $1871-1918$ & 3.388 \\
\hline Frauenverdienstkreuz in Gold, Verleihungsantrag & $1909-1913$ & 261 \\
\hline \multirow[t]{2}{*}{ Frauenverein } & $1861-1903$ & 577 \\
\hline & $1904-1915$ & 578 \\
\hline Freibadöffnung, Eintrittsgebühr & $1876-1892$ & 736 \\
\hline Freihandel, Agitation & $1879-1894$ & 2.890 \\
\hline Freiheitskriege, Jahrhundertfeier in Breslau & $1910-1913$ & 1.907 \\
\hline Freimaurerloge, Deponierung von Dokumenten u. Wertpapieren & $1879-1892$ & 619 \\
\hline Freimaurerloge, Hauserwerb & $1879-1892$ & 619 \\
\hline Freimaurerloge, Vorstand & $1879-1892$ & 619 \\
\hline Freitreppe, Beseitigung & $1872-1895$ & 985 \\
\hline Fremdelingen Armen Diaconie, Rechnungsprüfung & $1867-1891$ & 1.751 \\
\hline Fremdenverkehr, Verein zur Förderung in Emden & $1905-1911$ & 673 \\
\hline Friedhof, Missbrauch durch Schweineauftrieb & $1824-1920$ & 433 \\
\hline Friedhof, Regulativ der lutherischen Gemeinde & $1878-1904$ & 3.450 \\
\hline Friedhof, Schließung & 1901 & 3.401 \\
\hline Friedhofskasse, Kalkulation & $1894-1897$ & 3.462 \\
\hline Friedhofskasse, Rechnungsabnahme & $1898-1901$ & 3.437 \\
\hline Friedhofsordnung, Reformierte Gemeinde & $1891-1896$ & 3.395 \\
\hline Friedhofsregulativ, Deutsch-reformierte Kirchengemeinde & 1871 & 1.633 \\
\hline Friedhofsstatut, Lutherische Gemeinde & $1878-1904$ & 3.450 \\
\hline Frischgemüseanbau, Förderung & $1914-1916$ & 3.200 \\
\hline Fronterlebnisse, Magistratsmitglieder & $1914-1915$ & 9 \\
\hline Früchteeis, Vertrieb & $1904-1913$ & 2.899 \\
\hline Fuhrleute, Geldstrafen & $1866-1888$ & 1.929 \\
\hline Fuhrlohn, Streit & $1866-1913$ & 1.930 \\
\hline Fuhrmann, Zulassung & $1880-1894$ & 1.943 \\
\hline Fuhrmannschaft, Erwerb & $1880-1894$ & 1.928 \\
\hline Fuhrmannschaften, Besitzer & $1866-1913$ & 1.930 \\
\hline Fuhrmannschaften, Hypothekarisierung & $1866-1913$ & 1.930 \\
\hline Fuhrmannsgilde, Aufnahmeanträge & $1880-1894$ & 1.928 \\
\hline Fuhrmannsgilde, Monopol & $1866-1913$ & 1.930 \\
\hline Fuhrmannsgilde, Tätigkeitsfeld & $1866-1913$ & 1.930 \\
\hline Fuhrmannsstelle, Kauf & $1880-1894$ & 1.943 \\
\hline Fuhrmannsstellen, Besetzung & $1880-1894$ & 1.943 \\
\hline Fuhrmannswesen, Kommissar & $1866-1913$ & 1.930 \\
\hline Fuhrmannswesen, Verfügungen des Regierungspräsidenten & $1866-1913$ & 1.930 \\
\hline Fuhrtaxen, Festlegung & $1866-1913$ & 1.930 \\
\hline Führungszeugnis, Jacobus Dinkela & 1902 & 345 \\
\hline Fuhrunternehmer, Liquiditätsproblem & $1878-1899$ & 876 \\
\hline Fuhrwerke, Durchgehende & $1901-1912$ & 840 \\
\hline Fuhrwerke, Kennzeichnungspflicht & $1866-1913$ & 1.930 \\
\hline Fuhrwerke, Radnormen & $1879-1897$ & 2.019 \\
\hline Fuhrwerke, Sicherheitseinrichtungen & $1866-1913$ & 1.930 \\
\hline Fuhrwerke, Unerlaubtes Abstellen & $1897-1914$ & 838 \\
\hline Fuhrwerke, Zerstörungen & $1868-1883$ & 835 \\
\hline Fuhrwerk-Pferd, Schäden durch Durchgehen & $1897-1914$ & 838 \\
\hline Fuhrwesen, Erhebung & $1870-1914$ & 1.163 \\
\hline Fürsorgeanstalt, Einweisung & 1918 & 1.888 \\
\hline Fürsorgeerziehungsverfahren, Friedrich Tönjes & 1917 & 1.889 \\
\hline Fußballplatz, Einräumung & $1910-1911$ & 700 \\
\hline
\end{tabular}


Index

SACH

Indexbegriff
Fußballplatz, Einräumung

Laufzeit

Lfd.Nr.

Fußballsport, Werbung

1908-1913

$1908-1913$

701

Fußbodenpräparat, Anschaffung zur Staubbindung

$1871-1914$

701

Fußweg, Anlage

1878-1879

757

1877-1881

974

Fußweg, Anlegung

$1880-1881$

975

Fußweg, Ausbau zur Haltestelle Larrelter Str.

Fußweg, Bau

$1882-1908$

1.177

Fußweg, Beschädigung durch Fuhrwerke

Fußweg, Finanzierung

Fußweg, Lagerung von Baumaterial

Fußweg, Mittelbewilligung

Fußweg, Pflasterung

Fußweg, Streit mit Hauseigentümer

1883-1907

976

1875-1909 836

1883-1907 977

1897-1914 838

1880-1881 $\quad 1.177$

1882-1886 976

$1882-1886 \quad 976$

1883-1907 977

1889-1890 978

1890-1893 979

1880-1881 $\quad 1.177$

Fußweg, Unterhaltung

$1885-1911$

1.177
834

Fußweg, Versperrung

Fußwege, Beseitigung von Hindernissen

1882-1884

$1866-1902$

1.178

Fußwege, Blockade

Fußwege, Blockade und Enge

Fußwegebau, Beteiligung der Anlieger

$1901-1912$

828

1878-1909

840

851

Fußweg-Projekt, Planzeichnung

1891-1905

1877-1881

988

Futter, Bewirtschaftung

Futtermittel, Einfuhr

1918

975

1914-1918

3.303

Futtermittel, Marktpreise

1886-1889

3.245

Gamstöcke, Aufstellung

1866-1896

Gang, Abschließung

$1881-1886$

Gang, Benutzung

1867-1893

Gang, Blockade

Gang, Erklärung zur öffentlichen Straße

1899-1904

1899-1904

1904-1906

Gang, Herstellung eines Abflusses (Riele)

Gang, Streit um Reinigung und Unterhaltung

1876-1878

1870

Gang, Unterhaltung

1876-1878

1870

2.151

1876-1878

1.155

1.495

852

852

855

848

Gang, Veräußerung

1893-1897

2.574

Gang, Verbot der Sperrung

1904-1906

855

1899-1904

Garnison, Aufbau in Emden

1908-1912

1866

Garnison, Kirchen

1873-1889

Garnison, Mietsverhältnis

1867-1896

852

3.087

3.322

3.117

Garnison, Pulvermagazin

1908-1913

1.400

Garnison, Schießstand

Garnison, Verlegungsplan

1877-1878

3.134

Gas- und Elektrizitätssteuer 1908

3.084

Gas, Abgabe

Gasanlagen, Prüfung

1897-1914

2.911

1.042

1897-1914

1.042

Gasanschluss, Anträge

1897-1914

1.042

Gasanschlüsse, Herstellung

1897-1912

1.050

Gasanstalten, Betriebssysteme

1895-1912 
Index

\begin{tabular}{|c|c|c|}
\hline \multicolumn{3}{|c|}{ SACH } \\
\hline Indexbegriff & Laufzeit & Lfd.Nr. \\
\hline Gasbeleuchtung, Anschluss & $1867-1897$ & 2.419 \\
\hline Gasbeleuchtung, Auricher Chaussee & 1897-1904 & 1.058 \\
\hline Gasbeleuchtung, Betrieb in Privathäusern & $1881-1897$ & 1.040 \\
\hline Gasbeleuchtung, Einrichtung & $1897-1904$ & 1.058 \\
\hline Gasbeleuchtung, Presseberichte & $1895-1912$ & 1.021 \\
\hline Gaseinrichtungen, Übernahme & $1907-1913$ & 169 \\
\hline Gasexplosion, Haus Kleine Brückstraße & 1902 & 1.367 \\
\hline Gasflammen, Aufstellung über & 1904-1909 & 1.059 \\
\hline Gasgewinnung, Technische Anlagen & 1897-1899 & 1.032 \\
\hline Gaskassierer, Gehaltserhöhung & $1897-1911$ & 1.046 \\
\hline Gaskassierer, Kaution & $1897-1911$ & 1.046 \\
\hline Gaskohle, Angebote & 1897-1912 & 1.045 \\
\hline Gaskohle, Eignung & 1897-1912 & 1.045 \\
\hline Gaskoks, Preisfestlegung & $1897-1914$ & 1.057 \\
\hline Gaslaternen, Angebote & 1895-1912 & 1.021 \\
\hline Gaslaternen, Anschaffung & $1895-1912$ & 1.021 \\
\hline Gaslaternen, Beschädigung & 1900-1907 & 1.022 \\
\hline Gaslaternenanzünder, Lohnanhebung & $1897-1911$ & 1.046 \\
\hline Gasleitung, Anlegung & $1897-1914$ & 1.042 \\
\hline Gasleitung, Beschädigung & $1866-1893$ & 1.041 \\
\hline Gasleitungen und -Anschlüsse, Abnahme und Zulassung & $1881-1897$ & 1.040 \\
\hline Gasleitungen, Ausführung & 1897-1914 & 1.042 \\
\hline Gasleitungen, Beschädigung durch die Kanalisierung & 1885-1886 & 912 \\
\hline Gasleitungen, Hausanschlüsse & 1908-1909 & 1.145 \\
\hline Gasleitungen, Installationsmonopol & 1897-1914 & 1.042 \\
\hline Gasleitungen, Prüfungsvorschriften & $1897-1903$ & 1.139 \\
\hline Gasleitungen, Umverlegung wegen Kanalisierung & $1885-1886$ & 912 \\
\hline \multirow[t]{2}{*}{ Gasleitungen, Unbefugte Veränderungen } & 1897-1914 & 1.042 \\
\hline & 1897-1912 & 1.050 \\
\hline Gasleitungen, Verlegung & 1908-1909 & 1.145 \\
\hline Gasleitungserweiterung, Ausschreibung & 1897-1904 & 1.058 \\
\hline \multirow{2}{*}{ Gasleitungsnetz, Erweiterung } & 1897-1904 & 1.058 \\
\hline & 1904-1909 & 1.059 \\
\hline Gasleitungsnetz, Hafengebiet & 1897-1904 & 1.058 \\
\hline Gasleitungsnetz, Leckstellen & 1899 & 1.053 \\
\hline Gaslichtbeleuchtung, Verbot & $1891-1910$ & 1.136 \\
\hline Gasmeister, Beamtenstatus & 1897-1912 & 1.036 \\
\hline Gasmeister, Bewerbungen & 1897-1912 & 1.036 \\
\hline Gasmeister, Dienstanweisung & 1897-1912 & 1.036 \\
\hline Gasnetz, Anschluss Arbeiterhäuser & 1904-1909 & 1.059 \\
\hline Gasnetz, Prüfung & 1899 & 1.053 \\
\hline Gasrechnungen, Beitreibung offenstehender & $1866-1874$ & 1.039 \\
\hline Gasrechnungen, Rückstände & $1897-1914$ & 1.042 \\
\hline Gasrohre, Angebote & 1897-1904 & 1.058 \\
\hline \multirow{2}{*}{ Gasrohre, Verlegung } & $1881-1883$ & 1.028 \\
\hline & 1904-1909 & 1.059 \\
\hline Gasrohrverlegungsarbeiten, Arbeiten & 1897-1904 & 1.058 \\
\hline Gasrohrverlegungsarbeiten, Bedingungen & 1897-1904 & 1.058 \\
\hline Gassenkot, Verkauf & 1867-1906 & 865 \\
\hline Gast- und Schankwirtschaften, Aufstellung & 1867-1909 & 529 \\
\hline Gast- und Schankwirtschaften, Beschränkung & 1867-1909 & 529 \\
\hline Gast- und Schankwirtschaften, Polizeiliche Aufsicht & 1867-1909 & 529 \\
\hline Gastarife, Anfrage & 1906 & 1.077 \\
\hline Gasthaus, Anleihescheine & $1880-1904$ & 1.728 \\
\hline Gasthaus, Antike Möbel & 1877-1885 & 1.724 \\
\hline Gasthaus, Auflösungsdiskussion & 1913-1914 & 1.732 \\
\hline Gasthaus, Dampfkochkessel & 1877-1885 & 1.724 \\
\hline Gasthaus, Dienstordnung für Schullehrer & 1869 & 1.710 \\
\hline
\end{tabular}


Index

\begin{tabular}{|c|c|c|}
\hline \multicolumn{3}{|l|}{ SACH } \\
\hline Indexbegriff & Laufzeit & Lfd.Nr. \\
\hline Gasthaus, Diskussion der Auflösung & $1912-1918$ & 1.712 \\
\hline Gasthaus, Einweisung von Waisen & 1916-1918 & 1.885 \\
\hline Gasthaus, Gemälderestaurierung & $1877-1885$ & 1.724 \\
\hline Gasthaus, Gemäldeverkauf & $1877-1885$ & 1.724 \\
\hline Gasthaus, Hilfslehrer & $1869-1910$ & 1.716 \\
\hline Gasthaus, Kirchenabgaben auf Land in Hinte & $1902-1907$ & 1.719 \\
\hline Gasthaus, Kustos zur Kinderbeaufsichtigung & 1869 & 1.710 \\
\hline Gasthaus, Ländereien & $1876-1887$ & 3.424 \\
\hline Gasthaus, Landverwaltung & 1871-1872 & 1.717 \\
\hline Gasthaus, Lehrergehalt & 1869 & 1.710 \\
\hline Gasthaus, Pflegemutter & $1869-1910$ & 1.716 \\
\hline \multirow[t]{2}{*}{ Gasthaus, Sargmonopol } & $1868-1871$ & 1.711 \\
\hline & 1873 & 1.718 \\
\hline Gasthaus, Schule & 1869 & 1.710 \\
\hline Gasthaus, Statistiken & $1873-1912$ & 1.723 \\
\hline Gasthaus, Stiftung der Gertruda Stein & 1880-1904 & 1.728 \\
\hline Gasthaus, Turnraum & 1879-1909 & 1.727 \\
\hline Gasthaus, Untergebrachte mittellose Personen & $1866-1871$ & 1.709 \\
\hline Gasthaus, Verkauf von Betten und Bettwäsche & $1877-1885$ & 1.724 \\
\hline Gasthaus, Verkauf von Grundstücken & 1873-1906 & 1.721 \\
\hline Gasthaus, Vermessung von GRundstücken & 1873-1906 & 1.721 \\
\hline \multirow[t]{2}{*}{ Gasthaus, Vermietung seiner Häuser } & 1878-1904 & 1.729 \\
\hline & 1893-1909 & 1.730 \\
\hline Gasthaus, Vermittlung von schulentlassenen Waisen in Lehre & 1913-1915 & 1.872 \\
\hline \multirow[t]{2}{*}{ Gasthaus, Verwaltung } & $1871-1915$ & 3.423 \\
\hline & 1876-1887 & 3.424 \\
\hline Gasthaus, Waisen & 1913-1914 & 1.732 \\
\hline Gasthaus, Waisenabteilung & $1912-1918$ & 1.712 \\
\hline Gasthaus-Akten, Abgabe & 1857-1908 & 313 \\
\hline Gasthaus-Direktion, Ankauf von Immobilien & 1871-1872 & 1.714 \\
\hline Gasthaus-Direktion, Besetzung & 1913-1914 & 1.732 \\
\hline Gasthaus-Direktion, Mitglieder & $1872-1918$ & 1.713 \\
\hline Gasthaus-Direktion, Prozessführungsermächtigung & 1875 & 1.722 \\
\hline Gasthaus-Direktion, Rechnungsprüfung & 1873-1912 & 1.723 \\
\hline Gasthaus-Direktion, Vereidigung & $1872-1918$ & 1.713 \\
\hline Gasthaus-Direktion, Wahl & $1872-1918$ & 1.713 \\
\hline Gasthaus-Inspektor, Antisemitische Äußerungen & $1869-1910$ & 1.716 \\
\hline Gasthaus-Inspektor, Einstellung & $1869-1910$ & 1.716 \\
\hline Gasthaus-Inspektor, Gehalt & $1869-1910$ & 1.716 \\
\hline Gasthaus-Inspektor, Instruktionen & $1869-1910$ & 1.716 \\
\hline Gasthaus-Inspektor, Vertretung & 1917-1918 & 1.780 \\
\hline Gasthaus-Inspektor, Weiterbildung & $1869-1910$ & 1.716 \\
\hline Gasthaus-Inspektor, Witwenunterstützung & $1869-1910$ & 1.716 \\
\hline Gasthauskirche, Ablösungen & $1876-1891$ & 3.426 \\
\hline Gasthauskirche, Bauunterhaltung & $1871-1876$ & 3.409 \\
\hline \multirow[t]{2}{*}{ Gasthauskirche, Etat } & $1876-1887$ & 3.424 \\
\hline & $1876-1891$ & 3.426 \\
\hline Gasthauskirche, Feuerversicherung & $1876-1891$ & 3.426 \\
\hline Gasthauskirche, Gottesdienstnutzung & $1876-1891$ & 3.426 \\
\hline Gasthauskirche, Heizungsanlage & $1876-1891$ & 3.426 \\
\hline Gasthauskirche, Inventar & $1876-1887$ & 3.424 \\
\hline Gasthauskirche, Kostenträgerschaft & $1876-1891$ & 3.426 \\
\hline Gasthauskirche, Kronleuchterrestaurierung & $1876-1891$ & 3.426 \\
\hline Gasthauskirche, Organisten- und Vorsängerdienst & $1887-1913$ & 3.427 \\
\hline Gasthauskirche, Orgelrestaurierung & 1876-1887 & 3.424 \\
\hline Gasthauskirche, Rechtsanspruch der Reformierten & $1871-1876$ & 3.409 \\
\hline Gasthauskirche, Restaurierungsbedürftigkeit & $1876-1891$ & 3.426 \\
\hline Gasthauskirche, Sanierungsarbeiten & $1872-1875$ & 1.715 \\
\hline
\end{tabular}


Index

SACH

\begin{tabular}{l} 
Indexbegriff \\
\hline Gasthauskirche, Sitzplätze der städtischen Kollegien \\
Gasthauskirche, Sitzstellen \\
Gasthauskirche, Sitzstellenvermietung
\end{tabular}

Gasthauskirche, Stuhl des Magistrats und der Bürgervorsteher Gasthauskirche, Sturmschäden Gasthauskirche, Unterhaltung Gasthausländereien, Pächter Gasthausländereien, Verpachtung

Gasthausländereien, Verpachtung an die Emdener Papierfabrik Gasthausschule, Abschlussarbeiten Gasthausschule, Auflösungsdiskussion Gasthausschule, Aufseher Gasthausschule, Handwerklicher Unterricht Gasthausschule, Lokalschulinspektor Gasthausschule, Revision Gasthausschule, Umorganisation Gasthausschule, Verhältnisse Gasthausschullehrer, Instruktion Gasthausstiftungen Gasthausunterbringung, Kostenträgerermittlung Gasthausvermögen, Rechnungsführung Gasthausverwaltung, Rechte Gastschulgeld, Katholische Schüler aus Wolthusen Gaststätte, Protest gegen Zulassung Gaststätten, Alkoholfreie Gaststätten, Beleuchtungsvorschriften Gaststättengewerbe, Arbeitsbedingungen Gaststätten-Konzessionen, Einflusswunsch des Wirtevereins Gasuhr, Manipulationsbestrafung Gasuhren, Installation

Gasuhren, Manipulationsverbot

Gasversorgung, Mainz

Gaswerk, Anlage zur Herstellung von Ammoniumsulfat Gaswerk, Anlegung von Ammuniomsulfatanlage Gaswerk, Anleihe Gaswerk, Anschaffungen Gaswerk, Arbeiteraufenthaltsraum Gaswerk, Arbeitsordnung Gaswerk, Ausbau Gaswerk, Ausbaufinanzierung Gaswerk, Belästigung Gaswerk, Betriebsergebnisse Gaswerk, Betriebsergewinnverteilung

Gaswerk, Bewachung Gaswerk, Bilanz

Gaswerk, Bilanzen

Gaswerk, Brand

Gaswerk, Darlehen der Stadtkasse

Gaswerk, Erweiterung

Gaswerk, Erweiterungsbauten

Gaswerk, Etat

Laufzeit

Lfd.Nr.

1902

1879-1913

1876-1887

1876-1891

1874-1884

1876-1891

1912-1918

1878-1904

1878-1904

1893-1909

1882-1904

1897-1898

1913-1914

1885-1900

1878-1912

$1878-1912$

$1885-1900$

1885-1900

1913-1914

1885-1900

1879-1909

1915

1880-1904

1871-1915

1908-1909

1902

1867-1909

1867-1909

1867-1909

1904-1915

1866-1893

1881-1897

1897-1914

1886-1909

1899-1906

1897-1905

1914

1899-1912

1900-1909

1897-1911

1905-1909

1896-1904

1905-1909

1897-1905

1905-1912

1912-1913

1914-1916

1897-1912

1898-1904

1905-1912

1912-1913

1897-1914

1866-1893

1898-1903

1895-1898

1906-1909

1905-1913

1897-1905

3.428

3.430

3.424

3.426

1.720

3.426

1.712

1.729

1.729

1.730

1.731

3.621

1.732

1.726

1.725

1.725

1.726

1.726

1.732

1.726

1.727

1.883

1.728

3.423

227

551

529

529

529

667

1.041

1.040

1.042

1.019

1.072

1.047

1.025

1.069

1.034

1.046

1.073

3.003

1.073

1.047

1.055

1.056

3.152

1.050

1.054

1.055

1.056

1.057

1.041

1.035

1.031

1.075

1.076

1.047 
Index

\begin{tabular}{|c|c|c|}
\hline \multicolumn{3}{|c|}{ SACH } \\
\hline Indexbegriff & Laufzeit & Lfd.Nr. \\
\hline \multirow[t]{2}{*}{ Gaswerk, Etat } & $1904-1914$ & 1.048 \\
\hline & $1897-1914$ & 1.057 \\
\hline Gaswerk, Feuerversicherung & $1897-1908$ & 1.060 \\
\hline Gaswerk, Gebäuderenovierungsfinanzierung & $1897-1914$ & 1.057 \\
\hline Gaswerk, Geruchsbelästigung und Verschmutzungen & $1913-1914$ & 1.080 \\
\hline Gaswerk, Gewerbesteuer & $1897-1914$ & 1.057 \\
\hline Gaswerk, Gewinnabführung & $1897-1914$ & 1.057 \\
\hline Gaswerk, Gutachten zur Strukturverbesserung & 1896 & 1.026 \\
\hline Gaswerk, Haftpflichtversicherung & $1897-1913$ & 1.070 \\
\hline Gaswerk, Handwerkerarbeiten & 1913 & 1.081 \\
\hline Gaswerk, Kassenrevision & $1897-1914$ & 1.057 \\
\hline Gaswerk, Kohlenbrechmaschine & $1898-1902$ & 1.033 \\
\hline Gaswerk, Kohlenkauf & $1897-1912$ & 1.045 \\
\hline Gaswerk, Kohlenlagerplatz & $1900-1909$ & 1.034 \\
\hline Gaswerk, Kohleschuppen & $1900-1909$ & 1.034 \\
\hline Gaswerk, Lieferung von Badeöfen & $1913-1914$ & 1.080 \\
\hline Gaswerk, Lieferung von Koks & $1899-1912$ & 1.069 \\
\hline Gaswerk, Mängel & $1896-1897$ & 1.030 \\
\hline Gaswerk, Mitgliedschaft in Vereinen und Verbänden & $1897-1913$ & 1.070 \\
\hline Gaswerk, Monatsstatistik & $1898-1900$ & 1.049 \\
\hline Gaswerk, Ofenanlage & $1897-1899$ & 1.032 \\
\hline Gaswerk, Ofenanlagenerweiterung & $1898-1903$ & 1.035 \\
\hline Gaswerk, Ofenausstattung & $1898-1903$ & 1.035 \\
\hline Gaswerk, Pachtverhältnis & $1880-1881$ & 1.027 \\
\hline Gaswerk, Personal & $1897-1912$ & 1.036 \\
\hline Gaswerk, Produktionsstatistik & $1905-1909$ & 1.073 \\
\hline Gaswerk, Prozessführungsberechtigung & $1910-1914$ & 1.078 \\
\hline Gaswerk, Rechnungsabschluss & $1897-1914$ & 1.057 \\
\hline Gaswerk, Revision & $1903-1909$ & 1.071 \\
\hline Gaswerk, Schiedsgericht & $1866-1893$ & 1.041 \\
\hline Gaswerk, Spezialetat wegen Erweiterung und Umbau & 1897-1905 & 1.047 \\
\hline Gaswerk, Tarife & $1897-1912$ & 1.050 \\
\hline Gaswerk, Technische Angestellte & $1897-1912$ & 1.036 \\
\hline Gaswerk, Technische Ausstattung & $1895-1898$ & 1.031 \\
\hline Gaswerk, Übernahme durch die Stadt Emden & $1880-1881$ & 1.027 \\
\hline Gaswerk, Umbau & 1897-1899 & 1.032 \\
\hline Gaswerk, Verkauf von Teer und Asche & $1897-1914$ & 1.042 \\
\hline Gaswerk, Verordnungen zum Betrieb & $1897-1912$ & 1.050 \\
\hline Gaswerk, Verpachtung & $1896-1897$ & 1.029 \\
\hline Gaswerk, Verpachtungsaufhebung & 1896-1897 & 1.030 \\
\hline Gaswerk, Verwaltungsordnung & $1897-1912$ & 1.050 \\
\hline Gaswerk, Werkswohnung & $1900-1909$ & 1.034 \\
\hline Gaswerk, Zahlungsverkehr & $1897-1914$ & 1.057 \\
\hline Gaswerke, Betriebsvergleiche & $1886-1909$ & 1.019 \\
\hline Gaswerke, Presseartikel & $1895-1912$ & 1.021 \\
\hline Gaswerksanlagen, Prospekt & $1880-1881$ & 1.027 \\
\hline Gaswerksarbeiter, Dienstjubiläum & $1897-1911$ & 1.046 \\
\hline Gaswerksbuchhalter, Antrag auf Beamtenstatus & $1897-1912$ & 1.036 \\
\hline Gaswerksbuchhalter, Gehaltserhöhung & $1897-1911$ & 1.046 \\
\hline Gaswerksdirektor, Bewerbung & $1880-1881$ & 1.027 \\
\hline Gaswerksdirektor, Bewerbungen & $1904-1911$ & 1.052 \\
\hline Gaswerksdirektor, Dienstanweisung & 1896-1908 & 1.051 \\
\hline Gaswerksdirektor, Kaution & $1896-1908$ & 1.051 \\
\hline Gaswerksdirektor, Pensionierungsantrag & 1896-1908 & 1.051 \\
\hline Gaswerksdirektor, Todesanzeige & 1896-1908 & 1.051 \\
\hline Gaswerksdirektor, Übernahme im Stadtdienst & 1896-1908 & 1.051 \\
\hline Gaswerksdirektor, Urlaubsgesuch & $1904-1911$ & 1.052 \\
\hline Gaswerksdirektor, Verbeamtung & $1896-1908$ & 1.051 \\
\hline
\end{tabular}


Index

SACH

Indexbegriff
Gaswerksdirektor, Vereidigung

Gaswerkserweiterung, Finanzierung

Gaswerkserweiterung, Genehmigung

Gaswerkserweiterung, Genehmigungsverfahren

Gaswerkserweiterung, Schutz der Anwohner

Gaswerkserweiterung, Umweltbelastung

Gaswerkserweiterung, Widerstand

Gaswerksgelände, Bauten

Gaswerksgelände, Pfortenbenutzung

Gaswerkskommission, Konstituierung

Gaswerkskommission, Mitgliederwahl

Gaswerkskommission, Sitzungen

Gaswerkspächter, Bevollmächtigter

Gebäude, Bauliche Veränderungen

Gebäude, Verkauf

Gebäude, Vermietung städtischer

Gebäudebestand, Nachweisung

Gebäudebestandslisten, Führung

Gebäudesteuer, Befreiung des luth. Schulverbands

Gebäudesteuer, Städtische Wohnhäuser

Gebietsaustausch, Stadt Emden und Gemeinde Larrelt

Gebührenpflicht, Briefträger für die Übersetzung nach Nesserland

Gebührentarif, Dortmund-Ems-Kanal

Geburtshilfe, Ausbildung

Gedenken, 100. Todestag von Friedrich v. Schiller

Gedenktag, Wiederzugehörigkeit Ostfrieslands zu Preußen

Gefangene, Beschäftigung

Gefangenentransporte, Kostenträgerschaft

Gefangenentransporte, Organisation

Gefangenenwärter, Pflichten

Gefängniswärter, Geldstrafe wegen Fahrlässigkeit

Gefängniszellen, Nutzung

Geflügelausstellung, Ehrenpreis der Stadt Emden

Geflügelausstellung, Rauchverbot

Geflügelausstellung, Schanksteuer

Geflügelausstellungen, Auflagen

Geflügelausstellungen, Verlosung

Gefrierfleisch, Angebot aus Australien

Gehaltspfändung, Beantragung

Gehaltszuschuss, Streichung

Geheimer Kommerzienrat, Titelverleihung

Geheimmittel, Verbot als Arznei

Geisteskranke, Übersicht

Geisteskranke, Unterbringung in Gerichtsgefängnisse

Geisteskranke, Unterbringung in Neusandhorst

Geistliche, Alterszulagen

Geistliche, Dienstwohnungen

Geistliche, Festmahle bei Einführung

Geistliche, Gehaitszuschussstreichung

Laufzeit

1896-1908

$1905-1909$

1898-1899

1906-1909

1906-1909

1906-1909

1906-1909

1900-1909

1911

1895-1911

1895-1911

1896-1905

1902-1905

1906-1908

$1909-1912$

1913

1914-1917

1866-1873

1866-1896

$1885-1914$

1867-1876

1878-1901

1881-1909

1881-1909

$1880-1890$

1881-1903

1867-1907

1877-1885

1895-1914

1898-1918

1905

1891

1868-1911

1899-1908

1868-1911

1868-1911

1899-1913

1902-1907

1879-1904

1903-1913

1903-1913

1903-1913

1903-1913

1903-1913

1911-1913

1912-1915

1887-1889

1912-1918

1872-1914

1896

1869-1917

1855-1912

1909-1913

1909-1913

1871-1911

1887-1888
Lfd.Nr.

1.051

1.073

1.043

1.075

1.075

1.075

1.075

1.034

1.079

1.061

1.061

1.062

1.063

1.064

1.065

1.066

1.067

1.037

1.155

2.431

2.415

2.416

1.164

1.164

3.659

2.406

237

440

462

764

568

201

525

527

525

525

523

526

522

800

800

800

800

800

479

347

3.457

263

767

520

524 
Index

\begin{tabular}{|c|c|c|}
\hline \multicolumn{3}{|l|}{ SACH } \\
\hline Indexbegriff & Laufzeit & Lfd.Nr. \\
\hline \multirow[t]{21}{*}{ Geistliche, Gehaitszuschussstreichung } & 1891-1894 & 3.357 \\
\hline & 1891-1892 & 3.358 \\
\hline & 1898 & 3.359 \\
\hline & 1894 & 3.360 \\
\hline & 1895 & 3.361 \\
\hline & 1897 & 3.362 \\
\hline & 1898 & 3.363 \\
\hline & 1894-1905 & 3.364 \\
\hline & 1904 & 3.365 \\
\hline & 1898 & 3.366 \\
\hline & 1890 & 3.367 \\
\hline & $1890-1895$ & 3.368 \\
\hline & 1894 & 3.369 \\
\hline & 1895 & 3.370 \\
\hline & $1891-1898$ & 3.371 \\
\hline & 1898 & 3.372 \\
\hline & 1898 & 3.373 \\
\hline & 1891 & 3.374 \\
\hline & 1891 & 3.375 \\
\hline & 1894-1904 & 3.376 \\
\hline & 1894-1904 & 3.377 \\
\hline Geistliche, Gehaltsbeihilfe & 1869-1891 & 3.438 \\
\hline Geistliche, Gutachterfunktion & $1871-1911$ & 3.320 \\
\hline Geistliche, Qualifikation & 1873-1879 & 3.327 \\
\hline Gelände, Pachtantrag & 1909 & 2.591 \\
\hline Geländestreifen, Abtretung & $1876-1902$ & 2.503 \\
\hline Geländestreifen, Erwerbsantrag & 1878 & 2.496 \\
\hline Geländestreifen, Vererbpachtung & 1873-1888 & 2.484 \\
\hline \multirow[t]{2}{*}{ Geländestreifen, Verpachtung } & $1873-1888$ & 2.484 \\
\hline & $1875-1878$ & 2.506 \\
\hline Gelbfieber, Quarantäne & $1879-1913$ & 775 \\
\hline Gelbfieber-Epidemie, Kuba und Brasilien & $1879-1913$ & 775 \\
\hline Gemälde, Großer Kurfürst & 1894-1895 & 2.657 \\
\hline Gemälde, Schenkung an Stadt Emden & $1866-1907$ & 2.620 \\
\hline \multirow[t]{3}{*}{ Gemeinde Wolthusen, Polizeiliche Angelegenheiten } & $1890-1910$ & 252 \\
\hline & 1906-1912 & 253 \\
\hline & $1880-1913$ & 254 \\
\hline Gemeinde, Etat & 1894-1897 & 3.420 \\
\hline Gemeinde, Fusion & 1894-1897 & 3.420 \\
\hline Gemeindeabgaben, Gesetzentwurf zu & 1877 & 2.937 \\
\hline Gemeindeausschussmitglieder, Vereidigung in Wolthusen & 1906-1912 & 253 \\
\hline Gemeindebesitz, Lutherische Gemeinde & 1898 & 3.477 \\
\hline Gemeindebezirksgrenze, Veränderung & 1892-1899 & 224 \\
\hline Gemeindefonds, Verwaltung & $1881-1884$ & 3.394 \\
\hline Gemeindegrenze, Emden - Wolthusen & 1871-1904 & 228 \\
\hline Gemeindemitgliederverein, Begründung für jüdische Gemeinde & $1910-1913$ & 493 \\
\hline Gemeindeorgane, Vollzähligkeit der Reformierten & $1888-1910$ & 3.397 \\
\hline Gemeindestatut, Reformierte & 1877-1896 & 3.407 \\
\hline Gemeindesteuer, Einführung & 1874-1888 & 3.473 \\
\hline \multirow[t]{2}{*}{ Gemeindesteuer, Streit in Wolthusen } & $1890-1910$ & 252 \\
\hline & 1906-1912 & 253 \\
\hline Gemeinde-Synodalordnung, Ausführung & $1888-1910$ & 3.397 \\
\hline Gemeindeverbände, Landkreis und Stadtkreis Emden & 1887-1912 & 812 \\
\hline Gemeindeverfassung,, Lutheraner & $1866-1897$ & 3.461 \\
\hline Gemeindevermögen, Lutherische Kirche Emden & 1875-1902 & 3.445 \\
\hline Gemeindeversammlung, Fernbleiben von Geladenen in Borssum & 1893 & 249 \\
\hline Gemeindevorsteher, Einspruch gegen Wahl & 1911-1912 & 247 \\
\hline Gemeindevorsteher, Kampagne gegen & $1911-1912$ & 247 \\
\hline
\end{tabular}


Index

$\longrightarrow$ SACH

Indexbegriff
Gemeindevorsteher, Rücktritt

Gemeindevorsteher, Unregelmäßige Rechnungsführung

Gemeindevorsteher, Vorwurf der Unterschlagung

Gemeindevorsteher, Wahl

Gemeindewahl, Annullierung

Gemeindeweg, Ausbau

Gemeindeweg, Emden nach Uphusen

Gemeindewege, Schauungen

Gemeinheitsteilungen, Durchführungserlass

Gemeinheitsteilungen, Öffentliche Lasten

Gemeinheitsteilungs- und Verkoppelungsgesetz, Umsetzung

Gemüsebau, Hebung

Gemüsebauern, Hafersonderzuteilungsantrag

Gemüsebauern, Winterkursus

Gemüsebauschule Gründung in Ostfriesland

Gemüsebauverein, Gründung

Gemüsebauverein, Statuten

Gemüsebauverein, Vorstand

Gemüsefelder, Betretungsverbot

General- und Berufsvormund, Bestellung

Generalkonsuln, Akkreditierung

Generalsuperintendent, Ernennung

Generalsuperintendent, Vertretung

Genickstarre, Bekämpfung

Genickstarre, Todesfall in Emden

Genossenschaftsbankwesen, Erlasse und Verfügungen

Gerichtsassessor, Informatorische Tätigkeit bei Kommune

Gerichtsdiener, Bewerbung

Gerichtsgefängnisse, Nutzung

Gerüstbau, Verstoß gegen Sicherheitsvorschriften

Gerüste, Errichtung an der Straße

Gesangbuch, Einführung in lutherischen Gemeinden

Geschäftsberichte, Eichamt

Geschäftsberichte, Hannover. gemeinn. Ansiedelungsgesellschaft

Geschäftsberichte, Lutherische Klassenschule

Geschäftsführer, Eintellung beim Emder Hafenbetriebsverein

Geschäftsführung, Normen

Geschäftsschilder, Beeinträchtigung der Straßenlaternen

Geschäftsschilder, Regelung der Anbringung

Geschlechtskrankheit, Behandlungskostenträgerschaft

Geschlechtskrankheit, Zwangsbehandlung

Geschlechtskrankheiten, Bekämpfung

Geschworenenlisten, Auslegung

Gesellschaft für dtsch. Erziehungs- u. Schulgeschichte, Statuten

Gesetz- und Verordnungsblatt, Reformierte Kirche

Gesundheitlsverhältnisse, Verbesserung

Gesundheitskommissione, Bildung

Gesundheitszeugnis, Jacobus Dinkela

Getreide, Abgabepflicht

Getreide, Ausdruschmenge

Getreide, Bewirtschaftung

\section{Laufzeit}

1892-1895

1911-1912

1911-1912

1911-1912

1892-1895

1911-1912

1906-1912

$1876-1890$

$1876-1890$

1874-1901

1867-1887

1887-1912

1867-1887

1902-1911

1917-1918

1902-1911

1902-1911

1878-1894

1878-1894

1878-1894

1870-1914

1914-1923

1906-1916

1888-1889

1888-1889

1871-1914

1906

1895-1904

1913

1908-1912

1869-1917

1870-1900

1901-1912

1883

1899-1900

1907-1915

1873-1887

1913-1914

1868-1914

1901-1912

1866-1913

1915-1917

1915-1917

1905-1914

1867-1875

1893-1913

1884

1871-1914

1884-1915

1902

1917-1918

1917-1918

1914-1916

1917-1918

1917-1918

1917-1918

1873-1898

1901-1916
Lfd.Nr.

246

247

247

247

246

247

253

2.040

2.040

2.038

810

812

810

803

3.244

803

803

798

798

798

809

1.704

2.114

3.459

3.459

757

769

1.921

428

365

524

1.161

840

3.454

321

682

3.660

715

329

840

832

1.884

1.884

688

167

633

3.353

757

772

345

3.299

3.300

3.243

3.299

3.300

3.299

2.116

1.902

Getreide, Preise im Großhandel 
Index

\begin{tabular}{|c|c|c|}
\hline \multicolumn{3}{|l|}{$\mathrm{SACH}$} \\
\hline Indexbegriff & Laufzeit & Lfd.Nr. \\
\hline Getreide, Zwischenhandelsverbot & 1917-1918 & 3.299 \\
\hline Getreidehändler, Konflikt mit Kornmrsser & $1869-1911$ & 2.134 \\
\hline Getreidelieferungen, Organisation für das Heer & $1914-1917$ & 3.239 \\
\hline Getreidemakler, Bewerbungen & $1871-1913$ & 419 \\
\hline Getreidemakler, Ernennung & $1871-1913$ & 419 \\
\hline Getreidemakler, Geschäftsschmälerung & $1871-1913$ & 419 \\
\hline Getreidemakler, Journalbuch & $1871-1913$ & 419 \\
\hline Getreidemakler, Vereidigung & $1871-1913$ & 419 \\
\hline Getreidemakler, Vorschlag & $1871-1913$ & 419 \\
\hline Getreidespeicher, Aufbau & $1903-1911$ & 2.079 \\
\hline Getreidespeicher, Finanzierung & $1903-1911$ & 2.079 \\
\hline Getreideversorgungsgebiet, Kreis und Stadt Emden & 1914-1916 & 3.243 \\
\hline Getreidevorräte, Erfassung in Emden & 1914-1916 & 3.243 \\
\hline Getreidezoll, Erhöhung & $1879-1894$ & 2.890 \\
\hline Gewässer, Geruchsbelästigung & 1907-1908 & 953 \\
\hline Gewässer, Verbot der Verunreinigung & $1885-1902$ & 929 \\
\hline \multirow[t]{2}{*}{ Gewässer, Verschlammung } & $1867-1910$ & 1.490 \\
\hline & $1875-1901$ & 1.494 \\
\hline \multirow[t]{3}{*}{ Gewässer, Zuschüttung } & 1885 & 958 \\
\hline & $1867-1896$ & 1.492 \\
\hline & $1867-1893$ & 1.495 \\
\hline Gewässerverschmutzungen, Gesetz zur Verhinderung & $1896-1913$ & 950 \\
\hline Gewehrschäfte, Härtung & $1908-1913$ & 2.642 \\
\hline Gewerbeanlagen, Genehmigung und Überwachung & 1873-1909 & 2.182 \\
\hline Gewerbeanlagen, Genehmigungsverfahren & $1873-1875$ & 2.187 \\
\hline Gewerbeanlagen, Revision & $1892-1910$ & 2.389 \\
\hline Gewerbeanlagen, Zulassung & 1873-1909 & 2.182 \\
\hline Gewerbeausstellung, Ausstellungsbeschicker & $1878-1879$ & 2.125 \\
\hline Gewerbeausstellung, Ausstellungsstücke aus der Rüstkammer & $1878-1879$ & 2.125 \\
\hline Gewerbeausstellung, Finanzierung & $1887-1912$ & 2.127 \\
\hline Gewerbeausstellung, Förderung & $1887-1912$ & 2.127 \\
\hline Gewerbeausstellung, Organisation & $1887-1912$ & 2.127 \\
\hline Gewerbeausstellung, Teilnahme & $1878-1879$ & 2.125 \\
\hline Gewerbeausstellungen, Förderung & $1881-1910$ & 1.906 \\
\hline \multirow[t]{2}{*}{ Gewerbeausstellungen, Material } & $1881-1910$ & 1.906 \\
\hline & $1910-1913$ & 1.907 \\
\hline \multirow[t]{4}{*}{ Gewerbebetriebe, Konzessionierung } & 1902 & 1.939 \\
\hline & 1909 & 1.940 \\
\hline & 1900 & 1.941 \\
\hline & $1892-1893$ & 1.942 \\
\hline Gewerbebetriebe,. Kraftmaschinen und Motore & $1872-1904$ & 2.382 \\
\hline Gewerbeförderung, Preußen & $1881-1910$ & 1.906 \\
\hline Gewerbegebiet, Aufbau am Emder Hafen & $1883-1897$ & 2.010 \\
\hline Gewerbehalle, Beschwerde gegen Geschäftsführer & $1866-1903$ & 1.924 \\
\hline Gewerbehalle, Betrieb & $1866-1903$ & 1.924 \\
\hline Gewerbehalle, Krise & $1866-1903$ & 1.924 \\
\hline Gewerbehalle, Städtische Vertreter im Verwaltungsrat & $1866-1903$ & 1.924 \\
\hline Gewerbehalle, Unwirtschaftlichkeit & $1866-1903$ & 1.924 \\
\hline Gewerbehalle, Verwendung für Schulzwecke & $1866-1903$ & 1.924 \\
\hline Gewerbekammer, Besetzung & $1885-1887$ & 2.113 \\
\hline Gewerbekammer, Einrichtung & $1885-1887$ & 2.113 \\
\hline Gewerbekammer, Jahresbericht & $1885-1887$ & 2.113 \\
\hline Gewerbekammer, Räumlichkeiten & $1885-1887$ & 2.113 \\
\hline Gewerbekammer, Sitzungsprotokoll & $1885-1887$ & 2.113 \\
\hline Gewerbe-Legitimationskarten, Ausfertigung & 1907-1909 & 2.898 \\
\hline Gewerbe-Legitimationskarten, Erteilung & $1866-1901$ & 2.897 \\
\hline Gewerbeordnung, Änderung & $1894-1896$ & 1.931 \\
\hline Gewerbeordnung, Ausführungsbestimmungen & $1906-1913$ & 1.905 \\
\hline
\end{tabular}


Index

\begin{tabular}{|c|c|c|}
\hline \multicolumn{3}{|l|}{ SACH } \\
\hline Indexbegriff & Laufzeit & Lfd.Nr. \\
\hline Gewerbeschulbeitrag, Erhebung & $1909-1918$ & 2.358 \\
\hline Gewerbeschule, Aufgabenverteilung & $1873-1880$ & 2.330 \\
\hline Gewerbeschule, Aufsicht & $1866-1871$ & 2.329 \\
\hline \multirow[t]{3}{*}{ Gewerbeschule, Beihilfen } & 1874-1914 & 2.346 \\
\hline & $1880-1911$ & 2.347 \\
\hline & $1912-1918$ & 2.348 \\
\hline Gewerbeschule, Bibliothek & 1872 & 2.338 \\
\hline Gewerbeschule, Erweiterung & $1873-1880$ & 2.330 \\
\hline \multirow[t]{5}{*}{ Gewerbeschule, Etat } & $1866-1871$ & 2.329 \\
\hline & $1873-1880$ & 2.330 \\
\hline & 1879-1884 & 2.331 \\
\hline & $1880-1898$ & 2.332 \\
\hline & $1899-1911$ & 2.333 \\
\hline Gewerbeschule, Inspektion & $1899-1911$ & 2.333 \\
\hline Gewerbeschule, Inventar & $1879-1884$ & 2.331 \\
\hline \multirow[t]{2}{*}{ Gewerbeschule, Lehr- und Stundenpläne } & $1879-1884$ & 2.331 \\
\hline & 1880-1898 & 2.332 \\
\hline Gewerbeschule, Lehrer & $1895-1917$ & 2.352 \\
\hline Gewerbeschule, Lehrerqualifikation & 1904-1914 & 2.344 \\
\hline \multirow[t]{2}{*}{ Gewerbeschule, Lehrplan } & $1899-1911$ & 2.333 \\
\hline & $1897-1917$ & 2.354 \\
\hline Gewerbeschule, Modellierklasse für Bauhandwerker & 1880-1898 & 2.332 \\
\hline Gewerbeschule, Private Trägerschaft & $1892-1894$ & 2.349 \\
\hline Gewerbeschule, Protest gegen Unterricht am Sonntag & $1892-1894$ & 2.349 \\
\hline \multirow[t]{2}{*}{ Gewerbeschule, Prüfung } & 1879-1884 & 2.331 \\
\hline & $1880-1898$ & 2.332 \\
\hline Gewerbeschule, Raumvermietung a. d. reformierte Klassenschule & $1890-1901$ & 3.635 \\
\hline Gewerbeschule, Rechnungslegung & $1879-1884$ & 2.331 \\
\hline Gewerbeschule, Schüler aus dem Umland & $1899-1911$ & 2.333 \\
\hline \multirow[t]{4}{*}{ Gewerbeschule, Schulgeld } & $1866-1871$ & 2.329 \\
\hline & $1879-1884$ & 2.331 \\
\hline & $1880-1898$ & 2.332 \\
\hline & $1915-1918$ & 2.339 \\
\hline Gewerbeschule, Staatsbeihilfe & $1873-1880$ & 2.330 \\
\hline Gewerbeschule, Staatsbeihilfe für Lehrmittel & 1880-1898 & 2.332 \\
\hline \multirow[t]{2}{*}{ Gewerbeschule, Statistik } & $1866-1871$ & 2.329 \\
\hline & 1874-1914 & 2.346 \\
\hline Gewerbeschule, Statuten & $1869-1914$ & 2.343 \\
\hline Gewerbeschule, Unterricht & $1899-1911$ & 2.333 \\
\hline Gewerbeschule, Verbesserung & $1873-1880$ & 2.330 \\
\hline Gewerbeschule, Vorstandsergänzung durch Bürgervorsteher & $1880-1898$ & 2.332 \\
\hline \multirow[t]{5}{*}{ Gewerbeschule, Vorstandssitzungen } & $1891-1894$ & 2.334 \\
\hline & 1895-1899 & 2.335 \\
\hline & $1900-1904$ & 2.336 \\
\hline & $1905-1908$ & 2.337 \\
\hline & 1908 & 2.359 \\
\hline \multirow[t]{3}{*}{ Gewerbeschule, Vorstandswahlen } & $1873-1880$ & 2.330 \\
\hline & $1879-1884$ & 2.331 \\
\hline & 1899-1911 & 2.333 \\
\hline Gewerbeschule, Zeichenlehrer & $1895-1917$ & 2.352 \\
\hline Gewerbeschule, Zeichenunterricht & 1897-1914 & 2.350 \\
\hline Gewerbeschüler, Ausstellung von Arbeiten & $1880-1898$ & 2.332 \\
\hline Gewerbeschüler, Beschwerden & $1880-1898$ & 2.332 \\
\hline Gewerbeschüler, Prämierung & 1879-1884 & 2.331 \\
\hline Gewerbeschüler, Unterrichtsstörungen & $1873-1880$ & 2.330 \\
\hline \multirow[t]{2}{*}{ Gewerbeschulgebäude, Unterhaltung } & 1879-1884 & 2.331 \\
\hline & $1880-1898$ & 2.332 \\
\hline Gewerbeschullehrer, Fortbildung & $1880-1898$ & 2.332 \\
\hline
\end{tabular}


Index

\begin{tabular}{l}
\hline Indexbegriff \\
\hline Gewerbeschullehrer, Fortbildung \\
Gewerbeschullehrer, Honorar \\
Gewerbeschullehrer, Vertretung im Krankheitsfall \\
Gewerbeschulpflicht, Ausdehnung \\
Gewerbeschulpflicht, Einführung \\
Gewerbeschulpflicht, Jugendliche Arbeiter \\
Gewerbeschulpflicht, Verstöße
\end{tabular}

Gewerbeschulunterricht, Befreiung

Gewerbeschulunterricht, Genehmigungspflicht Töchterschullehrer Gewerbeschulunterricht, Überschneidung Konfirmandenunterricht Gewerbeschulvorstand, Ersatzwahl

Gewerbesteuer, Einführung

Gewerbesteuer, Erhebung

Gewerbesteuer, Veranlagung der Mühlen

Gewerbesteuer, Widersprüche

Gewerbesteuer, Widersprüche gegen die Veranlagung

Gewerbesteuerausschuss, Neuwahl

Gewerbesteuermusterordnung

Gewerbesteuerordnung, Stadt Emden

Gewerbesteuerordnungen, Richtlinien

Gewerbesteuerrecht, Verstöße

Gewerbesteuerrolle, Stadt Emden

Gewerbesteuerwesen, Regelung

Gewerkschaften, Überwachung

Gift, Abfüllung

Giftwaren, Lagerung und Verabfolgung

Gildegebühren, Rückstände

Glasfabrik, Planung

Glasfenster, Stiftung

Glasmalereien, Restaurierung

Glasmalereien, Schutz

Glocken, Ablieferung für die Kriegswirtschaft

Glückwunschtelegramm, Stadt Emden zum Regierungsjubiläum Gnadenunterstützung, Gesuche

Gobelin, Restaurierung

Gold- und Effektenmakler, Bewerbung

Goldaufkäufer, Verdacht

Goldene Buch, Stadt Emden

Goldenes Kreuz, Verleihung

Goldgeldmünzen, Umtausch gegen Papiergeld

Gosse, Einleitung von Jauche

Gosse, Gesundheitsgefährdung durch Einleitungen

Gosse, Umbau in eine unterirdische Riole

Gosse, Verseuchung der Roste mit Fäkalien

Gosse, Verstopfung

\section{SACH}


Index

\begin{tabular}{|c|c|c|}
\hline \multicolumn{3}{|l|}{ SACH } \\
\hline Indexbegriff & Laufzeit & Lfd.Nr. \\
\hline Gosse, Verstopfung & $1875-1882$ & 970 \\
\hline Gossen, Reparaturbedürftigkeit & $1870-1879$ & 888 \\
\hline Gossenreinigung, Unterbliebene & $1870-1879$ & 888 \\
\hline Gottesdienstbetrieb, Abgabe für Räume & $1871-1897$ & 3.415 \\
\hline Gotteskammern, Baufälligkeit & 1879-1909 & 1.727 \\
\hline Gotteskammern, Erwerbsangebot & 1879-1909 & 1.727 \\
\hline Gotteskammern, Rechtsstatus & $1879-1909$ & 1.727 \\
\hline Graben, Geruchsbelästigung durch Schlachtabfälle & 1874-1884 & 892 \\
\hline Gräben, Instandsetzung & $1873-1875$ & 2.450 \\
\hline Graben, Reinhaltung & $1902-1903$ & 1.498 \\
\hline Graben, Reinigung & 1887 & 969 \\
\hline Graben, Unerlaubte Aufstauung & $1869-1893$ & 2.473 \\
\hline Graben, Unterhaltung & $1870-1882$ & 891 \\
\hline Graben, Verunreinigung & 1893-1901 & 940 \\
\hline Gräber, Tiefe & 1871 & 1.633 \\
\hline Gräber, Übertragung der Eigentumsrechte & 1899-1909 & 3.317 \\
\hline Grabreden, Berechtigung & 1868-1905 & 3.447 \\
\hline Grabstellen, Veräußerung & 1899-1909 & 3.317 \\
\hline \multirow[t]{2}{*}{ Grasmahd, Verpachtung } & $1866-1893$ & 2.454 \\
\hline & $1894-1911$ & 2.455 \\
\hline Grasschnitt, Verpachtung & 1879 & 2.499 \\
\hline \multirow{2}{*}{ Grasung, Verpachtung } & $1884-1896$ & 2.494 \\
\hline & $1896-1901$ & 2.495 \\
\hline Gratulation, Emden zum Dienstjubiläum des Prinzen Heinrich & $1874-1911$ & 190 \\
\hline Graupferdstief, Zuschüttung & 1884-1896 & 900 \\
\hline Greifbagger "Granat" & 1899 & 2.233 \\
\hline \multirow[t]{2}{*}{ Greifbagger "Krabbe" } & 1899 & 2.232 \\
\hline & 1900 & 2.240 \\
\hline Grenze, Emder Feldmark & 1861-1865 & 235 \\
\hline Grenzfestlegung, Städtische Grundstücke & 1885 & 2.443 \\
\hline Grenzgräben, Städtische und private Grundstücke & 1881-1909 & 2.402 \\
\hline Grenzgraben, Zuschüttungsantrag & 1883-1898 & 971 \\
\hline Grenzkorrektur, Emden und Borssum & $1892-1899$ & 224 \\
\hline Grenzkorrektur, Stadt Emden - Gemeinde Wolthusen & 1885 & 225 \\
\hline Grenzregulierung, Stadt Emden und Umlandgemeinden & $1867-1907$ & 237 \\
\hline Grenzstreit, Grundstücklsbesitzer & $1873-1875$ & 2.450 \\
\hline Grenzverlauf, Vorland vor dem Königspolder & $1906-1914$ & 236 \\
\hline Grenzverletzung, Beschwerde gegen & 1904 & 223 \\
\hline Grenzverletzung, Grundstück & 1876-1889 & 843 \\
\hline Große Kirche, Grabsteine & $1883-1884$ & 3.411 \\
\hline Große Kirche, Haushaltsmittel & $1877-1897$ & 3.410 \\
\hline Große Kirche, Inventar & 1877-1897 & 3.410 \\
\hline Große Straße, Kanalisierung & 1896-1906 & 998 \\
\hline Große Straße, Verlängerung & 1896-1906 & 998 \\
\hline Großwerft, Aufbau in Emden & $1902-1903$ & 1.464 \\
\hline Grund- und Immobilienbesitz, Stadt Emden & 1885 & 2.443 \\
\hline Grundbesitz, Große Kirche & 1881 & 3.408 \\
\hline Grundbesitz, Neue Kirche & 1897 & 3.406 \\
\hline Grundbesitz, Nutzungsvergütung & $1909-1911$ & 2.948 \\
\hline Grundbesteuerung, Modus & $1899-1914$ & 2.984 \\
\hline Grundbuch, Berichtigung & 1899 & 2.568 \\
\hline Grundbuch, Besitztiteleintragung & 1898-1902 & 2.561 \\
\hline Grundbuch, Eintragung eines Grundstücks & $1900-1901$ & 1.548 \\
\hline Grundbuch, Korrekturen & $1895-1896$ & 2.536 \\
\hline \multirow[t]{2}{*}{ Grundbuch, Städtische Grundstücke } & $1877-1910$ & 2.403 \\
\hline & 1874 & 2.993 \\
\hline Grundbuchänderungen, Veräußerung von Grundstücken & $1883-1887$ & 1.435 \\
\hline Grundbuchauszüge, Städtische Grundstücke & 1899-1903 & 2.441 \\
\hline
\end{tabular}


Index

SACH

\begin{tabular}{l} 
Indexbegriff \\
\hline Grundbucheintragung, Prozess \\
Grundbücher, Berichtigung \\
Grundeigentum, Beeinträchtigung \\
Grundeigentum, Enteignung \\
Grundeigentum,. Rechtsstreit
\end{tabular}

Grundfläche, Abtretung

Grundfläche, Verkauf

Grundfläche, Verpachtung

Grundflächen, Abtretung

Grundflächen, Austausch

Grundgehalt, Lehrer und Kirchendiener in Borssum

Grundpachten, Ablösung

Grundsteuer, Erstattung für Stadtbesitz

Grundsteuer, Ordnung

Grundsteuer, Regulierung wegen Verkoppelungen

Grundsteuer, Senkungsinitiative der Hausbesitzervereine

Grundsteuerfestsetzungsverfahren, Beteiligung

Grundsteuerkataster, Berichtigung

Grundsteuerverwaltung, Koordination

Grundstreifen, Abtretung

Grundstreifen, Verpachtung

Grundstück, Abtretung

Grundstück, Abtretung durch die Stadt Emden

Grundstück, Beeinträchtigung städtischen Besitzes

Grundstück, Besitzansprüche

Grundstück, Eigentumsverhältnisse

Grundstück, Erschließung

Grundstück, Erschließungsverweigerung

Grundstück, Erwerb durch Stadt Emden

Grundstück, Erwerb für Spiel- und Turnplatz

Grundstück, Grensfestlegung

Grundstück, Grenzfestlegung

Grundstück, Grenzfestsetzung

Grundstück, Grenzregulierung

Grundstück, Grenzverlauf

Grundstück, Grenzverletzung

Grundstück, Hypotheken

Grundstück, Kauf

Grundstück, Kuperei am Strohdeich

Grundstück, Tausch

\section{Laufzeit}

$1915-1917$

$1867-1911$

$1876-1889$

1890-1899

1875-1881

1877-1881

1874-1877

1877-1882

$1880-1881$

1899

1899-1900

1901-1908

1903-1904

1904-1909

1904-1916

1898-1902

1895-1897

1898

1876

1885

1895

1867-1887

1907-1913

1870-1914

1867-1887

1890-1913

1897-1898

1901-1904

1900-1906

1879

1898-1909

1904-1906

1869-1873

1870-1882

1875-1878

1875-1886

1879

1866-1872

1907

1906-1907

1901-1908

1873-1882

1878-1882

1907-1912

1900-1901

1866-1900

1880-1906

1887-1889

1904-1912

1866-1903

1901

1901-1908

1903-1904

1900-1904

1901

1866-1900

1880-1881

1885-1896

\section{Lfd.Nr.}

2.601

2.858

843

2.400

2.510

2.511

2.512

2.513

2.514

2.572

2.555

2.559

2.580

2.582

2.583

2.561

2.560

245

3.414

2.443

2.985

810

602

1.163

810

2.879

2.571

2.578

2.564

2.526

2.552

2.598

2.466

2.502

2.506

2.507

2.516

2.472

1.173

1.170

2.445

2.518

2.520

2.594

2.567

2.481

1.179

2.540

2.600

2.451

2.557

2.445

2.553

2.562

2.786

2.481

2.469

2.529 
IV

Index

SACH

Indexbegriff

Grundstück, Verkauf

Laufzeit

Grundstück, Verkauf durch Stadt Emden

Grundstück, Verkauf zum Bau einer Werft

Grundstück, Verpachtung

Grundstück, Verpachtung zum Bau einer Werft

Grundstück, Verpachtung zum Bau einer Zementfabrik Grundstücke, Abtretung

Grundstücke, Ankauf für Oberpostdirektion

Grundstücke, Eisenbahnverwaltung an die Stadt Emden

Grundstücke, Enteignung

Grundstücke, Grenzregulierung

Grundstücke, Grenzziehung

Grundstücke, Käufe durch die Stadt Emden

1904-1905

1880-1881

1872-1876

Lfd.Nr.

2.829

2.469

2.485

2.593

1906-1911 2.439

1872-1878 2.467

1866-1874 2.468

1901-1908 2.445

1868-1881 2.449

$1873-1875 \quad 2.450$

$1866-1903 \quad 2.451$

1866-1893 2.454

$1866-1893 \quad 2.456$

1895-1909 2.457

1867-1897 2.464

$1866-1872 \quad 2.472$

1866-1894 2.482

1873-1877 2.483

$1876 \quad 2.497$

1879-1905 2.517

1874-1884 2.521

$1889-1902 \quad 2.533$

1889-1896 2.538

$1884-1914 \quad 2.541$

1857-1905 2.551

1900-1904 $\quad 2.554$

1901-1903 2.556

1901-1903 2.558

1900-1904 2.562

$1901-1906 \quad 2.563$

$1902-1906 \quad 2.569$

$1901-1906 \quad 2.576$

$1905-1913 \quad 2.584$

1905-1906 2.586

1906-1913 2.587

$1907-1910 \quad 2.588$

1904-1910 2.589

1907-1912 2.595

1866-1874 2.468

$1869 \quad 2.474$

1901-1905 2.565

1904-1905 2.818

1897-1902 2.820

$1905-1906 \quad 2.821$

$1905 \quad 2.822$

$1905-1916 \quad 2.823$

1894-1905 $\quad 2.827$

1887-1896 2.532

$1872-1889 \quad 2.475$

1888-1895 2.537

1907-1913 2.592

1885-1888 2.534

1884-1914 2.541

$1885-1886 \quad 2.546$

$1901-1905 \quad 2.565$

$1872-1888 \quad 2.442$

1906-1911 $\quad 2.824$

1899-1911 2.847 
IV

Index

SACH

Indexbegriff

Laufzeit

1881-1912

1902-1904

1896-1897

Grundstücke, Veräußerung

Grundstücke, Vererbpachtung

1880-1913

1884-1885
1875-1914

1878

1914

1889-1891

1874

1880-1911

1870

1873-1886

1876-1897

1868

1871

1872-1918

1876-1879

1879-1910

1879-1899

1880-1891

1876-1909

1874-1888

1880-1881

$1880-1883$

1867-1887

1880-1883

1880-1881

1880-1904

1881-1898

$1880-1890$

1881-1894

1877-1904

1881-1882

1888-1889

1883-1897

1882-1884

1883-1884

1883-1885

1885

1885-1903

1884-1900

1885-1908

1884-1895

1886-1890

1886-1899

1885-1903

1886-1891

1887-1898

1886-1892

1887-1911

1888-1892

1888-1891

1888-1889

1888-1891

1889-1891

1890-1891

1890-1891
Lfd.Nr.

2.523

2.772

2.778

2.704

2.679

2.680

2.681

2.682

2.683

2.684

2.685

2.686

2.687

2.688

2.689

2.690

2.691

2.692

2.693

2.694

2.695

2.696

2.697

2.698

2.699

2.700

2.701

2.702

2.703

2.705

2.706

2.707

2.708

2.709

2.710

2.711

2.712

2.713

2.714

2.715

2.716

2.717

2.719

2.720

2.721

2.722

2.723

2.724

2.725

2.726

2.727

2.728

2.729

2.730

2.731

2.732

2.733

2.734 
IV

Index

SACH

\begin{tabular}{|c|c|c|}
\hline Indexbegriff & Laufzeit & Lfd.Nr. \\
\hline \multirow[t]{41}{*}{ Grundstücke, Vererbpachtung } & $1890-1897$ & 2.735 \\
\hline & $1890-1907$ & 2.736 \\
\hline & 1890-1899 & 2.737 \\
\hline & $1891-1904$ & 2.738 \\
\hline & $1889-1893$ & 2.739 \\
\hline & $1890-1897$ & 2.740 \\
\hline & $1897-1908$ & 2.741 \\
\hline & 1892 & 2.742 \\
\hline & $1890-1895$ & 2.743 \\
\hline & 1894-1914 & 2.744 \\
\hline & 1894-1911 & 2.745 \\
\hline & $1895-1897$ & 2.746 \\
\hline & $1896-1897$ & 2.747 \\
\hline & 1896-1898 & 2.748 \\
\hline & $1896-1898$ & 2.749 \\
\hline & $1896-1898$ & 2.750 \\
\hline & $1897-1910$ & 2.751 \\
\hline & 1899 & 2.752 \\
\hline & 1897 & 2.753 \\
\hline & $1900-1903$ & 2.757 \\
\hline & $1900-1902$ & 2.758 \\
\hline & $1901-1910$ & 2.761 \\
\hline & $1900-1903$ & 2.763 \\
\hline & 1899-1901 & 2.764 \\
\hline & 1899-1904 & 2.771 \\
\hline & $1900-1902$ & 2.773 \\
\hline & 1893-1896 & 2.776 \\
\hline & 1893-1895 & 2.777 \\
\hline & $1896-1899$ & 2.780 \\
\hline & $1901-1909$ & 2.782 \\
\hline & $1901-1907$ & 2.784 \\
\hline & $1900-1901$ & 2.793 \\
\hline & $1902-1903$ & 2.801 \\
\hline & $1902-1903$ & 2.802 \\
\hline & 1903-1906 & 2.807 \\
\hline & $1905-1907$ & 2.830 \\
\hline & $1905-1907$ & 2.832 \\
\hline & $1905-1907$ & 2.836 \\
\hline & $1905-1908$ & 2.842 \\
\hline & 1908 & 2.846 \\
\hline & $1890-1901$ & 2.848 \\
\hline \multirow[t]{17}{*}{ Grundstücke, Verkauf } & $1889-1891$ & 2.604 \\
\hline & 1898-1899 & 2.754 \\
\hline & 1899 & 2.755 \\
\hline & $1899-1900$ & 2.756 \\
\hline & $1900-1901$ & 2.759 \\
\hline & $1899-1901$ & 2.760 \\
\hline & $1900-1901$ & 2.762 \\
\hline & $1900-1901$ & 2.765 \\
\hline & $1891-1901$ & 2.766 \\
\hline & $1898-1901$ & 2.767 \\
\hline & 1899 & 2.768 \\
\hline & 1899 & 2.769 \\
\hline & 1901 & 2.770 \\
\hline & $1900-1902$ & 2.774 \\
\hline & $1901-1902$ & 2.775 \\
\hline & $1899-1901$ & 2.779 \\
\hline & $1896-1898$ & 2.781 \\
\hline
\end{tabular}


IV

Index

SACH

\begin{tabular}{|c|c|c|}
\hline Indexbegriff & Laufzeit & Lfd.Nr. \\
\hline \multirow[t]{42}{*}{ Grundstücke, Verkauf } & 1893-1908 & 2.783 \\
\hline & 1900-1902 & 2.788 \\
\hline & 1900-1902 & 2.789 \\
\hline & 1899-1906 & 2.790 \\
\hline & 1899-1902 & 2.791 \\
\hline & 1900-1902 & 2.792 \\
\hline & 1902-1904 & 2.794 \\
\hline & 1902 & 2.795 \\
\hline & $1902-1904$ & 2.796 \\
\hline & 1902 & 2.797 \\
\hline & $1902-1903$ & 2.798 \\
\hline & $1902-1904$ & 2.804 \\
\hline & 1903-1904 & 2.805 \\
\hline & 1903 & 2.806 \\
\hline & $1903-1905$ & 2.808 \\
\hline & 1904-1906 & 2.809 \\
\hline & 1904-1905 & 2.810 \\
\hline & 1904-1905 & 2.811 \\
\hline & 1904 & 2.812 \\
\hline & 1904 & 2.813 \\
\hline & 1904 & 2.814 \\
\hline & 1904 & 2.815 \\
\hline & 1904-1905 & 2.816 \\
\hline & 1905-1908 & 2.817 \\
\hline & $1888-1906$ & 2.819 \\
\hline & 1906-1908 & 2.825 \\
\hline & $1907-1911$ & 2.828 \\
\hline & 1904-1905 & 2.829 \\
\hline & 1905 & 2.831 \\
\hline & 1905 & 2.833 \\
\hline & 1904-1905 & 2.834 \\
\hline & $1905-1907$ & 2.835 \\
\hline & $1906-1907$ & 2.837 \\
\hline & 1906-1907 & 2.838 \\
\hline & $1906-1907$ & 2.839 \\
\hline & 1906-1908 & 2.840 \\
\hline & 1906 & 2.841 \\
\hline & 1905 & 2.843 \\
\hline & 1906-1909 & 2.845 \\
\hline & $1906-1913$ & 2.850 \\
\hline & $1906-1911$ & 2.851 \\
\hline & 1904-1906 & 2.852 \\
\hline Grundstücksbesteuerung & 1899-1914 & 2.984 \\
\hline Grundstücksgrenze, Streit & $1876-1880$ & 1.496 \\
\hline Grundstücksgrenzen, Streitigkeiten & 1876-1889 & 843 \\
\hline Grundstückskauf, Stadt Emden & 1904-1905 & 2.446 \\
\hline Grundstücksstreifen, Abtretung & 1903-1904 & 2.579 \\
\hline \multirow[t]{3}{*}{ Grundstücksstreifen, Entschädigung für Abtretung } & $1902-1903$ & 2.577 \\
\hline & $1901-1904$ & 2.578 \\
\hline & $1902-1903$ & 2.581 \\
\hline \multirow[t]{8}{*}{ Grundstückstausch } & 1873-1882 & 2.518 \\
\hline & $1875-1876$ & 2.519 \\
\hline & $1890-1893$ & 2.545 \\
\hline & $1901-1904$ & 2.785 \\
\hline & $1901-1903$ & 2.787 \\
\hline & 1902-1903 & 2.799 \\
\hline & $1902-1903$ & 2.800 \\
\hline & 1902 & 2.803 \\
\hline
\end{tabular}


Index

\begin{tabular}{|c|c|c|}
\hline \multicolumn{3}{|l|}{ SACH } \\
\hline Indexbegriff & Laufzeit & Lfd.Nr. \\
\hline \multirow[t]{3}{*}{ Grundstückstausch } & $1906-1912$ & 2.826 \\
\hline & 1906 & 2.844 \\
\hline & 1904 & 2.849 \\
\hline Grundstückstausch, Stadt Emden mit Bahnfiskus & 1893-1894 & 2.535 \\
\hline \multirow{2}{*}{ Grundstückstausch, Stadt Emden mit Domänenfiskus } & $1899-1901$ & 233 \\
\hline & $1900-1905$ & 2.566 \\
\hline Grundstückstausch, Stadt Emden mit Fa. Ysaac \& Bernhard Brons & $1891-1902$ & 2.597 \\
\hline Grundstückstausch, Stadt Emden mit Gemeinde d. Großen Kirche & 1877 & 2.501 \\
\hline Grundstückstausch, Stadt Emden mit Postfiskus & $1874-1876$ & 2.488 \\
\hline Grundstückstausch, Stadt Emden mit reformierte Kirche & $1877-1897$ & 3.392 \\
\hline Grundstückstausch, Stadt Emden mit Schiffsbaumeister Janssen & 1896 & 2.573 \\
\hline Grundstückstausch, Stadt Emden mit Schmied G. Boomgaarden & 1898 & 2.570 \\
\hline Grundstückstausch, Stadt Emden mit Zollverwaltung & 1894-1900 & 2.458 \\
\hline Grundstückstausch, Verhandlungen & $1875-1878$ & 2.506 \\
\hline Grundstückstausch; Emden mit Gastwirt Eggers & $1906-1912$ & 2.599 \\
\hline Grundstücksübernahme, Stadt Emden & $1906-1911$ & 2.439 \\
\hline Grundstücksveränderungen, Anzeige & $1887-1912$ & 812 \\
\hline Grundstücksverkäufe, Verhandlungen & $1871-1896$ & 2.509 \\
\hline Grundwassererschließung, Regelungen & $1903-1912$ & 1.167 \\
\hline Grundwasserverhältnisse, Erhebung & $1903-1912$ & 1.167 \\
\hline Grünfläche, Verpachtung & $1892-1901$ & 2.543 \\
\hline Grünstreifen, Abtretung & 1888 & 2.547 \\
\hline Grünstreifen, Verpachtung & 1896-1902 & 2.548 \\
\hline Guttemplerorden, Druckschriften & $1902-1913$ & 659 \\
\hline Guttemplerorden, Jubiläum & $1902-1913$ & 659 \\
\hline Guttemplerorden, Mitglieder in Emden & $1902-1913$ & 659 \\
\hline Gymnasialdirektor, Ernennung & 1909 & 3.712 \\
\hline Gymnasium, Bau in Emden & $1869-1884$ & 3.713 \\
\hline Gymnasium, Kasernenstandort & 1876-1909 & 2.424 \\
\hline Gymnasium, Namensverleihung & $1869-1884$ & 3.713 \\
\hline Gymnasium, Neubau & $1872-1892$ & 2.427 \\
\hline Gymnasium, Planzeichnung & 1876-1909 & 2.424 \\
\hline Gymnasium, Rückkauf & 1876-1909 & 2.424 \\
\hline Gymnasium, Staatsbeihilfe zum Bau & $1869-1884$ & 3.713 \\
\hline Gymnasium, Verstaatlichung & $1872-1916$ & 330 \\
\hline Hafen- und Kajungsgebühren, Eintreibung & $1873-1893$ & 1.559 \\
\hline Hafen- und Kanalprojekte, Bauleitung & $1875-1882$ & 1.431 \\
\hline Hafen- und Kaygeld, Befreiung & $1871-1885$ & 2.934 \\
\hline Hafen- und Kaygeld, ERhebung & $1871-1885$ & 2.934 \\
\hline Hafen- und Schleusenanlage, Eröffnung & 1902 & 1.451 \\
\hline Hafen, Baggerungen und Spülungen & $1887-1912$ & 1.437 \\
\hline Hafen, Bedeutung für Industriegebiet & $1876-1903$ & 1.432 \\
\hline Hafen, Entschlammung & $1887-1888$ & 1.436 \\
\hline \multirow[t]{5}{*}{ Hafen, Erweiterung } & 1903-1908 & 1.443 \\
\hline & $1868-1891$ & 1.450 \\
\hline & 1904 & 2.002 \\
\hline & 1905 & 2.003 \\
\hline & $1891-1893$ & 2.025 \\
\hline Hafen, Erweiterung in Emden & & Vorwort \\
\hline Hafen, Gleisanschluss & 1881 & 1.449 \\
\hline Hafen, Historische Entwicklung & 1876 & 1.438 \\
\hline Hafen, Kampagne gegen Emden & 1904-1912 & 1.528 \\
\hline \multirow{2}{*}{ Hafen, Kanalanschluss } & 1891 & 1.453 \\
\hline & $1891-1893$ & 2.025 \\
\hline Hafen, Modernisierung & $1868-1891$ & 1.450 \\
\hline Hafen, Propaganda & $1906-1907$ & 2.089 \\
\hline Hafen, Reportage & 1899 & 2.130 \\
\hline
\end{tabular}


Index

\begin{tabular}{|c|c|c|}
\hline \multicolumn{3}{|c|}{ SACH } \\
\hline Indexbegriff & Laufzeit & Lfd.Nr. \\
\hline Hafen, Sonderdruck & 1907 & 2.004 \\
\hline Hafen, Statistik & $1899-1913$ & 2.027 \\
\hline Hafen, Strukturprobleme & & Vorwort \\
\hline Hafen, Übergang nach Preußen & $1872-1916$ & 330 \\
\hline Hafen, Verkehrsstatistik & 1914-1918 & 463 \\
\hline \multirow[t]{2}{*}{ Hafen, Verschlammung } & $1883-1887$ & 1.435 \\
\hline & 1876 & 1.438 \\
\hline Hafen, Wassertiefe & $1887-1888$ & 1.436 \\
\hline \multirow{2}{*}{ Hafen, Zustand } & 1869 & 1.531 \\
\hline & $1869-1912$ & 2.121 \\
\hline Hafenabgaben, Ausnahmeregelungen & $1873-1893$ & 1.559 \\
\hline Hafenabgaben, Erhebung & $1873-1893$ & 1.559 \\
\hline Hafenabgaben, Ermäßigung & 1873-1893 & 1.559 \\
\hline Hafenabgaben, Monita & $1873-1893$ & 1.559 \\
\hline Hafenabgaben, Streit um Entrichtung & $1873-1893$ & 1.559 \\
\hline Hafenamt, Auflösung & 1914 & 1.529 \\
\hline Hafenamt, Führungsstruktur & $1887-1888$ & 1.507 \\
\hline Hafenamtsgeschäfte, Übertragung & 1914 & 1.529 \\
\hline Hafenamtsleiter, Erlöschen der Funktion & 1914 & 1.529 \\
\hline Hafenamtsleiter, Honorarforderung & 1914 & 1.529 \\
\hline Hafenanlagen, Anschluss an die ostfriesische Küstenbahn & 1896 & 2.075 \\
\hline Hafenanlagen, Artikel & $1897-1901$ & 182 \\
\hline \multirow[t]{2}{*}{ Hafenanlagen, Eigentumsübertragung } & 1875-1882 & 1.431 \\
\hline & $1879-1883$ & 1.433 \\
\hline \multirow[t]{2}{*}{ Hafenanlagen, Erweiterung } & $1887-1888$ & 1.436 \\
\hline & 1893-1897 & 2.026 \\
\hline Hafenanlagen, Gleisanschluss & 1893-1897 & 2.026 \\
\hline Hafenanlagen, Gutachten zur Modernisierung & $1870-1914$ & 1.430 \\
\hline \multirow[t]{2}{*}{ Hafenanlagen, Kanalanschluss } & $1887-1888$ & 1.436 \\
\hline & 1893-1897 & 2.026 \\
\hline Hafenanlagen, Modernisierung & $1870-1914$ & 1.430 \\
\hline Hafenanlagen, Plan & 1903-1908 & 1.443 \\
\hline Hafenanlagen, Propaganda & $1905-1906$ & 2.088 \\
\hline Hafenanlagen, Verbesserung & $1870-1914$ & 1.430 \\
\hline \multirow{6}{*}{ Hafenanlagen, Verstaatlichung } & $1870-1914$ & 1.430 \\
\hline & $1876-1903$ & 1.432 \\
\hline & $1875-1882$ & 1.434 \\
\hline & $1883-1887$ & 1.435 \\
\hline & $1887-1888$ & 1.436 \\
\hline & $1887-1912$ & 1.437 \\
\hline Hafenanlagen, Werbung & 1912 & 2.100 \\
\hline Hafenarbeiterstreiks, Erschwerung & 1906-1907 & 677 \\
\hline Hafenausbau & 1899 & 2.028 \\
\hline Hafenausbau, Erdaushub & 1895-1896 & 2.029 \\
\hline Hafenausbau, Finanzierung duirch Anleihe & $1875-1888$ & 2.994 \\
\hline Hafenbahn, Angebot & $1899-1903$ & 1.454 \\
\hline Hafenbauprojekt, Bauunternehmer Theilen & $1868-1891$ & 1.450 \\
\hline Hafenbauten, Aufsätze über & $1912-1914$ & 1.429 \\
\hline Hafenbecken, Planung in Delfzyl & 1903 & 2.077 \\
\hline Hafenbecken, Verschlammung & $1870-1914$ & 1.430 \\
\hline Hafenbeleuchtung, Gasbetriebener Dynamo & $1897-1914$ & 1.042 \\
\hline Hafenbetrieb, Einzelvorgänge & 1904-1912 & 1.528 \\
\hline Hafenbetrieb, Statistiken & 1904-1912 & 1.528 \\
\hline Hafenbetriebs- und Lagerhausgesellschaft, Engagement & $1902-1903$ & 1.442 \\
\hline Hafendamm, Kostenträgerschaft & 1895-1896 & 2.029 \\
\hline Hafenerweiterung, Einziehung des städtischen Anteils & $1902-1911$ & 1.446 \\
\hline \multirow[t]{2}{*}{ Hafenerweiterung, Finanzierung } & 1904-1914 & 1.440 \\
\hline & $1902-1903$ & 1.442 \\
\hline
\end{tabular}


Index

\begin{tabular}{|c|c|c|}
\hline \multicolumn{3}{|c|}{$\mathrm{SACH}$} \\
\hline Indexbegriff & Laufzeit & Lfd.Nr. \\
\hline Hafenerweiterung, Kostenträgerschaft & $1902-1903$ & 1.442 \\
\hline Hafenerweiterung, Nutzung des Königspolders & $1904-1914$ & 1.440 \\
\hline Hafenerweiterung, Nutzungsanteil der Stadt Emden & $1904-1914$ & 1.440 \\
\hline Hafenerweiterung, Planfeststellung & $1893-1897$ & 2.026 \\
\hline Hafenerweiterung, Verhandlungen & $1890-1891$ & 2.023 \\
\hline Hafengebiet, Grundstücke & $1887-1912$ & 1.437 \\
\hline Hafengebühren, Befreiungsanträge & $1873-1893$ & 1.559 \\
\hline Hafengebühren, Erhebung & $1857-1885$ & 418 \\
\hline Hafengebühren, Erlass & 1902 & 186 \\
\hline Hafengebühren, Gleichstellung der Dampferlinien & $1873-1907$ & 2.017 \\
\hline Hafengeschichte, Dokumente & $1876-1903$ & 1.432 \\
\hline Hafenmeister, Dienstinstruktion & 1873 & 421 \\
\hline Hafenmeister, Gebührenerhebung & $1857-1885$ & 418 \\
\hline Hafenmeister, Stellenbesetzung durch Zivilscheininhaber & $1857-1885$ & 418 \\
\hline Hafenmeister, Vereidigung & $1857-1885$ & 418 \\
\hline Hafenmeister, Widersätzlichkeit von Schiffskapitänen & 1857-1885 & 418 \\
\hline Hafenmeister-Einnahmen, Abgabe auf & $1857-1885$ & 418 \\
\hline Hafenmeisterstellen, Vereinigung & $1857-1885$ & 418 \\
\hline Hafennutzung, Verinbarungsablehnung & 1907 & 1.428 \\
\hline Hafenordnung, Emden & $1873-1912$ & 1.505 \\
\hline Hafenordnung, Erlass & $1880-1914$ & 1.508 \\
\hline Hafenordnung, Verstöße & $1873-1912$ & 1.505 \\
\hline Hafenpläne, Aktualisierung & $1900-1908$ & 1.510 \\
\hline Hafenpläne, Emder Hafen & $1900-1908$ & 1.510 \\
\hline Hafenpläne, Erstellung & $1900-1908$ & 1.510 \\
\hline Hafenpläne, Vervielfältigung & $1900-1908$ & 1.510 \\
\hline Hafenpolizei, Dienstanweisungen & $1880-1914$ & 1.508 \\
\hline Hafenpolizei, Erlasse und Verfügungen & $1880-1914$ & 1.508 \\
\hline Hafenpolizei, Verbesserung & $1873-1912$ & 1.505 \\
\hline Hafenstatistik, Emden & $1899-1903$ & 1.527 \\
\hline \multirow[t]{2}{*}{ Hafenstraße, Anlegung } & 1894-1898 & 993 \\
\hline & $1897-1900$ & 994 \\
\hline Hafentarif, Emden & $1873-1893$ & 1.559 \\
\hline Hafentarif, Neufassung & $1873-1893$ & 1.559 \\
\hline Hafenunterhaltung, Beitrag der Stadt Emden & $1870-1914$ & 1.430 \\
\hline Hafenwasserstand, Erhöhung & $1881-1909$ & 894 \\
\hline Hafenzufahrt, Verbesserung & $1870-1914$ & 1.430 \\
\hline Hafer, Bewirtschaftung & 1917-1918 & 3.244 \\
\hline Haferlieferung, Monierung & 1917-1918 & 3.244 \\
\hline Haferration, Festlegung und Verteilung & $1917-1918$ & 3.244 \\
\hline Haferration, Herabsetzung & 1917-1918 & 3.244 \\
\hline Häftlinge, Betreuung & $1868-1911$ & 525 \\
\hline Häftlingsfürsorge & $1899-1908$ & 527 \\
\hline Hammrichshaus, Abriss auf Nesserland & $1875-1876$ & 2.425 \\
\hline Hammrichshaus, Vermietung auf Nesserland & $1866-1881$ & 2.459 \\
\hline Handakte, Fürbringer & $1905-1912$ & 2.105 \\
\hline Handarbeitslehrerin, Bewerbung & $1887-1890$ & 3.774 \\
\hline Handarbeitslehrerin, Bewerbungen & $1886-1905$ & 3.683 \\
\hline Handarbeitslehrerin, Unterstützung & $1908-1911$ & 3.590 \\
\hline Handarbeitslehrerinnenstelle, Hilfsschule & $1911-1913$ & 3.598 \\
\hline Handarbeitsunterricht, Organisation & $1868-1891$ & 3.502 \\
\hline Handels- und Schifffahrtsfragen, Presseartikel & $1905-1912$ & 2.105 \\
\hline Handelskammer, Aufnahme von Mitgliedern & $1867-1871$ & 2.110 \\
\hline \multirow[t]{2}{*}{ Handelskammer, Jahresberichte } & 1871-1909 & 2.107 \\
\hline & $1910-1914$ & 2.108 \\
\hline \multirow[t]{3}{*}{ Handelskammer, Mitgliedsbeiträge } & 1871-1909 & 2.107 \\
\hline & $1867-1871$ & 2.110 \\
\hline & $1866-1871$ & 2.111 \\
\hline
\end{tabular}


Index

\begin{tabular}{|c|c|c|}
\hline \multicolumn{3}{|c|}{ SACH } \\
\hline Indexbegriff & Laufzeit & Lfd.Nr. \\
\hline Handelskammer, Mitgliedschaft & $1866-1898$ & 2.135 \\
\hline Handelskammer, Mitwirkung im Handelsschulvorstand & $1869-1879$ & 2.328 \\
\hline Handelskammer, Neuorganisation & 1871-1909 & 2.107 \\
\hline \multirow[t]{2}{*}{ Handelskammer, Sitz } & 1871-1909 & 2.107 \\
\hline & $1910-1914$ & 2.108 \\
\hline Handelskammer, Statuten & $1866-1871$ & 2.111 \\
\hline Handelskammer, Verhandlungen und Mitteilungen & $1910-1914$ & 2.108 \\
\hline Handelskammer, Verhandlungsprotokolle & $1868-1871$ & 2.109 \\
\hline \multirow[t]{2}{*}{ Handelskammer, Wahlberechtigte Mitglieder } & $1867-1871$ & 2.110 \\
\hline & $1869-1911$ & 2.134 \\
\hline Handelskammer, Wahlbezirke & $1871-1909$ & 2.107 \\
\hline Handelskammern, Konstituierung & 1871-1909 & 2.107 \\
\hline Handelskammern, Nachrichten & $1910-1914$ & 2.108 \\
\hline Handelskompanie, Gründung & $1905-1907$ & 2.085 \\
\hline Handelsmarine, Verträge über Ergreifung von Deserteuren & 1874-1909 & 500 \\
\hline Handelsregister, Eintragung & $1913-1917$ & 1.485 \\
\hline Handelsregister, Eintragung der Nordseewerke & $1902-1905$ & 1.455 \\
\hline Handelsregister, Veränderungsmitteilung zu Nordseewerke & $1913-1917$ & 1.485 \\
\hline Handelsreisende, Gewerbebetrieb & $1866-1901$ & 2.897 \\
\hline Handelsreisende, Gewerbesteuerbefreiung & 1867-1906 & 2.032 \\
\hline Handelsschiffe, Mannschaftsräume und sanitäre Anlagen & $1905-1912$ & 1.424 \\
\hline Handelsschule, Beihilfen & $1864-1880$ & 2.342 \\
\hline Handelsschule, Einrichtung & $1864-1890$ & 2.341 \\
\hline Handelsschule, Etat & $1864-1880$ & 2.342 \\
\hline Handelsschule, Fremdsprachenunterricht & $1864-1880$ & 2.342 \\
\hline Handelsschule, Ortsstatut & $1869-1914$ & 2.343 \\
\hline Handelsschule, Private Trägerschaft & $1910-1912$ & 3.858 \\
\hline \multirow[t]{2}{*}{ Handelsschule, Schulgeld } & $1869-1879$ & 2.328 \\
\hline & $1864-1880$ & 2.342 \\
\hline Handelsschule, Statistik & $1864-1880$ & 2.342 \\
\hline \multirow[t]{2}{*}{ Handelsschule, Statut } & $1869-1879$ & 2.328 \\
\hline & $1864-1890$ & 2.341 \\
\hline Handelsschule, Stundenplan & $1864-1880$ & 2.342 \\
\hline Handelsschule, Vorstand & $1869-1879$ & 2.328 \\
\hline Handelsschule, Weibliche Lehrlinge & $1864-1880$ & 2.342 \\
\hline Handelsschüler, Antisemitische Handlungen & $1864-1890$ & 2.341 \\
\hline Handelsschüler, Unterrichtsstörung & $1864-1890$ & 2.341 \\
\hline Handelsschulgebäude, Planzeichnung & $1864-1880$ & 2.342 \\
\hline Handelsschullehrer, Fortbildung & $1904-1914$ & 2.344 \\
\hline Handelsschulpflicht & $1864-1880$ & 2.342 \\
\hline Handelsschulpflicht, Ausdehnung & $1869-1879$ & 2.328 \\
\hline Handelsschulpflicht, Einführung & $1869-1879$ & 2.328 \\
\hline Handelsschulpflicht, Frauen & $1869-1914$ & 2.343 \\
\hline Handelsschulpflicht, Verstöße & $1869-1914$ & 2.343 \\
\hline Handelsschulwesen, Presseartikel & $1864-1880$ & 2.342 \\
\hline Handelsvertrag, Deutschland und Russland & $1893-1894$ & 1.557 \\
\hline Handfertigkeits- und Werkunterricht, Einführung & $1887-1914$ & 2.345 \\
\hline Handfertigkeitsunterricht, Statistik & $1887-1914$ & 2.345 \\
\hline Handfeuerlöschgeräte, Anschaffung & $1869-1913$ & 1.387 \\
\hline Händler, Zollbestimmungen & 1867-1906 & 2.032 \\
\hline Handwerk, Genossenschaftskreditkassenprojekt & $1893-1912$ & 1.926 \\
\hline Handwerk, Organisation & $1893-1912$ & 1.926 \\
\hline Handwerkerbund, Gründung & $1893-1912$ & 1.926 \\
\hline Handwerkerdachverbände, Statutengenehmigung & $1880-1890$ & 1.936 \\
\hline Handwerkerfachvereine, Datenerhebung & $1881-1910$ & 1.906 \\
\hline Handwerker-Witwenkasse, Anerkennung als Kleiner Verein & $1877-1918$ & 1.672 \\
\hline Handwerker-Witwenkasse, Beschwerde gegen & $1877-1918$ & 1.672 \\
\hline Handwerker-Witwenkasse, Kassenberichte & $1877-1918$ & 1.672 \\
\hline
\end{tabular}


IV

Index

SACH

Indexbegriff
Handwerker-Witwenkasse, Lotterieantrag

Handwerker-Witwenkasse, Mitgliederverzeichnis

Handwerker-Witwenkasse, Statuten

Handwerker-Witwenkasse, Unterstützte Witwen

Handwerksordnung, Reform

Hannoverscher Städtekalender

Hauptversammlung, Ostfriesischer Lehrerverein

Haus- und Landsteuerordnung, Stadt Emden

Haus, Bauantrag

Haus, Bauliche Mängel

Haus, Situationsplan

Haus, Ungenehmigte Bretterwand

Haus, Ungenehmigter Anbau

Haus, Vermietung als Dienstwohnung an Oberbürgermeister

Haus, Vermietung eines Städtischen

Hausbesitzer, Verzeichnis

Hausbesitzerkongress, Einladung

Hausbrände, Verheimlichung

Häuser, Feuergefährliche in Emden

Häuser, Übergang auf den städtischen Armenverband

Häuser, Verkauf

Hausfriedensbruch, Anzeige

Haushaltsjahr, Neufestsetzung

Haushaltsjahr, Umstellung

Haushaltsplan, Berichtsmodus

Haushaltsplan, Gemeinde Borssum

Haushaltsplan, Stadt Emden

\section{Laufzeit}

1877-1918

1877-1918

1877-1918

1877-1918

1894-1896

1912-1914

1903-1909

1899-1914

1880-1906

1906-1907

1902

1906

1905-1908

1905

1905-1906

1875-1905

1875-1905

1914

1907-1913

1876

1904

1873-1886

1873-1886

1872-1910

1867-1888

1876-1877

1867-1888

1915-1916

1869

1870

1871

1872

1891-1892

1892-1893

1893-1894

1894-1895

1895-1904

1895-1896

1896-1897

1897-1898

1898-1899

1899-1900

1900-1901

1901-1902

1902-1903

1903-1904

1904-1905

1905-1906

1906-1907

1907-1908

1909-1910

1910-1911

1911-1912

1912-1913

1913-1914

1914-1915

1915-1916

1916-1917
Lfd.Nr.

1.672

1.672

1.672

1.672

1.931

709

661

2.984

1.179

1.190

1.196

1.189

1.187

1.188

1.191

2.423

2.423

457

602

1.258

1.269

2.422

2.422

1.869

3.012

3.018

3.012

243

3.044

3.045

3.046

3.047

3.048

3.049

3.050

3.051

3.052

3.053

3.054

3.055

3.056

3.057

3.058

3.059

3.060

3.061

3.062

3.063

3.064

3.065

3.066

3.067

3.068

3.069

3.070

3.071

3.072

3.073 
Index

\begin{tabular}{|c|c|c|}
\hline \multicolumn{3}{|c|}{ SACH } \\
\hline Indexbegriff & Laufzeit & Lfd.Nr. \\
\hline Haushaltsplan, Stadt Emden & 1917-1918 & 3.074 \\
\hline Haushaltsplan, Volksschule in Borssum & 1915 & 244 \\
\hline Haushaltsrubriken, Gestaltung & $1866-1867$ & 3.013 \\
\hline Haushaltungsschule, Beihilfe zum Schulbetrieb & $1905-1917$ & 3.857 \\
\hline Haushaltungsschule, Einrichtung & 1905-1917 & 3.857 \\
\hline Haushaltungsschule, Revision & $1905-1917$ & 3.857 \\
\hline Haushaltungsschule, Schulpflicht & $1905-1917$ & 3.857 \\
\hline Haushaltungsschule, Statistik & $1905-1917$ & 3.857 \\
\hline Hauskauf, Verhandlungen & 1871-1888 & 1.151 \\
\hline Hauskollekte, Formblatt & 1899-1901 & 3.338 \\
\hline Hausmieten, Eintreibung von Rückständen & 1866-1904 & 2.676 \\
\hline Hausnummern, Anzeigen wegen Nichtanbringung & 1901-1912 & 840 \\
\hline Hausnummern, Einführung & 1876-1888 & 1.134 \\
\hline Hausnummernbretter, Unvorschriftsmäßige & 1871-1909 & 1.158 \\
\hline Hausnummernschilder, Anbringung & $1866-1913$ & 832 \\
\hline Hausnummernschilder, Anzeige wegen Nichtanbringung & $1866-1913$ & 832 \\
\hline Hausverkauf, Reformierte Gemeinde & 1901-1902 & 3.393 \\
\hline Hebamme, Auswanderung & 1867-1895 & 763 \\
\hline Hebamme, Erlaubnis zum Schröpfen und Blutegelsetzen & $1867-1895$ & 763 \\
\hline Hebamme, Zulassung & $1898-1918$ & 764 \\
\hline Hebammen, Altersversorgung & $1898-1918$ & 764 \\
\hline Hebammen, Aus- und Fortbildung & $1898-1918$ & 764 \\
\hline Hebammen, Befreiung von Alkoholsteuer & 1898-1918 & 764 \\
\hline Hebammen, Bezüge & $1881-1900$ & 765 \\
\hline Hebammen, Desinfektionsmittel & $1881-1900$ & 765 \\
\hline Hebammen, Diensttagebücher & 1867-1895 & 763 \\
\hline Hebammen, Fortbildung & $1867-1895$ & 763 \\
\hline Hebammen, Gebührenordnung & $1898-1918$ & 764 \\
\hline Hebammen, Nachprüfung & $1898-1918$ & 764 \\
\hline Hebammen, Revision & 1867-1895 & 763 \\
\hline Hebammen, Zulassung & 1867-1895 & 763 \\
\hline Hebammenausbildung, Zulassungen & $1867-1895$ & 763 \\
\hline Hebammengebühren, Festsetzung & $1867-1895$ & 763 \\
\hline Hebammengebühren, Mittellose Frauen & 1913-1915 & 1.872 \\
\hline Hebammentasche, Angebot & $1898-1918$ & 764 \\
\hline Hebammenwesen, Organisation & $1898-1918$ & 764 \\
\hline Hebammenwesen, Reform & $1881-1900$ & 765 \\
\hline Hebammenwesen, Regelung durch Innenminister & $1898-1918$ & 764 \\
\hline Heer, Lieferunganforderungen & 1914-1918 & 3.245 \\
\hline Heereslieferungen, $\mathrm{Heu}$ & 1918 & 3.298 \\
\hline Heeresversorgung, Organisation & 1914-1918 & 3.245 \\
\hline Heilbehandlung, Kostenanforderung & $1912-1914$ & 1.878 \\
\hline Heimatscheine, Ausstellung & $1879-1922$ & 449 \\
\hline Heimkehrscheine, Anträge auf & $1861-1871$ & 448 \\
\hline Hellinggrundstüxck, Kauf durch die Stadt Emden & $1905-1909$ & 2.448 \\
\hline Heringsfischerei & & Vorwort \\
\hline Heringsfischerei-Unternehmen, Ansiedlung & 1894-1914 & 2.744 \\
\hline Heringsköpfe, Sammlung zur Ölgewinnung & $1915-1918$ & 3.242 \\
\hline Heringslogger "Consul Valk" & 1907 & 2.176 \\
\hline Heringslogger "AE 7" & $1875-1900$ & 1.628 \\
\hline Heringslogger "Borkum" & 1907 & 2.176 \\
\hline Heringslogger "Dortmund" & 1907 & 2.177 \\
\hline Heringslogger "Norderney" & 1907 & 2.176 \\
\hline Heringslogger, Ausstattung mit Dampfkessel & 1906 & 2.164 \\
\hline & 1906 & 2.166 \\
\hline & 1898 & 2.172 \\
\hline & 1900 & 2.173 \\
\hline & 1907 & 2.176 \\
\hline
\end{tabular}


Index

\begin{tabular}{|c|c|c|}
\hline \multicolumn{3}{|l|}{$\mathrm{SACH}$} \\
\hline Indexbegriff & Laufzeit & Lfd.Nr. \\
\hline Heringslogger, Ausstattung mit Dampfkessel & 1907 & 2.177 \\
\hline Heringslogger, Kollision & $1875-1900$ & 1.628 \\
\hline Heringslogger, Rettungsboote & $1875-1912$ & 1.414 \\
\hline Heringslogger, Rettungsgerät & $1875-1912$ & 1.414 \\
\hline Heringslogger, Seeunfall & $1875-1900$ & 1.628 \\
\hline Heringslogger, Verzeichnis & 1896-1897 & 1.401 \\
\hline \multirow[t]{2}{*}{ Herrlichkeitsgefälle } & 1886-1899 & 2.664 \\
\hline & $1900-1906$ & 2.665 \\
\hline Herrlichkeitsgefälle, Erhebung & 1867-1909 & 2.663 \\
\hline Heu, Bewirtschaftung & 1918 & 3.298 \\
\hline Heu, Selbstentzündung & 1872 & 1.302 \\
\hline Heumengen, Kontrolle nach Einlagerung & 1902-1909 & 1.249 \\
\hline Hilfsbedürftige, Unterstützung Emder in anderen Orten & 1913-1915 & 1.872 \\
\hline Hilfsfonds, Verbesserung der Feuerlöscheinrichtungen & 1867-1869 & 1.284 \\
\hline Hilfsfonds, Zulassung & 1904-1906 & 3.492 \\
\hline Hilfslehrer, Beschäftigung an der Kaiser-Friedrich-Realschule & $1907-1916$ & 3.721 \\
\hline Hilfslehrerstelle, Umwandlung in eine ordentlichen Stelle & 1867-1884 & 3.668 \\
\hline Hilfslehrerstellen, Besetzung & 1892-1908 & 3.723 \\
\hline Hilfspolizei, Bildung im Krieg von 1866 & 1866 & 509 \\
\hline \multirow[t]{2}{*}{ Hilfsschule, Aufnahmekriterien } & 1900-1907 & 3.708 \\
\hline & $1908-1918$ & 3.709 \\
\hline Hilfsschule, Aufsicht & $1900-1907$ & 3.708 \\
\hline Hilfsschule, Ausstattung & $1908-1918$ & 3.709 \\
\hline Hilfsschule, Beihilfeantrag & $1908-1918$ & 3.709 \\
\hline Hilfsschule, Dienstanweisung für Leiter & $1908-1918$ & 3.709 \\
\hline Hilfsschule, Errichtung in Emden & $1900-1907$ & 3.708 \\
\hline Hilfsschule, Etat & $1908-1918$ & 3.709 \\
\hline Hilfsschule, Konstituierung & $1908-1918$ & 3.709 \\
\hline Hilfsschule, Lehrplan & $1900-1907$ & 3.708 \\
\hline Hilfsschule, Leitung & $1900-1907$ & 3.708 \\
\hline Hilfsschule, Organisation & 1900-1907 & 3.708 \\
\hline Hilfsschule, Revision & 1900-1907 & 3.708 \\
\hline Hilfsschule, Schulbetrieb & $1908-1918$ & 3.709 \\
\hline Hilfsschule, Staatszuschuss & 1900-1907 & 3.708 \\
\hline Hilfsschule, Überweisung von Schülern & $1908-1918$ & 3.709 \\
\hline Hilfsschullehrer, Gehaltszulagen & $1909-1911$ & 3.532 \\
\hline Hilfsverein, Aktivitäten & $1870-1872$ & 593 \\
\hline Hindenburg-Feier, Organisation & 1916-1917 & 3.314 \\
\hline Hindenburg-Gabe & 1916-1917 & 3.314 \\
\hline Hindenburg-Spende, Aufruf & 1916-1917 & 3.314 \\
\hline Hinterbliebenenversorgung, Erster Weltkrieg & $1914-1918$ & 3.189 \\
\hline Hintergebäude, Bauantrag & 1906 & 1.194 \\
\hline Hochofenanlage, Rentabilitätsberechnung & 1905-1909 & 2.361 \\
\hline Hochofenwerk, Aktienzeichnung & 1905-1909 & 2.361 \\
\hline Hochofenwerk, Ansiedlung in Emden & $1905-1906$ & 2.360 \\
\hline Hochofenwerk, Aufbau & $1905-1909$ & 2.361 \\
\hline Hochofenwerk, Betriebsgelände & $1906-1910$ & 2.374 \\
\hline Hochofenwerk, Gründungsprämie & 1905-1909 & 2.361 \\
\hline Hochschule, Programm & 1913 & 3.710 \\
\hline Hochseefischereigesellschaft, Gründung in Emden & 1914-1918 & 3.232 \\
\hline Hochspannungsleitung, Anlage & 1912 & 1.092 \\
\hline Hochspannungsleitung, Störung d. Telegrafenleitung & 1914 & 1.095 \\
\hline Hochspannungsleitungsmasten, Warntafeln & $1887-1913$ & 1.248 \\
\hline Hochspannungsnetze, Sicherheitsvorschriften & $1887-1913$ & 1.248 \\
\hline Höchstpreise, Festsetzung & 1916-1918 & 3.282 \\
\hline Höchstpreisverordnung, Verstoß & $1917-1918$ & 3.308 \\
\hline Höchstpreisverordnung, Verstöße & $1914-1916$ & 3.194 \\
\hline Hochverrat, Berichterstattungspflicht bei Auftreten & $1867-1884$ & 510 \\
\hline
\end{tabular}


Index

\section{SACH}

Indexbegriff

Hochwasserstände, Nachrichtenübermittlung

Hochzeitsgabe, Kronprinzenpaar

Hof- und Staatshandbuch, Daten der Stadt Emden

Hohenzollerndynastie, Regierungsjubiläum

Hohenzollernhütte, Aktienkaufangebote

Hohenzollernhütte, Erbpacht

Hohenzollernhütte, Kapitalerhöhung

Hohenzollernhütte, Sanierung

Hohenzollernorden, Verleihung an Lehrer

Höhere Töchterschule, Schuldiener

Holzbude, Abbruch

Holzdarre, Verbotsdiskussion

Holzschuhe, Bewirtschaftung

Holzschuhe, Preise

Honorarvertrag, Christian Boysen als Hilfsschreiber

Hoppesaugbagger "Berlin"

Hufschmiede, Prüfungsordnung

Hufschmiede, Zulassung

Hühnerstall, Abrissverfügung

Hühnerstall, Geruchsbelästigung und Rattenplage

Hundefuhrwerke, Regelung

Hundeschlachtung

Hundesteuer, Befreiung

Hundesteuer, Erhebung

Laufzeit

1877-1916

$1886-1909$

1904-1905

1823-1914

1915

1905-1909

1905-1909

1910-1911

1910-1911

1910-1911

1900-1911

1906-1918

1901-1908

1872-1903

1917-1918

1917-1918

1912-1915

1908

1887-1891

1887-1891

1906

1897-1912

1889-1892

1881-1910

1867-1889

1893-1898

1867-1889

1893-1898

1892-1893

1867-1889

1867-1889

1893-1898

1893-1898

1893-1898

1867-1889

1867-1889

1900-1903

1887-1907

1871-1914

1885-1914

1866-1888

1914

1914

1914-1918

1888-1913

1871-1913

1865-1895

1895-1910

Industrialisierung

Industrie, Erschließung von Land

Industrie, Statistische Berichte

Industrieansiedlung
1903-1904

1881-1909

1881-1900

1900-1906

1896-1901

1902-1912

1896-1899

1906-1907
Lfd.Nr.

1.556

1.413

197

192

200

2.361

2.361

2.362

2.362

2.362

259

3.782

2.445

1.250

3.296

3.296

347

2.313

1.951

1.951

1.222

1.157

833

726

2.931

2.932

2.931

2.932

2.933

2.931

2.931

2.932

2.932

2.932

2.931

2.931

1.165

1.393

757

2.431

2.486

3.234

3.241

3.204

3.458

419

746

747

Vorwort

2.132

2.364

2.365

2.366

2.370

2.371 
Index

SACH

Indexbegriff

Infanterie-Regiment, Jubiläumsfeier

Infektionskrankheiten, Anzeige

Infektionskrankheiten, Bekämpfung

Ingenieurbüros, Angebote über Beratung und Ausführung

Inhaftierung, Verweigerung wegen fehlenden Haftbefehl

Innungs- und Handwerksgesetz, Diskussion

Innungswesen, Reform

Innungswesen, Wiederbelebung

Inschutzhaftnahme, Geisteskrankheit

Inselbahn, Borkum

Inselbahn, Finanzierung

Inselbahn, Umwandlung in aktiengesellschaft

Insignien, Rücksendung

Installateur, Zulassungsantrag für Gasleitungen und - Anschlüsse

Internat, Einrichtung

Invaliden- und Hinterbliebenenversicherung, Vorgänge

Invaliden, Spendensammlung für Notleidende

Invaliden, Unterstützung

Invaliden, Unterstützungszahlungen

Invalidenrente, Übertragung

Inventarium, Französisch-reformierte Gemeinde

Inventar-Veränderungen, Lutherische Gemeinde

Inventarverzeichnis, Reformierte Klassenschule

Irrenanstalt, Grundstücke für den Bau

Irrenanstalt, Initiative zur Errichtung

Isolierbaracke, Anschaffung für das Krankenhaus

Israelitische Gemeinde, Bestätigung der Vorstandswahl

Israelitische Gemeinde, Datenanforderung über

Israelitische Gemeinde, Gemeindestatut

Israelitische Gemeinde, Protest gegen Vorstandswahl

Israelitische Gemeinde, Revision der Gemeinde-Statuten

Israelitische Gemeinde, Statuten

Israelitische Gemeinde, Statutenänderung

Israelitische Gemeinde, Vereidigung der Vorstandsmitglieder

Israelitische Gemeinde, Vorstandswahl

Israelitische Kranken- und Beerdigungsbruderschaft, Statuten

Israelitische Kranken- und Beerdigungsbruderschaft, Strafen

Jagd, Verbotene auf dem Königspolder

Jagd, Verpachtung im städtischen Teil des Kaiser-Wilhelm-Polder

Jagdpacht, Anteil

Jagdpacht, Ermäßigung

Jagdstrecke, Rückgang

Jahresbericht, Flottenbund deutscher Frauen

Jahresberichte, Dtsch. Zentralver. z. Fürs. f. d. schulentl. Jugend

Jahresberichte, Firmen in Emden

Jahresberichte, Henriettenstiftung in Hannover

Jahresberichte, Kaiser-Friedrichs-Realschule

Jahresberichte, Ostfriesische reformierte Pfarrtöchterkasse

Jahresberichte, Verein für Diakonissen-Krankenpflege

Jahresberichte, Vereine

Jahreskollekte, Kaiser-Wilhelm-Stiftung f. dtsch. Invaliden

Laufzeit

Lfd.Nr.

1907

1.243

$1891-1913$

3.089

$1871-1914$

757

$1871-1914$

757

1906

769

1908

1.087

1909-1911

1874-1913

1.088

172

1893-1912

1.926

1.936

1880-1890

1880-1890

1916

1.936

1.886

1883-1901

2.044

2.044

2.044

259

1.040

1900-1911

1881-1897

1903

1912

1900-1909

1901-1912

1885

1887

1898-1917

1869-1895

1868-1905

1890

1896

1896

1904-1906

1865-1903

1867-1903

1858-1911

1865-1903

1902-1903

1902-1903

1902-1903

1865-1903

1865-1903

1847-1902

1847-1902

1869-1900

1870-1911

1870-1911

1870-1911

1870-1911

1907-1908

1902-1913

1895-1914

1861-1903

1904-1915

1888-1903

1900-1911

1861-1903

1904-1915

1867-1901

1887
3.754

1.683

264

590

579

580

1.882

3.417

3.447

3.624

520

520

1.696

490

483

489

490

487

487

487

490

490

494

494

819

820

820

820

820

685

660

462

577

578

3.715

650

577

578

310

580 
Index

\begin{tabular}{|c|c|c|}
\hline \multicolumn{3}{|l|}{ SACH } \\
\hline Indexbegriff & Laufzeit & Lfd.Nr. \\
\hline \multirow[t]{3}{*}{ Jahresrechnung, Kaiser-Wilhelm-Stiftung für deutsche Invaliden } & 1894-1897 & 581 \\
\hline & 1899-1908 & 583 \\
\hline & 1908-1909 & 584 \\
\hline Jahrmärkte, Ruhestörung & $1877-1910$ & 2.146 \\
\hline Jahrmärkte, Verhinderung von Ausschreitungen & $1877-1910$ & 2.146 \\
\hline Jauchegrube, Beschwerde gegen & 1909-1910 & 826 \\
\hline Jaucheschuppen, Bau & 1879 & 867 \\
\hline Jesuiten-Orden, Verbot & $1872-1873$ & 3.324 \\
\hline Johanniter - Hospital, Gründungsinitiative & $1882-1883$ & 1.690 \\
\hline Jubiläumsausgabe, "Ostfriesische Zeitung" & $1912-1914$ & 721 \\
\hline Juden, Ausgewiesene aus Russland & 1914 & 498 \\
\hline Juden, Auswanderung & $1867-1876$ & 484 \\
\hline Juden, Ausweisung von Ausländern aus Russland & $1867-1895$ & 502 \\
\hline Juden, Familiennamensänderung im Fall des Glaubenswechsels & 1867-1903 & 483 \\
\hline Juden, Förderung der Assimilation & 1867-1909 & 486 \\
\hline Jüdischer Friedhof, Verbot der ungenehmigten Ausdehnung & $1847-1902$ & 494 \\
\hline Jugend, Militärische Vorausbildung & 1913-1914 & 517 \\
\hline Jugendhilfe, Einrichtungen & $1902-1913$ & 660 \\
\hline Jugendliche, Beschäftigung als Arbeiter & $1872-1904$ & 2.382 \\
\hline Jugendliche, Sachbeschädigungen & $1892-1913$ & 516 \\
\hline \multirow{2}{*}{ Jugendpflege, Denkschriften und Publikationen } & $1892-1913$ & 516 \\
\hline & 1913-1914 & 517 \\
\hline Jugendpflege, Einrichtungen & 1913-1914 & 517 \\
\hline \multirow{2}{*}{ Jugendpflege, Förderung von Vereinen } & $1892-1913$ & 516 \\
\hline & 1913-1914 & 517 \\
\hline Jugendpflege, Verein "Jugendwohl Frisia" & 1913-1914 & 517 \\
\hline Jugendpflege, Verein "Patriotische Jugendwehr" & 1913-1914 & 517 \\
\hline Jugendpflege, Versicherung & 1913-1914 & 517 \\
\hline Kabeltrasse, Plan & $1912-1913$ & 1.110 \\
\hline Kaffee, Ersatz & $1915-1918$ & 3.242 \\
\hline Kaffeegrund-Sammlung & 1916-1918 & 3.230 \\
\hline Kaigeld, Befreiung & $1852-1875$ & 451 \\
\hline Kaimauer, Abrissantrag & $1876-1908$ & 266 \\
\hline Kaimauer, Bau & 1876-1908 & 266 \\
\hline Kaiserbesuch & $1902-1903$ & 177 \\
\hline \multirow[t]{2}{*}{ Kaiserbesuch, Absage } & 1901 & 181 \\
\hline & $1897-1901$ & 182 \\
\hline Kaiserbesuch, Ausschmückung & 1902 & 184 \\
\hline Kaiserbesuch, Ausstellung von Urkunden & 1902 & 186 \\
\hline Kaiserbesuch, Danktelegramm & 1902 & 186 \\
\hline Kaiserbesuch, Dekoration & 1901 & 181 \\
\hline Kaiserbesuch, Drucksachen & 1902 & 185 \\
\hline Kaiserbesuch, Durchlasskarten & 1902 & 185 \\
\hline Kaiserbesuch, Ehrenkompanie & 1902 & 186 \\
\hline Kaiserbesuch, Einfahrt der Kaiser-Yacht in die Ems & 1902 & 186 \\
\hline \multirow[t]{2}{*}{ Kaiserbesuch, Einladungen } & 1902 & 183 \\
\hline & 1902 & 185 \\
\hline Kaiserbesuch, Einladungen an Fürbringer nach Hannover & 1898 & 188 \\
\hline Kaiserbesuch, Einladungskarten, Eintrittskarten, Speiseplan & 1902 & 179 \\
\hline Kaiserbesuch, Eintrittskarten & 1902 & 185 \\
\hline Kaiserbesuch, Erinnerungsmedaille & 1901-1913 & 187 \\
\hline Kaiserbesuch, Festessen & 1901 & 181 \\
\hline Kaiserbesuch, Festschrift & $1897-1901$ & 182 \\
\hline Kaiserbesuch, Fotoausstellung & 1903-1904 & 2.637 \\
\hline Kaiserbesuch, Galavorstellung in Hannover & 1898 & 188 \\
\hline Kaiserbesuch, Hannover & 1898 & 188 \\
\hline Kaiserbesuch, Kosten & 1901 & 181 \\
\hline
\end{tabular}


Index

SACH

\begin{tabular}{l} 
Indexbegriff \\
\hline Kaiserbesuch, Kritik des ostfriesischen Sängerbundes \\
Kaiserbesuch, Organisation \\
Kaiserbesuch, Personenschutz \\
Kaiserbesuch, Planung \\
Kaiserbesuch, Presseberichte
\end{tabular}

Kaiserbesuch, Presseberichte in Hannover

Kaiserbesuch, Rathausausschmückung

Kaiserbesuch, Rechnungsrevision

Kaiserbesuch, Reden des Oberbürgermeisters L. Fürbringer

Kaiserbesuch, Speiseplan und Musik

Kaiserbesuch, Sperrungen

Kaiserbesuch, Straßenausschmückung

Kaiserbesuch, Veranstaltungen

Kaiserbesuch, Verkauf von Bildern

Kaiserbildnis, Überweisung

Kaiser-Denkmal, Enthüllungsfeier

Kaiser-Denkmal, Errichtung

Kaiser-Friedrich-Realschule, Etat

Kaiser-Friedrich-Realschule, Freistellen

Kaiser-Friedrich-Realschule, Namensverleihung

Kaiser-Friedrich-Realschule, Staatszuschuss

Kaiser-Friedrich-Realschule, Statuten

Kaisergeburtstag, Feier

Kaiserin-Auguste-Viktoria-Schule, Direktorenwahl

Kaiserparade, Hannover,

Kaiserparade, Teilnahme des Emder Kriegervereins

Kaiserreisen, Garderobenordnung

Kaiserreisen, Verhaltensbestimmungen für Zivilbehörden

Kaiserreisen, Verkehrsbeschränkungen

Kaiserstandbild, Angebote

Kaiserstandbild, Errichtung

Kaiserstandbild, Planung

Kaiserstandbild, Spendenaufruf

Kaisertage, Teilnahme des emder Oberbürgermeisters

Kaistraße, Überdachung

Kajegeld, Verwaltung

Kajung, Anlageerlaubnis

Laufzeit

Lfd.Nr.

$\begin{array}{cc}1902 & 186 \\ 1902 & 186 \\ 1900-1901 & 176 \\ 1900-1901 & 176\end{array}$

1897-1901 182

$1902 \quad 185$

$1902 \quad 186$

$1898 \quad 188$

1897-1901 182

$1901 \quad 181$

$1902 \quad 186$

$1898 \quad 188$

$1902 \quad 186$

$1902 \quad 184$

$1902 \quad 183$

$1902 \quad 185$

$1902 \quad 186$

1900-1909 264

1895-1899 202

1895-1899 202

$1892-1900 \quad 3.758$

1901-1906 $\quad 3.759$

1914-1917 $\quad 3.761$

1888-1889 $\quad 3.745$

$1893-1910 \quad 3.757$

1893-1910 $\quad 3.757$

1917-1918 $\quad 199$

1901-1912 643

$1910 \quad 3.813$

$1898 \quad 188$

1873-1910 598

1874-1911 190

1874-1911 190

1874-1911 190

1888-1902 194

1888-1902 194

1879-1880 193

$1879-1880 \quad 193$

$1907 \quad 195$

$1902-1905 \quad 1.960$

1857-1885 418

$1868 \quad 2.689$

$1871 \quad 2.690$

1876-1880 $\quad 1.496$

1888-1903 $\quad 1.503$

$1892-1893 \quad 1.504$

1901-1907 1.502

1873-1897 2.549

1876-1901 $\quad 1.501$

1876-1901 1.501

1869-1901 1.159

$1866-1893 \quad 1.533$

1873-1875 $\quad 2.450$

$1876-1880 \quad 1.496$

1910-1912 $\quad 1.160$

1888-1903 1.503

1869-1901 $\quad 1.159$

Kajung, Ungenehmigte Anlage

$1888-1903 \quad 1.503$

Kajungen, Abtretung an den Staat 
IV

Index

SACH

Indexbegriff

Kajungen, Eigentumsrechte

Kajungen, Reparaturanordnung

Kajungen, Reparaturkosten

Kajungen, Schadhafte

Kajungen, Wester- und Osterbutvenne

Kajungswesen, Emden

Kakao, Erfassung

Kalksandstein, Prüfung auf Brandfestigkeit

Kämmerei, Einnahmen und Ausgaben

Kämmerei, Tagesabschlüsse

Kämmerei, Tageseinnahmen und Ausgaben

Kämmereietat, Außerordentliche Ausgaben

Kämmereietat, Bemerkungen

Kämmereietat, Festsetzung

Kämmereietat, Stadt Emden

\section{Laufzeit}

1878-1888

1888-1903

1888-1903

1888-1903

1910-1912

1876-1901

1888-1903

1914-1918

1904-1905

1889-1890

1893-1894

1917-1918

1902-1903

1891-1892

1867-1888

1871-1875

1876-1877

1878

1879-1880

1880-1881

1881-1882

1882-1883

1883-1884

1885-1886

1886-1887

1888

1888-1889

1890-1891

1891-1892

1892-1893

1893-1894

1894-1895

1895-1896

1896-1898

1898-1899

1900-1901

1901-1902

1902-1903

1903-1904

1904-1905

1906-1911

1870

1871

1872

1891-1892

1892-1893

1893-1894

1894-1895

1895-1896

1896-1897

1897-1898

1898-1899

1899-1900

1900-1901

1901-1902

1902-1903

1903-1904

1904-1905

\section{Lfd.Nr.}

1.493

1.503

1.503

1.503

1.160

1.501

1.503

3.245

1.273

3.082

3.083

3.080

3.081

3.048

3.012

3.017

3.019

3.020

3.021

3.022

3.023

3.024

3.025

3.026

3.027

3.028

3.029

3.030

3.031

3.032

3.033

3.034

3.035

3.036

3.037

3.038

3.039

3.040

3.041

3.042

3.043

3.045

3.046

3.047

3.048

3.049

3.050

3.051

3.053

3.054

3.055

3.056

3.057

3.058

3.059

3.060

3.061

3.062 
Index

\begin{tabular}{|c|c|c|}
\hline \multicolumn{3}{|l|}{ SACH } \\
\hline Indexbegriff & Laufzeit & Lfd.Nr. \\
\hline \multirow[t]{12}{*}{ Kämmereietat, Stadt Emden } & 1905-1906 & 3.063 \\
\hline & $1906-1907$ & 3.064 \\
\hline & $1907-1908$ & 3.065 \\
\hline & $1909-1910$ & 3.066 \\
\hline & $1910-1911$ & 3.067 \\
\hline & 1911-1912 & 3.068 \\
\hline & $1912-1913$ & 3.069 \\
\hline & 1913-1914 & 3.070 \\
\hline & 1914-1915 & 3.071 \\
\hline & $1915-1916$ & 3.072 \\
\hline & 1916-1917 & 3.073 \\
\hline & $1917-1918$ & 3.074 \\
\hline Kämmereikasse, Kassenführung & $1866-1881$ & 2.991 \\
\hline Kämmereikasse, Kassenkredit & 1892-1894 & 2.998 \\
\hline Kämmereikasse, Kassenkredite & $1866-1881$ & 2.991 \\
\hline Kämmereikasse, Zahlungsverkehr & $1866-1881$ & 2.991 \\
\hline Kämmereirechnung, Auszüge & 1867-1888 & 3.012 \\
\hline Kämmerei-Schreiber, Bewerbung & $1891-1892$ & 341 \\
\hline Kämmerei-Schreiber, Einstellung & 1891-1892 & 341 \\
\hline Kämmerei-Schreiber, Entlassungsgesuch & 1891-1892 & 341 \\
\hline Kammerjägerwesen, Regelung & 1870 & 515 \\
\hline Kampher, Ersatz & 1903-1914 & 1.686 \\
\hline \multirow[t]{2}{*}{ Kanal, Anpassung an Schiffsgrößen } & $1891-1893$ & 2.025 \\
\hline & 1893-1897 & 2.026 \\
\hline Kanal, Beschwerde der Landwirtschaft & $1890-1891$ & 2.023 \\
\hline Kanal, Einweihung & $1887-1912$ & 1.437 \\
\hline Kanal, Festschrift & 1875-1882 & 1.434 \\
\hline Kanal, Förderung & 1899 & 2.028 \\
\hline Kanal, Presseberichte & $1899-1913$ & 2.027 \\
\hline Kanal, Schleusenanschluss & $1879-1883$ & 1.433 \\
\hline Kanal, Sperrung & 1899-1913 & 2.027 \\
\hline Kanal, Veräußerung von Grundflächen & 1875-1882 & 1.431 \\
\hline Kanal, Verkehrsbehinderungen & 1887-1912 & 1.437 \\
\hline Kanal, Verkehrsförderung & 1899-1913 & 2.027 \\
\hline Kanal, Verkehrsregelungen & 1902 & 1.509 \\
\hline Kanal, Verkehrsstatistik & 1899-1913 & 2.027 \\
\hline Kanal, Verlaate & 1879-1883 & 1.433 \\
\hline Kanal, Verstopfung & $1880-1907$ & 893 \\
\hline Kanal, Von der Mühlenstraße zum Falderndelft & 1885 & 972 \\
\hline Kanal, Wasserpegel & 1887-1912 & 1.437 \\
\hline Kanalabgabe, Ausdehnung & 1873-1898 & 1.562 \\
\hline Kanalabgabe, Befreiung von mit Dung beladener Schiffe & 1873-1898 & 1.562 \\
\hline Kanalabgabe, Beschwerden von Fehnschiffern & 1873-1898 & 1.562 \\
\hline Kanalabgabe, Entschädigungsforderung f. entgangene Einnahmen & $1900-1912$ & 1.563 \\
\hline Kanalabgabe, Hebung in Emden & 1873-1898 & 1.562 \\
\hline Kanalabgabe, Umgehung & $1868-1897$ & 1.564 \\
\hline Kanalabgabe, Verpachtung & 1873-1898 & 1.562 \\
\hline Kanalabgabeneinnehmer, Bewerbungen & $1900-1912$ & 1.563 \\
\hline Kanalabgabeneinnehmer, Dienstaufgaben & 1873-1898 & 1.562 \\
\hline \multirow[t]{2}{*}{ Kanalabgabeneinnehmer, Einstellung } & 1873-1898 & 1.562 \\
\hline & $1900-1912$ & 1.563 \\
\hline Kanalanlage, Übertragung & 1885 & 972 \\
\hline Kanalanschluss, Kostenträgerschaft & 1903 & 943 \\
\hline Kanalanschlussbeiträge, Festlegung & 1903 & 943 \\
\hline Kanalanschlüsse, Kontrollverweigerung & $1886-1888$ & 931 \\
\hline Kanalanschlüsse, Mängel & $1886-1888$ & 931 \\
\hline Kanalanschlüsse, Reinigungspflicht & $1886-1888$ & 931 \\
\hline Kanalanschlussgebühren, Festlegung & $1893-1901$ & 940 \\
\hline
\end{tabular}


Index

\section{SACH}

\begin{tabular}{|c|c|c|}
\hline Indexbegriff & Laufzeit & Lfd.Nr. \\
\hline Kanalanschlussgebühren, Festlegung & $1902-1906$ & 942 \\
\hline Kanalanschlussgebühren, Überschuss & $1900-1904$ & 938 \\
\hline Kanalbau Arbeiterfürsorge & $1890-1891$ & 2.023 \\
\hline Kanalbau, Antipropaganda & 1884-1886 & 2.024 \\
\hline Kanalbau, Architektenpreis & $1884-1886$ & 2.024 \\
\hline Kanalbau, Bauleitung & $1890-1891$ & 2.023 \\
\hline \multirow[t]{2}{*}{ Kanalbau, Beiträge der Stadt Emden } & $1879-1883$ & 1.433 \\
\hline & $1883-1887$ & 1.435 \\
\hline Kanalbau, Enteignungen & $1883-1887$ & 1.435 \\
\hline Kanalbau, Enteignungsverfahren & $1890-1891$ & 2.023 \\
\hline Kanalbau, Grunderwerb & $1893-1897$ & 2.026 \\
\hline \multirow[t]{2}{*}{ Kanalbau, Grunderwerbskosten } & $1890-1891$ & 2.023 \\
\hline & $1884-1886$ & 2.024 \\
\hline Kanalbau, Kosten & $1875-1882$ & 1.431 \\
\hline Kanalbaubeiträge, Befreiungsantrag & $1885-1900$ & 907 \\
\hline Kanalbaufirmen, Werbeschriften & $1885-1910$ & 905 \\
\hline Kanalbauzwecke, Grundstücke & $1885-1910$ & 905 \\
\hline Kanalbetrieb & $1899-1913$ & 2.027 \\
\hline Kanäle, Benutzungsgebühr & $1895-1913$ & 2.982 \\
\hline Kanäle, Übersichtskarte & $1890-1891$ & 2.023 \\
\hline Kanalgebühren, Festsetzung & $1885-1914$ & 932 \\
\hline Kanalgebührenordnung, Stadt Emden & $1877-1912$ & 324 \\
\hline Kanalhausanschlüsse, Reinigungspflicht & $1885-1902$ & 929 \\
\hline Kanalisation, Abortanschlüsse & $1911-1913$ & 957 \\
\hline Kanalisation, Altertümer & $1885-1887$ & 916 \\
\hline \multirow[t]{2}{*}{ Kanalisation, Anlage } & $1884-1896$ & 900 \\
\hline & $1900-1903$ & 1.165 \\
\hline \multirow[t]{3}{*}{ Kanalisation, Anschluss } & $1885-1900$ & 907 \\
\hline & 1886 & 926 \\
\hline & 1904 & 946 \\
\hline Kanalisation, Anschluss des Bahnhofes & 1888-1895 & 2.537 \\
\hline Kanalisation, Anschluss in Wolthusen & 1906-1912 & 253 \\
\hline Kanalisation, Anschluss Wolthusen an Emden & $1906-1913$ & 952 \\
\hline \multirow[t]{2}{*}{ Kanalisation, Anschlüsse } & $1880-1907$ & 893 \\
\hline & $1887-1910$ & 935 \\
\hline Kanalisation, Aufbau & $1886-1894$ & 870 \\
\hline Kanalisation, Ausbau & $1892-1912$ & 881 \\
\hline Kanalisation, Bau & $1880-1907$ & 893 \\
\hline Kanalisation, Beantragung & $1890-1901$ & 896 \\
\hline Kanalisation, Bekanntmachung & 1884-1896 & 900 \\
\hline Kanalisation, Beleuchtung der Baugruben & $1885-1886$ & 912 \\
\hline Kanalisation, Beschwerden & $1885-1886$ & 918 \\
\hline \multirow[t]{3}{*}{ Kanalisation, Beschwerden wg. Funktionsstörungen } & $1885-1886$ & 919 \\
\hline & $1886-1895$ & 920 \\
\hline & $1893-1914$ & 937 \\
\hline Kanalisation, Düker & $1885-1896$ & 924 \\
\hline Kanalisation, Durchlass durch die Küstenbahn & $1886-1887$ & 925 \\
\hline Kanalisation, Entschädigung für Grundbesitzer & $1885-1896$ & 924 \\
\hline Kanalisation, Entschädigung von Grundbesitzer & $1885-1896$ & 924 \\
\hline Kanalisation, Finanzielle Belastung & $1884-1885$ & 904 \\
\hline Kanalisation, Finanzierung & 1884-1896 & 900 \\
\hline Kanalisation, Fossilien & $1885-1887$ & 916 \\
\hline Kanalisation, Gartenstraße & $1911-1913$ & 957 \\
\hline Kanalisation, Gasexplosion & $1893-1914$ & 937 \\
\hline Kanalisation, Gebäudeschäden & $1886-1895$ & 920 \\
\hline \multirow[t]{2}{*}{ Kanalisation, Geruchsbelästigung } & 1886-1895 & 920 \\
\hline & 1888-1909 & 928 \\
\hline Kanalisation, Gutachten & 1883-1885 & 914 \\
\hline
\end{tabular}


Index

\begin{tabular}{|c|c|c|}
\hline \multicolumn{3}{|l|}{ SACH } \\
\hline Indexbegriff & Laufzeit & Lfd.Nr. \\
\hline Kanalisation, Hausanschlüsse & $1885-1910$ & 905 \\
\hline Kanalisation, Konzipierung und Kostenschätzung & 1884 & 902 \\
\hline Kanalisation, Kostenträgerschaft für Anschluss & $1887-1910$ & 935 \\
\hline \multirow[t]{2}{*}{ Kanalisation, Kostenvoranschläge } & $1884-1885$ & 904 \\
\hline & $1896-1913$ & 950 \\
\hline Kanalisation, Legung durch Bahntrasse & 1904-1905 & 947 \\
\hline Kanalisation, Massenberechnung & 1884 & 903 \\
\hline Kanalisation, Organisationsvorbilder & 1909-1912 & 951 \\
\hline Kanalisation, Planzeichnungen & $1885-1910$ & 905 \\
\hline Kanalisation, Pumpsysteme & 1885-1907 & 909 \\
\hline Kanalisation, Reservoir & 1888-1909 & 928 \\
\hline Kanalisation, Schäden durch Leckagen & 1886-1895 & 920 \\
\hline Kanalisation, Stammsiel durch Eisenbahntrasse & $1886-1900$ & 923 \\
\hline Kanalisation, Statut über Anlage & $1885-1886$ & 930 \\
\hline Kanalisation, Straßenschäden & $1886-1895$ & 920 \\
\hline \multirow[t]{2}{*}{ Kanalisation, Umgestaltung } & 1905-1908 & 948 \\
\hline & $1899-1900$ & 949 \\
\hline Kanalisation, Verstopfung in Wolthusen & $1890-1910$ & 252 \\
\hline Kanalisation. Offener Abflussgraben & 1888-1909 & 928 \\
\hline Kanalisations- und Entwässerungsfragen, Presseberichte & 1884 & 902 \\
\hline Kanalisationsanlage, Ermscher Brunnen & $1910-1911$ & 955 \\
\hline Kanalisationsarbeiten, Ausgaben & $1885-1891$ & 908 \\
\hline Kanalisationsarbeiten, Zahlungen & $1885-1891$ & 908 \\
\hline \multirow[t]{2}{*}{ Kanalisationsbauten, Abnahme } & 1887 & 933 \\
\hline & 1893-1894 & 936 \\
\hline \multirow[t]{2}{*}{ Kanalisationsfragen, Verhandlungen } & 1884-1896 & 900 \\
\hline & 1884-1885 & 901 \\
\hline Kanalisationskosten, Anteile & $1902-1903$ & 1.498 \\
\hline Kanalisationsplan, Erläuterungen & 1884-1885 & 904 \\
\hline Kanalisationsplan, Unzulässiger & $1905-1906$ & 1.191 \\
\hline Kanalisationspläne, Gutachten & 1884-1885 & 904 \\
\hline Kanalisationsprojekt, Aktenstücke & 1883-1885 & 914 \\
\hline Kanalisationsprojekt, Plan & $1909-1910$ & 251 \\
\hline Kanalisationsprojekt, Staatszuschuss & $1896-1913$ & 950 \\
\hline Kanalisationsprojekt, Stellungnahme & $1909-1910$ & 251 \\
\hline Kanalisationswärter, Kanalreinigungs-Aufgabe & $1906-1912$ & 432 \\
\hline Kanalisationszwang, Einführung & 1885-1902 & 929 \\
\hline Kanalisierung, Abtretung städtischer Ländereien & 1885 & 913 \\
\hline Kanalisierung, Anleihe & $1885-1891$ & 908 \\
\hline Kanalisierung, Antrag & 1905 & 954 \\
\hline Kanalisierung, Auftragsvergabe & $1885-1889$ & 906 \\
\hline Kanalisierung, Bauleitung & 1884-1888 & 911 \\
\hline Kanalisierung, Bauleitungsbüro & $1885-1887$ & 921 \\
\hline Kanalisierung, Beantragung & $1902-1903$ & 1.498 \\
\hline Kanalisierung, Bentincksweg & 1888-1902 & 983 \\
\hline Kanalisierung, Bentincksweg und Grüner Weg & 1902-1906 & 942 \\
\hline Kanalisierung, Beschäftigte Beamte & 1884-1888 & 911 \\
\hline \multirow[t]{2}{*}{ Kanalisierung, Boltentorviertel } & 1893-1894 & 936 \\
\hline & $1899-1900$ & 949 \\
\hline Kanalisierung, Buch- und Rechnungsführer & 1884-1888 & 911 \\
\hline Kanalisierung, Drucksachen & $1883-1885$ & 914 \\
\hline Kanalisierung, Enteignungsverfahren & $1902-1905$ & 959 \\
\hline Kanalisierung, Erweiterungsprojekt & $1896-1913$ & 950 \\
\hline Kanalisierung, Finanzierung & $1885-1891$ & 908 \\
\hline Kanalisierung, Gebiet des Bahnhofs West u. des Kleinbahnhofs & 1907 & 956 \\
\hline Kanalisierung, Gefundenes Skelett & $1885-1887$ & 916 \\
\hline Kanalisierung, Graben am Schwarzen Weg & $1886-1887$ & 927 \\
\hline Kanalisierung, Graben an der Petkumer Landstraße & 1881-1909 & 894 \\
\hline
\end{tabular}


Index

\begin{tabular}{|c|c|c|}
\hline \multicolumn{3}{|l|}{ SACH } \\
\hline Indexbegriff & Laufzeit & Lfd.Nr. \\
\hline Kanalisierung, Große Ee & 1867-1896 & 1.492 \\
\hline Kanalisierung, Kosten & $1910-1911$ & 1.014 \\
\hline \multirow[t]{2}{*}{ Kanalisierung, Kostenträgerschaft } & $1867-1896$ & 1.492 \\
\hline & $1867-1893$ & 1.495 \\
\hline Kanalisierung, Kostenvoranschläge & 1885 & 958 \\
\hline Kanalisierung, Lieferung von Tonröhren & 1885 & 958 \\
\hline \multirow[t]{2}{*}{ Kanalisierung, Mittelfreigabe } & 1900 & 941 \\
\hline & $1902-1906$ & 942 \\
\hline Kanalisierung, Nesserlander Straße & 1900-1904 & 938 \\
\hline Kanalisierung, Neutorsbreitergang & 1903 & 943 \\
\hline Kanalisierung, Nordertorstraße & 1893-1901 & 940 \\
\hline Kanalisierung, Oster- und Brauerspiepentief & $1885-1907$ & 909 \\
\hline Kanalisierung, Pactkündigungen & 1885 & 913 \\
\hline Kanalisierung, Projektbeschreibung & 1902-1905 & 959 \\
\hline Kanalisierung, Schweckendieckstraße u. Nesserlander Straße & 1904-1905 & 947 \\
\hline Kanalisierung, Staatszuschuss & 1905-1908 & 948 \\
\hline Kanalisierung, Stinktief & $1867-1893$ & 1.495 \\
\hline Kanalisierung, Straßenschäden & 1885-1889 & 906 \\
\hline Kanalisierung,Teil der Bahnhofsstraße & 1900 & 941 \\
\hline Kanalisierung,Teil der Provinzial-Chaussee Emden-Aurich & $1901-1905$ & 939 \\
\hline Kanalisierungsarbeiten, Ausschreibung & $1885-1889$ & 906 \\
\hline Kanalisierungsarbeiten, Kaution & $1885-1889$ & 906 \\
\hline Kanalleitung, Führung durch die Trasse der Hafenbahn & $1900-1904$ & 938 \\
\hline Kanalnetz, Ausbauplan & 1901 & 2.064 \\
\hline Kanalnetz, Modernisierung & & Vorwort \\
\hline \multirow[t]{2}{*}{ Kanalprojekt, Agitation } & $1882-1883$ & 2.021 \\
\hline & 1885-1889 & 2.022 \\
\hline Kanalprojekt, Bedeutung & 1900 & 2.056 \\
\hline Kanalprojekt, Denkschrift & $1882-1883$ & 2.021 \\
\hline Kanalprojekt, Förderantrag & 1905 & 2.082 \\
\hline Kanalprojekt, Kosten & $1882-1883$ & 2.021 \\
\hline Kanalprojekt, Kritik & 1900 & 2.056 \\
\hline Kanalprojekt, Landtagsverhandlungen & $1884-1886$ & 2.024 \\
\hline \multirow[t]{2}{*}{ Kanalprojekt, Presseberichte } & $1884-1886$ & 2.024 \\
\hline & $1891-1893$ & 2.025 \\
\hline Kanalprojekt, Realisierung & $1885-1889$ & 2.022 \\
\hline \multirow[t]{2}{*}{ Kanalprojekt, Widerstand } & $1906-1907$ & 2.086 \\
\hline & $1909-1913$ & 2.087 \\
\hline \multirow[t]{2}{*}{ Kanalprojekte, Gefahr für den Emder Hafen } & 1906-1907 & 2.086 \\
\hline & $1909-1913$ & 2.087 \\
\hline \multirow[t]{4}{*}{ Kanalprojekte, Presseberichte } & $1892-1898$ & 2.054 \\
\hline & $1899-1900$ & 2.055 \\
\hline & 1900 & 2.056 \\
\hline & $1900-1901$ & 2.057 \\
\hline Kanalrohr, Beschädigung & 1886-1895 & 920 \\
\hline Kanalrohr, Führung & 1893-1894 & 936 \\
\hline Kanalrohr, Tieferlegungsantrag & $1885-1896$ & 924 \\
\hline Kanalröhre, Legung durch Kasernengelände & $1885-1910$ & 905 \\
\hline Kanalschiffe, Beschaffung & $1896-1910$ & 2.051 \\
\hline Kanalschifffahrt, Rückgang & $1866-1891$ & 1.488 \\
\hline Kanaltarif, Festlegung & 1893-1897 & 2.026 \\
\hline Kanalverein, Gründung & $1883-1889$ & 2.136 \\
\hline Kanalverein, Statut & $1883-1889$ & 2.136 \\
\hline Kanalverein, Veranstaltungen über verschiedene Kanalprojekte & 1883-1889 & 2.136 \\
\hline Kanalverkehr, Prognose & 1893-1897 & 2.026 \\
\hline Kanalvorlage & $1899-1900$ & 2.055 \\
\hline Kanalvorlage, Verhandlung im preußischen Herrenhaus & 1884-1886 & 2.024 \\
\hline Kandelaber, Aufstellung & $1895-1912$ & 1.021 \\
\hline
\end{tabular}


Index

SACH

\begin{tabular}{l} 
Indexbegriff \\
\hline Kaninchenzucht, Schüler \\
Kanonenboot "Tiger" \\
Kanonenrohre, Schenkung \\
Kantine, Betriebserlaubnis \\
Kanzleischreiber, Einstellung \\
Kanzlist, Bewerbung \\
Kanzlist, Dienstanordnung \\
Kanzlist, Einstellung
\end{tabular}

Kanzlist, Entlassung

Kanzlist, Gehaltserhöhung

Kanzlist, Gehaltszahlung

Kanzlist, Vereidigung

Kanzlist, Zeugnis

Kanzlisten, Bewerbungen

Kanzlisten, Stellenausschreibung

Kapitalvermögen, Große Kirche

Kapitalvermögen, Neue Kirche

Karte, Anfertigung für Umland der Stadt Emden

Kartell, Emder Hafenbetriebe gegen Gewerkschaft

Kartensteuer, Einführung in Emden

Kartoffel, Bewirtschaftung

Kartoffelkäfer, Bekämpfung

Kartoffellieferung, Armen-Arbeitshaus

Kartoffelpilzkrankheiten, Anzeige

Kartoffelrationierung

Käseimporte, Niederlande

Kaserne, Anlage in Emden

Kaserne, Bau

Kaserne, Bauentwürfe

Kaserne, Belegung

Kaserne, Einrückungsfeier

Kaserne, Entwässerung

Kaserne, Kläranlage

Kaserne, Mietfestsetzung

Kaserne, Nutzungsentgelt

Kaserne, Planung

Kaserne, Privatbetrieb

Kaserne, Revision

Kaserne, Schließung

Kaserne, Übergabetermin

Kaserne, Verpachtung

Kaserne, Wasserversorgung

Kasernenabwasser, Einleitung in das Hinter Tief

Kasernenausstattung, Finanzierung

Kasernenbau, Ausführung

Kasernenbau, Ausschreibungsverfahren

Kasernenbau, Lieferfirmen

Kasernenbau, Materiallieferungen und Werkleistungen

Kasernenbau, Rechnungslegung

Kasernenbau, Vorgaben

Kasernenbauprojekt, Angebote

SACH 


\section{SACH}

Indexbegriff

Kaserneneinrichtung, Ausstattung

Kaserneneubau, Abnahme

Kasernengebäude, Feuerversicherung

Kasernengebäude, Vermietung an den Militärfiskus

Kasernengelände, Einfriedung

Kasernengelände, Überwachung

Kasernengrundstück, Grenzstreit

Kasernengründstück, Vermessung

Kasernenplatz, Kauf durch die Stadt Emden

Kassenassistent, Dienstanweisung

Kassenassistent, Gehaltserhöhungsgesuch

Kassenassistent, Personalbogen

Kassenführer, Einstellung am Gymnasium

Kassenkredit, Aufnahme

Kassenkredite, Kämmereikasse

Katasteramt, Feststellungsbehörde der Grundsteuer

Katasteramtsleiter, Ernennung

Katasteraufnahme, Vorland des Königspolders

Katasterkarten, Aktualisierung

Katastervermessungen, Feststellung

Katasterverwaltung, Organisation

Katholische Gemeinde, Prozessionen

Katholische Gemeinde, Statistik

Katholische Gemeinde, Vertretungsorgane

Katholische Kirche, Jubiläum in Emden

Katholische Kirche, Lockerung der Aufsichtsgesetze

Katholische Kirche, Überwachung

Katholische Kirchengemeinde, Organe

Kattewall, Pflasterung

Kauffahrteischiffe, Registrierung

Kaufmännische Deputation, Generalversammlung

Kaufmännische Deputation, Mitgliederversammlung

Kaufmännische Deputation, Mitgliedsbeiträge

Kaufmännische Deputation, Regulativ und Statuten

Kaufmännische Deputation, Vermögen

Kaufmännische Deputation, Vorstandswahlen

Kaution, Gaswerkspächter

Kayung, Plan

Kehrmaschine, Anschaffung

Kehrtaxe, Festlegung

Kehrzwang, Ausnahme von Fabrikschornsteinen

Kelleraufgang, Sicherung

Kellerluken, Gefährdung der Verkerkehrssicherheit

Kellerluken, Sicherung

Kiekerhaus, Verkauf

Kiekerhäuser, Beschreibung

Kiekerhäuser, Pachtbedingungen

Kindbettfieber, Anzeigen

Kindbettfieber, Anzeigepflicht

Kindbettfieber, Todesfälle

Kindbettfieber, Tödliche Erkrankungen in Emden

Kindbettfieber, Vorbeugung

Kinderarbeit, Unerlaubte

Kinderbewahranstalt, Errichtung

Kinderbewahranstalt, Instandsetzung
Laufzeit

1866-1867

$1866-1870$

1871-1877

1908-1912

1909-1911

1908-1912

1909-1911

1909-1911

$1909-1912$

1909-1912

1890-1892

1873-1916

1873-1916

1873-1916

1909

1885-1891

1868-1902

1890-1913

1890-1913

$1906-1914$

1890-1913

1890-1913

1890-1913

1902-1914

1880-1900

1875

1902-1914

1886

1872-1892

1902-1914

1870

1879-1904

1866-1898

1866-1898

1869-1911

1869-1911

1869-1911

1866-1898

1866-1898

1866-1893

1906-1908

1878-1909

1907-1916

1907-1916

1876

1901-1913

1897-1903

1871-1883

1866-1909

1866-1909

1881-1900

1881-1900

1881-1900

1881-1900

1906

1879-1900

1900-1908

1868-1890
Lfd.Nr.

3.121

3.122

3.123

3.128

3.135

3.087

3.133

3.135

3.138

3.138

2.544

435

435

435

3.712

908

2.989

2.879

2.879

236

2.880

2.879

2.879

3.489

3.494

3.490

3.489

3.491

3.488

3.489

849

1.572

2.135

2.135

2.134

2.134

2.134

2.135

2.135

1.041

1.011

851

1.264

1.264

1.176

1.221

1.139

2.421

2.675

2.675

765

765

765

765

769

2.184

2.432

3.847 
Index

\begin{tabular}{|c|c|c|}
\hline \multicolumn{3}{|l|}{$\mathrm{SACH}$} \\
\hline Indexbegriff & Laufzeit & Lfd.Nr. \\
\hline Kinderbewahranstalt, Reglement & $1868-1890$ & 3.847 \\
\hline Kinderbewahranstalt, Umbau & 1907-1908 & 3.854 \\
\hline Kinderbewahranstalten & $1868-1890$ & 3.847 \\
\hline Kinderbewahranstalten, Beihilfe & $1868-1890$ & 3.847 \\
\hline Kinderbewahranstalten, Beihilfen zum Betrieb & $1905-1912$ & 3.853 \\
\hline Kinderbewahranstalten, Haushaltspläne & $1905-1912$ & 3.853 \\
\hline \multirow[t]{2}{*}{ Kinderbewahranstalten, Jahresberichte } & $1903-1905$ & 3.850 \\
\hline & 1905-1912 & 3.853 \\
\hline Kinderbewahranstalten, Unterstützung & 1903-1905 & 3.850 \\
\hline Kinderbewahranstalten, Visitation durch Kreisarzt & $1905-1912$ & 3.853 \\
\hline Kindergarten, Etat & $1873-1914$ & 3.851 \\
\hline Kindergarten, Statuten & $1873-1914$ & 3.851 \\
\hline Kindergarten, Stundenplan & $1873-1914$ & 3.851 \\
\hline Kindergarten, Trägerschaft & $1873-1914$ & 3.851 \\
\hline Kindergartenbetrieb, Beihilfe & $1873-1914$ & 3.851 \\
\hline Kindergärtnerinnen - Seminar, Planung & 1873-1914 & 3.851 \\
\hline Kindergärtnerinnen-Seminar, Projekt & $1889-1890$ & 3.852 \\
\hline Kindergärtnerinnen-Seminar, Trägerschaft & $1889-1890$ & 3.852 \\
\hline Kinderkrippe, Anlegung und Organisation & $1917-1918$ & 760 \\
\hline Kinderkrippe, Beiträge von Firmen & $1917-1918$ & 760 \\
\hline Kinderkrippe, Einrichtung in Emden & 1914-1916 & 759 \\
\hline Kinderkrippe, Eröffnungsfeier & $1917-1918$ & 760 \\
\hline Kinderkrippe, Förderung & $1914-1918$ & 3.193 \\
\hline Kinderkrippe, Mängel & $1917-1918$ & 760 \\
\hline Kinderkrippe, Statistik & $1913-1915$ & 1.872 \\
\hline Kinderkrippe, Tagespflegesätze & 1917-1918 & 760 \\
\hline Kinderkrippe, Zustände im Emder Gasthaus & $1916-1918$ & 761 \\
\hline Kirche, Erbpachten & $1869-1876$ & 3.391 \\
\hline Kirche, Gasbeleuchtung & 1880-1903 & 3.451 \\
\hline Kirche, Heizungsanlage & $1880-1903$ & 3.451 \\
\hline Kirche, Umlagen & $1885-1886$ & 3.348 \\
\hline Kirchen- und Pfarrhausbauten, Staatliche Beihilfen & 1910 & 3.332 \\
\hline Kirchen- und Pfarrländereien, Ankauf & $1866-1888$ & 2.486 \\
\hline Kirchen- und Schulbauten, Beihilfen & $1866-1892$ & 3.319 \\
\hline Kirchen- und Schulgebäude, Aufsicht & 1870 & 3.323 \\
\hline Kirchen- und Schulgemeinde, Patronat & 1886 & 3.481 \\
\hline Kirchen- und Schullasten, Rechtsstatus & 1871-1906 & 3.321 \\
\hline Kirchen- und Schulpflichtigkeit, Bewohner der Emder Feldmark & $1885-1901$ & 3.337 \\
\hline Kirchen- und Schulrechnungswesen, Regelung & $1867-1884$ & 3.336 \\
\hline Kirchen- und Schulsteuer, Erhebung & 1883-1907 & 3.344 \\
\hline Kirchen- und Schulsteuer, Streit um Heranziehung & 1903-1905 & 3.345 \\
\hline Kirchen und Schulvisitationen, Organisation & $1871-1911$ & 3.320 \\
\hline Kirchen, Beaufsichtigung & $1879-1885$ & 3.328 \\
\hline Kirchen, Gestühl für Magistrat und Bürgervorsteher & 1866-1885 & 2.650 \\
\hline Kirchen, Rechtsvertretungen & $1871-1911$ & 3.320 \\
\hline Kirchen, Wertpapierverwaltung & $1871-1911$ & 3.320 \\
\hline Kirchenälteste, Ernennung & 1869-1907 & 3.485 \\
\hline Kirchenbesichtigungen, Gebühren & 1901 & 3.331 \\
\hline Kirchenbesitz, Reallasten & 1871-1906 & 3.321 \\
\hline Kirchenbibliothek, Aufwendungen & 1869-1910 & 3.350 \\
\hline Kirchenbuch, Änderungsanträge für Eintragungen & 1868-1892 & 3.442 \\
\hline Kirchenbucheintragungen, Änderungsanträge & 1867-1896 & 3.389 \\
\hline Kirchenbücher, Führung & 1867-1896 & 3.389 \\
\hline Kirchenchor, Bildung & 1878-1904 & 3.450 \\
\hline Kirchendiener, Besoldungszuschuss & 1911 & 3.333 \\
\hline Kirchendiener, Grundgehalt & 1898 & 245 \\
\hline Kirchengebäude, Bauunterhaltung & $1872-1912$ & 3.444 \\
\hline Kirchengebäude, Bauzustand & $1898-1911$ & 3.399 \\
\hline
\end{tabular}


Index

\begin{tabular}{|c|c|c|}
\hline \multicolumn{3}{|l|}{ SACH } \\
\hline Indexbegriff & Laufzeit & Lfd.Nr. \\
\hline Kirchengebäude, Feuerversicherung & $1872-1912$ & 3.444 \\
\hline Kirchengemeinde, Fusion & $1871-1897$ & 3.418 \\
\hline \multirow[t]{2}{*}{ Kirchengemeinde, Patronatsrecht } & 1901 & 3.482 \\
\hline & 1869-1907 & 3.485 \\
\hline \multirow[t]{2}{*}{ Kirchengemeinden, Fusion } & $1871-1897$ & 3.415 \\
\hline & 1869-1871 & 3.483 \\
\hline Kirchengemeinden, Geschäftsberichte & $1896-1905$ & 3.518 \\
\hline Kirchengemeinden, Vermögen & 1896-1905 & 3.518 \\
\hline Kirchengemeindenzugehörigkeit, Arbeiterkolonie & $1902-1914$ & 3.340 \\
\hline Kirchengesangbuch, Verwendung in der reformierten Volksschule & $1869-1910$ & 3.350 \\
\hline Kirchenhandlungen, Gebühren & 1875-1904 & 3.446 \\
\hline Kirchenheizung & 1881-1882 & 3.329 \\
\hline Kircheninventaria, Aufstellung & 1894-1906 & 3.464 \\
\hline Kirchenkasse, Einnahmen und Ausgaben & 1891-1898 & 3.413 \\
\hline \multirow[t]{2}{*}{ Kirchenkassenrechnung, Abnahme } & 1890-1899 & 3.432 \\
\hline & 1903-1914 & 3.433 \\
\hline Kirchenkommission, Organisation & 1874-1918 & 3.349 \\
\hline Kirchenkommissionen für Schulsachen, Aufhebung & $1889-1917$ & 3.509 \\
\hline Kirchenland, Feudallast-Rechtsstreit & $1886-1889$ & 2.668 \\
\hline Kirchenland, Heranziehung zu den Deich- und Siellasten & 1869-1910 & 3.350 \\
\hline \multirow{4}{*}{ Kirchenlasten, Trägerschaft } & $1890-1894$ & 3.383 \\
\hline & 1890 & 3.384 \\
\hline & $1899-1900$ & 3.385 \\
\hline & $1887-1893$ & 3.386 \\
\hline Kirchenrat, Wahl & 1869-1907 & 3.485 \\
\hline Kirchenratsmitglieder, Wahl & $1869-1907$ & 3.485 \\
\hline Kirchenräume, Beihilfe für Öfen & 1871-1897 & 3.418 \\
\hline Kirchenräume, Französisch-reformierte Gemeinde & $1871-1897$ & 3.415 \\
\hline Kirchenräume, Nutzungsabgabe & $1871-1897$ & 3.418 \\
\hline Kirchenräume, Unterhaltung & 1871-1897 & 3.418 \\
\hline Kirchenrechnung, Prüfung & $1876-1896$ & 328 \\
\hline Kirchensitze, Ehemalige Diakonie der Haussitzenden Armen & $1872-1873$ & 1.762 \\
\hline Kirchensteuer, Einführung in der lutherischen Gemeinde & 1874-1888 & 3.473 \\
\hline Kirchensteuer, Erhöhungsantrag & $1887-1889$ & 3.457 \\
\hline Kirchensteuer, Gesetzliche Bestimmungen & 1893-1906 & 3.346 \\
\hline \multirow[t]{2}{*}{ Kirchensteuer, Heranziehung } & 1871-1906 & 3.321 \\
\hline & 1898-1904 & 3.343 \\
\hline Kirchensteuer, Lutherische Gemeinde & 1873-1914 & 3.449 \\
\hline Kirchensteuer, Lutherische Gemeindeverfassung & 1893-1906 & 3.346 \\
\hline Kirchensteuer, Stimmrecht für Frauen & 1893-1906 & 3.346 \\
\hline \multirow[t]{2}{*}{ Kirchensteuer, Streit um Heranziehung } & 1898-1904 & 3.343 \\
\hline & 1907-1909 & 3.347 \\
\hline Kirchensteuerlisten, Lutherische Gemeinde & 1918 & 3.475 \\
\hline Kirchensteuern, Erhebung in den katholischen Gemeinden & 1905-1906 & 3.493 \\
\hline Kirchenverbände, Landkreis und Stadtkreis Emden & 1887-1912 & 812 \\
\hline Kirchenverwaltung, Berichterstattung & 1866-1892 & 3.319 \\
\hline Kirchenvisitationen, Ausführung in der reformierten Gemeinde & $1898-1911$ & 3.399 \\
\hline Kirchenwesen, Organisation & 1882-1909 & 3.334 \\
\hline Kirchvogt, Gehaltserhöhung & $1868-1911$ & 3.379 \\
\hline Klappsiel, Anlage & 1884 & 903 \\
\hline \multirow[t]{2}{*}{ Kläranlage, Angebote } & 1903-1904 & 944 \\
\hline & 1904-1908 & 945 \\
\hline Kläranlage, Emder Papierfabrik & $1885-1900$ & 907 \\
\hline \multirow[t]{2}{*}{ Kläranlagen, Angebote } & 1894-1908 & 872 \\
\hline & 1892-1912 & 881 \\
\hline Klassenlehrer, Beförderung zum Hauptlehrer & $1873-1887$ & 3.660 \\
\hline Klassenlotterie, Losmangel & 1886-1904 & 558 \\
\hline Klassenschule, Unterhaltungskosten & $1867-1890$ & 3.626 \\
\hline
\end{tabular}


IV

Index

SACH

Indexbegriff

Klassensteuer, Anträge auf Befreiung von oder Ermäßigung

Klassensteuer, Befreiung

Klassensteuer, Einziehung

Klassensteuer, Ertrag in Emden

Klassensteuer, Heranziehung der Beamten und Staatsdiener

Klassensteuer, Veranlagung

Klassensteuer, Veranlagung Auswärtiger

Klassensteuer, Veranlagung der Offiziere

Klassensteuer, Veranlagung von Lehrern und Beamten

Klassensteuerpflicht, Veteranen

Klassensteuerpflichtige, Statistik für Emden

Klassenwahlrecht

Klassifizierte Einkommenssteuer, Veranlagung

Kleidermacher-Innung, Auflösung

Kleidermacher-Innung, Statuten

Kleidersammlung

Kleidungsstücke, Verwendung von schulgefertigter

Kleinbahn, Agitation

Kleinbahn, Aktiengesellschaft als Betriebsgesellschaft

Kleinbahn, Aktienzeichnung

Kleinbahn, Angebote

Kleinbahn, Anschluss

Kleinbahn, Beschäftigte

Kleinbahn, Betriebs-AG

Kleinbahn, Emden nach Pewsum

Kleinbahn, Ertragsberechung

Kleinbahn, Finanzierung

Kleinbahn, Grunderwerb

Kleinbahn, Haltestellen

Kleinbahn, Konzession

Kleinbahn, Kosten- und Rentabilitätsberechnung

Kleinbahn, Nachweisungen

Kleinbahn, Rentabilitätsberechnung

Kleinbahn, Trasse

Kleinbahn, Trassenführung

Kleinbahn, Trassenplan

Kleinbahn. Förderantrag

Kleinbahnbau, Angebote

Kleinbahnbetrieb, Regelungen

Kleinbahnen, Angebote

Laufzeit

1891-1907

1877-1888

1882-1883

$1885-1886$

$1889-1890$

$1869-1873$

1885

1885-1886

1889-1890

1877-1888

1882-1883

$1885-1886$

$1889-1890$

1877-1888

1882-1883

1885-1886

1889-1890

1867-1886

1867-1870

1873

1867-1914

1882-1883

1875-1881

1885

1879-1889

1879-1889

1918

1908-1914

1895-1906

1910-1916

1907

1880-1917

1901

1915-1918

1906-1907

1895-1900

1906-1907

1910-1916

1905-1906

1906-1907

1905-1906

1905-1906

1907

1900-1914

1915-1918

1901

1908-1909

1907-1914

1901

1908-1909

1905-1906

1906-1907

1906-1907

1895-1900

1901-1910

1915-1918

1908
Lfd.Nr.

3.627

2.866

2.867

2.868

2.869

2.864

2.874

2.868

2.869

2.866

2.867

2.868

2.869

2.866

2.867

2.868

2.869

2.872

2.871

2.865

3.107

2.867

Vorwort

2.870

2.877

1.934

1.934

3.292

3.546

2.059

2.074

2.072

2.046

2.066

2.049

2.071

2.063

2.071

2.074

2.070

2.071

2.070

2.070

2.072

2.047

2.048

2.066

2.073

2.091

2.066

2.073

2.070

2.071

2.071

2.063

2.067

2.049

1.087 
Index

\begin{tabular}{|c|c|c|}
\hline \multicolumn{3}{|c|}{ SACH } \\
\hline Indexbegriff & Laufzeit & Lfd.Nr. \\
\hline Kleinbahnen, Angebote & $1909-1911$ & 1.088 \\
\hline Kleinbahnlinie, Beteiligung der Stadt Emden & $1907-1914$ & 2.091 \\
\hline Kleinbahnlinie, Grunderwerb & $1907-1914$ & 2.091 \\
\hline Kleinbahnlinie, Kreuzung mit staatsbahn & $1910-1916$ & 2.074 \\
\hline Kleinbahnlinie, Prüfung & $1908-1909$ & 2.073 \\
\hline Kleinbahnlinie, Streckenführung & 1907-1914 & 2.091 \\
\hline Kleinbahnlinien, Ostfriesland & $1880-1917$ & 2.046 \\
\hline Kleinbahnprojekt, Beteiligung der Stadt Emden & 1899-1900 & 2.065 \\
\hline Kleinbahnprojekt, Emden - Rysum, - Groothusen & 1907-1914 & 2.091 \\
\hline \multirow[t]{10}{*}{ Kleinbahnprojekt, Emden-Riepe-Ostgroßefehn } & $1899-1900$ & 2.065 \\
\hline & 1901 & 2.066 \\
\hline & $1901-1910$ & 2.067 \\
\hline & $1904-1910$ & 2.068 \\
\hline & 1901-1904 & 2.069 \\
\hline & $1905-1906$ & 2.070 \\
\hline & $1906-1907$ & 2.071 \\
\hline & 1907 & 2.072 \\
\hline & 1908-1909 & 2.073 \\
\hline & $1910-1916$ & 2.074 \\
\hline \multirow[t]{2}{*}{ Kleinbahnprojekt, Finanzierung } & 1901-1904 & 2.069 \\
\hline & 1908-1909 & 2.073 \\
\hline Kleinbahnprojekt, Förderung & 1907 & 2.072 \\
\hline Kleinbahnprojekt, Genehmigungsverfahren & $1901-1904$ & 2.069 \\
\hline Kleinbahnprojekt, Landerwerb & 1901-1904 & 2.069 \\
\hline Kleinbahnprojekt, Prüfung & 1908-1909 & 2.073 \\
\hline Kleinbahnprojekt, Umsetzung & $1899-1900$ & 2.065 \\
\hline Kleinbahnunternehmen, Konzessionierung & $1880-1917$ & 2.046 \\
\hline Kleinbahnverkehrsverbindungen, Erhebung & 1901-1904 & 2.069 \\
\hline Kleinbahnwesen, Gesetze, Erlasse, Verfügungen & $1880-1917$ & 2.046 \\
\hline Kleinbahnwesen, Material & $1880-1917$ & 2.046 \\
\hline Kleiner Kreuzer SMS "Emden" & & Vorwort \\
\hline Kleinkinderfürsorge, Ausbau & 1914-1916 & 759 \\
\hline Kleinkinderschule, Errichtung & 1903-1906 & 2.437 \\
\hline Kleinkinderschule, Lehrerinnenwohnung & 1903-1906 & 2.437 \\
\hline Kleinviehhaltung, Förderung & 1916 & 3.254 \\
\hline Kleinwohnhäuser, Planung & $1912-1914$ & 967 \\
\hline Kleinwohnungsbau, Zweithypothek & $1912-1914$ & 1.244 \\
\hline Klunderburg, Erwerb durch die Stadt Emden & 1866-1889 & 3.124 \\
\hline \multirow[t]{2}{*}{ Knochen, Geruchsbelästigung } & 1891-1899 & 744 \\
\hline & 1871-1903 & 758 \\
\hline Knochen, Verfügung über Abtransport & 1891-1899 & 744 \\
\hline Knochenhandel, Vorschriften & 1891-1899 & 744 \\
\hline Knochenlager, Abrissverfügung & 1891-1899 & 744 \\
\hline Kohl, Bewirtschaftung & 1917-1918 & 3.308 \\
\hline Kohl, Ernteausfälle & 1917-1918 & 3.308 \\
\hline Kohle, Bezug über den Dortmund-Ems-Kanal & 1897-1912 & 1.045 \\
\hline Kohle, Transportraten & 1897-1912 & 1.045 \\
\hline Kohlefuhrwerk, Unfall in Wolthusen & $1890-1910$ & 252 \\
\hline Kohllagerschuppen, Bau & $1902-1911$ & 803 \\
\hline Kohlweißling, Bekämpfung & $1875-1914$ & 814 \\
\hline Koksbrechmaschine, Anschaffung durch Gaswerk & 1899-1912 & 1.069 \\
\hline Kolbenschilf, Sammlung zur Tau- und Gurtherstellung & 1915-1918 & 3.242 \\
\hline \multirow[t]{3}{*}{ Kollekte, Kaiser-Wilhelm-Stiftung für deutsche Invaliden } & 1900 & 582 \\
\hline & 1899-1908 & 583 \\
\hline & 1910 & 585 \\
\hline Kollekte, Kirchenbau in Ostafrika & 1899-1901 & 3.338 \\
\hline Kollekte, Opfer eines Schiffsuntergangs & 1879 & 606 \\
\hline Kollekte, Verein für Diakonissen-Krankenpflege & 1861-1903 & 577 \\
\hline
\end{tabular}


Index

\begin{tabular}{|c|c|c|}
\hline \multicolumn{3}{|l|}{ SACH } \\
\hline Indexbegriff & Laufzeit & Lfd.Nr. \\
\hline Kollekten, Genehmigung & $1870-1902$ & 645 \\
\hline Kollekten, Genehmigungspflicht & $1868-1914$ & 557 \\
\hline Kollektenwesen, Regulierung & $1893-1914$ & 724 \\
\hline Kolonialspende & 1918 & 3.312 \\
\hline Kolonie, "Friesland" & $1869-1913$ & 829 \\
\hline Kolonien, Kirchliche Verhältnisse & $1887-1912$ & 812 \\
\hline \multirow[t]{2}{*}{ Kommerzienrat, Titelverleihung } & $1900-1911$ & 259 \\
\hline & $1912-1918$ & 263 \\
\hline Kommission für die Verwaltung der Gasthauskirche, Mitglieder & $1871-1915$ & 3.423 \\
\hline Kommission für die Verwaltung der Gasthauskirche, Sitzungen & $1875-1917$ & 3.425 \\
\hline Kommission für die Verwaltung der Gasthauskirche, Verhandlungen & 1876-1887 & 3.424 \\
\hline Kommission, Konstituierung & $1902-1903$ & 1.442 \\
\hline Kommission, Sitzungseinladungen & $1905-1915$ & 1.971 \\
\hline Kommunalabgaben, Heranziehung & 1886-1894 & 2.981 \\
\hline Kommunalabgaben, Vereinheitlichung & 1886-1894 & 2.981 \\
\hline \multirow[t]{3}{*}{ Kommunalabgabengesetz, Ausführung } & $1886-1894$ & 2.981 \\
\hline & $1895-1913$ & 2.982 \\
\hline & $1894-1914$ & 2.983 \\
\hline Kommunalabgabengesetz, Gebühren & $1895-1913$ & 2.982 \\
\hline \multirow[t]{2}{*}{ Kommunalabgabengesetz, Novellierung } & $1895-1913$ & 2.982 \\
\hline & 1894-1914 & 2.983 \\
\hline Kommunalbeamte, Hinterbliebenenabsicherung & 1891-1895 & 1.651 \\
\hline Kommunalsteuer, Erhebung & $1870-1873$ & 2.978 \\
\hline Kommunalsteuer, Ertrag & $1884-1887$ & 2.979 \\
\hline Kommunalsteuer, Statut & $1870-1873$ & 2.978 \\
\hline Kommunalsteuer-Pfänder, Freigabeanträge & $1872-1902$ & 2.980 \\
\hline Kommunalsteuerpflicht, Befreiung & $1870-1873$ & 2.978 \\
\hline Kondolenzschreiben, Staatssekretär Dr. v. Stephan & 1894-1897 & 2.394 \\
\hline Konfirmandenunterricht, Rekruten & $1869-1905$ & 3.498 \\
\hline Königsbesuch, Wilhelm I. in Emden & 1869 & 175 \\
\hline Königspolder, Nutzungsstreit & $1912-1914$ & 1.441 \\
\hline Königspolderdeich, Schauungen & $1867-1890$ & 1.536 \\
\hline Konsul, Beobachtungsanordnung & 1906-1916 & 2.114 \\
\hline Konsuln, Akkreditierung & $1906-1916$ & 2.114 \\
\hline Konsuln, Exequaturentzug & $1906-1916$ & 2.114 \\
\hline Konzert, Zensur & $1911-1916$ & 563 \\
\hline Konzessionierung, Ratskeller in Leer & $1892-1893$ & 1.942 \\
\hline Kornbörse, Aufbau in Emden & $1892-1903$ & 2.115 \\
\hline Kornbörse, Preisnotierungen und Übermittlung & $1892-1903$ & 2.115 \\
\hline Kornbörse, Reglement & $1892-1903$ & 2.115 \\
\hline Kornbörse, Umsatz & $1892-1903$ & 2.115 \\
\hline Korndarre, Belästigung durch Schwefeldämpfe & $1872-1903$ & 1.250 \\
\hline Kornmesser, Errichtung einer Totenlade & $1879-1906$ & 1.641 \\
\hline Kornmesser, Wahl & $1883-1890$ & 423 \\
\hline Kornmessergilde, Umgehung & 1873-1898 & 2.116 \\
\hline Kornmesser-Institut, Kassen- und Rechnungswesen & 1873-1898 & 2.116 \\
\hline Kornschuppen, Bauantrag & $1880-1906$ & 1.179 \\
\hline Körungen, Eber- und Schafböcke & $1912-1915$ & 797 \\
\hline Körungen, Hengste & 1912-1915 & 797 \\
\hline Körungen, Stiere & $1912-1915$ & 797 \\
\hline Kraftwerk, Anlage & $1905-1907$ & 1.086 \\
\hline \multirow[t]{2}{*}{ Kraftwerk, Aufbau } & $1907-1911$ & 1.104 \\
\hline & 1911 & 1.105 \\
\hline Kraftwerk, Bau & 1907-1908 & 1.083 \\
\hline Kraftwerk, Bau in Emden & $1905-1911$ & 1.074 \\
\hline Kraftwerk, Bau und Betrieb & $1906-1912$ & 1.098 \\
\hline Kraftwerk, Bauangebot & $1895-1912$ & 1.021 \\
\hline Kraftwerk, Plan & 1898-1909 & 2.552 \\
\hline
\end{tabular}


Index

\begin{tabular}{|c|c|c|}
\hline \multicolumn{3}{|c|}{ SACH } \\
\hline Indexbegriff & Laufzeit & Lfd.Nr. \\
\hline Kraftwerke, Presseartikel & 1895-1912 & 1.021 \\
\hline Krähen, Antrag auf Erschießug & $1881-1913$ & 727 \\
\hline Kran, Beseitigung am Herrentor & 1868-1902 & 2.016 \\
\hline Kranbagger Nr. 103 & 1892 & 2.196 \\
\hline Krangeldtarif, Festsetzung & 1868-1902 & 2.016 \\
\hline Krankengeldzahlungen, Beschwerden & 1918 & 1.679 \\
\hline Krankenhaus, Aufnahme Mittelloser & $1903-1914$ & 1.686 \\
\hline Krankenhaus, Barackenprospekte & 1906-1907 & 1.692 \\
\hline Krankenhaus, Bau einer Heizungsanlage & $1891-1896$ & 1.689 \\
\hline Krankenhaus, Dampfwäscherei & $1909-1910$ & 1.700 \\
\hline Krankenhaus, Elektrifizierung & 1894-1900 & 1.685 \\
\hline Krankenhaus, Hausordnung & $1894-1900$ & 1.685 \\
\hline Krankenhaus, Heizungsanlage & 1907 & 1.699 \\
\hline Krankenhaus, Isolierabteilung für TBC-Kranke & 1907-1908 & 1.698 \\
\hline Krankenhaus, Isolierbaracke & 1904-1906 & 1.697 \\
\hline Krankenhaus, Jahresberichte & 1894-1900 & 1.685 \\
\hline Krankenhaus, Malerarbeiten & $1891-1896$ & 1.689 \\
\hline \multirow[t]{2}{*}{ Krankenhaus, Neubau } & 1890-1895 & 1.688 \\
\hline & 1891-1896 & 1.689 \\
\hline Krankenhaus, Nutzung durch Belegärzte & 1894-1900 & 1.685 \\
\hline Krankenhaus, Praktikanten & $1902-1913$ & 1.702 \\
\hline Krankenhaus, Statut & 1894-1900 & 1.685 \\
\hline Krankenhaus, Unterhaltungsbibliothek & 1903-1914 & 1.686 \\
\hline Krankenhaus, Vermietung von Räumen & 1889-1909 & 2.433 \\
\hline Krankenhaus, Verwaltungsausschuss & 1894 & 1.701 \\
\hline Krankenhausanbau & 1907-1908 & 1.698 \\
\hline Krankenhausarzt, Einstellung & $1902-1913$ & 1.702 \\
\hline Krankenhausarzt, Konflikt mit Aufsichtsratsvorsitzenden & 1894-1900 & 1.685 \\
\hline Krankenhausarzt, Konflikt mit Schwestern & 1894-1900 & 1.685 \\
\hline Krankenhausarzt, Stellenauschreibung & 1894-1900 & 1.685 \\
\hline Krankenhausärzte, Stellung & 1894-1900 & 1.685 \\
\hline Krankenhausbau, Emden & 1884-1893 & 1.687 \\
\hline Krankenhausbau, Finanzierung & $1892-1897$ & 2.999 \\
\hline Krankenhausbauprojekt, Verhandlungen & 1884-1893 & 1.687 \\
\hline Krankenhausbehandlung, Gerätekosten & 1894-1900 & 1.685 \\
\hline Krankenhausbehandlung, Kostenträgerschaft & 1916 & 1.886 \\
\hline Krankenhausbehandlung, Verpflegungskosten & 1894-1900 & 1.685 \\
\hline Krankenhausbelegung, Statistik & 1894-1900 & 1.685 \\
\hline Krankenhausbettenkapazitäten, Kriegsfall & 1903-1914 & 1.686 \\
\hline Krankenhäuser, Datenerhebung & 1903-1914 & 1.686 \\
\hline Krankenhausetat & 1894-1900 & 1.685 \\
\hline Krankenhausgarten, Einfriedung & 1904-1906 & 1.697 \\
\hline Krankenhausgarten, Neugestaltung & 1903-1914 & 1.686 \\
\hline Krankenhauskapazitäten, Kriegsfall & 1903-1914 & 1.686 \\
\hline Krankenhausordnung & 1894-1900 & 1.685 \\
\hline Krankenhauspatienten, Behandlung durch Hausärzte & $1890-1891$ & 1.691 \\
\hline Krankenhausprojekt, Vaterländischer Frauenverein Emden & 1884-1893 & 1.687 \\
\hline Krankenhausstatistik, Emden & 1903-1914 & 1.686 \\
\hline Krankenkasse, Auflösung & 1869-1916 & 1.647 \\
\hline Krankenkasse, Erhöhung der Beiträge & 1847-1902 & 494 \\
\hline Krankenkasse, Satzungen & 1869-1916 & 1.647 \\
\hline Krankenkasse, Vereinigung mit der Beerdigungskasse & 1869-1916 & 1.647 \\
\hline \multirow[t]{2}{*}{ Krankenpflege, Engagement von Frauenvereinen } & 1861-1903 & 577 \\
\hline & 1904-1915 & 578 \\
\hline Krankenpflege, Katholische Gemeinde & $1902-1911$ & 3.495 \\
\hline Krankenschwesterräume, Feuchtigkeit & 1903-1914 & 1.686 \\
\hline Krankentransport, Verzögerung & 1903-1914 & 1.686 \\
\hline Krankentransportwesen, Organisation & $1903-1913$ & 1.667 \\
\hline
\end{tabular}


Index

\begin{tabular}{|c|c|c|}
\hline \multicolumn{3}{|l|}{ SACH } \\
\hline Indexbegriff & Laufzeit & Lfd.Nr. \\
\hline Krankenunterstützungsverein, Auflösung & 1905-1908 & 1.659 \\
\hline Krankenunterstützungsverein, Satzungen & $1905-1908$ & 1.659 \\
\hline Krankenversicherung, Arbeitgeberanteil & 1912 & 1.682 \\
\hline Kranordnung, Emden & 1868-1902 & 2.016 \\
\hline Kranverwalter, Honorar & $1868-1902$ & 2.016 \\
\hline Krätzeerkrankung, Anzeige & $1871-1914$ & 757 \\
\hline Kreditnot, Linderung & 1914 & 3.238 \\
\hline Kreditprogramm, Mittelstand & 1914 & 3.238 \\
\hline Kreditvermittung, Geldvermittlungsstelle & $1911-1915$ & 3.008 \\
\hline Kreisarzt, Dienstanweisung & $1866-1914$ & 762 \\
\hline Kreisarzt, Dienststellung & $1866-1914$ & 762 \\
\hline Kreisarzt, Kompetenzen & $1866-1914$ & 762 \\
\hline Kreisarzt, Kontrolle ärztlicher Approbationen & $1866-1914$ & 762 \\
\hline Kreisarzt, Vertretung & $1866-1914$ & 762 \\
\hline Kreis-Ersatz-Kommission, Aufgaben & $1866-1918$ & 3.092 \\
\hline Kreis-Ersatz-Kommission, Bildung & $1866-1918$ & 3.092 \\
\hline Kreis-Ersatz-Kommission, Mitglieder & 1866-1918 & 3.092 \\
\hline Kreishauptmann, Bestellung für Kreis Emden & $1868-1887$ & 210 \\
\hline Kreishauptmann, Trauerfeier & $1868-1887$ & 210 \\
\hline Kreishauptmann, Urlaubsbekanntmachung & $1868-1887$ & 210 \\
\hline Kreishauptmann, Wegegeldfreiheit bei Dienstreise & $1868-1887$ & 210 \\
\hline Kreisordnung, Bedenken gegen & $1880-1881$ & 211 \\
\hline Kreisordnung, Provinz Hannover & $1880-1881$ & 211 \\
\hline Kreisphysicus, Bewerbung & $1866-1914$ & 762 \\
\hline Kreisphysicus, Ernennung & 1866-1914 & 762 \\
\hline Kreisschulinspektoren, Einsetzung & $1889-1917$ & 3.509 \\
\hline Kreisschulinspektoren, Geschäftsgang & 1889-1917 & 3.509 \\
\hline Kreisschulinspektoren, Zuständigkeiten & 1889-1917 & 3.509 \\
\hline Kreisstutenschau, Ostfriesland & $1912-1915$ & 797 \\
\hline Kreisstutenschau, Termine & $1912-1915$ & 797 \\
\hline Kreistage, Neuwahl & $1868-1879$ & 212 \\
\hline Kreistagswahlen, Erlasse und Verfügungen & 1868-1879 & 212 \\
\hline Kreistagswahlen, Neuansetzung bei Formalverstößen & $1868-1879$ & 212 \\
\hline Kreistagswahlen, Vornahme & $1868-1879$ & 212 \\
\hline Kreisturnfest, Organisation & 1895-1914 & 730 \\
\hline Krematorien, Einrichtung & 1907-1914 & 680 \\
\hline Krieg, Propaganda & $1915-1918$ & 3.147 \\
\hline \multirow[t]{2}{*}{ Krieg, Umstellung von Staat und Wirtschaft } & 1914-1915 & 3.146 \\
\hline & $1915-1918$ & 3.147 \\
\hline Krieg, Wirtschaftliche Folgen & 1914 & 3.241 \\
\hline Kriegerdenkmal, Plan in Emden & $1879-1880$ & 193 \\
\hline Kriegerheimstätten, Initiative zum Bau & 1915 & 3.212 \\
\hline Kriegertag, Ostfriesischer Kriegerverein & 1895-1899 & 202 \\
\hline Kriegerverein, Ausleihe von Gewehren und Trommeln & $1872-1913$ & 599 \\
\hline Kriegerverein, Bekämpfung der Sozialdemokratie & $1872-1913$ & 599 \\
\hline \multirow[t]{2}{*}{ Kriegerverein, Fahnenerlaubnis } & $1873-1910$ & 598 \\
\hline & 1913-1914 & 712 \\
\hline Kriegerverein, Gründungsversammlung & $1872-1913$ & 599 \\
\hline Kriegerverein, Missstände bei militärischer Bestattung & $1872-1913$ & 599 \\
\hline Kriegerverein, Plan einer Volksbibliothek & $1872-1913$ & 599 \\
\hline \multirow[t]{3}{*}{ Kriegerverein, Statuten } & $1873-1910$ & 598 \\
\hline & $1872-1913$ & 599 \\
\hline & 1913-1914 & 712 \\
\hline Kriegerverein, Verleihung von Fahnenschmuck u. Wappennadel & $1872-1913$ & 599 \\
\hline Kriegervereine, Ausschluss politisch Unzuverlässiger & $1873-1910$ & 598 \\
\hline Kriegervereine, Beaufsichtigung & $1873-1910$ & 598 \\
\hline Kriegervereine, Beobachtung & $1876-1896$ & 328 \\
\hline Kriegervereine, Geschäftsberichte & 1899-1913 & 634 \\
\hline
\end{tabular}


Index

\begin{tabular}{l}
\hline SACH \\
\hline Indexbegriff \\
\hline Kriegervereine, Organisation von Bestattungsfeiern von Soldaten \\
Kriegervereine, Organisationsverbot \\
Kriegervereine, Unterstützungskasse \\
Kriegervereine, Waffenkauf \\
Kriegervereinsfahnen, Genehmigungspflicht \\
Kriegervereinsfahnen, Muster \\
Kriegervereinsfahnen, Richtlinien zur Erlaubnis \\
Kriegervereinsfahnen, Verbot der kirchlichen Weihe \\
Kriegervereinswesen, Emden \\
Kriegsanleihe, Anleihe zur Zeichnung \\
Kriegsanleihe, Hypothek auf Grundbesitz \\
Kriegsanleihe, Stadt Emden \\
Kriegsanleihe, Werbung
\end{tabular}

Kriegsanleihe, Zeichnung

Kriegsanleihe, Zeichnungen Kriegsanleihe, Zeichnungsaufrufe Kriegsausbruch, Aufruf des Kaisers zum Jahrestag Kriegsbereitschaftsplan, Rotes Kreuz Kriegsbeschädigte, Emden Kriegsbeschädigte, Reintegration Kriegsbüchereien Kriegsbüchereien; Fahrbare für die Front Kriegsdienst, Anträge auf Befreiung

Kriegsdienst, Anträge auf Befreiung städtischer Beamter Kriegsdienst, Anträge auf Emtlassung Kriegsdienst, Anträge auf Entlassung Kriegsdienst, Befreiungsanträge Kriegsdienst, Beurlaubungsanträge Kriegsdienst, Einziehung von Beamten Kriegsdienst, Erfassung Kriegsdienst, Familienunterstützung Kriegsdienst, Rückstellungsanträge

Kriegsdienst, Unabkömmlichkeit städt. Beamter und Bediensteter Kriegsdienst, Unabkömmlichkeit städtischer Bediensteter Kriegsflüchtlinge, Aufnahme Kriegsflüchtlinge, Hilfeaufruf für Ostpreußen Kriegsflüchtlinge, Rückführung Kriegsflüchtlinge, Unterbringung Kriegsfürsorge, Aufbau eines Nationalen Frauendienstes Kriegsfürsorge, Isdern Kerl Kriegsfürsorge, Liebesgaben Kriegsfürsorge, Organisation

\section{Laufzeit}

Lfd.Nr.

1914-1916

1873-1910

$1899-1913$

1873-1910

$1868-1913$

1868-1913

1868-1913

1868-1913

1873-1910

1916-1917

1916-1917

1916-1917

1914-1916

1916-1917

1917

1918

1914-1916

1916-1917

1917

1918

1917

1916-1917

1914-1916

1901-1913

1915-1916

1915-1916

1915-1919

1916

1915-1918

1917-1918

1916-1918

1914-1918

1914-1916

1917-1918

1914-1916

1916-1918

1914-1918

1914-1916

1914-1915

1915-1917

1914-1918

1914-1918

1915-1918

1916-1918

1916-1918

1914-1917

1917-1918

1916-1918

1914-1918

1914-1916

1914-1916

1914-1916

1914-1916

1914-1916

1914-1915

1914-1915

1915-1918

1914-1915
3.201

598

634

598

597

597

597

597

598

3.236

3.236

3.236

3.235

3.236

3.237

3.297

3.235

3.236

3.237

3.297

3.237

3.236

3.148

3.173

3.205

3.205

3.315

3.209

3.180

3.182

3.183

3.181

3.153

3.184

3.151

3.162

3.142

3.151

3.150

3.139

3.141

3.142

3.143

3.144

3.145

3.160

3.161

3.290

3.142

3.153

3.203

3.203

3.203

3.203

3.191

3.191

3.192

3.191 
IV

Index

\begin{tabular}{|c|c|c|}
\hline \multicolumn{3}{|l|}{ SACH } \\
\hline Indexbegriff & Laufzeit & Lfd.Nr. \\
\hline Kriegsfürsorge, Organisation & 1915-1918 & 3.192 \\
\hline Kriegsfürsorge, Organisationen & $1915-1916$ & 3.208 \\
\hline \multirow[t]{2}{*}{ Kriegsfürsorge, Spenden von Amerika-Ostfriesen } & 1914-1915 & 3.191 \\
\hline & $1915-1918$ & 3.192 \\
\hline Kriegsfürsorge, Spendenaktionen & $1915-1918$ & 3.192 \\
\hline \multirow{2}{*}{ Kriegsfürsorge, Spendenaufrufe } & 1914-1915 & 3.191 \\
\hline & 1914-1918 & 3.193 \\
\hline Kriegsfürsorge, Unterstützung & 1914-1918 & 3.193 \\
\hline Kriegsfürsorge, Wohnraumsicherung & 1914-1918 & 3.197 \\
\hline Kriegsfürsorgeausschuss, Bildung & $1914-1915$ & 3.191 \\
\hline Kriegsgefangene, Durchgangslager für entlassene Deutsche & 1916-1918 & 3.286 \\
\hline Kriegsgefangene, Entlassungen & 1918 & 3.303 \\
\hline Kriegsgefangene, Ersatz & 1918 & 3.303 \\
\hline Kriegsgefangene, Flucht & 1914-1917 & 3.196 \\
\hline Kriegsgefangene, Fürsorge & $1915-1918$ & 3.192 \\
\hline Kriegsgefangene, Medizinische Behandlung & 1914-1917 & 3.196 \\
\hline Kriegsgefangene, Spendenaktion & 1918 & 3.186 \\
\hline Kriegsgefangene, Unterbringung & $1914-1917$ & 3.196 \\
\hline Kriegsgefangene, Verpflegung & 1914-1917 & 3.196 \\
\hline Kriegsgefangener, Bestattung & 1914-1916 & 3.201 \\
\hline Kriegsgemüseanbau, Förderung & 1914-1916 & 3.200 \\
\hline Kriegshinterbliebene, Spendenaktion & 1914-1918 & 3.199 \\
\hline Kriegsinvaliden, Spendenaktion & 1918 & 3.219 \\
\hline Kriegskinderfürsorge & 1915 & 3.211 \\
\hline Kriegskreditkasse, Gründung & 1914 & 3.238 \\
\hline Kriegsleistungsgesetz, Kommissar zur Ausführung & $1876-1918$ & 3.168 \\
\hline \multirow[t]{2}{*}{ Kriegslieferungen, Vergütung } & 1871-1872 & 3.114 \\
\hline & 1914-1917 & 3.239 \\
\hline Kriegsnachlass; Erbe & 1915-1918 & 3.192 \\
\hline Kriegsopfer, Emden & 1914-1918 & 3.190 \\
\hline Kriegsopfer, Gedenkblatt & 1914-1918 & 3.190 \\
\hline Kriegsopfer, Mitteilungen & 1915-1918 & 3.217 \\
\hline \multirow[t]{16}{*}{ Kriegsopfer, Unterstützung } & 1869-1896 & 591 \\
\hline & 1873-1914 & 592 \\
\hline & 1870-1872 & 593 \\
\hline & 1870 & 594 \\
\hline & 1870 & 595 \\
\hline & $1870-1871$ & 596 \\
\hline & 1874-1875 & 603 \\
\hline & 1876 & 604 \\
\hline & $1877-1878$ & 605 \\
\hline & 1879 & 606 \\
\hline & $1880-1881$ & 607 \\
\hline & $1882-1883$ & 608 \\
\hline & 1884-1885 & 609 \\
\hline & 1886-1887 & 610 \\
\hline & 1898 & 611 \\
\hline & 1901-1903 & 612 \\
\hline Kriegssachleistungen, Entschädigung & 1914-1917 & 3.167 \\
\hline Kriegsschäden, Regulierung & $1876-1918$ & 3.168 \\
\hline Kriegsschiff, "Cyclop" & 1866 & 509 \\
\hline Kriegsschiff, Sammlung zur Finanzierung & 1907-1908 & 685 \\
\hline Kriegsschiffe, Einlaufen fremder & 1873-1912 & 1.505 \\
\hline Kriegsschreibstube, Einrichtung & 1914-1915 & 3.154 \\
\hline Kriegsteilnehmer, Siedlung für & $1872-1916$ & 330 \\
\hline Kriegstod, H. Hoogklimmer & 1913 & 428 \\
\hline Kriegstote, Ehrenhaine & $1915-1917$ & 3.207 \\
\hline Kriegstote, Erster Weltkrieg & 1914-1917 & 3.188 \\
\hline
\end{tabular}


IV

Index

SACH

\begin{tabular}{l} 
Indexbegriff \\
\hline Kriegstote, Hinterbliebenenfürsorge \\
Kriegstote, Spendenaktion \\
Kriegsunterstützungsausschuss, Fu \\
Kriegsversicherung, Mitgliederlisten \\
Kriegsveteranen, Ehrenspende \\
Kriegswaisen- und Witwenrente, Ge \\
Kriegswirtschaft, Ablieferung von M \\
Kriegswirtschaft, Ablieferung von Strof \\
Kriegswirtschaft, Alteisen \\
Kriegswirtschaft, Arbeitskleidung \\
Kriegswirtschaft, Aufbau \\
Kriegswirtschaft, Beschlagnahmung
\end{tabular}

Kriegswirtschaft, Lebensmittelbewirtschaftung

Kriegswirtschaft, Nutzung von Kraftwagen Kriegswirtschaft, Sammlungen von Kleidung Kriegswirtschaft, Sammlungen von Material Kriegswirtschaft, Übergang Kriminalpolizeisergeant, Amtsbezeichnung Kronenorden 3. Klasse, Verleihungsantrag 
IV

Index

\section{SACH}

\begin{tabular}{l} 
Indexbegriff \\
\hline Kronenorden 4. Klasse, Verleihungsantrag \\
Küchenabfälle, Sammlung \\
Kuhmilch, Regelung seiner Verwendung als Nahrungsmittel \\
Kulturkampf, Gegen die katholische Kirche \\
Kundgebung, Emden für preußischen König \\
Kunstdrechsler-Handwerk, Zulassung \\
Kunstgewerbeausstellung, Entsendung von Kunstwerken \\
Kupfer und Kupferlegierung, Ablieferung \\
Kupfer, Ablieferung für Kriegswirtschaft
\end{tabular}

Kupfer, Beschlagnahmung für Kriegswirtschaft

Kupfer, Entschädigungszahlung

Kupferkabel, Rückkauf

Kupferschmiedezunft, Verkauf des Gildehauses

Kupferschmiedezunft, Vorstand

Kuratorium, Mitglieder

Kuratorium, Schulorganisation

Kuratoriumsvorsitzender, Stimmrecht

Küstenbahn Emden-Norden Wittmund

Küstenbahn, Abgabe von Landflächen

Küstenbahn, Akquirierung von Landflächen

Küstenbahn, Anbindung Aurichs

Küstenbahn, Anbindung des Emder Hafens

Küstenbahn, Anbindung Emdens

Küstenbahn, Anlage

Küstenbahn, Ausbauinitiative

Küstenbahn, Brücke als Verbindungsteil

Küstenbahn, Delftquerung

Küstenbahn, Durchlass

Küstenbahn, Einweihung

Küstenbahn, Fahrgeschwindigkeit

Küstenbahn, Fahrplan

Küstenbahn, Finanzierung

Küstenbahn, Gleisverbindung zum Ems-Jade-Kanal

Küstenbahn, Nebengleis

Küstenbahn, Planungen

Küstenbahn, Realisierung

Küstenbahn, Rentabilität

\section{Laufzeit}

$1912-1918$

1915-1918

1911-1913

1876-1896

1866

1866

1876-1878

1917-1918

1915-1916

1916

1916

1916

1916

1917

1917-1918

1917

1917

1917

1917

1915-1916

1916

1917-1918

1913

1870-1872

1870-1872

1895-1911

1885-1890

1891-1901

1902-1910

1893-1910

1877-1893

1882-1908

1883-1897

1879-1882

1878-1892

1882-1908

1883-1897

1879-1882

1882-1908

1883-1897

1879-1882

1879-1882

$1867-1890$

1895-1896

1879-1882

1879-1882

1886-1887

1882-1908

1882-1908

1882-1908

1879-1882

1878-1892

1882-1908

1877-1878

1877-1878

1869-1878

1878-1892

1877-1878
Lfd.Nr.

263

3.242

755

328

174

1.944

2.126

3.273

3.249

3.250

3.251

3.252

3.253

3.267

3.268

3.269

3.276

3.277

3.278

3.310

3.253

3.268

1.128

1.927

1.927

3.756

3.716

3.717

3.718

3.757

2.005

2.009

2.010

2.011

2.008

2.009

2.010

2.011

2.009

2.010

2.011

2.011

1.536

2.050

2.011

2.011

925

2.009

2.009

2.009

2.011

2.008

2.009

2.006

2.006

2.007

2.008

2.006 
Index

\begin{tabular}{|c|c|c|}
\hline \multicolumn{3}{|l|}{ SACH } \\
\hline Indexbegriff & Laufzeit & Lfd.Nr. \\
\hline Küstenbahn, Rentabilität & $1869-1878$ & 2.007 \\
\hline Küstenbahn, Streckenführung & $1877-1893$ & 2.005 \\
\hline Küstenbahn, Trassenänderung & $1882-1908$ & 2.009 \\
\hline Küstenbahn, Trassenplan & $1879-1882$ & 2.011 \\
\hline Küstenbahn, Übergänge & $1882-1908$ & 2.009 \\
\hline \multirow[t]{3}{*}{ Küstenbahn, Verhandlungen } & $1877-1878$ & 2.006 \\
\hline & $1869-1878$ & 2.007 \\
\hline & $1878-1892$ & 2.008 \\
\hline Küstenbahn, Wunsch nach Ostverlagerung & $1895-1906$ & 2.059 \\
\hline Küstenbahn, Zuschüsse von Ostfriesischer Landschaft & $1878-1892$ & 2.008 \\
\hline Küstenfahrer, Fahrgrenze & $1877-1915$ & 1.567 \\
\hline Küstenfahrt, Befähigungsnachweis & $1877-1915$ & 1.567 \\
\hline Küstenfischer, Fahrtenbuch & $1897-1914$ & 1.575 \\
\hline Küstenhandel, Deutsche Schiffe im Ausland & 1873-1909 & 1.561 \\
\hline Küstenschfffahrt, Abgabenermäßigung & $1873-1909$ & 1.561 \\
\hline Küstenschfffahrt, Förderung & $1873-1909$ & 1.561 \\
\hline Küstenschifffahrt, Zulassung niederländischer Schiffe & $1873-1909$ & 1.561 \\
\hline Küster, Vereidigung in katholischen Gemeinden & $1872-1892$ & 3.488 \\
\hline Küsterstelle, Gasthauskirche & 1905 & 3.429 \\
\hline Küsterstellen, Besetzung & $1868-1911$ & 3.379 \\
\hline Küsterwohnung, Gasthauskirche & 1905 & 3.429 \\
\hline Laboratorium, Einrichtung & $1899-1909$ & 781 \\
\hline Ladeeinrichtungen, Ausbau & $1896-1910$ & 2.051 \\
\hline Ladenöffnungszeiten, Festsetzung & $1911-1916$ & 563 \\
\hline Lagerbuch, Grundbesitz und Vermögenswerte der Stadt Emden & 1866 & 2.401 \\
\hline Lagerbuch, Grundstücke u. Vermögen der Stadt Emden & 1866 & 2.401 \\
\hline Lagergebäude, Verbot nach außen schlagender Fenster & $1900-1903$ & 1.166 \\
\hline Lagerhäuser, Sicherheitsprüfung & $1882-1908$ & 2.009 \\
\hline Lagerhausgesellschaft, Planung & $1903-1904$ & 2.132 \\
\hline Lagerplätze, Nutzungsgebühr & $1901-1911$ & 2.942 \\
\hline Landarbeiter, Sesshaftmachung & 1907 & 1.243 \\
\hline Landarbeitermangel, Behebung & $1885-1907$ & 1.543 \\
\hline Landarmenverband, Beitrag von der Stadt Emden & $1872-1905$ & 1.893 \\
\hline Landeplätze, Evaluierung & $1909-1913$ & 2.097 \\
\hline Ländereien, Enteignung & $1868-1875$ & 2.465 \\
\hline Ländereien, Verpachtung & $1896-1901$ & 2.550 \\
\hline Ländereien, Verpachtung auf Nesserland & $1866-1881$ & 2.459 \\
\hline \multirow[t]{4}{*}{ Ländereien, Verpachtung durch Stadt Emden } & $1874-1889$ & 2.453 \\
\hline & $1872-1893$ & 2.470 \\
\hline & $1871-1904$ & 2.491 \\
\hline & $1899-1912$ & 2.492 \\
\hline \multirow[t]{3}{*}{ Ländereien, Verpachtung städtischer } & $1866-1897$ & 2.460 \\
\hline & $1866-1883$ & 2.461 \\
\hline & $1897-1904$ & 2.462 \\
\hline Landesherrschaft, Hannoversche & & Vorwort \\
\hline Landessynode, Beitragsermittlung & $1869-1891$ & 3.438 \\
\hline Landflächen, Organisation als genossenschaftliche Feldmark & $1900-1904$ & 1.539 \\
\hline Landkreise, Statistiken & $1880-1881$ & 211 \\
\hline Landrabbinat, Aktenaufbewahrung & $1870-1886$ & 481 \\
\hline Landrabbiner, Bewerbungen um Funktion & 1874 & 491 \\
\hline Landrabbiner, Gebührenordnung & $1867-1894$ & 480 \\
\hline Landrabbiner, Gebührentaxe & $1867-1894$ & 480 \\
\hline Landrabbiner, Honorierung kultischer Handlungen & $1870-1886$ & 481 \\
\hline Landrabbiner, Honorierung von erteilten Religionsuntericht & $1870-1886$ & 481 \\
\hline Landrabbiner, Interim & $1911-1922$ & 482 \\
\hline Landrabbiner, Pflichten & $1911-1922$ & 482 \\
\hline Landrabbiner, Staatsfeindliche Handlungen & $1870-1886$ & 481 \\
\hline
\end{tabular}


Index

\begin{tabular}{l}
\hline \\
\hline Indexbegriff \\
\hline Landrabbiner, Traugebühr \\
Landrabbiner, Verzögerung des Amtsantritts \\
Landrabbiner, Wahl \\
Landrabbiner, Zuwendung von Brennholz \\
Landrabbinerwahl, Beschwerde gegen Verfahren \\
Landschaft, Aktivitäten und Finanzlage \\
Landschaftsdelegierte, Wahlempfehlung \\
Landschaftskollegium, Jahresbericht \\
Landschaftsversammlung, Deputierte der Stadt Emden \\
Landschaftsversammlung, Ladungen und Tagesordnung \\
Landschaftsversammlung, Vollmacht für Emder Deputierte \\
Landstraße, Trasse \\
Landstraße, Unpassierbarkeit \\
Landstraße, Unterhaltung \\
Landstraßen, Bau \\
Landstraßen, Unterhaltung \\
Landstraßen, Wegegelderhebung \\
Landstraßenaufseher, Geschäftsanweisung \\
Landstraßenbau, Ankauf von Steinen \\
Landstraßenbau, Beteiligung der Stadt Emden
\end{tabular}

Landstraßenbau, Finanzierung

Landstraßennetz, Ausbau im Rheiderland

Landstreicher, Sicherheitshaft

Landstück, Ankauf durch Stadt Emden

Landstück, Verpachtung

Landsturm, Unabkömmlichkeitsatteste für Telegrafenbeamte

Landsturmdienst, Rückstellungsanträge

Landsturmmänner, Räume für Einkleidung

Landsturmoffiziere, Ersatz für gefallene Heeresoffiziere

Landsturmpflichtige, Musterung

Landtag, Ersatzwahlen

Landtag, Wahl und Wahlmodus

Landtagsabgeordneter, Ersatzwahl

Landtagsabgeordneter, Mandatsrückgabe

Landtagswahl, Erlasse und Bestimmungen

Landtagswahlen

Landtagswahlen, Durchführung

Landungsbrücke

Landungsbrücke, Bau auf Borkum

Landungsbrücke, Blockade

Landungsbrücke, Finanzierung

Landungsbrücke, Nutzungsrechte

Landwirtschaft, Kriegsausrichtung

Landwirtschaftliche Winterschule, Errichtung

Landwirtschaftliche Winterschule, Jahresbericht

Landwirtschaftliche Winterschule, Kosten

Landwirtschaftliche Winterschule, Raumstreit

Landwirtschaftskammer, Beitragserhebung

Landwirtschaftskammer, Errichtung

Landwirtschaftsstatistik

Landwirtschaftsstatistik, Datenerhebung

Lärm, Spielende Kinder

$\mathrm{ACH}$ 
Index

\begin{tabular}{|c|c|c|}
\hline \multicolumn{3}{|l|}{ SACH } \\
\hline Indexbegriff & Laufzeit & Lfd.Nr. \\
\hline Lärmbelästigung, Beschwerden & 1898-1909 & 2.180 \\
\hline Lärmbelästigung, Krähen von Hähnen & 1897-1912 & 1.157 \\
\hline Larrelter Straße, Auspflasterung & $1895-1900$ & 990 \\
\hline Larrelter Straße, Niedrigerlegung & $1895-1900$ & 990 \\
\hline Lastenaufzüge, Aufstellung in Emden & $1900-1913$ & 1.255 \\
\hline Lastengeld, Initiative zur Aufhebung & 1889 & 1.560 \\
\hline Lateinschule, Gedenkstein & $1885-1914$ & 2.431 \\
\hline \multirow{2}{*}{ Laternenanzünder, Instruktion } & $1897-1912$ & 1.036 \\
\hline & 1897-1911 & 1.046 \\
\hline Laternenanzünder, Kontrolle & $1866-1893$ & 1.041 \\
\hline Latrinenabfuhr, Organisation & $1869-1885$ & 869 \\
\hline Lazarett, Kaufverhandlungen & 1889-1892 & 2.542 \\
\hline Lazarett, Spende & 1870 & 594 \\
\hline Lazarette, Aufbau & 1914-1917 & 3.239 \\
\hline Lazarette, Lebensmittellieferungen & 1914-1917 & 3.239 \\
\hline Lazarettwesen, Freiwillige Krankenpflege & $1915-1918$ & 3.192 \\
\hline \multirow[t]{2}{*}{ Lebensmittel, Bewirtschaftung } & $1914-1916$ & 3.194 \\
\hline & 1918 & 3.303 \\
\hline \multirow[t]{2}{*}{ Lebensmittel, Preisfeststellung } & 1901-1916 & 1.902 \\
\hline & 1901-1909 & 1.903 \\
\hline Lebensmittel, Preisstatistik & $1911-1913$ & 479 \\
\hline Lebensmittel, Verkauf nach Gewicht & $1880-1904$ & 1.925 \\
\hline Lebensmittel, Versteigerung an der Waage & 1883-1902 & 1.909 \\
\hline Lebensmittel, Vorräte & $1901-1916$ & 1.902 \\
\hline Lebensmittelbewirtschaftung, Vorbereitung & 1914-1918 & 3.245 \\
\hline Lebensmittelpreise, Erhebungen & 1911-1913 & 479 \\
\hline Lebensmittelpreise, Feststellung & $1881-1918$ & 2.154 \\
\hline Lebensmittelpreise, Steigerung & 1911-1913 & 479 \\
\hline \multirow{2}{*}{ Lebensmittelüberwachung } & 1880-1902 & 749 \\
\hline & 1879-1912 & 750 \\
\hline Lebensmittelüberwachung, Regelung & $1879-1910$ & 748 \\
\hline Lebensmitteluntersuchung, Gebühren & $1879-1910$ & 748 \\
\hline Lebensmitteluntersuchungsamt, Aufbau & $1879-1910$ & 748 \\
\hline Lebensmitteluntersuchungsamt, Ausstattung & $1880-1902$ & 749 \\
\hline Lebensmitteluntersuchungsamt, Gebührenforderung & 1879-1912 & 750 \\
\hline Lebensmitteluntersuchungsamt, Gebührensätze & $1879-1910$ & 748 \\
\hline Lebensmitteluntersuchungsamt, Statistik & $1879-1910$ & 748 \\
\hline \multirow[t]{2}{*}{ Lebensmitteluntersuchungsamt, Status als öffentliche Anstalt } & $1879-1910$ & 748 \\
\hline & 1880-1902 & 749 \\
\hline \multirow[t]{2}{*}{ Lebensmitteluntersuchungsamt, Unterhaltung } & $1879-1910$ & 748 \\
\hline & 1880-1902 & 749 \\
\hline Lebensmitteluntersuchungsamt, Untersuchungen & 1879-1912 & 750 \\
\hline Lebensmitteluntersuchungsamt, Untersuchungsbezirk & 1879-1910 & 748 \\
\hline Lebensmitteluntersuchungsamt, Zuständigkeit & $1879-1910$ & 748 \\
\hline Lebensrettungen, Belohnungen & 1869-1890 & 741 \\
\hline Lebensrettungen, Berichte & $1869-1890$ & 741 \\
\hline Ledererersatzstoffe, Angebote & 1917-1918 & 3.294 \\
\hline Lederersatzstoff, Sohlen & 1918 & 3.295 \\
\hline Ledermengen, Zuteilung & $1908-1915$ & 3.545 \\
\hline Lederschuhe, Zuteilungsantrag & 1918 & 3.295 \\
\hline Legat, Auguste Rosenthal für jüdisches Waisenhaus & 1903-1917 & 495 \\
\hline Legat, Grabunterhaltung & 1885-1914 & 3.456 \\
\hline Legate, Annahmeanträge & 1871-1918 & 3.388 \\
\hline Legate, Lutherische Gemeinde & $1885-1914$ & 3.456 \\
\hline Legate, Reformierte Gemeinde & 1871-1918 & 3.388 \\
\hline Legate, Unterhaltung der Friedhöfe & $1871-1918$ & 3.388 \\
\hline Lehramts-Abschlüsse, Anerkennung & $1912-1913$ & 3.540 \\
\hline Lehramtskandidaten, Gehälter & 1913-1916 & 3.812 \\
\hline
\end{tabular}


IV

Index

\section{SACH}

\begin{tabular}{l} 
Indexbegriff \\
\hline Lehrer - und Kirchendienerstellen, Nachweisung \\
Lehrer- Küster und Organistenstelle, Oldersum \\
Lehrer- u. Lehrerinnen, Ruhegehaltsberechtigte Einkommen
\end{tabular}

Lehrer- und Lehrerinnenstellen, Ruhegehaltsberechtigte Einkommen Lehrer, Alterszulage Lehrer, Bedürfniszulage Lehrer, Beschäftigung an der Kaiser-Friedrich-Realschule Lehrer, Dienstanweisung Lehrer, Diensteinkommen

Lehrer, Diensteinkommen an nichtstaatlichen höh. Lehranstalten Lehrer, Einstellungsverfahren

Lehrer, Ersatz

Lehrer, Gehaltsklassen

Lehrer, Gehaltspfändung

Lehrer, Gehaltszulagen

Lehrer, Gewinnung qualifizierter

Lehrer, Grundgehalt

Lehrer, Kriegsdienstbefreiung

Lehrer, Kriegsteuerungszulage

Lehrer, Kriegstod

Lehrer, Lutherische Klassenschule

Lehrer, Mietentschädigung

Lehrer, Nachruf

Lehrer, Ordensverleihung

Lehrer, Ortszulage

Lehrer, Reformierte Klassenschule Emden

Lehrer, Teuerungszulage

Lehrer, Unterstützungsgesuche

Lehrer, Wahl

Lehrer, Wahl in Oldersum

Lehrer, Wahl in Wolthusen

Lehrerbeerdigungsverein, Anerkennung als "Kleiner Verein"

Lehrerbeerdigungsverein, Begutachtung

Lehrerbeerdigungsverein, Jahresberichte

Lehrerbeerdigungsverein, Monita wg. Satzungsänderungen

Lehrerbeerdigungsverein, Statuten

Lehrerbeerdigungsverein, Versicherungstechnisches Gutachten

Lehrerbeerdigungsverein, Wertpapierdeponierung

Lehrerbesoldung, Normaletat

Lehrerbesoldung, Regelung

Lehrerbesoldung, Staatsbeihilfe
Lfd.Nr.

1897-1905

1889

3.524

1893-1895

3.673

1895-1900

3.514

1903-1917

3.515

1915-1918

3.516

1867-1884

3.534

3.668

1907-1916

3.721

1887-1890

3.665

1867-1884

1907

1909-1915

3.668

3.725

3.726

1896-1908

3.810

1908-1914

1913-1916

3.811

1885-1903

3.812

3.720

3.719

3.684

3.664

3.739

3.533

3.660

245

3.632

3.728

3.785

3.794

3.652

3.653

3.524

3.560

3.783

3.812

3.620

3.653

3.684

3.407

3.652

3.653

3.672

3.669

1.645

1.645

1.644

1.645

1.644

1.644

1.645

1.644

1.644

3.725

3.726

3.620

3.723

3.513

3.518

3.519

3.533 
IV

Index

SACH

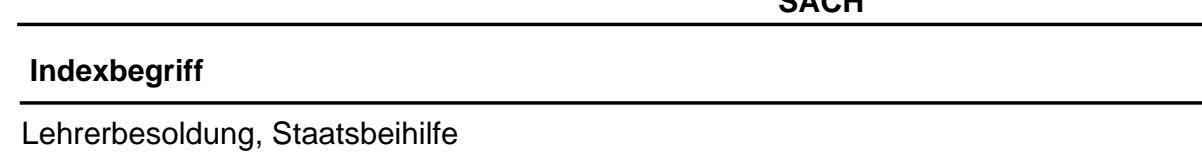

Lehrerbesoldung, Staatsbeihilfe zur Finanzierung

Lehrerbesoldungsgesetz, Novellierung

Lehrer-Dienstwohnung, Umbau

Lehrer-Dienstwohnungen, Wertfeststellung

Lehrerfortbildung, Handfertigkeit

Lehrerinnen, Alterszulage

Lehrerinnen, Diensteinkommen

Lehrerinnen, Gehalt

Lehrerinnen, Gehaltserhöhungsgesuche

Lehrerinnen, Gehaltsklassen

Lehrerinnen, Teuerungszulage

Lehrerinnen-Seminar, Errichtung

Lehrerinnenseminar, Staatsbeihilfe

Lehrerinnen-Stelle, Reformierte Klassenschule

Lehrerinnenstellen, Errichtung an der lutherischen Klassenschule

Lehrerpensionskasse, Schließung

Lehrerpersonalakte

\section{Laufzeit}

$1915-1918$

1909-1915

1885-1903

1907

1908-1909

1899-1909

1899-1909

1887-1914

1875-1892

1896-1908

1908-1914

1913-1916

1872-1899

1875-1892

1875-1892

1897-1905

1915-1918

1875-1879

1901-1907

1900-1902

1891-1907

1885-1889

1912-1914

1909-1912

1910-1912

1912-1915

1913-1914

1912-1914

1918

1912-1914

1909-1912

1911-1918

1908-1910

1889-1917

1910-1914

1906-1917

1905-1917

1904-1911

1909-1910

1906-1913

1911-1918

1882-1911

1914

1907-1910

1915-1918

1917-1918

1915-1918

1908-1917

1874-1910

1894

1913-1916

1868-1910

1912-1918

1913-1918

1915

1915

1877-1918

1909-1913

\section{Lfd.Nr.}

3.534

3.535

3.720

3.725

3.533

3.522

3.522

2.345

3.772

3.810

3.811

3.812

3.775

3.772

3.772

3.524

3.534

3.843

3.833

3.641

3.653

3.637

3.552

3.553

3.554

3.555

3.556

3.557

3.558

3.559

3.560

3.561

3.562

3.563

3.564

3.565

3.566

3.567

3.568

3.569

3.570

3.571

3.572

3.573

3.574

3.575

3.576

3.577

3.578

3.579

3.580

3.581

3.582

3.583

3.584

3.585

3.586

3.587 
IV

Index

SACH

Indexbegriff

Laufzeit

1912-1914

1906-1910

1917-1918

1912-1918

$1891-1917$

1913-1918

1914-1918

1912

1909-1916

1884

1913-1914

1914-1917

1913-1914

1913-1918

1914-1918

1914-1918

1904-1916

1917-1918

1915-1917

1908-1914

1908-1916

1917-1918

1913-1914

1905-1907

Lehrerpersonalakte, Kaiser-Friedrich-Realschule

Lehrerpersonalakte, Städtische Volksschule

Lehrerpersonalakten, Städtische Volksschule

Lehrerstelle, Besetzung in Wolthusen

Lehrerstelle, Bewerbungen

Lehrerstelle, Errichtung an der lutherischen Klassenschule

Lehrerstelle, Gehaltsfestlegung

Lehrerstellen, Ausschreibung

Lehrerwahl, Stimmrecht

Lehrerwaisen, Fürsorge

Lehrerwitwen- und Waisenkasse, Bezirksvorstand

Lehrerwitwen- und Waisenkasse, Rechnungslegung

Lehrerwitwen- und Waisenkasse, Register
Lfd.Nr.

3.588

3.589

3.591

3.592

3.593

3.595

3.596

3.597

3.599

3.600

3.601

3.602

3.603

3.604

3.605

3.606

3.607

3.608

3.609

3.610

3.611

3.612

3.613

3.719

3.727

3.729

3.730

3.732

3.734

3.735

3.736

3.737

3.738

3.739

3.741

3.742

3.676

3.677

3.678

3.679

3.680

3.681

3.685

227

3.687

3.653

3.664

3.767

3.768

3.769

3.770

3.771

3.636

3.517

3.695

3.637

3.696

3.698 
Index

\begin{tabular}{|c|c|c|}
\hline \multicolumn{3}{|c|}{ SACH } \\
\hline Indexbegriff & Laufzeit & Lfd.Nr. \\
\hline Lehrerwitwen- und Waisenkasse, Registerführung & $1873-1880$ & 3.697 \\
\hline Lehrerwitwen- und Waisenkasse, Statut & $1885-1889$ & 3.637 \\
\hline Lehrerzeugnisse, Anerkennung & $1912-1913$ & 3.540 \\
\hline Lehrkraft, Beihilfeantrag zur Einstellung & 1902 & 3.702 \\
\hline Lehrlinge, Prämierte & $1881-1882$ & 2.041 \\
\hline Lehrlingsarbeiten, Ausstellung & $1881-1882$ & 2.041 \\
\hline Lehrlingsausbildung, Regelungsrecht & $1879-1892$ & 1.933 \\
\hline Lehrlingsheime, Förderung & $1899-1905$ & 644 \\
\hline Lehrlingszahl, Regulierung & $1893-1912$ & 1.926 \\
\hline Leichenbitter, Instruktionen & $1824-1920$ & 433 \\
\hline Leichenbitter, Revision & $1824-1920$ & 433 \\
\hline Leichenbitter, Trunkenheit im Dienst & $1824-1920$ & 433 \\
\hline Leichenbitter, Vereidigung & $1824-1920$ & 433 \\
\hline Leichenbitter, Vertretung & $1824-1920$ & 433 \\
\hline Leichenbittergebühren, Festsetzung & $1824-1920$ & 433 \\
\hline Leichenbitterstellen, Bewerbungen & $1824-1920$ & 433 \\
\hline Leichenhalle, Bau & $1880-1910$ & 1.632 \\
\hline Leichenhalle, Protest gegen Bau & $1880-1910$ & 1.632 \\
\hline \multirow[t]{2}{*}{ Leichenpässe, Ausstellung } & $1867-1918$ & 1.634 \\
\hline & 1905-1909 & 1.635 \\
\hline Leichenpässe, Ausstellungsgebühr & $1867-1918$ & 1.634 \\
\hline Leichenschau, Raumpflicht & $1886-1900$ & 2.430 \\
\hline Leichenträger, Zahlfestlegung & $1867-1918$ & 1.634 \\
\hline Leichentransport, Regelung & $1905-1909$ & 1.635 \\
\hline Leichenwagen, Anschaffung & $1867-1918$ & 1.634 \\
\hline Leichenwagen, Benutzungsgebühr & $1867-1918$ & 1.634 \\
\hline Leitungsverlegungsarbeiten, Beschwerden & 1912 & 1.118 \\
\hline Lesehalle, Bitte um Zuschuss & $1899-1905$ & 644 \\
\hline Leuchtbojenversuch & $1878-1891$ & 1.412 \\
\hline Leuchtgas, Qualität & 1897-1899 & 1.032 \\
\hline Leuchtgassteuer, Kampagne gegen & $1866-1893$ & 1.041 \\
\hline Lichtleitung, Installationserlaubnisantrag & $1905-1911$ & 1.097 \\
\hline Liebesgaben, Sammlung und Versand zur Front & $1914-1915$ & 3.191 \\
\hline Linden, Anpflanzung & $1878-1888$ & 1.493 \\
\hline Logger "Allard" & 1895 & 2.218 \\
\hline Logger "Altair" & 1904 & 2.286 \\
\hline Logger "Altona" & 1904 & 2.288 \\
\hline Logger "Anna und Emma" & 1899 & 2.234 \\
\hline Logger "Arnoldine Marie" & 1899 & 2.234 \\
\hline Logger "Bahrenfeld" & 1904 & 2.288 \\
\hline Logger "Betty" & 1903 & 2.277 \\
\hline Logger "Brandenburg" & 1905 & 2.296 \\
\hline Logger "Braunschweig" & $1875-1900$ & 1.628 \\
\hline \multirow{2}{*}{ Logger "Bückeburg" } & 1897 & 2.221 \\
\hline & 1899 & 2.234 \\
\hline Logger "Catharina Christina" & 1899 & 2.234 \\
\hline Logger "Catharina Maria" & 1900 & 2.243 \\
\hline Logger "Catherina" & 1895 & 2.212 \\
\hline Logger "Cera" & 1903 & 2.276 \\
\hline Logger "Clara" & 1901 & 2.254 \\
\hline Logger "Cornelia" & 1903 & 2.277 \\
\hline Logger "Danzig" & 1903 & 2.276 \\
\hline Logger "David" & 1899 & 2.234 \\
\hline Logger "Doggerbank" & 1899 & 2.235 \\
\hline Logger "Dollart" & 1900 & 2.243 \\
\hline Logger "Ems" & 1900 & 2.243 \\
\hline Logger "Fanny" & 1903 & 2.277 \\
\hline Logger "Finkenwarder" & 1905 & 2.293 \\
\hline
\end{tabular}


IV

Index

\begin{tabular}{|c|c|c|}
\hline \multicolumn{3}{|c|}{ SACH } \\
\hline Indexbegriff & Laufzeit & Lfd.Nr. \\
\hline Logger "Fortuna" & 1896 & 2.216 \\
\hline Logger "Frankfurt" & 1908 & 2.307 \\
\hline Logger "Friedrich Wilhelm" & 1905 & 2.296 \\
\hline Logger "Fürst von Bismarck" & 1899 & 2.234 \\
\hline Logger "Gerhardine" & 1903 & 2.277 \\
\hline Logger "Heinrich Daniel" & 1904 & 2.287 \\
\hline Logger "Henry \& Markus" & 1903 & 2.279 \\
\hline Logger "Ida" & 1899 & 2.235 \\
\hline Logger "Ingwalde" & 1904 & 2.287 \\
\hline Logger "Jacob" & 1899 & 2.234 \\
\hline Logger "Jennie" & 1895 & 2.218 \\
\hline Logger "Johanna Theodora" & 1900 & 2.243 \\
\hline Logger "Johannes" & 1895 & 2.218 \\
\hline Logger "Juno" & 1903 & 2.276 \\
\hline Logger "Köln" & 1899 & 2.234 \\
\hline Logger "Königsberg" & 1908 & 2.307 \\
\hline Logger "Kurprinz" & 1905 & 2.297 \\
\hline Logger "Louise" & 1901 & 2.254 \\
\hline Logger "Louise Henriette" & 1905 & 2.296 \\
\hline Logger "Magarethe" & 1895 & 2.218 \\
\hline Logger "Marie" & 1905 & 2.296 \\
\hline Logger "Memel" & 1903 & 2.276 \\
\hline Logger "Minister Dr. Lucius" & 1899 & 2.234 \\
\hline Logger "Morian" & 1905 & 2.297 \\
\hline Logger "Nella" & 1900 & 2.243 \\
\hline Logger "Nesserland" & 1900 & 2.243 \\
\hline Logger "Oberbürgermeister Fürbringer" & 1897 & 2.221 \\
\hline Logger "Ocean" & 1902 & 2.267 \\
\hline Logger "Oldenburg" & 1899 & 2.234 \\
\hline Logger "Ora et Labora" & 1902 & 2.268 \\
\hline Logger "Oranien" & 1905 & 2.296 \\
\hline Logger "Orion" & 1904 & 2.286 \\
\hline \multirow[t]{2}{*}{ Logger "Osnabrück" } & 1897 & 2.221 \\
\hline & 1899 & 2.234 \\
\hline Logger "Ostfriesland" & 1899 & 2.234 \\
\hline Logger "Pallas" & 1903 & 2.276 \\
\hline \multirow{2}{*}{ Logger "Phoenix" } & 1895 & 2.218 \\
\hline & 1900 & 2.243 \\
\hline Logger "Prinz Ludwig" & 1905 & 2.296 \\
\hline Logger "Rostock" & 1903 & 2.276 \\
\hline Logger "Sirius" & 1905 & 2.292 \\
\hline Logger "Spanien" & 1905 & 2.297 \\
\hline Logger "Stadt Emden" & 1899 & 2.234 \\
\hline Logger "Stadt Leer" & 1899 & 2.234 \\
\hline Logger "Stella" & 1897 & 2.221 \\
\hline Logger "Stettin" & 1903 & 2.276 \\
\hline Logger "Susanna Henriette" & 1903 & 2.279 \\
\hline Logger "Venus" & 1908 & 2.308 \\
\hline Logger "Vesta" & 1903 & 2.276 \\
\hline Logger "Wega" & 1904 & 2.286 \\
\hline Logger "Westfalen" & 1899 & 2.234 \\
\hline Logger "Wilhelmine" & 1899 & 2.234 \\
\hline Logger "Windhund" & 1905 & 2.297 \\
\hline Logger "Y. Brons" & 1903 & 2.277 \\
\hline Löhne, Feststellung & $1901-1916$ & 1.902 \\
\hline Lohntarifvertrag, Hafenarbeiter d. christlichen Gewerkschaft & 1913-1914 & 715 \\
\hline Lokalschulinspektor, Katholische Volksschule in Emden & $1878-1890$ & 3.704 \\
\hline Lokomotive, Einbau eines Dampfkessels & 1906 & 2.165 \\
\hline
\end{tabular}


IV

Index

\section{SACH}

\begin{tabular}{|c|c|c|}
\hline Indexbegriff & Laufzeit & Lfd.Nr. \\
\hline Löscharbeiten, Bericht zum Ablauf & $1896-1897$ & 1.354 \\
\hline Löscharbeiten, Probleme & $1874-1875$ & 1.296 \\
\hline Löscharbeiten, Schäden & 1872 & 1.301 \\
\hline Löscheimer, Ausschreibung & 1879-1904 & 1.398 \\
\hline Löscheinsatz, Bericht & 1888 & 1.342 \\
\hline Löscheinsatz, Prämie & $1882-1904$ & 1.384 \\
\hline Löscheinsatz, Verletzung & $1869-1874$ & 1.306 \\
\hline Löschgerät, Angebote & $1867-1869$ & 1.388 \\
\hline Löschgeräte, Einsatz & 1887 & 1.341 \\
\hline Löschhilfe, Regelung & 1886-1905 & 1.251 \\
\hline Löschplatz, Verpachtung & 1879-1909 & 2.500 \\
\hline \multirow[t]{2}{*}{ Löschprämie, Antrag } & 1888-1889 & 1.344 \\
\hline & 1900 & 1.358 \\
\hline Löschprämie, Gewährung & 1911-1912 & 1.378 \\
\hline Löschprämie, Wegfall & 1888 & 1.342 \\
\hline \multirow[t]{3}{*}{ Löschwesen, Angestellte } & $1868-1869$ & 1.391 \\
\hline & $1870-1886$ & 1.392 \\
\hline & 1887-1907 & 1.393 \\
\hline Löschwesen, Mittel zur Verbesserung & $1866-1903$ & 1.385 \\
\hline \multirow[t]{2}{*}{ Löschwesen, Verbesserungsvorschläge } & 1882-1904 & 1.384 \\
\hline & $1866-1903$ & 1.385 \\
\hline Lotsdampfer, Ausstattung mit Dampfkessel & 1906 & 2.168 \\
\hline Lotsenschoner "Ems" & 1874 & 1.753 \\
\hline Lotsenstation, Bau & $1880-1881$ & 2.469 \\
\hline Lotsenzwang, Befreiungsantrag & 1906-1909 & 2.090 \\
\hline Lotsenzwang, Diskussion & $1872-1912$ & 2.122 \\
\hline Lots-Gesellschaft, Jubiläum & $1872-1912$ & 2.122 \\
\hline Lots-Wesen, Geschäftsberichte & $1872-1912$ & 2.122 \\
\hline Lots-Wesen, Tarife & $1872-1912$ & 2.122 \\
\hline Lotterie-Einnehmer, Aufstellung & 1886-1904 & 558 \\
\hline Lotterie-Einnehmer, Zulassungsgesuch & $1868-1914$ & 557 \\
\hline Lotterien, Genehmigungspflicht & 1868-1914 & 557 \\
\hline Lotterien, Preise & 1868-1914 & 557 \\
\hline Lotterien, Verbot & 1886-1904 & 558 \\
\hline Lotterien, Zulassung für gemeinnutzige Zwecke & 1886-1904 & 558 \\
\hline Lotteriewesen, Gesetze und Erlasse & $1868-1914$ & 557 \\
\hline \multirow[t]{3}{*}{ Ludendorffspende } & 1918 & 3.219 \\
\hline & 1918 & 3.220 \\
\hline & 1917-1918 & 3.311 \\
\hline Ludendorffspende, Ertrag in Emden & 1918 & 3.219 \\
\hline Luftalarmsystem, Aufbau & $1915-1918$ & 3.210 \\
\hline Luftangriff, Verhaltensrichtlinien & $1915-1918$ & 3.210 \\
\hline Luftangriffe, Verdunkelung bei Nacht & 1915-1918 & 3.210 \\
\hline Luftfahrt, Förderung & $1912-1915$ & 714 \\
\hline Luftschautag, Veranstaltung & $1909-1913$ & 2.097 \\
\hline Luftschifffahrt, Förderung & 1909-1913 & 2.097 \\
\hline Luftschiffhafen, Angebote & 1913-1914 & 2.104 \\
\hline \multirow[t]{2}{*}{ Luftschiffhalle, Anlage } & $1912-1913$ & 2.103 \\
\hline & 1913-1914 & 2.104 \\
\hline Luftschiffhalle, Landerwerb & $1912-1913$ & 2.103 \\
\hline Luftschiffhalle, Material & 1913-1914 & 2.104 \\
\hline Luftschiffhalle, Planung & $1912-1913$ & 2.103 \\
\hline Luftschiffhalle, Subventionierung & $1912-1913$ & 2.103 \\
\hline Luftschiffhalle, Subventionierungsrückzug & 1913-1914 & 2.104 \\
\hline Luftschiffskonstruktion, Werbeschrift & 1899-1910 & 512 \\
\hline Luftschiffslandeplatz, Anlage & 1909-1913 & 2.097 \\
\hline Luftschutz, Erster Weltkrieg & $1915-1918$ & 3.210 \\
\hline Luftverschmutzung, Beschwerden & 1898-1909 & 2.180 \\
\hline
\end{tabular}


Index

\begin{tabular}{|c|c|c|}
\hline \multicolumn{3}{|c|}{ SACH } \\
\hline Indexbegriff & Laufzeit & Lfd.Nr. \\
\hline Lustbarkeitssteuer, Befreiung & $1901-1912$ & 643 \\
\hline \multirow[t]{3}{*}{ Lustbarkeitssteuer, Befreiungsanträge } & $1912-1914$ & 567 \\
\hline & $1872-1913$ & 599 \\
\hline & $1888-1915$ & 668 \\
\hline Lustbarkeitssteuer, Einziehung & $1886-1914$ & 574 \\
\hline Lustbarkeitssteuer, Ermäßigungsanträge & $1907-1913$ & 1.734 \\
\hline Lustbarkeitssteuer, Musikautomaten & $1907-1913$ & 1.734 \\
\hline Lustbarkeitssteuer, Ordnung & $1890-1895$ & 1.733 \\
\hline Lustbarkeitssteuer, Rechtliche Grundlagen & $1890-1903$ & 1.735 \\
\hline Lustbarkeitssteuerordnung, Novellierung & $1907-1913$ & 1.734 \\
\hline Lustbarkeitsteuer, Erhöhung & $1907-1913$ & 1.734 \\
\hline Lutheraner, Einpfarrung nach Emden & $1902-1914$ & 3.340 \\
\hline \multirow{2}{*}{ Lutheraner, Gemeindezugehörigkeit } & 1896-1914 & 3.330 \\
\hline & 1908-1909 & 3.342 \\
\hline Lutheraner, Gemeindezugehörigkeit auf Nesserland & $1866-1897$ & 3.461 \\
\hline Lutherische Gemeinde, Staatsaufsicht & $1869-1891$ & 3.438 \\
\hline Lutherische Gemeinde, Vermögenslage & $1891-1914$ & 3.439 \\
\hline Lutherische Gemeinde, Visitation & $1869-1891$ & 3.438 \\
\hline Mädchenhandel, Bekämpfung & $1912-1913$ & 708 \\
\hline Magistrat, Vereidigung auf die preußische Verfassung & 1868 & 8 \\
\hline Magistratsassessor, Trennung vom Amtsanwaltsbereich & $1913-1914$ & 7 \\
\hline Magistratssiegel, Verwendung & $1848-1915$ & 1 \\
\hline Magistratszimmer, Antikmöbelangebot & 1884-1895 & 2.426 \\
\hline Makler, Butter- und Käsemarkt & $1902-1910$ & 420 \\
\hline Makler, Manipulation & $1902-1910$ & 420 \\
\hline Makler, Rücktritt & $1902-1910$ & 420 \\
\hline Makler, Stadt Emden & $1871-1913$ & 419 \\
\hline Makler, Zulassung & $1902-1910$ & 420 \\
\hline Maler-Innung, Selbstauflösung & $1873-1889$ & 1.932 \\
\hline Maler-Innung, Statuten & $1873-1889$ & 1.932 \\
\hline Maler-Innung, Struktur & $1873-1889$ & 1.932 \\
\hline Maler-Innung, Wiederaufrichtung & 1873-1889 & 1.932 \\
\hline Männerturnverein, Geschäftsberichte & $1882-1914$ & 729 \\
\hline Männerturnverein, Jubiläumsschrift & $1895-1914$ & 730 \\
\hline Männerturnverein, Korporationsrechte & $1882-1914$ & 729 \\
\hline \multirow[t]{2}{*}{ Männerturnverein, Statuten } & $1882-1914$ & 729 \\
\hline & $1895-1914$ & 730 \\
\hline \multirow[t]{2}{*}{ Männerturnverein, Veranstaltungen } & $1882-1914$ & 729 \\
\hline & $1895-1914$ & 730 \\
\hline Männerturnverein, Vorstandswahl & $1895-1914$ & 730 \\
\hline Mannschaftsbibliothek, SMS "Emden" & $1908-1914$ & 271 \\
\hline Manufakturwarenlager, Angestellte & 1917-1918 & 3.289 \\
\hline Manufakturwarenlager, Anmietung von Räumen & 1916-1918 & 3.286 \\
\hline Manufakturwarenlager, Rechnungslegung & 1918 & 3.288 \\
\hline Margarinezuteilungen, Polizeischutz & 1914-1916 & 3.194 \\
\hline Marine, Bau einer Elektroleitung & $1916-1917$ & 3.157 \\
\hline Marinereservisten, Abmeldepflicht & $1869-1890$ & 1.577 \\
\hline Marineverein für Emden und Umgebung, Fahnenweihe & $1905-1913$ & 671 \\
\hline Marineverein für Emden und Umgebung, Satzung & $1905-1913$ & 671 \\
\hline Marinevereine, Beaufsichtigung & $1873-1910$ & 598 \\
\hline Marinevereine, Fahnenmuster & $1868-1913$ & 597 \\
\hline Markisen, Ablasshöhe & 1871-1909 & 1.158 \\
\hline Markisen, Unvorschriftsmäßige & $1871-1909$ & 1.158 \\
\hline Markt- und Waage-Meister, Vereidigung & $1877-1910$ & 2.653 \\
\hline Markt, Lärmbelästigung & $1909-1918$ & 2.654 \\
\hline Marktbuden, Verpachtung & 1866-1909 & 2.675 \\
\hline Marktfragen, Regulierung & 1880 & 2.141 \\
\hline
\end{tabular}


Index

\begin{tabular}{|c|c|c|}
\hline \multicolumn{3}{|l|}{ SACH } \\
\hline Indexbegriff & Laufzeit & Lfd.Nr. \\
\hline Markthalle, Grundriss & $1876-1905$ & 2.150 \\
\hline Marktkalender, Emden & 1902 & 2.142 \\
\hline \multirow[t]{3}{*}{ Marktkalender, Festlegung } & $1870-1884$ & 2.138 \\
\hline & $1885-1896$ & 2.139 \\
\hline & $1908-1917$ & 2.140 \\
\hline \multirow[t]{3}{*}{ Marktkommission, Mitglieder } & 1876-1908 & 2.147 \\
\hline & 1883-1895 & 2.148 \\
\hline & $1900-1918$ & 2.149 \\
\hline \multirow[t]{3}{*}{ Marktkommission, Sitzungsprotokolle } & $1876-1908$ & 2.147 \\
\hline & 1883-1895 & 2.148 \\
\hline & $1900-1918$ & 2.149 \\
\hline \multirow[t]{2}{*}{ Marktkommission, Statut } & $1876-1908$ & 2.147 \\
\hline & $1900-1918$ & 2.149 \\
\hline Marktmeister, Beschwerden gegen & $1877-1910$ & 2.653 \\
\hline \multirow[t]{2}{*}{ Marktmeisterdienst, Verpachtung } & $1877-1910$ & 2.653 \\
\hline & 1909-1918 & 2.654 \\
\hline Marktordnung, Aushang & $1877-1910$ & 2.146 \\
\hline Marktplatz, Reinigung & $1877-1910$ & 2.146 \\
\hline Marktpreise, Butter und Käse & $1881-1896$ & 2.143 \\
\hline Marktstandsgebühr, Verpachtung der Erhebung & $1877-1910$ & 2.653 \\
\hline Marktstandsgebühren, Eintreibung & $1868-1909$ & 2.144 \\
\hline Marktstandsgebühren, Festlegung & 1868-1909 & 2.144 \\
\hline Marktstandsgebühren, Tarif & 1868-1909 & 2.144 \\
\hline Marktstandsgebühren, Umrechnung in Mark & 1868-1909 & 2.144 \\
\hline \multirow[t]{3}{*}{ Markttage, Festlegung } & $1870-1884$ & 2.138 \\
\hline & $1885-1896$ & 2.139 \\
\hline & $1908-1917$ & 2.140 \\
\hline Marktwaren, Definition nach Steuerrecht & $1877-1910$ & 2.146 \\
\hline Marktwesen, Regulierung & $1908-1917$ & 2.140 \\
\hline Marktzeit, Verlängerungsanträge & $1877-1910$ & 2.146 \\
\hline Maschinenschreiberin, Beschäftigung & $1916-1918$ & 339 \\
\hline Maschinenschreiberin, Bewerbung & $1916-1918$ & 339 \\
\hline Maschinenschreiberin, Gehalt & $1916-1918$ & 339 \\
\hline Maß- und Gewichte-Revision, Verzeichnis & $1872-1880$ & 2.158 \\
\hline Massenquartiere, Missstände & $1909-1911$ & 1.231 \\
\hline Mäuse- und Rattenplage & $1866-1889$ & 3.124 \\
\hline Mäuse, Bekämpfung durch Mäusetyphus & $1898-1914$ & 817 \\
\hline Medizinalbeamte, Besoldung & $1866-1914$ & 762 \\
\hline Mehl-Akzise & $1895-1897$ & 2.927 \\
\hline Mehlakzise, Erhebung als Pauschalsumme & 1904-1908 & 2.930 \\
\hline Meldedienst, Einrichtung & 1905-1906 & 1.423 \\
\hline Meliorationsarbeiten, Kosten & 1874-1904 & 2.493 \\
\hline Meliorationsarbeiten, Verhandlungen & 1884-1896 & 2.494 \\
\hline Meliorationstechniker, Aufgaben & $1867-1887$ & 810 \\
\hline Meliorationsverbände, Kreditangebot & $1867-1881$ & 816 \\
\hline Mennonitengemeinde, Korporationsrechte & 1901-1902 & 3.486 \\
\hline Mennonitengemeinde, Mitglieder & 1901-1902 & 3.486 \\
\hline Messing, Ablieferung & 1915-1918 & 3.242 \\
\hline \multirow[t]{3}{*}{ Messing, Ablieferung für Kriegswirtschaft } & 1916 & 3.250 \\
\hline & 1916 & 3.251 \\
\hline & 1916 & 3.252 \\
\hline Metall, Beschlagnahmung für Kriegswirtschaft & 1917-1918 & 3.263 \\
\hline Metallpfeifen, Bleigehalt & 1898-1907 & 753 \\
\hline Metallsammlung, Organisation & $1915-1918$ & 3.242 \\
\hline Miesmuschelgenuss, Anzeige von Vergiftungen & 1885 & 751 \\
\hline Mietbeihilfen, Familien eingezogener Soldaten & 1893-1914 & 3.185 \\
\hline Mieten, Beitreibung der Rückstände von städtischen Gebäuden & 1866-1909 & 2.675 \\
\hline Mieter, Kündigung & 1900-1908 & 2.432 \\
\hline
\end{tabular}


Index

\begin{tabular}{|c|c|c|}
\hline \multicolumn{3}{|l|}{ SACH } \\
\hline Indexbegriff & Laufzeit & Lfd.Nr. \\
\hline Mietkontrakte, Verlängerungsanträge & $1866-1904$ & 2.676 \\
\hline Mietminderung oder -Stundung, Anträge & $1866-1904$ & 2.676 \\
\hline Mietpegel, Emden & 1887-1902 & 1.228 \\
\hline Mietshaus, Gesundheitsschädliche Zustände & $1903-1907$ & 1.186 \\
\hline Mietwohnungen, Plan der Bahnverwaltung & 1904-1905 & 1.192 \\
\hline Mietwohnungen, Räumungsanträge & $1857-1907$ & 514 \\
\hline Mietwohnungen, Unbewohnbarkeit & $1857-1907$ & 514 \\
\hline Milch, Bewirtschaftung & $1915-1916$ & 3.307 \\
\hline Milch, Kontrolle & $1879-1910$ & 748 \\
\hline Milch, Wert als Nahrungsmittel & 1912 & 754 \\
\hline Milchpreise, Steigerung & $1911-1913$ & 479 \\
\hline Militärdienst, Vorzeitige Entlassungen & $1906-1913$ & 3.103 \\
\hline Militärdienstleistungen, Entschädigung & $1876-1918$ & 3.168 \\
\hline Militärpersonen, Freier Eintritt zur Rüstkammer & 1904-1907 & 2.638 \\
\hline Militärseelsorge, Organisation & $1867-1911$ & 3.086 \\
\hline Militärübung, Antrag auf Rückstellung & $1897-1911$ & 1.046 \\
\hline Militärverein, Fahnenrecht & $1901-1912$ & 643 \\
\hline Militärverein, Lärmbelästigung durch nächtliche Märsche & $1901-1912$ & 643 \\
\hline Militärverein, Mitgliederverzeichnis & $1901-1912$ & 643 \\
\hline Militärverein, Satzung & $1901-1912$ & 643 \\
\hline Militärverein, Zulassung & $1901-1912$ & 643 \\
\hline Minenschiffes SMS "Arcona" & & Vorwort \\
\hline Minensuchschiff "Arcona" & $1912-1913$ & 3.088 \\
\hline Minensuchschiff, Förderantrag für Buchprojekt & $1912-1913$ & 3.088 \\
\hline Minensuchschiff, Stationierung in Emden & $1912-1913$ & 3.088 \\
\hline Missbrauch, Ermittlungen gegen Lehrer & $1909-1910$ & 3.568 \\
\hline \multirow[t]{3}{*}{ Missstände, Bau von Gebäuden } & $1866-1872$ & 1.216 \\
\hline & $1872-1879$ & 1.217 \\
\hline & $1908-1912$ & 1.218 \\
\hline Mistabfuhr, Erhalt für J. Dirksen & 1904-1905 & 1.008 \\
\hline Mistareal, Geruchsberlästigung durch Schlachtabfälle & $1868-1911$ & 825 \\
\hline Misthaufen, Anträge auf Genehmigung & $1909-1910$ & 826 \\
\hline Misthaufen, Unerlaubte Anlegung & $1875-1896$ & 1.156 \\
\hline Misthaufenareal, Anlage & $1868-1911$ & 825 \\
\hline Misthaufenareal, Nutzer & $1868-1911$ & 825 \\
\hline Misthaufenareal, Schließung & $1868-1911$ & 825 \\
\hline Misthaufenareale, Pachtberechnung & $1868-1911$ & 825 \\
\hline Misthaufenareale, Pachtgelder & $1868-1911$ & 825 \\
\hline Misthaufenareale, Stadt Emden & $1868-1911$ & 825 \\
\hline Misthaufen-Plätze, Aufstellung & $1868-1911$ & 825 \\
\hline Misthaufen-Plätze, Verpachtung & $1868-1911$ & 825 \\
\hline Mitglieder, Emder Hafenverein & 1906-1907 & 677 \\
\hline Mitgliederliste, Verein "Lemaan Zion" & 1904 & 485 \\
\hline Mitgliederverzeichnis, Club zum Guten Endzweck & $1881-1912$ & 626 \\
\hline Mittellosigkeit, Unterstützungsantrag & 1916-1918 & 1.887 \\
\hline \multirow[t]{2}{*}{ Mittelschule für Mädchen, Einrichtung } & $1905-1911$ & 3.830 \\
\hline & $1911-1913$ & 3.831 \\
\hline \multirow[t]{2}{*}{ Mittelschule, Diskussion des Schulprojektes } & $1880-1881$ & 3.614 \\
\hline & $1913-1914$ & 3.615 \\
\hline Mittelwall, Abtragung & 1896-1906 & 998 \\
\hline Mobilisierungsfall, Beschlagnahmung von Waffen und Munition & $1902-1914$ & 3.174 \\
\hline Mobilisierungsfall, Organisation der Krankenpflege & $1901-1913$ & 3.173 \\
\hline Mobilisierungsfall, Qzarantänestation & $1900-1912$ & 3.172 \\
\hline Mobilmachung, Bekanntmachungen & 1914-1916 & 3.163 \\
\hline Mobilmachung, Reservelazarette & $1900-1912$ & 3.172 \\
\hline Mobilmachungsbekanntmachungen, Insertionskosten & $1914-1916$ & 3.163 \\
\hline Mobilmachungsfall, Personal für Luftschifferzwecke & 1901 & 3.171 \\
\hline Mobilmachungsfall, Datensammlung zu Luftschiffsanlagen & 1901 & 3.171 \\
\hline
\end{tabular}


Index

\begin{tabular}{|c|c|c|}
\hline \multicolumn{3}{|l|}{ SACH } \\
\hline Indexbegriff & Laufzeit & Lfd.Nr. \\
\hline Mobilmachungsfall, Einberufungsbescheide & 1902-1908 & 3.169 \\
\hline Mobilmachungsfall, Pressezensur & $1909-1914$ & 3.179 \\
\hline Mobilmachungsfall, Regelungen & $1901-1912$ & 590 \\
\hline Monilia, Bekämpfung & $1898-1914$ & 817 \\
\hline Monopol, Vorwürfe & 1873-1907 & 2.017 \\
\hline Montierungskammer, Renovierung & $1871-1887$ & 3.127 \\
\hline Monument, Rede des Kaisers Wilhelm II. & $1902-1903$ & 177 \\
\hline Moore, Besichtigung & 1894-1905 & 2.603 \\
\hline Moorentwässerung & $1905-1908$ & 1.448 \\
\hline Moorfläche, Erwerbsplan der Stadt Emden & 1881 & 2.524 \\
\hline Moorflächen, Kaufinteressen & 1894-1905 & 2.603 \\
\hline Moorflächen, Kultivierung & 1894-1905 & 2.603 \\
\hline Mormonen, Ausweisung & $1867-1910$ & 3.497 \\
\hline Motobootslinie, Emden nach Wilhelmshaven & 1892 & 2.045 \\
\hline Motorbootsbetrieb, Bilanz & $1907-1918$ & 1.952 \\
\hline Motorbootslinie, Errichtung im Emder Hafen & 1892 & 2.045 \\
\hline Motorbootslinie, Fahrplan & $1907-1918$ & 1.952 \\
\hline Motorbootsverbindung, Emden und Greetsiel & 1897 & 2.052 \\
\hline Motoren, Gasbetrieben & $1897-1914$ & 1.042 \\
\hline Mühle, Umwandlung von einer Sägemühle in eine Kornmühle & $1866-1888$ & 2.379 \\
\hline Mühlengewerbe, Besteuerung & $1867-1870$ & 2.904 \\
\hline Müll- und Fäkalienabfuhr-Gebührenordnung, Stadt Emden & $1877-1912$ & 324 \\
\hline Mülltonnen, Angebot & $1905-1912$ & 863 \\
\hline Müllverbrennungsöfen, Angebot & $1905-1912$ & 863 \\
\hline Müllwagen, Angebot & $1905-1912$ & 863 \\
\hline Mündelregister & $1878-1889$ & 1.705 \\
\hline Münzgas, Belieferung & $1897-1914$ & 1.042 \\
\hline Münzprägestempel, Restaurierung & $1874-1901$ & 2.622 \\
\hline Münzwesen, Erlasse und Verfügungen & $1866-1912$ & 257 \\
\hline Museen und Sammlungen, Erfassung der Bestände & $1884-1917$ & 2.396 \\
\hline Museum, Kosten & $1884-1917$ & 2.396 \\
\hline Museum, Planungen & 1900-1909 & 2.607 \\
\hline Musikdirektor, Amtsniederlegung & $1881-1890$ & 554 \\
\hline Musikdirektor, Beihilfe & $1881-1890$ & 554 \\
\hline Musikdirektor, Bewerbung & $1881-1890$ & 554 \\
\hline Musikschulen, Aufsicht & 1913 & 3.848 \\
\hline Musikschulen, Emden & 1913 & 3.848 \\
\hline Musikunterricht, Lärmbelästigung & $1879-1900$ & 2.184 \\
\hline Musikverein, Unterstützungsgesuch & $1902-1909$ & 654 \\
\hline Musterrolle, Eintragungen & $1869-1890$ & 1.577 \\
\hline Musterrolle, Schiff "Antje Dirks" & $1873-1975$ & 1.578 \\
\hline Mütterberatungsstelle, Einrichtung in Emden & 1914-1916 & 759 \\
\hline Nachruf, Ernst Heinrich Hantelmann & $1853-1891$ & 12 \\
\hline Nachtwächter, Antrag auf Waffentragen & $1881-1913$ & 727 \\
\hline Nachtwächter, Instruktion & $1884-1896$ & 434 \\
\hline Nachtwächter, Kontrolluhr & $1869-1896$ & 436 \\
\hline Nachtwächter, Nebeneinkünfte & 1884-1906 & 413 \\
\hline Nachtwächter, Vereidigung & 1884-1906 & 413 \\
\hline Nachtwächtergeld, Wolthusen & $1880-1913$ & 254 \\
\hline Nachtwachtmeister, Beschwerde gegen & 1884-1906 & 413 \\
\hline Nachtwachtmeister, Beschwerden wegen Körperverletzung & 1898-1905 & 394 \\
\hline Nachtwachtmeister, Besoldung & 1884-1906 & 413 \\
\hline Nachtwachtmeister, Bewerbungen & 1898-1905 & 394 \\
\hline Nachtwachtmeister, Dienstanweisung & 1898-1905 & 394 \\
\hline Nachtwachtmeister, Dienstanweisungen & $1898-1905$ & 394 \\
\hline Nachtwachtmeister, Dienstinstruktionen & 1898-1905 & 394 \\
\hline Nachtwachtmeister, Disziplinarverfahren & 1884-1906 & 413 \\
\hline
\end{tabular}


Index

\begin{tabular}{|c|c|c|}
\hline \multicolumn{3}{|l|}{ SACH } \\
\hline Indexbegriff & Laufzeit & Lfd.Nr. \\
\hline \multirow[t]{2}{*}{ Nachtwachtmeister, Einstellung } & $1898-1905$ & 394 \\
\hline & $1884-1906$ & 413 \\
\hline Nachtwachtmeister, Entlassung & $1884-1906$ & 413 \\
\hline Nachtwachtmeister, Krankmeldungen & $1898-1905$ & 394 \\
\hline Nachtwachtmeister, Personalakte & $1884-1906$ & 413 \\
\hline Nachtwachtmeister, Unfall wg. Trunkenheit & $1884-1906$ & 413 \\
\hline Nachwachtmeister, Instruktionen & $1884-1906$ & 413 \\
\hline Nahrungsmitteluntersuchungsamt, Gerätebedarf & 1879 & 756 \\
\hline Namensänderungen, Anträge & $1869-1916$ & 454 \\
\hline Namensänderungen, Gesuchsbearbeitung & $1869-1916$ & 454 \\
\hline Namensschilder, Regelung der Anbringung & $1866-1913$ & 832 \\
\hline Nationalliberale, Mitglieder & $1879-1880$ & 623 \\
\hline Naturparkidee, Werbung & $1911-1914$ & 600 \\
\hline Navigationslehrer, Einberufung & $1905-1916$ & 1.584 \\
\hline Navigationslehrer, Einstellung & $1870-1871$ & 1.582 \\
\hline Navigationslehrer, Enntsendung & $1905-1916$ & 1.584 \\
\hline Navigationslehrer, Entlassungsgesuch & $1870-1871$ & 1.582 \\
\hline Navigationslehrer, Gehaltsfestlegung & $1905-1916$ & 1.584 \\
\hline Navigationslehrer, Nebentätigkeit & $1905-1916$ & 1.584 \\
\hline Navigationslehrer, Nebentätigkeiten & $1875-1894$ & 1.617 \\
\hline Navigationslehrer, Persönliche Verhältnisse & $1905-1916$ & 1.584 \\
\hline Navigationslehrer, Prüfungsgskomm. f. Schiffer u. Steuermänner & $1870-1909$ & 1.591 \\
\hline Navigationslehrer, Unterstützungsgesuch & $1893-1895$ & 1.583 \\
\hline Navigationslehrer, Urlaubsgesuche & $1905-1916$ & 1.584 \\
\hline Navigationslehrer, Versetzung & $1905-1916$ & 1.584 \\
\hline Navigationslehrer, Vertretung & $1893-1895$ & 1.583 \\
\hline Navigationsschulbibliothek, Inventar & 1870 & 1.593 \\
\hline Navigationsschuldiener, Entlassungsgesuch & $1875-1905$ & 1.594 \\
\hline Navigationsschuldirektor. Versetzung & $1870-1910$ & 1.597 \\
\hline Navigationsschule, Aktenverzeichnis & 1918 & 1.626 \\
\hline Navigationsschule, Anmietung eines Schulgebäudes & $1875-1905$ & 1.594 \\
\hline Navigationsschule, Auflösung & 1918 & 1.626 \\
\hline Navigationsschule, Bauunterhaltung & $1895-1918$ & 1.622 \\
\hline Navigationsschule, Bauunterhaltung des Schulgebäudes & $1880-1894$ & 1.592 \\
\hline Navigationsschule, Beaufsichtigung & $1870-1911$ & 1.619 \\
\hline Navigationsschule, Englischunterricht & $1870-1871$ & 1.582 \\
\hline Navigationsschule, Erste-Hilfe- und Gesundheitsprüfungen & $1910-1917$ & 1.624 \\
\hline Navigationsschule, Etat & 1893 & 1.586 \\
\hline Navigationsschule, Etatverwaltung & $1874-1896$ & 1.618 \\
\hline Navigationsschule, Freistellen & $1875-1914$ & 1.605 \\
\hline Navigationsschule, Fremdnutzung eines Klassenzimmers & $1913-1917$ & 1.615 \\
\hline Navigationsschule, Fremdnutzung von Räumen & $1872-1895$ & 1.589 \\
\hline \multirow[t]{2}{*}{ Navigationsschule, Jubiläum } & 1887 & 1.604 \\
\hline & $1880-1885$ & 1.623 \\
\hline Navigationsschule, Jubiläumsschrift & $1880-1885$ & 1.623 \\
\hline Navigationsschule, Kassenführer & $1872-1890$ & 1.585 \\
\hline Navigationsschule, Kuratorium & $1870-1910$ & 1.597 \\
\hline Navigationsschule, Kuratoriumsmitgliedschaft & $1870-1910$ & 1.597 \\
\hline Navigationsschule, Kuratoriumsvorsitz & $1870-1910$ & 1.597 \\
\hline Navigationsschule, Kuratoriumszuständigkeit & $1870-1910$ & 1.597 \\
\hline Navigationsschule, Lehrerwohnungen & $1880-1894$ & 1.592 \\
\hline Navigationsschule, Navigationsschuldirektor & $1870-1910$ & 1.597 \\
\hline Navigationsschule, Neubaudiskussion & $1875-1914$ & 1.605 \\
\hline Navigationsschule, Nutzung des Regierungsdampfers & $1875-1914$ & 1.605 \\
\hline \multirow[t]{2}{*}{ Navigationsschule, Observatorium } & $1875-1914$ & 1.605 \\
\hline & $1875-1894$ & 1.617 \\
\hline Navigationsschule, Personalsachen & $1875-1894$ & 1.617 \\
\hline Navigationsschule, Prüfungsgebühren & $1870-1914$ & 1.579 \\
\hline
\end{tabular}


Index

\begin{tabular}{l}
\hline Indexbegriff \\
\hline Navigationsschule, Prüfungskommission f. Schiffer a. kl \\
Navigationsschule, Rangerhöhungsantrag \\
Navigationsschule, Rechnungsabnahme \\
Navigationsschule, Rechnungsführung \\
Navigationsschule, Rechnungsprüfung \\
Navigationsschule, Schifferprüfungen für "Kleine Fahrt" \\
Navigationsschule, Schülerlisten der Steuemannskurse \\
Navigationsschule, Schülerzahlen \\
Navigationsschule, Schulgeld \\
Navigationsschule, Schulstandortssicherung \\
Navigationsschule, Seekartenanschaffung \\
Navigationsschule, Steuermannsklasse \\
Navigationsschule, Steuermannskurse
\end{tabular}

Navigationsschule, Steuermannsprüfungsaufgaben Navigationsschule, Steuermannsprüfungsergebnisse Navigationsschule, Steuermannsprüfungskommission Navigationsschule, Steuermannsskurse Navigationsschule, Vorbereitungsschule Navigationsschule, Werbekampagne Navigationsschule, Zeitschriftenabonnementskündigung Navigationsschule, Zurückweisung von Bewerbern Navigationsschulen, Farbsichtigkeitsuntersuchungen Navigationsschulen, Prüfungsstatistik

\section{SACH}

Navigationsschüler, Beleidigung Navigationsschüler, Farbsichtigkeit Navigationsschüler, Unterstützung

Navigationsschulgebäude, Beihilfe zur Renovierung Navigationsschullehrerdienstwohnung, Gasanschluss Navigationsschullehrerdienstwohnung, Renovierung Navigationsschulwärter, Einstellung Navigationsschulwärter, Vergütung Navigationsschulwärterstelle, Ausschreibung Navigationsschulwartin, Alters- und Invaliditätsversicherung Navigationsvorschulen, Regulativ Nebelhornpflicht, Einführung für Dampfschiffe Nesserland, Pegel- und Windverhältnisse Neubau, Nichtgenehmigung Neubau, Ungenehmigter Neubauabnahmen, Baupolizeiliche Regelungen Neubauten, Revision Neue Kirche, Besitzstände und Vermögen Neupfortssiel, Überfahrt Neupfortssielbrücke, Befahrensverbot Nickel, Ablieferung für die Kriegswirtschaft

\section{Laufzeit}

1870-1910

1880-1885

1870-1898

$1870-1914$

$1872-1890$

1902-1914

$1872-1890$

1874-1888

1871-1895

$1875-1914$

1870-1898

$1875-1914$

1872-1895

1870-1871

1871-1895

1872-1895

1875-1914

$1870-1910$

$1872-1895$

$1870-1910$

1870-1871

1887

$1875-1914$

1872-1895

1870-1909

1893-1914

1898-1899

1905-1906

1900-1904

1909-1911

1912-1914

1915-1917

1893-1895

1893-1914

1893-1896

1894-1896

1875-1914

1880-1894

1895-1918

1895-1918

1875-1905

1875-1905

1875-1905

1891-1903

1894

1880-1912

1898-1899

1905

1903-1904

1897-1903

1906-1913

1868-1910

1868-1883

1868-1883

1915-1918

1916

1916

1916

\section{Lfd.Nr.}

1.597

1.623

1.580

1.579

1.585

1.620

1.585

1.590

1.588

1.605

1.580

1.605

1.589

1.587

1.588

1.589

1.605

1.597

1.589

1.597

1.587

1.604

1.605

1.589

1.591

1.607

1.608

1.609

1.610

1.611

1.612

1.613

1.583

1.607

1.595

1.596

1.605

1.592

1.622

1.622

1.594

1.594

1.594

1.606

1.627

1.405

1.486

1.197

1.185

1.139

1.224

3.387 
Index

\begin{tabular}{|c|c|c|}
\hline \multicolumn{3}{|c|}{$\mathrm{SACH}$} \\
\hline Indexbegriff & Laufzeit & Lfd.Nr. \\
\hline Nickelmünzen, Ersatz & 1914-1916 & 3.240 \\
\hline Niederlassungsrecht, Stadt Emden & $1861-1871$ & 448 \\
\hline Niedersachsentag, Programm & $1907-1912$ & 695 \\
\hline Niederschlagswässer, Ableitung & $1876-1884$ & 862 \\
\hline Nordseewerke, Abschlussrechnung & $1912-1913$ & 1.478 \\
\hline Nordseewerke, Aktien bei der Stadt Emden & $1906-1907$ & 1.460 \\
\hline \multirow[t]{2}{*}{ Nordseewerke, Aktienkaufangebote } & 1904-1908 & 1.462 \\
\hline & $1908-1910$ & 1.466 \\
\hline Nordseewerke, Aktienkäufe durch Stadt Emden & $1905-1907$ & 1.461 \\
\hline Nordseewerke, Aktienkurse & $1905-1907$ & 1.461 \\
\hline Nordseewerke, Aktienverkäufe durch Stadt Emden & $1905-1907$ & 1.461 \\
\hline Nordseewerke, Aktienzeichnung & 1903 & 1.463 \\
\hline Nordseewerke, Aktionäre & $1903-1904$ & 1.458 \\
\hline Nordseewerke, Anleihen & 1904-1908 & 1.462 \\
\hline Nordseewerke, Arbeitsunfall & $1909-1911$ & 1.472 \\
\hline Nordseewerke, Aufsichtsratssitzungen & $1903-1904$ & 1.458 \\
\hline Nordseewerke, Aufträge & 1904-1908 & 1.462 \\
\hline \multirow[t]{2}{*}{ Nordseewerke, Beteiligung der Stadt Emden } & 1902-1905 & 1.455 \\
\hline & $1906-1907$ & 1.460 \\
\hline Nordseewerke, Betriebsbilanz & $1910-1911$ & 1.479 \\
\hline Nordseewerke, Betriebseinweihungsfeierboykott & 1904-1908 & 1.462 \\
\hline Nordseewerke, Betriebseröffnung & $1902-1905$ & 1.455 \\
\hline Nordseewerke, Betriebsgeländeerweiterung & $1911-1912$ & 1.484 \\
\hline Nordseewerke, Bewerbungen & $1902-1910$ & 1.456 \\
\hline \multirow[t]{2}{*}{ Nordseewerke, Bilanz } & $1908-1910$ & 1.466 \\
\hline & $1908-1911$ & 1.467 \\
\hline Nordseewerke, Bilanzen & 1904-1908 & 1.462 \\
\hline Nordseewerke, Direktor & $1911-1912$ & 1.484 \\
\hline Nordseewerke, Dockanlage & $1906-1907$ & 1.460 \\
\hline Nordseewerke, Einnahmen und Ausgaben & $1910-1912$ & 1.457 \\
\hline Nordseewerke, Erbpachtsvertragsänderungen & $1910-1912$ & 1.480 \\
\hline Nordseewerke, Erbpachtszahlungen durch Hauptgläubiger & $1910-1912$ & 1.480 \\
\hline Nordseewerke, Erwerb durch Hauptgläubiger & $1910-1911$ & 1.481 \\
\hline Nordseewerke, Förderung & $1903-1904$ & 1.459 \\
\hline Nordseewerke, Fürbringer Mitglied des Aufsichtsrates & 1903-1904 & 1.458 \\
\hline Nordseewerke, Generalversammlung & $1906-1907$ & 1.460 \\
\hline Nordseewerke, Geschäftsbilanz & $1905-1912$ & 2.105 \\
\hline Nordseewerke, Grundkapital & 1904-1908 & 1.462 \\
\hline Nordseewerke, Hypotheken & 1910 & 1.471 \\
\hline \multirow[t]{2}{*}{ Nordseewerke, Hypothekenantrag } & 1904-1908 & 1.462 \\
\hline & $1908-1910$ & 1.466 \\
\hline Nordseewerke, Hypothekenkündigung & $1908-1910$ & 1.466 \\
\hline Nordseewerke, Instandhasltung im Konkurs & $1910-1911$ & 1.473 \\
\hline Nordseewerke, Investorensuche & $1910-1911$ & 1.468 \\
\hline Nordseewerke, Investorsuche & $1908-1911$ & 1.467 \\
\hline Nordseewerke, Kapitalaufstockung & 1906-1907 & 1.460 \\
\hline Nordseewerke, Kapitalerhöhung & 1904-1908 & 1.462 \\
\hline Nordseewerke, Kaufangebot & $1910-1911$ & 1.470 \\
\hline Nordseewerke, Kaufpreis & $1910-1911$ & 1.470 \\
\hline Nordseewerke, Kaufvermittlung & $1910-1911$ & 1.470 \\
\hline Nordseewerke, Konkurs und Weiterbeschäftigung & $1909-1911$ & 1.472 \\
\hline \multirow[t]{2}{*}{ Nordseewerke, Konkursverfahren } & $1908-1911$ & 1.467 \\
\hline & $1910-1911$ & 1.474 \\
\hline Nordseewerke, Konstituierung & $1902-1905$ & 1.455 \\
\hline Nordseewerke, Kreditgeber & $1903-1904$ & 1.459 \\
\hline Nordseewerke, Kreditkündigung & $1908-1910$ & 1.466 \\
\hline Nordseewerke, Liquiditätskredite & 1907-1909 & 1.469 \\
\hline Nordseewerke, Liquiditätskrise & 1907-1909 & 1.469 \\
\hline
\end{tabular}


Index

\begin{tabular}{|c|c|c|}
\hline \multicolumn{3}{|l|}{ SACH } \\
\hline Indexbegriff & Laufzeit & Lfd.Nr. \\
\hline Nordseewerke, Neukonzeption & $1910-1911$ & 1.468 \\
\hline Nordseewerke, Patentrechtskonflikt & $1910-1911$ & 1.483 \\
\hline Nordseewerke, Postverkehr & $1906-1907$ & 1.460 \\
\hline Nordseewerke, Presseberichte & $1906-1907$ & 1.460 \\
\hline Nordseewerke, Sanierung & 1906-1907 & 1.460 \\
\hline \multirow[t]{2}{*}{ Nordseewerke, Sanierungsplan } & $1905-1907$ & 1.461 \\
\hline & $1908-1911$ & 1.467 \\
\hline Nordseewerke, Sanierungsverhandlungen & 1907-1909 & 1.469 \\
\hline \multirow{2}{*}{ Nordseewerke, Sanierungsvorschläge } & 1904-1908 & 1.462 \\
\hline & $1908-1910$ & 1.466 \\
\hline Nordseewerke, Schiffsbauten & 1903-1904 & 1.459 \\
\hline Nordseewerke, Schuldenumwandlung & $1908-1910$ & 1.466 \\
\hline Nordseewerke, Statuten & 1903-1904 & 1.458 \\
\hline \multirow[t]{2}{*}{ Nordseewerke, Übernahme } & $1911-1912$ & 1.484 \\
\hline & 1913-1917 & 1.485 \\
\hline Nordseewerke, Übernahmeangebot an Marinewerft & 1911 & 1.476 \\
\hline \multirow[t]{2}{*}{ Nordseewerke, Verkauf } & $1872-1916$ & 330 \\
\hline & 1911-1912 & 1.477 \\
\hline Nordseewerke, Verpachtung & 1911 & 1.475 \\
\hline Nordseewerke, Versicherungsbeitrag & $1908-1911$ & 1.467 \\
\hline Nordseewerke, Versicherungsschutz & $1910-1911$ & 1.482 \\
\hline Nordseewerke, Verwendung im Kriegsfall & 1911 & 1.476 \\
\hline Nordseewerke, Werftbau & 1899-1903 & 1.454 \\
\hline Nordseewerke, Werftdirektor & 1903-1904 & 1.458 \\
\hline Nordseewerke, Zahlungsschwierigkeiten & 1906-1907 & 1.460 \\
\hline Norgine-Fabrik, Rentabilität & 1905-1906 & 2.377 \\
\hline Norgine-Fabrik, Werbung & 1905-1906 & 2.377 \\
\hline Notar, Zulassung & 1876-1904 & 170 \\
\hline Notariatsakten, Abgabe & 1857-1908 & 313 \\
\hline Notfonds, Beteiligung der lutherischen Gemeinde & 1894-1900 & 3.463 \\
\hline Notsignale, Regelung & $1880-1912$ & 1.405 \\
\hline Nutzungsgebühr, Städtisches Grundeigentum & 1873-1901 & 2.935 \\
\hline Obdachlosigkeit, Meldungen & 1873-1914 & 1.227 \\
\hline Oberbürgermeister, Dienstjubiläum & $1875-1913$ & 13 \\
\hline Oberbürgermeister, Gehalt & $1875-1913$ & 13 \\
\hline Oberbürgermeister, Nachruf & $1875-1913$ & 13 \\
\hline Oberbürgermeister, Personalbogen & $1875-1913$ & 13 \\
\hline Oberbürgermeister, Porträt & $1875-1913$ & 13 \\
\hline Oberbürgermeister, Ruhestand & $1875-1913$ & 13 \\
\hline Oberbürgermeister, Ruhestandsgehalt & $1875-1913$ & 13 \\
\hline Oberbürgermeister, Titelverleihung & $1875-1913$ & 13 \\
\hline Oberbürgermeister, Zulage & $1875-1913$ & 13 \\
\hline Oberbürgermeisterstelle, Bewerberliste & 1912 & 11 \\
\hline Oberbürgerneister, Geheimer Regierungsrat & $1875-1913$ & 13 \\
\hline Oberlehrer, Rang Rat IV. Klasse & 1901-1918 & 3.777 \\
\hline Oberlehrer, Rüge wg. Kritik an Fürbringer & $1887-1910$ & 3.738 \\
\hline Oberlehrer, Titel Professor & $1901-1918$ & 3.777 \\
\hline Oberlehrerinnen, Wohngeldzuschuss & 1908-1914 & 3.811 \\
\hline Oberlehrerinnen, Wohnungszulage & 1913-1916 & 3.812 \\
\hline Oberlehrerstellen, Ausschreibung & $1886-1903$ & 3.724 \\
\hline Obligationen, Ablösung & 1866-1887 & 2.990 \\
\hline Obstbäume, Beschädigung & $1878-1884$ & 2.522 \\
\hline Oelkocherei,, Anlagen & $1872-1893$ & 2.470 \\
\hline Offiziere, Einkommen & $1867-1870$ & 2.871 \\
\hline Orden "Adler der Inhaber des kgl. Hausordens", Verleihungsantrag & $1909-1913$ & 261 \\
\hline Orden, Erlaubnis zum Tragen ausländischer Insignien & $1900-1911$ & 259 \\
\hline Orden, Niederlassungen & $1902-1911$ & 3.495 \\
\hline
\end{tabular}


Index

\begin{tabular}{|c|c|c|}
\hline \multicolumn{3}{|l|}{ SACH } \\
\hline Indexbegriff & Laufzeit & Lfd.Nr. \\
\hline Orden, Verleihung & 1900-1909 & 264 \\
\hline Orden, Verleihung an Oberbürgermeister Fürbringer & $1875-1913$ & 13 \\
\hline Orden, Verleihung an Wilhelm Hahn & $1912-1914$ & 721 \\
\hline Ordeninsignien, Rückgabe & 1867-1899 & 265 \\
\hline \multirow{2}{*}{ Ordensträger, Liste } & $1886-1898$ & 258 \\
\hline & $1900-1911$ & 259 \\
\hline Ordensträger, Stadt Emden & 1886-1898 & 258 \\
\hline Ordensverleihungen, Antragsformalien & $1900-1911$ & 259 \\
\hline Ordensverleihungen, Statistik & $1900-1911$ & 259 \\
\hline \multirow{2}{*}{ Ordenswesen, Erlasse und Verfügungen } & $1898-1910$ & 260 \\
\hline & $1911-1919$ & 262 \\
\hline Ordnungsarbeiten, Rechnung des Registrators & 1857-1908 & 313 \\
\hline Organisten, Besoldung & $1868-1911$ & 3.379 \\
\hline Organistenstellen, Besetzung & $1868-1911$ & 3.379 \\
\hline Orgel, Finanzierung durch Anleihe & 1890-1902 & 3.431 \\
\hline Orgelpfeifen, Beschlagnahmung für Kriegswirtschaft & $1917-1918$ & 3.263 \\
\hline \multirow[t]{2}{*}{ Orgelprospekte, Abgabe } & 1917 & 3.259 \\
\hline & 1917 & 3.260 \\
\hline Orgelreparatur, Finanzierung durch Anleihe & $1890-1902$ & 3.431 \\
\hline Orientlinie, Plan & 1905 & 2.081 \\
\hline Ortskrankenkasse, Beschwerde gegen & 1918 & 1.673 \\
\hline Ortsstatut, Änderung & 1915 & 240 \\
\hline \multirow[t]{2}{*}{ Ortsstatut, Anlegung und Veränderung von Straßen und Plätzen } & $1876-1888$ & 1.134 \\
\hline & $1894-1913$ & 1.135 \\
\hline Ortsstatut, Novellierung & $1894-1913$ & 1.135 \\
\hline Ortsstatut, Revision & $1858-1893$ & 5 \\
\hline Ortsverband der städtischen Beamten, Mitglieder & $1898-1913$ & 635 \\
\hline Ortsverband der städtischen Beamten, Statuten & $1898-1913$ & 635 \\
\hline Osterpiepe, Senkung der Brücke & $1870-1900$ & 1.497 \\
\hline Ostfriesische Landschaft, Aktivitäten & 1909 & 208 \\
\hline Ostfriesische Landschaft, Finanzlage & 1909 & 208 \\
\hline Ostfriesische Landschaft, Unterstützung & $1867-1877$ & 207 \\
\hline Ostfriesische Landschaft, Verhandlungen & $1867-1877$ & 207 \\
\hline Ostfriesische Zeitung, Geschäftsleitung & $1912-1914$ & 721 \\
\hline Ostfriesischer Schützenbund, Satzung & $1886-1914$ & 574 \\
\hline Ostfriesland, Besetzung & & Vorwort \\
\hline Ostfriesland, Forderung der Eingliederung nach Westfalen & $1867-1891$ & 719 \\
\hline Ostfriesland, Sammlung von Gesetzen und Verordnungen & 1912 & 209 \\
\hline Ostfrieslandtour, Märkisches Wandertheater & $1912-1914$ & 555 \\
\hline Ostpreußenhilfe & $1915-1919$ & 3.315 \\
\hline Ölgemälde, Erwerb & $1866-1912$ & 2.632 \\
\hline Ölgemälde, Hohenzollernkaiser & $1888-1907$ & 2.656 \\
\hline Ölgemälde, Rathaus & $1866-1912$ & 2.632 \\
\hline Ölgemälde, Restaurierung & $1866-1912$ & 2.632 \\
\hline \multirow[t]{2}{*}{ Ölgemälde, Schenkung an die Stadt Emden } & 1888-1907 & 2.656 \\
\hline & 1894-1895 & 2.657 \\
\hline Ölgemälde, Vererbung & 1885-1907 & 2.391 \\
\hline Ölgemälde, Versicherungswert & $1866-1912$ & 2.632 \\
\hline Ölgewinnung, Obstkerne & $1915-1918$ & 3.242 \\
\hline Ölkochereianlage, Genehmigung & $1873-1874$ & 2.186 \\
\hline Ölpflanzen, Anbauförderung & 1914-1916 & 3.194 \\
\hline \multirow[t]{2}{*}{ Pächter, Entschädigung } & $1866-1873$ & 2.463 \\
\hline & $1896-1901$ & 2.550 \\
\hline Pachtermäßigung, Anträge & $1866-1893$ & 2.456 \\
\hline Pachtermäßigung, Anträge auf & 1895-1909 & 2.457 \\
\hline Pachtraten, Erhebung & $1905-1912$ & 2.585 \\
\hline
\end{tabular}


Index

\begin{tabular}{|c|c|c|}
\hline \multicolumn{3}{|c|}{ SACH } \\
\hline Indexbegriff & Laufzeit & Lfd.Nr. \\
\hline Pachtung, Kündigung & $1901-1903$ & 2.556 \\
\hline \multirow[t]{2}{*}{ Pachtung, Kündigungen } & 1884-1896 & 2.494 \\
\hline & $1896-1901$ & 2.495 \\
\hline Pachtvertrag, Kündigung & $1900-1906$ & 2.564 \\
\hline Pachtverträge, Kündigung & $1901-1906$ & 2.563 \\
\hline Packhaus, Bauantrag & 1897-1898 & 1.182 \\
\hline Panzerschiff "Großer Kurfürst" & 1879 & 606 \\
\hline Papier, Anschaffung & $1893-1912$ & 274 \\
\hline Papierfabrik, Abwasserreinigung & $1885-1896$ & 2.385 \\
\hline Papierfabrik, Anschluss an die Kanalisation & $1885-1900$ & 907 \\
\hline Papierfabrik, Auflagen zur Abwasserentsorgung & $1872-1884$ & 2.384 \\
\hline Papierfabrik, Besichtigung durch den Gewerbeinspektor & $1872-1904$ & 2.382 \\
\hline Papierfabrik, Entwässerung & $1883-1885$ & 914 \\
\hline \multirow[t]{2}{*}{ Papierfabrik, Gewässerverunreinigung } & $1872-1884$ & 2.384 \\
\hline & $1885-1896$ & 2.385 \\
\hline Papierfabrik, Illegale Beschäftigung Jugendlicher bei Nacht & $1872-1884$ & 2.384 \\
\hline Papierfabrik, Kläranlage & $1872-1884$ & 2.384 \\
\hline Papierfabrik, Landerwerb & $1872-1884$ & 2.384 \\
\hline Parochialgrenze, Emden und Hinte & $1896-1914$ & 3.330 \\
\hline Parochialgrenze, Festlegung & $1902-1914$ & 3.340 \\
\hline Parochialgrenze, Regulierung & $1885-1901$ & 3.337 \\
\hline Passagierdampfer. Liste & $1905-1912$ & 1.424 \\
\hline Passagiere, Aussetzung auf der Nesserlander Schleuse & $1873-1907$ & 2.017 \\
\hline Pastorei, Errichtung & $1891-1906$ & 3.466 \\
\hline Pastoren, Besoldungszuschussantrag für Lutheraner & 1890 & 3.478 \\
\hline Pastorenbesoldung, Beihilfe zur & $1902-1913$ & 3.402 \\
\hline Pastorengehälter, Lutherische Gemeinde & $1872-1907$ & 3.479 \\
\hline Pastorenstelle, Besetzung & 1876 & 3.484 \\
\hline Patengeschenk, SMS "Emden" & $1908-1914$ & 271 \\
\hline \multirow[t]{2}{*}{ Patenschaft, Kaiser für kinderreiche Familie } & $1886-1898$ & 258 \\
\hline & $1900-1911$ & 259 \\
\hline Patenschaft, König für Kinder & $1867-1899$ & 265 \\
\hline Patenschaftsantrag, Kaiserin Auguste Viktoria & $1912-1918$ & 263 \\
\hline Patronat, Kirchengemeinde Uphusen & 1876 & 3.484 \\
\hline Patronat, Pflichtanforderungen an die Stadt Emden & $1876-1882$ & 2.666 \\
\hline Patronatsrecht, Stadt Emden über Wolthusen & $1837-1915$ & 3.316 \\
\hline \multirow[t]{3}{*}{ Patronatsrecht, Ablösung } & $1884-1901$ & 3.480 \\
\hline & $1869-1871$ & 3.483 \\
\hline & 1876 & 3.484 \\
\hline Patronatsrecht, Ablösung in Tergast & 1886 & 3.481 \\
\hline Patronatsrechte, Abtretungsverhandlungen & 1884-1901 & 3.480 \\
\hline Patrontsrecht, Ablösung & 1901 & 3.482 \\
\hline Patronvertreter, Ernennung & 1869-1907 & 3.485 \\
\hline Pegelkommission, Aufgaben & $1866-1883$ & 1.487 \\
\hline Pegelkommission, Konstituierung & $1866-1883$ & 1.487 \\
\hline Pegelkommission, Streit mit dem Magistrat & $1866-1883$ & 1.487 \\
\hline Pegelkommission, Versammlungseinberufung & $1866-1883$ & 1.487 \\
\hline Pegelkommission, Wahl der Mitglieder & $1866-1883$ & 1.487 \\
\hline Personalakte, Antrag auf Einsicht & $1912-1915$ & 347 \\
\hline Personalakte, Schulwärterin & $1879-1880$ & 3.682 \\
\hline Personenbahnhof, Planung für Kaiser-Wilhelm-Polder & 1895-1906 & 2.059 \\
\hline Personenbahnhof, Protest gegen Verlegungsplan & $1895-1906$ & 2.059 \\
\hline Personenschraubendampfer "Kaiser Wilhelm II." & 1897 & 2.222 \\
\hline Persönliche Steuer & 1905 & 2.862 \\
\hline Pest, Anzeige & $1879-1913$ & 775 \\
\hline Pest, Chile & $1879-1913$ & 775 \\
\hline Pest, Desinfektionsvorschriften & $1879-1913$ & 775 \\
\hline Pest, Einfuhrbeschränkungen & $1879-1913$ & 775 \\
\hline
\end{tabular}


Index

\begin{tabular}{|c|c|c|}
\hline \multicolumn{3}{|c|}{ SACH } \\
\hline Indexbegriff & Laufzeit & Lfd.Nr. \\
\hline Pest, Glasgow und Liverpool & $1879-1913$ & 775 \\
\hline Pest, Maßnahmen gegen Einschleppung & $1899-1909$ & 781 \\
\hline \multirow[t]{2}{*}{ Pest, Paraguay } & $1879-1913$ & 775 \\
\hline & $1872-1899$ & 778 \\
\hline Pest, Quarantäne & $1879-1913$ & 775 \\
\hline Pestalozzistiftung, Jahresbericht & $1913-1915$ & 1.872 \\
\hline Pestausbruch, Südchina & $1879-1913$ & 775 \\
\hline Pestepidemie, Abwehr & $1894-1900$ & 1.685 \\
\hline Pesterreger, Bekämpfung & $1899-1909$ & 781 \\
\hline Pestgefahr, Kontrolle von Schiffen & $1879-1913$ & 775 \\
\hline Pestkranke, Erfassung & $1899-1909$ & 781 \\
\hline Petroleum, Transportantrag & $1893-1895$ & 987 \\
\hline Petroleumanlagen, Revision & $1882-1904$ & 1.253 \\
\hline Petroleumhafen, Anfrage & $1893-1897$ & 2.026 \\
\hline Petroleumhandel & $1882-1904$ & 1.253 \\
\hline Petroleumhandel, Brandschutzbestimmungen & $1882-1904$ & 1.253 \\
\hline Petroleumhandel, Expansion & $1857-1905$ & 2.551 \\
\hline Petroleumleuchter, Verbot in Dreschkammern & $1886-1905$ & 1.251 \\
\hline Petroleumschuppen, Abrissverfügung & $1892-1906$ & 1.265 \\
\hline Petroleumschuppen, Genehmigungsverfahren & $1892-1906$ & 1.265 \\
\hline Petroleumschuppen, Verpachtung städtischer Grundstücke & $1892-1906$ & 1.265 \\
\hline Pfahl- oder Stellgeld, Einnahme & $1866-1910$ & 2.137 \\
\hline Pfandbriefanstalt, Gründungsdiskussion & $1898-1916$ & 1.916 \\
\hline Pfandleihkasse, Kreditzinsen & $1867-1917$ & 1.915 \\
\hline Pfarrbesoldung, Finanzierung in der lutherischen Gemeinde & 1874-1888 & 3.473 \\
\hline Pfarrbezirke, Neufestsetzung & $1896-1914$ & 3.330 \\
\hline Pfarrkassen-Rechnungsführung, Einführung & 1901 & 3.400 \\
\hline Pfarrkassenrechnungsführung, Lutherische Gemeinde & 1901 & 3.471 \\
\hline Pfarrtöchterkasse, Jahresberichte & $1901-1916$ & 1.684 \\
\hline Pfarrtöchterkasse, Statuten & $1901-1916$ & 1.684 \\
\hline Pfarrverbände, Landkreis und Stadtkreis Emden & $1887-1912$ & 812 \\
\hline Pferd, Unerlaubtes Weiden & $1897-1912$ & 1.157 \\
\hline Pferde, Kriegswirtschaftliche Bedeutung & $1917-1918$ & 3.244 \\
\hline Pferde, Scheuen durch Peitschenknallen & $1878-1891$ & 830 \\
\hline Pferdebahn, Anlage & $1883-1884$ & 1.953 \\
\hline Pferdebahn, Bau & $1883-1884$ & 1.953 \\
\hline Pferdebahn, Besichtigung & 1884-1889 & 1.955 \\
\hline Pferdebahn, Betriebs- und Konzessionierungsvertrag & $1891-1895$ & 1.956 \\
\hline Pferdebahn, Betriebsvorschriften & $1881-1897$ & 2.042 \\
\hline Pferdebahn, Bürgschaft & $1883-1884$ & 1.953 \\
\hline Pferdebahn, Darlehensprozess & 1884-1889 & 1.955 \\
\hline Pferdebahn, Genehmigungsverfahren & $1883-1884$ & 1.953 \\
\hline Pferdebahn, Konzessionierung & $1883-1901$ & 2.044 \\
\hline Pferdebahn, Schadensersatzprozess & $1885-1887$ & 1.954 \\
\hline Pferdebahn, Trasse & $1883-1884$ & 1.953 \\
\hline \multirow[t]{2}{*}{ Pferdebahn, Vertragsstreit } & 1884-1889 & 1.955 \\
\hline & 1891-1895 & 1.956 \\
\hline Pferdebahn, Zeichnungen der Wagenremise mit Stallungen & $1883-1884$ & 1.953 \\
\hline Pferdebahnen, Konzessionierung & $1881-1897$ & 2.042 \\
\hline Pferdeeisenbahn, Behinderung & $1866-1913$ & 832 \\
\hline Pferdemusterung, Armeedienst & $1909-1918$ & 3.164 \\
\hline Pflanzenschädlinge, Anzeige & $1898-1914$ & 817 \\
\hline Pflastererarbeiten, Vergabe & 1912 & 1.112 \\
\hline Pflasterung, Burg- und Schweckendiekstraße & 1896-1906 & 998 \\
\hline Pflasterung, Finanzierung durch Anlieger & $1902-1903$ & 984 \\
\hline Pflegeanstalt, Ausstattung der Insassen & $1855-1912$ & 521 \\
\hline Pflegeanstalt, Kosten der Unterbringung & $1855-1912$ & 521 \\
\hline Pflegegeld, Kind der mittellosen Alma Jungk & $1915-1917$ & 1.881 \\
\hline
\end{tabular}


IV

Index

SACH

\begin{tabular}{l} 
Indexbegriff \\
\hline Pflichtfeuerwehr, Musterstatut \\
Pforte, Ungenehmigte \\
Pförtnerhäuschen, Vermietung \\
Physicatsprüfung, Zulassung \\
Pinasse "Bernard" \\
Pissoir, Öffentliches \\
Pissoirs, Anträge auf Beseitigung \\
Pissoirs, Errichtung \\
Pläne, Bitte um Rückgabe \\
Planfeststellungsverfahren, Finanzierung der Vorarbeiten \\
Platin, Beschlagnahmung für Kriegswirtschaft \\
Plattform, Ungesicherte als Laderampe \\
Plätze, Aufstellung \\
Plenarsitzungen, Magistrat mit Bürgervorsteher-Kollegium
\end{tabular}

Pocken, Ausbruch in Emden

Pocken, Impfaktion

Pockenepidemie, Isolierbaracken

Pockenerkrankungen, Niederlande

Polder, Eigentumsrecht

Polder, Einpolderung

Polder, Entwäasserung

Polder, Ertragsberechnung

Polder, Erwerb durch Stadt Emden

Polder, Katasterkarte

Polder, Katastrierung

Polder, Parzellierung

Polderland, Verpachtung

Polderwege, Pflasterung

Polizei, Tätigkeitsberichte

Polizei, Uniformen

Polizei, Verstärkung

Polizeiaufsicht, Bestimmungen im Strafgesetzbuch

Polizeiaufsicht, Erlasse zu

Polizeibeamte, Besoldungsdienstaltersfestsetzung

Polizeibeamte, Gehalt

Polizeibeamte, Kriegsteuerungszulage

Polizeibote, Beförderungsanregung

Polizeibote, Bewerbung

Polizeibote, Dienstkleidung

Polizeibote, Einstellung

Polizeibote, Gehalt

Polizeibote, Ruhestandsgehalt

Polizeibote, Stellenausschreibung

Polizeidienst, Entlassungsgesuch

\section{Laufzeit}

1907-1914

1908

1866-1904

1866-1914

1905

1866-1911

1888-1905

$1866-1911$

1888-1905

1903-1909

1885-1889

1917

1879-1888

1878-1909

1867-1869

1870-1872

1873-1874

1873

1875-1878

1879-1881

1882-1884

1885-1888

1889-1893

1894-1910

1910-1914

1915-1919

1859-1877

1859-1877

1902-1917

1879-1913

1867-1890

1867-1890

1867-1890

1896-1901

1883-1911

1881-1901

1881-1888

1867-1890

1874-1904

1884-1896

1896-1901

1896-1901

1903

1880-1887

1880-1887

1868-1907

1868-1907

1904-1918

1904-1918

1904-1918

1890-1921

1890-1921

1890-1921

1890-1921

1890-1921

1890-1921

1890-1921

1902

\section{Lfd.Nr.}

1.389

1.205

2.676

762

2.298

962

964

962

964

312

2.022

3.267

1.215

851

155

156

157

158

159

160

161

162

163

164

165

166

773

773

1.693

775

2.476

2.476

2.476

2.495

231

2.477

2.480

2.476

2.493

2.494

2.495

2.495

511

414

414

503

503

415

415

415

410

410

410

410

410

410

410

345 
IV

Index

\section{SACH}

$\frac{\text { Indexbegriff }}{\text { Polizeidienst, Entlassungsgesuch }}$

Polizeidienst, Unfähigkeit wegen Trunkenheit

Polizeidienst-Bewerber, Lebenslauf

Polizeigefangene, Statistik

Polizeigefangene, Verpflegungssätze

Polizeigefängnis, Abschiebungen und Auslieferungen

Polizeigefängnis, Arrest für Bahnbeamte

Polizeigefängnis, Betrieb

Polizeigefängnis, Haftbedingungen

Polizeigefängnis, Inspektion

Polizeigefängnis, Reparaturen

Polizeihaft, Rohe Behandlung

Polizeikommissar, Alkoholmissbrauch

Polizeikommissar, Beschwerde gegen

Polizeikommissar, Bewerbung

Polizeikommissar, Bewerbungsunterlagen

Polizeikommissar, Entlasungsgesuch

Polizeikommissar, Gehalt

Polizeikommissar, Laufbahn

Polizeikommissar, Lebenslauf

Polizeikommissar, Nominierung als Vertreter d. Amtsanwalts

Polizeikommissar, Pensionierungsantrag

Polizeikommissar, Pensionierungsgesuch

Polizeikommissar, Unterstützungsgesuch der Witwe

Polizeikommissar, Vereidigung

Polizeikommissar, Zeugnisse

Polizeikontrolleur, Einstellung

Polizeikontrolleur, Instruktionen

Polizeisekretär, Einstellung

Polizeisekretär, Pension

Polizeisekretär, Pensionierung

Polizeisergeant, Alkoholmissbrauch

Polizeisergeant, Altersunterstützung

Polizeisergeant, Beförderung

Polizeisergeant, Bewerbung

\section{Laufzeit}

1893-1899

1912-1915

1905

1892

1869-1917

1869-1917

$1899-1913$

1869-1917

1879-1904

1879-1904

1899-1913

1879-1904

$1912-1915$

1886-1895

1855-1896

1886-1895

1871-1891

1886-1895

1899-1928

1899-1928

1886-1895

1855-1896

1899-1928

1855-1896

1855-1896

1855-1896

1871-1891

1855-1896

1855-1896

1863-1892

1863-1892

1879

1907

1907-1914

1859-1915

1900-1919

1907

1897-1902

1907

1905-1915

1908-1912

1902-1907

1911-1912

1905

1859-1915

1882

1880-1882

1905-1906

1905-1910

1907-1909

1908-1909

1905-1907

1905-1907

1905-1912

1889-1893

1906-1907

1884

1907
Lfd.Nr.

346


IV

Index

SACH

Polizeisergeant, Dienstjubiläum Polizeisergeant, Dienstkleidung Polizeisergeant, Dienstpflichtverletzung Polizeisergeant, Dienstunfähigkeit Polizeisergeant, Dienstvergehen Polizeisergeant, Dienstvernachlässigung Polizeisergeant, Einberufung wg. Militärübung Polizeisergeant, Einstellung

\section{Laufzeit}

Lfd.Nr.

Polizeisergeant, Bewerbung

1906

1909-1911

1893-1913

1903-1904

1888

1907

1905

1893-1894

1907-1914

1907-1908

1907-1911

1882-1884

1896-1901

1901-1902

1906-1907

1859-1884

1882-1884

1906-1907

1903-1905

1905-1907

1909-1911

1909-1911

1902

1893-1899

1905

1892

1900-1919

1907-1908

1902

1907

1907-1911

1908-1912

1902-1907

1911-1912

1905

1859-1915

1880-1882

1905-1906

1905-1910

1907-1909

1908-1909

1905-1907

1890-1893

1905-1912

1889-1893

1906-1907

1884

1907

1906

1909-1911

1893-1913

1903-1904

1907

1905

1859-1884

1903-1905

1893-1894

1907-1914

\section{6}

387

388

389

390

391

392

399

400

402

403

405

407

408

411

393

405

411

396

380

387

387

345

346

349

351

353

355

357

360

363

365

366

367

368

369

371

372

373

374

375

377

378

381

382

383

384

385

386

387

388

389

391

392

393

396

399

400 
IV

Index

SACH

Polizeisergeant, Entlassung

Polizeisergeant, Entlassungsgesuch

Polizeisergeant, Entlassungsgesuch wegen Stellenwechsel

Polizeisergeant, Entlassungsgesuch wg. Mobbing

Polizeisergeant, Ermittlung wg. Urkundenfälschung

Polizeisergeant, Ermittlungen wegen Sittenvergehen

Polizeisergeant, Ermittlungen wegen Verletzung der Polizeistunde

Polizeisergeant, Ermittlungen wg. Gefangenenmisshandlung

Polizeisergeant, Gehalt

Polizeisergeant, Gehaltsgruppierung

Polizeisergeant, Heiratsanzeige

Polizeisergeant, Hochzeit

Polizeisergeant, Kriegsbeorderung

Polizeisergeant, Kriegstod

Polizeisergeant, Kündigung wegen unsittlicher Beziehung

Polizeisergeant, Kündigungsfrist

Polizeisergeant, Nichtbestätigung der Einstellung

Polizeisergeant, Personalakte

Polizeisergeant, Probezeit

Polizeisergeant, Reisekostenerstattung

Polizeisergeant, Schuldforderungen gegen

Polizeisergeant, Sittenstraftat der künftigen Schwiegermutter

Polizeisergeant, Stellenberwerbung

Polizeisergeant, Stellenbesetzung

Polizeisergeant, Stellenbewerbung
Lfd.Nr.

Laufzeit

402

1907-1908

1907-1911

1912-1913

1896-1901

1901-1902

1906-1907

1897-1902

1909-1911

1905-1915

1905-1907

1903-1905

1907-1914

1906-1907

1868-1872

1907-1911

1902-1907

1905-1910

1907-1909

1905-1907

1890-1893

1905-1912

1907

1906

1903-1904

1905

1893-1894

1907-1908

1907-1911

1882-1884

$1912-1913$

1896-1901

1908-1912

1889-1893

1909-1911

1907

1906-1907

1907-1909

1906-1907

1905-1906

1909-1911

1893-1913

1908-1909

1899-1928

1912-1917

1912-1917

1905

1907-1909

1882

1909-1911

1912-1914

1900-1919

1901-1902

1903-1905

1903-1904

1902

1868-1872

1893-1899

1912-1915 
IV

Index

\section{SACH}

\begin{tabular}{l} 
Indexbegriff \\
\hline Polizeisergeant, Stellenbewerbung \\
Polizeisergeant, Stellenverzicht \\
Polizeisergeant, Stellenwechsel \\
Polizeisergeant, Strafverfahren \\
Polizeisergeant, Strafverfahren wg. Vergewaltigungsversuch \\
Polizeisergeant, Trunkenheit \\
Polizeisergeant, Unerlaubter Kneipenbesuch \\
Polizeisergeant, Unsittliche Affäre \\
Polizeisergeant, Unterhaltsforderungen gegen \\
Polizeisergeant, Unterstützungsgesuch \\
Polizeisergeant, Vakanzvertreter \\
Polizeisergeant, Vereidigung
\end{tabular}

Polizeisergeant, Verfehlungen

Polizeisergeant, Verletzung bei Festnahme

Polizeisergeant, Verschuldung

Polizeisergeant, Wahl

Polizeisergeant, Witwenunterstützung

Polizeisergeant, Zeugnis

Polizeisergeant, Zeugnisanforderung

Polizeisergeanten, Beschwerden wegen roher Behandlung Polizeisergeanten, Beschwerden wg. Festnahme

Laufzeit

Lfd.Nr.

$\begin{array}{cc}1905 & 35 \\ 1900-1919 & 353 \\ 1907-1908 & 355 \\ 1905 & 368 \\ 1907-1908 & 355 \\ 1905-1906 & 372\end{array}$

1908-1909 375

1905-1915 364

1906-1907 376

1905-1910 373

1907-1914 400

$1907 \quad 385$

1896-1901 407

1907-1909 $\quad 374$

1874-1875 $\quad 404$

1912-1915 347

$1880 \quad 350$

1868-1872 358

$1907 \quad 360$

1912-1917 361

1907-1911 363

$1905-1915 \quad 364$

1908-1912 365

1906-1907 383

1903-1904 389

$1888 \quad 390$

$1905 \quad 392$

1907-1908 402

$1907-1911 \quad 403$

1906-1907 411

$1905 \quad 352$

1893-1913 388

1907-1914 400

1901-1902 408

1912-1915 347

$1880 \quad 350$

$1905 \quad 352$

$1859-1915 \quad 369$

$1893-1913$

1859-1884 393

$1905 \quad 352$

1897-1902 359

$1905-1915 \quad 364$

1911-1912 367

1880-1882 371

$1905-1910 \quad 373$

1907-1909 $\quad 374$

$1884 \quad 384$

1905-1912 381

1909-1911 387

1907-1908 402

1907-1911 403

1912-1913 406

1896-1901 407

1901-1902 408

1906-1907 411

1912-1915 347

1912-1915 347 
Index

\begin{tabular}{|c|c|c|}
\hline \multicolumn{3}{|l|}{ SACH } \\
\hline Indexbegriff & Laufzeit & Lfd.Nr. \\
\hline Polizeisergeanten, Stellenausschreibung & $1905-1907$ & 395 \\
\hline Polizeistunde, Bekanntmachung & 1904-1915 & 667 \\
\hline Polizeistunde, Festsetzung & 1867-1909 & 529 \\
\hline Polizeistunde, Verschiebungsantrag & 1902-1904 & 545 \\
\hline Polizeiverordnung, Wartende Arbeitslose & $1867-1914$ & 504 \\
\hline \multirow[t]{2}{*}{ Polizeiverordnungen, Erlass } & $1867-1914$ & 504 \\
\hline & $1858-1903$ & 506 \\
\hline Polizeiverordnungen, Form & $1867-1914$ & 504 \\
\hline Polizeiverordnungen, Fuhrwesen & $1867-1914$ & 504 \\
\hline Polizeiverordnungen, Gaststättenwesen & $1867-1914$ & 504 \\
\hline Polizeiverordnungen, Prüfung durch Regierungspräsident & $1867-1914$ & 504 \\
\hline Polizeiverordnungen, Stadt Emden & $1867-1914$ & 504 \\
\hline Polizeiverordnungen, Strafbestimmungen & $1867-1914$ & 504 \\
\hline Polizeiwachtgebäude, Pachtgesuche & 1905 & 2.438 \\
\hline Polizeiwesen, Reorganisation & $1887-1888$ & 412 \\
\hline Polygon-Punkte, Festlegung, Finanzierung und Instandhaltung & $1889-1891$ & 272 \\
\hline Portofreiheit & 1917 & 3.279 \\
\hline Porzellanbrennerei, Bauliche Auflagen & 1879-1907 & 1.213 \\
\hline Post- und Telegraphenamt, Bau in Emden & 1876-1908 & 266 \\
\hline Postamt, Gebäuderissplan & $1874-1876$ & 2.488 \\
\hline Postamtsgebäude, Erweiterung & $1874-1876$ & 2.488 \\
\hline Postgebäude, Erweiterung & 1876-1908 & 266 \\
\hline Postgebäude, Verkauf & $1866-1868$ & 2.420 \\
\hline Postgerechtsame, Ablösung & 1877-1909 & 269 \\
\hline Postprüfungskommission, Mitglieder & 1914 & 3.177 \\
\hline Prämiensparen, Denkschrift & 1895-1904 & 1.921 \\
\hline Prediger, Amtseinführung & $1874-1910$ & 3.378 \\
\hline \multirow[t]{2}{*}{ Prediger, Beihilfe zur Besoldung } & 1869-1889 & 3.325 \\
\hline & 1897-1898 & 3.326 \\
\hline Prediger, Deutsch reformierte Gemeinde & $1874-1910$ & 3.378 \\
\hline Prediger, Diensteinkommen & 1871-1897 & 3.419 \\
\hline Prediger, Einstellung & 1871-1897 & 3.419 \\
\hline Prediger, Ermittlungen gegen & 1869-1905 & 3.498 \\
\hline Prediger, Gehaltsverhältnisse & 1874-1910 & 3.378 \\
\hline Prediger, Liste der Reformierte & 1890 & 3.405 \\
\hline Prediger, Pensionierung & $1874-1910$ & 3.378 \\
\hline Prediger, Reise- und Umzugskosten & $1887-1911$ & 3.318 \\
\hline Prediger, Sozialkritik & $1874-1910$ & 3.378 \\
\hline Prediger, Staatsbeihilfe zum Gehalt & 1883-1888 & 3.416 \\
\hline Prediger, Unterstützungsantrag für Hinterbliebene & $1837-1915$ & 3.316 \\
\hline Prediger, Vereidigung & $1874-1910$ & 3.378 \\
\hline Prediger, Vormundschaften & $1874-1910$ & 3.378 \\
\hline Prediger, Wahl & $1874-1910$ & 3.378 \\
\hline Prediger, Wahl in Tergast & 1886 & 3.481 \\
\hline Prediger, Wahl in Wolthusen & $1837-1915$ & 3.316 \\
\hline Prediger, Wohngeldzuschuss für Reformierte & $1881-1884$ & 3.394 \\
\hline Predigerfonds, Rechnungsabnahme & $1868-1871$ & 3.434 \\
\hline Predigerstelle, Besetzung & $1837-1915$ & 3.316 \\
\hline Predigerwitwen, Unterstützungsgesuche von Reformierten & $1869-1910$ & 3.350 \\
\hline Prediger-Witwenkasse, Rechnungsabnahme & $1868-1914$ & 3.435 \\
\hline Prediger-Witwenkasse, Rechnungslegung & $1898-1913$ & 3.421 \\
\hline Prediger-Witwenkasse, Revision & $1876-1896$ & 328 \\
\hline Prediger-Witwenkasse, Statuten & $1898-1913$ & 3.421 \\
\hline Predigerwitwen-Stiftung, Vermögen & 1899 & 3.436 \\
\hline \multirow[t]{2}{*}{ Preise, Feststellung } & $1901-1916$ & 1.902 \\
\hline & $1901-1909$ & 1.903 \\
\hline Preise, Lebensmittel und Güter des täglichen Bedarfs & $1866-1900$ & 1.904 \\
\hline Preisgestaltung, Regelungen & $1881-1910$ & 1.906 \\
\hline
\end{tabular}


Index

\begin{tabular}{l} 
PACH \\
\hline Indexbegriff \\
\hline Preisindex \\
Preisstatistik, Emden \\
Pressegesetz, Ausführung \\
Pressezensur, Durchführung im Kriegsfall \\
Privat-Feuerversicherungen, Aufsicht \\
Privat-Handelsschule, Prospekt \\
Privatkajungen, Bauanträge \\
Privatkajungen, Neubau \\
Privatkajungen, Reparatur \\
Privatschulbesuch, Zulassung \\
Privatschulen, Aufsicht \\
Privatschulen, Meldepflicht \\
Privatschulen, Prospekte \\
Privatschulen, Zulassung \\
Privatstraße, Antrag auf Genehmigung \\
Privatversicherungsunternehmen, Gesetzliche Regelung \\
Privatversicherungsunternehmen, Zulassung \\
Prostituierte, Behandlung von Geschlechtskrankheiten \\
Prostituierte, Syphillis \\
Prostituierte, Verfolgung Unkonzessionierter \\
Prostituierte, Verhinderung des Besuchs von Soldaten \\
Prostitution, Bekämpfung \\
Provinzialirrenanstalt, Planung für Ostfriesland \\
Provinzialirrenanstalt, Standort \\
Provinziallandtag, Wahl der Abgeordneten \\
Provinziallandtagsabgeordnete, Wahlverfahren \\
Provinziallandtagsabgeordneter, Mandatsniederlegung \\
Provinziallandtagsabgeordneter, Wahl in Emden \\
Provinziallandtagswahlen, Regelung \\
Provinzial-Witwen- und Waisenkasse, Beiträge \\
Proning und Waisenkasse, Beitragsanpassung
\end{tabular}

SACH

Provinzial-Witwen- und Waisenkasse, Beitragsberechnung Provinzial-Witwen- und Waisenkasse, Beitritt

Provinzial-Witwen- und Waisenkasse, Beitritt d. Stadt Emden Provinzial-Witwen- und Waisenkasse, Beitritt von Lehrern

Provinzial-Witwen- und Waisenkasse, Gründungsinitiative Provinzial-Witwen- und Waisenkasse, Ordnung Provinzial-Witwen- und Waisenkasse, Satzungen Provinzial-Witwen- und Waisenkasse, Statuten Provinzial-Witwen- und Waisenkasse, Statutenänderung Provinzial-Witwen- und Waisenkasse, Versicherte

\begin{tabular}{|c|c|c|}
\hline & Laufzeit & Lfd.Nr. \\
\hline & 1905-1906 & 2.368 \\
\hline & $1895-1914$ & 462 \\
\hline & $1914-1918$ & 463 \\
\hline & 1911 & 464 \\
\hline & 1867-1891 & 719 \\
\hline & $1909-1914$ & 3.179 \\
\hline & 1877-1903 & 1.271 \\
\hline & $1910-1912$ & 3.858 \\
\hline & 1869-1901 & 1.159 \\
\hline & 1869-1901 & 1.159 \\
\hline & 1869-1901 & 1.159 \\
\hline & $1886-1916$ & 3.849 \\
\hline & 1886-1916 & 3.849 \\
\hline & $1886-1916$ & 3.849 \\
\hline & $1886-1916$ & 3.849 \\
\hline & 1886-1916 & 3.849 \\
\hline & 1908-1909 & 1.013 \\
\hline & 1901-1906 & 1.668 \\
\hline & $1910-1918$ & 1.670 \\
\hline & $1910-1918$ & 1.669 \\
\hline & $1910-1918$ & 1.670 \\
\hline & 1867-1907 & 725 \\
\hline & $1867-1907$ & 725 \\
\hline & $1867-1907$ & 725 \\
\hline & $1867-1907$ & 725 \\
\hline & $1875-1913$ & 1.703 \\
\hline & 1896 & 520 \\
\hline & 1896 & 520 \\
\hline & 1867-1915 & 204 \\
\hline & 1867-1915 & 204 \\
\hline & $1867-1915$ & 204 \\
\hline & $1867-1915$ & 204 \\
\hline & 1867-1915 & 204 \\
\hline & $1867-1915$ & 204 \\
\hline & 1904-1907 & 1.654 \\
\hline & $1907-1910$ & 1.655 \\
\hline & 1891-1895 & 1.651 \\
\hline & $1896-1900$ & 1.652 \\
\hline & 1904-1907 & 1.654 \\
\hline & $1911-1915$ & 1.656 \\
\hline & $1916-1918$ & 1.657 \\
\hline$g$ & 1891-1895 & 1.651 \\
\hline & $1891-1895$ & 1.651 \\
\hline & $1896-1900$ & 1.652 \\
\hline & 1901-1909 & 1.653 \\
\hline & $1907-1910$ & 1.655 \\
\hline & 1911-1915 & 1.656 \\
\hline & $1916-1918$ & 1.657 \\
\hline den & $1876-1889$ & 1.650 \\
\hline & 1901-1909 & 1.653 \\
\hline & $1907-1910$ & 1.655 \\
\hline & $1876-1889$ & 1.650 \\
\hline & $1876-1889$ & 1.650 \\
\hline & 1891-1895 & 1.651 \\
\hline & 1901-1909 & 1.653 \\
\hline & 1891-1895 & 1.651 \\
\hline & 1904-1907 & 1.654 \\
\hline & $1907-1910$ & 1.655 \\
\hline
\end{tabular}


IV

Index



$\frac{\text { Indexbegriff }}{\text { Provinzial-Witwen- und Waisenkasse, Versicherte }}$

Provinzial-Witwen- und Waisenkasse, Versicherungsberechtigte Provinzial-Witwen- und Waisenkasse, Versicherungsleistungen

Prozesse, Reeder und Direktor Paul G. Roer

Pulvermagazin, Anlage

Pulvermagazin, Anlegeverbot

Pulvermagazin, Entnahme von Schießpulver

Pulvermagazin, Gebührenordnung

Pulvermagazin, Inspektion

Pulvermagazin, Plan

Pulvermagazin, Revision

Pulver-Schrot-Kartuschen, Unerlaubtes Abbrennen

Pulverschuppen Vermietung

Pulvervorräte, Lagerung

Pulvervorräte, Revision

Pumpe, Unterhaltung

Pumpenaufseher, Wahl

Pumpenbagger "121"

Pumpenbagger "122"

Pumpenbagger "123"

Pünte, Hebung

Quaranränestation, Errichtung in Emden

Quarantäne, Verhängung wegen Pocken

Quarantänestation, Gebührenordnung

Quarantänestation, Verpflegung

Quarantänestationen, Baracken vom Roten Kreuz

Rabbiner, Zuwendung von Brennmaterial

Raddampfer "Emden"

Radfahrer, Gefährdung von Passanten

Radfahrverbot, Diskussion

Radfelgenbeschläge, Normen

Radium, Angebote

Rampe, Beseitigungsanordnung

Rateler, Ersetzung durch Polizeisergeanten

Ratelerwache, Garnisonszwecke

Ratelerwache, Vermietung von Räumen

Rathaus, Abortanlage

Rathaus, Ausschmückung

Rathaus, Bauunterhaltung

Rathaus, Bibliothek des Oberbürgermeisters

Rathaus, Brandschutz

Rathaus, Büro des Oberbürgermeisters

Rathaus, Deckendekoration im Vorraum

Rathaus, Gasbeleuchtung

Rathaus, Glasmalereien

Rathaus, Illumination

Rathaus, Jubiläum der Grundsteinlegung

Laufzeit

1911-1915

1916-1918

1876-1889

1891-1895

$1896-1900$

1901-1909

1904-1907

1907-1910

1911-1915

1916-1918

$1905-1911$

1867-1896

$1867-1896$

1867-1896

1867-1896

1867-1896

1867-1896

1871-1887

1881-1913

1867-1896

1867-1896

1867-1896

1885

1875-1882

1898

1898

1898

1888-1892

$1899-1900$

1859-1877

1883-1900

1892-1903

1902-1917

1870-1886

1893

1901-1912

1896-1912

1879-1897

1903-1914

1876

1887-1888

1866-1904

1866-1904

1866-1897

1899-1912

1884-1895

1866-1897

1899-1912

1909

1866-1897

1909

1901

1867-1897

1903-1904

1895-1915

1866-1897
Lfd.Nr.

1.656

1.657

1.650

1.651

1.652

1.653

1.654

1.655

1.656

1.657

2.375

1.400

1.400

1.400

1.400

1.400

1.400

3.127

727

1.400

1.400

1.400

972

970

2.226

2.226

2.226

1.535

783

773

782

777

1.693

481

2.201

840

844

2.019

1.686

1.175

412

2.418

2.418

2.411

2.412

2.426

2.411

2.412

2.414

2.411

2.414 


\begin{tabular}{|c|c|c|}
\hline \multicolumn{3}{|l|}{ SACH } \\
\hline Indexbegriff & Laufzeit & Lfd.Nr. \\
\hline Rathaus, Klingelanlage & $1866-1897$ & 2.411 \\
\hline Rathaus, Markisen & $1866-1897$ & 2.411 \\
\hline \multirow[t]{2}{*}{ Rathaus, Mobilien } & $1868-1880$ & 2.625 \\
\hline & $1866-1916$ & 2.626 \\
\hline Rathaus, Rattenbefall & $1866-1897$ & 2.411 \\
\hline \multirow[t]{2}{*}{ Rathaus, Umstrukturierung der Büroräume } & 1907-1909 & 2.413 \\
\hline & 1909 & 2.414 \\
\hline Rathaus, Vermietung von Räumen & 1867 & 2.417 \\
\hline Rathaus, Versicherung des Gebäudes & $1899-1912$ & 2.412 \\
\hline Rathaus, Zeichnung & $1882-1902$ & 2.608 \\
\hline Rathausbogen, Antrag auf Bilderkasten & 1866-1897 & 2.411 \\
\hline Rathausbogen, Beschädigung & $1866-1897$ & 2.411 \\
\hline Rathausbrücke, Restaurierung & 1914 & 2.605 \\
\hline \multirow[t]{4}{*}{ Rathausdelft, Teilzuschüttung } & $1883-1885$ & 914 \\
\hline & $1885-1887$ & 915 \\
\hline & $1885-1888$ & 917 \\
\hline & 1886-1895 & 920 \\
\hline Rathausdelft, Zuschüttung & 1884-1896 & 900 \\
\hline Rathaussdelft, Zuschüttung & $1888-1896$ & 934 \\
\hline Ratsarchiv, Aktenverzeichnis & 1901 & 2.639 \\
\hline \multirow{2}{*}{ Ratsbibliothek, Angebote an } & $1867-1901$ & 310 \\
\hline & $1901-1913$ & 311 \\
\hline \multirow[t]{2}{*}{ Ratsbibliothek, Anschaffungen } & $1867-1901$ & 310 \\
\hline & 1901-1913 & 311 \\
\hline \multirow[t]{2}{*}{ Ratssilber, Ausleihen } & 1878-1898 & 2.630 \\
\hline & 1902-1908 & 2.631 \\
\hline Ratssilber, Kaufangebote & 1878-1898 & 2.630 \\
\hline Ratssilber, Reparatur & 1902-1908 & 2.631 \\
\hline Ratssilber, Verkaufspläne & 1878-1898 & 2.630 \\
\hline Ratten, Bekämpfung durch Rattentyphus & 1898-1914 & 817 \\
\hline Rattenvertilgungsverfahren & 1899-1909 & 781 \\
\hline Räucherkammern, Anträge auf Erlaubnis & 1879-1907 & 1.213 \\
\hline Rauchgasverbrennung, Verfahren & 1905 & 1.267 \\
\hline Räume, Anmietung für militärische Zwecke & $1871-1887$ & 3.127 \\
\hline Realgemeinden, Organisation und Verfassung & 1886 & 811 \\
\hline Reallasten, Ablösung & 1869-1899 & 2.857 \\
\hline Reallasten, Stiftungen, Kirchen und Schulen in Emden & 1880 & 2.853 \\
\hline Realschule, Ausbau zur Oberrealschule & 1904-1911 & 3.753 \\
\hline Realschule, Einrichtung & $1881-1889$ & 3.714 \\
\hline Realschule, Stundentafel & $1905-1910$ & 3.755 \\
\hline Realschule,Teilung von Klassen & $1905-1910$ & 3.755 \\
\hline Reblaus, Bekämpfung & $1875-1914$ & 814 \\
\hline Reblausbefall, Reben des Amtsgerichtsrats Lohskötter & $1875-1914$ & 814 \\
\hline Rechnung, Diakonie d. Haussitzenden Armen u. d. Gasthauses & $1871-1874$ & 1.708 \\
\hline Rechnungsführung, Richtlinien & $1872-1890$ & 1.585 \\
\hline Rechnungsprüfung, Luth. Gemeinde u. Nellnersche Stiftung & $1891-1914$ & 3.460 \\
\hline Rechnungsprüfung, Neue Kirche & 1867-1902 & 3.381 \\
\hline Rechtsanwälte, Mangel & 1876-1904 & 170 \\
\hline Rechtsanwälte, Niederlassung & 1876-1904 & 170 \\
\hline Rechtsanwälte, Zulassung & $1876-1904$ & 170 \\
\hline Recognitionsgebühren, Hebung & 1916-1918 & 2.956 \\
\hline Rede, Leo Fürbringer als Landtagsabgeordneter & 1904-1912 & 10 \\
\hline Reederei, Gründung & 1904 & 2.080 \\
\hline Reedereien, Anforderung von Jahresberichten & 1913-1918 & 1.419 \\
\hline Reformierte Klassenschule, Ausbau & $1890-1901$ & 3.635 \\
\hline Reformierte Klassenschule, Dienstsiegel & 1869-1909 & 3.622 \\
\hline Reformierte Klassenschule, Erweiterung & $1880-1885$ & 3.639 \\
\hline Reformierte Klassenschule, Inventar & 1868-1908 & 3.630 \\
\hline
\end{tabular}


Index

\begin{tabular}{|c|c|c|}
\hline \multicolumn{3}{|l|}{ SACH } \\
\hline Indexbegriff & Laufzeit & Lfd.Nr. \\
\hline Reformierte Klassenschule, Modernisierung & 1890-1901 & 3.635 \\
\hline Reformierte Klassenschule, Revision & 1869-1909 & 3.622 \\
\hline Reformierte Klassenschule, Schulgeldsätze & 1882-1907 & 3.638 \\
\hline Reformierte Klassenschule,, Neuorganisation & 1869-1909 & 3.622 \\
\hline Reformierte. Kirchenverfassung & 1897 & 3.362 \\
\hline Regatta, Ruderverein & 1909-1912 & 689 \\
\hline Regenbacke, Unbrauchbarkeit & $1870-1879$ & 888 \\
\hline Regenwasserbacken, Einfassungen & $1869-1890$ & 1.214 \\
\hline Regenwasserkanal, Herstellung & 1907-1908 & 953 \\
\hline Regenwasserkanal, Plan & $1907-1908$ & 953 \\
\hline Regierungsjubiläum, Feiern in Emden & 1913 & 198 \\
\hline Regierungsjubiläum, Kaiser Wilhelm II. & 1913 & 198 \\
\hline Regierungspräsident, Verfügungen & 1876-1896 & 328 \\
\hline Registrator, Bewerbung & 1857-1908 & 313 \\
\hline Registrator, Ernennung & $1879-1907$ & 334 \\
\hline Registraturordnung, Stadt Emden & 1857-1908 & 313 \\
\hline Reichsbankstelle, Dienstgebäude & 1876-1904 & 1.922 \\
\hline Reichsbankstelle, Schließung & 1896 & 1.912 \\
\hline Reichsgassteuer, Kampagne gegen & $1897-1913$ & 1.070 \\
\hline Reichskommissar, Entlassungsgesuch & $1878-1880$ & 1.631 \\
\hline Reichskommissar, Vergütung & $1878-1880$ & 1.631 \\
\hline Reichskommissar, Vertretung & $1878-1880$ & 1.631 \\
\hline \multirow[t]{2}{*}{ Reichstag, Auflösung } & 1907-1908 & 219 \\
\hline & 1911-1912 & 221 \\
\hline Reichstag, Ersatzwahl & $1867-1869$ & 217 \\
\hline \multirow[t]{2}{*}{ Reichstag, Ersatzwahl im I. Hannoverschen Wahlkreis } & 1907-1908 & 219 \\
\hline & 1908 & 220 \\
\hline \multirow[t]{4}{*}{ Reichstag, Neuwahlen } & $1870-1903$ & 218 \\
\hline & 1907-1908 & 219 \\
\hline & 1908 & 220 \\
\hline & 1911-1912 & 221 \\
\hline \multirow[t]{5}{*}{ Reichstagsabgeordnete, Wahl } & $1870-1903$ & 218 \\
\hline & 1907-1908 & 219 \\
\hline & 1908 & 220 \\
\hline & $1911-1912$ & 221 \\
\hline & 1911-1912 & 222 \\
\hline Reichstagswahl, Bekanntmachung & $1866-1867$ & 216 \\
\hline Reichstagswahlen, Ergebnis & $1870-1903$ & 218 \\
\hline \multirow[t]{5}{*}{ Reichstagswahlen, Organisation } & $1870-1903$ & 218 \\
\hline & 1907-1908 & 219 \\
\hline & 1908 & 220 \\
\hline & 1911-1912 & 221 \\
\hline & 1911-1912 & 222 \\
\hline Reichswollwoche, Organisation & $1915-1918$ & 3.242 \\
\hline Reifeprüfung, Ordnung & $1893-1910$ & 3.757 \\
\hline Reifflinge, Verbot & $1881-1913$ & 727 \\
\hline Reisegepäck, Desinfizierung & 1884-1915 & 772 \\
\hline Reisekosten, Erstattung & 1902-1909 & 3.550 \\
\hline Reisekosten, Erstattungsantrag & 1911-1917 & 33 \\
\hline Reisekosten, Klage auf Rückestattung & 1902-1909 & 3.550 \\
\hline Reisekosten-Entschädigung, Polizeikommissar & 1868-1904 & 171 \\
\hline Reiseplan, König von Preußen & 1869 & 175 \\
\hline Reiseverkehr, Nach Borkum & 1881-1885 & 2.014 \\
\hline Reiseverkehr, Regelung mit Russland bezgl. Pässe und Visa & 1867-1895 & 502 \\
\hline Reitweg, Anlage für die Garnison & 1914 & 3.090 \\
\hline Rektorenstelle, Ausschreibung & $1898-1910$ & 3.765 \\
\hline Renaissance-Fassade, Planzeichnung & 1899-1901 & 2.397 \\
\hline Renaissance-Giebel, Restaurierung & 1899-1901 & 2.397 \\
\hline
\end{tabular}


Index

\begin{tabular}{|c|c|c|}
\hline \multicolumn{3}{|l|}{ SACH } \\
\hline Indexbegriff & Laufzeit & Lfd.Nr. \\
\hline Rendant, Reformierte Klassenschule & 1868 & 3.645 \\
\hline Rendantur, Organisation & $1874-1881$ & 3.688 \\
\hline Reservelazarett, Bestimmung & 1873-1914 & 592 \\
\hline Reservelazarett, Errichtung & $1876-1918$ & 3.168 \\
\hline Reservelazarett, Materiallieferungen & $1900-1912$ & 3.172 \\
\hline Reservelazarette, Standorte in Emden & $1900-1912$ & 3.172 \\
\hline Resolutionen, Abstimmung durch Bürgervorsteher & $1854-1914$ & 74 \\
\hline Rettungsanstalt, Einweisungen & 1867-1887 & 1.706 \\
\hline Rettungsanstalt, Spendensammlung & 1867-1887 & 1.706 \\
\hline Rettungsanstalt, Werbung & $1867-1887$ & 1.706 \\
\hline Rettungsgerät, Anbringung & $1891-1912$ & 742 \\
\hline Rettungsgeräte, Schutz & $1891-1912$ & 742 \\
\hline Rettungskasten, Anbringung & $1891-1912$ & 742 \\
\hline Rettungskasten, Fehlende Utensilien & $1891-1912$ & 742 \\
\hline Rettungskraft, Wiederbeschaffungsbeihilfe für Kleidung & 1904 & 1.370 \\
\hline Rettungssäcke, Evakuierung von Akten im Brandfall & $1869-1913$ & 1.387 \\
\hline Rettungsschlauch, Anschaffung & 1879-1904 & 1.398 \\
\hline Rettungsutensilien, Nichtnutzung & $1891-1912$ & 742 \\
\hline Rettungsutensilien, Verzeichnis & $1891-1912$ & 742 \\
\hline \multirow[t]{2}{*}{ Rettungswesen, Organisation } & 1906-1912 & 706 \\
\hline & $1903-1913$ & 1.667 \\
\hline Revision, Landschaftliche Kassen & $1867-1877$ & 207 \\
\hline Rhein-Elbe-Kanal, Planung & 1899 & 2.078 \\
\hline \multirow[t]{3}{*}{ Rhein-Nordseekanal, Plan } & $1910-1912$ & 2.094 \\
\hline & 1912 & 2.095 \\
\hline & $1913-1914$ & 2.096 \\
\hline Rheinschifffahrtsabgabe, Konferenz & 1908 & 1.421 \\
\hline \multirow{5}{*}{ Riole, Anlage } & 1867 & 890 \\
\hline & $1866-1880$ & 968 \\
\hline & 1887 & 969 \\
\hline & $1875-1882$ & 970 \\
\hline & 1883-1898 & 971 \\
\hline Riole, Einleitung von Fäkalien und Schlachtabfälle & $1866-1880$ & 968 \\
\hline Riole, Finanzierung & 1879 & 981 \\
\hline Riole, Hausanschlüsse & $1866-1880$ & 968 \\
\hline Riole, Qualität & $1867-1896$ & 1.492 \\
\hline Riole, Reparaturbedürftigkeit & $1875-1882$ & 970 \\
\hline Riole, Unterhaltungsarbeit & $1867-1896$ & 1.492 \\
\hline Riole, Unterhaltungspflicht & $1870-1882$ & 891 \\
\hline Riole, Verbot der Einleitung von Fäkalien & $1870-1882$ & 891 \\
\hline Riole, Verstopfung & 1889 & 973 \\
\hline Riole, Verstopfung durch Schlachtabfälle & $1874-1884$ & 892 \\
\hline Riole, Zuleitungen & $1875-1882$ & 970 \\
\hline Riolen, Reparaturbedürftigkeit & $1870-1879$ & 888 \\
\hline Riolen-Verzeichnis & $1870-1879$ & 888 \\
\hline Risszeichnung, Grundstück Kuperei am Strohdeich & $1866-1900$ & 2.481 \\
\hline Roggen, Aufkauf durch Stadt Emden & $1914-1916$ & 3.243 \\
\hline Roggen, Beschlagnahmung für den Bedarf der Stadt Emden & 1914-1916 & 3.243 \\
\hline Roggen, Marktpreise & $1886-1889$ & 2.151 \\
\hline Roggenmehlpreise, Prüfung & $1914-1916$ & 3.243 \\
\hline Roheisenkontingente, Verweigerung & $1910-1911$ & 2.362 \\
\hline Röhrenmeister, Bewerbungen & $1897-1912$ & 1.036 \\
\hline Röhrenmeister, Einstellung & $1897-1912$ & 1.036 \\
\hline \multirow{2}{*}{ Rote-Kreuz-Medaille, Verleihungsantrag } & $1900-1911$ & 259 \\
\hline & $1909-1913$ & 261 \\
\hline Roter-Adler-Orden 2. Klasse, Verleihungsantrag & $1912-1918$ & 263 \\
\hline \multirow{2}{*}{ Roter-Adler-Orden 4. Klasse, Verleihung } & $1900-1911$ & 259 \\
\hline & $1909-1913$ & 261 \\
\hline
\end{tabular}


Index

\begin{tabular}{l}
\hline \\
\hline Indexbegriff \\
\hline Roter-Adler-Orden 4. Klasse, Verleihungsantrag \\
Rotes Kreuz, Aktivitäten \\
Rotes Kreuz, Beitritt der Stadt Emden \\
Rotes Kreuz, Jahresrechnung \\
Rotes Kreuz, Kollekte \\
Rotkreuzschwestern, Ausbildung und Einsatz \\
Rüben, Aufbereitung \\
Rüben, Bewirtschaftung \\
Rückwanderer, Deutsche aus Russland \\
Ruderregatta, Programm \\
Ruhegehaltskasse, Beiträge \\
Ruhegehaltskassen, Errichtung und Funktion \\
Ruhestandsgehälter, Nachweisung \\
Rüstkammer, Angebote von Waffen \\
Rüstkammer, Ansichtskarten \\
Rüstkammer, Artikel über \\
Rüstkammer, Aufseher \\
Rüstkammer, Ausleihe von Waffen \\
Rüstkammer, Ausleihungen \\
Rüstkammer, Ausstellungsschränke \\
Rüstkammer, Baselisken \\
Rüstkammer, Bauliche Ausstattung \\
Rüstkammer, Beleuchtung \\
Rüstkammer, Beschreibung \\
Rüstkammer, Besichtigungen \\
Rüstkammer, Besichtigungsgebührentarif \\
Rüstkammer, Besichtigungszeiten \\
Rüstkammer, Besucher \\
Rüstkammer, Bildatlas \\
Rüstkammer, Diebstahl \\
Rüstkammer, Drucksachen \\
Rüstkammer, Eintriitskartenverkauf \\
Rüstkammer, Eintritt \\
Rintrittskarten \\
Rumerb von Kriegsbeutewaffen
\end{tabular}

SACH

$\frac{\text { Indexbegriff }}{\text { Roter-Adler-Orden 4. Klasse, Verleihungsantrag }}$

\section{Laufzeit}

1900-1911

1909-1913

1912-1918

1905-1914

1902-1917

1898

1901-1903

1908

1909-1910

1914-1915

1918

1918

1914-1916

1909-1912

1893-1895

1903-1917

1903-1917

1893-1895

1882-1906

1907-1912

1904-1912

1902-1908

1902-1914

1908-1913

1866-1907

1906-1911

1903-1904

1906-1911

1882-1902

1900-1912

1874-1901

1908-1914

1908-1914

1908-1914

1901-1906

1908-1916

1903-1905

1903-1904

1874-1901

1904-1907

1882-1906

1905-1907

1866-1907

1882-1906

1907-1912

1907-1912

1866-1907

1903-1917

1901-1904

1900-1907

1908-1914

1902-1908

1903-1904

1874-1901

1907-1909

1882-1902

1902-1903

1908-1916
Lfd.Nr.

259

261

263

589

1.693

611

612

613

614

3.191

3.306

3.306

3.203

689

3.514

3.516

3.516

3.514

2.610

2.611

2.647

2.621

2.644

2.642

2.620

2.617

2.637

2.617

2.608

2.606

2.622

2.643

2.643

2.643

2.619

2.623

2.614

2.637

2.622

2.638

2.610

2.613

2.620

2.610

2.611

2.611

2.620

2.646

2.618

2.649

2.643

2.621

2.637

2.622

2.413

2.608

2.616

2.623

Rüstkammer, Instandhaltung von Waffen und Rüstungen 
Index

\begin{tabular}{|c|c|c|}
\hline \multicolumn{3}{|c|}{ SACH } \\
\hline Indexbegriff & Laufzeit & Lfd.Nr. \\
\hline Rüstkammer, Inventar & $1866-1907$ & 2.620 \\
\hline \multirow[t]{2}{*}{ Rüstkammer, Katalog } & $1868-1875$ & 2.629 \\
\hline & $1901-1914$ & 2.635 \\
\hline Rüstkammer, Katalog der Bestände & 1882-1902 & 2.608 \\
\hline Rüstkammer, Katalogisierung & $1900-1902$ & 2.609 \\
\hline Rüstkammer, Kommission als Aufsichtsgremium & 1882-1902 & 2.648 \\
\hline Rüstkammer, Meistersiegel & $1900-1912$ & 2.606 \\
\hline Rüstkammer, Münzsammlung & $1908-1913$ & 2.642 \\
\hline Rüstkammer, Nachträge für das Hauptinventar & $1880-1903$ & 2.615 \\
\hline Rüstkammer, Nebeninventar & $1880-1903$ & 2.615 \\
\hline \multirow[t]{2}{*}{ Rüstkammer, Neuordnung } & 1882-1902 & 2.608 \\
\hline & 1901 & 2.636 \\
\hline Rüstkammer, Neuorganisation & 1900-1902 & 2.609 \\
\hline \multirow[t]{2}{*}{ Rüstkammer, Öffnungszeiten } & 1904-1907 & 2.638 \\
\hline & $1902-1914$ & 2.644 \\
\hline Rüstkammer, Ordnung & $1900-1912$ & 2.606 \\
\hline \multirow[t]{2}{*}{ Rüstkammer, Organisation } & 1900-1912 & 2.606 \\
\hline & $1901-1914$ & 2.635 \\
\hline Rüstkammer, Publikation & 1874-1901 & 2.622 \\
\hline Rüstkammer, Publikationen & 1903-1904 & 2.637 \\
\hline Rüstkammer, Reorganisation & 1903-1904 & 2.637 \\
\hline \multirow[t]{2}{*}{ Rüstkammer, Restaurierung } & $1902-1904$ & 2.612 \\
\hline & $1908-1913$ & 2.642 \\
\hline Rüstkammer, Restaurierungen & 1903-1904 & 2.637 \\
\hline Rüstkammer, Rüstungsrestaurierung & $1908-1913$ & 2.642 \\
\hline Rüstkammer, Schenkungen & $1866-1907$ & 2.620 \\
\hline Rüstkammer, Tauschaktionen mit anderen Institutionen & 1905-1907 & 2.613 \\
\hline Rüstkammer, Übertragungsantrag & $1908-1913$ & 2.642 \\
\hline Rüstkammer, Umsiedlung & 1900-1902 & 2.609 \\
\hline Rüstkammer, Unterbringung in der Klunderburg & $1900-1912$ & 2.606 \\
\hline Rüstkammer, Verkauf von Waffen & $1882-1906$ & 2.610 \\
\hline Rüstkammer, Waffenstände & 1904-1907 & 2.638 \\
\hline Rüstkammer, Waffentausch & 1874-1901 & 2.622 \\
\hline Rüstkammer, Werkstatt & 1899-1912 & 2.412 \\
\hline Rüstkammer, Zugänge an Waffen & 1908-1916 & 2.624 \\
\hline Rüstkammer, Zustand der Waffen & 1904-1907 & 2.638 \\
\hline Rüstkammerführer, Neuauflage & $1908-1916$ & 2.624 \\
\hline Rüstkammer-Katalog, Herstellung & 1902-1904 & 2.612 \\
\hline Rüstmeister, Antrag auf Dienstwohnung & $1903-1907$ & 430 \\
\hline Rüstmeister, Dienstanweisung & 1902-1907 & 2.645 \\
\hline \multirow[t]{2}{*}{ Rüstmeister, Einstellung } & $1902-1903$ & 429 \\
\hline & 1903-1907 & 430 \\
\hline Rüstmeister, Gehaltserhöhungsgesuch & $1902-1903$ & 429 \\
\hline Rüstmeister, Gewährung einer Zulage & $1903-1907$ & 430 \\
\hline \multirow[t]{2}{*}{ Rüstmeister, Kündigung } & $1902-1903$ & 429 \\
\hline & 1903-1907 & 430 \\
\hline Rüstmeister, Pensionsfeststellung & 1903-1907 & 430 \\
\hline Rüstmeister, Probezeit & 1903-1907 & 430 \\
\hline Rüstmeister, Tätigkeitsbericht & 1874-1901 & 2.622 \\
\hline Rüstmeister, Vereidigung & 1903-1907 & 430 \\
\hline Rüstmeister, Vertretung & 1903-1907 & 430 \\
\hline Rüstmeister-Stelle, Besetzung & 1902-1907 & 2.645 \\
\hline Rüstmeister-Werkstatt, Einrichtung & $1902-1903$ & 2.616 \\
\hline Rüstungsarbeiter, Arbeitskleidung & 1918 & 3.292 \\
\hline Saalbesitzer, Verzeichnis & 1897-1909 & 1.141 \\
\hline Saalbetrieb, Auflagen & 1897-1909 & 1.141 \\
\hline Sachspenden. Zugunsten Verwundeter & 1870 & 594 \\
\hline
\end{tabular}


IV

Index

\begin{tabular}{|c|c|c|}
\hline \multicolumn{3}{|l|}{ SACH } \\
\hline Indexbegriff & Laufzeit & Lfd.Nr. \\
\hline Sackstraße, Bauantrag & $1894-1913$ & 1.135 \\
\hline Säle, Festsetzung der Personenzahl & $1881-1897$ & 1.140 \\
\hline Säle, Personenzahl & 1897-1909 & 1.141 \\
\hline Säle, Revision & $1909-1913$ & 1.142 \\
\hline Salpeter, Vorräte & 1914-1918 & 3.245 \\
\hline \multirow[t]{2}{*}{ Salzungsanlage für ungegerbte Tierfelle, Zulassungsantrag } & $1892-1893$ & 2.200 \\
\hline & $1892-1893$ & 2.203 \\
\hline Sammelhaftpflichtversicherung, Wegeunterhaltungspflichtige & $1912-1914$ & 839 \\
\hline Sammlungen, Genehmigte & 1893-1914 & 724 \\
\hline Sammlungen, Silberhochzeit des Kaiserpaares & 1903-1906 & 196 \\
\hline Sammlungen, Unerlaubte & 1893-1914 & 724 \\
\hline Sandwater, Eigentumsrechte & 1882-1905 & 2.670 \\
\hline Sanitätspersonal, Eignung zum Kriegseinsatz & 1903-1914 & 1.686 \\
\hline Sanitätsrat, Titelverleihung & 1886-1898 & 258 \\
\hline Satzung, Alten- und Siechenhaus "Bethanien" & 1904-1915 & 578 \\
\hline Satzung, Ostfriesische reformierte Pfarrtöchterkasse & $1900-1911$ & 650 \\
\hline Satzung, Verein der Maschinisten und Heizer "Volldampf" & 1903-1908 & 657 \\
\hline Satzung, Windthorstbund & 1907 & 684 \\
\hline Satzungen, Hannover. gemeinnützige Ansiedelungsgesellschaft & $1907-1915$ & 682 \\
\hline Satzungen, Internationaler Verband der Schifffahrtskongresse & 1903-1908 & 665 \\
\hline Satzungen, Musikverein Emden & 1902-1909 & 654 \\
\hline Satzungen, Verein für Feuerbestattung & 1907-1914 & 680 \\
\hline Satzungen,Telegraphen-Gehülfen-Verein & 1907 & 683 \\
\hline Sauerkraut, Absatzordnung & $1917-1918$ & 3.308 \\
\hline Sauerkrautfabrik, Errichtung & $1902-1911$ & 803 \\
\hline Saugbagger "Germania II" & 1908 & 2.304 \\
\hline Saugbagger "Gouda" & 1907 & 2.178 \\
\hline Saugbagger "Peking" & 1908 & 2.305 \\
\hline Sauggasanlagen, Genehmigung & $1902-1911$ & 2.390 \\
\hline Säuglings- und Kleinkinderfürsorge, Kreisstellen & 1917-1918 & 760 \\
\hline Säuglings- und Kleinkinderfürsorge, Organisation & $1917-1918$ & 760 \\
\hline Säuglings- und Kleinkinderschutz, Opfertag & 1917 & 3.221 \\
\hline Säuglingsbetreuung, Ausbau der öffentlichen & $1914-1916$ & 759 \\
\hline Säuglingsfürsorge, Ausbau & 1914-1916 & 759 \\
\hline Säuglingsfürsorge, Wanderausstellung & 1916-1918 & 761 \\
\hline Säuglingskrippe, Aufgenommene Kinder & 1911-1914 & 702 \\
\hline Säuglingskrippe, Einweihung & $1911-1914$ & 702 \\
\hline Säuglingssterblichkeit, Bekämpfung & 1914-1916 & 759 \\
\hline Säuglingssterblichkeit, Statistik für Emden & 1914-1916 & 759 \\
\hline Schächtegeld, Steigerung & $1858-1911$ & 489 \\
\hline Schaden, Kuh auf fremder Weide & $1866-1887$ & 824 \\
\hline Schädlingsvertilgungsmittel, Überwachung der Lagerung & $1888-1913$ & 768 \\
\hline Schaffelle, Desinfektion von Einfuhrware & $1879-1913$ & 775 \\
\hline Schaffelle, Geruchsbelästigung & $1871-1903$ & 758 \\
\hline Schafstall, Ungenehmigte Anlage & $1875-1896$ & 1.156 \\
\hline Schafweidung, Unerlaubte & $1875-1896$ & 1.156 \\
\hline \multirow[t]{12}{*}{ Schankerlaubnis, Beantragung } & 1898 & 530 \\
\hline & 1898 & 531 \\
\hline & 1898 & 532 \\
\hline & 1898 & 533 \\
\hline & 1899 & 534 \\
\hline & 1899 & 535 \\
\hline & $1899-1900$ & 536 \\
\hline & $1900-1901$ & 537 \\
\hline & 1900 & 538 \\
\hline & 1900 & 539 \\
\hline & 1901 & 540 \\
\hline & 1901 & 541 \\
\hline
\end{tabular}


Index

SACH

Schankerlaubnissteuer, Befreiung Indexbegriff

Schankerlaubnis, Beantragung

SACH

\section{Schankkonzessionssteuer}

Schankwirtschaft, Betriebserlaubnis

Scharlach, Anzeigepflicht

Scharlachfälle, Erhebung

Schaubezirksgrenzen, Streit

Schaufenster, Zertrümmerung

Schaukästen, Ungenehmigte

Schausteller, Konzessionen für das Schützenfest

Scheinausstellungen, Bekämpfung

Scheunenbrand, Bericht

Schiedsgerichte, Einrichtung für Gewerbe

Schießanlage, Gefährdung von Passanten

Schießplatz, Anlage im Königspolder

Schießpulver, Bestandserfassung

Schießpulver, Handelserlaubnis

Schießpulver, Lagerung bei Kaufleuten

Schießpulver, Verkehrsvorschriften

Schießstand, Anlegung

Schiff "Adelchi Bignami"

Schiff "Antje Dirks"

Schiff "Bertha"

Schiff "Catharine"

Schiff "Cornelia"

Schiff "Eduard"

Schiff "Etta"

Schiff "Hilke"

Schiff "Jacobus"

Schiff "Maja"

Schiff "Margaretha"

Schiff "Marie Agnes", Auswanderertransport

Schiff "Nil Desperandum"

Schiff Nr. 433 "Peter Wessels Witwe"

Schiff "Rose"

Schiff, Umflaggung

Schiffahrtsgesellschaft, Gründungsplan

Schiffe, Desinfizierung

Schiffe, Gesunkene und Verschollene

Schiffe, Heimathafen Emden

Schiffe, Kollision

Schiffe, Löschprobleme

Schiffe, Rettungsgeräte

Schiffe, Strandung

Schiffe, Tieferladung

Schiffe, Tiefgang

\section{Laufzeit}

1901-1902

1901-1902

1901-1902

1902-1904

1902

1902

1902

1902

1902

1902

1903-1906

1902

1912

1907-1914

1909

1906

1906

1865-1895

1897-1914

1866-1913

1886-1914

1881-1910

1868

1870-1872

1870-1908

1866-1881

1897-1918

1867-1896

1867-1896

1897-1918

1870-1908

1874

1873-1975

1859-1877

$1875-1900$

1875-1900

1875-1900

1875-1900

$1875-1900$

1875-1900

1875-1900

$1875-1900$

1852-1875

1879-1904

1903

1875-1900

1879-1904

1902

1884-1915

$1872-1890$

1881-1891

1881

1875-1900

1876

1875-1912

1875-1900

1873-1912

1876
Lfd.Nr.

542

543

544

545

546

547

548

549

550

551

552

553

2.987

2.986

1.940

769

769

746

838

832

574

1.906

1.309

2.112

575

3.085

1.260

1.400

1.400

1.260

575

1.777

1.578

773

1.628

1.628

1.628

1.628

1.628

1.628

1.628

1.628

451

1.572

2.281

1.628

1.572

2.084

772

1.402

1.403

1.407

1.628

1.438

1.414

1.628

1.505

1.438 
IV

Index

SACH

Indexbegriff

Schiffer auf Kleiner Fahrt, Prüfung

Schiffer, Befähigungszeugnisse

Schiffer, Gewerbezulassung

Schiffer, Qualifikationsnachweis

Schiffer-Gilden-Witwen-Kasse, Auflösung

Schiffer-Gilden-Witwen-Kasse, Jahresberichte

Schiffer-Gilden-Witwen-Kasse, Kassenbericht

Schiffer-Gilden-Witwen-Kasse, Prüfung

Schiffer-Gilden-Witwen-Kasse, Rentensatzerhöhung

Schiffer-Gilden-Witwen-Kasse, Statuten

Laufzeit

1881

$1870-1900$

$1867-1879$

$1881-1883$

1884-1885

$1886-1890$

$1890-1894$

$1895-1903$

1877-1915

1903-1918

$1901-1911$

1903-1918

1901-1911

$1903-1918$

1903-1918

1903-1918

1870-1881

$1901-1911$

1903-1918

Schiffer-Gilden-Witwen-Kasse, Vermögensverwaltung

Schiffer-Gilden-Witwen-Kasse, Versicherungstechn. Gutachten

Schifferjugend, Fortbildung

Schiffer-Witwen- und Waisenkasse "Eendragt", Kassenlage

Schifferwitwen, Unterstützung

Schifffahrt, Finanzierung eines Wegweisers

Schifffahrt, Förderung

Schifffahrtsabgaben, Regelung

Schifffahrtskongress, Mailand

Schifffahrtskongress, Programm

Schifffahrtspolizei, Dortmund-Ems-Kanal

Schifffahrtspolizeiverordnung, Dortmund-Ems-Kanal

Schifffahrtsstatistiken, Kategorisierung

Schifffahrtsvertrag, Norddeutscher Bund mit Italien

Schiffsankünfte und -Abfahrten, Emder Hafen

Schiffsapotheke, Auffüllung

Schiffsbesatzungen, Unfallfürsorge im Ersten Weltkrieg

Schiffsbesichtiger, Bewerbung

Schiffsbesichtiger, Nichtzulassung als Gutachter

Schiffsbesichtiger, Reglement

Schiffsbesichtiger, Vorschlag

Schiffsbrüchige, Verpflegung

Schiffsdampfkessel, Zulassung
1870-1881

1901-1911

1903-1918

1908

1904-1906

1903-1918

1899-1909

1889

1867-1890

1903-1908

1901-1902

1899-1913

1902

1896-1897

1867-1890

1866

1866-1867

1905-1912

1915

1900-1902

1900-1902

1900-1902

1900-1902

1874

1890

1890

1891

1892

1892

1893

1893

1893

1895

1895

1896

1895

1897

1897

1897

\section{Lfd.Nr.}

1.407

1.621

1.565

1.599

1.600

1.601

1.602

1.603

1.567

1.756

1.755

1.756

1.755

1.756

1.756

1.756

1.754

1.755

1.756

1.754

1.755

1.756

1.598

1.752

1.756

1.418

1.560

1.558

665

1.416

2.027

1.509

1.401

1.558

1.514

1.515

1.424

3.206

422

422

422

422

1.777

2.193

2.194

2.195

2.197

2.198

2.201

2.204

2.207

2.211

2.212

2.216

2.218

2.220 
IV

Index

SACH

\begin{tabular}{|c|c|c|}
\hline Indexbegriff & Laufzeit & Lfd.Nr. \\
\hline \multirow[t]{58}{*}{ Schiffsdampfkessel, Zulassung } & 1898 & 2.225 \\
\hline & 1899 & 2.234 \\
\hline & 1899 & 2.235 \\
\hline & 1899 & 2.237 \\
\hline & 1900 & 2.239 \\
\hline & 1900 & 2.242 \\
\hline & 1900 & 2.243 \\
\hline & 1900 & 2.247 \\
\hline & 1900 & 2.249 \\
\hline & 1900 & 2.250 \\
\hline & 1900 & 2.251 \\
\hline & 1901 & 2.254 \\
\hline & 1901 & 2.258 \\
\hline & 1911 & 2.260 \\
\hline & 1901 & 2.261 \\
\hline & 1902 & 2.262 \\
\hline & 1902 & 2.264 \\
\hline & 1902 & 2.266 \\
\hline & 1902 & 2.267 \\
\hline & 1902 & 2.268 \\
\hline & 1902 & 2.270 \\
\hline & 1903 & 2.272 \\
\hline & 1903 & 2.273 \\
\hline & 1903 & 2.274 \\
\hline & 1903 & 2.275 \\
\hline & 1903 & 2.276 \\
\hline & 1903 & 2.277 \\
\hline & 1903 & 2.279 \\
\hline & 1903 & 2.280 \\
\hline & 1903 & 2.281 \\
\hline & 1904 & 2.282 \\
\hline & 1904 & 2.284 \\
\hline & 1904 & 2.285 \\
\hline & 1904 & 2.286 \\
\hline & 1904 & 2.287 \\
\hline & 1904 & 2.288 \\
\hline & 1905 & 2.289 \\
\hline & 1905 & 2.290 \\
\hline & 1905 & 2.291 \\
\hline & 1905 & 2.292 \\
\hline & 1905 & 2.293 \\
\hline & 1908 & 2.295 \\
\hline & 1905 & 2.296 \\
\hline & 1905 & 2.297 \\
\hline & 1905 & 2.298 \\
\hline & 1908 & 2.300 \\
\hline & 1908 & 2.301 \\
\hline & 1908 & 2.303 \\
\hline & 1908 & 2.304 \\
\hline & 1908 & 2.305 \\
\hline & 1908 & 2.306 \\
\hline & 1908 & 2.307 \\
\hline & 1908 & 2.308 \\
\hline & 1908 & 2.309 \\
\hline & 1908 & 2.310 \\
\hline & 1908 & 2.311 \\
\hline & 1908 & 2.312 \\
\hline & 1908 & 2.313 \\
\hline
\end{tabular}


Index

\begin{tabular}{|c|c|c|}
\hline \multicolumn{3}{|l|}{ SACH } \\
\hline Indexbegriff & Laufzeit & Lfd.Nr. \\
\hline \multirow[t]{13}{*}{ Schiffsdampfkessel, Zulassung } & 1908 & 2.314 \\
\hline & 1908 & 2.315 \\
\hline & 1908 & 2.316 \\
\hline & 1909 & 2.317 \\
\hline & 1909 & 2.318 \\
\hline & 1910 & 2.319 \\
\hline & 1910 & 2.320 \\
\hline & 1910 & 2.321 \\
\hline & 1910 & 2.322 \\
\hline & 1910 & 2.323 \\
\hline & 1910 & 2.325 \\
\hline & 1910 & 2.326 \\
\hline & 1910 & 2.327 \\
\hline Schiffsführer, Qualifikationsnachweis & 1867-1892 & 1.568 \\
\hline Schiffsführer, Umgehung von Qualifikationsvorschriften & 1877-1915 & 1.567 \\
\hline Schiffsführer, Zulassung von Niederländern auf Heringslogger & $1877-1915$ & 1.567 \\
\hline Schiffsgasmaschine, Patentverwendung & 1904-1905 & 1.425 \\
\hline Schiffsjunge, Hilfeersuchen & 1868-1891 & 1.576 \\
\hline Schiffskollisionen, Verhinderung & $1880-1912$ & 1.405 \\
\hline Schiffsmaschine, Genehmigung zum Betrieb als Sägewerksantrieb & 1897-1901 & 2.185 \\
\hline Schiffsmeldedienst, Ems & 1901-1902 & 2.062 \\
\hline Schiffsmeldungen, Formulare & $1880-1883$ & 1.404 \\
\hline Schiffsmeldungen, Gesetz & $1880-1883$ & 1.404 \\
\hline Schiffsmeldungen, Nichtabgabe & $1880-1883$ & 1.404 \\
\hline Schiffsmodell, Nachbau & 1905 & 2.659 \\
\hline Schiffsmodelle, Verkaufsangebot & 1908 & 2.399 \\
\hline Schiffspassage, Emder Binnenhafen & 1882-1908 & 2.009 \\
\hline \multirow[t]{8}{*}{ Schiffspassagen, Nesserlander Schleuse } & $1866-1867$ & 1.516 \\
\hline & 1867-1868 & 1.517 \\
\hline & $1869-1870$ & 1.518 \\
\hline & $1870-1871$ & 1.519 \\
\hline & 1873 & 1.520 \\
\hline & $1873-1874$ & 1.521 \\
\hline & 1874-1875 & 1.522 \\
\hline & 1876 & 1.523 \\
\hline Schiffspersonal, Fahrtenbücher & 1877-1915 & 1.567 \\
\hline Schiffsregister, Änderungseintragungen & $1865-1875$ & 1.427 \\
\hline \multirow[t]{2}{*}{ Schiffsregister, Löschungen und Veränderungen } & $1872-1890$ & 1.402 \\
\hline & $1881-1891$ & 1.403 \\
\hline Schiffsregister, Veränderungen & 1868-1912 & 1.574 \\
\hline \multirow[t]{2}{*}{ Schiffsregisterauszüge } & $1872-1890$ & 1.402 \\
\hline & $1881-1891$ & 1.403 \\
\hline Schiffsrequisitions-Kommission, Mitglieder & $1896-1907$ & 3.170 \\
\hline Schiffsschleuse, Plan & $1870-1914$ & 1.430 \\
\hline \multirow[t]{2}{*}{ Schiffsstatistik } & $1872-1896$ & 1.570 \\
\hline & $1900-1902$ & 1.571 \\
\hline \multirow[t]{3}{*}{ Schiffsstatistik, Passagegebührenpflichtige Binnenschiffer } & 1872 & 1.524 \\
\hline & $1878-1879$ & 1.525 \\
\hline & 1884-1885 & 1.526 \\
\hline \multirow[t]{8}{*}{ Schiffsstatistik, Schleusenpassagen } & $1866-1867$ & 1.516 \\
\hline & $1867-1868$ & 1.517 \\
\hline & $1869-1870$ & 1.518 \\
\hline & $1870-1871$ & 1.519 \\
\hline & 1873 & 1.520 \\
\hline & $1873-1874$ & 1.521 \\
\hline & 1874-1875 & 1.522 \\
\hline & 1876 & 1.523 \\
\hline Schiffstagebuch, Führungsvorschriften & 1879-1904 & 1.572 \\
\hline
\end{tabular}


Index

\begin{tabular}{|c|c|c|}
\hline \multicolumn{3}{|c|}{ SACH } \\
\hline Indexbegriff & Laufzeit & Lfd.Nr. \\
\hline Schiffsunfälle, Statistik & $1912-1913$ & 1.629 \\
\hline Schiffsverkehr, Emder Hafen & $1899-1903$ & 1.527 \\
\hline Schiffsverkehr, Situation & 1876 & 1.438 \\
\hline Schiffsverkehr, Statistik & $1898-1899$ & 1.486 \\
\hline Schiffsverkehrslinie, Transatlantisch & 1914 & 2.102 \\
\hline Schiffsverkehrsregeln, Ahndung von Verstößen & $1880-1912$ & 1.405 \\
\hline \multirow[t]{3}{*}{ Schiffsverkehrsstatistik } & 1866-1902 & 1.511 \\
\hline & 1903 & 1.512 \\
\hline & $1903-1906$ & 1.513 \\
\hline Schiffsvermessungen, Regelung in Italien & $1867-1890$ & 1.558 \\
\hline Schiffsversicherungen, Tätigkeit & $1870-1871$ & 1.422 \\
\hline Schiffsversicherungsgesellschaft, Geschäftsbericht & $1867-1887$ & 2.117 \\
\hline Schiffsversicherungsgesellschaft, Konzessionierung & $1867-1887$ & 2.117 \\
\hline Schiffsversicherungswesen, Datenerhebung & $1867-1887$ & 2.117 \\
\hline Schiffsversicherungswesen, Statistik & $1871-1885$ & 1.895 \\
\hline Schiffswerften, Statistische Berichte & $1871-1885$ & 1.895 \\
\hline Schilf, Beseitigung & $1875-1901$ & 1.494 \\
\hline Schiller-Feier, Organisation in Emden & 1905 & 568 \\
\hline Schiller-Gedenkbücher, Anschaffung & 1905 & 568 \\
\hline Schlacht- und Fleisch-Akzise, Rückerstattung an Garnison & $1868-1881$ & 2.919 \\
\hline Schlachtabfälle, Ungesetzliche Lagerung & $1879-1900$ & 2.184 \\
\hline Schlachter, Aufstellung für Emden & $1880-1883$ & 795 \\
\hline Schlachterei, Verweigerung der Betriebsgenehmigung & 1878 & 1.938 \\
\hline \multirow[t]{2}{*}{ Schlachtereien, Zulassung } & $1873-1909$ & 2.182 \\
\hline & $1879-1900$ & 2.184 \\
\hline Schlachthauspflicht, Entschädigungsforderung & 1914 & 238 \\
\hline Schlachthauszwang, Ausdehnung & 1914 & 238 \\
\hline Schlachthauszwang, Einführung & $1877-1900$ & 794 \\
\hline Schlachthof, Aufsicht & $1880-1883$ & 795 \\
\hline Schlachthof, Etat & $1877-1900$ & 794 \\
\hline \multirow[t]{2}{*}{ Schlachthof, Norm für Anlage } & 1893 & 784 \\
\hline & 1893 & 793 \\
\hline Schlachthof, Planung & $1880-1883$ & 795 \\
\hline \multirow[t]{8}{*}{ Schlachthof, Statistik } & $1898-1900$ & 785 \\
\hline & 1901 & 786 \\
\hline & 1895 & 787 \\
\hline & 1896 & 788 \\
\hline & 1897 & 789 \\
\hline & 1898 & 790 \\
\hline & 1902 & 791 \\
\hline & 1903 & 792 \\
\hline Schlachthofgebühren, Erhöhung & $1877-1900$ & 794 \\
\hline Schlachttiere, Schutz vor grausamer Schlachtung & 1873-1909 & 2.182 \\
\hline Schlachtvieh, Aufkauf & $1915-1916$ & 3.309 \\
\hline Schlachtviehversicherungen, Bericht & 1873-1905 & 805 \\
\hline Schlachtviehversicherungen, Regulierung & $1903-1911$ & 806 \\
\hline Schlafdeichstrecke, Verkauf & $1896-1911$ & 1.549 \\
\hline Schlauchmaterial, Schäden & 1869 & 1.308 \\
\hline Schlauchwagen, Erwerb für die Feuerwehr & 1867-1909 & 1.397 \\
\hline Schleppdampfer "Concurrent" & 1907 & 2.179 \\
\hline Schleppdampfer "Dollart" & 1908 & 2.312 \\
\hline Schleppdampfer "Hedwig" & 1898 & 2.225 \\
\hline Schleppdampfer "Sophie Wessels" & 1902 & 2.262 \\
\hline Schleppdampfer "Westfalen" & 1900 & 2.250 \\
\hline Schleppdampfer, Anschaffung & $1899-1904$ & 2.060 \\
\hline Schleppdampfer, Ausstattung mit Dampfkessel & 1907 & 2.179 \\
\hline Schleppdampfer, Kesselanlage & 1906 & 2.171 \\
\hline Schleppdampfer, Liste & $1905-1912$ & 1.424 \\
\hline
\end{tabular}


Index

\begin{tabular}{|c|c|c|}
\hline \multicolumn{3}{|c|}{ SACH } \\
\hline Indexbegriff & Laufzeit & Lfd.Nr. \\
\hline Schleppdampfer, Sanitäranlagen & $1905-1912$ & 1.424 \\
\hline Schleppdampfer, Stationierung auf der Ems & $1899-1904$ & 2.060 \\
\hline Schleppdienst, Beschwerden & $1899-1904$ & 2.060 \\
\hline Schleppdienst, Kosten & $1899-1904$ & 2.060 \\
\hline Schleppkähne, Konzipierung & $1883-1889$ & 2.136 \\
\hline Schleppmonopol & $1911-1913$ & 2.030 \\
\hline Schleuse, Ausbau & $1879-1883$ & 1.433 \\
\hline Schleuse, Beschädigung durch Schiffe & $1873-1878$ & 1.534 \\
\hline Schleuse, Ebbetore & $1866-1893$ & 1.533 \\
\hline Schleuse, Fluttore & $1866-1893$ & 1.533 \\
\hline Schleuse, Planung & $1899-1913$ & 2.027 \\
\hline Schleuse, Planzeichnung & $1875-1882$ & 1.434 \\
\hline Schleuse, Rammen durch Dampfer & $1883-1901$ & 2.044 \\
\hline Schleuse, Schiffsunfall & $1888-1892$ & 1.535 \\
\hline Schleusenbau, Finanzierung & $1904-1914$ & 1.440 \\
\hline Schleusendeich, Weiderechtsstreit & $1877-1885$ & 440 \\
\hline Schleuseneinweihung, Feier & 1913 & 1.452 \\
\hline Schleusenmaße, Angleichung & 1899 & 2.078 \\
\hline Schleusenmeister, Entlassungsgesuch & $1877-1885$ & 440 \\
\hline Schleusenmeisterstelle, Ausschreibung & $1877-1885$ & 440 \\
\hline Schleusenmeisterstelle, Bewerbung & $1877-1885$ & 440 \\
\hline Schleusensystem, Projekt & $1866-1893$ & 1.533 \\
\hline Schleusentor, Wartung & $1879-1883$ & 1.433 \\
\hline \multirow[t]{2}{*}{ Schleusentore, Zustand } & $1887-1888$ & 1.436 \\
\hline & $1887-1912$ & 1.437 \\
\hline Schleusenwasserstand, Regulierung & $1879-1883$ & 1.433 \\
\hline Schleusungen, Gebührenfreiheit & $1887-1888$ & 1.436 \\
\hline Schleusungen, Gebührensätze & $1887-1912$ & 1.437 \\
\hline Schloothälfte, Verpachtung & $1876-1901$ & 2.504 \\
\hline Schlosser- und Schmiedeinnung, Statuten & $1885-1891$ & 1.937 \\
\hline Schlosser- und Schmiedeinnung, Sterbekasse & $1885-1891$ & 1.937 \\
\hline Schlosser- und Schmiedeinnung, Vorstand & $1885-1891$ & 1.937 \\
\hline Schlosser, Erlaubnis der Lagerung von Material a.d. Straße & $1901-1912$ & 840 \\
\hline Schmiede, Erlaubnis von Lagerung von Material a.d. Straße & $1901-1912$ & 840 \\
\hline Schmiedewerkstatt, Lärmbelästigung & $1879-1900$ & 2.184 \\
\hline Schnelldampferlinie, Emden nach London & $1912-1913$ & 2.101 \\
\hline Schnelldampferlinie, Planung & $1912-1913$ & 2.101 \\
\hline Schnellzug, Einrichtung & $1882-1908$ & 2.009 \\
\hline Schokolade, Protest gegen Verkauf zu Fabrikpreisen & $1898-1908$ & 636 \\
\hline Schonerbrigg "Margarethe" & $1875-1900$ & 1.628 \\
\hline Schonhovenstraße, Durchfahrtsbeschränkungen & $1875-1909$ & 836 \\
\hline Schornstein, Belästigung wegen Undichtigkeit & 1873-1906 & 1.263 \\
\hline \multirow[t]{2}{*}{ Schornsteinbrand, Anzeige } & 1868 & 1.225 \\
\hline & 1869 & 1.308 \\
\hline \multirow[t]{2}{*}{ Schornsteinbrand, Anzeigen } & $1872-1878$ & 1.212 \\
\hline & $1879-1907$ & 1.213 \\
\hline Schornsteinbrand, Ursache & $1868-1871$ & 1.211 \\
\hline Schornsteinbrände & 1873-1906 & 1.263 \\
\hline Schornsteinbrände, Anzeigen & $1867-1873$ & 1.262 \\
\hline \multirow[t]{3}{*}{ Schornsteine, Baufehler } & $1868-1871$ & 1.211 \\
\hline & $1872-1878$ & 1.212 \\
\hline & $1879-1907$ & 1.213 \\
\hline Schornsteine, Belästigung & $1879-1907$ & 1.213 \\
\hline \multirow[t]{4}{*}{ Schornsteine, Feuergefahr } & $1868-1871$ & 1.211 \\
\hline & $1872-1878$ & 1.212 \\
\hline & $1879-1907$ & 1.213 \\
\hline & $1873-1906$ & 1.263 \\
\hline Schornsteine, Reinigung & $1867-1873$ & 1.262 \\
\hline
\end{tabular}


Index

\begin{tabular}{|c|c|c|}
\hline \multicolumn{3}{|c|}{ SACH } \\
\hline Indexbegriff & Laufzeit & Lfd.Nr. \\
\hline Schornsteine, Reinigung & $1907-1916$ & 1.264 \\
\hline \multirow[t]{2}{*}{ Schornsteine, Reinigungsintervalle } & $1867-1873$ & 1.262 \\
\hline & 1907-1916 & 1.264 \\
\hline Schornsteine, Zuteilung zur Reinigung & 1873-1906 & 1.263 \\
\hline Schornsteinfeger, Honorar & $1867-1873$ & 1.262 \\
\hline Schornsteinfeger, Unfallschutz & 1873-1906 & 1.263 \\
\hline \multirow[t]{2}{*}{ Schornsteinfegerbezirke, Festlegung } & $1867-1873$ & 1.262 \\
\hline & 1873-1906 & 1.263 \\
\hline Schornsteinfegerbezirke, Organisierung & $1907-1916$ & 1.264 \\
\hline Schornsteinfegergewerbe, Bestimmungen & $1907-1916$ & 1.264 \\
\hline \multirow[t]{2}{*}{ Schornsteinfegermeister, Konzessionsentzug } & $1867-1873$ & 1.262 \\
\hline & 1873-1906 & 1.263 \\
\hline \multirow[t]{2}{*}{ Schornsteinfegermeister, Zulassung } & $1867-1873$ & 1.262 \\
\hline & 1873-1906 & 1.263 \\
\hline \multirow[t]{2}{*}{ Schornsteinfegerstellen, Bewerbungen } & $1867-1873$ & 1.262 \\
\hline & 1873-1906 & 1.263 \\
\hline Schornsteinfegerwesen, Organisation & 1907-1916 & 1.264 \\
\hline Schornsteinfegerzwang, Einführung & $1867-1873$ & 1.262 \\
\hline Schrebergärten, Werbeschriften & 1907-1909 & 2.590 \\
\hline Schreiberstelle, Schaffung & 1891-1892 & 341 \\
\hline \multirow{2}{*}{ Schriften, Bekämpfung erotischer Literatur } & $1867-1891$ & 719 \\
\hline & $1880-1891$ & 720 \\
\hline \multirow[t]{2}{*}{ Schriften, Verbote } & $1867-1891$ & 719 \\
\hline & $1880-1891$ & 720 \\
\hline \multirow[t]{3}{*}{ Schuhe, Bewirtschaftung } & $1916-1918$ & 3.285 \\
\hline & $1916-1918$ & 3.287 \\
\hline & 1918 & 3.295 \\
\hline Schuhe, Höchstpreise & $1916-1918$ & 3.282 \\
\hline Schuhkurse, Angebot & $1917-1918$ & 3.294 \\
\hline Schuhmacher-Innung, Gründung & 1879-1892 & 1.933 \\
\hline Schuhmacher-Innung, Mitglieder & 1879-1892 & 1.933 \\
\hline Schuhmacher-Innung, Statuten & 1879-1892 & 1.933 \\
\hline Schuhmacher-Innung, Vorstand & 1879-1892 & 1.933 \\
\hline Schuhmacher-Innung, Witwenunterstützungskasse & 1879-1892 & 1.933 \\
\hline Schul-Aborte, Revision & $1866-1911$ & 962 \\
\hline Schulakten, Abgabe & 1857-1908 & 313 \\
\hline Schulaufsicht, Kritik & $1866-1868$ & 3.620 \\
\hline Schulaufsicht, Organisation & $1872-1888$ & 3.657 \\
\hline Schulbänke, Anschaffung & $1908-1914$ & 3.546 \\
\hline Schulbaracken, Angebot & $1905-1911$ & 3.539 \\
\hline Schulbau, Finanzierung & $1902-1904$ & 3.642 \\
\hline Schulbau, Staatsbeihilfe & 1912 & 3.842 \\
\hline Schulbaukasse, Datenerhebung & 1903-1905 & 3.526 \\
\hline Schulbauten, Gebäudeversicherung & 1903-1905 & 3.526 \\
\hline Schulbeginn, Festlegung & 1868-1891 & 3.502 \\
\hline Schulbeiträge, Eintreibung & $1867-1890$ & 3.626 \\
\hline Schulbeiträge, Lutherische Volksschule & $1872-1888$ & 3.650 \\
\hline Schulbesuch, Kontrolle & $1875-1888$ & 3.703 \\
\hline Schulbezirke, Bildung & 1906-1908 & 3.616 \\
\hline Schuldiener, Gewerbeschule und Handelsschule & $1880-1918$ & 2.353 \\
\hline \multirow[t]{2}{*}{ Schuldiener, Kaiser-Friedrich-Realschule } & $1910-1914$ & 3.731 \\
\hline & $1888-1910$ & 3.740 \\
\hline Schuldiener, Reformierte Klassenschule Emden & $1866-1868$ & 3.620 \\
\hline Schuldienerstelle, Ausschreibung & 1905-1906 & 3.795 \\
\hline Schuldienst, Verweigerung der Entlassung & 1903 & 3.792 \\
\hline Schuldirektor, Beförderung & $1895-1918$ & 3.733 \\
\hline Schuldirektor, Personalakte & $1895-1918$ & 3.733 \\
\hline Schuldpapiere, Verwaltung & $1866-1887$ & 2.990 \\
\hline
\end{tabular}


Index

\begin{tabular}{|c|c|c|}
\hline \multicolumn{3}{|l|}{ SACH } \\
\hline Indexbegriff & Laufzeit & Lfd.Nr. \\
\hline Schuldzinsen, Nachweisung & $1888-1890$ & 2.995 \\
\hline Schule, Errichtungsantrag für Transvaal & $1909-1912$ & 3.594 \\
\hline Schule, Erweiterung & 1908-1909 & 227 \\
\hline Schule, Feuerversicherung & $1886-1890$ & 3.760 \\
\hline Schule, Inventar & 1881 & 3.649 \\
\hline Schule, Neubau & $1900-1909$ & 3.666 \\
\hline Schule, Revision & $1902-1904$ & 3.642 \\
\hline Schule, Schulmöbelausstattung & $1886-1890$ & 3.760 \\
\hline Schüler, Schwachbegabte & $1908-1918$ & 3.709 \\
\hline Schüler, Umschulung nach Emden & 1887-1895 & 3.507 \\
\hline Schüler, Verweis aus der reformierten Klassenschule & 1869-1909 & 3.622 \\
\hline Schülerinnen, Disziplinarstrafen & $1875-1890$ & 3.836 \\
\hline \multirow[t]{2}{*}{ Schuletat, Deutsch-reformierte Gemeinde } & $1867-1890$ & 3.626 \\
\hline & $1891-1907$ & 3.627 \\
\hline Schuletats, Aufstellung & $1907-1910$ & 3.511 \\
\hline Schulfeier, 25. Regierungsjubiäum des Kaisers Wilhelm II. & $1908-1915$ & 3.545 \\
\hline Schulgebäude, Einweihungsfeier & 1888-1889 & 3.746 \\
\hline Schulgebäude, Emder Schulverbände & 1903-1905 & 3.526 \\
\hline \multirow{2}{*}{ Schulgebäude, Feuerversicherung } & 1893-1908 & 3.722 \\
\hline & 1893-1907 & 3.838 \\
\hline Schulgebäude, Grundsteinlegung & $1888-1889$ & 3.746 \\
\hline \multirow[t]{2}{*}{ Schulgebäude, Neubau } & $1902-1904$ & 3.642 \\
\hline & $1880-1890$ & 3.659 \\
\hline Schulgebäude, Revision & $1880-1890$ & 3.659 \\
\hline Schulgebäude, Umbau & 1903 & 3.472 \\
\hline Schulgebäude, Wasserleitungsschaden-Versicherung & 1893-1907 & 3.838 \\
\hline Schulgelände, Erweiterung & $1880-1890$ & 3.659 \\
\hline Schulgeld, Auswärtige Schulkinder & $1898-1900$ & 3.521 \\
\hline Schulgeld, Anträge auf Erlass oder Ermäßigung & $1906-1915$ & 3.816 \\
\hline Schulgeld, Befreiung & $1882-1907$ & 3.638 \\
\hline Schulgeld, Befreiungsanträge & $1875-1888$ & 3.703 \\
\hline Schulgeld, Ermäßigungsanträge & $1914-1917$ & 3.761 \\
\hline \multirow[t]{3}{*}{ Schulgeld, Höhere Töchterschule } & 1876-1905 & 3.814 \\
\hline & $1905-1914$ & 3.815 \\
\hline & $1906-1915$ & 3.816 \\
\hline Schulgeld, Städtische Volksschule & $1874-1881$ & 3.688 \\
\hline Schulgeldbefreiung, Kriterien & 1899-1918 & 3.743 \\
\hline Schulgeldrestanden, Katholische Volksschule & $1875-1888$ & 3.703 \\
\hline Schulgeldrückstände, Eintreibung & $1899-1918$ & 3.743 \\
\hline Schulgeldsätze, Lutherische Klassenschule & 1887-1905 & 3.651 \\
\hline Schulgeldtarife, Kaiser-Friedrich-Realschule & $1899-1918$ & 3.743 \\
\hline Schulgrundstück, Eigentumsrechte & $1880-1890$ & 3.659 \\
\hline Schulgrundstück, Einfriedung & $1902-1904$ & 3.642 \\
\hline Schulgrundstück, Nutzungsrechte & $1880-1890$ & 3.659 \\
\hline Schulgrundstück, Rechte & 1903 & 3.667 \\
\hline Schulgrundstück, Verkauf & 1904-1905 & 3.644 \\
\hline Schulgrundstück, Verzicht & 1903 & 3.643 \\
\hline Schulinventar, Lutherische Klassenschule & $1866-1879$ & 3.654 \\
\hline Schulinventarien, Aufstellung & 1891 & 3.512 \\
\hline Schulkasse, Ausgaben und Einnahmen & 1897-1898 & 3.621 \\
\hline \multirow[t]{2}{*}{ Schulkasse, Etat } & $1867-1890$ & 3.626 \\
\hline & $1891-1907$ & 3.627 \\
\hline Schulkasse, Rechnungsprüfung & 1868-1908 & 3.630 \\
\hline \multirow[t]{2}{*}{ Schulkasse, Revision } & $1858-1911$ & 489 \\
\hline & 1889-1909 & 3.705 \\
\hline Schulkassenrechnung, Abnahme & 1867-1908 & 3.655 \\
\hline Schulkinder aus Umlandgemeinden in Emder Höheren Schulen & 1905 & 3.529 \\
\hline Schulkinder aus Umlandgemeinden in Emder Volksschulen & 1905 & 3.529 \\
\hline
\end{tabular}


Index

\begin{tabular}{|c|c|c|}
\hline \multicolumn{3}{|l|}{ SACH } \\
\hline Indexbegriff & Laufzeit & Lfd.Nr. \\
\hline Schulkinder, Delikte & $1882-1914$ & 3.541 \\
\hline Schulkinder, Gewerbliche Beschäftigung & $1872-1904$ & 2.382 \\
\hline Schulkinder, Mittagessen & $1876-1878$ & 3.700 \\
\hline Schulklasse, Einrichtung in der katholischen Volksshule & $1875-1888$ & 3.703 \\
\hline Schulkommission, Ersatzwahlen & 1886-1894 & 3.840 \\
\hline Schulkommission, Sitzungen & 1873-1891 & 3.674 \\
\hline Schulkommission, Sitzungsprotokolle & 1896-1906 & 3.686 \\
\hline Schulkommissionen, Zusammenfassung & 1878 & 3.504 \\
\hline Schullasten, Beschwerden & $1868-1896$ & 3.663 \\
\hline Schullasten, Heranziehung der Geistlichen und Lehrer & 1868 & 3.631 \\
\hline Schullasten, Heranziehung zu & 1877-1897 & 3.392 \\
\hline Schullasten, Streit Borssum gegen Emden & 1909-1912 & 3.538 \\
\hline \multirow[t]{3}{*}{ Schullehrer, Diensteinkommen } & 1908-1909 & 3.533 \\
\hline & $1915-1918$ & 3.534 \\
\hline & 1909-1915 & 3.535 \\
\hline Schullehrer-Witwen und Sterbekasse, Mitgliedschaft & $1869-1910$ & 3.350 \\
\hline Schulmöbel und -Utensilien, Feuerversicherung & $1912-1917$ & 3.549 \\
\hline Schulneubau, Abnahme & 1902-1904 & 3.642 \\
\hline Schulneubau, Einweihung & 1900-1909 & 3.666 \\
\hline Schulneubau, Einweihung. & 1902-1904 & 3.642 \\
\hline Schulneubau, Einweihungsgeschenk & $1901-1913$ & 187 \\
\hline Schulneubau, Finanzierung & 1900-1909 & 3.666 \\
\hline Schulneubau, Reformierte Klassenschule & $1890-1901$ & 3.635 \\
\hline Schulordnung, Kaiser-Friedrich-Realschule & $1893-1910$ & 3.757 \\
\hline Schulordnung, Lutherische Klassenschule & $1887-1890$ & 3.665 \\
\hline Schulordnung, Reformierte Klassenschule & 1877-1883 & 3.623 \\
\hline Schulpflicht, Verlängerung & 1873-1887 & 3.660 \\
\hline Schulrat, Titelverleihung & $1900-1911$ & 259 \\
\hline Schulrendant, Lutherische Volksschule & 1894 & 3.648 \\
\hline Schulspeisung, Erhebung & $1880-1913$ & 628 \\
\hline Schulspielplatz & 1908-1914 & 3.546 \\
\hline Schulstatistik & 1905-1906 & 2.368 \\
\hline Schulsteuer, Heranziehung & $1869-1910$ & 3.350 \\
\hline Schulsteuer, Verweigerung & 1882-1907 & 3.638 \\
\hline Schulsteuerpflichtige, Erfassung & 1869-1909 & 3.622 \\
\hline Schulutensilien & $1886-1890$ & 3.760 \\
\hline Schulverband, Etat & 1907 & 3.543 \\
\hline Schulverband, Heranziehung der Franz. Reformierten Gemeinde & $1872-1881$ & 3.640 \\
\hline Schulverband, Heranziehung der Mennoniten & $1872-1881$ & 3.640 \\
\hline Schulverband, Umbenennung & 1873-1887 & 3.660 \\
\hline Schulverband, Zugehörigkeit von Französisch-Reformierten & $1881-1883$ & 3.661 \\
\hline Schulverband, Zugehörigkeit von Mennoniten & $1881-1883$ & 3.661 \\
\hline Schulverbände, Finanzielle Leistungsfähigkeit & 1893-1896 & 3.520 \\
\hline Schulverbände, Gehaltsaufwändungen & $1909-1914$ & 3.500 \\
\hline Schulverbände, Landkreis und Stadtkreis Emden & $1887-1912$ & 812 \\
\hline Schulverbände, Rechnungsprüfung & 1889-1897 & 3.510 \\
\hline \multirow[t]{2}{*}{ Schulverbände, Staatsbeihilfe } & $1896-1905$ & 3.518 \\
\hline & 1899-1907 & 3.519 \\
\hline Schulverbände, Staatszuschuss für Lehrergehälter & $1909-1914$ & 3.500 \\
\hline Schulverbände, Stadt und Land umfassende & 1904 & 3.527 \\
\hline Schulvorstand, Besetzung & $1887-1890$ & 3.665 \\
\hline Schulvorstand, Mitgliedschaft von Lehrern & 1889 & 3.662 \\
\hline Schulvorstand, Satzung & $1868-1903$ & 3.625 \\
\hline Schulvorstand, Suspendierung von Mitgliedern & $1868-1903$ & 3.625 \\
\hline Schulvorstand, Wahl der Mitglieder & $1868-1903$ & 3.625 \\
\hline Schulvorsteher, Verpflichtungen & $1878-1890$ & 3.704 \\
\hline Schulwärterdienst, Dienstmädchen des Navigationsschullehrers & $1875-1905$ & 1.594 \\
\hline Schulwärterin, Lutherische Volksschule & 1894 & 3.648 \\
\hline
\end{tabular}


Index

\begin{tabular}{|c|c|c|}
\hline \multicolumn{3}{|l|}{ SACH } \\
\hline Indexbegriff & Laufzeit & Lfd.Nr. \\
\hline \multirow[t]{2}{*}{ Schuppen, Abrissverfügung } & 1903-1907 & 1.186 \\
\hline & $1883-1884$ & 1.220 \\
\hline Schüttgeld, Festlegung & $1866-1887$ & 824 \\
\hline Schüttstallkonzession, Erteilung & $1866-1887$ & 824 \\
\hline Schützen-Corps, Statuten & $1886-1914$ & 574 \\
\hline Schützenfeste, Genehmigung & $1886-1914$ & 574 \\
\hline Schützenplatz, Ruhe und Ordnung & $1886-1914$ & 574 \\
\hline Schutzschleuse, Neubau & 1866 & 1.530 \\
\hline Schwarzbrot, Kartoffelmehlzugabe & 1914-1916 & 3.243 \\
\hline Schweckendiekdenkmal, Enthüllungsfeier & $1906-1915$ & 273 \\
\hline Schweckendiekdenkmal, Errichtung & $1906-1915$ & 273 \\
\hline Schweine- und Schafhaltung, Einstellungsverpflichtung & $1875-1896$ & 1.156 \\
\hline Schweine, Unerlaubtes Weiden & $1875-1896$ & 1.156 \\
\hline \multirow[t]{2}{*}{ Schweine, Untersuchungsstatistik } & $1865-1895$ & 746 \\
\hline & $1895-1910$ & 747 \\
\hline Schweinebestand, Zwischenerhebung & 1917 & 3.226 \\
\hline Schweinefleisch, Bewirtschaftung & $1915-1916$ & 3.309 \\
\hline Schweinefleisch, Höchstpreis & $1915-1916$ & 3.309 \\
\hline \multirow[t]{2}{*}{ Schweinefleisch, Untersuchung } & 1865-1895 & 746 \\
\hline & $1895-1910$ & 747 \\
\hline Schweinefleisch, Verkauf an der Waage & 1883-1902 & 1.909 \\
\hline Schweinefleisch, Verkauf von Verdorbenem & 1883-1902 & 1.909 \\
\hline Schweinefleisch, Verkaufsverbot in der städtischen Waage & 1883-1902 & 1.909 \\
\hline Schweinefleisch, Vertreibung von Ungetestetem & $1895-1910$ & 747 \\
\hline Schweinehalter, Aufstellung & $1897-1912$ & 1.157 \\
\hline Schweinehalter, Stadt Emden & $1875-1896$ & 1.156 \\
\hline Schweinehaltung, Geruchsbelästigung & $1897-1912$ & 1.157 \\
\hline Schweinehaltung, Hygienische Verhältnisse & $1875-1896$ & 1.156 \\
\hline Schweinemast, Rüben & 1914-1918 & 3.245 \\
\hline Schweinepreise, Stützung & 1914-1918 & 3.245 \\
\hline \multirow[t]{2}{*}{ Schweineställe, Anträge auf Genehmigung } & $1875-1896$ & 1.156 \\
\hline & $1897-1912$ & 1.157 \\
\hline Schweineställe, Baupolizeiliche Regelungen & $1897-1903$ & 1.139 \\
\hline Schweineställe, Beaufsichtigungsgebühr & $1875-1896$ & 1.156 \\
\hline Schweineställe, Ungenehmigte & $1897-1912$ & 1.157 \\
\hline Schwestern, Lebensführung & $1894-1900$ & 1.685 \\
\hline Schwimmdock, Verkaufsverhandlungen & $1908-1910$ & 1.466 \\
\hline Schwimmdock-Anlage, Angebot & $1899-1903$ & 1.454 \\
\hline Schwimmunterricht, Durchführung & $1876-1882$ & 734 \\
\hline Sedanstag, Einführung als Feiertag & $1871-1875$ & 570 \\
\hline Sedanstag, Fackelzug & $1895-1910$ & 571 \\
\hline \multirow[t]{2}{*}{ Sedanstag, Feiern } & $1871-1875$ & 570 \\
\hline & $1895-1910$ & 571 \\
\hline Sedanstag, Kranz für Soldatengräber & $1895-1910$ & 571 \\
\hline Sedanstag, Literatur & $1895-1910$ & 571 \\
\hline Sedanstag, Überkonfessioneller Gottesdienst & $1871-1875$ & 570 \\
\hline Sedanstag, Veteranenehrung & $1895-1910$ & 571 \\
\hline Sedan-Turnfest, Etablierung & $1895-1914$ & 730 \\
\hline See- und Küstenschiffe, Klassifikation & 1881 & 1.407 \\
\hline Seeamt, Reichskommissar & $1878-1880$ & 1.631 \\
\hline Seedampfschiffs-Maschinisten, Befähigung & $1882-1889$ & 1.569 \\
\hline Seedampfschiffs-Maschinisten, Befugnisse der versch. Klassen & $1882-1889$ & 1.569 \\
\hline Seedampfschiffs-Maschinisten, Prüfungsordnung & $1882-1889$ & 1.569 \\
\hline Seefahrtsschulstandort, Emden & $1917-1918$ & 1.581 \\
\hline Seefahrtsschulstandort, Kampf um Erhalt & $1917-1918$ & 1.581 \\
\hline Seehäfen, Fortentwicklung & $1876-1903$ & 1.432 \\
\hline Seehafen, Plan für die Knock & 1868 & 1.445 \\
\hline Seehafen, Plan für die Unterems & 1868 & 1.445 \\
\hline
\end{tabular}


Index

\begin{tabular}{|c|c|c|}
\hline \multicolumn{3}{|l|}{ SACH } \\
\hline Indexbegriff & Laufzeit & Lfd.Nr. \\
\hline Seehafen, Votum für Logum & 1868 & 1.445 \\
\hline Seeleute, Anzeigen wegen Heuerzahlungsausfälle & $1868-1891$ & 1.576 \\
\hline Seeleute, Behandlung von Geschlechtskrankheiten & $1897-1914$ & 1.575 \\
\hline Seeleute, Farbblindheit & $1893-1914$ & 1.607 \\
\hline Seeleute, Gesetz gegen Abwerbung & 1881 & 1.408 \\
\hline Seeleute, Heuerforderungen & $1868-1891$ & 1.576 \\
\hline Seeleute, Hilfe zur Heimreise bei Erkrankung & $1868-1891$ & 1.576 \\
\hline Seeleute, Hilfe zur Heimreise bei Schiffsbruch & $1868-1891$ & 1.576 \\
\hline Seeleute, Nachlassabwicklung & $1868-1912$ & 1.574 \\
\hline Seeleute, Nachlassüberweisung & $1868-1891$ & 1.576 \\
\hline Seeleute, Nachmusterung für Ostasienfahrten & $1869-1890$ & 1.577 \\
\hline Seeleute, Strafvollstreckung & $1897-1914$ & 1.575 \\
\hline Seeleute, Tauglichkeitsuntersuchungen & 1905 & 1.614 \\
\hline Seeleute, Verfahren wegen Vertragsbruch & $1868-1912$ & 1.574 \\
\hline Seelsorge, Verteilung unter lutherischen Pastoren & $1896-1897$ & 3.468 \\
\hline Seemann, Heimatschein & $1868-1891$ & 1.576 \\
\hline Seemann, Herkunftsanfrage & $1868-1891$ & 1.576 \\
\hline Seemannskasse, Geschichte & $1875-1892$ & 1.749 \\
\hline Seemannskasse, Rechnungsprüfung & $1875-1892$ & 1.749 \\
\hline Seemannskasse, Statut & $1875-1892$ & 1.749 \\
\hline Seemaschinisten, Unterstützungsgesuch für Fachschule & $1903-1908$ & 657 \\
\hline Seeminenexplosion, Todesfall & $1916-1918$ & 1.887 \\
\hline Seeschiffe, Desinfizierung & $1883-1900$ & 782 \\
\hline Seeschiffe, Kontrolle auf Ratten & $1899-1909$ & 781 \\
\hline Seeschiffe, Löschzeiten im Emder Hafen & $1873-1912$ & 1.505 \\
\hline Seeschiffe, Rettungsboote & $1875-1912$ & 1.414 \\
\hline Seeschiffe, Revision & 1885 & 1.410 \\
\hline Seeschiffer, Emden & $1867-1872$ & 1.566 \\
\hline Seeschiffer, Wohlfahrtseinrichtungen & $1900-1904$ & 1.758 \\
\hline Seeschifffahrt, Abgrenzumg von der Binnenschifffahrt & 1884 & 1.409 \\
\hline Seeschleuse, Bauanregung & $1887-1912$ & 1.437 \\
\hline Seeschleuse, Grundsteinlegung & $1904-1914$ & 1.440 \\
\hline Seeschleuse, Notwendigkeit & $1902-1911$ & 1.446 \\
\hline Seeschleuse, Plan & $1882-1883$ & 2.021 \\
\hline Seeschleuse, Zuschuss zum Bau & $1902-1911$ & 1.446 \\
\hline Seestraßenrecht, Vorschriften & $1880-1912$ & 1.405 \\
\hline Seetransport, Feuergefährliche Güter & $1886-1914$ & 1.254 \\
\hline Seetüchtigkeit, Attestierungsantrag & $1875-1900$ & 1.628 \\
\hline Seeunfälle, Emder Schiffe & $1875-1900$ & 1.628 \\
\hline Seeunfälle, Gesetzesnovellierungsantrag & $1878-1880$ & 1.631 \\
\hline Seewarte, Beihilfeantrag wegen Errichtung einer Zweigstation & 1869 & 2.036 \\
\hline Seewasser, Einlassung zur Spülung & $1877-1916$ & 1.556 \\
\hline Seezeichen, Bekanntmachungen & $1878-1891$ & 1.412 \\
\hline Segellogger "Cornelia" & 1908 & 2.309 \\
\hline Segellogger "Dortmund" & 1910 & 2.321 \\
\hline Segellogger "Heinrich Daniel" & 1910 & 2.323 \\
\hline Segellogger "Lübeck" & 1908 & 2.303 \\
\hline Segellogger "Münster" & 1910 & 2.320 \\
\hline Segellogger "Nesserland" & 1908 & 2.310 \\
\hline \multirow{2}{*}{ Segellogger "Satorius" } & 1908 & 2.295 \\
\hline & 1905 & 2.296 \\
\hline Segellogger "Ysaac Brons" & 1908 & 2.315 \\
\hline \multirow{6}{*}{ Segellogger, Umrüstung } & 1908 & 2.300 \\
\hline & 1908 & 2.303 \\
\hline & 1908 & 2.309 \\
\hline & 1908 & 2.310 \\
\hline & 1908 & 2.315 \\
\hline & 1910 & 2.320 \\
\hline
\end{tabular}


IV

Index

SACH

\section{Indexbegriff}

Segellogger, Umrüstung

Seifensiederei, Genehmigungsverfahren

Seifensiederei, Veränderungsantrag

Seilerbahn, Kauf durch Stadt Emden

Seilerhaus, Risszeichnung

Sektiererei, Verbotsaufhebung

Seminar-Übungsschule, Einrichtung

Seminar-Vorschule, Einrichtung

Senator, Amtseinführung

Senator, Amtsniederlegung

Senator, Dispensationsantrag als Geschworener

Senator, Entlassungsgesuch

Senator, Nachlass

Senator, Nachruf

Senator, Vereidigung

Senator, Wahl

\section{Laufzeit}

Lfd.Nr.

1910

1910

1881

1887

1874-1893

1874-1893

$1867-1910$

1907-1912

1911-1913

1908

$1859-1870$

$1885-1894$

1866-1872

$1866-1872$

$1872-1890$

1883-1887

1889-1912

1872-1879

1869-1905

1877-1911

1890-1901

1879-1885

1883-1887

1859-1870

1885-1894

1869-1875

1875-1899

1889-1912

1877-1911

1866-1872

1866-1872

1872-1890

1875-1899

1883-1887

1889-1912

1872-1879

1869-1875

1869-1905

1877-1911

1879-1885

1859-1870

1885-1894

1866-1872

1866-1872

1872-1890

1875-1899

1894

1883-1887

1889-1912

1872-1879

1869-1875

1869-1905

1877-1911

1890-1901

1879-1885

1859-1870

1885-1894

1877-1911
2.321

2.323

2.183

2.189

2.444

2.444

3.497

3.828

3.831

3.832

28

29

15

16

17

20

21

22

24

25

26

27

20

28

29

23

18

21

25

15

16

17

18

20

21

22

23

24

25

27

28

29

15

16

17

18

19

20

21

22

23

24

25

26

27

28

29

25 
IV

Index

\section{SACH}

Indexbegriff

Senatoren, Wahl

Senatorenwahl, Anfechtung

Seuchengefahr, Bekämpfung

Seuchenschutz, Einfuhrregulierung und Quarantäne

Seuchenschutz, Quarantäne über einlaufende Schiffe

Seumestraße, Anbindung

Sicherheitsleistungen, Öffentliche Aufträge

Sicherheitspolizei, Aufsicht

Siebengang, Abwässerung

Siebengang, Unterhaltung

Siedlungsanlage, Öffentliche Lasten

Siedlungsbau, Genehmigungsauflage

Siel, Schauung

Siel, Umwandlung in eine Kammerschleuse

Siel, Verschlammung

Sielachtsbeitrag, Veranlagung

Sielbude, Abbruchskostentragung

Sielbude, Eigentumsverhältnisse

Siele, Besichtigungen

Siele, Übersichtskarte

Sielnottüre, Bruch

Sielrollen, Auslegung

Sieltief, Sperrung

Sieltiefe, Ausbaggerung

Sielwärter, Einstellung

Signalformen, Regelung

Signalkode, Schleusensperrung und Spülung

Silberhochzeit, Kaiserpaar

Silbermünze, Stiftung

Sitzungen, Magistrat

Laufzeit

1870-1887

1904-1905

1904-1905

1914

1872-1899

1872-1899

1900-1903

$1882-1913$

1867-1884

1867-1908

1867-1908

1887-1912

1913-1914

1883-1900

1885-1907

1875-1901

1883-1884

1875

1875

1867-1890

1904

1875

1883-1884

1875-1901

1867-1910

1892-1900

1880-1912

1873-1912

1903-1906

1908-1913

1872-1876

1878

1879

1880

1881

1882

1885

1883

1884

1886

1887

1888

1889

1890

1891

1893

1892

1894

1895

1896

1897

1898

1899

1900

1901

1902

1906

1903

\section{Lfd.Nr.}

6

3.198

778

778

1.165

2.408

510

846

846

812

1.149

1.537

909

1.494

1.489

2.487

2.487

1.536

1.551

1.555

1.489

1.494

1.490

1.545

1.405

1.505

196

2.642 


SACH

\begin{tabular}{l} 
Indexbegriff \\
\hline Sitzungen, Magistrat \\
Skorbut, Verhütung durch Gemüsekonserven \\
SMS "Emden", Leichter Kreuzer \\
Soldaten, Tapferkeitsprämie \\
Soldaten, Unterbringung in der alten Kaserne \\
Soldaten, Unterstützung Hinterbliebener \\
Soldaten, Wahlberechtigte \\
Soldatenheime, Spende \\
Sommerzeit, Einführung \\
Sonderöffnungszeiten, Sonntage vor Weihnachten \\
Sonn- und Feiertage, Schutz
\end{tabular}

Sonn- und Feiertagsarbeit, Statistik für Emden Sonntage, Sonderöffnungszeiten Sonntagsarbeit, Anträge auf Zulassung

Sonntagsruhe, Handel in Emden

Sozialdemokratie, Bekämpfung

Sozialdemokratie, Verbot von Schriften

Sozialdemokratischer Arbeiterverein in Emden, Statuten Sparkasse, Bilanzen

Sparkasse, Kreditvergabe an Genossenschaften Sparkasse, Satzungsmodernisierung

Sparkasse, Statuten

Sparkasse, Zentralisierungsprojekt

Sparkassengesetz, Novellierung

Sparkassenüberschüsse, Verwendung

Sparkassenwesen, Erlasse u. Verfügungen

Speiseanstalt, Errichtungsantrag für Nesserland Spenden, Verwendung

Spendenaufrufe, Kaiserliches Regieungsjubiläum

Spendensammlung, Bau eines Turms a. d. kath. Kirche in Emden Spendensammlung, Hinterbliebene d Besatzung Lotsenschoner Sperlinge, Antrag auf Erschießen

Spielorte, Märkisches Wandertheater

Spielpläne, Märkisches Wandertheater

Spielplatz, Anlageantrag

Spionage, Bekämpfung

Spirituosen, Außerhausverkauf

Laufzeit

1903

1904

1905

1907

1911

1912

1914

1916

1915

1919

1920

1910

1897-1914

1908-1910

1908-1914

1914-1915

1874-1888

1917-1918

1866-1867

1917

1916-1917

1912-1916

1911-1916

1891-1898

1898-1911

1911-1916

1885

1911-1916

1891-1898

1898-1911

1911-1916

1911-1916

$1880-1913$

1888-1915

1867-1891

1880-1891

1891-1912

1860-1871

1904-1913

1898-1916

1874-1906

1874-1906

1901-1902

1888-1893

1881-1912

1871-1909

1881-1912

1867-1876

1916

1913

1872-1892

1874

1881-1913

1912-1914

1912-1914

1909-1910

1914-1915

1904-1915
Lfd.Nr.

62


Index

\begin{tabular}{l}
\hline \\
\hline Indexbegriff \\
\hline Spirituosen, Kleinhandelszulassung \\
Spirituosen-Akzise, Befreiungsanträge \\
Spirituosen-Akzise, Einführung \\
Spirituosen-Akzise, Satzungsversöße \\
Spirituosenhandel, Zulassung \\
Sportruderboot, Antrag auf Überlassung \\
Sprengstoff, Überladen \\
Sprengwagen, Anschaffung \\
Spritzenprämie, Anträge \\
Spritzenprämien, Hydranten-Abteilung \\
Spritzenprämien-Gelder, Nachweis \\
Spülgraben, Anlage \\
Staatsangehörigkeitsausweise, Anforderung von Formularen \\
Staatsangehörigkeitsscheine, Austellung \\
Staatsbauten, Zuständigkeiten im Genehmigungsverfahren \\
Staatsbeamte, Bescheinigung über leer stehende Wohnung \\
Staatsbeihilfe, Kaiser-Friedrich-Realschule
\end{tabular}

Staatsbürgerrecht, Einführung des preußischen in Hannover Staatsgebäude, Baupolizeiliche Zuständigkeit

Staatsschuldverschreibungen, Anlage der reformierten Gemeinde Staatssteuern, Rückstände der Gemeinde Borssum

Stacket, Zaun vor dem Heyl'schen Haus

Stackett, Anordnung der Zurücksetzung

Stadt Emden, Gebührenordnungen

Stadt Emden, Mitgliedschaft im Verein gegen das Moorbrennen

Stadt Emden, Ortsbeschreibung

Stadt Emden, Prozesse wegen Forderungen

Stadt Emden, Statistische Berichte

Stadt Emden, Vereinsmitgliedschaft

Stadt Emden, Vermögens- und Schuldenstand

Stadt Emden, Verträge

Stadt- und Hafenanlage, Erweiterung

Stadtansichten, Angebote

Stadtausbau, Gebietserweiterung

Stadtausklingler, Gebührensatzung

Stadtausklingler, Instruktionen

Stadtausklinglerstellen, Bewerbungen

Stadtbauaufseher, Bewerbung

Stadtbauaufseher, Dienstinstruktion

Stadtbauaufseher, Einstellung

Stadtbauaufseher, Einstellung und Besoldung

Stadtbauaufseher, Entlassung

Stadtbauaufseher, Ermittlungen wegen Unfall

Stadtbauaufseher, Vereidigung

Stadtbauaufseher, Wahl

Stadtbauaufseherstelle, Ausschreibung

Stadtbaumeister, Wahl

Stadtbezirke, Neueinteilung

Stadtbrunnen

Stadtdeiche, Schauungen

Stadtdiener, Besoldung

Stadtdünger, Verkauf

\section{Laufzeit}

Lfd.Nr.

1869

1883-1905

1867-1879

1883-1902

1866-1886

1901-1912

1873-1912

1878-1909

1889-1896

1882-1904

1897-1911

1882-1904

1883-1885

1879-1922

1879-1922

1897-1903

1868-1898

1886-1900

1898-1903

1902-1903

1905-1909

1908-1918

1866-1913

1870-1900

1870-1885

1910-1911

1879-1888

1880-1906

1877-1912

1879-1880

1904-1911

1866-1871

1871-1891

1904-1911

1879-1880

1905-1909

1872-1916

1896-1906

1867-1901

1867-1907

1867-1882

1867-1882

1867-1882

1865-1871

1865-1871

1865-1871

1876

1865-1871

1865-1871

1865-1871

1865-1871

1865-1871

1858

1903

1875-1895

1867-1890

1865-1866

1876-1882

\subsection{9}

2.921

2.918

2.922

1.950

642

1.505

851

861

1.384

1.386

1.384

914

449

449

1.139

1.245

3.744

3.747

3.748

3.749

3.750

452

1.161

3.382

248

1.215

1.179

324

621

456

2.674

455

456

623

2.988

330

998

310

237

431

431

431

438

438

438

1.207

438

438

438

438

438

441

1.536 
Index

SACH

Indexbegriff

Stadtentwicklung, Statistische Berichte

\section{Laufzeit}

1884-1896

$1871-1891$

1904-1911

1900

1901

1902

1903

1904

1905

1906

1907

1908

1909

1910

1911

1912

1913

Städteordnung, Initiative zur Veränderung

Städteordnung, Reform

Stadterweiterung, Planung der Straßen

Städtetag, Einladungen

Städtetag, Entsendung Emder Vertreter

Städtetag, Pressebericht

Städtetag, Tagung in Leer

Städtetag, Tätigkeitsbericht

Stadtführer, Emden

Stadtgarten, Beleuchtung

Stadtgarten, Schutz

Stadtgarten, Verbot der Passage von Waren

Stadtgebiet, Erweiterung

Stadtgebiet, Gutachten für Erweiterung

Stadtgericht, Einnahmen und Ausgaben

Stadtgericht, Gehälter

Stadtgeschichte, Fachpublikationen

Stadtgräben, Ausbaggerung

Stadtgräben, Pegelungen

Stadtgräben, Reinigung

Stadtgraben, Verbreiterung

Stadtküche, Modell

Stadtpark, Initiative

Stadtphysicus, Verankerung in das Ortsstatut der Stadt Emden

Stadtplan, Abgabe

Stadtplan, Druckangebote

Stadtplan, Herstellung

Stadtpolder, Aufhöhung

Stadtreinigung, Etat

Stadtrelief, Angebot für SMS Emden

Stadtschuldeputation, Bildung

Stadtschuldeputation, Geschäftsführung

Stadtschuldeputation, Kompetenzabgrenzung

Stadtschuldeputation, Sitzungsprotokolle

Stadtsekretär, Dienstanweisung

Stadtsekretär, Ehrengeschenk

Stadtsekretär, Ernennung

Stadtsekretär, Gehaltszulage
1848-1915

1876-1907

1896-1906

1888-1893

1894-1901

1894-1901

1894-1901

1905-1906

1905-1906

1905-1911

1897-1907

1872-1895

1872-1895

1883-1911

1883-1911

1848-1915

1848-1915

1867-1901

1867-1910

1867-1910

1867-1910

1875-1901

1916

1905-1911

1866-1914

1902-1907

1902-1907

1902-1907

1885-1887

1886-1894

1908-1910

1906-1908

1908-1914

1908-1914

1908-1911

1902-1911

1854-1888

1902-1911

1902-1911

1879-1907

1854-1888
Lfd.Nr. 900 455

456

465

466

467

468

469

470

471

472

473

474

475

476

477

478

1

4

998

586

587

587

587

588

588

673

1.017

985

985

231

231 
Index

\begin{tabular}{l}
\hline \\
Indexbegriff \\
\hline Stadtsekretär, Nachruf \\
Stadtsekretär, Pensionierung \\
Stadtsekretär, Pensionierungsleiden \\
Stadtsekretär, Vereidigung \\
Stadtsekretär, Wahl \\
Stadtsiegelgeld, Abgabe bei Umschreibung d. Besitztitel \\
Stadtsiegelgeld, Einnahmen
\end{tabular}

Stadtsiegelgeld, Rechnungsabnahme

SACH

Stadtsiel, Nottüren

Stadtsiele, Außerfunktionssetzung

Stadtsiele, Beseitigung

Stadtsiele, Besichtigung

Stadtsiele, Erhaltungsklage

Stadtsyndicus, Bestätigung durch Allerhöchste Kabinettsordre

Stadtsyndicus, Bewerberlisten

Stadtsyndicus, Bewerbung

Stadtsyndicus, Gehaltserhöhung

Stadtsyndicus, Gehaltszulage

Stadtsyndicus, Gerichtsfunktion

Stadtsyndicus, Pensionierung

Stadtsyndicus, Stellenausschreibung

Stadtsyndicus, Stellenschaffung

Stadtsyndicus, Verabschiedung

Stadtsyndicus, Vereidigung

Stadtsyndicus, Vertretung des Oberbürgermeisters

Stadtsyndicus, Wahl

Stadtsyndicus, Wahl in Aufsichtsrat

Stadtsyndicus, Weggang

Stadtwaage, Verpachtung

Standbild, Friedrich Wilhelm, Kurfürst v: Brandenburg

Standbild, Preuißischer König Friedrich II.

Standbilder, Enthüllung

Standgebühren, Vergnügungsbuden

Stapellauf, SMS Emden

Stapellauf, SMS "Emden"

Starkstromanlagen, Sicherheitsvorschriften

Starkstromleitung, Genehmigungsverfahren

Starkstromwegegesetz, Verhandlungen

Statistik, Berichte zu Verwaltungsbereichen

Laufzeit

1902-1911

1879-1907

1854-1888

1879-1907

1854-1888

1854-1888

1897-1899

1901-1912

1902

1907

1908

1909

1897-1899

1901-1912

1867-1890

1885-1888

1885-1888

1867-1910

1878-1888

1885-1888

1901-1908

1907-1911

1901-1908

1868-1912

1911-1917

1907-1911

1868-1912

1901-1908

1907-1911

1868-1912

1901-1908

1901-1908

1911-1917

1901-1908

1868-1912

1901-1908

1907-1911

1911-1917

1901-1908

1907-1911

1911-1917

1877-1910

1909-1918

1900-1901

1900-1901

1901

1868-1909

1908-1910

1908-1914

1887-1913

1909-1910

1887-1913

1868-1869

1869-1870

1870-1871

1895-1914

1914-1918

1911
Lfd.Nr.

333

334

335

335

2.940

2.941

2.943

2.944

2.945

2.946

2.940

2.941

1.536

917

917

1.490

1.493

917

31

32

31

30

33

32

30

31

32

30

31

31

33

31

30

31

32

33

31

32

33

2.653

2.654

203

203

181

2.144

270

271

1.248

1.096

1.248

318

319 
Index

\begin{tabular}{|c|c|c|}
\hline \multicolumn{3}{|l|}{ SACH } \\
\hline Indexbegriff & Laufzeit & Lfd.Nr. \\
\hline Statistik, Berichte zu Verwaltungsbereichen & 1905-1906 & 2.368 \\
\hline Statistik, Emder Hafenverkehr & 1905-1906 & 2.368 \\
\hline Statistik, Gesundheitswesen & 1905-1906 & 2.368 \\
\hline Status, Verein für Diakonissen-Krankenpflege & $1861-1903$ & 577 \\
\hline Statuten, Asyl für altersschwache und hilfsbedürftige Israeliten & 1885-1895 & 496 \\
\hline Statuten, Bezirksverein für den 1. und 2. Bezirk der III Wyk & 1902 & 653 \\
\hline Statuten, Freier Verein vom Roten Kreuz (Enthaltsamkeitsverein) & 1907 & 681 \\
\hline Statuten, Hannoverscher Obstbauverein & 1879-1905 & 796 \\
\hline Statuten, Landwirtschaftliche Gesellschaft & 1879-1905 & 796 \\
\hline Statuten, Landwirtschaftlicher Verein für Ostfriesland & $1879-1905$ & 796 \\
\hline Statuten, Schiffer-Witwen- und Waisenkasse "Eendragt" & 1904-1906 & 1.752 \\
\hline Statuten, Seemaschinistenverein für Emden und Umgegend & 1903-1908 & 657 \\
\hline Statuten, Singverein "Frohsinn" & 1877 & 652 \\
\hline Statuten, Verein für Diakonissen-Krankenpflege & $1861-1903$ & 577 \\
\hline Statuten, Zentralverband der Zimmerer Deutschlands & $1901-1907$ & 655 \\
\hline Staubsauger, Antrag auf Anschaffung & 1893-1912 & 274 \\
\hline Steinhauerhandwerk, Zulassung & $1866-1867$ & 1.945 \\
\hline Stellennachweise, Kaufmännische Angestellte & 1911-1914 & 713 \\
\hline Stempel, Anschaffung & 1893-1912 & 274 \\
\hline Stempel, Erlass über Gebrauch & 1893-1912 & 274 \\
\hline Stenographie - Systeme, Vergleich & $1901-1913$ & 693 \\
\hline Stenographie, Wettbewerb & $1901-1913$ & 693 \\
\hline Stephans-Denkmal, Enthüllungsfeier & 1894-1897 & 2.394 \\
\hline Stephans-Denkmal, Spendenaufruf & 1894-1897 & 2.394 \\
\hline Sterbe- und Pensionskassen, Verzeichnis für die Stadt Emden & $1910-1918$ & 1.670 \\
\hline Sterbekassen, Satzungen & $1902-1913$ & 1.671 \\
\hline Sterbekassen, Versicherung von Kinder & $1902-1913$ & 1.671 \\
\hline Sterbekassen, Versicherungsmathematische Prüfung & $1902-1913$ & 1.671 \\
\hline Steuer, Ablösung direkte durch indirekte & 1879-1894 & 2.890 \\
\hline Steuerakten, Vernichtung & $1866-1914$ & 317 \\
\hline Steuerforderung, Pfändung & 1908-1914 & 2.878 \\
\hline \multirow[t]{5}{*}{ Steuerleute, Gewerbezulassung } & $1881-1883$ & 1.599 \\
\hline & 1884-1885 & 1.600 \\
\hline & $1886-1890$ & 1.601 \\
\hline & 1890-1894 & 1.602 \\
\hline & $1895-1903$ & 1.603 \\
\hline Steuermänner, Befähigungszeugnisse & $1867-1879$ & 1.565 \\
\hline Steuermänner, Emden & $1867-1872$ & 1.566 \\
\hline Steuermänner, Prüfungsordnung & $1877-1915$ & 1.567 \\
\hline Steuermänner, Qualifikationsnachweis & 1877-1915 & 1.567 \\
\hline Steuermänner, Zulassung von Niederländern auf Heringslogger & $1877-1915$ & 1.567 \\
\hline Steuermanns- und Schifferprüfungen, Ausschlüsse & 1870-1909 & 1.591 \\
\hline Steuermanns-Prüfungskommission, Ernennung von Mitgliedern & 1871-1895 & 1.588 \\
\hline Steuern, Umgehung durch Umzug & 1900-1905 & 255 \\
\hline Steuerpflicht, Feststellung & 1905 & 2.862 \\
\hline \multirow[t]{4}{*}{ Steuerpflichtige, Verbindlichkeiten } & $1877-1888$ & 2.866 \\
\hline & $1882-1883$ & 2.867 \\
\hline & $1885-1886$ & 2.868 \\
\hline & $1889-1890$ & 2.869 \\
\hline Steuer-Restanten, Aufstellung für Borssum & $1910-1911$ & 248 \\
\hline Steuersystem, Einführung des preußischen & 1867 & 2.873 \\
\hline Steuertarife, Anpassung an Münzneuordnung & $1866-1912$ & 257 \\
\hline Steuerverhältnisse, Datenerhebung & $1895-1913$ & 2.982 \\
\hline Stichwahl, Reichstag & $1866-1867$ & 216 \\
\hline Stiftung, Errichtung & $1884-1914$ & 3.465 \\
\hline Stiftung, Unterstützung lutherischer Arme & 1879-1909 & 1.727 \\
\hline Stiftung, Unterstützungen & 1867-1902 & 3.455 \\
\hline Stiftung, Vermögen & 1904 & 3.469 \\
\hline
\end{tabular}


IV

Index

\section{SACH}

\begin{tabular}{l} 
Indexbegriff \\
\hline Stiftung, Vermögen \\
Stiftungen, Inventarien \\
Stiftungen, Rechnungslegung in der lutherischen Gemeinde \\
Stiftungsfest, Anzeige
\end{tabular}

Stiftungsgelder, der Gesellschaft zur Rettung Schiffsbrüchiger Stiftungskapital, Anlage

Stigt, Benutzung

Stigt, Verbotene Ablagerung von Dünger

Stigte, Reinigung

Stigte, Schadhafte

Stol-Gebühren, Aufhebung

Stotterheilanstalt, Errichtung

Straferlass, Auswanderung ohne Erlaubnis

Strafgefangene, Entlassungsnachricht

Strafgesetzbuch, Einführung und Umsetzung

Strandungsgut, Einnahmeverwendung

Straße "Am Hundepfad", Ausbau

Straße, "Abdena-Straße"

Straße, "Am Falderntor"

Straße, "Am Pannewarf"

Straße, Anlegung

Straße, "Annastraße"

Straße, "Auricher Straße"

Straße, "Außer dem alten Neutor"

Straße, "Außer dem Neuen Tor"

Straße, "Außer dem Nordertor"

Straße, "Beuljenstraße"

Straße, "Bismarckstraße"

Straße, "Bolardus-Straße"

Straße, Borssumer Landstraße

Straße, "Brandenburger Straße"

Straße, "Celos-Straße"

Straße, "Edzard-Str."

Straße, "Eggena-Straße"

Straße, "Elisabethstraße"

Straße, "Emsmauerstraße"

Straße, "Emsstraße"

Straße, "Faberstraße"

Straße, "Fletumer Str."

Straße, "Franz-Merkensstr."

Straße, "Gartenstraße"

Straße, "Große Straße"

Straße, "Hafenstraße"

Straße, "Hinter dem alten Schlachthaus"

Straße, "Hinter dem Deich"

Straße, "Hinter der Emsmauer"

Straße, Hof von Holland

Straße, "Küstenbahnstraße"

Straße, "Neptunstraße"

Straße, "Neutors Breitergang"

Straße, "Nordertorstraße"

Straße, "Parallelstraße"

Straße, Pflasterung

Straße, "Ringstraße"

Straße, Schmälerung durch "Wanderung"

Straße, "Schweckendieckstraße"

\section{Laufzeit}

1899-1913

1906

1895-1918

1903-1908

1903-1907

1879-1905

1867-1902

1869-1912

1898-1913

1898-1913

1910-1912

1872-1892

1890

1866-1913

1871-1872

1874-1913

1870-1881

1900-1901

1869-1913

1905-1909

1904-1905

1893-1895

1896-1898

1869-1913

1869-1913

1869-1913

1869-1913

1869-1913

1903

1869-1913

1869-1913

1900-1907

1869-1913

1869-1913

1869-1913

1869-1913

1869-1913

1869-1913

1869-1913

1869-1913

1869-1913

1869-1913

1869-1913

1903-1904

1869-1913

1869-1913

1869-1913

1869-1913

1869-1913

1869-1913

1869-1913

1898-1900

1906-1907

1869-1913

1888-1902

1869-1913

1874-1905

1869-1913
Lfd.Nr.

3.470

3.476

3.467

657

658

622

3.455

2.121

854

854

1.160

3.488

3.856

452

1.707

172

1.630

1.001

829

1.009

1.008

987

991

829

829

829

829

829

1.006

829

829

1.023

829

829

829

829

829

829

829

829

829

829

829

1.007

829

829

829

829

829

829

829

1.004

1.010

829 
Index

SACH

Indexbegriff

Straße, St. Joris-Str.

Straße, "Stephans-Platz"

Straße, Streit um Reinigung

Straße, "Theda-Straße"

Straße, "Ulrich-Str."

Straße, Verbreiterung

Straße, Verkabelung

Straße, Verschmutzung

Straße, "Wilhelmsstraße"

Straßen, Aufsellung

Straßen, Benennung

Straßen, Blockade

Straßen, Blockierung

Straßen, Hindernis

Straßen, Umbenennung

Straßen, Umgestaltung in der Emder Innenstadt

Straßen, Unpassierbarkeit

Straßen, Unterhaltung

Straßenanlage, Finanzierungsabsicherung

Straßenausbau, Finanzierung durch Anlieger

Straßenbahn, Abschreibungskosten

Straßenbahn, Aktenstücke zur Gründungsgeschichte

Straßenbahn, Anlage

Straßenbahn, Anschaffungen für

Straßenbahn, Arbeitertarife

Straßenbahn, Ausbauplan

Straßenbahn, Bahntakt

Straßenbahn, Bau

Straßenbahn, Beschwerden

Straßenbahn, Betrieb

Straßenbahn, Betriebseinnahmen

Straßenbahn, Betriebsergebnisse

Straßenbahn, Betriebslager

Straßenbahn, Betriebsleiter

Straßenbahn, Betriebsordnung

Straßenbahn, Betriebsorganisation

Straßenbahn, Betriebsstörungen

Straßenbahn, Betriebsvorschriften

Straßenbahn, Bilanz

Straßenbahn, Bürgschafts- und Garantieverträge

Straßenbahn, Bürogebäude

Straßenbahn, Darlehen

\section{Laufzeit}

1869-1913

1869-1913

1869-1913

1867-1908

1869-1913

1869-1913

1905-1909

1912-1913

1901-1912

1869-1913

1878-1909

1869-1913

1876-1889

1901-1912

1897-1914

1869-1913

1896-1906

1875-1909

1870

1900-1903

1901-1902

1900-1901

1898-1900

1910-1911

1901-1904

1900-1901

1900-1901

1902-1905

1902-1917

1907

1912-1914

1902-1907

1900-1909

1910-1913

1914-1918

1902-1913

1896-1910

1908-1910

1902-1915

1902-1915

1904

1902-1917

1902-1913

1900-1909

1910-1913

1914-1918

1896-1910

1902-1917

1909-1910

1910-1911

1911-1912

1915-1916

1918-1919

1900-1902

1908-1910

1902-1905

1908-1910

1896-1910
Lfd.Nr.

829

829

829

846

829

829

1.009

1.107

840

829

851

829

843

840

838

829

998

836

849

1.165

1.000

1.001

1.004

1.983

1.988

1.957

1.958

1.960

1.968

1.993

1.994

1.967

1.970

1.972

1.973

1.969

1.976

1.961

1.977

1.977

1.989

1.992

1.974

1.970

1.972

1.973

1.976

1.992

1.982

1.983

1.984

1.985

1.986

1.964

1.961

1.960

1.961

1.976 
Index

SACH

\begin{tabular}{|c|}
\hline Indexbegriff \\
\hline
\end{tabular}

Straßenbahn, Defizit

Straßenbahn, Entlastung der Betreiberfirma

Straßenbahn, Erneuerungsfonds

Straßenbahn, Erweiterungsplan

Straßenbahn, Fahrplan

Straßenbahn, Fahrpläne

Straßenbahn, Fahrpreisermäßigungen

Straßenbahn, Finanzierungsfragen

Straßenbahn, Gütertarif

Straßenbahn, Haltestelle auf Nesserland

Straßenbahn, Inspektion

Straßenbahn, Jahresabschluss

Straßenbahn, Jahresrechnung

Straßenbahn, Kapitalerhöhung

Straßenbahn, Konzessionierung

Straßenbahn, Kostenvoranschlag

Straßenbahn, Lagernutzung

Straßenbahn, Leitungsnetz

Straßenbahn, Linienführung

Straßenbahn, Presse

Straßenbahn, Realisierung

Straßenbahn, Rechnungsabschluss

Straßenbahn, Rechnungsführung

Straßenbahn, Rechnungsjahr

Straßenbahn, Rechnungslegung

Straßenbahn, Rechnungsprüfung

Straßenbahn, Rentabilitätsberechnung

Straßenbahn, Sabotage

Straßenbahn, Schülertarif

Straßenbahn, Spezialreservefonds

Straßenbahn, Tarife

Straßenbahn, Triebwagen

Straßenbahn, Unfälle

Straßenbahn, Verhandlungen

Straßenbahn, Verpachtung

\section{Laufzeit}

1911-1912

1918-1919

1904-1906

1906-1912

1908-1909

1909-1910

1909-1910

$1912-1917$

1908-1909

1907

1902-1907

1902-1917

1902-1907

1902-1917

1900-1909

1910-1913

1914-1918

1902-1907

1896-1910

1902-1917

1904-1906

1906-1912

1911-1912

1903-1904

1904-1906

1908-1909

1909-1910

1910-1911

1911-1912

1915-1916

1918-1919

1902-1905

1904

1900-1901

1904

1900-1904

1900-1901

1900-1901

1900-1901

1910-1911

1908-1909

1902-1903

1910-1911

1903-1904

1906-1912

1909-1910

1910-1911

1902-1905

1896-1910

1902-1917

1914

1902-1907

1902-1917

1902-1905

1908-1910

1896-1910

1900-1901

1902-1907
Lfd.Nr.

1.984

1.986

1.979

1.980

1.981

1.982

1.982

1.975

1.981

1.990

1.967

1.968

1.967

1.968

1.970

1.972

1.973

1.967

1.976

1.992

1.979

1.980

1.984

1.978

1.979

1.981

1.982

1.983

1.984

1.985

1.986

1.960

2.000

1.957

1.989

1.965

1.957

1.957

1.958

1.983

1.981

1.963

1.983

1.978

1.980

1.982

1.983

1.960

1.976

1.968

1.995

1.967

1.968

1.960

1.961

1.976

1.958

1.967 
Index

\begin{tabular}{|c|c|c|}
\hline \multicolumn{3}{|l|}{ SACH } \\
\hline Indexbegriff & Laufzeit & Lfd.Nr. \\
\hline \multirow[t]{2}{*}{ Straßenbahn, Waggonhalle } & 1902-1905 & 1.960 \\
\hline & $1908-1910$ & 1.961 \\
\hline Straßenbahn, Wertpapiere & 1911-1912 & 1.984 \\
\hline Straßenbahn, Zahlungsabwicklung & $1901-1906$ & 1.962 \\
\hline Straßenbahn, Zinsen für Baudarlehen & $1910-1911$ & 1.983 \\
\hline Straßenbahn, Zinszahlungen an Betreiberfirma & 1908-1909 & 1.981 \\
\hline Straßenbahnbedienstete, Alkoholverein & $1902-1917$ & 1.992 \\
\hline Straßenbahnbedienstete, Gehaltsanpassung & $1902-1917$ & 1.992 \\
\hline Straßenbahnbedienstete, Sicherheitsbestimmungen & 1902-1917 & 1.992 \\
\hline Straßenbahnbedienstete, Verhaltensregeln & $1902-1917$ & 1.992 \\
\hline Straßenbahnbetrieb, Energiebezug & $1901-1914$ & 1.966 \\
\hline Straßenbahnbetrieb, Jahresabschluss & $1902-1918$ & 1.997 \\
\hline Straßenbahnbetrieb, Rechnungsabnahme & 1905-1908 & 1.998 \\
\hline Straßenbahnbetrieb, Schulden & $1901-1912$ & 1.999 \\
\hline Straßenbahnbetrieb, Sicherheitsvorschriften & $1902-1917$ & 1.992 \\
\hline Straßenbahnen, Material & 1900 & 1.959 \\
\hline Straßenbahnhaltestellen, Vandalismus & 1904-1910 & 1.991 \\
\hline Straßenbahnhaltestellen, Wartehallen & $1904-1910$ & 1.991 \\
\hline Straßenbahnhaltestellen, Wartehäuschen & 1904-1910 & 1.991 \\
\hline Straßenbahnlinie, Konzessionierungsantrag & 1904 & 1.987 \\
\hline Straßenbahnnetz, Ausbau & 1907-1908 & 1.083 \\
\hline Straßenbahnverbindung, Emden in die Krummhörn & $1880-1882$ & 1.996 \\
\hline Straßenbau, Ausschreibung & 1893-1895 & 987 \\
\hline Straßenbau, Beihilfeauszahlung & 1875-1889 & 2.035 \\
\hline Straßenbau, Bodenabtretung & $1875-1879$ & 1.015 \\
\hline Straßenbau, Umlage & $1867-1878$ & 2.031 \\
\hline \multirow[t]{3}{*}{ Straßenbaufinanzierung, Anlieger } & 1896-1898 & 991 \\
\hline & 1897-1902 & 992 \\
\hline & $1897-1900$ & 994 \\
\hline Straßenbäume, Angebot & 1893-1895 & 987 \\
\hline Straßenbauprojekte, Anleihen & 1896-1906 & 998 \\
\hline Straßenbauprojekte, Beihilfe der Provinz Hannover & $1867-1881$ & 2.033 \\
\hline Straßenbauprojekte, Beschreibung und Kosten & 1875-1889 & 2.035 \\
\hline Straßenbauverwaltung, Organisation & $1867-1878$ & 2.031 \\
\hline Straßenbeleuchtung, Anlage an der Borssumer Landstraße & 1900-1907 & 1.023 \\
\hline Straßenbeleuchtung, Ausgaben & 1897-1907 & 1.017 \\
\hline Straßenbeleuchtung, Bahnhofsgebiet & 1881-1897 & 1.020 \\
\hline Straßenbeleuchtung, Betrieb mit Wassergas & 1892-1899 & 1.068 \\
\hline Straßenbeleuchtung, Gasbasis & $1897-1907$ & 1.017 \\
\hline Straßenbeleuchtung, Gaslicht & 1895-1912 & 1.021 \\
\hline Straßenbeleuchtung, Herstellung i. d. Ring- u. Schweckendieckstraße & 1904-1909 & 1.059 \\
\hline Straßenbeleuchtung, Installation & $1900-1903$ & 1.165 \\
\hline Straßenbeleuchtung, Larrelter Haltestelle & $1881-1897$ & 1.020 \\
\hline Straßendung, Absatz & $1869-1885$ & 869 \\
\hline Straßengeld, Abschaffung & 1870 & 849 \\
\hline Straßenkot, Düngerwert & 1869-1885 & 869 \\
\hline \multirow[t]{4}{*}{ Straßenkot, Verkauf } & $1905-1912$ & 863 \\
\hline & 1882-1885 & 864 \\
\hline & $1867-1906$ & 865 \\
\hline & $1876-1882$ & 871 \\
\hline Straßenlaternen, Anschaffung & 1876-1897 & 1.016 \\
\hline \multirow[t]{2}{*}{ Straßenlaternen, Aufstellung } & $1897-1907$ & 1.017 \\
\hline & $1908-1911$ & 1.018 \\
\hline Straßenlaternen, Aufstellung über & $1876-1897$ & 1.016 \\
\hline Straßenlaternen, Austausch & $1876-1897$ & 1.016 \\
\hline \multirow[t]{3}{*}{ Straßenlaternen, Beschädigung } & $1876-1897$ & 1.016 \\
\hline & $1897-1907$ & 1.017 \\
\hline & $1908-1911$ & 1.018 \\
\hline
\end{tabular}


Index

\begin{tabular}{|c|c|c|}
\hline \multicolumn{3}{|l|}{ SACH } \\
\hline Indexbegriff & Laufzeit & Lfd.Nr. \\
\hline Straßenlaternen, Beschädigung durch Fuhrwerke & $1866-1893$ & 1.041 \\
\hline Straßenlaternen, Brennkalender & 1886-1909 & 1.019 \\
\hline Straßenlaternen, Emden & $1895-1912$ & 1.021 \\
\hline Straßenlaternen, Erneuerung & $1876-1897$ & 1.016 \\
\hline Straßenlaternen, Ersetzung der mit Petroleum betriebenen & $1897-1907$ & 1.017 \\
\hline Straßenlaternen, Erwerb durch Gaswerk & 1914 & 1.025 \\
\hline Straßenlaternen, Haftung bei Beschädigung & $1875-1899$ & 1.038 \\
\hline Straßenlaternen, Leuchtqualität & 1886-1909 & 1.019 \\
\hline \multirow[t]{2}{*}{ Straßenlaternen, Nachtbetrieb } & $1897-1907$ & 1.017 \\
\hline & $1908-1911$ & 1.018 \\
\hline Straßenlaternen, Rechnungen zum Betrieb & $1881-1897$ & 1.020 \\
\hline Straßenlaternen, Reparatur die Angestellte des Gaswerks & $1875-1899$ & 1.038 \\
\hline Straßenordnung, Entwurf & 1874-1894 & 845 \\
\hline Straßenordnung, Stadt Emden & $1901-1912$ & 840 \\
\hline Straßenordnung, Wolthusen & $1880-1913$ & 254 \\
\hline Straßenpflasterung, Mängel & $1900-1903$ & 1.165 \\
\hline Straßenpolizei, Regelungen zu Kutschen, Reitern u. Fuhrwerken & $1878-1891$ & 830 \\
\hline Straßenreinigung, Angebote von Maschinen und Geräten & 1894-1908 & 872 \\
\hline \multirow[t]{2}{*}{ Straßenreinigung, Ausschreibung } & $1882-1885$ & 864 \\
\hline & 1867-1906 & 865 \\
\hline Straßenreinigung, Beschwerden & 1879-1909 & 877 \\
\hline Straßenreinigung, Organisation & $1888-1895$ & 2.537 \\
\hline \multirow[t]{7}{*}{ Straßenreinigung, Pflicht der Anlieger } & $1897-1914$ & 838 \\
\hline & 1899-1902 & 853 \\
\hline & 1906-1908 & 856 \\
\hline & 1906-1908 & 857 \\
\hline & 1908-1909 & 858 \\
\hline & $1909-1911$ & 859 \\
\hline & 1910 & 860 \\
\hline Straßenreinigung, Übernahme durch die Stadt & $1878-1909$ & 851 \\
\hline Straßenreinigung, Unterlassene & 1867-1906 & 865 \\
\hline Straßenreinigung, Vergabe & 1878-1909 & 851 \\
\hline \multirow[t]{2}{*}{ Straßenreinigung, Verweigerung } & 1908-1909 & 858 \\
\hline & $1909-1911$ & 859 \\
\hline Straßenreinigungsmaschinen, Angebote & $1889-1896$ & 861 \\
\hline Straßenumzüge, Anträge & $1901-1912$ & 840 \\
\hline Straßenverzeichnis, Angaben zu Fluchtlinien u. Bebauungspläne & 1911 & 1.152 \\
\hline Straßenverzeichnis, Brandkataster der Stadt Emden & $1869-1913$ & 829 \\
\hline Streik, Schutz arbeitswilliger Hafenarbeiter & $1905-1906$ & 675 \\
\hline Stricklehrerin, Ruhestandsgehalt & 1886-1905 & 3.683 \\
\hline Stroh- und Heuhaufen, Lagerung & 1867-1908 & 1.293 \\
\hline Stroh, Bewirtschaftung & 1918 & 3.302 \\
\hline Stroh, Feuergefährliche Lagerung & 1867-1902 & 1.257 \\
\hline Strohdeich, Abtragung & 1894-1898 & 993 \\
\hline Strohdeich, Schutz durch Rampe & $1885-1907$ & 1.543 \\
\hline Strom, Einspeisungsangebot & $1905-1911$ & 1.097 \\
\hline Strombezug, Antrag auf Genehmigung & $1905-1911$ & 1.097 \\
\hline Stromkunden, Erfassung & 1907-1908 & 1.083 \\
\hline Stromleitung, Anlegungsantrag & $1905-1911$ & 1.097 \\
\hline Stromleitung, Beschädigung & 1912 & 1.106 \\
\hline Stromleitung, Beschwerde wegen Führung & 1912 & 1.106 \\
\hline Stromleitungen, Besitzbeeinträchtigung & 1913 & 1.119 \\
\hline Stromleitungen, Führung über wasserbaufiskalisches Gebiet & $1912-1913$ & 1.110 \\
\hline \multirow[t]{2}{*}{ Stromleitungen, Masten } & 1912 & 1.116 \\
\hline & 1912 & 1.117 \\
\hline \multirow[t]{2}{*}{ Stromleitungen, Verlegung über Bahngelände } & 1912 & 1.106 \\
\hline & $1910-1913$ & 1.109 \\
\hline Stromleitungsanschlüsse, Emden & $1912-1913$ & 1.107 \\
\hline
\end{tabular}


Index

\section{SACH}

\begin{tabular}{l} 
Indexbegriff \\
\hline Stromleitungsbau, Kosten \\
Stromleitungskabel, Bahngelände \\
Stromleitungsnetz, Anschluss an fiskalisch \\
Stromleitungsnetz, Anschlüsse \\
Stromleitungsnetz, Anschlussvorschriften \\
Stromleitungsnetz, Anschlusswillige \\
Stromleitungsnetz, Aufbau
\end{tabular}

Stromleitungsnetz, Aufbau und Unterhaltung

Stromleitungsnetz, Beratertätigkeit des Oberingenieurs Sturm Stromleitungsnetz, Beratungsangebote

Stromleitungsnetz, Einrichtung

Stromleitungsnetz, Hausanschlüsse

Stromleitungsnetz, Hausanschlüsse durch freie Installateure

Stromleitungsnetz, Lieferungsbedingungen

Stromleitungsnetz, Rentabilitätsberechnung

Stromleitungsnetz: Bauverzögerung

Stromleitungsplan, Emden

Stromleitungspläne

Stromlieferungsvertrag, Abschluss

Stromlieferungsverträge, Beratung durch Experten

Stromlieferungsverträge, Entwürfe

Stromnetz, Anlage

Stromnetz, Anschluss

Stromnetz, Konzeptangebot

Stromnetzbetreiber, Broschüren

Stromnetzbetreiber, Vertragsentwürfe

Stromnetzbetreiber, Wettbewerbsverhinderung

Strompreise, Ermäßigungsanträge

Strompreise, Protest

Stromtarife, Zeitungsannoncen

Stromzähler, Angebote

Stromzähler, Anschaffung und Installierung

Stübergeld, Abzugsfähigkeit von der Einkommenssteuer

Stübergeld, Befreiungsantrag

Stübergeld, Erhebung

Stübergeld, Widerspruch gegen Festsetzung

Sturmflut, Bericht

Submissionswesen, Streikklausel

Südfalderndeich, Abtragung

Süßigkeiten, Verkaufsverbot

Synagogengemeinden, Unterstützung

Synagogenvorsteher, Antrag auf Suspendierung

Synagogenvorsteher, Rücktritt

Synphoniekonzert, Genehmigung am Buß- und Bettah
Laufzeit

Lfd.Nr.

1914
1912

1.094

1910-1913

$1912-1913$

1912

1.126

1.109

1.111

1.090

1912-1913

1.093

1907-1912

1908-1911

1912

1908-1916

1907-1911

1911

1912

1912-1913

1912

1906-1912

1912-1913

1908-1916

1907-1912

1912

1913

1912

1909-1915

1912

1912

1912

1912-1913

1912-1915

1908-1911

1908

1909-1911

1908

1908-1911

1911-1912

1912-1914

1912-1913

1908-1916

1907-1912

1908-1916

1914-1915

1912

1908-1916

1908

1912

1912

1868-1893

1880-1897

1868-1893

1867-1885

1877-1916

1882-1913

1900-1903

1868-1897

1867-1903

1865-1903

1865-1903

1911-1916
1.103

1.102

1.099

1.100

1.104

1.105

1.106

1.107

1.125

1.098

1.121

1.100

1.103

1.114

1.128

1.129

1.130

1.123

1.091

1.127

1.107

1.120

1.085

1.087

1.088

1.084

1.085

1.131

1.089

1.121

1.100

1.103

1.100

1.124

1.123

1.100

1.084

1.122

1.122

2.912

615

2.912

2.913

1.556

2.408

1.005

1.946

483

490

490 
Index

\begin{tabular}{|c|c|c|}
\hline \multicolumn{3}{|l|}{ SACH } \\
\hline Indexbegriff & Laufzeit & Lfd.Nr. \\
\hline Tagung, Organisation & 1900-1902 & 649 \\
\hline Tagungen, Einladung & 1902 & 647 \\
\hline Taler, Bestandsaufstellung & $1866-1912$ & 257 \\
\hline Tangbestände, Erhebung & 1905-1906 & 2.377 \\
\hline Tankanlage, Genehmigungsantrag & 1905 & 2.188 \\
\hline Tankanlagen, Planung & 1857-1905 & 2.551 \\
\hline Tanzsaal, Notausgänge & $1881-1897$ & 1.140 \\
\hline Tanzsäle, Revision wegen Brandschutz & $1881-1897$ & 1.140 \\
\hline Tanzveranstaltungen, Einschränkung während der Passionszeit & 1908 & 3.341 \\
\hline Taubstumme, Gottesdienste & $1868-1905$ & 3.447 \\
\hline Taubstumme, Unterbringungskostenträgerschaft & $1880-1913$ & 254 \\
\hline Taufe, SMS "Emden" & $1908-1914$ & 271 \\
\hline Taufgeschenk, SMS Emden & $1908-1910$ & 270 \\
\hline Taufrede, SMS "Emden" & 1908-1914 & 271 \\
\hline Taxationsgebühren, Rechnung & $1870-1871$ & 1.305 \\
\hline Taxationsgebühren, Zahlung & 1869 & 1.308 \\
\hline Taxatoren, Pferdeaushebung & 1903-1915 & 3.176 \\
\hline Taxatoren, Schätzer d. Feuerversicherungswerte & $1866-1908$ & 1.283 \\
\hline Technikerverein für Emden und Umgegend, Mitglieder & 1898-1902 & 637 \\
\hline Technikerverein für Emden und Umgegend, Statuten & 1898-1902 & 637 \\
\hline Technikerverein für Emden und Umgegend, Vorstand & $1898-1902$ & 637 \\
\hline Technische Lehranstalten, Förderantrag & 1877-1896 & 3.508 \\
\hline Tee, Ersatz & $1915-1918$ & 3.242 \\
\hline Teerkochbehälter, Anschaffung für das Gaswerk & 1898-1899 & 1.044 \\
\hline Teermagazin-Miete, Umrechnung in Mark & 1874-1879 & 2.388 \\
\hline Teeröltankanlage, Genehmigungsverfahren & 1905 & 1.268 \\
\hline Telefonleitung, Emden nach Oldenburg & 1881-1899 & 2.053 \\
\hline Telefonleitung, Errichtung & $1880-1911$ & 2.181 \\
\hline Telefonleitungen, Sicherung & 1887-1913 & 1.248 \\
\hline Telefonzellen, Aufstellung & 1911 & 842 \\
\hline Telegrafenleitung, Bau & $1871-1910$ & 2.037 \\
\hline Telegrafenleitung, Beschädigung & $1871-1910$ & 2.037 \\
\hline Telegrafenleitung, Oberirdische Verlegung & $1871-1910$ & 2.037 \\
\hline Telegrafenleitung, Planzeichnung & $1871-1910$ & 2.037 \\
\hline Telegrafenleitung, Trasse & $1871-1910$ & 2.037 \\
\hline Telegrafenverbindung, Deutschland nach England & $1871-1910$ & 2.037 \\
\hline Telegraphenleitungen, Kostenträgerschaft d. Schutzmaßnahmen & $1912-1915$ & 1.120 \\
\hline \multirow[t]{3}{*}{ Telegraphenleitungen, Schutz } & $1882-1912$ & 1.082 \\
\hline & $1909-1910$ & 1.096 \\
\hline & 1912 & 1.123 \\
\hline \multirow[t]{2}{*}{ Telegraphenleitungen, Schutz vor Starkstromleitungen } & $1912-1913$ & 1.107 \\
\hline & $1912-1915$ & 1.120 \\
\hline Tellersammlung, Genehmigung & 1903-1914 & 696 \\
\hline Teuerungszulagen, Angestellte $\mathrm{u}$. Beamte im Kriegsdienst & 1917-1918 & 3.229 \\
\hline Teuerungszulagen, Berechnung & 1917-1918 & 3.229 \\
\hline Teuerungszulagen, Einmalige & 1917-1918 & 3.229 \\
\hline Teuerungszulagen, Überzahlung an Bürogehilfen & $1900-1917$ & 338 \\
\hline \multirow[t]{3}{*}{ Textilien, Bewirtschaftung } & 1917-1918 & 3.283 \\
\hline & 1916-1918 & 3.285 \\
\hline & 1916-1918 & 3.287 \\
\hline Textilwaren, Bewirtschaftung & 1917-1918 & 3.304 \\
\hline Theateraufführungen, Verbot in der Karwoche & 1891-1898 & 561 \\
\hline Theatergesellschaft, Gründungsinitiative & 1908-1912 & 556 \\
\hline Tiefbau-Berufsgenossenschaft, Beiträge & $1890-1898$ & 1.662 \\
\hline \multirow[t]{3}{*}{ Tiefbau-Berufsgenossenschaft, Beitragsbemessung } & 1890-1898 & 1.662 \\
\hline & 1899-1912 & 1.663 \\
\hline & 1911-1915 & 1.664 \\
\hline Tiefbau-Berufsgenossenschaft, Einordnung d. Straßenbauarbeiter & 1890-1898 & 1.662 \\
\hline
\end{tabular}


IV

Index

\begin{tabular}{l}
\hline \\
\hline Indexbegriff \\
\hline Tiefbau-Berufsgenossenschaft, Etat- und Verwaltungsberichte \\
Tiefbau-Berufsgenossenschaft, Gefahrengruppenklassifizierung \\
Tiefbau-Berufsgenossenschaft, Gewerbliche Mitglieder \\
Tiefbau-Berufsgenossenschaft, Mitgliedschaft der Stadt Emden \\
Tiefbau-Berufsgenossenschaft, Statuten \\
Tiefbau-Berufsgenossenschaft, Unfallverhütungsvorschriften \\
Tiefbohrungen, Regelungen \\
Tier- und Menschenversuche, Schriften gegen \\
Tierfelle, Lagerung \\
Tierfuttergewinnung \\
Tierhäute, Geruchsbelästigung \\
Tierschutz \\
Tierschutz, Hunde \\
Tobsüchtige, Zelle \\
Töchterschuldirektor, Bewerbungsverfahren \\
Töchterschule, Aufsicht \\
Töchterschule, Aula \\
Töchterschule, Ausbau \\
Töchterschule, Bauunterhaltung
\end{tabular}

Töchterschule, Brunnen

Töchterschule, Dirigierender Lehrer

Töchterschule, Einweihungsfeier

Töchterschule, Eröffnungsfeier

Töchterschule, Erweiterung

Töchterschule, Etat

Töchterschule, Etatdefizite

Töchterschule, Freistellen

Töchterschule, Haushaltspläne

Töchterschule, Klassenteilung

Töchterschule, Lehramtsbewerber

Töchterschule, Lehrbetrieb

Töchterschule, Lehrerinnen

Töchterschule, Lehrerpersonalakte

\section{Laufzeit}

1890-1898

1899-1912

1911-1915

1890-1898

1899-1912

1899-1912

1890-1898

1890-1898

1890-1898

1903-1912

1881-1910

1871-1903

1916-1918

1871-1903

1881-1910

1889-1892

1894-1900

1876

1872

1888-1906

1904

1872-1891

1872-1879

1880-1889

1890-1899

1900-1910

1911-1914

1872-1891

1872

1898-1910

1905

1872

1874

1898-1910

1872-1879

1880-1889

1890-1899

1900-1910

1911-1914

1877-1909

1872-1882

1893-1918

1893-1918

1898-1910

1872-1879

1880-1889

1890-1899

1900-1910

1911-1914

1872-1896

1880-1902

1876

1875-1892

1872-1899

1901-1918

1913-1918

1908-1910

1876-1884

\section{Lfd.Nr.}

1.662

1.663

1.664

1.662

1.663

1.663

1.662

1.662

1.662

1.167

726

758

3.230

758

726

833

1.685

3.809

3.764

3.824

3.826

3.763

3.767

3.768

3.769

3.770

3.771

3.763

3.766

3.765

3.827

3.764

3.841

3.765

3.767

3.768

3.769

3.770

3.771

3.818

3.819

3.837

3.837

3.765

3.767

3.768

3.769

3.770

3.771

3.846

3.823

3.789

3.772

3.775

3.777

3.778

3.779

3.780 
Index

SACH

Indexbegriff
Töchterschule, Lehrerpersonalakte

\section{Laufzeit}

1909-1914

1873-1914

1910-1916

1909-1910

1887-1892

1918

1885-1914

1872-1909

1903

1909-1910

1910

1905-1906

1891-1910

1903-1909

1914-1917

1916-1918

1872-1898

1914

1898-1918

1878-1880

1906-1908

1872-1878

1897-1908

1877-1911

1914-1918

1875-1876

Töchterschule, Lehrerstelle

Töchterschule, Oberlehrerinnenstelle

Töchterschule, Organisation

Töchterschule, Parallelklassen

Töchterschule, Patronat der Kaiserin

Töchterschule, Personalakte

Töchterschule, Prospekt

Töchterschule, Rechnung

Töchterschule, Rendant

Töchterschule, Revision

Töchterschule, Schulbänke

Töchterschule, Schulgeld

Töchterschule, Schulgeldhebungslisten

Töchterschule, Schulgeldmehreinnahmen

Töchterschule, Schulordnung

Töchterschule, Schulordnungen

Töchterschule, Schulwärterin

Töchterschule, Schulwärterstelle

Töchterschule, Staatsbeihilfe

Töchterschule, Statistiken

Töchterschule, Stundenplan

Töchterschule, Stundentafel

Töchterschule, Technische Lehrerinnen

Töchterschule, Turngeräte

Töchterschule, Turnunterricht

Töchterschule, Verstaatlichungsdiskussion

Töchterschule, Vorklasse

Töchterschule, Wissenschaftliche Lehrer

Töchterschule,, Schulbetrieb
1872-1899

1872

1908-1912

1904-1905

1906-1918

1878-1905

1872

1872

$1872-1882$

1888-1906

1880-1902

1913-1917

$1875-1876$

1880-1902

1890-1899

1890-1909

1875-1895

1878-1905

1889

1901-1907

1915-1917

1872-1890

1880-1902

1872

1887-1890

1880-1902

1875-1879

1880-1902

1872

1880-1902

1889-1891

1872-1879

\section{Lfd.Nr.}

3.781

3.783

3.785

3.786

3.787

3.788

3.790

3.791

3.792

3.793

3.794

3.795

3.796

3.797

3.798

3.799

3.800

3.801

3.802

3.803

3.804

3.805

3.806

3.807

3.808

3.773

3.775

3.764

3.829

3.825

3.782

3.784

3.764

3.764

3.819

3.824

3.823

3.835

3.820

3.823

3.769

3.839

3.821

3.784

3.844

3.833

3.834

3.845

3.823

3.764

3.774

3.823

3.843

3.823

3.762

3.823

3.776

3.767 
Index

SACH

\begin{tabular}{l} 
Indexbegriff \\
\hline Töchterschule,, Schulbetrieb
\end{tabular}

Töchterschulkommission, Sitzungsprotokolle

Töchterschullehrer, Hinterbliebenenversicherung

Töchterschullehrer, Hinterbliebenenversorgung

Töchterschullehrer, Ruhegehalt

Todeserklärung, Oberlehrer Dittmers

Tonnen-Abfuhrwesen, Etat

Tonnenleerung, Ausgebliebene

Tonnenschuppen, Antrag des Rudervereins auf Überlassung

Tonnensystem, Einführung

Tonnensystem, Erfahrungen

Tonnensystem, Missstände

Torfakzise, Befreiung der Fabriken

Torfakzise, Befreiungsanträge

Torfakzise, Einführung

Torfakzise, Heranziehung Nesserlands

Torfakzise, Nichtzahlung

Torfakzise, Tarif

Torfaufsetzer, Gebührenfestsetzung

Torfaufsetzer, Instruktionen

Torfaufsetzer, Vereidigung

Torfaufsetzer, Vorschlag von Personen

Torfbuchalterstelle, Bewerbung

Torfbuchhalter, Antrag auf Zuschuss

Torfbuchhalter, Dienstkaution

Torfbuchhalter, Einnahmen

Torfbuchhalter, Wahl

Torfbuchhalter-Witwe, Unterstützungsgesuch

Torffuhren, Ausverdingung

Torfkörbe, Instandhaltung

Torfkörbe, Lieferung

Torfmesserinnen

Torfmesserinnen, Prüfung

Torfmesserinnen, Vereidigung

Torfmesserinnen, Wahlen

Torfmesskörbe, Revision

Torfpreise, Emden

Torfschiffe, Emder Binnentiefe

Torfschiffe, Register

Torfträger, Listen

Torfträger, Monopol

Torftransport, Tarif

Torfwaagen, Unterhaltung

Torfwagen, Verkauf

Laufzeit

1880-1889

1890-1899

1900-1910

1911-1914

1898-1910

1872

1872-1879

1880-1889

1890-1899

1900-1910

1911-1914

1894-1912

1880-1913

1894-1912

1916-1918

1886-1894

1876-1882

1901-1912

1869-1885

1886-1894

1886-1894

1905-1908

1867-1902

1867-1902

1867-1878

1895-1897

1867-1902

1867-1907

1858-1912

1858-1912

1858-1912

1858-1912

1894-1913

1894-1913

1894-1913

1894-1913

1894-1913

1894-1913

1866-1899

1900-1914

1866-1899

1900-1914

1866-1899

1900-1914

1866-1899

1858-1912

1867-1904

1867-1904

1858-1912

1866-1899

1866-1900

1866-1883

1882-1887

1867-1904

1867-1907

1867-1907

1866-1899

1900-1914
Lfd.Nr.

3.768

3.769

3.770

3.771

3.765

3.766

3.767

3.768

3.769

3.770

3.771

3.817

3.822

3.817

1.657

870

871

642

869

870

870

948

2.917

2.917

2.914

2.927

2.917

2.892

425

425

425

425

426

426

426

426

426

426

2.627

2.628

2.627

2.628

2.627

2.628

2.627

425

424

424

425

2.627

1.904

1.487

2.916

424

2.892

2.892

2.627

2.628 
Index

\begin{tabular}{|c|c|c|}
\hline \multicolumn{3}{|l|}{$\mathrm{SACH}$} \\
\hline Indexbegriff & Laufzeit & Lfd.Nr. \\
\hline Torfwesen, Auflösung & $1900-1914$ & 2.628 \\
\hline Torfwesen, Defizit & $1900-1914$ & 2.628 \\
\hline Torfwesen, Regulativ & 1866-1899 & 2.627 \\
\hline Torpedoboot "S 42" & 1902 & 186 \\
\hline Torpedoboot "Sleipner" & $1900-1909$ & 264 \\
\hline Totengräber, Berufsbezeichnung & $1824-1920$ & 433 \\
\hline Totengräber, Gehälter & $1868-1911$ & 3.379 \\
\hline Totengräber, Instruktionen & $1824-1920$ & 433 \\
\hline Totengräber, Unfallversicherung & $1868-1911$ & 3.379 \\
\hline Totengräbergebühren, Festsetzung & $1824-1920$ & 433 \\
\hline Totengräberstelle, Besetzung & $1824-1920$ & 433 \\
\hline Totenkasse, Beitrag & $1879-1906$ & 1.641 \\
\hline Totenkasse, Jahresberichte & $1899-1917$ & 1.649 \\
\hline Totenkasse, Mitglieder & $1879-1906$ & 1.641 \\
\hline Totenkasse, Rechnungsbuch & $1866-1902$ & 1.643 \\
\hline Totenkasse, Rechnungsprüfung & 1879-1906 & 1.641 \\
\hline Totenkasse, Satzungen & $1899-1917$ & 1.649 \\
\hline Totenkasse, Statuten & $1879-1906$ & 1.641 \\
\hline Totenkasse, Versicherungsleistungen & $1899-1917$ & 1.649 \\
\hline Totenkasse, Versicherungsschutz & $1879-1906$ & 1.641 \\
\hline Totenkasse, Versicherungstechnisches Gutachten & $1899-1917$ & 1.649 \\
\hline Totenkasse, Zulassung & $1903-1911$ & 1.637 \\
\hline Totenkasse, Zulassung als "Kleiner Verein" & $1899-1917$ & 1.649 \\
\hline Totenkassen, Anerkenung als Versicherungsverein & $1902-1913$ & 1.671 \\
\hline Totenlade, Jahresberichte & $1902-1918$ & 1.638 \\
\hline Totenlade, Rechnungsbuch & 1883-1907 & 1.642 \\
\hline Totenlade, Satzungen & $1902-1918$ & 1.638 \\
\hline \multirow{2}{*}{ Totenlade, Zulassung } & $1902-1918$ & 1.638 \\
\hline & $1869-1916$ & 1.647 \\
\hline Totenruhe, Lutherischer Friedhof & $1878-1904$ & 3.450 \\
\hline Trafosäule, Platzierung & $1912-1913$ & 1.115 \\
\hline Transformatoren-Stationen, Einrichtung & $1912-1913$ & 1.113 \\
\hline Transformatoren-Stationen, Finanzierung & $1912-1913$ & 1.113 \\
\hline Transport Aktiengesellschaft, Bildung & $1896-1910$ & 2.051 \\
\hline Transport Aktiengesellschaft, Geschäftsberichte & $1896-1910$ & 2.051 \\
\hline Transportarbeiterverband, Agitation & $1891-1912$ & 632 \\
\hline Trauerkundgebung, Geh. Oberregierungsrat Carl Schweckendieck & 1901-1906 & 267 \\
\hline Traugebühr, Einführung & $1875-1905$ & 3.390 \\
\hline Trauscheine, Anträge auf & $1862-1868$ & 447 \\
\hline Trichinenschau, Organisation & $1865-1895$ & 746 \\
\hline Trichinenuntersuchung, Einführungsdiskussion & $1865-1895$ & 746 \\
\hline Trinkerheilstätte, Frauen & 1900-1909 & 560 \\
\hline Trinkerheilstätte, Gründung & $1900-1909$ & 560 \\
\hline Trinkerheilstätte, Jahresberichte & $1900-1909$ & 560 \\
\hline Trockenlegung, Plan für Uphuser Meer & $1885-1889$ & 2.667 \\
\hline Trocknungsanlage für ungegerbte Tierfelle, Zulassungsantrag & $1892-1893$ & 2.199 \\
\hline Tuberkulin & $1890-1911$ & 770 \\
\hline \multirow[t]{2}{*}{ Tuberkulose, Bekämpfung } & $1890-1911$ & 770 \\
\hline & $1902-1904$ & 779 \\
\hline Tuberkulose, Heilmittel & $1890-1911$ & 770 \\
\hline Tuberkulose, Sonderstationen für Erkrankte & $1902-1904$ & 779 \\
\hline Turmbau, Lutherische Gemeinde & $1870-1886$ & 3.440 \\
\hline Turmwächter, Alkoholmissbrauch & $1869-1896$ & 436 \\
\hline Turmwächter, Beschwerden wegen Dienstvernachlässigung & $1869-1896$ & 436 \\
\hline Turmwächter, Bewerbungen & $1869-1896$ & 436 \\
\hline Turmwächter, Dienstinstruktion & $1869-1896$ & 436 \\
\hline Turmwächter, Eidesformel & $1869-1896$ & 436 \\
\hline Turmwächter, Entlassung & $1869-1896$ & 436 \\
\hline
\end{tabular}


Index

\begin{tabular}{|c|c|c|}
\hline \multicolumn{3}{|l|}{ SACH } \\
\hline Indexbegriff & Laufzeit & Lfd.Nr. \\
\hline Turmwächter, Entlassungsgesuch & 1869-1896 & 436 \\
\hline Turmwächter, Gehalt & 1869-1896 & 436 \\
\hline Turmwächterstellen, Abschaffung & $1869-1896$ & 436 \\
\hline Turn- und Handarbeitslehrerinen, Einstellung & 1908 & 3.548 \\
\hline Turn- und Handarbeitslehrerinnen, Gehalt & 1908 & 3.548 \\
\hline Turner-Feuerlöschtruppe, Unterstützung & $1867-1869$ & 1.388 \\
\hline Turnhalle, Bau für lutherische Klassenschule & 1900-1909 & 3.666 \\
\hline \multirow{2}{*}{ Turnhalle, Bauprojekt } & $1882-1914$ & 729 \\
\hline & $1895-1914$ & 730 \\
\hline \multirow[t]{2}{*}{ Turnhalle, Errichtung } & $1899-1900$ & 3.693 \\
\hline & 1900-1906 & 3.694 \\
\hline Turnhalle, Grundsteinlegung & $1895-1914$ & 730 \\
\hline Turnhalle, Nutzung & 1869-1904 & 3.633 \\
\hline Turnhalle, Nutzungsantrag & 1900-1906 & 3.694 \\
\hline Turnlehrer, Einstellung & $1868-1879$ & 728 \\
\hline Turnlehrer, Fortbildungskurse & $1868-1879$ & 728 \\
\hline Turnlehrer, Gehaltserhöhung & 1869-1904 & 3.633 \\
\hline Turnlehrer, Unterhaltssicherung & $1868-1879$ & 728 \\
\hline Turnlehrerin, Bewerbung & $1887-1890$ & 3.774 \\
\hline Turnpflichtunterricht, Einführung & 1869-1904 & 3.633 \\
\hline Turnunterricht, Anschaffung von Turnschuhen & 1902-1904 & 3.687 \\
\hline Turnunterricht, Organisation & $1868-1879$ & 728 \\
\hline Turnunterricht, Pflichtfach an der lutherischen Klassenschule & $1869-1870$ & 3.658 \\
\hline Turnverein, Statuten & $1904-1913$ & 664 \\
\hline Türsteherinnen, Gehaltserhöhung & $1868-1911$ & 3.379 \\
\hline Typhus, Anzeige & 1878-1894 & 774 \\
\hline Typhus, Ausbruch & $1875-1882$ & 970 \\
\hline Typhus, Ausbruch unter Soldaten & $1867-1891$ & 3.126 \\
\hline Typhus-Epidemie, Gasthaus-Bewohner & $1872-1875$ & 1.715 \\
\hline Typhuserkrankungen, Auftreten & 1878-1894 & 774 \\
\hline Typhuserkrankungen, Ursache & $1878-1894$ & 774 \\
\hline U-Boot-Spende & 1917 & 3.215 \\
\hline U-Boot-Spende, Flaschensammlung & 1915-1918 & 3.242 \\
\hline Ulmen, Beschneidung & 1914-1916 & 966 \\
\hline Ulmen, Ersetzung & 1914-1916 & 966 \\
\hline Umbauten, Unerlaubte & 1871-1888 & 1.151 \\
\hline Umfriedung, Projekt & $1879-1888$ & 1.215 \\
\hline Umgemeindung, Kaiser- Wilhelm-Polder & 1904-1908 & 230 \\
\hline Umgemeindung, Klage gegen & $1900-1903$ & 229 \\
\hline Umgemeindung, Königspolder & $1900-1903$ & 229 \\
\hline Umgemeindung, Parzelle am Stadtgraben & 1885 & 225 \\
\hline Umgemeindung, Vergleichsangebot & $1900-1903$ & 229 \\
\hline Umgemeindungen, Grundstücke der Gemeinde Wolthusen & $1883-1911$ & 231 \\
\hline Umsatz- und Wertzuwachssteuer, Odnung in Emden & 1896-1914 & 2.947 \\
\hline Umsatzsteuer, Befreiungsanträge & 1896-1908 & 2.938 \\
\hline Umsatzsteuer, Klage & $1910-1911$ & 2.939 \\
\hline Umsatzsteuer, Nordseewerke & 1913-1915 & 2.977 \\
\hline \multirow[t]{2}{*}{ Umzugskosten, Erstattungsantrag } & 1905-1915 & 364 \\
\hline & $1859-1915$ & 369 \\
\hline Umzugskosten, Gesuch um Erstattung & 1907-1914 & 400 \\
\hline Unfall- und Invaliditätsversicherung, Vertrauensärzte & 1910 & 1.658 \\
\hline Unfallschutz Ausstellungen & 1903-1913 & 1.667 \\
\hline Unfallverhütungsgesetz, Ausführung im Baubereich & 1910 & 1.658 \\
\hline Uniformen, Verwaltungsbeamte & 1917 & 3.293 \\
\hline Universitätsbund, Eintrittswerbung & 1914 & 3.711 \\
\hline Unrat, Auf den Straßen & 1871-1897 & 823 \\
\hline Untehaltungspflicht, Anlieger öffentlicher Straßen & $1912-1914$ & 839 \\
\hline
\end{tabular}


Index

\begin{tabular}{|c|c|c|}
\hline \multicolumn{3}{|l|}{ SACH } \\
\hline Indexbegriff & Laufzeit & Lfd.Nr. \\
\hline Unterhaltspflicht, Verletzung & 1916-1918 & 1.887 \\
\hline Unterleibstyphus, Anzeige & 1871-1914 & 757 \\
\hline Unteroffiziere, Einkommen & $1867-1870$ & 2.871 \\
\hline Unterstützung, J. Steinhuizen u. Frau Johanna, geb. Boer & $1912-1914$ & 1.878 \\
\hline \multirow{2}{*}{ Unterstützung, Verein für Diakonissen-Krankenpflege } & $1861-1903$ & 577 \\
\hline & 1904-1915 & 578 \\
\hline Unterstützungen, Familien von Kriegsteilnehmern & 1893-1914 & 3.185 \\
\hline Unterstützungsantrag, Familie des Matrosen Johann Jetses & 1914-1915 & 1.879 \\
\hline Unterstützungsfall, Elisabeth Janssen, verw. Tiemann, geb. Decker & 1913-1916 & 1.874 \\
\hline Unterstützungsfall, Matrose Hermann Hans Jacob & 1913 & 1.873 \\
\hline Unterstützungskasse "Verbrüderung", Auflösung & $1879-1901$ & 1.757 \\
\hline Unterstützungskasse "Verbrüderung", Mitglieder & 1879-1901 & 1.757 \\
\hline Unterstützungskasse "Verbrüderung", Statuten & 1879-1901 & 1.757 \\
\hline \multirow[t]{2}{*}{ Unterstützungswohnsitz, Feststellung } & $1906-1912$ & 253 \\
\hline & 1902 & 397 \\
\hline \multirow[t]{4}{*}{ Unterstützungswohnsitz, Gesetzesausführung vor Ort } & 1871 & 1.764 \\
\hline & 1871 & 1.765 \\
\hline & 1871-1877 & 1.766 \\
\hline & $1872-1881$ & 1.767 \\
\hline \multirow[t]{4}{*}{ Unterstützungswohnsitz, Gesetzliche Regelung } & $1870-1909$ & 1.763 \\
\hline & $1881-1889$ & 1.768 \\
\hline & 1894-1909 & 1.769 \\
\hline & 1908-1912 & 1.770 \\
\hline Unterstützungswohnsitz, Streit & 1873 & 1.759 \\
\hline Unterstützungswohnsitz, Unterstützung & 1914 & 1.880 \\
\hline Unterstüzungsfall, Agge Janssen & 1914 & 1.875 \\
\hline Unterstüzungsfall, Schiffsbauer Johann Heinrich Friedrich Jarks & 1914-1915 & 1.876 \\
\hline Unterstüzungsfall, Witwe Alberta Jacobs, geb. Janssen & 1914 & 1.877 \\
\hline Untersuchungsgefangene, Überführung & $1899-1913$ & 523 \\
\hline Untersuchungshäftlinge, Unbefugte Kontaktaufnahme & 1886 & 528 \\
\hline Unterwasserkabel, Verlegung & 1912 & 1.108 \\
\hline Urwahlbezirke, Emden & 1913 & 215 \\
\hline Urwahlmänner, Wahl & 1913 & 215 \\
\hline Überlandzentrale, Anschluss der Stadt Emden an Wiesmoor & 1907-1908 & 1.083 \\
\hline Überlandzentrale, Anschluss Emden & 1908 & 1.084 \\
\hline Überlandzentralen, Agitation & $1908-1916$ & 1.100 \\
\hline Überschwemmung, Schadensersatzansprüche & 1875 & 1.555 \\
\hline Überschwemmung, Schadensersatzforderungen & $1877-1916$ & 1.556 \\
\hline Überschwemmungen, Berichte & $1877-1916$ & 1.556 \\
\hline Überschwemmungen, Hilfeleistung durch Militär & $1877-1916$ & 1.556 \\
\hline Überschwemmungsopfer, Hilfe & $1877-1916$ & 1.556 \\
\hline Vagabunden, Ausweisung & 1867-1895 & 502 \\
\hline Vandalismus, Anzeige & 1874-1905 & 831 \\
\hline Vaterländischer Frauenverein, Statuten & 1882 & 616 \\
\hline \multirow[t]{4}{*}{ Veranda, Ungenehmigte } & 1905-1908 & 1.187 \\
\hline & 1905 & 1.188 \\
\hline & 1906-1907 & 1.190 \\
\hline & 1905-1906 & 1.191 \\
\hline Verbindungskanal, Dortmund-Ems-Kanal nach der Weser & 1906-1907 & 2.086 \\
\hline Verdienstkreuz in Gold, Verleihungsantrag & $1912-1918$ & 263 \\
\hline Verdienstmedaille für Rettung aus Gefahr, Verleihung & $1869-1890$ & 741 \\
\hline Verdingungswesen, Organisation & $1882-1913$ & 2.408 \\
\hline Verein deutscher Lokomotivführer und Heizer, Satzung & $1900-1912$ & 639 \\
\hline Verein, Ankauf von Immobilien & $1881-1912$ & 626 \\
\hline Verein, Auflösung & $1892-1893$ & 631 \\
\hline Verein, Aufnahmeverfahren & $1881-1912$ & 626 \\
\hline
\end{tabular}


IV

Index

SACH

Indexbegriff
Verein, Gründung
Verein, Gründungsversuch

Verein, Mitgliedsbeiträge

Verein, Mitgliedschaft der Stadt Emden

Laufzeit

1907

$1907-1914$

1907

1907-1915

1907

1905

1907-1908

$1912-1915$

1914

1893-1913

1903-1906

1900-1902

1903-1908

1903-1911

1906-1915

$1907-1915$

1905-1914

1912-1914

1911

1905

Verein, Räume

Verein, Status einer juristischen Persönlichkeit

Verein, Statutenänderung

Verein, Vertrauensmann

Verein, Vogelschutz

Verein, Vorstandswahlen

Vereine, Anträge auf Genehmigung von Veranstaltungen

Vereine, Anzeige des Stiftungsfestes

Vereine, Deponierung von Wertpapieren

Vereine, Mitglieder

Vereine, Petitionsrecht

Vereine, Polizeiliche Überwachung

Vereine, Satzungen

Vereine, Statuten

Vereine, Tagung in Emden

Vereine, Überlassung von Räumen

Vereine, Überwachung katholischer Vereine

Vereine, Werbung um Unterstützung 
IV

Index

\begin{tabular}{l}
\hline Indexbegriff \\
\hline Vereinsbezeichnung, Streit \\
Vereinsfeste, Genehmigungsanträge \\
Vereinsgesetz \\
Vereinsgesetz, Verstoß wegen Gewerkschaftsgründung \\
Vereinshaus, Grundsteinlegung und Inbetriebnahme \\
Vereinsorgan, "Die Luftflotte" \\
Vereinsregister, Eintragung
\end{tabular}

Vereinsregister, Eintragung Verein für Diakonissen-Krankenpflege Vereinsregister, Eintragung von Rudervereinen

Vereinsregister, Eintragungen

Vereinsstatuten, Genehmigungsanträge

Vereinsveranstaltungen, Räumlichkeiten

Vereinsverbote, Sozialdemokratische Agitation

Vereinsversammlungen

Vereinsvorstände, Bestätigung

Vereinswesen, Gerichtsurteile

Vereinswesen, Verfügungen

Vereinszulassungen

Vererbpachtung

Verfassungen, Städte

Vergnügungssteuer, Befreiung

SACH

Vergnügungssteuer, Befreiungsantrag

Vergnügungssteuer, Erlassantrag

Laufzeit

Lfd.Nr.

1900-1912

675

1888-1906

639

1867-1914

672

1867-1914

576

1903-1914

576

1912-1915

696

1900-1911

714

1904-1915

650

1904-1914

667

1905-1913

1905-1906

669

1909-1912

1903-1914

675

$1861-1903$

689

1901-1912

696

1867-1914

577

642

576

1883-1893

1880-1913

617

1901-1912

620

1906-1907

643

1867-1914

1879-1905

576

1883-1893

622

1867-1914

617

576

1867-1914

576

1867-1914

576

1874-1884

2.678

1894-1901

587

1901-1912

643

1902-1909

654

671

1907-1914 1.389

1900-1912

639

693

698

1911-1913

702

1911-1914

703

Verkaufsbude, Betrieb

1911-1913

1.946

1868-1897 $\quad 1.946$

Verkaufsbude, Pachtung

Verkaufsbude, Sortimentserweiterung auf Bier und Milch

Verkaufsbude, Verlegung

1868-1897

1.946

1868-1897

1.946

1868-1897

1.946

Verkaufsbude,, Vergrößerungsantrag

1868-1897

1.946

Verkehrsabgaben, Bestrafung der Hinterziehung

Verkehrsabgaben, Erhebung

1897-1900

822

1882-1910

2.936

1901-1912

840

1867-1887

810

Verkoppelungen, Forcierung

1867-1887

810

Verlaate

Verlaate, Beseitigung

Verlaate, Kanalanschluss

Verlaatswärter, Aufgaben

Verlaatswärter, Bewerbung

1866-1891

1.488

1866-1891

1.488

1879-1883

1.433

1866-1891

1.488

1866-1891

1.488

Verlaatswärter, Honorarforderung

1866-1891

1.488

Verlaatswärter, Instruktionen

1866-1891

Verlaatswärter, Vereidigung

1866-1891

Verlosung, Antrag auf Zulassung

1880-1897

.488

1.488 
IV

Index

SACH

\begin{tabular}{l} 
Indexbegriff \\
\hline Vermietung, Räume in der alten Kaserne \\
Verpachtung, Stadtländereien \\
Verpflegungskosten, Kranke Arme im Krankenhaus \\
Verpflegungsstationen, Durchziehende Arbeiter \\
Versicherungsgelder, Entzug bei Brandstiftung \\
Versicherungsgelder, Klage \\
Versicherungsgesellschaften, Datenerhebung \\
Versicherungspflicht, Befreiung \\
Versicherungsschaden, Abwicklung \\
Versicherungsschaden, Feststellung
\end{tabular}

SACH

Laufzeit

1889-1909

1905

1914

1882-1913

1891-1908

1915-1918

1868-1887

1904

1879

1887

1874-1875

1873

1873

1873

1872

1872

1872

1870-1871

1867

1867

1867

1875

1878

1878

1878

1879

1879

1879

1879

1876

1877

1878

1878

1879

1879

1879

1880-1881

1880

1880

1880

1881

1881

1880-1887

1888-1898

1888-1898

1888-1898

1893

1888-1889

1888-1889

1890

1891-1892

1892

1892

1895-1896

1895

1895-1896

1896

1896
Lfd.Nr.

2.433

2.440

1.891

1.636

1.288

2.602

1.900

3.339

1.319

1.341

1.296

1.298

1.299

1.300

1.301

1.302

1.303

1.305

1.310

1.311

1.313

1.314

1.315

1.316

1.317

1.318

1.319

1.320

1.321

1.322

1.323

1.324

1.325

1.326

1.327

1.328

1.329

1.330

1.331

1.332

1.333

1.334

1.335

1.336

1.337

1.338

1.339

1.343

1.344

1.345

1.346

1.347

1.348

1.349

1.350

1.351

1.352

1.353 
IV

Index

\section{SACH}

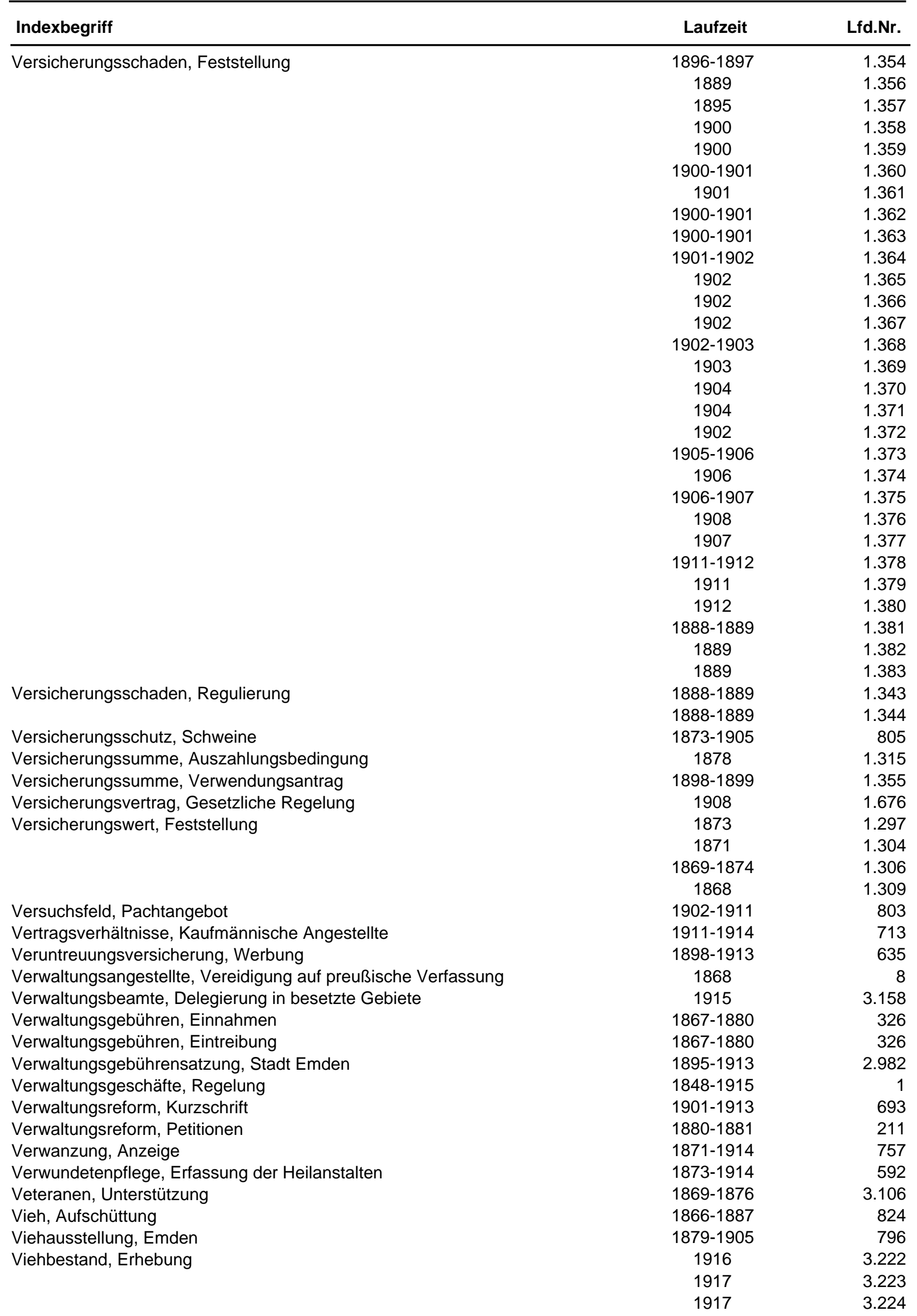




\begin{tabular}{|c|c|c|}
\hline \multicolumn{3}{|c|}{ SACH } \\
\hline Indexbegriff & Laufzeit & Lfd.Nr. \\
\hline \multirow[t]{3}{*}{ Viehbestand, Erhebung } & 1917 & 3.225 \\
\hline & 1917 & 3.227 \\
\hline & 1918 & 3.228 \\
\hline Viehimport, Verbot wegen Cholera & $1892-1903$ & 777 \\
\hline Viehimporte, Niederlande & 1914-1918 & 3.245 \\
\hline Viehmarkt, Abgrenzung & $1866-1910$ & 2.137 \\
\hline Viehmarkt, Pfähle & $1866-1910$ & 2.137 \\
\hline Viehmarkt, Standgebühren & 1868-1909 & 2.144 \\
\hline Viehmarkt, Terminüberschneidung & 1902 & 2.142 \\
\hline Vieh-Quarantäne-Anstalt, Plan & $1899-1900$ & 783 \\
\hline Viehschätzung, Gutachter & $1886-1914$ & 808 \\
\hline Viehtransporte, Organisation & $1883-1897$ & 827 \\
\hline Viehtransporte, Schutz der Bevölkerung gegen Bullen & $1883-1897$ & 827 \\
\hline Viehtreiben, Schäden durch Schweine & $1883-1897$ & 827 \\
\hline Viehtreiben, Verbot durch Stadt Emden & $1883-1897$ & 827 \\
\hline Viehverladungsstation, Errichtungsantrag & 1907 & 2.093 \\
\hline Viehverschickung, Anfrage für Emder Hafenanlagen & 1907 & 2.092 \\
\hline Viehverschneider, Prüfungsordnung & 1867 & 1.948 \\
\hline Viehversicherungen, Bildung & 1877-1903 & 804 \\
\hline Viehversicherungen, Datenerhebung & $1906-1913$ & 807 \\
\hline \multirow[t]{2}{*}{ Viehversicherungen, Jahresberichte } & 1873-1905 & 805 \\
\hline & $1906-1913$ & 807 \\
\hline \multirow[t]{2}{*}{ Viehversicherungen, Mustersatzung } & 1877-1903 & 804 \\
\hline & $1903-1911$ & 806 \\
\hline Viehversicherungen, Regulierung & $1903-1911$ & 806 \\
\hline \multirow[t]{2}{*}{ Viehversicherungen, Statuten } & 1877-1903 & 804 \\
\hline & 1873-1905 & 805 \\
\hline Viehversicherungen, Suche nach Vertreter & $1906-1913$ & 807 \\
\hline Viehversicherungen, Vereinsstatus & 1873-1905 & 805 \\
\hline Viehversicherungsanstalten, Betrieb & $1873-1905$ & 805 \\
\hline Viehwaage, Anschaffung & $1867-1896$ & 2.156 \\
\hline Vierdup, Verbotene Verwendung & $1872-1880$ & 2.158 \\
\hline Viktoria, Kaiserwitwe und Mutter von Wilhelm II. & $1897-1901$ & 182 \\
\hline Vogelschutz, Anlegung von Gehölzen & $1912-1914$ & 967 \\
\hline Vogelschutz, Druckschriften & $1873-1912$ & 625 \\
\hline Völkerschlacht bei Leipzig, Jubiläum & $1912-1914$ & 567 \\
\hline Volksbüro, Agitationsmittel & $1888-1915$ & 668 \\
\hline Volksbüro, Tätigkeit & $1888-1915$ & 668 \\
\hline Volksernährung, Sicherung & $1914-1916$ & 3.194 \\
\hline Volksheime, Initiative & $1899-1905$ & 644 \\
\hline Volksküche, Einrichtung in Emden & 1914-1918 & 3.245 \\
\hline Volksküchen, Einrichtung & 1916 & 3.213 \\
\hline Volkskultur, Hebung & $1899-1905$ & 644 \\
\hline Volksschulbauten, Finanzierung & $1868-1891$ & 3.502 \\
\hline Volksschule, Ausbau & $1899-1900$ & 3.693 \\
\hline Volksschule, Auslagerung einer Klasse & 1880 & 3.689 \\
\hline Volksschule, Ausstattung & $1908-1911$ & 3.707 \\
\hline Volksschule, Bau & 1908-1909 & 3.671 \\
\hline Volksschule, Bauliche Unterhaltung & $1876-1878$ & 3.700 \\
\hline Volksschule, Betriebsbeihilfe & 1915 & 3.670 \\
\hline Volksschule, Denkschrift über Organisation & $1876-1878$ & 3.700 \\
\hline \multirow[t]{4}{*}{ Volksschule, Etat } & 1915 & 3.670 \\
\hline & $1902-1904$ & 3.687 \\
\hline & $1876-1878$ & 3.700 \\
\hline & $1908-1911$ & 3.707 \\
\hline Volksschule, Finanzierung & $1886-1890$ & 3.505 \\
\hline Volksschule, Handarbeitsunterricht & $1876-1878$ & 3.700 \\
\hline Volksschule, Heizung & $1898-1903$ & 3.692 \\
\hline
\end{tabular}


Index

\begin{tabular}{|c|c|c|}
\hline \multicolumn{3}{|c|}{ SACH } \\
\hline Indexbegriff & Laufzeit & Lfd.Nr. \\
\hline Volksschule, Kassenrechnung & $1877-1878$ & 3.699 \\
\hline Volksschule, Lehrereinstellung & $1876-1878$ & 3.700 \\
\hline Volksschule, Lehrmittel & $1875-1890$ & 3.690 \\
\hline Volksschule, Lehrplan & $1876-1878$ & 3.700 \\
\hline \multirow[t]{2}{*}{ Volksschule, Organisation } & $1868-1891$ & 3.502 \\
\hline & $1891-1901$ & 3.701 \\
\hline Volksschule, Plan einer städtischen & $1873-1874$ & 3.634 \\
\hline Volksschule, Prüfungsordnung & $1876-1878$ & 3.700 \\
\hline Volksschule, Rechnungslegung & $1876-1878$ & 3.700 \\
\hline Volksschule, Regulativ & $1873-1874$ & 3.675 \\
\hline Volksschule, Rektor & $1871-1917$ & 3.679 \\
\hline Volksschule, Rektorenwahl & $1876-1878$ & 3.700 \\
\hline Volksschule, Revision & $1902-1907$ & 3.706 \\
\hline Volksschule, Sachbeschädigung & $1908-1911$ & 3.707 \\
\hline Volksschule, Schenkung einer Orgel & 1891 & 3.691 \\
\hline Volksschule, Schulfeier zum Kaisergeburtstag & $1876-1878$ & 3.700 \\
\hline Volksschule, Schulsparkasse & 1876-1878 & 3.700 \\
\hline Volksschule, Städtische Einrichtung & $1873-1874$ & 3.675 \\
\hline Volksschule, Unterrichtszeiten & $1876-1878$ & 3.700 \\
\hline Volksschulen, Bibliothek & $1908-1915$ & 3.545 \\
\hline Volksschulen, Brennmaterial & $1908-1915$ & 3.545 \\
\hline Volksschulen, Reinigungsmittel & 1908-1915 & 3.545 \\
\hline Volksschulen, Schulaufsicht & $1869-1888$ & 3.629 \\
\hline Volksschulen, Schulbücher & $1908-1915$ & 3.545 \\
\hline Volksschulen, Schülerzahl & 1906 & 3.531 \\
\hline Volksschulen, Trittnähmaschinenanschaffung & $1908-1915$ & 3.545 \\
\hline Volksschulen, Unterhaltung & 1906-1908 & 3.616 \\
\hline Volksschulen, Werbeschreiben von Organisationen & $1908-1915$ & 3.545 \\
\hline Volksschuletats & 1918 & 3.544 \\
\hline Volksschulgebäude, Baulicher Zustand & 1880 & 3.689 \\
\hline Volksschulgesetz, Novellierung & $1868-1891$ & 3.502 \\
\hline Volksschullehrer Besoldungsordnung & 1897-1909 & 3.525 \\
\hline \multirow[t]{4}{*}{ Volksschullehrer, Alterszulage } & $1869-1890$ & 3.503 \\
\hline & $1890-1896$ & 3.513 \\
\hline & 1897-1905 & 3.524 \\
\hline & 1897-1909 & 3.525 \\
\hline \multirow[t]{3}{*}{ Volksschullehrer, Besoldung } & $1869-1890$ & 3.503 \\
\hline & $1890-1896$ & 3.513 \\
\hline & $1867-1871$ & 3.646 \\
\hline Volksschullehrer, Besoldungsordnung & $1909-1913$ & 3.536 \\
\hline \multirow[t]{3}{*}{ Volksschullehrer, Diensteinkommen } & 1897 & 3.523 \\
\hline & $1897-1905$ & 3.524 \\
\hline & 1897-1909 & 3.525 \\
\hline Volksschullehrer, Gehälter und Versorgung & $1909-1914$ & 3.500 \\
\hline Volksschullehrer, Hinterbliebenenversicherung & $1870-1879$ & 3.501 \\
\hline \multirow[t]{2}{*}{ Volksschullehrer, Mietentschädigung } & 1897-1909 & 3.525 \\
\hline & $1908-1909$ & 3.533 \\
\hline Volksschullehrer, Ortszulage & 1909-1915 & 3.535 \\
\hline Volksschullehrerinnen, Diensteinkommen & 1897-1905 & 3.524 \\
\hline Volksschullehrerinnen, Überstundenentgelt & $1915-1918$ & 3.534 \\
\hline Volksschulwesen, Berichte & 1893-1908 & 3.530 \\
\hline Volksschulwesen, Geschäftsberichte & $1872-1883$ & 3.628 \\
\hline \multirow[t]{2}{*}{ Volksschulwesen, Kommunalisierung } & 1906-1908 & 3.616 \\
\hline & & Vorwor \\
\hline Volksschulwesen, Neuordnung in Emden & 1906-1908 & 3.616 \\
\hline Volksschulwesen, Organisation & $1908-1911$ & 3.547 \\
\hline \multirow{2}{*}{ Volksschulwesen, Reorganisation } & 1887-1889 & 3.506 \\
\hline & 1907-1908 & 3.618 \\
\hline
\end{tabular}


Index

\begin{tabular}{|c|c|c|}
\hline \multicolumn{3}{|l|}{$\mathrm{SACH}$} \\
\hline Indexbegriff & Laufzeit & Lfd.Nr. \\
\hline Volksschulwesen, Vereinheitlichung & 1887-1889 & 3.506 \\
\hline Volksversammlung, Vereinswerbung & $1891-1894$ & 630 \\
\hline Volkszählung, Bekanntmachung & 1918 & 461 \\
\hline \multirow[t]{2}{*}{ Volkszählung, Durchführung in Emden } & 1916 & 459 \\
\hline & 1917 & 460 \\
\hline Volkszählung, Lehrer als Zähler & 1918 & 461 \\
\hline Volkszählung, Verordnung & 1918 & 461 \\
\hline \multirow[t]{2}{*}{ Volkszählung,Teilnahme der Lehrer als Zähler } & 1916 & 459 \\
\hline & 1917 & 460 \\
\hline Vollziehungsbeamte, Gehaltserhöhungswunsch & $1900-1919$ & 353 \\
\hline Vollziehungsbeamter, Antrag auf Regenmantel & $1900-1919$ & 353 \\
\hline Vollziehungsbeamter, Beschwerde wg. Dienstführung & $1885-1890$ & 379 \\
\hline Vollziehungsbeamter, Bewerbung & $1885-1890$ & 379 \\
\hline Vollziehungsbeamter, Botendienst & $1900-1919$ & 353 \\
\hline Vollziehungsbeamter, Cienstkaution & 1890 & 354 \\
\hline Vollziehungsbeamter, Entlassungsgesuch & $1885-1890$ & 379 \\
\hline Vollziehungsbeamter, Nachruf & $1900-1919$ & 353 \\
\hline Vollziehungsbeamter, Stellenausschreibung & $1885-1890$ & 379 \\
\hline Vollziehungsbeamter, Unterschlagung & 1890 & 354 \\
\hline Vollziehungsbeamter, Vereidigung & $1885-1890$ & 379 \\
\hline Vollziehungsbeamter, Vertretung & $1900-1919$ & 353 \\
\hline Vorleser- und Sänger,. Gehaltserhöhung & $1868-1911$ & 3.379 \\
\hline Vormundschaften, Erteilung & $1875-1913$ & 1.703 \\
\hline Vorsänger, Jüdische Synagogengemeinde & 1883-1905 & 492 \\
\hline Vorschulklassen, Errichtung zur Vorbereitung auf Höhere Schulen & 1909 & 3.537 \\
\hline Vorstandswahl, Emder Turnverein & $1867-1914$ & 576 \\
\hline Vorstandswahlen, Vaterländischer Frauenverein & $1880-1897$ & 615 \\
\hline Waage, Aichung & $1867-1896$ & 2.156 \\
\hline Waage, Lagerung von Molkereiprodukten & $1867-1896$ & 2.156 \\
\hline Waage, Raumvermietung & $1867-1896$ & 2.156 \\
\hline Waage, Tarife & $1867-1896$ & 2.156 \\
\hline Waage, Unzulässige Gewichte & $1867-1896$ & 2.156 \\
\hline Waagen, Angebote & $1867-1896$ & 2.156 \\
\hline Waagen, Beschlagnahmung & $1872-1880$ & 2.158 \\
\hline Waage-Nutzung, Tarif & $1877-1910$ & 2.653 \\
\hline Wachthaus, Abbruch & $1886-1900$ & 2.430 \\
\hline Wachthaus, Nutzung als Leichenkammer & $1886-1900$ & 2.430 \\
\hline Wachthaus, Nutzung als Notdomizil & $1886-1900$ & 2.430 \\
\hline Wachthaus, Nutzung als Pulvermagazin & $1886-1900$ & 2.430 \\
\hline Wachthäuschen, Funktionsplanung als Leichenhaus & $1878-1891$ & 2.428 \\
\hline Wachthäuschen, Umbau & $1878-1891$ & 2.428 \\
\hline Wachthäuschen, Umbau zum Stallgebäude & $1878-1891$ & 2.428 \\
\hline Wachthäuschen, Vermietung & $1878-1891$ & 2.428 \\
\hline Waffen und Munition, Sammlung aus Privatbesitz & $1915-1918$ & 3.242 \\
\hline Waffen- und Munitionsbesitzer, Emden & $1915-1918$ & 3.242 \\
\hline Waffen, Abgabe Beschlagnahmter & $1881-1913$ & 727 \\
\hline Waffen, Katalogisierung & $1900-1912$ & 2.606 \\
\hline Waffenrecht, Ausland & $1881-1913$ & 727 \\
\hline Waffenrecht, Vorschriften & $1881-1913$ & 727 \\
\hline Wagenspur, Einführung der Breiten im Kgr. Hannover & $1879-1897$ & 2.019 \\
\hline Wäger, Reglements & $1899-1906$ & 2.129 \\
\hline Wäger, Sonn- und Feiertagsvergütung & $1899-1906$ & 2.129 \\
\hline Wäger, Wiegegebähr & $1899-1906$ & 2.129 \\
\hline Wahlbezirke, Bildung & $1866-1867$ & 216 \\
\hline \multirow[t]{3}{*}{ Wahlbezirke, Emden } & $1866-1867$ & 216 \\
\hline & 1907-1908 & 219 \\
\hline & 1908 & 220 \\
\hline
\end{tabular}


Index

\begin{tabular}{|c|c|c|}
\hline \multicolumn{3}{|c|}{ SACH } \\
\hline Indexbegriff & Laufzeit & Lfd.Nr. \\
\hline Wahlbezirke, Emden & $1911-1912$ & 222 \\
\hline Wahlergebnis, Reichstagswahl in Emden & $1911-1912$ & 222 \\
\hline Wählerliste, Stadt Emden & $1866-1867$ & 216 \\
\hline Wählerlisten, Anträge auf Registrierung & $1908-1916$ & 83 \\
\hline Wählerlisten, Erstellung & $1866-1867$ & 216 \\
\hline Wählerlisten, Stadt Emden, & $1902-1903$ & 205 \\
\hline Wählerregister, Aufnahme & $1879-1890$ & 79 \\
\hline Wählerregister, Bürgervorsteherwahl & $1903-1911$ & 105 \\
\hline Wählerregister, Eintragungen & $1901-1902$ & 77 \\
\hline Wahlkommissare, Ernennung & $1875-1912$ & 213 \\
\hline Wahllokale, Stadt Emden & 1908 & 220 \\
\hline Wahlplakate, Ungenehmigtes Aufkleben & $1897-1914$ & 838 \\
\hline Wahlrecht, Erfassung von Bürgern ohne Hausbesitz & $1848-1915$ & 1 \\
\hline Wahlrecht, Erfassung von Grundbesitzern & $1848-1915$ & 1 \\
\hline Wahlrecht, Erfassung von Steuerzahler & $1848-1915$ & 1 \\
\hline Wahlrecht, Lehrer der jüdischen Schule & 1895 & 488 \\
\hline Wahlrechtsreform, Diskussion & $1917-1918$ & 2 \\
\hline Wahlverein, Zentrum & 1907 & 684 \\
\hline \multirow[t]{3}{*}{ Wahlvorstände, Emden } & $1866-1867$ & 216 \\
\hline & $1907-1908$ & 219 \\
\hline & 1908 & 220 \\
\hline \multirow[t]{2}{*}{ Wahlvorsteher, Emden } & $1902-1903$ & 205 \\
\hline & 1911-1912 & 222 \\
\hline Waisen- und Witwenunterstützungskassen, Statistik & $1902-1913$ & 1.671 \\
\hline Waisenfürsorge, Jüdische Gemeinde & $1903-1917$ & 495 \\
\hline Waisenfürsorge, Organisation & $1913-1914$ & 1.732 \\
\hline Waisenhaus, Bauvorschlag & $1913-1914$ & 1.732 \\
\hline Waisenhausorganisation, Druckschriften & $1913-1914$ & 1.732 \\
\hline Waisenkinder, Verpflegung & $1885-1900$ & 1.726 \\
\hline Waisenrat, Ablehnung der Nominierung & $1875-1913$ & 1.703 \\
\hline Waisenrat, Beschimpfung & $1914-1923$ & 1.704 \\
\hline Waisenrat, Einführung des Amtes & $1875-1913$ & 1.703 \\
\hline Waisenrat, Mitglieder & $1871-1913$ & 1.864 \\
\hline Waisenräte, Aufgaben & $1875-1913$ & 1.703 \\
\hline Waisenräte, Bestellung von Frauen & $1875-1913$ & 1.703 \\
\hline Waisenräte, Bestellung von Geistlichen & $1875-1913$ & 1.703 \\
\hline Waisenräte, Ersatz & $1914-1923$ & 1.704 \\
\hline Waisenräte, Wahl & $1875-1913$ & 1.703 \\
\hline Waisenräte, Zusammenarbeit mit Emder Gasthaus & $1875-1913$ & 1.703 \\
\hline Waisenrats-Kollegium, Ausscheiden von Mitgliedern & 1914-1923 & 1.704 \\
\hline Waisenratsordnung, Stadt Emden & $1871-1913$ & 1.864 \\
\hline Wall, Beschädigung & 1914-1916 & 966 \\
\hline Wallanlagen, Aufstellung von Vogelhäuschen & $1912-1914$ & 967 \\
\hline Wallanlagen, Bewässerung & $1912-1914$ & 967 \\
\hline Wallanlagen, Papierkörbe & $1912-1914$ & 967 \\
\hline Wallanlagen, Unbefugte Benutzung einer Böschung & $1912-1914$ & 967 \\
\hline Wallbäume, Beschädigung & $1878-1884$ & 2.522 \\
\hline Wallböschung, Einfriedung & $1914-1916$ & 966 \\
\hline Wallmühlen, Windfeld & 1866-1905 & 2.378 \\
\hline Wallwärter, Einstellung & 1914-1916 & 966 \\
\hline Wanderausstellung zur Tuberkulose-Aufklärung & $1908-1913$ & 780 \\
\hline \multirow[t]{2}{*}{ Wandergewerbe, Regulierung durch Besteuerung } & $1874-1876$ & 2.893 \\
\hline & $1898-1912$ & 2.894 \\
\hline \multirow[t]{2}{*}{ Wandergewerbescheine, Beantragung } & $1910-1911$ & 2.895 \\
\hline & $1911-1912$ & 2.896 \\
\hline \multirow[t]{2}{*}{ Wandergewerbescheine, Übersicht } & $1910-1911$ & 2.895 \\
\hline & $1911-1912$ & 2.896 \\
\hline Wanderlagerbetrieb, Zollgrenzbezirke & $1888-1912$ & 1.910 \\
\hline
\end{tabular}


Index

\begin{tabular}{|c|c|c|}
\hline \multicolumn{3}{|l|}{ SACH } \\
\hline Indexbegriff & Laufzeit & Lfd.Nr. \\
\hline Wanderlager-Betriebe, Steuerhinterziehung & $1888-1912$ & 1.910 \\
\hline Wanderplätze, Beseitigung & $1885-1911$ & 834 \\
\hline Wanderplätze, Eigentumsrechte & $1885-1911$ & 834 \\
\hline Wanderplätze, Katasterplan & $1885-1911$ & 834 \\
\hline Wanderplätze, Umzäunte Rondelle vor den Häusern & $1885-1911$ & 834 \\
\hline Wanderpreis, Stiftung & $1901-1913$ & 693 \\
\hline Wanderpreis, Stiftung für Regatta & $1909-1912$ & 689 \\
\hline Wanderung, Eigentumsübergang an die Stadt Emden & $1868-1880$ & 980 \\
\hline Wanderung, Schaden an & 1874-1905 & 831 \\
\hline \multirow[t]{3}{*}{ Wanderungen, Beseitigung am Delft } & $1900-1905$ & 995 \\
\hline & 1901 & 996 \\
\hline & $1901-1903$ & 997 \\
\hline Wandgemälde, Kaiserbesuch & $1915-1919$ & 178 \\
\hline Warenhäuser, Lagerung brennbarer Stoffe & $1891-1910$ & 1.136 \\
\hline Warenhaussteuer, Einführung & $1900-1908$ & 2.909 \\
\hline Warenhaussteuerpflicht, Definition & $1900-1908$ & 2.909 \\
\hline Warenqualität, Regelungen & $1881-1910$ & 1.906 \\
\hline Warmbadbetreiber, Betriebskostenzuschuss & $1881-1911$ & 737 \\
\hline Warmbadeanstalt, Angebote & $1881-1911$ & 737 \\
\hline Warmbadeanstalt, Betreiber & $1876-1890$ & 738 \\
\hline Warmbadeanstalt, Betriebsbeihilfe & $1897-1913$ & 740 \\
\hline \multirow[t]{2}{*}{ Warmbadeanstalt, Errichtung } & $1876-1890$ & 738 \\
\hline & $1897-1913$ & 740 \\
\hline Warmbadeanstalt, Plan & $1876-1890$ & 738 \\
\hline Warmbadeanstalt, Planung & $1881-1911$ & 737 \\
\hline \multirow[t]{2}{*}{ Warmbadeanstalt, Verhandlungen } & $1881-1911$ & 737 \\
\hline & $1876-1890$ & 738 \\
\hline Wartehäuschen, Haltestelle Transvaal & $1902-1905$ & 1.960 \\
\hline Wäschereianlage, Besichtigungseinladung & $1903-1914$ & 1.686 \\
\hline Wäschetrocknungsgestelle, Aufstellen a.d. Straße & $1901-1912$ & 840 \\
\hline Wasser- und Halbwassergase, Verbot & 1886-1909 & 1.019 \\
\hline Wasserbacken, Sicherungsvorschrift & $1887-1897$ & 1.138 \\
\hline \multirow[t]{2}{*}{ Wasser-Closetts, Anschluss an die Kanalisation } & $1896-1903$ & 880 \\
\hline & $1892-1912$ & 881 \\
\hline Wasser-Closetts, Zulassung & 1896-1903 & 880 \\
\hline Wasserentnahme, Streit in Wolthusen & $1906-1912$ & 253 \\
\hline Wasserflächen, Erwerb & $1901-1908$ & 2.012 \\
\hline Wassergasanlagen, Presseberichte & $1892-1899$ & 1.068 \\
\hline Wassergasfabrik, Plan der Anlage & $1892-1899$ & 1.068 \\
\hline Wassergasproduktion, Technik & $1892-1899$ & 1.068 \\
\hline Wassergasproduktionsanlage, Planzeichnung & $1892-1899$ & 1.068 \\
\hline Wassergesetz, Novellierung in Preußen & $1901-1908$ & 718 \\
\hline Wassergeusen, Aktenabschriften & $1883-1887$ & 2.393 \\
\hline Wasserklärung, Preisausschreibung & 1879-1905 & 796 \\
\hline Wasserläufe, Beeinträchtgung durch Abwässer & 1906-1908 & 1.500 \\
\hline Wasserläufe, Vertiefung & 1897 & 2.052 \\
\hline Wasserleitung, Anschluss der Kanalabgaberneinnehmerwohnung & $1900-1912$ & 1.563 \\
\hline Wasserleitung, Reparaturkosten & 1899-1909 & 1.234 \\
\hline Wasserleitungen, Erstellung & 1908-1909 & 1.145 \\
\hline Wasserleitungen, Hausanschlüsse & $1908-1909$ & 1.145 \\
\hline Wasserpreis, Senkungsantrag des Gaswerks & $1897-1914$ & 1.057 \\
\hline Wasserreinigungssystem, Angebot & $1905-1912$ & 863 \\
\hline Wasserschaden, Manipulierte Riolen & $1870-1879$ & 888 \\
\hline Wasserstandsmeldungen & $1877-1916$ & 1.556 \\
\hline Wasserstraßenbeiräte, Reform & $1905-1908$ & 1.448 \\
\hline Wasserstraßennetz, Verbesserung in der Provinz Hannover & $1899-1900$ & 2.055 \\
\hline Wassertürme, Bewachung & 1914-1916 & 3.152 \\
\hline Wassertürme, Schutz & 1914 & 3.198 \\
\hline
\end{tabular}


Index

\begin{tabular}{|c|c|c|}
\hline \multicolumn{3}{|l|}{ SACH } \\
\hline Indexbegriff & Laufzeit & Lfd.Nr. \\
\hline Wasserversorgung, Seeschiffe & $1892-1903$ & 777 \\
\hline Wasserwerk, Betrieb & $1872-1916$ & 330 \\
\hline Wassrstände, Klagen & $1866-1883$ & 1.487 \\
\hline Watte, Verwendungsverbot & $1881-1910$ & 1.906 \\
\hline WC-Anlage, Installation im städtischen Krankenhaus & $1892-1912$ & 881 \\
\hline WC-Anlage, Prospekt & $1896-1903$ & 880 \\
\hline WC-Anlage, Recognitionsgebühr für Kanalanschluss & $1892-1912$ & 881 \\
\hline WC-Anlage, Ungenehmigter Anschluss an Kanalisation & $1908-1910$ & 884 \\
\hline WC-Anlagen, Angebote & $1892-1912$ & 881 \\
\hline WC-Anlagen, Aufstellung & $1892-1912$ & 881 \\
\hline WC's, Zulassung & $1866-1911$ & 962 \\
\hline Web- und Strickwaren, Höchstpreise & 1916-1918 & 3.282 \\
\hline Weberzunft, Gräber & 1899-1909 & 3.317 \\
\hline Weg, Ausbau & $1881-1896$ & 2.020 \\
\hline Weg, Unterhaltung & $1881-1896$ & 2.020 \\
\hline Wegbau-Inspektor, Dienstanweisung & $1867-1878$ & 2.031 \\
\hline Wege, Blockade & $1876-1889$ & 843 \\
\hline Wege, Hindernisse & $1897-1914$ & 838 \\
\hline Wege, Reinigung und Unterhaltung & $1912-1914$ & 839 \\
\hline Wege, Streit um Unterhaltung & $1912-1914$ & 839 \\
\hline Wege, Unpassierbarkeit & $1875-1909$ & 836 \\
\hline Wegebau, Finanzierung & $1876-1890$ & 2.040 \\
\hline Wegegerechtigkeit, Regelung & $1882-1889$ & 2.530 \\
\hline Wegerecht, Einräumung & $1872-1918$ & 2.691 \\
\hline Wegeunterhaltung, Strafe wegen Unterlassung & $1874-1901$ & 2.038 \\
\hline Wegeunterhaltung, Zuständigkeit außerhalb der Stadtgrenze & $1867-1881$ & 2.033 \\
\hline Wegeverband, Rendant & $1875-1889$ & 2.035 \\
\hline Wegweiser, Schifffahrt auf der Ems & 1899-1909 & 1.418 \\
\hline \multirow[t]{2}{*}{ Wehrdienst, Entlassungsanträge } & $1910-1914$ & 3.104 \\
\hline & $1907-1910$ & 3.105 \\
\hline Wehrpflicht, Erlass & $1893-1911$ & 3.094 \\
\hline \multirow{2}{*}{ Wehrpflichtige, Erfassung } & $1876-1886$ & 3.093 \\
\hline & $1893-1911$ & 3.094 \\
\hline \multirow[t]{5}{*}{ Wehrpflichtige, Klassifizierung } & 1901 & 3.095 \\
\hline & 1902 & 3.096 \\
\hline & 1904 & 3.097 \\
\hline & 1905 & 3.098 \\
\hline & 1905 & 3.099 \\
\hline Wehrpflichtige, Musterung & $1902-1914$ & 3.100 \\
\hline Weihnachtsgaben, Sammlung für Frontsoldaten & $1915-1918$ & 3.242 \\
\hline Weinhändler, Liste für Emden & $1909-1911$ & 743 \\
\hline Weinkontrolle, Gebühren & $1909-1911$ & 743 \\
\hline Weißkohl, Ankauf aus den Niederlanden & $1917-1918$ & 3.308 \\
\hline Weizenmühle, Zuwegung & 1870 & 849 \\
\hline Welfen-Anhänger, Gründung eines Kriegervereins & 1911 & 704 \\
\hline Weltausstellung, Beteiligung Reedereien und Werfte & 1898 & 2.128 \\
\hline Weltausstellung, Emder Beitrag & $1902-1904$ & 2.131 \\
\hline Weltausstellung, Exponate & $1902-1904$ & 2.131 \\
\hline Weltausstellung, Förderung des Besuches & $1873-1874$ & 2.124 \\
\hline Weltausstellung, Präsentation des Emder Hafens & $1902-1904$ & 2.131 \\
\hline Weltkrieg, Aufrufe und Plakate & $1915-1919$ & 3.315 \\
\hline \multirow[t]{2}{*}{ Weltkrieg, Einquartierung } & 1914 & 3.149 \\
\hline & $1914-1915$ & 3.150 \\
\hline Weltkrieg, Einquartierungslisten & 1914-1915 & 3.150 \\
\hline Weltkrieg, Erfassung von Kriegsmaterial & 1914-1916 & 3.148 \\
\hline Weltkrieg, Erlaubnisschein für Hafengebiet & 1914-1916 & 3.148 \\
\hline \multirow[t]{2}{*}{ Weltkrieg, Gefallener Lehrer } & $1910-1914$ & 3.564 \\
\hline & $1912-1918$ & 3.592 \\
\hline
\end{tabular}


Index

\begin{tabular}{|c|c|c|}
\hline \multicolumn{3}{|l|}{ SACH } \\
\hline Indexbegriff & Laufzeit & Lfd.Nr. \\
\hline \multirow[t]{4}{*}{ Weltkrieg, Gefallener Lehrer } & 1909-1916 & 3.599 \\
\hline & 1913-1914 & 3.601 \\
\hline & 1914-1917 & 3.602 \\
\hline & 1914-1918 & 3.606 \\
\hline Weltkrieg, Internierte & $1914-1916$ & 3.148 \\
\hline Weltkrieg, Kriegsmaßnahmen & 1914-1916 & 3.148 \\
\hline Weltkrieg, Mieten und Hypotheken & 1914-1918 & 3.197 \\
\hline Weltkrieg, Mobilmachung & 1914-1916 & 3.151 \\
\hline Weltkrieg, Postverkehr & 1914-1917 & 3.313 \\
\hline \multirow[t]{2}{*}{ Weltkrieg, Pressezensur } & $1914-1916$ & 3.148 \\
\hline & 1914-1917 & 3.313 \\
\hline Weltkrieg, Spendenaufruf für Liebesgaben und Verwundete & 1914-1916 & 3.151 \\
\hline Weltkrieg, Vermisster Lehrer & $1905-1917$ & 3.566 \\
\hline Werbeartikel, Emden & 1899 & 2.130 \\
\hline Werbeschrift, Niedersächsischer Herbergsverband & $1912-1914$ & 710 \\
\hline Werbetafeln, Anträge auf Aufstellungsgenehmigung & $1866-1913$ & 832 \\
\hline Werbung, Historischer Verein für Niedersachsen & 1902 & 647 \\
\hline Werft- und Dockanlagen, Notwendigkeit & 1899-1903 & 1.454 \\
\hline Werft, Angebote & $1902-1910$ & 1.456 \\
\hline Werft, Genehmigungsantrag & 1900 & 2.241 \\
\hline Werft, Gründerausschuss & $1903-1904$ & 1.459 \\
\hline Werft, Lärmbelästigung & $1879-1900$ & 2.184 \\
\hline Werft, Planzeichnung & 1902-1905 & 1.455 \\
\hline Werftanlagen, Verpachtung & $1910-1911$ & 1.468 \\
\hline Werftansiedlung, Angebote & 1899-1903 & 1.454 \\
\hline Werftansiedlung, Verhandlungen & 1899-1903 & 1.454 \\
\hline Werftarbeitersiedlung, Anlage & 1913-1914 & 1.149 \\
\hline Werftarbeitersiedlung, Finanzierung & 1903-1910 & 1.465 \\
\hline Werftarbeitersiedlung, Planung & 1903-1910 & 1.465 \\
\hline Werftarbeitersiedlung, Sicherstellung d. Erschließungskosten & $1903-1910$ & 1.465 \\
\hline \multirow{2}{*}{ Werftbauten, Stand } & 1902-1905 & 1.455 \\
\hline & 1903-1904 & 1.458 \\
\hline \multirow[t]{2}{*}{ Werftbetrieb, Erstattung vorgeschossener Gelder } & 1911-1912 & 1.477 \\
\hline & $1912-1913$ & 1.478 \\
\hline Werftbetrieb, Sicherung durch Vorschüsse & $1910-1911$ & 1.479 \\
\hline Werftbetrieb, Voraussetzungen & 1903-1904 & 1.459 \\
\hline Werftgründung, Presseberichte & 1903-1904 & 1.459 \\
\hline Werfthäuser, Finanzierung der Erschließungskosten & $1902-1910$ & 1.456 \\
\hline Werftindustrie, Ansiedlungswerben & $1890-1891$ & 2.023 \\
\hline Werftmaschinen, Angebot & 1899-1903 & 1.454 \\
\hline \multirow[t]{2}{*}{ Wertpapiere, Depot bei der Stadt Emden } & $1880-1897$ & 615 \\
\hline & $1900-1910$ & 641 \\
\hline Wertpapiere, Stempelung für die lutherische Gemeinde & 1868-1905 & 3.447 \\
\hline Wertpapiere, Verwaltung & $1866-1881$ & 2.991 \\
\hline Wertzuwachsbesteuerung, Regelung & 1913 & 2.882 \\
\hline \multirow[t]{2}{*}{ Wertzuwachssteuer, Einnahmen } & 1908 & 2.945 \\
\hline & 1909 & 2.946 \\
\hline \multirow[t]{9}{*}{ Wertzuwachssteuer, Einzug } & 1915 & 2.968 \\
\hline & 1915 & 2.969 \\
\hline & 1916 & 2.970 \\
\hline & 1917 & 2.971 \\
\hline & 1917 & 2.972 \\
\hline & 1917 & 2.973 \\
\hline & 1917 & 2.974 \\
\hline & 1917 & 2.975 \\
\hline & 1917 & 2.976 \\
\hline Wertzuwachssteuer, Feststellung der Steuerpflicht & 1916 & 2.883 \\
\hline Wertzuwachssteuer, Gesetz über Erhebung & 1911-1916 & 2.881 \\
\hline
\end{tabular}


IV

Index

\begin{tabular}{|c|c|c|}
\hline \multicolumn{3}{|l|}{ SACH } \\
\hline Indexbegriff & Laufzeit & Lfd.Nr. \\
\hline \multirow[t]{18}{*}{ Wertzuwachssteuer, Hebung } & $1907-1916$ & 2.949 \\
\hline & 1914 & 2.950 \\
\hline & 1914 & 2.951 \\
\hline & 1914 & 2.952 \\
\hline & 1914 & 2.953 \\
\hline & 1914 & 2.954 \\
\hline & 1914 & 2.955 \\
\hline & 1914 & 2.957 \\
\hline & 1914 & 2.958 \\
\hline & 1914 & 2.959 \\
\hline & 1914 & 2.960 \\
\hline & 1914 & 2.961 \\
\hline & 1914-1915 & 2.962 \\
\hline & 1914 & 2.963 \\
\hline & 1914-1915 & 2.964 \\
\hline & 1915 & 2.965 \\
\hline & 1915 & 2.966 \\
\hline & 1915 & 2.967 \\
\hline \multirow[t]{3}{*}{ Wertzuwachssteuer, Klage } & 1913 & 2.884 \\
\hline & 1913 & 2.885 \\
\hline & 1913-1914 & 2.886 \\
\hline Wertzuwachssteuer, Streit um Einziehung & 1915-1918 & 242 \\
\hline \multirow[t]{3}{*}{ Wertzuwachssteuer, Veranlagung } & 1914-1915 & 2.887 \\
\hline & 1914-1915 & 2.888 \\
\hline & 1914-1918 & 2.889 \\
\hline \multirow[t]{4}{*}{ Weser-Elbekanal, Projekt } & $1892-1898$ & 2.054 \\
\hline & $1899-1900$ & 2.055 \\
\hline & 1900 & 2.056 \\
\hline & $1900-1901$ & 2.057 \\
\hline Westbahn, Anbindung des linken Emsufers & 1897 & 2.015 \\
\hline Westfälischer Verein zur Förderung des Kleinwohnungswesens & 1909-1911 & 1.231 \\
\hline Wetten, Verbot von Ausländischen & 1909 & 559 \\
\hline Wetterballone, Behandlung bei Fund & $1899-1910$ & 512 \\
\hline Wetterberichte, Aushangskasten im Rathausdurchgang & 1904-1911 & 1.150 \\
\hline Wetterkasten, Anbringung & 1904-1911 & 1.150 \\
\hline Wetterkasten, Unterhaltung & 1904-1911 & 1.150 \\
\hline Wetterstation, Betreuung durch Navigationslehrer & $1905-1916$ & 1.584 \\
\hline Wiegegebühr, Neufestsetzung & 1899-1906 & 2.129 \\
\hline Wiegevorrichtungen, Angebote & 1867-1896 & 2.156 \\
\hline Windgeld, Abschaffung & $1866-1897$ & 2.900 \\
\hline Windgeld, Mühlenbetrieb & $1866-1897$ & 2.900 \\
\hline Windthorstbund, Mitglieder & 1907 & 684 \\
\hline Wirtetag, Emden & 1904-1915 & 667 \\
\hline Wirteverein, Mitgliederlisten & 1904-1915 & 667 \\
\hline Wissenschaftlicher Hilfslehrer, Abordnung & 1905 & 3.741 \\
\hline Witwen und Waisenkasse, Gründungsinitiative für Emden & 1901-1909 & 1.653 \\
\hline Witwen- und Waisenkasse, Rechnungsüberprüfung & $1886-1887$ & 3.352 \\
\hline Witwen- und Waisenkasse, Wertpapiere & $1886-1887$ & 3.352 \\
\hline Wochenmarkt, Einrichtung & $1876-1911$ & 2.145 \\
\hline Wochenmarkt, Gemüseverkauf & $1876-1911$ & 2.145 \\
\hline Wochenmarkt, Marktordnung & $1876-1911$ & 2.145 \\
\hline Wochenmarkt, Standgebühr & $1876-1911$ & 2.145 \\
\hline Wochenmarkts-Ordnung, Stadt Emden & 1877-1912 & 324 \\
\hline Wochenschrift "Der Rhein" & 1906-1907 & 2.089 \\
\hline Wohltätigkeitskonzert, Kinderkrippe & 1917-1918 & 760 \\
\hline Wohltätigkeitskonzerte, Zugunsten Verwundeter & 1870 & 594 \\
\hline Wohnhaus, Erster Nachwachtmeister und Gefangenenwärter & 1901-1903 & 2.434 \\
\hline Wohnhaus, Plan & 1876-1909 & 2.696 \\
\hline
\end{tabular}


Index

\begin{tabular}{|c|c|c|}
\hline \multicolumn{3}{|l|}{ SACH } \\
\hline Indexbegriff & Laufzeit & Lfd.Nr. \\
\hline Wohnhäuser, Bau & 1901-1909 & 1.183 \\
\hline Wohnhäuser, Vermietung städtischer & $1866-1904$ & 2.676 \\
\hline Wohnschiffe, Missstände & $1873-1914$ & 1.227 \\
\hline Wohnschiffe, Unhygienische Verhältnisse & $1895-1910$ & 873 \\
\hline Wohnsitz, Emder Beschäftigte in Wolthusen & 1913-1922 & 256 \\
\hline Wohnungen, Errichtung für Arbeiter & $1890-1911$ & 687 \\
\hline Wohnungen, Leere in Emden & $1909-1911$ & 1.231 \\
\hline Wohnungsbau, Baugenossenschaften & $1902-1914$ & 1.235 \\
\hline Wohnungsbauten, Aufstellung & 1887-1902 & 1.228 \\
\hline Wohnungsbrände, Ausbruch & $1867-1902$ & 1.257 \\
\hline Wohnungsfürsorge, Arbeiter und Beamte & $1909-1911$ & 1.231 \\
\hline Wohnungskongress, Verhandlungen & $1904-1914$ & 1.238 \\
\hline Wohnungsmakler, Zulassungsantrag & $1873-1914$ & 1.227 \\
\hline Wohnungsmangel, Berichte & $1873-1914$ & 1.227 \\
\hline Wohnungsmarkt, Eingriffe & 1873-1914 & 1.227 \\
\hline Wohnungsnot, Arbeiter & 1887-1902 & 1.228 \\
\hline Wohnungsräumung, Wolthusen & $1880-1913$ & 254 \\
\hline Wohnungsverein, Revisor & $1902-1914$ & 1.235 \\
\hline Wohnungsverhältnisse, Berichte & 1887-1902 & 1.228 \\
\hline Wohnverhältnisse, Emden & 1904 & 1.269 \\
\hline Wolle, Sammlung für Frontsoldaten & $1915-1918$ & 3.242 \\
\hline Wucher, Bekämpfung durch Wechselordnung & 1880 & 1.911 \\
\hline Wucherblume, Bekämpfung & 1898-1914 & 817 \\
\hline Wusche, Holzbuden & 1869-1901 & 1.159 \\
\hline Wykverein für die III. Wyk, Satzung & 1904 & 670 \\
\hline Wykverein, Statuten & 1902 & 648 \\
\hline Yacht "SMS Hohenzollern" & 1902 & 186 \\
\hline Zaun, Gefährdung durch Bauart & 1901-1912 & 840 \\
\hline Zäune, Anträge & 1866-1902 & 828 \\
\hline Zeichenlehrer, Bewerber & 1886-1903 & 3.724 \\
\hline Zeichenlehrer, Fortbildungskurse & 1904-1906 & 3.528 \\
\hline Zeitball, Initiativen zur Einrichtung & 1904-1908 & 1.426 \\
\hline Zeitpacht, Umwandlungsantrag & $1907-1910$ & 2.588 \\
\hline Zeitpächter, Aufstellung & $1905-1912$ & 2.585 \\
\hline Zeitschrift "Stahl und Eisen" & 1905-1906 & 2.088 \\
\hline Zeitung, Kaution für Herausgabe & $1867-1891$ & 719 \\
\hline Zentralverein z. Hebg. d. Fluss- u. Kanalschifffahrt, Mitglieder & 1904 & 2.002 \\
\hline Zentralverein z. Hebg. d. Fluss- u. Kanalschifffahrt, Satzung & 1907 & 2.004 \\
\hline \multirow{3}{*}{ Zentralverein z. Hebg. d. Fluss- u. Kanalschifffahrt, Versammlung } & 1904 & 2.001 \\
\hline & 1904 & 2.002 \\
\hline & 1905 & 2.003 \\
\hline Zeugen, Entschädigungsgebühr & 1868-1904 & 171 \\
\hline Zeugnis, Berechtigung zur Ausstellung & 1891 & 3.751 \\
\hline Zeugnisse, Ausstellung für Beamte & 1901 & 439 \\
\hline Ziegeleigewerbe, Arbeiterschutz & $1872-1904$ & 2.382 \\
\hline Ziegenstall, Geruchsbelästigung & 1897-1912 & 1.157 \\
\hline Ziegen-Versicherungsverein, Jahresberichte & 1913-1917 & 1.678 \\
\hline Ziegen-Versicherungsverein, Ruhen der Tätigkeit & 1913-1917 & 1.678 \\
\hline Ziegen-Versicherungsverein, Statuten & 1913-1917 & 1.678 \\
\hline Ziegen-Versicherungsverein, Zulassung & 1913-1917 & 1.678 \\
\hline Zigarren, Produktion in Emden & 1886-1912 & 2.386 \\
\hline Zigarrenfabriken, Betriebsrichtlinien & $1886-1912$ & 2.386 \\
\hline Zimmerleute-Totenlade, Anerkennungsverfahren & 1904-1911 & 1.675 \\
\hline Zimmerleute-Totenlade, Kassenberichte & 1904-1911 & 1.675 \\
\hline Zimmerleute-Totenlade, Satzungen & 1904-1911 & 1.675 \\
\hline Zimmerleute-Totenlade, Versicherungstechnisches Gutachten & 1904-1911 & 1.675 \\
\hline
\end{tabular}


Index

\begin{tabular}{|c|c|c|}
\hline \multicolumn{3}{|l|}{ SACH } \\
\hline Indexbegriff & Laufzeit & Lfd.Nr. \\
\hline Zink, Beschlagnahmung für Kriegswirtschaft & 1917 & 3.267 \\
\hline \multirow[t]{5}{*}{ Zinn, Beschlagnahmung für die Kriegswirtschaft } & $1916-1917$ & 3.256 \\
\hline & 1917 & 3.257 \\
\hline & 1917 & 3.258 \\
\hline & 1917 & 3.259 \\
\hline & 1917 & 3.260 \\
\hline Zinn, Entschädigungszahlungen & $1916-1917$ & 3.256 \\
\hline Zinskoupons & 1912 & 3.009 \\
\hline Zionismus, Jüdische Gemeinde in Emden & 1904 & 485 \\
\hline Zisterne, Planung & $1869-1910$ & 2.634 \\
\hline Zisterne, Preis für wasserentnahme & $1869-1910$ & 2.634 \\
\hline Zisterne, Verpachtung & $1868-1869$ & 2.633 \\
\hline Zisternen, Anlage & $1869-1910$ & 2.634 \\
\hline Zisternen, Entfernung verschmutzter & 1878-1894 & 774 \\
\hline Zisternen, Untersuchung wegen Infektionsgefahr & $1879-1912$ & 750 \\
\hline Zisternenanlagen, Beseitigung & $1897-1907$ & 999 \\
\hline Zisternenmündung, Beseitigung wegen Verkehrsgefährdung & 1875-1879 & 982 \\
\hline Zivilflugzeuge, Kriegseinsatz & 1912 & 3.233 \\
\hline Zivilversorgungsschein, Ausstellung & $1867-1914$ & 3.107 \\
\hline Zivilversorgungsscheininhaber, Stellen in der Kanzlei & 1907 & 3.108 \\
\hline Zivilverwaltungsstellen, Besetzung mit Veteranen und Invaliden & $1867-1914$ & 3.107 \\
\hline Zollabfertigungsstelle, Ausbau & 1866-1904 & 2.418 \\
\hline Zollamtsgebäude, Bau & $1902-1912$ & 2.409 \\
\hline Zollbedienstete, Steuierbefreiung & $1867-1906$ & 2.032 \\
\hline Zollbehörde, Mietung eines Gebäudes & 1866-1904 & 2.418 \\
\hline Zolleinnahmen, Verteilung der Überschüsse & $1885-1902$ & 2.891 \\
\hline Zollfreiheit, Emder Hafen & 1900-1905 & 2.061 \\
\hline Zolltarife, Änderungen & 1893-1894 & 1.557 \\
\hline Zolltarife, Gütertransport durch die Schweiz nach Frankreich & $1893-1894$ & 1.557 \\
\hline Zollverein, Anschluss Kgr. Hannover & 1867-1906 & 2.032 \\
\hline Zucker, Bewirtschaftung & 1914-1916 & 3.194 \\
\hline Zuckerfabrik, Genehmigungsverfahren & $1866-1900$ & 2.481 \\
\hline Zuckerwaren-Automaten, Begrenzung & 1901 & 518 \\
\hline Zugpferde, Schutz & $1881-1910$ & 726 \\
\hline Zugtiere, Schutz & $1881-1910$ & 726 \\
\hline Zugtrittbrett, Sturz von & $1882-1908$ & 2.009 \\
\hline Zungenkai, Beleuchtung & $1897-1907$ & 1.017 \\
\hline Zuwegung, Herstellung & $1881-1886$ & 850 \\
\hline Zwangseintreibung, Beiträge zur Alterszulagenkasse für Lehrer & $1910-1911$ & 248 \\
\hline Zwangseintreibung, Rückständige Staatssteuern in Borssum & $1910-1911$ & 248 \\
\hline Zwangskehrbezirke, Einrichtung & $1907-1916$ & 1.264 \\
\hline Zwangslotse, Stellung zum Schiffer & 1888 & 1.415 \\
\hline Zwangslotsgeld, Erhebung & 1891-1902 & 2.123 \\
\hline Zwangsversteigerungen, Anmeldung städtischer Rechte & $1886-1911$ & 2.661 \\
\hline Zweckverbandsgesetz & 1911 & 226 \\
\hline Zweifamilienhaus, Bauantrag & 1905-1906 & 1.169 \\
\hline & $1910-1911$ & 1.203 \\
\hline
\end{tabular}


Konkordanz: alte Registratur-Signatur - Ifd. Nr.

alte Registratur-Signatur

Lfd.Nr.

B IV a 12.

2605

C I 10

3351

Cl 35

3431

E 593

3103

G III 27 / 3

966

I Ca 2

I Ca 5

I Cb 1

I Cc 10

I Cc 4

I Cc 4

$\mathrm{I} \mathrm{Cd}$

I Cd 1

I Cd 1

I Cd 1

I Cd 1

I Cd 1

I Cd 1

I Cd 1

I Cd 1

I Cd 2

I Cd 2

I Cd 7

I Cd 7

I Cd 7

I Cd 7

I Cd 7

I Cd 7

I Cd 7

I Cd 7

I Cd 7

I Cd 7

I Cd 7

I Cd 7

I Cd 7

I Cd 7

I Cd 7

I Cd 7

I Cd 7

I Cd 7

I Cd 7

I Cd 7

I Cd 7

I Cd 7

I Cd 7

I Cd 7

I Cd 7

I Cd 7

I Cd 7

I Cd 8

I Ce 1

I Ce 1

I Ce 1

I Db 2

I Db 3

I Dc

I Dc

I Dc

I DC

I Dc 
Konkordanz: alte Registratur-Signatur - Ifd. Nr.

alte Registratur-Signatur

Lfd.Nr.

I DC

I DC

I Dc

I Dc

I Dc

I Dc

I Dc

I Dc

I Dd 1

I Dd 4

I Dd 5

I Dd 6

I De 2

I E 10

I E 14

I E 15

I E 45

I F 09

IF 11

I F 13

I Ga 01

I Ga 01

I Ga 03

I Ga 08

I Ga 1

I Ga 19

I Ga 21

I Ga 25

I Ga 34

I Gaa 1

I Gb 11

I Gb 18

I Gb 24

I Gb 25

I Gb 25

I Gb 25

I Gb 25

I Gb 25

I Gb 25

I Gb 25

I Gb 25

I Gb 25

I Gb 25

I Gb 25

I Gb 25

I Gb 25

I Gb 25

I Gb 25

I Gb 25

I Gb 25

I Gb 25

I Gb 25

I Gb 25

I Gb 25

I Gb 25

I Gb 25

I Gb 25

I Gb 25

I Gb 25

I Gb 25

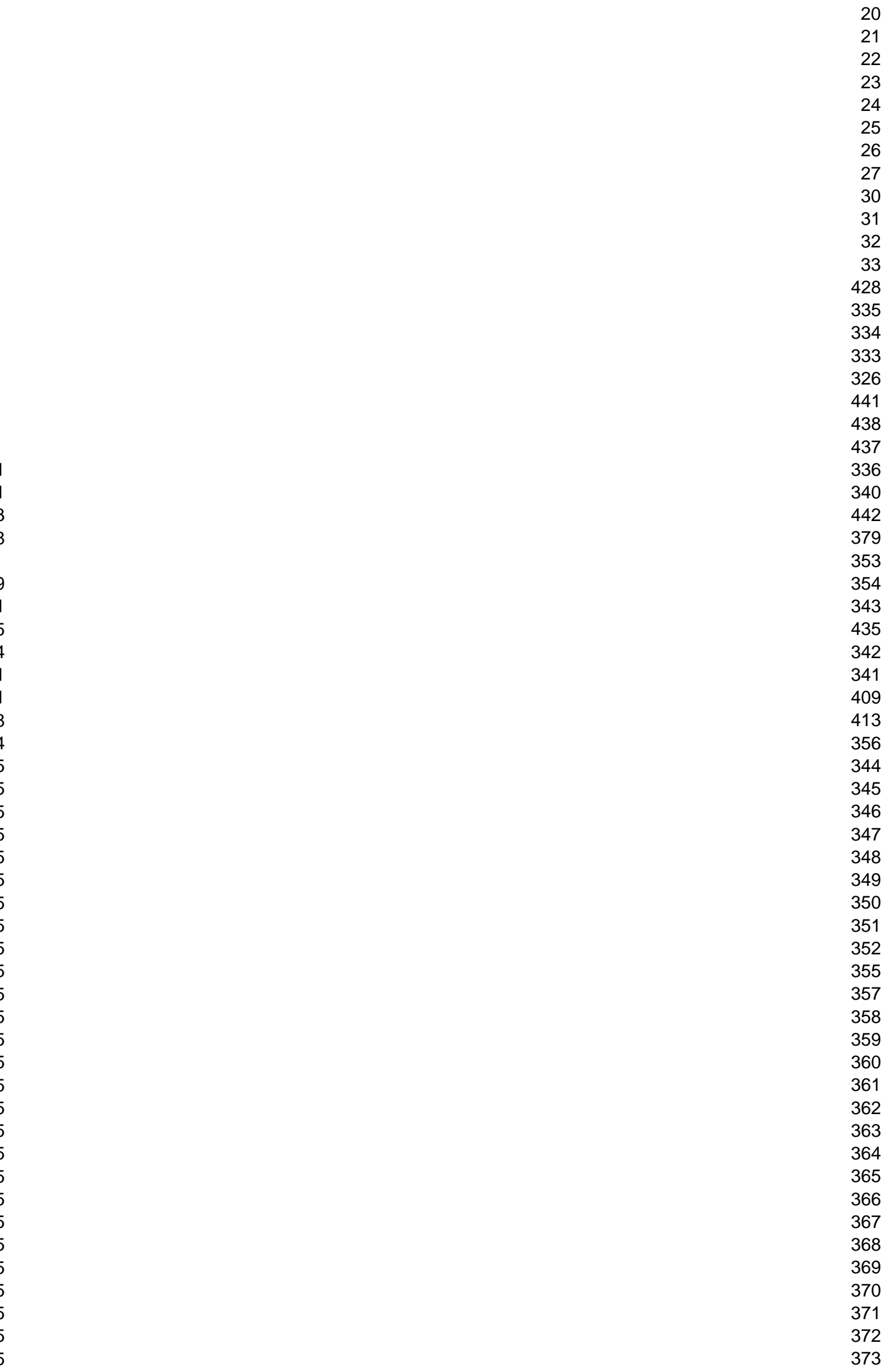


Konkordanz: alte Registratur-Signatur - Ifd. Nr.

alte Registratur-Signatur

Lfd.Nr.

I Gb 25

374

I Gb 25

I Gb 25

I Gb 25

I Gb 25

I Gb 25

I Gb 25

I Gb 25

I Gb 25

I Gb 25

I Gb 25

I Gb 25

I Gb 25

I Gb 25

I Gb 25

I Gb 25

I Gb 25

I Gb 25

I Gb 25

I Gb 25

I Gb 25

I Gb 25

I Gb 25

I Gb 25

I Gb 25

I Gb 25

I Gb 25

I Gb 25

I Gb 25

I Gb 25

I Gb 25

I Gb 25

I Gb 25

I Gb 25

I Gb 25

I Gb 25

I Gb 25

I Gb 25

I Gc 020

I Gc 029

I Gc 039

I Gc 039

I Gc 039

I Gc 041

I Gc 055

I Gc 057

I Gc 060

I Gc 108

I Gd 6

I Ge 03

I Ge 03

I Ge 08

I Ge 11

I Ge 11

I Ge 50

I Ge 51

I Ge 52

I Gf 5

II A 01

II A 01 
Konkordanz: alte Registratur-Signatur - Ifd. Nr.

alte Registratur-Signatur

Lfd.Nr.

II $A 01$

II A 01

II $A 01$

II A 01

II A 01

II $A 01$

II $A 01$

II $A 01$

II $A 01$

II $A 01$

II $A 01$

II A 01

II $A 01$

II $A 01$

II A 01

II $A 01$

II $A 01$

II $A 01$

II $A 01$

II $A 01$

II A 01

II $A 01$

II A 01

II A 01

II $A 01$

II A 01

II $A 01$

II $A 01$

II A 01

II $A 01$

II A 01

II A 01

II $A 01$

II A 01

II A 03

II A 05

II A 06

II A 06

II A 06

II A 10

II A 12

II A 13

II A 14

II A 16

II $B$

II B

II B

II B 5

II B 6

II B 7

II B 7 b

II B 7b, 41

II B 7b, 7

II B 8

II B 8

II B 8

II B 8

II B 8

II B 9

II B 9 
Konkordanz: alte Registratur-Signatur - Ifd. Nr.

alte Registratur-Signatur

Lfd.Nr.

II B 9

II B 9

II B 9

II B 9

II $B$

II B 9

II $\mathrm{B} 9$

II B 9

II B 9

II B 9

II B 9

II B 9

II B 9

II Bc

II Bc 29

II Bc 35

II Be 3

II C 11

II C 46

II E 38

II E 38

II E 47

II E 52

II E 52

II E 61

II E 65

II E 67

II E 68

II E 79

II F 14

III Aa 09

III Aa 15

III Aa 16

III Aa 17

III Aa 19

III Aa 20

III Aa 22

III Ab 05

III Ab 06

III Ab 07

III Ab 08

III Ab 09

III Ab 09

III Ab 09

III Ab 09

III Ab 10

III Ab 10

III Ab 10

III $A b 10$

III $A b 10$

III Ab 10

III Ab 10

III Ab 11

III $A b 11$

III Ac 11

III Ad 3

III Ad 3

III Ad 7

III Bb 04

III Bb 09

466

467

468

469

470

471

472

473

474

475

476

477

478

13

215

205

7

232

1912

322

323

329

331

332

2393

2394

327

325

328

1149

174

201

199

196

197

198

200

189

175

190

188

176

180

181

182

177

178

183

184

185

186

187

179

195 
Konkordanz: alte Registratur-Signatur - Ifd. Nr.

alte Registratur-Signatur

Lfd.Nr.

III Bb 13

III Bb 22

III Bb 23

III $\mathrm{Bb} 35$

III Bc 02

III Bc 29

III Bc 34

III Bd 01

III Bd 18

III Bd 18

III Bd 18

III Bd 19

III Be 1

III Bf 5

III Bg 1

III C

III C 01

III C 02

III C 02

III C 02

III C 09

III C 10

III C 12

III C 12

III C 16

III C 16

III C 16 a

III C 18

III C 18

III C 19

III C 21

III C 22

III C 22

III C 22

III C 22

III C 22

III C 22

III C 22

III C 22

III C 22

III C 22

III C 22

III C 22

III C 22

III C 22 I

III C 23

III C 23

III C 25

III C 33

III C 33

III C 33

III C 33

III C 33 IIh

III Dc 3

III Dc 5

III Dc 6

III Df 2

III Df 2

III Df 2

III Df 2 
Konkordanz: alte Registratur-Signatur - Ifd. Nr.

alte Registratur-Signatur

Lfd.Nr.

III Df 2

III Df 2

III Df 2

III Df 2

III Dg 07

III Dg 08

III Dg 08

III Dg 10

III Ea 3

III Ea 3

III Ea 3

III Ea 3

III Ea 3

ÎII Ea 3

III Eb 1-2

IV

IV A 1

IV A 2

IV A2c 15

IV B 03

IV B 19

IV B I| 30

IV B4 06

IV B4 06

IV B4 06

IV B4 06

IV B4 06

IV B4 06

IV B4 06

IV B4 06

IV B4 06

IV B4 06

IV B4 06

IV B4 06

IV B4 06

IV B4 06

IV B4 06

IV B4 06

IV B4 06

IV B4 06

IV B4 06

IV B4 06

IV B4 06

IV B4 06

IV B4 06

IV B4 06

IV B4 06

IV B4 06

IV B4 06

IV B4 06

IV B4 06

IV B4 06

IV B4 06

IV B7 2

IV Ba 13

IV Ba 53

IV Bb 4, 33

IV Bc 4

IV Bc 8

IV Bd 1

262

263

264

265

508

270

271

3231

218

219

220

221

222

217

216

714

317

330

3482

452

3316

3751

3777

3778

3779

3780

3781

3782

3783

3784

3785

3786

3787

3788

3790

3791

3792

3793

3794

3795

3796

3797

3798

3799

3800

3801

3802

3803

3804

3805

3806

3807

3808

3614

273

1942

1759 
Konkordanz: alte Registratur-Signatur - Ifd. Nr.

alte Registratur-Signatur

Lfd.Nr.

IV BI 05

3379

IV C 07

274

IV C 09

2392

IV C 25

192

IV Cb

1150

IV Cb 02

457

IV Cb 02

458

IV Cb 16

459

IV Cb 16

460

IV Cb 16

461

IV Cb 16

IV Cd 02, 2

822

IV Cd 12

74

IV Cd 12

455

IV Cd 13

456

IV Cd 13

2365

IV Cd 13

2366

IV Cd 17

2368

IV Cd 39

2364

IV Cd 39

1902

IV Cd 39

1903

IV Cd 46

1904

IV Cd 48

1401

IV Cd 81

1894

IV Cd 84

2988

IV CI 33

479

IV Cl 41

3458

IV Db 06

3464

IV Db 11

489

IV Db 24

487

IV Db 25

490

IV Dc 08

488

IV Dc 10

IV Dc 12

480

481

IV Dc 14

492

IV Dh 05

482

IV Dh 07

494

IV Dh 08

483

IV Dh 14

IV Dh 15

IV Dh 16

IV Dh 18

IV Ea 06

IV Ea 11

IV Ea 12

IV Ea 13

IV Ea 18

IV Ea 19

486

495

485

493

496

502

509

510

499

498

500

IV Ea 21

501

IV Ea 21

1248

IV Ea 22

IV Ea 23 


\section{IV}

Konkordanz: alte Registratur-Signatur - Ifd. Nr.

alte Registratur-Signatur

Lfd.Nr.

IV Eg 2

575

IV Eg 3

574

IV Ei 05

522

IV Ei 05

523

IV Ei 26

524

IV Ei 27

525

IV Ei 32

527

IV Ei 33

526

IV F 6

2369

IV Fa 03

IV Fa 04

725

IV Fa 08

515

IV Fa 14

514

IV Fa 14

IV Fa 16

512

IV Fa 16

513

IV Fa 18

516

IV $\mathrm{Fb} 01$

IV $\mathrm{Fb} 24$

IV Fc 09

IV Fc 15

IV Fd 4

IV Fd 7

IV Fd 9

IV Fe 13

IV Ff 11

IV Ff 12

IV Ff 60

IV Fg 02

IV Fg 02

IV Fg 02

IV Fg 07

IV Fg 07

IV Fg 08

IV Fg 09

IV Fg 10

IV Fg 11

IV Fg 12

IV Fg 13

IV Fg 15

IV Fg 16

IV Fg 35

IV Fg 49

IV Fg 49

IV Fi 005

IV Fi 008

IV Fi 012

IV Fi 012

IV Fi 013

IV Fi 013

IV Fi 013

IV Fi 013

IV Fi 013

IV Fi 013

IV Fi 013

IV Fi 013

IV Fi 013

IV Fi 013

IV Fi 014

IV Fi 014

518

529

453

554

555

557

558

559

556

974

975

560

561

562

563

570

571

569

564

572

565

566

573

568

567

1032

1051

1052

1924

576

577

578

579

580

581

582

583

584

585

586

587

588

718

2001 
Konkordanz: alte Registratur-Signatur - Ifd. Nr.

alte Registratur-Signatur

Lfd.Nr.

IV Fi 014

IV Fi 014

IV Fi 014

IV Fi 015

IV Fi 015

IV Fi 015

IV Fi 015

IV Fi 015

IV Fi 015

IV Fi 015

IV Fi 015

IV Fi 015

IV Fi 015

IV Fi 015

IV Fi 015

IV Fi 015

IV Fi 015

IV Fi 015

IV Fi 015

IV Fi 015

IV Fi 015

IV Fi 015

IV Fi 015

IV Fi 016

IV Fi 018

IV Fi 019

IV Fi 019

IV Fi 020

IV Fi 021

IV Fi 022

IV Fi 022

IV Fi 023

IV Fi 024

IV Fi 025

IV Fi 026

IV Fi 027

IV Fi 028

IV Fi 028

IV Fi 032

IV Fi 033

IV Fi 034

IV Fi 035

IV Fi 037

IV Fi 038

IV Fi 039

IV Fi 040

IV Fi 043

IV Fi 050

IV Fi 051

IV Fi 052

IV Fi 053

IV Fi 054

IV Fi 055

IV Fi 056

IV Fi 057

IV Fi 058

IV Fi 058

IV Fi 059

IV Fi 060

IV Fi 061

2002

2003

2004

589

590

591

592

593

594

595

596

603

604

605

606

607

608

609

610

611

612

613

614

597

598

599

625

624

623

617

672

622

621

620

619

618

615

616

1905

629

628

626

627

630

631

632

633

635

636

637

634

638

640

639

641

650

1684

642

649

651 
IV

Konkordanz: alte Registratur-Signatur - Ifd. Nr.

alte Registratur-Signatur

Lfd.Nr.

IV Fi 062

IV Fi 063

IV Fi 063 b

IV Fi 064

IV Fi 065

IV Fi 066

IV Fi 068

IV Fi 069

IV Fi 070

IV Fi 071

IV Fi 072

IV Fi 073

IV Fi 074

IV Fi 075

IV Fi 076

IV Fi 077

IV Fi 078

IV Fi 079

IV Fi 080

IV Fi 081

IV Fi 082

IV Fi 083

IV Fi 084

IV Fi 086

IV Fi 087

IV Fi 089

IV Fi 090

IV Fi 091

IV Fi 093

IV Fi 094

IV Fi 095

IV Fi 096

IV Fi 097

IV Fi 098

IV Fi 099

IV Fi 100

IV Fi 101

IV Fi 102

IV Fi 104

IV Fi 105

IV Fi 106

IV Fi 107

IV Fi 108

IV Fi 109

IV Fi 110

IV Fi 111

IV Fi 113

IV Fi 114

IV Fi 115

IV Fi 116

IV Fi 117

IV Fi 120

IV Fi 121

IV Fi 122

IV Fi 123

IV Fi 126

IV Fi 128

IV Fi 129

IV Fi 130

IV Fi 131

643

652

644

645

646

647

648

659

653

654

655

660

656

657

661

662

658

663

664

665

666

667

670

669

668

671

673

674

686

688

675

676

677

678

679

680

681

682

683

684

685

687

689

690

691

692

693

694

701

695

696

697

698

699

602

700

702

703

704

600 
Konkordanz: alte Registratur-Signatur - Ifd. Nr.

alte Registratur-Signatur

Lfd.Nr.

IV Fi 132

IV Fi 133

IV Fi 134

IV Fi 137

IV Fi 138

IV Fi 139

IV Fi 140

IV Fi 141

IV Fi 142

IV Fi 144

IV Fi 145

IV Fi 146

IV Fk 7 a

IV Fk 7 b

IV Fk 9

IV Fm 4

IV Fr 1

IV Fv 1

IV Ga 01

IV Ga 01

IV Ga 07

IV Ga 11

IV Ga 12

IV Ga 13

IV Ga 13

IV Ga 20

IV Ga 20

IV Ga 21

IV Ga 22

IV GA 30

IV Ga 33

IV Ga 38 a

IV Ga 41

IV Ga 51

IV Ga 52

IV Gb 1

IV Ge 35

IV Gh 1

IV Gh 1

IV Gk 01

IV Gk 02

IV Gk 12

IV Gk 15

IV Gk 18

IV Gk 18

IV Gk 19

IV Gk 21

IV Gk 22

IV Gk 24

IV Gk 25

IV Gk 26

IV Gk 27

IV Gk 30 a

IV Gk 30 b

IV Gk 30 c

IV Gq 1

IV Gr 03

IV Gr 09

IV Gr 10

IV Gs 01 
Konkordanz: alte Registratur-Signatur - Ifd. Nr.

alte Registratur-Signatur

Lfd.Nr.

IV Gs 01

793

IV Gs 02

785

IV Gs 02

786

IV Gs 02

787

IV Gs 02

788

IV Gs 1

IV Gs 17

795

IV Gs 17

789

IV Gs 17

790

IV Gs 17

791

IV Gs 18

792

IV Ha 04

IV Ha 06

796

IV $\mathrm{Ha} 08$

IV Ha 09

815

IV Ha 10

809

IV $\mathrm{Ha} 11$

797

IV Ha 12

798

IV Ha 17

799

817

IV Ha 18

800

IV $\mathrm{Ha} 19$

IV Ha 20

801

IV $\mathrm{Hb} 2$

803

IV $\mathrm{Hb} 3$

810

IV Hb 4

IV $\mathrm{Hb} 5$

811

IV Hc 1

IV Hc 3

IV Hg 02

IV Hg 07

IV Hg 08

IV Hg 18

IV Hh 1

IV Hh 1

IV Hh 1

IV Hh 1

IV I

IV Ja 01

IV Ja 02

IV Ja 04

IV Ja 04

IV Ja 05

IV Ja 07

IV Ja 07

IV Ja 08

812

813

816

814

818

819

820

821

804

805

806

807

1015

1155

823

1156

1157

824

826

845

IV Ja 08

825

IV Ja 13

827

IV Ja 14

828

IV Ja 16

830

IV Ja 19

831

IV Ja 21

834

IV Ja 24

832

IV Ja 26

IV Ja 27

829

IV Ja 30

835

IV Ja 31

IV Ja 33

833

IV Ja 35

837

IV Ja 35

IV Ja 35 
Konkordanz: alte Registratur-Signatur - Ifd. Nr.

alte Registratur-Signatur

Lfd.Nr.

IV Ja 37

IV Ja 41

IV Jb 02

IV Jb 03

IV Jb 05

IV Jb 10

IV Jb 11

IV Jb 12

IV Jb 13

IV Jb 14

IV Jb 15

IV Jb 17

IV Jb 18

IV Jb 19

IV Jb 20

IV Jb 21

IV Jc 02

IV Jc 03

IV Jc 03

IV Jc 03

IV Jc 04

IV Jc 04

IV Jc 04

IV Jc 04

IV Jc 04

IV Jc 04

IV Jc 04

IV Jc 04

IV Jc 05

IV Jc 05

IV Jc 06

IV Jc 07

IV Jc 08

IV Jc 09

IV Jc 10

IV JC 10

IV Jc 12

IV Jc 13

IV Jc 13

IV Jc 14

IV Jc 16

IV Jc 19

IV Jd 1

IV Jd 2

IV Jd 3

IV Jd 4

IV Jd 6

IV Je 08

IV Je 09

IV Je 10

IV Je 11

IV Je 12

IV Je 13

IV Je 14

IV Je 15

IV Je 16

IV Je 18

IV Je 18

IV Je 18

IV Je 19 
Konkordanz: alte Registratur-Signatur - Ifd. Nr.

alte Registratur-Signatur

Lfd.Nr.

IV Je 20

973

IV Je 21

896

IV Je 22

897

IV Je 23

899

IV Je 24

898

IV Jf 07

980

IV Jf 07

981

IV Jf 10

982

IV Jf 13

1175

IV Jf 14

1176

IV Jf 15

IV Jf 16

IV Jf 17

1177

IV Jf 18

IV Jf 19

IV Jf 19

IV Jf 20

IV Jf 20

IV Jf 21

IV Jf 22

1178

976

IV Jf 23

IV Jf 24

IV Jf 25

IV Jf 26

IV Jf 27

IV Jf 28

IV Jf 30

IV Jf 31

IV Jf 32

IV Jf 32

IV Jf 32

IV Jf 33

IV Jf 34

IV Jf 35

IV Jf 36

IV Jf 37

IV Jf 38

IV Jf 39

IV Jf 40

IV Jf 41

IV Jf 42

IV Jf 43

IV Jf 45

IV Jf 46

IV Jf 47

IV Jf 48

IV Jf 49

IV Jf 50

IV Jg 03

IV Jg 03

IV Jg 03

IV Jg 18

IV Jg 20

IV Jg 21

IV Jg 22

IV Jg 24

IV Jg 26

IV Jg 27

IV Jg 28

977

978

979

983

984

985

986

987

988

989

990

991

992

993

994

995

996

997

998

999

1000

1001

1002

1003

1004

1005

1006

1007

1008

1009

1010

1011

1012

1013

1014

1016

1017

1018

1040

1041

1039

1038

1037

1019

1027

IV Jg 29 
Konkordanz: alte Registratur-Signatur - Ifd. Nr.

alte Registratur-Signatur

Lfd.Nr.

IV Jg 30

1020

IV Jg 31

1026

IV Jg 32

1029

IV Jg 33

1030

IV Jg 34

1031

IV Jg 37

1033

IV Jg 38

IV Jg 39

1034

IV Jg 40

1035

IV Jg 41

1036

IV Jg 42

IV Jg 43

1042

IV Jg 44

1043

IV Jg 45

IV Jg 46

IV Jg 46

IV Jg 47

IV Jg 48

IV Jg 50

IV Jg 51

IV Jg 51

IV Jg 51

IV Jg 52

IV Jg 53

IV Jg 53

IV Jg 54

IV Jg 55

IV Jg 55

IV Jg 55

IV Jg 55

IV Jg 55

IV Jg 55

IV Jg 55

IV Jg 56

IV Jg 58

IV Jg 59

IV Jg 60

IV Jg 61

IV Jg 62

IV Jg 63

IV Jg 64

IV Jg 65

IV Jg 65

IV Jg 65

IV Jg 65

IV Jg 65

IV Jg 65

IV Jg 65

IV Jg 65

IV Jg 65

IV Jg 65

IV Jg 65

IV Jg 65

IV Jg 65

IV Jg 65

IV Jg 65

IV Jg 65

IV Jg 65

IV Jg 65

IV Jg 65

1044

1045

1046

1047

1048

1049

1050

1053

1054

1055

1056

1057

1058

1059

1060

1061

1062

1063

1064

1065

1066

1067

1021

1068

1069

1070

1022

1071

1072

1073

1074

1083

1084

1085

1086

1087

1088

1089

1090

1091

1092

1093

1094

1095

1097

1098

1099

1100

1101 
Konkordanz: alte Registratur-Signatur - Ifd. Nr.

alte Registratur-Signatur

Lfd.Nr.

IV Jg 65

1102

IV Jg 65

1103

IV Jg 65

1104

IV Jg 65

1105

IV Jg 65

1106

IV Jg 65

1107

IV Jg 65

1108

IV Jg 65

1109

IV Jg 65

1110

IV Jg 65

1111

IV Jg 65

1112

IV Jg 65

1113

IV Jg 65

1114

IV Jg 65

1115

IV Jg 65

1116

IV Jg 65

1117

IV Jg 65

1118

IV Jg 65

1119

IV Jg 65

1120

IV Jg 65

1121

IV Jg 65

1122

IV Jg 65

1123

IV Jg 65

1124

IV Jg 65

1125

IV Jg 65

1126

IV Jg 65

1127

IV Jg 65

1128

IV Jg 65

1129

IV Jg 65

1130

IV Jg 65

1131

IV Jg 65

1132

IV Jg 65

1133

IV Jg 66

1075

IV Jg 67

1076

IV Jg 68

1077

IV Jg 69

1023

IV Jg 70

1096

IV Jg 71

1024

IV Jg 72

1078

IV Jg 73

1079

IV Jg 74

1080

IV Jg 75

1081

IV Jg 76

1025

IV Jh 01

843

IV Ji 01

900

IV Ji 01

901

IV Ji 01

902

IV Ji 01

903

IV Ji 01

904

IV Ji 01

905

IV Ji 02

906

IV Ji 03

907

IV Ji 05

908

IV Ji 06

909

IV Ji 07

910

IV Ji 09

911

IV Ji 10

912

IV Ji 11

913

IV Ji 12

914

IV Ji 13 
Konkordanz: alte Registratur-Signatur - Ifd. Nr.

alte Registratur-Signatur

Lfd.Nr.

IV Ji 14

IV Ji 15

IV Ji 16

IV Ji 16

IV Ji 17

IV Ji 18

IV Ji 19

IV Ji 20

IV Ji 20

IV Ji 21

IV Ji 22

IV Ji 23

IV Ji 24

IV Ji 25

IV Ji 26

IV Ji 27

IV Ji 28

IV Ji 29

IV Ji 30

IV Ji 31

IV Ji 32

IV Ji 33

IV Ji 34

IV Ji 35

IV Ji 36

IV Ji 38

IV Ji 39

IV Ji 40

IV Ji 41

IV Ji 41

IV Ji 42

IV Ji 43

IV Ji 44

IV Ji 44

IV Ji 44

IV Ji 44

IV Ji 45

IV Ji 46

IV Ji 47

IV Ji 48

IV Ji 49

IV Ji 50

IV Ka 02

IV Ka 05

IV Ka 05

IV Ka 05

IV Ka 06

IV Ka 08

IV Ka 08

IV Ka 10

IV Ka 11

IV Ka 12

IV Ka 12

IV Ka 12

IV Ka 12

IV Ka 12

IV Ka 13

IV Ka 14

IV Ka 16

IV Ka 16

916

917

918

919

920

921

922

923

924

925

926

927

928

929

930

931

932

933

934

935

936

937

938

939

940

941

942

943

944

945

946

947

948

949

950

951

952

953

954

955

956

957

1210

1211

1212

1213

1158

1159

1160

1161

1179

1137

1138

1139

1143

1162

1181

1163

1140 
Konkordanz: alte Registratur-Signatur - Ifd. Nr.

alte Registratur-Signatur

Lfd.Nr.

IV Ka 16

IV Ka 17

1142

IV Ka 18

1180

IV Ka 19

1151

IV Ka 20

1152

IV Ka 20

1134

IV Ka 21

1135

IV Ka 23

1153

IV Ka 24

1136

IV Ka 25

1154

IV Ka 28

1164

IV Ka 29

1166

IV Ka 30

1182

IV Ka 31

1183

IV Ka 32

1184

IV Ka 33

1185

IV Ka 34

1186

IV Ka 34

1144

IV Ka 36

1145

IV Ka 36

1187

IV Ka 36

1188

IV Ka 36

1189

IV Ka 36

1190

IV Ka 37

1191

IV Ka 38

1192

IV Ka 38

1193

IV Ka 39

1194

IV Ka 39

1167

IV Ka 39

1195

IV Ka 41

1196

IV Ka 43

1197

IV Ka 43

1198

IV Ka 44

1199

IV Ka 45

1200

IV Ka 46

1168

IV Ka 47

1169

IV Ka 49

1170

IV Ka 54

1171

IV Ka 55

1172

IV Ka 59

1173

1201

IV Ka 61

1202

IV Ka 62

1203

IV Ka 63

1146

IV Ka 64

1204

IV Ka 65

1205

IV Ka 66

1174

IV Ka 67

1147

IV Kb 04

1206

IV Kb 04

1207

IV Kb 05

1208

IV Kb 06

1209

IV Kc 46

1214

IV Kc 52

1215

IV Kc 55

1216

IV Kc 55

1217

IV Kc 55

1218

IV Kc 60

1219

IV Kc 61

1220

IV Kc 62 
Konkordanz: alte Registratur-Signatur - Ifd. Nr.

alte Registratur-Signatur

Lfd.Nr.

IV Kc 64

1223

IV Kc 65

1224

IV Kd 01

1226

IV Kd 02

1227

IV Kd 03

1228

IV Kd 03

1229

IV Kd 03

IV Kd 03

1230

IV Kd 04

1231

IV Kd 05

IV Kd 06

IV Kd 08

IV Kd 10

1232

1233

1234

1235

1236

IV Kd 11

IV Kd 12

1237

1238

IV Kd 13

1239

IV Kd 13

1240

IV Kd 13

1241

IV Kd 15

1242

IV Kd 16

1243

IV Kd 17

IV La 02

1244

1262

IV La 02

1263

IV La 02

1264

IV La 07

1249

IV La 08

1271

IV La 11

1293

IV La 12

1250

IV La 17

1260

IV La 18

1257

IV La 19

1388

IV La 21

1258

IV La 23

1259

IV La 24

1389

IV La 26

IV La 27

1251

1252

1253

La 28

1261

IV La 29

1254

1265

IV La 32

1266

IV La 34

1390

IV La 35

1267

IV La 40

1268

IV La 41

1269

IV La 42

1270

IV Lb 1

1272

IV Lb 1

1273

IV Lb 1

1274

IV Lb 1, 1

1277

1278

IV Lb 1, 1

1279

IV Lb 1, 1

1280

IV Lb 1, 1

1281

Lb 1, 1

1282

IV Lb 1, 1

IV Lb 2

1276

IV Lbl 1

1291

IV Lbl 1

1292

IV Lbl 3 
Konkordanz: alte Registratur-Signatur - Ifd. Nr.

alte Registratur-Signatur

Lfd.Nr.

IV LbI 5

IV Lbl 5

1284

IV Lbl 6

1285

IV Lbl 7

1286

IV Lbl 7

1287

IV Lbl 9

1288

IV Lbl 9

1289

IV Lc 067

1290

IV Lc 068

1313

IV Lc 069

1312

IV LC 070

1311

IV Lc 071

1310

IV Lc 072

1225

IV Lc 073

1309

IV Lc 074

1308

IV Lc 075

1307

IV LC 076

1306

IV Lc 077

1305

IV Lc 078

IV Lc 079

1303

IV LC 080

1302

IV LC 081

1301

IV Lc 082

1300

IV Lc 083

1299

IV Lc 084

1298

IV Lc 085

1297

IV Lc 086

1296

IV Lc 087

1295

IV Lc 088

1314

IV Lc 089

1315

IV Lc 090

1316

IV Lc 091

1317

IV Lc 092

1318

1319

IV Lc 093

1320

IV Lc 094

1321

IV Lc 095

1322

IV Lc 096

1323

IV Lc 097

1325

IV Lc 098

1324

IV Lc 099

1326

IV Lc 100

1327

IV LC 100

1328

IV LC 102

1329

IV LC 103

1330

IV Lc 104

IV Lc 105

IV LC 106

1333

IV LC 107

1334

IV LC 108

1335

IV LC 108

1336

IV LC 108

1337

IV LC 108

1338

IV LC 109

1339

IV LC 110

1340

IV LC 111

IV LC 112 
IV

Konkordanz: alte Registratur-Signatur - Ifd. Nr.

alte Registratur-Signatur

Lfd.Nr.

IV Lc 117

1383

IV LC 118

1345

IV Lc 119

1346

IV LC 120

1347

IV Lc 121

1348

IV Lc 122

1357

IV Lc 123

1349

IV Lc 124

1350

IV Lc 125

1351

IV Lc 126

IV LC 127

1352

1353

IV LC 128

1354

IV Lc 129

1355

IV LC 130

1356

IV LC 131

1358

IV Lc 132

1359

IV Lc 133

1360

IV LC 134

1361

IV LC 135

1362

IV Lc 136

1363

IV LC 137

1364

IV LC 138

1365

IV Lc 139

1366

IV Lc 140

1367

1368

IV Lc 142

1369

IV Lc 143

1370

IV LC 144

1371

IV LC 145

1372

IV Lc 146

1373

IV LC 147

1374

IV Lc 148

1375

IV Lc 149

1376

IV LC 150

1377

IV Lc 151

1378

1379

V LC 152

1380

IV Ld 3

1384

IV Ld 4

1385

1387

VLd 5

1386

1391

IV Le 4

IV Le 4

1392

1393

1394

IV Le 7

IV Le 8

1395

1396

1397

IV Lf 5

1398

1399

IV Lh 1

1400

IV Li 1

1402

IV Ma 13

1403

IV Ma 13

1430

Ma 13

1431

IV Ma 20

1432

IV Ma 20

1433

IV Ma 20

1434

IV Ma 20

1435

IV Ma 20

1436 
IV

Konkordanz: alte Registratur-Signatur - Ifd. Nr.

alte Registratur-Signatur

Lfd.Nr.

IV Ma 20

1437

IV Ma 20

1438

IV Ma 22

1404

IV Ma 23

1405

IV Ma 24

1406

IV Ma 25

IV Ma 26

IV Ma 27

1407

1408

1411

IV Ma 28

1409

IV Ma 29

1410

IV Ma 31

1412

IV Ma 32

1413

IV Ma 35

1414

IV Ma 36

IV Ma 37

1439

1415

IV Ma 39

1454

IV Ma 39

IV Ma 39

1455

1456

IV Ma 39

1457

IV Ma 39

1458

IV Ma 39

1459

IV Ma 39

1460

IV Ma 39

1461

IV Ma 39

IV Ma 39

1462

1463

IV Ma 39

1464

IV Ma 39

1465

IV Ma 39

1466

IV Ma 39

1467

1468

IV Ma 39

1469

IV Ma 39

IV Ma 39

1470

IV Ma 39

1471

IV Ma 39

1472

IV Ma 39

1473

IV Ma 39

1474

1475

IV Ma 39

1476

IV Ma 39

1477

IV Ma 39

1478

IV Ma 39

1479

IV Ma 39

1480

IV Ma 39

1481

IV Ma 39

1482

IV Ma 39

1483

IV Ma 40

1416

IV Ma 41

1451

IV Ma 42

1417

IV Ma 43

IV Ma 44

1418

1444

1446

1419

IV Ma 47

1426

IV Ma 48

1445

1449

IV Ma 48

1425

IV Ma 49

1442

IV Ma 49

1424

Ma 50

1423

IV Ma 51

1440 
IV

Konkordanz: alte Registratur-Signatur - Ifd. Nr.

alte Registratur-Signatur

Lfd.Nr.

IV Ma 52

IV Ma 53

IV Ma 56

IV Ma 57

IV Ma 58

IV Ma 59

IV Ma 60

IV Ma 61

IV Mb 1

IV Mb 2

IV Md 4

IV Md 5

IV Md 5

IV Md 6

IV Md 7

IV Md 8

IV Me 06

IV Me 08

IV Me 09

IV Me 18

IV Me 19

IV Me 19

IV Me 20

IV Me 21

IV Me 22

IV Me 24

IV Me 24

IV Me 26

IV Me 36

IV Me 38

IV Mf 07

IV Mf 12

IV Mf 12

IV Mf 13

IV Mg 03

IV Mg 04

IV Mg 06

IV Mg 07

IV Mg 08

IV Mg 09

IV Mg 10

IV Mg 10

IV Mg 10

IV Mg 10

IV Mg 10

IV Mg 10

IV Mg 10

IV Mg 10

IV Mg 10

IV Mg 10

IV Mg 10

IV Mg 10

IV Mg 10

IV Mg 10

IV Mg 10

IV Mg 10

IV Mg 10

IV Mg 11

IV Mg 13

IV $\mathrm{Mg} 7$ 
IV

Konkordanz: alte Registratur-Signatur - Ifd. Nr.

alte Registratur-Signatur

Lfd.Nr.

IV Mh 11

1539

IV Mh 12

1532

IV Mh 24

1530

IV Mh 24

IV Mh 25

IV Mh 33

1450

IV Mh 44

IV Mi 01

1533

1534

IV Mi 02

1540

IV Mi 04

1541

IV Mi 06

1542

IV Mi 11

1543

IV Mi 11

1544

IV Mi 11

1545

IV Mi 12

1546

IV Mi 13

1547

1548

IV Mi 14

1549

IV Mi 15

1550

IV Mi 16

1551

IV Mi 17

1552

IV Mi 17

IV Mi 20

1553

1554

IV Mk 12

1555

IV Mk 13

IV Ml 01

1556

1560

IV MI 15

1557

IV MI 16

1558

IV MI 17

1561

IV $\mathrm{Mm} 1$

1562

IV $\mathrm{Mm} 1$

1563

IV $\mathrm{Mm} 2$

IV Mn 1

1564

IV Mn 2

1565

IV Mn 4

1567

1566

IV Mn 5

1568

IV Mn 6

1569

IV Mo 01

1570

IV Mo 01

1571

IV Mo 11

1572

IV Mp 3

1573

IV Ms 2

1574

IV Ms 3

1577

IV Ms 7

1575

IV Ms 8

1576

IV Ms 9

1578

IV Mt 01

IV Mt 02

1593

IV Mt 03

1594

1595

IV Mt 03

1596

IV Mt 04

1597

IV Mt 05

1598

IV Mt 06

1579

IV Mt 06

1580

IV Mt 06

1585

IV Mt 06

1586

IV Mt 07

1581

IV Mt 08

1587

IV Mt 09

1582

IV Mt 09

1583

IV Mt 09 
IV

Konkordanz: alte Registratur-Signatur - Ifd. Nr.

alte Registratur-Signatur

Lfd.Nr.

IV Mt 10

1588

IV Mt 10

1589

IV Mt 11

1590

IV Mt 12

1591

IV Mt 13

1592

IV Mt 14

IV Mt 14

IV Mt 14

1599

1600

IV Mt 14

1601

1602

IV Mt 14

IV Mt 15

IV Mt 16

IV Mt 17

1603

1604

1605

1606

IV Mt 18

IV Mt 19

1607

IV Mt 19

1608

1609

IV Mt 19

1610

IV Mt 19

1611

IV Mt 19

1612

IV Mt 19

1613

IV Mt 20

IV Mt 21

1614

1615

IV Mt 22

1616

IV Mt 23

1617

1618

V Mt 24

1619

1620

1621

IV Mt 25

1622

1623

IV Mt 25

1624

IV Mt 25

1625

IV Mt 25

1626

Mt 28

1627

1628

1630

IV Mu 5

1629

1631

IV Mu 9

3163

3164

IV N 02

3165

IV N 04

3167

IV N 04

9

IV Na 3

1632

IV Nb 6

1633

IV Nb 6

IV Nd 3

1634

IV Pa 3

1635

IV Pa 5

728

IV Pa 5

729

IV Pa 7

730

IV $\mathrm{Pb} 1$

731

IV Pb 5

IV Pb 5

732

733

IV Pb 5

734

735

IV $\mathrm{Pb} 5$

736

IV $\mathrm{Pb} 6$

737

IV $\mathrm{Pb} 6$

IV $\mathrm{Pb} 8$

IV $\mathrm{Pb} 9$ 
IV

Konkordanz: alte Registratur-Signatur - Ifd. Nr.

alte Registratur-Signatur

Lfd.Nr.

IV Pc 2

IV Pc 3

IV Qu 12

IV Qu 13

IV Ra 03

IV Ra 03

IV Ra 04

IV Ra 05

IV Ra 14

IV Ra 14

IV Ra 18

IV Ra 19

IV Rc 6

IV Rd 5

IV Re 011

IV Re 012

IV Re 013

IV Re 013

IV Re 037

IV Re 038

IV Re 039

IV Re 047

IV Re 047

IV Re 049

IV Re 049

IV Re 050

IV Re 054

IV Re 055

IV Re 055

IV Re 055

IV Re 055

IV Re 055

IV Re 055

IV Re 055

IV Re 055

IV Re 060

IV Re 061

IV $\operatorname{Re} 076$

IV $\operatorname{Re} 083$

IV Re 086

IV Re 086

IV Re 086

IV Re 089

IV Re 109

IV Re 110

IV Re 111

IV Re 111

IV Re 111

IV Re 111

IV Re 112

IV Re 113

IV Re 114

IV Re 117

IV Re 119

IV Re 121

IV Re 122

IV Re 123

IV Re 124

IV Re 125

IV Rf 02

741

742

173

1245

1913

1914

1915

1917

1918

1919

1920

1916

1636

1921

1637

1638

1639

1640

1641

1642

1643

1644

1645

1646

1647

1648

1649

1650

1651

1652

1653

1654

1655

1656

1657

1658

1659

1660

1661

1662

1663

1664

1665

1666

1667

1668

1669

1670

1671

1672

1673

1674

1675

1676

1677

1678

1679

1680

1681

1685 
IV

Konkordanz: alte Registratur-Signatur - Ifd. Nr.

alte Registratur-Signatur

Lfd.Nr.

IV Rf 02

IV Rf 05

IV Rf 05

IV Rf 05

IV Rf 07

IV Rf 09

IV Rf 10

IV Rf 11

IV Rf 14

IV Rf 15

IV Rf 15

IV Rf 16

IV Rf 17

IV Rf 18

IV Rf 32

IV Rf 37

IV Rf 38

IV Rh 1

IV Rh 1

IV RI 16

IV RI 28

IV Sb 20

IV Sb 4

IV Sc 01

IV Sc 21

IV Sc 29

IV Sc 35

IV Sd 078

IV Sd 078

IV Sd 078

IV Sd 117

IV Sd 119

IV Sd 120

IV Sd 122

IV Sd 125

IV Sd 125

IV Sd 125

IV Sd 125

IV Sf 1

IV Sg 1

IV Sg 2

IV Sg 4

IV Sg 4

IV Sg 5

IV Sg 5

IV Sg 5

IV Sg 8

IV Sg 8

IV Sh 12

IV Sk 03

IV Sk 09

IV Sk 10

IV Sk 12

IV Sk 18

IV Skl 01

IV Skl 04

IV Skl 06

IV Skl 14

IV Skl 14

IV Skl 14

1686

1687

1688

1689

1690

1691

1692

1693

1694

1695

1699

1696

1697

1698

1700

1701

1702

2931

2932

1682

1683

1708

1707

1709

1710

1711

1712

1733

1734

1735

1736

1746

1747

1748

1742

1743

1744

1745

1751

1752

1749

1750

1753

1754

1755

1756

1757

1758

1706

1760

1761

1861

1862

1762

1771

1772

1773

1774

1775

1776 
IV

Konkordanz: alte Registratur-Signatur - Ifd. Nr.

alte Registratur-Signatur

Lfd.Nr.

IV Skl 16

1863

IV Skl 20

1777

IV Skl 26

1778

IV SkI 31

1779

IV SkI 32

1780

IV SkI, 02

1763

IV Skl, 02

1764

IV SkI, 02

1765

IV Skl, 02

1766

IV Skl, 02

1767

IV Skl, 02

1768

IV Skl, 02

1769

IV Skl, 02

1770

IV Skll 01

1864

IV Skll 02

1867

IV Skll 02

1868

IV Skll 03

1865

IV Skll 04

1866

IV SkIII 01

1870

IV SkIII 03

1871

IV SkIII 05

1781

IV SkIII 05

1869

IV SkIII 07

1782

IV SkIII 10

1783

IV SkIII 10

1784

IV SkIII 10

1785

IV SkIII 10

1786

IV SkIII 10

1787

IV SkIII 10

1788

IV SkIII 10

1789

IV SkIII 10

1790

IV SkIII 10

1791

IV SkIII 10

1792

IV SkIII 10

1793

IV SkIII 10

1794

IV SkIII 10

1795

1796

IV SkIII 10

1797

IV SkIII 10

1798

V SkIII 10

1799

V SkIll 10

1800

IV SkIII 10

1801

IV SkIII 10

1802

IV SkIII 10

1803

IV SkIII 10

1804

IV SkIII 10

1805

IV SkIII 10

1806

IV SkIII 10

1807

IV SkIII 10

1808

IV SkIII 10

1809

IV SkIII 10

1810

IV SkIII 10

1811

IV SkIII 10

1812

IV SkIII 10

1813

IV SkIII 10

1814

IV SkIII 10

1815

IV SkIII 10

1816

IV SkIII 10

1817

IV SkIII 10

1818

IV SkIII 10 
IV

Konkordanz: alte Registratur-Signatur - Ifd. Nr.

alte Registratur-Signatur

Lfd.Nr.

IV SkIII 10

1820

IV SkIII 10

1821

IV SkIII 10

1822

IV SkIII 10

1823

IV SkIII 10

1824

IV SkIII 10

1825

IV SkIII 10

1826

IV SkIII 10

1827

IV SkIII 10

1828

IV SkIII 10

1829

IV SkIII 10

1830

IV SkIII 10

1831

IV SkIII 10

1832

IV SkIII 10

1833

IV SkIII 10

1834

IV SkIII 10

1835

IV SkIII 10

1836

IV SkIII 10

1837

IV SkIII 10

1838

IV SkIII 10

1839

IV SkIII 10

1840

IV SkIII 10

1841

IV SkIII 10

1842

IV SkIII 10

1843

IV SkIII 10

1844

IV SkIII 10

1845

IV SkIII 10

1846

IV SkIII 10

1847

IV SkIII 10

1848

IV SkIII 10

1849

IV SkIII 10

1850

IV SkIII 10

1851

IV SkIII 10

1852

IV SkIII 10

1853

IV SkIII 10

1854

IV SkIII 10

1855

1856

IV SkIII 10

1857

IV SkIII 10

1858

V SkIII 10

1859

SkIII 10

1860

IV SkIV 002

1713

IV SkIV 003

1714

1715

IV SkIV 006

1716

IV SkIV 006

1717

IV SkIV 007

1718

1719

IV SkIV 012

1720

1721

IV SkIV 013

1722

1723

IV SkIV 016

1724

IV SkIV 018

1725

1727

IV SkIV 024

1728

IV SkIV 025

1729

V SkIV 026

1730

1731

IV SkIV 027

1732 
Konkordanz: alte Registratur-Signatur - Ifd. Nr.

alte Registratur-Signatur

Lfd.Nr.

IV SI 2

IV Sm 001

1893

IV Sm 011

1872

IV Sm 013

1873

IV Sm 014

IV Sm 015

1875

IV Sm 016

1876

IV Sm 017

1877

IV Sm 019

1878

IV Sm 020

1879

IV Sm 021

1880

IV Sm 022

IV Sm 023

1882

IV Sm 024

IV Sm 025

1883

1884

IV Sm 029

1885

1886

IV Sm 029

1887

IV Sm 032

1888

IV Sm 126

1889

IV Sm 130

1890

IV Sm 131

1891

IV Sm 132

1892

IV T1

2900

IV T1 26

1906

IV T1 26

1907

IV T1 27

1908

IV T1 29

1925

IV T1 33

2107

IV T1 33

2108

IV T1 33

2109

IV T1 33

2110

IV T1 33

2111

IV T1 34

2112

IV T1 35

1910

IV T1 36

IV T1 37

1911

1909

IV T1 38

2113

IV T1 40

1926

IV T10

2141

IV T10 01

2137

IV T10 02

2138

IV T10 02

2139

IV T10 02

2140

IV T10 02

2142

IV T10 03

2146

IV T10 04

2143

IV T10 06

2144

IV T10 07

2145

IV T10 08

2147

IV T10 08

2148

IV T10 08

2149

IV T10 16

2150

IV T10 20

2151

IV T10 21

2152

IV T10 22

IV T10 23

2154

IV T10 24

2155

IV T11 20

2157

IV T11 23

2158

IV T11 23

2159 
Konkordanz: alte Registratur-Signatur - Ifd. Nr.

alte Registratur-Signatur

Lfd.Nr.

IV T11 28

2160

IV T12 05

2186

IV T12 06

2187

IV T12 07

2382

IV T12 17

2182

IV T12 22

2184

IV T12 27

2183

IV T12 37

2185

IV T13 01

1931

IV T13 02

1932

IV T13 04

1933

IV T13 05

1934

IV T13 06

1935

IV T13 07

IV T13 07

1936

IV T2 45

1937

IV T3 14

1927

IV T3 15

1944

IV T5

1945

IV T5 19

2000

IV T5 21

1946

IV T5 22

1947

IV T5 23

1948

IV T5 23

1949

IV T5 25

1950

IV T5 25

1957

IV T5 26

1958

1951

IV T5 27

IV T5 27

1953

1954

IV T5 27

1955

IV T5 27

1956

IV T5 29

1959

IV T5 30

1960

IV T5 30

1961

IV T5 30

IV T5 30

1962

1963

1964

IV T5 32

1965

IV T5 34

1966

V T5 35

1967

1V 156

1968

IV T5 37

1969

IV T5 38

1970

IV T5 38

1971

IV T5 38

1972

IV T5 38

1973

IV T5 40

1974

IV T5 41

1975

IV T5 42

1976

IV T5 43

1977

IV T5 45

1978

IV T5 45

1979

IV T5 45

1980

IV T5 45

1981

IV T5 45

1982

IV T5 45

1983

IV T5 45

IV T5 45

1984

IV T5 45

1985

IV T5 46

1986

1952 
Konkordanz: alte Registratur-Signatur - Ifd. Nr.

alte Registratur-Signatur

Lfd.Nr.

IV T5 47

IV T5 48

IV T5 49

IV T5 50

IV T5 51

IV T5 53

IV T5 54

IV T5 54

IV T5 56

IV T6 001

IV T6 002

IV T6 007

IV T6 018

IV T6 021

IV T6 021

IV T6 022

IV T6 030

IV T6 034

IV T6 040

IV T6 041

IV T6 044

IV T6 049

IV T6 051

IV T6 051

IV T6 051

IV T6 055

IV T6 056

IV T6 056

IV T6 056

IV T6 056

IV T6 056

IV T6 056

IV T6 056

IV T6 061

IV T6 061

IV T6 061

IV T6 061

IV T6 061

IV T6 061

IV T6 061

IV T6 061

IV T6 061

IV T6 061

IV T6 061

IV T6 065

IV T6 069

IV T6 073

IV T6 076

IV T6 087

IV T6 089

IV T6 092

IV T6 093

IV T6 096

IV T6 099

IV T6 100

IV T6 100

IV T6 100

IV T6 102

IV T6 104

IV T6 107

1987

1988

1989

1990

1991

1992

1993

1994

1995

1996

2018

2156

2114

1928

1943

2115

2019

2116

2020

1929

2016

2017

2012

2013

2014

2015

2005

2006

2007

2008

2009

2010

2011

1453

2021

2022

2023

2024

2025

2026

2027

2028

2029

2030

2031

2032

2117

2118

2120

1922

2121

2122

2123

1930

2033

2034

2035

2036

2037

1900 
Konkordanz: alte Registratur-Signatur - Ifd. Nr.

alte Registratur-Signatur

Lfd.Nr.

IV T6 108

2124

IV T6 110

2038

IV T6 111

2125

IV T6 112

2039

IV T6 115

2040

IV T6 116

2126

IV T6 117

2041

IV T6 118

2042

IV T6 119

2181

IV T6 120

2043

IV T6 121

2127

IV T6 122

2044

IV T6 124

2045

IV T6 125

IV T6 125

1997

IV T6 125

1998

IV T6 125

1999

IV T6 125

2046

IV T6 125

2047

2048

IV T6 125

2049

IV T6 127

2050

IV T6 129

2051

IV T6 131

2370

IV T6 131

2371

IV T6 131

2372

IV T6 131

2373

IV T6 132

2052

IV T6 133

2053

IV T6 134

2128

IV T6 135

2054

IV T6 135

2055

IV T6 135

2056

IV T6 135

2057

IV T6 136

2129

IV T6 137

2058

IV T6 139

2059

IV T6 141

2060

IV T6 142

2061

IV T6 143

2062

IV T6 145

2063

IV T6 146

2064

IV T6 147

IV T6 147

2065

IV T6 147

2066

IV T6 147

2067

IV T6 147

2068

IV T6 147

2069

IV T6 147

2070

IV T6 147

2071

IV T6 147

2072

IV T6 147

2073

IV T6 149

2074

IV T6 150

2130

IV T6 152

2131

IV T6 153

2075

2076

IV T6 154

2132

IV T6 155

2077

IV T6 156

2078

IV T6 156 
Konkordanz: alte Registratur-Signatur - Ifd. Nr.

alte Registratur-Signatur

Lfd.Nr.

IV T6 160

2081

IV T6 161

2360

IV T6 161

2361

IV T6 161

2362

IV T6 161

2363

IV T6 161

2374

IV T6 162

2082

IV T6 163

2375

IV T6 164

2083

IV T6 165

2084

IV T6 166

2085

IV T6 167

2086

IV T6 167

2087

IV T6 168

2088

IV T6 169

2376

IV T6 169

2377

IV T6 170

1428

IV T6 171

2089

IV T6 172

2090

IV T6 173

2091

IV T6 174

2092

IV T6 175

2093

IV T6 176

2094

IV T6 176

2095

IV T6 176

2096

IV T6 179

2097

IV T6 179

2098

IV T6 179

2099

IV T6 180

2100

IV T6 180

2106

IV T6 183

1484

IV T6 183

1485

IV T6 184

2101

IV T6 186

2103

IV T6 186

2104

IV T6 187

2102

IV T6 188

1901

IV T6 189

1923

IV T6 190

2133

IV T6 192

2105

IV T6 202

2134

IV T6 202

2135

IV T6 203

2136

IV T6 204

3232

IV T7 01

2328

IV T7 01

2329

IV T7 01

2330

IV T7 01

2331

IV T7 01

2332

IV T7 01

2333

IV T7 02

2334

IV T7 02

2335

IV T7 02

2336

IV T7 02

2337

2338

IV T7 05

2339

IV T7 05

2341

V T7 07

2342

2340

IV T7 08

2343 
Konkordanz: alte Registratur-Signatur - Ifd. Nr.

alte Registratur-Signatur

Lfd.Nr.

IV T7 12

2345

IV T7 14

2346

IV T7 14

2347

IV T7 14

2348

IV T7 16

2349

IV T7 17

2350

IV T7 18

2351

IV T7 22

2344

IV T7 23

2352

IV T7 23

2353

IV T7 28

2354

IV T7 29

2355

IV T7 30

2357

IV T7 31

2356

IV T7 32

2358

IV T7 50

2359

IV T9 15

2378

IV T9 23

2379

IV T9 28

2383

IV T9 29

2384

IV T9 29

2385

IV T9 30

2386

IV T9 31

2387

IV T9 32

2388

IV T9 34

2389

IV T9 40

2380

IV T9 40

2390

IV T9 41

2381

IV Tz 69

3317

IV U 01

2395

IV U 02

2396

IV U 04

2397

IV U 08

2398

IV U 10

2399

IX B || 22

3744

IX B || 22

3747

|X B || 22

3748

IX B || 22

3749

IX B || 22

3750

IX Cl 40

IX / VIII a 001

3463

IX / VIII a 010

2188

IX / VIII a 014

2189

IX / VIII a 018

2190

IX / VIII a 022

2191

IX / VIII a 024

2192

IX / VIII a 025

2193

2194

IX / VIII a 028

2195

IX / VIII a 032

2196

IX / VIII a 033

2197

IX / VIII a 039

2198

IX / VIII a 042

2199

IX / VIII a 043

2200

IX / VIII a 044

2201

IX / VIII a 045

2202

IX / VIII a 046

2203

IX / VIII a 049

2204

IX / VIII a 051

2205

IX / VIII a 052

2206

IX / VIII a 054 
IV

Konkordanz: alte Registratur-Signatur - Ifd. Nr.

alte Registratur-Signatur

Lfd.Nr.

IX / VIII a 055

IX / VIII a 061

2208

IX / VIII a 062

2209

IX / VIII a 063

2210

IX / VIII a 064

2211

IX / VIII a 065

2212

IX / VIII a 066

2213

IX / VIII a 067

2214

IX / VIII a 069

2215

IX / VIII a 070

2216

IX / VIII a 071

2217

IX / VIII a 072

2218

IX / VIII a 073

2219

IX / VIII a 074

2220

IX / VIII a 075

2221

IX / VIII a 076

2222

2223

IX / VIII a 077

2224

IX / VIII a 079

2225

IX / VIII a 081

2226

IX / VIII a 083

2227

IX / VIII a 084

2228

IX / VIII a 086

2229

IX / VIII a 086

2230

IX / VIII a 087

2231

IX / VIII a 088

2232

IX / VIII a 089

2233

IX / VIII a 090

2234

IX / VIII a 091

2235

IX / VIII a 092

2236

IX / VIII a 093

2237

IX / VIII a 094

2238

IX / VIII a 095

2239

IX / VIII a 096

2240

IX / VIII a 096

2241

IX/ VIII a 101

2242

IX / VIII a 102

2243

IX / VIII a 103

2244

IX / VIII a 104

2245

IX/ VIII a 105

2246

IX / VIII a 106

2247

IX/ VIII a 107

2248

IX / VIII a 108

2249

IX/VIII a 109

2250

IX/ VIII a 110

2251

IX / VIII a 111

2252

IX / VIII a 112

2253

IX / VIII a 113

2254

IX / VIII a 114

2255

IX/ VIII a 115

2256

IX / VIII a 116

2257

IX/ VIII a 117

2258

IX / VIII a 118

2259

IX / VIII a 118

2261

IX / VIII a 122

2262

IX / VIII a 123

2263

IX / VIII a 124

2264

IX / VIII a 125

2265

IX/ VIII a 127

2266

IX / VIII a 128

2267

IX / VIII a 129

2268 
IV

Konkordanz: alte Registratur-Signatur - Ifd. Nr.

alte Registratur-Signatur

Lfd.Nr.

IX / VIII a 130

2269

IX / VIII a 131

2270

IX / VIII a 132

2271

IX/ VIII a 133

2272

IX / VIII a 134

2273

IX/ VIII a 135

2274

IX/ VIII a 136

2275

IX / VIII a 137

2276

IX/ VIII a 138

2277

IX / VIII a 139

2278

IX/ VIII a 140

2279

IX/ VIII a 141

2280

IX / VIII a 142

2281

IX / VIII a 144

2282

IX / VIII a 145

2283

IX/ VIII a 146

2284

IX/ VIII a 147

2285

IX / VIII a 148

2286

IX/ VIII a 149

2287

IX / VIII a 150

2288

IX / VIII a 156

2289

IX/ VIII a 157

2290

IX / VIII a 159

2291

IX / VIII a 160

2292

IX/ VIII a 161

2296

IX / VIII a 164

2297

IX / VIII a 165

2293

IX/ VIII a 167

2298

IX / VIII a 168

2294

IX / VIII a 196

2299

IX / VIII a 197

2300

IX / VIII a 198

2301

IX / VIII a 199

2302

IX / VIII a 201

2295

IX / VIII a 202

2303

IX / VIII a 203

2304

IX / VIII a 204

2305

IX / VIII a 205

2306

IX / VIII a 206

2308

IX / VIII a 207

2307

IX / VIII a 208

2309

IX / VIII a 208

2310

IX / VIII a 209

2315

IX / VIII a 211

2311

IX / VIII a 213

2313

IX / VIII a 214

2314

IX / VIII a 215

2316

IX / VIII a 216

2317

IX / VIII a 217

2312

IX / VIII a 217

2318

IX / VIII a 218

2319

IX / VIII a 219

2320

IX / VIII a 220

2321

IX / VIII a 221

2322

IX / VIII a 222

2323

IX / VIII a 224

2324

IX / VIII a 224

2325

IX / VIII a 225

2326

IX / VIII a 226

2327

IX / VIII a 228

2260 
IV

Konkordanz: alte Registratur-Signatur - Ifd. Nr.

alte Registratur-Signatur

Lfd.Nr.

IX 3a 15

IX 3a 16

IX 3a 27

IX 3b 17

IX 3B3 e

IX 3 B3 e 13

IX 3B3 e 18

IX 3 B3 e 24

IX $3 B 3$ e 24

IX $3 B 3$ e 24

IX 3B3e 07

IX 3B3e 07

IX 3B3e 07

IX 3B3e 07

IX 3B3e 07

IX 3B3e 07

IX 3B3e 07

IX 3B3e 07

IX 3B3e 07

IX 3B3e 09

IX 3B3e 09

IX A 1028

IX A 1a 01

IX A 2a 03

IX A 2a 06

IX A 2a 12

IX A 2a 15

IX A 2a 16

IX A 2a 17

IX A 2a 19

IX A 2a 19

IX A 2b 01

IX A 2b || 10

IX A1 011

IX A1 013

IX A1 015

IX A1 020

IX A1 022

IX A1 023

IX A1 024

IX A1 025

IX A1 025

IX A1 026

IX A1 029

IX A1 031

IX A1 032

IX A1 033

IX A1 034

IX A1 035

IX A1 036

IX A1 038

IX A1 039

IX A1 040

IX A2b 12

IX A2b 12

IX A2b 19

IX A2b 25

IX A2b 25

IX A2b 25

IX A2b 26

3631

3632

3640

3651

3689

3690

3692

3696

3697

3698

3676

3677

3678

3679

3680

3681

3682

3683

3685

3686

3687

3328

3334

3335

3336

3337

3338

3339

3340

3341

3342

3349

3621

3318

3319

3320

3321

3322

3323

3324

3325

3326

3327

3329

3330

3343

3331

3344

3345

3346

3347

3332

3333

3410

3430

3352

3423

3424

3425

3426 
IV

Konkordanz: alte Registratur-Signatur - Ifd. Nr.

alte Registratur-Signatur

Lfd.Nr.

IX A2b 28

3411

IX A2b 29

3353

IX A2b 30

3348

IX A2b 31

3427

IX A2b 34

3428

IX A2b 35

3354

IX A2b 36

3355

IX A2b 36

3356

IX A2b 36

3357

IX A2b 36

3358

IX A2b 36

3359

IX A2b 36

3360

IX A2b 36

3361

IX A2b 36

3362

IX A2b 36

3363

IX A2b 36

3364

IX A2b 36

3365

IX A2b 40

3370

IX A2c 07

3480

IX A2c 11

3483

IX A2c 12

3481

IX A2c 13

3484

IX A2c 14

3485

IX A2c 37

3366

IX A2c 38

3367

IX A2c 39

3368

IX A2c 40

3369

IX A2c 40

3371

IX A2c 40

3372

IX A2c 40

3373

IX A2c 40

3374

IX A2c 40

3375

IX A2c 41

3376

IX A2c 42

3377

IX A3 11

3487

IX A3 12

3488

IX A3 13

3703

IX A3 20

3489

IX A3 20a

3490

IX A3 25

3704

IX A3 26

IX A3 27

3491

IX A3 28

3705

3495

IX A3 29

3706

IX A3 30

3492

IX A3 31

3493

3486

IX A4 04

3497

IX A5 01

3496

3498

IX A5 05

3624

IX B 3a 02

3628

IX B 3a 11

3629

3a 12

3630

IX 3 3

3633

IX B 3a 19

3634

IX B 3a 21

3635

IX B 3a 23

3637

IX B 3a 23

3638 
IV

Konkordanz: alte Registratur-Signatur - Ifd. Nr.

alte Registratur-Signatur

Lfd.Nr.

IX B 3 a 25

3639

IX B I 39

3541

IX B || 003

3715

IX B || 19

3722

|X B || 19

3727

IX B || 19

3728

IX B || 19

3729

IX B || 19

3730

IX B || 19

3731

|X B || 19

3732

IX B || 19

IX B || 19

3733

IX B || 19

3734

IX B || 19

IX B || 19

IX B || 19

3735

3736

3737

3738

|X B || 19

3739

IX B || 19

3740

|X B || 19

3741

IX B II 19

3742

IX B || 19 a

3723

IX B I| 19 a

3724

IX B II $19 \mathrm{~b}$

3725

IX B || $19 b$

3726

|X B || 20

3743

|X B || 25

3746

IX B || 26

3745

IX B || 34

3752

|X B || 37

3753

IX B || 38

3754

|X B || 43

3755

|X B || 44

3710

IX B || 45

3711

IX B || 46

3756

IX B || 47

3757

|X B || 47

3758

|X B || 47

3759

IX B || 50

3761

IX B1 01

3499

IX B2 04

3714

IX B3 04

3620

IX B3a 01

3622

IX B3a 01

3623

3625

IX B3a 03

3626

IX B3a 09

3627

IX B3a 09

IX B3a 22

3636

IX B3a 28

3641

IX B3a 29

3642

IX B3a 30

3643

IX B3a 31

3644

IX B3a 32

3645

IX B3b 04

IX B3b 04

3652

3653

3654

IX B3b 10

3655

IX B3b 11

3656

X B3b 12

3657

X B3b 13

3658

IX B3b 14

3659 
IV

Konkordanz: alte Registratur-Signatur - Ifd. Nr.

alte Registratur-Signatur

Lfd.Nr.

IX B3b 16

3660

IX B3b 18

3663

IX B3b 19

3661

IX B3B 19

3693

IX B3b 20

3662

IX B3b 20

3664

IX B3b 21

IX B3b 22

3665

IX B3b 23

3666

IX B3b 26

3667

IX B3B e 17

3668

IX B3B e 23

IX B3B e 24

3694

IX B3c 01

3695

IX B3c 02

3669

IX B3c 02

3670

IX B3c 03

3671

IX B3c 07

3672

IX B3e 04

3675

IX B3e 07

3684

IX B3e 10

3688

IX B3e 21

3708

IX B4 07

3814

IX B4 07

3815

IX B4 07

3816

IX B4 04

3762

IX B4 04

3763

IX B4 04

IX B4 04

3764

3766

IX B4 05

3765

IX B4 05

3767

IX B4 05

3768

IX B4 05

3769

IX B4 05

3770

IX B4 05

3771

IX B4 06

3772

IX B4 06

3773

IX B4 06

3774

IX B4 06

IX B4 06

3775

3776

IX B4 06

3789

IX B4 06

3809

IX B4 06b

3810

IX B4 06b

3811

IX B4 06b

3812

IX B4 06e

3813

IX B4 09

3817

IX B4 10

3818

IX B4 10

3819

IX B4 10

3820

IX B4 10

3821

IX B4 12

3822

IX B4 15

3823

IX B4 15

3824

IX B4 16

3825

IX B4 17

3826

IX B4 18

3827

IX B4 21

3828

IX B4 22

3829

IX B4 23 
Konkordanz: alte Registratur-Signatur - Ifd. Nr.

alte Registratur-Signatur

Lfd.Nr.

IX B4 23

IX B4 24

IX B4 25

IX B4 25

IX B4 25

IX B4 25

IX B4 26

IX B4 27

IX B4 27

IX B4 27

IX B4 28

IX B4 28

IX B4 29

IX B4 30

IX B4 45

IX B4 45

IX B5 02

IX B5 02

IX B5 03

IX B5 04

IX B5 05

IX B5 05

IX B5 06

IX B5 06

IX B5 06

IX B5 07

IX B5 09

IX B6 01

IX B6 02

IX B6 03

IX B6 04

IX B6 05

IX B6 09

IX B6 12

IX B6 13

IX B6 13

IX B6 18

IX B6 18

IX B6 18

IX B6 19

IX B6 20

IX B6 20

IX B6 21

IX B6 21

IX B6 23

IX B6 24

IX B6 29

IX B6 30

IX B6 30

IX B6 30

IX B6 30

IX B6 30

IX B6 30

IX B6 30

IX B6 30

IX B6 30

IX B6 31

IX B6 31

IX B6 31

IX B6 31

3831

3832

3833

3834

3835

3836

3837

3838

3839

3840

3841

3842

3843

3844

3845

3846

3847

3853

3849

3855

3850

3851

3848

3852

3857

3856

3858

3616

3854

3617

3618

3699

3619

3542

3543

3544

3545

3546

3707

3700

3547

3550

3701

3709

3548

3549

3551

3552

3553

3554

3555

3556

3557

3558

3559

3560

3561

3562

3563

3564 
Konkordanz: alte Registratur-Signatur - Ifd. Nr.

alte Registratur-Signatur

Lfd.Nr.

IX B6 31

IX B6 31

IX B6 31

IX B6 31

IX B6 31

IX B6 31

IX B6 31

IX B6 31

IX B6 31

IX B6 32

IX B6 32

IX B6 32

IX B6 32

IX B6 32

IX B6 32

IX B6 32

IX B6 32

IX B6 32

IX B6 32

IX B6 32

IX B6 32

IX B6 32

IX B6 32

IX B6 32

IX B6 32

IX B6 32

IX B6 32

IX B6 32

IX B6 32

IX B6 32

IX B6 32

IX B6 32

IX B6 32

IX B6 32

IX B6 32

IX B6 33

IX B6 33

IX B6 33

IX B6 33

IX B6 33

IX B6 33

IX B6 33

IX B6 33

IX B6 33

IX B6 33

IX B6 34

IX B6 34

IX B6 38

IX B6 44

IX B7 3

IX BI 03

IX BI 05

IX BI 06

IX BI 06

IX BI 07

IX BI 10

IX BI 10

IX BI 11

IX BI 11

IX BI 12

3566

3567

3568

3569

3570

3571

3572

3573

3574

3575

3576

3577

3578

3579

3580

3581

3582

3583

3584

3585

3586

3587

3588

3589

3590

3591

3592

3593

3595

3596

3610

3611

3612

3613

3599

3600

3601

3602

3603

3604

3605

3606

3607

3609

3597

3598

3608

3594

3615

3378

3674

3412

3500

3380

3381

3501

3382

3413

3502 
Konkordanz: alte Registratur-Signatur - Ifd. Nr.

alte Registratur-Signatur

Lfd.Nr.

IX BI 13

3387

IX BI 15

3388

IX BI 15

3503

IX BI 17

3389

IX BI 20

3409

IX BI 22

3390

IX BI 23

3391

IX BI 24

3350

IX BI 25

3392

IX BI 26

IX BI 27

3393

IX BI 28

3395

IX BI 29

3396

IX BI 30

IX BI 32

3397

IX BI 35

3398

IX BI 35

3399

IX BI 36

3504

IX BI 38

3400

IX BI 39

3402

IX BI 39

3401

IX BI 41

3403

IX B| 41

3505

IX BI 42

3506

IX BI 43

3383

IX BI 43

3384

IX BI 43

3385

IX BI 43

3386

IX BI 44

3507

IX BI 45

3508

IX BI 46

3509

IX BI 47

3510

IX BI 48

3511

IX BI 49

IX BI 50

3429

IX BI 50

3513

IX BI 51

3405

IX BI 51

3514

IX BI 51

IX BI 51

3515

IX BI 52

3516

IX BI 52

3406

IX BI 52

3408

IX BI 54

3517

IX BI 54

3407

IX BI 54

3414

IX BI 56

3520

IX BI 57

3521

3522

IX BI 60

3523

IX BI 60

3524

IX BI 60

3525

IX BI 61

3529

IX BI 63

3518

IX BI 63

3519

IX BI 64

3526

IX BI 67

3527

IX BI 68

3528

IX BI 70

3530

IX BI 71

3531

IX BI 74 
Konkordanz: alte Registratur-Signatur - Ifd. Nr.

alte Registratur-Signatur

Lfd.Nr.

IX BI 74

3533

IX BI 74

3534

IX BI 74

3535

IX BI 74 a

3536

IX BI 77

3537

IX BI 83

3538

IX BI 83

3539

IX BI 89

3540

IX BII 001

3716

IX B|l 001

3717

IX B|I 001

3718

IX BII 011

3712

IX BII 16

3713

IX BII 19

3719

IX BII $19 \mathrm{~b}$

3720

IX BII $19 \mathrm{c}$

3721

IX BII 49

3760

IX C1 20

3448

IX Cl 03

3432

IX Cl 03

3433

IX Cl 04

3434

IX Cl 05

3435

IX Cl 05

3436

IX Cl 06

3437

IX Cl 07

3439

IX Cl 07

3440

IX Cl 08

3441

IX Cl 10

3438

IX Cl 11

3442

IX Cl 12

3443

IX Cl 13

3648

IX Cl 15

3444

IX Cl 16

3445

IX Cl 17

3446

IX Cl 19

3447

IX Cl 21

3449

IX Cl 25

3450

IX Cl 26

3451

IX Cl 27

IX Cl 28

3452

3453

IX Cl 30

3455

IX Cl 31

3456

IX Cl 32

3457

IX Cl 34

3459

IX Cl 36

3460

IX Cl 37

3461

IX Cl 38

3462

IX Cl 41

3465

IX Cl 42

3466

IX Cl 43

3467

IX Cl 44

3468

IX Cl 47

3469

IX Cl 48

3470

IX Cl 49

IX CI 50

IX CI 53

IX Cl 53

IX CI 56 
Konkordanz: alte Registratur-Signatur - Ifd. Nr.

alte Registratur-Signatur

Lfd.Nr.

IX Cl 57

3478

IX Cl 60

3479

IX CII 08

3650

IX CII 58

3649

IX D || 01

3646

IX D || 02

3416

IX D || 03

3647

|X D || 04

3417

IX D || 05

3415

IX D || 05

3418

IX D || 05

3419

IX D || 12

3422

IX D || 33

3420

IX D || 34

3421

IX VI 29

3454

Sd 118

1737

Sd 118

1738

Sd 118

1739

Sd 123

1741

Sd 124

1740

St XX 159

2409

St XVIII 150

1246

VI B 041

2862

VI C 08

2863

VI C 12

VI C 12

2864

VI C 12

2865

VIC 12

2866

VIC 12

2867

VI C 12

2869

VI C 13

2870

VIC 15

2871

VI C 16

2872

VIC 21

VI C 21

2874

VIC 25

VI C 30

2875

2876

VI C 30

2877

VIC 32

2878

VI D 11

2879

VI D 13

2880

VI D 14

2881

VI D 15 a

2882

VI D $15 \mathrm{~b}$

2883

VI D 16

2884

VI D 17

2885

VI D 18

2886

VI D 19

2887

VI D 19

2888

VI D 19

2889

VI G 09

2890

VI G 09

2891

VI J 078

3208

VI J1 01

2893

VI J1 01

2894

VI J1 02

2895

VI J1 02

2896

VI J1 02

2897

VI J1 05

VI J1 06 
Konkordanz: alte Registratur-Signatur - Ifd. Nr.

alte Registratur-Signatur

Lfd.Nr.

VI J2 01

2901

VI J2 01

2902

VI J2 01

2903

VI J2 03

2904

VI J2 04

2905

VI J2 06

2906

VI J2 08

2907

VI J2 10

2908

VI J2 11

2909

VI J2 12

2910

$\mathrm{VI} \mathrm{J} 213$

2911

VI Rh 1

2933

VII

3137

VII A 1

3084

VII A 10

3085

VII A 18

3086

VII A 2 c 082

2505

VII B 30

3092

VII B 41

3093

VII B 41

3094

VII B 56

VII B 56

3095

VII B 56

3096

3097

VII B 56

3098

VII B 56

3099

VII B 57

3140

VII B 58

3100

VII C 18

3102

VII C 20

3101

3104

3105

VII D 53

3141

3142

VII D 54

VII D 54

3144

VII D 54

3145

VII G 002

3109

VII G 002

3110

VII G 002

VII G 002

3119

3120

3152

VII G 029

3111

VII G 063

3121

3122

VII G 068

3123

VII G 068

3124

VII G 070

3125

VII G 071

3126

VII G 075

3127

VII G 083

3112

VII G 083

3113

VII G 085

3114

VII G 085

VII G 086

3115

VII G 110

3116

3117

VII G 115

3118

VII G 125

3087

VII G 128

VII G 128

VII G 128 
IV

Konkordanz: alte Registratur-Signatur - Ifd. Nr.

alte Registratur-Signatur

Lfd.Nr.

VII G 130

3132

VII G 131

3131

VII G 132

3133

VII G 134

3134

VII G 137

3135

VII G 138

3136

VII G 140

3138

VII G 143

3088

VII H 010

3312

VII H 011

3189

VII Ha 28

3190

VII J 010

3311

VII J 020

3188

VII J 023

VII J 024

3148

VII J 024

3149

VII J 025

3150

VII J 025

3146

VII J 025

VII J 026

3151

VII J 026

VII J 027

3191

3192

3193

VII J 028

3200

VII J 03

3187

VII J 030

3194

VII J 033

3195

VII J 035

3153

VII J 036

VII J 037

3196

3197

VII J 037

3313

VII J 038

3198

VII J 040

3199

VII J 041

3234

VII J 042

3235

VII J 042

3236

VII J 042

3237

VII J 043

3238

VII J 044

3239

VII J 046

3240

VII J 047

3201

VII J 048

3202

VII J 049

3241

VII J 050

3203

VII J 051

3314

VII J 052

3154

VII J 053

3204

VII J 054

3242

3243

VII J 055

3244

VII J 056

3155

VII J 058

3156

VII J 058

3245

VII J 059

3205

VII J 060

3206

VII J 061

VII J 062

3246

VII J 064

VII J 065

VII J 074 
IV

Konkordanz: alte Registratur-Signatur - Ifd. Nr.

alte Registratur-Signatur

Lfd.Nr.

VII J 074

3250

VII J 074

3251

VII J 074

3252

VII J 077

3253

VII J 079

3209

VII J 080

3210

VII J 082

321

VII J 083

3254

VII J 084

3212

VII J 084 a

3157

JII 085

3255

VII J 086

3158

VII J 087

3159

VII J 088

3213

VII J 089

3214

VII J 090

3256

VII J 090

3257

VII J 090

3258

VII J 091

3259

VII J 091

3260

VII J 092

3263

VII J 093

3264

VII J 093

3265

VII J 093

3266

VII J 094

3267

VII J 095

3268

VII J 095

3269

VII J 095

3270

VII J 095

3271

VII J 095

3272

VII J 096

3273

VII J 096

3274

VII J 096

3275

VII J 096

3276

VII J 096

3277

VII J 096

3278

VII J 098

3279

VII J 100

3280

VII J 101

3281

VII J 103

3282

VII J 104

3283

VII J 104

3284

VII J 108

3285

VII J 109

3286

VII J 109

3288

VII J 111

3287

VII J 112

3289

VII J 113

3290

VII J 114

3291

VII J 115

3292

VII J 115

3293

VII J 116

3294

VII J 117

3295

VII J 118

3296

VII J 129

3297

VII J 130

3215

VII J 131

3216

VII J 132

3217

VII J 133

VII J 134 
Konkordanz: alte Registratur-Signatur - Ifd. Nr.

alte Registratur-Signatur

Lfd.Nr.

VII J 150

3219

VII J 150

3220

VII J 150 a

3186

VII J 151

3221

VII J 152

3298

VII J 153

3299

VII J 154

3300

VII J 155

3301

VII J 156

3302

VII J 156

VII J 157

3304

VII Kn 2

3303

VII Kn 2

3160

VII L 18

VII M 13

3161

VII M 22

3162

3106

VII M 23

VII M 24

VII M 26

3107

3089

3108

3091

VII M 34

3090

VII N 04

VII N 04

3166

VII N 05

3168

3172

VII N 13

3170

VII N 15

3171

VII N 16

3173

VII N 18

3174

VII N 21

VII N 22

3175

3176

VII N 23

3233

VII N 24

3177

VII N 25

3178

VII N 26

3179

VII N 54 I

VII N 54 II

3182

VII N 55

3183

VII N 57

3180

VII N 58

VII Nn 08

3169

VIII 2 a 03

2402

VIII 2 a 05

VIII 2 b 029

2415

VIII 2 b 029

2416

VIII 2 b 034

VIII 2 b 036

VIII 2 b 046

2422

VIII 2 b 048

2427

VIII 2 b 051

2428

VIII 2 b 054

2429

VIII 2 b 059

2430

VIII 2 b 060

VIII 2 c 024

2464

VIII 2 c 152

2603

VIII A 100

2173

VIII A 138

2785

VIII A 140

VIII A 158

VIII A 159

VIII A 172 
IV

Konkordanz: alte Registratur-Signatur - Ifd. Nr.

alte Registratur-Signatur

Lfd.Nr.

VIII A 173

2161

VIII A 173

2163

VIII A 175

2164

VIII A 176

2165

VIII A 177

2166

VIII A 178

2167

VIII A 179

2168

VIII A 180

2169

VIII A 181

2170

VIII A 182

2171

VIII A 183

2174

VIII A 184

2175

VIII A 190

2176

VIII A 191

2177

VIII A 192

2178

VIII A 195

2179

VIII A 2 a 04

2441

VIII A 2 b 015

2410

VIII A 2 b 016

2411

VIII A 2 b 016

2412

VIII A 2 b 016

2413

VIII A 2 b 020

2675

2676

VIII A 2 b 024

2405

VIII A 2 b 025

2404

2406

2417

VIII A 2 b

2443

VIII A 2 b 037

2419

2420

VIII A 2 b 042

2421

VIII A 2 b 044

2444

VIII A 2 b 045

2423

2424

VIII A 2 b 049

2425

VIII A 2 b 050

2426

2445

2408

1247

2432

2433

2434

2435

2436

2437

2446

2447

2438

2448

2439

2414

2440

2474

2449

2450

2451

2452

2453

VIII A 2 c 007

2454

VIII A 2 c 011

2455 
IV

Konkordanz: alte Registratur-Signatur - Ifd. Nr.

alte Registratur-Signatur

Lfd.Nr.

VIII A 2 c 012

VIII A 2 c 012

2456

VIII A 2 c 015

2457

VIII A 2 c 018

2458

VIII A 2 c 019

2459

VIII A 2 c 019

2460

VIII A 2 c 019

2461

VIII A 2 c 020

2462

VIII A 2 c 026

2463

VIII A 2 c 028

2466

VIII A 2 c 031

2467

VIII A 2 c 032

2468

VIII A 2 c 037

2465

VIII A 2 c 044

2469

VIII A 2 c 049

2470

VIII A 2 c 051

2471

VIII A 2 c 053

2472

VIII A 2 c 060

2473

VIII A 2 c 061

2475

VIII A 2 c 061

2476

VIII A 2 c 061

2477

VIII A 2 c 061

2478

VIII A 2 c 061

2479

VIII A 2 c 062

2480

VIII A 2 c 063

2481

VIII A 2 c 064

2482

2483

VIII A 2 c 065

2484

VIII A 2 c 066

2485

VIII A 2 c 067

2486

VIII A 2 c 069

2487

VIII A 2 c 070

2488

VIII A 2 c 072

2489

2490

III A 2 c 073

2491

VIII A 2 c 074

2492

2493

2494

VIII A 2 c 076

2495

VIII A 2 c 076

2509

2506

2508

VIII A 2 c 079

2507

VIII A 2 c 080

2498

2504

VIII A 2 c 088

2503

VIII A 2 c 089

2497

VIII A 2 c 090

2502

VIII A 2 c 092

2501

VIII A 2 c 093

2500

VIII A 2 c 094

2499

2496

VIII A 2 c 095

2512

VIII A 2 c 096

2510

VIII A 2 c 098

2511

2513

VIII A 20099

2514

VIII A 2 c 100

2515

VIII A 2 c 101

2516

VIII A 2 c 102

2517

VIII A 2 c 103 
IV

Konkordanz: alte Registratur-Signatur - Ifd. Nr.

alte Registratur-Signatur

Lfd.Nr.

VIII A 2 c 104

VIII A 2 c 106

2519

VIII A 2 c 108

2520

VIII A 2 c 109

2521

VIII A 2 c 111

2522

VIII A 2 c 112

2523

VIII A 2 c 113

2526

VIII A 2 c 114

2524

VIII A 2 c 115

2525

VIII A 2 c 117

2528

VIII A 2 c 118

2527

VIII A 2 c 119

VIII A 2 c 121

2530

VIII A 2 c 122

2531

VIII A 2 c 124

2532

VIII A 2 c 126

2533

2534

VIII A 2 c 127

2535

VII A 2 c 127

2537

VIII A 2 c 128

2538

VIII A 2 c 130

2539

VIII A 2 c 131

2540

VIII A 2 c 133

2541

2542

2604

VIII A 2 c 135

2543

VIII A 2 c 140

2544

VIII A 2 c 141

2545

VIII A 2 c 142

2546

VIII A 2 c 146

2547

2548

VIII A 2 c 147

2549

VIII A 2 c 150

2550

VIII A 2 c 155

2551

VIII A 2 c 161

2552

VIII A 2 c 163

2553

VIII A 2 c 165

2554

2555

VIII A 2 c 166

2556

VIII A 2 c 174

2557

VIII A 2 c 178

2558

VIII A 2 c 179

2559

VIII A 2 c 180

2560

VIII A 2 c 181

2562

VIII A 2 c 182

2563

VIII A 2 c 186

2561

VIII A 2 c 190

2564

VIII A 2 c 192

2565

VIII A 2 c 193

2566

VIII A 2 c 194

2567

VIII A 2 c 195

2568

VIII A 2 c 196

2569

VIII A 2 c 197

2570

VIII A 2 c 201

2536

VIII A 2 c 202

2571

VIII A 2 c 205

2572

VIII A 2 c 206

2573

VIII A 2 c 207

2574

VIII A 2 c 209

2575

VIII A 2 c 212

2576

VIII A 2 c 213 
IV

Konkordanz: alte Registratur-Signatur - Ifd. Nr.

alte Registratur-Signatur

Lfd.Nr.

VIII A 2 c 215

2578

VIII A 2 c 216

2579

VIII A 2 c 221

2580

VIII A 2 c 223

2581

VIII A 2 c 232

2582

VIII A 2 c 234

2583

VIII A 2 c 236

2584

VIII A 2 c 239

2585

VIII A 2 c 241

2586

VIII A 2 c 241

2587

A 2 c 247

2588

VIII A 2 c 249

2589

VIII A 2 c 251

2590

VIII A 2 c 264

2591

VIII A 2 c 266

2592

VIII A 2 c 271

2593

VIII A 2 c 281

2594

A 2 c 282

2595

VIII A 2 c 283

2596

VIII A 2 c 284

2597

VIII A 2 c 286

2598

VIII A 2 c 287

2599

VIII A 2 c 290

2600

VIII A 2 c 298

2601

VIII A 2 c 299

2602

VIII A 2 e 59

2442

VIII A 304 i

2612

VIII A 80

2172

A1 01

2401

2639

VIII A3 03

2650

VIII A3 04

2622

VIII A3 04

2623

2636

VIII A3 04

2637

VIII A3 04

2638

VIII A3 04 a

2606

VIII A3 04 b

2607

VIII A3 $04 \mathrm{c}$

2608

VIII A3 $04 \mathrm{f}$

2610

VIII A3 $04 \mathrm{f}$

2611

VIII A3 $04 \mathrm{~g}$

2609

VIII A3 $04 \mathrm{~g}$

2613

VIII A3 $04 \mathrm{~h}$

2614

VIII A3 $04 \mathrm{j}$

VIII A3 04 k1

2615

2616

VIII A3 04 k2

2617

VIII A3 04 I

2618

VIII A3 $04 \mathrm{~m}$

2619

VIII A3 $04 n$

2620

VIII A3 $04 p$

VIII A3 $04 \mathrm{q}$

VIII A3 $04 r$

2642

VIII A3 $04 \mathrm{~s}$

2643

VIII A3 $04 \mathrm{t}$

VIII A3 $04 \mathrm{u}$

VIII A3 $04 \mathrm{v}$

2646

VIII A3 $04 \mathrm{v}$ 
Konkordanz: alte Registratur-Signatur - Ifd. Nr.

alte Registratur-Signatur

Lfd.Nr.

VIII A3 045

2919

VIII A3 04y

2635

VIII A3 06

2651

VIII A3 07

2640

VIII A3 07

2641

VIII A3 11

2627

VIII A3 11

2628

VIII A3 13

2629

VIII A3 13

2630

VIII A3 13

2631

VIII A3 16

VIII A3 16

2632

VIII A3 22

2634

VIII A3 24

VIII A3 24

2652

2653

VIII A3 26

2654

VIII A3 28

2655

VIII A3 31

2656

VIII A3 32

VIII A3 36

2658

VIII A3 38

2659

VIII A4 03

2914

VIII A4 08

2892

2660

VIII A4 09

2661

VIII A5 10

2663

VIII A5 11

2664

VIII A5 11

2665

VIII A5 12

VIII A5 40

2662

VIII A5 41

2669

2666

VIII A5 50

2667

VIII A5 51

2668

VIII A5 52

2670

VIII A5 60

VIII A5 61

2672

VIII A5 62

2673

VIII A6 027

2674

VIII A8 002

2677

VIII A8 004

2678

VIII A8 005

2679

VIII A8 006

2680

VIII A8 007

2681

VIII A8 008

2682

VIII A8 009

2683

VIII A8 010

2859

VIII A8 014

2684

VIII A8 018

2685

VIII A8 024

2689

VIII A8 025

2686

VIII A8 026

2690

VIII A8 027

2687

VIII A8 028

2691

VIII A8 030

2688

VIII A8 031

2692

VIII A8 032

2693

VIII A8 033

2694

VIII A8 034

2695

VIII A8 035

2696

VIII A8 037

2697

VIII A8 038

2698 
IV

Konkordanz: alte Registratur-Signatur - Ifd. Nr.

alte Registratur-Signatur

Lfd.Nr.

VIII A8 039

2699

VIII A8 040

2700

VIII A8 041

2701

VIII A8 042

2702

VIII A8 043

2703

VIII A8 044

2704

VIII A8 045

2705

VIII A8 046

2706

VIII A8 048

2707

VIII A8 049

2708

VIII A8 050

2709

VIII A8 051

2710

VIII A8 052

2711

VIII A8 053

2712

VIII A8 055

2713

VIII A8 057

2714

VIII A8 058

2715

VIII A8 059

2716

2717

A8 060

2718

IIII A8 062

2719

VIII A8 063

2720

2721

VIII A8 064

2722

VIII A8 067

2723

2724

VIII A8 069

2725

VIII A8 070

2726

VIII A8 071

2727

2728

VIII A8 073

2729

VIII A8 075

2730

VIII A8 077

2731

VIII A8 078

2732

VIII A8 079

2733

VIII A8 080

2734

2735

VIII A8 081

2736

VIII A8 082

2737

VIII A8 083

2738

2739

VIII A8 085

2740

VIII A8 086

2741

2742

VIII A8 088

2743

VIII A8 089

2744

VIII A8 091

2745

2746

VIII A8 092

VIII A8 093

2748

III A8 094

2749

VIII A8 097

2751

VIII A8 098

2752

2753

VIII A8 099

2754

VIII A8 100

2755

VIII A8 102

2756 
IV

Konkordanz: alte Registratur-Signatur - Ifd. Nr.

alte Registratur-Signatur

Lfd.Nr.

VIII A8 107

2759

VIII A8 108

2760

VIII A8 110

2762

VIII A8 112

2763

VIII A8 113

2764

VIII A8 114

2765

VIII A8 116

2766

VIII A8 117

2767

VIII A8 118

2768

VIII A8 119

2769

VIII A8 120

2770

VIII A8 121

2771

VIII A8 122

2772

VIII A8 123

2773

VIII A8 124

2774

VIII A8 125

2775

VIII A8 125

2776

VIII A8 127

2777

VIII A8 128

2778

VIII A8 129

2779

VIII A8 130

2780

VIII A8 131

2781

VIII A8 133

2782

VIII A8 134

2783

VIII A8 136

2784

VIII A8 139

2786

VIII A8 143

2788

VIII A8 144

2789

VIII A8 145

2790

2791

VIII A8 146

2792

VIII A8 147

2793

VIII A8 148

2794

2795

2796

VIII A8 154

2797

2798

2801

2802

2804

2805

2806

2807

2808

2809

2810

2811

2812

2813

2814

2815

2816

2817

2818

2819

2820

2821

2822

2823

2824 
IV

Konkordanz: alte Registratur-Signatur - Ifd. Nr.

alte Registratur-Signatur

Lfd.Nr.

VIII A8 189

2825

VIII A8 190

2826

VIII A8 191

2827

VIII A8 192

2828

VIII A8 193

2829

VIII A8 194

2830

VIII A8 197

2831

VIII A8 199

2832

VIII A8 200

2833

VIII A8 201

2834

VIII A8 202

2835

VIII A8 203

2836

VIII A8 204

2837

VIII A8 205

2838

VIII A8 208

2839

VIII A8 209

2840

VIII A8 211

2841

A8 213

2842

2843

VIII A8 215

2844

VIII A8 216

VIII A8 217

2845

VIII A8 219

2846

2847

VIII A8 223

2848

VIII A8 225

2849

VIII A8 225

2850

VIII A8 226

2851

VIII A8 227

2852

VIII A9 03

2857

VIII A9 08

2855

VIII A9 08

2856

VIII A9 08

2858

VIII A9 12

2860

VIII A9 12

2861

VIII Ag 9

2853

2912

2913

VIII B1 39

2915

VIII B3 38

2916

2917

2918

VIII B3 43

2920

VIII B3 45

2921

2922

VIII B3 50

2923

VIII B3 51

2924

VIII B3 54

2925

2926

VIII B3 57

2927

VIII B3 58

2928

2929

VIII B3 59

2930

VIII B3 60

2934

VIII B6 10

2935

VIII B6 20

2936

VIII B6 21

2937

VIII B6 23

2938

VIII B6 23

2939

VIII B6 24

2940

VIII B6 24 
Konkordanz: alte Registratur-Signatur - Ifd. Nr.

alte Registratur-Signatur

Lfd.Nr.

VIII B6 25

2942

VIII B6 26

2943

VIII B6 26

2944

VIII B6 26

2945

VIII B6 26

2946

VIII B6 27

2947

VIII B6 29

2948

VIII B6 33

2956

VIII B6 37

2949

VIII B6 37

2950

VIII B6 37

2951

VIII B6 37

2952

VIII B6 37

2953

VIII B6 37

VIII B6 37

2954

VIII B6 37

2955

VIII B6 37

2957

VIII B6 37

2958

VIII B6 37

2959

VIII B6 37

2960

VIII B6 37

VIII B6 37

2961

2962

2963

VIII B6 37

2964

VIII B6 37

2965

VIII B6 37

2966

VIII B6 37

2967

VIII B6 37

2968

VIII B6 37

VIII B6 37

2969

VIII B6 37

2970

VIII B6 37

2971

VIII B6 37

VIII B6 37

2972

2973

VIII B6 37

2974

VIII B6 37

2975

VIII B6 44

2976

VIII B7 01

2977

2978

VIII B7 02

2979

VIII B7 07

2980

VIII B8 001

2981

VIII B8 001

2982

VIII B8 001

2983

VIII B8 004

2984

VIII B8 005

2985

VIII B8 008

2986

VIII B8 008

2987

VIII B8 109

530

VIII B8 110

531

VIII B8 110

532

VIII B8 112

533

VIII B8 120

534

VIII B8 124

535

VIII B8 124

536

VIII B8 131

537

VIII B8 135

538

VIII B8 139

539

VIII B8 140

540

VIII B8 144

VIII B8 149

VIII B8 149 a 
Konkordanz: alte Registratur-Signatur - Ifd. Nr.

alte Registratur-Signatur

Lfd.Nr.

VIII B8 150

544

VIII B8 151

545

VIII B8 152

546

VIII B8 153

547

VIII B8 157

548

VIII B8 158

549

VIII B8 159

550

VIII B8 160

551

VIII B8 161

553

VIII B8 176

552

VIII C 023

2989

VIII C 026

2990

VIII C 027

2991

VIII C 028

2992

VIII C 032

2993

VIII C 037

2994

VIII C 039

2995

VIII C 040

2996

VIII C 041

2997

VIII C 042

2998

VIII C 043

VIII C 045

2999

VIII C 047

3000

VIII C 054

3001

VIII C 070

VIII C 083

3002

3003

3004

VIII C 085

3005

VIII C 091

VIII C 093

3006

3007

3008

3009

VIII C 102

3010

VIII D1 008

3012

VIII D1 020

3013

VIII D1 021

3014

VIII D1 022

3011

3015

VIII D1 022

3016

VIII D1 024

3017

3018

VIII D1 030

3019

VIII D1 031

3021

VIII D1 033

3022

3023

VIII D1 035

3024

VIII D1 036

3025

VIII D1 038

3026

3027

VIII D1 040

3028

VIII D1 041

3029

3030

3031

VII D1 044

3032

VIII D1 046

3033

3034

VIII D1 048

3035

VIII D1 049

3036

VIII D1 050

3037

VIII D1 054 
IV

Konkordanz: alte Registratur-Signatur - Ifd. Nr.

alte Registratur-Signatur

Lfd.Nr.

VIII D1 056

3040

VIII D1 057

3041

VIII D1 058

3042

VIII D1 059

3043

VIII D1 060

3044

VIII D1 061

3045

VIII D1 062

3046

VIII D1 063

3047

VIII D1 064

3048

VIII D1 065

3049

VIII D1 066

3050

VIII D1 066

3051

VIII D1 067

3052

VIII D1 068

3053

VIII D1 069

3054

VIII D1 070

3055

VIII D1 071

3056

VIII D1 072

3057

VIII D1 073

3058

VIII D1 074

3059

VIII D1 075

3060

VIII D1 076

3061

VIII D1 077

3062

VIII D1 092

3020

VIII D1 098

3063

VIII D1 099

3064

VIII D1 100

3065

VIII D1 101

3066

VIII D1 102

3067

3068

VIII D1 104

3069

VIII D1 105

3070

VIII D1 106

3071

VIII D1 107

3072

VIII D1 108

3073

VIII D1 109

3074

VIII D2 04

3075

VIII D2 04

3076

VIII D2 07

3077

VIII D2 09

3078

VIII D2 09

3079

VIII D2 11

3080

VIII D2 11

3081

VIII D2 11

3082

VIII D2 11

3083

X A3 19

3702

XI IX Nr. 01 
Konkordanz: alte Archiv-Signatur - Ifd. Nr. 
IV

Konkordanz: Bestell-Signatur - Ifd. Nr.

Bestell-Signatur

Lfd.Nr.

IV 00001

IV 00002

IV 00003

IV 00004

IV 00005

IV 00006

IV 00007

IV 00008

IV 00009

IV 00010

IV 00011

IV 00012

IV 00013

IV 00014

IV 00015

IV 00016

IV 00017

IV 00018

IV 00019

IV 00020

IV 00021

IV 00022

IV 00023

IV 00024

IV 00025

IV 00026

IV 00027

IV 00028

IV 00029

IV 00030

IV 00031

IV 00032

IV 00033

IV 00034

IV 00035

IV 00036

IV 00037

IV 00038

IV 00039

IV 00040

IV 00041

IV 00042

IV 00043

IV 00044

IV 00045

IV 00046

IV 00047

IV 00048

IV 00049

IV 00050

IV 00051

IV 00052

IV 00053

IV 00054

IV 00055

IV 00056

IV 00057

IV 00058

IV 00059 
IV

Konkordanz: Bestell-Signatur - Ifd. Nr.

Bestell-Signatur

Lfd.Nr.

IV 00060

IV 00061

IV 00062

IV 00063

IV 00064

IV 00065

IV 00066

IV 00067

IV 00068

IV 00069

IV 00070

IV 00071

IV 00072

IV 00073

IV 00074

IV 00075

IV 00076

IV 00077

IV 00078

IV 00079

IV 00080

IV 00081

IV 00082

IV 00083

IV 00084

IV 00085

IV 00086

IV 00087

IV 00088

IV 00089

IV 00090

IV 00091

IV 00092

IV 00093

IV 00094

IV 00095

IV 00096 a

IV 00096 b

IV 00097 a

IV 00097 b

IV 00098 a

IV 00098 b

IV 00099 a

IV 00099 b

IV 00100

IV 00101

IV 00102

IV 00103

IV 00104

IV 00105

IV 00106

IV 00107

IV 00108

IV 00109

IV 00110

IV 00111

IV 00112

IV 00113

IV 00114

IV 00115 
IV

Konkordanz: Bestell-Signatur - Ifd. Nr.

Bestell-Signatur

Lfd.Nr.

IV 00116

IV 00117

IV 00118

IV 00119

IV 00120

IV 00121

IV 00122

IV 00123

IV 00124

IV 00125

IV 00126

IV 00127

IV 00128

IV 00129

IV 00130

IV 00131

IV 00132

IV 00133

IV 00134

IV 00135

IV 00136

IV 00137

IV 00138

IV 00139

IV 00140

IV 00141

IV 00142

IV 00144

IV 00145

IV 00146

IV 00147

IV 00148

IV 00149

IV 00150

IV 00151

IV 00152

IV 00153

IV 00154

IV 00155

IV 00156

IV 00157

IV 00158

IV 00159

IV 00160

IV 00161

IV 00162

IV 00163

IV 00164

IV 00165

IV 00166

IV 00167

IV 00168

IV 00169

IV 00170

IV 00171

IV 00172

IV 00173

IV 00174

IV 00175

IV 00176 
Konkordanz: Bestell-Signatur - Ifd. Nr.

Bestell-Signatur

Lfd.Nr.

IV 00176 a

IV 00177

IV 00178

IV 00179

IV 00180

IV 00181

IV 00182

IV 00183

IV 00184

IV 00185

IV 00186

IV 00187

IV 00188

IV 00189

IV 00190

IV 00191

IV 00192

IV 00193

IV 00194

IV 00195

IV 00196

IV 00197

IV 00198

IV 00199

IV 00200

IV 00201

IV 00202

IV 00203

IV 00204

IV 00205

IV 00206

IV 00207

IV 00208

IV 00209

IV 00210

IV 00211

IV 00212

IV 00213

IV 00214

IV 00215

IV 00216

IV 00217

IV 00218

IV 00219

IV 00220

IV 00221

IV 00222

IV 00223

IV 00224

IV 00225

IV 00226

IV 00227

IV 00228

IV 00229

IV 00230

IV 00231

IV 00232

IV 00233

IV 00234

IV 00235 
IV

Konkordanz: Bestell-Signatur - Ifd. Nr.

Bestell-Signatur

Lfd.Nr.

IV 00236

IV 00237

IV 00238

IV 00239

IV 00240

IV 00241

IV 00242

IV 00243

IV 00244

IV 00245

IV 00246

IV 00247

IV 00248

IV 00249

IV 00250

IV 00251

IV 00252

IV 00253

IV 00254

IV 00255

IV 00256

IV 00257

IV 00258

IV 00259

IV 00260

IV 00261

IV 00262

IV 00263

IV 00264

IV 00265

IV 00266

IV 00267

IV 00268

IV 00269

IV 00270

IV 00271

IV 00272

IV 00273

IV 00274

IV 00275

IV 00276

IV 00277

IV 00278 a

IV 00278 b

IV 00279

IV 00280

IV 00281

IV 00282

IV 00283

IV 00284

IV 00285

IV 00286

IV 00287

IV 00288

IV 00289

IV 00290

IV 00291

IV 00292

IV 00293

IV 00294 
IV

Konkordanz: Bestell-Signatur - Ifd. Nr.

Bestell-Signatur

Lfd.Nr.

IV 00295

IV 00296

IV 00297

IV 00298

IV 00299

IV 00300

IV 00301

IV 00302

IV 00303

IV 00304

IV 00305

IV 00306

IV 00307

IV 00308

IV 00309

IV 00310

IV 00311

IV 00312

IV 00313

IV 00314

IV 00315

IV 00316

IV 00317

IV 00318

IV 00319

IV 00320

IV 00321

IV 00322

IV 00323

IV 00324

IV 00325

IV 00326

IV 00327

IV 00328

IV 00329

IV 00330

IV 00331

IV 00332

IV 00333

IV 00334

IV 00335

IV 00336

IV 00337

IV 00338

IV 00339

IV 00340

IV 00341

IV 00342

IV 00343

IV 00344

IV 00345

IV 00346

IV 00347

IV 00348

IV 00349

IV 00350

IV 00351

IV 00352

IV 00353

IV 00354 
IV

Konkordanz: Bestell-Signatur - Ifd. Nr.

Bestell-Signatur

Lfd.Nr.

IV 00355

IV 00356

IV 00357

IV 00358

IV 00359

IV 00360

IV 00361

IV 00362

IV 00363

IV 00364

IV 00365

IV 00366

IV 00367

IV 00368

IV 00369

IV 00370

IV 00371

IV 00372

IV 00373

IV 00374

IV 00375

IV 00376

IV 00377

IV 00378

IV 00379

IV 00380

IV 00381

IV 00382

IV 00383

IV 00384

IV 00385

IV 00386

IV 00387

IV 00388

IV 00389

IV 00390

IV 00391

IV 00392

IV 00393

IV 00394

IV 00395

IV 00396

IV 00397

IV 00398

IV 00399

IV 00400

IV 00401

IV 00402

IV 00403

IV 00404

IV 00405

IV 00406

IV 00407

IV 00408

IV 00409

IV 00410

IV 00411

IV 00412

IV 00413

IV 00414 
Konkordanz: Bestell-Signatur - Ifd. Nr.

Bestell-Signatur

Lfd.Nr.

IV 00415

IV 00416

IV 00417

IV 00418

IV 00419

IV 00420

IV 00421

IV 00422

IV 00423

IV 00424

IV 00425

IV 00426

IV 00427

IV 00428

IV 00429

IV 00430

IV 00431

IV 00432

IV 00433

IV 00434

IV 00435

IV 00436

IV 00437

IV 00438

IV 00439

IV 00440

IV 00441

IV 00442

IV 00443

IV 00444

IV 00445

IV 00446

IV 00447

IV 00448

IV 00449

IV 00450

IV 00451

IV 00452

IV 00453

IV 00454

IV 00455

IV 00456

IV 00457

IV 00458

IV 00459

IV 00460

IV 00461

IV 00462

IV 00463

IV 00464

IV 00465

IV 00466

IV 00467

IV 00468

IV 00469

IV 00470

IV 00471

IV 00472

IV 00474

IV 00475 
IV

Konkordanz: Bestell-Signatur - Ifd. Nr.

Bestell-Signatur

Lfd.Nr.

IV 00476

IV 00477

IV 00478

IV 00479

IV 00480

IV 00481

IV 00482

IV 00483

IV 00484

IV 00485

IV 00486

IV 00487

IV 00488

IV 00489

IV 00490

IV 00491

IV 00492

IV 00493

IV 00494

IV 00495

IV 00496

IV 00497

IV 00498

IV 00499

IV 00500

IV 00501

IV 00502

IV 00503

IV 00504

IV 00505

IV 00506

IV 00507

IV 00508

IV 00509

IV 00510

IV 00511

IV 00512

IV 00513

IV 00514

IV 00515

IV 00516

IV 00517

IV 00518

IV 00519

IV 00520

IV 00521

IV 00522

IV 00523

IV 00524

IV 00525

IV 00526

IV 00527

IV 00528

IV 00529

IV 00530

IV 00531

IV 00532

IV 00533

IV 00534

IV 00535 
Konkordanz: Bestell-Signatur - Ifd. Nr.

Bestell-Signatur

Lfd.Nr.

IV 00536

IV 00537

IV 00538

IV 00539

IV 00540

IV 00541

IV 00542

IV 00543

IV 00544

IV 00545

IV 00546

IV 00547

IV 00548

IV 00549

IV 00550

IV 00551

IV 00552

IV 00553

IV 00554

IV 00555

IV 00556

IV 00557

IV 00558

IV 00559

IV 00560

IV 00561

IV 00562

IV 00563

IV 00564

IV 00565

IV 00566

IV 00567

IV 00568

IV 00569

IV 00570

IV 00571

IV 00572

IV 00573

IV 00574

IV 00575

IV 00576

IV 00577

IV 00578

IV 00579

IV 00580

IV 00581

IV 00582

IV 00583

IV 00584

IV 00585

IV 00586

IV 00587

IV 00588

IV 00589

IV 00590

IV 00591

IV 00592

IV 00593

IV 00594

IV 00595 
Konkordanz: Bestell-Signatur - Ifd. Nr.

Bestell-Signatur

Lfd.Nr.

IV 00596

IV 00597

IV 00598

IV 00599

IV 00600

IV 00601

IV 00602

IV 00603

IV 00604

IV 00605

IV 00606

IV 00607

IV 00608

IV 00609

IV 00610

IV 00611

IV 00612

IV 00613

IV 00614

IV 00615

IV 00616

IV 00617

IV 00618

IV 00619

IV 00620

IV 00621

IV 00622

IV 00623

IV 00624

IV 00625

IV 00626

IV 00627

IV 00628

IV 00629

IV 00630

IV 00631

IV 00632

IV 00633

IV 00634

IV 00635

IV 00636

IV 00637

IV 00638

IV 00639

IV 00640

IV 00641

IV 00642

IV 00643

IV 00644

IV 00645

IV 00646

IV 00647

IV 00648

IV 00649

IV 00650

IV 00651

IV 00652

IV 00653

IV 00654

IV 00655 
IV

Konkordanz: Bestell-Signatur - Ifd. Nr.

Bestell-Signatur

Lfd.Nr.

IV 00656

IV 00657

IV 00658

IV 00659

IV 00660

IV 00661

IV 00662

IV 00663

IV 00664

IV 00665

IV 00666

IV 00667

IV 00668

IV 00669

IV 00670

IV 00671

IV 00672

IV 00673

IV 00674

IV 00675 a

IV 00675 b

IV 00676

IV 00677

IV 00678

IV 00679

IV 00680

IV 00681

IV 00682

IV 00683

IV 00684

IV 00685

IV 00686

IV 00687

IV 00688

IV 00689

IV 00690

IV 00691

IV 00692

IV 00693

IV 00694

IV 00695

IV 00696

IV 00697

IV 00698

IV 00699

IV 00700

IV 00701

IV 00702

IV 00703

IV 00704

IV 00705

IV 00706

IV 00707

IV 00708

IV 00709

IV 00710

IV 00711

IV 00712

IV 00713

IV 00714 
IV

Konkordanz: Bestell-Signatur - Ifd. Nr.

Bestell-Signatur

Lfd.Nr.

IV 00715

IV 00716

IV 00717

IV 00718

IV 00719

IV 00720

IV 00721

IV 00722

IV 00723

IV 00724

IV 00725

IV 00725 a

IV 00725 b

IV $00725 \mathrm{c}$

IV $00725 d$

IV 00726

IV 00727

IV 00728

IV 00729

IV 00730

IV 00731

IV 00732

IV 00733

IV 00734

IV 00735

IV 00736

IV 00737

IV 00738

IV 00739

IV 00740

IV 00741

IV 00742

IV 00743

IV 00744

IV 00745

IV 00746

IV 00747

IV 00748

IV 00749

IV 00750

IV 00751

IV 00752

IV 00753

IV 00754

IV 00755

IV 00756

IV 00757

IV 00758

IV 00759

IV 00760

IV 00761

IV 00762

IV 00763

IV 00764

IV 00765

IV 00766

IV 00767

IV 00768

IV 00769

IV 00770

650

651

652

653

654

655

656

657

658

659

660

661

662

663

664

665

666

667

668

669

670

671

672

673

674

675

676

677

678

679

680

681

682

683

684

685

686

688

687

689

690

691

692

693

694

695

696

697

698

699

700

701

702

703

704

705

706

707

708

709 
IV

Konkordanz: Bestell-Signatur - Ifd. Nr.

Bestell-Signatur

Lfd.Nr.

IV 00771

IV 00772

IV 00773

IV 00774

IV 00775

IV 00776

IV 00777

IV 00778

IV 00779 a

IV 00779 b

IV 00780

IV 00781

IV 00782

IV 00783

IV 00784

IV 00785

IV 00786

IV 00787

IV 00788

IV 00789

IV 00790

IV 00791

IV 00792

IV 00793

IV 00794

IV 00795

IV 00796

IV 00797

IV 00798

IV 00799

IV 00800

IV 00801

IV 00802

IV 00803

IV 00804

IV 00805

IV 00806

IV 00807

IV 00808

IV 00809

IV 00810

IV 00811

IV 00812

IV 00813

IV 00814

IV 00815

IV 00816

IV 00817

IV 00818

IV 00819

IV 00820

IV 00821

IV 00822

IV 00823

IV 00824

IV 00825

IV 00826

IV 00827

IV 00828

IV 00829 
IV

Konkordanz: Bestell-Signatur - Ifd. Nr.

Bestell-Signatur

Lfd.Nr.

IV 00830

IV 00831

IV 00832

IV 00833

IV 00834

IV 00835

IV 00836

IV 00837

IV 00838

IV 00839

IV 00840

IV 00841

IV 00842

IV 00843

IV 00844

IV 00845

IV 00846

IV 00847

IV 00848

IV 00849

IV 00850

IV 00851

IV 00852

IV 00853

IV 00854

IV 00855

IV 00856

IV 00857

IV 00858

IV 00859

IV 00860

IV 00861

IV 00862

IV 00863

IV 00864

IV 00865

IV 00866

IV 00867

IV 00868

IV 00869

IV 00870

IV 00871

IV 00872

IV 00873

IV 00874

IV 00875

IV 00876

IV 00877

IV 00878

IV 00879

IV 00880

IV 00881

IV 00882

IV 00883

IV 00884

IV 00885

IV 00886

IV 00887

IV 00888

IV 00889 
IV

Konkordanz: Bestell-Signatur - Ifd. Nr.

Bestell-Signatur

Lfd.Nr.

IV 00890

IV 00891

IV 00892

IV 00893

IV 00894

IV 00895

IV 00896

IV 00897

IV 00898

IV 00899

IV 00900

IV 00901

IV 00902

IV 00903

IV 00904

IV 00905

IV 00906

IV 00907

IV 00908

IV 00909

IV 00910

IV 00911

IV 00912

IV 00913

IV 00914

IV 00915

IV 00916

IV 00917

IV 00918

IV 00919

IV 00920

IV 00921

IV 00922

IV 00923

IV 00924

IV 00925

IV 00926

IV 00927

IV 00928

IV 00929

IV 00930

IV 00931

IV 00932

IV 00933

IV 00934

IV 00935

IV 00936

IV 00937

IV 00938

IV 00939

IV 00940

IV 00941

IV 00942

IV 00943

IV 00944

IV 00945

IV 00946

IV 00947

IV 00948

IV 00949 
IV

Konkordanz: Bestell-Signatur - Ifd. Nr.

Bestell-Signatur

Lfd.Nr.

IV 00950

IV 00951

IV 00952

IV 00953

IV 00954

IV 00955

IV 00956

IV 00957

IV 00958

IV 00959

IV 00960

IV 00961

IV 00962

IV 00963

IV 00964

IV 00965

IV 00966

IV 00967

IV 00968

IV 00969

IV 00970

IV 00971

IV 00972

IV 00973

IV 00974

IV 00975

IV 00976

IV 00977

IV 00978

IV 00979

IV 00980

IV 00981

IV 00982

IV 00983

IV 00984

IV 00985

IV 00986

IV 00987

IV 00988

IV 00989

IV 00990

IV 00991

IV 00992

IV 00993

IV 00994

IV 00995

IV 00996

IV 00997

IV 00998

IV 00999

IV 01000

IV 01001

IV 01002

IV 01003

IV 01004

IV 01005

IV 01006

IV 01007

IV 01008

IV 01009 
IV

Konkordanz: Bestell-Signatur - Ifd. Nr.

Bestell-Signatur

Lfd.Nr.

IV 01010

1012

IV 01011

IV 01012

IV 01013

IV 01014

IV 01015

IV 01016

IV 01017

IV 01018

IV 01019

IV 01020

IV 01021

IV 01022

IV 01023

IV 01024

IV 01025

IV 01026

IV 01027

IV 01028

IV 01029

IV 01030

IV 01031

IV 01032

IV 01033

IV 01034

IV 01035

IV 01036

IV 01037

IV 01038

IV 01039

IV 01040

IV 01041

IV 01042

IV 01043

IV 01044

IV 01045

IV 01046

IV 01047 a

IV 01047 b

IV 01048

IV 01049

IV 01050

IV 01051

IV 01052

IV 01053

IV 01054

IV 01055

IV 01056

IV 01057

IV 01058

IV 01059

IV 01060

IV 01061

IV 01062

IV 01063

IV 01064

IV 01065

IV 01066

IV 01067

IV 01068

1013

1014

1016

1017

1018

1019

1026

1027

1028

1082

1020

1029

1030

1031

1032

1033

1034

1035

1036

1037

1038

1039

1040

1041

1042

1043

1044

1045

1046

1047

1048

1049

1050

1051

1052

1053

1054

1055

1056

1057

1058

1059

1060

1061

1062

1063

1064

1065

1066

1067

1021

1068

1069

1070

1022

1071

1072

1073

1074 
IV

Konkordanz: Bestell-Signatur - Ifd. Nr.

Bestell-Signatur

Lfd.Nr.

IV 01069

IV 01070

IV 01071

IV 01072

IV 01073

IV 01074

IV 01075

IV 01076

IV 01077

IV 01078

IV 01079

IV 01080

IV 01081

IV 01082

IV 01083

IV 01084

IV 01085

IV 01086

IV 01087

IV 01088

IV 01089

IV 01090

IV 01091

IV 01092

IV 01093

IV 01094

IV 01095

IV 01096

IV 01097

IV 01098

IV 01099

IV 01100

IV 01101

IV 01102

IV 01103

IV 01104

IV 01105

IV 01106

IV 01107

IV 01108

IV 01109

IV 01110

IV 01111

IV 01112

IV 01113

IV 01114

IV 01115

IV 01116

IV 01117

IV 01118

IV 01119

IV 01120

IV 01121

IV 01122

IV 01123

IV 01124

IV 01125

IV 01126

IV 01127

IV 01128 
Konkordanz: Bestell-Signatur - Ifd. Nr.

Bestell-Signatur

Lfd.Nr.

IV 01129

IV 01130

IV 01131

IV 01132

IV 01133

IV 01134

IV 01135

IV 01136

IV 01137

IV 01138

IV 01139

IV 01140

IV 01141

IV 01142

IV 01144

IV 01145

IV 01146

IV 01147

IV 01148

IV 01149

IV 01150

IV 01151

IV 01152

IV 01153

IV 01154

IV 01155

IV 01156

IV 01157

IV 01158

IV 01159

IV 01160

IV 01161

IV 01162

IV 01163

IV 01164

IV 01165

IV 01166

IV 01167

IV 01168

IV 01169

IV 01170

IV 01171

IV 01172

IV 01173

IV 01174

IV 01175

IV 01176

IV 01177

IV 01178

IV 01179

IV 01180

IV 01181

IV 01182

IV 01183

IV 01184

IV 01185

IV 01186

IV 01187

IV 01188

IV 01189 
Konkordanz: Bestell-Signatur - Ifd. Nr.

Bestell-Signatur

Lfd.Nr.

IV 01190

IV 01191

IV 01192

IV 01193

IV 01194

IV 01195

IV 01196

IV 01197

IV 01198

IV 01199

IV 01200

IV 01201

IV 01202

IV 01203

IV 01204

IV 01205

IV 01206

IV 01207

IV 01208

IV 01209

IV 01210

IV 01211

IV 01212

IV 01213

IV 01214

IV 01215

IV 01216

IV 01217

IV 01218

IV 01219

IV 01220

IV 01221

IV 01222

IV 01223

IV 01224

IV 01225

IV 01226

IV 01227

IV 01228

IV 01229

IV 01230

IV 01231

IV 01232

IV 01233

IV 01234

IV 01235

IV 01236

IV 01237

IV 01238

IV 01239

IV 01240

IV 01241

IV 01242

IV 01243

IV 01244

IV 01245

IV 01246

IV 01247

IV 01248

IV 01249 
Konkordanz: Bestell-Signatur - Ifd. Nr.

Bestell-Signatur

Lfd.Nr.

IV 01250

1172

IV 01251

1173

IV 01252

1201

IV 01253

1202

IV 01254

1203

IV 01255

1146

IV 01256

1204

IV 01257

1205

IV 01258

1174

IV 01259

1147

IV 01260

1206

IV 01261

1207

IV 01262

1208

IV 01263

1209

IV 01264

1214

IV 01265

1215

IV 01266

1216

IV 01267

1217

IV 01268

1218

IV 01269

1219

IV 01270

1220

IV 01271

1221

IV 01272

1222

IV 01273

1223

IV 01274

1224

IV 01275

1226

IV 01276

1227

IV 01277

1228

IV 01278

1229

IV 01279

1230

IV 01280

1231

IV 01281

1232

IV 01282

1233

IV 01283

1234

IV 01284

1235

IV 01286

1236

IV 01287

1237

IV 01288

1238

IV 01289

1239

IV 01290

1240

IV 01291

1241

IV 01292

1242

IV 01293

1243

IV 01294

1244

IV 01295

1294

IV 01296

1251

IV 01297

1252

IV 01298

1253

IV 01299

1261

IV 01300

1262

IV 01301

1263

IV 01302

1264

IV 01303

1254

IV 01304

1265

IV 01305

1266

IV 01306

1390

IV 01307

1267

IV 01308

1268

IV 01309

1269

IV 01310 
Konkordanz: Bestell-Signatur - Ifd. Nr.

Bestell-Signatur

Lfd.Nr.

IV 01311

IV 01312

1272

IV 01313

1273

IV 01314

1274

IV 01315

1275

IV 01316

1276

IV 01317

1277

IV 01318

1278

IV 01319

1279

IV 01320

1280

IV 01321

1281

IV 01322

1282

IV 01323

1283

IV 01324

1284

IV 01325

1285

IV 01326

1286

IV 01327

1287

IV 01328

1288

IV 01329

1289

IV 01330

1290

IV 01331

1291

IV 01332

1292

IV 01333

1295

IV 01334

1296

IV 01335

1297

1298

IV 01336

1299

IV 01337

IV 01338

1300

IV 01339

1301

1302

IV 01340

1303

IV 01341

IV 01342

1304

IV 01343

1305

IV 01344

1306

IV 01345

1307

IV 01346

1308

1309

IV 01347

1225

IV 01348

1310

IV 01349

1311

IV 01350

1312

IV 01351

1313

IV 01352

1314

IV 01353

1315

IV 01354

1316

IV 01355

IV 01356

1317

1318

IV 01357

1319

IV 01358

1320

IV 01359

1321

IV 01360

1322

IV 01361

1323

IV 01362

1325

IV 01363

1324

IV 01364

1326

IV 01365

1327

IV 01366

1328

IV 01367

1329

IV 01368

1330

IV 01369

1331

IV 01370 
Konkordanz: Bestell-Signatur - Ifd. Nr.

Bestell-Signatur

Lfd.Nr.

IV 01371

IV 01372

IV 01373

IV 01374

IV 01375

IV 01376

IV 01377

IV 01378

IV 01379

IV 01380

IV 01381

IV 01382

IV 01383

IV 01384

IV 01385

IV 01386

IV 01387

IV 01388

IV 01389

IV 01390

IV 01391

IV 01392

IV 01393

IV 01394

IV 01395

IV 01396

IV 01397

IV 01398

IV 01399

IV 01400

IV 01401

IV 01402

IV 01403

IV 01404

IV 01405

IV 01406

IV 01407

IV 01408

IV 01409

IV 01410

IV 01411

IV 01412

IV 01413

IV 01414

IV 01415

IV 01416

IV 01417

IV 01418

IV 01419

IV 01420

IV 01421

IV 01422

IV 01423

IV 01424

IV 01425

IV 01426

IV 01427

IV 01428

IV 01429

IV 01430 
IV

Konkordanz: Bestell-Signatur - Ifd. Nr.

Bestell-Signatur

Lfd.Nr.

IV 01431

IV 01432

IV 01433

IV 01434

IV 01435

IV 01436

IV 01437

IV 01438

IV 01439

IV 01440

IV 01441

IV 01442

IV 01443

IV 01444

IV 01445

IV 01446

IV 01447

IV 01448

IV 01449

IV 01450

IV 01451

IV 01452

IV 01453

IV 01454

IV 01455

IV 01456

IV 01457

IV 01458

IV 01459

IV 01460

IV 01461

IV 01462

IV 01463

IV 01464

IV 01465

IV 01466

IV 01467

IV 01468

IV 01469

IV 01470

IV 01471

IV 01472

IV 01473

IV 01474

IV 01475

IV 01476

IV 01477

IV 01478

IV 01479

IV 01480

IV 01481

IV 01482

IV 01483

IV 01484

IV 01485

IV 01486

IV 01487

IV 01488

IV 01489

IV 01490 
Konkordanz: Bestell-Signatur - Ifd. Nr.

Bestell-Signatur

Lfd.Nr.

IV 01491

IV 01492

IV 01493

IV 01494

IV 01495

IV 01496

IV 01497

IV 01498

IV 01499

IV 01500

IV 01501

IV 01502

IV 01503

IV 01504

IV 01505

IV 01506

IV 01507

IV 01508

IV 01509

IV 01510

IV 01511

IV 01512

IV 01513

IV 01514

IV 01515

IV 01516

IV 01517

IV 01518

IV 01519

IV 01520

IV 01521

IV 01522

IV 01523

IV 01524

IV 01525

IV 01526

IV 01527

IV 01528

IV 01529

IV 01530

IV 01531

IV 01532

IV 01533

IV 01534

IV 01535

IV 01536

IV 01537

IV 01538

IV 01539

IV 01540

IV 01541

IV 01542

IV 01543

IV 01544

IV 01545

IV 01546

IV 01547

IV 01548

IV 01549

IV 01550 
Konkordanz: Bestell-Signatur - Ifd. Nr.

Bestell-Signatur

Lfd.Nr.

IV 01551

IV 01552

IV 01553

IV 01554

IV 01555

IV 01556

IV 01557

IV 01558

IV 01559

IV 01560

IV 01561

IV 01562

IV 01563

IV 01564

IV 01565

IV 01566

IV 01567

IV 01568

IV 01569

IV 01570

IV 01571

IV 01572

IV 01573

IV 01574

IV 01575

IV 01576

IV 01577

IV 01578

IV 01579

IV 01580

IV 01581

IV 01582

IV 01583

IV 01584

IV 01585

IV 01586

IV 01587

IV 01588

IV 01589

IV 01590

IV 01591

IV 01592

IV 01593

IV 01594

IV 01595

IV 01596

IV 01597

IV 01598

IV 01599

IV 01600

IV 01601

IV 01602

IV 01603

IV 01604

IV 01605

IV 01606

IV 01607

IV 01608

IV 01609

IV 01610 
Konkordanz: Bestell-Signatur - Ifd. Nr.

Bestell-Signatur

Lfd.Nr.

IV 01611

1574

IV 01612

1577

IV 01613

1575

IV 01614

1576

IV 01615

1578

IV 01616

1593

IV 01617

1594

IV 01618

1595

IV 01619

1596

IV 01620

1597

IV 01621

1598

IV 01622

1599

IV 01623

1600

IV 01624

1601

IV 01625

IV 01626

IV 01627

IV 01628

IV 01629

IV 01630

IV 01631

IV 01632

IV 01633

IV 01634

IV 01635

IV 01636

IV 01637

IV 01638

IV 01639

IV 01640

IV 01641

IV 01642

IV 01643

IV 01644

IV 01645

IV 01646

IV 01647

IV 01648

IV 01649

IV 01650

IV 01651

IV 01652

IV 01653

IV 01654

IV 01655

IV 01656

IV 01657

IV 01658

IV 01659

IV 01660

IV 01661

IV 01662

IV 01663

IV 01664

IV 01665

IV 01666

IV 01667

IV 01668

IV 01669

IV 01670

1602

1603

1604

1605

1606

1607

1608

1610

1609

1611

1612

1613

1630

1631

1614

1615

1616

1617

1618

1619

1620

1621

1622

1623

1624

1625

1626

1627

1632

1633

1634

1635

728

729

730

731

732

733

734

735

736

737

738

739

740

741 
IV

Konkordanz: Bestell-Signatur - Ifd. Nr.

Bestell-Signatur

Lfd.Nr.

IV 01671

IV 01672

173

IV 01673

1245

IV 01674

1913

IV 01675

1914

IV 01676

1915

IV 01677

1916

IV 01678

1917

IV 01679

1918

IV 01680

1919

IV 01681

1920

IV 01682

1921

IV 01683

795

IV 01684

1636

IV 01685

1637

IV 01686

IV 01687

1638

IV 01688

1639

IV 01689

1640

IV 01690

IV 01691

IV 01692

IV 01693

IV 01694

IV 01695

1641

1642

1643

1644

1645

1646

1647

IV 01696

IV 01697

IV 01698

1648

1649

IV 01699

1650

1651

IV 01700

1652

IV 01701

1653

IV 01702

1654

IV 01703

1655

IV 01704

IV 01705

1656

1657

1658

1659

IV 01708

1660

IV 01709

1661

IV 01711

IV 01712

1662

1663

IV 01713

1664

IV 01714

1665

IV 01715

1666

IV 01716

IV 01717

1667

IV 01718

1668

IV 01719

1669

IV 01720

1670

IV 01721

1671

IV 01722

1672

IV 01723

1673

IV 01724

1674

IV 01725

1675

IV 01726

1676

IV 01727

1677

IV 01728

1678

IV 01729

1679

IV 01730

1680

IV 01731 
IV

Konkordanz: Bestell-Signatur - Ifd. Nr.

Bestell-Signatur

Lfd.Nr.

IV 01732

IV 01733

IV 01734

IV 01735

IV 01736

IV 01737

IV 01738

IV 01739

IV 01740

IV 01741

IV 01742

IV 01743

IV 01744

IV 01745

IV 01746

IV 01747

IV 01748

IV 01749

IV 01750

IV 01751

IV 01752

IV 01753

IV 01754

IV 01755

IV 01756

IV 01757

IV 01758

IV 01759

IV 01760

IV 01761

IV 01762

IV 01763

IV 01764

IV 01765

IV 01766

IV 01767

IV 01768

IV 01769

IV 01770

IV 01771

IV 01772

IV 01773

IV 01774

IV 01775

IV 01776

IV 01777

IV 01778

IV 01779

IV 01780

IV 01781

IV 01782

IV 01783

IV 01784

IV 01785

IV 01786

IV 01787

IV 01788

IV 01789

IV 01790

IV 01791

1693

1694

1695

1696

1697

1698

1699

1700

1701

1702

2931

2932

1682

1683

1707

1708

1709

1710

1711

1712

1733

1734

1735

1736

1737

1738

1739

1740

1741

1742

1743

1744

1745

1746

1747

1748

1751

1752

1749

1753

1750

1754

1755

1756

1757

1758

1706

1760

1761

1861

1862

1762

1763 
Konkordanz: Bestell-Signatur - Ifd. Nr.

Bestell-Signatur

Lfd.Nr.

IV 01792

IV 01793

1764

IV 01794

1765

IV 01795

1766

IV 01796

1767

IV 01797

1768

IV 01798

1769

IV 01799

1770

IV 01800

1771

IV 01801

1772

IV 01802

1773

IV 01803

1774

IV 01804

1775

IV 01805

1776

IV 01806

1863

IV 01807

1777

IV 01808

1778

IV 01809

1779

1780

IV 01810

1864

IV 01811

1867

IV 01812

1868

IV 01813

1865

IV 01814

1866

IV 01815

1869

IV 01816

1870

IV 01817

1871

IV 01818

1781

IV 01819

1782

IV 01820

1684

IV 01821

IV 01822

IV 01823

845

1783

IV 01824

1784

IV 01825

1785

IV 01826

1786

1787

IV 01827

1788

IV 01828

1789

IV 01829

1790

IV 01830

1791

IV 01831

1792

IV 01832

1793

IV 01833

1794

IV 01834

1795

IV 01835

1796

IV 01836

IV 01837

1797

IV 01838

1798

IV 01839

1799

1800

IV 01840

1801

IV 01841

1802

IV 01842

1803

IV 01843

1804

IV 01844

1805

IV 01845

1806

IV 01846

1807

IV 01847

1808

IV 01848

1809

IV 01849

1810

IV 01850

1811

IV 01851 
IV

Konkordanz: Bestell-Signatur - Ifd. Nr.

Bestell-Signatur

Lfd.Nr.

IV 01852

IV 01853

IV 01854

IV 01855

IV 01856

IV 01857

IV 01858

IV 01859

IV 01860

IV 01861

IV 01862

IV 01863

IV 01864

IV 01865

IV 01866

IV 01867

IV 01868

IV 01869

IV 01870

IV 01871

IV 01872

IV 01873

IV 01874

IV 01875

IV 01876

IV 01877

IV 01878

IV 01879

IV 01880

IV 01881

IV 01882

IV 01883

IV 01884

IV 01885

IV 01886

IV 01887

IV 01888

IV 01889

IV 01890

IV 01891

IV 01892

IV 01893

IV 01894

IV 01895

IV 01896

IV 01897

IV 01898

IV 01899 a

IV 01899 b

IV 01900

IV 01901

IV 01902

IV 01903

IV 01904

IV 01905

IV 01906

IV 01907

IV 01908

IV 01909

IV 01910 
Konkordanz: Bestell-Signatur - Ifd. Nr.

Bestell-Signatur

Lfd.Nr.

IV 01911

1725

IV 01912

1726

IV 01913

1727

IV 01914

1728

IV 01915

1729

IV 01916

1730

IV 01917

1731

IV 01918

1732

IV 01919

1893

IV 01920

1872

IV 01921

1873

IV 01922

1874

IV 01923

IV 01924

1875

IV 01925

1876

IV 01926

1877

IV 01927

IV 01928

1878

1879

1880

IV 01929

1881

IV 01930

IV 01931

IV 01932

IV 01933

IV 01934

IV 01935

IV 01936

IV 01937

IV 01938

IV 01939

IV 01940

IV 01941

IV 01942

IV 01943

IV 01944

IV 01945

IV 01946

IV 01947

IV 01948

IV 01949

IV 01950

IV 01951

IV 01952

IV 01953

IV 01954

IV 01955

IV 01956

IV 01957

IV 01958

IV 01959

IV 01960

IV 01961

IV 01962

IV 01963

IV 01964

IV 01965

IV 01966

IV 01967

IV 01968

IV 01969

IV 01970

1882

1883

1884

1885

1886

1887

1888

1889

1890

1891

1892

1906

1907

1908

1925

2107

2108

2109

2110

2111

2112

2113

1909

1910

1911

1926

1927

1944

1945

1946

1947

1948

1949

1950

1951

1953

1954

1955

1956

1957

1958 
IV

Konkordanz: Bestell-Signatur - Ifd. Nr.

Bestell-Signatur

Lfd.Nr.

IV 01971

IV 01972

IV 01973

IV 01974

IV 01975

IV 01976

IV 01977

IV 01978

IV 01979

IV 01980

IV 01981

IV 01982

IV 01983

IV 01984

IV 01985

IV 01986

IV 01987

IV 01988

IV 01989

IV 01990

IV 01991

IV 01992

IV 01993

IV 01994

IV 01995

IV 01996

IV 01997

IV 01998

IV 01999

IV 02000

IV 02001

IV 02002

IV 02003

IV 02004

IV 02005

IV 02006

IV 02007

IV 02008

IV 02009

IV 02010

IV 02011

IV 02012

IV 02013

IV 02014

IV 02015

IV 02016

IV 02017

IV 02018

IV 02019

IV 02020

IV 02021

IV 02022

IV 02023

IV 02024

IV 02025

IV 02026

IV 02027

IV 02028

IV 02029

IV 02030 
Konkordanz: Bestell-Signatur - Ifd. Nr.

Bestell-Signatur

Lfd.Nr.

IV 02031

2117

IV 02032

2118

IV 02033

2119

IV 02034

2120

IV 02035

1922

IV 02036

2121

IV 02037

2122

IV 02038

2123

IV 02039

1930

IV 02040

2033

IV 02041

2034

IV 02042

2035

IV 02043

2036

IV 02045

2037

IV 02046

1900

IV 02047

2124

IV 02048

2038

IV 02049

2125

IV 02050

2039

IV 02051

2040

IV 02052

2126

IV 02053

2041

IV 02054

2042

IV 02055

2181

IV 02056

2043

IV 02057

2127

IV 02058

2044

IV 02059

2045

IV 02060

2046

IV 02061

2047

IV 02062

2048

IV 02063

2049

IV 02064

1997

IV 02065

1998

IV 02066

1999

IV 02067

2050

IV 02068

2051

IV 02069

2370

IV 02070

2371

IV 02071

2372

IV 02072

2373

IV 02074

2052

IV 02075

2053

IV 02076

2128

IV 02077

2054

IV 02078

2055

IV 02079

2056

IV 02080

2057

IV 02081

2129

IV 02082

2058

IV 02083

2059

IV 02084

2060

IV 02085

2061

IV 02086

2062

IV 02087

2063

IV 02088

2064

IV 02089

2065

IV 02090

2066

IV 02091

2067

IV 02092 
Konkordanz: Bestell-Signatur - Ifd. Nr.

Bestell-Signatur

Lfd.Nr.

IV 02093

2069

IV 02094

2070

IV 02095

2071

IV 02096

2072

IV 02097

2073

IV 02098

2074

IV 02099

2130

IV 02100

2131

IV 02101

2075

IV 02102

2076

IV 02103

2132

IV 02104

2077

IV 02105

2078

IV 02106

2360

IV 02107

2361

IV 02108

2362

IV 02109

2363

IV 02110

2079

IV 02111

2080

IV 02112

2081

IV 02113

2374

IV 02114

2082

IV 02115

2375

IV 02116

2083

IV 02117

2084

IV 02118

2085

IV 02119

2086

IV 02120

2087

IV 02121

2088

IV 02122

2376

IV 02123

2377

IV 02124

2089

IV 02125

2090

IV 02126

2091

IV 02127

2092

IV 02128

2093

IV 02129

2094

IV 02130

2095

IV 02131

2096

IV 02132

2097

IV 02133

2098

IV 02134

2099

IV 02135

2100

IV 02136

1484

IV 02137

1485

IV 02138

2101

IV 02139

2102

IV 02140

2103

IV 02141

2104

IV 02142

1901

IV 02143

1923

IV 02144

2133

IV 02145

718

IV 02146

2105

IV 02147

3714

IV 02148

2134

IV 02149

2135

IV 02150

2136

IV 02151

3232

IV 02152

2328 


\section{IV}

Konkordanz: Bestell-Signatur - Ifd. Nr.

Bestell-Signatur

Lfd.Nr.

IV 02153

2329

IV 02154

2330

IV 02155

2331

IV 02156

2332

IV 02157

2333

IV 02158

2334

IV 02159

2335

IV 02160

2336

IV 02161

2337

IV 02162

2338

IV 02163

2339

IV 02164

2340

IV 02165

2341

IV 02166

2342

IV 02167

2343

IV 02168

2344

IV 02169

2345

IV 02170

2346

IV 02171

2347

IV 02172

2348

IV 02173

2349

IV 02174

2350

IV 02175

2351

IV 02176

2352

IV 02177

2353

IV 02178

2354

IV 02179

2355

IV 02180

2356

IV 02181

2357

IV 02182

2358

IV 02183

2359

IV 02184

2182

IV 02185

2183

IV 02186

2184

IV 02187

2185

IV 02188

2186

IV 02189

2187

IV 02190

2382

IV 02191

2378

IV 02192

2379

IV 02193

2383

IV 02194

2384

2385

IV 02195

2386

IV 02196

2387

IV 02197

2388

IV 02199

2389

IV 02200

2380

IV 02201

2390

IV 02202

2381

IV 02203

2137

IV 02204

2138

IV 02205

2139

IV 02206

2140

IV 02207

2141

IV 02208

2142

IV 02209

2143

IV 02210

2144

IV 02211

2145

IV 02212

2146 
Konkordanz: Bestell-Signatur - Ifd. Nr.

Bestell-Signatur

Lfd.Nr.

IV 02213

IV 02214

IV 02215

IV 02216

IV 02217

IV 02218

IV 02219

IV 02220

IV 02221

IV 02222

IV 02223

IV 02224

IV 02225

IV 02226

IV 02227

IV 02228

IV 02229

IV 02230

IV 02231

IV 02232

IV 02233

IV 02234

IV 02235

IV 02236

IV 02237

IV 02238

IV 02239

IV 02240

IV 02241

IV 02242

IV 02243

IV 02244

IV 02245

IV 02246

IV 02247

IV 02248

IV 02249

IV 02250

IV 02251

IV 02252

IV 02253

IV 02254

IV 02255

IV 02256

IV 02257

IV 02258

IV 02259

IV 02260

IV 02261

IV 02262

IV 02263

IV 02264

IV 02265

IV 02266

IV 02267

IV 02268

IV 02269

IV 02270

IV 02271

IV 02272 
Konkordanz: Bestell-Signatur - Ifd. Nr.

Bestell-Signatur

Lfd.Nr.

IV 02273

IV 02274

IV 02275

IV 02276

IV 02277

IV 02278

IV 02279

IV 02280

IV 02281

IV 02282

IV 02283

IV 02284

IV 02285

IV 02286

IV 02287

IV 02288

IV 02289

IV 02290

IV 02291

IV 02292

IV 02293

IV 02294

IV 02295

IV 02296

IV 02297

IV 02298

IV 02299

IV 02300

IV 02301

IV 02302

IV 02303

IV 02304

IV 02305

IV 02306

IV 02307

IV 02308

IV 02309

IV 02310

IV 02311

IV 02312

IV 02313

IV 02314

IV 02315

IV 02316

IV 02317

IV 02318

IV 02319

IV 02320

IV 02321

IV 02322

IV 02323

IV 02324

IV 02325

IV 02326

IV 02327

IV 02328

IV 02329

IV 02330

IV 02331

IV 02332

2898

2899

2901

2902

2903

2904

2905

2906

2907

2908

2909

2910

2911

2933

3084

3085

3086

3092

3093

3094

3095

3096

3097

3098

3099

3140

3100

3101

3102

3104

3141

3142

3143

3144

3145

3105

3233

3187

3188

3146

3147

3109

3110

3111

3121

3122

3123

3124

3125

3126

3127

3112

3113

3114

3115

3311

3116

3117

3118

3087 
Konkordanz: Bestell-Signatur - Ifd. Nr.

Bestell-Signatur

Lfd.Nr.

IV 02333

IV 02334

IV 02335

IV 02336

IV 02337

IV 02338

IV 02339

IV 02340

IV 02341

IV 02342

IV 02343

IV 02344

IV 02345

IV 02346

IV 02347

IV 02348

IV 02349

IV 02350

IV 02351

IV 02352

IV 02353

IV 02354

IV 02355

IV 02356

IV 02357

IV 02358

IV 02359

IV 02360

IV 02361

IV 02362

IV 02363

IV 02364

IV 02365

IV 02366

IV 02367

IV 02368

IV 02369

IV 02370

IV 02371

IV 02372

IV 02373

IV 02374

IV 02375

IV 02376

IV 02377

IV 02378

IV 02379

IV 02380

IV 02381

IV 02382

IV 02383

IV 02384

IV 02385

IV 02386

IV 02387

IV 02388

IV 02389

IV 02390

IV 02391

IV 02392 
Konkordanz: Bestell-Signatur - Ifd. Nr.

Bestell-Signatur

Lfd.Nr.

IV 02393

IV 02394

IV 02395

IV 02396

IV 02397

IV 02398

IV 02399

IV 02400

IV 02401

IV 02402

IV 02403

IV 02404

IV 02405

IV 02406

IV 02407

IV 02408

IV 02409

IV 02410

IV 02411

IV 02412

IV 02413

IV 02414

IV 02415

IV 02416

IV 02417

IV 02418

IV 02419

IV 02420

IV 02421

IV 02422

IV 02423

IV 02424

IV 02425

IV 02426

IV 02427

IV 02428

IV 02429

IV 02430

IV 02431

IV 02432

IV 02432 a

IV 02433

IV 02434

IV 02435

IV 02436

IV 02437

IV 02438

IV 02439

IV 02440

IV 02441

IV 02442

IV 02443

IV 02444

IV 02445

IV 02446

IV 02447

IV 02448

IV 02449

IV 02450

IV 02451

3209

3210

3211

3254

3157

3212

3255

3158

3159

3213

3214

3256

3257

3258

3259

3260

3261

3262

3263

3264

3265

3266

3267

3268

3269

3270

3271

3272

3273

3274

3275

3276

3277

3278

3279

3280

3281

3282

3283

3284

3285

3286

3287

3288

3289

3290

3291

3292

3293

3294

3295

3296

3297 
Konkordanz: Bestell-Signatur - Ifd. Nr.

Bestell-Signatur

Lfd.Nr.

IV 02452

3215

IV 02453

3216

IV 02454

3217

IV 02455

3218

IV 02456

3315

IV 02457

3219

IV 02458

3220

IV 02459

3186

IV 02460

3221

IV 02461

3298

IV 02462

3299

IV 02463

3300

IV 02464

3301

IV 02465

3302

IV 02466

3303

IV 02467

273

IV 02468

1451

IV 02469

1452

IV 02470

1428

IV 02471

2106

IV 02472

2409

IV 02473

1246

IV 02474

3304

IV 02475

3106

IV 02476

3160

IV 02477

3161

IV 02478

IV 02479

3162

IV 02480

3107

3089

IV 02481

IV 02482

3108

IV 02483

3090

3091

IV 02484

3163

IV 02485

3164

IV 02486

3165

IV 02487

3166

IV 02488

3167

IV 02489

3168

IV 02490

3169

IV 02491

3170

IV 02492

3171

IV 02493

3172

IV 02494

3173

IV 02495

3174

IV 02496

IV 02497

3175

3176

IV 02498

3177

IV 02499

3178

IV 02500

3179

IV 02501

3180

IV 02502

3181

IV 02503

3182

IV 02504

3183

IV 02505

IV 02506

IV 02507

IV 02508

IV 02509 
Konkordanz: Bestell-Signatur - Ifd. Nr.

Bestell-Signatur

Lfd.Nr.

IV 02512

IV 02513

2410

IV 02514

2411

IV 02515

2412

IV 02516

2413

IV 02517

IV 02518

2414

IV 02519

2675

IV 02520

2676

IV 02521

IV 02522

IV 02523

IV 02524

IV 02525

IV 02526

IV 02527

IV 02528

IV 02529

IV 02530

IV 02531

IV 02532

IV 02533

IV 02534

IV 02535

IV 02536

IV 02537

IV 02538

IV 02539

IV 02540

IV 02541

IV 02542

IV 02543

IV 02544

IV 02545

IV 02546

IV 02547

IV 02548

IV 02549

IV 02550

IV 02551

IV 02552

IV 02553

IV 02554

IV 02555

IV 02556

IV 02557

IV 02558

IV 02559

IV 02560

IV 02561

IV 02562

IV 02563

IV 02564

IV 02565

IV 02566

IV 02567

IV 02568

IV 02569

IV 02570

IV 02571

203

1210

1453

1247

2605

2404

2405

2406

2415

2416

2407

2417

2418

2443

2444

2419

2420

2421

2422

2423

2424

2425

2426

2427

2428

2429

2430

2431

2408

2445

2432

2433

2434

2435

2436

2437

2446

2447

2438

2448

2439

2449

2450

2451

2452

2453

2454

2455

2456

2457

2458

2459 
Konkordanz: Bestell-Signatur - Ifd. Nr.

Bestell-Signatur

Lfd.Nr.

IV 02572

IV 02573

IV 02574

IV 02575

2460

IV 02576

IV 02577

IV 02578

IV 02579

IV 02580

IV 02581

IV 02582

IV 02583

IV 02584

IV 02585

IV 02586

IV 02587

IV 02588

IV 02589

IV 02590

IV 02591

IV 02592

IV 02593

IV 02594

IV 02595

IV 02596

IV 02597

IV 02598

IV 02599

IV 02600

IV 02601

IV 02602

IV 02603

IV 02604

IV 02605

IV 02606

IV 02607

IV 02608

IV 02609

IV 02610

IV 02611

IV 02612

IV 02613

IV 02614

IV 02615

IV 02616

IV 02617

IV 02618

IV 02619

IV 02620

IV 02621

IV 02622

IV 02623

IV 02624

IV 02625

IV 02626

IV 02627

IV 02628

IV 02629

IV 02630

IV 02631

2461

2463

2464

2465

2466

2467

2468

2469

2470

2471

2472

2473

2474

2475

2476

2477

2478

2479

2480

2481

2482

2483

2484

2485

2486

2487

2488

2489

2490

2491

2492

2493

2494

2495

2496

2497

2498

2499

2500

2501

2502

2503

2504

2505

2506

2507

2508

2509

2510

2511

2512

2513

2514

2515

2516

2517

2518

2519 
Konkordanz: Bestell-Signatur - Ifd. Nr.

Bestell-Signatur

Lfd.Nr.

IV 02632

IV 02633

2520

IV 02634

2521

IV 02635

2522

IV 02636

2523

IV 02637

2524

IV 02638

2525

IV 02639

2526

IV 02640

2527

IV 02641

2528

IV 02642

2529

IV 02643

2530

IV 02644

2531

IV 02645

2532

IV 02646

2533

IV 02647

2534

IV 02648

2535

IV 02649

2536

IV 02650

2537

IV 02651

2538

IV 02652

2539

IV 02653

2540

IV 02654

2541

IV 02655

2604

IV 02656

2542

IV 02657

2543

IV 02658

2544

IV 02659

2545

IV 02660

2546

IV 02661

2547

IV 02662

2548

IV 02663

2549

IV 02664

2550

IV 02665

2603

IV 02666

2551

IV 02667

2552

2553

IV 02668

2554

IV 02669

2555

IV 02670

2556

IV 02671

2557

IV 02672

2558

IV 02673

2559

IV 02674

2560

IV 02675

2561

IV 02676

IV 02677

2562

IV 02678

2563

2564

IV 02679

2565

IV 02680

2566

IV 02681

2567

IV 02682

2568

IV 02683

2569

IV 02684

2570

IV 02685

2571

IV 02686

2572

IV 02687

2573

IV 02688

2574

IV 02689

2575

IV 02690

2576

IV 02691 
Konkordanz: Bestell-Signatur - Ifd. Nr.

Bestell-Signatur

Lfd.Nr.

IV 02692

IV 02693

2578

IV 02694

2579

IV 02695

2580

IV 02696

2581

IV 02697

2582

IV 02698

2583

IV 02699

2584

IV 02700

2585

IV 02701

2586

IV 02702

2587

IV 02703

2588

IV 02704

2589

IV 02705

2590

IV 02706

2591

IV 02707

2592

IV 02708

2593

IV 02709

2594

IV 02710

2595

IV 02711

2596

IV 02712

2597

IV 02713

2598

IV 02714

2599

IV 02715

2600

IV 02716

2601

IV 02717

2602

IV 02718

264

IV 02719

265

IV 02720

2606

IV 02721

2607

IV 02722

2608

IV 02723

2609

IV 02724

2610

IV 02725

2611

IV 02726

2612

IV 02727

2613

IV 02728

2614

IV 02729

2615

IV 02730

2616

IV 02731

2617

IV 02732

2618

IV 02733

2619

IV 02734

2620

IV 02735

2621

IV 02736

2622

IV 02737

2623

IV 02738

2624

IV 02739

2625

IV 02740

2626

IV 02741

2627

IV 02742

2628

IV 02743

2629

IV 02744

2630

IV 02745

2631

IV 02746

2632

IV 02747

2633

IV 02748

2634

IV 02749

3702

IV 02750

2635

IV 02751

2636

2637 
Konkordanz: Bestell-Signatur - Ifd. Nr.

Bestell-Signatur

Lfd.Nr.

IV 02752

2638

IV 02753

2639

IV 02754

2640

IV 02755

2641

IV 02756

2642

IV 02757

2643

IV 02758

2644

IV 02759

2645

IV 02760

2646

IV 02761

2647

IV 02762

2648

IV 02763

2649

IV 02764

2650

IV 02765

2651

IV 02766

2652

IV 02767

2653

IV 02768

2654

IV 02769

2655

IV 02770

2656

IV 02771

2657

IV 02772

2658

IV 02773

2659

IV 02774

2892

IV 02775

2660

IV 02776

2661

IV 02777

2662

IV 02778

2663

IV 02779

2664

IV 02780

2665

IV 02781

2666

IV 02782

2667

IV 02783

2668

IV 02784

2677

IV 02785

2678

IV 02786

2669

IV 02787

2670

IV 02788

2671

IV 02789

2672

IV 02790

2673

IV 02791

2674

IV 02792

2679

IV 02793

2680

IV 02794

2681

IV 02795

2682

IV 02796

IV 02797

2683

IV 02798

2684

2685

IV 02799

2686

IV 02800

2687

IV 02801

2688

IV 02802

2689

IV 02803

2690

IV 02804

2691

IV 02805

2692

IV 02806

2693

IV 02807

2000

IV 02808

2694

IV 02809

2695

IV 02810

2696

IV 02811 
Konkordanz: Bestell-Signatur - Ifd. Nr.

Bestell-Signatur

Lfd.Nr.

IV 02812

IV 02813

IV 02814

IV 02815

IV 02816

IV 02817

IV 02818

IV 02819

IV 02820

IV 02821

IV 02822

IV 02823

IV 02824

IV 02825

IV 02826

IV 02827

IV 02828

IV 02828 a

IV 02829

IV 02830

IV 02831

IV 02832

IV 02833

IV 02834

IV 02835

IV 02836

IV 02837

IV 02838

IV 02839

IV 02840

IV 02841

IV 02842

IV 02843

IV 02844

IV 02845

IV 02846

IV 02847

IV 02848

IV 02849

IV 02850

IV 02851

IV 02852

IV 02853

IV 02854

IV 02855

IV 02856

IV 02857

IV 02858

IV 02859

IV 02860

IV 02861

IV 02862

IV 02863

IV 02864

IV 02865

IV 02866

IV 02867

IV 02868

IV 02869

IV 02870

2698

2699

2700

2701

2702

2703

2704

2705

2706

2707

2708

2709

2710

2711

2712

2713

2714

2715

2716

2717

2718

2719

2720

2721

2722

2723

2724

2725

2726

2727

2728

2729

2730

2731

2732

2733

2734

2735

2736

2737

2738

2739

2740

2741

2742

2743

2744

2745

2746

2747

2748

2749

2750

2751

2752

2753

2754

2755

2756

2757 
Konkordanz: Bestell-Signatur - Ifd. Nr.

Bestell-Signatur

Lfd.Nr.

IV 02871

2758

IV 02872

2759

IV 02873

2760

IV 02874

2761

IV 02875

2762

IV 02876

2763

IV 02877

2764

IV 02878

2765

IV 02879

2766

IV 02880

2767

IV 02881

2768

IV 02882

2769

IV 02883

2770

IV 02884

2771

IV 02885

2772

IV 02886

2773

IV 02887

2774

IV 02888

2775

IV 02889

2776

IV 02890

2777

IV 02891

2778

IV 02892

2779

IV 02893

2780

IV 02894

2781

IV 02895

2782

IV 02896

2783

IV 02897

2784

IV 02898

2785

IV 02899

2786

IV 02900

2787

IV 02901

2788

IV 02902

2789

IV 02903

2790

IV 02904

2791

IV 02905

2792

IV 02906

2793

IV 02907

2794

IV 02908

2795

IV 02909

2796

IV 02910

2797

IV 02911

2798

IV 02912

2799

IV 02913

2800

IV 02914

2801

IV 02915

2802

IV 02916

2803

IV 02917

2804

IV 02918

2805

IV 02919

2806

IV 02920

2807

IV 02921

2808

IV 02922

2809

IV 02923

2810

IV 02924

2811

IV 02925

2812

IV 02926

IV 02927

2813

IV 02928

2814

IV 02929

2815

IV 02930

2816
2818 
Konkordanz: Bestell-Signatur - Ifd. Nr.

Bestell-Signatur

Lfd.Nr.

IV 02931

2817

2819

IV 02933

2820

IV 02934

2821

IV 02935

2822

IV 02936

2823

IV 02937

2824

IV 02938

2825

IV 02939

2826

IV 02940

2827

IV 02941

2828

IV 02942

2829

IV 02943

2830

IV 02944

2831

IV 02945

2832

IV 02946

2833

IV 02947

2834

IV 02948

2835

IV 02949

2836

IV 02950

2837

IV 02951

2838

IV 02952

2839

IV 02953

2840

IV 02954

2841

IV 02955

2842

IV 02956

2843

IV 02957

2844

IV 02958

2845

IV 02959

2846

IV 02960

2847

IV 02961

IV 02962

2848

IV 02963

2849

IV 02964

2850

IV 02965

2851

IV 02966 a

2852

IV 02966 b

2855

IV 02967

2856

IV 02968

2857

IV 02969

2858

IV 02970

2859

IV 02971

2860

IV 02972

2861

IV 02973

2912

IV 02974

2913

IV 02975

2914

IV 02976

2915

2916

IV 02977

2917

IV 02978

2918

IV 02980

2919

IV 02981

2920

IV 02982

2921

IV 02983

2922

IV 02984

2923

IV 02985

2924

IV 02986

2925

IV 02987

2926

IV 02988

2927

IV 02989

2928

IV 02990 
Konkordanz: Bestell-Signatur - Ifd. Nr.

Bestell-Signatur

Lfd.Nr.

IV 02991

IV 02992

IV 02993

IV 02994

IV 02995

IV 02996

IV 02997

IV 02998

IV 02999

IV 03000

IV 03001

IV 03002

IV 03003

IV 03004

IV 03005

IV 03006

IV 03007

IV 03008

IV 03009

IV 03010

IV 03011

IV 03012

IV 03013

IV 03014

IV 03015

IV 03016

IV 03017

IV 03018

IV 03019

IV 03020

IV 03021

IV 03022

IV 03023

IV 03024

IV 03025

IV 03026

IV 03027

IV 03028

IV 03029

IV 03030

IV 03031

IV 03032

IV 03033

IV 03034

IV 03035

IV 03036

IV 03037

IV 03038

IV 03039 a

IV $03039 \mathrm{~b}$

IV 03039 c

IV 03040

IV 03041

IV 03042

IV 03042 a

IV 03043

IV 03044

IV 03045

IV 03046

IV 03047

2930

2934

2935

2936

2937

2938

2939

2940

2941

2942

2943

2944

2945

2946

2947

2948

2949

2950

2951

2952

2953

2954

2955

2956

2957

2958

2959

2960

2961

2962

2963

2964

2965

2966

2967

2978

2979

2980

2968

2969

2970

2971

2972

2973

2974

2975

2976

2977

2981

2982

2983

2984

2985

2986

2987

530

531

532

533

534 
IV

Konkordanz: Bestell-Signatur - Ifd. Nr.

Bestell-Signatur

Lfd.Nr.

IV 03048

535

IV 03049

536

IV 03050

537

IV 03051

538

IV 03052

539

IV 03053

540

IV 03054

541

IV 03055

542

IV 03056

IV 03057

543

IV 03058

IV 03059

545

IV 03060

546

IV 03061

548

IV 03062

549

IV 03063

550

IV 03064

551

IV 03065

552

IV 03066

553

IV 03067

2989

IV 03068

2990

IV 03069

2991

IV 03070

2992

IV 03071

IV 03072

2993

IV 03073

2994

IV 03074

2995

IV 03075

2996

IV 03076

2997

2998

IV 03077

2999

IV 03078

3000

IV 03079

3001

IV 03080

3002

IV 03081

IV 03082

3003

IV 03083

IV 03084

IV 03085

IV 03086

3011

3005

3006

3007

IV 03087

3008

IV 03088

3009

IV 03089

3010

IV 03090

3012

IV 03091

3013

IV 03092

IV 03093

3014

3015

3016

IV 03094

3017

IV 03095

IV 03096

IV 03097

3018

IV 03098

3019

IV 03099

3020

IV 03100

3021

IV 03101

3022

3023

IV 03102

3024

IV 03103

3025

IV 03104

3026

IV 03105

3027

IV 03106

3028

IV 03107 
IV

Konkordanz: Bestell-Signatur - Ifd. Nr.

Bestell-Signatur

Lfd.Nr.

IV 03108

IV 03109

IV 03110

IV 03111

IV 03112

IV 03113

IV 03114

IV 03115

IV 03116

IV 03117

IV 03118

IV 03119

IV 03120

IV 03121

IV 03122

IV 03123

IV 03124

IV 03125

IV 03126

IV 03127

IV 03128

IV 03129

IV 03130

IV 03131

IV 03132

IV 03133

IV 03134

IV 03135

IV 03136

IV 03137

IV 03138

IV 03139

IV 03140

IV 03141

IV 03142

IV 03143

IV 03144

IV 03145

IV 03146

IV 03147

IV 03148

IV 03149

IV 03150

IV 03151

IV 03152

IV 03153

IV 03154

IV 03155

IV 03156

IV 03157

IV 03158

IV 03159

IV 03160

IV 03161

IV 03162

IV 03163

IV 03164

IV 03165

IV 03166

IV 03167

3030

3031

3032

3033

3034

3035

3036

3037

3038

3039

3040

3041

3042

3043

3075

3044

3045

3046

3047

3048

3049

3050

3051

3052

3053

3054

3055

3056

3057

3058

3059

3060

3061

3062

3063

3064

3065

3066

3067

3068

3069

3070

3071

3072

3073

3074

3076

3077

3078

3079

3080

3081

3082

3083

3318

3319

3320 
IV

Konkordanz: Bestell-Signatur - Ifd. Nr.

Bestell-Signatur

Lfd.Nr.

IV 03168

IV 03169

IV 03170

IV 03171

IV 03172

IV 03173

IV 03174

IV 03175

IV 03176

IV 03177

IV 03178

IV 03179

IV 03180

IV 03181

IV 03182

IV 03183

IV 03184

IV 03185

IV 03186

IV 03187

IV 03188

IV 03189

IV 03190

IV 03191

IV 03192

IV 03193

IV 03194

IV 03195

IV 03196

IV 03197

IV 03198

IV 03199

IV 03200

IV 03201

IV 03202

IV 03203

IV 03204

IV 03205

IV 03206

IV 03207

IV 03208

IV 03209

IV 03210

IV 03211

IV 03212

IV 03213

IV 03214

IV 03215

IV 03216

IV 03217

IV 03218

IV 03219

IV 03220

IV 03221

IV 03222

IV 03223 a

IV 03223 b

IV 03224

IV 03225

IV 03226 
IV

Konkordanz: Bestell-Signatur - Ifd. Nr.

Bestell-Signatur

Lfd.Nr.

IV 03227

IV 03228

IV 03229

IV 03230

3377

IV 03231

IV 03232

IV 03233

IV 03234

IV 03235

IV 03236

IV 03237

IV 03238

IV 03239

IV 03240

IV 03241

IV 03242

IV 03243

IV 03244

IV 03245

IV 03246

IV 03247

IV 03248

IV 03249

IV 03250

IV 03251

IV 03252

IV 03253

IV 03254

IV 03255

IV 03256

IV 03257

IV 03258

IV 03259

IV 03260

IV 03261

IV 03262

IV 03263

IV 03264

IV 03265

IV 03266

IV 03267

IV 03268

IV 03269

IV 03270

IV 03271

IV 03272

IV 03273

IV 03274

IV 03275

IV 03276

IV 03277

IV 03278

IV 03279

IV 03280

IV 03281

IV 03282

IV 03283

IV 03284

IV 03285

IV 03286

3378

3379

3412

3380

3620

3381

3382

3413

3383

3384

3385

3386

3387

3388

3389

3390

3391

3350

3392

3393

3394

3395

3396

3397

3398

3399

3400

3401

3402

3403

3404

3429

3405

3406

3414

3407

3408

3409

3430

3621

3432

3433

3434

3435

3436

3437

3438

3439

3440

3441

3442

3443

3648

3444

3445

3446

3447

3448

3449 
IV

Konkordanz: Bestell-Signatur - Ifd. Nr.

Bestell-Signatur

Lfd.Nr.

IV 03287

IV 03288

IV 03289

IV 03290

IV 03291

IV 03292

IV 03293

IV 03294

IV 03295

IV 03296

IV 03297

IV 03298

IV 03299

IV 03300

IV 03301

IV 03302

IV 03303

IV 03304

IV 03305

IV 03306

IV 03307

IV 03308

IV 03309

IV 03310

IV 03311

IV 03312

IV 03313

IV 03314

IV 03315

IV 03316

IV 03317

IV 03318

IV 03319

IV 03320

IV 03321

IV 03322

IV 03323

IV 03324

IV 03325

IV 03326

IV 03327

IV 03328

IV 03329

IV 03330

IV 03331

IV 03332

IV 03333

IV 03334

IV 03335

IV 03336

IV 03337

IV 03338

IV 03339

IV 03340

IV 03341

IV 03342

IV 03343

IV 03344

IV 03345

IV 03346 
IV

Konkordanz: Bestell-Signatur - Ifd. Nr.

Bestell-Signatur

Lfd.Nr.

IV 03347

IV 03348

IV 03349

IV 03350

IV 03351

IV 03352

IV 03353

IV 03354

IV 03355

IV 03356

IV 03357

IV 03358

IV 03359

IV 03360

IV 03361

IV 03362

IV 03363

IV 03364

IV 03365

IV 03366

IV 03367

IV 03368

IV 03369

IV 03370

IV 03371

IV 03372

iV 03373

IV 03374

IV 03375

IV 03376

IV 03377

IV 03378

IV 03379

IV 03380

IV 03381

IV 03382

IV 03383

IV 03384

IV 03385

IV 03386

IV 03387

IV 03388

IV 03389

IV 03390

IV 03391

IV 03392

IV 03393

IV 03394

IV 03395

IV 03396

IV 03397

IV 03398

IV 03399

IV 03400

IV 03401

IV 03402

IV 03403

IV 03404

IV 03405

IV 03406

3493

3496

3497

3498

3499

3674

3500

3501

3502

3503

3504

3505

3506

3507

3508

3509

3510

3511

3512

3513

3514

3515

3516

3517

3518

3519

3520

3521

3522

3523

3524

3525

3526

3527

3528

3529

3530

3531

3532

3533

3534

3535

3536

3537

3538

3539

3540

3715

3716

3717

3718

3712

3713

3719

3720

3721

237

3722

3723

3724 
Konkordanz: Bestell-Signatur - Ifd. Nr.

Bestell-Signatur

Lfd.Nr.

IV 03407

IV 03408

IV 03409

IV 03410

3725

IV 03411

3727

IV 03412

IV 03413

IV 03414

IV 03415

IV 03416

IV 03417

IV 03418

IV 03419

IV 03420

IV 03421

IV 03422

IV 03423

IV 03424

IV 03425

IV 03426

IV 03427

IV 03428

IV 03429

IV 03430

IV 03431

IV 03432

IV 03433

IV 03434

IV 03435

IV 03436

IV 03437

IV 03438

IV 03439

IV 03440

IV 03441

IV 03442

IV 03443

IV 03444

IV 03445

IV 03446

IV 03447

IV 03448

IV 03449

IV 03450

IV 03451

IV 03452

IV 03453

IV 03454

IV 03455

IV 03456

IV 03457

IV 03458

IV 03459

IV 03460

IV 03461

IV 03462

IV 03463

IV 03464

IV 03465

IV 03466 
IV

Konkordanz: Bestell-Signatur - Ifd. Nr.

Bestell-Signatur

Lfd.Nr.

IV 03467

IV 03468

IV 03469

IV 03470

IV 03471

IV 03472

IV 03473

IV 03474

IV 03475

IV 03476

IV 03477

IV 03478

IV 03479

IV 03480

IV 03481

IV 03482

IV 03483

IV 03484

IV 03485

IV 03486

IV 03487

IV 03488

IV 03489

IV 03490

IV 03491

IV 03492

IV 03493

IV 03494

IV 03495

IV 03496

IV 03497

IV 03498

IV 03499

IV 03500

IV 03501

IV 03502

IV 03503

IV 03504

IV 03505

IV 03506

IV 03507

IV 03508

IV 03509

IV 03510

IV 03511

IV 03512

IV 03513

IV 03514

IV 03515

IV 03516

IV 03517

IV 03518

IV 03519

IV 03520

IV 03521

IV 03522

IV 03523

IV 03524

IV 03525

IV 03526 
Konkordanz: Bestell-Signatur - Ifd. Nr.

Bestell-Signatur

Lfd.Nr.

IV 03527

IV 03528

IV 03529

IV 03530

3770

IV 03531

IV 03532

IV 03533

IV 03534

IV 03535

IV 03536

IV 03537

IV 03538

IV 03539

IV 03540

IV 03541

IV 03542

IV 03543

IV 03544

IV 03545

IV 03546

IV 03547

IV 03548

IV 03549

IV 03550

IV 03551

IV 03552

IV 03553

IV 03554

IV 03555

IV 03556

IV 03557

IV 03558

IV 03559

IV 03560

IV 03561

IV 03562

IV 03563

IV 03564

IV 03565

IV 03566

IV 03567

IV 03568

IV 03569

IV 03570

IV 03571

IV 03572

IV 03573

IV 03574

IV 03575

IV 03576

IV 03577

IV 03578

IV 03579

IV 03580

IV 03582

IV 03583

IV 03584

IV 03585

IV 03586

IV 03587 
IV

Konkordanz: Bestell-Signatur - Ifd. Nr.

Bestell-Signatur

Lfd.Nr.

IV 03588

IV 03589

IV 03590

IV 03591

IV 03592

IV 03593

IV 03594

IV 03595

IV 03596

IV 03597

IV 03598

IV 03599

IV 03600

IV 03601

IV 03602

IV 03603

IV 03604

IV 03605

IV 03606

IV 03607

IV 03608

IV 03609

IV 03610

IV 03611

IV 03612

IV 03613

IV 03614

IV 03615

IV 03616

IV 03617

IV 03618

IV 03619

IV 03620

IV 03621

IV 03622

IV 03623

IV 03624

IV 03625

IV 03626

IV 03627

IV 03628

IV 03629

IV 03630

IV 03631

IV 03632

IV 03633

IV 03634

IV 03635

IV 03636

IV 03637

IV 03638

IV 03639

IV 03640

IV 03641

IV 03642

IV 03643

IV 03644

IV 03645

IV 03646

IV 03647

3830

3831

3832

3833

3834

3835

3836

3837

3838

3839

3840

3841

3842

3843

3844

3845

3846

3847

3849

3850

3848

3851

3852

3853

3854

3855

3856

3857

3858

3616

3617

3618

3619

3699

3542

3543

3544

3545

3546

3707

3700

3547

3701

3709

3548

3549

3550

3551

3552

3553

3554

3555

3556

3557

3558

3559

3560

3561

3562

3563 
Konkordanz: Bestell-Signatur - Ifd. Nr.

Bestell-Signatur

Lfd.Nr.

IV 03648

IV 03649

IV 03650

IV 03651

IV 03652

IV 03653

IV 03654

IV 03655

IV 03656

IV 03657

IV 03658

IV 03659

IV 03660

IV 03661

IV 03662

IV 03663

IV 03664

IV 03665

IV 03666

IV 03667

IV 03668

IV 03669

IV 03670

IV 03671

IV 03672

IV 03673

IV 03674

IV 03675

IV 03676

IV 03677

IV 03678

IV 03679

IV 03680

IV 03681

IV 03682

IV 03683

IV 03684

IV 03685

IV 03686

IV 03687

IV 03688

IV 03689

IV 03690

IV 03691

IV 03692

IV 03693

IV 03694

IV 03695

IV 03696

IV 03697

IV 03698

IV 03699

IV 03700

IV 03701

IV 03702

IV 03703

IV 03704

IV 03705

IV 03706

IV 03707

3564

3565

3566

3567

3568

3569

3570

3571

3572

3573

3574

3575

3576

3577

3578

3579

3580

3581

3582

3583

3584

3585

3586

3587

3588

3589

3590

3591

3592

3593

3594

3595

3596

3597

3598

3599

3600

3601

3602

3603

3604

3605

3606

3607

3608

3609

3610

3611

3612

3613

3614

3615

2188

2189

2190

2191

2192

2193

2194

2195 
Konkordanz: Bestell-Signatur - Ifd. Nr.

Bestell-Signatur

Lfd.Nr.

IV 03708

IV 03709

IV 03710

IV 03711

IV 03712

IV 03713

IV 03714

IV 03715

IV 03716

IV 03717

IV 03718

IV 03719

IV 03720

IV 03721

IV 03722

IV 03723

IV 03724

IV 03725

IV 03726

IV 03727

IV 03728

IV 03729

IV 03730

IV 03731

IV 03732

IV 03733

IV 03734

IV 03735

IV 03736

IV 03737

IV 03738

IV 03739

IV 03740

IV 03741

IV 03742

IV 03743

IV 03744

IV 03745

IV 03746

IV 03747

IV 03748

IV 03749

IV 03750

IV 03751

IV 03752

IV 03753

IV 03754

IV 03755

IV 03756

IV 03757

IV 03758

IV 03759

IV 03760

IV 03761

IV 03762

IV 03763

IV 03764

IV 03765

IV 03766

IV 03767

2196

2197

2198

2199

2200

2201

2202

2203

2204

2205

2206

2207

2208

2209

2210

2211

2212

2213

2214

2215

2216

2217

2218

2219

2220

2221

2222

2223

2224

2225

2226

2227

2228

2229

2230

2231

2232

2233

2234

2235

2236

2237

2238

2239

2240

2241

417

2242

2243

2244

2245

2246

2247

2248

2249

2250

2251

2252

2253

2254 
Konkordanz: Bestell-Signatur - Ifd. Nr.

Bestell-Signatur

Lfd.Nr.

IV 03768

IV 03769

2255

IV 03770

2256

IV 03771

2257

IV 03772

2258

IV 03773

2259

IV 03774

2260

IV 03775

2261

IV 03776

2262

IV 03777

2263

IV 03778

2264

IV 03779

2265

IV 03780

2266

IV 03781

2267

IV 03782

2268

IV 03783

2269

IV 03784

2270

IV 03785

2271

IV 03786

2272

IV 03787

2273

IV 03788

2274

IV 03789

2275

IV 03790

2276

IV 03791

2277

IV 03792

2278

IV 03793

2279

2280

IV 03794

2281

IV 03795

2282

IV 03796

2283

IV 03797

2284

IV 03798

2285

IV 03799

2286

IV 03800

2287

IV 03801

2288

IV 03802

2289

2290

IV 03803

2291

IV 03804

2292

IV 03805

2293

IV 03807

2294

IV 03808

2295

IV 03809

2296

IV 03810

2297

IV 03811

2298

IV 03812

808

IV 03813

2299

IV 03814

2300

IV 03815

2301

IV 03816

2302

IV 03817

2303

IV 03818

2304

IV 03819

2305

IV 03820

2306

IV 03821

2307

IV 03822

2308

IV 03823

2309

IV 03824

2310

IV 03825

2311

IV 03826

2312

IV 03827

2313 
IV

Konkordanz: Bestell-Signatur - Ifd. Nr.

Bestell-Signatur

Lfd.Nr.

IV 03828

IV 03829

2314

IV 03830

2315

IV 03831

2316

IV 03832

2317

IV 03833

2318

IV 03834

2319

IV 03835

2320

IV 03836

2321

IV 03837

2322

IV 03838

2323

IV 03839

2324

IV 03840

2325

IV 03841

2326

IV 03842

IV 03843

3305

IV 03844

3306

IV 03845

3308

IV 03846 


\section{Inhaltsverzeichnis}

Seite

Vorwort

Gliederung

Akten

Index

Konkordanz: alte Registratursignatur - Ifd. Nr.

Konkordanz: alte Archiv-Signatur - Ifd. Nr.

Konkordanz: Bestell-Signatur - Ifd. Nr. 